Ema Elena Aveleyra

Melisa Alejandra Proyetti Martino (coords.)

\title{
Escenarios
}

y recursos

para la

enseĩanza

con tecnologia:

destafios $y=$ retos

Prólogo de: Francisco Martínez, Julio Cabero y Jesús Salinas 


\section{Escenarios y recursos para la enseñanza con tecnología: desafíos y retos}

Ema Elena Aveleyra Melisa Alejandra Proyetti Martino (coords.) 


\section{Prólogo}

\section{1 | Innovación Docente}

Adaptación del Diseño Metodológico Docente: de la Presencialidad Adaptada a la Enseñanza Remota Mediante la Utilización de Herramientas Tic. García Mirón, Silvia.

Primeras Ideas de los Futuros Docentes Sobre el Pensamiento

Computacional. Bueno-Baquero, Andrea; del Olmo-Muñoz, Javier; Tirado-Olivares, Sergio; Cózar-Gutiérrez, Ramón; González-Calero, José Antonio.

Enseñar y Aprender Remotamente Fisicoquímica en Tiempos de

La Competencia Digital Docente en Educación Superior. Parra Bernal, Lina Rosa; Canales Reyes, Roberto; Alzate Gallego, Yorladis; Morales, María Julia.

Repensar la Práctica Docente en Entornos Combinados: Una Experiencia 


\section{1 | Innovación Docente}

Sistema de Gamificación de un Entorno Aumentado: Estimulando las

Habilidades Comunicativas en Alumnado con TEA. López Bouzas,

Nerea; Del Moral Pérez, Ma Esther.

Alcances e Implicaciones de los Mapas Mentales Colaborativos en el

Aprendizaje Móvil. Mg. Estrada Villa, Erika Juliana; Dra. Marín Juarros,

Victoria Irene; Salinas Ibáñez, Jesús.

La Formación Continua como Espacio de Criticidad y los Dilemas

Educativos. Educación Inclusiva en Tiempos de Pandemia.

Domínguez, María Alejandra.

Experiencias de Educación Virtual en Tecnología: Algoritmia y

Programación para Carreras de Ingeniería. Jiménez Rey, Elizabeth;

Servetto, Arturo; Calvo, Patricia.

Un Análisis de la Implementación de la Evaluación Formativa en el

Aula Virtual. Bravo Barletta, Virginia; Hollisch, Gisele.

Diseño y Validación de una Herramienta de Evaluación de la

Usabilidad de un Entorno Web. Farré Fustagueras, Marta.

Enseñanza Virtual de Física en Cátedras Masivas en el Marco de la

Pandemia Covid-19. Hernandez, Federico; Caro, German; Belloca,

Cristina; Camuyrano, Mario; Fontana, Marcelo.

La Clase Invertida en un Escenario de Aprendizajes Semi-Presencial.

204

De Luca, Marina Patricia.

Enseñar Estadística en Tiempos de Covid. Elaboración de Materiales

Adaptados al Nuevo Paradigma Educativo. Pérez Giménez, Virgilio;

Aybar Arias, Cristina; Pavía Miralles, Jose M.

Abriendo Puertas de la Pandemia. Nuevos Entornos y Lenguajes, la

Producción del Conocimiento en la Cultura Digital: Reflexiones de una

Experiencia. Weber, Verónica.

Transformación Educativa: Cualificación Docente desde las

Tecnologías Emergentes. Zamudio, Leidi; Rubiano, Mary Luz;

Avendaño, Henry; Torres, Cristóbal.

La Aplicación de Recursos Tecnológicos Digitales para Mejorar el Nivel de Comprensión Lectora en Lengua Catalana. Un Estudio de Caso.

Buendia Barberà, Marina. 


\section{1 | Innovación Docente}

Las TICs y Las Prácticas Pre-Profesionales de los Estudiantes de la

264

Carrera de Contador Público. Butigué, Silvia; Mussolini, María Susana;

Martinez, Natalia; Tassone, Matías.

Aprendices en Expansión en la Red Social. Dans Álvarez de

Sotomayor, Isabel.

Influencers: Los Nuevos Bardos. Redes Sociales para Enseñar Inglés.

Pereda Nieto, Alba; Dans Álvarez de Sotomayor, Isabel.

Diseño, implementación y evaluación de una sesión de videoconferencia

interactiva con alumnado senior. Fernández Montero, Isabel.

Un Proyecto de Investigación Operativa con Datos Reales con

Colaboración Olímpica. Ramos, Silvia Adriana.

Diseño de un Repositorio de Recursos Tic Para Trabajar la

Lectoescritura. Parra García, Ana María.

¿Otro Tipo de Gamificación es Posible?: Experiencia de Retos

Gamificados y de Evaluación entre Iguales desde el Aprendizaje

Cooperativo y la Atención a la Diversidad. Lluch-Molins, Laia;

Cano-García, Elena; Valero-García, Miguel; Meseguer-Pallares, Roc.

Podcast como Herramienta Educativa en el Proceso de Enseñanza-

Aprendizaje en Educación Superior. Jiménez Mariscal, Laura María;

Luque Rojas, María Jesús.

Reflexionando sobre la Innovación Educativa: Diseño de una experiencia de aprendizaje a través de los podcast. Martínez-Pérez, Jorge; Recio Muñoz, Francisco.

Análisis de una Experiencia de Gamificación Basada en Escape Room en Gestión de Proyectos. Amante, Beatriz; Romero-García, Carmen; Guinart, Aleix.

Propuesta Experimental para Estudiar el Movimiento Oscilatorio de un Cuerpo Rígido no Homogéneo Usando Celulares Inteligentes. Barber, Matías; Chiabrando, Laura; Duplaá, María Celeste; Rivas Rojas, Patricia.

Tdic na Formação em Educação para o Desenvolvimento Sustentável em Projetos Envolvendo Objetivos do Desenvolvimento Sustentável. Leopoldo Mercado, Luis Paulo. 


\section{1 | Innovación Docente}

Las TIC en la Intervención del Alumnado con Dificultades de

409

Aprendizaje a Través de la Producción Científica. García-Albaladejo,

Eva; Gilabert-Cerdá, Alba.

Deserción y Menor Motivación en un Curso Virtual de Fisiología

Humana en la Universidad Nacional del Comahue. Scapini, Celina.

El Desafío de la Evaluación en Prácticas Remotas de Química Inorgánica en la Facultad de Ingeniería de la UBA Durante la

Pandemia Sars-Cov-2. Herme, Carlos A.; Debandi, María V.; Menchaca Nal, Sandra; Noli, Joaquín l.; Jacobo, Silvia E.

Química Universitaria Básica y Pandemia: El Mundo como Aula, la

Casa como Laboratorio. Lucy Coria; Héctor Fasoli; Sandra Menchaca

La Modalidad Virtual en Electrotecnia General como Motivacion para el Rediseño de Estrategias Didácticas Orientadas a la Sustentabilidad Curricular. Ferreira, Fabiana.

Aula invertida y e-actividades: aprendizajes de su implementación en una asignatura universitaria de ciencias económicas. Golden, Hugo David

La Actividad Situada como Estrategia para la Enseñanza y Aprendizaje en un Proceso de Toma de Decisiones Bajo Incertidumbre para la Carrera de Contador Público. Gallardo, Juan Manuel; Cassano, María Virginia; Bissio, Lucrecia.

Herramientas Digitales Utilizadas por el Profesorado de Educación Superior de Argentina en Contexto de Pandemia. Galli María Gabriela; Kanobel, María Cristina; Chan, Débora.

Adaptación Semipresencial en Tiempos de Covid-19: Recursos TIC, Motivación y Percepción del Alumnado Universitario en la Clase de IFE. Rodríguez Peñarroja, Manuel.

Estrategias de Pensamiento Visual Aplicadas a los Estudios de Arte e Historia en Bachillerato: Cuestiones Cognitivas, Percepción Sensorial y Praxis Didáctica. González Torres, Javier. 


\section{2 | Investigación en Tecnología Educativa}

El Vídeo en la Enseñanza. Una Aproximación a la Visión del

Profesorado. Martí Climent, Alícia.

Efectos de la Pandemia Covid-19 en la Enseñanza de la Ingeniería:

Experiencias y Consideraciones del Estudiantado.

Zambrano-Sandoval, Heidy; Díaz-García, Juan Isidro.

Percepciones Docentes sobre el Uso de la Realidad Aumentada y la Realidad Virtual para la Enseñanza del Inglés y la Educación Bilingüe.

Huertas-Abril, Cristina A.; Palacios-Hidalgo, Francisco J.

Telecolaboración y Formación del Profesorado de Educación Primaria

Bilingüe: Estudio de las Percepciones de los Docentes.

Palacios-Hidalgo, Francisco J.; Huertas-Abril, Cristina A.

Análisis de la Adicción a los Smartphone desde el Contexto Educativo:

Estudio Bibliomético. Colomo Magaña, Ernesto; Cívico Ariza, Andrea;

Cuevas Monzonís, Nuria; Gabarda Méndez, Vicente; Ruiz Palmero, Julio.

Sistema de Tutorías. Un Reto en la Universidad de la Ciénega del Estado de Michoacán de Ocampo (Ucemich). Barajas-Pérez, Karla;

Carrera-Farran, Xavier; Santiago-Campión, Raúl.

Aportes al Desarrollo de la Competencia Digital Docente desde la Propuesta del Modelo TEP. Pinto-Santos, Alba Ruth; Pérez Garcias, Adolfina; Darder Mesquida, Antonia.

Diseño de Escala E-Portafolio para Educación. Zambrano Matamala, Carolina; Sanhueza Lesperguer, Elizabeth; Rojas Díaz, Darío; Friz Carrillo, Miguel.

LEXLIVE: Registro y Análisis de Pruebas de Disponibilidad Lexica para el Aula. Rojas Díaz, Darío; Zambrano Matamala, Carolina; Salcedo Lagos, Pedro.

Innovación Educativa en Escenarios de Aprendizaje Móvil con Recursos de Acceso Abierto. Tagua, Marcela. 


\section{2 | Investigación en Tecnología Educativa}

Regreso al Pasado: El Entorno Virtual Cospaces Edu para la

Los Docentes Frente a la Utilización de Tics: Propuesta de un Modelo de Seguimiento en Docentes de Facultad de Ciencias Económicas de UNC 2021. Casini, Rosanna.

Uso de las Redes Sociales Virtuales en el Proceso de EnseñanzaAprendizaje por Estudiantes de Ingeniería Ambiental. Leal Ríos, Fernando; Flores Morelos, Ma. M; Lucio Castillo, Mariby; González García, Agustín; Cabero Almenara, Julio.

Revisión Sistemática Sobre la Aplicación del Robot Bee-Bot para la Enseñanza del Alumnado de Educación Infantil y Educación Primaria. Pérez Vázquez, Elena; Lorenzo Lledó, Gonzalo; Lledó Carreres, Asunción; Gilabert Cerdá, Alba.

Aplicación de las Tecnologías de la Información y la Comunicación (TICS) para el Trastorno del Espectro Autista: Realidad Aumentada. Gilabert-Cerdá, Alba; Lorenzo Lledó, Gonzalo; Lorenzo Lledó, Alejandro; García-Albaladejo, Eva.

Los Itinerarios Flexibles en Entornos Virtuales para el Desarrollo de Habilidades de Aprendizaje Autorregulado. Tur, Gemma; Pérez-Garcias, Adolfina; Villatoro, Sofía; Darder Mesquida, Antònia.

La Competencia Digital Docente y el Estado de las Tecnologías Digitales en los Centros Escolares desde la Perspectiva de los Referentes Digitales en Cataluña (España). Domínguez Navarro, Estíbaliz; Lores-Gómez, Beatriz.

Diferencias y Similitudes en la Competencia Digital del Alumnado que Inició el Grado en Educación Primaria Antes y Después de la Pandemia. López-de-Arana Prado, Elena; Rappoport Redondo, Soledad.

Proyecto Educativo Institucional: Integración de Nuevas Tecnologías y Trabajo Colaborativo. Instrumento de Autoevaluación y Diagnóstico. Mujica, María Genoveva; Nóbrega González, María Laura. 


\section{2 | Investigación en Tecnología Educativa}

Validez, Confiabilidad, Análisis de reactivos y Actividades Cognitivas

de un Instrumento: Recursos digitales para un estudio Cuantitativo.

Aguilar-Romero, Juan Hadad; Juárez-Ruiz, Estela.

Sistema de Memoria Transactiva. Una Aproximación al Procesamiento de Información Grupal en el Proceso de Aprendizaje Colaborativo en EVA. García-Chitiva, María del Pilar.

Métodos Univariantes Aplicados a la Competencia Digital del Futuro Docente en Relación a su Actitud, Conocimiento y Uso de las TIC.

Guillén Gámez, Francisco D.; Linde-Valenzuela, Teresa.

YouTube, una Nueva Ventana al Aprendizaje. Lozano-Blasco, Raquel;

Gil-Lamata, Mercedes; Arce-Romeral, Lorena.

La Plataforma AskQue en el Aprendizaje Universitario. Diego Racero;

Ema Aveleyra; Santiago Beroch.

Las Tecnologías de la Información y Comunicación y su Usabilidad en Estudiantes de Educación Superior en Tamaulipas: ¿Se Amplía o Reduce la Brecha Digital? Hernández Rodríguez, Abigail; Echavarría Sánchez, Anabell; De la Cruz Borrego, José Gpe.; Azuela Flores, Cristabell; Roux Ramírez, Rhodas.

Los Recursos Educativos Abiertos como Acceso a Derechos Culturales en una Universidad Pública Argentina. Aranciaga, Ignacio.

La Experiencia de Aula Invertida Gamificada en Futuros Docentes para Trabajar el Pensamiento Computacional. Percepción de los Estudiantes. Carpena Arias, Jesús; Esteve-Mon, Francesc M.; Valdeolivas Novella, Ma Gracia.

Formación del Profesorado en Investigación Educativa Mediante una

Aplicación Móvil. Ayuso del Puerto, Desirée; Galván Malagón, Carmen;

Gutiérrez Esteban, Prudencia; Alonso Díaz, Laura.

Virtualización en la Detección de Parámetros Relacionados con el Acoso Escolar Mediante Orden Sistémico Educativo Situacional. Escribano Valle, Jon; Castro-León, Elke; Íñigo Mendoza, Victoria; Nestares Hervías, Eva Mạ. 


\section{3 | Políticas y Gestión de las Tecnologías}

Programa de Vinculación de Alumnos de los Posgrados en Inteligencia

Artificial, Sistemas Embebidos e Internet de las Cosas de la UBA con

Organismos Públicos y Empresas: Métodos y Resultados. Menéndez,

Martín Nicolás; Gomez, Pablo Martín; Lutenberg, Ariel.

Reconceptualizaciones y Giros en la Formación Docente Universitaria en Tiempos de Pandemia: Innovaciones y Nuevos Horizontes.

Capelari, Mirian; Ayuso, María Luz; Ingrassia, Clara; Rodríguez, Dario;

Ragone, María Florencia.

Análisis Exploratorio de una Escala de uso Académico de Tecnologías

Digitales Para la Formación Inicial Docente. Cerda, Cristian; León, Miriam.

Propósitos de Uso Académico de Tecnologías Digitales en Formación

Inicial Docente. Cerda, Cristian; León, Miriam.

La Gestión de la Tecnología en la FCV UBA, los Avatares del Tsunami

Virtual. Fabiana Grinsztajn; Roxana Szteinberg; Gabriel Sánchez,

Mariana Vaccaro.

Universidades Ante la Comunidad Digital: Adecuación de la Academia a las Redes Sociales, Una Comparativa Entre España y Francia.

Mira-Aladrén, Marta; Lozano-Blasco, Raquel; Latorre-Martínez, Ma Pilar.

\section{4 | Inclusión Digital}

Aplicación de Juegos Serios como Herramienta de Enseñanza en

Tiempos de Pandemia. Parkinson, Christian; Martínez, Roxana.

Realidad Aumentada en la Intervención de Estudiantes con Trastorno

del Espectro Autista. Alcívar Pincay, Anabel; Pantaleón Cevallos, Yisela;

Corral Joza, Karen.

Papel de la Personalidad Situacional en la Adquisición de

Competencias Digitales de Alumnos del Grado de Maestro.

Martín-García, Mã Inés; Cebrián Martínez, Antonio; García-Perales,

Ramón; López Parra, Emilio.

Educación Digital en Escuelas Medias: Un Enfoque TRIC Hacia el Aprendizaje Basado en Pensamiento. Hernández Silvera, Dides Iliana.

La Representación de la Diversidad en los Materiales Didácticos Digitales de Educación Infantil: ¿'Reto o Realidad? Pardo Baldoví, M. Isabel; Vidal 


\section{4 | Inclusión Digital}

La Inclusión de las TIC como Apoyo al Alumnado Universitario

con Discapacidad a Través de la Revisión Bibliográfica. Fernández

Batanero, José María; Montenegro Rueda, Marta; Fernández Cerero,

José; Román Graván, Pedro.

Funcionalidad de la Inclusión de la Educación en Programación en la

Etapa de Educación Primaria. García-Perales, Ramón; Palomares-Ruiz,

Ascensión; Martín-García, María Inés; López-Parra, Emilio.

La Motivación y el Chat del Aula Virtual como Recurso para Evitar la

1006

Deserción en el Ámbito Universitario Durante las Primeras Etapas de la

Pandemia. Soto Pascacio, Flor.

Herramientas Tecnológicas para la Superación de Barreras Educativas

1020

de las Personas con Discapacidad Auditiva Desde un Análisis

Bibliométrico. Antón Ros, Nuria.

Resultados Descriptivos del Análisis de Noticias por Parte de

Estudiantes Universitarios Posterior a un Seminario sobre Noticias Falsas

en Redes Sociales. Meza Cano, José Manuel; González Santiago, Edith.

Uso y Apropiación de Tecnología con Perspectiva Interseccional y

Feminista de Género: Una Experiencia en la Universidad Pedagógica

Nacional Unidad 095 para Reducir la Desigualdad. Ramírez Camacho,

Adriana Guadalupe.

La Competencia Digital de Estudiantes Universitarios: El caso de una

\section{5 | Aprendizaje en Red}

Evaluación de Preguntas de Opción Múltiple Utilizando Herramientas

1071 de Clasificación Estadística dentro del Ámbito de las Ingenierías.

Dadamia, Danilo; Ferrini, Adrián; Gomez Toba, Gonzalo Hernan.

La Telepresencia en un Programa Doctoral en Red. Perspectivas de 


\section{5 | Aprendizaje en Red}

Una Investigación Cualitativa Acerca del Oficio Docente en la

Actualidad. Pereira de Lucena, María Julia.

La Virtualidad, Dispositivo para Favorecer la Agencia en las Prácticas

Letradas del Profesorado en Formación Inicial. Hernández Yépez Ma.

Antonia; Salinas Quintanilla Alma Ma. del Amparo.

A Interatividade no Processo de Ensino e Aprendizagem no Contexto do Ensino Online Emergencial. Vieira de Almeida, Douglas; Pereira da Silva, Flávio; Leopoldo Mercado, Luis Paulo.

Percepción de los Equipos Directivos Valencianos Sobre la Gestión Educativa del Confinamiento por la Covid-19 y sus Soluciones Digitales a la Pandemia. Álvarez Herrero, Juan Francisco.

Colaborando en Línea con Madres, Padres y Docentes para Promover la Alfabetización Emergente en Preescolares. Vega Pérez, Lizbeth; Poncelis Raygoza, María Fernanda; Núñez Márquez, Guadalupe; Guarneros Reyes, Esperanza.

Dificultades del Alumnado Universitario y Medios para el Desarrollo de la Evaluación Durante el Covid-19. Lorenzo-Lledó, Alejandro; Lledó Carreres, Asunción; Pérez-Vázquez, Elena; Antón Ros, Núria.

El Uso de los Blogs en la Educación Infantil en Tiempos de Pandemia. Análisis de su Uso y Función. Álvarez Herrero, Juan Francisco.

Formación de Estudiantes Predoctorales para el Buen Uso de Imágenes

Científicas. Mir, Ricardo; Muñoz, Adolfo; Seguí-Simarro, Jose María.

Curso Virtual de Capacitación y Sensibilización Dirigido a los Docentes de la Institución Educativa Técnica Jacinto Vega de Santa Maria Boyacá Acerca de Educación Inclusiva. Borbón Cipriam, Aura Ruth.

El Aula Virtual de Traducción para la Formación Profesional: Recursos 1214 Digitales para el Aprendizaje Interactivo. Gava, Ileana Yamina; Blanco, Candela; Cobresle, Kemel Karim.

Plataforma REA como Espacio para la Formación Virtual en el Puesto de Trabajo, a Través de Metodologías Activas. Martínez Guzmán, María Dolores.

La Evaluación Formativa, el Recorrido de una Experiencia de la Pontificia Universidad Católica Argentina en Tiempos de Pandemia. Mujica, Ma. Genoveva; Sisto, Marcela Inés.

El Trabajo Colaborativo Mediado por TIC: Aportes para la Formación Integral en Experiencias Universitarias de Internacionalización Curricular en Casa. Bayonés, Marcela; Vargas, Matías Rodrigo; Gramaglia, Carina; Guedes, Mauricio; Clérico, Gracia María. 


\section{6 | Escenarios con Tecnología}

Interacciones y Consideraciones Sistémicas en el Aula Virtual. Lara, Luis Rodolfo.

Virtualidad en Asignaturas del Área de Ingeniería Estructural. Folino,

Paula; Traiber, Claudia.

Interactuar en la Virtualidad: Experiencia en Cursos Iniciales de Física Universitaria. Chiabrando, Laura; Duplaá, María Celeste; Garea, María Teresa; Repetto, Viviana Cristina.

Desarrollo de Habilidades Comunicativas en la Segunda Lengua Inglés en Niños con Discapacidad Intelectual Leve por Medio de un Tablero Didáctico Digital. Gutierrez Montenegro, Lina.

Aprendizajes en Física Universitaria: Descripción de una Experiencia con uso de Recursos Computacionales Desarrollados Mediante Lenguaje de Programación Python. Saccone, Fabio Daniel.

Ponele Onda a tu Voz y Contalo en Forma de Podcast. Federico Emanuel Ravera Marbán.

Integración Curricular de Aplicaciones Educativas en el Ámbito de la Enseñanza de Lenguas Extranjeras. El Caso de Beelinguapp para Aprender Español en la Universidad Portuguesa. Sapiña, Joan; Cao Míguez, Ana Belén.

Repositorios de Universidades Argentinas: Oportunidad para Potenciar el Acceso Abierto y la Alfabetización Informacional. Coraglia, María Inés; Vázquez, Manuela.

La Inclusión como Derecho Habilitador en la Modalidad Virtual: Universidad Autónoma de Tamaulipas. Espinosa Barajas, Jeny Haideé; Lladó Lárraga Dora. Ma.; Ruíz Méndez, Manuel.

Análisis del Uso de Vídeos Didácticos en Una Situación de Emergencia Sanitaria. Comparación de Dos Escenarios: Docencia Remota de Emergencia y Docencia Híbrida. Museros, Pedro; Lapuebla-Ferri, Andrés; Espinós, Ana; Benlloch-Dualde, José V.

Repositorio Institucional de Acceso Abierto de Fich Unl: Diseño, Desarrollo e Implementación de un Software de Gestión de Producciones Científico Académicas. Bas, Natalia; Giorgetti, Carlos; Romero, Lucila. 


\section{6 | Escenarios con Tecnología}

La Gamificación Como Herramienta de Aprendizaje de Una Segunda Lengua y su Percepción como Fuente de Motivación en Estudiantes de Grado. Fruttero, María José; Gimenez, Lucía; Rossiano, Paula; Periales, Sol Ximena; Rejep Vargas, Milagros Martina.

El Modelo de Formación de Aulas Amigas Como Dinamizador de un Ecosistema de Innovación Educativa. Agudelo, Olga Lucía; Chica, Sandra Milena.

Evaluación Remota en Química Universitaria con Herramientas de Google. Gottardo, Marcelo; Dominighini, Claudio; Cataldi, Zulma.

COVID19 y Nuevos Retos en la Docencia de Botánica: la Respuesta en la Red Vives de Universidades. Simon Pallisé, Joan.

Eficacia de una Intervención Online Grupal Basada en el Protocolo Unificado Transdiagnóstico para la Gestión Emocional. Arrigoni, Flavia.

Simulación de los Problemas de Mezcla y Drenado de un Tanque: Implementación de un Objeto de Aprendizaje en un Curso de Ecuaciones Diferenciales. Haye, Elisabet; Genzelis, Lucas; Zucarelli, Agostina.

Crecimiento Competencial en la Escuela y su Relación con Transferencia Digital en Proyectos de Huertos Escolares. Blanc, Sara; Benlloch-Dualde José V.; Grindei, Laura; Nájera, Inmaculada

Las Estrategias Metacognitivas y Socioafectivas para el Aprendizaje 1482 Autodirigido y Colaborativo de la Traducción Especializada a Distancia. Gava, Ileana Yamina.

Conectando Aprendizajes: Experiencia de Atención a Estudiantes Durante la Pandemia en la Escuela Normal Superior de Bucaramanga. Ayala Moreno, Johanna Beatriz; Chapeta, Germán.

Diseño de Estrategias Mediadas por Scratch para Apoyar el Proceso Lector en Niños y Niñas Disléxicos. Garcia Medina, Maria Angelica; Acosta Meza, David de Jesus; Primera Diaz, Haison Luis; Álvarez Aguirre, Oscar Alberto.

Utilización y Adaptación de Diferentes Innovaciones Tecnológicas Durante la Covid19 y la Postpandemia. Sánchez García, José Manuel.

Resultados en el Uso de Realidad Aumentada en Introducción a la Ingeniería Electrónica al Inicio de la Pandemia Covid-19. García Marra, Sebastián; Carducci, Leonardo Martín; Bonelli, Fernando; Veiga, Ricardo Alfredo. 


\section{Prólogo}

En los últimos meses, o mejor decir en los últimos dos años, hemos podido asistir a una generalización de las tecnologías de la comunicación; generalización que ha venido impuesta, no sólo por la tecnología, sino también por una pandemia que ha obligado a cambiar los usos y costumbres de relación de la sociedad. Todas las actividades humanas han quedado más o menos afectadas: las relaciones afectivas, familiares, comerciales, de ocio, de trabajo.

La enseñanza, que no es ajena a la sociedad, no se ha librado de esa implementación, más bien ha sido donde la repercusión ha tenido una manifestación más generalizada y con un impacto social posiblemente más perceptible. Se ha pasado de la clase presencial a la teleclase.

Las aulas se han vaciado y las clases han continuado en un "no lugar", en el ciberespacio, donde profesores y alumnos han podido coincidir y mantener un desarrollo académico más o menos aceptable gracias a la tecnología.

Dado que la situación ha venido de improviso, la enseñanza, como el resto de la sociedad, no tenía previsto un plan a aplicar y ha sido necesario improvisar. Profesores y centros procuraron hacer frente a los estragos del confinamiento desde el compromiso y la responsabilidad, apoyándose sobre todo en la disponibilidad de instrumentos que permitieron el aislamiento físico de los sujetos sin que ello supusiese un aislamiento comunicativo.

La enseñanza, mejor los políticos responsables de la enseñanza, generalizaron las teleclases. Profesores y alumnos, en sus respectivos domicilios, se mantuvieron conectados por la tecnología. Partiendo de la idea de su disponibilidad generalizada y que su utilización nunca sería un problema se olvidaron de algo importante: "Las tecnologías son herramientas que tienes que entender, esto es importante pero la tecnología no va a acudir en tu ayuda, ya que no le importas, no tiene valores" (Leonhard, 2019, 21). A las tecnologías, de momento, hay que decirles qué hacer y, concretamente en la enseñanza, cómo hacer, y esas dos cuestiones se han olvidado en la solución curricular pandémica a que estamos asistiendo.

Alumnos y profesores necesitaban y siguen necesitando de una formación acorde con el nuevo modelo de relación entre los alumnos, los profesores, los contenidos y el aprendizaje, en definitiva con los criterios pedagógicos que deben sustentar los nuevos modelos didácticos. 
No es que no exista información sobre esa relación, el presente libro es un ejemplo de las numerosas experiencias que con estas tecnologías se están desarrollando en estos momentos. Experiencias que responden al interés y a la inquietud de docentes para hacer con ellas un uso coherente y adecuado.

El profesorado, por su parte, se ha visto obligado a improvisar unas nuevas formas de hacer sin que en ningún momento se le haya formado, o al menos informado, sobre qué podía hacer y cómo hacerlo. La falta de formación de los docentes, para el uso de las nuevas tecnologías de la comunicación, se ha puesto claramente de manifiesto a lo largo de estos meses.

A esta falta de formación se le une una falta de motivación: "para aceptar el uso de las tecnologías los docentes deben percibir su relevancia y beneficio en su práctica profesional. Para esto, su nivel de confianza en sus propias capacidades de aplicación juega un rol fundamental"' (Scherer et al., 2019), y si no hubo formación difícilmente puede haber confianza.

Por otro lado, y al igual que los docentes, los alumnos se han encontrado en situaciones a las que con muchas dificultades han tratado de dar respuesta, una diversidad de respuestas. Hubo desde los que se adaptaron a la situación colocando a los alumnos y sus familias en el centro de preocupación -generalmente centros que estaban ya inmersos en procesos de innovación y de transformación hacia una mayor flexibilidad curricular y organizativa-, hasta los que intentaron trasladar el modelo tradicional presencial al ámbito virtual, obviamente con poco éxito.

De lo dicho se deduce que, ante la nueva situación, se hace imprescindible una formación adecuada y permanentemente actualizada de docentes y alumnos, situación en la que los roles son diferentes a los tradicionales de la enseñanza presencial y que conllevan a asumir roles y responsabilidades distintas a las que venían siendo tradicionales.

Otra pieza importante a tener en cuenta, y que nos la ha mostrado la situación actual, es la necesidad de investigación, trabajos que permitan disponer de modelos contrastados de enseñanza en los que la presencialidad no sea el centro de la misma. La tecnología va a estar siempre cambiando y nos obligará a que siempre tengamos que descubrir y evaluar nuevas formas de hacer, lo que nos conducirá a que permanentemente tengamos que aprender algo nuevo.

Quedan dos aspectos que se han manifestado fundamentales en esta situación de docencia pandémica. Por un lado, la organización de los centros y de la enseñanza como proceso curricular. Implementar modelos no presenciales en organizaciones creadas para la coincidencia presencial son difíciles de encajar, creando situaciones difícilmente superables.

Por otro lado, es imprescindible tener resuelta la disponibilidad de tecnologías adecuadas para poder desarrollar las metodologías pertinentes a los nuevos modelos didácticos. Y, si bien los equipamientos tecnológicos no deben ser el centro sobre el que pivote la enseñanza, también es verdad que sin estas tecnologías difícilmente se puedan desarrollar. 
De todo lo aprendido en esta situación, y tratando de prepararnos para lo que puede ser un futuro más o menos cercano, podemos pensar en tres etapas. Una primera, de evolución, en la que docentes y alumnos se vayan aproximando a los nuevos modelos. Una segunda, de innovación, en la que se integren con naturalidad estos modelos sin conflicto con los que han venido siendo tradicionales. Y, por último y esto en su caso, puede venir impuesto desde fuera una revolución en la que los sistemas de enseñanza sean diferentes a los que conocemos, y para ello habrá que estar preparado.

A partir de las consideraciones hechas, una estrategia con vistas a futuro puede partir del modelo SAMR propuesto por Puentedura (2006), en el que, tomando como eje las repercusiones de la tecnología en los nuevos modelos didácticos, podríamos hablar en un primer momento de sustitución en el que la tecnología actúa como un sustituto directo sin ningún cambio funcional. Posteriormente se puede abordar una fase de aumento en el que la tecnología actúa, ahora sí, como sustituto suponiendo una mejora funcional (López, 2015).

Superadas estas dos etapas, con los consiguientes desarrollos formativos, es posible abordar lo que hemos denominado revolución por medio de dos nuevas etapas: modificación significativa de las tareas, mediante la utilización de las tecnologías, que nos llevaría a una redefinición con nuevas tareas en las que previamente no había sido posible y que ahora las tecnologías nos la facilitan.

Es posible lograr el cambio que la sociedad y las circunstancias están pidiendo a la enseñanza y buena muestra de ello es esta obra que tenemos el honor de prologar. Pero ese cambio requiere de planificación y saber hacer, y no de improvisación para salir del paso, o de donaciones indiscriminadas de medios tecnológicos sin sentido ni objetivos. El futuro es difícil de predecir, pero lo que sí podemos hacer es participar en su construcción. Trabajemos todos juntos para saber a dónde vamos, por dónde y cómo hacemos el camino.

\section{Julio}

\section{Cabero Almenara}

Vicepresidente EDUTEC

\section{Francisco}

Martínez Sánchez

Presidente EDUTEC

\section{Jesús}

Salinas Ibáñez

Vicepresidente EDUTEC 


\section{Referencias}

Leonhard, G. (2019). Entrevista a Gerd Leonhard. Telos 110_Enlighted, 16-23.

López, J.C. (2015). SAMR, modelo para integrar las TIC en procesos educativos. Eduteka. https://eduteka.icesi.edu.co/articulos/samr.

Puentedura, R. (2006). Transformation, Technology, and Education. http://hippasus. com/resources/tte/

Scherer, R., Siddiq, F. y Tondeur, J. (2019). The technology acceptance model (TAM): A meta-analytic structural equation modeling approach to explaining teachers' adoption of digital technology in education. Computers and Education, 128, 13-35. https://doi.org/10.1016/j.compedu.2018.09.009 


\section{Adaptación del Diseño Metodológico Docente: de la Presencialidad Adaptada a la Enseñanza Remota Mediante la Utilización de Herramientas Tic}

\section{García Mirón, Silvia}

orcid.org/0000-0001-8951-6051

Universidade de Vigo

silviamiron@uvigo.es 


\title{
ADAPTACIÓN DEL DISEÑO METODOLÓGICO DOCENTE: DE LA PRESENCIALIDAD ADAPTADA A LA ENSEÑANZA REMOTA MEDIANTE LA UTILIZACIÓN DE HERRAMIENTAS TIC
}

\author{
García Mirón, Silvia \\ orcid.org/0000-0001-8951-6051 \\ Universidade de Vigo \\ silviamiron@uvigo.es
}

\section{Resumen}

El presente texto se centra en exponer el proceso de adaptación de una materia del grado en Comunicación Audiovisual, de docencia presencial a remota, mostrando la utilización en cada caso de diversas herramientas de carácter tecnológico y digital que ayudan en el proceso de enseñanza-aprendizaje. La experiencia se contextualiza en el curso 2020/2021, año académico posterior a la declaración del estado de alarma en España provocado por la pandemia por Covid-19. Durante este curso todavía pervivía la incertidumbre y la inmediatez en la organización de la docencia o incluso improvisación ante las nuevas olas de contagios que provocaron cambios en las medidas sanitarias aplicadas a los distintos ámbitos de convivencia e interacción ciudadana como el entorno educativo. Si bien en muchas universidades se comenzaba el curso optando por la modalidad presencial o semipresencial (en función del aforo de las aulas), ante la continuidad de la pandemia fue ofreciéndose la posibilidad de docencia no presencial para todas aquellas personas que integraban los grupos vulnerables y de alto riesgo. Este hecho supuso que la materia que se aborda en esta propuesta pasase a impartirse de forma online una vez ya iniciado el curso, obligando a una modificación de la planificación ya prevista e intentando modificar en la menor medida posible la metodología y las actividades prácticas y trabajos tutorizados que se tenían planteados como fórmula principal de evaluación de la misma, favoreciendo la conectividad con los y las alumnos/as y apoyándose en distintas herramientas tecnológicas para la elaboración de las prácticas.

\section{Palabras clave}

Docencia universitaria, TIC, docencia online, docencia presencial, comunicación audiovisual. 


\section{Introducción}

La situación provocada por el Covid-19 provocó el establecimiento obligatorio de la docencia no presencial en todos los ámbitos educativos, entre ellos, también el universitario, con retos y escenarios desconocidos hasta el momento (Zubillaga y Gortazar, 2020; Alas et. al., 2020). A partir del mes de marzo de 2020 (es decir, ya iniciado el segundo cuatrimestre del curso académico 2019/2020 en España), los estudiantes universitarios se vieron encerrados en sus casas siguiendo su educación a distancia, de una forma virtual. Este hecho condujo a que comenzase a cuestionarse la docencia presencial como principal opción de enseñanza en la universidad y conllevó la incorporación de nuevas herramientas educativas tecnológicas y digitales en el proceso de enseñanza-aprendizaje y en la relación docente-alumno, advirtiéndose la necesidad de tener en consideración otras posibilidades: aprendizaje mixto, combinado o semipresencial (blended learning) y con modelos educativos flexibles desde este punto y hacia el futuro.

Ya en el curso académico 2020/2021 las universidades se vieron obligadas a realizar adaptaciones en los aforos de sus aulas, cambios en los horarios y en el tipo de enseñanza (semipresencial, aulas espejo, etc.), así como modificaciones en las técnicas y herramientas de la docencia. Así, la principal propuesta fue la docencia mixta (presencial y remota) y se flexibilizó la docencia no presencial en determinados casos personales de acuerdo con los reconocidos grupos vulnerables y de alto riesgo (edad avanzada, embarazadas, personas con problemas pulmonares, enfermedades cardíacas, cáncer y ciertos trastornos sanguíneos, diabetes y obesidad, enfermedades renales, hepática crónica o síndrome de Down).

Se plantea en este contexto la siguiente propuesta educativa que tiene como objetivo describir e ilustrar el proceso de adaptación de la metodología de enseñanza y evaluación de la materia Técnicas de Programación Para Televisión, una materia optativa que se cursa en el tercer curso del grado en Comunicación Audiovisual de la Universidade de Vigo. Configurada para ser impartida con carácter presencial, tras varias semanas de clase se adaptó a un formato online. En este sentido, se lleva a cabo una comparativa entre la planificación inicial -en términos de desarrollo temporal, uso de metodologías de enseñanza, sistemas de evaluación y utilización de herramientas TIC-para una docencia presencial en casi su totalidad y la planificación para una docencia remota.

El objetivo principal de esta investigación se centra en identificar y presentar los cambios que se han llevado a cabo en el proceso de adaptación de la materia objeto de estudio a una metodología propia de la docencia no presencial. Como segundo objetivo se pretende realizar una descripción de las herramientas tecnológicas utilizadas en ambos contextos prestando especial atención a aquellas empleadas en la docencia no presencial que puedan ser de utilidad en la docencia de carácter presencial con la finalidad de mejorar las competencias digitales y tecnológicas de futuros alumnos. 


\section{Método/Descripción de la experiencia}

\section{Descripción del contexto y de los participantes}

El contexto en el que se desarrolla la experiencia es el correspondiente al curso académico posterior a que se declarase el estado de alarma, es decir, el curso 2020/2021. Un contexto de incertidumbre ante la evolución de la enfermedad, el incremento en los contagios (nuevas olas) y la aparición de nuevas variantes (Alfa, Beta, Gamma, Delta, etc.) que suponían adaptaciones en las medidas de prevención, contención y coordinación para hacer frente a la crisis sanitaria ocasionada por el Covid-19. Estas incidencias junto con las consecuentes medidas sanitarias influyen de forma directa en el ámbito educativo, teniendo que llevarse a cabo adaptaciones y manteniendo por parte de los docentes una postura flexible ante la asistencia y la evaluación continua. Es decir, este contexto suponía pasar de la "docencia remota de emergencia" a la "presencialidad adaptada" (Sánchez Carracedo, et al., 2020).

Debemos tener en cuenta que el $68,07 \%$ del profesorado nunca había impartido docencia en línea hasta ese momento si atendemos a datos de la comunidad autónoma gallega (cfr. Fernández-Regueira et al., 2020), por lo que en general se apostó "por una metodología y evaluación basada en la transmisión de contenidos" y la intervención institucional se dirigió "a dotar de soporte técnico; sufragar las carencias instrumentales con ausencia del análisis pedagógico; y articular medidas de control" (Fernández-Regueira et al., 2020).

La experiencia se estudia en torno a una materia optativa que se imparte en el tercer año académico del grado en Comunicación Audiovisual de la Universidade de Vigo. Los participantes son, por tanto, los/as alumno/as de la misma, un total de 33 estudiantes y la docente de la materia, la propia autora.

\section{Procedimiento}

El diseño de investigación utilizado se enmarca en los métodos no experimentales, es decir, se presenta mediante un diseño esencialmente descriptivo, recurriendo a un estudio de caso como técnica con la finalidad de ilustrar una propuesta de adaptación a la docencia no presencial en el ámbito universitario que pueda servir de ayuda e inspiración para otras propuestas e incluso contextos.

Para la realización inicial de la programación y diseño metodológico de la materia y su posterior adaptación se atendieron a las indicaciones de diversos autores sobre la integración de herramientas TIC en el aula, como fue el caso de Area-Moreira et al. (2016) para el uso de las TIC en las escuelas y las distintas herramientas de uso (libros de texto, pizarra, otros libros, audiovisuales, pizarra digital interactiva, internet, ordenadores); Colás-Bravo et al. (2018), atendiendo a los efectos o incidencia de la inclusión de las TIC en las enseñanzas de Educación Secundaria y Educación Primaria; o Sangrà (2020), que en su decálogo para la docencia online recoge diversas propuestas para educar en contextos presenciales discontinuos con ideas para el diseño de las e-actividades o claves para la evaluación en línea, entre otras cuestiones y de donde se recoge como fundamental la necesidad de generar más feedback con los/as alumnos/as durante todo el proceso de aprendizaje y sobre la elaboración de las actividades, más allá de las correcciones finales. 
En este sentido resulta de interés reseñar que ya en las escuelas, y de acuerdo con "Ios nuevos medios digitales, como es el caso de las PDI (Pizarras Digitales Interactivas), están desplazando y sustituyendo a los medios audiovisuales tradicionales o analógicos", lo que aplicado al ámbito universitario, no disponiendo de PDIs, podría traducirse en un uso cada vez mayor de los ordenadores individuales (especialmente si hablamos de títulos relacionados con la comunicación en los que resulta prácticamente imprescindible disponer de un equipo propio) y también detecta una relación o vinculación directa entre el modelo o patrón de uso didáctico de las TIC en el aula y el grado de utilización del docente de las tecnologías en su vida cotidiana, "a mayor grado de competencia y participación ciudadana digital del profesor se incrementa el uso pedagógico de las tecnologías en el aula" (Area-Moreira et al., 2016).

Se intentó mejorar la propuesta en el uso de las TIC, y no realizar una mera adaptación, ya que semeja ser este uno de los principales problemas en este sentido, "muchas de las prácticas didácticas que se llevan a cabo con las tecnologías digitales, no representan una verdadera innovación o mejora con respecto a las prácticas tradicionales de enseñanza" (Christian y Mathrani, 2014). Por ello, se ha tratado de poner en valor la idea de potenciar el papel activo del alumno en su propio proceso de aprendizaje, tal y como señalan Colás-Bravo et al. (2018).

"[e]l aspecto más llamativo es que los roles de los profesores y alumnos se orientan a trabajar de forma constructivista, en tanto se potencia que el profesor se convierta en facilitador y guía del proceso de enseñanza-aprendizaje, mientras que se propicia que el alumno tenga un papel más activo en su proceso de aprendizaje, así como una mayor autonomía y responsabilidad en los procesos de toma de decisiones, a la mediación de las TIC en los procesos de enseñanza y aprendizaje, y a los aprendizajes.

Por otra parte, también se tuvieron en consideración otras experiencias de enseñanza remota de emergencia, tanto en el ámbito universitario (Fernández-Regueira et al., 2020), así como en la formación profesional (García-de-Paz y Santana Bonilla, 2021).

Como instrumento de recogida de información se utilizó, por último, un cuestionario realizado al grupo de alumnos/as compuesto por 10 preguntas a través de las que se hacía una evaluación de la materia en sus primeras sesiones presenciales adaptadas y en las sesiones del resto del cuatrimestre con docencia remota.

\section{Resultados}

La materia Técnicas de programación para televisión comenzó impartiéndose de forma presencial, si bien con la excepción para las sesiones teóricas al no disponer del aforo suficiente en ningún aula: la mitad de la clase se encontraba en el aula de forma presencial y, la otra mitad, seguía la clase a través del campus remoto de la Universidade de Vigo (campusremotouvigo.gal), un sistema propio desarrollado por los servicios informáticos de la Universidade de Vigo durante el primer confinamiento (marzo 2020) y que, poco a poco, fue mejorándose e incorporando más funcionalidades de acuerdo con las necesidades de los distintos docentes y materias de la universidad. Las sesiones prácticas, al encontrarse los alumnos ya divididos en dos grupos, podían desarrollarse presencialmente sin incidencias llamativas. 
Se impartieron de forma presencial las 4 primeras sesiones, sin embargo, y derivado de una situación personal y temporal de la docente, a partir del 21 de octubre, se dio paso a la docencia virtual, tanto para las sesiones teóricas como prácticas. Así, a partir de este momento, tuvo que realizarse una adaptación de la planificación inicial de la materia sin perder de vista el objetivo principal: "la universidad debe ofrecer una docencia de calidad que permita a los estudiantes adquirir las competencias de su titulación" (Sánchez Carracedo et al., 2020).

Tabla 1. Planificación inicial de la materia Técnicas de programación para televisión

\begin{tabular}{|l|l|l|}
\hline Sem. & Sesión teoría & Sesión práctica \\
\hline 1 & Presentación & Explicación e inicio Trabajo Tutorizado 1 \\
\hline 3 & $\begin{array}{l}\text { Presentación } \\
\text { proyecto práctico }\end{array}$ & $\begin{array}{l}\text { Entrega Práctica 1 } \\
\text { Comentarios resultados Práctica 1 }\end{array}$ \\
\hline 4 & Tema 1 & Práctica 2: Análisis parrillas. \\
\hline 5 & Tema 2 & $\begin{array}{l}\text { Sesión tutorización Trabajo Tutorizado 1 } \\
\text { Entrega Práctica 2 }\end{array}$ \\
\hline 6 & Tema 4 & $\begin{array}{l}\text { Práctica 3. Propuesta de estrategia transmedia para contenido } \\
\text { televisivo }\end{array}$ \\
\hline 7 & Tema 4 & $\begin{array}{l}\text { Entrega y exposiciones Trabajo Tutorizado 1 } \\
\text { Explicación e inicio Trabajo Tutorizado 2 }\end{array}$ \\
\hline 8 & Tema 5 & $\begin{array}{l}\text { Práctica 4. Cuestionario “Situación actual del medio televisivo } \\
\text { en España" }\end{array}$ \\
\hline 9 & Tema 5 & $\begin{array}{l}\text { Explicación e inicio Trabajo Tutorizado 3 } \\
\text { Sesión tutorización Trabajo Tutorizado 2 }\end{array}$ \\
\hline 10 & Tema 3 & Entrega y exposiciones Trabajo Tutorizado 2 \\
\hline 11 & Tema 3 & $\begin{array}{l}\text { Sesión tutorización Trabajo Tutorizado 3 } \\
\text { Propuesta concurso }\end{array}$ \\
\hline 12 & Tema 6 & $\begin{array}{l}\text { Entrega y exposiciones Trabajo Tutorizado 3 finales de los trabajos tutorizados, otras actividades } \\
\text { prácticas y las exposiciones } \\
\text { Tutorías en despacho virtual }\end{array}$ \\
\hline
\end{tabular}

\section{Fuente: Elaboración propia}

Para impartir la docencia de forma remota se utilizaron diversas herramientas TIC (si bien algunas de ellas ya se empleaban con la docencia presencial): el Campus Remoto de la Universidade de Vigo con sus diversas funcionalidades, la plataforma de teledocencia Moovi, el correo electrónico y otras posibilidades de visionado de video online. 


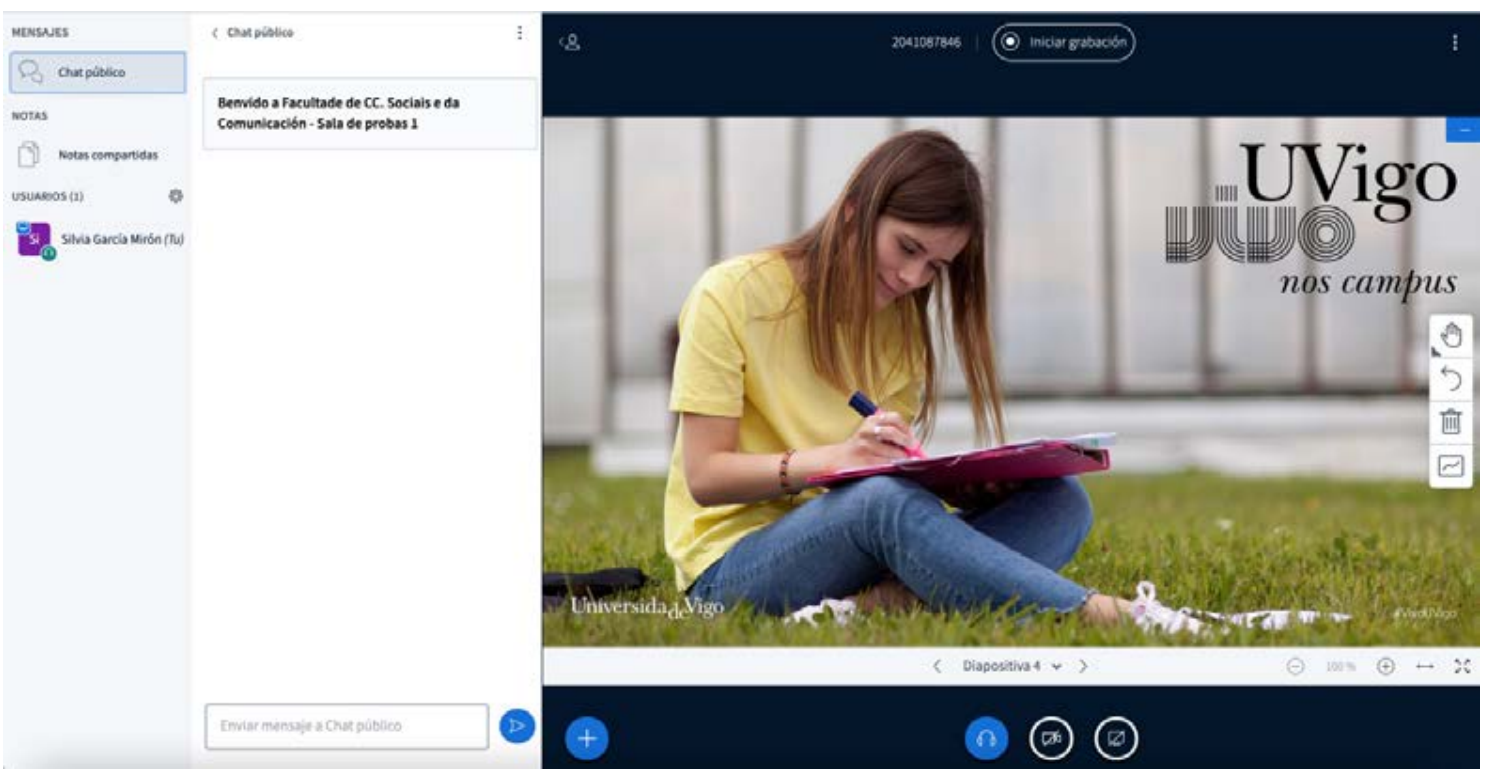

Fuente. campusremotouvigo.gal

\section{Imagen 1. Ejemplo de aula online del campus remoto de la Universidade de Vigo}

- Aulas virtuales en el campus remoto para la docencia síncrona en los mismos horarios de la docencia inicial presencial, tanto para las sesiones teóricas como prácticas; se utilizaron como aulas en directo virtuales que permitieron impartir la docencia mediante videoconferencia, y dispone de funcionalidades adicionales como chat, la opción de grabar la sesión o la posibilidad de compartir pantalla o el formato de presentación. Son gestionadas por la dirección de los propios centros.

- Opción "salas externas" del campus remoto: salas independientes pero vinculadas con el aula virtual en directo. Fueron utilizadas para el trabajo en grupo de las sesiones prácticas, así como para la realización de las tutorías de la docente con los grupos (sesiones de seguimiento de los trabajos tutelados, feedback sobre el proceso y el trabajo ya realizado).

- Despacho online a través del campus remoto: permite que el alumno pueda conectar la cámara y dispone de un sistema de espera y autorización de entrada en el despacho por parte del docente. Utilización para tutorías.

- Plataforma de teledocencia de la Universidade de Vigo (Moovi) con sistema Moodle, para facilitar el material teórico (tanto el visto en clase como otra documentación para ver bien antes de alguna sesión o documentación complementaria al material visto en aula), indicaciones de los trabajos y prácticas o para gestionar la entrega de actividades.

- Espacio de "Anuncios" a través de la plataforma de teledocencia Moovi para los comunicados sobre la planificación y otros avisos.

- Función "Cuestionario" de la plataforma de teledocencia Moovi para la realización de la Práctica 4. 
- Correo electrónico institucional de la Universidade de Vigo.

- Portal de contenidos audiovisuales Youtube, para el visionado de contenidos relacionados con la materia: programas, piezas de continuidad y autopromociones, etc. y dónde podían almacenar sus videos de presentación del trabajo tutorizado 3 (video-pitching).

- Página web de Radiotelevisión Española, para el visionado de la serie documental "50 años de TVE".

- Red social Facebook, para la participación en una comunidad online donde se realiza un seguimiento de programas en emisión.

Debemos reseñar que resultó fundamental e indispensable el uso del correo junto con el despacho online en el campus remoto para la realización de las tutorías y el contacto permanente con el alumnado, ayudando a la adaptación y seguimiento de la materia.

Pese al uso de todas las herramientas puestas a disposición por la propia universidad a partir de la declaración del estado de alarma y el inicio de la docencia remota por emergencia (en concreto el Campus Remoto), determinadas actividades tuvieron que verse modificadas ante la imposibilidad de encontrar una fórmula que permitiese un desarrollo lo más similar posible al presencial, de acuerdo con las indicaciones recogidas y publicadas en la guía docente de la materia.

Con respecto a los contenidos y las prácticas realizadas se llevaron a cabo cambios con respecto a la planificación inicial. En primer lugar, en relación con las sesiones teóricas se observa la pérdida de participación en un alto grado, comportamiento ya observado durante la fase de docencia remota de emergencia en el curso académico anterior: los alumnos no son proclives a la participación online en el campus remoto, no conectan la cámara ni el audio y las intervenciones a través del chat no acaba funcionando para un desarrollo fluido de la sesión. En segundo lugar, también se advierte la pérdida de fluidez en las sesiones teóricas con el visionado de material audiovisual que complementa o ilustra determinados contenidos de la materia. Por ello se acaba optando para algunas sesiones por incluir un enlace en el propio chat y posteriormente en la plataforma de teledocencia para que pudiesen visionarlos cada uno de forma individual en su casa en otro momento o, incluso, para algunos contenidos, enviar previamente el material para su visionado antes de la sesión.

En cuanto a la parte práctica, los principales cambios que alteran la planificación inicial de la materia se determinan en el desarrollo de las exposiciones de los trabajos tutorizados. Las defensas orales de los trabajos ( $y$ algunas prácticas) se vieron influenciadas y mermadas en su evaluación, debido a diversas situaciones en las que los/as alumnos/as o bien no podían conectar la cámara o no podía seguirse correctamente el discurso de la presentación por problemas con el propio audio. Estas incidencias tecnológicas influían en el desarrollo de la propia presentación (y forzaba que se dejase de trabajar con determinados elementos como la limitación en el tiempo) y en los criterios de la evaluación (si no podían conectar la cámara, no se podría evaluar aspectos relacionados con la comunicación no verbal), pero también en la propia seguridad del alumnado que repercutía en su nerviosismo y en la claridad discursiva. Por esta razón trataron de plantearse soluciones. De este modo, para 
el trabajo tutorizado 3 (el último de los trabajos) se solicitó la exposición grabada en video (video-pitching). Esto suponía la pérdida de espontaneidad y la posibilidad de efectuar una sesión de preguntas y respuestas inmediata si bien, no obstante, se pudieron evaluar otras competencias relacionadas con las herramientas TIC (pero que no resultaba una complejidad añadida puesto que los participantes eran estudiantes de Comunicación Audiovisual), la capacidad de comunicación (verbal y no verbal) ante una cámara, motivando la capacidad en la venta de ideas. Este formato de exposición es uno de los cambios relacionados con las TIC que se ha decidido mantener para los próximos cursos al permitir desarrollar otras competencias de la comunicación verbal y no verbal de los/as alumnos/as y muy orientado y acertado para el sector audiovisual en el que al presentar propuestas en algunas convocatorias de ayudas públicas para el desarrollo de proyectos o en algunos festivales audiovisuales se solicita precisamente la presentación de propuestas en formato video (video-pitching).

La última de las modificaciones vino de la mano de la imposibilidad de poder realizar una de las prácticas: un concurso sobre los contenidos de la materia inspirado en el conocido quiz televisivo "Pasapalabra". Como en el programa de televisión, la actividad se desarrollaba por grupos y con distintas fases: una primera con distintas preguntas y una segunda con el "rosco". En este caso se adaptaba a preguntas relacionadas con la televisión, las estrategias de programación, la audiencia y la identidad televisiva, entre otras cuestiones. No se consiguió plantear una fórmula adecuada para su desarrollo de forma online, puesto que perdería la espontaneidad en la rapidez de las respuestas que requiere la actividad.

\section{Discusión y conclusiones}

El presente texto ha planteado una experiencia docente en la que se han recogido los cambios en la adaptación de la materia Técnicas de programación para televisión, cursada en tercero de Comunicación Audiovisual de la Universidade de Vigo, describiendo las herramientas tecnológicas utilizadas durante su docencia. A partir de aquí se han identificado ciertas ideas a modo de conclusión que permiten reconocer necesidades en el ámbito universitario actual pero también ideas para mejorar la docencia de la propia materia.

La planificación inicial de la materia objeto de esta experiencia (Técnicas de programación para televisión) se realizó durante los meses de mayo y junio del curso académico previo (2020/2021) contemplando la opción de que la docencia ya se desarrollaría en su totalidad de forma presencial, pero incluyendo, no obstante, la posibilidad de adaptación a docencia remota. Sin embargo, a pesar de contemplar esta posibilidad, tuvieron que llevarse a cabo modificaciones en el planning y en las tareas propuestas que, en gran parte de los casos se produjo como consecuencia de una conexión a internet inestable por parte del alumnado, lo que imposibilitaba las exposiciones de los trabajos y otras prácticas y plantearon problemas en los criterios de evaluación previstos.

Las adaptaciones previas de otras materias impartidas por la autora durante el periodo de confinamiento y la experiencia explicada en este texto permitieron a la autora entender la docencia remota y el empleo de herramientas TIC en el proceso de enseñanza-aprendizaje desde otro enfoque, no únicamente como un apoyo (para el 
material utilizado en las sesiones u otra documentación complementaria, así como para la resolución de dudas) sino como la punta de lanza de este proceso, planteándose una reconfiguración en las propuestas de actividades para su continuidad en un contexto de docencia presencial y no una simple adaptación circunstancial. Así se tuvieron en cuenta los resultados del cuestionario realizado al alumnado que entendían la importancia de ciertas prácticas que se basaban en el empleo de las TIC, si bien confirmaban su preferencia por la docencia presencial frente a la remota en el $100 \%$ de los casos.

El actual es un escenario de cambio y flexibilidad en el ámbito educativo que inevitablemente está y estará dominado por la tecnología y el empleo de herramientas educativas tecnológicas y digitales que necesitarán de internet para su utilización. Todo ello hace que este tipo de reconfiguraciones en la propia concepción inicial de la planificación docente no solo afecten al profesorado -que necesita de un aprendizaje relativo a estas competencias digitales y en relación al propio paradigma tradicional de la enseñanza a través de los contenidos mediante sesiones magistrales y ejercicios prácticos con entregas en formatos convencionales- sino que debe establecerse un nuevo proceso de enseñanza-aprendizaje en el que el alumno ocupa en todo momento el rol central, siendo el que gestione sus propios avances. Para ello, como se ha observado en otras investigaciones consultadas y reseñadas, las instituciones universitarias no deben limitarse a ofrecer herramientas (plataformas de teledocencia, campus virtuales, etc.) sino que deben brindar la posibilidad de formación continua y constante al profesorado, buscando su actualización tecnológica pero también motivando el cambio de metodologías.

\section{Referencias}

Alas, M., Hernández, R., Moncada, G.E., Borjas, O.N. y Chinchilla, B. (2020). La situación educativa hondureña en el contexto de la pandemia del Covid-19: Escenarios para el futuro como una importante oportunidad de mejora. Informe Técnico. COVID-19 CSUCA. https://bit.ly/3jVEGcM

Area-Moreira, M., Hernández-Rivero, V. y Sosa-Alonso, J.J. (2016). Modelos de integración didáctica de las TIC en el aula. Comunicar, 47(24), 79-87. https://doi. org/10.3916/c47-2016-0

Bartolomé, A. (2008). Entornos de aprendizaje mixto en educación superior. Revista Iberoamericana de Educación a Distancia. RIED, 11(1), 15-51.

Colás-Bravo, M., de Pablos-Pons, J. y Ballesta-Pagán, J. (2018). Incidencia de las TIC en la enseñanza en el sistema educativo español: Una revisión de la investigación. Revista de Educación a Distancia, 18(56). Recuperado a partir de https://bit.ly/2GUX3Ax

Fernández-Regueira, U., Gewerc, A., Llamas-Nistal, M. (2020). El profesorado universitario de Galicia y la enseñanza remota de emergencia: condiciones contradicciones. Campus Virtuales, 9(2), 9-24.

García-de-Paz, S. y Santana Bonilla, P. J. (2021). La Transición a entornos de educación virtual en un contexto de emergencia sanitaria. Estudio de caso de un equipo 
docente en Formación Profesional Básica. RED (Revista de Educación a Distancia). Vol. 21 Núm. 65. https://doi.org/10.6018/red.450791

Sangrà, A. (editor) (2020). Decálogo para la mejora de la docencia online: propuestas para educar en contextos presenciales discontinuo. Barcelona: Editorial UOC.

Sánchez Carracedo, F., López Álvarez, D., Llorens Largo, F., Badía Contelles, J. M. \& Marco Galindo, M. J. (2020, 18 de junio). La universidad que viene: de la 'docencia remota de emergencia' a la 'presencialidad adaptada'. The conversation. Recuperado de https://theconversation.com/la-universidad-que-viene-de-la-docencia-remota-de-emergencia-a-la-presencialidad-adaptada-140794

UNICEF (2020). La educación frente al COVID-19. Propuestas para impulsar el derecho a la educación durante la emergencia. UNICEF-España. https://bit.ly/2Aem8mt

Zubillaga, A. y Gortazar, L. (2020). COVID-19 y educación: problemas, respuestas y escenarios. Fundación COTEC para la Innovación. https://bit.ly/2ASbHos 


\section{Primeras Ideas de Ios Futuros Docentes Sobre el Pensamiento Computacional}

Bueno-Baquero, Andrea orcid.org/0000-0001-5567-7535 Andrea.Bueno@uclm.es

del Olmo-Muñoz, Javier orcid.org/0000-0001-8754-0648 Javier.OImo@uclm.es

Tirado-Olivares, Sergio orcid.org/0000-0002-8557-5115 Sergio.Tirado@uclm.es

Cózar-Gutiérrez, Ramón orcid.org/0000-0001-8255-6376

Ramon.Cozar@uclm.es

González-Calero, José Antonio orcid.org/0000-0003-0842-8151 Jose.GonzalezCalero@uclm.es 


\title{
PRIMERAS IDEAS DE LOS FUTUROS DOCENTES SOBRE EL PENSAMIENTO COMPUTACIONAL
}

\author{
Bueno-Baquero, Andrea \\ del Olmo-Muñoz, Javier \\ Tirado-Olivares, Sergio \\ Cózar-Gutiérrez, Ramón \\ González-Calero, José Antonio
}

\section{Resumen}

Como resultado de las demandas de la sociedad, el pensamiento computacional está ganando atención en los últimos años por parte de investigadores, profesionales y legisladores del ámbito educativo y, del mismo modo, está siendo cada vez más creciente su importancia en los niveles de la escuela elemental. Sin embargo, existe un desconocimiento generalizado sobre este tema entre los estudiantes de las facultades de educación y futuros profesores. El presente estudio examina las concepciones y perspectivas de 88 futuros docentes de la Facultad de Educación de Albacete (España) sobre este tema. Utilizando una metodología mixta, se pretende conocer sus percepciones y determinar su grado de preparación para la promoción del pensamiento computacional entre los estudiantes de Educación Primaria. Los resultados muestran una falta de conexión entre lo que los futuros maestros asocian al pensamiento computacional y lo que establece la literatura científica. Más concretamente, los futuros docentes tienden a asociar incorrectamente el pensamiento computacional con ciertos aspectos como, por ejemplo, el uso genérico de dispositivos tecnológicos. A pesar de esto, hay algunos signos alentadores, como la asociación por parte de los participantes del pensamiento computacional con la resolución de problemas, algo que sí correspondería con la bibliografía. Este estudio pone de manifiesto la necesidad de que los futuros docentes se capaciten en pensamiento computacional, con el objetivo de mitigar las concepciones erróneas que puedan estar presentes.

\section{Palabras clave}

Pensamiento computacional, percepciones, futuros docentes, universidad. 


\section{Introducción}

Actualmente se están implementando muchas innovaciones educativas con el objetivo de brindar una enseñanza de alta calidad que se adapte a los nuevos desafíos en la educación. Una de ellas es el pensamiento computacional (PC), que goza desde hace poco más de una década de una creciente popularidad en la investigación, las políticas y la práctica educativa (INTEF, 2017). Como muestra de ello, es sabido que muchos países han modificado o están modificando sus planes de estudio educativos para promover el desarrollo del PC y conceptos relacionados. En Europa, por ejemplo, no sólo están aumentando las iniciativas de PC no curriculares, sino que muchos países están comenzando también a incluirlo en la enseñanza obligatoria para ofrecer clases de PC a todos los alumnos como un elemento obligatorio de su educación (Bocconi et al., 2016). Del mismo modo, en América Latina el PC se ha convertido en una tendencia emergente, tanto por parte de iniciativas gubernamentales como de iniciativas no gubernamentales o de índole privada (Brackmann et al., 2016; Vázquez Uscanga et al., 2019).

En estos tiempos, la inclusión del PC en la educación obligatoria se justifica desde dos perspectivas: la primera ve estas habilidades como una oportunidad para que los niños y jóvenes piensen de nuevas formas y, como resultado, puedan resolver problemas del mundo real desde un punto de vista diferente; la segunda busca inculcar habilidades de computación en los estudiantes con el fin de prepararlos para las futuras necesidades en el ámbito laboral (INTEF, 2017). Cualquiera que sea el caso, parece que estamos ante una nueva alfabetización, que debería comenzar en las primeras etapas de la educación y para la cual se debe preparar a maestros y profesores (Zapata-Ros, 2015). En un estudio sobre la adquisición de habilidades de PC en niños de Educación Primaria, Caballero-González y García-Valcárcel (2020) apoyan la idea de una nueva alfabetización, sugiriendo que el objetivo principal sería afrontar los retos del día a día por medio de las TIC. Según los mismos autores, es necesario que la población participe activamente utilizando este tipo de pensamiento y dejando atrás el rol pasivo que suele observar en la sociedad, lo que denominan como "consumidores tecnológicos".

La noción de PC cobró fuerza ya en los trabajos de Papert (1980), donde éste enfatizó la "relación entre programación y habilidades de pensamiento" (Zhang y Nouri, 2019 , p. 3). A partir de entonces, se han propuesto numerosas definiciones, algunas de ellas están recogidas en la Tabla 1.

\begin{tabular}{|l|l|}
\hline Definición & Autor \\
\hline $\begin{array}{l}\text { "Los conceptos computacionales se utilizan para enfocar y resolver } \\
\text { problemas reales, comunicarnos con otras personas y gestionar } \\
\text { múltiples aspectos de nuestra vida cotidiana." (p.4). }\end{array}$ & Berrocoso et al., (2015) \\
\hline $\begin{array}{l}\text { "Una serie de conceptos y procesos de pensamiento de las ciencias } \\
\text { de computación, que facilitan la formulación de problemas así como } \\
\text { su resolución en diferentes disciplinas." (p. 585). }\end{array}$ & Kalelioglu et al. (2016) \\
\hline
\end{tabular}




\begin{tabular}{|l|l|}
\hline $\begin{array}{l}\text { "El pensamiento computacional involucra elementos como } \\
\text { problemas definidos, recopilaciones, análisis y representación de } \\
\text { datos, identificación y evaluación de posibles soluciones contra un } \\
\text { criterio, y la generalización de pensamiento computacional en los } \\
\text { procesos de resolución de problemas." (p.2). }\end{array}$ & Hsu et al. (2019) \\
\hline $\begin{array}{l}\text { "Consideramos el pensamiento computacional como procesos de } \\
\text { pensamiento involucrados en la formulación de problemas para que } \\
\text { sus soluciones puedan ser representadas como pasos y algoritmos." } \\
\text { (p.832). }\end{array}$ & Aho (2012) \\
\hline $\begin{array}{l}\text { "El pensamiento computacional es una metodología basada en } \\
\text { la implementación de los conceptos básicos de las ciencias de la } \\
\text { computación para resolver problemas cotidianos, diseñar sistemas } \\
\text { domésticos y realizar tareas rutinarias." (p.3). }\end{array}$ & Basogain-Olabe et al. (2015) \\
\hline "Una colección de ideas computacionales y hábitos mentales que \\
$\begin{array}{l}\text { las personas en disciplinas informáticas adquieren a través de su } \\
\text { trabajo en el diseño de programas, software, simulaciones y cálculos } \\
\text { realizados por maquinaria" (p. 120). }\end{array}$
\end{tabular}

Tabla 1. Definiciones de PC.

Sin embargo, aunque como se ha visto existen muchas definiciones diferentes de PC, la más conocida es la de Wing (2006), quien afirma que el PC abarca "la resolución de problemas, el diseño de sistemas y el entendimiento del comportamiento humano, todo basado en conceptos fundamentales de la informática” (p. 33). Además, la autora añade que este pensamiento es necesario para todos, no solo para los científicos, comparándolo con otras habilidades como leer, escribir o la aritmética.

A raíz del $P C$, surgieron diferentes metodologías que partieron de la necesidad de enseñar el PC. Brackmann et al. (2017) distingue en general dos corrientes: por un lado la enseñanza del PC mediante dispositivos tecnológicos (actividades conectadas), y por otro lado la enseñanza de esta habilidad sin la necesidad de utilizar herramientas tecnológicas (actividades desconectadas). Esta última es una de las más conocidas, denominándose también como Unplugged. Involucra actividades e ideas utilizadas para enseñar ciencias de la computación sin necesidad de utilizar medios digitales y principalmente pretende captar la atención de alumnos de Educación Primaria (Bell \& Vahrenhold, 2018).

Diferentes autores (p. ej., Hershkovitz et al., 2019; Korkmaz et al., 2017; Tsarava et al., 2019) apoyan la idea de que el PC está vinculado a distintas destrezas como las habilidades sociales, la cooperación o la creatividad. Otros, como Tsarava et al. (2019), lo asocian a habilidades de razonamiento visual-espacial, así como la aritmética. Estos autores hablan además del PC como un indicador temprano de éxito escolar, definiéndolo incluso como una habilidad necesaria para cubrir las necesidades de los ciudadanos en el mundo digital. La Tabla 2, muestra un resumen de algunas de las habilidades que se han asociado al PC. 


\begin{tabular}{|l|l|}
\hline Habilidad & Estudios \\
\hline Aritmética y razonamiento visual-espacial & Tsarava et al. (2019) \\
\hline Creatividad & $\begin{array}{l}\text { Hershkovitz et al., (2019), Korkmaz et al., (2017), } \\
\text { Zapata-Ros (2015) }\end{array}$ \\
\hline Resolución y formulación de problemas & $\begin{array}{l}\text { Ata y Cevik (2020), Korkmaz et al. (2017), } \\
\text { Zapata-Ros (2015) }\end{array}$ \\
\hline Pensamiento algorítmico & Ata y Çevik (2020), Korkmaz et al. (2017) \\
\hline Cooperación & Korkmaz et al. (2017), Zapata-Ros (2015) \\
\hline Patrones, sistemas & Zapata-Ros (2015) \\
\hline
\end{tabular}

\section{Tabla 2. Resumen de principales habilidades asociadas al PC.}

Con todo ello, dadas las dificultades para llegar a un consenso sobre una definición de PC entre los expertos en la materia, así como en las habilidades asociadas al mismo, es razonable esperar que muchos docentes se pierdan en un mar de conceptos e ideas (Prieto-Rodriguez y Berretta, 2015). En esta situación, se deduce que comprender las percepciones de los docentes sobre el PC es un paso crítico para obtener la capacitación del profesor (Sands et al., 2018).

En este sentido, el tema de investigación que aborda el presente estudio es la potencial falta de conocimientos sobre PC entre los futuros docentes de Educación Primaria. De esta forma, se pretende determinar qué saben los futuros maestros sobre este tipo de pensamiento. Para lograrlo, se utilizará un enfoque mixto, combinando un test validado en Sands et al. (2018) con una pregunta abierta. El estudio forma parte de un proyecto más amplio dirigido a difundir y promover el PC entre los docentes, siendo el objetivo de este trabajo examinar las concepciones y percepciones iniciales sobre el PC entre los futuros docentes de Educación Primaria.

\section{Método}

\section{Descripción del contexto y de los participantes}

En este estudio participaron 88 estudiantes de la Facultad de Educación de Albacete (Universidad de Castilla-La Mancha). La investigación se llevó a cabo desde la asignatura de Ciencias Sociales II Historia y su Didáctica, que forma parte del segundo curso del Grado de Maestro en Educación Primaria.

\section{Instrumentos}

En este estudio se utilizó un instrumento validado desarrollado por Sands et al. (2018) para analizar las concepciones de los docentes sobre el PC. Los futuros maestros debían puntuar cada uno de los ítems en una escala Likert de 5 puntos (1- Totalmente en desacuerdo; 2- En desacuerdo; 3- Ni de acuerdo ni en desacuerdo; 4- De acuerdo; 5- Totalmente de acuerdo). Por otro lado, los datos cuantitativos se complementaron cualitativamente con las respuestas de los estudiantes a una pregunta abierta en la que se les pidió que definieran el PC, y cuyas respuestas se analizaron e interpretaron utilizando un proceso de análisis de contenido a través de Atlas.ti. 


\section{Procedimiento}

El proyecto en global abarca seis sesiones, si bien sólo la primera de ellas entra dentro del alcance de este trabajo. En la primera, de la que emerge este estudio, se pidió a los estudiantes que completasen un cuestionario sobre sus percepciones sobre el PC y respondieran a una pregunta abierta en la que debían aportar una definición de PC. Dicha sesión fue seguida de cuatro sesiones de instrucción divididas en dos fases claramente diferenciadas: dos sesiones de trabajo fueron basadas en el PC desconectado, y las otras dos sesiones, en PC conectado. Después de las fases de instrucción, se realizó un post-test equivalente al pre-test. Además, se solicitaron participantes voluntarios para la realización de una serie de grupos focales con el fin de extraer comentarios de más valor sobre la experiencia.

\section{Resultados}

Los resultados del cuestionario basado en Sands et al. (2018) se recogen en la Tabla 3. Debe aclararse en este punto que, según el mencionado estudio, los ítems 1, 2, 3 y 4 corresponderían a aspectos específicos del PC, mientras que no lo harían los ítems 6, 7, 8, 9 y 10. El ítem 5 estaría fuera de clasificación debido a que no habría suficientes evidencias de su correspondencia con la definición de PC.

\section{El pensamiento computacional implica... $\quad$ Promedio Mediana}

\begin{tabular}{|l|l|l|}
\hline 1. $\quad$ Resolver problemas & 3,989 & 4 \\
\hline 2. Utilizar algoritmos & 3,652 & 4 \\
\hline 3. El pensamiento lógico & 3,946 & 4 \\
\hline 4. Pensar como un ordenador & 2,369 & 2 \\
\hline 5. Codificar/programar & 3,688 & 4 \\
\hline 6. Hacer matemáticas & 3,204 & 3 \\
\hline 7. Usar ordenadores & 4,172 & 4 \\
\hline 8. Saber cómo usar un ordenador & 4,141 & 4 \\
\hline 9. Utilizar tecnología & 4,344 & 4 \\
\hline 10. Jugar a juegos online & 2,860 & 3 \\
\hline
\end{tabular}

\section{Tabla 3. Resultados del cuestionario de concepciones docentes sobre el PC.}

Como se muestra en la Tabla 3, el ítem de menor valor, por amplio margen, es el número 4 (pensar como un ordenador), seguido del ítem 10 (jugar a juegos online). Ambos ítems están por debajo del límite de 3 puntos. Por el contrario, en los ítems 7, 8 y 9 se obtuvieron los valores más altos, todos ellos por encima del límite de 4 puntos. Finalmente, los ítems del 1 al 6 se encontrarían entre 3 y 4 puntos.

La categorización de términos que se realizó a partir del análisis de contenido de las definiciones de PC presentadas por los participantes en el estudio se resume en la Tabla 4. La categoría con mayor representación es la relacionada con la formulación y resolución de problemas (29). También destaca la categoría sobre el uso de la tecnología y la informática (27), seguida del pensamiento lógico (25) y el uso de una computadora (22). Las categorías con menos apariciones fueron aquellas que relacionaban el PC con los juegos (1) y el desarrollo de habilidades sociales (1). 


\begin{tabular}{|l|l|}
\hline Código & Citas \\
\hline Algoritmos & 5 \\
\hline Habilidad social & 1 \\
\hline Juegos & 1 \\
\hline Matemáticas & 13 \\
\hline Uso de ordenador & 22 \\
\hline Pensar como un ordenador & 8 \\
\hline Patrón/Sistema & 11 \\
\hline Pensamiento crítico & 5 \\
\hline Pensamiento espacial & 3 \\
\hline Pensamiento lógico & 25 \\
\hline Problemas & 29 \\
\hline Programación & 12 \\
\hline Sistema & 2 \\
\hline Uso de tecnología/Informática & 27 \\
\hline Vida real & 5 \\
\hline TOTAL & $\mathbf{1 6 9}$ \\
\hline
\end{tabular}

Tabla 4. Categorización de términos realizada a partir de las definiciones de PC aportadas.

\section{Discusión y conclusiones}

Las respuestas obtenidas a partir del cuestionario realizado por los estudiantes revelan una desconexión entre lo que establece la literatura y lo que los futuros docentes creen que el PC implica. Esto es, los ítems que corresponderían al PC según diferentes estudios relevantes, recibieron puntuaciones más bajas por parte de los participantes que aquellos que, de hecho, no serían constituyentes del PC. La única excepción es el concepto de "Jugar a juegos online", que los futuros profesores asociaron correctamente como una característica básica no constituyente del PC.

Respecto a las definiciones que los futuros docentes formulan sobre PC, se observa con nitidez que los estudiantes para maestro entienden que este tipo de pensamiento está asociado a la resolución y formulación de problemas, como indican la mayoría de los autores que definen este concepto (p. ej., Wing, 2006). Sin embargo, emergen ideas erróneas, como la asociación inherente entre PC y el uso de tecnología.

Los hallazgos de este estudio ponen de manifiesto la necesidad de formación de los futuros docentes respecto al PC, con el fin de mitigar las concepciones erróneas que pudieran darse a este respecto. La contribución de este trabajo a la investigación y enseñanza del PC concierne principalmente a la capacitación de un profesorado que parece inevitablemente destinado a trasladar dichas enseñanzas a sus futuros discentes. 


\section{Referencias}

Aho, A. V. (2012). Computation and computational thinking. Computer Journal, 55(7), 833-835. https://doi.org/10.1093/comjnl/bxs074

Ata, R., \& Çevik, M. (2020). Understanding predictor effects of computational thinking skills and media and technology use and attitudes of pre-service teachers for STEM awareness. Kedi Journal of Educational Policy, 17(1), 99-121. http://earsiv.kmu. edu.tr/xmlui/handle/11492/3785

Basogain-Olabe, X., Olabe-Basogain, M. Á., \& Olabe-Basogain, J. C. (2015). Pensamiento Computacional a través de la Programación: Paradigma de Aprendizaje. Revista de Educación a Distancia (RED), 46, 46. https://doi.org/10.6018/red/46/6

Bell, T., \& Vahrenhold, J. (2018). CS unplugged-How is it used, and does it work? In Lecture Notes in Computer Science (including subseries Lecture Notes in Artificial Intelligence and Lecture Notes in Bioinformatics): Vol. 11011 LNCS (pp. 497-521). Springer Verlag. https://doi.org/10.1007/978-3-319-98355-4_29

Berrocoso, J. V., Sánchez, M. R. F., \& Arroyo, M. del C. G. (2015). El pensamiento computacional y las nuevas ecologías del aprendizaje. Revista de Educación a Distancia (RED), 46. https://revistas.um.es/red/article/view/240311

Bocconi, S., Chioccariello, A., Dettori, G., Ferrari, A., \& Engelhardt, K. (2016). Developing Computational Thinking in Compulsory Education. https://doi.org/10.2791/792158

Brackmann, C., Barone, D., Casali, A., Boucinha, R., \& Munoz-Hernandez, S. (2016). Computational thinking: Panorama of the Americas. 2016 International Symposium on Computers in Education (SIIE), 1-6. https://doi.org/10.1109/SIIE.2016.7751839

Brackmann, C. P., Román-González, M., Robles, G., Moreno-León, J., Casali, A., \& Barone, D. (2017). Development of Computational Thinking Skills through Unplugged Activities in Primary School. Proceedings of the 12th Workshop on Primary and Secondary Computing Education, 65-72. https://doi.org/10.1145/3137065.3137069

Caballero-González, Y. A., \& García-Valcárcel, A. (2020). ¿Aprender con robótica en Educación Primaria? Un medio de estimular el pensamiento computacional. Education in the Knowledge Society (EKS), 21, 15-15. https://doi.org/10.14201/EKS.22957

Hershkovitz, A., Sitman, R., Israel-Fishelson, R., Eguíluz, A., Garaizar, P., \& Guenaga, M. (2019). Creativity in the acquisition of computational thinking. Https://Doi.Org/1 0.1080/10494820.2019.1610451, 27(5-6), 628-644. https://doi.org/10.1080/1049482 0.2019 .1610451

Hsu, Y.-C., Irie, N. R., \& Ching, Y.-H. (2019). Computational Thinking Educational Policy Initiatives (CTEPI) Across the Globe. TechTrends 2019 63:3, 63(3), 260-270. https://doi.org/10.1007/S11528-019-00384-4

INTEF. (2017). El Pensamiento Computacional en la Enseñanza Obligatoria (Computhink) Implicaciones para la política y la práctica. https://doi.org/10.2791/792158 
Kalelioglu, F., Gulbahar, Y., \& Kukul, V. (2016). A Framework for Computational Thinking Based on a Systematic Research Review. Baltic Journal of Modern Computing, 4(3), 583-596. \$\%7Bdspace.baseUrl\%7D/xmlui/handle/11727/3831

Korkmaz, Ö., Çakir, R., \& Özden, M. Y. (2017). A validity and reliability study of the computational thinking scales (CTS). Computers in Human Behavior, 72. https://doi. org/10.1016/j.chb.2017.01.005

Papert, S. (1980). Mindstorms: children, computers, and powerful ideas. Basic Books.

Prieto-Rodriguez, E., \& Berretta, R. (2015). Digital technology teachers' perceptions of computer science: It is not all about programming. Proceedings - Frontiers in Education Conference, FIE, 2015-February(February). https://doi.org/10.1109/ FIE.2014.7044134

Sands, P., Yadav, A., \& Good, J. (2018). Computational thinking in K-12: In-service teacher perceptions of computational thinking. In Computational Thinking in the STEM Disciplines: Foundations and Research Highlights (pp. 151-164). Springer International Publishing. https://doi.org/10.1007/978-3-319-93566-9_8

Tedre, M., \& Denning, P. J. (2016). The long quest for computational thinking. ACM International Conference Proceeding Series, 120-129. https://doi. org/10.1145/2999541.2999542

Tsarava, K., Leifheit, L., Ninaus, M., Román-González, M., Butz, M. V., Golle, J., Trautwein, U., \& Moeller, K. (2019). Cognitive Correlates of Computational Thinking: Evaluation of a Blended Unplugged/Plugged-In Course. Proceedings of the 14th Workshop in Primary and Secondary Computing Education, 1-9. https://doi. org/10.1145/3361721.3361729

Vázquez Uscanga, E. A., Bottamedi, J., \& Brizuela, M. L. (2019). Pensamiento computacional en el aula: el desafío en los sistemas educativos de Latinoamérica. Revista Interuniversitaria de Investigación En Tecnología Educativa. https://doi.org/10.6018/ riite.397901

Wing, J. M. (2006). Computational thinking. Communications of the ACM, 49(3), 33. https://doi.org/10.1145/1118178.1118215

Zapata-Ros, M. (2015). Pensamiento computacional: Una nueva alfabetización digital. Revista de Educación a Distancia (RED), 46(46). https://doi.org/10.6018/red/46/4

Zhang, L., \& Nouri, J. (2019). A systematic review of learning computational thinking through Scratch in K-9. Computers \& Education, 141, 103607. https://doi.org/10.1016/j. compedu.2019.103607 


\section{Enseñar y Aprender Remotamente Fisicoquímica en Tiempos de Reclusión Pandémica.}

\section{Flores, Pedro}

Universidad Nacional de General Sarmiento (UNGS)

paflores@campus.ungs.edu.ar

Soriano, M. R.

Universidad Nacional de General Sarmiento (UNGS)

\section{Barbiric, Dora A.}

Facultad de Ingeniería (UBA)

dbarbiri@fi.uba.ar 


\title{
ENSEÑAR Y APRENDER REMOTAMENTE FISICOQUÍMICA EN TIEMPOS DE RECLUSIÓN PANDÉMICA.
}

\author{
Flores, Pedro \\ Soriano, M. R. \\ Barbiric, Dora A.
}

\section{Resumen}

EI COVID-19 nos enfrentó al desafío de cursos totalmente virtuales en la universidad. En este trabajo nos enfocamos en un curso de Fisicoquímica para la carrera de Ingeniería Química en la Universidad Nacional General Sarmiento. Las cohortes eran reducidas en los cursos presenciales y se desarrollaba un trabajo muy participativo con los estudiantes, formando grupos pequeños de discusión. ¿Cómo hacer algo así en encuentros a través de las pantallas? La propuesta: que ellos mismos explicaran los temas de la asignatura y diseñaran los problemas. Se les ofreció una carpeta de apuntes subidos a la Cátedra Virtual, pero tenían libertad de recurrir a las fuentes que quisieran. Hubo que escuchar atentamente sus reclamos y ser capaces de hacer modificaciones, en consecuencia. Las evaluaciones semanales realizadas ayudaron a todos. A los docentes para analizar el progreso de los estudiantes, detectar problemas y hacer cambios a tiempo. A los alumnos para ir viendo en forma cotidiana qué esperaban los docentes de ellos y ser capaces a la vez de comprobar su progreso. A pesar de los problemas de conexión, el curso llevó un buen ritmo. El espacio que se les proporcionó para generar su propio material, nos reveló una capacidad creativa muy interesante. El trabajo realizado bajo esta metodología nos dejó un material sumamente valioso para los próximos cursos.

\section{Palabras clave}

COVID-19, curso virtual, PLTL, Fisicoquímica, Ingeniería Química. 


\section{Introducción}

En 2020 enfrentamos una situación inédita: debíamos quedarnos en nuestras casas y en las universidades los cursos habrían de ser totalmente virtuales. Lo inesperado de la pandemia nos encontró poco preparados para encarar esta crisis sin precedentes (Sokal et al., 2020; Aguilera-Hermida, 2020; Dhawan, 2020). Había que desarrollar -e incluso improvisar- de forma urgente y de algún modo ingenioso, cursos diferentes. Era necesario un despliegue especial para lograr un buen aprendizaje a distancia usando una variedad de formatos y plataformas con las que no estábamos familiarizados.

La emergencia llevó a un cierre masivo de los centros de estudio, lo que obligó a una transición de la forma de enseñanza cara-a-cara a la forma remota. En muy poco tiempo los docentes debimos adaptar los procesos de enseñanza a un formato exclusivamente virtual. No había a la mano antecedentes del tema ni forma de buscar ayuda a expertos. Tuvimos que hacer un camino propio, arriesgar e improvisar; poner especial atención en las herramientas virtuales para lograr diseños innovadores, adecuados y que favorecieran el aprendizaje. Jugaban en contra la falta de habilidades tecnológicas y un estilo de enseñanza difícil de adaptar a una comunicación a distancia. Pasado un año del momento en que hubo que tomar decisiones, hay mucho publicado sobre esta problemática en las que los autores vuelcan sus experiencias (Reyes-Chua et al., 2020; Coman et al., 2020; Mishra et al., 2020).

En nuestros cursos de fisicoquímica contábamos con un Aula Virtual (AV). En ella ofrecemos apuntes relacionados con los temas de la asignatura, las guías de problemas del curso, y problemas diferentes que consideramos desafiantes; ideas novedosas, sitios web y videos que muestran temas afines. Se trata de un aula en la que cambiamos cada año gran parte del contenido, ya que esa es una de las virtudes que nos ofrecen las tecnologías de la información (TIC). Los estudiantes suelen ser muy habilidosos con las TIC, pero no los vemos contactar el AV tanto como quisiéramos.

Los cursos de Fisicoquímica (FQ) en UNGS se iniciaron en 2014 con una única alumna; desde entonces los grupos permanecen reducidos pero la matricula ha ido creciendo. Grupos pequeños nos permiten dedicarle atención especial a cada alumno: ver diferencias, reconocer dificultades y aciertos. En el aula los temas se discuten, no se exponen. Llevando problemas planificados podemos ayudarles a ir comprendiendo por sí mismos, a preguntarse y responderse colaborando entre los grupos para entender los nuevos temas. Algunos lo logran antes que otros, y respetar los tiempos individuales tiene que ver con insistir sobre los que tienen dificultades para que dediquen más tiempo al estudio porque hay un cronograma que respetar. La Facultad es parte de una institución, tiene reglas y otorga diplomas. Se pide a los estudiantes desarrollar un proyecto vinculado con los temas de la asignatura, con aplicaciones e interés ingenieril; aunque lo exponen en dos etapas, hay un seguimiento periódico. En los días de clase, agrupados alrededor de varias mesas, los estudiantes discuten problemas sobre papel o sobre pantallas. Los docentes observamos de cerca su desenvolvimiento y discusiones e intervenimos en cualquier momento. Los vemos progresar, entender y ayudamos a que ellos perciban su propio progreso. Es un estilo de clase que nos hace buscar y ofrecer permanentemente nuevo material, problemas interesantes, publicaciones actuales, datos experimentales para que ellos analicen mediante los temas aprendidos. Al ser grupos reducidos, notamos de manera directa su avance, cómo crece su autonomía en el proceso de aprendizaje, y también nos ayuda a nosotros mismos a progresar (Eberlein et al., 2008; Lundin et al., 2018; Han 2021) y mejorar cada año. 
Un curso desarrollado bajo esta metodología de enseñanza con trabajo guiado, donde el docente es el facilitador del aprendizaje y no el informador, donde el estudiante explora, profundiza, integra y aprehende los temas de la asignatura, era difícil de imaginar en la virtualidad. El AV no podía ser nuestra única ayuda. No era posible basar el curso en apuntes o en exposiciones sincrónicas o asincrónicas. Pasar clases en un power-point con fórmulas, ecuaciones, gráficos era un retroceso. La virtualidad era un elemento esencial para enfrentar la continuidad de las clases, pero hacía falta pensar en cómo hacerlo. Este trabajo describe las opciones elegidas para enfrentar la crisis, sabiendo que se necesitaba ingenio, algo de improvisación y hasta estar preparados para reprogramar, si había errores.

\section{Descripción de la experiencia}

El curso de FQ dispone de una clase presencial de seis horas semanales. Para el curso virtual 2020 optamos por dos encuentros online, de respectivamente dos y cuatro horas cada semana. Agregamos encuentros de consultas, muy interesantes y concurridos por los estudiantes. Así pudimos acercarnos a ellos que fueron ganando confianza, consultando sus dudas y ellos mismos respondiéndoselas. Los alumnos exponían los temas en las clases.

Se organizaron en seis grupos de tres alumnos cada uno, conocidos entre sí o no. Les presentamos un listado de temas, cada uno con fecha programada en un cronograma de exposiciones. Ellos debían elegir los temas que expondrían a lo largo de la cursada. Les acercamos, a través del AV, carpetas con apuntes recomendados como ayuda para la preparación de sus clases, seleccionados por provenir de buenos autores, por ser claros, completos y del nivel requerido. Esto fue una oferta inicial, pues ellos podían buscar ayuda donde quisieran y preparar sus clases con toda libertad. Cada semana un grupo exponía y en el encuentro siguiente se discutían los problemas. Evaluábamos las exposiciones semanalmente y enviábamos a los expositores un detallado informe. Respecto a los problemas, los alumnos que habían explicado el tema colaboraban especialmente en la discusión de la resolución. Muchos problemas de la asignatura se pueden desarrollar sobre una planilla de datos, así que les pedimos enviar el trabajo grupal para ver los logros y devolverles observaciones en las clases de consulta o por e-mail. La clase virtual permite exponer la pantalla del docente, pero también la de los estudiantes, de modo que los alumnos podían mostrar sus avances sobre la hoja de cálculos. Esto posibilitaba que, con intervención de todos, se resolvieran dudas e inconvenientes.

\section{Pros y contras de la propuesta inicial}

La propuesta de que los alumnos explicaran los temas, colaboraran en la discusión de problemas, enviaran su resolución de problemas en hojas de cálculo mostraron pros y contras ya en las primeras semanas de clases.

Podemos señalar a favor que los alumnos expusieron con la profundidad que requiere la asignatura; fueron organizados e ingeniosos con los recursos. Hablaban claro, pausado, preguntaban. Presentaron problemas muy bien elegidos. Cada miembro del grupo, al inicio de su explicación, retomaba las ideas del expositor anterior, o incluso las expuestas por otro grupo, mostrando haber prestado atención a las disertaciones 
precedentes y haber establecido interconexiones. Los estudiantes mostraron habilidades para resolver problemas de conexión y nos ofrecieron información útil sobre diferentes plataformas y pizarras electrónicas.

Aspectos en contra fueron los problemas de conexión, cortes de electricidad, servicio de internet deficiente y que algunos alumnos contaran solo con un celular. Además pudimos saber que las exigencias resultaban demasiadas. No podían entregar semanalmente trabajos; preparar exposiciones y problemas; leer apuntes y resolver problemas de temas nuevos. A los grupos integrados por alumnos antes desconocidos entre sí, les resultó aún más complicado organizarse en el trabajo virtual conjunto. Había que buscar otras propuestas. Los escuchamos y realizamos cambios.

\section{Replantear la modalidad}

Ante la demanda de los estudiantes, decidimos dedicar una semana a consultas y a reforzar los temas vistos. Hubo muchas preguntas y fue bueno, ya que sabemos que se aprende mucho planteando buenas preguntas. Hubo respuestas de ellos y nuestras, y durante una semana retomamos temas que no habían quedado claros. El diálogo fluido y la posibilidad del ajuste para darles tiempo de asimilar y comprender, les devolvió confianza en el curso y en sí mismos. Realizamos cambios en el cronograma: les dejamos a ellos parte de los temas y los docentes nos hicimos cargo de los restantes.

Finalmente quedaron tres exposiciones por grupo. Al escucharlas, aprendimos a apreciar las habilidades y virtudes de varios de los alumnos para explicar con claridad y en forma interesante los temas. En su propio lenguaje exponían a sus compañeros las dificultades que habían encontrado en el tema y cómo las habían superado. Algunos grupos mejoraron marcadamente entre una exposición y la siguiente: buscaron aplicaciones interesantes y ejemplos apropiados para el tema; optimizaron la claridad y los tiempos; aprendieron unos de otros diferentes habilidades sobre la plataforma para enriquecer las exposiciones. Ellos mismos comentaron cuánto les ayudaron tanto nuestras detalladas observaciones sobre sus clases, cuanto escuchar a los compañeros también. Podemos señalar que cada grupo expositor aprendía mucho sobre su tema y los oyentes, también, escuchaban la clase con sumo interés y hacían comentarios muy apropiados. Los temas se desarrollaban en un lenguaje más cercano al de los estudiantes, sin perder claridad ni profundidad.

\section{Una evaluación diferente}

Las exposiciones de los estudiantes fueron solo una de las claves de su evaluación. También solicitamos entregas de trabajos realizados en hojas de cálculo. Tenemos preparados TTPP para analizar temas como: Propiedades Parciales Molares, Adsorción de gases sobre sólidos y Gases Reales. El primer caso se trata del análisis detallado del comportamiento de una mezcla $\mathrm{NaOH}-\mathrm{H}_{2} \mathrm{O}$, que presenta un comportamiento interesante para hacer un análisis muy completo, basado en datos experimentales de mezclas, para las que contamos con datos precisos de densidad y molalidad. El segundo es un trabajo basado en dos publicaciones (Amora Jr et al., 2009; Delevar et al., 2010), una con datos de adsorción de tres hidrocarburos pequeños sobre carbón activado y el otro, con datos a diferentes temperatura para 
uno de ellos. El tercero analiza el comportamiento de $\mathrm{CO}_{2}$ ya que tenemos un conjunto bien medido de valores de $Z$ (coeficiente de compresibilidad) a diferentes temperaturas. Por otro lado los problemas de equilibrio Líquido-Vapor se pueden enriquecer trabajando sobre una hoja de cálculos. Lo hacemos en las clases presenciales, en las virtuales les solicitamos ir presentando en pantalla y luego enviarlos para su revisión. Para la entrega de los trabajos hubo fechas límites. Los informes fueron exhaustivos, bien presentados, en formato libre. Algunos lo presentaron en la hoja de cálculo con gráficos y tablas; otros lo presentaron en documento aparte con la inserción de gráficos y tablas correspondientes.

A la evaluación de las exposiciones y las entregas de los TTPP agregamos un experimento sencillo que pudieran realizar en sus casas para analizar "tensión superficial". El grupo a cargo del tema "capilaridad" presentó espontáneamente un experimento sencillo en el que analizaron, también con medios caseros, la altura de la columna del capilar relacionándola con la temperatura y para diferentes líquidos (aceite, agua, alcohol). Los trabajos estaban acompañados de videos y de un informe bien redactado.

A mitad del curso se les pidió presentar dos problemas integradores por grupo. Esto no es común y así debieron elaborarlos ellos mismos. Las instrucciones para estas entregas eran claras y bien estipuladas: Preparar dos problema que comprenda dos o más de los temas vistos vinculándolos en forma interesante de modo que los temas se interrelacionen e integren de forma coherente. El problema debe ser original, novedoso pero similar a los desarrollados en clase, con nivel curso de FQ, solicitando calcular propiedades o parámetros que vimos a lo largo del curso. Será valioso si se relaciona con aplicaciones concretas: tecnológicas, medioambientales, prácticas, etc. Hacer una corta presentación, dos renglones o tres, en la que explican qué temas están desarrollando correspondientes a la asignatura, en el problema. Poner los nombres de todos los integrantes del grupo que presenta el problema. Describir en forma sintética cómo proponen que se resuelva el problema. Les puede ayudar pensarlo como un problema que podrá incluirse en la guía de problemas de FQ. Una nueva guía de Problemas integradores o bien un problema que aparecería al final de alguna de las guías existentes. Al acabar la cursada se volvió a pedir un problema pero esta vez debía integrar al menos tres de los temas vistos. Los trabajos, que fueron evaluados, debieron respetar las fechas de entrega y las devoluciones también se hacían en forma casi inmediata porque consideramos que recibir nuestra apreciación de su trabajo ayudaba a mejorar el siguiente.

Estas exigencias hicieron que cuatro alumnos, que no pudieron cumplirlas, dejaran el curso. Los cinco grupos restantes entregaron diez problemas, la mayoría muy bien desarrollados (ver Anexo I). La presentación de los problemas, la redacción e incluso el esquema de resolución que los autores proponían, revelaban puntos que no habían quedado claros, lo que nos permitió retomar esos temas y revisarlos entre todos. Nuestros comentarios ayudaron a los autores y también a los demás.

Para continuar valorando el desempeño, intercambiamos los problemas presentados para que otro grupo lo resolviera y entregara. Lo importante es que pedíamos una crítica constructiva y aguda del problema desarrollado por no expertos. Los alumnos supieron hacer un análisis muy interesante sobre defectos y virtudes de los problemas ajenos diseñados. Para ejemplificar reproducimos uno de los comentarios de los estudiantes sobre el problema que les tocó resolver: A primera vista, 
se percibe un enunciado extenso que intimida pero que facilita la comprensión del problema. Se destaca el buen empleo de herramientas visuales que dan contexto a la situación planteada. Además, se aprecia la utilización de una situación real en el problema, que aborda la temática teórico-práctica vista en clase. Un detalle menor es la ausencia de epígrafe sobre la tabla de datos. Como conclusión grupal, podemos decir que el ejercicio propuesto por el equipo resultó ser novedoso y motivó a la aplicación de resoluciones, algunas de ellas conocidas y otras que requirieron de apoyo bibliográfico. Sin embargo, si tenemos en cuenta que este ejercicio puede llegar a ser evaluado de forma presencial, nos resulta excesivo ya que los tiempos de resolución y razonamiento fueron extensos. Finalmente, se considera haber cumplido con los objetivos propuestos y esperamos que las críticas constructivas sirvan de soporte para mejorar el enunciado.

La construcción de problemas que interrelacionan temas, el esquema de resolución presentado por los autores y finalmente la resolución del problema por parte de pares, nos permitió reforzar nuestro conocimiento sobre el progreso y la comprensión de cada uno.

\section{Resultados}

Evaluar semanalmente el trabajo de los estudiantes y enviarles un escrito detallado sobre las observaciones como devolución nos hizo dedicarle mucho tiempo al curso. Ponemos como ejemplo nuestros comentarios a uno de los problemas presentados en primera instancia: El Problema 2 es un problema tradicional de Equilibrio Químico, bien planteado y adecuado en dificultad. No se entiende por qué se pide la $K_{T}$ a $50 \mathrm{~atm}$ en el item a), si en el ítem a) se trabaja a $70 \mathrm{~atm}$. De esta forma no parece haber conexión entre los distintos items. ¿Habrá sido un error? Combinan un problema de equilibrio como los de la guía (cálculo de $K_{T}$ y composición en el equilibrio), lo analizan a partir de datos de Kp en función de la presión, que no es lo que más hemos visto, lo que es un aporte valioso. Hay que encontrar fugacidades porque se trata de gases reales por la presión algo elevada (¿50 atm o 70 atm?), aunque la temperatura es muy elevada y puede que el $J(\varphi)$ termine siendo cercano a 1. Por otra parte, resultó interesante que hayan empleado una reacción diferente de la obtención del amoníaco (muy usada) y hayan buscado otra. El único inconveniente es que, por la estequiometría de la reacción, la resolución podría haber involucrado un polinomio de grado 4. Esto no es grave, porque es totalmente resoluble, pero sería un poco complicado el tiempo de resolución.

En conjunto los dos problemas son muy buenos, el primero es más del tipo de lo que esperamos, completo, original, diferente, novedoso, y a la vez reconocible; aunque tenga detalles a revisar. Es uno de los problemas elegidos para que lo resuelva otro grupo.

Las exposiciones también fueron cuidadosamente evaluadas, a modo de ejemplo: Una presentación muy clara. Este grupo remarca y aclara las dificultades que pueden presentar ciertos desarrollos, una verdadera ayuda para los demás al hacer sus presentaciones. Destacable los problemas elegidos. Son muy buenos en su trabajo de preparación en grupo. Estuvieron muy bien, mejorando notablemente su presentación respecto de la primera exposición: más aplomados y seguros. Un progreso notable. En todos los casos se señalaron virtudes y defectos. Los alumnos se mostraron conformes y agradecidos por los comentarios; ellos mismos dijeron que les 
ayudaban a mejorar y a apreciar su aprendizaje más que una nota numérica, que también recibían. Por otro lado, cruzar problemas sirvió para que vieran errores en problemas de no expertos: falta de claridad en la redacción o ausencia de algunos datos. Pero también descubrieron que sus propios compañeros habían sido capaces de presentar problemas muy interesantes, completos y originales.

Al finalizar el curso, como ya se mencionó, se pidió un problema que reuniera al menos tres temas del curso y, como la vez anterior, estuvo todo claramente especificado.

Recibimos muy buenos trabajos (Anexo II) basados en datos experimentales buscados en distintas publicaciones que citaron al pie de la presentación, superaron largamente la calidad de los primeros problemas, que había sido buena. Estos problemas novedosos, bien planteados, con pequeñas correcciones podrán incluirse en nuestras guías de problemas. El curso desarrollado de este modo, con múltiples evaluaciones extensamente comentadas y un seguimiento permanente, fue una exigencia para nosotros, pero nos dejó una enorme enseñanza. Contamos con ocho o nueve evaluaciones por alumno y somos conscientes que tuvieron que dedicarle tiempo y esfuerzo al aprendizaje, análisis y razonamiento crítico para poder progresar a lo largo del curso.

\section{Discusión y conclusiones}

Los cursos virtuales marcaron diferencias: claramente perdimos el contacto personal, tan importante, pero también nos ahorraron los tiempos de traslados, que se perciben como tiempos muertos, desaprovechados, y apareció el tiempo ganado. La pérdida del contacto personal resultó un desafío para docentes y estudiantes, mientras que el tiempo ganado hizo que algunos estudiantes se inscribieran en más asignaturas que las habituales. Salir de un aula virtual para entrar en otra era solo cuestión de segundos en un medio electrónico. Sin embargo, a medida que los cursos avanzaban, los que habían hecho esta opción tuvieron que admitir que hay un tiempo de comprensión y reflexión, un tiempo de ejercitación y práctica, que no se acorta de ninguna manera. Esos tiempos para apropiarse del conocimiento son muy personales, y pueden variar dependiendo del tema. La ayuda que significa interactuar con los otros en forma personal y directa es siempre importante, valiosa. $Y$ en este caso no hubo tal interacción. Los estudiantes fueron descubriendo estas dificultades, por eso hubo quienes renunciaron a completar algunas de las asignaturas en las que estaban inscriptos. Para nosotros el tiempo dedicado a enviar semanalmente devoluciones extensas, exhaustivas y detalladas excedió sobradamente nuestro tiempo de traslado.

El curso de FQ en UNGS siempre recurrió a las herramientas TIC. Además del AV, renovada cada año, usamos planillas de cálculo con tanta normalidad como el papel, y los videos y páginas web nos permiten presentar experimentos que no podríamos hacer en nuestros laboratorios. Con estos recursos bien administrados nos encontró la crisis del 2020 y nos impuso con urgencia, un cambio no pautado, el salto a una completa virtualidad. Sin duda nuestro trabajo previo fue de gran ayuda, pero perder la relación personal con los estudiantes exigía otros cambios. Nuestro curso, basado en el trabajo en equipo en clase sobre actividades especialmente desarrolladas para que los estudiantes aprendan mejor, estando activamente comprometidos y construyendo su propio conocimiento, parecía difícil de lograr en un trabajo totalmente online. 
La idea fue invertir roles. Ellos mismos deberían preparar las clases y diseñar los problemas. Los alumnos aceptaron el reto. Hubo que equilibrar cantidad de clases y qué temas prepararían, la urgencia causó que tuviéramos adelantos y retrocesos, pero con saldo positivo. Los estudiantes participaron activamente, se comprometieron, nos sorprendieron con ideas y trabajos muy bien desarrollados. En las primeras semanas, el grupo que debía exponer se presentaba en los horarios de consulta cargado de inquietudes, queriendo consultar si estaban bien preparados en el desarrollo de la clase a presentar. Con el tiempo ganaron autonomía, aprendieron a aprender, a ayudarse entre ellos y valoraron el encuentro virtual con docentes para la pregunta y la repregunta. Hubo un cambio notable. Sabemos que con este grupo de estudiantes ganamos una experiencia muy valiosa, tenemos un material de trabajo que enriquece el curso y entendemos que algunos aspectos de la modalidad desarrollada deberán persistir en los cursos presenciales. No podemos negar, sin embargo, que extrañamos y deseamos regresar a los cursos cara-a-cara.

\section{Referencias}

Aguilera-Hermida, A. P. (2020). College students' use and acceptance of emergency online learning due to COVID-19. International Journal of Educational Research Open, 1:100011. Recuperado de https://doi.org/10.1016/j.ijedro.2020.100011

Amora Jr, M. R., Canabrava, D. V., Bastos-Neto, M., Torres, A. E. B., Cavalcante Jr, C. L., and Azevedo, D. C. (2009). Equilibrium adsorption of binary mixtures of light hydrocarbons in activated carbon. Latin American Applied Research, 39(2), 153-156. Recuperado de https://www.researchgate.net/publication/262498769

Coman, C., Tiru, L., Mesesan-Schmitz, L., Staciu, C., and Bularca, M. C. (2O2O). Online Teaching and Learning in Higher Education during Coronavirus Pandemic: Student's Perspective. Sustainability, 12(24):10367. Recuperado de https://doi.org/10.3390/su122410367

Delavar, M., Ghoreyshi, A. A., Jahanshahi, M., and Irannejad, M. (2010). Experimental evaluation of Methane adsorption on granular activated carbon (GAC) and determination of model isotherm. World Academy of Science, Engineering and Technology, 62, 47-50

Dhawan, S. (2020). Online learning: A panacea in the Time of COVID-19 Crisis. Journal of Education Technology Systems, 49(1), 5-22. Recuperado de https://doi. org/10.1177/0047239520934018

Eberlein, T., Kampmeier, J., Minderhout, V., Moog, R., Platt, T., Varma-Nelson, P., and White, H. (2008). Pedagogies of engagement in science. A comparison of PBL, POGIL and PLTL. Biochemistry and Molecular Biology Education, 36(4), 262-273. Recuperado de https://doi.org/10.1002/bmb.20204

Han, F. (2021). The Relations between Teaching Strategies, Students' Engagement in Learning, and Teachers' Self-Concept. Sustainability, 13(9):5020. Recuperado de https://doi.org/10.3390/su13095020

Lundin, M., Bergviken Rensfeldt, A., Hillman, T., Lantz-Andersson, A., and Peterson, L., (2018). Higher education dominance and siloed knowledge: a systematic review of flipped classroom research. Int J Educ Technol High Educ, 15:20. Recuperado de https://doi.org/10.1186/s41239-018-0101-6 
Mishra, L., Gupta, T., and Shree, A. (2020) Online teaching-learning in higher educaction during lockdown period of COVID-19 pandemic. International Journal of Education Research Open, 1:100012. Recuperado de https://doi.org/10.1016/j.ijedro.2020.100012

Reyes-Chua, E., Sibbaluca, B., Miranda, R., Palmario, G., Moreno, R., and Solon, J. (2020) The status of implementation of the e-learning classroom in selected higher education institutions region IV-A amidst the COVID-19 crisis. Journal of critical reviews, 7(11), 253-258. Recuperado de https://dx.doi.org/10.31838/jcr.07.11.41

Sokal, L., Trudel, L., and Babb, J. (2020). Canadian Teachers' attitudes toward change, efficacy and burnout during the COVID-19 pandemic. International Journal of Educational Research Open, 1:100016. Recuperado de https://doi.org/10.1016/j.ijedro.2020.100016

\section{Anexo I}

Problema integrando dos temas del curso presentado por uno de los grupos a mitad de la cursada (se ha respetado el texto original).

\section{PROBLEMA 1}

Una empresa de industria cosmética desea comenzar con la fabricación de quitaesmalte con el fin comercializarlo en todas sus tiendas a nivel nacional. Para ello programan la fabricación de un Lote piloto de 2000 kg.

El quitaesmalte se encuentra compuesto por un $94 \%$ de solventes ( $24 \%$ de Acetona y un $76 \%$ de Acetato de etilo) y un $6 \%$ restante corresponde a otros componentes que retardan el proceso de evaporación de dichos solventes al momento de su aplicación.

Como es un producto nuevo, el ingeniero de procesos se encarga de hacer los cálculos correspondientes de las masas que se deben adicionar de cada materia prima para la eficiente elaboración del producto, y para ello parte de la siguiente tabla de datos experimentales:

\begin{tabular}{|l|l|l|}
\hline \% de Acetona & \% Acetato de etilo & Densidad registrada $(\mathbf{g} / \mathbf{m L})$ \\
\hline 27,89 & 72,11 & 0,84198 \\
\hline 23,98 & 76,02 & 0,84748 \\
\hline 20,87 & 79,13 & 0,85218 \\
\hline 17,59 & 82,41 & 0,85748 \\
\hline 15,42 & 84,58 & 0,86121 \\
\hline 12,46 & 87,54 & 0.86662 \\
\hline 10,00 & 90,00 & 0.87142 \\
\hline 8,24 & 91,76 & 0.87502 \\
\hline 6,07 & 93,93 & 0.87971 \\
\hline
\end{tabular}


Determinar el volumen parcial molar de cada componente en la mezcla cuando se alcanza el \% deseado para la calidad final de producto.

Determinar los volúmenes requeridos de cada uno de los solventes para la fabricación de batch piloto sabiendo que las densidades para la Acetona y para el Acetato de etilo son $0,79 \mathrm{~g} / \mathrm{ml}$ y $0,92 \mathrm{~g} / \mathrm{ml}$ correspondientemente. (Se sugiere utilizar método grafico en ambos ítems)

\section{Grafico ilustrativo del equipo de fabricación utilizado.}

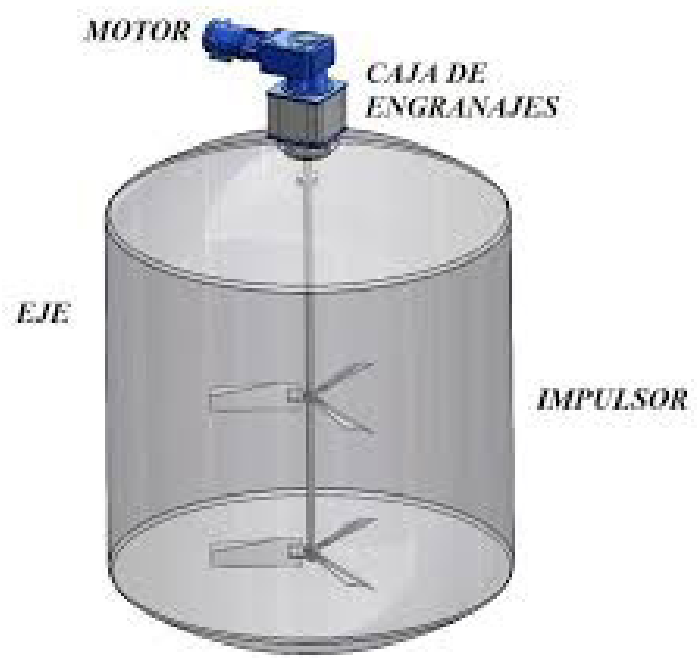

Una vez fabricado el producto se procede a llevar una muestra al laboratorio de control de calidad en el cual los técnicos determinaran si los cálculos del ingeniero fueron correctos y el producto cumple con los parámetros de calidad deseados. Sin embargo, al momento de analizar las muestras por el cromatógrafo gaseoso denotan que este ultimo se quedo sin Helio (gas Carrier utilizado como fase móvil del equipo) y el proveedor demora 24 hs en reponer el tubo.

Por lo cual como el laboratorio cuenta con un dispositivo para medir la presión y un recipiente hermético adecuado, el técnico decide experimentar y calcular las fracciones molares de cada componente en la mezcla para tener una idea aproximada de como se encuentra compuesto el producto elaborado. El técnico parte sabiendo que las presiones de vapor de la Acetona pura y del Acetato de etilo puro son 181,72 $\mathrm{mmHg}$ a $20^{\circ} \mathrm{C}$ y $173 \mathrm{mmHg}$ a $20^{\circ} \mathrm{C}$ y que la presión final que alcanza el recipiente luego de la mezcla es de 40 torr.

Realice todos los cálculos correspondientes para determinar las fracciones molares de cada componente en la mezcla liquida y en fase vapor, luego exprese los resultados obtenidos en \% P/P.

Sabiendo que los puntos de ebullición para la Acetona y para el Acetato de etilo son $56,5^{\circ} \mathrm{C}$ y $77,1^{\circ} \mathrm{C}$ correspondientemente vincule en forma teórica estos datos, con los datos obtenidos en el ítem anterior, con las presiones de vapor y con las respectivas estructuras químicas de cada componente. 


\section{Anexo II}

Problema Integrador Final. Fisicoquímica 2020. Problema presentado por uno de los grupos. (se ha respetado el texto original).

Desarrollar un problema integrador, en base a algunos de los temas vistos en la materia.

Actualmente, las industrias descargan entre 10\%-15\% de la producción de tintes en aguas residuales.

Debido a que los métodos tradicionales de purificación no son del todo efectivos, se propone la eliminación de azul de metileno (MB) por adsorción, mediante carbón de bambú como adsorbente.

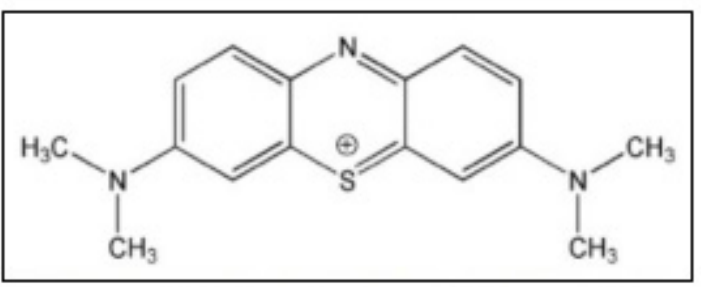

Figura 1: Molécula de azul de metileno.

1) En base a la Figura 2, explique el comportamiento de las siguientes curvas y las tendencias observadas.

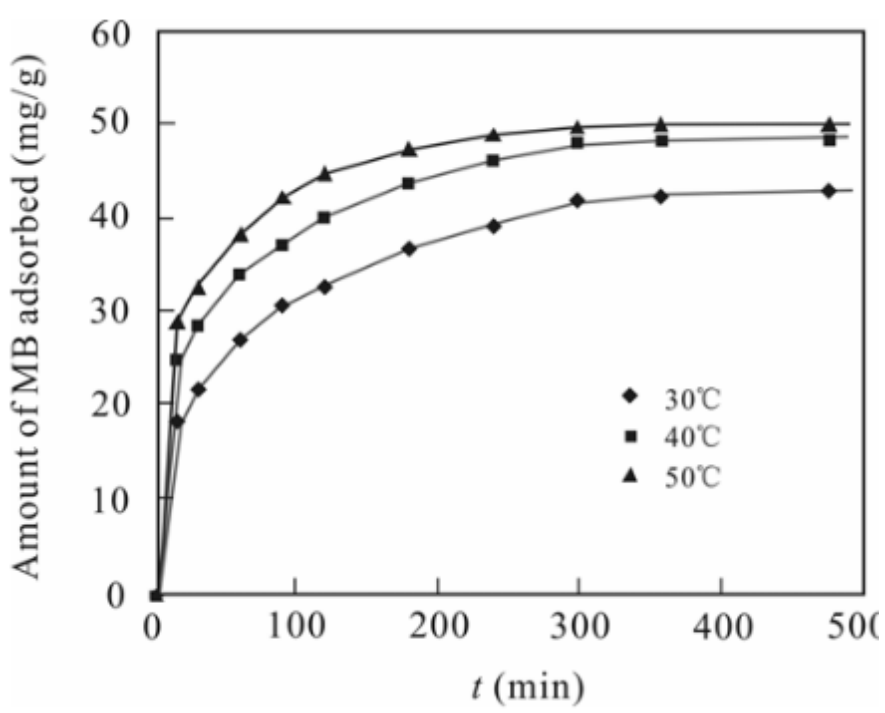

Figura 2: Masa de azul de metileno adsorbido por gramo de carbón de bambú en función del tiempo, para distintas temperaturas. 


\section{Respuesta 1}

Tema abordado: Isotermas de adsorción.

En este ítem, esperamos se pueda predecir que ocurre con la masa de MB adsorbida en función del tiempo y también el efecto de la temperatura en el proceso de adsorción.

2) Experimentalmente se determinó que la adsorción de azul de metileno sigue un modelo de segundo orden.

a) Plantee las ecuaciones que describen esta condición.

b) A partir de la Tabla 1, siendo $k_{2}$ la constante de segundo orden, grafique y obtenga la energía de activación mediante la linealización de la ecuación de Arrhenius.

\begin{tabular}{cc}
\hline Temperature $\left({ }^{\circ} \mathrm{C}\right)$ & $k_{2} /(\mathrm{g} /(\mathrm{mg} \cdot \mathrm{min}))$ \\
\hline 30 & 0.000557 \\
40 & 0.000723 \\
50 & 0.001100 \\
\hline
\end{tabular}

Tabla 1: Parámetros cinéticos de segundo orden para la adsorción de azul de metileno en carbon de bambú.

\section{Respuesta 2}

Tema abordado: Cinética Química (adsorción). Orden de reacción. Energía de activación.

Se espera que se pueda identificar la ecuación que responde a la cinética de segundo orden, su linealización y de esta forma obtener la energía de activación.

3) Determine si se trata de un proceso de fisisorción o quimisorción. El proceso, ¿es endotérmico o exotérmico?

Considere $\Delta \mathrm{S}^{\circ}=0,1621 \mathrm{KJ} / \mathrm{Mol} . \mathrm{K}$

\begin{tabular}{ccc}
\hline $\mathrm{T}\left({ }^{\circ} \mathrm{C}\right)$ & $K_{\mathrm{L}}\left(\mathrm{m}^{3} / \mathrm{mol}\right)$ & $\Delta G(\mathrm{~kJ} / \mathrm{mol})$ \\
\hline 30 & 136.33 & -12.382 \\
40 & 251.42 & -14.384 \\
50 & 336.27 & -15.625 \\
\hline
\end{tabular}

Tabla 2: Parámetros termodinámicos de la adsorción de azul de metileno en carbón de bambú. 


\section{Respuesta 3}

Tema abordado: Termodinámica Química. Ecuación de Van’t Hoff.

Se espera que obtengan el valor de $\Delta H^{\circ}$ a partir de la ecuación de Van't Hoff, para identificar el tipo de adsorción y si se trata de un proceso endotérmico o exotérmico.

\section{Conclusión}

En el desarrollo del problema integrador logramos incorporar los temas vistos en la cursada. Como base, tomamos la devolución del primer parcial realizada por los compañeros y los docentes. Además, intentamos mejorar nuestro trabajo en equipo, el cual supimos percibir que fue un tanto escaso en la primera etapa.

\section{Bibliografía}

- "ADSORPTION REMOVAL OF METHYLENE BLUE FROM AQUEOUS SOLUTION BY USING BAMBOO CHARCOAL" Yinian Zhu*, Dunqiu Wang, Xuehong Zhang and Hongdong Qin, China, 2009.

- Levine, I. N., Fisicoquímica, 4a Edición, Vol I, México, McGraw-Hill, 1996. 


\section{La Competencia Digital Docente en Educación Superior}

Parra Bernal, Lina Rosa

ORCID 0000-0001-9838-478

Canales Reyes, Roberto ORCID 0000-0002-1088-5004

Alzate Gallego, Yorladis

Morales, María Julia

ORCID 0000-0002-3462-8379 


\title{
LA COMPETENCIA DIGITAL DOCENTE EN EDUCACIÓN SUPERIOR
}

\author{
Parra Bernal, Lina Rosa \\ Canales Reyes, Roberto \\ Alzate Gallego, Yorladis \\ Morales, María Julia
}

\section{Resumen}

En este texto se presentan los resultados parciales de la investigación denominada "Apropiación de las Competencias Digitales en Docentes de Educación Superior y su contribución en la generación de Ambientes Educativos Innovadores", la cual indaga acerca del uso y apropiación de las competencias digitales que poseen los profesores de educación superior. Derivado del análisis acerca de los distintos marcos y estándares de competencias digitales docentes - CDD de España, Inglaterra, Estados Unidos, Colombia, Chile y Unesco entre otros, se realiza el diseño y validación de un instrumento que permita evaluar la CDD en educación superior desde las dimensiones: pedagógica, investigación, gestión de la información, desarrollo profesional, vinculación e intervención social, comunicación y colaboración, ciudadanía y responsabilidad digital. De esta manera se busca aportar insumos para la mejora educativa y el perfeccionamiento de la carrera docente.

\section{Palabras clave}

Competencia Digital Docente, Evaluación de la Competencia Digital Docente, Marcos de Competencia Digital Docentes. 


\section{Introducción}

Las Tecnologías de la Información y la Comunicación - TIC, a lo largo de los años, han propiciado cambios significativos en la educación, los cuales se han visto reflejados en los procesos de enseñanza y aprendizaje. Apoyados en las investigaciones de Coll (2008) se puede expresar que del uso de estas tecnologías surgen diversas formas de comunicación e interacción y una nueva ecología de medios, lo que ha llevado a que las Instituciones de Educación Superior, incorporen en sus modelos, las nuevas pedagogías que emergen alrededor del avance científico - tecnológico, para adentrarse así en la era del aprendizaje digital. Como lo afirman (Busque,et al, 2013), citados por (Viñals y Cuenca, 2016, p.105), "Ias TIC han provocado nuevos alfabetismos que potencian habilidades y competencias propias del siglo XXI, las cuales se ejercitan principalmente en las prácticas digitales que los jóvenes llevan a cabo en contextos de aprendizaje informal", de allí la importancia que tiene para el docente de educación superior, reflexionar acerca del cómo enseñar y cómo aprenden sus estudiantes en esta era digital.

Con el interés de aportar a las reflexiones y discusiones en este ámbito, se viene adelantando este proceso investigativo, el cual indaga acerca del uso y apropiación de las competencias digitales, que poseen los docentes de educación superior, para lo cual es necesario identificar el tipo de competencias que poseen relacionadas con el "[...] diseño, implementación y evaluación de espacios educativos significativos mediados por TIC", (Valencia et al., 2016. p.16). Desde la investigación se busca contribuir a esta necesidad, a partir del diagnóstico de las competencias digitales de los profesores (de las universidades participantes así: Universidad Católica de Manizales -Colombia, Universidad de los Lagos - Chile, Universidad de la República - Uruguay), a través del cual se podrá identificar las competencias referidas al conocer, utilizar y transformar las TIC en sus prácticas pedagógicas. Este texto tiene como propósito presentar los principales hallazgos del rastreo teórico realizado en la investigación, el cual ha permitido identificar y conceptualizar las dimensiones a considerar en un instrumento para evaluar la competencia digital docente en educación superior.

\section{Aproximaciones teóricas}

La competencia digital docente se comprende como el conjunto de conocimientos, habilidades y estrategias propias de la profesión docente que permiten solucionar los problemas y retos educativos que plantea la denominada sociedad del conocimiento (Cabero y Palacios, 2020; Prendes y Gutiérrez, 2013), con las cuales se espera que los profesores universitarios puedan formar a los ciudadanos que demanda esta nueva sociedad. Actualmente se referencian distintos marcos de estándares y orientaciones para definir dimensiones e indicadores respecto al nivel de CDD de los y las docentes, a continuación, se presentan algunos de los abordados en la investigación. 
Competencias y Estándares TIC para la Profesión Docente - Modelo Enlaces: Centro de Educación y Tecnología, Enlaces de Chile, desde el Ministerio de Educación (2007). Actualizado en 2011.

\section{Pedagógica}

Técnica

Gestión, social, ética y legal

Desarrollo profesional

Cada dimensión se asocia con competencias que cumplen roles determinados y contemplan una serie de criterios

El marco de competencias está constituido en seis aspectos propios de la práctica docente, contemplando 18 competencias y tres niveles de uso pedagógico de las TIC.

Comprensión del papel de las tic en la educación Currículo y evaluación

Pedagogía

Aplicación de competencias digitales Organización y administración

Aprendizaje profesional de los docentes

Presenta la competencia digital estructurada

Marco Común de Competencia Digital Docente - INTEF

Instituto Nacional de Tecnologías Educativas y Formación del Profesorado (INTEF), organismo del Ministerio de Educación, Cultura y Deporte (MECD) del gobierno español.

\section{en 5 áreas competenciales y 21 competencias} estructuradas en 6 niveles competenciales. Información y alfabetización informacional

Comunicación y colaboración

Creación de contenidos digitales

Seguridad

Resolución de problemas

Se estructura en cinco competencias: tecnológica

Competencias TIC para el desarrollo profesional docente.

Ministerio de Educación de Colombia comunicativa, pedagógica, gestión investigativa.

Presentan las competencias y estándares TIC desde una visión pedagógica

Diseño

Implementación

evaluación

fundamentadas en tres niveles de apropiación así: Nivel 1 - Integrar, Nivel 2 Re-orientar y Nivel 3 Integrar 


\section{Método}

\section{Descripción del contexto}

La investigación se encuentra en desarrollo de la primera fase correspondiente al rastreo documental, el cual ha permitido identificar los diferentes marcos de competencia digital docente en algunos países de América Latina y Europa. Los insumos obtenidos han permitido la construcción de un instrumento diagnóstico, cuyo objetivo es evaluar las competencias digitales de los docentes de las universidades participantes en el estudio.

Con el interés de realizar la revisión documental de la investigación para la exploración de las CDD y su contribución a la generación de ambientes educativos innovadores, se realiza la búsqueda de información en las bases de datos SCOPUS y SCIELO, empleando como ecuación de búsqueda "competence*" AND "high* education". Se consultaron 131 artículos, de los cuales se seleccionaron y analizaron 46, y con ellos se elabora una matriz de análisis en la que se tuvieron en cuenta los datos de autoría, fecha de publicación, palabras claves, resumen, metodología, técnicas y resultados. Este rastreo permitió la consolidación de un fondo documental con las categorías: Competencia digital docente en educación superior y evaluación de la competencia digital docente, las cuales cumplían con los criterios de pertinencia teórica y conceptual.

\section{Procedimiento}

La revisión documental contempla el análisis de resúmenes, metodología, posturas teóricas, conclusiones y fuentes bibliográficas, de igual manera, la trayectoria de algunos de los autores analizados permitió ampliar la búsqueda, ya que aportan aspectos esenciales a considerar en la evaluación de la CDD. Seguidamente desde la perspectiva cualitativa, se realiza el análisis de contenido que en palabras de Galeano (2009, p.124) va "más allá de la frecuencia de aparición de un símbolo, término o palabra, el análisis de contenido tiene mayor fortaleza en la construcción de categorías y en la contextualización de la información”. La autora, al referirse a los estudios documentales, plantea que, en estos, se realiza la búsqueda y recuperación sistemática de información y a su vez permiten la reflexión acerca del conocimiento objeto de la investigación, (Galeano, 2009).

Es por esto que, en esta fase, el proceso para la recolección y análisis información, se realiza a partir de las fases planteadas como se presenta en la figura 1. 


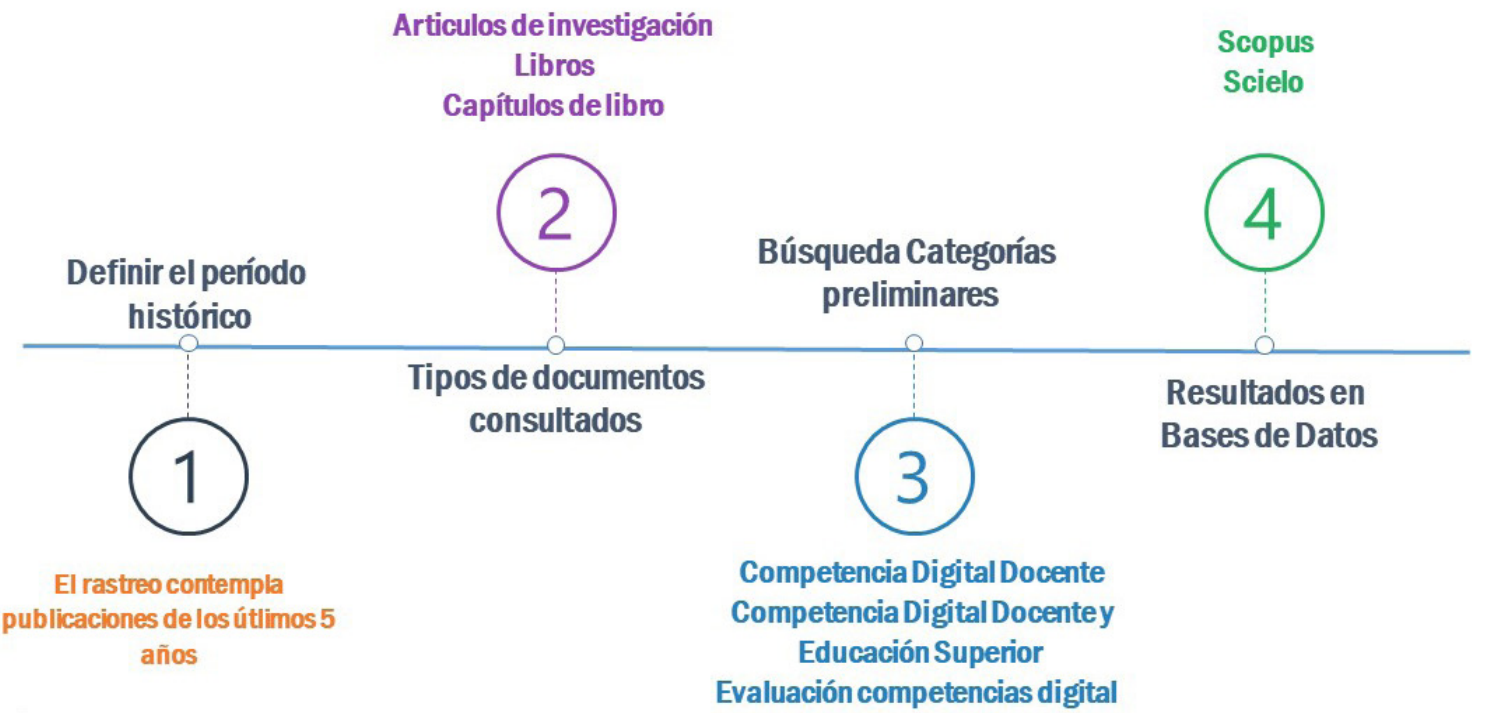

Figura 1. Procedimiento rastreo documental

Autoría propia

Una vez obtenido el acervo documental, se consolida el material empírico, las unidades de análisis, la codificación y categorización de los datos, el análisis y presentación de los resultados a partir de las categorías nodales, competencia digital docente - CDD y evaluación de la competencia digital docente y se realiza la elaboración del instrumento para el diagnóstico de la CDD en profesores de educación superior, como se presenta a continuación en los resultados.

\section{Resultados}

\section{Competencia digital docente:}

Se destacan las investigaciones focalizadas en el desarrollo de competencia digital docente en la formación inicial de los profesores como es el caso de Chile y Uruguay en el estudio realizado por Silva et al. (2019), se presenta un desarrollo básico en las cuatro dimensiones de la CDD y se destaca el porcentaje de hombres que alcanza competencias digitales avanzadas para la dimensión de planificación, organización y gestión de espacios y recursos tecnológicos. Los autores recomiendan que las instituciones formadoras de docentes implementen políticas a diferentes plazos y en diversos ámbitos de la FID como el sistema educativo, la formación y la docencia, para mejorar el nivel de desarrollo de la CDD.

Para el caso de Colombia se identifican un buen número de publicaciones acerca del tema, entre las cuales se reconocen los alcances planteados por el Ministerio de Educación y la Universidad Pontificia Javeriana con el documento Modelo de Competencias y estándares TIC desde la dimensión pedagógica (2013), donde se presentan las competencias y estándares TIC desde una visión pedagógica, contribuyendo a la identificación y reconocimiento de las prácticas y/o estrategias educativas adaptadas por los docentes y su correspondiente evaluación. 
El estudio realizado por Pérez. (2019) en el cual se analizan las competencias digitales docentes de profesores universitarios, concluye que los docentes presentan un nivel de formación en TIC suficiente o bueno, evidenciado en el manejo técnico de herramientas tecnológicas y el acceso a Internet; pero cuando se requiere del diseño e implementación de ambientes de aprendizaje lúdicos e interactivos que vinculen otro tipo de contenidos digitales su competencia disminuye, lo que pone de manifiesto el desarrollo de procesos de formación en usos pedagógicos de herramientas digitales. La formación docente ha de considerarse en un aspecto relevante en las instituciones de educación superior, puesto que la calidad del proceso de enseñanza, aprendizaje y evaluación se constituye en el eje nodal de estas instituciones, desde esta perspectiva Cipagauta (2020) plantea que los profesores han de estar actualizados tanto en su saber específico como en pedagogía.

\section{Evaluación de la competencia digital docente}

La Competencia Digital Docente, se ha reportado en resultados de numerosas investigaciones focalizadas en la educación superior, sin embargo en su gran mayoría se implementan instrumentos que buscan conocer, describir y analizar las potencialidades de experiencias de aprendizaje, niveles, dominios y necesidades formativas, pero desde una perspectiva de autoevaluación, grados de percepción y/o autopercepción a través de encuestas, grupos focales o cuestionarios tipo Likert (Usart et al., 2021; Cabero, Barroso et al., 2020; Domingo et al., 2020; Falcó, 2017; Alonso, 2018; y Moreno et al., 2018). Los estándares utilizados preferentemente como referentes son el Marco Europeo de Competencia Digital para Docentes DigComEdu, seguido por el Marco Común de Competencia Digital Docente del INTEF (Cabero, Romero et al., 2020) y el Marco Competencial TIC para Docentes de la UNESCO (2018).

Los resultados de las investigaciones revisadas son variados, así quienes aplicaron el COMDID-A de autoevaluación de la CDD para la FID en una muestra de 144 estudiantes de grado de educación en una universidad catalana, refieren sus conclusiones en función de cuatro dimensiones competenciales propuestas por Lázaro y Gisbert (2015), planteando a nivel de resultados que los estudiantes mayores se autoevalúan así mismos como menos competentes que los más jóvenes. No se observan diferencias de género. Se evidencia que el instrumento se puede implementar como evaluación formativa. (Usar et al, 2021).

En otro estudio que busca conocer el nivel de CDD del profesorado de educación superior y las diferencias significativas de su autopercepción, antes y después de aplicar el DigComEdu Chek-in, a una muestra de 2.262 docentes de 9 universidades públicas de Andalucía en España, presentan como resultados que la percepción frente a su dominio de las CDD es moderada, especialmente en el compromiso profesional y en recursos digitales, con niveles bajos en la CDD. La puntuación más elevada se asocia a la competencia "pedagogía digital" (Cabero, Romero, Barroso et al., 2020).

Domingo et al., 2020 por su parte, investigaron la percepción de estudiantes y docentes sobre la CDD a través de grupos de discusión y cuestionarios de autopercepción con preguntas cerradas tipo Likert, aplicado a 1.051 docentes y 473 estudiantes de pedagogía de 9 universidades catalanas. Concluyen que la formación universitaria se debería sincronizar con la escuela y la sociedad. El dominio de la CDD del profesorado universitario es deficiente y la alfabetización digital del alumnado es una necesidad. Por otro lado, la dimensión prioritaria de la competencia digital 
metodológica es la comunicación y colaboración, así mismo enfatizan en la ética y civismo digital como una dimensión emergente a contemplar durante la actividad educativa. Por último, se plantea la importancia del uso de recursos digitales útiles para enseñar y aprender.

En otro ámbito, un estudio que indaga las potencialidades de una experiencia sobre ABP para contribuir a la CDD en la FID del grado de educación infantil en la Universidad de Santiago de Compostela, aplicaron una encuesta tipo Likert considerando los modelos propuestos por (Krumsvik, 2011; Ministerio de Educación de España, 2011; Mishra y Koehler, 2006) para conocer el grado de satisfacción a partir de una muestra de 50 estudiantes. Los resultados reportan una gran satisfacción del alumnado con la propuesta, especialmente con la posibilidad de implementar sus proyectos en las visitas a la escuela, lo que contribuye al desarrollo del componente didáctico-pedagógico y el desarrollo profesional de la competencia digital docente. El estudio pone de manifiesto la importancia de las metodologías activas en la FID, así como la necesaria colaboración entre escuela y universidad. (Alonso, 2018).

Por último, el estudio de autopercepción de futuros graduados en Educación Infantil y Primaria en relación a su CDD utilizando el marco de DigComEdu y la UNESCO 2014 con su Orientación Normativa Estratégica de la Alfabetización Mediática e Informacional, se aplicó un cuestionario tipo Likert a 104 estudiantes de los grados mencionados en la Universidad Internacional de Valencia, los resultados evidencian que los alumnos muestran un nivel competencial avanzado en las áreas de información, comunicación y creación de contenidos audiovisuales, lo que garantiza competencias tanto multimedia e informacionales como digitales, mientras que las habilidades más bajas están vinculadas con la seguridad y la innovación tecnológica. (Moreno, Gabarda y Rodríguez, 2018).

\section{Instrumento para evaluación de la competencia digital docente en educación superior}

El abordaje de los modelos de competencias digitales se convirtió en insumo para la construcción de un instrumento diagnóstico de las competencias digitales docentes para educación superior. Este permite evaluar el desempeño de los docentes en el manejo de las herramientas TIC. El análisis realizado a los modelos de competencias más relevantes se convirtió en el punto de partida para la definición de las dimensiones y criterios pertinentes a evaluar en profesores de educación superior, ya que la mayoría de los estudios en este ámbito se han centrado en la evaluación de competencias digitales en la formación inicial docente.

El contenido del instrumento, así como su estructura ha sido sometido a un proceso de validación, para ello se aplicó la técnica de juicio de expertos propuesta por Escobar y Cuervo (2008), quienes afirman que este "se define como una opinión informada de personas con trayectoria en el tema, que son reconocidas por otros como expertos cualificados.

La valoración para la competencia digital docente se estructura a través de 55 criterios agrupados en ocho dimensiones, toma como base la escala de Likert con los siguientes niveles de respuesta: 1: Nunca, 2: Casi siempre, 3: A veces, 4: Siempre, tal como se presenta en la (Figura 2). 


\section{Pedagógica Investigación Comunicaciony Gestión dela $\begin{gathered}\text { Ciudadaniay } \\ \text { responsabilidad Desanollo Vinculacióne }\end{gathered}$ Pedagogica Investigación colaboración información responsabilidad profescional intervenciónsocial}

Figura 2. Dimensiones de la CDD en Educación Superior

Elaboración propia

En el anexo 1. Matriz de criterios para evaluar la Competencia Digital Docente en Educación Superior, se presentan las dimensiones y los criterios considerados para cada una de ellas.

\section{Discusión y conclusiones}

Las investigaciones abordadas acerca del desarrollo de la competencia digital docente en educación superior, permiten evidenciar la necesidad que tienen las universidades de continuar formando a sus profesores con respecto al uso y apropiación de las tecnologías digitales, puesto que en la mayoría de las investigaciones se concluye la baja autopercepción de los docentes en este campo. Puesto que, si bien en los últimos años se ha venido trabajando en el proceso de alfabetización digital, aún no se refleja directamente en la práctica pedagógica. Al parecer la responsabilidad se le ha designado solo al profesor. Sin embargo, la crisis sanitaria derivada por el covid 19, ha puesto de frente a las instituciones de educación superior ante esta necesidad de formación.

La inserción de las TIC en el desarrollo de procesos de enseñanza, aprendizaje y evaluación, está asociada a los procesos de formación, a las intencionalidades pedagógicas y al desarrollo de habilidades y competencias digitales desde una perspectiva integradora hacia la transformación de las prácticas pedagógicas y educativas.

Revisando los distintos marcos y estándares tecnológicos de las CDD de España, Inglaterra, Estados Unidos, Colombia, Chile y Unesco entre otros, se ha realizado el proceso diseño y validación de un instrumento que permita evaluar la CDD en educación superior en las dimensiones pedagógica, investigación, comunicación y colaboración, gestión de la información, ciudadanía y responsabilidad digital, desarrollo profesional y vinculación e intervención social, para así aportar insumos para la mejora educativa y el perfeccionamiento docente.

\section{Referencias}

Alonso-Ferreiro, Almudena (2018) "Aprendizaje Basado en Proyectos para el desarrollo de la Competencia Digital Docente en la Formación Inicial del Profesorado" Revista Latinoamericana de Tecnología Educativa, 17(1) https://doi.org/10.17398/1695-288X.17.1.9

Cabero-Almenara, J., Barroso-Osuna, J., Rodríguez-Gallego, M., \& Palacios-Rodríguez, A. (2020). La Competencia Digital Docente. El caso de las universidades andaluzas. Aula Abierta, 49(4), 363-372. https://doi.org/10.17811/rifie.49.4.2020.363-372 
Cabero-Almenara, J., Romero-Tena, R., \& Palacios-Rodríguez, A. (2020). Evaluation of Teacher Digital Competence Frameworks Through Expert Judgement: the Use of the Expert Competence Coefficient. Journal of New Approaches in Educational Research, 9(2), 275-293. doi:10.7821/naer.2020.7.578

Cabero-Almenara, J., Romero-Tena, R., Barroso-Osuna, J., \& Palacios-Rodríguez, A. (2020). Marcos de Competencias Digitales Docentes y su adecuación al profesorado universitario y no universitario. RECIE. Revista Caribeña De Investigación Educativa, 4(2), 137-158. https://doi.org/10.32541/recie.2020.v4i2.pp137-158

Cipagauta Moyano, M. E. (2020). Perspectivas de la formación permanente de los docentes de educación superior. RIDE Revista Iberoamericana para la Investigación y el Desarrol/o Educativo, 11(21). https://doi.org/10.23913/ride.v11i21.738

Domingo-Coscolla, M., Bosco,A., Carrasco Segovia, S y Sánchez Valero, J.A. (2020) Fomentando la competencia digital docente en la universidad: Percepción de estudiantes y docentes. Revista de Investigación Educativa, 38(1), 167-782. DOI: http:// dx.doi.org/10.6018/rie.340551

Escobar Pérez, J. E., y Cuervo Martínez, Á. C. (2008). Validez de contenido y juicio de expertos: una aproximación a su utilización. Avances en Medición, 6(1), 27-36. https://bit.ly/3sUR56d

Falcó, J. M. (2017). Evaluación de la competencia digital docente en la comunidad autónoma de Aragón. Revista Electrónica de Investigación Educativa, 19(4), 73-83. https://doi.org/10.24320/redie.2017.19.4.1359

Galeano, M. (2009). Estrategias de investigación social cualitativa. Medellín: La Carreta. Editores.

Krumsvik, R. (2011). Digital competence in norwegian teacher education and schools. Högre Utbildning, 1(1), 39-51

Lázaro Cantabrana, José L. y Gisbert Cervera, Mercè (2015). El desarrollo de la competencia digital docente a partir de una experiencia piloto de formación en alternancia en el Grado de Educación. EDUCAR, 51(2), 321-348. [Fecha de Consulta 15 de Junio de 2021]. ISSN: 0211-819X. Disponible en: https://www.redalyc.org/articulo. oa?id=342141427006

Mishra, P. \& Koehler, M.J. (2006). Technological Pedagogical Content Knowledge: A Framework for Teacher Knowledge. Teachers College Record, 108(6), 1017-1054. Retrieved October 11, 2021 from https://www.learntechlib.org/p/99246/.

Moreno Rodríguez, M.D., Gabarda Méndez, V. y Rodríguez Martín, A. M. (2018). Alfabetización informacional y competencia digital en estudiantes de magisterio. Profesorado. Revista de Currículum y Formación de Profesorado, 22(3), 253-270. DOI: 10.30827/profesorado.v22i3.8001

Pérez Diaz, R. (2019). Competencia digital docente en los institutos superiores de formación de maestros: caso de República Dominicana. Pixel-Bit: Revista de Medios y Educación, 55, 75-97. DOI 10.12795/pixelbit.2019.i55.05 
Prendes Espinoza, M. y Gutiérrez Porlán, I. (2013). Competencias Tecnológicas del profesorado en las universidades españolas. Revista de Educación, 361, mayo-agosto, 196-222. DOI: 10.4438/1988-592X-RE-2011-361-140

Silva, J., Usart, M., \& Lázaro-Cantabrana, J. L. (2019). Competencia digital docente en estudiantes de último año de Pedagogía de Chile y Uruguay. Comunicar: Revista Científica de Comunicación y Educación, 27(61), 33-43.

Usart Rodríguez, M.; Lázaro Cantabrana, J.L. \& Gisbert Cervera, M. (2021). Validation of a tool for self-evaluating teacher digital competence. Educación XX1, 24(1), 353373, http://doi. org/10.5944/educXX1.27080

Valencia, T., Serna, A., Ochoa, S., Caicedo, A.M., Montes, J.A. y Chaves, J.D. (2016) Competencias y Estándares Tic desde la Dimensión Pedagógica. Una perspectiva desde los niveles de apropiación de las TIC en la práctica educativa docente. Pontificia Universidad Javeriana, Cali: Multimedios.

Viñals Blanco, Ana, y Cuenca Amigo, Jaime (2016). El rol del docente en la era digital. Revista Interuniversitaria de Formación del Profesorado, 30(2),103-114. [fecha de Consulta 30 de septiembre de 2021]. ISSN: 0213-8646. Disponible en: https://www. redalyc.org/articulo.oa?id $=27447325008$ 


\section{Anexo 1.}

Matriz de criterios para evaluar la Competencia Digital Docente en Educación Superior

\section{Dimensiones Criterios}

Planifico actividades de enseñanza y aprendizaje con apoyo de las tecnologías digitales.

Diseño e implemento ambientes de enseñanza y aprendizaje incorporando el uso de las tecnologías digitales.

Diseño experiencias de aprendizaje que fomentan la diversidad e inclusión con el apoyo de tecnologías digitales.

Utilizo recursos digitales de aprendizaje (webs educativas, textos en línea, video de YouTube, etc.) como mediación pedagógica.

Implemento estrategias de aprendizaje que fomentan: búsqueda, localización y selección de información en la Web.

Diseño e implemento estrategias de evaluación empleando tecnologías digitales.

D1: Pedagógica Incorporo estrategias innovadoras apoyadas con tecnologías digitales en las aulas de clase.

Utilizo diferentes herramientas digitales para la tutoría y acompañamiento pedagógico.

Diseño recursos digitales como (blogs, sitios web, infografías, podcast, cápsulas informativas, entre otras) como apoyo y mediación en el proceso de enseñanza y aprendizaje.

Utilizo entornos virtuales de aprendizaje de fácil acceso para garantizar igualdad de oportunidades a los estudiantes.

Promuevo la interacción y el trabajo colaborativo con el uso de tecnologías digitales a través de estrategias tales como: resolución de problemas, métodos basados en proyectos, aprendizaje colaborativo, entre otras.

Selecciono las herramientas digitales más pertinentes a los contenidos y competencias requeridas en los cursos que orienta.

Exploro acerca de las tendencias investigativas propias de mi disciplina con el apoyo de las tecnologías digitales y las incorporo a mi práctica docente.

Analizo datos derivados de mis investigaciones con el apoyo de tecnologías digitales (Excel, SPSS, Nvivo, Atlas TI).

Diseño proyectos de investigación colaborativos utilizando tecnologías digitales.

Desarrollo proyectos de investigación relacionados con: formación virtual, formación a distancia, formación del profesorado en y con TIC, competencias digitales de los docentes.

\section{D2: Investigativa}

Busco información en línea empleando descriptores y operadores lógicos para encontrar la información de manera precisa y oportuna en las bases de datos indexadas.

Utilizo gestores de información (Zotelo, Mendeley, Ednote entre otros) como apoyo a los procesos investigativos.

Implemento instrumentos para la recolección de datos mediante el uso de tecnologías digitales (forms, surveymonkey, entre otros).

Publico los resultados de mi investigación científica con el apoyo de las tecnologías digitales.

Transfiero el conocimiento producido en las investigaciones a través de medios digitales (congresos en línea, revistas, redes de colaboración científica). 


\begin{tabular}{|c|c|}
\hline \multirow{10}{*}{$\begin{array}{l}\text { D3: Comunicación } \\
\text { y colaboración }\end{array}$} & $\begin{array}{l}\text { Colaboro con pares académicos en la implementación de experiencias de } \\
\text { aprendizaje con apoyo de tecnologías digitales. }\end{array}$ \\
\hline & $\begin{array}{l}\text { Trabajo de manera colaborativa con pares académicos para explorar nuevos } \\
\text { recursos digitales. }\end{array}$ \\
\hline & $\begin{array}{l}\text { Utilizo herramientas para la comunicación en línea con pares y estudiantes } \\
\text { como foros, mensajería instantánea, chat, entre otros. }\end{array}$ \\
\hline & $\begin{array}{l}\text { Comparto información y contenido educativo en: redes sociales, } \\
\text { comunidades académicas y diversos espacios virtuales. }\end{array}$ \\
\hline & $\begin{array}{l}\text { Promuevo la generación redes de conocimiento para apoyar los procesos de } \\
\text { enseñanza y aprendizaje con uso de tecnologías digitales. }\end{array}$ \\
\hline & $\begin{array}{l}\text { Utilizo las plataformas institucionales y el software para videoconferencias con } \\
\text { que cuenta la institución educativa y los incorporo en mi práctica docente. }\end{array}$ \\
\hline & $\begin{array}{l}\text { Incluyo la marca de identidad digital de mi institución en la comunicación y } \\
\text { colaboración con otros pares académicos. }\end{array}$ \\
\hline & $\begin{array}{l}\text { Utilizo los recursos digitales de la institución educativa como apoyo a la labor } \\
\text { administrativa y pedagógica. }\end{array}$ \\
\hline & Diseño presentaciones que me permiten comunicar el conocimiento. \\
\hline & $\begin{array}{l}\text { Fomento el uso de normas básicas de comportamiento y de comunicación } \\
\text { en la red. (Netiqueta, evitar el plagio) }\end{array}$ \\
\hline \multirow{5}{*}{$\begin{array}{l}\text { D4: Gestión de la } \\
\text { información }\end{array}$} & $\begin{array}{l}\text { Utilizo herramientas de productividad digital (procesador de textos, hoja } \\
\text { de cálculo, presentaciones, entre otras) para generar diversos tipos de } \\
\text { documentos. }\end{array}$ \\
\hline & $\begin{array}{l}\text { Utilizo diferentes buscadores (Google, Bing, Yahoo! Search, etc.) para } \\
\text { localizar y seleccionar la información más relevante en el ámbito de mi } \\
\text { gestión. }\end{array}$ \\
\hline & $\begin{array}{l}\text { Empleo recursos digitales para gestionar procesos académicos y } \\
\text { administrativos (expedición de certificados - actualización de plataformas en } \\
\text { línea - gestores de información, calendarios académicos, etc.) propios de las } \\
\text { funciones sustantivas: docencia, investigación e intervención social. }\end{array}$ \\
\hline & $\begin{array}{l}\text { Empleo herramientas digitales para dinamizar la labor académica a través de } \\
\text { plataformas de videoconferencias y herramientas de colaboración. }\end{array}$ \\
\hline & Gestiono y almaceno información en la "nube". \\
\hline \multirow{8}{*}{$\begin{array}{l}\text { D5: Ciudadanía y } \\
\text { responsabilidad } \\
\text { digital }\end{array}$} & $\begin{array}{l}\text { Participo en actividades que promueven el compromiso social, responsable y } \\
\text { ético del uso de las tecnologías digitales. }\end{array}$ \\
\hline & $\begin{array}{l}\text { Utilizo las tecnologías digitales como apoyo a la solución de problemas del } \\
\text { contexto local y global para un mundo más pacífico y sostenible. }\end{array}$ \\
\hline & $\begin{array}{l}\text { Promuevo el respeto por la diversidad cultural hacia el desarrollo de } \\
\text { competencias para una ciudadanía global. }\end{array}$ \\
\hline & $\begin{array}{l}\text { Fomento la conciencia crítica frente al impacto tecnológico en el medio } \\
\text { ambiente. }\end{array}$ \\
\hline & $\begin{array}{l}\text { Conozco los derechos de autor y distintos tipos de licencias (copyright, } \\
\text { copyleft y creative commons) relacionados con los contenidos digitales. }\end{array}$ \\
\hline & $\begin{array}{l}\text { Realizo en forma periódica tareas de mantenimiento básico de los } \\
\text { dispositivos (pc, tablets, etc.). }\end{array}$ \\
\hline & Contribuyo a generar conocimiento de bien público \\
\hline & $\begin{array}{l}\text { Comprendo el actuar ético y legal con respecto al uso de software y } \\
\text { tecnologías digitales. }\end{array}$ \\
\hline
\end{tabular}




\begin{tabular}{|c|c|}
\hline \multirow{6}{*}{$\begin{array}{l}\text { D6: Desarrollo } \\
\text { profesional } \\
\text { docente }\end{array}$} & Realizo formación y actualización continua en competencias digitales. \\
\hline & $\begin{array}{l}\text { Reflexiono acerca de los resultados y logros alcanzados en experiencias de } \\
\text { aprendizaje con apoyo de tecnologías digitales. }\end{array}$ \\
\hline & $\begin{array}{l}\text { Diseño instrumentos de autoevaluación para analizar el resultado de la } \\
\text { práctica docente con apoyo de tecnologías digitales }\end{array}$ \\
\hline & $\begin{array}{l}\text { Fomento el diálogo con pares y otros actores de la comunidad educativa, } \\
\text { acerca del uso de las tecnologías digitales en la práctica docente. }\end{array}$ \\
\hline & $\begin{array}{l}\text { Poseo habilidades para incorporar reflexivamente las tecnologías digitales en } \\
\text { la práctica docente. }\end{array}$ \\
\hline & $\begin{array}{l}\text { Utilizo las tecnologías para la comunicación y colaboración con iguales y } \\
\text { la comunidad educativa en general con miras a intercambiar reflexiones, } \\
\text { experiencias y productos que coadyuven a su actividad docente. }\end{array}$ \\
\hline \multirow{5}{*}{$\begin{array}{l}\text { D5: Vinculación con } \\
\text { el medio }\end{array}$} & $\begin{array}{l}\text { Implemento proyectos de vinculación e intervención social con apoyo de } \\
\text { tecnologías digitales. }\end{array}$ \\
\hline & $\begin{array}{l}\text { Divulgo los resultados de las buenas prácticas de proyectos de vinculación e } \\
\text { intervención social en medios digitales (revistas, conferencias, etc.) }\end{array}$ \\
\hline & $\begin{array}{l}\text { Utilizo las tecnologías digitales como medios para la apropiación del modelo } \\
\text { de intervención social de mi institución. }\end{array}$ \\
\hline & $\begin{array}{l}\text { Utilizo las tecnologías digitales para fomentar actividades de cooperación, } \\
\text { vinculación e intervención social (email, sitios web, WhatsApp, redes). }\end{array}$ \\
\hline & $\begin{array}{l}\text { Fomento a través de las tecnologías digitales estrategias de innovación para } \\
\text { contribuir al desarrollo humano y social. }\end{array}$ \\
\hline
\end{tabular}




\section{Repensar la Práctica Docente en Entornos Combinados: Una Experiencia Formativa en el Ámbito Universitario}

Siñanes, Lidia Gabriela

ORCID 0000-0002-4173-3871 


\title{
REPENSAR LA PRÁCTICA DOCENTE EN ENTORNOS COMBINADOS: UNA EXPERIENCIA FORMATIVA EN EL ÁMBITO UNIVERSITARIO
}

\author{
Siñanes, Lidia Gabriela
}

ORCID 0000-0002-4173-3871

\section{Resumen}

Ante las condiciones que se fueron dando en un contexto de pandemia, las instituciones educativas tuvieron que replantear diversas dimensiones (gestión institucional, pedagógicas-didácticas, administrativas, tecnológicas entre otras). En el caso de la Universidad Nacional de Salta, se diseñaron diversos proyectos de formación para asesorar, acompañar y posibilitar el desarrollo de las actividades académicas. Entre las acciones formativas que actualmente tienen continuidad, se encuentran los cursos de formación a distancia destinada a los equipos docentes de las seis Facultades dependientes de la universidad. Las temáticas propuestas estuvieron orientadas hacia la producción de materiales didácticos digitales, la evaluación en entornos virtuales, el diseño de estrategias de enseñanza y la organización de las aulas virtuales. En la presente comunicación se desarrolla la organización, modalidad y valoración de un ciclo de formación de postgrado sobre enseñanza universitaria mediada por tecnologías digitales. En la evaluación del curso, realizada a través de una encuesta, los docentes participantes consideraron que las temáticas y actividades lograron satisfacer sus expectativas, destacaron los encuentros síncronos con especialistas invitados y las orientaciones dadas para el rediseño de planificaciones tendientes a posibilitar la articulación entre los escenarios presenciales y entornos virtuales; así también, valoraron positivamente las prácticas tutoriales.

\section{Palabras clave}

Formación, virtualidad, universidad. 


\section{Introducción}

Ante un contexto de pandemia, las universidades transitan una situación inédita ante la no presencialidad por lo que debieron generar acciones con un denominador común: tener una visión integral estratégica para afrontar esta contingencia. Entre los macro-desafíos asumidos por nuestra universidad durante el 2020, estuvo la adecuación y creación de condiciones para el desarrollo de estrategias pedagógicas y recursos tecnológicos sobre enseñanza y el aprendizaje en entornos virtuales. Para el presente año académico se prevé alternar con esquemas de presencialidad, garantizando la igualdad en los procesos de formación y el acceso a los conocimientos por parte de los estudiantes.

De allí la importancia de posibilitar la continuidad en los procesos de formación pedagógica-didáctica de los equipos docentes de la universidad en metodologías y recursos mediados por las tecnologías de la información y comunicación (TIC) para articular los diferentes escenarios educativos (aulas, laboratorios, gabinetes y entornos virtuales). Esto implica el replanteo de la tarea docente y reorganización de roles y funciones que, si bien se han dado desde el 2020, se requieren nuevos acuerdos o revisar aquellos que se habían definido en prepandemia. Las configuraciones de entornos híbridos demandan definir fundamentos pedagógicos-didácticos según las características de la disciplina a cargo para así diseñar y gestionar recursos tecnológicos atendiendo a diversas dimensiones (institucional, curricular, contextual, perfil de estudiantes, tiempos, espacios, disponibilidad de recursos tecnológicos, entre otros) que inciden en la elaboración de la programación educativa.

La metodología de trabajo mixta o combinada implica, entonces, la integración de estrategias, actividades y recursos tecnológicos con sentido didáctico (Maggio,2018:82) para posibilitar mayor interacción en el aula y el trabajo autónomo para posibilitar aprendizajes significativos. En este sentido, surgen interrogantes tales como: ¿qué cambios se pueden dar desde lo pedagógico, lo tecnológico y de organización en los equipos docentes e institucionales cuando se combinan actividades presenciales con otras virtuales?, ¿qué criterios pedagógicos y didácticos orientarán la articulación de actividades presenciales en entornos digitales?, ¿cómo desarrollar las prácticas tutoriales de los equipos docentes en ambos escenarios educativos?, ¿qué desafíos y retos pueden surgir en esta nueva metodología?, ¿cómo integrar, recuperar aquellas prácticas docentes desarrolladas en la virtualidad y en la presencialidad?, entre otros.

Por tal motivo, se generaron espacios de formación, de intercambio de experiencias, de encuentros dialógicos entre expertos y docentes para analizar las prácticas de enseñanza, aprendizaje y tecnologías que permitan analizar críticamente el presente para proyectar decisiones sobre un futuro, ya próximo, de la tarea docente.

\section{Algunas consideraciones teóricas}

La enseñanza en la universidad se presenta como un espacio lleno de complejidades y, como toda práctica social, expresa conflictos y contradicciones. Así también, no fueron pocos los retos y desafíos realizados por los equipos docentes universitarios afrontados diariamente desde 2020 ante un contexto complejizado ante la situación sanitaria. 
Desde hace un tiempo, diversas investigaciones analizaron como la presencia de las tecnologías de la información y la comunicación (TIC) han interpelado a las instituciones educativas una nueva manera de entender el saber ya que se han desplazado los ejes tradicionales (el libro y el docente) frente a la aparición de múltiples flujos y circuitos en los cuales se producen y consumen los discursos sociales. Por ello, a los dispositivos tradicionales (los materiales impresos y la clase expositiva) se incorporaron nuevos modos de tratamiento, organización y presentación de los contenidos, caracterizados por las potencialidades hipertextuales que ofrecen las actuales TIC entendidas como herramientas que posibilitan almacenar, procesar, difundir y presentar información en diferentes formatos (Lion, 2020). Se va construyendo así un complejo escenario de transformación cultural, social y de convergencia tecnológica, cultural y mediática donde se están produciendo nuevos modos de acceso y tratamiento de la información, de prácticas comunicativas y culturales y de participación en diferentes ámbitos de la sociedad. (Jenkins, 2008).

Así también, el estudio de las prácticas de enseñanza relacionadas con las tecnologías se viene desarrollando desde diferentes perspectivas, algunas con más énfasis en el reconocimiento de las potencialidades del objeto tecnológico mientras que otras procuran centrarse en el estudio de los procesos reflexivos y criterios que desarrolla el docente para la inclusión de las tecnologías

Ante la virtualización de la enseñanza presencial, los equipos docentes debieron rediseñar planificaciones, proyectos educativos y desarrollar los procesos de enseñanza y aprendizaje mediada por diferentes tecnologías digitales. La construcción de los nuevos escenarios educativos se fundamentó en el reconocimiento de diversas potencialidades y oportunidades que ofrecían las TIC. Dicho reconocimiento fue resultado de la exploración, análisis y selección de aquellas consideradas como más adecuadas para la presentación de trabajos, la comunicación multidireccional, la producción colaborativa o individual en diferentes formatos. Por ello, cobra relevancia la indagación en los criterios pedagógicos-didácticos considerados por los equipos docentes al momento de decidir la inclusión o no de las TIC.

Actualmente, se está transitando hacia un regreso gradual a las aulas universitarias, pero desde una nueva manera de organizar la enseñanza y el aprendizaje articulando lo presencial y lo virtual, es decir, la bimodalidad. Por ello, a inicios de 2021 se diseñaron diferentes acciones formativas de postgrado desde la Secretaría Académica de Rectorado de la Universidad y la Facultad de Ciencias de la Salud para preparar a los equipos docentes en el desarrollo de propuestas innovadoras para una inclusión genuina de las nuevas tecnologías (Maggio, 2012) desde una mirada situada y reflexiva sobre la bimodalidad en el ámbito universitario. En la presente comunicación, se describe y analiza un ciclo de posgrado destinado a los docentes de la Universidad Nacional de Salta.

\section{Descripción de la experiencia}

\section{Propósitos y temáticas}

El Ciclo de postgrado "La enseñanza en entornos combinados: presencial y virtual. Distintas estrategias para promover aprendizajes en la universidad" será acreditable para la certificación de Postgrado "Diplomado en enseñanza universitaria mediada por TIC". 
Tuvo como propósitos generar un espacio de formación universitaria sobre prácticas docentes mediada por las nuevas tecnologías para reflexionar y diseñar planificaciones que articulen la presencialidad y la virtualidad a efectos de posibilitar procesos de construcción de conocimiento por parte de los estudiantes considerando la idea de que "la expansión de las herramientas digitales como extensión de los recursos y posibilidades de conocimiento y acción" (Pérez Gómez, 2012:61) Así también, se buscó analizar las posibilidades que ofrecen los entornos virtuales para la elaboración de andamiajes a cargo del profesor tutor.

Las temáticas se desarrollaron en los siguientes cursos:

Curso 1: Entornos presenciales y virtuales en el contexto universitario: puntos de partida para la articulación.

Curso 2: Estrategias de enseñanza y aprendizaje mediadas por tecnologías.

Curso 3: Actividades y herramientas digitales.

Los destinatarios de esta propuesta formativa fueron los docentes de todas las Facultades de las diferentes Sedes Regionales y de los Institutos de Enseñanza Media de la Universidad Nacional de Salta. Se registraron como interesados 342 docentes de los cuales 179 finalizaron y aprobaron el Ciclo.

\section{Metodología}

El Ciclo se dictó mediante la opción pedagógica didáctica a distancia donde la relación docente alumno se encuentra separada en el tiempo y/o espacio durante el proceso educativo. Se diseñaron entornos virtuales de enseñanza y aprendizaje basados en una propuesta pedagógica que buscó promover la cultura del diálogo para reconstruir la tarea docente desde diferentes escenarios educativos, problematizar la relación entre enseñanza y tecnologías, enfatizar la toma de decisiones con sentido didáctico, combinar estrategias, formatos y voces para la comprensión de las temáticas propuestas.

Para el desarrollo del proyecto estuvo a cargo de una Coordinación General que tuvo a su cargo la conformación de un equipo multidisciplinar (diseñador del aula virtual, editor de contenidos, correctora y el administrador de la plataforma) que desarrolló su actividad a partir de las clases elaboradas por expertos en tecnología educativa y educación a distancia quienes actuaron como docentes contenidistas. Se sumaron a la propuesta docentes especialistas de otras universidades para abordar temas específicos (enseñanza universitaria, evaluación, materiales didácticos) mediante conversatorios. Así también, se incorporaron los docentes tutores los cuales desempeñaron diversas funciones (acompañamiento académico, el apoyo y la orientación tecnopedagógica a los participantes). A efectos de acordar metodologías de trabajo y criterios de evaluación, se realizaron reuniones semanales lo cual permitió un trabajo en equipo y en comunicación constante para intercambiar experiencias y modos de resolución de situaciones diversas (desarrollo de actividades, acceso a recursos, funcionamiento de herramientas, entre otros).

El desarrollo del curso se realizó en tres aulas virtuales alojadas en plataforma Moodle 3.8.2, dependiente del Rectorado de la Universidad. En el aula virtual los participantes accedieron a clases elaboradas por especialistas en las temáticas propuestas, material 
bibliográfico específico, tutoriales en formato digital, recursos audiovisuales y sitios de interés respetando las normas de propiedad intelectual y autoría vigentes. La clase funciona como organizador de los materiales, recursos y estrategias que utilizamos en el proceso formativo. (Asisten, 2012: 45)

Las actividades y recursos del aula virtual estuvieron orientados a problematizar la comprensión de los contenidos (Lion, 2020:29). Se enfatizó el trabajo colaborativo a través de tareas grupales, discusión en foros y de instancias de reflexión posibilitando a los participantes repensar su práctica docente y generar propuestas de enseñanza combinadas o mixtas. Así también, se desarrollaron encuentros síncronos con diversos expertos quienes realizaron aportes para la comprensión de las temáticas abordadas.

\section{Resultados}

En la presente comunicación, se presentan las valoraciones y reflexiones de 156 docentes participantes del curso. Los mismos pertenecían a seis Facultades de la Universidad (Ciencias Jurídicas, Económicas y Sociales, Ciencias de la Salud, Ciencias Exactas, Ciencias Naturales, Ingeniería, Humanidades), junto a los docentes de los Institutos de Enseñanza Media (Sede Tartagal y Sede Salta). Cabe aclarar que, al finalizar el curso, entre las actividades de cierre se solicitó a los docentes que participaran en una encuesta de valoración no obligatoria mediante un cuestionario digital de preguntas cerradas y abiertas disponible en el aula virtual. Las preguntas se organizaron en las siguientes categorías: Facultad de dependencia laboral, metodología de trabajo (síncronas y asíncronas), materiales didácticos y práctica tutorial y una escala de valoración.

Sobre un total de 156 respuestas, se reconoce un alto nivel de satisfacción en cuanto a la metodología de trabajo desarrollada en el Ciclo. Las actividades mejor valoradas (50\% Excelentes y $40 \%$ Muy buenas) fueron las videoconferencias a cargo de especialistas en diferente temáticas de cada curso siendo especialmente destacadas las que se vincularon a escenarios tecnológicos y enseñanza universitaria (65\%), las actividades y recursos en entornos digitales (61\%) y la planificación en entornos combinados (53,5\%). Esto guarda relación con las actividades propuestas a los participantes en el aula virtual ya que el $65 \%$ las valora como muy satisfactorio el hecho de rediseñar las planificaciones y programas para articular lo presencial y lo virtual junto a la socialización de relatos sobre una situación de enseñanza que actualmente desarrollan (61\%). En relación al diseño y organización de los materiales didácticos lo valoran como muy adecuado (66\%) y adecuado (32\%). Con respecto a la práctica tutorial, los participantes consideraron que el asesoramiento y acompañamiento para el desarrollo de las actividades síncronas (tutorías y talleres) fueron muy adecuadas (58\%) y adecuadas (38\%) y la comunicación e interacción con las docentes tutoras fueron muy satisfactorias (66\%) y satisfactorias (31\%).

\section{Discusión y conclusiones}

La virtualización de la enseñanza universitaria implicó diversos desafíos a los equipos docentes y a las instituciones. Por ello, cobró valor el análisis de las prácticas de la enseñanza mediada por tecnologías ya que los docentes pudieron retomar sus propuestas, analizarlas y debatirlas junto a otros docentes, tutores y especialistas. Esto fue posible porque se diseñó un dispositivo de formación que buscó promover procesos reflexivos individuales y grupales sobre las prácticas docentes, el tratamiento de 
aportes conceptuales y metodológicos, además de las interacciones de manera síncrona y asíncrona para la elaboración de producciones colaborativas. Ello implicó también diseñar y organizar un entorno virtual flexible, la selección de contenidos relevantes y la priorización de herramientas que colaboren con los propósitos del curso.

Las diferentes actividades tuvieron como propósito problematizar las prácticas docentes y analizarla desde diversos aportes teóricos para posibilitar una apropiación significativa y crítica. Al retomar las planificaciones, programas y secuencias didácticas fue posible visibilizar sentidos y prácticas sobre la relación entre enseñanza y tecnologías. Así también, implicó abordar estrategias para fortalecer el vínculo pedagógico, un tema complejo considerando las diferentes situaciones que vivencian los estudiantes.

Las actividades llevadas a cabo por el equipo de tutores permitieron que los docentes pudieran contar con un docente que los acompañó, asesoró y atendió a sus consultas tanto para la comprensión de los temas como cuestiones de tipo tecnológico.

Los aportes realizados por especialistas e investigadores junto a las producciones elaboradas por los docentes contenidistas permitieron enriquecer el sentido de las tecnologías en la enseñanza. De esa manera, las temáticas del curso pudieron ser abordadas desde diferentes miradas, modos de entender los procesos de enseñanza y aprendizaje, la función de los recursos didácticos digitales y estrategias para la producción de contenidos.

El volver a las aulas no significa hacer lo mismo (Lion, 2020), seguramente se plantearán otros desafíos, inquietudes, incertidumbres e interrogantes, pero también, nuevas posibilidades para generar cambios significativos en las prácticas docentes.

\section{Referencias}

Asisten, G., Espiro, M., J. Asisten (2012) Construyendo la clase virtual. Métodos, estrategias y recursos tecnológicos para buenas prácticas docentes. Novedades Educativas.

Buckingham, D. (2008) Más allá de la tecnología. Bs, As, Manantial.

Cabero, J. Y Román, P. (2006) Actividades. Un referente básico para la formación en Internet . Editorial MAD Eduforma.

Jenkins, H. (2008) Convergence Culture. La cultura de la convergencia de los medios de comunicación. Paidós

Maggio, M. (2018). Reinventar la clase en la universidad. Paidós.

Lion, C (2017) "Tecnologías y aprendizaje: claves para repensar la escuela." En N., Montes. Comp., Educación y TIC de las políticas a las aulas. Buenos Aires. EUDEBA

Lion, C. (2020) Aprendizaje y Tecnologías. Novedades Educativas.

Maggio, M. (2012) Enriquecer la enseñanza. Los ambientes con alta disposición tecnológica como oportunidad. Paidós

Maggio, M (2018) Habilidades del siglo XXI. Cuando el futuro es hoy. Documento Básico. XIII Foro Latinoamericano de Educación. Fundación Santillana. Bs. As. 


\section{Instrucciones para que Fracase el Proceso Enseñanza-Aprendizaje en Modalidad Remota}

\section{Diz, Virginia}

Universidad Católica Argentina,

Facultad de Ingeniería y Ciencias Agrarias

virginiadiz@uca.edu.ar

\section{Fasoli, Héctor}

Universidad Católica Argentina,

Facultad de Ingeniería y Ciencias Agrarias

hector_fasoli@uca.edu.ar

\section{Tarzi, Olga}

Universidad Católica Argentina,

Facultad de Ingeniería y Ciencias Agrarias

olgatarzi@uca.edu.ar 


\title{
INSTRUCCIONES PARA QUE FRACASE EL PROCESO ENSEÑANZA-APRENDIZAJE EN MODALIDAD REMOTA
}

\author{
Diz, Virginia \\ Fasoli, Héctor \\ Tarzi, Olga
}

\section{Resumen}

La pandemia originada por el virus SARS-CoV2 (COVID-19) que se inició entre fines de 2019 y comienzos de 2020 puso a prueba a los sistemas educativos del mundo; en el caso de la Argentina, el inicio del aislamiento social preventivo y obligatorio (ASPO) coincidió prácticamente con el comienzo del ciclo lectivo.

Probablemente por primera vez la pedagogía práctica enfrentaba un desafío tan grande. La educación argentina en general y los docentes en particular se adaptaron rápida y eficientemente al uso de plataformas ya existentes, pero empleadas hasta entonces de manera focalizada y poco dinámica, por lo general con mínima interacción entre estudiantes y profesores. La tecnología pareció ser el eje central y se apuró a dar un nombre equivocado a esta diferente manera de enseñar. Pocos autores (entre ellos nosotros), sostuvieron desde el principio el error de llamarla enseñanza virtual y utilizó el de Enseñanza Remota Sincrónica y Asincrónica para diferenciarla tanto de la enseñanza presencial convencional como de la enseñanza a distancia. De hecho, actualmente se ha aceptado la denominación de Enseñanza Remota de Emergencia. En esta confusión entre los extremos, se ha acertado bastante y también se ha errado mucho. En este trabajo presentamos una lista de instrucciones de lo que hemos observado que no debe realizarse para que el proceso de enseñanza-aprendizaje por esta metodología no esté condenado al fracaso (el éxito, por ahora, sigue garantizado mayoritariamente por la habilidad y el esfuerzo de cada profesor y de cada estudiante).

\section{Palabras clave}

Pandemia, proceso enseñanza-aprendizaje, investigación cualitativa. 


\section{Introducción}

En cuestión de pocas horas, la educación argentina se vio conmocionada en sus bases por el cambio radical en la metodología de la enseñanza, obligado por la declaración de la pandemia de coronavirus (COVID-19) [Organización Mundial de la Salud, 2020]. El decreto que estableció el aislamiento social preventivo y obligatorio en la Argentina, ASPO, [Boletín Oficial, 2020] confinó en sus hogares a alumnos y profesores de todos los niveles de enseñanza. En general, la comunidad educativa reaccionó rápidamente: la comunicación a través de telefonía móvil, principalmente por redes sociales y Whatsapp fue la principal forma de contacto a distancia. La universidad fue cuidadosa en asegurar por un lado la enseñanza y por el otro los estándares comprometidos. La adopción de plataformas para videoconferencias requirió un esfuerzo técnico y económico enorme. La gran mayoría del personal docente se adaptó de manera rápida y eficiente al manejo de medios de comunicación con los que no estaba familiarizado. Cada facultad se alineó de manera comprometida con las indicaciones de la autoridad universitaria y la acción de comités de crisis establecidos para dar respuesta a las circunstancias; mencionamos, como ejemplos cercanos a los autores, a la Facultad de Ingeniería y Ciencias Agrarias de la Universidad Católica Argentina (UCA) y la Facultad de Ingeniería de la Universidad de Buenos Aires (UBA). Las circunstancias mostraban que la modalidad de enseñanza que debió adoptarse no podía denominarse a distancia ya que ésta tiene estándares muy precisos y diferentes a los aceptados para la enseñanza presencial y que están indicados en el marco normativo del sistema de educación a distancia de cada Universidad; algunos autores señalaron tempranamente esta circunstancia [Paredes Torrens, 2020]. Difundido a través de los medios de comunicación, se introdujo el término equivocado de "enseñanza virtual” [Medina Rivilla, Domínguez Garrido \& Sánchez Romero, 2011], propio de la jerga informática y que hasta comienzos de 2020 no estaba incorporado en el Diccionario de la Lengua Española [2020] ni en el Merrian-Webster Dictionary [2020]. Independientemente del uso de las palabras y de sus significados (a nuestro juicio, importantísimo), los aspectos instrumentales de la enseñanza remota o no presencial quedó en manos del profesor, la cara visible, determinante e interactuante con el estudiante, como ya se identificó hace casi dos décadas [Cebrián, 2003].

En ese esfuerzo enorme se ha acertado y se ha errado mucho. El objetivo de este trabajo es mostrar la notoria diferencia que existe entre enseñanza remota de emergencia (ERE), la enseñanza a distancia (ED) y la enseñanza presencial (EP). Para ello, presentamos una lista de procedimientos y conductas que se han aplicado o utilizado y que son propias de estas dos últimas modalidades de enseñanza, pero que no son útiles en la ERE. Para efectuar el trabajo realizamos un relevamiento de la experiencia de colegas y estudiantes de diferentes carreras y niveles educativos. Empleamos los métodos bien conocidos y descriptos de investigación cualitativa utilizados en las disciplinas antropológicas ("sociales") [Babbie, 2014], incluyendo la observación participante [Restrepo, 2018; Chevalier \& Buckles, 2013], y que nosotros mismos hemos empleado con anterioridad en estudios socio-ambientales [Fasoli et al., 2004; 2006].

A estas "instrucciones" -resultado de la experiencia de casi 18 meses de trabajo ininterrumpido- las consideramos claves para que el proceso de enseñanza-aprendizaje por esta metodología esté condenados al fracaso, ya que el éxito, por ahora, sigue garantizado mayoritariamente por la habilidad y el esfuerzo de cada profesor y de cada estudiante. 


\section{Método}

La parte descriptiva de este trabajo se realizó mediante evaluación cualitativa de observación de participantes [Chevalier \& Buckles, 2013], método que resulta útil en estudios de campo de diversas áreas antropológicas, como salud [Cardoso Gómez, M., Reyes-Audiffred,V., Meraz Rosas, M.A., Ostiguín Meléndez, M., 2018] y educación [Thompson, 2016]. Los participantes fueron principalmente colegas de diferentes facultades de universidades de gestión pública y privada (12 profesores de 7 facultades, incluidos los autores); así como profesores de educación media (4), primaria e inicial (3). Los estudiantes fueron todos de nivel universitario de una amplia variedad de carreras (ingeniería, ciencias exactas, filosofía y letras y psicología; en total, 27 entrevistados). La hipótesis de partida fue que es posible identificar procedimientos y conductas inadecuados para hacer eficiente el proceso de enseñanza-aprendizaje en modalidad remota. Del resultado de las entrevistas y la experiencia propia, cada uno de los autores identificó elaboró una lista de procedimientos y conductas que retrasaban o directamente anulaban el esfuerzo realizado mediante las actividades remotas sincrónicas y asincrónicas durante la ERE.

La metodología aplicada consiste en recopilar modos de comportamiento del alumnado y procedimientos de los docentes, en situación de enseñanza remota de emergencia; evaluar las consecuencias de las distintas estrategias utilizadas (muchas de ellas no por improvisadas son menos valiosas): por ejemplo, el costo-beneficio de digitalizar todos los contenidos que habitualmente se utilizan en forma presencial; elaborar formas de evaluar que manifiesten el esfuerzo individual del alumno y que sean representativos de los objetivos que se quieren lograr. Finalmente se comparan los resultados basados en la percepción de los colegas y estudiantes, pero que, aún en forma cualitativa, se sostienen en términos de: deserción del alumnado, frecuencia de consultas y nivel de aprobación de la materia con los que habitualmente se vienen obteniendo en la enseñanza de la misma disciplina en forma presencial, percepción del estudiante en cuanto a su desempeño en forma presencial y en modalidad remota. A partir de esa información cualitativa, mediante puesta en común de los autores, se elaboraron las listas de indicaciones que se presentan en cada sección.

\section{Desarrollo}

\section{Breve discusión semántica}

El Diccionario de la Lengua Española [Real Academia Española, 2020] incorporó recientemente una cuarta acepción al adjetivo virtual: 4. Inform. Que está ubicado o tiene lugar en línea, generalmente a través de internet. Tienda, campus, curso, encuentro virtual. Las tres acepciones hasta la Edición del Tricentenario son: 1. Que tiene virtud para producir un efecto, aunque no lo produce de presente, frecuentemente en oposición a efectivo o real; 2. Implícito, tácito; 3. Fís. Que tiene existencia aparente y no real. Es curioso: la acepción de la Física es la más alejada de la acepción informática de las tres. La polisemia lleva a confusión, especialmente aquí en que el significado del neologismo contradice al que es aceptado. Virtual, a nuestro juicio, puede acompañar al sustantivo aula, campus o al entorno general donde se enseña o se aprende, pero la enseñanza, definitivamente, no es virtual. Hablar de virtualidad genera una sensación de irrealidad que atenta -a nuestro juicio- contra la actitud de permanencia y existencia (estar aquí y ahora) que requiere el proceso 
enseñanza-aprendizaje. El oxímoron realidad-virtual ha sido discutido desde la filosofía [Fabris, 2009], y entra de manera subrepticia en el inconsciente de estudiantes y docentes. La enseñanza en modo remoto cuenta con la presencia de los actores del proceso educativo, en tiempo real, aunque no ocupando el mismo espacio físico. Esta limitación espacial, sin embargo, se subsana parcialmente con la comunicación visual (por eso la importancia de que todos los interlocutores estén con cámara encendida). Sin embargo, lo que no puede sustituir la enseñanza remota es el contacto visual entre los presentes, probablemente uno de los aspectos más importantes que se perdieron durante esta pandemia.

Por eso no se puede caer en la simpleza de contraponer virtual-real como se contrapusiera virtual-presencial. Ya discutimos la diferencia entre virtualidad y realidad como un obvio oxímoron. El sustantivo presencia puede, sin embargo, ser acompañado por el adjetivo virtual: evocar las palabras de un maestro, sentirse acompañado por un ser querido que está lejos o ya no está definitivamente, habla de la realidad de esas presencias virtuales que son pocos los que no las han experimentado.

\section{Instrucciones para fracasar en la enseñanza remota en pandemia}

La enseñanza remota de emergencia se caracterizó entre otras cosas porque el proceso de enseñanza-aprendizaje quedó claramente dividido por el medio de comunicación (esto es, principalmente, la videollamada). Si bien es claro que en el proceso tanto el estudiante como el docente tienen responsabilidades que se van potenciando con el intercambio personal cotidiano, en la ERE esas responsabilidades quedaron muy bien delimitadas, lo que nos permitió identificar con relativa facilidad los caminos del fracaso.

\section{Parte 1. Clase sincrónica}

1. No es necesaria, puede prescindirse de ella.

2. No reflexionar acerca de cómo adaptar los contenidos dados en la clase presencial.

3. No es necesario prepararse física ni espiritualmente para la clase. Los alumnos no notarán el desgano y la falta de motivación.

4. Transmitir decepción por el método de enseñanza improvisado y la convicción de que es inconducente e improductivo.

5. Si sabe de educación a distancia, iadelante! Esta modalidad es idéntica y no requiere adaptación alguna.

7. Mantener la cámara apagada: no es necesario establecer un vínculo docente-alumno.

8. Permitir que los estudiantes mantengan su cámara apagada: el lenguaje corporal y el brillo de los ojos no tienen ningún significado en la comunicación remota.

9. Hablar de manera monótona, sin matices, y rápida. Importa el qué, no el cómo.

10. No preguntar si los conceptos fueron claros o si necesitan hacer preguntas. 
12. Recomendar bibliografía inaccesible. O no recomendar ninguna.

13. Con hablar durante toda clase es suficiente. No utilizar otras herramientas.

14. No motivar el aprendizaje a través de preguntas, ejercicios o trabajo colaborativo.

15. No hacer un corte en la clase: es fácil mantener la concentración permanente.

16. Optar por la clase magistral: el aprendizaje está centrado en el docente.

17. Sermonear sistemáticamente sobre la importancia de no copiarse e integrarse (comportamientos ambos que el docente no puede manejar).

18. Generar incertidumbre e indefensión en los estudiantes, ocultando información sobre la forma de evaluar los contenidos

\section{Parte 2. Aula en entornos virtuales}

Los entornos virtuales son herramientas muy valiosas tanto para el que enseña como para el que aprende. Prácticamente todo el curso puede administrarse adecuadamente desde el aula asincrónica, lo que permite una interacción fluida y debidamente controlada de los contenidos, las ejercitaciones y las evaluaciones. Sin embargo, hay aspectos que, aplicados, conducen a un fracaso inevitable, por ejemplo:

1. No reflexionar de antemano acerca de los objetivos de aprendizaje, las estrategias de enseñanza necesarias y el diseño de actividades y evaluaciones.

2. No aprender a usar el aula virtual ni buscar información para hacerlo de manera eficiente: es lo mismo si la página del aula tiene o no una disposición clara, ordenada y amena.

3. Una secuencia didáctica que incluya las propuestas de aprendizaje, evaluaciones, bibliografía y un cronograma no es necesaria en absoluto.

6. No fomentar el uso de canales de comunicación como los foros.

7. Cargar todo el material de una vez: combinado con la ausencia de cronograma generará el caos adecuado para garantizar la inutilidad del aula.

8. No mantener informados a los estudiantes de las actualizaciones realizadas o del material cargado recientemente: hacer recaer en ellos todas las responsabilidades del seguimiento del curso.

9. No revisar las tareas que entregan los estudiantes ni realizar la retroalimentación correspondiente: las entregas son obligatorias, señalar las dificultades es optativo.

10. No responder consultas en los foros ni por correo electrónico. O si se responden, hacerlo cuando ya se esté trabajando en otro tema: el caos es parte del aprendizaje.

11. No discutir en forma general las consultas individuales que puedan resultar interesantes para comentar a todo el curso: en la enseñanza también la información es poder. 
12. No explicitar los criterios de evaluación ni de calificación: el alumno no tiene por qué conocer qué se espera de él.

13. Las evaluaciones son irrelevantes. No dedicar tiempo a elaborarlas: tomar ejercicios escritos igual que en una evaluación presencial, o preguntas de opción múltiple con solo dos opciones (ver 14).

14. Complicar hasta el infinito las evaluaciones por opción múltiple: dar a optar por más de seis posibilidades, usar redacción capciosa, varias respuestas similares donde la diferencia sea casi imperceptible y dudosa.

15. Centrar la preocupación de la evaluación por evitar la copia.

\section{Instrucciones para fracasar en el aprendizaje en forma remota}

Aprender a través de una plataforma de videollamadas no es una trivialidad a la que se asiste cómodamente desde un sitio de confort no solo espiritual sino también material, como ser la seguridad de nuestro hogar. Las demandas que requiere el aprovechamiento de la enseñanza son más de las que podría pensarse sin dedicarle unos momentos a la reflexión sobre el asunto. Las siguientes son las instrucciones que invariablemente, combinadas adecuadamente, conducirán a que el grado de comprensión o aprendizaje profundo sea bajo o nulo:

\section{Parte 1. Clase sincrónica}

1. Adoptar una actitud pasiva: todo depende del profesor. No es necesario ver ni trabajar sobre el material del tema a tratarse antes de la clase.

2. No prepararse para la clase. No importa desde donde asistir a ella.

3. No cuidar las formas: utilizar el celular durante la clase, navegar por internet, etc.

4. No activar la cámara: no es importante para establecer la comunicación con nadie.

5. No apagar el micrófono. Ni habilitarlo para intervenir en clase.

6. Ante posibles distracciones, interrumpir y preguntar: el prójimo no importa.

7. Insistir en que todas las clases sean grabadas. Importa el qué, no el cómo ni cuándo.

8. Conectarse a la clase con la computadora, pero no estar presente.

9. No participar en absoluto de la clase, aun cuando las dudas sean relevantes

10. Desviar continuamente la atención hacia temas relacionados con la evaluación.

11. Si hay clases de consultas, ir para ver de qué se habla, o para "captar" información para los exámenes: lo importante no es saber sino aprobar. 


\section{Parte 2. Aula en entornos virtuales}

Contrariamente a lo que suele creerse y difundirse a través de los medios, los docentes se adaptaron mucho más rápidamente a la nueva forma de enseñanza que los estudiantes, a los que se da por sentado como expertos en comunicación digital; a pesar de que recientemente surgieron voces de alerta sobre los riesgos que corren os más jóvenes frente al dominio de las redes sociales, se sigue subestimando la capacidad de los docentes [Braginski, 2020]. La realidad nos muestra que la adaptación de los estudiantes universitarios no fue tan entusiasta como se esperaba y que sus profesores debieron actualizarlos en el uso de algunas aplicaciones (en nuestro caso Doodle, Teams y Meet). Las actitudes del estudiante en el aula virtual, que condenan al fracaso el proceso de enseñanza-aprendizaje son:

1. Estudiar en línea: no descargar ningún material del campus. Con suerte permanecerá allí hasta que se pueda rendir el examen final, y después de aprobada la asignatura, todo material es inservible.

2. No familiarizarse con el entorno virtual, aula ni su contenido cuando comienza el curso.

4. No consultar el cronograma, no leer el reglamento de la asignatura ni averiguar desde el comienzo las fechas de los exámenes.

3. Revisar las novedades en el aula del campus digital no tiene sentido. Es más sencillo preguntarles a los compañeros.

4. No participar de los foros, no realizar las actividades propuestas por el docente ni entregarlas en el plazo solicitado.

5. No realizar actividades optativas, total, ¿no son opcionales?

6. No atender los mensajes de novedades que llegan regularmente a través del correo del campus digital.

7. Utilizar únicamente apuntes cargados en el campus, o enciclopedias digitales sin verificar las fuentes originales. No emplear la abundante bibliografía digital (e-books) con la que cuentan muchas instituciones.

\section{Resultados}

La experiencia recogida en casi dieciocho meses de trabajo ininterrumpido, casi sin períodos de receso por superposición de fechas de exámenes con la cursada, o desplazamiento de fechas entre dos instituciones, lleva a opiniones muy coincidentes entre colegas: las malas prácticas descriptas en este trabajo, combinadas en mayor o menor proporción, conducen a que el proceso de enseñanza-aprendizaje se resienta profundamente. Quienes de manera intuitiva o por experiencia comprendieron que la situación de enseñanza presentada de forma tan repentina debía encararse con nuevos paradigmas, alejados de la enseñanza presencial tradicional y de la enseñanza distancia tal como se comprende actualmente, rápidamente pudieron estabilizar un formato de enseñanza que, sustancialmente, debía estar centrada en 
el estudiante pero que tenía al docente como protagonista clave, dotando al proceso de una presencia que trascendiera su presencia física.

En la experiencia de los autores, empleando niveles de exigencia similares a la enseñanza presencial, en las materias de química básica de la UCA (donde los tres comparten las mismas asignaturas) se lograron índices de aprobación similares a los conseguidos en 2019 (ca. 80\%). La deserción fue ligeramente superior (8 \% contra $5 \%$ ) y la reinscripción en el cuatrimestre siguiente de los estudiantes que abandonaron la asignatura fue superior durante la ERE ( 8 de cada 10 contra 4 de cada 10).

De manera infrecuente, se recibieron numerosos mensajes de agradecimiento de los estudiantes por los esfuerzos realizados por sus docentes (contabilizamos medio centenar entre dos cursos cuatrimestrales con aproximadamente 60 estudiantes cada uno (primeros cuatrimestres de 2020 y 2021, Química General e Inorgánica, UCA). Las muestras de reconocimiento de los estudiantes sorprendieron también a colegas de otras instituciones, aunque no disponemos de evaluación cuantitativa (ni hace falta, ya que el "efecto sorpresa" aportó un significativo elemento cualitativo). Todos los entrevistados, estudiantes y profesores manifestaron un manifiesto agotamiento físico y mental frente a las prolongadas y múltiples obligaciones adquiridas, donde muchas veces fue difícil poner límites para la atención de consultas y la corrección de actividades. La sobrecarga de material también fue un reclamo reiterado de los estudiantes, frente a docentes que no podían o no sabían poner límites a la información puesta a disposición en los campus digitales.

\section{Discusión y conclusiones}

La prolongada situación de aislamiento aceleró el empleo de recursos que debieron ponerse en práctica anteriormente. No parece caber duda, al menos para muchos, que esta forma de enseñar y aprender, al menos parcialmente, vino para quedarse y que puede ser aprovechada para beneficio de todos los niveles educativos. [Mangisch, 2021]

Haciendo un sutil equilibrio entre lo conocido y lo desconocido, entre la educación formal y la informal, la enseñanza presencial y a distancia, la comunicación con horarios fijos y la conexión casi continua, docentes y estudiantes respondieron rápidamente y de la mejor manera posible al desafío de enseñar y aprender en situaciones de emergencia. Queda mucho por hacer y saber qué no hacer es el punto de partida para mejorar: este trabajo consiguió ese objetivo a través del diálogo continuo con colegas y estudiantes, que trabajaron con modestia, seriedad, entusiasmo y - por qué no - sentido del humor para enfrentar una situación imprevista e inusitadamente prolongada.

\section{Referencias}

Babbie, E. (2020). The basics of social research. Wadsworth Cengage Lerning: Belmont, Calif. 542 pp.

Boletín Oficial de la República Argentina. (19 de marzo de 2020). Decreto 297/2020. Obtenido de https://www.boletinoficial.gob.ar/detalleAviso/ primera/227042/20200320 
Bragisnki, R (2020). Preocupa la forma en que los chicos se vinculan en Internet y lanzan un programa para formar a los maestros. Clarín, 20/9/20; recuperado de: https://www.clarin.com/sociedad/preocupa-forma-chicos-vinculan-internet-lanzan-programa-formar-maestros_o_ecMmGkYvx.html

Cardoso Gómez, M., Reyes-Audiffred,V., Meraz Rosas, M.A., Ostiguín Meléndez, M. (2018). Evaluación Cualitativa: una alternativa para la praxis de la enfermería. Revista de enfermería y humanidades, XII(51), 160-168. Recuperado de https://rua.ua.es/ dspace/bitstream/10045/77598/1/CultCuid_51_18.pdf

Cebrián de la Serna, M. (2003). La Enseñanza virtual para la innovación Universitaria. Narcea, Narcea: Madrid, 196 pp.

Chevalier, J. ; Buckles, (2013). Participatory action research : theory and practice for engaged inquiry. Routledge: New York, 496pp.

Fabris, A. (2009). Los sentidos de lo virtual (o sea: la realidad como límite), Eikasia. Revista de Filosofía, IV (24) pp. 5-1 a 5-11. Recuperado de: http://www.revistadefilosofia.org

Fasoli, H. et al. (2004). Propuesta de Plan de Manejo, Puerto Bonito, Epuyén. Informe para la Municipalidad de Epuyén, provincia de Chubut. Programa de Investigación Geográfico Político Patagónico, Universidad Católica Argentina. 45pp.

Fasoli, H. et al (2006). Análisis físico-químicos y aspectos sociales del agua de consumo en la ciudad de San Miguel, prov. de Buenos Aires. Informe presentado a legisladores del H. Conceso Deliberante del Municipio de General Sarmiento. PIGPP/UCA, julio, 95pp.

Mangisch, G. (2021). El desafío de la inclusión digital. Perfil, 08/05/21, recuperado de: https://www.perfil.com/noticias/opinion/el-desafio-de-la inclusion-digital.phtml

Medina Rivilla A., Domínguez Garrido M. C y Sánchez Romero C. (2011). La comunicación didáctica en la tutoría virtual. ETD - Educ. Tem. Dig., (12), 12-30. Recuperado de https://doi.org/10.20396/etd.v12i0.1201

Merrian-Webster Dictionary (2020). Recuperado de https://www.merriam-webster. com/dictionary/virtual.

Organización Mundial de la Salud. (20 de marzo de 2020). Brote de enfermedad por coronavirus (COVID-19). Recuperado de https://www.who.int/es/emergencies/ diseases/novel-coronavirus-2019

Paredes Torrens, J. No es educación a distancia, no es enseñanza virtual. Interfase educativa, publicado el 5/4/20; recuperado de: http://interfase-educativa.blogspot. com/2020/04/

Real Academia Española (2020). Diccionario de la Lengua Española, Recuperado de: https://dle.rae.es/virtual.

Restrepo, E. (2018). Etnografía:alcances, técnicas y éticas. Fondo editorial de la Universidad Nacional Mayor de San Marcos: Lima, 56pp. 


\section{Realidad Aumentada como Tecnología Disruptiva para la Educación de Química Orgánica}

\section{Bustillo, Mario}

Facultad de Ingeniería, Universidad Nacional de Cuyo.

Mendoza, Argentina.

mabustillo02@gmail.com

\section{Ferrer, Liliana}

Facultad de Ingeniería, Universidad Nacional de Cuyo.

Mendoza, Argentina.

liliana.ferrer@ingenieria.uncuyo.edu.ar 


\title{
REALIDAD AUMENTADA COMO TECNOLOGÍA DISRUPTIVA PARA LA EDUCACIÓN DE QUÍMICA ORGÁNICA
}

\author{
Bustillo, Mario \\ Ferrer, Liliana
}

\section{Resumen}

La Realidad Aumentada (RA) es una prometedora tecnología disruptiva que puede ayudar a mejorar la comprensión y apropiación de conocimientos de Química. La implementación de esta tecnología es una oportunidad para innovar en las metodologías didácticas respecto a la enseñanza tradicional, con el objetivo de facilitar el proceso de aprendizaje y enseñanza del estudio de las estructuras de moléculas químicas. Entorno a la aplicación de la tecnología de Realidad Aumentada enfocada a la química, se plantea AUMENTED, una plataforma educativa desarrollada para el dictado de la clase de Química Orgánica, la cual permite la visualización de estructuras tridimensionales de moléculas químicas. Mediante el proyecto se pretende la incorporación de estas nuevas Tecnologías de Información y Comunicación (TIC) con la finalidad de mantener la atención del estudiante y lograr un aprendizaje de acuerdo con el contexto tecnológico y social en el que vive, ya que pertenece a una generación que está en contacto permanente con dispositivos digitales. La valoración de los estudiantes que cursaron la asignatura, muestra que la misma contribuyó a generar mayor interés por la asignatura y mejorar la comprensión de los contenidos. La intervención del material educativo basado en estas tecnologías, contribuye de manera significativa en el aprendizaje de la configuración de moléculas básicas de la química orgánica, que no son perceptibles a simple vista para los estudiantes. Se destaca también que el uso de dispositivos móviles durante las clases representa una tendencia novedosa, capaz de captar la atención del público joven.

\section{Palabras clave}

Realidad Aumentada, Innovación Pedagógica, Tecnología de Información y Comunicación (TIC), Química Orgánica. 


\section{Introducción}

Las tecnologías han tenido un impacto significativo en la sociedad de hoy en día, ha cambiado la forma en la que pensamos, sentimos, actuamos, y cómo nos comunicamos e interactuamos entre nosotros. Además, los avances tecnológicos están cambiando muy rápido las formas en que aprendemos y enseñamos. (Correa, 2021).

Una de las preocupaciones que han surgido en los últimos años en la educación de las ciencias tiene que ver con la dificultad que se genera en el estudiante para entender, comprender y relacionar los temas desarrollados en el aula de clase con su aplicabilidad en el diario vivir, ya que la ciencia que se enseña necesita acercarse a las demandas y necesidades de los estudiantes en el mundo contemporáneo.

Posiblemente las estrategias didácticas utilizadas por el docente no incluyen situaciones que acerquen al educando a su contexto social, ocasionando que los aprendizajes en el aula se manifiesten de manera repetitiva y memorística causando el rechazo hacia el trabajo científico y el aprendizaje de manera significativa de los conceptos químicos.

La Química, a su vez, es considerada como una ciencia compleja, se encuentra ligada a la representación continua de diversas estructuras que permitan un adelanto en la comprensión de conceptos y definiciones (Cerillo, 2020). Por esto, se requiere perfeccionar e implementar tecnologías al proceso de diseño mental en el cual el estudiante puede representar los procesos y cambios químicos de manera práctica y con mayor realidad. Es aquí donde surge la necesidad de implementar las nuevas Tecnologías de Información y Comunicación (TIC) a diferentes sectores (como el educativo), para responder a las necesidades que determina la población en la actualidad.

Hoy en día existe una tecnología, que hace posible definir una visión del mundo digital directa o indirecta en el mundo real, es la Realidad Aumentada (RA), que es un medio interactivo que añade objetos virtuales a la realidad del usuario, a través de una cámara y observado por medio de la pantalla de la computadora, permitiendo ampliar información de un tema específico (Ramos ,2015). Esta tecnología hace uso de los recursos que brindan las TIC, las cuales permiten crear contenidos educativos capaces de apoyar el proceso docente durante la formación académica. De manera que aplicada a una secuencia de enseñanza y aprendizaje, propone la manipulación, interacción e integración de formatos de información tridimensional; que permite una mejor conexión entre los aspectos teóricos y la experiencia práctica que guía un proceso de transformación de fenómenos científicos.

Al implementar las TIC en el contexto pedagógico, las cuales son estructuras organizadas y diseñadas por equipos multidisciplinarios; se pueden usar las ventajas que brinda la RA para captar la atención del público al cual va dirigida la enseñanza y mejorar el acercamiento de los jóvenes a la construcción de un pensamiento científico y, sobre todo, la formación universitaria hacia las ciencias duras en un contexto de innovación tecnológica educativa. No obstante, es evidente el crecimiento que han tenido estas tecnologías de manera que han permitido realizar gran variedad de aplicaciones digitales, muchas de estas herramientas enfocadas a la educación, Ilegando a facilitar la interacción con los estudiantes creando totalmente un ambiente de aprendizaje. 
Tal como expresa Cerillo (2020), la enseñanza de la química enfrenta una serie de retos como la evaluación educativa y la didáctica. Dentro de esta última, se localizan las acciones prácticas, las cuales van de los contenidos a la praxis del estudiante. Estas actividades fenomenológicas recaen, principalmente, en ejercicios prácticos y experiencias. Es aquí donde la RA podría mejorar el acercamiento de los jóvenes a la construcción de un pensamiento científico y, sobre todo, la formación universitaria hacia las ciencias duras en un contexto de innovación tecnológica educativa, sin olvidar el enfoque científico del proyecto hacia las carreras de Ingeniería.

Así como menciona Merino (2014), se presenta la oportunidad para innovar e investigar en la enseñanza de la Química con RA. Al implementar estrategias de secuencias de enseñanza y aprendizaje con RA, se inició con la reproducción del esquema clásico que moviliza a la investigación científica: identificar un problema e intentar resolverlo.

Mediante la intervención de este material educativo apoyado por la RA, se motiva a los estudiantes a involucrarse de una manera más profunda con las tareas, conceptos y recursos estudiados a través del uso de superposiciones de información, permitiendo establecer conexiones más significativas y duraderas en lo que al conocimiento se refiere.

Utilizar estas nuevas tecnologías para la formación puede aumentar la motivación en el aprendizaje, favorecer la interacción, aumentar la creatividad del estudiante y favorecer una comunicación bidireccional, ya que la comunicación entre alumno y profesor es más fluida (Correa, 2021). Por otra parte, no debemos olvidar que su uso propicia la contextualización de los conceptos al facilitar el conocimiento de la realidad.

Para acceder al uso de esta tecnología, es necesario disponer de diferentes elementos:

- Dispositivo con cámara; PC u ordenador portátil con webcam (netbook, notebook), Tablet o Smartphone.

- Un software encargado de hacer las transformaciones necesarias para facilitar la información adicional.

- Un disparador, conocido también como "trigger" o activador de la información; imagen o entorno físico (paisaje, espacio urbano, medio observado), marcador, objeto o Código QR.

El objetivo general del proyecto es diseñar y desarrollar una plataforma basada en tecnologías de RA, para contribuir de manera significativa en el aprendizaje de las estructuras químicas de algunas moléculas de interés en el dictado de la clase de Química Orgánica, así como innovar en las metodologías de enseñanza y aprendizaje durante el dictado de la clase.

\section{Método de la experiencia}

El proyecto surge a partir de la necesidad de implementar estrategias y herramientas TIC en la cátedra de Química Orgánica de la Facultad de Ingeniería de la Universidad Nacional de Cuyo, en el marco del proyecto "Implementación del uso de las 
TIC en el proceso enseñanza aprendizaje de la Química Orgánica” (segunda parte). Esto con la finalidad de mejorar el trabajo individual, la autonomía del alumnado, y la posibilidad de modificar y adaptar los métodos de evaluación para mejorar la calidad de la enseñanza.

En el proceso de aprendizaje y enseñanza de la Química Orgánica, se comprobó que los estudiantes presentaban dificultad con ciertos temas básicos que son fundamentales para poder llevar la continuidad de la materia. Uno de los problemas detectados fue la complicada visualización o imaginación de las estructuras químicas de las moléculas, es por ello que surge la iniciativa de plantear una solución para que este problema se atienda desde el principio. De manera que el estudiante alcance de manera sinérgica una mejor continuidad de la materia.

En la primera etapa del proyecto de investigación "Uso de las TIC como apoyo al proceso de enseñanza-aprendizaje de Química Orgánica", realizado en la Facultad de Ingeniería, Universidad Nacional de Cuyo; se llevó a cabo la recolección de datos, a través de sondeos a estudiantes y recopilación de información de las distintas herramientas disponibles para incorporar a la clase. En base a las encuestas realizadas, surgió la necesidad de buscar una nueva metodología, a partir de herramientas didácticas que incluyeran el uso de dispositivos digitales, de manera que usen el celular en clase y les genere más entusiasmo a los estudiantes.

Por lo expuesto, surge la idea de diseñar, desarrollar e implementar una plataforma educativa apoyada en la tecnología de RA, que permita enseñar conceptos de la Química Orgánica de forma novedosa, simple y entretenida. Lo que se busca es mejorar la motivación, estimulación e interés de los estudiantes a adquirir conocimiento, y profundizar en conceptos y teorías más avanzadas de la materia, por ello se plantea AUMENTED - Realidad Aumentada.

AUMENTED es una plataforma educativa basada en la tecnología de RA, que incluye los conceptos teóricos y pedagógicos necesarios para ser utilizada en el nivel educativo correspondiente. La plataforma permite la visualización de moléculas de Química Orgánica mediante el uso de RA.

Al igual que Ramos (2015), el proyecto incorpora las tecnologías de RA en el campo educativo, ofreciendo un valor agregado que permite generar y captar el interés por parte de los estudiantes hacia las áreas del saber, de esta forma las asignaturas en las cuales un estudiante tenga dificultades de aprendizaje, se tornarán interactivas, facilitando así la comprensión y aprendizaje de un tema particular.

A partir de estos aspectos, el enfoque del trabajo es destinado al proceso de diseño e implementación de tecnologías disruptivas enfocadas a la enseñanza de la Química enriquecidas con el uso de la RA, destinado al desarrollo del proceso de aprendizaje en la Química dirigido a las carreras de Ingeniería.

\section{Implementación de Realidad Aumentada}

En la enseñanza de la Química universitaria son comúnmente empleados los programas de modelación molecular y las bases de datos. Por otra parte, se encuentran relativamente pocas aplicaciones de la RA en la enseñanza de la Química en comparación con otras áreas del conocimiento. Quizás esto último se deba a que resulta 
poco visible, en la bibliografía revisada, un vínculo entre lo ampliamente conocido (programas de modelación molecular y las bases de datos) y la tecnología de RA a pesar de las ventajas demostradas en otras áreas. (Martinez-Hung, 2017).

Luego de una serie de pruebas con distintas plataformas existentes en el momento, las cuales permitían el uso de RA, se decidió crear una plataforma que incluyera los modelos tridimensionales de las moléculas químicas orgánicas que puedan representarse empleando la RA. El tipo de plataforma desarrollada es de estilo WebAR, que consiste en un navegador web que da acceso a la RA.

La integración de este tipo de plataforma fue un desafío y una oportunidad que permitió presentar al estudiante contenidos altamente interactivos que responden a sus expectativas y necesidades con el fin de que puedan interpretar los contenidos, relacionarlos con el mundo real y evolucionar de la visualización y uso de información desde contextos en 2D (p. ej. Libros de texto) hacia uno de 3D (p. ej. Manipulación, interacción, perspectiva, complejidad, integración, etc.), construyendo así puentes entre la teoría y la experiencia práctica (modelización). (Merino, 2014).

\section{Arquitectura de la plataforma de Realidad Aumentada}

La integración entre el mundo real (físico) y el mundo virtual es el objetivo principal de la tecnología de RA. Para el desarrollo de la plataforma de RA se implementaron los softwares de open source AR.js y A-FRAME, los cuales son los que permiten la visualización de la RA de las moléculas. Estos softwares tienen la ventaja de su versatilidad para funcionar y ser compatible en gran mayoría de navegadores web y sus versiones.

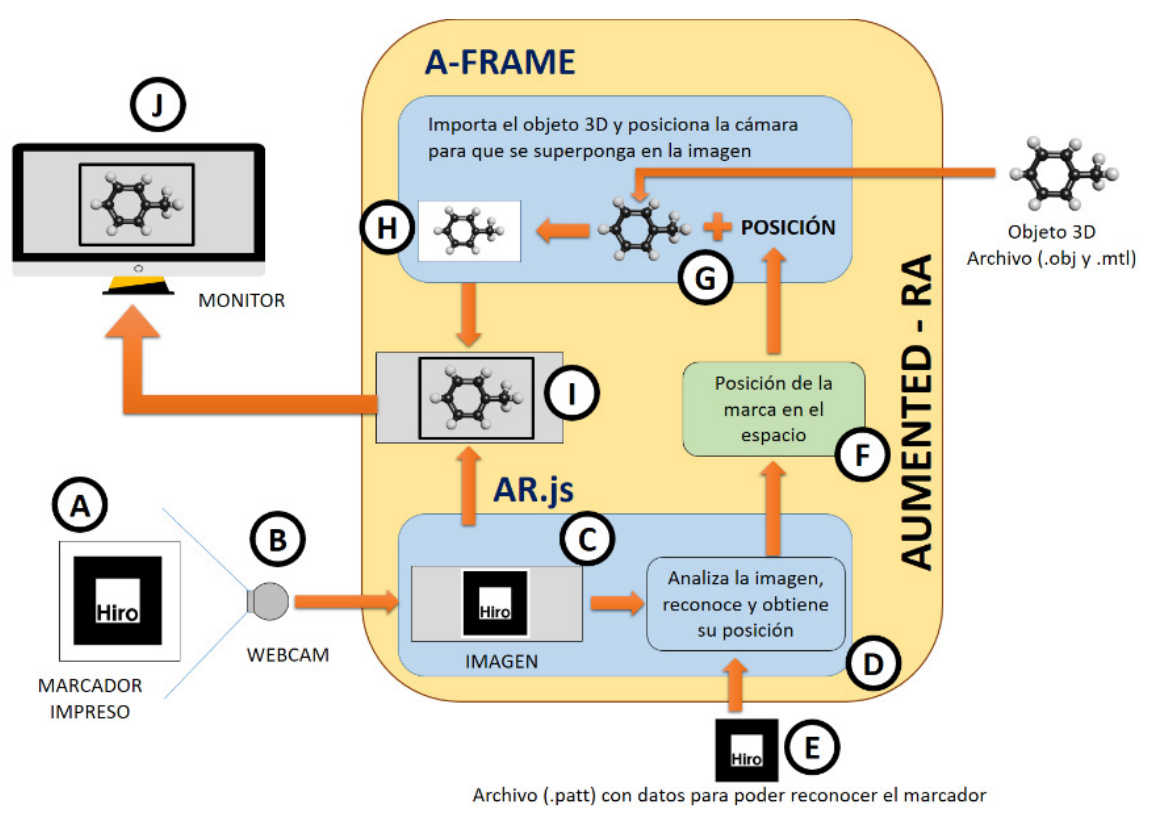

Figura 1: Arquitectura de la plataforma de AUMENTED.

Así, para que la RA pueda reproducirse, el flujo de procesos que se ejecutan (ver figura 1) son los siguientes: 
1. Se parte de un marcador, el cual es una imagen en la que se superpondrá el objeto 3D cuando sea reconocido por el software de RA (Figura 1-A). Esta imagen funciona como referencia para la interpretación y creación del objeto virtual.

2. La cámara web del dispositivo toma una imagen. (Figura 1-B).

3. La imagen captada es leída por el software de AR.js (Figura 1-C).

4. El software de AR.js analiza la imagen para obtener los puntos clave visuales (contraste, la cantidad de líneas, los cambios de textura, etc.) en busca de posibles marcas captadas en el marcador. (Figura 1-D).

5. Si encuentra una marca, la compara con las del marcador para ver si es una de las marcas que busca. Las marcas del marcador son un archivo con formato .patt, que se obtuvo cuando se creó el marcador. (Figura 1-E).

6. Si la marca coincide con el marcador, obtiene su posición (X, Y, Z) y Rotación. Guarda la posición en una variable. (Figura 1-F).

7. A-FRAME importa el objeto 3D (archivo .obj y .mtl) (Figura 1-G).

8. A-FRAME coloca la cámara virtual según la posición anteriormente guardada (Figura 1-H). Se superpone la imagen digital que se crea a partir de un modelo 3D sobre la imagen de la cámara y el objeto se posiciona sobre la marca del marcador. (Figura 1-I).

9. La imagen que se muestra en el dispositivo móvil es la unión de la imagen virtual y el modelo 3D. (Figura 1-J).

El resultado de este proceso, es la plataforma de AUMENTED, que devuelve los modelos tridimensionales de las estructuras químicas de las moléculas a través de una pantalla mediante el uso de RA (Figura 2).

A)
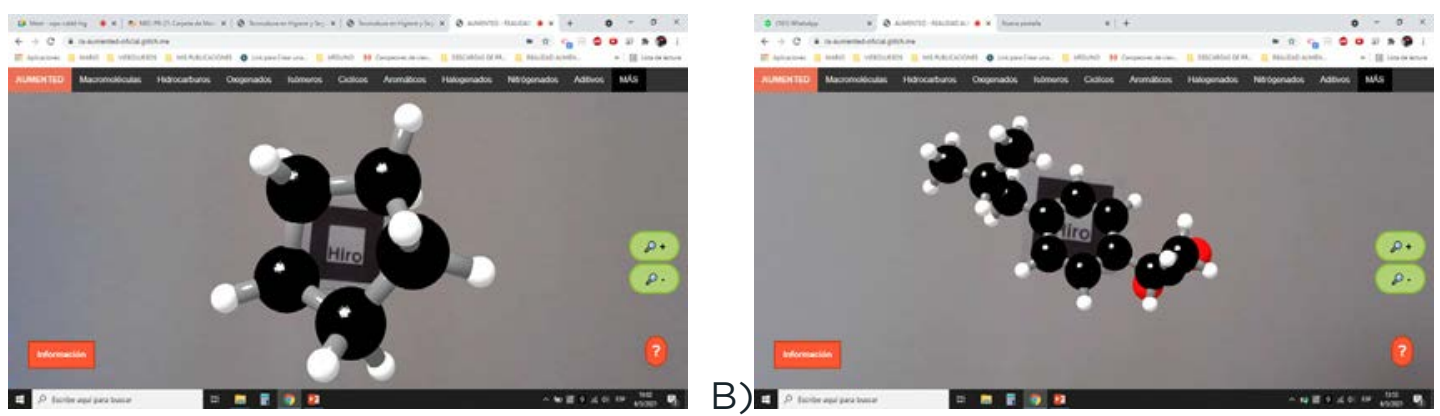

Figura 2: Visualización de moléculas con la plataforma de AUMENTED.

A) Ciclopentano. B) Ibuprofeno.

El proceso por el que se produce la RA es bastante sencillo de entender y está integrado por los elementos descritos en el apartado anterior. Al disponer de un dispositivo con acceso a la plataforma de AUMETED, el primer paso sería ingresar a la plataforma web en cuestión. Luego, enfocar con la cámara del dispositivo la realidad física sobre la que queremos obtener la información adicional y capturarla. 
Es decir, enfocar al marcador disparador de la plataforma, ejecuta la RA. De forma inmediata y tras la transformación de los datos por parte del software de la plataforma, la pantalla del dispositivo mostrará la información adicional que conlleva asociada la realidad que ha sido capturada por la cámara.

De esta manera, para la interacción con la plataforma web no se requiere instalar ninguna aplicación o programa adicional para su uso. Además, posee una interfaz de sencilla compresión e intuitiva para el usuario.

\section{Procedimiento para el desarrollo e implementación de experiencia incorporando Realidad Aumentada}

La ejecución e implementación del trabajo de investigación se dividió en seis fases:

1. Selección de los temas y tipología de las clases donde se aplicará la RA.

2. Selección de los objetos a representar.

3. Construcción de los objetos tridimensionales y conversión a la plataforma de RA.

4. Instrucción y tutoría de la plataforma de Realidad Aumentada.

5. Aplicación de la realidad aumentada en el proceso docente.

6. Validación de la aplicación mediante encuesta a los estudiantes.

En la primera fase, se seleccionó como grupo muestra a todos los estudiantes de segundo año de Ingeniería Industrial e Ingeniería en Petróleos de la Facultad de Ingeniería, de la Universidad Nacional de Cuyo. Quienes cursaron la materia de Química Orgánica, dictada en el segundo semestre durante el año electivo 2020 y 2021.

Mientras tanto, en la segunda fase se comenzó con una revisión del programa del dictado de la clase. La asignatura consta de cinco unidades temáticas; los grupos funcionales y macromoléculas. De estos temas, se escogieron las moléculas representativas de interés de la clase pertenecientes a cada tema y se realizaron los modelos tridimensionales. Principalmente se seleccionaron moléculas de los grupos funcionales por considerarse que la comprensión de las estructuras y los conceptos estudiados, se vería favorecida con el empleo de la tecnología de RA. Los temas teóricos-prácticos tratados fueron:

1. Hidrocarburos. Compuestos Aromáticos.

2. Compuestos Oxigenados.

3. Compuestos Halogenados.

4. Compuestos Nitrogenados.

5. Macromoléculas. Polímeros. Lípidos. Aminoácidos. Carbohidratos. 
Luego, en la tercera etapa para la creación de los modelos tridimensionales, se parte de la representación estructural de cada molécula (figura 3-A). Estas representaciones se ingresan al programa Chem3D v17.0 para obtener un modelo tridimensional de la molécula, de manera que se obtiene un archivo con formato Protein Data Bank (.PDB) (figura 3-B). Luego se importa este archivo al programa Blender v2.82 para convertir el formato del archivo y obtenerlo en formato OBJ (.obj) y MTL (.mtl). Posteriormente se suben ambos archivos (.obj y . $\mathrm{mtl}$ ) al repositorio de modelos de las moléculas químicas de la plataforma y se añaden las líneas de código correspondientes al código de la plataforma. Una vez realizado esto, se obtiene un modelo tridimensional de la molécula que se logra visualizar mediante la tecnología de RA en la plataforma de AUMENTED (figura 3-C). Este proceso se repitió con cada molécula.

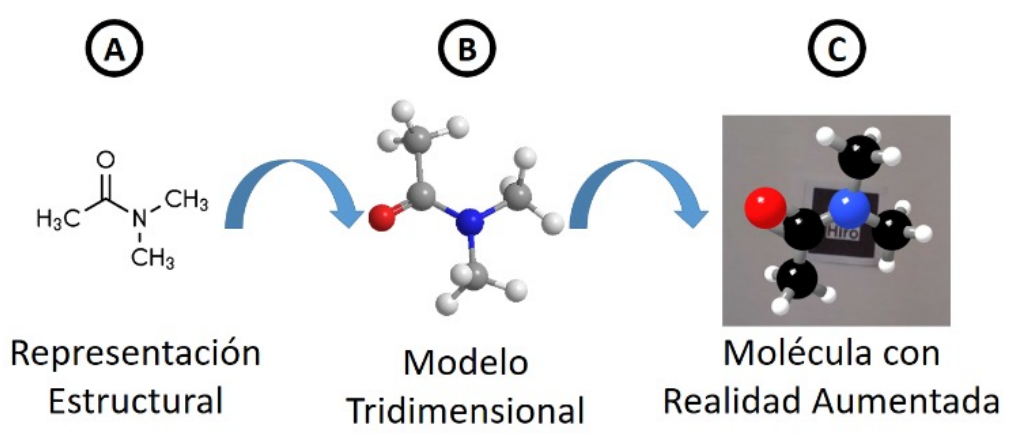

Figura 3: Secuencia de pasos para la incorporación de una molécula a la plataforma de AUMENTED. Molécula de Dimetilacetamida.

Sin embargo, en la mayoría de los casos fue necesario superponerles elementos construidos en el programa Blender, que representan aromaticidad y enlaces múltiples, los cuales se pierden en el proceso de conversión de formatos de archivos. Esta metodología es extensible a otras fuentes de modelos moleculares, ya que los softwares de código abierto permiten archivos con formato OBJ (.obj) y GLTF (.gltf). Además pueden ser usados otros programas de diseño gráfico tridimensional similares a Blender.

En la cuarta fase, previo a la implementación de la plataforma de Realidad Aumentada en el dictado de la clase, se entrenó al equipo de la cátedra de Química Orgánica sobre el uso de la plataforma. Luego, durante el comienzo del cursado, los estudiantes fueron instruidos sobre el uso de la plataforma de AUMENTED, la cual fue empleada como gestor de la tecnología de RA. También se les explicó el objetivo del proyecto y los elementos básicos a considerar en el diseño de los insumos digitales. Se les da a conocer una nueva aplicación de la RA en escenarios formativos y sus posibilidades pedagógicas en contextos educativos.

Durante la quinta fase, a lo largo del cursado como parte de la metodología de evaluación continua, se propusieron actividades evaluativas dentro de los trabajos prácticos. Se les pidió a los estudiantes realizar un video sobre Hidrocarburos para englobar todos los conocimientos que habían adquirido hasta el momento. Para la elaboración del video debieron seleccionar un compuesto del grupo funcional alqueno que se encontrara disponible en la plataforma de AUMENTED y debían mencionar su nombre según la IUPAC; su isomería (cis - trans o Z - E); sus propiedades físicas como su 
punto de ebullición, punto de fusión, solubilidad; sus propiedades química y proponer una reacción característica del compuesto y dar la ecuación química correspondiente. Además comentar lo aprendido sobre la misma, por ejemplo el tipo de reacción, condiciones en las que se lleva a cabo, nombre de los productos, cuál/es y por qué es/ son producto/s principal/es etc. Así como la estructura en 3D de la molécula. El video, además, debía contener la voz de los participantes como parte de su explicación.
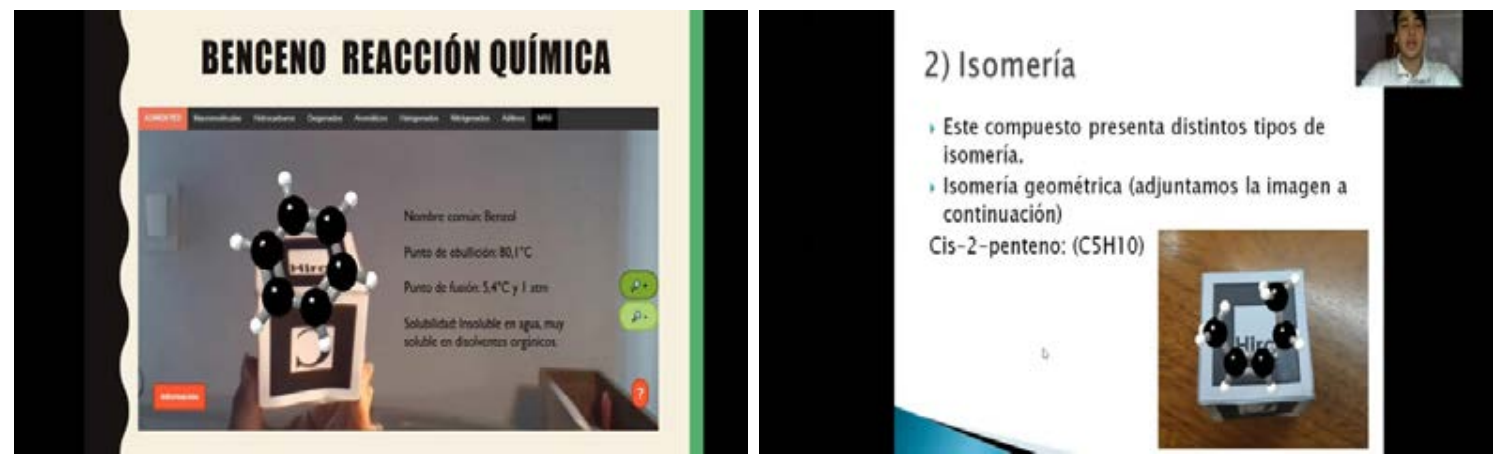

Figura 4: Carátulas de trabajos finales presentados por los estudiantes utilizando la plataforma de AUMENTED (Año electivo 2021).

Asimismo, se incluyeron pequeñas actividades evaluativas donde los estudiantes a partir de la estructura tridimensional debían escribir su fórmula molecular; identificar si la molécula presenta isomería de cadena, posición y/o función; escribir al menos un isómero de cada tipo encontrado y nombrarlos respectivamente. En la Figura 4 se muestran algunas carátulas de los trabajos presentados por los estudiantes.

Finalmente, en la fase de evaluación y validación del proyecto, al finalizar el cursado se aplicó una encuesta de satisfacción de las tecnologías implementadas durante el cursado en contexto de pandemia, una de ellas la de Realidad Aumentada. La actividad fue de carácter individual.

\section{Otras recomendaciones generales}

Desde el equipo de investigación, se considera que el uso de las TIC por sí mismas no garantiza la adquisición de conocimientos, si no que resulta necesario pensar estrategias que las incluyan para motivar, estimular y retener al estudiantado en esta nueva modalidad, así como mejorar las condiciones de aprendizaje en la Química. Además, fortalecen el desarrollo de aptitudes de trabajo colaborativo, no sólo en el aula universitaria sino también a nivel de preparación para el mundo laboral, de esa forma adquieren otras capacidades que forman al perfil del ingeniero, como competencias tecnológicas, pensamiento crítico, capacidad para aprender en forma continua y autónoma.

\section{Resultados parciales}

Durante el análisis de la experiencia didáctica de la plataforma de Realidad Aumentada con el alumnado universitario se ha evidenciado como resultado que el uso de la plataforma potencia escenarios formativos más motivadores, colaborativos e interactivos. También contribuye a una educación más abierta y creativa. 
En la implementación del proyecto se evidenció gran agrado e interés de los estudiantes, al conocer el cambio en el paradigma de aprendizaje, haciendo uso de un teléfono móvil que permitió tener una mejor experiencia educativa al interactuar con objetos de tercera dimensión multimedia que se despliegan en la pantalla del dispositivo móvil al enfocar el marcador de RA, mostrando características relevantes de las moléculas químicas. De manera que la RA permitió una mejor conexión entre los aspectos teóricos y la experiencia práctica.

Como estrategia didáctica para el grupo experimental, que durante la observación pudo dar cuenta de cómo los estudiantes tomaron una postura atractiva sobre el objeto de RA, se evidencia la incidencia de captar el interés del estudiante, además de contribuir de manera significativa en el aprendizaje de la configuración estructural y molecular de compuestos químicos. Si bien fue evidente el entusiasmo que presentaron los estudiantes ante los recursos de RA trabajados, se les hizo una pequeña encuesta a fin de determinar individualmente que era lo que más destacaban de la experiencia realizada.

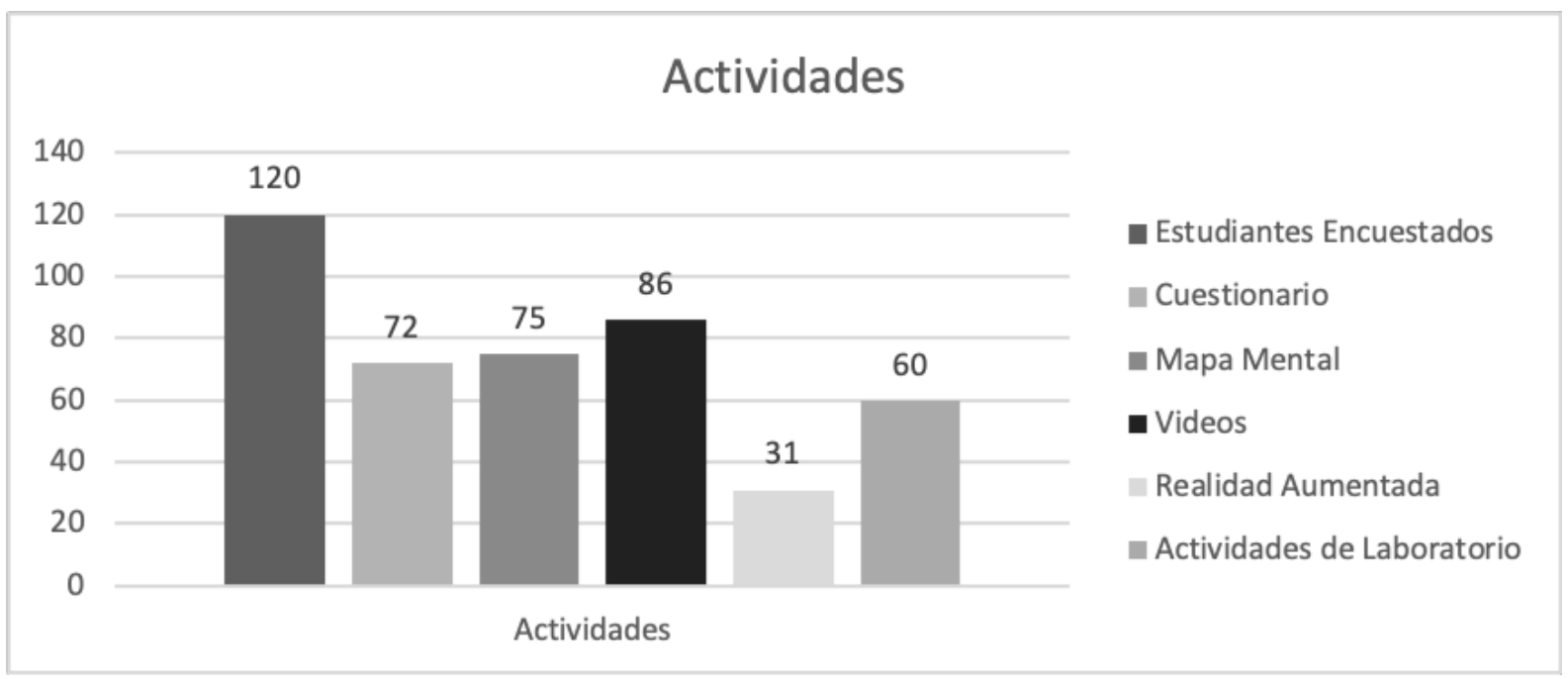

Figura 5: Resultados de las encuestas de validación de actividades semestrales (2020).

Dado los resultados en las encuestas de validación de las actividades de las tecnologías que se implementaron durante el dictado de la clase de Química Orgánica en el segundo semestre del año electivo 2020 (ver Figura 5). Se observa que respecto a las actividades pedagógicas en las que se implementó la tecnología de RA no fue del todo conveniente para fijar conocimientos de manera eficiente. Por lo tanto, para el próximo semestre en que se dicte la asignatura, se deberá replantear una nueva actividad evaluativa que incluya la tecnología de RA y que de la misma manera cumpla los lineamientos de evaluación de la asignatura. Al ser la implementación de RA reciente en el campo de las ciencias, se encuentra la dificultad de la existencia de pocas fuentes bibliográficas de materiales educativos y experiencias educativas para su incorporación a la enseñanza, por lo que será un perfeccionamiento y mejora continua la implementación de esta tecnología en el dictado de la clase. 


\section{Discusión y conclusiones}

Mediante el proyecto, se pretendió lograr la incorporación de la aplicación de la tecnología de RA a la química para esclarecer la interacción de los elementos y sus aplicaciones con el fin de generar talleres que complementen el aprendizaje así como también un aprendizaje tecnológico que ayude a los alumnos a familiarizarse con la tecnología e informática en general, así como generar experiencias de aprendizajes a los estudiantes. Se trató de llevar el conocimiento desde una manera más clara, entretenida y fácil de visualizar; para generar una mayor compresión de los contenidos.

La RA es una tecnología con un futuro prometedor, dado que posee la capacidad de enriquecer elementos de la realidad con información detallada pudiendo aplicarse en ámbitos muy variados. En el ámbito educativo puede utilizarse para complementar los materiales didácticos con modelos virtuales que estimulen la percepción y ayuden a la comprensión de los conceptos.

Estamos de acuerdo con Merino (2014) en que el desarrollo de esta innovación en la docencia puede contribuir a la retención y promoción de estudiantes, la apropiación y la comprensión de contenidos científicos de alta abstracción, y la promoción de habilidades cognitivas espaciales en los estudiantes.

Específicamente en el caso de la química, es posible explorar estructuras de la materia que en un entorno 2D no sería posible visualizarlas. Coincidimos con Urzúa Reyes (2021) en que la riqueza de esta tecnología brinda a los estudiantes la posibilidad de ver una molécula desde todos sus ángulos, visualizar cómo se organizan los átomos en un elemento, de qué manera se llevan a cabo los enlaces hasta comprender conceptos químicos más abstractos. Con ello, se estimula la creatividad de los estudiantes y su interés al involucrarse en sus procesos de aprendizaje.

Estamos de acuerdo con Araya Poblete (2016) que aumentar las habilidades de los alumnos a través de nuevas tecnologías resulta ser una situación muy beneficiosa al momento de ilustrar ramos complejos como lo son las ciencias, esto va en específico al desarrollo de las destrezas de formación de los estudiantes, además de incentivar el gusto por la química por medio de metodologías más afables, se aportará al desarrollo tecnológico del país generando nuevas competencias en los alumnos, favoreciendo el autoaprendizaje y el entendimiento de la química de una manera más didáctica y enriquecedora.

Sin embargo el desafío de incorporar la RA en los contextos educativos, implica la voluntad de centrar el aprendizaje en la participación activa del estudiante, en sus intereses, en situaciones relevantes y directamente relacionadas con su vida real, lo cual supone un cambio en los planteamientos pedagógicos que exigen el diseño de nuevas propuestas metodológicas y el uso de recursos didácticos capaces de facilitar los nuevos procesos. Para ello, se requiere conocer y aprender a utilizar estas herramientas, para luego mediar el contenido de su disciplina desde una mirada pedagógica - didáctica, pudiendo vislumbrar las posibilidades educativas de la RA para enriquecer los procesos de enseñanza - aprendizaje; brindando escenarios para explorar, interactuar y relacionarse con su entorno, generando recursos y conocimientos de manera creativa y lúdica. (Guerrero, 2017). 


\section{Agradecimientos}

Este trabajo pertenece a uno de los proyectos de investigación de tipo 1 con resolución $N^{\circ} 4142$, financiados por la Secretaría de Investigación, Internacionales y Posgrados (SIIP) de la Universidad Nacional de Cuyo (UNCuyo).

A los miembros y coautores del proyecto de Investigación: "Uso de las TIC en el proceso de aprendizaje-enseñanza en la Química Orgánica" (segunda etapa) (20192021), y miembros de la cátedra de Química Orgánica de la Facultad de Ingeniería, Universidad Nacional de Cuyo (UNCuyo); por la incorporación de la plataforma en el transcurso del desarrollo del proyecto y dictado de la clase de Química Orgánica (año electivo 2020 y 2021).

A los estudiantes de Ingeniería et al. que formaron parte del grupo muestra, por su participación en la prueba piloto y validación de la plataforma de realidad aumentada aplicada a la Química Orgánica.

\section{Referencias}

Correa, A. I. P. (2021). Diseño y desarrollo de herramientas y mecanismos tecnológicos que permitan mejorar los procesos de aprendizaje mediante la utilización de tecnologías disruptivas. Gestión Del Repositorio Documental de La Universidad de Salamanca (GREDOS). [Online]. https://gredos.usal.es/handle/10366/146721

Cerillo, S. R. (2020). Realidad aumentada y aprendizaje en la química orgánica. Revista Apertura, 12(1), [pp.] 106-117. [Online]. http://dx.doi.org/10.32870/Ap.v12n1.1853

Ramos Geliz, F. (2015). Objeto virtual de aprendizaje para la enseñanza de la química del carbono soportado en dispositivos móviles y realidad aumentada. Repositorio Digital de Universidad Nacional Autónoma de México [Online]. https://reposital. cuaieed.unam.mx:8443/xmlui/handle/20.500.12579/3950

Merino, C. (2014). Realidad aumentada para el diseño de secuencias de enseñanza-aprendizaje en química. Educación Química 26(2), [pp.] 94-99. [Online]. http:// www.revistas.unam.mx/index.php/req/article/view/52916

Martinez-Hung H. (2017). Modelos de Realidad Aumentada aplicados a la enseñanza de la Química en el nivel universitario. Revista Cubana de Química. 29(1), [pp.] 13-25. [Online] http://scielo.sld.cu/scielo.php?script=sci_abstract\&pi$\mathrm{d}=\mathrm{S} 2224-54212017000100002 \& \operatorname{lng}=\mathrm{es} \& \mathrm{nrm}=\mathrm{iso}$

Araya Poblete, E. M. (2016). APRENDIZAJE DE LA QUIMICA CON REALIDAD AUMENTADA. Sistema de Biblioteca PUCV. [Online]. http://opac.pucv.cl/pucv_txt/txt6500/UCD6685_01.pdf

Urzúa Reyes, M. D. (2021). Realidad aumentada para el aprendizaje de la química. Sarraute Educación. [Online]. https://sarrauteducacion.com/2021/03/23/realidad-aumentada-para-el-aprendizaje-de-la-quimica/ 
Guerrero, A. M. J. (2017, 17 octubre). Realidad aumentada, realidad virtual e interacción tangible para la educación. Repositorio Institucional de la Universidad Nacional de La Plata. [Online]. http://sedici.unlp.edu.ar/handle/10915/62975

\section{Anexos}

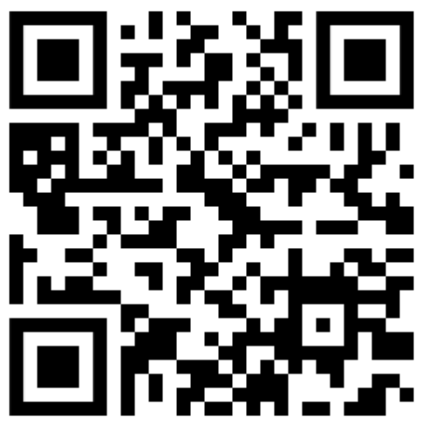

Anexo 1: Código QR de acceso a la plataforma de AUMETED

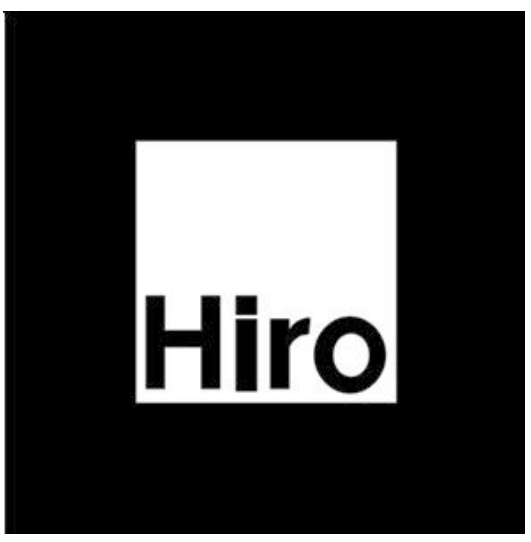

Anexo 2: Marcador disparador de la plataforma de AUMENTE 


\section{Innovación en el Aula de Química Orgánica: Experiencia de Enseñanza Remota en Pandemia}

\section{Ferrer, Liliana}

Facultad de Ingeniería. UNCuyo.

liliana.ferrer@ingenieria.uncuyo.edu.ar

\section{Bustillo, Mario}

Facultad de Ingeniería. UNCuyo.

mabustillo02@gmail.com 


\title{
INNOVACIÓN EN EL AULA DE QUÍMICA ORGÁNICA: EXPERIENCIA DE ENSEÑANZA REMOTA EN PANDEMIA
}

\author{
Ferrer, Liliana \\ Bustillo, Mario
}

\section{Resumen}

El año 2020 fue un año particular en lo que concierne a la enseñanza de la asignatura Química Orgánica. La pandemia estableció un momento histórico único en nuestra práctica educativa, obligándonos a generar innovaciones forzadas. La asignatura Química orgánica se cursa en el segundo semestre del segundo año de las carreras de Ingeniería Industrial y de Petróleos de la Facultad de Ingeniería de la Universidad Nacional de Cuyo. En este contexto de pandemia nos encontramos con 6 semanas menos de cursado, además que éste debería realizarse totalmente de manera virtual, por lo tanto, se hizo imprescindible reinventar las clases para adaptarlas a esta nueva forma de educación remota de emergencia. En este trabajo se relata la experiencia de cursada virtual llevada a cabo en Química Orgánica. Se repensó la manera de impartir las clases y se decidió por clases invertidas mediadas con tecnologías, para ello se utilizaron distintas metodologías como mapas mentales, cuestionarios, evaluación entre pares, realidad aumentada, cuestionarios lúdicos, videos intervenidos con preguntas, entre otras. Las evaluaciones también se realizaron de manera novedosa para la asignatura. Se encuestó a los estudiantes obteniendo una muy buena aceptación de la propuesta. Se espera mantener en un futuro aquellos cambios introducidos en la virtualidad y en la materia en general que fueron superadores.

\section{Palabras clave}

Química orgánica, TIC, innovación, virtualidad. 


\section{Introducción}

Las nuevas exigencias en la educación superior se centran en la mejora del proceso educativo. En tal sentido, la integración de las TIC facilita aspectos relacionados con la mejora del trabajo individual, la autonomía del alumnado, la facilidad para el desarrollo de trabajos en equipo y colaborativos, la posibilidad de modificar y adaptar los métodos de evaluación y la interacción entre el profesorado y el alumnado (Barrera Rea y Guapi Mullo, 2018).

Crosetti et al. (2021) afirma que tradicionalmente, en la enseñanza de las ciencias se ha utilizado la metodología de trasmitir los conocimientos desde el docente a los estudiantes, quienes los reciben de manera pasiva. Esta afirmación coincide con $\mathrm{Ba}-$ ggio (2020) cuando asegura que los métodos tradicionales de enseñanza han sido y son criticados, y han puesto en evidencia la necesidad de incorporar estrategias didácticas innovadoras para favorecer el aprendizaje, de modo que puedan ser empleadas en el aula con el fin de lograr que el alumno, en vez de solamente almacenar conocimiento, sea capaz de incorporarlo a su estructura cognitiva, transformarlo, y, quizás lo más importante, usarlo en la solución de problemas.

La pandemia de COVID 19 fue un evento que interrumpió nuestra cotidianeidad a partir del 20 de marzo de 2020. Y la educación no fue ajena a ella cuando en Argentina el gobierno nacional decretó el Aislamiento Social Preventivo y Obligatorio. El sistema educativo y las universidades en particular tuvieron que adaptarse a este nuevo escenario y nuestra cátedra decidió aprovechar esta situación de emergencia para innovar en las prácticas educativas.

En el contexto de la pandemia, se hizo necesario buscar técnicas que permitan lograr un aprendizaje significativo; utilizar estrategias y diseñar actividades que tengan significado concreto para los alumnos y sin que haya existido encuentro presencial ni conocimiento previo entre docente y estudiantes. (Baumann, 2021)

Si bien el equipo de docentes de Química Orgánica venía trabajando desde algún tiempo utilizando las TIC como apoyo a la presencialidad, fue necesario reinventar las clases para adaptarlas a esta situación inédita.

El objetivo de este trabajo es relatar la experiencia de enseñanza y aprendizaje en el abrupto cambio de educación presencial a educación remota ocasionado por la pandemia.

\section{Descripción de la experiencia}

En la Facultad de Ingeniería, las clases en el segundo semestre comenzaron a mediados del mes de octubre, por lo que en este contexto de pandemia nos encontramos con 6 semanas menos de cursado, además que éste debería realizarse solamente de forma virtual. De esta manera, se hizo imprescindible reinventar las clases para adaptarlas totalmente a la virtualidad. Aunque en la cátedra se venía trabajando con un modelo b-learning (blended learning), utilizando aula virtual como apoyo a la presencialidad. 


\section{Metodología para el desarrollo de las clases}

\section{Adaptación del programa}

Debió adaptarse el programa de la asignatura al período de cursado más corto. Para ello, el criterio para priorizar contenidos fue que los estudiantes tuvieran los conceptos básicos que nos piden los docentes del ciclo superior. Por lo general es nomenclatura, propiedades físicas y químicas. Excepto en Ingeniería en Petróleos, que piden que conozcan el mecanismo de reacción de la pirólisis, no se nos han solicitado conocimiento de muchos mecanismos que en los años anteriores sí se enseñaban y ocupaban una gran extensión de la materia. Se hizo hincapié en las propiedades químicas y físicas de los compuestos orgánicos y se incorporó el estudio de macromoléculas como polímeros, carbohidratos, proteínas y grasas, aceites, jabones y detergentes.

\section{Clases}

Se utilizó la modalidad de aula invertida, esta estrategia usa las TIC para proporcionar una experiencia de aprendizaje autónomo utilizando recursos multimediales fuera de la clase. Este formato de clases rompe el esquema de teoría (expuesta o presentada por el docente) seguido de práctica a cargo del estudiante (modelo de aprendizaje por recepción) característico de las clases presenciales expositivas desarrolladas en el nivel universitario. (Dettorre y Sabaini, 2020) Esto permite posicionar a los estudiantes como activos partícipes en la construcción de conocimientos a lo largo de toda la secuencia didáctica. El estudiante es quien gestiona su aprendizaje y, por ello, el tiempo de clase sincrónica fue usado para debatir y trabajar puntos clave, así como cualquier pregunta o dificultad que presentaran los estudiantes. Las clases sincrónicas se hicieron utilizando la plataforma Zoom, trabajando con grupos de 100 alumnos aproximadamente y con dos docentes a cargo.

Se utilizó el aula virtual de la Facultad de Ingeniería para la carga de elementos teóricos y prácticos.

\section{Recursos utilizados en las clases}

Se intentó trabajar desde un modelo de aprendizaje centrado en la construcción activa del conocimiento por parte de los estudiantes.

Se utilizaron distintos recursos:

- mapas mentales: Un mapa mental es una herramienta que traduce los pensamientos en elementos visuales y tiene muchas ventajas sobre las técnicas tradicionales de toma de notas y redacción.

- cuestionarios Moodle de autoevaluación: Permite a los profesores el crear una gran variedad de preguntas para obtener retroalimentación de los estudiantes, por ejemplo, en un curso o en actividades.

- evaluación entre pares: La evaluación entre pares es una herramienta de evaluación del aprendizaje en la que, con la ayuda de una rúbrica, los alumnos se evalúan entre sí siguiendo los criterios de valoración que en ella se definen y categorizan. 
- realidad aumentada: se utilizó la plataforma AUMENTED que es una plataforma educativa realizada por un alumno de la carrera de Ingeniería en Mecatrónica de la facultad, basada en la tecnología de Realidad Aumentada. Incluye los conceptos teóricos y pedagógicos necesarios para ser utilizada en el nivel educativo correspondiente. La plataforma permite la visualización de moléculas de Química Orgánica mediante el uso de realidad aumentada.

- Kahoot!: es una plataforma gratuita que permite la creación de cuestionarios de evaluación. Es una herramienta por la que el profesor crea concursos en el aula para aprender o reforzar el aprendizaje y donde los alumnos son los concursantes. Los alumnos eligen su alias o nombre de usuario y contestan a una serie de preguntas por medio de un dispositivo móvil. Existen 2 modos de juego: en grupo o individual. Las partidas de preguntas, una vez creadas, son accesibles por todos los usuarios de manera que pueden ser reutilizadas e incluso modificadas para garantizar el aprendizaje. Se puede modificar el tiempo de cuenta atrás, las posibles respuestas y se pueden añadir fotos o vídeos. Finalmente gana quien obtiene más puntuación. Una ventaja es que los estudiantes no necesitan crear un perfil personal ni descargar la aplicación para usar en sus celulares.

- Socrative: Es una aplicación gratuita que permite al docente motivar a los estudiantes a participar en el aula y realizar un seguimiento de su evolución mediante pruebas de tipo test, evaluaciones u otras actividades. Compatible con cualquier dispositivo (los estudiantes usan su teléfono celular), una de sus ventajas es que los estudiantes no tienen que crearse un perfil personal para poder usar la aplicación; con que el docente tenga el suyo, ligado a una cuenta de correo electrónico, será suficiente.

- Videos intervenidos con preguntas: En nuestro usamos EdPuzzle, que es una herramienta utilizada para convertir cualquier video en una clase interactiva. Con Edpuzzle se puede cortar el video, añadir una pista de audio para explicarlo, incluir un test o preguntas abiertas. Los beneficios que otorga son que los estudiantes pueden recibir retroalimentación inmediata, se puede adaptar a cualquier contenido, su uso es sencillo.

- Producción de videoinformes: consistió en la grabación de videos explicando propiedades físicas, químicas y características de determinado compuesto elegido en la plataforma de realidad aumentada, incorporando narraciones en off que les permitieron adquirir competencias comunicativas. (Fig. 1)
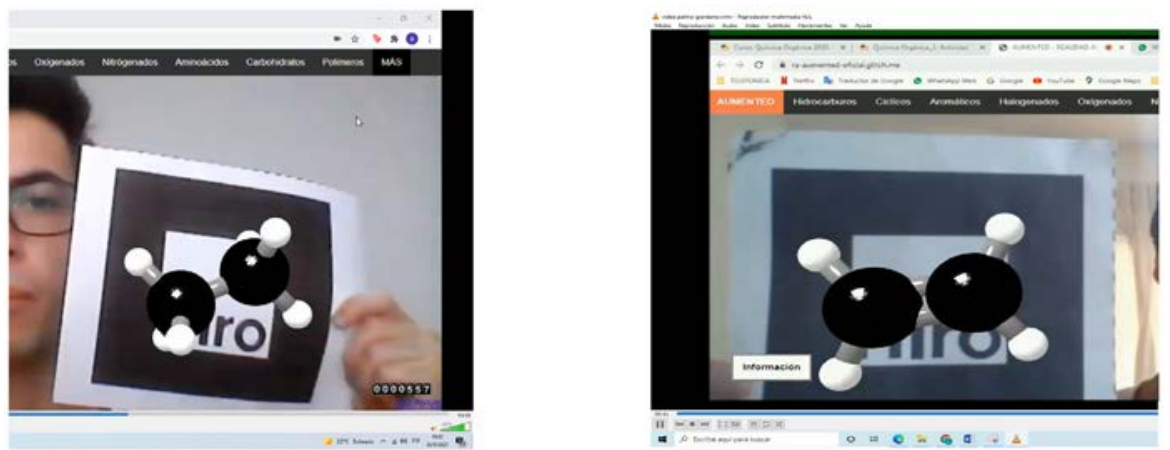

Fig, 1: Capturas de pantalla de videoinformes utilizando realidad aumentada 


\section{Evaluación}

Se repensó también la evaluación de la asignatura y se decidió por una evaluación continua. Por ello, se rediseñaron las evaluaciones haciéndolas más creativas, para hacer su resolución menos mecánica, fomentando una participación más activa, y el pensamiento crítico.

Los estudiantes que en las actividades realizadas a lo largo del cursado obtuvieron un promedio de 6 o superior, quedaron en condiciones de rendir el examen de promoción.

Cuando hablamos de evaluación no podemos dejar de pensar en las palabras de Maggio (2018), "la evaluación suele ser el lugar donde se interrumpen la mayor parte de las innovaciones y no se suele constituir como una parte más del proceso educativo". Por eso la evaluación final y de promoción también se realizaron de manera novedosa para la asignatura y consistió en la asignación de un compuesto orgánico que figura en el Código Alimentario Argentino a grupos de dos estudiantes. Con ese compuesto los estudiantes debieron realizar una exposición corta indicando nombre común, nombre IUPAC, propiedades físicas y químicas, usos, toxicidad si la hubiera, o ingesta diaria admitida. Una vez que fue expuesto el tema, se realizó un coloquio con los docentes, en el cual defendieron el trabajo integrador, teniendo en cuenta los aspectos teóricos de la asignatura. La evaluación se realizó a través de una rúbrica que fue presentada previamente a los estudiantes junto con las consignas.

\section{Resultados}

Del total de alumnos que comenzaron a cursar la asignatura, aprobó un 85\% en una primera instancia. El alumnado trabajó motivado y entusiasmado, lo que se pudo corroborar con las encuestas realizadas a los estudiantes, las cuales indicaron muy buena aceptación de la propuesta.

\section{Discusión y conclusiones}

En base a estos resultados podemos concluir que la modalidad virtual no resulta ser un impedimento para que el estudiante universitario aprenda y obtenga un buen desempeño. Este resultado no es casual, sino que es el resultado de trabajo y empeño por parte de docentes y estudiantes. Esta forma de trabajo virtual nos obligó a los docentes a modificar nuestras formas de evaluar e incorporar otros métodos de evaluación, los cuales se seguirán utilizando en esta nueva cursada, con las modificaciones que permitan mejorar la evaluación formativa. Concluimos que fue muy importante que los docentes de la asignatura contáramos con cierta capacitación y experiencia en la virtualidad debido al trabajo previo de usar aula virtual como apoyo a la presencialidad.

Estamos de acuerdo con Crosetti et al (2021) cuando afirma que la pandemia aceleró un proceso que inexorablemente debía ocurrir y que nos llevó a replantearnos la forma de enseñar, acompañada por el uso de las TIC. En esta nueva modalidad el alumno asume un rol protagónico en el proceso de aprendizaje y el docente necesita disponer de nuevas herramientas para adaptarse. 
Coincidimos con Crosetti et al (2021), en que la cursada ha sido exitosa ya que hemos podido cumplir con el programa de la materia, logrando un buen desempeño y feedback por parte de los alumnos. Nos resta un camino de aprendizaje y mejora continua de las prácticas de enseñanza, enfocándonos en la innovación y motivación hacia el alumno.

\section{Referencias}

Baggio, S. (2020) Actividades lúdicas digitales para el aula de química. Educación en la Química en Línea, 26 (01), p. 23-26.

Baumann, A. J. (2021). Cambios en la estrategia de enseñanza. Aplicación del aprendizaje basado en problemas ante la pandemia. Educación En La Química, 27 (01), 110-114. http://educacionenquimica.com.ar/ojs/index.php/edenlaq/article/view/25

Barrera Rea, F, Guapi Mullo, A (2018). La importancia del uso de las plataformas virtuales en la educación superior. Revista Atlante: Cuadernos de Educación y DesarroI/o, https://www.eumed.net/rev/atlante/2018/07/plataformas-virtuales-educacion. html//hdl.handle.net/20.500.11763/atlante1807plataformas-virtuales-educacion

Crosetti, V, Caggiano, C, Casella,M. (2021). La importancia de los recursos virtuales en épocas de pandemia. El curso de Química Analítica I de la UNNOBA como caso de estudio, Revista Iberoamericana de Tecnología en Educación y Educación en Tecnología, no. 28, pp. 83-92. https://teyet-revista.info.unlp.edu.ar/TEyET/article/ view/1499

Dettorre, L y Sabaini, M (2020) VI. Diseño e implementación de asignaturas bimodales: el caso de "Química Orgánica Ecocompatible" y "Química Verde. En Zinni, A., Rembado, F. y López, S. "Nuevos procesos de formación. Buenos Aires: Colección Ideas de Educación Virtual. Universidad Nacional de Quilmes. http://libros.uvq.edu. ar/assets/libro9/vi_diseo_e_implementacin_de_asignaturas_bimodales_el_caso_ de_qumica_orgnica_ecocompatible_y_qumica_verde.html

Maggio, M. (2018). Reinventar la clase en la universidad. (1ra ed.). Paidós. 


\section{Anexos}

Anexo 1: Rúbrica de evaluación del mapa mental en una evaluación entre pares

\begin{tabular}{|c|c|c|c|c|}
\hline \multirow{2}{*}{$\begin{array}{l}\text { Criterios } \\
\text { Aspecto } \\
\text { Visual }\end{array}$} & \multicolumn{4}{|l|}{ Niveles } \\
\hline & $\begin{array}{l}\text { Sólo utiliza palabras y un } \\
\text { color para representar } \\
\text { todos los conceptos }\end{array}$ & $\begin{array}{l}\text { Utiliza palabras y algunos colores } \\
\text { para representar las ideas }\end{array}$ & $\begin{array}{l}\text { Utiliza distintos colores para las } \\
\text { ramas, y sustituye algunas palabras } \\
\text { por imágenes. }\end{array}$ & $\begin{array}{l}\text { Cada rama principal tiene asignado un color, así como } \\
\text { las ramas que derivan de ellas. Utiliza principalmente } \\
\text { Imágenes }\end{array}$ \\
\hline $\begin{array}{l}\text { Ortografía y } \\
\text { presentación }\end{array}$ & $\begin{array}{l}\text { El texto tiene más de dos } \\
\text { errores y no es prolijo el } \\
\text { mapa mental y no parte de } \\
\text { una idea central }\end{array}$ & $\begin{array}{l}\text { El texto tiene dos errores de } \\
\text { ortografía o sintaxis o no es prolijo el } \\
\text { mapa mental y no es clara la idea } \\
\text { central de la que parte }\end{array}$ & $\begin{array}{l}\text { El texto tiene un error de ortografía } \\
\text { o sintaxis pero es prolijo el mapa } \\
\text { mental y parte desde el centro de } \\
\text { una idea central }\end{array}$ & $\begin{array}{l}\text { El texto es correcto desde el punto de vista de } \\
\text { ortografía y sintaxis y el mapa mental es prolijo desde } \\
\text { el punto de vista de la presentación y parte desde el } \\
\text { centro de una idea central }\end{array}$ \\
\hline $\begin{array}{l}\text { Grupos } \\
\text { funcionales }\end{array}$ & $\begin{array}{l}\text { El mapa mental tiene tres } \\
\text { grupos funcionales menos }\end{array}$ & $\begin{array}{l}\text { El mapa mental contiene dos grupos } \\
\text { funcionales menos }\end{array}$ & $\begin{array}{l}\text { Ol mapa mental contiene un grupo } \\
\text { funcional menos }\end{array}$ & $\begin{array}{l}\text { El mapa mental contiene todos los grupos funcionales } \\
\text { de los hidrocarburos }\end{array}$ \\
\hline Nomenclatura & $\begin{array}{l}\text { Hay más de dos errores en } \\
\text { la nomenclatura }\end{array}$ & Hay dos errores en la nomenclatura & Hay un error en la nomenclatura & La nomenclatura de todos los ejemplos es correcta \\
\hline $\begin{array}{l}\text { Isomería y } \\
\text { estructura } \\
\text { geométrica }\end{array}$ & Hay más de dos errores & Hay dos errores & Hay un error & No hay ningún error \\
\hline
\end{tabular}

Anexo 2: Rúbrica de evaluación final

\begin{tabular}{|c|c|c|c|}
\hline Criterio & Muy bueno (2) & Bueno (1) & Necesita mejorar (0) \\
\hline $\begin{array}{l}\text { Nomenclatura y } \\
\text { estructura } \\
\text { Nombre común y } \\
\text { IUPAC } \\
\text { Fórmula molecular } \\
\text { Fórmula estructural } \\
\text { Fórmula 3D }\end{array}$ & $\begin{array}{l}\text { Escribe correctamente } \\
\text { todos los nombres y } \\
\text { fórmulas. Identifica } \\
\text { correctamente los } \\
\text { grupos funcionales }\end{array}$ & $\begin{array}{l}\text { Hay entre } 1 \text { y } \\
2 \text { errores en } \\
\text { los nombres y } \\
\text { fórmulas. Identifica } \\
\text { correctamente los } \\
\text { grupos funcionales }\end{array}$ & $\begin{array}{l}\text { Hay más de dos errores en } \\
\text { los nombres y fórmulas. No } \\
\text { identifica correctamente los } \\
\text { grupos funcionales }\end{array}$ \\
\hline $\begin{array}{l}\text { Isomería * } \\
\text { Geométrica. }\end{array}$ & $\begin{array}{l}\text { Dibuja y nombra } \\
\text { correctamente el } \\
\text { isómero }\end{array}$ & $\begin{array}{l}\text { Dibuja o nombra } \\
\text { correctamente el } \\
\text { isómero pero hay } \\
\text { un error en el dibujo } \\
\text { o el nombre }\end{array}$ & $\begin{array}{l}\text { No dibuja ni nombra } \\
\text { correctamente el isómero }\end{array}$ \\
\hline $\begin{array}{l}\text { Isomería * } \\
\text { Óptica. Dibujar } \\
\text { el isómero y } \\
\text { nombrarlos }\end{array}$ & $\begin{array}{l}\text { Dibuja y nombra } \\
\text { correctamente el } \\
\text { isómero }\end{array}$ & $\begin{array}{l}\text { Dibuja o nombra } \\
\text { correctamente el } \\
\text { isómero pero hay } \\
\text { un error en el dibujo } \\
\text { o el nombre }\end{array}$ & $\begin{array}{l}\text { No dibuja ni nombra } \\
\text { correctamente el isómero }\end{array}$ \\
\hline $\begin{array}{l}\text { Propiedades Físicas } \\
\text { Explica punto de } \\
\text { ebullición y/o punto } \\
\text { de fusión } \\
\text { Explica solubilidad }\end{array}$ & $\begin{array}{l}\text { Explica correctamente } \\
\text { las fuerzas } \\
\text { intermoleculares y las } \\
\text { relaciona correctamente } \\
\text { con el punto de } \\
\text { ebullición, de fusión y } \\
\text { solubilidad }\end{array}$ & $\begin{array}{l}\text { Hay un error } \\
\text { en las fuerzas } \\
\text { intermoleculares } \\
\text { y/o en su relación } \\
\text { con el punto de } \\
\text { ebullición, de fusión } \\
\text { y solubilidad. }\end{array}$ & $\begin{array}{l}\text { Hay más de un error en las } \\
\text { fuerzas intermoleculares } \\
\text { y/o en su relación con el } \\
\text { punto de ebullición, de } \\
\text { fusión y solubilidad. }\end{array}$ \\
\hline
\end{tabular}




\begin{tabular}{|l|l|l|l|}
\hline $\begin{array}{l}\text { Usos. Problemática } \\
\text { ambiental o a la } \\
\text { salud humana }\end{array}$ & $\begin{array}{l}\text { Explica correctamente } \\
\text { los usos y los problemas } \\
\begin{array}{l}\text { Problemas a } \\
\text { la salud o al } \\
\text { medioambiente que } \\
\text { provoca. }\end{array}\end{array}$ & $\begin{array}{l}\text { No explica todos } \\
\text { los usos y los } \\
\text { problemas a la salud }\end{array}$ & $\begin{array}{l}\text { No indica los usos y los } \\
\text { problemas a la salud o } \\
\text { al medio ambiente si }\end{array}$ \\
\hline
\end{tabular}

\begin{tabular}{|c|c|c|c|}
\hline $\begin{array}{l}\text { Diseño de la } \\
\text { presentación } \\
\text { Duración de la } \\
\text { presentación } \\
\text { Audio } \\
\text { Video } \\
\text { Dicción de los } \\
\text { participantes } \\
\text { Vocabulario }\end{array}$ & $\begin{array}{l}\text { El audio se escucha de } \\
\text { manera clara. El video } \\
\text { tiene imágenes claras. La } \\
\text { dicción es clara. Utilizan } \\
\text { vocabulario pertinente a } \\
\text { la materia } \\
\text { La presentación dura } 6 \\
\text { minutos o menos }\end{array}$ & $\begin{array}{l}\text { El audio o el video } \\
\text { no se escuchan o } \\
\text { no tienen imágenes } \\
\text { claras. La dicción } \\
\text { no es clara. Utilizan } \\
\text { vocabulario } \\
\text { pertinente a la } \\
\text { materia } \\
\text { La presentación } \\
\text { dura } 6 \text { a } 6,15 \\
\text { minutos }\end{array}$ & $\begin{array}{l}\text { El audio no se escucha de } \\
\text { manera clara. El video no } \\
\text { tiene imágenes claras. La } \\
\text { dicción no es clara. Utilizan } \\
\text { vocabulario no pertinente a } \\
\text { la materia } \\
\text { La presentación dura más } \\
\text { de } 6,15 \text { minutos }\end{array}$ \\
\hline $\begin{array}{l}\text { Conocimiento y } \\
\text { preparación de los } \\
\text { temas teóricos de } \\
\text { la asignatura } \\
\text { Dominio del } \\
\text { contenido para la } \\
\text { defensa del trabajo }\end{array}$ & $\begin{array}{l}\text { Demuestra solvencia y } \\
\text { confianza al expresar } \\
\text { sus conocimientos } \\
\text { presentando información } \\
\text { clara y pertinente }\end{array}$ & $\begin{array}{l}\text { Demuestra } \\
\text { confianza al } \\
\text { expresar sus } \\
\text { conocimientos pero } \\
\text { falla en algunos } \\
\text { momentos al } \\
\text { expresar algunos } \\
\text { conceptos }\end{array}$ & $\begin{array}{l}\text { Demuestra poco } \\
\text { conocimiento del tema y } \\
\text { escasa información }\end{array}$ \\
\hline $\begin{array}{l}\text { Bibliografía } \\
\text { utilizada }\end{array}$ & $\begin{array}{l}\text { Consigna correctamente } \\
\text { la bibliografía utilizada }\end{array}$ & & $\begin{array}{l}\text { No consigna la bibliografía } \\
\text { utilizada }\end{array}$ \\
\hline
\end{tabular}




\section{Reimaginar el Prácticum: Evaluación y Adaptación a un Entorno Virtual de Apredinzaje Durante la Covid-19}

Seoane, Rocío C. orcid.org/0000-0001-6031-5459 Universidad de La Laguna rocio.seoane@ull.edu.es

\section{Callejas Castro, Enrique} orcid.org/0000-0002-1259-901X Universidad de La Laguna ecalleja@ull.edu.es 


\title{
REIMAGINAR EL PRÁCTICUM: EVALUACIÓN Y ADAPTACIÓN A UN ENTORNO VIRTUAL DE APREDINZAJE DURANTE LA COVID-19
}

\author{
Seoane, Rocío C. \\ Callejas Castro, Enrique
}

\section{Resumen}

La declaración del estado de alarma debido a la COVID-19 obligó a reimaginar los escenarios de enseñanza-aprendizaje. Este estudio describe la adaptación de un Prácticum de Mención en Atención a la Diversidad del Grado en Maestro/a en Educación Primaria. El objetivo fue la evaluar viabilidad y la efectividad del prácticum virtual e identificar los factores clave para una buena implementación. Participaron 22 estudiantes de cuarto curso del Grado en Maestro/a en Educación Primaria de la [Referencia oculta]. Se empleó una metodología de análisis cualitativo temático y estadística descriptiva. En líneas generales, el prácticum virtual fue percibido como una oportunidad para desarrollar competencias digitales, pero como una barrera para desarrollar competencias de atención a la diversidad. Los resultados sugieren que existe una relación moderada y positiva entre la participación del alumnado y su rendimiento final. Por último, se discuten las implicaciones educativas de esta propuesta para futuras adaptaciones de prácticas profesionales a entornos virtuales de aprendizaje.

\section{Palabras clave}

Prácticum, maestros/as en formación, entorno virtual de aprendizaje, COVID-19. 


\section{Introducción}

Las prácticas profesionales (prácticum) son un componente central en la formación docente (Kim, 2020; Kosar y Bedir, 2019) que ofrece a los futuros maestros/as la oportunidad de aplicar diferentes tipos de conocimiento (v.gr., conocimiento del contenido, curricular o pedagógico) (Shulman, 1987) a situaciones reales de enseñanza-aprendizaje. La situación originada por la COVID-19 y la declaración del estado de alarma supuso el cese de la actividad presencial en los centros educativos de España. Los grados universitarios de Educación se vieron obligados a suspender la experiencia práctica presencial desconociendo el impacto de esta medida sobre el desarrollo profesional de los futuros docentes. El objetivo de este estudio es describir y analizar el proceso de adaptación de un prácticum de maestros/as en formación a un entorno virtual de aprendizaje.

\section{La formación en línea y el desarrollo profesional de maestros/as}

La investigación en educación ha demostrado ciertas ventajas que la formación en línea puede ofrecer sobre la formación presencial (Fishman et al., 2013). La accesibilidad, la flexibilidad o la eficiencia de costes para transmitir el conocimiento son algunas de las ventajas más reconocidas del formato en línea (Albhnsawy y Aliweh, 2016; O'brien et al., 2011; Shand y Farrelly, 2018). Asimismo, los estudiantes bajo la modalidad en línea pueden alcanzar un razonamiento más completo sobre el contenido (Dumford y Miller, 2018). Entre las principales desventajas destacan la falta de comunicación, problemas en la accesibilidad a internet o la falta de autonomía por parte del estudiante para el aprendizaje (Lee et al., 2015).

El aprendizaje en línea requiere que los estudiantes desplieguen habilidades complejas como la organización de una amplia variedad materiales de trabajo (Chigeza y Halbert, 2014). Sin embargo, es posible superar estas desventajas identificando elementos clave en el diseño del entorno virtual: la organización y presentación estructurada del curso, la claridad de los objetivos y los estándares de rendimiento, el potencial de la interacción interpersonal o el uso eficiente de los recursos tecnológicos (Jaggars y Xu, 2016).

En relación con la comprensión de la enseñanza en línea como herramienta didáctica para la formación de docentes, se ha demostrado que la retroalimentación escrita en el espacio virtual es más eficiente, organizada y crítica; mientras que el soporte en vídeo genera una retroalimentación más comunicativa, larga y de apoyo (Borup et al. 2015). Por otro lado, las herramientas sincrónicas (v.gr., chat, videoconferencia) en el espacio en línea permiten superar la distancia relacional y mejorar la práctica educativa a través de actividades específicas, como las discusiones sobre temas concretos a partir de la reproducción de vídeos (Peercy et al., 2016).

En cuanto a las percepciones de los universitarios sobre el entorno virtual en términos de efectividad, eficiencia y satisfacción. La satisfacción parece estar relacionada con la capacidad del usuario para acceder a todos los recursos disponibles dentro de la plataforma Moodle (Torun y Tekedere, 2015), siendo necesario el desarrollo de medidas para fomentar las competencias relacionadas con el uso de las Tecnologías de la Información y la Comunicación (TICS) (McVey, 2016). No obstante, tras la participación en experiencias virtuales los estudiantes reportan sentirse más capacitados en el entorno virtual y tienen una mejor valoración de la enseñanza en línea (Luo et al., 2017). 


\section{La transición forzosa a la enseñanza en línea debido al COVID-19}

La pandemia de COVID-19 provocó una transición muy rápida y forzosa de la educación presencial a la educación en línea. Desde entonces, diferentes estudios se han centrado en describir cómo se llevó a cabo esta transición en centros de educación obligatoria (Bergdahl y Nouri, 2020; Middleton, 2020) y centros de enseñanza universitaria (Moorhouse, 2020; Nuere y de Miguel, 2020; Yang et al., 2020). De forma específica, Kim (2020) se centró en cómo rediseñar un prácticum para estudiantes de Educación Infantil brindando a los futuros maestros/as oportunidades de aprender y enseñar en línea. Tras la adaptación, llevada a cabo en tres fases diferenciadas (preparación, implementación y reflexión), se encontró que tanto la reflexión en grupo como la reflexión individual, eran herramientas epistemológicas que los estudiantes universitarios empleaban para desarrollar ideas sobre cómo promover el desarrollo y el aprendizaje de los escolares de Educación Infantil por medio del uso de herramientas de comunicación en línea.

Para nuestro conocimiento, hasta el momento no existen aportaciones en nuestro país que informen sobre como la suspensión del prácticum presencial, y su adaptación al contexto de enseñanza en línea, ha impactado en el desarrollo profesional de los futuros docentes.

\section{Objetivos del estudio y preguntas de investigación}

En este estudio describimos y analizamos la adaptación del Prácticum de Atención a la Diversidad del Grado en Maestro/a en Educación Primaria a una modalidad virtual debido a la crisis de la COVID-19. El objetivo principal fue evaluar la viabilidad y la efectividad del prácticum virtual e identificar los factores clave para una buena implementación. Para ello, exploramos la percepción del alumnado sobre la adaptación de la asignatura y el impacto en su desarrollo profesional. Además, evaluamos su participación, su rendimiento académico y la relación entre ambos. Se plantean las siguientes preguntas de investigación:

1. ¿Cómo percibió el alumnado universitario la adaptación del prácticum?

2. ¿Cómo evaluó el alumnado universitario la adaptación del prácticum en relación con su desarrollo profesional?

3. ¿Cuál fue el grado de participación del alumnado universitario?

4. ¿Existe una relación entre el grado de participación del alumnado universitario y su rendimiento académico?

\section{Método}

\section{Descripción del contexto y de los participantes}

Participaron 22 estudiantes de cuarto curso del Grado en Maestro/a en Educación Primaria de la [Referencia oculta]. Veinte de ellos se identificaron como mujeres y dos como hombres. Todos ellos, excepto uno, eran menores de 25 años. Los estudiantes estaban repartidos equitativamente en dos grupos que dirigidos por dos 
profesores del Departamento de Psicología Evolutiva y de la Educación de [Referencia oculta]. Ambos grupos siguieron un mismo cronograma de actividades y fueron evaluados con los mismos instrumentos de evaluación.

\section{Instrumentos}

Rúbrica de evaluación final. Los tutores diseñaron una rúbrica para evaluar el rendimiento académico del alumnado a través del informe final de la asignatura. La rúbrica ofrecía una puntuación final de $\mathrm{O}$ a 10 puntos dividida en cuatro apartados: informe del contexto, actividades de evaluación continua, propuesta de intervención, reflexión final. La rúbrica detallaba las características de cada apartado de acuerdo con los niveles de calidad insuficiente, bien y excelente.

Informe de actividad de la plataforma Moodle. El aula virtual de la asignatura estaba alojada en la plataforma Moodle. El informe de actividad en línea consistió en un informe extraído de forma automática del aula virtual. En este informe se detalló la actividad en línea de cada estudiante indicando los días de conexión y el número total de clics realizados dentro del aula virtual.

\section{Procedimiento}

Preparación de la asignatura. Se propuso que el alumnado realizase el diseño de una propuesta de intervención en el ámbito de la mención de Atención a la Diversidad. Esta propuesta podía desarrollarse: (1) para una situación de enseñanza ordinaria y hacer una reflexión sobre cómo podría adaptarse la propuesta docente a un escenario de enseñanza-aprendizaje no presencial; (2) para una situación de no presencialidad como la provocada durante el confinamiento. En esta propuesta de intervención, el alumnado seleccionaba o elaboraba algún material educativo digital. Además, la propuesta debía contextualizarse en una realidad concreta. Una vez realizado el diseño de la intervención, el alumnado debía exponer un resumen de su propuesta en un seminario grupal y realizar un ejercicio reflexivo que girase en torno al diseño de la programación y su posible puesta en práctica. Los profesores de la asignatura realizaron seminarios y tutorías de seguimiento estableciendo un registro de asistencia. Si algún estudiante no disponía de los medios para la realización de los seminarios, se podían realizar las adaptaciones oportunas (e.g., facilitar dispositivos, flexibilizar fechas de entrega).

Implementación de la asignatura. Se desarrollaron cuatro seminarios grupales de forma semanal durante los meses de abril y mayo de 2020. Las sesiones tuvieron una duración aproximada de 90 minutos y se impartieron a través de la plataforma Google Meet. La primera sesión tuvo por objetivo la presentación de la adaptación de la asignatura y la exposición de los principios básicos de la atención a la diversidad en Educación Primaria. La segunda sesión abordó la inclusión educativa y el uso de las TICs en educación. En la tercera sesión se trabajaron los contenidos relativos al diseño de una propuesta de intervención y a la evaluación de la calidad de los recursos educativos digitales. En la cuarta sesión los estudiantes presentaron su trabajo final que consistió en el diseño de una propuesta de intervención con medidas específicas de atención a la diversidad. Tras la presentación el alumnado recibió retroalimentación por parte de su tutor/a y del resto del grupo para elaborar el informe final. 
Durante la asignatura, el alumnado tuvo acceso a la plataforma Moodle donde podía exponer sus dudas, consultar materiales adicionales y subir las tareas del curso. Además, los estudiantes podían contactar con su tutor/a en cualquier momento a través del correo electrónico institucional. Finalmente, los informes finales fueron entregados la primera semana de junio a través del aula virtual y las calificaciones fueron publicadas la segunda semana de junio.

\section{Plan de análisis}

Para conocer cómo el alumnado universitario percibió la adaptación de la asignatura y cómo evaluó dicha adaptación en su desarrollo profesional se llevó a cabo un análisis temático de los informes finales (Braun y Clarke, 2006). Habitualmente este análisis se ha empleado para estudiar los procesos de implementación y el impacto de la experiencia en los estudiantes, ya que ofrece información sobre líneas concretas de mejora y sobre la percepción subjetiva de aprendizaje, que es un factor clave en el desarrollo profesional (Kabilan 2013; Scott et al, 2014).

Para conocer el grado de participación del alumnado, se analizaron los estadísticos descriptivos (i.e., mínimo, máximo, media, desviación típica) de la asistencia a los seminarios, el número contactos establecidos con el profesorado y variables de uso de la plataforma Moodle (i.e., días de conexión y número total de clics).

Por último, para conocer si existe una relación entre la participación del alumnado y la calificación final obtenida en la asignatura, se llevó a cabo un análisis de correlación bivariada. Con este objetivo, se analizó el rendimiento académico mediante estadísticos descriptivos de su calificación final, y se estudió su relación con las variables de implementación a través del coeficiente de correlación de Pearson, considerando la significación a partir de $p<.05$ y con los intervalos de significación baja (0.2-0.4), moderada (0.4-0.6), alta (0.6-0.8) y muy alta (0.8-1.0) (Amón, 1990).

En el análisis de los datos se empleó el paquete de programación Python 3.7 para el análisis cuantitativo y el programa Atlas.ti v8 para el análisis cualitativo.

\section{Resultados}

\section{¿Cómo percibió el alumnado universitario la adaptación del prácticum?}

En la reflexión personal acerca de la adaptación de la asignatura, se identificaron tres temas: (1) el entorno virtual de aprendizaje como facilitador; (2) las limitaciones de la modalidad virtual del prácticum; y (3) la satisfacción e insatisfacción con la adaptación de la asignatura. Los estudiantes comentaron con mayor frecuencia la adaptación del aprendizaje virtual como facilitador (27 citas) en comparación con las limitaciones de aprendizaje (21 citas); y la satisfacción con la adaptación (13 citas) en comparación con la insatisfacción (7 citas). A continuación, se presentan algunas citas literales para cada uno de los temas identificados con el fin de ilustrar las percepciones del alumnado sobre la implementación del prácticum (ver Tabla 1). 
T1. El entorno virtual de aprendizaje como facilitador

T2. Las limitaciones de la modalidad virtual del prácticum insatisfacción con la adaptación de la asignatura
C1. "La realización de este prácticum de manera telemática me ha servido para aprender a usar y desarrollar medios telemáticos, haciendo especial énfasis en el uso de las TICs como medio de enseñanza, comunicación y transmisor de información. Asimismo, he tenido que desarrollar la autonomía por el autoaprendizaje." (Estudiante 12)

C2. "Considero que he adquirido nuevos conocimientos realizando este prácticum no presencial. Además, de ponerme en el papel y empatizar con los docentes que se encuentran ejerciendo su trabajo de forma telemática con sus alumnos/as." (Estudiante 11)

C3. "No se aprende a tratar a un niño con NEAE [Necesidades Específicas de Apoyo Educativo], estudiando su caso desde fuera y simulando una posible actuación, se aprende viéndole, comparando su comportamiento a medida que pasan los días y llegando a tener una relación cercana con ese alumno/a. Por esta razón, creo que este tipo de prácticum que hemos realizado debido a la situación actual que estamos pasando, no ha sido lo más adecuado para adquirir las competencias que expone la guía docente que debería conseguir un maestro/a de primaria con mención en atención a la diversidad."

(Estudiante 2)

C4. "Los conocimientos que hemos podido adquirir, virtualmente y a distancia durante este prácticum, han sido útiles e interesantes pero no suficientes. Solo la práctica nos puede brindar la gran oportunidad de ganar experiencia y aprender de los errores, pudiéndonos acercar así a un contexto cotidiano y realista, al cual los docentes deben de enfrentarse día tras día." (Estudiante 4)

C5. "Considero que los temas tratados en los seminarios han sido realmente importantes para volver a centrarnos en la mención, en las diferentes necesidades que puedan tener los alumnos de un centro de educación primaria, centros de educación especial, etc." (Estudiante 4)

C6. "Cuando colgaron en la plataforma la adaptación del prácticum a la enseñanza no presencial, la verdad es que me sentí un poco decepcionada, pues no podría impartir clases en los centros ni tampoco conocer, de primera mano, la realidad del alumnado con NEAE en las aulas." (Estudiante 13)

\section{Tabla 1. Citas ilustrativas de cada tema}

Tema 1. El entorno virtual de aprendizaje como facilitador. El alumnado valoró la implementación del prácticum a través de entornos virtuales (v.gr., plataforma Moodle, reuniones de Google Meet) como facilitador del aprendizaje de competencias digitales (C1). Además, mostró empatía con el profesorado en servicio que estaba haciendo frente a la nueva situación de los centros educativos como consecuencia de la COVID-19 (C2).

Tema 2. Las limitaciones de la modalidad virtual del prácticum. La adaptación de la asignatura a una modalidad virtual fue percibida como una barrera significativa para el aprendizaje de competencias prácticas relacionadas con la atención a la diversidad en el aula (C3 y C4).

Tema 3. Satisfacción e insatisfacción con la adaptación de la asignatura. El alumnado expresó su satisfacción general en la reflexión del informe final (C5). Más de la mitad de ellos (13), mostró comentarios positivos, mientras que un tercio (7) también expresó disconformidad con la adaptación (C6). 


\section{¿Cómo evaluó el alumnado la adaptación del prácticum en relación con su desa- rrollo profesional?}

De las competencias propuestas en la Guía Docente del Prácticum [Referencia oculta, 2020], el alumnado reportó haber adquirido más competencias generales que específicas (Tabla 2).

\begin{tabular}{llll} 
Competencias & Mínimo & Máximo & M (DT) \\
\hline Competencias generales (18) & 0 & 5 & $2.18(1.84)$ \\
\hline Competencias específicas (6) & 0 & 5 & $1.05(1.53)$ \\
\hline Competencias totales & 0 & 7 & $3.23(2.49)$ \\
\hline
\end{tabular}

\section{Tabla 2. Percepción de competencias adquiridas}

Nota. $M=$ media, DT= desviación típica.

La competencia general más mencionada fue "Conocer y aplicar las TICs en el aula" (10 citas), seguida de "Diseñar, planificar y evaluar procesos de enseñanza y aprendizaje" (7 citas), "Diseñar y regular espacios de aprendizaje en contextos de diversidad" (7 citas), "Reflexionar sobre las prácticas de aula para innovar" (7 citas), "Asumir la necesidad de perfeccionamiento continuo de la profesión" (5 citas), y "Adquirir hábitos y destrezas para el aprendizaje autónomo y cooperativo" (3 citas). Las competencias "Estimular y valorar el esfuerzo", "Comprender la función de la educación en la actualidad", "Conocer la organización de los centros educativos", "Trabajo con los distintos sectores educativos", "Fomentar la educación democrática" y "Discernir selectivamente la información audiovisual que contribuya a los aprendizajes" fueron mencionadas en una o dos ocasiones. El resto de las competencias generales no fueron mencionadas.

Respecto a las competencias específicas, las más mencionadas fueron "Diseñar y desarrollar los procesos de enseñanza para el desarrollo de competencias básicas" (7 citas) y "Reelaborar los contenidos curriculares en saberes útiles para la vida" (7 citas); seguidas de "Orientar los procesos de enseñanza y aprendizaje" (3 citas), "Conocer las líneas de investigación educativa y su contribución a la práctica docente" (3 citas) y "Enseñar los contenidos instrumentales básicos de lengua y matemáticas" (2 citas). Por el contrario, "Conocer y enseñar a valorar el [información oculta]" no fue mencionada.

\section{¿Cuál fue el grado de participación del alumnado universitario?}

Todo el alumnado contó con los recursos para acceder al aula virtual y a los seminarios grupales. El alumnado vistió el aula virtual casi la mitad de los 47 días que duró la impartición de la asignatura y realizó aproximadamente una docena de clics en cada día de conexión. En relación con el contacto con el profesorado, contactaron unas 5 veces de media, aunque existe una alta variabilidad. Por último, el porcentaje de asistencia a los seminarios fue del 96.5\% (Tabla 3). 


\begin{tabular}{llll} 
Variable & Mínimo & Máximo & M (DT) \\
\hline Visitas al aula virtual (días) & 12 & 31 & $19.14(4.73)$ \\
\hline Clics en el aula virtual & 127 & 383 & $226.18(75.17)$ \\
\hline Clics por día de conexión & 8.27 & 17.41 & $11.86(2.70)$ \\
\hline Contactos con el profesorado & 0 & 30 & $4.77(6.07)$ \\
\hline Asistencia a los seminarios (número de sesiones) & 3 & 4 & $3.86(0.35)$ \\
\hline
\end{tabular}

Tabla 3. Uso de la plataforma Moodle y participación del alumnado.

Nota. $M=$ media, $D T=$ desviación típica.

\section{¿Existió una relación entre la participación del alumnado y su rendimiento acadé-} mico?

El rendimiento académico medio fue de sobresaliente $(M=9.03 / 10 ; D T=0.86)$. Además, se encontró una correlación moderada de carácter positivo entre el rendimiento académico y el uso del estudiante de la plataforma Moodle (Clics/Conexión) $(r=.489 ; p<.05)$ (Figura 1).

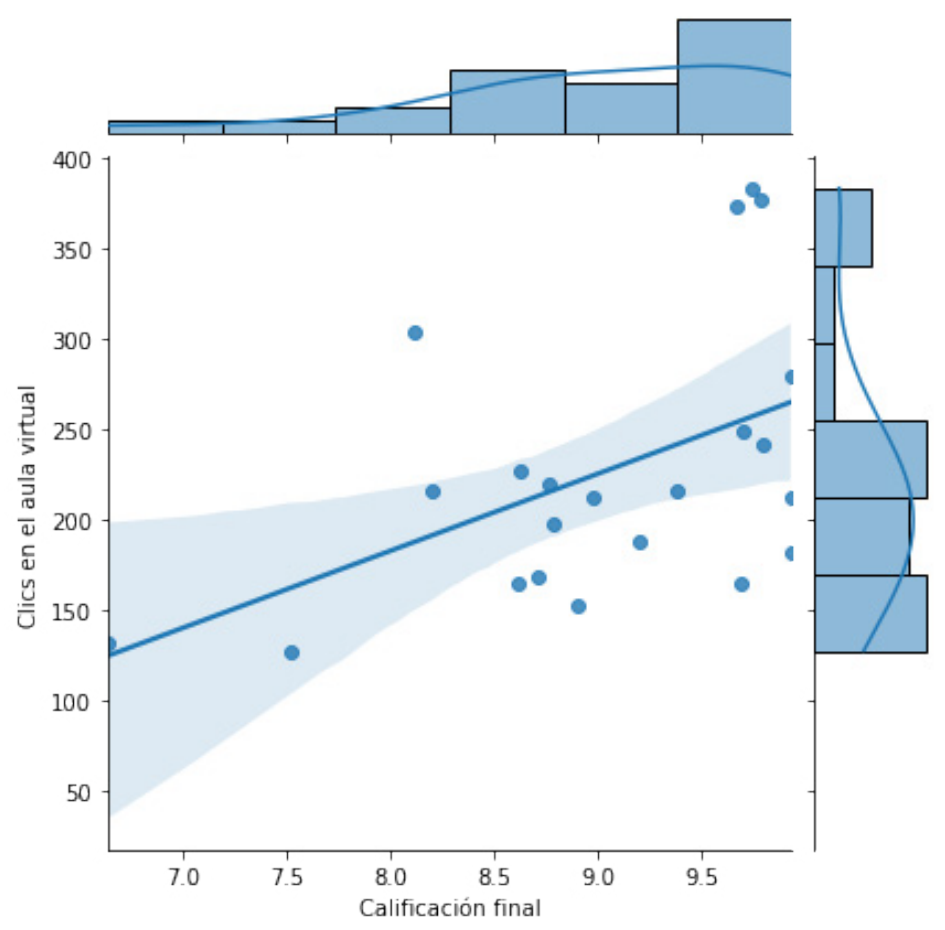

Figura 1. Diagramas de dispersión y distribución de calificación final y uso del aula virtual 
No se encontraron correlaciones significativas entre el rendimiento académico y otras variables como contactos con el profesorado, días de conexión o clics en el aula virtual (Figura 2).

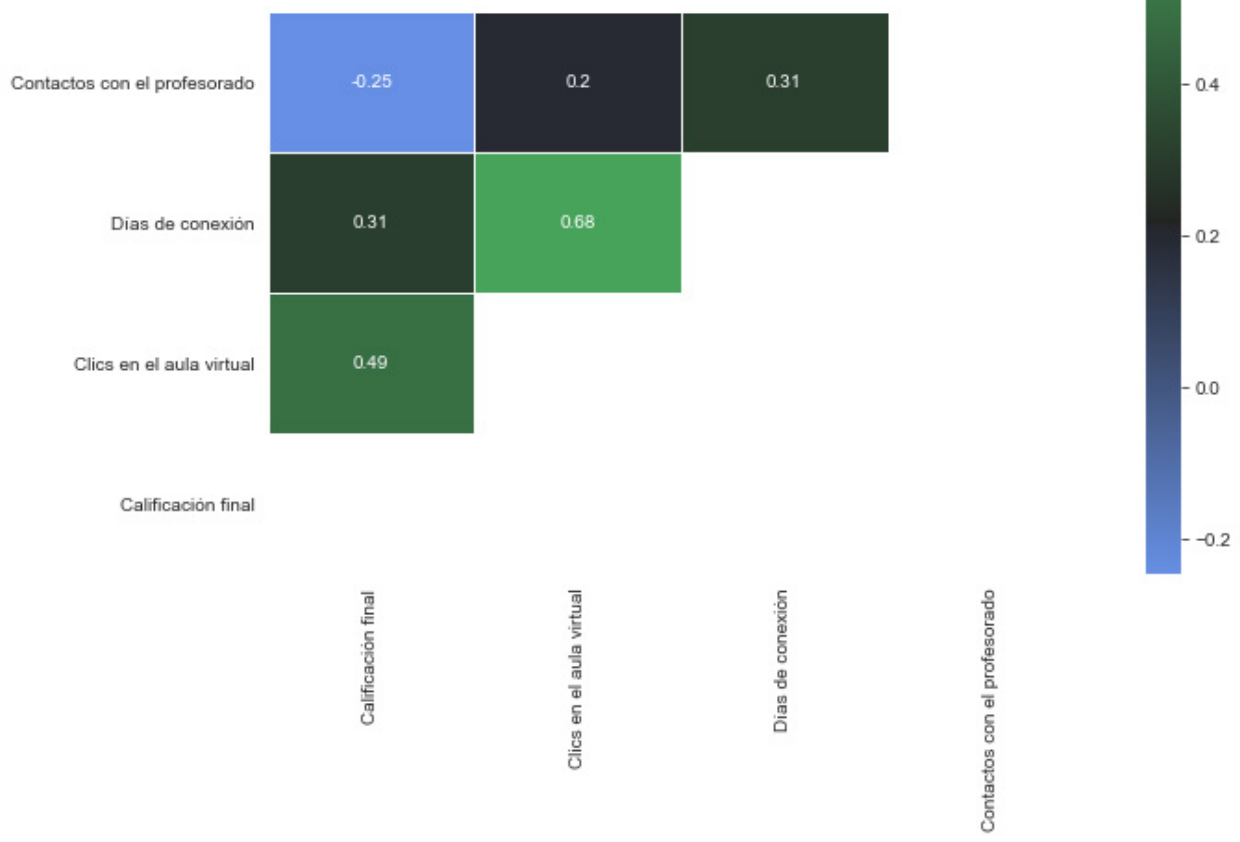

Figura 2. Mapa de calor de las correlaciones

\section{Discusión y conclusiones}

Este trabajo estudia la viabilidad y la efectividad de la adaptación del prácticum a una modalidad virtual identificando factores clave para una buena implementación online.

Con respecto a la percepción del alumnado sobre la adaptación del prácticum, el alumnado valoró el uso del entorno virtual de aprendizaje como un facilitador del aprendizaje de competencias digitales. Estos resultados están en la línea de experiencias previas en las que el profesorado en formación valora mejor el uso de las TICs después de una experiencia de aprendizaje virtual (Luo et al., 2017). Además, suponen un avance en la formación de competencias relacionadas con las TICs que hasta hace un tiempo se encontraban entre las competencias peor valoradas por el alumnado de magisterio (Pesquero-Franco et al., 2008). Por el contrario, la adaptación a una modalidad virtual fue percibida como una barrera para el aprendizaje de competencias profesionales de atención a la diversidad. Aunque el diseño de esta propuesta de intervención tuvo un carácter eminentemente práctico, el desarrollo de ciertas competencias, como la regulación de espacios de aprendizaje en contextos de diversidad, exige la resolución de problemas en tiempo real y el análisis de la propia práctica (Medina y Domínguez, 2006). 
En general, el alumnado ofreció una valoración positiva de la asignatura. La accesibilidad del aula virtual (Torun y Tekedere, 2015) y las posibilidades de interacción grupal que ofrecían los seminarios virtuales (Luo et al., 2017) pueden ser elementos que expliquen la alta satisfacción. Por el contrario, la insatisfacción con la adaptación de la asignatura pudo deberse a las expectativas previas sobre la realización de un prácticum presencial (Scott et al., 2014) y al cambio forzoso a una modalidad virtual que no fue elegida.

Respecto a la evaluación del alumnado de la adaptación del prácticum en relación con su desarrollo profesional, el alumnado percibió que había adquirido competencias tanto generales como específicas pese a que se nombraron más competencias generales que específicas. Una posible justificación a esta diferencia es que la percepción del desarrollo de competencias generales se asentaba sobre la experiencia de asignaturas y prácticas profesionales previas. Además, las competencias específicas de atención a la diversidad son más difíciles de adquirir sin el desarrollo de experiencias prácticas (Scott et al., 2014). De forma específica, el manejo de las TICs fue la competencia más citada, quizás por la naturaleza de la propia experiencia. Seguidamente, las competencias más citadas estaban relacionadas con el diseño de propuestas de intervención educativa y la elaboración de contenidos curriculares, aspectos directamente ligados con el informe final de la asignatura. Aunque este es un resultado positivo, que avala la efectividad de la adaptación propuesta, también señala la necesidad de incluir experiencias en un contexto real en el que se promuevan competencias como la detección de las necesidades del alumnado o el manejo del aula. A este respecto se plantean alternativas como la participación en las clases virtuales de los centros educativos (Kidd y Murray, 2020) o el desarrollo de clases simuladas (Sasaki et al., 2020).

En relación con la participación, el alumnado mostró una participación alta, haciendo un uso frecuente de la plataforma Moodle y asistiendo de forma regular a los seminarios grupales. La adaptación forzosa a un entorno virtual, que rompía con las expectativas de realizar un prácticum presencial, representaba un reto para mantener los niveles de compromiso habituales en circunstancias de normalidad (Scott et al., 2014). La exposición inicial de la adaptación y la publicación de una rúbrica de evaluación pudieron contribuir al compromiso del alumnado y a la autorregulación de su aprendizaje respectivamente (Jaggars y Xu, 2016).

Por último, los resultados sugieren que existe una relación entre la utilización de los recursos en línea y la asistencia a los seminarios en la calificación final. Estos resultados apuntan a que el uso activo del aula virtual y la participación en las reuniones grupales contribuyen al rendimiento académico (Peercy et al., 2016). Por otro lado, la claridad y la estructuración del proceso de evaluación y el acceso a los materiales pudo contribuir al alto rendimiento en la asignatura (Jaggars y Xu, 2016).

Este estudio proporciona evidencia útil sobre la adaptación de un prácticum a una modalidad virtual. No obstante, es importante mencionar algunas de sus limitaciones. Primero, el reducido tamaño muestral impidió desarrollar análisis inferenciales para estudiar los predictores del rendimiento académico. Segundo, por restricciones de la plataforma Moodle, no se pudieron registrar variables relevantes relacionadas con el uso de la plataforma como el tiempo empleado en cada conexión o las horas de conexión. 
Por último, es importante resaltar que esta adaptación se realizó para el alumnado universitario que había superado de forma presencial más de la mitad de las horas de las prácticas profesionales del Grado. No se recomienda la adaptación completa de las prácticas profesionales ya que puede comprometer el desarrollo profesional de los futuros maestros y maestras. Entre los elementos de implementación exitosos en la adaptación de la asignatura destacan: (1) la realización de actividades de carácter práctico; (2) la claridad de los estándares de evaluación a través de una rúbrica; (3) el uso de un aula virtual estructurada; y (4) el desarrollo de seminarios grupales interactivos. Con el fin de suplir la adquisición de competencias específicas, se recomienda que experiencias futuras incorporen la participación del alumnado universitario en situaciones de enseñanza-aprendizaje en línea con escolares y docentes en activo.

\section{Referencias}

Albhnsawy, A. A. y Aliweh, A. M. (2016). Enhancing student teachers' teaching skills through a blended learning approach. International Journal of Higher Education, 5(3), 131-136. https://doi.org/10.5430/ijhe.v5n3p131

Amón, J. (1990). Estadística para psicólogos. Madrid: Pirámide.

Bergdahl, N. y Nouri, J. (2020). Covid-19 and crisis-promted distance education in Sweden. Technology, Knowledge and Learning. https://doi.org/10.1007/s10758-02009470-6

Borup, J., West, R. E. y Thomas, R. (2015). The impact of text versus video communication on instructor feedback in blended courses. Educational Technology Research and Development, 63(2), 161-184. http://dx.doi.org/10.1007/s11423-015-9367-8

Braun, V., y Clarke, V. (2006). Using thematic analysis in psychology. Qualitative Research in Psychology, 3(2): 77-101.

Chigeza, P. y Halbert, K. (2014). Navigating e-learning and blended learning for pre-service teachers: Redesigning for engagement, access and efficiency. Australian Journal of Teacher Education, 39(11), 133-146. https://doi.org/10.14221/ajte.2014v39n11.8

Dumford, A. D. y Miller, A. L. (2018). Online learning in higher education: exploring advantages and disadvantages for engagement. Journal of Computing in Higher Education, 30(3), 452-465.

Fishman, B., Konstantopoulos, S., Kubitskey, B. W., Vath, R., Park, G., Johnson, H. y Edelson, D. C. (2013). Comparing the impact of online and face-to-face professional development in the context of curriculum implementation. Journal of Teacher Education, 64(5), 426-438. https://doi.org/10.1177/0022487113494413

Jaggars, S. S. y Xu, D. (2016). How do online course design features influence student performance? Computers and Education, 95, 270-284. https://doi.org/10.1016/j. compedu.2016.01.014 
Kabilan, M. K. (2013). A phenomenological study of an international teaching practicum: Pre-service teachers' experiences of professional development. Teaching and Teacher Education, 36, 198-209. https://doi.org/10.1016/j.tate.2013.07.013

Kidd, W. y Murray, J. (2020). The Covid-19 pandemic and its effects on teacher education in England: how teacher educators moved practicum learning online. European Journal of Teacher Education, 1-17. https://doi.org/10.1080/02619768.2020.182 0480

Kim, J. (2020). Learning and teaching online during Covid-19: Experiences of student teachers in an early childhood education practicum. International Journal of Early Childhood, 52(2), 145-158. https://doi.org/10.1007/s13158-020-00272-6

Kosar, G. y Bedir, H. (2019). A comprehensive evaluation of practicum experience: From the view preservice EFL teachers. International Online Journal of Education and Teaching, 6(4), 1001-1016. https://files.eric.ed.gov/fulltext/EJ1246502.pdf

Lee, E., Pate, J. A. y Cozart, D. (2015). Autonomy support for online students. TechTrends, 59(4), 54-61. https://doi.org/10.1007/s11528-015-0871-9

Luo, T., Hibbard, L., Franklin, T. y Moore, D. R. (2017). Preparing teacher candidates for virtual field placements via an exposure to K-12 online teaching. Journal of Information Technology Education: Research, 16. http://dx.doi.org/10.28945/3626

McVey, M. (2016). Preservice teachers' perception of assessment strategies in online teaching. Journal of Digital Learning in Teacher Education, 32(4), 119-127. https://doi. org/10.1080/21532974.2016.1205460

Medina, A. y Domínguez, M. C. (2006) Los procesos de observación del Prácticum: análisis de las competencias, Revista Española de Pedagogía, 233, 69-102. https:// dialnet-unirioja-es.accedys2.bbtk.ull.es/servlet/articulo?codigo=1973266

Middleton, K. V. (2020). The longer-term impact of COVID-19 on K-12. Student Learning and Assessment, 39(3), 41-44. https://doi.org/10.1111/emip.12368

Moorhouse, B. L. (2020). Adaptations to a face-to-face initial teacher education course 'forced' online due to the COVID-19 pandemic. Journal of Education for Teaching, OO(O0), 1-3. https://doi.org/10.1080/02607476.2020.1755205

Nuere, S. y de Miguel, L. (2020). The digital/technological connection with COVID-19: An unprecedented challenge in university teaching. Technology, Knowledge and Learning, 1-13. https://doi.org/10.1007/s10758-020-09454-6

O’brien, C., Hartshorne, R., Beattie, J. y Jordan, L. (2011). A Comparison of large lecture, fully online, and hybrid sections of introduction to special education. Rural Special Education Quarterly, 30(4), 19-31. https://doi.org/10.1177/875687051103000404

Peercy, M. M., DeStefano, M., Kidwell, T. y Ramirez, R. (2016). Co-constructing practice in an online ESOL literacy methods course. Professional Development in Education, 42(5), 752-766. https://doi.org/10.1080/19415257.2015.1118707 
Pesquero-Franco, E., Sánchez-Martín, M.E., González-Ballesteros, Martín del Pozo, R., Guardia-González, S., Cervelló-Collazos, J., Fernández-Lozano, P., Martínez-Aznar, M. y Varela-Nieto. (2008). Las competencias profesionales de los maestros de Primaria. Revista española de pedagogía, 241, 447-466. https://dialnet-unirioja-es.accedys2. bbtk.ull.es/servlet/articulo?codigo $=2709002$

Sasaki, R., Goff, W., Dowsett, A., Paroissien, D., Matthies, J., Di lorio, C., Montey, S., Rowe, S. y Puddy, G. (2020). The practicum experience during Covid-19 - supporting pre-service teachers practicum experience through a simulated classroom. Journal of Technology and Teacher Education, 28(2), 329-339. https://www.learntechlib.org/ primary/p/216244/

Scott, L. A., Gentry, R. y Phillips, M. (2014). Making preservice teachers better: Examining the impact of a practicum in a teacher preparation program. Educational Research and Reviews, 9(10), 294-301. https://doi.org/10.5897/ERR2014.1748

Shand, K. y Farrelly, S. G. (2018). The art of blending: Benefits and challenges of a blended course for preservice teachers. Journal of Educators Online, 15(1). https:// doi.org/10.9743/JEO2018.15.1.10

Shulman, L. (1987). Knowledge and teaching: Foundations of the new reform. Harvard Educational Review, 57(1), 1-23. https://doi.org/10.17763/haer.57.1.j463w79r56455411

Torun, F. y Tekedere, H. (2015). The usability analysis of an e-learning environment. Turkish Online Journal of Distance Education,16 (4),50-66. https://doi.org/10.17718/ tojde.99146

Yang, D., Tu, C. C. y Dai, X. (2020). The effect of the 2019 novel Coronavirus pandemic on college students in Wuhan. Psychological Trauma: Theory, Research, Practice, and Policy, 12, 6-14. https://doi.org/10.1037/tra0000930

Zhang, Z., Li, J., Liu, F. y Miao, Z. (2016). Hong Kong and Canadian students experiencing a new participatory culture: A teacher professional training project undergirded by new media literacies. Teaching and Teacher Education, 59, 146-158. https://doi. org/10.1016/j.tate.2016.05.017

\section{Aclaraciones}

Ambos autores contribuyeron por igual en la elaboración de este capítulo de libro. 
Sistema de

Gamificación de un

Entorno Aumentado:

Estimulando

las Habilidades

Comunicativas en

Alumnado con TEA

\section{López Bouzas, Nerea}

orcid.org/0000-0003-0753-0672

U0257373@uniovi.es

\section{Del Moral Pérez, Ma Esther}

orcid.org/0000-0002-9143-5960

emoral@uniovi.es 


\title{
SISTEMA DE GAMIFICACIÓN DE UN ENTORNO AUMENTADO: ESTIMULANDO LAS HABILIDADES COMUNICATIVAS EN ALUMNADO CON TEA
}

\author{
López Bouzas, Nerea \\ Del Moral Pérez, Ma Esther
}

\section{Resumen}

Los Entornos Gamificados Aumentados (EGA) constituyen escenarios inmersivos que involucran a los sujetos en su proceso de aprendizaje a partir de una narrativa gamificada que integra mecánicas y dinámicas de juego, favoreciendo una experiencia multisensorial al interactuar con recursos de realidad aumentada utilizando dispositivos digitales. El objetivo del presente estudio es describir el sistema de gamificación que sustenta un EGA como recurso didáctico diseñado para estimular las habilidades comunicativas del alumnado con TEA. Se adopta una metodología cualitativa centrada en el estudio de caso para describir su diseño, atendiendo a tres dimensiones: narrativa, proceso de gamificación y realidad aumentada. El entorno resultante incorpora una narrativa que recrea una aventura pirata con personajes animados en un ambiente marinero, cuyo proceso de gamificación incluye: a) dinámicas como fórmulas de avance en el juego, adopción de roles y promoción de status; y, b) mecánicas cifradas en la visibilización del progreso y evolución, escalado de niveles, acumulación y colección de puntos e items, expresión y avance. Todo ello se apoya en recursos que incorporan varios niveles de realidad aumentada, los cuales proporcionan distintos tipos de interacción e inmersión. Finalmente, hay que resaltar que el carácter lúdico-inmersivo de este prototipo, apoyado en realidad aumentada y centrado en la superación de misiones enmarcadas en una aventura pirata, le dota de gran potencial para estimular las habilidades comunicativas de este alumnado con TEA.

\section{Palabras clave}

Narrativa, entorno digital, gamificación, realidad aumentada, TEA. 


\section{Introducción}

En la última década, la tecnología está jugando un papel fundamental en las intervenciones dirigidas a Alumnado con Necesidades Específicas de Apoyo Educativo (ACNEAE), utilizando aplicaciones informáticas y recursos tecnológicos diseñados a propósito para activar las competencias clave (Parlamento Europeo y Consejo, 2006). Este hecho se alinea con la consecución de los Objetivos de Desarrollo Sostenible (2015-2030) -formulados por Naciones Unidas-. Especialmente, en el marco de Educación y Calidad, Reducción de las Desigualdades y Salud y Bienestar, pues se busca dispensar una educación de calidad que reduzca las desigualdades y contribuya a la plena inclusión socio-educativa de estas personas, donde las tecnologías emergentes como la realidad aumentada y virtual adquieren protagonismo en el desarrollo de sus habilidades sociales (Alharbi y Huang, 2020).

En ocasiones, las personas con Trastorno del Espectro Autista (TEA) presentan un habla telegráfica, no comprenden las metáforas, chistes o frases hechas (Atencia, 2010; Eigsti et al., 2011), constatándose una reducida competencia comunicativa, manifestada en la dificultad para la interacción, reciprocidad social y emocional (Atencia, 2010) y reconocer la intención comunicativa ajena (Kjellmer et al., 2012). Por ello, precisan intervenciones educativas específicas en las primeras etapas para minimizar sus limitaciones, algunas se apoyan en recursos tecnológicos (García-Guillén et al., 2016; Wass y Porayska, 2014) para estimular la comunicación (Buil et al., 2019; Marín, 2015). Otras potencian sus relaciones interpersonales (Lozano et al., 2013) adoptando metodologías y técnicas innovadoras, próximas al juego, como la gamificación (Navan y Khaleghi, 2020).

En la revisión de Tárraga et al. (2019) se identifican investigaciones recientes con sujetos con TEA que incorporan ordenadores, vídeos interactivos, tabletas digitales, robots, generadores de voz, entornos virtuales de aprendizaje colaborativo, etc. con resultados positivos. Por su parte, la realidad aumentada (RA) supone la superposición de objetos virtuales a entornos reales (Prendes, 2015), que utilizada con fines educativos puede favorecer el desarrollo de diversas competencias en las primeras edades (Neira et al., 2019), y posibilitar la simulación de interacciones comunicativas en alumnado con TEA (Romero y Harari, 2017).

Hay estudios que constatan la efectividad del uso RA en este alumnado (Arief y Efendi, 2018; Chen et al., 2016; Kolomoiets y Kassim, 2018; Sahin et al., 2018a; Taryadi y Kurniawan, 2018). Algunos resaltan la utilidad para facilitar su autonomía (McMahon et al., 2012) e interacción social (Khowaja et al., 2020; Lee et al., 2018a, 2018b; Lorenzo et al., 2019; Sahin et al., 2018b; Wang y Lee). Otros estudian la incidencia en su comportamiento social (Cihak et al., 2016), autorregulación conductual (Liu et al., 2017) y reconocimiento facial en la comunicación (Soares et al., 2017). En general, suelen abarcar tres ámbitos: reconocimiento emocional, lenguaje y desarrollo de habilidades sociales (Baixauli et al., 2017; Moore et al., 2005; Parsons et al. 2006; Shane y Albert, 2008).

Keshav et al. (2017) utilizan un sistema de gafas inteligentes (Brain Power Autism System) para simular situaciones de interacción social. Bhatt et al. (2014) diseñan juegos de RA como Emotions Game o Happy Minion Game y Alharbi y Huangan (2020) crean Ying para favorecer el reconocimiento emocional y el contacto visual. Farr et al. (2012) adaptan el juego Augmented Knight's Castle atendiendo a las 
necesidades de estos usuarios. Da Silva et al. (2014) crean diseños para activar las habilidades sociales, Chung y Cheng (2017) se focalizan en el desarrollo del lenguaje, y Bai et al. (2015) en la representación mental de situaciones de juego.

Concretamente, la gamificación -en tanto técnica que extrapola las mecánicas y dinámicas del juego a contextos no lúdicos (Zichermann y Cunningham, 2011)-, incrementa la motivación hacia el aprendizaje en el contexto escolar (Prieto et al., 2014). Se involucra al alumnado en su proceso cognitivo a partir de estrategias lúdicas (Kapp, 2012) al incorporar retos, desafíos, recompensas, niveles, etc. permitiéndole alcanzar objetivos educativos (Deterding et al., 2011), al dotar de un enfoque creativo a la enseñanza (Marín, 2015). Sin embargo, el proceso de gamificación debe sistematizarse para fomentar la adquisición y/o activar competencias o habilidades concretas.

Esta técnica puede potenciar la interacción social en alumnado con TEA, pues les ayuda a visibilizar y reconocer sus logros (Díaz y Troyano, 2013), lo que incrementa su motivación y hace asequibles tareas complejas (González, 2014). Minimiza el esfuerzo cognitivo que pueden suponer determinadas actividades, creando un escenario de juego a partir de la superación de retos y resolución de problemas (Del Moral, 2020). Los sistemas gamificados incrementan la motivación e implicación del alumnado a través de la experimentación, generando aprendizajes más significativos y funcionales (Glover, 2013; Kenny y McDaniel, 2011; Rodrigues da Silva et al., 2019).

Así, la adopción de tecnologías inmersivas combinadas con técnicas gamificadas pueden contribuir a reducir las mencionadas limitaciones de estas personas, aprovechando su potencial motivador. Las evidencias reflejadas en la investigación subrayan las ventajas de la gamificación en procesos educativos, junto a las aportaciones de la realidad aumentada para el alumnado con TEA, permiten intuir la potencialidad de intervenciones en las que converjan la gamificación y la realidad aumentada para impulsar la interacción social en estas personas. Los Entornos Gamificados Aumentados (EGA) constituyen escenarios inmersivos que involucran a los sujetos en su proceso de aprendizaje a partir de una narrativa que integra mecánicas y dinámicas lúdicas, favoreciendo una experimentación multisensorial a través de la interacción con recursos de RA mediante dispositivos digitales (Del Moral y López-Bouzas, 2020).

Así pues, el objetivo de la presente comunicación se centra en la descripción del diseño del Entorno Gamificado Aumentado (EGA): De Grumete a Capitán: en busca del tesoro perdido. Por un lado, se especifica el sistema de gamificación inherente a las actividades o misiones integradas -junto a la narrativa que las sustenta-, y, por otro, se identifican los recursos de RA incorporados para favorecer las habilidades comunicativas en alumnado con TEA.

\section{Método}

La metodología adoptada es de carácter cualitativo, centrada en el estudio de caso único (Bono y Arnau, 2014) que describe un Entorno Gamificado Aumentado (EGA) diseñado experimentalmente para este alumnado, atendiendo a distintas dimensiones de análisis. 
a) Narrativa, vertebradora del recurso didáctico, siguiendo los criterios de Jenkins (2004): trama, personajes, escenarios y elementos narrativos.

b) Proceso de gamificación del entorno (Cornellà et al., 2020), identificando: mecánicas, acumulación de puntos, escalado de niveles, obtención de premios, desafíos, misiones o retos; dinámicas, guión argumental, tipo de implicación emocional, visibilización del avance de juego y status.

c) Realidad aumentada: a) nivel de RA siguiendo a Cawood y Fiala (2008), b) tipo de interacción -exploratoria, manipulativa y contributiva- (Parés y Parés, 2006) y c) poder inmersivo (Calvert y Pathak, 2015), ligado a una implicación multisensorial básica, media, alta o muy alta.

\section{Resultados}

A continuación, se procede a realizar la descripción del entorno diseñado atendiendo a las distintas dimensiones de análisis:

\section{a) Dimensión Narrativa}

El diseño del EGA, en tanto escenario inmersivo, se apoya en los constructos teóricos de la gamificación e incorpora la realidad aumentada y recursos digitales, tomando como soporte la plataforma Genially (https://n9.cl/zh1od). En concreto, la narrativa vertebradora parte de una historia en un escenario marinero (Figura 1), donde los protagonistas de la serie de animación Jack y los piratas de Nunca Jamás invitan al alumnado a una aventura pirata, cuyo objetivo principal es encontrar un tesoro perdido. Así, el alumnado debe recorrer un itinerario plasmado en un mapa y realizar distintas tareas a partir de las indicaciones de los personajes para superar los distintos desafíos que entraña la trama (Figura 2). Además, la narrativa oral y escrita muestra el itinerario, incluyendo pictogramas, dibujos, imágenes reales, escenarios coloristas y vídeos para garantizar la inmersión.

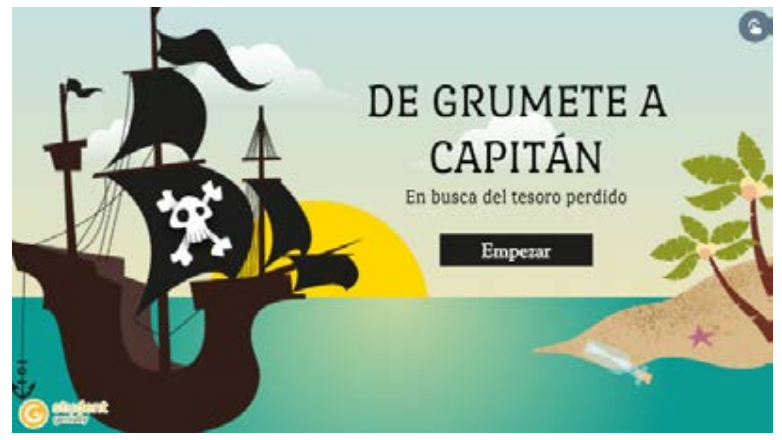

Figura 1. Pantalla de presentación.

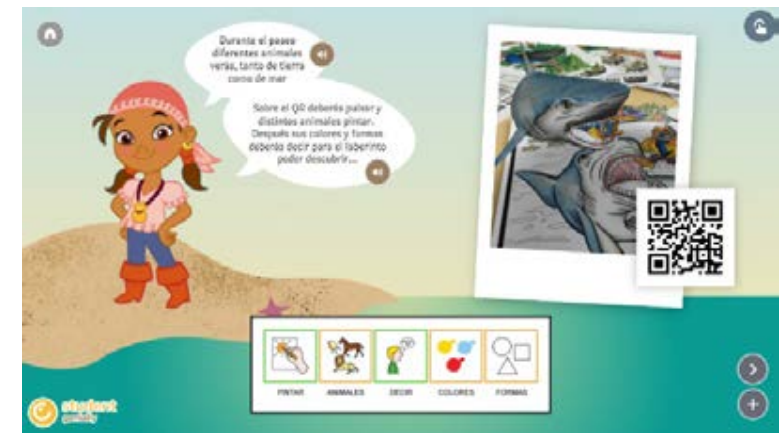

Figura 2. Pantalla de actividad.

\section{b) Dimensión proceso de gamificación del entorno}

Las dinámicas incorporadas para garantizar la implicación emocional del alumnado se relacionan con la posibilidad de asumir distintos roles para concluir las misiones propuestas, así como la constatación del propio avance en el juego, permitiéndole 
conocer su progreso a través de la secuenciación de actividades plasmada en un mapa introductorio a cada misión (Figura 3). Junto a la posibilidad de promocionar de status, pues existe una jerarquía definida en función de los logros alcanzados, que transita de grumete a capitán (Figura 4).

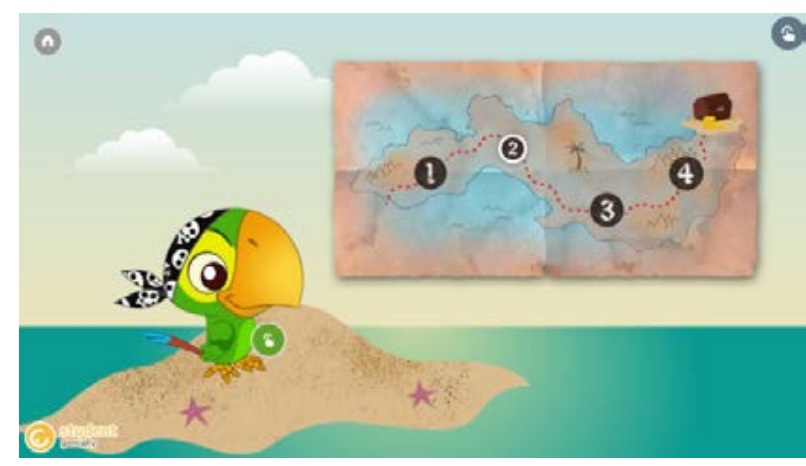

Figura 3. Pantalla de recorrido.

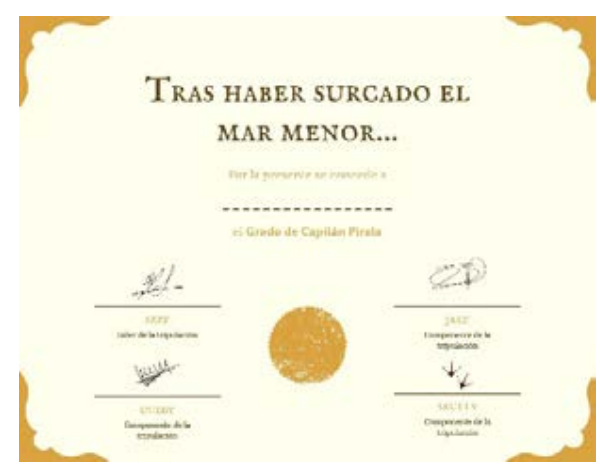

Figura 4. Diploma de Capitán.

Inicialmente se explican las condiciones de victoria y las reglas a través de locuciones para que el alumnado conozca lo que tiene que hacer y cómo debe hacerlo. Se contemplan distintas mecánicas de juego de progreso y evolución: existe un escalado de niveles (1) y (2) ligado a la ejecución de las misiones para avanzar en la historia. El punto de partida se ajusta a las peculiaridades de cada alumno, dependiendo del diagnóstico inicial. La realización de las misiones permite acumular puntos -en este caso, doblones de oro-, que dotan de valor a sus ejecuciones e incrementan su motivación como refuerzos positivos. Mecánicas de colección: se conceden premios o regalos al superar los objetivos educativos iniciales a través de doblones de oro. Se establece un sistema de recompensas intermedias en las que el alumno adquiere complementos propios de la narrativa (parche, garfio, catalejo, sombrero), así como una recompensa final con mayor valor al culminar la historia (Figura 4).

También se incluyen mecánicas de expresión al incorporar actividades como el coloreado de láminas y páginas web, el juego de rol para inferir estados emocionales ajenos o la interpretación de narrativas a través de cuentos, vídeos y simulaciones virtuales. Otras mecánicas incorporadas son las de avance, existen puntos de acción, botones y elementos interactivos en el entorno que el alumno debe activar para descubrir las pistas de los personajes. Finalmente, las misiones orientadas a encontrar el tesoro perdido, implican la realización de distintas actividades que activan las habilidades lingüísticas y socio-emocionales.

\section{c) Dimensión realidad aumentada}

Las actividades se apoyan en recursos digitales y aplicaciones de realidad aumentada que promueven diferentes grados de interacción e implicación multisensorial del alumnado (Figura 5). Los recursos incrementan el poder inmersivo del entorno al integrar gran variedad de códigos (visual, verbal y/o sonoro), y dotan al EGA de una navegación amigable (Figura 6) e intuitiva, adaptándose al nivel madurativo del alumnado. 


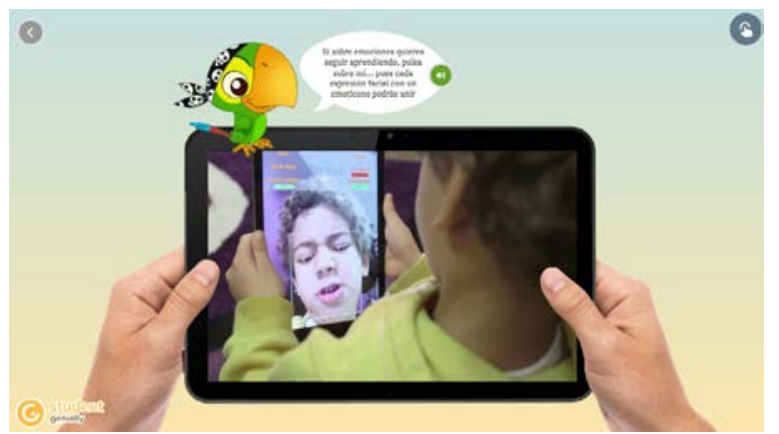

Figura 5. Pantalla de actividad.

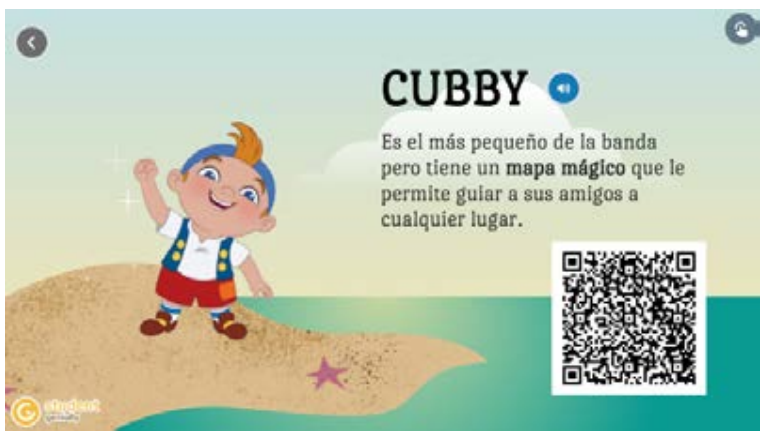

Figura 6. Pantalla de actividad.

En cuanto al nivel de RA incorporado, y siguiendo a Cawood y Fiala (2008), se incluye: Nivel O: basado en códigos QR que hiperenlazan contenidos; Nivel 1: marcadores con patrones 2D o reconocimiento 3D de objetos (láminas Quiver); y Nivel 2: imágenes y objetos como activadores superpuestos en imágenes reales (Merge Cube). Por su parte, el tipo de interacción que se promueve incluye las tipificadas por Parés y Parés (2006): exploratoria, basada en códigos QR; manipulativa, apoyada en juegos online; y contributiva, ligada a la utilización de láminas que promueven su coloreado. Por último, el poder inmersivo del entorno diseñado, entendido como el nivel de implicación multisensorial suscitado (Calvert y Pathak, 2015), es alto, pues las actividades propuestas implican la activación de tres sentidos: vista, oído y tacto. Además, promueve una inmersión empática y social (Haggis-Burridge, 2020), al facilitar la conexión emocional del alumnado con los personajes y la trama del juego, incrementando su inmersión en el entorno.

\section{Conclusiones}

Se contempla una intervención individualizada con un EGA para propiciar una comunicación funcional y espontánea en el alumnado con TEA para constatar su evolución respecto a la estimulación de las habilidades lingüísticas y socio-emocionales. El EGA descrito integra un sistema de gamificación apoyado en la utilización de realidad aumentada para favorecer la inmersión en el entorno. Las actividades -agrupadas en distintos niveles- implican la activación de las habilidades comunicativas a partir de una narrativa gamificada que sumerge al alumnado en el relato y le responsabiliza del desenlace de la trama. El carácter lúdico-inmersivo de este recurso apoyado en realidad aumentada le dota de gran potencial para estimular las habilidades comunicativas de este alumnado con TEA a partir de la superación de misiones enmarcadas en una aventura pirata. Al ser un prototipo, se espera obtener resultados positivos y una mejora cualitativa en este colectivos tras su próxima implementación.

\section{Referencias}

Ahmed, A. y Sutton, M.J. (2017). Gamification, serious games, simulations, and immersive learning environments in knowledge management initiatives. World Journal of Science, Technology and Sustainable Development, 14(2/3), 78-83. https://doi. org/10.1108/WJSTSD-02-2017-0005 
Alharbi, M. y Huang, S. (2020). An Augmentative System with Facial and Emotion Recognition for Improving Social Skills of Children with Autism Spectrum Disorders. In 2020 IEEE International Systems Conference (SysCon) (pp. 1-6). IEEE. http://doi. org/10.1109/SysCon47679.2020.9275659

American Psychiatric Association (2013). Diagnostic and Statistical Manual of Mental Disorders (DSM-5). American Psychiatric Association.

Arief, M. y Efendi, M. (2018). The book of pop up augmented reality to increase focus and object recognition capabilities for children with autism. Journal of International Conference on Special Education in Southeast Asia Region (ICSAR), 2(1), 9-14. http:// dx.doi.org/10.17977/um005v2i12018p009

Atencia, A. (2010). El maestro/a de audición y lenguaje en la identificación de las necesidades educativas especiales de los alumnos/as con autismo. Innovación y Experiencias educativas, 33, 1-12.

Bai, Z., Blackwell, A.F. y Coulouris, G. (2015). Using Augmented Reality to Elicit Pretend Play for Children with Autism. IEEE Transactions on Visualization and Computer Graphics, 21(5), 598-610. http://doi.org/10.1109/TVCG.2014.2385092

Baixaulli, I., Roselló, B., Berenguer, C., Colomer, C. y Grau, M. (2017). Intervenciones para promover la comunicación social en niños con trastorno del espectro autista. Revista de neurología, 64, 39-44. https://doi.org/10.33588/rn.64S01.2017013

Bhatt, S.K., De Leon, N.I y Al-Jumaily, A. (2014). Augmented Reality Game Therapy for Children with Autism Spectrum Disorder. International Journal on Smart Sensing \& Intelligent Systems, 7(2), 519-536. https://doi.org/10.21307/ijssis-2017-668

Bono, R., \& Arnau, J. (2014). Diseños de caso único en ciencias sociales y de la salud. Síntesis.

Buil, L., Esteller, À., Aguilar, E. y Martínez, M. (2019). Propuesta de gamificación para el aprendizaje de los trastornos del lenguaje: Panel de diagnósticos. IN-RED 2019. Actas del V Congreso de Innovación Educativa y Docencia en Red, (pp. 928-934), Universitat Politècnica de València. https://doi.org/10.4995/INRED2019.2019.10461

Calvert, G. y Pathak, A. (2015, 7 de abril). Marketing multisensorial: cómo el futuro pasará por experiencias inmersivas [Entrada de blog] Marketing. https://bit.ly/2kGEh4G

Cawood, S. y Fiala, M. (2008). Augmented Reality: A Practical Guide. Pragmatic Bookshelf.

Chen, C.H., Lee, I.J. y Lin, L.Y. (2016). Augmented reality-based video-modeling storybook of nonverbal facial cues for children with autism spectrum disorder to improve their perceptions and judgments of facial expressions and emotions. Computers in Human Behavior, 55, 477-485. https://doi.org/10.1016/j.chb.2015.09.033

Chung, C.H. y Chen, C.H. (2017). Augmented reality based social stories training system for promoting the social skills of children with autism. Advances in Ergonomics Modeling, Usability \& Special Populations, 486, 495-505. https://doi.org/10.1007/9783-319-41685-4_44 
Cihak, D.F., Moore, E.J, Wright, R.E., Mcmahon, D.D., Gibbons, M.M. y Smith, C. (2016). Evaluating augmented reality to complete a chain task for elementary students with autism. Journal Special Education Technology, 31(2), 99-108. https://doi. org/10.1177/0162643416651724

Cornellà, P., Estebanell, M., \& Brusi, D. (2020). Gamificación y aprendizaje basado en juegos. Enseñanza de las Ciencias de la Tierra, 28(1), 5-19. https://raco.cat/index. php/ECT/article/view/372920

Da Silva, C.A., Fernandes, A.R. y Grohmann, A.P. (2014). Assisting speech therapy for autism spectrum disorders with an augmented reality application. In S. Hammoudi, L. Maciaszek and J. Cordeiro (eds.) Proceedings of the 16th International Conference on Enterprise Information Systems (ICEIS), vol. 2, (pp. 38-45). ICEIS. http://doi. org/10.5220/0004893200380045

Del Moral, M.E. (2020). Aprendizaje basado en Juegos Digitales: Claves para implementar una metodología innovadora en el aula. Comunicación \& Pedagogía, 321-322, 7-10.

Del Moral, M.E. y López-Bouzas, N. (2020). Entornos Gamificados Aumentados para Educación Primaria: Claves para su diseño. Congresso Internacional de Educação e Inovação, 9-11 diciembre, Universidad de Coimbra (Portugal).

Del Moral, M.E. y Neira, M.R. (2020). Realidad Aumentada e Literatura Infantil na Educação Infantil. Revista Debates em Educação, 12(27), 724-743. https://n9.cl/9afe

Deterding, S., Sicart, M., Nacke, L., O’Hara, K. y Dixon, D. (2011, May). Gamification. Using game-design elements in non-gaming contexts. In CHI'11 Extended Abstracts on Human Factors in Computing Systems (pp. 2425-2428). ACM. https://doi. org/10.1145/1979742.1979575

Díaz, J. y Troyano, Y. (2013). El potencial de la gamificación aplicado al ámbito educativo. En III Jornadas de Innovación Docente. Innovación Educativa: respuesta en tiempos de incertidumbre. Universidad de Sevilla. Facultad de Ciencias de la Educación. https://idus.us.es/handle/11441/59067

Eigsti, I.M., de Marchena, A.B., Schuh, J.M. y Kelley, E. (2011). Language acquisition in autism spectrum disorders: A developmental review. Research in Autism Spectrum Disorders, 5(2), 681-691. https://doi.org/10.1016/j.rasd.2010.09.001

Farr, W., Yuill, N. y Hinske, S. (2012). An augmented toy and social interaction in children with autism. International Journal of Arts and Technology, 5(2-4), 104-125. https://doi.org/10.1504/IJART.2012.046270

García-Guillén, S., Garrote, D. y Jiménez-Fernández, S. (2016). Uso de las TIC en el Trastorno de Espectro Autista: aplicaciones. EDMETIC, 5(2), 134-157. https://doi. org/10.21071/edmetic.v5i2.5780

Glover, I. (2013). Play As You Learn: Gamification as a Technique for Motivating Learners. In J. Herrington, A. Couros \& V. Irvine (Eds.), Proceedings of EdMedia: World Conference on Educational Media and Technology (pp. 1999-2008). Victoria, Canadá: AACE. https://n9.cl/r7rg 
González, C. (2014). Videojuegos para la transformación social. Universidad de Deusto. https://bit.ly/2GpczEc

Haggis-Burridge, M. (2020). Four categories for meaningful discussion of immersion in video games. Academy for Games \& MediaCreative and Entertainment Games. https://n9.cl/ytkia

Jenkins, H. (2004). Game design as narrative architecture. Computer, 44(3), 118-130.

Kapp, K. (2012). The Gamification of Learning and Instruction: Game-Based Methods and Strategies for Training and Education. John Wiley \& Sons.

Kenny, R. y McDaniel, R. (2011). The role teachers' expectations and value assessments of video games play in their adopting and integrating them into their classrooms. British Journal of Educational Technology, 42(2), 197-213. https://n9.cl/4v19

Keshav, N.U., Salisbury, J.P., Vahabzadeh, A. y Sahin, N.T. (2017). Social communication coaching smartglasses: Well tolerated in a diverse sample of children and adults with autism. Journal of Medical Internet Research (Mhealth Uhealth), 5(9), 132-140. http://doi.org/10.2196/mhealth.8534

Khowaja, K., Banire, B., Al-Thani, D., Tahri, M., Aqle, A. y Shah, A. (2020). Augmented Reality for Learning of Children and Adolescents With Autism Spectrum Disorder (ASD): A Systematic Review. IEEE, 8, 78779-78807. http://doi.org/10.1109/ ACCESS.2020.2986608

Kjellmer,L., Hedvall, A., Fernell, E., Gillberg, C. y Norrelgen, F. (2012). Language and communication skills in preschool children with autism spectrum disorders: Contribution of cognition, severity of autism symptoms, and adaptive functioning to the variability. Research in developmental disabilities, 33(1), 172-180. https://doi.org/10.1016/j.ridd.2011.09.003

Kolomoiets, T.H. y Kassim, D.A. (2018). Using the augmented reality to teach of global reading of preschoolers with autism spectrum disorders. In A. Kiv \& V.Soloviev (eds.), Proceedings of the 1st International Workshop on Augmented Reality in Education. CEUR-WS, vol. 2257, (pp. 237-246). https://bit.ly/3OPCRGL

Lee, I.J., Chen, C.H., Wang, C.P. y Chung, C.H. (2018a). Augmented reality plus concept map technique to teach children with $A S D$ to use social cues when meeting and greeting. The Asia-Pacific Education Researcher, 27(3), 227-243. https://doi. org/10.1007/s40299-018-0382-5

Lee, I.J., Lin, L.Y., Chen, C.H., \& Chung, C.H. (2018b). How to create suitable augmented reality application to teach social skills for children with ASD. State of the Art Virtual Reality and Augmented Reality Knowhow, 8, 119-138. http://doi.org/10.5772/ intechopen.76476

Liu, R.P, Salisbury, J.P., Vahabzadeh, A. y Sahin, N.T. (2017). Feasibility of an autism-focused augmented reality smartglasses system for social communication and behavioral coaching. Frontiers Pediatrics, 5(145), 1-8. http://doi.org/10.3389/ fped.2017.00145 
Lorenzo, G., Gómez-Puerta, M., Arráez-Vera, G. y Lorenzo-Lledó, A. (2019). Preliminary study of augmented reality as an instrument for improvement of social skills in children with autism spectrum disorder. Education and Information Technologies, 24(1), 181-204. https://doi.org/10.1007/s10639-018-9768-5

Lozano, J., Ballesta, F., Cerezo, M.C. y Alcaraz, S. (2013). Las tecnologías de la información y comunicación (TIC) en el proceso de enseñanza y aprendizaje del alumnado con trastorno del espectro autista (TEA). Fuentes, 14, 193-208.

Marín, V. (2015). La Gamificación educativa. Una alternativa para la enseñanza creativa. Digital Education Review, 27, 1-4. http://greav.ub.edu/der/

McMahon, D., Cihak, D.F. y Wright, R. (2012). Augmented reality as a navigation tool to employment opportunities for postsecondary education students with intellectual disabilities and autism. Journal of Research on Technology in Education, 47, 157-172. http://doi.org/10.1080/15391523.2015.1047698

Moore, D.J., Cheng, Y., McGrath, P. y Powell, N.J. (2005). Collaborative virtual environment technology for people with autism. Focus on Autism and Other Developmental Disabilities, 20(4), 231-243. https://doi.org/10.1177/10883576050200040501

Navan, A. y Khaleghi, A. (2020). Using Gamification to Improve the Education Quality of Children with Autism. Revista Cientifica, 37(1), 90-106. https://doi. org/10.14483/23448350.15431

Neira, M.R., Del Moral, M.E y Fombella, I. (2019). Aprendizaje inmersivo y desarrollo de las inteligencias múltiples en Educación Infantil a partir de un entorno interactivo con realidad aumentada. Magister, 31(2), 1-8. https://bit.ly/2Gaj2m5

Parés, N., y Parés, R. (2006). Towards a model for a virtual reality experience: the virtual subjectiveness. Presence: Teleoperators and Virtual Environments, 15(5), 524538. http://doi.org/10.1162/pres.15.5.524

Parlamento Europeo y Consejo (2006). Recomendación 2006/962/CE de 18 de diciembre de 2006 del Parlamento Europeo y del Consejo sobre las competencias clave para el aprendizaje permanente. Diario Oficial L 394 de 30.12.2006.

Parsons, S., Leonard, A. y Mitchell, C. (2006). Virtual Environments for Social Skills Training: Comments from Two Adolescents with Autistic Spectrum Disorder. Computers \& Education, 47(2), 186-206. https://doi.org/10.1016/j.compedu.2004.10.003

Prendes, C. (2015). Realidad aumentada y educación: análisis de experiencias prácticas. Píxel-Bit, 46, 187-203. http://doi.org/10.12795/pixelbit.2015.i46.12

Prieto, A., Díaz, D., Monserrat, J. y Reyes, E. (2014). Experiencias de aplicación de estrategias de gamificación a entornos de aprendizaje universitario. Revisión. Revista de Investigación en Docencia Universitaria de la Informática, 7(2), 76-92. https://bit.ly/2SqhBCL

Rodrigues da Silva, R. J., Gouveia, R. y Pereira, C. T. (2019). Gamification in management education: A systematic literature review. BAR-Brazilian Administration Review, 16(2), e180103. https://doi.org/10.1590/1807-7692bar2019180103 
Romero, M. y Harari, I. (2017). Uso de nuevas tecnologías TICS-realidad aumentada para tratamiento de niños TEA un diagnóstico inicial. Universidad Internacional SEK, 6, 1-7. http://repositorio.uisek.edu.ec/handle/123456789/2985

Sahin, N.T., Abdus-Sabur, R., Keshav, N.U., Liu, R., Salisbury, J.P. y Vahabzadeh, A. (2018a). Case Study of a Digital Augmented Reality Intervention for Autism in School Classrooms: Associated With Improved Social Communication, Cognition, and Motivation via Educator and Parent Assessment. Frontiers in Education, 3(57), 1-13. https://doi.org/10.3389/feduc.2018.00057

Sahin, N.T., Keshav, N.U., Salisbury, J.P. y Vahabzadeh, A. (2018b). Safety and Lack of Negative Effects of Wearable Augmented-Reality Social Communication Aid for Children and Adults with Autism. Journal of Clinical Medicine, 7(188), 1-17. https://doi. org/10.3390/jcm7080188

Shane, H.C. y Albert, P.D. (2008). Electronic screen media for persons with autism spectrum disorders: Results of a survey. Journal of Autism and Developmental Disorders, 38(8), 1499-1508. https://doi.org/10.1007/s10803-007-0527-5

Soares, K.P., Burlamaqui, A.M.F., Gonçalves, L.M.G., Da Costa, V.F., Cunha, M.E., Da Silva Burlamaqui, A.A.R.S. (2017). Preliminary studies with augmented reality tool to help in psycho-pedagogical tasks with children belonging to autism spectrum disorder. IEEE Latin America Transactions, 15(10), 2017-2023. http://doi.org/10.1109/ TLA.2017.8071250

Tárraga, R., Vélez, X., La Cruz, I. y Sanz, P. (2019). Efectividad del uso de las TIC en la intervención educativa con estudiantes con TEA. Didáctica, innovación y multimedia, 37, 1-9.

Taryadi, D. y Kurniawan, I. (2018). The improvement of autism spectrum disorders on children communication ability with PECS method multimedia augmented reality-based. Journal of Physics: Conference Series, 47(1), 1-8. http://doi.org/10.1088/1742$6596 / 947 / 1 / 012009$

Wang, W. Z. y Lee, I. J. (2020). Social Intervention Strategy of Augmented Reality Combined with Theater-Based Games to Improve the Performance of Autistic Children in Symbolic Play and Social Skills. En International Conference on Human-Computer Interaction (pp. 401-411). Springer. https://n9.cl/o2uhs

Wass, S. y Porayska, K. (2014). The uses of cognitive training technologies in the treatment of autism spectrum disorders. Autism, 18(8), 851-871. http://doi. org/10.1177/1362361313499827

Zichermann, G. y Cunningham, C. (2011). Gamification by Design: Implementing Game Mechanics in Web and Mobile Apps. O'Reilly Media. 


\section{Alcances e Implicaciones de los Mapas Mentales Colaborativos en el Aprendizaje Móvil}

Mg. Estrada Villa, Erika Juliana

ORCID orcid.org/0000-0001-5445-2895

Universitat de les Illes Balears

\section{Dra. Marín Juarros, Victoria Irene}

ORCID orcid.org/0000-0002-4673-6190

Universidad de Lleida

victoria.marin@udl.cat

\section{Salinas Ibáñez, Jesús}

ORCID orcid.org/0000-0002-3043-845

Universitat de les Illes Balears

jesus.salinas@uib.es 


\title{
ALCANCES E IMPLICACIONES DE LOS MAPAS MENTALES COLABORATIVOS EN EL APRENDIZAJE MÓVIL
}

\author{
Mg. Estrada Villa, Erika Juliana \\ Dra. Marín Juarros, Victoria Irene \\ Salinas Ibáñez, Jesús
}

\section{Resumen}

El aprendizaje móvil tiene varias dimensiones, una de ellas, el aspecto social, imbrica la comunicación, la cooperación y la conversación -transversales en los aprendizajes-, y es importante a la hora de ganar la atención de los estudiantes en una sesión sincrónica. Este trabajo analiza los resultados de una experiencia educativa en el contexto de un curso virtual de posgrado, en el que se utilizó la aplicación móvil de mapas mentales Coogle para apoyar el aprendizaje colaborativo. Para ello, se seleccionaron los datos procesados de un instrumento más amplio, y se filtraron los códigos asociados utilizando el software de análisis cualitativo Atlas.ti. Los resultados, y la buena aceptación entre el grupo de estudiantes implicados en la experiencia, muestran que la aplicación Coogle favorece la colaboración en actividades académicas mediadas por el aprendizaje móvil. En suma, la presente publicación presenta una experiencia de aprendizaje móvil y colaborativo mediante el empleo de Coogle.

\section{Palabras clave}

Aprendizaje colaborativo, aprendizaje móvil, mapas mentales, educación virtual, educación superior. 


\section{Introducción}

En la educación virtual en posgrado es cada vez más difícil comprobar la atención de los estudiantes; esta situación se ha acentuado durante la pandemia (Shah et al., 2021), en parte porque su estilo de aprendizaje y metodología de enseñanza se basa en la andragogía y el aprendizaje autónomo. Las tecnologías de la información y la comunicación (TIC) ofrecen a un grupo de personas la posibilidad de colaborar, compartir, aprender e interactuar.

El mapa mental se convierte en una técnica didáctica dentro de las sesiones virtuales de una sesión sincrónica. Según Buzan (1997), los mapas mentales son herramientas que facilitan organizar y representar información en diagramas que armonizan las habilidades cognitivas, lo cual favorece los procesos de enseñanza y la toma de decisiones. Siguiendo el punto de vista del autor y el interés particular en los mapas, en esta contribución se presenta una experiencia sobre los mapas mentales a través de la aplicación móvil Coogle colaborativo.

Los mapas como estrategia didáctica se adaptan bien al proceso metacognitivo, porque como explican Griffith y Ruan (2006), este es un proceso mental donde el estudiante tiene el control de su cognición. Por ello la metacognición ha sido aplicada a los mapas mentales, y como actividad de aprendizaje a través de los dispositivos móviles, debe contar con una planeación, objetivo, secuencia didáctica, evaluación -bien sea sumativa o formativa-, y retroalimentación.

Investigaciones como las de Muñoz, Serrano y Marín (2014), Novoa-Castillo et al. (2021), Laal y Ghodsi (2012) y Kiong et al. (2012), describen experiencias exitosas del uso de los mapas mentales (Elhoseiny y Elgammal, 2016). Hoy en día, hay diversidad de herramientas digitales para crear estos mapas. Un ejemplo es Coogle, que ofrece una aplicación con la cual los estudiantes desarrollan actividades académicas en cualquier lugar, o e-actividades, como las define Cabero-Almenara y Palacios-Rodríguez (2021). Para ello pueden utilizar las ventajas del aprendizaje móvil, que, según O'Malley et al. (2005) (citados en Estrada-Villa y Boude-Figueredo, 2018), integran las bondades del aprendizaje colaborativo, el aprendizaje ubicuo y el aprendizaje situado. La herramienta les sirve a los estudiantes para aplicar los aprendizajes y colaborar, usando una invitación que llega a su correo para editar el mapa; así pueden compartir las ideas y retroalimentar las de sus compañeros.

Teniendo en cuenta lo anterior, se trazó el objetivo de esta contribución, consistente en analizar los resultados de una experiencia educativa basada en el modelo de aprendizaje móvil de Koole (2009). Este modelo presenta las intersecciones entre los dispositivos móviles y el aprendizaje de los estudiantes junto con su interacción social, y se esquematiza a través de un diagrama de Venn (figura 1). Tal como lo menciona la autora, el escenario ideal del aprendizaje móvil debe integrar teorías como el aprendizaje significativo, junto con los dispositivos móviles, para que favorezca la interiorización de los conocimientos, la socialización y la interacción social. 
Figura 1. Diagrama FRAME de c

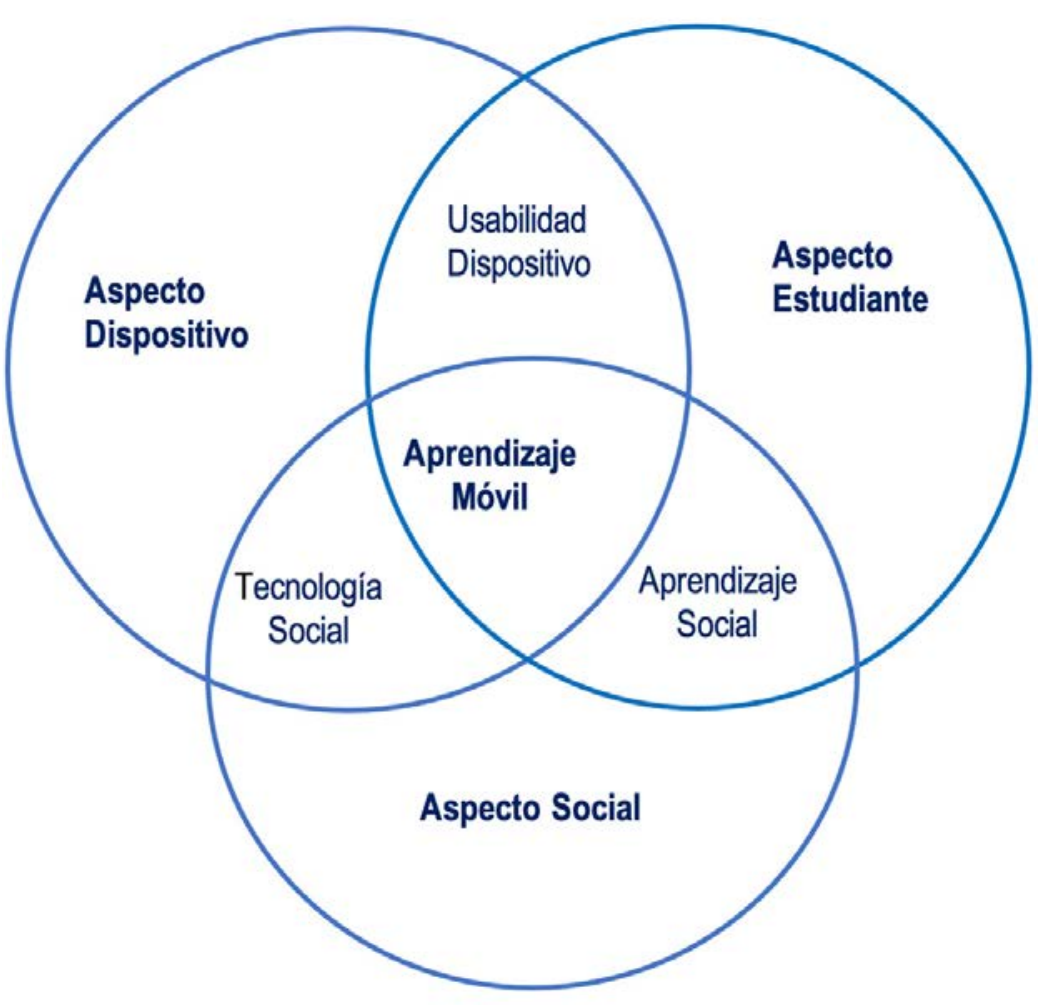

\section{Fuente: Koole (2009).}

El modelo de Koole (2009) destaca los aspectos sociales que pueden promover los variados canales de comunicación de los dispositivos móviles en entornos virtuales de aprendizaje; para este caso, en el contexto de un curso virtual de posgrado, en el que se empleó la aplicación móvil de mapas mentales de Coogle.it, con el fin de apoyar el aprendizaje colaborativo para obtener la atención y participación en clase virtual de estudiantes de posgrado. Tras la implementación, se recogió la opinión de los estudiantes de maestría respecto al Coogle colaborativo y cómo este contribuye a su participación.

\section{Aproximación conceptual: mapas mentales en entornos virtuales de aprendizaje}

La virtualidad se ha erigido como canal educacional, toda vez que la pandemia de la covid-19 (Shah et al., 2021) obligó a asumir este modelo educativo como alternativa a la presencialidad, entendiendo que no podía ser permanente el cese de clases en todos los niveles. Aunque lo virtual forma parte del ámbito educativo desde hace varios años, aún seguía siendo una herramienta tímida, y la mayor parte de los docentes y estudiantes no se atrevía a migrar de lleno a dicha modalidad; sin embargo, dadas las actuales circunstancias, la educación superior ha tenido que incorporarla de manera más amplia para mantener viva la vocación de estudio de sus estudiantes, y garantizar la continuidad de un proceso que marca su impronta en el desarrollo humano, económico y social del país, de allí que esta experiencia presenta los mapas conceptuales como herramienta y estrategia para el proceso de enseñanza-aprendizaje en entornos virtuales. 
Según Buzan (2004), citado por Muñoz, Vega e Hidalgo (2020), "el mapa mental es una técnica mnemotécnica multidimensional que utiliza las funciones inherentes al cerebro para grabar en él, de manera más efectiva, los datos y la información" (p. 2), lo que implica sacar provecho de la visualización de contenidos de manera ordenada, agrupando palabras clave que permitan recordar la información más relevante. A través de este recurso o técnica didáctica no solo se promueve el conocimiento, sino la creatividad de los estudiantes, ya que estos pueden construir modelos mentales.

Según Novak (1991), también citado en Muñoz et al. (2020), el uso de los mapas mentales en la educación deviene de la teoría del aprendizaje constructivista, en la que el conocimiento previo es la base para adquirir y aprovechar el nuevo conocimiento. Lo anterior pondera la utilización de estos recursos educativos como una forma de integrar lo que se conoce con lo que se desea aprender o se aprenderá, algo que en posgrado resulta fundamental, pues los estudiantes tienen trayectoria académica y experiencia laboral, que debe reforzarse y complementarse para consolidar actitudes y aptitudes que fortalezcan las capacidades requeridas en las disciplinas en las cuales se especializan.

El auge del uso de los dispositivos móviles ha hecho que la educación torne su mirada hacia esta modalidad, cada vez más involucrada en la educación formal e informal. Las aplicaciones en educación, en este caso los mapas mentales, son concebidas como herramientas para presentar toda la información importante que se desea transmitir, con la ventaja de que todos colaboran sin exceder los tiempos establecidos en las plataformas, ni hacer tediosas las videollamadas. Los entornos virtuales de aprendizaje permiten acortar distancias, flexibilizar horarios y distribuir el tiempo de manera particular para cada estudiante, y la información organizada y práctica de los mapas mentales los hacen amigables con el entorno virtual educativo. Los mapas mentales sirven para describir y obtener ideas principales, lo que facilita mucho comprender lo que se lee y lo que se estudia, ya que sintetizan la información más relevante, y por ende potencian la eficacia en el aprendizaje. Desde cuando los dispositivos móviles arribaron al aula, comenzó a abrirse un horizonte de posibilidades para la construcción de mapas mentales, con la consecuente diversificación de las estrategias educativas.

Actualmente, se han creado aplicaciones y herramientas web que usan mapas mentales orientados al trabajo individual o colaborativo, y se ha fortalecido su uso como organizadores esquemáticos para diversas necesidades, haciendo a un lado las falencias del individuo para el dibujo y la representación; ahora es bastante sencillo modificar la posición de los elementos en los mapas mentales, añadir o quitar elementos y poner color, entre otros. En las tiendas de aplicaciones de los dispositivos móviles hay varias opciones que tienen gran aceptación entre la comunidad educativa.

Los mapas mentales se pueden configurar en función del modelo educativo en posgrado, en el que es necesario implementar un modelo andragógico para lograr que el estudiante adulto asuma de manera responsable su formación, con altos estándares de calidad. La androgogía es una disciplina que conceptualiza los modelos educativos para adultos, de forma que puedan lograr su desarrollo académico y personal de manera continua, ampliando sus experiencias, lo que ya saben, y adquiriendo nuevos conocimientos. 
Por ello, la virtualidad y el aprendizaje móvil deben aliarse con la andragogía, pues en ese nivel el estudiante busca calidad, practicidad y simpleza; el adulto toma lo que requiere para aprender y cualificarse en su profesión, y busca herramientas y estrategias para aprovechar el tiempo, que en esta etapa de la vida es limitado debido, entre otras, a las responsabilidades familiares y laborales.

De igual manera, el aprendizaje móvil propicia un desarrollo prospectivo que requiere fortalecer aspectos como la autonomía y la colaboración, en busca de responder acertadamente a las necesidades y pensando en cómo será el aprendizaje del futuro. Por esa razón, se debe favorecer el desarrollo del aprendizaje autónomo, ya que, según Sierra (2006), en este tipo de aprendizaje los estudiantes desarrollan la autorregulación, la disciplina y buenos hábitos de estudio, lo que les brinda autonomía, una característica implícita de la andragogía.

En busca de esa autonomía, los mapas mentales tienen un rol preponderante, ya que le permiten al estudiante esquematizar por sí solo, y según su conveniencia, el contenido que considere importante. En este orden de ideas, Cabero-Almenara (2006) menciona que en la comunidad virtual se interactúa con los objetivos de enseñanza y aprendizaje, y a su vez con los compañeros, con quien el estudiante se relaciona socialmente.

El trabajo en grupo beneficia el aprendizaje y también las relaciones interpersonales; el aprendizaje colaborativo no es una contraparte del aprendizaje autónomo, sino que ambos se complementan (AI-Samarraie y Saeed, 2018). Herramientas colaborativas como Coogle apoyan tanto uno como otro, pues luego del análisis individual, los encuentros virtuales permiten confrontar opiniones y propiciar ideas (Muñoz, Serrano y Marín, 2014).

\section{Coogle.it: una herramienta de aprendizaje móvil para crear mapas mentales}

Coogle.it es una herramienta gratuita para uso a través de aplicación (APP) y web, que ofrece una plataforma digital para trabajar actividades académicas colaborativamente en cualquier momento y lugar, de forma sincrónica o asincrónica. Los mapas mentales permiten integrar distintos sistemas de representación en un contexto formal, favorecen que los estudiantes aprendan a pensar visualmente, dado que facilitan el plano visual de los hechos, pensamientos y conocimientos, y contribuyen a crear relaciones entre ellos desde cualquier lugar. Por eso Coogle.it es otro ejemplo para la incorporación de los dispositivos móviles a las actividades académicas (Estrada-Villa, 2016).

En suma, el potencial de los dispositivos móviles reside también en su capacidad para adaptarse a los entornos virtuales de aprendizaje que integran la semiótica y amplían las posibilidades de representar, procesar, transmitir y compartir información (Eco, 1994). Cabe señalar, además, el potencial del aprendizaje móvil para adaptarse a los diferentes estilos de aprendizaje de los estudiantes, y del contexto en el cual desarrollan y apropian sus ideas y las comparten. 


\section{Método/Descripción de la experiencia}

\section{Descripción del contexto y de los participantes}

El presente estudio forma parte de una investigación más amplia en la cual se diseña y valida una estrategia de aprendizaje móvil para la investigación formativa de maestrías virtuales (Estrada, Marín y Salinas, 2020). La muestra la constituyen 17 estudiantes de maestría de una institución de educación superior colombiana dentro del módulo virtual de metodología de la investigación, la cual se configura dentro de un estudio de caso (Stake, 2010).

\section{Experiencia}

Dentro de las sesiones sincrónicas, la actividad académica de Coogle colaborativo consta de tres partes: en la primera el docente expone los contenidos del módulo, lo que se llamaría "clase magistral"; en la segunda se pasa al Coogle y cada estudiante escribe su intervención acorde a los contenidos orientados, y en la tercera se discute y se revisan las ideas puestas en el Coogle. En el ejemplo de la figura 2, para la segunda fase la docente ya tenía un mapa raíz alusivo a la temática, y los aportes de los estudiantes eran sobre su investigación; las líneas amarillas son los aportes de los estudiantes. Esta experiencia se hizo con la aplicación móvil y versión web gratuita de Coogle.

Figura 2. Evidencia Coogle colaborativo como e-actividad para la idea de investigación

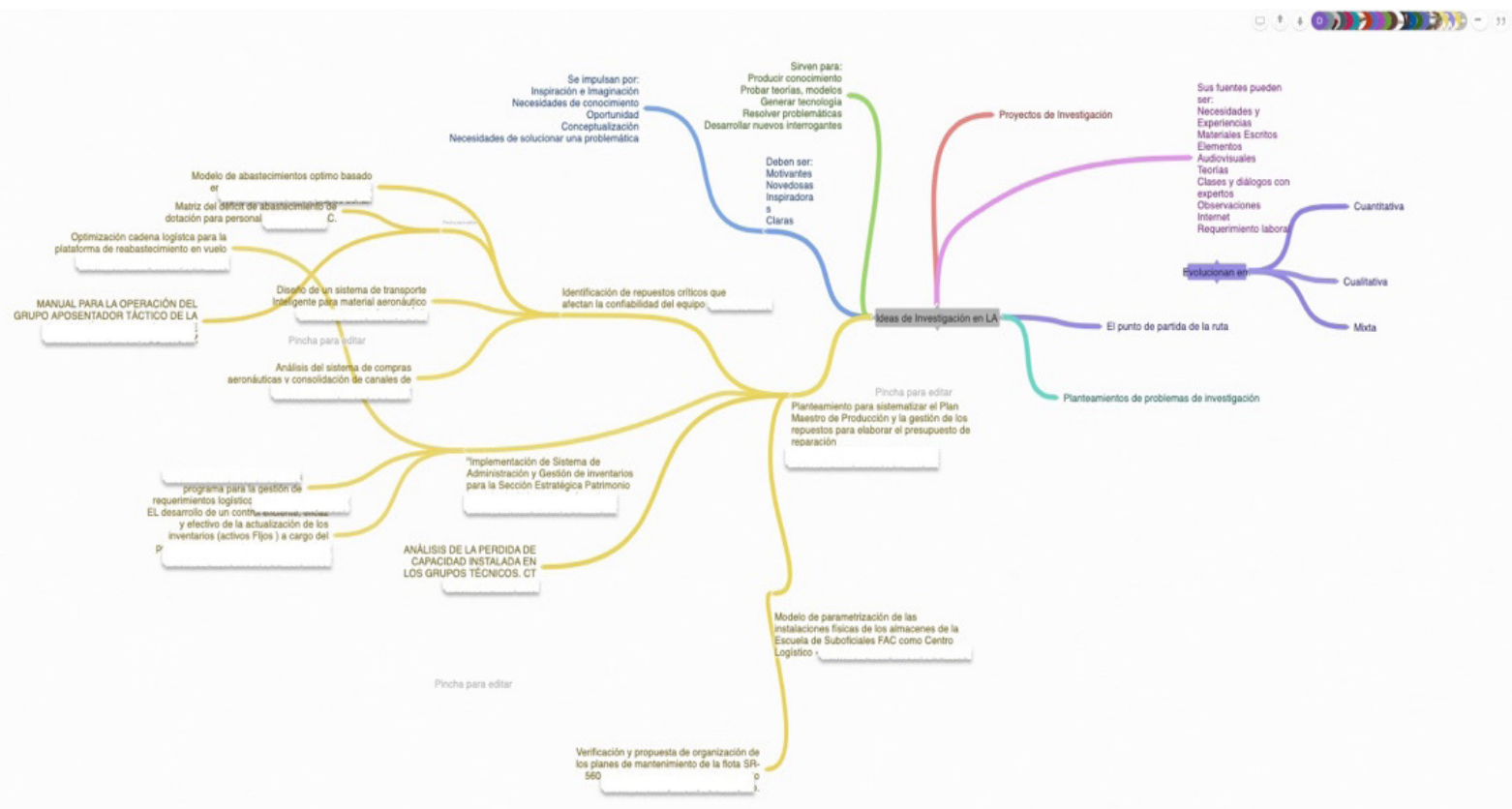

Fuente: elaboración propia

\section{Instrumentos}

Se elaboró un cuestionario general para la estrategia de aprendizaje móvil (investigación más amplia) después de su implementación, y se extrajeron las respuestas 
para la experiencia de uso de la herramienta de mapas mentales. De los datos cuantitativos se presentaron la frecuencia y el porcentaje, y de manera complementaria los resultados de Atlas.ti, en el cual se procesaron diversos instrumentos de naturaleza cualitativa (diario de campo, observaciones a través de grabaciones de las sesiones, análisis de las evidencias del Coogle, cuestionario).

\section{Resultados}

Los resultados del estudio indican una buena acogida de la herramienta colaborativa para trabajar los mapas mentales por parte de los estudiantes. Los ítems fueron valorados positivamente. Se destacan usos de Coogle adicionales a los académicos, en otros escenarios. La respuesta se evidencia en la tabla 1.

Tabla1. Coogle y contextos de aplicación por parte de la muestra

\begin{tabular}{lll} 
[APP Coogle] & Frecuencia & Porcentaje \\
\hline Contexto Académico & 9 & 52.9 \\
\hline Contexto investigativo & 3 & 17.6 \\
\hline Ámbito Personal & 2 & 11.8 \\
\hline No la he empleado & 3 & 17.6 \\
\hline Total & $\mathbf{1 7}$ & $\mathbf{1 0 0}$ \\
\hline
\end{tabular}

Se les pidió a los estudiantes valorar de forma específica el uso de Coogle, que constituye un elemento de la estrategia. El 52.9 \% refiere que le ha parecido útil y relevante (tabla 2a). Igualmente, frente a la pregunta, "¿cree que va a seguir utilizando el Coogle?”, el $94.1 \%$ respondió positivamente (tabla $2 b$ ).

Tabla 2. Valoración y uso del Coogle por parte de la estrategia.

\begin{tabular}{lll}
$\begin{array}{l}\text { [Acceder y participar en los mapas colaborativos } \\
\text { de Coogle] }\end{array}$ & Frecuencia & Porcentaje \\
\hline $\begin{array}{l}\text { Creo que no lo aplicaría } \\
\text { en mi futuro personal y } \\
\text { profesional }\end{array}$ & 3 & 17.6 \\
\hline $\begin{array}{l}\text { Me ha gustado } \\
\text { Me ha parecido útil y } \\
\text { relevante }\end{array}$ & 2 & 11.8 \\
$\begin{array}{l}\text { Lo he encontrado } \\
\text { sencillo/fácil }\end{array}$ & 3 & 52.9 \\
\hline Total & $\mathbf{1 7}$ & 17.6 \\
\hline
\end{tabular}

[Herramientas de creación de mapas mentales APP Coogle]

\begin{tabular}{lll} 
& Frecuencia & Porcentaje \\
\hline Dudo & 1 & 5.9 \\
Sí & 16 & 94.1 \\
\hline Total & $\mathbf{1 7}$ & $\mathbf{1 0 0 . 0}$ \\
\hline
\end{tabular}

2 b. Seguirá utilizando la herramienta 
Frente al análisis cualitativo de la figura 3, se evidencia cómo la coocurrencia es fuerte entre el código "App Coogle" y los códigos "Habilidades Investigativas" y "Aspectos Sociales 2" (para este caso, la actividad central de mapas estaba en la Unidad 2), seguidos por los códigos "Comunicación", "Conversación" y "Cooperación", los cuales a priori están basados en el modelo de Koole (2009).

Figura 3. Diagrama de Sankey de coocurrencias entre códigos relacionados con el Coogle Colaborativo mediante Atlas.ti

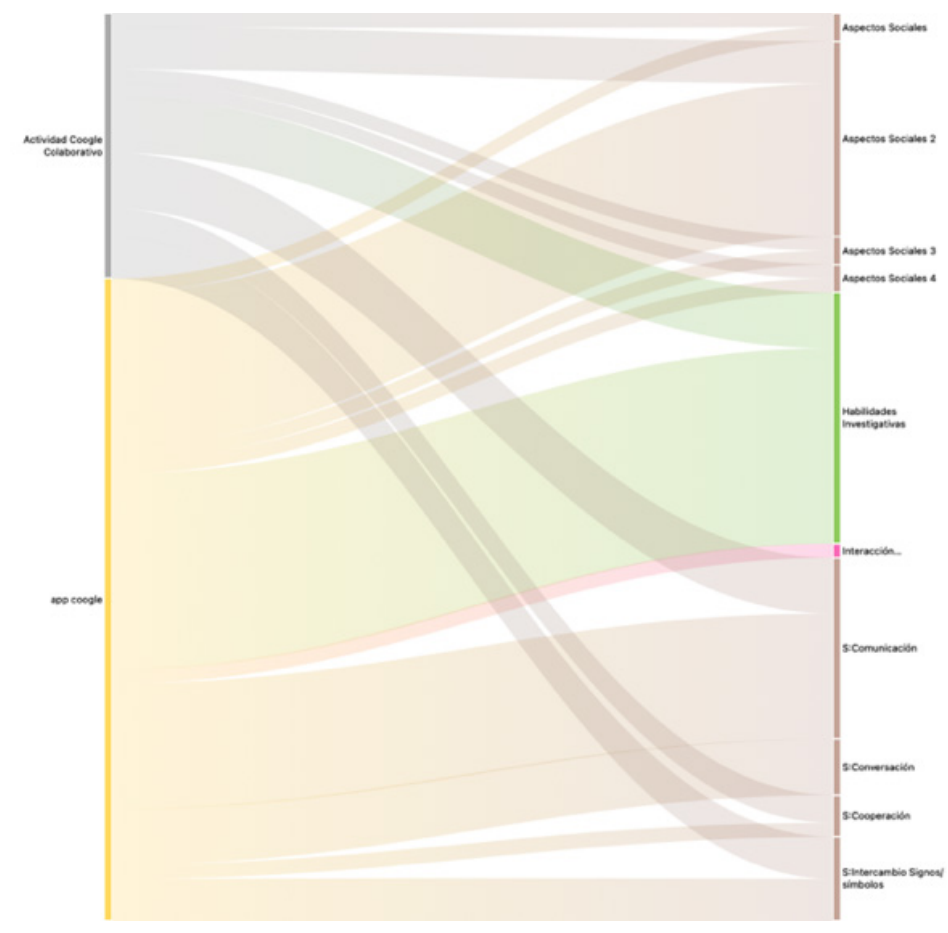

\section{Fuente: elaboración propia}

La actividad académica mediada por los dispositivos móviles planteada, parte de la necesidad de establecer la idea de investigación, hecho que resulta crucial cuando la virtualidad está en auge en las universidades y centros educativos en general, debido a la emergencia sanitaria decretada por la covid-19 (Shah et al., 2021). Para abordar este requerimiento, se ha recurrido al modelo de aprendizaje basado en Koole (2009) y a una técnica de representación externa como los mapas mentales. La aplicación seleccionada para crear mapas mentales, Coogle.it, ofrece una plataforma idónea para que los estudiantes puedan integrar, interactuar e interrelacionar los contenidos y construir aprendizajes, en conexión con los demás participantes de la actividad.

Evidentemente, el diseño de actividades académicas que involucran tecnología y su aplicación, hace que su versión técnica asuma un matiz más íntegro y flexible, lo que se relaciona con lo que se mencionó al inicio en la conceptualización, en función de aprender en cualquier momento y lugar combinando las ventajas del aprendizaje colaborativo. Tal flexibilidad de horarios y apropiación de los dispositivos móviles por parte de cada uno de los estudiantes, en cierta medida los responsabiliza de su propio proceso de aprendizaje; principalmente dentro del aprendizaje móvil, 
donde se establece mayor autonomía y donde en el aprendizaje también interviene el contexto. En este sentido, implementar mapas mentales colaborativos en entornos de maestrías virtuales, tiene como fines trabajar el aprendizaje autónomo en los estudiantes, promover su pensamiento crítico y capacidad creativa, reforzar su capacidad de análisis, y estimular la síntesis de información extensa e importante para su investigación.

A partir de lo observado en la creación del mapa mental, se pudo orientar el desarrollo de la idea de investigación. Volcar el conocimiento en un mapa mental permitió a los estudiantes compartir el esquema, y posibilitó un acompañamiento por parte de la docente, quien puede acceder al mapa mental compartido para supervisar e intervenir en el proceso como un usuario más del Coogle colaborativo.

\section{Discusión y conclusiones}

Investigaciones previas indican la importancia del aprendizaje colaborativo (Laal y Ghodsi, 2012) y el uso de los mapas mentales (Elhoseiny y Elgammal, 2016) en la educación virtual, y la necesidad de incorporar el $m$-Learning (Estrada, et al., 2020) a las e-actividades (Cabero-Almenara y Palacios-Rodríguez, 2021). Los resultados de esta experiencia han ayudado a comprender las e-actividades. A su vez, las e-actividades, a través del empleo de una técnica didáctica como los mapas mentales, contribuye a garantizar la congruencia y el sentido de la práctica docente relacionadas con las actividades en las sesiones sincrónicas de un módulo virtual de posgrados. Los mapas mentales como técnica de trabajo colaborativa en línea coadyuvan a la atención por parte de los estudiantes, a través de las formas, los colores y las diversas ideas que allí se plasman. La actividad descrita e implementada a través del Coogle, tiene el propósito de facilitar los procesos de aprendizaje, vertebrar temáticas, y presentar y priorizar ideas, entre otros.

En complemento, con el modelo de Koole (2009) a partir de la implementación de los mapas en los dispositivos móviles, y como se observa en la figura 3, se logró identificar que de los aspectos relacionados con el modelo que convergen entre sí, surgen algunos fenómenos en la realidad observada, como la imbricación entre el dispositivo y el "aspecto estudiante", porque la intersección relacionada con la usabilidad aparece cuando los estudiantes entran en contacto con un dispositivo móvil. La usabilidad tiene en cuenta elementos como la portabilidad, acceso a la información y funcionalidad, entre otros aspectos visuales y psicológicos que traen estos dispositivos, los cuales están relacionados con los contenidos y por ende con los aprendizajes. A su vez, cuando el "aspecto social" interviene mediante la interacción con los compañeros y el docente en el plano digital, que en este caso se da mediante la tecnología, en la aplicación de Coogle.it se observaron cómo emergen dentro de la comunidad virtual de aprendizaje la comunicación, la socialización, la colaboración, la conectividad, etc. En el centro del modelo confluyen los aspectos del aprendizaje relacionados con la tecnología, lo social y el estudiante, que es lo que aporta a la construcción del conocimiento mediado por los dispositivos móviles, lo cual se da a través del acceso a la información, selección, depuración, interiorización e internacionalización del conocimiento. En suma, de las relaciones de los códigos analizados en la figura 3, se puede inferir como Coogle favorece el trabajo colaborativo y la inclusión del aprendizaje móvil en las actividades académicas. 
Por su parte, se evidencia en el trabajo de aula que los mapas mentales contribuyen a la metacognición de los procesos y a la investigación formativa, en especial en la comprensión en la búsqueda de la información que integra textos a la idea de investigación (Griffith y Ruan, 2006).

Se observa cómo el mapa mental permite plasmar información en una herramienta en línea, en este caso Coogle, de una manera más aproximada a como lo maneja la mente, en vez de presentarse de forma rígida. Por ello cada mapa mental es único del estudiante que lo diseña (Buzan, 1997) y no existen mapas mentales incorrectos ni formas esquemáticas rígidas, y no se pueden juzgar a priori.

También puede decirse que los mapas mentales desempeñan un papel fundamental en el ámbito virtual, porque permiten graficar información y presentarla de modo integral, lo que reduce el tiempo al revisarla y transmitirla, debido a la rapidez de lo virtual frente a lo que sucede en la presencialidad. Además, son herramientas de uso en diversas áreas, incluso la empresarial, pues generan discusiones abiertas e interesantes a partir de la conceptualización que cada persona involucrada ha hecho, y es allí donde se configura la sinergia de los mapas mentales con el aprendizaje autónomo y colaborativo.

No obstante, se debe continuar estudiando si el uso del Coogle colaborativo favorece las habilidades investigativas en los estudiantes de posgrado, y ahondar en la calidad de estos aprendizajes, así como en la evaluación de las e-actividades que dan soporte a la interacción en la educación virtual.

\section{Referencias}

Al-Samarraie, H. y Saeed, N. (2018). A systematic review of cloud computing tools for collaborative learning: opportunities and challenges to the blended learning environment. Computer \& Education, 124, 77-91. https://doi.org/10.1016/j.compedu.2018.05.016.

Buzan, T. (1997). El libro de los mapas mentales. Ediciones Urano.

Cabero-Almenara, J. (2006). Comunidades virtuales para el aprendizaje. Su utilización en la enseñanza. Edutec. Revista Electrónica de Tecnología Educativa (20), a053. https://doi.org/10.21556/edutec.2006.20.510.

Cabero-Almenara, J. y Palacios-Rodríguez, A. (2021). La evaluación de la educación virtual: Las e-actividades. Revista Iberoamericana de Educación a Distancia, 24(2), 169-188. http://dx.doi.org.mindefensa.basesdedatosezproxy.com/10.5944/ried.24.2.28994.

Elhoseiny, M. y Elgammal, A. (2016). Text to multi-level MindMaps. Multimedia Tools \& Applications, 75(8), 4217-4244. https://doi.org/10.1007/s11042-015-2467-y.

Eco, U. (1994). La estructura ausente: introducción a la semiotica (5. a ed.). Lumen.

Estrada, E., Marín, V. y Salinas, J. (2020). Habilidades investigativas y medios virtuales en educación superior: una revisión sistemática. En Sánchez, E., Colomo, E., Palmero, J. y Sánchez, J. (coords.). Tecnologías educativas y estrategias didácticas. (pp. 1392-1403). Universidad de Málaga. 
Estrada-Villa, E. J. (2016). Códigos QR basado en el aprendizaje móvil como estrategia para la investigación formativa: Un caso piloto. Ciencia y Poder Aéreo, 11(1), 230-241. https://doi.org/10.18667/cienciaypoderaereo.500.

Estrada-Villa, E. y Boude-Figueredo, Ó. (2018). Análisis multivariado a los factores relacionados con el aprendizaje móvil en la educación superior en Colombia. Revista Electrónica Educare, 22(3), 1-19. https://doi.org/10.15359/ree.22-3.6.

Griffith, P. y Ruan, J. (2006). What is metacognition and what should be its role in literacy instruction? En Israel, S., Collins, C., Bauserman, K. y Kinnucan-Welsch, K. (eds.). Metacognition in literacy learning (pp. 25-40). Routledge. https://www. taylorfrancis.com/books/e/9781410613301/chapters/10.4324/97814106133 01-10.

Kiong, T. T., Yunos, J. B. M., Mohammad, B. B., Othman, W. B., Heong, Y. M., y Mohamad, M. M. B. (octubre de 2012). The Development and Evaluation of the Qualities of Buzan Mind Mapping Module. Procedia - Social and Behavioral Sciences, 59, 188196. https://doi.org/https://doi.org/10.1016/j.sbspro.2012.09.264.

Koole, M. (2009). A Model for Framing Mobile Learning. En Ally, M. (ed.), Mobile Learning: Transforming the Delivery of Education and Training (vol. 1, pp. 25-47). AU Press. http://www.aupress.ca/index.php/books/120155.

Laal, M. y Ghodsi, S. (2012). Benefits of collaborative learning. Procedia - Social and Behavioral Sciences, 31, 486-490. https://doi.org/https://doi.org/10.1016/j.sbspro.2011.12.091.

Muñoz, J., Serrano, R. y Marín, V. (2014). El aprendizaje colaborativo y su desarrollo a través de mapas mentales. Una innovación educativa en la formación inicial docente. Educatio Siglo XXI, 32(1), 193-212. https://bit.ly/3fMXKdr.

Muñoz, J., Vega, E. e Hidalgo, M. (2020). El aprendizaje del mapa mental grupal mediante las TIC en educación superior. Revista Educación y Sociedad, 41, 1-16. https:// doi.org/10.1590/ES.219656.

Novoa-Castillo, P., Inga-Arias, M., Rivera, J., Ramos-Palacios, W. y Salvatierra, Á. (2021). Estrategias metacognitivas en plataforma digital para estudiantes universitarios con baja comprensión de textos. Revista Ibérica de Sistemas e Tecnologias de Informação, 41(2), 258-275. https://www-proquest-com.mindefensa.basesdedatosezproxy.com/scholarly-journals/estrategias-metacognitivas-en-plataforma-digital/ docview/2493869952/se-2?accountid=143348.

Shah, S. S., Shah, A. A., Memon, F., Kemal, A. A. y Soomro, A. (julio-diciembre de 2021). Online learning during the COVID-19 pandemic: Applying the self-determination theory in the 'new normal'. Revista de Psicodidáctica, 26(2), 168-177. https://doi. org/https://doi.org/10.1016/j.psicod.2020.12.004.

Sierra. R. (2006). La andragogía, modelo propicio para el desarrollo de la educación de adultos. Revista Prospectiva, 4(1), 100-102. https://www.redalyc.org/ pdf/4962/496251107016.pdf.

Stake, R. (2010). Investigación con estudio de casos. (R. Fiella, trad.), (5. a ed.) Ediciones Morata. 


\section{La Formación Continua como Espacio de Criticidad y los Dilemas Educativos. Educación Inclusiva en Tiempos de Pandemia}

\section{Domínguez, María Alejandra}

orcid.org/0000-0002-6293-1957 


\title{
LA FORMACIÓN CONTINUA COMO ESPACIO DE CRITICIDAD Y LOS DILEMAS EDUCATIVOS. EDUCACION INCLUSIVA EN TIEMPOS DE PANDEMIA
}

\author{
Domínguez, María Alejandra \\ orcid.org/0000-0002-6293-1957
}

\section{Resumen}

En este estudio se presenta la formación continua como un espacio que genera criticidad cuando se emplean dispositivos de discusión, en ciclos de descripciones, narraciones y reelaboraciones, con los docentes, en pos de hacer conscientes los significados asociados a determinadas experiencias. En particular se da a conocer el análisis sobre los dilemas que atravesaron/atraviesan cuando éstos docentes diseñan y concretan propuestas, para todos/as, en tiempos de pandemia con la mediación de tecnología. A partir de un análisis de contenido, se construyeron categorías emergentes para cuatro dimensiones: Docente, Estudiantes, Medios tecnológicos y educación y Diseños de propuestas didácticas. Producto de la vinculación con los referentes teóricos se identificaron las decisiones didácticas, organizativas y las referidas a los aspectos relacionales y en particular, cómo cada una se integraba a la educación inclusiva o para todos/as. Como consecuencia de las tensiones identificadas se presentan consideraciones para repensar los escenarios de enseñanza y de aprendizaje con tecnologías. Entre ellas la revisión necesaria de las instituciones y de sus supuestos sobre la enseñanza y el aprendizaje en relación con los/las sujetos/ as a quienes se dirige la educación; la inclusión de los recursos tecnológicos para construir y reconstruir significados y como verdaderos apoyos para el aprendizaje necesita la construcción de criterios y, por último, la enseñanza se adapta a la heterogeneidad del grupo y se gestiona según las posibilidades.

\section{Palabras clave}

Dilemas, Pandemia, Docentes de Ciencias Naturales y de Matemática, Tecnologías, Educación inclusiva. 


\section{Introducción}

Entre las infinitas preguntas, situaciones y dilemas, que transitamos los/las docentes, los diferentes actores educativos y las familias, en este estudio recortamos a un nudo central que se relaciona con los dilemas de las/los docentes y las decisiones didácticas, organizativas y vinculadas a facetas relacionales, en la educación para todos y en tiempos de pandemia. Fundamentalmente porque se asume que el/la docente toma decisiones, siempre en un escenario complejo y en estas oportunidades, con una marcada incertidumbre, atravesado/a por el dolor, la angustia, porque en esta ocasión el escenario incierto, no sólo lo era (es) para los estudiantes sino para todos los/las actores educativos y las familias. Por primera vez para muchos, teníamos en común ese dolor y la incertidumbre; aunque las condiciones para atravesarlo eran diferentes. Todo aquello relacionado con lo escolar, la gestión del tiempo, del espacio, de los contenidos se vio tensionado abruptamente, sin tiempo para la reflexión y para modificar nuestras anteriores categorías, que servían como norte en la práctica docente. La emergencia sanitaria nos obligó a rediseñar "las clases" y los espacios de aprendizaje.

Nuestra hipótesis y anticipación de sentido es que el espacio de formación continua permite generar criticidad sobre la práctica. Es en un espacio de trayecto formativo, como lo es la Diplomatura Universitaria Superior: Enseñanza de la Física en la Educación Secundaria- DEFES-, que se generaron actividades para identificar cómo se desarrollaron los rediseños de los espacios de enseñanza y de aprendizaje a partir de las decisiones involucradas. El interjuego entre los referentes teóricos y la empiria es lo que permitirá la construcción de categorías analíticas.

Durante todo el trayecto formativo se realizan ciclos de descripciones, narraciones y reelaboraciones, con los docentes, en pos de hacer conscientes los significados asociados a determinadas experiencias. Uno de los objetivos de la propuesta es intentar desocultar la expresión para conocer lo no dicho, lo sugerido, lo implícito (Bardin, 1986). “... las escuelas están cargadas, saturadas, de historias, y los/as docentes son a un mismo tiempo los actores de sus tramas y los/as autores de sus relatos.." (Suárez, Dávila y Ochoa De la Fuente, 2003, p. 3). En comunicaciones anteriores se ha rescatado que la dinámica propuesta en este trayecto formativo es prometedora porque permite el encuentro de diferentes voces y experiencias. Particularmente se ha propuesta el análisis sobre la Enseñanza invertida y la superación de las TIC como recursos para asumirlas e integrarlas en las propuestas de enseñanza como mediadoras de la construcción de significados (Garcia, D. y Domínguez, M. A., 2019). Asimismo, se ha comunicado el proceso de problematización en este marco de formación acerca de la educación inclusiva (Domínguez, M. A.; Acosta, G. y Garcia, D., 2019) revelando que los docentes manifiestan trabajo en soledad en el aula, respuestas del tipo que combinan delegación de funciones y responsabilidad compartida en la construcción de apoyos

En esta oportunidad el análisis se definió en tres ejes problematizadores: los dilemas de los docentes en escenario ASPO; los mitos de la educación inclusiva en pandemia y un análisis de respuestas de los mismos docentes a experiencias compartidas sobre educación inclusiva en tiempos de no pandemia. Aquí se presenta el análisis realizado sobre el primero de ellos. 
Brailovsky (2020) señala cuando se problematiza la tecnología en la educación:

....un forcejeo simplificado, reducido al dilema acerca de incorporar o no incorporar tecnologías en la enseñanza. Así pensado, en forma binaria y banal, el tironeo tiene menos que ver con las propias tecnologías, y más con los modos en que elegimos mirar el lugar del docente. (p. 150).

Nunca antes se sacudió con tanta celeridad la duda casi permanente sobre las funciones de la tecnología en y con la educación. No hubo tiempo para ello. La accesibilidad se convirtió en el punto de inicio, en la condición necesaria para volver a conectarnos; aunque no fue (es) garantía de reelaboración de vínculos pedagógicos (Amuchástegui et al, 2021).

La discusión que se presenta se enmarca en un enfoque interpretativo y tiene como objetivos la comprensión de los significados de las decisiones que desarrollan los profesores cursantes. Se asume la postura de Bruner (1997) por la cual los significados se comprenden como construcciones consensuadas entre el hombre y la cultura en la que se halla inmerso. La población está formada por 17 profesores que dictan clases de Física en la educación secundaria con formación inicial de profesor en Física, Matemática, Biología y Química. Lo que se comunica corresponde a una actividad (escrita) de reflexión con preguntas orientadoras sobre algunas posibles dificultades en el diseño de sus clases. El corpus de análisis está configurado por el conjunto de registros narrativos elaborados por los docentes. A partir de un análisis de contenido, se construyeron categorías emergentes, producto de la interpretación de los escritos producidos de manera individual. Las mismas se relacionan con los estudiantes (dificultades, familia y necesidades, emociones), con los medios tecnológicos necesarios para la comunicación y en esta oportunidad para la educación, con los docentes (prioridades y decisiones, sobreexigencias) y con el diseño de propuestas didácticas en este contexto (contenidos, conocimientos previos, evaluación, actividades, dinámica de trabajo).

\section{Marco teórico}

En el marco de la oferta educativa descrita se diseñan y proponen dispositivos pedagógicos, en el sentido de Souto (1999), como aquello en su doble condición de artificio técnico y también como lo que se pone a disposición o que provoca en otros disposición para. Es decir, como medio que nos permite a los docentes y a los estudiantes acceder a las experiencias subjetivas de los sujetos y a sus significados. Asimismo, tomando a Anijovich (2009) los dispositivos narrativos "consisten en la producción de relatos escritos como un medio para acceder a la experiencia subjetiva de los estudiantes" (p. 38). Planteamos que estos dispositivos representan la oportunidad para tomar conciencia y tal vez, producir reelaboraciones de ciertos significados y decisiones y con ello, cambios en las prácticas de enseñanza. Una aproximación posible resulta habilitar oportunidades de reflexión, de externalización mediante la narrativa de esas experiencias, de las preguntas que socavan nuestro interior en el momento de tomar decisiones para diseñar, concretar y evaluar nuestras propuestas didácticas. Es decir, para ello necesitamos generar un espacio para dar lugar a cuestionamientos y rupturas. En el contexto particular de pandemia vivenciado durante el año 2020, en contexto ASPO, y el que transcurre, los y las docentes se vieron expuestos a desafíos relacionados con diferentes cuestiones, y 
señaladas por ellos/os mismos/as: ¿Cómo desarrollar clases, en el mejor de los escenarios, con plataformas educativas? y ¿en el peor de ellos, sin posibilidad de comunicación con los estudiantes y sus familias? ¿Cuáles contenidos priorizar? ¿Qué sucederá con los contenidos que se dejan de lado? ¿Cómo se evaluará? ¿Cómo conocer lo que los estudiantes están aprendiendo?, ¿Cómo lograr esas evidencias de aprendizaje? ¿Podemos atrevernos a pensar que hay aprendizaje? ¿De qué manera? ¿Qué actividades plantear de manera de incluir a todos/as? ¿Cómo va a cambiar la forma "conocida" de educación a largo plazo? ¿Cuánto de lo que hacía (antes de la pandemia) era realmente inclusivo? ¿Cuánto de lo que intento transmitir es relevante para cada estudiante en su contexto? Las preguntas son abundantes y de diferente índole. Nunca antes tan presentes, vivas, retumbando en nosotros y retomando palabras de Perrenoud, actuar en la urgencia:

“(...) es actuar sin tener tiempo de pensar, de sopesar pro y contra, de consultar obras de referencia y de buscar consejo. Decidir en la incertidumbre significa decidir cuando la razón ordenaría no decidir, porque no disponemos de modelos de realidad que nos permitan calcular con cierta certeza lo que sucedería si (...)" (Perrenoud, 2001, p.16).

La actuación implica decisiones, tomadas en la urgencia o producto de la reflexión son las decisiones las iniciadoras de la actuación. Podemos distinguir entre decisiones didácticas relacionadas con el modo de promover los aprendizajes, es decir relativas a objetivos, propósitos, contenidos, formas de actividad y materiales tanto en instancias preactivas como interactivas y postactivas (Basabe y Cols, 2007, p. 155). Pero también hay otro tipo de decisiones "organizativas" relacionadas con la gestión del tiempo, de los espacios, la distribución de los roles, la regulación de los intercambios. Por último, según Basabe y Cols (2007) se identifican también para la enseñanza una "...faceta "relacional", que concierne al logro y mantenimiento de la relación pedagógica, al acompañamiento y sostén emocional del alumno en el proceso de aprendizaje" (p. 155).

En esta comunicación nos proponemos configurar un primer análisis de esas decisiones a partir de la implementación de dispositivos narrativos, lo que permitió a las docentes-investigadoras identificar significados construidos para esas decisiones en contexto de pandemia. Por esa razón, consideramos relevante durante la cursada 2020:

(...) generar situaciones experimentales para que los sujetos que participen en él se modifiquen a través de la interacción consigo mismos y/o con otros, adaptándose activamente a situaciones cambiantes, apropiándose de saberes nuevos, desarrollando disposiciones y construyendo capacidades para la acción. (Anijovich, 2009, p.37).

El análisis propuesto, que identifica dificultades, algunas ya superadas y otras en vías de lograrlo, es un aporte necesario para pensar cómo se sigue en una realidad que ya no volverá a ser la de antes de marzo de 2019. Necesitamos rediseñar los espacios de aprendizaje y repensar cómo innovar en ellos. "(...) creemos que la pandemia nos da la posibilidad de revalorizar y construir nuevas prácticas, a fin de potenciar y habilitar que todes encuentren en las aulas (presenciales y virtuales) posibilidades de aprender." (Bedacarratx, 2020, p.10). 


\section{Aspectos metodológicos y operativización sobre los datos}

La discusión se enmarca en un enfoque interpretativo y se orienta hacia la comprensión de los significados de los dilemas y las decisiones didácticas, organizativas y vinculadas a la faceta relacional en la educación para todos/as en tiempos de pandemia de los profesores cursantes. La población está formada por 17 profesores que dictan clases de Física en la educación secundaria con formación inicial de profesor en Física, Matemática, Biología y Química. Estos/as profesores/as cursan durante un año el Diplomatura en forma virtual. Este espacio formativo se desarrolla a partir de 5 módulos de estudio, donde semana a semana abordan un tema diferente de la formación continua que incluye principalmente: el diseño y el análisis de propuestas didácticas en temas de Física, considerando la tecnología como medio para construir significados, y enriquecer los procesos cognitivos; enfoques de enseñanza que consideran al sujeto que quiere aprender y la educación inclusiva.

Producto de la operacionalización sobre el objeto de estudio y en estrecha relación con la teoría, las decisiones involucradas (Basabe y Cols, 2007) y los dispositivos de formación (Anijovich, 2009 y Souto, 1999) se identificaron cuatro dimensiones: las referidas a los docentes, a los estudiantes, a los medios tecnológicos y educación y al diseño de propuestas didácticas. Las decisiones didácticas, organizativas y las vinculadas con la faceta relacional se estudiaron en las cuatro dimensiones citadas.

\section{Procedimientos para el análisis}

El análisis se realizó en cuatro momentos que implican diferentes transformaciones de los discursos registrados. Un primer momento donde los registros se analizaron según las dimensiones citadas. Para ello se procedió a registrar e identificar los discursos según la dimensión. Se conserva el anonimato de cada docente y por esa razón se los identifica con números. Se cuenta con el consentimiento de cada uno/a de ellos/as para realizar el estudio. A modo de ejemplo, se propone la tabla I:

\begin{tabular}{|c|c|}
\hline Dimensión & Discursos \\
\hline Docente & $\begin{array}{l}\text { - A veces me atribuía toda la responsabilidad de no poder haber logrado una } \\
\text { vinculación total, de no haber hecho hasta lo imposible por hacerles llegar mis } \\
\text { propuestas, pero la mayoría de las razones estaban fuera de mi alcance o eran por el } \\
\text { resultado de la actuación de muchos actores en los que no era la única responsable. } \\
\text { Me da mucha pena y preocupación no haber tenido vínculo con todos mis alumnos y } \\
\text { me hace repensar si la educación fue igual o no para todos (Profesor/a 11) } \\
\text {..................... }\end{array}$ \\
\hline Estudiantes & $\begin{array}{l}\text { - Tener el micrófono silenciado ordena la clase de mejor manera y puedo explicar y } \\
\text { compartir rápidamente. Por otro lado, es mucho más difícil que participen. (Profesor/a } \\
\text { 1) Tener el micrófono abierto, favorece que cada uno hable sin "miedo" tal como pasa } \\
\text { en presenciales pero es un caos sumando los ruidos de cada casa.(Profesor/a 1) } \\
\text { - Muchas veces no sabemos cómo docentes si nuestros alumnos están } \\
\text { verdaderamente detrás de sus dispositivos (Profesor/a } 3 \text { ) } \\
\text { - Uno de los argumentos dados por un papá es que una de sus hijas tiene autismo } \\
\text { y por momentos grita o corre en la casa cuando el hermano está en la clase, a este } \\
\text { papá lo angustiaba mucho que los profesores insistan en que su hijo prenda la } \\
\text { cámara porque realmente es muy difícil para él exponerse y manifestó que estaba } \\
\text { dando lo mejor de él para cumplir con todas las materias (Profesora x) } \\
\text {................. }\end{array}$ \\
\hline
\end{tabular}

Tabla l: registro diferenciado de los discursos según corresponda a alguna de las 4 dimensiones estudiadas. En este caso se presentan dos de ellas. 
El mismo procedimiento se realizó para las otras dos dimensiones que restan: medios tecnológicos y educación y diseño de propuestas didácticas y que por cuestiones de extensión no se presentan.

El segundo momento de análisis representó la identificación de las decisiones involucradas del tipo didácticas, organizativas y del tipo decisiones vinculadas con la faceta relacional. Se utilizó el criterio de segmentación gramatical por oración para realizar la separación en unidades de análisis y cada una de ellas se codificó de la siguiente forma, según el orden presentado: Decisiones didácticas- DD-, Decisiones organizativas -DO- y Decisiones vinculadas a la faceta relacional -DFR-. Asimismo, a la par que se identificaron esas decisiones se consideró en los discursos cuándo esas decisiones eran atravesadas por preocupaciones/consideraciones por todos/as los/las estudiantes en pos de identificar indicios y claves de una educación inclusiva. Para ello la codificación fue modificada con la incorporación de una ET: Educación para todos/as. En la tabla II se presenta el segundo momento con la codificación mencionada (por razones de espacio se presentan sólo dos o tres expresiones por dimensión):

\begin{tabular}{|c|c|}
\hline Dimensión & Discursos \\
\hline Docente & $\begin{array}{l}\text { - A veces me atribuía toda la responsabilidad de no poder haber logrado una } \\
\text { vinculación total, de no haber hecho hasta lo imposible por hacerles llegar mis } \\
\text { propuestas, pero la mayoría de las razones estaban fuera de mi alcance o eran } \\
\text { por el resultado de la actuación de muchos actores en los que no era la única } \\
\text { responsable. Me da mucha pena y preocupación no haber tenido vínculo con } \\
\text { todos mis alumnos y me hace repensar si la educación fue igual o no para todos } \\
\text { (Profesor/a 11) DFR ET } \\
\text { - ¿Cómo acompaño el proceso teniendo en cuenta todas las realidades personales? } \\
\text { (Profesor/a 5) DO ET } \\
\text {---- }\end{array}$ \\
\hline Estudiantes & $\begin{array}{l}\text { - Tener el micrófono silenciado ordena la clase de mejor manera y puedo explicar } \\
\text { y compartir rápidamente. Do Por otro lado, es mucho más difícil que participen. } \\
\text { (Profesor/a 1) DFR } \\
\text { - Tener el micrófono abierto, favorece que cada uno hable sin "miedo" tal } \\
\text { como pasa en presenciales pero es un caos sumando los ruidos de cada casa. } \\
\text { DFR DO Muchas veces no sabemos como docentes si nuestros alumnos están } \\
\text { verdaderamente detrás de sus dispositivos. DFR (Profesor/a 1) } \\
\text { - Uno de los argumentos dados por un papá es que una de sus hijas tiene autismo } \\
\text { y por momentos grita o corre en la casa cuando el hermano está en la clase, a este } \\
\text { papá lo angustiaba mucho que los profesores insistan en que su hijo prenda la } \\
\text { cámara porque realmente es muy difícil para él exponerse y manifestó que estaba } \\
\text { dando lo mejor de él para cumplir con todas las materias (Profesor/a 15) DFR ET } \\
\text {--------- }\end{array}$ \\
\hline $\begin{array}{l}\text { Medios } \\
\text { tecnológicos } \\
\text { y educación }\end{array}$ & $\begin{array}{l}\text { - La gran mayoría de mis alumnos no tienen acceso a internet, lo que dificultó casi } \\
\text { todas las vías de comunicación posible, (Profesor/a 2) Do } \\
\text { - La crisis existencial fue cuando empezaron a llegar todas esas actividades por } \\
\text { todos los medios de comunicación: mail, whats app, y en el mejor de los casos } \\
\text { plataforma Edmodo (Profesora 14) Do } \\
\text { - Sin embargo, el trabajo se vio muy afectado por el escaso acceso a la virtualidad } \\
\text { que tenían nuestros alumnos, los causas son variadas: un único dispositivo por } \\
\text { familia (que en muchos casos no se prestaba), sin acceso a internet, falta de } \\
\text { almacenamiento, etc. (Profesor/a 11) DO } \\
\text {----------- }\end{array}$ \\
\hline
\end{tabular}




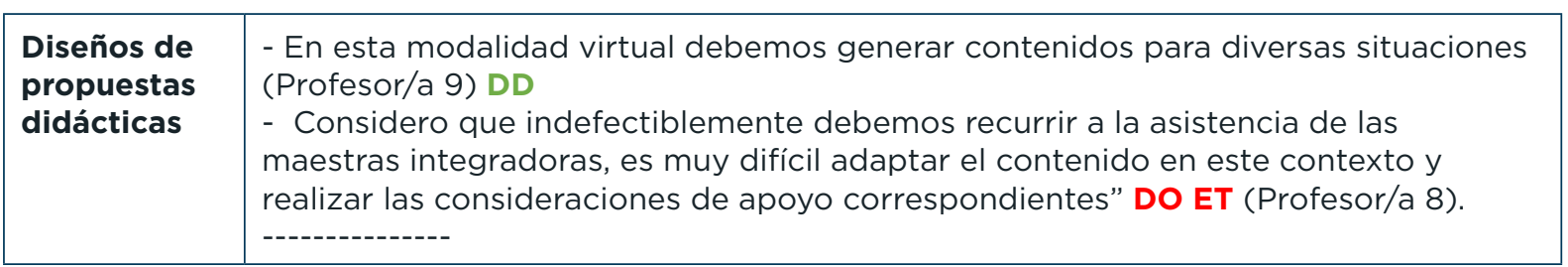

Tabla Il: codificación de cada unidad de análisis.

Cabe señalar que una misma línea de discurso del docente podría calificarse como la combinación de varias decisiones. Si bien la distinción entre estas decisiones resulta útil desde un punto de vista analítico, no las tratamos como entidades discretas.

En un tercer momento, producto de releer y configurar relaciones, se identificaron aspectos regulares para cada dimensión de estudio y en cuáles de ellas hubo expresiones relacionadas con la educación para todos/as. Por ej. en la dimensión de los estudiantes se reflejan, producto de las regularidades, las siguientes categorías: impacto en las emociones; preocupación por el aprendizaje; conexión; ayudas posibles. Específicamente para el impacto sobre las emociones y preocupación por el aprendizaje se identificó que un docente expresa lo siguiente: "¿Cuánto de lo que hacía (antes de la pandemia) era realmente inclusivo? Y no me refiero solo a las adaptaciones de acceso o de contenidos" (Profesor/a 4).

Para la dimensión docente se construyen las siguientes categorías: rol docente, concepción del aprendizaje; reordenamiento de prioridades; reflexiones sobre el vínculo social; sobreexigencias. Específicamente para el rol docente se identificó sólo una expresión relacionada con la educación inclusiva: "Me da mucha pena y preocupación no haber tenido vínculo con todos mis alumnos y me hace repensar si la educación fue igual o no para todos" (Profesor/a 11).

En la tercera dimensión, diseño de propuestas didácticas, identificamos: contenidos; tipos de actividades; evaluación; dinámica de trabajo. En esta dimensión, en las categorías Dinámica de trabajo y Tipo de actividades, se identificaron dos expresiones de diferentes docentes relacionadas con la educación para todos/as:

"Considero que indefectiblemente debemos recurrir a la asistencia de las maestras integradoras, es muy difícil adaptar el contenido en este contexto y realizar las consideraciones de apoyo correspondientes" DO ET (Profesora 8).

¿Qué actividades les planteamos a los estudiantes con proyectos de Inclusión? DD ET ¿Cómo diseñamos una clase virtual con ellos? DO ET y DD ET (Profesor/a 3).

En la dimensión medios tecnológicos y educación identificamos: canales de comunicación y predisposición a las video llamadas. Sobre esta dimensión no se identificó ninguna expresión en el sentido de educación para todos/as. La tecnología en los diseños didácticos para la educación inclusiva viene siendo señalada por diferentes autores (Cabera Almenara y Fernández Bastanero, 2014; Maldonado, Carrera Farran, Selga Casarraomona, López Arias, Golobardes, 2016). También se ha señalado la necesidad de que las escuelas cuenten con mediadores, asesores, entre la tecnología disponible y las necesidades del alumnado (Cobeñas, 2015). Específicamente en trabajos anteriores se identificó que todos los estudiantes, pero principalmente, en un estudio de caso, un estudiante con TDAH, logró trabajar el acceso a la información 
desde otros canales, usando los sentidos auditivo, visual, táctil, pudo manipular variables, predecir comportamientos y verificarlos, volver a comenzar todas las veces que sea necesario (atención a la frustración) y representan desde lo cognitivo; un factor desafiante propuesto a través del juego (Domínguez y Sitpcich, 2017).

La Figura I que sigue refleja cada dimensión con las categorías identificadas como aspectos sobresalientes y regulares en cada una de ellas. Especialmente las categorías que están con negrita y cursiva son las que reflejan decisiones vinculadas a la educación para todos/as.

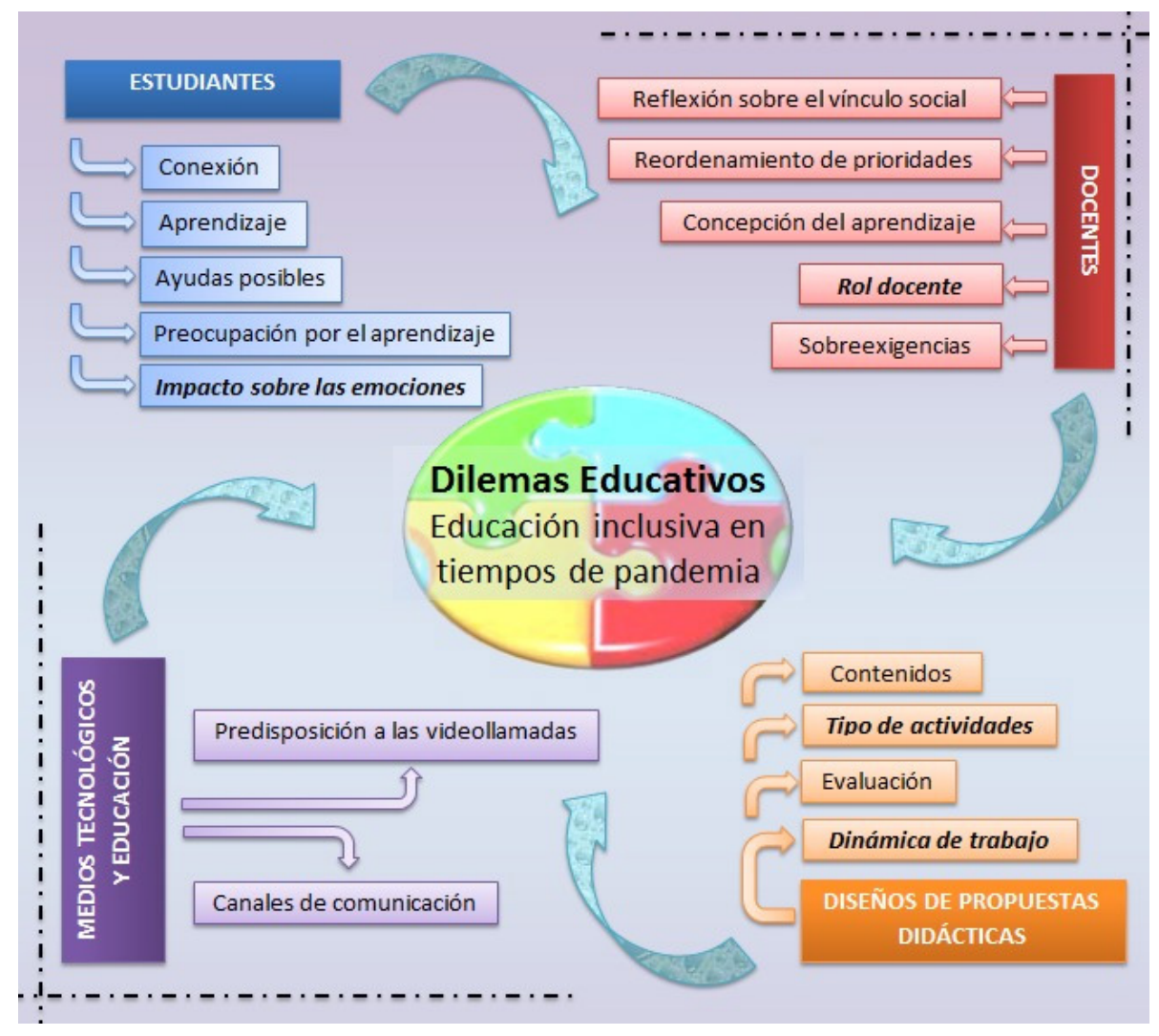

\section{Figura I. Dilemas educativos. Educación inclusiva en tiempos de pandemia}

El último y cuarto momento involucra el análisis de las diferentes decisiones, sus relaciones, y los aspectos identificados para cada dimensión, lo que nos permite identificar las siguientes articulaciones:

- El aprendizaje significativo y la conexión;

- La escuela que entra a los hogares de docentes y también al de los y las estudiantes;

- La reconfiguración de los escenarios de aprendizaje y las nuevas oportunidades para la clase y, por último,

- La educación inclusiva en tiempos de pandemia. 


\section{Resultados}

En este apartado resaltamos las principales características identificadas en las decisiones docentes, tanto didácticas, como organizativas o vinculadas a la faceta relacional, que un grupo de docentes manifiesta en un trayecto formativo, en tiempos de pandemia, en relación con los necesarios rediseños de los escenarios educativos en el marco de la situación epidemiológica. Estas decisiones involucran fuertemente tensiones y articulaciones que resumimos en los siguientes puntos:

\section{Aprendizaje significativo vs conexión}

¿Cómo lograr relación y conexión con los estudiantes con/sin micrófono y/o con/sin cámara y a su vez lograr aprendizajes significativos? En palabras de una docente: "El desafío es independiente de que el alumno tenga la cámara o micrófono encendido, sino que consiste en ayudar a los alumnos a pensar de maneras diferentes" (Profesor/a 6). En esta presentación se identifica que una de las mayores preocupaciones circuló en relación a las dificultades para lograr un vínculo pedagógico y/o aprendizajes a partir de no ver caras, no tener acceso a miradas: "¿cómo notar a través del lenguaje escrito sensaciones que normalmente reconocemos al "mirar" sus caras?" (Profesor/a 2). En palabras de Baquero (2020) asumiendo que el aprendizaje implica estar situados...pero ahora es de una forma que es desconocida y conocida. Existe una ausencia de los cruces de miradas, los cuerpos que pueden estar pero de otra forma, y las palabras que a veces están ausentes. “... las nuevas tecnologías no eximen el papel que tienen y que seguirán teniendo los maestros y profesores en la creación de condiciones en el aula que apoyen y fomenten las discusiones, conversaciones, debates y reflexiones para desplegar la cognición de los estudiantes y la construcción conjunta de conocimientos". (Palacios, 2015, p. 155). Esto nos Ileva a considerar que el escenario educativo cambió y necesita revisarse qué precisan los estudiantes para aprender, qué necesitamos los/las docentes para enseñar y en ese sentido discutir las condiciones didácticas en escenario virtuales, combinados o presenciales. Evidentemente las condiciones no son las mismas, aunque seguramente sí lo es lograr aprendizajes significativos teniendo en cuenta el contexto.

\section{La escuela entra a los hogares de los y las estudiantes, pero también a la de los y las docentes}

¿Cómo trabajar si se vulneran los derechos de los docentes y sobreexigencias frente a la inmediatez de dar respuestas en una situación límite?. En palabras de una docente "He sentido todo este tiempo una sobreexigencia y vulneración de mis derechos, ya que en ocasiones no me quedaba espacio y tiempo para el trabajo con mis hijos y su aprendizaje de nivel primario. Ha sido una época muy difícil para todos, donde los límites se han corrido, sin saber hasta donde era adecuado o suficiente" (Profesor/a 10). De una forma abrupta se abrió la discusión, ya presente en el campo académico, de educar en el distanciamiento. Pero esta discusión se inscribió en una realidad en la cual la salud no era garantía, la tecnología no era un recurso presente en todas las realidades familiares y tampoco en la de los/las docentes. " "Mi casa pasó a ser mi aula», expresa una maestra. Transformar el espacio doméstico y destinar, separar y cortar un tiempo para desarrollar el propio trabajo necesitó de ajustes" (Redondo, 2020, p. 139). ¿Qué lugar ocupó el estado en la toma de estas decisiones? Podría adelantarse que los y las docentes no tuvieron acompañamiento necesario, en algunas oportunidades, de la institución escolar y del estado. Con urgencia se necesita de un equipo directivo, 
y de una comunidad educativa comprometida, que posibilite el análisis de la gestión de la enseñanza y la revisión de los escenarios de aprendizaje.

¿Ahora que no tenemos horario de entrada a la escuela, no tenemos recreo, ni tenemos los ritos para iniciar la jornada escolar, tampoco tenemos claridad para distinguir dónde empieza la escuela y dónde está el «afuera», cómo podemos dar la clase?” (Roldán, 2021, p.27).

Será urgente rediseñar los espacios didácticos, en y fuera de la escuela. Si antes podíamos pensar otros espacios más allá del aula, como por ejemplo el patio, la biblioteca, el pasillo, ahora nos urge rediseñar un aula virtual que se gestiona por un medio tecnológico pero se concreta en el hogar, en un núcleo familiar y preguntarnos hasta dónde podemos invadir esos espacios, cómo negociar con los que convivimos esa nueva configuración de aula virtual...

\section{Reconfiguración y nuevas oportunidades para la clase sin equipamiento material y cultural}

Los escenarios educativos se vieron tensionados por una realidad cruda, ¿cómo sostener y desarrollar procesos de enseñanza cuando no existía el equipamiento tecnológico, o era escaso, o debía ser compartido por varios? Esas necesidades eran materiales pero también lo eran simbólicas. "En los grupos de whats app circulaban los comentarios y los links hacia aquellos servicios, plataformas, medios, formatos que no requerían gasto de datos" (Profesor/a 8). Eran las familias, adultos y adultas o hermanos/as mayores quienes tuvieron que acompañar esos procesos. "la gran mayoría de mis alumnos no tienen acceso a internet, lo que dificultó casi todas las vías de comunicación posible. (Profesor/a 2)" Estas palabras nos plantea que los docentes y las familias tuvieron que reacomodarse, cuando fue posible y/o cuando quisieron hacerlo, comprando nuevos equipos y aprendiendo sin orden, sin gestión previa cómo y para qué utilizar un classroom, un servicio de videoconferencia, un zoom.... "En este contexto las condiciones objetivas inciden sobre las subjetivas en los intercambios cotidianos domésticos y en los académicos, generando multiplicidad de efectos como la impotencia y la frustración” (Laina y Gómez, 2021, p. 128.). La comunicación se volvió esencial, el whats app, las llamadas telefónicas, las bolsas en las tranqueras en el campo, todo formato era bienvenido y repensado en función de las necesidades y de las posibilidades. Sin embargo, el gran reto era y es ¿cómo convertir, gestionar, transformar e incorporar esas tecnologías para que se produzcan las mediaciones esperadas en los procesos de enseñanza y de aprendizaje? ¿Cómo convertirlos en escenarios posibles donde el acto educativo tuviera lugar? ¿Cómo crear y recrear las condiciones didácticas para que se produzca el encuentro humano, el encuentro entre estudiantes y entre estudiantes y docente? La desigualdad social, económica, cultural quedó al desnudo, y tuvimos que actuar en la urgencia. "Entendimos necesario actuar, pero sabiendo que dejábamos también al descubierto las imposibilidades de estar, inaugurando muchos de nosotros un lenguaje que no poseíamos: el de las redes, la tecnología, la conectividad, ...." (Mercado, 2021, p. 23). Asumimos que la respuesta viene de la mano, por lo menos, en dos direcciones que se cruzan y se vuelven trascedentes cuando se dan conjuntamente: la responsabilidad institucional y de respuesta de gestión estatal y la proyección de políticas públicas de formación docente, las posibilidades de seguir estudiando y perfeccionándose. Se plantea la carga estatal de brindar equipamiento (ya sea material como cultural) a las instituciones escolares y a los/las actores educativos. 
El escenario nos obliga a flexibilizar, actualizar y reacomodar nuestros modos de enseñanza entendiéndolos como situados, relacionados a nuestro estilo como docente, a los estudiantes, al contexto, a los contenidos...Como señalan Harf (2021) "las innovaciones y mejoras podrán tener de trampolín o plataforma de despegue en los modos de enseñar que se emplearon en plena etapa de excepcionalidad" (p. 210).

\section{Educación inclusiva para todos y todas en tiempos de pandemia}

En estas condiciones especiales que se transitaron (y transitan) la posibilidad de lograr una educación para todos y todas se volvió un interrogante permanente. Tal vez, muchos se sintieron identificados con la exclusión, cuando la realidad de las carencias materiales te deja afuera, pero también las condiciones simbólicas, tanto de las familias, como la de las instituciones y la de los/las docentes. "Me da mucha pena y preocupación no haber tenido vínculo con todos mis alumnos y me hace repensar si la educación fue igual o no para todos". (Profesora 11). Tal vez, por primera vez, quienes no se habían sentido excluidos lo sintieron por diferentes razones, porque no sabían cómo diseñar una propuesta de aula en la virtualidad, porque carecían de conocimientos tecnológicos del contenido, conocimientos didácticos- tecnológicos, conocimientos tecnológicos- didácticos del contenido; porque no disponían de equipamiento material; porque no accedían a un servicio de red de internet...

Nos preguntamos si todo esto nos invitó a repensar lo que se venía haciendo en la escuela, en palabras de Cobeñas (2020):

(...) desde la mirada de muchos chicos la continuidad pedagógica ya estaba en problemas antes de la pandemia. Ir a la clase de apoyo mientras los compañeros están en la clase común, la recomendación de ir menos horas a la escuela o de retirarse antes, la intermitencia en la asistencia a escuela común y especial o la derivación, la negación a asistir el día que el acompañamiento terapéutico falte: son todas situaciones que hacen que los alumnos con discapacidad vivan de forma discontinua el ir a la escuela y estar participando y estar aprendiendo en el salón de clases. (Línea, 17).

La realidad de los equipos de orientación trabajando conjuntamente con las familias, con los/las actores educativos, era un tema de debate antes de la pandemia, y en estas circunstancias una docente nos comparte: "¿Qué actividades les planteamos a los estudiantes con proyectos de Inclusión? ¿Cómo diseñamos una clase virtual con ellos? Considero que indefectiblemente debemos recurrir a la asistencia de las maestras integradoras, es muy difícil adaptar el contenido en este contexto y realizar las consideraciones de apoyo correspondientes". (Profesor/a 16). Es innegable que los docentes fuimos formados bajo un paradigma segregacionista y en el mejor de los casos, integracionista...y lo mismo sucede con los docentes de la Educación Especial. Esto nos invita a repensar cómo dialogar y cómo trabajar conjuntamente cuando los paradigmas han cambiado pero los planes de formación docente aún no. "(...) la formación docente de común y especial son parte de la gran barrera a la inclusión. Es decir, no son las condiciones institucionales y el modo de trabajo, sino que la formación constituye uno de los grandes problemas:" (Cobeñas, 2021, p. 375). La autora plantea repensar lo modos de organización del trabajo, desarrollar apoyos institucionales y a los docentes. Al referirse a lo institucional se refiere a la escuela, a las familias, a la universidad, a especialistas...a un trabajo conjunto y colaborativo en la generación de propuestas de enseñanza y de aprendizaje. 
Para cerrar este apartado dejamos abierto el interrogante que nos ofrece una docente para seguir pensando cómo gestionar la enseñanza y cómo replantearnos ese encuentro con el otro. "¿Cuánto de lo que hacía (antes de la pandemia) era realmente inclusivo? Y no me refiero solo a las adaptaciones de acceso o de contenidos... (Profesor/a 2).

\section{Discusión y conclusiones}

Por último, producto de las tensiones identificadas se presentan consideraciones para repensar los escenarios de enseñanza y de aprendizaje con tecnologías:

- Las instituciones educativas necesitan revisar sus supuestos acerca de para quién enseñan, para qué y cómo se realiza, concreta y evalúa la enseñanza en función de garantizar una educación para todos y todas. Esto sólo es posible si se trabaja en conjunto con la sociedad, con las familias, con los y las estudiantes, con especialistas, con la universidad,.... de manera colaborativa para construir una propuesta pedagógica institucional desde una perspectiva inclusiva (Cobeñas, 2021). En ese sentido la inclusión de recursos tecnológicos como mediadores en la construcción de significados y como apoyos se vuelve esencial.

- Los equipos directivos han de gestionar espacios de discusión sobre los modos de enseñar que se desarrollan y las posibilidades y ayudas que se diseñan y organizan para el aprendizaje.

- Promover aprendizajes significativos y situados necesita de gestión de prácticas en las que las tareas sean significativas, auténticas (Anijovich, 2009), que posibiliten la construcción y reconstrucción de significados a partir de lo que los estudiantes conocen.

- Las actividades propuestas requieren de retroalimentación donde el/la estudiante pueda hacerse cargo de conocer cuáles procesos tiene que desarrollar, cuáles objetivos están implicados, cómo a partir de las devoluciones puede revisar su producción, corregirla, modificarla, mejorarla e ir logrando autonomía.

- La enseñanza se adapta a la heterogeneidad del grupo y se gestiona según las posibilidades. Eso implica que las propuestas no sean las mismas para todos/as, sino que se propone un abanico de posibilidades a partir de los intereses comunes que el grupo comparte. Un equilibrio entre la actividad personalizada y la misma para todos. Por ejemplo, una propuesta se diseña con objetivos de enseñanza y de aprendizaje y se puede presentar en varios formatos (que consideren al grupo destinatario) y permita una interacción de dos o tres maneras diferentes que el grupo maneja (en formato escrito, en audio, en vídeo).

- La flexibilidad no implica desbande o desorganización, sino por el contrario identificar las oportunidades de gestionar el espacio, el tiempo, los medios para comunicarse y para enseñar y las tareas de acuerdo a las posibilidades del grupo.

- Una gran parte de las tecnologías que están al alcance de muchos/as permiten tareas que van más allá de la reproducción, sino que posibilitan la construcción de nuevos significados, el trabajo colaborativo, la producción de diferentes 
materiales (vídeos, audios, podcast, infografías, etc.), el desarrollo de la criticidad y de la argumentación. La gestión y el análisis de los recursos en la enseñanza requiere la construcción de criterios para su selección e inclusión en las propuestas didácticas a partir de las posibilidades del grupo destinatario y de la historia escolar de esa institución escolar.

Dussel, Ferrante y Pulfe (2020) en el prólogo de Presentar la educación en tiempos de pandemia, señalan: “¿Cómo imaginar el mundo que sigue? ¿Qué herencias, marcas y daños quedarán de este tiempo inclemente? ¿Cuáles son los escenarios que se avecinan y se abren frente a nosotros?" Todos estos interrogantes y otros nos están marcando desde el principio, están socavando nuestro interior, desde aquellos que nos aprietan y presionan por lo urgente, y estos otros que conocemos.... tendrán respuestas dolorosas. Pero también es cierto que como menciona Adriana Puiggrós: "La ciencia ocupó un lugar extraño: concentra la esperanza y la confianza". Asumiendo que no podemos cambiar lo sucedido, sí podemos pensar e imaginar un escenario futuro, siempre desde el análisis de las condiciones pero con proyectos y anticipaciones en pos de acompañar para que la esperanza encuentre un espacio en el futuro.

\section{Referencias}

Anijovich, R. (2009). La retroalimentación en la evaluación en R. Anijovich (Comp.). La evaluación significativa. Buenos Aires: Paidós

Amuchástegui, M.A.; Caverzacio, M.; Cuello; S.A.; Díaz.; F. G.; Doerflinger, C.E.; Jarchum; P.; Marconi, N. V. (2021). Experiencias de aprendizaje en la formación docente complementaria: escenas de la Práctica Docente II en la virtualidad Aprendizajes y prácticas educativas en las actuales condiciones de época : COVID-19 .(pp 305, 312) /Córdoba : Universidad Nacional de Córdoba. Facultad de Filosofía y Humanidades. Libro digital, PDF

Bardin, L. (1986). Análisis de Contenido. Ediciones Akal. Madrid, España.

Basabe, L. y Cols, E. (2007). La enseñanza. En A. Camilloni (Ed). El saber didáctico. (pp.125-158). Paidos.

Baquero, R. (2020). Los docentes, las clases y las pedagogías pandémicas la torsión del espacio escolar. En Inés Dussel, Patricia Ferrante y Darío Pulfer compiladores. Pensar la educación en tiempos de pandemia Entre la emergencia, el compromiso y la espera (pp. 231- 242) Ciudad Autónoma de Buenos Aires: UNIPE: Editorial Universitaria, 2020. Libro digital, PDF - (Políticas educativas ; 6)

Bedacarratx, v. (2020). Seguimos educando... ¿pero... cómo? Reflexiones en torno a continuidades y rupturas en la vida escolar en tiempos de pandemia. En Lucía Beltramino. (Comp) Aprendizajes y prácticas educativas en las actuales condiciones de época : COVID-19 .(pp. 14-19)/Córdoba : Universidad Nacional de Córdoba. Facultad de Filosofía y Humanidades. Libro digital, PDF. 
Brailovsky, D. (2020). Ecos del tiempo escolar. En Inés Dussel, Patricia Ferrante y Darío Pulfer compiladores. Pensar la educación en tiempos de pandemia Entre la emergencia, el compromiso y la espera (PP 149,162) Ciudad Autónoma de Buenos Aires: UNIPE: Editorial Universitaria, 2020. Libro digital, PDF - (Políticas educativas; 6)

Bruner, J. (1997), La construcción narrativa de la realidad, en Bruner, J., La educación, puerta de la cultura. Madrid: Visor

Cabero Almenara, J. y Fernández Batanero, J. (2014) Una mirada sobre las Tic y la Educación Inclusiva, Comunicación y Pedagogía, nº 279-280

Cobeñas, P. (2015) Buenas prácticas inclusivas en la educación de personas con discapacidad en la provincia de Buenos Aires y desafíos pendientes. Buenos Aires: Asociación por los Derechos Civiles.

Cobeñas, P. ... [et al.] (2021). La enseñanza de las matemáticas a alumnos con discapacidad, La Plata: EDULP, Libro digital, PDF

Cobeñas, P. (2020) Mitos iEs posible enseñar y aprender en la escuela de la pandemia? Publicación desde la Asociación azul Asociación no gubernamental. https:// www.facebook.com/AsociacionAzulVI/posts/1675436115929417/

Domínguez, M. A.; Acosta, G. y Garcia, D. (2019). La formación continua de profesores de Ciencias Naturales, Matemática e Informática para la Educación Inclusiva. Una experiencia en el marco de la Diplomatura -DEFES- II Encuentro de Educación. Disponible en: https://ojs2.fch.unicen.edu.ar/ojs-3.1.0/index.php/espacios-en-blanco/issue/view/60

Domínguez, María Alejandra; Stipcich, Silvia (2017). El caso de un estudiante con TDAH: la enseñanza y el aprendizaje de Física mediados por TIC en J. Silva Quiroz (Ed.), Investigación, Innovación y Tecnologías, la triada para transformar los procesos formativos, pp. 510 - 516). Editorial Usach

Dussel, I.; Ferrante, P. y Pulfe, D. (2020). Pensar la educación en tiempos de pandemia. UNIPE

Garcia, D. y Domínguez, M. A. (2019). Concepciones de profesores de Matemática y Ciencias Naturales acerca de la Enseñanza Invertida- barreras y potencialidades- en el marco de la Diplomatura Universitaria Superior: Enseñanza de la Física. V Jornadas de Enseñanza e Investigación Educativa en el campo de las Ciencias Exactas y Naturales Fac. de Humanidades y Ciencias de la Educación. UNLP. Disponible en: http://sedici.unlp.edu.ar/bitstream/handle/10915/78543/Documento_completo. pdf-PDFA. pdf? sequence=1\&isAllowed $=y$

Harf, R. (2021).Tiene sentido pensar en "actualizar" modos de enseñar, "modificar" modos de enseñar o "innovar y crear"modos de enseñar. En R. Harf (Ed.), Nuevos escenarios educativos (pp. 207-211). Noveduc.

Laino, D. y Gómez,S.M. ( 2020). Aprendizaje en contextos de aislamiento. En Lucía Beltramino (Comp.) Adaptación de las prácticas y construcción de nuevos esquemas y hábitos. Aprendizajes y prácticas educativas en las actuales condiciones de época : COVID-19 .(pp. 124-132) /Córdoba : Universidad Nacional de Córdoba. Facultad de Filosofía y Humanidades. Libro digital, PDF. 
Mauri, E.; Carrera, X.; Selga, M., López, C. \& Macià, M. (2016). Análisis de experiencias educativas con tabletas digitales para una educación inclusiva. EDUTEC, Revista Electrónica de Tecnología Educativa, 56. http://www.edutec.es/revista. https://doi. org/10.21556/edutec.2016.56.658

Mercado, P. (2020). Notas pedagógicas en pandemia: imágenes sobre aprender y responsabilidad en contexto. En L. Abrate (Comp). Aprendizajes y prácticas educativas en las actuales condiciones de época: covid - 19.UNC.

Perrenoud, P. (2001). Ensinar: Agir na urgência, decidir na incerteza. Saberes e compêtencias em uma profissão complexa. Porto Alegre, Artmed Editora.

Palacios, A. (2015). Lenguaje, interactividad y aprendizaje en el aula En Analía Palacios (Comp). Claves para incluir: aprender, enseñar y comprender. (pp. 133-155) Ciudad autónoma de Buenos Aires: Centro de Publicaciones Educativas y Material Didáctico

Redondo, P. (2020) Educar a la primera infancia en tiempos de excepción En Inés Dussel, Patricia Ferrante y Darío Pulfer (Compiladores). Pensar la educación en tiempos de pandemia Entre la emergencia, el compromiso y la espera (pp. 137- 148) Ciudad Autónoma de Buenos Aires: UNIPE: Editorial Universitaria, 2020. Libro digital, PDF - (Políticas educativas ; 6)

Roldan, P. (2020). Dar clase con medios digitales. En Lucía Beltramino (Comp.) Aprendizajes y prácticas educativas en las actuales condiciones de época: COVID-19 .(pp. 26- 31)/Córdoba : Universidad Nacional de Córdoba. Facultad de Filosofía y Humanidades. Libro digital, PDF.

Suárez, D., Dávila, P. y Liliana Ochoa, L. De la Fuente (2003). Narrativas docentes y prácticas escolares. Hacia la reconstrucción de la memoria pedagógica y el saber profesional de los docentes. Disponible en: https://www.dgeip.edu.uy/documentos/2014/aprender/NARRATIVAS_DOCENTES_PRACTICAS_ESCOLARES.pdf

Souto, M. (2019) Acerca de la noción de dispositivo en la formación universitaria. Educación, Lenguaje y Sociedad. EISSN 2545-7667 Vol. XVI № 16 pp. 1-16 DOI:http:// dx.doi.org/10.19137/els-2019-161602 


\section{Experiencias de Educación Virtual en Tecnología: Algoritmia y Programación para Carreras de Ingeniería}

\section{Jiménez Rey, Elizabeth}

Universidad de Buenos Aires

ejimenezrey@fi.uba.ar

\section{Servetto, Arturo}

orcid.org/0000-0003-0907-9416

\section{Calvo, Patricia}

Universidad de Buenos Aires

pmcalvo@fi.uba.ar 


\title{
EXPERIENCIAS DE EDUCACIÓN VIRTUAL EN TECNOLOGÍA: ALGORITMIA Y PROGRAMACIÓN PARA CARRERAS DE INGENIERÍA
}

\author{
Jiménez Rey, Elizabeth \\ Servetto, Arturo \\ Calvo, Patricia
}

\section{Resumen}

Se presentan tres experiencias de cambio de educación presencial a educación virtual o a distancia, correspondientes a cursos distintos de una asignatura de formación básica para carreras de ingeniería que tiene como objetivo principal el desarrollo del pensamiento computacional. Este paradigma de resolución de problemas resulta una innovación disruptiva para los estudiantes y representa una alta demanda de dedicación, por lo que usualmente se verifican altos índices de deserción. Se comunican los resultados de las experiencias y se analizan en el contexto de las condiciones excepcionales en que se llevaron a cabo.

\section{Palabras clave}

Modalidad virtual, enseñanza Computación en ingenierías, pensamiento computacional, evaluación formativa. 


\section{Introducción}

En la Facultad de Ingeniería de la Universidad de Buenos Aires, las decisiones y acciones institucionales debido a la pandemia en el año 2020 determinaron la puesta en marcha de un calendario académico atípico en modalidad virtual. Los condicionamientos desfavorables habituales se intensificaron con la educación a distancia. Los profesores enfrentamos el desafío de planificar la enseñanza en una nueva modalidad, seleccionar las herramientas tecnológicas disponibles y adaptar los contenidos para asegurar el aprendizaje de los estudiantes. En tres cursos de Computación, asignatura obligatoria de ciencias básicas en las ingenierías, se aplicaron diferentes estrategias con el propósito de posibilitar a los alumnos la adquisición de la capacidad de construir la solución de problemas con la computadora (mediante el ingenio de algoritmos y su codificación como programas).

En general, los alumnos de Computación son estudiantes que recién ingresan a la FIUBA en un contexto curricular de alta concentración de asignaturas de ciencias básicas que cursan en simultáneo. La demanda creciente de tiempo y esfuerzo hace que frecuentemente prioricen a otras asignaturas que, por el sistema de correlatividades, si no son aprobadas ralentizan el avance en sus respectivas carreras, por lo cual se verifica una alta deserción en las primeras semanas de cursada de Computación. Por otra parte, al comenzar el cursado se suele observar en los alumnos escasa motivación o interés por los contenidos de la asignatura por no percibir la afinidad con sus campos profesionales. El pensamiento computacional es un paradigma para resolver problemas que en muchas ocasiones a los nuevos estudiantes les resulta algo extraño; éstos a menudo evidencian serias dificultades para elaborar abstracciones, dan preponderancia a los hábitos de aprendizaje mecánico y memorístico, y manifiestan dificultades tanto para analizar problemas como para articular estrategias de resolución (Jiménez Rey, Servetto y Calvo, 2020).

Las competencias de la asignatura que los autores se proponen que adquieran los alumnos no sólo son cognitivas (saber), procedimentales/instrumentales (saber hacer), y actitudinales (ser), sino también transversales o genéricas (asociadas a actividades, no a contenidos):

- Competencias cognitivas. Conocimiento de vocabulario técnico que facilite la comunicación con profesionales de la Informática para el trabajo interdisciplinar. Conocimiento general sobre algoritmia como paradigma de resolución de problemas. Conocimientos básicos de la sintaxis de un lenguaje de programación de alto nivel. Conocimiento de estructuras de datos fundamentales. Conocimientos básicos de complejidad computacional.

- Competencias procedimentales/instrumentales. Capacidad para descomponer un problema real para su posterior codificación en un programa; documentar programas con claridad y sencillez; analizar la complejidad de algoritmos; interpretar y utilizar las diferentes estructuras de control y de datos para implementar soluciones a problemas específicos; comprender documentación técnica y reutilizar código desarrollado por terceras partes.

- Competencias actitudinales. Capacidad de resolución de problemas mediante algoritmos. Motivación por la claridad, sencillez y eficiencia en la resolución de problemas. Capacidad para debatir y concluir las distintas soluciones a un problema. 
Competencias transversales o genéricas. Capacidad para la autoorganización y planificación del trabajo individual y del proceso de aprendizaje. Capacidad para el trabajo en grupo. Capacidad de análisis y síntesis. Motivación por la calidad del resultado.

\section{Método/Descripción de la experiencia}

Se rediseñaron estrategias pedagógicas en la virtualidad para promover el desarrollo del pensamiento computacional como competencia clave, articular con otras formas de pensamiento (lógico, matemático, ingenieril) y favorecer procesos de análisis, síntesis, creatividad y comunicación en la formación de estudiantes de ingenierías. Enseñar a pensar computacionalmente es el desafío en el proceso de aprender a ingeniar algoritmos para solucionar problemas con programas (Gómez, 2020).

\section{Descripción de experiencia 1}

La práctica educativa a distancia se desarrolló en dos cursos a través de clases sincrónicas (diapositivas vía Google Meet) y asincrónicas (diapositivas con audios en el Aula Virtual del campus FIUBA). Se realizó una adaptación de la modalidad de enseñanza presencial implementada en el año anterior (Jiménez Rey, Aveleyra y Barranquero, 2019) para sostener la construcción del conocimiento. Se continuó con la estrategia de intervención docente en el proceso creativo de descubrimiento de algoritmos. Los estudiantes conformaron grupos de trabajo colaborativo (tres integrantes) en talleres propios donde completaron tablas definidas por la profesora responsable para diseñar algoritmos en Google Drive Institucional y luego codificarlos en el entorno de desarrollo y aprendizaje IDLE Python. Los talleres grupales posibilitaron el avance hacia el encuentro de la solución a los problemas propuestos por sucesivos aportes de los integrantes y devoluciones de la profesora, y permitieron hacer visible el pensamiento de los estudiantes (Ritchhart, Church y Morrison, 2014). Resulta necesario promover una cierta toma de conciencia orientada a comprender que lo que se hace con otros es mejor que lo que se hace solo, y poner en juego los desafíos que implica la colaboración en la propuesta de formación (Maggio, 2018).

La evaluación continua mediante seis actividades formativas grupales para la apropiación de cada nueva herramienta de programación, dos trabajos prácticos integradores grupales para la resolución de problemas de mayor complejidad y dos evaluaciones parciales individuales para la resolución de un problema integrador, se constituyeron en instrumentos para la práctica activa y reflexiva en el proceso de construcción de programas. Las devoluciones grupales e individuales valoraron tres aspectos: funcionamiento del programa (eficacia), metodología de desarrollo (inteligibilidad) y calidad de diseño (eficiencia).

Las rutinas de pensamiento (Proyecto Cero de la Escuela de Educación de Harvard, s. f.), Conectar-Ampliar-Desafiar y Afirmar-Apoyar-Cuestionar, fueron seleccionadas y utilizadas para abordar la solución de problemas con la computadora por ser consideradas las más apropiadas para la adaptación al proceso de descubrimiento de un algoritmo y para ofrecer al estudiante las condiciones para pensar con sus pares y con la profesora. La rutina Conectar-Ampliar-Desafiar ofrece una estructura en la que el pensamiento de los estudiantes inspirado por una nueva situación problemática se puede hacer visible. Permite sintetizar y organizar las ideas. Se interpela a los estudiantes y a través de preguntas, se provoca la escucha activa en lugar del 
oír pasivo y se los prepara para que tomen conciencia de la nueva experiencia de aprendizaje estableciendo conexiones (Conectar) entre el conocimiento nuevo y el conocimiento previo, identificando nuevas ideas para pensar en nuevas direcciones (Ampliar) y buscando cómo las nuevas ideas desafían a pensar en nuevas maneras de solucionar problemas o a cuestionar suposiciones (Desafiar). La rutina Afirmar-Apoyar-Cuestionar ofrece una estructura abarcadora para examinar las ideas y generar nueva comprensión. Permite explorar las ideas más profundamente. Los estudiantes buscan patrones, detectan generalizaciones e identifican aseveraciones (Afirmar), la profesora les ayuda a que tomen conciencia de sus afirmaciones y se focalicen en las evidencias (Apoyar) y formula preguntas para que prueben y validen sus interpretaciones (Cuestionar). (Jiménez Rey, 2020)

En ambos cursos se requirió a los estudiantes (al igual que en el segundo cuatrimestre del año 2019) la aprobación del cursado con la entrega de actividades formativas grupales y trabajos prácticos integradores grupales, y con la aprobación de las evaluaciones parciales individuales (cada una con dos instancias de recuperación) de los contenidos procedimentales de la asignatura. En el segundo parcial práctico integrador se valora la adquisición de las habilidades de diseñar y codificar algoritmos al finalizar el cuatrimestre y se ofrece así al estudiante la oportunidad de promocionar la parte práctica de la asignatura. La calificación de aprobación de la cursada de Computación constituye también el 70\% de la calificación de aprobación de la asignatura.

\section{Descripción de experiencia 2}

La estrategia pedagógica que se empleaba para el desarrollo de contenidos, antes del cambio a la virtualidad, se apoyaba en la utilización de Moodle para la introducción de principios conceptuales y procedimentales mediante material elaborado por el profesor, y luego en clases presenciales de laboratorio, con hasta tres alumnos por computadora, se desarrollaba primero un caso de estudio con la interacción de docentes y estudiantes, y luego se planteaba otro problema a resolver por los grupos de trabajo por computadora con la asistencia y supervisión del profesor y un auxiliar. La evaluación se realizaba mediante un examen parcial durante el cursado y una evaluación integradora final postcursado.

A partir del primer cuatrimestre del año 2020 las clases presenciales se sustituyeron por conexiones sincrónicas vía Google Meet, que se enfocaron en el desarrollo de casos de estudio por parte del profesor, manteniendo la modalidad de clases invertidas: el material con la introducción de cada tema se puso a disposición en el curso virtual Moodle, y en las clases a distancia se desarrollaron algoritmos y programas solicitando la participación de los estudiantes. Los encuentros sincrónicos se grabaron y pusieron a disposición de los estudiantes en el curso en Moodle.

Las actividades colaborativas de trabajo presencial en laboratorio se sustituyeron por actividades formativas, para desarrollar en grupos de dos o tres integrantes, cuyas enunciaciones y entregas se instrumentaron mediante tareas de Moodle, y para las que se establecieron pautas de documentación y condiciones de trabajo y de entrega verificables para fomentar competencias no sólo procedimentales sino también actitudinales. Los alumnos tuvieron la posibilidad de realizar consultas sobre las actividades asincrónicas mediante foros o mensajería interna del curso virtual, así como también en los encuentros sincrónicos. 
La evaluación parcial se sustituyó por las evaluaciones de las actividades formativas, y las evaluaciones finales individuales, virtuales, no cambiaron respecto a su enfoque para los temas procedimentales, pero para los contenidos conceptuales se rediseñaron de manera que se pudieran resolver a libro abierto, es decir, se plantearon enunciados que requieren análisis, síntesis, o evaluaciones comparativas con respuestas elaboradas.

\section{Descripción de experiencia 3}

Previamente a la pandemia, las clases presenciales se llevaban a cabo presentando los temas habitualmente a través de un problema se generaba la motivación adecuada para luego realizar el desarrollo de los conceptos.

Por lo general se combinaba la presentación de los nuevos conceptos con el desarrollo de soluciones para la situación planteada, de modo que fuera claramente apreciable por los estudiantes la utilidad de los conceptos que se presentaban como herramientas que permitían una solución a los problemas presentados, o en ocasiones, una solución más eficiente que la que se hubiera desarrollado previamente.

Los alumnos resolvían las situaciones problemáticas generalmente en grupos de dos o tres por cada computadora, y la docente orientaba a cada grupo. Luego de una puesta en común de los desarrollos realizados, frecuentemente algunos de esos grupos presentaban su diseño de solución en la pizarra, a sus compañeros.

La plataforma Moodle almacenaba los apuntes, las presentaciones, orientaciones, indicaciones o recomendaciones de trabajos o lecturas para la clase siguiente, ejercicios resueltos (por la docente o por algunos estudiantes), y otros materiales adicionales (en formato presentación o texto; no se utilizaba antes de la pandemia, el formato de audio o de video) que pudiera apoyar el aprendizaje, y se utilizaba en ocasiones de forma posterior al desarrollo del tema, y en otras ocasiones se les solicitaba a los estudiantes que leyeran previamente alguno de los contenidos subidos al aula del campus virtual de la facultad.

A partir del dictado de la materia en pandemia, se desarrollaron clases sincrónicas a través de Google Meet, con explicaciones utilizando cámara de video y pizarrón, o compartiendo presentaciones o el entorno de desarrollo de Python. La modalidad de la clase mantuvo en general la estructura de problema motivador introductorio, participando los alumnos en la elaboración de soluciones, como se hacía en las clases presenciales. Estas clases fueron grabadas y publicadas en el aula virtual, igual que presentaciones, videos con explicaciones de algunos de los temas fundamentales del programa, y también videos con desarrollos de soluciones para problemas seleccionados. Si bien la modalidad de clase sincrónica mantuvo en parte la organización de la clase presencial, cabe señalar que se presentaron dificultades adicionales cuando los estudiantes diseñaban las soluciones a los problemas propuestos, dado que por lo general era muy dificultoso para los alumnos el trabajo grupal durante la clase sincrónica, por lo que éstos habitualmente preferían desarrollar las soluciones de manera individual, lo cual requiere que la docente dedique tiempo a un número mayor de desarrollos de soluciones (habitualmente uno por alumno) que se elaboran. Sin un número adecuado de docentes auxiliares se resiente el aprendizaje de materias que requieren desarrollos grupales, en particular en las clases sincrónicas. 
Durante la cursada a distancia se indicó a los estudiantes cuáles eran las tareas propuestas para cada semana a través del Foro de Novedades del aula virtual del campus, especificando material a leer, conceptos a fijar, lecturas sugeridas y ejercitación propuesta. Fue muy importante la utilización del Foro de consultas para que los alumnos enviaran preguntas y dudas, y de este modo explicitaran-visibilizaran sus ideas a través de texto, código de programas o capturas de pantalla de situaciones a resolver. La puesta en palabras en un texto de la dificultad, o la situación "conflictiva" en el desarrollo de un algoritmo, o de una solución, fue de gran utilidad para los estudiantes, según ellos mismos manifestaron.

Se desarrollaron dos trabajos prácticos grupales colaborativos, para los cuales, en sucesivas clases se realizó orientación y guía por parte de la docente. Se realizó una evaluación parcial individual con modalidad virtual, con dos instancias de recuperación, que consistió en desarrollar una solución codificada para un problema planteado, y preguntas adicionales sobre algunos temas teóricos. Los trabajos grupales fueron corregidos por la docente realizándose una devolución escrita que consideró diferentes aspectos del material producido, comentándose también los resultados con cada grupo, de forma oral.

El coloquio final consistió en la resolución individual de un problema integrador (también desarrollado con modalidad virtual).

\section{Resultados}

En los cursos correspondientes a la primera experiencia, en el primer cuatrimestre se inscribieron 32 alumnos en ambos cursos; las deserciones fueron del 46,9\% y $53,1 \%$, y resultaron aprobados el $94,1 \%$ y el $100 \%$. En el segundo cuatrimestre, sobre la misma cantidad de inscriptos en los dos cursos, las deserciones fueron del $43,8 \%$ y $62,5 \%$, y los porcentajes respectivos de aprobación de la cursada, 83,3\% y 91,7\%.

\begin{tabular}{|l|c|c|c|c|c|c|}
\hline & \multicolumn{2}{c}{$\begin{array}{c}\text { Primer Cuatrimestre } \\
\text { 2020 }\end{array}$} & \multicolumn{2}{c}{$\begin{array}{c}\text { Segundo Cuatrimestre } \\
\text { 2020 }\end{array}$} & \multicolumn{2}{c|}{$\begin{array}{c}\text { Segundo Cuatrimestre } \\
\text { 2019 }\end{array}$} \\
\hline Curso 1 & \multicolumn{2}{c}{ Curso 2 } & Curso 1 & Curso 2 & Curso 1 & Curso 2 \\
\hline Inscriptos & 32 & 32 & 32 & 32 & 32 & 32 \\
\hline Evaluados & 32 & 32 & 32 & 32 & 33 & 32 \\
\hline Desertaron & 17 & 15 & 18 & 12 & 20 & 21 \\
\hline Aprobaron & 16 & 17 & 14 & 20 & 13 & 11 \\
\hline Nota >=6 & 12 & 15 & 15 & 11 & 20 & 20 \\
\hline
\end{tabular}

1 Resultados de la Experiencia 1 en contraste con la modalidad presencial de 2019

Para la segunda experiencia, en el primer cuatrimestre, para 40 inscriptos hubo una deserción del 37,5\% y aprobó el 64\%; y para el segundo, sobre 53 inscriptos desertó el $21 \%$ y aprobó la cursada el $50 \%$. 


\begin{tabular}{|c|c|c|c|}
\hline & $\begin{array}{l}\text { Primer Cuatrimestre } \\
2020\end{array}$ & $\begin{array}{l}\text { Segundo Cuatrimestre } \\
2020\end{array}$ & $\begin{array}{c}\text { Segundo Cuatrimestre } \\
2019\end{array}$ \\
\hline Cupos & 40 & 40 & 40 \\
\hline Inscriptos & 40 & 53 & 41 \\
\hline Evaluados & 25 & 43 & 29 \\
\hline Desertaron & 15 & 11 & 12 \\
\hline Aprobaron & 16 & 21 & 24 \\
\hline Nota $>=6$ & 13 & 16 & \\
\hline
\end{tabular}

\section{Resultados de la Experiencia 2 en contraste con la modalidad presencial de 2019}

En la tercera experiencia, en el primer cuatrimestre sobre un total de 30 inscriptos hubo una tasa de deserción del $43 \%$, aprobando el $82 \%$. En el segundo cuatrimestre de 2021 sobre un total de 30 alumnos la deserción fue del 20 \% y aprobó la cursada el $96 \%$.

\begin{tabular}{|l|c|c|c|}
\hline \multicolumn{1}{|c}{} & $\begin{array}{c}\text { Primer Cuatrimestre } \\
\mathbf{2 0 2 0}\end{array}$ & $\begin{array}{c}\text { Segundo Cuatrimestre } \\
\mathbf{2 0 2 0}\end{array}$ & $\begin{array}{c}\text { Segundo Cuatrimestre } \\
\mathbf{2 0 1 9}\end{array}$ \\
\hline Cupos & 30 & 30 & 30 \\
\hline Inscriptos & 30 & 30 & 49 \\
\hline Evaluados & 17 & 24 & 46 \\
\hline Desertaron & 13 & 6 & 3 \\
\hline Aprobaron & 14 & 23 & 42 \\
\hline Nota $>=6$ & 7 & 16 & 36 \\
\hline
\end{tabular}

3 Resultados de la Experiencia 3 en contraste con la modalidad presencial de 2019

\section{Discusión y conclusiones}

Se presentaron tres experiencias de cambio de educación presencial a educación virtual o a distancia, y se analizaron en el contexto de las condiciones excepcionales en que se llevaron a cabo.

Se intensificó el rol docente para sostener el aprendizaje de los estudiantes. No obstante, en los cursos de todas las experiencias, la deserción fue mayor durante los 2 cuatrimestres del año 2020 con relación al segundo cuatrimestre del año 2019. En general, los estudiantes comunicaron la razón del abandono de la cursada: cambio de carrera, demanda de otras materias, realidad actual, falta de tiempo para la práctica y el estudio, necesidad laboral, entre otras; y agradecieron la enseñanza recibida. Los alumnos que demostraron compromiso con el propio aprendizaje y responsabilidad con el trabajo colaborativo lograron un buen rendimiento académico en ambos cuatrimestres (cursadas aprobadas con nota mayor o igual que 6): 41/57 en los cursos de la primera experiencia, $29 / 37$ y $23 / 37$ en los cursos de la segunda y tercera experiencia respectivamente.

Los mencionados porcentajes de aprobación con buen concepto permiten inferir la efectividad de la estrategia didáctica. 


\section{Referencias}

Gómez, N.S. (2020). Pensamiento computacional, innovación y perspectivas interdisciplinarias en ámbitos educativos (Tesis de maestría). Recuperado de:

http://sedici.unlp.edu.ar/handle/10915/111306

Jiménez Rey, E. (2020). El Impacto del Pensamiento Computacional en el Diseño y la Codificación de Algoritmos. Actas del 8vo Congreso Nacional Ingeniería Informática / Sistemas de Información Virtual 2020 CONAIISI, pp. 630-636. Recuperado de: http://conaiisi2020.frsfco.utn.edu.ar/

Jiménez Rey, E., Aveleyra, E., Barranquero, F. (2019). Competencias en Algoritmia y Programación como Formación Básica en Ingenierías: el Rol del Pensamiento Visible y la Mediación Tecnológica. IV CIECIBA Congreso Internacional de Enseñanza de las Ciencias Básicas, Actas de Resúmenes, pp. (14-15). Recuperado de: http://cieciba. multisitio.interior.edu.uy/presentacion-de-trabajos/

Jiménez Rey, E., Servetto, A., y Calvo, P. (2020). Desarrollo de Pensamiento Computacional en Estudiantes de Ingeniería. Memorias de las 3 ㅇ Jornadas sobre las prácticas docentes en la Universidad Pública. "El proyecto político académico de la Educación Superior en el contexto nacional y regional”, pp. 598-608. Recuperado de: http://sedici.unlp.edu.ar/handle/10915/111431

Maggio, M. (2018). Habilidades del siglo XXI. Cuando el futuro es hoy. Documento básico. XIII Foro Latinoamericano de Educación. Santillana.

Proyecto Cero de la Escuela de Educación de Harvard (s. f.). Recuperado de: http://www.pz.harvard.edu/projects/visible-thinking

Ritchhart, R., Church, M. y Morrison, K. (2014). Hacer visible el pensamiento. Paidós. 


\section{Un Análisis de la Implementación de la Evaluación Formativa en el Aula Virtual}

\section{Bravo Barletta, Virginia}

Universidad Argentina de la Empresa

vbravobarletta@uade.edu.ar

\section{Hollisch, Gisele}

Universidad Argentina de la Empresa

Universidad de Buenos Aires

ghollisch@uade.edu.ar 


\title{
UN ANÁLISIS DE LA IMPLEMENTACIÓN DE LA EVALUACIÓN FORMATIVA EN EL AULA VIRTUAL
}

\author{
Bravo Barletta, Virginia \\ Hollisch, Gisele
}

\section{Resumen}

La evaluación formativa se lleva a cabo a la par del proceso de enseñanza-aprendizaje. Se trata de comprender la manera de aprender de los alumnos, identificar obstáculos y errores en el aprendizaje para así adaptar o ajustar las condiciones pedagógicas (estrategias, actividades) considerando estas dificultades.

En este artículo se describe y analiza una experiencia acerca de este tipo de evaluación implementada en el año 2020 en un curso integrado por veinte alumnos de la materia Análisis Matemático I de la Universidad Argentina de la Empresa (UADE). La modalidad de las clases fue virtual y se dictaron a través de la plataforma Teams.

En líneas generales, entre las ventajas de implementar este tipo de evaluación podemos afirmar que tanto la entrega diaria de actividades por parte de los alumnos como la devolución o feedback, tanto individual como grupal por parte del docente de las tareas realizadas, así como el uso continuo en clase de aplicaciones interactivas tales como GeoGebra, Socrative o Kahoot fueron algunas de las cuestiones que favorecieron el aprendizaje de los alumnos. El tiempo que insume al docente tanto la preparación de las tareas como la corrección de las mismas son algunas de las desventajas que podemos mencionar en el momento de pensar en una evaluación formativa.

\section{Palabras clave}

Evaluación formativa, aprendizaje, recursos interactivos. 


\section{Introducción}

El año 2020 fue un año en el que se produjeron profundos cambios en las aulas universitarias: como consecuencia de la pandemia, las clases de todos los niveles del sistema educativo comenzaron a dictarse de manera virtual. Este novedoso y repentino contexto obligó a los docentes a repensar y rediseñar sus clases, adaptándolas al nuevo panorama. En este sentido, las formas de evaluar también se vieron modificadas: la no presencialidad obligó también a buscar formas alternativas de evaluación. En este artículo se describe y analiza la implementación en el aula virtual de un tipo particular de evaluación: la formativa.

Este tipo de evaluación se lleva a cabo junto con el proceso de enseñanza-aprendizaje. Se basa en reconocer las dificultades y obstáculos de los alumnos para así ajustar la enseñanza y diseñar las actividades de acuerdo a estas necesidades. Es por tal motivo que resulta fundamental obtener información acerca del desempeño de cada alumno en cada instancia del proceso de enseñanza-aprendizaje.

La experiencia que analizamos en este artículo se realizó durante el mes de septiembre, en un curso correspondiente a la materia Análisis Matemático I de la Universidad Argentina de la Empresa (UADE), integrado por 20 alumnos. La mayoría de los estudiantes del curso ya habían cursado la materia, por lo que contaban con cierta idea de los temas estudiados En líneas generales, la evaluación consistió en la realización de dos exámenes parciales a la vez que se realizó un seguimiento continuo y remoto del trabajo de los alumnos mediante la entrega diaria de actividades a través de la plataforma Teams.

Si bien estas entregas fueron de carácter no obligatorio, la mayoría de los alumnos realizó clase a clase la tarea sugerida por la docente. Estas entregas tuvieron un doble objetivo: así como les posibilitaron a los alumnos sumar puntos en el parcial en caso de estar éste aprobado, le ofrecieron información al docente acerca del grado de comprensión de los temas y qué aspectos del contenido eran necesarios reforzar y retomar la clase siguiente.

Vale aclarar que la docente a cargo del curso no contaba con experiencia previa en la implementación de la una evaluación formativa. Realizar una evaluación de este tipo lleva tiempo y dedicación, trabajo continuo tanto de docentes como de los alumnos. Es por ello que, en base a lo descripto anteriormente, nos preguntamos: ¿Vale la pena realmente llevar a cabo un proceso de evaluación formativa? ¿Mejora el rendimiento y las competencias de los alumnos? Nos proponemos en este artículo describir y analizar la experiencia realizada e intentar responder estas preguntas.

\section{Marco Teórico}

Evaluar es una acción que a diario todos realizamos. Estimar, medir, caracterizar, diagnosticar, valorar, calcular el valor de algo, es un hecho cotidiano en la vida del ser humano. En particular, en el ámbito educativo, la evaluación es un componente fundamental del proceso de enseñanza-aprendizaje.

Black and William (1998) definen la evaluación formativa como el "conjunto de actividades llevadas a cabo por el profesor y/o sus alumnos, las cuales aportan información 
para ser usada como "feedback" (retroalimentación) para modificar las actividades de enseñanza y aprendizaje" (Black and William, 1998). Esta definición describe a la evaluación como una actividad formadora, en la que el centro del proceso es el alumno, dejando así de ser una actividad únicamente a cargo del docente.

La evaluación formativa constituye una alternativa ante la evaluación tradicional (Fimia, Moreno, y Libotton, 2013). A diferencia de otros tipos de evaluación, se aplica a lo largo de todo el proceso de enseñanza-aprendizaje. Se sustenta en el análisis de la evidencia recolectada por los docentes acerca del desempeño de los alumnos; esta información posibilita implementar acciones para mejorar la comprensión de los estudiantes, transformando in situ el proceso de enseñanza- aprendizaje. Involucra un proceso de ida y vuelta, en el que los docentes hacen visibles el pensamiento de los estudiantes, realizan inferencias sobre el nivel de comprensión alcanzado y actúan con base en la información disponible con el fin de alcanzar los objetivos de aprendizaje establecidos (Cowie y Bell, 1999; Furtak, 2012).

De acuerdo a Anijovich (2017) entre las fortalezas de una evaluación formativa podemos mencionar el papel activo y la implicación de los estudiantes en el proceso de aprendizaje; el hecho de favorecer la comprensión de aprendizajes complejos; el desarrollo de habilidades metacognitivas y de aprendizaje continuo; el valor del feedback; el diálogo que promueve entre estudiante y docente; la contribución a mejorar la práctica docente, entre otras cuestiones.

Sin embargo, implementar este tipo de evaluación conlleva también sus obstáculos y debilidades (Anijovich, 2017). Entre ellos podemos mencionar la inexperiencia de los estudiantes para abordar los modos alternativos que la evaluación formativa propone para hacer visibles sus fortalezas y debilidades, sobre todo en el ámbito universitario; la percepción de estudiantes y profesores acerca de una carga de trabajo excesiva dado que se utilizan variedad de instrumentos y recogen evidencias múltiples a lo largo del proceso; el poco uso que los estudiantes hacen del feedback recibido de sus pares y profesores; los hábitos muy arraigados de una cultura tradicional de evaluación como las pruebas de lápiz y papel; las mirada casi exclusiva sobre las calificaciones, la evocación de información como propósito principal de los exámenes, entre otras cuestiones.

En una evaluación formativa, tanto el tratamiento del error como el feedback tienen un papel fundamental. Respecto al primero, lejos de ser sancionado, el error puede llegar a considerarse un puntapié para comenzar a trabajar cierto contenido. El error le informa al docente sobre un obstáculo en la comprensión de un determinado tema $\mathrm{y}$, de esta manera, se convierte en una oportunidad para repensar las actividades y estrategias de enseñanza. Asimismo, también es una oportunidad para que los estudiantes reconozcan qué han aprendido, dónde tienen dificultades y qué pueden hacer para enfrentar el obstáculo. En este sentido, es importante identificar los diferentes tipos de error: no es lo mismo un error sistemático o un error conceptual que un error de cuenta. Los errores que observemos en los estudiantes, ya sea en las representaciones mentales como en sus estrategias, son una fuente de información del proceso de aprendizaje y, por tanto, ayudarán a precisar el tipo de dificultades u obstáculos a los que nos estamos enfrentando, lo que permitirá definir el tipo de apoyo requerido.

Otro elemento importante en la evaluación formativa es el feedback, el cuál debe er constante, suficiente y pertinente. El feedback o retroalimentación se define como 
la información proporcionada por un agente (un profesor, compañero, libro, padre, etc.) en relación con aspectos de un desempeño (Hattie y Timperley, 2007). Lo interesante de esta definición es que no es el profesor el único agente que puede retroalimentar el desempeño de los estudiantes, sino que diversos agentes pueden proporcionar información correctiva. Así, la retroalimentación tiene el potencial de apoyar el rendimiento académico, promover la motivación, la autorregulación y la auto eficacia, permitiendo a los estudiantes acortar la brecha entre su desempeño actual y el deseado (BlackyWiliam, 1998; Sadler, 1989).

La información que proporciona el profesor a los estudiantes es un elemento esencial en el proceso de aprendizaje; particularmente, en un escenario de educación superior virtual, en el cuál en ocasiones el feedback es asincrónico. Fortalecer una relación fraterna entre el docente y el estudiante tiende a asegurar que éste pueda alcanzar los objetivos y competencias principales de la asignatura y simultáneamente, desarrollar su capacidad de autorregulación (Batalla-Busquets, 2014).

Sadler (2009) por su parte identifica tres condiciones para que un estudiante se beneficie del feedback:

- que tenga claridad acerca del nivel de aprendizaje que quiere alcanzar

- que pueda comparar el nivel actual con el que quiere alcanzar

- que esté comprometido con el aprendizaje y tenga estrategias orientadas para reducir la brecha entre el nivel actual y el que tiene que alcanzar.

Así, los docentes no sólo tienen que compartir con sus alumnos los objetivos de aprendizaje y los criterios de evaluación, sino que también tienen que favorecer un entorno que posibilite oportunidades para que los estudiantes pongan en juego recursos y estrategias acerca de cómo monitorear y regular la calidad de sus aprendizajes.

La evaluación formativa, en consecuencia, implica un reto y un desafío para el docente: demanda conocimientos sólidos de la disciplina, atención constante a las ideas expresadas por los alumnos, reconocimiento de las dificultades de aprendizaje más comunes y familiaridad con un repertorio de estrategias de enseñanza que respondan a las distintas necesidades de los estudiantes (Atkin, Coffey, Moorthy, Sato y Thibeault, 2005).

\section{Descripción de la experiencia}

La experiencia que estudiamos se llevó a cabo en el mes de septiembre de 2020 en las clases correspondientes a la materia Análisis Matemático I, destinadas a los alumnos de primer año de las carreras de Ingeniería. Las clases se dictaron a través de la plataforma Teams. La cursada de la materia fue de carácter intensivo, con clases de lunes a jueves durante un mes. Cada clase tuvo una duración de tres horas aproximadamente. El curso estaba integrado por 20 alumnos quienes, en su mayoría, ya habían cursado la materia. 
Como señalamos, la evaluación formativa involucra un proceso en el que el docente "explora" las ideas de los estudiantes y realiza inferencias acerca del nivel de comprensión alcanzado. Con el objetivo de conocer estas ideas, cada clase finalizó siempre de la misma manera: con un cuestionario de cinco preguntas preparado en aplicaciones interactivas como Kahoot o Socrative. En base a las respuestas obtenidas, el docente recolectó información acerca del grado de comprensión del tema tratado alcanzado por los estudiantes. Esta información se utilizó para planificar el inicio de la clase siguiente y para conocer qué aspectos del tema eran necesario reforzar,

A fin de realizar un seguimiento continuo del trabajo de los estudiantes, además de los cuestionarios interactivos, otra herramienta que contribuyó a este objetivo fue la entrega diaria de actividades: a través de la sección Tareas de la plataforma Teams, Los alumnos tuvieron la posibilidad de realizar dos ejercicios (no obligatorios) de una clase para la siguiente. La devolución de la tarea era casi instantánea por parte del docente, señalando los errores o destacando el buen trabajo del alumno en los casos correspondientes.

Los errores más comunes fueron tratados y discutidos en clase, Si un alumno resolvió mal alguno de los ejercicios de la entrega, la devolución apuntó a señalarle el error y proponerle realizar nuevamente la actividad, con el objetivo de acercarlo al nivel requerido para la materia.

De esta manera, la retroalimentación tuvo lugar en ambas direcciones: no sólo el docente corrigió las tareas entregadas explicando los errores cometidos sino que también tanto las tareas como las respuestas dadas en Kahoot por los alumnos brindaron información al docente acerca de cómo seguir o qué aspectos retomar del tema que se estaba tratando. El feedback fue bidireccional, de ida y vuelta

Podemos describir dos situaciones que ejemplifican lo anterior: en la primera de las entregas los alumnos tuvieron que hallar el conjunto de ceros de dos funciones (ver anexo). Se detectaron errores algebraicos (despeje de ecuaciones) y conceptuales (los algunos alumnos no tuvieron en cuenta el dominio de la función) por lo que en la clase siguiente se resolvió este ejercicio en forma conjunta con los alumnos.

Otra situación tuvo lugar al finalizar la primera clase sobre derivadas: fue alto el porcentaje de alumnos que respondió bien sólo dos de las cinco preguntas realizadas por Kahoot. El cuestionario era sobre el uso de las reglas de derivación. Por tal motivo, la clase siguiente comenzó con un repaso de estas reglas y la realización de un ejercicio propuesto por el docente sobre el tema.

La mejora de la evaluación implica incidir previamente no sólo en el contenido que se enseña sino también en cómo se enseña (Bolívar, 2000). Así, las clases no se redujeron a la mera exposición teórica sino que fueron dinámicas, con alta participación de los alumnos (ya sea respondiendo preguntas, ya sea enviando vía chat la resolución de ejercicios), Las explicaciones del docente se apoyaron también en el uso de GeoGebra, lo que aportó a los alumnos una mejor comprensión de temas como polinomio de Taylor o recta tangente, entre otros.

Implementar una evaluación formativa implicó modificaciones en los contenidos a enseñar. Considerando el programa analítico de la materia, quedaron excluidos de la cursada, por cuestiones de tiempo, temas como el teorema de Bolzano o los teoremas 
de Rolle, Lagrange y Cauchy. Asimismo, los objetivos de aprendizaje (manejar correctamente los aspectos operativos asociados a los contenidos; interpretar las funciones como modelos matemáticos de situaciones reales de otras disciplinas en las que existe dependencia de una variable respecto de otra; construir e interpretar gráficos en coherencia con los aspectos analíticos estudiados; interpretar, analizar y resolver situaciones problemáticas sencillas mediante la aplicación de los contenidos desarrollados) no se vieron modificados. Es más, creemos que promover la realización diaria de actividades tanto dentro como fuera del aula virtual fue una de las cuestiones que contribuyó al desarrollo de los mismos.

La mayoría de los estudiantes universitarios reduce la evaluación a la nota numérica obtenida en los exámenes. En esta materia, en lo que respecta a las condiciones de aprobación, la cursada se aprueba con una nota de 4 o más puntos (sobre un total de 10) en cada uno de los dos exámenes parciales. Si el alumno obtiene siete o más puntos en cada parcial promociona la materia. Por cuestiones institucionales, no fue posible prescindir del examen parcial. Sin embargo, como consecuencia del trabajo realizado a lo largo de todas las clases y del seguimiento continuo del trabajo individual de cada alumno, los parciales no resultaron complicados para los estudiantes. Cada parcial se consideró como "una entrega más". En la nota final de la cursada se tuvieron en cuenta todas las actividades entregadas.

Que tanto docentes como alumnos hagan el "click" y piensen en una evaluación continua, reflexiva, que no se reduzca a la mera toma de exámenes no es tarea sencilla. Implica tiempo de trabajo y dedicación de ambas partes, además de modificar la manera tradicional de pensar la evaluación. En el actual contexto de enseñanza virtual pensamos que es necesario tanto para conocer el trabajo de los alumnos en relación a cierto contenido como para saber en qué medida están comprendiendo los temas.

\section{Resultados}

Para analizar y obtener conclusiones sobre la experiencia, se recolectó información del trabajo de cada alumno a través de las entregas realizadas (trece entregas en total durante la cursada) así como también de los exámenes parciales realizados. Recordemos que se trató de un curso "chico", integrado por 20 alumnos: dos de ellos estuvieron siempre ausentes y una sola alumna no realizó las entregas correspondientes. Si bien las entregas diarias eran de carácter no obligatorio, los alumnos respondieron afirmativamente a la nueva propuesta, tal vez por el hecho de que ya habían cursado la materia y buscaban promocionnarla.

Los resultados fueron buenos: de los alumnos que se presentaron a ambos parciales, el 90\% promocionó la materia. El examen parcial estaba integrado por cuatro ejercicios, de complejidad similar a la de los ejercicios trabajados a lo largo de las clases. En caso de estar aprobado, las tareas entregadas fueron consideradas en la nota de parcial: cada dos tareas correctas su sumó un punto adicional. Como ya dijimos, en caso de que la actividad presentase errores, el alumno tuvo la posibilidad de realzar nuevamente la entrega. En caso de que lo hiciese correctamente, el puntaje extra en el parcial se redujo a la mitad.

La respuesta de los alumnos a la propuesta, como ya dijimos, fue buena. Consideramos que el buen desempeño que tuvieron en la materia se debió, principalmente, a 
la entrega continua de las actividades propuestas por el docente. En las encuestas realizadas por la Universidad al finalizar el cuatrimestre, se registraron comentarios positivos por parte de los alumnos. Algunos fueron "Me re sirvió lo de las entregas", "Sirvió mucho trabajar todas las clases para estar al día", "Me gustó la cursada y todo lo que hicimos".

Si analizamos los trabajos individuales, observamos un notorio progreso individual a lo largo de la cursada. En las primeras clases, los ejercicios presentaron errores (cálculo de dominio, resolución de ecuaciones) que no se evidenciaron en las últimas entregas.

Entre los aspectos negativos de la experiencia, podemos mencionar el tiempo que implicó para el docente tanto la corrección como la preparación de las actividades, el armado de las clases, los cuestionarios y las simulaciones en GeoGebra. Cada clase se planificó considerando el desempeño en los trabajos entregados y lo realizado la clase anterior; en aquellos casos en los que el docente consideró necesario reforzar un tema, las actividades a desarrollar se decidieron en el momento (contando de antemano con algunas propuestas).

En este caso tratamos con un curso "chico" (sólo 20 alumnos), El grupo aceptó esta forma de evaluar y respondió positivamente a la propuesta. A pesar de la virtualidad, fue posible conocer el desempeño de los alumnos. Creemos que en cursos más numerosos se hace difícil hacer un seguimiento continuo de este trabajo.

\section{Discusión y conclusiones}

En la introducción de este artículo nos preguntamos si valía la pena este trabajo extra por parte del docente para implementar un modelo de evaluación formativa. Son muchos los factores a tener en cuenta: la disposición de los alumnos para trabajar, el tiempo con el que cuenta el docente para corregir y preparar las actividades clase a clase, entre otros. En el caso descripto se trató de un curso integrado por pocos alumnos y muchos de ellos recursantes; estas cuestiones pudieron haber ayudado al hecho de que la experiencia haya resultado satisfactoria.

Hay cuestiones a mejorar: el manejo del tiempo (hubo temas del programa que quedaron excluidos de la cursada), La guía de trabajos prácticos de la materia incluye muchos ejercicios aplicados: en clase se resolvieron sólo aquellos que posibilitaban dar inicio a un nuevo tema. El resto de los ejercicios se "eliminaron" de la guía. En este sentido, pensamos que los ejercicios de los trabajos prácticos (comunes a todos los cursos de la materia) quedaron relegados a un segundo plano y que los alumnos se preocuparon por resolver únicamente las actividades propuestas por el docente. El feedback formativo orienta al estudiante para la mejora de sus aprendizajes futuros: creemos que las devoluciones debieron ser más completas y no reducirse a señalar el error cometido.

El resultado final depende tanto de docentes como de alumnos, ya que requiere un compromiso de ambas partes. De todos modos, en el actual contexto de virtualidad, consideramos que es necesario un mayor seguimiento del trabajo de los estudiantes, de modo que se sientan más acompañados por el docente. 


\section{Referencias}

Atkin, J. M., Coffey, J. E., Moorthy, S., Sato, M., \&amp; Thibeault, M. (2005).Designing everyday assessment in the science classroom. Teachers College Press.

Anijovich, R.(2017). La evaluación formativa en la enseñanza superior. Voces de la educación, 2(1) pp. 31-38

Batalla-Bsquet, J. (2014). La importancia del feedback en un entorno virtual de aprendizaje. Revista Oikonomics. Revista de Economía, Empresa y Sociedad, (1) Dossier

Black, P., William, D. (1998). Assessment and classroom learning. Assessment in Education, 5(1), [pp]5-74.

Black, P., Wiliam,D.(2009) Developing the theory of formative assessment. Educational Assessment, Evaluation and Accountability, 5 (1),[pp] 5-21

Bolívar, A. (2000). La evaluación en la acción. El dossier progresivo de los alumnos, Díada.

Cowie, B., Bell, B. (1999) A model of formative assessment in science education. Assessment in Education: Principles, Policy \& Practice,9 (2), [pp] 6:101

Furtak, E. (2012) Linking a learning progression for natural selection to teachers' enactment of formative assessment. Journal of Research in Science Teaching; 49(9) [pp] 1181-1210

González Pérez, M. (2000). Evaluación Del Aprendizaje En La Enseñanza Universitaria. Editorial de la Universidad de La Habana.

Gulikers, J., Bastiaens, T. y Kirschner, P. (2004). Perceptions of authentic assessment. Five dimensions of authenticity». Educational Technology Research \& Development, 52 (3), [pp ] 67-86.

Hattie, J., Timperley, H. (2007). The Power of Feed Back. Review of Educational Research, 77 (1), [pp] 81-112

Sadler, D.(1989) Formative assessment and the design of instructional systems. Instructional Scienc, 24(3), [pp] 18:118. 


\section{Anexo}

Presentamos a continuación algunos de los ejercicios que tenían que entregar los alumnos:

\section{Clase I}

1. Dadas las siguientes funciones se pide:

a. Determinar el conjunto $A=$ Dominio de $f$.

b. Determinar analíticamente el conjunto de ceros.

i. $f(t)=\frac{t-2}{t^{2}-4}$

ii. $f(x)=x+\frac{1}{x}$

\section{Clase III}

Determinar analíticamente los puntos de intersección entre los gráficos de las siguientes funciones

$$
\left\{\begin{array}{c}
f(x)=\sqrt{x+1}-4 \\
g(x)=x+5
\end{array}\right.
$$

\section{Clase VII}

Hallar los puntos para los cuales la recta tangente al gráfico de es paralela al eje x.

\section{Clase IX}

Dada $R \rightarrow R / f(x)=\left(1+\frac{1}{x}\right)^{x} /$ calcular $\lim _{x \rightarrow+\infty} f(x)$

\section{Clase $X$}

Determinar los intervalos de crecimiento y decrecimiento, máximos y mínimos de la función

$$
f(x)=\frac{\ln (x-5)}{x-5}
$$




\section{Diseño y Validación de una Herramienta de Evaluación de la Usabilidad de un Entorno Web}

Farré Fustagueras, Marta

orcid.org/0000-0002-6077-6690 


\section{DISEÑO Y VALIDACIÓN DE UNA HERRAMIENTA DE EVALUACIÓN DE LA USABILIDAD DE UN ENTORNO WEB}

\section{Farré Fustagueras, Marta}

orcid.org/0000-0002-6077-6690

\section{Resumen}

En esta comunicación se presenta una herramienta de evaluación de la usabilidad diseñada adhoc para evaluar un espacio formativo online. La usabilidad se concibe, según Shakel (2009), como la habilidad de que un entorno, en este caso una web, sea fácil de usar y eficiente para un grupo específico de usuarios, con un entrenamiento previo y soporte, de completar un especifico rango de tareas, en un espacio delimitado de escenarios. Se basa en el análisis heurístico propuesto por Neilsen y Molich (1990) y se inspira en la propuesta creada por Hassan Montero y Martín Fernández (2003). Una primera versión de la misma, planteada en forma de rúbrica, se somete a juicio de expertos para su validación. Posteriormente, se adecua y finaliza. La herramienta final cuenta con 22 ítems estructurados en 7 categorías distintas (general, identidad e información, lenguaje y redacción, rotulado, estructura y navegación, diseño de la página y control y retroalimentación) en forma de rúbrica de 5 niveles, de los cuales se describen los niveles centrales (1, 3 y 5 ), en que se detallan los aspectos a valorar y que se esperan en cada puntuación. Evaluar la usabilidad es un aspecto imprescindible en los entornos web, como en los de formación, y tener una herramienta que permita evaluarlo sin ser un experto, facilita su consideración en el diseño.

\section{Palabras clave}

Usabilidad, evaluación, herramienta de evaluación, web. 


\section{Introducción}

Cuando se diseña un entorno web hay distintos aspectos a tener en cuenta para promover una buena experiencia del usuario que la utiliza. Uno de los más importantes es la usabilidad, junto con otros como la accesibilidad (Pastor Sánchez, 2010). Se entiende la usabilidad como "la medida de la cualidad de la experiencia de usuario en interaccionar con alguna cosa, tanto si es una web o una aplicación de software personalizada o cualquier otra herramienta que el usuario pueda utilizar" (Nielsen, 1999; citado en Tateo, 2021. pg. 2), de manera que tiene relación con la facilidad de uso que el usuario pueda tener con un objeto (web, software u otros) y la prevención de posibles intromisiones que puedan dificultarla. Shakel (2009) la define en 4 características sobre lo que la usabilidad proporciona a una web: efectividad, de fácil aprendizaje, flexibilidad y actitud. De esta manera, el usuario es capaz de usarla con facilidad, de forma eficaz, adaptada a sus necesidades y promueve que vuelva en un futuro. Dada la importancia de la usabilidad, existen estándares ISO que regularizan y uniformizan su aplicación a nivel práctico.

La usabilidad se puede evaluar de distintas formas. Concretamente se engloban los métodos en 3 grupos (Massa, De Guisti y Pesado, 2012): métodos de inspección, indagación y test. El más conocido y utilizado forma parte del primer grupo, los de inspección, es la evaluación heurística de Nielsen. Esta se define por el propio autor como una forma de evaluar una interfaz observándola y juzgándola (Nielsen y Molich, 1990) aunque, posteriormente, han querido darle más objetividad y de formalidad. Otra definición más actual es que este método consiste en "analizar la conformidad de la interfaz con unos principios reconocidos de usabilidad" (Massa, De Guisti y Pesado, 2012). Estos 10 principios o heurísticos son del propio autor, destacado experto del campo en cuestión.

En el caso que incumbe a este artículo, se plantea realizar un análisis heurístico en un entorno formativo en línea. Después de una primera búsqueda para buscar una herramienta, se detecta una falta de adaptación de las propuestas para realizar análisis heurísticos sin tener conocimientos técnicos, que se requieren en los principios de Nielsen y Molich. Por lo que se valora la necesidad de crear una herramienta propia para evaluar la usabilidad, dada su importancia en el diseño web y, teniendo en cuenta la necesidad de adaptarlo al contexto propio se plantea un objetivo:

- Diseñar y crear una herramienta de evaluación de la usabilidad en un entorno web siguiendo la idea de evaluación heurística de Nielsen. 


\section{Descripción de la experiencia}

\section{Proceso de diseño y validación de la herramienta}

\section{Fases}

Para llevar a cabo este proceso de diseño y validación de esta herramienta, se siguen 4 fases diferenciadas:

- Fase 1: Búsqueda bibliográfica. Una etapa inicial de búsqueda, en la cual, el objetivo es encontrar dimensiones o categorías relevantes a tener en cuenta cuando se valora la usabilidad, así como un modelo en el que basarse para desarrollar la herramienta.

- Fase 2: Creación de la herramienta. Consiste en, a partir de los modelos u/o categorías encontradas en la fase anterior, realizar una propuesta propia.

- Fase 3: Validación de la herramienta. Se trata que la herramienta diseñada sea sometida a un juicio de expertos a través de un formulario.

- Fase 4: Finalización de la herramienta. Con las valoraciones y apreciaciones de los expertos, modificarla para adecuarla y poderla usar.

\section{Búsqueda bibliográfica y creación de la herramienta}

La herramienta se crea a partir de la propuesta de Hassan Montero y Martín Fernández (2003), quienes a través de sus conocimientos y partiendo del análisis heurístico, presentan su versión para evaluar una web. Una de las características que se tienen en cuenta al escogerla es la posibilidad de un usuario-diseñador de observar los distintos ítems que se tienen en cuenta sin tener conocimientos técnicos. Se observa que otras propuestas no se pueden adaptar por este hecho.

A partir de esta, se plantea crear una modelo que sea fácilmente observable para cualquier persona, de esta forma se decide plantear la herramienta en forma de rúbrica. Una rúbrica se asimila, según Cano García (2015), a una matriz de valoración que consta de 2 ejes: en uno, los criterios de ejecución de una tarea y, en otro, una escala en la cual se describe cada nivel. De esta forma, se muestra de forma clara e inequívoca la opción escogida y los distintos aspectos que se tienen en cuenta. También se escogen y se adecuan las categorías e ítems de la propuesta original.

\section{Validación de la herramienta}

Una vez la herramienta está creada se requiere de un juicio de expertos para dar validez a la propuesta. De esta forma, se modifica y perfeccionan los aspectos que los profesionales valoren en la fase posterior y final de finalización de la herramienta.

Para hacer este procedimiento, se crea un formulario en el que se explica el motivo del envío del mismo, la herramienta y su contexto de posterior aplicación, el cual se encuentra en el siguiente enlace, en el idioma original: https://forms.gle/qR4EsKPq2mcQtDg68. En este, se propone evaluar en una escala Likert 1-5 cada uno de los 23 ítems y los 3 niveles que se encuentran descritos en la rúbrica (1, 3 y 5) que conforma la herramienta en 3 parámetros distintos: 
- Pertinencia (suficiencia): Si el ítem es pertinente en la dimensión o categoría en la que se encuentra.

- Importancia (relevancia): El ítem es importante, trata de aspectos esenciales para el propósito de la herramienta.

- Claridad: La afirmación se comprende fácilmente, es decir, es sintácticamente i semánticamente adecuada.

De manera que son, en total, 46 preguntas a responder, divididas en las 7 categorías que la conforman (general, identidad e información, lenguaje y redacción, rotulado, estructura y navegación, diseño de la página y control y retroalimentación). También se añade un espacio para comentarios después de cada una de las 23 afirmaciones para que los profesionales puedan aportar sus apreciaciones y comentarios respecto al ítem en cuestión. De esta forma, la evaluación de los expertos es exhaustiva y precisa, y permite recoger tanto valores cuantitativos como cualitativos en cada afirmación y niveles.

El formulario se hace llegar a 7 expertos profesionales de las tecnologías educativas, de los que 3 responden, en este caso, todos hombres, de edades comprendidas entre 36 y 65, dedicados todos a la universidad. 2 de los expertos tienen entre 16 y 20 años de experiencia y uno más de 20 años.

\section{Resultados de la validación}

Los resultados de la validación, como se comenta anteriormente, se valoran en una escala Likert de 1 al 5 (de menor a mayor puntuación). Para valorarlos de forma posterior, se toma el 3 como valor aceptable. Las que son superiores se evalúan como idóneas; las que se sitúan por debajo, se valora su modificación o eliminación, en este último caso si sucede en los 3 parámetros valorados. También se toman en cuenta los comentarios de los profesionales en cada ítem.

En la siguiente tabla en la que constan los resultados de este proceso de validación, los ítems se encuentran numerados y se diferencia entre la afirmación y los niveles. Las letras P, I y C se refieren a "pertenencia", "importancia" y "claridad". Asimismo, en cada ítem consta la mediana de las puntuaciones de los profesionales que la valoran. 


\begin{tabular}{|c|c|c|c|c|c|c|c|}
\hline \multicolumn{1}{|c}{$\mathbf{P}$ Ítem } & \multicolumn{7}{c|}{ C Niveles rúbrica } \\
\hline \multicolumn{4}{|c|}{ 1. General } & P & I & C & Mediana \\
\hline 1.1 & 5 & 4,67 & 4 & 4,67 & 4,33 & 4,33 & 4,5 \\
\hline 1.2. & 4,67 & 4,67 & 4 & 4,67 & 4,67 & 3 & 4,28 \\
\hline 1.3. & 5 & 5 & 5 & 5 & 5 & 5 & 5 \\
\hline 1.4. & 3,67 & 3 & 4 & 4 & 4 & 4,67 & 3,89 \\
\hline 1.5. & 4,67 & 5 & 3 & 4,67 & 4,33 & 3,67 & 4,22 \\
\hline 1.6. & 5 & 5 & 4,67 & 5 & 5 & 5 & 4,94 \\
\hline Ítem & $\mathbf{P}$ & $\mathbf{I}$ & $\mathbf{C}$ & & Niveles rúbrica &
\end{tabular}

\begin{tabular}{|c|c|c|c|c|c|c|c|}
\hline \multicolumn{4}{|c|}{ 2. Identidad y información } & $\mathbf{P}$ & I & C & Mediana \\
\hline 2.1. & 4,67 & 4,67 & 5 & 5 & 5 & 5 & 4,89 \\
\hline 2.2. & 4,67 & 4,67 & 4 & 5 & 5 & 5 & 4,72 \\
\hline 2.3 . & 5 & 5 & 5 & 5 & 5 & 4,67 & 4,94 \\
\hline Ítem & $\mathbf{P}$ & I & C & & s r r & & \\
\hline \multicolumn{4}{|c|}{ 3. Lenguaje y redacción } & $\mathbf{P}$ & I & C & Mediana \\
\hline 3.1. & 4,67 & 5 & 5 & 5 & 5 & 4,67 & 4,89 \\
\hline 3.2. & 4,67 & 5 & 5 & 5 & 5 & 5 & 4,94 \\
\hline 3.3. & 4,67 & 4,67 & 5 & 5 & 5 & 5 & 4,89 \\
\hline
\end{tabular}

$\begin{array}{lllll}\text { Ítem } & \mathbf{P} & \mathbf{I} & \mathbf{C} & \text { Niveles rúbrica }\end{array}$

\begin{tabular}{|c|c|c|c|c|c|c|c|}
\hline \multicolumn{4}{|c|}{ 4. Rotulado } & $\mathbf{P}$ & $\mathbf{I}$ & C & Mediana \\
\hline 4.1. & 3,67 & 3,33 & 3,67 & 3,67 & 3,67 & 4 & 3,67 \\
\hline Ítem & $\mathbf{P}$ & I & C & \multicolumn{4}{|c|}{ Niveles rúbrica } \\
\hline \multicolumn{4}{|c|}{ 5. Estructura y navegación } & $\mathbf{P}$ & I & C & Mediana \\
\hline 5.1. & 5 & 5 & 5 & 5 & 5 & 5 & 5 \\
\hline 5.2. & 5 & 5 & 5 & 5 & 5 & 5 & 5 \\
\hline 5.3. & 5 & 4,67 & 5 & 4,67 & 5 & 4,33 & 4,78 \\
\hline 5.4 . & 5 & 4,33 & 4,67 & 5 & 5 & 5 & 4,83 \\
\hline Ítem & $\mathbf{P}$ & I & C & & les $r$ & & \\
\hline
\end{tabular}

\begin{tabular}{|c|c|c|c|c|c|c|c|}
\hline \multicolumn{4}{|c|}{ 6. Diseño de la página } & P & I & C & Mediana \\
\hline 6.1. & 5 & 5 & 4,67 & 5 & 5 & 4,67 & 4,89 \\
\hline 6.2. & 4,33 & 4,67 & 5 & 4,67 & 4,67 & 5 & 4,72 \\
\hline 6.3. & 5 & 5 & 5 & 5 & 5 & 5 & 5 \\
\hline 6.4. & 4,67 & 4,67 & 5 & 5 & 5 & 5 & 4,89 \\
\hline
\end{tabular}

$\begin{array}{lllll}\text { Ítem } & \mathbf{P} & \mathbf{I} & \mathrm{C} & \text { Niveles rúbrica }\end{array}$

\begin{tabular}{|c|c|c|c|c|c|c|c|}
\hline \multicolumn{4}{|c|}{ 7. Control y retroalimentación } & P & I & C & Mediana \\
\hline 7.1. & 4,67 & 4,67 & 3,67 & 4,67 & 4,67 & 4 & 4,39 \\
\hline 7.2. & 4,67 & 4,67 & 4,33 & 5 & 5 & 5 & 4,78 \\
\hline 7.3. & 5 & 5 & 5 & 5 & 5 & 5 & 5 \\
\hline 7.4. & 2,67 & 3,33 & 3 & 3 & 3 & 3 & 3 \\
\hline
\end{tabular}

\section{Tabla 1. Resultados del juicio de expertos}

Se observa que la mayoría de las medianas superan el 4 , hecho que visibiliza la adecuación e idoneidad de las preguntas planteadas, así como de los distintos niveles 
de la rúbrica. Hay algunos ítems como el 1.3., 5.1, 5.2., 6.3. y 7.3., que llegan a la puntuación máxima tanto en la afirmación como en los niveles de la rúbrica. En 3 casos, las valoraciones descienden del 4, concretamente en los ítems 1.4., 4.1. y en el 7.4. En este último caso,4. la mediana desciende hasta el 3, siendo una puntuación más baja que los demás ítems. Además, si se observa la puntuación de la pertinencia, esta consigue un 2,67 de mediada entre los expertos, por lo que se valora como no pertinente. Asimismo, en las demás puntuaciones (de la importancia y claridad, tanto de la afirmación, como de los niveles de la rúbrica), son menores de 4.

\section{Discusión y conclusiones}

Como se observan en las puntuaciones de la tabla 1, en general, se valora de forma positiva (superiores a 4) y en 3 casos, descienden del 4 . Además, se tienen en cuenta los comentarios de los expertos para mejorar los ítems. Todos estos distintos aspectos se tienen en cuenta para crear esta herramienta, aunque principalmente adaptada para valorar espacios web de formación, para evaluar la usabilidad.

Los resultados a nivel general se sitúan por encima de 3, exceptuando un ítem, el 7.4 en que, tanto la afirmación como los distintos niveles descritos en la rúbrica, se puntúan alrededor de 3, incluso en la pertinencia la puntuación media es de 2,66. Este ítem se elimina de la herramienta final. Los demás, se tienen en cuenta especialmente las puntuaciones comprendidas entre 3 y 4, como también los comentarios. Por eso, se adaptan y mejoran la redacción de algunos de ellos para hacerlos más comprensibles.

Con la validación y la posterior modificación, se crea el instrumento para el análisis y la evaluación de la usabilidad en entornos web por personas no expertas, el cual se añade a los anexos de este artículo.

La usabilidad es una característica básica para la experiencia del usuario, por los distintos motivos que expone Shackel (2009) y que facilitan al visitante su navegación por la web:

- Efectividad, por lo tanto, que presente pocos errores y poder realizar las tareas esperables.

- De fácil aprendizaje, de esta forma el usuario se guía de forma intuitiva y sencilla por la web.

- Flexibilidad, de manera que se pueda adaptar en parte a las tareas y contextos del usuario, que sea una web con una comunicación fácil con los administradores,

- Actitud, es decir, que predisponga al usuario que vuelva a la web, que sea una experiencia agradable y que no produzca frustraciones ni cansancio en usarla.

Con este instrumento creado se promueve conseguir estos objetivos que interesan a cualquier espacio formativo y así, satisfacer a un usuario en su navegación por el mismo. 


\section{Referencias}

Cano García, E. (2015). Las rúbricas como instrumento de evaluación de competencias en Educación Superior: ¿Uso o abuso? Profesorado. Revista de CurrícuIum y Formación de Profesorado, 19(2), 265-280. Retrieved from http://hdl.handle. net/10481/37376

Hassan Montero, Y., \& Martín Fernández, F. J. (2003, 03 30). Guía de Evaluación Heurística de Sitios Web. No solo usabilidad. http://www.nosolousabilidad.com/articulos/heuristica.htm

Massa, S. M., De Giusti, A., \& Pesado, P. (2012). Métodos de evaluación de usabilidad: una propuesta de aplicación en Objetos de Aprendizaje. XIV Workshop de Investigadores en Ciencias de la Computación, 922-925.

Nielsen, J. (1999). Designing Web Usability. New Riders Publishing.

Nielsen, J., \& Molich, R. (1990). Heuristic evaluation of user interfaces. Conference on Human Factors in Computing Systems - Proceedings, 249-256. https://doi. org/10.1145/97243.97281

Pastor Sánchez, J. A. (2010). Bases para un Diseño Web Integral a través de la convergencia de la Accesibilidad, Usabilidad y Arquitectura de la Información. Scire: Representación Y Organización Del Conocimiento, 16(1), 65-80. https://www.ibersid. eu/ojs/index.php/scire/article/view/1536

Shackel, B. (2009). Usability - Context, framework, definition, design and evaluation. Interacting with Computers, 21(5-6), 339-346. https://doi.org/10.1016/j.intcom.2009.04.007

\section{Anexos}

\begin{tabular}{|l|l|l|l|l|l|l|}
\hline \multicolumn{1}{|c|}{ 1. GENERAL } & $\begin{array}{l}\text { Observa- } \\
\text { ciones }\end{array}$ & \multicolumn{1}{|c|}{$\mathbf{1}$} & $\mathbf{2}$ & $\mathbf{3}$ & $\mathbf{4}$ & $\mathbf{5}$ \\
\hline $\begin{array}{l}\text { 1.1. Los objetivos de la } \\
\text { página web están bien } \\
\text { definidos y presentes. }\end{array}$ & $\begin{array}{l}\text { No se encuen- } \\
\text { tran presentes } \\
\text { en la página } \\
\text { web. }\end{array}$ & $\begin{array}{l}\text { Están presentes } \\
\text { de forma implí- } \\
\text { cita y pueden } \\
\text { inferirse en el } \\
\text { contexto de la } \\
\text { página. }\end{array}$ & $\begin{array}{l}\text { Están presen- } \\
\text { tes. Tienen un } \\
\text { espacio que } \\
\text { los explica de } \\
\text { forma explícita, } \\
\text { como también } \\
\text { la finalidad de } \\
\text { cada apartado. }\end{array}$ \\
\hline $\begin{array}{l}\text { 1.2. Los contenidos y } \\
\text { servicios ofrecidos se } \\
\text { corresponden con los } \\
\text { objetivos. }\end{array}$ & $\begin{array}{l}\text { Los objetivos y } \\
\text { los contenidos } \\
\text { y servicios no } \\
\text { tienen relación } \\
\text { entre sí. }\end{array}$ & $\begin{array}{l}\text { En general, los } \\
\text { contenidos y los } \\
\text { servicios corres- } \\
\text { ponden con los } \\
\text { objetivos. }\end{array}$ & $\begin{array}{l}\text { Los servicios } \\
\text { y contenidos } \\
\text { tienen una co- } \\
\text { rrespondencia } \\
\text { y coherencia }\end{array}$ \\
\hline $\begin{array}{l}\text { adecuada con } \\
\text { los objetivos de } \\
\text { la web. }\end{array}$
\end{tabular}




\begin{tabular}{|c|c|c|c|}
\hline $\begin{array}{l}\text { 1.3. Los contenidos son } \\
\text { relevantes, completos y } \\
\text { actuales. }\end{array}$ & $\begin{array}{l}\text { Son confusos, } \\
\text { insuficientes o } \\
\text { incompletos. }\end{array}$ & $\begin{array}{l}\text { Dan información } \\
\text { relevante, pero } \\
\text { incompleta o } \\
\text { parte del con- } \\
\text { tenido no está } \\
\text { actualizado. }\end{array}$ & $\begin{array}{l}\text { La información } \\
\text { es relevante, } \\
\text { completa y } \\
\text { actualizada. } \\
\text { Proporciona } \\
\text { una curación de } \\
\text { contenidos y los } \\
\text { enlaza. }\end{array}$ \\
\hline $\begin{array}{l}\text { 1.4. La dirección URL } \\
\text { principal es clara y fácil } \\
\text { de recordar, como tam- } \\
\text { bién la de las páginas } \\
\text { internas son claras y } \\
\text { permanentes. }\end{array}$ & $\begin{array}{l}\text { La dirección } \\
\text { URL de la pá- } \\
\text { gina principal } \\
\text { como de las } \\
\text { internas, son } \\
\text { difíciles de re- } \\
\text { cordar. Asimis- } \\
\text { mo, no son ni } \\
\text { permanentes ni } \\
\text { claras. }\end{array}$ & $\begin{array}{l}\text { La dirección URL } \\
\text { de la página } \\
\text { principal i de las } \\
\text { páginas internas } \\
\text { son sencillas de } \\
\text { recordar. Ade- } \\
\text { más, son perma- } \\
\text { nentes y/o claras } \\
\text { la mayoría de } \\
\text { veces. }\end{array}$ & $\begin{array}{l}\text { La dirección } \\
\text { URL de la } \\
\text { página inicial y } \\
\text { de las internas } \\
\text { son sencillas de } \\
\text { recordar, claras } \\
\text { y, también, son } \\
\text { permanentes, } \\
\text { facilitando el } \\
\text { acceso del } \\
\text { usuario a lo lar- } \\
\text { go del tiempo. }\end{array}$ \\
\hline $\begin{array}{l}\text { 1.5. Se muestran de for- } \\
\text { ma precisa y completa } \\
\text { los servicios/contenidos } \\
\text { que ofrece la web. }\end{array}$ & $\begin{array}{l}\text { No están claros } \\
\text { cuales son los } \\
\text { servicios/con- } \\
\text { tenidos que } \\
\text { ofrece la web. }\end{array}$ & $\begin{array}{l}\text { Los servicios/ } \\
\text { contenidos se } \\
\text { muestran en } \\
\text { algunas páginas, } \\
\text { aunque, no que- } \\
\text { da claro todos los } \\
\text { que se ofrecen. }\end{array}$ & $\begin{array}{l}\text { Se muestran en } \\
\text { la página inicial } \\
\text { los servicios/ } \\
\text { contenidos que } \\
\text { se ofrecen y, } \\
\text { también, son } \\
\text { consultables } \\
\text { en cualquier } \\
\text { página. El usua- } \\
\text { rio conoce con } \\
\text { facilidad el que } \\
\text { se le ofrece. }\end{array}$ \\
\hline $\begin{array}{l}\text { 1.6. El diseño general del } \\
\text { entorno web es agrada- } \\
\text { ble, coherente y facilita } \\
\text { la navegación. }\end{array}$ & $\begin{array}{l}\text { El diseño de } \\
\text { la web y la } \\
\text { situación de los } \\
\text { elementos co- } \\
\text { munes, el uso } \\
\text { de los colores... } \\
\text { no mantiene } \\
\text { un tratamien- } \\
\text { to uniforme, } \\
\text { como tampoco } \\
\text { coherencia en } \\
\text { las distintas } \\
\text { páginas. }\end{array}$ & $\begin{array}{l}\text { En general, el } \\
\text { diseño de la web } \\
\text { es uniforme y } \\
\text { coherente en la } \\
\text { mayoría de las } \\
\text { páginas, con } \\
\text { alguna confusión. } \\
\text { También es así la } \\
\text { situación de los } \\
\text { elementos comu- } \\
\text { nes y del uso del } \\
\text { color. }\end{array}$ & $\begin{array}{l}\text { El diseño de } \\
\text { la web es } \\
\text { coherente y } \\
\text { uniforme en la } \\
\text { situación de } \\
\text { los elementos } \\
\text { comunes como } \\
\text { también las } \\
\text { estructuras y } \\
\text { colores a todas } \\
\text { las páginas. La } \\
\text { navegación por } \\
\text { la web es agra- } \\
\text { dable y sencilla. }\end{array}$ \\
\hline
\end{tabular}

\section{IDENTIDAD E INFORMACIÓN}

\begin{tabular}{|l|l|l|l|l|l|l|}
\hline \multicolumn{1}{|c|}{ Ítem } & $\begin{array}{l}\text { Observa- } \\
\text { ciones }\end{array}$ & $\mathbf{1}$ & $\mathbf{2}$ & $\mathbf{3}$ & $\mathbf{5}$ \\
\hline $\begin{array}{l}\text { 2.1. Se muestra la iden- } \\
\text { tidad de la entidad en } \\
\text { todas las páginas. }\end{array}$ & $\begin{array}{l}\text { No se muestra } \\
\text { la identidad de } \\
\text { la organización } \\
\text { en ninguna de } \\
\text { las páginas, } \\
\text { sea en forma } \\
\text { de logotipo } \\
\text { texto. }\end{array}$ & $\begin{array}{l}\text { La identidad, } \\
\text { texto o logotipo, } \\
\text { se muestra en al- } \\
\text { guna página. No } \\
\text { obstante, cambia } \\
\text { de sitio o no se } \\
\text { encuentra en el } \\
\text { mismo sitio. }\end{array}$ & $\begin{array}{l}\text { Se muestra la } \\
\text { identidad (logo- } \\
\text { tipo o texto) en } \\
\text { todas las pági- } \\
\text { nas de la web. } \\
\text { De hecho, se } \\
\text { mantiene en la } \\
\text { misma posición } \\
\text { en las distintas } \\
\text { páginas. }\end{array}$ \\
\hline
\end{tabular}




\begin{tabular}{|c|c|c|c|}
\hline $\begin{array}{l}\text { 2.2. Se facilitan mecanis- } \\
\text { mos (formulario, e-mail, } \\
\text { teléfono...) para contac- } \\
\text { tar con la entidad. }\end{array}$ & $\begin{array}{l}\text { No se ofre- } \\
\text { ce ninguna } \\
\text { manera para } \\
\text { contactar con } \\
\text { la entidad. }\end{array}$ & $\begin{array}{l}\text { Hay algún } \\
\text { sistema para } \\
\text { contactar con la } \\
\text { entidad, pero no } \\
\text { tiene un apartado } \\
\text { concreto y no es } \\
\text { sencillo ni rápido } \\
\text { de usar. }\end{array}$ & $\begin{array}{l}\text { Hay un aparta- } \\
\text { do específico } \\
\text { a la web para } \\
\text { contactar con la } \\
\text { entidad, fácil- } \\
\text { mente visible en } \\
\text { cada página. }\end{array}$ \\
\hline $\begin{array}{l}\text { 2.3. Se facilita informa- } \\
\text { ción sobre la protección } \\
\text { de datos de carácter } \\
\text { personal de los usuarios } \\
\text { o de los derechos de } \\
\text { autor de los contenidos } \\
\text { de la página web. }\end{array}$ & $\begin{array}{l}\text { No hay infor- } \\
\text { mación sobre } \\
\text { la protección } \\
\text { de datos ni } \\
\text { sobre los dere- } \\
\text { chos de autor. }\end{array}$ & $\begin{array}{l}\text { Hay información } \\
\text { sobre uno de los } \\
\text { dos elementos } \\
\text { (protección de } \\
\text { datos o derechos } \\
\text { de autor). Cuan- } \\
\text { do no está, se } \\
\text { tiene que inferir. } \\
\text { Se puede inferir } \\
\text { con dificultades. }\end{array}$ & $\begin{array}{l}\text { Hay informa- } \\
\text { ción clara y } \\
\text { directa sobre } \\
\text { la protección } \\
\text { de datos de ca- } \\
\text { rácter personal } \\
\text { como también } \\
\text { de los derechos } \\
\text { de autor de la } \\
\text { página web. }\end{array}$ \\
\hline
\end{tabular}

\section{LENGUAJE Y REDACCIÓN}

\begin{tabular}{|c|c|c|c|c|c|c|}
\hline Ítem & $\begin{array}{c}\text { Observa- } \\
\text { ciones }\end{array}$ & 1 & 2 & 3 & 4 & 5 \\
\hline $\begin{array}{l}\text { 3.1. El espacio web usa } \\
\text { un lenguaje adecuado } \\
\text { a los usuarios, como } \\
\text { también técnico y pro- } \\
\text { fesional. }\end{array}$ & & $\begin{array}{l}\text { El lenguaje } \\
\text { textual o la ter- } \\
\text { minología no } \\
\text { son adecuados } \\
\text { a los destinata- } \\
\text { rios. }\end{array}$ & & $\begin{array}{l}\text { En general, el } \\
\text { lenguaje, la es- } \\
\text { tructura textual } \\
\text { y la terminología } \\
\text { son adecuados al } \\
\text { público destina- } \\
\text { tario, aunque no } \\
\text { siempre. }\end{array}$ & & $\begin{array}{l}\text { El lenguaje, } \\
\text { la estructura } \\
\text { textual y la ter- } \\
\text { minología son } \\
\text { adecuados a los } \\
\text { usuarios. Gene- } \\
\text { ra profesionali- } \\
\text { dad y especiali- } \\
\text { zación para los } \\
\text { usuarios. }\end{array}$ \\
\hline $\begin{array}{l}\text { 3.2. Se usa un lenguaje } \\
\text { claro, conciso y gramá- } \\
\text { ticamente correcto. }\end{array}$ & & $\begin{array}{l}\text { El lenguaje } \\
\text { es recargado, } \\
\text { aporta informa- } \\
\text { ción no nece- } \\
\text { saria o poco } \\
\text { relevante. }\end{array}$ & & $\begin{array}{l}\text { El lenguaje es ge- } \\
\text { neralmente claro. } \\
\text { No obstante, en } \\
\text { ocasiones, aporta } \\
\text { información no } \\
\text { relevante. }\end{array}$ & & $\begin{array}{l}\text { El lenguaje es } \\
\text { entendedor } \\
\text { y expresa la } \\
\text { información de } \\
\text { forma clara y } \\
\text { concisa. }\end{array}$ \\
\hline $\begin{array}{l}\text { 3.3. El lenguaje es ami- } \\
\text { gable y próximo. }\end{array}$ & & $\begin{array}{l}\text { El lenguaje es } \\
\text { distante, no } \\
\text { es próximo ni } \\
\text { amigable. No } \\
\text { promueve ni } \\
\text { facilita la co- } \\
\text { municación por } \\
\text { la distancia que } \\
\text { se crea entre } \\
\text { los usuarios. }\end{array}$ & & $\begin{array}{l}\text { Frecuentemente, } \\
\text { el lenguaje es } \\
\text { próximo y amiga- } \\
\text { ble, no obstante, } \\
\text { no siempre. }\end{array}$ & & $\begin{array}{l}\text { El lenguaje es } \\
\text { próximo y ami- } \\
\text { gable. Favorece } \\
\text { la comunicación } \\
\text { necesaria para } \\
\text { la participación, } \\
\text { la expresión } \\
\text { profesional y la } \\
\text { resolución de } \\
\text { dudas. }\end{array}$ \\
\hline \multicolumn{7}{|l|}{ 4. ROTULADO } \\
\hline Ítem & $\begin{array}{l}\text { Observa- } \\
\text { ciones }\end{array}$ & 1 & 2 & 3 & 4 & 5 \\
\hline $\begin{array}{l}\text { 4.1. Utiliza rotulado } \\
\text { estándar, que se puede } \\
\text { encontrar en la mayoría } \\
\text { de webs (mapa de la } \\
\text { web, contacto, quienes } \\
\text { somos/sobre, etc.) }\end{array}$ & & $\begin{array}{l}\text { No utiliza } \\
\text { ningún rotulo } \\
\text { estándar. }\end{array}$ & & $\begin{array}{l}\text { Mayoritariamen- } \\
\text { te, hace uso de } \\
\text { rotulado están- } \\
\text { dar. }\end{array}$ & & $\begin{array}{l}\text { Utiliza rótulos } \\
\text { estándares en } \\
\text { todo momento } \\
\text { para facilitar } \\
\text { la navegación } \\
\text { de los partici- } \\
\text { pantes en el } \\
\text { entorno web. }\end{array}$ \\
\hline
\end{tabular}


5. ESTRUCTURA Y NAVEGACIÓN

\begin{tabular}{|c|c|c|c|c|c|c|}
\hline Ítem & $\begin{array}{c}\text { Observa- } \\
\text { ciones }\end{array}$ & 1 & 2 & 3 & 4 & 5 \\
\hline $\begin{array}{l}\text { 5.1. Los enlaces son } \\
\text { fácilmente reconocibles. } \\
\text { Su caracterización indi- } \\
\text { ca su estado (visitados, } \\
\text { activos, etc.). }\end{array}$ & & $\begin{array}{l}\text { Los enlaces no } \\
\text { son reconoci- } \\
\text { bles como tal, } \\
\text { tampoco cam- } \\
\text { bian su estado } \\
\text { cuando se han } \\
\text { usado. }\end{array}$ & & $\begin{array}{l}\text { En general, pero } \\
\text { no siempre, los } \\
\text { enlaces son fá- } \\
\text { cilmente recono- } \\
\text { cibles e indican } \\
\text { el cambio de } \\
\text { estado. }\end{array}$ & & $\begin{array}{l}\text { Los enlaces se } \\
\text { identifican con } \\
\text { facilidad, tam- } \\
\text { bién su estado: } \\
\text { si se han usado } \\
\text { o no. }\end{array}$ \\
\hline $\begin{array}{l}\text { 5.2. Se ha controlado } \\
\text { que ningún enlace no } \\
\text { lleve a ningún sitio. }\end{array}$ & & $\begin{array}{l}\text { La mayoría de } \\
\text { enlaces no con- } \\
\text { ducen a alguna } \\
\text { página. }\end{array}$ & & $\begin{array}{l}\text { La mayoría de } \\
\text { enlaces condu- } \\
\text { cen a otra pági- } \\
\text { na. No obstante, } \\
\text { alguno de los } \\
\text { enlaces no lleva a } \\
\text { ninguna página. }\end{array}$ & & $\begin{array}{l}\text { Todos los en- } \\
\text { laces tienen un } \\
\text { destino. }\end{array}$ \\
\hline $\begin{array}{l}\text { 5.3. Hay elementos de } \\
\text { navegación que orien- } \\
\text { tan al usuario sobre } \\
\text { dónde está i como des- } \\
\text { hacer su navegación. }\end{array}$ & & $\begin{array}{l}\text { No hay elemen- } \\
\text { tos que facili- } \\
\text { ten al usuario } \\
\text { situarse, ni a } \\
\text { deshacer las } \\
\text { acciones reali- } \\
\text { zadas. }\end{array}$ & & $\begin{array}{l}\text { Hay algunos } \\
\text { elementos que } \\
\text { permiten al } \\
\text { usuario situarse } \\
\text { y deshacer la } \\
\text { navegación. }\end{array}$ & & $\begin{array}{l}\text { Hay elementos } \\
\text { que facilitan } \\
\text { saber dónde } \\
\text { se encuentra el } \\
\text { usuario y des- } \\
\text { hacer la acción } \\
\text { realizada. Así, } \\
\text { puede controlar } \\
\text { la navegación } \\
\text { en el entorno } \\
\text { web. }\end{array}$ \\
\hline $\begin{array}{l}\text { 5.4. Las imágenes-enla- } \\
\text { ce se reconocen como } \\
\text { clicables e incluyen } \\
\text { un atributo (texto que } \\
\text { emerge en situar el } \\
\text { cursor encima de un } \\
\text { elemento) describiendo } \\
\text { la página de destino. }\end{array}$ & & $\begin{array}{l}\text { Las imáge- } \\
\text { nes-enlace no } \\
\text { se distinguen } \\
\text { de las demás, } \\
\text { tampoco tie- } \\
\text { nen atributo } \\
\text { que informen } \\
\text { de la página de } \\
\text { destino. }\end{array}$ & & $\begin{array}{l}\text { En general, las } \\
\text { imágenes-enlace } \\
\text { son reconocibles } \\
\text { y tienen atributos } \\
\text { que informan de } \\
\text { su destino. }\end{array}$ & & $\begin{array}{l}\text { Las imágenes } \\
\text { se reconocen } \\
\text { como enlaces } \\
\text { e incluyen un } \\
\text { atributo, hacho } \\
\text { que facilita al } \\
\text { usuario conocer } \\
\text { como acceder } \\
\text { a una página de } \\
\text { forma previa. }\end{array}$ \\
\hline
\end{tabular}

6. DISEÑO DE LA PÁGINA

\begin{tabular}{|l|l|l|l|l|l|}
\hline \multicolumn{1}{|c|}{ Ítem } & $\begin{array}{c}\text { Observa- } \\
\text { ciones }\end{array}$ & $\mathbf{1}$ & $\mathbf{2}$ & $\mathbf{3}$ & $\mathbf{4}$ \\
\hline $\begin{array}{l}\text { 6.1. Es una interfaz } \\
\text { limpia, sin ruido visual } \\
\text { (elementos molestos } \\
\text { O desagradables que } \\
\text { distraen del contenido } \\
\text { importante). }\end{array}$ & $\begin{array}{l}\text { La interfaz } \\
\text { presenta un } \\
\text { exceso de estí- } \\
\text { mulos, algunos } \\
\text { de ellos no } \\
\text { aportan infor- } \\
\text { mación nece- } \\
\text { saria y distraen } \\
\text { de los conteni- } \\
\text { dos relevantes. }\end{array}$ & $\begin{array}{l}\text { En general, los } \\
\text { espacios de la } \\
\text { interfaz de la pá- } \\
\text { gina son limpios } \\
\text { y sin ruido visual. }\end{array}$ & $\begin{array}{l}\text { La interfaz de } \\
\text { las páginas } \\
\text { es limpia, sin } \\
\text { ruido visual. El } \\
\text { entorno web } \\
\text { es visualmente } \\
\text { agradable. }\end{array}$ \\
\hline
\end{tabular}




\begin{tabular}{|c|c|c|c|c|c|c|}
\hline $\begin{array}{l}\text { 6.2. Existen zonas en } \\
\text { blanco entre los objetos } \\
\text { informativos de la pági- } \\
\text { na para poder descan- } \\
\text { sar la vista. }\end{array}$ & & $\begin{array}{l}\text { No hay espa- } \\
\text { cios en blanco } \\
\text { entre objetos } \\
\text { informativos. } \\
\text { Los apartados } \\
\text { se presentan } \\
\text { de forma muy } \\
\text { compacta y } \\
\text { densa, difi- } \\
\text { cultando una } \\
\text { visión estructu- } \\
\text { rada. }\end{array}$ & & $\begin{array}{l}\text { Hay espacios en } \\
\text { blanco entre al- } \\
\text { gunos apartados, } \\
\text { hecho que facilita } \\
\text { el descanso entre } \\
\text { estos. }\end{array}$ & & $\begin{array}{l}\text { Hay zonas en } \\
\text { blanco entre ob- } \\
\text { jetos informati- } \\
\text { vos, para que el } \\
\text { usuario descan- } \\
\text { se visualmente } \\
\text { entre apartados. } \\
\text { Los apartados } \\
\text { se presentan de } \\
\text { forma adecua- } \\
\text { da, espaciado, } \\
\text { facilitando la } \\
\text { visión estructu- } \\
\text { rada. }\end{array}$ \\
\hline $\begin{array}{l}\text { 6.3. Se hace un uso } \\
\text { correcto del espacio de } \\
\text { la página. }\end{array}$ & & $\begin{array}{l}\text { Los apartados } \\
\text { y contenidos no } \\
\text { están distribui- } \\
\text { dos adecuada- } \\
\text { mente, ocupan } \\
\text { demasiado o } \\
\text { poco espacio, } \\
\text { de manera que } \\
\text { se dificulta la } \\
\text { visión completa. }\end{array}$ & & $\begin{array}{l}\text { En general, los } \\
\text { apartados están } \\
\text { bien distribuidos, } \\
\text { aunque algunos } \\
\text { ocupan demasia- } \\
\text { do espacio o los } \\
\text { espacios no se } \\
\text { encuentran bien } \\
\text { delimitados. }\end{array}$ & & $\begin{array}{l}\text { Los aparta- } \\
\text { dos están bien } \\
\text { distribuidos. } \\
\text { El tamaño de } \\
\text { los elementos } \\
\text { es adecuado y } \\
\text { promueve que } \\
\text { la experiencia } \\
\text { del usuario sea } \\
\text { buena. Así, tam- } \\
\text { bién se puede } \\
\text { visualizar de } \\
\text { forma correcta } \\
\text { independien- } \\
\text { temente del } \\
\text { dispositivo en el } \\
\text { que se use. }\end{array}$ \\
\hline $\begin{array}{l}\text { 6.4. Los elementos } \\
\text { visuales (iconos, imáge- } \\
\text { nes) de la página tienen } \\
\text { un estil uniforme. }\end{array}$ & & $\begin{array}{l}\text { Los elementos } \\
\text { visuales de } \\
\text { la página no } \\
\text { tienen un estilo } \\
\text { uniforme. }\end{array}$ & & $\begin{array}{l}\text { La mayoría de } \\
\text { elementos visua- } \\
\text { les que incorpora } \\
\text { la página tienen } \\
\text { unidad de estilo. }\end{array}$ & & $\begin{array}{l}\text { Los elementos } \\
\text { visuales que } \\
\text { incorpora la } \\
\text { página tienen } \\
\text { una unidad de } \\
\text { estilo i favore- } \\
\text { cen la compren- } \\
\text { sión visual de } \\
\text { la estructura, la } \\
\text { navegación y la } \\
\text { localización de } \\
\text { la información. }\end{array}$ \\
\hline \multicolumn{7}{|c|}{ 7. CONTROL I RETROALIMENTACIÓN } \\
\hline Ítem & $\begin{array}{c}\text { Observa- } \\
\text { ciones }\end{array}$ & 1 & 2 & 3 & 4 & 5 \\
\hline $\begin{array}{l}\text { 7.1. El usuario tiene con- } \\
\text { trol de toda la interfaz, } \\
\text { es decir, no hay ele- } \\
\text { mentos invasivos que } \\
\text { le dificulten realizar las } \\
\text { acciones que desea. }\end{array}$ & & $\begin{array}{l}\text { Hay publicidad } \\
\text { invasiva que no } \\
\text { se puede evitar, } \\
\text { tampoco se } \\
\text { puede escoger } \\
\text { a que paginas } \\
\text { acceder, ya } \\
\text { que se tiene la } \\
\text { obligación de } \\
\text { seguir una ruta } \\
\text { determinada. }\end{array}$ & & $\begin{array}{l}\text { La mayoría de las } \\
\text { veces, el usuario } \\
\text { puede escoger } \\
\text { las acciones que } \\
\text { desea realizar, } \\
\text { ya que no hay } \\
\text { elementos que } \\
\text { molesten. De } \\
\text { todas formas, en } \\
\text { alguna ocasión } \\
\text { hay publicidad } \\
\text { invasiva. }\end{array}$ & & $\begin{array}{l}\text { El usuario en } \\
\text { todo momento } \\
\text { puede contro- } \\
\text { lar la interfaz. } \\
\text { No hay ele- } \\
\text { mentos que } \\
\text { imposibiliten la } \\
\text { navegación y la } \\
\text { realización de } \\
\text { la acción que } \\
\text { desea. }\end{array}$ \\
\hline
\end{tabular}




\begin{tabular}{|c|c|c|c|}
\hline $\begin{array}{l}\text { 7.2. En el caso de formu- } \\
\text { larios, fórums o valo- } \\
\text { raciones, se informa al } \\
\text { usuario sobre qué ha } \\
\text { pasado, por ejemplo, si } \\
\text { se ha enviado el men- } \\
\text { saje o si puede modifi- } \\
\text { carlo. }\end{array}$ & $\begin{array}{l}\text { Cuando el } \\
\text { usuario utiliza } \\
\text { un formulario } \\
\text { o un foro no } \\
\text { está informado } \\
\text { del que sucede } \\
\text { y de las posi- } \\
\text { bilidades que } \\
\text { tiene. }\end{array}$ & $\begin{array}{l}\text { El usuario está, } \\
\text { frecuentemente, } \\
\text { informado sobre } \\
\text { que sucede cuan- } \\
\text { do interactúa con } \\
\text { algún elemento. }\end{array}$ & $\begin{array}{l}\text { Los elementos } \\
\text { con los cuales el } \\
\text { usuario interac- } \\
\text { túa (foros, for- } \\
\text { mularios, etc.) } \\
\text { sabe qué ha } \\
\text { pasado: si se ha } \\
\text { enviado, si ha } \\
\text { habido un error } \\
\text { o si se puede } \\
\text { modificar. }\end{array}$ \\
\hline $\begin{array}{l}\text { 7.3. Si se produce un } \\
\text { error, se informa de } \\
\text { forma clara al usuario } \\
\text { qué pasa (qué error se } \\
\text { produce) y que accio- } \\
\text { nes puede llevar a cabo } \\
\text { para solucionarlo. }\end{array}$ & $\begin{array}{l}\text { Si se produce } \\
\text { un error, el } \\
\text { usuario no reci- } \\
\text { be ningún tipo } \\
\text { de información } \\
\text { y, por lo tanto, } \\
\text { no puede solu- } \\
\text { cionarlo. }\end{array}$ & $\begin{array}{l}\text { Generalmen- } \\
\text { te, cuando se } \\
\text { produce un error, } \\
\text { se informa al } \\
\text { usuario. }\end{array}$ & $\begin{array}{l}\text { En caso de } \\
\text { error, el usuario } \\
\text { está informado } \\
\text { sobre qué ha } \\
\text { pasado y que } \\
\text { puede hacer } \\
\text { para solucio- } \\
\text { narlo. }\end{array}$ \\
\hline
\end{tabular}




\section{Enseñanza Virtual de Física en Cátedras Masivas en el Marco de la Pandemia Covid-19}

\section{Hernandez, Federico} Universidad de Buenos Aires fahernandez@fi.uba.ar

\section{Caro, German}

Universidad de Buenos Aires gcaro@fi.uba.ar

\section{Bellocq, Cristina}

Universidad de Buenos Aires ebelloca@fi.uba.ar

\section{Camuyrano, Mario}

Universidad de Buenos Aires mcamuyrano@fi.uba.ar

\section{Fontana, Marcelo}

orcid.org/0000-0002-4861-0997

mfontan@fi.uba.ar 


\title{
ENSEÑANZA VIRTUAL DE FÍSICA EN CÁTEDRAS MASIVAS EN EL MARCO DE LA PANDEMIA COVID-19
}

\author{
Hernandez, Federico \\ Caro, German \\ Bellocq, Cristina \\ Camuyrano, Mario \\ Fontana, Marcelo
}

\section{Resumen}

Frente a la emergencia sanitaria ocasionada por la COVID-19 desde comienzos del año 2020 se produjeron cambios en los procesos de enseñanza y aprendizaje mediante la utilización de herramientas de comunicación digitales. Estos cambios han planteado un debate sobre el formato de transmitir la currícula de una asignatura. En este trabajo se plasman las innovaciones implementadas para la enseñanza virtual de la asignatura Física a alumnos que cursan primer año en la Facultad de Ingeniería de la Universidad de Buenos Aires (FIUBA) buscando optimizar el proceso enseñanza - aprendizaje. Se desarrollaron clases sincrónicas y asincrónicas de carácter individual y grupal sobre la plataforma Moodle. El objetivo del trabajo es presentar nuestra experiencia docente utilizando tecnologías de información y comunicación y valorar las respuestas de los alumnos sobre la utilidad otorgada a: a) las clases sincrónicas versus asincrónicas, b) las actividades grupales: resolución de problemas y experimentación a distancia. Los resultados muestran que las clases sincrónicas fueron más útiles que las asincrónicas. Además, las actividades asincrónicas grupales fueron consideradas útiles por más del $60 \%$ de los alumnos. En conclusión, se puede afirmar que la innovación digital sincrónica y la interconectividad favorecen el aprendizaje y facilitan la enseñanza virtual.

\section{Palabras clave}

Virtualidad - Interconectividad - Clases sincrónicas - Actividades asincrónicas. 


\section{Introducción}

La problemática de la enseñanza virtual en general y en el área de las ciencias exactas e ingeniería en particular es un tema de investigación de gran actualidad [Cabero Almenara 2007]. En estos días, la popularidad del e-learning se ha incrementado significativamente en muchos países debido al confinamiento producido por la pandemia mundial COVID-19 [Sanchez Rivas E., Colomo Magaña, E., Ruiz Palmero, J. y Sanchez Rodriguez, J. 2020)]. La situación actual ha generado un desafío trascendente en los planteles docentes que debieron adecuar en forma acelerada la enseñanza de la asignatura a un entorno totalmente virtual [Charte F., Rivera A. J., Medina, J. y Espinilla, M. (2020).].

La nueva realidad presenta cambios, por ejemplo, el espacio áulico que en la educación universitaria es una compleja relación entre profesores y alumnos pues se sostiene sobre marcos sociales, culturales e individuales propios a la historia de cada uno de ellos, desaparece físicamente como espacio de desarrollo de las clases en esta etapa. De acuerdo con la teoría sociohistórica de Vigotsky en el aula coexisten la individualidad y además la construcción social que tiene sentido en un momento o proceso histórico (Steiman, 2005) como lo es la actual pandemia ante la Covid-19. Frente a esta situación en particular, el rol del docente se activó de manera acelerada y comprometida con la enseñanza y el aprendizaje. Se debe identificar los obstáculos que la enseñanza tradicional tiene por la pérdida momentánea de la herramienta aula y potenciar los medios que favorezcan los procesos de enseñanza y aprendizaje de manera interactiva eliminando la barrera espacio-tiempo entre docente y alumno. La situación de confinamiento nos puso frente a este desafío y buscamos procesos de enseñanza innovadores.

De acuerdo con Da Cunha y Lucarelli (2005): “...se entenderá la innovación por oposición y contraste con una situación presente habitualmente en las aulas universitarias, asociada a prácticas de enseñanza que alteren, de alguna manera, el sistema de relaciones unidireccional que caracteriza una clase tradicional: esto es, aquella centrada solamente en la transmisión de la información, emitida por el docente, un impreso, o a través de un medio tecnológico más sofisticado como el que se produce a través de la comunicación virtual. En este sentido una innovación en el aula supone siempre una ruptura con el estilo didáctico impuesto por la epistemología positivista, aquel que habla de un conocimiento cerrado, acabado, conducente a una "didáctica de la transmisión" que regida por la racionalidad técnica, reduce al estudiante a un sujeto destinado a recepcionar pasivamente cualquier información. Innovar, en consecuencia significa alterar el sistema relacional intersubjetivo de una clase... se ponen en acción estrategias que garanticen la libertad del alumno sin modificar su relación con el saber."

Una forma de innovación se da empleando tecnologías de información y de comunicación, TICs, las cuales en el nivel medio se implementaron de manera más ágil. Sin embargo, se observó que en el nivel superior/universitario esa incorporación fue más lenta (Ferrini- Avelyra 2006).

Ante una situación inesperada, como esta pandemia, que cambia el escenario de las clases tradicionales universitarias, el docente necesita competencias y modelos de enseñanza que no han sido adquiridos anteriormente en su formación (Díaz Barriga, 2005). El docente debe replantearse sus metodologías y estrategias de enseñanza, 
las características del contexto de aula donde las desarrolla, los límites de validez de las herramientas aplicadas y las necesidades de los alumnos (Gómez Lima, 2002).

Por lo tanto, la innovación aplicada en la enseñanza de la materia Física en el primer año en FIUBA se basa en el paso de las clases desarrolladas en el aula a las clases sincrónicas utilizando TICs. Las herramientas de comunicación sincrónica permiten que docentes y alumnos puedan interactuar entre ellos y proveer así una retroalimentación permanente y continua (Giesbers, Rienties, Tempelaar, \& Gijselaers, 2013). También se propicia la modificación en la interacción y roles desempeñados por alumnos y docentes. Los docentes ahora se desempeñan más como tutores y los alumnos como actores activos. Es por ello que entre las estrategias a trabajar se propició una mayor interacción entre los docentes, por ejemplo, el desarrollo de reuniones semanales, con la finalidad de replantear nuevas estrategias que optimicen las habilidades grupales e individuales de los alumnos. Maldonado (2008) plantea el concepto de trabajo colaborativo y en nuestro curso hemos tratado de acercarnos a esa forma de trabajo de tal manera que nuestra labor docente fuera resultado de la interacción continua semanal enriqueciéndonos de los conocimientos y habilidades que cada uno aporta. En este sentido, trabajar con pares es un proceso de reflexión que enriquece y facilita la innovación. Tal como lo expone Mesa (2011) compartimos que la llegada de nuevas tecnologías ha venido a transformar la tarea docente.

En particular, resulta motivador el desafío de enseñar contenidos curriculares de materias del área de Física en cátedras masivas para estudiantes universitarios de los primeros años. En este trabajo se muestran las innovaciones implementadas en un curso (de aproximadamente 100 alumnos) de la asignatura Física 1 de la Facultad de Ingeniería de la Universidad de Buenos Aires (FIUBA). Esta asignatura es requerida por todas las carreras de Ingeniería y tiene una matrícula promedio de 1500 alumnos por cuatrimestre. En presencialidad, la materia tiene una carga horaria de 8 horas semanales distribuidas entre clases de contenido teórico, de contenido práctico y de Laboratorio. El contenido curricular de la asignatura abarca las siguientes unidades temáticas: Cinemática y Dinámica del Punto, Trabajo y Energía del Punto, Sistema de Partículas, Cuerpo Rígido, Ondas mecánicas y su propagación, Óptica geométrica y Óptica Física.

Nuestro objetivo es la valoración de los alumnos sobre la utilidad que le otorgan a las clases sincrónicas vs asincrónicas y a las actividades grupales.

\section{Método/Descripción de la experiencia}

La propuesta docente se llevó a cabo en un curso de Física para alumnos de primer año de la FIUBA y se basó en actividades sincrónicas y asincrónicas. Las primeras consisten en clases on-line, en tiempo real donde se desarrollaron contenidos teóricos y prácticos, evaluaciones parciales y finales o integradoras. Para las clases sincrónicas se utilizó la plataforma Google Meet, mientras que para las evaluaciones se empleó un Campus Virtual. Este Campus de la FIUBA emplea la Plataforma Moodle que es un espacio virtual al que los alumnos tienen acceso en forma permanente mediante la utilización de computadoras personales y telefonía celular entre otros medios físicos. Previamente al inicio de las clases, se les asignó a los alumnos una cuenta de mail institucional y fueron matriculados en el Campus para acceder a los contenidos asincrónicos. El equipo docente estuvo integrado por un profesor titular 
a cargo de las clases teóricas, un jefe de trabajos prácticos responsable de las clases de problemas y prácticas de laboratorio, dos ayudantes de primera y un ayudante de segunda.

\subsection{Actividades sincrónicas}

\subsubsection{Clases de contenido o perfil teórico}

Estas clases se centran en la enseñanza de conceptos generales. La duración de cada clase fue de dos horas con una frecuencia bi-semanal. Se utilizaron presentaciones en PowerPoint que incluían videos demostrativos, simulaciones realizadas en Geogebra y ejemplos prácticos. Al empleo de presentaciones en PowerPoint se adosó como innovación el uso de la plataforma Moodle. Además, se utilizó una herramienta de Google denominada encuestas para confeccionar un cuestionario muy ágil que evaluó lo aprendido por los alumnos al finalizar la clase.

\subsubsection{Clases de contenido o perfil práctico}

Estas clases están centradas en la resolución de ejercicios y son refuerzo de conceptos teóricos. La duración de cada clase fue de dos horas con una frecuencia bi-semanal. Se utilizaron presentaciones de PowerPoint, pizarra con marcador y uso de Tablet o Wacom. Se mostraron videos y explicaciones de interés con ejemplos prácticos de aplicación en ingeniería o en física. A continuación, se cita algunos ejemplos desarrollados:

a) En la clase de conservación del momento angular se mostró el video de una simulación de la interacción de dos agujeros negros muy cercanos realizada cuando se detectaron ondas gravitatorias en 2015 (Laboratorio LIGO).

b) En la clase de conservación de energía mecánica se utilizaron conceptos asociados a choques elásticos para mostrar cómo las naves Voyager I y II de NASA utilizaron las órbitas de planetas intermedios para incrementar su velocidad sin gasto de combustible.

c) En la clase de conservación del momento lineal y angular se mostraron videos de experimentos realizados en la Estación Espacial Internacional en micro-gravedad.

d) En la clase de difracción de la luz se realizaron experiencias demostrativas de este fenómeno usando luz láser y empleando un CD y un DVD como redes de difracción. También se mostró la difracción a través de una rendija construída con objetos hogareños (pequeños listones de madera).

Tanto las clases de contenido teórico como práctico fueron grabadas y subidas a la plataforma Youtube y al Campus, lo que permite una consulta permanente de las mismas por parte de los alumnos.

\subsubsection{Evaluaciones parciales, finales o integradoras}

De acuerdo con lo establecido por la cátedra, se efectuaron tres evaluaciones parciales formativas con una instancia de recuperación para cada una de ellas. La aprobación de la cursada habilita a los alumnos a rendir el examen final o integrador de la asignatura. 


\subsection{Actividades asincrónicas}

Algunas de las actividades asincrónicas propuestas son de desarrollo y/o presentación individual, mientras que otras son de desarrollo y/o presentación grupal. A su vez estaban divididas en actividades de carácter obligatorio y de carácter optativo. Las consignas y desarrollos de estas se canalizaron a través del Campus de la FIUBA.

\subsubsection{Actividades individuales}

a) Clases asincrónicas de contenido teórico subidas a la plataforma Youtube.

b) Clases asincrónicas de resolución y desarrollo de problemas subidas a la plataforma Youtube.

c) Autoevaluación de carácter obligatorio de cada unidad temática: Al terminar una unidad, cada alumno debe realizar una autoevaluación obligatoria que consiste en unos diez ejercicios o preguntas conceptuales con un tiempo máximo de cuatro días para su realización.

d) Foro de discusión abierto por cada unidad temática donde los alumnos consultan. El foro permite la discusión entre pares que luego es supervisada y respondida por los docentes. Se logra una participación interactiva entre alumnos y docentes.

e) Realización de diferentes actividades optativas presentadas en el Campus, videos conceptuales, videos de experiencias demostrativas, cuestionarios, simulaciones, propuestas de lectura bibliográfíca y otras actividades (simulaciones de experimentos on-line, etc.).

\subsubsection{Actividades grupales}

Para incentivar el trabajo en grupo y fomentar la interacción e integración de los alumnos con sus compañeros y con los docentes se realizaron actividades obligatorias de entrega grupal. Para ello los alumnos fueron divididos en grupos de trabajo de 5 o 6 personas. Se realizaron las siguientes actividades:

\section{Problemas obligatorios}

Al terminar una unidad temática, cada grupo de trabajo debe entregar la resolución de un problema obligatorio propuesto. Se realiza la evaluación y devolución con tres posibles resultados: aprobación con una calificación numérica, desaprobación, desaprobación con re-entrega de otro problema obligatorio.

Prácticas obligatorias de Laboratorio en casa

Se realizaron dos experiencias de Laboratorio con materiales hogareños [Aveleyra Fontana, 2020], estas son:

1. Práctica de Mediciones e Incertezas, donde se determina el volumen de tres cuerpos cotidianos de diferentes longitudes (por ejemplo, lata de conserva, hoja de papel y moneda de curso legal). 
2. Práctica de Péndulo ideal, donde se modela y se mide el periodo del péndulo ideal en función de la longitud.

Los objetivos planteados de las prácticas de laboratorio son:

a) La correcta medición de magnitudes físicas, básicamente en estas prácticas se mide longitud (usando reglas graduadas o calibre) y tiempo.

b) Aprendizaje de teoría de errores e incertezas, y propagación de errores.

c) Obtención de valores experimentales de magnitudes físicas de interés. En particular se determinó la aceleración de la gravedad.

Para finalizar la actividad, cada grupo de trabajo realiza la entrega de un informe de cada experiencia que luego es evaluado.

\subsubsection{Actividades de consulta}

Para realizar consultas sobre las actividades individuales y grupales, dudas surgidas en las actividades sincrónicas o en la resolución de los ejercicios propuestos, se cuenta con distintas instancias de consulta:

Durante las clases sincrónicas se fomenta que los alumnos realicen preguntas sobre el contenido que se está desarrollando.

Para las actividades asincrónicas, se introduce la utilización de TIC de modo que los alumnos cuenten con las siguientes herramientas supervisadas por los docentes: Foro en la Campus FIUBA, grupo de Whats-app y comunicación más personalizada por e-mail. Las consultas por Whats-app permiten que los alumnos consulten en forma más dinámica las dudas sobre lo que están trabajando en el momento. Por otra parte, las consultas en el foro permiten que los alumnos se nutran de respuestas quedando un registro permanente de estas.

\subsection{Seguimiento y planificación del aprendizaje}

La pandemia produce efectos en los vínculos interpersonales e implicó la ruptura de las actividades habituales presenciales del proceso de enseñanza. Por lo que el contexto de emergencia sanitaria obligó a buscar nuevas respuestas donde las nuevas tecnologías han facilitado el proceso de educación virtual. Con el objeto de innovar en vistas a mejorar el proceso de aprendizaje en este escenario, nuestro equipo docente decidió realizar reuniones semanales de coordinación no sólo para organizar y planificar las actividades a desarrollar durante el período de clases y evaluar el aprendizaje, sino también para fortalecernos como grupo y en el aspecto comunicacional hacia los alumnos. El trabajo en grupo de los docentes favorece e incentiva la necesidad de desarrollo de nuevas competencias digitales y estrategias didácticas contextualizadas a la naturaleza de las clases virtuales. Las reuniones semanales del equipo docente permiten incrementar el uso de herramientas tecnológicas, retroalimentarnos en la forma de encarar la enseñanza del temario y administrar mejor el tiempo de clase sin perder de vista las actividades de los alumnos. Consideramos que un buen trabajo grupal de coordinación docente produce en los alumnos un mejor vínculo con el equipo docente, lo cual se puso de manifiesto en el interés y el rendimiento de nuestro alumnado. 


\section{Resultados}

\section{Resultado de una encuesta realizada a los alumnos}

Al finalizar la cursada se realizó una encuesta a una población de aproximadamente 100 alumnos con el objeto de evaluar la utilidad de clases sincrónicas, clases asincrónicas, autoevaluaciones, problemas obligatorios, prácticas de laboratorio y foros de discusión. La encuesta se basó en seis preguntas y los resultados pueden verse en la Figura 1. El análisis y la discusión de los resultados se muestran en la sección 4.
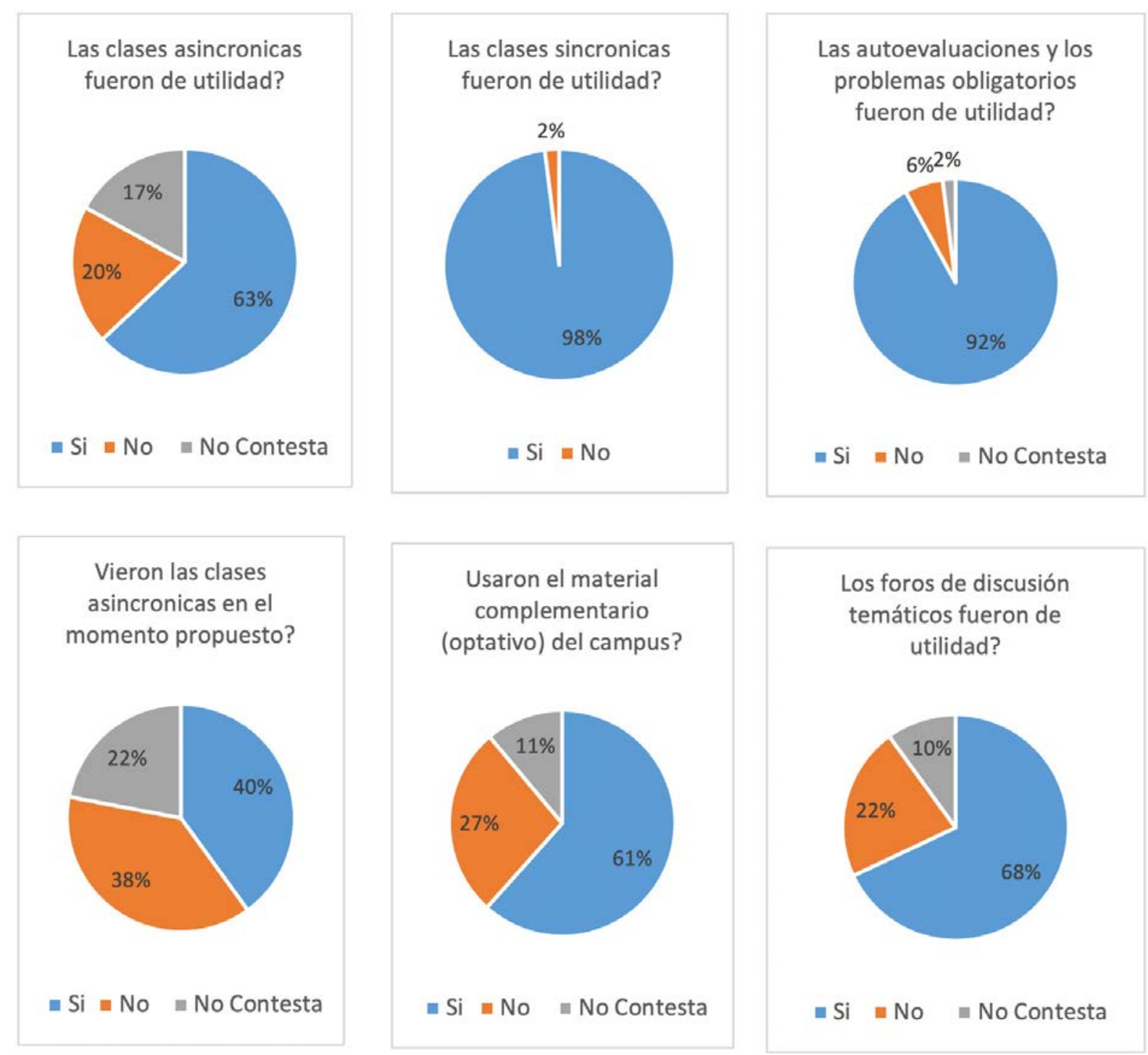
Los foros de discusión temáticos fueron de utilidad?

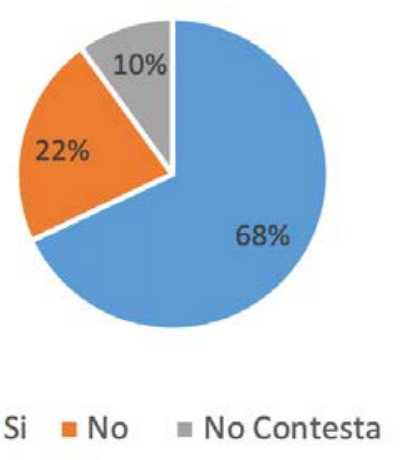

Figura 1 Resultados de la encuesta realizada a una población de aproximadamente 100 alumnos, se muestran las preguntas realizadas y las respuestas recibidas. 


\section{Discusión y Conclusiones}

\subsection{Clases sincrónicas y asincrónicas}

El análisis de la encuesta muestra que los alumnos le otorgan una utilidad del $98 \%$ a las clases on-line sincrónicas. Por otro lado, si bien más de un $60 \%$ de los alumnos contesta que las clases asincrónicas fueron de utilidad sólo un 40 \% contesta que las vio en el momento propuesto por los docentes. Reafirmando lo mostrado por la encuesta y considerando las condiciones particulares (alumnado de primer año en cátedras masivas) en las que desarrolló la experiencia, creemos importante destacar las siguientes ventajas de las clases sincrónicas:

- Los alumnos de primer año están en formación y necesitan la guía cercana de los docentes respecto a métodos de aprendizaje y de estudio.

- Imponen un ritmo de estudio con cumplimientos de entrega en plazos establecidos.

- Son participativas y fomentan la interacción entre alumnos y docentes generando preguntas/consultas en el momento de la clase. Esta forma de trabajo produce una retroalimentación propositiva docente-alumno que mejora el ciclo enseñanza-aprendizaje.

- La presentación de ejemplos adecuados y aplicaciones a la tecnología y a la vida cotidiana incentivan al alumno a conectarse y genera motivación de estudio.

Por lo expuesto precedentemente consideramos que, para el universo de alumnos con los que se trabajó, una combinación de actividades sincrónicas y asincrónicas centradas en las primeras resulta de mayor utilidad frente a clases exclusivamente asincrónicas.

\subsection{Trabajos grupales obligatorios}

Se destaca que un alto porcentaje de los alumnos (mayor al $90 \%$ ) ven provechoso el trabajo en grupo. Es de destacar que en esta nueva forma de trabajo virtual (en el marco de la pandemia) es fundamental fomentar la interacción entre los alumnos para mejorar el aprendizaje, algo que se da naturalmente en la presencialidad, pero se ve muy dificultado en este marco. Por ello creemos que tanto los problemas obligatorios así como el laboratorio en casa fomentan la socialización y trabajo en grupo.

\subsection{Autoevaluaciones, foros, material complementario}

Dentro de las actividades individuales, el 92\% de los alumnos consideran muy útiles a las autoevaluaciones. La discusión en foros tuvo una aceptación del 68\% y la utilización del material complementario es del $61 \%$.

\subsection{Conclusiones}

La implementación de tecnologías de comunicación a distancia y las modificaciones en la utilización de las herramientas clásicas para mejorar los procesos de enseñanza y de aprendizaje son alentadoras. Se advierte en esta virtualidad educativa que 
hay indicios positivos manifestados por los alumnos que sugieren una revisión del enfoque tradicional de la enseñanza en pos de otro enfoque más dinámico al que podemos catalogar de innovador.

Se reconoce que a partir del trabajo en colaboración se pueden generar movimientos en las prácticas de los docentes universitarios que, si bien no implican el abandono total de todas las prácticas tradicionales, promueven el desarrollo de nuevas prácticas que lo complementan. Se considera que un factor determinante del trabajo en equipo es el proceso de reflexión y discusión con los pares lo que provoca un aumento de las modalidades comunicativas para planificar y mejorar las clases.

Un debate actual de uno de los elementos principales del e-learning es la sincronicidad o a-sincronicidad de la propuesta pedagógica. Este debate está abierto, es motivo de discusión y claramente depende del auditorio al que está dirigida la enseñanza. Este trabajo pretende mostrar los buenos resultados obtenidos de una experiencia educativa de enseñanza de Física en cátedras masivas para alumnos de primeros años cuyo elemento fundamental y principal está basado en las clases sincrónicas.

Los cambios en la forma de enseñanza y de aprendizaje impuestos por un agente externo a la educación como es la pandemia de COVID-19 y asociados principalmente a la virtualidad están en proceso de evolución y de revisión. Nos proponen nuevos planteos y la adquisición de conocimientos que tiendan a fortalecer la formación de los alumnos como futuros profesionales empleando las tecnologías de información y comunicación.

\section{Referencias}

Aveleyra E. y Fontana M. (2020). Laboratorio en casa, realidad aumentada (experiencias reales y virtuales con uso de celulares) y laboratorio remoto. Conversatorio: De la física en pandemia a la posibilidad de un Banco de Experimentos en línea. 68 Asamblea Plenaria de CONFEDI, 24-30 noviembre 2020.

Cabero Almenara, J. (2007). Nuevas Tecnologías aplicadas a la educación. Mc Graw Hill.

Charte F., Rivera A. J., Medina, J. y Espinilla, M. (2020). El ecosistema de aprendizaje del estudiante universitario en la post-pandemia. Metodologías y herramientas. Enseñanza y Aprendizaje de Ingeniería de Computadores, 10, 15-38.

Da Cunha, M. I. y Lucarelli, E. (2005). Innovación en el aula universitaria y saberes docentes: experien- cias de investigación y formación que aproximan a Argentina y Brasil. En Actas del I Congreso de la Sociedad Argentina de Estudios Comparados en Educación, UNLP.

Díaz-Barriga, A. (2005). El profesor de educación superior frente a las demandas de los nuevos debates educativos. Perfiles Educativos, 27(108), pp. 9-30.

Ferrini, A. y Aveleyra, E. (2006). El desarrollo de prácticas de laboratorio de Física básica mediadas por las NTIC s, para la adquisición y análisis de datos, en una expe- 
riencia universitaria con modalidad b- learning. I Congreso de Tecnología en Educación y Educación en Tecnología, UNLP.

Giesbers, B., Rienties, B., Tempelaar, D., \& Gijselaers, W. (2013). A dynamic analysis of the interplay between asynchronous and synchronous communication in online learning: The impact of motivation. Journal of Computer Assisted Learning, 30, 30-50

Gomes Lima, Paulo. «El educador reflexivo: notas para la orientación de sus prácticas docentes». Educar, [en línea], 2002, n. 30, pp. 57-67, https://raco.cat/index. php/Educar/article/view/20763.

Maldonado, M. (2008). Aprendizaje Basado En Proyectos Colaborativos. Una Experiencia En Educación Superior. Laurus, 14(28), pp. 158-180.

Mesa, L. (2011). El trabajo colaborativo del profesorado como oportunidad formativa. CEE Participación Educativa, pp. 69-88.

Sanchez Rivas E., Colomo Magaña, E., Ruiz Palmero, J. y Sanchez Rodriguez, J. (2020). Tecnologías educativas y estrategias didácticas. Innoeduca.

Steiman, J. (2005). ¿Qué debatimos hoy en la didáctica? Las prácticas de enseñanza en la educación superior. Bs. As.: UNSAM. 


\section{La Clase Invertida en un Escenario de Aprendizajes Semi-Presencial}

\section{De-Luca, Marina Patricia}

Universitat Rovira i Virgili, España

marinapatricia.deluca@alumni.urv.cat 


\title{
LA CLASE INVERTIDA EN UN ESCENARIO DE APRENDIZAJES SEMI-PRESENCIAL
}

\author{
De-Luca, Marina Patricia
}

Universitat Rovira i Virgili, España

marinapatricia.deluca@alumni.urv.cat

\section{Resumen}

En la Provincia de Buenos Aires, durante un año, veintidós docentes de Institutos Superiores de Formación Docente (ISFD) se formaron en un tramo de formación pedagógica para el nivel superior en el espacio curricular Talleres TIC semi-presenciales. El problema de investigación fue reconocer las estrategias transferibles desde la formación en Tecnologías de la Información y la Comunicación (TIC) hacia otros espacios curriculares implementados en entornos tecnológicos semi-presenciales. Las y los docentes aprendieron sobre usos pedagógicos de las TIC, produjeron recursos y configuraron entornos digitales para formar en otros campos del saber. Sus producciones y la competencia digital auto-percibida evidencian resultados de la estrategia formativa que se configuró, principalmente, mediante la clase invertida (flipped classroom) y los proyectos colaborativos en un escenario áulico-hogareño-ubicuo. Se concluye que la estrategia didáctica y las tecnologías digitales utilizadas, especialmente el aula virtual, ampliaron el escenario áulico de formación, los recursos disponibles, y los tiempos de la enseñanza y de los aprendizajes. Las diversas trayectorias se reflejan en las producciones. La clase invertida usando entornos tecnológicos es un gran cambio metodológico respecto de la clase magistral; los aprendizajes dependieron más de la actividad de quienes se formaron que de la transmisión de contenidos y en producciones colaborativas de recursos educativos se promovieron interacciones comunicativas a distancia y en presencia. Esta estrategia de formación compensó la escasez de dispositivos digitales y promovió entre docentes los saberes, habilidades, competencias y la criticidad necesaria para usar las TIC en cada campo disciplinar de la formación docente; transformando la Educación.

\section{Palabras clave}

Flipped classroom, formación docente, aulas virtuales, escenarios de aprendizaje. 


\section{Introducción}

Con la irrupción de la pandemia se generalizó abruptamente la educación a distancia de emergencia, a la vez, de modo intermitente se enseñó y aprendió en escenarios semi-presenciales y emergieron como alternativa los espacios híbridos de formación; en los cuales la presencia de las y los estudiantes en el salón de clase es tanto física como virtual. No obstante, la organización de las clases no solo puede ser pensada según el grado de presencialidad. Según Bartolomé, et., al. (2016) con la irrupción de las tecnologías de la información y la comunicación (TIC) se derribaron las barreras espacio-temporales ligadas al aprendizaje tradicional, formal, presencial e irrumpieron nuevos escenarios de aprendizaje personal y colectivo que entraman la educación formal, no formal e informal porque permiten acceder a la información en modo ubicuo, generando nuevos lenguajes y formas de representación del saber. La revisión de Cabero y Llorente (2015) indica que debido a la penetración de las TIC la escuela atraviesa grandes cambios; en sus funciones, en los roles de quienes interactúan en el proceso formativo, en disponer de dichas tecnologías para la intervención docente, en la ampliación de los escenarios y en el modelo de diseño de la formación. Sin embargo, para Cabero y Llorente (2015) las herramientas (que permiten aprender con imágenes, sonidos, o multimedia) no son importantes; lo verdaderamente importante son los diversos escenarios de comunicación que permiten crear nuevos escenarios de formación caracterizados por ubicar a los estudiantes al centro, promover aprendizajes con actividades sociales y colaborativas, ampliar los tipos de fuentes de información, utilizar herramientas y sistemas simbólicos diversos, y que el alumno produzca mensajes mediados. Considerando la importancia de estos escenarios, que facilitan la formación y los aprendizajes, se estudia una intervención didáctica realizada antes de la pandemia en la Provincia de Buenos Aires en unos Talleres TIC semi-presenciales de un tramo de formación pedagógica para docentes en servicio en el nivel superior. Según Libedinsky (2016) no es posible entender las innovaciones educativas como la introducción de nuevos medios o recursos sino como propuestas pedagógicas nuevas en las que se trabaja para enriquecerlas. En nuestro caso, el estudio de dicha innovación educativa hibridó hacia un proyecto de investigación-acción.

\section{El aula y los aprendizajes se expanden con la clase invertida}

La noción de aprendizaje semi-presencial (blended learning) no es unívoca, se entiende como el "enfoque de aprendizaje que combina tanto el aprendizaje a distancia como el aprendizaje en persona (UNESCO, s.f.)", es decir, considerando matices entre distancia y presencialidad. También, entre otras perspectivas, el blended learning es entendido en Marqués, et. al. (2011) como un modelo de aprendizaje en el cual se definen estrategias en las que se combinan diferentes métodos de trabajo y la utilización de diversos tipos de recursos en función de la situación y del contexto del proceso de enseñanza-aprendizaje. Como modelo de naturaleza híbrida, exige experimentación, desarrollo de actividades que conlleven la aplicación de los conceptos, ideas o contenidos; y para ello una de las claves está en una buena selección de los recursos utilizados y la existencia de una evaluación de los resultados obtenidos (p. 60). Es decir, que es un modelo organizativo que requiere de estrategias de enseñanza seleccionadas y organizadas según su contexto.

Se piensa que en espacios de formación flexibles como lo es un escenario de aprendizajes semi-presencial, para poder potenciar las estrategias de aprendizaje quien 
enseña ha de considerar todos los componentes de la intervención didáctica; sin embargo este estudio se focaliza en las estrategias más relevantes utilizadas en una formación en TIC. Además, se consideran a la enseñanza y al aprendizaje como procesos distintos y complementarios, a la vez, multívocos y experimentados en modos diversos; por lo tanto, en este estudio se entienden en el mismo tipo de relación sistémica a las estrategias de enseñanza y a las de aprendizaje, y del mismo modo la relación entre la clase invertida (flipped classroom) y el aprendizaje invertido (flipped learning). Entonces, se parte de la intervención didáctica basada en teorías del aprendizaje socio-constructivistas, implementando la estrategia de flipped classroom con mediación de TIC. Para Torrecilla y García (2020) "Una propuesta educativa que aúna el enfoque centrado en el aprendizaje, la incorporación de las TIC y el ajuste al perfil individual del alumnado es el Flipped Classroom" (p. 114). En Tucker (2012) la idea central del "aula invertida" es invertir el enfoque común de la instrucción; con recursos creados por los maestros se accede en casa a la instrucción antes de la clase. De este modo, la clase en el aula se convierte en el lugar para aprender por medio de problemas, profundizar conceptos y colaborar; lo más importante es que sean repensados todos los aspectos de la instrucción para maximizar el recurso de aprendizaje más escaso: el tiempo. Además, lo que marca la diferencia no son los recursos instructivos por sí mismos sino cómo se integran en una estrategia general. Basándose en la revisión de veinticuatro estudios en el contexto norteamericano Bishop y Verleger (2013) sugirieron que la investigación sobre el aula invertida deberá utilizar métodos que examinen objetivamente el desempeño estudiantil. Mediante una revisión sistemática Hinojo Lucena, et. al. (2019) analizaron la producción científica entre 2012 y 2017 de estudios empíricos sobre el aula invertida (norteamericanos e hispanoamericanos) para comprobar su impacto en el rendimiento académico; los estudios revisados comparaban resultados entre el grupo de control y el experimental, y concluyeron que la mayoría de los estudios comprobaron que el rendimiento académico aumentó en grupos donde se implementó el aula invertida frente al método tradicional. En dicho sentido, Torrecilla y García (2020) compararon la eficacia del flipped classroom con la clase tradicional en el aprendizaje de ciencias en una escuela primaria de Madrid; los resultados demuestran beneficios en la media grupal y una mejora significativa en el alumnado con menor dominio de estrategias de aprendizaje respecto del alumnado que dispone de mayores estrategias.

En conclusión, se hace necesario invertir la clase para expandir el aula y las estrategias de aprendizaje. La formación docente objeto de este estudio son unos Talleres TIC semi-presenciales, por dicho motivo las estrategias de aprendizaje que han de poner en juego quienes se forman están íntimamente relacionadas con la construcción de competencias digitales docentes en un escenario cuya expansión no solo la provocan las tecnologías sino, principalmente, las estrategias empleadas en la formación.

\section{Formación docente como estrategia para el cambio educativo}

En el contexto de este estudio, uno de los fines de la Ley de Educación Nacional legisla: "Desarrollar las competencias necesarias para el manejo de los nuevos lenguajes producidos por las tecnologías de la información y la comunicación" (LEN № 26206/06, art. 11 m.). La legislación garantiza derechos y responsabilidades acordes a la sociedad del conocimiento, cuyas transformaciones culturales, socio-económicas y educativas están muy vinculadas a la irrupción y generalización del uso de distinto tipo de dispositivos digitales y de la conectividad que potenciaron procesos 
de información y comunicación ubicuos, asimismo, generaron nuevas desigualdades sociales que no pasan desapercibidas en las instituciones de formación docente. Para Schneider et al. (2007) las nuevas tecnologías han sido la puerta de entrada de nuevos paradigmas que impactan en la vida cotidiana de las instituciones educativas y de los docentes (p.15). La pandemia cambió abruptamente las prioridades de formación permanente en la docencia, dado que la educación a distancia de emergencia trasladó sus escenarios a entornos virtuales, se aceleró la frenética progresión de renovación y creación de las aplicaciones que portan las TIC intensificando las necesidades de formación para enseñar con dichas tecnologías. Este es un tema de gran complejidad. La inclusión de TIC en la enseñanza, en ocasiones, representa una innovación sin cambio en los métodos. Cabero (2001), Litwin (2005), Maggio (2012), Libedinsky (2016) coinciden en que es imposible garantizar la transformación didáctica basándose exclusivamente en la alta disponibilidad de tecnologías digitales en los espacios educativos. En dicho sentido, para Fandos Garrido (2009) en la formación con TIC "el problema surge cuando, a pesar de estar convencidos de las potencialidades que estas nos pueden ofrecer, se opta por seguir modelos clásicos y tradicionales para dar respuesta a los problemas pedagógicos que se nos presentan" (p. 207). Según Marqués, et. al. (2011) tres variables interactúan decisivamente en la modalidad semi-presencial: el cambio metodológico, la utilización de entornos tecnológicos, y los procesos interactivos con elevado grado de colaboración y trabajo en equipo. Las tres dimensiones están presentes en la intervención estudiada, pues un entorno tecnológico del tipo de un aula virtual, por sí mismo, no configura al escenario de aprendizajes semi-presencial potenciador del cambio metodológico. Según De Luca (2021) son las personas, no las tecnologías, quienes deciden sobre los sentidos atribuidos a estos espacios de formación y sobre las formas de circulación de los saberes (p. 149). Se piensa que la presencia de las TIC como medio y/o entorno formativo, por sí misma, no transforma la enseñanza ni los aprendizajes, sin embargo, su función como plataformas (en sentido tecnológico y pedagógico) las convierte en necesarias.

Por todo lo dicho, la formación docente debe fortalecer su calidad, pensando que mayor cantidad de dispositivos digitales o de capacitaciones no equivalen a transformar a la Educación. Según Lázaro y Gisbert (2015) la transformación en cuanto al qué, al cual se aprende y el cómo se enseña en los centros educativos depende tanto de la competencia digital desarrollada por los ciudadanos como de las destrezas y habilidades, cada vez más complejas que el profesorado necesita en relación a la incorporación de las tecnologías digitales en los procesos de enseñanza-aprendizaje y que forman parte de la competencia digital docente (CDD).

\section{Otras aproximaciones al objeto estudiado}

A casi dos años del cambio de escenarios de aprendizajes impulsado por la pandemia, se revisan investigaciones recientes sobre formación docente con tecnologías digitales. En el contexto Latinoamericano, Guayara y Vázquez (2017) en Colombia investigaron el impacto en las prácticas áulicas de una formación docente en TIC, indagaron las percepciones docentes en cinco dimensiones de competencias y concluyeron que "se deben realizar proyectos de intervención y fortalecimiento en el tema de uso y apropiación de TIC" (p.15). En Chaco, Argentina Frencia y Jara (2020) partieron de reconocer las competencias básicas en TIC en docentes, según los estándares de UNESCO (2008), para indagar en las repercusiones de las prácticas docentes en ambientes de alta disposición tecnológica en un Instituto de Educación 
Superior (IES); concluyen que las TIC se usan en la enseñanza y que mejoran aspectos de la formación docente, sus usos "pueden potenciarse y adaptarse al contexto para propiciar una mejora sustancial en la enseñanza, independientemente de los niveles de formación y capacitación con que se cuenta. (...) Hay una creciente necesidad de capacitaciones en el uso educativo de las TIC" (p.747). En los grados de Educación Infantil, Primaria y Pedagogía de la Universidad de las Islas Baleares, en seis materias relacionadas con la aplicación educativa de las TIC, De Benito, et. al. (2020) estudiaron la organización de herramientas y configuraciones tecnológicas que facilitan el codiseño de itinerarios de aprendizaje en la educación superior. Proponen integrar tres componentes: la plataforma institucional (Moodle) usada como herramienta integradora y para organizar contenidos, herramientas de comunicación, y el seguimiento y gestión de actividades; con herramientas externas para tareas colaborativas; y con una aplicación en Moodle para gestionar las secuencias de aprendizaje configuradoras de los itinerarios. En otras palabras, el aula del campus virtual integra un ecosistema que permite co-diseñar itinerarios de aprendizaje y actividades colaborativas; sin depender de la presencia física. Aproximándonos a los métodos de formación, Prendes y Cerdán (2021) en su revisión analítica de experiencias didácticas, en la categoría herramientas para la educación (EVEA y apps.), destacan la clase invertida como ejemplo de buenas prácticas educativas con tecnologías avanzadas.

Estas y otras investigaciones reafirman la intención de centrar el objeto en las estrategias implementadas para la formación transversal en TIC destinada a docentes que forman docentes; ya que no solo importan el escenario y el contenido sino ¿cómo enseñarlo? Por lo expuesto, se estudian el diseño y la intervención en los Talleres TIC semi-presenciales, utilizando el método de investigación-acción. Se aborda la formación situada, en el nivel micro-sistémico y en dos espacios curriculares: Talleres TIC 1 y TIC 2 semi-presenciales de un tramo de formación pedagógica para el nivel superior. Nos preguntamos ¿Cuáles son las estrategias transferibles desde esta formación docente en TIC hacia otros espacios curriculares semi-presenciales? Son objetivos: identificar las estrategias de formación que desarrollaron las Competencias Digitales Docentes (CDD); comprobar aprendizajes (que transforman vidas) y la CDD auto-percibida en docentes que forman docentes. Se piensa que las estrategias de formación serían válidas si los materiales didácticos digitales producidos comprobasen aprendizajes y mayores niveles de competencias digitales en el ámbito de la enseñanza.

\section{Método}

\section{Descripción del contexto y de los participantes}

Los Talleres TIC tuvieron carga horaria total de 64 hs., distribuidas en 4 bimestres, con una frecuencia semanal de 1 hora presencial y 1 hora a distancia, en el plan de estudios de postgrado: tramo de formación pedagógica para el nivel superior. El plan abarca la República Argentina, se desarrolla en los Institutos Superiores de Formación Docente (ISFD) y se destina a docentes formadores de docentes de los niveles inicial, primaria y secundaria. La formación investigada se sitúa en una institución de gestión pública, en la jurisdicción de la Provincia de Buenos Aires, y fue implementada antes de la pandemia. 
La muestra abarca la totalidad del universo áulico y está conformada por veintidós sujetos mayores de 25 años, diecinueve mujeres y tres hombres; con titulaciones en tecnicatura en informática y de licenciatura en las áreas de derecho, arquitectura, artes gráficas y audiovisuales, ciencias de la salud y biología, servicios sociales, seguridad industrial.

\section{Instrumentos}

En el proyecto de investigación doctoral se usaron distintos instrumentos. En este artículo, los resultados provienen del instrumento validado rúbrica de auto-percepción de la CDD de Lázaro y Gisbert (2015), de las producciones digitales realizadas por y entre quienes se formaron en los Talleres TIC, y de las notas de campo de la formadora.

\section{Procedimiento}

En este estudio descriptivo-interpretativo se indagaron los Talleres TIC con el método de investigación-acción y el modelo Mc Kernan (1996) que integra ciclos de acción. Cada ciclo se compone de seis fases: detectar una situación problema, hipótesis, planificación, desarrollar el plan de acción, reflexionar y evaluar, y decidir para redefinir la situación problemática avanzando al próximo ciclo de acción. Son informantes la formadora y quienes se formaron, asimismo, las evidencias provienen de producciones elaboradas durante la formación y de la comparación entre el nivel inicial y final de CDD auto-percibida. La rúbrica se aplicó solicitando a quienes se formaron que diferenciaran con dos colores el nivel de CDD al inicio y al final de la formación.

\section{Resultados}

El análisis de resultados de CDD auto-percibida (tabla 1) muestra los valores promedio (de todos los indicadores y sujetos) en los niveles inicial y final (entre cero y cuatro), y la variación entre ambos.

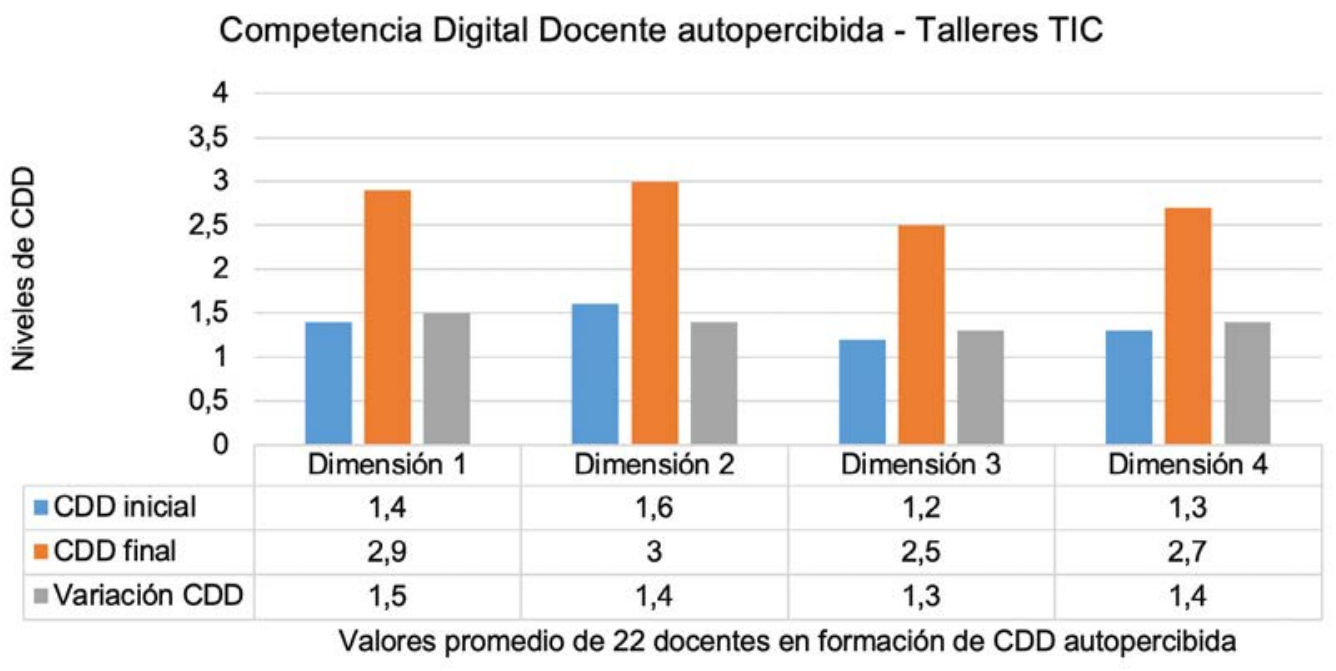

Tabla 1. Competencia Digital Docente auto-percibida en Talleres TIC. Elaboración propia. 
La rúbrica de Lázaro y Gisbert (2015) agrupa veintidós indicadores en cuatro dimensiones y describe cuatro niveles de CDD. Cada indicador oscila entre 0 y 4 , siendo 4 el máximo. Son dimensiones: didáctica, curricular y metodológica (D1); planificación, organización y gestión de espacios y recursos de tecnología digital (D2); relacional, ética y seguridad (D3); personal y profesional (D4). En esta comunicación los resultados se informan cuantitativamente, promediándose los indicadores al interior de cada dimensión. Los cuatro niveles de desarrollo de la CDD son: principiante, medio, experto y transformador. Como resultado se observa que la media del nivel de partida del profesorado estaba entre el nivel inicial y el medio en las cuatro dimensiones de CDD, y que como resultado de la formación la media grupal alcanza el nivel experto en todas las dimensiones.

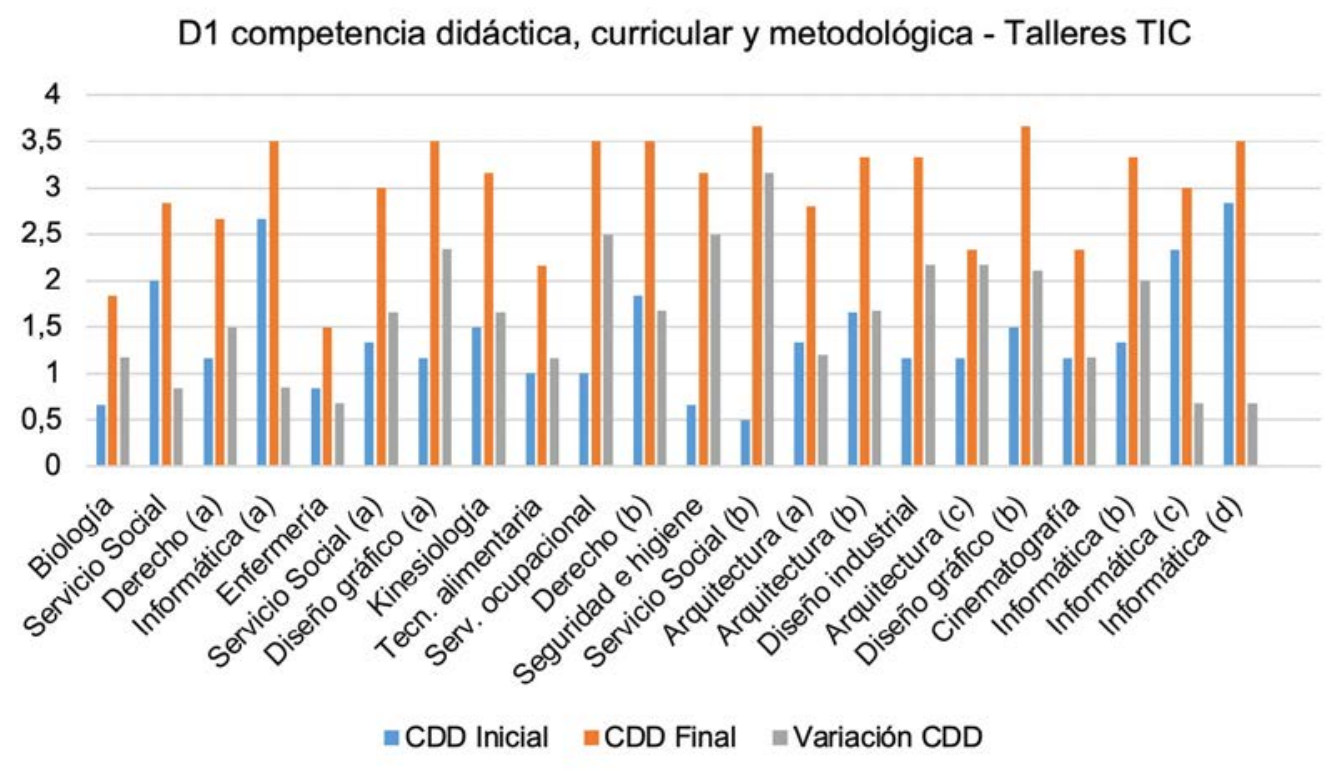

Tabla 2 D1, Competencia didáctica, curricular y metodológica en Talleres TIC. Elaboración propia.

Los resultados individuales autopercepción de la dimensión D1, competencia didáctica, curricular y metodológica (tabla 2 ) indican que $12 / 22$ o el $55 \%$ de los sujetos lograron el nivel transformador, de los cuales $3 / 12$ partían del nivel principiante, 7/12 del nivel medio y 2/12 del experto. Uno de los cuatro informáticos demuestra un notorio desarrollo de la D1 y lo corrobora en otros instrumentos aplicados. El gráfico anterior demuestra que la formación en los Talleres TIC se inició con docentes con competencias digitales diversas y que se representan en cuatro niveles sin depender de su formación de base. 
D1 Grupos interdisciplinares y disciplinares - Talleres TIC

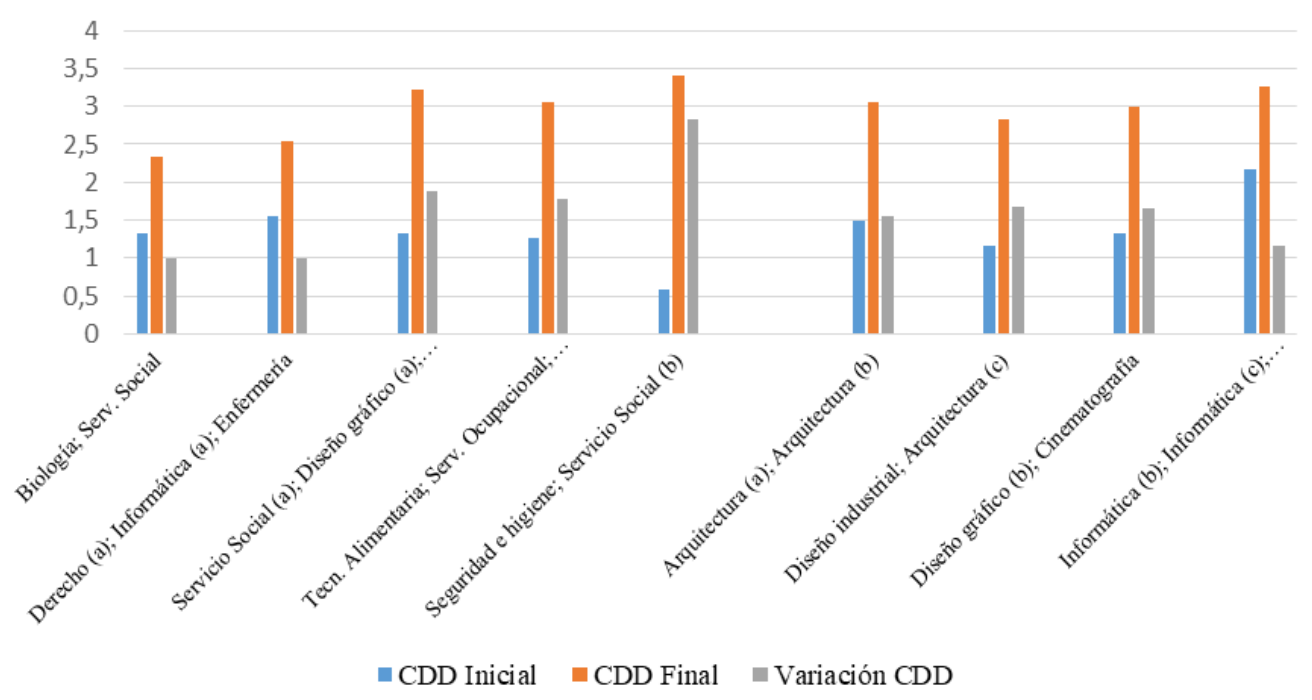

Tabla 3. D1, en grupos disciplinares e interdisciplinares en Talleres TIC. Elaboración propia.

Los resultados de la CDD en la dimensión didáctica, curricular y metodológica en cada grupo de aprendizaje colaborativo (tabla 3 ) evidencian que en 3/9 de los grupos se logró el nivel transformador; que todos los grupos integrados por profesionales de una misma disciplina, indistintamente del nivel de partida, lograron el nivel competencial experto; que un grupo conformado por profesionales de distintos campos disciplinares logró el mayor desarrollo de la D1 de la CDD y alcanzó el nivel transformador partiendo de un bajísimo nivel principiante; y que junto a otros, el grupo de informáticos se sitúa entre los de menor desarrollo en la dimensión competencia didáctica, curricular y metodológica.

La cuantificación de los recursos producidos no refleja la calidad de su contenido que en muchos casos fue sorprendente, destacando las producciones en grupos interdisciplinares.

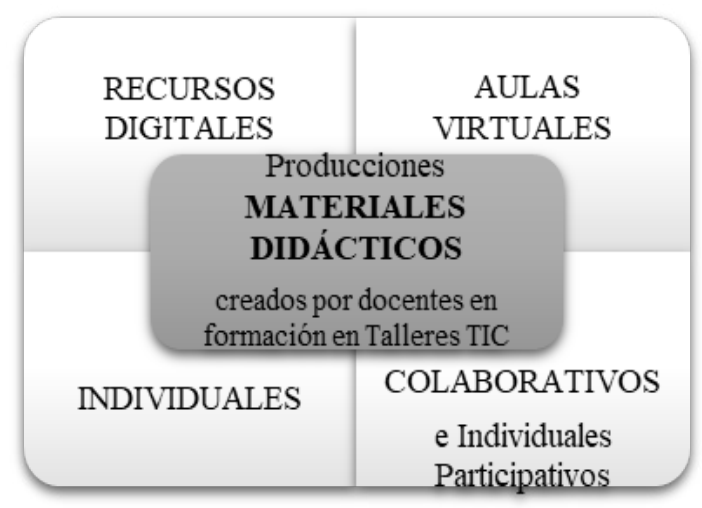

Imagen 4. Clasificación de los materiales creados. Fuente: elaboración propia. 
No se referencian los materiales didácticos y aulas virtuales creadas como recursos y entornos para la formación en los Talleres TIC sino los materiales didácticos digitales producidos en doce proyectos de formación: recursos didácticos y aulas virtuales creadas por y entre docentes para formar docentes enseñar su disciplina. Los materiales creados (imagen 4) se clasifican en recursos digitales y aulas virtuales (EVEA o simplemente entornos digitales) y en producciones individuales, colaborativas e individuales participativas. Según el tipo de agrupamiento, los contenidos de los recursos creados fueron transpuestos en la lógica de una disciplina o en modo transdisciplinar. Estas producciones dan cuenta de aprendizajes y de haber desarrollado CDD. Algunas de las apps o herramientas que aprendieron a descargar y/o usar para crear dichos recursos didácticos digitales fueron: office, c-map, wikis, Padlet, blogs, aula virtual, Movie Maker. En una progresión iniciada con proyectos individuales, que prosiguió con proyectos colaborativos y se incrementó construyendo un ecosistema de plataformas de formación y comunicación; constituido por el aula virtual institucional (mensajería interna, foros, wiki, archivos, enlaces, cuestionarios, diario de clases) con el blog colaborativo y las google classroom enlazadas al diario de clases virtual, más la mensajería externa y el whatsapp. Los recursos creados fueron: las webquest, cacerías, mapas conceptuales, presentaciones, un blog colaborativo, portafolios digitales, aulas virtuales, entre otros, y respondieron a intereses disciplinares e interdisciplinares. Los dispositivos más utilizados en presencia fueron los teléfonos smart (móviles o celulares), también una tablet y tres netbooks del programa Conectar Igualdad, y desde el hogar los dispositivos de sobremesa (ordenadores o PC).

Las aulas virtuales creadas en google classroom (imagen 5), son ejemplos de creaciones individuales con usos participativos, donde cada docente en formación simuló enseñar su disciplina y sus pares actuaron como si fuesen estudiantes; la formadora tutorizó el proceso participando en la classroom y al finalizar la simulación evaluó con un comentario en cada aula virtual.

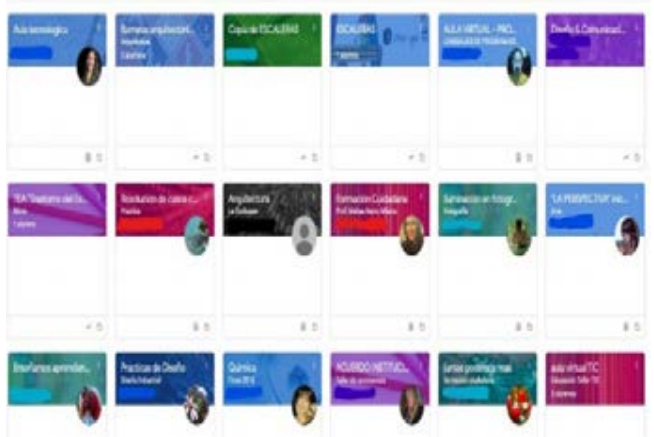

Imagen 5. Aulas virtuales creadas en los Talleres TIC. Fuente: imagen propia.

\section{Discusión y conclusiones}

La clase invertida (flipped classroom) se organizó en secuencias de cuatro clases (imagen 6) y destacó entre otras estrategias de la formación porque articuló presencia y distancia en un escenario de aprendizajes cuyos espacios fueron áulicos, hogareños y ubicuos. Cada secuencia flipped classroom, alternó e integró cuatro sesiones: breve introducción (clase cero), actividades de familiarización/investigación no presenciales (clase1), resolución de problemas en clase presencial (clase 2), actividades de producción no presenciales (clase 3), y finalmente presentación de la producciones y debate didáctico presencial (clase 4).

El aula virtual (principal) de estos Talleres TIC, alojada en el campus virtual institucional, conectó participantes, elementos y espacios del escenario de aprendizajes; 
fue consultada en modo ubicuo (a veces en la clase presencial). Su diario virtual se instituyó como el recurso estratégico, porque permitía articular la inversión de las clases en secuencias que conducían al desarrollo de los proyectos. En dicho diario virtual de clases se consultaban las consignas, textos sobre usos de las TIC en educación, se enlazaban otras aplicaciones del ecosistema y las herramientas necesarias para crear cada tipo de material didáctico, también se reseñaban los debates áulicos.

Cada secuencia de cuatro clases 'representa' la organización de clases invertidas que se sucedieron en un año de formación (una secuencia para cada proyecto), con contenidos y recursos diferentes pero semejantes en la estrategia flipped y el escenario de aprendizajes semi-presencial. El ecosistema digital, era omnipresente y accesible desde el hogar, el aula o en modo ubicuo. La autopercepción de las CDD desarrolladas y las producciones digitales (materiales didácticos: recursos y entornos) comprueban que se aprendió a saber (conocer), a colaborar y a saber usar TIC con fines didácticos.

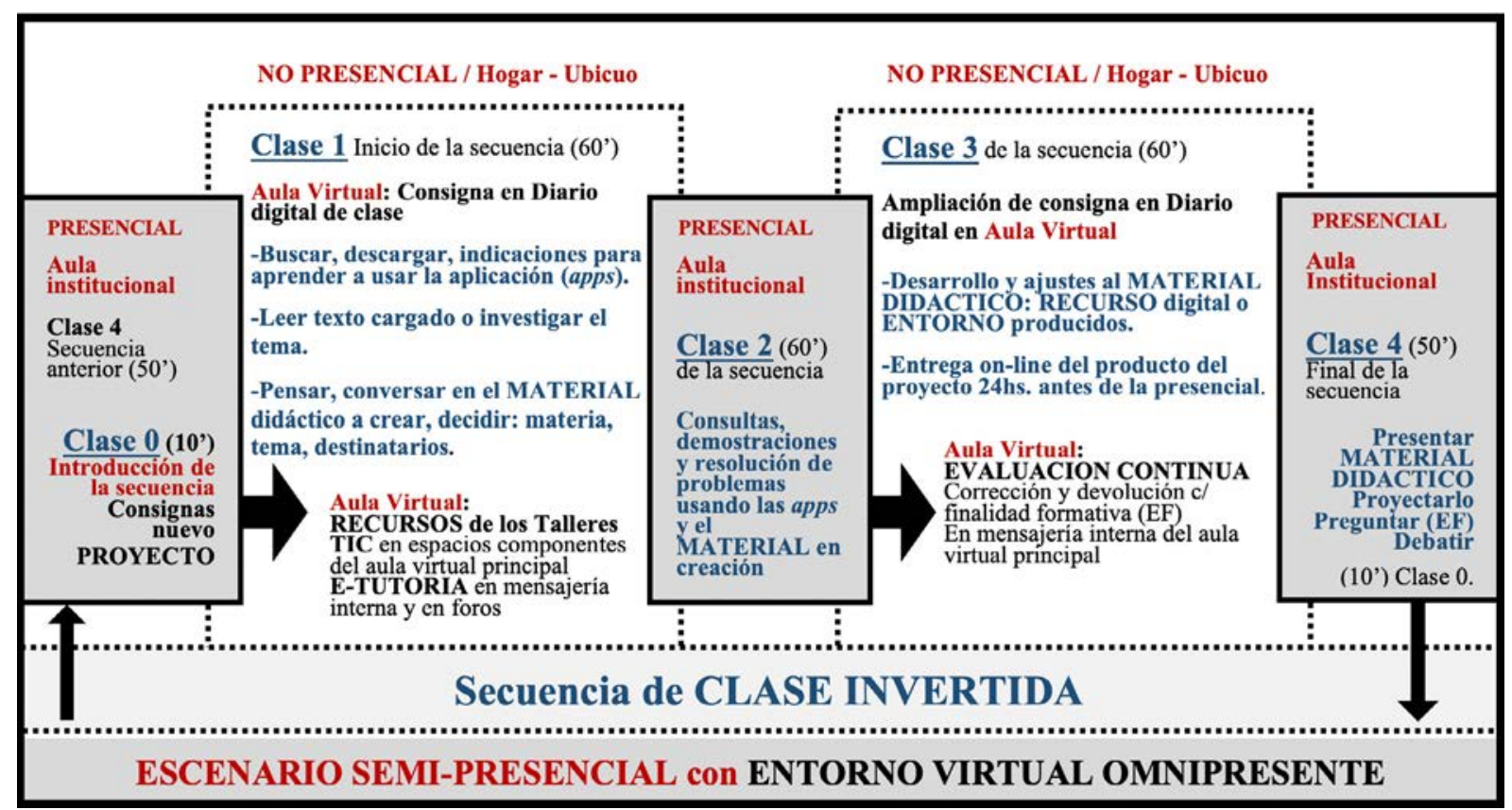

Imagen 6. Procedimientos en cada secuencia de clase invertida en un escenario de aprendizajes semi-presencial. Fuente: elaboración propia.

Se piensa que los resultados de este estudio validan las estrategias didácticas de estos Talleres TIC, confirmando la hipótesis del diseño de investigación. En Cano (2005) usar las 'nuevas' TIC es para el profesorado una competencia esencial, tanto en su dimensión instrumental transversal para las necesidades profesionales como en la que trasciende el instrumento transformando los modelos comunicativos interpersonales y de los procesos de enseñanza y de aprendizaje.

En conclusión, la educación a distancia de emergencia irrumpió y evidenció falencias preexistentes en calidad y equidad en los sistemas educativos, y en los subsistemas de formación inicial y permanente del profesorado. En los talleres investigados las y los docentes aprendieron sobre usos pedagógicos de las TIC, produjeron recursos y configuraron entornos digitales para formar en otros campos del saber. 
Sus producciones y voces son evidencias de resultados de la estrategia formativa integrada por los métodos de clase invertida y de proyectos colaborativos en un escenario áulico-hogareño-ubicuo. Las estrategias didácticas y las tecnologías digitales, principalmente el aula virtual, ampliaron el escenario áulico de formación, los recursos disponibles, y los tiempos para la enseñanza y los aprendizajes. Las diversas trayectorias se reflejan en el contenido de los materiales didácticos digitales producidos individual y colaborativamente. La hibridación de la innovación didáctica hacia una investigación-acción transformó cada fase de la formación con el aval de las evidencias y de las interacciones pedagógicas.

Invertir la clase enseñando y aprendiendo mediante entornos y recursos digitales 'antes' de asistir al aula (presencial o virtualmente) provoca que el salón de clases se expanda, derribando barreras espacio-temporales y, en nuestro caso, que las y los docentes se formaran en modo ubicuo porque disponían de recursos para aprender además de espacios de comunicación y tutoría en un ecosistema digital conformado por un aula virtual principal, otras aulas y aplicaciones. La clase invertida usando entornos tecnológicos es un gran cambio metodológico respecto de la clase magistral; los aprendizajes dependieron más de la actividad de quienes se formaron que de la transmisión de contenidos. La dicotomía entre presencialidad y virtualidad fue superada. La flipped 'lesson' con procedimientos colaborativos para producir materiales educativos digitales requirió de interacciones comunicativas mediadas por TIC. La estrategia de formación compensó la escasez de dispositivos digitales y promovió entre docentes los saberes, las habilidades, competencias y la criticidad necesaria para usar en modos diversos las TIC en otros campos de saberes de la formación docente; transformando la Educación.

\section{Referencias}

Bartolomé, A., Salinas, J., Grané, M., Pernías, P., Esteve-González, V. y Cela-Ranilla, J. (2016). Nuevos escenarios de aprendizaje. En M. Gisbert y J. González (Eds.), New learning environments from a transformative perspective, [pp.] 131-164. Wolters Kluwer. Recuperado de [https://www.academia.edu/26035893/Nuevos_escenarios_de_aprendizaje]

Bishop, J. y Verleger, M. A. (2013). The Flipped Classroom: A Survey of the Research. American Society for Engineering Education. Annual Conference \& Exposition, Atlanta. [pp.] 1-18. Paper ID \#6219 Recuperado de [https://peer.asee.org/the-flippedclassroom-a-survey-of-the-research]

Cabero Almenara, J. (2001). Tecnología educativa. Diseño y producción de medios en la enseñanza. Paidós.

Cabero Almenara, J. y Llorente Cejudo, M. (2015). Tecnologías de la Información y la Comunicación (TIC): escenarios formativos y teorías del aprendizaje. Revista LasaIlista de investigación, (12), Núm. 2, [pp.] 186-193. Recuperado de [http://www.scielo. org.co/pdf/rlsi/v12n2/v12n2a19.pdf]

Cano, E. (2005). Cómo mejorar las competencias docentes. Guía para la autoevaluación y el desarrollo de las competencias del profesorado. Editorial Graò, serie desarrollo personal del profesorado. 
De Benito, B., Moreno, J. y Villatoro. S. (2020). Codiseño de situaciones educativas enriquecidas con TIC. EDUTEC. Revista Electrónica de Tecnología Educativa. Núm. 74 [pp.] 85-93. Recuperado de [https://www.edutec.es/revista/index.php/edutec-e/ article/view/1843/805]

De Luca, M. P. (2021). Las aulas virtuales en la formación docente como estrategia de continuidad pedagógica en tiempos de pandemia. Usos y paradojas. En Fundación Carolina (eds.). La educación superior en Iberoamérica en tiempos de pandemia. Impacto y respuestas docentes. Cap.7, [pp.] 147-157. Recuperado de [https://www.fundacioncarolina.es/fundacion-carolina-lanza-el-libro-la educacion-superior-en-iberoamerica-en-tiempos-de-pandemia-impacto-y-respuestas-docentes/]

Fandos Garrido, M. (2009). Las tecnologías de la información y la comunicación: un proceso de cambio. Publicacions Universitat Rovira i Virgili, URV.

Frencia, D.C. y Jara, J. E. (2020). Prácticas docentes mediadas por TIC en institutos de formación docente. Ponencia de investigación. Tecnológico de Monterrey. Memorias Congreso Internacional Innovación Educativa (4) [pp.] 744-748. Recuperado de [https://ciie.itesm.mx/es/memorias/]

Guayara Ramírez, M. A. y Vásquez Guerra, L. A. (2017). Impacto en las prácticas de aula de la formación docente en TIC para el desarrollo profesional docente en la Institución de Educación Superior - ITFIP. Memorias Virtual Educa. [pp.] 1-17. Recuperado de [https://reposital.cuaieed.unam.mx:8443/xmlui/handle/20.500.12579/919]

Hinojo Lucena, F. J.; Aznar Díaz, I.; Romero Rodríguez, J. M. y Marín Marín, J. A. (2019). Influencia del aula invertida en el rendimiento académico. Una revisión sistemática. Revista Campus Virtuales, 8 (1), [pp.] 9-18. Recuperado de [https://redined.educacion.gob.es/xmlui/bitstream/handle/11162/184523/Art.\%201.pdf?sequence=1\&isAllowed=y]

Lázaro, J. y Gisbert, M. (2015). Elaboración de una rúbrica para evaluar la competencia digital del docente. Universitas Tarraconensis. Revista de Ciències de l'Educació, (1), [pp.] 30-47. Recuperado de [https://revistes.urv.cat/index.php/ute/article/ view/648/781]

Libedinsky, M. (2016). La innovación educativa en la era digital. Paidós.

Litwin, E. (2005). La tecnología educativa en el debate didáctico contemporáneo. En Litwin, E. (Ed.), Tecnologías educativas en tiempos de Internet. [pp.] 13-34. Amorrortu.

Marqués, L., Espuny, C., González, J. y Gisbert, M. (2011). La creación de una comunidad de aprendizaje en una experiencia de blended learning. Píxel Bit. Revista de Medios y Educación, Núm. 39, [pp.] 55-68. Recuperado de [https://www.redalyc. org/pdf/368/36818685006.pdf]

Maggio, M. (2012). Enriquecer la enseñanza. Ambientes con alta disposición tecnológica como oportunidad. Paidós. 
Mc Kernan, J. (1996). Curriculum Action Research. A Handbook of Methods and Resources for the Reflective Practitioner. Routledge.

Prendes Espinosa, M. P. y Cerdán Cartagena, F. (2021). Tecnologías avanzadas para afrontar el reto de la innovación educativa. RIED. Revista Iberoamericana de Educación a Distancia, 24 (1), [pp.] 35-53. Recuperado de [doi: http://dx.doi.org/10.5944/ ried.24.1.28415]

Schneider, D., Abramowski, A. y Laguzzi, G. (2007). Uso pedagógico de las tecnologías de la información y la comunicación. Alfabetización digital. Módulo para capacitadores. Ministerio de Educación, Ciencia y Tecnología de la Nación. Recuperado de [http://www.bnm.me.gov.ar/giga1/documentos/EL002052.pdf]

Torrecilla Manresa, S. y García García, M. (2020). Flipped Classroom: estrategias de aprendizaje y rendimiento en ciencias. EDUTEC Revista Electrónica De Tecnología Educativa, (72), [pp.] 111-124. Recuperado de [https://doi.org/10.21556/ edutec.2020.72.1525]

Tucker, B. (2012). The flipped classroom: online instruction at home frees class time for learning. Education Next, vol. 12, no 1, invierno 2012 [pp.] 82-83. Recuperado de [https://go.gale.com/ps/i.do?id=GALE\%7CA274874890\&sid=googleScholar\&$v=2.1 \& i t=r \&$ linkaccess $=a b s \& i s s n=15399664 \& p=A O N E \& s w=w \& u s e r G r o u p N a m e=a-$ non\%7E9f7e3276]

UNESCO. (2008). Normas UNESCO sobre Competencias en TIC para Docentes. UNESCO. [pp.] 1-47. Recuperado de [https://www.campuseducacion.com/blog/ wp-content/uploads/2017/O2/Normas_UNESCO_sobre_Competencias_en_TIC_ para_Docentes]

(s.f.). Aprendizaje semipresencial, blended learning. Thesaurus UNESCO. Recuperado de [http://vocabularies.unesco.org/thesaurus/concept17113] 


\section{Enseñar Estadística en Tiempos de Covid. Elaboración de Materiales Adaptados al Nuevo Paradigma Educativo}

Pérez Giménez, Virgilio orcid.org/0000-0002-7628-2855 virgilio.perez@uv.es

\section{Aybar Arias, Cristina}

orcid.org/0000-0001-8887-8405

cristina.aybar@uv.es

\section{Pavía Miralles, Jose M.}

orcid.org/0000-0002-0129-726X

pavia@uv.es 


\title{
ENSEÑAR ESTADÍSTICA EN TIEMPOS DE COVID. ELABORACIÓN DE MATERIALES ADAPTADOS AL NUEVO PARADIGMA EDUCATIVO
}

\author{
Pérez Giménez, Virgilio \\ Aybar Arias, Cristina \\ Pavía Miralles, Jose M.
}

\section{Resumen}

A comienzos del curso académico 2020/21, los centros educativos, siguiendo las recomendaciones de las autoridades sanitarias, establecieron unos protocolos de actuación que permitieron iniciar las clases en el mes de septiembre, aunque con notables cambios respecto a cursos anteriores. Estos protocolos se fueron ajustando con el paso del tiempo, atendiendo a la evolución de la pandemia, lo que ha posibilitado finalizar uno de los cursos más atípicos que se recuerdan. En un contexto en el que todos los esfuerzos se han centrado en evitar que el rendimiento académico de los estudiantes se viera afectado negativamente por una docencia lejos de las aulas, se ha implementado una metodología docente basada en la elaboración de nuevos materiales, permitiendo a los alumnos hacer un correcto seguimiento de la asignatura Estadística. Este documento pone de manifiesto la dificultad que conlleva impartir asignaturas de perfil cuantitativo en formato a distancia y, en consecuencia, la importancia de, por un lado, elaborar materiales curriculares de calidad y, por otro lado, implantar metodologías docentes alternativas, que permitan al alumnado realizar un adecuado seguimiento de este tipo de asignaturas en tiempos de semipresencialidad. Los resultados obtenidos de una encuesta realizada al final del curso afloran varias conclusiones, entre las que destacamos dos: i) los profesores deben ser capaces de adaptarse a un modelo educativo altamente condicionado por la tecnología, y elaborar materiales de calidad adaptados a este nuevo paradigma; y ii) los alumnos prefieren un modelo educativo basado en la presencialidad, pese a disponer de los recursos expuestos en el presente documento.

\section{Palabras clave}

Docencia Híbrida, Materiales Curriculares, Universidad, Estadística, COVID-19. 


\section{Introducción}

Como en cualquier disciplina de la vida, la actitud con la que afrontamos los retos es crucial para lograr los objetivos marcados. Y así ocurre también en la formación postobligatoria. Recientes estudios afirman que existen varios factores que determinan la superación (o no) de las asignaturas cuantitativas en estudios universitarios: i) la utilidad, percibida por el alumno, de estas asignaturas; ii) el entorno de aprendizaje, es decir, la implicación del profesorado o los recursos utilizados en la docencia; y iii) la predisposición del estudiante a aprender (Singh et al., 2017). Cuando no se tienen en cuenta estos factores, o no se trabaja en ellos lo suficiente, la motivación del alumnado cae y la tasa de abandono se dispara. De hecho, las materias relacionadas con matemáticas o estadística son las que, habitualmente, acumulan un mayor porcentaje de suspensos (Hidalgo Alonso et al., 2004), los cuales pueden deberse, no a la falta de preparación de los estudiantes, sino a un mal planteamiento docente (Murtonen y Lehtinen, 2003).

El curso 2020/21 ha sido uno de los más atípicos que se recuerdan, marcado por la pandemia del coronavirus. A comienzos del curso académico, los centros educativos, siguiendo las recomendaciones de las autoridades sanitarias, establecieron unos protocolos de actuación que permitieron iniciar las clases en el mes de septiembre, siguiendo el calendario académico tradicional, aunque con notables cambios respecto a cursos anteriores: reducción del aforo en las aulas, reducción de la presencialidad en los campus, utilización de sistemas de videoconferencia, medidas de ventilación en espacios cerrados, y un largo etcétera. Estos protocolos se han ido ajustando con el paso del tiempo, atendiendo a las necesidades coyunturales y a la evolución de la pandemia.

Con el objetivo de conseguir una mayor implicación del alumnado, se ha puesto en marcha una nueva metodología docente en las clases de la asignatura Estadística Básica (materia obligatoria de primer curso en los Grados de Administración y Dirección de Empresas (ADE) y Economía de la Universidad de Valencia (UV). Esta metodología ha consistido, fundamentalmente, en elaborar materiales y recursos educativos y en utilizar diferentes recursos tecnológicos, todos ellos gratuitos, ofreciendo a los alumnos las herramientas necesarias para poder seguir, y superar, la asignatura con garantías.

El resto del documento está organizado de la siguiente manera. En la segunda sección se describe la experiencia realizada en el curso 2020/21, exponiendo con detalle los diferentes recursos elaborados/utilizados. La tercera sección está dedicada a analizar los resultados obtenidos. En la cuarta sección se ofrece, por un lado, una breve discusión sobre la elaboración de recursos docentes y, por otro lado, se exponen las conclusiones obtenidas tras la implementación del proyecto docente descrito. También se proponen nuevas líneas de investigación.

\section{Descripción de la experiencia}

Los principios metodológicos empleados en este proyecto educativo potencian que el alumnado sea el protagonista de su propio aprendizaje, favoreciendo la motivación y aumentando el interés por la asignatura. El rol del docente es el de diseñar tareas que posibiliten el aprendizaje con la resolución de problemas y la aplicación de conocimientos, potenciando la creatividad, la capacidad de relación entre iguales, 
el diálogo, el respeto, la cooperación y la solidaridad. Esta metodología se concibe como una mezcla de diferentes elementos, los cuales, en su conjunto, ofrecen una potente alternativa al método docente clásico basado en la clase teórica magistral. Algunos de los mecanismos utilizados se exponen a continuación.

\section{Encuesta inicial}

Con el objetivo de conocer al alumnado desde el principio, y establecer un vínculo profesor-alumno que permitiera atender de forma personalizada las inquietudes de los estudiantes, durante la primera sesión del curso, tras la presentación del equipo docente, se realizó una encuesta, utilizando un cuestionario confeccionado previamente en Aula Virtual (sistema, basado en Moodle, utilizado por la UV para gestionar el contenido docente de cada curso). Existen estudios que verifican la relación directa entre un clima escolar positivo y ciertas variables académicas, tales como i) el rendimiento, ii) el aprendizaje efectivo o iii) el desarrollo de actitudes positivas hacia el estudio (Moreno Madrigal et al., 2011). De dicha encuesta se obtuvo, de cada estudiante, la siguiente información: i) nombre; ii) edad; iii) género; iv) país de nacimiento; v) forma de acceso a los estudios universitarios; vi) número de veces que ha cursado la asignatura; vii) calificación esperada al finalizar el curso; viii) profesión deseada al finalizar los estudios; ix) actividades de interés. Con esta información, además de conocer los intereses de los alumnos y poder aplicar una atención más personalizada, lo cual los alumnos agradecen enormemente (Núñez del Río y Fontana Abad, 2009), se pudieron plantear, a lo largo del cuatrimestre, diferentes actividades, las cuales comentaremos a continuación.

\section{Presentaciones teóricas locutadas}

Tradicionalmente las sesiones presenciales en esta asignatura se han basado en impartir los contenidos teóricos en base al método docente de la clase magistral presencial. Durante este curso, puesto que las restricciones sanitarias han impedido, hemos tenido que plantear alternativas que permitan mantener el nivel de calidad expositiva de los últimos años, pero adaptándonos a las circunstancias. En este sentido, se ha optado por añadir voz a las presentaciones que habitualmente se venían utilizando en estas sesiones magistrales. La ventaja de este recurso es evidente, ya que el alumno ha podido visualizar tantas veces como ha estimado conveniente cada video. Un aspecto que hemos tenido en cuenta en la maquetación de estos vídeos ha sido la duración, ajustándonos a un máximo de 15 minutos por recurso. Con esto hemos pretendido reducir la dispersión de los alumnos, que aumenta en vídeos de larga duración. Este recurso se ha puesto a disposición del alumnado atendiendo a una planificación rigurosa, evitando sobrecargar innecesariamente a los estudiantes, ya que, tal y como se ha comentado anteriormente, ofrecer todo el material desde el principio del curso puede resultar contraproducente.

\section{Vídeos "paso a paso"}

Las asignaturas de perfil cuantitativo se suelen sustentar en una base teórica, pero deben estar complementadas de material práctico, que ejemplifiquen los métodos propuestos y las hipótesis planteadas. En tal sentido, hemos creído conveniente complementar los recursos puramente teóricos, comentados en el subapartado anterior, con una serie de videos denominados "paso a paso". En estos vídeos se han desarrollado ejemplos muy básicos, ayudando al estudiante a comprender el funcionamiento 
y aplicación de los contenidos impartidos en la asignatura. Un total de 16 vídeos conforman la serie "paso a paso".

\section{Ejercicios desarrollados y ejercicios propuestos}

En línea con lo expuesto en el punto anterior, los ejercicios suponen una herramienta educativa muy potente, que permiten y/o ayudan al estudiante a asimilar los contenidos teóricos. Los profesores del área de Métodos Cuantitativos (Departamento de Economía Aplicada de la Universidad de Valencia) siempre hemos intentado acercar la realidad económica y empresarial a las aulas, elaborando y planteando escenarios que permitan al estudiante conocer de primera mano el contexto en el cual se puede poner en práctica los conocimientos adquiridos en esta asignatura. Habitualmente, este tipo de ejercicios se planteaban, desarrollaban y resolvían completamente en clase. Este curso, dadas las circunstancias, hemos tenido que idear una alternativa para seguir manteniendo este recurso a disposición del alumnado, pero desde la distancia. Hemos optado por elaborar, como siempre, ejercicios y problemas que ejemplifiquen situaciones que se puedan dar perfectamente en la vida real, pero en esta ocasión los hemos desarrollado completamente, resolviéndolos por escrito con todo lujo de detalles. Este recurso permite al alumnado reforzar lo aprendido mediante el material anteriormente expuesto, pero además le sirve de guía para saber cómo debe resolver otros ejercicios y problemas, así como el porqué de cada uno de los pasos necesarios para una correcta resolución. Además de estos ejercicios completamente desarrollados se ha puesto a disposición de los estudiantes una batería de problemas (entre 10 y 15 por unidad didáctica) de una dificultad similar a los que se encontrarán en la prueba de síntesis al finalizar el cuatrimestre.

\section{Pruebas de evaluación individualizadas}

Tal y como se establece en la guía docente correspondiente, la asignatura de Estadística Básica está estructurada en dos grandes bloques: i) Estadística descriptiva (temas uno a cuatro); y ii) Probabilidad (temas cinco a siete). El principal objetivo de esta materia es que el estudiante adquiera los conocimientos necesarios para afrontar con garantías otras asignaturas cuantitativas impartidas en cursos posteriores (Inferencia, Econometría o Fundamentos de investigación de mercados, entre otras). Para valorar si los alumnos van asumiendo los conceptos impartidos, se han realizado, a lo largo del curso, tres pruebas de evaluación: i) temas uno y dos; ii) temas tres y cuatro; iii) temas cinco, seis y siete. No obstante, cabe recordar que la idiosincrasia de la materia conlleva que los conceptos adquiridos en cada tema sean utilizados, de forma recurrente, en temas posteriores, de manera que el alumno debe seguir la asignatura de una manera global y continuada. Por ello, se ha considerado oportuno incluir, en la segunda prueba de evaluación, problemas y cuestiones de los cuatro primeros temas, mientras que en la tercera prueba de evaluación se han incluido problemas y cuestiones que han abordado la totalidad del temario.

En cada prueba se han planteado varios ejercicios (entre tres y cinco), mediante los cuales los estudiantes han podido demostrar los conocimientos adquiridos hasta ese momento. Los ejercicios planteados en las diferentes pruebas han consistido en trasladar el mundo laboral a las aulas, en el sentido de hacer ver al alumno la importancia de dominar determinados conceptos estadísticos. Para ello, además de manejar datos reales, extraídos fundamentalmente de la página web del Instituto Nacional de Estadística (INE), se ha utilizado la información extraída de la encuesta 
inicial para generar enunciados personalizados. Para ofrecer un mayor dinamismo a la asignatura, se han planteado diferentes modelos de prueba, donde cada alumno ha tenido que resolver ejercicios distintos a los de otros compañeros, manteniendo siempre un nivel de complejidad similar. De este modo, y teniendo en cuenta algunas investigaciones previas (Reinig et al., 2011), tras finalizar cada prueba, los alumnos ponían en común las dificultades presentadas, pudiendo resolver entre todo el grupo el problema planteado. Este sistema ha ayudado a mantener una elevada motivación entre los estudiantes durante todo el curso.

La puesta en práctica de estos cuestionarios ha estado condicionada por la semipresencialidad, teniendo que realizar estas pruebas en el aula y online de forma síncrona. Para ello, hemos activado una sesión de videoconferencia para que los alumnos no presentes en el aula pudieran atender las indicaciones pertinentes, así como plantear las dudas que fueran surgiendo, reduciendo notablemente el nivel de ansiedad e incertidumbre que en ocasiones suponen este tipo de pruebas.

La confección de las diferentes combinaciones de enunciados se ha conseguido mediante la utilización del software libre R Studio (https://rstudio.com), implementando las opciones que el paquete R-exams ofrece (http://www.r-exams.org). En la actualidad, hay disponible en internet una gran cantidad de información acerca del funcionamiento de este software gratuito, así como de las posibilidades que ofrece, permitiendo, a cualquiera que lo desee, implementar nuevos métodos de evaluación.

\section{Utilización de dispositivos móviles con fines docentes}

Otro aspecto relevante de la metodología implementada en el aprendizaje estadístico ha sido la utilización de la herramienta Kahoot! (https://kahoot.com). Esta herramienta permite la creación de cuestionarios online para que, posteriormente, sean implementados en las aulas, accediendo desde los teléfonos móviles de los alumnos.

Actualmente, no podemos negar el estrecho vínculo que hay establecido entre el estudiante universitario y su dispositivo móvil (Licorish et al., 2018). La evolución de las Tecnologías de Información y Comunicación (TIC) está permitiendo generar nuevos escenarios educativos, favoreciendo con ello el desarrollo de modalidades educativas con una mejor adaptación a las necesidades de los estudiantes (Basantes et al., 2017). Por ello, hemos considerado muy útil introducir este tipo de herramientas docentes en las aulas, consiguiendo aumentar notablemente la implicación del alumnado (Tan Ai Lin et al., 2018).

Se han realizado siete cuestionarios a lo largo del curso, uno por tema. En cada cuestionario se han planteado diez preguntas cortas, relacionadas tanto con los aspectos teóricos de la materia como con los aspectos prácticos. En cada pregunta se planteaban cuatro posibles respuestas, de las cuales solo una era correcta. La implementación de esta herramienta ha sido muy útil, tanto para el aprendizaje de la materia como para mantener una atención adecuada y una elevada motivación, cumpliendo así con las expectativas generadas en estudios previos (Bicen y Kocakoyun, 2018). El hecho de que los alumnos no pudieran acudir al campus no ha sido impedimento para poner en práctica este tipo de pruebas, ya que se ha utilizado la herramienta Blackboard Collaborate para realizar videoconferencias con todos los alumnos del grupo. Así, el profesor compartía la pantalla, del mismo modo que en clase la proyecta, y los estudiantes marcaban la respuesta a cada pregunta utilizando sus dispositivos móviles. 


\section{Resultados}

El presente estudio se ha realizado tomando como muestra a un grupo de 217 alumnos, matriculados en la asignatura Estadística Básica durante el curso 2020/21. Para valorar si la metodología expuesta en el presente documento proporciona alguna mejoría respecto a otras metodologías, implementadas en otros grupos, se han comparado las calificaciones finales, en primera convocatoria, de alumnos matriculados en diferentes grupos (ver Tabla 1). No se observan diferencias significativas entre el número de alumnos presentados a la primera convocatoria del examen final de la asignatura. Por lo que respecta al número de notables/sobresalientes, tampoco se observan diferencias entre grupos. No obstante, la calificación media sí es algo inferior, en promedio, en los grupos en los que se ha implementado la metodología expuesta. Esto puede ser debido dos motivos: i) los perfiles de los alumnos de cada grupo son muy diferentes (ver Tabla 2); ii) los grupos que tradicionalmente ofrecen un rendimiento mayor ( $A R, G A$ y GK) no han participado en el proyecto.

\begin{tabular}{|c|c|c|c|c|c|c|c|}
\hline \multirow{2}{*}{ Calificación } & \multicolumn{7}{|c|}{ Número de alumnos por grupo } \\
\hline & GC & GG & $\mathbf{G H}$ & GM & Método SI & Método NO & Total \\
\hline Suspenso [0 - 4.9] & 25 & 16 & 2 & 16 & 59 & 187 & 246 \\
\hline Aprobado [5 - 6.9] & 43 & 11 & 4 & 35 & 93 & 419 & 512 \\
\hline Notable [7 - 8.9] & 8 & 3 & 3 & 6 & 20 & 75 & 95 \\
\hline Sobresaliente / MH [9 - 10] & 1 & 0 & 0 & 1 & 2 & 10 & 12 \\
\hline No Presentado & 7 & 17 & 8 & 11 & 43 & 166 & 209 \\
\hline Alumnos matriculados & 84 & 47 & 17 & 69 & 217 & 857 & 1074 \\
\hline Calificación media & 5,12 & 4,33 & 5,89 & 5,30 & 5,08 & 5,32 & 5,27 \\
\hline \% Alumnos presentados & 91,7 & 63,8 & 52,9 & 84,1 & 80,2 & 80,6 & 80,5 \\
\hline
\end{tabular}

Tabla 1. Calificaciones finales, en primera convocatoria, de los alumnos matriculados en la asignatura Estadística Básica / Estadística I (grados en Administración y Dirección de Empresas y Economía) diferenciando los grupos en los que se ha implementado la metodología propuesta de los que no.

Por otro lado, para valorar las impresiones del alumnado, se ha realizado una encuesta anónima al finalizar el curso, mediante la cual los estudiantes han podido valorar la metodología implementada con total sinceridad. En dicha encuesta, compuesta por catorce preguntas (cuatro de clasificación, cuatro de opción múltiple, tres de tipo Likert y tres de respuesta abierta), participaron 95 alumnos.

\begin{tabular}{|l|c|c|c|c|c|}
\hline Grupo & \multicolumn{2}{c}{ Idioma } & \multicolumn{2}{c|}{ Turno } & \multicolumn{2}{c|}{ Repetidores } \\
\hline GC & $X$ & & $X$ & & 8,33 \\
\hline$G G$ & & $X$ & & $X$ & 4,23 \\
\hline$G H$ & $X$ & & & $X$ & 76,47 \\
\hline$G M$ & $X$ & & & $X$ & 8,70 \\
\hline
\end{tabular}

Tabla 2. Perfil de los alumnos de los grupos que han participado en el proyecto. 
Una de las preguntas estaba enfocada a valorar los recursos implementados. De esta cuestión observamos que los vídeos "paso a paso" y los ejercicios completamente desarrollados son los que mejor acogida han tenido por parte de los estudiantes (ver Figura 1). De este resultado extraemos que la parte práctica de la asignatura es la que los alumnos valoran más positivamente. No se observan diferencias significativas en función de la edad o del género de los estudiantes.

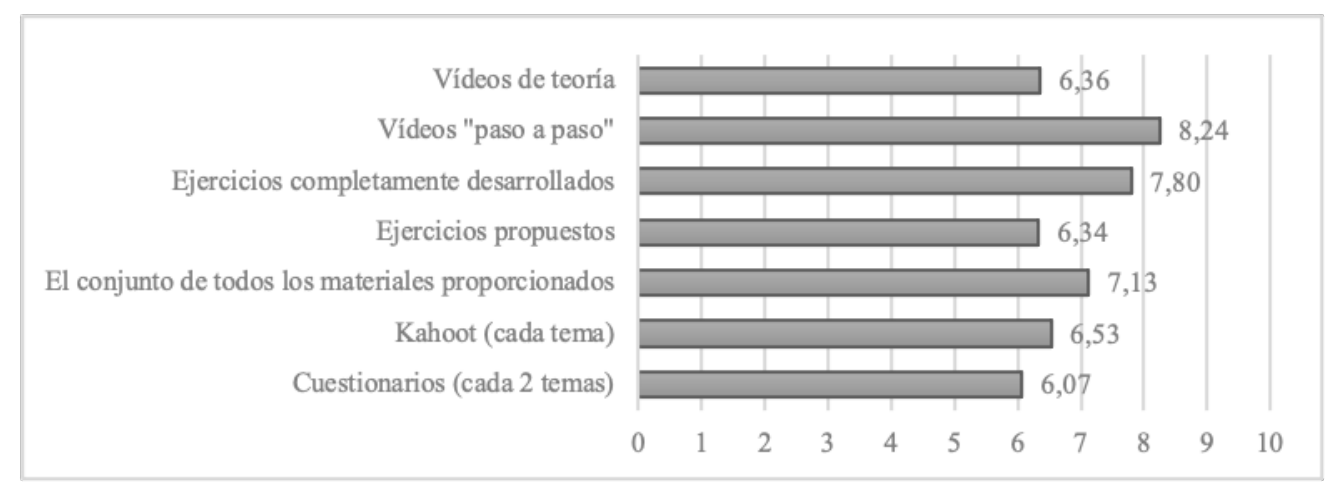

Figura 1. Respuestas (promedio) a la pregunta núm. 6 de la encuesta: "Valora de $\mathrm{O}$ a 10 la utilidad de...".

Otra de las cuestiones planteadas en la encuesta hacía referencia al nivel de conocimientos adquiridos (percepción del estudiante) tras cursar la asignatura. En la Figura 2 se ofrecen los resultados obtenidos, observando que más del $60 \%$ de los alumnos valoran su rendimiento en la asignatura muy positivo.

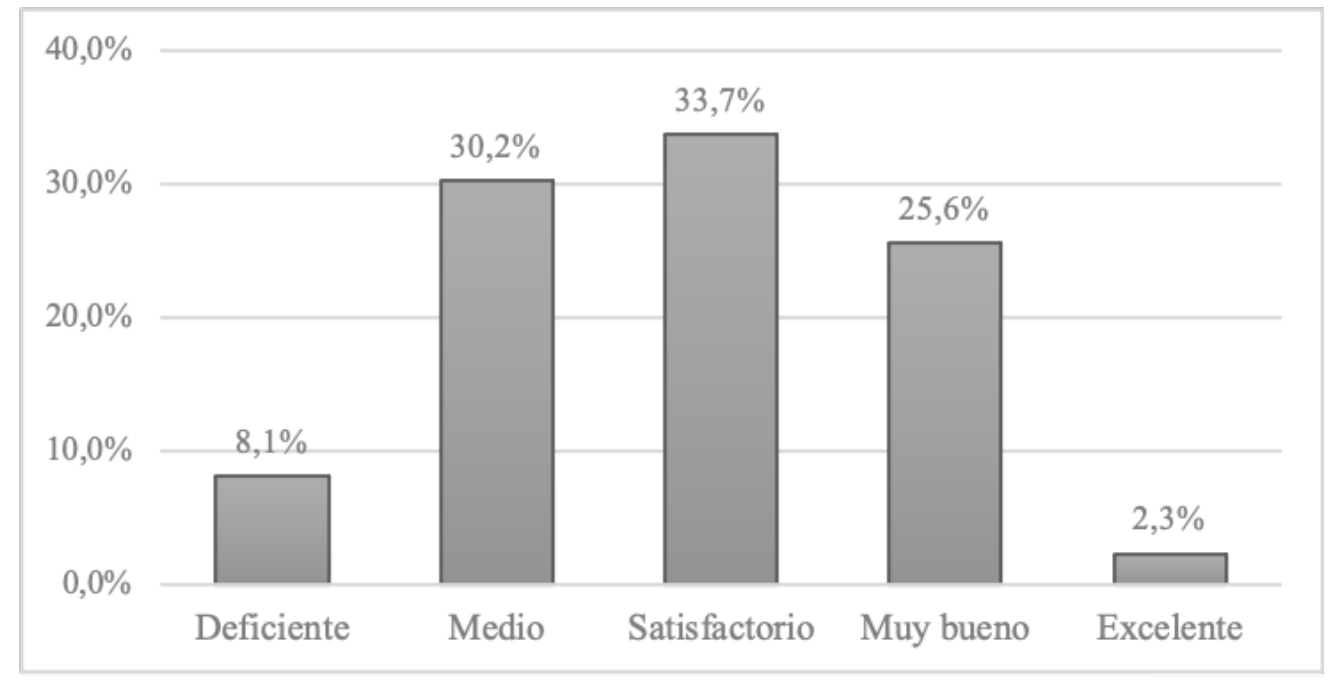

Figura 2. Respuestas a la pregunta núm. 10 de la encuesta: "Valora los conocimientos adquiridos durante el curso (nivel de habilidades o conocimientos)".

También se preguntó sobre cómo desearían los alumnos que fuera la docencia en el curso 2021/22. Para ello se plantearon diferentes escenarios (ver Figura 3). Como se puede observar, los alumnos prefieren la docencia presencial, incluso disponiendo de todo el material ofrecido este curso. Para los estudiantes es mucho más importante acudir a las aulas y mantener un contacto cercano con profesores y compañeros que disponer de todos los recursos educativos comentados en este documento. 


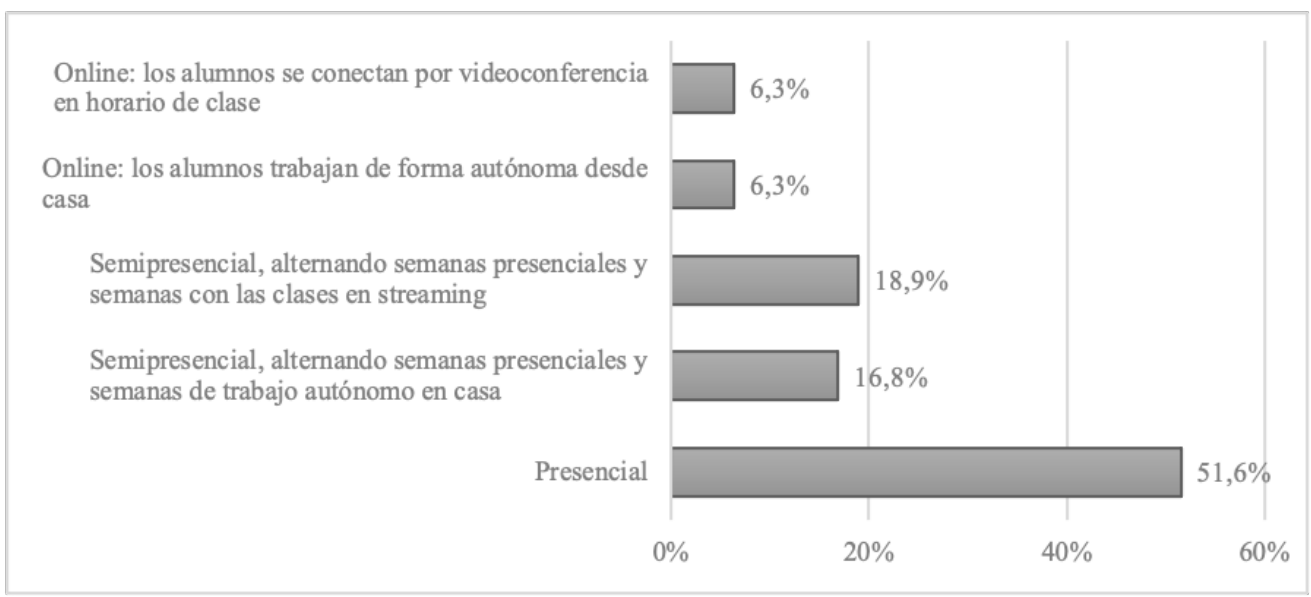

Figura 3. Respuestas a la pregunta núm. 11 de la encuesta: "Durante el próximo curso seguiremos sin estar en completa normalidad. Si dispusieras de TODOS LOS MATERIALES que se han proporcionado en esta asignatura, ¿qué tipo de docencia preferirías que se llevase a cabo?".

\section{Discusión y conclusiones}

Tal y como muestran estudios previos (Singh et al., 2017), es muy conveniente que los docentes tengamos en cuenta aquellos factores que influyen directamente en el aprendizaje de los alumnos, sobre todo en aquellas materias que generalmente provocan cierto rechazo entre los estudiantes. Por ello, es fundamental adaptarse a los alumnos e implementar metodologías docentes que favorezcan el aprendizaje en el contexto actual, tal y como se ha hecho en la experiencia docente comentada en este documento.

No obstante, este planteamiento puede ser contraproducente, puesto que, en ocasiones, el hecho de ofrecer una mayor cantidad material puede ocasionar que el alumno: i) se vea desbordado por no ser capaz de revisar la documentación proporcionada; y ii) se desvincule del grupo, asistiendo cada vez menos a las clases presenciales o no conectándose a las sesiones síncronas de videoconferencia, provocando un absentismo que puede llegar a ocasionar la no superación de la asignatura, o incluso el abandono de la misma.

También consideramos conveniente resaltar la capacidad que los docentes tenemos para elaborar materiales nuevos. Si bien es cierto que las nuevas tecnologías ofrecen un sinfín de posibilidades, es necesario hacer una criba concienzuda de los recursos educativos que se pueden obtener en la red. Pero para poder realizar ese filtrado, los profesores deben tener los conocimientos necesarios. Recientes estudios indican que el nivel de competencia digital docente en España se sitúa en niveles intermedios en lo que respecta a las habilidades para comunicarse y colaborar con los demás, pero se encuentra en niveles bajos en el resto de las áreas competenciales, especialmente en lo que se refiere a problemas técnicos (Garzón, 2021). 
Por otro lado, la capacidad de trabajo e imaginativa de cada profesor es distinta. Por ello, sería más que recomendable crear alguna herramienta que permita poner en común, como se viene haciendo en los congresos de innovación educativa, los proyectos e ideas que los docentes ponemos en marcha. Actualmente existen varias páginas web, creadas por profesores, que tienen como objetivo reunir los programas de sus asignaturas, ofrecer materiales de apoyo al aprendizaje que ofrecen a sus estudiantes y compartir su experiencia docente con otros colegas (Marquès, 2004). La formación previa/continua en TIC resulta, por tanto, necesaria a todos los niveles, también en el ámbito docente universitario.

Una de las muchas conclusiones que se extraen de este trabajo es que el profesorado debe ser capaz de utilizar las TIC para mejorar la enseñanza y el aprendizaje del alumnado, y no solo para transformar la docencia presencial en virtual, recurriendo de forma reiterativa a la retransmisión de clases por streaming. Debemos ser capaces de elaborar y proporcionar materiales curriculares adaptados a las circunstancias actuales, que favorezcan una transición suave al nuevo paradigma docente, marcado por un uso cada vez mayor de las TIC. Para ello, establecer programas de formación para el profesorado adecuados puede resultar de gran utilidad.

El presente estudio se ha basado en la experiencia vivida en una única asignatura (Estadística básica), tomando como referencia una muestra de 217 de alumnos, de varios grupos y titulaciones. Convendría, como línea futura de investigación, ampliar el tamaño de la muestra, teniendo en cuenta también otras materias, tales como Matemáticas, Estadística avanzada o Econometría, por ejemplo.

Así mismo, también sería interesante abordar otras titulaciones de la rama de ciencias sociales, como Economía, Sociología, Relaciones Laborales o Derecho, entre otras. Además, es preciso recordar que el curso 2020/21 ha sido un curso atípico, en cuanto a las circunstancias derivadas de la crisis sanitaria. Por ello, sería conveniente mantener esta metodología durante los próximos años y observar si, en un escenario estable, similar a cursos anteriores, se mantienen los resultados obtenidos.

Por lo que respecta a la muestra analizada, hemos observado que, a pesar del esfuerzo realizado por los docentes elaborando materiales ad-hoc, no se han conseguido los resultados esperados, al menos no se han visto reflejados en las calificaciones de la asignatura. En este sentido, debemos reflexionar sobre el papel que tienen los alumnos en su propio aprendizaje, y observar que no por facilitar más cantidad de material está todo hecho. El esfuerzo de los estudiantes debe ser un elemento fundamental para la consecución de sus propios objetivos, no dejándolo todo en manos de una metodología docente más o menos acertada, o en unos recursos educativos u otros.

\section{Referencias}

Basantes, A., Naranjo, M., Gallegos, M., y Benítez, N. (2017). Los dispositivos móviles en el proceso de aprendizaje. Formación universitaria, 10(2), [pp.] 79-88.

Bicen, H. y Kocakoyun, S. (2018). Perceptions of Students for Gamification Approach: Kahoot as a Case Study. International Journal of Emerging Technologies in Learning, 13(2), [pp.] 72-93. [https://doi.org/10.3991/ijet.v13i02.7467] 
Garzón, E., Sola, T., Trujillo, J. M. y Rodríguez, A. M. (2021). Competencia digital docente en educación de adultos: un estudio en un contexto español. Pixel-Bit. Revista de medios y Educación, 62, [pp.] 209-234. [https://doi.org/10.12795/pixelbit.89510]

Hidalgo Alonso, S., Maroto Sáez, A. y Palacios Picos, A. (2004). ¿Por qué se rechazan las matemáticas? Análisis evolutivo y multivariante de actitudes relevantes hacia las matemáticas. Revista de educación, 334, [pp.] 75-95.

Licorish, S. A., Owen, H. E., Daniel, B. y George, J. L. (2018). Students' perception of Kahoot!'s influence on teaching and learning. Research and Practice in Technology Enhanced Learning, 13(1), 9. [https://doi.org/10.1186/s41039-018-0078-8]

Marquès, P. (2004). Las webs docentes instrumentos eficaces para la mejora de los sistemas educativos. Bordón, 56(3), [pp.] 493-506.

Moreno Madrigal, C., Díaz Mújica, A., Cuevas Tamarín, C., Nova Olave, C. y Bravo Carrasco, I. (2011). Clima social escolar en el aula y vínculo profesor-alumno: Alcances, herramientas de evaluación y programas de intervención. Revista Electrónica de Psicología Iztacala, 14(3), [pp.] 70-84.

Murtonen, M. y Lehtinen, E. (2003). Difficulties Experienced by Education and Sociology Students in Quantitative Methods Courses. Studies in Higher Education, 28(2), [pp.] 171-185. [https://doi.org/10.1080/0307507032000058064]

Núñez del Río, M. C. y Fontana Abad, M. (2009). Competencia socioemocional en el aula: Características del profesor que favorecen la motivación por el aprendizaje en alumnos de Enseñanza Secundaria Obligatoria. Revista Española de Orientación y Psicopedagogía, 20(3), [pp.] 257-269.

Reinig, B., Horowitz, I. y Whittenburg, G. (2011). The effect of team-based learning on student attitudes and satisfaction. Decision sciences journal of innovative education, 9(1), [pp.] 27-47.

Singh, S., Misra, R. y Srivastava, S. (2017). An empirical investigation of student's motivation towards learning quantitative courses. The International Journal of Management Education, 15(2), [pp.] 47-59.

Tan Ai Lin, D., Ganapathy, M. y Kaur, M. (2018). Kahoot! It: Gamification in Higher Education. Pertanika Journal of Social Sciences \& Humanities, 26(1), [pp.] 565-582. 
Abriendo Puertas de la Pandemia. Nuevos Entornos y Lenguajes, la Producción del Conocimiento en la Cultura Digital: Reflexiones de una Experiencia.

\section{Weber, Verónica}

UNAHUR

veronica.weber@unahur.edu.ar 


\title{
ABRIENDO PUERTAS DE LA PANDEMIA. NUEVOS ENTORNOS $Y$ LENGUAJES, LA PRODUCCIÓN DEL CONOCIMIENTO EN LA CULTURA DIGITAL: REFLEXIONES DE UNA EXPERIENCIA.
}

\author{
Weber, Verónica \\ UNAHUR \\ veronica.weber@unahur.edu.ar
}

\section{Resumen}

El trabajo presenta fundamentos y reflexiones acerca del diseño de reconfiguración de la propuesta de enseñanza de la materia común a todas las carreras de la Universidad Nacional de Hurlingham (UNAHUR): Nuevos Entornos y Lenguajes. La producción del conocimiento en la cultura digital durante 2020 y 2021. El período se caracterizó por una pandemia que imposibilitó la realización de clases presenciales en las instituciones educativas. Esta situación límite se erigió como una oportunidad para la "reinvención" de la enseñanza de la asignatura. En el texto se ponen en foco algunas dimensiones que resultan potentes para analizar la propuesta: como las condiciones institucionales, la perspectiva tecnopedagógica y el fundamento didáctico. Se hace referencia al compromiso político para dar continuidad pedagógica, frente a la imposibilidad de impartir clases presenciales. Se enuncian las estrategias generadas en el diseño de la experiencia con presencialidad mediada tecnológicamente fundamentalmente en el entorno virtual de la universidad. Se consideran aspectos referidos a la enseñanza y al trabajo interno del equipo docente, como espacio de capacitación privilegiado. Se reconocen así los cambios contextuales, producto de la pandemia; así como otros referidos a la situación de la institución, en particular a la creciente matrícula del período referido y la construcción ofrecida como respuesta y el aprovechamiento de la situación crítica para la capacitación y organización del equipo de trabajo a partir de la tarea de reconfiguración de la materia y en torno al diseño de la propuesta de enseñanza.

\section{Palabras clave}

Virtualización, reconfiguración de la enseñanza, diseño pedagógico, producción colaborativa. 


\section{Introducción. De lo que era y ya no es ni será.}

Corría marzo de 2020 y en la UNAHUR siguiendo las políticas públicas nacionales, dejó de ser posible ofrecer clases presenciales. El edificio físico de la Universidad sólo siguió abierto para algunas actividades sanitarias o particulares; pero para la enseñanza fue el campus virtual el que se erigió como escenario principal. Rápidamente se definieron estrategias institucionales de apoyo y acompañamiento a lo que algunos caracterizaron como virtualización de emergencia. Autoridades, profesores, profesoras y personal no docente se sumaron a estos desafíos desconcertantes, insólitos e inciertos. Se constituyó un equipo de referentes tecno pedagógico didácticos, que organizaron capacitaciones y acompañamiento a los equipos docentes; poniendo el foco en la situación contextual, pero proyectando cambios estructurales en la enseñanza pospandémica. Se buscaba además de dar respuesta a una necesidad puntual, considerar la enseñanza como objeto de discusión en vías a lo que vendría cuando fuera que pasara la situación límite de referencia.

La UNAHUR es una universidad pública y gratuita y estructura su oferta académica en base a cuatro ejes: salud, educación, producción y ciencia. Se encuentra en la zona oeste del "conurbano bonaerense" en la provincia de Buenos Aires, Argentina. Se creó en 2014 y comenzó a funcionar en 2016. Dentro de la oferta académica de la universidad, la materia "Nuevos entornos y lenguajes: la producción de conocimiento en la cultura digital" se inscribe en el tramo inicial del plan de estudios de todas las carreras, por lo que su cursada y aprobación son de carácter obligatorio.

Desde 2020, y con una matrícula creciente la cursan alrededor de 3000 (tres mil) estudiantes por cuatrimestre. El equipo docente está formado por 20 (veinte) profesoras coordinadas por la autora del trabajo. El espacio curricular tiene dos propósitos centrales: el primero es la alfabetización digital en el contexto de la formación académica; el segundo consiste en promover la reflexión crítica acerca del impacto de las tecnologías digitales en la vida cotidiana, en la vida académica y en el desempeño profesional. Se toman en consideración las características de las carreras y los perfiles de los estudiantes en colaboración con los directores de los diferentes institutos en los que las carreras están insertas.

La propuesta de enseñanza trasciende el mero uso instrumental de la tecnología digital, para avanzar hacia el uso reflexivo, que promueve el análisis crítico a partir de la construcción de dimensiones teóricas en base a la bibliografía y a los materiales de referencia propuestos por la cátedra. Se busca la emancipación en torno a la producción con y de tecnologías; trabajando en propuestas concretas, situadas en contextos reales y trascendiendo las fronteras de la materia y la institución.

Estas líneas o ejes de trabajo derivan en tensiones cuya resolución complejiza el diseño de la enseñanza. Entre estas tensiones se destaca la diversidad en los conocimientos y formación previa de los y las estudiantes, no sólo ligada al acceso, a la utilización y al manejo de dispositivos sino también a las condiciones simbólicas y materiales para la incorporación y la continuidad en la vida universitaria. Asimismo, las particularidades de las diferentes carreras conllevan consideraciones particulares acerca del sentido de la inclusión tecnológica y los conocimientos específicos ligados a la formación académica y profesional. 
En este trabajo se comparten algunas ideas básicas y reflexiones desplegadas en la reconstrucción de la propuesta de enseñanza durante la pandemia valiéndonos de una metáfora que se describe a continuación.

\section{Descripción de la experiencia: De puertas y llaves para una materia rediseñada}

\section{La metáfora:}

El equipo docente está llegando a un palacio (el edificio de la UNAHUR). Al acercarse a la puerta, principal, está se cierra bruscamente. Las profesoras preocupadas, angustiadas y muy activas, toman la decisión de buscar entradas alternativas a esa puerta reconocida como principal. Identifican puertas laterales y ventanas que deciden abrir. Buscan y construyen entonces las herramientas y llaves necesarias para abrirlas y/o romperlas. Así entran a este "nuevo edificio".

\section{Puerta a la virtualización}

Llave: reconceptualizar la noción de clase. El tiempo y el espacio se vieron resignificados en la mediación tecnológica.

La necesidad de ofrecer la materia sin presencialidad física "empujó" al equipo docente a reconsiderar la modalidad a distancia como una alternativa potente, posible, viable y necesaria, para desplegar la propuesta de enseñanza.

Se priorizó el uso del aula virtual en la asincronía por sobre los encuentros sincrónicos obligatorios y sistemáticos, teniendo en cuenta las dificultades de conectividad de los y las estudiantes, así como el potencial del entorno virtual para construir variedad de mediaciones para abordar los contenidos de la materia. La sincronía fue ofrecida en clases en 3 (tres): al inicio, antes del primer examen parcial y durante el período de realización del segundo examen parcial.

Por un lado, aparecieron obstáculos: los contenidos propios de la materia, en torno a la alfabetización digital básica. Para algunos y algunas estudiantes fue difícil sostener la cursada, especialmente por falta de acceso material y/o simbólico a dispositivos digitales adecuados para el estudio; para contrarrestar se concretaron acciones como: en los períodos en que fue posible se ofrecieron computadoras en la Universidad, tutorías presenciales para acompañar a estos y estas estudiantes y becas de apuntes. En el otro extremo: numerosos estudiantes valoraron especialmente lo aprendido en la materia porque les fue de gran utilidad para transitar el resto de las materias en este contexto.

\section{Puerta a la capacitación del equipo docente}

Llave: La tarea como oportunidad de reflexión y capacitación. Aprovechar el potencial de cada profesora, distribución de tareas. Hacia una comunidad de práctica.

Traducir la propuesta de enseñanza prevista para la presencialidad supuso un enorme desafío. Hasta 2019, cada profesora integrante del equipo desarrollaba su plan 
de clases en la presencialidad, partiendo de un programa y un cronograma común. Pero en la virtualidad, el equipo en su conjunto aceptó el reto de rediseñar la enseñanza entre todas, aprovechando el potencial de cada compañera (con formaciones y experiencias diversas) y buscando optimizar los recursos y tiempos de cada una.

Se acordó trabajar en una propuesta común, colaborativa, buscando aprovechar las oportunidades que genera la asincronía. Podían compartirse materiales y recursos, las tareas docentes podían distribuirse de un modo alternativo que pudiera generar propuesta, objetos y dispositivos colectivos; aprovechando la asincronía, el entorno común.

El trabajo en colaboración, al modo de comunidad de práctica, posibilitó que el colectivo de docentes se capacitara individualmente y a la vez creciera en tanto equipo de trabajo. Unas asistían, asesoraban y complementaban los saberes, inquietudes y necesidades de las otras.

La capacitación individual y colectiva se refirió a cuestiones vinculadas a los contenidos de la materia (tanto los instrumentales como los conceptuales), sobre aspectos referidos a la inclusión tecnológica para la enseñanza y el aprendizaje, a la didáctica y a la modalidad a distancia.

\section{Puerta a la experimentación en la enseñanza}

Llave: Una narrativa integral y elementos lúdicos fueron la clave para desacralizar la cursada.

Se pensó en una propuesta disruptiva, que permitiera incorporar elementos lúdicos, con una narrativa potente que estimulara la cursada: un viaje, el propio PLE como escenario). La propuesta volvió a revisarse cada cuatrimestre en pandemia. Se definieron contenidos nodales, otros electivos y otros optativos. En cada caso ofreciendo actividades, propuestas, dispositivos y/u objetos digitales de participación obligatorios; optativos como la elección de diferentes niveles en talleres de contenidos instrumentales básicos de la materia y complementarios. De destacar el "Festientornos" -una "fiesta" de dispositivos y actividades de libre elección en las que se abordaron contenidos "de borde" de la materia que pudieran estimular y enriquecer la construcción de trayectorias de cursada alternativas.

\section{Puertas a repensar la enseñanza a largo plazo}

La llave: Transitar y prepararse para la incertidumbre como característica de época.

El equipo recurre en momentos críticos de estas cursadas a mirar en perspectiva, cómo era la materia y cómo será en la postpandemia. Cambios y continuidades atraviesan las reflexiones en torno al contexto como marco para entender la práctica. El aumento en la matrícula y las posibles dificultades para cursar presencialmente en aulas de la Universidad, resultan un indicador crucial de que algo cambió y ya no volverá a ser igual. Es y será necesario seguir pensando el escenario de enseñanza en modalidad híbrida, combinando la presencialidad con una virtualidad adecuada.

Aceptar que hay en este tiempo una marcada presencia de lo incierto, de lo provisorio en lo que vivimos. El equipo docente (así como los y las estudiantes) fue vivenciando a lo largo de este tiempo períodos complejos, difíciles, trágicos para varios de sus 
miembros. Participar en colaboración, permitió acompañar a cada una en lo personal y sostener la cursada para estudiantes que sentían la posibilidad de cursar como un espacio de resguardo.

\section{Puerta a más estudiantes}

Llave: cambiaron las condiciones de estudio y de trabajo; por lo tanto resulta imprescindible cambiar la modalidad de enseñanza.

La matrícula se multiplicó en la universidad y siendo ésta materia común y de primer año, también aumentó desmedidamente la inscripción a su cursada. Entendiendo que es una asignatura clave para acompañar y preparar la cursada de otras materias, especialmente en este contexto: se promovió su aprovechamiento.

El cupo en cada uno de los cursos y la relación entre docentes y estudiantes aumentó significativamente. Se pasó de 60 estudiantes por profesora (divididos en dos grupos) a un grupo de alrededor de 140. Esto implicó cambios sustantivos en la forma de encarar las clases.

\section{Puertas a sostener el compromiso político pedagógico}

Llave: compromiso político de seguir enseñando de manera situada y en contexto.

El sistema educativo en su conjunto a través de políticas de Estado debe estar presente en tiempos complejos y en la materia, en la UNAHUR el compromiso político y pedagógico de cada profesora se sostuvo desde el comienzo.

Fue necesario repensar la enseñanza, no esperar a que las condiciones se acomodaran a la propuesta previa para seguir enseñando.

Estar para quienes pueden y quieren continuar estudiando en este tiempo fue el propósito de la materia en correspondencia con los propósitos de la Universidad. Esperar y acompañar a quienes no pudieron sostener el estudio, pero se mantuvieron cerca desde otras posibilidades que la institución ofrece. Volver a buscar a quienes se fueron, es un desafío de la institución y de la materia.

\section{Resultados. De la íncertidumbre a la reconfiguración}

El cambio abrupto que supuso el aislamiento en 2020 y que continúa sumado a la firme convicción de seguir enseñando del equipo docente en una institución que desde el primer día eligió construir andamios de capacitación y espacios de colaboración de la comunidad UNAHUR; empujó a una propuesta de nuevo tipo. La nueva propuesta, totalmente virtualizada, con mediaciones tecnológicas en cada clase, pasó de desarrollarse en presencialidad en las aulas del edificio físico a desplegarse totalmente en modalidad a distancia; que pasó de involucrar a 1500 estudiantes por cuatrimestre a 3000 y que implicó el desafío de creación, atendiendo a las circunstancias, al contexto y a las necesidades de estudiantes y docentes. Consolidó un diseño totalmente diferente; signado por la incorporación de nuevas docentes, la necesidad de capacitación sobre aspectos vinculados a la enseñanza en la virtualidad y al potencial de diseñar la enseñanza en colaboración y como una oportunidad de cambio, de reflexión, de proyección hacia la Universidad hacia la que vamos. 
En 2020 el aula de la materia en el campus virtual UNAHUR se erigió como el único escenario de exposición, producción, encuentro e intercambio. Cada clase dejó de ser un encuentro fisico de dos horas en un día determinado con un apoyo en el entorno virtual para pasar a ser un encuentro extendido a lo largo de una semana, con propuestas de lecturas, presentación de recursos en distintos soportes, propuestas de actividades, interacciones, producciones en el aula virtual. La clase se reconvirtió, dejó de ser lo que era. Las coordenadas tiempo y espacio se vieron absolutamente alteradas en el desarrollo de la propuesta.

El cambio vertiginoso convocó al equipo de profesoras a rediseñar la propuesta de enseñanza y el entorno virtual aprovechando el potencial de la producción colectiva. La colaboración al modo de una comunidad de pares resultó ser crucial dada la necesidad de ajustar la propuesta a la nueva modalidad mientras servía de objeto y estímulo a la capacitación individual y colectiva del equipo docente.

Se aprovechó la oportunidad para revisar la propuesta y el programa de la materia de modo integral proyectando ajustes contextualizados. Diferentes dimensiones de la enseñanza fueron sometidos a discusión, proponiendo alternativas sustantivas al modo en que venían desarrollándose.

\section{Discusión y conclusiones}

La propuesta se está implementando y sigue en revisión permanente. Con reuniones semanales del equipo para ajustar la propuesta de manera integral y para cada uno de sus grupos de trabajo.

Entre los datos sobresalientes, podemos confirmar que el porcentaje de estudiantes que completó y aprobó la cursada en pandemia fue similar a lo que ocurría en la presencialidad. Algo que se valora especialmente.

En los cuatrimestres que se desarrolló la propuesta:

Quedó expuesto el potencial de la propuesta virtual, en tanto alternativa a los escenarios presenciales. La presencialidad mediada tecnológicamente con algunos encuentros sincrónicos optativos y sobre todo en entornos virtuales como soporte de construcción de escenarios educativos resultó evidente.

La propuesta de enseñanza se vio enriquecida por el aprovechamiento de tecnologías disponibles en un contexto en el que la virtualidad era la única posibilidad de sostener la cursada de los y las estudiantes.

Las limitaciones para algunos estudiantes resultaron ser un dilema. La oportunidad de seguir cursando para quienes podían hacerlo resultó oportuna.

La proyección de escenarios híbridos en los que la propuesta involucren el campus virtual, las clases sincrónicas y el encuentro físico desafían al equipo en cuanto a la construcción de propuestas ricas y variadas. Se prevé el diseño de trayectorias, mediaciones y propuestas diferenciadas. Variados formatos para cursar; por ejemplo presencialidad completa para quienes lo necesitan; bimodalidad y virtualidad plena para quienes lo elijan. 
La colaboración en el equipo docente fue clave en el proceso; no sólo por la producción construida; sino sobre todo por el valor de creación de una propuesta de nuevo tipo como recurso para la capacitación interna del conjunto de profesoras.

La fuerza de la creación y la potencia de animarse a probar algo nuevo y en red, resultó motor de desarrollo y valor de una propuesta potente que irá más allá de la pandemia.

\section{Referencias}

DÁngelo, G.; Trevor, P y Weber, V. (2019) Lo singular de lo heterogéneo. Tensiones pedagógicas en la alfabetización digital académica. II Encuentro Internacional de Educación. UNC. Tandil. 4, 5 y 6 de diciembre. Disponible en: https://indico.fch.unicen.edu.ar/event/2/contributions/84/

Maggio, M. (2018) Reinventar la clase en la Universidad. Buenos Aires: Paidós.

Mendonza, Pedroza y Wallach (2019) La UNAHUR en marcha. Memorias, proyectos y desafíos. Buenos Aires: Libros de UNAHUR.

El equipo docente de la materia está conformado por las siguientes profesoras:

APARICIO DANA; AÑINO, CAROLINA; CANNIZZO, MARCELA; CARIGLINO PATRICIA ; D ANGELO MARIA GABRIELA; FERRERO CAROLINA; FURRER KAREN ABIGAIL;ITURRIA TERESA ANA LAURA; MAROTIAS LAURA; MARTINEZ PREDIGER CLARISA; MATHEUS NORMA LERIDA; OLANO LEDA; NOEMI; RATTO JULIETA; RODRIGUEZ DIANA; ROMANO AGUSTINA; ROMERO FLORENCIA ANDREA; PICALLO LAURA GRACIELA; TREVOR, PATRICIA; TURREZ VERONICA y VERÓNICA WEBER 


\section{Transformación Educativa: Cualificación Docente desde las Tecnologías Emergentes}

\section{Zamudio, Leidi}

orcid.org/0000-0002-5966-8270.

Corporación Universitaria Iberoamericana leidi.zamudio@ibero.edu.co

\section{Rubiano, Mary Luz}

orcid.org/0000-0002-0848-6653.

Corporación Universitaria Iberoamericana. mary.rubiano@ibero.edu.co

\section{Avendaño, Henry}

orcid.org/0000-0002-8378-4917.

Corporación Universitaria Iberoamericana.

henry.avendano@ibero.edu.co

\section{Torres, Cristóbal}

orcid.org/0000-0003-2893-8044.

Universidad Internacional de Valencia.

cristobal.torres@campusviu.es 


\title{
TRANSFORMACIÓN EDUCATIVA: CUALIFICACIÓN DOCENTE DESDE LAS TECNOLOGIAS EMERGENTES
}

\author{
Zamudio, Leidi \\ Rubiano, Mary Luz \\ Avendaño, Henry \\ Torres, Cristóbal
}

\section{Resumen}

En este artículo se presentan los resultados preliminares de un estudio que tiene una doble perspectiva: innovación e investigación. Por una parte, la investigación estaba enfocada en la cualificación de docentes de Educación Superior de la Facultad de Educación de la Universidad Internacional de Valencia (España) y de la Corporación Universitaria Iberoamericana (Colombia). Por otra parte, la innovación se centró en el diseño de un curso de cualificación docente en ambiente virtual para la inclusión en Educación Superior. En el curso se involucraron elementos de realidad virtual y aumentada con el fin de promover una educación inclusiva desde el reconocimiento de la diversidad. En la parte investigativa, se utilizó una metodología cuantitativa, descriptiva en su modalidad de encuesta en el momento inicial de caracterización de los sujetos del estudio, administrándose como instrumento de recogida de datos el "Cuestionario sobre necesidades e intereses de cualificación docente para la inclusión desde la realidad aumentada". En la parte innovadora, se utilizó una combinación metodológica de enfoque ADDIE y gamificación. Los resultados preliminares reflejaron que un $89.31 \%$ de los sujetos pensaba que la tecnología promueve la inclusión social y educativa dentro de un proceso de formación y un 95.3\% expresó que la tecnología facilita la inclusión social y educativa dentro de un proceso de formación.

\section{Palabras clave}

Transformación educativa, tecnologías emergentes, Realidad Virtual (RV), Realidad aumentada (RA). 


\section{Introducción}

Las instituciones de Educación Superior en su labor misional acorde a las recomendaciones de la Comisión Económica para América Latina y el Caribe (CEPAL) mediante los Objetivos para el Desarrollo Sostenible (ODS), específicamente el número cuatro (4), invitan a promover la educación de calidad, entendida bajo los pilares de accesibilidad, cobertura y pertinencia en los contenidos bajo la premisa de "educación para todos"; por tanto, entendiendo la heterogeneidad cultural de los seres humanos, se requiere cualificar a los docentes en estrategias y herramientas pedagógicas mediadas por tecnologías digitales, que les permitan comprender, apropiar conceptos y empoderarse en estrategias y herramientas de la era digital, con el fin de proponer objetivos de aprendizaje dentro de los entornos escolares diversos en un marco de inclusión y respeto por la diversidad, donde la flexibilidad en tiempo, espacio y rutas de aprendizaje promuevan en el aprendizaje.

En este sentido, la UNESCO en el 2021 manifiesta que la educación e-Learning aumentó en un $85 \%$ para el 2021; esto significa que las instituciones educativas deben preparar una estrategia de cualificación docente que permita responder a las brechas de acceso a la información y a la educación por medio de la modalidad híbrida o blended. La brecha digital está dada por el escaso acceso a la tecnología, la falta de cualificación de los docentes para el manejo de las herramientas y tecnologías emergentes, la conectividad de docentes y estudiantes. Por consiguiente, García et al., (2020) señala tres tipos de brecha:

Figura 1. Brechas de acceso a la tecnología

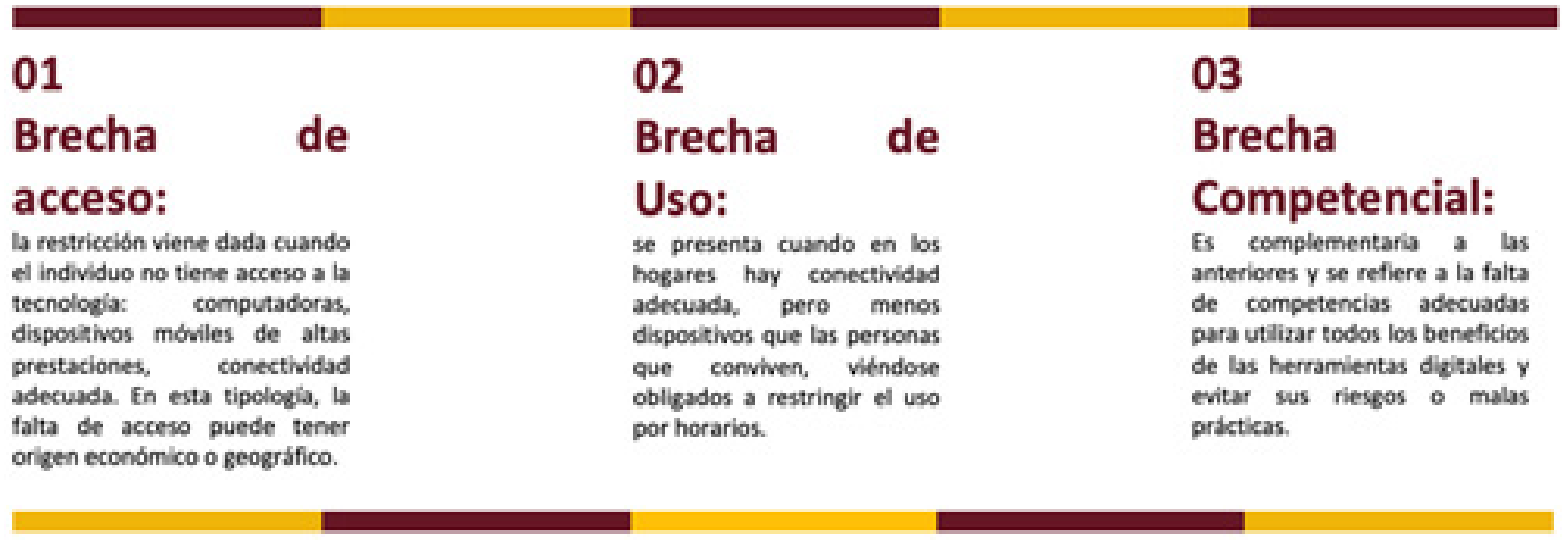

\section{Fuente: García, Correl, Abella y Grande (2020).}

Estas brechas permean las prácticas dentro del proceso de enseñanza aprendizaje y referente a este tema en el Informe Horizon 2017, se resalta que la competencia digital no es entender cómo usar las tecnologías, sino que es preponderante comprender la importancia y el impacto de las tecnologías en la educación "mundo digital", por tanto, se debe promover y cualificar a los docentes para responder a estos nuevos retos.

En este sentido, Espinosa et al. (2018) proponen un modelo que se sustenta en cinco dimensiones (técnica, informacional/comunicativa, educativa, analítica y socio-ética), así como en tres ámbitos de aplicación (docencia, investigación y gestión retomando a Prendes (2017). los ámbitos que se consideraron en la estructuración del 
curso y que pretenden ubicar al docente desde una perspectiva crítica y reflexiva se su accionar pedagógico.

De igual forma, las competencias del docente en la era digital desde el informe de la red Eurydice (2011) y el Ministerio de Educación Nacional $(2013,2016)$ encuentran "que la importancia de la innovación en las instituciones de enseñanza y, de forma más específica, las innovaciones orientadas a la mejora de la enseñanza y el aprendizaje mediante la utilización de nuevas tecnología" (Espinosa et al., 2018. p.3) se da desde el docente y sus prácticas diarias por lo tanto al encontrar el interés de los docentes de las dos instituciones se ratifica la importancia de curso "Ambientes educativos incluyentes desde la realidad virtual y aumentada" cuyo objetivo principal es que los docentes comprendan la inclusión como elemento para la transformación social y educativa, desde la implementación de ambientes virtuales en entornos de realidad aumentada y virtual.

Por consiguiente, se plantea un estudio en el que su objetivo general es "diseñar un curso de cualificación docente en ambientes virtuales para la inclusión en Educación Superior desde el Marco de la Diversidad”.

Asimismo, los objetivos específicos son los siguientes:

- Identificar los antecedentes y referentes locales, nacionales e internacionales sobre cualificación docente en entornos virtuales que promuevan inclusión educativa desde el Marco de la Diversidad.

- Determinar la estructura del curso de cualificación docente en la apropiación de la realidad virtual y aumentada como herramientas de generación de ambientes virtuales.

- Formular un producto digital que involucre la realidad virtual y aumentada que propendan por la cualificación docente en inclusión educativa.

\section{Método/Descripción de la experiencia}

El proyecto de innovación se centró en aprovechar las herramientas digitales emergentes como lo son la realidad virtual y aumentada para generar propuestas educativas con recursos que promuevan el interés por el aprender, el conocer, el indagar y el apropiar conocimiento. Para lograr esto, se propuso el fortalecimiento de las competencias digitales del docente mediante cursos de cualificación permitiendo el reconocimiento, uso y apropiación de los recursos digitales emergentes de manera que como experto temático el docente este en la posibilidad de formular propuestas innovadoras desde su área disciplinar reconociendo la diversidad y heterogeneidad de contextos donde se encuentra inmerso el sujeto de aprendizaje.

En la perspectiva de innovación se utilizó un enfoque que combinó la gamificación con el enfoque de Diseño Instruccional ADDIE, que obedece a Análisis, Diseño, Desarrollo, Implementación y Evaluación. Pese a que no se ha atribuido autoría alguna a esta metodología, (Morales-González et al., 2014) refiere que fue Russel Watson en 1981 quien la propuso, el modelo condensa la teoría del conocimiento humano adaptado a fases de aprendizaje que se convierten en prerrequisitos de fases de 
avance posteriores, inculcando así la autonomía y eficacia en las acciones que los estudiantes emprenden en el entorno virtual de aprendizaje.

En la perspectiva de investigación se utilizó un enfoque metodológico cuantitativo, descriptivo y en su modalidad de encuesta que permitió registrar las percepciones de los sujetos del estudio.

El proyecto, por consiguiente, establece las siguientes fases o momentos:

- Momento 1: determinar los elementos, estructura, alcances y recursos que se pueden lograr con las tecnologías emergentes (RV - RA) y relacionarlos con elementos propios dentro de un ámbito formativo que potencie el aprendizaje de una disciplina o área de conocimiento.

- Momento 2: Formular estrategias de aprendizaje mediadas por la Realidad virtual y aumentada

- Momento 3: Identificar la estructura temática que permita cualificación y empoderamiento del sujeto docente sobre la potencialidad de la realidad virtual y aumentada que pueda ser aprovechada para el logro de objetivos de aprendizaje.

- Momento 4: FASE 2- 2022 Generar un prototipo de cualificación docente que le permita formular propuestas pedagógicas desde ambientes digitales que utilicen la realidad virtual y aumentada en la generación de entornos y disposición de recursos para el aprendizaje.

Para determinar la necesidad de cualificación del curso se administró el "Cuestionario sobre necesidades e intereses de cualificación docente para la inclusión desde la realidad aumentada" (véase Anexo 1), que permitió identificar el interés por la temática sobre la articulación de tecnologías emergentes en los procesos educativos, lo que posteriormente conllevo a estructurar el curso, para ello se implementó un sondeo de opinión, a través de encuestas, que permite establecer una caracterización que permite ampliar el análisis y la discusión respecto a la educación superior inclusiva en un marco de atención a la diversidad.

Dicha caracterización se estructuraba conforme a los tres grandes bloques de preguntas que dirigieron la opinión de los encuestados, siendo estos bloques:

- Bloque 1. Datos generales.

- Bloque 2. Datos identificativos.

- Bloque 3. Necesidades e intereses de los sujetos.

Si bien el cuestionario fue diseñado bajo el modelo de opción múltiple con única respuesta, en el bloque III se permitió un espacio para la justificación de dicha respuesta, logrando así identificar algunos elementos complementarios que a través de las encuestas pudiese representar alguna limitación. 


\section{Resultados}

Dando cumplimiento a los objetivos planteados, en la muestra se recolectó información correspondiente a 64 participantes (esta cantidad corresponde al 100\% de los consultados), atendiendo, en porcentajes iguales, un 50\% por cada una de las instituciones consultadas, siendo estas: la Corporación Universitaria Iberoamericana y la Universidad Internacional de Valencia.

El 79.7\% de la muestra corresponde a participantes de Modalidad Distancia Virtual; el $12.5 \%$ a modalidad Presencial; y $7.8 \%$ a Modalidad Distancia Tradicional. El $45.4 \%$ de los encuestados corresponde a dos programas académicos en pedagogía de la Universidad Internacional de Valencia; el $44.4 \%$ hacen parte de los diferentes programas en licenciatura (educación básica primaria, educación especial, humanidades, educación informática) que oferta la Corporación Universitaria Iberoamericana; y el restante $10.2 \%$ corresponden al programa de Ingeniería de Software (modalidad virtual) también de la universidad iberoamericana.

La edad de la población encuestada, en un $98.4 \%$ se encuentra en un rango superior a los 30 años discriminados de la siguiente manera de mayor a menor porcentaje: 40.6\% con una edad entre 31 a 40 años; 35.9\% con edad entre 41 a 50 años; y finalmente $21.9 \%$ con edades entre 51 a 60 años. De esta muestra, más del 50\% de los participantes son de nacionalidad colombiana, un $1.6 \%$ de nacionalidad española, y un $3,2 \%$ de nacionalidad chilena y dominicana. El $54.7 \%$ tienen estudios de maestrías y el $42.2 \%$ han obtenido título de doctorado. Tal como se evidencia, existe un elevado grado formativo, que coincide con el gran porcentaje de población joven con estos niveles de formación posgraduales lo que representa un criterio muy visionario y profesional destacado para el desarrollo de la propuesta y que reconoce algunas necesidades y emergencias para la educación inclusiva. A esto se le suma la acumulada experiencia como docente universitario la cual representa un total del $50 \%$ de profesionales que han ejercido en educación superior por más de 10 años, y un porcentaje del $29.7 \%$ cuya experiencia se refleja entre 5 a 10 años.

Entre la población encuestada, el 98.4\% manifestó no presentar algún tipo de discapacidad, entre el porcentaje que expresa alguna discapacidad no mencionan a cuál corresponde.

El último bloque de preguntas atendió a recoger los intereses formativos que puedan contribuir en el desarrollo de programas académicos dirigidos a una educación superior inclusiva. Para este caso, se cuenta con los datos arrojados a través de las encuestas, así como precisiones o justificaciones de algunas preguntas que permiten ampliar la opinión de los participantes.

Se consultó sobre la preferencia a ciertas temáticas asociadas la inclusión, donde los intereses se inclinaron, con una tendencia de mayor a menor importancia de la siguiente manera: Tecnología como herramienta de inclusión que apoya la práctica pedagógicas (40\% de interés); Tecnología como mediación a la inclusión en entornos virtuales (37\%) de interés; Inclusión en contextos virtuales (34\% de interés); y finalmente, la temática con menor grado de interés correspondió a Inclusión en contextos presenciales ( $27 \%$ de interés). Dichos resultados denotan la importancia en el aprovechamiento de los recursos tecnológicos como herramientas para la formación inclusiva. La tecnología al servicio de la inclusión en educación superior. 
Dicho interés por el uso de las tecnologías para la educación inclusiva coincide con los resultados a las preguntas ¿Piensa usted que la tecnología promueve la inclusión social y educativa dentro de un proceso de formación? y ¿Piensa usted que la tecnología facilita la inclusión social y educativa dentro de un proceso de formación? donde un $89.1 \%$ y un $95.3 \%$ contestó que sí (respectivamente a cada pregunta), frente al $10.9 \%$ y $4.7 \%$ que no lo considera de esta manera.

Cuando se consultó si la tecnología garantizaba accesibilidad y adaptabilidad dentro de un proceso formativo (pregunta 4 y 5 del bloque III), las opiniones estuvieron más enfrentadas, puesto que para el caso de la accesibilidad solo el $62 \%$ la vio posible, y frente a la adaptabilidad alcanzó un 73\%. Aquí cobra relevancia las tendencias de quienes no la consideran tan efectiva puesto que argumentan: de un lado, en razón a la accesibilidad, no todos tienen acceso a la educación a través del uso de las tecnologías; no se ha fortalecido un diseño universal de accesibilidad; debe alcanzarse un mayor índice de uso de dichas herramientas por parte de los docentes; se puede mostrar como facilitadora pero no garantizable (sic); debe evidenciarse mayor voluntad para que sea posible dicha accesibilidad; de otro lado, sobre la adaptabilidad, mencionan que puede existir una flexibilización que no necesariamente denote adaptación; la cantidad de experiencias que ofrece la tecnología implica una permanente y rigurosa actualización que no siempre se realiza; las flexibilizaciones tecnológicas deben atender los diferentes escenarios de exclusión que no siempre son atendidos detalladamente.

En ese orden, dicha información permitió conocer la relación de los docentes de las universidades Corporación Universitaria Iberoamericana y la Universidad Internacional de Valencia frente al manejo e importancia que tiene, o puede tener, la tecnología en los procesos de inclusión educativa. El grado de profesionalismo, basado en sus estudios y experiencia, permite establecer propuestas, mediadas tecnológicamente, que posibiliten el acceso y permanencia a la educación superior de calidad para personas con algún tipo de discapacidad, contribuyendo así en el desarrollo social de distintos contextos.

Bajo esa información se realizó la estructuración del curso bajo el modelo de competencias (véase Tabla 1). 
Tabla 1. Estructura del curso

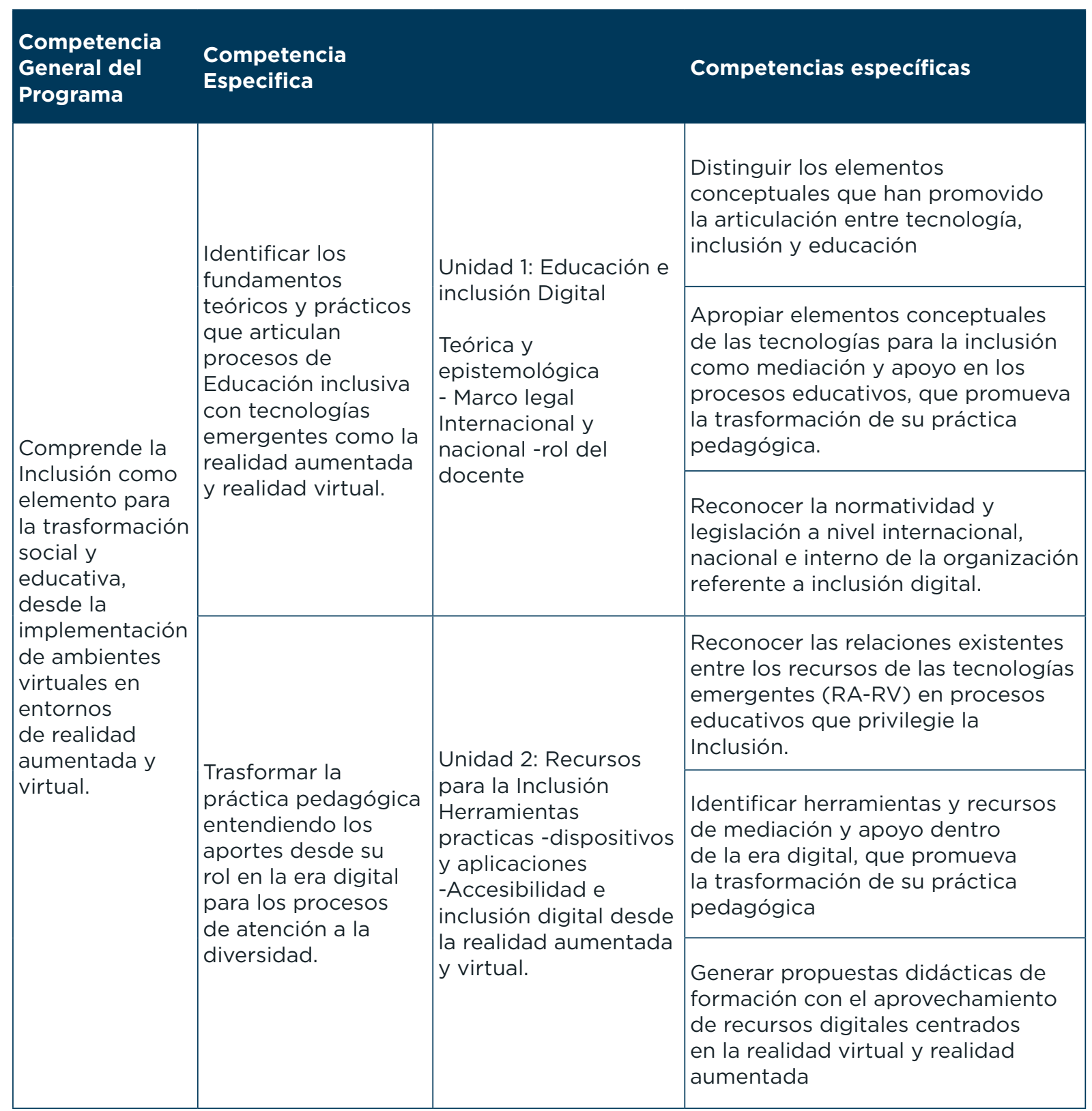

Fuente: elaboración propia.

\section{Discusión y conclusiones}

De la Horra (2017, p. 11) afirma que "las nuevas generaciones, a la que algunos estudiosos del tema llaman "nativos digitales" (Prensky, 2001), viven actualmente rodeadas y en numerosas ocasiones, desbordadas, por la tecnología. Una tecnología cuyo uso está en la punta del iceberg, pero que posee un gran potencial". En este caso, es preciso destacar la idea de que "la realidad aumentada permite un aprendizaje activo, vinculado a la realidad de los contenidos independientemente del nivel educativo en el que nos ubiquemos" (Marín, 2017, p. 1). 
En relación con el estudio presentado, dentro del proceso investigativo se permitió reafirmar la heterogeneidad de contextos, culturales, políticos, sociales que han de ser conocidos, comprendidos y respetados por las instituciones de educación superior. Por tanto, se ratificó el interés en promover la generación de capital humano mediante procesos de cualificación profesional que redunde en su comunidad y contexto.

Se evidencio que los intereses de los encuestados (docentes) frente a la usabilidad y disponibilidad de la tecnología para el beneficio de la inclusión social y educativa plantea, con porcentajes superiores al $80 \%$, un escenario esperanzador basado en el carácter de intermediación, funcionalidad, diverso, multimodal que representa la tecnología. Para los encuestados, la tecnología debe posibilitar cambios importantes para alcanzar una equidad en los aspectos sociales, pero ello implica, a su vez, un amplio desafío tanto de quienes administran y usan los recursos, así como del mismo progreso tecnológico. La tecnología debe atender a satisfacer muchas necesidades, máxime de inclusión, pero debe disponerse de recursos, programas y políticas que faciliten ese aprovechamiento de la tecnología misma.

Entre las razones mencionadas por los participantes se considera positivamente el uso de la tecnología como promotora de inclusión social y educativa, pues se debe a su flexibilidad para hacer posible su acceso; permite la democratización del conocimiento; posibilita un desarrollo integral; genera experiencias que no serían posibles en la presencialidad; las posibilidades de adaptación y adecuación pedagógicas y didácticas a través de los currículos; el carácter multimodal para su implementación; permite ajustarla a las necesidades y ritmos de aprendizaje, entre otras que amplían las razones para su importancia.

En este sentido, suscribimos, por consiguiente, el argumento de Álvarez et al. (2016, p. 209) que plantea que "gracias a la realidad aumentada se puede realizar un seguimiento de las partes del cuerpo, con imágenes, referencias, añadir contenidos multimedia interactivos para hacer la transferencia de conocimientos de una manera más potente".

Respecto a los motivos que no consideran que la tecnología promueve o facilita la inclusión, estos obedecen al desconocimiento de herramientas tecnológicas o falta de referentes que demuestren su viabilidad, no se manifiesta alguna desconfianza hacia los recursos técnicos sino a la ausencia de estos. Igualmente, expresan los encuestados que dichas tecnologías que puedan contribuir en una educación inclusiva aún no han logrado un impacto en la educación presencial y la oportunidad para un buen efecto de manera a distancia o virtual implica inversión que no se ha hecho posible.

Por tanto, las TIC se perfilan como "instrumentos idóneos para dar respuesta a las necesidades educativas para las personas con barreras de aprendizaje, en nuestro artículo en concreto nos hemos centrado en las herramientas educativas para trabajar la discapacidad intelectual, motora, auditiva y visual" (Rodríguez y Arroyo, 2014, p. 125), así como también "permiten la promoción y el desarrollo de alfabetizaciones múltiples y, en definitiva, de aprendizajes constructivos" (Rodríguez y Arroyo, 2014, p. 125).

En conclusión y como afirman (Sevillano y Rodríguez, 2013), las TIC potencian el desarrollo pleno de ciertas claves y puntos que ubican al estudiante como el coprotagonista de su propio proceso de enseñanza-aprendizaje, a la vez que se aumenta la motivación y se despierta un interés y una curiosidad por identificar, comprender 
y aprender, todo ello mediante la inmediata transmisión y recepción de información, pero siempre desde una perspectiva flexible en la que se consideran el ritmo y el tiempo de aprendizaje de cada sujeto.

\section{Referencias}

Álvarez Morales, E., Bellezza, A. y Caggiano, V. (2016). Realidad aumentada: Innovación en educación. Didasc@lia: Didáctica y Educación, 7(1), 195-212.

De la Horra Villacé, I. (2017). Realidad aumentada, una revolución educativa. EDMETIC, 6(1) 9-22.

Espinosa, P., Porlán, G., y Sánchez, M. (2018). Competencia digital: una necesidad del profesorado universitario en el siglo XXI. Revista de Educación a Distancia (RED), (56), 1-22.

García-Peñalvo, F.J., Correl, A., Abella-García, V. y Grande, M. (2020). La evaluación online en la educación superior en tiempos de la COVID-19. Education in the Knowledge Society (EKS), 21, 26.

Marín Díaz, V. (2017). La emergencia de la Realidad Aumentada en la educación. EDMETIC, 6(1), 1-3.

Ministerio de Educación Nacional de Colombia (20 de abril de 2019). Índice de inclusión para educación superior INES. Recuperado de https://www.mineducacion.gov. co/1759/w3-article-357277.html?_noredirect=1

Ministerio de Educación Nacional. (2013). Competencias TIC para el desarrollo profesional Docente. Recuperado de https://www.mineducacion.gov.co/1759/articles-339097_archivo_pdf_competencias_tic.pdf

Ministerio de Educación Nacional. (2016). Compendio Estadístico de la Educación Superior colombiana. Imprenta Nacional de Colombia.

Morales-González, B., Edel-Navarro, R. y Aguirre-Aguilar, G. (2014). Modelo ADDIE (análisis, diseño, desarrollo, implementación y evaluación): su aplicación en ambientes educativos. En Ismael E. Gámez (coord.). Los modelos tecno-educativos, revolucionando el aprendizaje del siglo XXI (pp. 33-46). México: Universidad Veracruzana-Región Veracruz.

Pelletier, K., Brown, M. Brooks, C., McCormack, M., Reeves, J. \& Arbino, N. with Bozkurt, A., Crawford, S., Czerniewicz, L., Gibson, R., Linder, K., Mason, J. y Mondelli, V. (2021). EDUCAUSE Horizon Report ${ }^{\circledR}$ Teaching and Learning Edition (2021) Recuperado de https://library.educause.edu/-/media/files/library/2021/4/2021hrteachinglearning. pdf?la=en\&hash=C9DEC12398593F297CC634409DFF4B8C5A60B36E

Prendes Espinosa, M.P. (2017). La competencia digital: nuevos actores en los nuevos espacios de formación. Una mirada desde la Tecnología Educativa. [Proyecto de Cátedra (inédito). Universidad de Murcia]. 
Prensky, M. (2001). Enseñar a nativos digitales. SM.

Rodríguez Correa, M. y Arroyo González, M.J. (2014). Las TIC al servicio de la inclusión educativa. Digital Education Review, (25), 108-126.

Sevillano, M. y Rodríguez, R. (2013). Integración de tecnologías de la información y comunicación en educación infantil en Navarra. Píxel-Bit. Revista de Medios y Educación, (42), pp. 75-87

UNESCO (1990). Declaración Mundial sobre educación para todos "Satisfacción de las necesidades básicas de aprendizaje”. Recuperado de https://www.oei.es/historico/efa2000jomtien.htm

UNESCO (2020). COVID-19 y educación superior. De los efectos inmediatos al día después. Análisis de impacto, respuestas políticas y recomendaciones. Recuperado de https://www.iesalc.unesco.org/wp-content/uploads/2020/O4/COVID-19070420-ES-2-1.pdf

\section{Anexos}

\section{ANEXO I. CUESTIONARIO SOBRE NECESIDADES E INTE- RESES DE CUALIFICACION DOCENTE PARA LA INCLUSIÓN DESDE LA REALIDAD AUMENTADA}

Agradecemos que responda a este breve cuestionario y contribuya con sus opiniones a este estudio.

\section{DATOS GENERALES}

\section{Marque según corresponda a su opción de respuesta}

1. Institución a la cual pertenece

Corporación Universitaria Iberoamericana / Universidad Internacional de Valencia

2. Modalidad académica a la que pertenece

Modalidad Presencial / Modalidad Distancia tradicional / Modalidad Distancia virtual

3. Programa Académico al que pertenece

\section{Corporación Universitaria Iberoamericana}

IBERO. Ingeniería de Software - Virtual

IBERO. Licenciatura en Educación Básica Primaria - Distancia

IBERO. Licenciatura en Educación Especial - Distancia

IBERO. Licenciatura en Educación Infantil - Distancia

IBERO. Licenciatura en Humanidades y Lengua Castellana - Distancia

IBERO. Licenciatura en Educación Especial - Presencial

IBERO. Licenciatura en Educación Infantil - Presencial 


\section{Universidad Internacional de Valencia}

VIU. Grado en Educación Infantil.

VIU. Grado en Educación Primaria.

\section{DATOS IDENTIFICATIVOS}

1. Edad:

21-30 años 31-40 años 41-50 años 51-60 años Más de 60 años

2. Correo electrónico:

3. Nacionalidad:

4. Nivel de escolaridad:

- Pregrado / Estudios de Grado / Estudios de Licenciatura

- Posgrado/Maestría / Máster Oficial

- Doctorado

5. Años de experiencia como docente en educación superior Menos de 5 años De 5-10 años Más de 10 años

6. ¿Presenta usted alguna discapacidad?

Sí / No

6a. Indique qué discapacidad presenta.

\section{NECESIDADES E INTERESES DE LOS SUJETOS}

1. ¿En qué grado le interesan las siguientes temáticas? Responda según la siguiente escala de 1 a 5 , donde 1 representa menor interés y 5 de mayor interés.

La inclusión en contextos virtuales

La inclusión en contextos presenciales.

La tecnología como herramienta de inclusión que apoya la práctica pedagógica.

La tecnología como mediación a la inclusión en entornos virtuales.

2. ¿Piensa usted que la tecnología promueve la inclusión social y educativa dentro de un proceso de formación?

Sí / No

2a. ¿'Por qué?

3. ¿Piensa usted que la tecnología facilita la inclusión social y educativa dentro de un proceso de formación?

Sí / No

3a. ¿Por qué? 
4. ¿Piensa usted que la tecnología garantiza la accesibilidad en la inclusión social y educativa dentro de un proceso de formación?

Sí / No

4a. ¿’Por qué?

5. ¿Piensa usted que la tecnología garantiza la adaptabilidad para la inclusión social y educativa dentro de un proceso de formación?

Sí / No

5a. ¿'Por qué?

6. ¿Piensa usted que la tecnología permite la usabilidad favoreciendo la inclusión social y educativa dentro de un proceso de formación?

Sí / No

6a. ¿Por qué?

7. ¿Piensa usted que la tecnología genera la disponibilidad de recursos en beneficio de la inclusión social y educativa dentro de un proceso de formación?

Sí / No

7a. ¿Por qué?

8. ¿Tiene usted conocimiento sobre qué es la Realidad Virtual?

Sí / No

9. ¿Tiene usted conocimiento sobre qué es la Realidad Aumentada?

Sí / No

10. ¿Conoce las posibilidades de interacción que ofrece la Realidad Aumentada para la formación?

Sí / No

10a. ¿Cuáles conoce?

11. ¿Conoce las limitaciones que presenta la Realidad Aumentada para la formación? Sí / No

11a. ¿Cuáles conoce?

12. ¿Estaría usted interesado en realizar un curso de cualificación docente para la inclusión por medio de la Realidad Aumentada?

Sí / No

12a. ¿Por qué? 


\section{La Aplicación de Recursos Tecnológicos Digitales para Mejorar el Nivel de Comprensión Lectora en Lengua Catalana. Un Estudio de Caso.}

\section{Buendia Barberà, Marina}

orcid.org/0000-0003-4313-0756

mbuendia2@gmail.com 


\section{LA APLICACIÓN DE RECURSOS TECNOLÓGICOS DIGITALES PARA MEJORAR EL NIVEL DE COMPRENSIÓN LECTORA EN LENGUA CATALANA. UN ESTUDIO DE CASO.}

\section{Buendia Barberà, Marina}

orcid.org/0000-0003-4313-0756

mbuendia2@gmail.com

\section{Resumen}

Esta investigación se ha llevado a cabo en la escuela de educación primaria La Floresta (Tarragona), donde se ha estudiado la relación entre la aplicación de recursos tecnológicos digitales y la mejora del nivel de comprensión lectora en lengua catalana de los estudiantes. Se han utilizado los documentos la Evaluación de la Comprensión Lectora (ACL) y el Estudio Internacional de Progreso en Comprensión Lectora (PIRLS) como pruebas pre-test y post-test. Los principales resultados demuestran la mejora del nivel de comprensión lectora del grupo, llegando a la normalidad e, individualmente, aumentando uno, dos y hasta tres grados, en cuatro meses. Además, en el test PIRLS, la media grupal superó la internacional y la española en tres de los cuatro textos y, en el cuarto se quedó a sólo 4 puntos. Finalmente, podemos concluir que el uso de recursos tecnológicos digitales pueden contribuir a aumentar el nivel de comprensión lectora en lengua catalana a corto plazo.

\section{Palabras clave}

Tecnologías del Aprendizaje y el Conocimiento, Comprensión Lectora, Lengua Catalana, Educación Primaria, Evaluación de la Comprensión Lectora, Estudio Internacional de Progreso en Comprensión Lectora (PIRLS). 


\section{Introducción}

Esta investigación la hemos implementado en la escuela La Floresta, fundada en el año 1975 (Tarragona, Cataluña, España), la cual se localiza en la zona norte de la ciudad de Tarragona. Forman el barrio 2000 habitantes. Es un centro considerado de máxima complejidad por estar ubicado en un entorno social y económico desfavorecido (Resolución EDU/1051/2020, de 15 de mayo de 2020, p. 11). Esta compuesta por 160 estudiantes, de los cuales un 32\% pertenece a familias magrebíes, un 10\% son familias originarias de Sud-América, un $1 \%$ familias de Rumanía y un 57\% son familias españolas. La mayoría del alumnado es castellanohablante (65\%) y un $2 \%$ es catalanoparlante. La mayoría del $43 \%$ restante tiene como lengua materna el árabe, entre otros idiomas como el inglés, el rumano o el ruso. La competencia lectora es la habilidad para comprender y utilizar aquellas formas lingüísticas requeridas por la sociedad y/o valoradas por el individuo. Los jóvenes lectores son capaces de construir significados y de crear conocimiento a partir de textos que se encuentran en una amplia variedad de formas. Leen para aprender, para participar en las comunidades de lectores del ámbito escolar y de la vida cuotidiana, y para su disfrute personal. (PIRLS, 2016, p. 11) Uno de los pilares es la comprensión, la cual es clave para adquirir cualquier aprendizaje. Es por ello que "la sociedad demanda al sistema escolar alumnos preparados, capaces de desarrollarse con autonomía en los diferentes campos sociales; y reconoce la lectura como uno de los ejes que atraviesa las otras disciplinas. Por lo tanto, ser un buen lector otorga al sujeto mayores ventajas en el plano personal, formativo y profesional respecto a otros que no dominan este campo" (Cabero et al., 2018, p. 145). Tener suficiente conocimiento de la lengua en la cual está escrito un texto es básico para poder comprenderlo. Si la lengua materna o familiar del alumnado difiere de las lenguas oficiales españolas, este se enfrenta con una barrera de acceso al conocimiento. En Cataluña convive alumnado procedente de más de 170 estados, el cual necesita ayuda para acceder a la lengua catalana y, así, acceder al mundo académico y social que lo rodea. Las Tecnologías del Aprendizaje y el Conocimiento (TAC) ofrecen ricas oportunidades para desarrollar las habilidades digitales del alumnado y dar soporte a su aprendizaje. "Su implementación en el ámbito escolar, potencializa nuevas estrategias de enseñanza" (Toro y Monroy, 2017, p. 144) "al promover que cada uno pueda trabajar a su propio ritmo, se lleva a cabo un verdadero proceso individual de enseñanza" (Cabero et al., 2018, p. 156), "promoviendo la creatividad y la equidad de acceso a la educación" (Droguett y Aravena, 2018, p. 130).

Los objetivos que se exponen se han llevado a cabo para validar la siguiente hipótesis: La utilización de recursos tecnológicos digitales educativos en las sesiones de clase de lengua catalana de cuarto curso de educación primaria, mejora los resultados de las pruebas ACL y PIRLS sobre el nivel de comprensión lectora del alumnado, con y sin dificultades.

1.- Realizar un estudio del estado de arte sobre: la comprensión lectora y la tecnología educativa (Tecnologías de la Información y la Comunicación - Tecnologías del Aprendizaje y el Conocimiento, TIC-TAC) y la relación que hay entre ellos.

2.. Trabajar la comprensión lectora enriqueciendo las lecturas impresas de los libros de texto de lengua catalana con hiperenlaces que den explicación a palabras, frases, situaciones a partir de imágenes, definiciones o dibujos y llevar a cabo actividades de enseñanza-aprendizaje a través de las TAC. 
3. Evaluar y comparar los resultados de las evaluaciones estándares ACL y PIRLS usadas como pre-test y post-test del grupo estudio y extraer conclusiones sobre la posible mejora del nivel de comprensión lectora individual, grupal y de las diferentes tipologías (literal, inferencial, reorganizativa y crítica).

Es en el paradigma interpretativo donde se enmarca esta investigación, el cual tiene como última finalidad, la de "comprender e interpretar la realidad educativa, los significados de las personas, percepciones, intenciones y acciones" (Bisquerra et al., 2004, p. 72). Existe una interrelación directa por parte de la investigadora y los sujetos investigados ya que es la propia tutora del grupo estudio. La investigación se ha focalizado como un estudio de caso, ya que se centra en un grupo exclusivo y particular. Se ha tenido como objetivo comprender una realidad concreta mediante una metodología cualitativa, y la investigadora ha sido el principal instrumento de obtención de la información.

La literatura encontrada sobre investigaciones orientadas al uso de las TIC-TAC para trabajar el nivel de comprensión lectora, des del año 2010 hasta la actualidad, es escasa. Aún así, es suficiente para corroborar que trabajar la comprensión lectora a través de las TIC-TAC mejora el nivel de esta competencia.

Uno de los objetivos específicos de la presente investigación fue digitalizar las lecturas impresas del libro de texto y enriquecerlas con hiperenlaces que ayudase al alumnado a su comprensión y conexión con sus conocimientos previos, coincidiendo con el estudio de Sánchez et al. (2018), el cual tenía como finalidad conocer las valoraciones de los usuarios sobre un conjunto de lecturas digitales diseñadas con UDL Book-Builder. La mayoría del alumnado prefería estas lecturas digitales frente a los mismos textos en formato impreso. En la línea de la investigación, como se ha expuesto en el segundo objetivo, encontramos varios estudios sobre recursos didácticos para desarrollar o mejorar el nivel de la comprensión lectora. Martínez y Esquivel (2017) plantearon la hipótesis siguiente: la aplicación de estrategias de lectura mediadas por TIC en estudiantes de bachillerato tecnológico, mejora la adquisición de la competencia lectora en inglés. Ésta fue apoyada por el análisis estadístico de la prueba de comprensión en texto TOEFL ITP, la cual mostró que el grupo experimental superó al de control significativamente. Además, en el artículo "Material educativo multimedia para el aumento de estrategias metacognitivas de comprensión lectora", Cabero et al. (2018, p. 156) afirma que "crea un entorno de interacción, participación y motivación para el estudiante, que propicia que se erija en el verdadero protagonista de su aprendizaje", coincidiendo con el estudio de Suárez et al. (2019) donde implementaron la propuesta pedagógica llamada Con las TIC leo y comprendo. Como hemos comentado, la implementación de las TIC-TAC en el aula acarrea ventajas y dificultades. En la investigación de Droguett y Aravena (2018), concluyeron que "existe una influencia positiva al incorporar el uso de las TIC, siempre que se realice de manera sistemática, planificada y como apoyo al docente. Para ello resulta indispensable que la institución educativa provea los recursos y la capacitación necesaria". Finalmente, si tomamos en cuenta el tercer objetivo de la presente investigación, la prueba PIRLS es una de las escogidas para aplicarse como pre-test y post-test en numerosos estudios al ser una prueba reconocida mundialmente y tener facilidad de acceso. En Taiwán, Hong et al. (2020) exploró dos formas de enseñanza de la lectura en alumnado de tercer curso. Durante un semestre el grupo experimental trabajó con un soporte tecnológico innovador llamado Knowledge Building $(K B)$, mientras que el grupo control trabajó con un sistema tradicional de instrucción directa. Los resultados demostraron que el grupo experimental superó al grupo control en la evaluación PIRLS. 


\section{Método/Descripción de la experiencia}

\section{Descripción del contexto y de los participantes}

El estudio se ha realizado en el curso de cuarto formado por 14 estudiantes. Seguidamente, se presentan sus características: aunque la mayoría haya nacido en Cataluña, ninguno tiene la lengua catalana como lengua materna, sólo 5 de ellos tiene la lengua castellana como lengua materna, los otros 9 estudiantes hablan árabe o inglés fuera de la escuela, la lengua de comunicación entre ellos es el castellano.

\section{Instrumentos}

Los instrumentos usados se centran en el análisis documental para dar objetividad al estudio. Los test estándar Evaluación de la Comprensión Lectora (ACL) y el Estudio Internacional para el Progreso en la Comprensión Lectora (PIRLS) se han aplicado como pre-test y post-test como instrumentos de medida que dan credibilidad, transferibilidad y confirmación de los criterios de calidad.

\section{Procedimiento}

Se inició y finalizó el proceso evaluando el nivel de comprensión lectora del alumnado aplicando las pruebas ACL y PIRLS como pre-test y post-test. Después de realizar el pre-test, se leyeron las lecturas del libro de texto digitalizadas y enriquecidas con hiperenlaces que diesen explicación a palabras, frases y párrafos de difícil comprensión o de conexión con los conocimientos previos del alumnado. A continuación, se llevaron a cabo las unidades didácticas (Tabla 1) diseñadas usando diversos recursos de tecnología educativa, las cuales tenían en común la primera, segunda y cuarta actividad.

\begin{tabular}{|l|l|}
\hline $\begin{array}{l}\text { Actividades } \\
\text { comunes a } \\
\text { las diferentes } \\
\text { unidades } \\
\text { didácticas }\end{array}$ & $\begin{array}{l}\text { Actividad 1: } \\
\text { Lectura del texto digital individualmente en el ordenador. } \\
\text { Localización y exploración de los diferentes hiperenlaces del texto. } \\
\text { Discusión grupal sobre el argumento del texto y de la información aportada por } \\
\text { los hiperenlaces. }\end{array}$ \\
\cline { 2 - 2 } & $\begin{array}{l}\text { Actividad 2: } \\
\text { Completar un test con respuestas múltiples sobre la lectura con la aplicación } \\
\text { Kahoot. }\end{array}$ \\
\cline { 2 - 3 } & $\begin{array}{l}\text { Actividad 4: } \\
\text { Rellenar la rúbrica evaluando el propio trabajo y la aplicación utilizada. }\end{array}$ \\
\hline \multirow{2}{*}{$\begin{array}{l}\text { Unidad } \\
\text { didáctica 1 }\end{array}$} & $\begin{array}{l}\text { Actividad 3: } \\
\text { Crear un cómic donde se resuma la historia e inventar un final para la misma con } \\
\text { la aplicación Toondoo. } \\
\text { Exponer y explicar el cómic al grupo clase. }\end{array}$ \\
\hline $\begin{array}{l}\text { Unidad } \\
\text { didáctica 2 }\end{array}$ & $\begin{array}{l}\text { Actividad 3: } \\
\text { Definir las características del protagonista principal a través de la aplicación } \\
\text { Storybird. }\end{array}$ \\
\hline $\begin{array}{l}\text { Unidad } \\
\text { didáctica 3 }\end{array}$ & $\begin{array}{l}\text { Actividad 3: } \\
\text { Escribir una historia sobre el personaje principal de la lectura y sus características } \\
\text { con la aplicación Book Creator. }\end{array}$ \\
\hline $\begin{array}{l}\text { Unidad } \\
\text { didáctica 4 }\end{array}$ & $\begin{array}{l}\text { Actividad 3: } \\
\text { Inventar y escribir un diario de cinco a diez días sobre el campamento vivido por } \\
\text { el protagonista de la lectura con la aplicación Calaméo. }\end{array}$ \\
\hline
\end{tabular}




\section{Resultados}

En este apartado, se presentan los resultados de las pruebas ACL y PIRLS aplicadas como pre-test y post-test de la investigación después de haber leído los textos digitalizados y haber realizado y evaluado las actividades de enseñanza-aprendizaje a través de las TAC.

\section{Resultados de la Evaluación de la Comprensión Lectora (ACL)}

A continuación, se exponen los resultados de la prueba ACL del grupo estudio de los años anteriores para compararlos con los obtenidos al trabajar la comprensión lectora mediante las actividades didácticas diseñadas. Como se ha mencionado anteriormente, esta prueba es interna de cada centro y los resultados no se publican, por lo que no se pueden comparar ni con distintos centros ni a nivel autonómico.

En la Figura 1, se pueden visualizar los resultados de las medias del grupo estudio de inicio y final de cada curso des de primero a cuarto de educación primaria, implementándose la investigación en este último año.

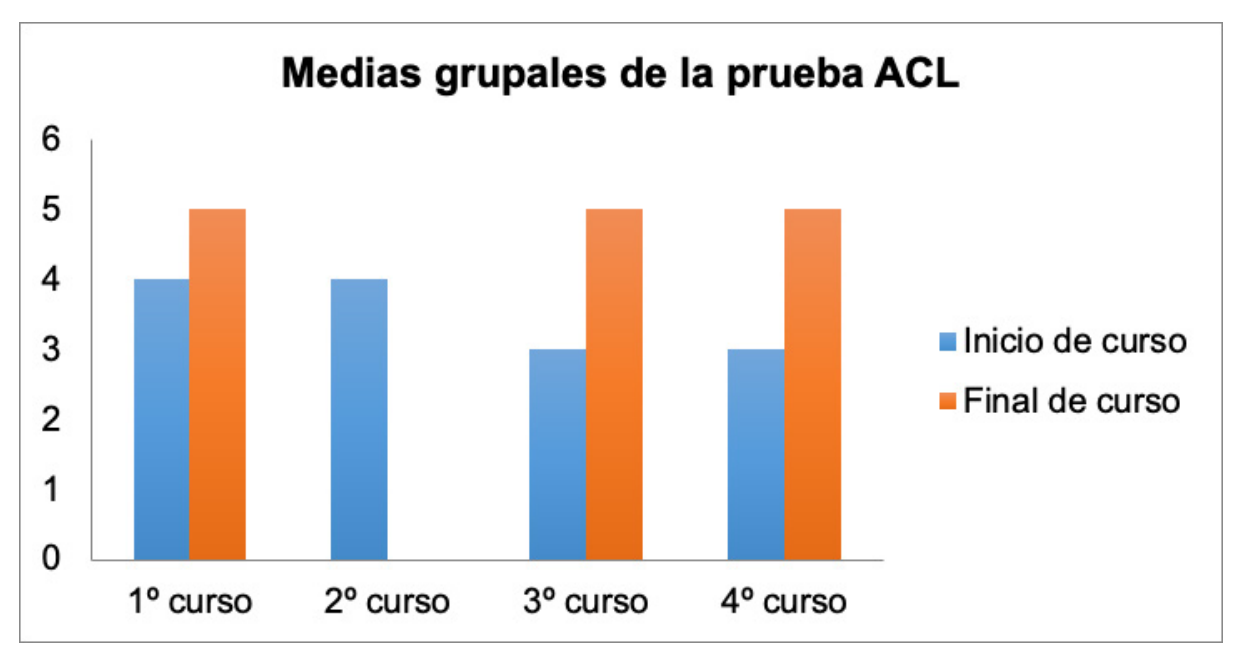

Figura 1. Medias grupales de la prueba ACL

En el primer curso de educación primaria, el grupo estudio estaba compuesto por 13 alumnos y obtuvo una media de cuatro decatipos a principio de curso, correspondiente al primer nivel de normalidad de comprensión lectora. A final de curso el resultado fue de cinco decatipos, correspondiente al segundo nivel dentro de la normalidad. Por tanto, la media aumentó un nivel. En el segundo curso de educación primaria, la prueba ACL solo se aplicó una vez, a inicio de curso. Se desconoce el motivo por el cual no fue aplicada a final de curso. La media grupal, donde se evaluaron 12 alumnos, fue de cuatro decatipos, correspondiente a un nivel bajo. Durante el tercer curso de educación primaria, fueron evaluados los 14 alumnos que actualmente forman parte del grupo estudio. A principio de curso la media obtenida fue tres decatipos, un nivel de comprensión lectora moderadamente baja y, a final de curso, la media fue de cinco decatipos, correspondiente a un nivel de comprensión lectora normal. Durante el cuarto curso de educación primaria, año en el cual se implementa la investigación, la media del grupo-clase en el pre-test, realizado en febrero, fue de tres decatipos, un nivel de comprensión lectora moderadamente bajo. 
La media grupal en el post-test, realizado en mayo, fue de cinco decatipos, un nivel de comprensión lectora dentro de la normalidad. Por lo tanto, el nivel aumentó dos grados. Comparando y analizando todas las medias grupales con los años anteriores, la mejora del nivel de comprensión lectora fue la misma, estando inicialmente por debajo de la normalidad y acabando dentro de esta. Ahora bien, los resultados de la investigación son significativos, ya que el tiempo requerido entre la primera evaluación y la segunda fue de cuatro meses. En cambio, los años anteriores, el tiempo entre la primera y la segunda evaluación fue de siete meses o más. Por lo tanto, la implementación de las TAC tanto en la digitalización y enriquecimiento de los textos del libro impreso como las actividades didácticas llevadas a cabo con recursos digitales tecnológicos para trabajar cada tipo de comprensión lectora, hicieron que, con un tiempo más reducido, se consiguiesen mejores resultados.

A continuación, en la Figura 2, se pueden visualizar los resultados individuales de la prueba ACL del primer curso de educación primaria. En la primera evaluación: 6 estudiantes obtuvieron un nivel inferior, 2 estudiantes un nivel bajo, 4 estudiantes un nivel normal y 1 estudiante llegó al moderadamente alto. En la segunda evaluación: 2 alumnos obtuvieron el mismo nivel inferior, 2 estudiantes obtuvieron el nivel bajo, 4 estudiantes alcanzaron el grado de normalidad, 2 estudiantes llegaron al nivel moderadamente alto y, otros 2 estudiantes, al nivel alto. Comparando dichas evaluaciones, 2 alumnos quedaron en el mismo nivel de comprensión lectora, 7 alumnos mejoraron un nivel, 2 alumnos mejoraron dos niveles y, otros 2 estudiantes, mejoraron tres niveles.

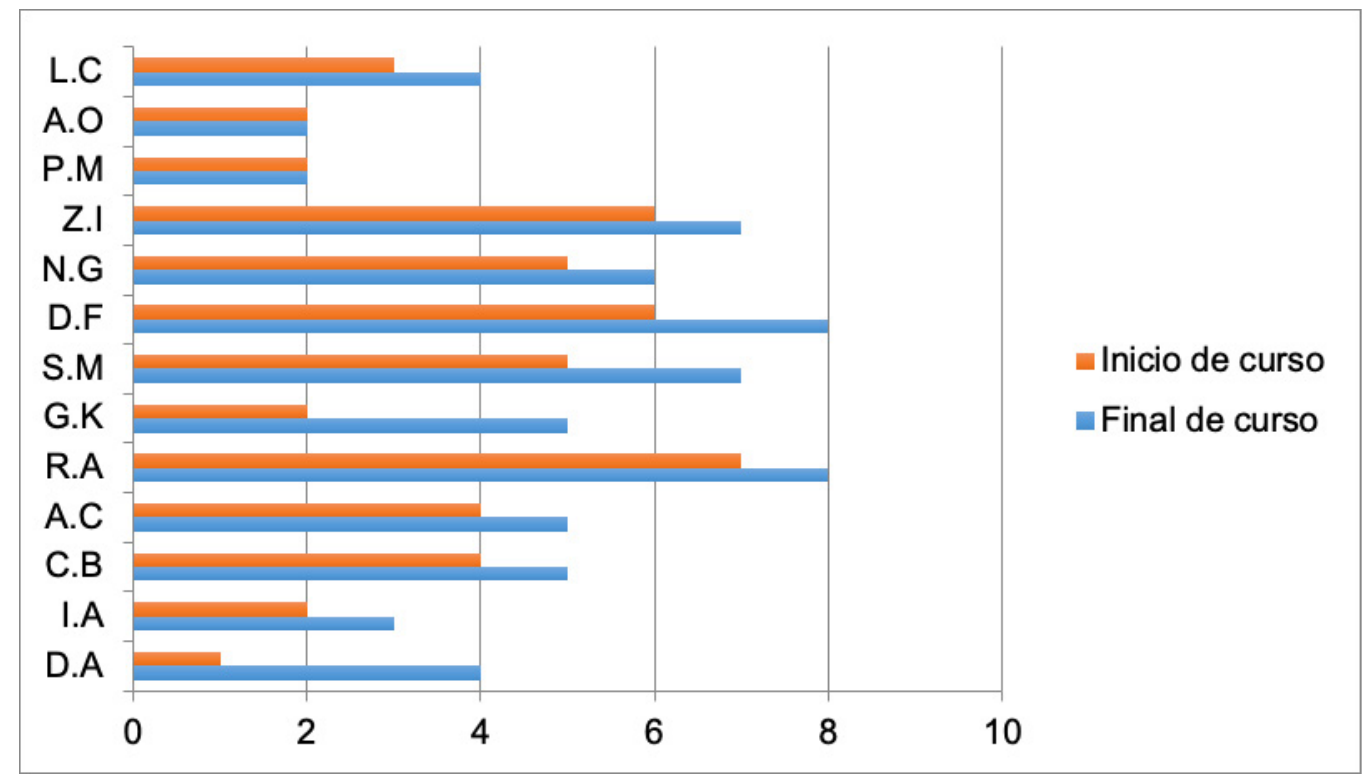

Figura 2. Resultados individuales de la prueba ACL (1ํㅡㄴ)

En la Figura 3 se puede observar los resultados individuales del segundo curso de educación primaria. En la única evaluación que se hizo, 4 alumnos obtuvieron un nivel de comprensión lectora inferior, 6 alumnos, un nivel bajo; 1 alumno llegó al nivel normal y, otro, al nivel moderadamente alto. 


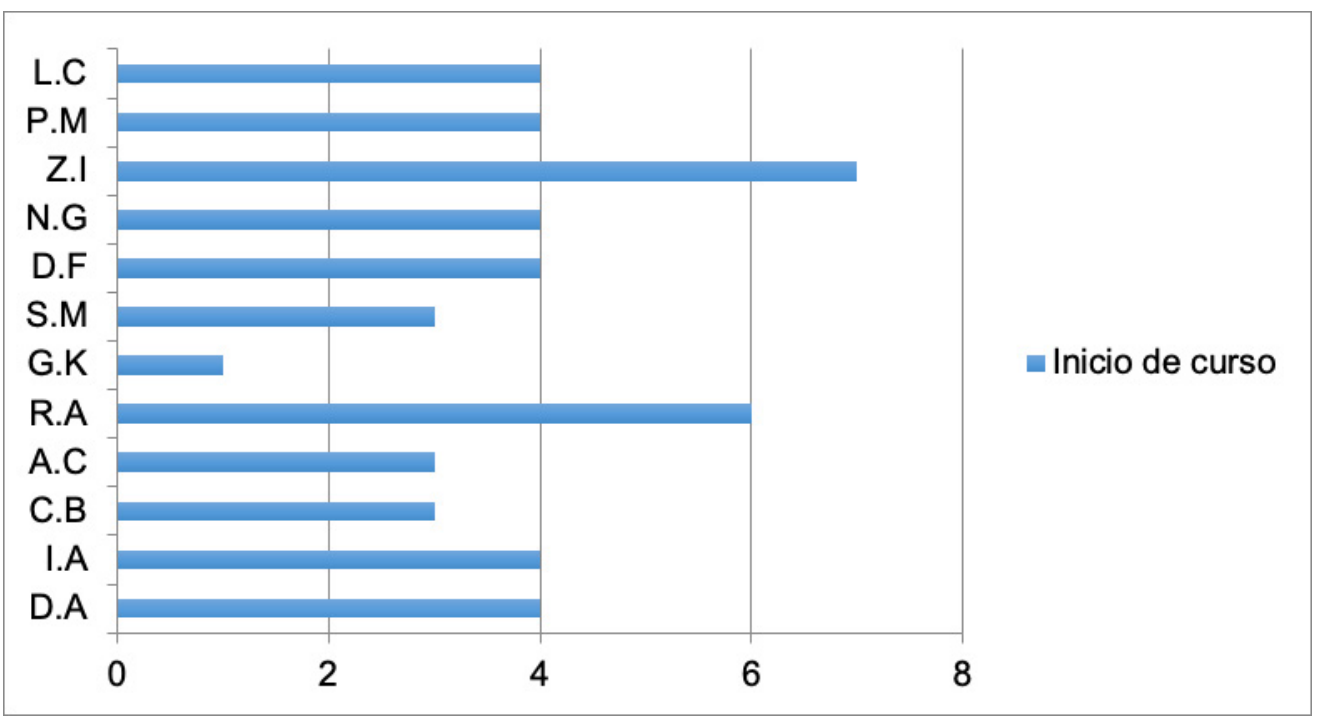

\section{Figura 3. Resultados individuales de la prueba ACL (2 curso)}

En la Figura 4 se exponen los resultados individuales del tercer curso. Después de la primera evaluación: 4 alumnos obtuvieron un nivel de comprensión lectora bajo, 5 estudiantes obtuvieron un nivel moderadamente bajo, 3 alumnos llegaron a un nivel normal y, los otros 2 estudiantes, a un grado moderadamente alto. Después de la segunda evaluación: 1 alumna disminuyó su resultado a un nivel muy bajo, 2 alumnos obtuvieron un nivel bajo, 6 estudiantes llegaron al nivel de normalidad y, 5 estudiantes al nivel moderadamente alto. Visualizando la gráfica, 1 estudiante disminuyó un nivel de comprensión lectora, 4 estudiantes se quedaron en el mismo nivel, otros 4 estudiantes mejoraron un nivel, 3 alumnos mejoraron dos niveles y, los otros 2 estudiantes mejoraron tres y cuatro niveles respectivamente.

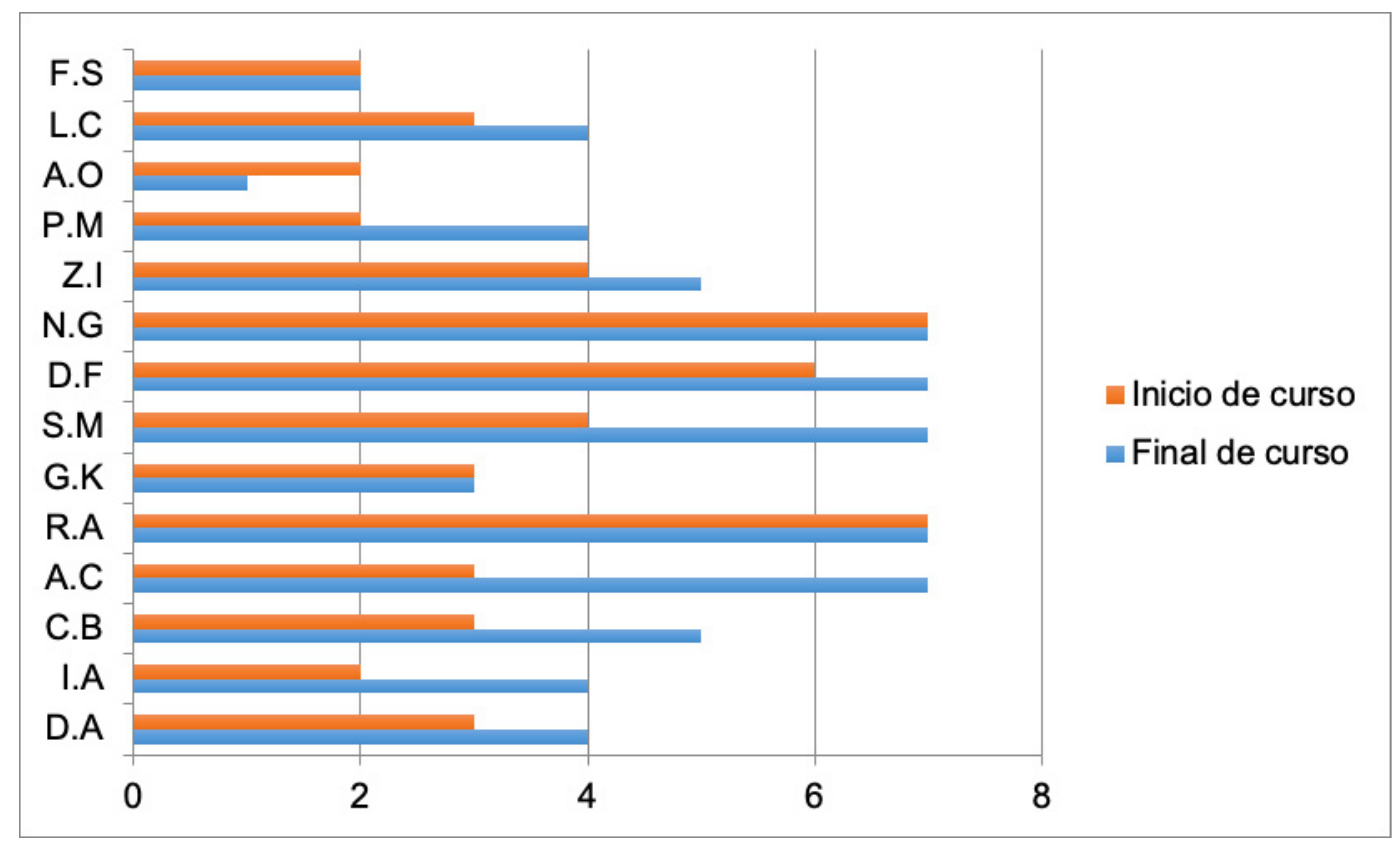

Figura 4. Resultados individuales de la prueba ACL (3ํㅜ curso) 
En la Figura 5 se presentan los resultados individuales del cuarto curso, año de la investigación. Al finalizar el pre-test, 5 estudiantes obtuvieron un nivel de comprensión lectora normal y 9 alumnos quedaron por debajo de este. Concretamente, 7 alumnos obtuvieron un nivel inferior y 2 alumnos el nivel bajo. Después del post-test, 4 estudiantes llegaron al nivel alto de comprensión, 3 estudiantes al nivel normal y 7 se quedaron por debajo de la normalidad, quedando 4 al nivel inferior y 3 al nivel bajo.

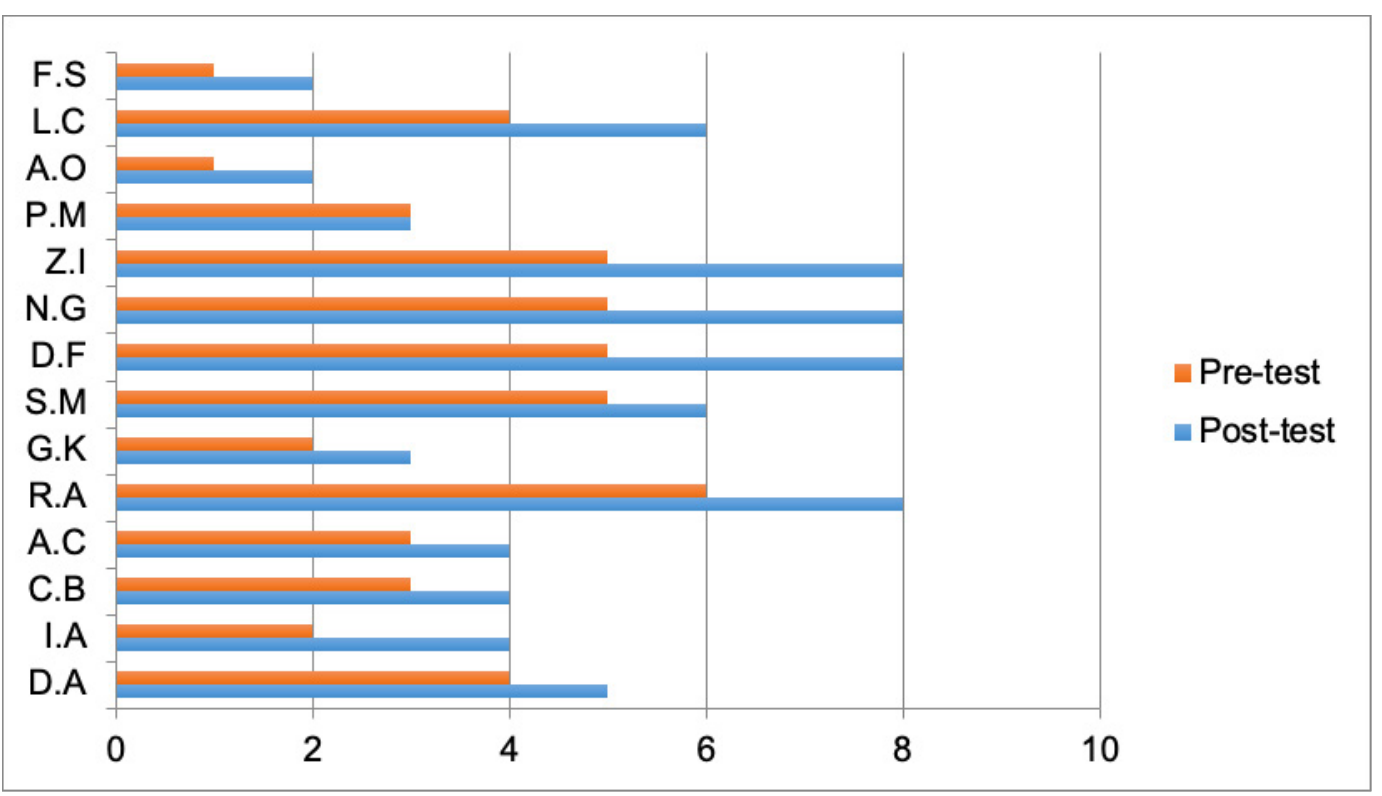

Figura 5. Resultados individuales de la prueba ACL (investigación)

Analizando los tres cursos donde podemos comparar los resultados individuales de inicio y de final de curso, el alumnado obtuvo una mejora sustancial después de haber implementado las TAC en las clases de lengua catalana, ya que el número de estudiantes que disminuyó su nivel fue nulo; 7 estudiantes mejoraron 1 nivel igual que en el primer curso; 3 estudiantes mejoraron 2 niveles igual que en el segundo curso y, hasta 3 estudiantes mejoraron 3 niveles, hecho que no había ocurrido antes y en un tiempo más corto que los anteriores cursos, como se ha mencionado anteriormente, corroborando que la aplicación de las TAC en el trabajo del nivel de comprensión lectora mejora el resultado individual en más grados que llevando a cabo actividades didácticas del libro de texto.

En segundo lugar, en la Figura 6, se presentan los resultados de cada tipo de comprensión lectora. En primer lugar, el resultado grupal de la compresión literal aumentó un $13 \%$, siendo de $56 \%$ en el pre-test y del $69 \%$ de aprobados en el post-test. Individualmente, 6 estudiantes de 14 no superaron esta parte en el pre-test. En el post-test, sólo fueron 3 . En segundo lugar, la comprensión reorganizativa obtuvo los peores resultados en ambos test y sólo mejoró un $7 \%$ el resultado global, siendo $29 \%$ de aprobados en el pre-test y $36 \%$ en el post-test. La mayoría del alumnado obtuvo un nivel de suficiencia en este tipo de preguntas. A continuación, se puede comprobar que la comprensión inferencial incrementó un $18 \%$, siendo de $36 \%$ en el pre-test y del $54 \%$ al post-test. Al final del pre-test, sólo 4 estudiantes superaron esta parte, pero en el post-test el número aumentó a 10. Finalmente, la comprensión crítica obtuvo los mejores resultados incrementado un $31 \%$ de aprobados, llegando al $81 \%$ en el post-test. 


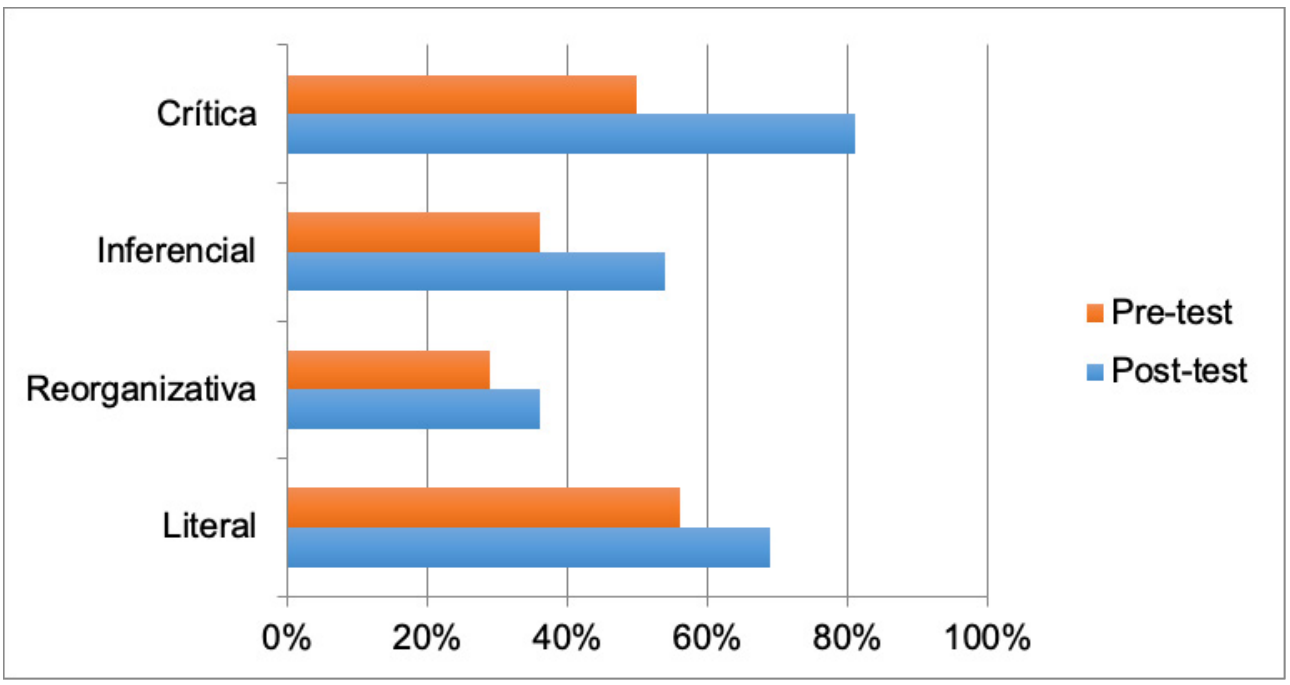

\section{Figura 6. Resultados logrados de cada tipo de comprensión lectora de la prueba ACL (investigación)}

Observando los resultados de cada tipo de comprensión lectora, se puede concluir que todos mejoraron, obteniendo más de la mitad de aprobados en el post-test y, en una mejora menor, se encuentra la comprensión reorganizativa.

Resultados del Estudio Internacional para el Progreso en la Comprensión Lectora (PIRLS)

La prueba PIRLS se divide en cuatro lecturas con sus pertinentes preguntas, las cuales evalúan los cuatro tipo de comprensión lectora (literal, reorganizativa, inferencial y crítica). Seguidamente, se presentan los resultados.

En primer lugar, en la Figura 7, se presentan los resultados del pre-test y del posttest de cada texto junto a la media internacional y la española. En ella, se puede observar que los dos primeros textos superaron ambas medias. El cuarto texto superó la media española y alcanzó el mismo resultado que la internacional, y, por último, el tercer texto es el único que se quedó a 4 puntos de la media internacional. En cuatro meses de trabajo mediante las TAC, se pudo profundizar más en cada tipo de comprensión y, consiguientemente, en el resultado de las medias grupales, las cuales no sólo mejoraron, sino que superaron las medias española e internacional. 


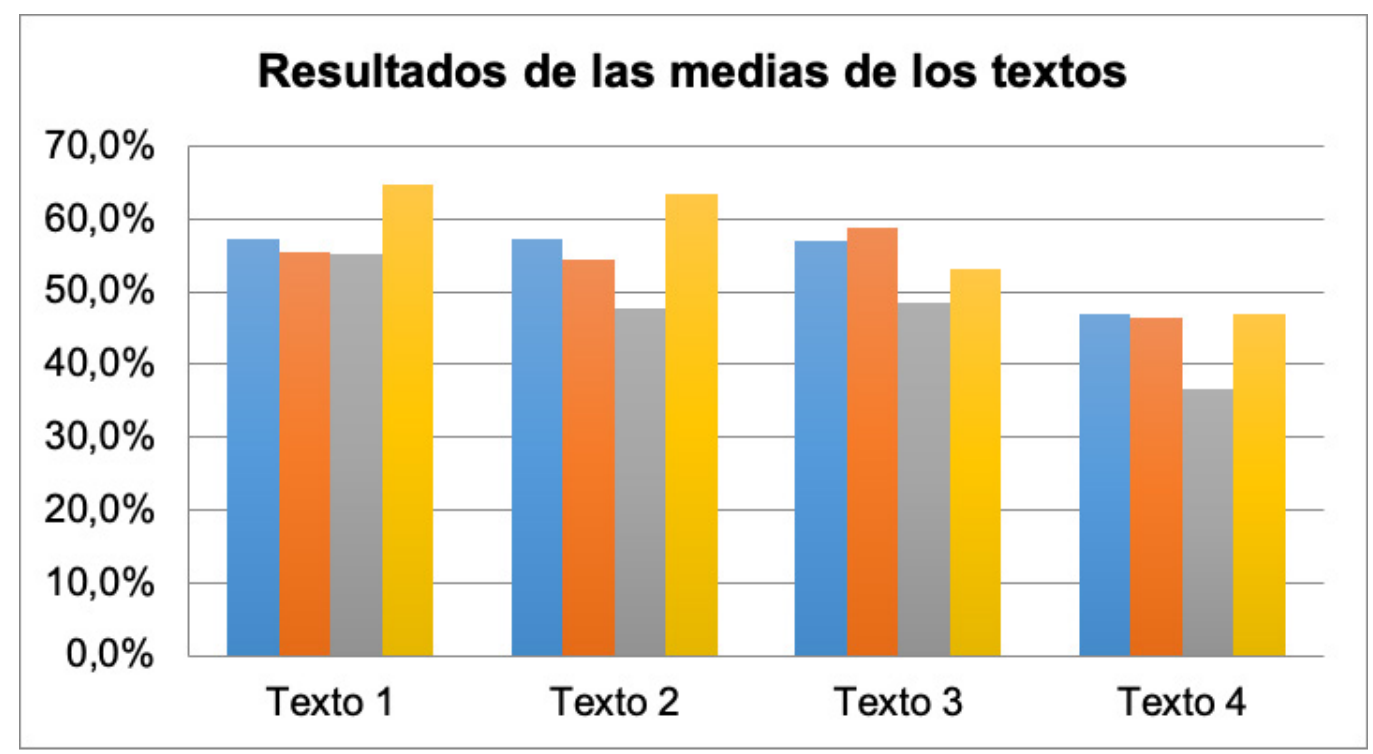

Figura 7. Resultados de las medias de los textos

A continuación, se exponen los resultados de cada tipo de comprensión lectora de los cuatro textos.

El primer texto se titula "Excursión de un día" (PIRLS 2011). En la Figura 8, se puede ver que la comprensión reorganizativa es la única que obtuvo una mejora, donde la mitad del alumnado la superó en el post-test. Por otro lado, las comprensiones literal e inferencial las superaron el 75\% del alumnado y, la comprensión crítica, un 50\%.

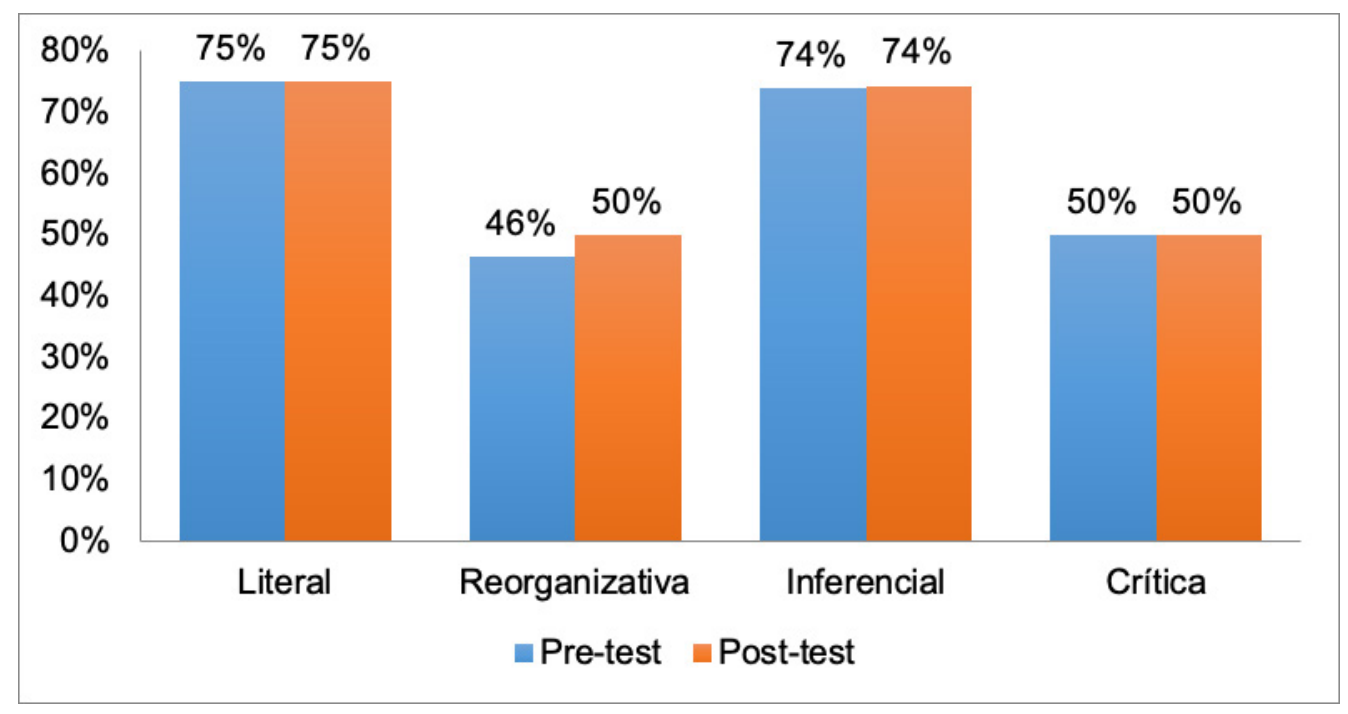

Figura 8. Resultados de cada tipo de comprensión del primer texto (PIRLS)

El segundo texto se titula "Vuela, águila, vuela. Un cuento africano" (PIRLS 2011). Observando el resultado de cada tipo de comprensión en la Figura 9, la comprensión literal es la que obtuvo un resultado más alto en el post-test, aumentando el nivel de aprobados hasta el $86 \%$. Aunque fue la comprensión inferencial la que logró una mejora más elevada comparando el resultado del pre-test y del post-test en un 
29\%. La comprensiones reorganizativa y crítica mejoraron en un $11 \%$ y en un $12 \%$, respectivamente. La crítica es la que obtuvo los peores resultados.

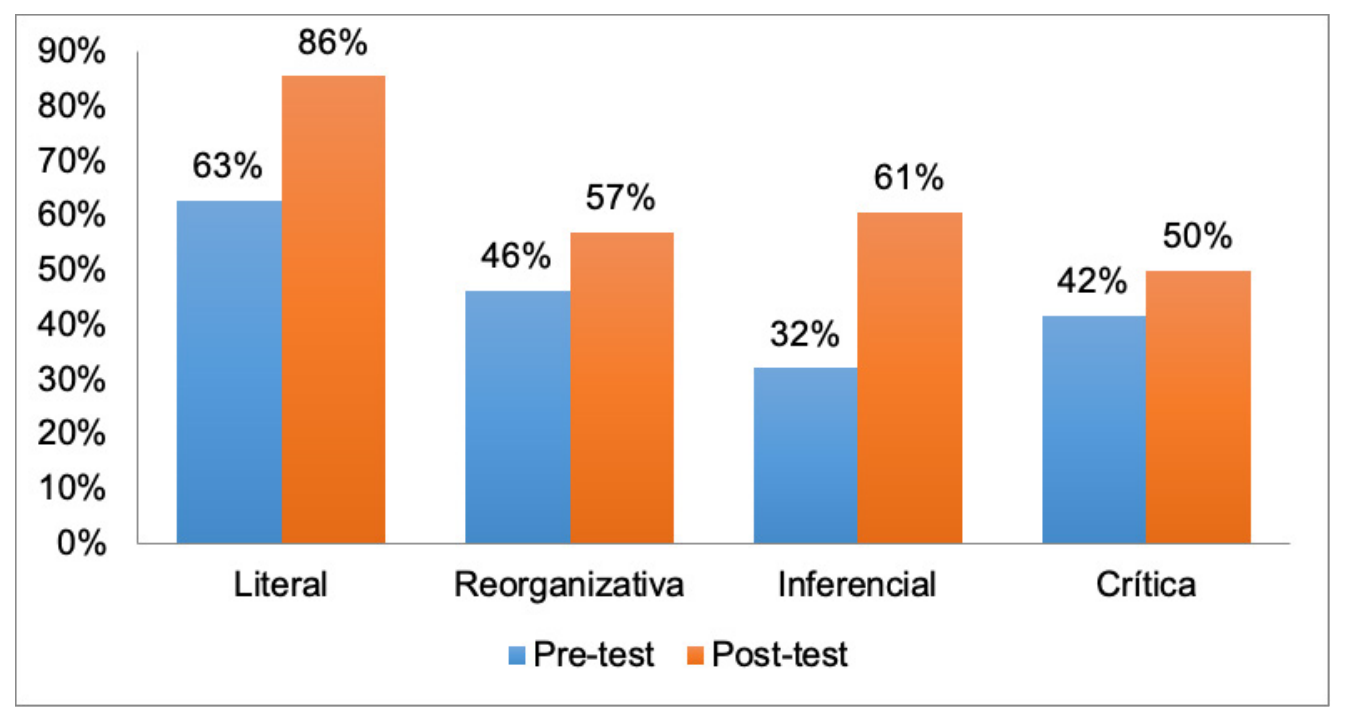

Figura 9. Resultados de cada tipo de comprensión del segundo texto (PIRLS)

El tercer texto evaluado se titula "Pastel para enemigos" (PIRLS 2011). Como se observa en la Figura 10, todos los tipos de comprensión lograron una mejora menos la comprensión reorganizativa, que disminuyó un 9\%. La comprensión crítica, en cambio, es la que aumentó más, un $26 \%$.

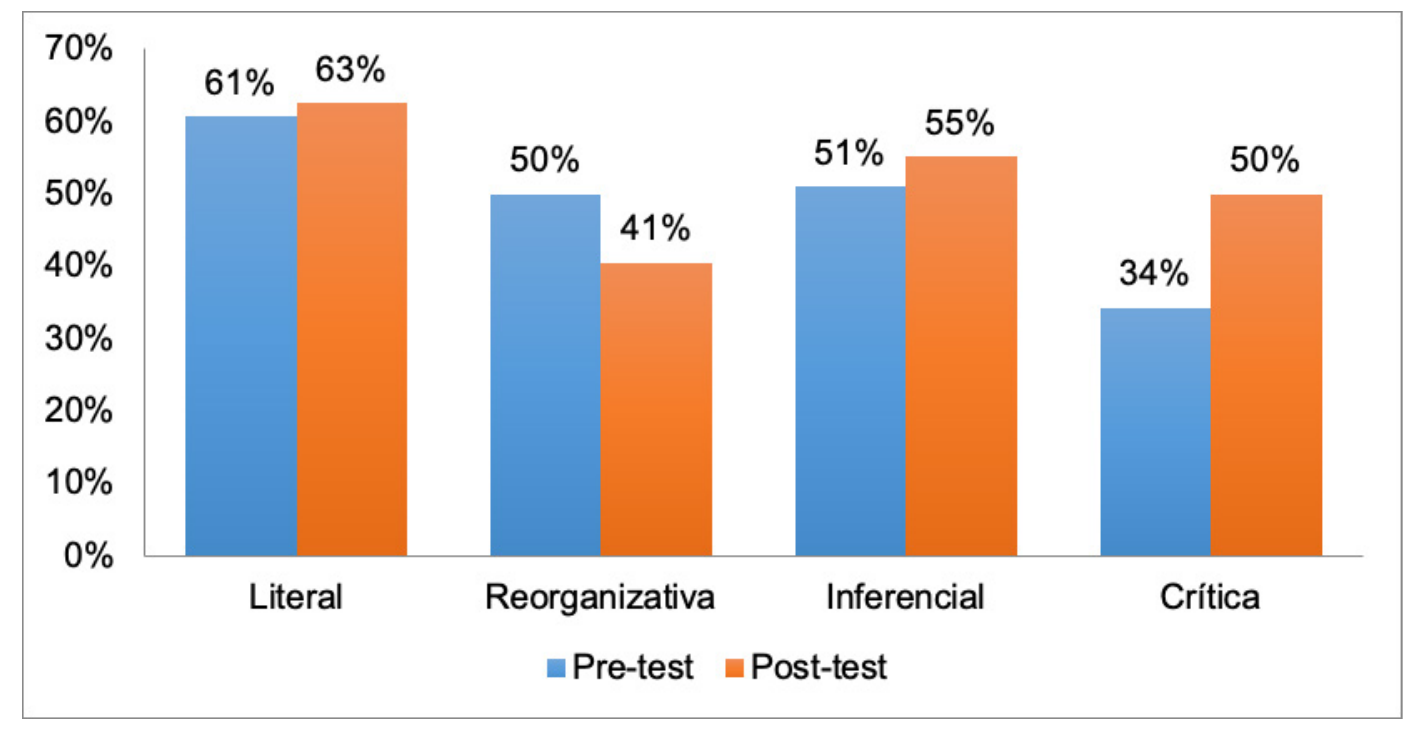

Figura 10. Resultados de cada tipo de comprensión del tercer texto (PIRLS)

El cuarto texto se titula "El misterio del diente gigante" (PIRLS 2011). En la Figura 11, se observa que las comprensiones literal y reorganizativa obtuvieron unos resultados peores en el post-test, disminuyendo un $1 \%$ y un $2 \%$, respectivamente. La comprensión reorganizativa logró el resultado más negativo. La comprensión inferencial mejoró un $8 \%$, siendo $49 \%$ de aprobados en el pre-test y, 57\% en el posttest. La comprensión crítica fue la que obtuvo un aumento de aprobados más elevado pasando del $19 \%$ al $42 \%$. 


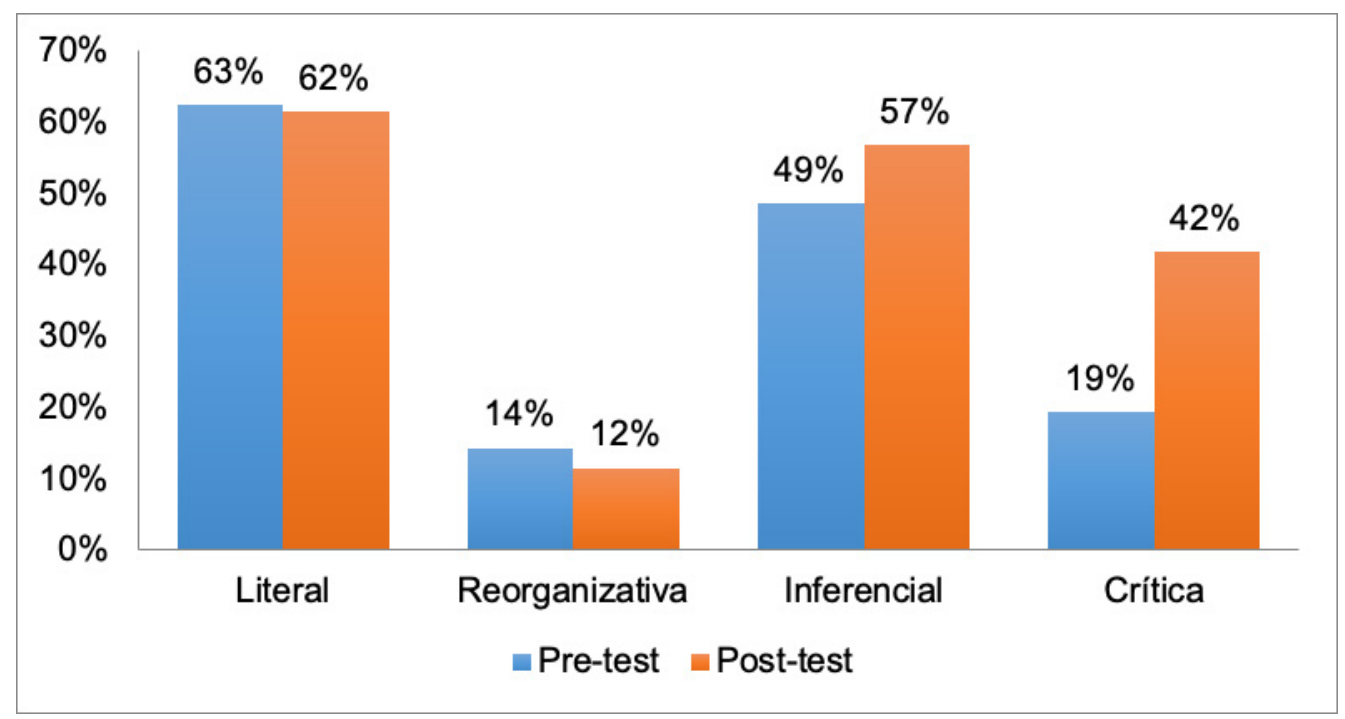

Figura 11. Resultados de cada tipo de comprensión del cuarto texto (PIRLS)

\section{Discusión y conclusiones}

Esta investigación se ha desarrollado en la línea de estudios como los de Martínez y Rodríguez (2011) o Martínez y Esquivel (2017), ya que en ellos se han aplicado recursos tecnológicos digitales con el fin de mejorar el nivel de comprensión lectora. El potencial, la variedad y el relevante papel que están adquiriendo en la sociedad, hace que la escuela tome las TIC-TAC para impulsar el desarrollo de todas las habilidades y competencias del alumnado. Finalizada la investigación y centrándonos en los resultados de las pruebas ACL y PIRLS, podemos concluir que la hipótesis se corrobora ya que los recursos tecnológicos digitales implementados han llevado al alumnado a trabajar cada tipo de la comprensión lectora con una mayor profundidad, haciendo que, en apenas cuatro meses, el nivel de comprensión lectora tanto individual como grupal mejorasen significativamente. Las limitaciones derivadas de las características de este estudio no permiten la generalización de los resultados, pero los datos apuntan a poder considerarlos como herramientas idóneas para apoyar el desarrollo de la competencia lectora. Analizando los resultados de la prueba ACL, podemos observar que la media grupal del nivel de comprensión lectora mejoró hasta llegar a la normalidad. Todos los estudiantes aumentaron su resultado individual en uno, dos y hasta tres niveles, llegando cuatro de ellos a un nivel alto de comprensión. Además, comparando los resultados con los años anteriores, los resultados del nivel de mejora durante la investigación son significativos, ya que el tiempo requerido entre la primera evaluación y la segunda fue de cuatro meses. En cambio, los años anteriores, el tiempo fue de siete meses. Por otro lado, observando los resultados de cada tipo de comprensión lectora, se puede concluir que todos mejoraron, obteniendo un número más elevado de aprobados en el post-test, aunque la comprensión reorganizativa fue la que recibió una mejora menor. Analizando los resultados de la prueba PIRLS, se puede concluir que, aunque el tercer texto se quedó a 4 puntos por debajo de la media internacional, los otros tres superaron ambas medias en el post-test. En general, la comprensión reorganizativa es la que obtuvo peores resultados. En cambio, los otros tipos de comprensión (literal, inferencial y crítica) obtuvieron buenos resultados. Al implementar las TAC en el aula se derivan algunos factores positivos, como son: la 
motivación, el aprendizaje significativo, la atención y concentración, el autoaprendizaje, el respeto a los ritmos de aprendizaje, la consideración de las inteligencias múltiples, la capacitación a una nueva alfabetización, la promoción de la creatividad y la equidad de acceso a la educación. Por otro lado, tenemos que tener en cuenta las dificultades que nos podemos encontrar ante esta implementación, como pueden ser la insuficiente capacitación de los docentes, la dispersión que se puede crear en la clase, la dependencia económica que puede suponer tener los dispositivos y las licencias actualizadas, no disponer de una banda ancha efectiva y tener problemas de conectividad y, por último, que el alumnado se caracterice por padecer la brecha digital (Droguett y Aravena, 2018).

\section{Referencias}

Bisquerra, R. (coord), Dorio, I., Gómez, J., Latorre, A., Martínez, F., Massot, I., Mateo, J., Sabariego, M., Sans, A., Torrado, M. y Vilà, R. (2009). Metodología de la investigación educativa. Madrid: La Muralla

Cabero, J., Piñero, R. y Reyes, M.M. (2018). Material educativo multimedia para el aumento de estrategias metacognitivas de comprensión lectora. Perfiles Educativos, 40(159), 144-159.

Consejo Superior de Evaluación del Sistema Educativo. (2016). Documentos. 34 PIRLS 2016. Síntesis del marco conceptual e items liberados.

Droguett, P. y Aravena, M. (2018). Tecnologías de la información y comunicación en el proceso de adquisición de la lectoescritura. Foro Educacional, (31), 117-133.

Hong, H-Y., Leanne, M., Lin, P-Y. y Yuan-Hsuan Lee, K. (2020). Advancing third graders' reading comprehension through collaborative Knowledge Building: A comparative study in Taiwan. Computers \& Education, 157.

Martínez, W. y Esquivel, I. (2017). Efectos de la instrucción de estrategias de lectura, mediadas por TIC, en el comprensión lectora del inglés. Perfiles Educativos, 39(157), 105-122

Martínez, R. del C. y Rodríguez, B.P. (2011). Estrategias de comprensión lectora mediadas por TIC. Una alternativa para mejorar las capacidades lectoras en secundaria. Escenarios, 9(2),18-25.

Resolución EDU/1051/2020, de 15 de mayo, DOGC núm. 8137.

Sánchez-Serrano, J.M., Alba-Pastor, C. y Sánchez-Antolín, P. (2018). Valoraciones del alumnado de Educación Primaria sobre lecturas digitales diseñadas con UDL Book-Builder como apoyo en los procesos lectores. Aula Abierta, 47(4), 481-490.

Suárez Palacio, P.A., Vélez Múnera, M. y Londoño-Vásquez, D.A. (2019). Niveles de literacidad en tercer grado de una institución educativa de Bello. Enunciación, 24(1), 15-28.

Toro, C. M. y Monroy, M.N. (2017). Las TIC: estrategia para mejorar la competencia lectora-interpretativa en el área de lenguaje. Revista Universidad Católica Luis Amigó, 1, 126-148. 


\section{Las TICs y Las Prácticas Pre-Profesionales de los Estudiantes de la Carrera de Contador Público}

\section{Butigué, Silvia}

UNRC, sbutigue@fce.unrc.edu.ar

\section{Mussolini, María Susana}

UNRC,mmussolini@fce.unrc.edu.ar

\section{Martinez, Natalia}

UNRC, nataliamartinez@fce.unrc.edu.ar

\section{Tassone, Matías}

UNRC, mtassone@fce.unrc.edu.ar 


\title{
LAS TICS Y LAS PRÁCTICAS PRE-PROFESIONALES DE LOS ESTUDIANTES DE LA CARRERA DE CONTADOR PÚBLICO
}

\author{
Butigué, Silvia \\ Mussolini, María Susana \\ Martinez, Natalia \\ Tassone, Matías
}

\section{Resumen}

El objetivo general de esta ponencia es la socialización y comunicación de la innovación docente llevada a cabo en el Taller de Práctica II, en la carrera de Contador Público en la Facultad de Ciencias Económicas de la Universidad Nacional de Río Cuarto. Su desarrollo se llevó a cabo por un equipo conformado por docentes de las distintas áreas de formación académica. Se tuvo en cuenta el contexto de incertidumbre y cambio permanente en el que se desarrollará profesionalmente el Contador Público. La metodología empleada fue la de práctica situada y la técnica didáctica el Método de Aprendizaje basado en Problemas (Escribano, A. y Del VaIle, A., 2016). El resultado de la innovación permitió a los estudiantes la vinculación teórico-práctica de múltiples contenidos previos desarrollados en asignaturas como Matemática, Cálculo Financiero, Estadística, Costos, Análisis e Interpretación de Estados Contables y con la incorporación de las TIC se les facilitó el análisis de la información. Además, pudieron observar que los cambios tecnológicos han impulsado la aparición de nuevos servicios, nuevos productos y nuevas formas de hacer negocios. Esta actividad se desarrolló en una empresa agroindustrial de la ciudad de Río Cuarto, incorporando así prácticas para el futuro graduado en Ciencias Económicas (Carneiro, 2010).

\section{Palabras clave}

Tecnología, práctica, información. 


\section{Introducción}

Dentro de los antecedentes teóricos en cuanto a proyectos de innovación docente, existe en general una aceptación acerca de que el proceso de formación de los profesionales está estrechamente vinculado con el desarrollo de capacidades para la acción en prácticas situadas, en donde se propicia el avance en el desarrollo de capacidades y actitudes en los contextos reales de la acción. Asimismo, los nuevos diseños curriculares para la formación de grado han incorporado espacios significativos de formación en las prácticas a lo largo de toda la carrera, como trayecto educativo progresivo, destinados al desarrollo de capacidades en situaciones y contextos reales, tal como señala Carneiro (2010).

"El estudiante a lo largo de su carrera, incorpora saberes teóricos y prácticos, y a su vez, prácticas de intervención en el medio, cuyas finalidades definen en gran parte su perfil profesional. Por ello, las carreras de grado deben garantizar ámbitos y modalidades de formación teórico-práctica que colaboren en el desarrollo de competencias profesionales acordes con la intencionalidad formativa. Por consiguiente, cada unidad académica, atendiendo al contexto socioeconómico y al tipo de inserción laboral de sus graduados, podrá contemplar diversas formas de llevar adelante esta capacitación.

Así, la teoría y la práctica se muestran como ámbitos mutuamente constitutivos que definen una dinámica específica del proceso de enseñanza y de aprendizaje, donde los criterios de intensidad de la formación práctica deberán contemplar este aspecto para evitar interpretaciones fragmentarias o reduccionistas de la práctica" (Consejo de Universidades, 2017).

Tal como afirma Sunkel (2010), en la actualidad existe un reconocimiento del papel central que la educación desempeña en los procesos de desarrollo. En el marco de una conceptualización más compleja, la educación deja de ser entendida como una mera consecuencia del crecimiento económico para ser concebida como una de las fuentes del proceso de desarrollo que impacta tanto en sus aspectos sociales y políticos como en aquellos estrictamente económicos. En suma, existe una tendencia en la región a considerar que la educación constituye un elemento decisivo para el desarrollo, entendido este como un proceso de transformación complejo y multidimensional. En la concepción de la educación como fuente del desarrollo, esta se enfrenta a nuevos desafíos: expandir y renovar permanentemente el conocimiento, dar acceso universal a la información y promover la capacidad de comunicación entre individuos y grupos sociales.

Por otra parte, la información se ha convertido en un valor en sí misma, el acceso es muy fácil en donde se debe saber discriminar y aprender a utilizarla como vinculo de cultura. En este sentido, las organizaciones cuentan con gran cantidad de datos provenientes de las operaciones que realizan y la evolución de las TIC ha consolidado la importancia del papel desempeñado por la gestión de los sistemas de información en las organizaciones (Carneiro, 2010).

En el Ámbito Académico el uso de estas nuevas herramientas incorporadas a los contenidos curriculares, permite exponer la información de una manera diferente a como lo hacían los tradicionales libros y vídeos. Se trata de contenidos dinámicos con una cualidad distintiva fundamental: la interactividad. Ello promueve una 
actitud activa y una mayor implicancia del estudiante en las temáticas abordadas. Los nuevos contenidos permiten la creación de simulaciones, proyecciones, realidades virtuales, que hacen posible la adaptación del material a las características nacionales o locales y es posible actualizarlos y modernizarlos con mayor facilidad.

Desde el espacio curricular Taller de Práctica II, se procura un proceso de formación de competencias profesionales que posibiliten la intervención en la problemática específica de la realidad socioeconómica, contemplando un ámbito curricular de articulación teórico-práctica, recuperando dos ámbitos del aprendizaje práctico: el relativo al proceso de enseñanza-aprendizaje y el referido a la transversalidad de la práctica profesional incentivando la utilización de las nuevas TIC. La práctica fue realizada en una empresa agroindustrial de nuestra región, aplicando contenidos disciplinares provenientes de la administración, la matemática aplicada y la contabilidad en escenarios con tecnologías.

El objetivo general de esta ponencia es socializar y comunicar la innovación docente llevada a cabo en el Taller de Práctica II en relación a la incorporación de situaciones de práctica profesional en campos reales. Los objetivos específicos: integrar las herramientas que brindan las TIC en la formación teórica-práctica y facilitar procesos educativos que resulten significativos para los estudiantes.

\section{Método/Descripción de la experiencia}

En el marco del dictado del espacio curricular Taller de Práctica II, se procedió a contactarse con una empresa agroindustrial de la ciudad de Río Cuarto dedicada a la producción, acopio y venta de bioetanol y subproductos.

En las entrevistas entre docentes, personal administrativo y técnico de la organización, se detectó la existencia de procesos administrativos, técnicos, contables y de presupuesto que se llevaban a cabo a través de softwares complejos o técnicas manuales. A partir de esta situación, docentes en colaboración con estudiantes, planificaron, propusieron y desarrollaron herramientas de gestión haciendo uso de planillas electrónicas y software de inteligencia empresarial: MS Power BI.

\section{CASO CMI}

Puntualmente, y luego de realizar un abordaje teórico de la temática, se trabajó con el Cuadro de Mando Integral (CMI) de la empresa agroindustrial, herramienta que, mediante el uso de una serie de indicadores, permite medir diferentes aspectos de una organización comprometidos con su visión y estrategia. (Kaplan, R. y otro, 1996).

El CMI se desarrolló con la herramienta de inteligencia empresarial MS Power BI, permitiendo tener información actualizada, continua, concurrente y multiplataforma (PC, Tablet, celulares). 

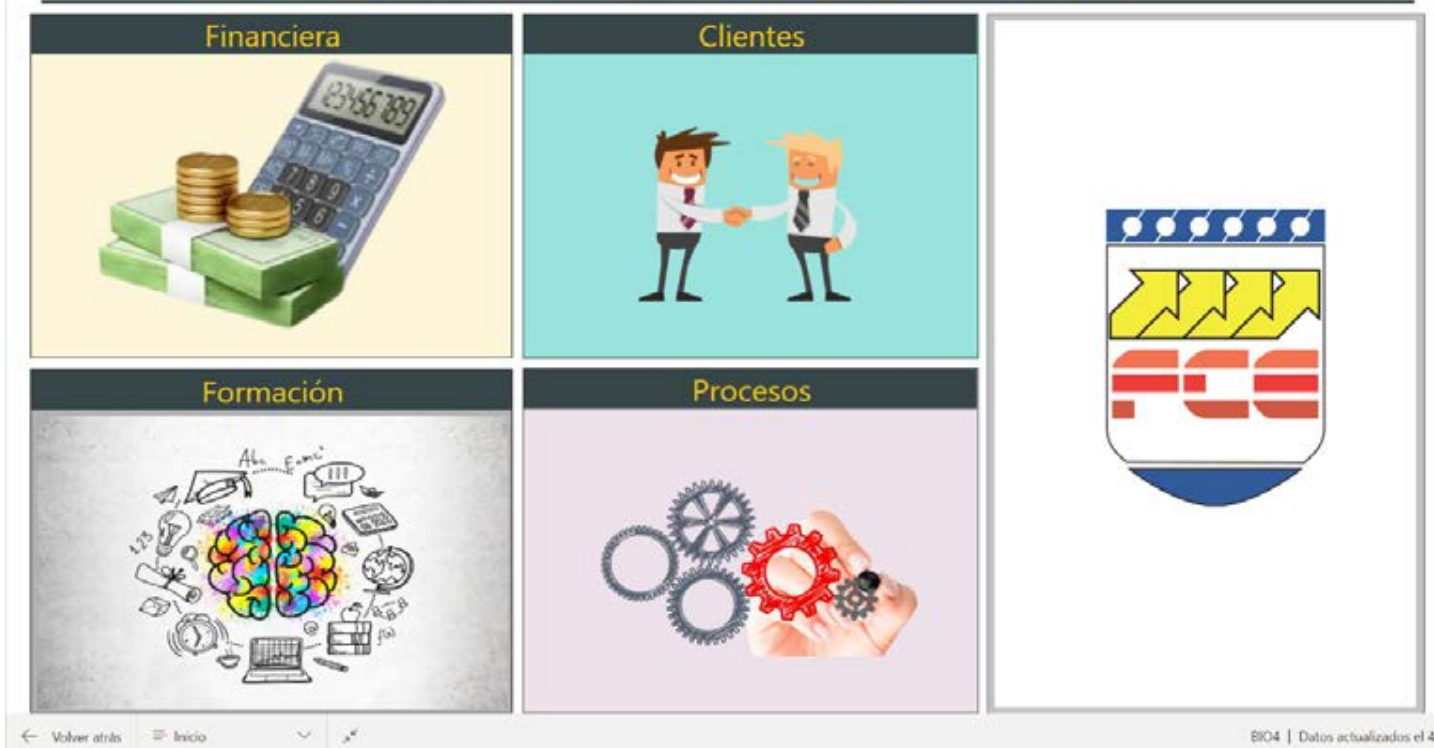

alos | Datos actuliados el \&/11/79

Figura 1: Visualizaciones del CMI de la empresa agroindustrial. Fuente: elaboración propia.

Considerando las 4 perspectivas que plantean Kaplan y Norton, se seleccionaron algunos indicadores clave, solicitando para ello datos pertinentes a la empresa. Con esta información los estudiantes realizaron modelaciones e iteraciones y lo presentaron de una manera que consideraran más amigable para el usuario, y más rica en información, según quien fuera el destinatario de la misma.

Posteriormente, se solicitó a los estudiantes armar indicadores alternativos al CMI, a partir de aspectos que consideraran de importancia para la organización.

Los trabajos desarrollados por los estudiantes, luego de haber sido presentados a los docentes y analizados por ellos, fueron transferidos a la empresa, de esta forma los estudiantes asumieron el rol de profesionales al asesorar sobre las virtudes del software, por un lado, y la importancia del manejo de la información en tiempo real, por el otro. 


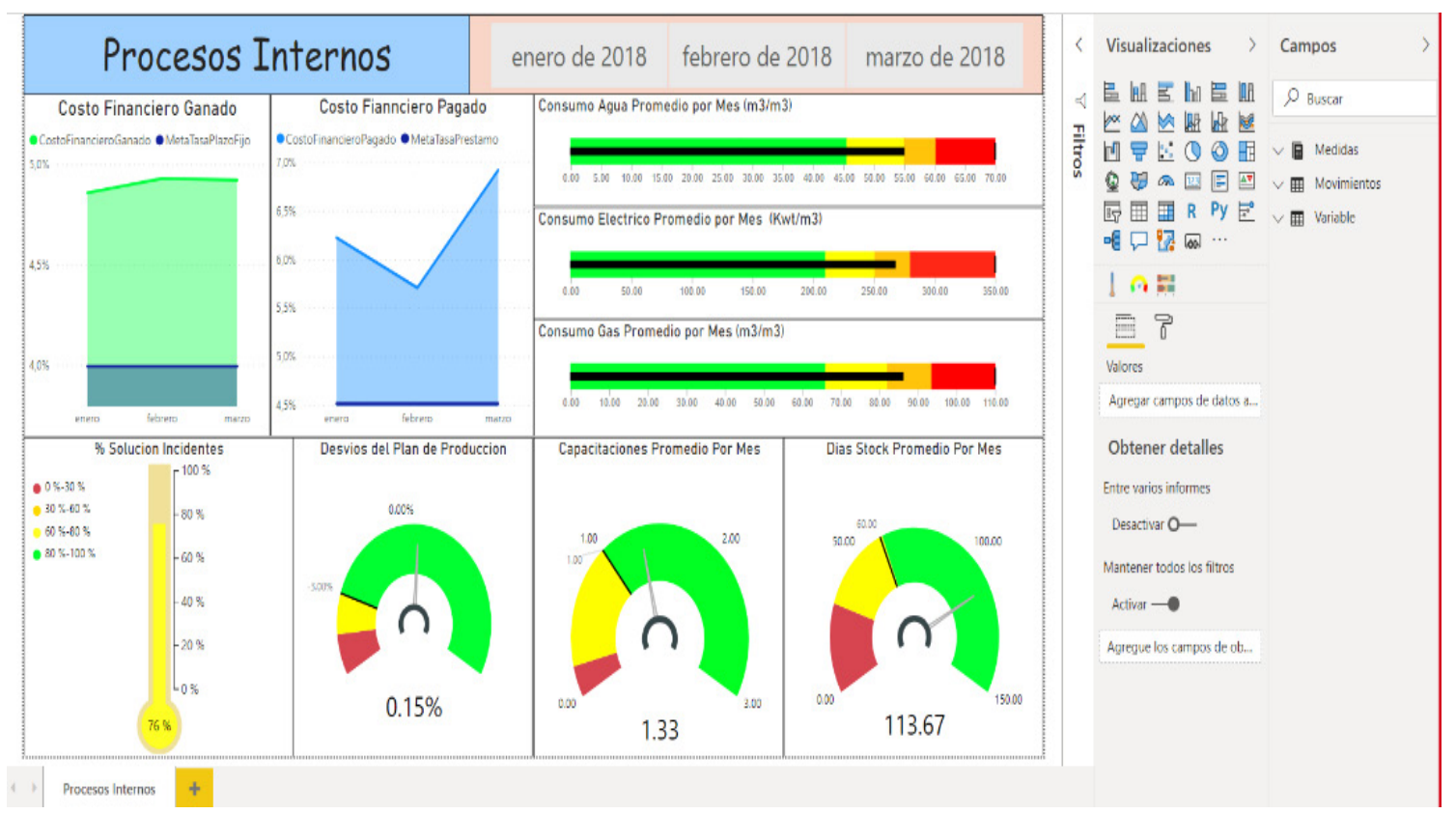

Figura 2: Visualizaciones de los indicadores del Proceso Interno. Fuente: elaboración propia

\section{CASO EECC Proyectados.}

El vértigo del cambio y la creciente inestabilidad del entorno plantean la exigencia de mejorar los elementos para la toma de decisiones, volviéndose insuficientes, en algunos casos, la información provista por los estados contables tradicionales, problemáticas que pretenden ser resultas con la implementación de Estados contables Proyectados.

Los estados contables proyectados son el resultado de la presupuestación integral que efectúa una organización.

En el Taller de Práctica II se propuso a los alumnos la confección de un estado de resultado proyectado de la empresa bajo análisis. Se realizó un diagnóstico y mediante el uso de técnicas de inferencia estadística se simularon posibles escenarios relacionados con los futuros resultados de la empresa. Se utilizaron coeficientes de variación para considerar variables ciertas e inciertas de acuerdo al contexto de incertidumbre del entorno, realizando pronósticos de las condiciones exógenas, endógenas que afecta a la organización. (ver figura 2).

La resolución se modeló, desarrolló y resolvió con la herramienta MS Excel.

Se muestra a continuación el proceso realizado por los estudiantes.

Se realizaron proyecciones de costos y ventas, a partir de cálculos estimados, que permitieron conocer la previsión de costos y ventas de la empresa en un período de tiempo futuro. 


\section{Proyección de Costos}

Para proyectar el costo, los estudiantes investigaron, recopilaron y procesaron información histórica de los costos directos e indirectos de la organización.

Se clasificaron en variables ciertas e inciertas para para estimar su comportamiento Futuro.

Las variables inciertas se proyectaron utilizando diferentes técnicas estadísticas.

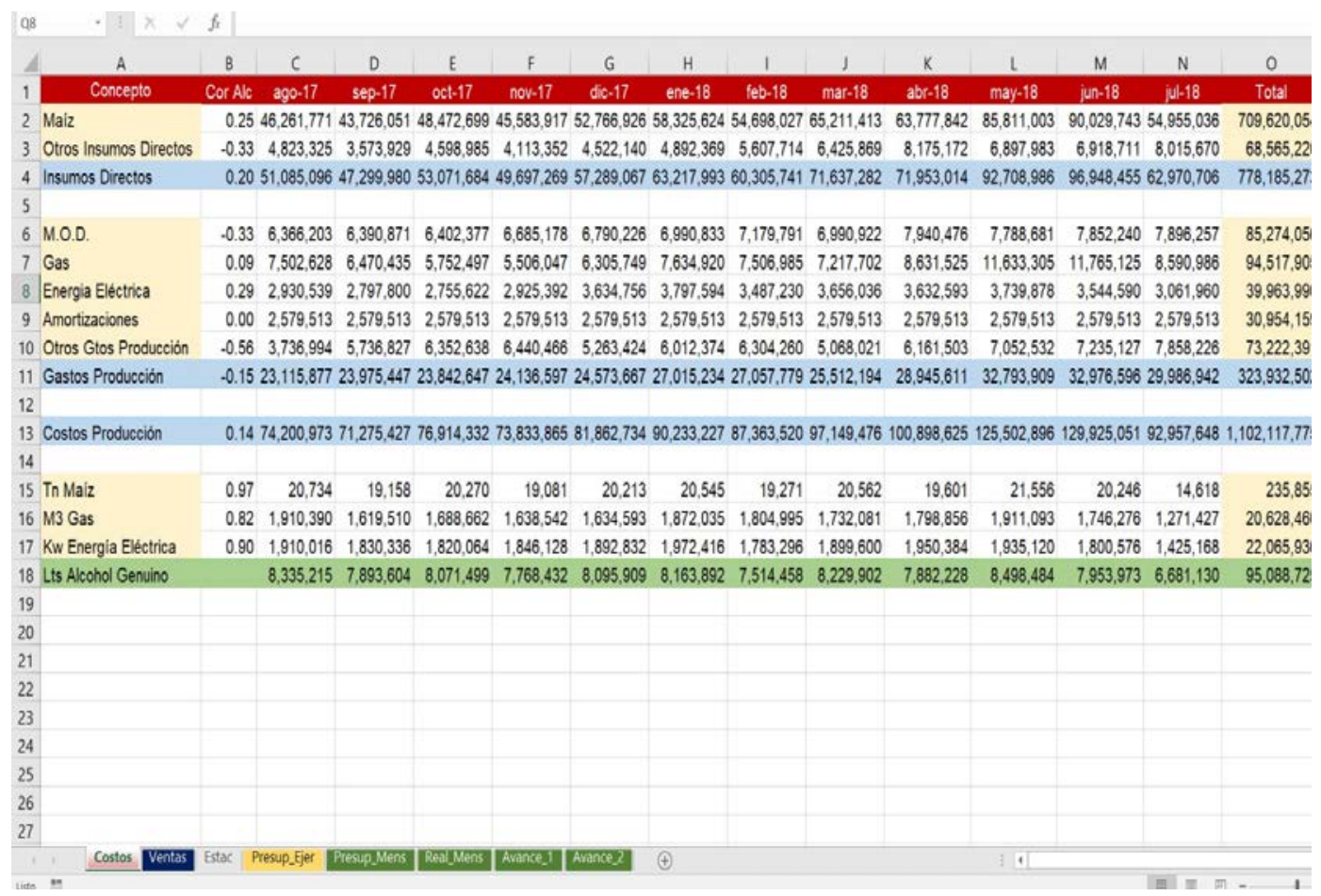

Figura:3: Visualización de la proyección de costos en monto y cantidad. Fuente: elaboración propia.

\section{Proyección de Ventas}

Para la proyección de ventas, los estudiantes investigaron la estacionalidad de los diferentes productos y servicios que comercializa la empresa. Con esta información y simulando ciertas variables que influyen en los ingresos de la Organización (Cotización Dólar, Cotización Maíz) se proyectaron las ventas de los próximos meses. 


\begin{tabular}{|c|c|c|c|c|c|c|c|c|c|c|c|c|c|c|c|}
\hline A & B & C & D & $E$ & $\mathrm{~F}$ & G & H & 1 & J & K & L & M & $\mathrm{N}$ & 0 & P \\
\hline Concepto & Cor Alc & ago-17 & sep-17 & oct-17 & nov-17 & dic-17 & ene-18 & feb-18 & mar-18 & $a b r-18$ & may-18 & jun-18 & jul-18 & Total & \\
\hline Bioetanol & 0,78 & 88.219 .486 & 92.136 .645 & 84.857 .587 & 93.062 .466 & 108.101.518 & 124.092 .425 & 94.745 .386 & 95.519 .354 & 94.553 .755 & 109.708 .572 & 103.690 .218 & 102.497.372 & 1.191.184.783 & \\
\hline Bioetanol - Merc.Exter & 0,05 & 1.422 .849 & 2.393 .745 & 1.031 .816 & 1.059 .122 & 4.393 .361 & 3.314 .414 & 3.085 .840 & 3.988 .125 & 3.722 .999 & 4.378 .744 & 4.982 .050 & 7.246 .486 & 41.019 .550 & \\
\hline DDG/DDGS & $-0,33$ & 2.669 .044 & 2.605 .181 & 1.984 .368 & 1.590 .070 & 1.941 .453 & 2.004 .000 & 2.045 .238 & 2.342 .864 & 2.763 .478 & 3.383 .443 & 4.461.424 & 2.617 .954 & 30.408 .536 & \\
\hline DDG/DDGS - Merc. Exter & 0,54 & 1.480 .372 & 0 & -268.602 & 1.560 .502 & 660.370 & 2.924 .041 & 3.146 .068 & 0 & 2.475 .677 & 1.895 .640 & 1.368 .906 & -38.810 & 15.204 .164 & \\
\hline Sementera & $-0,29$ & 0 & 0 & 0 & 0 & 0 & 0 & 0 & 0 & 0 & 0 & 0 & 5.488 .769 & 5.488 .769 & \\
\hline Soja & 0,06 & 0 & 0 & 0 & 0 & 260.544 & 511.968 & 0 & 0 & 0 & 639.537 & 1.833 .840 & 0 & 3.245 .889 & \\
\hline WDGS & $-0,21$ & 4.442 .893 & 5.089 .862 & 5.057 .895 & 5.174 .320 & 5.465 .852 & 5.302 .339 & 5.472 .586 & 6.853 .981 & 7.884.014 & 8.924 .415 & 9.713 .754 & 10.349 .470 & 79.731 .381 & \\
\hline Ventas & 0,57 & 98.234 .645 & 102.225.432 & 92.663 .064 & 102.446 .479 & 120.823 .098 & 138.149 .186 & 108.495 .117 & 108.704 .344 & 111.399 .922 & 128.930 .352 & 126.050 .192 & 128.161.242 & 1.366.283.072 & \\
\hline & & & & & & & & & & & & & & & \\
\hline 1 Lts Alcohol Genuino 2018 & & 7.035 .062 & 7.229 .329 & 6.450 .949 & 8.401 .560 & 9.325 .717 & 10.503 .139 & 7.790 .299 & 7.856 .890 & 8.130 .422 & 8.438 .820 & 7.052 .639 & 6.863 .916 & 95.078 .742 & \\
\hline 2017 & & 6.110 .478 & 5.321 .832 & 5.701 .287 & 6.138 .379 & 6.309 .527 & 6.514 .269 & 5.656 .426 & 6.424 .562 & 6.053 .503 & 7.315 .610 & 5.327 .888 & 6.766 .973 & 73.640 .734 & \\
\hline 2016 & & 7.067.751 & 7.276 .160 & 7.012 .491 & 6.795 .206 & 7.003 .524 & 7.705 .996 & 6.284 .887 & 5.870 .188 & 4.400 .478 & 4.307 .899 & 4.355 .118 & 4.379 .257 & 72.458 .955 & \\
\hline 4 Coef.Estacionalidad & & 1,02 & 0,99 & 0,97 & 1,06 & 1,12 & 1,22 & 0,98 & 1,00 & 0,91 & 0,99 & 0,83 & 0,90 & 12,00 & \\
\hline & & & & & & & & & & & & & & & \\
\hline 6 Cor Alc Prod/Nta & 0,31 & & & & & & & & & & & & & & \\
\hline & & & & & & & & & & & & & & & \\
\hline & & & & & & & & & & & & & & & \\
\hline & & & & & & & & & & & & & & & \\
\hline & & & & & & & & & & & & & & & \\
\hline & & & & & & & & & & & & & & & \\
\hline & & & & & & & & & & & & & & & \\
\hline & & & & & & & & & & & & & & & \\
\hline Costos & Ventas & Estac & Presup_Ejer & Presup_Me & Real_N & Mens & & ance_2 & † & & & 1 & & & \\
\hline
\end{tabular}

Figura 4: Visualización de la proyección de ventas. Fuente: elaboración propia.

\section{Estado de Resultado Proyectado}

Para tomar decisiones, los usuarios de la información contable-financiera de un ente realizan diferentes tipos de análisis. Los estados contables tradicionales exponen información que permite determinar la situación de una empresa en un momento dado, evaluando su solvencia y rentabilidad. Además de cumplir con diversos requisitos impuestos por las resoluciones técnicas vigentes, los estados contables exhiben información útil para la toma de decisiones de distintas categorías de usuarios.

La creciente inestabilidad del contexto, exige otra información a la contenida en los estados contables tradicionales. Tomando cada vez mayor relevancia los estados contables proyectados, exponentes de la situación que tendrá la empresa, siempre y cuando los pronósticos, premisas e hipótesis del planeamiento se mantengan y cumplan. Así como se efectúa el análisis de información perteneciente a situaciones del pasado que nos permite determinar la situación financiera de una empresa, es posible evaluar también la solvencia y rentabilidad que le espera en el futuro.

Con información histórica y aplicando estadísticos que permiten inferir comportamientos de variables inciertas, se procede a elaborar el estado de resultados proyectado. 


\begin{tabular}{|c|c|c|c|c|c|c|c|c|c|c|c|c|}
\hline 4 & A & B & c & D & $\mathrm{E}$ & $\mathrm{F}$ & G & $\mathrm{H}$ & 1 & J & K & L \\
\hline $\begin{array}{l}1 \\
2\end{array}$ & Nombre & $\begin{array}{l}\text { Correl } \\
\text { Nv.Act }\end{array}$ & $\begin{array}{l}\text { Presup } \\
\text { Ejercicio }\end{array}$ & Mínimo & Máximo & Alfa & Alea & $\begin{array}{c}\text { Simulación } \\
\text { Independiente }\end{array}$ & $\begin{array}{l}\text { Variac } \\
\text { Indepte }\end{array}$ & $\begin{array}{l}\text { Variac } \\
\text { Nv.Act }\end{array}$ & $\begin{array}{l}\text { Simulación } \\
\text { Total }\end{array}$ & \\
\hline 3 & Bioetanol & 1,00 & 2.300 .000 .000 & & & & & & & $10,2 \%$ & 2.535.614.977 & \\
\hline 4 & Bioetanol - Merc.Exter & 0,90 & 80.000 .000 & & & & & & & $9,2 \%$ & 87.375 .773 & \\
\hline 5 & Ventas Bioetanol & & 2.380 .000 .000 & 2.000 .000 .000 & 2.800 .000 .000 & 2,90 & 0,94 & 2.623 .810 .280 & & & 2.622 .990 .750 & \\
\hline 6 & WDGS & 0,80 & 150.000 .000 & & & & & & & $8,2 \%$ & 162.292 .955 & \\
\hline 7 & DDG/DDGS & 0,80 & 58.000 .000 & & & & & & & $8,2 \%$ & 62.753 .276 & \\
\hline 8 & DDG/DDGS - Merc.Exter & 0,60 & 29.000 .000 & 15.000 .000 & 50.000 .000 & 2,60 & 0,32 & 26.461 .006 & $-3,5 \%$ & $6,1 \%$ & 29.766 .881 & \\
\hline 9 & Otras Ventas & 0,00 & 17.000 .000 & 10.000 .000 & 30.000 .000 & 2,40 & 0,11 & 13.318 .282 & $-21,7 \%$ & & 13.318 .282 & \\
\hline 10 & Ventas & & 2.634 .000 .000 & & & & & & & & 2.891.122.144 & \\
\hline 11 & Maíz & 0,97 & $(1.400 .000 .000)$ & & & & & & & $9,9 \%$ & (1.539.115.278) & \\
\hline 12 & Otros Insumos Directos & 0,85 & $(135.000 .000)$ & & & & & & & $8,7 \%$ & (146.755.139) & \\
\hline 13 & Insumos Directos & & $(1.535 .000 .000)$ & & & & & & & & (1.685.870.416) & \\
\hline 14 & M.O.D. & 0,35 & $(160.000 .000)$ & & & & & & & $3,6 \%$ & (165.736.712) & \\
\hline 15 & Gas & 0,82 & $(190.000 .000)$ & & & & & & & $8,4 \%$ & $(205.960 .354)$ & \\
\hline 16 & Energia Eléctrica & 0,90 & $(82.000 .000)$ & & & & & & & $9,2 \%$ & (89.560.168) & \\
\hline 17 & Amortizaciones & 0,00 & $(60.000 .000)$ & & & & & & & & $(60.000 .000)$ & \\
\hline 18 & Otros Gtos Producción & 0,56 & $(72.000 .000)$ & $(76.000 .000)$ & $(69.000 .000)$ & 3,29 & 0,28 & (72.992.028) & $0,6 \%$ & $5,7 \%$ & $(76.566 .925)$ & \\
\hline 19 & Gastos Producción & & $(564.000 .000)$ & & & & & & & & (597.824.159) & \\
\hline 20 & Costos Producción & & $(2.099 .000 .000)$ & & & & & & & & (2.283.694.575) & \\
\hline 21 & Utilidad Bruta & & 535.000 .000 & & & & & & & & 607.427 .569 & \\
\hline \multicolumn{13}{|c|}{22} \\
\hline \multicolumn{13}{|l|}{23} \\
\hline \multicolumn{13}{|l|}{24} \\
\hline \multicolumn{13}{|l|}{25} \\
\hline \multicolumn{13}{|l|}{26} \\
\hline \multirow{2}{*}{\multicolumn{13}{|c|}{27}} \\
\hline 28 & & & & & & & & & & & & \\
\hline & Costos & Ventas & Estac & up_Ejer & p. Mens & 1 Mens & Av: & rance 1 & ce 2 & $(+)$ & & \\
\hline
\end{tabular}

Figura 5: Visualización del Estado de Resultado Proyectado. Fuente: elaboración propia.

\section{Avance Presupuestario Vs real}

Administrar es un proceso continuo, que se desarrolla ante la exigencia de nuevas decisiones, frente a situaciones también nuevas y el control como el sistema que proporciona información y detecta oportunidades de decidir. Contar con herramientas y metodologías de gestión adecuadas para el momento actual, son consideradas como alternativas válidas para la obtención de mejores resultados.

Para ello, el presupuesto elaborado es cotejado con el presupuesto real para analizar desviaciones y poder tomar decisiones que permitan corregir aspectos críticos.

El presupuesto, es un instrumento de programación, de ejecución de políticas de gestión y de evaluación, resulta fundamental que su implementación se oriente a maximizar la eficacia y eficiencia de la gestión, así como el logro de resultados. 


\begin{tabular}{|c|c|c|c|c|c|}
\hline K13 & $x \quad \checkmark \quad f_{x}$ & & & & \\
\hline 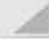 & A & B & C & D & $\mathrm{E}$ \\
\hline 1 & & Presupuesto & Real & Sens & - \\
\hline 2 & Nombre & Acumulado & Acumulado & $5 \%$ & - \\
\hline 3 & Bioetanol & $571,379,963$ & $548,953,910$ & $-4 \%$ & \\
\hline 4 & Bioetanol - Merc.Exter & $19,886,677$ & $18,101,919$ & $-9 \%$ & \\
\hline 5 & Ventas Bioetanol & $591,266,640$ & $567,055,829$ & $-4 \%$ & \\
\hline 6 & WDGS & $37,311,129$ & $34,591,710$ & $-7 \%$ & \\
\hline 7 & DDG/DDGS & $14,426,970$ & $13,855,801$ & $-4 \%$ & \\
\hline 8 & DDG/DDGS - Merc. Exter & $7,222,614$ & $7,251,481$ & $0 \%$ & \\
\hline 9 & Otras Ventas & $4,250,000$ & $4,358,809$ & $3 \%$ & \\
\hline 10 & Ventas & $654,477,352$ & $627,113,630$ & $-4 \%$ & \\
\hline 11 & Maíz & $(347,862,604)$ & $(323,611,080)$ & $-7 \%$ & \\
\hline 12 & Otros Insumos Directos & $(33,569,392)$ & $(32,029,800)$ & $-5 \%$ & \\
\hline 13 & Insumos Directos & $(381,431,996)$ & $(355,640,880)$ & $-7 \%$ & \\
\hline 14 & M.O.D. & $(39,911,860)$ & $(37,915,737)$ & $-5 \%$ & \\
\hline 15 & Gas & $(47,254,782)$ & $(44,032,142)$ & $-7 \%$ & \\
\hline 16 & Energia Eléctrica & $(20,383,844)$ & $(21,809,856)$ & $7 \%$ & \\
\hline 17 & Amortizaciones & $(15,000,000)$ & $(15,120,999)$ & $1 \%$ & \\
\hline 18 & Otros Gtos Producción & $(17,936,539)$ & $(17,143,469)$ & $-4 \%$ & \\
\hline 19 & Gastos Producción & $(140,487,025)$ & $(136,022,203)$ & $-3 \%$ & \\
\hline 20 & Costos Producción & $(521,919,021)$ & $(491,663,083)$ & $-6 \%$ & \\
\hline 21 & Utilidad Bruta & $132,558,331$ & $135,450,547$ & $2 \%$ & \\
\hline \multicolumn{6}{|l|}{22} \\
\hline 23 & & & & & \\
\hline
\end{tabular}

Figura 6: Visualización del Avance Presupuestario Vs real. Fuente: elaboración propia.

Cabe destacar que, previo a la presentación formal de los trabajos de los estudiantes ante la empresa, el equipo docente procuró la colaboración de un equipo de psicólogos, que los introdujeron en los conceptos de inteligencia y gestión de emociones, con la finalidad de brindar herramientas útiles para la exposición en un ambiente laboral.

\section{Resultados}

El desarrollo del Taller proveyó a futuros egresados en Ciencias Económicas elementos para resolver situaciones de implementación de sistemas de información propios de su incumbencia profesional, empleando para ello métodos de relieve técnico y recursos tecnológicos actuales. Para evaluar los resultados en relación al aprendizaje se utilizaron instrumentos en base a características técnicas, a través de medidas directas.

Las medidas directas son aquellas en que se observa un producto del trabajo del estudiante, en este caso en particular la evaluación fue realizada en basa a criterios de competencia en cuanto al logro de un cierto nivel en el desarrollo del CMI, la selección de los indicadores apropiados y la elaboración de los presupuestos financieros proyectados en el marco de las TIC.

La evaluación referida a criterios demuestra que: La experiencia posibilitó la práctica y el desarrollo de habilidades, la interacción y el intercambio con problemas de la realidad organizacional enriqueciendo la actividad académico-científica de la universidad con su interacción y comunicación con el contexto actual. Se transfirió a la organización donde se realizó la práctica, respuestas novedosas y se aplicaron recursos propios de la inteligencia de negocios. Los estudiantes pudieron apropiarse del 
conocimiento en la vinculación, la capacitación y el asesoramiento a través de una experiencia de práctica pre profesional muy similar a la experiencia real que tendrán una vez egresados.

\section{Discusión y conclusiones}

El diseño de actividades de aprendizaje dio lugar a un trabajo de análisis y reelaboración conceptual que permitió su transferencia al campo profesional, posibilitando, de esta manera, una comprensión integral del rol del graduado en Ciencias Económicas.

La transferencia llevada a cabo sirvió para la elaboración de liquidaciones e informes de gestión, facultando a la organización a: 1) Tomar mejores decisiones, más rápidas, que ayudaron a mejorar su desempeño. 2) Se convirtieron los datos en información, estableciendo el puente que una las grandes cantidades de datos y la información que los tomadores de decisiones requieren cotidianamente. 3) Se potenció el empleo transversal de los recursos provistos por la Tecnología, que democratizan posibilidades y simplifican cuestiones de orden práctico-técnico.

Para dar continuidad a este proceso, se pretende revalorizar la relación que existe entre la disciplina y las prácticas, articuladas con el aprendizaje de contenidos del campo profesional y científico, a través de la interacción con problemas de la realidad social.

Se considera la necesidad de proyectar una sociedad de conocimiento, no sólo de información. Para alcanzarla, será prioridad trabajar desde un enfoque pedagógico para realizar un uso correcto de las TIC, a través del cual la creación de entornos de aprendizaje virtuales y el tratamiento de la información, la generación de nuevas estrategias de comunicación y de aprendizaje sean imprescindibles. Para ello, se necesita un profesorado capacitado en este ámbito, que involucre a las TIC en la enseñanza de sus estudiantes y los oriente en un uso adecuado de ellas.

\section{Referencias}

Escribano, A. y Del Valle, A. (2016): El Aprendizaje Basado en Problemas: Una Propuesta Metodológica en Educación Superior. Narcea SA Ediciones. Madrid.

Carneiro, R. y otros (2010): Los desafíos de las TIC para el cambio educativo. Editorial Fundación Santillana. Buenos Aires, Argentina.

Consejo de Universidades (2017). Despacho C.A.A. N 127.

Hernández Sampieri, R. y otros (2018): Metodología de la Investigación: las rutas cuantitativa, cualitativa y mixta. Editorial Mc Graw Hill. Ciudad de México.

Kaplan, R. y otro (1996): The Balanced Scorecard. Harvard Business. School Press.

Sunkel, G. (2010): Las TIC y los nuevos paradigmas educativos: la transformación de la escuela en una sociedad que se transforma. Editorial Fundación Santillana. Buenos Aires, Argentina. 


\section{Aprendices en Expansión en la Red Social}

\section{Dans Álvarez de Sotomayor, Isabel}

orcid.org/0000-0003-0676-4127 


\section{APRENDICES EN EXPANSIÓN EN LA RED SOCIAL}

Dans Álvarez de Sotomayor, Isabel

orcid.org/0000-0003-0676-4127

\section{Resumen}

En este trabajo se pone el foco en las potencialidades de Twitter para dar respuesta a la necesidad de alfabetización digital del alumnado del primer curso del grado de Educación Infantil. Se utiliza la red social como plataforma de interacción didáctica en la asignatura de Procesos de mejora y uso de las TIC. A fin de contribuir a la identidad digital de los estudiantes, sirve la herramienta como portfolio, punto de encuentro e interacción con profesionales de la enseñanza, donde aprenden cómo participar en la conversación de los medios sociales con su propia narración sobre el aprendizaje de las TIC.

\section{Palabras clave}

Red social, aprendizaje, educación superior; Twitter. 


\section{Introducción}

La educación superior ha incorporado las tecnologías como parte del contexto global de la sociedad del conocimiento. En concreto, el uso de las redes sociales en educación ha sido más potenciado en esta etapa que en los demás niveles reglados (Malik, Heyman-Schrum y Johri, 2019). Por un lado, el acceso legal se supone en 14 años y el uso de un espacio digital compartido no está exento de dificultades, por los permisos parentales que requiere y los riesgos que de su empleo se derivan, al menos, hasta el momento. La aparición de una forzosa educación a distancia o combinada fruto de la situación mundial provocada por la pandemia quizá abra las puertas a un cambio, que tímidamente ya puede comprobarse en el aumento de pantallas con fines escolares. Por otro lado, la investigación se ha centrado en el alumnado universitario, quizá por ser objeto de mayores innovaciones, el más próximo a las figuras investigadoras o por la propia esencia de la red social Twitter como canal de contenido alejado de los intereses adolescentes.

Las redes sociales en las que se han centrado las experiencias didácticas con estudiantes universitarios son Facebook y Twitter en mayor medida (Bodily, Leary y West, 2019), quedando desplazado el análisis de otras herramientas, tales como Snapchat o Instagram (Manca, 2020). Estas dos últimas se han vinculado con mayor frecuencia a experiencias lúdicas. El caso de Twitter es paradigmático porque no se trata de la red social más utilizada en términos de población y, de hecho, ha descendido su frecuencia diaria. En el año 2019 la posición que ostentaba era de quinta en el ránking de uso en España detrás de WhatsApp, Facebook, Youtube e Instagram (IAB, 2019, p. 18). Sin embargo, ya desde su concepción inicial el microblogging (Orihuela, 2011) es óptimo para atender a la finalidad instructiva de los procesos de enseñanza superior. Si bien es cierto que el desarrollo de la herramienta ha ido completando sus funcionalidades y aun integrando las que pertenecieron en origen a otras (el uso de vídeo e imagen fundamentalmente). Lo cual no entorpece su posible uso educativo, sino que lo enriquece con la posibilidad de un discurso más visual e informal.

Los cambios se producen en el entorno de la motivación, como ha sido recogido en numerosas publicaciones (Ricoy y Feliz, 2016; Alamri, 2019). Este estímulo en el entorno educativo favorece el interés por aprender y las relaciones interpersonales (Vahedi et al., 2019). Se han señalado las ventajas de Twitter para la educación universitaria en numerosas publicaciones, entre las cuales destaca el aprendizaje colaborativo, la interacción entre iguales, la creación de conocimiento compartido y el fomento del pensamiento crítico (Gao, Luo y Zhang 2012; Tang y Hew 2017). Otros autores niegan la contribución eficaz de la red social, como recogen Abella y Delgado (2015, p. 366), "apenas contamos con evidencias empíricas sobre su uso y sus efectos en el aprendizaje" o bien se advierten de limitaciones tales como las consecuencias de la multitarea en la atención (Pedro, Barbosa y santos, 2018).

\section{Contextualización}

El aprendizaje sobre las tecnologías de la información y comunicación ha ganado terreno como recurso para abordar la enseñanza. De hecho son utilizadas en todas las etapas educativas y con diversos objetivos didácticos. En particular, a nivel universitario forma parte del plan de estudios de las facultades de Ciencias de la 
Educación como asignaturas ("Procesos y mejora de uso de las TIC", "Escuela, comunidad y TIC", etc.) y es una competencia transversal de estos estudios. Sin embargo, la transferencia de la tecnología social o para el entretenimiento al aprendizaje no es un fenómeno automático (Kennedy, Judd, Churchward, Gray, Krause, 2008).

En este trabajo se pone el foco en las potencialidades de este enfoque para dar respuesta a la necesidad de alfabetización digital del alumnado del primer curso del grado de Educación Infantil. Concretamente, se hace una propuesta de uso de la red social Twitter como plataforma de interacción didáctica. Se trata de una experiencia desarrollada dentro de la asignatura de "Procesos de mejora y uso de las TIC".

La investigación-acción está relacionada con los resultados de la implementación efectiva de un escenario interactivo. A fin de contribuir a la identidad digital de los estudiantes, futuras maestras y maestros, se utiliza la red social como portfolio de aula y punto de encuentro conversacional con otros profesionales de la enseñanza. El uso de Twitter sirve para enseñar a los estudiantes cómo sintetizar ideas y cómo participar en la conversación de los medios sociales con su propia narración sobre el aprendizaje. Se convierte así la práctica en un instrumento al servicio del modelo competencial, pues permite aprender haciendo en la realidad del espacio virtual. Habitualmente no utilizan la red como espacio de aprendizaje y, en ocasiones contadas, como lugar para la reflexión crítica (Pedro, Barbosa y Santos, 2018).

El uso de los medios sociales acontece en un contexto real excepcional: las aulas se cierran físicamente y los procesos de enseñanza-aprendizaje se trasladan a las pantallas y a los hogares. El caso del confinamiento vivido durante la situación de emergencia sanitaria a partir de marzo de 2020 agudiza la necesidad de contar con canales alternativos de comunicación no presencial. Y es precisamente en este momento en el que se desarrollaba la experiencia de uso de Twitter como espacio de aprendizaje de la asignatura.

\section{Descripción de la experiencia}

La alfabetización digital es objeto de la competencia transversal propia de los estudios universitarios en el Grado de Maestra/o en Educación Infantil: "Conocimiento instrumental de las tecnologías de la información y de la comunicación”. Además, se trata del objeto de la asignatura que cursaban los participantes en la experiencia. A ello se une el giro radical del curso académico 2019/2020 en el mes de marzo con el traslado de la enseñanza a la modalidad a distancia. No se trataba ya de una habilidad necesaria en términos generales de formación para la profesión, sino de una cuestión urgente dadas las circunstancias limitadoras de la actividad docente presencial.

La experiencia con Twitter toma como base la que han publicado otros investigadores (Junco, Heiberger, Loken, 2011; Ricoy y Feliz, 2016), aunque difiere en algunas cuestiones. Se compone de tres fases. En primer lugar, se realiza una reflexión conjunta sobre la utilización de las redes sociales para los procesos de enseñanza-aprendizaje. Para ello se recogerá la situación de partida del alumnado en un cuestionario inicial. En segundo lugar, la docente crea una cuenta con un perfil ad hoc para la experiencia donde se identifica como profesora y se les pide a los estudiantes que mantengan una cuenta en Twitter. Aunque algunas personas ya están 
registradas en la red social, la cuenta utilizada debe tener fines académicos. El uso de la red social sirve para localizar contactos relevantes en el área de tecnología educativa y educación, compartir objetos digitales creados en el aula y reflexionar sobre los contenidos de la asignatura. De ahí que se analicen las producciones en la red. En tercer lugar, se recogerán las principales aportaciones mediante una selección personal y el grado de satisfacción con la experiencia.

La experiencia parte de los siguientes objetivos:

- Potenciar la reflexión y ayudar a formularse preguntas sobre el uso de la tecnología al mismo tiempo que se opina en el medio.

- Conocer y compartir el aprendizaje con el grupo-clase: favorecer la colaboración e interacción.

\section{Resultados}

Partimos de la realidad de un alumnado que hace pocos meses todavía cursaba bachillerato o un ciclo superior. La diversidad en el modo en que utilizan las herramientas tecnológicas es amplia, aunque centrada en el ocio, tal como se recoge en el cuestionario inicial para conocer mejor su situación como usuarios. De hecho, como puede verse en el gráfico 1, el 60,6\% declara no haber usado las tecnologías para el aprendizaje "nunca" en la etapa de Educación Infantil.

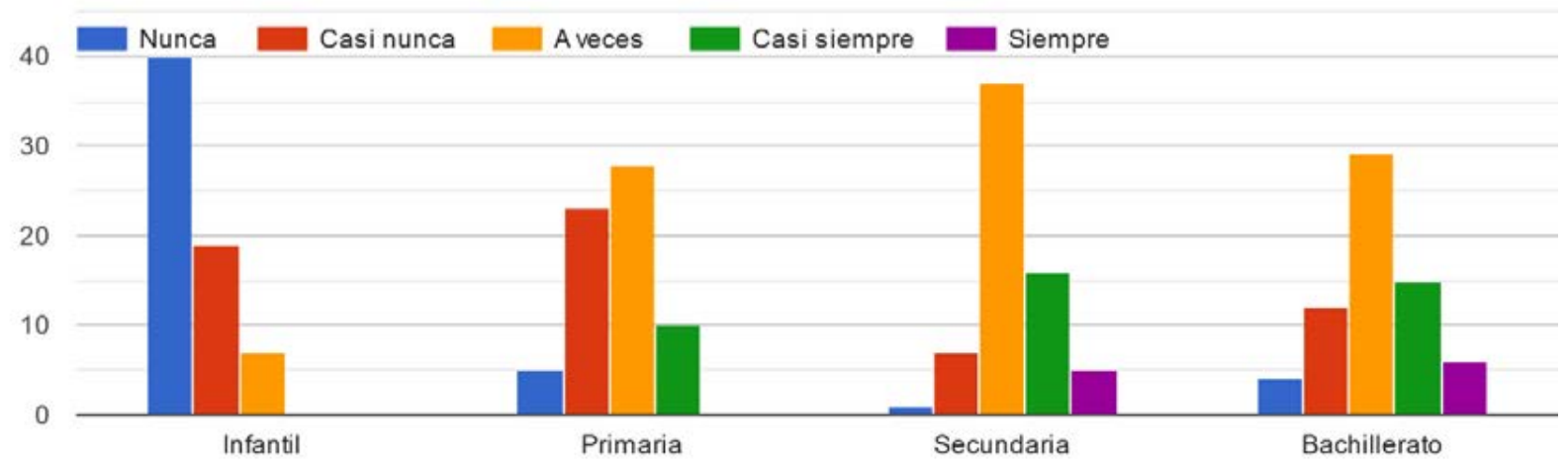

\section{Gráfico 1. Utilización de las TIC en la escuela}

Con este punto de partida, se trata de averiguar si se cumple lo que otros autores señalan como un fenómeno común cuando se emplean las redes sociales en el aula: el aprendizaje es más participativo y aumenta el interés (Ricoy y Feliz, 2016). Para los estudiantes el principal beneficio de la tecnología en el aula es la ampliación de los canales de conocimiento $(42,4 \%)$ seguido de la facilitacion del aprendizaje (30,3\%), como puede observarse en el gráfico 2 a continuación: 


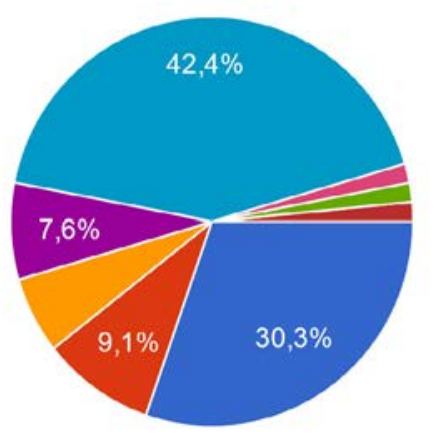

Facilita el aprendizaje

Aumenta la motivación

Ahorra tiempo

Ahorra costes

Mejora la comunicación

Amplía los canales de conocimiento

Permite aprender contidos de forma

máis sinxela

Facilitia el aprendizaje, ahorra tiempo...

Aumenta la motivación, ahorra costes...

\section{Gráfico 2. Beneficios de la tecnología en el aula}

Junto a ello es relevante examinar cuáles eran las actitudes del alumnado frente a las ventajas y riesgos del empleo de las redes sociales con fines educativos (gráfico 3 ). Destaca sobremanera la falta de atención que provocarían las tecnologías $(53,8 \%)$ como fuente de dispersión y bajo rendimiento.

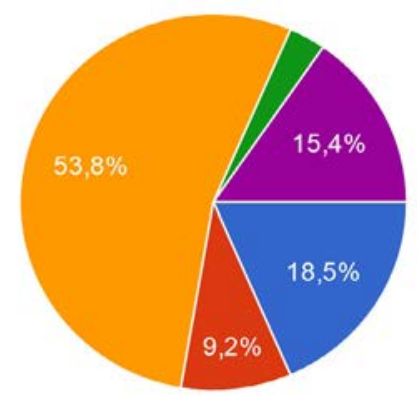

Riesgos de ciberdelitos

- La automatización va contra la personalización

Falta de atención y concentración

No favorece la profundidad en el estudio

- Existen diferencias en los dispositivos entre el alumnado y los centros

\section{Gráfico 3. Desventajas de las TIC en el aula}

Ante estas percepciones la incorporación de la red social en la asignatura está enfocada hacia el intercambio colaborativo de contenidos educativos relevantes y de las prácticas digitales diseñadas para Educación Infantil. Como puede verse en la imagen posterior las interacciones más frecuentes sucedieron entre miembros de la asignatura, pero aparecen otros relevantes que aportan conocimiento especializado, como son un periódico nacional, el ministerio de educación o una revista sobre innovación educativa y tecnología. 


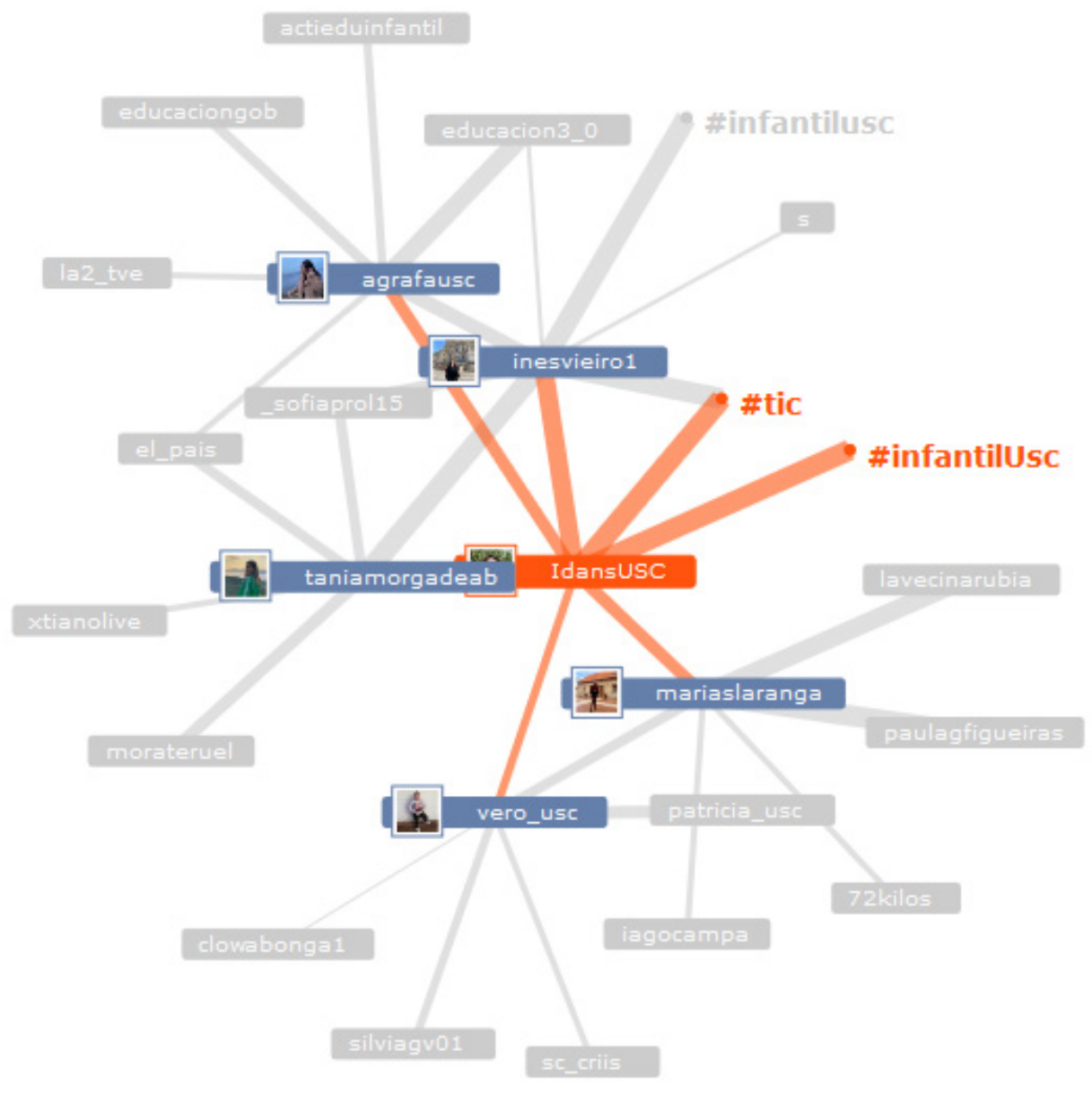

\section{Imagen 1. Mapa de interacciones en Twitter}

Los mensajes producidos han sido de dos tipos: los referidos a noticias relacionadas son educación infantil, la tecnología educativa o el aprendizaje en general y los que mostraban los productos digitales elaborados por el alumnado (creación de rutinas para PDI, videotutoriales científicos, videocuentos, canciones, etc.) o por otros docentes localizados en la red. Los tuits han sido valorados por los jóvenes, quienes han destacado las reflexiones, recomendaciones y consejos de propios compañeras y compañeros como las mejores aportaciones. Se presentan aquí algunos de esos ejemplos seleccionados por quienes cursaban la materia: 

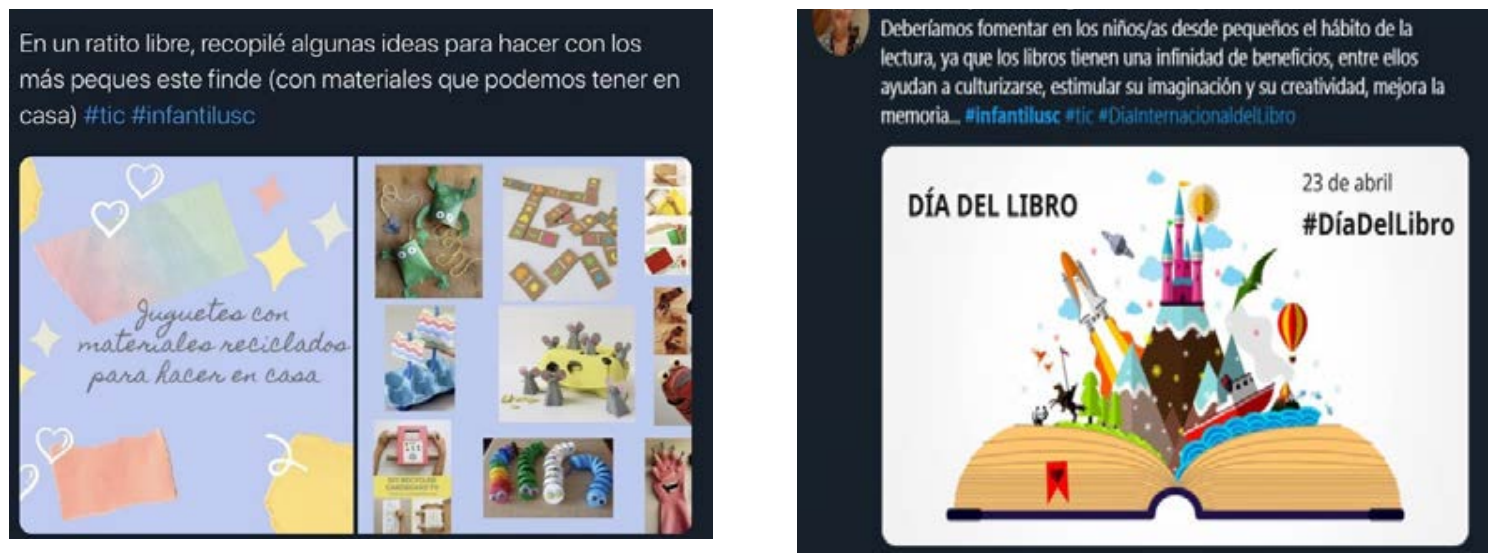

Lendo "La nueva educación" de

@cccesssarrr atópome con esto. Ollo ao punto tres compañeiras $9 \mathrm{q}$ \#infantilusc

\#TIC

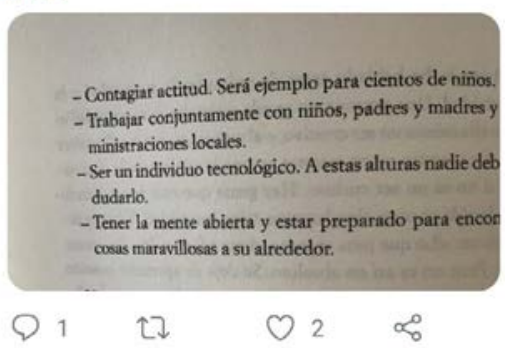

\section{Imagen 2. Reflexiones educativas y del alumnado}

Por último, es interesante destacar el crecimiento socioemocional fruto de esta experiencia. Siendo las redes sociales un instrumento de potencial mejora de las relaciones 0 , al menos, de la comunicación docente-alumnado y entre iguales, la situación excepcional vivida de confinamiento forzoso en nuestros hogares ha provocado un uso de la red social como canal de contacto personal. En el siguiente gráfico se aprecia claramente cómo aumentan las impresiones de los tuits en el mes de marzo:

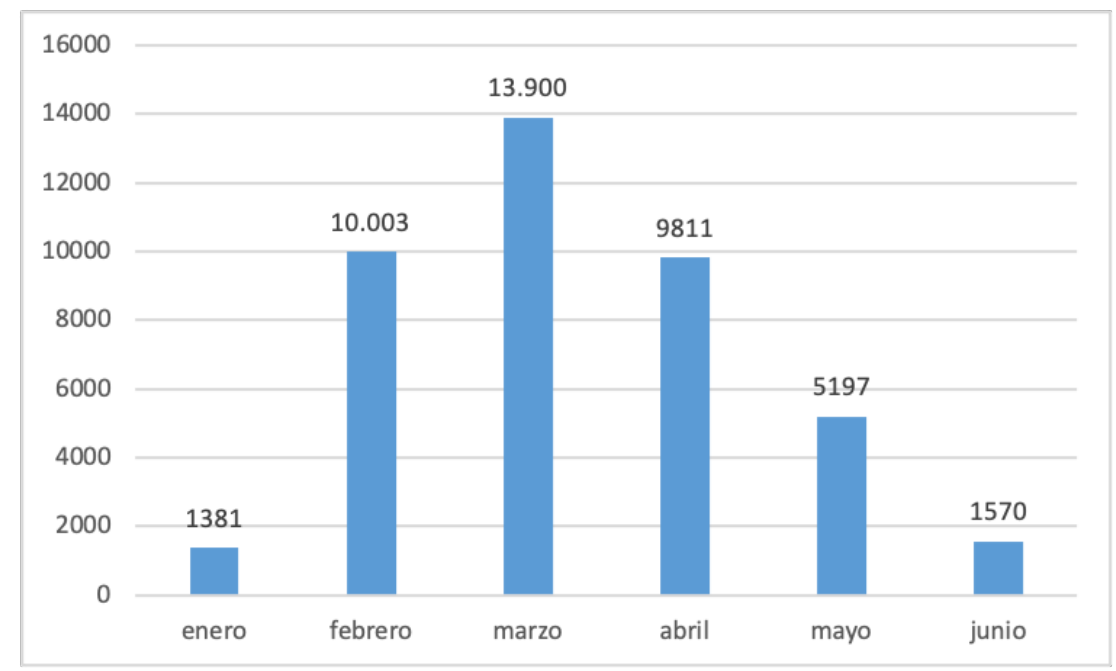


Los estudiantes referían anécdotas de sus vivencias personales en esta época manifestando su estado de ánimo. Incluso la orientación de las prácticas digitales tomó un nuevo cariz dado que se pretendía cubrir el déficit de atención escolar de los menores con producciones alternativas para la educación a distancia. Además de compartirlas en Twitter, el alumnado optó por subir a Youtube sus creaciones para contribuir a dar este servicio a las familias y al profesorado de Infantil (imagen 3):

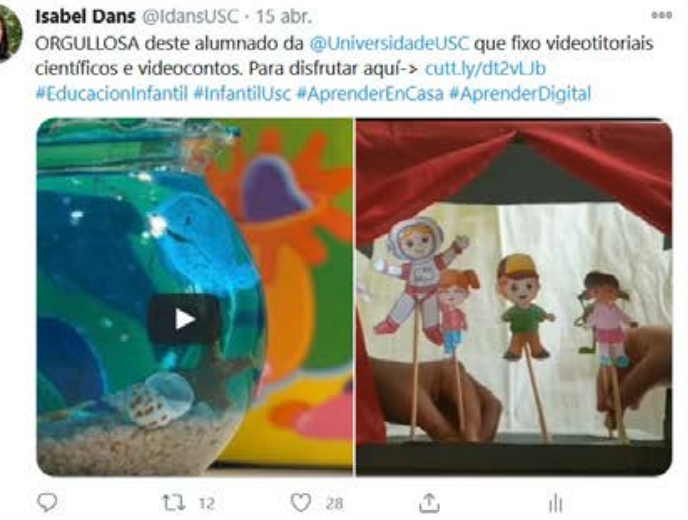

Imagen 3. Tuit sobre las creaciones audiovisuales del alumnado

La ayuda en el aprendizaje no solo se comparte para educadores de niñas y niños de Educación Infantil, sino que se trasfieren a la red las experiencias familiares en el confinamiento surgidas gracias a las prácticas con las herramientas digitales de la asignatura.
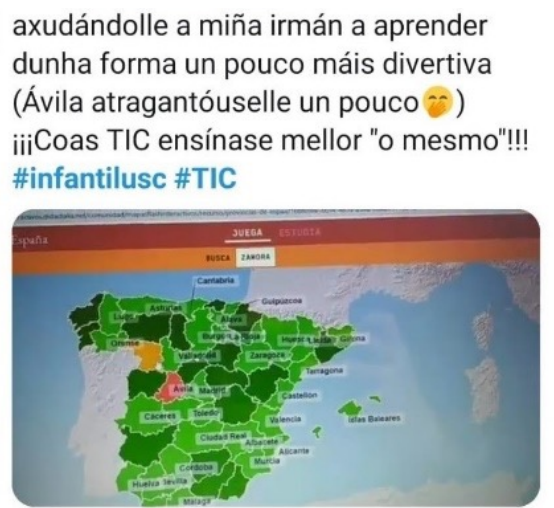

44 reproducciones

O $5 \alpha_{n}^{0}$

Que alegría ver cómo nestos días que estamos a pasar o videoconto que creamos as miñas compañeiras e máis eu lle serviu a meus avós a desconectar e sacarlle un sorriso! Encantoulle e insisten en que llo mandemos á tele! \#infantilusc \#tic
Q 1
七
O 3 
Al finalizar el curso académico se realizó una evaluación de la experiencia mediante un cuestionario en línea (gráfico 5), donde se destaca la mejora profesional que supone esta iniciativa. De este modo, las respuestas del alumnado confirman una valoración muy positiva del uso de Twitter como fuente de aprendizaje.

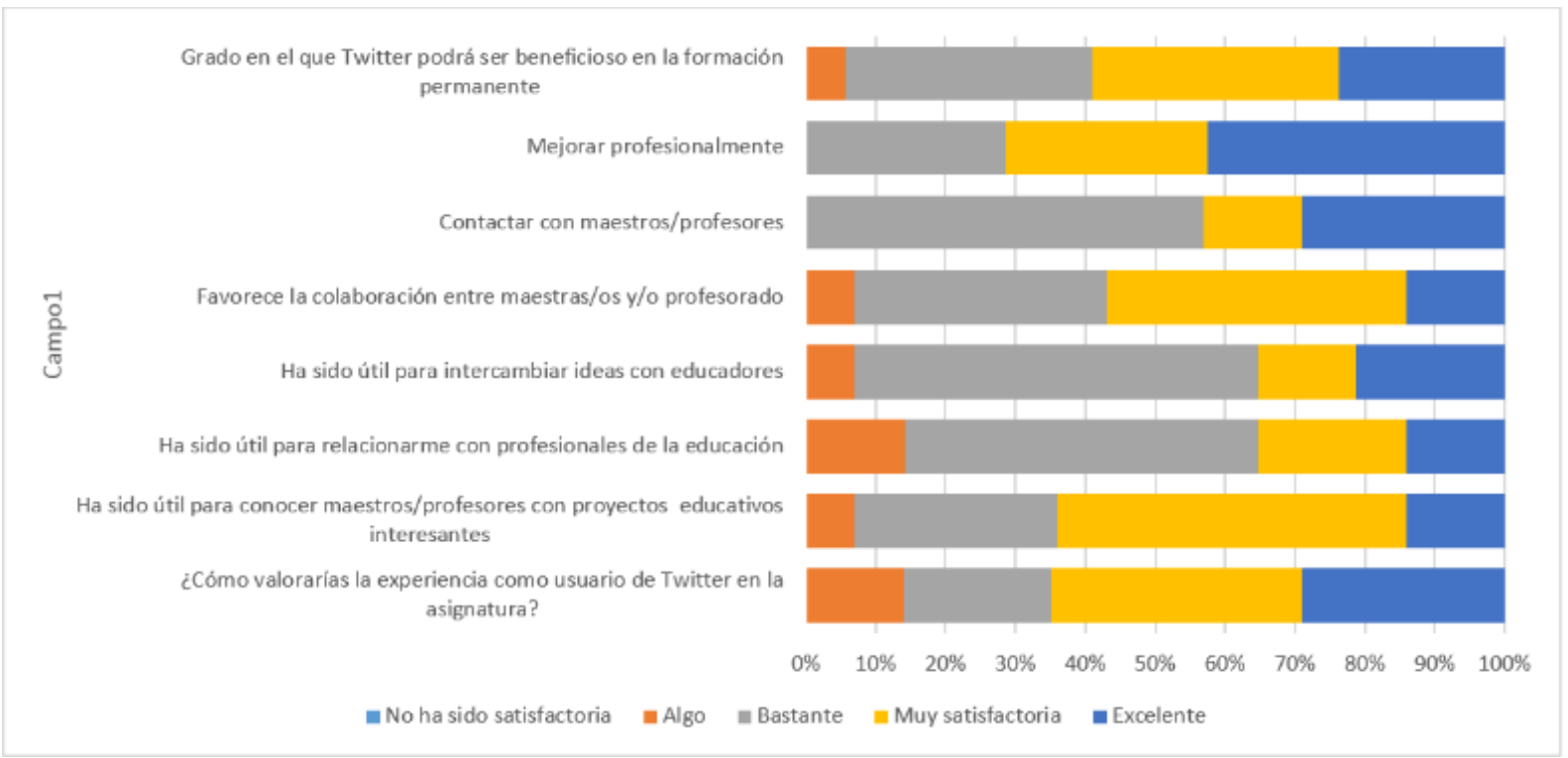

Gráfico 5. Niveles de satisfacción con la experiencia de aprendizaje en Twitter

\section{Discusión y conclusiones}

Esta propuesta pone de manifiesto la necesidad de alfabetizar digitalmente al alumnado universitario que será el encargado de educar en el medio. Así mismo, se constata la complejidad de la educación en la red y, en concreto, las oportunidades de una formación ética y técnica. Además de ser un posible elemento motivador para la pedagogía universitaria, se mejora la competencia digital, el aprendizaje de los contenidos propios de la asignatura y se fortalece la identidad digital de los participantes. En palabras de una usuaria: "Me parece que se trata de una herramienta muy útil para conocer a maestros y también para dar a conocer tu trabajo a estos mismos".

Se favorece la educación digital profesionalizante en orden a la consecución de las competencias propias del grado universitario. La red es así una plataforma de aprendizaje colaborativa, por lo que también adquieren un estilo didáctico útil para implementar en su futura práctica docente. Twitter tiene potencial para mejorar las capacidades de aprendizaje de los estudiantes, así como mejorar el interés por los procesos de enseñanza-aprendizaje con redes sociales. Producir objetos digitales y compartirlos en un contexto abierto de la red social genera la posibilidad de formular un ambiente para la reflexión sobre el propio objeto de estudio y contribuye al desarrollo de su identidad digital. Esta iniciativa también facilita la relación didáctica entre docente y alumnado, pues mejora las interacciones personales y la preocupación por todos los miembros del aula. En particular, las circunstancias sobrevenidas por el confinamiento domicilitario potenciaron el uso de este medio. 


\section{Referencias}

Abella García, V., Delgado Benito, V. (2015). Aprender a usar twitter y usar twitter para aprender. Profesorado, 19(1): 364-378.

Alamri, M. M. (2019). Undergraduate Students' Perceptions toward Social Media Usage and Academic Performance: A Study from Saudi Arabia. International Journal of Emerging Technologies in Learning, 14(03), 61-79.

Bodily, R., Leary, H., \& West, R. E. (2019). Research trends in instructional design and technology journals. British Journal of Educational Technology, 50(1), 64-79.

Gao, F., Luo,T. y Zhang, K. (2012). Tweeting for learning: A critical analysis of research on microblogging in education published in 2008-2011. British Journal of Educational Technology, 43(5),783-801.

IAB y Elogia (2019). Estudio anual redes sociales en España 2019. Recuperado de https://iabspain.es/estudio/estudio-anual-de-redes-sociales-2019/

Junco, R., Heiberger, G. y Loken, E. (2011). The effect of Twitter on college student engagement and grades. Journal of computer assisted learning, 27(2), 119-132.

Kennedy, G. E., Judd, T. S., Churchward, A., Gray, K. y Krause, K. L. (2008). First year students' experiences with technology: Are they really digital natives? Australasian journal of educational technology, 24(1).

Malik, A., Heyman-Schrum, C. y Johri, A. (2019). Use of Twitter across educational settings: a review of the literature. International Journal of Educational Technology in Higher Education, 16(1), 36.

Manca, S. (2020). Snapping, pinning, liking or texting: Investigating social media in higher education beyond Facebook. The Internet and Higher Education, 44, 100707.

Orihuela, J. L. (2011). Mundo Twitter: una guía para comprender y dominar la plataforma que cambió la red. Grupo Planeta Spain.

Pedro, L., C. Barbosa y C. Santos (2018). A critical review of mobile learning integration in formal educational contexts, International Journal of Educational Technology in Higher Education, 15(1), 1-10.

Ricoy, M. C. y Feliz, T. (2016). Twitter as a learning community in higher education. Journal of Educational Technology \& Society, 19(1), 237-248.

Tang, Y. y Hew, K.F. (2017). Using twitter for education: Beneficial or simply awaste oftime? Computers\&Education, 106, 97-118.

Vahedi, Z., Zannella, L. y Want, S. C. (2019). Students' use of information and communication technologies in the classroom: Uses, restriction, and integration. Active Learning in Higher Education. 


\section{Influencers: Los Nuevos Bardos. Redes Sociales para Enseñar Inglés}

\section{Pereda Nieto, Alba}

Universidad de Santiago de Compostela

alba.pereda@rai.usc.es

\section{Dans Álvarez de Sotomayor, Isabel}

orcid.org/0000-0003-0676-4127 


\title{
INFLUENCERS: LOS NUEVOS BARDOS. REDES SOCIALES PARA ENSEÑAR INGLÉS
}

\author{
Pereda Nieto, Alba \\ Dans Álvarez de Sotomayor, Isabel
}

\section{Resumen}

La destreza de mediación incorporada en el curso 2019/2020 a los planes curriculares de las EOIs supone una oportunidad para aventurarse en el terreno de la literatura popular como vehículo para el aprendizaje de lenguas extranjeras. El propósito de este artículo es ofrecer una propuesta educativa concreta en torno a la mediación para el aprendizaje del inglés. Para ello se proporciona la inserción de la literatura popular irlandesa y gallega en el nivel C1.2 de inglés en EOI gracias al uso de las redes sociales. Más concretamente, esta propuesta aborda la integración de la mediación a las destrezas ya evaluadas anteriormente a través de la contextualización del alumnado en un marco ficticio y su posterior recreación y proyección en redes sociales para dar respuesta a un problema real. Se posibilita así una reflexión crítica acerca de la propia identidad, tanto la individual como la colectiva y la digital. Se fomenta el aprendizaje situado y el aprendizaje significativo a través del trabajo colaborativo. Se propicia de este modo la creación de una comunidad de aprendizaje y la educación permanente, así como la propuesta de un diseño de actividades significativo que rompa barreras frente a los desafíos de la utilización de redes sociales en el aula. Igualmente, se favorece una apertura de miras hacia la lengua ambiental: la lengua gallega y hacia el mundo anglófono.

\section{Palabras clave}

Mediación, literatura popular, innovación educativa, redes sociales, adultos. 


\section{Introducción}

La innovación educativa en la enseñanza de adultos carece de una amplia proyección en el terreno de la investigación académica. En concreto, en el caso particular de las escuelas de idiomas (EOI) en ocasiones se asiste a un panorama tecnicista que provoca la limitación del aprendizaje de lenguas extranjeras únicamente a la consecución de competencias lingüísticas. Frente a ello se posiciona la apuesta por la interactividad en la enseñanza de idiomas, en el caso de los adultos se advierten reticencias ante el trabajo colaborativo (Petersen y Nassaji, 2016). Dado que poseen capacidad crítica cuestionan tanto los contenidos formativos como los lingüísticos (Johnson, 2005). Por ello el docente encuentra una serie de factores desafiantes. El adulto desea interactuar exclusivamente con él, porque supone una figura de referencia lingüística y de corrección. Asimismo, las diferencias generacionales entre los alumnos implican no solamente diferentes ritmos de aprendizaje, sino también la convergencia de varias filosofías bajo las que entender los elementos de la educación, que derivan del crecimiento por diferentes sociedades, sistemas educativos y el paradigma actual, que exige life-long-learning skills y especialización (Hanson y Orsuwan, 2010). Igualmente resultan frecuentes las situaciones en las que la brecha digital se revela como aliada de dificultades de aprendizaje (Morales, 2013). No obstante, la gran motivación intrínseca y extrínseca, y la generalizada ausencia de conflictos disciplinarios constituyen características destacables del alumnado adulto (Dell'Ordine, 2001). Por ello, resultaría posible la elisión de tareas de repetición positiva para centrarse en actividades libres (Azpilicueta-Martínez, 2020).

Estas se presentan como una oportunidad única a través de la mediación, que permitiría la incorporación de estrategias de enseñanza-aprendizaje que incidan en el trabajo colaborativo horizontal y el logro de nuevos objetivos abiertos. Esto implica que los aprendices además de poseer conocimiento lingüístico del idioma o idiomas implicados y ser capaces de transmitir el significado adecuado del mensaje desarrollan la habilidad de languaging (Consejo de Europa, 2018: 33), para solventar la brecha de comunicación o communication gap (Stathopoulou, 2015: 5). La EOI se centra principalmente en mediación lingüística y textual y puntualmente en la de conceptos. Para el primer tipo de mediación las tareas se basan en extraer y resumir la información más relevante; traducción a vista; toma de notas; explicación de representaciones como gráficos o mapas; y la expresión de una respuesta personal ante textos creativos y literarios. Por su parte, las actividades vinculadas a la mediación de conceptos se encaminan hacia la construcción del conocimiento: entender la conversación como trabajo en equipo, cooperar y colaborar para que la conversación resulte productiva y velar por una equilibrada distribución de los turnos de palabra (Consejo de Europa, 2018).

Sin embargo, adecuarse a la toma de este enfoque más interactivo que refleja el MCER en el ámbito de educación para adultos a menudo se asocia erróneamente a la infantilización del alumnado (Delicado et al. 2009). Otras perspectivas achacan esta percepción a los aspectos mercantilistas que rodean la enseñanza de idiomas (Córdoba y Araya ,2010), como la enseñanza únicamente de determinadas variantes lingüísticas (Litzler, 2020). Igualmente, debido a las exigencias curriculares y la elevada ratio de las aulas, áreas como las destrezas orales se ven desequilibradas frente al estudio de la gramática. Además, en la EOI, es preciso añadir el carácter exam-based que la realización de pruebas externas finales y de certificación confiere a las enseñanzas de estos centros (Rodríguez, 2018). Por ello los propios alumnos 
consideran más competente a un docente capaz de mimetizase con el libro de texto, con el currículo, con esas variedades standard y así su labor se ve reducida en ocasiones a una perspectiva demasiado tecnicista que presupone que solamente debe poseer competencias lingüísticas (Calvillo, 2016).

Esta propuesta de innovación educativa responde al ajuste metodológico y al enfoque orientado a la acción promovido por el MCER. Para ello se fomenta el aprendizaje situado y significativo integrando las redes sociales mediante la literatura popular gallega e irlandesa en la educación de alumnado adulto.

La combinación de la literatura popular desarrollada en dos territorios diferentes, pero con elementos comunes propicia la toma de conciencia plurilingüe (Molina, 2016). Esta, además, constituye un aspecto mediador debido a que su razón de ser nace de la necesidad del pueblo de encontrar y acordar un significado para ciertos elementos que les rodean, transformar espacios en lugares y difundir estos nuevos significados que se crean para que sus destinatarios los comprendan de tal manera que puedan integrarlos en su cotidianidad.

Otro factor positivo de su inserción en la didáctica de lenguas extranjeras es la capacidad que presenta para huir del "pintoresquismo" (Díaz, 2005: 38). El folklore, al ser un proceso de transmisión de creencias, costumbres y rituales provoca una retroalimentación entre la tradición y la modernidad. Por ello se puede emplear de espejo para visualizar uno de los grandes problemas de la posmodernidad y la posverdad como es la veracidad de la información difundida en redes sociales y en el ámbito digital. De este modo, la literatura popular revitaliza la tradición, cuyos relatos son permeables a los acontecimientos históricos del momento, a la sociedad, a la economía y a la cultura (Carrassi, 2017: 33).

La presencia de estos elementos basados en el contexto real de los alumnos constituye los nodos especializados que despiertan el aprendizaje y mediante los que establecen conexiones de calidad entre sus conocimientos potenciando la educación permanente (Tham et al. 2021). La deficiente adquisición de conocimiento profundo por parte de los estudiantes supone un gran obstáculo para desarrollar actividades cuya base sea el aprendizaje cooperativo. Esto viene derivado tanto de la falta de diseño significativo en las tareas grupales como de la prevalencia de estrategias tradicionales de aprendizaje colaborativo como dividirse el contenido o el temor de ciertos estudiantes a mostrarse participativos. La inclusión de la red social Instagram supone el asentamiento de un entorno de aprendizaje en red y permite incorporar elementos más cercanos a un modelo en espiral propio del conectivismo al poner de manifiesto el rol de la creación individual, el proceso de refinamiento de ideas y conocimientos pasando por la retroalimentación entre equipos hasta alcanzar el producto final, y la posterior divulgación de los trabajos de los estudiantes al público en general (Chen et al. 2021). Esta propuesta sirve para facilitar un diseño significativo y adaptado al contexto del alumnado, que rompa las barreras y los desafíos de los profesores frente a la inclusión de ambientes de aprendizaje en red, como son la ausencia de nitidez de la identidad, la falta de atención de los estudiantes o la inquietud ante la redefinición del rol del docente (Dans et al. 2021).

Por otra parte, la inserción de redes sociales en contextos académicos expande la educación en inteligencia social del mundo analógico al virtual. De este modo, se favorece la oportunidad de reflexionar en el aula sobre los componentes actitudinales 
del manejo de redes sociales como el respeto a la privacidad e intimidad digital de uno mismo y de los demás y la transparencia y fiabilidad de los contenidos. También se analizan comportamientos por parte de la sociedad y de uno mismo hacia individuos y compañeros cuya competencia digital no está desarrollada, para concienciar sobre la convivencia y simbiosis del trabajo en equipo y el individual (Pacheco, 2019 y Fuentes et al. 2021). Así mismo, se impulsa el debate sobre la identidad analógica y digital, incidiendo en los comportamientos negativos y positivos que se dan de forma diferente en cada una estas dos facetas y las razones de este fenómeno. De este modo se conciencia sobre la capacidad de empatía y de respeto para hacer de las redes sociales plataformas seguras de creación y difusión colectiva.

\section{Descripción de la experiencia}

\section{Proyecto de innovación didáctica: Influencer is the new bard}

Esta propuesta educativa se sitúa en un aula de inglés de la Escuela Oficial de Idiomas (EOI) de Santiago de Compostela para el nivel C1.2 para un grupo de 15 alumnos cuyo perfil profesional y formativo es diverso. El proyecto de innovación educativa recibe el nombre de Influencer is the new bard, (Influencers: Ios nuevos bardos). Esta propuesta se encuadra en la metodología de aprendizaje basado en problemas.

El problema que los alumnos tienen que resolver articula la trama del proyecto es, que se formula a través de una noticia periodística ficticia. En ella se presenta a la Santa Compaña como una empresa con intenciones de redefinir y modernizar su imagen corporativa para luchar contra la pérdida de la literatura popular. La corporación decide contratar influencers para llevar a cabo estas tareas. Así, se anima a los alumnos a postularse como candidatos para el puesto de trabajo. Para obtener el contrato definitivo deben superar diferentes tareas que en el contexto ficticio se corresponden con el periodo de formación.

Los alumnos se organizan en parejas y a través de las diferentes actividades individuales y colectivas descifran contenidos sobre la literatura celta y la literatura popular irlandesa, y al compararla con la gallega practican todas las destrezas y en especial la mediación. Cada vez que finalicen una actividad deben realizar un post en Instagram que contenga una fotografía representativa y creativa de la actividad acompañado de un pequeño texto escrito donde se responda a una cuestión relacionada con la tarea previa sin emplear dead words y utilizando hagstags comunes previamente acordados con toda la clase para filtrar la información. Finalmente, para compensar la pérdida de leyendas, los alumnos tienen que crear su propia leyenda para compensar la pérdida de relatos tradicionales. También tienen que acompañar su creación literaria de un folleto que atraiga a los demás a leerla y deberán exponerla explicando su proceso creativo.

El trabajo con redes sociales como parte esencial del proyecto se cimienta en que estas herramientas brindan una modalidad para proyectar la cultura local cuando converge con elementos de la globalización. La interacción en comunidades culturales que se originan en la red rompe con la estructura piramidal tradicional de divulgación de conocimientos. Debido a ello, las redes sociales intensifican la capacidad de actuación de los usuarios y su deseo de manifestar al exterior el sentimiento de pertenencia a las mismas, por lo que se consolida un refugio colaborativo identitario 
y distintivo ante al mundo globalizado. Además, la ambientación de la propuesta en un contexto que contiene al mismo tiempo elementos reales y aspectos imaginarios proporciona claves a los estudiantes acerca del funcionamiento de la creación de significado (meaning-making) (Liu, 2019), que también resulta un componente clave de la medicación.

Los textos que se incluyen presentan diversos formatos y registros, que varían desde textos académicos, conferencias, monólogos orales, textos publicitarios hasta tiras cómicas. Así se facilita la inclusión de elementos reales dentro del contexto ficticio en el que se encuadran a los estudiantes como, por ejemplo, las figuras del estudioso del folklore Eddie Leniham, del diseñador gráfico Luis Davila, la realización de un Curriculum Vitae en formato Europass, o lugares de interés turístico como la Torre de Hércules o los cruceiros.

\section{Objetivos}

Los objetivos generales del proyecto son los siguientes:

- Fortalecer la habilidad en las destrezas: comprensión de textos orales; comprensión de textos escritos; producción y coproducción de textos orales; producción y coproducción de textos escritos; y mediación

- Fomentar una mirada amplia del mundo, que incluya la cultura literaria popular y su expresión digital.

- Potenciar la mediación en el uso de un vocabulario y textos complejos.

- Aprender a trabajar colaborativamente en las redes sociales.

En cuanto a los objetivos específicos indicamos los siguientes:

- Elaborar presentaciones y discursos estructurados, detallados y de una extensión considerable.

- Adecuar la comunicación al tipo de público al que se dirige.

- Captar matices de significado, así como puntos de vista, significados y opiniones implícitos y explícitos de los textos orales y escritos independientemente de su soporte y de su ámbito.

- Producir textos escritos y orales que reflejen una reflexión y un pensamiento crítico hacia textos producidos por otros autores.

\section{Actividades}

Las actividades quedan articuladas en una introducción y cuatro capítulos, que dotan de cohesión y de forma de relato al proyecto, ya que no son estancos. De esta manera, la introducción sirve para presentar la noticia ficticia, que actúa como elemento sorpresa que motiva y ambienta a los alumnos en el contexto ideado. La introducción permite insertar el cuestionario de conocimientos previos acerca de las redes sociales, la literatura popular y el autoconcepto del estudiante. Posibilita 
el debate inicial sobre las fake news y la conservación de las historias entre generaciones. Igualmente, los estudiantes explican la diferencia entre un perfil en redes sociales profesional y uno personal. Para el post en Instagram el alumno debe responder en qué en qué medida se puede comparar la literatura popular y los relatos que cuentan los influencers.

El primer capítulo lleva por nombre Setting the basis (sentando las bases), donde se analiza la explicación del folklore y cómo este se manifiesta o se puede trasladar a nuestros días. Para trabajar la comprensión de textos y la mediación se utilizan los textos orales de los divulgadores Lynne McNeill y Jack Werner y del contador irlandés Eddie Lenihan. Dado que los ejercicios propuestos implican documentarse sobre literatura folklórica gallega y explicar las similitudes y diferencias que posee con la irlandesa otra tarea que se incluye es la de identificar si una página web es fiable. Como post se indica que cuenten qué características del folklore les han sorprendido más.

El bloque dos lleva por nombre Becoming a true bard (convirtiéndonos en verdaderos bardos) e incluye la compresión de textos escritos y orales a través de documentación acerca del arte de Seanchaí o Storytelling y de un monólogo de Quico Cadaval sobre el que los alumnos practican la mediación explican una serie de conceptos culturales y mecanismos que producen el humor y que aparecen en dichos textos. Igualmente, en este capítulo se estudian las posibilidades de los discursos escritos y orales cotidianos y cómo se pueden enriquecer para su divulgación. Para Instagram los alumnos deben explicar conceptos y vivencias relacionados con el storytelling.

En el tercer capítulo, Travelling further into folklore (adentrándonos más en la literatura popular) se examinan ejemplos tradicionales y contemporáneos de leyendas, mitos, lugares y personajes típicos de la literatura popular. Este capítulo permite combinar diferentes tipos de textos como tiras cómicas y folletos publicitarios, entre otros. Para los posts de Instagram los estudiantes buscan una moraleja para el mito elegido. Igualmente deben escribir en la red social sobre conceptos y emplazamientos específicos vistos en los textos y realizar una reflexión sobre la publicidad local e internacional.

Por último, el cuarto capítulo, The litmus test (la prueba de fuego) comprende la elaboración de un texto escrito y oral por parte de los alumnos. Primero deben confeccionar su propia leyenda e idear un póster o un folleto original y atractivo para acompañar la exposición de la misma a los compañeros. En Instagram los alumnos, además de compartir sus productos finales comentan su experiencia y las contribuciones de este proyecto al aprendizaje inglés como lengua extranjera.

\section{Evaluación}

Con el propósito de paliar la ambigua percepción de progreso por parte del alumnado adulto (Petersen y Nassaji, 2016) se ha adoptado como instrumento para evaluar el trabajo realizado por los alumnos las rúbricas de la EOI de las pruebas finales de certificación. Dado que se trata de un documento interno de las EOIs, también se emplean unas rúbricas creadas ad hoc. Tanto al finalizar cada bloque como en la tarea final del proyecto cada grupo evaluará a los demás con estos instrumentos. Estas rúbricas facilitan la evaluación profesor-alumno, así como la autoevaluación y la evaluación entre pares. 
Para comprobar la eficacia del proyecto se han diseñado dos cuestionarios que los alumnos cumplimentan. El primero de ellos encamina a constatar sus conocimientos previos y percepciones iniciales acerca de la literatura popular y el uso de las redes sociales tanto para fines académicos como personales. El segundo cuestionario se completa al finalizar el proyecto y ayuda a manifestar las posibles mejoras a introducir en la propuesta, si ha habido un cambio de hábitos y consideraciones por parte de los estudiantes sobre los temas trabajaos y a la hora de desenvolverse con las redes sociales ya sea en el terreno personal o en el estudiantil o profesional. Otros recursos que permiten evaluar la faceta más lingüística del proyecto son los trabajos y exámenes previos y posteriores a la implantación de la propuesta.

\section{Resultados}

La aplicación de esta propuesta permite cerciorarse de la elección acertada de Instagram como material de trabajo frente a otras redes sociales. Pues la incorporación de la misma se basa en que ofrece un formato y un servicio en tiempo real muy visual, se utilizan hagstags para agrupar información y permite guardar publicaciones. Además, incorpora la posibilidad de crear perfiles privados y así es sencillo controlar el acceso de público a la cuenta, dado que la privacidad de los estudiantes suele suponer una traba para incluir las redes sociales en el aula. Igualmente ofrece herramientas como filtros, encuestas y crear carpetas donde se permite acceder a publicaciones almacenadas con anterioridad.

Igualmente, este proyecto proporcionaría claves para afrontar las desventajas que se presentan al emplear redes sociales y las tecnologías de la información y comunicación (TIC) en el aula, entre las que se encuentran el exceso de información (Doval-Avendaño et al. 2018: 482); el hecho de que ciertos contenidos subidos se puedan catalogar de estéticos pero no por ello verídicos ni informativos; y la provisión de recursos tecnológicos materiales pero sin la correspondiente alfabetización digital real del profesorado (Muñoz-Carril et al. 2019).

Tras la implementación de esta propuesta también sería viable comprobar si el aprendizaje interactivo que impulsan las redes sociales resulta un aliciente para la cohesión del grupo y evita el absentismo y el abandono en cursos de enseñanza no obligatoria por falta de motivación del alumnado (Santoveña-Casal y López, 2021).

\section{Discusión y conclusiones}

Esta propuesta se basa en el diseño de actividades para el aprendizaje de ILE y se cimienta tanto en la proyección de las producciones de los alumnos en redes sociales como en su alfabetización en dicho terreno, por lo que podría ser aplicada en la enseñanza de adultos. El trabajo realizado permite señalar la necesidad de potenciar la investigación sobre innovación educativa en adultos, para evitar el prejuicio de que esta práctica deriva en infantilizar a este tipo de alumnado de lenguas extranjeras. Además, pone de manifiesto el elenco de diversos recursos creativos que facilitan las tecnologías digitales y sirven a la enseñanza de una lengua extranjera. Para planificar una propuesta con mayores probabilidades de éxito, por ejemplo, se podría situar las prácticas en contextos determinados y asociados, a priori, a la población adulta e incluir aspectos asociados a las experiencias vitales de esta franja etaria. Igualmente, beneficiarse de las características de los adultos resulta vital para potenciar sus 
capacidades de educarse a sí mismos, en lugar de concebir el curso de idiomas en la EOI como un espacio únicamente válido para surtir herramientas técnicas y formativas. Por ello, una actitud globalizadora favorece que el aprendizaje logrado en el aula quede integrado y se aproveche en otras facetas que pueda presentar el alumno como individuo. De igual modo, también se persigue con la innovación educativa que los alumnos exploten sus capacidades y sus conocimientos previos para resolver las prácticas planteadas en el aula y paliar las diferencias formativas.

En cuanto al empleo de redes sociales en el aula, se avista un claro paisaje de escaso encuentro entre ellas en el caso de la enseñanza de idiomas para adultos. Por una parte, su introducción en este contexto supone numerosas ventajas para alumnos y profesores como la adquisición de nuevas competencias tanto profesionales como formativas, así como nuevas formas de descubrir y orientar el aprendizaje del alumnado (Fuentes et al. 2021). También propician la oportunidad de reforzar la educación de la inteligencia interpersonal, puesto que abren el debate sobre si su uso está realmente extendido a todos los grupos poblacionales, si en estos se ponen en marcha suficientes iniciativas para su capacitación digital o sobre si las redes sociales no están exentas de riesgo exclusión social (Pacheco, 2019). Por otra parte, la aplicación de las tecnologías en contextos educativos realza la necesidad de suturar las fisuras en la formación del profesorado mediante la configuración de políticas nacionales y supranacionales que promuevan su competencia digital real más allá de la dotación de recursos materiales relacionados con este campo (Muñoz-Carril et al. 2019).

El modo de empleo de Instagram configura otro rasgo distintivo de este proyecto, ya que el principal uso educativo de Instagram se orienta en la difusión fotografías que han sido realizadas en clase o fuera de ellas y posteriormente referenciarlas y analizarlas (Manca, 2019: 3). Sin embargo, esta propuesta se inicia en primer lugar con una reflexión guiada que se divulga posteriormente por esta red social mediante el enlace de imagen y texto.

Igualmente, otra pieza fundamental del rompecabezas de este proyecto es su adaptación a la incorporación de la mediación, una destreza nueva en los planes de estudio de la EOI. Además, se incluye como elemento sorpresa la fusión entre la tradición (literatura folklórica) y la modernidad (las redes sociales) ya que así se incentiva el entendimiento crítico de la cultura que se decide consumir y proteger o difundir. De este modo se estimula el intercambio digital, plurilingüe e intercultural. Aspectos de un valor incalculable que no se pueden dejar caer en vano, pues constituyen la raíz primigenia del proceso de enseñanza-aprendizaje.

\section{Referencias}

Azpilicueta-Martínez, R. (2020). Verbal Evidence of Task-related Strategies in EFL: Children and Adult Interactions. International Journal of English Studies, 20(3), 1-28. Doi:10.6018/ijes.409961

Calvillo, M. (2016). La formación del profesorado de educación permanente de personas adultas en Andalucía. eCO. Revista Digital de Educación y Formación del Profesorado. (13). Recuperado de: http://revistaeco.cepcordoba.org/index.php?option=com_content $\&$ view $=$ article $\& i d=314$ 
Carrassi, V. (2017). Between Folk and Lore: Performing, Textualising and (mis)Interpreting the Irish Oral Tradition. Estudios Irlandeses, Special Issue. 12(2), 32-46. Doi: 10.24162/ei2017-7554

Chen, W. et al. (2021). The spiral model of collaborative knowledge improvement: an exploratory study of a networked collaborative classroom. International Journal of Computer-Supported Collaborative Learning, 16(1), 7-35. Doi: 10.1007/s11412-02109338-6

Consejo de Europa (2018). Common European framework of reference for languages: learning, teaching, assessment companion volume with new descriptors. Recuperado de: https://rm.coe.int/cefr-companion-volume-with-new-descriptors-2018/1680787989

Córdoba, G. y Araya, K. (2010). Principios epistemológicos y axiológicos del saber docente en la enseñanza del inglés. Actualidades Investigativas en Educación. 10(3),141. Recuperado de: https://www.redalyc.org/articulo.oa?id=447/44717980009

Dans, I., et al. (2021). El reto de los profesores de secundaria ante las redes sociales. Educar, 57(1), 207-222. Doi:10.5565/rev/educar.1151

Delicado et al. (2009). Venciendo miedos en la enseñanza de inglés a adultos. Un caso práctico: la ciudad, sus leyendas y los espacios web. Tejuelo. (4), 56- 73. Recuperado de: https://dialnet.unirioja.es/servlet/articulo?codigo=2793129

Dell'Ordine, J. (2001). El aprendizaje de una lengua extranjera L2, en la formación continua. Recuperado de: https://www.alipso.com/monografias/el_aprendizaje_de_ una_lengua_extranjera_f_cintinua/

Díaz, L. (2005). Sobre el folklore en la actualidad y la pluralidad en la lectura. Revista OCNOS. (1), 35 - 42. Recuperado de: https://revista.uclm.es/index.php/ocnos/article/view/ocnos_2005.01.03

Doval-Avendaño, M. et al. (2018). El uso ritual de las pantallas entre jóvenes universitarios/as. Una experiencia de dieta digital. Revista Prisma Social. (21), 480-499. Recuperado a partir de https://revistaprismasocial.es/article/view/2323

Fuentes, D. R.,et al. (2021). Las redes sociales digitales: una valoración socioeducativa. Revisión sistemática. Revista Fuentes, 1(23), 41-52. Doi: 10.12795/revistafuentes.2021.v23.i1.11947

Hanson, D. y Orsuwan, M. (2010). Do teachers make a life-long learner? Examining the effect of teacher quality on their students' attitudes towards life-long learning. Conferencia impartida en "International conference on Education and New Learning Technology". Recuperado de: https://library.iated.org/view/HANSON2010DOT

Johnson, S. (2015). Adult learning in the language classroom. Multilingual Matters

Liu, S. (2019). Using Science Fiction Films to Advance Critical Literacies for EFL Students in China. International Journal of Education and Literacy Studies,7(3). 1-9. Doi: 10.7575/aiac.ijels.v.7n.3p.1. 
Litzler, M. F. (2020). Native English speakers in Madrid's classrooms: Difficulties reported by assistants. Tejuelo. Didáctica de la Lengua y la Literatura. (31), 47-76. Doi: 10.17398/1988-8430.31.47

Molina, M. (2016) La traducción de literatura infantil y juvenil como instrumento de mediación cultural en la enseñanza de lenguas extranjeras: estudio de un caso. (Tesis doctoral). Recuperado de: https://dialnet.unirioja.es/servlet/tesis?codigo $=142330$

Morales, P. (2013). El uso de las TIC y la formación permanente del adulto: una mejora de la calidad de vida. Ariadna; cultura, educación y tecnología,1, 58-62. Doi:10.6035/ ariaDna.2013.1.9

Muñoz-Carril, P., Dans, I. y González, M. (2019). Social Networks and Their Uses in the Field of Secondary Education. En Dey, N. et al. (Eds). Social Network Analytics. Computational Research Methods and Techniques (p.203-226). Elsevier.

Petersen, C. y Nassaji, H. (2016). Project-Based Learning through the Eyes of Teachers and Students in Adult ESL Classrooms. Canadian Modern Language Review, 72(1), 13-39. Doi: 10.3138/cmlr.2096.

Rodríguez, C. (2018). Teachers as Testers: The Case of EOI Teachers in Galicia, Spain. Teacher Involvement in High-Stakes Language Testing, 127-153.Doi: 10.1007/978-3319-77177-9_8

Santoveña Casal, S. y López, S. R. (2021). Aprendizaje conectado en redes sociales. Psychology, Society \& Education, 13(1), 1. Doi: 10.25115/psye.v1i1.2485

Stathopoulou, M. (2015). Cross-Language Mediation in Foreign Language Teach (New Perspectives on Language and Education). Multilingual MattersPacheco, A. (2019). Juegos digitales en la educación de personas mayores. En Empoderamiento del alumnado adulto y de las personas mayores para una ciudadanía activa (59-72). UNOeditorial

Tham, J. et al. (2021). Connectivism for writing pedagogy: Strategic networked approaches to promote international collaborations and intercultural learning. Computers and Composition, 60, 102643. Doi: 10.1016/j.compcom.2021.102643 


\section{Diseño, Implementación y Evaluación de Una Sesión de Videoconferencia Interactiva con Alumnado Senior}

\section{Fernández Montero, Isabel}

Isabel Fernández Montero

Universidad de la Illes Balears (España)

ifemon5@yahoo.es 


\title{
DISEÑO, IMPLEMENTACIÓN Y EVALUACIÓN DE UNA SESIÓN DE VIDEOCONFERENCIA INTERACTIVA CON ALUMNADO SENIOR
}

\author{
Fernández Montero, Isabel \\ Isabel Fernández Montero \\ Universidad de la Illes Balears (España) \\ ifemon5@yahoo.es
}

\section{Resumen}

Tras detectarse una falta de interacción del alumnado senior de la Universidad Abierta para Mayores (UOM) de las Islas Baleares en las sesiones online, se planteó como objetivo llevar a cabo un diseño, implementación y evaluación de una sesión de videoconferencia con contenidos musicales pero cuyo finalidad principal es que el alumnado participe, interactúen entre ellos, se lleven a cabo dinámica de grupos y en general que disfruten de la sesión interactiva. Para ello se ha optado por una metodología de investigación basada en diseño(IBD), poniéndose en práctica a través de la realización de cuatro sesiones online, en las que se han recogido resultados tanto positivos como negativos que has permitido la realización de cambios interactivos hasta dar lugar a la propuesta didáctica final. Por lo tanto el producto final obtenido ha sido una propuesta didáctica para una sesión online basada en contenidos musicales que se ajusta a la temporalización propuesta y al nivel de aprendizaje de las personas seniors. Sobre la sensación y el impacto que han recibido los participantes al recibir estas sesiones online, se verifica que la aplicación didáctica propuesta favorece la interacción, comunicación, incrementa la motivación del alumno y les permite ser protagonistas llevando a cabo un rol activo y participativo.

\section{Palabras clave}

Videoconferencia, sesión interactiva, música, alumnado senior y recursos multimedia. 


\section{INTRODUCCIÓN}

El trabajo de investigación está enfocado hacia la realización del diseño de una propuesta didáctica, su implementación y evaluación que se va a llevar a cabo a través de sesiones interactivas de videoconferencias en las que el hilo conductor es la música y el instrumento principal de trabajo las TIC.

El motivo por el que se va a llevar a cabo el diseño, ejecución, implementación y evaluación de varias sesiones on line con personas mayores es debido a que la mayoría de sesiones de videoconferencias que reciben en la Universidad Abierta para Mayores (UOM), los alumnos tienen un papel de mero receptor de la información, en el que echan en falta poder interactuar entre ellos a través de las TIC, hablar, llevar a cabo dinámicas de grupo, etc. Por lo tanto la UOM solicita que se lleve a cabo un diseño de intervención educativa online que se ajuste a las necesidades de los alumnos, en la que se pide que haya interactividad entre los alumnos, que las actividades propuestas y el uso del material multimedia cubra dichas necesidades y que se utilice la plataforma Zoom para llevar a cabo dicha videoconferencia.

En general todas la universidades y en concreto la Universidad Abierta para Mayores (UOM), pone a disposición de los alumnos una oferta educativa de programas formativos y conferencias que se ajusta a los intereses de los alumnos, pero no siempre la metodología de trabajo que se pone en práctica permite a los alumnos asumir un rol activo y participativo en dichas conferencias o programas educativos, delimitando la participación activa de estos alumnos. Por lo tanto a través de la aplicación de esta propuesta didáctica se van a ofrecer las posibilidades de interactuar, expresar sus sentimientos, sentirse escuchados, exponer sus puntos de vista y escuchar a los demás siempre a través del respeto y la confianza dando lugar a un ambiente de aprendizaje dinámico e interactivo.

El hilo conductor de la propuesta de actividades de la sesión interactiva va a ser la música, ya que es un contenido que está estrechamente vinculado con la identidad individual y social (MacDonald, et al, 2017) que sigue desarrollándose en todas las fases de la vida. En la fase adulta, la actividad musical estará vinculada al contexto social (O’Neill, 2017).

\section{MARCO TEÓRICO.}

\subsection{Videoconferencia y sesión interactiva}

Para la Agencia de Noticias Univalle (2015) el uso de la videoconferencia en educación ha modificado la manera de llevar a cabo el proceso enseñanza-aprendizaje cambiando el espacio físico de la clase por el espacio virtual.

Según Álvarez (2011), el uso de la videoconferencia está vinculado a la educación del siglo XXI, donde el alumno es el constructor de su propio aprendizaje. A través de la videoconferencia se puede interactuar con otras personas que aporten a los alumnos nuevas ideas y conocimientos y así poder complementar la educación que se reciben en los colegios. 


\subsection{Música}

La música es un arte que contribuye a la motivación de los ciudadanos. (Cremades, et al, 2011), considera que "La capacidad de motivación y el carácter ameno que despierta la música en el alumnado hacen que el proceso de enseñanza-aprendizaje se convierta en una experiencia gratificante donde se aprende significativamente a través de la acción" (p. 160).

Según (Touriñán, 2014c), a través de la música se trabajan muchos valores:

- Potencia la memoria y la capacidad de argumentar y observar.

- Incrementa la colaboración entre compañeros, intercambio de ideas y mejora la comunicación.

- Permite el desarrollo de valores tales como la solidaridad, socialización, el compañerismo, la amistad, etc.

\subsection{Alumnado senior}

Las universidades ofrecen programas y ciclos de conferencias adaptados a las personas seniors. Estos programas están integrados por las siguientes características.

- Tienen una labor social.

- Las personas mayores tienen que ser protagonistas, y tendrán un papel activo y participativo en los programas o conferencias.

- Los contenidos que se van a trabajar se seleccionarán de manera que se potencia la integración social de los alumnos.

Las personas de avanzada edad se han convertido en consumidores pasivos de las TIC (Santibáñez, et al, 2012), por lo tanto, hay que ofrecerles una formación digital que les permita contribuir al envejecimiento activo (Román, et al, 2016).

\subsection{Recursos multimedia}

Tomando como referencia autores como Area (2017) los materiales didácticos se definen como: "un objeto cultural, físico o digital, elaborado para generar aprendizaje en una determinada situación educativa" (p. 17).

Actualmente se puede acceder a una amplia variedad de recursos didácticos como pueden ser blog, revistas, webs etc. Muchos materiales didácticos que utilizan los docentes son materiales digitales multimedia que se obtienen a través de la red, utilizando plataformas digitales, software educativo, etc.

Según González (2013), los recursos didácticos multimedia se componen de diferentes medios, como por ejemplo el texto, la imagen, el sonido, o videos y animaciones que pueden ser de carácter interactivo. 


\subsection{Estado de la cuestión: estudios vinculados al uso de videoconferencias en la educación superior}

Cabe destacar que antes de seleccionar los estudios correlacionados con este trabajo, se ha hecho una amplia selección, buscando en dos sitios web como referencia: Google Académico y la Biblioteca Universitaria de las Islas Baleares siguiendo las indicaciones de búsqueda facilitadas en la web de la propia biblioteca. En primer lugar, se han filtrado como criterios de búsqueda las dos variables de estudio: el uso de videoconferencias y la educación superior. Por lo general, se han encontrado numerosos estudios vinculados a la rama sanitaria, los cuales han sido descartados porque no se relacionaban con los intereses de este estudio.

Resulta oportuno mencionar estudios como el desarrollado por Romero (2019) trataban de mostrar la utilidad de la videoconferencia como sistema de comunicación entre los diferentes agentes de la comunidad educativa, siendo un elemento clave para la transmisión de información manteniendo la temporalidad real de manera síncrona. Para ello, a través de este estudio trata de analizar los usos de la videollamada comprendiendo sus funciones y elementos básicos, así como las características más reivindicativas de este instrumento como medio de comunicación en la educación a distancia.

Por otro lado, el uso de la videoconferencia en la educación superior y, por ende, el e-learning conlleva un cambio a nivel administrativo e institucional, ya que el sistema debe adaptarse a los tiempos que corren y facilitar la gestión educativa del alumnado en la educación superior, de modo que el sistema educativo recurra a metodologías flexibles e innovadoras basadas en el uso de las TIC.

En este sentido, esta autora afirma que para que el desarrollo del e-learning por medio de videoconferencia sea útil y funcional, debería estar regulado, entendiendo la competencia digital docente como un aspecto clave para el desarrollo de estas prácticas educativas en la educación superior.

Por otro lado, cabe destacar la investigación expuesta por Palazón (2021) quien estudia el uso de herramientas digitales para la implementación de sesiones didácticas por medio de la videoconferencia, entendiendo que el uso de las mismas es un medio práctico y eficaz cuando no pueden ser desarrolladas sesiones presenciales, siendo una alternativa para atender a las necesidades de los estudiantes.

Son numerosos los factores que afectan a la necesidad de implementar sesiones educativas por medio de la videoconferencia, entre ellos encontramos la distancia geográfica entre discentes y docente, la flexibilidad horario, así como el ahorro de costes en recursos para los estudiantes que, por motivos de diversa índole, no pueden acudir de manera presencial al centro educativo.

Entre estos factores, cabe destacar la factibilidad de llevar a la práctica acciones educativas fundamentadas en las TIC dada la fiabilidad del acceso a Internet en las últimas décadas, las cuales se caracterizan por conexiones más rápidas, eficaces e intuitivas. Estos beneficios contribuyen a que el profesorado se plantee, con cada vez más frecuencia, la utilidad del uso de herramientas digitales para el desarrollo del proceso de enseñanza y aprendizaje, con el fin de ofrecer una respuesta eficaz a las necesidades educativas del alumnado. 
Otro estudio como el presentado por Barrera (2020) expone la evolución desarrollada en el uso de videoconferencias en contextos educativos, atendiendo a sus características, implicación pedagógica, así como las ventajas o desventajas que conllevan para los estudiantes. De esta manera profundizó en herramientas como Microsoft Skype, zoom, Google Meet y Cisco Webex. Entre los objetivos de la investigación constaron aspectos clave como la grabación de la sesión, la creación de espacios virtuales donde compartir información o pantallas, así como un espacio común para la creación de sesiones y charlas.

\section{MARCO METODOLÓGICO}

\subsection{Contexto}

La Universidad Abierta para Mayores (UOM) es un programa de desarrollo social y cultural que se lleva a cabo en la Universidad de las Islas Baleares, dirigido a fomentar las relaciones intergeneracionales, el conocimiento y la cultura, incrementando la calidad de vida de las personas seniors.

Tomando como referencia los datos de la página webs de la UOM, los objetivos generales de los diferentes programas de la Universidad Abierta para Mayores son:

- Promover la participación de las personas seniors en la Universidad de las Islas Baleares.

- Incrementar el aprendizaje de las personas mayores a lo largo de toda la vida.

- Contribuir a mejorar las relaciones intergeneracionales.

- Continuar con los acuerdos establecidos entre la Administración pública y las distintas instituciones que trabajan con las personas mayores.

- Potenciar programas educativos de aprendizaje continuo para personas seniors.

- Fomentar una mayor participación de las personas mayores en el uso y funcionamiento de las TIC.

La UOM se estructura en varias sedes: Mallorca, Menorca, Ibiza y Formentera.

La UOM está enfocada en personas mayores de 50 años que poseen estudios primarios y están interesadas en realizar alguna de las actividades o de los programas que se imparten en la Universidad, en las distintas sedes universitarias, o en centros universitarios municipales.

La Universidad Abierta de Mayores es un proyecto vivo y dinámico que, además de otorgar los títulos propios, certificados y llevar a cabo distintas actividades complementarias en diferentes municipios de las Islas, dispone de un espacio desde el que se preparan nuevos programas y actividades adaptándose a las demandas del alumnado. 


\subsection{Objetivos y pregunta de investigación}

El objetivo general que se pretende alcanzar con este trabajo es:

- Diseñar, implementar y evaluar una sesión online interactiva sobre temática de contenido musical, a través de la cual se consiga incrementar la participación de las personas mayores.

Además también se pretenden conseguir otros objetivos específicos:

- Diseñar una propuesta didáctica sobre contenidos musicales que se ajuste a la temporalización establecida de la sesión online

- Implementar la propuesta didáctica para que se adapte a las necesidades del alumnado senior.

Una vez concretados los objetivos tanto general como los específicos y en relación a dichos objetivos se plantean las siguientes preguntas de investigación: ¿Qué elementos se tendrán en cuenta en una sesión de videoconferencia dirigida al alumnado senior de las Islas Baleares? ¿La metodología utilizada en la sesión online interactiva ha favorecido la interacción y participación de los alumnos?

\subsection{Metodología de Investigación Basada en Diseño}

A través de este trabajo se pretende diseñar y desarrollar una intervención didáctica tomando como hilo conductor la música. Para poder llevarla a cabo se ha fundamentado en una Investigación Basada en Diseño (IBD), siempre adaptándose al contexto del que se parte y tomando como referencia el problema real del que se parte. A través de esta IBD se pretende dar respuesta a la siguiente pregunta de investigación: ¿La metodología utilizada en la sesión online interactiva ha favorecido la interacción y participación de los alumnos?

Por lo tanto este estudio abarca el diseño, exploración y mejora de la calidad del aprendizaje a través de un proceso de innovación educativa, ciñéndose a un contexto real en el que el docente es protagonista de esa investigación. A través de esta investigación se va a llevar a cabo un análisis de la situación llevándose a cabo las mejoras y modificaciones pertinentes para que los resultados obtenidos sean óptimos.

Como consideran De Benito y Salinas (2016) una IBD se trata de una investigación con implicaciones sobre la ejecución de la práctica.

Una IBD comprende las siguientes características, en primer lugar se centra en problemas complejos basados en contextos reales, seguidamente busca soluciones a esos problemas a través de entornos de aprendizaje innovadores.

De esta manera, relacionando dichas características a esta investigación, podríamos establecer las siguientes relaciones: 


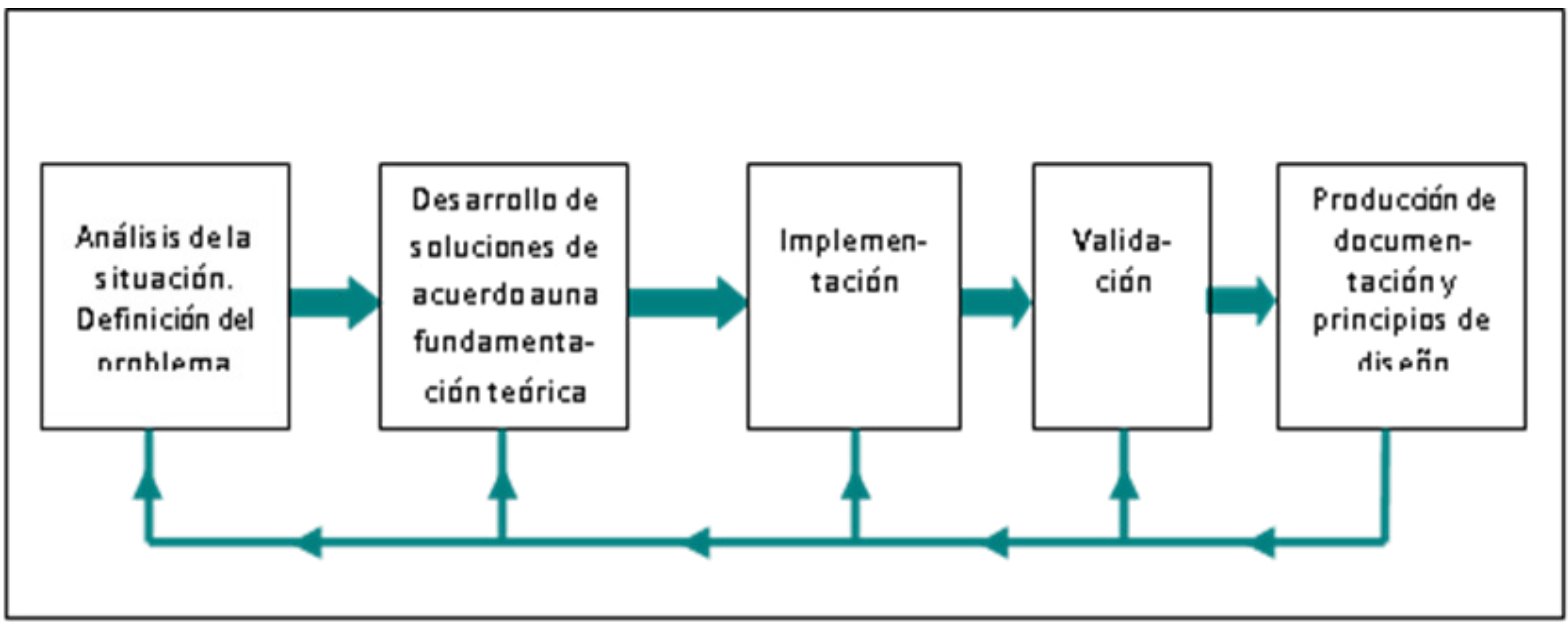

Figura 1. Estructura de la investigación del proyecto según enfoque IBD. Fuente: adaptado de Reeves (2000 en de Benito, 2006, citado en de Benito y Salinas, 2016).

Hay que hacer hincapié en que una IBD no tiene una única metodología de trabajo, es decir es una metodología mixta que se basa tanto en el método cualitativo como en el cuantitativo, aunque es cierto que en este tipo de investigación se suelen utilizar más los métodos cualitativos. Lo que si caracteriza a la IBD es que es una metodología colaborativa y participativa, formándose un vínculo entre el investigador y los participantes.

\subsection{Instrumentos para la recogida de datos}

Este apartado incluye los distintos instrumentos que se han utilizado para la recogida de datos. Por un lado se han recogido datos en un cuestionario que nos permiten obtener información sobre el grado de satisfacción de los alumnos respecto a la sesión interactiva que han recibido.

La parte pedagógica y didáctica de la sesión se ha evaluado a través de una entrevista realizada a un profesor de un grupo de alumnos de Menorca que ha asistido a la sesión online y ha ayudado a dinamizar la actividad.

En tercer lugar se ha evaluado el material multimedia utilizado en las sesiones online a través de otro cuestionario. Este material ha sido evaluado por dos expertas profesionales de las Tecnologías de la Educación y contribuyentes en la formación para personas mayores.

\subsection{Participantes}

En total de alumnos de la UOM del programa educativo Senior, curso académico 2020/2021 que participan en las sesiones de videoconferencia interactiva online son 38 , formando un grupo heterogéneo tanto en género como en edad. 


\section{ANÁLISIS DE LOS RESULTADOS}

3.1 Resultados de la evaluación de los alumnos participantes: grado de satisfacción

1ER GRUPO IBIZA

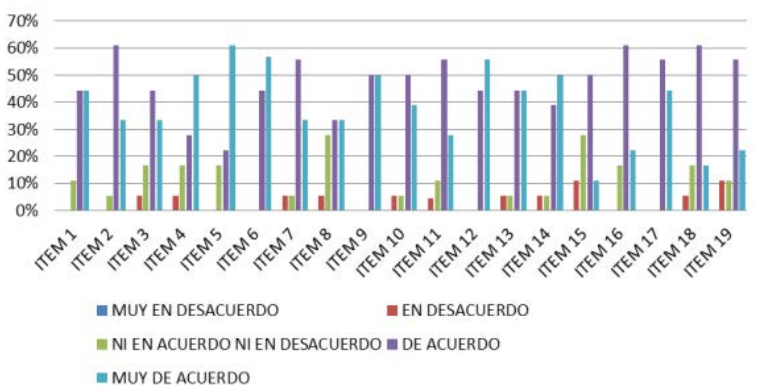

Gráfico 1. Resultados primer grupo Ibiza.

1ER GRUPO MENORCA

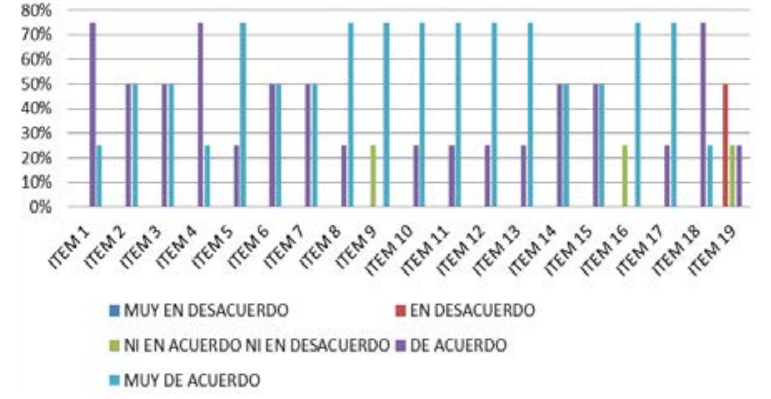

Gráfico 3. Resultados primer grupo Menorca
2 GRUPO IBIZA

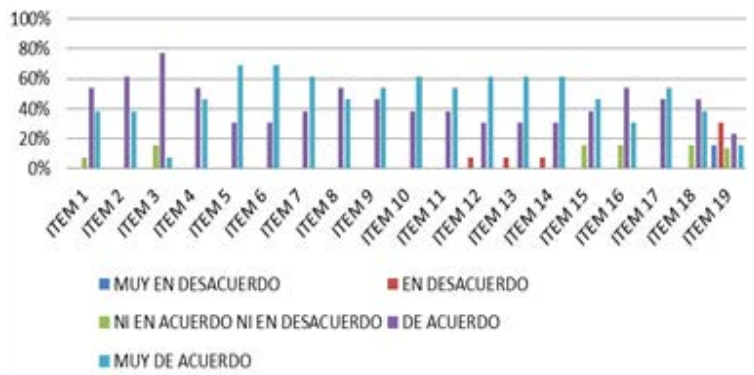

Gráfico 2. Resultados segundo grupo Ibiza.

20 GRUPO MENORCA

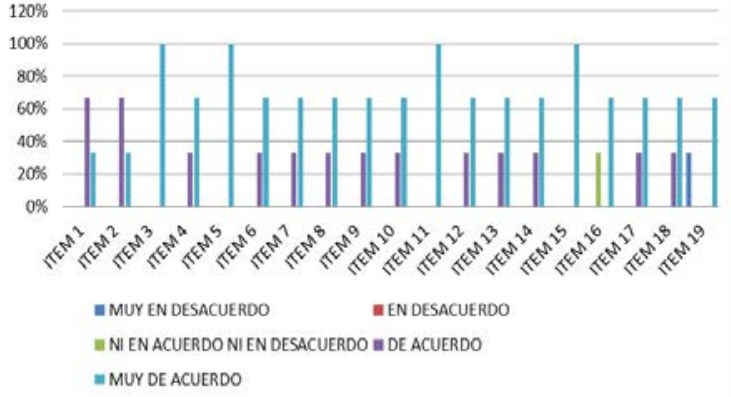

Gráfico 4. Resultados segundo grupo Menorca

\subsection{Resultados de la evaluación de un profesor participante en la sesión online: parte didáctica y pedagógica}

\section{a) Profesora}

La primera dimensión de análisis es una valoración del docente hacia la profesora que ejecutó la intervención didáctica, en este caso en primera persona. El análisis de los resultados expuestos por el docente son claros y concisos, destacando entre los puntos favorables la capacidad de la profesora para explicar al alumnado la funcionalidad de las sesiones, así como el hecho de clarificar lo que debían hacer en cada sesión. En líneas similares, el docente destaca el entusiasmo expuesto por la profesora en el desarrollo de las sesiones, marcando un espíritu interactivo y dinámico en el desarrollo de las mismas, afirmando un desarrollo ameno de las sesiones.

\section{b) Alumnos}

Resalta la satisfacción de los alumnos no solo mediante la observación directa, sino que afirma que los comentarios que los estudiantes le han hecho al respecto han 
sido muy positivos, afirmando lo mucho que han aprendido de una manera divertida y lúdica, aspecto que resulta bastante esperanzador. Por otro lado, uno de los beneficios que destaca en relación a la necesidad de que los estudiantes de edades más avanzadas hagan uso de las nuevas tecnologías es el hecho de que se vayan familiarizando con la sociedad tecnológica en la que estamos inmersos, adaptándose a la realidad social que facilita la comunicación en el ámbito escolar.

\section{c) Sesión online}

A nivel generalizado, el docente considera que las sesiones se adecuaron a las expectativas puestas sobre las mismas, ya que resultaron adecuadas y motivantes para sus destinatarios.

\subsection{Resultado de la evaluación de expertas: material multimedia}

Continuando con los resultados de la evaluación de expertas, cabe destacar que se ha llevado a cabo un cuestionario, el cual ha sido dividido en dimensiones de investigación diferentes a las de la entrevista, destacando: dimensión musical, dimensión técnica estética y dimensión pedagógica-funcional.

\section{a) Dimensión musical}

Las encuestadas consideran que la calidad de los archivos sonoros es buena. Además consideran que el contenido musical se adecua de manera aceptable al nivel educativo de los alumnos.

Finalmente, en cuanto a la cantidad de contenidos ambas expertas los consideran altos o muy altos con puntuaciones entre los 5 y 6 puntos. Este hecho nos lleva a reflexión: la alta cantidad de contenidos no va ligada a la cantidad de los mismos, lo cual no es un hecho demasiado alentador.

\section{b) Dimensión técnica-estética}

Entre estos aspectos, en primer lugar se cuestiona el diseño de las pantallas, donde una de las encuestadas proporciona una valoración positiva, otorgando 4 puntos y considerando aceptable dicho diseño. Por otro lado, la otra experta encuestada otorga una puntuación de 1, es decir, la puntuación más baja con una valoración de diseño que la cataloga como nula, sin lugar a dudas, una puntuación muy baja que nos lleva a pensar en cambiar ciertos aspectos del diseño de las pantallas.

\section{c) Dimensión pedagógica-funcional}

La dimensión pedagógica funcional nos da a conocer en qué medida la herramienta puede ser útil para suscitar nuevos aprendizajes. En referencia a la capacidad de motivación, las opiniones se encuentran divididas: por un lado, una de las expertas encuestadas considera que la capacidad de motivación es alta, proporcionando una puntuación de 5; por otro lado, la otra experta valora este ítem con una puntuación de 3 puntos, considerando el poder motivacional como bajo. 
3.4 Cambios y mejoras planteadas para las siguientes sesiones on-line: implementación.

\section{Sesión:}

-Ampliar el tiempo de sesión: 1h y media

-Mejorar el sonido de audios

-Cambiar el orden de las actividades

$3^{\circ}$ Sesión:

2Sesión:

-Actividad ¿Qué instrumento suena?: Aumentar duración de los audios

-Juegos musicales: ampliar tiempos de las canciones modernas

-Reducir el tiempo de las actividades para que se puedan trabajar todas aunque no en su totalidad
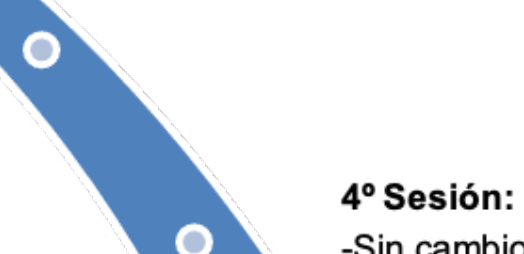

-Sin cambios en la intervención educativa

Producto final: propuesta didáctica interactiva. 


\subsection{Diseño final}

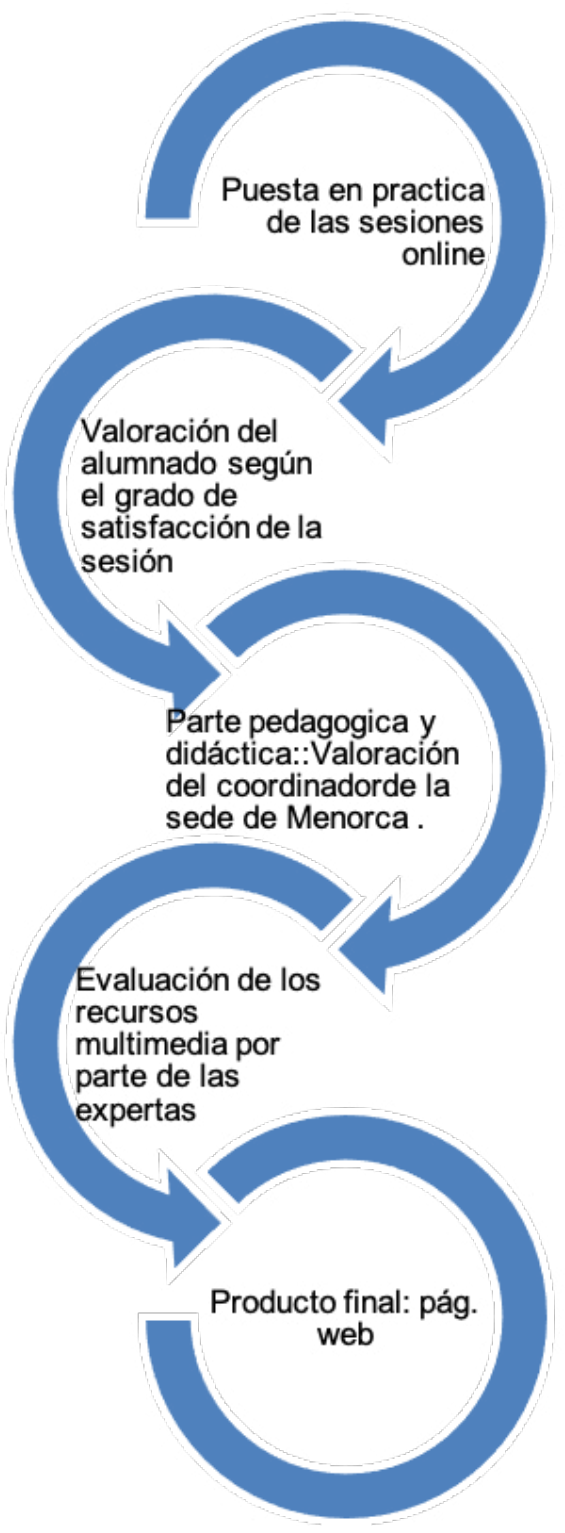

Figura 3. Implementación final. Fuente: Elaboración propia.

Los resultados obtenidos de este trabajo de investigación han sido la propuesta didáctica final, implementada y validada gracias a la realización de las distintas sesiones de videoconferencia online.

Teniendo en cuenta los resultados obtenidos en los distintos instrumentos de evaluación se ha llevado a cabo un diseño final que por falta de tiempo no se ha podido poner en práctica con todos los alumnos de la UOM

El diseño final se ha plasmado en una web elaborada con la plataforma Google Sites, teniendo en cuenta las siguientes recomendaciones sobre el material multimedia de las expertas: mejorar la calidad de los contenidos y reducir la cantidad, 
ofrecer contenido didáctico de calidad que incita en mayor medida al aprendizaje o la elaboración de una guía para facilitar la navegación. Por otro lado, se alude a los derechos de autor para la exposición de las canciones e imágenes mostradas. Todos estos aspectos son un ápice para mejorar la calidad de la herramienta para otorgar un mayor valor a la intervención.

A continuación se podrá visualizar el diseño final de la sesión online en el que se incluyen la presentación, la intervención didáctica y el resumen de la sesión en el siguiente enlace: https://sites.google.com/murciaeduca.es/www/propuesta-did\%c3\%Alctica-musical

\section{DISCUSIÓN Y CONCLUSIONES.}

Romero (2019) exponía que el uso de las TIC en la educación superior es un vehículo a través del cual cambiar la mentalidad del discente en referencia a la tarea educativa al convertirse en constructor de su propio conocimiento, lo cual conlleva a la creación de aprendizajes exponencialmente significativos. No obstante, los ítems del cuestionario con los que se relaciona esta afirmación, nos muestra que al menos un $40 \%$ de los alumnos encuestados está en desacuerdo en referencia a la interactividad de la actividad, siendo un precursor para la creación de contenidos desafiantes y estimulantes, frente a un 50\% que están de acuerdo. Esto nos lleva a una división de opiniones, donde la educación presencial sigue siendo preferente para cierta parte del alumnado, no obstante, los resultados muestran que hay un mayor número de alumnos que consideran estas sesiones interactivas y un medio de aprendizaje y comprensión del tema.

Por otro lado, el estudio expuesto por Barrera (2020) exponía la evolución desarrollada en el uso de videoconferencias en contextos educativos, atendiendo a sus características, implicación pedagógica, así como las ventajas o desventajas que conllevan para los estudiantes, asegurando que el profesorado tuvo que iniciarse de manera obligatoria en la planificación, desarrollo y evaluación de materiales digitales, familiarizándose con herramientas, vídeos y exposición de contenidos de manera alejada de la práctica convencional. En relación a estas afirmaciones, los resultados muestran una implicación docente con resultados visibles para los estudiantes, ya que, por ejemplo, la gran mayoría denota la implicación del docente y la calidad del material, señalando que estaba especialmente diseñado y explicado.

Finalmente, la investigación expuesta por Palazón (2021) entendía que el uso de las videoconferencias es un medio práctico y eficaz cuando no pueden ser desarrolladas sesiones presenciales, siendo una alternativa para atender a las necesidades de los estudiantes. En este sentido, cabe destacar que al analizar los resultados de la entrevista y de los cuestionarios a los estudiantes, ambos señalan la funcionalidad de las sesiones por videconferencia en su mayor parte, remarcando la utilidad de las sesiones, la implicación docente para atender a las necesidades que surgen durante el desarrollo de las mismas, así como la ausencia de problemas técnicos, lo cual es un añadido a la eficacia de la enseñanza a distancia.

Para concluir este trabajo hay que analizar los distintos objetivos específicos del TFM que se plantearon al inicio del trabajo de investigación, viendo si estos se han cumplido o no a lo largo de la puesta en práctica del trabajo de investigación. 
Respecto al objetivo específico no 1: Diseñar una propuesta didáctica sobre contenidos musicales que se ajuste a la temporalización establecida de la sesión online:

- Se ha necesitado de una planificación de actividades, enmarcada en el contexto de la UOM, que se ajustaran a las necesidades y expectativas de los alumnos.

- Seguidamente el diseño se ha llevado a cabo utilizando recursos lúdicos y motivadores, elaborándose gracias a distintas herramientas y software educativos digitales.

Este objetivo se ha conseguido satisfactoriamente tanto por parte de los alumnos como de la profesora, eso se refleja en los resultados obtenidos en el cuestionario.

El objetivo específico n2: Implementar la propuesta didáctica para que se adapte al nivel de aprendizaje del alumnado.

- Se ha llevado a cabo una implementación de la propuesta didáctica desde el momento en el que se eligió cuál iba a ser el hilo conductor de la sesión de videoconferencia hasta la puesta en práctica de la cuarta sesión en la que ya se ha trabajado con la propuesta didáctica final. En todas las sesiones online se han obtenido datos a través de la observación directa y teniendo en cuenta las opiniones de los participantes que han contribuido a las distintas modificaciones que se han hecho para que el resultado de la propuesta didáctica final cumpla con el objetivo general propuesto.

- Aplicar esta propuesta didáctica con personas mayores: El contexto en el que se ha llevado a cabo el diseño de la intervención educativa ha sido muy enriquecedor. Trabajar con alumnos mayores de la UOM ha supuesto trabajar en un ambiente de respeto, motivación, participación y compañerismo, en el que han compartido y recordado vivencias muy positiva para ellos. Cabe destacar la vitalidad y ganas de aprender de los participantes como un referente a destacar para las nuevas generaciones.

\section{LIMITACIONES Y LÍNEAS DE TRABAJO FUTURAS}

\subsection{Limitaciones}

Durante el desarrollo de cualquier trabajo de investigación se pueden acontecer limitaciones que hacen que la investigación no se lleve a cabo como se esperaba. A continuación se detallan las que se han encontrado en este trabajo de investigación.

Una de las limitaciones ha sido a la hora de encontrar artículos que sirvan de referencia para llevar a cabo el diseño, implementación y evaluación de la propuesta didáctica para aplicar con un contexto en el que los participantes sean personas mayores. Esta limitación está vinculada a la reciente puesta en práctica de la modalidad de enseñanza online que se lleva a cabo en los centros educativos incluidos universidades.

Otra limitación ha venido marcada por la poca participación de alumnos a la hora de llevar a cabo las sesiones online, sobre todo en las tres últimas sesiones: las dos de Menorca y la de Mallorca que al final no se pudo llevar a cabo. 
En tercer lugar nos hemos encontrado otra limitación que hace referencia a la temporalización de la sesión online. Esta temporalización no puede ser fija, es decir, debería ser variable dependiendo de la cantidad de alumnos que participen en la sesión y si son más participativos o menos.

Al estar trabajando con personas mayores ha habido participantes que han tenido problemas de conexión, sobre todo al realizar la actividad de "Las canciones de mi vida" en la que la profesora creaba nuevas salas de conexión para trabajar por grupos. Algunos han preguntado a la profesora y se ha solucionado el problema, pero otros han optado por abandonar la sesión online directamente y salirse de la sesión.

Y por último debido a que el diseño final de las sesiones online se ha elaborado una vez finalizadas las prácticas con los alumnos senior, teniendo en cuenta los resultados de los instrumentos de evaluación y por falta de tiempo en el calendario del periodo lectivo de los alumnos de la UOM, no se ha podido poner en práctica con todos los alumnos.

\subsection{Líneas de trabajo futuras}

Cómo futuras líneas de trabajo en relación a este Trabajo de Fin de Máster se proponen:

- Exponer un estudio empírico ampliando el campo de estudio, es decir, hacer una indagación peninsular a nivel estatal, recogiendo datos de otras Comunidades Autónomas.

- Realizar una indagación teórica sobre estudios similares que hayan sido desarrollados, incidiendo en los cambios que ha traído la situación de Covid-19 para la implementación de las videoconferencias en las aulas.

- Realizar un estudio empírico similar pero en diferentes niveles educativos, remarcando las diferencias existentes entre la educación obligatoria, bachillerato o estudios universitarios. Se puede llevar a cabo una comparativa entre los diferentes niveles educativos.

- Modificar la temática para comprobar si la motivación del alumnado puede ser determinante para el aprendizaje, de tal modo, pasaríamos un cuestionario sobre hobbies, con el fin de adecuados a los intereses de los estudiantes y buscar actividades en relación a eso, de manera que los aprendizajes resulten más significativos en comparación con el estudio desarrollado.

\section{REFERENCIAS BIBLIOGRÁFICAS}

Álvarez, M. (2011). Videoconferencia educativa. https://darkrimosa.wordpress. com/2011/07/16/videoconferencia-interactiva/

Area, M. (2017). La metamorfosis digital del material didáctico tras el paréntesis Gutenberg/The digital metamorphosis of didactic material after the parenthesis Gutenberg. Revista Latinoamericana de Tecnología Educativa-RELATEC, 16(2), 13-28. https://doi.org/10.17398/1695-288X.16.2.13 
Barrera, S. (2020). La videoconferencia como herramienta digital para el trabajo colaborativo en la educación superior. Revista Iberoamericana para la investigación y el desarrollo educativo, 11(21). https://doi.org/10.23913/ride.v11i21.959

Cremades, B.A., Gutiérrez, C.R., y Perea, D. B. (2011). La interdisciplinariedad de la música en la etapa de educación primaria. Revista de Ciencias Humanas, 25, 151-161. https://dialnet.unirioja.es/servlet/articulo?codigo=3877921

De Benito, B. y Salinas, J. M. (2016). La investigación basada en diseño en Tecnología Educativa. RIITE. Revista Interuniversitaria de Investigación en Tecnología Educativa, 0, 44-59. https://revistas.um.es/riite/article/view/260631/195691

González, Y. (2013). Multimedia en la educación, una necesidad. Vida científica. Universidad Autónoma del estado de Hidalgo, 1(2). https://www.uaeh.edu.mx/scige/ boletin/prepa4/n1/index.html

MacDonald, R., Hargreaves, D. J. y Miell, D. (2017). Handbook of Musical Identities. Oxford University Press.

O’Neill, S. (2017). Musical identity, interest, and involvement. En R. MacDonald, D. J. Hargreaves, y D. Miell, (Eds.). Handbook of Musical Identities (pp. 176-196). Oxford University Press.

Palazón, J. (2021). Herramientas de videoconferencia para la práctica de un instrumento musical. ResearchGate. https://www.researchgate.net/publication/304792807

Romero, J. (2019). La videollamada como recurso tecnológico para la educación superior a distancia. Revista REDINE 11(1), 56 - 61. https://revistas.uclave.org/index. php/redine/article/view/1993

Santibáñez, J., Renés, P., Ramírez, A. (2012). Ciudadanía y competencia audiovisual en La Rioja: Panorama actual en la tercera edad. Icono, 10(3), 6-28, 2012. http://dx. doi.org/10.7195/ri14.v10i3.195

Touriñán, J. M. (2014c). Dónde está la educación: actividad común interna y elementos estructurales de la intervención. Netbiblo. 


\section{Un Proyecto de Investigación Operativa con Datos Reales con Colaboración Olímpica}

\section{Ramos, Silvia Adriana}

Universidad de Buenos Aires, Facultad de Ingeniería

saramos@fi.uba.ar 


\section{UN PROYECTO DE INVESTIGACIÓN OPERATIVA CON DATOS REALES CON COLABORACIÓN OLÍMPICA}

\section{Ramos, Silvia Adriana}

Universidad de Buenos Aires, Facultad de Ingeniería saramos@fi.uba.ar

\section{Resumen}

En este trabajo se presenta una experiencia de trabajo práctico estilo proyecto en un curso inicial de Investigación Operativa en la Facultad de Ingeniería de la Universidad de Buenos Aires. La propuesta implicó trabajar con herramientas informáticas y modelos matemáticos lineales, en un problema real, que se estaba desarrollando al mismo tiempo que el cuatrimestre de cursada, para que los estudiantes actuaran como investigadores consiguiendo los datos, y produjeran un trabajo colaborativo entre los distintos grupos de trabajos prácticos que formaban parte del mismo curso. Se incorporó el relevamiento de datos para poder resolver el problema, dado que es una actividad fundamental del trabajo profesional de un Licenciado en Análisis de Sistemas y de un Ingeniero en Informática. De este modo el aprendizaje de la asignatura se incorporó a la práctica profesional. La tarea colaborativa entre distintos grupos de estudiantes estuvo mayormente focalizada en la etapa del relevamiento de datos, porque los distintos grupos compartían la información que habían conseguido para poder resolver el problema, y también los formatos informáticos para poder utilizar esa información en la resolución de los modelos matemáticos.

\section{Palabras clave}

Proyectos, datos, problema real, modelización matemática. 


\section{Introducción}

Modelos y Optimización I es una materia obligatoria del área de Investigación Operativa para los alumnos de las carreras de Licenciatura en Análisis de Sistemas y de Ingeniería en Informática de la Facultad de Ingeniería de la Universidad de Buenos Aires. En ella, se expone a los alumnos al análisis de problemas, trabajando, desarrollando y resolviendo modelos matemáticos de los mismos.

Desde hace varios años, como se indicó en Ramos et al (2014 y 2015), el objetivo principal del trabajo práctico que se incluye en la asignatura es el de presentar a los alumnos un abanico de problemas de optimización y situaciones reales que pueden ser planteadas mediante modelos lineales, que, aunque computacionalmente complejos, pueden ser resueltos mediante heurísticas. Con esto, el trabajo práctico se ha vuelto más complejo de analizar, modelizar y resolver, requiriendo más tiempo y esfuerzo por parte de estudiantes y docentes. Este esfuerzo es compensado por el trabajo de los y las estudiantes, que, cuando el problema que tienen que resolver está relacionado con su propia realidad, se sienten interpelados y participan mucho más en la resolución.

Como primera entrega del trabajo se pide un relevamiento de la situación problemática, que en este caso incluyó también la entrega de los datos relevados por los estudiantes, como detallaremos más adelante. La segunda entrega es el planteo del modelo matemático lineal del problema combinatorio que mejor se adapte a la situación que se quiere resolver. Por último, en la entrega final resuelven el modelo utilizando un software de resolución de programación lineal y también con un algoritmo heurístico desarrollado por el grupo de estudiantes. A partir de 2015, como se indica en Ramos et al (2015), se incorporó que todas las entregas del trabajo práctico se hacen a través del campus de la asignatura en el Moodle de la Facultad de Ingeniería (campus.fi.uba.ar/7114) lo que permite armar portafolios con las entregas, trabajar con foros para las preguntas de cada entrega que van surgiendo de los estudiantes, hacer trabajo colaborativo entre los distintos grupos de estudiantes, y saber cómo va a ser evaluada cada entrega del trabajo, ya que se incorporan rúbricas en el mismo campus (ver Ramos et al, 2014)

Desde el año 2014 en adelante, para el trabajo práctico se trató de buscar situaciones que para los estudiantes fuesen "de todos los días".

En la enseñanza de la Investigación Operativa, como lo indica Moazeni (2010) debemos promover un "aprendizaje activo", en el cual el estudiante se sienta parte, y para el cual podamos utilizar los conocimientos previos y los intereses para poder avanzar en la discusión de nuevos temas y en la resolución de nuevos problemas. En este caso quisimos que los estudiantes hicieran su propio proceso de investigación para poder analizar el problema y conseguir los datos para su resolución. También que esa tarea no fuera necesariamente individual, o de los estudiantes que formaban parte de un determinado grupo sino del curso en su conjunto, colaborando entre todos. Esto representaba el primer desafío, lograr una tarea lo suficientemente interesante como para que todos los estudiantes desearan colaborar.

En cuatrimestres anteriores, se había fomentado desde el equipo docente, tareas colaborativas, instando a través de foros y temas disparadores, que los estudiantes colaboraran entre sí, no solamente los de un mismo grupo sino todos los del curso. 
En un principio la colaboración se planteaba desde el punto de vista de que el análisis de la situación problemática se hiciera en conjunto, que todos colaboraran diciendo qué tipo de problema (dentro de los problemas combinatorios de la Investigación Operativa) se puede asemejar al problema que se les está planteando. Las experiencias no habían sido totalmente satisfactorias, en algunos casos algún grupo trataba de plantear algún tipo de problema y los demás grupos parecían estar algo temerosos de plantear una diferencia o disidencia con lo que los primeros grupos planteaban. Por eso se trató de que la colaboración entre grupos no fuera algo que se hace al comienzo del trabajo, sino que a lo largo de todo el proyecto los estudiantes colaboraran.

\section{Descripción de la experiencia}

\section{Elección de un problema real para el proyecto}

Para la elaboración del tema del trabajo práctico es importante que la temática sea convocante y que los estudiantes lo vean como un problema propio, que les resulta interesante resolver.

En el segundo cuatrimestre de 2018, el problema elegido se vinculó con los Juegos Olímpicos de la Juventud, que se llevaron a cabo en octubre de 2018 en la Ciudad Autónoma de Buenos Aires. Más allá del cliente ficcional que se propuso para el trabajo (un supuesto canal de televisión por cable dedicado a los deportes, que quería determinar qué competencias transmitir) los datos de las competencias, con sus horarios, especificidades, etc., surgieron de la realidad, y los alumnos tuvieron que relevarlos. El enunciado se presenta en los anexos I, II y III. En principio se presentó al problema con el texto que se muestra en el Anexo I y luego de la caracterización de la situación se presentaron los anexos II y III.

El trabajo con la realidad, en especial cuando ésta está desarrollándose al mismo tiempo, como este caso, también ayuda a la motivación de los estudiantes. Al respecto dice Cárdenas (2018): "Es cierto que no hay aprendizaje sin compromiso del alumno, pero en nosotros está enriquecer esa responsabilidad y no entorpecerla. La motivación se nutre del desafío y de la constatación de progresos, no de monerías y payasadas externas al conocimiento".

\section{Trabajo de relevamiento de datos previo a la resolución del problema}

Dado que era la primera vez para la asignatura en la cual los datos no eran suministrados por los docentes, los estudiantes no solamente tuvieron que relevarlos, sino además elegir el formato en el cual los tenían que presentar, para poder usarlos en la resolución por software del modelo matemático a elaborar. Los datos de días y horarios de las competencias (además de las características de estas, si eran finales, preliminares, etc.) fueron relevados por los distintos grupos de estudiantes. En este punto se generó aprendizaje en red, dado que el relevamiento que realizó cada grupo de estudiantes se compartía mediante el foro del relevamiento del campus de la asignatura (en Moodle). Los grupos discutieron en foros acerca del formato de los datos, a efectos de introducir los mismos en el modelo matemático para resolver la situación problemática. La manera de introducir los datos en el modelo, y como trabajarlos, puede parecer un problema menor, pero dado que estamos trabajando con 
estudiantes de las carreras de Ingeniería en Informática y de Licenciatura en Análisis de Sistemas, es importante que todas las asignaturas en las cuales se trabaje con proyectos, sirvan para que los estudiantes incorporen una cultura de cómo trabajar de manera correcta en proyectos informáticos, competencias de trabajo en grupo, la forma de presentar los resultados ante una audiencia o ante un grupo de directivos, herramientas para poder contestar preguntas acerca de su trabajo, etc.

Se generaron interesantes discusiones entre los distintos grupos en los foros, porque los datos de las distintas competencias de los Juegos Olímpicos de la Juventud eran públicos, pero el formato en el cual eran comunicados esos datos públicos a la sociedad no estaba pensado para que esos datos fueran usados en un programa de software y mucho menos como datos de entrada de un modelo matemático, así que las planillas de cálculo o los archivos en formato PDF que se podían obtener, tenían que procesarse para que los datos fueran útiles para la tarea.

En el anexo IV se muestran algunos ejemplos de la colaboración de los distintos grupos, cuando compartían la información que cada uno de los grupos había conseguido, y discutían la manera de utilizar esa información para la formulación del modelo matemático. También se puede ver que se plantean problemas para el ingreso de los datos en el modelo matemático, que fueron respondidos por otros grupos. Siempre las respuestas fueron moderadas por los docentes, pero el trabajo colaborativo era comandado por los y las estudiantes de los distintos grupos.

Finalmente, cada uno de los grupos resolvió el problema mediante un modelo matemático, que tenían que resolver de manera exacta con un software de resolución de modelos matemáticos complejos (CPLEX o GLPK) y además con una heurística. La tarea finalizaba con una presentación que los estudiantes de cada grupo hicieron delante del resto del curso, en la cual mostraban sus resultados y conclusiones, y el curso podía comparar las distintas soluciones, generándose un interesante debate.

Como indican al respecto Lion y Pertosi (2014): "La colaboración es entendida como un proceso de interacción en el que los miembros del grupo se asumen responsables de sus acciones e integran las habilidades y contribuciones de sus pares en un esfuerzo coordinado para la resolución de un determinado problema. Los roles de los miembros del grupo no están asignados para una división del trabajo independiente sino que surgen de la dinámica de interdependencia en la que cada uno es responsable y dependiente de la genuina participación del otro." (p. 7)

\section{Resultados}

Todos los grupos de trabajos prácticos consiguieron resolver el problema adecuadamente y realizaron una presentación ante el resto del curso acerca de su resolución y conclusiones, con lo que cada uno de los trabajos se convirtió en una presentación para la empresa que encarga el trabajo. De las encuestas del curso, el nivel de satisfacción de los estudiantes con el trabajo fue alto en el 75\% de los casos (sobre 22 estudiantes).

En oportunidad del cambio en la modalidad de trabajo práctico, con la incorporación de problemas combinatorios más complejos en lugar de un ejercicio sencillo - ver Ramos et al (2014) y Ramos et al (2015) - se evidenció cierta preocupación por 
la posibilidad de que representase un aumento excesivo en la dificultad. Sin embargo, más allá de que se notó una recarga sobre el trabajo de los alumnos, solamente el $40 \%$ de los que completaron la cursada lo consideró difícil y, como contrapartida, se lograron algunos trabajos de muy buen nivel. Al haberse trabajado con un problema más atractivo para los estudiantes, y que estaba en progreso mientras se desarrollaba el cuatrimestre de cursada, la participación aumentó, los estudiantes sintieron "como propio" el problema, y la fase de análisis tuvo interesantes resultados, evidenciados a través del campus. El trabajo colaborativo, durante la fase de relevamiento, resultó fructífero, a diferencia de experiencias anteriores en la misma asignatura, en los cuales la colaboración se estimulaba únicamente mediante la participación en foros, pero no con un objetivo común como era este caso.

\section{Discusión y conclusiones}

Se presentaron algunas dificultades en el trabajo práctico con la resolución utilizando software. Esta dificultad se convirtió en una oportunidad de colaboración, porque los alumnos comenzaron a compartir consejos de cómo convertir el modelo a un formato apropiado para resolver con CPLEX, cómo hacer para que resuelva más rápido, etc. En este sentido se cumplió con el objetivo colaborativo que se buscaba con el problema.

Sin embargo, la participación de los estudiantes en el campus virtual es algo que necesita seguir mejorándose. Se implementó la posibilidad de foros del trabajo práctico para que los estudiantes debatieran antes de la primera entrega y plantearan hipótesis, pero se necesitó de la participación de los docentes para que los estudiantes comenzaran a responder. Paradójicamente, algunos estudiantes no calificaron positivamente el hecho de que no se suministraran los datos, y que ellos tuvieran que buscarlos y elegir el formato. Cabe señalar que la experiencia, si bien remeda a la realidad, es mucho más sencilla que ésta, porque en una situación real habría que relevar en qué lugar están los datos, pero aquí se podían buscar en Internet, estaban a disposición de cualquier persona. Un posible motivo para esta especie de queja puede ser el hecho de que en las demás asignaturas no es común que los datos tengan que ser relevados por los estudiantes, sino que son suministrados por el grupo docente, y al tener que buscarlos les agregaba tiempo al desarrollo del trabajo. Sin embargo, la gran mayoría de los estudiantes elogió el trabajo colaborativo de la etapa de relevamiento y el equipo docente ratificó que oportunidades como esa estimulaban la participación de los estudiantes en los foros, que había sido baja en otros cuatrimestres en los cuales no se incorporó la fase de relevamiento de datos en el trabajo práctico. Los estímulos para participar surgieron de los propios estudiantes, que tuvieron que relevar los datos y los compartían.

La senda ya está trazada y necesita tiempo para que se pueda trabajar en ella y ser recorrida apropiadamente. A medida que se amplíen los desafíos y los estudiantes puedan aprovechar la experiencia para colaborar entre ellos y encontrar la mejor solución conjunta, se podrá seguir avanzando en el conocimiento. 


\section{Referencias}

Cárdenas H. (2018) Construir matemática. Experiencias desde el aula, Ed. Paidós.

Lion C.y Perosi M.V. (2014) Módulo 3: Prismas entramados. Expandir la cognición a través de las tecnologías: propuestas Citep Mic. $1^{\circ}$ ed. Dentro del Programa Virtual de Formación Docente del Centro de Innovación en Tecnología y Pedagogía de la Secretaría de Asuntos Académicos del Rectorado de la Universidad de Buenos Aires.

Moazeni S. (2010) Effective strategies to teach operations research to non-mathematics majors. CTE research report, 2010, University of Waterloo, 200 University Avenue West, Waterloo, Ontario, Canada N2L 3G1.

Ramos S., Colombo P., Marín E., Troyanovich N., Dausá J. y Terzano I. (mayo 2014) Una experiencia de modelización con resolución exacta y heurística de problemas combinatorios en un curso inicial de Investigación Operativa. Anales del encuentro XXVII ENDIO-XXV EPIO. San Nicolás, Argentina.

Ramos S., Colombo P., Marín E., Troyanovich N., y Terzano I. (mayo 2015) Motivación en las clases de Investigación Operativa. El problema importa. Anales del encuentro XXVIII ENDIO-XXVI EPIO. Bahía Blanca, Argentina. 


\section{Anexos}

ANEXO /

PRESENTACIÓN DEL TEMA Un medio periodístico desea realizar la cobertura de los Juegos Olimpicos de la
Juventud 2018 en Buenos Aires. Cuenta con un plantel de periodistas especializados en distintas disciplinas deportivas $y$ desea agruparlos en equipos, con los que desea cubrir las distintas competencias.

La composición de los equipos periodísticos está determinada de antemano. Para cada equipo se conoce la cantidad de integrantes, las especialidades deportivas que puede cubrir cada uno y su nivel en cada una de dichas

Se debe determinar la forma en que se realizará la cobertura con dichos equipos, para lo que se deberan relevar las posibles restricciones, parametros y validar las definiciones tomadas.

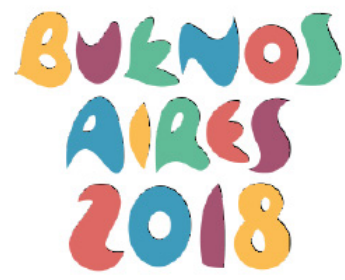

YOUTH OLYMPIC GAMES

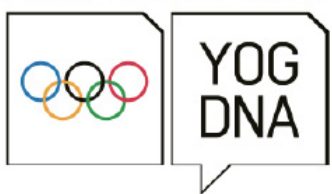

\section{ANEXO //}

\section{TRABAJO PRÁCTICO}

DEFINICIONES DEL PROBLEMA

- No se van a considerar todos los deportes o actividades de los juegos olímpicos, solamente las que están en la tabla adjunta.

- Se define como evento el desarrollo de una jornada de un deporte específico.

- Si en un mismo día el deporte tiene un horario partido se considerarán como tantos eventos separados como lapsos continuos tenga.

- Todas las transmisiones son en directo.

- Hay dos canales por los que se puede transmitir.

- Existen eventos intercalables que se pueden transmitir en paralelo con otro evento intercalable por el mismo canal (a lo sumo, dos en paralelo). Los eventos que no son intercalables no pueden compartir canal en ningún momento de su desarrollo.

- Los deportes se agrupan en categorías

- Para cada equipo se conoce qué categorías pueden cubrir (no todos los equipos pueden cubrir cualquier evento) y para qué deportes cuenta con especialistas.

- Los equipos no pueden cambiar de sede en un mismo día y no pueden transmitir eventos de más de un deporte al mismo tiempo aunque estén en la misma sede. Es decir que se necesita un equipo por cada deporte que se quiera transmitir en simultáneo.

- Las finales (eventos donde se otorgue una medalla) deben ser transmitidas por un equipo en el que haya un especialista en el deporte. No se pueden transmitir las finales de un deporte para el cual no se haya transmitido algún evento anterior a las finales.

- La calidad de la cobertura depende del deporte y el equipo que lo cubre (si tiene un especialista en el deporte o no). 


\section{ANEXO // (continuación):}

Deportes y sus datos

Los valores $\mathrm{Ci}$, ACi y ACEi son constantes conocidas (se proporcionarán para realizar la corrida)

\begin{tabular}{|c|l|c|c|c|c|c|}
\hline Nro. & Deporte & Categoría & Intercalable & $\begin{array}{c}\text { Calidad por } \\
\text { evento } \\
\text { transmitido }\end{array}$ & $\begin{array}{c}\text { Aumento } \\
\text { calidad por } \\
\text { evento final }\end{array}$ & $\begin{array}{c}\text { Aumento } \\
\text { calidad por } \\
\text { especialista }\end{array}$ \\
\hline 1 & Arquería & B & SI & C1 & AC1 & ACE1 \\
\hline 2 & Atletismo & A & SI & C2 & AC2 & ACE2 \\
\hline 3 & Badminton & D & NO & C3 & AC3 & ACE3 \\
\hline 4 & Baile deportivo & E & SI & C4 & AC4 & ACE4 \\
\hline 5 & Básquet & C & NO & C5 & AC5 & ACE5 \\
\hline 6 & Vóley playa & C & NO & C6 & AC6 & ACE6 \\
\hline 7 & Boxeo & B & NO & C7 & AC7 & ACE7 \\
\hline 8 & Ciclismo & A & SI & C8 & AC8 & ACE8 \\
\hline 9 & Equitación & D & SI & C9 & AC9 & ACE9 \\
\hline 10 & Escalada & E & SI & C10 & AC10 & ACE10 \\
\hline 11 & Esgrima & A & NO & C11 & AC11 & ACE11 \\
\hline 12 & Futsal & C & NO & C12 & AC12 & ACE12 \\
\hline 13 & Gimnasia & A & SI & C13 & AC13 & ACE13 \\
\hline 14 & Golf & D & SI & C14 & AC14 & ACE14 \\
\hline 15 & Halterofilia (pesas) & A & SI & C15 & AC15 & ACE15
\end{tabular}

\begin{tabular}{|l|l|c|c|c|c|c|}
\hline 16 & Hockey & C & NO & C16 & AC16 & ACE16 \\
\hline 17 & Judo & B & NO & C17 & AC17 & ACE17 \\
\hline 18 & Karate & B & NO & C18 & AC18 & ACE18 \\
\hline 19 & Lucha libre & B & NO & C19 & AC19 & ACE19 \\
\hline 20 & Natación & A & SI & C20 & AC20 & ACE20 \\
\hline 21 & Pentatlon & A & SI & C21 & AC21 & ACE21 \\
\hline 22 & Remo & A & SI & C22 & AC22 & ACE22 \\
\hline 23 & Rugby 7 & C & NO & C23 & AC23 & ACE23 \\
\hline 24 & Taekwondo & B & NO & C24 & AC24 & ACE24 \\
\hline 25 & Tenis & C & NO & C25 & AC25 & ACE25 \\
\hline 26 & Tenis de mesa & C & NO & C26 & AC26 & ACE26 \\
\hline 27 & Tiro y sus variantes & D & SI & C27 & AC27 & ACE27 \\
\hline 28 & Triatlón & A & SI & C28 & AC28 & ACE28 \\
\hline 29 & Navegación a Vela & D & SI & C29 & AC29 & ACE29 \\
\hline 30 & Voley playa & C & NO & C30 & AC30 & ACE30 \\
\hline
\end{tabular}

\section{Equipos periodísticos}

Los equipos que pueden hacer las transmisiones son:

Equipe 1: Tiene a Gonzalo Bonadeo que es especialista en todos los deportes excepto Baile deportivo. Puede cubrir todas las categorías.

Equipe 2: Tiene a Domingo Di Nubila que es experto en Baile deportivo (sobre todo

Breakdance) y otro integrante que es especialista en los deportes categoría C. Puede cubrir también categoría $\mathrm{B}$, aunque no tenga especialistas en esa categoría.

Equipo 3: Tiene un especialista en los deportes categoría B y otro especialista en deportes categoría C. Puede cubrir también categoría A, aunque no tenga especialistas en ese categoría.

Equipo 4: Tiene un especialista en deportes categoría A y otro especialista en deportes

categoría D. Puede cubrir también categoría C aunque no tenga especialistas en esa categoría.

Equipe 5: Tiene un especialista en deportes categoría A y otro especialista en deportes

categoría B. No puede cubrir deportes de otras categorías que no sean A o B. 


\section{Campus $_{k}$}

71.14 - Modelos y Optimización I - Curso Colombo

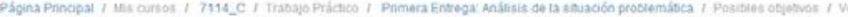

Primera Entrega: Análisis de la situación problemática

Espacio para trabajar colaborativamente sobre las definiciones del Trabajo Práctico

Ver Editar Comentarios Historia Mapa Ficheros Administración

\section{Posibles objetivos}

B Version imprimible

- Determinar la sede y los eventos dentro de la misma a cubrir por cada equipo para maximizar la cantidad de eventos cubiertos por dia de los YOS - Determinar la sede y los eventos dentro de la misma a cubrir por cada equipo para maximizar el ingreso por la transmision de deportes durante los juegos olimpicos

Determinar la sede y los eventos dentro de la misma a cubrir por cada equipo para maximizar la calidad de la transmisión de los deportes durante los juegos olimpicos (donde caldad es una función de la aptitud de un equipo para su tarea, tanto en cantudad de integrantes como en especializaciones, ti importancia del evento y el canal donde se transmite).

- Determinar para cada equipo y día los eventos a cubrir para maximizar la cantidad total de eventos cubiertos durante los juegos olimpicos

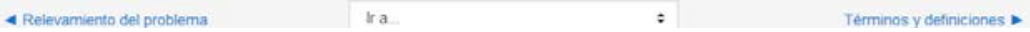

\section{ANEXO IV}

Información General y sedes

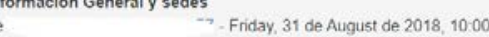

Buenos dias, agrego información general del evento y un detalle de las sedes, tomadas de la wikipedia

En el adjunto están las sedes con información más detallada de la localidad donde se encuentran.

Fuente - hittps./les.wnkipedia.org'wiki/Juegos_Ol\%C3\%ADmpicos_de_la_Juventud_de_Buenos_Aires_2018

Re: Información General y sedes

det

- Saturday, 1 de September de 2018, 00:25

Holat

Tengo para aportar las distancias lineales (para simplificar) entre las sedes que calcule que podrian ser utles y los puse en una tabla de doble entrada

https://docs. google. com/spreadshects/d/11BrZ3i6RN243tkRys.JXBKCUQ2hOxT50jQIPAax70Qrk/edit?usp=sharing

Los puntos para las distancias los tome en cuenta en base a esta pagina donde dice los transportes posibles a los distintos lugares.

https / / umw buenosaires 2018 com/transports? Ing-es 
ANEXO IV (continuación)

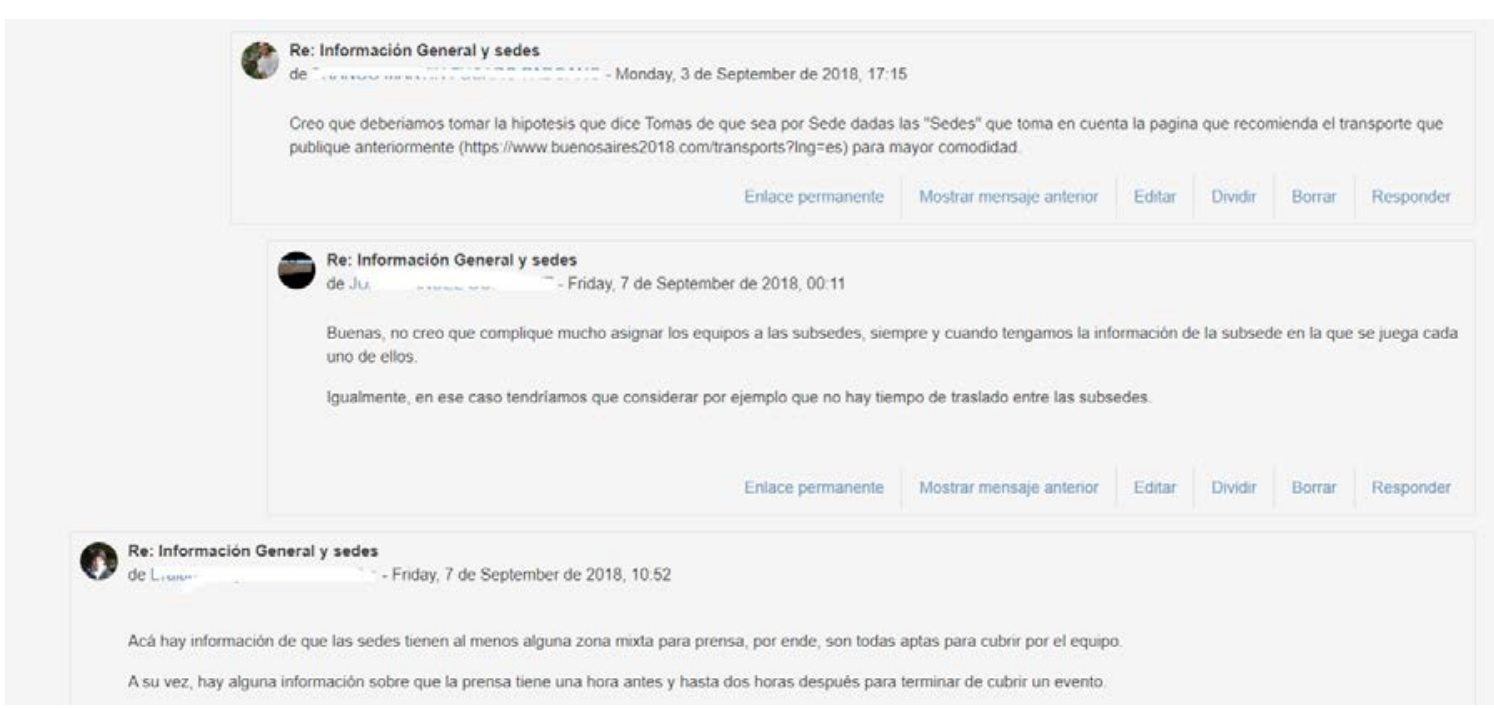

\section{ANEXO V}

7. Duda sobre como cargar desde un archivo csV

de

Holal

Tenemos un archivo CSV con las constantes de calidad (asi mismo con eventos y otros) y queremos cargarlo a gipk. El problema es que no estariamos pudiendo encontrar la manera de hacerlo y los ejemplos que hay en internet no nos ayudaron.

Tenemos un set de DEPORTES y un set de las calidades posibles (este ultimo, CA_DATA_TITLES) posee los 3 tipos de calidad que existen, la normal, la aumentada por evento final y la aumentada por especialista. Luego tenemos un parametro que toma de estos dos para armar las calidades por deporte.

Las definiciones son las siguientes:

Set CA_DATA_TITLES:

set DEPORTES;

Luego en data:

set DEPORTES $=1,30$

Set CA_DATA_TITLES, = "C" "AC" "ACE";

Y en el archivo csv tenemos un header que es 10 ," C","AC", "ACE" y luego cada flia posee el id de deporte y sus calidades asociadas.

Intentamos algo similar al ejemplo "oficiar" (https.//en. wikibooks. org/wik//GLPK/Tabie_Statement) pero no logramos conseguir que nos de otra cosa que "syntax error in data section".

Podrian darnos una mano?

Muchas oracias!

\section{Generacion de restricciones automatica}

de J $J$ cic.

Hola,

en el modelo que planteamos para la segunda entrega utilizamos el concepto de conjuntos maximales. Segun lo que encontramos GLPK no permite utilizar conjuntos de conjuntos, por lo que para implementar nuestra solucion seria necesario escribir las restricciones una por una (en vez de definir conjuntos en el set de datos)

Aprovechando esta idea que ya nos obliga a generar las restricciones a priori (lo cual es un poco malo -el mod no se aiusta a cualquier dato de entrada) podemos aprovechar para optimizar otras cosas, como evitar definiciones de variables que no se utilizan, generandolas con el mismo script.

En resumen, dos preguntas:

1) Esta bien generar el modelo a traves de un script que escribe restricciones y variables segun el set de datos? Agregamos el script a la entrega?

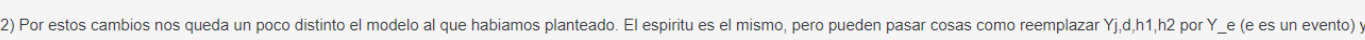
por eso tener que definir e___e (existencia de especialista en el equipo i-esimo para el evento e) en vez de lo que estaba en el modelo, e___d (existencia de especialista en el equipo i-esimo para el deporte d). Estos cambios creemos que son necesarios porque de otra manera, al usar la sintaxis de GLPK sobre el modelo original, nos quedan muchas variables que no se utilizan. Agregamos al informe de resultados una introducción comentando estos cambios?

Gracias!

Saludos 


\section{Diseño de un Repositorio de Recursos Tic Para Trabajar la Lectoescritura}

\section{Parra García, Ana María}

Universidad de les Illes Balears (España)

apg1929@hotmail.com 


\section{DISEÑO DE UN REPOSITORIO DE RECURSOS TIC PARA TRABAJAR LA LECTOESCRITURA}

\section{Parra García, Ana María}

Universidad de les Illes Balears (España)

apg1929@hotmail.com

\section{Resumen}

El presente trabajo de investigación-intervención, se centra en la creación de un repositorio de recursos y herramientas TIC para trabajar la competencia en comunicación lingüística con alumnado con necesidades educativas especiales (ACNEE) y que presenta dificultades en el aprendizaje de la lectura y la escritura. Este estudio se enmarca dentro del TFM del máster Oficial en Tecnología Educativa: e- learning de la Universidad de les Illes Balears El repositorio de recursos surge como necesidad de una maestra de Audición y Lenguaje ( $A L)$, de disponer de recursos educativos digitales para así poder elaborar entornos personales de aprendizaje (PLE). El desarrollo de este proyecto ha generado un Aprendizaje servicio ApS. Tras una revisión y fundamentación teórica se desarrolla una investigación de corte mixto, basada en un estudio de caso teniendo en cuenta la metodología de Investigación Basada en Diseño (IBD) y desarrollando los pasos del modelo de gestión de proyectos IPECC. En cuanto al resumen general de los resultados, tras el análisis de las respuestas de la evaluación del repositorio creado se puede resaltar que $85,35 \%$ de los expertos está totalmente de acuerdo con el repositorio. Una vez finalizado el estudio y tras el análisis de los resultados, se puede afirmar que se cumplen con los objetivos marcados, resaltando las limitaciones encontradas en cuanto a la implementación del PLE en este curso escolar.

\section{Palabras clave}

Entornos personales de aprendizaje PLE, Necesidades Educativas Especiales NEE, Competencia en Comunicación Lingüística CCL, Recursos TIC. 


\section{Introducción}

Este trabajo surge ante la demanda y necesidad de una maestra de Audición y Lenguaje de un CEIP de la ciudad de Lorca España, de disponer de recursos digitales para trabajar la CCL en alumnos con necesidades educativas especiales. Se lleva a cabo en este trabajo una metodología del aprendizaje servicio ApS, ya que se presta un servicio en un entorno real al tiempo que tiene lugar una formación y un aprendizaje, (Ganga-Contrera, et al., 2021), dando lugar un ApS a través de tecnología digitales (Sandia y Montilla, 2020).

La intención de la maestra es crear PLE con los ACNEE con la intención de trabajar y mejorar la CCL, a través de las TIC. Lo que se pretende es tener alternativas a los métodos tradicionales de enseñanza y poder disponer de recursos y herramientas más motivadoras e interesantes para los niños y niñas.

Un PLE "es el conjunto de herramientas, fuentes de información, conexiones y actividades que cada persona utiliza de forma asidua para aprender" (Adell y Castañeda, 2010, pág. 23). El trabajar con PLE hace que los alumnos sean el centro de atención, ya que se adaptan a sus necesidades y características siendo el alumno el protagonista de su aprendizaje (Castañeda y Adell, 2013) favoreciendo el desarrollo personal y el aprendizaje. El trabajar con PLE favorece la inclusión educativa en las aulas ya que se adaptan a los ritmos de aprendizaje, necesidades e intereses de los alumnos. En el trabajo de Miranda y Morales (2019) desarrollan una experiencia donde el trabajo con PLE favorece la inclusión educativa, atendiendo a la diversidad del alumnado. Se resalta que el trabajar con las TIC se favorece el interés y la motivación del alumnado.

El alumno con necesidades educativas especiales tiene en las TIC como una vía que facilita la inclusión e integración en la sociedad. Son una herramienta didáctica a la hora que les ayuda a fortalecer capacidades y habilidades de aprendizaje (Rodríguez y Arroyo, 2014).

Las TIC y el uso de las tablets se convierten en un complemento a los métodos tradicionales de enseñanza. El uso de las aplicaciones móviles y digitales para el aprendizaje de la lectura y la escritura en educación Infantil y Primaria (Hernádez y Rovira, 2018); (Sanchís, 2019) son cada día más frecuentes en las aulas.

El trabajo de investigación que se presenta ha consistido en el diseño y elaboración de un repositorio de recursos y herramientas a través de las TIC, para trabajar la competencia en comunicación lingüística CLL centrándonos en el aprendizaje de la lectura y la escritura, dirigido a ACNEE.

La pregunta de investigación que surge ante esta problemática sería ¿Cuáles son las características que debe tener un repositorio de recursos TIC para trabajar la competencia en comunicación lingüística centrados en el aprendizaje de la lectoescritura dirigido a alumnos de necesidades educativas especiales?

El objetivo que se pretende alcanzar con este trabajo es el de diseñar un repositorio de recursos y herramientas TIC para trabajar la competencia en comunicación lingüística, centrado en el aprendizaje de la lectoescritura dirigido a alumnos con necesidades educativas especiales. 
A partir de la pregunta de investigación del objetivo general se plantean los siguientes objetivos de investigación:

O.E.1 Realizar un estudio de necesidades de la maestra de Audición y Lenguaje.

O.E.2 Seleccionar recursos TIC para trabajar la competencia en comunicación lingüística relacionados con el aprendizaje de la lectura y escritura.

O.E.3 Desarrollar el repositorio de recursos TIC para trabajar la competencia en comunicación lingüística, centrado en el aprendizaje de la lectoescritura.

O.E.4 Validar el repositorio de recursos TIC por la maestra de Audición y Lenguaje y por un grupo de expertos para después difundirlo por la comunidad educativa.

\section{Método/Descripción de la experiencia.}

La metodología que se ha llevado a cabo para poder desarrollar esta investigación ha sido una metodología de Investigación Basada en Diseño (IBD), a partir del estudio de caso y teniendo en cuenta el modelo IPECC de gestión de proyectos. Una investigación de diseño de enfoque metodológico mixto ya que recoge técnicas tanto del modelo cuantitativo como del cualitativo.

La IBD, según Benito y Salinas (2016) así como el modelo IPECC de gestión de proyectos, (Lynch y Roecker, 2007) tratan de dar respuesta a un problema o necesidad educativa planteado, en este caso la necesidad de recursos y herramientas TIC para trabajar la CCL. Lo que se ha pretendido es dar respuesta a este problema a través del estudio y de la investigación.

El modelo de gestión de proyectos IPECC se desarrolla siguiendo las siguientes fases: Inicio, Planificación, Ejecución, Control y Cierre. Este modelo se caracteriza por ser modelo abierto y flexible que permite repetir fases o ciclos, ya que se realiza una reevaluación continua de los resultados lo que da lugar a realizar cambios si fuese necesario hasta poder llegar a la fase de cierre. 


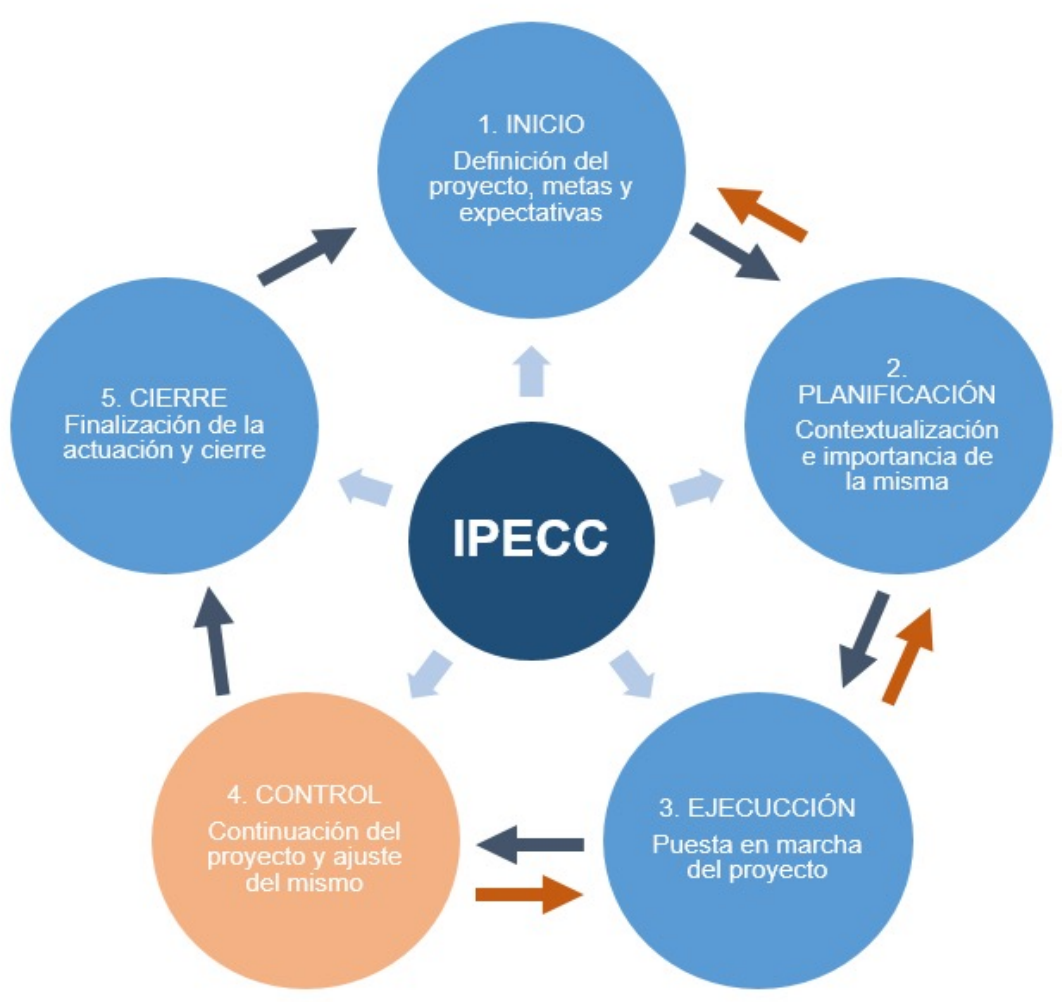

Figura. Fases IPECC. Fuente elaboración propia a partir de Lynch y Roecker (2007)

En la fase Inicial se realiza un estudio de las necesidades planteadas por la maestra. En la fase de Planificación, en la que a partir de las necesidades planteadas se crea a un repositorio de recursos, se determinan las acciones a realizar, los recursos necesarios y el cronograma del proyecto. A continuación, tiene lugar la fase de Ejecución donde se procede al diseño y creación del blog. En la fase de control del modelo IPECC, se procede a la realización de las pruebas y evaluación del blog y realizar posibles mejoras hasta obtener y cumplir con los objetivos planteados. Para finalizar se ha procedido a la revisión, valoración de la experiencia y de los resultados del proyecto para realizar la entrega definitiva del mismo, completando así la fase de Cierre del modelo IPECC. Esta investigación de diseño es un modelo mixto ya que asume aspectos tanto del modelo cualitativo como del cuantitativo.

\section{Descripción del contexto y de los participantes}

El contexto donde se ha realizado la investigación ha sido un colegio de Educación Infantil y Primaria de la ciudad de Lorca, región de Murcia, España. Es un centro multicultural donde actualmente conviven varias culturas. De los 220 alumnos matriculados de etnia gitana son el $40 \%$, del Magreb $56 \%$ y de otras culturas $4 \%$ de los alumnos. Es un colegio catalogado como centro de actuación preferente. Actualmente tiene un número significativo de alumnos/as con necesidades específicas de apoyo educativo asociadas al desconocimiento del español, por desfase curricular significativo, por integración tardía en el sistema educativo y por condiciones personales o de historia escolar. La mayoría de estos alumnos presentan problemas en el aprendizaje de la lectura y escritura. En este curso escolar, 2020-2021, de los 220 alumnos/as matriculados en el centro educativo, 29 son atendidos por la maestra de Audición y Lengua y de pedagogía terapéutica PT. 
Esta investigación va dirigida a alumnos/as de educación primaria de necesidades educativas especiales con un desarrollo curricular de primero de primaria en el área de lengua castellana y literatura, que presentan dificultades en el desarrollo de la competencia en comunicación lingüística, en la lectura y la escritura. Son un grupo formado por 5 alumnos/as, dos niñas y tres niños. Dos de estos alumnos se encuentran escolarizados en primero de primaria y tres en segundo de primaria.

\section{Instrumentos}

Los instrumentos utilizados para poder llevar a cabo esta investigación ha sido la entrevista, cuestionario y rúbrica, son de elaboración propia y no han sido sometidos a un proceso de validación ya que han sido creados para poder alcanzar los objetivos y metas de este proyecto y no se contempla la posibilidad que se puedan utilizar en otras investigaciones o proyectos.

Entrevista. En esta investigación se han realizado dos entrevistas estructuradas dirigidas a la maestra de AL Una para ver y analizar las necesidades que planteaba la maestra, esta tuvo lugar en la fase de Planificación del IPECC y ayuda a cumplir uno de los objetivos específicos de esta investigación, el realizar un estudio de necesidades de la maestra de AL. Y la segunda entrevista se realiza con el fin de poder evaluar el prototipo de recursos creado y realizar posibles mejoras en el mismo, esta entrevista tuvo lugar en la fase de Control del IPECC.

Cuestionario se realizar para analizar las necesidades docentes sobre las TIC por el grupo de expertos y así poder disponer de más datos para realizar el estudio de las necesidades que dará paso al diseño del repositorio de recursos TIC. La escala que se ha utilizado en la elaboración del cuestionario ha sido una escala de tipo Likert con seis niveles de respuesta que va desde: 1 "En total desacuerdo" a 6 "Totalmente de acuerdo". La información que se pretendía conseguir con el cuestionario es la siguiente: Observar y analizar el uso de las TIC a la hora de buscar información y recursos. Ver el uso de las TIC en el aprendizaje de la lectoescritura. Analizar la necesidad de un repositorio de recursos TIC sobre la lectoescritura. Ver la idoneidad del uso del blog como herramienta para presentar el repositorio de recursos encontrado. Valorar el uso del PLE para aprender a leer y escribir.

Rúbrica. La escala que se ha utilizado en la rúbrica ha sido una escala de tipo Likert con seis niveles de respuesta. La rúbrica de evaluación del blog, se encuentra dividida en 5 partes para facilitar la evaluación del mismo. Estas partes coinciden con páginas del blog. Los aspectos a evaluar en el blog a través de los distintos ítems de la rúbrica son los siguientes: Ver si el contenido de la página se cubre correctamente. Si el contenido de la página es apropiado. La calidad de la información ofrecida es acorde con el fin que pretende cubrir. Si los enlaces y links se activan sin error y son funcionales. Valorar el diseño de la página: letra, color, distribución, etc. Idoneidad de los recursos presentados. Relación de los contenidos del blog con el currículum de Primaria e Infantil. La variedad y número de recursos. Adecuación del tipo de recurso, si son funcionales. Adecuación del tipo de recurso, si son atractivos.

En el proceso de validación y evaluación del blog se ha realizado a partir de la técnica de control o consulta a expertos. El grupo de expertos los forman 10 personas, 3 hombres y 7 mujeres. El perfil de estos expertos es que son docentes en activo con distintas especialidades de magisterio y con tiempo de servicio. 


\section{Procedimiento}

La búsqueda y selección de recursos que forman parte del repositorio de recurso TIC se ha realizado teniendo en cuenta que estos fuesen gratuitos y compatibles con dispositivos Android.

La selección y búsqueda de recursos se centró en canales de YouTube, Webs y APPS. La búsqueda se ha realizado a través de los siguientes buscadores: YouTube, Google Chrome y Bing. Para la selección y búsqueda de las aplicaciones apps se ha utilizado las siguientes webs: Appyautism, Brindgingapps y Google Play. A la hora de realizar la selección y búsqueda de las apps se ha tenido en cuenta aquellas que estaban diseñadas para alumnado con algún tipo de necesidad educativa. Se han seleccionado apps con pictogramas, para alumnado de necesidades educativas, alumnado con problemas en al ámbito del lenguaje, TEA.

El medio elegido para presentar y dar a conocer el repositorio de recursos TIC fue el blog, creado a través de la aplicación web blogger. Es una aplicación gratuita, sencilla, con un back-end fácilmente configurable y un front-end vistoso, estructurado y de fácil interacción.

\section{Resultados}

El blog creado se titula "Escucha, habla, escribe y lee con recursos TIC". Está formado por 6 páginas más la entrada de inicio. Al principio de cada una de las páginas se ofrece al lector una breve explicación de lo que se desarrolla en ella, así como las pautas de navegación. En todas las páginas del blog se brinda la posibilidad al lector de participar y dejar su opinión. En la primera página de Inicio-Presentación se explica el motivo de la creación del blog y se dan las pautas de cómo navegar por él. En la página PLE el visitante encuentra información sobre los PLE, su definición así como pautas para poder elaborar uno. En YouTube el lector encontrará una selección de 14 canales relacionados con el aprendizaje de la lectoescritura. En la página Web se presentan 18 plataformas educativas. En Apps se describen 19 aplicaciones para dispositivos Android y gratuitas o con modo de prueba gratis y por último la página de Opinión, donde los lectores pueden dejar sus impresiones.

El análisis de las respuestas por el grupo de expertos del cuestionario de percepción docente sobre las TIC, permitió y ayudó a completar el estudio de necesidades que planteaba la maestra de Al para la construcción del repositorio de recursos. Del análisis de las respuesta e extrae que las TIC pueden ser muy útiles para acceder a información y recursos a la hora de trabajar la competencia lingüística y que son una herramienta para obtener información. Un 60\% de los expertos consideran conveniente disponer de un repositorio de recursos TIC para la enseñanza de la lectoescritura. Un 70\% de los expertos consideran que el blog puede ser una buena herramienta para dar a conocer los recursos TIC de un repositorio. Un $60 \%$ del grupo de expertos está totalmente de acuerdo al considerar que trabajar con PLE puede beneficiar al alumnado en el aprendizaje de la lectura y la escritura mientras.

Los resultados a nivel porcentual de cada una de las partes del blog tras analizar el resultado de los ítems de la rúbrica es el siguiente: Inicio-Presentación, bastante de acuerdo $15.71 \%$ y totalmente de acuerdo 84,29\%; PLE, bastante de acuerdo 17\% 
y totalmente de acuerdo $83 \%$; YouTube, bastante de acuerdo $14 \%$ y totalmente de acuerdo 86\%; Webs, en general en desacuerdo 10\%, bastante de acuerdo $13 \%$ y totalmente de acuerdo 86\%; Apps, bastante de acuerdo 13\% y totalmente de acuerdo $87 \%$. Una vez finalizada la evaluación del blog por el grupo de expertos a través de la implantación de la rúbrica, podemos apreciar y observar que el rango de respuesta de los ítems se recogen entre totalmente de acuerdo y bastante de acuerdo por lo que el producto final ha sido aprobado y validado por el grupo de expertos de manera satisfactoria y el blog cumple con los requisitos y necesidades que planteaba la maestra de AL. Llegado a esta fase de la investigación el blog ya cumple con los requisitos para poder ser difundido entre la comunidad educativa. Para la difusión del blog se utilizan redes como; facebook, instagram, twitter. Con este propósito, también se quiere dar a conocer el blog entre grupos de whatsapp de docentes de diferentes colegios.

\section{Discusión y conclusiones.}

Este proyecto de investigación ha sido fruto de una demanda y necesidad que presentaba una maestra de AL de un colegio de Lorca, Murcia, de poder disponer de recursos TIC para trabajar la lectoescritura, dando lugar a un ApS a través de tecnologías digitales, (Sandia y Montilla, 2020). El objetivo de poder disponer de un repositorio de recursos TIC para trabajar la lectura y la escritura en los alumnos con necesidades educativas, se ha materializado en el blog: Escucha, habla, escribe y lee con recursos TIC.

La valoración del servicio y del aprendizaje obtenido es muy positiva ya que el desarrollo de esta iniciativa implica conocer y analizar las características que tiene que tener un gestor de contenidos que se adapte a los objetivos planteados con el repositorio. Ha permitido estudiar y analizar estudios compatibles con esta investigación que han ayudado a dar respuesta a los objetivos marcados en el proyecto. Otra de las aportaciones es que ha permitido identificar y analizar recursos y herramientas TIC para trabajar la lectoescritura.

El objetivo general planteado era el de diseñar un repositorio de recursos y herramientas TIC para trabajar la competencia en comunicación lingüística, centrado en el aprendizaje de la lectoescritura dirigidos a alumnos con necesidades educativas especiales.

A partir de este objetivo general se plantearon cinco objetivos específicos que tras intentar la resolución de los mismos se ha pretendido dar respuesta a la pregunta de investigación de este proyecto. ¿Cuáles son las características que debe tener un repositorio de recursos TIC para trabajar la competencia en comunicación lingüística centrados en el aprendizaje de la lectoescritura dirigido a alumnos de necesidades educativas especiales?

El primer objetivo específico de esta investigación es realizar un estudio de necesidades de la maestra de Audición y Lenguaje. Para poder alcanzar este objetivo y dar inicio a la investigación se plantea realizar dos acciones. Por un lado el diseño de una entrevista estructurada a la maestra de AL con el objetivo de conocer y analizar las necesidades que planteaba de disponer de recursos TIC para trabajar la lectoescritura con ACNEE. Otra de las acciones que se realiza para completar el estudio de 
necesidades y poder tener más información para ir desarrollando el repositorio de recursos TIC es la realización de un cuestionario dirigido al grupo de expertos con el objetivo de ver la percepción docente sobre las TIC.

El análisis de las respuestas obtenidas tanto de la entrevista realizada a la maestra como del cuestionario sobre la percepción docente sobre las TIC permite concretar el estudio de las necesidades de la maestra. Es el diseñar un repositorio con variedad en recursos TIC para trabajar la lectoescritura. Recursos como páginas webs, canales de YouTube, aplicaciones donde la maestra pueda consultar, obtener información y trabajar contenidos relacionados con la enseñanza y aprendizaje de la lectura y la escritura. Estos recursos deben de ser variados, sencillos de utilizar, que resulten atractivos y motivantes para el alumnado y con cierto carácter lúdico. Otro de los requisitos que se extrae es que los recursos tienen que ser gratuitos y compatibles con la plataforma Android.

A la hora de diseñar el repositorio hay que tener en cuenta que este sea fácil y sencillo de utilizar. Que se pueda manejar de manera intuitiva.

La intención de la maestra es de disponer de variedad de recursos para poder diseñar y trabajar con sus alumnos a través de PLE favoreciendo así el aprendizaje personalizado centrado en las necesidades, características y motivaciones de cada uno de ellos, Salas (2016) favoreciendo la atención a la diversidad.

Con lo expuesto hasta ahora podemos afirmar que se ha alcanzado el primer objetivo de esta investigación el de realizar un estudio de necesidades de la maestra AL del colegio de Lorca.

Una vez extraídas y analizadas las necesidades que planteaba la maestra es momento de dar respuesta al segundo objetivo específico el seleccionar recursos TIC para trabajar la competencia en comunicación lingüística relacionados con el aprendizaje de la lectura y escritura.

La búsqueda y selección de los recursos para dar forma al repositorio se ha realizado teniendo en cuenta las características y necesidades que manifestó la maestra en la entrevista. Esta búsqueda se centró en canales de YouTube, Webs y Apps relacionadas con el aprendizaje de la lectura y escritura.

Lo que se pretende es poder dar respuestas a las necesidades e inquietudes del alumnado con variedad de materiales y recursos favoreciendo así la atención a la diversidad de los mismos, tal y como se recoge en el Decreto 359 de 2009, por el que se establece y regula la respuesta a la diversidad del alumnado en la Comunidad Autónoma de la Región de Murcia. Recursos que ayudan a adquirir y alcanzar el aprendizaje de la lectoescritura, favoreciendo el desarrollo de la CCL. Por lo que se puede decir que el segundo objetivo específico, seleccionar recursos TIC para trabajar la CCL relacionados con el aprendizaje de la lectura y la escritura, se ha cumplido.

El siguiente objetivo específico que se planteó en este trabajo es desarrollar el repositorio de recursos TIC para trabajar la competencia en comunicación lingüística, centrado en el aprendizaje de la lectoescritura. 
Una vez establecida las categorías de recursos a buscar: canales de YouTube, Webs y App se vio necesario de elegir la plataforma, medio de presentar el repositorio, que fue el blog. El gestor de contenido elegido para crear el blog fue Blogger. Ya que recoge las necesidades que planteaba la maestra en la entrevista inicial sobre cómo debía ser el repositorio de recursos TIC. Blogger permite crear blogs con un formato fácil, sencillo e intuitivo de utilizar convirtiéndose en un medio cómodo para el usuario que no requiere de muchos conocimientos en el uso de la TIC a la hora de navegar por él.

En el blog se presentan los recursos encontrados para trabajar la lectoescritura por distintas categorías, convirtiéndose estas categorías en páginas del blog: YouTube, Webs y Apps. Además de estas páginas, el blog cuenta con las siguientes páginas: Inicio-Presentación, de Opinión y PLE que se incluyó tras la primera evaluación y revisión del blog por la maestra de AL a través de una entrevista estructurada.

Las características de los contenidos y recursos que presenta el blog son los que se establecieron tras el estudio de las necesidades que planteaba la maestra de AL. Recursos relacionados para el aprendizaje de la lectoescritura dirigidos al ACNEE que están aprendiendo a leer y escribir. Recursos variados con carácter lúdico y que llamen la atención y despierten el interés del alumnado. Otra de las características de estos recursos es que son gratuitos y compatible con el sistema operativo Android.

Una de las ventajas a la hora de usar los blogs son las aplicaciones educativas y didácticas que estos ofrecen. Son herramientas flexibles que se adaptan a necesidades concretas, como es este caso, y pueden convertirse en alternativas a los métodos tradicionales de enseñanza-aprendizaje (Barberá, 2008) favoreciendo el trabajo individualizado y la atención a la diversidad.

El diseño del repositorio de recursos TIC se realizó siguiendo las fases del modelo IPECC dando lugar al blog de nombre, "Escucha, habla, escribe y lee con recursos TIC" por lo que se puede decir que se ha alcanzado el tercer objetivo específico de esta investigación.

El cuarto objetivo específico de este trabajo ha sido el de validar el repositorio de recursos TIC por la maestra de Audición y Lenguaje y por un grupo de expertos para después difundirlo por la comunidad educativa. La validación del repositorio de recursos, blog se ha realizado por la maestra de $A L$ a través de una entrevista estructurada y por un grupo de expertos del que formaba parte esta maestra a través de una rúbrica.

Tras la entrevista realizada a la maestra para evaluar y analizar el primer prototipo del blog se realizaron mejoras en el mismo para cumplir con las expectativas y objetivos que se habían propuesto con el blog. El grupo de expertos fue el encargado de evaluar el repositorio de recursos TIC a través de una rúbrica diseñada para este fin. Los resultados obtenidos en la rúbrica dieron el visto bueno al repositorio de recursos TIC creado y presentado a través del blog. Por lo que podemos decir que el blog tiene calidad y fiabilidad ya que son dos criterios que tiene que reunir un instrumento tras ser validado por un grupo de expertos. (Robles y Rojas, 2015)

1 https://escuchahablaescribeleeconrecursostic.blogspot.com/ 
Al ir alcanzando y cumpliendo con los distintos objetivos específicos de esta investigación se da por alcanzado y cumplido el objetivo general que es el diseñar un repositorio de recursos y herramientas TIC para trabajar la competencia en comunicación lingüística, centrado en el aprendizaje de la lectoescritura dirigidos a alumnos con necesidades educativas especiales.

Llega el momento de dar respuesta a la pregunta de investigación de este trabajo. ¿Cuáles son las características que debe tener un repositorio de recursos TIC para trabajar la competencia en comunicación lingüística centrados en el aprendizaje de la lectoescritura dirigido a alumnos de necesidades educativas especiales?

Una de las características principales que tiene que tener el repositorio de recursos TIC para trabajar la CCL centrado en el aprendizaje de la lectoescritura en ACNEE es que sea una herramienta con posibilidades educativas y que favorezca el trabajo individualizado y la atención a la diversidad El blog se puede convertir en un complemento y alternativa a las metodologías tradicionales de aprendizaje ya que favorece el trabajo individualizado y la atención a la diversidad. (Barberá, 2008), a través de la creación de PLE que se adaptan a las características y necesidades del alumnado. En nuestro caso a ACNEE.

Otra de las características es que la información aparece bien estructurada y que se facilite la navegación por él, siendo esta otra de las características. Los recursos encontrados para trabajar la lectoescritura se presentan en varias categorías, convirtiéndose estas categorías en páginas del blog: YouTube, Webs y Apps. El visitante no precisa tener muchos conocimientos en TIC para poder navegar por él. La navegación por el blog es fácil e intuitiva.

Otra de las características que presenta el blog es que en él se recopilan recursos gratuitos y variados, tanto para el alumnado como para los profesionales y resto de la comunidad educativa

El blog se puede convertir en punto de encuentro y reflexión a través de los comentarios y opiniones que dejan los visitantes. Convirtiéndose este aspecto en otra de las características que definen el blog.

Con todo lo expuesto podemos decir que la pregunta de investigación de este trabajo queda resuelta. Se responde a la pregunta de investigación con el diseño de un repositorio de recursos TIC a través de un blog, que recoge recursos y herramientas TIC para trabajar la competencia en comunicación lingüística centrada en el aprendizaje de la lectoescritura dirigido a alumnos de necesidades educativas especiales.

\section{Limitaciones y Perspectivas futuras de investigación.}

Como se ha señalado en apartados anteriores debido a la falta de tiempo, lo avanzado del curso escolar y las circunstancias covid-19, no se ha podido implementar el trabajo con PLE y recursos TIC con el ACNEE y ver y analizar el progreso que realizan estos alumnos en el desarrollo de la CCL. Para el siguiente curso escolar 2021/2022 sí estará recogido en las programaciones del colegio la implementación del PLE y estudiar las mejoras en el alumnado convirtiéndose en una de las perspectivas futuras de la investigación. 
Otras de las expectativas futuras de investigación sería ampliar los destinatarios de este estudio. El blog y los recursos que se recogen en él, puede convertirse en un herramienta muy útil tanto para los niños y niñas que están empezando a leer y escribir, último curso de educación infantil y primer curso de primaria, como para aquellos menores con desconocimiento del idioma que necesitan aprender castellano. La presencia de alumnos que presentan desconocimiento del español es una realidad frecuente en las aulas de los colegio a día de hoy.

La difusión del blog por la comunidad educativa para que tanto docentes, familias y alumnado puedan hacer uso de los recursos que se presentan en el blog, sería otra de las expectativas futuras. El blog y los recursos que se presentan en él, se pueden convertir en una ayuda a la hora de iniciar y consolidar el aprendizaje de la lectura y escritura en el alumnado. Ofrece recursos y alternativas para aprender a leer y escribir de una forma más lúdica y divertida.

\section{Referencias}

Adell, J. y Castañeda, L. (2010). "Los Entornos Personales de Aprendizaje (PLEs): una nueva manera de entender el aprendizaje". En Roig Vila, R. \& Fiorucci, M. (Eds.) Claves para la investigación en innovación y calidad educativas. La integración de las Tecnologías de la Información y la Comunicación y la Interculturalidad en las aulas. Stumenti di ricerca per l'innovaziones e la qualità in ámbito educativo. La Tecnologie dell'informazione e della Comunicaziones e l'interculturalità nella scuola.Alcoy: Marfil - Roma TRE Universita degli studi. Disponible en Digitum http://digitum. um.es/xmlui/bitstream/10201/17247/1/Adell\%26Castañeda_2010.pdf

Adell, J. y Castañeda, L. (2013). El ecosistema pedagógico de los PLEs. En L. Castañeda y J. Adell (Eds.), Entornos Personales de Aprendizaje: Claves para el ecosistema educativo en red (pp. 29-51). Alcoy: Marfil. Disponible en Digitum http://digitum. um.es/xmlui/bitstream/10201/30409/1/capitulo2.pdf

Barberá, E. (2008). El estilo e-portafolio. Barcelona: UOC.

De Benito Crosetti, B., y Salinas Ibáñez, J. M. (2016). La Investigación Basada en Diseño en Tecnología Educativa. Revista Interuniversitaria de Investigación en Tecnología Educativa. https://doi.org/10.6018/riite2016/260631.

Ganga-Contreras, F., Rodríguez-Quezada, E., \& Guiñez-Cabrera N. (2021). Metodología de aprendizaje-servicio en un proyecto integrado de costos y marketing. Alteridad, 16(1), 51-64. https://doi.org/10.17163/alt.v16n1.2021.04

Hernández Ortega, P.y Rovira-Collado, J. (2018). Enseñanza de la Lectoescritura en Educación Infantil y desarrollo de la competencia profesional del alumnado para maestro. En: Roig-Vila,Rosabel (coord.). Redes de Investigación en Docencia Universitaria. Volumen 2018. Alicante:Universidad de Alicante, Instituto de Ciencias de la Educación (ICE) [pp.] 555-565.

Lynch, M. M. y Roecker, J. (2007). Project managing e-learning: A handbook for successful design, delivery and management. USA: Routledge. 
Miranda Carrasco, K.G., y Morales Vera, B.Y. (2019) Los ambientes personales del aprendizaje PLE en la inclusión educativa de los estudiantes de décimo año en la asignatura de estudios sociales. Plataforma E-Learning. [Tesis Proyecto Educativo previo a la obtención del Título de Licenciado de la Educación Mención: Sistemas Multimedia, Universidad de Guayaquil]. http://repositorio.ug.edu.ec/handle/redug/40564

Robles Garrote, P., y Rojas, M. del. (2015). La validación por juicio de expertos: dos investigaciones cualitativas en Lingüística aplicada. Revista Nebrija De Lingüística Aplicada a La Enseñanza De Lenguas, 9(18), 124-139. https://doi.org/10.26378/rnlael918259

Rodríguez, M. y Arroyo, M. J. (2014). Las TIC al servicio de la inclusión educativa. Digital Education Review, 25, 108-126. Recuperado de http://revistes.ub.edu/index. php/der/article/viewFile/11331/pdf

Salas, M. (2016). Reflexiones en torno a los maestros de pedagogía terapéutica. Padres y Maestros, 365, 6-11. https://doi.org/10.14422/pym.i365.y2016.001

Sanchis Amat, Víctor Manuel. "Aplicaciones digitales para el desarrollo de la lectoescritura para el alumnado de Educación Infantil y Primaria". En: Roig-Vila, Rosabel (coord.). Redes de Investigación e Innovación en Docencia Universitaria. Volumen 2019. Alicante: Universidad de Alicante, Instituto de Ciencias de la Educación (ICE), 2019. ISBN 978-84-09-07186-9, pp. 721-730

Sandia S., B. E., \& Montilva C., J. A. (2020). Tecnologías Digitales en el Aprendizaje-Servicio para la Formación Ciudadana del Nuevo Milenio. RIED. Revista Iberoamericana De Educación a Distancia, 23(1), 129-148. https://doi.org/10.5944/ ried.23.1.24138 


\section{¿Otro Tipo de Gamificación es Posible?: Experiencia de Retos Gamificados y de Evaluación entre Iguales desde el Aprendizaje Cooperativo y la Atención a la Diversidad.}

\section{Lluch-Molins, Laia}

orcid.org/0000-0002-7288-2028, Universitat de Barcelona (UB), laia.lluch@ub.edu

\section{Cano-García, Elena}

orcid.org/0000-0003-2866-5058, Universitat de Barcelona (UB), ecano@ub.edu

\section{Valero-García, Miguel}

orcid.org/0000-0003-2092-027X, Universitat Politècnica de Catalunya (UPC),

miguel.valero@upc.edu

\section{Meseguer-Pallares, Roc}

orcid.org/0000-0002-9414-646X, Universitat Politècnica de Catalunya (UPC), roc. meseguer@upc.edu 


\title{
¿OTRO TIPO DE GAMIFICACIÓN ES POSIBLE?: EXPERIENCIA DE RETOS GAMIFICADOS Y DE EVALUACIÓN ENTRE IGUALES DESDE EL APRENDIZAJE COOPERATIVO Y LA ATENCIÓN A LA DIVERSIDAD.
}

\author{
Lluch-Molins, Laia \\ Cano-García, Elena \\ Valero-García, Miguel \\ Meseguer-Pallares, Roc
}

\section{Resumen}

En esta contribución se presenta el diseño pedagógico de una asignatura mediante actividades gamificadas sustentadas por herramientas tecnológicas y se avanzan los resultados de los cuestionarios de satisfacción y percepción de aprendizaje administrados al finalizar la experiencia. Se planifica e implementa la gamificación como estrategia de aprendizaje colaborativo y como estrategia docente de seguimiento y apoyo al estudiantado para promover la autorregulación del aprendizaje y desarroIlar la competencia transversal de aprender a aprender. Si bien existen numerosas experiencias de gamificación, la característica diferencial de esta propuesta es que se arma desde el aprendizaje cooperativo y la atención a la diversidad. La experiencia se ha desarrollado con 53 estudiantes de un grupo de la asignatura obligatoria de formación básica del primer curso del Grado de Maestro de Educación Primaria de la Universitat de Barcelona (UB).

\section{Palabras clave}

Competencia de aprender a aprender, gamificación, herramientas tecnológicas, innovación, maestro de educación primaria. 


\section{Introducción}

Desde la perspectiva de la formación inicial de futuros profesores, debemos abordar los cambios en la educación desarrollando actividades de formación que incluyan las oportunidades y las estrategias más adecuadas, para adquirir con éxito no sólo las habilidades docentes (Esteve et al., 2014), sino también aquellas fundamentales para resolver problemas y situaciones del mundo digital, las cuales contribuyen al desarrollo de la competencia docente.

El aprendizaje es un proceso activo que requiere motivación tanto para iniciar como para persistir en él. Aprender requiere de interés y disposición del aprendiz por su propio aprendizaje o por las actividades que le llevan a él (motivación), del uso de las habilidades, acciones y pensamientos que tienen lugar durante el aprendizaje (estrategias), y también qué concepción de aprendizaje mantiene el estudiante y cómo lo aborda (enfoques de aprendizaje) (Domínguez y Mora, 2014). En educación superior, la motivación para aprender a menudo se puede ver disminuida sobre todo cuando, en contextos como el que ha dibujado la pandemia, se requiere un elemento de autodirección y autonomía (OCDE, 2000). Es necesario emplear nuevas estrategias educativas de enseñanza-aprendizaje que, además de involucrar al alumnado, haga más significativo su aprendizaje.

En los últimos años se está usando con frecuencia el término gamificación para hacer referencia a diferentes recursos metodológicos aplicables a situaciones y disciplinas variadas (Domínguez y Mora, 2014). La gamificación emerge como una herramienta de transformación educativa (Landers y Callan, 2011; Muntean, 2011; Corchuelo-Rodríguez, 2018) desde que el término fue acuñado por Pelling en 2002 por referirse a la adaptación del juego en la educación. De hecho, tanto el Informe Horizon de Educación superior, como el de Infantil y Primaria, publicado en 2014 ya destaca la gamificación y el aprendizaje basado en juego como tendencias de gran impacto en el ámbito educativo en los próximos años. El uso del juego como herramienta para potenciar el aprendizaje ha sido utilizado en varios niveles educativos, sobre todo, en la educación infantil, primaria y secundaria. Sin embargo, en la universidad esta estrategia no se ha desarrollado de manera tan generalizada.

Cuando se describe la gamificación, se hace referencia a el juego como "un sistema en el que los jugadores se involucran en un desafío abstracto, definido por las reglas, la interactividad y la retroalimentación que da lugar a un resultado cuantificable que provocan, a menudo, una reacción emocional" (Kapp, 2012, p. 7). Se considera que la gamificación es una oportunidad para hacer frente a dos problemas en educación: la motivación y el compromiso (Lee et al., 2013), no obstante, "el éxito de una estrategia de gamificación en educación superior radica en el diseño" (Corchuelo-Rodriguez, 2018, p. 39). Si bien se dispone en la actualidad de numerosas experiencias de gamificación, en ocasiones adolecen de un diseño didáctico y/o de una clara conexión con las competencias.

La vinculación de la gamificación con la motivación ha sido largamente estudiada (Deterding et al., 2011; Burke, 2011; Simões, 2013; Hamar, Koivisto y Sarsa, 2014; Monguillot et al., 2017; Contreras y Eguías, 2017). Sin embargo, no faltan las voces críticas que asocian la gamificación a modelos conductuales y/o el estímulo de la motivación extrínseca (Posada, 2017) que generan competitividad, aportan un desequilibrio entre lo lúdico y lo formativo, y no consideran la atención a la diversidad. 
Según Pineda (2019), las actividades de gamificación en el aprendizaje colaborativo inciden en un 58\% en el aprendizaje colaborativo; de ahí que en esta propuesta se contempla aprovechar la gamificación como estrategia de colaboración (Glover, 2013; Pineda, 2019; García, 2019), seguimiento y orientación para ofrecer ayudas ajustadas (Coll, 1999) a todos los alumnos.

Por otra parte, aunque hay algunas experiencias, como la relatada por Domínguez y Mora (2014) y Zambrano-Álava, et al. (2020), todavía no se dispone de suficientes evidencias del funcionamiento de la gamificación en términos de fortalecimiento de la autorregulación del aprendizaje. Con ello, la pregunta que guía este trabajo es si otro tipo de gamificación es posible, para que el propio estudiante pueda vincularla a la autorregulación del aprendizaje, esto es, la planificación, monitoreo y evaluación de la propia actividad (Panadero y Alonso-Tapia, 2014) y le permita estar informado de su progreso identificando sus fortalezas y aspectos de mejora (Oliva, 2016), a la vez que estimule la motivación intrínseca. En esta línea, los llevará a incorporar estas habilidades como competencias propias que podrán trasladar a sus áreas de desempeño profesional (Núñez et al., 2006). En la presente contribución se presentan los resultados de la experiencia piloto desarrollada durante el curso 2021-2022 con 53 estudiantes.

\section{Descripción de la experiencia}

La experiencia de innovación presentada tiene por objetivo general diseñar, implementar y evaluar sistemáticamente retos gamificados ideados en formatos móviles y nuevas tecnologías (Victoria González, 2020), con el fin de contribuir al desarrollo de la competencia de aprender a aprender desde el aprendizaje cooperativo y la atención a la diversidad. Se pretende garantizar el desarrollo del aprendizaje cooperativo cumpliendo las cinco condiciones presentadas por Johnson et al. (1984): interdependencia positiva, interacción cara a cara, responsabilidad individual, habilidades sociales y procesamiento grupal autónomo.

Las características más comunes de los diferentes marcos o modelos de gamificación han sido planteadas por diversos autores (Lamprinou y Paraskeva, 2015, Mora et al., 2015; Huang y Soman, 2014; Knapp, 2014; Scott, 2012). Uno de los referentes mundiales en gamificación, Karl Kapp, la define como "el uso de los mecanismos, la estética y el pensamiento de los juegos para atraer a las personas, incitar a la acción, promover el aprendizaje y resolver problemas" (Kapp, 2012, p. 9), siguiendo diferentes etapas (Baldeón, Puig y Rodriguez, 2016, p. 5-8):

1. Identificar los objetivos de aprendizaje que quieren ser gamificados.

2. Conocer a los alumnos / jugadores y el contexto.

3. Diseño de las actividades gamificadas: definir las mecánicas de aprendizaje y las mecánicas de gamificación.

4. Realización de las sesiones gamificadas.

5. Evaluar el aprendizaje y la gamificación. 
Es por ello que los diferentes aspectos en el diseño que van a influir en la gamificación son (Baldeón et al., 2016):

- Los objetivos de aprendizaje (competencias) / Objetivos de la gamificación.

- Los alumnos / Los jugadores.

- Las mecánicas de aprendizaje / Las mecánicas de gamificación.

- La evaluación del aprendizaje / La evaluación de la gamificación.

Todos estos aspectos son desarrollados en el siguiente epígrafe de esta contribución.

\section{Contexto de la experiencia}

La experiencia se ha implementado a modo de experiencia piloto durante el curso 2021-2022, con docencia mixta o híbrida, combinando sesiones presenciales y online al $50 \%$.

\begin{tabular}{|c|c|}
\hline $\begin{array}{l}\text { Asignatura / } \\
\text { Contexto }\end{array}$ & $\begin{array}{l}\text { Planificación, diseño y evaluación del aprendizaje y la actividad docente de } \\
\text { carácter teórico-práctico del primer curso del Grado de Maestro en Educación } \\
\text { Primaria, Facultad de Educación de la Universitat de Barcelona (UB). }\end{array}$ \\
\hline $\begin{array}{l}\text { Competencias } \\
\text { específicas del } \\
\text { Grado (súper- } \\
\text { poder) }\end{array}$ & $\begin{array}{l}\text { - Capacidad para integrar las tecnologías de la información y de la } \\
\text { comunicación en las actividades de enseñanza y aprendizaje guiadas y } \\
\text { autónomas. (súper-poder: tecnología) } \\
\text { - Capacidad para expresarse oralmente y por escrito en lengua catalana } \\
\text { y castellana con la fluidez y la corrección necesarias para desarrollar la } \\
\text { enseñanza en la etapa de primaria. (súper-poder: comunicación) } \\
\text { - Capacidad para asumir que el ejercicio de la función docente debe mejorar, } \\
\text { actualizarse y adaptarse a los cambios científicos, pedagógicos, sociales y } \\
\text { culturales. (súper-poder: creatividad) } \\
\text { - Habilidad para diseñar y desarrollar proyectos educativos, unidades de } \\
\text { programación, entornos, actividades y materiales (incluidos los digitales), } \\
\text { que permitan adaptar el currículo a la diversidad del alumnado. (súper-poder: } \\
\text { inteligencia) } \\
\text { - Capacidad para usar la evaluación en su función pedagógica y no sólo } \\
\text { acreditativa, como elemento regulador y promotor de la mejora de la } \\
\text { enseñanza, del aprendizaje y de la misma formación, asumiendo la necesidad } \\
\text { de desarrollo profesional continuo mediante la reflexión, la autoevaluación y } \\
\text { la investigación. (Esta competencia está planteada de manera transversal). }\end{array}$ \\
\hline $\begin{array}{l}\text { Alumnos / } \\
\text { jugadores }\end{array}$ & 53 estudiantes entre 18 y 21 años que usan constantemente la tecnología. \\
\hline
\end{tabular}

Tabla 1. Elementos de la estrategia de gamificación implementada en la asignatura siguiendo las aportaciones de Baldeón et al. (2016). 
En este contexto, se persigue desarrollar diferentes objetivos de aprendizaje a partir de las estrategias de evaluación presentadas a continuación:

\section{Objetivos de aprendizaje Estrategias y técnicas de recogida de información}

- Desarrollar la capacidad de aprender a aprender a través de experiencias de gamificación.

- Desarrollar el trabajo cooperativo con los compañeros a través de las experiencias de gamificación.

- Comprender los objetivos de los retos-juegos y sus criterios de evaluación.
Se evalúa la capacidad de aprender a aprender del alumnado con el cuestionario validado MSLQ, a modo de pre y post-test, al inicio y final de la asignatura.
- Desarrollar la capacidad de evaluar a los compañeros/as y de autoevaluarse con criterios comunes y compartidos.
Se evalúa el desarrollo de un aprendizaje colaborativo y cooperativo a partir de la administración del cuestionario de satisfacción y percepción de aprendizaje, al finalizar la asignatura y la experiencia.

Se desarrollan estrategias de comprensión e integración de los objetivos y los criterios de evaluación de los diferentes retos-juegos en el marco de la asignatura; donde el docente asume un rol de guía.

Se desarrollan estrategias de evaluación multi-agente: co-, autoevaluación y por parte del docente, estrategias clave en el marco de la formación inicial de maestros. Los feedbacks son recogidos y evaluados por el docente para asegurarse que se ha comprendido en qué consiste un feedback de calidad.

Se evalúa con la administración del cuestionario MSLQ y se recoge la atribución dada por el estudiantado de la aplicación de la gamificación con el rendimiento académico, y con el desarrollo de la competencia de aprender a aprender con el cuestionario de satisfacción y percepción de aprendizaje.

Tabla 2. Objetivos de aprendizaje de la experiencia y estrategias y técnicas de evaluación.

En el conjunto de cada asignatura en que se aplicará este proyecto de innovación, se evalúa la calidad de la participación y el desarrollo de actividades de aprendizaje y de actividades de evaluación de la asignatura (retos-juegos diseñados e implantados), recogiendo la percepción de los docentes participantes en el proyecto.

\section{Procedimiento}

En primer lugar, al inicio del semestre (febrero de 2021) se configuraron los grupos de trabajo. Los 53 estudiantes se repartieron en 11 grupos de 4-6 miembros, bajo su criterio de elección.

Se indicó la temporalización y se expusieron los "súper-poderes": creatividad, comunicación, inteligencia y tecnología, los cuales recogen de manera sintética las competencias específicas del Grado de Maestro de Educación Primaria. Sobre estos 4 "súper-poderes" versaron los retos como indicadores vinculados a las competencias de la asignatura. 
Se presentaron las características de interacción, dinámicas y mecánicas (Werbach y Hunter, 2012) de los diferentes retos que iban a desarrollarse durante todo el semestre. Después, se presentó al alumnado la plataforma de registro y seguimiento de la gamificación, Classpip (véase Imagen 1), la cual ha sido diseñada por profesorado de la Universitat Politècnica de Catalunya (UPC) y se encuentra en desarrollo. También, se informó y se solicitó el consentimiento informado para participar en esta experiencia.

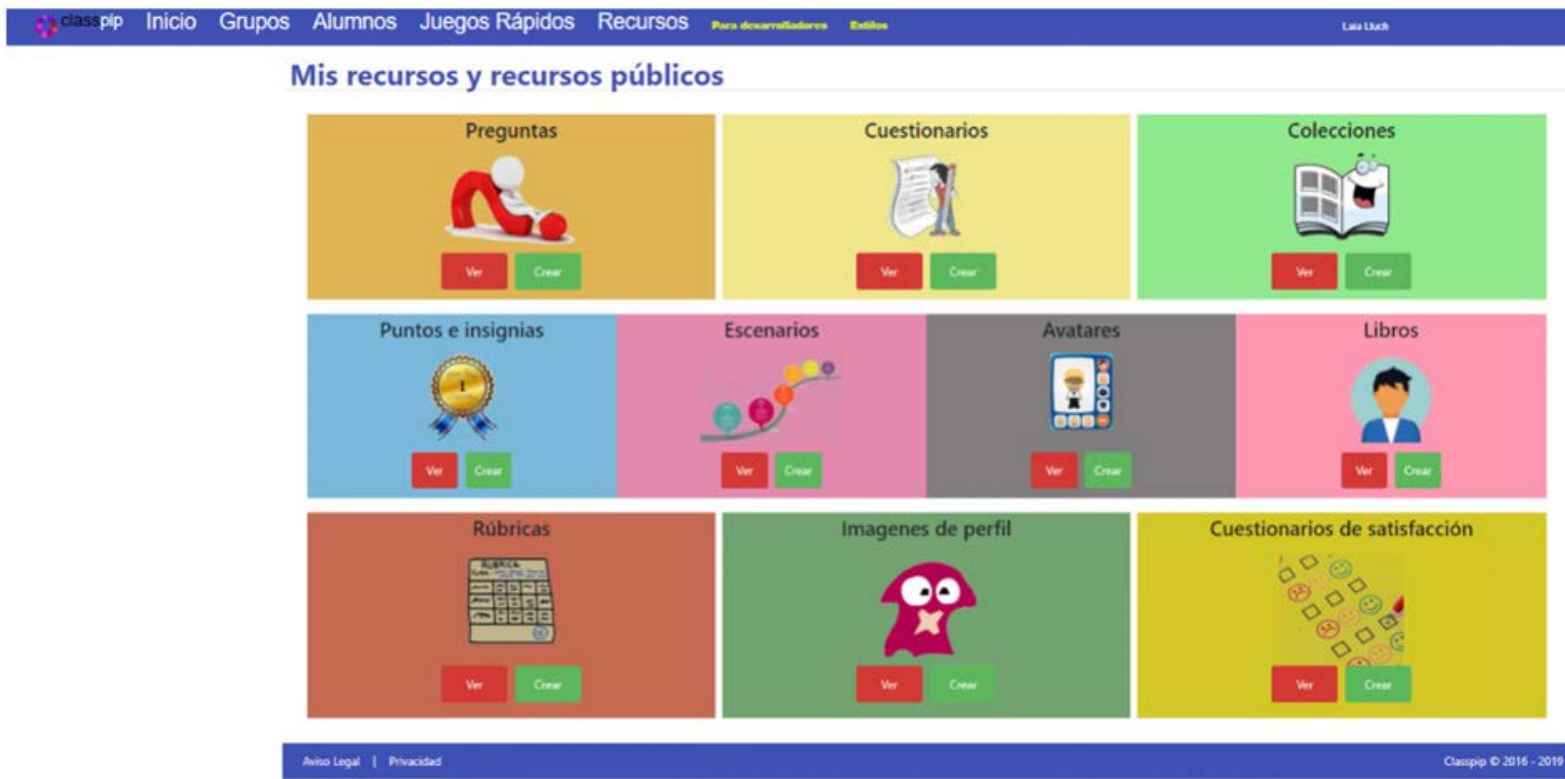

\section{Figura 1. Recursos de los que dispone la plataforma de Classpip.}

Durante la experiencia, se ha llevado a cabo un tipo evaluación formativa a partir del uso de herramientas tecnológicas, un feedback autorregulador del aprendizaje, donde predominan experiencias de evaluación entre pares. Se contempla tanto la tarea (proceso y resultado), como la calidad del feedback proveído a un igual con el rol de evaluador. El docente asume un rol de guía, orientador y facilitador del aprendizaje.

Los 8 retos desarrollados por los alumnos (véase Tabla 3) son tareas auténticas con propósito formativo, coherencia y alineación con las competencias, y participación activa del alumnado; y cumplen las tres categorías básicas (Werbach y Hunter, 2012) de cualquier actividad gamificada. 


\begin{tabular}{|c|c|c|c|c|}
\hline DINÁMICA & $\begin{array}{l}\text { MECÁNICA } \\
\text { Evaluación entre igua- } \\
\text { les: EI / Evaluación en- } \\
\text { tre grupos: EG /Evalua- } \\
\text { ción docente: ED }\end{array}$ & \multicolumn{2}{|l|}{ COMPONENTES } & $\begin{array}{l}\text { TIPO DE } \\
\text { JUEGO } \\
\text { CONFIGURADO } \\
\text { EN CLASSPIP }\end{array}$ \\
\hline $\begin{array}{l}\text { Reto 1. Tarea } \\
\text { individual } \\
\text { (infografía). }\end{array}$ & $\begin{array}{l}\text { El: según los } 4 \text { "sú- } \\
\text { per-poderes" (escala } \\
\text { Likert 1-5) y comentario } \\
\text { cualitativo. }\end{array}$ & \multicolumn{2}{|c|}{$\begin{array}{l}\text { Clasificación individual visible: } \\
\text { exposición de los estudiantes más } \\
\text { valorados en cada "súper-poder". }\end{array}$} & $\begin{array}{l}\text { Juego de } \\
\text { votación }\end{array}$ \\
\hline & & \multicolumn{2}{|c|}{ Clasificación por grupos: } & \\
\hline $\begin{array}{l}\text { Reto 2. Proyecto } \\
\text { grupal (fase 1). }\end{array}$ & $\begin{array}{l}\text { El: feedback cualitativo } \\
\text { según } 5 \text { criterios y feed- } \\
\text { back cuantitativo según } \\
\text { los } 4 \text { "súper-poderes" } \\
\text { (escala Likert 1-5). }\end{array}$ & $\begin{array}{l}\text { Los } 6 \text { primeros } \\
\text { grupos tienen } \\
+5 \text { ' para desa- } \\
\text { rrollar el Reto } 6 \text {. }\end{array}$ & $\begin{array}{l}\text { Los } 5 \text { grupos si- } \\
\text { guientes tienen } \\
\text { la oportunidad } \\
\text { de un encuen- } \\
\text { tro extraordi- } \\
\text { nario con la } \\
\text { docente sobre } \\
\text { el Reto } 3 .\end{array}$ & $\begin{array}{l}\text { Juego de } \\
\text { evaluación } \\
\text { Juego de } \\
\text { votación }\end{array}$ \\
\hline $\begin{array}{l}\text { Reto 3. Tarea } \\
\text { grupal (marco } \\
\text { teórico). }\end{array}$ & $\begin{array}{l}\text { EG (técnica del folio } \\
\text { rotario): feedback cua- } \\
\text { litativo a los } 10 \text { grupos. } \\
\text { Después, se valora el } \\
\text { grupo/s que más le } \\
\text { ha servido de ayuda, } \\
\text { otorgando } 10 \text { puntos de } \\
\text { manera libre. }\end{array}$ & \multicolumn{2}{|c|}{$\begin{array}{l}\text { Clasificación de los } 3 \text { grupos que } \\
\text { más han ayudado: se les ofrece } \\
\text { +0.05 de puntuación en la tarea } \\
\text { grupal. }\end{array}$} & $\begin{array}{l}\text { Juego de } \\
\text { puntos por } \\
\text { grupos }\end{array}$ \\
\hline & & \multicolumn{2}{|c|}{ Clasificación por grupos: } & \\
\hline $\begin{array}{l}\text { Reto } 4 \text {. Proyecto } \\
\text { grupal (fase } 2 \text { ). }\end{array}$ & $\begin{array}{l}\text { El: feedback cualitativo } \\
\text { según } 5 \text { criterios y feed- } \\
\text { back cuantitativo según } \\
\text { los } 4 \text { "súper-poderes" } \\
\text { (escala Likert 1-5). }\end{array}$ & $\begin{array}{l}\text { Los } 6 \text { primeros } \\
\text { grupos tienen el } \\
\text { rol de organizar } \\
\text { el Reto } 6 .\end{array}$ & $\begin{array}{l}\text { Los } 5 \text { grupos si- } \\
\text { guientes tienen } \\
\text { la oportunidad } \\
\text { de recibir fee- } \\
\text { dback docente } \\
\text { antes de entre- } \\
\text { gar la versión } \\
\text { definitiva del } \\
\text { proyecto. }\end{array}$ & $\begin{array}{l}\text { Juego de } \\
\text { evaluación } \\
\text { Juego de } \\
\text { votación }\end{array}$ \\
\hline $\begin{array}{l}\text { Reto } 5 \text {. Tarea } \\
\text { de reflexión } \\
\text { individual (vídeo). }\end{array}$ & $\begin{array}{l}\text { ED: feedback cuantita- } \\
\text { tivo según los } 4 \text { "sú- } \\
\text { per-poderes" (escala } \\
\text { Likert 1-5) y comentario } \\
\text { cualitativo. }\end{array}$ & \multirow{2}{*}{\multicolumn{2}{|c|}{$\begin{array}{l}\text { Clasificación individual que } \\
\text { permite otorgar un carnet con el } \\
\text { "súper-poder" más desarrollado a } \\
\text { cada alumno. } \\
\text { Juego de votación }\end{array}$}} & $\begin{array}{l}\text { Juego de } \\
\text { votación }\end{array}$ \\
\hline $\begin{array}{l}\text { Reto 6. "Puesta } \\
\text { en escena" del } \\
\text { proyecto grupal. }\end{array}$ & $\begin{array}{l}\text { El según los } 4 \text { "sú- } \\
\text { per-poderes" (escala } \\
\text { Likert 1-5). }\end{array}$ & & & \\
\hline $\begin{array}{l}\text { Reto 7. Tarea } \\
\text { individual de } \\
\text { meta-reflexión } \\
\text { (vídeo). }\end{array}$ & $\begin{array}{l}\text { El con escala Likert del } 1 \\
\text { al } 5 \text { (cada alumno debe- } \\
\text { rá visualizar un total de } 5 \\
\text { tareas). }\end{array}$ & \multicolumn{2}{|c|}{ Clasificación individual: } & $\begin{array}{l}\text { Juego de } \\
\text { votación }\end{array}$ \\
\hline $\begin{array}{l}\text { Reto 8. Dinámicas } \\
\text { de aula } \\
\text { desarrolladas. }\end{array}$ & $\begin{array}{l}\text { Puntuaciones indivi- } \\
\text { duales en función del } \\
\text { azar y la participación } \\
\text { en: role-playing, lluvia } \\
\text { de ideas, debates en } \\
\text { foros, cuestionarios tipo } \\
\text { Kahoot!. }\end{array}$ & $\begin{array}{l}\text { Los } 14 \text { primeros } \\
\text { estudiantes ob- } \\
\text { tienen }+0.25 \text { de } \\
\text { calificación. }\end{array}$ & $\begin{array}{l}\text { Los siguien- } \\
\text { tes } 13,+0.20 \text {, } \\
\text { los siguientes } \\
13,+0.15 \text { y los } \\
\text { siguientes } 13, \\
+0.10 \text {. }\end{array}$ & $\begin{array}{l}\text { Juegos de } \\
\text { cuestionario } \\
\text { Juego de } \\
\text { puntos }\end{array}$ \\
\hline
\end{tabular}


Esta propuesta integra la gamificación en el aprendizaje cooperativo por la distribución de los roles en los diferentes retos grupales. También, integra la atención a la diversidad, en el sentido de que todos y cada uno de los estudiantes reciben soporte $u$ orientación ajustada en función de la calidad del reto desarrollado. Además, la tipología de retos planteados y los procesos de evaluación llevados a cabo en esta experiencia dan soporte a la planificación, monitoreo y evaluación de la propia actividad como componentes de la competencia de aprender a aprender.

\section{Resultados}

En esta contribución se ha detallado el diseño pedagógico de la experiencia desarrollada sustentado por diferentes retos gamificados y herramientas tecnológicas, en proceso de estudio, en la asignatura del primer curso del Grado de Maestro de Educación Primaria. Tal y como queda plasmado en la Tabla 2, el desarrollo del aprendizaje cooperativo, con la distribución de diferentes roles para desarrollar los retos grupales con el soporte de las TIC, y de las evaluaciones vía Classpip no solamente alumno-alumno (véase Imagen 2), sino también grupo-grupo persiguen el estímulo de una motivación de tipo intrínseco y el estar informado del propio progreso de aprendizaje identificando las fortalezas y los aspectos de mejora (véase Imagen 3).

\section{Valoració REPTE 1}

Evaluacion Individual

\section{Dessctivar}
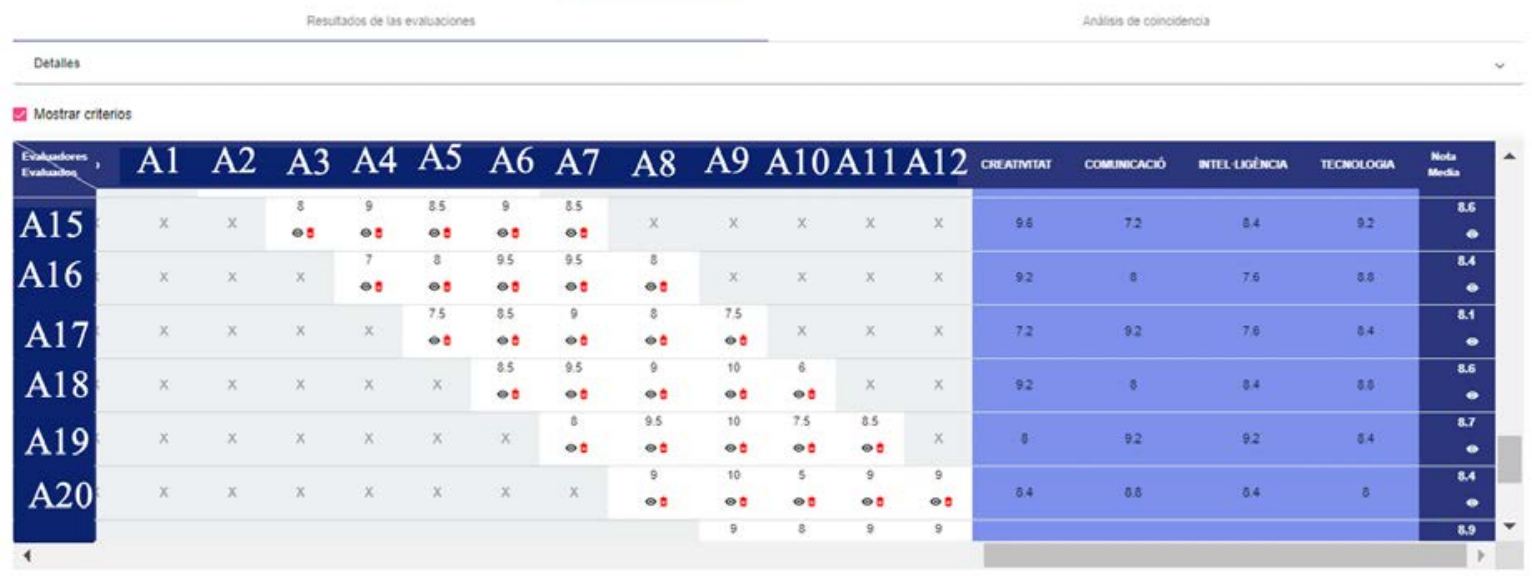


\begin{tabular}{|c|c|c|c|c|}
\hline Posición Global & Nombre & Miembros & Puntos & \\
\hline 1 & E.T mi nave & $\ddot{\ddot{ }}$ & 39 & $\checkmark$ \\
\hline 2 & Les guardianes de la Galaxia & $\ddot{\ddot{~}}$ & 13 & $\checkmark$ \\
\hline 3 & REUS51 & $\ddot{\sim}$ & 13 & $\checkmark$ \\
\hline 4 & Star teachers & $\ddot{\ddot{~}}$ & 12 & $\checkmark$ \\
\hline 5 & Space Team Abuser & $\ddot{\ddot{~}}$ & 8 & $\checkmark$ \\
\hline 6 & Domingos estelares & $\ddot{\ddot{~}}$ & 7 & $\checkmark$ \\
\hline 7 & Extraterrestres sexys & $\ddot{\sim}$ & 6 & $\checkmark$ \\
\hline 8 & Vendo Opel Corsa & $\ddot{\Delta}$ & 5 & $\checkmark$ \\
\hline 9 & Código 8 & $\ddot{\ddot{~}}$ & 4 & $\checkmark$ \\
\hline 10 & Sporting de Brugal & $\ddot{\sim}$ & 2 & $\checkmark$ \\
\hline 11 & Supernoves & $\ddot{\ddot{~}}$ & 1 & $\checkmark$ \\
\hline
\end{tabular}

Imagen 3. Clasificación resultante del juego de puntos del Reto 3, de valoración grupal con Classpip. Otorgación de 10 puntos de manera libre al grupo o grupos que mayor ayuda han proporcionado.

Del conjunto de alumnos matriculados en la asignatura $(N=53)$ en que se ha llevado a cabo la experiencia piloto, titulada Planificación, diseño y evaluación del aprendizaje y la actividad docente, durante el segundo semestre del curso 2020-2021, se han analizado las respuestas $(n=49)$ del cuestionario de satisfacción y percepción de aprendizaje administrado el 2 de junio de 2021, resultando datos relevantes como los mostradas a continuación (véase Imagen 4).

El estudiantado, con una media de $\bar{x}=4.53$ (de una escala Likert del 1 al 5) indica que la herramienta utilizada le ha facilitado tener la información ordenada y organizada, además de facilitar un acceso al feedback recibido por un igual siempre que ha sido necesario $(\bar{x}=4.37)$ y de poderlo ofrecer $(\bar{x}=4.31)$. La herramienta Classpip también ha hecho sentir a los alumnos más cómodos por no tener que decir directamente la valoración del trabajo a su compañero/a $(\bar{x}=3.96)$ y les ha generado más aprendizajes que si la evaluación hubiera sido en papel u oralmente $(\bar{x}=3.92)$. 


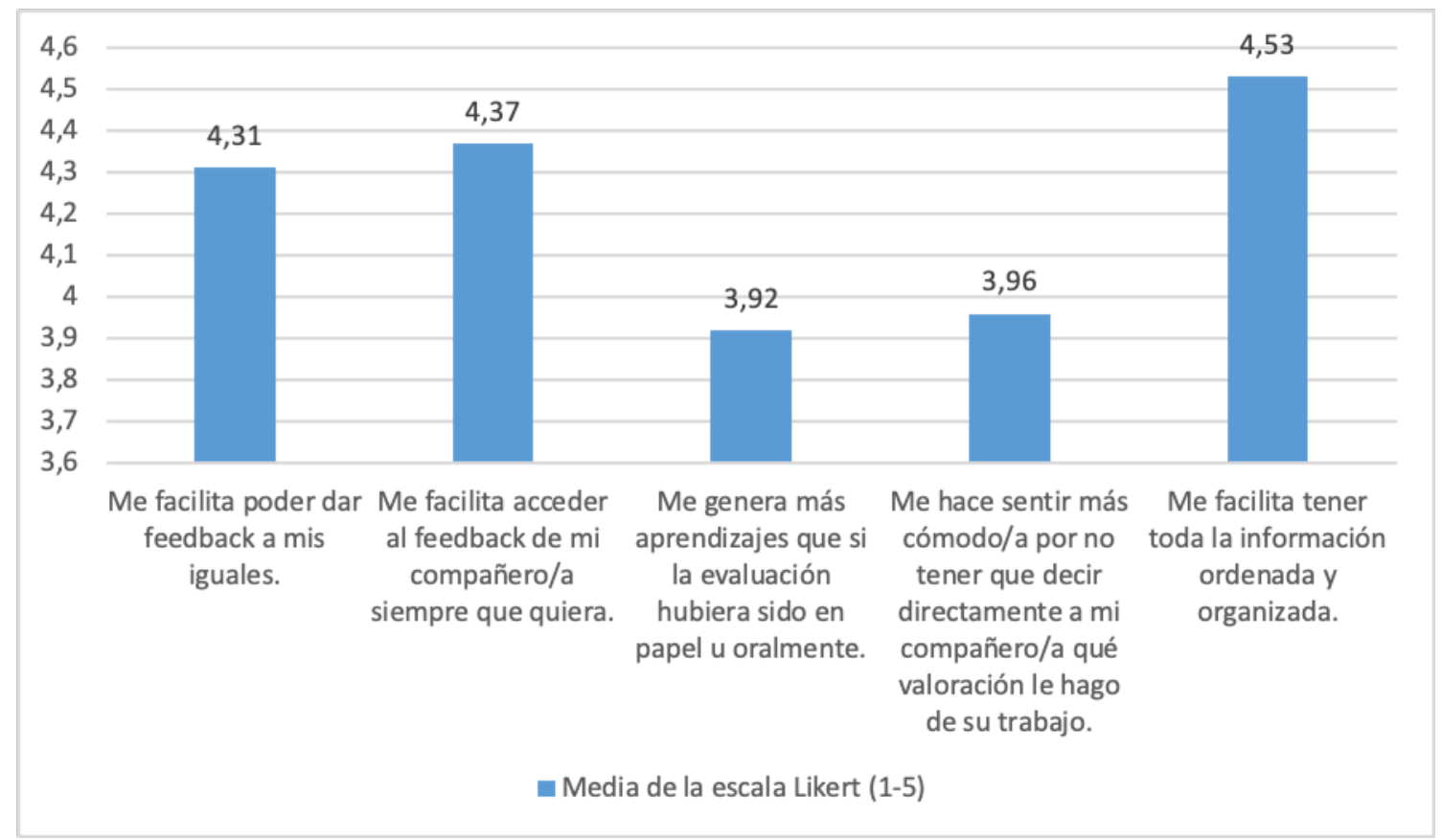

\section{Imagen 4. Resultados del cuestionario de satisfacción y percepción de aprendizaje en relación con las preguntas relativas a la herramienta utilizada (Classpip).}

También se ha consultado sobre el grado de satisfacción global para con la experiencia de gamificación desarrollada, cuyo resultado es de: $\bar{x}=4.57$, de una escala Likert del 1 al 5. Aparte, su satisfacción con la herramienta tecnológica ha sido de: $\overline{\mathrm{x}}=4.53$, de una escala Likert del 1 al 5.

La experiencia de evaluación entre iguales vía Classpip ha sido también evaluada con preguntas abiertas por parte de los participantes, los estudiantes. Las tres preguntas relevantes para la experiencia: 1) ¿Cómo te ha ayudado la experiencia de evaluación entre iguales a mejorar tu competencia de aprender a aprender? ¿Qué acciones o factores crees que han sido más relevantes para fortalecer esta competencia? 2) ¿Cuál consideras que es el principal punto fuerte de la experiencia de evaluación entre iguales? 3) ¿Cuál consideras que es el aspecto de la experiencia de evaluación entre iguales que se debería mejorar?

Una vez procesadas las respuestas a estas tres preguntas abiertas, usando codificación, se han clasificado en 7 categorías que nos interesan en esta experiencia. Se puede observar el porcentaje de respuesta de cada pregunta correspondientes a cada categoría (véase Imagen 5). 


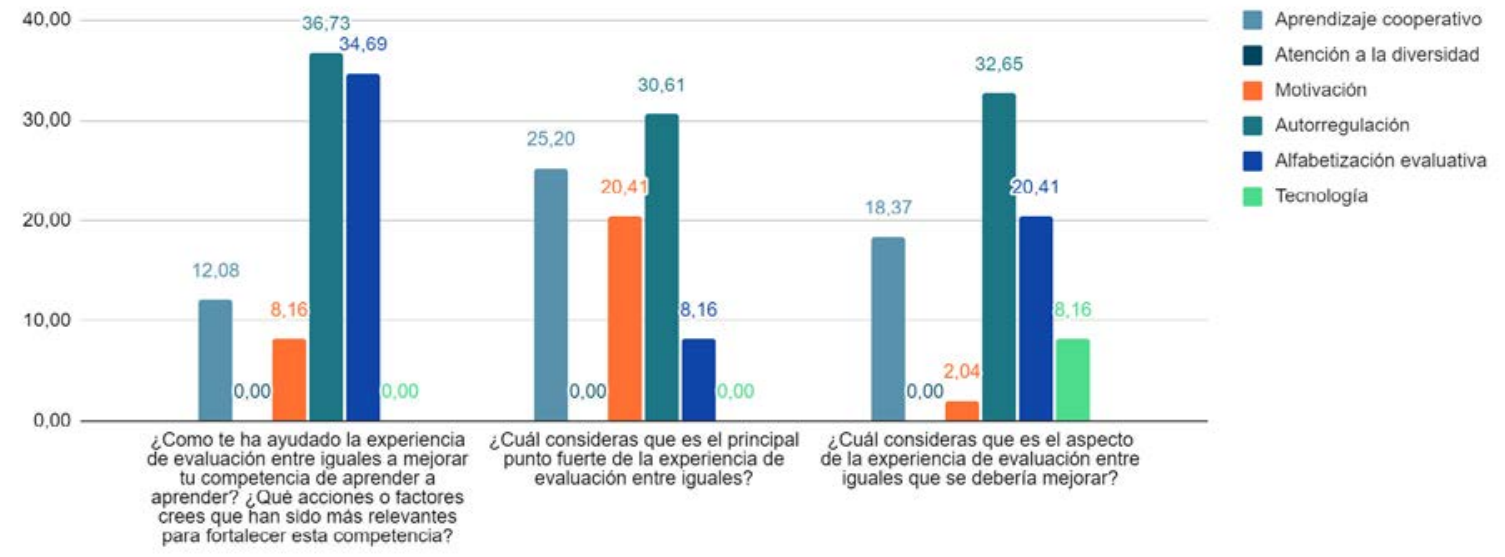

Imagen 5. Resultados de la codificación de las preguntas de respuesta abierta. Se muestra el porcentaje de preguntas relacionadas con la categoría correspondiente.

En la Imagen 5 se pueden hacer tres observaciones generales. Además, considerando que dos de los principales defectos de la post-codificación son el empobrecimiento del contenido y eliminación de las respuestas raras; motivo por el que se complementan los datos cuantitativos con algunas citas de respuestas de estudiantes.

La primera, la nula percepción (0\%, O\% y O\%) por parte de los estudiantes del foco en la Atención a la diversidad. El motivo puede ser que haya quedado enmascarado por el resto de categorías, percibidas como más importantes por los estudiantes.

La segunda, la alta importancia (34.69\%, 8.16\% y 20,41\%) de la Alfabetización evaluativa; y de la autorregulación (36.73\%, 30.61\% y 32,65\%). El motivo puede ser por ser estudiantes de Maestro de Educación Primaria, comprender la importancia de una evaluación de calidad y percibir la necesidad de mejorar en cuanto a cómo llevar a cabo un feedback formativo y formador. Además, algunos estudiantes han destacado que aprender sobre evaluación de calidad y sobre cómo evaluar es un elemento importante para su futuro profesional: "Yo creo que el factor que más me ha gustado de estos feedbacks ha sido el hecho de que la evaluación entre iguales. Mientras somos estudiantes nos hemos podido sentir un poco como futuros profesores para poder evaluar y sobre todo ayudar a nuestros compañeros, y creo que este factor es el más importante" (A6, P1), "Me ha ayudado a saber desarrollar las capacidades de comentar de manera adecuada para evaluar a los compañeros, y así, poder ayudar a mejorar su trabajo y aprender entre todos. Los factores que han sido más relevantes ha sido el hecho de ir dando feedbacks, es decir, que no lo ha dejado todo por el final, sino que casi cada reto se ha dado uno y se ha podido ir mejorando" (A15, P1).

La tercera, es sobre la tecnología. El uso de nuevas tecnologías no es transparente. La tecnología tiene impacto en el proceso y queda confirmado con ese $8.16 \%$ de la tercera pregunta. En este aspecto, es importante resaltar que las valoraciones han sido sugerencias de mejora con respecto a la dinámica y uso de la tecnología: "El hecho de que sea online ha sido difícil, pero por las partes de la que consta creo que están muy acertadas" (A47, P3), "Quizás hacerlo mediante encuentros con el GoogleMeet, además de la información escrita” (A14, P3). 
Finalmente, con respecto a la motivación, especialmente intrínseca, los estudiantes indican, por ejemplo, cuando hablan de los beneficios de la experiencia de evaluación entre iguales con los diferentes retos gamificados: "El principal fuerte es como he dicho antes el simple hecho de que a medida que evalúas, te das cuenta de tus errores y posteriormente los puedes aplicar, y el querer hacerlo bien para recibir buenas valoraciones también pienso que es un punto fuerte" (A4, P2), "Que nos podemos ayudar entre todos, ya que los compañeros te pueden decir los puntos fuertes y puntos débiles que ven en tu tarea y de esta manera poder ir mejorando cada vez más y aumentar el aprendizaje", "El aprendizaje que te da y la motivación" (A15, P2).

\section{Discusión y conclusiones}

La experiencia de innovación presentada tiene por objetivo general diseñar, implementar y evaluar sistemáticamente retos gamificados ideados en formatos móviles y nuevas tecnologías, con el fin de contribuir al desarrollo de la competencia de aprender a aprender desde el aprendizaje cooperativo y la atención a la diversidad.

La propuesta de innovación actualmente se ha implementado en el segundo semestre del curso académico 2020-2021, a modo de experiencia piloto. En esta contribución se han mostrado los resultados de la experiencia, principalmente los resultados del cuestionario administrado al finalizar la experiencia sobre la satisfacción y percepción de aprendizaje de los estudiantes. Asimismo, se esperan lograr resultados que permitan el diseño definitivo de la propuesta, así como la obtención de datos sobre la progresión de la capacidad de autorregulación del estudiantado con la administración, a modo de pre y post test, del cuestionario de autopercepción Motivated and Self-Regulated Learning Questionnaire (MSLQ) (Pintrich, 1991).

La propuesta de innovación se ha implementado en una asignatura del primer curso del Grado de Maestro de Educación Primaria, con la idea de mejorar el diseño de la experiencia y, durante el curso 2021-2022 se pueda llevar a cabo en asignaturas de primer curso y, también, de segundo curso con el objetivo de perseguir a un mismo grupo de estudiantes.

El impacto de la experiencia se ha estudiado a partir de un cuestionario administrado como pre y post-test, así como por la percepción y satisfacción del estudiante. De futuro, teniendo en cuenta los comentarios cualitativos ofrecidos por los estudiantes en los cuestionarios, será interesante contemplar el estudio del impacto y aceptación del uso de la tecnología para el desarrollo de esta propuesta; además de llevar a cabo experiencias de evaluación entre iguales multi-agente desde el aprendizaje cooperativo (más de un alumno evaluando una misma tarea, tal y como algunos estudiantes proponen) y llevar a cabo experiencias de alfabetización evaluativa para que el estudiantado comprenda e integre cómo ofrecer un feedback de calidad, y por qué es importante tanto para su formación inicial como para su ejercicio profesional.

\section{Referencias}

Baldeon, J., Puig, A. y Rodriguez, I. (2016). Com dissenyar la gamificació en l'aula? A: Congrés català d'educació matemàtica, Congrés C2EM 2016, 11-13 de juliol. Recuperado de https://c2em.feemcat.org/wp-content/uploads/actes/2C159-1.pdf 
Brown, A. L. (1980). Metacognitive development and reading. Theoretical issues in reading comprehension, 453-481.

Burke, B. (2011). Innovation Insight: Gamification Adds Fun and Innovation to Inspire Engagement. Gartner.

Christensen, C. M. y Raynor, M. E. (2003). The Innovator's Solution: Creating and Sustaining Successful Growth. Harvard University Press, Cambridge, MA. ISBN: 9781578518524.

Coll, C. (1999). La concepción constructivista como instrumento para el análisis de las prácticas educativas escolares. En: C. Coll (coord.). Psicología de la instrucción: la enseñanza y el aprendizaje en la Educación Secundaria (pàg. 15-44). Barcelona: Horsori/ICE UB.

Contreras, R. S. y Eguías, J. L. (2017). Experiencias de gamificación en las aulas. En InCom-UAB Publicacions, 15. Bellaterra: Institut de la Comunicació.

Corchuelo Rodriguez, C. A. (2018). Gamificación en educación superior: experiencia innovadora para motivar estudiantes y dinamizar contenidos en el aula. Edutec. Revista Electrónica De Tecnología Educativa, (63), 29-41. https://doi.org/10.21556/ edutec.2018.63.927

Deterding, S., Dixon, D., Khaled, R., y Nacke, L. (2011). From game design elements to gamefulness. Proceedings of the 15th International Academic MindTrek Conference on Envisioning Future Media Environments - MindTrek '11, September, 9-15. https:// doi.org/10.1145/2181037.2181040

Domínguez, R. y Mora, J. A. (2014). Proyecto LUDUS: Impacto de una metodología gamificada en los procesos de autorregulación de estudiantes de educación superior. IV Jornadas de Innovación Docente. Abriendo caminos para la mejora educativa. Depósito de Investigación, Universidad de Sevilla. Recuperado de https://idus. us.es/handle/11441/59123

Esteve, F., Adell, J. y Gisbert, M. (2014). Diseño de un entorno 3D para el desarrollo de la competencia digital docente en estudiantes universitarios: usabilidad, adecuación y percepción de utilidad. Revista Latinoamericana de Tecnología Educativa, 13(2), 5-47.

García, I. (2019). Escape Room como propuesta de gamificación en Educación. Revista educativa Hekademos, 27, 71-79.

Glover, I. (2013). Play as you learn: gamification as a technique for motivating learners. En: Herrington, J., Couros, A. and Irvine, V. (eds.) Proceedings of World Conference on Educational Multimedia, Hypermedia and Telecommunications 2013. Chesapeake, VA, AACE, 1999-2008.

Hamari, J., Koivisto, J. i Sarsa, H. (2014). Does Gamification Work? - A Literature Review of Empirical Studies on Gamification. En: Proceedings of the 47th Hawaii International Conference on System Sciences, Hawaii, USA, January 6-9, 2014. 
Huang, W. H-Y. y Soman, D. (2013). Gamification of education. Technical report, Research Report Series: Behavioural Economics in Action.

Johnson, D. W., Johnson, R. T., \& Smith, K. A. (1984). Cooperative learning. New Brighton: Interaction Book Company.

Kapp, K. M. (2012). The Gamification of Learning and Instruction: Game-Based Methods and Strategies for Training and Education (1st ed.). Pfeiffer.

Knapp, D. (2014). Gamified - revolutionize the learning experience through gamification.

Lamprinou, D. y Paraskeva, F. (2015). Gamification design framework based on sdt for student motivation. En: Interactive Mobile Communication Technologies and Learning (IMCL), 2015 International Conference on, pages 406-410. IEEE.

Landers, R.N. y Callan, R.C. (2011). Casual social games as serious games: The psychology of gamification in undergraduate education and employee training. In: Ma, M., Oikonomou, A. and Jain, L.C. (ed.), Serious games and edutainment applications (pp. 399-423). London, England: Springer-Verlag.

Lee, J. J., Ceyhan, P., Jordan-Cooley, W. y Sung, W. (2013). GREENIFY: A Real-World Action Game for Climate Change Education. Simulation and Gaming, 44(2-3), 349365. https://doi.org/10.1177/1046878112470539

Monguillot, M., González, C., Zurita, C., Almirall, L. y Guitert, M. (2017). Play the Game: gamificación y hábitos saludables en educación física. Apunts. Educación Física y Deportes, 119, 71-79.

Mora, A., Zaharias, P., González, C. y Arnedo-Moreno, J. (2015). Fraggle: a framework for agile gamification of learning experiences. En: Proceedings of the Games and Learning Alliance Conference (GALA Conf 2015).

Muntean, C.I. (2011). Raising engagement in e-learning through gamification. Proceedings of the 6 th International Conference on virtual learning.

Núñez, J.C., Solano, P., González-Pienda, J.A. y Rosário, P. (2006). El aprendizaje autorregulado como medio y meta de la educación. Infocop, 3 (21).

OCDE (2000). Motivating Students for Lifelong Learning. OECD Publishing. http:// dx.doi.org/10.1787/9789264181830-en

Oliva, H. A. (2016). La gamificación como estrategia metodológica en el contexto educativo universitario. Realidad y reflexión, 44, 29-47.

Panadero, E. y Alonso-Tapia, J. (2014) ¿Cómo autorregulan nuestros alumnos? Revisión del modelo cíclico de Zimmerman sobre autorregulación del aprendizaje. Anales de psicología, 30(2), 450-462. http://dx.doi.org/10.6018/analesps.30.2.167221

Pineda, E. R. (2019). Percepción de las actividades de gamificación en el aprendizaje colaborativo para alumnos de Ingeniería Civil de una universidad pública. Universidad César Vallejo. 
Posada, F. (2017). Gamifica tu aula: experiencia de gamificación TIC para el aula. Colecciones V Congreso Internacional de Videojuegos y Educación (CIVE’17). Recuperado de http://riull.ull.es/xmlui/handle/915/6791

Quintanal, F. (2016). Aplicación de herramientas de gamificación en física y química de secundaria. Opción, 12, 327-348 ISSN 1012-1587 / ISSNe: 2477-9385.

Renobell Santarén, V. y García Gaitero, F. (2016). Gamificación en la educación: Reinventando la rueda. Revista DIM: Didáctica, Innovación y Multimedia, 3, 45-58. ISSN-e $1699-3748$

Scott, N. (2012). A user-centered theoretical framework for meaningful gamification. Games+ Learning+ Society, 8.

Simões, J., Díaz Redondo, R. y Fernández Vilas, A. (2013). A social gamification framework for a K-6 learning platform, Computers in Human Behavior, Elsevier, 29(2), 345-353.

Victoria González, C. (2020). Herramientas TIC para la gamificación en Educación Física. Edutec. Revista Electrónica de Tecnología Educativa, (71), 67-84. https://doi. org/10.21556/edutec.2020.71.1453

Werbach, K. y Hunter, D. (2012). For the win: how gamethinking can revolutionize your business. Philadelphia: Wharton Digital Press.

Zambrano-Álava, A., Lucas-Zambrano, A., Lucas-Zambrano, M. y Luque-Alcívar, K. (2020). Gamificación y aprendizaje autorregulado. EPISTEME KOINONIA, 3(5). https://doi.org/10.35381/e.k.v3i5.847 


\section{Podcast como Herramienta Educativa en el Proceso de Enseñanza-Aprendizaje en Educación Superior}

\section{Jiménez Mariscal, Laura María}

Universidad de Málaga

laurijima@uma.es

\section{Luque Rojas, María Jesús}

Universidad de Málaga

mjluquerojas@uma.es

orcid.org/0000-0003-1627-3233 


\title{
PODCAST COMO HERRAMIENTA EDUCATIVA EN EL PROCESO DE ENSEÑANZA-APRENDIZAJE EN EDUCACIÓN SUPERIOR
}

\author{
Jiménez Mariscal, Laura María \\ Luque Rojas, María Jesús
}

\section{Resumen}

Las nuevas tecnologías y la web 2.0 han influido en la vida de las personas englobando tanto el ámbito personal como profesional. Este avance trae grandes cambios que se mueven rápidamente y los cuales vienen acompañados de abundante información. Cultural y socialmente también hemos sufrido una repercusión y esta situación de pandemia requiere una mejora y transformación en los espacios educativos para poder mantener la motivación en su línea más constante, siento este el eje principal en el proceso de enseñanza-aprendizaje. Para cubrir esto, se ha optado por la utilización de Podcast como herramienta educativa para fomentar la participación tanto en el alumnado como en el profesorado, teniendo en cuenta la importancia de la motivación del discente. La educación superior ha sufrido durante esta inestabilidad en situación de pandemia y este recurso es factible en su desarrollo presencial, bimodal u online, ya que su flexibilidad es amplia y la facilidad de creación e interés que proporciona es sumamente interesante. En el presente trabajo recogemos la importancia de la perspectiva pedagógica y la importancia de reflexionar sobre nuevos recursos educativos que ayuden al profesorado en su practica y al alumnado en su aprendizaje, haciendo de este una experiencia complementaria y compartida.

\section{Palabras clave}

Educación Superior, Podcast, Recurso Educativo, TIC. 


\section{Introducción}

La motivación de las personas es el factor primordial para el avance de estas, ya que actúa como "motor" para iniciar, continuar y terminar cualquier acción. Es importante cubrir esta idea ya que el alumnado necesita mantener en mayor medida la motivación para poder así tener un aprendizaje placentero y real, en el que el proceso de enseñanza-aprendizaje quede marcado y ofreciendo al profesorado esta misma motivación. Esto hace del proceso un circulo vicioso ya que la motivación y trabajo de ambos es esencial en la práctica educativa. Las nuevas tecnologías de la información y la comunicación suponen nuevos avances en el aprendizaje y la transformación de herramientas para la mejora educativa. Es necesario cubrir nuevas carencias que surgen de avances que tenemos en todos los ámbitos, en el que la educación es uno de los pilares principales en la vida de las personas, siendo de gran importancia adaptarnos, investigar y crear nuevas ideas de mejora. Las tecnologías están inmersas en nuestro día a día y debemos ajustarnos a sus demandas y a su nueva forma de desenvolvernos en la vida diaria tanto a nivel educativo, personal y profesional, por lo que Podcast es una herramienta que se ajusta a nuestras demandas siendo muy flexible para su uso online, presencial o semipresencial. Este ha sido uno de los problemas en los tiempos actuales de pandemia, puesto que el profesorado ha tenido que adaptarse y buscar soluciones de manera inmediata a la hora de ajustar su práctica docente, afectando tanto al profesorado como al alumnado.

Tener en cuenta herramientas como Podcast, Vodcast o Audioblog como recursos complementarios en la docencia universitaria es una forma de mejorar en esta. A partir de las demandas de la sociedad dadas por el cambio y el progreso, estos recursos se vuelven más atractivos para los estudiantes, pudiendo dejar atrás formas de enseñanza tradicionales como son las clases magistrales, diapositivas,etc. Así mismo, el uso de estas herramientas favorece la autonomía de los estudiantes, refuerza el aprendizaje, y se fomenta el sentimiento de ser guiados y no dirigidos por el docente, teniendo en cuenta la libertad del discente. Según Skiba (2006, como se citó en Solano y Sánchez, 2010), la herramienta Podcast manifiesta un gran potencial puesto que se resiste a barreras temporales, gráficas y psíquicas, permitiendo la transferencia y reproducción de audio y video (Vodcast), así como haciendo flexible el acceso a la información.

Solano y Sánchez (2010), en su interés en la definición de Podcast, se refiere a él un medio didáctico a través de un archivo sonoro, el cual cuenta con contenidos educativos que son creados a partir de un proceso de planificación didáctica, pudiendo ser creado tanto por el docente como por el discente. Por otro lado, es interesante considerar que es una herramienta inmersa en el día a día de las personas, especialmente de los jóvenes, siendo un medio en el que se reproducen infinitos temas. Señalando la importancia del valor pedagógico que presenta Podcast en el proceso de enseñanza-aprendizaje, separando la idea del aprendizaje clásico, apartando del alumnado el papel pasivo en el proceso de adquisición de información y adjudicándole y manteniendo un papel activo y consistente. Centrándonos en la educación superior, al utilizar esta herramienta es importante tener en cuenta elementos tecnológicos y pedagógicos, centrándonos en qué medio utilizar, para quién va dirigido, cómo usarlo y qué pretendemos con su creación.

Favorecer el proceso de Enseñanza-Aprendizaje desde factores como la motivación y emoción por el aprendizaje debería ser algo imprescindible en el ámbito educativo 
y, concretamente, en Educación Superior, contando con el desarrollo y maduración de los estudiantes, donde su autonomía y protagonismo en el aprendizaje debería ser clave. En este sentido, el uso de recursos como Podcast (Vodcast o Audioblog) es una herramienta que aporta un gran número de posibilidades en el desarrollo de las clases (presenciales o no) junto con la adquisición de contenidos y trabajo de estos.

Tal y como comentan Solano y Sánchez (2010) es necesario tener en cuenta a la hora de realizar un podcast dos aspectos: los aspectos tecnológicos los cuales utilizan técnicas y aplicaciones para elaborar el Podcast y los aspectos pedagógicos que señalan las características a tener en cuenta para poder realizar el Podcast educativo. Para poder la realización del Podcast es importante tener en cuenta algunas de diseño pedagógico como, por ejemplo: cuáles son las características, intereses y motivaciones, a quién va dirigido el Podcast, la temporalización, el procedimiento metodológico, las estrategias para desarrollar los contenidos... Además, es necesario tener en cuenta y plantear las actividades a desarrollar, así como sus componentes didácticos que contribuyen al proceso de enseñanza aprendizaje y el cual requiere definir una estructura didáctica.

No se entiende igual una clase magistral donde el estudiante es un mero receptor a una situación donde el estudiante pueda trabajar los contenidos de una asignatura determinada de forma previa a acudir al aula, visualizando o escuchando esos contenidos con total libertad. Este uso de este tipo de recursos favorece la libertad para crear del propio estudiante, pudiendo ser protagonista de su propio proceso de Enseñanza-Aprendizaje.

A partir de este trabajo, se pretende trasladar al lector los objetivos que se buscan al introducir este tipo de recursos en el aula. Así, se intenta alcanzar, como se decía anteriormente, esa sensación por parte del estudiante de poder ser partícipe directo en su aprendizaje y evitar afirmaciones del tipo, "el estudiante siempre ha estado dirigido por el profesor bajo las instrucciones a seguir", afirmación que deja al estudiante en una situación de algo parecido a dependencia, viéndose confuso cuando cuenta con libertad para crear su propio trabajo. Por ello, entre los objetivos podemos encontrar (Luque-Rojas et al., 2021):

- Buscar y trabajar habilidades para saber decidir y actuar ante determinadas situaciones que pudieran tener un cariz más o menos cotidiano.

- Trasladar e instaurar la premisa de Emocionar para aprender.

- Desarrollar habilidades de reflexión, se trata de ir más allá de lo meramente instructivo y trabajo de aula.

- Saber cómo trasladar el trabajo de forma cooperativa y pública, a partir de la exposición de contenidos trabajados.

\section{Método/Descripción de la experiencia}

Situándonos en el contexto universitario, en el área de ciencias de la educación y titulaciones impartidas en Facultades de Educación, podemos centrar la presente experiencia en la Universidad de Málaga, en el grado de Pedagogía, en una asignatura de tercer curso, la asignatura de Orientación Educativa. 
Esta asignatura se pretenderá desarrollar un proceso de enseñanza-aprendizaje a través de la motivación y atención del estudiante como persona autónoma en su aprendizaje. Para ello, en primer lugar, se establecerán grupos de entre 4 y 5 personas (con adaptaciones según las circunstancias), a las que se les dará a elegir un supuesto práctico para desarrollar en su Podcast. Este supuesto presentará la necesidad de guiar a un demandante (madre, padre, docente, orientador u orientadora...) a través de Podcast siendo útil para los demás oyentes y pudiendo resolver varias dudas y la posibilidad de guiar a las personas, es decir, dando orientaciones pedagógicas. Las líneas temáticas a elegir serán las siguientes (aunque siempre con la posibilidad de aceptar sugerencias o temas de interés):

- Actuaciones de compensatoria (Atención a la diversidad).

- Lectoescritura (Enseñanza-aprendizaje).

- Alumnado NEE (Atención a la diversidad).

- Consumo de sustancias tóxicas (Atención a la diversidad).

- Asesoramiento al profesorado (Acción tutorial).

- Absentismo y disciplina (Convivencia).

- Asesoramiento Bachillerato (Orientación académico-profesional).

- Razonamiento y lectura comprensiva (Enseñanza-aprendizaje).

- Respuesta educativa NEE (Atención a la diversidad).

- Interculturalidad (Atención a la diversidad).

- Disciplina y convivencia (Acción tutorial).

- Mala disposición de trabajo escolar (Acción tutorial).

- Bullying (Convivencia).

- Tutorías 4ำ de ESO (Orientación académico-profesional).

- Asesoramiento profesorado (Enseñanza-aprendizaje).

- Abandono de estudios (Orientación académica profesional).

- Apáticos y motivados (Enseñanza-aprendizaje).

- Tránsito (Acción tutorial).

- Neuropsicología aplicada a la educación (Prevención en Educación Infantil; Motivación y Prevención en Educación Primaria; Bajo rendimiento escolar en Educación Secundaria y Bachillerato).

- Trastornos del neurodesarrollo (Evaluación e intervención en TDAH; Diagnóstico y actuación en Dislexia y Discalculia; Evaluación e intervención en Dificultades del lenguaje).

- Neurociencia Educativa y desarrollo creativo (Procesos de creatividad aplicados a procesos de aprendizaje; Desarrollo de Inteligencias Múltiples en el aula; Diseño de metodologías innovadoras).

- Neurociencia Educativa en la adolescencia (Diseño de actividades para el trabajo sobre el conocimiento del consumo de sustancias; Trabajar la Educación sexual; Adicciones).

Para facilitar la organización del Podcast realizaremos una escaleta con el contenido del mismo, en la que se reflejará en un cuadro los diferentes bloques en los que se distribuye el desarrollo del podcast (presentación, desarrollo y cierre), el texto de cada bloque con su respectiva duración (en minutos) y el audio de cada bloque. De esta forma tendremos de forma escrita y organizada lo que en el Podcast se presenta. 


\section{Resultados}

En el caso de la experiencia obtenida con la puesta en marcha del uso de podcast como recurso educativo en el aula universitaria, se puede describir una experiencia piloto realizada en el curso 2020-21 en la Universidad de Málaga en el grado en Pedagogía. Esta experiencia ha sido favorecida por la situación actual de emergencia sanitaria provocada por el Covid-19.

Se presentan varias experiencias, en primer lugar, la descripción en modo de trabajos realizados por estudiantes en el aula junto con un ejemplo de escaleta para uno de los contenidos realizados para uno de los estos Podcasts. Y, en otro caso, el desarrollo del uso de Vodcasts para la impartición de la asignatura.

En el caso de la estructura de trabajo realizada en la asignatura, en la creación de trabajos a partir de Podcasts y Vodcasts, se estableció la siguiente estructura:

- Desarrollo del campus virtual y su acceso al contenido.

- Indicar los recursos facilitados.

- Señalar la autonomía en la elección de la temática de trabajo por parte del estudiante, buscando la asociación con la definición de la asignatura. Se facilitan ejemplos.

- Apuntar acerca de la estructura del formato de trabajo. Indicar la diversidad de opciones. Enseñar ejemplos.

- Vodcast con apoyo de recurso gráficos.

Podemos destacar, en la siguiente gráfica, como un alto porcentaje de estudiantes destacaban la importancia en la elección propia de su temática de trabajo. Resultando en un 91,4\% (sumando los valores 4 y 5) (figura 1) la importancia de esa elección:

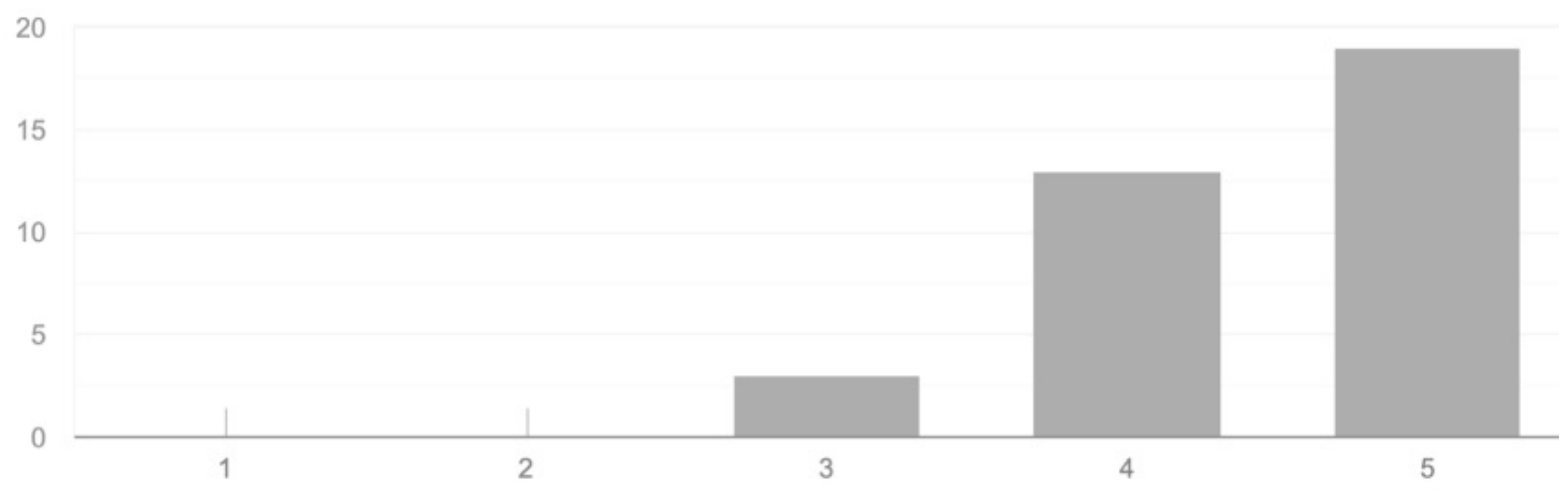

Figura 1: Importancia de la elección del estudiante su temática de trabajo de investigación en la asignatura. 
Asimismo, en cuanto a la necesidad de adaptación a la situación actual de emergencia sanitaria, se preguntó a los estudiantes acerca de la utilidad en la incorporación de recursos digitales en su trabajo en la asignatura, como, por ejemplo, Canva, creación de videos, TikTok, Instagram, Podcast... En la figura 2 se observa como un 96\% (sumando las respuestas de los valores 4 y 5 ) de las respuestas destacan una clara necesidad de uso de ese tipo de recursos que favorecen la docencia.

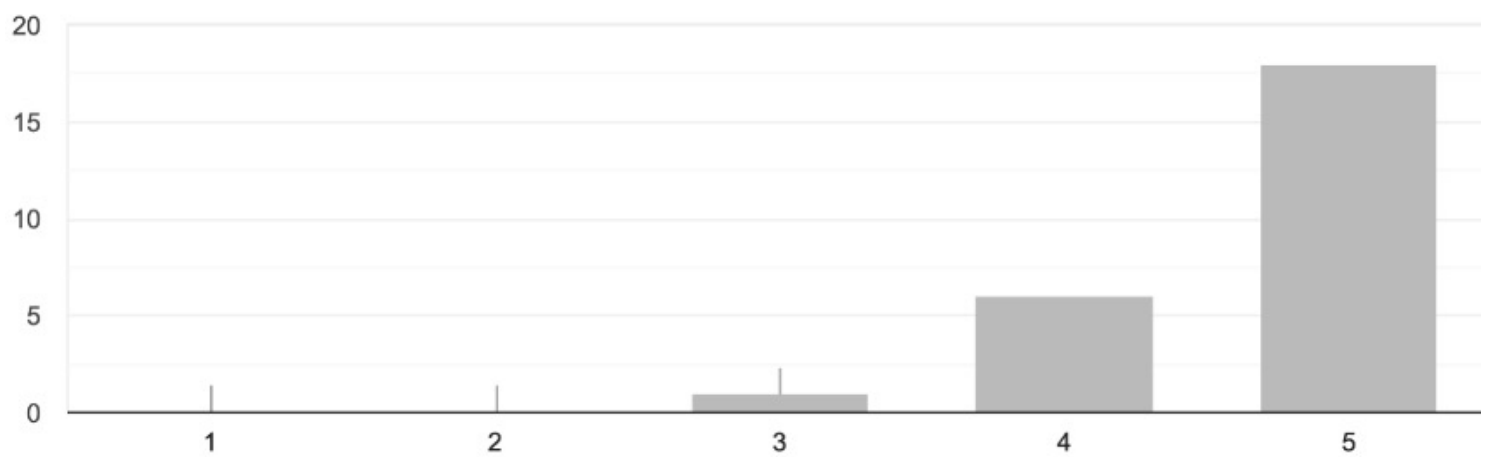

Figure 2: Utilidad de la incorporación de recursos digitales en el trabajo y aula universitaria. /

En otro caso, se presentan ejemplos de Vodcasts (Ejemplo 1; Ejemplo 2) realizados para la impartición de parte del temario de la asignatura de Orientación Educativa del grado en Pedagogía como experiencia piloto. A continuación, en la figura 3, se muestra el porcentaje de respuestas por parte del estudiante acerca de la utilidad del uso de estos Vodcasts en la asignatura para el desarrollo del temario. Observando como el $84 \%$ (sumando valores de 4 y 5 ) indica que es un buen recurso en el aula universitaria.

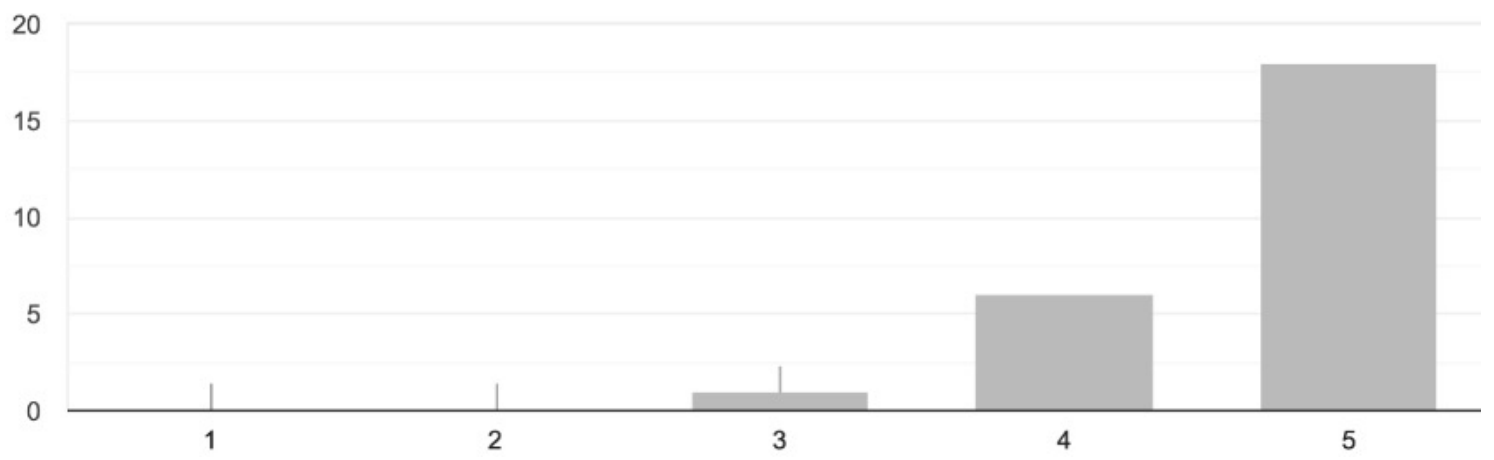

Figure 3: Uso de Vodcasts en la impartición del temario.

\section{Discusión y conclusiones}

A raíz de los objetivos fijados, el estudiantado desarrolla la capacidad de decidir y actuar, ya que las líneas temáticas dadas y la libertad les ayuda a que su autoestima y motivación aumente llevando esto a la autonomía. Las emociones realizan con nosotros y nosotras nuestro día a día, siendo todas igual de necesarias, pues es importante emocionar para poder aprender ya que a cada uno de estos aprendizajes 
que se quedan marcados en las personas se le concede una emoción que lo mantiene en nosotros y nosotras, así al trabajar con esta herramienta educativa como es el Podcast en la que la motivación está presente, se crea un proceso de aprendizaje que marca al alumnado. El trabajo del docente es guiar y acompañar al alumnado, dejando total libertad en la toma de decisiones haciendo esto que lleguen a la reflexión desde ellos y ellas mismas, tomando así iniciativas y decisiones que hacen de la experiencia más agradable e importante. Mediante la publicación de los Podcast realizados en la asignatura, trabajamos la importancia de compartir y de trabajar de forma cooperativamente fomentando el aprendizaje de todos y todas y aportando varias perspectivas que generan el desarrollo de la empatía. Con todo esto, desarrollamos los objetivos expuestos y se obtienen beneficios tanto personales como profesionales en docentes y discentes.

Se trata de fomentar, mediante esta optimización de recursos y habilidades de aprendizaje, la introducción de otros elementos, no sólo contenidos, que ayuden a manejar y "manipular" nuestro propio aprendizaje con factores tan necesarios como la atención, emoción o curiosidad.

Con este trabajo, se pretende actuar desde la base, es decir, desde el comienzo del desarrollo del aprendizaje. Todo ello, se verá traducido a un proceso de cambio, en el que se prime la calidad, la elaboración y decisión propia, y social, de nuestro aprendizaje (Luque-Rojas et al., 2021).

\section{Referencias}

Luque-Rojas, M. J., de la Peña Álvarez, C., \& Scheithauerová, L. (2021). Research in the Pedagogy Classroom: The Student Research. Teaching Coordination Project in Health Emergencies and Pandemics. 3rd World Conference on Teaching and Education. Prague. Czech Republic.

Piñeiro-Otero, T. (2012). Los podcasts en la educación superior. Hacia un paradigma de formación intersticial. Revista Iberoamericana de Educación, 58(1), 1-12.

Solano, I.M. \& Sánchez, M. M. (2010). Aprendiendo en cualquier lugar: el podcast educativo. Pixel-Bit. Revista de Medios y Educación, 36, 125-139. 


\section{Anexos}

\begin{tabular}{|c|c|c|c|}
\hline Bloque & Texto & $\begin{array}{l}\text { Dura- } \\
\text { ción }\end{array}$ & Audio \\
\hline Presentación & $\begin{array}{l}\text { Hola a todos los oyentes de este Podcast, semana tras } \\
\text { semana nos acompañáis en nuestro recorrido por la } \\
\text { salud, física y mental. } \\
\text { Para los que me acompañáis por primera vez, bienveni- } \\
\text { dos, con nuestro podcast pretendemos tener ese espa- } \\
\text { cio común donde trabajar para la salud mental y física. } \\
\text { Factores tan necesarios en el desarrollo de la persona, } \\
\text { por ello, de necesidad trabajarlos desde bien temprano } \\
\text { en el aula. } \\
\text { Hoy, seguimos compartiendo reflexiones y conversacio- } \\
\text { nes para ayudar a conseguir la calma que todos necesi- } \\
\text { tamos a lo largo del día, al menos por un ratín. }\end{array}$ & $2^{\prime}$ & $\begin{array}{l}\text { Careta de } \\
\text { Entrada y } \\
\text { Música chill out }\end{array}$ \\
\hline \multirow[b]{2}{*}{ Desarrollo } & $\begin{array}{l}\text { Se trata de hablar de lo que hemos llamado como } \\
\text { "RESPIRA". } \\
\text { ¿Puede algo tan sencillo como respirar ayudarnos a en- } \\
\text { contrarnos mejor? SÍ, La respuesta es rotunda. } \\
\text { El Podcast de hoy busca intentar explicar la importancia } \\
\text { de la respiración y la conexión con, por ejemplo, Yoga, } \\
\text { para el cuidado físico y mental. }\end{array}$ & $5^{\prime}$ & \\
\hline & $\begin{array}{l}\text { Uno de mis hobbies es la práctica de Pilates y yoga y hace } \\
\text { varios años, entendí la necesidad de saber cómo y porqué } \\
\text { de la importancia de respirar. } \\
\text { Pilates y yoga son práctica más allá de estirar una pier- } \\
\text { na, es un modo de vida. } \\
\text { Siempre creí que yoga era solo respirar y poco más, } \\
\text { pero luego comprendí la importancia de la suma: Yoga/ } \\
\text { Pilates + Respirar + Salud. } \\
\text { En el aula, no todos los estudiantes están igual de moti- } \\
\text { vados ya que cada uno presenta una situación diferente } \\
\text { y única. Para ello, la práctica del yoga marcando la im- } \\
\text { portancia en la respiración ya que este control y rela- } \\
\text { jación, consigue que las personas estén más presentes } \\
\text { mentalmente en el momento y, además, disfrutar de la } \\
\text { asignatura. Por otro lado, es importante tener en cuenta } \\
\text { que el nivel de motivación se eleva ya que la persona } \\
\text { tiene a centrarse en su autoestima y en sus necesidades. } \\
\text { Yoga y Pilates son dos disciplinas que pueden parecerse } \\
\text { que nos ayudan a estar en forma, física y mentalmente. } \\
\text { Estas dos disciplinas, nos dan muchas respuestas a dife- } \\
\text { rentes preguntas que podamos tener. } \\
\text { Aquí hablamos de respiración pudiendo relacionarlo con } \\
\text { Meditación. } \\
\text { Ahora, quiero compartir con vosotros un espacio donde } \\
\text { se explica de forma clara que la meditación es mucho más } \\
\text { que sentarse en la posición de loto y mantenerse en calma. }\end{array}$ & 8' & $\begin{array}{l}\text { Bosa Nova } \\
\text { Covers https:// } \\
\text { open.spotify. } \\
\text { com/artist/6lkr } \\
\text { kVSqgzJZz2jg } \\
\text { uafSAy?si=THT } \\
\text { 8xLNCS1Gu2z- } \\
\text { 2PDR8xA }\end{array}$ \\
\hline Cierre & $\begin{array}{l}\text { La próxima semana seguiremos con nuestro análisis } \\
\text { de la respiración en nuestra salud, lo veremos con un } \\
\text { profesional, con un fisioterapeuta experto en la unión } \\
\text { del ejercicio y el dolor desde la educación de la persona } \\
\text { y el cuerpo. } \\
\text { Gracias a todos por una semana más hablando del equili- } \\
\text { brio y salud mental y física en Educación. }\end{array}$ & $2^{\prime}$ & $\begin{array}{l}\text { Música chill out } \\
\text { y Careta } \\
\text { de Salida }\end{array}$ \\
\hline
\end{tabular}




\section{Reflexionando sobre la Innovación Educativa: Diseño de una experiencia de aprendizaje a través de los podcast}

\section{Martínez-Pérez, Jorge}

ORCID (orcid.org/0000-0003-0090-6040)

Universidad Internacional de Valencia (VIU)

jorge.martinezp@campusviu.es

\section{Recio Muñoz, Francisco}

ORCID (orcid.org/0000-0002-1586-1343)

Universidad Internacional de Valencia (VIU)

fjrecio@universidadviu.com 


\title{
REFLEXIONANDO SOBRE LA INNOVACIÓN EDUCATIVA: DISEÑO DE UNA EXPERIENCIA DE APRENDIZAJE A TRAVÉS DE LOS PODCAST
}

\author{
Martínez-Pérez, Jorge \\ Recio Muñoz, Francisco
}

\section{Resumen}

En el presente trabajo se analizarán algunos de los resultados alcanzados tras un proceso de innovación docente desarrollado en el Máster Universitario en Tecnologías de la Información y la Comunicación (TIC) aplicadas a la Educación de la Universidad Internacional de Valencia (VIU) durante el curso académico 2020/2021, donde se emplearon los podcasts como propuesta didáctica para reflexionar acerca del tópico principal de una de las asignaturas: "Las TIC como herramienta de innovación educativa" (O2MTIC). El objetivo general de dicha actividad consistía en analizar ideas de sociólogos educativos y pedagogos acerca de los retos y necesidades que plantea actualmente la sociedad, con sus avances tecnológicos en la educación. El enfoque radica en el Aprendizaje Basado en Tareas (Clarke y Roche, 2018; Johnson et al., 2014) donde a partir de la lectura de uno de los tres artículos científicos dispuestos en la actividad, el alumnado debía reflexionar, sintetizar y dialogar acerca del mismo empleando una herramienta colaborativa de podcasting. Los resultados establecen un elevado grado de satisfacción en el uso de herramientas digitales para elaborar podcasts y manifiestan su intención de compartir esta experiencia con sus propios alumnos y compañeros en sus centros educativos. El avance de la tecnología en el seno educativo está diversificando las posibilidades de establecer un proceso de enseñanza-aprendizaje más actual y adaptado a las necesidades de estudiantes y docentes del siglo XXI, donde los podcasts se sitúan como herramientas alternativas para promover la digitalización del aprendizaje junto con habilidades y competencias indispensables centradas en el diálogo, el debate, la síntesis y la reflexión.

\section{Palabras clave}

Podcast, innovación docente, tecnologías digitales, aprendizaje en red. 


\section{Introducción}

Los dispositivos electrónicos mantienen un papel fundamental en nuestra vida cotidiana, puesto que "hay una cuestión que toma más vigencia que nunca y es que mientras McLuhan afirmaba que los medios eran extensiones de los seres humanos, se subraya que más que extensiones ya forman parte de nosotros, somos adictos a estos objetos. Son como órganos integrados en nuestro cuerpo" (Aparici y Martínez-Pérez, 2021), pero es indispensable repensarlos dentro de un contexto educativo en el que su naturaleza sea eminentemente práctica y sustancial para potenciar un aprendizaje activo entre los estudiantes

Ya no es novedad destacar que las potencialidades del podcasting educativo son diversas, posibilitando la generación de experiencias de aprendizaje como la radio escolar, audiocuentos, reportajes, entrevistas, diarios reflexivos o tertulias de debate. El análisis de libros y artículos científicos por parte de los estudiantes proviene de una tradición marcada por la pasividad y la reproducción (Bordieu y Passeron, 2018) como ejes vertebrales en el trabajo de estos textos académicos. Las tecnologías digitales nos brindan espacios de interacción entre los estudiantes y las fuentes bibliográficas con objeto de marcar una nueva tendencia en la exploración, interpretación, análisis y reflexión académica. De entre todos ellos, nos gustaría destacar los podcasts.

El fenómeno podcasting tiene su origen en Estados Unidos, a comienzos del siglo XXI como un medio de comunicación que provee objetos sonoros en formato digital (García-Marín, 2019). Su evolución desde la radio analógica hasta la digital ha promovido una nueva manera de comunicarse, de relacionarse y ha generado una asociación directa en una integración adosada a la sociedad del conocimiento.

Siguiendo a Laaser et al. (2010, p.2), por podcasting aludiríamos al "método de distribución de archivos de audio a través de Internet utilizando la sindicación, para la reproducción en dispositivos móviles y computadoras personales".

Podemos encontrar algunos antecedentes en el uso de podcasts en la Educación Superior como recurso didáctico de mejora en la comprensión oral de la lengua inglesa (Manzano et al., 2010), en el área de marketing de turismo (Lee y Wicks, 2010) o como superación de obstáculos en la pronunciación del inglés como lengua extranjera (Al-Ahdal, 2020). Principalmente están orientados al desarrollo y mejora de las habilidades orales, tanto receptivas como productivas. El uso de podcasts en Educación Superior además de potenciar la competencia comunicativa en otras lenguas, nos brinda la oportunidad de redefinir la lectura y reflexión de textos científicos con objeto de generar un clima de aprendizaje interactivo, interrelacional y crítico.

Ante la posibilidad de innovar en la reflexión y diálogo sobre textos académicos, invitamos al alumnado del Máster Universitario en TIC aplicadas a la Educación a realizar un podcast cooperativo y grupal donde pudiesen debatir y analizar distintos textos científicos, con objeto de dinamizar y promover un modelo de interrelación empleando un uso de tecnología orientado a la creación de contenido digital. Para ello hemos empleado un cuestionario mixto que combina la perspectiva cualitativa y cuantitativa con objeto de recoger las opiniones y percepciones de este grupo de estudiantes universitarios en su experiencia con podcasts educativos. 
Como objetivo principal planteamos:

- Analizar la experiencia de los estudiantes en la elaboración de podcasts grupales dentro del Máster Universitario en TIC aplicadas a la Educación de la Universidad Internacional de Valencia (VIU) y su posterior difusión en las aulas.

Los objetivos específicos que giran en torno a nuestro estudio son los siguientes:

- Conocer las principales ventajas y desventajas de su experiencia con podcasts desde una perspectiva tecnológica.

- Averiguar sus expectativas como docentes en cuanto a la utilización de podcasts.

- Redefinir el trabajo y reflexión de textos académicos desde una perspectiva cooperativa, crítica y dialógica mediante el uso de podcasts.

Asimismo, hemos diseñado las siguientes hipótesis:

- El uso de podcasts en la Educación Superior contribuye a potenciar un uso crítico y reflexivo de la tecnología.

- La elaboración de podcasts educativos establece una nueva manera de analizar y reflexionar críticamente en torno a textos académicos y científicos.

\section{Método/Descripción de la experiencia}

\section{Descripción de la experiencia}

Como parte de la asignatura "Las TIC como herramienta de innovación educativa" (O2MTIC) del Máster Universitario en TIC aplicadas a la Educación de la Universidad Internacional de Valencia (VIU), se propuso al alumnado, a partir de la lectura de uno de los tres artículos científicos facilitados para la actividad, generar un podcast donde reflexionaran desde un punto de vista crítico y reflexivo acerca de los retos y necesidades de la sociedad actual.

El trabajo se realizó de manera colaborativa, empleando distintas herramientas que posibilitasen la producción, edición, publicación y difusión de podcasts en la nube. El objeto de estudio está orientado hacia la elaboración de podcasts para el análisis y reflexión académica de documentación científica fomentando la creación cooperativa de contenido digital desde una perspectiva crítica. Para ello se realizó un cuestionario a 129 estudiantes del máster, desde un modelo de investigación mixta, donde se puede encontrar la simbiosis entre el modelo cualitativo y cuantitativo con objeto de reforzar cada uno de esos sistemas por separado y profundizar en la obtención y análisis de los datos obtenidos.

\section{Descripción del contexto y de los participantes}

La muestra proviene de 129 estudiantes que han cursado el Máster Universitario en TIC aplicadas a la Educación en la Universidad Internacional de Valencia (VIU), 
donde de media están dentro de una franja de edad comprendida entre los 20 y 35 años. Destacamos que un elevado número de respuestas proviene de mujeres, alcanzando un $78 \%$.

La investigación se ha realizado de manera totalmente voluntaria, animando a los estudiantes hacia su participación, pero sin imprimir un sentido de obligación hacia su cumplimentación.

\section{Instrumentos}

El instrumento que se ha llevado a cabo para esta investigación ha sido un cuestionario a través de Google Forms, debido, entre otras razones, a su accesibilidad, difusión y simplificación en la recogida de datos y su posterior análisis.

Consistió en varias preguntas de corte demográfica para conocer edad, sexo, grupo de trabajo al que pertenecen, etc. Y otras preguntas abiertas para consultar sobre las dificultades encontradas en el desarrollo de la actividad, uso de otras herramientas digitales, aprendizajes adquiridos, proceso seguido para el desarrollo del podcast, utilidad, etc.

\section{Procedimiento}

Durante la asignatura "Las TIC como herramientas de Innovación Educativa" (O2MTIC) se le solicitó al alumnado la realización de un podcast en base a uno de los tres textos científicos que completaron las fuentes recomendables de uso con objeto de reflexionar sobre las ideas y principios que se anunciaban en estos artículos académicos. Los textos con los que han trabajado los estudiantes son los siguientes: La institución escolar en la sociedad de la información y el conocimiento (Enguita, 2010), La educación formal en la nueva ecología del aprendizaje: tendencias, retos y agenda de investigación (Coll, 2013) y Una escuela para la sociedad del conocimiento (Feito, 2015).

Dicho podcast colaborativo lo realizaron, en su mayoría, con la herramienta Anchor', que se caracteriza principalmente por ser gratuita y permitir la grabación, edición y producción en línea y colaborativamente, tanto desde el propio pc como desde el teléfono móvil. Otros grupos se decantaron por emplear Blackboard (la plataforma de la Universidad) en una sala locutada y hubo otros estudiantes que se inclinaron por grabar sus pistas de manera individual y posteriormente editarlas desde programas como Adobe Audition o Audacity.

Al final de la asignatura, en la última sesión, se les propuso responder a un cuestionario para aportar con su valoración acerca de esta actividad de manera más sistemática. Entre los parámetros más destacables podemos destacar el contexto, los aspectos tecnológicos del proceso de elaboración del podcast, los aspectos procesuales de diseño, así como aspectos del contenido y su posterior puesta en práctica como docentes. 


\section{Resultados}

En base al análisis que hemos llevado a cabo nos gustaría esbozar algunos de los resultados obtenidos desde las distintas dimensiones con objeto de brindar una aproximación al objeto de estudio. En primer lugar, como podemos advertir en la Figura 1, y basándonos en la libre elección del texto académico con el que trabajar para la posterior elaboración del podcast, podemos destacar que casi uno de cada cuatro grupos de estudiantes se inclinó por el texto de Feito (2015), seguidos de un 18,6\% que escogió el artículo de Coll (2013) y, por último, las líneas desarrolladas por Fernández-Enguita (2010) con un 7,8\%.

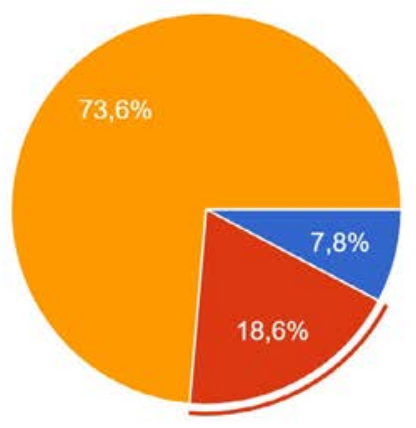

\section{Figura 1: Resultados pregunta Q5 (Fuente: elaboración propia).}

Desde la Figura 2 nos centraremos en aspectos procesuales de elaboración del podcast, donde apreciamos que cuatro de cada diez estudiantes asemejan el proceso a una forma de conocer las reflexiones de otros compañeros, seguido de un 35,7 \% de los mismos que se inclinan hacia reflexionar con otros compañeros. Dos de cada diez estudiantes lo enfocan hacia una forma de seleccionar las ideas principales del texto, sintetizarlas y exponerlas oralmente. Por último, un 3\% hace alusión a una forma de reflejar las ideas principales del autor del texto, exponiéndose de manera oral.

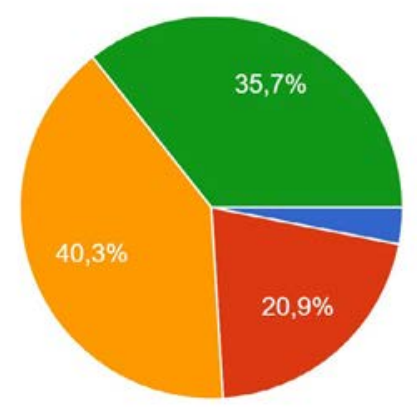

Una forma de reflejar las ideas principales del autor del texto, exponiendolas de manera oral.

Una forma de seleccionar las ideas principales del texto, sintetizarlas y exponerlas oralmente.

Una forma de conocer las reflexiones de otros compañeros acerca del texto...

- Una forma de reflexionar con otros compañeros sobre una serie de ideas...

\section{Figura 2: Resultados pregunta Q6 (Fuente: elaboración propia).}

Resulta muy esclarecedor conocer la etapa y nivel educativo en que imparten docencia el estudiantado que conforma la muestra de estudio, con objeto de analizar posteriores respuestas en base a la puesta en marcha de podcasts educativos en sus aulas en un futuro. El $70 \%$ de la muestra está ejerciendo la docencia, tal y como podemos advertir en la Figura 3, destacando que la mitad de los mismos se 
encuadra en la etapa de Educación Primaria, seguida por uno de cada cuatro estudiantes que imparte docencia en Educación Infantil, un 11,1\% que lo hace en Secundaria y/o Bachillerato, y podríamos destacar que la respuesta "otros" es la siguiente con más valoración, alcanzando un 6,7\%.

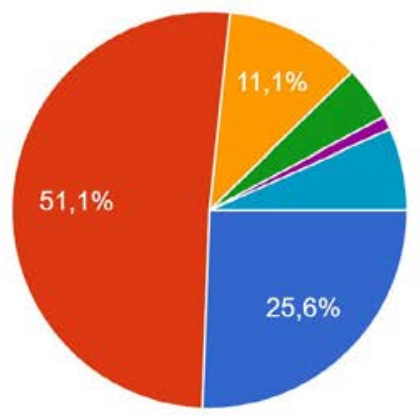

Educación Infantil

Educación Primaria

Educación Secundaria y/o Bachillerato

Formación Profesional

Universidad

Otros

Figura 3: Resultados pregunta Q8 (Fuente: elaboración propia).

Los grupos de estudiantes tuvieron la oportunidad de compartir sus trabajos en un foro del propio aula virtual de la asignatura con objeto de favorecer un clima de colaboración y abrir un diálogo acerca de las virtudes y posibles mejoras de cada podcast. Asimismo, el hecho de elegir un mismo texto entre grupos diferentes ofrece la oportunidad de enriquecer el contenido y la posterior reflexión crítica.

Resulta determinante que casi 8 de cada 10 estudiantes han escuchado podcasts de sus compañeros. Al ofrecerse esta posibilidad de manera voluntaria, mantiene una mayor significación, inclinándonos a pensar que este modelo de trabajo para enfocar la reflexión, lectura y síntesis de textos académicos es un incentivo para que el alumnado potencie su aprendizaje.

¿Has escuchado algún podcasts de alguno de los otros grupos?

129 respuestas
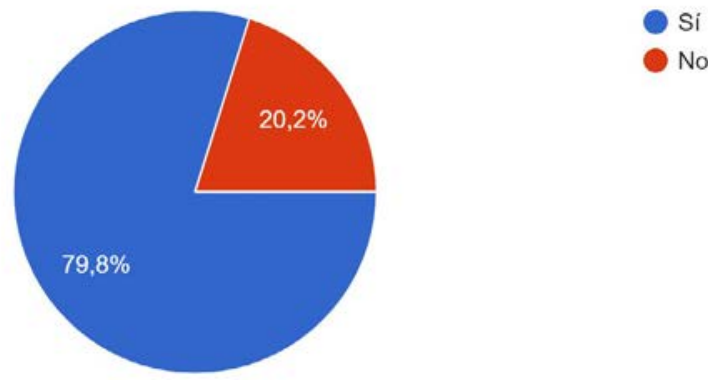

Figura 4: Resultados pregunta Q9 (Fuente: elaboración propia).

Tras la explicación teórica y puesta en práctica del podcast educativo en la asignatura del Máster, creímos indispensable analizar la probabilidad de proponer a sus estudiantes, en un futuro, la elaboración de un podcast colaborativo.

Como podemos apreciar en la Figura 5, casi seis de cada diez estudiantes tiene muy claro que sí llevaría a cabo este tipo de dinámicas en sus clases. Casi uno de cada 
tres estudiantes está a favor de llevarlo a su aula, y uno de cada diez no muestra interés por pedir a sus estudiantes la elaboración de estos contenidos digitales de manera colaborativa.

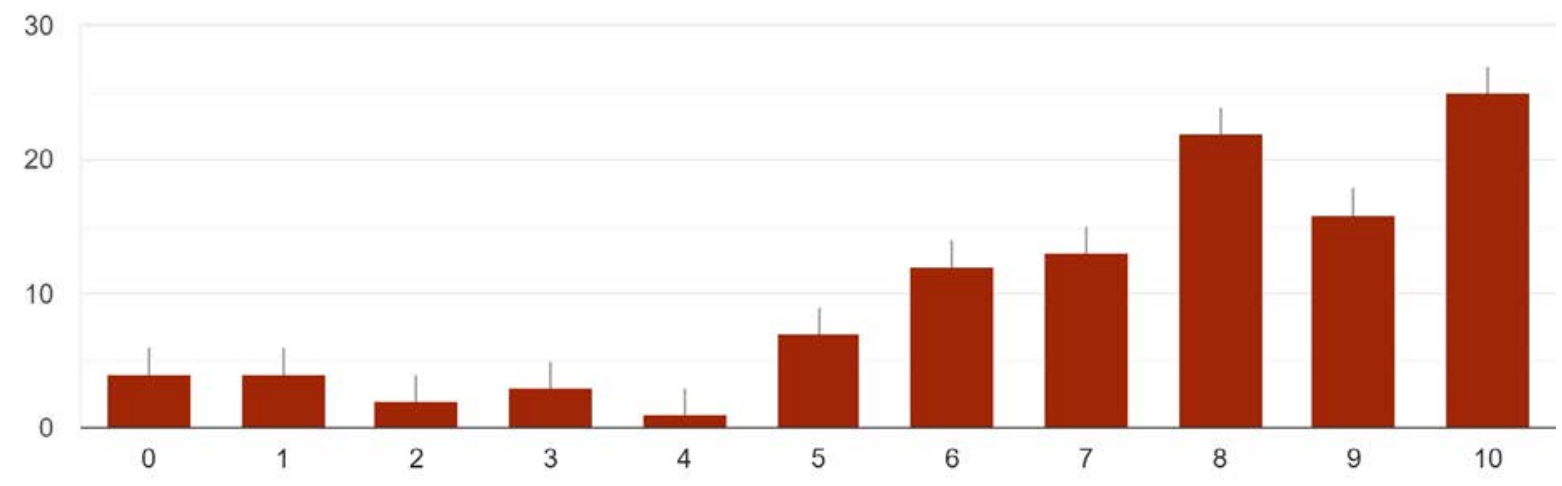

Figura 5: Resultados pregunta Q10 (Fuente: elaboración propia).

\section{Discusión y conclusiones}

Los podcasts se muestran como una herramienta que combina la tecnología con importantes habilidades como la dialéctica o la expresión oral. Tras la experiencia vivida en la asignatura del Máster Universitario en TIC aplicadas a la Educación, el estudiantado ha descubierto en los podcasts un nuevo recurso tecnológico con el que profundizar, debatir, reflexionar, dialogar de manera colaborativa y crítica sobre distintos textos académicos.

Entre las conclusiones, destacamos un uso sencillo e intuitivo de las aplicaciones que permiten la grabación y posterior edición del audio, así como las enormes posibilidades de difusión entre la comunidad educativa gracias a la flexibilidad del podcasting en cuanto a su adaptabilidad a diferentes metodologías colaborativas. Los estudiantes han destacado la versatilidad que ofrecen estos espacios digitales para trabajar de manera cooperativa y la posibilidad de otorgar al alumnado un rol protagonista y principal, mostrándose el docente como guía de su aprendizaje.

El trabajo con textos académicos y científicos en la Educación Superior mantiene una tradición ligada al individualismo y habilidades marcadas por la pasividad en vez de fomentar la autoría y creación de contenidos. Desde esta experiencia hemos tratado de apostar por un uso de las tecnologías integrador, interactivo y coherente, donde se muestren como herramientas que facilitan el aprendizaje en vez de ser un fin en sí mismas.

Como principal obstáculo nos gustaría destacar, por un lado, las dificultades para el trabajo sincrónico online de los estudiantes, que en algunos casos se han solventado con la grabación de pistas individuales para la posterior conformación del producto final. También hemos detectado limitaciones en algunas herramientas y aplicaciones para realizar la grabación de manera cooperativa y sincrónica, ya sea por estar asociadas a un plan de pago o por su naturaleza digital, pensada para un uso más individual que colectivo. 
Subrayamos que esta experiencia en Educación Superior ha promovido que el estudiantado se muestre especialmente proactivo hacia su futura implementación en las aulas, como docentes, principalmente en Primaria e Infantil, al contemplarlo como una nueva manera de integrar la tecnología en las clases, de despertar la motivación, la curiosidad y el interés de los estudiantes de forma interdisciplinaria y cooperativa.

\section{Referencias}

Aparici, R. y Martínez-Pérez, J. (2021). El algoritmo de la incertidumbre. Gedisa.

Bourdieu, P. y Passeron, J.C. (2018). La reproduction: éléments pour une théorie du système d'enseignement. Minuit.

Clarke, D. y Roche, A. (2018). Using contextualized tasks to engage students in meaningful and worthwhile mathematics learning. The Journal of Mathematical Behavior, 51, 95-108. https://doi.org/10.1016/j.jmathb.2017.11.006

Coll, C. (2013). La educación formal en la nueva ecología del aprendizaje: tendencias, retos y agenda de investigación. En J. L. Rodríguez Illera (Comp.). Aprendizaje y educación en la sociedad digital. (p.156-170). Universitat de Barcelona. https://doi. org/10.1344/106.000002060

Feito, R. (2015). Una escuela para la sociedad del conocimiento. El sentido de la educación escolar. En V.M. Rodríguez-Muñoz \& A. del Pozo Palomo (Coords.). El desafío de educar en un mundo incierto. (p.45-57). Fuhem.

Fernández-Enguita, M. (2010). La institución escolar en la sociedad de la información y el conocimiento. En R. Feito (Coord.). Sociología de la Educación Secundaria (p.9-21). Editorial Graó.

García-Marín, D. (2019). La radio en pijama. Origen, evolución y ecosistema del podcasting español. Estudios Sobre El Mensaje Periodístico, 25(1), 181-196. https://doi. org/10.5209/ESMP.63723

Johnson, D. W., Johnson, R. T. y Smith, K. A. (2014). Cooperative learning: Improving university instruction by basing practice on validated theory. Journal on Excellence in University Teaching, 25(4), 85-118.

Laaser, W., Liliana Jaskilioff, S., y Rodríguez Becker, L. C. (2010). Podcasting: ¿Un nuevo medio para la Educación a Distancia?. Revista de Educación a Distancia (RED), (23). https://revistas.um.es/red/article/view/111681 


\section{Análisis de una Experiencia de Gamificación Basada en Escape Room en Gestión de Proyectos}

Amante, Beatriz orcid.org/0000-0001-5231-1706 beatriz.amante@upc.es

\section{Romero-García, Carmen} orcid.org/0000-0003-3937-9399 mariadelcarmen.romero@unir.net

\section{Guinart, Aleix}

orcid.org/0000-0002-3457-9124

aleix.guinart@upc.edu 


\title{
ANÁLISIS DE UNA EXPERIENCIA DE GAMIFICACIÓN BASADA EN ESCAPE ROOM EN GESTIÓN DE PROYECTOS
}

\author{
Amante, Beatriz \\ Romero-García, Carmen \\ Guinart, Aleix
}

\section{Resumen}

La gamificación es una estrategia metodológica que hace referencia a la integración de elementos del diseño de juegos en actividades de aprendizaje. Una forma de aplicar la gamificación es el Escape room, en el que se plantea una narrativa que enmarca los retos que los participantes deben superar. El objetivo de este estudio ha sido evaluar una experiencia de gamificación basada en un Escape room y analizar la satisfacción del alumnado con la misma. Se ha utilizado una metodología cuantitativa con un diseño descriptivo tipo encuesta. En la experiencia han participado 25 estudiantes de educación superior que cursaban la asignatura de Gestión de Proyectos durante el curso académico 2020-2021. Como instrumentos se utilizaron, la escala de experiencia de juego gamificado validada previamente por Parra-González y Segura-Robles (2019) y un cuestionario diseñado ad hoc para conocer el grado de satisfacción del alumnado. Todos los ítems fueron valorados siguiendo la escala Likert (1 totalmente en desacuerdo y 5 completamente de acuerdo). Los resultados muestran que la experiencia de gamificación ha sido divertida y entretenida, el alumnado se ha implicado y se ha sentido confiado, despertando su imaginación en el transcurso del experimento. Así mismo, la satisfacción del alumnado con la experiencia de aprendizaje realizada se ha considerado aceptable (por encima del 75\%) y demuestra que el alumnado ha disfrutado de la experiencia mientras profundizaba en aspectos claves de la asignatura.

\section{Palabras clave}

Gamificación, Escape room, Experiencia de Aprendizaje, Aprendizaje Cooperativo, Gestión de Proyectos, Educación Superior, Análisis de riesgo. 


\section{Introducción}

En las universidades se han realizado cambios en las metodologías de enseñanza/aprendizaje desde antes del 2010, pero más concretamente con el plan Bolonia (Montero Curiel, 2010). Entre las diferentes metodologías de enseñanza/aprendizaje, en las escuelas técnicas destacan aquellas en las que se realiza aprendizaje experimental. Los estudios de Ariza, 2010 y López \& Zuluaga, 2016, subrayan el hecho de haber mejorado considerablemente el nivel de aprendizaje por parte del alumno al usar dichos modelos de aprendizaje experienciales. Esta necesidad se hace aún más importante en estudios o áreas de conocimiento donde se demuestra una baja motivación por parte de los alumnos, ya que estos tienden por naturaleza a aprender menos(Ross \& Bell, 2019). Hay diferentes tipos de aprendizaje experiencial que ayudan a desarrollar e incentivar ambientes positivos de aprendizaje, así como fomentar la motivación entre el alumnado (Kolb \& Kolb, 2017). Una de las metodologías propuestas es la gamificación (Kalogiannakis et al., 2021).

La gamificación es una estrategia metodológica innovadora que hace referencia a la integración de los elementos propios del diseño de juegos en contextos formales no lúdicos para recompensar acciones específicas en diferentes contextos (Huang et al., 2018). Pero algunos estudios demuestran que sus orígenes se remontan hasta el s. XV y s. XVI donde algunos matemáticos utilizaban dichos principios como formas novedosas y atractivas de adquirir conocimiento, técnica, moral o ética (Belmas, 2021). Hoy en día, su uso se está extendiendo a diferentes campos, aunque en el sector de la educación se ha consolidado como una tendencia con un impacto notable (Rodrigues et al., 2019). Aplicada a educación se constituye como una estrategia con un gran potencial para el diseño de acciones formativas. Numerosos estudios evidencian su potencial educativo, de los que podemos destacar de este último año a Bencsik et al. (2021); Bilro et al. (2021); Contreras et al. (2021); Liu et al. (2021); Ouriques et al. (2021). Estos autores destacan que la gamificación permite presentar los contenidos y procedimientos a aprender en un formato atractivo, siendo este posiblemente uno de los motivos por los que la gamificación actúe además aumentando la motivación e interés del alumnado por la temática y su participación en el proceso de aprendizaje (Armstrong \& Landers, 2018; Cuevas Monzonís et al., 2021; Pegalajar Palomino, 2021; Pérez-Manzano \& Almela-Baeza, 2018). La utilización de la gamificación, potencia en el alumnado la capacidad de pensamiento crítico mediante la reflexión sobre sus propias decisiones (Khan \& Zhao, 2021), siendo el propio juego quien proporciona una retroalimentación rápida y coherente sobre las decisiones tomadas, consiguiéndose una profunda interiorización de lo aprendido (Xi \& Hamari, 2019).

Un tipo de actividad gamificada que ha sido aplicado con éxito en diferentes áreas curriculares en Educación Superior son los Escape room (Borrego et al., 2017; Cohen et al., 2021; Davis et al., 2021; Friedrich et al., 2019; Kaul et al., n.d.; Pfeifer et al., 2021). En el desarrollo de esta actividad se plantean los logros de aprendizaje en forma de diferentes retos, a resolver en equipo (Eukel et al., 2017). Para ello, se plantea una narrativa o contexto (Chiang et al., 2021) que enmarca los desafíos que los participantes deben superar, y que permite que la experiencia sea más atractiva. La superación de los retos planteados, junto a las recompensas recibidas, guían al alumnado para avanzar hacia una metal final o resolución de un problema complejo (Nicholson, 2016). Los estudiantes se interesan por el tema objeto de estudio al percibir la enseñanza de forma divertida, generando un mayor compromiso del 
alumnado que se motiva e implica de forma efectiva (Liu et al., 2021). Su implementación en el aula potencia el pensamiento crítico y la asimilación de los contenidos, mediante la reflexión sobre sus propias decisiones, creando una experiencia inmersiva donde el alumno tiene la oportunidad de ver de forma práctica y motivadora el resultado de las acciones que toma, que no solo consigue un mayor desempeño, sino que también le aporta un aprendizaje diferenciado y contextualizado sobre el contenido propuesto en el aula (Xi \& Hamari, 2019). Asimismo, diversos estudios inciden en la importancia de las emociones en el proceso de aprendizaje, así como el efecto multiplicador de este sobre el nivel de resultados obtenidos (Bulás Montoro et al., 2020). En este sentido, el estudio de Sierra Daza \& Fernández-Sánchez (2019), determinan un efecto sobre las emociones en experiencias de gamificación, pues determinan un aumento de la diversión y de la ansiedad, hechos que demuestran una mayor voluntad de participación en el aula, así como una mayor retención de los contenidos propuestos (Farber, 2020).

Teniendo en cuenta lo argumentado anteriormente los objetivos de este estudio han sido:

- valorar una experiencia de gamificación basada en un Escape room en cuanto a su efecto en diversión, absorción o evasión del entorno, pensamiento creativo, activación o implicación, falta de afecto negativo y dominio o confianza.

- analizar la satisfacción del alumnado con la experiencia realizada al finalizar la misma.

\section{Método}

En esta investigación se ha seguido un diseño metodológico descriptivo y transversal de tipo encuesta para determinar la percepción del alumnado con respecto a la experiencia de gamificación implementada.

\section{Descripción del contexto y de los participantes}

El muestreo empleado ha sido el no probabilístico por conveniencia, cuya muestra resultante ha estado formada por 25 estudiantes que cursaban la asignatura de Gestión de Proyectos del Máster Universitario en Ingeniería de Sistemas Automáticos y Electrónica Industrial (MUESAI). Asignatura impartida por el Departamento de Ingeniería de Proyectos y de la Construcción (DEPC), en la Escuela Superior de Ingenierías Industrial, Aeroespacial y Audiovisual de Tarrasa (ESEIAAT) de la Universidad Politécnica de Cataluña (UPC), durante el curso académico 2020/2021. En la muestra podemos ver que un $4 \%$ de los participantes son mujeres y un $96 \%$ hombres, siendo la edad media de 28,3 años.

\section{Instrumentos}

Para recabar información sobre la experiencia de gamificación se ha utilizado la escala de experiencia de juego gamificado validada previamente por Parra-González y Segura-Robles (2019). Se compone de seis dimensiones en torno a la experiencia de los participantes en actividades gamificadas formadas por un número variable de ítems. La dimensión Diversión mide el grado de disfrute del alumnado con la experiencia ( 5 ítems), por otro lado, tenemos la dimensión Absorción, para determinar la evasión del entorno y la conciencia de la noción del tiempo durante la experiencia 
(5 ítems). En cuanto a la dimensión de Pensamiento creativo, analiza el grado de imaginación o creatividad que el estudiante percibe que desarrolla durante la experiencia (3 ítems). La dimensión Activación mide el grado de implicación en la actividad desarrollada (4 ítems) y la dimensión Ausencia de efecto negativo, mide la percepción de emociones negativas por parte del alumnado (3 ítems). Finalmente, la dimensión Dominio, pretende analizar la confianza que el estudiante tiene en sí mismo durante la experiencia ((4 ítems). Cada ítem fue valorado según una escala tipo Likert (1 Totalmente en desacuerdo, 2 - En desacuerdo, 3 - Ni acuerdo ni desacuerdo, 4 - De acuerdo, 5 - Completamente de acuerdo). El análisis de fiabilidad del instrumento, realizado mediante Alpha de Cronbachk fue de 0.90, por lo que podemos considerar que el instrumento presenta una adecuada fiabilidad para el estudio.

Para conocer el grado de satisfacción del alumnado, se diseña un instrumento ad hoc formado por tres dimensiones: Aprendizaje y Planificación docente, ambas con tres ítems y Evaluación constituida por dos ítems. Además, se incluye un ítem para que el alumnado valore la experiencia globalmente. De nuevo todos los ítems fueron valorados según una escala tipo Likert (1 - Totalmente en desacuerdo, 2 - En desacuerdo, 3 - Ni acuerdo ni desacuerdo, 4 - De acuerdo, 5 - Completamente de acuerdo).

Los cuestionarios fueron elaborados en Google Forms y se compartieron con los estudiantes al finalizar la experiencia de gamificación de forma online.

\section{Procedimiento}

Un factor clave en el diseño de un Escape room sin duda es la elección del tema y la narrativa (Chiang et al., 2021; Nicholson, 2015). En este estudio se ha diseñado un Escape Room denominado "Reserva tiempo y dinero para los riesgos de un proyecto" en el que el alumnado ha trabajado conceptos de identificación de riesgos en el contrexto de una misión o proyecto a ejecutar, han realizado un análisis cualitativos y cuantitativos de los mismos, y finalmente, han realizado el cálculo para las reservas de contingencias (a nivel de tiempo y costos). La actividad fue diseñada en Google Sites. La página web contiene una pestaña para cada uno de los elementos del juego: historia o narrativa, instrucciones, retos y código final. La narrativa del Escape Room está inspirada en la serie española "La casa de papel" producida por Atresmedia y particularmente centrada en el personaje "el profesor". En el ejercicio, se le explica al alumno que va a participar en una nueva operación destinada a terminar con la polución provocada por los coches de combustión y el profesor les va a pedir ayuda para conseguir el secreto de la batería eléctrica de la compañía Tesla, Inc, una de las compañías estadounidenses más importantes en la fabricación de vehículos y baterías eléctricas, en estos tiempos.

Además, en el transcurso del juego, el alumnado debe resolver una serie de retos. Entre estos retos se incluye descubrir una palabra clave tras haber realizado un ejercicio o encontrar un código secreto para poder escapar del Escape room. Tras cada reto los estudiantes deben contestar un cuestionario, en el que dejan constancia del proceso utilizado para resolver dicho reto. Los cuestionarios fueron elaborados en Google forms. En este cuestionario, deberán colgar ficheros de ejecución, responder preguntas de varios tipos, etc, para que el propio formulario les proporcione las claves o pistas necesarias para seguir o para responder el siguiente reto. Se puede acceder al juego mediante el siguiente enlace: https://sites.google.com/upc.edu/ riesgos/una-misión-con-riesgo/. La actividad se realizó de forma colaborativa en grupos formados por 4 a 6 alumnos. 
Una vez recabada la información sobre la percepción del alumnado con la experiencia de gamificación presentada anteriormente, los datos fueron organizados, codificados y analizados utilizando el paquete estadístico SPSS v.24.0.

\section{Resultados}

Para presentar los resultados, en primer lugar, se realizaremos un análisis de las diferentes dimensiones que hemos medido en el cuestionario y reflexionaremos sobre lo obtenido. Esto nos permitirá saber el grado de implicación y motivación de los estudiantes en esta experiencia.

En el Gráfico 1 se presenta la media obtenida en cada una de las dimensiones de la escala utilizada para valorar la experiencia de gamificación. Cabe destacar que las dimensiones en las que se alcanza un mayor nivel son Diversión $(3,61)$, seguida de Pensamiento crítico $(3,15)$ y de Dominio $(3,03)$. Por otro lado, la media de la dimensión Falta de afecto negativo $(1,83)$, pone de manifiesto que no se han generado emociones negativas durante la experiencia de aprendizaje implementada.

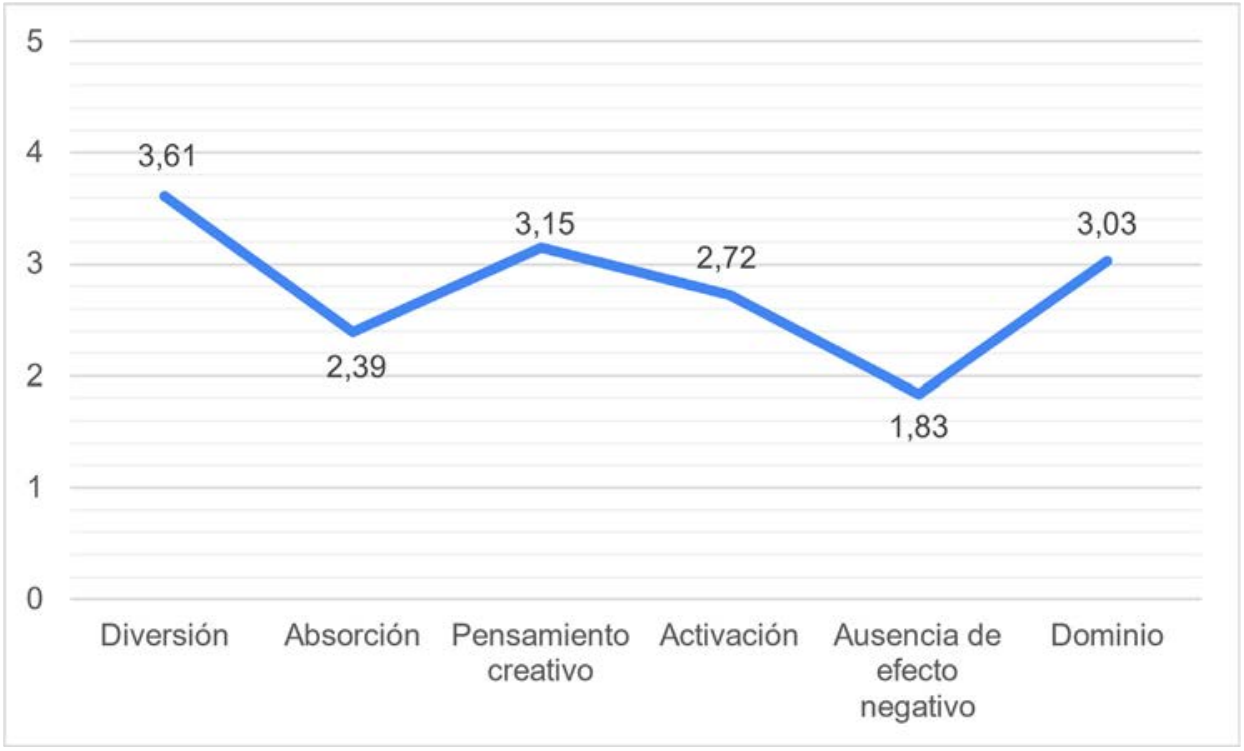

Gráfico 1. Media de las puntuaciones obtenidas para cada dimensión de la escala de gamificación.

Para profundizar en cada una de las dimensiones se presentan los resultados del análisis de cada uno de los ítems que las conforman en la Tabla 1. Los ítems que alcanzan una media superior son los que se refieren a que la experiencia "Ha sido divertida y "Me gustó" (ambos con un valor de 3,72 ) seguidos muy de cerca por "Creo que la experiencia fue muy entretenida" $(3,67)$, todos ellos pertenecientes a la dimensión Diversión. Dentro de la dimensión Activación, el alumnado destaca "Me sentí activo" $(3,44)$ y en la dimensión Dominio "Me sentí confiado" $(3,22)$. Finalmente, en la dimensión Pensamiento creativo destaca el ítem "Despertó mi imaginación" $(3,22)$. En la dimensión Ausencia de afecto negativo, las medias más altas se han alcanzado para los ítems "Me sentí frustrado" $(2,06)$ y "Me sentí molesto" $(2,00)$ y denotan que la experiencia no ha generado en gran medida emociones negativas. 
En cuanto a la dimensión Absorción, el ítem que alcanza la mayor media es "Me hizo olvidar donde estaba" $(2,67)$ y refleja que el alumnado no ha conseguido abstraerse de la realidad al participar en la experiencia.

\begin{tabular}{|c|c|c|c|}
\hline Dimensión & Ítems & Media & DT \\
\hline \multirow{5}{*}{ Diversión } & Ha sido divertida & 3,72 & 0,75 \\
\hline & Me gustó & 3,72 & 0,75 \\
\hline & Disfruté mucho & 3,39 & 0,92 \\
\hline & La experiencia fue placentera & 3,56 & 0,98 \\
\hline & Creo que la experiencia fue muy entretenida & 3,67 & 0,97 \\
\hline \multirow{5}{*}{ Absorción } & Me hizo olvidar donde estaba & 2,67 & 0,97 \\
\hline & Me olvidé de mi entorno inmediato & 2,56 & 0,98 \\
\hline & Después me sentí como volver al "mundo real" después de un viaje & 2,33 & 1,19 \\
\hline & Me alejó de todo & 2,28 & 0,96 \\
\hline & Estaba completamente ajeno a todo lo que me rodeaba & 2,11 & 1,08 \\
\hline \multirow{3}{*}{$\begin{array}{l}\text { Pensamiento } \\
\text { creativo }\end{array}$} & Despertó mi imaginación & 3,18 & 1,28 \\
\hline & Me sentí creativo & 3,06 & 1,26 \\
\hline & Sentí que podía explorar cosas & 3,11 & 1,18 \\
\hline \multirow{4}{*}{ Activación } & Me sentí activo & 3,44 & 0,98 \\
\hline & Me sentí nervioso & 2,56 & 1,04 \\
\hline & Me sentí frenético & 2,17 & 1,04 \\
\hline & Me sentí emocionado & 2,72 & 0,96 \\
\hline \multirow{3}{*}{$\begin{array}{l}\text { Ausencia } \\
\text { de efecto } \\
\text { negativo }\end{array}$} & Me sentí molesto & 2,00 & 1,08 \\
\hline & Me sentí hostil & 1,44 & 0,70 \\
\hline & Me sentí frustrado & 2,06 & 0,94 \\
\hline \multirow{4}{*}{ Dominio } & Tuve la sensación de estar al mando & 2,78 & 1,17 \\
\hline & Me sentí influyente & 3,00 & 1,08 \\
\hline & Me sentí autónomo & 3,11 & 1,02 \\
\hline & Me sentí confiado & 3,22 & 1,06 \\
\hline
\end{tabular}

Tabla 1. Media y desviación típica (DT) para cada uno de los items de la escala de gamificación (en una escala de 1 a 5)

Se determina la satisfacción del alumnado con la experiencia de gamificación realizada analizando las medias de los ítems de las tres dimensiones. En la dimensión referida al Aprendizaje (Gráfico 2) los resultados muestran una media global de 3,28, siendo el ítem mejor valorado el que hace referencia a "Me permitió aumentar mi compresión en la parte de Riegos de la asignatura" $(3,61)$. 
5

4

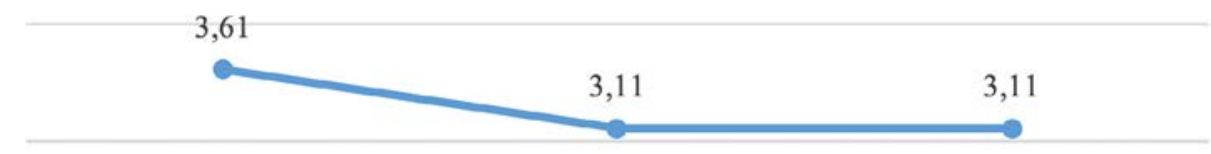

2

Me permitió aumentar mi

comprensión en la parte de

Este tipo de actividades han Este tipo de actividades han

Riesgos de la asignatura

aumentado mi interés por la aumentado mi motivación por

asignatura o parte de ella la asignatura o parte de ella

Gráfico 2. Media de los ítems de la dimensión Aprendizaje (Escala de 1 a 5)

Respecto a la dimensión de Planificación docente, la media global alcanzada es de 3,63. En este caso, el ítem con mayor media es el referido a "Ha estado bien diseñada" 3,78 (gráfico 3).

5

3,78

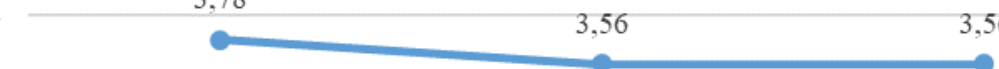

3

2

1

0

Crees que ha estado bien Permiten ver la aplicación de Permiten alcanzar los diseñada los conceptos a situaciones objetivos propuestos reales

Gráfico 3. Media de los ítems de la dimensión Planificación docente (Escala de 1 a 5)

En la última dimensión, referida a la Evaluación, se alcanza una media de 3,81. Los dos ítems que conforman la dimensión tienen una media por encima de 3,7, destacando el ítem referido a que "El profesor ha proporcionado feedback durante la realización de las actividades gamificadas" con una media de 3,89 (gráfico 4). 


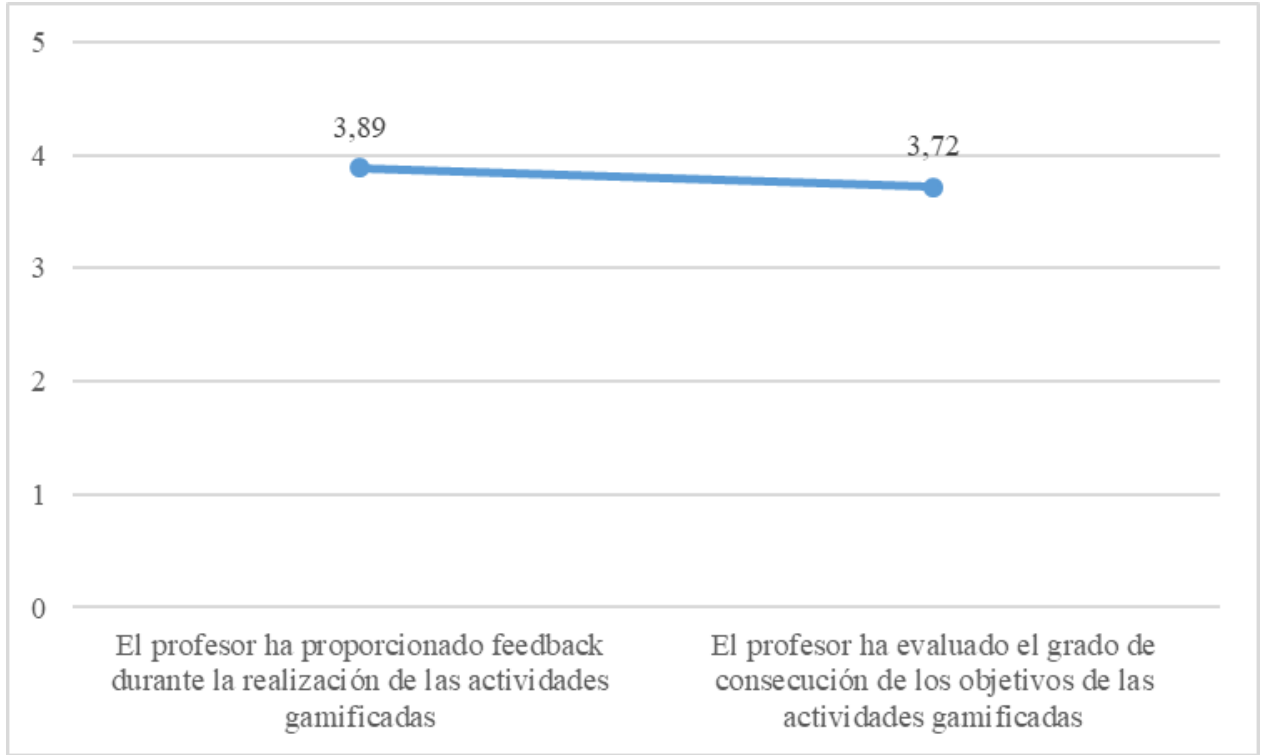

\section{Gráfico 4. Media de los ítems de la dimensión Evaluación (Escala de 1 a 5)}

En relación con el grado de satisfacción con la formación recibida, obtenido también por un cuestionario de satisfacción de las actividades realizadas, el alumnado indica tener un nivel de satisfacción global aceptable $(3,6)$. Así mismo, un 77,8\% manifiestan que recomendarían esta experiencia de aprendizaje basada en la gamificación a otros estudiantes.

Por último, para verificar que el contenido formativo trabajado por la experiencia de gamificación fue adquirido, se valoró el entregable del proyecto dedicado a los riesgos. Comentar que esta asignatura de gestión de riesgos, cuenta con una parte práctica que supone el $50 \%$ de la asignatura, donde realizan toda la documentación necesaria para la gestión, el seguimiento y control de un proyecto dado. Esta documentación la van desarrollando a lo largo del cuatrimestre y la presentan en forma de entregables. En total tienen 10 entregables evaluables. Uno de ellos es el informe y análisis de riesgos del proyecto, con el plan de contingencia asociado. Dicho entregable fue desarrollado después de la experiencia de gamificación realizada con el Escape Room. Podemos destacar que en dicho entregable se obtuvo una calificación media de un 9,2 sobre 10 puntos, siendo unos de los entregables con nota media de calificación más alta. Sabiendo que la nota media de la asignatura es de 7,5 , entendemos que la experiencia de gamificación es adecuada dentro del modelo de aprendizaje utilizado y que les ayudó a retener conceptos de forma más lúdica y motivadora.

\section{Discusión y conclusiones}

Este estudio indaga sobre el impacto que ha tenido una experiencia de aprendizaje digital, utilizando el modelo de Escape Room para así poder comprobar su efecto sobre el alumno, así como analizar la satisfacción del mismo, y por último entender la adecuación del modelo de aprendizaje basado en un entorno gamificado para retener los conceptos y teoría propuestos en el aula. 
Los resultados presentados en este trabajo han permitido analizar estos tres objetivos inicialmente planteados. Los estudiantes han comprendido los contenidos trabajados, percibiéndose esta estrategia metodológica, como relevante para generar un aprendizaje significativo (Pegalajar, 2021) ya que en la gran mayoría han coincidido que el ejercicio les ha permitido mejorar y ampliar sus conocimientos en los materiales propuestos. Posiblemente, debido a que el estudiante se ha divertido e implicado (Borrego et al., 2017; Eukel et al., 2017) durante la experiencia, lo que incide en un aumento de la motivación y desempeño general en la asignatura (Cuevas Monzonís et al., 2021). No se han promovido emociones negativas, como nerviosismo o ansiedad, en contra de lo propuesto por Sierra Daza \& Fernández-Sánchez (2019) en una experiencia basada en un Escape room. Esto quizás, se relaciona con la percepción del estudiantado de que la experiencia ha estado bien diseñada y que el docente ha ofrecido retroalimentación continuado durante la realización de la actividad. Por último, se ha podido analizar la adecuación de dicho ejercicio a las metodologías impartidas en la docencia del aula, dado que el alumno ha presentado altos índices de retención de conocimiento y de satisfacción en la actividad.

Si bien es cierto que los tres objetivos se han cumplido de forma satisfactoria, cabe argumentar que la tecnología y la interacción entre los estudiantes durante el experimento, ha sido clave en la ejecución y compleción de la actividad. Es sabido que, a lo largo de la evolución de la educación en las últimas décadas, se han podido aprovechar las tecnologías para desarrollar nuevas formas de educar (Cloete, 2017). No solo la tecnología ha permitido un mayor acceso a diferentes recursos, sino que ha sido una herramienta indispensable en los últimos años a causa de la pandemia global para sociedades avanzadas (Daniel, 2020). Pero la tecnología ya no es la única herramienta esencial en el diseño de un modelo educativo, sino que las experiencias están tomando cada vez un mayor papel en el mundo educativo (Dede, 2009). La experiencia aquí presentada no es más que una primera aproximación a un modelo inmersivo de educación, y muchos estudios demuestran que aún estamos en una etapa de conceptualización de dichas tecnologías y usos (Boejen \& Grau, 2011; Hardie et al., 2020) .

Asimismo, se demuestra que no sólo es importante el modelo o metodología educativa empleada en la actividad, sino que también juega un papel clave el medio o contexto en el que se desarrolla la actividad de carácter educativo.

Se concluye que la experiencia de un aprendizaje basado en un juego por medio de un Escape room, ha sido positiva incidiendo en la motivación y mejora del aprendizaje del alumnado. Pero a pesar de todos los indicadores positivos en este primer nivel, también se destaca que el alumno desafortunadamente no se ha sentido completamente inmerso en la actividad, y se demuestra en varios de los ítems de una de las dimensiones. Dicho efecto seguramente se da a causa del medio estático en el que se presenta (Scholz \& Smith, 2016).

Si bien es cierto que una experiencia digital mejora el acceso a recursos educativos, así como juega un papel crítico en la sociedad de la información (Wikramanayake, 2005), desarrollar nuevos modelos educativos inmersivos pretenden dar un valor añadido al modo en el que se le transmiten dichos conocimientos al estudiante. Es por ello que no solo se propone futuros trabajos para profundizar en la incidencia del aprendizaje y emociones de las experiencias de gamificación en un aprendizaje basado en experiencias, sino también explorar posibles tecnologías o medios que 
ayuden a que la experiencia sea más inmersiva para el usuario, ya que dichas investigaciones o experimentos podrían ayudar a explorar la interacción entre, un estudiante cada vez más acostumbrado a la tecnología y experiencias digitales inmersivas para la educación. Esto nos permitirá a su vez, poder abordar de forma mucho más holística la educación en nuestra sociedad.

\section{Referencias}

Ariza, M. R. (2010). El Aprendizaje Experiencial Y Las Nuevas Demandas Formativas. Revista de Antropología Experimental, 8, 89-102.

Armstrong, M. B., \& Landers, R. N. (2018). Gamification of employee training and development. International Journal of Training and Development, 22(2), 162-169. https://doi.org/10.1111/IJTD.12124

Belmas, E. (2021). The Origins of the Gamification Process: The case of Pre-industrial Societies. The Gamification of Society, 47-65. https://doi.org/10.1002/9781119821557.CH3

Bencsik, A., Mezeiova, A., Learning, B. S.-I. J. of, \& 2021, U. (2021). Gamification in Higher Education (Case Study on a Management Subject). Ij/ter.Org. http://www.ijlter. org/index.php/ijlter/article/view/3649

Bilro, R. G., Loureiro, S. M. C., \& Angelino, F. J. de A. (2021). The Role of Creative Communications and Gamification in Student Engagement in Higher Education: A Sentiment Analysis Approach. Journal of Creative Communications. https://doi. org/10.1177/0973258621992644

Boejen, A., \& Grau, C. (2011). Virtual reality in radiation therapy training. Surgical Oncology, 20(3), 185-188. https://doi.org/10.1016/J.SURONC.2010.07.004

Borrego, C., Fernández, C., Blanes, I., \& Robles, S. (2017). Room escape at class: Escape games activities to facilitate the motivation and learning in computer science. JOTSE, ISSN-e 2013-6374, Vol. 7, No. 2, 2017 (Ejemplar Dedicado a: 9th International Conference on University Teaching and Innovation (CIDUI): Learning and Teaching Innovation Impacts), Págs. 162-171, 7(2), 162-171. https://dialnet.unirioja.es/servlet/articulo?codigo $=6119702 \&$ info $=$ resumen\&idioma $=$ ENG

Bulás Montoro, M., Ramírez Camacho, A. L., \& Corona Galindo, M. G. (2020). Relevancia de las competencias emocionales en el proceso de enseñanza aprendizaje a nivel de posgrado. Revista de Estudios y Experiencias En Educación, 19(39), 57-73. https://doi.org/10.21703/rexe.20201939bulas4

Chiang, P., And, G. C.-I. J. of M. R., \& 2021, U. (2021). Escape Rooms as a method of teaching Non-technical Skills: A Narrative Review. Mdpub.Net. http://www.mdpub. net/?mno=36712

Cloete, A. L. (2017). Technology and education: Challenges and opportunities. HTS Teologiese Studies / Theological Studies, 73(4). https://doi.org/10.4102/HTS. $\vee 7314.4589$ 
Cohen, T., Griggs, A., ... F. K.-J. of P., \& 2021, undefined. (2021). Advancing team cohesion: Using an escape room as a novel approach. Journals.Sagepub.Com, 26(3), 126-134. https://doi.org/10.1177/25160435211005934

Contreras, G., Escobar, J., Cepa, C., \& Fernández, I. (2021). The Role of Games Through Gamification in Higher Education. https://doi.org/10.12988/ces.2021.91675

Cuevas Monzonís, N., Cívico Ariza, A., Gabarda Méndez, V., \& Colomo Magaña, E. (2021). Percepción del alumnado sobre la gamificación en la educación superior. ReiDoCrea: Revista Electrónica de Investigación Docencia Creativa. https://doi. org/10.30827/DIGIBUG.66757

Daniel, S. J. (2020). Education and the COVID-19 pandemic. Prospects, 49(1-2), 9196. https://doi.org/10.1007/S11125-020-09464-3

Davis, K., Lo, H. ying, Lichliter, R., Wallin, K., Elegores, G., Jacobson, S., \& Doughty, C. (2021). Twelve tips for creating an escape room activity for medical education. Medical Teacher. https://doi.org/10.1080/0142159X.2021.1909715

Dede, C. (2009). Immersive interfaces for engagement and learning. Science, 323(5910), 66-69. https://doi.org/10.1126/SCIENCE.1167311

Eukel, H. N., Frenzel, J. E., \& Cernusca, D. (2017). Educational Gaming for Pharmacy Students - Design and Evaluation of a Diabetes-themed Escape Room. American Journal of Pharmaceutical Education, 81(7). https://doi.org/10.5688/AJPE8176265

Farber, M. (2020). Global perspectives on gameful and playful teaching and learning. doi:10.4018/978-1-7998-2015-4

Friedrich, C., Teaford, H., Taubenheim, A., Boland, P., \& Sick, B. (2019). Escaping the professional silo: an escape room implemented in an interprofessional education curriculum. Journal of Interprofessional Care, 33(5), 573-575. https://doi.org/10.108 O/13561820.2018.1538941

Hardie, P., Darley, A., Carroll, L., Redmond, C., Campbell, A., \& Jarvis, S. (2020). Nursing \& Midwifery students' experience of immersive virtual reality storytelling: An evaluative study. BMC Nursing, 19(1). https://doi.org/10.1186/S12912-020-00471-5

Huang, B., Hew, K. F., \& Lo, C. K. (2018). Investigating the effects of gamification-enhanced flipped learning on undergraduate students' behavioral and cognitive engagement. Https://Doi.Org/10.1080/10494820.2018.1495653, 27(8), 1106-1126. https:// doi.org/10.1080/10494820.2018.1495653

Kalogiannakis, M., Papadakis, S., \& Zourmpakis, A. I. (2021). Gamification in science education. A systematic review of the literature. Education Sciences, 11(1), 1-36. https://doi.org/10.3390/educsci11010022

Kaul, V., Morris, A., Chae, J., Town, J., Chest, W. K.-, \& 2021, undefined. (n.d.). Delivering a novel medical education "Escape Room" at a national scientific conference-first live, then pivoting to remote learning due to COVID19. Elsevier. Retrieved September 20, 2021, from https://www.sciencedirect.com/science/article/pii/ S0012369221009041 
Khan, T. A., \& Zhao, X. (2021). Perceptions of Students for a Gamification Approach: Cities Skylines as a Pedagogical Tool in Urban Planning Education. Springer, Cham. https://doi.org/10.1007/978-3-030-85447-8_64

Kolb, A. Y., \& Kolb, D. A. (2017). Learning Styles and Learning Spaces: Enhancing Experiential Learning in Higher Education. Https://Doi-Org.Recursos.Biblioteca. Upc.Edu/10.5465/Am/e.2005.17268566, 4(2), 193-212. https://doi.org/10.5465/ AMLE.2005.17268566

Liu, T., and, M. L.-I. J. of E. R., \& 2021, undefined. (2021). Sports gamification: Evaluation of its impact on learning motivation and performance in higher education. Mdpi. Com, 18. https://doi.org/10.3390/ijerph18031267

López, H., \& Zuluaga, C. (2016). El modelo de aprendizaje experiencial como alternativa para mejorar el proceso de aprendizaje en el aula. Ánfora, 23 (41)(aprendizaje experiencial), 37-54. http://www.redalyc.org/pdf/3578/357848839002.pdf

Montero Curiel, M. (2010). El Proceso de Bolonia y las nuevas competencias. Tejuelo, 9(9), 19-37. http://www.doaj.org/doaj?func=abstract\&amp;id=619478

Nicholson, S. (2015). Peeking Behind the Locked Door: A Survey of Escape Room Facilities. White Paper, 1-35. http://scottnicholson.com/pubs/erfacwhite.pdf

Nicholson, S. (2016). Peeking Behind the Locked Door: A Survey of Escape Room Facilities. White Paper. http://scottnicholson.com/pubs/erfacwhite.pdf

Ouriques, L., Castro, D., ... D. O.-... : P. of the, \& 2021, U. (2021). A Systematic Mapping of Gamification in Higher Education. Abse/-Ojs-Ttu.TdI.Org. https://absel-ojs-ttu.tdl. org/absel/index.php/absel/article/view/3293

Parra-González, M. E., \& Segura-Robles, A. (2019). Traducción y validación de la escala de evaluación de experiencias gamificadas (GAMEX). Bordón. Revista de Pedagogía, 71(4), 87-99. https://doi.org/10.13042/BORDON.2019.70783

Pegalajar Palomino, M. del C. (2021). Implicaciones de la gamificación en Educación Superior: una revisión sistemática sobre la percepción del estudiante. Revista de Investigación Educativa, 39(1), 169-188. https://doi.org/10.6018/RIE.419481

Pérez-Manzano, A., \& Almela-Baeza, J. (2018). Gamificación transmedia para la divulgación científica y el fomento de vocaciones procientíficas en adolescentes. Grupo Comunicar, 26(55), 93-103. https://doi.org/10.3916/C55-2018-09

Pfeifer, M., Völker, B., Böttcher, S., Köhler, S., \& Scholl, P. M. (2021). Teaching Embedded Systems by Constructing an Escape Room. SIGCSE 2021 - Proceedings of the 52nd ACM Technical Symposium on Computer Science Education, 1103-1109. https:// doi.org/10.1145/3408877.3432485

Rodrigues, L. F., Oliveira, A., \& Rodrigues, H. (2019). Main gamification concepts: A systematic mapping study. Heliyon, 5(7), e01993. https://doi.org/10.1016/j.heliyon.2019.e01993 
Ross, R., \& Bell, C. (2019). Turning the classroom into an escape room with decoder hardware to increase student engagement. IEEE Conference on Computatonal InteIligence and Games, CIG, 2019-Augus, 1-4. https://doi.org/10.1109/CIG.2019.8848020

Scholz, J., \& Smith, A. N. (2016). Augmented reality: Designing immersive experiences that maximize consumer engagement. Business Horizons, 59(2), 149-161. https:// doi.org/10.1016/J.BUSHOR.2015.10.003

Sierra Daza, M. C., \& Fernández-Sánchez, M. R. (2019). Gamificando el aula universitaria. Análisis de una experiencia de Escape Room en educación superior. Revista de Estudios y Experiencias En Educación, 18(36), 105-115. https://doi.org/10.21703/ REXE.20191836SIERRA15

Wikramanayake, G. N. (2005). Impact of Digital Technology on Education. Conference Paper · August 2005. https://www.researchgate.net/publication/216361364_Impact_of_Digital_Technology_on_Education

Xi, N., \& Hamari, J. (2019). Does gamification satisfy needs? A study on the relationship between gamification features and intrinsic need satisfaction. International Journal of Information Management, 46, 210-221. https://doi.org/10.1016/J.IJINFOMGT.2018.12.002 


\section{Propuesta Experimental para Estudiar el Movimiento Oscilatorio de un Cuerpo Rígido no Homogéneo Usando Celulares Inteligentes}

\section{Barber, Matías}

Universidad de Buenos Aires

mbarber@fi.uba.ar

\section{Chiabrando, Laura}

Universidad de Buenos Aires

Ichiabra@fi.uba.ar

\section{Duplaá, María Celeste}

Universidad de Buenos Aires

cduplaa@fi.uba.ar

\section{Rivas Rojas, Patricia}

ORCID 0000-0001-7800-0666

privas@fi.uba.ar 


\title{
PROPUESTA EXPERIMENTAL PARA ESTUDIAR EL MOVIMIENTO OSCILATORIO DE UN CUERPO RÍGIDO NO HOMOGÉNEO USANDO CELULARES INTELIGENTES
}

\author{
Barber, Matías \\ Chiabrando, Laura \\ Duplaá, María Celeste \\ Rivas Rojas, Patricia
}

\section{Resumen}

Las prácticas experimentales pueden ser modernizadas y ampliadas empleando celulares con tecnología inteligente, dado que existen aplicaciones gratuitas que hacen uso de los sensores incorporados en estos dispositivos para medir distintos parámetros físicos. Considerando la disponibilidad y versatilidad de los celulares como instrumentos de medición, es posible diseñar nuevas experiencias que utilicen elementos cotidianos para proponer un montaje que sea propicio en su implementación. Este interés se vio acentuado por la situación epidemiológica debido al COVID-19 que conllevó a que los cursos de Física 1 en la Facultad Ingeniería de la Universidad de Buenos Aires se dictaran en modalidad virtual desde el primer cuatrimestre del 2020. Repensar las prácticas de enseñanza y en particular, considerar opciones para incluir prácticas experimentales que se puedan realizar fuera del ámbito de los laboratorios de enseñanza motivó este trabajo. En éste se describe el diseño de una práctica para determinar el radio de giro baricéntrico de un cuerpo rígido no homogéneo que realiza pequeñas oscilaciones, utilizando la aplicación Phyphox para registrar la velocidad angular en función del tiempo. Se presenta el análisis de los datos y se proponen dos alternativas para validar el diseño experimental. Se considera que esta propuesta metodológica es una innovación para la toma de datos y su posterior análisis, que pueden ser aplicados tanto para compensar las prácticas presenciales en una cursada con modalidad a distancia, como para diseñar prácticas experimentales con un nuevo enfoque.

\section{Palabras clave}

Actividad experimental, cuerpo rígido, movimiento oscilatorio, nivel universitario, celulares inteligentes. 


\section{Introducción}

A partir del primer cuatrimestre del 2020 los cursos presenciales de Física 1 en la Facultad de Ingeniería de la Universidad de Buenos Aires se dictan con modalidad virtual debido al aislamiento preventivo social y obligatorio debido al COVID-19 (decreto del Poder Ejecutivo Nacional $N^{\circ}$ 297/2020). En este contexto fue necesario repensar las prácticas de enseñanza y estructurarlas en el paradigma de aprendizaje a distancia (Aveleyra y Rossi, 2021).

En la búsqueda de alternativas para adaptar la cursada a esta nueva modalidad, se encuentra un particular interés por considerar opciones para modernizar las prácticas de los laboratorios de enseñanza e incluir experiencias que se puedan realizar fuera de ellos.

Los teléfonos móviles inteligentes tienen sensores que pueden utilizarse como instrumentos de medición y de esta manera incorporarse en el aula como laboratorios activos para realizar algunas experiencias pertinentes para los contenidos de física básica universitaria. Diversas propuestas didácticas se han presentado apostando a que los estudiantes desarrollen competencias, habilidades y actitudes necesarias para implementar el método científico (Gibbs, Viau y Ferreira, 2019; Kaps, Splith y Stallmach, 2021; Kuhn y Vogt, 2013).

El estudio de movimientos oscilatorios ha captado particular atención, con propuestas que incluyen distintas alternativas en el montaje y sensores empleados. Lopez y Arias (2019) presentan una exhaustiva revisión de los trabajos publicados en este tema en Iberoamérica entre 2008 y 2018. Los autores de esta revisión señalan que la mayoría de los artículos se enfocan en el uso instrumental de tecnología y en cambio encuentran pocos reportes sobre el impacto del uso de celulares en el aula como herramienta para la enseñanza de fenómenos físicos.

En la literatura se encuentran trabajos experimentales que hacen uso de los celulares inteligentes para describir características del movimiento de cuerpos rígidos (velocidad, aceleración, conservación de energía, etc.). En cambio, en este artículo se propone determinar el radio de giro baricéntrico de un objeto no homogéneo, que es un parámetro característico del cuerpo rígido, planteando como respaldo dos posibles métodos de validación.

Para utilizar los sensores como instrumentos de medición existen distintas aplicaciones específicamente orientadas a la enseñanza de la Física, que se pueden descargar de forma gratuita para los sistemas operativos más comunes. Entre ellas se destacan Phyphox (https://phyphox.org) y Physics Toolbox (https://www.vieyrasoftware.net) por la gran cantidad de sensores del celular que usan. Para llevar a cabo esta propuesta se elige Phyphox, dado que promueve el trabajo colaborativo y posee un amplio repositorio de datos y experiencias. Al mismo tiempo, y siguiendo con la idea de emplear herramientas libres y gratuitas, para el procesamiento de los datos obtenidos se usa el software SciDAVis (http://scidavis.sourceforge.net).

Ramírez Castro (2019) publica un detallado documento en el que presenta diversos experimentos que se pueden hacer en los ámbitos clásicos de la física organizados por temas y en el que indica los sensores y aplicaciones que utiliza cada experimento. En todas las experiencias descritas se hace referencia a los conceptos involucrados y en varios de ellos se hace una descripción del marco teórico. 
A continuación, se presenta el diseño de una práctica experimental que puede proponerse en un curso virtual, cuyo objetivo es determinar el radio de giro baricéntrico de un cuerpo rígido no homogéneo que realiza un movimiento armónico simple en el plano vertical. El mismo montaje experimental puede ser adaptado para estudiar el movimiento oscilatorio de un péndulo simple.

\section{Descripción de la experiencia}

En esta sección se presenta el contexto para el cual se planifica la práctica experimental, se describe el modelo físico, se detalla el diseño experimental y se analizan los datos obtenidos. Finalmente se proponen dos alternativas para validar los resultados.

\section{Contexto}

La experiencia está planificada para cursos de Física en el nivel universitario donde se estudia el movimiento armónico simple de cuerpos rígidos. Esto surge como una propuesta para un curso en modalidad virtual, pero puede implementarse para modernizar las prácticas realizadas tradicionalmente en modalidad presencial.

Se sugiere haber realizado previamente una introducción a teoría de la medida y a mecánica de movimientos armónicos simples, incluyendo el trabajo experimental de péndulo simple para la determinación de la aceleración de la gravedad.

\section{Modelo del movimiento armónico simple para un cuerpo rígido}

La suma de torques de las fuerzas que actúan sobre un cuerpo rígido bidimensional de masa $M$ que realiza pequeñas oscilaciones en el plano vertical alrededor de un eje fijo "O" es:

$$
-M \cdot g \cdot d \cdot \operatorname{sen}(\alpha)=I_{O} \cdot \gamma_{(1)}
$$

Donde es la aceleración de la gravedad, es la distancia del punto "O" al centro de masa (CM) del cuerpo rígido, es el momento de inercia del objeto respecto de "O" y es la aceleración angular.

Considerando que el objeto realiza pequeñas oscilaciones, se encuentra que la pulsación es:

$$
\omega=\sqrt{\frac{M \cdot g \cdot d}{I_{0}}}
$$

El desarrollo teórico que deriva en (2) se detalla en el Anexo. El momento de inercia respecto del centro de masa de un objeto () en función del radio de giro baricéntrico () es:

$$
I_{C M}=k^{2} \cdot M
$$


Y, por el teorema de Steiner, se puede escribir el radio de giro baricéntrico como:

$$
k=\sqrt{\frac{g \cdot d}{\omega^{2}}-d^{2}}
$$

Si se aplica este modelo a una partícula que realiza pequeñas oscilaciones alrededor de un eje fijo "O" que se encuentra a una distancia $L$ (péndulo simple de longitud reducida), se puede considerar que, por lo tanto se obtiene de (4) que para esta situación la pulsación angular es:

$$
\omega^{\prime}=\sqrt{\frac{g}{L}}
$$

Comparando la pulsación obtenida para el modelo de cuerpo rígido (2) y para el modelo de partícula (5) se puede deducir que éstos son sincrónicos si se cumple que:

$$
L=\frac{k^{2}}{d}+d
$$

En la Figura 1 se muestra el diagrama del cuerpo rígido y en forma comparativa el del péndulo simple de longitud reducida. Se indican los puntos de suspensión, el centro de masa del cuerpo rígido y se representa con un círculo el anillo equivalente cuyo radio corresponde al radio de giro baricéntrico.

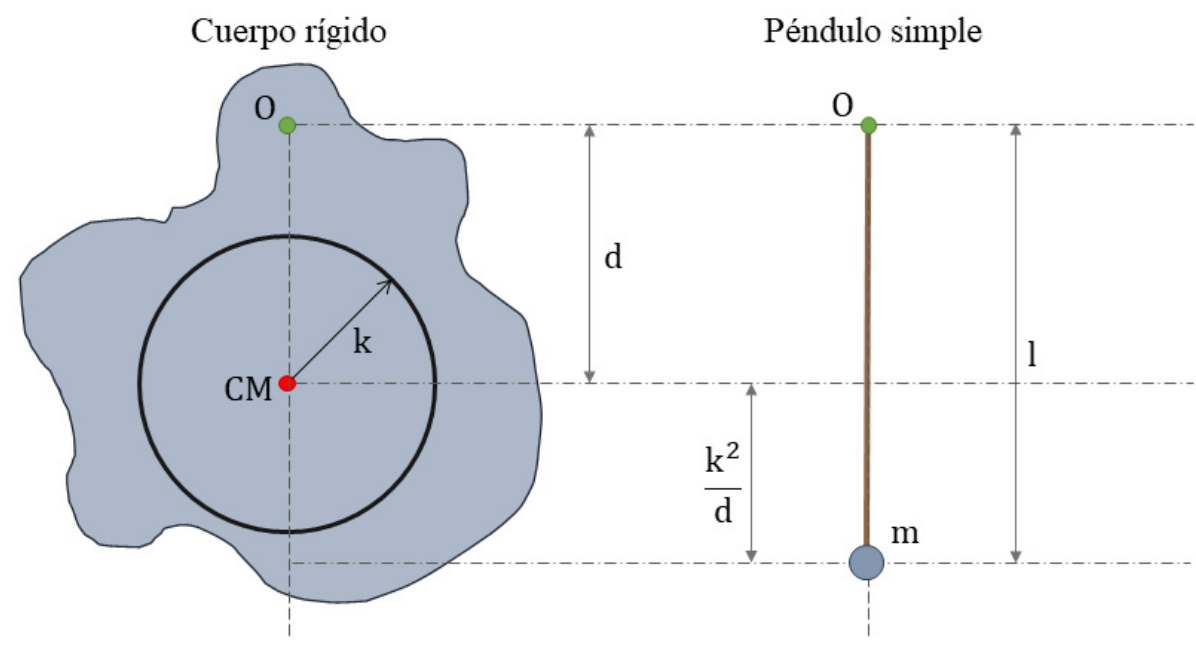

Figura 1. Diagrama de un cuerpo rígido no homogéneo y del péndulo simple de longitud equivalente. 


\section{Diseño experimental}

Para el diseño y montaje experimental se propone el uso de elementos cotidianos y de fácil acceso. Los elementos necesarios son: un objeto bidimensional (cartón, madera, lámina acrílica o chapa metálica), una varilla rígida que actúe como eje (aguja de tejer o palo de brochette), hilo, un objeto pesado que actúe como plomada, celular y material para sujetarlo (funda plástica, cinta adhesiva, etc).

El cuerpo rígido está compuesto por el objeto bidimensional y el celular sujetado al mismo. La funda plástica recubre al celular y se adhiere al objeto con la cinta. El objeto debe tener al menos dos orificios en posiciones elegidas al azar para poder suspenderse con la varilla rígida. En la Figura 2 se muestra como ejemplo el dispositivo utilizado.

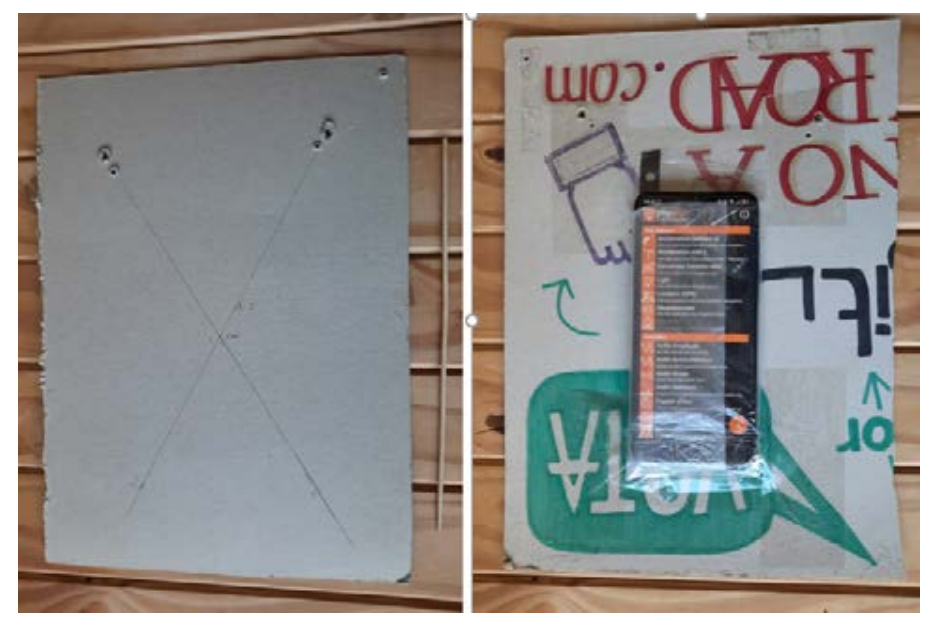

Figura 2. Frente (izquierda) y dorso (derecha) del dispositivo utilizado como cuerpo rígido.

\section{Mediciones}

Para identificar el centro de masa (CM) del cuerpo rígido se suspende al cuerpo rígido de uno de los orificios y con la plomada se traza la vertical sobre el objeto. Se repite el procedimiento para el otro orificio. La intersección de ambas rectas determina la ubicación del CM como muestra la Figura 2 (izquierda), la distancia entre este punto y el de suspensión se denomina d1. Por último, utilizando la función giroscopio de la aplicación Phyphox, se aparta el cuerpo del equilibrio y se mide la velocidad angular en función del tiempo para pequeñas oscilaciones en el plano vertical.

Es importante destacar que la función giróscopo (disponible tanto en el Phyphox como en el Suite Toolbox) permite medir directamente la velocidad angular en torno a cada uno de los ejes cartesianos como se indica en la Figura 3. 


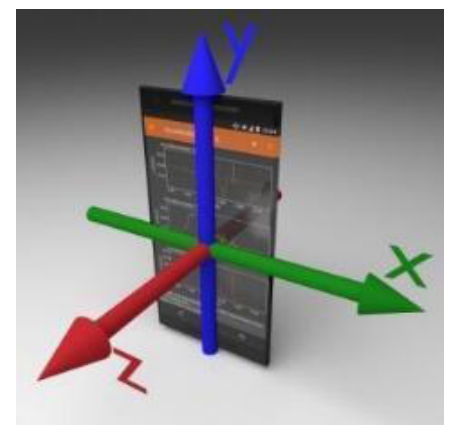

Figura 3. Sistema de coordenadas utilizado por la aplicación Phyphox (https://phyphox.org).

\section{Análisis de las mediciones}

Exportar al programa de análisis los datos obtenidos de la velocidad angular en función del tiempo. Por el montaje solo es de interés la componente " $z$ " de la velocidad angular, como queda implícito observando las Figuras 2 y 3 , dado que el objeto oscila en el plano vertical. Al graficarlos se debe identificar una región representativa de un movimiento armónico simple, para la cual se pueda despreciar el efecto del amortiguamiento consecuencia de la fricción del cuerpo con el aire y en los distintos puntos de suspensión.

Para ajustar la curva medida, se define una función personalizada tipo sinusoidal, donde los parámetros de ajuste corresponden a la amplitud (), la frecuencia de pulsación $(\omega)$ y el desfasaje inicial $(\varphi)$. Se sugiere inicializar los parámetros de ajuste en función de la observación de la curva experimental (identificar la amplitud y el período para determinar la frecuencia de pulsación). La curva obtenida y su correspondiente ajuste se muestran en la Figura 4. En este gráfico, los puntos representan el registro experimental y la curva continua roja el ajuste de la función sinusoidal.

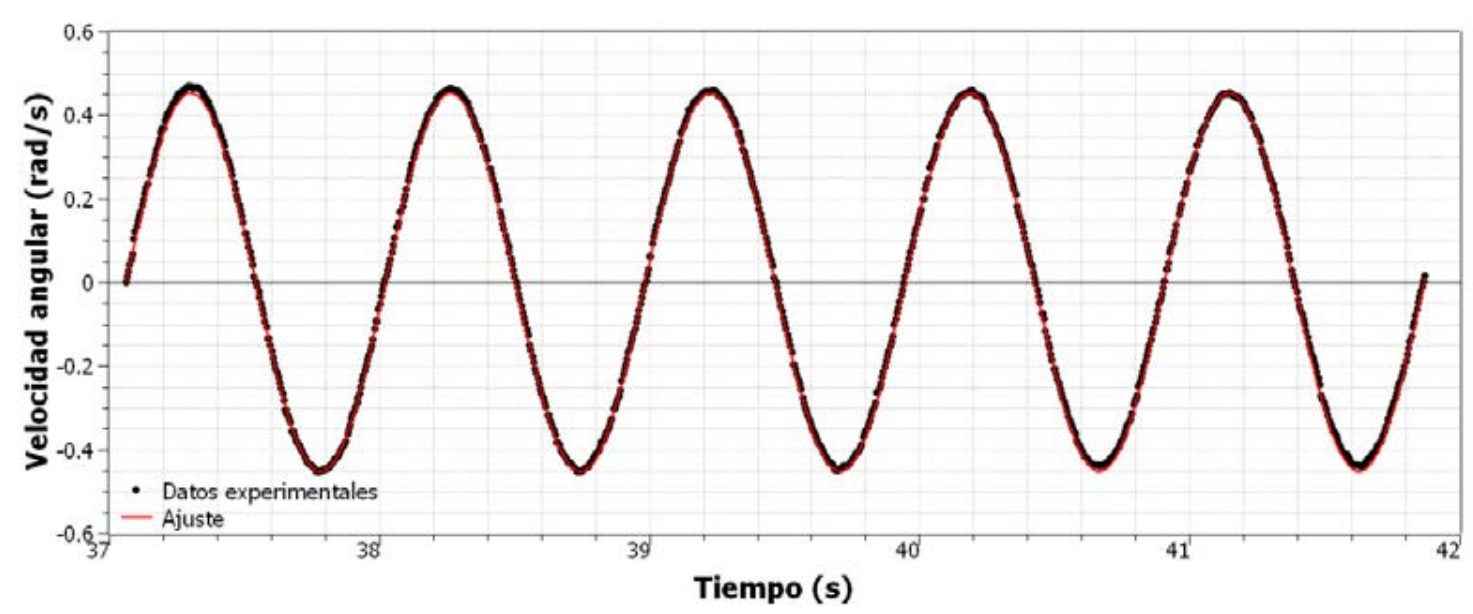

Figura 4. Velocidad angular en función del tiempo

Los datos experimentales, los parámetros de ajuste y el resultado obtenido para el radio de giro baricéntrico a partir de la ecuación (4), se muestran en la Tabla 1. 


\begin{tabular}{|c|c|c|}
\hline Datos experimentales & Parámetros de ajuste & Resultados \\
\hline$d_{1}=(0,193 \pm 0,005) m$ & $\Omega_{0}=(0,4495 \pm 0,0003) s^{-1}$ & \\
$g=(9,8 \pm 0,1) \frac{m}{s^{2}}$ & $\omega=(6,5381 \pm 0,0003) s^{-1}$ & $k_{1}=(0,084 \pm 0,008) m$ \\
& $\varphi=(-3,56 \pm 0,01)$ & \\
& & \\
\hline
\end{tabular}

Tabla 1. Datos experimentales, parámetros de ajuste y radio de giro baricéntrico $\left(k_{1}\right)$.

Es importante señalar que la distancia d1 se determina con una regla milimetrada y que la aceleración de la gravedad se obtuvo previamente en una experiencia en la que se estudia el periodo de oscilación de un péndulo simple.

\section{Métodos de validación del modelo experimental}

Una opción consiste en repetir el procedimiento descrito previamente desde otro punto de suspensión. Los resultados obtenidos se presentan de manera comparativa en la Tabla 2.

Primera medida

$$
d_{1}=(0,193 \pm 0,005) m
$$$$
k_{1}=(0,084 \pm 0,008) m
$$

\section{Segunda medida}

$$
\begin{aligned}
& d_{2}=(0,135 \pm 0,005) m \\
& k_{2}=(0,080 \pm 0,005) m
\end{aligned}
$$

Tabla 2. Radio de giro baricéntrico para el cuerpo rígido calculado desde dos puntos de suspensión.

Otra opción es medir el periodo de oscilación de un péndulo simple cuya longitud corresponde a la longitud reducida y compararlo con el del cuerpo rígido. En este caso, hay que calcular la longitud del péndulo simple a partir de los datos obtenidos con la ecuación (6). Según los datos experimentales correspondientes a $d_{1}$ y $k_{1}$, la longitud reducida es $L_{1}=(0,23 \pm 0,02) m$

Utilizando una plomada y un hilo con esta longitud se mide con un cronómetro el tiempo de 5 oscilaciones para este sistema (este procedimiento es el mismo que se utiliza en la práctica experimental para determinar la aceleración de la gravedad). Finalmente, en la Tabla 3 se comparan el periodo del cuerpo rígido (determinado a partir de la pulsación angular obtenida del ajuste de los datos experimentales) y del péndulo simple de longitud reducida.

\begin{tabular}{|c|c|}
\hline Periodo del cuerpo rígido & Período del péndulo con longitud equivalente \\
\hline$T_{C R}=(0,96101 \pm 0,00009) s$ & $T_{P S}=(0,94 \pm 0,04) s$ \\
\hline
\end{tabular}

Tabla 3. Período del cuerpo rígido y del péndulo equivalente. 


\section{Resultados}

A partir de las mediciones realizadas con un teléfono inteligente, se obtuvo una curva que describe la dependencia temporal de la velocidad angular de un cuerpo bidimensional que oscila respecto de un eje. Estas mediciones fueron fácilmente analizadas en conjunto aprovechando un programa de análisis de datos.

En este trabajo se presenta una alternativa a la práctica tradicional para calcular el radio de giro baricéntrico de un cuerpo no homogéneo, obteniéndose para el cuerpo estudiado $k_{1}=(0,084 \pm 0,008) m$. Esta metodología pudo validarse repitiendo el procedimiento desde otro punto de suspensión, para el cual se obtuvo un valor comparable de $\mathrm{k}_{2}=(0,080 \pm 0,005) \mathrm{m}$.

Por otra parte, fue posible determinar el período de oscilación del cuerpo rígido, obteniendo $T_{C R}=(0,96101 \pm 0,00009) s$ y se encontró que era comparable al período del péndulo simple equivalente de longitud reducida $T_{P S}=(0,94 \pm 0,04)$ s. Se puede observar que la incerteza relativa analizando los datos obtenidos con el celular como instrumento de medición es 0,009\% mientras que empleando un cronómetro para medir el periodo de oscilación del péndulo equivalente es $4 \%$. Esto último corresponde a un enfoque tradicional que, a pesar de su simpleza, representa una metodología poderosa para validar esta propuesta.

Es de destacar que la mejora sustancial del método propuesto se debe a que aumenta significativamente la frecuencia de toma de datos y a que no intervienen las incertezas introducidas por el tiempo de reacción del experimentador, como ocurre en el método en el que se mide el período en forma manual. Además, analizar el volumen de datos proporcionados por el celular en conjunto, permite maximizar la información que puede ser extraída al comparar el sistema con el modelo físico propuesto.

\section{Discusión y conclusiones}

Se puso a prueba el montaje de un cuerpo rígido a partir de materiales accesibles y empleando como instrumento de medición un teléfono inteligente, partiendo de una práctica experimental contemplada en los contenidos de Física básica universitaria.

Esta actividad es una innovación para compensar las prácticas en los laboratorios de enseñanza en la virtualidad, así como también para modernizar las experiencias tradicionales. Aprovechar la disponibilidad de los sensores incluidos en los dispositivos móviles ofrece alternativas accesibles y de precisión para la toma de datos de parámetros físicos con fines educativos. La propuesta metodológica aquí realizada es sólo una muestra del alcance del uso de estos dispositivos como instrumentos de medición.

El diseño y las validaciones aquí presentadas pretenden conceptualizar parámetros característicos de un cuerpo rígido, que por lo general suelen quedar relegados a ser entidades abstractas. Como línea futura se propone evaluar la implementación de esta propuesta y su relevancia pedagógica. 


\section{Referencias}

Aveleyra, E. E. y Rossi, D. S. (2021). Aprender en la virtualidad. Revista Iberoamericana de Tecnología en Educación y Educación en Tecnología, Especial (28), [pp.] 403-408. Recuperado de https://teyet-revista.info.unlp.edu.ar/TEyET/article/view/1567/1210

Gibbs, H., Viau J. y Tintori Ferreira, A. (2019). Propuesta de actividades experimentales en las clases de física mediante el uso de teléfonos inteligentes. Revista de Enseñanza de la Física, 31(extra), [pp.] 359-367. Recuperado de https://revistas.unc. edu.ar/index.php/revistaEF/article/view/26592/28297

Kaps, A., Splith, T. y Stallmach, F. (2021). Implementation of smartphone-based experimental exercises for physics courses at universities. Physics Education, 56(3), [pp.] 1-9. Recuperado de https://iopscience.iop.org/article/10.1088/1361-6552/abdee2/pdf

Kuhn, J. y Vogt, P. (2013). Smartphones as experimental tools: Different methods to determine the gravitational acceleration in classroom physics by using everyday devices. European Journal of Physics Education, 4(1), [pp.] 16-27. Recuperado de http://www.eu-journal.org/index.php/EJPE/article/view/81/78

Lopez, V.J. y Arias, V. (2019). Aporte de una propuesta de enseñanza basada en aplicaciones móviles, para el aprendizaje del movimiento pendular y sistema masa resorte: Estado del arte. Latin American Journal of Science Education, 6(2), [pp.] 1-12. Recuperado de http://www.lajse.org/nov19/2019_22003_2.pdf

Patrinopoulos, M. y Kefalis, C. (2015). Angular velocity direct measurement and moment of inertia calculation of a rigid body using a smartphone. The Physics Teacher, 53(9), [pp.] 564-565. Recuperado de https://aapt.scitation.org/doi/ pdf/10.1119/1.4935774

Ramírez Castro, J.L. (2019). Experimentación en física con dispositivos móviles. Recuperado de http://creativecommons.org/licenses/by-sa/3.0/(Editorial).

\section{Anexo}

A partir de la suma de torques de las fuerzas que actúan sobre un cuerpo rígido bidimensional de masa $M$ que realiza pequeñas oscilaciones en el plano vertical alrededor de un eje fijo "O" se obtiene:

$-M \cdot g \cdot d \cdot \operatorname{sen}(\alpha)=I_{O} \cdot \gamma_{(\mathrm{A} 1)}$

donde es la aceleración de la gravedad, es la distancia del punto "O" al centro de masa (CM) del cuerpo rígido, es el momento de inercia del objeto respecto de "O" y es la aceleración angular.

Por definición, la aceleración angular es:

$\gamma=\frac{d^{2} \alpha}{d t^{2}}$. 
Considerando que el objeto realiza pequeñas oscilaciones, se cumple que:

$\operatorname{sen}(\alpha) \cong \alpha \cdot(\mathrm{A} 3)$

A partir de las ecuaciones (A2) y (A3), la ecuación de movimiento ( $A 1$ ) se puede escribir como:

$-M \cdot g \cdot d \cdot \alpha=I_{O} \cdot \frac{d^{2} \alpha}{d t^{2}} \cdot($ A 4$)$

Para esta ecuación diferencial de segundo orden se propone como solución que el apartamiento angular es:

$\alpha(t)=A \cdot \operatorname{sen}\left(\omega \cdot t+\alpha_{0}\right)$ (A5)

Y esta solución es válida sólo si la pulsación es:

$$
\omega=\sqrt{\frac{M \cdot g \cdot d}{I_{0}}} \text { (A6) }
$$

Considerando que el momento de inercia respecto del centro de masa de un objeto () en función el radio de giro baricéntrico () es:

$$
I_{C M}=k^{2} \cdot M \cdot(\mathrm{A} 7)
$$

Utilizando el teorema de Steiner, se puede escribir el momento de inercia respecto del eje de giro como

$$
I_{0}=\left(k^{2}+d^{2}\right) \cdot M \cdot(\mathrm{A} 8)
$$

Bajo estas consideraciones, el radio de giro baricéntrico es

$$
k=\sqrt{\frac{g \cdot d}{\omega^{2}}-d^{2}} \text {. }
$$

Si se aplica este modelo a una partícula que realiza pequeñas oscilaciones alrededor de un eje fijo "O" que se encuentra a una distancia $L$ (péndulo simple de longitud reducida), se puede considerar que, por lo tanto se obtiene de la ecuación (A9) que para esta situación la pulsación angular es:

$$
\omega^{\prime}=\sqrt{\frac{g}{L}} \text { (A10) }
$$

Comparando la pulsación obtenida para el modelo de cuerpo rígido (A6) y para el modelo de partícula (A10) se puede deducir que éstos son sincrónicos si se cumple que:

$$
L=\frac{k^{2}+d^{2}}{d}
$$

Lo cual es equivalente a:

$$
L=\frac{k^{2}}{d}+d \text {. }
$$


Tdic na Formação em Educação para o Desenvolvimento Sustentável em Projetos Envolvendo Objetivos do Desenvolvimento Sustentável

\section{Leopoldo Mercado, Luis Paulo}

orcid.org/0000-0001-8491-4080

luispaulomercado@gmail.com 


\title{
TDIC NA FORMAÇÃO EM EDUCAÇÃO PARA O DESENVOLVIMENTO SUSTENTÁVEL EM PROJETOS ENVOLVENDO OBJETIVOS DO DESENVOLVIMENTO SUSTENTÁVEL
}

\author{
Leopoldo Mercado, Luis Paulo
}

orcid.org/0000-0001-8491-4080

luispaulomercado@gmail.com

\section{Resumo}

O artigo apresenta experiência com a Agenda 2030 envolvendo a inclusão dos Objetivos de Desenvolvimento Sustentável (ODS) em intervenções didáticas com letramentos enfocando tecnologias digitais da informação e comunicação (TDIC) e Educação para o Desenvolvimento Sustentável (EDS) na formação de professores da educação básica. Apresenta experiência de construção de projetos integrando conteúdos dos ODS no currículo, como estratégia didática para explorar a EDS envolvendo construção autoral com múltiplas linguagens na produção de sequências didáticas em padlets. A metodologia se caracterizou como pesquisa experiencial com produção de material didático em projetos ODS para EDS, experimentadas por futuros professores utilizando TDIC nas suas práticas pedagógicas. As etapas da pesquisa foram: estudo teórico/bibliográfico; construção de Projetos ODS voltados para a EDS; formação de professores para uso de TDIC em projetos de EDS; criação de sequências didáticas para utilizar ODS e análise dos dados dos projetos ODS.

\section{Palabras-chaves}

Educação para o Desenvolvimento Sustentável, Formação de Professores; Letramento Digital; Objetos do Desenvolvimento Sustentável. 


\section{Introdução}

A Agenda 2030, compromisso mundial assumido em 2015, reconhece que a erradicação da pobreza em todas as suas formas e dimensões é o maior desafio global e um requisito indispensável para o desenvolvimento sustentável (Unesco, 2015).

A Agenda 2030 envolve um conjunto de 17 Objetivos do Desenvolvimento Sustentável (ODS) e 167 metas universais e transformadoras, abrangentes, de longo alcance e centrado nas pessoas, comprometidas com o Desenvolvimento Sustentável (ONU, 2015), visando assegurar os direitos humanos, acabar com a pobreza, lutar contra a desigualdade e a injustiça, alcançar a igualdade de gênero e o empoderamento de mulheres e meninas e enfrentar os desafios dos tempos atuais (Unesco, 2015). Visam também criar condições para um crescimento inclusivo e economicamente sustentado, prosperidade compartilhada e trabalho decente para todos, tendo em conta os diferentes níveis de desenvolvimento e capacidades nacionais (ONU 2015).

As temáticas dos ODS (Figura 1), como sustentabilidate através da educação e estilo de vida sustentável, direitos humanos, igualdade de gênero, promoção da cultura de paz e não violência, cidadania global e valorização da diversidade cultural e da contribuição da cultura são propostos para serem trabalhados na Educação para o Desenvolvimento Sustentável (EDS).

Figura 1 - Objetivos de Desenvolvimento Sustentável
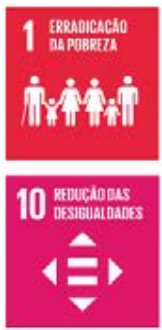
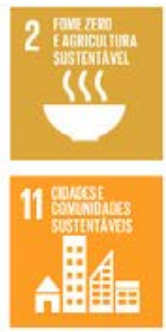
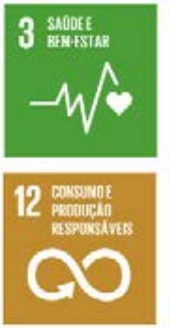
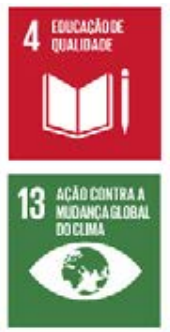
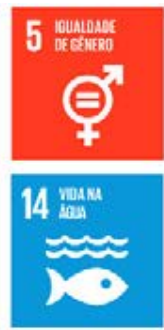

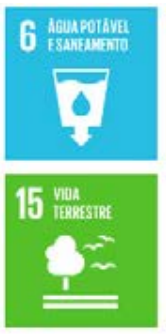

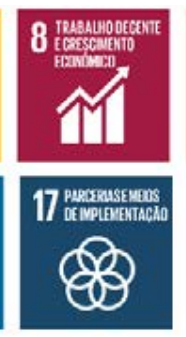

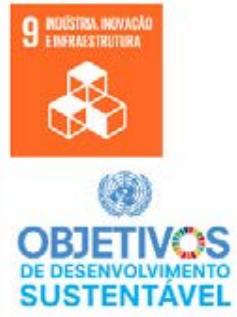

Fonte: ONU (2015)

A Agenda 2030, em seu ODS 4 confere ao ensino superior importante papel na formação de futuros professores para implementação dos ODS, incorporando-os nas inovações metodológicas e recursos das tecnologias digitais da informação e comunicação (TDIC) em contextos presencial, híbridos e online. As TDIC abrem amplas possibilidades para o progresso humano e desempenham "um papel facilitador ou de apoio, particularmente na criação de capacidades" (Sanchez et al, 2019, p. 6). O ODS 4 contempla indicadores de habilidades com TDIC e acessibilidade das escolas à internet com fins pedagógicos e o ODS 5 prevê o aumento do uso de TDIC para promover o empoderamento das mulheres.

Esta experiência de inovação curricular foi realizada na disciplina Educação e Tecnologias da Informação e Comunicação do curso de Pedagogia da Universidade Federal de Alagoas, Brasil e teve como objetivos desenvolver metodologias inovadoras para uso de TDIC em práticas pedagógicas integrando ODS no currículo na perspectiva da EDS na educação básica. Para atingir esse objetivo, os futuros professores elaboraram material pedagógico de suporte ao trabalho do professor, voltado para EDS no processo ensino-aprendizagem com produção de sequências 
didáticas e trilhas de aprendizagem envolvendo projetos ODS, utilizando TDIC visando práticas pedagógicas renovadas.

Esta experiência envolveu a inclusão dos ODS no currículo da formação de professores para educação básica para integrar os princípios e valores de sustentabilidade nos contextos educacionais e formativos, atendendo a Agenda 2030. Apresenta intervenções didáticas envolvendo TDIC e EDS na construção de projetos autorais integrando os ODS no currículo.

\section{Método/Descrição da Experiência}

O estudo envolveu pesquisa experiencial (Bates, 2016; Miccoli, 2010 e 2014) na produção de sequências didáticas em projetos ODS utilizando TDIC nas suas práticas pedagógicas. A formação prática é uma maneira de capacitar estudantes em aprender fazendo, enfatiza a aprendizagem em contextos reais em laboratórios, oficinas, formação prática, aprendizagem cooperativa (Bates, 2016).

A aprendizagem centrada no estudante, envolvendo prática experimental parte da convicção de que os sujeitos aprendem fazendo e interagindo. Miccoli (2014, p. 19) defende a "a importância das experiências de aprendizagem em contextos formais informais, para uma compreensão ampliada do processo. De acordo com Miccoli (2010), a experiência pode ser um construto e unidade de análise daquilo que acontece, podendo ser uma via de acesso para a compreensão da complexidade de eventos em salas de aula. Chegar a este construto remonta a um interesse por compreender 0 processo de aprendizagem sob o ponto de vista daqueles que o vivenciam.

As turmas foram divididas em grupos e cada grupo criou o site padlet do projeto ODS (Figura 2) com diferentes materiais didáticos pesquisados na internet, trabaIhados em sequências didáticas propostas e desenvolvidas com objetivo de aprofundar os conhecimentos necessários para pesquisar, selecionar e fundamentar o uso das TDIC no desenvolvimento de um ambiente de aprendizagem.

\section{Sites padlets produzidos - Pedagogia Ufal 2020.1 e 2020.2}

Pobreza em Evidência - https://padlet.com/anaeisabelle/ddgsyww3220olj2u

Fome O: Agricultura Sustentável X Nutrição: https://padlet.com/Lillity/qO28ytjofer6m9y8 Educação de Qualidade: https://padlet.com/ufalclaudiatamara/gemjn6xkyj2us085 Igualdade de Gênero e Empoderamento: https://padlet.com/perfilpad/tgoawk62qh6juvc1

Energizando o Mundo: https://padlet.com/pa_calet/b7ap8u2va8ax3bva Industrialização Inovadora: https://padlet.com/jaquersana/eorczzpjkszwc69 Cidades e Comunidades Sustentáveis: https://padlet.com/ufaletdic/I1r9va94rO4hj4n4 Assegurar Padrões de Produção e de Consumo Sustentáveis: https://padlet.com/jubarrosrocha7/gx4z2trukonr5gnu

Melhoria nos Processos Climáticos: https://padlet.com/joyceenevesods/rh4bh906rxrcsc5h 
Conservação e Uso Sustentável dos Oceanos, dos Mares e dos Recursos Marinhos para o Desenvolvimento Sustentável: https://padlet.com/pedagogiatecnologica/wgp0ph2ky685ggid

Sustentabilidade e Biodiversidade: https://pt-br.padlet.com/luannasantos2/5qqbq161ffz7erby

Paz, Justiça e Instituções Eficazes: https://padlet.com/caio16emanuele/zeku8aavik1k7qxx O Mundo Tem Sede de Iniciativas: https://padlet.com/gestaosustentavel/wg54nxy7b5ywgb9k

Fome Zero e Agricultura Sustentável: https://padlet.com/thalinesantos/z7v89vmhybvkcgp6

Paz, Justiça e Instituições Efizaces: https://padlet.com/stefanevieiraa/tpsy4hsywrq3lqkc Ação Contra a Mudança Global do Clima: https://padlet.com/tdciods13/swq2olnbwsfvunb5 Igualdade de Gênero: https://padlet.com/ods5tdic/6qrbhe2eltefwdOb

Vida Terrestre: https://padlet.com/rickysantthos/cuotziwaporf290x

Saúde e Bem Estar: https://padlet.com/beatrizarruda2/h6fhruiq07tnlr7d

Indústria, Inovação e Infraestrutura: https://padlet.com/murizanroque09/Bookmarks Energia Acessível e Limpa: https://padlet.com/agenda2020ods7/gtvvvmnsufo7ngdd Erradicação da Pobreza: https://padlet.com/torreslucas000/31786c7k1mgovaat Água Potável e Saneamento: https://padlet.com/ods6ufal/dwtjvkmz88ojskjl Vida na Água: https://pt-br.padlet.com/pedagogia20202/Bookmarks

Os futuros professores construíram projetos num dos 17 ODS usando o mural eletrônico padlet para disponibilizar todos os materiais produzidos para serem usados em aulas na educação básica. As TDIC foram trabalhadas nas diversas atividades voltadas para a EDS propostas nas sequências didáticas a partir das orientações disponibilizadas no blog da disciplina (https://ticeducaufal.blogspot.com/).

Figura 2 - Exemplo de site padlet de grupo ODS

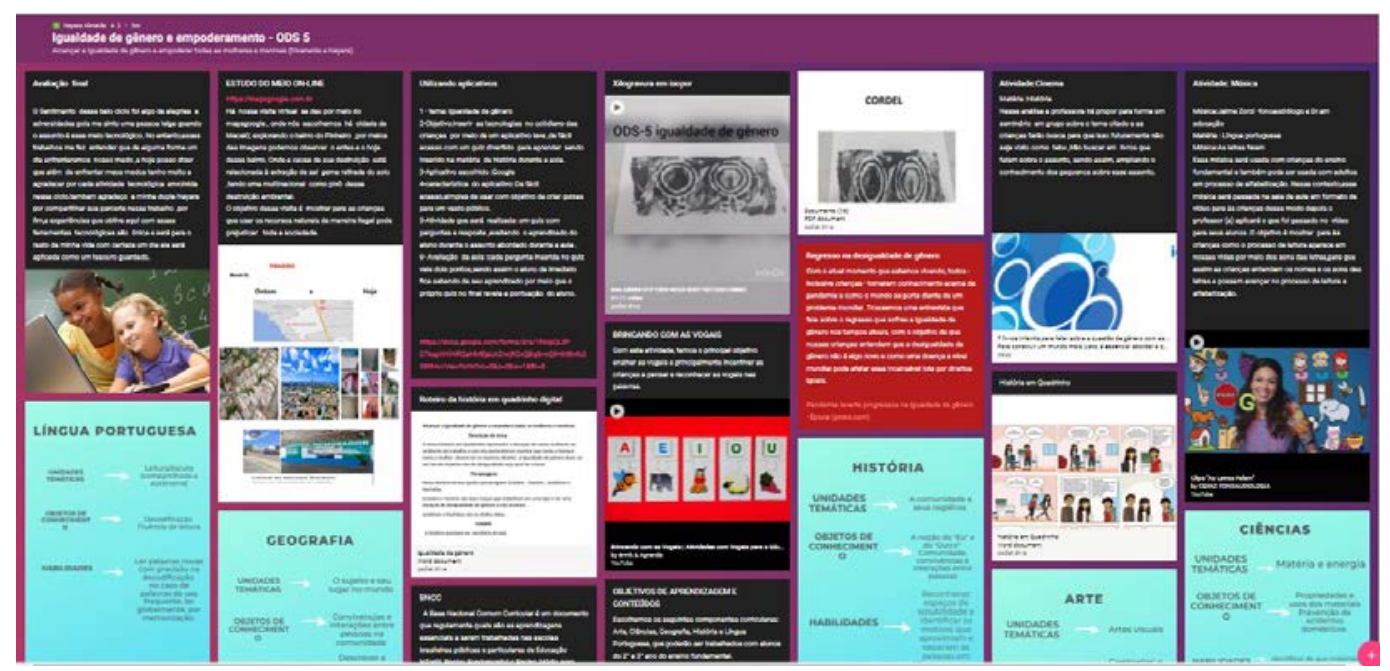

Fonte: https://padlet.com/gestaosustentavel/wg54nxy7b5ywglb9k 
Foram produzidas sequências didáticas envolvendo experiências de letramento digital com infográficos, histórias em quadrinhos digitais, viagens virtuais, construção de cordel, produção de vídeos dentre outras, disponibilizadas no padlet do grupo com exploração de conteúdos relacionados à promoção do desenvolvimento sustentável, articulados com os conteúdos da Base Nacional Comum Curricular (BNCC). A prática experiencial na produção de material didático com uso de TDIC em projetos experimentadas pelos estudantes utilizou várias TDIC voltadas para aulas híbridas e online.

Os conteúdos trabalhados nas sequências didáticas foram selecionados a partir das competências e habilidades da BNCC, voltadas para a educação básica. Foram trabalhados objetivos relacionados aos ODS: sensibilizar os estudantes para conhecer a Agenda 2030 e as metas e indicadores dos ODS; conhecer experiências didáticas usando os ODS; propor estratégias para inclusão dos ODS no currículo e práticas pedagógicas; e tomar decisões que contribuam com o alcance dos ODS.

A análise crítico-reflexiva dos resultados dos projetos levaram em consideração o envolvimento e comprometimento dos sujeitos da pesquisa com a proposta, as concepções elaboradas e as transformações evidenciadas, sobretudo na elaboração do planejamento e no desenvolvimento das aulas com TDIC como recurso pedagógico.

\section{Educação para o Desenvolvimento Sustentável}

A EDS é crucial para capacitar as pessoas a terem conhecimentos, habilidades, valores e atitudes para enfrentar crises e outros desafios do desenvolvimento sustentável e para o processo de reconstrução da educação pós-pandemia e fortalecer políticas e práticas, temática explorada na Conferência Mundial da Unesco sobre EDS ocorrida em maio de 2021 na Alemanha (Unesco, 2021).

De acordo com Tomas e Menoyo (2020, p. 94), em 2014 a Conferencia Geral da Unesco aprovou o Programa Mundial para o Desenvolvimento Sustentável no qual se destaca a necessidade de iniciar processos de sensibilização curricular para integrar os princípios e valores da sustentabilidade no modelo educacional (Unesco, 2014).

O Programa enfatiza a inclusão de conhecimentos acerca dos problemas ambientais e a formação de novas competências entre os objetivos formativos deles no currículo, com a finalidade de que os estudantes possam afiançar os comportamentos e valores necessários para analisar as informações, relacionar fatos, na medida de suas possibilidades, tomar decisões a favor do meio ambiente assim como prevenir em sua manutenção por iniciativa própria ou em colaboração com outros grupos de interesse.

A EDS habilita os professores para tomar decisões fundamentadas e adotar medidas responsáveis a favor da integridade do meio ambiente, a viabilidade econômica e de lograr a justiça social para as gerações atuais e futuras, respeitando ao mesmo tempo a diversidade cultural. Se trata de uma aprendizagem ao longo da vida e forma oarte integral de uma educação de qualidade.

O papel das universidades como espaço de formação de professores e a utilização de TDIC nesta é chave para a implementação da Agenda 2030 e a consecução das metas dos 17 ODS (REDS, 2020). Além disso, a presença das TDIC na cultura digital 
está em constante mudanças, sendo adaptadas frequentemente ao uso educacional, trazendo novas formas de linguagens, pensamentos, expressões e conhecimentos (Perez Gómez, 2015).

Com o acelerado desenvolvimento tecnológico nos últimos anos, as TDIC tornaram-se instrumentos indispensáveis para todos os campos das atividades humanas, além de proporcionarem a estudantes e professores ambientes nos quais a aprendizagem pode ser estimulada, através da união dos recursos tecnológicos com os objetivos dos componentes curriculares, visando o desenvolvimento de projetos interdisciplinares e cooperativos.

As TDIC tem grande importância na atualidade, no contexto da cultura digital na qual a geração que se encontra na sala de aula é tecnológica e o professor está aprendendo a manusear artefatos que podem garantir aprendizado e tem bons resultados incorporando as TDIC no ensino e aprendizagem com algo interessante para crianças e jovens.

No Brasil, a BNCC propõe para o currículo da educação básica competências e habilidades envolvendo letramento digital e letramento científico, destacando-se as competências (Brasil, 2018) a serem trabalhadas na proposta de projetos ODS voltados para a EDS: valorização e utilização dos conhecimentos a cerca do mundo digital para entender e explicar a realidade; pensamento científico, crítico e criativo para investigar causas, elaborar e testar hipóteses, formular e resolver problemas, criar soluções; uso de diferentes TDIC e linguagens para a produção da comunicação; compreensão, utilização e criação das TDIC de forma crítica, significativa e ética para comunicar-se, acessar e produzir informações e conhecimentos, resolver problemas e exercer protagonismo e autoria na cultura digital; agir pessoal e coletivamente com autonomia, responsabilidade, flexibilidade, resiliência e determinação, permitindo tomar decisões co base em princípios éticos, democráticos, inclusivos, sustetáveis e solidários.

A inclusão de competências relacionadas com o desenvolvimento sustentável e inclusivo, necessários para a construção de uma cidadania global, na formação dos futuros professores permite incorporar os ODS no currículo e nas aulas, desenvolvendo competências relacionadas à sustentabilidade, a responsabilidade social, as atividades profissionais e aos letramentos da cultura digital.

Os desafios atuais postos aos professores, estudantes e gestores, ampliados pela pandemia da Covid-19 exigem dispor de ambientes que permitam a autoria de conteúdos, a interação, a mediação pedagógica, a produção de conhecimento colaborativo e o desenvolvimento de competências na utilização de TDIC

Dentre várias questões, uma de relevância fundamental é a aprendizagem com uso das TDIC no ambiente de ensino e nos diversos componentes curriculares. Professores se queixam da falta de valorização e de condições de acesso a materiais pedagógicos de qualidade, às inovações oferecidas pelas TDIC, bem como da falta de equipamentos e apoio pedagógico nas escolas, o que compromete o processo de integração das TDIC nas ações didáticas conduzidas pelos professores (Guerra, 2010).

Integrar as TDIC ao currículo de maneira significativa e incorporá-las às práticas de sala de aula bem sucedidas, como a educação baseada em aprendizagem colaborativa é um desafio colocado aos professores (Mercado, 1999 e 2009) e 
poderá fornecer um contexto autêntico em que os estudantes desenvolvam conhecimento, habilidades e valores.

Na formação inicial do professor, a inserção das TDIC nas práticas pedagógicas propicia a construção de novos meios de ensinar e aprender, a partir de novos veículos de diálogo e de trocas comunicativas, contribuindo assim para que o estudante assuma o protagonismo na construção do conhecimento e se constitua em um sujeito criativo em potencial (Forquim Junior e Cirino, 2020).

\section{Formação em EDS}

As possibilidades oferecidas pelos ODS para uma prática docente inovadora são orientadas à formação das competências em sustentabilidade com o tratamento detalhado de cada ODS em conteúdo dos componentes curriculares da BNCC (Brasil, 2018), explorando estes com objetivo de formar competências em sustentabilidade e contribuir com metodologias/estratégias didáticas/atividades incorporadas na prática pedagógica (Minano e Garcia Haro, 2020, p.88).

Enfatizam a utilização de múltiplas linguagens que incidem na cultura digital, com o desenvolvimento da linguagem escrita, visual e sonora. São trabalhadas habilidades ligadas aos letramentos digitais, que são "[...] habilidades individuais e sociais necessárias para interpretar, administrar, compartilhar e criar sentido eficazmente no âmbito crescente dos canais de comunicação digital” (Dudeney et al (2016).

A implementação da Agenda 2030 no currículo da formação de profssores permite alcançar os ODS e formar futuros professores para implementá-los. Esta formação proporciona conhecimentos, habilidades e atitudes necessárias para abordar os complexos desafios do desenvolvimento sustentável (Minano e Garcia Haro, 2020).

A inclusão de temas de sustentabilidade nos currículos e resultados de aprendizagem relacionados a este é uma das metas de integração dos ODS o currículo defendidas pela Unesco (2017). Desenvolver competências de EDS envolve a capacidade de professores ajudarem as pessoas a desenvolver competências de sustentabilidade por meio de uma série de práticas inovadoras de ensino e aprendizagem.

A educação é crucial para a consecução do Desenvolvimento Sustentável, para criar um mundo mais sustentável e engajamento das pessoas em questões relacionadas à sustentabilidade descrita nos ODS e os indivíduos podem se tornar agentes de mudanças direcionadas à sustentabilidade. Para isso, precisam de conhecimentos, habilidades, valores e atitudes que Ihes permitam contribuir para o desenvolvimento sustentável (Lorente et al, 2021).

\section{Incorporação das TDIC na Prática Pedagogica}

O cenário crítico da pandemia da Covid-19 mostra os desafios do uso das TDIC na escola, que vão além da inclusão digital ou infoinclusão dos estudantes e professores para usarem ou quererem aprender a usar as TDIC na suas práticas pedagógicas. Mostrou também as necessidades de formação continuada para criar habilidades de uso e construção de propostas didáticas de incorporação das TDIC em aulas híbridas e online. 
Outro desafio é a elaboração de material didático e propostas de atividades interessantes envolvendo uso das TDIC voltados para temas inovadores no currículo como é o caso da EDS, que não sejam apenas exercitação de conteúdos técnicos da área.

O professor, para trabalhar com aulas inovadoras na cultura digital, utilizando TDIC necessita desenvolver novas competências e habilidades: ser coordenador de aprendizagem, sujeito aberto à aprendizagem, que aprende com seus estudantes; construir novas habilidades no seu percurso formativo, como saber usar as TDIC numa perspectiva didática; construir proposta pedagógica que valorize a autonomia, a construção coletiva e a autoria dos envolvidos; valorizar a construção do conhecimento em detrimento da reprodução de informações modelo ainda muito presente nas práticas pedagógicas atuais com ou sem TDIC.

A introdução das TDIC nas instituições educacionais exige atividades dinâmicas que envolvam a perspectiva da autoria, em que os estudantes e professores se tornam autores utilizando aplicativos, redes sociais e outros artefatos tecnológicos.

A formação do professor precisa incorporar na sua metodologia: o conhecimento das TDIC e da maneira de aplicá-las; a promoção da aprendizagem do estudante, para construção do conhecimento num ambiente com aplicativos e outros artefatos tecnológicos que o desafia, motiva para a exploração e a reflexão, propondo planos que resultem em trabalho cooperativo realizado pelos envolvidos no processo de aprendizagem; o estímulo à pesquisa como base de construção do conteúdo a ser veiculado através da internet; o saber pesquisar e transmitir o gosto pela investigação a estudantes de todos os níveis.

\section{Aprendizagem por projetos com TDIC}

A aprendizagem por projetos (Hernandez, 1998) com ODS utilizando TDIC faz parte das estratégias experienciais conduzidas pelos professores com objetivo de tornar a aprendizagem mais dinâmica e envolvente, visando reestruturar, repensar, recriar as concepções e as práticas educacionais. O trabalho com projetos leva em consideração que o estudante é o sujeito da própria aprendizagem e o objetivo final da aprendizagem escolar é que este saiba utilizar seus saberes em situações não-escolares.

O papel do professor nos cenários com TDIC e projetos é o de planejar atividades que possam contribuir para que os estudantes deem significado aos conteúdos do componente curricular. Nesse sentido, é preciso a construção de novas práticas e descoberta de novas possibilidades metodológicas com integração de TDIC.

Projetos ODS podem levar os estudantes a enfrentarem situações concretas, que fazem parte do cotidiano do professor e para as quais muitas vezes tem que usar de muita criatividade para alcançar os objetivos propostos. Dessa maneira, a participação ativa, a interação, a motivação, a provocação para questionar e produzir são pontos positivos do uso dessa metodologia e ferramentas das TDIC empregarem nas sequências didáticas trabalhadas nos projetos ODS. As aprendizagens proporcionadas e o potencial evidenciado de criação dos estudantes, fundamentado na aprendizagem colaborativa tem grande importância na formação deles e na avaliação das práticas do próprio professor. 
O uso das TDIC disponíveis nas instituições educacionais tem influenciado a autoria e protagonismo juvenil e o incremento qualitativo da aprendizagem tem ajudado os indivíduos a compreender e desenvolver habilidades relativas a conceitos matemáticos, cartográficos, tecnológicos, culturais e artísticos, de raciocínio lógico-matemático, de pesquisa, de comunicação, e de leitura e escrita de modo dinâmico (Franco e Lopes, 2009).

\section{Resultados}

Os futuros professores foram questionados da importância de trabalhar com os ODS nas aulas dos Anos Iniciais do Ensino Fundamental e enfatizaram que desde cedo as crianças precisam estar conscientes dessa proposta e possam fazer parte de uma sociedade mais sustentável, aprendendo a valorizar, cuidar e respeitar os pontos trabalhados nos ODS. É importante conscientizar as crianças dos recursos que elas tem hoje, pois amanhã poderão não ter mais. Além disso, é necessário ensinar a respeitar a natureza igual devemos respeitar as pessoas ao nosso redor.

O trabalho com os ODS é de extrema relevância, pois trás a percepção de cuidado e respeito ao meio ambiente, e isso sendo trabalhando desde criança. Neste trabalho nos anos inicias é possível exercitar o respeito e a admiração dos alunos características muito necessárias em nossos futuros adultos e profissionais. Lecionar sobre o respeito pelo planeta e seus recursos naturais é trabalhar o que temos de mais precioso: a humanidade. Também são de fundamental importância para que nossos alunos se habituem com os conceitos de responsabilidade, respeito, direitos e deveres, bem como pensar em maneiras para minimizar os desequilíbrios existentes em nossa sociedade.

Em relação a aprendizagem na construção, interação e exploração dos projetos ODS, os futuros professores enfatizaram que assistir e olhar os trabalhos dos colegas os enriqueceu com mais conhecimento e também em conhecer mesmo que virtualmente os colegas da sala.

A construção dos sites padlet trabalhando o tema da ODS possibilitou usar diversas TDIC como recursos diferentes para compreender e me aprofundar nessa problemática tão importante, além de os participantes aprenderem muito com os ODS trabalhadas, sua importância e necessidade de serem abordados.

As TDIC foram utilizadas em contextos embasando os ODS e foi muito interessante poder pesquisar e criar atividades a serem desenvolvidas com as crianças em diversos ambientes, sendo virtual, usando a tecnologia, como também nas atividades dinâmicas presencialmente para que atendam as demandas através de um ensino igualitário, social, e estimulantes à prática da alimentação saudável.

A aprendizagem foi significativa, pois a maioria dos participantes nunca tinha escutado falar em ODS, sendo enriquecedor trabalhar esse tema em vários componentes curriculares e também puderam acompanhar os trabalhos dos outros grupos, sendo muito enriquecedor a construção de diversas propostas didáticas que poderão ser usadas em situações futuras em sala de aula.

O professor oferecer percursos para explorar conhecimentos e desafiou os participantes, método que ajudou e os motivou a executar as atividades com êxito. 
O trabalho com os ODS mostrou importância de levar a temática para discussões em sala de aula, no qual a utilização dos recursos oferecidos pela disciplina TDIC facilita o processo de ensino e aprendizagem.

A construção de projetos ODS com sequencias didáticas usando TDIC em sites padlets aliando criatividade, permitiu o aprendizado lúdico e contextualizado, constituindo alternativa pedagógica viável e interessante para professores da educação básica.

As sequências didáticas desenvolvidas geraram produções autorais na vivencia prática, instigando os estudantes a explorarem as TIC, de modo a convergir o uso destas em direção de potencializar o processo de ensino e aprendizagem na área do conhecimento e/ou componente curricular que atua ou atuará na educação básica. Na realização das atividades propostas foi utilizada a perspectiva do ensinar e aprender, valorizando a autonomia do estudante e o princípio da pesquisa como aprendizado, proporcionando um vínculo entre teoria e prática, em uma experiência que articulou conhecimentos-competências.

Os diversos projetos ODS trouxeram fontes de conhecimento para os participantes, trabalho muito focado e que exigia total comprometimento dos mesmos. Todas as atividades foram muito interessantes e divertidas ao convidar os usuários para a produção de um conteúdo original, único e pessoal.

\section{Discussão e conclusões}

A análise das produções e a avaliação dos estudantes disponibilizadas nos padlets de cada grupo mostrou que a utilização de metodologias inovadoras com TIC oportunizou atividades problematizadoras e integradoras no currículo. Os projetos ODS construídos constituíram experiência produtiva do ponto de vista da experiência da inserção das TDIC, das metodologias ativas, como estratégia didática a ser trabaIhada na educação básica.

As principais contribuições cientificas, tecnológicas ou inovadoras dos projetos foram: investigação da utilização das TDIC pelos estudantes envolvendo atividades de ensino; estudo de novas metodologias para EDS com projetos ODS usando aplicativos e outros artefatos tecnológicos; melhoria no uso das possibilidades interativas entre estudantes utilizando recursos das TDIC no ensino.

A prioridade da Educação na Agenda 2030 que traz compromisso para as pessoas, o planeta e para a prosperidade, reconhecendo os desafios globais e requisitos indispensáveis para o desenvolvimento sustentável, presentes nos ODS e metas de abrangência universal buscam assegurar os direitos humanos, acabar com a pobreza, lutar contra a desigualdade e a injustiça, alcançar a igualdade de gênero e o empoderamento de mulheres e meninas e enfrentar os desafios dos tempos atuais, propostas para serem trabalhados na EDS.

A aprendizagem por projetos com ODS faz parte das estratégias experienciais conduzidas nesta experiência com objetivo de tornar a aprendizagem dinâmica e envolvente, visando repensar as concepções e as práticas educacionais. Os projetos desenvolvidos tiveram como objetivo desenvolver metodologias inovadoras para uso de TIC em práticas pedagógicas híbridas e online integrando ODS no currículo na perspectiva da EDS na educação básica. 


\section{Referências}

Bates, A. W. (2016). Educar na era digital: design, ensino e aprendizagem. São Paulo: Artesanato Educacional.

Brasil (2018). Base Nacional Comum Curricular. Brasília: MEC.

Dudeney, G.; Kockly, N. y Pegrum, M. (2016) Letramentos digitais. São Paulo: Parábola.

Forquim Júnior, D. P. y Cirino, M. M. (2020) Webquest X webexercices: uma analise das produções de estagiários do Programa Institucional de Bolsas de Inicialção a Docência (PIBID) de Química utilizando a Taxonomia Digital de Bloom. Ciência \& Educação, Bauru, v. 26, e20008.

Franco, J. F. y Lopes, R. D. (2009). Three-dimensional digital environments and computer graphics influencing k-12 individuals' digital literacy development and interdisciplinary lifelong learning. Proceedings of the 2nd ACM SIGGRAPH Conference and Exhibition in Asia 2009, Educators Program, 16-19 December, Yokohama, Japan.

Guerra, A. F. (2010). As tecnologias educacionais na formação em Educação Ambiental para a sustentabilidade1. Rev. Diálogo Educ., Curitiba, v. 10, n. 31, p. 561-579, set./dez.

Hernandez, F. (1998). Transgressão e mudança na educação: os projetos de trabalho. Porto Alegre: Artmed.

Lorente, L. M. y TORT, E. G. Diseño de estrategias para la incorporación de los ODS a la docencia en la formación inicial y permanente del profesorado. En: Pallas, A. G.; Moreira, M. A.; Acosta, J. M. y Alonso, J. J. (orgs). La transformación digital de la universidad. Tenerife: Universidad de La Laguna, 2021.

Mercado, L. P. (1999). Formação continuada de professores e novas tecnologias. Maceió: Edufal/INEP.

Mercado, L. P. (2009). Integração de mídias nos espaços de aprendizagem. Em Aberto, Brasília, v. 22, n. 79, p. 1-197, jan.

Miccolli, L. (2014). A evolução da pesquisa experiencial: uma trajetória colaborativa. En: Miccolli, L. (org). Pesquisa experiencial em contextos de aprendizagem: uma abordagem em evolução. Campinas: Pontes, pp. 17-75.

Miccolli, L. (2010). Ensino e aprendizagem de inglês: experiências, desafios e possibilidades. Campinas: Pontes.

Minano, R. y Garcia Haro, M. (2020). Implementando la Agenda 2030 em la universidad. Madrid: Red Española para el Desarollo Sustentable.

ONU (2015). Transformando nosso mundo: a Agenda 2030 para o Desenvolvimento Sustentável. Nova York: ONU.

ONU (2016). Roteiro para a localização dos Objetivos de Desenvolvimento Sustentável: implementação e acompanhamento em nível subnacional. Nova York: ONU. 
Perez-Gomez , Á. I. (2015). Educação na era digital: a escola educativa. Porto Alegre: Penso.

Reds (2020). Como evaluar los ODS en las universidades: manual. Red Española para El Desarollo Sostenible.

Sanchez, O. D. et al. (2019). TIC para o desenvolvimento sustentável: recomendações de políticas públicas que garantem direitos. Paris: Unesco.

Tomas, M. P. y Menoyo, M. A. (2020). El marco curricular de la educación secundária obrigatória: possibilidades para la formación de competencias en sostenibilidad. Revista Intermacional de Comunicación y Desarrollo,ano 3, n.13, pp.90-109.

Unesco (2015). Marco da educação 2030: Declaração de Incheon. Incheon, Coréia do Sul: Unesco.

Unesco (2017). Educação para os Objetivos de Desenvolvimento Sustentável: objetivos de aprendizagem. Paris: Unesco.

Unesco (2021). Declaracion de Berlin sobre la Educación para el Desarollo Sostenible. Paris: Unesco.

Unesco (2014). Hoja de ruta: para la ejecución del Programa de Acción Mundial de Educación para el Desarollo Sustenible. Paris: Unesco. 


\section{Las TIC en la Intervención del Alumnado con Dificultades de Aprendizaje a Través de la Producción Científica}

\section{García Albaladejo, Eva}

orcid.org/0000-0003-0124-6160

ega44@alu.ua.es

\section{Gilabert Cerdá, Alba}

orcid.org/0000-0003-3765-7826

alba.gilabert@ua.es 


\title{
LAS TIC EN LA INTERVENCIÓN DEL ALUMNADO CON DIFICULTADES DE APRENDIZAJE A TRAVÉS DE LA PRODUCCIÓN CIENTIIFICA
}

\author{
García Albaladejo, Eva \\ Gilabert Cerdá, Alba
}

\section{Resumen}

Durante los últimos años, el uso de las tecnologías en el ámbito educativo se ha convertido en una herramienta fundamental para incentivar al alumnado en diferentes contextos. Diversos estudios plantean que las Tecnologías de la Información y Comunicación (TIC) son una herramienta muy útil para alcanzar un aprendizaje significativo y que estas juegan un papel clave en el proceso de inclusión. Es decir, las TIC hacen accesible a todo el alumnado el proceso de enseñanza-aprendizaje de acuerdo con sus necesidades, donde se incluyen las dificultades de aprendizaje (DA). Por todo ello, el objetivo principal de este trabajo es realizar una revisión del estado del arte de las investigaciones que han aplicado las TIC con estudiantes con DA. Concretamente, la investigación realizada se ejecutó desde la modalidad documental y el procedimiento general se hizo en tres etapas; en primer lugar, búsqueda y selección de los documentos de acuerdo con la información; a continuación, clasificación según los descriptores de los documentos encontrados y, por último, el análisis de los documentos. Los resultados de los escritos analizados ponen de manifiesto que el uso de las TIC con alumnado con DA apoyadas en diferentes materiales es favorable para su inclusión como herramienta de apoyo en la intervención educativa. No obstante, el número limitado de participantes de los estudios analizados y el hecho de que ninguna investigación haya utilizado el grupo control no permite descartar otros factores que puedan influir.

\section{Palabras clave}

Tecnologías de la Información y Comunicación, Intervención, Dificultades de Aprendizaje, análisis, bibliométrico. 


\section{Introducción}

Las herramientas TIC diversifican las opciones del profesorado y alumnado, especialmente útiles son las que mitigan las dificultades generadas en el modelo de transmisión y adquisición del conocimiento (Fernández-Quero, 2021). La formación de los docentes en la atención a las Necesidades Educativas Especiales (NEE) y en particular a las dificultades de aprendizaje (DA) es un tema necesario de abordar. Por ello es imprescindible exponer el significado que ha adquirido el término de dificultades de aprendizaje (DA) a lo largo de los años. En relación con la legislación española, por primera vez en el año 1990, concretamente en la Ley Orgánica 1/1990, de 3 de octubre, de Ordenación General del Sistema Educativo (LOGSE) es donde, por primera vez en nuestro país, se hace un esfuerzo por delimitar conceptualmente qué se entiende por dificultades de aprendizaje, quedando englobada bajo el término Necesidades Educativas Especiales, expresión inglesa que procede del Informe Warnock (1987) como indica Montero (1991).

No será hasta más tarde, cuando en la Ley Orgánica 2/2006, de 3 de mayo, de Educación (LOE) tuvo lugar un cambio significativo clave para el desarrollo del campo de las DA. Se hace referencia de manera pionera a la concepción de las Dificultades Específicas de Aprendizaje (DEA) como una categoría propia del diagnóstico en la Educación Especial. La Ley Orgánica 8/2013, de 9 de diciembre, para la mejora de la calidad educativa (LOMCE) contiene varias referencias a los alumnos con dificultades de aprendizaje, añadiendo una referencia expresa al Trastorno por Déficit de Atención con Hiperactividad (TDAH) y estableciendo los principios de normalización, inclusión y no discriminación e igualdad efectiva en el acceso y permanencia en el sistema educativo.

El alumnado que tiene reconocido un grado de discapacidad suele obtener el reconocimiento de NEE y puede acceder a recursos específicos. Sin embargo, existe un colectivo de estudiantes con DA que, sin mostrar dificultades de carácter intelectual, sensorial, físico o perceptivo, presenta carencias en su aprendizaje en el contexto del aula ordinaria, presentando un desfase curricular con el resto del grupo-clase en los aprendizajes que por su edad deberían haber alcanzado (Alemany, 2019). Pese a sus Necesidades Específicas de Apoyo Educativo (NEAE), no reciben la calificación de NEE y, por lo tanto, muchos de estos discentes, no acceden a la atención de los Equipos de Orientación Educativa y Pedagógica ni a los apoyos de los maestros especialistas.

Cuando se hace referencia al término Dificultades de Aprendizaje se encuentran una serie de obstáculos para definir de manera clara y sencilla a qué aludimos exactamente debido a las diversas manifestaciones y características que los estudiantes pueden presentar (Corredor, 2018). Por su parte, Romero y Lavigne (2005) destacan que las dificultades en el aprendizaje se refieren a un grupo de dificultades que frecuentemente suelen confundirse entre sí. Las razones fundamentales de tal confusión son: la falta de una definición clara, ya que existen las Dificultades de Aprendizaje y los trastornos de aprendizaje en los trastornos pueden integrarse dificultades en el aprendizaje, y, la heterogeneidad de la población escolar a la que se refieren que puede ocasionar confusión.

Siguiendo a Manzano (2015) el criterio prioritario para identificar a un alumno/a con DA, es lo referente a la discrepancia entre la capacidad potencial y el nivel de rendimiento real, observándose dificultades significativas en la adquisición y uso de 
la comprensión y expresión oral, de la lectura, de la escritura, o del razonamiento y habilidades matemáticas, que pueden ser de origen evolutivas o adquiridas (García, 2017). Por todo ello, suelen presentarse perfiles heterogéneos con dificultades en una o varios de estos aspectos y con diferentes niveles de significatividad. Las Dificultades de Aprendizaje se dan en aquellas personas que fallan en el aprendizaje en circunstancias bajo las cuales la mayoría de las personas de la misma cultura o estrato social ordinariamente aprenden (De Solórzano, 2021). En otras palabras, las Dificultades de Aprendizaje, son inconvenientes que se evidencian en el desenvolvimiento académico del alumno desde los primeros años y que pueden constituir una limitación para lograr alcanzar las metas a futuro (Molano y Polanco, 2018).

Debido al hecho de que los estudiantes con DA no reciben la ayuda necesaria para lograr un aprendizaje de calidad, el profesor/a debe buscar estrategias para hacer sus clases más interesantes y amenas (García y Izquierdo, 2017; Játiva et al., 2021) para acceder a este colectivo. En este sentido, si se tiene en cuenta que la identidad se construye a partir del contexto, y si Internet conforma la mayor parte de tiempo del alumnado, se puede dilucidar un impacto en la construcción de la personalidad. Es por este motivo que existe una clara necesidad de abordar y trabajar la identidad digital del alumnado desde los centros educativos, como ratifica Muñoz y Cardoso-Pulido (2021).

Las Tecnologías de la Información y la Comunicación (TIC), posicionadas desde finales del siglo XX, en la vida social, cultural y educativa (Caro, 2015) pueden ser una buena herramienta. Asimismo, el uso de emociones positivas generadas tras en el uso de las tecnologías en el aula, como el asombro o la diversión, se ha convertido en una herramienta muy útil para alcanzar un aprendizaje significativo (Arriasseca y Santos, 2017). Por su parte, García y López (2012), al centrarse en la atención a la diversidad, defienden el uso de las TIC como instrumento fundamental para cumplir con el principio de equidad educativa, puesto que permiten reducir las barreras al aprendizaje o a los aspectos de desarrollo social, como son la participación, la comunicación o el juego.

A su vez, debido a la importancia de la motivación intrínseca en el aprendizaje, además del hecho de que las Dificultades de Aprendizaje pueden tener consecuencias importantes en los resultados académicos de los estudiantes dando lugar al fracaso escolar y el abandono escolar prematuro (Bolívar y López, 2009; Fernández Guerrero, 2011) es necesario reforzar la misma con nuevos métodos, como la utilización de las Tecnologías de la Información y Comunicación (Adebisi et al., 2015), que consigan mejorar la implicación de estos estudiantes y, con ello, perfeccionar el rendimiento académico.

Entre las ventajas de las TIC aplicadas al alumnado con DA se encuentra: la facilidad de adaptación en el aula, donde se favorece una enseñanza adaptada a sus necesidades en un ambiente colaborativo e inclusivo, evitando que las Dificultades de Aprendizaje que presentan sean un impedimento para su rendimiento académico (Del Rocío y Guevara-Vizcaíno, 2020); la mejora de la independencia, porque a menudo estos discentes dependen de una segunda persona (familia, amistades y profesorado) para recibir ayuda y, las tecnologías ofrecen a los sujetos con DA una forma de realizar tareas específicas por sí mismos, completar tareas educativas y participar en igualdad de condiciones que el resto de estudiantes; la posibilidad de ensayo y error que tienen los estudiantes sin la exposición pública Corredor (2018); 
el feedback inmediato sobre su actuación así como, el hecho de que los estudiantes pueden tener un mayor control sobre sus acciones, pueden entender en qué fallaron y tienen mayor tiempo para razonar sus respuestas, lo cual eleva la motivación, entre otros beneficios.

Por todo ello, la presente investigación tiene como objetivo realizar una revisión del estado del arte de las investigaciones que han aplicado las Tecnologías de la Información y Comunicación con estudiantes con Dificultades de Aprendizaje. Las preguntas de investigación son:

- ¿Cuáles son las diferentes Tecnologías de la Información y Comunicación recogidas en los artículos?

- ¿Cuántos participantes intervienen en los trabajos recopilados?

- ¿Cuáles son las principales Dificultades de Aprendizaje de los artículos?

- ¿Cuáles son las áreas trabajadas en la intervenciones educativas?

- ¿Cuáles son las distintas implicaciones educativas que se derivan de los documentos seleccionados?

\section{Método/Descripción de la experiencia}

Según la clasificación de Montero y León (2002) esta investigación se basa en un estudio ex post facto de carácter retrospectivo bibliométrico, en el que se presentan los resultados de un análisis bibliométrico. Para ello, se han seguido los siguientes pasos: en primer lugar, búsqueda y selección de los documentos de acuerdo con la información; a continuación, clasificación según los descriptores de los documentos encontrados y, por último, el análisis de los documentos (Rosa et al., 1996).

\section{Participantes}

La muestra está conformada por 5 documentos publicados entre los años 2015 y 2021, que tienen como finalidad la utilización de las Tecnologías de la Información y Comunicación como estrategias de aprendizaje para la intervención con estudiantes con Dificultades de Aprendizaje (DA), obtenidos tras realizar una búsqueda y selección de artículos entre el mes de abril de 2021 y junio del mismo año. Se ha utilizado la base de datos Web of Science para la búsqueda de documentos.

\section{Procedimiento}

Se ha llevado a cabo una revisión sistemática a través de la base de datos Web of Science (última revisión 29/07/2021), sin restricción de fecha, utilizando un concepto amplio de "learning difficulties" "learning disabilities" (abarcando dislexia, discalculia, digrafía, TDA/TDAH, SD y TEA) y "technologies". A través de estos tópicos, se encontraron 315 documentos, que se discriminaron de la siguiente manera: 
Fase 1. En primer lugar, se efectuó una búsqueda en las bases de datos Web of Science con la finalidad de seleccionar los artículos relacionados con Tecnologías de la Información y Comunicación como metodología de aprendizaje en alumnado con DA.

Fase 2. Una vez seleccionados, se tuvieron en cuenta para su análisis solo los trabajos en inglés y tipo "article".

Fase 3. A continuación, se refinaron los documentos en base a las categorías "Education, educational research" y "Education Special".

Fase 4. En esta última fase, se han eliminado aquellos trabajos que no estaban comprendidos en los últimos 5 años.

De este modo, se eliminaron 301 salidas de la web. En primera instancia se selecciona- ron, por lo tanto, 14 artículos: aquellos que recogen de forma específica los criterios de inclusión de la investigación, las TIC aplicadas al alumnado con Dificultades de Aprendizaje (de los que, una vez estudiado el texto completo, se elimina 1 por imposibilidad de acceso al texto completo, 2 por ser artículos bibliométricos y 4 por no corresponderse con los tópicos usados y, finalmente, 2 artículos más fueron descartados por no tener muestra de participantes). Por todo esto, el total de documentos analizados fue de 5.

Con el objetivo de completar la tabla con la información pertinente. Asimismo, se determinó la información que queríamos extraer de cada uno de los documentos para su correspondiente análisis y descripción, con el fin de responder a las preguntas de investigación planteadas.

\section{Resultados}

En relación con los resultados, en las tablas que se muestran a continuación se dilucidan las publicaciones seleccionadas, así como, algunos datos relacionados con sus investigaciones como son el número de participantes, la Dificultad de Aprendizaje estudiada, el tipo de tecnología que se ha utilizado, el área trabajada y las implicaciones educativas que conllevan cada uno de los estudios finalmente seleccionados.

Concretamente, en la Tabla 1 se han plasmado los diversos tipos de tecnología que han servido como base metodológica en cada una de las investigaciones desarrolladas

\begin{tabular}{|c|c|}
\hline \multicolumn{1}{|c|}{ Referencias } & Tipo de tecnología \\
\hline Satsangi et al., (2019) & Modelado en vídeo \\
\hline Satsangi et al., (2018b) & Manipulativos virtuales \\
\hline Satsangi et al., (2018a) & Manipulativos virtuales \\
\hline Pacheco et al., (2018) & Página web “Transition 2.0” \\
\hline Song (2017) & Tecnología móvil y Web 2.0 \\
\hline
\end{tabular}

Tabla 1 Relación de artículos que utilizan las TIC con el alumnado con DA y el tipo de tecnología utilizada 
En cuanto al tipo de tecnología utilizada, se puede observar que se emplean diversas tecnologías educativas con diferentes características, desde el modelado en vídeo, pasando por tecnologías manipulativas virtuales, hasta páginas web y tecnologías móviles.

Por otro lado, en la Tabla 2, se puede observar el número de participantes de las investigaciones desarrolladas en los diferentes artículos seleccionados.

\begin{tabular}{|l|l|}
\hline Referencias & Participantes \\
\hline Satsangi et al., (2019) & 3 estudiantes mujeres de 14,15 y 16 años. \\
\hline Satsangi et al., (2018b) & 3 estudiantes de 15 años, dos hombres y una mujer \\
\hline Satsangi et al., (2018a) & 3 estudiantes de 14 y 16 años, dos hombres y una mujer \\
\hline Pacheco et al., (2018) & $\begin{array}{l}19 \text { participantes entre los } 18 \text { y los } 24 \text { años, no se } \\
\text { especifica el sexo }\end{array}$ \\
\hline Song (2017) & 1 participante mujer de 23 años \\
\hline
\end{tabular}

Tabla 2 Relación de artículos que utilizan las TIC con el alumnado con DA y los participantes

A nivel general, en referencia a los participantes, se aprecia que las muestras utilizadas en los estudios son limitadas, ya que, a excepción de uno de los estudios que presenta una muestra de 19 participantes, las muestras utilizadas son de un máximo de 3 estudiantes. En este sentido, cabe destacar que ninguno de las investigaciones utiliza grupo control para comparar los resultados obtenidos.

Asimismo, por otra parte, la Tabla 3 muestra las Dificultades de Aprendizaje con las que se ha intervenido en cada uno de los trabajos.

\begin{tabular}{|l|l|} 
Referencias & DA \\
\hline Satsangi et al., (2019) & DA en matemáticas \\
\hline Satsangi et al., (2018b) & DA en matemáticas \\
\hline Satsangi et al., (2018a) & DA en matemáticas y lengua \\
\hline Pacheco et al., (2018) & Dificultades Visuales \\
\hline Song (2017) & Dislexia y TDAH \\
\hline
\end{tabular}

Tabla 3 Relación de artículos que utilizan las TIC con el alumnado con DA y el tipo de DA

Igualmente, en consideración a las Dificultades de Aprendizaje utilizadas en los estudios, se puede remarcar que 3 de ellos trabajan las dificultades en el área de matemáticas, uno de ellos acompañada de dificultades en lengua. Sin embargo, los dos artículos restantes ponen el foco en dificultades visuales y dislexia y TDAH, respectivamente. 
A continuación, en la Tabla 4, se dilucidan las áreas trabajadas en cada una de las investigaciones.

\begin{tabular}{l|l|} 
Referencias & Área trabajada \\
\hline Satsangi et al., (2019) & Matemáticas (área, perímetro y longitud) \\
\hline Satsangi et al., (2018b) & Matemáticas (ecuaciones algebraicas) \\
\hline Satsangi et al., (2018a) & Matemáticas (ecuaciones algebraicas) \\
\hline Pacheco et al., (2018) & Orientación (descubrir un espacio nuevo, la universidad) \\
\hline Song (2017) & Aprendizaje y actividades académicas \\
\hline $\begin{array}{l}\text { Tabla } 4 \text { Relación de artículos que utilizan las T/C con el alumnado con DA y el área } \\
\text { trabajada }\end{array}$
\end{tabular}

Las dificultades de aprendizaje están estrechamente relacionadas con el área trabajada y, por ello, es obvio que las investigaciones que han intervenido en relación con la dificultad en matemáticas hayan trabajado en base a diversos conceptos matemáticos, como son la geometría y las ecuaciones algebraicas. Además de ello, el estudio relacionado con las dificultades visuales se ha empleado para desarrollar la orientación de los discentes a través del descubrimiento de un espacio nuevo como es la Universidad; y la investigación relativa a la dislexia y el TDAH se ha basado en el área del aprendizaje y las actividades académicas.

Finalmente, la Tabla 5 expone las implicaciones educativas de cada uno de los estudios seleccionados en la búsqueda bibliográfica.

\begin{tabular}{|l|l|}
\hline Referencias & Implicaciones educativas \\
\hline Satsangi et al., (2019) & $\begin{array}{l}\text { - Aumento de la autonomía } \\
\text { - Múltiples opciones de aprendizaje } \\
\text { - Oportunidad de diferenciar la forma en la que aprenden } \\
\text { - Recurso permanente }\end{array}$ \\
\hline Satsangi et al., (2018b) & $\begin{array}{l}\text { - Múltiples aplicaciones } \\
\text { - Fortalecimiento de la comprensión } \\
\text { - Trabajo individual y grupal } \\
\text { - Mayor independencia }\end{array}$ \\
\hline Satsangi et al., (2018a) & $\begin{array}{l}\text { - Trabajo individual y grupal } \\
\text { - Permite las "aulas autónomas" y los "periodos de recursos" } \\
\text { - Variedad de entornos de aprendizaje }\end{array}$ \\
\hline Pacheco et al., (2018) & $\begin{array}{l}\text { - Permite participar, interactuar y colaborar } \\
\text { - Gestiona los retos de la transición (problemas académicos, conexión } \\
\text { social...) } \\
\text { - Desarrolla confianza y habilidades de autodeterminación } \\
\text { - Fomenta el desarrollo personal }\end{array}$ \\
\hline
\end{tabular}




\begin{tabular}{|l|l|}
\hline Song (2017) & - Papel fundamental en la vida de los estudiantes universitarios \\
& - Permite el aprendizaje formal e informal \\
- Fomentan la motivación por el aprendizaje & - Aumentan la autoestima
\end{tabular}

Tabla 5 Relación de artículos que utilizan las TIC con el alumnado con DA y las implicaciones educativas

Por último, las implicaciones educativas de los proyectos varían en cada investigación y por ello se puede apreciar una gran diversidad de ellas.

\section{Discusión y conclusiones}

Tomando como referencia las preguntas de investigación propuestas, se procede a responder a las mismas a modo de conclusión:

En primer lugar, en cuanto a cuáles son las diferentes Tecnologías de la Información y Comunicación recogidas en los artículos se debe señalar que existen distintas tecnologías modelado en vídeo, manipulativos virtuales, página web "Transition 2.0", tecnología móvil y Web 2.0. El uso de las tecnologías, apoyada en diferentes materiales, así como, el formato utilizado, no influye en los resultados positivos obtenidos en las distintas intervenciones realizadas. De esta forma se constata la afirmación de Caro (2015) sobre el hecho de que las TICS pueden ser una buena herramienta para utilizar con el alumnado con DA.

Por otro lado, en cuanto a la segunda pregunta de investigación, el número de participantes es limitado y, lo que es más, ninguna investigación ha utilizado un grupo control por lo que no se permite descartar otros factores que puedan influir. Por ello, a pesar de la efectividad de las tecnologías, no se puede generalizar los resultados obtenidos, ya que los grupos experimental y control sirven para valorar la magnitud del efecto de intervenciones didácticas (Cobo-Huesa et al., 2021).

La tercera pregunta de investigación permite indagar sobre cuales son las principales Dificultades de Aprendizaje de los artículos. En este sentido, la DA que se repite en tres ocasiones son las dificultades en matemáticas quizás porque van unidas al área de trabajo, al ser un ámbito más práctico es más fácil trabajar con las TIC. Además, las matemáticas están presentes en la vida cotidiana, por ello su gran importancia dentro de todos los ámbitos, esta posee beneficios tales como favorecimiento el razonamiento, por tanto, las enseñanzas de las matemáticas deben estar orientadas en el desarrollo de las destrezas necesarias para la resolución de problemas presentes en su entorno social y a la vez mejorar el pensamiento lógico creativo (Medina, 2018).

Respecto a las áreas trabajadas en las intervenciones se aprecia un incremento en el uso de tecnologías para trabajar cualquier área de las matemáticas, discriminando el área de las lenguas, una de las principales DA indicadas por Manzano (2015). Es relevante, poner el foco de atención áreas de lengua, ya que desempeñan un rol de alfabetizador y mediador entre la cultura escrita como un todo y el niño/niña.

Por último, en cuanto a las implicaciones educativas sobre las TIC aplicadas al alumnado con Dificultades de Aprendizaje, se ratifica la opinión de Adebesi et al., (2015) 
que señala que las TIC mejoran las habilidades básicas, ayudan a aumentar la autonomía de los participantes e igualan la participación de los sujetos a las condiciones del resto de estudiantes. De igual forma, se dilucida que las TIC permiten aumentar la autoestima del alumnado con DA, ya que se obtiene una corrección inmediata sin la exposición pública como afirma Corredor (2018); además como ya señalaba de forma pionera Gettinger (1984) el potencial de las herramientas tecnológicas es ilimitado como la imaginación de los estudiantes.

Para finalizar, de manera general como identifica Fernández-Quero (2021) las herramientas TIC diversifican las opciones del profesorado y del alumnado especialmente. Se observa que las personas con DA necesitan una adecuación de la enseñanza tradicional: ayuda individualizada, confianza y motivación (Vílchez y Vílchez, 2021). Por ello, es fundamental utilizar herramientas adecuadas; como afirma Caro (2015) las TIC permiten la adaptación al estilo de aprendizaje de este tipo de estudiantes.

\section{Referencias}

Adebisi, R. O., Liman, N. A., \& Longpoe, P. K. (2015). Using Assistive Technology in Teaching Children with Learning Disabilities in the 21st Century. Journal of Education and Practice, 6(24), 14-20.

Alemany Panadero, C. (2019). Las consecuencias sociales de las dificultades de aprendizaje en niños y adolescentes. EHQUIDAD. Revista Internacional De Políticas De Bienestar Y Trabajo Social, (11), 91-122. https://doi.org/10.15257/ehquidad.2019.0004

Arriassecq, I. y Santos, G. (2017). Nuevas tecnologías de la información como facilitadoras de aprendizaje significativo. Archivos de Ciencias de la Educación, 11(12), e030. https://doi.org/10.24215/23468866e030

Bolívar, A. \& López, L. (2009) Las grandes cifras del fracaso y los riesgos de exclusión educativa. Revista Currículum y Formación de Profesorado, 13(3), 51-78.

Caro, G. M. (2015). Mediación tecnológica como herramienta de aprendizaje de la lectura y escritura. Alteridad: revista de educación, 10(2), 205-221. https://doi. org/10.17163/alt.v10n2.2015.06

Cobo-Huesa, C., Ariza, M. R., \& Abril, A. M. (2021). Investigación basada en el diseño en la formación inicial de docentes para una enseñanza integrada de la naturaleza de la ciencia y el pensamiento crítico. Revista Eureka sobre Enseñanza y Divulgación de las Ciencias, 3801-3801.

Corredor, Z. (2018). Dificultades de Aprendizaje: Una Perspectiva Inclusiva. En Z. Corredor (Ed.), Educación Inclusiva (pp. 296-351). Ediciones del Vicerrectorado Académico, 2018.

De Solórzano, S. C. (2021). Impacto multidimensional de la definición y sistema de clasificación de las dificultades de aprendizaje. Analogías del Comportamiento, (2). 
Del Rocío Macas-Macas, A., \& Guevara-Vizcaíno, C. F. (2020). Uso de herramientas digitales para mejorar la dislexia en estudiantes de Educación Básica. Dominio de las Ciencias, 6(3), 197-218.

Fernández Guerrero, A.B. (2011). El fracaso escolar. Revista Innovación y Experiencias Educativas, $40(1)$.

Fernández-Quero, J. L. (2021). El uso de las TIC como paliativo de las dificultades del aprendizaje en las ciencias sociales. Digital Education Review, (39), 213-237. https:// doi.org/10.1344/der.2021.39.213-237

García, M. M. L. (2017). La formación de los profesores y las dificultades de aprendizaje. Revista de Educación Inclusiva, 7(2).

García, J. G. J., \& Izquierdo, S. J. (2017). GeoGebra, una propuesta para innovar el proceso enseñanza-aprendizaje en matemáticas. Revista electrónica sobre tecnología, educación y sociedad, 4(7).

García, M. \& López, R. (2012). Explorando, desde una perspectiva inclusiva, el uso de las TIC para atender a la diversidad. Profesorado, revista de currículum y formación del profesorado, 16(1), 277-293.

Gettinger, M. (1984). Individual differences in time needed for learning: A review of literature. Educational psychologist, 19(1), 15-29.

Játiva, E., Del Águila, M., Mera, G., \& Reza, L. (2021). La educación inclusiva y su eficacia a través de las tecnologías de la información y la comunicación TIC' s. Revista Clake Education, 2(01), 3-3.

Ley Orgánica 8/2013, de 9 de diciembre, de mejora de la calidad educativa. Boletín Oficial del Estado (España), 10 de diciembre de 2013, 295, 97858-97921.

Ley Orgánica 2/2006, de 3 de mayo, de Educación. Boletín Oficial del Estado (España), 4 de mayo de 2006, 106, 17158-17207.

Ley Orgánica 1/1990, de 3 de octubre, de Ordenación General del Sistema Educativo. Boletín Oficial del Estado (España), 4 de octubre de 1990, 238, 28927-28942.

Manzano, J. L. G. (2015). Análisis crítico sobre la evaluación e intervención en las dificultades de aprendizaje. Instituto Psicopedagógico EOS Perú Revista Digital EOS PERÚ Rev. digit. EOS Perú, 5(1),35-61.

Medina, M. (2018). Estrategias metodológicas para el desarrollo del pensamiento lógico-matemático.Didasc@lia: Didáctica y Educación, 9(1), 125-132.

Molano, G., \& Polanco, Á. (2018). Dificultades de aprendizaje y su incidencia en la adolescencia. Revista Prisma Socia/(23), 366-387.

Montero, I. y León, O.G. (2002). Clasificación y descripción de las metodologías de investigación en Psicología. Revista Internacional de Psicología Clínica y de la Salud/ International Journal of Clinical and Health Psychology, 2, 503-508. 
Montero, L. A. A. (1991). El informe Warnock. Cuadernos de pedagogía, (197), 62-64.

Muñoz Muñoz, L y Cardoso-Pulido, MJ (2021). Estudio sobre las dificultades de aprendizaje y uso de la identidad digital en el aula de Primaria. REIDOCREA, 10(10), $1-20$.

Pacheco, E., Lips, M., \& Yoong, P. (2018). Transition 2.O: Digital technologies, higher education, and vision impairment. The Internet and Higher Education, 37, 1-10. https://doi.org/10.1016/j.iheduc.2017.11.001

Porter, J. (2018). Entering Aladdin's cave: Developing an app for children with Down syndrome. Journal of Computer Assisted Learning, 34(4), 429-439. https://doi. org/10.1111/jcal.12246

Romero Pérez, J. F., Lavigne Cerván, R., Casquero Arjona, L., Elósegui Bandera, E., García Román, J., Herrera Abril, A., ... \& Valdayo Merchante, A. (2005). Dificultades en el Aprendizaje: Unificación de Criterios Diagnósticos II. Procedimientos de Evaluación y Diagnósticos. Junta de Andalucía

Rosa, A., Huertas, J., \& Blanco, J. (1996). Methodology of the history of psychology. Alianza Editorial.

Satsangi, R., Hammer, R., \& Evmenova, A. S. (2018a). Teaching multistep equations with virtual manipulatives to secondary students with learning disabilities. Learning Disabilities Research \& Practice, 33(2), 99-111. https://doi.org/10.1111//drp.12166

Satsangi, R., Hammer, R., \& Hogan, C. D. (2018b). Studying virtual manipulatives paired with explicit instruction to teach algebraic equations to students with learning disabilities. Learning Disability Quarterly, 41(4), 227-242. https://doi. org/10.1177/0731948718769248

Satsangi, R., Hammer, R., \& Hogan, C. D. (2019). Video modeling and explicit instruction: A comparison of strategies for teaching mathematics to students with learning disabilities. Learning Disabilities Research \& Practice, 34(1), 35-46. https://doi. org/10.1111/ldrp.1218

Song, H. (2017). Personalising Mobile Learning Spaces in Higher Education: A Case Study of a Malaysian Student with Learning Difficulties. In Mobile Learning in Higher Education in the Asia-Pacific Region (pp. 341-357). Springer.

Vílchez, F. T., \& Vílchez, J. R. T. (2021). Inclusión del alumnado con dificultades específicas de aprendizaje. In Estudios sobre innovación e investigación educativa (pp. 485-494). Dykinson. 


\section{Deserción y Menor Motivación en un Curso Virtual de Fisiología Humana en la Universidad Nacional del Comahue}

\section{Scapini, Celina}

ORCID orcid.org/0000-0002-4971-4181

celina.scapini@facimed.uncoma.edu.ar 


\title{
DESERCIÓN Y MENOR MOTIVACIÓN EN UN CURSO VIRTUAL DE FISIOLOGÍA HUMANA EN LA UNIVERSIDAD NACIONAL DEL COMAHUE
}

\author{
Scapini, Celina \\ ORCID orcid.org/0000-0002-4971-4181 \\ celina.scapini@facimed.uncoma.edu.ar
}

\section{Resumen}

Este trabajo describe y analiza una experiencia de cursado completamente virtual para la asignatura Fisiología Humana en un contexto de distanciamiento social preventivo obligatorio por la pandemia Covid-19. Los recursos tecnológicos utilizados fueron la plataforma Pedco y el servicio de videoconferencias Zoom, ambos provistos por la Universidad. Las actividades de enseñanza se organizaron en tres dimensiones: conceptual, procedimental y actitudinal; en cada una de ellas propusimos actividades sincrónicas y asincrónicas para asegurar el acceso de los estudiantes a la información, organizar los espacios de comunicación y disponer de instancias de evaluación flexibles. De los 317 estudiantes inscriptos en el aula virtual, 75 abandonaron el cursado antes de la primera evaluación sumativa lo que representa un $24 \%$ de Ausentes; hubo además 40 estudiantes que se desmatricularon del curso. A partir de una encuesta realizada al final del cursado, pudimos evidenciar que la motivación durante los encuentros fue "no satisfactoria" mientras que la formulación y diseño de un proyecto más las variables relacionadas con el liderazgo y trabajo en equipo mostraron ser "satisfactorias". La cantidad de alumnos que iniciaron el curso virtual y luego se ausentaron fue similar al segmento presencial del cursado del año anterior. La motivación durante los encuentros disminuyó mientras que mejoró la importancia del trabajo grupal.

\section{Palabras clave}

Aula virtual, aula invertida, competencias, motivación. 


\section{Introducción}

Este trabajo describe y analiza una experiencia de cursado completamente virtual para la asignatura Fisiología Humana de la carrera de Medicina de la Universidad Nacional del Comahue en Argentina desde agosto 2020 a junio 2021 en un contexto de distanciamiento social preventivo obligatorio por la pandemia Covid-19.

El modelo pedagógico constructivista ubica al estudiante como protagonista de su propio aprendizaje (Vygotsky, 1979) (Piaget, 1991); sin embargo, para que la intervención docente sea exitosa debe ofrecerle una utilidad significativa (Rodríguez Palmero, 2010). La ejercitación de competencias básicas y transversales permitee construir una forma de pensamiento compleja como metodología de acción cotidiana cualquiera sea el campo en el que desempeñemos nuestro quehacer (Morin, 1998) (Paul \& Elder, 2005) (Cano García, 2008) (Villa Sanchez, 2020). Los aprendizajes relacionados con destrezas procedimentales, actitudes y valores se acompañan de instancias de evaluación por observación directa que deben estar sistematizadas para evitar la subjetividad del observador (Galli, 2014). La rúbrica es un instrumento en el que se definen los estándares y criterios de valoración para los niveles progresivos de un determinado proceso formativo permitiendo tutorizar, valorar y evaluar distintos niveles de desempeño y dominio de competencias procedimentales y actitudinales (Alsina Masmitjà, 2013) (Raposo \& Martínez, 2011) (Bjork \& Bjork, 2019) (Silva Quiroz \& Maturana Castillo, 2017) (León Urquijo et al., 2014). Según la metodología del aula invertida el estudiante realiza la lectura, comprensión y reflexión del material bibliográfico provisto fuera del aula mientras que la aplicación práctica del contenido, la resolución de dudas y la discusión de la interpretación de los conceptos se realiza en la clase con los pares y el docente (González Zamar \& Abad Segura, 2020).

Fisiología Humana es la asignatura del Ciclo Biomédico con mayor cantidad de estudiantes por año y su cursado se ubica en ellos cuatrimestres IV y $V$ que corresponden a $2^{\circ}$ y $3^{\circ}$ año de la carrera respectivamente. Además de perseguir la concreción de las metas de aprendizaje propuestas, el objetivo primordial de este cursado atípico fue maximizar la participación y permanencia de los estudiantes inscriptos.

\section{Descripción de la experiencia}

\section{Contexto y Participantes}

El distanciamiento social preventivo y obligatorio impuesto por la pandemia covid-19 obligó a suspender las actividades de enseñanza presenciales y adecuarlas al entorno virtual. Los estudiantes inscriptos en el aula virtual para el cursado de la asignatura Fisiología Humana 2020-2021 fueron 317; no tuvimos notificación por parte de Bienestar Estudiantil que alguno de los inscriptos tuviera carencia de recursos tecnológicos tangibles y conectividad al aula virtual.

\section{Recursos tecnológicos y organización de las actividades de enseñanza}

Los recursos tecnológicos utilizados fueron la plataforma Pedco y el servicio de videoconferencias Zoom, ambos provistos por la Universidad. Las actividades de enseñanza se organizaron en tres dimensiones: conceptual, procedimental y 
actitudinal; en cada una de ellas propusimos actividades sincrónicas y asincrónicas para asegurar el acceso de los estudiantes a la información, organizar los espacios de comunicación y disponer de instancias de evaluación flexibles.

El aula virtual en Pedco se organizó en 16 secciones correspondientes a las 13 unidades temáticas (UT) más la sección titulada Acerca de la Asignatura que contenía la información relacionada con la organización de la asignatura (fundamentos y objetivos, docentes, programa analítico, actividades de enseñanza, bibliografía, cronograma, sistema de evaluación y reglamento), otra sección denominada Unidad Temática Modelo donde se mostró la organización de las UT en las tres dimensiones y la sección destinada a la organización del trabajo grupal. Cada UT se habilitó de acuerdo con el cronograma presentado e incluyó actividades de enseñanza y evaluaciones formativas para cada dimensión propuesta.

En la dimensión conceptual las actividades tuvieron como objetivo facilitar el estudio, la definición e integración de los conceptos básicos de Fisiología Humana y, para ello, se presentaron las guías de autoestudio en formato pdf, los teóricos integradores como archivos PowerPoint sin locución, y un fichero cuyo contenido resumió conceptos importantes necesarios para el desarrollo de cada UT. La grabación de los teóricos y su reproducción por un canal de YouTube estuvo a cargo de los estudiantes que participaron del curso. La evaluación formativa de esta dimensión fue un cuestionario con diez preguntas múltiple opción cuya calificación y resolución se podía visualizar luego de la fecha de cierre.

En la dimensión procedimental las actividades tuvieron como finalidad desarrollar habilidades y destrezas; se presentaron las guías de trabajos prácticos (TP) y los videos de laboratorio realizados años anteriores por los ayudantes alumnos (alumnos que ya acreditaron la asignatura y que ayudan a los nuevos estudiantes a realizar las actividades). La evaluación formativa consistió en un checklist de 10 ítems donde los estudiantes debían optar por sí o no respecto a la realización de un procedimiento en forma satisfactoria.

En la dimensión actitudinal, implementamos el recurso "Lección” que permitió ofrecer los contenidos referidos a las competencias de manera dinámica y flexible favoreciendo la correcta interpretación con preguntas intercaladas en el recorrido de la presentación. El recurso se mantuvo disponible durante 10-15 días permitiendo al estudiante regular en qué momento hacer la actividad. Se trabajaron las siguientes competencias: responsabilidad, autoconocimiento, comunicación, pensamiento crítico y liderazgo. La evaluación formativa consistió en la entrega de una tarea asignada durante la lección en el espacio habilitado para tal fin. Además, se adjuntó la rúbrica según la cual se calificó la tarea. Ejemplos de tareas asignadas fueron: realizar un cuadro comparativo de la regulación local del flujo sanguíneo según los textos provistos de autores diferentes, realizar un video de hasta 3 minutos explicando la respuesta inmune frente a una bacteria extracelular, presentar 5 preguntas tipo test (con la respuesta correcta) acerca del tema eritrón con el material bibliográfico provisto. Durante la segunda mitad del cursado virtual, la actividad en esta dimensión consistió en el estudio de un caso clínico en forma grupal y la preparación de su presentación oral por Zoom. Para lograr la adecuada ejecución de las tareas, presentamos lecciones sucesivas referidas al trabajo en equipo, resolución de conflictos, gestión y evaluación de la información, comunicación oral, creatividad y autoconocimiento. Además, se publicaron los grupos (de hasta 4 integrantes organizados 
por orden alfabético), los casos clínicos, el cronograma de actividades grupales, la guía para el análisis del caso, la guía para construir una hoja de ruta, la guía para la presentación del caso, el cronograma de presentación y la grilla de evaluación del trabajo en equipo y de la presentación del caso. El plazo destinado a desarrollar esta actividad fue de 12 semanas y las instancias obligatorias fueron la entrega de la hoja de ruta en la semana 4, la entrega del PowerPoint en la semana 10 y las presentaciones orales durante las últimas dos semanas.

Cada actividad de enseñanza asincrónica se complementó con un encuentro por Zoom con los docentes o ayudantes no obligatorio (tabla 1).

Las evaluaciones sumativas integradoras fueron dos (la primera al finalizar la UT 7 y la segunda al finalizar el cursado) y tuvieron el formato de cuestionario en Pedco con 45-50 preguntas de opción múltiple en un período de tiempo entre 100-120 minutos con un solo intento válido; pudieron acceder a ellas los estudiantes que habían completado y aprobado el $100 \%$ de las lecciones y tareas de la dimensión actitudinal y el $80 \%$ de los checklist de cada semestre.

\begin{tabular}{|c|c|c|c|}
\hline & $\begin{array}{l}\text { Dimensión } \\
\text { conceptual }\end{array}$ & $\begin{array}{l}\text { Dimensión } \\
\text { procedimental }\end{array}$ & $\begin{array}{l}\text { Dimensión } \\
\text { actitudinal }\end{array}$ \\
\hline $\begin{array}{l}\text { Actividad de } \\
\text { enseñanza asincrónica }\end{array}$ & $\begin{array}{l}\text { a) Guías de } \\
\text { autoestudio } \\
\text { b) Teóricos }\end{array}$ & Guías de TP & $\begin{array}{l}\text { Lecciones y tareas } \\
\text { asignadas }\end{array}$ \\
\hline $\begin{array}{l}\text { Actividad de } \\
\text { enseñanza sincrónica }\end{array}$ & $\begin{array}{l}\text { a) Zoom con ayudantes } \\
\text { los miércoles de } 20 \text { a } \\
21.30 \text { hs } \\
\text { b) Zoom con docente } \\
\text { viernes de } 18 \text { a } 19.30 \text { hs }\end{array}$ & $\begin{array}{l}\text { Zoom con docentes los } \\
\text { martes y jueves de } 20 \\
\text { a } 21.30 \text { hs }\end{array}$ & $\begin{array}{l}\text { Zoom con docente } \\
\text { lunes de } 20 \text { a } 21 \text { hs }\end{array}$ \\
\hline Evaluación formativa & cuestionario & checklist & $\begin{array}{l}\text { Página de evaluación } \\
\text { en lección y rúbricas } \\
\text { para las tareas }\end{array}$ \\
\hline $\begin{array}{l}\text { Criterio para acceder a } \\
\text { la evaluación sumativa }\end{array}$ & No obligatorio & $80 \%$ realizado & $100 \%$ aprobado \\
\hline
\end{tabular}

\section{Tabla 1. Actividades de enseñanza y evaluaciones formativas para cada UT}

\section{Resultados}

De los 317 estudiantes inscriptos en el aula virtual, 75 abandonaron el cursado antes de la primera evaluación sumativa lo que representó un 24\% de Ausentes; 184 estudiantes aprobaron la primera evaluación sumativa en primera instancia y 14 lo hicieron en el recuperatorio. Durante la segunda mitad del cursado (marzo a junio 2021), 198 estudiantes estaban en condiciones de continuar el curso virtual pero sólo 161 realizaron el segundo parcial; no hubo desaprobados en esta instancia lo que representó un porcentaje final de aprobación del cursado del 50\% (figura 1) 


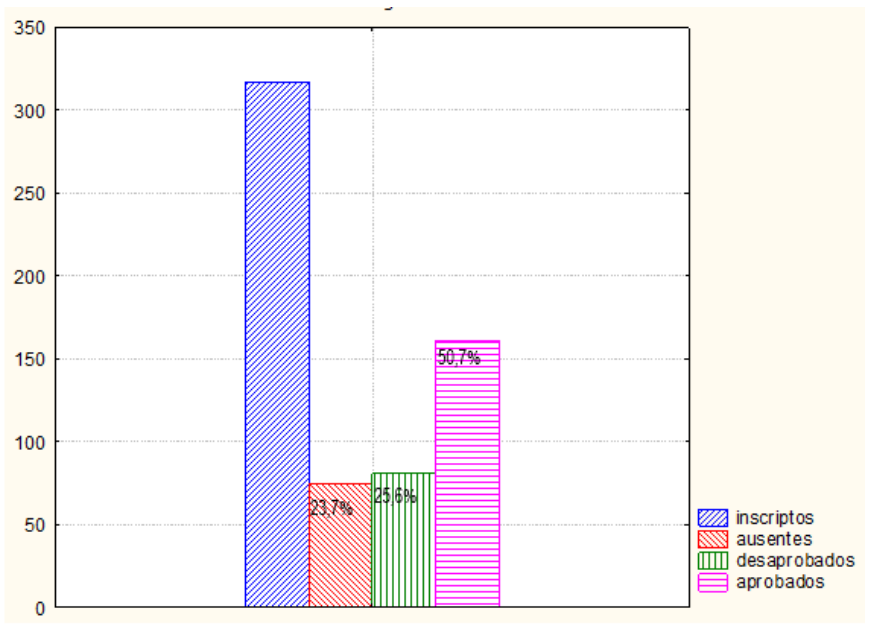

Figura 1. Distribución final de los estudiantes inscriptos en el curso virtual de Fisiología Humana.

Durante el recorrido de la lección correspondiente a la UT 13, los estudiantes debían contestar una encuesta relacionada con su percepción de la ejercitación de las competencias y del aprendizaje logrado. La encuesta fue de tipo Likert con opciones del 1 (en total desacuerdo) hasta 4 (completamente de acuerdo) e incluyó 35 ítems relacionados con los descriptores expresados en las rúbricas; la misma encuesta, pero con 37 ítems se había utilizado el año anterior con el mismo propósito. El alfa de Cronbach para la encuesta de 35 ítems fue de 0.88 y, entonces, el contenido fue válido y permitió continuar con el análisis de los datos. Cada uno de los 35 enunciados de la encuesta describió, con una sentencia afirmativa, una actividad ejercitada durante el cursado y 31 enunciados (89 \%) tuvieron medias mayores a 2,50, es decir que mostraron acuerdo por parte de los encuestados. El mayor grado de acuerdo fue para la variable "tuve que dedicar más tiempo del previsto para elaborar mis tareas propuestas" (media=3,55); y la variable que arrojó el valor medio más bajo fue "pude completar la guía de autoestudio y la de TP en los tiempos previstos a pesar de las dificultades" (media=1,86). Durante este cursado virtual, sin embargo, algunas variables modificaron su grado de acuerdo: "en todos los encuentros mantuve una gran atención y motivación" pasó a ser no satisfactoria con un valor medio de 2,19 mientras que "pude formular y diseñar un proyecto integrando distintas disciplinas" (media $=2,60$ ) más las cuatro variables relacionadas con el liderazgo y trabajo en equipo (medias entre 3,05 y 3,26) cambiaron a satisfactorias.

\section{Discusión y conclusiones}

Durante el ciclo lectivo 2020-2021 la asignatura Fisiología Humana de la Facultad de Medicina del Comahue implementó un cursado virtual que combinó la metodología tradicional expositiva y el aula invertida. En el curso previo ya habíamos logrado disminuir la carga presencial en un 70\% dejando solamente las actividades de laboratorio y de ejercitación de competencias como las únicas instancias presenciales y obligatorias; el resto de las actividades ya habían sido trasladadas a la plataforma Pedco.

El curso virtual fue desarrollado en las plataformas Pedco (para las actividades asincrónicas) y en Zoom (para los encuentros sincrónicos no obligatorios). El aula virtual en Pedco mostró 13 módulos correspondientes a las unidades temáticas del programa 
analítico y en cada uno de ellos las actividades propuestas y las evaluaciones formativas se organizaron en tres dimensiones: conceptual, procedimental y actitudinal. Creemos que esta presentación tradicional de los módulos acorde a las unidades temáticas facilitó la ubicación de los estudiantes en el aula virtual mientras que, la organización multidimensional de las actividades dentro de cada unidad temática propició la responsabilidad, el autoconocimiento y la metacognición.

El recurso Lección implementado en la dimensión actitudinal permitió tratar los contenidos referidos a las competencias de manera dinámica y flexible. La ejercitación de competencias se ha convertido en un pilar fundamental en nuestra asignatura y pudimos mantener ese espacio de intercambio en el formato virtual en forma satisfactoria.

El porcentaje de alumnos ausentes en el curso virtual fue del $24 \%$. Este valor es similar al $20 \%$ del cursado anterior donde hubo presencialidad durante un cuatrimestre y actividades destinadas a la ejercitación de competencias; y se mantiene en un valor inferior a años previos durante los cuales tuvimos entre un 40 y $50 \%$ de ausentes sin un espacio curricular para la ejercitación de las competencias básicas y transversales.

Respecto a la cantidad de alumnos inscriptos, es importante hacer una distinción entre los que estuvieron inscriptos en el aula virtual y la nómina de cursado provista por el sistema SIU Guaraní. La matriculación en el aula virtual estuvo a cargo de los docentes responsables de la asignatura en forma manual de acuerdo con la nómina de cursado, pero fue evidente que muchos estudiantes se desmatricularon en forma anticipada. Esto generó una discrepancia entre la cantidad de inscriptos en el aula virtual y en la nómina; se hizo evidente que hubo varios estudiantes con dificultad para iniciar el curso virtual, aunque desde la secretaría de bienestar estudiantil no tuvimos ninguna comunicación al respecto.

Los resultados de la encuesta fueron similares a los obtenidos durante el cursado anterior. La variable que muestra el mayor acuerdo se relaciona con la percepción de la falta de tiempo para realizar las tareas. La gestión del tiempo tiene un fuerte componente motivacional, de autocontrol y metacognitivo y recomiendan su entrenamiento desde el primer año universitario (Umerenkova \& Flores, 2018); la mala gestión del tiempo es una de las razones más importantes de la procrastinación (Gil Flores, de Beza Gutiérrez, \& Garzón Umerenkova, 2019). Sin embargo, hubo variables que mostraron un cambio en el valor medio lo que determina una interpretación diferente: pasaron a ser satisfactorias las variables relacionadas con la competencia liderazgo, el trabajo en equipo y el diseño de un proyecto mientras que la variable relacionada con la motivación fue no satisfactoria. La falta de encuentros presenciales en pequeños grupos para la ejercitación de competencias fue la principal explicación que encontramos a la caída de la motivación durante los encuentros. Si bien hubo espacios en Zoom destinados al encuentro entre docentes y estudiantes, éstos tuvieron baja participación; no fueron actividades obligatorias ya que los horarios y posibilidad de conexión fueron disímiles entre los participantes. Por otro lado, la propuesta de un proyecto grupal para la resolución de un caso clínico permitió mejorar la percepción de los estudiantes respecto al trabajo en equipo. Durante las presentaciones orales los estudiantes tuvieron un muy buen desempeño con un adecuado tratamiento del contenido y cumplimiento de las consignas. La organización de las actividades grupales de acuerdo con el cronograma presentado y el uso de las rúbricas permitió lograr este objetivo pedagógico.

Podemos concluir que la cantidad de alumnos ausentes durante el curso virtual de Fisiología Humana 2020-2021 fue similar al año anterior; sin embargo, hubo un 
grupo de estudiantes que directamente no inició el cursado bajo esta modalidad. Durante el curso virtual mantuvimos la ejercitación de competencias y el uso de rúbricas. A partir de la percepción expresada por los estudiantes en la encuesta al final del cursado y comparando con el cursado anterior, podemos concluir que la motivación durante los encuentros virtuales disminuyó mientras que mejoró la importancia del trabajo grupal y la gestión de proyectos.

\section{Referencias}

Alsina Masmitjà, J. (2013). Rúbricas para la evaluación de competencias. Octaedro.

Bjork, R., \& Bjork, E. (2019). Forgetting as the friend of learning: implications for teaching and self-regulated learning. Advances in Physiolgy Education, 43(2), 164-167.

Cano García, M. E. (2008). La evaluación por competencias en la educación superior. Profesorado. Revista de currículum y formación del profesorado, 12(3), 1-16.

Galli, A. (2014). Evaluación de los aprendizajes. Physiological Mini Reviews - Sociedad Argentina de Fisiología, 9-27.

Gil Flores, J., de Beza Gutiérrez, M., \& Garzón Umerenkova, A. (2019). ¿Por qué procastina el alumnado unviersitario? Análisis de motivos y caracterización del alumnado con diferentes tipos de motivaciiones. Revista de Investigación Educativa, 38(1), 183-200.

González Zamar, M., y Abad Segura, E. (2020). El aula invertida: un desafío para la enseñanza universitaria. Virtualidad, Educación y Ciencia, 11(20), 75-91.

Morin, E. (1998). Introducción al pensamiento complejo. Gedisa.

Paul, R., y Elder, L. (2005). Estándares de Competencia para el Pensamiento Crítico. Fundación para el pensamiento crítico.

Piaget, J. (1991). Introducción a la epistemología genética. Paidós.

Raposo, M., y Martínez, E. (2011). La rúbrica en la enseñanza universitaria: un recurso para la tutoría de grupos de estudiantes. Formación Universitaria, 4(4), 19-28.

Rodríguez Palmero, M. L. (2010). La teoría del aprendizaje significativo en la perspectiva de la psicología cognitiva. Octaedro.

Silva Quiroz, J., y Maturana Castillo, D. (2017). Una propuesta de modelo para introducir metodologías activas en educación superior. Innovación Educativa, 17(73), 117-131.

Umerenkova, A., \& Flores, J. (2018). Gestión del tiempo en alumnado universitario con diferentes niveles de rendimiento académico. Educação E Pesquisa, 44, 1-16.

Villa Sanchez, A. (2020). Aprendizaje basado en competencias: desarrollo e implementación en el ámbito universitario. Revista de Docencia Universitaria, 18(1), 19-46.

Vygotsky, L. (1979). El desarrollo de los procesos psicológicos superiores. Crítica. 


\section{El Desafío de la Evaluación en Prácticas Remotas de Química Inorgánica en la Facultad de Ingeniería de la UBA Durante la Pandemia Sars-Cov-2}

\section{Herme, Carlos A.}

Departamento de Química, Facultad de Ingeniería, Universidad de Buenos Aires cherme@fi.uba.ar

\section{Debandi, María V.}

Departamento de Química, Facultad de Ingeniería, Universidad de Buenos Aires mdebandi@fi.uba.ar

\section{Menchaca Nal, Sandra}

Departamento de Química, Facultad de Ingeniería, Universidad de Buenos Aires smenchaca@fi.uba.ar

\section{Noli, Joaquín I.}

Departamento de Química, Facultad de Ingeniería, Universidad de Buenos Aires jnoli@fi.uba.ar

\section{Jacobo, Silvia E.}

Departamento de Química, Facultad de Ingeniería, Universidad de Buenos Aires sjacobo@fi.uba.ar 


\title{
EL DESAFÍO DE LA EVALUACIÓN EN PRÁCTICAS REMOTAS DE QUÍMICA INORGÁNICA EN LA FACULTAD DE INGENIERÍA DE LA UBA DURANTE LA PANDEMIA SARS-COV-2
}

\author{
Herme, Carlos A. \\ Debandi, María V. \\ Menchaca Nal, Sandra \\ Noli, Joaquín I. \\ Jacobo, Silvia E.
}

\section{Resumen}

Entre los desafíos del dictado de clases prácticas de Química Inorgánica (63.13) en forma remota durante la cuarentena, estuvo el seguimiento de la comprensión y asimilación de temas por los estudiantes. El cuerpo docente implementó evaluaciones formativas mediante actividades semanales (preguntas conceptuales, ejercicios numéricos, cuestionarios de repaso e integración teórico-práctica), de entrega y resolución obligatoria, que estuvieron disponibles en el aula virtual del campus de la Facultad (implementado a través de la plataforma Moodle de la Facultad) una vez finalizada la exposición del tema. Asimismo, se publicó la resolución completa y comentada de los exámenes tomados. Las resoluciones debían entregarse en el sitio de tareas del aula virtual la semana siguiente. La devolución del docente-orientador no se limitó a calificar numéricamente, sino que hubo una retroalimentación, consistente en el análisis de los errores cometidos e indicaciones para mejorar la producción del alumno, en orden a lograr la autorregulación del aprendizaje. No se perdía la regularidad por tener actividades no aprobadas, pero los requisitos fueron entregarlas todas dentro del cuatrimestre y recuperar las "insuficientes" hasta tener 70\% o más de "satisfactorias". Estas instrucciones fueron cumplidas por todos los estudiantes que completaron la cursada, quienes de ese modo pudieron repasar de manera más organizada para los parciales y llegar mejor preparados a las actividades presenciales de laboratorio.

\section{Palabras clave}

Evaluación formativa, aprendizaje autorregulado, educación remota. 


\section{Introducción}

Cuando el dictado de la asignatura Química Inorgánica (63.13) para las carreras de Ingeniería Química e Ingeniería de Alimentos pasó a ser en modalidad remota en la Facultad de Ingeniería de la UBA (FIUBA, 2020), uno de los problemas que el cuerpo docente debió enfrentar fue de qué manera podría llevarse a cabo el seguimiento no presencial de cada estudiante en lo que respecta a la comprensión y asimilación de los diferentes temas impartidos en las actividades prácticas (Wigdorovitz de Camilloni et al, 1998; Barberá y Badia, 2005).

Aunque el marco de referencia era escaso (ONU, 2020), los propósitos de la Universidad de Buenos Aires y de la Facultad de Ingeniería en cuanto al sostenimiento del nivel de la enseñanza impartida eran precisos.

El punto de partida para cumplir estas directivas incluyó dos premisas claramente fijadas en las reuniones previas de la materia, realizadas poco después de establecido el aislamiento social preventivo obligatorio (ASPO): no debía tratarse el curso con los criterios de la modalidad a distancia y se debía evitar el concepto de "virtualidad". Publicaciones posteriores reforzaron estas ideas, sobre todo la primera (Del Ben et al, 2020; López, 2020).

Se daba por sentado que los alumnos no podrían perder la regularidad en el caso de no conectarse a un determinado porcentaje de las clases remotas. Se acordó entonces que una manera práctica de monitorear el avance de su aprendizaje era solicitarles regularmente una producción escrita sobre los temas vistos durante el cuatrimestre.

El objetivo buscado fue generar una retroalimentación entre cada estudiante y sus docentes auxiliares, mediante la calificación de sus resoluciones, la crítica de los errores y aciertos cometidos y el señalamiento de rumbos para elevar la calidad de sus producciones, de modo de conseguir un aprendizaje autorregulado.

\section{Descripción de las experiencias}

\section{Contexto y participantes}

El contexto original fueron las cursadas de la materia cuatrimestral Química Inorgánica (63.13) durante el primer y segundo cuatrimestres de 2020 (períodos abril-julio 2020 y septiembre 2020 -febrero 2021, respectivamente). Sin embargo, en este trabajo sólo se presentan resultados del segundo cuatrimestre de 2020 , ya que en el primero los criterios de calificación aún no estaban homologados.

Los participantes fueron los alumnos regulares inscriptos en ese período (96 estudiantes) y el cuerpo docente de la materia, compuesto por 12 docentes (2 profesores, 3 jefes de trabajos prácticos, 3 ayudantes primeros y 4 ayudantes segundos).

\section{Instrumentos}

El instrumento empleado para el sostenimiento del proceso enseñanza-aprendizaje de las actividades prácticas es el aula de la asignatura dentro del campus informático de la FIUBA, basado en el entorno virtual Moodle. 


\section{Procedimiento}

En cada semana de cursada se desarrolla una explicación teórica de los temas según la planificación. A continuación, en la correspondiente práctica, los estudiantes consultan dudas y se les presentan varias situaciones problemáticas para que determinen cuáles son los saberes previos, los pasos de resolución y sus justificaciones. Todo esto es dirigido por los docentes. Asimismo, se describen las reacciones a realizar en el laboratorio y se orienta a los alumnos para que establezcan la relación con el contenido teórico.

Se utilizan dos recursos didácticos: las "Actividades de Autoevaluación" y las "Resoluciones de 11 Puntos" (resolución detallada y comentada de exámenes parciales).

\section{Actividades de Autoevaluación}

Para cada una de las semanas de clase del cuatrimestre, de acuerdo con el calendario previamente informado (desde la tercera hasta la decimocuarta) los docentes auxiliares confeccionan por turnos una actividad para los estudiantes basada en la unidad de la asignatura que se acaba de explicar en la clase práctica.

Se dejan libres las dos primeras semanas de clase, como así también las que coinciden con la toma del primer examen parcial (la semana 9) y la de su primer recuperatorio (semana 12).

Los temas de dichas actividades pueden verse en la Tabla 1.

Tabla 1: Temas de las actividades de autoevaluación.

\begin{tabular}{|c|c|c|c|}
\hline Actividad \# & Semana \# (de 16) & Tema & Contenido del \\
\hline 1 & 3 & Tabla periódica & 1er Parcial \\
\hline 2 & 4 & Hidrógeno & 1er Parcial \\
\hline 3 & 5 & Dureza de aguas & 1er Parcial \\
\hline 4 & 6 & Halógenos & 1er Parcial \\
\hline 5 & 7 & Oxígeno & 1er Parcial \\
\hline 6 & 8 & Peróxido de hidrógeno & 1er Parcial \\
\hline 7 & 10 & Azufre & 2do Parcial \\
\hline 8 & 11 & Nitrógeno & 2do Parcial \\
\hline 9 & 13 & Carbono & 2do Parcial \\
\hline 10 & 14 & Boro & 2do Parcial \\
\hline
\end{tabular}

\section{Modalidad de las actividades}

Las tareas propuestas son variadas. Algunas consisten en ejercicios numéricos (Fig. 1) y otras en cuestionarios de preguntas conceptuales e integración teórico-práctica (Fig. 2). 


\section{ACTIVIDAD DE "AZUFRE"}

QUÍMICA INORGÁNICA - 63.13 - FIUBA

1) Estudiar en forma completa la estabilidad del ión tiosulfato en medio básico

$$
\mathrm{SO}_{3}{ }^{2-} \stackrel{-0,58 \mathrm{~V}}{\longrightarrow} \mathrm{S}_{2} \mathrm{O}_{3}{ }^{2-} \stackrel{-0,74 \mathrm{~V}}{\longrightarrow} \mathrm{S} \quad\left(1 / 2 \mathrm{OH}^{-}\right)
$$

2) Se hace reaccionar $20 \mathrm{~g}$ de azufre en $100 \mathrm{~cm}^{3}$ de solución acuosa de sulfito de sodio $50 \% \mathrm{~m} / \mathrm{m}\left(\delta=1,09 \mathrm{~g} / \mathrm{cm}^{3}\right)$. Se producen $56 \mathrm{~g}$ de tiosulfato de sodio. Calcular el rendimiento del proceso.

3) Completar y balancear:
a) $\mathrm{S}(\mathrm{s})+\mathrm{HNO}_{3}$ (c) $\rightarrow$
b) Obtención industrial del ácido sulfúrico
c) $\mathrm{FeS}(\mathrm{s})+\mathrm{HCl}(\mathrm{ac}) \rightarrow$
d) $\mathrm{AgNO}_{3}(\mathrm{ac})+\mathrm{H}_{2} \mathrm{~S}(\mathrm{ac}) \rightarrow$
e) Acción reductora del "ácido sulfuroso" $\left(\mathrm{SO}_{2}(\mathrm{ac})\right)$

Figura 1: Ejemplo de actividad con ejercicios.

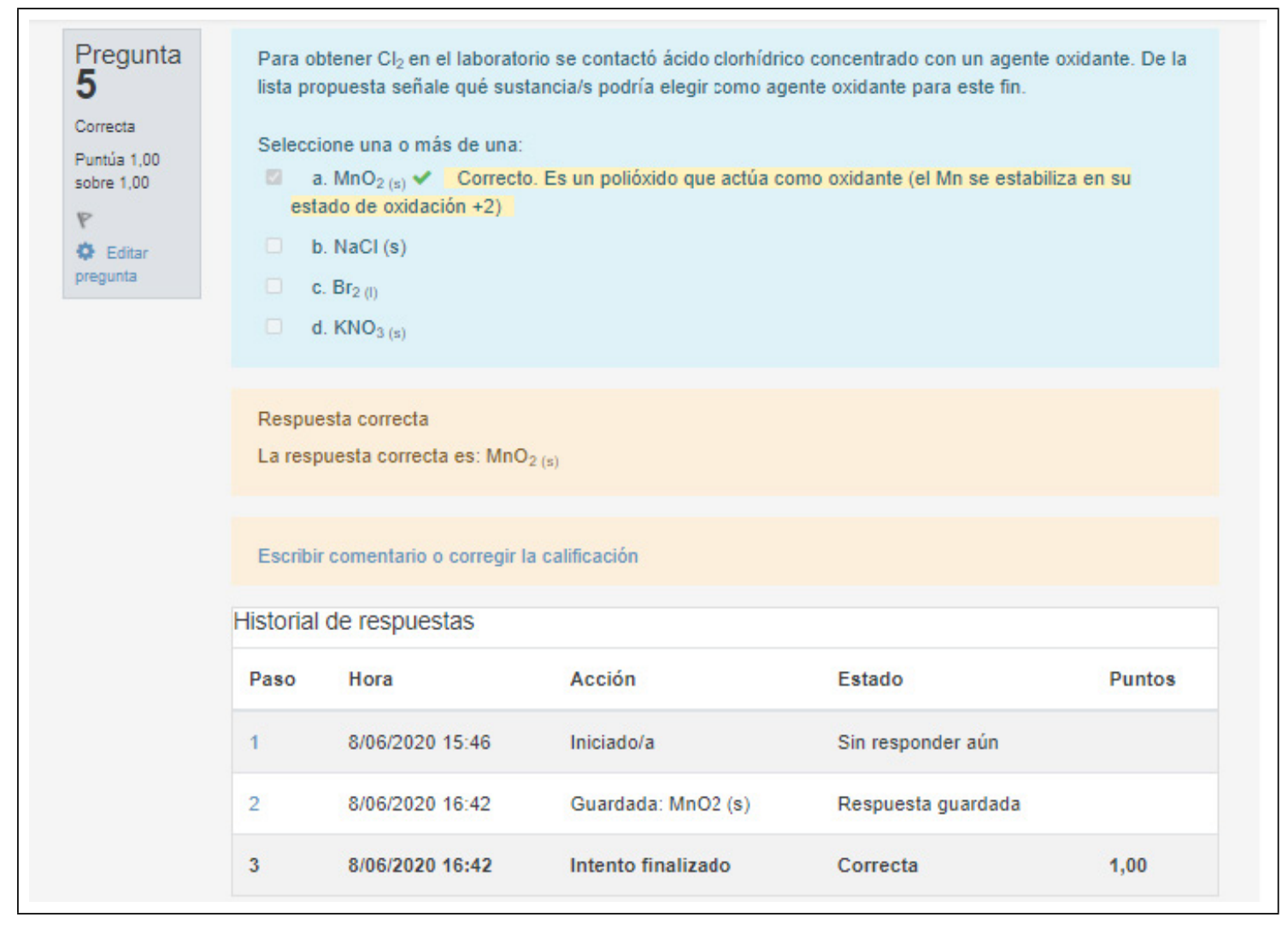

Figura 2: Ejemplo de actividad con cuestionario.

\section{Entrega de las producciones}

Los alumnos acceden al enunciado de la actividad cargada en el aula virtual de la materia un día y horario fijos cada semana. En la mayoría de los casos desarrollan sus resoluciones en forma asincrónica, ya sea de manera manuscrita o escribiendo y 
editando un archivo mediante un procesador de texto. Finalmente, dentro del plazo establecido (cuatro o cinco días) entregan la fotografía digital de su resolución o su archivo de texto, en el sitio de tareas preparado a tal efecto.

En otros casos (los menos) la actividad consiste en un cuestionario para resolver en línea mediante modalidad "Verdadero/Falso", o con opciones múltiples como respuestas.

\section{Calificación y devolución de las producciones}

Se registra la entrega (o no) por el estudiante de cada actividad, se corrige (tomando como base una nota máxima de 100 puntos) y se califica como "Aprobada" (60 o más puntos) o como "Insuficiente" (menos de 60).

La devolución consiste en la indicación de los resultados completos y correctos, como así también de los errores cometidos y de qué tipo son (errores de cálculo, arrastre de resultados parciales incorrectos, errores conceptuales, interpretación errónea del enunciado, omisión de unidades, falta de justificación, etc.).

En algunos casos el estudiante accede a su archivo de resolución sobrescrito, resaltado y comentado por el docente corrector, con las anotaciones correspondientes (Fig. 3). En otros, recibe por correo electrónico una explicación detallada de cuáles son sus aciertos y equivocaciones, junto con los puntajes parciales de cada ítem. 


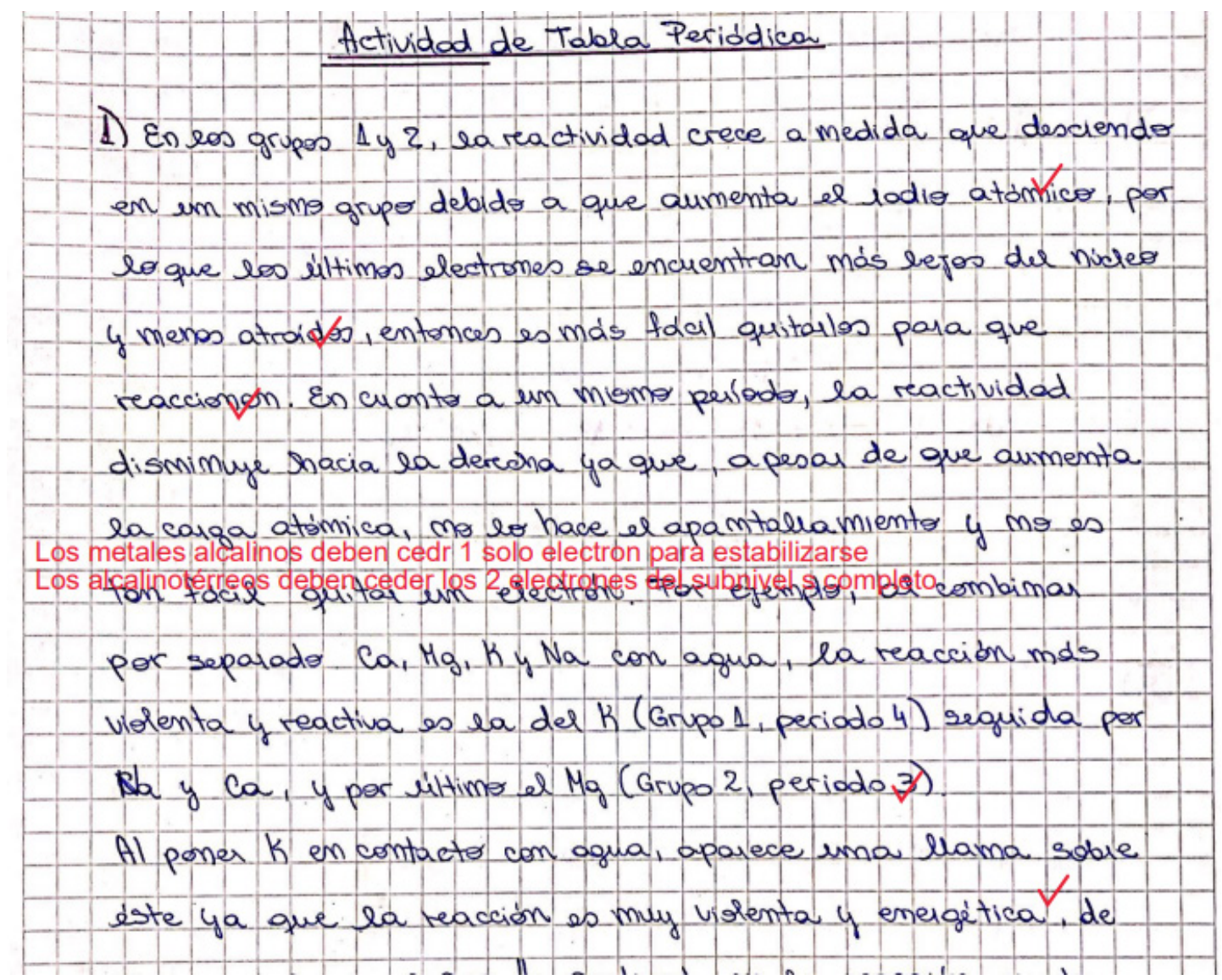

Figura 3: Ejemplo de devolución de una actividad por el docente corrector.

Aunque no se pierde la regularidad por tener actividades no aprobadas, los requisitos son entregar todas dentro del cuatrimestre y recuperar las "desaprobadas" hasta completar un 70\% o más de actividades "satisfactorias". Estas pautas fueron cumplidas por todos los estudiantes que completaron la cursada.

\section{Resolución Comentada de los Exámenes Parciales}

Después de cada evaluación parcial o examen recuperatorio, los docentes correctores escriben las resoluciones comentadas e ilustradas de cada uno de los ejercicios, tanto teóricos como prácticos. Con sus aportes, se confecciona un archivo de problemas resueltos, ordenados y presentados en un mismo formato denominado "Resolución de 11 Puntos" (según una propuesta inicial del Dr. Héctor J. Fasoli, profesor de la materia).

Esto hace referencia a que, además de los planteos, cálculos y resultados de los problemas, figuran observaciones útiles y conclusiones pertinentes, que exceden holgadamente lo que se espera de una resolución por parte de los estudiantes examinados (Fig. 4). La resolución es publicada en el aula virtual en el campus informático, simultáneamente con las calificaciones de los exámenes. 


\section{SEGUNDO RECUPERATORIO PRIMER EXAMEN PARCIAL 5/8/2020}

RESOLUCIÓN DE 11 PUNTOS

P-1) Se trata una aleación compuesta únicamente por Cu y Al con $500 \mathrm{~mL}$ de solución acuosa de ácido clorhídrico $0,01 \mathrm{M}$ y se recoge el gas formado. Una vez finalizada la reacción, el pH del medio es 2,80 . Si la muestra contiene $75 \%$ de cobre, calcular:

a) la masa total de la aleación tratada (suponer rendimiento $100 \%$ );

b) el volumen de gas desprendido, medido a $779 \mathrm{mmHg}$ y $20^{\circ} \mathrm{C}$.

Balancear la/s ecuación/es correspondiente/s y justificar el análisis propuesto.

Datos: $\quad E^{\circ}\left(\mathrm{Cu}^{2+} / \mathrm{Cu}\right)=+0,34 \mathrm{~V} \quad E^{\circ}\left(\left.\mathrm{A}\right|^{3+} / \mathrm{Al}\right)=-1,68 \mathrm{~V}$

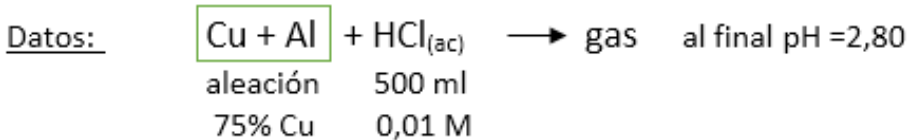

a) De los metales constituyentes de la aleación van a reaccionar aquellos que sean metales activos, es decir, los que tengan potencial de reducción menores que el potencial de reducción del hidrógeno.

Analizamos para ambos metales:

$$
\begin{array}{lll}
C u_{(s)} \rightarrow C u_{(a c)}^{2+}+2 e & E^{\circ}=0,34 \mathrm{~V} & \Delta E^{\circ}=0 \mathrm{~V}-0,34 \mathrm{~V}=-0,34 \mathrm{~V} \\
2 H_{(a c)}^{+}+2 e \rightarrow H_{2(g)} & E^{\circ}=0 \mathrm{~V} & \Delta E^{\circ}<0 \quad \Delta G^{\circ}>0 \text { no espontánea }
\end{array}
$$

El Cu no es un metal activo y no puede desplazar al hidrógeno del ácido.

\section{Figura 4: Ejemplo (solo el ejercicio P-1) de un archivo "Resolución de 11 Puntos".}

El acceso de los alumnos a este archivo, complementado con la posibilidad de consultar a los correctores vía mail, facilita una devolución fluida de los docentes a los estudiantes, superando las desventajas de la falta de una revisión presencial de los exámenes, con sus preguntas, objeciones y repreguntas habituales.

\section{Resultados}

Se clasificaron los resultados de las diez actividades del segundo cuatrimestre de 2020 como "Aprobadas", "Insuficientes" (inicialmente, no se tuvo en cuenta la recuperación posterior) o "No entregadas" (en la primera oportunidad). La distribución fue la que se muestra en la Fig. 5. 


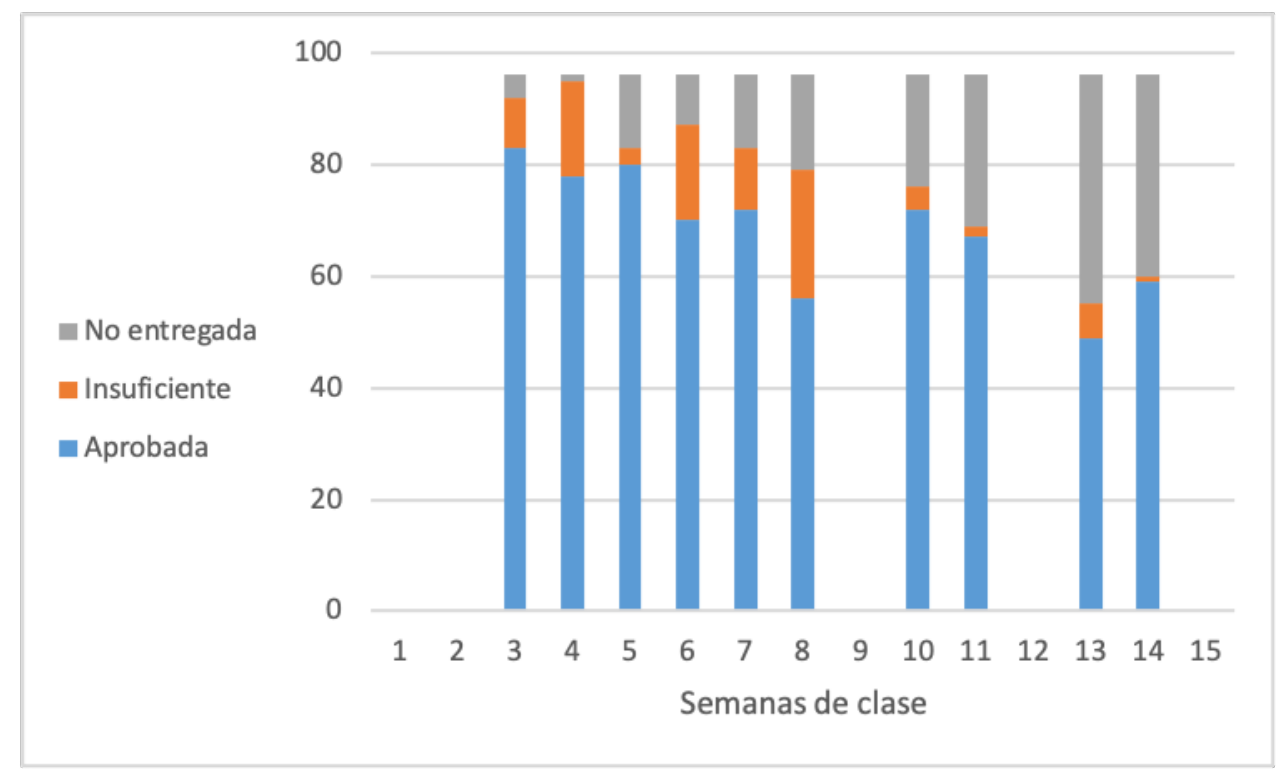

\section{Figura 5: Resultados de las Actividades de Autoevaluación.}

Cuando los estudiantes terminaron la cursada de la materia (aprobando los parciales y la práctica presencial de laboratorio), se presentaron a rendir la evaluación final. Una vez completadas las partes escrita y oral del examen integrador, los profesores les entrevistaron individualmente, para conocer sus opiniones sobre el dictado de la materia. Dos de los temas consultados fueron la evaluación mediante las actividades y las "Resoluciones de 11 Puntos".

\section{Discusión y conclusiones}

A partir del gráfico de barras (Fig. 5) se pueden extraer las siguientes conclusiones:

- Se produjo un aumento lineal del número de actividades no entregadas, coincidente con el progresivo desgranamiento, que es habitual en esta materia.

- En el total de actividades entregadas hubo en general un aumento en la proporción de las que fueron aprobadas en el primer intento (salvo para la sexta actividad).

- Esta tendencia se acentuó en el período comprendido entre el primer y el segundo parcial, lo que permite concluir que la comprensión de los enunciados y la calidad de la producción por parte de los estudiantes mejoró.

- La excepción a esta regla fue la actividad inmediatamente previa al primer parcial (la sexta, en la semana 8 de cursada). Esto se explicaría considerando que los estudiantes no tuvieron tiempo suficiente para asimilar dicho tema, formular consultas y despejar sus dudas.

La exigencia de cumplir con las actividades permitió a los estudiantes ser conscientes del avance de sus conocimientos y repasar de manera más organizada para los exámenes. 
Para cuantificar el éxito de esta experiencia se comparó el rendimiento de los 116 estudiantes del segundo cuatrimestre de 2019, que habían cursado en forma presencial, con el de los 96 alumnos del segundo de 2020, presentados en este trabajo (Fig. 6).

2do Cuatrimestre 2019

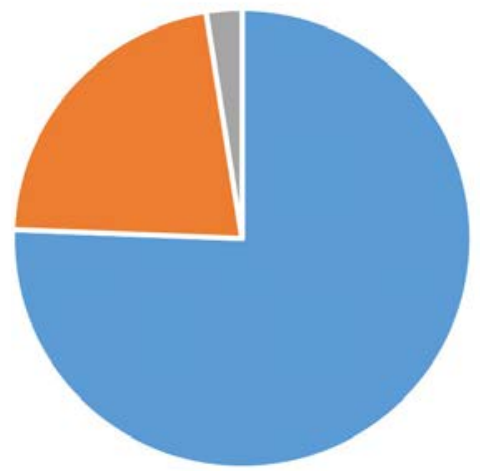

2do Cuatrimestre 2020

- Aprobados

- Libres

- Abandonaron

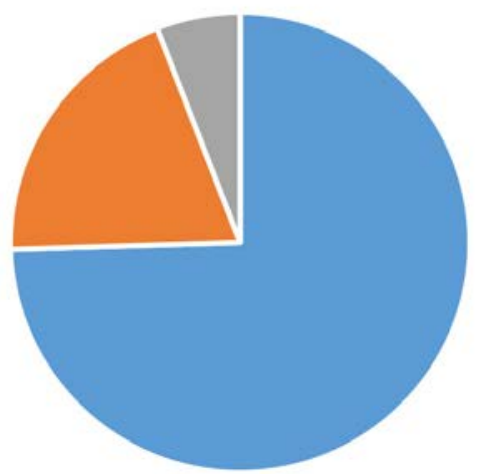

Figura 6: Porcentajes de aprobación de los alumnos en los 2dos cuatrimestres de 2019 y 2020

El porcentaje de alumnos que aprobaron los parciales (respecto del total que rindió por lo menos una evaluación) creció de 77,6 a 79,2\%. Se infiere, por lo tanto, que las actividades de autoevaluación podrían haber sido un factor que permitió la incorporación de conocimientos en las condiciones adversas de la modalidad remota frente a la cursada presencial.

\section{Agradecimientos}

Los autores agradecen a todos sus colegas docentes: Dr. Héctor Fasoli, Dr. Juan José Testa Fernández, Dra. Adriana Romero, Ing. Federico Viola, Sr. Juan Compte Alvaredo, Srta. Sol Bustos Fierro y Srta. Cecilia Kirne.

\section{Referencias}

FIUBA (2020). Resolución 856/2020.

Barberá, E. y Badia, A. (2005). Hacia el aula virtual: Actividades de enseñanza y aprendizaje en la red. Revista Iberoamericana de Educación, 36 (9), pp. 1-22.

Wigdorovitz de Camilloni, A. et al. (1998). La evaluación de los aprendizajes en el debate didáctico contemporáneo. 1ra Ed., PAIDÓS.

ONU (2020). Informe de políticas: La educación durante la COVID-19 y después de ella. Recuperado de https://www.un.org/sites/un2.un.org/files/policy_brief_-_education_during_covid-19_and_beyond_spanish.pdf 
Del Ben, P.; Rodríguez Queija, C; Villanueva Penedo, J. (2020). Enseñanza Remota de Emergencia: Textos para la discusión. Ed. The Learning Factor, Perú.

López, L. (2020). Educación remota de emergencia, virtualidad y desigualdades: pedagogía en tiempos de pandemia. 593 Digital Publisher CEIT. Recuperado de https://www.researchgate.net/publication/344731933_Educacion_remota_de_emergencia_virtualidad_y_desigualdades_pedagogia_en_tiempos_de_pandemia 


\section{Química Universitaria Básica y Pandemia: El Mundo como Aula, la Casa como Laboratorio}

\section{Lucy Coria}

Universidad Católica Argentina, Facultad de Ingeniería y Ciencias Agrarias lucycoria@uca.edu.ar

\section{Héctor Fasoli}

Universidad de Buenos Aires, Facultad de Ciencias Exactas y Naturales. hector_fasoli@uca.edu.ar

\section{Sandra Menchaca}

Universidad de Buenos Aires, Facultad de Ingeniería.

sandramenchaca@uca.edu.ar 


\title{
QUÍMICA UNIVERSITARIA BÁSICA Y PANDEMIA: EL MUNDO COMO AULA, LA CASA COMO LABORATORIO
}

\author{
Lucy Coria \\ Héctor Fasoli \\ Sandra Menchaca
}

\section{Resumen}

Las metodologías alternativas y desarrolladas al máximo con el inicio de la pandemia permitieron adaptarnos a un sistema de enseñanza poco explorado por la mayoría de docentes y estudiantes. Las materias experimentales como la química vienen acompañadas de cuestiones prácticas y de laboratorio, los cuales permiten que los conceptos sean interiorizados con mayor eficacia. En función a lo anterior, en este trabajo presentamos el abordaje realizado en cursos de Química de primer año para estudiantes de Ingeniería Ambiental. El enfoque de trabajo incluyó los siguientes aspectos de la enseñanza: presentación conceptual de los temas basados en aspectos de la vida cotidiana; ejercicios numéricos de aplicación metodológicamente ordenados; trabajo en grupos reducidos; atención personal del estudiante; uso de simulaciones y animaciones; entrenamiento en autoevaluación a través de test basados en diferentes plataformas educativas; evaluación personalizada mediante un método original y sencillo, junto con un examen de 10 puntos y realización de ejercicios experimentales basados en usos habituales en los dos grandes laboratorios de toda casa: la cocina y el baño. La respuesta de los estudiantes frente a las actividades propuestas fue considerablemente buena, adaptándose con gran facilidad y mostrando un rendimiento comparable o superior con lo observado en la presencialidad. Si bien es un reto poder transmitir no solo los conceptos teóricos sino los prácticos bajo estas circunstancias, la motivación de los docentes generó diversas propuestas que puedan ser utilizadas en otras materias.

\section{Palabras clave}

Enseñanza remota, evaluación sincrónica y asincrónica, autoevaluaciones, grupos reducidos, destreza experimental. 


\section{Introducción}

La pandemia iniciada a finales de 2019 (Organización Munidal de la Salud, 2020) y que llevó a establecer en la Argentina el aislamiento social preventivo obligatorio (ASPO) a comienzos del ciclo lectivo 2020 (Boletín Oficial de la República Argentina, 2020) constituyó un desafío para el sistema educativo en general y para los docentes en particular, quienes en muy poco tiempo debieron adaptar la metodología de la manera más eficaz posible. Las referencias sobre enseñanza en situaciones de emergencia, si bien no son escasas (Neira del Ben et al., 2020; Hodges et al., 2020; López-Morocho, 2020), requieren un tiempo de adaptación y entrenamiento para el manejo de plataformas educativas y, sobre todo, para el desarrollo de destrezas didácticas raramente ejercitadas con anterioridad.

Repentinamente, las plataformas empleadas como apoyo de la enseñanza y reservorios de material didáctico pasaron a jugar un papel central en la etapa de comunicación y, sobre todo, la evaluación de los estudiantes. Simultáneamente, se popularizaron los sistemas de comunicación por videollamada, de escasa utilización en la enseñanza formal en todos los niveles educativos (https://zoom.us/; https://meet.google.com/).

Por otra parte, la relación profesor-alumno es un factor que puede afectar el desarrollo del proceso de enseñanza-aprendizaje, estudios previos muestran que más del $70 \%$ de estudiantes consideran importante una buena comunicación con sus docentes (Rueda Beltrán et. al., 2019). En todo proceso educativo es importante comprender la relación entre la enseñanza y la evaluación, siendo este último un dispositivo utilizado al servicio de la "buena enseñanza" o buenos procesos de aprendizajes. Por ello la búsqueda de nuevas formas de evaluación por parte de los docentes se da con respecto a la forma en que encaran la actividad de evaluación y también la actividad de enseñanza. Esto implica la necesidad de utilizar mecanismos diferentes de acuerdo con el tipo de examen, cada una de estas requiere no solo instrumentos distintos sino también diferentes formas de interactuar con los estudiantes (Caamaño, 2008).

Las disciplinas fácticas como Física, Química y Biología debieron afrontar el difícil escollo de asumir una formación necesariamente incompleta, sin trabajos experimentales o con trabajos de laboratorio postergados hacia fines del cuatrimestre, en lapsos diarios extensos, en pocas jornadas de presencialidad.

Describimos aquí el conjunto de estrategias llevadas a cabo para optimizar el proceso enseñanza-aprendizaje de materias de Química de primer año de la carrera de Ingeniería Ambiental en la Facultad de Ingeniería y Ciencias Agrarias de la Universidad Católica Argentina. Abarcamos diferentes aspectos de la enseñanza, desde el manejo de las clases expositivas hasta las de ejercicios conceptuales y numéricos. Explicamos cómo se intentó superar -al menos parcialmente- el entrenamiento en el trabajo experimental. La base de la enseñanza se concentró en el análisis detallado de fenómenos y experiencias cotidianas, para internalizar un mundo que, inesperadamente, quedó limitado a las paredes del hogar, en el mejor de los casos.

\section{Método y estrategias}

La enseñanza se focalizó en el empleo de Zoom y el Entorno Virtual de Aprendizaje (EVA) basado en la plataforma Moodle. Las estrategias cubrieron los aspectos con- 
ceptuales, ejercicios numéricos y experimentales y evaluación, apoyados en material didáctico de uso libre o escrito por nosotros. La mayor parte de la experiencia se realizó en la asignatura Química General e Inorgánica (QGel) y, cuando se indica, en Química Orgánica (QO).

\section{Presentación conceptual y ejercicios}

La presentación de los temas en un curso inicial de Química es crucial debido a la heterogeneidad de los cursantes. Los temas se presentaron desde una perspectiva histórico-observacional, enfocada en el desarrollo de sucesos y observación de experiencias que permitan el entendimiento de los fenómenos estudiados, ubicando en contexto la temática y relacionándola con la experiencia cotidiana mediante experimentos con materiales y productos domésticos realizados durante la explicación remota. La exposición y discusión se hizo mediante uso de pizarra blanca. Aun con dificultades, se alentó el diálogo con cámara encendida. Las series de ejercicios se relacionaron con las clases en orden temático y de complejidad (Retahílas: serie de cosas que se mencionan de acuerdo a un orden (RAE)).

\section{Atención Personalizada}

La enseñanza remota tiene la deficiencia de la falta de comunicación inmediata del estudiante con el profesor fuera del horario de clases. La "puerta siempre abierta” del ámbito de la facultad se reemplazó por la comunicación a través de correo electrónico y la solicitud de entrevistas personales. También se establecieron horarios de consultas fijos, durante todo el cuatrimestre, y entrevistas con los estudiantes que fallan en las evaluaciones. Se utilizaron diversos medios de comunicación, que fueron variando de acuerdo con la disponibilidad de plataformas: Skype, Meet, Zoom; se evitó la interacción telefónica y vía mensajería de texto y, naturalmente, fue intensa la comunicación interpersonal por correo electrónico institucional.

\section{Ejercicios de actitud y destreza experimental (EADE)}

EI ASPO estableció una gran incertidumbre en cómo se formarían experimentalmente los estudiantes. Por esto, se propusieron los EADE: experimentos sencillos, cuali y cuantitativos, que los estudiantes pudieron realizar en sus propias casas, transformando actividades cotidianas rutinarias o específicas en centro de los tres pilares del método científico: observar, medir e interpretar. Las premisas fueron siempre claras y precisas, pero las tareas podían incluir actividades de elección libre que debieron ser optimizadas y "normalizadas" siguiendo una guía didáctica. Los estudiantes documentaron por escrito y de manera audiovisual lo realizado y cargarlo en el EVA. Pudieron contar con la colaboración de asistentes de sus familias, participación que alentamos fuertemente. De los trabajos diseñados para esta actividad mencionamos: a) descripción detallada de una actividad doméstica (limpiar, cocinar, tender la cama, rutina de ejercicios); b) cromatografía en papel de diario (optimizando varios solventes); c) rapidez de avance de la llama de un fósforo. 


\section{Materiales y actividades didácticas}

\section{Uso de simulaciones y animaciones}

El uso de simulaciones y animaciones en la enseñanza de ciencias experimentales juega un papel importante, ya que permite mostrar de manera gráfica y didáctica el proceso o fenómeno sobre el cual se está discutiendo. Estas herramientas se incluyeron en QGel y QO con el objetivo de complementar el desarrollo de las clases prácticas. Se utilizaron simulaciones interactivas libres (University of Colorado Boulder, 2020), animaciones desarrolladas por la Universidad de Oxford y el programa de modelado molecular ChemSketch desarrollado por ACD/Labs de acuerdo con las siguientes actividades descriptas a continuación:

- La simulación: "Formas y cambios de energía" se utilizó para explicar gráficamente el concepto de calor sensible desarrollado en la unidad 4, Energética, de la materia Qgel. Para ello, se calentó un bloque de hierro hasta el valor máximo alcanzado por el termómetro y se registró la temperatura relativa del recipiente con agua. Inmediatamente, se colocó el bloque de hierro en el recipiente con agua y se observó el cambió de temperatura registrado para ambas sustancias.

- La sección "modelo" de la simulación "Fórmula de la molécula" fue utilizada en el tema: Uniones químicas de la materia QO. Se construyeron moléculas e iones poliatómicos trabajados en clase, pudiendo observar la distribución espacial de los enlaces formados y los pares libres, así como las geometrías electrónica y molecular.

- La representación de estructuras Lewis, formulas semidesarrolladas, construcción de isómeros, así como la representación lineal y de Haworth de glúcidos, se realizó con el programa ChemSketch, permitiendo visualizar correctamente las estructuras de las moléculas y los enlaces presentes en ellas.

\section{Trabajo en grupos reducidos en aula virtual}

La incorporación y fomento de actividades que permitan una mayor interacción entre los estudiantes es importante a fin de preservar las relaciones sociales y el trabajo en equipo, frecuentes en la presencialidad. Esto se consiguió mediante la plataforma Zoom y control de la sesión del docente como anfitrión, trabajando temas específicos en grupos reducidos de estudiantes (no más de cinco), con una puesta en común final. Durante el tiempo de actividad en grupos reducidos, el docente fue migrando de sala en sala para observar el planteamiento propuestos por los estudiantes y absolver sus dudas, fue posible transmitir mensajes a todas las salas o ser llamado por alguna sala en particular, lo cual fue aprovechado por los estudiantes.

Por ejemplo, en la materia de QO para el desarrollo de diversas estructuras Lewis, fórmulas semidesarrolladas y la descripción de isómeros a partir de una fórmula molecular se trabajó en grupos reducidos, luego de lo cual los estudiantes de cada grupo mostraron y compartieron las respuestas que obtuvieron por cada problema asignado. 


\section{Test dinámicos de autoevaluación}

Los test dinámicos fueron diseñados como una herramienta de autoevaluación de los estudiantes, la cual se pudo desarrollar de manera optativa y anónima a través de la plataforma EVA, basándonos en el software en línea Genially.

Se crearon dos tests de autoevaluación sobre los temas: (i) formulación y nomenclatura y (ii) leyes ponderales y volumétricas de la química, de 20 y 10 preguntas respectivamente. La idea principal fue que no tomara más de 1 minuto elegir la respuesta correcta y que al finalizar el test el estudiante pudiera anotar la cantidad de preguntas correctas e incorrectas y autoevaluar su progreso en el tema.

\section{Evaluaciones personalizadas}

La propuesta de evaluaciones personalizadas puede ser usada para fomentar la autonomía del estudiante y analizar su metodología de estudio. Se diseñaron evaluaciones parciales con ejercicios cuyos datos dependieran del número de DNI de cada estudiante, garantizando de esta forma la individualidad del resultado. Con el apoyo de un programa en Excel fue fácil realizar la corrección personalizada de cada prueba. Se publicó luego el "Examen de 10 puntos" con la resolución detallada del examen, tendiente a la autoevaluación crítica.

En una evaluación referida a la unidad 2: Estequiometría, los estudiantes debían reemplazar las letras del enunciado con los números de su DNI según correspondía (Figura 1). En una segunda evaluación los datos de los problemas variaron dependiendo si el número de DNI terminaba en una cifra par o impar.

Escriba su número de DNI. Un dígito debajo de cada letra. Ejemplo: si su DNI es 42.133.845, escriba 4 debajo de la $A, 2$ debajo de la B, 1 debajo de la $C$, etc.

\begin{tabular}{|l|l|l|l|l|l|l|l|l|}
\hline & A & B & C & D & E & F & G & H \\
\hline DNI & & & & & & & & \\
\hline
\end{tabular}

\section{ENUNCIADO}

Reemplazar CON LÁPIZ la letra de cada cifra del ejercicio por el dígito que corresponda a su DNI. Por ejemplo, 4BCD g corresponde a $\mathbf{4 2 1 3} \mathrm{g}$ del ejemplo anterior. 38FG,0 L es 3084,0 L. Escribir el número completo sobre la cifra en gris del enunciado.

\section{Figura 1. Enunciado del primer tipo de autoevaluación.}

Para facilitar la calificación por parte de los docentes en la primera evaluación, se creó un archivo de Excel en donde se colocó el número de DNI del estudiante y se obtuvieron los resultados de la pregunta de manera automática (Figura 2). 


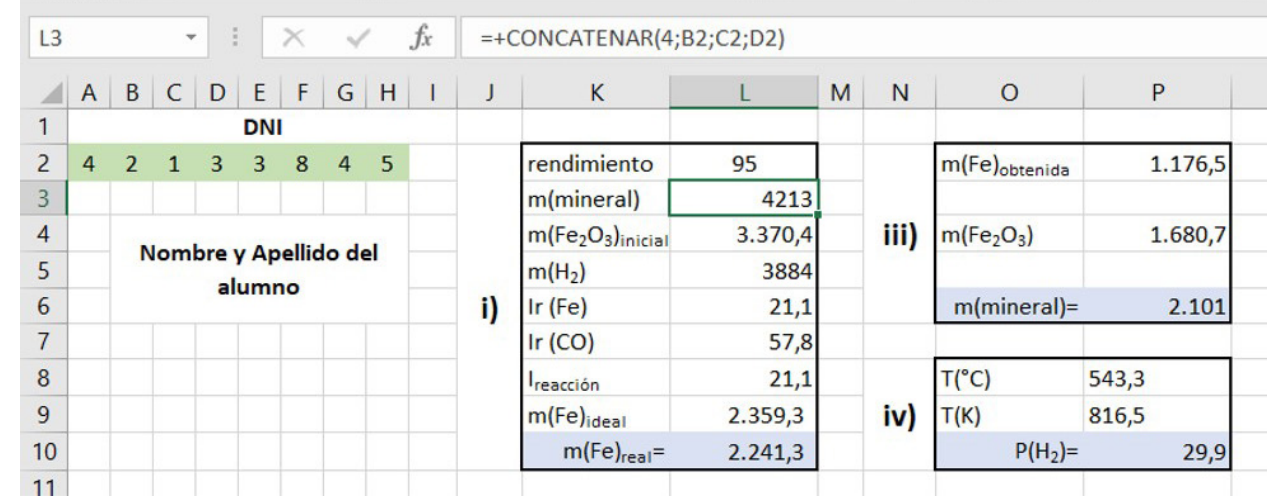

Figura 2. Visualización de la plantilla de Excel que muestra la automatización de los datos y resultados para cada estudiante en la evaluación.

\section{Resultados}

La integración de la parte conceptual, combinada con demostraciones simples frente a la cámara del cursante lograron el efecto de "presencialidad". La posibilidad de consultas grupales y personales fuera del horario curricular acercó al estudiante al ámbito de estudio universitario. El material didáctico, en todas sus variantes, permitió una mayor interiorización y entendimiento de los conceptos y procesos estudiados en las materias de Química. Las simulaciones y animaciones estimularon la visualización de estructuras y experimentos. El trabajo en grupos reducidos facilitó la comunicación entre estudiantes y con el docente. Las evaluaciones personalizadas fueron implementadas en toda la cursada de la materia QGel, con muy buenos resultados: los estudiantes fueron mejorando gradualmente su desempeño con cada una de las tres evaluaciones parciales.

\section{Discusión y conclusiones}

El uso de dispositivos y plataformas virtuales demuestran una creciente en la cultura digital expuesta principalmente por los estudiantes (Pérez Medina \& Ferreriro Concepción, 2019). Esta característica puede usarse como una ventaja al momento de plantear nuevas herramientas de enseñanza-aprendizaje en materias de primer año. Por ello los docentes no solo deben conocer la existencia de las mismas, sino trabajar en conjunto para implementar las herramientas tecnológicas disponibles adecuadas al trabajo, y así generar nuevas herramientas que beneficien el proceso de enseñanza-aprendizaje (Pérez Medina \& Ferreriro Concepción, 2019; Ferreiro Concepción \& Fernández Medina, 2020).

La cultura digital establecida, puede proponer además nuevas metodologías didácticas de enseñanza y de evaluación, en las que los alumnos se encuentren más involucrados en las clases, evaluaciones y autoevaluaciones (Ferreiro Concepción \& Fernández Medina, 2020). Dado que la educación implica un público definido, los estudiantes, estos serán los que seleccionen e interactúen con los contenidos audiovisuales que le resulten más atractivos (Marino-Jimenez et. al., 2020). El desarrollo de herramientas audiovisuales como las simulaciones y animaciones ofrece un 
método más eficiente de interacción ya que se visualiza y se escucha íntegramente (Xie et. al., 2019; Krutka et. a., 2019). Además, el tiempo, la utilidad, la forma de transmitir y el manejo del lenguaje son factores que afectarán en el impacto de la enseñanza basada en este tipo de herramientas (Marino-Jimenez et.al., 2020). Durante la incorporación de estas nuevas metodologías, fue importante contar con simulaciones y animaciones que resaltaran sobre todo por la facilidad de "contar" el fenómeno. El tiempo de duración de estas fue un factor importante ya que el ser cortas, sumado al hecho de que tome menos de 2 minutos entender cómo funcionan, permite que los estudiantes las puedan seguir explorando incluso sin acompañamiento del docente, mejorando su autonomía.

El tipo de comunicación y lenguaje utilizado para transmitir información a los estudiantes necesita enfocarse primordialmente en el público objetivo. Si no se consideran las características comunes que tienen los estudiantes, como expectativas y preferencias comunicativas, la herramienta empleada simplemente carecerá de eficacia y no generará interés (Marino-Jimenez et. al., 2020). Considerando esto, fue que se planteó el uso de test didácticos como herramienta de autoevaluación, con un entorno ameno y familiar para los estudiantes, teniendo en cuenta que son los principales consumidores de contenido digital que sea sencillo de manejar y entender. Estos test didácticos consistieron en preguntas cortas que no tomaran más de 1 minuto para elegir la respuesta correcta, lo que es un punto importante ya que tiempos largos de interacción disminuyen el interés del público objetivo como demuestran los autores (Galindo-Rubio, 2004).

La comunicación entre los estudiantes, y entre docente y estudiante no siempre ha sido efectiva incluso en la presencialidad (Rueda Beltrán et. al., 2019), y con la virtualidad esta se vio afectada en gran medida. Es por ello por lo que fomentar actividades que promuevan la interacción entre todos los participantes resulta de gran interés. La importancia del trabajo en equipo trasciende las aulas, ya que es una estrategia que permite desarrollar diversas competencias tanto intelectuales como sociales. Asimismo, esta habilidad permite desarrollar en los estudiantes actitudes de sinergia, trabajo cooperativo y compromiso que aplicaran durante su trabajo profesional (Ángel Jiménez et. al., 2013; Iborra \& Dasí, 2009). Estas actividades se pueden realizar de forma virtual empleando varias plataformas. Durante algunas clases, fue posible no solo organizar a los estudiantes en salas de grupos reducidos, sino también que el docente pueda observar, evaluar e interactuar con los estudiantes de manera más "cercana". La actividad permitió estrechar lazos de comunicación entre los estudiantes, formando grupos de estudio y generando clases de consultas con los docentes con una comunicación más fluida.

Otro de los cambios implementados en la materia fue en el modo de diseñar y ejecutar las evaluaciones. Si bien a menudo son erróneamente asociadas con el control y el disciplinamiento, estas constituyen desde su sentido didáctico, una estrategia muy valiosa para docentes y estudiantes (Caamaño, 2008).

La interrelación entre los aspectos conceptuales y la ejercitación permitieron aproximarnos mucho a lo observado en las clases presenciales: las dificultades para relacionar hechos con ideas fueron similares y el tiempo en comenzar a vincularlos fue similar. Los resultados de las evaluaciones remotas fueron comparables a los observados en cursos en el campus físico (ca. 70\% de aprobación), al igual que la relación de estudiantes que aprobaron la cursada (ca. $85 \%$ de quienes finalizaron 
el curso). La deserción fue ligeramente mayor (ca. 15\%) y obedeció a estudiantes que cambiaron de carrera o dejaron la universidad. Todos realizaron dos de los tres EADE propuestos y ocho de cada diez estudiantes completaron el tercero. Fue sorprendente la participación familiar (padres, hermanos, novios) y la calidad del material audiovisual recibido.

\section{Referencias}

Ángel Jiménez, G., Pareja Cadavid, A. M., \& Puerta Lasprilla, K. V. (2013). El trabajo en equipo como modalidad de enseñanza-aprendizaje. Revista Iberoamericana de Educación e Investigación en Enfermería, 3(1), 9-15.

Boletín Oficial de la República Argentina. (19 de marzo de 2020). Decreto 297/2020. Obtenido de https://www.boletinoficial.gob.ar/detalleAviso/prime$\mathrm{ra} / 227042 / 20200320$

Caamaño, Carmen. (2008) Evaluar para mejorar la enseñanza en la Universidad. Sentido didáctico y curricular de las evaluaciones. Cuadernos de Investigación Educativa, 2(15), 91-114.

Ferreiro Concepción, J. F., \& Fernández Medina, C. R. (2020). Una mirada a la evaluación por rúbricas a través de las TIC. Mendive, 18(1), 92-104.

Galindo-Rubio, F. (2004). Comunicación Audiovisual Corporativa. Cómo audiovisualizar la identidad de las organizaciones. España: Universidad Pontificia Salamanca.

Hodges, C., Moore, S., Lockee, B., Trust, T., \& Bond, A. (27 de marzo de 2020). The difference between energency remote teaching and online learning. Educause Review. Recuperado el 25 de mayo de 2021, de https://er.educause.edu/articles/2020/3/ the-difference-between-emergency-remote-teaching-and-online-learning

Iborra, M., \& Dasí, A. (2009). ¿Cómo aprender a trabajar en equipos integrados? El papel del aprendizaje cooperativo en la formación de directivos. @tic. Revista d'inovació educativa(3), 29-38.

Krutka, D., Carano, K., Casell, L., Lavoie, M., \& Davidson-Taylor, K. (2019). Wise practices and intercultural understandings: A framework for educator videoconferencing. Journal of Research on Technology in Education, 51(4), 356-376. doi:10.1080/153915 23.2019.1652869

López-Morocho, L. R. (2020). Educación remota de emergencia, virtualidad y desigualdades: pedagogía en tiempos de pandemia. 593 Digital Publisher CEIT, 5(5-2), 98-107. doi:10.33386/593dp.2020.5-2.347

Marino-Jimenez, M., Torres-Ravello, C., \& Valdivia-Llerena, G. (2020). Educación y medios audiovisuales: una reflexión sistémica para su implementación, fortalecimiento y sostenibilidad. Propósitos y Representaciones, 8(1), e438. doi:10.20511/ pyr2020.v8n1.438 
Neira del Ben, P., Rodríguez Queija, C., \& Villanueva Penedo, J. (2020). Enseñanza de emergencia a distancia: textos para la discusión. The Learning Factor. Recuperado el 07 de mayo de 2021, de http://www.educaccionperu.org/wp-content/ uploads/2020/04/Ensen\%CC\%83anza-Remota-de-Emergencia-Textos-para-la-discusio\%CC\%81n.pdf

Organización Munidal de la Salud. (20 de marzo de 2020). Brote de enfermedad por coronavirus (COVID-19). Obtenido de https://www.who.int/es/emergencies/diseases/novel-coronavirus-2019

Pérez Medina, Y., \& Ferreriro Concepción, J. F. (2019, junio). Los valores en la cultura digital. Revista Caribeña de Ciencias Sociales. Recuperado el 25 de 05 de https:// www.eumed.net/rev/caribe/2019/06/valores-cultura-digital.html

Rueda Beltrán, M., Fernández Lamarra, N., García, P., Bakieva, M., González Such, J., Jornet Meliá, J. M., . . . Bozo de Carmona, A. (2019). Prácticas y condiciones institucionales para el desarrollo de la docencia en universidades iberoamericanas. Publicaciones, 49(1), 19-37. doi:10.30827/publicaciones.v49i1.9850

University of Colorado Boulder. (2020). PhET Interactive Simulations. Recuperado el 05 de 05 de 2021, de PhET Interactive Simulations: https://phet.colorado.edu/

Xie, H., Mayer, R. E., Wang, F., \& Zhou, Z. (2019). Coordinating visual and auditory cueing in multimedia learning. Journal of Educational Psychology, 111(2), 235-255. doi:10.1037/edu0000285 


\section{La Modalidad Virtual en Electrotecnia General como Motivacion para el Rediseño de Estrategias Didácticas Orientadas a la Sustentabilidad Curricular}

\section{Ferreira, Fabiana}

Universidad de Buenos Aires

fferreir@fi.uba.ar 


\title{
LA MODALIDAD VIRTUAL EN ELECTROTECNIA GENERAL COMO MOTIVACIÓN PARA EL REDISEÑO DE ESTRATEGIAS DIDACTICAS ORIENTADAS A LA SUSTENTABILIDAD CURRICULAR
}

\author{
Ferreira, Fabiana \\ Universidad de Buenos Aires \\ fferreir@fi.uba.ar
}

\section{Resumen}

Hasta Marzo de 2020 el área curricular de Electrotecnia General de la Facultad de Ingeniería de la Universidad de Buenos Aires (FIUBA) desarrollaba sus clases, tanto teóricas como prácticas, en modalidad presencial. Las clases teóricas eran explicaciones dialogadas mientras que las prácticas incluían la resolución de problemas y la ejecución de prácticas de laboratorio. Al suspenderse las clases presenciales por la pandemia, en Marzo de 2020, fue necesario no sólo rediseñar las actividades didácticas para la modalidad virtual sino también replantear los objetivos de enseñanza en el marco de la sustentabilidad curricular, proponiendo que los docentes experimentaran diversas estrategias didácticas según su enfoque docente. Surgieron así nuevas actividades de enseñanza, que fueron progresivamente orientándose hacia el modelo de Aprendizaje Centrado en el Estudiante (ACE), con recursos didácticos diferenciados, diseñados e implementados por los equipos docentes a cargo de cada una de las clases, tanto teóricas como prácticas. Los estudiantes pudieron elegir, según sus habilidades, competencias y estilo de aprendizaje, la clase más adecuada a su perfil. Analizando los resultados del primer año de implementación se obtienen conclusiones respecto a la continuidad de la modalidad virtual y la necesidad de una variedad de estrategias didácticas que contemplen los diversos enfoques de aprendizaje. Se observó también el alto grado de motivación de los docentes al poder diseñar ellos mismos las actividades de sus clases.

\section{Palabras clave}

Ingeniería, virtualidad, Aprendizaje Centrado en el Estudiante, Electrotecnia. 


\section{Introducción}

El desarrollo de las tecnologías de la información y comunicación ha reorganizado la forma en que aprendemos (G.Siemens, 2005): se requieren competencias de auto aprendizaje para poder resolver problemas nuevos en contextos de incertidumbre y en sistemas sociales cada vez más interdependientes (E. Tenti Fanfani, 2009). Esto implica también un cambio en los procesos de enseñanza, para que sean reflectivos del medio social, incorporando los nuevos dispositivos tecnológicos y culturales que marcan desde una perspectiva cognitiva a nuestros alumnos (M. Maggio,2016). Surge, como nuevo paradigma de la Educación Superior, la sustentabilidad curricular que implica desarrollar estrategias de enseñanza holísticas e innovadoras, para "formar personas participativas y proactivas que sean capaces de tomar decisiones responsables, adquirir conciencia de los desafíos que plantea la globalización y promover el respeto a la diversidad y la cultura de la paz" (A Barrón et. al. , 2010).

Este paradigma requiere un nuevo curriculo que utilice la tecnología y las habilidades propias del estudiante para potenciar el aprendizaje (K, Overby, 2011) (Cukierman, 2018). Este enfoque, denominado Aprendizaje Centrado en el Estudiante (ACE), ubica al estudiante (aprendiz) en el centro del proceso. El instructor pone a disposición de los estudiantes "oportunidades de aprendizaje" para aprender en forma autónoma, con sus pares y/o acompañado por tutores (docentes o aprendices más avanzados) (J.W. Collins et al., 2011). La propuesta es integrar diversas estrategias didácticas (D. M. Parra Pineda, 2008) para motivar a los estudiantes a seguir aprendiendo, propiciar el desarrollo de nuevas habilidades / competencias, y alcanzar niveles más profundos de comprensión de la temática en estudio, teniendo en cuenta las capacidades individuales de cada aprendiz.

Para enfrentar estos nuevos desafíos, la Confederación de Decanos de Ingeniería de la República Argentina CONFEDI propuso "consolidar un modelo de aprendizaje centrado en el estudiante" (CONFEDI, 2018). En este documento se da particular importancia al perfil de egreso "que habilite al ingeniero para aprender y desarrollar nuevas tecnologías, con actitud ética, crítica y creativa para la identificación y resolución de problemas en forma sistémica...", detallando un listado de competencias genéricas de egreso tecnológicas, como sociales, políticas y actitudinales.

En la enseñanza de la Ingeniería en Argentina se han realizado diversas experiencias con este enfoque (O. Spositto et.al, 2017). En la FIUBA hemos implementado el Aprendizaje Basado en Proyectos (F. Ferreira y G. Musso, 2018), incluso en uno de los cursos de Electrotecnia General. Si bien los resultados de estas experiencias fueron alentadores, resultaba difícil incentivar a los docentes para extender el ACE a la totalidad de los cursos del área curricular Electrotecnia General.

La oportunidad de innovar la brindó, el 15 de Marzo de 2020, la suspensión repentina de las clases presenciales en todos los niveles educativos de la República Argentina: hubo que pasar en apenas pocas semanas de la modalidad presencial a la virtual. Se optó por potenciar la amplia experiencia de los docentes, dejándoles la libertad de elegir en cada curso qué estrategia didáctica adoptar. Así, pasar de la modalidad presencial a la de distancia promovió el desarrollo de nuevas estrategias docentes. El objetivo general de esta adaptación fue comenzar a experimentar con el ACE en concordancia con la propuesta para los nuevos estándares de ingeniería. Si bien este modelo pedagógico parecía adecuado para implementarlo en las clases prácticas, 
el desafío fue adaptar las clases teóricas, que se desarrollaban hasta ese momento con un enfoque docente ejecutivo (Fenstermacher et. al.,2015).

\section{Descripción de la experiencia}

\section{Descripción del contexto y de los participantes}

El Área curricular de Electrotecnia General abarca nueve asignaturas cuatrimestrales para diferentes terminales de Ingeniería, cuyo contenido es Circuitos Eléctricos, Fundamentos de Máquinas Eléctricas y de Instalaciones Eléctricas. Estas asignaturas se organizan en cursos cuatrimestrales de tres horas semanales de clases teóricas y cuatro horas semanales de clases prácticas. Las clases teóricas desarrollan los conceptos fundamentales mientras que las prácticas se ocupan de la ejercitación y de las actividades de laboratorio.

El Área cuenta con 8 (ocho) cargos docentes de Jefe de Trabajos Prácticos (JTP), 8 (ocho) cargos de Ayudante de Laboratorio y 5 (cinco) cargos de Profesores: en total 21 (veintiún) cargos docentes ocupados por 19 (diecinueve) docentes. Se realizaban habitualmente reuniones de coordinación docente, por lo que se han consolidado equipos con una buena dinámica de trabajo.

Para que los estudiantes puedan trabajar con seguridad en los laboratorios se ofertan 9 (nueve) cursos de 38 (treinta y ocho) vacantes cada uno, resultando así un total de 342 (trescientas cuarenta y dos) vacantes que siempre se cubren en forma completa e incluso no resultan suficientes.

Cuando el primer cuatrimestre de 2020 estaba a punto de iniciarse se decretó el Aislamiento Social Preventivo y Obligatorio, por lo que repentinamente hubo que transformar las clases a la modalidad a distancia. Para facilitar la adaptación la FIUBA prorrogó un mes la fecha de inicio de clases, con lo que se dispuso de tres semanas para rediseñar un cuatrimestre que estaba planificado como presencial. Por esta demora de inicio, el primer cuatrimestre de 2020 terminó a fines de Agosto y el segundo continuó en el mes de Febrero de 2021.

Ante esta situación, los docentes del área comenzamos a realizar reuniones para decidir como reorganizar las clases, las herramientas a utilizar y las estrategias de enseñanza.

\section{Procedimiento}

En este contexto se planteó el rediseño de las estrategias de enseñanza para adaptarlas a la modalidad virtual. Se estableció como objetivo principal sostener la comunicación didáctica mediante estrategias docentes orientadas a implementar el modelo de enseñanza propuesto por los nuevos estándares para las carreras de Ingeniería, tanto el desarrollo de competencias genéricas y especificas como el Aprendizaje Centrado en el Estudiante.

Dado que la implementación era de carácter urgente y obligatorio, sin posibilidad de experimentación previa, se planteó un avance progresivo hacia los objetivos propuestos. La FIUBA puso a disposición de los docentes el campus Moodle (campus.fi.uba.ar), 
las herramientas G Suite, Adobe Connect y Zoom. Para todos estos recursos hubo capacitación y asesoría on - line.

Del análisis de la situación inicial surgieron algunas restricciones :

- La única forma de contactar a los estudiantes era a través del campus, una vez que estuvieran inscriptos. No se disponía de las direcciones de email ni había posibilidad de encuentro presencial.

- La disponibilidad de recursos informáticos y accesibilidad era variable. Ante la situación de emergencia algunos docentes y estudiantes estaban varados en lugares sin conexión a Internet, sin computadoras o con computadoras compartidas con su grupo familiar.

- La falta de experiencia en clases virtuales: sólo se había dictado a distancia un cuatrimestre de una de las clases teóricas (F. Ferreira y L. Donzelli , 2018).

- El material didáctico ya digitalizado era escaso: algunas presentaciones, apuntes y un canal Youtube con videos de los contenidos completos.

\section{Diseño}

Se establecieron las siguientes pautas:

- De acuerdo a la relación docente-alumno se optó por que fueran las clases de práctica las que sostuvieran la comunicación continua con los estudiantes. Estas clases funcionarían en modalidad sincrónica y serían de asistencia obligatoria.

- Las clases teóricas no serían obligatorias, y los estudiantes podrían elegir libremente a cual asistir

- Las actividades y estrategias de enseñanza serían propuestas por cada docente a cargo de una clase. También se permitió a cada equipo docente la selección de las herramientas que le parecieran más adecuadas.

Surgieron así diferentes estrategias docentes tanto en los cursos de práctica como en los cursos de teoría. Por la limitación temporal, el diseño fue modificándose en la medida que avanzaba la experimentación.

Al priorizar la comunicación didáctica y el rol docente, el docente se transformó en el "guía o facilitador, ya que, desde su conocimiento y su experiencia como docente de la disciplina, configura las estrategias y acciones necesarias para que sea el alumno el que construya el conocimiento" (E. Litwin, 2016), surgiendo la necesidad del Aprendizaje Centrado en el Estudiante. Los docentes se enfrentaron entonces al desafío de proponer actividades didácticas virtuales que implementaran este enfoque en el marco de las restricciones ya detalladas.

\section{Implementación}

Las clases de práctica combinaron la modalidad sincrónica y la asincrónica, utilizando diversos recursos y herramientas. Para los repositorios de materiales algunos 
cursos eligieron el campus virtual, otros Google Drive y otros Classroom. Las estrategias activas que utilizaron las clases de práctica fueron el Método de Problemas, la enseñanza por descubrimiento, la tutoría y el Aprendizaje Basado en Proyectos.

Método de problemas: se reformuló la guía de problemas, planteándolos como desafíos de aprendizaje que los estudiantes deben intentar resolver por sí mismos para luego participar en foros o espacios de consulta virtuales abiertos en forma permanente. Se diseñaron también actividades de autoevaluación en el campus, en las que los alumnos discuten con sus pares las alternativas de solución.

Enseñanza por indagación: mediante la simulación de circuitos los estudiantes experimentan sus propias soluciones a diversas situaciones, investigando hasta obtener los valores óptimos. También se utilizan animaciones y videos de experiencias de laboratorio proponiendo que los alumnos indaguen sobre el funcionamiento de los diferentes tipos de máquinas eléctricas.

Tutorías: ante la desorientación e inquietud de los estudiantes por la suspensión repentina de las clases presenciales fue necesario realizar seguimientos individuales de situaciones particulares. Se implementaron foros para este tipo de consultas y los docentes estuvieron disponibles en forma permanente por email y chat para resolver las situaciones que se fueron presentando.

Método de Proyectos: en uno de los cursos se implementa un Proyecto Integrador que consiste en el diseño preliminar de una instalación eléctrica industrial. Se realizaron reuniones virtuales periódicas con los grupos y entregas periódicas de informes parciales a lo largo del cuatrimestre. Cada informe se revisa, se conversa y se reelabora en reuniones virtuales sincrónicas.

Las actividades de laboratorio se suspendieron hasta poder realizarlas en forma presencial en Febrero y Marzo de 2021. Al suspenderse la presencialidad nuevamente en 2021, quedaban todavía bastantes alumnos del 2020 que no habían realizado los laboratorios. Entre Junio y Agosto de 2021 se implementó una evaluación virtual que incluía la aprobación de un examen luego de una clase de explicación y la realización de un informe individual para cada práctica con un conjunto de datos personalizado. Para esto se destinó un equipo de 5 (cinco) docentes. Estas clases se configuraron así como una tutoría individual con seguimiento personalizado por email, campus y encuentros sincrónicos.

Las clases teóricas tuvieron como función principal la integración conceptual y orientación general de los estudiantes. La situación inicial fue complicada ya que había dos clases que no podían iniciarse por falta de conectividad del Profesor, que optó por grabar audios de sus clases. En este contexto cada profesor recurrió a los materiales que ya disponía y a las herramientas de software que manejaba, resultando en el primer cuatrimestre tres clases de características muy distintas (Tabla 1). 


\begin{tabular}{|c|c|c|c|}
\hline $\begin{array}{c}\text { Clase } \\
\text { Teórica }\end{array}$ & Clases sincrónicas & Recursos & Repositorio \\
\hline T1 & Zoom ( solo consultas ) & Apuntes (pdf), videos & Google Drive \\
\hline T2 & No & Apuntes (pdf), audios & Google Drive \\
\hline T3 & Zoom & $\begin{array}{c}\text { Presentaciones(ppt), videos web, } \\
\text { cuestionarios de autoevaluación }\end{array}$ & $\begin{array}{c}\text { Campus FIUBA- } \\
\text { Youtube }\end{array}$ \\
\hline
\end{tabular}

Tabla 1 - Características de las clases teóricas del primer cuatrimestre 2020

A partir de la experiencia del primer cuatrimestre se modificaron las estrategias didácticas para que los estudiantes tuvieran un rol más activo en las clases teóricas. Dos de las teóricas implementaron estrategias activas: el Método de Problemas, el Método de Casos y el Método de Indagación. La T1 decidió adoptar un esquema de clase invertida mientras que la T3 realizó actividades colaborativas. Para brindar a los estudiantes una opción similar a la anterior a la pandemia se decidió mantener la T2 con clases sincrónicas del mismo estilo que las presenciales,

\section{Resultados}

Los instrumentos de evaluación de resultados fueron la observación de clases, los resultados de evaluaciones y el relevamiento de opiniones de los participantes.

En los dos cuatrimestres de 2020 el abandono promedio fue del 28\%, bastante mayor que el de los cuatrimestres presenciales. Los docentes consideraron que esto podía originarse en el mayor compromiso y cantidad de tareas que requiere el nuevo modelo de enseñanza. Consultados los estudiantes mencionan "la falta de tiempo para realizar todas las actividades que piden los docentes", "el exceso de tareas por las clases a distancia" y diversas dificultades para organizar sus horarios y actividades ante el cambio de modalidad.

Se observaron importantes diferencias entre los cursos en los porcentajes de aprobación de cursada. Se destaca que el curso que implementó mejor las tutorías y la consulta continua, fue el que tuvo el mayor porcentaje de aprobados (mayor al $90 \%$ ). Los alumnos que han aprobado la cursada manifiestan "que han aprendido mejor" y que "prefieren seguir con esta modalidad".

No hubo inicialmente diferencias entre los porcentajes de estudiantes que asistían a clases teóricas en la modalidad presencial y los que lo hicieron en la modalidad virtual. En la medida que se fueron mejorando los materiales didácticos varios alumnos optaron por abandonar las clases teóricas e intentar el autoaprendizaje. En la primera implementación se observó que los alumnos solían cambiarse de teórica y un $11 \%$ de los estudiantes asistía a más de una teórica. Los de este grupo mencionan la utilidad de "ver varias veces el mismo tema con diferentes explicaciones". Al consultar a los estudiantes los motivos por los cuales elegían una de estas clases, el 52\% plantea como motivo principal el horario de las clases. Consultados aquellos que realizaron cambios manifiestan que "prefieren clases en las que se explique en forma tradicional y no se requiera su participación en forma permanente".

Los docentes coinciden en que debieron duplicar la dedicación horaria semanal para poder atender a los estudiantes. El primer cuatrimestre de 2020 fue percibido como 
"agotador", ya que se sumó al seguimiento de los cursos la preparación de los materiales. Otra cuestión que destacan es la cantidad de alumnos por docente que les pareció que no era adecuada para hacer un seguimiento personalizado. A pesar del cansancio y el esfuerzo realizado, los docentes están muy satisfechos con lo que han logrado, se han sentido motivados y con posibilidades de desarrollar su potencial.

El $95 \%$ de los estudiantes valoró positivamente los materiales digitales. Sobre el formato de su preferencia, el $67 \%$ indicó los videos, un $9 \%$ los audios y el resto los textos. Un 76 \% mencionó que no suele consultar los materiales antes de asistir a las clases.

En las evaluaciones integradoras los profesores observaron serias deficiencias conceptuales, mayores que las que se detectan en estudiantes que han cursado en modalidad presencial. Los aprobados fueron en su mayoría alumnos que asistieron a las clases teóricas.

\section{Conclusiones y perspectivas futuras}

La suspensión de las clases presenciales fue una motivación para transformar las estrategias didácticas, que se venían implementando de la misma forma hacía varios años.

Se lograron superar los prejuicios de los docentes respecto a la modalidad a distancia: han propuesto para el futuro la modalidad semipresencial. Se sintieron cómodos en su nuevo rol de "acompañantes en el camino de aprendizaje" (Litwin, 2016). en vez de ser "transmisores" o "distribuidores" de contenidos.

El Aprendizaje Centrado en el Estudiante facilitó los aprendizajes para la comprensión (M.S: Wiske, 1999) por lo que se continuará aplicando en el futuro esta estrategia de enseñanza. Algunos estudiantes prefieren el enfoque ejecutivo tradicional de las clases, por lo que se considera conveniente no forzar todavía la implementación del ACE en todos los cursos.

La libertad para elegir el modelo más adecuado a cada participante (estudiante o docente) podría potenciar el aprendizaje y mejorar la calidad de la enseñanza.

\section{Referencias}

Barrón, Á., Ferrer-Balas, D., Navarrete Salvador, A. (2010). Sostenibilización curricular en las universidades españolas. ¿ ha llegado la hora de actuar?.Revista Eureka Enseñanza y Divulgación Científica, vol. 7 ,pp. 388-399.

Collins J. W. ; O'Brien N. P.(2011). The Greenwood dictionary of education. ABC- CLIO.

CONFEDI (2018). Propuesta de estándares de segunda generación para la acreditación de carreras de Ingeniería en la Republica Argentina . Confederación de Decanos de Ingeniería de la Argentina.

Cukierman, U. (2018). Aprendizaje centrado en el estudiante: un enfoque imprescindible para la educación en ingeniería. de Aseguramiento de la calidad y mejora de la educación en ingeniería. Experiencias en América Latina, Bogotá, ACOFI/CONFEDI, 27-39. 
Fenstermacher, G., Soltis, J., \& Sanger, M. (2015). Approaches to teaching. Teachers College Press.

Ferreira F. , Donzelli L. (2018). Los videos de clases como herramienta para promover el Aprendizaje Basado en el Estudiante en Electrotecnia General. XIV Jornadas de Material Didáctico y Experiencias Innovadoras en Educación Superior. Buenos Aires.

Ferreira F. ; Musso G. (2018) . Diseño de una estrategia didáctica centrada en el estudiante para la enseñanza de Automatización Industrial. Primeras Experiencias en la FIUBA . XXVI Congreso Argentino de Control Automático . Buenos Aires

Litwin E. (2016). El oficio de enseñar. Condiciones y contextos. Paidós

Maggio, M. (2016). Enriquecer la enseñanza: los ambientes con alta disposición tecnológica como una oportunidad. Paidós.

Overby, K. (2011) . Student-centered learning. Essai. (9), 109-112.

Parra Pineda D. M. (2008). Manual de Estrategias de Enseñanza Aprendizaje . Servicio Nacional de Aprendizaje (SENA) .

Tenti Fanfani E. (2009). Sociología de la educación. Editorial Universidad Nacional de Quilmes.

Siemens, G. (2005). Connectivism: A learning theory for the digital age. International Journal of Instructional Technology and Distance Learning. Vol. 2(1), pp. 3-10.

Spositto O. et al. (2017) Enseñanza de la Ingeniería. Hacia un modelo Pedagógico Transformador. Editorial UNLaM.

Wiske, M. S. (1999). Enseñanza Para La Comprensión, Paidós. 


\section{Aula Invertida y E-actividades: Aprendizajes de su Implementación en Una Asignatura Universitaria de Ciencias Económicas.}

\section{Golden, Hugo David}

Universidad Católica Argentina

davidgolden@uca.edu.ar 


\section{AULA INVERTIDA Y E-ACTIVIDADES: APRENDIZAJES DE SU IMPLEMENTACIÓN EN UNA ASIGNATURA UNIVERSITARIA DE CIENCIAS ECONÓMICAS.}

\section{Golden, Hugo David}

Universidad Católica Argentina

davidgolden@uca.edu.ar

\section{Resumen}

El objetivo del presente trabajo es compartir la experiencia de implementación y evaluación del enfoque de aula invertida en la asignatura Finanzas Públicas y Control de la Universidad Católica Argentina, Facultad Teresa de Ávila, desarrollado durante el primer semestre de 2021. Dicha implementación es la primera en su tipo dentro de la facultad, se apoya tecnológicamente en un sistema de gestión del aprendizaje denominado EVA-UCA y contempla la utilización de e-actividades como núcleo de la propuesta pedagógica, siendo éstas a su vez los medios esenciales para la evaluación formativa del curso. Combinando diversas fuentes de datos, se indaga en las debilidades, amenazas, oportunidad y fortalezas de esta particular experiencia, extrayendo aprendizajes y conclusiones para la mejora de futuras experiencias.

\section{Palabras clave}

Tecnologías de información y comunicación, aula invertida, educación a distancia, ciencias económicas. 


\section{Introducción}

La implementación del enfoque invertido en la enseñanza universitaria ha ganado espacios como parte de un movimiento pedagógico más amplio a nivel internacional, en particular en la última década. Su implementación ha conllevado diversos beneficios, no sólo en cuanto a rendimiento académico, sino también en aprendizaje significativo, en aumento de la motivación, autorregulación y desarrollo de habilidades diversas, tales como el trabajo en equipo y la adquisición de competencias analíticas. (Hinojo Lucena, et al., 2019; Perdomo Rodríguez, 2017). Compatible con diversas metodologías y técnicas de enseñanza-aprendizaje, el enfoque invertido no requiere necesariamente modalidades de educación a distancia para su implementación, aunque la expansión de estas últimas lo ha potenciado por el creciente rol de las TIC en la educación universitaria.

En Argentina, las restricciones a la movilidad, así como las medidas de aislamiento y distanciamiento social desde 2020, profundizaron la aplicación generalizada de la educación a distancia (e-learning) o híbrida (b-learning) en el ámbito universitario. La introducción de TIC, como tecnología de soporte de estas modalidades educativas, exige la formulación de un diseño pedagógico y de una propuesta tecno-instruccional para el alumnado que resulten adecuados a los objetivos de aprendizaje y a las características del curso y sus destinatarios (Coll, 2004; 2008).

Durante el primer semestre de 2021, se puso en práctica un rediseño pedagógico de la asignatura Finanzas Públicas y Control, correspondiente al tercer año de la carrera de Contador Público de la Universidad Católica Argentina, sede Paraná. El rediseño no alteró los contenidos programáticos ni los objetivos de aprendizaje, sino sólo el enfoque y técnicas de instrucción, migrando del enfoque tradicional al de aula invertida y aplicando e-actividades como núcleo de la propuesta pedagógica. Luego de realizar la evaluación sobre esta experiencia, el objetivo de esta contribución es exponer algunos resultados y aprendizajes emergentes de la evaluación realizada sobre la implementación de dicho enfoque.

\section{Descripción de la experiencia}

A partir de la revisión de experiencias y capacitaciones docentes realizadas a lo largo de 2020, se desarrolló un rediseño pedagógico de la asignatura contemplando la posibilidad de que las modalidades de dictado fueran tanto a distancia como híbridas y aplicando las funcionalidades del sistema de gestión del aprendizaje de la universidad EVA-UCA (Moodle 3.8). Considerando la naturaleza y características de la materia, así como los objetivos de aprendizaje de la asignatura, se decidió adoptar un enfoque de aula invertida, siendo la primera experiencia en su tipo dentro de la Facultad. La abundante disponibilidad de material teórico-práctico online que ya solía utilizarse en la asignatura, así como su ubicación relativamente avanzada dentro del plan de carrera, constituyeron factores que apoyaron esta decisión.

El aprendizaje invertido constituye un enfoque pedagógico que mueve parte de la instrucción directa tradicional del aula hacia un espacio individual y transforma el aula en un entorno de aprendizaje dinámico e interactivo, en el cual el educador orienta la aplicación activa de la materia estudiada. (Flipped Learning Network, 2014) El aula invertida estipula una importante carga de actividades de instrucción 
extra áulicas al alumno pero sin abandonar totalmente la dinámica tradicional de clase magistral, la cual se sigue aplicando parcialmente en combinación con otras técnicas (Observatorio de Innovación Educativa, 2014).

\section{Implementación de la estrategia}

El curso rediseñado se implementó en el primer semestre de 2021, con una cohorte de 29 alumnos. Los contenidos dentro de EVA-UCA fueron organizados en secciones que emularon las unidades temáticas del programa oficial de la asignatura, diseñados específicamente, con páginas internas y otros recursos (etiquetas, videos, documentos introductorios y wikis hipervinculadas, glosario y noticias de actualidad), incluyendo una serie de foros organizados por núcleos temáticos. Una sección inicial fijada facilitó permanentemente consultas a docentes, cronograma actualizado, repositorio de lecturas, programa, guías de ejercitación y foro de comunicación horizontal, al cual fueron vinculados todos los alumnos matriculados en el curso.

En la primera clase se presentó el enfoque adoptado, así como el cronograma de temas/actividades. Entre 2 y 5 días previo a cada clase se emitió una comunicación breve, recordando los contenidos a analizar (tanto complementarios como de lectura obligatoria) y las e-actividades de aplicación que debían ser realizadas previo a la clase. Se buscó centrar la clase en una revisión breve de contenidos, interacciones profesor-estudiante y estudiante-estudiante, discutiendo resultados de las e-actividades y profundizando en aspectos de aplicación. Ello contribuyó a lograr una dinámica más adecuada para el desarrollo persistente de encuentros virtuales frecuentes.

Las e-actividades consistieron en una secuencia de acciones de aplicación teórico-práctica de los conceptos, habilidades y actitudes que se pretende desarrollar. Al realizarlas, los estudiantes ponen en juego habilidades y competencias de diversa índole, bajo metodologías activas apoyadas por las TIC, posibilitando un aprendizaje significativo. (Silva, 2017) Estas e-actividades constituyeron un aspecto central de la estrategia adoptada y se apoyaron en EVA-UCA, así como en recursos digitales de libre disponibilidad. En las primeras 3 semanas, el diseño de las e-actividades se orientó a objetivos básicos de la taxonomía de Bloom extendida para las competencias digitales (Churches, 2008): Recordar, Comprender y Aplicar contenidos. Esta situación se correspondió con asignaciones individuales y considerando el abordaje de contenidos introductorios y categorías conceptuales específicas básicas de la asignatura, cuya aprehensión por cada alumno resultaba esencial para un adecuado desarrollo de los objetivos de aprendizaje. Posteriormente, conforme se avanzó en contenidos de mayor complejidad, así como en una mayor adaptación a la dinámica invertida por los alumnos, se dio lugar a asignaciones fundamentalmente grupales y colaborativas, orientadas prioritariamente a perfeccionar capacidades de Analizar, Evaluar, Crear y Compartir. Las producciones escritas y audiovisual de los alumnos para cada e-actividad constituyeron los medios de evaluación formativa de la asignatura (Hamodi et al., 2015). En particular, una serie de actividades encadenadas secuencialmente en 3 etapas constituyeron un Trabajo Práctico Integrado (TPI) culminando en la publicación de una producción original escrita y audiovisual objeto, a su vez, de discusión entre pares. 


\section{Evaluación de la estrategia implementada}

La evaluación del nuevo diseño pedagógico implementado constituyó un aspecto inherente a su formulación, por tratarse de una experiencia novedosa y transformadora. Dicha evaluación comenzó en las últimas semanas de cursado y se extendió hasta 1 mes después del mismo, integrándose para ello múltiples datos cuanti-cualitativos sobre la performance de los alumnos y sus percepciones y opiniones. Se consideraron 3 dimensiones de análisis: EVA y educación a distancia; Enfoque de aula invertida del curso, y E-actividades del curso. Para cada dimensión se formularon interrogantes orientando la recopilación y análisis de datos (ver detalle en la Tabla 1), emulando experiencias análogas, aunque ninguna sobre asignaturas del ramo económico. Se utilizaron como fuentes: estadísticas y métricas de plataforma EVAUCA, encuesta voluntaria y entrevistas personales a alumnos. Se realizó por último un encuentro dialógico tipo taller con alumnos que no habían sido entrevistados para recuperar percepciones y opiniones. 


\begin{tabular}{|c|c|c|c|c|c|c|}
\hline & & & $\begin{array}{l}\text { Cuestiona- } \\
\text { rio estruc- } \\
\text { turado }\end{array}$ & $\begin{array}{c}\text { Métricas } \\
\text { EVA- } \\
\text { UCA }\end{array}$ & $\begin{array}{l}\text { Taller } \\
\text { DAFO }\end{array}$ & $\begin{array}{l}\text { Entrevis- } \\
\text { tas }\end{array}$ \\
\hline \multirow{7}{*}{ 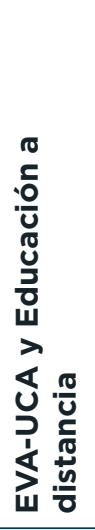 } & \multirow{2}{*}{$\begin{array}{l}\text { Dispositivos } \\
\text { utilizados }\end{array}$} & Para las clases & $x$ & & $x$ & $x$ \\
\hline & & $\begin{array}{l}\text { Para las e-actividades de } \\
\text { aplicación }\end{array}$ & $x$ & & $x$ & $x$ \\
\hline & \multirow{2}{*}{$\begin{array}{l}\text { Ámbitos } \\
\text { utilizados }\end{array}$} & Para las clases & $x$ & & $x$ & $x$ \\
\hline & & $\begin{array}{l}\text { Para las e-actividades de } \\
\text { aplicación }\end{array}$ & $x$ & & $x$ & $x$ \\
\hline & \multirow{3}{*}{$\begin{array}{l}\text { Utilización } \\
\text { de EVA- } \\
\text { UCA }\end{array}$} & $\begin{array}{l}\text { Experiencia previa con EVA- } \\
\text { UCA }\end{array}$ & $x$ & $x$ & $x$ & $x$ \\
\hline & & Dificultades de uso & $x$ & & $x$ & $x$ \\
\hline & & $\begin{array}{l}\text { Empleo en otras asignaturas } \\
\text { paralelas }\end{array}$ & $x$ & $x$ & $x$ & $x$ \\
\hline \multirow{11}{*}{ 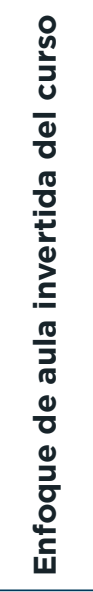 } & \multirow{11}{*}{ Percepción } & Accesibilidad & $x$ & & $x$ & $x$ \\
\hline & & Equidad & $x$ & & $x$ & $x$ \\
\hline & & Excelencia académica & $x$ & & $x$ & $x$ \\
\hline & & Aprovechamiento de clase & $x$ & & $x$ & $x$ \\
\hline & & Participación & $x$ & & $x$ & $x$ \\
\hline & & Motivación & $x$ & & $x$ & $x$ \\
\hline & & Rendimiento & $x$ & & $x$ & $x$ \\
\hline & & Satisfacción & $x$ & & $x$ & $x$ \\
\hline & & Evaluación formativa & $x$ & & $x$ & $x$ \\
\hline & & Competencias digitales & $x$ & & $x$ & $x$ \\
\hline & & Auto-organización & $x$ & & $x$ & $x$ \\
\hline \multirow{16}{*}{ 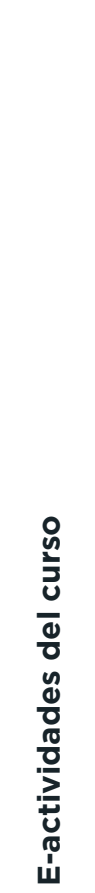 } & \multirow{3}{*}{$\begin{array}{l}\text { Percepción } \\
\text { General }\end{array}$} & Coherencia con contenidos & $x$ & & $x$ & $x$ \\
\hline & & $\begin{array}{l}\text { Coherencia con objetivos de } \\
\text { aprendizaje }\end{array}$ & $x$ & & $x$ & $x$ \\
\hline & & Utilidad y relevancia & $x$ & & $x$ & $x$ \\
\hline & \multirow{5}{*}{ Foros } & Interacciones & & $x$ & $x$ & $x$ \\
\hline & & Frecuencia de vistas & & $x$ & $x$ & $x$ \\
\hline & & Sobrecarga cuantitativa & $x$ & & $x$ & $x$ \\
\hline & & Utilidad y relevancia & $x$ & & & $x$ \\
\hline & & Nivel de dificultad & $x$ & & $x$ & $x$ \\
\hline & \multirow{4}{*}{ TPI } & Pertinencia & $x$ & & & $x$ \\
\hline & & Sobrecarga cuantitativa & $x$ & & $x$ & $x$ \\
\hline & & Utilidad y relevancia & $x$ & & & $x$ \\
\hline & & Nivel de dificultad & $x$ & & $x$ & $x$ \\
\hline & \multirow{4}{*}{$\begin{array}{l}\text { Comple- } \\
\text { mentos } \\
\text { (videos, do- } \\
\text { cumentos, } \\
\text { etc.) }\end{array}$} & Pertinencia & $x$ & & & $x$ \\
\hline & & Sobrecarga cuantitativa & $x$ & $x$ & & $x$ \\
\hline & & Utilidad y relevancia & $x$ & & & $x$ \\
\hline & & Nivel de dificultad & $x$ & & $x$ & $x$ \\
\hline
\end{tabular}

Tabla 1: Dimensiones, interrogantes y fuentes de datos de la evaluación. 


\section{Resultados}

Con una cohorte de similar tamaño, el curso 2021 se caracterizó por una proporción relativamente baja de alumnos regularizados, pero con una calificación promedio significativamente mayor para el conjunto de alumnos que regularizaron la asignatura. En dicho grupo se destaca la participación de Recursantes (39\% de quienes regularizaron).

\begin{tabular}{|c|c|c|c|c|c|c|}
\hline Curso & Inscriptos & Recursantes & Culminaron & $\begin{array}{l}\text { Regulariza- } \\
\text { ron }\end{array}$ & $\begin{array}{c}\text { Nota Media } \\
\text { Total }\end{array}$ & $\begin{array}{l}\text { Nota Media } \\
\text { Regulares }\end{array}$ \\
\hline 2018 & 36 & 0 & 34 & 24 & 4,5 & 5,3 \\
\hline 2019 & 32 & 1 & 29 & 18 & 4,5 & 5,2 \\
\hline 2020 & 28 & 3 & 25 & 23 & 4,8 & 5,0 \\
\hline 2021 & 29 & 7 & 26 & 18 & 4,7 & 5,8 \\
\hline
\end{tabular}

Tabla 2: Cantidad de alumnos y desempeño general, por año de cursado.

\section{Encuestas}

Diecinueve alumnos aceptaron completar una encuesta optativa mediante cuestionario estructurado electrónico una vez que las calificaciones de regularidad del curso estuvieron definidas, pero previo a su comunicación. Todos, sin excepción, reconocen un incremento significativo en la cantidad de actividades de aplicación realizadas vis a vis cualquier otro curso de la carrera, y la amplia mayoría $(89,5 \%)$ percibe una mayor accesibilidad a contenidos a partir del cursado a distancia (Tabla 3 ), considerando de modo favorable el enfoque invertido utilizado (Tabla 4).

\begin{tabular}{|c|c|c|c|c|c|c|c|c|}
\hline \multirow{2}{*}{$\begin{array}{l}\text { Con la modalidad virtual de cursado, } \\
\text { mi ACCESIBILIDAD a los contenidos }\end{array}$} & \multicolumn{8}{|c|}{ Calificación Regular } \\
\hline & 2 & 3 & 4 & 5 & 6 & 7 & 9 & Total \\
\hline Se FACILITÓ EN GRAN MEDIDA & 3 & 1 & 2 & 3 & & 1 & 1 & 11 \\
\hline Se FACILITÓ SOLO UN POCO & & & & 3 & 1 & 1 & 1 & 6 \\
\hline NO TUVO INFLUENCIA & & & 1 & & & & & 1 \\
\hline Se DIFICULTÓ EN GRAN MEDIDA & 1 & & & & & & & 1 \\
\hline
\end{tabular}

Tabla 3: opinión sobre de accesibilidad y calificación obtenida (cantidad de alumnos)

Calificación Regular

\begin{tabular}{|c|c|c|c|c|c|c|c|c|}
\hline Creo que el enfoque AULA INVERTIDA utilizada en el curso resultó & 2 & 3 & 4 & 5 & 6 & 7 & 9 & Total \\
\hline Un ENFOQUE MUY BUENO, útil y muy positivo para el cursado & & & 2 & 2 & & & & 4 \\
\hline Un BUEN ENFOQUE, que tiene ciertos puntos positivos & 1 & 1 & & 4 & 1 & 2 & 2 & 11 \\
\hline $\begin{array}{l}\text { Un ENFOQUE QUE NO TIENE VENTAJAS relevantes sobre el } \\
\text { tradicional }\end{array}$ & 1 & & & & & & & 1 \\
\hline Un MAL ENFOQUE, que tiene ciertos puntos en contra & 1 & & 1 & & & & & 2 \\
\hline Un ENFOQUE MUY MALO Y CONTRAPRODUCENTE para el cur & 1 & & & & & & & 1 \\
\hline
\end{tabular}

Tabla 4: opinión general sobre enfoque de aula invertida y calificación obtenida (cantidad de alumnos) 
Resulta indicativo que los principales factores de dificultad identificados en las encuestas se vinculan al escaso tiempo disponible por la competencia que suponen otras actividades (académicas y no académicas), así como a dificultades para administrar tiempo de calidad para las actividades extra áulicas (Tabla 5). Ello se relaciona con la intensa dedicación curricular semanal requerida en el plan de estudios de la carrera, aspecto que invariablemente persistirá, sumado al inicio de actividades laborales, frecuente en alumnos del 3er año.

\begin{tabular}{|l|c|c|}
\hline FACTOR & Frecuencia & \% \\
\hline $\begin{array}{l}\text { Actividades laborales / particulares regulares por fuera de la } \\
\text { universidad }\end{array}$ & 17 & $89 \%$ \\
\hline Muchas tareas demandadas por otras asignaturas que cursé en paralelo & 12 & $63 \%$ \\
\hline Tuve dificultad para organizar mi propio tiempo de estudio & 5 & $26 \%$ \\
\hline Ocurrieron distracciones en mi tiempo dedicado al curso & 4 & $21 \%$ \\
\hline Debí estudiar para exámenes finales de materias regularizadas & 3 & $16 \%$ \\
\hline Inconvenientes personales extraordinarios & 3 & $16 \%$ \\
\hline Problemas de conectividad recurrentes & 3 & $16 \%$ \\
\hline Tenía conocimientos previos insuficientes de otras asignaturas & 2 & $11 \%$ \\
\hline Dificultades para realizar tareas grupales del curso & 2 & $11 \%$ \\
\hline Hubo poco tiempo disponible para dedicar a cada actividad & 2 & $11 \%$ \\
\hline Dificultad para manejar la plataforma EVA & 1 & $5 \%$ \\
\hline SIN INCONVENIENTES & 1 & $5 \%$ \\
\hline
\end{tabular}

Tabla 5: principales factores de dificultad percibidos (cantidad de menciones)

Aun así, la exigencia impuesta por la asiduidad de las e-actividades semanales de aplicación, abonó en los alumnos la estructuración de rutinas de dedicación extra áulica que, en suma, fueron percibidas, en general, luego de algunas semanas como un aspecto facilitador (Tabla 6). Dicha percepción fue ampliamente destacada, ex post facto, en las entrevistas.

$\begin{aligned} & \text { Con aula invertida, mi PROPIA ORGANIZACIÓN de } \\
& \text { estudio se }\end{aligned}$
\begin{tabular}{|l|l|l|l|l|l|l|l|l|c|c|}
\hline CIFICULTÓ en ALGUNA MEDIDA & $\mathbf{3}$ & $\mathbf{4}$ & $\mathbf{5}$ & $\mathbf{6}$ & $\mathbf{7}$ & $\mathbf{9}$ & Total \\
\hline DIFICULTÓ en GRAN MEDIDA & 2 & 1 & 1 & & & & & 4 \\
\hline FACILITÓ en ALGUNA MEDIDA & 2 & & & & & & & 2 \\
\hline FACILITÓ en GRAN MEDIDA & & & 2 & 4 & 1 & 2 & 1 & 10 \\
\hline
\end{tabular}

Tabla 6: percepción del efecto sobre autoorganización y calificación obtenida (cantidad de alumnos)

La valoración ampliamente favorable sobre la evaluación formativa implementada constituyó un aspecto saliente de los resultados obtenidos (Tabla 7), ya que implicó la transformación de mayor impacto directo para los alumnos. Si bien la utilización de actividades de aplicación no constituye una novedad absoluta, si lo ha sido como baremo excluyente para la regularidad. 


\begin{tabular}{|c|c|c|c|c|c|c|c|c|}
\hline \multirow{2}{*}{$\begin{array}{l}\text { Comparada con los parciales tradicionales, considero } \\
\text { que la EVALUACION FORMATIVA resultó ser }\end{array}$} & \multicolumn{8}{|c|}{ Calificación Regular } \\
\hline & 2 & 3 & 4 & 5 & 6 & 7 & 9 & Total \\
\hline MUCHO MEJOR, LA PREFIERO FUERTEMENTE & & & & 1 & & & 1 & 2 \\
\hline ALGO MEJOR, LA PREFIERO & 2 & & 3 & 5 & 1 & 1 & 1 & 13 \\
\hline SIMILAR, ME DA LO MISMO & & 1 & & & & 1 & & 2 \\
\hline ALGO PEOR, NO LA PREFIERO & 1 & & & & & & & 1 \\
\hline MUCHO PEOR, LA RECHAZO ROTUNDAMENTE & 1 & & & & & & & 1 \\
\hline
\end{tabular}

Tabla 7: opinión sobre aplicación de evaluación formativa y calificación obtenida (cantidad de alumnos)

\section{Métricas}

Las métricas generales provenientes de EVA-UCA, sobre las interacciones de los alumnos con recursos y actividades en plataforma desde el inicio del curso no evidenciaron ninguna relación significativa entre comportamiento y rendimiento académico (ver Tabla 8). Es importante notar que dichas métricas contienen prácticas disímiles de difícil segmentación, en particular porque es imposible definir con precisión cuando las interacciones y sesión involucran un ejercicio activo y cuándo sólo reflejan tiempos muertos entre acciones fragmentadas. El análisis de interacciones por tipo de recurso (página de contenidos, secciones, documentos, foros, enlaces externos) tampoco mostró relación clara con el rendimiento académico.

Las métricas, sin embargo, confirman que el alumnado en general cambia drásticamente la intensidad de su dedicación al momento de obtener una calificación, decayendo abruptamente luego del anuncio. Dicho patrón se refleja tanto en situación de aprobación o desaprobación, en este caso, luego de anunciar la calificación de regularidad del curso (la única singularmente relevante del curso 2021). Dicho patrón es común a cursos previos bajo modalidad de evaluación tradicional (exámenes + recuperatorio). El haber acotado el anuncio a una calificación relevante al final del cronograma permitió alcanzar una mejor dedicación de los alumnos, contribuyendo a sostener la tensión y efectividad de las actividades; ello constituye, ciertamente, uno de los hallazgos positivos imprevistos de la experiencia. 


\begin{tabular}{|c|c|c|c|c|c|}
\hline \multirow[b]{2}{*}{$\begin{array}{c}\text { Alum- } \\
\text { no }\end{array}$} & \multirow[b]{2}{*}{ Días } & \multicolumn{4}{|c|}{ Hasta el anuncio de las notas } \\
\hline & & $\begin{array}{l}\text { Clicks } \\
\text { tota- } \\
\text { les }\end{array}$ & $\begin{array}{l}\text { Clicks } \\
\text { diarios }\end{array}$ & $\begin{array}{l}\text { Sesión } \\
\text { prome- } \\
\text { dio }\end{array}$ & Desvío \\
\hline 1 & 22 & 162 & 7,4 & $01: 23: 38$ & 03:05 \\
\hline 12 & 55 & 626 & 11,4 & $03: 50: 34$ & $04: 27$ \\
\hline 19 & 21 & 273 & 13,0 & $00: 56: 43$ & $01: 25$ \\
\hline 18 & 42 & 535 & 12,7 & $03: 52: 07$ & $04: 52$ \\
\hline 29 & 71 & 1.488 & 21,0 & $06: 43: 07$ & 05:13 \\
\hline 21 & 60 & 827 & 13,8 & $04: 24: 09$ & 05:19 \\
\hline 6 & 30 & 281 & 9,4 & 01:40:08 & $01: 50$ \\
\hline 13 & 35 & 401 & 11,5 & $02: 20: 57$ & 02:45 \\
\hline 7 & 63 & 601 & 9,5 & $02: 34: 53$ & 03:26 \\
\hline 27 & 56 & 927 & 16,6 & 03:15:36 & 03:46 \\
\hline 8 & 51 & 515 & 10,1 & $04: 21: 58$ & 05:24 \\
\hline 10 & 55 & 598 & 10,9 & 03:17:23 & $03: 23$ \\
\hline 11 & 19 & 208 & 10,9 & 02:14:19 & 03:29 \\
\hline 15 & 57 & 694 & 12,2 & 05:07:27 & $04: 52$ \\
\hline 16 & 44 & 550 & 12,5 & 03:12:40 & $03: 48$ \\
\hline 17 & 66 & 831 & 12,6 & 05:09:12 & $04: 20$ \\
\hline 26 & 48 & 787 & 16,4 & 03:25:51 & 05:04 \\
\hline 28 & 65 & 1.150 & 17,7 & 06:30:38 & 05:54 \\
\hline 23 & 42 & 621 & 14,8 & 02:39:13 & $03: 48$ \\
\hline 24 & 63 & 1.009 & 16,0 & $04: 52: 41$ & $04: 37$ \\
\hline 25 & 51 & 836 & 16,4 & 05:33:00 & $05: 48$ \\
\hline 3 & 34 & 260 & 7,6 & 02:18:05 & $03: 29$ \\
\hline 14 & 60 & 716 & 11,9 & $05: 41: 24$ & $04: 36$ \\
\hline 20 & 59 & 809 & 13,7 & $05: 52: 38$ & 05:26 \\
\hline 2 & 33 & 250 & 7,6 & $01: 36: 47$ & $02: 36$ \\
\hline 4 & 33 & 258 & 7,8 & $02: 43: 36$ & $04: 27$ \\
\hline 5 & 35 & 286 & 8,2 & 01:51:29 & $03: 28$ \\
\hline 9 & 51 & 528 & 10,4 & 06:10:48 & $07: 43$ \\
\hline 22 & 34 & 494 & 14,5 & $02: 51: 53$ & $04: 23$ \\
\hline Total & 82 & 17.521 & 213,7 & 04:05:18 & $04: 53$ \\
\hline
\end{tabular}

\begin{tabular}{|l|}
\hline Nota \\
\hline A \\
\hline$A$ \\
\hline$A$ \\
\hline 9 \\
\hline 9 \\
\hline 8 \\
\hline 7 \\
\hline 7 \\
\hline 6 \\
\hline 6 \\
\hline 5 \\
\hline 5 \\
\hline 5 \\
\hline 5 \\
\hline 5 \\
\hline 5 \\
\hline 5 \\
\hline 5 \\
\hline 4 \\
\hline 4 \\
\hline 4 \\
\hline 3 \\
\hline 3 \\
\hline 3 \\
\hline 2 \\
\hline 2 \\
\hline 2 \\
\hline 2 \\
\hline 2 \\
\hline
\end{tabular}

\begin{tabular}{|c|c|c|c|}
\hline \multicolumn{4}{|c|}{ Luego del anuncio } \\
\hline Días & $\begin{array}{c}\text { Clicks } \\
\text { tota- } \\
\text { les }\end{array}$ & $\begin{array}{l}\text { Clicks } \\
\text { diarios }\end{array}$ & $\begin{array}{c}\text { Sesión } \\
\text { promedio }\end{array}$ \\
\hline 5 & 8 & 1,6 & O০:00:12 \\
\hline 1 & 11 & 11,0 & 0०:11:00 \\
\hline 5 & 11 & 2,2 & $00: 00: 24$ \\
\hline 3 & 12 & 4,0 & $00: 14: 00$ \\
\hline & & & \\
\hline 10 & 33 & 3,3 & $00: 53: 48$ \\
\hline 2 & 14 & 7,0 & $00: 25: 00$ \\
\hline 3 & 3 & 1,0 & 00:00:00 \\
\hline 7 & 52 & 7,4 & $01: 53: 26$ \\
\hline 3 & 4 & 1,3 & 00:00:20 \\
\hline 1 & 4 & 4,0 & 00:01:00 \\
\hline 6 & 11 & 1,8 & 00:00:10 \\
\hline 1 & 3 & 3,0 & $00: 31: 00$ \\
\hline 2 & 2 & 1,0 & 00:00:00 \\
\hline 5 & 35 & 7,0 & $00: 21: 36$ \\
\hline 4 & 6 & 1,5 & 00:00:00 \\
\hline 5 & 6 & 1,2 & $00: 28: 00$ \\
\hline 5 & 14 & 2,8 & 00:01:48 \\
\hline 1 & 1 & 1,0 & 00:00:00 \\
\hline 2 & 7 & 3,5 & $00: 02: 00$ \\
\hline 1 & 2 & 2,0 & 00:00:00 \\
\hline 1 & 1 & 1,0 & 00:00:00 \\
\hline 21 & 240 & 11,4 & $00: 23: 44$ \\
\hline
\end{tabular}

Tabla 8: Métricas generales de interacciones en EVA-UCA del curso FPyC 2021

\section{Entrevistas y taller}

Nueve alumnos aceptaron ser entrevistados una vez concluido el cursado y otros 5 participaron del taller grupal ulterior, una vez expuestos los principales resultados de esta evaluación. Las opiniones recogidas destacaron ciertas dificultades para disponer de un ámbito (temporal y espacial) de calidad para las actividades académicas 
extra-áulicas poniendo de relieve una brecha respecto de las condiciones supuestas implícitamente por el diseño curricular original. Es relevante que esta brecha no refiere a un factor tecnológico o de conectividad, sino a limitaciones materiales para desarrollar rutinas de aprendizaje (carencia de espacio no sujeto a perturbaciones, simultaneidad de múltiples rutinas no académicas en el hogar, distracciones). En este punto la necesidad de cumplir regularmente con actividades con vencimiento (que implicaban además una dedicación previa para indagar en aspectos analíticos) fueron conceptuadas como un facilitador forzado del aprendizaje. A pesar de ello, los alumnos entrevistados parecen aguardar que dicha exigencia sea, necesariamente, demandada a ellos y no fruto de una pauta desarrollada motu proprio para alcanzar un empleo más eficiente del tiempo disponible. En este sentido, 6 entrevistados indicaron que les tomó entre 3 y 5 semanas asimilar el enfoque invertido y organizar el tiempo en una rutina regular por fuera de las clases sincrónicas.

La conjunción de e-actividades aunadas al empleo de recursos informativos y datos actuales no ficticios sobre finanzas públicas fue destacada como un aspecto llamativo y motivador de las e-actividades. La flexibilidad acotada y la necesidad de indagar y seleccionar recursos por parte de los alumnos en sus tareas constituyó un atractivo bien valorado. Más aún, esto mismo fue sindicado como susceptible de ser empleado en asignaturas previas de la carrera, respaldando la articulación de estrategias y diseños pedagógicos transversales al plan de estudios que se halla en curso, a fin de profundizar la inserción de estrategias análogas a lo largo del currículo. En particular, los alumnos identificaron como oportuno aplicar dicho enfoque en asignaturas previas, tales como Administración Avanzada y Macroeconomía, tanto para adquirir más temprano en su trayectoria universitaria hábitos y rutinas saludables, como para "hacer más práctica la cursada" (Ortíz, 2021).

En cuanto a la metodología de evaluación, algunos entrevistados destacaron sentirse desorientados por no tener una calificación numérica parcial del curso, y tener que aguardar "hasta prácticamente el final para saber si regularizaba o no" (Caino, 2021). Si bien los alumnos contaban con retroalimentación permanente de cada e-actividad semanal, la valoración era en términos cualitativos y orientada fundamentalmente a la motivación formativa. Este punto se considera susceptible de un análisis cuidadoso a la luz de los resultados (Tabla 7) ya que, por otro lado, limitó en alguna medida las estrategias de tipo especulativas en torno a la dedicación al cursado: incluso los alumnos que no lograron la calificación para regularizar culminaron el cursado completo, con un alto nivel de motivación y asimilando la insuficiencia de un modo más proactivo que si la misma hubiera emergido a mitad del cursado o bien motivada por la realización de un examen sumativo puntual.

\section{Discusión y conclusiones}

La experiencia reseñada es particularísima, pero su evaluación arroja indicaciones y aprendizajes susceptibles de aplicación al caso y a situaciones análogas. La implementación del enfoque invertido y de la evaluación formativa en el curso encontraron en alumnos aceptación amplia y reconocimiento positivo, aún con señalamientos para un perfeccionamiento del diseño en el futuro. Como aspectos inherentes al cursado, es posible destacar, en suma, algunas fortalezas y debilidades aprendidas. Con relación a impactos y condicionantes externos al cursado de la asignatura bajo el enfoque adoptado, se reseñan luego oportunidades y amenazas. 


\section{Fortalezas}

El enfoque permitió alcanzar un aprendizaje más significativo, de carácter aplicado y situado en una asignatura de cierta complejidad, que presupone la interrelación de conocimientos disciplinares diversos. Ello permitió no sólo la adquisición de una comprensión más profunda y, más aún, percibida además por el alumnado como un aliciente y motivador. Las e-actividades de mayor complejidad implicaron la aplicación de saberes blandos transversales y habilidades prácticas, entrañando desafíos de mayor complejidad abonando además actitudes que resulta necesario fomentar en alumnos (tales como disposición a la autoorganización, al trabajo colaborativo, curiosidad y a la formulación de interrogantes propios, entre otras). Por ello, el diseño implementado resulta acorde para una asignatura con las características de FPyC y aun con algunas otras del ramo económicas que la anteceden en el plan de estudios.

\section{Debilidades}

La principal debilidad para un aprovechamiento pleno del enfoque propuesto es la debilidad de base ampliamente extendida en el alumnado para alcanzar sin dilaciones una adecuada administración del tiempo de calidad destinado a las tareas extra-aulicas. Este señalamiento mantiene su vigencia aún suponiendo el empleo de estrategias tradicionales, pero se torna crítico bajo el enfoque invertido, ya que se torna con mayor facilidad en un factor negativo de peso. Mientras que una rápida asimilación de rutinas adecuadas constituye un motivador y un buen factor de éxito en el cursado, lo contrario se presenta como el principal obstáculo y factor explicativo de insuficiencia académica.

\section{Oportunidades}

Más allá de la asignatura, la dinámica invertida forzó en alumnos la adopción de rutinas y de una organización personal del tiempo que sólo luego de 3 a 5 semanas fueron internalizadas y percibidas mayoritariamente como positivas, permitiendo una aplicación más eficiente del diseño pedagógico previsto. Para acortar el plazo en que se alcanza dicho punto de inflexión, se considerará de inmediato un mayor énfasis y detenimiento en la presentación inicial del curso utilizando recursos motivadores (incluyendo la experiencia y consejos de alumnos anteriores) y un cuidadoso replanteo de las actividades del primer mes; y a mediano plazo, articulando la aplicación del enfoque invertido en asignaturas correlativas previas.

\section{Amenazas}

Las principales amenazas para una implementación adecuada del enfoque invertido apoyado en e-actividades y la evaluación formativa se vinculan, por un lado, a la debilidad de saberes y habilidades previas y, por otro lado, a la inherente competencia por el limitado tiempo y atención de calidad que el alumno representativo suele alcanzar en las actividades extra áulicas. En ambos aspectos, influyen adicionalmente las limitaciones que puede suponer la dedicación del equipo docente, particularmente durante las primeras 3 a 5 semanas, plazo aproximado en el cual maduran las rutinas de trabajo autónomo que permitirán sostener con mayor probabilidad las sanas exigencias de la propuesta pedagógica desarrollada. No es la cantidad de tiempo interactuando con la plataforma de gestión educativa (en este caso, EVAUCA) lo que parece abonar el rendimiento académico de un alumno, sino su utilización medida como apoyo y complemento al aprendizaje fuera de ella. 
Atendiendo al cambiante escenario de TIC en educación universitaria, es conveniente asumir el rediseño pedagógico como dimensión de la actitud innovadora, que lleve a un proceso más o menos continuo de mejora. Alcanzar enfoques, metodologías de instrucción y técnicas formativas adecuadas es más probable en este escenario, pero implica a la vez un desafío de mayor alcance, carga y exigencia para equipos docentes (Aguilera-Ruiz et. al, 2017), lo que puede requerir equipos docentes mejor provistos y más amplios, situación que muchas instituciones universitarias no afrontan adecuadamente, aun asumiendo que se dispone de las TIC adecuadas. A su vez, el uso extendido de TIC entraña riesgos para el logro de los objetivos de aprendizaje que deben ser sopesados con un cuidadoso diseño de las actividades.

\section{Referencias}

Aguilera-Ruiz, C.; Manzano-León, A.; Martínez-Moreno, I.; Lozano-Segura, M.C.; Casiano Yanicelli, C. (2017). El modelo flipped classroom. International Journal of Developmental and Educational Psychology, vol. 4, núm. 1, pp. 261-266. Recuperado de https://www.redalyc.org/pdf/3498/349853537027.pdf

Caino, A. (29 de Julio de 2021). Entrevista personal de opinión y percepción FPyC 2021-1. (H. D. Golden, \& S. G. González Holotte, Entrevistadores)

Churches, A. (2008). Bloom's Digital Taxonomy, Recuperado de https://www.researchgate.net/publication/228381038_Bloom's_Digital_Taxonomy/link/5d2ab7ff458515c11c2e24fb/download

Coll, C. (2004). Psicología de la educación y prácticas educativas mediadas por las tecnologías de la información y la comunicación. Una mirada constructivista. Revista Electrónica Sinéctica, núm. 25, agosto-enero, 2004, pp. 1-24 Recuperado de https:// www.redalyc.org/articulo.oa?id $=99815899016$

Coll, C. (2008). Aprender y enseñar con las TIC: expectativas, realidad y potencialidades. Boletín de la Institución Libre de Enseñanza, núm. 72, agosto-enero, 2004, pp. 17-40 Recuperado de https://www.educ.ar/recursos/70819/aprender-y-ensenar-con-las-tic-expectativas-realidad-y-potencialidades

Flipped Learning Network. (2014). The four Pillars of F-L-I-P. Recuperado de https:// flippedlearning.org/wp-content/uploads/2016/07/PilaresFlip.pdf

Hinojo Lucena, F., Aznar Díaz, I., Romero Rodríguez, J. M., \& Marín Marín, J. A. (2019). Influencia del aula invertida en el rendimiento académico. Una revisión sistemática. Campus Virtuales, 8(1), 9-18. Recuperado de http://uajournals.com/ojs/index.php/ campusvirtuales/article/download/384/300

Observatorio de Innovación Educativa. (2014). Aprendizaje Invertido. Edu Trends, Tecnológico de Monterrey. Recuperado de http://bit.ly/EduTrends-Invertido

Ortíz, L. J. (9 de Setiembre de 2021). Taller de resultados sobe opiniones y percepciones FPyC 2021-1. (H. D. Golden, \& S. González Holotte, Entrevistadores) 
Perdomo Rodríguez, W. (2017) Ideas y reflexiones para comprender la metodología Flipped Classroom, Revista Virtual Universidad Católica del Norte, núm. 50, pp. 143161. Recuperado de https://www.redalyc.org/pdf/1942/194250865009.pdf

Sánchez-Rivas, E.; Sánchez Rodríguez, J.; y Ruiz-Palmero, J. (2019). Percepción del alumnado universitario respecto al modelo pedagógico de clase invertida. Magis, Revista Internacional de Investigación en Educación, núm 11. 151-168. Recuperado de https://www.researchgate.net/publication/329864526_Percepcion_del_alumnado universitario_respecto_al_modelo_pedagogico_de_clase_invertida/link $/ 5 \mathrm{cld}$ f8e092851c22a33da8cc/download

Silva, J. (2017). Un modelo pedagógico virtual centrado en las E-actividades. Revista de Educación a Distancia (RED). N 17(53), Recuperado de https://revistas.um.es/ red/article/view/290021 


\section{La Actividad Situada como Estrategia para la Enseñanza y Aprendizaje en un Proceso de Toma de Decisiones Bajo Incertidumbre para la Carrera de Contador Público}

Gallardo, Juan Manuel

UNRC, Jgallardo@fce.unrc.edu.ar

\section{Cassano, María Virginia}

UNRC, vcassano@fce.unrc.edu.ar

Bissio, Lucrecia

UNRC, Ibissio@fce.unrc.edu.ar 


\title{
LA ACTIVIDAD SITUADA COMO ESTRATEGIA PARA LA ENSEÑANZA Y APRENDIZAJE EN UN PROCESO DE TOMA DE DECISIONES BAJO INCERTIDUMBRE PARA LA CARRERA DE CONTADOR PÚBLICO
}

\author{
Gallardo, Juan Manuel \\ Cassano, María Virginia \\ Bissio, Lucrecia
}

\section{Resumen}

El contexto en el que desarrollarán su profesión los actuales estudiantes de la carrera de Contador Público está permeado por cambios continuos de orden normativo, tecnológico, de mercado y operativo. Desde el espacio curricular "Taller de práctica II", se apunta a fortalecer las capacidades y habilidades tecnológicas y de toma de decisiones para actuar ante la realidad social y profesional de éstos. El propósito es evaluar la importancia de las TIC en los procesos de enseñanza y aprendizaje vinculadas al futuro desempeño profesional de los estudiantes y socializar una experiencia pedagógica. En la presente ponencia se aborda una actividad situada sobre la evaluación de un proyecto de inversión bajo incertidumbre. Se describe la actividad presentada a los estudiantes que cursaron la asignatura durante el año 2020. Se compara la metodología tradicional de enfocar y de enseñar este tipo de situaciones con un abordaje alternativo que utiliza a las TIC en el proceso de toma de decisiones de la elección más conveniente. Se abordan brevemente las características del método de Monte Carlo. Entre las principales conclusiones se rescata el reconocimiento que los estudiantes han dado al proceso de simulación de una asesoría contable, el que contribuye a su formación profesional y el aprendizaje vivenciado por el equipo de docentes.

\section{Palabras clave}

TIC - Decisión - Docencia - Incertidumbre. 


\section{Introducción}

En la actualidad el rol de los docentes de ciencias económicas está siendo interpelado constantemente por los cambios que ocurren en los escenarios sociales, ello demanda que éstos deban construir un saber y un saber hacer de sus prácticas en la educación. Para posibilitar dicha construcción es necesario que sean capaces de realizar procesos de reflexión sobre sus propias prácticas, de evaluar los resultados de éstas, de identificar dilemas y conflictos en sus contextos, y, fundamentalmente, de formular "nuevos modos" en su trabajo como educadores.

En particular, la carrera de Contador Público está atravesando los primeros procesos de estándares para la acreditación (Resolución 2641-E/2017, 2017). En dicha resolución no solamente se aprueban los contenidos curriculares básicos, la carga horaria mínima y en los criterios de intensidad de la formación práctica, sino que se delimita la nómina de actividades reservadas para quienes obtengan el respectivo título. Ello demanda que las instituciones educativas deban analizar y autoevaluar las condiciones y características de la formación de sus profesionales. Simultáneamente, la Universidad Nacional de Río Cuarto (UNRC) desde el año 2017 se encuentra transitando un momento histórico que alienta la revisión de los lineamientos curriculares de los planes de estudios como así también, la revisión de las prácticas de enseñanza (Resolución CS. 297/17, 2017).

Es sabido que el contexto en el que desarrollarán su profesión los actuales estudiantes de la carrera está permeado por cambios continuos de orden normativo, tecnológico, de mercado y operativo. Desde el espacio curricular "Taller de práctica Il", asignatura que ha sido incorporada a partir del nuevo plan de estudio de la Carrera de Contador Público, se apunta fortalecer las capacidades y habilidades tecnológicas y de toma de decisiones para actuar ante la realidad social y profesional de estos estudiantes.

Desde el punto de vista epistemológico, Mendoza (2018) considera que la formación del profesional de ciencias económicas debe ser panorámica y no debe limitarse a un conocimiento encapsulado en sí mismo. El tener capacidad para interrelacionar los conocimientos disciplinares con aquellas situaciones que surgen del entorno jurídico, sociológico, político y filosófico permitirá al Contador Público explicar con rigor los hechos económicos, logrando así, un salto desde la acción operativa a la posibilidad de brindar información útil para la toma de decisiones.

Para la elaboración del presente trabajo se consultaron dos investigaciones que van en línea con los objetivos detallados a continuación. Ruiz y Romero (2009) estudian algunas metodologías en el proceso económico de toma de decisiones, mientras que Muñetón et al. (2017) se enfocan en el estudio de las decisiones que realizan las personas en su vida cotidiana y discuten respecto al pasaje de la Economía del comportamiento a la Ciencia Aplicada al Comportamiento.

Como objetivo general de esta ponencia se pretende valorizar a la actividad situada como estrategia para la enseñanza y aprendizaje de un proceso de toma de decisiones bajo un contexto de incertidumbre. En particular, socializar una experiencia pedagógica abordada en el espacio curricular "Taller de Práctica Il" y distinguir la importancia de las TIC en los procesos de enseñanza y aprendizaje vinculadas al desempeño del profesional de las ciencias económicas. 
La presente ponencia se estructura de la siguiente manera. En primer lugar, se plantea el marco metodológico, luego se aborda una contextualización del problema de investigación, centrado principalmente en la necesidad de migrar de los métodos tradicionales empleados para la evaluación de proyectos de inversión a métodos más modernos que incorporan a la incertidumbre en este proceso y, posteriormente, presentar una descripción de una experiencia desarrollada en la asignatura bajo estudio. Por último, se presentan las principales conclusiones.

\section{Metodología}

La metodología utilizada es la de prácticas en contexto. Las teorías de la actividad situada brindan nuevas perspectivas del aprendizaje. El conocimiento está en estado de cambio y transcurre dentro de sistemas de actividad que se desenvuelven social, cultural e históricamente, involucrando a personas que se vinculan de maneras múltiples y heterogéneas (Chaiklin y Lave, 2001).

La actividad situada posibilita que los estudiantes apliquen lo aprendido en situaciones relevantes de su futura práctica profesional, favoreciendo de esta manera a la contextualización del aprendizaje y a una enseñanza significativa (Balderas et al., 2019).

Driscoll y Burner (2005) afirman que en el aprendizaje situado la construcción del conocimiento es concebida como una práctica en la experiencia, por lo que aprender implica involucrarse en una comunidad de práctica. Es aquí que el estudiante debe participar activamente del proceso educativo y ser protagonista en la construcción de su propio aprendizaje. Por su parte, el docente debe estimular y promover el desarrollo de competencias para afrontar de manera exitosa problemas similares a los que encontrará en su futura vida laboral.

Según Gagliardi (1986), en todo campo disciplinar es posible identificar un conjunto de categorías estructurales que forman la base sobre la cual se construye todo el conocimiento. En el proceso de formación de un estudiante, dichas categorías son incorporadas a nivel cognitivo, permitiendo que éste pueda adquirir nuevos conocimientos, construir nuevos significados, etc. Es por ello que resulta fundamental que los docentes reflexionen sobre qué contenidos se van a enseñar y el valor que tienen éstos en el contexto, de modo tal que se posibilite la construcción de saberes. Desde esta perspectiva, el citado autor expresa que "no sólo hay que saber cuáles son los temas por enseñar, sino cuáles son las actividades que favorecen su aprendizaje".

En este marco de discusión, Gess-Newsome (1999) identifica dos enfoques diferentes para abordar e interrelacionar el conocimiento disciplinar, didáctico y del contexto que todo equipo docente debe manejar al momento de diseñar las actividades curriculares que se desarrollarán en cada asignatura. La autora distingue entre un enfoque integrador (aditivo) y un enfoque transformador. El primer enfoque, de la superposición de los tres tipos de conocimientos resulta un conocimiento común denominado Modelo del Conocimiento Didáctico del Contenido (CDC). Para Orlay (2010), en este enfoque "basta con que el profesor cuente con unos sólidos cimientos conceptuales de estos saberes para que en la práctica los integre y se produzca así el CDC". Por otro lado, el segundo enfoque entiende que en la integración de los tres tipos de conocimiento existe un núcleo central denominado CDC, pero que es la transformación de cada tipo de conocimiento la que colabora a la obtención de un saber diferenciado. 
Es en ese enfoque que es necesario que el equipo docente sea capaz de repensar sus prácticas vinculándolas al desafío constante de generar aprendizajes significativos no sólo en los estudiantes sino, previamente, en ellos mismos.

Litwin (2009) y Mata et al. (2012) entienden que las buenas prácticas suceden cuando subyacen a ellas buenas intenciones, buenas razones $\mathrm{y}$, sustantivamente, el cuidado por atender la epistemología del campo en cuestión.

Partiendo de la premisa que "el aprendizaje y la contextualización se producen y sitúan socialmente" (Mussolini et al., 2019), el equipo docente entiende que "aprender" y "hacer" son acciones inseparables y, en consecuencia, para lograr un aprendizaje significativo en los estudiantes, es necesario privilegiar aquellas prácticas educativas que estén destinadas "al saber cómo" más que "al saber qué".

Durante el año 2020, los contenidos y actividades del Taller se desarrollan mediante clases tutoriales virtuales y como técnica didáctica se aplican métodos de Aprendizaje Basados en Problemas (ABP).

\section{Los nuevos profesionales, las nuevas demandas curriculares y el cambio de para- digma organizacional}

Con el paso del tiempo, el ámbito educativo ha ido modificándose, conjuntamente con ello las carreras universitarias. Son los nuevos procesos tecnológicos los que han moldeado su forma de pensar, vivir y comunicarse en sociedad. Dos características distinguen a estas nuevas generaciones, la inmediatez y la revalorización del conocimiento mediado multimediamente por sobre la palabra (Montero y Gewerc, 2018).

Actualmente se le da un peso muy importante a la información como la principal fuente de conocimiento que sostiene a la organización, pero no basta con tener información.

El constante uso de las tecnologías ha traído consigo un crecimiento explosivo en la producción de datos. A partir de este aumento de información se da la necesidad de extraer de ella patrones, tendencias y/o conocimiento, de forma rápida y eficiente, para lo cual, los métodos tradicionales han tenido que evolucionar en busca de rendimiento y escalabilidad (Tabares y Hernández, 2014). Se debe tener presente que, el fundamento de todas estas necesidades relacionadas a la producción de datos y su tratamiento para convertirlos en información, viene dado por la búsqueda de ventajas competitivas.

Es a partir de esta necesidad que, en 1989, Dresner incorpora la categoría "Inteligencia de Negocios" la que permite estudiar técnicas cuantitativas y cualitativas para el diseño de reportes, el estudio de escenarios y la generación de pronósticos, los que favorecen a mejorar el proceso de toma de decisiones en las organizaciones.

A este fenómeno, caracterizado por un mayor volumen de datos y la necesidad de un procesamiento más ágil y eficiente, hasta en algunos casos "en tiempo real", se lo ha denominado Big Data y hace referencia a tres términos conocidos como las $3 \mathrm{~V}$ "Volumen, Velocidad y Variedad" (Atzori et al., 2010). 
Ante este contexto, los procesos de enseñanza y aprendizaje no pueden implementarse como habitualmente se hacía tiempo atrás. Apoyando esta afirmación, Castells (2000a y 2000 b) señala que "estamos en la sociedad del conocimiento y la información”. (Pozo y Gómez Crespo, 2000) entienden que esta situación fomenta a un tipo particular de cultura de enseñanza-aprendizaje y consideran que los métodos que parecían muy apropiados hace algunos años, hoy ya no lo son.

El desafío que plantea la revolución denominada Big Data, para la docencia universitaria es aún mayor, a la luz de los elevados costos de innovación pedagógica y, fundamentalmente, de la naturaleza genérica de la formación superior, que prioriza formación de largo plazo por sobre el entrenamiento en cuestiones cortoplacistas (Sosa Escudero, 2017).

En síntesis, como afirma Sosa Escudero (2017), la revolución de Big Data plantea una excelente oportunidad para revisar seriamente la formación de los profesionales en Ciencias Económicas, siempre priorizando la educación por sobre el mero entrenamiento en tecnologías de moda. El auténtico desafío es lograr integrar las capacidades computacionales, matemáticas, estadísticas y comunicacionales en la formación curricular de nuestros profesionales.

\section{Evaluación de Inversiones en contextos de incertidumbre}

Ruiz y Romero (2009) entienden que los métodos tradicionales empleados para la evaluación de inversiones no logran valorar en forma exacta las oportunidades que presenta una alternativa de inversión en escenarios de alta incertidumbre.

Uno de los métodos tradicionales más utilizado es el método de los flujos de caja descontados, el cual asume un enfoque determinístico basado en un único grupo de variables de entrada, a la vez que supone una trayectoria fija de los resultados del proyecto, no considerando la flexibilidad de cambiar la decisión. Sin embargo, en un ambiente de mercado mundial tan dinámico como el actual, donde la incertidumbre es cada día mayor, la flexibilidad se ha tornado esencial a la hora de tomar ventajas de las oportunidades favorables para inversiones futuras; es aquí donde indicadores tradicionales como el valor presente neto deja de ser fuerte, si se entiende la flexibilidad como la capacidad de modificar decisiones estratégicas tomadas inicialmente de aspectos como: atrasar, abandonar, expandir, o llevar a cabo una inversión.

Algunos métodos alternativos para representar mejor el impacto de la incertidumbre propia del contexto del proyecto de inversión o del inversor, son la ecuación de Black - Scholes, Simulación de Monte Carlo, entre otros. En esta ponencia, a la hora de evaluar financieramente una inversión bajo incertidumbre, describiremos sintéticamente el método de Simulación de Monte Carlo propuesto por Boyle (1977).

El proceso de simulación busca representar miles de escenarios con diferentes valores para variables que intervienen en el proyecto, cuyo comportamiento puede ser aleatorio o determinístico y que, de su interacción, se producen los futuros flujos monetarios necesarios para la construcción de los indicadores de viabilidad financiera de decisión - TIR, VAN, Periodo de recupero, etc. - .

Con este método, lo que se logra es avanzar desde un análisis tradicional donde solo se cuenta con un valor determinado de los indicadores de viabilidad financiera, a la 
posibilidad de estimar qué probabilidad existe de que ese indicador se encuentre por encima o por debajo de determinado valor y de este modo evaluar la conveniencia según las expectativas del inversor, reduciendo así la incertidumbre existente en el contexto de inversión que se esté estudiando.

Esta evaluación dinámica, flexible y con incorporación de la incertidumbre al análisis, permite al futuro profesional de ciencias económicas, contar con una herramienta de asesoramiento mucho más potente y alineada a las demandas de las organizaciones en el contexto actual, caracterizado por una mayor accesibilidad a la información y herramientas tecnológicas que facilitan análisis más avanzados.

\section{Descripción del contexto, de los participantes y Recursos Tecnológicos Utilizados. Actividad Situada}

El espacio curricular "Taller de práctica //" tuvo un total de 19 estudiantes inscriptos durante el 2020. Todos ellos pertenecen al cuarto año de la carrera de Contador Público. La metodología de trabajo fue virtual debido a la situación de Aislamiento Social Preventivo y Obligatorio.

Para abordar la temática bajo estudio, el equipo docente plantea la experiencia denominada "Abasto Mayorista De Carne Vacuna". Las etapas desarrolladas son:

En una primera etapa, Elaboración de actividades y producción de material audiovisual. El equipo docente se reúne con "el abastecedor" (Potencial Cliente). Además, la cátedra se aboca al desarrollo de material audiovisual y de diapositivas en PowerPoint para la presentación del caso bajo estudio.

En una segunda etapa, Recolección de datos. Se presenta el caso a los estudiantes, se contextualiza la actividad económica del cliente y se concreta una reunión entre los distintos grupos de estudiantes, ahora "los asesores", y el abastecedor. Éste describe y comenta su actividad económica, detalla erogaciones, ingresos, zonas de comercialización, distintas opciones que deben tener en cuenta a la hora de tomar una decisión, etc., es decir, describe las variables que servirán para que los estudiantes puedan modelizar la situación.

En una tercera etapa, Modelización, elaboración de informes y transferencia de información en conocimiento. Los estudiantes modelizan la situación de acuerdo con lo expresado en la entrevista anteriormente descripta e identifican las variables que intervienen en cada alternativas de inversión y su naturaleza estadística (cierta o aleatoria). Por último, generan un informe por grupo indicando la decisión económica más conveniente. Es aquí donde más se pudo observar la profundidad con la que cada equipo quiso plasmar su impronta al momento de asesorar al inversor. Algunos equipos decidieron hacer hincapié en la regulación de los honorarios profesionales, donde tuvieron que indagar la página del Consejo profesional de ciencias económicas, otros evaluaron el impacto del costo laboral en el proyecto, otros se centraron en estudiar con gran detalle la metodología para el cálculo de indicadores financieros de decisión (TIR, VAN, etc.), otros analizaron los resultados estadísticamente, etc.

Con esta actividad se busca contribuir al mejoramiento de la evaluación de proyectos de inversión, mediante la medición de la incertidumbre asociada a los resultados de los indicadores financieros tradicionales. En el modelo propuesto por cada grupo 
de estudiantes, se contempló la incertidumbre propia del contexto del proyecto de inversión y dio respuesta al requerimiento de asesoramiento financiero.

A lo largo de este proceso los estudiantes tuvieron el acompañamiento del equipo docente y utilizaron recursos tecnológicos tales como videoconferencia, grupos de Whatsapp, herramientas colaborativas contempladas en Google Drive. El proceso de modelización y simulación se ejecutó a través de la confección de planillas de cálculo, diseñadas en Microsoft Excel.

\section{Resultados}

Al finalizar el cuatrimestre se ha realizado una encuesta diseñada para evaluar y valorar la experiencia previamente descripta, así como el resto de las actividades disciplinares realizadas durante todo el taller. Entre el conjunto de preguntas, se les solicitó a los estudiantes que respondan respecto a aspectos positivos y por mejorar de su experiencia durante el cursado, valoración de los contenidos y metodología abordada en el caso presentado y una opinión general del taller.

Los estudiantes respondieron favorablemente a las preguntas de la encuesta, mostrando particular interés en el caso planteado, principalmente visualizando la magnitud y complejidad de la situación que debieron analizar. Reconocieron que el proceso de la simulación de ser asesores contables contribuyó a su formación profesional.

Del procesamiento de las respuestas obtenidas, presentamos algunas de las principales ideas expresadas por los estudiantes:

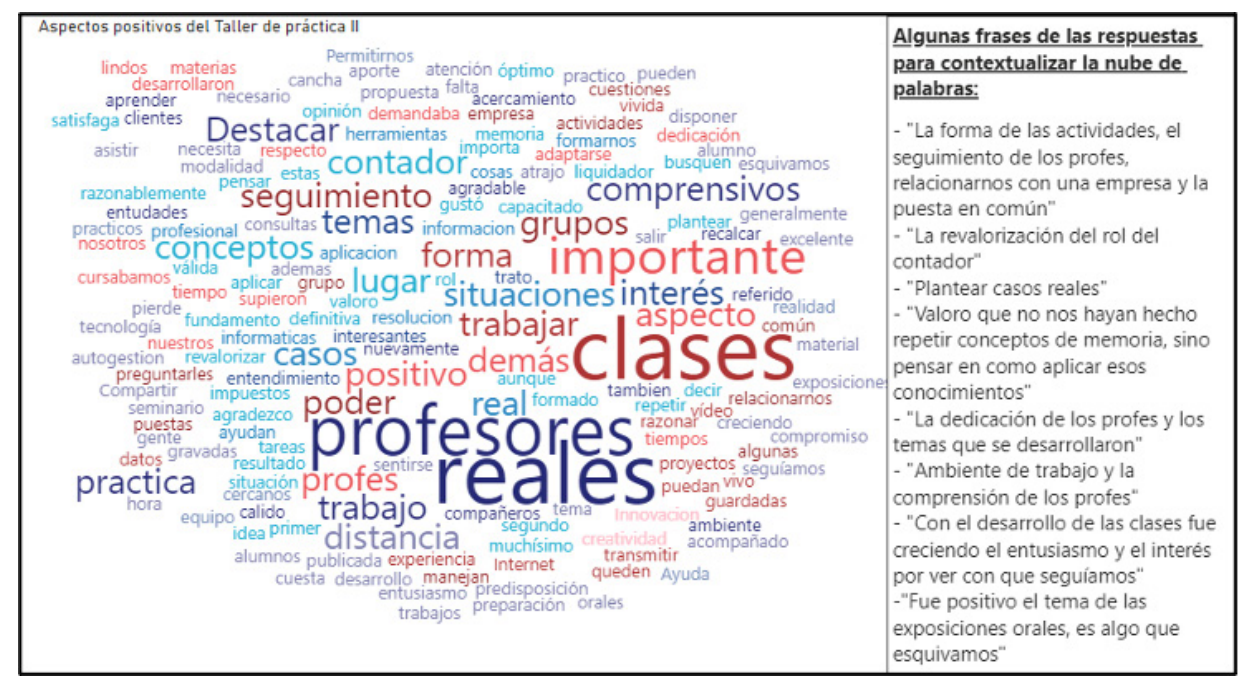

Fig 1: Aspectos positivos que destacan los estudiantes 


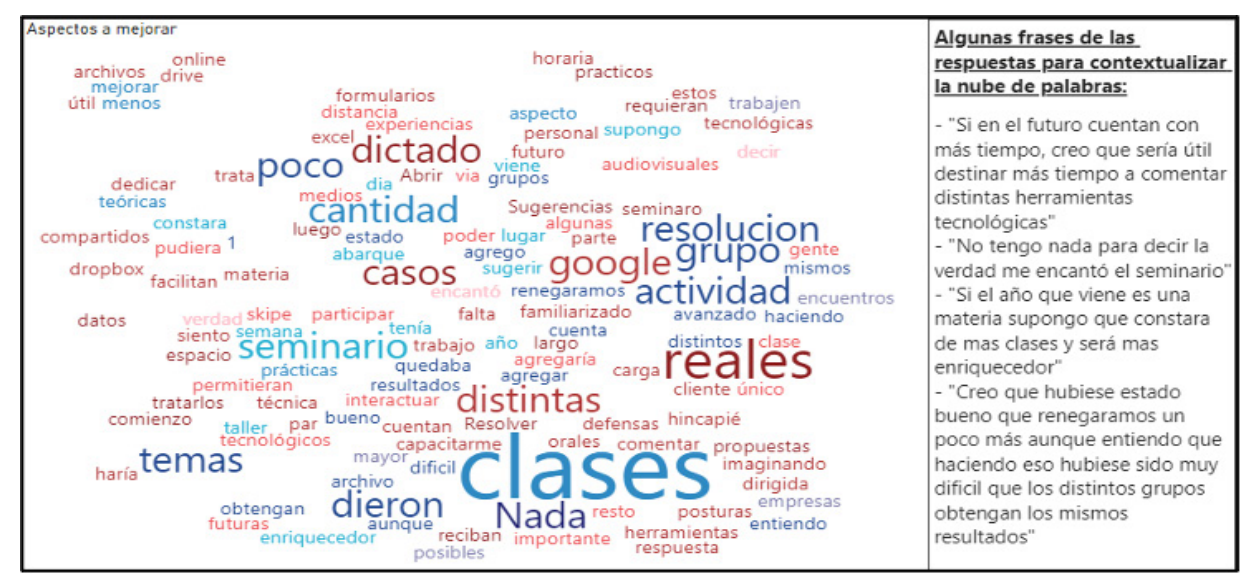

Fig. 2: Aspectos por mejorar que destacan los estudiantes

\begin{tabular}{|c|c|}
\hline 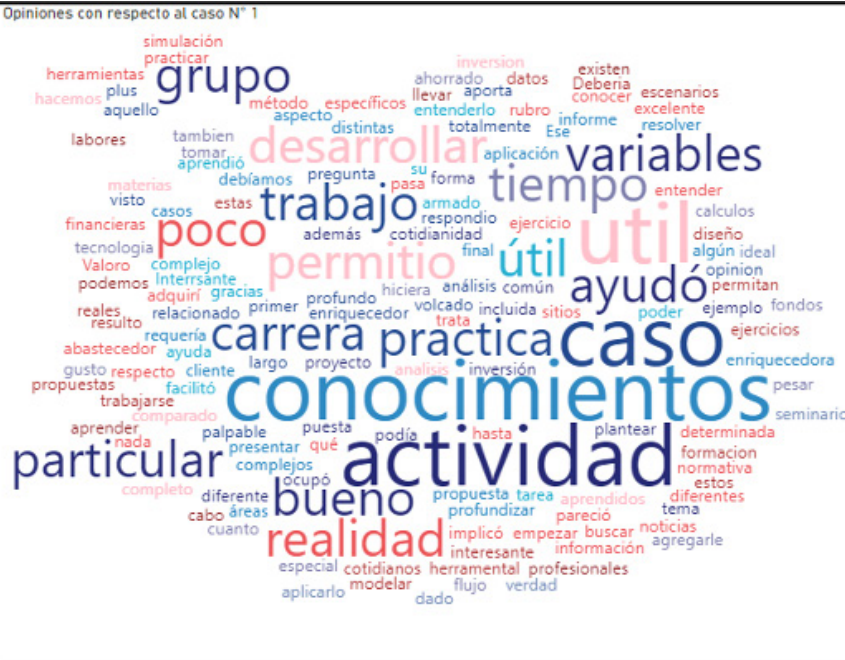 & $\begin{array}{l}\text { Algunas frases de las respuestas } \\
\text { para contextualizar la nube de. } \\
\text { palabras: } \\
\text { - "El proyecto de inversión estuvo } \\
\text { muy bueno ya que incluida muchas } \\
\text { variables de la cotidianidad de la } \\
\text { actividad" } \\
\text { - "Valoro la actividad, no tanto por los } \\
\text { conocimientos especificos que } \\
\text { adquirí respecto al rubro del } \\
\text { abastecedor, sino por el ejercicio que } \\
\text { implicó el conocer poco o nada de } \\
\text { una determinada realidad y empezar } \\
\text { a buscar información, normativa, } \\
\text { noticias en diferentes sitios, hasta } \\
\text { llegar a entender de qué se trata. } \\
\text { Creo que es algo que pasa mucho en } \\
\text { la realidad" } \\
\text {-"Era bastante complejo pero gracias } \\
\text { a su ayuda en el armado nos facilitó } \\
\text { bastante la tarea" } \\
\text {-"Fue un trabajo muy util, comparado } \\
\text { con los analisis de inversion que } \\
\text { hacemos en otras materias" }\end{array}$ \\
\hline
\end{tabular}

Fig. 3: Contenidos y Metodología abordada para el caso bajo estudio

\begin{tabular}{|c|c|}
\hline 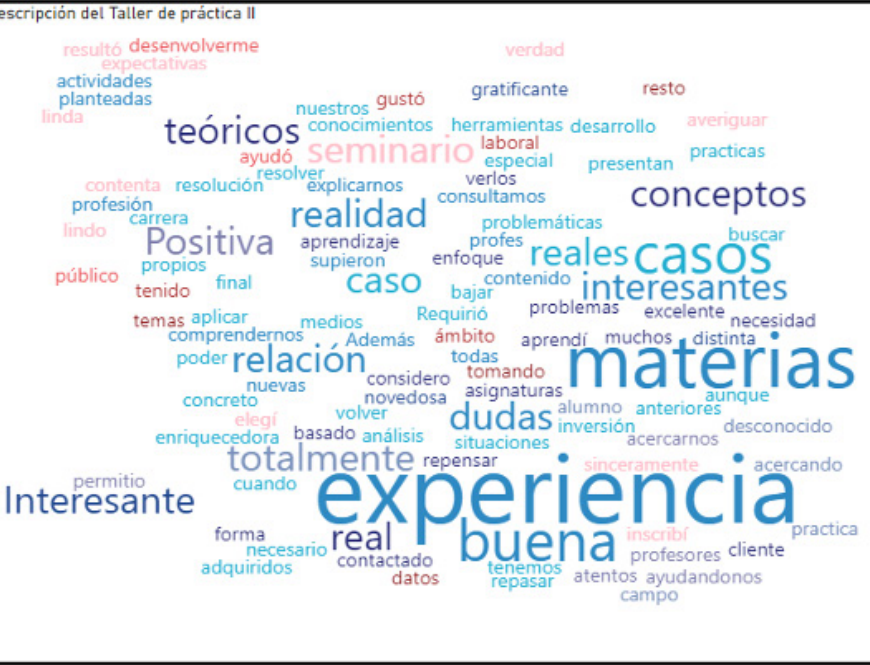 & $\begin{array}{l}\text { Algunas frases de las } \\
\text { respuestas para contextualizar } \\
\text { la nube de palabras: } \\
\text { - "Las actividades planteadas } \\
\text { fueron muy interesantes con la } \\
\text { realidad de la profesión" } \\
\text { - "Fue excelente, la considero } \\
\text { una de las asignaturas que más } \\
\text { aprendr" } \\
\text { - "El seminario me hizo repensar } \\
\text { muchos conceptos teóricos y } \\
\text { verlos de otra forma" } \\
- \text { "Experiencia totalmente } \\
\text { positiva, acercando a uno al } \\
\text { campo de la práctica, algo } \\
\text { totalmente desconocido para el } \\
\text { alumno" } \\
\text { - "Me ayudó a desenvolverme } \\
\text { en público" } \\
\text { - "Un seminario con temas muy } \\
\text { interesantes y mas aún tomando } \\
\text { datos y casos de la realidad que } \\
\text { en el resto de las materias no se } \\
\text { ven" }\end{array}$ \\
\hline
\end{tabular}

Fig. 4: Valoración respecto a la experiencia de cursado del Taller de Práctica II 


\section{Discusión y conclusiones}

Como educadores, en este nuevo contexto donde se demandan nuevas formas de construir el conocimiento es necesario re plantearnos las prácticas en educación. Generar "nuevos modos" es el gran desafío. El tener capacidad para interrelacionar el conocimiento disciplinar con aquellas situaciones que surgen del entorno permitirá al Contador Público explicar con rigor los hechos económicos, logrando así, un salto desde la acción operativa a la posibilidad de brindar información útil para la toma de decisiones. A través de la práctica situada previamente descripta se logra visualizar la importancia de las TIC en los procesos de enseñanza y aprendizaje vinculadas al futuro desempeño profesional.

Los estudiantes participaron activamente del proceso educativo y fueron protagonistas en la construcción de su propio aprendizaje, por su parte, el equipo docente estimuló el desarrollo de competencias para afrontar de manera exitosa problemas similares a los que encontrará en su futura vida laboral. El recorrido que vivenciaron los estudiantes desde el planteamiento original del caso hasta su solución, les permitió no sólo la posibilidad de trabajar de manera colaborativa en grupos, sino también de practicar y desarrollar habilidades, de interactuar e intercambiar, de reflexionar sobre actitudes y valores, favoreciendo de esta manera la adquisición de un conocimiento transformado.

Como equipo hemos aprendido que es posible motivar al estudiante en el proceso de enseñanza-aprendizaje con la ayuda de la tecnología, la interacción entre los sujetos y la posibilidad de resolver problemas concretos que se presentarán a lo largo de su vida laboral. Ello permite al estudiante que se dote de un espíritu creativo que pueda amoldarse a las distintas situaciones imprevistas e inciertas del contexto.

\section{Referencias}

Atzori, L., lera, A., \& Morabito, G. (2010). The Internet of Things: A survey. Computer Networks, 54(15), 2787-2805. https://doi.org/10.1016/J.COMNET.2010.05.010

Balderas, A., Navarro, C., Berlanga, K., \& Altamirano, R. (2019). El buen fin desde la perspectiva del cliente: una experiencia didáctica de vinculación. Revista de Divulgación Científica y Tecnológica, 1(1), 29-38.

Boyle, P. (1977). Options: A Monte Carlo approach. Journal of Financial Economics, 4(3), 323-338. https://doi.org/10.1016/0304-405X(77)90005-8

Castell, M. (2000). La era de la información: economía, sociedad y cultura. Alianza.

Castells, M. (2000). Internet y la sociedad Red.

Chaiklin, S., \& Lave, J. (2001). Estudiar Las Prácticas: Perspectivas sobre actividad y contexto. Amorrortu.

Resolución CS. 297/17, (2017). 
Dresner, H. (1989). Predicts the future of business intelligence. Retrieved January, 10, 2017.

Driscoll, M., \& Burner, K. (2005). Psychology of learning for instruction.

Gagliardi R. (1986). Los conceptos estructurales en el aprendizaje por investigación. Ensciencias.Uab.Cat, 4(I), 30-35. https://ensciencias.uab.cat/article/download/ v4-n1-gagliardi/3032

Gess-Newsome, J. (1999). Pedagogical Content Knowledge: An Introduction and Orientation. Examining Pedagogical Content Knowledge, 3-17. https://doi. org/10.1007/0-306-47217-1_1

Litwin, E. (2009). El oficio de enseñar: condiciones y contextos. Acción Pedagógica, 98-103.

Mata, Y., \& Bolívar, R. (2012). Litwin, E.(2012). El oficio de enseñar. Condiciones y contexto. Educacionencontexto.Net, I. https://educacionencontexto.net/journal/index.php/una/article/view/14

Mendoza, J. M. (2018). Epistemología de la administración: objeto, estatuto, desarrollo disciplinar y método. Pensamiento \&amp; Gestión, 45, 211-238. https://doi. org/10.14482/PEGE.45.10103

Resolución 2641-E/2017, (2017).

Montero, L., \& Gewerc, A. (2018). La profesión docente en la sociedad del conocimiento. Una mirada a través de la revisión de investigaciones de los últimos 10 años. Revista de Educación a Distancia, 56, 31-32. https://doi.org/10.6018/red/56/3

Muñetón, G., Ruiz, A., \& Loaiza, O. (2017). Toma de decisiones. Explicaciones desde la ciencia aplicada del comportamiento. Espacios, 38(13), 1-12.

Mussolini, M., Butigué, S., Gallardo, J. M., Cassano, M. V., Bissio, L. P., \& Gil, L. (2019). Las TICs y las matemáticas en contextos económicos. // Jornadas de Sociología.

Orlay, E. (2010). El conocimiento profesional del profesor: más que el conocimiento didáctico del contenido.

Pozo, J., \& Gómez Crespo, M. (2000). Aprender y enseñar ciencia. Morata.

Ruiz, A., \& Romero, E. (2009). Caracterización y análisis de modelos de evaluación económica de proyectos de inversión bajo incertidumbre. Revista Ingeniería Industrial, 8(1).

Sosa Escudero, W. (2017). Big data: desafíos para la docencia en Ciencias Económicas. Repositorio Institucional de La UNLP, 8(15), 8-10. http://sedici.unlp.edu.ar/ handle/10915/64317

Tabares, L., \& Hernández, J. (2014). Big Data Analytics: Oportunidades, Retos y Tendencias. Universidad de San Buenaventura, 1-21. 


\section{Herramientas Digitales Utilizadas por el Profesorado de Educación Superior de Argentina en Contexto de Pandemia}

\section{Galli María Gabriela}

orcid.org 0000-0002-6958-0926

ggalli@untref.edu.ar

\section{Kanobel, María Cristina}

orcid.org 0000-0001-5636-1823

cristina.kanobel@inspt.utn.edu.ar

\section{Chan, Débora}

orcid.org 0000-0003-0125-7345

debora.chan@inspt.utn.edu.ar 


\title{
HERRAMIENTAS DIGITALES
}

UTILIZADAS POR EL PROFESORADO

DE EDUCACIÓN SUPERIOR DE ARGENTINA EN CONTEXTO DE PANDEMIA

\author{
Galli María Gabriela \\ Kanobel, María Cristina \\ Chan, Débora
}

\section{Resumen}

En el contexto de la enseñanza remota de emergencia, debido a la Pandemia declarada por el virus responsable de la COVID-19, el rol docente y la mediación de artefactos y herramientas digitales durante los procesos de enseñanza cobraron protagonismo. Por ello, el presente estudio pretende describir y analizar el perfil del profesorado de Educación Superior del área STEAM (Ciencia, Tecnología, Ingeniería, Arte y Matemática) en comparación con el perfil de docentes de otras áreas del conocimiento en relación con el tipo de herramientas digitales que incorporan a sus prácticas, transcurrido más de un año de enseñanza remota en Argentina. Para el logro del objetivo, se aplicó un cuestionario voluntario y autoadministrado, el que recogió las voces, a nivel nacional, de 1149 profesoras y profesores del mencionado nivel. La metodología utilizada en el estudio es de corte cuantitativo y alcance descriptivo correlacional. A partir del análisis de los datos se observan diferencias significativas en los años de experiencia que el profesorado tiene en el uso de herramientas digitales empleadas en sus prácticas pedagógicas vinculas con el género, la edad, la zona de residencia, el tipo de institución donde desarrolla su labor y el área de desarrollo disciplinar. Teniendo presente que el trabajo con tecnología digital no conlleva necesariamente un proceso de rediseño de las prácticas de enseñanza, estos resultados pueden ser de interés para la toma de decisiones tanto en el interior de las instituciones y como dentro de las carreras, con vistas a la generación de proyectos que aborden cambios en las modalidades de intervención.

\section{Palabras clave}

Educación Superior, profesorado, enseñanza remota de emergencia, herramientas digitales, STEAM. 


\section{Introducción}

En el contexto de pandemia mundial por la COVID-19, declarada el 11 de marzo de 2020 por la Organización Mundial de la Salud (Ministerio de Salud de la Nación, 2020), el Estado argentino toma como medida de excepción la suspensión de las clases presenciales (Ministerio de Educación de la Nación, 2020) en todos los niveles educativos, migrando a la llamada enseñanza remota de emergencia (ERE) (Hodges et at., 2020; Kanobel, 2020). Así, las instituciones tuvieron que gestar estrategias para garantizar la continuidad pedagógica y tanto el profesorado como el estudiantado tuvieron que adaptarse a la nueva presencialidad mediada por dispositivos digitales con los artefactos, servicios de comunicación y saberes que disponía. En este contexto, "se hicieron evidentes las desigualdades en materia de inclusión digital que alcanzan a docentes y estudiantes universitarios” (Maggio, 2021, p.205).

Durante el 2020, el profesorado en general y de la Educación Superior (ES) en particular, se vieron obligados a replantear sus prácticas e incluir dispositivos y materiales didácticos digitales para mediar la enseñanza. Con respecto a las herramientas digitales (HD) con que trabajó el plantel docente de la ES durante el primer semestre del 2020, según Chan et al. (2021), las de mayor frecuencia de uso fueron las herramientas de comunicación asincrónica, procesadores de texto, presentaciones multimedia, manejo de archivos en la nube y entornos de gestión de aprendizaje. Las autoras identificaron tres grupos de docentes bien diferenciados: el primero, denominado tradicionalistas (quienes utilizan con mayor frecuencia herramientas de comunicación asincrónica, procesador de textos, presentaciones multimedia y de alojamiento y manejo archivos en la nube), el segundo constituido por los productivos y aplicativos (los que utilizan con mayor frecuencia entornos de desarrollo integrado, de edición de imágenes 2D o 3D, software específico, de edición de video, planilla de cálculo) y, el tercero, formado por los colaborativos (asociado a docentes más jóvenes quienes utilizan con mayor frecuencia herramientas de comunicación sincrónica, lúdicas, entornos de gestión de aprendizaje, de construcción colaborativa, multimedia online y redes sociales). Según Maggio (2021) durante el 2020 y el inicio del ciclo 2021, hay ciertos rasgos que se van consolidando en las prácticas universitarias entre las que se mencionan: i) programas de las materias, cursos y seminarios que no reflejan modificaciones sustantivas en su formulación; ii) las propuestas virtuales que se apoyan, en algunos casos, en la generalización del uso de los campus virtuales, videollamadas, servicios de colaboración en torno de archivos compartidos, sistemas de mensajería instantánea, uso de redes (especialmente de WhatsApp).

El uso de plataformas más integrales, la articulación con aplicaciones de colaboración y la inclusión de servicios de redes sociales son caminos que parecen desarmar los límites marcados por los campus virtuales y los eventos sincrónicos a través de videollamadas. ... Sin embargo, no son caminos que resulten evidentes a los equipos docentes y, por tanto, se dan en casos con experiencia en el rediseño de las prácticas de la enseñanza o porque son específicamente alentados y apoyados por instancias institucionales que tienen este propósito específico. Aun con la aceleración que se produjo en materia de adopción tecnológica en el transcurso de la pandemia, consideramos que siguen configurando casos excepcionales. (Maggio, 2021, p. 210)

En la Argentina, la ES está conformada por instituciones de educación universitaria (IEU) e institutos de educación superior (IES). En este nivel educativo, el 
ciclo lectivo 2021 se ha iniciado de forma heterogénea: presencial, mixta o híbrida o totalmente remota según las disposiciones jurisdiccionales. Luego de más de un año de ERE en contexto de pandemia, este artículo se propone analizar conjuntamente las características del perfil del profesorado de ES en Argentina y las herramientas que incorpora en sus intervenciones didácticas haciendo foco en la docencia en el área STEAM en relación con otras áreas del conocimiento. El presente estudio forma parte de una investigación más amplia denominada "Competencias digitales del profesorado argentino de nivel superior", que tiene como propósito diagnosticar el nivel de competencias digitales del profesorado de ES en Argentina.

\section{Metodología}

El enfoque del estudio es cuantitativo con alcance descriptivo correlacional. Se trata de una investigación no experimental de tipo transversal ya que los datos se recolectaron en abril de 2021 sin intervenir en el ambiente donde se desarrollaban los fenómenos.

El muestreo fue no probabilístico, teniendo en cuenta como criterio de selección la filiación docente a alguna institución de ES durante el 2021, momento donde las clases se dictaban en forma remota o híbrida en función de las resoluciones adoptadas por cada jurisdicción. Del estudio participaron, de forma voluntaria, 1149 docentes de ES, tanto de instituciones públicas como privadas, de las 24 jurisdicciones argentinas, las que fueron agrupadas en 7 regiones: Área metropolitana de Buenos Aires (AMBA); Buenos Aires excepto AMBA (PBA); Córdoba, La Pampa, Santa Fe y Entre Ríos (Centro); Mendoza, San Juan y San Luis (Cuyo); Chaco, Corrientes, Formosa y Misiones (NEA); Catamarca, Jujuy, La Rioja, Salta, Santiago del Estero y Tucumán (NOA); Chubut, Neuquén, Río Negro, Santa Cruz y Tierra del Fuego, Antártida e Islas del Atlántico Sur (Patagonia).

Para el relevamiento de la información se utilizó la técnica de la encuesta mediante un cuestionario anónimo autoadministrado, confeccionado con Microsoft Forms ${ }^{\circledR}$, compuesto por 31 preguntas de respuesta cerrada y 3 preguntas de respuesta abierta, distribuido vía correo electrónico desde las cuentas de correo con dominio institucional de las investigadoras. Para asegurar la fiabilidad de las respuestas, se envió el cuestionario a referentes institucionales de todas las jurisdicciones, quienes colaboraron con el proceso de distribución del instrumento, instando a su profesorado a la cumplimentación de este, lo que obedece a un muestreo por conveniencia. Fueron atendidos aspectos éticos de privacidad y confidencialidad, teniendo en cuenta que, en el mismo instrumento, cada participante prestó conformidad al uso de la información brindada para fines científicos.

El cuestionario estaba integrado por siete secciones: información personal (1), compromiso profesional (2), recursos digitales (3) pedagogía digital (4), evaluación y retroalimentación (5), capacitar al estudiantado (6) y facilitar la competencia digital en el estudiantado (7). Para la elaboración de este trabajo se utilizó la información obtenida correspondiente a las secciones 1 y 3 del formulario, teniendo en cuenta variables cualitativas nominales (género, zona de residencia, área de desempeño, tipo de institución y de herramienta); cualitativa ordinal (edad), y cuantitativas continuas (antigüedad en el ES y años de experiencia en el uso de HD). Con respecto al tipo de HD, estas han sido categorizadas de las siguiente manera: aplicaciones específicas de cada espacio curricular ( $\mathrm{H} 1)$, comunicación asincrónica (H2) y sincrónica 
(H3), cuestionarios digitales para la evaluación (H4); herramientas de construcción colaborativa ( $\mathrm{H} 5)$, entornos de gestión de aprendizaje (H6), de desarrollo de imágenes $2 \mathrm{D}$ y $3 \mathrm{D}$ ( $\mathrm{H7}$ ), lúdicas ( $\mathrm{H8}$ ), recursos multimedia $(\mathrm{H9})$, para alojar y manejar archivos $(\mathrm{H} 10)$, planilla de cálculo (H11), plataformas de comunicación unificada $(\mathrm{H} 12)$, posters y mapas mentales colaborativos (H13), presentaciones multimediales $(\mathrm{H} 14)$, procesador de texto $(\mathrm{H} 15)$ y simuladores $(\mathrm{H} 16)$.

Para el tratamiento y análisis de los datos se utilizaron métodos de visualización y de estadística univariada y multivariada. Inicialmente, se efectuó un análisis descriptivo de los datos atendiendo a las variables mencionadas. Posteriormente, para indagar sobre posibles relaciones entre variables, se aplicó un análisis de correlación mediante la prueba de Kruskal-Wallis. El procesamiento de la información fue realizado mediante planillas de cálculo y el software R (versión 4.0.2), considerando un nivel de significación estadística del 5\%.

\section{Resultados}

Del total de 1149 docentes de ES de la República Argentina que participaron del estudio, el 56,22\% corresponde al género femenino y el 43,78\% al masculino. Si bien la variable género se presentó en forma politómica en el instrumento, solo se han obtenido respuestas de género masculino y femenino. Las edades del colectivo docente oscilan entre los 22 hasta más de 70 años. Los resultados del análisis de variación no paramétrico (Prueba de Kruskal-Wallis) arrojaron diferencias estadísticamente significativas entre el género y los distintos grupos etarios ( $p$-valor $=9,42.10^{-8}$ ).

Por otro lado, se observa que el grupo participante del estudio posee una antigüedad en el ES entre 1 y 49 años, con media 16,26 años, mediana 14,5 años y desvío standard 10,38 años. La representación según las distintas regiones de la Argentina es la siguiente: 47,08\% pertenecen a la Región Metropolitana de Buenos Aires (AMBA), 18,80\% a la Provincia de Buenos Aires excepto AMBA, 12,62\% al Centro, $8,80 \%$ al Noroeste, $4,70 \%$ al Noreste, 2,95\% a Cuyo, 5,05\% a la Patagonia.

Con respecto al tipo de institución de ES donde los individuos encuestados desarrollan su labor, un $49,65 \%$ lo hace solo en el ámbito universitario, el 38,15\% en IES y el $12,20 \%$ en ambos tipos de instituciones. Tras la aplicación de la prueba de Kruskal-Wallis se encontraron diferencias significativas entre el tipo de institución donde desarrollan su actividad y el género ( $p$-valor $=1,8610^{-14}$ ). De la prueba de comparación múltiple a posteriori, se identificaron diferencias entre los grupos. En la figura 1 se observa una mayor presencia masculina en el nivel universitario, mientras que en las IES y en ambos tipos de instituciones hay una mayor presencia femenina. 


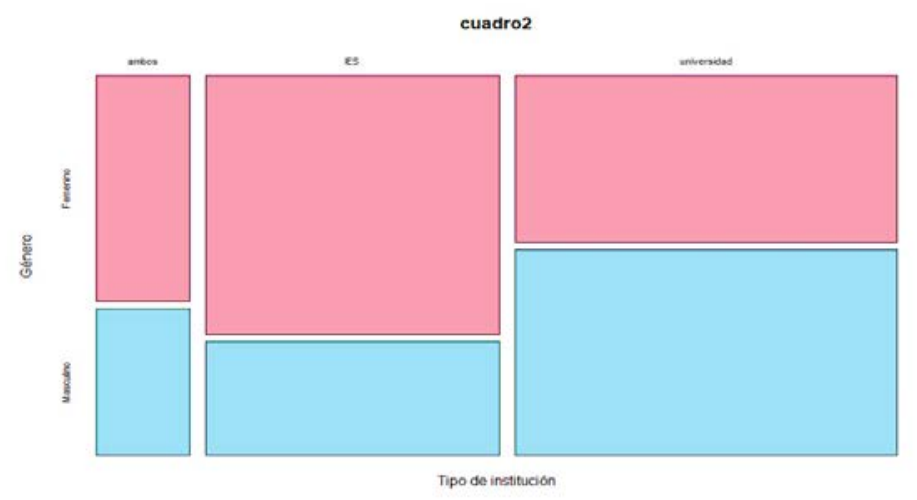

Figura 1: Distribución del profesorado por tipo de institución de pertenencia según género

Por otro lado, el $11,84 \%$ del profesorado desarrolla su tarea en el área de Arte, el $6,18 \%$ en Ciencias, el 27,15\% en Ingeniería, el 11,49\% en Matemática, el 9,92\% en Tecnología y el $33,42 \%$ en otras áreas del conocimiento. Los resultados de la aplicación de la Prueba de Kruskal-Wallis arrojaron diferencias significativas entre las áreas de desempeño docente y el género de los individuos encuestados ( $p$-valor=2,2.10-16).

Respecto de la existencia de posibles vinculaciones entre la edad y el área de desempeño del grupo docente, se concluye que existen diferencias significativas ( $p$-valor=0,0076). En la figura 2 se aprecian dichas diferencias además que en las áreas de Ciencia, Ingeniería y Matemática muestran medianas coincidentes que son mayores que en el resto de las áreas. Por otro lado, se destaca que el grupo de docentes de Ingeniería presenta la mayor variabilidad.

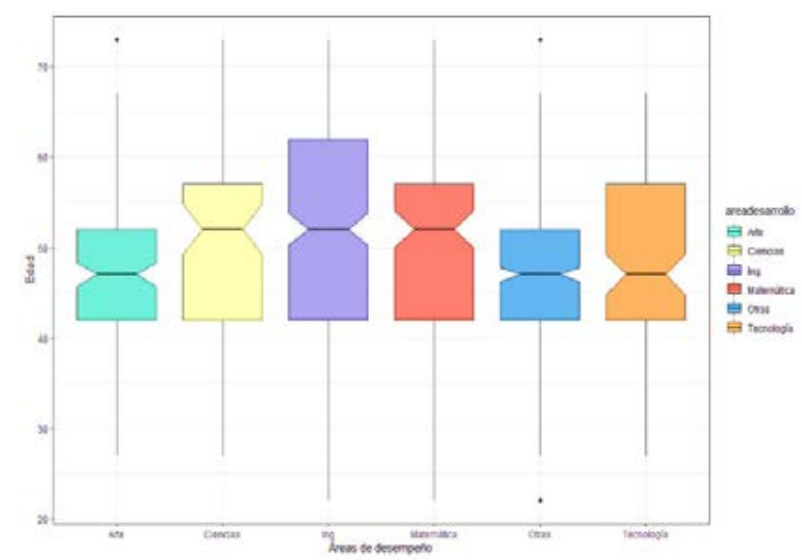

Figura 2: Áreas de desempeño según edad

\section{Inclusión de herramientas digitales en las prácticas pedagógicas}

Al indagar acerca de los años de experiencia que posee el profesorado en el trabajo con HD en sus prácticas pedagógicas, se desprende que la antigüedad promedio es de 8,64 años con un desvío de 5,78 años y un coeficiente de variación (CV) de $66,9 \%$, valor que indica que la muestra presenta una gran disparidad en los años de experiencia con dichas herramientas. 
Del análisis de la prueba de Kruskal-Wallis realizado sobre los años de experiencia en el uso de HD y las edades del colectivo docente participante del estudio, se concluye que existen diferencias significativas ( $p$-valor $=2,26.10^{-16}$ ).

Profundizando en el análisis, en la figura 3 se aprecia que en las zonas de AMBA, Cuyo y NEA no existen diferencias en los años de uso de HD según el género, mientras que sí existe en las restantes zonas. Particularmente, se destaca que en la región del Centro del país los profesores presentan una mayor variabilidad en años de experiencia en el uso de HD.

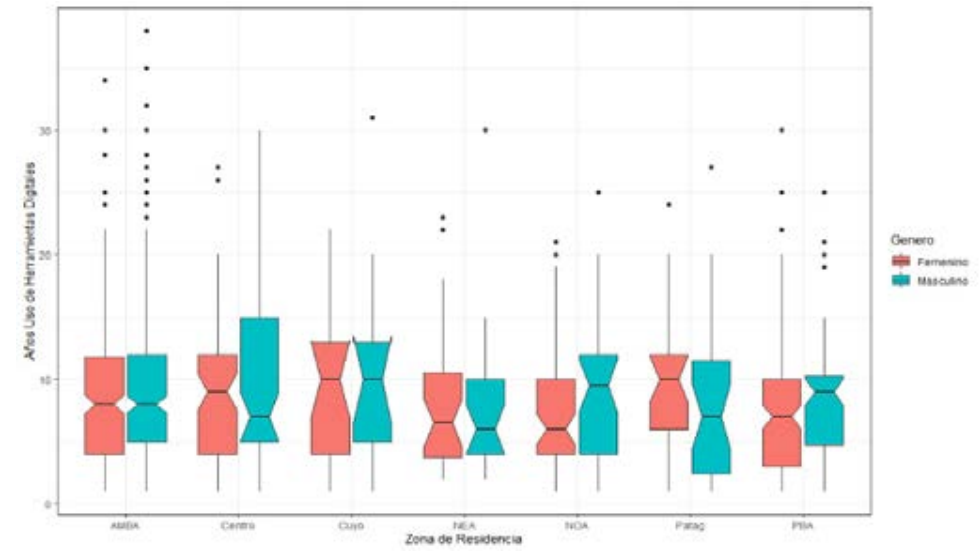

Figura 3: Zona de residencia según Años de uso de HD por Género

Asimismo, se han obtenido diferencias estadísticamente significativas entre los años de experiencia en el uso de HD y el tipo de institución donde el profesorado desarrolla su labor ( $\mathrm{p}$-valor=3,44.10-8). Al aplicar la prueba a posteriori, se desprende que los grupos de menor experiencia son de docentes que trabajan en IES (figura 4).

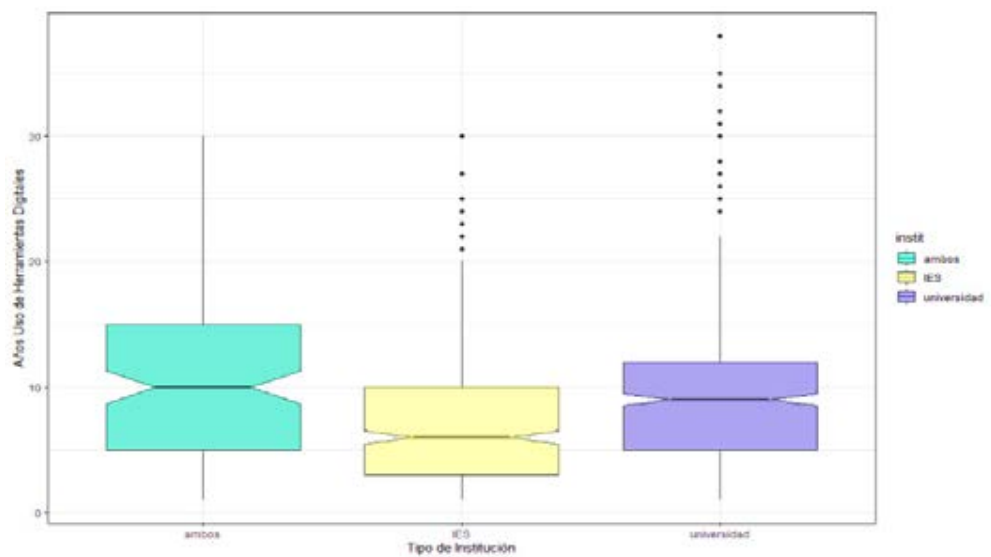

Figura 4: Distribución de docentes por tipo de institución según años de uso de HD

Al analizar posibles relaciones entre el tiempo de inclusión de HD en las prácticas pedagógicas por parte del profesorado y su área de desempeño, se detectan diferencias significativas ( $p$-valor $=9,28.10^{-9}$ ). A posteriori, se realizaron las comparaciones múltiples entre los grupos, encontrando diferencias estadísticamente significativas entre las áreas de Tecnología con el resto de las áreas de desarrollo disciplinar según figura 5. 


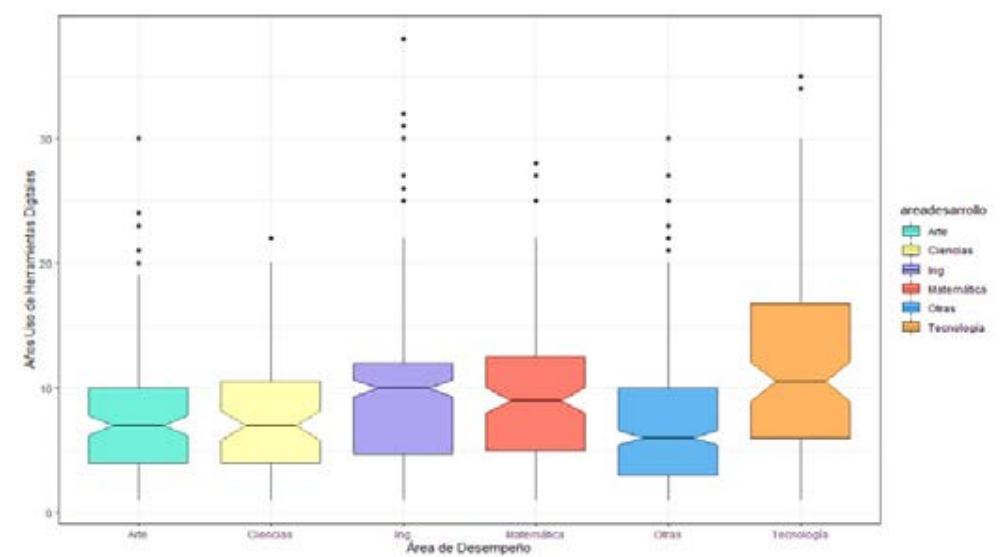

Figura 5: Distribución de los docentes por área de desempeño según Años de uso de HD

\begin{tabular}{|l|l|l|l|l|l|}
\hline Área & $\begin{array}{c}\text { Media } \\
\text { (años) }\end{array}$ & $\begin{array}{c}\text { Desvío } \\
\text { (años) }\end{array}$ & $\begin{array}{c}\text { CV } \\
\text { (\%) }\end{array}$ & $\begin{array}{l}\text { Tiempo de inclusión de } \\
\text { HD (años) }\end{array}$ & $\begin{array}{l}\text { Mediana } \\
\text { (años) }\end{array}$ \\
\hline Arte & 7.98 & 5.42 & 67.93 & 30 & 7 \\
\hline Ciencias & 8.14 & 5.19 & 63.77 & 22 & 7 \\
\hline Otras & 7.46 & 5.41 & 72.47 & 30 & 6 \\
\hline Ingeniería & 9.31 & 6.54 & 70.29 & 38 & 10 \\
\hline Matemática & 9.02 & 5.67 & 62.9 & 28 & 9 \\
\hline Tecnología & 12.35 & 8.12 & 65.77 & 35 & 11 \\
\hline
\end{tabular}

Tabla 1: Áreas de desempeño vs años de utilización de las herramientas digitales

En la tabla 1 se puede observar que, si bien hay mucha variabilidad en el tiempo de inclusión de HD en cada una de las áreas relevadas, los datos revelan que el grupo de docentes del campo de la Tecnología viene trabajando con aquellas desde hace una mayor cantidad de años. En cambio, quienes tienen menor antigüedad en la incorporación de HD no se desempeñan en las áreas STEAM.

Profundizando en el análisis, en la figura 6 se puede apreciar que, en las áreas de Arte, Ciencias y Tecnologías, el género femenino tiene una mayor antigüedad en el uso de HD que el género masculino, contrariamente a lo que sucede en Ingeniería y Matemática. Sin embargo, en otras áreas del conocimiento, tanto el género femenino como masculino tiene una antigüedad de uso similar. 


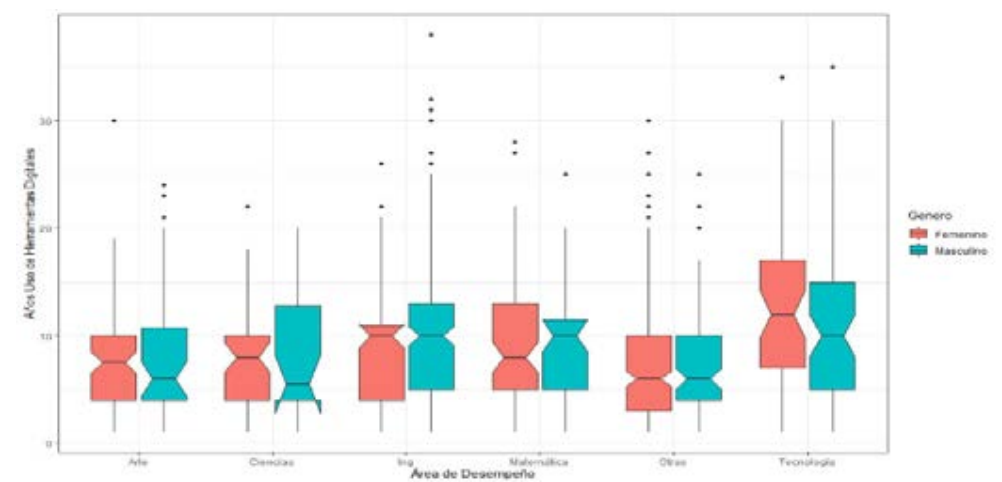

Figura 6: Área de desempeño según Años de uso de HD por Género

Con respecto a la frecuencia con que utiliza HD el profesorado en sus prácticas, se puede apreciar en la figura 7 , que las herramientas más utilizadas son H3, H2, H15, $\mathrm{H} 14, \mathrm{H} 10$ y $\mathrm{H} 6$ y, las menos $\mathrm{H} 16, \mathrm{H} 13, \mathrm{H} 8, \mathrm{H} 12$ y $\mathrm{H} 7$.

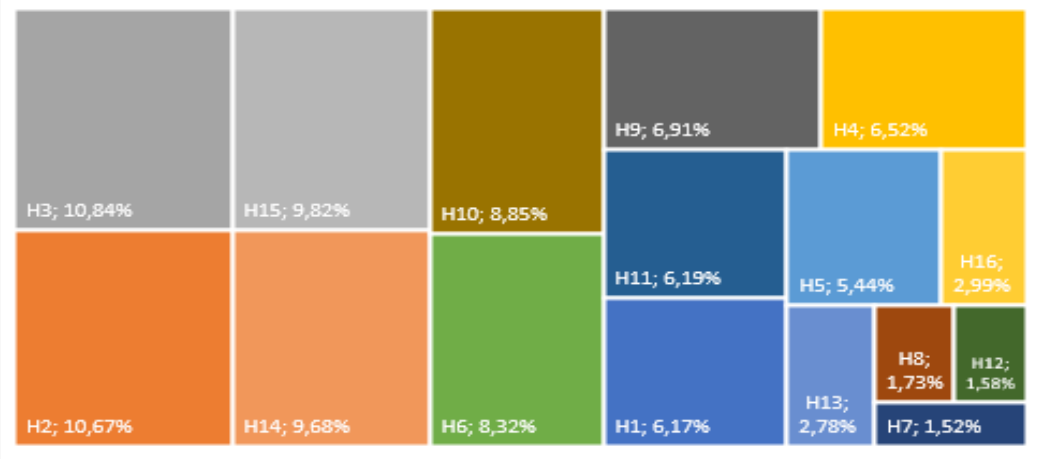

Figura 7: Porcentaje de HD utilizadas por el profesorado

Al analizar sobre posibles relaciones entre el tipo de HD utilizadas para mediar los procesos de enseñanza y las áreas de labor STEAM y otros campos del conocimiento no se encontraron diferencias estadísticas significativas con la inclusión de $\mathrm{H} 2$, $\mathrm{H} 3, \mathrm{H} 6$ y $\mathrm{H} 15$.

En contraposición, se halló asociación muy significativa ( $\mathrm{p} \leq 0.00001)$ con el uso de $\mathrm{H} 1, \mathrm{H} 4, \mathrm{H} 5, \mathrm{H} 8, \mathrm{H} 7, \mathrm{H}$, H10, H11, H12, H13, H14 y H16. En tabla 2 se presenta la proporción de docentes que utilizan las herramientas mencionadas.

\begin{tabular}{|l|l|l|l|l|l|l|l|l|l|l|l|l|}
\hline & H1 & H4 & H5 & H7 & H8 & H9 & H10 & H11 & H12 & H13 & H14 & H16 \\
\hline S & $6,23 \%$ & $8,02 \%$ & $6,27 \%$ & $3,52 \%$ & $7,41 \%$ & $5,72 \%$ & $5,55 \%$ & $6,90 \%$ & $4,05 \%$ & $7,31 \%$ & $6,62 \%$ & $13,21 \%$ \\
\hline T & $14,71 \%$ & $11,78 \%$ & $13,73 \%$ & $15,49 \%$ & $23,46 \%$ & $11,44 \%$ & $10,74 \%$ & $12,07 \%$ & $19,59 \%$ & $17,31 \%$ & $10,58 \%$ & $12,14 \%$ \\
\hline E & $27,16 \%$ & $30,11 \%$ & $18,24 \%$ & $28,17 \%$ & $17,90 \%$ & $21,79 \%$ & $25,69 \%$ & $35,86 \%$ & $36,49 \%$ & $16,15 \%$ & $29,22 \%$ & $53,21 \%$ \\
\hline A & $11,42 \%$ & $7,53 \%$ & $10,98 \%$ & $24,65 \%$ & $5,56 \%$ & $17,47 \%$ & $13,39 \%$ & $8,45 \%$ & $5,41 \%$ & $11,92 \%$ & $10,69 \%$ & $1,43 \%$ \\
\hline M & $17,65 \%$ & $12,11 \%$ & $10,39 \%$ & $7,04 \%$ & $7,41 \%$ & $10,05 \%$ & $11,82 \%$ & $12,93 \%$ & $15,54 \%$ & $7,69 \%$ & $9,92 \%$ & $14,29 \%$ \\
\hline Otras & $22,84 \%$ & $30,44 \%$ & $40,39 \%$ & $21,13 \%$ & $38,27 \%$ & $33,54 \%$ & $32,81 \%$ & $23,79 \%$ & $18,92 \%$ & $39,62 \%$ & $32,97 \%$ & $5,71 \%$ \\
\hline
\end{tabular}

Tabla 2: Proporción de uso de herramientas digitales por área 
Tomando las áreas STEAM, se observa que el profesorado del área de Ciencias (S) es el que utiliza en menor grado las HD en sus prácticas, mientras que en otras áreas del conocimiento y en Ingeniería (E) son más utilizadas. Si bien los porcentajes de inclusión son bajos, se destaca el uso de H16 en esta última área. Si se toman en cuenta las áreas no incluidas en el grupo STEAM, se destaca un mayor uso de $\mathrm{H} 4$, H5, H8, H9 y H13 y, a la vez, se observa un uso muy bajo de H16.

\section{Conclusiones}

Este estudio pone en evidencia las diferencias entre el profesorado de género masculino y femenino vinculado con el área de desempeño, tipo de institución donde desarrolla su labor docente y años de experiencia en el uso de HD.

Se concluye, que existe una gran disparidad en los años de experiencia que tiene el profesorado en el uso de HD para mediar los procesos de enseñanza. En las áreas de Arte, Ciencias y Tecnologías el género femenino tiene una mayor antigüedad en el uso de HD mientras que en Ingeniería y Matemática, la mayor antigüedad se corresponde con el género masculino. En general, el grupo de docentes participantes del estudio vinculados al área STEAM tiene una mayor antigüedad en el uso de HD que los de otros campos del conocimiento.

Más allá de los resultados obtenidos sobre la baja proporción de docentes que utilizan diversidad de herramientas en sus prácticas, en Ingeniería y en otros campos disciplinares por fuera del área STEAM, se destaca el número de HD que incorporan. Las HD de uso más frecuente relevadas en este estudio son las de comunicación sincrónica y asincrónica, para alojar y manejar archivos, presentaciones multimediales y procesador de texto, resultados que concuerdan con el estudio de Chan et al. (2021) durante el primer semestre 2020. Por otra parte, aunque los porcentajes de uso siguen siendo significativamente bajos, se debe destacar un leve incremento en el uso de herramientas de tipo colaborativo y lúdicas respecto del relevamiento realizado por dichas autoras. En conclusión, pasado un año del contexto de ERE, no se observan cambios significativos en modos de uso en la categorización de HD presentadas.

Queda planteado que, más allá de que la pandemia propició la incorporación de distintos artefactos y herramientas en las prácticas docentes de ES, consideramos que aún es necesario acompañar al profesorado en la inclusión de HD desde una perspectiva de mediación, que permitan el trabajo colaborativo y la experimentación. En este sentido, acordamos con Maggio (2021) en cuanto a que: "la pandemia tiene un efecto acelerador de la digitalización, pero no necesariamente de transformación de las propuestas que dé cuenta de los modos en que se construye el conocimiento en la contemporaneidad" (p. 212).

\section{Referencias}

Ardini, C., Barroso, M. y Corzo, L. (2020). Herramientas digitales de comunicación en contexto COVID 19. El impacto en la relación estudiantes-instituciones educativas en Argentina. Revista ComHumanitas, 11(2), pp. 98-122. 
Chan, D., Galli, Ma. Gabriela y Ramírez, R. (2021). El impacto del distanciamiento social en la Educación Superior: la arista docente. Revista Innovaciones Educativas, 23(34), pp.81-97

Hodges, C. et al. (2020). La diferencia entre la enseñanza remota de emergencia y el aprendizaje en línea. Recuperado de https://er.educause. edu/articles/2020/3/ the-difference-between-emergency-remote-teaching-and-online-learning

Kanobel, M. (2020). Motivación y rendimiento académico de estudiantes en contextos de enseñanza remota de emergencia: un estudio en el nivel universitario. En A. Rosas (Ed.), Resúmenes del $6^{\circ}$ Congreso Internacional de Matemática Educativa ( $\mathrm{p}$ 85-86). Editorial Lectorum.

Maggio, M. (2021). Enseñar en la Universidad. Pandemia... y después. Integración y Conocimiento, 10 (2), pp. 203-217.

Ministerio de Educación de la Nación. (10 de junio de 2020). Legislación y Avisos Oficiales. Obtenido de Resolución 108/2020: https://www.boletinoficial.gob.ar/detalleAviso/primera/226752/20200316

Ministerio de Salud de la Nación. (2020). Ministerio de Salud - Nuevo coronavirus COVID-19. https://www.argentina.gob.ar/salud/coronavirus-COVID-19/plan-operativo 


\section{Adaptación Semipresencial en Tiempos de Covid-19: Recursos TIC, Motivación y Percepción del Alumnado Universitario en la Clase de IFE.}

\section{Rodríguez Peñarroja, Manuel}

ORCID orcid.org/0000-0002-9917-6481

Universitat de València - SILVA group.

Universitat Jaume I - IULMA. 


\section{ADAPTACIÓN SEMIPRESENCIAL EN TIEMPOS DE COVID-19: RECURSOS TIC, MOTIVACIÓN Y PERCEPCIÓN DEL ALUMNADO UNIVERSITARIO EN LA CLASE DE IFE.}

\section{Rodríguez Peñarroja, Manuel}

ORCID orcid.org/0000-0002-9917-6481

Universitat de València - SILVA group.

Universitat Jaume I - IULMA.

\section{Resumen}

El uso de las tecnologías de la información y la comunicación así como los recursos digitales en línea han sido necesarios tanto en periodos de confinamiento como en la vuelta a la presencialidad en el ámbito educativo marcado por la pandemia. En este contexto, el presente estudio pretende analizar el efecto de la adaptación semipresencial de la asignatura de inglés para fines específicos 'Comunicación en lengua inglesa para turismo I' en diferentes aspectos motivacionales del alumnado así como la precepción del mismo en cuanto al uso de la tecnología con fines educativos. Con este propósito los participantes respondieron a un cuestionario con dos partes diferenciadas y un total de 32 ítems. Los primeros 29 ítems se corresponden a aspectos motivacionales basados en el cuestionario de motivación intrínseca y la teoría de autodeterminación. La segunda parte del cuestionario incluye 3 preguntas de respuesta abierta sobre la percepción del estudiantado en cuanto al uso de recursos tecnológicos en un contexto de aprendizaje semipresencial. Los resultados sugieren índices generales de motivación moderada-alta en relación a la adaptación semipresencial y el uso de los diferentes recursos tecnológicos. Se puede concluir que el impacto del uso de la tecnología con fines educativos en la motivación del estudiantado es similar a estudios llevados a cabo en contextos educativos anteriores a la pandemia.

\section{Palabras clave}

Inglés para fines específicos, aprendizaje semipresencial, Covid-19, tecnologías de la información y comunicación, motivación. 


\section{Introducción}

La declaración de emergencia de salud pública por la organización mundial de la salud (WHO, 2020, marzo) debido al brote del virus Covid-19 ha supuesto un cambio en el día a día de las personas a nivel internacional. Las restricciones de movilidad y periodos de confinamiento han precipitado la transición hacia entornos de enseñanza y aprendizaje en línea mediante el uso de las tecnologías de la información y comunicación (TICs) (Ali, 2020; Moorhouse, 2020). Profesores y estudiantes en la educación superior universitaria y otros ámbitos educativos han adaptado sus rutinas, recursos pedagógicos y metodologías de enseñanza a un contexto educativo sin precedentes que ha tenido a las TICs como principal aliado. Esta etapa sobrevenida hacia la digitalización de la enseñanza requiere de la revisión de los modelos de instrucción y recursos en línea así como la competencia digital del estudiantado y profesorado y los efectos del uso de las TICs y recursos web 2.0 en la motivación del alumnado.

En primer lugar, Fuentes-Hernández y Flórez (2020) describen las modalidades síncrona, asíncrona y semipresencial o blended learning (BL) como los principales modelos de enseñanza en línea. El modelo de instrucción en línea síncrono precisa de la presencia simultánea del profesorado y alumnado en un entorno virtual mediante el uso de software para videoconferencia. El modelo en línea asíncrono no requiere de la presencia simultánea profesor y estudiante, sin embargo se recomienda mantener una comunicación asíncrona vía correo electrónico o implementar un sistema de tutorías en línea síncronas. Asimismo se deben preparar los materiales necesarios para satisfacer las demandas del currículum educativo y fomentar un aprendizaje autónomo por parte del estudiantado, por ejemplo el uso de video presentaciones. Por último, la modalidad semipresencial combina el aprendizaje presencial síncrono ya sea en el aula o en línea a través de aplicaciones para videoconferencia como Google Meet o Blackboard Collaborate con el uso de las TICs y sistemas de gestión de aprendizaje (SGA) para completar la experiencia educativa del alumnado (Fathali y Okada, 2017, Lapitan et al., 2021).

Alammary et al. (2014) diferencian entre tres tipos de adaptaciones semipresenciales según el grado de adaptación del curso o asignatura de una modalidad presencial síncrona a una semipresencial. La adaptación de bajo impacto implica el diseño de tareas adicionales que requieren el uso de las TICs en un contexto en línea además de las actividades que ya se utilizan en la instrucción tradicional. La adaptación de medio impacto requiere el rediseño y la adaptación de las tareas en contextos de educación presencial a un entorno digital/virtual, es decir, modificar las actividades, tareas y proyectos basados en recursos tradicionales a otras mediadas a través de las TICs y aplicaciones web 2.0. Por último, la adaptación de alto impacto precisa una revisión completa de las necesidades curriculares del alumnado para la selección de los recursos TIC que mejor se adecuen al diseño de recursos en línea, en otras palabras, rediseñar y adaptar la asignatura a un entorno en línea desde cero.

Estudios sobre modelos de enseñanza semipresencial en contraposición a contextos exclusivamente presenciales síncronos u online asíncronos han demostrado las ventajas y viabilidad de este modelo de instrucción (Bernard et al., 2014). Castaño et al., (2017) concluyen que el aprendizaje semipresencial supone altos niveles de satisfacción en relación a aspectos metodológicos y de contenidos que se pueden ajustar a las necesidades y características del estudiantado. Los resultados del meta análisis de diferentes estudios que contrastan el aprendizaje online con el presencial muestran un mejor rendimiento del alumnado en contextos de aprendizaje online (Means et al., 2009). 
En segundo lugar, el uso de las TICs y aplicaciones web 2.0 como pueden ser blogs educativos y otros entornos en línea han tenido un papel importante en el proceso de enseñanza-aprendizaje en contextos de educación superior universitaria (Francis, 2017; Kaharuddin, 2020; Tavakoli et al, 2019). En relación a las modalidades de instrucción en línea previamente descritas, el uso de SGA como puede ser la plataforma Moodle funciona como nexo común de las mismas. Coates et al. (2005) describen algunas de las características principales de estas herramientas que facilitan la organización y el diseño de los cursos en línea: i) permiten una interacción síncrona y asíncrona entre profesorado-estudiantado o entre el estudiantado, ii) posibilitan la distribución y creación de contenidos y recursos, por ejemplo el diseño de tareas, talleres y cuestionarios, y iii) facilitan el seguimiento, la evaluación y los procesos de corrección y retroacción de las actividades, tareas y trabajos realizados por el estudiantado. Estas herramientas también permiten la gestión de grupos y disponen de un interfaz multilingüe que facilita su accesibilidad (Pagán y Medina, 2021; Polhun et al., 2021).

En tercer lugar, la competencia digital del estudiantado y el profesorado es indispensable en un contexto de digitalización de la enseñanza. En lo que respecta al alumnado, la concepción del mismo como nativos digitales puede llevar a la idea equivocada que asume la transferencia de su competencia digital a un entorno de enseñanza y aprendizaje tal y como sugieren Gisbert y Esteve (2016). El uso de las TICs suele estar ligado a las redes sociales y el entretenimiento (Valtonen et al., 2011), por lo tanto, aunque los estudiantes presenten una mayor destreza digital, es imprescindible no presuponer que su competencia digital con fines educativos se corresponde con su uso diario. En cuanto al profesorado, Ali (2020) y Vrasidas (2015) entre otros hacen hincapié en la necesidad de instruir a este colectivo de profesionales en el uso de recursos TIC y web 2.0 con fines educativos ya que son los docentes quienes ejercen de puente entre el alumnado y el uso de la tecnología en los procesos de enseñanza y aprendizaje.

Tradicionalmente, el uso de recursos TIC (ordenadores portátiles y tabletas) como complemento a modelos de instrucción más tradicionales ha tenido un efecto positivo en la motivación, dedicación y rendimiento del estudiantado tanto en líneas generales (Francis, 2017; Harandi, 2015) como en el aprendizaje de IFE (Kaharuddin, 2020; Rodríguez-Peñarroja, 2020) y el inglés como lengua extranjera (Fuentes-Hernández y Flórez, 2020; Tavakoli et al., 2019). De igual forma estudios sobre motivación y rendimiento académico en contextos de aprendizaje semipresencial sugieren un impacto positivo en el alumnado (Shyr y Chen, 2018; Spring et al., 2018). No obstante la motivación y actitud del estudiantado hacia la formación semipresencial pueden variar dependiendo de otros factores, por ejemplo los estilos de aprendizaje individual de cada alumno (Sana et al., 2013). En consecuencia, es necesario promover el diseño de tareas y actividades que propicien un aprendizaje activo y participativo para con sus necesidades y objetivos curriculares tal y como concluyen Spanjers et al. (2015) y Lane et al. (2021) en sus respectivos estudios sobre el aprendizaje semipresencial y sus efectos en el alumnado. Por otra parte, el estudio de aspectos motivacionales en la enseñanza semipresencial de IFE no ha proliferado tanto en el contexto Covid-19 como en condiciones de aprendizaje normal.

En este contexto, se presenta la adaptación de la asignatura de IFE Comunicación en lengua inglesa para Turismo I ( 6 ECTS) a un entorno de aprendizaje semipresencial de medio impacto (Alammary et al., 2014) que combina las clases presenciales 
síncronas con el uso del SGA Moodle (Moodle Docs, s.f.). Los objetivos principales del estudio son: i) determinar el impacto del uso de las TICs en la motivación del alumnado universitario de primer año en un contexto educativo de aprendizaje semipresencial forzado por la pandemia y ii) presentar las valoraciones de los estudiantes en cuanto al uso de Moodle como plataforma educativa y el programa de libre acceso Skype para practicar y grabar interacciones orales en inglés.

\section{Método}

\section{Descripción del contexto y de los participantes}

Este estudio se llevó a cabo durante el primer semestre del curso académico 20202021 en la Facultad de Economía de la Universitat de València. El contexto Covid-19 en el que se enmarca la investigación permitió la adaptación de la asignatura de IFE Comunicación en lengua inglesa para turismo I (6 ECTS) a un modo de docencia semipresencial síncrona siguiendo las recomendaciones sanitarias y directrices institucionales. Por otra parte, las actividades y proyectos del curso se adaptaron a una modalidad asíncrona mediante el uso de la plataforma Moodle como canal principal de comunicación en línea entre estudiantado y profesorado. La muestra de participantes en el estudio es de noventa y cuatro estudiantes de primer año ( $\mathrm{N}=94$ ) con edades comprendidas entre los dieciocho y veinte años $(M=18,19)$ (59 mujeres y 35 hombres).

\section{Instrumentos}

Para el estudio de los diferentes aspectos motivacionales del alumnado en cuanto al uso de las TICs se adaptó el cuestionario de motivación intrínseca "Intrinsic Motivation Inventory" (IMI) (SDT, s.f.) con el objetivo de obtener información sobre la experiencia subjetiva del alumno, la motivación intrínseca y los procesos de auto regulación en el aprendizaje. Este cuestionario se conforma de diferentes subescalas que corresponden a un número de aspectos motivacionales que pueden ser estudiados. La subescala de interés mide la motivación intrínseca del alumnado, las subescalas de aptitud y valor/utilidad determinan la percepción del estudiantado en cuanto a su competencia para acometer actividades, tareas o proyectos y la utilidad de las mismas. El empeño y la dificultad al acometer las tareas se mide en la subescala de esfuerzo, mientras que la percepción de la tensión del estudiantado la determina la subescala de presión. El diseño final del cuestionario de motivación con las subescalas, los ítems que las componen y la estimación de su consistencia con el coeficiente a de Cronbach se presentan en la tabla 1.

\begin{tabular}{|l|l|l|}
\hline Subescala & Ítems & .892 \\
\hline Interés & 5 & .807 \\
\hline Aptitud & 5 & .677 \\
\hline Esfuerzo & 3 & .893 \\
\hline Presión & 3 & .946 \\
\hline Valor/Utilidad & 13 & $\mathbf{. 8 9 9}$ \\
\hline Total & $\mathbf{2 9}$ & de Cronbach \\
\hline
\end{tabular}

Tabla 1. Valores de fiabilidad según la prueba a de Cronbach. 
Los resultados del estadístico a en la tabla 1 presentan valores no inferiores a 0.6, tal y como se recomienda en la descripción del cuestionario (SDT, s.f.). Este cuestionario se administró al finalizar el semestre académico mediante Google Docs y los estudiantes valoraron un total de 29 ítems en una escala Likert del 1 (totalmente en desacuerdo) al 5 (totalmente de acuerdo). Adicionalmente el alumnado respondió a tres preguntas de corte abierto con el objetivo de explicitar los inconvenientes y ventajas en el uso de Skype para completar las tareas de interacción oral así como el uso de Moodle como SGA para la gestión de los contenidos del curso, las tareas y retroacción del profesorado. Los diferentes estadísticos descriptivos así como las pruebas paramétricas y no parametricas se han calculado con el software SPSS v.26.

\section{Procedimiento}

La docencia en la asignatura de IFE se desarrolló durante un periodo de normalidad pandémica que permitió su adaptación a un modelo semipresencial de impacto medio (Alammary et al., 2014). En consecuencia, las actividades, tareas y proyectos para la evaluación continua del estudiantado se entregaron a través de la plataforma Moodle siendo la retroacción del profesorado asíncrona. Estas actividades y tareas incluyen i) diez test de elección múltiple que contienen aspectos gramaticales y léxicos para la autoevaluación de los alumnos, ii) tres actividades de producción escrita formal i.e. un folleto turístico promocional, un correo de disculpa y una carta de presentación que acompaña al currículum vítae, iii) cinco actividades de producción oral i.e. interacciones en parejas que requieren el uso de Skype y iv) un trabajo en grupo en el que los estudiantes promocionan un destino turístico en una exposición oral mediante el uso de PowerPoint.

Finalizado el semestre, los estudiantes completaron el cuestionario de 32 ítems para valorar su experiencia educativa y motivación con respecto al aprendizaje semipresencial en la clase de IFE mediante el uso de las TICs. La interpretación de los resultados del cuestionario IMI en base a las respuestas del alumnado en escala Likert obedece a los parámetros establecidos en la tabla 2.

\begin{tabular}{|l|l|}
\hline Media & Grado de motivación \\
\hline $1.00-1.80$ & Baja \\
\hline $1.81-2.60$ & Moderada-Baja \\
\hline $2.61-3.40$ & Moderada \\
\hline $3.41-4.20$ & Moderada-alta \\
\hline $4.21-5.00$ & Alta \\
\hline
\end{tabular}

Tabla 2. Intervalo de medias y grado de motivación.

En lo que respecta a los datos cualitativos que engloban las respuestas de los estudiantes a las preguntas de corte abierto, estas se han agrupado en diferentes aspectos que integran las principales reflexiones del estudiantado. 


\section{Resultados}

Los resultados cuantitativos y cualitativos se presentan en este orden respondiendo a los objetivos de la investigación. El primer objetivo se centra en el estudio cuantitativo de los factores motivacionales en los estudiantes en el contexto de educación semipresencial. Con este propósito, se calcularon las medias de las respuestas del alumnado por subescalas. Los resultados del cuestionario IMI se presentan en la tabla 3 que incluye las diferentes subescalas, el numero de ítems por escala, los valores medios mínimos y máximos y la desviación estándar.

\begin{tabular}{|l|l|l|l|l|l|}
\hline Subescala & \multicolumn{1}{l}{ Ítems } & Min & Max & \multicolumn{1}{l|}{ Media } & \multicolumn{1}{l|}{ SD } \\
\hline Interés & 5 & 1.00 & 5.00 & 3.53 & .84 \\
\hline Aptitud & 5 & 1.40 & 5.00 & 3.60 & .67 \\
\hline Esfuerzo & 3 & 1.33 & 5.00 & 4.33 & .68 \\
\hline Presión & 3 & 1.00 & 5.00 & 2.33 & 1.08 \\
\hline Valor/Utilidad & 13 & 1.69 & 5.00 & 3.94 & .74 \\
\hline Total & 29 & 2.61 & 4.60 & 3.55 & .39 \\
\hline
\end{tabular}

Tabla 3. Estadísticos descriptivos cuestionario de motivación.

El resultado total del cuestionario presenta un grado general de motivación moderada-alta $(M=3.55, S D=.39)$ en cuanto a la experiencia de aprendizaje semipresencial y el uso de las TICs en la asignatura de IFE. Los estudiantes consideran que el esfuerzo requerido para la consecución de las tareas de evaluación continua mediadas por las TICs ha sido elevado ( $M=4.33, S D=.68)$ mientras que las subescalas de valor/ utilidad $(M=3.94, S D=.74)$, aptitud $(M=3.60, S D=.67)$ e interés $(M=3.53, S D=.84)$ reflejan una tendencia motivacional moderada-alta. Por el contrario, la subescala de presión ( $M=2.33, \mathrm{SD}=1.08$ ) evidencia un resultado moderado-bajo.

En segundo lugar y teniendo en cuenta los estudios que relacionan positivamente el uso de las TICs con la motivación y al mismo tiempo advierten sobre la competencia digital del alumnado y sus efectos en diferentes aspectos motivacionales, se presenta en la tabla 4 la matriz de correlaciones entre las subescalas de motivación en este estudio. La finalidad del estudio de correlaciones es determinar la asociación de las subescalas, su fuerza y dirección.

\begin{tabular}{|l|l|l|l|l|l|l|}
\hline Subescala & \multicolumn{1}{c}{$\mathbf{1}$} & $\mathbf{2}$ & $\mathbf{3}$ & $\mathbf{4}$ & $\mathbf{5}$ \\
\hline \multirow{4}{*}{ 1. Interés } & Pearson $(r)$ & 1 & $.430^{* *}$ & $.359^{* *}$ & $-.449^{* *}$ & $.591^{* *}$ \\
\cline { 2 - 7 } & Sig. (bilateral) & & .000 & .000 & .000 & .000 \\
\cline { 2 - 7 } & $\mathrm{N}$ & 94 & 94 & 94 & 94 & 94 \\
\hline \multirow{3}{*}{ 2. Aptitud } & Pearson $(r)$ & $.430^{* *}$ & 1 & $.306^{* *}$ & $-.363^{* *}$ & $.456^{* *}$ \\
\cline { 2 - 7 } & Sig. (bilateral) & .000 & & .003 & .000 & .000 \\
\cline { 2 - 7 } & $\mathrm{N}$ & 94 & 94 & 94 & 94 & 94 \\
\hline \multirow{3}{*}{ 3. Esfuerzo } & Pearson $(r)$ & $.359^{* *}$ & $.306^{* *}$ & 1 & -.167 & $.310^{* *}$ \\
\cline { 2 - 7 } & Sig. (bilateral) & .000 & .003 & & .107 & .002 \\
\cline { 2 - 7 } & $\mathrm{N}$ & 94 & 94 & 94 & 94 & 94 \\
\hline
\end{tabular}




\begin{tabular}{|l|l|l|l|l|l|l|}
\hline \multirow{4}{*}{ 4. Presión } & Pearson $(r)$ & $-.449^{* *}$ & $-.363^{* *}$ & -.167 & 1 & $-.327^{* *}$ \\
\cline { 2 - 7 } & Sig. (bilateral) & .000 & .000 & .107 & & .001 \\
\cline { 2 - 7 } & $\mathrm{N}$ & 94 & 94 & 94 & 94 & 94 \\
\hline \multirow{3}{*}{ 5. Valor } & Pearson $(r)$ & $.591^{* *}$ & $.456^{* *}$ & $.310^{* *}$ & $-.327^{* *}$ & 1 \\
\cline { 2 - 7 } & Sig. (bilateral) & .000 & .000 & .002 & .001 & \\
\cline { 2 - 7 } & $\mathrm{N}$ & 94 & 94 & 94 & 94 & 94 \\
\hline
\end{tabular}

Nota: 1=Interés; 2=Aptitud; 3=Esfuerzo; 4=Presión; 5=Valor.

**. La correlación es significativa en el nivel 0.01 (bilateral).

\section{Tabla 4. Matriz de correlaciones entre las variables/subescalas del estudio.}

Los resultados en la tabla 4 presentan correlaciones significativas entre las diferentes subescalas de motivación a excepción de la asociación entre el esfuerzo y la presión $r(92)=-.16, p=.107$. Por lo general, el grado de asociación de las diferentes subescalas es estadísticamente significativo $(p=0<.01)$ y la fuerza de dicha asociación es moderada con valores $r$ entre .30 y .44. Centrándonos en la relación entre la percepción de la competencia del estudiantado (subescala aptitud) en cuanto al uso de las TICs y recursos web 2.0 y la motivación intrínseca (subescala interés), los resultados muestran una correlación positiva moderada con un valor de $r(92)=.43, p=.000$. Asimismo, la variable interés y la percepción del valor de las tareas presenta una relación positiva fuerte $r(92)=.59, p=.000$. También cabe destacar las correlaciones negativas entre la subescala de presión y las subescalas de interés, aptitud y valor/utilidad, es decir, a menor presión los estudiantes experimentan un grado mayor de motivación intrínseca y aptitud al mismo tiempo que valoran positivamente las tareas que requieren del uso de la tecnología.

El segundo objetivo de este estudio pretende recoger las percepciones de los estudiantes en relación al uso del programa Skype y el SGA Moodle como TICs y recursos digitales para el desarrollo, entrega y evaluación de sus tareas de evaluación continua. Los resultados respecto a las ventajas e inconvenientes identificados por los participantes se presentan en formato porcentual en los siguientes gráficos sectoriales. Los gráficos 1 y 2 muestran las ventajas e inconvenientes del uso de Skype como herramienta para grabar interacciones orales. Por otra parte, el gráfico 3 presenta las valoraciones del alumnado en relación al uso de Moodle como SGA.

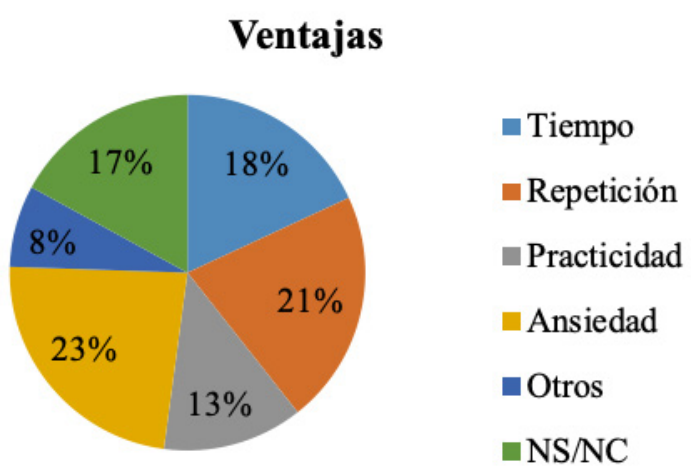

Gráfico 1. Ventajas en el uso de Skype para las interacciones orales. 
Las ventajas puntualizadas por los participantes sobre el uso de Skype para grabar las interacciones orales incluyen la posibilidad de repetir las interacciones hasta alcanzar el objetivo deseado (21\%) así como una reducción en niveles de ansiedad (23\%) al acometer las mismas. Asimismo, se valoran positivamente el tiempo para ejecutar la tarea (18\%) y la comodidad de realizar la tarea desde casa sin tener que estar físicamente presente en el mismo espacio (13\%). Un 17\% de los encuestados dejaron la respuesta en blanco mientras que un $8 \%$ alude a otras ventajas como por ejemplo el aprendizaje del uso de nuevas tecnologías y la mejora en sus habilidades orales en inglés.

\section{Inconvenientes}

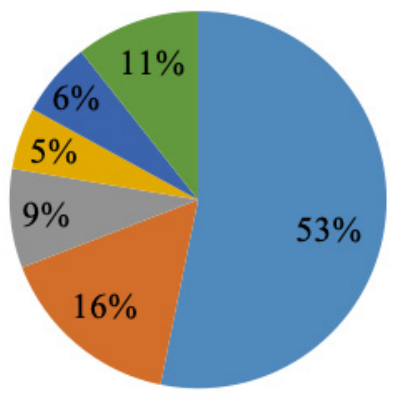

- Problemas técnicos

- Parámetros reales

- Tiempo

Retroacción

- Otros

$\because \mathrm{NS} / \mathrm{NC}$

\section{Gráfico 2. Inconvenientes en el uso de Skype para las interacciones orales.}

En cuanto a los inconvenientes, el 53\% de los participantes afirman haber experimentado problemas técnicos con la conexión, dispositivos electrónicos y la aplicación Skype. Un 16\% de la muestra expone que las interacciones mediadas por Skype pierden autenticidad y no se asemejan a las interacciones en contextos reales. En cuanto al tiempo para preparar la tarea, los estudiantes consideran que se dedica más tiempo en el contexto online (9\%). Por último, un $5 \%$ de los encuestados prefieren tener la retroacción del profesor en tiempo real y un $6 \%$ exponen otros inconvenientes como por ejemplo la posibilidad de leer de un texto escrito, la distancia física con el interlocutor y un grado más alto de complicación al utilizar la herramienta Skype.

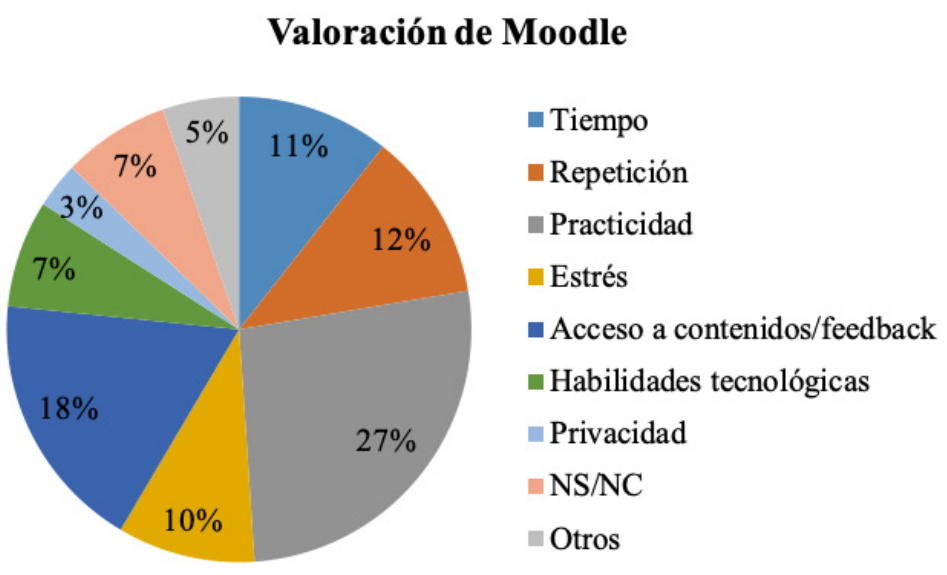

Gráfico 3. Valoración de Moodle como SGA. 
Para finalizar, se pidió a los estudiantes qua valoraran Moodle como plataforma para el aprendizaje y gestión del curso. Los estudiantes valoraron positivamente la funcionalidad práctica que esta herramienta ofrece (27\%), el acceso a los contenidos y las revisiones de tareas tantas veces como lo consideran necesario (18\%) y la posibilidad de repetir las tareas antes de entregar su versión final en la plataforma (12\%). Un $11 \%$ de los estudiantes sostienen que pueden gestionar mejor su tiempo al realizar las actividades y este hecho reduce el estrés que supone realizar las tareas en un tiempo limitado en la clase (10\%). Los estudiantes también exponen la privacidad que Moodle ofrece con respecto a sus calificaciones en las tareas (3\%) y los beneficios en el aprendizaje del uso de las TICs (7\%). Un 7\% de los encuestados no proporcionaron ninguna respuesta o no están seguros que Moodle tenga ventajas sobre la gestión del curso de manera presencial.

\section{Discusión y conclusiones}

El objetivo principal de este estudio es investigar el efecto de la adaptación curricular semipresencial de impacto medio (Alammary et al., 2014) en la motivación de los alumnos y su percepción en cuanto al uso de recursos TIC como Moodle y Skype en la asignatura de IFE 'Comunicación en lengua inglesa para Turismo l'. Los resultados cuantitativos del cuestionario IMI indican valores moderados-altos en el total del cuestionario y más específicamente en las subescalas de interés (motivación intrínseca), aptitud que denota una autoevaluación y un comportamiento positivo hacia las tareas y la variable de valor/utilidad. La subescala de esfuerzo presenta valores altos y la subescala de presión muestra resultados moderados-bajos. El estudio de correlaciones entre las subescalas del cuestionario IMI evidencia correlaciones positivas estadísticamente significativas en las variables o subescalas de motivación a excepción de la asociación dela variable presión que se relaciona negativamente con las demás.

Los resultados cualitativos en base a las preguntas de respuesta abierta presentan un número de ventajas en cuanto al uso de Skype como herramienta para practicar interacciones síncronas en línea. Por otra parte, el inconveniente más representativo viene dado por los problemas técnicos y de conexión a Internet que evidencia dificultades al utilizar el programa. Del mismo modo las valoraciones del estudiantado respecto al uso de Moodle como plataforma educativa han sido favorables y plantean una lista de beneficios en cuanto al modelo semipresencial que combina clases presenciales síncronas con la gestión de los contenidos del curso y tareas del estudiantado en un modo asíncrono.

Podemos concluir que la adaptación de la asignatura IFE 'Comunicación en lengua inglesa para turismo l' a el modelo semipresencial descrito anteriormente parece corroborar las conclusiones de estudios previos que presentan la factibilidad y los beneficios de este tipo de instrucción en la motivación, dedicación y compromiso del alumnado en contextos educativos pre pandemia (Bernard et al., 2014, Shyr y Chen., 2018; Spring et al., 2018). En relación al uso de las TICs así como los recursos digitales o en línea y la motivación del estudiantado, podemos establecer un cierto paralelismo con estudios previos que establecen una analogía entre la motivación y la responsabilidad propia del alumnado con el uso de las TICs en contextos de educación superior tal y como concluyen Francis (2017) y Harandi (2015) y más específicamente Kaharuddin (2020), Tavakoli, et al. (2020) y Rodríguez-Peñarroja 
(2020) en contextos de aprendizaje del inglés como lengua extranjera o con fines específicos. Por último y en relación a la competencia digital de los participantes del estudio, cabe remarcar su compromiso y carácter proactivo en el proceso de aprendizaje y su rápida adaptación a los recursos TIC utilizados (Lane et al., 2021).

Los resultados de este estudio deben ser interpretados con cierta cautela. Por una parte, el estudio de correlaciones no implica una causalidad directa y por otra la especificidad en cuanto a la adaptación de la asignatura de IFE a un modelo de docencia semipresencial de impacto medio puede limitar la extrapolación de los resultados a otros modelos de docencia en línea. En consecuencia, futuras investigaciones deben considerar el uso de pruebas estadísticas que reflejen causalidad como pueden ser los modelos de regresión y contextualizar el tipo de adaptación semipresencial que se ha llevado a cabo.

\section{Referencias}

Alammary, A., Sheard, J. y Carbone, A. (2014). Blended learning in higher education: Three different design approaches. Australasian Journal of Educational Technology, 30(4), 440-454. https://doi.org/10.14742/ajet.693

Ali, W. (2020). Online and remote learning in higher education institutes: A necessity in light of COVID-19 pandemic. Higher Education Studies, 10(3), 16-25. https://doi. org/10.5539/hes.v10n3p16

Bernard, R. M., Borokhovski, E., Schmid, R. F., Tamim, R. M. y Abrami, P. C. (2014). A meta-analysis of blended learning and technology use in higher education: From the general to the applied. Journal of Computing in Higher Education, 26(1), 87-122. https://doi.org/10.1007/s12528-013-9077-3

Castaño, R., Jenaro, C. y Flores, N (2017). Percepciones de estudiantes del Grado de Maestro sobre el proceso y resultados de la enseñanza semipresencial-Blended Learning-. (RED) Revista de educación a distancia, 52. http://dx.doi.org/10.6018/ $\mathrm{red} / 52 / 2$

Centre for Self-Determination Theory (SDT). (s.f.). Intrinsic motivation inventory. https://selfdeterminationtheory.org/intrinsic-motivation-inventory/

Coates, H., James, R., y Baldwin, G. (2005). A critical examination of the effects of learning management systems on university teaching and learning. Tertiary education and management, 11, 19-36. https://doi.org/10.1007/s11233-004-3567-9

Fuentes-Hernández, S. S. y Flórez, A. N. S. (2020). Online teaching during Covid-19: How to maintain students motivated in an EFL Class. Linguistics and Literature Review 6(2), 157-171. https://doi.org/10.32350/IIr.62.14

Fathali, S. y Okada, T. (2017). A self-determination theory approach to technology-enhanced out-of-class language learning intention: A case of Japanese EFL learners. International Journal of Research Studies in Language Learning, 6(4), 53-64. https://doi.org/10.5861/ijrsll.2016.1607 
Francis, J. (2017). The effects of technology on student motivation and engagement in classroom-based learning [Tesis Doctoral University of New England] https:// dune.une.edu/cgi/viewcontent.cgi?article $=1120 \&$ context $=$ theses.

Gisbert, M. y Esteve, F. (2016). Digital Learners: la competencia digital de los estudiantes universitarios. La cuestión universitaria, (7),32 48-59.

Harandi, S. R. (2015). Effects of e-learning on students' motivation. Procedia-Social and Behavioural sciences, 181, 423-430

Kaharuddin, A. (2020). Contributions of technology, culture, and attitude to English learning motivation during COVID-19 outbreaks. Systematic Reviews in Pharmacy, 11(11), 76-84. https://ssrn.com/abstract=3700381

Lane, S., Hoang, J. G., Leighton, J. P. y Rissanen, A. (2021). Engagement and Satisfaction: mixed-method analysis of blended learning in the sciences. Canadian Journal of Science, Mathematics and Technology Education, 21(1), 100-122. https://doi. org/10.1007/s42330-021-00139-5

Lapitan Jr, L. D., Tiangco, C. E., Sumalinog, D. A. G., Sabarillo, N. S. y Diaz, J. M. (2021). An effective blended online teaching and learning strategy during the COVID-19 pandemic. Education for Chemical Engineers, 35, 116-131. https://doi.org/10.1016/j.ece.2021.01.012

Means, B., Toyama, Y., Murphy, R., Bakia, M. y Jones, K. (2009). Evaluation of evidence-based practices in online learning: A meta-analysis and review of online learning studies. https://repository.alt.ac.uk/629/1/US_DepEdu_Final_report_2009.pdf

Moodle Docs. (s.f.). About Moodle. https://docs.moodle.org/311/en/About_Moodle

Moorhouse, B. L. (2020). Adaptations to a face-to-face initial teacher education course 'forced'online due to the COVID-19 pandemic. Journal of Education for Teaching, 46(4), 609-611. https://doi.org/10.1080/02607476.2020.1755205

Pagán, L. y Medina, A. (2021). The acceptance of Moodle learning management system in higher institution during Covid-19 pandemic. En Proceedings of INTED2021 Conference (Vol. 8, pp. 8024-8034).

Polhun, K., Kramarenko, T., Maloivan, M. y Tomilina, A. (2021). Shift from blended learning to distance one during the lockdown period using Moodle: test control of students' academic achievement and analysis of its results. En Journal of Physics: Conference Series (Vol. 1840, No. 1, p. 012053). IOP Publishing. https://doi. org/10.1088/1742-6596/1840/1/012053

Rodríguez-Peñarroja, M. (2020). La motivación y el uso de las TIC: Integrando el diseño web corporativo en la clase de inglés para fines específicos. En Sánchez Rivas, E. [et. al.] (coords.) Tecnologías educativas y estrategias didácticas (pp. 713-722). Servicio de Publicaciones Universidad de Málaga. https://hdl.handle.net/10630/20345

Sana, F., Weston, T. y Cepeda, N. J. (2013). Laptop multitasking hinders classroom learning for both users and nearby peers. Computers \& Education, 62, 24-31. https:// doi.org/10.1016/j.compedu.2012.10.003 
Shyr, W. J. y Chen, C. H. (2018). Designing a technology enhanced flipped learning system to facilitate students' self regulation and performance. Journal of Computer assisted learning, 34(1), 53-62. https://doi.org/10.1111/jcal.12213

Spanjers, I. A., Könings, K. D., Leppink, J., Verstegen, D. M., de Jong, N., Czabanowska, K. y van Merrienboer, J. J. (2015). The promised land of blended learning: Quizzes as a moderator. Educational Research Review, 15, 59-74. https://doi.org/10.1016/j. edurev.2015.05.001

Spring, K. J., Graham, C. R. y Ikahihifo, T. B. (2018). Learner engagement in blended learning. En M. Khosrow-Pour (Ed.) Encyclopedia of Information Science and Technology, Fourth Edition (pp. 1487-1498). IGI Global. Hershey, PA.

Tavakoli, H., Lotfi, A. R. y Biria, R. (2019). Effects of CALL-mediated TBLT on motivation for $\mathrm{L} 2$ reading. Cogent Education, 6 (1), 1-21. https://doi.or$\mathrm{g} / 10.1080 / 2331186 \times .2019 .1580916$

Valtonen, T., Pontinen, S., Kukkonen, J., Dillon, P., Väisänen, P. y Hacklin, S. (2011). Confronting the technological pedagogical knowledge of Finnish Net Generation student teachers. Technology, Pedagogy and Education, 20(1), 3-18. https://doi.or$\mathrm{g} / 10.1080 / 1475939 \times .2010 .534867$

Vrasidas, C. (2015). The rhetoric of reform and teachers' use of ICT. British Journal of Educational Technology, 46(2), 370-380. https://doi.org/10.1111/bjet.12149

World Health Organization. (2020). Mental health and psychosocial considerations during the COVID-19 outbreak, 18 March 2020. https://www.who.int/docs/default-source/coronaviruse/mental-health-considerations.pdf 


\section{Estrategias de}

Pensamiento Visual

Aplicadas a los Estudios

de Arte e Historia en

Bachillerato: Cuestiones

Cognitivas, Percepción

Sensorial y Praxis

Didáctica

\section{González Torres, Javier}

ORCID (orcid.org/0000-0001-9983-6657)

Universidad de Málaga

javier.gonzalez@fundacionvictoria.edu.es 


\title{
ESTRATEGIAS DE PENSAMIENTO VISUAL APLICADAS A LOS ESTUDIOS DE ARTE E HISTORIA EN BACHILLERATO: CUESTIONES COGNITIVAS, PERCEPCIÓN SENSORIAL Y PRAXIS DIDÁCTICA
}

\author{
González Torres, Javier \\ ORCID (orcid.org/0000-0001-9983-6657) \\ Universidad de Málaga \\ javier.gonzalez@fundacionvictoria.edu.es
}

\section{Resumen}

De entre las cuestiones que en las últimas décadas han suscitado la atención entre quienes se dedican al estudio de la práctica docente, destaca la utilización del pensamiento visual como canal pedagógico para la adquisición de conocimientos. Las múltiples posibilidades que esta herramienta ofrece, adaptándose tanto a materias como niveles educativos diversos, han sido objeto de atención por parte de destacadas firmas que han puesto su atención en su utilización a través del diseño de novedosas acciones formativas. Su implantación en las aulas ha permitido profundizar en el currículo de distintas disciplinas, incentivándose entre el alumnado la comprensión y asimilación de conceptos a partir de la interpretación de imágenes. No en vano, la mayor parte de los resultados obtenidos indican la validez de este tipo de actuaciones que, por su propia genealogía, pasan a convertirse en metodológico proceso que convierte lo complejo en sencillo. Siguiendo esa misma línea, entendida cual clave cognitiva y sensorial, exponemos en este trabajo una serie de iniciativas llevadas a cabo en tres materias concretas de los estudios de Bachillerato en España; estas son, Historia del Arte, Fundamentos del Arte e Historia de España. Para ello, se prestará atención a cuestiones relacionadas con la percepción, las dificultades encontradas en el desarrollo de diversas tareas, los avances conseguidos a través del establecimiento de evidencias o los aspectos que podrían ser mejorados. En definitiva, trataremos de establecer las claves nodales de un proceso que ahonda en la configuración de un estilo alternativo de aprendizaje a tener en cuenta.

\section{Palabras clave}

Innovación educativa, Visual Thinking, Conocimiento, Interacción, Herramientas de estudio. 


\section{Introducción}

En cuanto a metodología educativa, la definición más asentada de pensamiento visual es aquella que enrola esta herramienta a la forma en la que se perciben conceptos abstractos a través del uso premeditado de imágenes. La habilidosa correlación entre estas -expresadas a través de fotografías, dibujos, ilustraciones o infografías- y breves textos escritos, permiten la génesis de un método que facilita la asimilación de conocimientos complejos. Es justo el poder de la imagen el que permite el establecimiento de un proceso cognitivo-sensorial complementario que logra permutar el aspecto con el que se presenta una determinada información para convertirse en un medio mucho más asequible (Lovett \& Shah, 2007).

De hecho y teniendo en cuenta que en las aulas deben llevarse a cabos procesos que permitan establecer cuantos cauces contribuyan a una mejor transmisión de conceptos y que estos, a su vez, sean interiorizados de una manera natural y sencilla por el alumnado, procedemos en este trabajo a exponer el diseño de una serie de técnicas basadas, precisamente, en la comentada conceptualización:

- Es evidente que el estudiantado se encuentra con frecuencia ante una serie de dificultades que entorpecen su acercamiento a realidades históricas y estéticas acaecidas en épocas alejadas de su contexto vital. Con la idea de lograr una inmersión significativa, capaz de borrar los límites entre presente y pasado -por remoto que este pueda ser-, configuramos una propuesta pedagógica consistente en exprimir las múltiples posibilidades existentes entre imágenes concretas y estándares de aprendizaje recogidos en el currículo educativo de diversas materias de la etapa de Bachillerato. Para ello, un requisito previo indispensable es hacerse con una base fundamental de cuestiones teóricas que serán las que conformen el grueso de las tareas a desarrollar y que acabarán siendo, al final del proceso, las evidencias clave sobre las que se realice un trasvase de información.

- Aunque el proyecto cuenta con una base innovadora propia de la Era tecnológica en la que nos encontramos, será necesario bucear en técnicas docentes que, en décadas pasadas, ya indagaran en estas mismas posibilidades. Del estudio de lo realizado se podrán extraer aquellas cuestiones que sigan siendo válidas, adaptándola a todo tipo de necesidad presente. No se debe partir de cero puesto que existen experiencias que deben ser tenidas en cuenta; sobre todo, aspectos ya estudiados que vengan a respaldar la ejecución de hipótesis analíticas sobre las que se terminará configurando, tanto teórica como eficazmente, los pasos a dar en toda tarea.

- De ahí que, uno de los objetivos prioritarios a marcar, sea la posibilidad de aportar matices novedosos y complementarios a una metodología pedagógica donde las estrategias de aprendizaje queden unidas a cuestiones reflexivas y creativas (Joyce, Weil \& Calhoum, 1997, pp. 3-10). El fomento el espíritu crítico, la revalorización del talento innato al estudiante o la ejecución de actividades que se salen del habitual marco de trabajo diario vienen a respaldar un estilo educativo diferenciador, más rico en matices, que convierten el aula en un campo experimental que rompe con la unívoca transmisión de datos (Acaso, 2012). 


\section{Método/Descripción de la experiencia}

Para una mejor comprensión de las propuestas llevadas a cabo, se hace necesario repasar una serie de elementos clave que terminan dotando de sentido educativo a lo realizado:

\section{Descripción del contexto y de los participantes}

Entre los cursos 2017/2018, 2018/2019, 2019/2020 y 2021/2021, se han puesto en marcha una serie de tareas desde el departamento de Ciencias Sociales del CDP 'Santa Rosa de Lima', de Málaga -España-, centro sostenido con fondos públicos dependiente de la Fundación Victoria. En concreto, han participado en las mismas un número aproximado de 400 estudiantes de $1^{\circ}$ y $2^{\circ}$ de Bachillerato. Esa cifra responde a grupos diversos que presentan, a su vez, ritmos de aprendizaje, cualidades individuales y dificultades particulares distintas. Este aspecto es clave para establecer, desde inicio, un proceso metodológico que se adapte a cada una de las necesidades presentadas por los discentes y que a su vez proporcione una vía de conocimiento adicional a los cauces habituales. Al respecto, se debe tener en cuenta que el nivel de estudios en el que se han realizado las tareas culmina con la presentación de una prueba teórica, específica, que regula el acceso de quien la supera a la etapa universitaria. Este mecanismo teórico conlleva el desarrollo en los dos cursos preparatorios previos de una serie de aspectos tendentes a la comprensión de amplios contenidos curriculares.

\section{Instrumentos}

Otra de las bases fundamentales que están en la génesis de este proyecto parte de la necesidad de aplicar técnicas innovadoras al tradicional espacio de transmisión de conocimientos que se produce en las aulas. Este convencimiento no deviene en exclusiva de imposiciones legales sino, también, del análisis de la realidad social que se viven en los Centros educativos, de la propia evolución personal del estudiantado y de las experiencias compartidas con otros docentes. En caso que nos ocupa, se han tomando como base referencial tres materias que forman parte del catálogo normativo establecido en España para el nivel de enseñanza no obligatoria: Historia de España, común para todas las modalidades de Bachillerato; Fundamentos del Arte / y II, propia de los estudios específicos de Artes Plásticas y Diseño; e Historia del Arte, optativa para quienes optan por la rama de Ciencias Sociales y Humanidades. Se parte, también, de otro hecho asumido: el alumno no precisa del desarrollo de destrezas especiales para llevar a cabo las tareas conforme a las instrucciones dadas; no en vano, las iniciativas puestas en prácticas fomentan aspectos inherentes a todo estudiante, como su capacidad crítica, su creatividad y sus propios talentos.

\section{Procedimiento}

De entre los bloques temáticos que conforman las materias citadas, se han seleccionado una serie de estándares de aprendizaje que, partiendo de nociones histórico-artísticas, son susceptibles de ser abordados mediante vías distintas a las comúnmente establecidas. Es decir, que permitan un acercamiento mucho más significativo y profundo que el llevado a cabo en las habituales clases magistrales. En primer lugar, entendiendo que el modo más adecuado es el de la instrucción directa, método que, al amparo de conocidos estudios, permite la presentación de aspectos clave a partir 
del establecimiento de tareas prácticas iniciales y finales. De esta manera, se conseguiría establecer cuantos 'andamiajes' teóricos (Rosenshine \& Meister, 1992) fuesen necesarios con tal de esclarecer y/o recrear contextos específicos en los que se llevan a cabo acciones concretas, localizadas en el tiempo y en el espacio. Esta opción permite superar la habitual perspectiva temporal existente entre la época a estudiar y la óptica contemporánea, en un ejercicio de reposicionamiento personal que permite la eliminación de prejuicios y rutinas acostumbradas para acercarse, de la manera más objetiva e imparcial posible, a una realidad diferente a la que se vive en la actualidad.

Una vez completado ese paso de aproximación a momentos remotos, imbuidos de una cultura idiosincrática distintiva, llegaría el segundo y definitivo. Este consistiría en llevar a cabo tareas que permitan al alumnado asimilar fenómenos complejos y avanzar en su comprensión. En este sentido, la configuración de estas intentan abarcar tres aspectos clave que repercuten directamente en la concreción de un método de estudio alternativo: estaríamos hablando que se trata de una 'inversión' que es rentable a largo plazo, puesto que ofrece al estudiante las herramientas necesarias para realizar pruebas y tareas de manera exitosa; a su vez se estaría incentivando el uso de técnicas que ahondan en un perfeccionamiento memorístico e intelectual a partir del contraste permanente de elementos y procesos; y, a su vez, se alcanzaría una mejora sensible en el procesamiento visoespacial/perceptivo (Sweller, 1994, p. 295-312), permitiendo así que el análisis, la comprensión y el manejo del espacio histórico permita una toma de conciencia real sobre hechos, personajes y acciones determinadas.

La combinación de las dos cuestiones comentadas deviene en el diseño de actividades que suman, de un lado, lo cognitivo y, de otro, la praxis visual. Al alinear ambos preceptos debe tenerse en cuenta que, en relación con nociones básicas enraizadas en el arte y en la historia, el actual visual thinking no es una tarea novedosa. Al contrario, en su génesis cual elemento para la distribución y clarificación de conceptos, es consecuencia del diagrama que Alfred H. Barr Jr. realizó en 1936 con motivo de la celebración de una exposición celebrada en el Museo de Arte Moderno -MOMA-, de Nueva York, del que era director; el ejercicio, publicado en la sobrecubierta del catálogo, tenía por objetivo clarificar la comprensión, sobre una misma superficie soporte, del proceso evolutivo, transmutado y polifacético, que el hecho artístico había experimentado en las décadas anteriores. Dicho de otro modo, se expresaba mediante la combinación de textos y signos visuales los distintos caminos que el arte había adoptado en Europa, desde la irrupción de la tendencia impresionista hasta la diversificación vanguardista.

En nuestro caso particular, querríamos dar un paso más, dejando de lado esquemas tradicionales para, ejerciendo la creatividad y haciendo uso de la percepción individual del estudiante, logar la creación de una particular cartografía representativa de aspectos determinantes del currículo educativo. Se trataría de aplicar una visión contemporánea sobre las acciones comentadas, tomando de referencia las experiencias realizadas en décadas anteriores pero superándolas gracias al uso de recursos tecnológicos, elementos formales y conjuntos estéticos. En este sentido serán de utilidad el empleo de aspectos tales como la claridad expositiva, la aplicación de determinadas gamas cromáticas o la distribución de elementos referenciales que actúen de transmisores de una idea global. Y es que, en efecto, se da por asumido el carácter puramente comunicativo que posee la imagen. Su combinación con textos breves, a modo de constantes visuales, ayudarán a transmitir ideas y a solucionar problemas de comprensión. 
En efecto, los esquemas mentales, también conocidos como canvas, las metáforas visuales o los denominados diagramas de flujo, son vías que desarrollan -e incluso clarifican- estrategias necesarias para la organización de ideas a través de expresión icónico-formales. No deja de ser llamativo que su contribución es mayor cuando, en una misma superficie, se permite la comparación entre aspectos similares o disímiles, permitiendo así el ejercicio de rutinas de contraste que proporcionen al alumnado las herramientas necesarias para la construcción de conocimiento.

En esa misma línea, se hace necesario el establecimiento de una diferencia básica en el concepto de transmisión de una información. En este sentido, la comprensión de una determinada circunstancia histórica, que determina la creación de una acción concreta, no significa lo mismo que la asimilación del hecho en su conjunto. El contraste entre ambas acepciones, dentro del ámbito pedagógico, adquiere una distancia mayor cuando el profesorado, en el aula, debe guiar la implantación de una serie de canales que vivifiquen el aprendizaje dentro de un contexto de interacción bidireccional con el alumnado. Así, al optar por la vía del aprovechamiento cognitivo de la memoria, los datos previos, los ya conocidos, comienzan a conectarse de inmediato con otros nuevos, gracias a la relación semántica existente entre ellos. Y ello porque el gozne entre lo sabido y lo ahora descubierto se activa gracias a la interacción sensorial (Ausubel, 2000).

No es este el único vínculo pero sí el primero de una extensa cadena en la que la presencia de lo mnemotécnico y de lo visual continúan ejercitándose con tal de poner a funcionar la capacidad retentiva de la memoria a través del conocido proceso de codificación de datos, almacenamiento a corto/largo plazo y recuperación de lo aprendido a través de su aplicación práctica (Atkinson \& Shiffrin, 1968). En definitiva, los ejercicios propuestos pretenden impactar de lleno en la memoria sensorial del estudiantado, conectando la vivencia explícita de un hecho histórico con el recuerdo icónico con el que se ha asociado, dotándose el conjunto de un determinado significado.

Es más, una noción ampliamente contrastada es aquella que afirma que la capacidad de razonamiento que adquiere la mente humana no queda asociada de forma única a contenidos concretos, sino que, siendo más precisos, se articula cual canal organizativo que discrimina entre aspectos conocidos y otros que no lo son tanto (Davison, 1992, 73-98). De ahí que la labor del docente no pueda reducirse solo a actuar de mero transmisor de ideas; al contrario y siguiendo un fin propositivo, debe aportar al alumnado un amplio catálogo de herramientas diferenciadas para que este, por sí mismo, pueda construir un criterio propio basándose en una base empírica.

\section{Resultados}

Las evidencias obtenidas tras la realización de las tareas propuestas permiten aseverar que el desarrollo de ejercicios que tienen como base fundamental de su acción la plasmación del pensamiento visual conduce a una significativa asunción, por parte discente, de aspectos esenciales del currículo de las materias ligadas a las Artes y las Humanidades. Es más, se logra también con ellos concitar una atención que, en otras estrategias distintas, parece algo más dispersa y, también, fomentar un mayor interés que culmina en la profundización individual de procesos historiográficos determinados. 
Tres pruebas de ello son las que ofrecemos a continuación, vinculadas a las materias citadas con anterioridad. No son las únicas que hemos conseguido obtener en estos cursos pero quizá, por su resultados obtenidos, si resultan las que han logrado una mayor repercusión en las calificaciones derivadas de las pruebas teórico-prácticas llevadas a cabo por el alumnado.

\section{La estatuaria de la Antigua Grecia en Fundamentos del Arte}

El bloque de contenidos 3, recogido en la normativa estatal española para esta materia -y reproducido en sus líneas esenciales en las desarrolladas por las comunidades autónomas-, presta especial atención a la cultura griega al entenderla como base referencial para la construcción de la noción moderna de Europa. De entre estos, destaca sin duda el estudio evolutivo de la estatuaria helena que, en puridad, supone un ejercicio de representación apologético del cuerpo humano. La evolución existente entre los primitivos kuros y las korai, realizados a partir del siglo VIII a.C., y la eclosión de sentimientos, expresividad y tensión con que se caracteriza el período helenístico, que abarca desde el siglo IV a.C. al I a.C., constituye un amplio arco espacio-temporal en el que los conceptos filosóficos, los planteamientos formales y la pericia técnica se modifican a partir de etapas históricas definidas.

Las estrategias de aprendizaje establecen que, desde el ámbito docente, el alumnado consiga analizar de manera comparada cada uno de esos momentos, identificando los elementos más característicos de estos a través de autores, obras y procesos. También se le exige que sea capaz de diferenciar aquellos matices que hacen distinta esta clasificación historiográfica, mencionando las peculiaridades y singularidades más notables. Son tantos y tan variados que, incluso, marcan un significativo modelo que será seguido por culturas posteriores, en un claro ejercicio inspirador.

Para solventar esta tesitura, la propuesta que hacemos conlleva la realización de un mapa conceptual en el que tengan cabida los aspectos teóricos básicos, presentados de la manera más visual posible. Para ello, se propone en primer lugar la lectura y esquematización de los apuntes; para así, en un segundo momento, proceder al diseño de un amplio soporte rectangular en el que tengan cabida las características generales que dotan de una especial significación a la estatuaria griega. En este sentido resulta capital comprender que el período histórico a estudiar se divide de manera usual en cuatro etapas diferentes, conformando cada una de ellas amplias columnas verticales. En estas se disponen mediante breves textos los aspectos nodulares de cada una de ellas, vinculándose tanto a los autores más conocidos como a las obras más representativas. Estas adquieren protagonismo al exigirse la inserción de grabados y/o fotografías -lo más genéricas posibles- que transmitan, de manera visual, lo abordado desde la teoría.

Al dar estas amplias pautas, cada alumno/a puede ejecutarlas de la manera que estime más conveniente, aplicando un tiempo concreto del trabajo a la búsqueda, selección y tratamiento de las imágenes. No en vano hay quien además aprovecha para demostrar sus habilidades en la edición digital de estas, exhibiendo un ejercicio final compositivamente armónico; pero, también, se da el caso de otras personas que optan por confeccionar la tarea siguiendo procesos de elaboración mucho más tradicionales. En todos los casos y con independencia del valor que se le otorga a la presentación formal, la más alta calificación la obtienen aquellas evidencias en las que puede seguirse el objetivo propuesto al inicio de una manera clara, efectiva 
y directa. De igual manera, la utilización del ejercicio como herramienta válida de estudio se hace evidente en los resultados obtenidos en pruebas escritas basadas en la comparación técnico-formal de obras pertenecientes a épocas distintas. En el premeditado contraste de información subyace, sin duda, lo aprendido a través del ejercicio propuesto [Fig. 1]

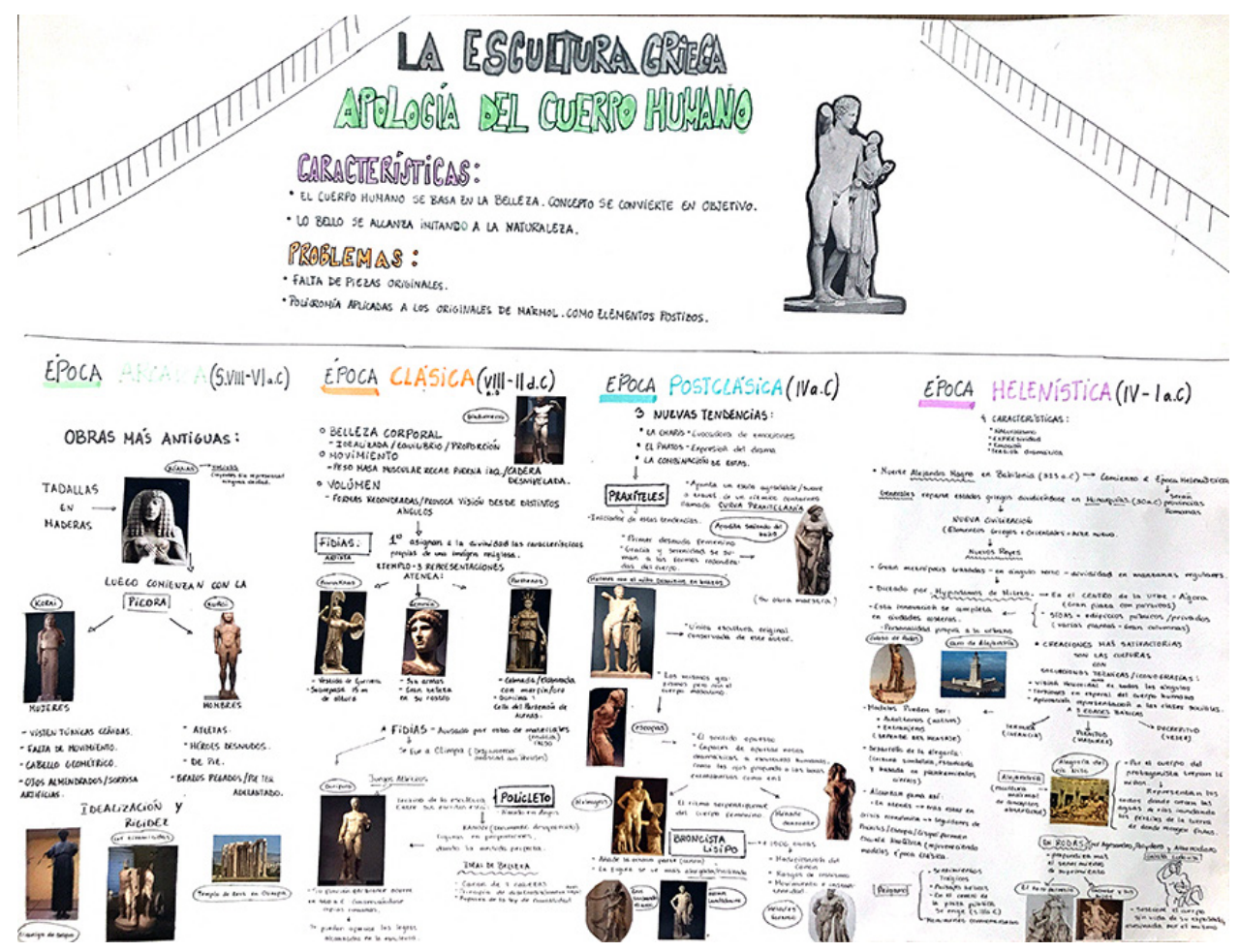

Fig. 1. Ejemplo correspondiente al estudio de la estatuaria griega

\section{La vida y la obra de Francisco de Goya en Historia del Arte}

Dentro de la denominación de 'El siglo XIX: el arte de un mundo en transformación', dada al bloque 4 de la materia de Historia del Arte, descuella como contenido inicial la figura del artista español Francisco de Goya. Convertido por méritos propios en un creador de reconocido interés internacional, su vida y su obra siguen siendo para la historiografía contemporánea todo un reto: a su ser polifacético se le une una trayectoria personal en continuo cambio, producto de haber vivido entre las centurias dieciochesca y decimonónica en la que la Guerra de Independencia marca a toda una generación de españoles; un hecho que repercute, además, en la labor de quien domina técnicas distintas y lenguajes estéticos diferentes, convirtiéndose incluso en precursor de tendencias que aún tardarán tiempo en aparecer y en renovador de temáticas tradicionales a las que consigue dotar de aires absolutamente novedosos.

El desarrollo conceptual de tales contenidos a través de estándares concretos que deben promoverse entre el alumnado lleva a este a interesarse por el análisis pormenorizado del itinerario vital del pintor. Su inmersión en ella le permite acercarse a cómo los episodios que experimenta constituyen el marco teórico desde el que comprender su variada producción pictórica. Así, su formación adolescente en la que trata 
de 'domar' a través del aprendizaje sus innatas habilidades, la búsqueda de una firma propia, su resituación social en una época en la que la pintura vive momentos inciertos o los cambios operados en su percepción de la realidad -motivados por un estado de salud cada vez más delicado-, terminan siendo entendidos como las claves maestras necesarias que dotan de significación una determinada época creativa.

Una vez establecidas esas pautas, se pasa a la acción. Y la tarea, en este caso, consiste en la realización de un mapa mental en el que las anteriores ramificaciones actúen cual ítems explicativos de unas determinadas acciones artísticas. Hay que tener en cuenta que el alumnado que realiza esta tarea pertenece al Bachillerato de Ciencias Sociales y Humanidades; y, que, por lo tanto, no posee a priori determinadas destrezas en dibujar o en el manejo de la composición. Sin embargo, si posee la madurez intelectual necesaria para convertir los datos teóricos en una representación gráfico-textual capaz de explicar, sencilla e icónicamente, la evolución del artista estudiado.

Y los resultados obtenidos refrendan tal aseveración. El contraste entre, por ejemplo, los cartones para tapices, los retratos de la nobleza y la clase política dirigente o los duros trazos de los grabados sobre los desastres de la guerra, así como el corpus elemental de las llamadas 'pinturas negras', terminan por concretar un ejercicio plagado de matices diferenciadores. En todos ello se observa que la palabra y la imagen conviven en armonía en pro de facilitar la comprensión significativa de todas esas variaciones visibles que se aprecian observando de conjunto las obras del artista [Fig. 2].

Así es como el objetivo primordial vuelve a cumplirse. Y se hace mucho más evidente, de nuevo, en las calificaciones obtenidas por el alumnado tras la realización de pruebas escritas que, a modo de ejercicios teóricos, son el refrendo de la praxis llevada a cabo en el aula. Se advierte, en ese sentido, que la mayoría de los datos ofrecidos en estos son fruto de una reflexión previa, asimiladora de cuantas cuestiones han derivado en la justificación de determinadas acciones. Goya es pues, entendido, como un artista inclasificable, dotado de una personalidad libre e independiente.

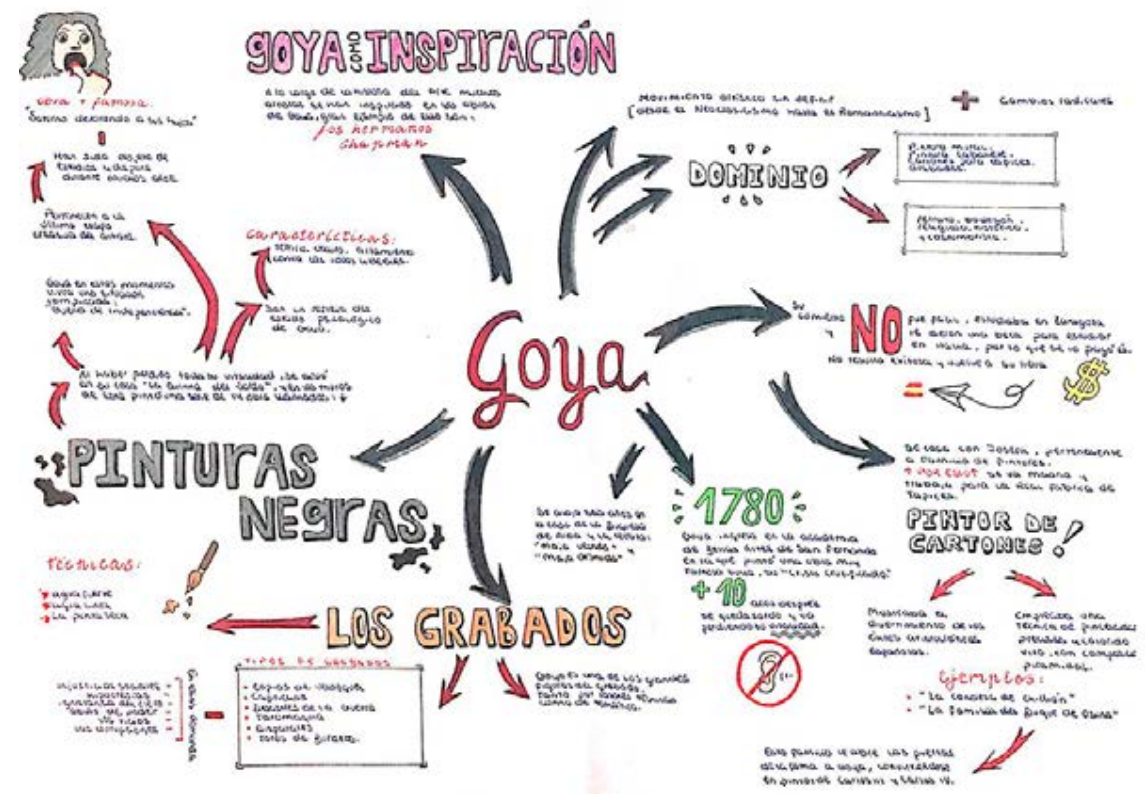




\section{El convulso reinado de Fernando VII y la Historia de España}

De entre los contenidos que conforman el bloque 5 de esta materia titulado 'La crisis del Antiguo Régimen (1788-1833): liberalismo frente a absolutismo', resultan determinantes las actuaciones Ilevadas a cabo por Fernando VII. Conocido por el pueblo tras su nacimiento como 'el deseado', su particular manera de entender la política y las relaciones personales marcan una época compleja en la que nación debe reconstruirse tras el final de la Guerra de Independencia. El impacto que la imagen del monarca suele causar entre discentes que, lógicamente, no vivieron aquel tiempo, resulta muy esclarecedor al toparse con un personaje que no les deja indiferentes.

En la normativa se regula que los estándares de aprendizaje deben enfocarse hacia la indagación detallada de las tres fases en las que, de manera general, suele dividirse su reinado, acaecido entre 1814 y 1833; para, esta manera, centrarse en los momentos de conflicto que a lo largo de este enfrenta a absolutista y liberales, grupos antagónicos que se asocian, de un lado, a la idea de un tradicionalismo basado en una monarquía absoluta $\mathrm{y}$, de otro, al establecimiento de una constitución en la que se recojan conceptos políticos avanzados -como la separación de poderes o la soberanía nacional-. El comportamiento del rey, voluble según los tiempos y dependiente de la influencia que sobre él ejerzan categóricos asesoramientos, marca un período inestable en el que las disputas entre grupos causan multitud de consecuencias negativas al pueblo español.

Ante tal situación histórica, al alumnado se solicita que sea capaz de analizar cada uno de esos momentos para extraer las ideas esenciales que los configuran. Y, con idea de hacer más inmersivo este acercamiento, se propone la ejecución de un visual thinking representativo de este reinado. Hay que tener en cuenta que esta experiencia didáctica se ha llevado a cabo en las cinco modalidades de Bachillerato que establece la legislación española, participando estudiantes de Tecnología, Ciencias de la Salud, Ciencias Sociales, Humanidades y Artes. Una diversidad que se percibe en actitudes e intereses profesionales distintos pero que, sin embargo, confluyen en una misma actitud proactiva a la hora de solventar el reto que se les presenta.

Al respecto, las indicaciones que se dan es la de establecer, a lo largo de una línea temporal, aquellos aspectos que determinen como consustanciales a los contenidos a explicitar. Y, para llevar a cabo la tarea, se les indica que el objetivo del ejercicio es la expresión de ideas y pensamientos gráficos, aprovechando el poder de la imagen como fuente de información y comunicación. Así mismo, se les aclara que el proceso que deben llevar a cabo los chicos y chicas de manera individual esté basado en una secuencia cuádruple:

- Primero, sobre la base teórica de los apuntes del bloque, realizarán una lectura pausada, esquematizando al máximo lo expresado a lo largo de estos;

- Segundo, reflexionarán sobre cuáles deben ser las fases, las etapas y los personajes que tendrán que resaltar;

- Tercero, interpretarán esos hechos a través de imágenes, constituyendo esta fase creativa un boceto general que se irá perfeccionándose conforme se vaya todo pasando a limpio; y, 
- Cuarto, rematarán formalmente el producto final, que podrá ser comparado con los realizados por otros estudiantes mediante una rúbrica de coevaluación.

La libertad con la que cada discente ejecuta los pasos anteriores determinará la configuración de un ejercicio final cuya apariencia formal no tiene porqué coincidir con los resultados presentados por sus semejantes. Es justo en la riqueza de opiniones en la que se observa, además de un fiel cumplimiento de las indicaciones del profesorado, la confección de un ejercicio distinto por su morfología a otros llevados a cabo en distintas materias. Una opinión que es compartida por el alumnado en la ficha de metacognición que suelen completar a posteriori, incidiendo en el hecho de que es justo en este tipo de recursos donde el tiempo invertido es proporcional al beneficio causado, facilitando la comprensión de sucesos y comprendiendo, por sí mismo, situaciones que, de no seguir esta esquematización, pronto caerían en el olvido [Fig. 3].
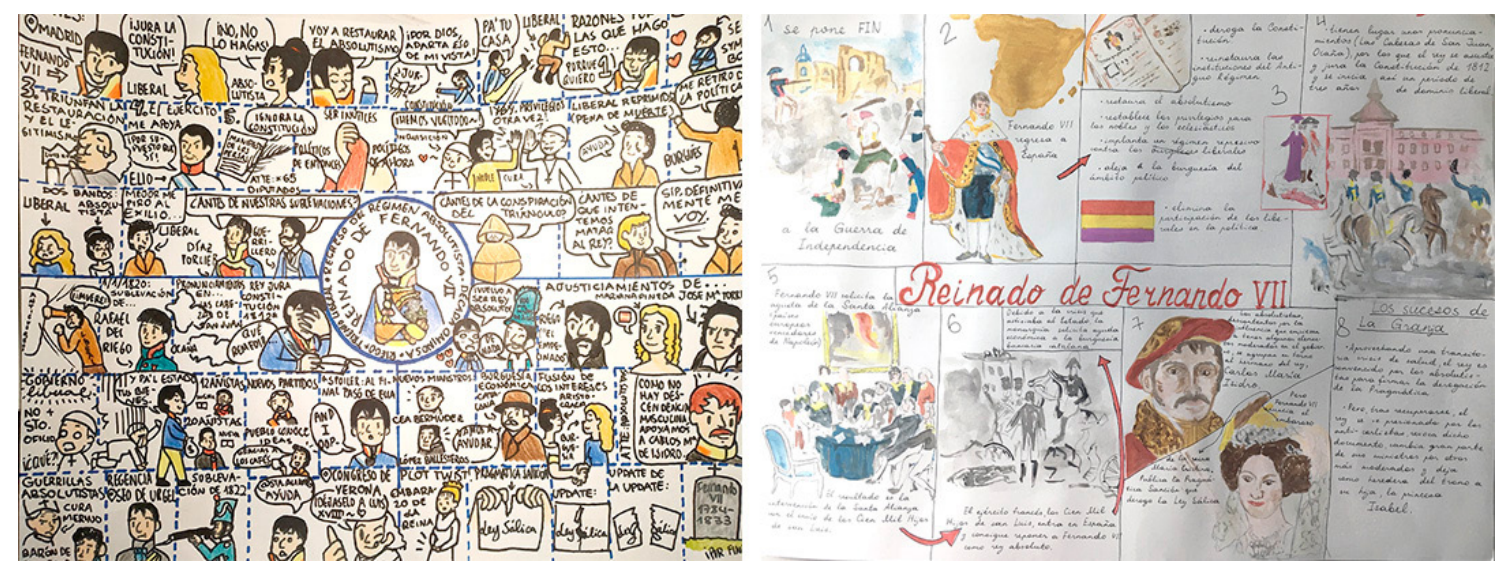

Fig. 3. Comparativa entre dos ejemplos distintos de visual thinking sobre el reinado de Fernando VII.

\section{Discusión y conclusiones}

Las acciones expuestas con anterioridad constituyen una oportunidad para realizar un replanteamiento tanto de los propios contenidos como de las formas en las que estos se presentan (Crespillo Marí \& González Torres, 2021). De hecho, la apuesta por la humanización en la transmisión/asimilación de conceptos y la facilitación de su acceso al alumnado por parte docente, tienen en las expresiones artísticas, en los productos culturales y en los hechos históricos un significativo punto de encuentro. Estos procesos puede complementarse y amplificarse de una manera exponencial si se aplican criterios heurísticos que impacten sobre los discentes, de forma que les lleve a investigar por su cuenta para así asimilar significados; y, al mismo tiempo, el uso de tecnologías avanzados y de los recursos innovadores en los que la imagen siempre está presente, facultan a quienes los utilizan a experimentar un aprendizaje mucho más significativo que el que puede llevarse a cabo a través de cauces más tradicionales.

Por lo tanto, una vez realizado el recorrido por las evidencias más notables de este proyecto, vinculado a la etapa de las enseñanzas del Bachillerato español, puede aseverarse que las tareas comentadas son un medio eficaz que ayuda a la asimilación de cuestiones nodales del currículo; especialmente, se entiende como adecuadas para 
verter sobre ellas la mayor parte de los estándares de aprendizaje secuenciados por la normativa estatal para las materias de Fundamentos del Arte. Historia del Arte e Historia de España. El estudio de casos presentado puede ampliarse, en base a las evidencias, hacia otras disciplinas afines, propias del Arte, las Humanidades y las Ciencias Sociales. Su adaptación, implantación y desarrollo ayudará también a fomentar visiones significativas de esta entre un alumnado heterogéneo, diverso y con necesidades distintas.

\section{Referencias}

Acaso, M. (2012). Pedagogías invisibles. El espacio del aula como discurso. Catarata.

Atkinson, R. C. \& Shiffrin, R. M. (1968). Human Memory: a proposed system and its control processes. Psychology of Learning and Motivation 2, 89-195.

Ausubel, D. P. (2000). The acquisition and retention of knowledge: a cognitive view. Springer.

Lovett, M. C \& Shah, P. (2007). Thinking with data. New York Psychology Press.

Crespillo Marí, L. y González Torres, J. (2021). La materia de Fundamentos del Arte (Lomce): oportunidad docente desde la heurística humanista y la innovación docente. En Celis Sánchez, M. A. (Coord.). Las Humanidades digitales como expresión y estudio del patrimonio digital (149-162). Universidad de Castilla-La Mancha.

Davison, D. (1992). Mente, mundo y acción. Paidós Estética.

Joyce, B., Weil, M. y Calhoum, E. (1997). Models of learning: tools for Teaching. Buckingham Open University Press.

Rosenshine, B. \& Meister, C. (1992). The use of scaffolds for teaching higher-level cognitive strategies. Educational Leadership 49 (7), 26-33.

Sweller, J. (1994). Cognitive Load Theory, Learning Difficulty and Instructional Design. Learning and Instruction 4 (4), 295-312. 
Eje temático

Investigación

en Tecnología

Educativa

$\circ \circ 0$

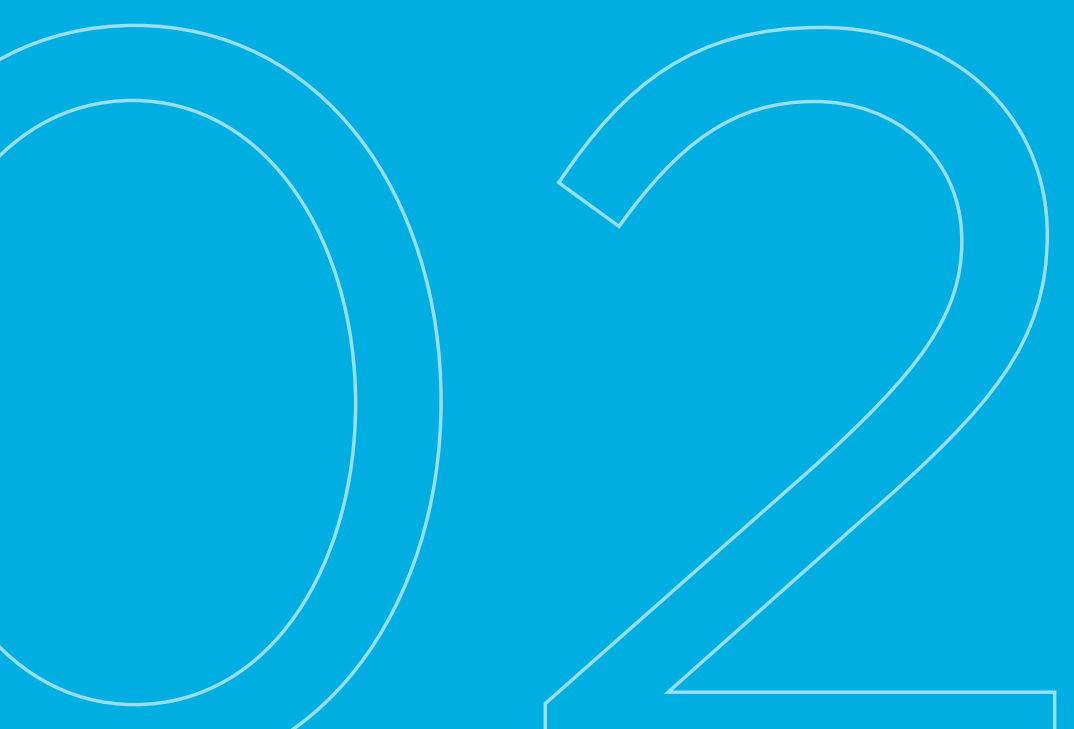




\section{El Vídeo en la Enseñanza. Una Aproximación a la Visión del Profesorado}

\section{Martí Climent, Alícia}

Universitat de València

https://orcid.org/0000-0003-1005-5630

alicia.marti@uv.es 


\title{
EL VÍDEO EN LA ENSEÑANZA. UNA APROXIMACIÓN A LA VISIÓN DEL PROFESORADO
}

\author{
Martí Climent, Alícia
}

Universitat de València

https://orcid.org/0000-0003-1005-5630

alicia.marti@uv.es

\section{Resumen}

El vídeo es un recurso didáctico que está presente en las aulas desde hace tiempo, pero actualmente el interés se focaliza en discutir cómo y para qué utilizar el vídeo en la enseñanza. En esta investigación cualitativa se analizan las respuestas del profesorado de Educación Secundaria y Educación Superior, durante el curso 202021, a un cuestionario, con el objetivo de conocer qué tipo de uso del vídeo se realiza en la enseñanza y con qué criterios se integra. Los resultados evidencian el predominio de la utilización del vídeo como transmisor de información e instrumento motivador y de conocimiento (Ballesteros-Regaña, 2013; Cebrián, 2005; Salinas, 1992). Asimismo, los criterios de integración del vídeo (Ballesteros-Regaña, 2013) más frecuentes son el destinatario, cómo y cuándo se utilizará, la finalidad, la contextualización y la participación e intervención de alumnado y profesorado. Desde la mirada docente, en los tiempos del Covid-19 se han ampliado las posibilidades de integración del vídeo en la enseñanza, aunque ni profesorado ni alumnado se han convertido, por lo general, en creadores, como recomienda García García (2014). El desarrollo de la competencia digital (Consejo de la Unión Europea, 2018) de ambos, que facilite la incorporación del vídeo en la docencia, continúa siendo un reto pendiente.

\section{Palabras clave}

Vídeo educativo, educación superior, educación secundaria, tecnología educativa. 


\section{Introducción}

Este trabajo forma parte de una investigación realizada en el marco del proyecto de innovación docente El vídeo en la educación superior. Prácticas innovadoras audiovisuales en la formación de docentes (UV-SFPIE_PID-1352182), desarrollado durante el curso 2020-2021 en la Universitat de València, cuyo objetivo fundamental es utilizar el vídeo para la mejora del aprendizaje lingüístico y literario.

El vídeo es uno de los recursos más utilizados en la enseñanza. Son muchas sus funciones didácticas en la educación (Ballesteros-Regaña, 2013; Cabero, 2007; Cabero y Barroso, 2016; Cebrián, 2005; Salinas, 1992): formativa, evaluativa, motivadora, informativa, investigadora, comunicativa, expresiva y creativa. Además, permite la alfabetización mediática, así como comprobar la capacitación en técnicas, estrategias didácticas y metodologías del profesorado (Cabero y Barroso, 2016).

Por otra parte, el uso del vídeo en la enseñanza presenta diferentes posibilidades y limitaciones. Ballesteros-Regaña (2013) destaca entre sus posibilidades la diversidad de funciones en la enseñanza, comentadas anteriormente, pero también la visualización ilimitada, la facilidad de manejo, la validez para distintos niveles educativos, la convergencia de diferentes tecnologías, la difusión en la red, la capacidad de síntesis, que favorece el uso activo y participativo del alumnado, la contextualización de contenidos y los diferentes tratamientos audiovisuales, entre otras. Sin embargo, algunas de sus limitaciones son la necesidad de dotación instrumental y de conocimientos técnicos y del lenguaje audiovisual, la existencia de diferentes formatos y sistemas, la posible pasividad del alumnado, y las restricciones de acceso y uso de algunos materiales.

Como apunta Fernández-Río (2018), se trata de una herramienta que ofrece más ventajas que inconvenientes en la práctica docente. Según Martí y Garcia Vidal (2020), la utilización del vídeo en el proceso de enseñanza-aprendizaje (E-A) mejora la motivación y la interacción del alumnado, amplía los recursos de apoyo en el aula, favorece el trabajo en grupo y refuerza el individual.

Además, de acuerdo con García García (2014), el vídeo debería enfocarse más hacia la producción, que no a la simple visualización, y ser parte fundamental de la educación mediática del alumnado. Lara et ál. (2009) señalan que la incorporación del vídeo en el trabajo académico posibilita incidir en aspectos clave para contribuir a un aprendizaje significativo, supone una alfabetización en y para la cultura digital y comporta un aumento de posibilidades de participación.

La docencia en los tiempos del Covid-19 ha intensificado el uso de la tecnología educativa (TE) en los procesos de E-A, y en particular la utilización del vídeo como recurso didáctico. En el ámbito territorial valenciano, tanto en Educación Secundaria como en Educación Superior, el curso 2019-2020 terminó con docencia a distancia, a causa del confinamiento domiciliario obligatorio establecido entre marzo y junio de 2020, y durante el curso 2020-21 se aplicó el modelo híbrido o blended learning (Young, 2002; Bartolomé Pina, 2004). Esta situación ha conllevado un aumento del uso del vídeo, por ejemplo, para la aplicación de la metodología flipped classroom (Bergmann y Sams, 2012), y también ha permitido explorar nuevas posibilidades del vídeo en la docencia. 
En este sentido, resulta interesante indagar en los principios para la selección y evaluación de los vídeos. Ballesteros-Regaña (2013, p. 177-178) establece los siguientes criterios para la evaluación de los vídeos educativos: a quién va dirigido, cuando se utilizará, qué se pretende, cómo se utilizará, la predisposición del alumnado y el profesorado hacia el vídeo como recurso didáctico, el contexto de E-A, las diferencias cognitivas entre el alumnado, la participación e intervención de alumnado y profesorado, las características técnicas, las características semántico-expresivas, la versatilidad y la interacción con otros medios de las tecnologías de la información y la comunicación (TIC).

El objetivo de este estudio es conocer qué tipo de uso del vídeo realiza el profesorado (funciones didácticas) y con qué criterios selecciona o evalúa las producciones audiovisuales para su integración en los procesos de E-A. Nuestra hipótesis inicial es que últimamente se ha producido una ampliación considerable de las diferentes posibilidades del vídeo en la docencia, tanto en la universidad como en la enseñanza secundaria.

\section{Método}

Presentamos una investigación cualitativa a partir de los datos obtenidos del análisis de las respuestas del profesorado a un cuestionario sobre la transformación digital de la docencia a causa del Covid-19.

\section{Descripción del contexto y de los participantes}

Se realizó un estudio comparativo sobre una muestra de 60 profesores de distintas áreas, en activo durante el curso 2020-21 en el ámbito territorial valenciano: 30 de Educación Secundaria y 30 de Educación Superior.

\section{Instrumentos}

Se utilizó un cuestionario como instrumento de investigación con objeto de conocer la experiencia del profesorado con relación al uso del vídeo en la enseñanza. El cuestionario se realizó mediante la plataforma Moodle y contenía preguntas abiertas sobre el tema de interés del estudio, por lo que se debe advertir que se obtuvo información no esperada. Además, no existía ningún límite de extensión en las respuestas.

\section{Procedimiento}

Se llevó a cabo un muestreo intencional, en el que se optó por examinar todas las respuestas obtenidas por los docentes en activo, con el fin de obtener una mayor información y poder contrastar los resultados obtenidos en las diferentes etapas educativas.

En este trabajo se analizan las respuestas del profesorado a una pregunta del mencionado cuestionario en la que se planteaba lo siguiente:

En tu tarea docente, de acuerdo con los trabajos de Salinas (1992), Cebrián (2005) y Ballesteros-Regaña (2013), ¿qué tipo de uso haces del vídeo? Y, de los criterios que plantea Ballesteros-Regaña (2013), ¿cuáles utilizas para seleccionar o evaluar un vídeo didáctico? Finalmente, debes proponer un vídeo para utilizar en tus clases, indicar qué criterios has utilizado para seleccionarlo y qué uso harás. 
Como se puede observar, la pregunta estaba guiada a través de distintas referencias bibliográficas sobre el objeto de estudio. De este modo, se consiguió centrar la atención en la dimensión exacta del problema en el que está interesada la investigadora: tipo de uso del vídeo en la docencia y criterios didácticos para su selección o evaluación. Aunque el corpus consta de 60 textos, la cuestión relacionada con el uso educativo del vídeo en la enseñanza solo fue respondida por 22 profesores de secundaria y 19 de universidad.

Se ha seguido un análisis de tipo inductivo, es decir, las categorías que organizan y representan los datos emergen de las respuestas obtenidas. El proceso de investigación realizado consta de las siguientes fases:

1. Identificación, clasificación y codificación de todos los cuestionarios.

2. Lectura de todas las respuestas de la pregunta abierta, mientras se toman notas para organizar los datos en categorías.

3. Aproximación inicial a un sistema de categorías que aglutine todas las posibles respuestas de la pregunta.

4. Revisión de los cuestionarios para comprobar la correspondencia de las respuestas con el borrador de clasificación realizado, a la vez que se anotan aquellas categorías que no quedan representadas.

5. Establecimiento de las categorías objeto de estudio y síntesis de los datos obtenidos.

\section{Resultados}

Los resultados obtenidos muestran que las funciones del vídeo predominantes en los procesos formativos (Ballesteros-Regaña, 2013; Cebrián, 2005; Salinas, 1992) son la utilización del vídeo como transmisor de información $(30,5 \%)$ e instrumento motivador $(26,6 \%)$ y de conocimiento $(19,5 \%)$.

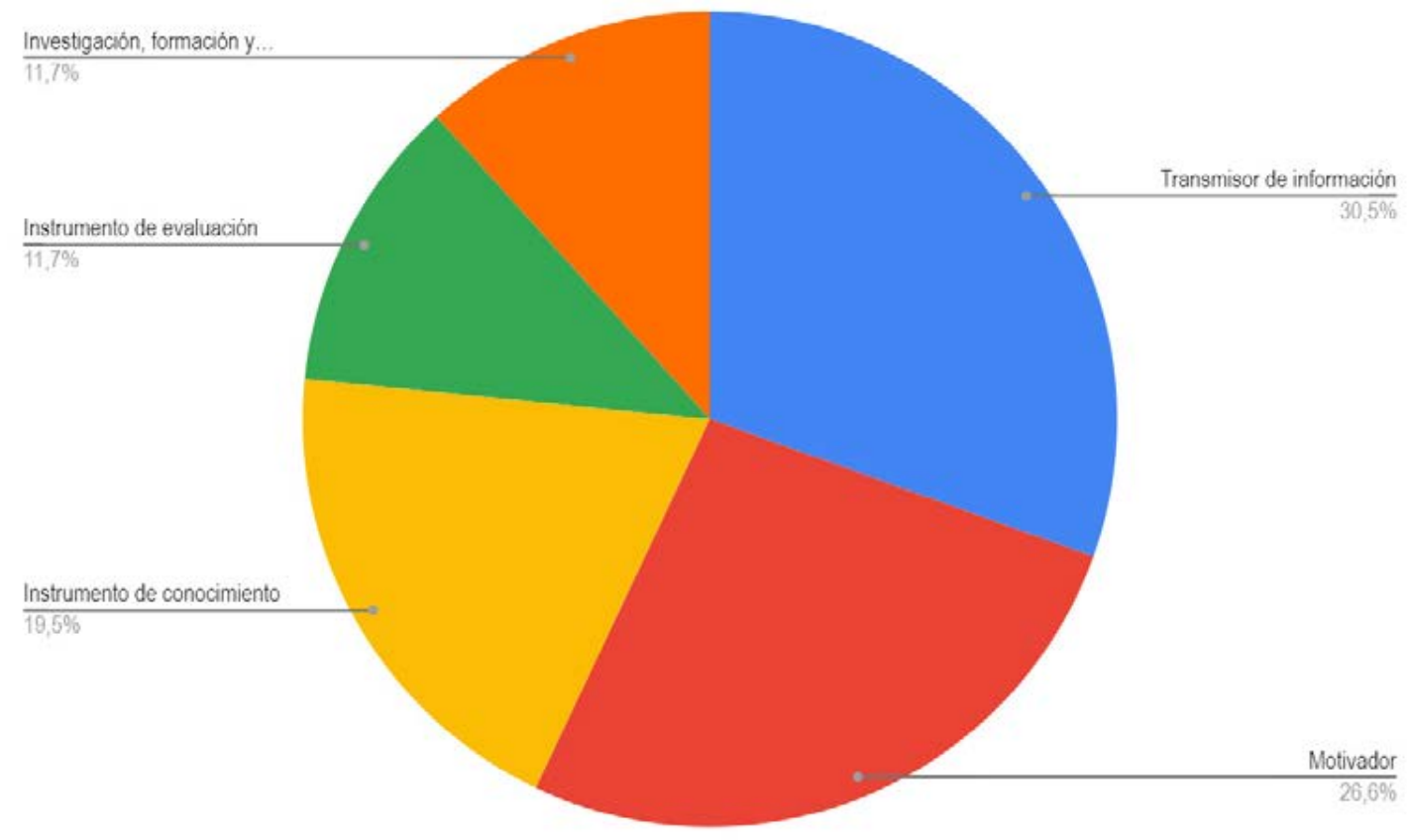

Gráfico 1. Funciones del vídeo en educación. 
Muchos docentes indican que emplean el vídeo para introducir información o conocimientos que quieren transmitir, ya sea como presentación del tema, refuerzo o ampliación:

Muchas veces he utilizado y sigo utilizando el vídeo como un recurso para complementar o ampliar las explicaciones sobre el contenido que estamos tratando. (S-16)

Utilizo el vídeo como recurso didáctico en prácticamente todas las clases de teoría de aula. Intento introducir uno o varios vídeos insertados en las presentaciones de teoría, con aspectos relacionados con la temática tratada. (U-6)

En algunos casos especifican que recurren a documentales o programas televisivos, producidos para el público en general, pero que pueden resultar de interés para atender sus necesidades didácticas: "Utilizamos el vídeo como un elemento transmisor de información en varias ocasiones durante el curso académico, donde visualizamos documentales dirigidos al público en general” (U-9).

En menor grado, como se puede observar en el gráfico anterior, aparece el uso del vídeo como instrumento de evaluación y como herramienta de investigación, formación y perfeccionamiento del profesorado:

Otro uso que le doy es el de creación de un vídeo, por parte del alumnado, que permita evaluar un contenido. Sería el caso de los trabajos de investigación sobre un bloque de historia, que aparte de exponerlos en clase, pueden grabar un vídeo para presentarlos a sus compañeros. Y también de los videos sobre uno de los dos libros de lectura que leemos al trimestre, siguiendo un guion [...]. (S-13)

Cada vez pido más actividades en las que, por ejemplo, el trabajo de la lectura de un libro voluntario tiene como resultado la grabación de un vídeo (booktrailer, final alternativo, versión del libro, videolit...). (S-14)

He utilizado el vídeo para mi formación como docente [...] para mejorar mis habilidades tanto pedagógicas como tecnológicas, metodológicas y lingüísticas. También lo he usado como técnica de evaluación, por ejemplo, para evaluar la expresión oral. (S-9)

La utilización del vídeo como instrumento de evaluación no es habitual, y en ningún caso se plantea la autoconfrontación como estrategia. Solo en algunas ocasiones se ha implementado la función evaluadora a causa de la situación generada por la pandemia e incluso algunos profesores se plantean su uso futuro como herramienta para evaluar los conocimientos, habilidades y destrezas del alumnado:

No lo utilizo como instrumento de evaluación en la mayoría de los casos. Durante la pandemia sí lo hice puesto que, en vez de hacer presentaciones en directo, tenían que hacer un vídeo con sus presentaciones. (U-8)

Indicar que el video no lo empleo en nada relacionado con la evaluación (para mí no es un instrumento de evaluación) ni como instrumento de investigación. De hecho, no me había planteado hasta este momento ninguna de estas posibilidades. Sin embargo, en ambos aspectos podría ser muy útil y no descarto su uso en un futuro cercano. (U-15) 
En este sentido, la realización del cuestionario y más concretamente la pregunta sobre el uso didáctico del vídeo, con la lectura previa de las referencias bibliográficas propuestas, ha aflorado la reflexión entre el profesorado sobre su práctica educativa.

Llevo cuatro años trabajando en educación, y durante estos cuatro años he utilizado muchos vídeos en el aula, como presentación del tema nuevo, para apoyar con vídeo un texto que hemos leído, para ayudarle a entender mejor un "listening", etc., pero nunca me había planteado qué uso estaba haciendo del vídeo realmente o qué funciones didácticas tenían. (S-9)

En consecuencia, algunos docentes pretenden que el alumnado se convierta en prosumidor, es decir quieren promover su alfabetización mediática (Cabero y Barroso, 2016) mediante la producción de vídeos por parte del alumnado (García García, 2014).

Hasta ahora el uso del vídeo en el aula me ha servido para introducir información y para favorecer la motivación y, en mucha menor medida, como herramienta para la transmisión colaborativa del conocimiento y para la evaluación realizado, individualmente o en equipo [...]. Son justamente estas últimas funciones las que debería introducir en mi maleta docente a fin de que el estudiante se sienta plenamente insertado en su aprendizaje, no ya como receptor sino como guionista, productor y director. (S-6)

A la forma de trabajar el vídeo en mis clases le falta la parte de creatividad del alumno, aquella en la que los alumnos son creadores y protagonistas de sus propias producciones a través de diversos formatos: videolit, reseña de vídeo, pequeñas producciones a partir de fragmentos teatrales, etc. [...] Es uno de los aspectos en los que he de trabajar para aplicarlo en mis clases. (S-20)

En efecto, la elaboración de vídeos por el alumnado es muy escasa y, por lo general, se trata de producciones realizadas como resultado de alguna investigación, o bien videorreseñas de lecturas o digital stories. Asimismo, el profesorado, en lugar de crear sus propios vídeos, se limita a buscar entre los recursos audiovisuales existentes. Sin embargo, lleva a cabo un visionado activo que propicia la escucha del vídeo.

La tarea nunca termina tras haber visto el vídeo, sino que siempre le suceden una serie de cuestiones y actividades de comprensión, así como actividades de búsqueda e investigación sobre varios de los aspectos narrados. (S-20)

También se recurre a la metodología flipped classroom, que transfiere el trabajo de determinados procesos de aprendizaje fuera del aula con el fin de facilitar y potenciar otros procedimientos de adquisición y práctica dentro del aula.

Últimamente enlazo los vídeos en AULES y la mayoría se deben visualizar en casa y ya en clase destacamos y comentamos algunos fragmentos. El alumnado y el profesor participamos e intervenimos en una puesta en común de manera que también se busca señalar los aspectos más destacables de la información que contiene el vídeo y, al mismo tiempo, garantizamos que haya sido accesible cognitivamente para todo el alumnado. (S-8) 
Por otra parte, si se comparan las distintas funciones del vídeo según la etapa educativa, se observa un mayor uso del vídeo como herramienta de investigación, formación y perfeccionamiento del profesorado en el ámbito universitario, sobre todo para la investigación. Adicionalmente dos profesores universitarios indican que utilizan el vídeo como instrumento de reflexión y valoración crítica.

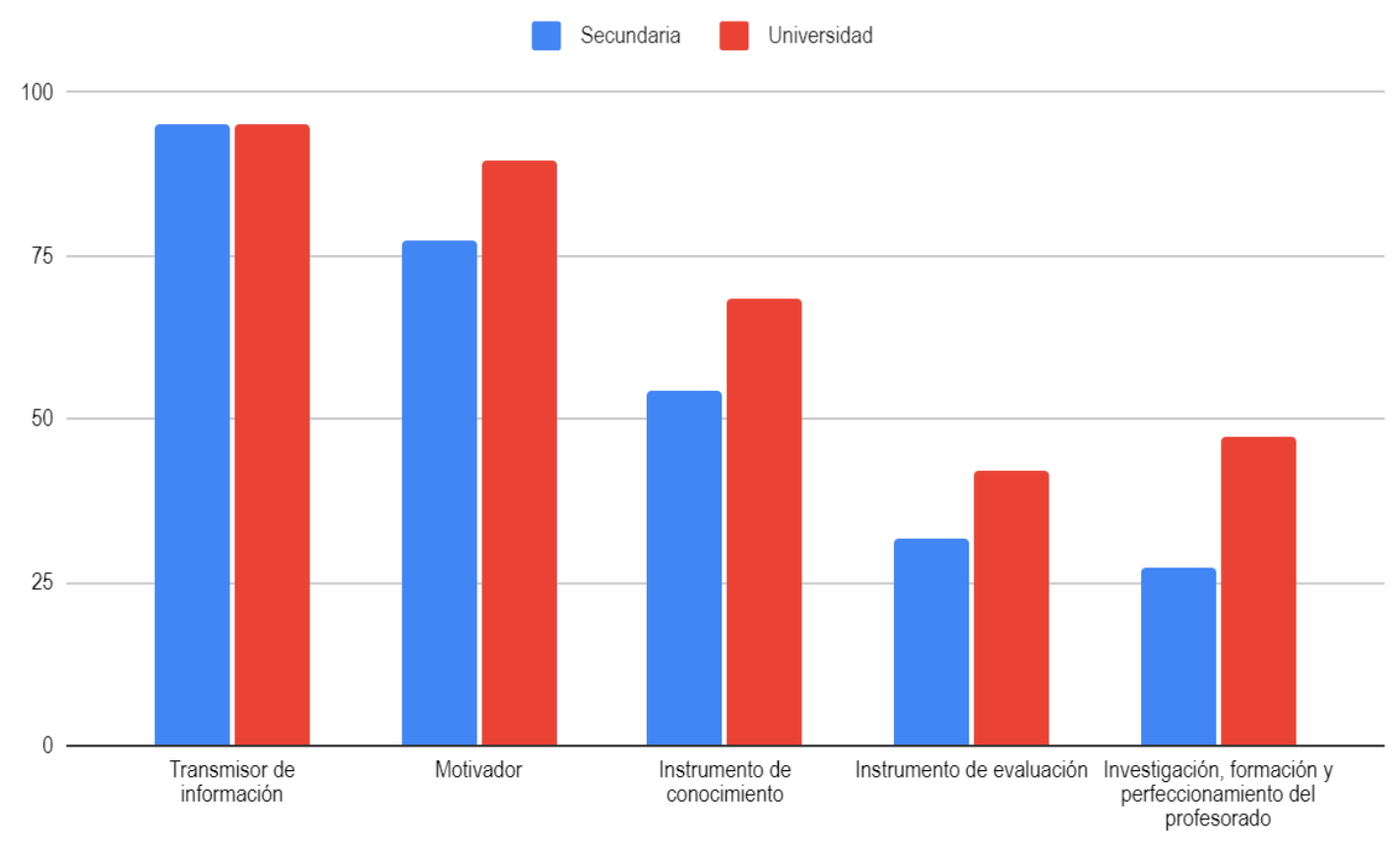

\section{Gráfico 2. Funciones del vídeo en secundaria y en universidad.}

Aunque no se pedía explícitamente en la consigna, algunos docentes mencionan las ventajas que supone la utilización del vídeo en la docencia, siguiendo a Ballesteros-Regaña (2013), por ejemplo, la visualización ilimitada:

El vídeo nos da opciones diferentes en el aula como docentes: se puede visionar tantas veces quieras, mientras que la clase presencial no. Una vez que yo como docente termine la explicación, el alumnado no puede volver a consultar esta explicación. El vídeo puede ayudarme a modificar las explicaciones, ya que al observarlo puedo editarlo y mejorar mi comunicación, y, por lo tanto, me beneficiará como docente y beneficiará a la larga mi manera de hacer las clases. También puede ser transferible y quizás incluso divertido ya que puedo intercalar elementos dentro del vídeo como imágenes, fragmentos de documentales, etc. (S-21)

Otra de sus ventajas es que se puede pausar la reproducción u omitir alguna parte, por ejemplo, para tener debates en clase o revisar alguna cuestión. Además, el vídeo es un recurso muy útil para mostrar cuestiones que no se pueden recrear en el aula. Su uso puede facilitar la comprensión de asignaturas más complejas o de temas altamente visuales. Especialmente en el ámbito universitario, el profesorado de algunas áreas apunta su utilidad para enseñar determinados procesos paso a paso o fórmulas: 
[...] son de gran utilidad los vídeos en los que se muestran procesos industriales y se ven todos los equipos que se emplean en dichos sectores, en particular en estos tiempos de pandemia, en los que las visitas a empresas no se han podido llevar a cabo. (U-14)

Durante las prácticas de laboratorio, he hecho uso del vídeo para mostrar de forma visual los procesos a desarrollar durante la experiencia práctica, para que los alumnos pudieran conocer el funcionamiento de las técnicas y equipamiento a utilizar. (U-10)

Mis clases en muchos casos son muy teóricas y en ocasiones demasiado centradas en ecuaciones que no siempre son digeribles para el alumnado. Mediante el vídeo nos acercamos más al uso práctico de esas ecuaciones. Se podría decir que el vídeo es un eslabón intermedio entre la clase puramente teórica y una clase práctica de laboratorio o empresa. Con el vídeo se ve más claramente que lo enseñado teóricamente tiene aplicación. (U-15)

Además, se incide en la ayuda que pueden proporcionar en la docencia a distancia:

Se pueden visionar vídeos de todos los contenidos que se imparten en esta asignatura de Tecnología: materiales técnicos, temas de dibujo como desarrollo de láminas con vistas acotadas, de tipos de perspectivas, de electricidad, de electrónica [...] o videos de seguridad e higiene [...]. En estos tiempos también nos ayuda a realizar la docencia a distancia. (S-7)

Sin embargo, se mencionan como inconvenientes la conectividad de los centros educativos de enseñanza secundaria, es decir, el acceso a Internet, y la publicidad que aparece en muchos vídeos, como los que podemos encontrar en YouTube.

La velocidad de bajada en el aula es pésima y, habitualmente, debo descargarme los vídeos en un lápiz de memoria en casa si quiero poder visualizar y comentar en el aula. Así me evito también la publicidad que continuamente está interrumpiendo si la conexión a Youtube se hace en línea. (S-8)

A pesar de sus posibles limitaciones (Ballesteros-Regaña, 2013), los docentes consideran que se debe acometer el reto que supone el amplio abanico de posibilidades que ofrece el vídeo como recurso didáctico.

[...] a pesar de los riesgos que conlleva el uso de los medios audiovisuales en el aula (conocimientos técnicos desiguales, dotación instrumental insuficiente, gran variedad de sistemas y formatos, etc.), las posibilidades que se abren son tantas y tan diversas que merece la pena asumir el reto de conocerlas y hacerlas nuestras según el grado de maestría que cada docente vaya desarrollando. (S-6)

En cuanto a los criterios que plantea Ballesteros-Regaña (2013) para la integración del vídeo en los procesos de E-A, el profesorado destaca los siguientes aspectos: a quién va dirigido (nivel educativo), la finalidad, el contexto de E-A, la participación e intervención de alumnado y profesorado, y también cómo y cuándo se usará. 


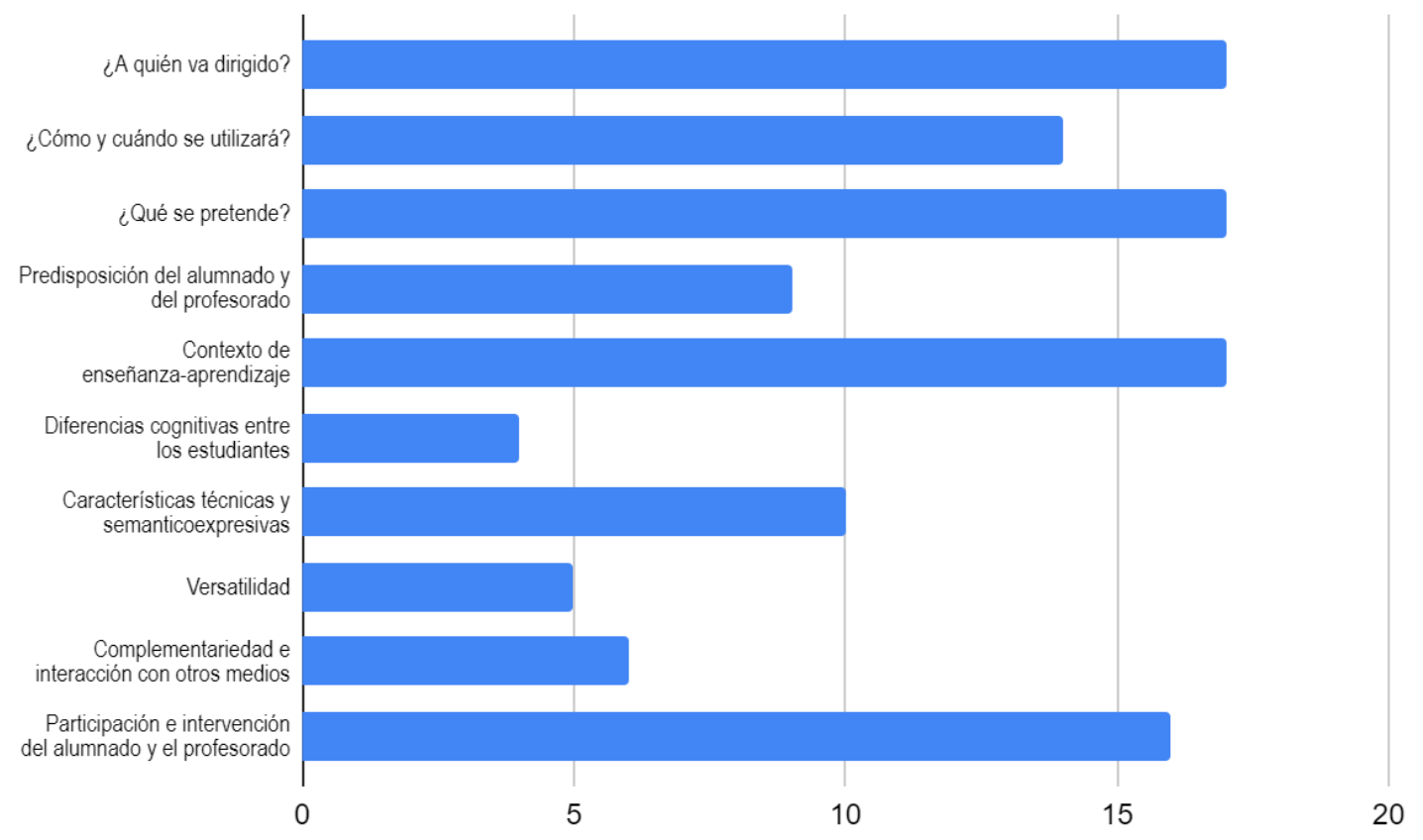

\section{Gráfico 3. Criterios para la selección del vídeo en educación.}

Por lo tanto, los docentes inciden en la importancia de tener en cuenta las características del alumnado (especialmente el curso educativo en que se encuentran), los objetivos y los contenidos que se pretenden trabajar, en qué momento del proceso de E-A se aplicará y qué función desempeñará.

Lo primero que hago cuando encuentro algún vídeo relacionado con el ámbito de conocimiento que trabajo en el aula es plantearme para qué nivel educativo sería provechoso y si lo es. [...] si se ajusta al currículo y al contexto de enseñanza-aprendizaje previsto para esa edad. (S-8)

Para seleccionar los vídeos analizo en qué punto de la unidad los utilizaré y con qué finalidad. (S-5)

Para seleccionar un vídeo, tengo en cuenta a quién va dirigido, cuándo se utilizará (si en clase presencial, o en clase virtual), especialmente respecto a su duración y el momento de la asignatura, y la predisposición del alumnado. (U-8)

El rol del estudiante también es un criterio a tener muy en cuenta ya que [...] los vídeos tienen gran utilidad a la hora de crear un debate en clase y animar a la participación de los alumnos, lo cual puede despertar el interés de los alumnos sobre un tema de la asignatura. (U-14)

El resto de criterios tienen una presencia bastante menor: las características técnicas y semánticoexpresivas (24,4\%), la predisposición del alumnado hacia el vídeo como recurso didáctico (22\%), la complementariedad e interacción con otros recursos TIC $(14,7 \%)$, la versatilidad (12,2\%) y las diferencias cognitivas entre el alumnado $(9,8 \%)$. 
Como se puede observar en los siguientes fragmentos, la adecuación y corrección de los textos audiovisuales, así como la calidad de imagen y sonido o la duración del vídeo son aspectos que apunta el profesorado para la elección y evaluación de los vídeos:

Con el fin de seleccionar un vídeo para el alumnado siempre busco que sea atractivo, que las explicaciones sean muy sencillas y visuales y que los contenidos se adecuan a lo que estamos trabajando en el aula. (S-18)

Para la elección y evaluación de un vídeo didáctico valoro sobre todo la calidad del contenido, que no tenga errores ortográficos, que complemente el contenido trabajado, que sea atractivo, breve y lo más claro y comprensible posible y que intente predisponer al alumnado hacia un visionado activo para lo que siempre intento hacer preguntas sobre el contenido del vídeo. (S-14)

En la selección del vídeo observo las características técnicas (algunos son antiguos, provienen de vídeos VHS / Beta digitalizados y tienen mala calidad). En estos casos, acostumbro a descartarlos para que los alumnos pueden llegar a relacionar negativamente el vídeo (mala calidad) con la materia (valenciano). $(\mathrm{S}-8)$

Lo que busco es que los videos estén bien estructurados, el ponente desarrolle correctamente el tema, sean didácticos y posibiliten la motivación y la ilusión de los alumnos. No sean excesivamente largos ni sea compleja su comprensión para poderlos poner en las clases de 1ำ de ESO del ámbito matemático-tecnológico. (S-7)

Solo cuatro docentes (9,8\%) -sorprendentemente uno de secundaria y tres de universidad- apuntan las diferencias cognitivas entre los discentes como una cuestión que condiciona la selección y utilización del vídeo en la enseñanza, por lo que recurren a estrategias complementarias para facilitar la inclusión educativa: "Intento combinar el vídeo con algún medio escrito o guía para intentar trabajar la inclusión del alumnado" (S-19). En efecto, algunos docentes indican que no tienen en cuenta este aspecto:

Aunque intento que haya un rol participativo del alumnado y hago una planificación 'antes-durante-después del video', me he dado cuenta que no tengo en cuenta las diferencias cognitivas de los estudiantes. (U-7)

Algunos de los aspectos en los que debo profundizar a la hora de elegir los materiales audiovisuales que empleo son el contexto de enseñanza-aprendizaje y las diferencias cognitivas entre los estudiantes. (S-20)

Por otra parte, dos profesores señalan como criterios de selección y evaluación de vídeos didácticos dos aspectos que no recoge Ballesteros-Regaña (2013): su accesibilidad (gratuidad) y su veracidad (fiabilidad de la fuente de información). 


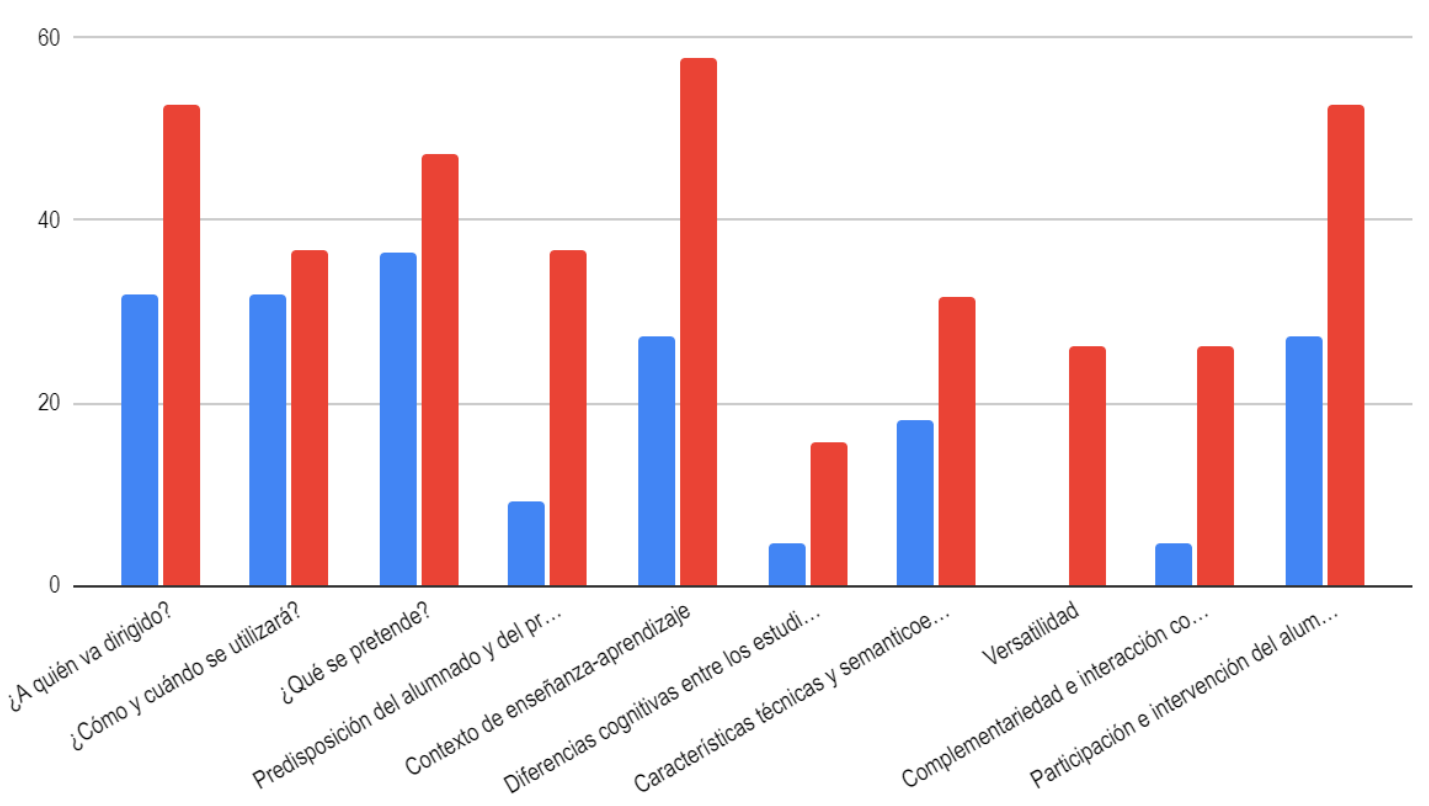

\section{Gráfico 4. Criterios para la selección del vídeo en secundaria y en universidad.}

Si observamos el gráfico 4, el profesorado universitario contempla más principios para la selección-evaluación del vídeo. De hecho, se pueden apreciar diferencias considerables según la etapa educativa. En el ámbito universitario destaca la importancia del destinatario, el contexto de E-A y la predisposición, participación e intervención del alumnado. Por ejemplo:

El contexto también es importante. Durante un tiempo impartí una misma asignatura en dos titulaciones diferentes (grado en Ingeniería Química y Grado en Ingeniería electrónica). Siendo el programa de las asignaturas el mismo, los videos que proponía eran diferentes. En un caso intentaba aplicar la materia (diseño de máquinas y equipos) a componentes electrónicos y en el otro caso a procesos químicos. (U-15)

Finalmente, nos gustaría subrayar que este estudio ha promovido la reflexión sobre la utilización del vídeo en la enseñanza. En este sentido, algunos profesores apuntan que se han producido cambios sustanciales, ya que antes el uso del vídeo se convertía en un espectáculo en el cual el alumnado simplemente era un espectador:

Experiencias pasadas de tiempo escolares desaprovechados en que se confundía espectáculo con docencia y espectadores con estudiantes: por un tiempo la sala de actos pasaba a ser sala de estar y, en definitiva, ni sala de actos ni sala de estar servían como espacio de aprendizaje, ni el alumnado era protagonista de nada de lo que sucedía durante los días de proyección. (S-6)

En cambio, actualmente se apuesta por la participación del alumnado en la elaboración de producciones audiovisuales, como recomienda García García (2014). 


\section{Discusión y conclusiones}

Esta investigación ha permitido conocer las funciones didácticas del vídeo en los procesos de E-A (Ballesteros-Regaña, 2013; Cebrián, 2005; Salinas, 1992) según el profesorado. Los datos evidencian que predomina la transmisión de información (contenidos curriculares) y la motivación del alumnado, las más frecuentes de acuerdo con Cabero y Barroso (2016). También abunda su utilización como instrumento de conocimiento, sobre todo a causa de la situación generada por la pandemia que ha promovido la producción de vídeos, como propone García García (2014), especialmente por parte del alumnado, por ejemplo grabaciones de exposiciones de trabajos o videoreseñas de lecturas. De este modo, se contribuye a adquirir y mejorar la alfabetización mediática de los discentes (Cabero y Barroso, 2016).

Los resultados confirman la hipótesis inicial. Se observa un aumento de las posibilidades del vídeo en la docencia, tanto en la universidad como en la enseñanza secundaria. La docencia virtual y semipresencial provocada por el Covid-19 ha propiciado la utilización del vídeo como instrumento de conocimiento y de evaluación. El alumnado ha asumido un papel activo para convertirse en creador y emisor de sus propias producciones audiovisuales. Asimismo, el profesorado ha recurrido al vídeo como herramienta para evaluar los conocimientos, habilidades y destrezas del alumnado. El aumento del uso de la TE en la modalidad de blended learning de la educación secundaria y universitaria ha facilitado la incorporación del flipped classroom y, por lo tanto, el mayor empleo del vídeo como recurso didáctico.

Por otra parte, el presente estudio muestra que la integración del vídeo en la enseñanza depende fundamentalmente de criterios como a quién va dirigido, la finalidad, la contextualización, la participación e intervención de alumnado y profesorado, y también cómo y cuándo se utilizará. A los principios para la selección-evaluación de las producciones audiovisuales de Ballesteros-Regaña (2013), se añaden aspectos como la gratuidad y la fiabilidad de la información proporcionada por el vídeo. Sin embargo, las diferencias cognitivas entre los discentes parecen no condicionar su uso.

En conclusión, se ha promovido la reflexión sobre las funciones didácticas del vídeo y los criterios para su selección y evaluación. Desde la mirada docente, en los tiempos del Covid-19 se han ampliado las posibilidades de integración del vídeo en la enseñanza, aunque ni profesorado ni alumnado se han convertido, por lo general, en creadores, como recomienda García García (2014). Los docentes están interesados en mejorar su formación para la incorporación de las TIC en la docencia y las consideran necesarias en la educación (Cabero y Marín, 2014), pero el desarrollo de la competencia digital (Consejo de la Unión Europea, 2018) de profesorado y alumnado, que facilite la incorporación del vídeo en la docencia, continúa siendo un reto pendiente.

\section{Referencias}

Ballesteros-Regaña, C. (2013). El vídeo en la enseñanza y la formación. En J. Barroso y J. Cabero (Coord.), Nuevos escenarios digitales: Las tecnologías de la información y la comunicación aplicadas a la formación y desarrollo curricular (pp. 167-186). Pirámide. 
Bartolomé Pina, A. (2004). Blended Learning. Conceptos básicos. Pixel-Bit. Revista de Medios y Educación, 23, 7-20. Recuperado de [https://recyt.fecyt.es/index.php/ pixel/article/view/61237/37251].

Bergmann, J., y Sams, A. (2012). Flip your Classroom: Reach Every Student in Every Class Every Day. International Society for Technology in Education (ISTE) \& Association for Supervision and Curriculum Development (ASCD).

Cabero, J. (2007). La investigación en el ámbito de la Tecnología Educativa. En J. Cabero (Coord.), Tecnología Educativa (pp. 249-261). Mc-Graw-Hill.

Cabero, J., y Barroso, J. (2016). El vídeo educativo. En J. Sánchez, J. Ruíz y M. Gómez (Coord.), Tecnologías de la comunicación y la información aplicadas a la educación (pp. 81-90). Síntesis.

Cabero, J. y Marín, V. (2014). Miradas sobre la formación del profesorado en tecnologías de información y comunicación (TIC). Enl@ce Revista venezolana de Información, Tecnología y Conocimiento, 11(2), 11-24.

Cebrián, M. (2005). Vídeo y educación I: los vídeos educativos versus vídeos didácticos. En M. Cebrián (Coord.), Tecnologías de la información y comunicación para la formación de docentes (pp. 83-92). Pirámide.

Consejo de la Unión Europea (2018). Recomendación del Consejo de la Unión Europea, de 22 de mayo de 2018, relativa a las competencias clave para el aprendizaje permanente. https://bit.ly/3s3KoxX

Fernández-Río, J. (2018). Creación de vídeos educativos en la formación docente: un estudio de caso. Revista Electrónica Interuniversitaria de Formación del Profesorado, 21(1), 115-127. http://dx.doi.org/10.6018/reifop.21.1.293121

García García, D. (2014). Creación y edición de vídeo. En F. Trujillo (Coord.), Artefactos digitales. Una escuela digital para la educación de hoy (pp.114-117). Graó.

Lara, T., Zayas, F., Alonso, N. y Larequi, E. (2009). La competencia digital en el área de Lengua. Octaedro.

Martí, A. y Garcia Vidal, P. (25-27 noviembre de 2020). Uso educativo del vídeo en el aprendizaje lingüístico y literario [Comunicación]. XXI Congreso Internacional de la SEDLL. Multimodalidad y nuevos entornos de aprendizaje en la enseñanza de las lenguas y las literaturas, Pamplona, España.

Salinas, J. (1992). Diseño, producción y evaluación de vídeos didácticos. Universitat de les Illes Balears.

Sánchez Rodríguez, J., Ruiz Palmero, J., y Gómez García, M. (Coord.) (2016). Tecnologías de la comunicación y la información aplicadas a la educación. Síntesis.

Young, J. F. (2002). 'Hybrid' teaching seeks to end the divide between traditional and online instruction. The Chronicle of Higher Education. 


\section{Efectos de la Pandemia Covid-19 en la Enseñanza de la Ingeniería: Experiencias y Consideraciones del Estudiantado}

\section{Zambrano-Sandoval, Heidy}

ORCID (0000-0002-6292-735X).

Universidad Nacional Experimental del Táchira, Venezuela.

hzambrano@unet.edu.ve

\section{Díaz-García, Juan Isidro}

ORCID (0000-0002-2650-793X).

Universidad Nacional Experimental del Táchira, Venezuela

jidiaz@unet.edu.ve 


\title{
EFECTOS DE LA PANDEMIA COVID-19 EN LA ENSEÑANZA DE LA INGENIERÍA: EXPERIENCIAS Y CONSIDERACIONES DEL ESTUDIANTADO
}

\author{
Zambrano-Sandoval, Heidy \\ Díaz-García, Juan Isidro
}

\section{Resumen}

El coronavirus o SARS-Cov-2, originó una nueva enfermedad infecciosa denominada la pandemia COVID-19, esta crisis sanitaria cambió de forma abrupta la manera de continuar las actividades de enseñanza en las universidades de todo el mundo. Presentamos un estudio de caso interpretativo, con una metodología cuantitativa de 19 estudiantes del noveno semestre de la carrera de Ingeniería Mecánica de la Universidad Nacional Experimental del Táchira en Venezuela, respecto a sus experiencias y consideraciones en la enseñanza de la ingeniería durante esta crisis. Se utilizó un cuestionario con preguntas dicotómicas, abiertas, de selección simple y tipo Likert, para registrar sus opiniones ante esta nueva realidad educativa, mediante la aplicación del administrador de encuestas Google Forms, el cual fue distribuido vía WhatsApp. Se determinó que en la UNET el profesorado que ha continuado con sus materias, ha utilizado el WhatsApp (89,5\%) como medio de enlace y el correo electrónico $(73,7 \%)$ para recibir los proyectos y tareas asignadas. Además, se utilizaron distintas plataformas, tratando de usar medios que se encuentren al alcance del estudiantado y el profesorado, resaltando la dificultad para continuar los estudios debido a la carencia en equipos, problemas en la plataforma, y en servicios como la electricidad y la conexión a internet para implementar el e-learning en la UNET.

\section{Palabras clave}

COVID-19, enseñanza en ingeniería, estudiantado, pandemia. 


\section{Introducción}

La pandemia COVID-19 afectó muchos aspectos de la vida social, cultural y económica incluida la educación. Aunque cada etapa educativa enfrentó desafíos únicos, en especial, para la Educación Superior implicó repensar cómo las universidades continuarían un plan de formación bajo el esquema de educación remota asistida por medios informáticos y telemáticos (De Castro et al.,2020; Estrada, 2020) debido a que, a partir del cierre de las instalaciones físicas, la vida académica empezó a transcurrir entre pantallas, chat y correos electrónicos (IISUE, 2020).

El cierre en casi su totalidad de escuelas y universidades con el fin de contener la propagación de la pandemia COVID-19, replanteó también cómo proseguir con el proceso pedagógico en todos los entornos educativos, para fortalecer los procesos de enseñanza y aprendizaje. La prosecución académica presentó múltiples obstáculos, uno de ellos fue la "baja conectividad y la falta de contenido en línea alineado con los planes de estudio nacionales hasta un profesorado no preparado para esta nueva normalidad", (IESALC UNESCO, 2020, p.5).

Es posible que el profesorado no conociera qué metodología utilizar por la variedad ilimitada de herramientas existentes, de un momento a otro pasamos a ser inmigrantes digitales a creadores de contenidos de manera forzada, a hacer teledocencia y teletrabajo. En un abrir y cerrar de ojos, la vida cambió, la educación se digitalizó abruptamente, por lo que, la prosecución académica ha sido todo un reto tanto para el estudiantado, como para el profesorado, en países como, Venezuela, lugar donde se desarrolló esta investigación, en gran medida por "el acceso desigual a las plataformas de aprendizaje digital: el acceso insuficiente a las tecnologías o a una buena conexión a Internet siendo un obstáculo para la continuidad del aprendizaje" (UNESCO, 2020).

En el marco de este contexto, se realizó un estudio sobre los efectos de la pandemia COVID-19, en el estudiantado de Ingeniería Mecánica del noveno semestre de la Universidad Nacional Experimental del Táchira (en adelante, UNET), ubicada en la ciudad de San Cristóbal, estado Táchira, Venezuela. Esta investigación tuvo como propósito explorar la opinión del estudiantado sobre el uso de los recursos educativos, las actividades de enseñanza y aprendizaje para la ingeniería realizadas por la universidad objeto de estudio, además de indagar sobre las estrategias y mecanismos utilizados para la continuidad de la enseñanza y aprendizaje en la UNET durante esta crisis sanitaria. Se consideraron dentro de las condiciones a estudiar, la infraestructura tanto física, como técnica, competencias digitales del profesorado, acceso al medio, conocimientos técnicos e integración didáctica del medio en la formación en ambientes virtuales.

La UNET presentó serios problemas para la prosecución de estudios, en palabras del Rector, Prof. Raúl Casanova, "La UNET no tiene una estructura cónsona para desarrollar actividades de docencia vía virtual”, (Porras, 2020), además, agregó que no hay una tecnología adecuada, en gran parte por el gravísimo problema de electricidad, ya que el Táchira es uno de los estados venezolanos con mayor número de fallas eléctricas (Bornacelly, 2021).

Por otra parte, es necesario precisar que no todo el profesorado estaba preparado para manejar herramientas pedagógicas y tecnológicas, ni mucho menos llevar adelante una 
formación a distancia. En tal sentido, el desarrollo de competencias digitales docentes es vital importancia tal como lo plantean (Álvarez, 2015; Padilla-Escobedo et al.,2019; Robles et al.,2016). Somos inmigrantes digitales, que enfrentan a diario a un estudiantado denominados millennials "generación nacida en el tránsito del cambio de milenio y es coetánea a la revolución digital. Representan lo que Prensky (2010) denominó como nativos digitales" (Área Moreira et al.,2015, p. 13).

Por lo tanto, exigen un tipo de aprendizaje más interactivo y rápido, ya que el uso de la tecnología, el internet, los teléfonos móviles y videojuegos, conforman un referente imprescindible para su vida cotidiana. Además, poner en práctica a largo plazo el aprendizaje en línea, permitirá flexibilizar la enseñanza, aprender desde cualquier lugar y en cualquier momento (Hodges et al., 2020) la rapidez en que ocurra este suceso, cambiará para siempre la forma de ver y hacer educación

Pese al panorama descrito y la poca disponibilidad de herramientas tecnológicas como computadoras y teléfonos actualizados, más la complejidad de proporcionar educación de manera remota en Venezuela, por la baja conectividad de internet, con respecto a la media de la región, es fundamental continuar brindando instrucción y acompañamiento, como sea posible, al estudiantado venezolano en su aprendizaje a distancia.

Conviene destacar que se desarrollaron diversos trabajos investigativos relacionados con los efectos de la pandemia COVID-19 en la enseñanza de la ingeniería, tanto en Argentina (Culzoni et al.,2021; Williner, 2021) como en Colombia (Erck et al., 2020). Por ejemplo, (Culzoni et al.,2021), tomaron como referencia las opiniones del estudiantado que formó parte de este proceso formativo en línea a través de una encuesta con un formulario, coincidiendo con nuestra investigación. Por su parte (Williner, 2021) destacó la importancia de la creación de comunidades de aprendizaje mediante grupos de WhatsApp y (Erck et al.,2020) identificaron algunas debilidades tanto en la enseñanza como en la evaluación.

\section{Pregunta de investigación y objetivo del estudio}

En esta investigación, se parte de la siguiente interrogante:

¿Cuáles son los efectos de la pandemia COVID-19 en la enseñanza de la ingeniería para dar continuidad a las actividades de enseñanza y aprendizaje en una universidad venezolana?

Esta interrogante conduce a plantear los siguientes objetivos de investigación:

- Explorar la opinión del estudiantado UNET sobre su experiencia en el uso de los diferentes recursos educativos para la virtualización de la educación en el país objeto de estudio.

- Indagar acerca de las estrategias y mecanismos puestos en práctica para la continuidad de las actividades de enseñanza y aprendizaje en la UNET durante la pandemia COVID-19. 


\section{Método}

La investigación se abordó como un estudio de caso interpretativo, con una metodología cuantitativa, de acuerdo con Stake (1999), "El estudio de casos es el estudio de la particularidad y de la complejidad de un caso singular, para llegar a comprender su actividad en circunstancias importantes" (p.11). Desde una perspectiva interpretativa, Pérez (2002), señala que "su objetivo básico es comprender el significado de una experiencia" (p.81). En palabras de (Cohen et al.,2007), "Los estudios de caso pueden establecer causa y efecto, reconociendo que el contexto es un determinante tanto de las causas como de los efectos" (p.253).

\section{Descripción del contexto y de los participantes}

Para la aplicación del instrumento se tomó una muestra compuesta por 19 estudiantes (2 mujeres y 17 hombres) del noveno semestre de Ingeniería Mecánica UNET.

\section{Instrumentos}

La técnica seleccionada fue el cuestionario como medio que aporta información sobre las distintas percepciones de las personas participantes objeto de estudio, para el caso, se estructuró una lista de preguntas, con 12 ítems, constituido por 3 preguntas dicotómicas (sí y no), 4 preguntas abiertas, 4 preguntas de selección simple y 1 pregunta, con escala tipo Likert.

\section{Procedimiento}

Para aplicar el cuestionario se utilizó la aplicación de administración de encuestas Google Forms, el cual fue distribuido vía WhatsApp al estudiantado, de acuerdo con (Leyva et al.,2018) "Los Formularios de Google permiten planificar eventos, enviar una encuesta, hacer preguntas a cierto público (estudiantes, en este caso) o recopilar otros tipos de información de forma fácil y eficiente” (p.7).

\section{Resultados}

El cuestionario tuvo por objetivo explorar la opinión del estudiantado UNET sobre el uso de los recursos educativos puestos en práctica para la continuidad de las actividades de enseñanza y aprendizaje en ingeniería durante la cuarentena por la pandemia COVID-19.

Se consultó si la universidad informó acerca de un plan de continuidad educativa para desarrollar actividades de clases en línea al estudiantado ver (Figura 1), obteniéndose que un $(89,5 \%)$ de los estudiantes UNET no fueron informados de un plan de continuidad, tal y como lo refieren algunas de las personas participantes en la investigación: "el Consejo Universitario no nos han informado acerca de ningún plan académico para las clases virtuales", "No he manejado cronogramas de ningún tipo hasta los momentos", y "No he recibido una propuesta clara para solucionar el tema de evaluaciones". En general se aprecia que la UNET, no proporcionó directrices oportunas ante la contingencia COVID-19. 


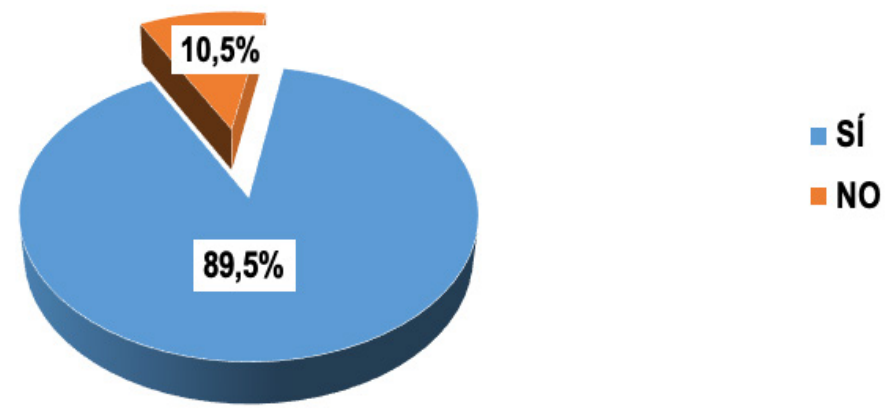

Figura 1. Información acerca del plan de continuidad educativa para desarrollar actividades en línea.

Al consultar sobre la capacidad de la plataforma de la universidad para el e-learning, ver (Figura 2), el (73,7\%) del estudiantado de la UNET señala que no considera apta la plataforma de la universidad y así lo relatan en sus respuestas: "El servidor no es estable, debido a los cortes de energía eléctrica depende de combustibles para prestar el servicio y es intermitente la conexión con la plataforma", "La plataforma de la universidad es poco interactiva, con una interfaz un poco obsoleta, sin mencionar por supuesto las fallas en el sistema", "Es difícil acceder a la plataforma, la mayoría de veces está caída", sin embargo, un (26,3\%) opina que la plataforma "Posee buenas herramientas para el proceso de aprendizaje, el gran detalle que presenta la plataforma de nuestra universidad, es que muy a menudo el acceso a la plataforma desde afuera del campus es imposible, lo que por ende imposibilita el hecho de poder acceder a los servicios que ofrece".

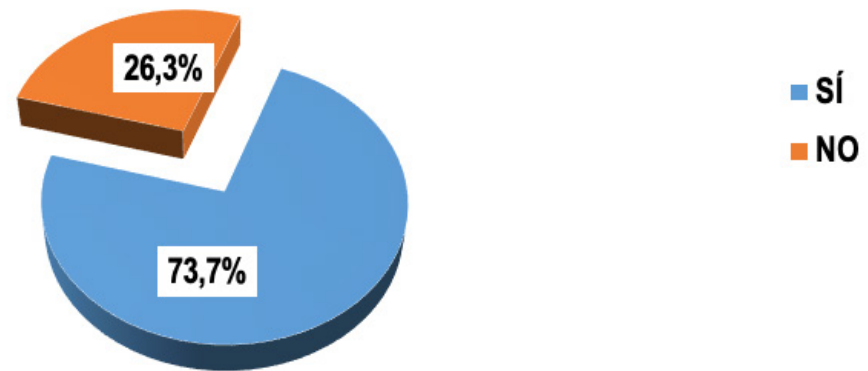

Figura 2. Estado de la plataforma de la universidad para el e-learning (enseñanza y aprendizaje en línea).

En la (Figura 3) se presentan los resultados sobre la disponibilidad de dispositivos electrónicos en casa para las clases en línea, al respecto el estudiantado de la UNET afirma que utiliza en primer lugar, con el $(89,5 \%)$ el teléfono inteligente, en segundo lugar, el computador portátil (57,9\%) y en tercer lugar el computador de mesa (36,8\%). El uso intensivo del teléfono inteligente se presume que pudiera estar asociado a la disponibilidad de los datos móviles (son datos destinados para el uso de internet en teléfonos), con los que cuenta el estudiantado de manera inmediata, para lograr comunicarse y desarrollar la enseñanza y aprendizaje en línea (Bravo y Quezada, 2021). Cabe destacar que el continuo racionamiento de energía eléctrica en la ciudad de San 
Cristóbal, estado Táchira, Venezuela, es un tema de especial preocupación para toda la colectividad en general, tal como lo señala Márquez (2020), "Los habitantes del Táchira han sido castigados con prolongados cortes de electricidad que en algunos lugares han superado las 20 horas continuas", por lo tanto, es más difícil el servicio de acceso a internet sobre banda ancha (Aba) de la Compañía Anónima Nacional Teléfonos de Venezuela (Cantv).

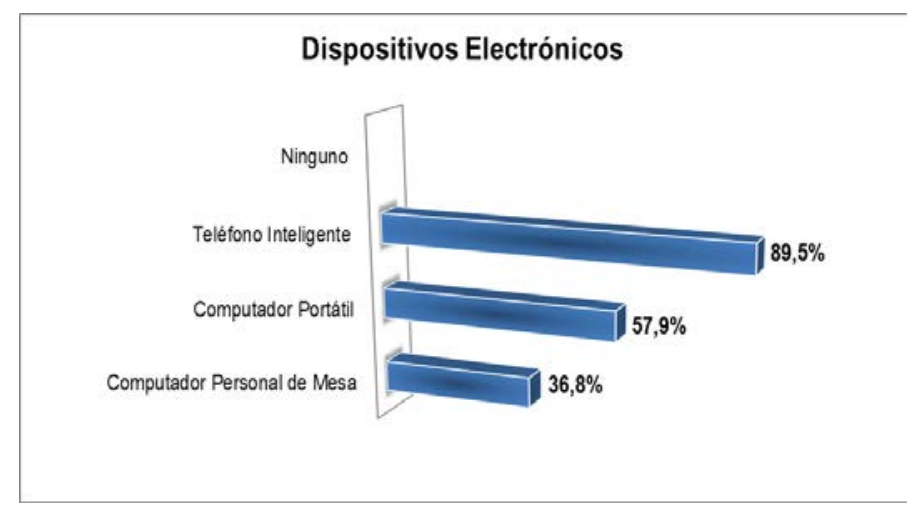

\section{Figura 3. Dispositivos electrónicos usados en casa para las clases en línea.}

Para el caso del acceso a internet en los dispositivos electrónicos, ver (Figura 4), el estudiantado de la UNET manifiesta que nunca tienen acceso a internet en sus computadoras de mesa en un $(57,9 \%)$ y en un $(31,6 \%)$ en sus computadoras portátiles. Algunas veces tienen acceso a internet, en sus computadoras de mesa $(31,6 \%)$ y computadoras portátiles $(52,6 \%)$ y un $(68,4 \%)$ en sus teléfonos inteligentes. Se obtuvieron valores bajos para la opción casi siempre de acceso a internet, con apenas $(10,5 \%)$ en computadoras de mesa, $(15,8 \%)$ en computadoras portátiles y un escaso (31.8\%) en teléfonos inteligentes. Ninguno de los encuestados de la UNET tiene siempre acceso a internet en alguno de los dispositivos usados para el e-learning. Al ser consultados el estudiantado de la UNET sobre la velocidad de conexión a internet expresan: "Muy deficiente e intermitente", "la velocidad del internet en Venezuela es realmente muy baja", "en ocasiones solo el hecho subir algún documento al correo para enviarla al docente es bastante difícil", "es poco estable y falla continuamente por los cortes de energía eléctrica", "muy lenta, donde vivo no hay luz al menos 9 horas al día y de resto el internet es muy malo".

Sandoval (2020) señala que en Venezuela se presenta "la cotidianidad de las fallas eléctricas que dificultan todo, además de la poca potencia de nuestros servicios de internet" (p.113). Conviene puntualizar que el problema de conectividad presentado por el estudiantado UNET, también ha sido reportado en trabajos desarrollados en otras universidades de provincia latinoamericanas (Hernández y Uscátegui, 2021; Grijalva y Briseño, 2021). 


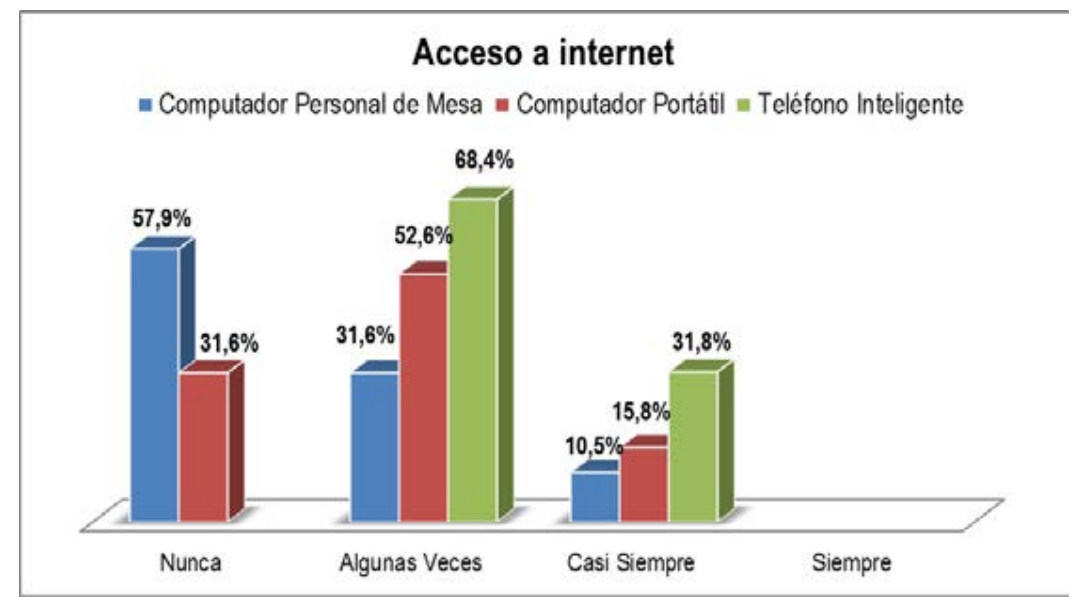

Figura 4. Frecuencia de acceso a internet en los dispositivos electrónicos utilizados en las clases en línea.

En el caso de las herramientas usadas para las clases en línea por parte del profesorado, ver (Figura 5), en las respuestas del estudiantado de la UNET se aprecia un uso intensivo del WhatsApp como medio de comunicación $(89,5 \%)$ seguido del correo electrónico (73,7\%), y valores más bajos para otras herramientas como Zoom. us (31,6\%), YouTube (26,3\%), Moodle (10,5\%), Google Classroom (10,5\%) y Telegram $(5,3 \%)$. Se aprecia una falta de unificación de criterios en el uso de herramientas debido a la ausencia de consenso en el uso de las mismas de parte de la universidad.

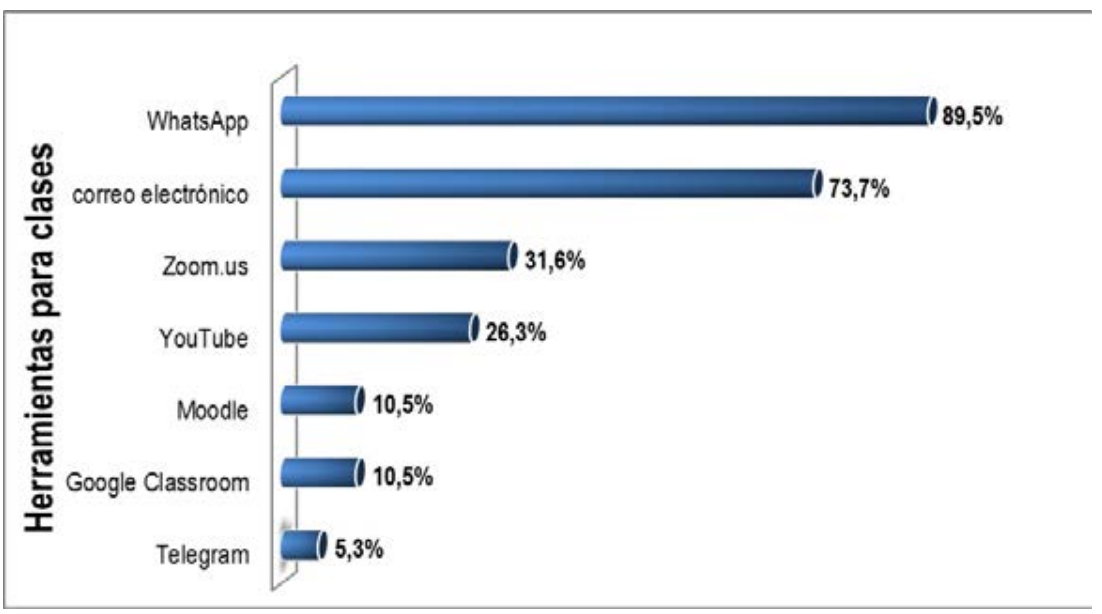

Figura 5. Herramientas usadas por el profesorado para las clases en línea.

También se consultaron los tipos de metodología pedagógica utilizadas por el profesorado de la universidad de estudio, ver (Figura 6), donde se obtuvo lo siguiente: la propuesta pedagógica con mayor porcentaje en la UNET, fue el uso de actividades de aprendizaje usando Whats App con (73,7\%), un (52,6\%) para las herramientas de aprendizaje a distancia que no precisan de conexión (uso de materiales escritos, libros de trabajo, etc.), un (36,8\%) para metodologías de aprendizaje con uso del correo electrónico, clases por video streaming $(15,8 \%)$ y un $(10,5 \%)$ para el uso de aulas virtuales. 


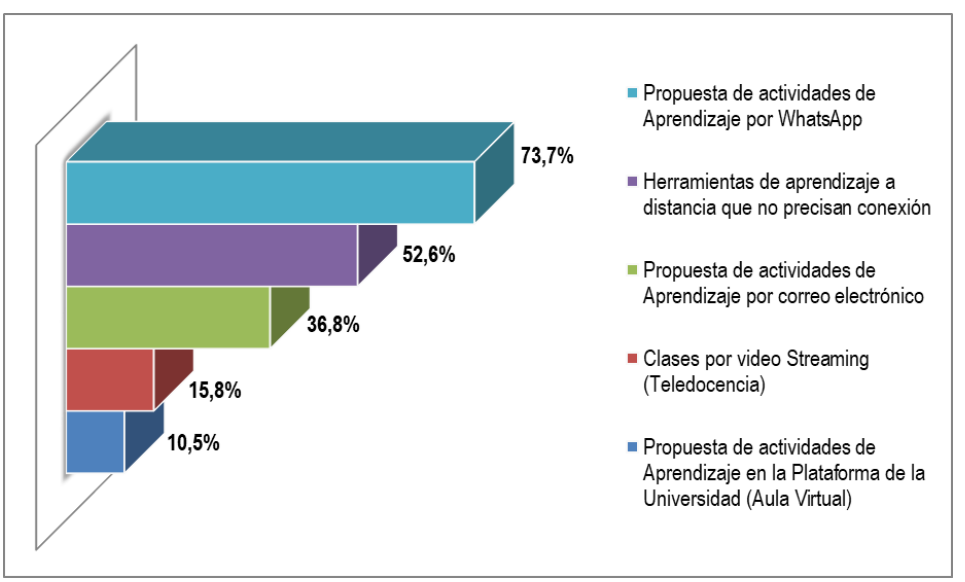

\section{Figura 6. Metodología pedagógica utilizada por el profesorado.}

La disposición del profesorado a ayudar en el proceso de enseñanza aprendizaje durante esta contingencia fue investigada mediante la pregunta: ¿Considera usted que sus profesores le han brindado el apoyo adecuado durante este proceso de confinamiento asociado a la COVID-19?, para el estudiantado UNET, en su mayoría opina que no ha recibido apoyo de parte del profesorado y lo expresan de la siguiente manera: "No, ningún profesor ha propuesto soluciones ante la situación", "He tenido algunos profesores negados completamente a continuar las evaluaciones vía online", "No han dado ningún apoyo, no han comentado nada de lo que pasa en la UNET, solo un profesor escribió por WhatsApp".

Por otro lado, también opinan: "Algunos profesores han realizado el esfuerzo para seguir cumpliendo las actividades académicas", "Supongo que a todos nos tomó por sorpresa, desde la suspensión de actividades presenciales, pocos son los profesores que se han comunicado, entendiendo que cada uno de nosotros atravesamos diferentes circunstancias en medio de esta crisis, por lo cual es entendible".

Estas opiniones expresadas por el estudiantado encuestado, son el reflejo de la situación de la educación universitaria en Venezuela, la cual está atravesando una profunda crisis, que está afectando directamente el salario del profesor, y su labor docente, según, Afonso (2020), "el salario de un profesor universitario del más alto escalafón y dedicación es USD 7", con una realidad como ésta, es complejo encontrar apoyo en un profesor. En palabras de Balbo (2020), la crisis es de tipo económica y social enmarcada en un reiterado recorte presupuestario, bajos sueldos y escasa asistencia social; el profesorado trata de sobrevivir, en menoscabo del desarrollo y formación profesional, afectando indiscutiblemente la labor científica y académica en la universidad.

Al ser consultados de forma general sobre los mecanismos y dispositivos con que cuenta la universidad para apoyar al estudiantado, ver (Figura7), la mayoría UNET el $(68,4 \%)$, considera que no tiene apoyo de tipo socioemocional, equipamiento y tecnológico. 


\section{Medios y dispositivos electrónicos}

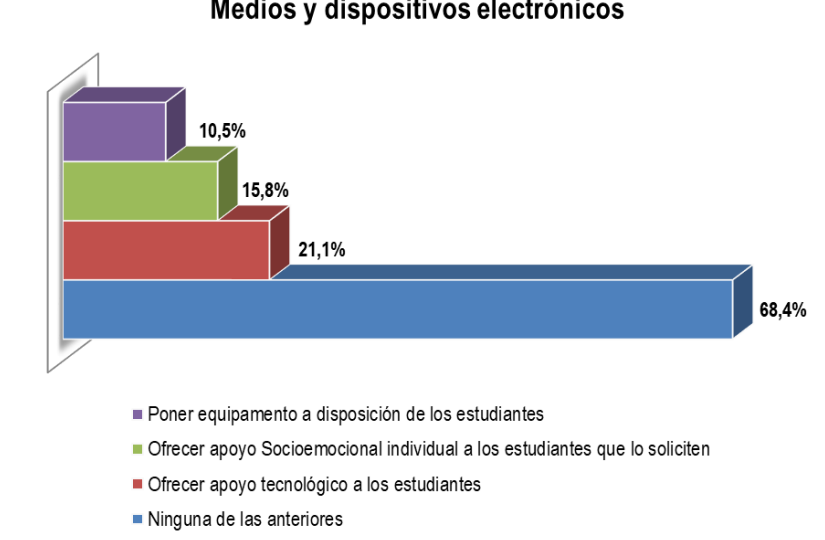

Figura 7. Mecanismos y dispositivos con que cuenta la universidad para sus estudiantes.

\section{Discusión y conclusiones}

Este trabajo determinó mediante consulta al estudiantado de Ingeniería Mecánica de la UNET en Venezuela, su opinión sobre el uso de los recursos educativos, las actividades de enseñanza y aprendizaje para la ingeniería y las estrategias y mecanismos puestos en práctica para la continuidad de las actividades académicas durante la pandemia COVID-19.

De acuerdo con las respuestas del estudiantado no se implementó un plan de continuidad educativa para la prosecución de sus estudios, y manifiestan no haber recibido directrices ante la contingencia asociada a la pandemia COVID-19 en cuanto a cronogramas o evaluaciones. Para seguir avanzando en su e-learning han implementado el uso del teléfono inteligente como medio de comunicación (89,5\%) debido a la falta de conexión a internet y las fallas en la red eléctrica, seguido del computador portátil $(57,9 \%)$ y el computador de escritorio (36,8\%). Es de resaltar que el estudiantado de la UNET reiteradamente manifiesta problemas de baja velocidad de conexión y continuas fallas eléctricas en los sectores donde residen. El profesorado que ha continuado sus materias ha utilizado el WhatsApp $(89,5 \%)$ como medio de enlace y el correo electrónico (73,7\%) para recibir los proyectos y tareas asignadas, también algunos han usado Zoom.us (31,6\%) y YouTube (26,3\%). Siendo las actividades de aprendizaje usando WhatsApp la más utilizada por el profesorado UNET $(73,7 \%)$, seguida de otras actividades que no necesitan de conexión (52,6\%). Además, el estudiantado en su mayoría opina que no ha recibido apoyo de parte de la universidad y del profesorado, debido en gran medida a la crisis general que vive el país antes de la llegada de la pandemia COVID-19, en sus palabras "a todos nos tomó por sorpresa y cada uno de nosotros atravesamos diferentes circunstancias en medio de esta crisis".

Como conclusión final, se tiene que las estrategias aplicadas para la continuidad de las actividades de enseñanza y aprendizaje durante la cuarentena, se basaron en distintas plataformas y tratando de usar aquellos medios que se encuentren al alcance del estudiantado y del profesorado venezolano. Se resalta que la dificultad para continuar los estudios en Venezuela está asociada a la deficiencia de los servicios básicos (electricidad e internet) de acuerdo con (Brizuela, 2020; Sandoval, 2020) y 
las continuas fallas del sistema eléctrico del estado Táchira (Bornacelly, 2020; Bornacelly, 2021; Márquez, 2020), a lo que se suma la desmotivación del profesorado ante los bajos salarios (Afonso, 2020) y la obsolescencia de equipos y plataformas para llevar adelante el e-learning en Venezuela.

Todo lo expresado por el estudiantado a través del cuestionario aplicado por Google Forms, indica que es necesario un cambio en equipos, plataforma y formación del profesorado para implementar el e-learning en la UNET, además de asegurar el acceso continuo y de calidad a servicios como la electricidad y el internet del estudiantado del estado Táchira en Venezuela.

\section{Agradecimientos}

Este trabajo fue posible gracias a la colaboración del estudiantado perteneciente a la promoción 65 de Ingeniería Mecánica de la UNET.

\section{Referencias}

Afonso, G. (20 de abril de 2020). El "Plan Universidad en Casa" carece de contenidos y factibilidad. PROVEA [Documento en línea]. https://www.derechos.org.ve/ opinion/el-plan-universidad-en-casa-carece-de-contenidos-y-factibilidad.

Álvarez, E. (2015). Estándares y competencias TIC de la dimensión técnica para la formación inicial docente: Estudio correlacional en estudiantes de seis carreras de pedagogía de la Universidad de Antofagasta. [Tesis de maestría, Universidad de Chile]. http://repositorio.uchile.cl/bitstream/handle/2250/136542/TESIS.pdf?sequence

Área Moreira, M; Borrás, J y San Nicolás, B. (2015). Educar a la generación de los Millennials como ciudadanos cultos del ciberespacio. Apuntes para la alfabetización digital. Revista de Estudios de Juventud, 109, 13-32. https://dialnet.unirioja.es/servlet/articulo?codigo $=5336879$

Balbo, J. (2020). La formación docente por competencias en el contexto actual venezolano. Un acercamiento desde la voz de profesores universitarios. Cuaderno de Pedagogía Universitaria, 17 (33), 57-70. doi: https://doi.org/10.29197/cpu.v17i33.374

Bornacelly, L. (1 de julio de 2021). Táchira registra 259 apagones en lo que va de 2021. El Pitazo. https://elpitazo.net/los-andes/tachira-registra-259-apagones-en-loque-va-de-2021/

Bornacelly, L. (1 de septiembre de 2020). Táchira registró 60 apagones durante agosto. El Pitazo. https://elpitazo.net/los-andes/tachira-registro-60-apagones-durante-agosto/

Bravo, F., y Quezada, T. (2021). Educación virtual en la universidad en tiempos de covid-19. Revista Científica Espíritu Emprendedor TES, 5 (1), 154-166. https://doi. org/10.33970/eetes.v5.n1.2021.238 
Brizuela, A. (17 de septiembre de 2020). La educación a distancia: un modelo fracasado en Venezuela. El Nacional. https://www.elnacional.com/venezuela/la-educacion-a-distancia-un-modelo-fracasado-en-venezuela

Cohen, L., Manion, L., y Morrison, K. (2007). Research methods in education. [Métodos de investigación en educación] (6th ed). NY: Routledge.

Culzoni, C., Panigatti, C., y Bergesse, C. (2021). El proceso de enseñanza y aprendizaje en asignaturas de matemática para ingeniería durante el aislamiento por Covid 19. Revista Iberoamericana de Tecnología en Educación y Educación en Tecnología, 28, 70-82. https://teyet-revista.info.unlp.edu.ar/TEyET/article/view/1492/1270

De Castro, M., De Castro M., y Villegas, L. (2020). Enseñar en tiempos de pandemia: reinventar la práctica docente desde la construcción colaborativa del aprendizaje con apoyo de la TIC. Revista Ciencias de la Educación, 30 (Edición Especial), 10911108.http://servicio.bc.uc.edu.ve/educacion/revista/56e/vol30nesp2020.pdf

Erck, I., Enríquez, H., Kowalski, V., Giordano, R., y Cirimelo, S. (2020). Enseñanza y evaluación en carreras de ingeniería en tiempos de pandemia: la experiencia de CoIombia. Actualidad y Nuevas Tendencias, 7 (25), 71-98. http://servicio.bc.uc.edu.ve/ ingenieria/revista/Inge-Industrial/vol7-n25/art04.pdf

Estrada, N. (2020). Estrategias de materiales virtuales: reto ante la inesperada pandemia COVID-19. Revista Ciencias de la Educación, 30 (Edición Especial), 1179-1196. http://servicio.bc.uc.edu.ve/educacion/revista/56e/vol30nesp2020.pdf

Grijalva, O., y Briseño, M. (Enero, 2021). El financiamiento de las universidades públicas en contextos de desigualdad social. En A. Guarro, M. Area, J. Marrero y J. Sosa. (Coords.), Pósters 06 presentado en el XI Congreso Iberoamericano de Docencia Universitaria, Universidad de La Laguna, Tenerife, España (pp. 2274-2285).

Hernández, G., y Uscátegui, M. (Enero, 2021). Tensiones de la digitalización: la evaluación como calificación. En A. Guarro, M. Area, J. Marrero y J. Sosa. (Coords.), Simposio XI Congreso Iberoamericano de Docencia Universitaria, Universidad de La Laguna, Tenerife, España (pp. 578-588).

Hodges, C.; Moore, S.; Lockee, B.; Trust, T.; and Bond, A. (2020). The Difference Between Emergency Remote Teaching and Online Learning. EDUCAUSE Review. https://er.educause.edu/articles/2020/3/the-difference-between-emergency-remote-teaching-and-online-learning

IESALC UNESCO (2020). Prólogo, por Stefania Giannini, Subdirectora General de Educación de la UNESCO. En COVID-19 y educación superior: De los efectos inmediatos al día después (pp.5-6). http://www.iesalc.unesco.org/wp-content/ uploads/2020/05/COVID-19-ES-130520.pdf

IISUE (2020). Educación y pandemia. Una visión académica. México: UNAM. https:// www.iisue.unam.mx/nosotros/covid/educacion-y-pandemia

Leyva, H.; Pérez, M.; y Pérez, V. (2018). Google Forms en la evaluación diagnóstica como apoyo en las actividades docentes. Caso con estudiantes de la Licenciatura 
en Turismo. Revista Iberoamericana para la Investigación y el Desarrollo Educativo, 9 (17), 1-28. doi: 10.23913/ride. v9i17.374

Márquez, B. (08 de mayo de 2020). Táchira entre bajones y apagones de luz de hasta 20 horas. Diario La Nación [Periódico en línea]. https://lanacionweb.com/regional/tachira-entre-bajones-y-apagones-de-luz-de-hasta-20-horas/.

Padilla-Escobedo, J., Ayala-Jiménez, G., Mora-García, O., y Ruezga-Gómez, A. (2019). Competencias Digitales Docentes en Educación Superior: caso Centro Universitario de Los Altos. Revista de Educación y Desarrol/o, 51, 89-95. https://www.researchgate.net/publication/337498619_Competencias_Digitales_Docentes_en_Educacion_ Superior

Pérez, G. (2002). Investigación Cualitativa. Retos e interrogantes. Métodos (Tomo I). Madrid: La Muralla.

Porras, N. (27 de marzo de 2020). Rector Raúl Casanova: "La Unet no tiene una estructura adecuada para realizar un trabajo docente virtual'. Diario La Nación. Recuperado de https://lanacionweb.com/regional/rector-raul-casanova-la-unet-no-tiene-una-estructura-adecuada-para-realizar-un-trabajo-docente-virtual/

Robles, K., Vales, J., y Angulo, J. (2016). Diagnóstico de competencias digitales docentes en profesores de educación superior. En M.E. Prieto y S.J. Pech (Eds.), La tecnología como instrumento para potenciar el aprendizaje (pp.79-85). Comunidad Internacional para el Avance de la Tecnología en el Aprendizaje.

Sandoval, C. (2020). Otro corazón de las tinieblas en Venezuela. Revista Universidades, 83, 117-117. https://doi.org/10.36888/udual.universidades.2019.83

Stake, R.E. (1999). Investigación con estudio de casos. Madrid: Ediciones Morata.

UNESCO Chair on Education for Social Justice (2020). UNESCO resalta algunas consecuencias negativas derivadas del cierre de centros escolares. [Cátedra de Educación para la Justicia Social]. Universidad Autónoma de Madrid. http://www. catedraeducacionjusticiasocial.org/unesco-resalta-algunas-consecuenciasperjudiciales-derivadas-del-cierre-de-centros-escolares\%E2\%80\%8B/

Williner, B (2021). La clase invertida a través de tareas. Una experiencia durante el periodo de aislamiento por COVID-19 en carreras de ingeniería. Revista Iberoamericana de Tecnología en Educación y Educación en Tecnología, 28, 48-55. http://portal.amelica.org/ameli/jatsRepo/24/241969007/html/index.html 


\section{Percepciones Docentes sobre el Uso de la Realidad Aumentada y la Realidad Virtual para la Enseñanza del Inglés y la Educación Bilingüe}

Huertas-Abril, Cristina A.

https://orcid.org/0000-0002-9057-5224

Palacios-Hidalgo, Francisco J. https://orcid.org/0000-0002-4326-209X 


\title{
PERCEPCIONES DOCENTES SOBRE EL USO DE LA REALIDAD AUMENTADA Y LA REALIDAD VIRTUAL PARA LA ENSEÑANZA DEL INGLÉS Y LA EDUCACIÓN BILINGÜE
}

\author{
Huertas-Abril, Cristina A. \\ Palacios-Hidalgo, Francisco J.
}

\section{Resumen}

La realidad aumentada ( $R A$ ) y la realidad virtual ( $R V$ ) destacan en los últimos años dentro de las tecnologías educativas emergentes debido especialmente a las numerosas posibilidades educativas que ofrecen sin necesidad de salir del aula, lo que queda reflejado en el aumento de los estudios sobre su potencial didáctico en distintos niveles y contextos educativos. Sin embargo, hasta la fecha son limitadas las investigaciones en el ámbito de la educación bilingüe (EB) y la enseñanza del inglés como lengua extranjera (EFL) y, además, no hay estudios que comparen las percepciones sobre RA y RV entre profesorado millennial y post-millennial. El presente trabajo recoge un estudio cualitativo exploratorio a partir de una experiencia didáctica con docentes $(n=11)$ que continúan su formación permanente con el Máster Universitario en Estudios Ingleses Avanzados (Lingüística Cognitiva/Literatura) y Educación Bilingüe de la Universidad de Córdoba (España), con el objetivo de conocer sus percepciones al respecto. La Teoría Fundamentada se utilizó para realizar una primera aproximación al fenómeno y, posteriormente, se llevó a cabo el análisis de contenido. Resulta interesante que una de las diferencias más destacables entre ambas generaciones radica en el hecho de que las docentes post-millennials identifican con mayor frecuencia que las millennials que esta tecnología proporciona una experiencia interactiva. No obstante, ambas generaciones coinciden en que la falta de formación del profesorado en este campo es una de las principales limitaciones para llevar a cabo una implementación eficaz de la RA y la RV en el aula de EB y de EFL.

\section{Palabras clave}

Tecnología educativa, realidad virtual, realidad aumentada, educación bilingüe, enseñanza del inglés como lengua extranjera. 


\section{Introducción}

En los últimos años, el desarrollo de apps y los avances en hardware que permiten el uso de la realidad aumentada (RA) y de la realidad virtual (RV), junto con una bajada de costes y una mayor potencia, ha aumentado notablemente las posibilidades que estas tecnologías ofrecen a la población en general. Esta situación ha derivado en un aumento exponencial de estudios sobre su potencial didáctico en distintos niveles y contextos educativos. Para entender estas tecnologías, resulta interesante el siguiente continuum mundo real-mundo virtual, donde se refleja la carga de los inputs pertenecientes al mundo real o al virtual (Figura 1).

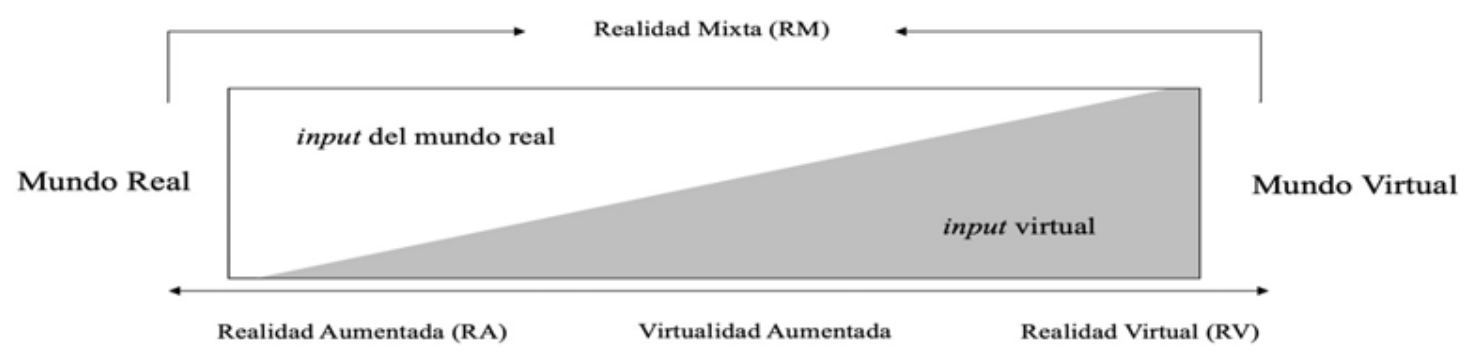

Figura 1. Continuum de realidades mundo real-mundo virtual (Huertas-Abril, 202Ob)

Las tecnologías objeto de nuestro estudio no deben confundirse: su diferencia fundamental radica en que la RV permite la inmersión del usuario de modo que no tenga acceso al mundo real, mientras que la RA permite al usuario ver el mundo real al que se le superponen elementos virtuales.

A pesar de sus aplicaciones didácticas, son limitadas las investigaciones en el ámbito de la educación bilingüe (EB) y la enseñanza del inglés como lengua extranjera (EFL) y, además, no hay estudios que comparen las percepciones sobre RA y RV entre profesorado millennial y post-millennial. El presente estudio cualitativo de carácter exploratorio tiene como objetivo comprender y analizar las percepciones de docentes sobre las posibles ventajas, limitaciones y aplicaciones de la RA y la RV en la enseñanza EFL y en EB, prestando especial atención a las diferencias existentes entre los docentes pertenecientes a la generación Y (millennials) y la generación Z (post-millennials).

\section{Método}

Para llevar a cabo el presente estudio, se optó por realizar un estudio cualitativo de carácter exploratorio. La investigación cualitativa permite examinar en detalle las opiniones y las experiencias de los participantes a fin de dar sentido o interpretar los fenómenos de acuerdo con el significado y el sentido que los participantes les otorgan (Denzin y Lincoln, 2017). Asimismo, y de acuerdo con Wallhagen y Yamamoto-Mitani (2006), este enfoque es de utilidad cuando se dispone de datos limitados y se busca obtener una comprensión más profunda de los fenómenos que la que permiten los métodos puramente cuantitativos. 


\section{Descripción del contexto y de los participantes}

La población objetivo de este estudio exploratorio fueron docentes en formación permanente cursando la asignatura "Language Teaching in the 21st Century: Collaborative Learning, Educational Guidance, and Design Thinking", asignatura del perfil profesional del Máster Universitario en Estudios Ingleses Avanzados (Lingüística Cognitiva/Literatura) y Educación Bilingüe de la Universidad de Córdoba (España), durante el año académico 2019/2020.

Mediante un muestreo no probabilístico por conveniencia se conformó una población objetivo de 11 personas, con criterios de selección basados en la proximidad y la participación en la asignatura, con la siguiente distribución grupal: todas las participantes eran mujeres, docentes de EFL y/o EB, y con una edad media de 25,91 años (rango: 23-32). Considerando los objetivos del estudio, se tuvo en cuenta si las participantes eran millennials (generación Y) o post-millennials (generación Z), tomando como referencia la fecha límite establecida por el Pew Research Center (Dimock, 2019): 1996. Concretamente, el 54,54 \% de las participantes eran millennials y el $45,45 \%$ eran post-millennials.

\section{Instrumento}

Para la recopilación de datos, se utilizó como instrumento una entrevista estructurada que constaba de tres preguntas de respuesta abierta sobre la utilidad de la RA y la RV para la EB y EFL. Las preguntas fueron las siguientes: (i) ¿Cuáles son las ventajas y las limitaciones del uso de la realidad aumentada en el aula EFL y de EB?; (ii) ¿Cuáles son las ventajas y las limitaciones del uso de la realidad virtual en el aula EFL y de EB?; y (iii) ¿Qué aplicaciones móviles, enfoques y actividades integrarías en tu aula EFL o EB basadas en realidad aumentada y en realidad virtual?

El diseño del instrumento se basó en los conocimientos de los investigadores sobre RA y RV, las características de las encuestadas, los recursos disponibles y el plazo necesario para informar de los resultados del estudio (Dillman et al., 2014). Posteriormente, el instrumento fue validado por tres expertos en el ámbito de la investigación del presente estudio (tecnología educativa, enseñanza del inglés como lengua extranjera y formación del profesorado) mediante el método Delphi (Keeney et al., 2006). El uso del instrumento elegido es adecuado para estudiar las percepciones de docentes en activo sobre el uso de la RA y la RV puesto que, como señala Seidman (2006), las entrevistas son una herramienta de investigación flexible y exploratoria que permite obtener información profunda y subjetiva sobre la experiencia de los individuos y explorar las dimensiones personales, algo que no sería posible utilizando ningún otro método de recogida de datos.

\section{Procedimiento}

Las entrevistas se desarrollaron en línea, a través de la plataforma Moodle de la Universidad de Córdoba, y en lengua inglesa. Se pidió a las participantes que respondieran a las preguntas en el plazo de una semana y no se estableció ningún límite de palabras para sus respuestas. Una vez recogidas todas las respuestas, la codificación y el análisis de las respuestas de las participantes se realizaron con el software NVivo 12 Plus para Windows. Las categorías iniciales para el análisis se derivaron de una revisión de la literatura sobre las expectativas y percepciones de profesorado y 
alumnado sobre la utilidad de la RA y la RV para la EB y de lenguas extranjeras, sus posibles aplicaciones, fortalezas y debilidades, entre las que se pueden mencionar las siguientes: Akçayır y Akçayır, 2017; Chou y Hoisington, 2018; Cooper et al., 2019; o Huertas-Abril et al., 2021, entre otros. Algunas de las categorías identificadas inicialmente se adecuaban a los datos y, por lo tanto, se tuvieron en cuenta para el estudio o se incluyeron en categorías más amplias (por ejemplo, la posibilidad de explorar lugares inaccesibles se consideró parte de una categoría más amplia relacionada con las implicaciones educativas y las actividades que utilizan la RA y la $\mathrm{RV}$, mientras que las dificultades técnicas se clasificaron como parte de la categoría relativa a las limitaciones). Por otra parte, otras categorías identificadas a priori se descartaron por no encontrarse en las respuestas de las participantes en el presente (por ejemplo, las dificultades de uso de los estudiantes).

Las categorías se reexaminaron y redefinieron mediante el análisis exhaustivo de las entrevistas para garantizar que las categorías de codificación se dirigieran a partir de los datos y no solo se determinaran a partir de investigaciones previas (Dörnyei, 2007), y siempre teniendo presentes las preguntas de investigación de este estudio. Además, se siguió el análisis temático, basado en la Teoría Fundamentada o Grounded Theory (Glaser y Strauss, 1967), al analizar los datos recogidos para determinar las relaciones precisas entre las participantes y, en última instancia, para codificar y categorizar los datos en temas (Alhojailan, 2012; Braun y Clarke, 2006). Al presentar los resultados, se ha prestado especial atención a las diferencias generacionales entre las participantes. Por último, la metodología y los resultados fueron evaluados de forma independiente por cada uno de los investigadores participantes en este estudio mediante la lista de verificación Consolidated Criteria for Reporting Qualitative Studies (COREQ) (Tong et al., 2007).

\section{Resultados}

En los siguientes apartados se presentan los principales resultados obtenidos tras el análisis de contenido, organizados en torno a tres grandes categorías: (1) Percepciones sobre ventajas de la RA y la RV, (2) Percepciones sobre limitaciones de la RA y la RV, y (3) implicaciones educativas, actividades y aplicaciones móviles.

\section{Percepciones sobre ventajas de la RA y la RV}

Dentro de las ventajas de la RA y la RV, se identificaron tres subcategorías clave: para el alumnado, para el proceso de aprendizaje y para el proceso de enseñanza.

En primer lugar, en cuanto los beneficios para el alumnado, se identificaron cuatro tipos de ventajas. La primera hacía referencia a las ventajas académicas de la aplicación de la RA y la RV en el aula bilingüe y de EFL, destacando especialmente el desarrollo de competencias y de las habilidades lingüísticas:

[La RA y la RV] desarrollan las competencias digitales y comunicativas [del alumnado] y es realmente significativa para la educación bilingüe. Gracias a la tecnología, [el alumnado] participará de manera frecuente, se facilita el trabajo colaborativo, y se fomentan la interacción y las competencias lingüísticas (Participante 11) 
La segunda subcategoría hacía referencia a los beneficios psicológicos para el alumnado, donde se destaca que la RA puede ayudar al alumnado a ser más creativos y a desarrollar su imaginación.

La tercera subcategoría, que aborda las ventajas afectivas de la aplicación de la RA y la RV, fueron las más señaladas por las participantes. En el caso de la RA, se contabilizaron cuatro temas: (i) hace que el aprendizaje sea más divertido para los estudiantes, (ii) ayuda a reducir el filtro afectivo de la lengua, (iii) aumenta la motivación del alumnado, y (iv) desarrolla la autoestima del alumnado. En cuanto a la $\mathrm{RV}$, se mencionaron dos de estos aspectos: (i) contribuye a reducir el filtro afectivo de la lengua y (ii) aumenta la motivación del alumnado.

Su uso en clase proporcionará a los docentes una poderosa herramienta para motivar al alumnado. Al utilizarlas, captamos fácilmente la atención y la curiosidad de nuestros alumnos. [...] En consecuencia, se sentirán motivados y abiertos a adquirir tanto nuevos conceptos como la lengua; en otras palabras, bajarán su filtro afectivo (Participante 2)

Atendiendo a las diferencias entre generaciones, parece haber una cierta tendencia entre las participantes millennials a considerar que la RA contribuye a reducir el filtro afectivo y a mejorar la autoestima de los estudiantes (no mencionada por los post-millennials); algo que también ocurre con la contribución de la RV a la mejora de la motivación del alumnado. Por otro lado, se encontraron discrepancias en relación con el poder de la RA para crear un entorno más agradable para el aprendizaje; este factor de "diversión" no fue considerado por los millennials:

El uso de aplicaciones de RA podría crear un ambiente relajado y agradable para que los estudiantes aprendan, ya que es una forma divertida de entender fácilmente los contenidos, [...] podrían disminuir las emociones negativas a la hora de aprender, como la ansiedad, la ira o la frustración, haciendo que el aprendizaje sea atractivo y estimulante (Participante 6)

La cuarta ventaja identificada para el alumnado implica una variedad de beneficios como la mejora de la actitud de los estudiantes hacia el aprendizaje y su aplicación práctica, es decir, la facilidad para utilizar las tecnologías porque los estudiantes están familiarizados con ellas. Sin embargo, cabe destacar que el hecho de que los alumnos tengan una experiencia interactiva solo se mencionó en relación con la RA, mientras que la familiarización con la tecnología solo se consideró como ventaja de la RV. Atendiendo a la comparación entre generaciones, se observaron diferencias relevantes en cuanto a la contribución de la RA a la actitud de los estudiantes hacia el aprendizaje y a la aplicación práctica, que solo fueron considerada por las docentes millennials. Del mismo modo, solo las participantes post-millennials mencionaron la experiencia interactiva derivada del uso de la RV.

En cuanto a las ventajas para el proceso de aprendizaje, no se encontraron muchas diferencias entre la RA y la RV con respecto a sus beneficios para el aprendizaje de lenguas y la educación bilingüe. Los resultados arrojan que tanto la RA como la RV promueven un aprendizaje eficaz, pueden adaptarse a los diferentes estilos de aprendizaje, fomentan la educación inclusiva y contribuyen a un aprendizaje significativo que se basa en experiencias y entornos del mundo real. 
Su integración en las aulas puede mejorar la calidad del aprendizaje de los estudiantes [...] Además, puede promover la educación inclusiva, junto con las capacidades de los estudiantes para experimentar nuevas oportunidades de aprendizaje. En otras palabras, este tipo de aprendizaje puede ser muy útil para los alumnos con dificultades lingüísticas (Participante 8)

La contribución al aprendizaje multimodal también recogió en las respuestas, concretamente haciendo referencia al aprendizaje activo, al aprendizaje colaborativo y al aprendizaje basado en juegos. Sin embargo, las respuestas parecen ser más exhaustivas en relación con la RA, pues también se hizo referencia a cómo esta técnica puede combinarse con el aprendizaje basado en proyectos e incluso a su relación con la Teoría de las Inteligencias Múltiples. El hallazgo más significativo en esta subcategoría se refiere al potencial de la RV para salvar las barreras lingüísticas; no obstante, este no parece ser una característica relevante de la RA, pues ninguna de las docentes lo mencionó en sus respuestas. En este sentido, las participantes afirmaron que los entornos de RV pueden ofrecer las mismas posibilidades de comunicación al alumnado, sea cual sea su origen cultural.

El uso de la RV en las clases de lenguas garantiza que no haya barreras lingüísticas. Esto se debe a la variedad de escenarios lingüísticos y culturales a los que pueden enfrentarse los alumnos (Participante 6)

Cabe destacar que las docentes millennials dieron más importancia que las post-miIlennials a que la RA y la RV ofrecen un entorno de aprendizaje activo, colaborativo y basado en proyectos, así como a sus posibilidades de adaptación a los diferentes estilos de aprendizaje del alumnado. La contribución de la RV a la reducción de las barreras lingüísticas fue reconocida casi por igual por ambas generaciones. Asimismo, todas las participantes post-millennials prestaron atención a cómo la RA y la RV fomentan el aprendizaje significativo al conectar con experiencias y situaciones de la vida real, valorando que pueden ayudar al alumnado a crear una imagen visual de los contenidos.

Atendiendo a las ventajas percibidas de la RA y la RV en relación con los procesos de enseñanza, se destaca que esta tecnología proporciona al profesorado una gran variedad de herramientas que pueden mejorar su desempeño docente.

La RV y la RA nos ofrecen un amplio abanico de oportunidades para incluirlas en nuestro trabajo diario en el aula, fomentando y dotando a nuestros alumnos de un aprendizaje significativo y centrado en el alumno, donde los niños sean los protagonistas de su aprendizaje (Participante 10)

Junto con lo anterior, esta subcategoría parece haber implicado más diferencias entre la RA y la RV que las anteriores. Por ejemplo, se mencionó de manera recurrente que la RV es una gran herramienta de andamiaje para el aula bilingüe y de $E F L$, mientras que en relación con la RA fue una respuesta más residual. Además, también se mencionaron las posibilidades de la RV para explorar y llevar a las aulas lugares y experiencias inaccesibles de otro modo.

Resulta interesante señalar que solo las docentes post-millennials consideraron que la RA puede funcionar como complemento de otras técnicas educativas, y defienden que este tipo de recursos es ecológico y más asequible que otros métodos de 
enseñanza. Por el contrario, solo las docentes millennials reconocieron el potencial de andamiaje de la RA. Finalmente, las millennials tienden a prestar más atención a la posibilidad que ofrece la RV para llevar a las aulas lugares y experiencias inaccesibles de otro modo, así como a sus posibilidades de andamiaje.

\section{Percepciones sobre limitaciones de la RA y la RV}

Dentro de las limitaciones de la RA y la RV, se identificaron tres subcategorías: para el alumnado, para el profesorado y para los procesos de enseñanza-aprendizaje.

En cuanto al alumnado, se destacaron cuatro limitaciones fundamentales: la disminución de las interacciones sociales, la adicción al uso de la tecnología, el peor desarrollo de las destrezas escritas y la limitada competencia digital del alumnado.

[Las aplicaciones de RA y RV] son muy adictivas y reducen la conexión con otros estudiantes. Es necesario mantener y desarrollar la socialización y a veces esta tecnología hace que los alumnos se encierren en símismos. Los profesores tienen que mantener la atención y guiarlos de forma correcta (Participante 11)

Se encontraron diferencias entre las generaciones en relación con la adicción: mientras que las post-millennials consideran que el alumnado podría volverse adicto cuando utilizaba RA, las millennials tenían esta percepción con la RV. Del mismo modo, con respecto a las interacciones sociales de los estudiantes, solo las docentes post-millennials afirmaban que podían verse afectadas por la RA, mientras que tanto millennials como post-millennials lo consideraban para la RV. Además, solo las millennials hacen referencia a la necesidad de desarrollar la competencia digital del alumnado, mientras que las post-millennials no consideraban que esta pudiera ser una limitación.

En cuanto a las limitaciones para el profesorado, se desveló una idea clave: la falta de formación del profesorado en este campo era una de las principales limitaciones para llevar a cabo una implementación eficaz de la RA y la RV en el aula bilingüe y de EFL.

Para trabajar con estas tecnologías, los docentes deben estar formados sobre cómo usarlas (Participante 3)

Asimismo, las participantes también mencionaron la frustración y el agotamiento de los docentes como una limitación. En este sentido, se mencionó que, puesto que el alumnado no siempre tiene una actitud positiva, los resultados pueden no ser los esperados y, como consecuencia, los docentes podrían cansarse o frustrarse al tratar de integrar esta tecnología en su aula. Sin embargo, esto fue solo recogido en las respuestas de las docentes post-millennials.

La mayoría de las limitaciones a la hora de integrar la RA y la RV en el aula bilingüe y de EFL estaban relacionadas con el proceso de enseñanza/aprendizaje. En este sentido, las participantes identificaron distintas limitaciones al referirse a la RA: la falta de disponibilidad de recursos, incluida la conexión a internet, las interrupciones en el aula, los posibles peligros del uso de la tecnología y la necesidad de que los docentes se aseguren de controlar su uso, el coste y la falta de financiación, los problemas técnicos y las limitaciones de tiempo. 
Como primer requisito, necesitamos un dispositivo digital y luego una buena conexión a internet para empezar a trabajar [...]. No es fácil implantar la RA en nuestra aula por cuestiones de tiempo y presupuesto. El tiempo es un factor importante al que hay que prestar atención (Participante 4)

Con respecto a las diferencias entre las generaciones, una mayor proporción de docentes millennials dio más importancia a las cuestiones técnicas. Por otro lado, las docentes post-millennials prestaron más atención a las interrupciones en el aula. Se encontraron importantes discrepancias en cuanto a las percepciones sobre la disponibilidad de recursos, la financiación limitada y el coste, lo que sugiere que las docentes post-millennials son más conscientes de las disparidades entre los centros educativos y del hecho de que no todos ellos pueden apoyar económicamente la compra de dispositivos.

\section{Implicaciones educativas, actividades y aplicaciones móviles}

Las participantes hicieron referencia a distintas aplicaciones de RA y RV que introducirían en su aula bilingüe o de EFL, entre las que destacan Quiver Vision (app de RA que permite animar en 3D imágenes que han coloreado previamente, especialmente útil para Educación Primaria), MEL Chemistry VR (app de RV en la que se explican fácilmente conceptos complejos de química), ImmerseMe (app que permite a los usuarios trasladarse virtualmente a lugares auténticos para aprender idiomas, mejorando la fluidez y la precisión en escenarios de la vida real), Google Expeditions (que permite experiencias tanto de RA como de RV en el aula) o Civilisations AR:

[Civilisations AR] es una potente aplicación que trabaja con realia y recursos auténticos, y es útil para las clases bilingües de Primaria y Secundaria ya que, por ejemplo, permite explorar una momia cuando se aprende sobre Egipto en clase (Participante 2)

Las participantes también propusieron aplicaciones de la RA y la RV que podrían mejorar el aprendizaje de idiomas. Por una parte, el uso de la RA puede ser útil para aprender palabras difíciles en 3D, ayudando así al alumnado a aprender cómo se escriben o pronuncian.

Phonic Tricksters utiliza un juego divertido e innovador en el que los usuarios deben atrapar pequeños monstruos a los que les gusta robar letras y sonidos. Con esta aplicación de RV, los estudiantes de idiomas aprenden fonética y escritura mientras juegan. Catchy Words AR es un juego en el que los jugadores deben caminar para atrapar las letras que faltan con su teléfono móvil para componer palabras. Es una herramienta sencilla y educativa para los niños que les permite aprender mientras exploran su entorno (Participante 6)

Por otra parte, con respecto a la RV se destaca la posibilidad de explorar lugares reales más allá de las paredes del aula que, de otra forma, serían inaccesibles para el alumnado.

Sería interesante una actividad en la que los alumnos se trasladaran a una ciudad real de habla inglesa y tuvieran que relacionarse con la gente, preguntarles por una dirección, ir de compras... Practicarían la conversación, los diferentes acentos y la cultura del país "visitado" (Participante 3) 


\section{Discusión y conclusiones}

El aumento de los estudios sobre el potencial didáctico de la realidad aumentada (RA) y de la realidad virtual ( $R V$ ) en distintos niveles y contextos educativos pone de manifiesto el interés que está despertando en los últimos años. Sin embargo, hasta la fecha son limitadas las publicaciones en el ámbito de la EB y la EFL (Huertas-Abril, 2020a) y, hasta donde los autores saben, no hay estudios que comparen las percepciones sobre RA y RV entre profesorado millennial y post-millennial.

En relación con las ventajas que la RA y la RV proporcionan al proceso de enseñan$z a$, los resultados de este estudio están en línea con investigaciones previas (Huang et al., 2019). Esto también ocurre con la referencia al uso de esta tecnología educativa atendiendo a los distintos estilos de aprendizaje, como puede ser su vinculación con el aprendizaje basado en proyectos (Gorham et al., 2018) o con la Teoría de las Inteligencias Múltiples (Tulgar, 2019). Encontramos una situación similar en el caso de las limitaciones, puesto que algunas de ellas corresponden con estudios previos; tal sería el caso del coste (Al-Azawi et al., 2019), las dificultades técnicas y el tiempo necesario (Huertas-Abril et al., 2021) y la frustración del docente si no funciona de manera adecuada (Redondo et al., 2020).

Resulta interesante que una de las diferencias más destacables entre ambas generaciones radica en el hecho de que las docentes post-millennials identifican con mayor frecuencia que las millennials que esta tecnología proporciona una experiencia interactiva. Esto sugiere que las personas nacidas después de 1996 pueden estar más familiarizadas y ser más exigentes con tecnologías que les proporcionan un entorno interactivo, puesto que como señala Teo (2016, p. 1729) "digital natives crave interactivity and immediate response thus lacking in tolerance to an environment that lacks this speed and interactivity". No obstante, ambas generaciones coinciden en que la falta de formación del profesorado en este campo es una de las principales limitaciones para llevar a cabo una implementación eficaz de la RA y la RV, al igual que se señala en el estudio de Simmons-Estes (2019). De manera más específica, Kozlova y Priven (2015) reflexionan sobre la escasez de investigaciones centradas en los conocimientos y habilidades que deben adquirir los educadores para una instrucción eficaz basada en la tecnología y animan a las universidades a incluir en los planes de estudio no solo las competencias pedagógicas, sino también las tecnológicas.

A pesar de las diferencias percibidas entre las docentes millennials y post-millennials, no cabe duda de que la actitud proactiva del profesorado, consciente de los beneficios que pueden aportar la RA y la RV al aula bilingüe y de EFL, puede ayudar a superar las limitaciones y dificultades que pudieran surgir con su uso. Así, y a tenor de lo expuesto anteriormente, consideramos que nos encontramos en un momento propicio para dar un impulso a estas tecnologías en la formación permanente del profesorado, de modo que puedan llevar la RA y la RV a las aulas de EFL y de EB de manera provechosa y satisfactoria.

\section{Referencias}

Akçayır, M., y Akçayır, G. (2017). Advantages and challenges associated with augmented reality for education: A systematic review of the literature. Educational Research Review, 20, 1-11. https://doi.org/10.1016/j.edurev.2016.11.002 
Al-Azawi, R., Albadi, A., Moghaddas, R., y Westlake, J. (2019). Exploring the potential of using augmented reality and virtual reality for STEM education. En L. Uden, D. Liberona, G. Sánchez, y S. Rodríguez-González (Eds.), Communications in computer and information science (vol. 1011, pp. 36-44). Springer.

Alhojailan, M. I. (2012). Thematic Analysis: A critical review of its process and evaluation. West East Journal of Social Sciences-December, 1(1), 39-47. https://bit. Iy/2ESXFIx

Braun, V., y Clarke, V. (2006). Using thematic analysis in psychology. Qualitative Research in Psychology, 31(2), 77-101. https://doi.org/10.1191/1478088706ap063oa

Chou, C. C., y Hoisington, D. A. (2018). Promises and constraints of virtual reality integration: perceptions from pre-service teachers and $\mathrm{K}-12$ students. En M. Chang, N.-S. Chen, R. Huang, K. Kinshuk, K. Moudgalya, S. Murthy, y D. G. Sampson (Eds.), 2018 IEEE 18th International Conference on Advanced Learning Technologies (pp. 361-363). IEEE.

Cooper, G., Park, H., Nasr, Z., Thong, L. P., y Johnson, R. (2019). Using virtual reality in the classroom: Preservice teachers' perceptions of its use as a teaching and learning tool. Educational Media International, 56(1), 1-13. https://doi.org/10.1080/09523987. 2019.1583461

Denzin, N. K. y Lincoln, Y. S. (Eds.). (2017). The SAGE handbook of qualitative research (5. ${ }^{\mathrm{a}}$ ed.). SAGE.

Dillman, D. A., Smyth, J. D., y Christian, L. M. (2014). Internet, phone, mail, and mixed-mode surveys. The tailored design method (4th ed.). John Wiley \& Sons.

Dimock, M. (2019). Where millennials end and Generation $Z$ begins. https://pewrsr. ch/2QggQux

Dörnyei, Z. (2007). Research methods in applied linguistics: Quantitative, qualitative, and mixed methodologies. Oxford University Press.

Glaser, B. y Strauss, A. (1967). The discovery of grounded theory. Aldine Press.

Gorham, T., Gorham, J., \& Courtney, M. W. (2018). Virtual embodiment and project-based learning with Google Earth VR. PanSIG Journal, 17, 91-98.

Huang, K.-T., Ball, C., Francis, J., Ratan, R., Boumis, J., y Fordham, J. (2019). Augmented versus virtual reality in education: An exploratory study examining science knowledge retention when using augmented reality/virtual reality mobile applications. Cyberpsychology, Behavior, and Social Networking, 22(2), 105-110.

Huertas-Abril, C. A. (2020a). Estudio sobre el uso de la Realidad Aumentada para la enseñanza del inglés como lengua extranjera y para la educación bilingüe. En E. López-Meneses, D. Cobos-Sanchiz, L. Molina-García, A. Jaén-Martínez y A. H. Martín Padilla (Eds.), Claves para la innovación pedagógica ante los nuevos retos. Respuestas en la vanguardia de la práctica educativa (pp. 1564-1573). Octaedro. 
Huertas-Abril, C. A. (2020b). Tecnologías para la educación bilingüe. Peter Lang.

Huertas-Abril, C. A., Figueroa-Flores, J. F., Gómez-Parra, M. E., Rosa-Dávila, E., y Huffman, L. F. (2021). Augmented reality for ESL/EFL and bilingual education: An international comparison. Educación XX1, 24(2), 189-208.

Keeney, S., Hasson, F., y McKenna, H. (2006). Consulting the oracle: Ten lessons from using the Delphi technique in nursing research. Journal of advanced nursing, 53(2), 205-212.

Kozlova, I., y Priven, D. (2015). ESL teacher training in 3D virtual worlds. Language Learning \& Technology, 19(1), 83-101.

Redondo, B., Cózar-Gutiérrez, R., González-Calero, J. A., y Sánchez, R. (2020). Integration of augmented reality in the teaching of english as a foreign language in early childhood education. Early Childhood Education Journal, 48, 147-155. https:// doi.org/10.1007/s10643-019-00999-5

Seidman, I. (2006). Interviewing as Qualitative Research. A Guide for researchers in education and the social sciences (3rd ed.). Teachers College Press.

Simmons-Estes, J. (2019). A call for teacher preparation programs to model technology integration into the instructional process. En Information Resources Management Association (Ed.), Pre-service and in-service teacher education: Concepts, methodologies, tools, and applications (pp. 1442-1458). IGI Global.

Teo, T. (2016). Do digital natives differ by computer self-efficacy and experience? An empirical study. Interactive Learning Environments, 24(7), 1725-1739.

Tong, A., Sainsbury, P., y Craig, J. (2007). Consolidated criteria for reporting qualitative research (COREQ): A 32-item checklist for interviews and focus groups. International Journal for Quality in Health Care, 19(6), 349-357. https://doi.org/10.1093/ intahc/mzm042

Tulgar, A. T. (2019). In between reality and virtuality: Augmented reality in teaching english to young learners. Selçuk Üniversitesi Sosyal Bilimler Enstitüsü Dergisi, 41, 356-364. https://bit.ly/2Qr22t4

Wallhagen, M. I., y Yamamoto-Mitani, N. (2006). The meaning of family caregiving in japan and the United States: A qualitative comparative study. Journal of Transcultural Nursing, 17(1), 65-73. https://doi.org/10.1177/1043659605281979 


\section{Telecolaboración y Formación del Profesorado de Educación Primaria Bilingüe: Estudio de las Percepciones de los Docentes}

Palacios-Hidalgo, Francisco J. https://orcid.org/0000-0002-4326-209X

Huertas-Abril, Cristina A.

https://orcid.org/0000-0002-9057-5224 


\title{
TELECOLABORACIÓN Y FORMACIÓN DEL PROFESORADO DE EDUCACIÓN PRIMARIA BILINGÜE: ESTUDIO DE LAS PERCEPCIONES DE LOS DOCENTES
}

\author{
Palacios-Hidalgo, Francisco J. \\ Huertas-Abril, Cristina A.
}

\section{Resumen}

La emergencia sanitaria provocada por la pandemia derivada de la COVID-19 ha supuesto que profesorado y alumnado deban enfrentarse a una serie de retos y demandas sin precedentes para garantizar la continuidad de la educación. En este contexto, la telecolaboración se ha erigido como una herramienta clave en los procesos de enseñanza-aprendizaje y así se observa en el creciente número de estudios publicados que analizan su potencial entre docentes en formación en cuanto al uso de habilidades comunicativas en lenguas extranjeras, al fomento de pensamiento crítico, al desarrollo de competencias y a la mejora de la integración de herramientas tecnológicas en el aula de lenguas y, en concreto, el aula bilingüe. Partiendo de una experiencia formativa de telecolaboración, este trabajo examina las percepciones de un grupo de futuros docentes de Educación Primaria bilingüe acerca de las posibilidades de la telecolaboración para su formación. Se utiliza una entrevista semiestructurada para la recogida de datos, así como la Teoría Fundamentada y el análisis de contenido como métodos cualitativos de análisis. Los resultados revelan que, pese a los problemas técnicos que pueden surgir, los docentes de Educación Primaria bilingüe en formación consideran que la telecolaboración tiene gran potencial para su futura labor como docentes.

\section{Palabras clave}

Actitudes del profesorado, formación de profesorado, telecolaboración, estudio cualitativo. 


\section{Introducción}

La pandemia provocada por el SARS-CoV-2 ha supuesto un aluvión de cambios en todas las esferas de la vida cotidiana. Las consecuencias de los inesperados estados de alarma decretados en los Estados del mundo han sido diversas, afectando no solo a la salud mental de los ciudadanos (González-Sanguino et al., 2021; Lavigne-Cerván et al., 2021), sino también al mercado laboral y a la forma de desarrollar las diferentes profesiones (Bell y Blanchflower, 2020; Okubo et al., 2020). En el ámbito educativo, la emergencia sanitaria también ha supuesto que profesorado y alumnado deban enfrentarse a una serie de retos y demandas sin precedentes. Así, tanto los docentes como la Administración se han visto obligados a buscar soluciones inmediatas para garantizar la continuidad de los procesos de enseñanza-aprendizaje. Sin embargo, esta adaptación no siempre ha sido algo sencillo debido a la dificultad de acceso a la tecnología en algunos casos y a las expectativas académicas (Whittle et al., 2020), así como a las poco ideales circunstancias para la enseñanza online (Hodges et al., 2020).

En este contexto, la telecolaboración se ha erigido como una herramienta clave en el ámbito educativo y así se observa en el creciente número de trabajos científicos publicados en el ámbito (Werneck-Barbosa y Ferreira-Lopes, 2021). Este tipo de colaboración en línea puede entenderse como la posibilidad de comunicarse con personas de contextos culturales o ubicaciones geográficas a través de medios digitales durante períodos prolongados de interacción (Çiftçi y Sava , 2018; O’Dowd, 2018). En este sentido, la literatura científica ha señalado su potencial para la formación de profesorado en cuanto al fomento de habilidades comunicativas en lenguas extranjeras (Bueno-Alastuey, 2013; Knipp-Silva y Bozhidar-Scarlota, 2021), al desarrollo de pensamiento crítico (Gajek y Calderón-Quindós, 2018), al desarrollo de competencias (Vinagre, 2016) y a la mejora de la integración de herramientas tecnológicas en el aula de lenguas y, en concreto, el aula bilingüe (Bueno-Alastuey et al., 2018). Además, son numerosos los estudios que analizan el potencial de la telecolaboración entre docentes en formación en el contexto de la crisis sanitaria causada por la COVID-19 (Eren, 2021; Huertas-Abril, 2020; Lawrence y Spector-Cohen, 2018; Sardegna y Dugartsyrenova, 2021).

Partiendo de una experiencia formativa de telecolaboración, este trabajo tiene como objetivo examinar las percepciones de un grupo de futuros docentes de Educación Primaria bilingüe acerca de las posibilidades de la telecolaboración para su formación. Para ello, se establecen dos preguntas de investigación: (1) ¿cómo percibe el profesorado de Educación Primaria bilingüe en formación la telecolaboración?; y (2) ¿cuáles son las ventajas y los inconvenientes de la telecolaboración según el profesorado de Educación Primaria bilingüe en formación?

\section{Método}

\section{Descripción del contexto y de los participantes}

La experiencia formativa se desarrolló en mayo de 2021 en el marco de la asignatura obligatoria de tercer curso "Idioma Extranjero para el Profesorado de Primaria (Inglés)", perteneciente al Grado en Educación Primaria y al Itinerario Conjunto en Educación Primaria y Estudios Ingleses de la Universidad de Córdoba (España). 
Esta consistió en el diseño de forma colaborativa de píldoras formativas en formato de vídeo en las que los futuros docentes debían explicar contenido de su elección perteneciente al área de inglés como lengua extranjera para alumnado de Educación Primaria. Debido al formato de enseñanza híbrida implantado en la Universidad de Córdoba durante el curso académico 2020/2021 como consecuencia de la COVID-19, los docentes debían idear formas de telecolaborar para lograr la creación de los vídeos. Tras la experiencia, los participantes respondieron una entrevista semiestructurada para conocer su opinión sobre la pertinencia y el potencial de la telecolaboración.

Mediante un muestreo no probabilístico por conveniencia se estableció la muestra, formada por 60 participantes, todos ellos de nacionalidad española, de los cuales $14(23,33 \%)$ fueron hombres y $46(76,67 \%)$ fueron mujeres, con una edad media de 20,37 años ( $D T=0,48$ ). Los criterios de selección se basaron en la proximidad y la participación en la experiencia formativa.

\section{Instrumento}

Tras la experiencia formativa, se administró una entrevista semiestructurada a la que los participantes debían responder de forma escrita. Esta constó de tres preguntas: (1) Como futuro docente, ¿qué opinas de la telecolaboración? ¿Te parece útil? ¿Por qué? / ¿Por qué no?; (2) ¿Crees que la telecolaboración es una buena forma de trabajar con otros docentes? ¿Por qué? / ¿Por qué no?; y (3) ¿Te ha beneficiado de alguna manera esta experiencia de telecolaboración? Si bien los participantes dieron consentimiento oral para participar en el estudio, las respuestas fueron anonimizadas para garantizar la confidencialidad.

\section{Procedimiento}

El estudio, de carácter exploratorio, siguió un enfoque cualitativo para el análisis de los datos. En primer lugar, se utilizó la Teoría Fundamentada para una comprensión inicial de las respuestas, un método sistemático inductivo, comparativo e interactivo que permite interrogar y conceptualizar los datos obtenidos (Charmaz y Henwood, 2017; Glaser y Strauss, 1967). Posteriormente, se llevó a cabo un análisis de contenido, una técnica de investigación que permite hacer inferencias de los textos a sus contextos de uso (Krippendorff, 2004), siguiendo las fases establecidas por Arbeláez-Gómez y Onrubia-Goñi (2014), a saber: pre-análisis, descripción-análisis e interpretación. En ambos casos, el análisis se realizó con Atlas.ti v.9.0.7 para macOS.

\section{Resultados}

Se seleccionaron un total de 208 referencias relevantes de las respuestas de los participantes. Utilizando la Teoría Fundamentada y realizando un análisis de los términos más utilizados, se derivaron seis categorías de codificación: (i) opinión sobre la telecolaboración, (ii) beneficios, (iii) desventajas, (iv) recomendaciones, (v) plataformas útiles, y (vi) otros aspectos. La Figura 1 muestra los términos más utilizados por los participantes, mientras que la Figura 2 presenta las seis categorías y su interrelación: 


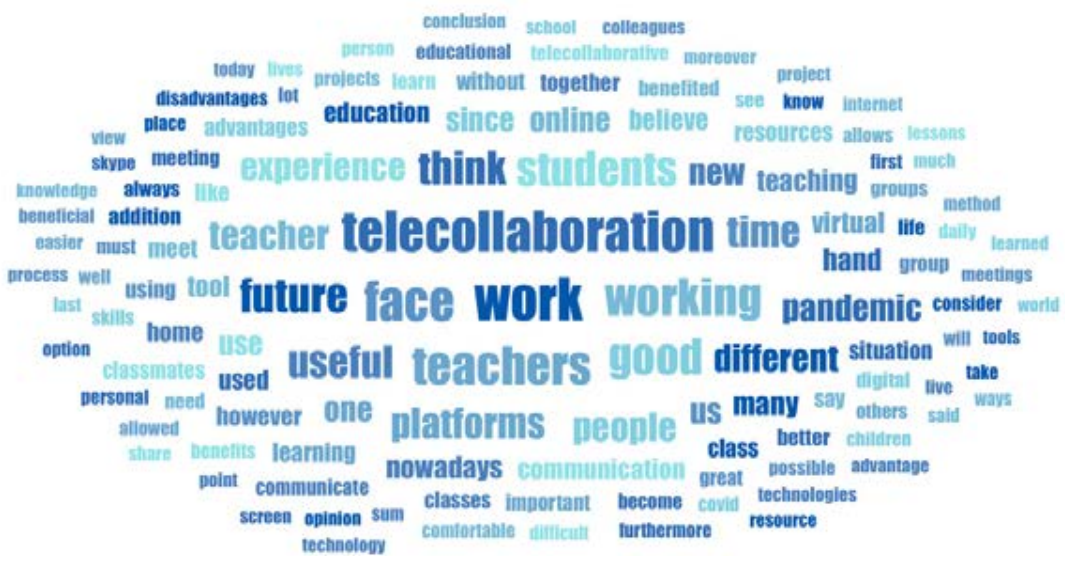

Figura 1. Términos más utilizados por los participantes. Fuente: Elaboración propia.

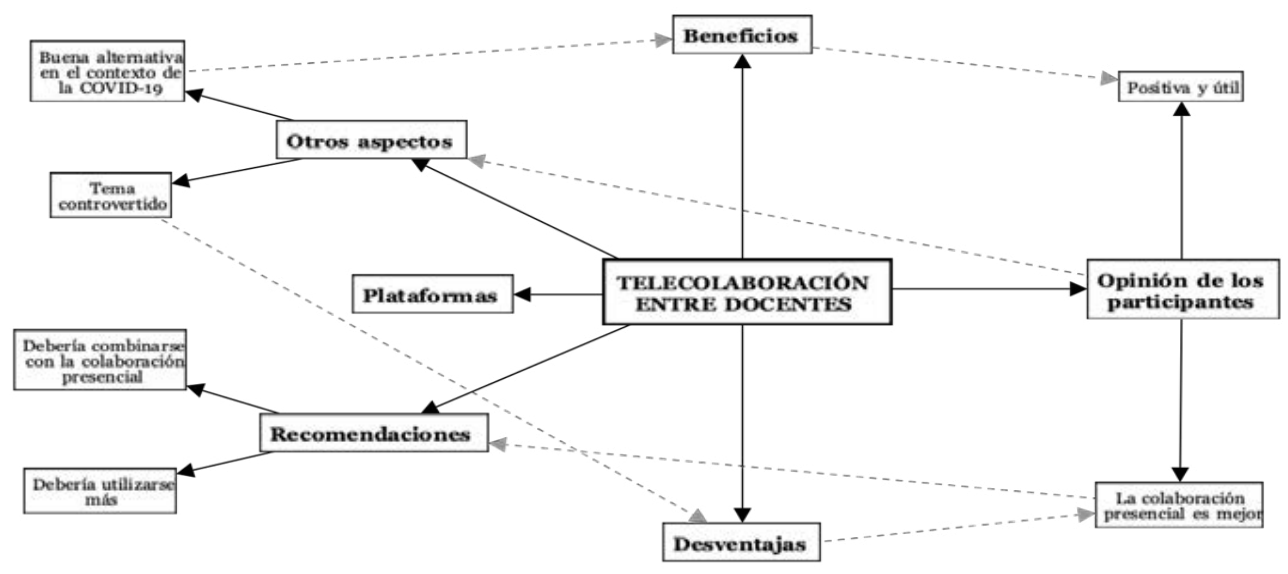

Figura 2. Categorías de codificación. Fuente: Elaboración propia.

Dentro de las seis categorías mencionadas, se identificaron un total de 45 temas, que se codificaron un total de 482 veces en las respuestas de los participantes. La Tabla 1 detalla las temáticas identificadas clasificadas por categorías: 


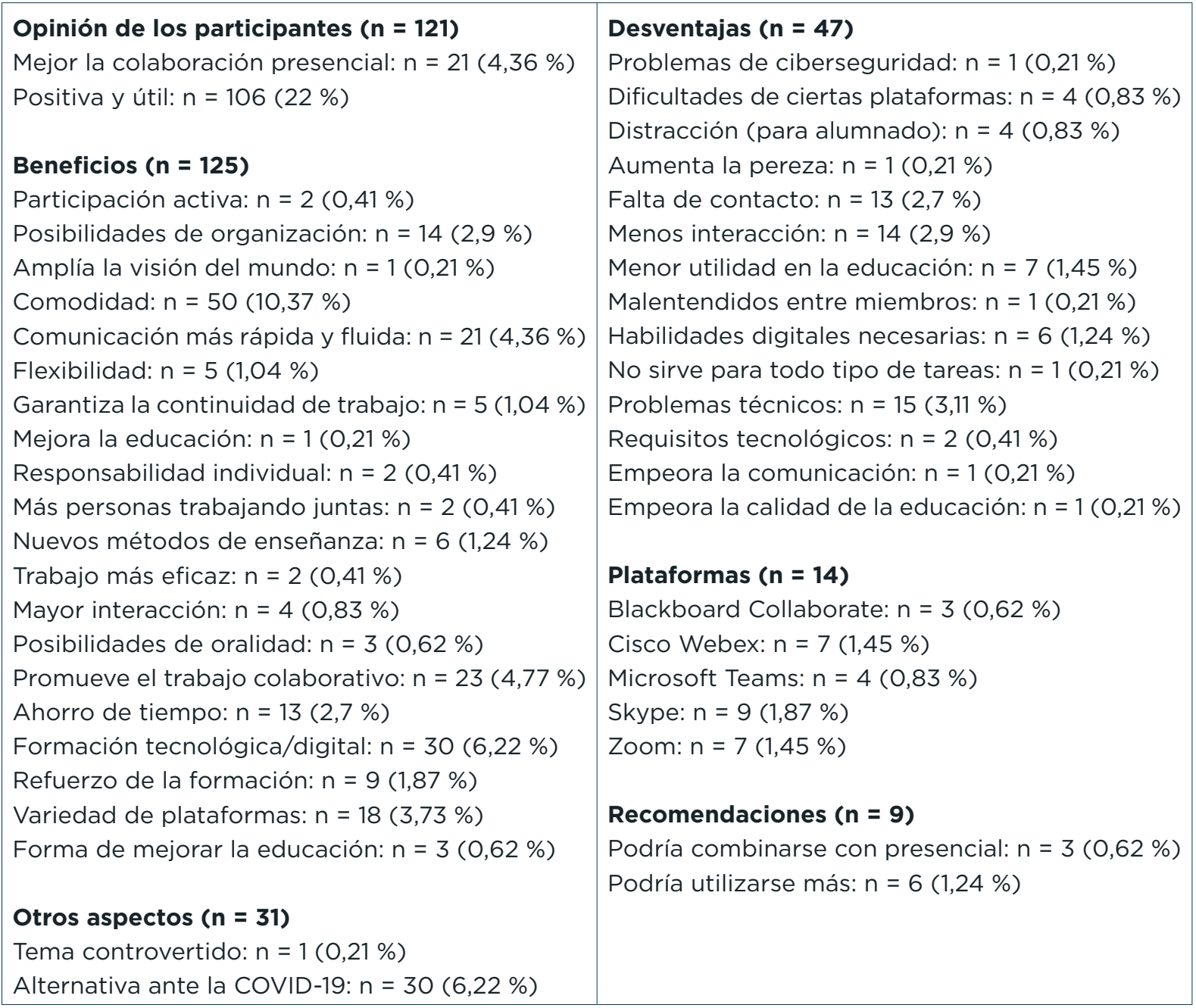

Tabla 1. Temáticas clasificadas por categoría. Fuente: elaboración propia.

Nota. Para cada temática se presenta la frecuencia y porcentaje de codificación.

En esta línea, la Figura 3 muestra un diagrama de Sankey que permite observar la contribución de las respuestas de los participantes a los principales temas identificados: 


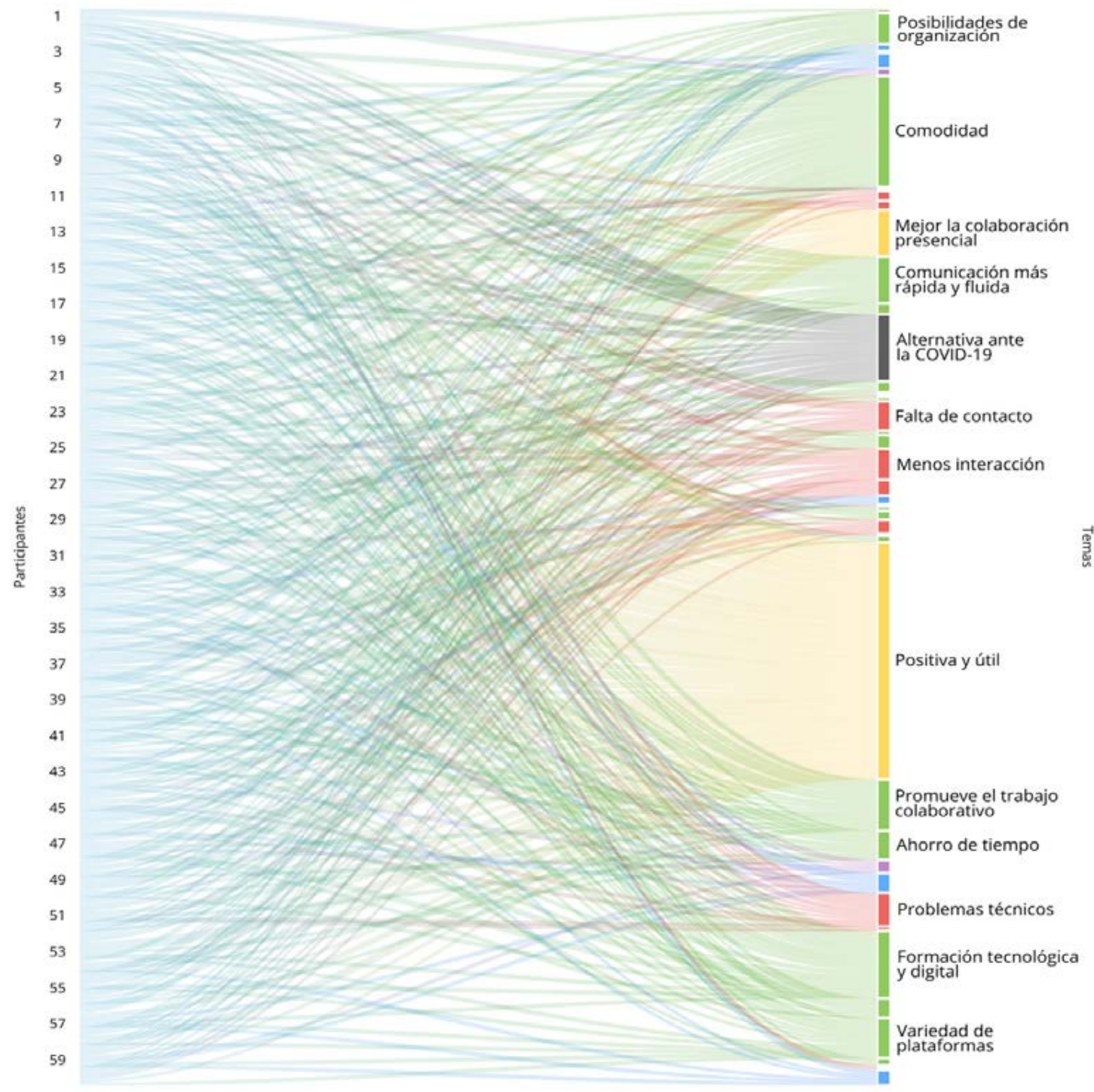

Figura 3. Diagrama de Sankey por principales temas identificados. Fuente: Elaboración propia.

A continuación, se detallan los principales resultados en torno a tres grandes temas: beneficios, desventajas y recomendaciones.

\section{Percepciones sobre los beneficios de la telecolaboración}

La mayoría de los entrevistados (53 participantes; 88,3 \%) considera que la telecolaboración con fines docentes es positiva y útil:

La telecolaboración es realmente útil en la actualidad. Ha mejorado enormemente no sólo los procesos de enseñanza-aprendizaje que se llevan a cabo en el aula, sino también el trabajo extraescolar. Podemos decir que nos gusta o no, pero lo que no podemos negar es que ha sido y es actualmente útil (Participante 27) 
En relación con las ventajas de la telecolaboración, las más recurrentes son: la comodidad en cuanto a la posibilidad de colaborar sin necesidad de desplazarse y sin tener limitaciones físicas (36 participantes, $60 \%$ ), la posibilidad de desarrollar la competencia digital y conocimientos relacionados con las nuevas tecnologías (25 participantes, 41,67\%), la promoción del trabajo colaborativo (22 participantes, $36,67 \%$ ) y la rapidez y fluidez en la comunicación (17 participantes, 28,33 \%):

Creo que el trabajo en grupo mediante el uso de plataformas virtuales es una alternativa original y útil para desarrollar habilidades tecnológicas y sociales. Considero que la telecolaboración es útil porque podemos aprender en base a una pedagogía no tradicional y, además, la comunicación puede ser entre personas que están distantes geográficamente entre sí. (Participante 51)

En la misma línea, también destacan entre las ventajas señaladas la variedad de plataformas online disponibles (18 participantes, $30 \%$ ), el hecho de que la telecolaboración ofrece mejores posibilidades de organización (14 participantes, 23,33 \%) y supone un refuerzo para su formación como docentes (9 participantes, $15 \%$ ):

Creo que [la telecolaboración] es una muy buena forma de trabajar en grupos cooperativos porque las plataformas que se suelen utilizar para ello nos ofrecen un amplio abanico de herramientas para trabajar, por ejemplo, compartir tu pantalla con el resto, pedir el turno de palabra o dividir en pequeños grupos de trabajo. (Participante 24)

[La telecolaboración] es una buena forma de trabajar con otros profesores porque tienen horarios más flexibles y evitan el desplazamiento a algún lugar. (Participante 63)

Aunque la telecolaboración falle de vez en cuando, creo que hemos adquirido muchas competencias, sobre todo tecnológicas, y como futuros profesores nos hemos visto obligados a mejorar, buscando nuevos recursos y formas de expresarnos. (Participante 14)

\section{Percepciones sobre las desventajas de la telecolaboración}

Una parte considerable de los entrevistados (19 participantes, 31,67 \%) opina que, si bien es una práctica beneficiosa en cuanto a la comodidad y flexibilidad que ofrece, es mejor la colaboración presencial:

La telecolaboración ha cambiado nuestra vida en general. Nos ha permitido comunicarnos mientras estamos en diferentes lugares y nos ha dado más libertad para adaptar el trabajo a nuestra rutina diaria. Por eso, como futura profesora, creo que este invento ha sido realmente útil. Sin embargo, me parece que la telecolaboración no siempre puede sustituir el trabajo presencial de los docentes. $Y$ es que a veces el trabajo con otros profesores y profesoras requiere un contacto personal. (Participante 61)

En cuanto a las principales desventajas asociadas a la colaboración en línea, los problemas técnicos asociados en cuanto a audio y conexión (14 participantes, 23,33\%) es la idea más destacada, tal y como señala una de las participantes: 
Las ventajas [de la telecolaboración] se ven mermadas cuando hay que conectarse vía telemática porque puede haber fallos de internet o cuando dos personas hablan a la vez, algo que puede ser muy estresante (Participante 2)

De forma similar, los docentes entrevistados también destacan entre las debilidades de la telecolaboración la limitada interacción frente a la colaboración presencial (13 participantes, 21,67\%) y la falta de contacto entre docentes (13 participantes, 21,67 \%):

La telecolaboración es más rápida que reunirse físicamente con mis compañeros [...]. Sin embargo, reconozco que la telecolaboración tiene algunos problemas asociados tales como la falta de contacto y de interacción cara a cara con los otros compañeros con los que queremos colaborar. (Participante 10)

Aunque en menor medida, los participantes también destacan la poca utilidad de la telecolaboración en el ámbito educativo frente a otros contextos laborales (7 participantes, $11,67 \%$ ), las habilidades digitales y tecnológicas necesarias para los docentes ( 6 participantes, $10 \%$ ) y las dificultades de uso de algunas plataformas (4 participantes, 6,67\%), lo que contrasta con ventaja que supone la variedad de plataformas disponibles.

La telecolaboración es útil cuando quieres trabajar en equipo porque puedes compartir el trabajo con tus compañeros. Sin embargo, no creo que sea muy útil para trabajar con otros profesores y profesoras porque no puedes hablar con ellos y ellas cara a cara. (Participante 48)

Hoy en día, estamos educados en tecnología, pero hace algún tiempo, nadie recibía esa formación. Por eso puede ser difícil para los profesores trabajar con ellos a través de ciertas apps por falta de conocimientos. (Participante 33)

[En el uso de plataformas digitales para telecolaborar] pueden surgir algunos problemas técnicos, como la conexión a internet o el difícil manejo de algunas plataformas. (Participante 25)

Finalmente, una de las participantes (1,67 \%) también menciona que esta práctica puede aumentar la pereza hacia el trabajo colaborativo:

Trabajar en grupo utilizando Skype o Microsoft Teams no es algo fácil, puesto que a veces puede haber malentendidos entre los miembros del grupo. Afortunadamente, después de un tiempo, los docentes hemos desarrollado algunas habilidades en el mundo de las TIC. Sin embargo, creo que me he vuelto más perezosa puesto que prestar atención a un ordenador durante 5 o 6 horas diarias es algo muy difícil. (Participante 39)

\section{Consideraciones adicionales y recomendaciones}

Además de los beneficios y dificultades asociados a la telecolaboración, algunos docentes entrevistados señalan otros aspectos que se deben tener en cuenta en el uso de esta metodología, así como algunas recomendaciones que podrían resultar útiles. En cuanto a los aspectos adicionales, destacan dos ideas: por una parte, el hecho de que la telecolaboración es una alternativa idónea a la colaboración física entre docentes en el contexto de la pandemia provocada por la COVID-19 (30 participantes, 
$50 \%)$; por otra parte, uno de los entrevistados (1,67\%) señala que no se puede obviar la controversia en torno a este tipo de colaboración:

Hoy en día, la telecolaboración está abarcando casi todos los campos de trabajo de la sociedad, incluido el educativo. En esta difícil situación, se ha convertido en un tema muy controvertido debido a todos los cambios a los que nos enfrentamos. [...] Sin embargo, creo que [la telecolaboración] es la opción más eficaz que tenemos para hacer frente a la situación de COVID-19 (Participante 19)

De forma similar, los participantes comparten dos sugerencias en cuanto al uso de la telecolaboración. Algunos de ellos (6 participantes, $10 \%$ ) indican que esta práctica debería utilizarse más y, de hecho, se muestran proclives a utilizarla más en el futuro:

Los centros escolares deberían promover la telecolaboración, pues esta beneficiaria a docentes y alumnado como ya se ha demostrado. (Participante 46)

Creo que en el futuro probablemente incluiría la telecolaboración en mi metodología docente como un nuevo tipo de trabajo para alumnos y alumnas y la promovería entre mis compañeros porque podría ser una buena oportunidad para renovar los métodos de enseñanza más tradicionales. (Participante 51)

Por otro lado, 3 participantes (5\%) recomiendan combinarla con la colaboración presencial como solución para conseguir un equilibrio entre los beneficios y las debilidades de ambas modalidades de colaboración en la formación de futuro profesorado:

La telecolaboración se ha convertido en una poderosa alternativa que ha evitado que el mundo deje de trabajar como consecuencia de la COVID-19. Sin embargo, creo firmemente que esta estrategia debe ser cuidadosamente coordinada con la comunicación presencial para conseguir un equilibrio entre los beneficios y las desventajas de ambos tipos de colaboración y tratar de utilizarlas de la manera más eficaz para todos. (Participante 53)

\section{Discusión y conclusiones}

Este estudio exploratorio ha buscado examinar las percepciones de futuros docentes de Educación Primaria bilingüe acerca de las posibilidades de la telecolaboración para su formación. De forma general, los resultados revelan que los futuros docentes de Educación Primaria bilingüe consideran que la telecolaboración es una práctica docente beneficiosa, coincidiendo con estudios previos que señalan que esta permite el desarrollo de competencias (Huertas-Abril, 2020; Vinagre, 2016). Entre las principales ventajas, los participantes señalan: (i) colaborar con otros docentes sin tener que desplazarse, (ii) desarrollar su competencia digital, (iii) aumentar su conocimiento sobre nuevas tecnologías, (iv) fomentar el trabajo colaborativo y (v) comunicarse rápidamente mediante la telecolaboración; algunas de las cuales también han sido identificadas por investigaciones similares previas (Eren, 2021; Huertas-Abril, 2020; Vinagre, 2016). De igual forma, la variedad de plataformas online que se pueden utilizar, las mejores posibilidades de organización y el potencial formativo de esta práctica también son mencionados por los entrevistados como ventajas de este tipo de colaboración, lo que está en sintonía con otros trabajos científicos que destacan los beneficios de la telecolaboración como una nueva experiencia formativa (Lawrence y Spector-Cohen, 2018). 
En contraposición, los problemas técnicos que pueden surgir, relacionados con la conexión y el audio, también destacan por dificultar el proceso de colaboración en línea, tal y como apuntan otras investigaciones (Lawrence y Spector-Cohen, 2018). En la misma línea, los participantes también señalan la limitación de la interacción y la falta de contacto entre los docentes que colaboran como debilidades, algo revelado en estudios similares como el desarrollado por Huertas-Abril (2020). En cualquier caso, la opinión generalizada entre los participantes es que la telecolaboración tiene gran potencial para la labor docente, como señala una de las participantes:

La telecolaboración es una forma ideal de trabajar con otros docentes porque amplía nuestra visión del mundo y nos permite intercambiar opiniones y visiones entre los diferentes sistemas educativos, así como las experiencias de cada uno de ellos. (Participante 22)

No obstante, estos resultados deberían interpretarse a la luz ciertas limitaciones. En primer lugar, puesto que se trata de un estudio exploratorio, se han seleccionado participantes de un único contexto (Universidad de Córdoba, España), por lo que las conclusiones pueden no ser extrapolables a otros entornos. En segundo lugar, los resultados cualitativos se basan en las autopercepciones de la muestra del estudio, por lo que estas pueden estar sesgadas por la subjetividad de los participantes. Futuros estudios deberían considerar ampliar la muestra a otros contextos y utilizar fuentes adicionales para la recogida de datos. En cualquier caso, el tamaño de la muestra y los resultados animan a seguir investigando acerca del potencial de la telecolaboración en el ámbito de la formación docente, una estrategia que, sin duda, tiene mucho que ofrecer a los profesionales de la educación.

\section{Referencias}

Arbeláez-Gómez, M. C. y Onrubia-Goñi, J. (2014). Análisis bibliométrico y de contenido. Dos metodologías complementarias para el análisis de la revista colombiana Educación y Cultura. Revista de Investigaciones UCM, 14(23), 14-31. https://bit.ly/31A2xbH

Bell, D. N. F. y Blanchflower, D. G. (2020). US and UK labour markets before and during the COVID-19 crash. National Institute Economic Review, 252, R52-R69. https:// doi.org/10.1017/nie.2020.14

Bueno-Alastuey, M. C. (2013). Interactional feedback in synchronous voice-based computer mediated communication: Effect of dyad. System, 41(3), 543-559. https:// doi.org/10.1016/j.system.2013.05.005

Bueno-Alastuey, M. C., Villarreal, I. y García-Esteban, S. (2018). Can telecollaboration contribute to the TPACK development of pre-service teachers? Technology, Pedagogy and Education, 27(3), 367-380. https://doi.org/10.1080/1475939X.2018.1471000

Charmaz, K., y Henwood, K. (2017). Grounded theory methods for qualitative psychology. En C. Willig y W. Stainton-Rogers (Eds.), The SAGE handbook of qualitative research in psychology (5a ed.) (pp. 240-260). SAGE. https://doi. org/10.4135/9781848607927.n14 
Çiftçi, E. Y. y Sava , P. (2018). The role of telecollaboration in language and intercultural learning: A synthesis of studies published between 2010 and 2015. ReCALL, 30(3), 1-21. https://doi.org/10.1017/S0958344017000313

Eren, Ö. (2021). Raising critical cultural awareness through telecollaboration: Insights for pre-service teacher education. Computer Assisted Language Learning, 1-24. https://doi.org/10.1080/09588221.2021.1916538

Gajek, E. y Calderón-Quindós, M. T. (2018). Developing a reflective practitioner through telecollaboration in language teacher preservice education - A bottom-up perspective. E-Mentor, 77(5), 44-52. https://doi.org/10.15219/em77.1388

Glaser, B. y Strauss, A. (1967). The discovery of grounded theory. Strategies for qualitative research. Aldine Press.

González-Sanguino, C., Ausín, B., Castellanos, M. A., Saiz, J. y Muñoz, M. (2021). Mental health consequences of the Covid-19 outbreak in Spain. A longitudinal study of the alarm situation and return to the new normality. Progress in Neuropsychopharmacology \& Biological Psychiatry, 107, 1-6. https://doi.org/10.1016/j. pnpbp.2020.110219

Hodges, C., Moore, S., Lockee, B., Trust, T. y Bond, A. (2020). The difference between emergency remote teaching and online learning. EDUCAUSE Review. https:// bit.ly/2DWKOYM

Huertas-Abril, C. A. (2020). Telecollaboration in emergency remote language learning and teaching. 2020 Sixth International Conference on E-Learning (Econf), 8791. https://doi.org/10.1109/ECONF51404.2020.9385425

Knipp-Silva, R. y Bozhidar-Scarlota, N. (2021). Breaking language and cultural barriers: A case study in telecollaboration at an EFL class in higher education. Revista de Estudios y Experiencias en Educación, 20(42), 401-416. https://doi.org/10.21703/ rexe. $20212042 \mathrm{knipp} 23$

Krippendorff, K. (2004). Content analysis: An introduction to its methodology (2 ${ }^{\text {a }}$ ed.). SAGE. https://bit.ly/2NROV5i

Lavigne-Cerván, R., Costa-López, B., Juárez-Ruiz de Mier, R., Real-Fernández, M., Sánchez-Muñoz de León, M. y Navarro-Soria, I. (2021). Consequences of COVID-19 confinement on anxiety, sleep and executive functions of children and adolescents in Spain. Frontiers in Psychology, 12, 1-11. https://doi.org/10.3389/fpsyg.2021.565516

Lawrence, G. y Spector-Cohen, E. (2018). Examining international telecollaboration in language teacher education. En D. Tafazoli, M. E. Gómez-Parra, y C. A. Huertas-Abril (Eds.), Cross-cultural perspectives on technology-enhanced language learning (pp. 322-345). IGI Global. https://doi.org/10.4018/978-1-5225-5463-9.ch018

O'Dowd, R. (2018). From telecollaboration to virtual exchange: State-of-the-art and the role of UNICollaboration in moving forward. Journal of Virtual Exchange, 1, 1-23. https://doi.org/10.14705/rpnet.2018.jve.1 
Okubo, T., Inoue, A. y Sekijima, K. (2020). Teleworker performance in the COVID-19 era in Japan. Asian Economic Papers, 20(2), 175-192. https://doi.org/10.1162/ asep_a_00807

Sardegna, V. G. y Dugartsyrenova, V. A. (2021). Facilitating pre-service language teachers' intercultural learning via voice-based telecollaboration: The role of discussion questions. Computer Assisted Language Learning, 34(3), 379-407. https://doi.org/1 0.1080/09588221.2020.1871028

Vinagre, M. (2016). Developing key competences for life-long learning through virtual collaboration: Teaching ICT in English as a medium of instruction. En C. Wang y L. Winstead (Eds.), Handbook of research on foreign language education in the digital age (pp. 170-187). IGI Global. https://doi.org/10.4018/978-1-5225-0177-0.ch008

Werneck-Barbosa, M. y Ferreira-Lopes, L. (2021). Emerging trends in telecollaboration and virtual exchange: A bibliometric study. Educational Review, 1-29. https:// doi.org/10.1080/00131911.2021.1907314

Whittle, C., Tiwari, S., Yan, S. y Williams, J. (2020). Emergency remote teaching environment: A conceptual framework for responsive online teaching in crises. Information and Learning Sciences, 121(5/6), 311-319. https://doi.org/10.1108/ILS-04-2020-0099 


\section{Análisis de la Adicción a los Smartphone desde el Contexto Educativo: Estudio Bibliomético}

Colomo Magaña, Ernesto

Universidad de Málaga orcid.org/0000-0002-3527-7937

ecolomo@uma.es

\section{Cívico Ariza, Andrea}

Universidad Internacional de Valencia orcid.org/0000-0003-3094-5841

andrea.civico@campusviu.es

\section{Cuevas Monzonís, Nuria}

Universidad Internacional de Valencia

orcid.org/0000-0001-9366-3038

nuria.cuevas@campusviu.es

\section{Gabarda Méndez, Vicente}

Universitat de Vàlencia

orcid.org/0000-0001-6159-5173

vicente.gabarda@uv.es

\section{Ruiz Palmero, Julio}

Universidad de Málaga

orcid.org/0000-0002-6958-0926

julio@uma.es 


\title{
ANÁLISIS DE LA ADICCIÓN A LOS SMARTPHONE DESDE EL CONTEXTO EDUCATIVO: ESTUDIO BIBLIOMÉTICO
}

\author{
Colomo Magaña, Ernesto \\ Cívico Ariza, Andrea \\ Cuevas Monzonís, Nuria \\ Gabarda Méndez, Vicente \\ Ruiz Palmero, Julio
}

\section{Resumen}

La adicción a los Smartphone es una realidad latente, incentivada por situaciones de interacción social como la originada por la COVID-19. Este uso excesivo queda vinculado a las diferentes apps disponibles en los terminales, siendo cada vez más habitual que estos comportamientos problemáticos afecten a aspectos de salud como el aislamiento social, ansiedad o físicos (sedentarismo, sobrepeso, etc.). Debido a ello, el interés de este estudio se centra en analizar la producción científica existente sobre adicción a los Smartphone relacionada con el ámbito educativo entre 2016 y 2020, utilizando para ello técnicas bibliométricas. La muestra final quedó conformada por 53 artículos, examinando dicho conjunto en función de diversas variables. Los resultados muestran un incremento continuo en el rango de años examinado, predominando el inglés y estando adscritos principalmente a las áreas de medicina, psicología y ciencias sociales. Las revistas más prolíficas provienen del ámbito sanitario, siendo Corea del Sur y Turquía los países con mayor producción, aunque es la Universidad de Granada (España) la institución con más artículos en estos años. Los artículos más relevantes se centran en la adicción a los teléfonos móviles y su impacto en aspectos como la satisfacción vital, la depresión o el rendimiento académico, aspecto también reflejado entre las palabras claves más habituales. Como conclusión, destacar la importancia de estos trabajos de análisis para conocer las principales investigaciones y poder definir nuevas líneas de trabajo y colaboración para seguir avanzando sobre el ámbito de la adicción a los Smartphone y el papel de la educación.

\section{Palabras clave}

Smartphone, adicción, educación, estudio bibliométrico. 


\section{Introducción}

En los últimos años, la tecnología ha avanzado a pasos agigantados, integrándose de manera gradual en las acciones cotidianas de las personas hasta tal punto, que es complejo concebir nuestro día a día sin la misma. Según el Instituto Nacional de Estadística (2020), se ha producido una digitalización, gracias a las tecnologías, de gran parte de las tareas más comunes que los individuos realizamos (trabajo, tareas del hogar o comunicación). Este hecho todavía se ha visto más acusado por la situación de pandemia, provocada por la COVID-19, que se ha vivido desde principios del 2020 y sigue vigente en todo el mundo. Esta ha supuesto grandes cambios en múltiples ámbitos como son la economía, la política, la sociedad o la educación.

El confinamiento vivido en España durante los primeros meses, y las posteriores restricciones de movilidad y reuniones con el fin de evitar la propagación de los contagios, han supuesto grandes cambios para la población. Por una parte, a nivel laboral, el teletrabajo ha aumentado de forma exponencial, suponiendo este hecho un reto en la organización de las familias. Por otra parte, a nivel educativo, los centros y los docentes han tenido que adaptar sus programaciones y sus prácticas para impartir los contenidos en línea (Cívico et al., 2021; Hodges et al., 2020), al igual que para los discentes ha supuesto una realidad nueva y abrupta, en determinadas situaciones, por no contar con los medios necesarios. Por último, se ha visto ampliamente afectado el disfrute del tiempo libre y el ocio, implicando esto un cambio en la socialización de las personas. Siguiendo a Dong et al. (2020), durante estos últimos meses ha crecido de forma exponencial la utilización de los juegos en línea, los videojuegos, las redes sociales y los servicios de mensajería instantánea, al constituir el principal canal de ocio y de relación entre las personas.

En este sentido, el Instituto Nacional de Estadística (2020) recoge que, durante la pandemia, las actividades más recurrentes de la población española fue el uso de WhatsApp, en un $89.5 \%$, la búsqueda de información en relación a bienes o servicio, en un $78.3 \%$, y la realización de videollamadas o llamadas telefónicas a través de internet, en un $77.7 \%$. Este resultado se relaciona con diversos factores como el aislamiento social impuesto durante estos meses de pandemia; la docencia a través de la utilización de elementos tecnológicos; el uso más frecuente de videojuegos (Martín, 2015); y la utilización de estos canales como comunicación e interacción entre las personas (García- et al., 2018; González et al., 2020; Viñals et al., 2014).

Sin embargo, aunque son amplios los beneficios que nos aportan las tecnologías, es imprescindible visualizar también los trastornos vinculados a la adicción producida por estas y la propia navegación en Internet, las cuales se vienen padeciendo desde hace años en diferentes contextos culturales y grupos de edad (Pedrero-Pérez et al., 2018; Tsitsika et al., 2013). Concretamente, para este estudio nos centraremos en la adicción hacia los dispositivos móviles. No obstante, se hace necesario relacionar estos con Internet, ya que es a través de los teléfonos inteligentes desde donde la mayor parte de la población accede a la red. Son varios los estudios (Griffiths et al., 2014; Jasso et al., 2017; Saikia et al., 2019) que relacionan el uso excesivo y la dependencia de Internet con un mayor aislamiento social, estados de ansiedad y graves problemas de salud (sobrepeso, diabetes tipo II, hipertensión, etc.) como consecuencia de la reducción de la práctica de actividad física. 
Centrándonos en los Smartphone, cabe resaltar que existe una disyuntiva entre si la adicción se genera respecto a la necesidad de utilizar el dispositivo o sobre las diferentes apps con las que el teléfono cuenta. En la actualidad, las personas desde el móvil podemos satisfacer cualquier necesidad o trámite que precisemos realizar: controlar y operar con las cuentas del banco; gestionar la agenda personal; controlar los niveles de actividad física; realizar la compra; leer las noticias; y la relación con las personas, tanto directa con Ilamadas y WhatsApp, como indirecta, con las redes sociales. Todas estas acciones se realizan con las apps que se pueden descargar y usar a través del teléfono. Cada una de estas apps, por sí mismas, también pueden generar adicción, como es el caso de las redes sociales, consideradas como un subtipo de adicción a Internet (Ruiz et al., 2019). Estudios como los de Peng et al. (2019) revelan que estas aplicaciones cuentan con estrategias que son capaces de generar comportamientos y condicionar respuestas, de forma que se genere la necesidad en el usuario de continuar conectados. Igualmente, desde el dispositivo móvil se puede jugar a diferentes juegos o videojuegos, con el potencial riesgo de un consumo excesivo de los mismos, aunque no suele ser lo habitual (Desai et al., 2010; Entwistle et al., 2020; Haagsman et al., 2012).

En España, la adicción a los smartphones puede desarrollarse a cualquier franja de edad (Pedrero et al., 2018), viéndose gravemente acrecentadas durante la pandemia (Dong et al., 2020). Junto a ello, tenemos el problema de las familias, como responsable de la socialización primaria de la población infante, las cuales no siempre cuenta con las herramientas y estrategias necesarias para prevenir un uso problemático de los teléfonos inteligentes (Orte et al., 2020), acusándose la situación al tratarse de dispositivos que los propios progenitores usan de forma constante y reiterada durante el tiempo que pasan con sus hijos/as.

Por todo ello, el tema de la adicción a los Smartphone se convierte en un ámbito de interés relevante para ahondar en los estudios realizados. De este modo, este estudio tiene como objetivo analizar las características de la producción científica sobre la adicción a Smartphone y su relación con la educación en la base de datos Scopus.

\section{Método}

Se parte de un enfoque analítico, el cual permitirá conocer tanto la evolución de las publicaciones como el estado actual de la producción científica sobre el tema objeto de estudio. Vinculado a ello, se estudian también las relaciones que se generan entre los descriptores de las diferentes publicaciones consideradas, utilizando el programa VOS-viewer.

Las palabras claves empleadas en el comando de búsqueda fueron "Smartphone Addiction" AND "Education", aplicando esta al título, resumen y palabras claves. El total de publicaciones devuelto por la base de datos Scopus fue de 71 publicaciones. Con esta muestra inicial, se decidió implementar un proceso de cribado, siempre respetando los principios establecidos por la declaración PRISMA. Los filtros se vincularon al tipo de documento, seleccionando solo aquellas que fueran artículos, y al año de publicación, fijando un filtro que incluyera un rango de 5 años, entre 2016 y 2020 ambos inclusive. La muestra final se redujo a 53 artículos, escritos en su mayoría en inglés ( 52 artículos en dicho idioma y 1 en español), a los que se aplicarán las técnicas de metaanálisis. 
En este sentido, fueron examinadas 7 variables, entre las que se encuentran: año de publicación, para conocer cómo ha sido la evolución de la producción en el tiempo analizado; área de indexación, para identificar los campos temáticos a los que se adscriben las publicaciones; revistas, para saber que publicaciones periódicas incluyen más artículos sobre el objeto de estudio; país, para descubrir en qué lugares se producen más artículos sobre esta temática; afiliación, para exponer cuáles son las universidades con mayor nivel de producción en el tema; publicaciones con más impacto, para dar a conocer los artículos más relevantes (mayor número de citas) dentro del objeto de estudio; palabras claves, para señalar los cuáles son los descriptores que han sido utilizados más habitualmente en el conjunto de artículos analizados.

Para el análisis de dichas variables, ha sido preciso considerar unos criterios de exclusión para poder focalizar el análisis en los datos más significativos. Dicha información se recoge en la tabla 1.

Tabla 1. Variables de estudio y criterios de exclusión

\begin{tabular}{|c|c|}
\hline Variables & Criterios de exclusión \\
\hline Año de publicación & $\begin{array}{l}\text { Artículos fuera del rango 2016-2020, ambos } \\
\text { inclusive }\end{array}$ \\
\hline Área de indexación & Todas las áreas con menos de 7 artículos \\
\hline Revistas & Todas las revistas con menos de 2 artículos \\
\hline País & Todos los países con menos de 3 artículos \\
\hline Afiliación & $\begin{array}{l}\text { Todas las instituciones de investigación con me- } \\
\text { nos de } 2 \text { artículos }\end{array}$ \\
\hline Publicaciones con más impacto & Todos los artículos con menos de 42 citas \\
\hline Palabras claves & $\begin{array}{l}\text { Todas las palabras claves que concurran menos } \\
\text { de } 6 \text { veces en los artículos que componen la } \\
\text { muestra }\end{array}$ \\
\hline
\end{tabular}

\section{Fuente: Elaboración propia.}

\section{Resultados}

Teniendo en cuenta los 53 artículos que conforman la muestra final de estudio, a continuación, se desarrollan los análisis de la producción científica a partir de las diferentes variables que han sido finalmente consideradas.

\section{Año de publicación}

Partiendo del filtro aplicado, donde hemos considerado en exclusiva los artículos incluidos en el rango 2016-2020 (ambos inclusive), observamos una evolución progresiva en lo que respecta al número de artículos (Tabla 2). El máximo se alcanza en el año 2020 (19), mientras que el mínimo de publicaciones se registró en el 2017 (2), estableciéndose un rango de 17 artículos en la muestra considerada. Destacar que, en los últimos 3 años contemplados, la producción siempre ha superado la decena de artículos. 
Tabla 2. Año de publicación

\begin{tabular}{|l|c|}
\hline Año & Número de artículos \\
\hline 2016 & 7 \\
\hline 2017 & 2 \\
\hline 2018 & 14 \\
\hline 2019 & 11 \\
\hline 2020 & 19 \\
\hline
\end{tabular}

\section{Fuente: Elaboración propia.}

\section{Área de indexación}

Antes de comentar los resultados, es preciso aclarar el carácter multiclasificación de esta variable. Esto se debe a que una misma investigación puede estar vinculada/ relacionada con diferentes campos de conocimiento a los que afecta o en los que se inscribe por su temática y el foco al que atiende. Debido a ello, un artículo se puede incluir en más de un área, razón por la que la suma de esta variable suele ser siempre superior al número total de artículos que conforman la muestra (Tabla 3). Recordar también que solo consideramos aquellas áreas que incluían al menos 7 artículos. Los resultados reflejan una adscripción mayoritaria al campo de la medicina (21), seguida de la psicología (15) y las ciencias sociales (14). Cabe destacar que es el componente implícito de salud en el objeto de estudio analizado lo que genera esta adscripción.

Tabla 3. Área de indexación

\begin{tabular}{|l|c|}
\hline Área & Número de artículos \\
\hline Medicina & 21 \\
\hline Psicología & 15 \\
\hline Ciencias sociales & 14 \\
\hline Ciencias de la computación & 10 \\
\hline Arte y humanidades & 8 \\
\hline Ciencias medioambientales & 7 \\
\hline Enfermería & 7 \\
\hline
\end{tabular}

\section{Fuente: Elaboración propia.}

\section{Revistas}

Para esta variable se estipuló la necesidad de registrar al menos 2 artículos para que la revista fuera considerada, obteniendo un total de 9 publicaciones periódicas que satisfacen dicho criterio (Tabla 4). Las revistas "Computers in Human Behavior", centrada en examinar el uso de los ordenadores desde un enfoque psicológico, y "International Journal of Environmental Research and Public Health (IJERPH)", dedicada a investigaciones sobre la salud desde diferentes perspectivas, registran 5 publicaciones cada una, siendo las más prolíficas en el rango de años de estudio (2016-2020). Entre las demás, reflejar una doble orientación entre sus temáticas: centradas en la 
salud, como "Medico legal Update" (3), "Perspective in Psychiatric Care" (3) o "BMC Psychiatry" (2); vinculada a educación, diferenciando entre revistas de temática plural (Education Sciences) y relacionadas con la tecnología (Computers and Education).

Tabla 4. Revistas indexadas en Scopus con más publicaciones

\begin{tabular}{|l|c|}
\hline Nombre revista & Número de artículos \\
\hline Computers In Human Behavior & 5 \\
\hline International Journal Of Environmental Research And Public Health & 5 \\
\hline Medico Legal Update & 3 \\
\hline Perspectives In Psychiatric Care & 3 \\
\hline BMC Psychiatry & 2 \\
\hline Computers And Education & 2 \\
\hline Education Sciences & 2 \\
\hline Indian Journal Of Public Health Research And Development & 2 \\
\hline Journal Of Behavioral Addictions & 2 \\
\hline
\end{tabular}

\section{Fuente: Elaboración propia.}

\section{País}

Se consideraron aquellos países que registraban un mínimo de 5 artículos (Tabla 5), destacando Corea del Sur y Turquía, ambas con 11 artículos. Les siguen España (6) y Estados Unidos (5), reflejando que el tema de la adicción a los Smartphone ha sido un tema de interés en diferentes lugares durante los últimos años.

Tabla 5. Países más prolíficos en Scopus

\begin{tabular}{|l|c|}
\hline País & Número de artículos \\
\hline Corea del Sur & 11 \\
\hline Turquía & 11 \\
\hline España & 6 \\
\hline Estados Unidos & 5 \\
\hline Estonia & 3 \\
\hline Líbano & 3 \\
\hline Malasia & 3 \\
\hline
\end{tabular}

\section{Fuente: Elaboración propia.}

\section{Afiliación}

El requisito para esta variable se estipuló en 2 artículos (Tabla 6). La universidad de Granada, en España, es la que mayor producción científica registra en los años estudiados (4), seguido de la Universidad de Notre Dame del Líbano (3), siendo coincidente este dato con el de la producción de dicho país (Tabla 5), al igual que ocurre con la Universidad Tartu Ülikool de estonia (3). También en España, destaca la Universidad de Toledo (2), englobando así toda la producción de dicho país junto con la de Granada. 
Tabla 6. Universidades con mayor producción en Scopus

\begin{tabular}{|l|c|}
\hline Universidad & Número de artículos \\
\hline Universidad de Granada & 4 \\
\hline Notre Dame University, Lebanon & 3 \\
\hline Tartu Ülikool & 3 \\
\hline Kyung Hee University & 2 \\
\hline Universidad de Toledo & 2 \\
\hline
\end{tabular}

\section{Fuente: Elaboración propia.}

\section{Publicaciones con más impacto}

Al trabajar esta variable podemos observar cuáles son los artículos más relevantes en el campo objeto de estudio. En este caso, el filtro que se aplicó de 42 citas o más, permitió incluir a un total de 6 artículos (Tabla 7).

Tabla 7. Artículos con más citas

\begin{tabular}{|c|c|c|c|c|c|}
\hline Autores & Año & Título & Revista & Citas & $\begin{array}{l}\text { Media } \\
\text { de citas } \\
\text { por año }\end{array}$ \\
\hline $\begin{array}{l}\text { Samaha, M., \& } \\
\text { Hawi, N.S. }\end{array}$ & 2016 & $\begin{array}{l}\text { Relationships among smartphone } \\
\text { addiction, stress, academic perfor- } \\
\text { mance, and satisfaction with life }\end{array}$ & $\begin{array}{l}\text { Computers in } \\
\text { Human Beha- } \\
\text { vior, } 57,321-325 .\end{array}$ & 353 & 70.6 \\
\hline $\begin{array}{l}\text { Hawi, N.S., \& } \\
\text { Samaha, M. }\end{array}$ & 2016 & $\begin{array}{l}\text { To excel or not to excel: Strong } \\
\text { evidence on the adverse effect of } \\
\text { smartphone addiction on acade- } \\
\text { mic performance }\end{array}$ & $\begin{array}{l}\text { Computers and } \\
\text { Education, } 98 \\
81-89 .\end{array}$ & 119 & 23.8 \\
\hline $\begin{array}{l}\text { Aljomaa, S.S., Al. } \\
\text { qudah, M.F., } \\
\text { Albursan, } \\
\text { I.S., Bakhiet, } \\
\text { S.F., \& } \\
\text { Abduljabbar, A.S. }\end{array}$ & 2016 & $\begin{array}{l}\text { Smartphone addiction among } \\
\text { university students in the light of } \\
\text { some variables }\end{array}$ & $\begin{array}{l}\text { Computers in } \\
\text { Human Beha- } \\
\text { vior, } 61,155-164 .\end{array}$ & 110 & 22 \\
\hline $\begin{array}{l}\text { Barnes, } \\
\text { S.J., Pressey, } \\
\text { A.D., \& Scorna- } \\
\text { vacca, E. }\end{array}$ & 2019 & $\begin{array}{l}\text { Mobile ubiquity: Understanding } \\
\text { the relationship between cognitive } \\
\text { absorption, smartphone addiction } \\
\text { and social network services }\end{array}$ & $\begin{array}{l}\text { Computers in } \\
\text { Human Beha- } \\
\text { vior, } 90,246- \\
258 .\end{array}$ & 56 & 28 \\
\hline $\begin{array}{l}\text { Lian, L., You, } \\
\text { X., Huang, J., } \\
\text { \& Yang, R. }\end{array}$ & 2016 & $\begin{array}{l}\text { Who overuses Smartphones? Ro- } \\
\text { les of virtues and parenting style } \\
\text { in Smartphone addiction among } \\
\text { Chinese college students }\end{array}$ & $\begin{array}{l}\text { Computers in } \\
\text { Human Beha- } \\
\text { vior, } 65,92-99\end{array}$ & 49 & 9.8 \\
\hline $\begin{array}{l}\text { Alhassan, } \\
\text { A.A., Alqadhib, } \\
\text { E.M., Taha, N.W., } \\
\text { Alahmai, R.A., } \\
\text { Salam, M., \& } \\
\text { Almutairi, A.F. }\end{array}$ & 2018 & $\begin{array}{l}\text { The relationship between addic- } \\
\text { tion to smartphone usage and } \\
\text { depression among adults: A cross } \\
\text { sectional study }\end{array}$ & $\begin{array}{l}\text { BMC Psychiatry, } \\
\text { 18(1), e148. }\end{array}$ & 42 & 14 \\
\hline
\end{tabular}


El artículo de Samaha y Hawi (2016) es el más citado (353), convirtiéndose en el máximo referente entre las publicaciones de la muestra analizada. Su trabajo se centra en la relación entre la adicción al teléfono móvil y la satisfacción vital, mediada por el estrés y el rendimiento académico, examinando así las posibles relaciones entre dichos constructos. Las mismas autoras, aunque invirtiendo el orden en la autoría (Hawi, \& Samaha, 2016), ocupan el segundo lugar (119), con una investigación sobre la influencia negativa de la adicción a los teléfonos móviles en el rendimiento académico. El resto de los trabajos, partiendo de la temática central de la adicción a los Smartphone, presenta diferencias respecto al foco desde el que se sitúa el estudio. El trabajo de Aljomma et al. (2016), analiza la adicción a móviles en estudiantes universitarios, atendiendo a variables como el sexo, estatus social, nivel educativo, ingresos mensuales y horas de uso diarias. El estudio de Barnes et al. (2019), abre una línea importante al diferenciar entre la adicción a móviles y redes sociales utilizadas a través de dichos positivos, examinando si el problema se sitúa en el medio (móvil) o en el fin (acceso a redes). Por su parte, Lian et al. (2016) se preocupa por los estilos parentales, evaluando si la aplicación de enfoques positivos (desarrollo de factores protectores) influye en la prevención de comportamientos adictivos respecto a los teléfonos móviles. Por último, el trabajo de Alhassan et al. (2018), incorpora el constructo de la depresión, para ver de qué modo este problema guarda relación con la adicción a los móviles.

\section{Palabras claves}

Para observar los descriptores más frecuentes, realizamos un análisis de co-ocurrencia, considerando todas las palabras claves (tanto las de autor como las del documento) y estableciendo como filtro la presencia conjunta en al menos 6 artículos de cada una de las mismas. Los resultados de los nodos relacionales generados entre las palabras claves se pueden observar en la siguiente figura (1).

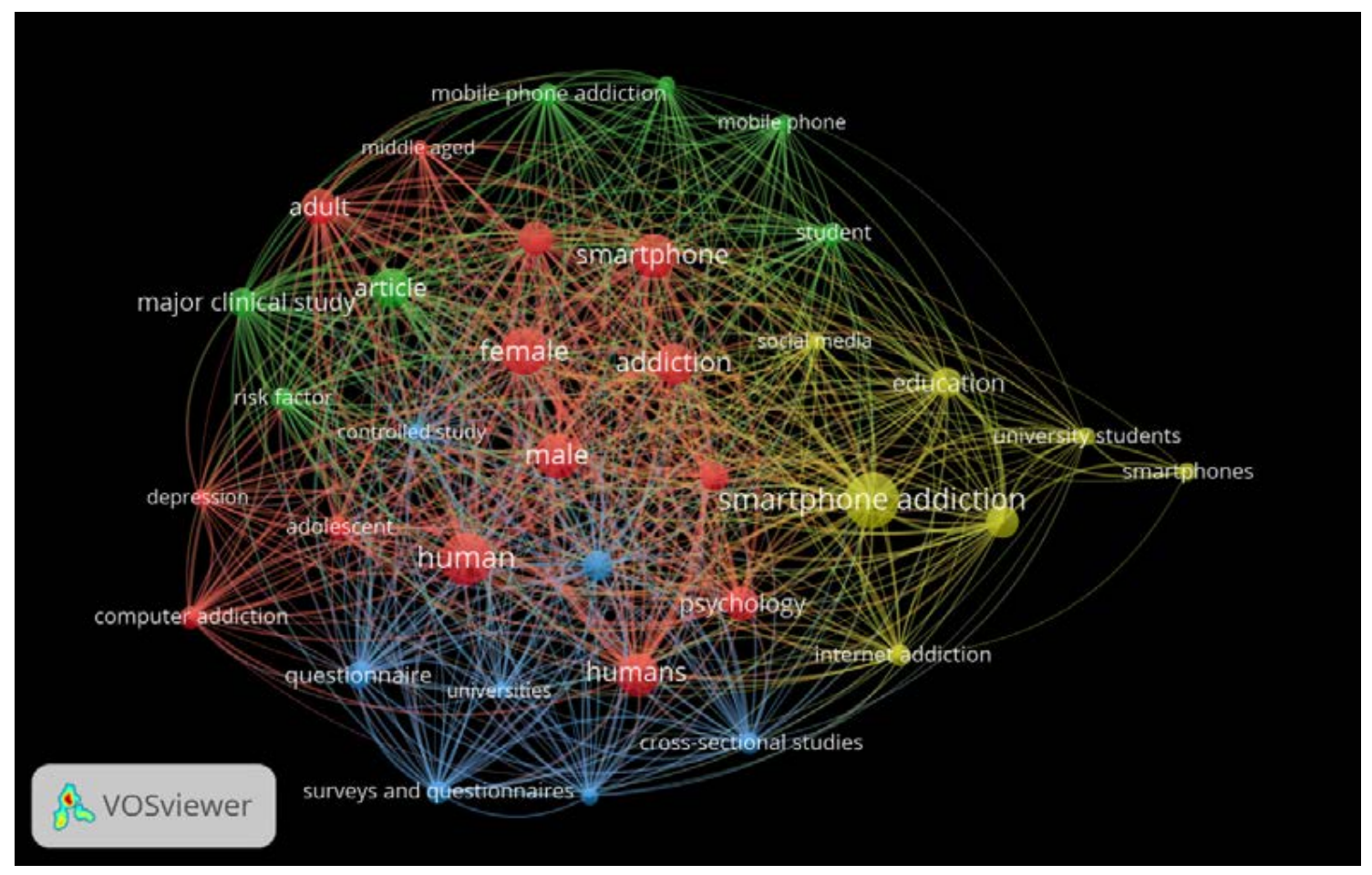

Figura 1. Concurrencia de palabras claves en la producción científica 
Es preciso indicar que el tamaño del nodo y del texto está relacionado con una mayor frecuencia de aparición del descriptor. Se generaron un total de 4 subconjuntos (amarillo, azul, rojo y verde), originándose también interrelaciones entre palabras claves de un subconjunto y otros. Cabe resaltar que el comando de búsqueda "Smartphone Addiction" fue la palabra clave con mayor presencia (33), mientras que el otro comando ("Education"), obtuvo una frecuencia de 15 registros. Los términos relacionados con las personas (Humano/s, hombre, mujer) fueron los más habituales, junto a otros como comportamiento adictivo y psicología, con 17 presencias. Gracias a este análisis, se pueden observar otras temáticas de estudio vinculadas a la que hemos analizado. De este modo, la adicción al ordenador (10), a internet (9) o los medios sociales (7), también despierta interés, junto con elementos vinculados a la salud mental como la depresión (7).

\section{Discusión y conclusiones}

El propósito de este trabajo era analizar las características de la producción científica sobre la adicción a Smartphone y su relación con la educación, empleando técnicas bibliométricas para ello.

La proliferación de artículos entre los años 2016-2020 (ambos inclusive) ha sido continua, creciendo el número de los mismos de forma progresiva hasta el año 2020, donde se produce el mayor registro (19). En este sentido, señalar un incremento significativo en el año de la pandemia mundial causada por la COVID-19, donde los problemas de adicción a dispositivos electrónicos se han constatado en diferentes estudios (González et al., 2020). En cuanto al área de indexación, los artículos se adscriben mayoritariamente al campo de la medicina, la psicología y las ciencias sociales, ámbitos de conocimientos vinculados a la educación y al tratamiento de los problemas de adicción. Las principales revistas, respecto al número de artículos registrados, están vinculadas mayoritariamente al ámbito de la salud, como "Computers in Human Behavior" y "International Journal of Environmental Research and Public Health (IJERPH)", o, en menor medida, al de la educación ("Education Science" y "Computers and Education"). Los países con mayor producción científica han sido Corea del Sur, Turquía, España y Estados Unidos, algo que se ha reflejado también en las afiliaciones de los investigadores, entre la que encontramos a la universidad de Granada (España), como la institución más prolífica en los años contemplados. Atendiendo a los artículos más citados, subrayar que 4 de ellos (Aljomma et al., 2016; Barnes et al., 2019; Lian et al., 2016; Samaha, \& Hawi, 2016) pertenecen a la revista "Computers in Human Behavior", la cual compartía liderazgo en esta variable junto a IJERPH. Los artículos más citados se estructuran en torno al constructo de la adicción a teléfonos móviles, viendo como incide en este proceso diferentes aspectos tales como: satisfacción vital (Samaha, \& Hawi, 2016), depresión (Alhassan et al., 2018), rendimiento académico (Hawi, \& Samaha, 2016), características sociodemográficas en población universitaria (Aljomma et al., 2016), estilos parentales positivos (Lian et al., 2016), o la diferencia entre la adicción a móviles y a redes sociales (Barnes et al., 2019). En lo que concierne a los descriptores más frecuentes, junto a los comandos de búsqueda introducidos, destacan los términos vinculados al ser humano, a diferentes tipos de adicciones y a los problemas psicológicos derivados de las mismas, convirtiéndose esté ámbito en un foco de potenciales investigaciones para entender todos los problemas que se derivan de la adicción a los teléfonos móviles y que posibles soluciones o acciones podemos aportar desde el contexto educativo. 
Este estudio atestigua que las publicaciones científicas vinculadas a la adicción a teléfonos móviles y la educación es un campo significativo y en crecimiento en los últimos años. Nuestra vida personal, profesional y social la podemos controlar desde un dispositivo sobre el que cada vez generamos una dependencia mayor. En este sentido, es importante prevenir ciertos comportamientos negativos y adictivos respecto a su uso, buscando desde el terreno educativo evidencias que demuestren su riesgo, así como posibles acciones para evitar un uso excesivo o peligroso de estos dispositivos. Sabiendo los factores que han sido analizados y los principales resultados encontrados, podemos seguir indagando en otros constructos que también nos permita entender cómo afecta la adicción a los smartphones en las personas y cómo, desde la educación, podemos mejorar el uso de los móviles de una forma más autónoma y libre sin riesgos. El conocimiento de la producción científica nos genera un status real de la situación, así como un abanico de posibilidades sobre las que seguir trabajando e indagando. Como posibles líneas futuras, podríamos incluir otras adicciones a tecnologías educativas de forma conjunta o individualmente, para atesorar una mayor información como cada uno de estos medios genera dependencia en la población respecto a su uso y el papel que la educación puede jugar en esta prevención.

\section{Referencias}

Alhassan, A.A., Alqadhib, E.M., Taha, N.W., Alahmai, R.A., Salam, M., \& Almutairi, A.F. (2018). The relationship between addiction to smartphone usage and depression among adults: A cross sectional study. BMC Psychiatry, 18(1), e148. https://doi. org/10.1186/s12888-018-1745-4

Aljomaa, S.S., Al.qudah, M.F., Albursan, I.S., Bakhiet, S.F., \& Abduljabbar, A.S. (2016). Smartphone addiction among university students in the light of some variables. Computers in Human Behavior, 61, 155-164. https://doi.org/10.1016/j.chb.2016.03.041

Barnes, S.J., Pressey, A.D., \& Scornavacca, E. (2019). Mobile ubiquity: Understanding the relationship between cognitive absorption, smartphone addiction and social network services. Computers in Human Behavior, 90, 246-258. https://doi.org/10.1016/j. chb.2018.09.013

Cívico, A., Cuevas, N., Colomo, E., y Gabarda, V. (2021) Jóvenes y uso problemático de las tecnologías durante la pandemia: una preocupación familiar. Hachetetepé. Revista científica De Educación Y Comunicación, (22), 1204. https://doi.org/10.25267/ Hachetetepe.2021.i22.1204

Desai, R.A., Krishnan, S., Cavallo, D., \& Potenza, M.N. (2010). Video-Gaming Among High School Students: Health Correlates, Gender Differences, and Problematic Gaming. Pediatrics, 126(6) e1414-e1424. https://doi.org/10.1542/peds.2009-2706

Dong, H., Yang, F., Lu, X., \& Hao, W. (2020). Internet Addiction and Related Psychological Factors Among Children and Adolescents in China During the Coronavirus Disease 2019 (COVID-19) Epidemic. Frontiers in Psychiatry, 11, 751. https://doi. org/10.3389/fpsyt.2020.00751 
Entwistle, G. J. M., Blaszczynski, A., \& Gainsbury, S. M. (2020). Are video games intrinsically addictive? An international online survey. Computers in Human Behavior, 112, 106464. https://doi.org/10.1016/j.chb.2020.106464

García, A., Tur, V., y Pastor, Y. (2018). Consumo mediático de adolescentes y jóvenes. Icono 14, 16(1), 22-46. https://doi.org/10.7195/ri14.v16i1.1101

González, E., Córdoba, A., y Gómez, M. (2020). Una semana sin smartphone: usos, abuso y dependencia del teléfono móvil en jóvenes. Bordón. Revista De Pedagogía, 72(3), 105-121. https://doi.org/10.13042/Bordon.2020.79296

Griffiths, M. D., Kuss, D. J., \& Demetrovics, Z. (2014). Social Networking Addiction An Overview of Preliminary Findings. In K. Paul \& L. Curtiss (Eds.), Behavioral Addictions (pp. 119-141). Elsevier. https://doi.org/10.1016/B978-0-12-407724-9.00006-9

Haagsman, M.C., Pietersey, M.E., \& Peters, O. (2012). The Prevalence of Problematic Video Gamers in The Netherlands. Cyberpsychology, Behavior, and Social Networking, 15(3), 162-168. https://doi.org/10.1089/cyber.2011.0248

Hawi, N.S., \& Samaha, M. (2016). To excel or not to excel: Strong evidence on the adverse effect of smartphone addiction on academic performance. Computers and Education, 98, 81-89. https://doi.org/10.1016/j.compedu.2016.03.007

Hodges, C., Moore, S., Lockee, B., Trust, T., \& Bond, A. (2020). The difference between emergency remote teaching and online learning. Educause Review. https:// bit.ly/3bONzx7

Instituto Nacional de Estadística (2020). Encuesta de población activa. Segundo trimestre.https://www.mites.gob.es/ITSS/ITSS/ITSS_Descargas/Atencion_ciudadano/Normativa_documentacion/Otra_docum/epaO220.pdf

Jasso, J. L., López, F., y Díaz, R. (2017). Conducta adictiva a las redes sociales y su relación con el uso problemático del móvil. Acta de Investigación Psicológica, 7(3), 2832-2838. https://doi.org/10.1016/j.aipprr.2017.11.001

Lian, L., You, X., Huang, J., \& Yang, R. (2016). Who overuses Smartphones? Roles of virtues and parenting style in Smartphone addiction among Chinese college students. Computers in Human Behavior, 65, 92-99. https://doi.org/10.1016/j.chb.2016.08.027

Martín, M. (2015). Videojuegos y aprendizaje colaborativo. Experiencias en torno a la etapa de Educación Primaria. Education in the Knowledge Society (EKS), 16(2), 69-89. https://doi.org/10.14201/eks20151626989

Orte, C., Ballester, L., \& Nevot, C, L. (2020). Family support against COVID-19. https:// doi.org/10.1590/SciELOPreprints.297

Pedrero, E.J., Ruiz, J.M., Rojo, G., Llanero, M., Pedrero, J., Morales, S., y Puerta, C. (2018). Tecnologías de la Información y la Comunicación (TIC): uso problemático de Internet, videojuegos, teléfonos móviles, mensajería instantánea y redes sociales mediante el MULTICAGE-TIC. Adicciones, 30(1), 19-32. https://doi.org/10.20882/ adicciones.806 
Peng, C.-T., Wu, T.-Y., Chen, Y., \& Atkin, D.J. (2019). Comparing and modeling via social media: the social influences of fitspiration on male instagram users' work out intention. Comput. Hum. Behav., 99, 156-167. https://doi.org/10.1016/j.chb.2019.05.011

Ruiz, J., Sánchez, E., Gómez, M., \& Sánchez, E. (2019). Future Teachers' Smartphone Uses and Dependence. Education Sciences, 9(3), e194. https://doi.org/10.3390/ educsci9030194

Saikia, A.M., Das, J., Barman, P., \& Bharali, M.D. (2019). Internet addiction and its relationships with depression, anxiety, and stress in Urban Adolescents of Kamrup District, Assam. J. Family Commun. Med., 26, 108-112. https://doi.org/10.4103/jfcm. JFCM 93 18.

Samaha, M., \& Hawi, N.S. (2016). Relationships among smartphone addiction, stress, academic performance, and satisfaction with life. Computers in Human Behavior, 57, 321-325. https://doi.org/10.1016/j.chb.2015.12.045

Tsitsika, A., Tzavela, E., Mavromati, F., \& EU NET ADB Consortium. (2013). Investigación sobre conductas adictivas a Internet entre los adolescentes europeos. http://www.injuve.es/sites/default/files/2013/03/publicaciones/FinalResearchInternet-ES.pdf

Viñals, A., Abad, M., y Aguilar, E. (2014). Jóvenes conectados: Una aproximación al ocio digital de los jóvenes españoles. Communication Papers -Media Literacy \& Gender Studies-, 3(4), 52-68. 


\section{Sistema de Tutorías. Un Reto en la Universidad de la Ciénega del Estado de Michoacán de Ocampo (Ucemich)}

\section{Barajas-Pérez, Karla}

Universidad de La Ciénega del Estado de Michoacán de Ocampo kfbarajas@ucemich.edu.mx

\section{Carrera-Farran, Xavier}

Universidad de Lleida

xavier.carrera@udl.cat

\section{Santiago-Campión, Raúl}

Universidad de La Rioja

raul.santiago@unirioja.es 


\title{
SISTEMA DE TUTORÍAS. UN RETO EN LA UNIVERSIDAD DE LA CIÉNEGA DEL ESTADO DE MICHOACÁN DE OCAMPO (UCEMICH)
}

\author{
Barajas-Pérez, Karla \\ Carrera-Farran, Xavier \\ Santiago-Campión, Raúl
}

\section{Resumen}

La Universidad de La Ciénega del Estado de Michoacán de Ocampo (UCEMICH) enfrenta grandes desafíos en el Área de Tutorías y Apoyo Psicopedadógico con la implementación y seguimiento del Programa Institucional de Tutorías (PIT). Actualmente no se cuenta con un sistema tecnológico que permita llevar los procesos de manera digital. Derivado de las necesidades presentadas se realiza esta investigación centrada en la metodología Design-Based Research por sus siglas en inglés (DBR), orientada a la innovación de procesos, partiendo de un análisis de la situación actual existente, para alcanzar el desarrollo de soluciones de acuerdo a la fundamentación teórica que permita llevar acabo la implementación y validación del sistema de tutorías. Actualmente la investigación se centra en las fases 7 y 10 relacionadas al desarrollo de relaciones de la funcionalidad entre catálogos, permisos y privacidad usuarios. para posteriormente dar paso a las fases 8, 9, 11 y 12 validaciones y pilotaje respectivamente; presentando así el desarrollo final del Sistema de Tutorías.

\section{Palabras clave}

Tutoría, Sistema Tecnológico, Design-Based Research. 


\section{Introducción}

El Gobierno Constitucional del Estado de Michoacán de Ocampo (2006) informa la construcción de una "Universidad en la Región de La Ciénega de Chapala que constituya un paradigma para el siglo XXl" (p.1), "como un organismo público descentralizado de la Administración Pública Estatal con personalidad jurídica y patrimonial propios, sectorizada a la Secretaría de Educación" (p.2) con la finalidad de incrementar "la oferta educativa en ese nivel y por virtud de la alta demanda social, que oriente sus esfuerzos hacia los sectores desprotegidos y que incluya a los migrantes nacionales" (p.1).

El Gobierno Constitucional del Estado de Michoacán de Ocampo (2006) hace énfasis que los alumnos forman parte fundamental de la UCEMICH, y que la educación que se imparta a los estudiantes estará:

Orientada para que posean y dominen las herramientas conceptuales, procedimentales y actitudinales necesarias para llevar a efecto las propuestas de estudio y solución elaboradas por él mismo o por otros grupos y personas, con respeto y consideración de la integridad social, cultural y material del medio en el que se desempeña. (p.8).

La UCEMICH, se encuentra ubicada en "la Región de La Ciénega de Chapala que comprende a los municipios colindantes de los Estados de Michoacán y Jalisco, que conforman la zona oriental del vaso del Lago de Chapala" (Aguado, G. et al., 2010).

Abrió sus puertas el 31 de agosto de 2006, ingresando un total de 208 candidatos al primer ciclo escolar como alumnos. "Las actividades iniciaron con cuatro licenciaturas: Innovación Educativa, Estudios Multiculturales, Genómica Alimentaria e Ingeniería en Energía, posteriormente en agosto del 2007 se abrieron dos nuevas licenciaturas: Gobernabilidad y Nueva Ciudadanía e Ingeniería en Nanotecnología" (Aguado, G. et al., 2010).

La UCEMICH, fundamenta sus acciones en cuatro valores fundamentales: compromiso, vanguardia, honestidad y responsabilidad, con la misión de ofrecer una educación que contribuya a la transformación de la sociedad mediante la formación integral de profesionistas éticos, críticos, reflexivos y sensibles al entorno; con sólidas bases científicas y humanistas, un alto sentido de equidad, rechazo a la discriminación y comprometidos con el desarrollo sustentable. Así mismo, desarrollar investigación básica y aplicada, vinculada con problemáticas sociales. (Aguado, G. et al., 2010, p.17).

Es una institución de educación superior con un fuerte compromiso social, estructura, funciones académicas, planes, programas de trabajo y en general todas las actividades académicas que se realizan, se sustentan en principios filosóficos, entre los que destacan; humanismo, educación, integralidad e interculturalidad. (Aguado, G. et al., 2010).

Con lo anterior se hace notar la importancia de la formación integral para todos los estudiantes de la UCEMICH, con "la ardua labor de acompañar al estudiante a lo largo de su desempeño institucional, orientarlo en los procesos de toma de decisiones 
en la organización de su currículo y apoyarlo de manera general e integral como persona" (Aguado, G. et al., 2010, p.21) mismo programa que se encuentra estipulado en su modelo educativo. Así también como lo establece la H. Junta Directiva (2009) en el Artículo 2, el Personal Académico debe prestar servicios de Tutorías a los estudiantes. Es así como se estableció la necesidad de contar con un Sistema de Tutorías que permita facilitar el desarrollo integral de los estudiantes a lo largo de su vida estudiantil.

De no tomarse en cuenta la propuesta presentada en esta investigación, no se podrá solventar según establece Cano (2009) "una actividad de carácter formativo que incide en el desarrollo integral de los estudiantes universitarios en su dimensión intelectual, académica, profesional y personal” (p.183).

Por lo anterior es fundamental que cuenten con un Sistema de Tutorías en la formación integral de cada uno de los estudiantes de la UCEMICH.

\section{Objetivo}

Diseñar, desarrollar, implementar y validar un Sistema de Tutorías con base en el levantamiento de requerimientos que permitan obtener un escenario de las necesidades que establece el Área de Tutorías y Apoyo Psicopedagógica-Tutor-Tutorado, y satisfacer mediante la implementación y validación de este.

\section{Método}

\section{Design-Based Research}

El modelo metodológico idóneo para la integración efectiva de la investigación en la teoría y práctica pedagógica a aplicar en esta investigación es Design-Based Research (DBR).

Convienen De Benito y Salinas (2016) que "la investigación basada en diseño se ocupa de problemas reales que son identificados por los profesionales en la práctica" (p.45).

Es un modelo metodológico que se orienta a la creación de nuevas teorías, artefactos y prácticas que tengan en cuenta problemas significativos e impacten en el aprendizaje y la enseñanza en contextos reales. (Barab y Squire, 2004, p.3)

EI DBR refiere Valverde-Berrocoso (2016) que inicia con un problema que tiene significado científico y práctico, por lo anterior para examinar el progreso de este es necesario incluir el tipo de problema abordado, las soluciones desarrolladas o las teorías elaboradas.

Por consiguiente, el requisito para desarrollar principios prácticos según Valverde-Berrocoso (2016) "es un elemento clave del DBR, frente a otro tipo de investigación educativa que unilateralmente examina determinadas variables en el aula y luego el investigador desaparece una vez que el experimento ha concluido" (p.67). 


\section{El modelo DBR consta de una serie de fases (Plomp, 2007, p.47):}

1. Investigación preliminar: necesidades y análisis del contexto, revisión de la literatura, desarrollo de un marco conceptual o teórico para el estudio.

2. Fase de prototipo: fase de diseño iterativo que consta de iteraciones, cada una de las cuales es un micro-ciclo de investigación, con evaluación formativa como la actividad de investigación más importante con el objetivo de mejorar y redefinir la intervención.

3. Fase de evaluación: para contribuir si la solución o intervención satisface las especificaciones predeterminadas.

Así mismo argumenta Reeves (2006) que no es posible considerar que DBR sea una nueva metodología de investigación puesto que utiliza métodos de investigación mixtos (cuantitativos y cualitativos) ya existentes y sigue las normas, utilizando los procesos y técnicas propias de cada método, aunque según De Benito y Salinas (2016) existe "cierta tendencia a utilizar métodos cualitativos. Lo que verdaderamente la caracteriza es ser participativa, colaborativa, desde el momento en que en el proceso se adopta un proyecto de grupo, por lo que el sistema de trabajo es básicamente colaborativo" (p.50).

Por su parte Cobb et al. (2003) la caracterizan como iterativa, centrada en procesos, intervencionista, colaborativa, multinivel, orientada a la utilidad, y fundamentada en la teoría. Esto representa una ventaja para la investigación relacionada con la Tecnología Educativa, dado que sus procesos de diseño se adaptan bien a cuestiones abiertas de las investigaciones.

Las fases y la estructura de la investigación contienen una serie de acciones comunes como son: definición del problema, diseño, desarrollo, implementación y evaluación (De Benito y Salinas, 2016).

En el modelo propuesto por Reeves (2000), inicia la investigación con el análisis de la situación y la definición del problema. Las posibles soluciones se diseñan a partir de un marco teórico de referencia, de ahí la importancia de la evaluación y revisión, que incide tanto sobre la fundamentación teórica como sobre los puntos positivos y negativos de la intervención. La fase siguiente implementación seguida de la recogida de información. El proceso de investigación se concreta mediante ciclos continuos de diseño, validación, análisis y rediseño, conduciendo las diferentes iteraciones a la mejora del cuerpo teórico y el perfeccionamiento de la intervención (figura 1).

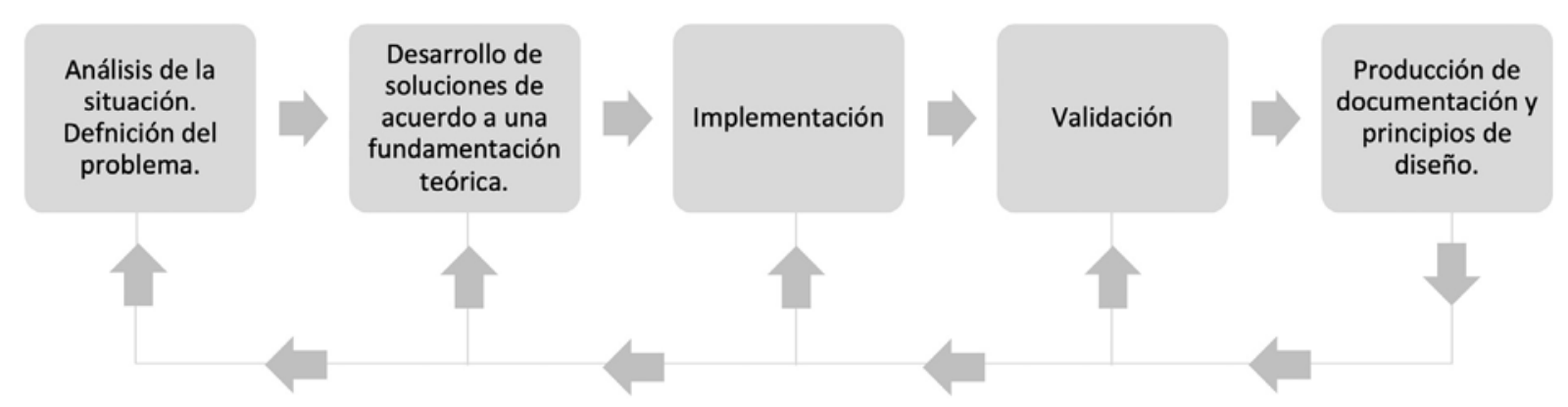

Figura 1. Proceso de investigación de desarrollo, Reeves (2000). 
Plomp (2007) señala algunas diferencias en la estructura y la organización de las fases de investigación en función de los objetivos de investigación si estos van encaminados a estudios de validación o si se trata de procesos de desarrollo.

Derivado de lo anterior según De Benito y Salinas (2016) especifican que los estudios basados en DBR ayudan a comprender todos los pasos del proceso de creación, elaboración, revisión, implantación y diseminación, en su caso, de cualquier programa o producto relacionado con las Tecnologías de Información y Comunicación en los procesos de enseñanza-aprendizaje, siendo su principal objetivo la creación de modelos de modos probables de andamiaje que favorezcan resultados de aprendizaje positivos. Se trata del diseño y desarrollo de una intervención como una solución (innovadora) a un problema complejo, y en consecuencia el punto de partida son problemas educativos para los que no existen o solo se dispone de unos pocos principios validados para estructurar y apoyar dichas actividades de diseño y desarrollo.

Razón primordial por la que se elige la metodología DBR en esta investigación se prevé efectuar con base en cuatro fases fundamentales bien estructuradas; la primer fase se encuentra enfocada al análisis detallado de la situación actual existente dentro de las diversas áreas de la UCEMICH y los participantes involucrados en relación a la implementación del Sistema de Tutorías, permitiendo detectar; descubrir; encontrar todas las necesidades; carencias e inquietudes existentes que atañen en la actualidad, permitiendo concretar claramente el problema en materia de tutorías de la UCEMICH consiguiendo así diseñar un escenario que permita visualizar todas las carencias existentes y dar continuidad a la segunda fase enfocada a desarrollar las soluciones, que se pueden brindar a las problemáticas; necesidades e inquietudes establecidas con anterioridad. Estas soluciones deberán cumplir con las expectativas descritas en la primera fase admitiendo desarrollar los catálogos, relaciones de la funcionalidad entre catálogos, permisos y privacidad de usuarios, validando y pilotando cada fase del Sistema de Tutorías, logrando representar como el sistema podrá contribuir de manera eficaz y eficiente en la tarea diaria que realizan los participantes involucrados en esta investigación.

Seguido de lo anterior se procede a la fase tres, misma que es considerada para la implementación del Sistema de Tutorías, implementando el sistema en las diversas áreas que se requieren y con los participantes involucrados aplicando la metodología y medidas necesarias para llevar acabo el correcto funcionamiento de dicho sistema y poder así dar inicio a la fase cuatro referente a la validación del rendimiento y correcto funcionamiento, de lo establecido desde un inicio en esta investigación permitiendo así aplicar los instrumentos necesarios que permitan validar el correcto funcionamiento del sistema para el uso de los participantes y áreas que intervienen dentro de la UCEMICH, lo anterior para ver culminado y cumplido el objetivo planteado en esta investigación.

\section{Participantes}

Las personas involucradas en el proceso de diseño, desarrollo e implementación como lo detalla Martínez y Bernal (2018) para esta investigación (figura 2): 


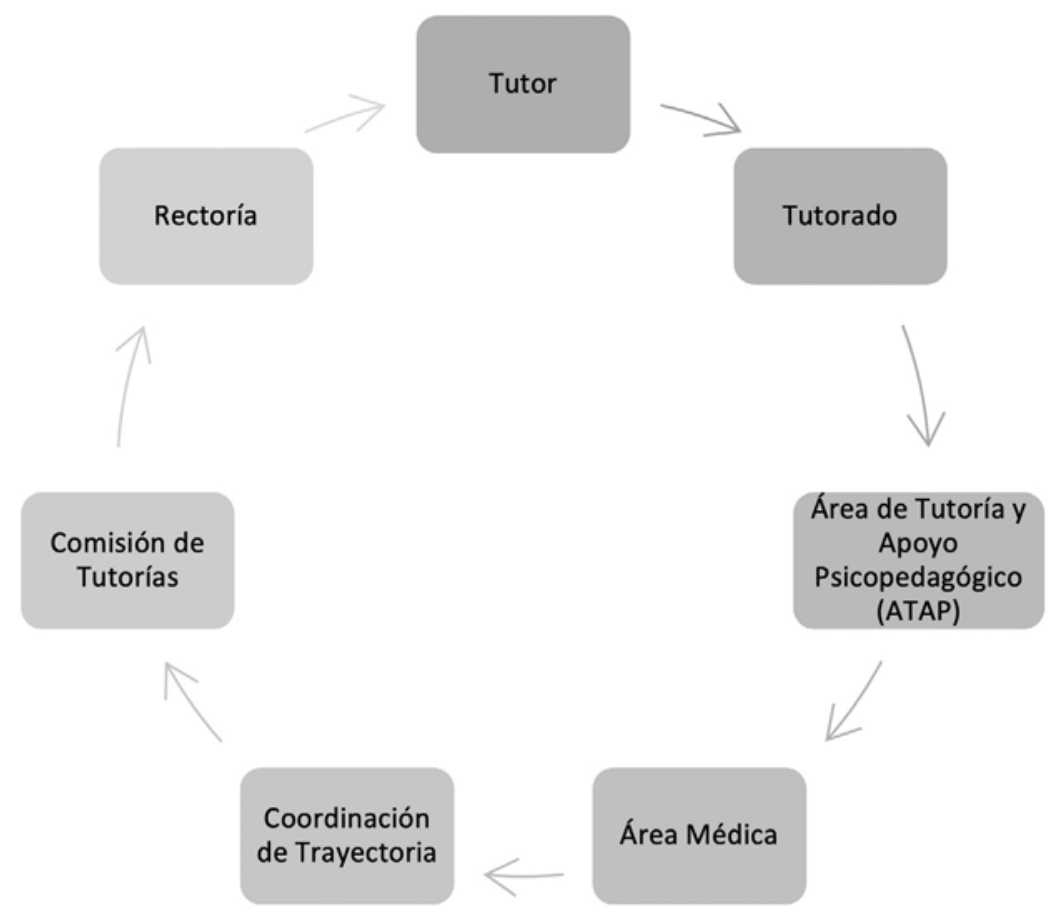

Figura 2. Participantes involucrados en el proceso de diseño, desarrollo e implementación.

\section{Instrumentos y técnicas de recogida de datos}

Los instrumentos y técnicas de recogida de datos como lo indica De Benito y Salinas (2016): Consisten en describir un fenómeno y para ello la observación sistemática de los fenómenos, una vez producidos, es básica. Para esta observación pueden utilizarse distintas técnicas que pertenecen tanto a la metodología cuantitativa, como a la cualitativa. La convergencia de distintos investigadores proporciona diversidad de perspectivas y en consecuencia mayor confianza sobre los datos y evidencias. (p.50)

Así también Goetz y LeCompte (1984) especifican que "las estrategias de recogida de datos comúnmente usadas en ciencias sociales son los instrumentos psicométricos y cuestionarios para la obtención de respuestas estandarizadas, las entrevistas no estructuradas, diversos protocolos y formularios de observación y la recogida de fuentes documentales escritas y otros artefactos humanos". (p.124)

Para esta investigación se utilizan los siguientes instrumentos para recabar información en relación con el objetivo planteado (tabla 1). 
Tabla 1. Instrumentos y técnica de recogida de información.

\begin{tabular}{|l|l|}
\hline Entrevistas & $\begin{array}{l}\text { Entablar una técnica para desarrollar el diseño de las interfaces para el } \\
\text { sistema de tutorías, tomando en consideración los servicios y funciona- } \\
\text { lidades que se establecen en los requisitos del Área de tutorías y Apoyo } \\
\text { psicopedagógica-Tutor-Tutorado. }\end{array}$ \\
\hline Observación & $\begin{array}{l}\text { Adquirir activamente información para la implementación del sistema de } \\
\text { tutorías cumpliendo con los módulos funcionales para que trabajen sin } \\
\text { inconvenientes. }\end{array}$ \\
\hline
\end{tabular}

La investigación se ha iniciado mediante algunas entrevistas al Área de Tutorías y Apoyo Psicopedagógico, Tutores y Tutorados que se encuentran trabajando en conjunto para lograr la implementación de las Tutorías en la UCEMICH.

Angell et al. (1992) afirma que "la entrevista como un mecanismo cuya finalidad es reunir datos requeridos para la verificación de hipótesis en la investigación social" (p. 311).

Como refiere Angell et al. (1992) la entrevista es poderoso instrumento para la investigación siendo muy útil para determinar las experiencias pasadas y la conducta futura del individuo. Las percepciones, las actitudes y las opiniones que no pueden inferirse de la observación, son accesibles para las entrevistas, puesto que las entrevistas comienzan con preguntas destinadas a desarrollar un interés activo por parte del sujeto.

Así pues, la observación participante o participativa es la principal técnica de recogida de datos así lo establecen Goetz y LeCompte (1984) haciendo claro énfasis en que el investigador pasa todo el tiempo posible con los individuos que estudia y vive del mismo modo que ellos, de la misma manera detallan que la observación participativa sirve para obtener de los individuos sus definiciones de la realidad y los constructos que organizan su mundo.

La observación como principal técnica conlleva a una serie de actividades relevantes a realizar para facilitar la comprensión de lo observado por tal razón es necesario seleccionar a las personas claves dentro de esta investigación, así como participar dentro del Programa de Tutorías aclarando todo lo observado por medio de entrevistas semiestructuradas tomando notas organizadas y estructuradas para facilitar su posterior interpretación, así pues se confirma la importancia de la observación puesto que da pie a la realización de entrevistas a diversos tutores como se ha realizado por el momento.

Angell et al. (1992) afirma que "La objetivación de métodos y técnicas constituye uno de los ideales de todo científico. Con esto queremos decir que aspira a observar, registrar e interpretar los sucesos en forma tal que observadores independientes puedan verificar sus hallazgos" (p.235).

\section{Procedimiento}

A continuación, se muestra la tabla 2 con relación a los instrumentos de investigación y tecnológicos necesarios para lograr desarrollar cada fase, con el objeto de dar cumplimiento al objetivo establecido, en cada fase podemos visualizar correctamente los participantes que intervienen. 
Tabla 2. Instrumentos y técnica de recogida de información.

\begin{tabular}{|c|c|c|c|c|}
\hline OBJETIVO & FASES & $\begin{array}{l}\text { INSTRUMENTOS } \\
\text { INVESTIGACIÓN }\end{array}$ & $\begin{array}{l}\text { INSTRUMENTOS TEC- } \\
\text { NOLÓGICOS }\end{array}$ & PARTICIPANTES \\
\hline \multirow{15}{*}{$\begin{array}{l}\text { Diseñar, desarrollar, } \\
\text { implementar y validar un } \\
\text { Sistema de Tutorías con } \\
\text { base en el levantamiento } \\
\text { de requerimientos que } \\
\text { permitan obtener un esce- } \\
\text { nario de las necesidades } \\
\text { que establece el Área de } \\
\text { Tutorías y Apoyo Psicope- } \\
\text { dagógica-Tutor-Tutorado, } \\
\text { y satisfacer mediante la } \\
\text { implementación y valida- } \\
\text { ción de este. }\end{array}$} & $\begin{array}{l}\text { Análisis de la situa- } \\
\text { ción. Detección de ne- } \\
\text { cesidades. Definición } \\
\text { del problema. }\end{array}$ & Observación & Lucidchart & $\begin{array}{l}\text { Área de Psicología, } \\
\text { Comisión de Profe- } \\
\text { sores-lnvestigadores, } \\
\text { Estudiantes y Rectoría. }\end{array}$ \\
\hline & Fundamentación. & Entrevista & Lucidchart & $\begin{array}{l}\text { Área de Psicología, } \\
\text { Comisión de Profeso- } \\
\text { res-Investigadores y } \\
\text { Rectoría. }\end{array}$ \\
\hline & $\begin{array}{l}\text { Desarrollo de solucio- } \\
\text { nes de acuerdo con } \\
\text { una fundamentación } \\
\text { teórica. }\end{array}$ & Entrevista & HostGator y MAMP & $\begin{array}{l}\text { Tutor, Tutorado, Área } \\
\text { de tutorías y Apoyo } \\
\text { psicopedagógico, } \\
\text { Área Médica, Coordi- } \\
\text { nación de trayectoria, } \\
\text { Comisión de tutorías y } \\
\text { Rectoría. }\end{array}$ \\
\hline & $\begin{array}{l}\text { Desarrollo de Catá- } \\
\text { logos. }\end{array}$ & Entrevista & $\begin{array}{l}\text { Dreamweaver y Sequel- } \\
\text { Pro }\end{array}$ & $\begin{array}{l}\text { Área de tutorías y Apo- } \\
\text { yo psicopedagógico. }\end{array}$ \\
\hline & Validaciones. & Observación & $\begin{array}{l}\text { Dreamweaver y Sequel- } \\
\text { Pro }\end{array}$ & $\begin{array}{l}\text { Área de tutorías y Apo- } \\
\text { yo psicopedagógico. }\end{array}$ \\
\hline & Pilotaje. & $\begin{array}{l}\text { Cuestionario de usa- } \\
\text { bilidad y satisfacción } \\
\text { para la evaluación de } \\
\text { herramientas web }\end{array}$ & $\begin{array}{l}\text { Navegadores y Google } \\
\text { Forms }\end{array}$ & $\begin{array}{l}\text { Área de tutorías y Apo- } \\
\text { yo psicopedagógico. }\end{array}$ \\
\hline & $\begin{array}{l}\text { Desarrollo de relacio- } \\
\text { nes de la funcionali- } \\
\text { dad entre Catálogos. }\end{array}$ & Entrevista & $\begin{array}{l}\text { Dreamweaver y Sequel- } \\
\text { Pro }\end{array}$ & $\begin{array}{l}\text { Área de tutorías y Apo- } \\
\text { yo psicopedagógico. }\end{array}$ \\
\hline & Validaciones. & Observación & $\begin{array}{l}\text { Dreamweaver y Sequel- } \\
\text { Pro }\end{array}$ & $\begin{array}{l}\text { Área de tutorías y Apo- } \\
\text { yo psicopedagógico. }\end{array}$ \\
\hline & Pilotaje. & $\begin{array}{l}\text { Cuestionario de usa- } \\
\text { bilidad y satisfacción } \\
\text { para la evaluación de } \\
\text { herramientas web }\end{array}$ & $\begin{array}{l}\text { Navegadores y Google } \\
\text { Forms }\end{array}$ & $\begin{array}{l}\text { Área de tutorías y Apo- } \\
\text { yo psicopedagógico. }\end{array}$ \\
\hline & $\begin{array}{l}\text { Permisos y privacidad } \\
\text { usuarios. }\end{array}$ & Entrevista & $\begin{array}{l}\text { Dreamweaver y Sequel- } \\
\text { Pro }\end{array}$ & $\begin{array}{l}\text { Área de tutorías y Apo- } \\
\text { yo psicopedagógico. }\end{array}$ \\
\hline & Validaciones. & Observación & $\begin{array}{l}\text { Dreamweaver y Sequel- } \\
\text { Pro }\end{array}$ & $\begin{array}{l}\text { Área de tutorías y Apo- } \\
\text { yo psicopedagógico. }\end{array}$ \\
\hline & Pilotaje. & $\begin{array}{l}\text { Cuestionario de usa- } \\
\text { bilidad y satisfacción } \\
\text { para la evaluación de } \\
\text { herramientas web }\end{array}$ & $\begin{array}{l}\text { Navegadores y Google } \\
\text { Forms }\end{array}$ & $\begin{array}{l}\text { Área de tutorías y Apo- } \\
\text { yo psicopedagógico. }\end{array}$ \\
\hline & $\begin{array}{l}\text { Implementación } \\
\text { general. }\end{array}$ & Observación & Navegadores & $\begin{array}{l}\text { Tutor, Tutorado, Área } \\
\text { de tutorías y Apoyo } \\
\text { psicopedagógico, } \\
\text { Area Médica, Coordi- } \\
\text { nación de trayectoria, } \\
\text { Comisión de tutorías y } \\
\text { Rectoría }\end{array}$ \\
\hline & Validación y pilotaje. & Cuestionario & $\begin{array}{l}\text { Navegadores y Google } \\
\text { Forms }\end{array}$ & $\begin{array}{l}\text { Tutor, Tutorado, Área } \\
\text { de tutorías y Apoyo } \\
\text { psicopedagógico, } \\
\text { Área Médica, Coordi- } \\
\text { nación de trayectoria, } \\
\text { Comisión de tutorías y } \\
\text { Rectoría }\end{array}$ \\
\hline & $\begin{array}{l}\text { Producción de docu- } \\
\text { mentación y princi- } \\
\text { pios de diseño. }\end{array}$ & Observación & Paquetería Office & $\begin{array}{l}\text { Área de tutorías y Apo- } \\
\text { yo psicopedagógico. }\end{array}$ \\
\hline
\end{tabular}




\section{Resultados}

Con base en la tabla 2, la investigación se encuentra situada en las fases 7 y 10 , una vez desarrolladas se pasará en conjunto la fase de validación y pilotaje correspondientes a las fases 8, 9, 11 y 12, previo a iniciar el desarrollo de las fases se atendieron las observaciones generadas a partir del pilotaje de las fases 4, 5 y 6 .

A continuación, se presenta el proceso de las fases actuales. En la figura 3 se muestra la codificación realizada para lograr relacionar los catálogos desarrollados en la fase 4. En la fase 7 se debe lograr establecer esa relación cuidando la veracidad de la información y evitando relacionarlos erróneamente.

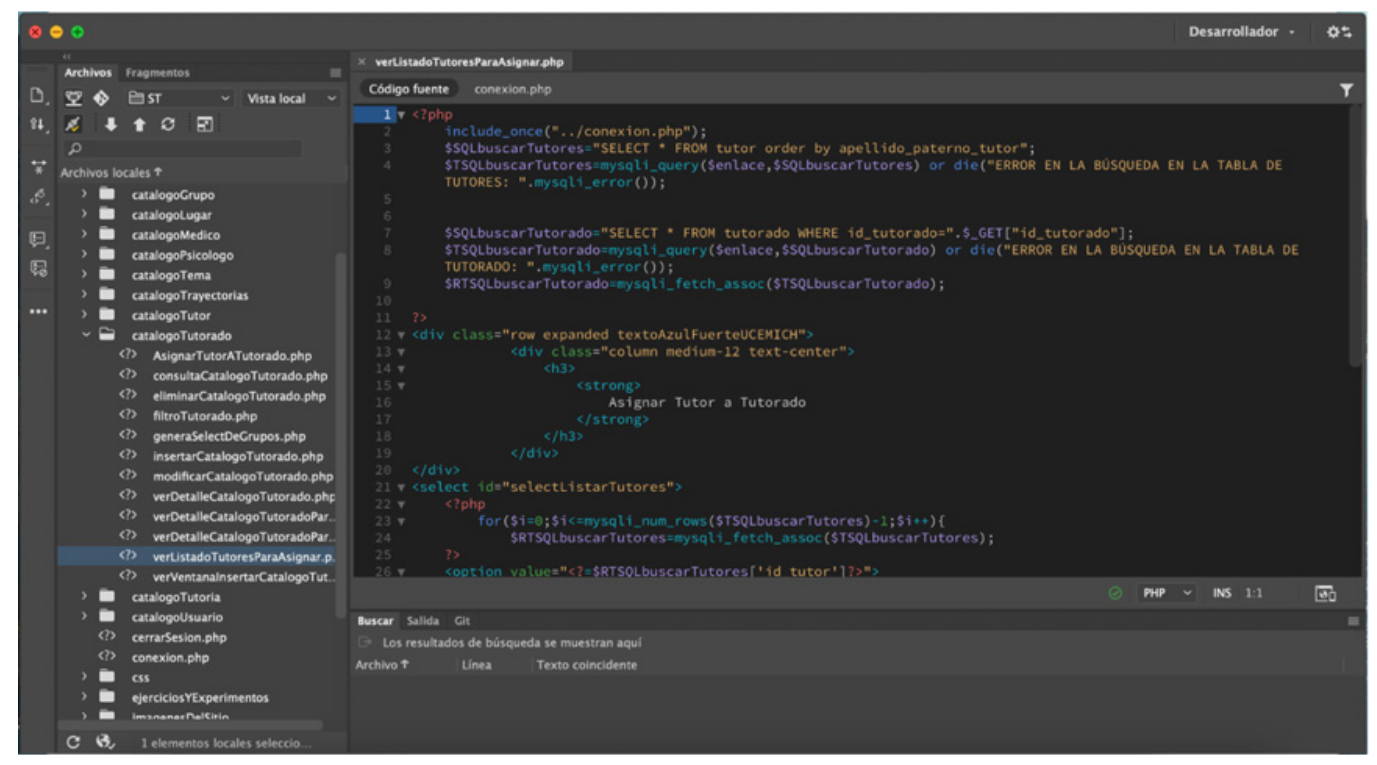

Figura 3. Programación para las relaciones de la funcionalidad entre Catálogos.

Una vez funcionando correctamente se puede establecer dicha relación y la realización de las asignaciones que atienden a lo solicitado por los diversos participantes. Ver figura 4 y 5.

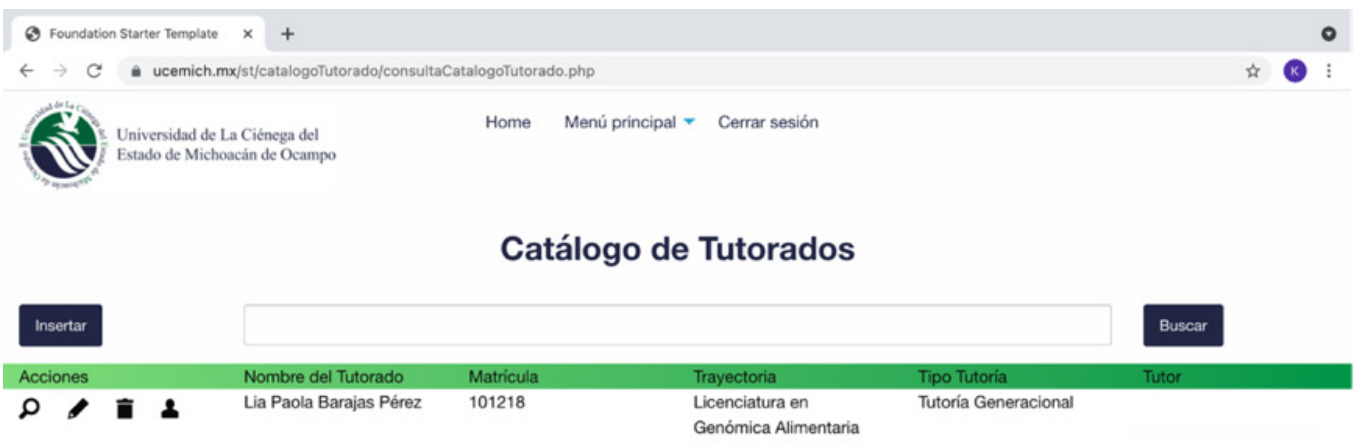




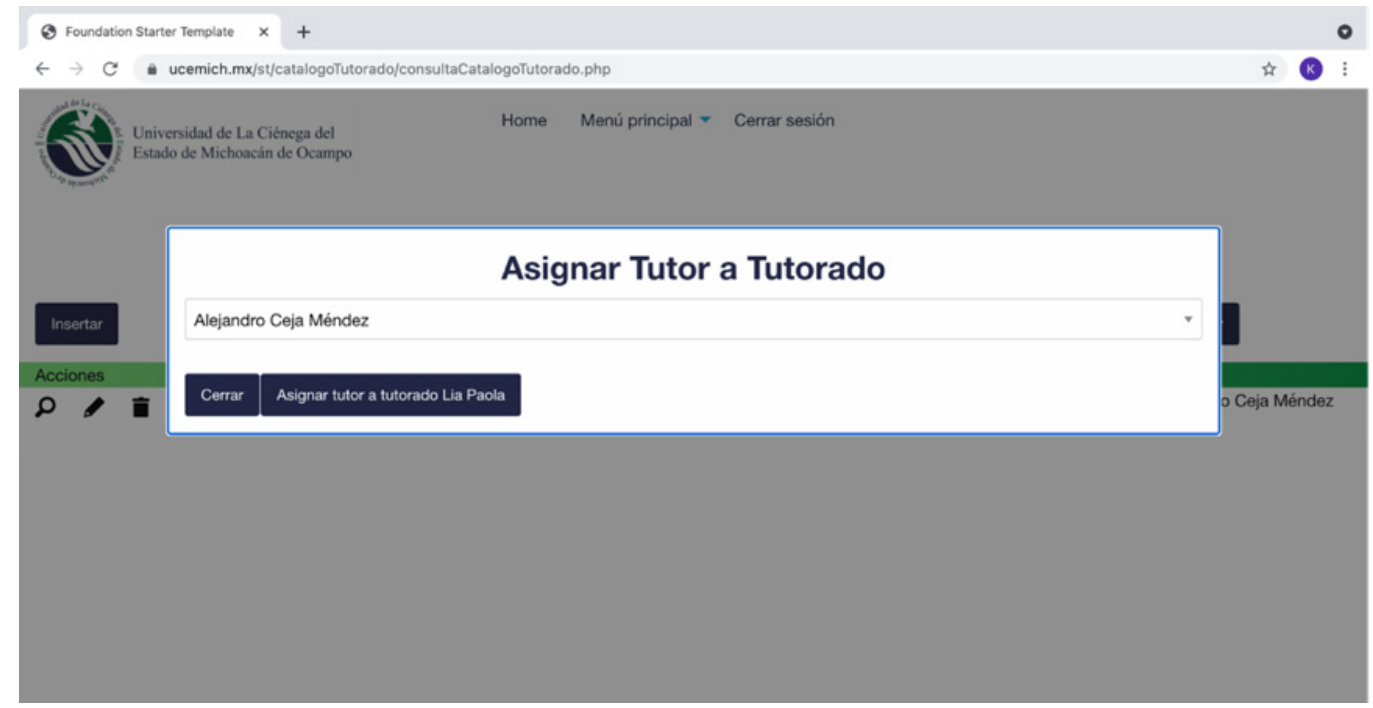

Figura 5. Asignación de Tutor al Tutorado dado de alta.

Para el buen uso y manejo de la información en el sistema en desarrollo es de suma importancia que los usuarios que harán uso de este cuenten con los permisos (accesos) indicados a la hora del ingreso al sistema, por lo que se diseño una base de datos que permita relacionar el tipo de usuario con el elemento del menú que podrá controlar. Ver figura 6.

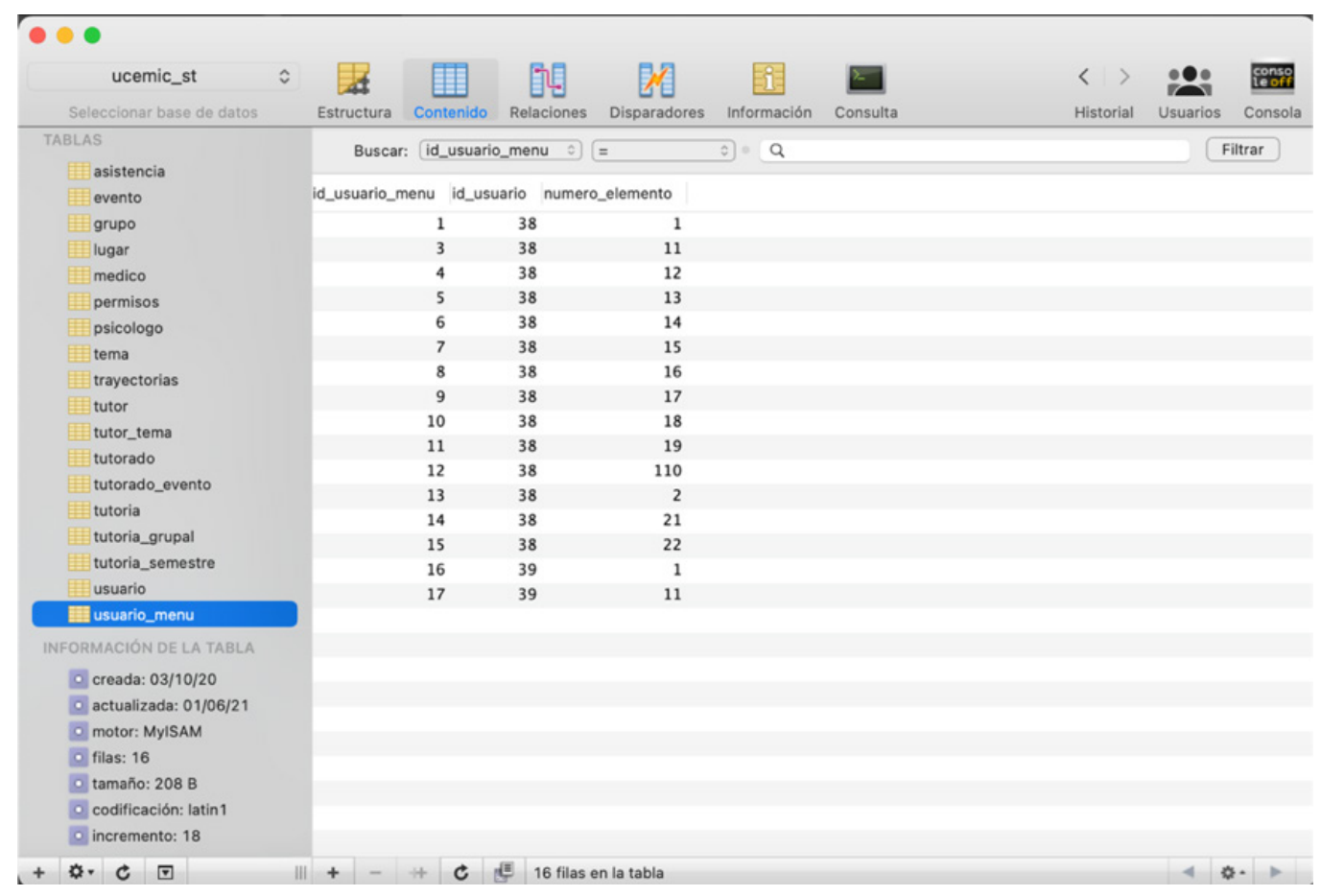

Figura 6. Permisos asignados para ingresar al sistema en desarrollo.

Una vez asignados los permisos, se realizan pruebas de ingreso al sistema, por medio de variables de sesión que permitan identificar el tipo de usuario que se encuentra 
realizando la petición del acceso, realiza la validación y en caso de ser correctas las credenciales se realiza el ingreso al mismo de manera exitosa como se visualiza en las figuras 7 .

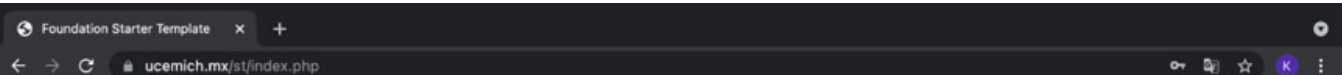

$\leftrightarrow C A$ ucemich.mx/stindex.php

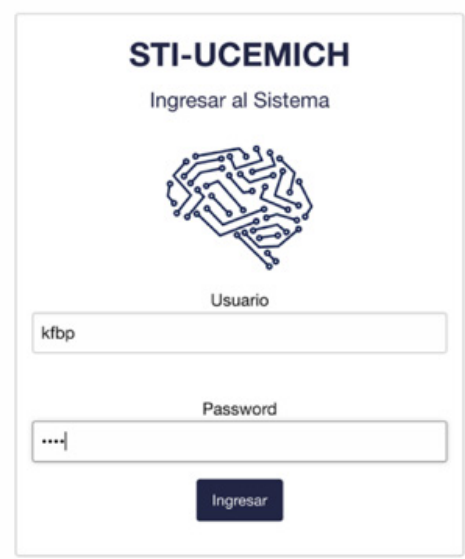

Figura 7. Introducción y validación de credenciales de usuario.

El sistema realiza la validación y revisa de que usuario se trata y solo le permite visualizar el catálogo correspondiente para su uso y manejo, ocultando los que no puede manipular, esto permite que la información se encuentre disponible solo para el tipo de usuario que así lo requiera. Ver figura 8.

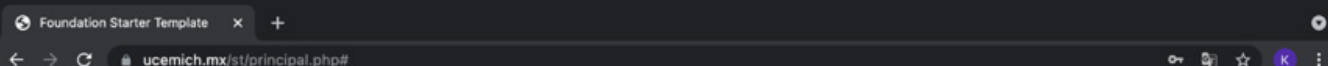

Home Menú principal Cerrar sesión 


\section{Discusión y conclusiones}

En cuanto a lo abordado en esta investigación se puede precisar que como primera instancia se realizó el levantamiento de requerimientos por medio del uso de instrumentos y técnicas de recogida de datos, tales como entrevistas y observación; mismos que permitieron obtener un panorama general de la situación actual existente en la UCEMICH en materia de tutorías. Con base en lo anterior se da inicio al desarrollo de las interfaces para la creación del sistema de tutorías, tomando en consideración los servicios y funcionalidades que establecieron en los requisitos del Área de Tutorías y Apoyo Psicopedagógica-Tutor-Tutorado.

En conclusión, el desarrollo del sistema de tutorías permitirá que las diversas áreas realicen el proceso de tutorías manera eficaz y eficiente utilizando instrumentos tecnológicos desarrollados acorde a sus necesidades.

\section{Referencias}

Angell, C. R, Campbell, A. A, Cannell, F. C, Cartwright, W. D, Coombs, H. C, Festinger, L.,...Zander, F. A. (1992). La reunión de datos mediante entrevistas. In C. Charles, K. Robert (Eds.), Los métodos de investigación en las ciencias sociales (pp. 310-352). The Dryden Press.

Angell, C. R, Campbell, A. A, Cannell, F. C, Cartwright, W. D, Coombs, H. C, Festinger, L.,...Zander, F. A. (1992). Los problemas de la observación objetiva . In P. Helen (Eds.), Los métodos de investigación en las ciencias sociales (pp. 235-285). The Dryden Press.

Aguado, G. S., Cornejo, C.B., Alarcón, Z.C., Elizarraraz, A.I., Yudico, A.L., Corona, F.C.,... Cruz, M.I. (2010). Plan de desarrollo institucional 2010-2022 [archivo PDF]. Recuperado de http://ucienegam.mx/wp-content/uploads/2018/08-Doc/Documentos/Oficiales/PDI_2010_2022La.pdf

Barab, S.A., y Squire, K. (2004). Design-Based Research: Putting a Stake in the Ground. The Journal of the Learning Sciences, 13(1), 1-14.

Cano, G. R. (2009). Tutoría universitaria y aprendizaje por competencias ¿Cómo lograrlo?. Revista Electrónica Interuniversitaria de Formación del Profesorado, 12(1), 181-204. Recuperado de http://www.aufop.com/

Cobb, P., Confrey, J., DiSessa, A., Lehrer, R., y Schauble, L. (2003). Design Experiments in Educational Research. Educational Researcher, 32(1), 9-13. Retrieved from http://www.jstor.org/stable/3699928

De Benito, C. B, y Salinas, I. J. (2016). La investigación basada en diseño en Tecnología Educativa. RIITE. Revista Interuniversitaria de Investigación en Tecnología Educativa(0), 44-59. http://dx.doi.org/10.6018/riite/2016/260631

Gobierno Constitucional del Estado de Michoacán de Ocampo. (2006). Decreto . Decreto mediante el cual se crea la Universidad de La Ciénega del Estado de Michoacán 
de Ocampo. Publicado en El Periodico Oficial del Gobierno Constitucional del Estado de Michoacán de Ocampo No. 34, del 21 de diciembre de 2006. México.

Goetz, J. P., y LeCompte, M. D. (1984). Etnografía y diseño cualitativo en investigación educativa. Madrid, España: Ediciones Morata, S.A.

H. Junta Directiva. (2009). Reglamento General del Personal Académico de La Universidad de La Ciénega del Estado de Michoacán de Ocampo. Universidad de La Ciénega del Estado de Michoacán de Ocampo. Publicado en la página institucional de la Univerdidad de La Ciénega del Estado de Michoacán de Ocampo, del 18 de diciembre de 2009.México.

Martínez, D. A, y Bernal, V. D. (2018). Programa Institucional de Tutorías de la UCEMICH [PIT] [archivo PDF]. Recuperado de https://ucienegam.mx/wp-content/ uploads/2019/08-Doc/Documentos/PIT_UCEMICH_aprobado_por_Junta_Directiva.pdf

Plomp, T., y Nieveen, N. M. (2007). An introduction to educational design research: Proceedings of the seminar conducted at the East China Normal University, Shanghai (PR China), November 23-26, 2007. Stichting Leerplan Ontwikkeling (SLO).

Reeves, T. C. (2000). Enhancing the Worth of Instructional Technology Research through "Design Experiments" and Other Development Research Strategies. International Perspectives on Instructional Technology Research for the 21st Century Symposium.

Reeves, T. C. (2006). Design research from the technology perspective. En J. van den Akker, K. Gravemeijer, S. McKenney, y N. Nieveen (Eds.), Educational design research (pp. 86- 109). London: Routledge.

Valverde-Berrocoso, J. (2016). La investigación en Tecnología Educativa y las nuevas ecologías del aprendizaje: Design-Based Research (DBR) como enfoque metodológico. RIITE. Revista Interuniversitaria de Investigación en Tecnología Educativa (O), 60-73. http://dx.doi.org/10.6018/riite/2016/257931 


\section{Aportes al Desarrollo de la Competencia Digital Docente desde la Propuesta del Modelo TEP}

Pinto-Santos, Alba Ruth orcid.org/0000-0001-8414-544X

Pérez Garcias, Adolfina orcid.org/0000-0002-1863-375X

Darder Mesquida, Antonia

orcid.org/0000-0003-2964-3301 


\title{
APORTES AL DESARROLLO DE LA COMPETENCIA DIGITAL DOCENTE DESDE LA PROPUESTA DEL MODELO TEP
}

\author{
Pinto-Santos, Alba Ruth \\ Pérez Garcias, Adolfina \\ Darder Mesquida, Antonia
}

\section{Resumen}

El Modelo TEP es una propuesta para fortalecer los dominios Tecnológico, Empoderado y Pedagógico de la Competencia Digital Docente (CDD) en la Formación Inicial Docente (FID). El propósito de este trabajo es presentar los principios, dominios e indicadores de competencia del modelo TEP. A nivel metodológico, se asume la investigación basada en diseño (IBD) para la preparación y evaluación del modelo. El modelo fue validado a través del método Delphi modificado por 11 expertos en tecnología educativa. Se concluye, a partir del análisis y ajustes desarrollados en las dos rondas de evaluación, que el modelo TEP es una propuesta centrada y válida para el contexto especifico de la FID ya que permite articular la formación de los futuros docentes a las necesidades del contexto profesional.

\section{Palabras clave}

Competencia Digital Docente (CDD), Formación Inicial Docente (FID), Modelo TEP, Método Delphi modificado. 


\section{Introducción}

Existe un consenso entre la comunidad académica y científica frente a que en la Formación Inicial Docente (FID) se requiere el desarrollo la Competencia Digital Docente (CDD). Desde esta perspectiva autores como Silva (2012), Flores (2014), Villant (2014), Flores-Lueg \& Vila (2016), Admiraal et al. (2016) entre otros, aseguran que se debe fortalecer las acciones que permitan la formación inicial y continua del profesorado de manera que se logren garantizar los conocimientos y habilidades que faciliten al docente aprovechar la tecnología digital en el ejercicio profesional. Asimismo, es necesario en el contexto latinoamericano mayor compromiso de los gobiernos, en el desarrollo y adopción de políticas para el desarrollo de la CDD (Silva et al., 2018).

No obstante, realizar propuestas para promover el desarrollo de la CDD sigue siendo un reto. Se requiere asumir la acreditación de la CDD como un requisito de la formación del docente que garantice la excelencia del ejercicio profesional, y para ello se necesitan modelos y estándares de referencia que sean orientadores de los procesos de formación de los futuros docentes y de los maestros en ejercicio (Silva, 2012; Masoumi, 2021; Pinto et al., 2021). Asimismo, "la implementación de las TIC en el ámbito educativo exige un replanteamiento profundo de los sistemas de formación inicial y permanente del profesorado, así como un planteamiento holístico para su transformación que suponga un revulsivo para la modificación o el cambio del actual modelo de enseñanza y aprendizaje" (Peirats-Chacón et al., 2018, p. 56).

Por lo tanto, se reconoce la necesidad de la FID de desarrollar las habilidades para integrar la tecnología educativa de manera efectiva en el ejercicio docente, y que coincida la formación en CDD del futuro docente con las demandas profesionales requeridas en el escenario laboral (Instefjord y Munthe, 2017; Voogt y McKenney, 2017; Pozas y Letzel, 202). En este sentido, este trabajo presenta los principios, dominios e indicadores de CDD en la formación inicial docente (FID) desde la propuesta del modelo TEP, que se convierte en referente en procesos de formación para la apropiación de la tecnología digital en el ejercicio profesional del docente.

\section{Visión general del Modelo Tecnológico, Empoderado, y Pedagógico}

EI Modelo TEP propone articular las propuestas de los marcos institucionales y modelos de CDD frente a las competencias laborales de docentes en tecnología digital con las competencias educacionales en la FID (Pinto, Pérez, y Darder, 2020). Es decir, se considera que se deben hacer mayores esfuerzos por incorporar en los currículos de los programas de magisterio el desarrollo de la CDD de manera trasversal, integradora, situada, autentica y flexible, desde el dominio tecnológico, empoderado, y pedagógico. El Modelo TEP es una propuesta para que las instituciones formadoras de maestros garanticen el desarrollo de las competencias que le permitan al futuro docente usar la tecnología digital de manera crítica, creativa, colaborativa, para promover los procesos de enseñanza aprendizaje, y para aprender a lo largo de la vida.

El modelo TEP presenta los principios: transversal, integrador, situado, autentico, y flexible, los cuales están descritos en la figura 1. El primero está asociado a la forma como diferentes campos de formación contribuyen al desarrollo de la CDD. Lo integrador se relaciona con la pretensión de que el individuo alcance conocimiento y habilidades que 
pueda aplicar en su ejercicio profesional. También se propone que los procesos de formación se desarrollen de manera situada atendiendo el contexto educativo. Asimismo, se plantean estrategias auténticas y flexibles en los procesos de enseñanza.

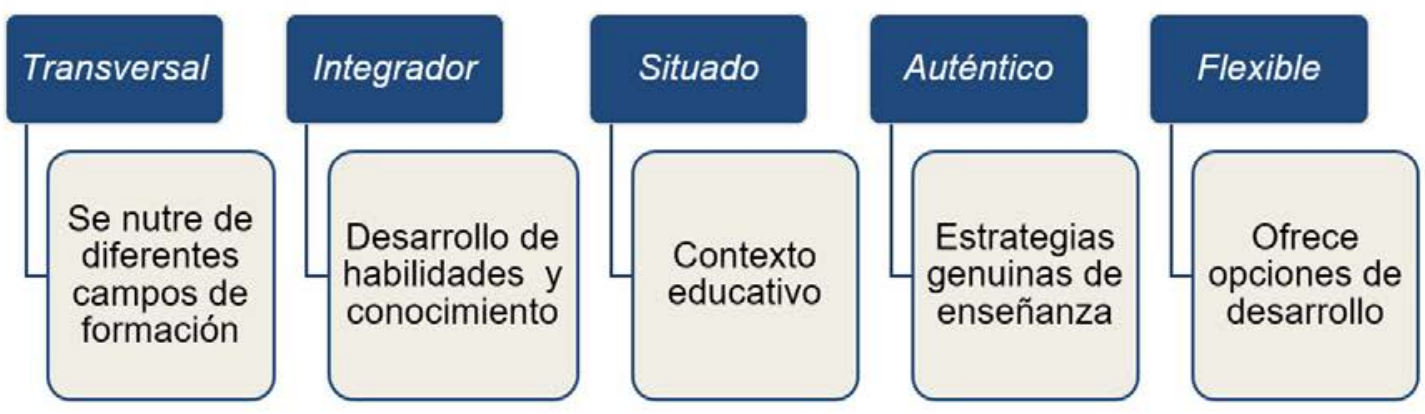

\section{Figura 1. Principios del Modelo TEP}

En la figura 2 se puede observar el esquema del Modelo TEP, en el cual los 5 principios descritos anteriormente son la base para desarrollar los dominios Tecnológico, Empoderado, y Pedagógico de la CDD. El dominio Tecnológico se relaciona con las capacidades frente al uso de la tecnología digital para la creación, uso y reutilización de recursos educativos, para aprender, participar, y promover el aprendizaje y desarrollo de competencias en los estudiantes. El dominio Empoderado se asocia a las capacidades y actitudes para aprovechar la tecnología digital en el ejercicio profesional de manera creativa, reflexiva, responsable, ética, y segura, para el mejoramiento de la práctica docente, y para promover la ciudadanía digital de los estudiantes. Finalmente, el dominio Pedagógico corresponde a los conocimientos y disposiciones para diseñar, implementar y evaluar metodologías de enseñanza innovadoras donde se aproveche la tecnología digital para generar prácticas educativas flexibles, retadoras, participativas, y que potencien la construcción de conocimiento.

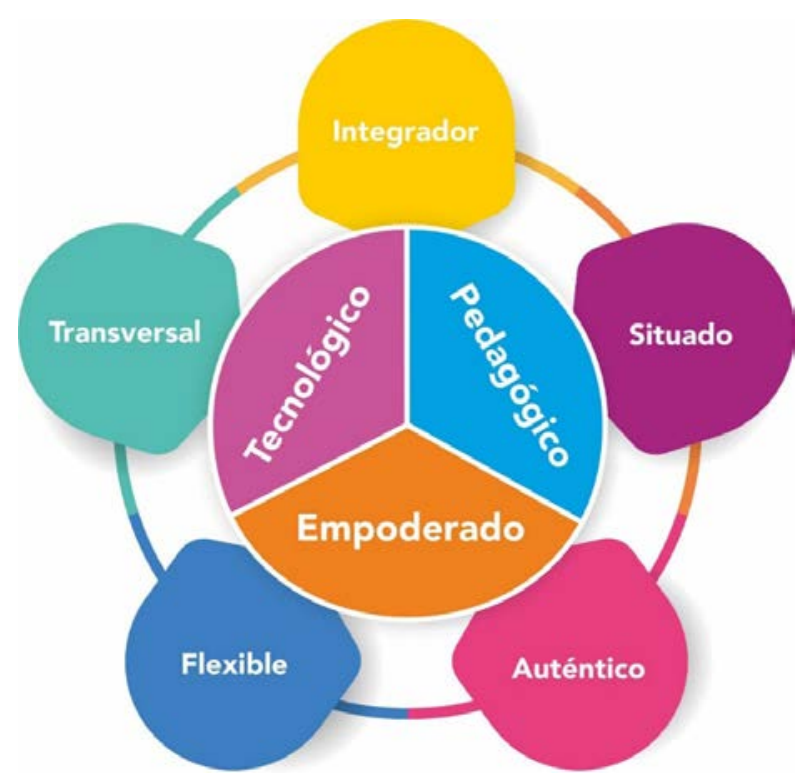

Figura 2. Esquema del Modelo TEP para el Desarrollo de la CDD en la FID 


\section{Método}

Esta investigación orientada al diseño y validación de un Modelo para el desarrollo de las CDD en la FID, asume los postulados de la Investigación Basada en Diseño (IBD), la cual consiste en una estrategia a largo plazo para desarrollar y evaluar procesos de innovación educativa desde el reconocimiento de problemáticas del contexto (Anderson, 2005), la cual ayuda a la integración de la teoría y la práctica (Valverde-Berrocoso, 2016), y promueve intervenciones educativas desde una serie de fases para mejorar el diseño (Plomp, 2010; De Benito \& Salinas, 2016).

Para la realización de la investigación se desarrollaron 4 etapas procedimentales. La primera consistió en la revisión sistemática de la literatura y la identificación de 7 marcos y estándares institucionales, y 5 modelos holísticos de la CDD. La segunda correspondió al análisis comparativo de los aspectos conceptuales, metodológicos, pedagógicos y prácticos que ofrecen tanto los marcos como los modelos de CDD para el proceso de la FID. La tercera etapa se relaciona con la formulación del Modelo TEP, siguiendo las especificaciones metodológicas del enfoque de investigación basado en diseño. Finalmente se realizó el proceso de validación del modelo TEP siguiendo los procesos establecidos por Cabero (2014) y Riaño \& Palomino (2015) para el método Delphi modificado.

El protocolo de evaluación y validación de jueces expertos con el método Delphi modificado, recibió la valoración y retroalimentación por parte de 11 expertos en tecnología educativa, en dos rondas de evaluación. Además, contó con una serie de indicadores para valorar cada uno de los principios, dominios, y competencias del modelo TEP, en una escala de evaluación que va de 1 a 5, siendo 1 el nivel más bajo y 5 el más alto. Asimismo, cada ítem contó con una opción para las observaciones y recomendaciones por parte de los expertos.

\section{Resultados}

A continuación, se puede observar en la tabla 1, que durante las dos rondas de evaluación realizadas por expertos en tecnología educativa, todas las valoraciones fueron positivas y superiores a $(4,0)$ para cada una de las dimensiones, lo cual permitió que los indicadores de cada dimensión recibieran ajustes de acuerdo a las recomendaciones de los expertos. Siendo los principios y los indicadores de evaluación los que presentaron mayor valoración por los expertos en la segunda ronda $(4,7$ y 4,8). En este sentido, no fue necesario sustituir elementos constitutivos de las dimensiones del modelo, pero si se mejoraron a partir de la retroalimentación de los expertos. 


\begin{tabular}{|l|l|l|l|l|}
\hline \multirow{2}{*}{ Dimensión de Evaluación } & \multicolumn{2}{|l|}{ Primera Ronda } & \multicolumn{2}{l|}{ Segunda Ronda } \\
\cline { 2 - 6 } & Media & $\begin{array}{l}\text { Desviación } \\
\text { Estándar }\end{array}$ & Media & $\begin{array}{l}\text { Desviación } \\
\text { Estándar }\end{array}$ \\
\hline Contextualización & 3,8 &, 43 & 4,6 &, 28 \\
\hline Esquema del modelo TEP & 3,9 &, 52 & 4,6 &, 33 \\
\hline Principios y Dominios del Modelo TEP & 4,0 &, 75 & 4,7 &, 20 \\
\hline $\begin{array}{l}\text { Indicadores de evaluación } \\
\text { del Modelo TEP }\end{array}$ & 4,1 &, 69 & 4,8 &, 20 \\
\hline Evaluación general & 3,9 &, 48 & 4,7 &, 16 \\
\hline
\end{tabular}

Tabla 1. Resultados generales de la segunda ronda de valoración por expertos

Posteriormente con las figuras 2 y 3 se presenta la comparación entre los promedios de los consolidados de los indicadores para las dimensiones principios y dominios, e indicadores de competencia. Es este sentido, se puede observar el cambio positivo en la calidad de las valoraciones entre la Ronda 1 y la Ronda 2.

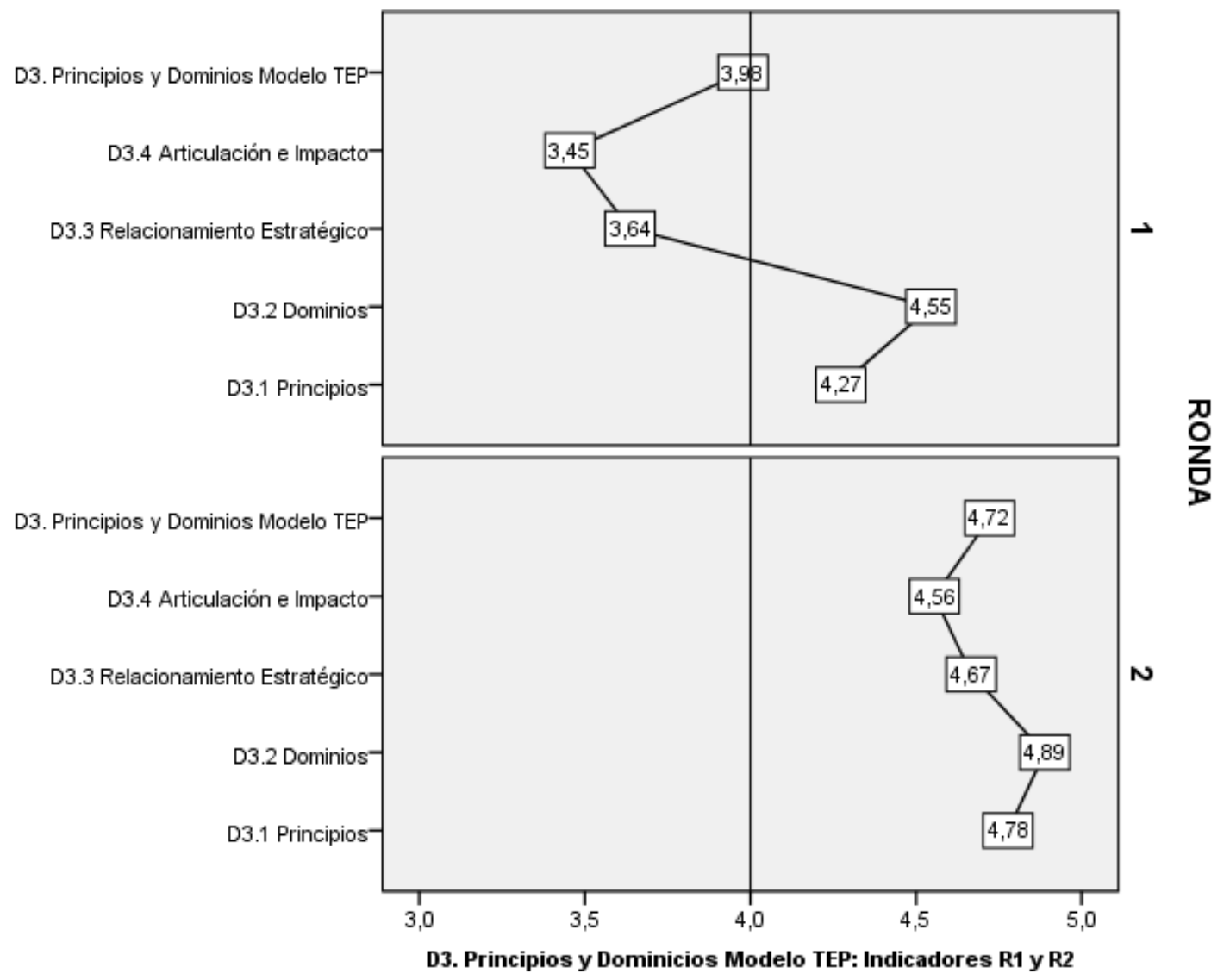

Figura 3. Comparación de las valoraciones entre la primera y segunda ronda de la dimensión principios y dominios del modelo TEP 


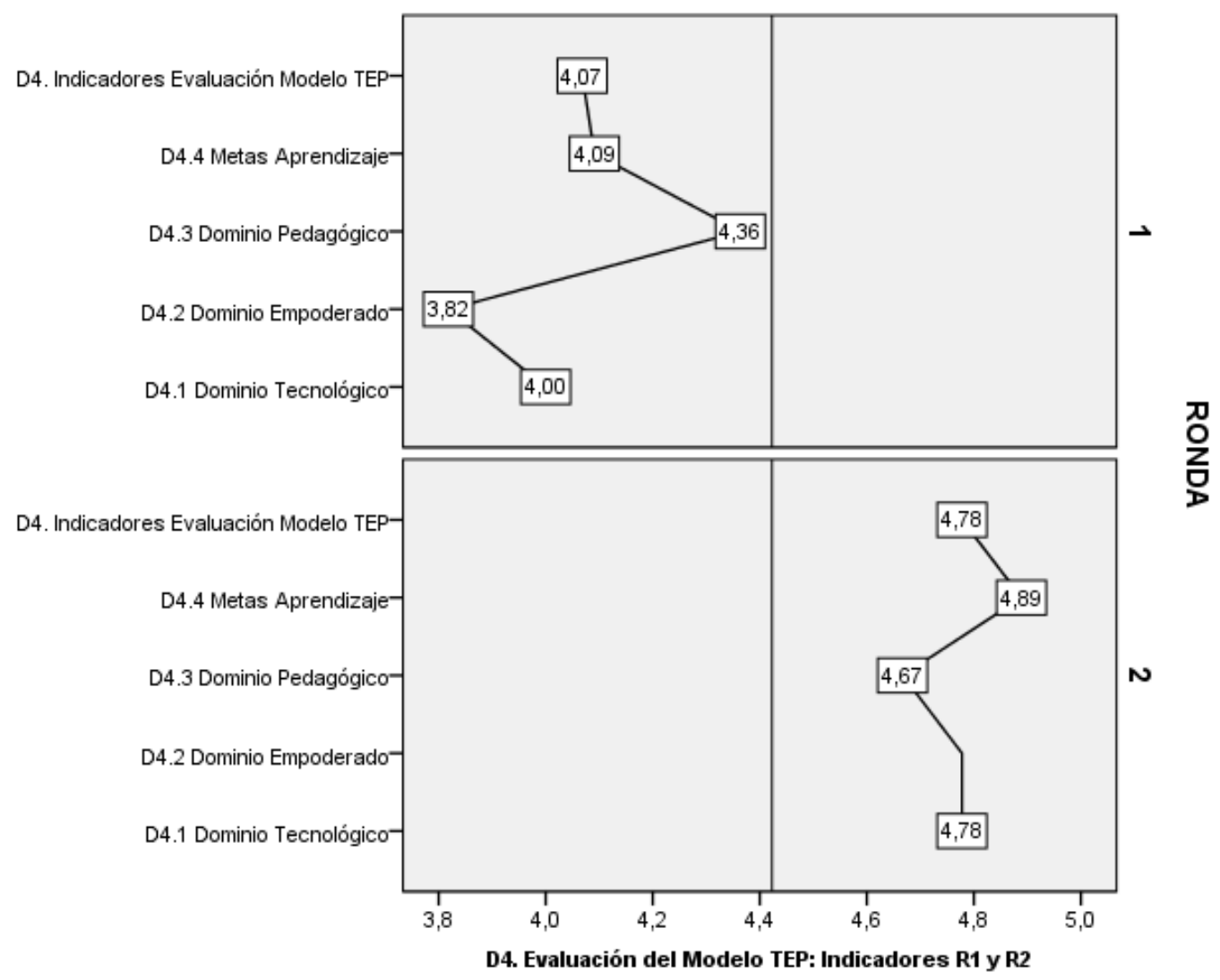

Figura 4. Comparación de las valoraciones entre primera y segunda ronda de la dimensión indicadores de competencias del modelo TEP

\section{Discusión y conclusiones}

Este estudio encontró que el Método Delphi modificado se convierte en una oportunidad de mejora a las propuestas de innovación educativa basadas en la Investigación Basada en Diseño (IBD) que permite la retroalimentación a las diferentes dimensiones de evaluación.

Asimismo, se resalta que el modelo TEP es una propuesta derivada de la revisión cuidadosa de la literatura que se ha nutrido de los marcos y modelos con aceptación internacional, y que cuenta con un proceso de valoración y retroalimentación a través de juicio de expertos, el cual se convierte en referente para diseñar políticas educativas para promover la CDD en la FID. En este sentido, los principios y dominios del modelo responden al llamado de académicos en torno a que en el contexto histórico actual es fundamental promover la CDD en los futuros maestros a través del aprendizaje situado y significativo (Alonso-Ferreiro, 2018; Tiede, 2020) y que es imprescindible realizar formaciones activas, contextualizadas, y colaborativas que permitan al estudiante de la FID acercarse a la realidad de su rol profesional (Esteve et al., 2016; Buss et al, 2015; Masoumi, 2021).

Se coincide con diversos autores en que el docente debe desarrollar múltiples competencias dentro de las cuales la CDD es indispensable para promover mejoras en 
el ejercicio docente (Cortes et al., 2015; Pinto et al., 2017; Silva et al., 2018; Cabero y Martínez, 2019; Soler-Costa, et al, 2021). Asimismo, ese aprovechamiento de la tecnología educativa a nivel profesional va desde la apropiación de la tecnología digital para aprender de manera permanente y continua, enseñar en diversos escenarios y atendiendo al contexto del que aprende, gestionar el progreso de los estudiantes de acuerdo a los objetivos educativos, colaborar y trabajar en equipo, aportar a las distintas necesidades de la comunidad educativa, participar en la construcción de conocimiento, e innovar en la práctica educativa).

Por su parte, se considera que el Modelo TEP es una propuesta centrada y respaldada por expertos en tecnología educativa que se encuentra en construcción, la cual toma el concepto de empoderamiento y participación, y busca que la FID se convierta en espacio de reflexión de la transformaciones de los escenarios de aprendizaje y el análisis de las pedagogías emergentes, en donde la acción de desarrollo de la CDD se centra en fortalecer de manera integrada los dominios tecnológico, empoderado y pedagógico desde procesos transversales, integradores, auténticos, situados, y flexibles.

\section{Referencias}

Admiraal, W., van Vuget, F., Kranenburg, F., Koster, B., Smit, B., Weijers, S., et al. (2016). Preparing pre-service teachers to integrate technology into K-12 instruction: Evaluation of a technology-infused approach. Technology, Pedagogy and Education, 26(1), 105-120. https://doi.org/10.1080/1475939X.2016.1163283

Alonso-Ferreiro, A. (2018). Project-Based Learning to Foster Preservice Teachers' Digital Competence. Latin American Journal of Educational Technology, 17(1). DOI: https://doi.org/10.17398/1695-288X.17.1.9

Anderson, T. (2005). Design-based research and its application to a call center innovation in distance education. Canadian Journal of Learning and Technology, 31(2), 69-84. Recuperado de https://www.learntechlib.org/p/42762/

Cabero Almenara, J. (2014). University teacher training in ICT. application of Delphi Method for the selection of training content. Educación XX1, 17 (1), 111-132. https:// doi.org/10.5944/educxx1.17.1.10707

Cabero-Almenara, J. \& Martínez, A. (2019). Information and Communication Technologies and initial teacher training. Digital models and competences. Profesorado. Revista de Currículum y Formación de Profesorado, 23(3), 247-268 https://doi. org/10.30827/profesorado.v23i3.9421

Cortes, O., Pinto. A, \& Atrio, S. (2015). E-portfolios as a tool for active constructionist learning in educational technology. Lasallista of Research Journal, 12(2), 36-44. https://doi.org/10.22507/rli.v12n2a4

Esteve-Mon, F. M., Cela-Ranilla, J. M., \& Gisbert-Cervera, M. (2016). ETeach3D: Designing a 3D virtual environment for evaluating the digital competence of preservice teachers. Journal of Educational Computing Research, 54(6), 816-839. https://doi. org/10.1177/0735633116637191 
Flores, C. (2014). Competencia digital docente: desempeños didácticos en la formación inicial del profesorado. Revista Hachetetepe, 9, 55-70. Recuperado de http:// revistaeducarnos.com/wp-content/uploads/2014/11/Libro-Nov.14-web.pdf

Flores-Lueg, C. \& Roig, R. (2016). Design and validation of a scale of self-assessment digital skills for students of education. Pixe/-Bit, 48, 209-224. http://dx.doi. org/10.12795/pixelbit.2016.i48.14

Peirats-Chacón, José; Gabaldón-Estevan, Daniel; Marín-Suelves, Diana. (2018). Percepciones sobre materiales didácticos y la formación en competencia digital, d'innovació educativa, núm. 20, 54-62 https://doi.org/10.7203/attic.20.12122

Pinto, A.R., Cortés, O. \& Alfaro, C. (2017). Hacia La Transformación De La Práctica Docente: Modelo Espiral De Competencias TICTACTEP Píxel-Bit. Revista de Medios y Educación. № 51. http://dx.doi.org/10.12795/pixelbit.2017.i51.03

Pinto-Santos, A .; Pérez, A.; Darder, A. (2020). Autopercepción de la competencia digital docente en la formación inicial del profesorado de educación infantil. Revista Espacios. 41 (18), 29. Recuperado de http://www.revistaespacios.com/ a20v41n18/20411829.html

Pinto-Santos, A .; Pérez, A.; Darder, A. (2021). Modelo TEP para el desarrollo de la competencia digital docente en la formación inicial docente. In Escenarios educativos investigadores: hacia una educación sostenible (pp.182-189). Dykinson. https:// dialnet.unirioja.es/servlet/articulo?codigo $=7898474$

Pozas, M., Letzel, V. "Do You Think You Have What it Takes?" - Exploring Predictors of Pre-Service Teachers' Prospective ICT Use. Tech Know Learn (2021). https://doi. org/10.1007/s10758-021-09551-0

Masoumi, D. Situating ICT in early childhood teacher education. Educ Inf Technol 26, 3009-3026 (2021). https://doi.org/10.1007/s10639-020-10399-7

Plomp, T. (2010). Educational Design Research: an Introduction. In An introduction to educational design research. Enschede: SLO - Netherlands Institute for Curriculum Development, 3rd Print. Recuperado de https://ris.utwente.nl/ws/portalfiles/ portal/14472302/Introduction_20to_20education_20design_20research.pdf

Riaño, C. E., \& Palomino, M. (2015). Diseño y elaboración de un cuestionario acorde con el método Delphi para seleccionar laboratorios virtuales (LV). Sophia, 11(2), 129-141.

Silva Quiroz, JE (2012). Estándares TIC para la formación inicial docente: una política pública en el contexto chileno. Archivos de análisis de políticas educativas , 20 , 7. https://doi.org/10.14507/epaa.v20n7.2012

Silva Quiroz, J., Lázaro, J. L., Miranda Arredondo, P., Canales Reyes, R. (2018). El desarrollo de la competencia digital docente durante la formación del profesorado. Opción, Año 34, No. 86 (2018): 423-449. https://digital.fundacionceibal.edu.uy/jspui/handle/123456789/288 
Soler-Costa, R.; Moreno-Guerrero, A.-J.; López-Belmonte, J.; Marín-Marín, J.-A. (2021). Co-Word Analysis and Academic Performance of the Term TPACK in Web of Science. Sustainability, 13, 1481. https://doi.org/10.3390/su13031481

Tiede, J. (2020). Conclusiones: Competencias educativas relacionadas con los medios de comunicación de los futuros profesores alemanes y estadounidenses. MedienPädagogik , 221-235.

Vaillant, D. E. (2019). Formación Inicial del Profesorado de Educación Secundaria en América Latina-Dilemas y Desafíos. Profesorado, Revista de Currículum y Formación del Profesorado, 23(3), 35-52. https://doi.org/10.30827/profesorado.v23i3.9516

Valverde-Berrocoso, J. (2016). La investigación en Tecnología Educativa y las nuevas ecologías del aprendizaje: Design-Based Research (DBR) como enfoque metodológico. Revista Interuniversitaria De Investigación En Tecnología Educativa. https://doi. org/10.6018/riite/2016/257931

Voogt, J. y McKenney, S. (2017). TPACK in teacher education: are we preparing teachers to use technology for early literacy?, Technology, Pedagogy and Education, 26:1, 69-83, DOI: 10.1080/1475939X.2016.1174730 


\section{Diseño de Escala E-Portafolio para Educación}

\section{Zambrano Matamala, Carolina} ORCID (https://orcid.org/0000-0002-9538-1816) carolinazambrano@gmail.cl

\section{Sanhueza Lesperguer, Elizabeth}

ORCID (https://orcid.org/0000-0002-8131-4874) esanhuezalesperguer@udd.cl

\section{Rojas Díaz, Darío}

ORCID (https://orcid.org/0000-0002-1675-2958) dariorojas@udec.cl

\section{Friz Carrillo, Miguel}

ORCID (https://orcid.org/0000-0002-5945-9559) mfriz@ubiobio.cl 


\title{
DISEÑO DE ESCALA E-PORTAFOLIO PARA EDUCACIÓN
}

\author{
Zambrano Matamala, Carolina \\ Sanhueza Lesperguer, Elizabeth \\ Rojas Díaz, Darío \\ Friz Carrillo, Miguel
}

\section{Resumen}

Debido a la pandemia por COVID 19 se aceleró la integración de tecnologías en la educación lo que tiene un impacto en el currículo para una orientación constructivista. En este contexto, el Portafolio Digital se presenta como una herramienta con características que permiten el desarrollo de diversas habilidades. Así, el objetivo de esta investigación fue i) Diseñar una escala para medir la utilidad del desarrollo de un portafolio digital en Educación desde aspectos curriculares, comunicacionales y de información. Además, de ii) Validar la escala propuesta aplicando análisis factorial exploratorio. El diseño fue instrumental y participaron 271 estudiantes de Educación Superior. La escala se diseñó a partir de la revisión de la literatura y la validación se realizó por jueces expertos y entrevistas cognitivas. Los resultados indican adecuados índices de validez y confiabilidad; quedando conformada por 22 ítems representados en 3 factores: 1) Desarrollo de Aspectos del Currículo, 2) Comunicación Digital, 3) Desarrollo de Información Digital. Se concluye que la escala puede ser útil para medir y hacer visibles las características y potencial pedagógico de los portafolios digitales en Educación en contextos de investigación y/o para docentes que busquen visibilizar en su enseñanza las características, habilidades y competencias que fomentan el desarrollo de portafolios digitales para el aprendizaje de los estudiantes.

\section{Palabras clave}

Portafolio digital, currículo, comunicación digital, información digital, aprendizaje. 


\section{Introducción}

El currículum educativo es el conjunto de objetivos, contenidos, metodologías y técnicas de evaluación que orientan la actividad académica para organizar el proceso de enseñanza y aprendizaje. El currículum puede tener un enfoque crítico social, un enfoque curricular de desarrollo del proceso cognoscitivo, un enfoque curricular basado en el constructivismo, entre otros (Chen \& Salas, 2019). En este contexto, debido a la pandemia por COVID 19 el currículo sufrió modificaciones que buscan promover ajustes y que pueden ser una oportunidad para realizar las innovaciones necesarias para el aprendizaje de los estudiantes (Díaz \& Barrón, 2020).

Asimismo, debido a la pandemia por COVID 19 se aceleró la Educación a Distancia como escenario para el proceso de enseñanza y aprendizaje en la Educación. Este nuevo escenario requiere un rol activo por parte de los estudiantes para planificar (Zambrano et al., 2021), aplicar estrategias (Zambrano et al., 2018; Zambrano et al., 2020) y evidenciar resultados de su aprendizaje (Zambrano, 2016). En este ámbito, las tecnologías de información y comunicación (TIC) convergen con la Educación y se pueden transformar en un medio para el desarrollo de ambientes de aprendizaje si el docente aprende a diseñar estos escenarios constructivistas para sus estudiantes que podrían ayudar a disminuir las brechas cognitivas (Cabero, 2020).

Un Portafolio Digital para el ámbito educativo es un repositorio que según la investigación educativa podría ayudar a evidenciar los resultados de aprendizaje de los estudiantes porque representan una colección de datos, información y conocimiento que ellos elaboran, argumentan y reflexionan en una comunidad virtual para el aprendizaje (Marinho, Fernández \& Pimentel, 2021; Syzdykova et al., 2021; Cabero et al., 2013).

También, el Portafolio Digital permite observar el desarrollo académico del estudiantado, relacionado con habilidades individuales, experiencias y resultados derivados de los procesos formativos (Vega \& Appelgren, 2019), posibilita la interacción entre estudiantes y profesores, así como entre estudiantes. Puede promover diálogos enriquecedores, contribuir a la retroalimentación del autor del Portafolio Digital y crear un entorno para el aprendizaje (Díaz et al. 2012; Arancibia et al. 2017). Además, permite el desarrollo de habilidades de comunicación digital y habilidades de desarrollo de información digital lo que coincide con investigaciones relacionadas con el desarrollo de Blogs Educativos (Marín, Sampedro \& Vega, 2016).

El portafolio digital aplicado como un recurso pedagógico permite a los estudiantes desempeñar un papel activo en la construcción de su propio conocimiento (Buzzetto-More, 2010). En otras palabras, el uso del portafolio asume un enfoque constructivista, donde el conocimiento se construye entre los estudiantes desde sus perspectivas individuales y experiencias de aprendizaje previas (Conrad \& Openo, 2018). En suma, las características del Portafolio Digital que han sido investigadas lo transforman en un medio para el desarrollo de habilidades y ambientes de aprendizaje. Destacan aspectos relacionados con:

i) Desarrollo del currículo: que se asocia con el desarrollo de los contenidos curriculares, la autoevaluación, los procesos de reflexión, entre otros.

ii) Desarrollo de Información Digital: se refiere a la creación de información digital bien organizada a través de herramientas tecnológicas. 
iii) Comunicación Digital: desde un punto de vista tecnológico, la comunicación digital es toda aquella transmisión de un mensaje en línea de una persona u organización mediante una amplia gama de canales online, hacia otro(s). En el Portafolio la comunicación digital se puede ver reflejada, por ejemplo, al crear videos, al realizar una video llamada para trabajar en equipo en un portafolio, entre otros (Marinho, Fernandes \& Pimentel, 2021; Syzdykova et al., 2021; Cabero et al., 2013).

Por los antecedentes anteriores, la presente investigación tiene como objetivos: 1) Diseñar una escala para medir la utilidad del desarrollo de un portafolio digital en Educación desde aspectos curriculares, comunicacionales y de información. 2) Validar la escala propuesta aplicando análisis factorial exploratorio.

La visibilización de las características favorables del desarrollo de Portafolios Digitales puede apoyar el proceso de enseñanza y aprendizaje con conciencia de procesos cognitivos, motivacionales y socio constructivos porque cada ítem representa una característica que apoya a la formación de esa conciencia que responde al ¿por qué? y ¿ipara qué? ocupo una determinada tecnología en el proceso de enseñanza y aprendizaje.

\section{Método}

\section{Diseño de la Investigación}

El enfoque es cuantitativo y se clasifica como un diseño instrumental (Ato et. al, 2013).

\section{Desarrollo de la Escala}

El procedimiento realizado para el desarrollo de la escala E-Portafolio se observa en la Figura 1 y consistió en cinco etapas:

1. Estudiar los aportes de Portafolios Digitales: durante esta etapa se estudiaron los aportes de los Portafolios Digitales según la evidencia científica.

2. Crear ítems del instrumento: A partir del estudio de la evidencia científica se crearon los ítems de la Escala E-Portafolio.

3. Revisión por juicio de expertos y entrevistas cognitivas: en esta etapa expertos revisaron la escala y luego estudiantes participaron en entrevistas cognitivas (online) para verificar, por ejemplo, la comprensión de los ítems.

4. Estudio 1: se aplicó la escala E-Portafolio a un grupo de 134 estudiantes del área de la salud y se realizó un primer análisis factorial exploratorio.

5. Estudio 2: se aplicó nuevamente la escala E-Portafolio a un grupo de 137 estudiantes del área de educación y se realizó un segundo análisis factorial exploratorio.

6. Estudio Integrado: se aplicó un análisis factorial exploratorio con la totalidad de los datos, es decir, 271 estudiantes para verificar los factores e ítems que se asocian a cada factor. 


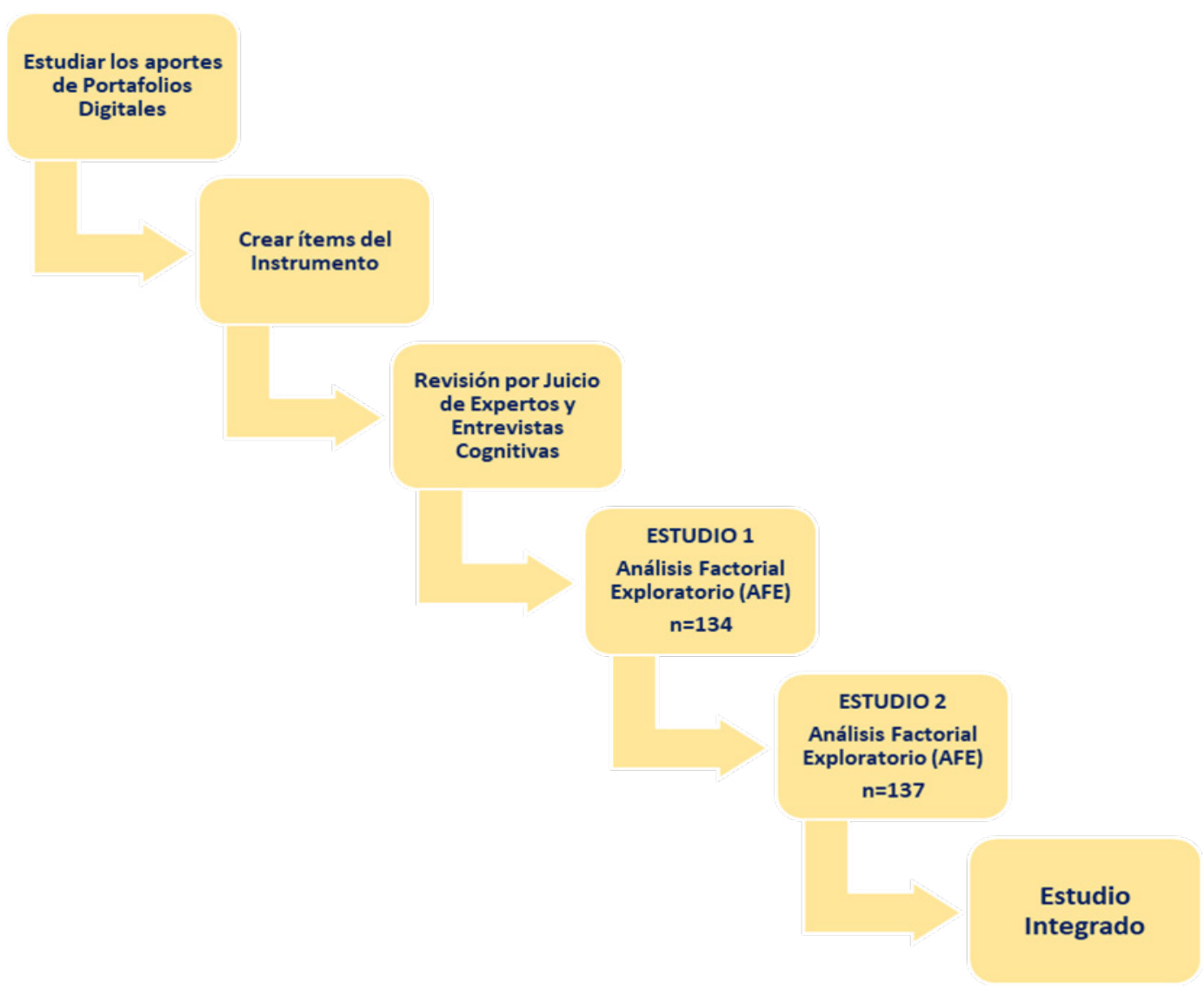

Figura 1: Procedimiento aplicado para el desarrollo de la escala E-Portafolio.

\section{Participantes}

Para la selección de los participantes se consideró como técnica el muestreo no probabilístico debido a que se escogió de forma intencionada estudiantes que cursaran carreras del área educación y del área de la salud de dos universidades de Chile. Participaron voluntariamente un total de 271 estudiantes, pertenecientes a cuatro carreras. El $24.4 \%$ de los participantes fueron hombres y el $75.6 \%$ mujeres. La edad media de los estudiantes es de 21.8 años.

En relación con el establecimiento educacional de origen, el $64.4 \%$ provienen de colegios particulares subvencionados, el $6 \%$ proviene de establecimientos particular pagados y el $29.6 \%$ proviene de establecimientos públicos denominados municipales. Se observa que la mayoría de los estudiantes pertenecen a establecimiento particular subvencionado lo que hace referencia a la segregación del sistema educativo chileno (Canales, Bellei \& Orellana, 2016; Valenzuela, Bellei \& De los Ríos, 2014; Bellei, Orellana \& Canales, 2020).

\section{Instrumento}

Se aplicó la escala diseñada para medir la utilidad del desarrollo de los portafolios digitales en Educación cuyos factores se definen a continuación. 
Factor 1 Desarrollo de Aspectos del Currículo: se refiere a aspectos del currículo asociados al contenido, desarrollo del pensamiento, evaluación y reflexión que se aplican con el desarrollo del portafolio digital.

Factor 2 Comunicación Digital: relacionado con el desarrollo de la expresión y comunicación digital. Desde un punto de vista tecnológico, la comunicación digital es toda aquella transmisión de un mensaje en línea de una persona u organización mediante una amplia gama de canales online, hacia otro(s).

Factor 3 Desarrollo de Información Digital: se refiere al desarrollo de información digital usando las tecnologías, por ejemplo, el desarrollo de las infografías.

\section{Procedimiento}

El instrumento diseñado se validó a través de juicio de expertos, entrevistas cognitivas y aplicaciones piloto (Smith-Castro \& Molina, 2011) para finalizar con un estudio integrado con la totalidad de los datos. El instrumento posee ítems politómicos (tipo Likert). Las aplicaciones se llevaron a cabo durante el segundo semestre del año académico 2020 de forma online. Los estudiantes contestaron de forma voluntaria y con consentimiento informado.

\section{Resultados}

Los 22 ítems del instrumento E-Portafolio que fueron diseñados y luego validados por juicio de expertos, entrevistas cognitivas y aplicaciones piloto (Smith-Castro \& Molina, 2011) se sometieron a dos estudios de análisis factorial exploratorio cuyos resultados mostraron la existencia de 3 factores. Luego, al integrar los datos también se observó los mismos tres factores que se exponen en la Tabla 1. El AFE estuvo basado en el método de extracción Principal Axis (PA) con rotación varimax.

La matriz de correlaciones fue cercano a cero, la medida de adecuación muestral Kaiser-Meyer-Olkin (KMO) obtuvo un valor de $.95 \mathrm{y}$ el test de esfericidad de Bartlett's se calculó en X2 = 3637.6 con $\mathrm{p}<.001$, los que corroboraron la pertinencia de realizar estudios con AFE. Para determinar la cantidad de factores latentes, se realizó un análisis paralelo de Horn, el cual recomendó mantener 3 componentes. La solución factorial mostró que los tres factores explican una varianza total del $78.67 \%$ y todos los ítems revelaron cargas factoriales mayores a 4.4.

De este modo, los factores que recomienda el análisis factorial exploratorio son los siguientes:

Factor 1 Desarrollo de Aspectos del Currículo: compuesto por 12 ítems.

Factor 2 Desarrollo de Información Digital: compuesto por 5 ítems.

Factor 3 Comunicación Digital: compuesto por 5 ítems. 
Factor 1: Desarrollo de Aspectos del Currículo

1. El desarrollo de un Portafolio Digital fomenta la creatividad

2. El desarrollo de un Portafolio Digital potencia el trabajo en grupo

3.El desarrollo de un Portafolio Digital ayuda a formar una visión crítica de los contenidos que debo incluir en el portafolio

4. El desarrollo de un Portafolio Digital ayuda a resolver mejor un proceso educativo en modalidad a distancia

5. El desarrollo de un Portafolio Digital estimula que yo como estudiante realice búsquedas de información online

6. El desarrollo de un Portafolio Digital permite aplicar el contenido que enseña el profesor

7. El desarrollo de un Portafolio Digital favorece trabajar de forma transversal el currículo de mi carrera

8. Un Portafolio Digital permite ampliar los contenidos desarrollados por el profesor

9. El desarrollo de un Portafolio Digital potencia los procesos de reflexión en los estudiantes

10. Los contenidos creados en el Portafolio Digital permiten que como estudiante pueda autoevaluar mi proceso de aprendizaje

11. Al desarrollar un Portafolio Digital se vinculan los contenidos curriculares de mi carrera de forma práctica

12. El desarrollo de un Portafolio Digital fomenta el pensamiento crítico

\begin{tabular}{|l|l|l|}
\hline .519 & & \\
\hline .562 & & \\
\hline .572 & & \\
\hline .599 & & \\
\hline .618 & & \\
\hline .639 & & \\
\hline .645 & & \\
\hline .686 & & \\
\hline .698 & & \\
\hline .708 & & \\
\hline .725 & & \\
\hline .742 & & \\
\hline
\end{tabular}

Factor 2: Desarrollo de Información Digital

13. El desarrollo de un Portafolio Digital en el ámbito educacional fomenta el uso de tecnologías para el desarrollo de información digital

14. El desarrollo de un Portafolio Digital fomenta la competencia de desarrollo de información digital mediante creación de gráficos

15. El desarrollo de un Portafolio Digital permite crear información digital bien organizada usando, por ejemplo, infografías.

16. El desarrollo de un Portafolio Digital potencia la comprensión lectora al crear textos digitales.

17. El desarrollo de un Portafolio Digital potencia la comprensión escrita al crear textos digitales

\section{Factor 3: Comunicación Digital}

18. Los Portafolios Digitales permiten el desarrollo de la competencia de comunicación digital

19. La competencia de comunicación digital se aplica mientras se desarrolla un Portafolio Digital, es decir, realizo video llamadas, uso correo electrónico, entre otros

20. El desarrollo de un Portafolio Digital fomenta la habilidad de comunicación oral al crear videos de contenido educativo y compartirlos en el Portafolio

21. El Portafolio Digital permite desarrollar la competencia de comunicación digital usando distintas tecnologías que permiten la comunicación de mensaje(s)

22. Los Portafolios Digitales ayudan a comunicar ideas y opiniones

\begin{tabular}{|l|l|l|}
\hline & .457 & \\
\hline & .617 & \\
\hline & .662 & \\
\hline & .738 & \\
\hline & .790 & \\
\hline
\end{tabular}

Tabla 1: Ponderación items Análisis Factorial Exploratorio (AFE) 


\section{Discusión y conclusiones}

Los objetivos de este trabajo fueron i) Diseñar una escala para medir la utilidad del desarrollo de un portafolio digital en Educación desde aspectos curriculares, comunicacionales y de información y ii) Validar la escala propuesta aplicando análisis factorial exploratorio.

En relación con el primer objetivo, se diseñó la escala E-Portafolio a través de un procedimiento que se evidenció en la Figura 1 desde el análisis de la literatura, la revisión por juicio de expertos y entrevistas cognitivas logrando crear la escala según los criterios y procedimientos recomendados (Matas, 2018). Por ello, la escala aporta con un instrumento que permite medir y visibilizar las oportunidades que ofrece el desarrollo de un portafolio digital.

Respecto al segundo objetivo, mediante un análisis factorial exploratorio se logró (Costello \& Osborne, 2011) evidenciar tres factores: factor 1: Desarrollo de aspectos del curriculum, factor 2: Comunicación digital y factor 3: Desarrollo de información digital, lo que permite sugerir la existencia de los tres factores que miden las tres dimensiones propuestas en el contexto del estudio. Así, en relación con otras investigaciones que proponen las mismas dimensiones como factores de utilidad de una tecnología en Educación coincidimos con Marín, Sampedro \& Vega (2016), diferenciándonos en los ítems que tratan sobre aspectos y/o características que se pueden desarrollar para el aprendizaje de los estudiantes mediante la aplicación de un portafolio digital.

Actualmente, en el ámbito de Educación a Distancia es fundamental que los estudiantes puedan aprender a desarrollar un portafolio digital mediante la tutoría y enseñanzas de un profesor que les permita aprender habilidades como la creatividad, la reflexión, el trabajo en equipo y la autoevaluación que son posibles de lograr de forma intencionada usando un portafolio digital (Arancibia et al., 2017; Cabero et al., 2013; Conrad \& Openo, 2018; Díaz et al., 2012).

Se concluye que la escala puede ser útil para medir y hacer visibles las características y potencial pedagógico de los portafolios digitales en Educación en contextos de investigación y/o para docentes que busquen visibilizar en su enseñanza las características, habilidades y competencias que fomentan el desarrollo de portafolios digitales para el aprendizaje de los estudiantes.

Finalmente, señalamos que puede ser interesante confirmar la estructura de la escala a nivel de Educación Superior a través de un análisis factorial confirmatorio.

\section{Referencias}

Ato, M., López J. \& Benavente, A. (2013). Un sistema de clasificación de los diseños de investigación en psicología, Anales de Psicología, 29(3), 1038-1059.

Arancibia, M., Halal, C., \& Romero, R. (2017). Valoración y barreras en la integración del e-portafolio en el proceso de práctica inicial por parte de docentes y estudiantes de Educación Superior. Pixel-Bit. Revista de Medios y Educación. 51, 151-163. 
Bellei, C., Orellana, V. \& Canales, M., (2020). Elección de Escuela en la Clase Alta Chilena. Comunidad, Identidad y Cierre Social. https://doi.org/10.14507/epaa.28.3884, Archivos Analíticos de Políticas Educativas, 28(5), 1-22.

Bellei, C., Canales, M., Orellana, V. \& Contreras, M., (2016) Elección de Escuela en Sectores Populares: Estado, Mercado e Integración Social, https://doi.org/10.4206/rev. austral.cienc.soc.2016.n31-06, Revista Austral de Ciencias Sociales, 31, 91-110.

Cabero, J., López, E. \& Jaén, A. (2013). Los portafolios educativos virtuales en las aulas universitarias. Instrumentos didácticos para la innovación docente y la calidad de los procesos de enseñanza y aprendizaje. Revista Enseñanza \& Teaching, 31, 43-70.

Cabero, J. (2020). Aprendiendo del Tiempo de la COVID-19, Revista Electrónica Educare, 24, 1-3.

Canales, M., Bellei, C. \& Orellana, V., (2016) ¿Por Qué Elegir una Escuela Privada Subvencionada? Sectores Medios Emergentes y Elección de Escuela en un Sistema de Mercado. https://doi.org/10.4067/S0718-07052016000400005, Estudios Pedagógicos, 42(3), 89- 109.

Chen, E., \& Salas, S. E. (2019). Referentes curriculares para la toma de decisiones en materia de planes de estudio de educación superior. Revista Electrónica Educare, 23(3), 130-160.

Conrad, D., \& Openo, J. (2018). Assessment strategies for online learning: Engagement and authenticity. Athabasca University Press. https://www.aupress.ca/ books/120279-assessment-strategies-for-online-learning/ Crossref.

Costello, A.B. \& Osborne, J.W (2011). Best practices in exploratory factor analysis: Four recommendations for getting the most from your analysis, Practical Assessment Research Evaluation, 10(7), 1-8.

Díaz, F., Romero, E., \& Heredia, A. (2012). Diseño tecnopedagógico de portafolios electrónicos de aprendizaje: Una experiencia con estudiantes universitarios. Revista Electrónica de Investigación Educativa, 14(2), 103-117.

Díaz, F., \& Tirado, C. B. (2020). Currículo y pandemia: Tiempo de crisis y oportunidad de disrupción. Revista Electrónica Educare, 24, 4.

Matas, A. (2018). Diseño del formato de escalas tipo Likert: un estado de la cuestión. Revista Electrónica de Investigación Educativa, 20(1), 38-47.

Marín, V., Sampedro, B. E. \& Vega, E. (2016). Construcción de una escala para determinar la utilidad de los blogs en la educación superior. Psychology, Society \& Education, 8(3), 217-228.

Marinho, P., Fernandes, P., \& Pimentel, F. (2021). The Digital Portfolio as an Assessment Strategy for Learning in Higher Education. Distance Education, 42(2), 253-267.

Syzdykova, Z., Koblandin, K., Mikhaylova, N., \& Akinina, O. (2021). Assessment of E-Portfolio in Higher Education. International Journal of Emerging Technologies in Learning, 16(2), 120-134. 
Smith, V., \& Molina, M. (2011). La entrevista cognitiva: Guía para su aplicación en la evaluación y mejoramiento de instrumentos de papel y lápiz. Cuaderno Metodológico, 5(1), 1-114.

Vega, M., \& Appelgren, D. (2019). E-portafolio: Una herramienta para el desarrollo de la práctica reflexiva de profesores en formación. Praxis, 15(1), 57-68.

Zambrano, C. (2016). Autoeficacia, prácticas de aprendizaje autorregulado y docencia para fomentar el aprendizaje autorregulado en un curso de Ingeniería de Software. Formación Universitaria, 9(3), 51-60.

Zambrano, C., Rojas, D., Díaz, A., \& Salcedo, P. (2018). Propiedades Psicométricas del Inventario de Estrategias de Autorregulación en Estudiantes de Pedagogía Chilenos. Formación Universitaria, 11(5), 85-92.

Zambrano, C., Díaz, A., Perez, M. V., \& Rojas, D. (2020). Análisis de estrategias de autorregulación en estudiantes de pedagogía de una universidad chilena. Formación Universitaria, 13(5), 223-232.

Zambrano, C., Bravo, I., Maluenda, J., \& Infante, V. A. (2021). Planificación y uso del tiempo académico asincrónico de estudiantes universitarios en condiciones de pandemia. Formación Universitaria, 14(4), 113-122. 


\section{LEXLIVE: Registro y Análisis de Pruebas de Disponibilidad Lexica para el Aula}

\section{Rojas Díaz, Darío}

ORCID (https://orcid.org/0000-0002-1675-2958)

dariorojas@udec.cl

\section{Zambrano Matamala, Carolina}

ORCID (https://orcid.org/0000-0002-9538-1816)

carozambrano@udec.cl

\section{Salcedo Lagos, Pedro}

ORCID (https://orcid.org/0000-0002-1741-714X)

psalcedo@udec.cl 


\title{
LEXLIVE: REGISTRO Y ANÁLISIS DE PRUEBAS DE DISPONIBILIDAD LEXICA PARA EL AULA
}

\author{
Rojas Díaz, Darío \\ Zambrano Matamala, Carolina \\ Salcedo Lagos, Pedro
}

\section{Resumen}

La prueba de disponibilidad léxica permite recuperar las palabras desde el lexicón mental a través de un estímulo relacionado con las categorías semánticas o centros de interés en un tiempo previamente determinado. Esta prueba se ha utilizado ampliamente en el ámbito educativo mostrando evidencia de su utilidad en el aula. No obstante, la captura del léxico disponible y su procesamiento es una actividad que, en el ámbito educativo, tiene poca sistematización y requiere bastante tiempo para su análisis. En este sentido, las plataformas online, cada día permiten un mayor acceso y facilidad a las funcionalidades para el registro y análisis de información. Por ello, el objetivo de esta investigación es describir el diseño y aplicación exploratoria de la plataforma online LEXLIVE en estudiantes universitarios. Esta plataforma permite registrar, analizar y utilizar la prueba de disponibilidad léxica en el aula en forma sincrónica y asincrónica, con tal de aprovechar los fundamentos lingüísticos que esta prueba ofrece para obtener y analizar profundamente las preconcepciones de los estudiantes en torno a una temática.

\section{Palabras clave}

Disponibilidad léxica, formación inicial docente, TIC, aprendizaje. 


\section{Introducción}

En el ámbito educacional es frecuente utilizar plataformas online como Mentimeter - Kahoot para generar "nubes de palabras" a partir de las repuestas de los estudiantes a una pregunta. Estas nubes de palabras asocian el tamaño de cada término en forma directamente proporcional a su frecuencia. Esta estrategia se utiliza en aula generalmente para introducir una temática, activar aprendizajes previos, iniciar lluvias de ideas, entre otros (Pratama, 2021; Dellos, 2015). Sin embargo, cuando la respuesta de cada participante está compuesta por más de una palabra, la frecuencia asociada al tamaño no logra capturar toda la información que se produce en dicha interacción. Por ejemplo, palabras con la misma frecuencia tendrán el mismo tamaño en la nube resultante. También, la ubicación espacial de las palabras en una nube de palabras representa un arreglo que persigue acomodar los elementos en un área restringida en lugar de entregar información de la relación y orden de producción de las palabras. En este contexto, la prueba de disponibilidad léxica representa un método más acorde para la cuantificación de este tipo de interacciones, pues entre otras características, toman en cuenta la secuencia en que son producidas las palabras desde el lexicón evocado, lo que es considerado un aspecto importante que otorga ventajas analíticas de la información (Rojas, Zambrano \& Salcedo, 2017).

El léxico disponible es definido como el conjunto de palabras que los hablantes poseen en su lexicón mental y que se activa con un estímulo llamado centro de interés (Bartol, 2006; López, 1995) o categoría semántica (Hernández, Izura \& Ellis, 2006). Para medir el léxico disponible se utiliza la prueba de disponibilidad léxica. En esta prueba se puede definir un tiempo límite para capturar las respuestas, por lo que solo se contabilizan las palabras que son evocadas dentro de un rango temporal.

Los estudios de disponibilidad léxica se han desarrollado en diversos ámbitos con el propósito de mejorar el léxico disponible de los hablantes en alguna área del conocimiento (Jiménez, 2017; Jiménez \& Alonso, 2019), utilizando diversos enfoques de investigación. Así, los estudios de disponibilidad léxica se pueden clasificar en (Zambrano, Rojas \& Salcedo, 2019): i) estudios del léxico disponible asociados al Proyecto Panhispánico (Hernández, 2015; Serfati, 2016; entre otros), ii) estudios del léxico disponible específico a un ámbito o contexto (Ferreira, Salcedo \& Del Valle, 2014; Salcedo, Ferreira \& Barrientos, 2013; Zambrano, 2021; entre otros) y iii) propuestas de métodos o herramientas de análisis del léxico (Rojas, Zambrano \& Salcedo, 2017; Rojas et. al, 2018; entre otros).

Entre las propuestas que han utilizado la disponibilidad léxica directamente en el aula se puede destacar el método de formación automática de grupos colaborativos (Rojas, Zambrano \& Salcedo, 2019), enfoque que utiliza la prueba de disponibilidad léxica para la selección de los miembros de cada grupo mediante técnicas de reconocimiento de patrones y comparación jerárquica. En la misma línea, se ha estudiado la evolución del léxico disponible mediante aplicación de estrategias didácticas para fomentar la interacción pedagógica, lo que posibilita la evolución del léxico disponible de los estudiantes (Zambrano et al., 2019).

En relación con programas y/o aplicaciones que permitan procesar la información generada por las pruebas de disponibilidad léxica se pueden destacar LexiDisp, DispoGrafo y Dispocen (Serfati, 2016; Echeverría et al., 2008; Ávila, Sánchez \& Odishelidze, 2021). 
En primer lugar, LexiDisp es una aplicación para Windows por lo que debe utilizarse desde ese entorno. Con dicha herramienta se pretende cubrir la necesidad de los investigadores de disponibilidad léxica en el mundo hispánico. Ofrece la posibilidad de relacionar la frecuencia de una unidad léxica (palabra) con su lugar de aparición en las listas, ya que, cuando una palabra está más disponible para un hablante, este la incluye en su lista de respuesta (léxico evocado), pues es recuperada más rápidamente desde su memoria (Serfati, 2016).

En segundo lugar, DispoGrafo es un software computacional de escritorio para el análisis psicolingüístico de las palabras evocadas mediante encuestas de léxico disponible. Utilizando un algoritmo basado fundamentalmente en las relaciones de secuencia de las palabras disponibles, genera automáticamente grafos cuyos nodos representan palabras y cuyas aristas simbolizan las relaciones entre ellas (Echeverría et al., 2008). Los grafos permiten visualizar las relaciones más relevantes. Es un software ampliamente utilizado por investigadores de disponibilidad léxica en el mundo hispánico.

Por último, DispoCen es un sistema para el análisis de la disponibilidad y la centralidad léxica, está basado en una biblioteca para el lenguaje de programación $\mathrm{R}$ y coloca al alcance de quienes estudian el léxico el desarrollo de múltiples aplicaciones y modelos originales. Se basa en códigos para ejecutar los análisis de la comunidad investigadora y se puede usar una utilidad gráfica que permite el acceso a los análisis más usuales.

Por otro lado, las pruebas de disponibilidad léxica representan un buen método para capturar respuestas contextuales a un concepto de interés (Cepeda et al., 2016). El léxico disponible representa las palabras más usadas en dicho contexto y son un reflejo del vocabulario de un grupo. Además, estas pruebas permiten el análisis discriminante al registrar el conocimiento previo sobre una materia o concepto desde el vocabulario (Rojas, Zambrano y Salcedo, 2019), por lo que pueden reflejar la evolución del léxico académico de un grupo de estudiantes en el tiempo (Zambrano, et al., 2019). Si adicionalmente, se agrega que este tipo de prueba tiene un profundo fundamento lingüístico (Hernández, Izura y Ellis, 2006), entonces, la existencia de una plataforma online de fácil acceso orientada a la actividad directa del aula es esencial para aprovechar las características principales de los softwares de investigación existentes y la sistematización del análisis de esta información.

Adicionalmente, debido al amplio ámbito investigativo en que ha sido utilizada la prueba de disponibilidad léxica, la propuesta de una plataforma online que permita su aplicación en el aula podría facilitar la integración de estrategias de mejoramiento del léxico disponible acordes a las diversas disciplinas o temáticas abordadas por docentes. En suma, se podría facilitar, en forma integral, la creación, registro y análisis de pruebas de disponibilidad léxica, sin la necesidad de instalar aplicaciones o utilizar softwares orientados a la investigación o bibliotecas asociadas a lenguajes de programación.

Por todo lo expuesto, el objetivo de este trabajo es presentar la plataforma online LEXLIVE para el registro y análisis de léxico disponible. Esta plataforma permite la creación y aplicación de pruebas de disponibilidad léxica en el aula, sin perder la capacidad descriptiva y analítica de estas pruebas. De esta forma se desea aportar con una alternativa que permita utilizar el fundamento lingüístico de las pruebas de disponibilidad léxica y proyectar estrategias didácticas que permitan aprovechar sus ventajas. 


\section{Método}

\section{Diseño de la investigación}

La investigación tiene un enfoque exploratorio, descriptivo y cuantitativo a través del análisis del léxico disponible que se obtiene mediante la plataforma online LEXLIVE. A través de un caso de estudio se describen las principales características de la plataforma y análisis realizados.

\section{Descripción de la plataforma}

Se implementó una plataforma para aplicar las pruebas de disponibilidad léxica a través del navegador web y teléfono móvil. El objetivo de esta plataforma es permitir a los docentes definir pruebas y obtener los análisis de disponibilidad léxica en forma sincrónica o asincrónica. De forma similar a otras plataformas educativas, los estudiantes pueden ingresar a la prueba mediante un código numérico y luego proceder a ingresar sus respuestas por cada estímulo definido. La plataforma es capaz de calcular los estadígrafos más comunes asociados al léxico disponible (Urzúa, Sáez \& Echeverría, 2006):

1. Estadígrafo de grupo XR: Promedio de la cantidad de vocablos indicados por los individuos de un grupo ante un estímulo o centro de interés.

2. Estadígrafo de grupo NPD: Cantidad de palabras distintas en el grupo, considerando cada palabra una sola vez.

3. Estadígrafo de grupo /C: Índice de Cohesión que indica el grado de coincidencia en la respuesta de los individuos (XR/NPD).

4. IDL: Índice de Disponibilidad Léxica que representa la frecuencia de la palabra ponderada por el orden de aparición en la producción de todos los individuos.

La aplicación fue implementada en una plataforma de Amazon Web Services (AWS) mediante el Framework Laravel+VueJS+Bootstrap. A continuación, se muestran las principales interfaces de la plataforma:

- Interfaz de Ingreso a la plataforma para participantes: la Figura 1 muestra la interfaz que se despliega a los participantes, donde se les solicita el código de la prueba y el nombre. La plataforma no exige el registro previo de los estudiantes.

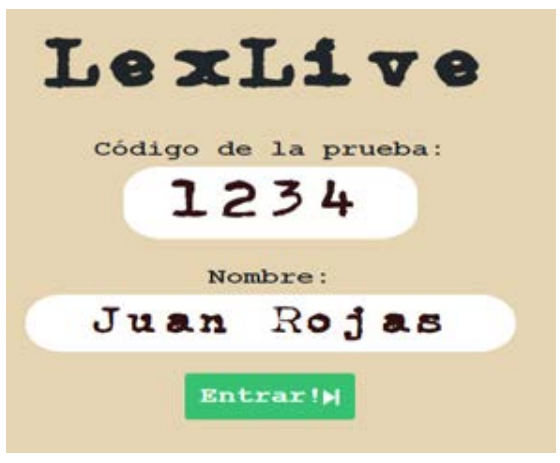


- Interfaz de Ingreso del léxico disponible: La Figura 2 muestra la interfaz donde se despliega, en la parte superior, el o los centros de interés (estímulos) en conjunto con un área dinámica que permite el ingreso una a una de las palabras producidas por el estudiante. La plataforma controla el tiempo disponible para responder a cada estímulo y los elementos visuales se acomodan a navegadores web de escritorio y dispositivos móviles.

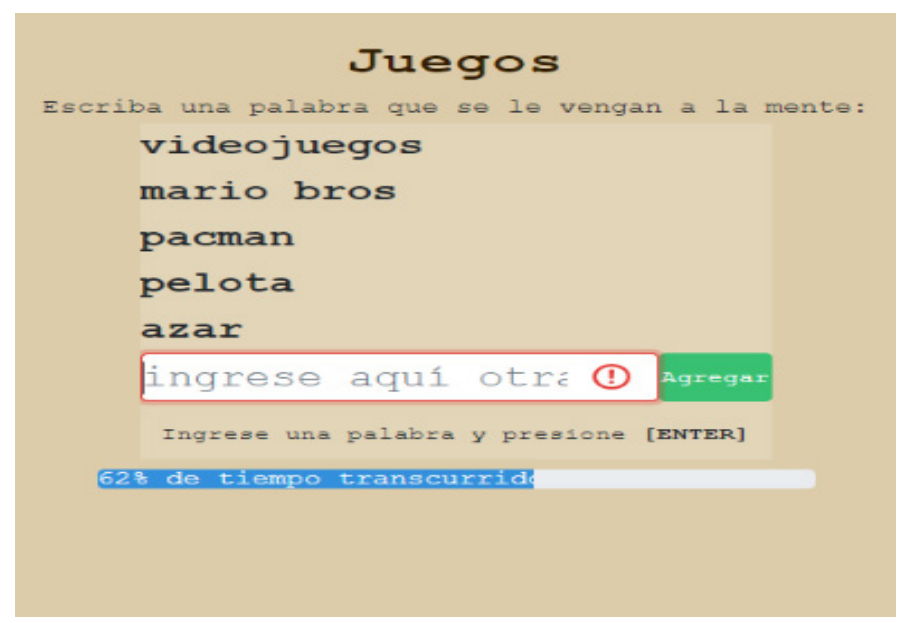

Figura 2. Ejemplo de Interfaz de Ingreso del léxico disponible por aplicación de la prueba de disponibilidad léxica

- Interfaz de Despliegue de Análisis de Disponibilidad Léxica: la Figura 3 muestra la interfaz donde se despliegan la nube de palabras, los lexicones (lista de palabras resaltadas con negro), la tabla de ranking con el IDL (color amarillo), y la tabla con estadígrafos que caracterizan al grupo (color gris). Esta interfaz permite seleccionar la creación de nube de palabras basadas en frecuencia o IDL y controlar el despliegue de palabras (largo de palabra, largo de lista, etc.) para facilitar la lectura de las respuestas. 


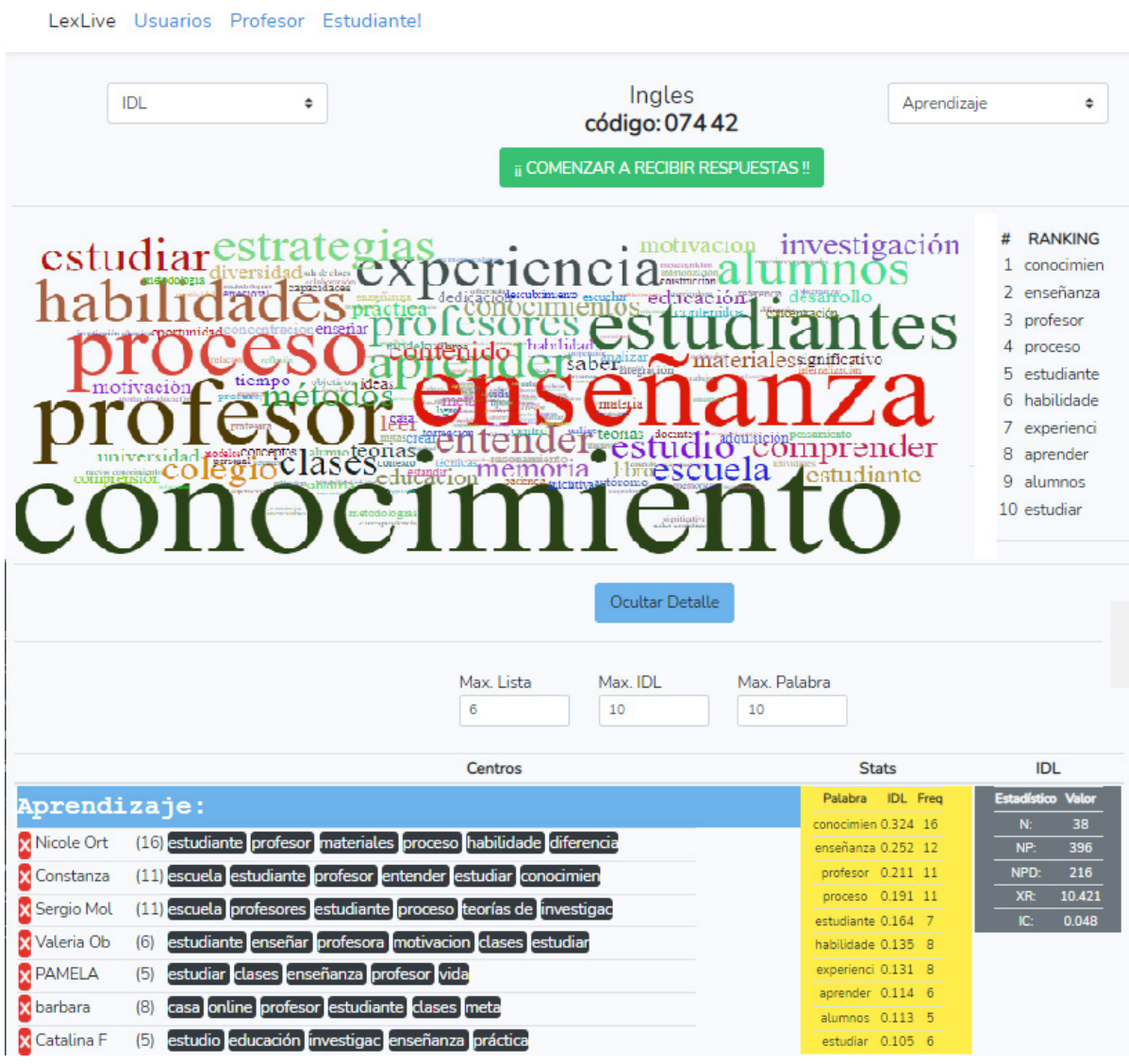

Figura 3. Ejemplo de Interfaz de Despliegue de Análisis de Disponibilidad Léxica

Cabe destacar que cada vez que se crea o configura una nueva prueba en la plataforma LEXLIVE, el docente puede establecer los estímulos (centros de interés) y tiempo de duración de la prueba según sus necesidades. Así mismo, los códigos de cada prueba son asignados automáticamente por la plataforma, por lo que el profesor solo requiere informar estos códigos a sus estudiantes.

\section{Ejemplos de aplicación de la plataforma en el aula}

El sistema se utilizó aplicando varias estrategias, tales como: 1) activar aprendizajes previos y conocer el léxico asociado a un concepto por parte de los estudiantes, 2) comparar el léxico disponible sobre un mismo estímulo entre dos carreras distintas y 3) comparar la evolución del léxico antes y después de una intervención.

Para cada ocasión se les proporcionó a los estudiantes un código de 5 dígitos (como el ejemplo de la Figura 1) para realizar la prueba. El sistema controla el ingreso y tiempo de duración de la prueba, los que para estos casos se establecieron en 2 minutos por cada centro de interés.

\section{Participantes}

La plataforma fue probada por dos docentes de educación superior. Los estudiantes que participaron pertenecían a las carreras de Educación Diferencial, Pedagogía en Matemática, Pedagogía en Inglés y estudiantes del Magíster en Informática Educacional 
de la Universidad de Concepción, con un total de 141 personas que produjeron 1176 lexicones. Para el caso de estudio, solo se presentan los resultados de las carreras de Educación Diferencial (34 estudiantes) y Pedagogía en Inglés (38 estudiantes).

\section{Instrumentos}

La plataforma utiliza una adaptación de la prueba de disponibilidad léxica empleada por Valencia y Echeverría (1999) adaptada al formato electrónico desplegado por LEXLIVE.

\section{Resultados}

A continuación, se presenta un caso de estudio representativo. El caso que se presenta trata sobre la comparación del léxico disponible entre estudiantes de pedagogía pertenecientes a dos disciplinas distintas: Educación Diferencial y Pedagogía en Inglés. Para ello, en este caso se auscultó sobre el centro de interés "Ser buen profesor" a ambas carreras. El registro y análisis de los resultados se realizó a través de la plataforma LEXLIVE.

Los resultados del léxico disponible de los dos grupos de estudiantes se organizan en las Tablas que se muestran a continuación. En las Tablas 1 y 2 se muestran el léxico disponible evocado por los estudiantes de Educación Diferencial. Luego, en las Tablas 3 y 4 se evidencian los resultados para el léxico disponible evocado por los estudiantes de Pedagogía en Inglés.

En la Tabla 1 se observa el léxico disponible ordenado según el IDL para el centro de interés "Ser buen profesor". En esta tabla se muestran las primeras 10 palabras más disponibles para el grupo de estudiantes de Educación Diferencial. Por su parte, en la Tabla 2 se muestran los estadígrafos de ese grupo.

\section{Tabla 1. Primeras 10 palabras más \\ disponibles para estudiantes de Educación \\ Diferencial según IDL}

\begin{tabular}{|l|l|l|}
\hline Palabra & IDL & Frecuencia \\
\hline vocación & 0.241 & 9 \\
\hline estrategia & 0.158 & 7 \\
\hline enseñar & 0.121 & 5 \\
\hline vocación & 0.112 & 4 \\
\hline innovador & 0.091 & 4 \\
\hline buenas prácticas & 0.077 & 3 \\
\hline Empatía & 0.077 & 3 \\
\hline dedicación & 0.074 & 3 \\
\hline diversidad & 0.068 & 3 \\
\hline
\end{tabular}

\section{Tabla 2. Estadígrafos de grupo para estudiantes de Educación Diferencial}

\begin{tabular}{|l|l|}
\hline Estadígrafo & Valor \\
\hline$N$ & 34 \\
\hline$N P$ & 160 \\
\hline NPD & 115 \\
\hline XR & 4.706 \\
\hline IC & 0.041 \\
\hline
\end{tabular}

En la Tabla 3 se observa el léxico disponible ordenado según el IDL para el centro de interés "Ser buen profesor" y las primeras 10 palabras más disponibles para el grupo de estudiantes de Pedagogía en Inglés. Luego, en la Tabla 4 se muestran los estadígrafos de ese grupo. 
Tabla 3. Primeras 10 palabras más disponibles para estudiantes de Pedagogía en inglés

\begin{tabular}{|l|l|l|}
\hline Palabra & IDL & Frecuencia \\
\hline Empatía & 0.207 & 10 \\
\hline Vocación & 0.196 & 9 \\
\hline Escuchar & 0.180 & 9 \\
\hline Aprender & 0.137 & 7 \\
\hline Responsable & 0.099 & 5 \\
\hline Comprender & 0.097 & 5 \\
\hline Entender & 0.090 & 4 \\
\hline Conocimiento & 0.088 & 5 \\
\hline Enseñar & 0.081 & 4 \\
\hline
\end{tabular}

Tabla 4. Estadígrafos de grupo para estudiantes de Pedagogía en inglés

\begin{tabular}{|l|l|}
\hline Estadígrafo & Valor \\
\hline $\mathrm{N}$ & 38 \\
\hline $\mathrm{NP}$ & 373 \\
\hline NPD & 257 \\
\hline XR & 9.816 \\
\hline IC & 0.038 \\
\hline
\end{tabular}

Adicionalmente, la Figura 4 muestra la nube de palabras en base al índice de disponibilidad léxica para ambos grupos, donde (a) representa la nube de palabras generada por el grupo de Educación Diferencial y (b) la nube de palabras generada por el grupo de Pedagogía en Inglés.

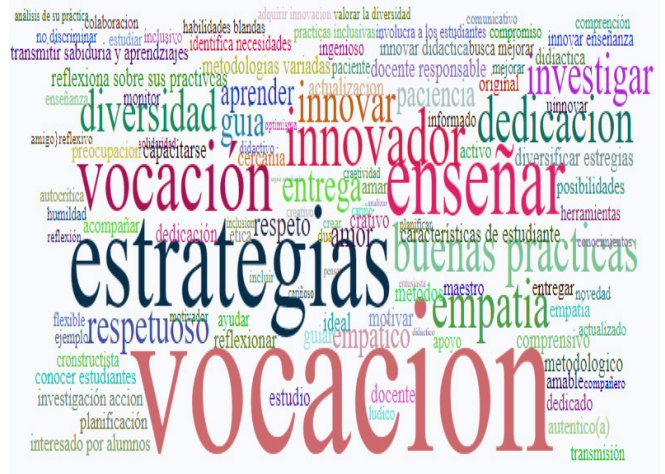

(a) Nube de Palabras Educación Diferencial

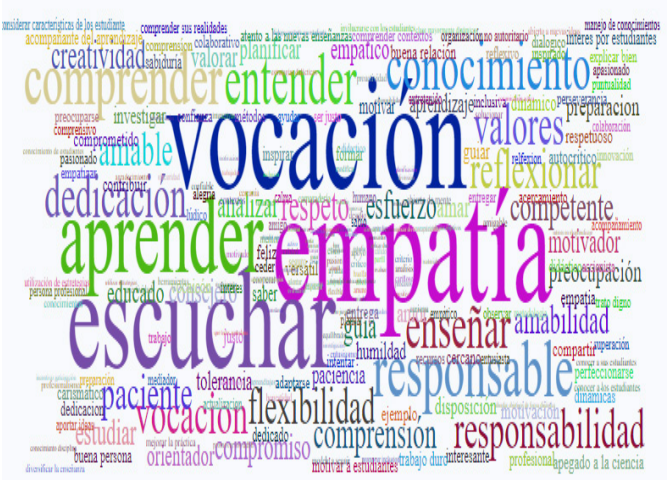

(b) Nube de Palabras de Pedagogía en Inglés

Figura 4. Nube de Palabras para Educación Diferencial(a) y Pedagogía en Inglés(b).

\section{Discusión y conclusiones}

El objetivo de este trabajo fue presentar la plataforma online LEXLIVE para la aplicación de pruebas de disponibilidad léxica en el aula, poniendo a disposición de docentes la capacidad descriptiva y analítica de esta prueba del ámbito de la lingüística aplicada. En este contexto, se logró el objetivo de describir la plataforma y su funcionalidad principal. Además, se realizó una aplicación de la plataforma en distintos contextos del aula universitaria, donde, en particular, se presenta un caso de estudio comparativo entre dos disciplinas.

Una de las características que destaca de esta plataforma con respecto a otras como LexiDisp, DispoGrafo y Dispocen (Serfati, 2016; Echeverría, et al., 2008; Ávila, Sánchez 
\& Odishelidze, 2021), es que tanto la aplicación de la prueba, como también su registro, se pueden hacer en tiempo real, lo que permite su utilización directa en el aula, pues no es necesario recurrir a otros medios de procesamiento como pruebas escritas, transcripciones o formularios electrónicos disociados del software de análisis.

En la misma línea, el análisis exploratorio del léxico disponible se puede realizar inmediatamente terminado el registro, con acceso a estadígrafos descriptivos y organización visual que permite el uso y aprovechamiento de esta información en la misma aula. Adicionalmente, es posible controlar el tiempo de aplicación de la prueba en forma autónoma, por lo que también es posible realizar la prueba de forma asincrónica, controlando el tiempo de respuesta de los participantes.

Otro aspecto importante para destacar, que la diferencian de otras soluciones de software, es que permite controlar, en tiempo real, el despliegue de las unidades léxicas, permitiendo definir límites de largo de lista, largo de palabras y eliminar lexicones que puedan no ser requeridos. Esto permite concentrar el análisis en las unidades más representativas con tal de facilitar la lectura por parte de los docentes que la utilicen.

Respecto al caso de estudio, en primer lugar, se puede observar que el IDL permite asignar una mayor importancia a la secuencia y orden de producción de los estudiantes, pudiendo verificar en la Tabla 3 que, a pesar de tener una frecuencia menor, el vocablo entender es más disponible que conocimiento, debido a que entender se produce generalmente antes que conocimiento. Esta información es relevante, pues significa que el grupo de estudiantes, en torno al concepto "Ser buen profesor" tienden a evocar con mayor disponibilidad la palabra entender en lugar de conocimiento. Además, en la misma tabla se puede apreciar que para palabras con la misma frecuencia como vocación y escuchar, el IDL permite distinguir que la palabra vocación es más disponible que escuchar. En este sentido, si la prueba es utilizada como una estrategia para iniciar una discusión, lo recomendable sería utilizar los conceptos de empatía y vocación, pues son las palabras que los participantes propenderían a evocar más naturalmente en ese contexto.

Por otro lado, las tablas de estadígrafos grupales permiten analizar la diferencia entre los grupos. Estos estadígrafos, por ejemplo, indican que los estudiantes de Inglés producen más palabras en promedio (XR), mientras que los estudiantes de Educación Diferencial presentan un léxico más homogéneo en su grupo (IC). En cuanto a la diferencias entre las palabras producidas, se puede destacar una notoria diferencia en la disponibilidad de la palabra empatía para los estudiantes de Ingles, mientras que los estudiantes de Educación Diferencial se destacan al incluir términos como buenas prácticas y diversidad en su léxico disponible, algo que guarda mucha relación con conceptos relevantes dentro de su disciplina. Esto coincide con otras investigaciones de léxico disponible, donde se puede verificar lo relevante de identificar las asociaciones léxicas y campo semántico al que hacen referencia las respuestas de los estudiantes, pues identificar la relación con el contexto, currículum y disciplina permite reconocer oportunidades de mejora en el vocabulario disciplinar de la Formación Inicial Docente (Herranz, 2018; Zambrano, 2021).

En conclusión, se puede destacar que el nivel de análisis que provee la prueba de disponibilidad léxica puede servir como un adecuado complemento para las actividades en el aula. Asimismo, la plataforma online LEXLIVE, permite utilizar el fundamento lingüístico sobre las pruebas de disponibilidad léxica para ser utilizado 
durante las clases en forma presencial u online. Además, debido al amplio ámbito educativo en que ha sido estudiada la prueba de disponibilidad léxica, la propuesta de una plataforma online abre la posibilidad de acceso y creación de nuevas estrategias didácticas que aprovechen la integración, en un solo lugar, de la aplicación, registro y análisis de la disponibilidad léxica en el contexto de cada disciplina.

\section{Referencias}

Ávila, A. M., Sánchez, J. M. \& Odishelidze, N. (2021). Dispocen. Mucho más que un programa para el cálculo de la disponibilidad léxica. ELUA, 35, 9-36. https://doi. org/10.14198/ELUA2021.35.1

Bartol, J. A. (2006). La disponibilidad léxica. Revista Española de Lingüística, 36(1), 349-378.

Cepeda, M., Cárdenas, Á., Carrasco, M., Castillo, N., Flores, J., González, C., \& Oróstica, M. (2016). Relación entre disponibilidad léxica y comprensión lectora, en un contexto de educación técnico profesional rural. Revista Sophia Austral, 81-93.

Dellos, R. (2015). Kahoot! A digital game resource for learning. International Journal of Instructional technology and distance learning, 12(4), 49-52.

Echeverría, M. S., Vargas, R., Urzúa, P., \& Ferreira, R. (2008). DispoGrafo: una nueva herramienta computacional para el análisis de relaciones semánticas en el léxico disponible. RLA. Revista de lingüística teórica y aplicada, 46(1), 81-91.

Ferreira, A., Salcedo, P. \& Del Valle, M. (2014). Estudio de disponibilidad léxica en el ámbito de las matemáticas. Estudios Filológicos, (54), 69-84.

Hernández, N., Izura, C. \& Ellis, A. (2006). Cognitive aspects of lexical availability. European Journal of Cognitive Psychology, 18(5), 730-755.

Hernández, N. (2015). The Assessment of Adult Lexical Competence: An Approach from Lexical Availability and Academic Specialization in Pre-university Students. Revista de Filología de la Universidad de la Laguna, 33, 79-99

Herranz, C. V. (2018). Disponibilidad léxica de los futuros profesores de Educación Infantil y Primaria. Revista Electrónica Interuniversitaria de Formación del Profesorado, 21(1), 143159.

Jiménez, R. M., (2017). Estudios de Disponibilidad Léxica en Español y en Inglés: Revisión de sus Fundamentos Empíricos y Metodológicos, Revista Nebrija de Lingüística Aplicada a la Enseñanza de Lenguas, 22,16-31

Jiménez, R. M. \& Alonso, A. C. (2019). El léxico disponible en inglés de chicos y chicas españoles adolescentes. ELIA: Estudios de Lingüística inglesa aplicada, (19), 157-176.

López, H. (1995). Los estudios de disponibilidad léxica: pasado y presente, Boletín de Filología, 35(1), pp. 245-259. Recuperado de https://boletinfilologia.uchile.cl/index.php/BDF/article/view/19231/20354 
Pratama, R. (2021). Comparison of the Students' Perception of Mentimeter and Google Classroom in Teaching Listening. IALLTEACH (Issues In Applied Linguistics \& Language Teaching), 3(1), 22-27.

Rojas, D., Zambrano, C. \& Salcedo, P. (2017). Metodología de Análisis de Disponibilidad Léxica en Alumnos de Pedagogía a través de la Comparación Jerárquica de Lexicones. Formación Universitaria, 10(4), 03-14.

Rojas, D., Zambrano, C., Salcedo, P., \& Friz, M. (2018). Un Enfoque de Reconocimiento de Patrones para el Análisis de Disponibilidad Léxica en Estudiantes de Pedagogía en Matemática. Estudios filológicos, (62), 333-358.

Rojas, D., Zambrano, C., \& Salcedo, P. (2019). Método para la formación de grupos colaborativos mediante disponibilidad léxica. Revista Electrónica de Investigación Educativa, 21.

Salcedo, P., Ferreira, A. \& Barrientos F. (2013). A Bayesian model for lexical availability of Chilean High School students in mathematics, Lecture Notes in Computer Science, Springer Verlag, Natural and Artificial Models in Computation and Biology, 7930 (1), 245-253

Serfati, M. (2016). Lexical Availability of University-level Moroccan Students: General Results, Philologica Canariensia, 22, 105-116.

Urzúa, P., Sáez, K., \& Echeverría, M. (2006). Disponibilidad léxica matemática: análisis cuantitativo y cualitativo, Revista de Lingüística Teórica y Aplicada, 44(2), pp. 59-76, Recuperado de https://doi.org/10.4067/S0718-48832006000200005

Valencia, A. \& Echeverría, M. (1999). Disponibilidad léxica en estudiantes chilenos, Santiago de Chile, Ediciones Universidad de Chile-Universidad de Concepción.

Zambrano, C., Rojas, D., \& Salcedo, P. (2019). Revisión sistemática a estudios de disponibilidad léxica en la base de datos Scielo y sus aportes a educación. Información Tecnológica, 30(4), 189-198.

Zambrano, C., Rojas, D., Salcedo, P., \& Valdivia, J. (2019). Análisis de la Evolución de la Disponibilidad Léxica en la Interacción Pedagógica. Formación Universitaria, 12(1), 65-72.

Zambrano, C. (2021). Un estudio de la disponibilidad léxica en el ámbito de la autorregulación del aprendizaje en la formación inicial docente. Lingüística y Literatura, 42(79), 11-33. 


\section{Innovación Educativa en Escenarios de Aprendizaje Móvil con Recursos de Acceso Abierto}

\section{Tagua, Marcela}

ORCID (orcid.org/0000-0003-0215-6028)

Universidad Nacional de Cuyo

mtagua@ffyl.uncu.edu.ar 


\title{
INNOVACIÓN EDUCATIVA EN ESCENARIOS DE APRENDIZAJE MÓVIL CON RECURSOS DE ACCESO ABIERTO
}

\author{
Tagua, Marcela \\ ORCID (orcid.org/0000-0003-0215-6028) \\ Universidad Nacional de Cuyo \\ mtagua@ffyl.uncu.edu.ar
}

\section{Resumen}

La presente publicación corresponde a un proyecto de investigación en proceso denominado "Innovación en los procesos de formación con tecnologías emergentes. Parte III", financiado por la SIIP de la Universidad Nacional de Cuyo. Está enmarcado en la innovación tecnológica y pedagógica con especial énfasis en escenarios de acceso abierto que permitan el desarrollo de propuestas de aprendizaje bajo la concepción de recursos educativos abiertos. El propósito de este trabajo es diseñar e implementar trayectos de formación con recursos multimediales disponibles a través de dispositivos móviles desde una concepción de prácticas educativas abiertas. Los objetivos específicos consisten en diseñar propuestas de formación sustentadas en el aprendizaje móvil, desarrollar recursos multimediales bajo un enfoque de acceso abierto y generar recursos con acceso libre y licencia de uso disponibles en un repositorio digital. El modelo de investigación es de enfoque mixto de tipo descriptivo. La tradición metodológica que subyace es investigación-acción. En virtud de la triangulación de métodos, el relevamiento de datos cualitativos se complementa con técnicas cuantitativas de recolección de datos. En virtud de la pandemia por COVID-19, el estudio se ha ajustado al contexto para adaptarse a la enseñanza remota de emergencia.

\section{Palabras clave}

Tecnología educativa, recursos educativos abiertos, repositorio digital, aprendizaje móvil. 


\section{Introducción}

El planteo de este proyecto surge a partir de los siguientes interrogantes: ¿favorece el aprendizaje el uso de tecnologías mediante dispositivos móviles?, ¿cómo se integran estudiantes y docentes en el diálogo educativo en línea bajo la modalidad m-learning?, ¿es factible el diseño de recursos educativos abiertos?, en el contexto de pandemia por COVID-19, ¿en qué medida estos escenarios móviles permitieron hacer frente a los nuevos desafíos? El estudio se enmarca en el paradigma interpretativo que enfatiza la importancia de la comprensión de los fenómenos, tanto en su globalidad como en sus contextos particulares, intentando sacar sentido de los fenómenos de acuerdo con los significados que tienen para los sujetos implicados. Básicamente la tradición metodológica que subyace es la investigación-acción y en virtud de la triangulación de métodos, el relevamiento de datos cualitativos se utiliza en forma conjunta con el manejo de técnicas cuantitativas.

El proyecto continúa una línea de investigación basada en las nuevas tendencias en educación en el marco de la innovación tecnológica y pedagógica, que permitió indagar acerca del movimiento educativo abierto, la incorporación de instancias de formación desde el enfoque de cursos masivos abiertos en línea (MOOC), la enseñanza y el aprendizaje mediante dispositivos móviles. Con relación a ello, se diseñaron propuestas de formación y perfeccionamiento docente con un formato MOOC para el manejo de una plataforma virtual y otra destinada a estudiantes enfatizando el aprendizaje móvil. La propuesta vigente, de carácter I+D+i, continúa la indagación acerca de la integración de las denominadas tecnologías emergentes en la universidad y se desarrollan propuestas de aprendizaje ubicuo a través de dispositivos móviles bajo la concepción de recursos educativos abiertos.

El objetivo general consiste en diseñar e implementar trayectos de formación con recursos multimediales disponibles a través de dispositivos móviles y, específicamente, diseñar propuestas de formación con recursos de acceso abierto y que estén disponibles en repositorios digitales.

\section{Método}

\section{Descripción del contexto y de los participantes}

En el contexto de la pandemia por COVID-19 tuvimos que enfrentarnos al desafío de enseñar completamente en línea. El impacto producido por la pandemia en las instituciones universitarias implicó tomar medidas para hacer frente a un cierre temporal y garantizar el derecho a la educación a una población que afectaba, según las estimaciones de UNESCO-IESALC (2020) a 23,4 millones de estudiantes de educación superior y a 1,4 millones de docentes en América Latina y el Caribe (más del 98\% de la población de estudiantes y profesores de educación superior de la región). Esta realidad nos llevó a prestar especial atención a la continuidad de los procesos de formación con el diseño de propuestas pedagógicas y mecanismos de seguimiento y apoyo a los estudiantes, con miras a una educación híbrida. Justamente, el contexto actual nos obligó a dejar de lado masivamente la enseñanza y el aprendizaje en entornos tradicionales con interacciones físicas donde el rol de los educadores se centró en dar respuesta con gran ingenio y creatividad. 
Su función fue más allá de aplicar tecnologías o técnicas didácticas, sino asumir plenamente su papel de facilitadores del conocimiento y guías pedagógicos. Deberá permitirse que la capacidad de iniciativa, experimentación e innovación que ha surgido durante las perturbaciones ocasionadas por la pandemia siga desarrollándose. UNESCO (2020, p.15).

¿De qué pudimos valernos? Observamos cómo a partir de la Web 2.0, nuevos escenarios posibilitan la innovación en educación. Por una parte, se visualizan nuevas formas de trabajo a través de la nube, lo cual permite que el almacenamiento de la información se realice en cualquier lugar sin necesidad de depender de un equipamiento tecnológico. Por otra parte, el aprendizaje ubicuo, tal como sostienen Vázquez Cano y Sevillano García (2015), representa un nuevo paradigma educativo lo cual es posible en función de los nuevos medios digitales ya que la convergencia de tecnologías y servicios permiten que el proceso educativo se lleve a cabo en todo momento, en cualquier lugar y a través de cualquier dispositivo.

El contexto actual implica una mirada prospectiva en este sentido (García Aretio, 2014). Justamente, la educación ubicua está centrada en cómo aprovechar la enorme cantidad de información al alcance de todos y la posibilidad de aprender en cualquier situación o contexto, aprender en, con, de y desde el entorno (Vázques, 2015). Los nuevos ambientes de aprendizaje que se configuran alrededor de las redes y tecnologías interactivas permiten redefinir los modelos didácticos (Cabero y Barroso, 2015) donde el énfasis está en el aprendizaje más que en la enseñanza, con prácticas de aprendizaje que se adaptan a situaciones educativas en permanente cambio (Castaño y Cabero, 2014).

En consonancia con estos autores, observamos que los dispositivos móviles se utilizan día a día para interactuar socialmente, para comunicarnos e intercambiar información, de esta manera el aprendizaje es visto como creación de significado culturalmente situado dentro y fuera de las instituciones educativas. De acuerdo con ello, las estratificaciones sociales, la compleja infraestructura tecnológica, "hacen que los aprendizajes se rijan por los marcos curriculares de las instituciones educativas con enfoques específicos hacia el uso de nuevos espacios culturales como recursos para el aprendizaje" (Vázquez Cano y Sevillano García, 2015, p. 25).

Conforme a datos estadísticos de UNESCO-IESALC (2020, p. 20-21), se advierte que "las tasas de líneas móviles son extremadamente elevadas y superan, en muchos casos, la cifra de una línea por persona". Esto es, sin duda alguna, una oportunidad que las Instituciones de Educación Superior tuvimos a nuestro alcance durante la Enseñanza Remota de Emergencia, con el necesario acompañamiento de políticas institucionales que permitieran disminuir las brechas ocasionadas por la falta de conectividad.

Ahora bien, este contexto de desarrollo tecnológico no necesariamente implica una integración adecuada en las instituciones educativas, se requieren propuestas innovadoras sustentadas en enfoques y paradigmas que posibiliten procesos de formación mediados por estas tecnologías, el diseño y estructuración de los contenidos, el desarrollo de materiales educativos con formatos adecuados (microcontenidos con diseño simple, multimedial de breve duración, adaptados al tamaño de la pantalla, actualizados y de renovación continua), formas de evaluación apropiadas y, principalmente, la forma de plantear el papel del estudiante en su proceso de formación para generar propuestas curriculares y didácticas flexibles "donde el énfasis está en 
el aprendizaje más que en la enseñanza, con una nueva relación con el saber, con nuevas prácticas de aprendizaje adaptables a situaciones educativas en permanente cambio" (Castaño Garrido y Cabero Almenara, 2014, p. 166).

Los objetos de aprendizaje son un modelo de trabajo en el diseño y producción de contenidos que son depositados en un repositorio de manera que estén a disposición de aquel que pueda estar interesado y que su vez pueda reformarlos, adaptarlos y reutilizarlos en su propio contexto. Esto permite la colaboración de los profesores y la consolidación de comunidades virtuales de docentes que intercambian sus propios materiales. Según Wiley (2000) se considera objeto de aprendizaje a cualquier recurso digital que pueda ser reutilizado con el propósito de facilitar el aprendizaje. Este es el aspecto diferenciador, por lo cual el criterio de clasificación no está relacionado con el diseño o producción de contenido sino con su finalidad y contexto de uso, de allí que la metáfora relacionada es justamente la de los bloques del Lego, para comprender el uso pedagógico de los objetos de aprendizaje.

Varas (2003) cit. en Prendes Espinosa et al (2010, p. 46) sostiene que los objetos de aprendizaje poseen fines instruccionales y que "deben ser albergados y organizados en Metadata de manera tal que el usuario pueda identificarlos, localizarlos y utilizarlos para propósitos educacionales en ambientes basados en Web 2.0". Ahora bien, si bien los objetos de aprendizaje son contenidos digitales que se utilizan con un propósito instruccional, no todos los contenidos digitales que utiliza un profesor constituyen un objeto de aprendizaje, para que esto ocurra es necesario que ese material didáctico esté alojado en un repositorio accesible por cualquier otro usuario para su reutilización, tal como una biblioteca digital, y que esté etiquetado con metadatos siguiendo criterios de estandarización para que puedan reutilizarse e interoperar entre diferentes sistemas y plataformas.

Un repositorio de objetos de aprendizaje puede ser definido como un espacio en el que se guarda información disponible en formato digital y que ha sido sometido previamente a un proceso de fragmentación quedando así la información dividida en pequeñas piezas en los términos descritos anteriormente. Un aspecto que resulta imprescindible en el engranaje de los repositorios son los metadatos, los cuales son elementos que permiten catalogar la información digital para reutilizarla en diferentes contextos, Prendes Espinosa et al (2010, p.57) sostienen que los metadatos "designan y califican datos de la información almacenada, para lo cual se utilizan elementos previamente seleccionados por las iniciativas de estandarización (Dublin Score, SCORM, IEE:LOM) en los se apoyan, tales como título, descripción, palabras clave, formato, publicación".

Con respecto a los repositorios de objetos de aprendizaje, Sánchez-Alonso, S. et al (2011), expresan que son colecciones digitales de recursos educativos o metadatos enfocados a facilitar el (re)uso de materiales en todo el mundo. Enfatizan que la construcción de un repositorio de recursos educativos abiertos no se limita a la instalación de un software de administración, sino que implica la organización y articulación de diferentes tareas en una serie de procedimientos institucionales, teniendo en cuenta el marco legal en el que se opera, la forma en la que se indexa el contenido y cómo se presentará a los usuarios finales.

Las actividades educativas de acceso abierto permiten prácticas formativas que utilizan recursos educativos abiertos (REA), la selección de recursos a través de re- 
positorios y la diseminación de prácticas en entornos académicos. UNESCO (2002) define a los REA como materiales en formato digital que se ofrecen de manera gratuita y abierta para educadores, estudiantes y autodidactas para su uso y re uso en la enseñanza, el aprendizaje y la investigación. En el contexto latinoamericano, cabe citar la Agenda Regional de Prácticas Educativas Abiertas que presenta directrices estratégicas para la apertura en la Educación Superior, el diseño de políticas y acciones destinadas a maximizar los beneficios de la utilización, reutilización y remezcla de REA como un medio para abrir el acceso al conocimiento (UNESCO, 2015). De esta forma, el acceso abierto y las licencias Creative Commons permiten la distribución de documentos digitales y constituyen un marco de reglamentación para el uso de contenidos. Esas políticas constituyen el marco de los repositorios institucionales a nivel nacional e internacional.

\section{Instrumentos}

Este proyecto se enmarca en el paradigma interpretativo que enfatiza la importancia de la comprensión de los fenómenos, tanto en su globalidad como en sus contextos particulares, intentando sacar sentido de los fenómenos de acuerdo con los significados que tienen para los sujetos implicados. La tradición metodológica que subyace es la investigación-acción. En virtud de la triangulación de métodos, el relevamiento de datos cualitativos se utiliza en forma conjunta con el manejo de técnicas cuantitativas. Las técnicas y estrategias de recolección de datos son el análisis documental de sitios y recursos en línea, observación y encuestas. Las estrategias de búsqueda y selección están enfocadas en los recursos educativos abiertos y repositorios digitales.

\section{Procedimiento}

A través de una encuesta en línea se realizó una pesquisa para conocer la utilización y familiarización de los sujetos con entornos virtuales desde una modalidad de aprendizaje móvil. A la par de ello, se están diseñando recursos educativos multimediales alojados en un canal de libre acceso y se trabaja además en un repositorio digital desde la Biblioteca Digital de la UNCuyo.

\section{Resultados}

En el marco de este proyecto en proceso, se realizó una pesquisa sobre el uso de dispositivos móviles y los destinatarios fueron los estudiantes que ingresaron a la universidad en el ciclo lectivo 2020. Para ello se confeccionó una encuesta en línea para ser respondida en forma anónima y voluntaria en la institución bajo estudio. La misma contenía descriptores sociales, de prácticas y opiniones que demostraron comportamiento, actitudes y apreciaciones. El propósito fue conocer la utilización y familiarización de los sujetos con entornos virtuales y analizar en qué medida es factible la modalidad m-learning en la universidad. La muestra fue de 250 sujetos.

El 52\% de los encuestados posee menos de 20 años, el 27,6 está en el rango de 20 a 25 años y el 20,4\% restante es mayor a 25 años. El 98,8\% utiliza habitualmente dispositivos móviles (teléfono celular, tablet). El 94,8\% posee conexión a internet en su dispositivo, ya sea a través de redes wi-fi, un $80,4 \% \mathrm{y} / \mathrm{o}$ paquetes de datos el $64,1 \%$. Con relación a la cantidad de horas diarias en promedio que se conectan a Internet a través de un dispositivo móvil, el $42 \%$ respondió entre 2 y 5 horas, el 27,6\% 
entre 5 y 7 horas, el 13\% más de 7 horas y el 12\% menos de 2 horas. El lugar de preferencia para utilizar internet es el hogar para el 95,2\% de los sujetos encuestados. Los servicios mayormente utilizados son WhatsApp (89,6\%), redes sociales $(77,6 \%)$, navegación por páginas web $(65,2 \%)$, correo electrónico $(50,4 \%)$ y aulas virtuales $(36,4)$. Con relación a esto último, el $88,4 \%$ accede a las aulas virtuales a través de un dispositivo móvil y el 78,4\% utiliza la App de Moodle. El 65,4\% puede acceder sin dificultad a los recursos que brinda el aula virtual desde su dispositivo móvil, el $32,5 \%$ a veces tiene dificultades de acceso y el $5 \%$ no ha podido acceder. El $48,8 \%$ considera que el trabajo en un aula virtual desde un dispositivo móvil demanda mayor esfuerzo que desde una PC, el 35,5\% opina que a veces y el 15,7\% respondió que no demanda mayor esfuerzo. Las ventajas de utilizar aulas virtuales a través de un dispositivo móvil son, para el 95,6\% la posibilidad de acceder en cualquier momento, para el 44,4\% la disponibilidad de los materiales en línea, para el 44,8\% la posibilidad de comunicación inmediata con los docentes. Acerca de las desventajas el 57,6\% está referido a inconvenientes de conectividad, el 55,6\% manifestó la dificultad de visualizar adecuadamente los materiales.

Este sondeo permitió contar con una primera aproximación acerca del uso de dispositivos móviles por parte de los ingresantes de diferentes carreras, lo cual, en este contexto de enseñanza remota de emergencia por COVID-19, fue un insumo a tener en cuenta para afrontar los nuevos desafíos de la incorporación de la virtualidad en educación superior. Como consecuencia de ello, en la capacitación docente se enfatizó que el diseño de materiales priorizara el desarrollo de recursos multimediales que permitan fácil acceso y adecuada visibilidad desde un móvil.

Para obtener evidencia del proceso en esta situación particular, se llevó a cabo un diagnóstico a través de una nueva encuesta suministrada en línea en forma anónima y voluntaria y que fue respondida por 1.050 estudiantes de carreras de grado en el período comprendido entre el 13 y 24 de abril de 2020 a 15 días de comenzar el dictado de clases en forma remota a causa de la pandemia por COVID-19. De esta manera, se pudo reorientar el acompañamiento y capacitación a los docentes con el propósito de mejorar el proceso de enseñanza desde la virtualidad. De los datos obtenidos en relación con el tema bajo estudio, se observó que, respecto a los dispositivos de uso, el 66,2\% utilizó teléfono móvil, el 5,9\% Tablet, el 67,7\% computadora portátil y el $27,2 \%$ computadora de escritorio. Se advierte que, en algunos casos, se dispuso de varios dispositivos para el seguimiento de las clases. El 48,6\% utilizó la App de Moodle y quienes la utilizaron, un 56,8\% pudo acceder adecuadamente a los recursos incorporados en el aula virtual, el 29,7\% en ocasiones se le dificultó acceder a los materiales desde la App y el 13,5\% no pudo acceder completamente a los recursos. Para el 40,4\% los materiales permitieron comprender los temas abordados y actividades propuestas, el $54,7 \%$ respondió que solo en parte y el $5 \%$ restante consideró que no pudo acceder. Acerca de la experiencia personal de trabajar en entornos virtuales desde dispositivos móviles, para el $41,3 \%$ fue satisfactoria, para el $37,6 \%$ fue medianamente satisfactoria, para el $16,1 \%$ fue poco satisfactoria y el $5 \%$ respondió que insatisfactoria.

Para el acompañamiento, formación y perfeccionamiento docente se diseñaron recursos educativos multimediales, desde un enfoque abierto y de libre acceso, los cuales estaban disponibles en un canal de YouTube. Esto posibilitó que, a partir de un relevamiento realizado a 211 docentes, el 60,7\% indicó que pudo adquirir competencias para elaborar videos propios para el desarrollo de sus clases, el 68,7\% usó videos de otros 
autores con acceso libre. Asimismo, el 51,2\% generó archivos de audio para sus clases. Además de este repositorio de recursos, los profesores contaron con 2 cursos auto asistidos bajo la concepción de cursos masivos, abiertos en línea, con licencia de uso CreativeCommons para adquirir conocimientos acerca de los recursos y actividades disponibles en la Plataforma Moodle.

\section{Discusión y conclusiones}

A modo de conclusión, y, en virtud que es un proyecto en etapa de ejecución, podemos afirmar que, frente a los retos que ofrece la sociedad actual a las instituciones educativas, es imprescindible que la docencia vaya acompañada de investigación, de manera tal que los procesos de formación desarrollados en entornos mediados por tecnologías propicien y promuevan la innovación pedagógica y tecnológica sobre la base de un modelo de calidad educativa.

Los avances en esta línea de investigación han permitido, al momento, diseñar y elaborar propuestas que propicien prácticas educativas mediante el uso de dispositivos móviles, desarrollar recursos educativos abiertos disponibles en internet, producir materiales con licenciamiento abierto, fomentar la curación de materiales contenidos en repositorios, diseminar recursos educativos en entornos académicos.

Si realizamos un breve recorrido en el tiempo, a través de las plataformas tecnológicas se incorporó el concepto de "virtualidad" que permite diluir distancias y tiempos para hacer posible el acceso al conocimiento, donde el papel activo del estudiante y el rol de guía y acompañante cognitivo del docente permiten recrear las instancias de aprendizaje a través de las TIC. En presencia de la Web 2.0 el aprendizaje formal da lugar también al aprendizaje no formal, abierto y masivo. Los saberes no sólo están contenidos en las instituciones educativas, sino que están diseminados en el mundo exterior. Todo conlleva que, ante la presencia de Internet, las aulas "sin muros" se convierten en aulas de bits y toma fuerza el concepto de ubicuidad. La interacción entre los actores, con los materiales y el entorno tecnológico constituyen un complemento valioso en la labor educativa.

Todo nos lleva a reflexionar acerca del sujeto del aprendizaje, los dispositivos de uso y sus formas de aprender, los nuevos lenguajes y cómo se concreta la comunicación mediada por tecnologías. Surge la necesidad de instaurar prácticas educativas que brinden sustento al proceso educativo y reconocer el lugar que ocupan las tecnologías como mediadoras, no solo como instrumentos o herramientas, sino en el sentido de constituirse como entornos de aprendizaje y puentes hacia el conocimiento.

\section{Referencias}

Cabero Almenara, J. y Barroso Osuna, J. (coords) (2015). Nuevos retos en Tecnología Educativa. Síntesis.

Castaño Garrido, C. y Cabero Almenara, J. (coords.) (2014). Enseñar y aprender en entornos m-learning. Síntesis. 
García Aretio, L. (2014) Bases, mediaciones y futuro de la educación a distancia en la sociedad digital. Síntesis.

Prendes Espinosa, M.P., Gutierrez Porlán, I. y Martínez Sanchez, F. (2010). Recursos educativos en red. Síntesis.

Sánchez-Alonso, S., Sicilia, M.A., García-Barriocanal, E., Pagés-Arévalo, C. y Lezcano, L. (2011). Social models in open learning object repositories: A simulation approach for sustainable collections. Simulation Modelling Practice and Theory. Volume 19, Issue 1. Recuperado de https://doi.org/10.1016/j.simpat.2010.06.022

UNESCO (2002). Forum on the Impact of Open Courseware for Higher Education in Developing Countries. Final report. 1-3 July 2002. William and Flora Hewlett Foundation and Western Cooperative for Educational Telecommunications, WCET. Recuperado de https://tinyurl.com/y6r8tgec

UNESCO-IESALC (2020). COVID-19 y educación superior: De los efectos inmediatos al día después. Análisis de impactos, respuestas políticas y recomendaciones. Recuperado de https://www.iesalc.unesco.org/wp-content/uploads/2020/05/COVID-19ES-130520.pdf

UNESCO (2020). La educación en un mundo tras la COVID: Nueve ideas para la acción pública Comisión internacional sobre Los futuros de la educación. Recuperado de https://unesdoc.unesco.org/ark:/48223/pf0000373717_spa

Vázquez-Cano, E. y Sevillano García, M.L. (edit.) (2015). Dispositivos digitales móviles en educación. El aprendizaje ubicuo. Narcea.

Wiley, D. A. (2000). Connecting learning objects to instructional design theory: A definition, a metaphor, and a taxonomy. The Instructional Use of Learning Objects: Online Version. Recuperado de http://reusability.org/read/chapters/wiley.doc 


\section{Regreso al Pasado: El Entorno Virtual \\ Cospaces Edu para la Enseñanza de Historia}

Tirado-Olivares, Sergio

https://orcid.org/0000-0002-8557-5115

Sergio.Tirado@uclm.es

del Olmo-Muñoz, Javier

https://orcid.org/0000-0001-8754-0648

Javier.OImo@uclm.es

\section{Bueno-Baquero, Andrea}

https://orcid.org/0000-0001-5567-7535

Andrea.Bueno@uclm.es

\section{Cózar-Gutiérrez, Ramón}

https://orcid.org/0000-0001-8255-6376

Ramon.Cozar@uclm.es

\section{González-Calero, José Antonio}

https://orcid.org/0000-0003-0842-8151

Jose.GonzalezCalero@uclm.es 


\title{
REGRESO AL PASADO: EL ENTORNO VIRTUAL COSPACES EDU PARA LA ENSEÑANZA DE HISTORIA
}

\author{
Tirado-Olivares, Sergio \\ del Olmo-Muñoz, Javier \\ Bueno-Baquero, Andrea \\ Cózar-Gutiérrez, Ramón \\ González-Calero, José Antonio
}

\section{Resumen}

Las tecnologías emergentes permiten nuevas formas de comprender el proceso de aprendizaje. La enseñanza de la historia basada únicamente en la memorización no tiene cabida en la educación del siglo XXI. Así pues, el presente trabajo tiene como objetivo conocer las perspectivas de los futuros docentes sobre el uso de entornos virtuales y sus aplicaciones educativas, tras una intervención en la que se les propuso crear su propio entorno virtual orientado a la enseñanza de contenidos históricos en Educación Primaria. Los resultados obtenidos muestran que los estudiantes para maestro tenían poca experiencia previa con el manejo de entornos virtuales. Sin embargo, después de la experiencia, enfatizan la capacidad de este tipo de herramientas para simular entornos del mundo real y generar motivación, interés y diversión en el alumno. Entre los hallazgos de este estudio se encuentra el deseo de los futuros maestros de utilizar esta tecnología en su vida profesional, algo para lo que creen necesaria una mayor formación.

\section{Palabras clave}

Realidad virtual, entornos virtuales, futuros docentes, Universidad, Historia. 


\section{Introducción}

Son varios autores los que en la actualidad sostienen que el enfoque pedagógico tradicional en historia, basado en lo memorístico, ya no tiene sentido (p. ej., Sáiz y Gómez, 2016). La enseñanza de la Historia, entendida como el docente en el papel de divulgador del conocimiento, el alumnado como mero receptor de este y el uso del libro de texto, en ocasiones como única herramienta de apoyo al proceso de aprendizaje, ya no tiene cabida en la actual era de la información y la comunicación gracias a las tecnologías emergentes (Gómez-Carrasco y Miralles-Martínez, 2017; Liceras y Romero, 2016). Actualmente, uno de los grandes objetivos de la educación en este campo de conocimiento es el desarrollo del pensamiento histórico; esto es, el proceso de creación para interpretar de manera reflexiva los hechos históricos (Seixas y Morton, 2013). Por ello, brindar nuevas herramientas a los docentes que permitan espacios de aprendizaje activo es, en estos momentos, un tema de interés en materia de investigación e innovación educativa.

En el contexto actual, la implementación de entornos digitales ha despertado mucho interés (Brown et al., 2020). La reducción de costes, los avances tecnológicos y la mayor conectividad han permitido integrar estos entornos en nuevas experiencias en la educación. Dentro de estas experiencias, el uso de la Realidad Virtual (RV) emerge como un recurso de alto potencial. Podríamos definir la RV como aquella tecnología que posibilita la inmersión virtual mediante el uso de una simulación por computadora, propiciando experiencias sensoriales y emocionales (Villena-Taranilla et al., 2019). Concretamente, su empleo permite sumergir al alumno en entornos con un nivel de realismo imposible de lograr con un libro de texto (Blascovich et al., 2002).

Existen varios tipos de RV según la profundidad de inmersión: desde una inmersión completa gracias al uso de dispositivos como las gafas de realidad virtual, a una no inmersiva, también conocida como de escritorio, pues se interactúa gracias a la pantalla de un dispositivo electrónico, ya sea un ordenador o tablet (Di Natale et al., 2020). En la experiencia aquí presentada, se utilizó un sistema de RV no inmersivo utilizando un entorno de escritorio. Este estudio es parte de un proyecto de investigación más amplio sobre el uso de entornos virtuales para la instrucción y el aprendizaje de la Historia, que pretende conocer la percepción que tienen los docentes en formación sobre su uso. Sobre este último aspecto, el presente estudio se plantea los siguientes tres objetivos:

- Conocer la experiencia previa que tienen los docentes en formación sobre el uso de las tecnologías emergentes en general, y de los entornos virtuales en particular, en materia de educación.

- Analizar las potencialidades que los estudiantes para maestro observan en los entornos virtuales y sus aplicaciones educativas para la didáctica de contenidos ligados a la historia.

- Evaluar las intenciones futuras en el uso de estos entornos virtuales por parte de los futuros docentes. 


\section{Método}

\section{Descripción del contexto y de los participantes}

Los participantes del presente estudio son 21 estudiantes del Grado de Maestro en Educación Primaria de la Facultad de Educación de Albacete (Universidad de Castilla-La Mancha), todos ellos matriculados en la mención de Historia, Cultura y Patrimonio. Durante nueve sesiones de dos horas cada una, se les instruyó en el uso de ambientes virtuales y participaron activamente en el proyecto, construyendo entornos virtuales para la enseñanza de los contenidos curriculares de Historia en Educación Primaria.

\section{Instrumentos}

Tras el proyecto se utilizó una versión modificada del cuestionario TAM (Technology Acceptance Mode/), que los participantes completaron usando Microsoft Forms de forma anónima con sus dispositivos electrónicos en la clase habitual donde se imparte la mención. Mediante una escala Likert con siete opciones, los estudiantes dieron su opinión sobre cada uno de los ítems presentados en el cuestionario. Para nuestro objetivo de investigación, utilizamos tres versiones validadas de TAM (Armenteros et al., 2013; Sánchez Prieto et al., 2016; Wei et al., 2021), traduciéndolas y adaptándolas para crear el instrumento de recogida de información. La combinación de los cuestionarios dio como resultado un total de 35 ítems distribuidos en 10 dimensiones.

Las primeras cinco dimensiones versan sobre el conocimiento y experiencia previa en el uso de las tecnologías emergentes, el interés por la innovación educativa, y la percepción sobre las facilidades y potencialidades de los entornos virtuales que los futuros docentes atribuyen a su uso como herramienta educativa. En concreto, estas cinco categorías son: Experiencia previa en el uso de la tecnología (EPT), Conciencia de los entornos virtuales (CEV), Innovación del educador (IE), Facilidad de uso percibida (FUP) y Disfrute percibido (DP). Los ítems que componen este primer conjunto de dimensiones son visibles en la Tabla 1.

\section{Experiencia previa en el uso de la tecnología (EPT)}

\begin{tabular}{|l|l|}
\hline EPT1 & ¿Cuál es tu experiencia usando diferentes dispositivos como Mac, PC, Blackberry o iPhone? \\
\hline EPT2 & ¿Cuál es tu experiencia usando Internet? \\
\hline EPT3 & ¿Cuál es tu experiencia usando PowerPoint? \\
\hline EPT4 & $\begin{array}{l}\text { ¿Cuál es tu experiencia usando dispositivos digitales (ordenador, tablet, móviles...) como } \\
\text { herramienta de enseñanza? }\end{array}$ \\
\hline EPT5 & ¿Cuál es tu experiencia usando entornos virtuales? \\
\hline Conciencia de los entornos virtuales (CEV) \\
\hline CEV1 & Soy consciente de que los entornos virtuales se pueden utilizar como material didáctico. \\
\hline CEV2 & Sé que los entornos virtuales nos permiten emular entornos reales en formato virtual. \\
\hline CEV3 & Sé que los entornos virtuales se pueden aplicar en varios campos. \\
\hline Innovación del educador (IE) \\
\hline IE1 & $\begin{array}{l}\text { Disfruto enseñando a mis alumnos a través de las plataformas de aprendizaje digital (por } \\
\text { ejemplo: Kahoot, Socrative, ClassDojo, CoSpaces). }\end{array}$ \\
\hline IE2 & Estoy al día con las nuevas tecnologías digitales en educación. \\
\hline
\end{tabular}




\begin{tabular}{|l|l|}
\hline IE3 & Me siento seguro con la tecnología digital en educación. \\
\hline IE4 & A menudo busco mejores materiales didácticos. \\
\hline Facilidad de uso percibida (FUP) \\
\hline FUP1 & Aprender a usar entornos virtuales en el aula sería fácil para mí \\
\hline FUP2 & Me resulta fácil interactuar con los entornos virtuales \\
\hline FUP3 & La interacción con los entornos virtuales es clara y fácil de entender para mí \\
\hline FUP4 & En general, considero que los entornos virtuales son fáciles de usar \\
\hline Disfrute percibido (DP) \\
\hline DP1 & Disfruto usando un entorno multimedia como PowerPoint o Internet en la enseñanza. \\
\hline DP2 & Disfruto usando entornos virtuales como herramienta de enseñanza. \\
\hline DP3 & Usar entornos virtuales como herramienta de enseñanza es satisfactorio. \\
\hline DP4 & Usar entornos virtuales como herramienta de enseñanza es divertido. \\
\hline DP5 & Usar entornos virtuales como herramienta de enseñanza es positivo. \\
\hline DP6 & Usar entornos virtuales como herramienta de enseñanza es interesante. \\
\hline DP7 & Usar entornos virtuales como herramienta de enseñanza es emocionante. \\
\hline
\end{tabular}

Tabla 1. Primeras cinco dimensiones del instrumento de recogida de información

Por otro lado, el segundo conjunto de dimensiones hace hincapié en la predisposición de los estudiantes encuestados, una vez han trabajado con los entornos virtuales durante el proyecto. Adicionalmente, se pretende conocer cuáles son los inconvenientes que le atribuyen a su implementación en su futura práctica docente. En concreto, las dimensiones de este bloque son: Actitud para adoptar Entornos Virtuales (AEV), Intención de uso (IU), Autoeficacia (AEF), Resistencia al cambio (RC) y Facilitar las condiciones (FC). Los ítems de estas dimensiones se pueden consultar en la Tabla 2.

\section{Actitud para adoptar Entornos Virtuales (AEV)}

\begin{tabular}{|l|l|}
\hline AEV1 & Me gusta la idea de usar entornos virtuales como una mejora para la enseñanza \\
\hline AEV2 & Creo que usar entornos virtuales en mi práctica docente es una buena idea \\
\hline AEV3 & $\begin{array}{l}\text { Creo que los entornos virtuales permiten a los alumnos disfrutar de entornos reales en } \\
\text { formato virtual }\end{array}$ \\
\hline AEV4 & Me siento bien con el diseño de entornos virtuales en mi práctica docente \\
\hline AEV5 & Puedo aceptar los entornos virtuales como material didáctico \\
\hline AEV6 & Me siento cómodo al adoptar entornos virtuales en mi práctica docente \\
\hline Intención de uso (IU) \\
\hline IU1 & Tengo la intención de utilizar los entornos virtuales en el aula \\
\hline IU2 & Creo que utilizaré los entornos virtuales en mi trabajo \\
\hline IU3 & Tengo planeado usar entornos virtuales en mi práctica docente \\
\hline Autoeficacia (AEF) \\
\hline AEF1 & Puedo integrar los entornos virtuales en mi práctica docente \\
\hline AEF2 & $\begin{array}{l}\text { Puedo usar los entornos virtuales como herramientas educativas incluso sin la ayuda de } \\
\text { nadie }\end{array}$ \\
\hline AEF3 & Puedo diseñar materiales y actividades en entornos virtuales sin ayuda externa \\
\hline
\end{tabular}




\begin{tabular}{|c|c|}
\hline \multicolumn{2}{|c|}{ Resistencia al cambio (RC) } \\
\hline $\mathrm{RC1}$ & $\begin{array}{l}\text { Me gustaría que los entornos virtuales cambiaran la forma en que se produce la práctica } \\
\text { docente }\end{array}$ \\
\hline $\mathrm{RC} 2$ & $\begin{array}{l}\text { Quiero que los entornos virtuales cambien la forma de interactuar entre profesores y estu- } \\
\text { diantes }\end{array}$ \\
\hline $\mathrm{RC3}$ & $\begin{array}{l}\text { Me resultaría fácil asumir los cambios metodológicos de enseñanza introducidos por los } \\
\text { entornos virtuales }\end{array}$ \\
\hline \multicolumn{2}{|r|}{ Facilitar las condiciones (FC) } \\
\hline $\mathrm{FC1}$ & Tengo el tiempo suficiente para incluir los entornos virtuales en mi práctica docente \\
\hline FC2 & $\begin{array}{l}\text { Tengo fácil acceso a los materiales que necesito para desarrollar actividades educativas } \\
\text { que usen entornos virtuales }\end{array}$ \\
\hline $\mathrm{FC} 3$ & $\begin{array}{l}\text { Tengo a mi disposición los recursos humanos necesarios para poder desarrollar activida- } \\
\text { des educativas por medio de entornos virtuales }\end{array}$ \\
\hline
\end{tabular}

\section{Tabla 2. Últimas cinco dimensiones del instrumento de recogida de información}

\section{Procedimiento}

Como puede apreciarse en la Figura 1 que se muestra a continuación, la fase de trabajo con los estudiantes se dividió en tres etapas:

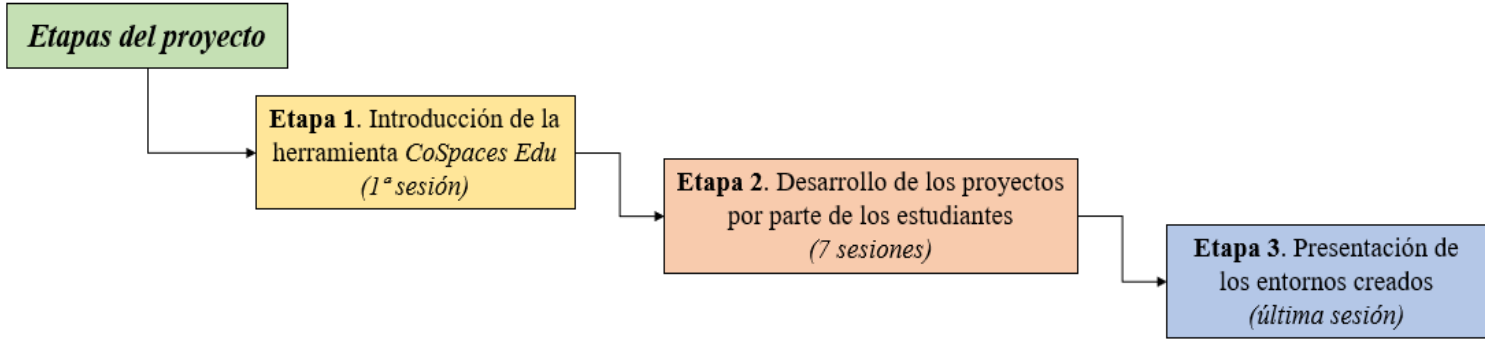

\section{Figura 1. Dinámica implementada durante las nueve sesiones en las que se dividió el} proyecto

En primer lugar, la primera sesión se utilizó para presentar la noción de entorno virtual a los participantes y explicarles el funcionamiento de la herramienta CoSpaces Edu para crear este tipo de entornos. A continuación, los estudiantes decidieron sobre los contenidos curriculares en los que centrarse y construir sus entornos, adaptados a los objetivos didácticos estatales marcados sobre esta área del conocimiento, todo ello a lo largo de siete sesiones. Finalmente, la última sesión del proyecto estuvo dedicada a que los estudiantes presentaran los entornos creados a sus compañeros, así como la cumplimentación individual del cuestionario TAM. La Figura 2 muestra un ejemplo de un entorno creado por uno de los estudiantes. 


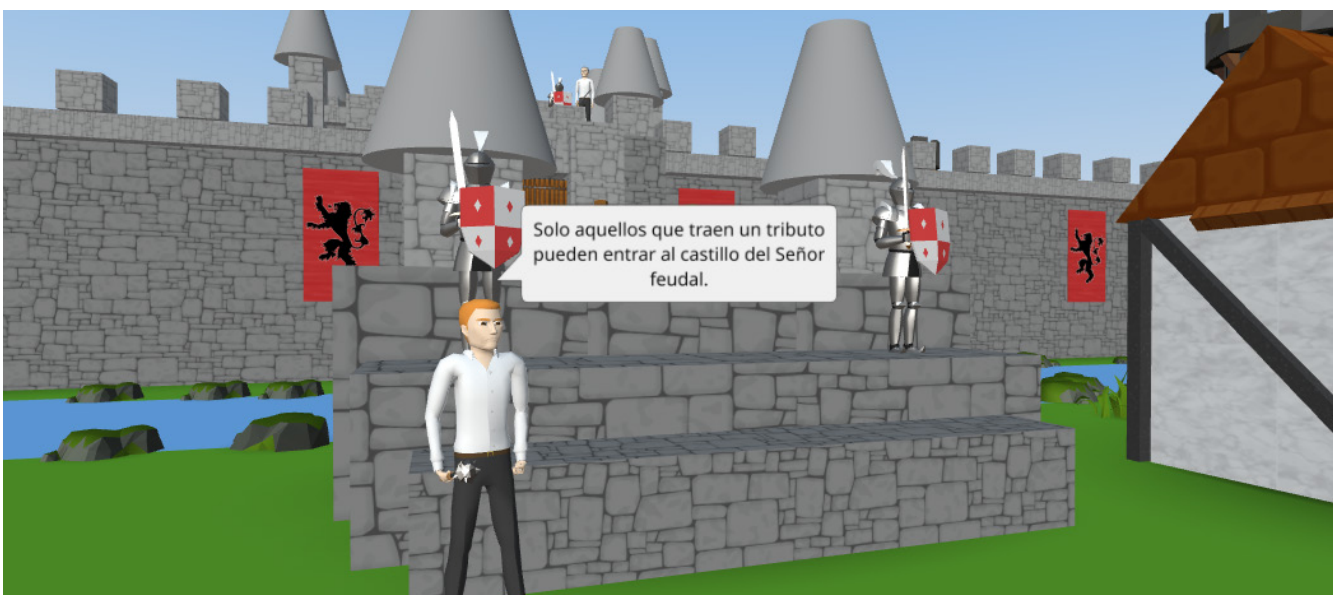

Figura 2. Ejemplo de entorno virtual creado por uno de los estudiantes

\section{Resultados}

Con respecto al primero de los objetivos de investigación planteados en la presente investigación, los resultados obtenidos son visibles en la Figura 3. Estos son referidos a la primera categoría sobre las experiencias previas con uso de la tecnología (EPT). A pesar de la interacción constante de los futuros educadores con las tecnologías emergentes, pues las usan habitualmente gracias a dispositivos electrónicos como ordenadores o teléfonos móviles para, por ejemplo, navegar por Internet o comunicarse, reconocen que tienen muy poca experiencia en el uso de estas tecnologías como recursos educativos. Esta carencia de implementación, con excepción de su uso para realizar presentaciones PowerPoint, es visible cuando se trata de la creación de entornos virtuales. Un $68,1 \%$ de encuestados reconoce no haber usado estas tecnologías para el diseño de entornos virtuales nunca, o prácticamente en ninguna ocasión anterior.

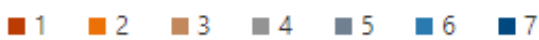

1. ¿Cuál es tu experiencia usando diferentes dispositivos como Mac, PC, Blackberry o iPhone?

2. ¿Cuál es tu experiencia usando Internet?

3. ¿Cuál es tu experiencia usando PowerPoint?

4. ¿Cuál es tu experiencia usando dispositivos digitales (ordenador, tablet, móviles...) como herramienta de...

5. ¿Cuál es tu experiencia usando entornos virtuales?
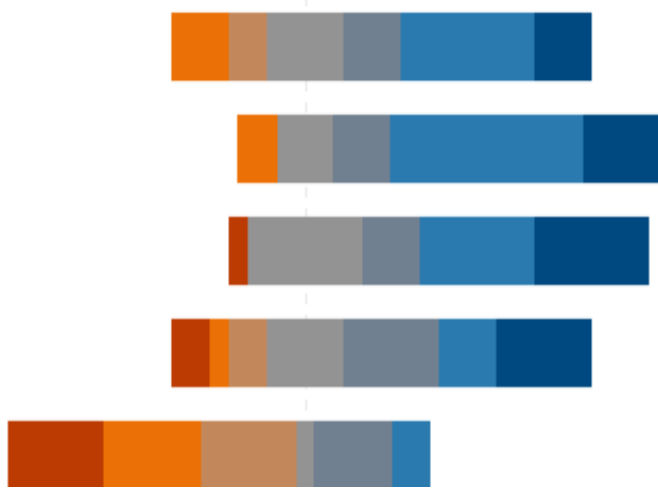

Figura 3. Experiencias previas con uso de las tecnologías emergentes en diferentes aspectos. La escala transcurre entre rojo oscuro (1) = ninguna experiencia y azul oscuro (7) mucha experiencia. 
Sin embargo, todos los futuros maestros encuestados afirman conocer, en mayor o menor medida, qué son los entornos virtuales y que estos pueden usarse como herramienta educativa (categoría CEV). En ninguno de los ítems que componen esta segunda categoría se obtuvieron puntuaciones por debajo del cinco en la escala de siete puntos. En esta línea, de acuerdo con el segundo objetivo de investigación planteado, son conscientes de su potencial educativo. Los estudiantes conocen, o dicen conocer, las ventajas que brindan debido a su capacidad de simular entornos del mundo real sin salir del aula (más del 90\% así lo considera), y a su versatilidad para aplicar a una amplia gama de contenidos teóricos (el 90,9\% se muestra de acuerdo o muy de acuerdo). De hecho, el $86,3 \%$ apuntan que el uso de estos entornos virtuales puede mejorar los procesos de enseñanza.

Tras la experiencia, la muestra encuestada destaca lo positivo y motivador (categoría DP) de usar los entornos virtuales dentro de la dinámica de clase. Estas afirmaciones son respaldadas por más del $80 \%$ en todas las ocasiones. Incluso, tal es esta percepción, que la totalidad de la muestra de participantes se muestra de acuerdo con las afirmaciones referidas a que su inclusión en el aula posibilita ambientes de aprendizaje activos y con mejora de la actitud durante el aprendizaje, enfatizando su capacidad para generar interés y diversión.

Sin embargo, incluso tras la fase práctica de uso de los entornos virtuales, los estudiantes muestran niveles de comodidad en su uso menores a los que sería deseable encontrar, lo que podría afectar a su predisposición a utilizarlas durante sus clases en el futuro (objetivo 3). De hecho, la categoría sobre la facilidad de uso percibida (FUP) es, junto a la categoría sobre la autoeficacia percibida (AP), la categoría donde más respuestas se han encontrado en las opciones ligadas a estar en desacuerdo con los ítems que las componen. Esta premisa, además, se justifica sobre la base de que los docentes en formación no creen estar lo suficientemente preparados, ni se sienten lo bastante seguros, como para utilizar las tecnologías digitales en materia de educación: únicamente un $31,3 \%$ se muestra seguro o muy seguro para aplicarlas en el aula de forma correcta.

Una vez finalizado el trabajo con Cospaces Edu, más del $40 \%$ continúa mostrando reticencias a considerar que el diseño de entornos virtuales les sería una tarea fácil, especialmente si deben hacerlo sin ayuda alguna (el $41 \%$ tiene reservas sobre considerarse capacitados para crear tales entornos en el futuro de manera autónoma). Así pues, se justifica la demanda de mayor formación que muchos encuestados señalan. Más de la mitad de los estudiantes reconocen una falta de formación en el uso de la tecnología en los procesos educativos. Por ello, solo el $28,6 \%$ se considera preparado para asumir con facilidad los cambios metodológicos que el uso de los entornos virtuales requiere.

A pesar de las necesidades formativas que los participantes subrayan, destaca la actitud receptiva de éstos hacia el uso de los entornos virtuales en contextos educativos. Todos los encuestados señalan que el uso de estos entornos virtuales puede mejorar su desempeño profesional. Sobresalen los niveles por encima del $75 \%$ obtenidos en las categorías acerca de la predisposición (AEV) e intención (IU) de uso futuros; alcanzándose incluso valores superiores al 95\% en los ítems ligados a querer realizar experiencias o proyectos similares en el futuro.

En esta línea, debemos resaltar la motivación por el conocimiento de nuevas formas de enseñar a través de las tecnologías y del uso en particular de plataformas digitales ya conocidas (p. ej., Kahoot o Socrative) para crear nuevas formas de dinamizar la 
clase (85,7\% destacan el disfrute durante su diseño). Los docentes en formación consideran que, tras una buena formación, tendrán las condiciones (FC) de tiempo (81\%), materiales $(80,4 \%)$ y recursos humanos $(71,4 \%)$ suficientes para su uso en el aula; descartándose, por tanto, estas afirmaciones como el motivo por el cual el uso de estas nuevas metodologías se encontraría de manera aislada en los colegios actuales.

\section{Discusión y conclusiones}

A la luz de los resultados obtenidos, podemos concluir que se han cumplido los objetivos planteados al inicio del presente estudio. Después de diseñar con éxito sus propios entornos virtuales para la enseñanza de la historia, los futuros docentes ven su uso como beneficioso. Los futuros docentes consideran que su implementación en etapas de educación obligatoria es positiva. Concretamente, recalcan su capacidad para crear entornos de aprendizaje lúdico-activos y cambiar así el aprendizaje memorístico, comúnmente asociado a la enseñanza tradicional de la Historia y basado en el uso del libro como recurso principal para el aprendizaje de los contenidos teóricos (Liceras y Romero, 2016; Sáiz y Gómez, 2016), por un aprendizaje reflexivo. Aprendizaje que puede estar basado en la indagación de la Historia desde dentro, desde la propia inmersión del alumnado en recreaciones históricas simuladas por ordenador; dando como resultado la capacidad del docente para fomentar el pensamiento histórico entre sus alumnos (Seixas y Morton, 2013). En este punto, es destacable además que, a diferencia de lo que sucede con un libro de texto, los entornos virtuales permiten envolver al alumnado en un grado de inmersión en contextos históricos difícilmente alcanzables con otros recursos de enseñanza tradicional (Blascovich et al., 2002), lo que justifica los niveles de motivación y emoción capaces de generar en el alumnado que los docentes atribuyen a su uso.

No obstante, a pesar de estos resultados, que continúan la línea de conclusiones obtenidas en otras investigaciones anteriores (p. ej., Di Natale et al., 2020; Villena-Taranilla et al., 2019) en las que ya se había comprobado las utilidades de la realidad y los entornos virtuales en materia educativa, los futuros docentes piensan que debe ampliarse la formación que reciben en este campo. La mayoría de los participantes, con anterioridad a este estudio, no habían tenido ningún contacto o apenas alguna experiencia que les permitiera trabajar de forma práctica en el diseño de entornos virtuales. Los estudiantes conocían de su existencia, sabían de sus potencialidades, pero demandan ser formados en su uso didáctico. Esta premisa se justifica con base en los resultados obtenidos sobre cómo de capacitados se sienten para integrar estos entornos de aprendizaje en su futura práctica docente. A pesar de todas las ventajas ya comentadas que los docentes han encontrado sobre su uso tras el proyecto, consideran que necesitan más experiencias similares a la realizada en este estudio para adquirir el suficiente conocimiento, y destreza en su manipulación, para sentirse con confianza para su uso de forma autónoma y con un marcado carácter pedagógico.

Por todo ello, los futuros maestros valoran muy positivamente este tipo de proyectos, en los que se abordan las tecnologías emergentes, y los entornos virtuales de forma particular, con un enfoque educativo. Estos proyectos les permiten valorar de primera mano las ventajas que estos recursos pueden producir en su futura práctica docente, pero demandan más actuaciones pedagógicas en esta línea para sentirse seguros en su uso futuro, pues es a partir de la formación del profesorado como verdaderamente se puede alcanzar una innovación educativa de calidad. 


\section{Referencias}

Armenteros, M., Liaw, S. S., Fernández, M., Díaz, R. F., \& Sánchez, R. A. (2013). Surveying FIFA instructors' behavioral intention toward the Multimedia Teaching Materials. Computers \& Education, 61, 91-104. https://doi.org/10.1016/j.compedu.2012.09.010

Blascovich, J., Loomis, J., Beall, A. C., Swinth, K. R., Hoyt, C. L., \& Bailenson, J. N. (2002). Immersive Virtual Environment Technology as a Methodological Tool for Social Psychology. Psychological Inquiry, 13(2), 103-124. https://doi.org/10.1207/ S15327965PLI13O2_O1

Brown, M., McCormack, M., Reeves, J., Brooks, D. C. y Grajek, S. (2020). 2020 EDUCAUSE Horizon Report Teaching and Learning Edition. https://www.educause.edu/ horizon-report-2020

Di Natale, A. F., Repetto, C., Riva, G., \& Villani, D. (2020). Immersive virtual reality in $\mathrm{K} 12$ and higher education: A 10 year systematic review of empirical research. British Journal of Educational Technology, 51(6), 2006-2033. https://doi.org/10.1111/ bjet.13030

Gómez-Carrasco, C. J., \& Miralles-Martínez, P. (2017). Los espejos de Clío. Usos y abusos de la Historia en el ámbito escolar. Silex

Liceras, Á., \& Romero, G. (2016). Didáctica de las Ciencias Sociales. Fundamentos, contextos y propuestas. Pirámide.

Sáiz, J. \& Gómez, C. J. (2016). Investigar pensamiento histórico y narrativo en la formación del profesorado: fundamentos teóricos y metodológicos. Revista Electrónica Interuniversitaria de Formación del Profesorado. 19(1), 175-190. http://dx.doi. org/10.6018/reifop.19.1.206701

Sánchez-Prieto, J. C., Olmos-Migueláñez, S., \& García-Peñalvo, F. J. (2016). Informal tools in formal contexts: Development of a model to assess the acceptance of mobile technologies among teachers. Computers in Human Behavior, 55, 519-528. https:// doi.org/10.1016/j.chb.2015.07.002

Seixas, P. y Morton, T. (2013). The big six historical thinking concepts. Nelson.

Villena Taranilla, R., Cózar-Gutiérrez, R., González-Calero, J. A., \& López Cirugeda, I. (2019). Strolling through a city of the Roman Empire: an analysis of the potential of virtual reality to teach history in Primary Education. Interactive Learning Environments, 1-11. https://doi.org/10.1080/10494820.2019.1674886

Wei, C. Y., Kuah, Y. C., Ng, C. P., \& Lau, W. K. (2021). Augmented Reality (AR) as an Enhancement Teaching Tool: Are Educators Ready for It?. Contemporary Educational Technology, 13(3), ep303. https://doi.org/10.30935/cedtech/10866 


\section{Los Docentes Frente a la Utilización de Tics: Propuesta de un Modelo de Seguimiento en Docentes de Facultad de Ciencias Económicas de UNC 2021}

\section{Casini, Rosanna}

Universidad Nacional de Córdoba, FCE rosanna.casini@unc.edu.ar 


\section{LOS DOCENTES FRENTE A LA UTILIZACIÓN DE TICS: PROPUESTA DE UN MODELO DE SEGUIMIENTO EN DOCENTES DE FACULTAD DE CIENCIAS ECONÓMICAS DE UNC 2021}

\section{Casini, Rosanna}

Universidad Nacional de Córdoba, FCE

rosanna.casini@unc.edu.ar

\section{Resumen}

El debate en relación a la evaluación y análisis de las competencias digitales de los docentes como una dinámica de retroalimentación se torna necesario en un contexto caracterizado por el vertiginoso avance de la virtualidad en el proceso de enseñanza y, substancialmente por la inminente aplicación de medios tecnológicos que debió realizarse en el año 2020 lo que condujo a una virtualidad obligada en todas las actividades docentes del nivel superior.

Si bien las investigaciones actualmente, se focalizan en los niveles de apropiación de TIC y su incidencia en las habilidades y destrezas necesarias del docente para enfrentar la enseñanza virtual, es de fundamental importancia relacionar estos aspectos con el contexto posterior a la pandemia.

Es por lo mencionado precedentemente que, en este trabajo, se propone un modelo que tiene como principal objetivo medir, fortalezas y debilidades de los docentes de la Facultad de Ciencias Económicas de la UNC, en cuanto a incorporación de tecnología en el proceso de enseñanza aprendizaje de un modo reflexivo para el desarrollo de nuevas propuestas de enseñanza.

\section{Palabras clave}

Modelo de evaluación de CDD, uso reflexivo de TIC. 


\section{Introducción}

La Globalización tecnológica y el avance de la comunicación desencadenados en las últimas décadas, han dado origen a nuevas demandas sociales que, entre otras, requieren profesionales con competencias digitales. Destacamos la siguiente reflexión que plantea interrogantes referidos al rol y capacidades de los docentes frente a los desafíos de la era digital.

La Era Digital nos abre un mundo de desafíos y también de oportunidades. Los continuos cambios tecnológicos que vivimos, exigen a los docentes perfeccionarse constantemente, para promover entre los estudiantes las habilidades y competencias que necesitan para ser parte de la sociedad del futuro. ¿Cuál es la importancia del rol docente en este nuevo entorno? ¿Qué habilidades debe poseer un docente en la Era Digital? (Briceño, 2021)

La Universidad, en este contexto, se configura como agente facilitador de competencias profesionales necesarias para satisfacer esas demandas en el desempeño de las funciones de cada sector. Al decir de Capanegra, et al. (2016) la enseñanza en el nivel superior deberá satisfacer las demandas de la sociedad con sentido crítico, ético, social y científico, garantizando la transferencia de los conocimientos de manera inclusiva, democrática y participativa, propiciando creatividad e innovación para la resolución sistematizada de situaciones problemáticas de la comunidad.

De este modo, los docentes, como protagonistas responsables de la formación profesional dentro de la comunidad educativa, quedaron involucrados en una progresiva necesidad de apropiación de tecnología para el desempeño de sus funciones (Gutiérrez \& Prendes, 2012).

El problema radica en la evaluación, autoevaluación y/o análisis sobre el uso reflexivo de tecnología en la enseñanza. En realidad, esto se torna más relevante aún, ante la aplicación inminente y acelerada por efecto de la necesaria virtualidad que atañe a todos los responsables y destinatarios del servicio educativo. No obstante, nos enfrentaremos a otro desafío no menos importante, la etapa de reincorporación al sistema mediante modalidad semipresencial o presencial con proyectos de enseñanza innovadores que establezcan una metodología, que, de forma creativa, combine ambos sistemas.

Al efecto, en lo que a docentes de educación superior se refiere, se iniciaron estudios e investigaciones que trataron de diagnosticar la percepción y el nivel de involucramiento responsable de los docentes con miras a un aprovechamiento en términos de calidad educativa y formación de competencias digitales en los educandos.

De modo tal que las investigaciones en la actualidad trascienden a la mera incorporación de TIC, focalizándose en los niveles de apropiación de tecnología y su incidencia en las competencias necesarias de los docentes para el desarrollo de su actividad, llamadas competencia digital docente (CDD). Rescatamos como relevante el estudio de Padilla et al. (2020) de carácter cualitativo, biográfico-narrativo del que surgieron, un listado de categorías y de indicadores para interpretar la CDD.

Asimismo, antecedentes de modelos de análisis cuantitativos se han construido generando valiosos resultados para el diagnóstico del nivel de competencia adquirida 
y percepción sobre TIC en la enseñanza. Citamos como referentes, el cuestionario de percepción docente sobre TIC en educación, COPIDES (Fernández-Márquez et al., 2017), el modelo de apropiación de TIC en tres niveles (Valencia Molina et al., 2016) y el proyecto MetaRed basado en el marco denominado "DigCompEdu" (Cabero-Almenara \& Palacios-Rodríguez, 2020).

Para abordar el problema citado precedentemente, se propone un estudio documental y descriptivo que permita definir un modelo propicio para analizar fortalezas y debilidades de los docentes en cuanto a la utilización reflexiva de tecnología en el proceso de enseñanza-aprendizaje y la posible adecuación a un sistema innovador que combine presencialidad y virtualidad.

Los objetivos propuestos en el presente trabajo se detallan a continuación:

- Realizar un análisis documental de modelos de evaluación y autoevaluación sobre uso de TIC en la enseñanza.

- Desarrollar y proponer un modelo para la reflexión y autoevaluación sobre CDD, en docentes de la FCE_ UNC.

\section{Método/Descripción de la experiencia}

Con el propósito de resaltar la percepción de docentes de la Facultad de Ciencias Económicas, en primera instancia, se detalla un análisis descriptivo sobre una encuesta de autoevaluación institucional realizada en el año 2018, facilitado por el área de evaluación institucional de la FCE UNC que, conjuntamente con el estudio documental de desarrollo institucional sobre incorporación de TIC, ha dado origen a un diagnóstico de situación.

Posteriormente se ha realizado un análisis documental sobre la evolución de algunas investigaciones y proyectos sobre el tema, cuyo objetivo principal es la instrumentación de un modelo basado en indicadores para estudiar la autopercepción sobre el nivel de apropiación de habilidades con TIC y competencias digitales de docentes de la FCE UNC.

Además de lo mencionado se pretende implementar una modalidad de enseñanza innovadora que permita enfrentar el desafío de una modalidad mixta en la que el aula virtual y las actividades virtuales se combinen con la presencialidad en concordancia con el nivel de competencia y percepción sobre TIC de cada docente.

\section{Contexto}

En el marco de un proyecto de investigación avalado por la Secretaría de Ciencia y Técnica de la UNC, se investiga el tema "aplicación de tecnología en la enseñanza". La Facultad de Ciencias Económicas ha iniciado una etapa de incorporación de medios tecnológicos a partir de la implementación del nuevo plan de estudios 2009. Formalmente ha generado el área de formación y perfeccionamiento docente, denominada Fype, donde se desarrollan proyectos que conducen a involucrar a los docentes en el uso de TIC. Se comenzó en el año 2018 con el traslado de aulas virtuales de la plataforma educativa a Moodle, sin embargo con el advenimiento del 
proceso covid_19, se produjo la necesidad de dictado virtual de las materias y la urgencia de replantear y planificar las actividades desde la virtualidad. En este contexto se considera necesaria la creación de instrumentos que permitan evaluar el perfil de los docentes en cuanto a competencias digitales y la forma en que el docente combina estos instrumentos con la disciplina en el método utilizado para enseñar.

\section{Diagnóstico de situación sobre percepción de docentes de la FCE -UNC, en cuanto a tecnología (año 2018)}

Para ahondar más en la situación de los docentes de la encuesta para autoevaluación institucional, información suministrada por la Secretaría de Evaluación Institucional de FCE, se describe el plantel docente en el año 2018 para los 254 docentes encuestados:

\section{Docentes por cargo}

$$
\begin{array}{r}
\text { Profesor Titular } \\
\text { Profesor Asociado } \\
\text { Profesor Adjunto } \\
\text { Profesor Asistente } \\
\text { Profesor Ayudante B } \\
\text { Profesor Ayudante A } \\
\text { Ayudante alumno }
\end{array}
$$

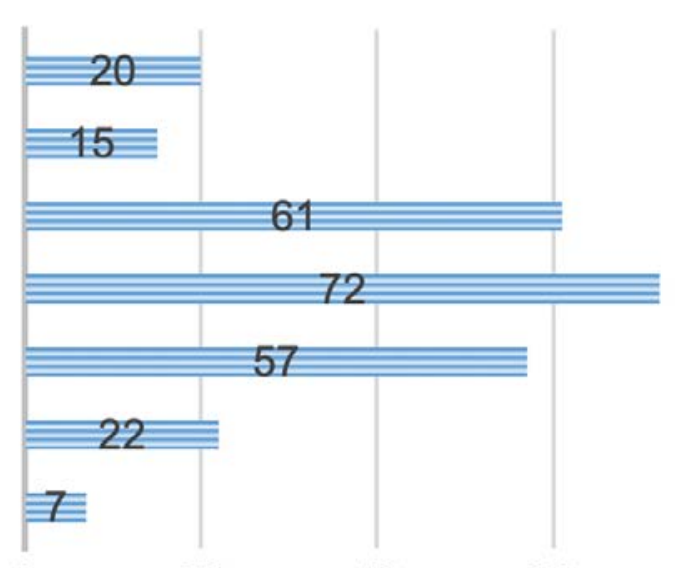

$\begin{array}{lllll}0 & 20 & 40 & 60 & 80\end{array}$

\section{Figura 1. Cargo de docentes. Fuente: Elaboración propia.}

Del procesamiento de la encuesta se ha observado en los siguientes gráficos que, en lo atinente a la satisfacción de los docentes sobre algunas herramientas vinculadas a tecnología, consideran que el área de formación docente tiene un buen desempeño y que el equipamiento tecnológico es una fortaleza en la institución, fundamentalmente en docentes de cargo de profesor titular, asociado y adjunto. 


\section{Como evalúa el desempeño del área de formación docente}

\footnotetext{
Profesor Titular

Profesor Adjunto

Profesor Asociado

Profesor Asistente

ofesor Ayudante B

ofesor Ayudante A

Ayudante alumno
}

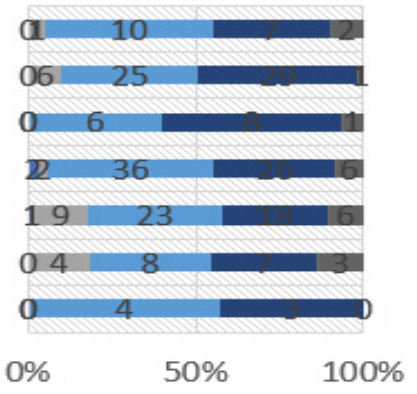

malo $\square$ Reg $\square$ Bueno $\square$ Muy bueno $\square$ NS/NC

\section{Fortalezas y debilidades en equipamiento tecnológico}

Profesor Titular

Profesor Asociado

Profesor Adjunto

Profesor Asistente

Profesor Ayudante B

Profesor Ayudante A

Ayudante alumno

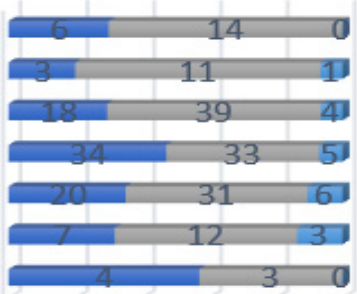

0\% 20\%40\%60\%80\%100\%

- Debilidad Fortaleza ns/Nc

Figura 2: Evaluación sobrevaloración de formación docente y equipamiento, por cargo. Fuente: elaboración propia.

En cuanto al grado de satisfacción con los medios tecnológicos disponibles en figura 3, se establece una asociación entre el cargo docente y la percepción respecto a la valoración sobre el uso de gabinetes, software y conexiones a red, detectando un nivel de bueno a muy bueno, fundamentalmente en docentes de cargos de profesor.

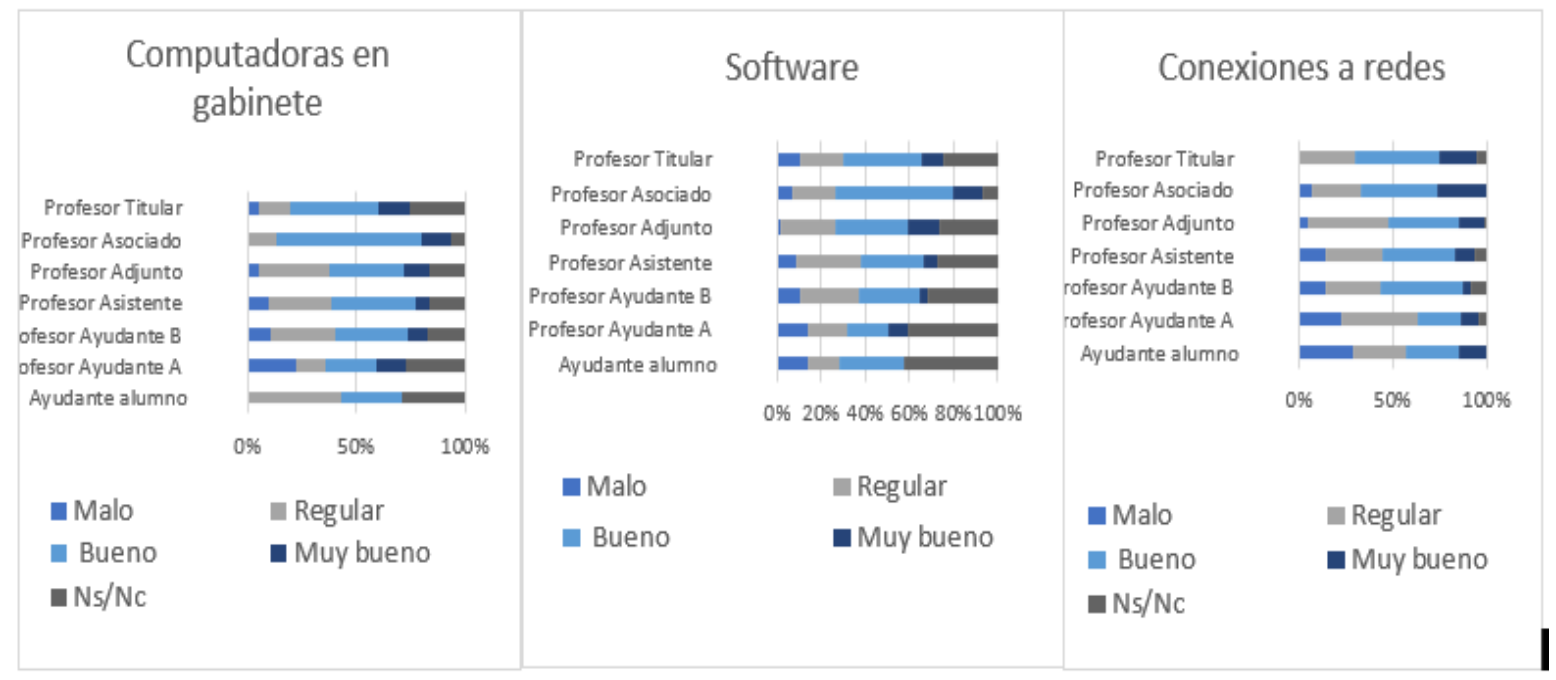

Figura 3: Evaluación sobre valoración de equipamiento tecnológico, por cargo. Fuente: elaboración propia.

Por último, en cuanto a la utilización del aula virtual, es de destacar que la gran mayoría de divisiones tenían en la fecha de la encuesta plataforma educativa con sólo algunas aulas Moodle para materias de dictado a distancia lo que influye significativamente en los resultados.

También se ha observado en figura 4 que los docentes que han realizado actividades de formación docente (FD), utilizan con mayor frecuencia el aula virtual. 


\title{
Utilizacion aula virtual vs actividades de FD
}

\author{
si ha realizado activ de FD \\ no ha realizado activ de FD
}

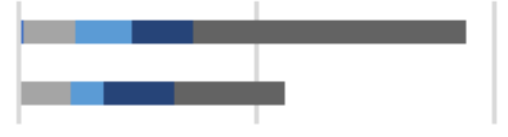

\begin{tabular}{|c|c|}
\hline — especial por año & $\begin{array}{c}50 \\
\text { Nunca }\end{array}$ \\
\hline $\begin{array}{l}\text { Casi nunca } \\
\text { Sí. regularmente }\end{array}$ & De vez en cuando \\
\hline
\end{tabular}

Figura 4: Evaluación sobre formación docente y utilización de aula virtual, por cargo. Fuente: elaboración propia.

\section{Instrumentos}

En el marco del proceso de Autoevaluación Institucional, en el mes de julio de 2018 se administra la encuesta a los docentes de la carrera de Contador Público "Autoevaluación Institucional 2018", estructurada sobre la base de los siguientes ejes: - Perfil docente - Investigación - Contexto Institucional - Infraestructura y equipamiento - Plan de estudios - Docencia - Tarea docente en cada asignatura.

De la mencionada encuesta se analizó información sobre la situación y percepción del docente en relación a temas vinculados a la aplicación de tecnología que se describieron precedentemente.

Cabe mencionar que, en el año 2020, por las razones que son de público conocimiento se aceleró el proceso de virtualización, obligando a toda la comunidad educativa a amigarse con la tecnología aplicando sus competencias en el estado en que se encontraban.

La Institución, a través del área de FyPE, viene desarrollando una amplia labor tendiente a la formación docente en el proceso de incorporación de TIC mediante, cursos, videos, instructivos y reuniones que comenzaron de manera presencial y luego por videoconferencia. Claramente, el contexto institucional se caracterizó mediante una importante motivación dirigida al plantel docente, cuyos documentos están totalmente incorporados a la web. (FyPE: Área de Formación Docente y Producción Educativa: www.eco.unc.edu.ar/fype)

Esto conlleva a la necesidad de investigar sobre competencia digital docente para un uso reflexivo de TIC con la finalidad de mejorar la calidad educativa y contribuir a la formación de competencia digital de los futuros profesionales, para lo cual se ha efectuado una revisión documental de los diversos modelos que se han aplicado principalmente en Latinoamérica, ya citados presentemente en el marco teórico del presente trabajo. 


\section{Resultados}

\section{Modelos de análisis de uso de TIC. Estudio documental}

Del análisis documental respecto a los modelos analizados en la bibliografía, se concluye en tres propuestas con metodologías diferentes que, concatenadas en un mismo modelo, permitirían tener un panorama conducente a contemplar: percepción, nivel de apropiación y vivencias sobre disponibilidad de medios tecnológicos en docentes de nivel superior.

El siguiente cuadro contiene una breve descripción de los modelos definidos como A, B y C, los objetivos y algunos aspectos relevantes de cada uno de ellos.

\section{Modelos cuantitativos Objetivos}

Competencias digitales $\quad$ Delimitar las competencias digitales del profesorado a partir del uso en docentes de educación de las Tecnologías de la Información y la Comunicación (TIC) y sus superior. Cuestionario percepciones sobre la importancia de favorecer el desarrollo en este COPIDES- (2017) tipo de competencias en el alumnado.

Competencias y estándares TIC en la dimensión pedagógica Valencia-Molina, et all. (2016)

\section{El modelo permite describir en qué medida el docente integra las} TIC a sus prácticas pedagógicas. De este modo se caracterizan las competencias docentes para el diseño, implementación y evaluación de prácticas educativas apoyadas en TIC, en sus diferentes modalidades de representación del saber (conocer, utilizar y transformar) sobre la tecnología integrada a la educación. A partir de dichas competencias y modos de representación del saber, se proponen niveles de apropiación definidos como: integración, reorientación y evolución.

DigCompEdu_Proyecto MetaRed en colaboración con el Joint Research Centre (JRC) de la Comisión Europea. Redecker, C. (2020)

Marco Europeo para la Competencia Digital de los Educadores: DigCompEdu.
El marco DigCompEdu distingue seis áreas diferentes en las que se pone de manifiesto la competencia digital de los educadores con un total de veintidós competencias. Las áreas son: Compromiso profesional. Contenidos digitales Enseñanza y aprendizaje. Evaluación y retroalimentación. Empoderamiento de los estudiantes. Desarrollo de la competencia digital de los estudiantes.

El modelo de progresión propuesto está destinado a ayudar a los educadores a entender sus fortalezas y debilidades personales, describiendo diferentes niveles de desarrollo de competencias digitales. En las dos primeras etapas del marco DigCompEdu, novel (A1) y explorador (A2), los educadores asimilan la nueva información y desarrollan prácticas digitales básicas; en las dos etapas siguientes, integrador (B1) y experto (B2), los educadores aplican, amplían y reflexionan sobre sus prácticas digitales; en las etapas líder (C1) y pionero (C2), los educadores transmiten sus conocimientos, juzgan de forma crítica la práctica existente y desarrollan nuevas prácticas.

Cuadro 1. Análisis documental. Modelos y objetivos.

Fuente: investigación documental.

\section{Propuesta de un modelo de análisis.}

Se trata de un modelo que contempla dos tipos de estudios: uno cualitativo y otro cuantitativo. En el primero sugerimos aplicar focus group para obtener un estado de situación docentes/institución (Padilla, et al., 2020); y en el segundo, la aplicación de un instrumento adaptado de DigiCompuEdu con 12 competencias de las 22 definidas 
en el formulario base, que permita detectar fortalezas y debilidades de los docentes en cuanto al grado de apropiación individual en la utilización de tecnología, y 15 preguntas de valoración sobre la utilización de TIC con puntaje de 1 a 7 , lo que permitirá detectar la importancia que le atribuye al tema.

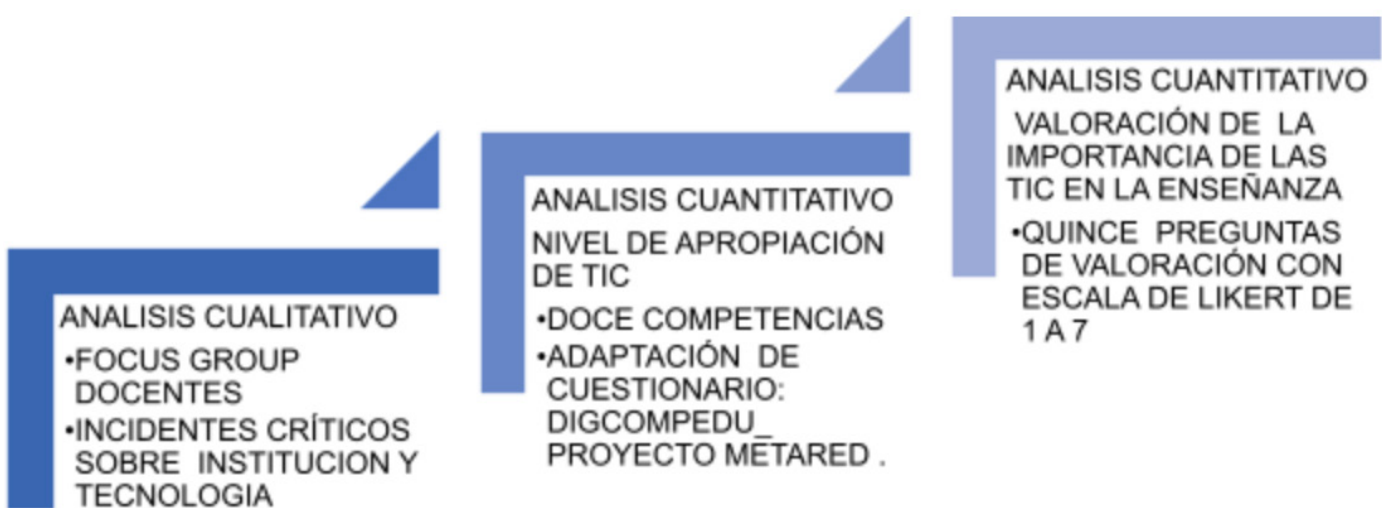

\section{Cuadro 2. Modelo de análisis sobre apropiación y competencia digital docente. Fuente: investigación documental.}

Con este trabajo se propicia la futura elaboración de un cuestionario para la realización de un estudio de análisis cuantitativo, basado en competencias e indicadores que permitirán la valoración de herramientas TIC y el nivel de apropiación de las herramientas que cada docente tiene, en su rol y en su entorno.

Es de destacar que se han observado resultados de la encuesta (Meta-red. Argentina, 2020), en argentina, y en general los docentes se muestran conformes con la tecnología y apoyo que ofrecen las instituciones, sin embargo, los resultados de cada docente no responden a un estándar factible de generalizar, Al efecto se destaca que la CDD es dinámica, puesto que está vinculada al contexto donde se sitúa y al carácter emergente de las tecnologías digitales (Ala-Mutka, 2011; Janssen et al., 2013).

Como mencionamos precedentemente, en el año 2020, la actividad debió ser virtual, motivo por el cual el contacto con las herramientas TIC, se ha dado per se, y se ha incorporado a la enseñanza para quedarse. La idea es mejorar y aprovechar lo adquirido, en un proceso de reflexión sobre la propia práctica, teniendo en cuenta las competencias adquiridas individualmente por cada docente y la propuesta de metodología con que se insertará en la presencialidad.

Los indicadores que dan origen al cuestionario sobre nivel de apropiación en TIC, se detallan en el siguiente cuadro:

\section{Competencias}

1. Práctica reflexiva.

Reflexionar, de modo individual y colectivo, sobre la práctica pedagógica digital personal y de la propia comunidad educativa, evaluarlas de forma crítica y desarrollarlas de forma activa.

2. Selección de recursos digitales

Localizar, evaluar y seleccionar recursos digitales para la enseñanza y el aprendizaje. Considerar, de forma específica, el objetivo de aprendizaje, el contexto, el enfoque pedagógico y el grupo de estudiantes al seleccionar los recursos digitales y programar su uso. 


\begin{tabular}{|c|c|}
\hline 3. Enseñanza & $\begin{array}{l}\text { Programar y poner en funcionamiento dispositivos y recursos digitales en } \\
\text { el proceso de enseñanza, a fin de mejorar la eficacia de las intervenciones } \\
\text { docentes. } \\
\text { Gestionar y coordinar adecuadamente las intervenciones didácticas } \\
\text { digitales. } \\
\text { Experimentar con nuevos formatos y métodos pedagógicos para la } \\
\text { enseñanza y desarrollarlos. }\end{array}$ \\
\hline $\begin{array}{l}\text { 4. Orientación y apoyo } \\
\text { en el aprendizaje }\end{array}$ & $\begin{array}{l}\text { Utilizar las tecnologías y servicios digitales para mejorar la interacción } \\
\text { individual y colectiva con el alumnado dentro y fuera de las sesiones } \\
\text { lectivas. Emplear las tecnologías digitales para ofrecer orientación } \\
\text { y asistencia pertinente y específica. Experimentar con nuevas vías y } \\
\text { formatos para ofrecer orientación y apoyo y desarrollarlos. }\end{array}$ \\
\hline $\begin{array}{l}\text { 5. Aprendizaje } \\
\text { colaborativo }\end{array}$ & $\begin{array}{l}\text { Utilizar las tecnologías digitales para fomentar y mejorar la colaboración } \\
\text { entre los estudiantes. Capacitar al alumnado para utilizar las tecnologías } \\
\text { digitales como parte de las tareas de colaboración, como un medio } \\
\text { para mejorar la comunicación, la cooperación y la creación conjunta de } \\
\text { conocimiento. }\end{array}$ \\
\hline $\begin{array}{l}\text { 6. Aprendizaje } \\
\text { autorregulado }\end{array}$ & $\begin{array}{l}\text { Utilizar las tecnologías digitales para favorecer procesos de aprendizaje } \\
\text { autorregulado, es decir, hacer que los estudiantes sean capaces de } \\
\text { planificar, supervisar y reflexionar sobre su propio aprendizaje, aportar } \\
\text { pruebas de los progresos realizados, compartir ideas y formular } \\
\text { soluciones creativas }\end{array}$ \\
\hline $\begin{array}{l}\text { 7. Estrategias de } \\
\text { evaluación }\end{array}$ & $\begin{array}{l}\text { Utilizar las tecnologías digitales para la evaluación formativa y sumativa. } \\
\text { Mejorar la diversidad e idoneidad de los formatos y enfoques de } \\
\text { evaluación. }\end{array}$ \\
\hline $\begin{array}{l}\text { 8. Analíticas de } \\
\text { aprendizaje }\end{array}$ & $\begin{array}{l}\text { Generar, seleccionar, analizar e interpretar de forma crítica las estadísticas } \\
\text { digitales sobre la actividad, el rendimiento y el progreso del alumnado } \\
\text { con el fin de configurar la enseñanza y el aprendizaje. }\end{array}$ \\
\hline $\begin{array}{l}\text { 9. Retroalimentación, } \\
\text { programación y toma } \\
\text { de decisiones }\end{array}$ & $\begin{array}{l}\text { Utilizar las tecnologías digitales para proporcionar retroalimentaciones } \\
\text { selectivas y oportunas a los estudiantes. Adaptar las estrategias de } \\
\text { enseñanza y proporcionar refuerzo específico a partir de los datos } \\
\text { generados por las tecnologías digitales utilizadas. Capacitar a los } \\
\text { estudiantes para que comprendan las pruebas que aportan las tecnologías } \\
\text { digitales y para que las utilicen en la toma de decisiones. }\end{array}$ \\
\hline $\begin{array}{l}\text { 10. Compromiso activo } \\
\text { de los estudiantes con } \\
\text { su propio aprendizaje }\end{array}$ & $\begin{array}{l}\text { Utilizar las tecnologías digitales para promover el compromiso activo } \\
\text { y creativo de los estudiantes con una materia. Integrar las tecnologías } \\
\text { digitales en estrategias pedagógicas que potencien las competencias } \\
\text { transversales de los estudiantes, el pensamiento complejo y la expresión } \\
\text { creativa. Abrir el aprendizaje a nuevos ámbitos, a contextos del mundo } \\
\text { real que involucren a los propios estudiantes en actividades prácticas, } \\
\text { en la investigación científica o en la resolución de problemas complejos } \\
\text { o que, por cualquier otro medio, fomenten la participación activa de los } \\
\text { estudiantes en temas complejos }\end{array}$ \\
\hline $\begin{array}{l}\text { 11. Información } \\
\text { y alfabetización } \\
\text { mediática }\end{array}$ & $\begin{array}{l}\text { Incorporar actividades de aprendizaje, tareas y evaluaciones que } \\
\text { requieran a los estudiantes expresar sus necesidades de información; } \\
\text { localizar información y recursos en entornos digitales; organizar, procesar, } \\
\text { analizar e interpretar la información y comparar y evaluar de forma crítica } \\
\text { la credibilidad y fiabilidad de la información y sus fuentes. }\end{array}$ \\
\hline
\end{tabular}




\begin{tabular}{|l|l|}
\hline $\begin{array}{l}\text { 12. Creación de } \\
\text { contenido digital }\end{array}$ & $\begin{array}{l}\text { Incluir actividades de aprendizaje, tareas y evaluaciones que requieran a los } \\
\text { estudiantes expresarse a través de medios digitales, así como modificar y } \\
\text { crear contenidos digitales en diferentes formatos. Enseñar a los estudiantes } \\
\text { cómo afectan a los contenidos digitales los derechos de autor y las } \\
\text { licencias, cómo hacer referencia a las fuentes y atribuir las licencias. }\end{array}$ \\
\hline
\end{tabular}

Cuadro 3. Indicadores sobre apropiación y competencia digital docente.

Fuente: investigación documental

\section{Discusión y conclusiones}

Conforme a lo ocurrido en el año 2018, mediante el proceso de autoevaluación, los docentes de la FCE UNC, utilizaban una plataforma virtual educativa con variadas aplicaciones, percibían en su mayoría que contaban con adecuado equipamiento tecnológico y se mostraban proclives a realizar actividades con utilización de medios tecnológicos. Mientras tanto la institución alentaba la incorporación gradual de aula Moodle en las cátedras, motivando mediante propuestas de cursos de perfeccionamiento del área de Formación Docente.

Cuando por las razones conocidas por toda la comunidad educativa del mundo, en el año 2020 surge la necesidad de clases virtuales, es que se acelera el proceso y los docentes debieron aplicar sí o sí tecnología para el dictado de clases, grabar videos, construir materiales, organizar aulas virtuales Moodle, utilizar video conferencias, buscar videos afines a sus temas en la web, etc.

En este contexto nos preguntamos, ¿cómo seguimos con esto hacia adelante? ¿Volveremos a las clases presenciales, dejando todo lo alcanzado?

Estos interrogantes indefectiblemente, conducen a realizar un análisis de seguimiento a docentes con la finalidad de proyectar escenarios futuros de enseñanza, concluyendo nuestro trabajo con un proyecto basado en fundamentos de la teoría que abarca tres aspectos:

a) Análisis cualitativo cuya fundamentación se basa en la diversidad de factores que definen la CDD para cada docente en su contexto. Esto deviene de lo mencionado por Padilla, et al., (2020) en su artículo, quien caracteriza a la CDD como dinámica y contextual. Ambos aspectos sustentan la importancia que le atribuimos a la posibilidad de establecer incidentes críticos que permitan formular indicadores como un punto de partida para fomentar actividades de formación y equipamiento acorde a la dinámica individual y contexto institucional en que se posicione el docente.

b) Cuestionario evaluativo que permita a cada docente contar con una calificación objetiva sobre el nivel en que se encuentra en términos de competencia digital, lo que se sustenta en trabajos publicados por (Meta-red. Argentina, 2020) donde se puede observar que los docentes de ciencias sociales alcanzaron un puntaje promedio de 54,45, lo que los califica en nivel B2: especialista (50 - 65 pts.).

c) Cuestionario perceptual que posibilite tener una perspectiva del perfil del educando en cuanto a la forma en que percibe pedagógicamente la docencia en escenarios virtuales. Al decir de Valencia, et al., (2016) la importancia de revisar la práctica docente asegurando coherencia entre contenidos, estrategias didácticas y uso de TIC. 


\section{Referencias}

Ala-Mutka, K. (2011). Mapping digital competence: Towards a conceptual understanding [Archivo pdf]. https://www.researchgate.net/publication/340375234

Briceño, Gabriela. (2021) Competencia digital docente: en la era de la tecnología. https://www.aucal.edu/blog/servicios-sociales-comunidad/competencia-digital-docente-educar-en-la-era-tecnologica/

Capanegra, H.A., Cabrera, G., Aguilar, M.L., Jorda, M.S. (2016). El empleo de las Tecnologías de Información y Comunicaciones (tics) en el ámbito universitario, DAAPGE, año 16, Nº 26 (ene-jun), 2016, pp. 159-190. Santa Fe, Argentina: UNL

Cabero-Almenara, J., y Palacios-Rodríguez, A. (2020). Marco Europeo de Competencia Digital Docente «DigCompEdu» y cuestionario DigCompEdu Check-In. EDMETIC, Revista de Educación Mediática y TIC, 9(1), pp. 213-234. https://doi.org/10.21071/ edmetic.v9i1.12462

Fernández-Márquez, E., Leiva-Olivencia, J. J. y López-Meneses, E. (2017). Competencias digitales en docentes de Educación Superior. Revista Digital de Investigación en Docencia Universitaria, 12(1), pp. 213-231. http://dx.doi.org/10.19083/ridu.12.558

FyPE: Área de Formación Docente y Producción Educativa https://www.eco.unc. edu.ar/fype.

Gutiérrez, I., Prendes, M. P. (2012). Modelo de análisis de las competencias TIC del profesorado universitario. En R. Roig, y C. Laneve (Eds.), La práctica educativa en la Sociedad de la Información: Innovación a través de la investigación. pp187- 200. Alicante: Marfil

Informe de Autoevaluación. Facultad de Ciencias Económicas. UNC. https://www.eco. unc.edu.ar/files/comunicacion/acreditacion/informe-autoeval-unidad-academica.pdf

Janssen, J.; Stoyanov, S.; Ferrari, A.; Punie, Y.; Pannekeet, K. y Sloep, P. (2013). Experts' views on digital competence: Commonalities and differences. Computers \& Education, 68, 473-481.

Meta-red. Argentina. (23 de marzo de 2021). Resultados: Estudios de las competencias digitales docentes. https://www.metared.org/ar/novedades/resultados--estudio-de-las-competencias-digitales-docentes--meta.html

Padilla A.L., Gámiz V. M.․․, Romero M.a A. Evolución de la competencia digital docente del profesorado universitario: incidentes críticos a partir de relatos de vida. Educar 2020, vol. 56/1 109-127. [Archivo PDF] . https://www.researchgate.net/publication/338928758

Valencia-Molina, T.; Serna-Collazos, A.; Ochoa-Angrino, S.; Caicedo-Tamayo, A.M.; Montes-González, J.A. y Chávez-Vescance, J.D. (2016). Competencias y estándares TIC desde la dimensión pedagógica: Cali: Pontificia Universidad Javeriana. [Archivo PDF] http://www.unesco.org/new/fileadmin/MULTIMEDIA/FIELD/Santiago/pdf/ Competencias-estandares-TIC.pdf 


\section{Uso de las Redes Sociales Virtuales en el Proceso de Enseñanza-Aprendizaje por Estudiantes de Ingeniería Ambiental}

\section{Leal Ríos, Fernando}

ORCID (0000-0003-1748-8674)

Flores Morelos, Ma. M

ORCID (0000-0002-8816-9710)

Lucio Castillo, Mariby

ORCID (0000-0003-3479-2504)

González García, Agustín

ORCID (0000-0001-5436-4684)

Cabero Almenara, Julio

ORCID (0000-0002-1113-6031) 


\title{
USO DE LAS REDES SOCIALES VIRTUALES EN EL PROCESO DE ENSEÑANZA-APRENDIZAJE POR ESTUDIANTES DE INGENIERÍA AMBIENTAL
}

\author{
Leal Ríos, Fernando \\ Flores Morelos, Ma. M \\ Lucio Castillo, Mariby \\ González García Agustìn \\ Cabero Almenara, Julio
}

\section{Resumen}

La educación aparece como uno de los campos privilegiados de explotación de las posibilidades comunicativas de la red y ante semejantes perspectivas, las redes sociales virtuales son las herramientas más representativas del cambio sustancial en la humanidad, además implican una oportunidad importante para generar puentes de comunicación más amigables entre estudiantes, profesores y otros actores relacionados con el ámbito educativo. El objetivo del trabajo fue conocer el uso de las redes sociales virtuales en el proceso enseñanza-aprendizaje por los estudiantes de ingeniería ambiental. La metodología utilizada fue descriptiva, transversal y cuantitativa, la muestra estuvo conformada por 50 alumnos del programa educativo de ingeniería ambiental. Los resultados encontrados indican que fue un $32 \%$ de mujeres las que cumplimentaron el cuestionario, el rango de edad de los participantes oscila entre los 18-21 años, los encuestados mencionan que el uso dentro del proceso de enseñanza-aprendizaje que les dan a las redes sociales es en la realización de tareas (40 \%). Así mismo los alumnos indican que el horario de la mañana y por la noche es en el que usan con más frecuencia las redes sociales. A manera de conclusión se encontró que la red social Facebook, así como el WhatsApp son utilizadas con mayor frecuencia por los estudiantes, y el uso del celular es el dispositivo más utilizado para conectarse, dentro del proceso de enseñanza-aprendizaje.

\section{Palabras clave}

Uso, redes sociales virtuales, estudiantes. 


\section{Introducción}

Las redes sociales están adquiriendo una significación bastante importante en nuestro entramado mediático y comunicativo, que las están llevando a convertirlas en uno de los medios tradicionales de interacción, sobre todo en las nuevas generaciones.

Tal es el impacto que están teniendo las TICs en la sociedad del conocimiento (Cabero, 2008), que ya se habla de alfabetizaciones múltiples, para hacer referencia con ella, a las capacidades que tanto el profesor como el alumno deben tener para desenvolverse en estos nuevos contextos, y donde ya no es suficiente con el dominio lecto-escritores de los códigos tradicionales, sino que se extienden a los lenguajes que emanan de los medios audiovisuales, informáticos y telemáticos.

Esta penetración que está teniendo en los contextos sociales generales, está también alcanzado al terreno educativo. $Y$ al respecto no estaría mal reconocer desde el principio que, aunque el concepto y la creación de redes sociales aplicadas a la educación no es nada nuevo, si últimamente gracias a Internet se ha visto notablemente impulsada. Se ha señalado en algunos estudios que las redes sociales se están convirtiendo en dispositivos tecnoculturales educativos que encaran prácticas pedagógicas y filosóficas educativas opuestas al desarrollo usual de las redes telemáticas en la educación, y pueden suponer un paso más hacia la descentralización del contenido y de los contactos en línea.

Las redes sociales pueden perfectamente utilizarse en los procesos de formación para construir con ellas entornos donde los estudiantes pueden compartir diferentes objetos de aprendizaje, y pueden de hacerlo en entornos abiertos y flexibles, que le permita al estudiante no sólo controlar las actividades y acciones que realizan, sino también qué personas son las que conforman el entorno de formación, y qué tipo de actividades realizan.

Las redes sociales virtuales implican una oportunidad importante para generar puentes de comunicación más amigables entre estudiantes, profesores y otros actores relacionados con el ámbito educativo.

Sánchez y Fernández (2010), mencionan que en un estudio realizado por la Universidad Camilo José Cela sobre los hábitos de los adolescentes en el uso de las redes sociales, la principal razón para usar este tipo de herramienta es para mantener el contacto con amigos y más lejos aparece otra razón social: "saber de gente con la que no se tiene relación habitual".

Según Cachia (2008) las redes sociales educativas presentan una serie de ventajas: crean una dimensión nueva de socialización; proporcionan la base para pensar en una formidable herramienta para la educación inclusiva; se están usando como un espacio de encuentro entre los distintos actores del proceso de aprendizaje/enseñanza; sirven de enlace con las empresas que ofrecen empleo; facilitan tareas de inmersión en un entorno lingüístico extranjero por medio de redes o comunidades; dinamizadores y constructoras de una identidad digital.

Los internautas emplean la web con objetivos diversos que no pueden catalogarse estrictamente como públicos o privados. Así, las redes sociales virtuales son sistemas de relaciones que las personas entablan con amigos/conocidos, llamados contactos, con los cuales se interrelacionan por medio de alguna plataforma electrónica 
asociada a la Internet (Cortés, 2015), como, por ejemplo, Facebook, Twitter e Instagram, por mencionar algunas.

Así, dependiendo también del uso que hagamos de las redes sociales para la educación, podríamos distinguir entre redes sociales para el desarrollo profesional docente y para la actividad de o para el alumnado.

Teniendo en cuenta que las redes sociales son generalmente utilizadas para la comunicación e interacción entre miembros con intereses comunes no resultaría ningún descubrimiento afirmar que éstas pueden contribuir al desarrollo profesional docente a través del intercambio de ideas y trabajo colaborativo, tal y como afirman Pérez y otros (2010), siendo ésta la primera distinción que realizamos dentro de las redes sociales para la educación.

El objetivo de la investigación fue conocer fue conocer el uso de las redes sociales virtuales en el proceso enseñanza-aprendizaje por los estudiantes de ingeniería ambiental y determinar estudiar si estos, vienen influenciado por el género de los estudiantes, edad, desde que tipo de dispositivo se conectaban, en que sitios lo hacían y cuáles eran sus redes sociales favoritas dentro del proceso enseñanza-aprendizaje.

La hipótesis planteada fue que no existen diferencias significativas entre el género, edad, frecuencia de uso de las redes sociales, de los alumnos del programa educativo de ingeniería ambiental, respecto a la frecuencia de uso de las redes sociales en el proceso enseñanza-aprendizaje.

\section{Método}

\section{Descripción del contexto y de los participantes}

El presente trabajo de investigación se realizó con alumnos del nivel licenciatura del programa educativo de ingeniería ambiental de la Facultad de Ingeniería y Ciencias de la Universidad Autónoma de Tamaulipas.

\section{Instrumentos}

El instrumento que se utilizó para la recogida de la información fue un cuestionario de carácter exploratorio que estaba conformado por 15 ítems, para conocer los hábitos de uso y consumo de las redes sociales virtuales por parte de los estudiantes dentro del proceso de enseñanza-aprendizaje. Para ello, en el cuestionario se preguntó a quienes participaron, entre otras interrogantes, cuáles eran sus redes favoritas para el proceso de enseñanza-aprendizaje, desde qué dispositivos se conectaban y en qué sitios lo hacían.

\section{Procedimiento}

La metodología utilizada fue descriptiva, de tipo transversal y cuantitativa, la muestra estuvo conformada por 50 alumnos. Y el cuestionario se administró al finalizar el curso académico 2020-01. El análisis de la información se realizó por medio de la minería de datos, como técnica para descubrir los patrones de uso de las redes sociales virtuales y su relación con las decisiones de los usuarios y enfocar su atención 
especialmente en las posibilidades de usar estas redes como herramientas dentro del proceso enseñanza-aprendizaje.

\section{Resultados}

Los alumnos que cumplimentaron el cuestionario fueron 50, de los cuales la gran mayoría $(f=34,68 \%)$ eran hombres y sólo el $32 \%(f=16)$ mujeres.

Se puede decir también que, la edad de los estudiantes esta entre la banda de edad de los 18 años a los 21, aquí nos encontramos con el $82 \%$ de la distribución. Al mismo tiempo, señalar que pocos son los que tiene más de 23 años ( $f=4,0.08 \%$ ).

Previamente, se comentó que el sitio web Alexa posicionaba a Facebook como la red más popular del mundo. Los datos recabados localmente coinciden con dicha aseveración, pero emergió un dato inesperado: la popularidad de WhatsApp, que no constituye propiamente una red, sino un servicio digital de mensajería instantánea que permite crear grupos de contactos -entiéndanse redes- específicos.

Por esta razón, no se incluyó en el diseño original del cuestionario, pero en el estudio los estudiantes voluntarios comentaron que debía incluirse, pues no sólo la utilizaban, sino que la concebían como una red social virtual. Ante esto, los resultados obtenidos fueron que el $27 \%$ de la muestra ubicó WhatsApp como la red con mayor índice de conexión, seguida por Facebook, con el 25 \%; YouTube, con el 16 \%; y Twitter, con el $11 \%$.

De acuerdo con los resultados Instagram es más popular que Google+. Por su parte, Tumblr y Skype apenas difieren con el $1 \%$, y Linkedln cierra con cero. Esta última no es utilizada por los voluntarios debido a que constituye una red cuyo enfoque no es profesional, es decir, procura contactos con intereses más específicos -laborales, de actualización, etcétera- que quizá no sean del gusto de los estudiantes que apenas inician su desempeño profesional.

En este trabajo se implementaron dos algoritmos para estudiar los comportamientos de los informantes con respecto a sus preferencias por una u otra red.

El primer algoritmo utilizado fue el Predictive Apriori, del cual se recuperaron 20 reglas de asociación. En el presente estudio se describen tres, las cuales se eligieron por su nivel de confianza y profundidad. Entre los resultados, destaca la gran popularidad del servicio de mensajería instantánea WhatsApp, en relación con los diferentes lugares y dispositivos de conexión, así como de las redes señaladas como predilectas.

El segundo algoritmo empleado fue el Apriori, que arrojó 20 reglas de asociación. A diferencia de los resultados expuestos por el Predictive Apriori, en estas reglas se observa más presencia de la red social Facebook.

Con los resultados obtenidos se refrenda el gran impacto de WhatsApp entre la población estudiada, incluso por encima de la red social virtual más popular del mundo, que es Facebook. Este resultado incluye un par de ideas que deben destacarse: la indiferenciación de los estudiantes con respecto de una red social virtual y un 
servicio de mensajería instantánea. También se aprecia el gran poder de penetración de tecnologías como el teléfono inteligente en la vida cotidiana de los individuos. Si bien WhatsApp cuenta, actualmente, con aplicaciones para computadora, su principal dispositivo continúa siendo el teléfono inteligente.

En la aplicación del algoritmo SimpleKMeans destaca la generación de grupos con hábitos de conexión a la Internet desde una computadora portátil o de escritorio en los rangos siempre y frecuentemente. Asimismo, se aprecia que YouTube figura como la red social virtual favorita de un grupo en particular.

Con respecto a los resultados de los algoritmos de asociación (Predictive Apriori y Apriori), se aprecia que las redes más populares son Facebook, YouTube y Twitter, pero los estudiantes reconocen el servicio de mensajería instantánea WhatsApp como una red social virtual, y ocupa un lugar importante entre las preferencias de los usuarios.

Por otro lado, los valores encontrados, señalan claras diferencias de género y en la población que participó en el experimento. En general, tanto hombres (34) como mujeres (16) manifiestan poca conexión a la Internet desde la escuela. Este comportamiento se debe, en parte, a las restricciones de conexión a la red inalámbrica en dispositivos móviles dentro de los campus de la UAT. En cambio, la frecuencia de conexión en casa por medio de una computadora portátil o de escritorio es permanente entre las mujeres y sólo frecuente entre los hombres.

Posteriormente, se generó con la información recabada tres grupos de estudiantes en los que destacan como atributos mutuamente excluyentes la frecuencia de conexión en la escuela y la frecuencia de conexión en casa mediante una computadora portátil o de escritorio. Los valores reportados indican que, en general, los alumnos se conectan poco en la escuela. También se pudo determinar incluso, que un grupo de alumnos manifestó que nunca se conecta allí. En cuanto a la frecuencia de conexión en casa por medio de una computadora portátil o de escritorio, la mayoría de los alumnos que participó en el experimento lo hacen siempre o frecuentemente.

\section{Discusión y conclusiones}

Del estudio que hemos realizado, se pueden extraer una serie de discusiones, que se presentar a continuación.

Con respecto a la presencia de la tecnología informática y de Internet en los domicilios de los alumnos, nos hemos encontrado, que en el primer caso el $74.0 \%$ tienen acceso al mismo, y en el segundo el $53.1 \%$. Porcentajes, que, si bien no son bajos, nos deben hacer reflexionar a que la Universidad debe adoptar medidas, para facilitar su utilización por parte de los estudiantes.

Por otra parte, señalar que, en el estudio expone con completa claridad que, el disponer en los domicilios de las tecnologías -en este caso de la computadora, conexión a Internet y laptop- ha repercutido en el uso y frecuencia de las redes sociales en el proceso de enseñanza-aprendizaje. Hecho que también se encontró en otros trabajos (Cabero, Llorente y Puentes, 2008). 
Algunos estudios recientes, enfocados en los usos y afectaciones de las redes sociales virtuales en entornos escolares de lberoamérica señalan un reconocimiento del potencial didáctico de la red por parte de los propios estudiantes que, incluso, están dispuestos a participar en este modo de comunicación para difundir y compartir materiales, opiniones y conocimientos (Alonso y Alonso, 2014; Cancelo, 2013; Cortés, 2015).

En la aplicación del algoritmo SimpleKMeans destaca la generación de grupos con hábitos de conexión a la Internet desde una computadora portátil o de escritorio en los rangos siempre y frecuentemente. Con el mismo algoritmo se encontraron tres grupos de estudiantes: uno que nunca se conecta a la Internet desde la escuela; otro que lo hace a veces y, finalmente, otro más que lo hace rara vez.

Lo anterior se traduce en que la escuela es uno de los sitios menos recurrentes para conectarse a la Internet, lo cual se contrapone con los resultados de la conexión desde el hogar. En este último caso, se observan tres grupos: uno que se conecta siempre, otro que lo hace frecuentemente y un tercero que nunca lo hace.

Esto implica que existe una condición socioeconómica importante, pues podría significar la existencia de un grupo de individuos cuyo poder adquisitivo es suficiente para contratar un servicio de Internet domiciliario y de otro que no puede hacerlo.

Con respecto a los resultados de los algoritmos de asociación (Predictive Apriori y Apriori), se aprecia que las redes más populares son Facebook, YouTube y Twitter, pero los estudiantes reconocen el servicio de mensajería instantánea WhatsApp como una red social virtual, y ocupa un lugar importante entre las preferencias de los usuarios.

Lo anterior revela una idea importante: si una tecnología particular es útil y amigable para la comunicación cotidiana de los individuos, la utilizarán, independientemente de si es una red o un servicio de mensajería instantánea, como ocurre, en este caso, con WhatsApp.

Se infiere que una de las razones por las cuales los estudiantes pudieron homologar una y otra en la categoría de red social virtual se debió a que WhatsApp permite crear listas de difusión o grupos específicos, y esto podría entenderse como una forma de red.

Hay un punto, sin embargo, que no puede dejar de considerarse: su influencia entre los estudiantes universitarios. Valerio y Valenzuela (2011) han realizado aportaciones destacadas al respecto, con especial atención en dichos sujetos.

Algunos estudios recientes, enfocados en los usos y afectaciones de las redes sociales virtuales en entornos escolares de Iberoamérica (Gómez, Roses y Farías, 2012) señalan un reconocimiento del potencial didáctico de la red por parte de los propios estudiantes que, incluso, están dispuestos a participar en este modo de comunicación para difundir y compartir materiales, opiniones y conocimientos (Alonso y Alonso, 2014; Cancelo, 2013; Cortés, 2015).

Las redes sociales virtuales implican una oportunidad importante para generar puentes de comunicación más amigables entre estudiantes, profesores y otros actores relacionados con el ámbito educativo. 
Vamos a considerar que nuestros alumnos/as tiene una doble vida, incluso muchas más, pero aquí solo nos interesa aquella que se centre en su vida dentro y fuera del aula, marcada en muchos casos por la presencia o no de las tecnologías y de una cultura mediática, hecho que puede influir y modificar su entorno de aprendizaje. Ahora bien, en estas dos vidas podemos afirmar que se producen algunas contradicciones. En su vida dentro del aula, el alumno/a sigue desarrollando su hemisferio izquierdo, aunque afuera se desarrolla más en un entorno visual. Como dicen las profesoras Aguiar y Farray (2007) hemos pasado de la generación Guttemberg a la generación Videns y por último a la Blade Runner.

En cuanto a los dispositivos de conexión, se aprecia que, pese a la gran aceptación del teléfono inteligente en la vida cotidiana, la presencia de la computadora portátil o de escritorio como dispositivo de conexión a la Internet sigue siendo la predilección de los universitarios.

Tampoco se han encontrado grandes diferencias significativas en la percepción y uso de las redes sociales virtuales dentro del proceso de enseñanza-aprendizaje por parte de los estudiantes en función de su edad y género.

\section{Referencias}

Aguiar, V.M. y Farray, J.I. (2007). Nuevas Tecnologías Aplicadas a la Educación. Las Palmas de G.C.: Servicio de publicaciones de la ULPGC.

Alonso, S., y Alonso, M. (2014). Las redes sociales en las universidades españolas. Revistas de Comunicación Vivat Academia, 126, pp. 54-62.

Cabero, J. (2008). La alfabetización digital de los alumnos. Competencias digitales para el siglo XXI. Revista de Pedagogía, 2, 7-28.

Cabero, J., Llorente, M. C. y Puentes, A. (2008). Alfabetización Digital: Un estudio en la Pontificia Universidad Católica Madre y Maestra. Sevilla: Fortic.

Cachia, R. (2008). Los sitios de creación de redes. Aspectos sociales. Revista Telos, 76. http://sociedadinformacion.fundacion.telefonica.com/telos/articulocuaderno. asp@idarticulo\%3D4\&rev\%3D76.

Cancelo, M. (2013). Estrategias comunicativas en redes sociales. Estudio comparativo entre las universidades de España y México. Historia y Comunicación Social, 18, pp. 423-435.

Cortes, R. (2015). Interacción en Redes Sociales Virtuales entre estudiantes de Licenciatura. Una aproximación con fines pedagógicos. Revista lberoamericana de Producción Académica y Gestión Educativa, 2015, 1. http://www.pag.org.mx/index. php/PAG/article/view/107/155 
Gómez. M, Roses, S., y Farías, P. (2012). El uso académico de las redes sociales en universitarios. Comunicar, 19(38), 131-138.

Pérez, T., Castillo E. y Marquina R. (2010). Las redes sociales y el desarrollo profesional del docente. Revista cognición, 26. http://www.cognicion.net/index.php?option=com_content\&task=view\&id=322 Itemid=228 .

Sánchez, A. y Fernández, M.P. (2010): Informe Generación 2.O. Hábitos de los adolescentes en el uso de las redes sociales. http://estaticos.elmundo.es/2010/07/06Generacion20.pdf

Valerio, G y Valenzuela, R. (2011). Redes sociales y estudiantes universitarios. Del nativo digital al informívoro saludable. El profesional de la información, 20(6), 667670 


\section{Revisión Sistemática Sobre la Aplicación del Robot Bee-Bot para la Enseñanza del Alumnado de Educación Infantil y Educación Primaria}

Pérez Vázquez, Elena

Universidad de Alicante elena.pv@ua.es

\section{Lorenzo Lledó, Gonzalo}

Universidad de Alicante

glledo@ua.es

\section{Lledó Carreres, Asunción}

Universidad de Alicante

asuncion.lledo@ua.es

\section{Gilabert Cerdá, Alba}

Universidad de Alicante agc136@ua.es 


\title{
REVISIÓN SISTEMÁTICA SOBRE LA APLICACIÓN DEL ROBOT BEE- BOT PARA LA ENSEÑANZA DEL ALUMNADO DE EDUCACIÓN INFANTIL Y EDUCACIÓN PRIMARIA
}

\author{
Pérez Vázquez, Elena \\ Lorenzo Lledó, Gonzalo \\ Lledó Carreres, Asunción \\ Gilabert Cerdá, Alba
}

\section{Resumen}

Desde la última década, la aplicación de la robótica pedagógica (RP) ha experimentado un gran auge en las aulas de Educación Infantil (EI) y de Educación Primaria (EP). Como consecuencia, se han diseñado un gran número de robots educativos con diferentes características. Entre este gran abanico de posibilidades destaca el robot Bee-Bot como uno de los mejores considerados y óptimos para el alumnado de El y primeros cursos de EP debido a su hardware. El objetivo de la presente investigación es realizar una revisión de carácter sistemático, en base a los criterios de la declaración PRISMA, sobre la aplicación del robot Bee-bot en las escuelas de Educación Infantil y Educación Primaria desde el año 2016 hasta el año 2020. Para lograr este objetivo, se trabajó a través de la colección principal de la Web of Science (WoS), obteniendo una muestra de 11 artículos. Partiendo de los indicadores establecidos previamente, los resultados indicaron este robot se emplea, con el fin de desarrollar el pensamiento computacional y las funciones ejecutivas a partir de actividades basadas en retos, tanto en la etapa de Educación Infantil como en la etapa de Educación Primaria. Como conclusión, se puede afirmar que la utilización de la robótica en las aulas se ha incrementado en los últimos años con el fin de trabajar habilidades de pensamiento computacional.

\section{Palabras clave}

Bee-Bot, pensamiento computacional, Educación Infantil, Educación Primaria, robótica. 


\section{Introducción}

Las conocidas como Tecnologías de la Información y la Comunicación (TIC) hacen referencia al conjunto de sistemas y programas informáticos, así como redes sociales y medios de comunicación destinados a recopilar, presentar y trasmitir información mediante distintos soportes (Al-Rahmi et al., 2020). Este tipo de tecnologías, cuya utilización comenzó a experimentar un gran auge a principios del siglo XXI (Aguirre \& Quiridumbay, 2021), se emplea cada vez de manera más asidua en el ámbito educativo (Castillo, 2020). Principalmente, esta utilización puede aportar, en palabras de Domingo \& Marquès (2011), una gran variabilidad de ventajas al proceso de enseñanza-aprendizaje, tales como: la consecución de objetivos, la comprensión de contenidos, una renovación metodológica y un incremento de la capacidad atencional del alumnado. Sin embargo, cabe recordar que la simple utilización de recursos digitales en el ámbito educativo no conduce directamente a una mejora del proceso de enseñanza-aprendizaje, sino que el peso fundamental del éxito recaerá en el diseño de actividades adecuadas (Nieto \& Marquès, 2015). De esta manera, se precisará de un equipo docente que no únicamente esté capacitado para utilizar las herramientas TIC necesarias, sino que posea los conocimientos suficientes para introducirlas en la metodología del aula (Granados, 2015).

Son muchos los tipos de TIC que se emplean actualmente en las escuelas, entre las cuales destaca la robótica. El avance de las tecnologías de la información y la comunicación, junto con la aparición de movimientos educativos renovadores que apuestan por una educación activa ha desembocado en que en la actualidad la robótica se conciba como un recurso educativo potencialmente beneficioso para todo alumnado (Acaso, 2013; Salamanca et al., 2010). Desde el diseño del primer robot educativo en 1967 y su posterior construcción dos años más tarde, donde recibió el nombre de Tortuga amarilla" (Ghitis \& Vásquez, 2014), el campo de la conocida como "Robótica Educativa" (RE) o "Robótica Pedagógica" (RP) (Kumar, 2004) ha experimentado un gran crecimiento (D’Abreu, 2017). La utilización de la RE se fundamenta en los principios del constructivismo de Piaget y de Papert (Bers \& Urrea, 2000), en los del aprendizaje colaborativo de Vygotsky y del aprendizaje por descubrimiento de Bruner (Piedade et al, 2020). En este sentido, la RE se configura un nuevo sistema de enseñanza de carácter multidisciplinar, a través de la cual se pueden trabajar de manera activa diferentes áreas del currículo (Vivas Fernández \& Sáez López, 2019). Específicamente, siguiendo a Moreno et al. (2012) podemos diferencias dos enfoques que puede adoptar la RE: aprendizaje de la robótica y aprendizaje con robótica. El primero de ellos, se basa en el diseño y la construcción de robots (Goodgame, 2018) y, en el segundo, los robots actúan como una herramienta de apoyo al proceso de enseñanza de aprendizaje de otro tipo de contenidos (Ramírez \& Sosa, 2013). Existen diferentes robots que se están aplicando en las aulas de Educación Infantil y Educación Primaria, en consonancia con ambos enfoques. De este modo, destacan, por ejemplo, el kit de robótica LEGO Mindstorms y LEGO WeDo, (Blackley \& Howell, 2019), el robot NAO (Hood et al., 2015), y el robot Bee-Bot (Pinto \& Osório, 2019).

Específicamente, el robot Bee-Bot es uno de los que se utilizan de manera más asidua en el contexto educativo, ya que se trata de un robot educativo que tiene forma de abeja y le resulta muy sencillo de utilizar al alumnado, tanto de Educación Infantil como de Educación Primaria (Diago et al., 2018). Con este robot se pueden crear actividades sencillas, pero al mismo tiempo atractivas para el alumnado (Bargagna et al., 2019). Para interactuar con el robot se utilizan los botones situados en la parte superior del mismo. Cada uno de estos botones se corresponde con una instrucción. 
Así pues, este robot puede programarse de dos formas distintas. La primera de ellas es de orden en orden. Esta opción consiste en pulsar el comando deseado y a continuación el comando de "GO". Es necesario recordar que si optamos por esta modalidad después de cada movimiento del robot debemos pulsar la instrucción de borrar, ya que el robot tiene memoria y se moverá acumulando las órdenes anteriores. Y, en segundo lugar, se puede utilizar la secuencia de programación a la vez, la cual consiste en apretar todos los comandos en el orden deseado y a continuación pulsar "GO".

El objetivo principal de este estudio es realizar una revisión de carácter sistemático, en base a los criterios de la declaración PRISMA, sobre la aplicación del robot Beebot en las escuelas de Educación Infantil y Educación Primaria desde el año 2016 hasta el año 2020. Para alcanzar este objetivo se han propuesto las siguientes preguntas de investigación:

1. ¿Ha aumentado la utilización del robot Bee-bot desde el año 2016?

2. ¿Se aplica el robot Bee-bot en mayor medida en Educación Infantil?

3. ¿Qué áreas de conocimiento se trabajan con el robot Bee-bot?

4. ¿Qué características poseen las actividades planificadas para utilizar el robot Bee-bot?

\section{Método}

Para responder al objetivo principal de la investigación se ha realizado una revisión de carácter sistemático (García González \& Ramírez-Montoya 2019). En el presente estudio se aborda este tipo de revisión debido a que a partir de esta se pueden identificar problemas en los estudios, responder a preguntas de investigación que no podrían ser respondidas de otra manera e identificar futuros objetivos en em ámbito investigador (Yepes- Nuñez et al., 2020). Para ello, se ha seguido el método defendido por Page \& Moher (2017) denominado PRISMA.

\section{Muestra}

Tras el proceso de búsqueda la muestra final de artículos quedó conformada por un total de 11 documentos publicados entre el año 2016 y el año 2020 que aplican el robot Bee-bot con el alumnado de Educación Infantil y de Educación Primaria con el objetivo de aprender diferentes habilidades.

\section{Instrumentos}

Entre las distintas bases de datos, se seleccionó la base de datos Web of Science (WOS) para realizar la búsqueda de estudios sobre la temática estudiada. Esta base de datos se seleccionó por ser una de las que recopilan un número mayor de revistas con alto impacto en comparación con otras bases de datos, como, por ejemplo, Scopus. (López-Illescas et al., 2008).

\section{Procedimiento}

PRISMA se concibe como una metodología que establece dos fases para llevar a cabo la revisión sistemática (Lorenzo et al., 2021). De acuerdo con esto, en una primera fase se establecieron las preguntas de investigación, así como los criterios de inclusión y exclusión y los indicadores. Todo ello queda reflejado en la tabla 1. 


\begin{tabular}{|c|c|c|}
\hline Criterios de inclusión & Criterios de exclusión & Indicadores \\
\hline $\begin{array}{l}\text { INC. } 1 \text { Periodo: 2016-2020 } \\
\text { INC 2. Tipo de } \\
\text { documentos: artículos } \\
\text { y documentos de } \\
\text { congresos. } \\
\text { INC 3. Idioma: inglés y } \\
\text { español. } \\
\text { INC 4. Participantes: } \\
\text { estudiantes de Educación } \\
\text { Infantil y Educación } \\
\text { Primaria. }\end{array}$ & $\begin{array}{l}\text { EXC 1. Documentos repetidos } \\
\text { EXC 2. Documentos sin acceso. } \\
\text { EXC 3. Investigaciones } \\
\text { realizadas en un contexto no } \\
\text { educativo. } \\
\text { EXC 4. Utilizan otro robot que } \\
\text { no es el robot Bee-bot. } \\
\text { EXC 5. Estudios centrados en } \\
\text { opiniones o percepciones o } \\
\text { revisiones. }\end{array}$ & $\begin{array}{l}\text { Etapa educativa. } \\
\text { Área trabajada. } \\
\text { Actividades } \\
\text { desarrolladas. } \\
\text { Conclusiones del } \\
\text { estudio. }\end{array}$ \\
\hline
\end{tabular}

\section{Tabla 1. Criterios de inclusión y exclusión e indicadores}

A continuación, los diferentes criterios de inclusión y exclusión, formulados en consonancia con el objetivo de la investigación, se fueron aplicando a lo largo del proceso destinado a la obtención de la muestra final de documentos. En la figura 1 se refleja el nombrado proceso.
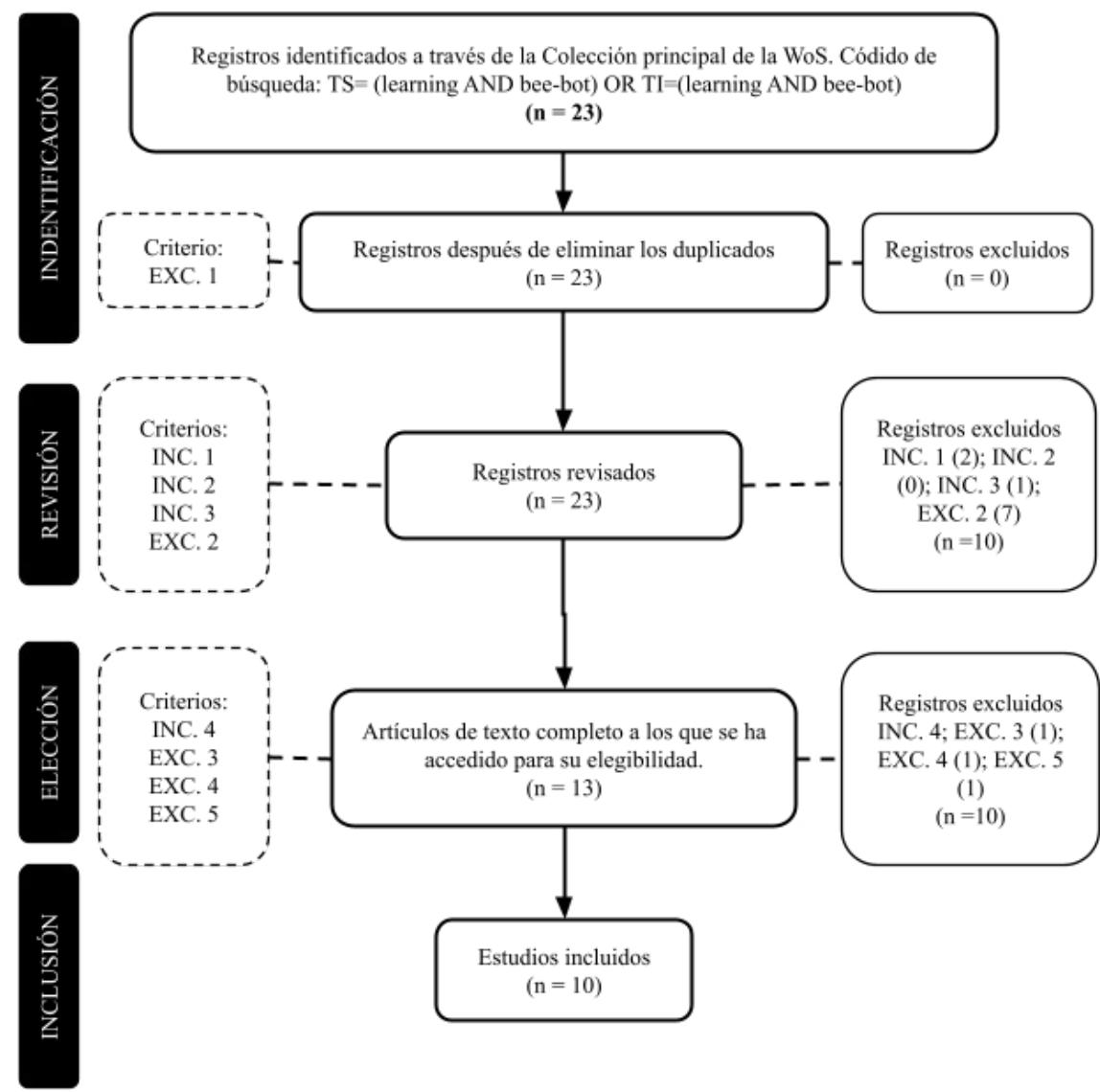

Figura 1. Proceso de selección de la muestra. 
En primer lugar, teniendo como referencia la declaración PRISMA, para la fase de identificación (fase 1) se identificaron a través de la colección principal de Web of Science un total de 23 documentos. Para ello, se aplicó el código de búsqueda avanzado que se presenta a continuación,

$$
\mathrm{TS}=\text { (learning AND bee-bot) OR TI=(learning AND bee-bot) }
$$

A continuación, se aplicó el criterio de exclusión número 1. Como resultado no se encontró ningún documento repetido y la muestra continuaba siendo de 23 documentos. En la segunda fase, denominada "revisión" se aplicaron los criterios de inclusión 1, 2 y 3 y el criterio de exclusión 2 . De este modo, se excluyeron un total de 10 documentos y se obtuvo una muestra de trece artículos. En la tercera fase, elección, se aplicaron, por un lado, los criterios de exclusión 3, 4 y 5 y, por otro lado, el cuarto criterio de inclusión. Tras la aplicación de dichos criterios, en la cuarta fase, denominada "inclusión", contamos con un total de 10 artículos.

\section{Resultados}

Tras el análisis de datos se muestran los resultados obtenidos. Estos resultados se presentan en función de las preguntas de investigación del presente estudio.

En primer lugar, en la figura 2 se reflejan la distribución de las investigaciones que conforman la muestra, las cuales aplican el robot Bee-bot con el alumnado de Educación Infantil y de Educación Primaria con el objetivo de aprender diferentes habilidades. desde el año 2016 hasta el año 2020.

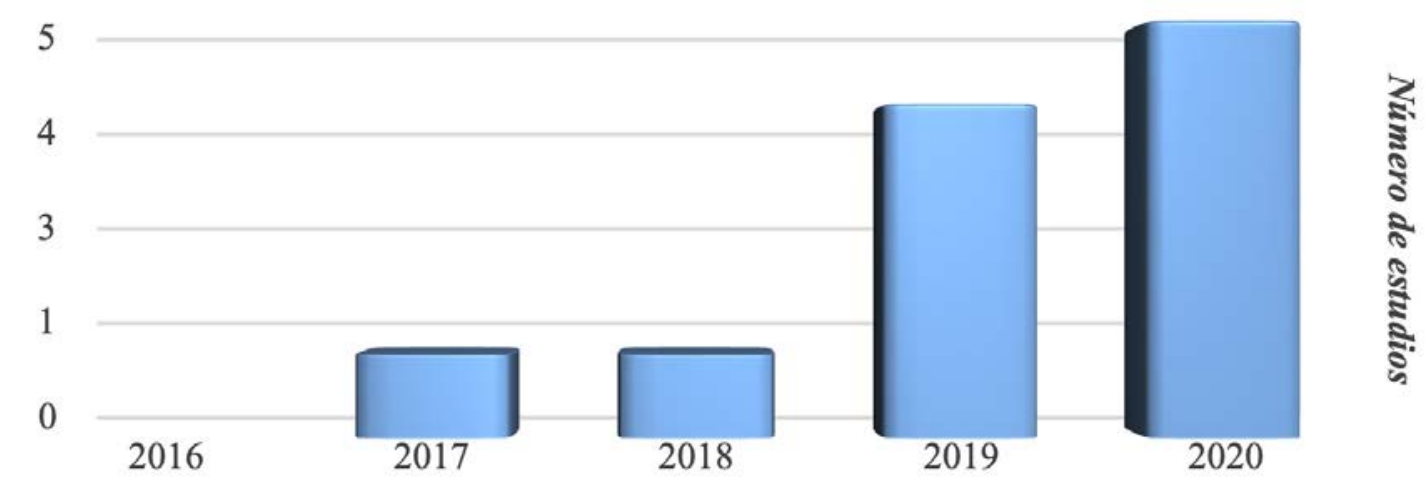

\section{Figura 2. Número de publicaciones por año.}

Tal y como se observa en la figura 2, el número de publicaciones que involucran investigaciones con el robot Bee-Bot en las etapas de Educación Infantil y Educación Primaria han ido incrementándose desde el año 2016. Particularmente, el año que mayor número de artículos de la temática se han publicado es el 2020 con un total de cinco publicaciones. Estas investigaciones son Angeli \& Valanides (2020), CabaIlero-González \& García-Valcárcel (2020), Cervera et al. (2020), Di Lieto, Pecini et al. (2020) y Di Lieto, Castro et al. (2020b) y conforman el $45,45 \%$ de la muestra.

En segundo lugar, con el objetivo de dar respuesta a la segunda, tercera y cuarta pregunta de investigación, se presenta a continuación la tabla 2. 


\begin{tabular}{|c|c|c|c|}
\hline Referencia & Etapa & Área trabajada & Actividades \\
\hline 1. Di Lieto et al., (2017) & El & $\begin{array}{l}\text { Funciones } \\
\text { ejecutivas } \\
\text { (Pensamiento } \\
\text { computacional }\end{array}$ & $\begin{array}{l}\text { - } 3 \text { sesiones (familiarización del uso de } \\
\text { Bee-Bot). } \\
\text { - Las actividades de las sesiones } 4^{a} \text { a } 7 \text { ạ } \\
\text { dirigidas a la memoria de trabajo, la } \\
\text { flexibilidad cognitiva y la planificación } \\
\text { visuoespacial. } \\
\text { - Las últimas seis sesiones se centraron } \\
\text { en el refuerzo de las competencias } \\
\text { adquiridas y en mejorar el control de la } \\
\text { inhibición y la interferencia. }\end{array}$ \\
\hline $\begin{array}{l}\text { 2. Caballero-González } \\
\text { \& García-Valcarcel } \\
\text { (2018) }\end{array}$ & $\mathrm{El}$ & $\begin{array}{l}\text { Pensamiento } \\
\text { computacional }\end{array}$ & $\begin{array}{l}\text { Las actividades tuvieron una duración } \\
\text { total de } 8 \text { horas. En estas actividades se } \\
\text { planteaban retos (Solve-Its challenges) y } \\
\text { el alumnado debía programar la secuencia } \\
\text { de movimientos para alcanzar la posición } \\
\text { deseada. Los alumnos escuchan diferentes } \\
\text { historias o canciones. Después se pide que } \\
\text { organicen letras o bloques de papel que } \\
\text { representen secuencialmente las acciones } \\
\text { descritas en la narración. }\end{array}$ \\
\hline $\begin{array}{l}\text { 3. Bargagna et al. } \\
\text { (2019) }\end{array}$ & EP & $\begin{array}{l}\text { Funciones } \\
\text { ejecutivas } \\
\text { Pensamiento } \\
\text { computacional }\end{array}$ & $\begin{array}{l}\text { - } 3 \text { sesiones (familiarización del uso de } \\
\text { Bee- Bot). } \\
\text { Las actividades de las sesiones } 4^{a} \text { a } 7 \text { ạ } \\
\text { dirigidas a la memoria de trabajo, la } \\
\text { flexibilidad cognitiva y la planificación } \\
\text { visuoespacial. } \\
\text { - Las últimas seis sesiones se centraron } \\
\text { en el refuerzo de las competencias } \\
\text { adquiridas y en mejorar el control de la } \\
\text { inhibición y la interferencia. }\end{array}$ \\
\hline 4. Ferrada et al. (2019) & EP & $\begin{array}{l}\text { Geometría, } \\
\text { y números y } \\
\text { operaciones. }\end{array}$ & $\begin{array}{l}\text { 1. El alumnado debe programar el } \\
\text { robot para trasladarlo hasta la figura } \\
\text { geométrica que haya aparecido tras el } \\
\text { lanzamiento de un dado. } \\
\text { 2. El alumnado debe programar el } \\
\text { robot para trasladarlo hasta la casilla } \\
\text { del número que le haya tocado. A } \\
\text { continuación, deberá contar cuánto } \\
\text { dinero hay en esa casilla. } \\
\text { 3. El alumnado debe programar el } \\
\text { robot para trasladarlo hasta la casilla } \\
\text { del número que le haya tocado. El } \\
\text { estudiante debe resolver la operación de } \\
\text { suma o resta que aparece en la casilla. }\end{array}$ \\
\hline $\begin{array}{l}\text { 5. Marín \& Campos } \\
\text { (2019) }\end{array}$ & EP & $\begin{array}{l}\text { Figuras musicales } \\
\text { y resolución de } \\
\text { problemas. }\end{array}$ & $\begin{array}{l}\text { Fases: } \\
\text { 1. Familiarización con los comandos del } \\
\text { robot. } \\
\text { 2. Desplazamiento de los robots por un } \\
\text { camino en el tablero, previamente } \\
\text { establecido. } \\
\text { 3. Esta vez el camino no estaba } \\
\text { establecido. }\end{array}$ \\
\hline $\begin{array}{l}\text { 6. Psara \& } \\
\text { Christodoulidou (2019) }\end{array}$ & $\mathrm{El}$ & $\begin{array}{l}\text { Pensamiento } \\
\text { computacional. }\end{array}$ & $\begin{array}{l}\text { Las actividades se desarrollaron durante } 6 \\
\text { sesiones. Estas actividades consistían en retos } \\
\text { que se desarrollaban haciendo uso de mapas. }\end{array}$ \\
\hline
\end{tabular}




\begin{tabular}{|c|c|c|c|}
\hline $\begin{array}{l}\text { 7. Angeli \& Valanides } \\
(2020)\end{array}$ & $\mathrm{El}$ & $\begin{array}{l}\text { Pensamiento } \\
\text { computacional }\end{array}$ & $\begin{array}{l}\text { Se utilizan tres escenarios de resolución de } \\
\text { problemas. Los alumnos deben programar } \\
\text { el robot para que realice el recorrido que } \\
\text { se narra en las tres historias contadas por } \\
\text { el investigador. Este último utiliza tarjetas } \\
\text { para indicarle al alumnado los diferentes } \\
\text { comandos que debe de pulsar. }\end{array}$ \\
\hline $\begin{array}{l}\text { 8. Caballero-González } \\
\text { \& García-Valcárcel } \\
(2020)\end{array}$ & El & $\begin{array}{l}\text { Habilidades } \\
\text { sociales y } \\
\text { habilidad } \\
\text { específica de } \\
\text { secuenciación, } \\
\text { (pensamiento } \\
\text { computacional) }\end{array}$ & $\begin{array}{l}\text { Se estructuraron } 6 \text { sesiones de } 2 \text { horas } \\
\text { cada una. Las actividades consistieron en } \\
\text { el diseño y programación de secuencias de } \\
\text { movimientos de nivel básico y de nivel medio. } \\
\text { Además, se planificaron dos sesiones de } \\
\text { evaluación en las cuales se plantearon } 4 \text { retos. }\end{array}$ \\
\hline 9. Cervera et al. (2020) & EP & $\begin{array}{l}\text { Pensamiento } \\
\text { computacional }\end{array}$ & $\begin{array}{l}\text { Se realizaron } 2 \text { sesiones. La primera de } \\
\text { ellas se destinaba a la familiarización del } \\
\text { alumnado con el robot Bee-Bot. En la } \\
\text { segunda, el alumnado realizó seis tareas de } \\
\text { programación de recorrido. }\end{array}$ \\
\hline $\begin{array}{l}\text { 10. Di Lieto, Pecini, et } \\
\text { al. (2020) }\end{array}$ & $\mathrm{El} / \mathrm{EP}$ & $\begin{array}{l}\text { Pensamiento } \\
\text { computacional } \\
\text { (funciones } \\
\text { ejecutivas) }\end{array}$ & $\begin{array}{l}\text { Se realizaron } 9 \text { tareas agrupadas en tres } \\
\text { bloques: (1) Conocimiento del uso de Bee-Bot, } \\
\text { (2) Planificar rutas visoespaciales complejas } \\
\text { con el Bee-Bot, y (3) capacidad de inhibición } \\
\text { provocada por uso del Bee-Bot. } \\
\text { Las actividades se realizaron } 3 \text { veces. }\end{array}$ \\
\hline $\begin{array}{l}\text { 11. Di Lieto, Castro, et } \\
\text { al. (2020) }\end{array}$ & EP & $\begin{array}{l}\text { Pensamiento } \\
\text { computacional } \\
\text { (funciones } \\
\text { ejecutivas) }\end{array}$ & $\begin{array}{l}\text { Se realizaron } 9 \text { tareas agrupadas en tres } \\
\text { bloques: (1) Conocimiento del uso de Bee-Bot, } \\
\text { (2) Planificar rutas visoespaciales complejas } \\
\text { con el Bee-Bot, y (3) capacidad de inhibición } \\
\text { provocada por uso del Bee-Bot. Las } \\
\text { actividades se realizaron durante } 10 \text { semanas. }\end{array}$ \\
\hline
\end{tabular}

Nota: El = Educación Infantil; EP = Educación Primaria.

Tabla 2. Investigaciones que aplican el robot Bee-Bot en las etapas de Educación Infantil y Educación Primaria

En referencia a la segunda pregunta de investigación, los resultados indican que el 50,00\% de los estudios (Caballero-González \& García-Valcarcel, 2018; 2020; Di Lieto et al., 2017; Di Lieto, Pecini et al., 2020; Psara \& Christodoulidou, 2019) se basan en aplicar el robot Bee-Bot con el alumnado de la etapa de Educación Infantil, mientras que el otro 50,00\% (Bargagna et al., 2019; Cervera et al., 2020; Di Lieto, Pecini et al., 2020; Di Lieto, Castro 2020; Ferrada et al., 2019; Marín \& Campos, 2019) aplica esta herramienta TIC en las aulas de Educación Primaria. Concretamente, el estudio desarrollado por Di Lieto, Pecini et al. (2020) donde el alumnado que hizo uso del robot Bee-Bot para desarrollar las actividades estaba escolarizado tanto en la etapa de Educación Infantil como en la etapa de Educación Primaria.

Respecto a la tercera pregunta de investigación, los resultados de la revisión sistemática apuntan a que la principal área de conocimiento trabajada, tanto en las aulas de Educación Infantil como en las aulas de Educación Primaria con el robot Bee-Bot, es el pensamiento computacional. De este modo, el 90,91\% de los estudios (Angeli \& Valanides, 2020; Bargagna et al., 2019; Cervera et al., 2020; Di Lieto et al., 2017; Di Lieto, Pecini et al., 2020a; Di Lieto, Castro et al., 2020; Caballero-González 
\& García-Valcarcel; 2018; 2020; Psara \& Christodoulidou, 2019) trabajan las habilidades de pensamiento computacional a través de las actividades planteadas en la intervención. Asimismo, en algunas de estas investigaciones, a parte de trabajar el pensamiento computacional, también se abordan otro tipo de habilidades como las funciones ejecutivas (Bargagna et al., 2019; Di Lieto et al., 2017; Di Lieto, Pecini et al., 2020a; Di Lieto, Castro et al., 2020). Así pues, entre las funciones ejecutivas que se trabajan encontramos inhibición de la respuesta, el control de la interferencia, la memoria de trabajo y la flexibilidad cognitiva. Estas investigaciones conforman el $36,36 \%$ de la muestra total. Por último, el $27,27 \%$ de los estudios trabajan otro tipo de contenido como las habilidades sociales (Caballero-González \& García-Valcárcel, 2020), la geometría, los números y las operaciones (Ferrada et al., 2019) o las figuras musicales (Marín \& Campos, 2019).

Por último, en cuanto a la cuarta pregunta de investigación, la cual hace referencia a las características de las actividades planificadas para utilizar el robot Bee-bot de los estudios que conforman la muestra, cabe señalar lo siguiente. Más de la mitad de los estudios (Bargagna et al., 2019; Di Lieto et al., 2017; Di Lieto, Pecini et al., 2020a; Di Lieto, Castro et al., 2020; Cervera et al., 2020; Marín \& Campos, 2019), el $54,55 \%$, incorporan una primera fase con actividades destinadas a la familiarización del alumnado con los comandos del robot. Asimismo, en todas las investigaciones el alumnado debe programar al robot para que este se desplace realizando la secuencia de movimientos para alcanzar la posición deseada. Por tanto, las actividades se basan en programar recorridos. Bien es cierto que la manera de plantear dichos recorridos al alumnado varía. Existe un porcentaje de estudios (Caballero-González \& García-Valcarcel, 2018; 2020; Psara \& Christodoulidou, 2019), concretamente el $27,27 \%$, donde el personal docente/investigador plantea al alumnado un reto que debe resolver y la resolución de este se corresponde con un recorrido concreto. Además, en la investigación desarrollada por Angeli \& Valanides (2020) se utiliza la narración de historias para describir el recorrido que debe programar el alumno o la alumna después de escucharla. Es importante señalar que en todas las investigaciones los recorridos del robot Bee-Bot que debe programar el alumnado aumentan de dificultad a medida que se avanza en el número de sesiones. Por último, el 27,27\% de las investigaciones (Bargagna et al., 2019; Caballero-González \& García-Valcárcel, 2020; Di Lieto et al., 2017) incluyen sesiones de repaso o de evaluación.

\section{Discusión y conclusiones}

A partir del objetivo general planteado en la introducción basado en realizar una revisión de carácter sistemático, en base a los criterios de la declaración PRISMA, sobre la aplicación del robot Bee-bot en las escuelas de Educación Infantil y Educación Primaria desde el año 2016 hasta el año 2020, se discuten los resultados obtenidos.

En primer lugar, los resultados apuntan a un aumento del uso del robot Bee-Bot en el contexto educativo los últimos años. Este incremento del uso de la robótica educativa también ha sido observado por autores como Di Lieto et al. (2017) y puede deberse a la mejora en la tecnología que compone los robots producida en la última década, lo que ha provocado que resulte mucho más sencillo para los estudiantes la manipulación de este tipo de tecnología (Richardson et al., 2018). Además, que este robot haya sido galardonado como el mejor hardware educativo (Janka, 2008), también puede haber influido en este incremento de su utilización. 
En segundo lugar, que el robot Bee-bot se aplique por igual en las aulas de Educación Infantil y en las aulas de Educación Primaria podría ser la consecuencia de la planificación de la experiencia educativa para diferentes niveles curriculares y no tanto del tipo de robot, ya que, tal y como apuntan López \& Andrade (2013), la propuesta resultará positiva siempre y cuando se base en un enfoque pedagógico prestando especial atención a las actividades, recursos, temporalización y la metodología.

En tercer lugar, que el robot Bee-Bot se aplique, en mayor medida, para trabajar el pensamiento computacional, guarda relación con que una de las potencialidades de este tipo de tecnología, es el desarrollo de habilidades digitales de programación y de este tipo de pensamiento entre los más pequeños (Chiazzese et al., 2017). Todo ello se debe principalmente a que, por un lado, la robótica permite al individuo generar ideas, diseñar modelos y construir soluciones a problemas o situaciones relacionadas con el mundo que les rodea. Y, por otro lado, a su carácter práctico el cual contribuye a lograr una interacción más dinámica interacción de los participantes en los entornos educativos.

Por último, que, por un lado, las sesiones planificadas con el robot Bee-Bot posean unas actividades de familiarización se debe a que el alumnado debe aprender a manejar los comandos y la programación y estos aprendizajes no son innatos. Por tanto, precisan de un proceso de aprendizaje, tal y como señalan Di Lieto et al. (2020a; $2020 b$ ). Por otro lado, que la mayoría de las actividades se basen en retos se debe a que están basados en se consideran una de las principales habilidades del pensamiento computacional (Caballero-González \& García-Valcárcel, 2020).

Sobre la base de las preguntas de investigación propuestas y los resultados obtenidos, se indican las siguientes conclusiones:

La utilización del robot Bee-bot en las aulas de Educación Infantil y Educación Primaria ha aumentado progresivamente desde el año 2016. El año 2020 fue el año que mayor número de investigaciones fueron publicadas.

El robot Bee-bot se aplica por igual en las aulas de Educación Infantil y de Educación Primaria.

El área de conocimiento que se trabaja en mayor medida con el robot Bee-Bot es el pensamiento computacional. En segundo lugar, las funciones ejecutivas. Y, por último, otro tipo de contenidos, ya sean curriculares o relacionados con las habilidades sociales.

En líneas generales, las sesiones planificadas para utilizar el robot Bee-Bot cuentan con unas actividades de familiarización, se basan en retos y cuentan con unas actividades de evaluación o repaso.

\section{Referencias}

Acaso, M. (2013). Reduvolution. Hacer la revolución en la educación, 1.

Aguirre, J. B., \& Quiridumbay, M. T. (2021). Perspectiva sobre la educación inicial y el acceso a las TIC: revisión crítica de la literatura. ReHuSo: Revista de Ciencias Humanísticas y Sociales, 6(2), 41-49. 
Al-Rahmi, W. M., Alzahrani, A. I., Yahaya, N., Alalwan, N., \& Kamin, Y. B. (2020). Digital communication: Information and communication technology (ICT) usage for education sustainability. Sustainability, 12(12), 5052.

Angeli, C., \& Valanides, N. (2020). Developing young children's computational thinking with educational robotics: An interaction effect between gender and scaffolding strategy. Computers in Human Behavior, 105, 105954.

Bargagna, S., Castro, E., Cecchi, F., Cioni, G., Dario, P., Dell'Omo, M., Di Lieto, M.C., Inguaggiato, E., Martinelli, A., Pecini, C., \& Sgandurra, G. (2019). Educational robotics in down syndrome: a feasibility study. Technology, knowledge and learning, 24(2), 315-323.

Bers, M., \& Urrea, C. (2000). Technological prayers: parents and children exploring robotics and values. Robots for kids: Exploring new technologies for learning experiences, 194-217.

Blackley, S., \& Howell, J. (2019). The next chapter in the STEM education narrative: Using robotics to support programming and coding. Australian Journal of Teacher Education (Online), 44(4), 51-64.

Caballero González, Y. A., \& García-Valcárcel Muñoz-Repiso, A. (2018, October). A robotics-based approach to foster programming skills and computational thinking: Pilot experience in the classroom of early childhood education. In Proceedings of the Sixth International Conference on Technological Ecosystems for Enhancing Multiculturality (pp. 41-45).

Caballero González, Y. A., \& García-Valcárcel Muñoz-Repiso, A. (2020). Fortaleciendo el pensamiento computacional y habilidades sociales mediante actividades de aprendizaje con robótica educativa en niveles escolares iniciales. Píxe/- BIT. Revista de Medios y Educación, 58, 117-142.

Castillo, D. (2020). Las TIC en los procesos de enseñanza-aprendizaje desarrollados por maestros tutores de Educación Primaria en la Región de Murcia. Revista Interuniversitaria de Investigación en Tecnología Educativa, 9, 1-14. https://doi.org/10.6018/riite.432061

Cervera, N., Diago, P. D., Orcos, L., \& Yáñez, D. F. (2020). The Acquisition of Computational Thinking through Mentoring: An Exploratory Study. Education Sciences, 10(8), 202.

Chiazzese, G., Fulantelli, G., Pipitone, V., \& Taibi, D. (2017, October). Promoting computational thinking and creativeness in primary school children. In Proceedings of the 5th International Conference on Technological Ecosystems for Enhancing Multiculturality (pp. 1-7).

D’Abreu, J. V. V. (2017). Educación y Robótica Educativa. RED. Revista de Educación a Distancia, (54), 1-13.

Diago, P. D., Arnau, D., \& González-Calero, J. A. (2018). La resolución de problemas matemáticos en primeras edades escolares con Bee-bot. Matemáticas, educación y sociedad, 1(2), 36-50. 
Di Lieto, M. C., Inguaggiato, E., Castro, E., Cecchi, F., Cioni, G., Dell'Omo, M., Laschi, C., Santerini, G., \& Dario, P. (2017). Educational Robotics intervention on Executive Functions in preschool children: A pilot study. Computers in human behavior, 71, 16-23.

Di Lieto, M. C., Pecini, C., Castro, E., Inguaggiato, E., Cecchi, F., Dario, P., Cioni, G., \& Sgandurra, G. (2020). Empowering executive functions in 5-and 6-year-old typically developing children through educational robotics: An RCT study. Frontiers in psychology, 10, 3084.

Di Lieto, M. C., Castro, E., Pecini, C., Inguaggiato, E., Cecchi, F., Dario, P., Cioni, G., \& Sgandurra, G. (2020). Improving executive functions at school in children with special needs by educational robotics. Frontiers in psychology, 10, 2813.

Domingo, M., \& Marquès, P. (2011). Aulas 2.0 y uso de las TIC en la práctica docente. Comunicar, 19(37), 169-175. https://doi.org/10.3916/C37-2011-03-09

Ferrada, C., Díaz-Levicoy, D., Salgado-Orellana, N., \& Parraguez, R. (2019). Propuesta de actividades STEM con Bee-bot en matemática. Edma O-6: Educación Matemática en la Infancia, 8(1), 33-43.

Ghitis, T., \& Vásquez, J. A. A. (2014). Los robots llegan a las aulas. Infancias imágenes, 13(1), 143-147. https://doi.org/10.14483/16579089.8122

Goodgame, C. (2018, March). Beebots and Tiny Tots. In Society for Information Technology \& Teacher Education International Conference (pp. 1179-1183). Association for the Advancement of Computing in Education (AACE).

Granados, A. (2015). Las TIC en la enseñanza de los métodos numéricos. Sophia Educación, 11(2), 143-154.

Hood, D., Lemaignan, S., \& Dillenbourg, P. (2015, March). When children teach a robot to write: An autonomous teachable humanoid which uses simulated handwriting. In Proceedings of the Tenth Annual ACM/IEEE International Conference on Human-Robot Interaction (pp. 83-90).

Janka, P. (2008, November). Using a programmable toy at preschool age: Why and how. In Teaching with robotics: didactic approaches and experiences. Workshop of International Conference on Simulation, Modeling and Programming Autonomous Robots (pp. 112-121).

Kumar, A. N. (2004). Three years of using robots in an artificial intelligence course: lessons learned. Journal on Educational Resources in Computing (JERIC), 4(3), 2-es.

López, P.A., \& Andrade, H. (2013). Aprendizaje con robótica, algunas experiencias. Educación, 47(1), 43-63.

López-Illescas, C., de Moya-Anegón, F., \& Moed, H. F. (2008). Coverage and citation impact of oncological journals in the Web of Science and Scopus. Journal of informetrics, 2(4), 304-316.

Marín, M. F. T., \& Campos, N. V. (2019). Enseñanza-aprendizaje músico-matemático utilizando robótica educativa. 3 c TIC: cuadernos de desarrollo aplicados a las TIC, 8(3), 13-37. 
Nieto, E., \& Marquès, P. (2015). La mejora del aprendizaje a través de las nuevas tecnologías y de la implantación del currículo bimodal. Multiárea. Revista de didáctica, 7, 7-30. https://doi.org/10.18239/mard.v0i7.692

Page, M. J., \& Moher, D. (2017). Evaluations of the uptake and impact of the Preferred Reporting Items for Systematic reviews and Meta-Analyses (PRISMA) Statement and extensions: a scoping review. Systematic reviews, 6(1), 1-14.

Piedade, J., Dorotea, N., Pedro, A., \& Matos, J. F. (2020). On teaching programming fundamentals and computational thinking with educational robotics: A didactic experience with pre-service teachers. Education Sciences, 10(9), 214.

Pinto, M. S. M., \& Osório, A. J. (2019). Aprender a programar en Educación Infantil: análisis con la escala de participación. Revista de medios y educación. Pixel Bit, 55, 133-156.

Psara, E. (2020). Robotics in Language Learning: A Systematic Review. https://ktisis. cut.ac.cy/handle/10488/22822

Ramírez, P. A. L., \& Sosa, H. A. (2013). Aprendizaje de y con robótica, algunas experiencias. Revista Educación, 37(1), 43-63. https://doi.org/10.15517/REVEDU.V3711.10628

Richardson, K., Coeckelbergh, M., Wakunuma, K., Billing, E., Ziemke, T., Gomez, P., ... \& Belpaeme, T. (2018). Robot enhanced therapy for children with autism (DREAM): A social model of autism. IEEE Technology and Society Magazine, 37(1), 30-39.

Salamanca, M. L. P., Lombana, N. B., \& Holguín, W. J. P. (2010). Uso de la robótica educativa como herramienta en los procesos de enseñanza. Ingeniería Investigación y Desarrollo: 12+ D, 10(1), 15-23.

Vivas-Fernandez, L., \& Sáez-López, J. M. (2019). Integración de la robótica educativa en Educación Primaria. Revista Latinoamericana de Tecnología Educativa-RELATEC, 18(1), 107-129.

Yepes-Nuñez, J. J., Urrútia, G., Romero-García, M., \& Alonso-Fernández, S. (2021). Declaración PRISMA 2020: una guía actualizada para la publicación de revisiones sistemáticas. Revista Española de Cardiología, 74(9), 790-799. 


\section{Aplicación de las Tecnologías de la Información y la Comunicación (TICS) para el Trastorno del Espectro Autista: Realidad Aumentada}

\section{Gilabert-Cerdá, Alba}

orcid.org/0000-0003-3765-7826

alba.gilabert@ua.es

\section{Lorenzo Lledó, Gonzalo}

orcid.org/0000-0002-1997-6260

glledo@gcloud.ua.es

\section{Lorenzo Lledó, Alejandro}

orcid.org/0000-0002-0224-5824

alejandro.lorenzo@gcloud.ua.es

\section{García-Albaladejo, Eva}

orcid.org/0000-0003-0124-6160

ega44@alu.ua.es 


\title{
APLICACIÓN DE LAS TECNOLOGÍAS DE LA INFORMACIÓN Y LA COMUNICACIÓN (TICS) PARA EL TRASTORNO DEL ESPECTRO AUTISTA: REALIDAD AUMENTADA
}

\author{
Gilabert-Cerdá, Alba \\ Lorenzo Lledó, Gonzalo \\ Lorenzo Lledó, Alejandro \\ García-Albaladejo, Eva
}

\section{Resumen}

Numerosas investigaciones educativas utilizan la Realidad Aumentada (RA), ya que aseguran que esta novedosa herramienta favorece la adquisición de aprendizajes debido a sus características principales: superposición de elementos virtuales a la imagen real e interacción en tiempo real. Específicamente, los discentes con Trastorno del Espectro Autista (TEA) se benefician de esa tecnología debido a que se adapta a su proceso de enseñanza-aprendizaje. Además, debido a que el TEA no es un trastorno neurodegenerativo y, por lo tanto, las dificultades manifiestas pueden mejorar a medida que los individuos puedan hacer frente a su entorno bajo las condiciones adecuadas; el profesorado debe adaptar su metodología con nuevas técnicas que beneficien a la totalidad de los estudiantes. En esta línea, este trabajo tiene el objetivo de analizar las conductas comunicativas y respuestas a tareas y rutinas de un alumno con TEA mediante el uso de la RA. El estudio utiliza un diseño cualitativo, más concretamente se trata de un estudio de casos de tipo instrumental. Los resultados obtenidos muestran un aumento en su comunicación receptiva (33\%) y expresiva (64\%), así como en sus habilidades sociales (67\%). Como futuras líneas de investigación, se plantea la continuación del estudio aplicando este proyecto en nuevos centros educativos y, por tanto, una ampliación de la muestra para observar si hay otros factores (edad, sexo, nivel de TEA) que influyen en el análisis de los resultados obtenidos. Este trabajo se encuentra en la línea de estudios del grupo de investigación de la Universidad de Alicante IncluTIC (VIRGROB-321).

\section{Palabras clave}

Trastorno del Espectro Autista (TEA), Realidad Aumentada (RA), Tecnologías de la Información y comunicación (TIC), educación inclusiva, intervención. 


\section{Introducción}

Actualmente, diferentes tecnologías emergentes están adquiriendo una fuerte presencia gracias a diversos acontecimientos, desde la creciente importancia de la web 2.0 a la reducción de costes de los equipos o la fuerte penetración de los dispositivos móviles, que ha influido en la deslocalización de las tecnologías y ha favorecido el acceso a la información independientemente del espacio y el tiempo. Todo ello está repercutiendo en la aparición de una escenografía tecnológica como nunca había ocurrido en la historia de la humanidad. En esta línea, el desarrollo de las tecnologías de la información y comunicación ha popularizado el concepto de ciberespacio. Este término hace referencia a una nueva dimensión donde se produce la comunicación electrónica, propiciada por la preponderancia de internet y la moderna telefonía móvil, que se encuentra casi totalmente liberada de los condicionantes de espacio y tiempo propios de la comunicación interpersonal (Cabero y García 2016).

En esta galaxia mediática, una de las tecnologías emergente es la Realidad Aumentada, del término inglés Augmented Reality, (RA), que está comenzado a utilizarse en diferentes sectores: la publicidad, el ocio, la información turística, el mundo de la moda, la industria o la educación. De forma sintética, la RA es la combinación de información digital e información física en tiempo real a través de diferentes dispositivos tecnológicos; es decir, consiste en utilizar un conjunto de dispositivos tecnológicos que añaden información virtual a la información física y, por tanto, implica añadir una parte sintética virtual a lo real, favoreciendo de esta forma el enriquecimiento de la información a la que puede acceder el alumnado o aportando información adicional a la realidad para facilitar su comprensión (Cabero et al., 2016). Es decir, lo que permite la Realidad Aumentada es potenciar los sentidos con los cueles se percibe la realidad, esto se logra a través de la información que existe en el mundo digital sobre las cosas que están alrededor de las personas, así que la RA actúa como una lente con la cual se ve el mundo (Melo, 2018).

La RA tiene un carácter multiformato, que va desde lo visual de una pantalla mediadora entre el mundo digital y el mundo físico, a lo auditivo o lo textual e hipertextual. Por esa diversidad de formatos, la RA puede considerarse como una tecnología adecuada para la diversidad de niveles, áreas y contextos educativos. En este sentido, la escolarización de estudiantes con Trastorno del Espectro Autista (TEA) en las aulas ordinarias está en aumento; hecho que supone un importante desafío para los profesionales del ámbito de la educación (Tárraga-Mínguez y Sanz-Cervera, 2018).

A semejanza de lo ocurrido en otros ámbitos, todo lo relativo al Trastorno del Espectro Autista y otras alteraciones graves de la personalidad, a su realidad y su tratamiento, ha sufrido profundos cambios. Por ello, es preciso enfatizar la conceptualización de este trastorno. Los inicios del autismo se sitúan a finales del siglo XIX, etapa en la que se comenzó a considerarse el trastorno en términos científicos. Concretamente fue Henry Maudsley (1867) el que describió comportamientos extravagantes en niños que presentaban psicosis. Sin embargo, a principios del siglo XX sería cuando Eugen Bleuler, en su libro Dementia praecox oder Gruppe der Schizophrenien (Alcantaud y Alonso, 2015), comenzó a utilizar el término "autismo" para denominar el déficit en las relaciones interpersonales y la relación con el mundo externo en general, que caracterizaba la esquizofrenia (Bleuler, 1911). Etimológicamente, la palabra "autismo" proviene del griego del término "autos", que significa "uno mismo". Basándose en esta definición, para Bleuler, el autismo era una separación 
de la realidad externa o del mundo social para sumergirse en sí mismo (Baron-Cohen, 2008; Sicile-Kira, 2014).

A mediados de este periodo se detectaron los primeros casos documentados de autismo, situándose como uno de los más relevantes el caso del niño salvaje de Aveyron (Bettelheim, 1959; Houston y Frith, 2000). Estas circunstancias propiciaron que en 1943 el psiquiatra Leo Kanner describiera 11 casos de niños con este tipo de sintomatología, que él denominó autismo infantil precoz, utilizando por primera vez este término de forma independiente a la esquizofrenia. Este hecho marcó una diferencia respecto a la conceptualización propuesta por Bleuler, ya que a partir de entonces se fundamenta en que los síntomas aparecen al inicio de la vida (Kanner, 1943). A pesar de todo, durante esa época el autismo continúa relacionándose con la esquizofrenia siendo considerado como un tipo de esquizofrenia infantil (Kanner, 1949). Unos años más tarde Hans Asperger presentó una serie de casos (Asperger, 1944) en línea con los expuestos por Kanner que posteriormente fueron denominados por Lorna Wing como Síndrome de Asperger.

No obstante, si damos un salto en el tiempo y nos situamos en el siglo XXI, se tiene una aproximación más específica del TEA. Según describe la American Psychiatric Association (2013) el Trastorno del Espectro Autista abarca un conjunto heterogéneo de síndromes del desarrollo neurológico asociado con déficits en la interacción social, habilidades comunicativas, flexibilidad mental y procesamiento sensorial. Esto afecta, directamente, a sus competencias social y comunicativa lo que dificulta el proceso de enseñanza-aprendizaje en el contexto escolar, situación que suele agravarse en la etapa adulta y obstaculiza la plena inclusión social (Pérez y López-Bouzas, 2021). Asimismo, el alumnado con TEA es un colectivo con riesgo y vulnerabilidad de sufrir maltrato y situaciones discriminatorias en el ámbito educativo (Carbonero et al., 2016).

Como asegura Ruiz Paredes (2020) un medio de individualización y adaptación a las necesidades particulares de aprendizaje para el alumnado con TEA, así como un medio tecnológico de enseñanza y apoyo en la intervención educativa es el uso de las nuevas Tecnologías de la Información y Comunicación (TIC). Por todo ello, las APPS de Realidad Aumentada ofrecen grandes posibilidades formativas al recrear experiencias que facilitan la simulación de interacciones sociales y comunicativas, mediante la superposición de elementos virtuales sobre objetos del mundo físico (Romero y Harari, 2017). Así pues, algunos estudios analizan su impacto en personas con TEA, destacando ciertas APPS que pueden favorecer tanto el reconocimiento y la respuesta a las expresiones emocionales observadas (Chen et al., 2016), como las habilidades de la vida diaria (Mahoney et al., 2004), la comunicación (Keshav et al., 2018), así como una mejora en la interacción social (Mitchell et al., 2007).

La investigación como vínculo entre teoría y práctica exige llevar a cabo un proceso inductivo de comprensión, que se inicia en la observación de la actividad que se desarrolla en el aula y se concreta en la interpretación de los datos obtenidos en el marco del contexto en que adquieren sentido. La presente investigación tiene como objetivo analizar las conductas comunicativas y respuestas a tareas y rutinas de un alumno con Trastorno del Espectro Autista mediante el uso de la Realidad Aumentada. Para obtener este propósito principal se han establecido las siguientes preguntas de investigación: 
- ¿Cómo repercute la Realidad Aumentada sobre la adquisición de conocimientos de un estudiante con Trastorno del Espectro Autista?

- ¿La herramienta de la Realidad Aumentada hará mejorar las conductas comunicativas verbales y no verbales y rutinas en el caso de estudio?

\section{Método/Descripción de la experiencia}

Rodríguez et al., (1996) y Stake (1998), tras el análisis de varios intentos en la conceptualización del "estudio de casos", consideran que todos ellos coinciden en que el estudio de casos es el estudio de la particularidad y de la complejidad de un caso singular, para llegar a comprender su actividad en circunstancias importantes. El caso puede ser más simple o complejo, en función de los intereses, objetivos y posibilidades del estudio. Puede ser una persona, un grupo u organización, un acontecimiento, un plan de estudios o una determinada acción, entre otros.

Stake (2005), por su parte, considera que existen tres grandes tipos de estudio de casos:

1) Intrínseco. El estudio se desarrolla porque queremos conseguir una mejor comprensión de un determinado caso. No optamos por un caso concreto porque éste represente a otros casos o porque sea ilustrativo de un determinado problema o fenómeno, sino porque es de interés por sí mismo.

2) Instrumental. Cuando examinamos un caso particular para proporcionar más información sobre un tema o para reformular una generalización. El caso adopta un papel secundario y su utilidad radica en la aportación de datos para comprender otro fenómeno.

3) Caso múltiple o colectivo. Un conjunto de casos que se estudia de forma conjunta para investigar un determinado fenómeno, población o condición general. En realidad, se trata de un estudio instrumental extendido a varios casos. Los casos pueden ser similares o no, ya que no es necesario conocer de antemano si tienen alguna característica en común.

El método del presente trabajo se trata de un diseño cualitativo, más concretamente se trata de un "estudio de casos" de tipo instrumental donde el objetivo principal es indagar sobre la herramienta de la Realidad Aumentada dentro del ámbito educativo a través de un caso de estudio para el que se ha escogido un alumno con Trastorno del Espectro Autista que acude a una clase específica de Educación Especial y se integra con el alumnado de $4^{\circ}$ de la etapa de Educación Primaria.

\section{Descripción del contexto y del participante}

Para llevar a cabo este estudio cualitativo, se ha escogido un Centro Educativo concertado y católico, de la provincia de Alicante, que promueve una educación integral: académica, humana y social; abierta al mundo y a las realidades humanas y en referencia a los valores del evangelio. Esta escuela oferta las siguientes etapas educativas: segundo ciclo de Educación Infantil; Educación Primaria, Educación Especial, Educación Secundaria Obligatoria y Formación Profesional Básica. Concretamente, 
la muestra está conformada por un estudiante de nueve años que acude al aula específica de Educación Especial y que, a su vez, se integra con su grupo de referencia en el aula de 4ํㅡㄹ Educación Primaria.

El estudiante lleva escolarizado en el centro desde 1ำ de Educación Primaria. Entre las características del alumno, se destaca que la única forma de trabajar es a nivel individual, pues tiene la atención dispersa y constantemente abandona el trabajo. Su atención es muy limitada y su comportamiento en ocasiones desafiante. Si te alejas de su lado deja de realizar la tarea y cuando estás cerca comienza a realizarla o no. Tiene muchas dificultades para permanecer sentado en la silla. Se levanta constantemente. Además, le cuesta seguir las pautas y realizar la tarea propuesta, aunque ésta sea un juego. Los tiempos de trabajo son muy cortos, ya que enseguida pierde el interés. No obstante, puede estar un rato largo haciendo algo repetitivo que le estimule como por ejemplo hacer rodar una moto/coche por el suelo.

La organización del tiempo es fundamental para crear un ambiente de confianza y seguridad, por lo que es primordial la creación de rutinas que se establezcan a lo largo de la jornada escolar, aunque esta debe ser flexible, adaptándose a los posibles cambios que se puedan producir. Esta rutina ayuda al alumno a prever lo que va a suceder, a anticipar, no produciendo incertidumbre ni desconcierto, eliminando o disminuyendo momentos de frustración o incluso problemas de conducta. La estructuración temporal implica el uso de claves: pictogramas, agendas y paneles de comunicación en las clases. Es necesario un ambiente estructurado que favorezca la recepción de la información, la anticipación de actividades y cambios, la espontaneidad comunicativa y el reconocimiento de los entornos en base a las actividades.

El proceso de enseñanza-aprendizaje del discente debe cumplir los siguientes requisitos:

- Partir del nivel de desarrollo del alumno y de sus aprendizajes previos.

- Asegurar la construcción de aprendizajes significativos a través de la movilización de sus conocimientos previos y de la memorización comprensiva.

- Posibilitar que el alumno realice aprendizajes significativos por sí mismo.

- Favorecer situaciones en las que el alumno deba actualizar sus conocimientos.

- Proporcionar situaciones de aprendizaje que tengan sentido para el alumno, con el fin de que resulten motivadores.

\section{Instrumento}

El instrumento de recogida para este trabajo ha sido el cuestionario Early Start Denver Model for Young Children with Autism (ESDM) de Sally J. Rogers y Geraldine Dawsona que ha sido adaptado por Gilabert, Lorenzo y Lledó. EI ESDM se basa en los actuales conocimientos empíricos acerca del aprendizaje de los niños pequeños y de los efectos del autismo sobre el desarrollo temprano. Su objetivo es reducir la gravedad de los síntomas y acelerar el ritmo de desarrollo del niño a todos los niveles, pero especialmente en los ámbitos cognitivo, socioemocional y lingüístico. 
Para proporcionar las bases del ESDM se han reunido varios enfoques diferentes pero complementarios. Entre ellos: el Modelo Denver original, desarrollado por Rogers y sus colegas a partir de 1981 (Rogers et al.,1986); el modelo de desarrollo interpersonal en el autismo, de Rogers y Pennington (1991); el modelo del autismo como trastorno de la motivación social, de Dawson y sus colaboradores (2004), y el entrenamiento de respuesta esencial (PRT, por las siglas de Pivotal Responde Training), un programa de enseñanza basado en el análisis conductual aplicado, que resalta la iniciativa y la espontaneidad del niño y que se puede impartir en contextos naturales.

Específicamente, el cuestionario adaptado se encuentra estructurado en dos partes y cuenta con un total de 38 ítems. Por un lado, la primera parte recoge preguntas sobre datos demográficos de los participantes e información sobre su informe sociopsicopedagógico que serán respondidas mediante una respuesta corta o señalando con una "X" la opción deseada.

Por otro lado, la segunda parte del cuestionario tiene como objetivo evaluar el dominio del alumnado TEA del Nivel 1 de dificultad del Modelo Denver en las áreas de comunicación receptiva (ítems 1-15), comunicación expresiva (ítems 16-29) y habilidades sociales (ítems 30-38). Estos ítems se deben responder señalando la presencia de dicha habilidad con la que el participante con TEA realiza los comportamientos descritos ( 1 = No presenta dicha habilidad, 2 = En proceso de adquisición de dicha habilidad y 3 = Presenta dicha habilidad). Este cuestionario se ha utilizado como pretest (antes de la intervención) y como postest (después de la intervención).

\section{Procedimiento}

Para llevar a cabo el procedimiento para completar el análisis del uso de la Realidad Aumentada en un caso con TEA se han seguido las siguientes fases:

1‥ Prestest. En primer lugar, se ha realizado la evaluación inicial (pretest), antes de la intervención mediante el uso de la Realidad Aumentada. Las áreas que serán evaluadas son: área de comunicación receptiva, área de comunicación expresiva y área de habilidades sociales mediante los 38 ítems que componen el cuestionario adaptado del ESDM.

2‥ Intervención. A continuación, ha tenido lugar la intervención en dichas áreas mediante el uso de la Realidad Aumentada y, por lo tanto, del dispositivo tecnológico de la tablet, donde se encuentra la aplicación de RA. Las actividades han sido diseñadas de acuerdo con el protocolo de actividades basadas en la RA en personas con TEA, siguiendo los pasos señalados en el trabajo realizado por Gilabert-Cerdá et al. (2020). En total se han realizado 10 sesiones de aproximadamente 30 minutos cada una de ellas durante un mes y medio.

3․ Postest. En tercer lugar, una vez finalizadas las actividades de Realidad Aumentada se realizó la evaluación final (postest), en las áreas de comunicación (expresiva y receptiva) y habilidades sociales mediante el cuestionario adaptado del ESDM.

4․ Análisis. Por último, se realizó un análisis de los resultados obtenidos comparando los datos del pretest y del postest con el fin de comprobar si hay diferencias significativas al aplicar la RA en un alumno con Trastorno del Espectro Autista en las áreas citadas con anterioridad. Asimismo, se comprobó en que grado hubo mejoras en la adquisición de conductas comunicativas y respuestas a rutinas. 


\section{Resultados}

Una vez finalizadas las diez sesiones de Realidad Aumentada con el caso de estudio se realizó el postest al sujeto donde a través de los 38 ítems que componen el cuestionario Early Start Denver Model for Young Children with Autism (ESDM) de Sally J. Rogers y Geraldine Dawsona adaptado por Gilabert, Lorenzo y Lledó; se comprobó el grado de consecución de éstos de acuerdo con la presencia de la habilidad ( $1=$ No presenta dicha habilidad, 2 = En proceso de adquisición de dicha habilidad y 3 = Presenta dicha habilidad). Seguidamente, se encuentra un gráfico que agrupa los resultados obtenidos en el pretest y en el postest (Véase Figura 1):

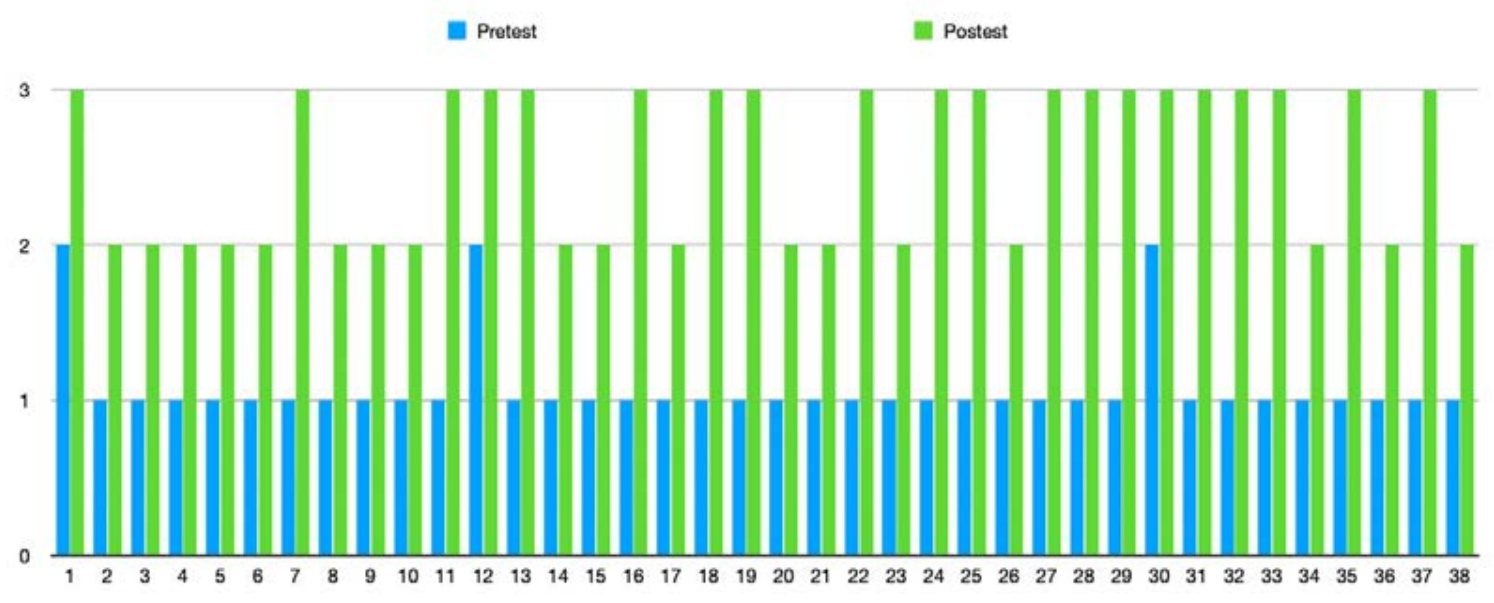

Figura 1. Consecución de los 38 items en el pretest y en el postest

Como se puede apreciar en el prestest, el participante comenzó con 35 ítems en el nivel 1 (no presenta dicha habilidad), tras la intervención con el uso de la Realidad Aumentada, el sujeto ha mejorado en todos los ítems que componen las áreas de comunicación receptiva y expresiva y las habilidades sociales, obtenido un porcentaje de $100 \%$ ya que, todos los ítems han aumentado de nivel. De estos 38 ítems, 18 están en proceso de adquisición de la habilidad y 20 han sido conseguidos en su totalidad representando un porcentaje del 53\%. A su vez, cada señalar que 17 de los 20 ítems han sido adquiridos desde el grado más bajo (no presenta dicha habilidad) hasta el grado más alto (presenta dicha habilidad).

A continuación, se exponen una serie de figuras que muestran el grado de consecución de los ítems de acuerdo con el área de evaluación: comunicación receptiva (ítems 1-15), comunicación expresiva (ítems 16-29) y habilidades sociales (ítems 30-38). 

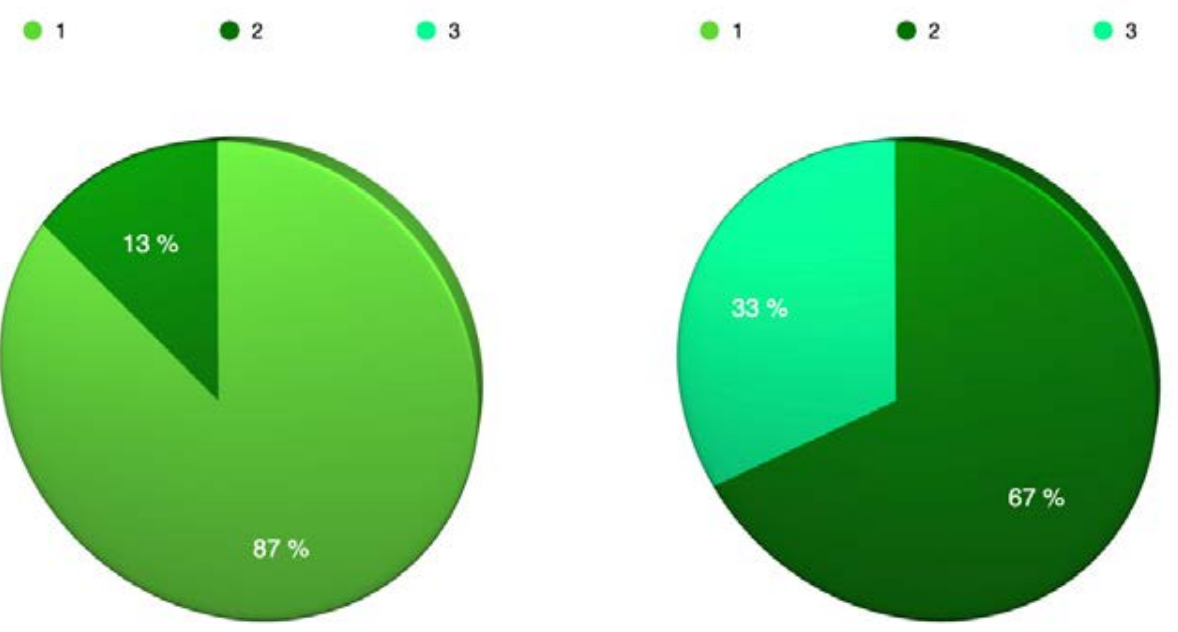

Figura 2. Comunicación receptiva (pretest) Figura 3. Comunicación receptiva (postest)

Si se observan la Figura 2 y la Figura 3 se puede apreciar el grado de consecución del área de comunicación receptiva tras el uso de la Realidad Aumentada. En esta área se incluyen ítems como "localiza los sonidos girándose hacia la fuente", "mira hacia sonidos vocales de juego" y "responde a la voz girándose hacia la persona". Antes la intervención 13 ítems se encontraban en nivel 1 (no presenta dicha habilidad) y 2 ítems en nivel 2 (en proceso de adquisición de dicha habilidad). Tras la intervención (postest) el 33\% de los 15 ítems que componen el área han sido a adquiridos en su totalidad.
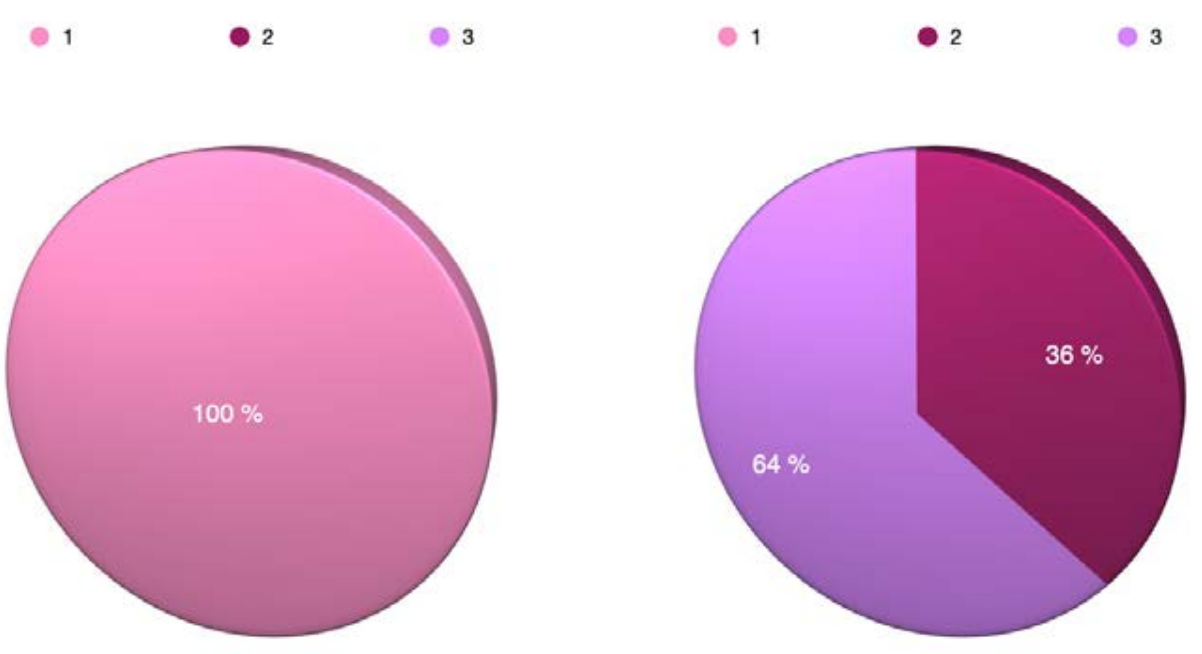

Figura 4. Comunicación expresiva (pretest) Figura 5. Comunicación expresiva (postest)

Seguidamente, se aprecia la Figura 4 y la Figura 5 correspondientes al área de la comunicación expresiva. Dentro de este apartado, se encuentran ítems como "utiliza el gesto de alcanzar con el brazo como petición", "vocaliza con intención" y "pide ayuda dando el objeto al adulto". En el pretest todos los ítems se encontraban en nivel 1 (no presenta dicha habilidad) pero, en el postest el $64 \%$ de los 14 ítems que componen el área han sido a adquiridos al mayor nivel. 

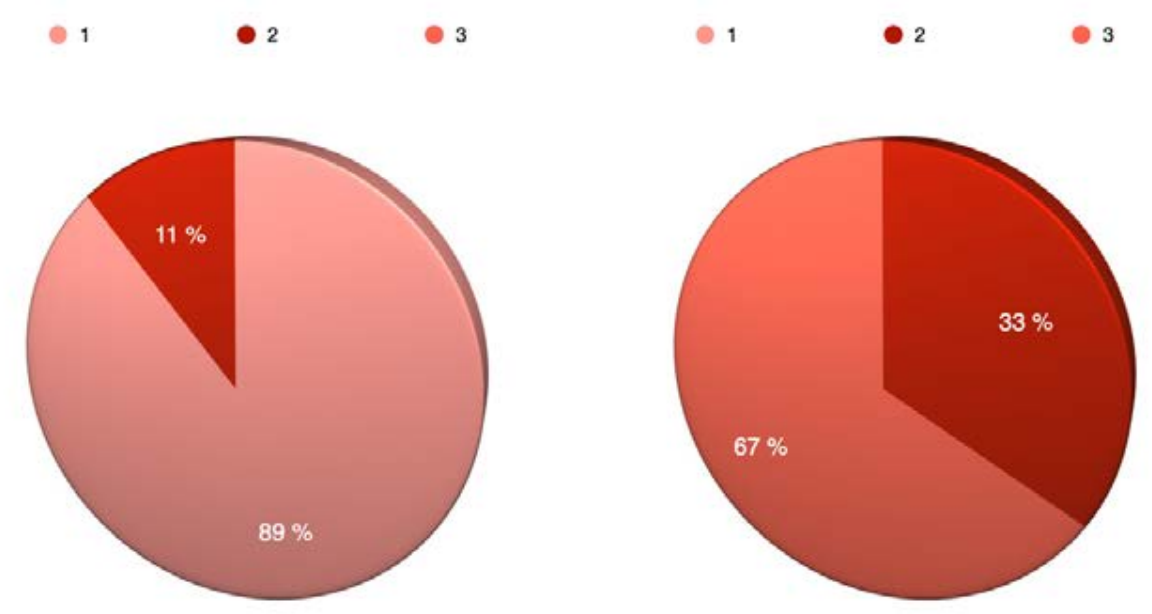

Figura 6. Habilidades sociales (pretest)

Figura 7. Habilidades sociales (postest)

En último lugar, en la Figura 6 y la Figura 7 están formadas por los ítems del área de habilidades sociales. "Acepta actividades y contactos sensoriales breves", "utiliza conducta motriz para iniciar o continuar una actividad sensorial social" y "atiende brevemente a otra persona con contacto ocular" son algunos de los ítems que componen este ámbito. Antes de realizar las actividades de RA únicamente el ítem 30 se encontraba en el nivel 2 mientras que el resto, 8 ítems pertenecían al nivel 1 (no presenta dicha habilidad). Sin embargo, en el postest el $67 \%$ de los ítems han sido a adquiridos plenamente (nivel 3).

\section{Discusión y conclusiones}

Para llevar a cabo la discusión de los resultados obtenidos se procede a analizar los datos expuestos en el apartado anterior.

En primer lugar, como se puede apreciar en la Figura 1 existe una notoria diferencia entre los resultados obtenidos en el pretest y en el postest. En el cuestionario que se realizó antes de la intervención se observa como de la totalidad de los ítems (38), 35 se encuentran en el nivel 1 (no presenta dicha habilidad) y 3 en el nivel 2 (en proceso de adquisición de dicha habilidad). Por el contrario, si dilucidamos los resultados obtenidos en el postest veremos que se encuentra 18 ítems en el nivel 2 (en proceso de adquisición de dicha habilidad) frente a los 20 ítems en el nivel 3 (presenta dicha habilidad), como se ha comentado con anterioridad.

Por otro lado, si se analizan todos los resultados de acuerdo con las tres áreas trabajadas en el pretest y en el postest: comunicación receptiva (Figura 2 y 3 ), comunicación expresiva (Figura 4 y 5) y habilidades sociales (Figura 6 y 7); se puede señalar que, en todas las áreas, después de la intervención con la Realidad Aumentada, los ítems estudiados han aumentado encontrándose en el nivel 2 (en proceso de adquisición de dicha habilidad) o en nivel 3 (presenta dicha habilidad).

El área que ha experimentado una mayor evaluación tras el uso de la RA ha sido la de habilidades sociales con un $67 \%$. Esto afirma los resultados obtenidos en los 
estudios realizados en Reino Unido (Bai et al., 2015) y Taiwan (Chung y Chen, 2017) que ratifican que existe una mejora significativa de la representación mental, la duración en el juego y la estimulación del saludo y, por tanto, de las habilidades sociales, una vez que se ha realizado una intervención con RA con niños TEA.

No obstante, las áreas de la comunicación receptiva y expresiva también han aumentado con un $33 \%$ (comunicación receptiva) y con un $64 \%$ (comunicación expresiva). De acuerdo con Arief y Efendi (2018) el uso de la RA aumenta la duración de la atención, de la comunicación y la comprensión del contenido estudiado.

Tras el análisis de los datos presentados con anterioridad, se puede deducir que, gracias a la utilización de la RA, se han conseguido en su mayoría los ítems establecidos con el caso de estudio en el ESDM adaptado. El alumno se ha acercado y entrado en contacto directo con esta novedosa herramienta y ha ido adquiriendo distintos hábitos de la comunicación receptiva, expresiva y habilidades sociales.

El carácter de la metodología empleada ha fomentado la consecución de los objetivos propuestos en el trabajo dejando que el propio estudiante se sienta motivado a trabajar y a aprender de una manera lúdica y mediante un dispositivo que le permite acercarse al mundo exterior desde otra mirada más apropiada para las personas TEA. De esta forma, se reafirma la definición de Cabero et al., 2016 que señala que la RA complementa al mundo real añadiéndole información adicional con la finalidad de enriquecer y ampliar los objetos físicos de nuestro alrededor.

Tomando en consideración la primera pregunta de investigación: se puede afirmar que, la RA deja que el propio estudiante se sienta motivado a trabajar y a aprender de una manera lúdica, y mediante un dispositivo que le permite acercarse al mundo exterior desde otra mirada más apropiada para las personas TEA, así que la RA actúa como una lente con la cual se ve el mundo Melo (2018).

De acuerdo con la segunda pregunta de investigación: se puede confirmar que esta herramienta metodológica, que se ha puesto en práctica en una situación real en un caso de estudio y ha funcionado de acuerdo con sus Necesidades Educativas Especiales, es de utilidad para el perfeccionamiento de la intervención en la educación. De esta forma, se favorece el desarrollo emocional de los estudiantes TEA motivándoles y mejorando los 3 aspectos en los que generalmente presentan más carencias: la comunicación expresiva y receptiva, así como a sus habilidades sociales.

A modo de conclusión, las personas con TEA trabajan con numerosos especialistas, pero ninguna de estas terapias consigue el logro de avances significativos en el proceso de enseñanza-aprendizaje. No obstante, la Realidad Aumentada ha conseguido avanzar en el logro de habilidades de manera transversal mientras se utilizaba un hilo conductor como el lavado de manos. Por ello, se puede señalar que esta herramienta ha logrado la mejora del proceso de enseñanza-aprendizaje, ya que ha sido utilizada como medio de individualización y adaptación de las necesidades particulares del alumno con TEA como identificó Ruiz Paredes (2020). 


\section{Referencias}

Alcantud, F. \& Alonso, Y. (2015). Trastornos del Espectro Autista. En E. M. Moreno (Ed.), Necesidades Educativas Especiales: Una mirada diferente (pp. 1-21). Fedune.

American Psychiatric Association (2013). Diagnostic and statistical manual of mental disorders. American Psychiatric Publishing, Inc.

Arief, M. \& Efendi, M. (2018). The book of pop up augmented reality to increase focus and object recognition capabilities for children with autism. Journal of International Conference on Special Education in Southeast Asia Region (ICSAR), 2(1), 9-14. http:// dx.doi.org/10.17977/um005v2i12018p009

Asperger, H. (1944). Autistic psychopathy in childhood. In U. Frith (Ed.). Autism and Asperger syndrome (pp. 37-92). Cambridge University Press.

Bai, Z., Blackwell, A.F. \& Coulouris, G. (2015). Using Augmented Reality to Elicit Pretend Play for Children with Autism. IEEE Transactions on Visualization and Computer Graphics, 21(5), 598-610. http://doi.org/10.1109/TVCG.2014.2385092

Baron-Cohen, S. (2008). Autism and Asperger syndrome. Oxford University Press.

Bettelheim, B. (1959). Feral children in autistic children. American Journal of Sociology, 64, 455-467.

Bleuler, E. (1911). Demencia Precoz. El grupo de las Esquizofrenias. Lumen-Hormé.

Cabero, J., \& García, F. (2016). Realidad Aumentada. Tecnología para la formación. Madrid: Síntesis.

Cabero Almenara, J., García Jiménez, F., Casado Parada, I., Gallego Pérez, O., Barroso Osuna, J., \& Gómez García M. (2016). Realidad Aumentada: tecnología para la formación. Sintesis.

Carbonero, D., Raya, E., Caparros, N., \& Gimeno., C. (2016). Respuestas transdisciplinares en una sociedad global. Aportaciones desde el Trabajo Social. Universidad de La Rioja.

Chen, C.H., Lee, I.J., \& Lin, L.Y. (2016). Augmented reality-based video-modeling storybook of nonverbal facial cues for children with autism spectrum disorder to improve their perceptions and judgments of facial expressions and emotions. Computers in Human Behavior, 55, 477-485. https://doi.org/10.1016/j.chb.2015.09.033

Chung, C.H., \& Chen, C.H. (2017). Augmented reality based social stories training system for promoting the social skills of children with autism. Advances in Ergonomics Modeling, Usability \& Special Populations, 486, 495-505. https://doi. org/10.1007/978-3-319-41685-4_44

Dawson G., Jones E.J., Merkle K., Venema K., Lowy R., Faja S., Kamara D., Murias M., Greenson J., Winter J., Smith M., Rogers S.J., Webb S.J. (2013). Early Behavioral Intervention is Associated with Normalized Brain Activity in Young Children with Autism. Journal of American Academy of Child and Adolescent Psychiatry. 51(11), 1150-1159. 
Gilabert-Cerdá, A., García-Albaladejo, E., Pérez-Vázquez, E., Lorenzo Lledó G., Lledó Carreres A., \&amp; Lorenzo-Lledó, A. (June 2020). Augmented Reality intervention with people with Autism Spectrum Disorder: protocol activities. [Paper Contribution]. International Conference on Education and New Developments 2019 (END 2019), Zagreb, Croatia.

Houston, R., \& Frith, U. (2000). Autism in History: The Case of Hugh Blair of Borgue. Blackwell.

Kanner, L. (1943). Autistic disturbances of affective contact. Nervous Child, 2, 217-250.

Keshav, N. U., Vahabzadeh, A., Abdus-Sabur, R., Huey, K., Salisbury, J. P., Liu, R., \& Sahin, N. (2018). Longitudinal socio-emotional learning intervention for autism via smartglasses: Qualitative school teacher descriptions of practicality, usability, and efficacy in general and special education classroom settings. Education Sciences, 8(3), 107. https://doi.org/10.3390/educsci8030107

Mahoney, G., Perales, F., Wiggers, B., \& Herman, B. (2006). Responsive Teaching: Early intervention for children with Down syndrome and other disabilities. Down Syndrome Research and Practice, 11(1), 18-28. https://doi.org/10.3104/perspectives.311

Maudsley, H. (1867). Insanity of early life. En H. Maudsley (Ed.). The Psysiology and Pathology of the Mind (pp. 259-293). Appleton.

Melo Bohórquez, I. M. (2018). Realidad aumentada y aplicaciones. Tecnología Investigación y Academia, 6(1), 28-35.

Mitchell, P., Parsons, S., \& Leonard, A. (2007) Using virtual environments for teaching social understanding to 6 adolescents with autistic spectrum disorders. Journal of Autism and Developmental disorders, 37(3) 589-600.

Pérez, M. E. D. M., \& López-Bouzas, N. (2021). Realidad aumentada y estimulación de la competencia socio-comunicativa en sujetos con TEA: Revisión de investigaciones. Revista de Educación a Distancia (RED), 21(66).

Rodríguez Gómez, G.; Gil, J. y García, E. (1996). Metodología de la investigación cualitativa. Málaga: Aljibe.

Rogers, S. J., Herbison, J. M., Lewis, H. C., Pantone, J., \& Reis, K. (1986). An approach for enhancing the symbolic, communicative, and interpersonal functioning of young children with autism or severe emotional handicaps. Journal of the Division for Early Childhood, 10(2), 135-148.

Rogers, S. J., \& Pennington, B. F. (1991). A theoretical approach to the deficits in infantile autism. Development and Psychopathology, 3(2), 137-162. https://doi. org/10.1017/S0954579400000043

Romero, M., \& Harari, I. (2017). Uso de nuevas tecnologías TICS-realidad aumentada para tratamiento de niños TEA un diagnóstico inicial. Universidad Internacional SEK, $6,1-7$. 
Ruiz Paredes, J. D. (2020, March). El uso de las nuevas tecnologías en las aulas para mejorar las necesidades educativas del alumnado autista. En Congreso Internacional de Investigación e innovación en educación infantil y primaria.

Sicile-Kira, C. (2014). Autism spectrum disorders: the complete guide to understanding autism. Tarcher Perigee.

Stake, R. E. (1998). Investigación con estudio de casos. Ediciones Morata.

Stake, R. E. (2005). Qualitative Case Studies. En: N. K. Denzin; Y. S. Lincoln (Ed.). The Sage Handbook of Qualitative Research (3." ed.) (pp. 273-285). Sage.

Tárraga-Mínguez, R. \& Sanz-Cervera, P. (2018). ¿Qué estrategias de intervención funcionan en la educación de los niños con trastorno del espectro autista? Revisión de evidencias en la literatura científica. ReiDoCrea, 7, 279-287. 


\section{Los Itinerarios Flexibles en Entornos Virtuales para el Desarrollo de Habilidades de Aprendizaje Autorregulado}

\section{Tur, Gemma}

http://orcid.org/0000-0003-4508-6808 gemma.tur@uib.es

\section{Pérez-Garcias, Adolfina}

http://orcid.org/0000-0002-1863-375X

fina.perez@uib.es

\section{Villatoro, Sofía}

https://orcid.org/0000-0003-2436-0468

sofia.villatoro@uib.es

\section{Darder Mesquida, Antònia}

http://orcid.org/0000-0003-2964-3301

antonia.darder@uib.es 


\title{
LOS ITINERARIOS FLEXIBLES EN ENTORNOS VIRTUALES PARA EL DESARROLLO DE HABILIDADES DE APRENDIZAJE AUTORREGULADO
}

\author{
Tur, Gemma \\ Pérez-Garcias, Adolfina \\ Villatoro, Sofía \\ Darder Mesquida, Antònia
}

\section{Resumen}

Las habilidades para el aprendizaje autorregulado se pueden ver potenciadas por propuestas pedagógicas basadas en la creación de itinerarios flexibles personales en entornos virtuales. Una asignatura del Máster Interuniversitario en Tecnología Educativa, que se realiza totalmente en la modalidad en línea, se ha diseñado como una estructura de varias secuencias didácticas cuya combinación permite el desarrollo de diferentes itinerarios de aprendizaje. En este caso, el contenido se estructura en torno a tres secuencias didácticas de las cuales dos ofrecen la posibilidad de elegir entre dos o tres opciones. Con una finalidad descriptiva, se diseña una metodología de investigación mixta que utiliza técnicas de investigación cuantitativas y cualitativas. Por una parte, a partir de un cuestionario de escala Likert se recogen las percepciones del alumnado en cada secuencia didáctica, y por otra parte, se analiza su selección a partir de un registro de actividades. Este trabajo presenta los datos recogidos en esta experiencia y pretende conocer los itinerarios recorridos por el alumnado y la percepción sobre las posibilidades de cada secuencia didáctica para el aprendizaje autorregulado. Los resultados permiten visualizar los itinerarios preferentes por el alumnado y las percepciones positivas para la planificación, monitorización y autoevaluación que las secuencias didácticas han promovido.

\section{Palabras clave}

Itinerarios flexibles, aprendizaje autorregulado, secuencia didáctica, percepciones del alumnado. 


\section{Introducción}

El aprendizaje flexible se ha definido como la adaptación de la organización del contenido, tiempos, diseño instruccional y objetivos, entre otros elementos (Buitrago et al., 2021). Especialmente en entornos virtuales, permite el desarrollo de habilidades para el aprendizaje autorregulado (Salinas y de Benito, 2020), que es entendido desde la perspectiva del estudiante, quien asume el control de su propio aprendizaje a partir de las variables metacognitivas, motivacionales y conductuales (Zimmerman, 1998; 2002). El aprendizaje autorregulado es potenciado mediante itinerarios de aprendizaje, descritos como el conjunto de actividades que llevan a la consecución de los objetivos (Janssen et al., 2011). Con la flexibilidad del aprendizaje el alumnado tiene un papel activo, seleccionando sus propias metas, planificando, eligiendo las estrategias y evaluando su actuación ante el aprendizaje (McCombs, 1989), es decir, llevando a cabo aquellas estrategias metacognitivas que permiten autorregular el aprendizaje. Esta concepción del proceso de aprendizaje se ve acentuada en entornos digitales que requieren de aprendices con autonomía (Agudelo y Salinas, 2015; Marín et al., 2020; Salinas y Agudelo, 2016). Cabe destacar que los itinerarios requieren un alto grado de diseño instruccional, como es el caso de las secuencias didácticas (SD) que Díaz-Barriga (2013) estructuró en tres tareas principales, de inicio, desarrollo y conclusión, lo que permite secuenciar el proceso de aprendizaje desde el planteamiento final, las tareas de desarrollo y el cierre.

En esta experiencia se propone un diseño de itinerarios flexibles para el aprendizaje en entornos virtuales y el trabajo de investigación relacionado pretende explorar la experiencia para conocer los itinerarios generados y las percepciones del alumnado en cuanto al desarrollo de habilidades para el aprendizaje autorregulado.

\section{Descripción de la experiencia}

En los cursos 19-20 y 20-21, la asignatura de Desarrol/o Profesional Docente en relación a las TIC del Máster Interuniversitario de Tecnología Educativa, que se imparte en modalidad virtual, se diseña a partir de una propuesta de itinerarios flexibles para la personalización del aprendizaje. En este caso, la actividad del alumnado se organiza en torno a tres SD de las cuales dos son optativas, y la tercera, que es común para todos los itinerarios, recoge la reflexión del alumnado desde el inicio, en la tarea $\mathrm{O}$, en la cual se requiere leer la descripción de las SD y hacer las elecciones en función de intereses y motivaciones. Brevemente, se pueden describir las secuencias didácticas así:

- SD1. Texto para la lectura individual y participación en el foro. Opción A: texto reflexivo sobre los roles docentes en una sociedad digital. Opción B: modelo de competencia digital docente. Ambos textos ofrecen visiones que permiten enfoques para el desarrollo profesional docente diferentes y complementarios. El planteamiento de la secuencia es similar, con estrategias de iniciación a la lectura, estrategias de monitorización para la comprensión del texto y trabajo de conclusión final sobre el aprendizaje realizado. Esta reflexión final se realiza en un foro, lo cual permite aprender de la experiencia de los pares. Es un criterio de calidad en la evaluación final que incluya referencias a las reflexiones realizadas por iguales. 
- SD 2. Trabajos de grupo para el diseño de un proyecto de formación. Opción A: proyecto de formación de un centro educativo. Opción B: diseño de una formación para la participación en proyectos internacionales. Opción C: entrevistas a docentes sobre la adaptación de la enseñanza a la virtualidad derivada de la crisis sanitaria por el COVID-19. En este caso, la secuencia se inicia con una introducción sobre el tema, el apoyo docente durante la fase de diseño del proyecto de formación y la reflexión final sobre el aprendizaje realizado en un cuestionario final individual.

- SD 3. Opción única. Incluye la tarea O de elección de SD y configuración del itinerario y tiene el objetivo de promover la reflexión sobre todo el proceso de aprendizaje experimentado. Es el único caso, en que la iniciación se establece en un momento diferente. El desarrollo implica la reflexión sobre el aprendizaje realizado desde la tarea inicial y la conclusión implica la respuesta de los cuestionarios que acompañan el proceso de reflexión. Como en el caso de la SD1, la reflexión se realiza en un foro, cuya evaluación incluye la referencia a los textos de pares, lo cual permite aprender de la experiencia vivida por el resto de miembros del grupo.

\section{Estudio}

\section{Preguntas de investigación}

Las preguntas que guían este estudio son las siguientes: ¿cómo configura el alumnado su itinerario?, y ¿̇cómo percibe el alumnado las SD de sus itinerarios en relación al aprendizaje autorregulado?

\section{Metodología}

Se plantea una metodología descriptiva con un enfoque mixto que combina técnicas de investigación cualitativas y cuantitativas. Mediante un cuestionario de escala Likert se recopilan datos de cada SD percibidos por el alumnado. Esta información se completa con la observación de las secuencias escogidas entre las cinco posibles para conocer los itinerarios trazados.

\section{Descripción del contexto y de los participantes}

En la experiencia participan un total de 80 alumnos y alumnas, de los cuales 71 (88\%) responden al cuestionario al finalizar cada SD (que se describe en el apartado siguiente).

\section{Instrumentos}

Para la descripción de los itinerarios se utiliza una hoja de registro de las actividades cursadas por cada SD. Para la recogida de datos sobre las percepciones del alumnado en cuanto a las posibilidades de las SD para el aprendizaje autorregulado, se utiliza un cuestionario de escala Likert con tres partes, de las cuales dos se basan en el trabajo de Salinas y de Benito (2020) y se refieren a cuestiones comunes a todas las SD; y la otra se realiza ad hoc para poder recoger las singularidades de la propuesta en concreto. Los ítems que se exploran en este trabajo son los comunes a todas las SD: 
1. El planteamiento de la secuencia me ha parecido motivador

2. He planificado por escrito las tareas que tenía que realizar

3. He seguido la planificación que me había hecho

4. He valorado mi trabajo antes de darlo por acabado

5. Me he sentido satisfecho por el trabajo que he realizado

6. Soy consciente de lo que ha aportado a mi conocimiento esta secuencia.

Como se puede observar, estos seis ítems obedecen a las estrategias metacognitivas correspondientes a las tres fases del aprendizaje autorregulado según la descripción de Zimmerman (2002) y Zimmerman y Moylan (2009): ítems 1 y 2 sobre la fase de planificación, ítems 3 y 4 sobre la fase de ejecución del aprendizaje e ítems, 5 y 6 sobre la fase de autorreflexión.

\section{Resultados}

En cuanto a la primera pregunta de investigación (¿cómo configura el alumnado su itinerario?), en la tabla 1 se presentan los resultados en relación a las opciones elegidas por el alumnado, y se puede observar como en el caso de la SD1, la opción B es la que se selecciona mayoritariamente (65\%) y en el caso de la SD2, la opción C es la más elegida (58\%).

\begin{tabular}{|l|l|l|l|}
\hline & OPCIÓN A & OPCIÓN B & OPCIÓN C \\
\hline SD1 & $25(35 \%)$ & $46(65 \%)$ & - \\
\hline SD2 & $27(38 \%)$ & $2(3 \%)$ & $41(58 \%)$ \\
\hline
\end{tabular}

Tabla 1. Elección de opciones en las dos SD

A partir de esta selección realizada por el alumnado, se puede obtener un retrato de los itinerarios que se configuran. En la siguiente tabla se muestran los porcentajes de alumnado según los seis posibles itinerarios resultantes. Destaca sobre todo, el itinerario 6 (resultado de la combinación de la SD1- Opción B con la SD2- Opción C) con casi una mitad del alumnado participante, seguido de los itinerarios 1 (fruto de la combinación de la SD1-Opción A con la SD2-Opción A) y 4 (SD1-Opción A con SD 2-Opción A). Cabe resaltar también la baja representatividad que tienen los itinerarios que se conforman con la SD2- Opción B, puesto que no se experimenta en ningún caso el itinerario 5 y el 2 apenas cuenta con un 3\% de participantes.

\begin{tabular}{|l|l|l|l|}
\hline & SD 2-OPCIÓN A & SD 2- OPCIÓN B & SD 2OPCIÓN C \\
\hline SD1- OPCIÓN A & ITINERARIO 1 & $\begin{array}{l}\text { ITINERARIO 2 } \\
\text { 2(3 \%) }\end{array}$ & $\begin{array}{l}\text { ITINERARIO 3 } \\
8(11 \%)\end{array}$ \\
\hline SD1- OPCIÓN B & $\begin{array}{l}\text { ITINER }) \\
\text { 13(18\%) }\end{array}$ & $\begin{array}{l}\text { ITINERARIO 5 } 4 \\
\text { O (O\%) }\end{array}$ & $\begin{array}{l}\text { ITINERARIO 6 } \\
34(48 \%)\end{array}$ \\
\hline
\end{tabular}

Tabla 2. Itinerarios resultantes. 
En los siguiente diagramas se visualizan los itinerarios resultantes desde la SD1:

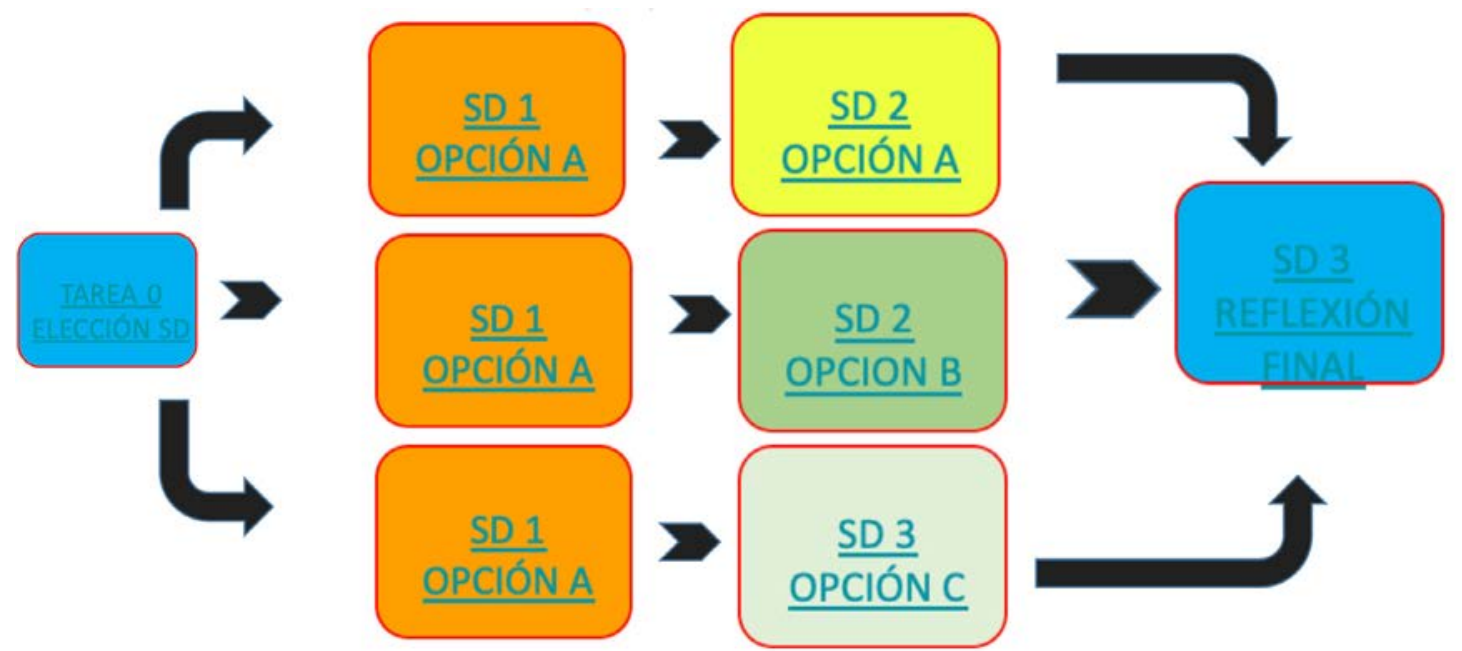

Figura 1. Rutas de itinerarios resultantes de la SD1-Opción A

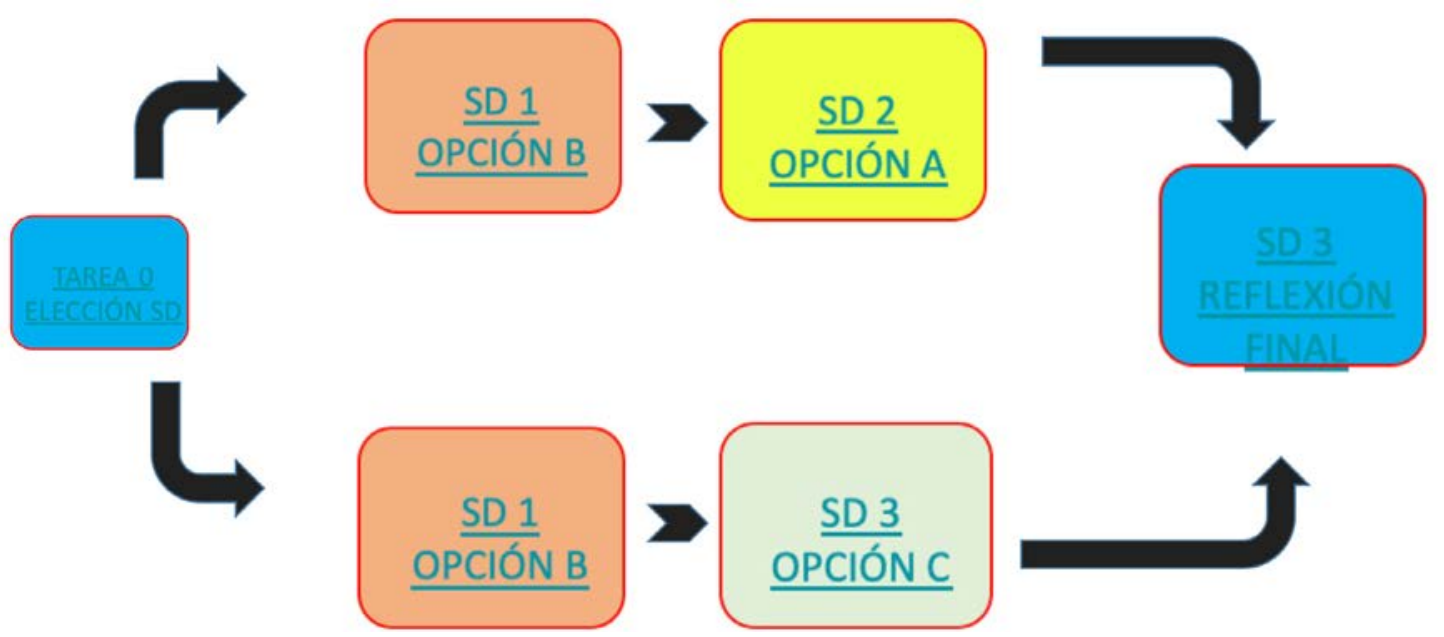

Figura 2. Rutas de itinerarios resultantes de la SD1- Opción B

En cuanto a la evaluación de los itinerarios, y respondiendo a la segunda pregunta de investigación (¿cómo percibe el alumnado las SD de sus itinerarios en relación al aprendizaje autorregulado?), se puede observar un patrón generalizado en la percepción en cada SD experimentada por el alumnado participante que consiste en entender positivamente las posibilidades para las diferentes fases del aprendizaje autorregulado.

En el caso de la SD 1(Tabla 3), tanto en las opciones A y B, se observa como una mayoría de respuestas se ubican en el nivel 5 de la escala Likert lo que significa un acuerdo total en cuanto a las dos opciones para generar motivación, estrategias de planificación y seguimiento de la tarea así como de evaluación final. En este caso, se contabilizan algunas respuestas en niveles bajos de la escala lo que significa cierta presencia de dificultades. 


\begin{tabular}{|l|l|l|l|l|l|l|l|l|l|l|}
\hline \multicolumn{7}{|l}{$\begin{array}{l}\text { SD1-OPCIÓN A: CURSO 19-20 } \\
\text { \& CURSO 20-21 (N=21) } \\
\text { \& CURSO 20-21 (N=50) }\end{array}$} \\
\hline 1 & 2 & 3 & 4 & 5 & 1 & 2 & 3 & 4 & 5 \\
\hline 1 & $0(0 \%)$ & $0(0 \%)$ & $0(0 \%)$ & $\begin{array}{l}13 \\
(61.9 \%)\end{array}$ & $8(38.1 \%)$ & $0(0 \%)$ & $0(0 \%)$ & $10(20 \%)$ & $\begin{array}{l}20 \\
(40 \%)\end{array}$ & $\begin{array}{l}20 \\
(40 \%)\end{array}$ \\
\hline 2 & $0(0 \%)$ & $0(0 \%)$ & $1(4.8 \%)$ & $\begin{array}{l}3 \\
(14.3 \%)\end{array}$ & $17(81 \%)$ & $1(2 \%)$ & $1(2 \%)$ & $6(12 \%)$ & $10(20 \%)$ & $\begin{array}{l}32 \\
(64 \%)\end{array}$ \\
\hline 3 & $0(0 \%)$ & $0(0 \%)$ & $1(4.8 \%)$ & $8(38.1 \%)$ & $\begin{array}{l}12 \\
(57.1 \%)\end{array}$ & $1(2 \%)$ & $2(4 \%)$ & $2(4 \%)$ & $15(30 \%)$ & $\begin{array}{l}30 \\
(60 \%)\end{array}$ \\
\hline 4 & $1(4.8 \%)$ & $0(0 \%)$ & $1(4.8 \%)$ & $4(19 \%)$ & $\begin{array}{l}15 \\
(71.4 \%)\end{array}$ & $0(0 \%)$ & $0(0 \%)$ & $2(4 \%)$ & $8(16 \%)$ & $\begin{array}{l}40 \\
(80 \%)\end{array}$ \\
\hline 5 & $0(0 \%)$ & $0(0 \%)$ & $0(0 \%)$ & $\begin{array}{l}11 \\
(52.4 \%)\end{array}$ & $\begin{array}{l}10 \\
(47.6 \%)\end{array}$ & $0(0 \%)$ & $0(0 \%)$ & $1(2 \%)$ & $17(34 \%)$ & $\begin{array}{l}32 \\
(64 \%)\end{array}$ \\
\hline 6 & $0(0 \%)$ & $0(0 \%)$ & $0(0 \%)$ & $8(38.1 \%)$ & $\begin{array}{l}13 \\
(61.9 \%)\end{array}$ & $0(0 \%)$ & $0(0 \%)$ & $0(0 \%)$ & $21(42 \%)$ & $\begin{array}{l}29 \\
(58 \%)\end{array}$ \\
\hline
\end{tabular}

Tabla 3. Percepción del alumnado sobre las SD1, Opciones A y B, para el aprendizaje autorregulado

Igual que en el caso de la SD 1, en las tres opciones de la SD2 (Tabla 4) se observa que la práctica totalidad de las respuestas se localizan en los niveles altos de la escala. Destaca que en este caso, se observa una menor presencia de respuestas negativas que en las dos opciones de la SD1. Dada su poca representatividad y el patrón similar, se deja fuera de la tabla la opción B, que tiene una mínima representatividad (como se observa en la Tabla 1), y cuyo análisis muestra el mismo patrón de aceptación que en el resto de SD analizadas (todas los ítems son respondidos con el nivel de total acuerdo, excepto los ítems 2 y 3 que obtienen una respuesta en el nivel 4 y otra en el 5).

\begin{tabular}{|c|c|c|c|c|c|c|c|c|c|c|}
\hline & \multicolumn{5}{|c|}{$\begin{array}{l}\text { SD2-OPCIÓN A: CURSO 19-20 } \\
\text { \& CURSO 20-21 (N=21) }\end{array}$} & \multicolumn{5}{|c|}{$\begin{array}{l}\text { SD2-OPCIÓN C: CURSO 19-20 } \\
\text { \& CURSO 20-21 (N=39) }\end{array}$} \\
\hline & 1 & 2 & 3 & 4 & 5 & 1 & 2 & 3 & 4 & 5 \\
\hline 1 & O (O\%) & O (O\%) & O (O\%) & $\begin{array}{l}7 \\
(33.3 \%)\end{array}$ & $\begin{array}{l}14 \\
(66.7 \%)\end{array}$ & $\mathrm{O}(0 \%)$ & $\mathrm{O}(0 \%)$ & $1(2.6 \%)$ & $\begin{array}{l}17 \\
(43.6 \%)\end{array}$ & $\begin{array}{l}21 \\
(53.8 \%)\end{array}$ \\
\hline 2 & $\mathrm{O}(0 \%)$ & $\mathrm{O}(0 \%)$ & $1(4.8 \%)$ & $\begin{array}{l}6 \\
(28.6 \%)\end{array}$ & $\begin{array}{l}14 \\
(66.7 \%)\end{array}$ & $\mathrm{O}(0 \%)$ & $\mathrm{O}(0 \%)$ & $2(5.1 \%)$ & $\begin{array}{l}14 \\
(35.9 \%)\end{array}$ & $\begin{array}{l}23 \\
(59 \%)\end{array}$ \\
\hline 3 & O (O\%) & O (O\%) & O (O\%) & $\begin{array}{l}7 \\
(33.3 \%)\end{array}$ & $\begin{array}{l}14 \\
(66.7 \%)\end{array}$ & O (O\%) & $\mathrm{O}(0 \%)$ & $1(2.6 \%)$ & $16(41 \%)$ & $\begin{array}{l}22 \\
(56.4 \%)\end{array}$ \\
\hline 4 & $\mathrm{O}(0 \%)$ & $\mathrm{O}(0 \%)$ & $\mathrm{O}(0 \%)$ & $\begin{array}{l}5 \\
(23.8 \%)\end{array}$ & $\begin{array}{l}16 \\
(76.2 \%)\end{array}$ & $\mathrm{O}(0 \%)$ & $\mathrm{O}(0 \%)$ & $2(5.1 \%)$ & $\begin{array}{l}28 \\
(20.5 \%)\end{array}$ & $\begin{array}{l}29 \\
(74.4 \%)\end{array}$ \\
\hline 5 & $\mathrm{O}(0 \%)$ & $\mathrm{O}(0 \%)$ & $\mathrm{O}(0 \%)$ & $\begin{array}{l}6 \\
(28.6 \%)\end{array}$ & $\begin{array}{l}15 \\
(71.4 \%)\end{array}$ & $\mathrm{O}(0 \%)$ & $\mathrm{O}(0 \%)$ & O (O\%) & $\begin{array}{l}13 \\
(33.3 \%)\end{array}$ & $\begin{array}{l}26 \\
(66.7 \%)\end{array}$ \\
\hline 6 & $\mathrm{O}(\mathrm{O} \%)$ & $\mathrm{O}(0 \%)$ & $\mathrm{O}(\mathrm{O} \%)$ & $\begin{array}{l}7 \\
(33.3 \%)\end{array}$ & $\begin{array}{l}14 \\
(66.7 \%)\end{array}$ & $0(0 \%)$ & $\mathrm{O}(0 \%)$ & $\mathrm{O}(\mathrm{O} \%)$ & $\begin{array}{l}15 \\
(38.5 \%)\end{array}$ & $\begin{array}{l}24 \\
(61.5 \%)\end{array}$ \\
\hline
\end{tabular}

Tabla 4. Percepción del alumnado sobre las SD2, Opciones A y B, para el aprendizaje autorregulado 
En cuanto a la SD3, cuya evaluación recoge todo el proceso desde la actividad 0 , se observa de nuevo una mayoría de respuestas en niveles de acuerdo ( 4 y 5 de la escala Likert) aunque el nivel 3, que representa la opinión neutral (ni en acuerdo ni en desacuerdo) obtiene un mayor porcentaje que en las SD 1 y 2.

\section{SD 3. Opción Única. CURSO 19-20 \& CURSO 20-21 ( $\mathrm{N}=61)$}

\begin{tabular}{|l|l|l|l|l|l|}
\hline & 1 & 2 & 3 & 4 & 5 \\
\hline 1 & $\mathrm{O}(0 \%)$ & $\mathrm{O}(\mathrm{O} \%)$ & $4(6.6 \%)$ & $27(44.3 \%)$ & $30(49.2 \%)$ \\
\hline 2 & $\mathrm{O}(0 \%)$ & $1(1.6 \%)$ & $6(9.8 \%)$ & $19(31.1 \%)$ & $35(57.4 \%)$ \\
\hline 3 & $\mathrm{O}(0 \%)$ & $1(1.6 \%)$ & $6(9.8 \%)$ & $19(31.1 \%)$ & $35(57.4 \%)$ \\
\hline 4 & $\mathrm{O}(0 \%)$ & $\mathrm{O}(\mathrm{O} \%)$ & $2(3.3 \%)$ & $14(23 \%)$ & $45(73.8 \%)$ \\
\hline 5 & $\mathrm{O}(0 \%)$ & $\mathrm{O}(0 \%)$ & $\mathrm{O}(0 \%)$ & $21(34.4 \%)$ & $40(65.6 \%)$ \\
\hline 6 & $\mathrm{O}(0 \%)$ & $\mathrm{O}(0 \%)$ & $1(1.6 \%)$ & $17(27.9 \%)$ & $43(70.5 \%)$ \\
\hline
\end{tabular}

Tabla 5. Percepción del alumnado sobre la SD3

\section{Discusión y conclusiones}

En esta fase del trabajo, por una parte, se ha analizado la estructura final de los itinerarios resultantes de las elecciones del alumnado, y por otra parte, se han observado sus percepciones.

En general, se puede concluir que la exposición de los resultados obtenidos confirma el logro de los principios fundamentales en los que se basan los itinerarios flexibles como son la flexibilidad y el protagonismo del alumnado que puede decidir sobre su propio aprendizaje (Salinas y Agudelo, 2016).

El análisis de las elecciones del alumnado nos permite detectar algunas tendencias en los itinerarios resultantes. De los seis posibles itinerarios que se generan de la combinación de las cinco SD optativas, sólo uno no se materializa y otro con una muy baja frecuencia. Ambos casos son itinerarios que tienen en común la SD2-Opción $B$, que consiste en un trabajo cuyo foco es la formación del profesorado para los proyectos internacionales. Este bajo interés del alumnado coincide con el diagnóstico general que se hace en relación a los proyectos de movilidad virtual, que a pesar de su potencialidad para el aprendizaje aún tienen una presencia limitada en la Educación Superior (Tur y Buchem, 2021; OpenVM, 2018). El resto de los itinerarios se implementan en mayor o menor medida, aunque destacan aquellos que tienen en común la SD2- Opción C, que permite entrevistas con profesionales de diferentes niveles sobre la adaptación de su tarea docente a la virtualidad obligada por la pandemia del COVID-19.

Además, la construcción, desarrollo y reflexión de su propio itinerario permite que el aprendiz experimente procesos de autorregulación, puesto que desarrolla habilidades para una mayor conciencia sobre su aprendizaje. Las fases en las que se articulan las secuencias que componen el itinerario coinciden con las fases propuestas en el modelo cíclico de Zimmerman (2002) y Zimmerman y Moylan (2009). Teniendo en cuenta esta perspectiva, los estudiantes han podido seleccionar sus itinerarios y 
han podido planificar, monitorizar y reflexionar sobre su propio aprendizaje. El análisis a las respuestas a las preguntas de las escalas Likert permiten evidenciar que se han otenciado las diferentes habilidades para el aprendizaje autorregulado en las tres fases principales, en línea con Salinas y de Benito (2020).

Las limitaciones de este estudio sobre todo tienen que ver con la brevedad de la experiencia y la pequeña muestra participante. Sería recomendable que en nuevas iteraciones del diseño se ampliará la muestra en número y diversidad de áreas del conocimiento, de manera que se pueda observar matices en los procesos de autorregulación del alumnado. También sería muy interesante explorar estas habilidades según las modalidades en línea y presencial.

Agradecimientos. Esta investigación ha sido financiada con la subvención EDU201784223-R del Ministerio de Ciencia e Innovación, la Agencia Estatal de Investigación (AEI) y el Fondo Europeo de Desarrollo Regional (FEDER).

\section{Referencias}

Agudelo, O., y Salinas, J. (2015). Flexible Learning Itineraries Based on Conceptual Maps. Journal of New Approaches in Educational Research, 4(2), 70-76. http://dx. doi.org/10.7821/naer.2015.7.130

Buitrago, R, Salinas, J., y Boude, O (2021). Designing and Representing Learning Itineraries: A Systematic Review of the Literature. Interaction Design and Architecture(s) Journal - IxD\&A, 47, 94-122. https://bit.ly/3vsmOfx

Díaz Barriga, Á. (2013). Secuencias de aprendizaje. ¿Un problema del enfoque de competencias o un reencuentro con perspectivas didácticas?. Profesorado. Revista de Currículum y Formación de Profesorado, 17(3),11-33.https://bit.ly/3iwKxEh

Janssen, J., Berlanga, A. J., y Koper, R. (2011). Evaluation of the Learning Path Specification. Educational Technology \& Society, 14 (3), 218-230. https://bit.ly/3e9UTcs

Marín, V. I., de Benito, B., y Darder, A. (2020). Technology-Enhanced Learning for Student Agency in Higher Education: a Systematic Literature Review. Interaction Design and Architecture(s) Journal - IXD\&A, 45, 15-49. https://bit.ly/3fsVYhA

Mccombs, B. L. (1989). Self-regulated learning and academic achievement: a phenomenological view. Springer-verlag. https://doi.org/10.1007/978-1-4612-3618-4_3

Open Virtual Mobility (2018). Resumen del proyecto. https://www.openvirtualmobility.eu/es_ES/about/444-project-summary/

Salinas, J., y Agudelo O. (2016). Itinerarios Flexibles de Aprendizaje y Mapas Conceptuales: un Abanico de Posibilidades para todos los Niveles Educativos. En A. J. Cañas, P. Reiska, J. D. Novak (Eds). Innovating with Concept Mapping. Proc. Of the Seventh Int. Conference on Concept Mapping (Vol 2), Tallinn University 
Salinas, J., y De-Benito, B. (2020). Construction of personalized learning pathways through mixed methods. Comunicar: Revista Científica de Comunicación y Educación, 28(65). https://doi.org/10.3916/C65-2020-03

Tur, G., y Buchem, I. (2021). Editorial del número especial Movilidad virtual: abriendo las movilidades educativas. Edutec. Revista Electrónica De Tecnología Educativa, (75), 1-8. https://doi.org/10.21556/edutec.2021.75.1987

Zimmerman, B. J. (1989). A Social Cognitive View of Self-Regulated Academic Learning. Journal of Educational Psychology, 81(3), 329-339. https://doi.org/10.1037/00220663.81.3.329

Zimmerman, B. J. (2002). Becoming a self-regulated learner: an overview. Theory into practice, 41(2), 64-70. http://dx.doi.org/10.1207/s15430421tip4102_2

Zimmerman, B. J., y Moylan, A. R. (2009). Self-Regulation: Where Metacognition and Motivation Intersect. En D. J. Hacker, J. Dunlosky, Y A. C. Graesser (Eds.), Handbook of Metacognition in Education. Routledge. 


\section{La Competencia Digital Docente y el Estado de las Tecnologías Digitales en los Centros Escolares desde la Perspectiva de los Referentes Digitales en Cataluña (España)}

Domínguez Navarro, Estíbaliz

Universitat Rovira i Virgili

estibaliz.dominguez@estudiants.urv.cat

\section{Lores-Gómez, Beatriz}

Universidad CEU Cardenal Herrera

beatriz.lores@uchceu.es 


\title{
LA COMPETENCIA DIGITAL DOCENTE Y EL ESTADO DE LAS TECNOLOGÍAS DIGITALES EN LOS CENTROS ESCOLARES DESDE LA PERSPECTIVA DE LOS REFERENTES DIGITALES EN CATALUÑA (ESPAÑA)
}

\author{
Domínguez Navarro, Estíbaliz \\ Lores-Gómez, Beatriz
}

\section{Resumen}

El presente trabajo pretende abordar la situación de los coordinadores TAC (Tecnologías del Aprendizaje y el Conocimiento) de tres comarcas de Cataluña (España). Con esta investigación se pretende averiguar la visión que tienen sobre su trabajo como referentes digitales de los centros educativos. Asimismo, se analiza el impacto de la crisis provocada por la COVID-19 y si esta, ha modificado su perspectiva sobre la Competencia Digital Docente de los claustros, así como la situación de las instalaciones y recursos digitales disponibles en los centros escolares. Los resultados obtenidos muestran que la situación de las Tecnologías Digitales se ha modificado tras el confinamiento al igual que lo han hecho los tipos de incidencias TAC que han de resolver. Por otro lado, se observa un aumento en la implicación de los docentes y de las instituciones gubernamentales para aumentar la formación digital y ampliar los recursos disponibles para así, superar los nuevos retos que plantea este nuevo paradigma educativo.

\section{Palabras clave}

Coordinadores TAC, Referentes Digitales, Tecnologías Digitales, Formación Digital Docente, Competencia Digital Docente. 


\section{Introducción}

La presente investigación pretende abordar la situación en la que se encuentran los coordinadores TAC (Tecnologías del Aprendizaje y del Conocimiento, en adelante). Este término se emplea para designar a las personas que en los centros educativos coordinan todo lo relativo a las Tecnologías Digitales (TD) y a su integración en el ámbito educativo) de los centros escolares, en relación con los equipamientos, recursos y formación digital docente tras el confinamiento, en los colegios e institutos de las comarcas del Alt Penedès, Baix Penedès y Garraf (Cataluña - España).

Este trabajo, combina la metodología cuantitativa y la cualitativa. En su paradigma cuantitativo, la herramienta escogida ha sido el cuestionario y en su vertiente cualitativa se ha optado por la realización de dos entrevistas en profundidad.

Estudios previos analizan la importancia de los referentes digitales (coordinadores TAC) de los centros escolares poniendo en manifiesto sus funciones en los centros así como la importancia de su papel en los mismos (Hernández, Castro y Vega, 2011; Alonso-Ferreiro y Gewerc, 2018; Álvarez, 2017; Área, Santana y Sanabria, 2020).

Los objetivos planteados en esta investigación son los siguientes:

- Averiguar la situación de los coordinadores TAC de los centros educativos (públicos, concertados y privados) del Alt Penedès, Baix Penedès y Garraf, después de la crisis provocada por la COVID-19.

- Identificar las necesidades formativas que posee el profesorado de Educación Primaria y Secundaria (zona Penedès-Garraf), según el punto de vista de los coordinadores TAC y las referentes TAC de los Centros de Recursos Pedagógicos (CRP, en adelante).

\section{Método/Descripción de la experiencia}

\section{Descripción del contexto y de los participantes}

La presente investigación se ha desarrollado en los territorios del Alt Penedès, Baix Penedès y Garraf, que son tres comarcas limítrofes entre ellas. El Garraf y el Alt Penedès, forman parte de la provincia de Barcelona y a nivel educativo, pertenecen al Servicio Territorial de Catalunya Comarcas. El Baix Penedès por su parte, corresponde a la provincia de Tarragona y, por lo tanto, al Servicio Territorial de Tarragona

Los participantes en el estudio han sido los coordinadores y coordinadoras TAC (actualmente denominados "referentes digitales") de esas tres zonas. En el estudio, también han participado las referentes TAC de los CRP del Alt Penedès y del Baix Penedès.

Por su distribución geográfica, el Alt Penedès cuenta con numerosas escuelas pequeñas situadas en los pueblos colindantes a la capital de comarca (Vilafranca del Penedès). De las tres comarcas, es la que dispone de un número mayor de colegios. Dispone de 40 escuelas de educación infantil y primaria públicas, 11 institutos y 6 centros concertados donde realizan educación infantil, primaria y secundaria. 
El Garraf, se situaría en segunda posición en relación a la cantidad de centros escolares que hay en la comarca. Dispone de 27 centros de educación primaria públicos, 15 centros de educación secundaria, 6 centros concertados y 5 centros de titularidad privada.

El Baix Penedès también dispone de 27 centros educativos públicos de educación infantil y primaria, 9 centros de educación secundaria y 3 centros concertados.

Cabe destacar que, en cada uno de los centros, tiene que haber un docente encargado de la figura de coordinador/a TAC (actualmente denominado "Referente Digital").

\section{Instrumentos}

Los instrumentos que se han utilizado para la obtención de datos para obtener los resultados des esta investigación, ha sido la elaboración de un cuestionario online a los/ las referentes digitales de los centros de las tres zonas analizadas y la realización de dos entrevistas en profundad a las referentes TAC de los CRP del Alt y Baix Penedès.

\section{Procedimiento}

El procedimiento que se ha llevado a cabo en esta investigación ha sido el siguiente:

1. Realización del cuestionario teniendo en cuenta las áreas, dimensiones y subdimensiones de análisis:

\section{Tabla 1. Dimensiones y subdimensiones del cuestionario. Fuente propia.}

\begin{tabular}{|c|c|}
\hline & \\
\hline $\begin{array}{l}\text { Identificación de las principales } \\
\text { funciones que realiza el } \\
\text { coordinador TAC del centro } \\
\text { escolar. }\end{array}$ & $\begin{array}{l}\text { 1. Características que debe poseer el coordinador TAC para } \\
\text { realizar sus funciones. } \\
\text { 2. Situaciones y demandas de la escuela que configuran las } \\
\text { funciones principales del coordinador TAC } \\
\text { 3. Nivel de importancia de su papel como coordinador TAC en la } \\
\text { escuela }\end{array}$ \\
\hline $\begin{array}{l}\text { Percepción y valoración de la } \\
\text { formación digital que poseen } \\
\text { los docentes de sus centros } \\
\text { escolares }\end{array}$ & $\begin{array}{l}\text { 4. Importancia de la formación TAC en los docentes según su } \\
\text { percepción. } \\
\text { 5. Tipo de formación más valorada después del confinamiento. } \\
\text { 6. Nivel de formación digital de los docentes, según el criterio } \\
\text { del coordinador TAC de los centros educativos. } \\
\text { 7. Preocupación sobre la FDD en la situación actual provocada } \\
\text { por la COVID19 }\end{array}$ \\
\hline $\begin{array}{l}\text { Análisis de las incidencias } \\
\text { habituales que tiene que } \\
\text { afrontar el coordinar TAC de } \\
\text { los centros escolares. }\end{array}$ & $\begin{array}{l}\text { 8. Situaciones y demandas actuales de la escuela } \\
\text { 9. Percepción del tipo de incidencias según su carácter } \\
\text { metodológico o funcional } \\
\text { 10. Dificultades que se encuentra el coordinador TAC este curso } \\
\text { tras el confinamiento }\end{array}$ \\
\hline $\begin{array}{l}\text { Percepción y valoración de la } \\
\text { implicación del Departament } \\
\text { d'Educació y del estado de los } \\
\text { recursos TAC de los centros }\end{array}$ & $\begin{array}{l}\text { 11. Nivel de implicación del Departament tras el confinamiento. } \\
\text { 12. Estado actual de las TAC en los centros } \\
\text { 13. Situación de la conectividad } \\
\text { 14. Planteamiento de presupuesto TAC }\end{array}$ \\
\hline
\end{tabular}


2. Preparación de las entrevistas en profundidad, siguiendo las fases presentadas por Bisquerra (2004) y Lores-Gómez (2017) en relación a la planificación de las entrevistas en profundidad: fase 1 preparación, fase 2 desarrollo y fase 3 valoración y análisis de los datos.

3. Extracción y análisis de los resultados de los cuestionarios y entrevistas.

4. Realización de la discusión de los resultados.

5. Síntesis de las conclusiones obtenidas.

\section{Resultados}

Basándonos en los resultados obtenidos a partir de las entrevistas y los cuestionarios realizados a los referentes digitales, de los centros que participaron en la investigación, se pueden obtener los siguientes resultados:

Por lo que a datos demográficos se refiere, destacar que la mayoría de los referentes digitales de las zonas estudiadas, son hombres con una media de edad de 38 años los cuales un gran porcentaje trabaja en la comarca del Garraf (pese a que en el Alt Penedès hay más escuelas) en centros educativos públicos donde se imparte educación infantil y primaria.

\section{Análisis Dimensión 1: Funciones del coordinador TAC (o referente digital).}

Los perfiles y aptitudes más valorados que ha de poseer un coordinador/a TAC son los de mantener un buen contacto con el equipo directivo, capacidad para expandir el uso de las Tecnologías Digitales entre familia y escuela y tener capacidad para coordinar y dinamizar la comisión TAC. Por otro lado, con relación a las funciones principales que ejecutan como coordinadores TAC son: gestionar el material informático del centro, coordinar y dinamizar la comisión TAC, solucionar problemas informáticos, así como confeccionar el Plan TAC del centro y gestionar las incidencias informáticas a través de la plataforma disponible. De forma general, los encuestados afirman que su papel en el centro como coordinador/a TAC es importante valorando su función con una nota de 8 sobre 10. En relación al tipo de incidencias que tienen que solventar de forma más asidua en los centros son de carácter funcional centrándose en la resolución de problemas informáticos de hardware o software. Para finalizar con el análisis global de esta dimensión destacar que la mayoría de centros, tienen en activo proyectos TAC. Cabe destacar que, un porcentaje importante (un $30 \%$ ) no lleva a cabo ningún proyecto TAC en la actualidad.

\section{Análisis Dimensión 2: percepción y valoración de la formación digital que poseen los docentes en los centros.}

La mayoría de los encuestados, valoran de forma significativa la formación TAC y su importancia, dándole una puntuación de 9 sobre 10. Tras el confinamiento, los coordinadores TAC valoran tanto la necesidad de una formación metodológica como funcional en relación a las Tecnologías Digitales. Por lo que refiere al nivel medio de formación TAC que perciben de los docentes del centro, la puntuación media obtenida ha sido un 6 y afirman, que la formación digital docente de sus claustros, 
ha mejorado tras la crisis provocada por la COVID-19. Referente a formación en Tecnologías Digitales a nivel de centro durante el confinamiento o este curso escolar, el $66 \%$ de los centros han realizado alguna formación en relación a las TAC. Sigue habiendo un porcentaje elevado (un 30\%) que afirman que no se ha realizado ninguna formación durante este periodo de tiempo pese a que los encuestados creen que ha habido un aumento en la preocupación docente por obtener una mejor formación digital. Por último, la reacción docente general cuando se plantea un nuevo proyecto TAC en el centro, suele ser de desconfianza y con muchas dudas pero que, finalmente, todo el equipo se esfuerza para poner en marcha el proyecto.

\section{Análisis Dimensión 3: incidencias habituales de los referentes digitales.}

En esta dimensión, se quería conocer el tipo de incidencias han tenido que resolver y gestionar los coordinadores/as TAC este curso tras el confinamiento. El tipo de incidencia más seleccionado ha sido funcionales (haciendo referencia a problemas informáticos relacionados con el hardware y software) con un $66,7 \%$. El 33,3\% de los encuestados, afirman que han tenido que solventar incidencias de ambos tipos tanto funcionales como metodológicas.

\section{Análisis Dimensión 4: percepción y valoración de la implicación del Departament d'Educació de la Generalitat de Catalunya tras la crisis provocada por la COVID-19 y el estado actual de los equipamientos y recursos TAC de los centros escolares.}

La mayoría de los encuestados aprueban la situación de los equipos TAC del centro con nota superior a 5 (siendo una valoración de 7 la más votada y de 4 y 6 las menos escogidas). En relación a la conectividad, pese a que un pequeño porcentaje mayoritario aprueba la conectividad de los centros, el 30\% afirma tener problemas puntuales y un $26,7 \%$ dicen tener mala conectividad. No obstante, la mayoría de los encuestados respalda que la situación de su centro en relación a la TAC ha mejorado tras la crisis provocada por el coronavirus. Por otro lado, la mayoría de los coordinadores TAC apuntan que, las dificultades del coordinador TAC de este curso, tras el confinamiento, no son las mismas que años anteriores. También afirman que la mayoría de los centros disponen de un presupuesto anual en mejoras TAC planteado a raíz de la crisis provocada por la COVID-19. Para finalizar, la mayor parte de los encuestados, creen que el Departament ha mostrado más preocupación por la situación TAC de los centros a raíz del coronavirus.

\section{Discusión y conclusiones}

Es innegable que la situación de emergencia que hemos vivido este último año ha impulsado un cambio en la sociedad, en la manera de interactuar e incluso en la forma de aprender. Las Tecnologías Digitales han sido la respuesta para dar una solución a la crisis provocada por la COVID-19. Domingo y Marquès (2014) ya nos advertían que, pese a la integración de las Tecnologías Digitales en las aulas, el sector educativo era el que avanzaba más lentamente en los que a adquisición y desarrollo de modelos tecnológicos se refiere. Ya, en ese momento, ponían en manifiesto una realidad que nos ha tocado vivir e intentar solventar, cómo buenamente se ha podido, durante la pandemia y es que, la distancia entre sociedad y escuela, en lo que a tecnología se refiere, era más que evidente. 
El coronavirus ha puesto en jaque a toda la sociedad y ha promovido una serie de mejoras e implicaciones por parte del sistema educativo de la Generalitat de Cataluña. La Enseñanza Remota de Emergencia ha puesto de manifiesto y de forma trasparente las fortalezas y las debilidades del sistema educativo en el conjunto de todos y cada uno de sus componentes (Moreno y Gortázar, 2020) y es por eso, que la crisis de la COVID-19 ha sido un propulsor para la aceleración y las mejoras en relación a las Tecnologías Digitales tanto a nivel docente, como de centro y alumnos (los cuales no se incluían en planes anteriores). Cóndor (2020) a partir de su análisis sobre la ERDE, ya planteaba tres consideraciones básicas de gran importancia para poder superar situaciones como la que vivimos hace un año y es que es básico que, para que este modelo cumpla con cierta calidad educativa, se ha de tener en cuenta la implementación de recursos tecnológicos, la capacitación docente, en lo que a Tecnologías Digitales se refiere, y la adaptación de los alumnos.

En el contexto que se ha vivido durante esta pandemia, donde ha habido un forzoso distanciamiento social, no ha habido más opciones que la de adaptarse a una educación virtual para dar continuación a los procesos educativos. Esto, hace hincapié a que los profesionales de la educación hayan tenido que desarrollar y trabajar sus competencias digitales para el manejo de recursos que sean útiles en sus clases y sean de provecho para los estudiantes y es por ello, que el desarrollo y fortalecimiento de competencias digitales en los docentes, resulta imperativo (Martínez y Garcés, 2020). La situación vivida, ha puesto en manifiesto que este curso, los docentes, de forma general, muestren más preocupación por afianzar sus conocimientos y competencias digitales.

Los centros, de forma generalizada, también han buscado optimizar su situación a través de las "mentorías digitales" y/o implantando proyectos TAC que les ayuden a mejorar en su día a día. Una de las propuestas básicas aportadas por Rogero en su artículo "La ficción de educar a distancia" (2020) como medida estructural para mejorar la superación de este nuevo escenario, fue la de la necesidad de dotar a los centros de la infraestructura y material para que haya una adecuada docencia tanto a nivel presencial como a distancia. El Departament de la Generalitat, ha respondido a estas demandas y se ha acelerado la transformación de los centros en Cataluña. La mayoría de los coordinadores/as TAC de los centros, así como las referentes TAC de zona, así lo respaldan.

No obstante, pese a las nuevas mejoras propuestas por el Departament a través de las formaciones, dotaciones y transformaciones de las instalaciones de los centros, así como en la puesta en escena del nuevo "Pla d'Educació Digital de Catalunya", se requiere de tiempo para que se puedan integrar de forma satisfactoria todos estos nuevos cambios en los centros escolares.

Es indudable afirmar que, la figura del coordinador/a TAC en los centros, es un elemento clave para la integración de las Tecnologías Digitales en las escuelas y centros de educación secundaria. Su figura, es el pilar que sustenta el buen funcionamiento de las TAC y es fundamental que se le reconozca su valía dentro de los claustros. Tanto los equipos directivos como el Departament, tienen que escuchar las demandas de los mismos porque, sólo de esta forma, mejorará la situación de las Tecnologías Digitales en los centros educativos. Es importante mejorar su situación, ofreciendo horas para realizar de forma efectiva sus tareas como coordinador/a así como ofrecer, por parte del Departament, más soluciones a los problemas funcionales aumentando las 
intervenciones del preventivo en los centros, así como los problemas de conectividad tan evidentes con los que se encuentran muchos centros escolares. Mejorando estas cuestiones, se ayudaría a que el coordinador/a TAC puede trabajar en la implementación de metodologías y prácticas que ayuden a integrar las Tecnologías Digitales en las aulas, de manera más efectiva. El/la coordinador/a TAC (actualmente ya denominado "referente digital") tiene que ser la figura que, bajo el soporte del equipo directivo, ofrezca herramientas y recursos a todos los miembros de la comunidad educativa para promover las Tecnologías Digitales en los diversos escenarios que suceden en el día a día de los centros educativos.

Es incuestionable, que estamos ante un tiempo con un proceso de cambio de gran calado en relación a las Tecnologías Digitales y se hace más presente aún, la necesidad de escuchar a las demandas reales de los centros y docentes, de fomentar una buena base en competencia digital y de unas políticas educativas adecuadas a las demandas actuales. Es indiscutible que la pandemia provocada por la COVID-19 ha acelerado este proceso de cambio.

Como conclusiones se destaca que:

1. La percepción de los coordinadores TAC de las zonas del Alt y Baix Penedès y Garraf refieren que la Competencia Digital Docente ha mejorado significativamente este curso y que, la preocupación por la misma ha aumentado pese a que aún queda mucho por mejorar.

2. La Generalitat de Catalunya a través del Departament d'Educació ha dado respuesta a la situación provocada por la COVID-19 iniciando una transformación digital indiscriminada de los centros y dotando de más formación online y recursos, pese a que la dotación de material y de mejoras en las infraestructuras, aún no ha llegado a todos.

3. La demanda de formación docente, en relación con fortalecer la competencia digital, ha aumentado, sobre todo, en las solicitudes de "mentorías digitales" en los mismos centros educativos.

4. El paradigma actual ha modificado las necesidades de los centros y ha provocado una variación en las incidencias más comunes de los coordinadores/as TAC siendo estas de carácter más funcional.

5. Se manifiesta una necesidad de retomar el espacio de reunión de los diferentes coordinadores/as TAC (los seminarios de coordinadores TAC de cada zona) para tener un lugar donde compartir experiencias y renovar aprendizajes.

6. Los perfiles/aptitudes que debe poseer un coordinador/a TAC bajo la perspectiva de los mismos son, sobre todo: mantener un buen contacto con el equipo directivo, tener capacidad para gestionar y coordinar la comisión TAC y saber para expandir el uso de las Tecnologías Digitales entre familia y escuela.

7. Los coordinadores/as TAC necesitan más horas para su coordinación con la finalidad de mejorar la implantación de las Tecnologías Digitales en las aulas y de esta forma, dar una mejor respuesta a las demandas de su centro. 


\section{Referencias}

Alonso-Ferreiro, A., \& Gewerc, A. (2018). Alfabetización mediática en la escuela primaria. Estudio de caso en galicia. Revista Complutense de Educacion, 29(2). https:// doi.org/10.5209/RCED.52698

Álvarez Núñez, Q. (2017). La dimensión olvidada. El papel de los factores organizativos en la formación de los maestros de primaria según las percepciones de su profesorado. Profesorado: Revista de Curriculum y Formación Del Profesorado, 21(1), 164-181. https://doi.org/10.30827/profesorado.v21i1.10357

Area Moreira, M., Santana Bonilla, P. J., \& Sanabria Mesa, A. . (2020). La transformación digital de los centros escolares. Obstáculos y resistencias. The digital transformation of schools. Obstacles and resistances. Digital Education Review, 37, 15-31.

Bisquerra, R., \& Alzina, R. B. (2004). Metodología de la investigación educativa (Vol. 1). Editorial La Muralla.

Cóndor-Herrera, O. (2020). Educar en tiempos de COVID-19. CienciAmérica, 9(2), 31. https://doi.org/10.33210/ca.v9i2.281

Domingo, M., \& Marquès, P. (2014). Experimentación del uso didáctico de la pizarra digital interactiva (PDI) en el aula: plan formativo y resultados. Enseñanza \& Teaching, 31(1).

Hernández Rivero, V., Castro León, F., \& Vega Navarro, A. (2011). El coordinador TIC en la escuela: Análisis de su papel en procesos de innovación. Profesorado, Revista de Currículum y Formación Del Profesorado, 15(1).

Martínez-Garcés, J., \& Garcés-Fuenmayor, J. (2020). Competencias digitales docentes y el reto de la educación virtual derivado de la covid-19. Educación y Humanismo, 22(39), 1-16. https://doi.org/10.17081/eduhum.22.39.4114

Moreno, J. M., \& Gortazar, L. (2020). Schooling in confinement: Natural experiment and stress test. Profesorado, 24(2), 168-181. https://doi.org/10.30827/PROFESORADO.V24I2.15540

Lores-Gómez, B. (2017). Estudio descriptivo del uso de las TIC en Educación Primaria como respuesta a la realidad educativa y social en la provincia de Castellón [Tesis doctoral].

Rogero-García, J. (2020). La ficción de educar a distancia. Revista de Sociología de La Educación-RASE, 13(2), 174. https://doi.org/10.7203/rase.13.2.17126 


\section{Diferencias y Similitudes en la Competencia Digital del Alumnado que Inició el Grado en Educación Primaria Antes y Después de la Pandemia}

\section{López-de-Arana Prado, Elena} orcid.org/0000-0002-6962-5469 elena.lopezdearana@uam.es

\section{Rappoport Redondo, Soledad} orcid.org/0000-0002-4752-3453

soledad.rappoport@uam.es 


\title{
DIFERENCIAS Y SIMILITUDES EN LA COMPETENCIA DIGITAL DEL ALUMNADO QUE INICIÓ EL GRADO EN EDUCACIÓN PRIMARIA ANTES Y DESPUÉS DE LA PANDEMIA
}

\author{
López-de-Arana Prado, Elena \\ Rappoport Redondo, Soledad
}

\section{Resumen}

Debido a la pandemia, muchos contextos educativos debieron reformularse bajo modalidades virtuales. Se piensa que esta transformación en el proceso de enseñanza-aprendizaje ha podido favorecer el desarrollo de las competencias digitales esenciales en el alumnado. Este estudio pretende conocer si la situación generada por la pandemia ha supuesto algún cambio en la competencia digital del alumnado que inicia el Grado en Educación Primaria en la Universidad Autónoma de Madrid. Para ello, se ha comparado la percepción que el alumnado pre-pandemia (curso 2019-2020) y post-pandemia (2020-2021) tiene sobre sus conocimientos digitales; 85 estudiantes participaron en el curso 2019-2020 y 80 en el curso 2020-2021. Todos ellos han rellenado el formulario TIC\&SOS que consta de 53 preguntas. Los resultados evidencian diferencias sustanciales entre ambos cursos en lo referente: al tiempo que destinan a utilizar herramientas digitales, a cómo perciben su propia formación en el uso de las TIC, y a la cantidad de recursos conocidos. Sin embargo, a pesar de haber estado casi medio año en un escenario virtual de enseñanza-aprendizaje, los hallazgos indican que la competencia digital del alumnado no ha variado en las dimensiones clave. Por lo tanto, se puede concluir que la mera transición del formato presencial al virtual no favorece, per se, un desarrollo competencial digital mayor.

\section{Palabras clave}

TIC, competencia digital, Grado de Educación Primaria, COVID-19, pandemia. 


\section{Introducción}

La emergencia sanitaria mundial causada por el virus SARS-CoV-2 ha puesto a prueba la capacidad de reacción de todos los agentes implicados en el proceso educativo (alumnado, familias, profesores, equipos directivos, administraciones competentes...).

Los y las docentes están acostumbrados y formados para sumergirse en procesos de innovación que faciliten la adecuación de la enseñanza-aprendizaje a los cambios que acontecen en la sociedad de la información y la comunicación. Sin embargo, durante este último año y medio, los procesos de innovación han destacado por su magnitud y vertiginosidad. Con el fin de reducir los contagios, los centros educativos se cerraron, y, por tanto, los y las docentes vieron interrumpida su dinámica de un día para otro, teniendo que transformar las actividades que se llevaban a cabo en el aula en un formato presencial, a una modalidad virtual (Zubillaga y Gortazar, 2020).

En este inesperado escenario, las Tecnologías de la Información y la Comunicación (TIC) han sido el recurso más relevante para la transformación de las propuestas didácticas al nuevo contexto de enseñanza-aprendizaje virtual (García, et al. 2020). El proceso de digitalización vivido durante la pandemia en los procesos formativos ha supuesto un incremento de la conciencia sobre las enormes posibilidades de las TIC y sobre los beneficios que puede traer consigo la educación a distancia.

La digitalización de los procesos de enseñanza-aprendizaje, ha puesto en relieve la urgencia de atender a determinadas cuestiones ya conocidas. Entre estas cuestiones se subrayan: las desigualdades provocadas por la falta de dispositivos o por la falta de conexión para poder acceder a internet, y la necesidad de promover las habilidades digitales tanto del alumnado como del profesorado desde un marco amplio y competencial, tal como vienen proclamando desde hace más de 5 años, organismos internacionales y nacionales, como la Comisión Europea (Punie y Redecker, 2017), el Instituto Nacional de Tecnologías Educativas y de Formación del Profesorado (INTEF, 2017) y la Organización para la Cooperación y el Desarrollo Económico (OECD, 2016), entre otros.

Con la intención de definir la competencia digital se elaboró el marco europeo DigComp. Desde dicho marco, la competencia digital se define en a través de veintiuna competencias organizadas en cinco áreas competenciales (ver Tabla 1): información y alfabetización digital, comunicación y colaboración, creación de contenido digital, seguridad, y resolución de problemas. 


\begin{tabular}{|c|c|}
\hline Área & Competencia \\
\hline \multirow[t]{3}{*}{ 1. Información y alfabetización digital } & $\begin{array}{l}\text { 1.1 Navegar, buscar y filtrar datos, información y } \\
\text { contenido digital }\end{array}$ \\
\hline & 1.2 Evaluar datos, información y contenido digital \\
\hline & 1.3 Gestionar datos, información y contenido digital \\
\hline \multirow[t]{6}{*}{ 2. Comunicación y colaboración } & 2.1 Interactuar a través de tecnologías digitales \\
\hline & 2.2 Compartir a través de tecnologías digitales \\
\hline & $\begin{array}{l}2.3 \text { Participar en la ciudadanía a través de tecnologías } \\
\text { digitales }\end{array}$ \\
\hline & 2.4 Colaborar a través de tecnologías digitales \\
\hline & 2.5 Netiqueta \\
\hline & 2.6 Gestionar la identidad digital \\
\hline \multirow[t]{4}{*}{ 3. Creación de contenido digital } & 3.1 Desarrollar de contenido digital \\
\hline & 3.2 Integrar y reelaborar contenido digital \\
\hline & 3.3 Derechos de autor y licencias de propiedad intelectual \\
\hline & 3.4 Programación \\
\hline \multirow[t]{4}{*}{ 4. Seguridad } & 4.1 Proteger los dispositivos \\
\hline & 4.2 Proteger los datos personales y la privacidad \\
\hline & 4.3 Proteger la salud y el bienestar \\
\hline & 4.4 Proteger el medio ambiente \\
\hline \multirow[t]{4}{*}{ 5. Resolución de problemas } & 5.1 Resolver problemas técnicos \\
\hline & 5.2 Identificar necesidades y respuestas tecnológicas \\
\hline & 5.3 Usar de manera creativa la tecnología digital \\
\hline & 5.4 Identificar las brechas de competencia digital \\
\hline
\end{tabular}

\section{Tabla 1. Áreas y competencias del marco europeo DigComp.}

Fuente: Carretero et al., 2017.

Algunos autores han previsto que la situación pandémica provocada por la COVID-19, al exigir una docencia virtual remota, ha podido favorecer el desarrollo de las competencias digitales esenciales (Murillo y Duk, 2020). Desde otros contextos, opinan que no resulta desatinado suponer que, sin dicho proceso de digitalización, las deficiencias en cuanto a la adquisición de contenidos curriculares hubiesen sido mucho mayores (Fundación Telefónica, 2021). Sin embargo, estas previsiones están siendo debatidas a la luz de los datos que emergen de los nuevos estudios.

Con el fin de comprobar la veracidad de esas expectativas, este estudio pretende conocer si la situación generada por la pandemia COVID-19 ha tenido repercusión en la competencia digital del alumnado que inicia el Grado de Educación Primaria de la Universidad Autónoma de Madrid. 


\section{Método/Descripción de la experiencia}

Se ha llevado a cabo un estudio descriptivo para comparar el nivel competencial digital con el que el alumnado "pre-pandemia" y "post-pandemia" inicia el Grado de Educación Primaria en la Universidad Autónoma de Madrid (UAM).

\section{Descripción del contexto}

La asignatura "TIC para la sociedad digital" de la UAM se ubica en el primer año del Grado en Maestro/a en Educación Primaria y tiene como objetivo hacer al alumnado competente digitalmente para que en un futuro puedan ser docentes integrales en un mundo digital.

Más concretamente, la asignatura tiene los siguientes objetivos de aprendizaje:

- Ser capaz de gestionar entornos enriquecidos para la enseñanza y el aprendizaje.

- Dominar las cinco dimensiones de la competencia digital: búsqueda de información, gestión de equipos, expresión, comunicación, ética.

\section{Descripción de los participantes}

En este estudio han participado un total 165 estudiantes. 85 cursaron la asignatura durante el curso 2019-2020 y 80 durante el curso 2020-2021. Sus edades están comprendidas entre 18 y 38 años (ver Gráfico 1). Por último, cabe destacar que, casi el $70 \%$ del total de las personas participantes son mujeres.

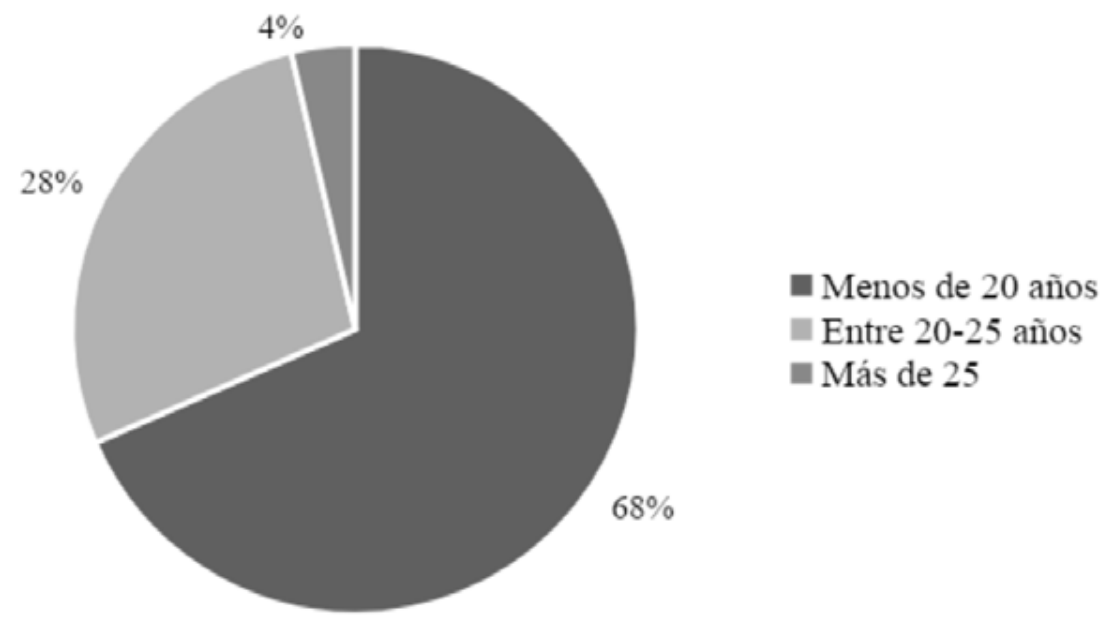

Gráfico 1. Edad de las personas participantes

\section{Instrumentos}

Se ha utilizado el cuestionario denominado TIC\&SOS (López-de-Arana \& Rappoport, 2021). El mismo se confeccionó a partir de 3 dimensiones y 24 categorías (ver Tabla 2). 
El cuestionario se ha pasado a través de Google Forms compuesto por un total de 53 preguntas, organizadas en 4 apartados diferentes. El primer apartado consta de 11 preguntas dirigidas a recabar información personal relacionada con las TIC. El segundo apartado está constituido por 16 preguntas orientadas a recoger información sobre las creencias que el alumnado tiene sobre las TIC. El tercer apartado trata de recoger el conocimiento que el alumnado tiene sobre las TIC y el uso que hacen de ellas, a través de 24 preguntas. Por último, el formulario tiene 2 preguntas para solicitar el consentimiento del tratamiento de los datos obtenidos.

\begin{tabular}{|c|c|}
\hline Dimensiones & Categorias \\
\hline 1. Información general & $\begin{array}{l}\text { 1.1. Cantidad de dispositivos con conexión de uso personal. } \\
\text { 1.2. Acceso a internet. } \\
\text { 1.3. Horas de uso de las TIC. } \\
\text { 1.4. Tipos de uso (ocio, formación y comunicación). } \\
\text { 1.5. Formación recibida vinculada al uso de las TIC. } \\
\text { 1.6. Años en el uso de las TIC. } \\
\text { 1.7. Expectativa sobre las TIC para el trabajo docente. }\end{array}$ \\
\hline $\begin{array}{l}\text { 2. Creencias sobre las } \\
\text { TIC }\end{array}$ & $\begin{array}{l}\text { 2.1. Relación entre nivel cultural, educativo, económico y uso de las TIC. } \\
\text { 2.2. Relación entre TIC como contenido curricular y brecha digital. } \\
\text { 2.3. TIC y trabajo colaborativo. } \\
\text { 2.4. TIC para la resolución de problemas. } \\
\text { 2.5. TIC y práctica docente. } \\
\text { 2.6. Uso de las TIC de los niños y las niñas. } \\
\text { 2.7. Necesidades de formación digital en la niños y niñas. } \\
\text { 2.8. TIC y atención a la diversidad. } \\
\text { 2.9. El riesgo del mundo digital en la infancia. } \\
\text { 2.10. Uso responsable de las TIC. }\end{array}$ \\
\hline $\begin{array}{l}\text { 3. Conocimiento y uso } \\
\text { de las TIC }\end{array}$ & $\begin{array}{l}\text { 3.1. Manejo de distintos Sistemas Operativos. } \\
\text { 3.2. Uso de herramientas ofimáticas para el tratamiento de la información. } \\
\text { 3.3. Herramientas digitales de comunicación. } \\
\text { 3.4. Aplicaciones para compartir de presentaciones visuales o videos. } \\
\text { 3.5. Seguridad e internet. } \\
\text { 3.6. Bases de datos para la búsqueda de información. } \\
\text { 3.7. Gestión de la información a través de lectores, recopiladores de } \\
\text { contenido y los bookmarks. } \\
\text { 3.8. Creación de contenidos digitales (imágenes, vídeos, audios, } \\
\text { presentaciones...). } \\
\text { 3.9. Herramientas para el trabajo colaborativo. } \\
\text { 3.10. Robótica. } \\
\text { 3.11. Ética con el uso de la información digital y de las TIC (respeto por los } \\
\text { derechos de autor, la propiedad intelectual y la documentación adecuada } \\
\text { de las fuentes). } \\
\text { 3.12. Participación en mundos virtuales. } \\
\text { 3.13. Curación de contenido digital. } \\
\text { 3.14. Redes sociales } \\
\text { 3.15. Herramientas virtuales para uso docente. } \\
\text { 3.16. Modelos pedagógicos innovadores para la inclusión de las TIC en } \\
\text { contextos educativos. }\end{array}$ \\
\hline
\end{tabular}

Tabla 2. Dimensiones y categorías del cuestionario TIC\&SOS

\section{Procedimiento}

El estudio se estructuró en cuatro fases. En la primera fase se diseñó el cuestionario y se volcaron las preguntas en Google Forms. Para el diseño del cuestionario se partió de cuestionarios previamente elaborados y publicados o compartidos con las autoras. 
La aplicación del cuestionario durante los cursos 2019-2020 y 2020-2021 del Grado de Educación Primaria constituyó la segunda fase. Este cuestionario, se pasa al alumnado de la asignatura "TIC para la sociedad digital" al inicio del semestre, antes de haber visto o ahondado en los contenidos que se van tratando. Así no se contaminan los datos, y podemos construir una panorámica de la competencia digital de la que parten.

En la tercera etapa, se realizaron estadísticos descriptivos y se analizaron los datos obtenidos poniéndolos en común. Para ello, se ha utilizado el SPSS. Algunos de los ítems que cuestionaban sobre el mismo tipo de conocimiento se han agrupado. Se calcularon las medias y se sacaron los porcentajes para poder ser comparados los resultados de los dos cursos encuestados.

Por último, en la cuarta fase, teniendo en cuento el objetivo que se pretendía con el estudio y los resultados hallados, se elaboraron las conclusiones. Para la elaboración de las conclusiones se han revisado trabajos similares con la intención de contrastar los datos y abrir debates futuros.

\section{Resultados}

Los resultados se organizan en dos apartados principales. El primero recoge las diferencias halladas entre el alumnado pre-pandemia y post-pandemia, y el segundo recoge las similitudes. Este último apartado se ha organizado en cuatro subapartados titulados de la siguiente manera: Percepciones que el alumnado tiene sobre las TIC en el aula, Conocimiento que el alumnado tiene de las TIC, Desconocimiento que el alumnado tiene de las TIC, y, Necesidades formativas en TIC que el alumnado percibe tener.

\section{Diferencias entre el alumnado pre-pandemia y post-pandemia}

Los resultados evidencian que el tiempo en el que los y las jóvenes utilizan las TIC se ha incrementado considerablemente en el curso afectado por la pandemia, respecto al curso anterior. En cuanto a la formación también se ha encontrado que el alumnado más afectado por la pandemia ha tenido que formarse de forma autónoma, reconociéndose como autodidacta en la materia, percepción que no tenía tanta fuerza en el curso anterior.

\begin{tabular}{|l|l|l|}
\hline Utilización de las TIC: Tiempo de conexión diaria. & $\mathbf{2 0 1 9 - 2 0 2 0}$ & $\mathbf{2 0 2 0 - 2 0 2 1}$ \\
\hline Formación sobre las TIC: Se consideran autodidactas. & 4 horas & 7 horas \\
\hline
\end{tabular}

Tabla 3. Diferencias entre los dos cursos.

\section{Similitudes entre el alumnado pre-pandemia y post-pandemia}

\section{Percepciones que el alumnado tiene sobre las TIC en el aula}

Poniendo el foco en las percepciones vinculadas a las TIC en el aula, en ambos cursos, la gran mayoría del alumnado considera que las herramientas digitales les ayudarán a desempeñar mejor su labor docente. Identifican varios beneficios vinculados a la utilización de las TIC en el aula. 
Por un lado, ambos cursos se perciben conscientes de las posibilidades que les ofrecen las TIC para generar y compartir información, así como capaces de tratar imágenes o vídeos. Por otro lado, al igual que el curso anterior a la pandemia, el alumnado del curso 2020-2021 reconoce en las TIC la posibilidad de trabajar de forma colaborativa y se percibe capaz de identificar recursos para ello.

En relación con las desigualdades sociales y el papel que las TIC pueden jugar como herramienta de compensación; el alumnado, sigue considerando que las TICs ofrecen recursos para responder a la diversidad. También, sigue siendo conscientes de la brecha digital y de las problemáticas vinculadas a éstas.

\begin{tabular}{|l|l|l|}
\hline Las TIC como claves para: & $\mathbf{2 0 1 9 - 2 0 2 0}$ & $\mathbf{2 0 2 0 - 2 0 2 1}$ \\
\hline su labor docente. & $83 \%$ & $86 \%$ \\
\hline generar y compartir información. & $90 \%$ & $93 \%$ \\
\hline trabajar de forma colaborativa. & $93 \%$ & $92 \%$ \\
\hline responder a la diversidad. & $87 \%$ & $85 \%$ \\
\hline paliar los efectos de la brecha digital. & $83 \%$ & $87 \%$ \\
\hline
\end{tabular}

Tabla 4. Similitudes entre los dos cursos sobre la percepción del papel de las TIC en la formación.

\section{Conocimiento que el alumnado tiene de las TIC}

Al igual que sus predecesores, el alumnado que ha cursado durante la pandemia se considera con conocimientos suficientes para establecer comunicaciones de forma síncrona y asíncrona, identificar recursos para colaborar, utilizar las redes sociales y los códigos QR. Por lo tanto, se puede decir que el alumnado ha mostrado coincidencia en las potencialidades o conocimientos percibidos en ambos cursos, el pre-pandémico y el post-pandémico.

\begin{tabular}{|l|l|l|}
\hline Conocimiento para: & $\mathbf{2 0 1 9 - 2 0 2 0}$ & $\mathbf{2 0 2 0 - 2 0 2 1}$ \\
\hline comunicarse de forma síncrona y asíncrona. & $95 \%$ & $97 \%$ \\
\hline identificar recursos para colaborar. & $62 \%$ & $73 \%$ \\
\hline utilizar las redes sociales. & $95 \%$ & $98 \%$ \\
\hline utilizar los códigos QR. & $63 \%$ & $63 \%$ \\
\hline
\end{tabular}

Tabla 5. Similitudes entre los dos cursos sobre el conocimiento que el alumnado tiene de las TIC.

\section{Desconocimiento que el alumnado tiene de las TIC}

Los estudiantes post-pandemia han mostrado coincidencia con sus predecesores en las debilidades o desconocimientos percibidos. Al igual que sus antecesores, el alumnado del curso 2020-2021 desconoce cómo protegerse cuando navega en la red, cómo tratar imágenes o vídeos, cómo utilizar los lectores y recopiladores de contenido, o cómo crear páginas webs, blogs, etc. Tampoco se siente competente en la búsqueda y gestión de la información, sigue sin participar en mundos virtuales, y no tienen mucho conocimiento sobre robótica. 


\begin{tabular}{|l|l|l|}
\hline Desconocimiento para: & $\mathbf{2 0 1 9 - 2 0 2 0}$ & $\mathbf{2 0 2 0 - 2 0 2 1}$ \\
\hline navegar de forma segura. & $70 \%$ & $\mathbf{7 5 \%}$ \\
\hline tratar imágenes o vídeos. & $67 \%$ & $62 \%$ \\
\hline utilizar los lectores y recopiladores de contenido. & $74 \%$ & $71 \%$ \\
\hline crear páginas webs, blogs, etc. & $65 \%$ & $63 \%$ \\
\hline buscar y gestionar la información. & $72 \%$ & $70 \%$ \\
\hline participar en mundos virtuales. & $81 \%$ & $71 \%$ \\
\hline la robótica. & $92 \%$ & $93 \%$ \\
\hline
\end{tabular}

Tabla 6. Similitudes entre los dos cursos sobre el desconocimiento que el alumnado tiene de las TIC.

\section{Necesidades formativas en TIC que el alumnado percibe tener}

Otras coincidencias halladas se relacionan con las falencias formativas identificadas. Aunque se les considere nativas y nativos digitales, al igual que los estudiantes del curso 2019-2020, el alumnado que ha cursado durante la pandemia la asignatura de TIC considera necesario seguir formándose para adquirir las competencias digitales que la profesión docente requiere; ya que desconocen el uso didáctico de las TIC que se les puede dar a las TIC. Su conocimiento pedagógico relativo a los recursos digitales sigue siendo escaso. Por último, relacionada con esa formación, siguen expresando la importancia de la ética en esta preparación.

2019-2020

Necesidad de formarse en las competencias digitales de forma ética.
2020-2021

$80 \%$

Tabla 7. Similitudes entre los dos cursos sobre las necesidades formativas en TIC que el alumnado percibe tener.

\section{Discusión y conclusiones}

El estudio realizado permite observar diferencias y similitudes en las percepciones sobre las TIC de los estudiantes del Grado de Educación Primaria, a partir de la pandemia. Para ello se han comparado las respuestas de los estudiantes que inician el Grado de Educación Primaria en la UAM en el curso 2019-2020, con las respuestas del alumnado que lo inician en el curso 2020-2021.

Entre los cambios destacados, se observa en el alumnado que ha sido afectado por la pandemia, un aumento en el tiempo empleado en navegar en Internet, así como un mayor desarrollado de estrategias auto formativas vinculadas a ciertos usos de las TIC. Sin embargo, pese a ello, la competencia digital percibida del alumnado no se ha visto incrementada de manera sustancial.

Esta afirmación se basa en los datos sobre el desconocimiento que el alumnado encuestado reconoce tener de las TIC. Tras el análisis de sus respuestas se observa que al inicio del Grado de Educación Primaria todavía no son capaces de navegar de forma segura, ni de tratar imágenes o vídeos, ni de utilizar los lectores y recopiladores de contenido, ni de crear páginas webs o blogs, ni de buscar y gestionar la información. 
La falta de conocimiento sobre cómo participar en mundos virtuales o la robótica no se consideran conocimientos tan esenciales, aunque sean importantes.

Por lo tanto, en coincidencia con otros estudios (Vargas et al., 2021), los datos aquí presentados muestran que, los y las participantes son capaces de desenvolverse en el ámbito digital, siempre y cuando los retos impliquen conocimientos básicos.

Estos hallazgos sugieren que la mera transición de formato educativo presencial al formato educativo virtual no favorece, per se, un desarrollo mayor de las competencias digitales requeridas que requieren los futuros docentes en la actualidad. Si bien es necesario mayores estudios para comprender las causas de este hallazgo, algunos trabajos recientes pueden aportar ciertas luces a la cuestión.

Vergas et al. (2021) han visto que una parte importante del tiempo se destina a participar en redes sociales mediante el teléfono móvil. Otros autores encuentran en la brecha digital uno de los posibles condicionantes formativos. En este sentido, se mencionan los problemas de acceso a dispositivos electrónicos y/o conexión a Internet que han experimentado muchos y muchas estudiantes durante el periodo pandémico (Cabrera, 2020).

Otra de las causas puede estar vinculada a que el profesorado de las etapas preuniversitarias no haya sido capaz de utilizar los recursos digitales con fines educativos (Cañón et al., 2016), esto es, no haya incorporado las TIC en el proceso de enseñanza y aprendizaje facilitando la búsqueda de información, y la participación o colaboración del alumnado en la creación de contenidos.

Teniendo esta última causa posible en cuenta, se considera que debería de convierte en un imperativo asegurar que los y las futuras generaciones cuenten con las habilidades digitales necesarias para que puedan utilizar las TIC en su vida y en su profesión. Por lo tanto, la educación obligatoria debería de alfabetizar digitalmente a todo su alumnado. Esta necesidad se ha vuelta aún más urgente partir de la situación pandémica vivida.

Para este fin, para lograr la alfabetización digital de la ciudadanía, la formación docente inicial tiene un rol protagónico. No cabe duda de que todavía queda mucho trabajo por hacer en torno a la alfabetización digital para asegurar la de todo el alumnado preuniversitario (Vargas et al., 2021). En este sentido, sigue siendo necesario insistir en aquellos aprendizajes que no se adquieren por simple inmersión digital. Los datos de este estudio desvelan que desde los Grados vinculados a Educación debemos incidir en temas como: la seguridad en la red, la búsqueda y gestión de la información, la ética en las TIC, y el uso didáctico de las TIC.

Se considera que asumir esta responsabilidad es ineludible. Por lo que hay que tratar de incluir en las formaciones destinadas a docentes la capacidad de crear contextos de aprendizaje que conjuguen los pedagógico y lo digital. Esta será la única manera de construir una sociedad alfabetizada digitalmente, y consecuentemente más sostenible, ética y justa. 


\section{Referencias}

Cabrera, L. (2020). Efectos del coronavirus en el sistema de enseñanza: aumenta la desigualdad de oportunidades educativas en España. Revista de Sociología de la Educación (RASE), 13(2) Especial, COVID-19, 114-139.

Cañón, R., Grande, M., \& Cantón, I. (2016). Brecha digital: Impacto en el desarrollo social y personal. Factores asociados. Tendencias Pedagógicas, 28, 115-132. https:// doi.org/10.15366/tp2016.28.009

Fundación Telefónica (2021). Sociedad Digital en España 2020-2021. Penguin Random House Grupo Editorial.

García, N., Rivero, M. L. \& Ricis, J. (2020). Brecha digital en tiempo del COVID-19. Revista Educativa HEKADEMOS, 28, 76-85.

INTEF (2017). Marco Común de Competencia Digital Docente, https://aprende.intef.es/sites/default/files/2018-05/2017_1020_Marco-Com\%C3\%BAn-de-Competencia-Digital-Docente.pdf

López-de-Arana, E., \& Rappoport, S. (2020). Competencia digital con la que el alumnado universitario inicia el Grado de Educación Primaria. En, E. Sánchez, E. Colomo, J. Ruiz, J. Sánchez (coord..), Tecnologías educativas y estrategias didácticas (13371346). Servicio de Publicaciones Universidad de Málaga.

Murillo, F. J., \& Duk, C. (2020). El Covid-19 y las Brechas Educativas. Revista Latinoamericana de Educación Inclusiva (RINACE), 14, 11-13.

OECD (2016). Skills for a Digital World: 2016 Ministerial Meeting on the Digital Economy Background Report. OECD Digital Economy Papers, No. 250, OECD Publishing, https://doi.org/10.1787/5jlwz83z3wnw-en

Punie, Y. (Ed.), \& Redecker, C. (2017). European Framework for the Digital Competence of Educators: DigCompEdu. Publications Office of the European Union, https://publications.jrc.ec.europa.eu/repository/handle/JRC107466

Vargas, A. L., Castro, J. A., \& Alarcón, J. B. (2021). Alfabetización digital y tic en la educación secundaria en Chile: Diagnóstico en tiempos de pandemia. Interciencia, 46(4), 148-155.

Zubillaga. A., \& Gortazar, L. (2020). COVID-19 y Educación: Problemas, Respuestas y Escenarios. Fundación Cotec para la Innovación. Madrid, España. https://bit.ly/3auXnP8 


\section{Proyecto Educativo Institucional: Integración de Nuevas Tecnologías y Trabajo Colaborativo. Instrumento de Autoevaluación y Diagnóstico}

\section{Mujica, María Genoveva}

Pontificia Universidad Católica Argentina

Campus Nuestra Señora del Rosario

Facultad de Derecho y Ciencias Sociales del Rosario

genoveva_mujica@uca.edu.ar

\section{Nóbrega González, María Laura}

Universidad de Lleida

Cátedra de Innovación Social

laura.nobrega@udl.cat 


\title{
PROYECTO EDUCATIVO
}

INSTITUCIONAL: INTEGRACIÓN DE

NUEVAS TECNOLOGÍAS Y TRABAJO COLABORATIVO.

\section{INSTRUMENTO DE AUTOEVALUACIÓN Y DIAGNÓSTICO}

\author{
Mujica, María Genoveva \\ Nóbrega González, María Laura
}

\section{Resumen}

Presentamos este trabajo como un segundo análisis y profundización del estudio realizado por Mujica \& Nóbrega González (2020). En esta oportunidad se realiza un estudio durante el período 2020-2021, en Argentina, se interroga sobre las conversaciones de los equipos directivos, la gestión de los procesos y los liderazgos que han asumido, la necesidad de desarrollar habilidades tecnológicas, administrativas y de relaciones humanas. Se avanza en implementar un instrumento de autoevaluación que permita realizar un diagnóstico o "hacer pie" sobre cómo se encuentran sus instituciones frente a la inminente hibridación del sistema, y poder planificar sus agendas y encauzar sus decisiones frente a este nuevo escenario. Para ello utilizamos la Matriz TIC, (Tecnologías de la Información y la Comunicación) Kelly \& Lugo UNESCO (2011). Los hallazgos se presentaron según el grado de avance de integración entre TIC y Proyecto Educativo Institucional (PEI) vinculado a la capacidad de diálogo de los equipos directivos. Entre algunos resultados se advierte en las respuestas un desfase entre las aspiraciones o deseos de contar un PEI integrado a las TIC y las herramientas, los recursos, capacidades de diálogo que poseen para ello.

\section{Palabras clave}

Autoevaluación institucional, aprendizaje colaborativo, cambio tecnológico. 


\section{Introducción}

En un estudio realizado en el 2020, Mujica \& Nóbrega González (2020) nos preguntamos cómo ha sido la intencionalidad en la comunicación de la identidad y sus elementos identitarios, durante el primer semestre, cuando la escuela se transformó en escuela remota de emergencia.

Un tema interesante fue investigar sobre las conversaciones de los equipos directivos. Qué cuestiones identitarias han priorizado con los docentes, estudiantes y familias, para tener indicios de cómo han sido sus agendas al pasar tan abruptamente de la modalidad presencial a la virtualidad.

De los resultados del trabajo, se destaca que, en relación a la identidad educativa, se ha optado por una mirada más conservadora, las decisiones que se han tomado han priorizado la "permanencia en el ser", en términos de Barcia (2012). Asimismo, es interesante remarcar que se han incorporado herramientas de innovación pedagógica en el "aula", no así en el equipo de gestión.

La gestión de los procesos y los liderazgos que han asumido, ha puesto en evidencia la necesidad de desarrollar habilidades tecnológicas, administrativas y de relaciones humanas. Trabajando para construir colaborativamente estructuras organizativas, abiertas, flexibles y en red.

En este estudio indagamos sobre la necesidad de contar con un instrumento de diagnóstico y autoevaluación sobre cómo se encuentran las instituciones frente a la inminente hibridación del sistema, que permita planificar sus agendas y encauzar sus decisiones frente a este nuevo escenario.

En primer lugar, porque el resultado de un diagnóstico es un instrumento que disminuye la brecha entre el hacer y el pensar. En palabras de Blejmar (2017), el sujeto-actor que gestiona, lo hace desde sus competencias técnicas como su saber y saber hacer en educación y en conducción educativa; también desde sus competencias genéricas o transversales. Quien gestiona es el actor desde el rol, pero empujado por el sujeto que está "detrás". En términos de Garay (2000), "desde el momento en que los seres humanos nos reunimos en y por la institución para trabajar, aprender, proyectar, sostener y sostenernos; que compartimos espacios, tiempos y prácticas con un lenguaje común, generamos representaciones, flujo de imágenes, comunes y también singulares". Mejorar la capacidad de gestión es desarrollar las competencias del actor desde su condición de sujeto: su reflexión, formación y capacitación. También, es mejorar las capacidades del sistema que lo contiene (procesos, políticas, administración, tecnología, entre otros) en lo curricular, en lo organizacional, en lo administrativo y en lo comunitario.

En segundo lugar, porque "hay algunos fenómenos que se hacen privilegiados por su poder organizador de las dinámicas institucionales, tanto más efectivos cuanto más profundos y desconocidos son" Garay (2000). En una buena escuela el equipo reflexiona permanentemente sobre cómo se hacen las cosas y cómo podrían hacerse mejor. Como expresa Romero (2008), la evaluación y la autoevaluación son elementos esenciales para la mejora del proyecto escolar. Porque posibilita que la escuela se responsabilice por los procesos que desarrolla y por los resultados que obtiene, identificando sus aciertos y los obstáculos que puedan presentarse. Por eso se evalúa y autoevalúa en forma permanente. 


\section{Método/Descripción de la experiencia}

\section{Descripción del contexto y de los participantes}

De la presente investigación participan 25 directivos de los cuatro niveles que existen en Argentina: inicial, primario, secundario y superior, universitario y no universitario. Las instituciones son de gestión oficial y de gestión privada. Los directivos son en su mayoría de instituciones de gestión privada, tienen un promedio de edad de entre 35 y 52 años y un rango de antigüedad en la docencia de entre 20 y 35 años.

Es interesante destacar que pertenecen a 8 distritos escolares de Argentina: Santa $\mathrm{Fe}$, Buenos Aires, Ciudad Autónoma de Buenos Aires, Córdoba, Mendoza, Tucumán, Entre Ríos y Corrientes. En general, las instituciones desarrollaron sus actividades según las modalidades que pueden observarse en el resto del mundo. Grupos de alumnos de no más de 15 por aula y divididos en semanas alternadas de trabajo presenciales y virtuales.

De acuerdo a este contexto, toda reflexión es el insumo indispensable para la mejora. Porque las realidades escolares en los diferentes distritos y niveles son hoy muy dispares. Incorporar la Matriz TIC preparada por María Teresa Lugo y Valeria Kelly para la UNESCO (2011), desde el área de Proyectos TIC del Instituto Internacional de Planeamiento de la Educación (IIPE), es adecuarnos al contexto que enfrentaremos de aquí en adelante en las instituciones educativas.

La integración de las nuevas tecnologías en nuestras organizaciones es un proceso complejo, por los aspectos a tener en cuenta, "requiere una mirada múltiple y consensuada", que se ha acelerado de forma abrupta en este último año luego de la declaración de Pandemia que hizo la Organización Mundial de la Salud el 11 de marzo de 2020.

\section{Instrumento}

La Matriz se ha preparado en la plataforma Google Forms. Las preguntas originales de la Matriz están agrupadas en 6 secciones: Gestión y planificación, las TIC en el desarrollo curricular, desarrollo profesional de los docentes, cultura digital en la institución escolar, recursos e infraestructura TIC, institución escolar y comunidad.

Hemos realizado un agregado para indagar el estado de las conversaciones en las instituciones educativas en relación a la integración de las TIC al PEI, basadas en tres competencias de los equipos directivos: saber ser, saber hacer y saber hacer con otros, y es aquí y en la sección gestión y planificación, donde pondremos foco. Porque es en el "hacer con otros", donde se encuentran los más grandes desafíos de los equipos directivos, a través de la calidad con la cual gestionan la palabra.

\section{Procedimiento}

El formato elegido, posibilita el envío por correo electrónico y WhatsApp y permite contar con respuestas que pueden llegar desde diferentes ciudades del país. Luego de realizado, se exponen los resultados de integración entre las TIC y PEI según el grado de avance (Inicial, Intermedio y Avanzado) de la sección Gestión y Planificación, conforme al estudio de Kelly \& Lugo (2011). Al mismo tiempo, nuestro aporte se 
encuentra en poder relacionar los grados de avance junto al estado del desarrollo del lenguaje y la capacidad de diálogo de los equipos directivos. Por ello, relacionamos el grado de avance en la integración de las TIC al PEI con las dimensiones del saber y les asignamos colores: Grado de avance inicial, dimensión de desarrollo del lenguaje identificado con el saber ser, color azul; Grado de avance intermedio, dimensión de desarrollo del lenguaje identificado con el saber hacer, color verde; Grado de avance avanzado, dimensión de desarrollo del lenguaje identificado con el saber hacer con otros, color naranja; Incorporamos también una cuarta opción en caso de que ninguna de las anteriores se correspondiera con los puntos antes mencionados.

\section{Resultados}

Presentamos algunos hallazgos relacionados con la importancia de contar con un instrumento de diagnóstico y autoevaluación para la toma de decisiones frente a la inminente hibridación del sistema. Por ello destacamos el eje de Gestión y planificación de Kelly\& Lugo (2011), el cual se subdivide en cuatro variables de análisis: a) Visión; b) Planificación; c) Integración y d) Coordinación.

a) En relación a la visión, como se observa en la Tabla 1, existen mayoría de respuestas que indican que las TIC están integradas totalmente en el conjunto de la visión escolar, representando un grado avanzado en la dimensión del lenguaje identificado con el saber hacer con otros (color naranja). En el nivel superior universitario y no universitario, se encuentran mayoría de respuestas de este grado, mientras que en el secundario se reconocen más respuestas referidas al grado de avance intermedio, dimensión de desarrollo del lenguaje identificado con el saber hacer (color verde). Sólo dos directivos han referido que ninguna de las opciones corresponde a la realidad de su institución.

\begin{tabular}{lllll}
\hline & $\begin{array}{l}\text { 1. La visión de } \\
\text { la integración } \\
\text { de TIC se enfoca } \\
\text { sobre todo en el } \\
\text { equipamiento. }\end{array}$ & $\begin{array}{l}\text { 2. La visión está } \\
\text { orientada por el } \\
\text { desarrollo profesional } \\
\text { docente y la cultura } \\
\text { digital. }\end{array}$ & $\begin{array}{l}\text { 3. Las TIC están } \\
\text { totalmente } \\
\text { integradas en el } \\
\text { conjunto de la visión } \\
\text { escolar. }\end{array}$ & $\begin{array}{l}\text { 4. Ninguna de las } \\
\text { tres opciones se } \\
\text { corresponde con } \\
\text { la realidad de mi } \\
\text { institución. }\end{array}$ \\
\hline Nivel Inicial & 0 & 0 & 1 & 0 \\
\hline Nivel Primario & 1 & 1 & 1 & 0 \\
\hline $\begin{array}{l}\text { Nivel } \\
\text { Secundario }\end{array}$ & 2 & 7 & 3 & 2 \\
\hline $\begin{array}{l}\text { Nivel } \\
\text { Superior no } \\
\text { Universitario }\end{array}$ & 1 & 0 & 3 & 0 \\
\hline $\begin{array}{l}\text { Nivel Superior } \\
\text { Universitario }\end{array}$ & 0 & 0 & 2 & 0 \\
\hline
\end{tabular}

\section{Tabla 1. Visión. Cantidad de respuestas por nivel educativo}

b) En referencia a la planificación, vemos en la Tabla 2 que casi la mitad de los directivos han optado por el grado avanzado de respuesta, refiriendo que el diseño del proyecto TIC está liderado por el equipo directivo o el equipo TIC, con la participación activa y aceptación de la comunidad escolar. En este punto, el nivel primario tiene una leve mayoría de respuestas de grado intermedio. 
En secundaria, encontramos respuestas similares en todos los grados. Es de destacar que encontramos un número importante en el grado de avance inicial, dimensión de desarrollo del lenguaje identificado con el saber ser (color azul).

\begin{tabular}{lllll} 
& $\begin{array}{l}\text { 1. Desde la } \\
\text { dirección se diseña } \\
\text { un proyecto } \\
\text { institucional para } \\
\text { integrar las TIC. }\end{array}$ & $\begin{array}{l}\text { 2. El proyecto TIC } \\
\text { institucional es } \\
\text { diseñado por un equipo } \\
\text { TIC, integrado por } \\
\text { directivos y docentes. }\end{array}$ & $\begin{array}{l}\text { 3. El diseño del } \\
\text { proyecto TIC está } \\
\text { liderado por el } \\
\text { equipo directivo o } \\
\text { el equipo TIC, con la } \\
\text { participación activa } \\
\text { y aceptación de la } \\
\text { comunidad escolar. }\end{array}$ & $\begin{array}{l}\text { 4. Ninguna de } \\
\text { las tres opciones } \\
\text { se corresponde } \\
\text { con la realidad } \\
\text { de minstitución. }\end{array}$ \\
\hline Nivel Inicial & 0 & 0 & 1 & 0 \\
\hline Nivel Primario & 0 & 0 & 1 & 0 \\
\hline Nivel Secundario & 4 & 2 & 4 & 3 \\
\hline $\begin{array}{l}\text { Nivel Superior } \\
\text { no Universitario }\end{array}$ & 0 & 3 & 3 & 0 \\
\hline $\begin{array}{l}\text { Nivel Superior } \\
\text { Universitario }\end{array}$ & 0 & 1 & 2 & 0 \\
\hline
\end{tabular}

\section{Tabla 2. Planificación. Cantidad de respuestas por nivel educativo}

c) En cuanto al eje de integración, la Tabla 3 nos muestra que la inclinación se da hacia las respuestas de grado de avance intermedio en casi todos los niveles, salvo en inicial, donde se adopta un enfoque estratégico de equipo para el planeamiento y la integración de las TIC en la institución. Junto a este nivel, encontramos también algunas referencias de nivel superior (universitario y no universitario), secundario y primario.

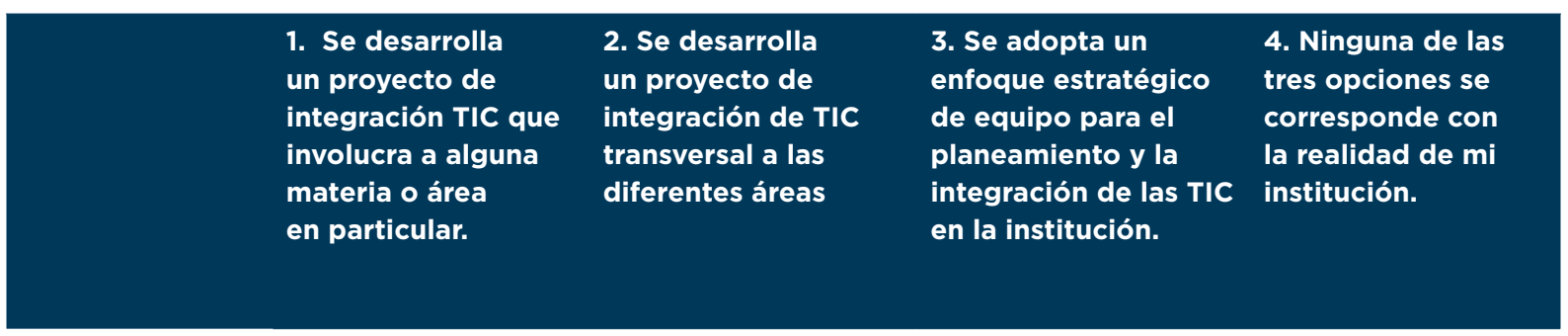

\begin{tabular}{lllll}
$\begin{array}{l}\text { Nivel } \\
\text { Inicial }\end{array}$ & 0 & 0 & 1 & 0 \\
\hline Nivel Primario & 0 & 2 & 1 & 0 \\
\hline Nivel Secundario & 1 & 9 & 3 & 1 \\
\hline $\begin{array}{l}\text { Nivel Superior } \\
\text { no Universitario }\end{array}$ & 0 & 2 & 2 & 0 \\
\hline $\begin{array}{l}\text { Nivel Superior } \\
\text { Universitario }\end{array}$ & 0 & 1 & 1 & 0 \\
\hline
\end{tabular}

Tabla 3. Integración. Cantidad de respuestas por nivel educativo

d) En relación a la coordinación, último punto del apartado gestión y planificación, se da la particularidad de que la tercera parte de las respuestas coinciden en elegir la opción que hace referencia a no corresponder con la realidad de la 
institución. Coordinación es el eje donde vemos menor cantidad de opciones en el grado avanzado e intermedio, no así en el grado inicial, donde el nivel secundario ha tenido un alto grado de respuestas.

\begin{tabular}{lllll} 
& $\begin{array}{l}\text { 1. Un docente o } \\
\text { directivo coordina } \\
\text { de hecho la } \\
\text { integración de las } \\
\text { TIC en la institución. }\end{array}$ & $\begin{array}{l}\text { 2. Un docente o } \\
\text { grupo de docentes } \\
\text { es designado } \\
\text { para asumir la } \\
\text { responsabilidad } \\
\text { de las TIC en la } \\
\text { institución. }\end{array}$ & $\begin{array}{l}\text { 3. Hay un docente designado } \\
\text { especificamente para } \\
\text { coordinar la implementación } \\
\text { de la integración de las TIC, } \\
\text { con tareas y responsabilidades } \\
\text { claramente definidas. }\end{array}$ & $\begin{array}{l}\text { 4. Ninguna de } \\
\text { las tres opciones } \\
\text { se corresponde } \\
\text { con la realidad } \\
\text { de minstitución. }\end{array}$ \\
$\begin{array}{l}\text { Nivel } \\
\text { Inicial }\end{array}$ & 0 & 0 & 1 & 0 \\
\hline $\begin{array}{l}\text { Nivel } \\
\text { Primario }\end{array}$ & 0 & 1 & 1 & 1 \\
\hline $\begin{array}{l}\text { Nivel } \\
\text { Secundario }\end{array}$ & 5 & 2 & 2 & 5 \\
\hline $\begin{array}{l}\text { Nivel } \\
\text { Superior no } \\
\text { Universitario }\end{array}$ & 0 & 1 & 1 & 2 \\
\hline $\begin{array}{l}\text { Nivel } \\
\text { Superior } \\
\text { Universitario }\end{array}$ & 1 & 1 & 0 & 0 \\
\hline
\end{tabular}

\section{Tabla 4. Coordinación. Cantidad de respuestas por nivel educativo}

\section{Discusión y conclusiones}

A continuación, se realizan algunas observaciones en función de los objetivos, referencias teóricas y hallazgos. En este sentido fue interesante indagar sobre la necesidad de contar con un instrumento de diagnóstico y autoevaluación, para conocer cómo se encuentran las instituciones de los diferentes niveles educativos argentinos frente a la inminente hibridación del sistema.

Hemos podido integrar la matriz TIC Kelly \& Lugo (2011) y nuestros aportes, al relacionar los niveles de respuesta de la misma con el grado de avance del estado de desarrollo del lenguaje y la capacidad de diálogo de los equipos directivos, en referencia a las dimensiones del saber: Grado de avance inicial, como dimensión de desarrollo del lenguaje identificado con el saber ser (color azul); Grado de avance intermedio, como dimensión de desarrollo del lenguaje identificado con el saber hacer (color verde); Grado de avance avanzado, como dimensión de desarrollo del lenguaje identificado con el saber hacer con otros (color naranja).

A partir de estos hallazgos, se evidencia que existe la necesidad de que los equipos directivos puedan contar con un marco de referencia que no sólo diagnostique y evalúe, sino que los ayude a liderar los diferentes procesos de innovación que se desarrollan en sus instituciones, haciendo foco en el "saber hacer con otros", porque es allí donde se encuentran los más grandes desafíos. Creemos en el "poder que tiene la palabra" como afirma Blejmar (2017), para "hacer que las cosas sucedan". En un contexto de turbulencia e incertidumbre como el que viven las sociedades actuales, 
y en ellas la escuela, el primer ejercicio de reconstrucción institucional pasa por reconstruir el lugar de la palabra. Aquella que hace sentido en los otros, palabra plena de significado y lejana del vacío del lugar común.

Identificamos a través de este proceso las capacidades de los equipos para vincularse a través de la gestión del lenguaje, en relación al grado de avance seleccionado en la matriz para las cuatro variables de análisis mencionadas: a) Visión; b) Planificación; c) Integración y d) Coordinación.

En referencia a las variables visión y planificación, encontramos que es quizás aquí donde más reflejado se ve el saber hacer con otros, diseñando proyectos TIC que no sólo están integrados al conjunto de la visión escolar, sino que también son aceptados por la comunidad.

En relación a la variable integración, se comprueba que cuesta adoptar un enfoque estratégico de equipo para el planeamiento y la integración de las TIC en la institución, pero si existe un enfoque transversal a las diversas áreas. "Transitamos un tiempo particular en el cual los espacios virtuales se han convertido en el lugar de encuentro de las comunidades educativas. Tiempo en el que se requieren nuevos perfiles de liderazgo, directivos que transformen sus instituciones en espacios inteligentes, que sean capaces desde la promesa educativa, llegar a un significativo destino, y allí ser expertos en futuro” Mujica \& Nóbrega González (2020).

Por último, y en referencia a la variable coordinación, es aquí donde se observan menores niveles de respuesta en saber hacer con otros y si más en relación al saber ser y a no poder enmarcar la institución en las respuestas que se proponen.

Como ya referenciaban sus autoras diez años atrás, "el contexto actual enmarca nuevas demandas y desafíos para las instituciones educativas" Kelly \& Lugo (2011). Hemos comprobado que el instrumento tiene algunas limitaciones y existe la necesidad de adecuar algunas variables. Un vicedirector de nivel secundario expresó: "Como sugerencia, en el formulario había muchas preguntas en las que quería marcar dos o tres respuestas y como no me lo permitía puse que ninguna era la realidad de mi escuela". Esta situación podría explicar la cantidad de respuestas en la opción "ninguna".

Asimismo, otro directivo de nivel superior universitario destacó la importancia de haber reflexionado sobre sus procesos de gestión mientras respondía el cuestionario, al manifestar: "Cuantas cosas me dejan pensando esas preguntas". Aquí podremos valorar en palabras de Kelly \& Lugo (2011), que trabajar sobre esta matriz tiene una doble finalidad, "permitir la elaboración de un estado de situación inicial, y además, de orientar el proceso de cambio mostrando posibles pasos a dar en función de los objetivos trazados".

Por ello es necesario perfilar un estado de situación TIC que identifique puntos fuertes y débiles, oportunidades, amenazas y los caminos alternativos para diseñar e implementar proyectos TIC articulados con las directrices del proyecto pedagógico institucional”. Kelly \& Lugo (2011).

Al mismo tiempo, se pudo analizar el grado de avance de las conversaciones referidas a la incorporación de las TIC en el PEI, según la clasificación de las capacidades de los equipos directivos en: saber ser, saber hacer y saber hacer con otros. Es allí en el saber hacer con otros, donde la visión compartida tiene lugar para hacer que 
las cosas sucedan, y es a través del diálogo donde es posible crear una conciencia colectiva que pueda ser mantenida.

"Al trabajar a partir de los problemas así detectados, la institución está en condiciones de desarrollar las líneas de acción para resolverlos, generar los compromisos necesarios para el logro de los objetivos y diseñar las estrategias de monitoreo y evaluación para la implementación de un proyecto TIC articulado con el proyecto institucional”. Kelly \& Lugo (2011).

La gestión de los procesos y los liderazgos que han asumido, ha puesto en evidencia la necesidad de desarrollar habilidades tecnológicas, administrativas y de relaciones humanas. Trabajando para construir colaborativamente estructuras organizativas, abiertas, flexibles y en red.

\section{Referencias}

Barcia, P. L, (2012). Cultura e Identidad Institucional. Ponencia en la Universidad Austral (Buenos Aires, Argentina). Recuperado de: https://www.youtube.com/watch?V=aBJTW3ZG-ZU

Blejmar, B. (2017). Gestionar es hacer que las cosas sucedan: competencias, actitudes y dispositivos para diseñar instituciones. Centro de Publicaciones Educativas y Material Didáctico. Ciudad Autónoma de Buenos Aires.

Calero Sánchez, C. (2019). La llegada de las nuevas tecnologías a la educación y sus implicaciones. International Journal of New Education. ISSN: 2605-1931 ·№ 4 - Diciembre 2019. Recuperado de http://dx.doi.org/10.24310/IJNE2.2.2019.7449

Costa; Perlo, (Directoras); De la Riestra; Cardu; López; Mandolesi; Cendra (Co. Autoras) (2019). Saber estar en las Organizaciones. Una perspectiva centrada en la vida, el diálogo y la afectividad. Editorial La Hendija.

Garay, Lucía (2000) Algunos conceptos para analizar instituciones educativas. Publicación del Programa de Análisis Institucional de la educación. Centro de Investigación de la Facultad de Filosofía y Humanidades. Universidad Nacional de Córdoba.

Lugo, M. T; Kelly, V (2011). La matriz TIC. Una herramienta para planificar las tecnologías de la información y la comunicación en las instituciones educativas - 1a ed. - Ciudad Autónoma de Buenos Aires: Instituto Internacional de Planeamiento de la Educación IIPE-Unesco.

Mujica, M. G; Nóbrega González, M. L., (2020). Identidad institucional escolar y nuevas tecnologías: ¿Cómo podrían las nuevas tecnologías colaborar en el fortalecimiento de las identidades de las instituciones educativas?". Tecnologías educativas y estrategias didácticas. Sánchez Rivas, E. [et. al.] (coords.)(2020). [pp 818] Málaga: UMA Editorial. Recuperado de https://riuma.uma.es/xmlui/handle/10630/20345

Romero, C. (2008). Hacer de la escuela una buena escuela. Buenos Aires: Aique. 


\section{Anexos}

Formulario de Google Forms enviado a los directivos https://forms.gle/ZNsxVYZcMUGnUpUC9

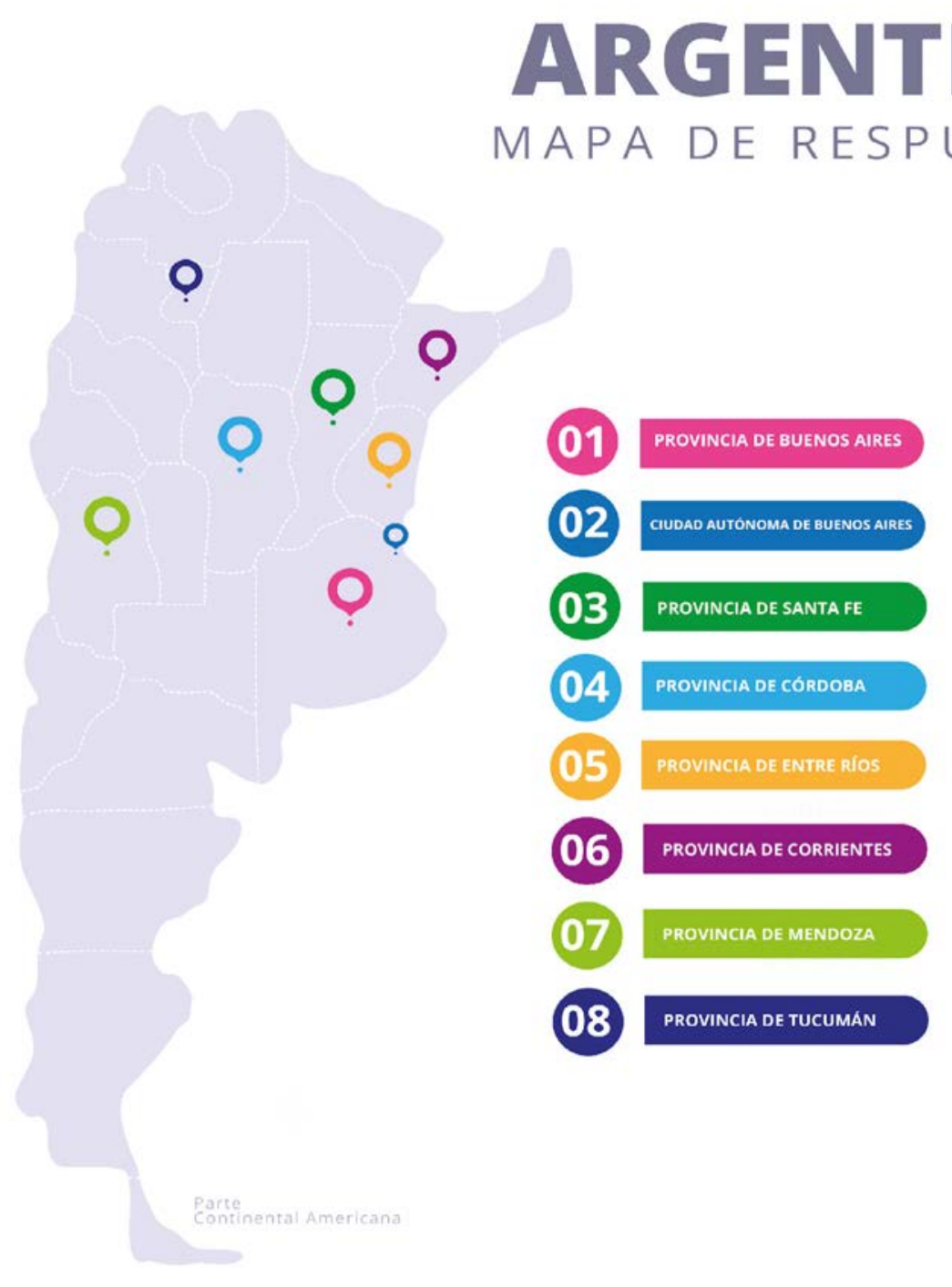

Imagen 1. Mapa de Argentina. Distritos que han participado del estudio 


\section{Validez, Confiabilidad, Análisis de reactivos y Actividades Cognitivas de un Instrumento: Recursos digitales para un estudio Cuantitativo}

Aguilar-Romero, Juan Hadad

https://orcid.org/0000-0002-5008-0980

juan.aguilarro@alumno.buap.mx

\section{Juárez-Ruiz, Estela}

https://orcid.org/0000-0002-2857-0772

estela.juarez@correo.buap.mx 


\title{
VALIDEZ, CONFIABILIDAD, ANÁLISIS DE REACTIVOS Y ACTIVIDADES COGNITIVAS DE UN INSTRUMENTO: RECURSOS DIGITALES PARA UN ESTUDIO CUANTITATIVO
}

\author{
Aguilar-Romero, Juan Hadad \\ Juárez-Ruiz, Estela
}

\section{Resumen}

En el presente trabajo se muestra el desarrollo de un estudio cuantitativo, así como las aplicaciones de Google que se utilizaron para la elaboración e implementación del instrumento en formato digital, que es parte medular de esta investigación. Este estudio se caracteriza por los siguientes procesos: validación de contenido, prueba de confiabilidad, análisis de reactivos y actividades cognitivas que fomenta el instrumento. El diseño del instrumento se compone de cuatro temas: lógica, conjuntos, álgebra booleana y la que corresponde a su articulación conceptual. Cada tema constó de ocho ítems, con respuestas de tres opciones. Primero, se realizó una validación de contenido del instrumento por medio del juicio de cinco expertos y se examinó la concordancia entre sus respuestas por medio del estadístico $\mathrm{V}$ de Aiken. Además, se probó su confiabilidad calculando la consistencia interna por medio del estadístico Kuder Richardson 20. Asimismo, se llevó a cabo el análisis de los reactivos aplicando el índice de dificultad, el índice de discriminación y el coeficiente de correlación biserial puntual. Para identificar las actividades cognitivas que el instrumento promueve, se consideraron los aportes de la Teoría de Registros de Representación Semiótica de Duval. Finalmente, se muestran los resultados del estudio cuantitativo, los cuales se obtuvieron mediante los recursos digitales Google Forms y Sheets.

\section{Palabras clave}

Validez, Confiabilidad, Reactivos, Representaciones Semióticas, Instrumento, Aplicaciones Google. 


\section{Introducción}

La presente investigación muestra el desarrollo de un estudio cuantitativo, en el cual se implementó un instrumento en cuyo diseño se incorporan cuatro temas de interés: lógica, conjuntos, álgebra booleana y la articulación conceptual entre ellos. El objetivo central es el poder identificar las dificultades que presentan los estudiantes durante la solución de ítems en el que intervienen diferentes registros y representaciones semióticas, además se lleva a cabo el reconocimiento de las actividades cognitivas que fomenta la prueba. Los temas corresponden a unidades que se abordan en las carreras de Electrónica y Mecatrónica, en las asignaturas de Matemáticas Elementales y Sistemas Digitales Combinacionales.

Es conveniente remarcar que los propósitos de algunos recursos digitales no necesariamente son para la educación o investigación. Sin embargo, en este trabajo se mostrarán dos procesos. El primero, es que docentes e investigadores consideren este aporte como una alternativa para elaborar, diseñar, implementar, recolectar y describir las dificultades que los estudiantes tienen en la aprehensión de diferentes representaciones semióticas. El segundo, es el hecho relevante de que los Recursos Digitales Abiertos permiten divulgar y dar a conocer los resultados que se obtuvieron, además son una propuesta que resulta adecuada para validar, probar la confiabilidad, y analizar los reactivos del instrumento.

Para identificar las actividades cognitivas que fomenta el instrumento, se consideraron los aportes de la Teoría de Registros de Representación Semiótica de Duval (2017a) en la que se destacan tres tipos de transformación durante el proceso matemático: formación de la representación, tratamiento y conversión. Para reconocer las últimos dos, es necesario ubicar el registro semiótico inicial y final. Cabe destacar que la conversión desde un punto de vista cognitivo tiene mayor dificultad y desde un punto de vista matemático el tratamiento es necesario para la solución de los ejercicios que se plantean.

Las dificultades reportadas en la literatura sobre la aprehensión de las diferentes representaciones que se gestionan en las asignaturas de nivel universitario, referidas al Álgebra Booleana (AB), se destacan a continuación.

El AB utiliza para su operación el Sistemas Numérico Binario (SNB), el cual se compone por dos valores: uno y cero. Franco (2008) menciona que aun cuando existan recursos didácticos para solucionar ejercicios referentes al SNB, también hay "dificultades para su comprensión, enseñanza y aprendizaje" (p. 119).

Según Herman y Handzik (2010) una de las dificultades que presentan los estudiantes es desconocer la equivalencia entre la Or Exclusiva (XOR) con otras compuertas, aun cuando la expresión booleana que la representa es: , es decir, la XOR está compuesta por las tres compuertas básicas AND, OR y NOT.

Entre los recursos que se abordan en el $A B$ escolar, se encuentran las tablas de verdad y el mapa de Karnaugh. El primero, permite hallar una expresión booleana la cual depende de la cantidad de combinaciones posibles y sus correspondientes salidas. El segundo, permite simplificar la expresión booleana considerando la relación entre las salidas. A pesar de que, una se puede derivar de la otra, los estudiantes tienen la dificultad de identificar la relación entre ambas (Longino et al., 2006). 
Como menciona Herman et al. (2012), el conocimiento de las leyes de simplificación de expresiones booleanas permite reducir la cantidad de operaciones. En caso contrario, se utilizarían más compuertas, como se muestra en la Figura 1, dificultad que se presentó durante la solución de un ejercicio textual que se implementó durante una entrevista clínica a un estudiante de la carrera de Electrónica, en la que se destaca la falta del uso de las leyes de simplificación de expresiones booleanas (Aguilar-Romero, 2021).

Figura 1. Solución del estudiante

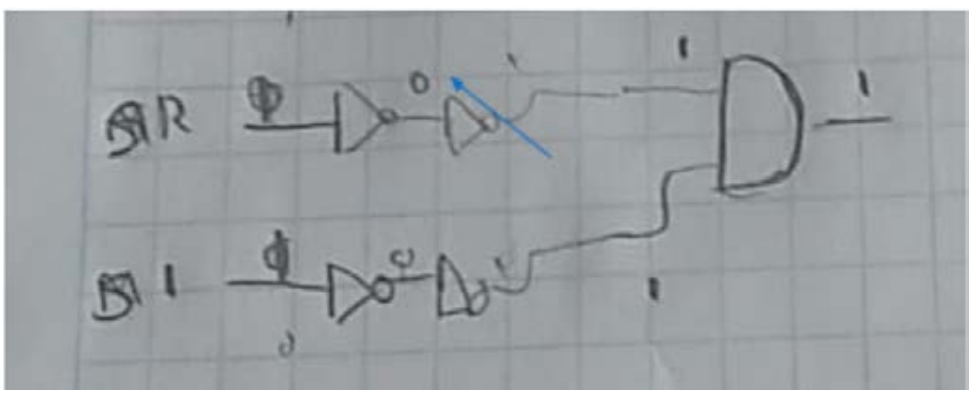

El uso de diferentes representaciones es común en los ejercicios planteados en la unidad de álgebra booleana. Un ejemplo se muestra en la Figura 2, la cual consiste en hallar la expresión a partir del diagrama de conexión de compuertas lógicas, hallar la tabla de verdad a partir de la expresión booleana y comprobar la relación entre los tres registros. Se muestra que el estudiante no se percata del error en dos combinaciones, aun cuando podría comparar los valores de salida con las otras dos representaciones.

Figura 2. Las combinaciones $a=0, b=1, c=0 \circ a=1, b=0, c=0$ no coinciden con el valor de $z$

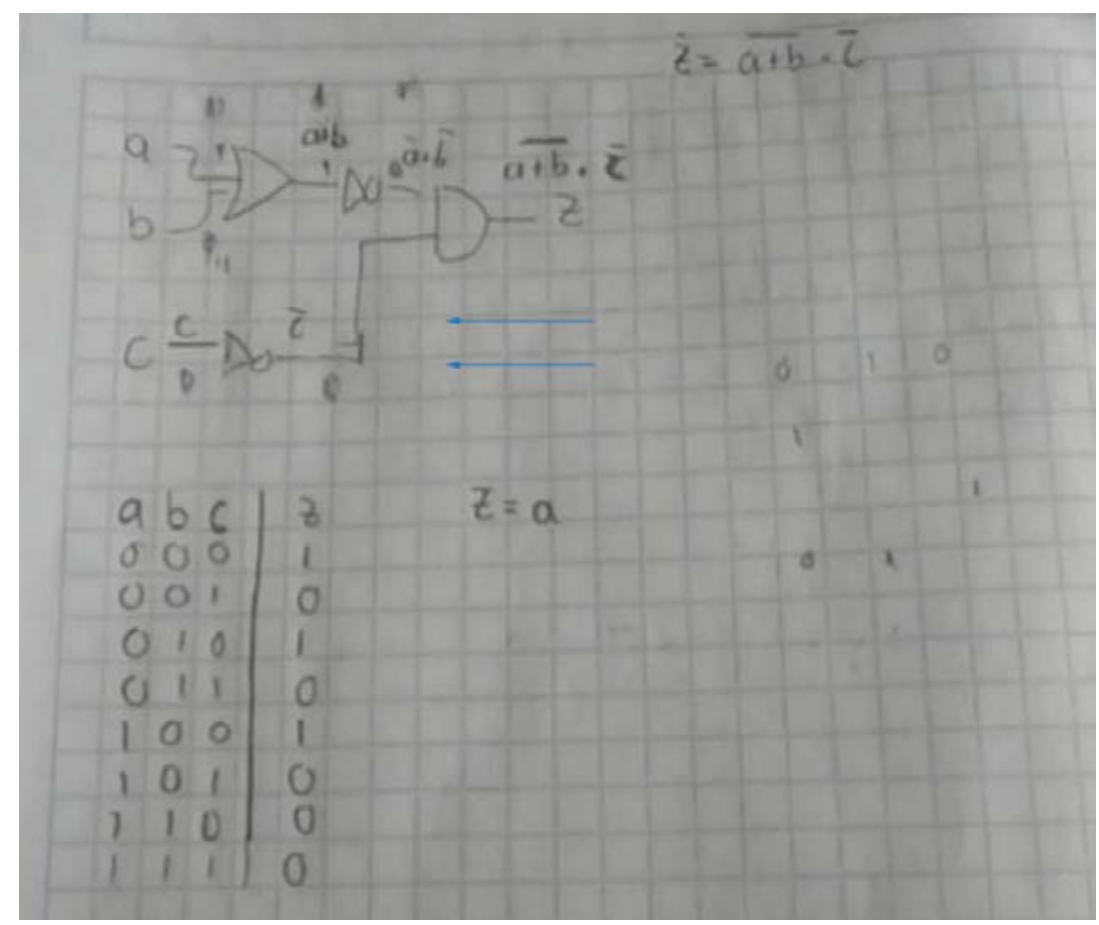


Para el diseño del instrumento, se considera que a partir de las dificultades descritas y reportadas en la literatura, es necesario que se tomen en cuenta los recursos teóricos y conceptuales que se abordan en el currículo de nivel superior acerca del $A B$. Además de tomar en cuenta los temas de Lógica y Conjuntos, debido a que las representaciones que se utilizan en estas unidades le anteceden al $A B$. Por lo que, forman parte de concepciones que le anteceden al $A B$ y que a su vez son parte del temario de las asignaturas del plan de estudios de las carreras de Electrónica y Mecatrónica.

Cabe destacar que el aprendizaje adecuado de los teoremas, axiomas, leyes, tablas de verdad, mapas de Karnaugh del AB, conllevan a simplificar expresiones booleanas. De acuerdo con Rey (2013) esto "en la práctica, resulta útil para abaratar costos en el armado de circuitos o para optimizar el tiempo empleado al efectuar una actividad ya que podemos obtener una expresión booleana equivalente pero más corta" (p. 23).

Tomando en cuenta este y otros conflictos que tienen los estudiantes en la solución de problemas del $A B$, es que se plantea la siguiente pregunta de investigación: ¿Qué actividades cognitivas promueve un instrumento válido y confiable para ser aplicado en estudiantes de las carreras de Electrónica y Mecatrónica?

El objetivo general del estudio cuantitativo es diseñar un instrumento válido y confiable que promueva las actividades cognitivas en estudiantes de las carreras de Electrónica y Mecatrónica.

\section{Marco Teórico}

\section{Teoría de Registros de Representaciones Semióticas (TRRS)}

La TRRS de Duval (2017a), ofrece un amplio panorama de los procesos que se llevan a cabo para la comprensión de objetos matemáticos. Aunque, para los profesores la gestión de diferentes representaciones puede ser habitual, para los estudiantes pueden no serlo tanto.

La TRRS destaca que los registros presentes en el proceso matemático son: gráfico, tabular, algebraico, lenguaje natural, escritura formal de la lógica o aritmético. Cada uno de estos registros puede tener diferentes representaciones semióticas. Por ello, se considera de que antes de la aprehensión conceptual de un objeto (Noesis), es necesaria la aprehensión de representaciones a partir de signos (Semiosis).

Como destaca Duval (2017a) las actividades cognitivas que están presentes son: la formación, el tratamiento y la conversión, dichas actividades se describen por él mismo de la siguiente manera:

- Identificar la representación es aquella transformación que "implica la selección de un cierto número de caracteres de un contenido percibido, imaginado o ya representado en función de las posibilidades de representación propias al registro escogido" (p. 78).

- El tratamiento "es la transformación de una representación (inicial) en otra representación (final), respecto a una cuestión, a un problema o a una necesidad" (p.78) en el mismo registro. 
- La conversión por su parte es la "transformación externa respecto al registro de la representación de partida” (p.80). Desde un punto de vista cognitivo, resulta un proceso complejo que idealmente se busca desarrollar y fomentar.

\section{Validación de Contenido}

En el diseño del instrumento, hay tres métodos para la evaluación por medio de juicio de expertos: agregados individuales, Delphi y consenso grupal o técnica grupo nominal. Para esta investigación se opta por el método de agregados individuales, debido a que para la evaluación de los ítems del instrumento los jueces expertos lo pueden hacer de forma independiente. Por consiguiente, los expertos deben estar al tanto de los objetivos, de la tabla de especificaciones y temas que aborda la prueba.

A partir del estadístico $\vee$ de Aiken (1985) se determina qué ítems pueden ser incluidos, cuáles no y aquellos que pueden ser replanteados. El resultado final está definido por la cantidad de expertos que está entre 2 a 25, las calificaciones obtenidas por categoría que se encuentran entre 2 a 7 y los niveles de significancia que pueden ser .05 0.01.

La fórmula que se utiliza para calcularlo es:

$$
V=\frac{S}{n(c-1)}
$$

Donde $n$ es el número de jueces que evalúan el instrumento, c corresponde al total de calificaciones que se consideran por categoría y $S$ a la suma de los valores ajustados de las calificaciones por categoría, mediante una escala de 0 que corresponde a la nota más baja y hasta la nota más alta que es 1.

Al conocer los resultados, se procede a probar una de las dos posibles hipótesis: nula $\left(\mathrm{H}_{\mathrm{o}}\right)$ o alternativa $\left(\mathrm{H}_{\mathrm{a}}\right)$, lo cual dependerá del valor desconocido poblacional $\left(V_{p}\right)$, así se decide si es $H_{0}^{a}: V_{p}=.5 \circ H_{a}: V_{p}>.5$, consideraciones que se toman en cuenta en investigaciones que aplican para la validez del instrumento por juicio de expertos, como el que presenta Juárez-Ruiz et al. (2020) en "Instrumento diagnóstico para la evaluación de habilidades espaciales en sólidos de revolución: Validación de contenido" (p. 97).

\section{Confiabilidad}

Meneses y colaboradores (2013) describen que "cuando los ítems de un test son dicotómicos y se codifican las dos alternativas posibles como 0 y 1" (p. 101), la consistencia interna del instrumento se calcula utilizando el estadístico propuesto por Kuder y Richardson (1937) para pruebas dicotómicas $\left(K R_{20}\right)$, la fórmula que se utiliza para calcularlo es

$$
K R_{20}=\frac{n-1}{n} \cdot \frac{\sigma_{t}^{2}-n \overline{p q}}{\sigma_{t}^{2}}
$$


Donde $n$ es el número de ítems de la prueba, $\sigma_{t}^{2}$ es la varianza de las calificaciones totales de la prueba y $n \overline{p q}=\sum p q$ es la suma del producto de la proporción de estudiantes que aciertan al ítem por la proporción de estudiantes que no aciertan al ítem.

\section{Análisis de Reactivos}

Para conocer la consistencia de los ítems y del instrumento se utilizan los estadísticos: índice de dificultad $(p)$, índice de discriminación $(D)$ y el coeficiente de correlación biserial puntual $\left(r_{\mathrm{bp}}\right)$.

\section{Índice de Dificultad}

Como señala Aiken (2003) para calcular $p$ se utiliza las variables $U_{p}$ que es el grupo con mayor número de aciertos en el ítem y $L_{p}$ el grupo con menor número de aciertos. Dichos grupos se forman a partir de dividir en tres el grupo, es decir, $25 \%$ formarían al grupo con más aciertos, otro $25 \%$ con menos aciertos y el tercer grupo el $50 \%$ faltante, debido a esto $U$ y $L$ serían iguales siendo cada uno de estos el número total de personas de los primeros dos grupos, la fórmula para conocer el $p$ es

$$
p=\frac{U_{p}+L_{p}}{U+L}
$$

Aunque, Lord (1952) destaca que "dependiendo del número de opciones del ítem un índice de dificultad pertinente sería: para dos opciones un $p=.835$, tres opciones $p=.759$, cuatro opciones $p=.713$, cinco opciones $p=.682$ y preguntas abiertas $p=.5^{\prime \prime}($ p. 68).

\section{Índice de Discriminación}

Para hallar el valor del índice de discriminación se consideran las siguientes variables: $U_{p}$ representa la cantidad de informantes del grupo con mayor número de aciertos, $L_{p}$ es la cantidad de informantes del grupo con menor número de aciertos y $U$ al total de informantes del grupo con mayor número de aciertos, la fórmula que se necesita es

$$
D=\frac{U_{p}-L_{p}}{U}
$$

\section{Coeficiente de Correlación Biserial}

Otro índice para calcular la discriminación de los ítems de acuerdo con Meneses y colaboradores (2013) es el índice de correlación biserial-puntual $\left(r_{\mathrm{bp}}\right)$ que "permite cuantificar la relación entre una variable binaria -el acertar o no el ítem- y una variable de escala -la puntuación total de la persona en la prueba-, idealmente sin tener en cuenta el ítem analizado" (p. 245). La forma para medir este coeficiente es por medio de la fórmula que detallan Attorresi, Galibert y Aguerri (1999) 


$$
r_{p b}=\frac{\left(\bar{Y}_{p}-\bar{Y}\right) \sqrt{\frac{n_{t} n_{p}}{\left[\left(n_{t}-n_{p}\right)\left(n_{p}-1\right)\right]}}}{S_{t}}
$$

Donde $n_{\mathrm{t}}$ es la cantidad total de examinados, $n_{\mathrm{p}}$ es la cantidad de examinados que resuelven correctamente el reactivo, es la media de las calificaciones de criterio de quienes pasan el reactivo, $\bar{Y}_{p}$ es la media de todas las calificaciones de criterio y $S_{t}$ es la desviación estándar de todas las calificaciones de criterio. Por lo tanto, si el $r_{\mathrm{pb}}$ es cercano a menos uno indicaría que el grupo con mayor número de aciertos contesta incorrectamente el ítem y el grupo con menor número de aciertos lo contesta de forma correcta.

\section{Método}

Se llevó a cabo un estudio cuantitativo en el que se usaron diferentes recursos digitales, tales como Google Forms y Sheets. La primera aplicación, se ocupó para enviar el cuestionario en formato digital a los expertos y estudiantes. El segundo recurso, permite trabajar en una hoja de cálculo los datos que se almacenaron en la primera aplicación.

\section{Descripción del contexto y los participantes}

El proceso de validación de contenido del cuestionario se llevó a cabo utilizando el estadístico $V$ de Aiken por medio de un juicio de expertos y una prueba de hipótesis. Para probar la confiabilidad del instrumento se calculó el coeficiente Kuder Richardson $20\left(\mathrm{KR}_{20}\right)$. Para el análisis de reactivos, las fórmulas que se utilizaron fueron las del índice de dificultad, el índice de discriminación y el coeficiente de correlación biserial puntual. Para identificar las actividades cognitivas que promueve la prueba, fue necesario analizar en cada ítem el registro inicial y el final para determinar si se llevó a cabo una transformación por tratamiento o por conversión.

La evaluación del instrumento estuvo a cargo por cinco expertos, con máximo grado de estudios entre Maestría y Doctorado de áreas de Electrónica, Mecatrónica, Matemáticas y Educación Matemática.

Por otro lado, para probar la confiabilidad del instrumento y realizar el análisis de reactivos, el instrumento se aplicó a un grupo de 84 estudiantes de los cuales se consideraron solamente 71 , debido a que 13 informantes no contestaron completamente la prueba, teniendo un total de 2 estudiantes de la carrera de Electrónica y 69 estudiantes de la carrera de Mecatrónica, de los cuales 61 fueron hombres y 10 mujeres. Ambas carreras pertenecen a una Universidad de la ciudad de Puebla, México. Los sujetos habían llevado previamente las materias de matemáticas elementales y sistemas digitales combinacionales, en las cuales se abordan los temas de lógica, conjuntos y álgebra booleana. El rango de edad de los estudiantes fue de entre 19 y 24 años con una media de 20 años. 


\section{Instrumento}

El formato que se presentó a los expertos estuvo conformado por seis secciones. La primera, recabó los datos generales del experto. De la segunda hasta la quinta, la evaluación de cada ítem; considerando las dimensiones de claridad, coherencia y relevancia, con una calificación ordinal de 1 a 3 , donde 1 significó no cumple con el nivel, 2 moderado nivel y 3 alto nivel. La última sección consistió en preguntas generales sobre el instrumento. Un ejemplo del formato que se utilizó corresponde al ítem 18 que se muestra en la Figura 3.

\section{Figura 3.}

Ejemplo de uso del recurso Google Forms para el ítem 18

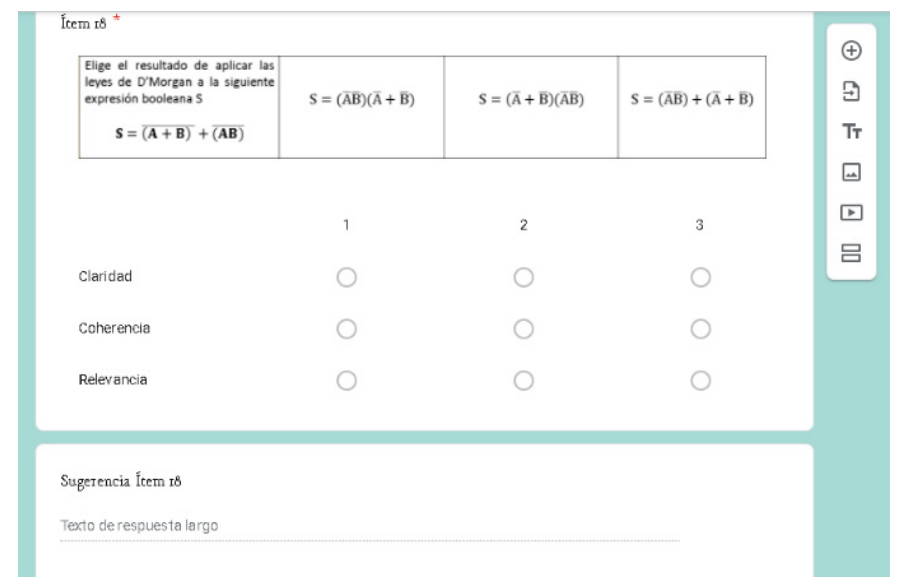

El formato del instrumento que se implementó al grupo piloto consistió en seis secciones. La primera fue para los datos generales del informante. De la segunda hasta la quinta, los ítems con sus respectivas tres opciones. La última, consistió en una serie de preguntas abiertas sobre los temas que se abordaron en el cuestionario y un apartado para que los estudiantes subieran en formato digital las producciones escritas que realizaron para responder los ítems del instrumento. Un ejemplo del formato se muestra en la Figura 4 que corresponde al ítem 8.

\section{Figura 4.}

Ítem, indicaciones y opciones del ítem 8, registro escritura simbólica y tabular

İtern 8

\begin{tabular}{|c|c|c|c|c|c|c|c|c|c|}
\hline Elije la tabla de verdad que & p & q & $\mathbf{r}$ & $\mathrm{p}$ & q & $\mathbf{r}$ & p & $\mathrm{q}$ & $r$ \\
\hline corresponda a la siguiente & v & v & $\mathrm{F}$ & $\mathrm{v}$ & v & $\mathrm{F}$ & $\mathrm{v}$ & V & $\mathrm{V}$ \\
\hline proposición compuesta & $\mathrm{v}$ & $\mathrm{F}$ & $\mathrm{v}$ & $\mathrm{v}$ & $\mathrm{F}$ & $\mathrm{v}$ & $\mathrm{v}$ & $\mathbf{F}$ & $\mathrm{F}$ \\
\hline & $\mathbf{F}$ & $\mathrm{V}$ & $\mathrm{v}$ & $\mathbf{F}$ & $\mathrm{v}$ & $\mathrm{v}$ & $\mathrm{F}$ & $\mathrm{V}$ & $\mathrm{F}$ \\
\hline$(\sim p \wedge q) \vee(p \wedge \sim q) \equiv r$ & $\mathrm{~F}$ & $\mathrm{~F}$ & $\mathrm{~F}$ & $\mathrm{~F}$ & $\mathrm{~F}$ & v & $\mathrm{F}$ & $\mathrm{F}$ & V \\
\hline
\end{tabular}


Las respuestas de los expertos e informantes se presentan en cuatro formatos que ofrece Google Forms: resumen, pregunta, individual y hoja de cálculo.

\section{Resultados}

\section{Validación de contenido por juicio de expertos}

En la Tabla 1 se muestran los resultados correspondientes a la primera evaluación, a través del estadístico $V$ de Aiken. El resultado obtenido debía ser mayor a .90. Por lo tanto, la categoría Claridad, no cumplió con el valor. Así que, fue necesario hacer ajustes al instrumento y realizar una segunda evaluación por parte de los expertos.

\section{Tabla 1}

Valores del promedio $\mathrm{V}$ de Aiken de las tres categorías

\section{V de Aiken por categoría}

\begin{tabular}{|lll|} 
Claridad & Coherencia & Relevancia \\
\hline 0.83 & 0.98 & 0.97 \\
\hline
\end{tabular}

El resultado de la segunda evaluación se muestra en la Tabla 2, la cual permite observar que fue posible rechazar la hipótesis nula en las tres categorías. A partir del resultado de la segunda evaluación, se concluye que se cuenta con un cuestionario válido, debido a que se obtuvieron valores que sobrepasan a .90.

\section{Tabla 2}

Valores del promedio $\vee$ de Aiken de las tres categorías

\begin{tabular}{|lll|}
\hline \multicolumn{2}{|l|}{ V de Aiken por categoría } & \\
\hline Claridad & Coherencia & Relevancia \\
\hline 0.950 & 0.988 & 0.925 \\
\hline
\end{tabular}

Los cálculos para obtener cada $V$ de Aiken por categoría se obtuvieron con las herramientas que proporciona Google Sheets, así como los estadísticos y gráficas que se presentan a continuación.

\section{Confiabilidad de pruebas dicotómicas}

De acuerdo con Doran (1980) el valor obtenido del estadístico Kuder Richardson 20 debe ser mayor o igual a .80. El resultado obtenido a partir de la implementación del instrumento al grupo piloto fue de .80. Por lo tanto, se cuenta con un instrumento confiable.

\section{Análisis de los Reactivos}

En la Figura 5 se muestra el valor del índice de dificultad para cada ítem de los treinta y dos que componen el cuestionario. Cabe destacar que de acuerdo con Aiken (2003), un índice de dificultad óptimo es aquel que está cercano a .5, por lo que los ítems $3,9,13,14,16,17,18,22,23,27,28,31$ y 32 cumplen con dicho criterio. 
Figura 5.

Resultados del índice de dificultad por ítem

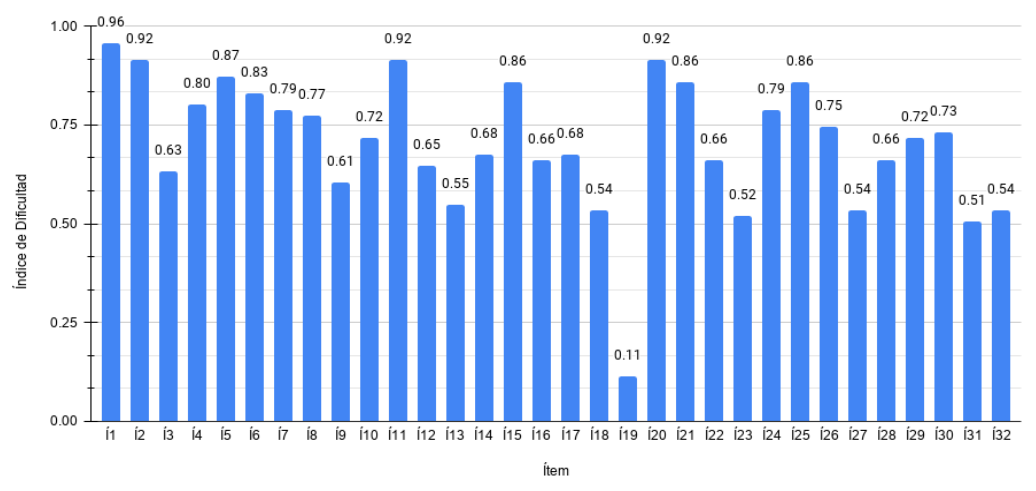

De acuerdo con el rango de valores utilizado en el trabajo de Medina et al. (2019), se considera que el instrumento cuenta con: ocho ítems que son muy fáciles, diecisiete ítems que son moderadamente fáciles, seis ítems moderadamente difíciles y uno muy difícil.

De acuerdo con Aiken (2003), los ítems con buen índice de discriminación son: 4, 5, $7,8,9,10,12,14,17,18,21,22,24,24,25,26,27,28,29,30,31,32$. El índice de discriminación para cada ítem se muestra en la Figura 6.

\section{Figura 6}

Índice de Discriminación por ítem

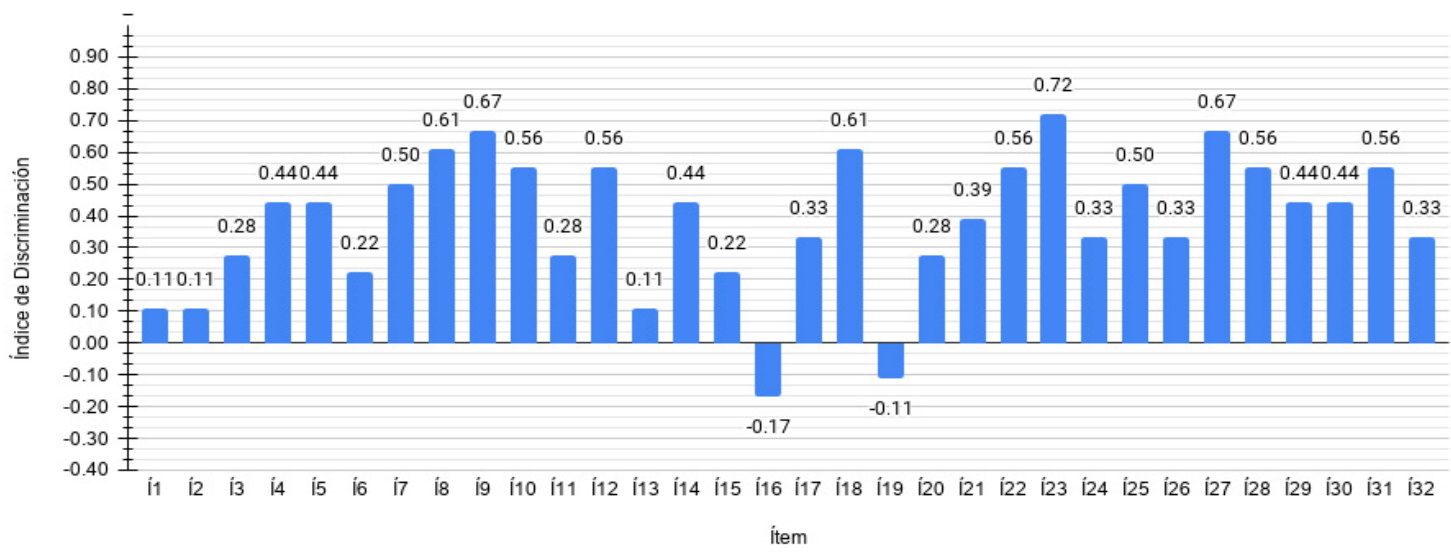

Por lo tanto, de acuerdo con la clasificación de Ebel y Frisbie (1991), el instrumento cuenta con diecisiete ítems muy buenos, cinco razonablemente buenos, cinco que requieren mejoras y cinco que deben ser mejorados mediante una revisión.

Según Aiken (2003), aquellos que deben de revisarse o incluso descartarse serían los que su coeficiente de correlación biserial puntual $\left(r_{b p}\right)$ sea menor o igual a 0 , por lo que de aplicarse dicha indicación serían los ítems 16 y 19 los que se descartarían, como se puede observar en el cálculo del $r_{b p}$ para cada ítem en la Figura 7. 


\section{Figura 7}

Coeficiente de correlación biserial puntual por ítem

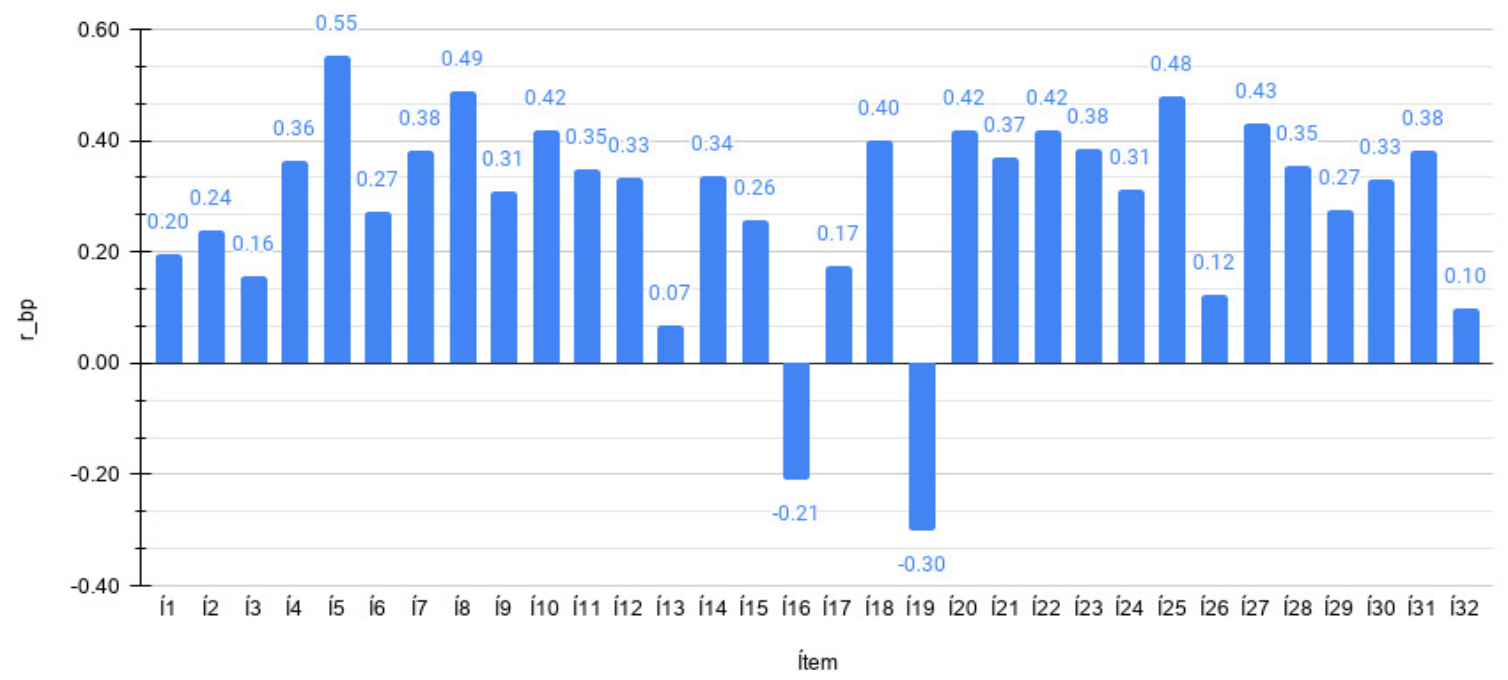

\section{Actividades Cognitivas}

En este instrumento, se pudieron identificar las siguientes actividades cognitivas por tema, las cuales se muestran en la Figura 8. Para el tema de lógica, de los ocho ítems, en cuatro se realizan conversiones entre registros de representación y en los otros cuatro tratamientos en el registro planteado en el ítem. Para el tema de conjuntos y $A B$ se tiene el mismo número de conversiones (6) y tratamientos (2). Finalmente, para la articulación entre temas, todos los ítems implicaron una conversión entre registros de representación semiótica.

\section{Figura 8.}

Actividades cognitivas que se fomentan por tema

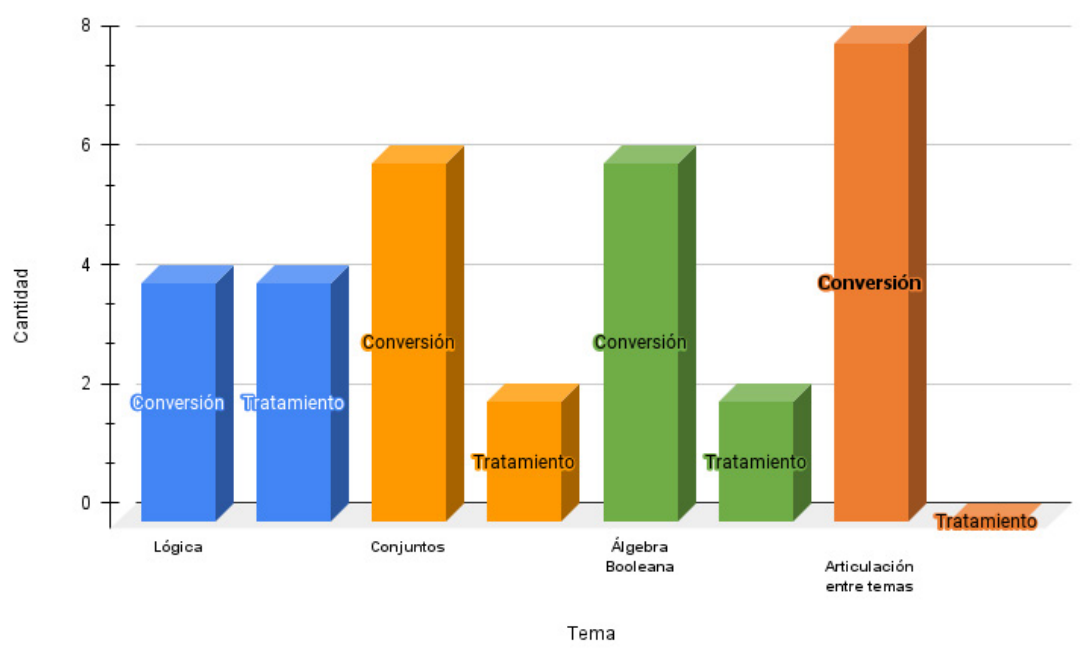




\section{Conclusiones}

Los gráficos presentados en la sección de resultados fueron producto de las plataformas Google Forms y Google Sheet. La primera, permitió la implementación del instrumento diseñado e incluso obtener diferentes formatos para presentar los resultados como: gráficos de pastel para preguntas dicotómicas, gráfico de frecuencia para conocer el rango y la media, gráficos de barra para saber el porcentaje de estudiantes que contestaron el inciso correcto y almacenar las evidencias que subieron los estudiantes en archivos PDF o JPG. Con la segunda, se llevó a cabo el cálculo de los diferentes estadísticos e incluso obtener el gráfico para cada índice y coeficiente. Para algunos de los que se presentaron, se utilizaron diferentes herramientas que incluye la aplicación. Por lo que, tendríamos diferentes recursos con características específicas para cada actividad que se desarrolló, las cuales en conjunto permitieron el desarrollo del estudio que se llevó a cabo.

Los resultados obtenidos permiten dar respuesta a la pregunta de investigación, debido a que fue posible probar que el instrumento es válido, confiable y con buena discriminación. Además de ofrecernos alternativas como replantear u omitir algunos de los ítems, debido a las mediciones que se obtuvieron.

Al identificar las actividades cognitivas y el contraste con el índice de dificultad, se observa que no necesariamente la conversión entre registros desde el punto de vista cognitivo sea tan compleja, debido a que se cuenta con un instrumento moderadamente fácil en promedio. Como ejemplo de esto, se presenta el caso de la última sección del instrumento, en el que la actividad cognitiva que se planteó fue en todos los ítems de conversión. Sin embargo, el nivel de dificultad promedio del último tema fue moderadamente fácil. Por lo tanto, se podría aprovechar estos ítems que propician la conversión sin resultar cognitivamente difíciles.

De acuerdo con Duval (2017a) el análisis de las funciones cognitivas contribuye en distintas áreas como la psicología cognitiva, inteligencia artificial y la didáctica. Por lo que, de acuerdo con Aguilar-Romero y Juárez-Ruiz (2021) para el caso particular de la inteligencia artificial en la educación, esta investigación contribuyó en el desarrollo de una red de registros de representación semiótica que entre sus posibles contribuciones es orientar al desarrollador en el diseño de un sistema tutorial inteligente, específicamente con el software Herramientas de Creación de Tutores Cognitivos (CTAT), debido a que la estructura de diseño con CTAT es similar al esquema de las redes de registros de representación semiótica. Por lo que, este trabajo fue base para otras investigaciones, orientadas en el desarrollo de tutores cognitivos en temas como lógica, conjuntos y álgebra booleana.

\section{Referencias}

Aiken, L. (2003). Tests psicológicos y evaluación. Pearson Education.

Aguilar-Romero, J. H. (2020). Uso de recursos digitales para el proceso de enseñanza-aprendizaje sobre álgebra booleana a técnicos en electrónica [Libro electrónico]. En E. Ruíz-Velasco \& J. Bárcenas-López (Eds.), Movilidad virtual de experiencias educativas (pp. 511-522). Sociedad Mexicana de Computación en la Educación (SOMECE). 
https://books.google.com.mx/books?id=BzQNEAAAQBAJ\&lpg=PP1\&hl=es\&p$\mathrm{g}=$ PA511\#v=onepage $\& \mathrm{q}=$ juan $\% 20$ hadad $\& \mathrm{f}=$ false

Aguilar-Romero, J., \& Juárez-Ruiz, E. (2021). Red de Registros de Representación Semiótica: Diseño y Elaboración. In A. Rosas (Ed.), Resúmenes del $7^{\circ}$ Congreso Internacional de Matemática Educativa (p. 74). Editorial Lectorum.

Doran, R. (1980). Basic Measurement and Evaluation of Science Instruction. Washington, D. C.: National Science Teachers Association.

Duval, R., (2017a), Semiosis y pensamiento. Registros semióticos y aprendizajes intelectuales. Universidad del Valle.

Duval, R. (2017b). Understanding the Mathematical Way of Thinking - The Registers of Semiotic Representations. In Understanding the Mathematical Way of Thinking - The Registers of Semiotic Representations. Springer International Publishing. https://doi.org/10.1007/978-3-319-56910-9

Ebel, R. \& Frisbie, D. (1991). Essentials of educational measurement. Englewood Cliffs, N. J.: Prentice-Hall.

Herman, G. L., \& Handzik, J. (2010). A preliminary pedagogical comparison study using the Digital Logic Concept Inventory. Proceedings - Frontiers in Education Conference, FIE, 1-6. https://doi.org/10.1109/FIE.2010.5673591

Herman, G. L., Loui, M. C., Kaczmarczyk, L., \& Zilles, C. (2012). Describing the what and why of students' difficulties in Boolean logic. ACM Transactions on Computing Education, 12(1). https://doi.org/10.1145/2133797.2133800

Medina, J., Ramírez, M. \& Miranda, I. (2019). Validez y confiablidad de un test en línea sobre los fenómenos de reflexión y refracción del sonido. Apertura, 11(2), 104-121. http://dx.doi.org/10.32870/Ap.v11n2.1622

Rey, A. (2013). La lógica booleana en la informática. Q.e.d. Ciencias Duras En Palabras Blandas, 6, 20-24.

https://bibliotecadigital.exactas.uba.ar/download/ged/qed_no06.pdf 


\section{Sistema de Memoria Transactiva. Una Aproximación al Procesamiento de Información Grupal en el Proceso de Aprendizaje Colaborativo en EVA}

\section{García-Chitiva, María del Pilar}

ORCID https://orcid.org/0000-0001-6776-3422

mdgarcia@poligran.edu.co 


\title{
SISTEMA DE MEMORIA TRANSACTIVA. UNA APROXIMACIÓN AL PROCESAMIENTO DE INFORMACIÓN GRUPAL EN EL PROCESO DE APRENDIZAJE COLABORATIVO EN EVA
}

\author{
García-Chitiva, María del Pilar \\ ORCID https://orcid.org/0000-0001-6776-3422 \\ mdgarcia@poligran.edu.co
}

\section{Resumen}

La emergencia generada por el COVID-19 y el confinamiento consecuencia de éste, dieron lugar que, a nivel global se viera la necesidad de acudir a la mediación de las TIC, particularmente a los LMS soportados por internet, para dar continuidad a los procesos educativos inclusive en procesos de formación que estaban exclusivamente diseñados para la modalidad presencial. Este hecho reiteró las virtudes de la virtualidad para soportar las barreras de tiempo, distancia y restricciones de aforos en espacios físicos, entre otros. Si bien la coyuntura se ha visto solventada por las tecnologías, es claro que la educación virtual posee problemas que aún o han sido superados, entre ellos las metodologías que privilegian el aprendizaje individual sobre el colaborativo, que refuerzan la instrucción homogénea y que desatienden las diferencias individuales. Para esto, el aprendizaje colaborativo es una opción favorable. No obstante, generalmente las diferencias individuales de los integrantes de los grupos pasan desapercibidas, así como la incidencia de éstas para el logro educativo del grupo. Por lo anterior, el objetivo de este trabajo fue analizar si las parejas homogéneas y heterogéneas según su estilo cognitivo, presentan procesos diferenciados en el logro educativo y el aprendizaje colaborativo (observado en su procesamiento de información grupal TMS). Los resultados evidenciaron que la configuración de TMS requiere periodos prolongados de trabajo conjunto, que la coordinación en la colaboración es mejor en parejas homogéneas que heterogéneas y que el logro educativo se relaciona con el estilo cognitivo, dependiendo la naturaleza y complejidad de la tarea.

\section{Palabras clave}

Aprendizaje colaborativo, Sistema de memoria transactiva (TMS), logro académico, procesamiento de información grupal. 


\section{Introducción}

Si bien, la educación virtual goza de gran popularidad y acogida gracias a las posibilidades de acceso sin límites de tiempo y espacio, a la facilidad de acceso a materiales en múltiples formatos de manera inmediata, así como a la interacción con mediaciones tecnológicas como el computador y los dispositivos celulares, entre otras mediaciones, es claro que también existen retos relacionados con problemáticas diversas, entre las cuales sobresalen la deserción y el bajo logro académico. De acuerdo con Hederich (2014) estos dos fenómenos o problemas de la educación virtual están relaciones con las promesas no cumplidas de la educación virtual en relación con la eficiencia y la calidad. Estas dos problemáticas, están vinculadas con factores asociados ajenos o externos al individuo, tales como las metodologías que se emplean para a enseñanza, las herramientas tecnológicas que facilitan el aprendizaje, formatos en los que se prefiere acceder a la información, etc. Otros, están vinculados directamente con aspectos o rasgos individuales y personales, es decir, internos, tal como los estilos cognitivos, la autopercepción que se tiene de sí mismo y autorregulación en tareas de naturaleza académica, habilidades en el desarrollo de diversas tareas y habilidades digitales, entre otros aspectos. Justamente, en relación con los aspectos de naturaleza externa, como la metodología, Ortega et al. (2010) refieren que, dado que la educación virtual privilegia el aprendizaje virtual sobre el colaborativo, las dificultades de los estudiantes se acentúan en la medida al no tener posibilidades de diálogo y retroalimentaciones en tiempo real, durante el proceso de ejecución de las tareas. Esto desencadena, en muchos casos, baja motivación para permanecer en sus estudios, ya que, de acuerdo con Ortega y sus colaboradores, el aislamiento social e intelectual al que se enfrentan los estudiantes de programas virtuales, dadas las limitaciones de interacción inmediata con docentes y compañeros de clase, impide compartir inquietudes emergentes, sentires e inclusive temores sobre sus procesos de procesos de aprendizaje.

Por otro lado, con respecto a los elementos de naturaleza individual e interna de los aprendientes, Goulão et al. (2015) plantean que los estudiantes de programas virtuales también tienen dificultades de orden personal relacionadas con, 1) bajas o altas competencias digitales que les permiten desempeñarse de manera fluida en los entornos virtuales de aprendizaje (EVA) o tener dificultades en ese proceso, 2) sus preferencias o afinidades para aprender, como su estilo de aprendizaje o estilo cognitivo (i.e., aprenden mejor acompañados o solos, se les facilita el aprendizaje de ciertos contenidos sobre otros, dependiendo el formato en el que se presente, etc.), 3) las percepciones de sí mismos frente a su desempeño y lo que pueden hacer, en términos de autoeficacia, y por ende en autogestión emocional para seguir adelante con sus estudios.

Dado lo anterior, en el presente estudio se propuso analizar la relación entre el proceso de aprendizaje colaborativo entre parejas de estudiantes que fueron asignadas de acuerdo con sus características similares o diferentes en su Estilo Cognitivo en la dimensión Independencia Dependencia de campo. Dichas parejas fueron conformadas como homogéneas y heterogéneas. De otra parte, se analizó la variable Sistema de memoria Transactiva (TMS) como un rasgo o característica interna de procesamiento de la información grupal y, finalmente, el logro educativo mediante los resultados de seis evaluaciones parte del proceso formativo de los participantes quienes estuvieron matriculados en un módulo de un programa virtual de Administración de empresas. 


\section{Aprendizaje colaborativo en entornos virtuales de Aprendizaje}

El concepto de aprendizaje colaborativo partió de los estudios que entre los 1970s y 1980s analizaron cómo se daba el aprendizaje entre dos o más personas. En esas décadas, los estudios se enfocaron en la dinámica de pequeños grupos y la interacción estudiantil cara a cara. Inicialmente los estudios ocurrieron en la educación primaria. Pero, se extendieron rápidamente a la educación secundaria y la universitaria. Una discusión muy popular relacionada con el aprendizaje colaborativo es si este es igual a aprendizaje cooperativo, o si colaboración y cooperación son sinónimos. Para Kreijns et al., (2003) aún no hay consenso sobre ese punto. Guitert \& Pérez-Mateo, (2013) que las diferencias entre uno y otro tienen que ver con las raíces etimológicas de cada término. El término cooperación "tiene sus raíces en el continente americano y, más concretamente, en los Estados Unidos de América; por el contrario, el concepto de colaboración nace en el continente europeo, siendo especialmente desarrollada por la tradición anglosajona" (p. 19). Al respeto, Dillenbourg (1999) planteó que la cooperación y colaboración parten del mismo supuesto, por lo cual, en ocasiones se usan como términos sinónimos, aludiendo en la cooperación los "socios que cooperan" dividen el trabajo, resuelven subtareas individualmente para luego realizar un engranaje de resultados parciales al igual que en la entrega final o culminación de la tarea. De esta manera de acuerdo con Vuopala et al., (2019), la generación de un nuevo conocimiento se deriva de dos fuentes de comprensión y desarrollo, una de naturaleza individual y otra grupal. tanto individual, como grupal. Dado que colaborar implica procesos consensuados (i.e. construir y mantener una concepción compartida del problema y alcanzar un objetivo común), es claro que al interior de un grupo colaborativo tienen lugar procesos de conciencia grupal (i.e., búsqueda y selección de estrategias, identificación de las habilidades de cada miembro) en el proceso de la consecución de la meta de aprendizaje (Vuopala et al., 2019).

\section{El Concepto de sistema de Memoria Transactiva (TMS)}

De otra parte, el concepto de TMS partió de los estudios que Wegner, Giuliano \& Hertel, (1985) adelantaron con el fin de explicar la ocurrencia de procesos cognitivos compartidos en diadas, en presencia de marcadas diferencias individuales. Originalmente los estudios se centraron en analizar la presencia de TMS en parejas, pero posteriormente trabajos como los de Hollingshead, (2001) y Jackson \& Moreland, (2009) plantearon la posibilidad de analizar el TMS en grupos de aprendizaje al desarrollar tareas de contenido académico. Un TMS configura partir de la experiencia y conocimiento de que los integrantes de un grupo van adquiriendo a partir de las interacciones, durante el trabajo colaborativo. En este proceso, los miembros identifican cuáles son sus áreas de experticia y la de sus compañeros (aprenden a identificar quién sabe qué). En este sentido, la presencia de TMS en un grupo permite que, de manera eficaz, los integrantes del equipo puedan realizar de manera eficiente procesos de codificación, almacenamiento y recuperación de la información en diferentes dominios (Hollingshead, 2001). Es decir, un TMS permite describir el sistema de procesamiento de información grupal ya que se refiere a los aspectos cognitivos transaccionales ( de intercambio de ideas, concepciones, conocimientos) entre los miembros colaboradores, durante el proceso de aprendizaje. Dentro de la propuestas presentes para analizar la presencia en TMS al interior de un grupo, la escala de Lewis (2003) refiere tres dimensiones relacionadas con los niveles de especialización, credibilidad y coordinación. La especialización da cuenta de la experticia y conocimiento de cada miembro del grupo en un aspecto puntual para la ejecución 
de la tarea; la coordinación, alude a habilidades de los integrantes del grupo para integrase, intercambiar ideas y estrategias, tomar decisiones en el desarrollo de la tarea. Finalmente, la credibilidad refiere a los niveles de confianza entre por lo que hacen los demás para la ejecución de la tarea.

\section{El concepto de Estilo Cognitivo}

Tuvo origen a mediados del siglo XX, en el marco del desarrollo teórico de la psicología acerca de las diferencias individuales. El estudio bajo este constructo se apartó de las teorías clásicas sobre inteligencia y, en cambio, se centró en la comprensión de las diferencias individuales de las personas en sus maneras de aproximarse al conocimiento. De hecho, aproximaciones teóricas como las de Witkin et al., (1975) asociaron los estilos cognitivos con maneras consistentes en las formas de aprender y de vincularse e interactuar socialmente. Justamente Witkin y sus colaboradores plantearon la Dimensión Independencia dependencia de campo en el marco de la teoría de los estilos cognitivos, con el fin de establecer que dada la naturaleza analítica de algunas personas para abordar las tareas y problemas, éstas tendían a la independencia de campo, mientras que quienes preferían aproximarse a las tareas y aprender de manera más acumulativa y holística eran considerados dependientes de campo. La dimensión Dependencia - Independencia de Campo (DIC) distingue la capacidad de reestructuración perceptual, como característica hacia la independencia del campo de cada individuo. Así, altas habilidades de restructuración perceptual implican independencia de campo y, en contraste, las bajas dan cuenta de la dependencia de campo.

En este sentido, se comprenden los estilos cognitivos en la Dimensión Independencia--Dependencia de Campo, como la manera particular de las personas para procesar la información e interactuar socialmente, por ende, esta cualidad de los individuos es de carácter neutral, y por ello el uno no es mejor que el otro. Al respecto, Hederich-Martínez \& Camargo-Uribe (2015) refieren que "tanto los individuos independientes del campo (FI) como los dependientes del campo (FD) están igualmente bien adaptados a las demandas del entorno; a pesar de que los modos de adaptación son claramente diferentes"

De esta manera, lo hasta aquí planteado revela la importancia de analizar la relación entre los tres contructos aquí planteados. El aprendizaje colaborativo, el sistema de memoria Transactiva (TMS) y el estilo cognitivo, con el fin de poder comprender cómo las cogniciones individuales contribuyen en la edificación de un sistema de procesamiento de información grupal mediante el TMS en grupos de estudiantes que aprenden colaborativamente.

Por lo anterior, en lo que sigue, se presenta el marco metodológico del estudio en el que se analizó la evolución de TMS y el logro educativo de parejas de estudiantes que aprendieron colaborativamente en un Entorno virtual de aprendizaje

\section{Método}

El estudio tuvo un diseño mixto de medidas repetidas (Howell, 2012; Campbell y Stanley, 1966). Dado que se pretendió establecer la relación existente entre las variables tipo de pareja según el estilo cognitivo en la DIC, TMS y logro, se realizaron tres mediciones de TMS al mismo grupo de estudiantes en tres momentos diferentes. 
Adicionalmente, se establecieron las relaciones existentes entre las variables tipo de pareja según el estilo cognitivo en la DIC, TMS y logro y se definieron los efectos intra e intersujetos.

\section{Descripción del contexto y de los participantes}

El estudio se llevó a cabo en programa virtual de Administración de empresas, en un módulo de 8 semanas de Entorno económico, en una institución universitaria del sector privado en Bogotá, Colombia, con 40 estudiantes.

\section{Instrumentos}

Los instrumentos empleados para el estudio fueron los siguientes:

1. Escala de Sistema de Memoria Transactiva (TMS) que Lewis (2003) propuso para identificar las manifestaciones de esta propiedad grupal al interior de los equipos que trabajan en conjunto.

2. Escala GEFT para determinar el Estilo Cognitivo en la dimensión DIC

3. Seis (6) evaluaciones estandarizadas en el módulo en el que aprendieron colaborativamente los participantes.

\section{Procedimiento}

1. Distribución del consentimiento informado a los participantes (40 estudiantes),

2. Preparación para colaborar antes del inicio del módulo. (https://www.youtube. com/watch?v=Xa9dgkL8Tbo)

3. Suministro del test de Estilos Cognitivos GEFT, Agrupación de parejas (homogéneas $D+D$ y $I+I$ y heterogéneas $D+I$ ) según $E C$ en al $D I C$.

4. Recolección de datos de TMS dos semanas y 5-Recolección de calificaciones al finalizar el módulo.

\section{Resultados}

De manera general, a través del análisis de varianza determinó que el Estilo Cognitivo no introdujo diferencias estadísticamente significativas en las tres mediciones de TMS: $1=[F(2,37)=0.785, p=0.469], 2=[F(2,37)=1.280, p=0.300]$ y $3=[F(2,37)$, $\mathrm{p}=2.980, \mathrm{p}=0.072]$, tal como se refleja en la Tabla 1 .

\begin{tabular}{|c|c|c|c|c|c|c|c|c|c|c|c|}
\hline & \multicolumn{3}{|c|}{$D+D$} & \multicolumn{3}{|c|}{$I+1$} & \multicolumn{3}{|c|}{ I+D } & \multirow{2}{*}{$F$} & \multirow[b]{2}{*}{$p$} \\
\hline & $\bar{x}_{2}$ & DS & $\mathrm{n}$ & $\bar{x}_{2}$ & DS & $n$ & $\bar{x}_{2}$ & DS & $\mathrm{n}$ & & \\
\hline $\begin{array}{l}\text { Medición } \\
\text { TMS } 1\end{array}$ & 59.10 & 5.76 & 10 & 54.60 & 13.03 & 10 & 55.75 & 12.77 & 20 & 0.785 & 0.469 \\
\hline $\begin{array}{l}\text { Medición } \\
\text { TMS } 2\end{array}$ & 60.60 & 4.06 & 10 & 57.90 & 10.68 & 10 & 56.55 & 10.15 & 20 & 1.280 & 0.300 \\
\hline $\begin{array}{l}\text { Medición } \\
\text { TMS } 3\end{array}$ & 59.90 & 5.66 & 10 & 58.00 & 10.17 & 10 & 49.25 & 17.46 & 20 & 2.980 & 0.072 \\
\hline
\end{tabular}


No obstante, al analizar el comportamiento de los tipos de pareja por cada una de las dimensiones de TMS, se logró determinar que sí hubo una diferencia estadísticamente significativa $(p=0,37)$ en tercera medición entre las parejas, tal como se aprecia en la figura 1. Esto indica que mientras las parejas homogéneas $(D+D$ y $I+I)$ reportaron altos procesos de coordinación, las parejas heterogéneas no coincidieron en este aspecto, tal como sucedió en las dos anteriores mediciones en esta misma dimensión, pero de manera más acentuada en la última.

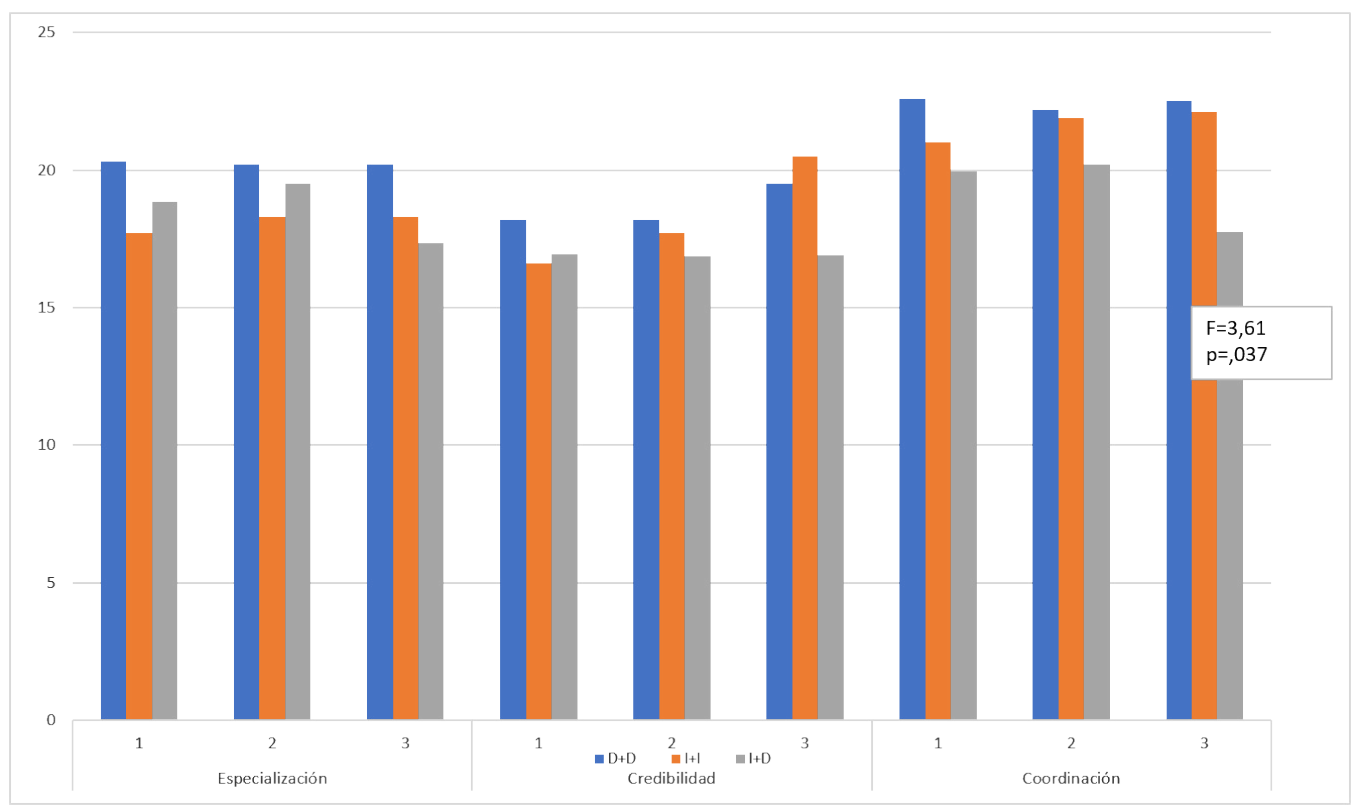

Figura 1. Comparación de promedios por dimensiones de TMS en resultados por tipo de pareja

Fuente: Elaboración propia

Finalmente, en relación con el logro educativo, mediante un análisis de varianza se determinó que solamente hubo una diferencia estadísticamente significativa ( $p=$ $0,051)$ entre las parejas colaborativas conformadas según su estilo cognitivo en la evaluación No. 3. En dicha actividad evaluativa (los estudiantes construir un artículo en inglés) se reveló un mejor desempeño de las parejas homogéneas $1+I(\bar{x}=0,58)$ sobre las parejas heterogéneas $D+D(\bar{x}=0,10)$ y $D+I(\bar{x}=-0,34)$. La diferencia del logro entre las parejas homogéneas y heterogéneas (Figura 2) se aborda en el apartado de la discusión. 


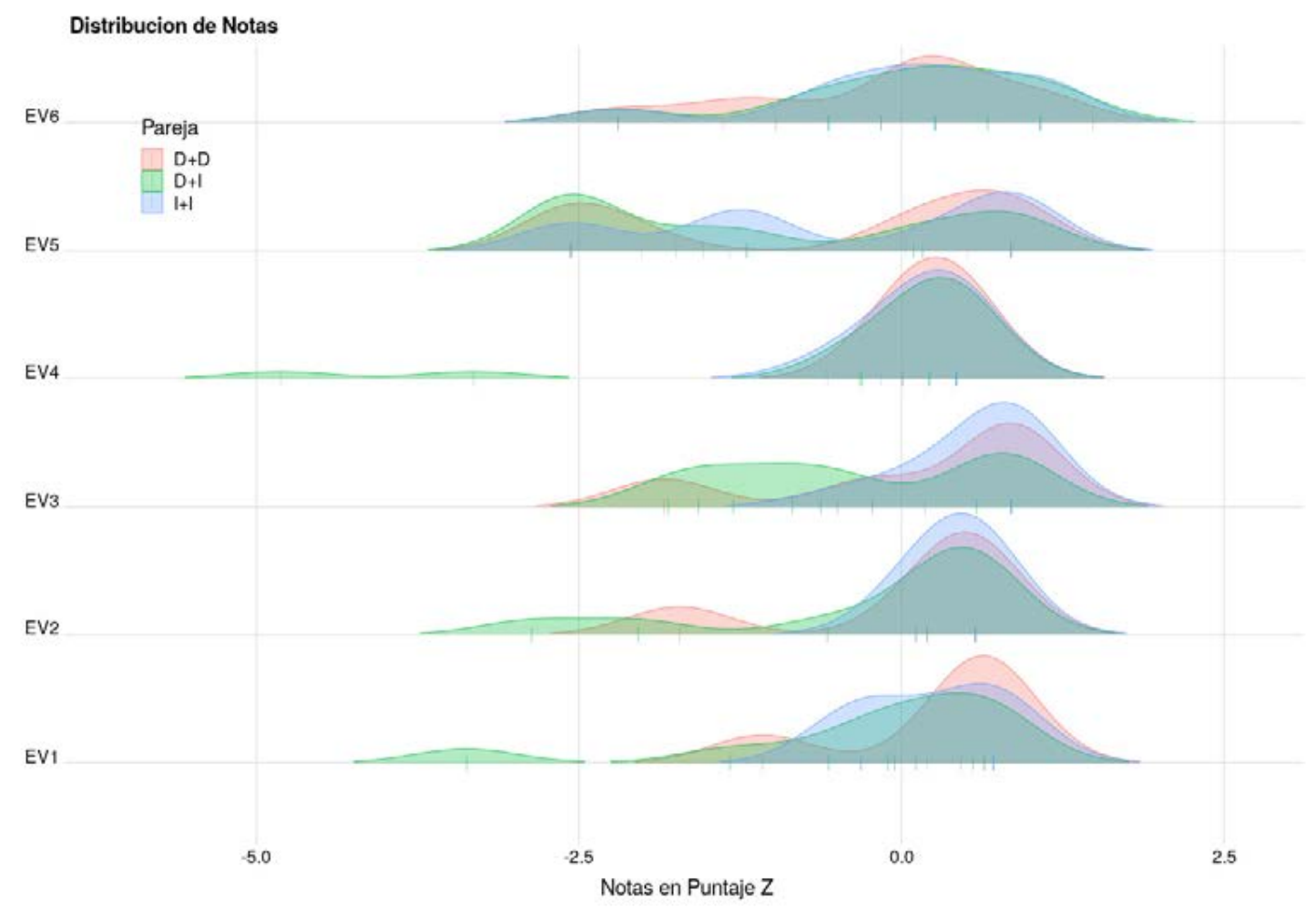

Figura 2. Distribución estadística observada para el logro de aprendizaje de las seis evaluaciones estudiantiles, según la pareja de Estilo Cognitivo

Fuente: Elaboración propia

\section{Discusión y conclusiones}

El objetivo de este trabajo se centró en analizar si existe relación entre los tipos pareja homogéneas y heterogéneas, según el estilo cognitivo en la DIC, el logro educativo y el aprendizaje colaborativo analizado desde el TMS de las parejas de aprendizaje. Los resultados mostraron que, si bien de manera general no hubo diferencias estadísticamente significativas entre las parejas homogéneas $(I+\mid$ y $D+D)$ y heterogéneas $(D+1)$ en relación con el TMS, sí se pudo identificar que a medida que pasó el tiempo los niveles de coordinación de las parejas heterogéneas decayeron en contraste con las heterogéneas. Este indicio resulta interesante, ya que la coordinación se refiere principalmente a los procesos de comunicación que entablan los integrantes de un equipo para construir de manera conjunta y desarrollar cohesionadamente las asignaciones. Este aspecto resulta revelador para los docentes que trabajen con grupos o parejas de estudiantes heterogéneas, ya que es preciso generar andamiajes que faciliten los procesos de comunicación y por ende de coordinación entre los estudiantes. De ahí que cobre relevancia lo referido por Kreijns et al., (2003) cuando afirma que la colaboración debe ser diseñada y orientada al interior del proceso de educativo, ya que la simple agrupación de estudiantes no garantiza no garantiza un proceso de aprendizaje colaborativo efectivo.

De otra parte, con respecto a la relación entre tipos de parejas y el TMS, se identificó que tal como lo anticipan estudios como el de Hollingshead (1998) y Hollingshead 
(2001), la consolidación los Sistemas de Memoria Transactiva - TMS requieren de la exposición de los equipos, parejas o grupos de aprendizaje colaborativo a periodos más prolongados de tiempo (más de 8 semanas - tiempo en el que se llevó a cabo el estudio), más aún cuando el entorno de aprendizaje es virtual. En este sentido, las actividades que se lleven a cabo en entornos virtuales de aprendizaje pueden incluir más actividades en las que los estudiantes intercambien y compartan información de sus habilidades y con sus compañeros, por ejemplo, foros de presentación, sesiones de conversación, entre otros. Los resultados estadísticamente significativos en la dimensión de coordinación evidenciaron que las afinidades de las parejas homogéneas facilitaron la coordinación, muestran que en las heterogéneas las diferencias es tendencia estilística de los integrantes de las parejas resultaron desventajosas para la coordinación intra-pareja.

Finalmente, con respecto al logro educativo, se identificó que la única diferencia estadísticamente significativa que se presentó en la evaluación 3 entre las parejas homogéneas y heterogéneas según su estilo cognitivo en la DIC, se relaciona con lo rexportado en estudios previos sobre estilos cognitivo en esta dimensión (Amador \& Forns, 1994), en los que se desataca la efectividad de los individuos independientes de campo en tareas que requieren mayores niveles de procesamiento de información, en contraste con los individuos dependientes de campo. En el caso de la tarea de la evaluación 3 los estudiantes debieron elaborar un artículo, lo cual en sí mismo es una tarea compleja. Elaborarlo en un idioma diferente a la legua materna adhirió un nivel de complejidad mayor.

\section{Referencias}

Amador, J., \& Forns, M. (1994). Dependencia-independencia de campo y eficacia en tareas cognitivas. Anuario de Psicología, 60, 35-48. https://doi.org/10.1344/\%25x

Campbell, D. T., \& Stanley, J. C. (1966). Disenos experimentales y cuasiexperimentales en la investigación social. Amorrortu Ed.

Dillenbourg, P. (1999). What do you mean by ' collaborative learning '? In P. Dillenbourg (Ed.), Collaborative -learning: Cognitive and computational approaches (Vol. 1, Issue 6, pp. 1-19). Elsevier. https://doi.org/10.1.1.167.4896

Guitert, M., \& Pérez-Mateo, M. (2013). La colaboración en la red: hacia una definición de aprendizaje colaborativo en entornos virtuales. Teoría de La Educación. Educación y Cultura En La Sociedad de La Información, 14(1), 10-31. http://www.redalyc. org/pdf/2010/201025739004.pdf

Hederich-Martínez, C., \& Camargo-Uribe, A. (2015). Cognitive style and educational performance. The case of public schools in Bogotá, Colombia. Educational Psychology, 36(4), 719-737. https://doi.org/10.1080/01443410.2015.1091916

Hollingshead, A. B. (1998). Communication, Learning, and Retrieval in Transactive Memory Systems. Journal of Experimental Social Psychology, 34, 423-442. https:// doi.org/10.1006/jesp.1998.1358 
Hollingshead, A. B. (2001). Cognitive interdependence and convergent expectations in transactive memory. Journal of Personality and Social Psychology, 81(6), 10801089. https://doi.org/10.1037/0022-3514.81.6.1080

Howell, D. (2012). Statistical Methods for Psychology (8th ed.). Cengage Learning.

Jackson, M., \& Moreland, R. L. (2009). Transactive Memory in the Classroom. Small Group Research, 40(5), 508-534. https://doi.org/10.1177/1046496409340703

Kreijns, K., Kirschner, P. A., \& Jochems, W. (2003). Identifying the pitfalls for social interaction in computer-supported collaborative learning environments: A review of the research. Computers in Human Behavior, 19(3), 335-353. https://doi.org/10.1016/ S0747-5632(02)00057-2

Lewis, K. (2003). Measuring transactive memory systems in the field: scale development and validation. Journal of Applied Psychology, 88(4), 587-604. https://doi. org/10.1037/0021-9010.88.4.587

Vuopala, E., Näykki, P., Isohätälä, J., \& Järvelä, S. (2019). Knowledge co-construction activities and task-related monitoring in scripted collaborative learning. Learning, Culture and Social Interaction, 21, 234-249. https://doi.org/10.1016/j.Icsi.2019.03.011

Wegner, Giuliano \& Hertel, P. (1985). Cognitive interdependence in close relationships. In Compatible and incompatible relationships (pp. 253-276). Springer-Verlag. https://doi.org/10.1007/978-1-4612-5044-9_12

Witkin, H., Moore, C., Goodenough, D., \& Cox, P. (1975). Field-development and field-independent cognitive styles and their educational implications. Review of Educational Research, 47(1), 1-64. https://doi.org/10.1002/j.2333-8504.1975.tb01065.x 


\section{Métodos Univariantes Aplicados a la Competencia Digital del Futuro Docente en Relación a su Actitud, Conocimiento y Uso de las TIC}

\section{Guillén Gámez, Francisco D.}

http://orcid.org/0000-0001-6470-526X dguillen@uco.es

\section{Linde-Valenzuela, Teresa}

https://orcid.org/0000-0002-7965-5768

teresalv@uma.es 


\section{MÉTODOS UNIVARIANTES}

APLICADOS A LA COMPETENCIA

DIGITAL DEL FUTURO DOCENTE

EN RELACIÓN A SU ACTITUD,

CONOCIMIENTO Y USO DE LAS TIC

\section{Guillén-Gámez, Francisco D. Linde-Valenzuela, T.}

\section{Resumen}

Este trabajo analiza y compara el nivel de competencia digital del futuro maestro de Educación infantil, Educación Primaria y Educación Social respecto a sus actitudes hacia las Tecnologías de la Información y la Comunicación (en adelante, TIC), conocimientos de recursos digitales y uso didáctico de los mismos. Para tal propósito ha sido utilizado un diseño no experimental ex post facto a través de encuesta, con un total de 229 participantes de la Universidad de Almería, durante el curso académico 2019-2020. Los resultados presentan que ambos tipos de futuros docentes tienen una actitud media-alta hacia las TIC, con puntuaciones ligeramente superiores en los participantes de Educación Infantil y Educación Primaria. Respecto al nivel de conocimiento y uso de recursos digitales, se ha evidenciado que son los participantes de Educación Social quienes poseen una competencia digital baja, mientras que los de Educación Primaria e Infantil poseen un nivel medio. Estos resultados pueden deberse al tipo de asignaturas y público al que va destinado a ofrecer su futura labor profesional, ya que los participantes de Educación Infantil y Primaria se focalizan en la docencia de escolares, mientras que los de Educación Social se centran más en la intervención socioeducativa con los miembros de la comunidad.

\section{Palabras clave}

Competencia digital, magisterio, educación, métodos. 


\section{Introducción}

El curso académico 2019-2020 se vio afectado terriblemente a consecuencia de la pandemia sanitaria provocada por la COVID-19. Ante la situación de emergencia, los centros educativos de todas las etapas se vieron en la necesidad de cerrar sus puertas para comenzar a impartir su docencia de manera online a través de recursos digitales (Arufe-Giráldez et al., 2020; Devitt et al., 2020; Sanrey et al., 2020). Para poder lograr que esta modalidad implantada de una semana a otra tuviera la máxima calidad posible, en comparación con la modalidad presencial de enseñanza que se venía impartiendo hasta ese momento, se requería que tanto el profesorado como el alumnado (y sus familias, en los niveles enseñanza obligatoria) tuvieran adquiridas unas competencias digitales básicas que les permitieran poder seguir desarrollando el proceso de enseñanza-aprendizaje.

El análisis de las oportunidades y las necesidades de la formación en línea que emerge tras la reflexión de lo que ha supuesto esta circunstancia sanitaria para la enseñanza para todos los niveles educativos durante esta etapa Monleón Oliva (2021), vislumbra como algo fundamental las competencias digitales del profesorado que está en formación inicial para acometer, además de situaciones como la vivida durante el periodo de confinamiento, la realidad cotidiana del aula, cada vez más digitalizada, y favorecer el proceso de enseñanza-aprendizaje enriquecido a través de las tecnologías.

Para ello, el profesorado universitario debe ser digitalmente competente, y de este modo facilitar la adquisición de estas destrezas digitales en la formación inicial de docentes de Educación Infantil, Educación Primaria y profesionales de Educación Social. Así, Cabero-Almenara et al. (2021) realiza un análisis sobre la competencia digital del profesorado universitario en relación a los parámetros del marco de referencia DigComEdu, en función de su área de conocimiento, edad y sexo. Si bien, los resultados de esta investigación muestran la necesidad de formación del profesorado de educación superior en competencias digitales, en todos los rangos de edad y en ambos sexos, puesto que el nivel de competencia que presentan está en el intervalo de nivel A2 y B1. Si bien, el profesorado masculino de la rama de conocimiento de Ciencias Sociales y Jurídicas mostraba la mejor puntuación en relación a otras especialidades.

Además de la necesidad de formación en competencias digitales y tecnológicas del profesorado universitario, hay que considerar el entorno virtual de aprendizaje donde se desarrolla el proceso educativo. Sobre ello, el estudio de Marín-Díaz et al. (2021), recoge la opinión de estudiantes universitarios de Educación Infantil y Primara de la Universidad de Córdoba sobre la plataforma de gestión del aprendizaje utilizada como entorno virtual de aprendizaje durante el periodo de confinamiento, que requirió la enseñanza en línea como única opción en ese momento. La investigación evidencia que el grupo de futuros docentes considera la estructuración del contenido en la plataforma como un elemento importante para su uso, si bien, no les motiva utilizarla como medio de aprendizaje, pues la mayoría afirma tener preferencia por la enseñanza presencial. Además, se indica que no se optimiza el uso de las actividades y herramientas de la plataforma, pues el grupo de estudiantes únicamente usan las que conocen, por lo que el profesorado podría proponer actividades prácticas y otro tipo de tareas para ampliar las posibilidades de un uso más completo del entorno virtual. 
Romero Andonegui et al. (2021) presentan la percepción de estudiantes universitarios de Grado en Educación, en la Universidad del País Vasco, sobre los recursos relacionados con las TIC en la universidad y su uso, comparando el uso tecnológico que hacen en el contexto académico y en su ámbito personal. El grupo de estudiantes prefiere la enseñanza presencial, haciendo el menor uso posible de las TIC, aunque reconocen que estas favorecen su éxito académico. En este aspecto se muestra la semejanza con el trabajo de Marín-Díaz et al. (2021), donde el grupo de futuros docentes coincide en la elección de la presencialidad por encima de otra modalidad de enseñanza. También, coincide con el desconocimiento de las posibilidades educativas de las TIC en el contexto académico, puesto que, como concluye Romero Andonegui et al. (2021), el grupo de docentes en formación inicial sólo conoce las aplicaciones y entornos virtuales de aprendizaje que son obligatorios para sus estudios, y su participación en estos es pasiva. Además, el uso e integración de las TIC en su proceso de enseñanza-aprendizaje influye en las expectativas del alumnado universitario.

Visto lo anterior, la formación docente adecuada a la era digital se convierte en una preocupación global, puesto que, en España, tal y como muestra el trabajo de Cabero y Martínez (2019), el colectivo docente no está preparado adecuadamente para la utilización educativa de las TIC. Para formar en competencias digitales al colectivo docente de las etapas escolares en formación inicial, y también a futuros profesionales de la educación social, es fundamental que el conjunto de estudiantes universitarios tenga una actitud digital que promueva el proceso de enseñanza-aprendizaje (Christ et al., 2017; Guillén-Gámez \& Mayorga-Fernández, 2020). En esta línea, el estudio de Roa et al. (2021), valida un instrumento para diagnóstico del uso educativo de las TIC por parte de profesorado universitario, basado en el modelo de competencia digital docente en el siglo XXI (Prendes et al., 2018), con el fin de elaborar un plan de formación en competencias digitales al colectivo docente universitario en su contexto colombiano, con un enfoque de aprendizaje basado en retos, relacionados con la tarea docente. Los resultados de aplicar el instrumento evidencian la necesidad de reforzar las competencias digitales docentes en educación superior, pues el $12 \%$ del profesorado participante se ubicó en los niveles iniciales, de exploración. Además, un $77 \%$ se situó en el nivel medio, el integrador, mientras que tan sólo el 11\% se posicionó en el nivel más complejo, de innovación.

Este estudio se centra en:

- Conocer qué competencias digitales tenía una muestra de futuros docentes y profesionales de Educación (Infantil, Primaria y Social) procedentes de la Facultad de Educación de la Universidad de Almería (España) durante el segundo semestre del año 2020.

- Analizar si existían diferencias significativas en las puntuaciones del alumnado, acorde a su correspondiente grado educativo.

\section{Método/Descripción de la experiencia}

Para cumplir con los objetivos propuestos para este estudio, se decidió utilizar una metodología cuantitativa a través de un diseño ex post facto por encuestas. 


\section{Descripción del contexto y de los participantes}

Los participantes fueron seleccionados a través de un muestreo no probabilístico de manera intencional. Concretamente, la muestra estuvo compuesta por un total de 229 estudiantes del grado de Educación de la Facultad de Educación de la Universidad de Almería, durante el curso académico 2019-2020. El 26.2\% de la muestra procedía del sexo masculino, mientras que el $73.8 \%$ restante procedía del sexo femenino. Respecto al tipo de alumnado, el $21.4 \%$ de la muestra pertenecía al grado de Educación Social $(n=49)$, el $24.00 \%$ estaba matriculado en el grado de Educación Infantil, y el $54.60 \%$ de la muestra pertenecía al grado de Educación Primaria.

\section{Instrumentos}

Para medir el nivel de competencia digital del futuro maestro de Educación, ha sido utilizado el cuestionario ACUTIC, elaborado por Ruiz et al. (2015). Se compone de 31 ítems tipo Likert de 5 puntos en las que los alumnos deben responder según su grado de acuerdo con la afirmación propuesta (desde completamente en desacuerdo, valor 0 puntos, hasta completamente de acuerdo, valor 4 puntos). El instrumento se compone de tres dimensiones: dimensión actitud, que incluye 7 ítems sobre pensamientos, creencias o actitudes hacia las ICT. La dimensión conocimiento, compuesta por 13 ítems sobre el conocimiento hacia herramientas 2.0 y aplicaciones web enfocadas a la enseñanza. Finalmente, la dimensión uso, compuesta por los mismos 13 ítem que la dimensión de conocimiento tecnológico, pero enfocadas en el uso que realiza de ellas.

Respecto a la fiabilidad, ha sido llevada a cabo por consistencia interna ( $\boldsymbol{\alpha}$ de Cronbach) con unos valores de: para el instrumento total $\alpha=0.932$ y para cada una de las escalas, $\boldsymbol{\alpha}=.904$ (actitud), $\boldsymbol{\alpha}=0.899$ (conocimiento) y $\boldsymbol{\alpha}=0.860$ (uso).

\section{Resultados}

El actual apartado está dividido de la siguiente forma: la primera parte se centra en analizar descriptivamente las puntuaciones otorgadas en las diferentes dimensiones del instrumento, para cada tipo de alumnado; la segunda parte está enfocado en conocer si existen diferencias significativas entre los diferentes agentes implicados, para cada dimensión del instrumento.

\section{Análisis descriptivo en las puntuaciones del alumnado para cada dimensión}

En la figura 1 se recoge las tres dimensiones del instrumento. Respecto a las actitudes hacia las TIC (A), a nivel general se observa que ambos tipos de alumnos de los tres grados educativos analizados obtienen un nivel medio-alto en sus actitudes hacia la tecnología. 

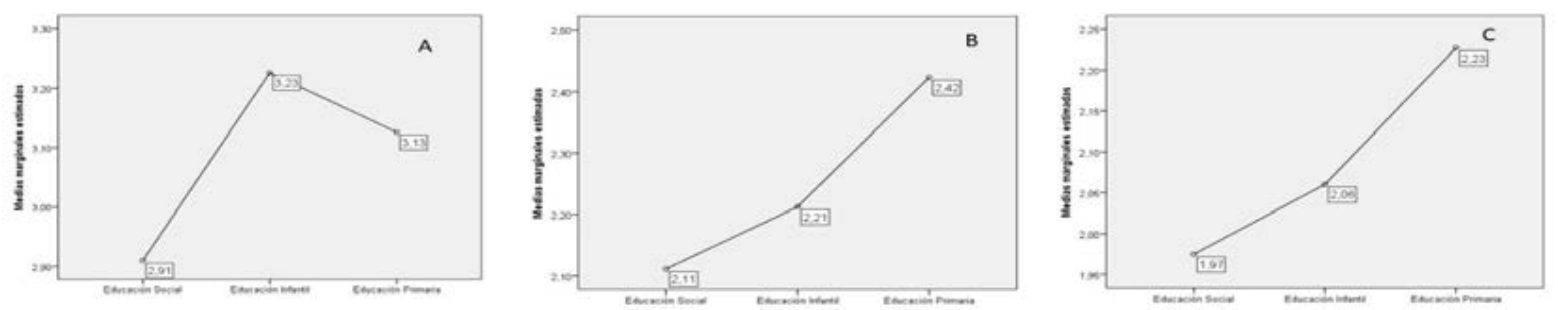

Figura 1. A) Actitudes hacia las TIC. B) conocimiento hacia las TIC. C) Uso hacia las TIC

Comparativamente, se observa que es el futuro maestro de Educación Infantil quien percibe una mayor actitud $(M=3.23)$, mientras que la actitud más baja se encentra en el futuro maestro de Educación Social ( $M=2.91)$. Respecto a los de Educación Primaria, se encuentran en una posición intermedia $(M=3.13)$. Respecto al conocimiento global del futuro maestro en relación a recursos y dispositivos TIC (B), se observa que, en el dominio conceptual de estos recursos digitales, el grupo con una media ligeramente superior es el futuro maestro de Educación Primaria (2.42), en comparación por ejemplo con los de Educación Social los cuales perciben un nivel más bajo $(M=2.11)$. A nivel general, para los tres tipos de futuros alumnos, los valores en relación a competencia digital son medios en relación a la escala Likert de cinco puntos. Por último, las medias globales en relación al uso didáctico que el futuro maestro de Educación realizada sobre las TIC (C), se asocian a los encontrados en la dimensión anterior, ya que son los futuros alumnos de Educación Primaria los que perciben hacer un mayor uso de recursos digitales $(M=2.23)$, en comparación por ejemplo con los de Educación Social $(M=1.97)$ los cuales perciben un nivel menor. A nivel general, se observa que tanto el futuro maestro de Educación Infantil y Educación Primaria posee unos niveles medios en competencia digital los de Educación Social poseen un nivel medio-bajo respecto a su uso.

\section{Aplicación de ANOVA (análisis de la varianza)}

Con el propósito de poder utilizar técnicas paramétricas, se comprobó la normalidad de los datos a través del test de Kolmogorov-Smirnov, al tener una muestra de participantes bastante elevada. Los resultados mostraron que no existían problemas a la vista sobre dicha normalidad (KS = 0.062; gl= 229; sig. =.051). Por lo tanto, se procedió a utilizar este tipo de estadística, concretamente, ANOVA univariante por comparaciones múltiples con el método de Tukey.

Respecto a la dimensión actitud hacia las TIC, el modelo ANOVA univariante planteado no fue significativo (F, 2.351; sig., 0.098) por lo que a nivel general no existían diferencias en las actitudes del alumnado. Sin embargo, al realizar las comparaciones múltiples, los resultados fueron más precisos. La tabla $X$ muestra los valores de significación, junto a las diferencias de medias y sus intervalos de confianza. Se observa que existen diferencias estadísticamente significativas en las puntuaciones entre el alumnado de Educación Social y el alumnado de Educación Infantil sobre sus actitudes al usar las TIC en su proceso de enseñanza-aprendizaje (sig. $=0.036$ ). 
Tabla 1 Comparaciones múltiples sobre las actitudes hacia el uso de las TIC

\begin{tabular}{|c|c|c|c|c|c|c|}
\hline \multirow[b]{2}{*}{ Grado } & \multirow[b]{2}{*}{ Grado } & \multirow{2}{*}{$\begin{array}{l}\text { Diferencia } \\
\text { de medias }\end{array}$} & \multirow{2}{*}{$\begin{array}{l}\text { Error } \\
\text { estándar }\end{array}$} & \multirow[b]{2}{*}{ Sig. } & \multicolumn{2}{|c|}{$\begin{array}{l}95 \% \text { de intervalo de confianza para } \\
\text { diferencia }\end{array}$} \\
\hline & & & & & Límite inferior & Límite superior \\
\hline \multirow[t]{2}{*}{ Social } & Infantil & $-0.316^{*}$ & 0.150 & 0.036 & -0.611 & -0.021 \\
\hline & Primaria & -0.216 & 0.128 & 0.094 & -0.469 & 0.037 \\
\hline \multirow[t]{2}{*}{ Infantil } & Social & $0.316^{*}$ & 0.150 & 0.036 & 0.021 & 0.611 \\
\hline & Primaria & 0.100 & 0.123 & 0.417 & -0.143 & 0.343 \\
\hline \multirow[t]{2}{*}{ Primaria } & Social & 0.216 & 0.128 & 0.094 & -0.037 & 0.469 \\
\hline & Infantil & -0.100 & 0.123 & 0.417 & -0.343 & 0.143 \\
\hline
\end{tabular}

En la tabla 2 se muestra los valores obtenidos al realizar las comparaciones múltiples en la dimensión conocimiento tecnológico digital. El modelo planteado de ANOVA univariante fue significativo (F, 3.186; sig., 0.043), por lo que existían diferencias en las puntuaciones del alumnado sobre sus conocimientos tecnológicos. A través de la columna de significación se observa que existen diferencias significativas entre el alumnado de Educción Social y de Educación Primaria en sus conocimientos sobre herramientas digitales (sig. $=0.021$ ). Entre el resto de colectivos implicados, no se han evidenciado diferencias significativas.

Tabla 2 Comparaciones múltiples sobre el conocimiento hacia las TIC

\begin{tabular}{lllllll} 
& & & & & \multicolumn{3}{c}{$\begin{array}{l}\text { 95\% de intervalo de confianza para } \\
\text { diferencia }\end{array}$} \\
\cline { 3 - 7 } Grado & Grado & $\begin{array}{l}\text { Diferencia } \\
\text { de medias }\end{array}$ & $\begin{array}{l}\text { Error } \\
\text { Sestándar }\end{array}$ & Sig. & Límite inferior & Límite superior \\
\hline \multirow{2}{*}{ Infantil } & Infantil & -0.101 & 0.157 & 0.519 & -0.410 & 0.208 \\
\cline { 2 - 7 } & Primaria & $-0.312^{*}$ & 0.134 & 0.021 & -0.577 & -0.047 \\
\cline { 2 - 7 } & Social & 0.101 & 0.157 & 0.519 & -0.208 & 0.410 \\
\hline \multirow{2}{*}{ Primaria } & Social & -0.211 & 0.129 & 0.104 & -0.465 & 0.044 \\
\cline { 2 - 7 } & Infantil & 0.211 & 0.134 & 0.021 & 0.047 & 0.577 \\
\hline
\end{tabular}

En la tabla 3 se muestra los valores obtenidos al realizar las comparaciones múltiples en la dimensión uso sobre diferentes aplicaciones digitales. Aunque el modelo de ANOVA a nivel global no fue significativo (F, 2.258; sig., 0.107), sí que se observaron que existían diferencias estadísticamente significativas al realizar las comparaciones múltiples entre pares de colectivos. Concretamente, se evidenciaron diferencias entre el alumnado de Educación Social y el alumnado de Educación Primaria (sig. = 0.049). Entre el resto de colectivos, no fueron encontrado diferencias significativas. 
Tabla 3 Comparaciones múltiples sobre el uso hacia las TIC

\begin{tabular}{lllllll} 
& & & & & \multicolumn{3}{c}{$\begin{array}{l}\text { 95\% de intervalo de confianza para } \\
\text { diferencia }\end{array}$} \\
\cline { 3 - 7 } Grado & Grado & $\begin{array}{l}\text { Diferencia } \\
\text { de medias }\end{array}$ & $\begin{array}{l}\text { Error } \\
\text { Sostándar }\end{array}$ & Sig. & Límite inferior & Límite superior \\
\cline { 2 - 7 } & Infantil & -0.085 & 0.150 & 0.570 & -0.380 & 0.210 \\
\hline \multirow{2}{*}{ Infantil } & Social & 0.085 & 0.150 & 0.570 & -0.210 & 0.001 \\
\cline { 2 - 7 } & Primaria & -0.167 & 0.123 & 0.177 & -0.410 & 0.380 \\
\hline \multirow{2}{*}{ Primaria } & Social & 0.252 & 0.128 & 0.049 & -0.001 & 0.076 \\
\cline { 2 - 7 } & Infantil & 0.167 & 0.123 & 0.177 & -0.076 & 0.505 \\
\hline
\end{tabular}

A nivel general, sin distinguir entre las diferentes dimensiones del instrumento, es decir, el modelo de ANOVA fue significativo (F, 2,923; sig., 0.047) por lo que se encontraron evidencias de diferencias significativas en las competencias digitales entre los diferentes tipos de alumnado. En la tabla 4 se ha encontrado diferencias estadísticamente significativas entre el alumnado de Educación Social y el alumnado de Educación Primaria (sig. 0.018). Entre el resto de agentes implicados, no fueron encontradas diferencias significativas en sus competencias digitales.

Tabla 4 Comparaciones múltiples sobre las competencias digitales globales del alumnado

\begin{tabular}{lllllll} 
& & & & & \multicolumn{3}{c}{$\begin{array}{l}\text { 95\% de intervalo de confianza para } \\
\text { diferencia }\end{array}$} \\
\cline { 6 - 7 } Grado & Grado & $\begin{array}{l}\text { Diferencia } \\
\text { de medias }\end{array}$ & $\begin{array}{l}\text { Error } \\
\text { estándar }\end{array}$ & Sig. & Límite inferior & Límite superior \\
\hline \multirow{2}{*}{ Infantil } & Infantil & -0.168 & 0.127 & 0.187 & -0.417 & 0.082 \\
& Social & 0.168 & 0.109 & 0.018 & -0.474 & 0.046 \\
\hline \multirow{2}{*}{ Primaria } & $-0.260^{*}$ & 0.127 & 0.187 & -0.082 & 0.417 \\
& Primaria & -0.092 & 0.104 & 0.377 & -0.298 & 0.113 \\
\hline
\end{tabular}




\section{Discusión y conclusiones}

Los grandes cambios que se están produciendo actualmente debido a la COVID-19 en todas las esferas de la vida, hace que la formación del estudiantado en tecnología educativa sea realmente necesaria para su futura labor como docentes en los centros educativos, cuya actitud hacia las mismas así como el conocimiento y uso de recursos tecnológicos es un requisito indispensable si de verdad se quiere una integración real de las mismas en el proceso de enseñanza-aprendizaje, y que consecuentemente, sea de la mejor calidad posible.

Por ello, estamos de acuerdo con Oliva (2021) al afirmar las necesidades que tiene la comunidad educativa para formar digitalmente al alumnado, así como a sus familias, principalmente cuando estos últimos meses se ha tenido que desempeñar el proceso educativo a través de plataformas virtuales (Marín-Díaz et al.; 2021). Con este no-nuevo modelo educativo (y decimos no-nuevo ya que lleva muchos años entre nosotros, aunque quizás, desconocido para aquellos que no están en contacto diario con la tecnología educativa), el proceso de enseñanza-aprendizaje se ha visto favorecido respecto a la comunicación entre los miembros de la comunidad educativa. Pero para llegar a tal punto, se quiere de una buena formación previa en competencias digitales.

Los resultados obtenidos a través de este estudio han evidenciado que sigue existiendo una carencia en competencias digitales de los futuros maestros de Educación, cualquiera que sea su mención. Aunque es cierto que los participantes muestran una actitud media-alta respecto a las TIC, tal y como corroboran Christ et al. (2017), los conocimientos en tecnología educativa y su posterior uso en procesos educativos sigue siendo ineficiente, resultados en relación a los obtenidos por Cabero-Almenara et al. (2021).

Respecto a los resultados en relación al uso educativo de las TIC en el proceso educativo por parte del alumnado, se ha encontrado que el alumnado procedente de Educación Infantil y Educación Primaria realiza un uso medio de los diferentes recursos digitales que su entorno le pone a disposición, en comparación con el estudiantado de Educación Social que hace un uso inferior de dichos recursos. Ante estos hallazgos, quizás habría que hacer más hincapié en como formar y motivar a este último colectivo con el propósito de conseguir una integración real de las TIC. Estamos de acuerdo con Romero Andonegui et al. (2021) sobre la importancia que tiene conseguir una efectiva integración real de los recursos digitales, ya que ello va a influir significativamente en las expectativas del alumnado, y que sin duda alguna, para conseguirlo se requiere tanto de una actitud favorable del alumnado como de su profesorado (Christ et al., 2017; Guillén-Gámez \& Mayorga-Fernández, 2020).

Paralelamente, se aprecia a través del análisis descriptivo comparativo que, en todas las dimensiones, son los participantes de Educación Social los que poseen unos niveles inferiores en competencias digitales respecto al resto de tipologías. Estos resultados ponen en evidencia no solo la urgente capacitación en cualquiera que sea la mención, sino también de cursos específicos destinados donde se forme en herramientas y recursos que vayan ligados a su futura profesión docente, ya que probablemente, el futuro docente de Educación Infantil o Primaria no vaya a utilizar las mismas herramientas digitales que los de Educación Social, debido al público al que va destinado su labor profesional. 
Los resultados alcanzados en este estudio, podrían tener varias implicaciones a nivel educativo e investigador. Desde la perspectiva de institución educativa, con el propósito de focalizarse en acciones formativas por ejemplo a través de cursos MOOC, en aquellos constructos y herramientas digitales que el alumnado presente una mayor dificultad o actitud respecto hacia su uso en términos educativos. Desde la perspectiva metodológica, la importancia de seguir investigando en esta tríada de dimensiones y sus posibles predictores que afecten tanto a su adquisición como desarrollo competencial.

\section{Referencias}

Arufe-Giráldez, V., Cachón Zagalaz, J., Zagalaz Sánchez, M. L., Sanmiguel-Rodríguez, A., \& Valero, G. G. (2020). Equipamiento y uso de Tecnologías de la Información y Comunicación (TIC) en los hogares españoles durante el periodo de confinamiento. Asociación con los hábitos sociales, estilo de vida y actividad física de los niños menores de 12 años. Revista Latina de Comunicación Social, 78, 183-204. https://doi. org/10.4185/RLCS-2020-1474

Cabero-Almenara, J., Guillén-Gámez, F.D., Ruiz-Palmero, J. \& Palacios-Rodríguez, A. (2021). Digital competence of higher education professor according to DigCompEdu. Statistical research methods with ANOVA between fields of knowledge in different age ranges. Education and Information Technologies 26, 4691-4708. https://doi. org/10.1007/s10639-021-10476-5

Cabero Almenara, J., y Martínez Gimeno, A. (2019). Las tecnologías de la información y comunicación y la formación inicial de los docentes: modelos y competencias digitales. Profesorado: Revista de Currículum y Formación de Profesorado, 23(3), 247-268. https://doi.org/10.30827/profesorado.v23i3.9421

Christ, T., Arya, P. \&amp; Chiu, M.M. (2017). Video use in teacher education: An international survey of practices. Teaching \&amp; Teacher Education, 63, 22-35. http:// dx.doi.org/10.1016/j.tate.2016.12.005

Devitt, A., Colman, R., Bray, A., \& Banks, J. (2020). Parent Perspectives on Teaching and Learning during Covid-19 School Closures: Lessons learned from Irish Primary Schools. Trinity College Dublin. http://bit.ly/3oGkTjY

Guillén-Gámez, F. D., \& Mayorga-Fernández, M. J. (2020). Identification of variables that predict teachers' attitudes toward ICT in higher education for teaching and research: A study with regression. Sustainability, 12(4), 1312.

Marín-Díaz, V., Reche, E. \& Martín, J. (2021). University Virtual Learning in Covid Times. Technology, Knowledge and Learning . https://doi.org/10.1007/s10758-02109533-2

Monleón Oliva, V. (2021). Educación en tiempos de Covid-19. Reflexión educativa desde las aulas de Educación Infantil hasta los talleres con personas adultas. Aularia: Revista Digital de Comunicación, 10(1), 71-74. 
Roa Banquez, K., Rojas Torres, C. G. V., González Rincón, L. J., y Ortiz Ortiz, E. G. (mayo-agosto, 2021). El docente en la era 4.0: una propuesta de formación digital que fortalezca el proceso de enseñanza y aprendizaje. Revista Virtual Universidad Católica de/ Norte, (63), 126- 160. https://www.doi.org/10.35575/rvucn.n63a6

Romero Andonegui, A., Tejada Garitano, E., López de la Serna, A., \& Bilbao Quintana, N. (2021). Diversidad de uso tecnológico en el alumnado universitario; lo académico vs. Io personal. Innoeduca. International Journal of Technology and Educational Innovation, 7(1), 19-30. https://doi.org/10.24310/innoeduca.2021.v7i1.7868

Ruiz, A. B. M., Sánchez, F. A. G., \& Pina, F. H. (2015). Cuestionario para el estudio de la actitud, el conocimiento y el uso de TIC (ACUTIC) en Educación Superior. Estudio de fiabilidad y validez. Revista interuniversitaria de formación del profesorado, (83), 75-89.

Sanrey, C., Stanczak, A., Goudeau, S., \& Darnon, C. (2020). Confinement et école à la maison: L’illusion de la solution numérique. Psychologie \& Éducation, 2, 31-44. 


\section{YouTube, una Nueva Ventana al Aprendizaje}

Lozano-Blasco, Raquel ORCID: 0000-0002-6958-0926 Universidad de Zaragoza rlozano@unizar.es

\section{Gil-Lamata, Mercedes} ORCID: 0000-0002-1816-5394 Universidad de Zaragoza mercedesgil@unizar.es

\section{Arce-Romeral, Lorena} ORCID: 0000-0003-0851-1967 Universidad de Valladolid lorena.arce@uva.es 


\title{
YOUTUBE, UNA NUEVA VENTANA AL APRENDIZAJE
}

\author{
Lozano-Blasco, Raquel \\ Gil-Lamata, Mercedes \\ Arce-Romeral, Lorena
}

\section{Resumen}

Como consecuencia del rápido incremento del uso de las redes sociales, han surgido nuevos roles sociales, grandes volúmenes de datos, nuevas maneras de publicitarse y nuevos roles sociales. Este incremento todavía ha sido mayor tras la Covid-19, que ha generado nuevos nuevas formas de comunicarnos, trabajar y estudiar. Concretamente, el presente trabajo se centra en la comunicación a través de la red social Youtube en las cuentas que publican vídeos para la enseñanza de idiomas en niños. Para ello, se monitorizan 17 cuentas dedicadas a ello para el periodo temporal que va desde el 1 de enero hasta el 20 de abril de 2021. Para dicho fin, se han utilizado las herramientas de FanPage Karma y Voyant Tools; obteniendo, como resultado, un crecimiento continuo de seguidores, me gusta e interacciones, en términos generales. A partir de ahí, se concluye, de forma general, que los canales de YouTube dedicados al aprendizaje en inglés muestran un crecimiento constante. Si bien los canales deben tomar acciones a fin de aumentar y mantener el compromiso y las visualizaciones conforme crecen en número de seguidores. Finalmente, se obtiene que YouTube adquiere un nuevo rol en la infancia estableciendo una fuerte relación entre canales y seguidores.

\section{Palabras clave}

Aprendizaje, educación, inglés, redes sociales, YouTube. 


\section{Introducción}

Actualmente, y desde hace unos años, las redes sociales han supuesto un cambio en la manera en que nos comunicamos, nos relacionamos, trabajamos, nos entretenemos e incluso aprendemos. Consecuentemente, se ha producido un cambio en el que se encuentra un nuevo horizonte donde se dan nuevos roles sociales. Uno de los más importantes son los influencers (Trainor et al., 2014). En una sociedad, eminentemente tecnológica, es necesario tener en cuenta el gran volumen de datos que se genera mediante estas redes sociales (Katz et al., 2016). Como consecuencia directa de esta generación de grandes volúmenes de datos, se ha producido un cambio en la publicidad, el marketing y los valores sociales (González-Bailón y Wang, 2016; Kim y Hastak, 2018).

Por otro lado, los influencers tienen un papel fundamental en las redes sociales, por su gran impacto en la imagen de las empresas. Ello se debe a que son los encargados de interactuar con sus seguidores o también llamada comunidad y persuadir al consumidor para que compren sus productos de una manera cercana, yendo más allá de la publicidad tradicional (Weismueller et al., 2020) y, a pesar de tener matices profesionales, la jerga utilizada está caracterizada por la sencillez (Bhatia, 2018; Burgess y Green, 2009; Lange, 2014). Por otro lado, se hace necesaria la explicación del uso del posicionamiento web que realizan las cuentas y canales mediante el uso de hashtags, de forma que tratan de aumentar la visibilidad y la viralidad de la publicación (McGoogan, 2017; Lipsman et al., 2012), siendo el objetivo fundamental fidelizar a los seguidores de dichas cuentas. En otras palabras, las redes sociales funcionan como un espacio comercial persuasivo (Observatorio de Redes Sociales, 2013; Pérez y Luque, 2018). Para ello comienza un proceso de comunicación a través de relaciones parasociales, en las cuales el influencer trata a través de la función fáctica del lenguaje establecer un vínculo emocional con su comunidad (de Bérail et al., 2019).

Sin embargo, la función comercial de este espacio se interrelaciona con la comparación social.

De manera concreta, si nos centramos en YouTube, esta es una red social basada en contenidos de vídeo y audio en la cual se suben videos sobre cuestiones muy diversas (estilo de vida, educación, intereses o gustos, entre otros) o de famosos (Ferchaud et al., 2018). Esta red social paga a los influencers de acuerdo con el número de minutos de vídeo reproducidos, y a su vez las marcas pagan grandes cantidades de dinero para publicitarse mediante, por ejemplo, anuncios entre los vídeos de los influencers.

Actualmente, nos encontramos en una situación de pandemia mundial consecuencia de la Covid-19. Ello ha hecho que el uso de redes sociales crezca exponencialmente. Otra consideración que se debe tener en cuenta es que la comunicación a través de las redes sociales es todavía más notoria si se realiza mediante cuentas institucionales académicas, ya que tienen una mayor credibilidad y autoridad científica (Ruz et al., 2020).

Cada vez son más las propuestas que abogan por el uso de plataformas virtuales, y concretamente de Youtube, para la enseñanza de lenguas extranjeras (Cancelas Ouviña y Herrera Barba, 2914). Concretamente, Jaramillo y Solano Jaramillo (2019) afirman que los vídeos de dicha plataforma favorecen el proceso de aprendizaje del vocabulario, así como las habilidades de comprensión y expresión oral en lengua inglesa. 
El objetivo del presente estudio es monitorizar 17 cuentas de Youtube dedicadas a la enseñanza de idiomas en niños y estudiar la naturaleza diferencial de las cien publicaciones más relevantes según el número de me gusta. Las hipótesis de partida son: H1: Los youtubers que lideran en términos de Me gusta, también lideran en número de comentarios; H2: Los vídeos que más Me gusta reciben son aquellos que tienen competencias educativas y H3: Se da un gran compromiso entre la audiencia y los youtubers.

\section{Metodología}

A fin de exponer la metodología que se ha seguido para el abordaje de este estudio, se ha dividido este apartado en tres subapartados, a saber, Descripción del contexto $y$ de los participantes, Instrumentos y Procedimientos.

\section{Descripción del contexto y de los participantes}

La muestra seleccionada, y estudiada, está compuesta por 17 cuentas de Youtube dedicadas a la enseñanza de idiomas; concretamente, orientadas a niños. En la tabla que sigue (cfr. Tabla 1) se indica el nombre de cada uno de los canales, así como número de seguidores y su correspondiente enlace directo de acceso. El estudio de la presente muestra se realiza a través de la plataforma Fanpage Karma, diseñada para tal fin, pues permite la monitorización, captación y el tratamiento de los diferentes KPIs (esto es, indicadores clave de rendimiento o medidores de desempeño). Asimismo, y una vez seleccionada la muestra, se han escogido las cien publicaciones - vídeos subidos de Youtube- con mayor popularidad -es decir, mayor número de likes-, para su estudio y extracción de resultados (cfr. Resultados).

Tabla 1. Muestra

Fuente: Elaboración propia a partir de los datos obtenidos en Youtube

\begin{tabular}{|c|c|c|}
\hline Nombre del canal & $\begin{array}{l}\text { N. } \cong \text { de } \\
\text { seguidores }\end{array}$ & Enlace \\
\hline $\begin{array}{l}\text { Little Angel: Nursery } \\
\text { Rhymes \& Kids Songs }\end{array}$ & 23.000 .000 & $\begin{array}{l}\text { https://www.youtube.com/results? search_ } \\
\text { query=Little+Angel\%3A+Nursery+Rhymes+\%26+Kids+Songs }\end{array}$ \\
\hline $\begin{array}{l}\text { Cocomelon - Nursery } \\
\text { Rhymes }\end{array}$ & 111.000 .000 & https://www.youtube.com/channel/UCbCmjCuTUZos6Inko4u57UQ \\
\hline $\begin{array}{l}\text { Pinkfong! Kids' Songs \& } \\
\text { Stories }\end{array}$ & 47.700 .000 & https://www.youtube.com/user/SmartBooksMedia \\
\hline Super Simple Songs & 28.500 .000 & $\begin{array}{l}\text { https://www.youtube.com/results?search } \\
\text { query=Super+Simple+Songs }\end{array}$ \\
\hline Bounce Patrol Kids & 22.600 .000 & $\begin{array}{l}\text { https://www.youtube.com/results?search } \\
\text { query=Bounce+Patrol+Kids }\end{array}$ \\
\hline LittleBabyBum & 11.900 .000 & $\begin{array}{l}\text { https://www.youtube.com/results?search_ } \\
\text { query=LittleBabyBum+\%C2\%AE }\end{array}$ \\
\hline Mother Goose Club & 8.150 .000 & https://www.youtube.com/channel/UCJkWoS4RsldA1coElot5yDA \\
\hline
\end{tabular}




\begin{tabular}{|c|c|c|}
\hline $\begin{array}{l}\text { Learn English with } \\
\text { EnglishClass101.com }\end{array}$ & 5.400 .000 & $\begin{array}{l}\text { https://www.youtube.com/results?search } \\
\text { query=Learn+English+with+EnglishClass101.com }\end{array}$ \\
\hline TuTiTuTV & 4.290 .000 & https://www.youtube.com/results?search_query=TuTiTuTV \\
\hline HooplaKidz & 4.270 .000 & $\begin{array}{l}\text { https://www.youtube.com/results?sp=mAEB\&search_ } \\
\text { query=HooplaKidz }\end{array}$ \\
\hline $\begin{array}{l}\text { EnglishLessons4U - Learn } \\
\text { English with Ronnie! [engVid] }\end{array}$ & 4.100 .000 & https://www.youtube.com/channel/UC4cmBAit8i_NJZE8qK8sfpA \\
\hline KidsTV123 & 3.960 .000 & https://www.youtube.com/results?search_query=KidsTV123 \\
\hline $\begin{array}{l}\text { Learn English With TV } \\
\text { Series }\end{array}$ & 3.960 .000 & $\begin{array}{l}\text { https://www.youtube.com/results?search } \\
\text { query=Learn+English+With+TV+Series }\end{array}$ \\
\hline $\begin{array}{l}\text { BabyFirst Learn Colors, } \\
\text { ABCs, Rhymes \& More }\end{array}$ & 2.230 .000 & $\begin{array}{l}\text { https://www.youtube.com/channel/UCmJ6eP- } \\
\text { 7_6gqm8moQukzd4A }\end{array}$ \\
\hline Turtle Interactive & 1.820 .000 & https://www.youtube.com/user/turtleinteractive \\
\hline APPUSERIES & 1.770 .000 & $\begin{array}{l}\text { https://www.youtube.com/results?sp=mAEB\&search_ } \\
\text { query=APPUSERIES }\end{array}$ \\
\hline $\begin{array}{l}\text { British Council | } \\
\text { LearnEnglish Kids }\end{array}$ & 253.000 & $\begin{array}{l}\text { https://www.youtube.com/results?search } \\
\text { query=British+Council+\%7C+LearnEnglish+Kids }\end{array}$ \\
\hline
\end{tabular}

Cabe destacar, en primer lugar, el periodo temporal estudiado. En concreto, hemos analizado los datos relativos a tres meses; concretamente, desde 1 enero hasta el 20 de abril de 2021.

\section{Instrumentos}

Para seleccionar los canales de Youtube destinados a la enseñanza de idiomas para niños, se ha realizado una búsqueda en Youtube, a partir de la cual, hemos obtenido la muestra objeto de estudio (cfr. Tabla 1). A continuación, para la monitorización de los canales se ha utilizado FanPage Karma. Seguidamente, nos hemos valido de la herramienta Voyant Tool. Enunciados los instrumentos, se procede, a continuación, a explicar el procedimiento que se ha seguido.

\section{Procedimiento}

En primer lugar, para la selección de las cuentas con mayor popularidad en enseñanza de idiomas para niños, se ha realizado una búsqueda manual en Youtube, a partir de la cual, hemos configurado la muestra (cfr. Tabla 1, Apartado Selección de la muestra).

A continuación, como se ha mencionado previamente, para la monitorización de dichos canales, así como para la obtención de los datos, que posteriormente han sido analizados, se ha empleado FanPage Karma (cfr. Figura 1): 
Figura 1. Monitorización de la muestra en FanPage Karma

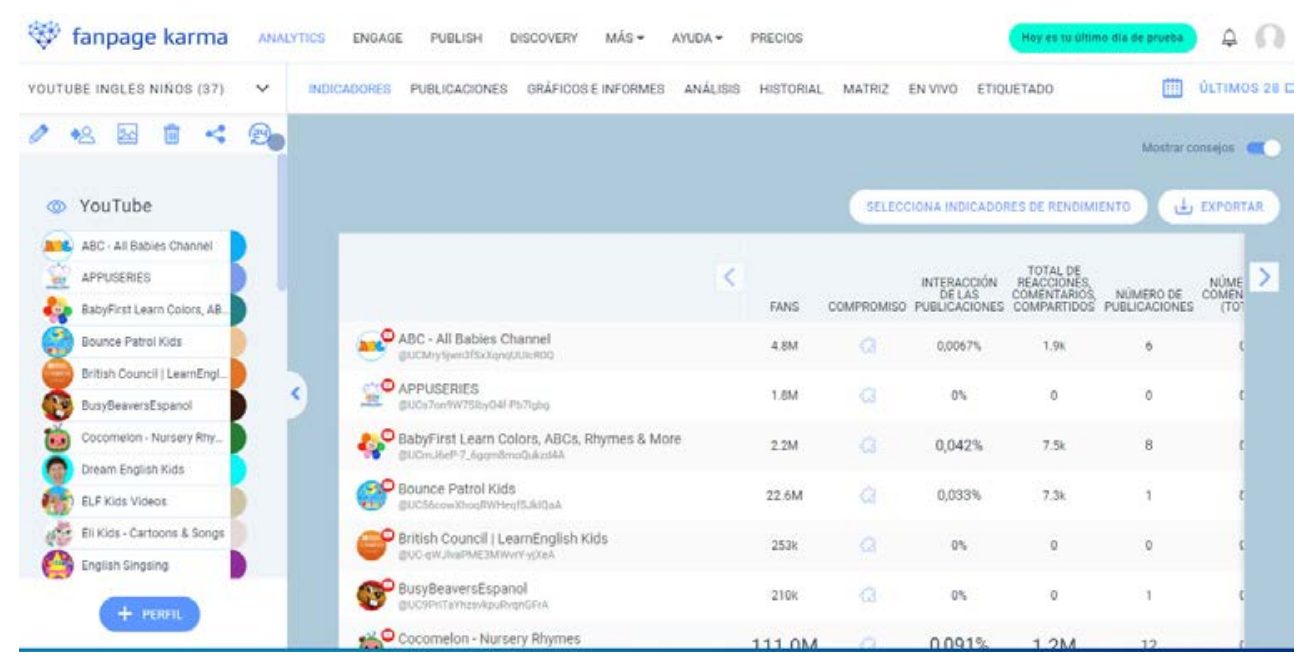

Esta herramienta permite, de forma general, analizar la actividad de las redes sociales o canales, por lo que es particularmente útil para medir su crecimiento. Concretamente, dicho programa permite el estudio de redes sociales, -basada en la minería de datos o, lo que es lo mismo, «social media analysis»-. De entre los KPIs que se pueden estudiar en FanPage Karma, para este estudio se han seleccionado los siguientes, a saber, Interacciones, Me gusta y Crecimiento de seguidores en la media semanal, del total de la muestra - los 17 canales de Youtube seleccionados-, así como de las cien publicaciones con mayor número de Likes.

Seguidamente, y a partir de las cien publicaciones más importantes, se ha llevado a cabo un análisis lingüístico con la herramienta Voyant Tools, que trabaja mediante el reconocimiento de algoritmos del lenguaje humano con vistas a seleccionar las palabras -o combinaciones de palabras - más recurrentes. Concretamente, se ha generado una nube con las palabras, o fraseología, utilizada en los títulos de dichas publicaciones, lo que esperamos permite dar cuenta, en cierto modo, de las ecuaciones de búsqueda más utilizadas por el público que hace uso de este tipo de canales. Dicha herramienta es muy sencilla en cuanto a su uso, pues únicamente se copia el texto de las publicaciones en el espacio habilitado para ello y, a continuación, se selecciona la opción «Revelar», tal y como se presenta en la siguiente figura (cfr. Figura 2). Cabe destacar, además, que se trata de una herramienta gratuita que se utiliza en línea.

Figura 2. Interfaz de Voyant Tools
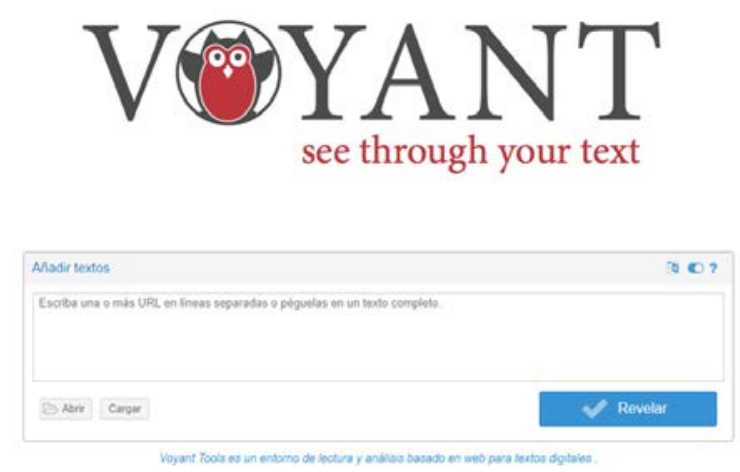
Una vez copiado el texto de los títulos, se ha generado la siguiente nube de palabras (cfr. Figura 3):

Figura 3. Nube de palabras de las cien publicaciones con mayor índice de Me gusta

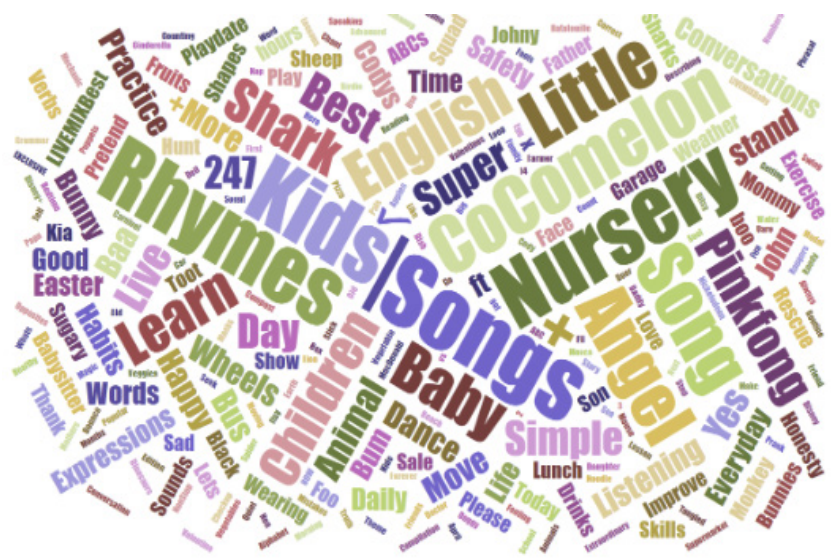

La figura que sigue es un resumen del protocolo de estudio marcado, así como una presentación de los objetivos esperados y resultados alcanzados (cfr. Figura 4). Se incluye, además, las herramientas empleadas en cada una de las fases.

Figura 4. Metodología protocolizada seguida para la realización del estudio

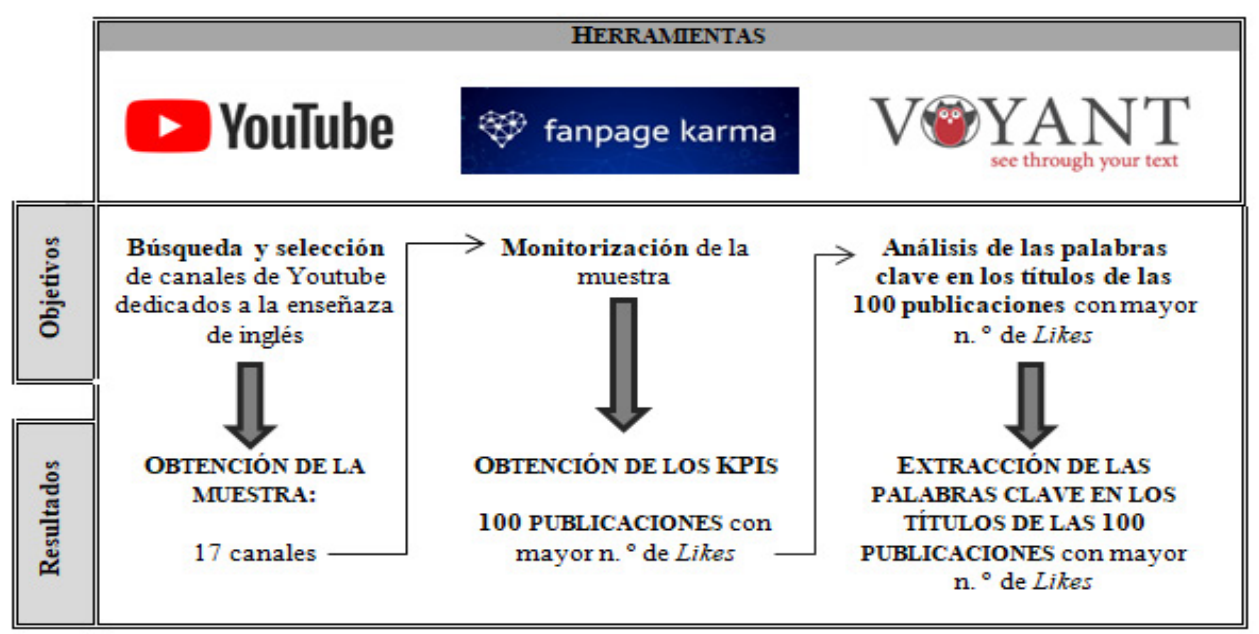

\section{Resultados}

Los resultados de los KPIs muestran un crecimiento continuo en cuanto al número de seguidores, Me gusta e interacciones (cfr. Gráfico 1, Gráfico 2 y Gráfico 3). Sin embargo, destacan importantes picos que deben ser analizados. En el Gráfico 1, se observa como el canal Cocomelon - Nursey Rhymes presenta un crecimiento de seguidores media semanal en porcentaje muy superior a la media pero constante. Es decir, el canal realiza acciones muy eficientes en la capacidad de captar nuevos seguidores. En lo referente a la cantidad de me gusta (Gráfico 2), encontramos como de nuevo Cocomelon - Nursey Rhymes es el canal que mayor cantidad de me gusta alcanza, observándose un importante pico el día 1 de abril de 2021 alcanzado cerca de 883490 
Me gusta en un sólo día. Sin embargo, el canal que consigue mayor índice de interacciones, es decir el cómputo de Me gusta, No me gusta, compartir y escribir comentarios es Little Angel: Nursery Rhymes \& Kids Songs. Es decir, la comunidad virtual es más activa en este canal.

Gráfico 1. Desarrollo longitudinal del crecimiento de seguidores media semanal en porcentaje por canales

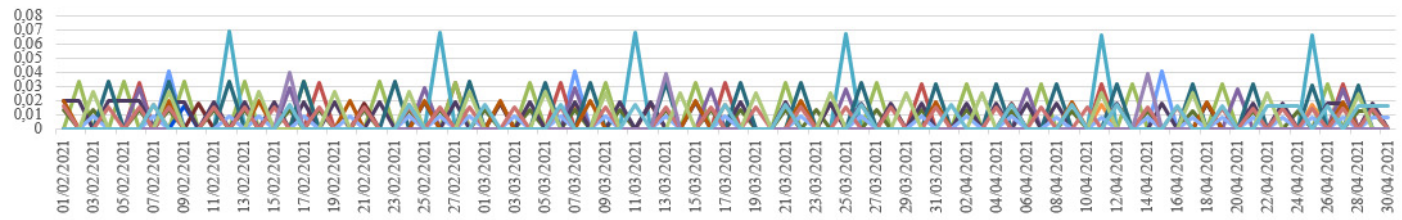

-APPUSERIES
- Bounce Patrol Kids
- Cocomelon - Nursery Rhymes
— HooplaKidz
— Leam English with EnglishClass 101.com
— Little Angel: Nursery Rhymes \& Kids Songs
- Mother Goose Club
- Super Simple Songs
- TuTiTuTV

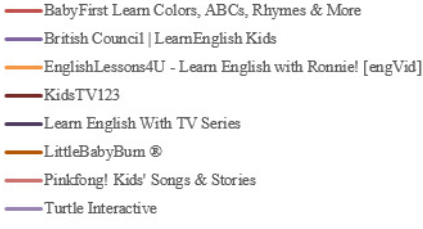

Gráfico 2. Desarrollo longitudinal según el índice de me gusta por canales

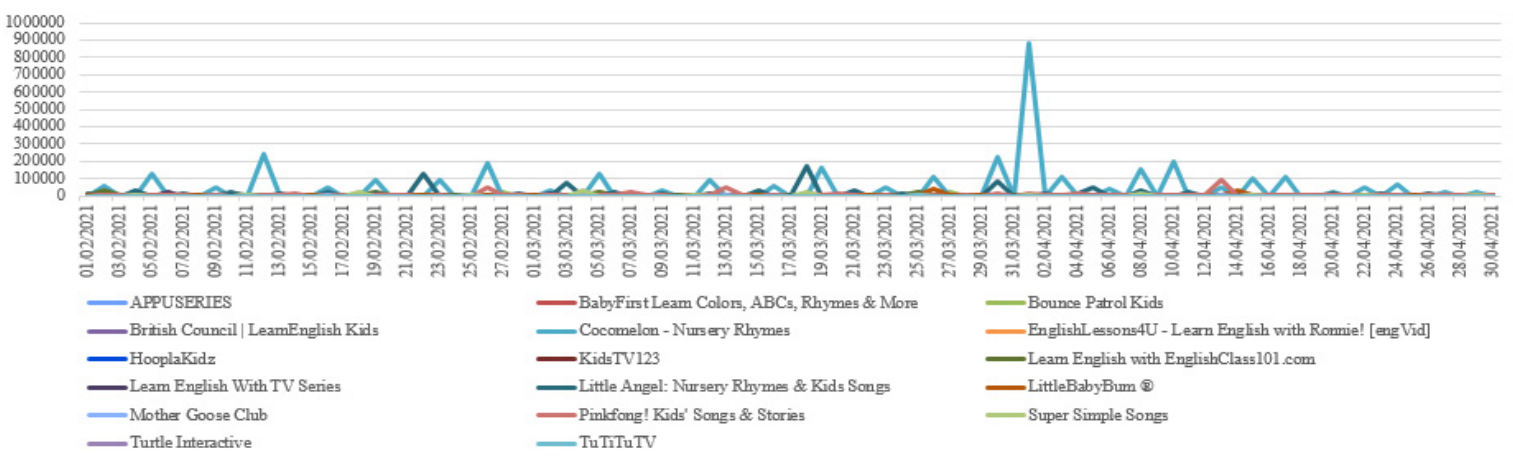

Gráfico 3. Desarrollo longitudinal según las interacciones de las publicaciones por canales.

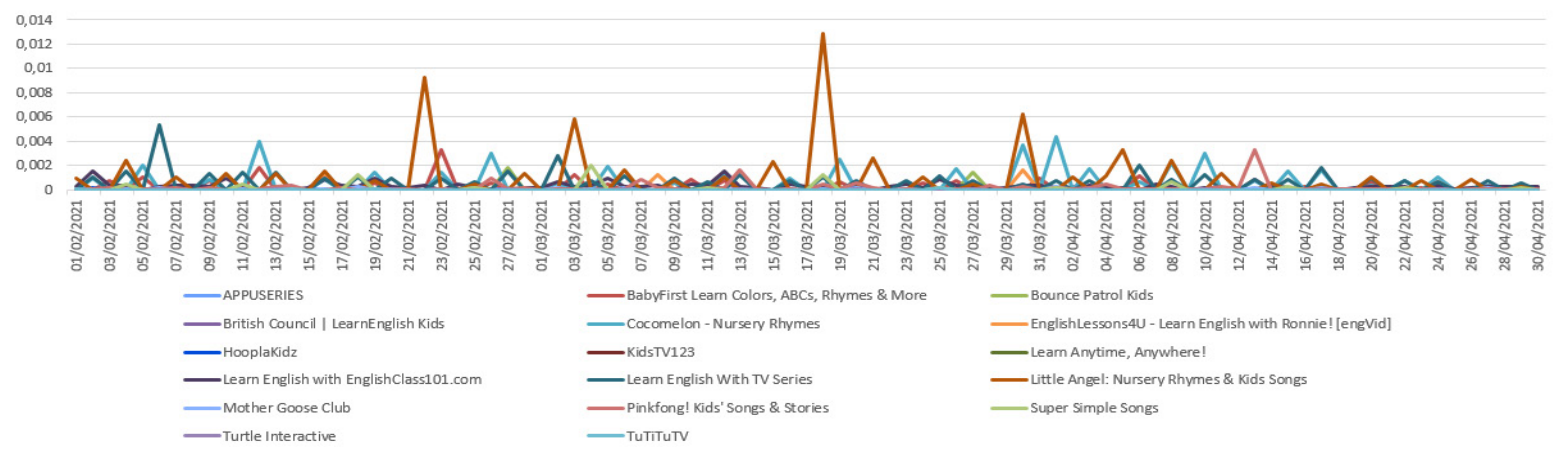


Por otra parte, es necesario exponer cuál fue el top 10 de los vídeos que mayor cantidad de «Me Gusta» consiguieron (cfr. Tabla 2). En este sentido, se observa de nuevo la predominancia del canal Cocomelon - Nursery Rhymes, el cual logra no sólo una elevada cantidad de me gusta por sus vídeos sino también una interacción moderada. Por otra parte, es necesario señalar como todos los vídeos se relacionan con competencias educativas, siendo mayoritariamente la competencia de conocimiento del entorno la más demandada. De este modo, los vídeos que mayor interés despiertan a la comunidad son aquellos que tratan temáticas cotidianas en la primera infancia que fomentan el conocimiento del medio y la autonomía del niño.

Tabla 2. Top 10 de videos más populares según el número de Me Gusta

\begin{tabular}{|c|c|c|c|c|c|}
\hline Título & Perfil & $\begin{array}{l}\text { N. a Me } \\
\text { gusta }\end{array}$ & $\begin{array}{l}\text { Interacción } \\
\text { de las } \\
\text { publicaciones }\end{array}$ & $\begin{array}{l}\text { Competencias } \\
\text { educativas }\end{array}$ & Link \\
\hline $\begin{array}{l}\text { Wheels On The Bus - ABC Song } \\
\text { - Baa Baa Black Sheep + More } \\
\text { CoComelon Nursery Rhymes \& } \\
\text { Kids Songs }\end{array}$ & $\begin{array}{l}\text { Cocomelon } \\
\text { - Nursery } \\
\text { Rhymes }\end{array}$ & 677834 & 0.0098 & $\begin{array}{l}\text { Rutinas y hábitos: } \\
\text { asistencia a la escuela } \\
\text { Conocimiento del } \\
\text { entorno: animales de } \\
\text { granja } \\
\text { Lingüística }\end{array}$ & Link \\
\hline $\begin{array}{l}\text { Bedtime Songs + More Nursery } \\
\text { Rhymes \& Kids Songs - } \\
\text { CoComelon }\end{array}$ & $\begin{array}{l}\text { Cocomelon } \\
\text { - Nursery } \\
\text { Rhymes }\end{array}$ & 245171 & 0.0039 & $\begin{array}{l}\text { Rutinas y hábitos } \\
\text { Lingüística }\end{array}$ & Link \\
\hline $\begin{array}{l}\text { Old MacDonald I CoComelon } \\
\text { Nursery Rhymes \& Kids Songs }\end{array}$ & $\begin{array}{l}\text { Cocomelon } \\
\text { - Nursery } \\
\text { Rhymes }\end{array}$ & 226096 & 0.0036 & $\begin{array}{l}\text { Conocimiento del } \\
\text { entorno: animales de } \\
\text { granja } \\
\text { Lingüística } \\
\end{array}$ & Link \\
\hline $\begin{array}{l}\text { Yes Yes Vegetable Song + More } \\
\text { Nursery Rhymes \& Kids Songs - } \\
\text { CoComelon }\end{array}$ & $\begin{array}{l}\text { Cocomelon } \\
\text { - Nursery } \\
\text { Rhymes }\end{array}$ & 197945 & 0.0030 & $\begin{array}{l}\text { Conocimiento del } \\
\text { entorno: las verduras } \\
\text { Lingüística }\end{array}$ & Link \\
\hline $\begin{array}{l}\text { Learn to Count with Apples + } \\
\text { More Nursery Rhymes \& Kids } \\
\text { Songs - CoComelon }\end{array}$ & $\begin{array}{l}\text { Cocomelon } \\
\text { - Nursery } \\
\text { Rhymes }\end{array}$ & 187001 & 0.0029 & $\begin{array}{l}\text { Matemática } \\
\text { Lingüística }\end{array}$ & Link \\
\hline $\begin{array}{l}\text { Baby John And The Rescue Squad } \\
+ \text { More Little Angel Kids Songs \& } \\
\text { Nursery Rhymes }\end{array}$ & $\begin{array}{l}\text { Little Angel: } \\
\text { Nursery } \\
\text { Rhymes \& Kids } \\
\text { Songs }\end{array}$ & 174828 & 0.0128 & $\begin{array}{l}\text { Conocimiento } \\
\text { del entorno: las } \\
\text { profesiones } \\
\text { Lingüística }\end{array}$ & Link \\
\hline $\begin{array}{l}\text { Reading Song + More Nursery } \\
\text { Rhymes \& Kids Songs - } \\
\text { CoComelon }\end{array}$ & $\begin{array}{l}\text { Cocomelon } \\
\text { - Nursery } \\
\text { Rhymes }\end{array}$ & 163300 & 0.0024 & $\begin{array}{l}\text { Lingüística: fomento } \\
\text { de la lectura }\end{array}$ & Link \\
\hline $\begin{array}{l}\text { Shapes In My Lunch Box Song } \\
+ \text { More Nursery Rhymes \& Kids } \\
\text { Songs - CoComelon }\end{array}$ & $\begin{array}{l}\text { Cocomelon } \\
\text { - Nursery } \\
\text { Rhymes }\end{array}$ & 150452 & 0.0022 & $\begin{array}{l}\text { Matemática } \\
\text { Lingüística }\end{array}$ & Link \\
\hline $\begin{array}{l}\text { Cody Moves Next Door Song + } \\
\text { More Nursery Rhymes \& Kids } \\
\text { Songs - CoComelon }\end{array}$ & $\begin{array}{l}\text { Cocomelon } \\
\text { - Nursery } \\
\text { Rhymes }\end{array}$ & 136132 & 0.0020 & $\begin{array}{l}\text { Autonomía } \\
\text { Lingüística }\end{array}$ & Link \\
\hline $\begin{array}{l}\text { Pizza Song + More Nursery } \\
\text { Rhymes \& Kids Songs - } \\
\text { CoComelon }\end{array}$ & $\begin{array}{l}\text { Cocomelon } \\
\text { - Nursery } \\
\text { Rhymes }\end{array}$ & 127810 & 0.0020 & $\begin{array}{l}\text { Conocimiento del } \\
\text { entorno: los alimentos } \\
\text { Lingüística }\end{array}$ & Link \\
\hline $\begin{array}{l}\text { My Mommy Is The Best I Little } \\
\text { Angel Kids Songs \& Nursery } \\
\text { Rhymes }\end{array}$ & $\begin{array}{l}\text { Little Angel: } \\
\text { Nursery } \\
\text { Rhymes \& Kids } \\
\text { Songs }\end{array}$ & 124143 & 0.0092 & $\begin{array}{l}\text { Conocimiento del } \\
\text { entorno: la familia } \\
\text { Lingüística }\end{array}$ & Link \\
\hline
\end{tabular}


En lo que respecta al análisis del corpus lingüístico encontramos como las palabras claves más importantes son "nursey rhymes" (canciones infantiles), "English" (inglés), "songs" (canciones), children (niños), little (pequeño), "learn" (aprender). Todos ellos evocan el mundo de la infancia y permiten a las familias procurar visualizaciones que les gusten a sus hijos y traten aspectos de la cotidianidad y relacionados con elementos del entorno inmediato.

\section{Discusión y conclusiones}

A la luz de los resultados encontrados se expone que se aceptan las hipótesis de partida. En primer lugar, se ha evidenciado como, en efecto, los youtubers que lideran en términos de número de Me gusta, también lideran en número de comentarios. De este modo, la comunidad digital mediante la opción de «Me Gusta» y «Comentario» interactúa con el resto de usuarios de manera que se muestran muy activos y comprometidos (González-Bailón y Wang, 2016).

Por otra parte, los resultados confirman que los vídeos con mayor número de $\mathrm{Me}$ gusta reciben son aquellos que tienen competencias educativas, lo que implica un uso educativo de YouTube en el aprendizaje de inglés en la primera infancia. De este modo, se coincide con investigaciones anteriores en las que se señala como YouTube se está instaurando como una plataforma de enseñanza-aprendizaje de lenguas extranjeras mediante componentes de gamificación (Cancelas Ouviña y Herrera Barba, 2914). Se coincide con los autores Jaramillo y Solano Jaramillo (2019) en que los videos más visualizados tienen una competencia educativa que permite adquirir y aprender vocabulario en lengua inglesa a la vez que inicia a los alumnos en habilidades de comprensión y expresión oral en lengua inglesa.

Finalmente, se confirma que se da un gran compromiso entre la audiencia y los youtubers, coincidiendo con investigaciones previas, donde los influencers es una figura relevante en la comunidad digital (González-Bailón y Wang, 2016; Katz et al., 2016; Kim y Hastak, 2018; Trainor et al., 2014). De este modo, de acuerdo con otros autores, YouTube forma parte de la cultura digital, donde la sociedad aprende e interactúa de acuerdo a una serie de formalismos y lenguaje concreto (Bhatia, 2018; Burgess y Green, 2009; Lange, 2014).

\section{Referencias}

Bhatia, A. (2018). Interdiscursive performance in digital professions: The case of YouTube tutorials. Journal of Pragmatics, 124, 106-120. https://doi.org/10.1016/j. pragma.2017.11.001.

Burgess, J. y Green, J. (2009). YouTube: Online Video and Participatory Culture. Cambridge, UK: Polity Press.

Burnette, C. B, Kwitowski, M. A. y Mazzeo, S. E. (2017). "I Don't Need People to Tell Me I'm Pretty on Social Media: A Qualitative Study of Social Media and Body Image in Early Adolescent Girls." Body Image, 23, 114-25. https://doi.org/10.1016/j. bodyim.2017.09.001. 
Cancelas Ouviña, L. P. y Herrera Barba, J. M. (2014). Reflexiones sobre la potencia de YouTube en la enseñanza y aprendizaje de una lengua extranjera. Hachetetepé. Revista científica De Educación y Comunicación, (8), 71-81. https://doi.org/10.25267/ Hachetetepe.2014.v1.i8.7.

Ceron, A., Curini, L., lacus, S. M. y Porro, G. (2014). Every tweet counts? How sentiment analysis of social media can improve our knowledge of citizens' political preferences with an application to Italy and France. New media and society, 16 (2), 340358. https://doi.org/10.1177/1461444813480466.

De Bérail, P., Guillon, M. y Bungener, C. (2019). The relations between YouTube addiction, social anxiety and parasocial relationships with YouTubers: A moderated-mediation model based on a cognitive-behavioral framework. Computers in Human Behavior, 99 (April), 190-204. https://doi.org/10.1016/j.chb.2019.05.007.

Ferchaud, A., Grzeslo, J., Orme, S. y LaGroue, J. (2018). Parasocial attributes and YouTube personalities: Exploring content trends across the most subscribed YouTube channels. Computers in Human Behavior, 80, 88-96. https://doi.org/10.1016/j. chb.2017.10.041.

González-Bailón, S. y Wang, N. (2016). Networked discontent: The anatomy of protest campaigns in social media. Social networks, 44, 95-104. https://doi.org/10.1016/j. socnet.2015.07.003.

Jaramillo, M. y Solano Jaramillo, L. M. (2019). Los ídeos musicales de youtube en inglés como recurso educativo para enseñar vocabulario y mejorar las habilidades de escucha y habla. Analysis. Claves de Pensamiento Contemporáneo, 22, (dic. 2019), 103-106.

Katz, V. S. y González, C. (2016). Toward meaningful connectivity: Using multilevel communication research to reframe digital inequality. Journal of communication, 66 (2), 236-249. https://doi.org/10.1111/jcom.12214.

Kim, D. H., Seely, N. K. y Jung, J. H. (2017). Do you prefer, Pinterest or Instagram? The role of image-sharing SNSs and self-monitoring in enhancing ad effectiveness. Computers in Human Behavior, 70, 535-543. https://doi.org/10.1016/j.chb.2017.01.022.

Kim, J. y Hastak, M. (2018). Social network analysis: Characteristics of online social networks after a disaster. International journal of information management, 38 (1), 86-96. https://doi.org/10.1016/j.ijinfomgt.2017.08.003

Lange, P. (2014). Commenting on YouTube rants: perceptions of inappropriateness or civic engagement? Journal of Pragmatics, 73, 53-65. https://doi.org/10.1016/j. pragma.2014.07.004.

Lipsman, A., Mudd, G., Rich, M. y Bruich, S. (2012). The power of "like": How brands reach (and influence) fans through social-media marketing. Journal of Advertising Research, 52(1), 40-52. DOI: 10.2501/JAR-52-1-040-052.

McGoogan, C. (2017). Hashtag turns 10: Seven facts you didn't know about the trending symbol. Retrieved September 10, 2020, from ttp://www.telegraph.co.uk/technology/2017/08/23/hashtag-turns-10-seven-facts-didnt-know-trending-symbol/. 
Ruz, G. A., Henríquez, P. A., y Mascareño, A. (2020). Sentiment analysis of Twitter data during critical events through Bayesian networks classifiers. Future generation computer systems, 106, 92-104. https://doi.org/10.1016/j.future.2020.01.005.

Schmuck, D., Karsay, K., Matthes, J. y Stevic, A. (2019). "Looking Up and Feeling Down". The influence of mobile social networking site use on upward social comparison, self-esteem, and well-being of adult smartphone users. Telematics and Informatics, 42(May). https://doi.org/10.1016/j.tele.2019.101240.

Trainor, K. J., Andzulis, J. M., Rapp, A. y Agnihotri, R. (2014). Social media technology usage and customer relationship performance: A capabilities-based examination of social CRM. Journal of business research, 67 (6), 1201-1208. https://doi.org/10.1016/j. jbusres.2013.05.002.

Observatorio de Redes Sociales (2013). 5a oleada. Antena Media Cat. Recuperado de http://antenamediacat.com/rcs_auth/convocatories/5oleadaobservatoriorr-ss-130416061017- phpapp01_1_.pdf.

Pérez Curiel, C., y Luque Ortiz, S. (2018). El marketing de influencia en moda. Estudio del nuevo modelo de consumo en Instagram de los millennials universitarios. AdComunica. Revista Científica de Estrategias, Tendencias e Innovación en Comunicación, 15, 255-281. https://doi.org/10.6035/2174-0992.2018.15.13.

Trainor, K.J., Andzulis, J. M., Rapp, A., y Agnihotri, R. (2014). Social media technology usage and customer relationship performance: A capabilities-based examination of social CRM. Journal of business research, 67 (6), 1201-1208. https://doi.org/10.1016/j. jbusres.2013.05.002.

Verrastro, V., Fontanesi, L., Liga, F., Cuzzocrea, F. y Gugliandolo, M. C. (2020). Fear the Instagram: Beauty stereotypes, body image and Instagram use in a sample of male and female adolescents. Qwerty, 15(1), 31-49. https://doi.org/10.30557/QW000021.

Weismueller, J., Harrigan, P., Wang, S. y Soutar, G. N. (2020). Influencer endorsements: How advertising disclosure and source credibility affect consumer purchase intention on social media. Australasian Marketing Journal. https://doi.org/10.1016/j. ausmj.2020.03.002.

Yau, J. C. y Reich, S. M. (2019). "It's Just a Lot of Work": Adolescents' Self-Presentation Norms and Practices on Facebook and Instagram. Journal of Research on Adolescence, 29(1), 196-209. https://doi.org/10.1111/jora.12376.

Yu, Y., Duan, W. y Cao, Q. (2013). The impact of social and conventional media on firm equity value: A sentiment analysis approach. Decision support systems, 55 (4), 919-926. https://doi.org/10.1016/j.dss.2012.12.028. 


\section{La Plataforma AskQue en el Aprendizaje Universitario}

\section{Diego Racero}

Facultad de Ingeniería de la Universidad de Buenos Aires sberoch@fi.uba.ar

\section{Ema Aveleyra}

https://orcid.org/0000-0002-0322-8778

eaveley@fi.uba.ar

\section{Santiago Beroch}

Facultad de Ingeniería de la Universidad de Buenos Aires sberoch@fi.uba.ar 


\title{
LA PLATAFORMA ASKQUE EN EL APRENDIZAJE UNIVERSITARIO
}

\author{
Diego Racero \\ Ema Aveleyra \\ Santiago Beroch
}

\section{Resumen}

El Centro de Tecnologías Educativas de la Facultad de Ingeniería de la Universidad de Buenos Aires (CETEC) desarrolló la plataforma AskQue de encuestas con el objetivo de crear e implementar cuestionarios que permitan detectar el avance del aprendizaje para todas las asignaturas de la facultad. Es una aplicación que tiene las siguientes características: se puede utilizar tanto desde un desktop como desde una terminal móvil, permite a los estudiantes acceder sólo con el link de generación del cuestionario, se responde en forma anónima, permite que el estudiante pueda visualizar el resultado correcto una vez que respondió y, desde el panel de respuestas, puede acceder al resumen de respuestas totales y a la cantidad de ítems correctos en un formato de gráfico de barras. La plataforma que, todavía está en proceso de testing, se está aplicando en la asignatura Física I de la mencionada institución. Se muestran resultados obtenidos y se indican algunas modificaciones realizadas que permitieron mejorar la experiencia de usuario tanto para el docente como para el estudiante.

\section{Palabras clave}

Seguimiento del aprendizaje, evaluación, cuestionario. 


\section{Introducción}

La influencia educativa es una acción importante para la construcción del conocimiento, aunque el proceso en sí mismo sea individual e interno. Sin ella, es poco probable que la construcción permita una apropiación adecuada de los contenidos que son objeto de dicha acción educativa (Coll et al., 2008). Para que las ayudas sean las adecuadas y, para que las representaciones compartidas sobre los contenidos y sus aplicaciones vayan evolucionando e incidan en la dirección necesaria para su reelaboración, es deseable indagar en forma constante al estudiante sobre el nivel de sus conocimientos. Además, para incrementar su responsabilidad y autonomía en el logro de sus metas y objetivos, es aconsejable que los docentes pongan en práctica el concepto de evaluación formativa y compartida (Charte et al., 2020; Walss Aurioles, 2021). Esto es particularmente crítico a la hora de enseñar ciencias duras, para tener una noción clara no sólo del punto de partida sino de la apropiación adecuada conceptual y de los modelos científicos. De acuerdo con la experiencia recabada como docentes se observa que proporcionar la ayuda adecuada al estudiante, en el momento que lo necesita, facilita la comprensión adecuada de conceptos, modelos y teorías que habitualmente son complejos de interpretar y aplicar (Aveleyra, 2018).

Con la intención de conocer y mejorar la situación de aprendizaje de los estudiantes en cursos masivos y no sólo a través de exámenes es que, entre otras acciones, se empezaron a utilizar plataformas de encuestas en la facultad. Inicialmente se hicieron intentos de uso con aplicaciones tales como Kahoot (https://kahoot.com/) o Mentimeter (https://www.mentimeter.com/). La primera es una plataforma para consultas online diseñada principalmente para el aprendizaje social. Si bien es una plataforma muy popular, su orientación a la gamificación y su perfil escolar no la hace muy apta para la enseñanza universitaria. Por otro lado, Mentimeter es un software que permite crear cuestionarios interactivos de forma rápida. La aplicación dispone de diferentes formatos de participación a los estudiantes, pudiendo responder a través de sus móviles. Los resultados obtenidos se almacenan y también se pueden mostrar en la pantalla en tiempo real. La desventaja de su uso es que las opciones de la versión gratuita para preguntas de respuesta múltiple son escasas (Badoiu et al., 2020; Jaber et al., 2016; Little, 2016; Marcello, 2019).

Con el propósito que la plataforma respondiera a las necesidades propias de las asignaturas en la facultad y permitiera introducir adaptaciones a través del tiempo, el CETEC junto con dos estudiantes de la carrera de ingeniería informática diseña y desarrolla AskQue. Para ello, se utilizó una arquitectura Web moderna, separando el área lógica y de datos (Back-End) de la vista del usuario (Front-End). Esto presenta enormes ventajas para la aplicación: escalabilidad, flexibilidad y facilidad de mantenimiento. Las características de la aplicación son las siguientes: permite generar cuestionarios en el momento de la clase pero también pre y post clase guardando las respuestas obtenidas, admite la introducción de fórmulas como imágenes, no requiere la instalación de ningún tipo de app para utilizarse en celulares, posibilita que los docentes puedan compartir encuestas y tiene un perfil institucional que permite identificarlo con facilidad. La encuesta se realiza en forma anónima y sólo se releva la cantidad de respuestas correctas o incorrectas. La web app se aloja en un servidor Ubuntu de la propia facultad.

El objetivo de este trabajo fue obtener y analizar los resultados de la aplicación de la plataforma AskQue en una prueba piloto, estudiar sus alternativas concretas de 
uso pedagógico, conocer las dificultades de los usuarios -docentes y estudiantes- y proponer soluciones que permitan modificar y optimizar su uso.

\section{Método/Descripción de la experiencia}

\section{Descripción del contexto y de los participantes}

La herramienta AskQue se implementa en un curso de física básica que se desarrolla con modalidad e-learning en la Facultad de Ingeniería (UBA). Se recogen y analizan los registros de las participaciones de los estudiantes a través de una web app. En el marco de la incorporación de las TIC a la enseñanza universitaria, se coloca como centro de análisis la elaboración y aplicación de cuestionarios para medición de conocimientos previos y avance en el aprendizaje de las ciencias.

La población bajo estudio comprende a 80 estudiantes recursantes (quienes aprobaron una cursada anterior pero no la evaluación final). Esto impone poner más el foco en las dificultades concretas de los estudiantes ya que tienen conocimiento previo de todas las unidades temáticas de la asignatura.

\section{Instrumentos}

Se selecciona una metodología de investigación acción, con la que se propone mejorar las prácticas docentes a través de un ciclo en espiral. Este tipo de investigación tiene mucha importancia ya que ofrece una vía para superar dicotomías como teoría-práctica y educador-investigador (Kemmis \& Mc Taggart, 1988).

En un primer estudio, se realizó un análisis de todos los aportes realizados por los estudiantes mediante las herramientas de la propia web app (Vallely \& Gibson, 2018). Terminado el primer cuatrimestre del 2021 se midió el grado de satisfacción de los estudiantes con la plataforma, utilizando para ello la metodología de Net Promoter Score conocido como NPS.

Para determinar el NPS, se envía una encuesta simple a los estudiantes con dos preguntas que se responden asignando a cada una, un valor de 1 a 10 . Una vez que el usuario ha calificado, puede proporcionar comentarios adicionales. Para ello, es posible brindarle un campo de texto abierto, en el que pueda introducir por escrito lo que le gusta o le disgusta. Cuando una persona ofrece una calificación se le puede clasificar, según su respuesta, de la siguiente forma:

- Detractores. Estos encuestados dan una puntuación entre 0 y 6 y lo más probable es que no estén satisfechos, en este caso con el uso de la plataforma.

- Pasivos. Estos encuestados dan una puntuación de 7 u 8. Estas personas están satisfechas, pero en cualquier momento pueden dejar de usar la aplicación.

- Promotores. Los participantes dan una puntuación de 9 o 10, ya que se encuentran muy satisfechos con el uso de la aplicación.

El Net Promoter Score se calcula utilizando la fórmula \%promotores-\%detractores (https://www.questionpro.com/blog/es/metodologia-net-promoter-score/). 


\section{Importancia del uso de Net Promoter Score}

Entre las principales ventajas de la metodología NPS se encuentran las que se mencionan a continuación.

a) Es un método fácil de implementar, ya que el NPS se puede calcular con una sola pregunta, la cual se puede responder ofreciendo una puntuación en una escala del 1 al 10. Los estudiantes pueden responder con facilidad en poco tiempo.

b) Es un buen indicador de crecimiento. Se puede medir fácilmente el grado de satisfacción y la cantidad de usuarios que responden cuatrimestre a cuatrimestre.

c) Se puede adaptar con facilidad en forma transversal a cualquier tipo de asignatura y, para cualquier cambio que desee medirse, no está acotado a implementaciones de software.

d) Una de las razones por las que la metodología NPS es tan popular es por su reputación. Está asociado con el crecimiento y es algo que cualquiera puede entender fácilmente. Para que su medición sea efectiva se deben seguir ciertos lineamientos, estos son:

- EI NPS debe registrarse continuamente para determinar cambios a lo largo del tiempo.

- Hay que analizar la causa de la segmentación de los alumnos en promotores, neutros y detractores.

- Permite comparar las diferentes puntuaciones según el momento de la encuesta para descubrir los puntos débiles.

- Permite disponer de comentarios y sugerencias de los estudiantes, no sólo de los promotores sino también de los detractores.

- Reacciona rápidamente a los comentarios debido a la forma de calcularlo, ya que el resultado del índice NPS varía ampliamente con las calificaciones de promotores o detractores.

- Conviene aplicarse en varios puntos del trayecto del estudiante. Lo cual ayuda a determinar qué aspectos del proceso se pueden mejorar y qué aspectos funcionan sin problemas.

\section{Procedimiento}

De acuerdo con una metodología de investigación-acción se siguen los siguientes pasos: a) identificación del problema, b) búsqueda de posibles soluciones, c) selección de la solución más adecuada, d) pruebas en cursos modelos para comprobar la efectividad de la solución propuesta, e) evaluación de la implementación.

Los pasos a), b) y c) se concretaron con el desarrollo de la plataforma. Para llevar a cabo el paso d) se diseñan cuestionarios que incluyen preguntas que habitualmente presentan algún tipo de dificultad en el estudiante. Para ello, previo a cada clase se 
genera y envía un link al estudiante para que pueda acceder al cuestionario a través del foro de novedades del aula virtual en el Campus institucional. De este modo, al iniciar la clase el docente puede conocer las dificultades que presentan los estudiantes y enfocar el desarrollo teórico-práctico de la clase en función de ellas. La evaluación, como se dijo, se realiza con las estadísticas propias de la plataforma y con la aplicación de la metodología NPS.

\section{Resultados}

El grado de participación en los cuestionarios de la web app, muestra que el recurso es importante para los estudiantes ya que no es una actividad obligatoria. El desarrollo de la clase on-line permite al docente conocer el nivel inicial y el seguimiento de la comprensión de un tema. Es de notar la libertad que manifiesta el estudiante al contestar preguntas de todo tipo ya que su identidad nunca es revelada, sólo se conoce si la respuesta que dio es correcta o no. Se verifica también que los docentes pueden adoptar el recurso sin problemas gracias a lo sencillo e intuitivo de su uso.

Sirve también como diagnóstico inicial y luego como monitoreo del avance en el tema, facilitando la introducción de refuerzos en espiral a través de la integración de conceptos nuevos y revisión de los anteriores.

Se observa que, gracias a este recurso, también es posible evaluar rápidamente la efectividad de la clase a posteriori de esta. Desde el punto de vista del aprendizaje, esta herramienta permite al estudiante indagar, revisar y construir conceptos teóricos. Los estudiantes ponen a prueba sus preconcepciones y sus conocimientos de los modelos físicos al realizar todas las semanas un cuestionario.

A su vez, los resultados obtenidos permiten alimentar una base de datos de dificultades con el objetivo de crear un chat bot académico de preguntas frecuentes para la asignatura, y que es el objetivo de un proyecto aprobado y financiado por la Universidad de Buenos Aires.

A largo plazo el hecho de implementar un sistema como AskQue asociado a un sistema de business intelligence, como Google Data Studio, permitirá obtener datos acerca de la evolución de los cambios introducidos en la búsqueda de la mejora de la calidad educativa y, los docentes podrán ser más asertivos en el diagnóstico de las falencias de conocimientos previos.

A continuación se muestran los resultados obtenidos como aplicación del NPS. 


\section{Figura 1}

¿Qué tan sencillo resultó utilizar la plataforma Askque?

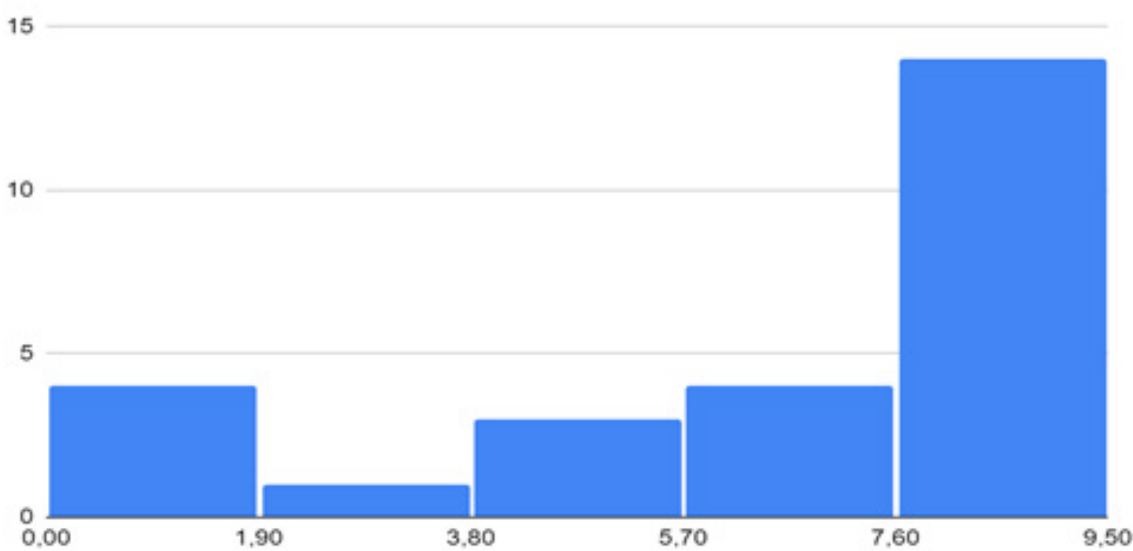

\section{Figura 2}

¿Recomendarías su uso en otras asignaturas?

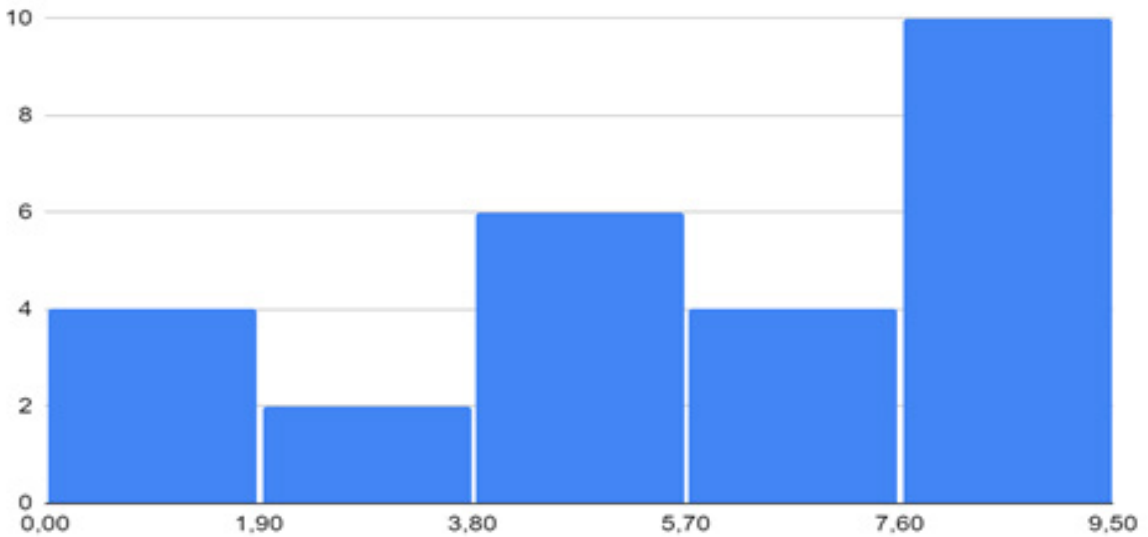

Con estos datos se obtuvo un índice NPS de 0.23. Este valor está dentro del rango de valores considerados como muy positivos.

\section{Discusión y conclusiones}

La enseñanza universitaria y en particular de la física tiene en el uso de las encuestas online un instrumento útil, ya que permite interactuar con un gran número de estudiantes y conocer el nivel de dificultad promedio de la clase. Por otro lado, el docente puede realizar un adecuado seguimiento del proceso de aprendizaje y de este modo evaluar y/o modificar los apoyos y soportes que sean necesarios.

Este antecedente abre la posibilidad para aplicar el sistema de consultas en forma transversal para todas las asignaturas de la facultad, inclusive para aquellas que no pertenecen estrictamente al campo de las ciencias básicas, considerando la necesi- 
dad de aplicar las TIC a las aulas universitarias para satisfacer demandas crecientes de otras modalidades y de otras estrategias de enseñanza.

A continuación, se mencionan dos modificaciones para mejorar la experiencia de usuario, una ya finalizada para que AskQue funcione como Aplicación Web Progresiva y la otra, relacionada con la generación de notificaciones web push. Esta última está en proceso y permitirá mejorar la comunicación con el estudiante.

\section{AskQue como Aplicación Web Progresiva}

Las aplicaciones web progresivas son una evolución natural de las aplicaciones web que difumina la barrera entre la web y las aplicaciones instalables, pudiendo realizar tareas que generalmente sólo las aplicaciones nativas podrían llevar a cabo. Algunos ejemplos son las notificaciones o el funcionamiento sin conexión, aspecto clave para usuarios con complicaciones para el acceso a Internet.

Es por ello que se llevaron a cabo ciertos desarrollos para que AskQue funcione como Aplicación Web Progresiva, o PWA. Transformar esta aplicación consistió en las siguientes tareas:

- Configurar el manifiesto de la aplicación web, donde se especifican las características de la aplicación tales como nombres, iconos y temas, para ser utilizados en entornos mobile.

- Registrar un "service-worker", que permite el funcionamiento fuera de línea. Este intercepta las peticiones al navegador y las dirige a Internet, si hay conexión, o busca la información localmente ahorrando un tráfico de datos de red.

- Atender las necesidades de performance. Para permitir la instalación como PWA los navegadores tienen requisitos de performance, por lo que hubo que cambiar el modo de ejecución con el que se servía AskQue hasta el momento.

Este último punto representaba un problema con los demás requisitos que tenía AskQue, es decir, responder únicamente ante conexiones seguras mediante el protocolo HTTPS, redireccionar el tráfico HTTP a HTTPS y ejecutarse como servicio para recuperarse de fallas en el servidor. Para poder cumplir con todo esto se instaló un servidor NGINX, utilizando sus funcionalidades como proxy inverso, redirigiendo el tráfico correctamente. Utilizar esta tecnología es muy positivo para el futuro, ya que con poca configuración se podría, por ejemplo, utilizarlo como balanceador de carga para atender un gran caudal de peticiones simultáneas.

\section{Web Push Notifications, en busca de una mejor comunicación}

Las notificaciones push son mensajes emergentes que aparecen en los dispositivos de los usuarios cuando visitan un sitio web o repentinamente en sus teléfonos móviles.

Para colaborar con la atención de los estudiantes y considerando que es cada vez más difícil, casi imposible, encontrar un estudiante que no tenga celular, se decide implementar notificaciones web push para el grupo de estudiantes registrados en un canal de preguntas. Con este servicio, se pueden adherir a la aplicación en forma automática cuando reciben la primera pregunta del docente o del grupo docente. 
La idea, detrás de la implementación, es establecer una estrategia omnicanal que se ajuste a las distintas pautas de consumo de información de los estudiantes. Se trata de una herramienta clave y sin dudas es fundamental a la hora de afianzar la relación con ellos.

Las push notifications generan numerosas interacciones y eso también puede significar una participación más activa de los estudiantes (Cuzco, 2020).

\section{Referencias}

Aveleyra, E. (2018). Aportes para el debate: Las tecnologías en la enseñanza universitaria: nuevos escenarios, nuevos desafíos. En C. Nosiglia (comp.). La Universidad de Buenos Aires. Aportes para la CRES 2018 (pp.177-189). Editorial Universitaria de Buenos Aires (EUDEBA).

Badoiu, G. A., Escrig, A. B., Segarra, M., García, B., \& Salvador, A. (2020). Herramientas de gamificación: efectos sobre el aprendizaje significativo, el engagement y el estrés de los estudiantes. INNODOC 2020, 487-494. Editorial Universitat Politècnica de València. http://dx.doi.org/10.4995/INN2020.2020.11848

Charte, F., Rivera, A.J., Medina, J., \& Espinilla, M., (2020). El ecosistema de aprendizaje del estudiante universitario en la post-pandemia. Metodologías y herramientas. Enseñanza y Aprendizaje de Ingeniería de Computadores, 10, 15-38. https://dialnet. unirioja.es/servlet/articulo?codigo $=7954422$

Coll, C., Onrubia, J., \& Maurí, T. (2008). Ayudar a aprender en contextos educativos: el ejercicio de la influencia educativa y el análisis de la enseñanza. Revista de educación, 346, 33-70. http://www.revistaeducacion. mec.es/re346/re346_02.pdf

Cuzco, J. (2020). Aplicación pedagógica de la tecnología push en el proceso de identificación de estilos de aprendizaje. Revista Espacios, 41 (30), 343-357. https:// www.revistaespacios.com/a20v41n30/a20v41n30p28.pdf

Jaber, J.R., Arencibia, A., Carrascosa, C., Ramírez, A.S., Rodríguez Ponce, E., Melián C., Castro, P., \& Farray, D. (2016). Empleo de Kahoot como herramienta de gamificación en la docencia universitaria. En A. Ravelo, S. Pérez, J. Alonso, J. Canino, C. Travieso, D. Sánchez (coord.). InnoEducaTIC 2016 (pp. 225-227) Universidad de Las Palmas de Gran Canaria. https://accedacris.ulpgc.es/bitstre am/10553/20472/1/0730076_00000_0032.pdf

Kemmis, S., \& Mc Taggart, R. (1988). Cómo planificar la Investigación Acción. BarceIona, España: Laertes.

Little, C. (2016). Reporte tecnológico: sistema de respuesta del estudiante de Mentimeter smartphone. Brújula, diario de aprendizaje y enseñanza, 9 (13), 64-66. https:// journals.gre.ac.uk/index.php/compass/article/view/328

Marcello, J., Cabrera F., Rodríguez D., \& Eugenio F. (2019). Análisis comparativo de herramientas TIC para presentaciones participativas. En D. Sánchez (ed.), A. Ravelo, 
C. Travieso, J. Alonso, J. Canino, S. Pérez (coord). VI Jornadas Iberoamericanas de Innovación Educativa en el Ámbito de las TIC y las TAC (pp. 177-183). Universidad de Las Palmas de Gran Canaria. https://accedacris.ulpgc.es/handle/10553/58141

Vallely, K., \& Gibson, P. (2018). Involucrar a los estudiantes en sus dispositivos con Mentimeter. Journal of Learning and Teaching, 11(2). https://journals.gre.ac.uk/index.php/compass/article/view/843

Walss Aurioles, M.E. (2021). Diez herramientas digitales para facilitar la evaluación formativa. Tecnología, Ciencia y Educación, 18, 127-139. https://doi.org/10.51302/ tce. 2021.575 


\section{Las Tecnologías de la Información y Comunicación y su Usabilidad en Estudiantes de Educación Superior en Tamaulipas: ¿Se Amplía o Reduce la Brecha Digital?}

\section{Hernández Rodríguez, Abigail}

Universidad Autónoma de Tamaulipas

ahernandezr@docentes.uat.edu.mx

\section{Echavarría Sánchez, Anabell}

Universidad Autónoma de Tamaulipas

aechavarria@docentes.uat.edu.mx

\section{De la Cruz Borrego, José Gpe.}

Universidad Autónoma de Tamaulipas

jborrego@docentes.uat.edu.mx

\section{Azuela Flores, Cristabell}

Universidad Autónoma de Tamaulipas

cristabell.azuela@docentes.uat.edu.mx

\section{Roux Ramírez, Rhodas}

Universidad Autónoma de Tamaulipas

rrouxra@docentes.uat.edu.mx

\section{0}




\title{
LAS TECNOLOGÍAS DE LA INFORMACIÓN Y COMUNICACIÓN Y SU USABILIDAD EN ESTUDIANTES DE EDUCACIÓN SUPERIOR EN TAMAULIPAS: ¿SE AMPLÍA O REDUCE LA BRECHA DIGITAL?
}

\author{
Hernández Rodríguez, Abigail \\ Echavarría Sánchez, Anabell \\ De la Cruz Borrego, José Gpe. \\ Azuela Flores, Cristabell \\ Roux Ramírez, Rhodas
}

\section{Resumen}

La presente investigación estableció como objetivo general caracterizar la usabilidad de las tecnologías de la información y el nivel de habilidades de los estudiantes de Instituciones de Educación Superior (IES) en Tamaulipas, y, a la luz de los resultados, dilucidar si la incorporación de las TIC en la vida académica se constituye en un factor que favorece o reduce la brecha digital. La investigación tuvo un diseño cuantitativo, no experimental de nivel descriptivo y se empleó un diseño muestral estratificado considerando la ubicación geográfica de las IES en las distintas regiones del Estado de Tamaulipas. Una vez definido el tamaño muestral de instituciones y de los sujetos (estudiantes de las IES), se aplicó un cuestionario (previamente validado) a 188 estudiantes de 39 IES de Tamaulipas. Los resultados evidenciaron que los estudiantes accedían escasamente a las TIC con fines académicos, por lo que corresponde al uso de plataformas, correo electrónico institucional, búsqueda y obtención de información por medios tecnológicos, asistencia a eventos académicos en línea. Las reflexiones finales giran en torno a la velocidad en que, en el último año, se transitó de una cultura de trabajo basada en la presencialidad hacia la virtualidad y sobre el cuestionamiento acerca de si este suceso ha hecho que se amplíe aún más la brecha digital en la actividad de los estudiantes universitarios y, por ende, llegar a la definición de los nuevos objetos de estudio.

\section{Palabras clave}

Usabilidad de TIC, estudiantes universitarios, brecha digital 


\section{Introducción}

Las tecnologías de información y comunicaciones (en los sucesivo TIC), tuvieron su evolución en las décadas de los $80^{\prime}$ s y $90^{\prime}$ s, durante este proceso su aplicación a la educación fue creciendo conforme se veían las ventajas que representaban para el proceso de enseñanza aprendizaje. Los países desarrollados tomaron la delantera en este aspecto; los Estados Unidos e Inglaterra fueron países que se aplicaron en generar iniciativas en políticas públicas encaminadas a introducir las TIC en sus sistemas educativos.

En este dinamismo las políticas públicas de los años 80 de los Estados Unidos, se propusieron introducir computadores en laboratorios escolares con el propósito, por un lado, de crear competencias tecnológicas y, por el otro, apoyar mediante esta herramienta a los procesos de enseñanza y aprendizaje de los planteles (Zayas, Parra, Lopez, \& Torres, 2015).

En 1981 se lanzó la primera política pública de TIC para escuelas en Inglaterra, denominada "Microcomputadores para las Escuelas". Posteriormente se le da un enfoque más educativo con el objetivo general de poner las TIC al servicio del currículum de los estudiantes en 1987, bajo el enfoque del Ministerio de Educación y Ciencias a través del programa "Nuevas Tecnologías" para mejores escuelas (Odetti \& Caldeiro, 2017).

Europa continental no permanece ajena a estos progresos y en 1997 se creó EuropeanSchool.net, una asociación de portales educativos de 28 ministerios de educación europeos, la que permite la cooperación entre escuelas y gobiernos a través de su plataforma (Jara, 2008).

Finalmente, se da cuenta en este trabajo de los avances tecnológicos de los países asiáticos, la Universidad Tecnológica Real de Melbourne decidió construir, junto con inversionistas privados, un campus de 50 millones de dólares en la ciudad Ho Chi Minh, situada en Vietnam, donde se impartirán programas virtuales con apoyo de las actividades en TIC (Brunner, 2000).

Progresivamente, los países del mundo están respondiendo a esta demanda, desarrollando políticas para incorporar masivamente las TIC en sus escuelas. Se espera que estos esfuerzos disminuyan la brecha digital al interior de los países y preparen a los jóvenes en las nuevas competencias vinculadas con estas tecnologías (Gómez, Alvarado, Martinez, \& Diaz, 2018).

Hoy en día se puede decir que las TIC juegan un papel importante en la educación en todos los niveles; sin embargo, en su incorporación al proceso educativo es posible observar grandes diferencias al comparar el tipo y tamaño de la infraestructura, así como el dominio y uso de las tecnologías para la enseñanza de los estudiantes en las diferentes áreas y clases sociales. Más específicamente, esta diferencia se conoce como "brecha digital" y se refiere a los diferentes contextos caracterizados por la perspectiva con la que se enfrenta, pero tienen una base común, la falta de acceso a la información mediante el internet y el acceso a la herramienta tecnológica.

Por lo tanto, el concepto de brecha digital incorpora los siguientes enfoques: Hacia la infraestructura: la posibilidad / dificultad de tener computadoras conectados a la red mundial. Hacia competencias TIC: la capacidad / dificultad de usar estas tecnologías. 
Hacia el uso de los recursos: la limitación / posibilidad de que la gente tiene, para utilizar los recursos disponibles (Ambrosi, Peugeot, \& Pimienta, 2005).

De lo anterior, se deriva y fundamenta la estrategia de investigación, dado que los factores que se analizan son la infraestructura tecnológica existente, las competencias tecnológicas y el uso de las herramientas o recursos. Estos tres factores representan la herramienta para evaluar la brecha digital en la investigación ejecutada en el sistema educativo del estado de Tamaulipas, y representan así la alineación de modelo de Van Dijk (2012) Ilamado "Teoría del Modelo de Apropiación de los recursos". En esta propuesta de Van Dijk, el autor argumenta que hasta ahora sigue siendo importante la exclusión absoluta de acceso a los medios digitales, tanto para los países desarrollados y no desarrollados, pero ahora las diferencias entre las personas que ya tienen acceso a las tecnologías se asocian con las desigualdades relativas de habilidades y uso. Van Dijk argumentó que estas diferencias son aún más importantes en la sociedad de la información y de la sociedad en red, porque son nuevos tipos de desigualdad.

Sobre esta temática ya existen una variedad de estudios, la revisión de literatura advierte que el uso de las TIC ayuda a los estudiantes en el acceso a la información digital eficiente y eficazmente. Brush, Glazewski \& Hew (2008) han señalado, que las TIC se utilizan como un instrumento para los estudiantes dado que les ayuda descubrir temas de aprendizaje, resolver problemas y generar soluciones a los problemas en el proceso de aprendizaje. Así mismo, apoyan el aprendizaje auto-dirigido y centrado en el estudiante, los estudiantes están ahora más cerca del uso de computadoras (Castro \& Alemán, 2011), con el fin de construir nuevos conocimientos a través de acceder, seleccionar, organizar e interpretar información y datos. Además, producen un ambiente de aprendizaje creativo, las TIC contribuyen a desarrollar una nueva comprensión de los estudiantes en los temas de aprendizaje (Chai, Koh, \& Tsai, 2010).

Así mismo, las TIC ofrecen más oportunidades para desarrollar habilidades de pensamiento crítico (de orden superior) basados en un enfoque de aprendizaje constructivista, también las TIC ayudan a los estudiantes concentrarse en conceptos de alto nivel en lugar de hacerlo en tareas menos significativas (Levin \& Wadmany, 2006). De igual forma, McMahon (2009) mostró que había correlaciones estadísticamente significativas entre estudiar con las TIC y la adquisición de habilidades de pensamiento crítico.

Lowther, Inan, Strahl y Ross (2008) mencionan que debe agregarse así mismo que las TIC coadyuvan a mejorar la enseñanza y aprendizaje de calidad, y que hay tres características importantes y necesarias para desarrollar la buena calidad de enseñanza y aprendizaje mediante ellas: autonomía, capacidad y creatividad; lo cual coincide con lo propuesto por Van Deursen \& Van Dijk (2010).

Hay una variedad de estudios realizados para valorar el nivel de incorporación de las TIC en el proceso educativo y el nivel de dominio de herramientas tecnológicas de parte de los docentes, así lo demuestran los trabajos de Viñals y Cuenca (2016), Boelens, Voet y De Wever (2018), Zempoalteca, Barragan, Gonzalez y Guzmán (2017), Zepeda, Méndez y Galván (2019), Rangel y Peñalosa (2013) y de López, González y López (2018). 
Son escasos los estudios sobre los estudiantes, pero aquí se destaca el trabajo de Santos, Batista y Marques (2019), desarrollado en Portugal cuyo objetivo era analizar la perspectiva de los estudiantes sobre el uso de esas tecnologías para comunicarse con sus maestros, investigar con qué objetivos y funciones los estudiantes usan las tecnologías y comprender cuáles son sus expectativas. Para respaldar el estudio, se conceptualizó y se implementó un modelo de análisis en un estudio de caso realizado en una universidad portuguesa. La recopilación de datos se llevó a cabo mediante la administración de un cuestionario en línea a 570 estudiantes en 2018. Los resultados mostraron que los estudiantes prefieren las aplicaciones que permiten la comunicación interpersonal, así como la publicación y el intercambio de tecnologías para comunicarse con sus maestros. Además del uso, se analizaron las respuestas con respecto a la facilidad de uso, expectativa, actitud hacia el uso, satisfacción, frecuencia de uso, entre otras variables consideradas en el modelo de análisis y presentadas en esa investigación (Santos, Batista, \& Marques, 2019).

A la luz de las problemáticas descritas en párrafos anteriores y de los resultados de investigaciones previas que se relacionan con el tema que se propone en el presente escrito; el objetivo que se establece es caracterizar la usabilidad de las tecnologías de la información y el nivel de habilidades de los estudiantes de IES en Tamaulipas, $\mathrm{y}$, con base en los resultados, dilucidar si la incorporación de las TIC en la vida académica se constituye en un factor que favorece o reduce la brecha digital.

\section{Método}

\section{Descripción del contexto y de los participantes}

Para el presente estudio de investigación se tomó la base de datos general certificada por la Secretaría de Educación de Tamaulipas. Siendo el universo de 132 universidades dentro del Estado, de las cuales se eligieron 39 instituciones de cinco regiones del estado y se seleccionaron 188 estudiantes de 50 licenciaturas impartidas en ellas.

Las licenciaturas impartidas en departamentos, escuelas o divisiones en las universidades analizadas se distribuyeron geográficamente de la siguiente manera: 16 pertenecen a la región Centro, 10 forman parte de la región fronteriza, 2 corresponden a la región del altiplano, 4 forman parte de la región Mante y 18 son de la región sur.

Para determinar la muestra del proyecto de investigación que cubre el análisis de los sistemas educativos del estado de Tamaulipas seleccionamos el método Kish (1995), con el que se obtiene una muestra adecuada a través del muestreo estratificado con el enfoque de racimos o estratos, basándose en el principio de que la estratificación aumenta la precisión de la muestra e implica el uso deliberado de diferentes tamaños de muestra para cada estrato.

\section{Instrumento}

Los instrumentos fueron cuestionarios diseñados para el estudio de los efectos de las brechas digitales en los procesos educativos de Tamaulipas cuya clave CONACYT-FOMIX es MO021-2010-27 y cuyo número es el 152546. En esta investigación se usó uno de los instrumentos aplicados en el proyecto global específicamente el 
diseñado para los alumnos del nivel superior que se denomina "Superior Alumno", en el cual se valora el uso de las TIC en los procesos de enseñanza aprendizaje de los alumnos de educación superior.

El instrumento cuenta con los apartados de Datos referenciales y Uso de los recursos, este último cuenta con 15 preguntas de tipo escala Likert; Para conjuntar la información recopilada se utilizó la herramienta Survey Monkey que utiliza el SPSS para obtener resultados eficientes. La validación del instrumento se llevó a través de una cuidadosa adaptación y validación a través de la revisión de tres o cinco expertos del área del conocimiento. (Corral, 1999) Al procesar los datos con el paquete estadístico SPSS se obtuvo un Coeficiente de Confiabilidad Alpha-Chronbach de .888 aproximadamente .9 , valor cercano a 1.

\section{Procedimiento}

Este estudio es una investigación aplicada de diseño cuantitativo no experimental, de nivel exploratorio y descriptivo debido a que pretende indagar el uso de las TIC en los alumnos de las universidades seleccionadas.

\section{Resultados}

Al recabar los datos en las encuestas de los alumnos de nivel superior, se generaron las evidencias siguientes en el apartado de usabilidad en las TIC. La encuesta contiene 15 preguntas, a continuación, se muestra el uso de Internet de los estudiantes según el área de conocimiento en la que se encuentre. (Gráfica 1)

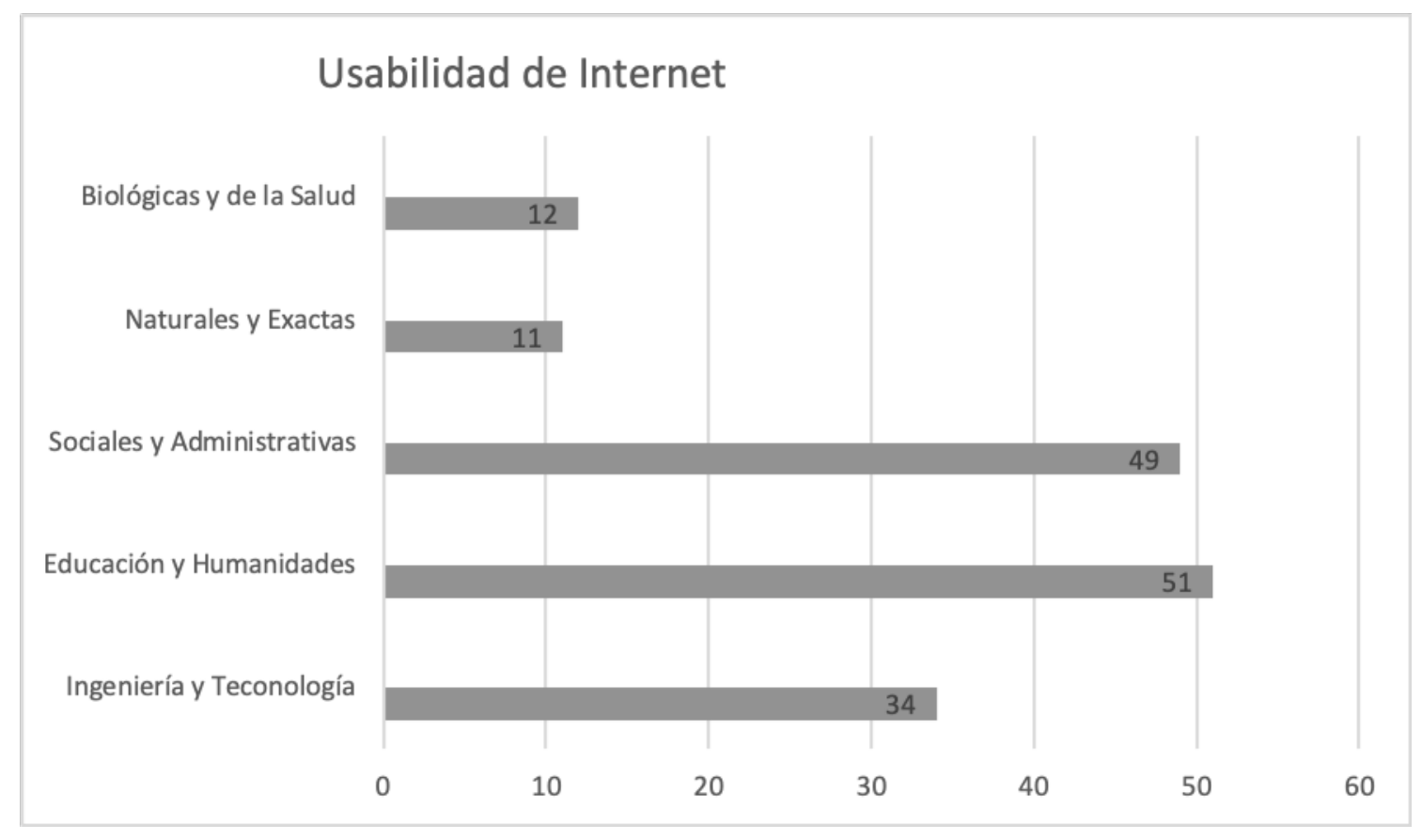


De acuerdo con los resultados obtenidos se aprecia que los estudiantes de las áreas de conocimiento de Educación y Humanidades, así como Sociales y Administrativas son quienes tienen mayor usabilidad de Internet, en comparación con los de las otras áreas, esto se puede explicar si consideramos que los estudiantes de estas áreas realizan un mayor número de prácticas de campo, lo cual no les permite hasta cierto modo estar frente a una computadora o laptop por mucho tiempo.

A continuación, se presenta una tabla con la frecuencia preponderante para analizar las respuestas a los diferentes ítems que conformaban el cuestionario por los estudiantes encuestados.

Tabla 1. Frecuencia preponderante expresada en porcentaje para cada uno de los ítems del cuestionario

\begin{tabular}{|c|c|c|c|c|c|}
\hline Ítem & Nunca & $\begin{array}{l}\text { Una vez por } \\
\text { semana }\end{array}$ & $\begin{array}{l}\text { Dos veces } \\
\text { por sema- } \\
\text { na }\end{array}$ & $\begin{array}{c}\text { Tres veces } \\
\text { por sema- } \\
\text { na }\end{array}$ & $\begin{array}{l}\text { Todos los } \\
\text { días }\end{array}$ \\
\hline Visita al centro de cómputo & 51 & 22 & 14 & 10 & 3 \\
\hline $\begin{array}{l}\text { Uso de correo electrónico } \\
\text { (Alumno a Maestro) }\end{array}$ & 31 & 26 & 18 & 14 & 11 \\
\hline $\begin{array}{l}\text { Uso de correo electrónico } \\
\text { (Maestro a Alumno) }\end{array}$ & 31 & 27 & 19 & 13 & 10 \\
\hline Uso de redes sociales & 3 & 5 & 6 & 19 & 67 \\
\hline $\begin{array}{l}\text { Uso de internet en comercio } \\
\text { electrónico }\end{array}$ & 81 & 13 & 3 & 2 & 1 \\
\hline $\begin{array}{l}\text { Uso de internet en juegos inte- } \\
\text { ractivos }\end{array}$ & 58 & 16 & 10 & 11 & 5 \\
\hline Ítem & Nunca & $\begin{array}{l}\text { Una vez por } \\
\text { semana }\end{array}$ & $\begin{array}{l}\text { Dos veces } \\
\text { por sema- } \\
\text { na }\end{array}$ & $\begin{array}{l}\text { Tres veces } \\
\text { por sema- } \\
\text { na }\end{array}$ & $\begin{array}{l}\text { Alguna vez } \\
\text { en el perio- } \\
\text { do de clase }\end{array}$ \\
\hline $\begin{array}{l}\text { Uso de internet en resolución } \\
\text { de problemas }\end{array}$ & 11 & 22 & 25 & 21 & 21 \\
\hline $\begin{array}{l}\text { Uso de internet y computado- } \\
\text { ra en actividades académicas } \\
\text { relacionadas con las materias } \\
\text { cursadas }\end{array}$ & 1 & 7 & 18 & 59 & 15 \\
\hline $\begin{array}{l}\text { Uso de internet y computadora } \\
\text { para actividades académicas } \\
\text { de creación de diseños, consul- } \\
\text { ta de wiki, crear animaciones }\end{array}$ & 11 & 10 & 23 & 43 & 13 \\
\hline $\begin{array}{l}\text { Uso de computadora e internet } \\
\text { para actividades académicas } \\
\text { de edición de audios, consultar } \\
\text { blogs, crear y consultar videos } \\
\text { académicos, tomar cursos en } \\
\text { línea }\end{array}$ & 19 & 25 & 17 & 22 & 17 \\
\hline $\begin{array}{l}\text { Uso de computadora e internet } \\
\text { para actividades académicas } \\
\text { en participación de foros, bajar } \\
\text { e insertar imágenes en trabajos } \\
\text { o tareas }\end{array}$ & 16 & 20 & 23 & 30 & 11 \\
\hline
\end{tabular}




\begin{tabular}{|l|c|c|c|c|c|}
\hline $\begin{array}{l}\text { Investigación en libros digitales } \\
\text { O artículos de revistas }\end{array}$ & 9 & 20 & 29 & 31 & 11 \\
\hline $\begin{array}{l}\text { Participación en Teleconferen- } \\
\text { cias o Congresos en línea }\end{array}$ & 79 & 5 & 3 & 3 & 10 \\
\hline $\begin{array}{l}\text { Impartición e interacción de } \\
\text { una tarea a través de una pla- } \\
\text { taforma LMS }\end{array}$ & 78 & 4 & 5 & 4 & 9 \\
\hline
\end{tabular}

\section{Discusión}

A partir del objetivo planteado en la investigación de campo se generó información que indica un uso académico muy por debajo de lo que debería tener en promedio un alumno de educación superior en cuanto a la usabilidad y operación de la infraestructura TIC en los centros de cómputo, correo electrónico para comunicarse con sus maestros e interacción con plataformas LMS y congresos en línea, mientras que en el manejo de aplicaciones así como búsqueda y obtención de información en la computadora e internet se muestra un adecuado uso académico de más de tres veces por semana.

De manera similar los resultados describen que los alumnos coinciden en usar diariamente el internet para aspectos académicos. También procuran mantenerse comunicados con sus docentes por medio de correo electrónico por lo menos una vez por semana.

En este proceso de igual manera se conoció la frecuencia con la que manejan las redes sociales dando por resultado que diariamente son utilizadas como esparcimiento o como parte de sus actividades académicas.

Entonces para poder responder al cuestionamiento si se ha logrado ampliar o reducir la brecha digital, retomando la definición de Ambrosi, Peugeot y Pimienta (2005), en este escrito, al hablar de brecha digital, se hace referencia a aspectos tales como: la infraestructura (la posibilidad / dificultad de tener computadoras conectados a la red mundial), el desarrollo de las competencias tecnológicas (la capacidad / dificultad de usar estas tecnologías) y el uso de las herramientas tecnológicas (la limitación / posibilidad de que la gente tiene, para utilizar los recursos disponibles). El autor Van Dijk (2012) retoma estos elementos y los integra en su "Teoría del Modelo de Apropiación de los recursos".

Los datos presentes en la problemática reflejan que ha habido esfuerzos de los países encaminados a reducir la brecha digital.

En la actualidad siguen surgiendo nuevos modelos que buscan aprovechar los nuevos dispositivos tecnológicos, cada uno con sus respectivas promesas educativas, se discuten propuestas de computación de tecnologías móviles con redes inalámbricas, proyectores y pizarras interactivas, entre otras, los países en vías de desarrollo deben atender las nuevas demandas y oportunidades simultáneamente con la implementación de políticas para superar la pobreza y resolver problemas básicos de cobertura y alfabetización en sus sistemas educativos. Sin embargo, muchas veces hay dificultades para destinar los cuantiosos recursos que requieren las políticas de TIC para las escuelas (Cala, Diaz, Espi, \& Tituaña, 2018) 
Un dato interesante en este sentido según la OCDE y el Banco Mundial, es que más del $90 \%$ de las escuelas en los países desarrollados cuenta con equipamiento y está conectada a Internet, la mayor parte a banda ancha. Por ejemplo, los países europeos tienen hoy un promedio de 9 alumnos por computador, y menos de 5 alumnos en Estados Unidos, Inglaterra, Australia, Corea o Canadá (OCDE, 2016)

En este sentido, se puede deducir que, para el caso de los alumnos de Instituciones de Educación Superior de Tamaulipas, el tema de la infraestructura sigue siendo un tema pendiente y motivo de mantener la brecha digital.

El aspecto de la infraestructura va asociado al desarrollo de competencias en los estudiantes, dado que algunos autores señalan que el uso de las herramientas tecnológicas en el proceso educativo favorece la resolución de problemas, el aprendizaje auto-dirigido y centrado en el estudiante, la búsqueda de información y construcción de nuevos conocimientos y el aprendizaje creativo (Brush, Glazewski \& Hew: 2008). Otros autores como Levin y Wadmany (2006) se refieren al pensamiento crítico y significativo; y Van Deursen y Van Dijk (2010), hacen referencia a las competencias sobre autonomía, capacidad y creatividad.

Con base en lo anterior se advierte que los resultados de la investigación evidencian que, para los estudiantes de educación superior en Tamaulipas el desarrollo de las competencias antes citadas se vuelve limitado, debido al escaso uso de las tecnologías de la información.

\section{Conclusiones}

A la luz de la pandemia, que se dejó sentir a partir de marzo de 2020, podríamos preguntarnos qué tanto se ha modificado la situación de incorporación de las TIC en la educación; ya se han realizado varios estudios sobre este tema; sin embargo, no se han reportado resultados del impacto que tuvo este acelerado proceso de trabajar virtualmente con los estudiantes a través de diversas herramientas tecnológicas: ¿se amplió o redujo la brecha digital?

Con base en los resultados obtenidos en la aplicación del instrumento se concluye que aún existe una marcada brecha digital en la Educación Superior, uno de los principales motivos es el poco interés que muestran los estudiantes en la usabilidad de las TIC para atender aspectos académicos, a pesar de hacer un uso diario de estas como un medio para socializar.

A pesar de identificar en esta investigación un escaso uso de los Centros de cómputo en las instituciones por parte de los estudiantes, habría que indagar sobre las razones por las cuales no los utilizan.

Por otro lado se pueden a partir de los resultados obtenidos en esta investigación se pueden proponer nuevas líneas de investigación entre las que se pueden mencionar:

1. Evaluar las estrategias que implementaron las IES de Tamaulipas para atender a sus estudiantes de manera virtual. 
2. Identificar los medios de comunicación usados en el proceso enseñanza aprendizaje y si éstos favorecieron el logro de los objetivos planteados.

3. Investigar cómo se sustituyó la actividad práctica de laboratorios, talleres, las prácticas profesionales y el servicio social.

4. Determinar cuántos estudiantes lograron superar satisfactoriamente, académicamente hablando, este reto de la educación virtual.

5. Indagar sobre la organización de los estudiantes en su familia, sobre la usabilidad de la computadora, cuando solo se contaba con un equipo.

6. Examinar la proporción de estudiantes que suspendieron sus estudios y se incorporaron al trabajo.

7. Valorar en términos generales los efectos de la pandemia en el proceso formativo.

\section{Referencias}

Ambrosi, A., Peugeot, V., \& Pimienta, D. (2005). Hacia sociedades de saberes compartidos. En A. Ambrosi, V. Peugeot, \& D. Pimienta, Palabras en juegoEnfoques Multiculturales sobrelas Sociedades de la Información (págs. 15-18). Francia: C\&F Editions.

Boelens, R., Voet, M., \& De Wever, B. (Mayo de 2018). The design of blended learning in response to student diversity in higher education: Instructors' views and use of differentiated instruction in blended learning. Computers\&Education, 120, 196-212.

Brunner, J. J. (23 de Agosto de 2000). Archive.org. Recuperado el 2011, de Internet Archive: http://www.schwartzman.org.br/simon/delphi/pdf/brunner.pdf

Brush, T., Glazewski, K., \& Hew, K. (2008). Development of an Instrument to Measure Preservice Teachers' Technology Skills, Technology Beliefs, and Technology Barriers. Computers in the Schools, 25, 112-125.

Cala, R., Diaz, L., Espi, N., \& Tituaña, J. (2018). El Impacto del Uso de Pizarras Digitales Interactivas (PDI) en el Proceso de Enseñanza Aprendizaje. Un Caso de Estudio en la Universidad de Otavalo. Información Tecnológica, 29(5), 61-70.

Castro, J., \& Alemán, E. (2011). Teachers opinion survey on the use of ICT tools to support attendance-based teaching. Journal Computers and Education, vol.56, 911-915.

Chai, C., Koh, J., \& Tsai, C. (2010). Facilitating preservice teachers' development of technological, pedagogical, and content knowledge (TPACK). Educational Technology and Society, 13, 63-73.

Corral, Y. (1999). "Validez y confiabilidad de los instrumentos de investigación para la recolección de datos",. Obtenido de REVISTA CIENCIAS DE LA EDUCACIÓN, Segunda Etapa / Año 2009 / Vol 19/ № 33. Valencia, Enero - Junio p.p. 228-247.

Gómez, D., Alvarado, R., Martinez, M., \& Diaz, C. (Julio de 2018). La brecha digital: una revisión conceptual y aportaciones metodológicas para su estudio en México. 
Entreciencias: Diálogos en la Sociedad del Conocimiento, 6(16), 49-64.

Jara, I. (2008). Las políticas de tecnología para escuelas en América Latina y el mundo: visiones y lecciones. Comisión Económica para América Latina y el Caribe (CEPAL), 1-42.

Kish, Leslie (1995), Diseño estadístico para la investigación, Centro de Investigaciones Sociológicas ( $\mathrm{CIS}$ ), Colección Monografías N 146, Madrid.

Levin, T., \& Wadmany, R. (2006). Teachers' Beliefs and Practices in Technology-based Classrooms: A Developmental View. Journal of Research on Technology in Education, 39, 417-441.

López, J., Gonzalez, E., \& Lopez, R. (Julio de 2018). Formación y uso de TIC en educación superior: opiniones del profesorado. CPU-e Revista de Investigación Educa$\operatorname{tiva(27).}$

Lowther, D., Inan, F., Strahl, D., \& Ross , S. (2008). Does Technology Integration "Work" when Key Barriers Are Removed? Educational Media International, 45(3), 195-213.

McMahon, G. (2009). Critical Thinking and ICT Integration in a Western Australian Secondary. Technology and Society. 12(4): 269-281.

OCDE. (2016). Perspectivas de la OCDE sobre la economía digital 2015. Recuperado el Febrero de 2019, de http://dx.doi.org/10.1787/9789264259256-es

Odetti , V., \& Caldeiro, G. (2017). Identidades digitales en construcción. En F. Tarasow, \& M. Luna, Educar en la era digital. Docencia, tecnología y aprendizaje (1 ed., pág. 203). Guadalajara, Jalisco, México: Pandora.

Rangel, A., \& Peñalosa, E. (julio de 2013). ALFABETIZACIÓN DIGITAL EN DOCENTES DE EDUCACIÓN SUPERIOR: CONSTRUCCIÓN Y PRUEBA EMPÍRICA DE UN INSTRUMENTO DE EVALUACIÓN. Pixel-Bit. Revista de Medios y Educación(43), 9-23.

Sánchez, C., Gama, J., \& Zannata, M. (2015). COMPETENCIAS DIGITALES EN DOCENTES UNIVERSITARIOS. XIII Congreso Nacional de Investigación Educativa, 1-13.

Santos, H., Batista, J., \& Marques, R. (2019). Digital transformation in higher education: the use of communication technologies by students. Procedia Computer Science , 123-130.

Van Deursen, A., \& Van Dijk, J. (2010). Internet skills and the digital divide. New Media \& Society, 13, 893-911.

Van Dijk J. (2012). The Evolution of the Digital Divide: The Digital Divide turns to Inequality of Skills and Usage. Digital Enlightenment Yearbook. 57-75.

Viñals, A., \& Cuenca , J. (Agosto de 2016). El rol del docente en la era digital. Revista Interuniversitaria de Formación del Profesorado , 30(2), 103-114. 
Zayas, I., Parra, D., Lopez, R., \& Torres, J. (15 de Mayo de 2015). La innovación, competitividad y desarrollo tecnológico en las MIP y ME's del municipio de Angostura, Sinaloa. Revista Mexicana de Ciencas Agricolas , 6(3), 603-617.

Zempoalteca, B., Barragan, J., Gonzales, J., \& Guzman, T. (abril de 2017). Formación en TIC y competencia digital en la docencia en instituciones públicas de educación superior. Apertura, 9(1), 80-96.

Zepeda, H., Mendez, M., \& Galvan, H. (Junio de 2019). Evaluación de la Competencia Digital en Profesores de Educación Superior de la Costa Norte de Jalisco. Revista Iberoamericana de Producción Académica y Gestión Educativa , 6(11) 


\section{Los Recursos Educativos Abiertos como Acceso a Derechos Culturales en una Universidad Pública Argentina}

\section{Aranciaga, Ignacio}

orcid.org/0000-0002-2866-6811

aiaranciaga@gmail.com 


\title{
LOS RECURSOS EDUCATIVOS ABIERTOS COMO ACCESO A DERECHOS CULTURALES EN UNA UNIVERSIDAD PÚBLICA ARGENTINA
}

\author{
Aranciaga, Ignacio \\ orcid.org/0000-0002-2866-6811 \\ aiaranciaga@gmail.com
}

\section{Resumen}

Los recursos educativos abiertos como derechos culturales, la adopción de los Repositorios de Recursos Educativos Abiertos representan un desafío para las universidades públicas argentinas en tanto y en cuanto son inexistentes o se encuentran subutilizados. El desarrollo de la investigación se enmarca en las metodologías de investigación, basadas en diseño. La constitución de los repositorios REA generan que los docentes revisiten su formación, trayectoria y experiencia y pueda ser puesta a disposición de más docentes logrando la sociabilización y apertura del conocimiento y ampliando derechos culturales. En este sentido los REA incorporan a las prácticas didácticas nuevos reconocimientos de saberes de los docentes. El derecho de acceso a la educación y cultura es uno de los objetivos estatutarios de las universidades públicas del país, cuando las prácticas didácticas de los REA se vinculan con iniciativas pedagógicas innovadoras se posibilita el acceso al conocimiento libre.

\section{Palabras clave}

Recursos Educativos Abiertos, Repositorios, Prácticas docentes, Educación a Distancia. 


\section{Introducción}

En la región se han desarrollados acciones, proyectos y propuestas formativas en la modalidad a distancia con diferentes matices según los contextos político institucionales en los últimos 30 años (Bergomas, 2011; Coiçaud, 2011; González y Roig 2018; Mena, 2007; Rojas et al 2020; Watson, 2007; Watson y Marchisio, 2009). Los mismos enfatizaron las miradas sobre las propuestas formativas y sus modos de implementación. De su análisis emerge la necesidad de replantear cuál es el lugar que se le otorga a la perspectiva derechos al acceso culturales; y el lugar de los Repositorios de Recursos Educativos Abiertos (RREA) en las prácticas docentes.

El abordaje de la problemática que nos ocupa, requiere para su análisis y comprensión de un punto de partida que advierta sobre las características de la comunicación, la educación y las tecnologías, pero y sobre todo, que reconozca, la condición pedagógica, comunicacional, organizacional, cultural, social, política, económica e histórica de la misma. Esta perspectiva implica correr la mirada de la visión artefactual y tecnicista de la relación entre comunicación, educación y tecnologías, visión que reduce la modalidad a incorporación de tecnologías como soporte instrumental o mera herramienta.

Este artículo busca desarrollar, en primera instancia, la conceptualización de los recursos educativos abiertos para luego describir la adopción de los Repositorios de Recursos Educativos Abiertos como derechos culturales. Para dar cuenta de dicha adopción recorremos la noción de los REA, sus dimensiones educativa, institucional y tecnológica.

Se buscará indagar si la incorporación de las tecnologías en el sistema educativo señala y demarca una nueva agenda para los REA en las instituciones, como ser, las influencias que la lucha por la hegemonía de determinadas innovaciones tecnológicas -de última generación- tiene en el ámbito pedagógico, social y político.

\section{Método}

Este proyecto de investigación se enmarca en las metodologías de investigación relacionadas con el trabajo de diseño y de desarrollo (Reeves, 2006; De Benito y Salinas 2016), ya que se busca la adopción de Repositorios de Recursos Educativos Abiertos como derechos culturales vinculados a las prácticas docentes en Universidades Nacionales de Argentina, considerando las dimensiones política, pedagógica, legal, tecnológica y organizacional de las entidades involucradas.

El valor de la metodología de la investigación basada en diseño de dispositivos debe ser fundamental para la construcción del Prototipo de Repositorio REA, siendo este desarrollo iterativo potencial solución a complejos problemas educativos referidos al acceso al conocimiento.

Las características de este tipo de investigación pueden definirse siguiendo a Reeves, Herrington y Oliver (2002) dado que están centradas en amplios problemas complejos en contextos reales, que implica colaboración intensiva entre investigadores y practicantes, que integrar principios de diseño reconocidos e hipotéticos con las potencialidades tecnológicas para proporcionar soluciones realizables a problemas 
complejos, para refinar entornos de aprendizaje así como para definir principios de diseño, requiriendo intervención a largo plazo que permita el rediseño continuado de protocolos formativos con la resolución de problemas del mundo real.

La actividad recursiva y reflexiva permite un proceso de diseño y desarrollo de dispositivos que genera tanto a los individuos como a los expertos participar completamente del proceso de revisión y reformulación de la metodología de la investigación de diseño y la estructura del método de análisis, diseño, desarrollo e implementación: ADDIE'.

\section{Principales conceptualizaciones de los REA}

Los Recursos Educativos Abiertos recuperan y recrean el trabajo de nuestros docentes, posibilitando que, las capacidades de estos, su formación, trayectoria y experiencia, pueda ser puesta a disposición de más docentes que lo necesitan. No se trata de desarrollar un REA en paralelo con las actuales actividades, sino de atravesar las prácticas educativas con las oportunidades que las herramientas tecnológicas ofrecen tanto para la gestión curricular como para la gestión de Repositorios REA; de manera tal que permita ampliar los recursos educativos disponibles para la formación de los alumnos y potenciar la relación con la docencia. Al mismo tiempo busca que se pueda reflexionar sobre las propias prácticas docentes y proponer diferentes proyectos pedagógicos innovadores; teniendo como premisa el fortalecimiento de los cuerpos docentes.

De acuerdo con la Recomendación UNESCO para REA (2019), estos pueden ser definidos como:

materiales de aprendizaje, enseñanza e investigación en cualquier formato y medio que residen en el dominio público o están bajo derechos de autor que han sido liberados bajo una licencia abierta, que permiten el acceso, la reutilización, la reutilización, la adaptación y la redistribución sin costo alguno por terceros.

Para las instituciones educativas, la adopción y desarrollo de los REA implican dimensiones legales, administrativas, financieras, técnicas, tecnológicas y pedagógicas; para los educadores, están involucradas las formas de enseñanza en el marco del currículum, junto con un sentido de identidad que es a la vez personal y profesional. Para los estudiantes y autodidactas el acceso a los recursos es un aspecto fundamental que plantea posibilidades de acceso al conocimiento global. Sin embargo, cabe señalar que la existencia de gran cantidad de recursos disponibles en web no implica ni acceso legal, ni buenas prácticas de uso. Es necesario diseñar y desarrollar prácticas educativas abiertas en el marco de políticas institucionales que promuevan modelos pedagógicos innovadores.

\footnotetext{
${ }^{1}$ EI modelo ADDIE es una metodología de diseño que se utiliza para ayudar a organizar y optimizar la producción del contenido de un curso. Su denominación "ADDIE" es un acrónimo de las cinco etapas de un proceso de desarrollo: análisis, diseño, desarrollo, implementación y evaluación y se fundamenta en que cada etapa se realice en el orden dado, pero con un enfoque en la reflexión y la iteración.
} 
En el mismo sentido, es relevante mejorar las características de usabilidad, accesibilidad y visibilidad de los REA. Existe un número creciente de Instituciones de Educación Superior (IES) que están adhiriendo al movimiento mundial de acceso abierto al conocimiento y la educación (Open Education) y se están realizando esfuerzos para liberar los contenidos académicos como materiales abiertos, introducidos con el nombre extendido de Recursos Educativos Abiertos (REA). Las prácticas de creación, uso y compartición de recursos educativos digitales y la adopción de herramientas tecnológicas que las facilitan, como los repositorios de recursos educativos digitales, distan de estar generalizadas en los ambientes educativos.

Ante la falta de consideración del tema del acceso a la educación desde la perspectiva de los Derechos Humanos han surgido varios movimientos que bregan por el principio de acceso al conocimiento.

Otros modelos de publicación son posibles, pero falta una oferta de Repositorios REA como propuesta desde las Universidades Nacionales. En los últimos años los REA y los Libros de Texto Abiertos se han convertido en un tema muy relevante a nivel mundial.

Su diferencia radica en su modo de publicación, que se realiza optando por las licencias abiertas en lugar del copyright tradicional. Permite la apertura de los contenidos educativos, que van desde habilitar su distribución gratuita y legal hasta la posibilidad de traducción, modificación, mezcla, reutilización, etc.

En el 2005 el Instituto Internacional para la Planificación Educativa de la UNESCO (IIEP) lanzó un foro de discusión sobre REA, afirmando sus principios y dándole carácter global al movimiento. Y más recientemente, en el año 2012, este mismo foro de la UNESCO, a través de la Declaración de París, exhortó a los gobiernos de todo el mundo al licenciamiento abierto de los materiales educativos de uso público financiados por el Estado.

Las instituciones educativas públicas, y los Estados, se benefician al adoptar políticas de publicación abiertas pues permiten, por un lado, garantizar la remuneración a los autores y por otro, favorecer el acceso ilimitado a los recursos educativos por parte de la población, favoreciendo el acceso a las fuentes relevantes de conocimiento.

Existen escasos Repositorios de REA y los mismos están subutilizados donde el acercamiento a la perspectiva del sujeto productor de REA y a las percepciones y actitudes que inciden en la adopción del paradigma abierto.

Las prácticas de creación, uso y compartición de REA, la generación de Repositorios, la adopción de herramientas tecnológicas, distan de estar generalizadas en todos los niveles educativos. Fundación Vía Libre y Creative Commons Argentina. realizan esfuerzos sin financiamiento y en las UUNN su desarrollo es marginal. 


\section{Dimensión Tecnológica de los Repositorios de Recursos Educativos Abiertos}

Esta dimensión implica reconocer que la inclusión de tecnologías no es neutral y que, no sólo cumple una función instrumental, sino que también modifica sustancialmente los modos de relacionarse, comunicarse, percibir y de pensar. (Aranciaga, 2016; Bijcker, 1997; Hughes, 1983; Ferrer, 2011; Albornoz y López Cerezo, 2010; Latour, 2008; Knorr Cetina, 2005) Siendo éstas actividades constitutivas nodales en los escenarios educativos y el objeto central de desarrollo de acciones institucionales que terminan representándose en los modos de hacer de los actores que componen las instituciones. (Ambrosino y Aranciaga, 2017; Bates, 2001; Cabero, 2004; De Benito y Salinas 2016).

\section{Dimensión educativa de los RREA}

La concepción de los REA como instrumento de equidad e inclusión educativa nace en los países centrales como solución a los problemas estructurales de la Educación Superior, sometida a corrientes neoliberales, privatizadoras y de retiro del Estado, colonizando al movimiento de los REA con una retórica propia y marcos de acción de estos ámbitos centrales (Rodés et al., 2019)

Resulta posible observar tendencias de REA en las prácticas de enseñanza y gestión comprendidas tradicionalmente en la modalidad a distancia y que se desarrollan en diferentes ámbitos educativos presenciales y virtuales (Alcaraz et al., 2018; Ambrosino, 2014; González y Roig, 2018; Rodés et al., 2019)

\section{Resultados}

Los REA entonces son un dispositivo dinámico dado que a partir de ellos se generan repositorios y comunidades de práctica, pero en ese dinamismo también se encuentra sus limitaciones cuando no es apoyado política e institucionalmente. Los REA dan cuenta de un debate político-cultural entre las nuevas expresiones democráticas.

Se generó un prototipo de Repositorio REA, con sus condiciones tecnológicas, sus procedimientos informáticos, sus requerimientos de hardware y software, para ser implementado con licencias libres y abiertas para su reutilización.

Se estableció una guía detallada para implementar políticas de prácticas y experiencias de incorporación de REA en la Educación Superior, con licencias libres y abiertas para su reutilización.

Se diseño de un seminario autogestivo para la incorporación de REA en instituciones de educación superior, que contemple las dimensiones pedagógica, metodológica y tecnológica, su repositorio en software libre, con licencias libres y abiertas para su reutilización.

Se estableció un reglamento del repositorio de recursos educativos abiertos donde se define que los RREA UNPA es el Repositorio de Recursos Educativos de Acceso Abierto de la Universidad Nacional de la Patagonia Austral creado para gestionar y 
mantener una plataforma digital de acceso libre y abierto desde donde se accede a recursos que se generan y utilizan en las actividades de formación de la UNPA. Tiene como propósitos: Integrar y ordenar la producción académica en relación directa con la propuesta académica de la UNPA; Aumentar la visibilidad y difusión de la producción académica de la UNPA; Gestionar el acervo digital garantizando su preservación y recuperación. La obra se pondrá a disposición del público para que haga de ella un uso justo y respetuoso de los derechos de autor bajo una licencia de uso no exclusiva. Las licencias de uso soportadas desde el repositorio pertenecen a la familia Creative Commons que habilitan la descarga, el uso y compartición de los contenidos siempre que se mencionen la obra y al autor original.

Desde el REA UNPA se propiciará la licencia: Reconocimiento - Compartir Igual (by-sa): Se permite el uso comercial de la obra y de las posibles obras derivadas, la distribución de las cuales se debe hacer con una licencia igual a la que regula la obra original. El Repositorio REA UNPA debe asegurar la accesibilidad, legibilidad y preservación digital a tiempo indefinido de todas las obras que alberga.

\section{Discusión y conclusiones}

Los REA transforman las prácticas de nuestros docentes, posibilitando que, las capacidades de estos, su formación, trayectoria y experiencia, pueda ser puesta a disposición de más docentes que lo necesitan. No se trata de desarrollar un REA en paralelo con las actuales actividades, sino de atravesar las prácticas educativas con las oportunidades que las herramientas tecnológicas ofrecen tanto para la gestión curricular como para la gestión de Repositorios REA; de manera tal que permita ampliar los recursos educativos disponibles para la formación de los alumnos y potenciar la relación con los docentes. Desde estas prácticas docentes se obtienen diferentes proyectos pedagógicos innovadores; teniendo como premisa el fortalecimiento de los cuerpos docentes y garantizar el derecho de acceso a la educación y cultura.

La UNPA implementa en el Sistema Institucional de Educación a Distancia (Aranciaga, 2021) nuevas formas de interaccionar entre ambientes digitales, docentes, estudiantes y gestores. EI SIED-UNPA genera una propuesta pedagógica y de gestión que se adaptan, complementan, constituyen y construyen un nuevo modelo pedagógico para la UNPA con los Recursos Educativos Abiertos en el RREA y desarrollan e implementan una articulación vertical de las prácticas incluidas en cada uno de los espacios curriculares de manera de asegurar desde la gestión curricular la integración de los aprendizajes y un modelo de tutor orientado a hacer un seguimiento adecuado de los estudiantes.

Por otro lado, es importante considerar que la UNPA, se encuentra en un proceso de expansión en la gestión institucional por la educación remota de emergencia durante el 2020-2021, que potencian las posibilidades de extender sus proyectos utilizando al máximo la relación entre educación y tecnologías.

En este sentido, genera proyectos sobre las condiciones necesarias para llevar a cabo estos procesos son: Repositorios de Recursos Educativos Abiertos, infraestructura de comunicaciones adecuada, contenido de alta calidad, un nivel apropiado de interactividad, acceso permanente a un entorno virtual de enseñanza y aprendizaje, 
equipos multidisciplinarios de apoyo y asesoramiento para la comunidad educativa y profesionales docentes-investigadores capacitados en el uso y aprovechamiento de las tecnologías para fines educativos y de gestión, resulta ser un resultado significativo para la UNPA.

\section{Referencias}

Albornoz, M. Lopez Cerezo. (2010). Ciencia Tecnología y Universidad en Iberoamérica. Ed. Eudeba, Bs. As.

Alcaraz M, Azcarate C e Ignacio Aranciaga. (2018). Tradiciones de la educación a distancia en universidades nacionales y su vigencia para pensar los desafíos de la expansión y la inclusión. Revista El Cardo. Paraná (Entre Ríos). Facultad de Ciencias de la Educación -UNER, ISSN: 1851-1562

Ambrosino, A. (2014). El proceso de virtualización en Programas Académicos de la Universidad Nacional del Litoral: posibilidades para la Docencia Virtual. Revista Itinerarios Educativos (7), 130-150.

Ambrosino A., Aranciaga I. (2017). Educación a distancia: una investigación prospectiva de contextos institucionales emergentes en Argentina en Investigación, Innovación y Tecnologías. La triada para transformar los procesos formativos. Silva Juan (eds.), 30-38. isbn 978-956-303-369-4 USACH, Santiago de Chile.

Bates, A.W. (2001). Cómo Gestionar el cambio Tecnológico. Ed. Gedisa, Barcelona.

Bijker, W. E. (1997). Of bicycles, bakelites, and bulbs: Toward a theory of sociotechnical change. MIT press.

Cabero, J. (2004). Cambios organizativos y administrativos para incorporación de las TICs en la formación. Edutec., revista electrónica de Tecnología educativa. (18).

Coiçaud Silvia. (2011). Reflexiones sobre la educación a distancia, la red y las universidades. De legados y horizontes para el siglo XXI: veinte años de la RUEDA. Tandil: Universidad Nacional del Centro de la Provincia de Buenos Aires.

De Benito, B. y Salinas, J.M. (2016). La investigación basada en diseño en Tecnología Educativa. RIITE. Revista Interuniversitaria de Investigación en Tecnología Educativa. 44-59. Doi: http://dx.doi.org/10.6018/riite/2016/260631.

Ferrer, C. (2011). El entramado: el apuntalamiento técnico del mundo. Ed. Godot Argentina. Buenos Aires.

González, A. y Roig, H. (2018). Normativa de educación a distancia para la universidad argentina: avances y desafíos pendientes. Virtualidad, Educación y Ciencia. 16 (9), 152-157.

Hughes, T. P. (1983). Networks of Power: Electrification in Western Society, 18801930. Baltimore: John Hopkins University Press. 
Knorr Cetina, K. (2005). La fabricación del conocimiento. Un ensayo sobre el carácter constructivista y contextual de la ciencia. Bernal, Ed. UNQ.

Latour, B. (2008). Reensamblar lo social: una introducción a la teoría del actor-red. Manantial. Buenos Aires.

Mena, M. (2007). Construyendo la nueva agenda de las Educación a Distancia. Ed. La Crujía. Buenos Aries.

Pinch, Trevor. (1997). La construcción social de la tecnología: una revisión. Santos, M.J. y Díaz Cruz, R. (comps.). Innovación tecnológica y procesos culturales. Nuevas perspectivas teóricas. México. Fondo de Cultura Económica.

Reeves, T., Herrington, J. \& Oliver, R. (2002). Authentic activities and online learning, in Quality Conversations. Proceedings of the 25th HERDSA Annual Conference. Perth. Western Australia.

Reeves, T. C. (2006). Design research from the technology perspective. J. van den Akker, K. Gravemeijer, S. McKenney, \& N. Nieveen (Eds.). Educational design research. 86-109. London, Routledge.

Rodés, V., Gewerc-Barujel, A., \& Llamas-Nistal, M. (2019). University Teachers and Open Educational Resources: Case Studies from Latin America. The International Review of Research in Open and Distributed Learning, 20 (1). https://doi.org/10.19173/ irrodl.v20i1.3853.

Rojas H, Marquez, E. Bain, M. Aranciaga, I e Ramos, S. (2020). Prolegómenos del Unpabimodal. Edudesignios, Tecnodestinos en Historia de la Educación a Distancia. Unpa Edita. Rio Gallegos.

Salinas, J. (2007). Blended Learning: Niveles de virtualización de la educación superior. Virtualización de la educación superior. Universidad de Costa Rica. Costa Rica.

Scheneider, D. y Aranciaga, I. (2016). La educación a distancia en las universidades públicas argentinas: consolidaciones institucionales, desafíos normativos y enfoques para proyectos pedagógicos de inclusión en La Universidad y el desafío de construir sociedades inclusivas: debates y propuestas sobre modelos universitarios desde una perspectiva comparativa. UNPA Edita. Rio Gallegos. ISBN: 978- 987-3714-31-3

Watson, M.T. (2007). Historia de la educación a distancia en Argentina: Un contexto de surgimiento. Revista Rueda Red Universitaria de Educación a Distancia. 6.Buenos Aires.

Watson M, T, y Marchisio S. (2009). Tecnología educativa y educación a distancia: unas hebras de sus primeras tramas teóricas en Argentina. IV Congreso Nacional y $1^{\circ}$ Internacional de Investigación Educativa. Cipolletti. Argentina. 


\section{La Experiencia de Aula Invertida Gamificada en Futuros Docentes para Trabajar el Pensamiento Computacional. Percepción de los Estudiantes.}

Carpena Arias, Jesús

Universitat Jaume I

carpena@uji.es

\section{Esteve-Mon, Francesc M.}

0000-0003-4884-1485

festeve@uji.es

Valdeolivas Novella, Ma Gracia 0000-0002-5490-3286

valdeoli@uji.es 


\title{
LA EXPERIENCIA DE AULA INVERTIDA GAMIFICADA EN FUTUROS DOCENTES PARA TRABAJAR EL PENSAMIENTO COMPUTACIONAL. PERCEPCIÓN DE LOS ESTUDIANTES.
}

\author{
Carpena Arias, Jesús \\ Esteve-Mon, Francesc M. \\ Valdeolivas Novella, Ma Gracia
}

\section{Resumen}

En el presente trabajo se abordan dos elementos clave. Por un lado, el flipped learning (en adelante, $F L$ ), estrategia didáctica que desplaza fuera del aula ciertos aprendizajes para poder utilizar el espacio de clase para realizar otras dinámicas de aprendizaje. Y, por otro lado, la gamificación, experiencia metodológica que incorpora elementos y estructuras del juego en el sistema educativo. Este estudio, que forma parte de una investigación más extensa de design-based research (DBR), intenta analizar la motivación y satisfacción del alumnado del grado de Maestro/a de Educación Primaria, después de implementar una intervención didáctica de aula invertida gamificada en la que se trabaja el pensamiento computacional. El proyecto se compone de 7 fases (motivación, explicación del proyecto, investigación y puesta en práctica, reflexión, elaboración del producto, presentación del producto final y evaluación del proyecto), y al finalizar se administró un cuestionario para su evaluación. Los resultados, demuestran la satisfacción de los estudiantes con la propuesta didáctica de aula invertida gamificada, así como una elevada motivación e interés por las actividades, lo cual deberá seguir comprobándose de una manera más amplia en las siguientes fases del proyecto.

\section{Palabras clave}

Estrategia didáctica, gamificación, flipped learning, design-based research, pensamiento computacional. 


\section{Introducción}

La implementación y el uso de dispositivos digitales está teniendo un papel muy relevante en los centros educativos. En estos últimos años, hemos presenciado cómo han irrumpido de forma generalizada en las aulas, modificando el contexto educativo, favoreciendo el desarrollo de la competencia digital (en adelante, CD) y exigiendo un cambio en el rol del profesorado y el papel del alumnado. Ferrari (2012) define la CD como el conjunto de conocimientos, actitudes, y habilidades necesarias cuando se utilizan las TIC, para realizar diversas tareas, de una manera eficaz, eficiente, apropiada, flexible o crítica. Como parte de esta CD, la Comisión Europea (2018) incluye el pensamiento computacional (en adelante, PC), el cual es objeto de trabajo en el presente estudio, tal y como describiremos a continuación. Sánchez-Vera y González-Martinez (2019), exponen que la utilización de la robótica educativa (RE) para desarrollar el PC es un recurso didáctico valioso que permite la realización de actividades como apoyo en el proceso de enseñanza-aprendizaje.

Respecto al concepto del PC, existen dos ideas diferenciadas. La primera sitúa el foco de atención en aspectos informáticos y de programación, mientras que, la segunda se centra en el aprendizaje de estrategias orientadas a la resolución de problemas, aplicando el pensamiento lógico-matemático (Adell et al., 2019). La implementación del PC en los centros educativos (Adell et al. 2017) requiere, por una parte, de la actualización de la formación docente específica en CD, y por otra parte, posibilita la introducción de metodologías donde el alumnado pueda tomar un papel activo. En este sentido, Méndez y Trillo (2010) plantean que las metodologías activas promueven y facilitan el aprendizaje e interacción con el alumnado siendo este quien gestiona su propio aprendizaje, como pueden ser las estrategias de gamificación o la metodología de flipped learning (FL), como seguidamente se describe.

La gamificación es una estrategia didáctica que consiste en utilizar elementos y estructuras del juego (Werbach, 2012), diferenciándose a su vez del aprendizaje basado en el juego en que, la gamificación, utiliza un sistema de recompensa como son las insignias, por el esfuerzo realizado en las tareas propuestas. Esto permite alcanzar una mayor motivación en el alumnado (Fernández et al., 2016), y contribuye a desarrollar una mayor participación entre los estudiantes, así como a obtener mayores resultados y rendimiento académico (Parra-González et al., 2020).

En cuanto a la metodología flipped learning, conocida en castellano como aula invertida, traslada el trabajo de ciertos aprendizajes fuera del aula (trabajo individual) aprovechando así el tiempo en clase para el trabajo grupal, junto con la experiencia del docente. Sus inicios se remontan al año 2009, cuando Bergmann y Sams (2009) se propusieron grabar los contenidos de sus clases para aquellos estudiantes que no podían asistir a ellas. Este modelo de $F L$ permite optimizar el tiempo empleado en clase para realizar actividades más prácticas por parte de los estudiantes, ya que los contenidos conceptuales y teóricos han sido trabajados previamente en sus casas (Bergam y Sams, 2009). No obstante, esta estrategia metodológica puede acarrear un mayor esfuerzo por parte del docente y del estudiante (Jordan et al., 2014).

Pero, para realizar una propuesta didáctica basada en el $F L$, es necesario diseñar actividades que requieran un mayor nivel de complejidad y no priorizar tanto la creación de vídeos (Santiago y Bergmann, 2018), ya que, con el uso de esta metodología, tal y como se ha dicho anteriormente, el alumnado toma un rol más activo 
en su proceso de aprendizaje, así como una mayor responsabilidad. Por tanto, deja de ser un mero receptor de contenidos, para pasar a ser un sujeto activo y con mayor protagonismo, favoreciendo así un aprendizaje más significativo a diferencia del enfoque metodológico tradicional. El concepto de aula invertida gamificada es la unión de las estrategias metodológicas aula invertida y gamificación (Zainuddin, 2018). Por tanto, el aula invertida gamificada permite no solo el estudio previo que se realiza en casa, sino la incorporación de elementos basados en juegos para trabajar en el aula (Zainuddin, 2018).

En la presente investigación se pretende diseñar y desarrollar una intervención educativa de aula invertida gamificada en el grado de Maestro/a de Educación Primaria para trabajar un aspecto concreto del plan de estudios: el pensamiento computacional. El objetivo principal del presente artículo es conocer el grado de utilidad y practicidad percibida por parte de los estudiantes. Respecto a los objetivos específicos, se pretende: (1) Comprobar si la metodología aula invertida gamificada ha sido motivante para los estudiantes; (2) Identificar qué aspectos positivos tiene para el alumnado la implementación de esta metodología.

\section{Método}

\section{Descripción del contexto y de los participantes}

El presente trabajo forma parte de una investigación más amplia, basada en el diseño (DBR, design-based research) (Plomp y Nieveen, 2009). A partir de diferentes iteraciones, se pretende crear una intervención educativa basada en principios de FL y gamificación, para el desarrollo del pensamiento computacional de los futuros docentes.

El siguiente trabajo se ha Ilevado a cabo en la Universidad Jaume I, con estudiantes del segundo curso del grado de Maestro/a de Educación Primaria, concretamente en la asignatura Tecnologías de la información y la comunicación en educación, la cual cuenta con un total de 63 personas matriculadas. Se trata de una universidad pública y presencial, de tamaño medio, que cuenta con cerca de 14.000 estudiantes y 1.200 docentes. En el curso 2020-2021 y debido a la pandemia de la Covid-19, esta asignatura se llevó a cabo mediante una metodología híbrida o blended learning. Las clases virtuales eran utilizadas para trabajar los aspectos teóricos, mientras que, en las presenciales, se trabajaba la parte práctica de la asignatura.

\section{Instrumento}

En la presente fase del DBR se pretende comprobar la utilidad y practicidad (motivación y satisfacción) de la propuesta. El instrumento utilizado para el análisis de datos ha sido un cuestionario diseñado por Roig-Vila (2019), adaptado para la presente investigación y que cuenta con 10 preguntas que hacen referencia a la utilidad y practicidad de la intervención de aula invertida gamificada. Estos ítems siguen una escala de tipo Likert de cuatro alternativas, siendo 1 "completamente desacuerdo" y 4 "completamente de acuerdo". Además de ello, las 3 últimas cuestiones eran de carácter abierto, en las que se les pedía que dieran su opinión acerca de los aspectos positivos y negativos de la metodología aula invertida gamificada y qué consideraban necesario para mejorar dicha estrategia educativa. 
A continuación, podemos ver los ítems del cuestionario de valoración sobre aula invertida gamificada adaptado de Roig-Vila (2019):

1. ¿Crees que la estrategia aula invertida gamificada aula te ha sido útil para comprender mejor los contenidos del proyecto pensamiento computacional?

2. ¿Piensas que estas prácticas educativas benefician tu estudio y el trabajo personal como estudiante?

3. ¿Consideras que ha mejorado tu rendimiento académico con este modelo educativo?

4. ¿Crees tú motivación como alumno/a respecto a la asignatura ha mejorado con este diseño metodológico?

5. ¿Estás satisfecho/a con esta práctica educativa a lo largo del proyecto?

6. ¿Elegirías el aula invertida gamificada antes que el método tradicional para los cursos sucesivos?

7. ¿Recomendarías esta estrategia metodológica en otras áreas de tu carrera universitaria?

8. ¿Qué características positivas crees que tiene la clase invertida gamificada?

9. ¿Qué características negativas destacas de este modelo educativo?

Específica aquella otra información relevante que creas necesaria para el uso de la clase invertida gamificada en los próximos cursos.

\section{Procedimiento}

A continuación, se describe el procedimiento llevado a cabo en el aula mediante la estrategia de $F L$ y gamificación. La utilización del modelo invertido nos permite disponer de más tiempo para realizar en clase actividades donde el alumnado tuviera una mayor implicación, para ello optamos por combinar el modelo de aula invertida con la estrategia de gamificación. Para el desarrollo de este proyecto didáctico, el alumnado preparaba previamente, en casa, los contenidos teóricos mediante el visionado de tutoriales, estudio de diapositivas, audición de podcast y la lectura de artículos. Paralelamente, para comprobar, el profesorado, el estudio realizado por el estudiante se utilizaba la plataforma de pruebas Quizziz.

Por su parte, el trabajo en el aula estaba acompañado de la metodología de gamificación cuya narrativa estaba basada en una historia ficticia. Para ello utilizamos la plataforma de código abierto My Class Game. Para gestionar la dinámica del aula llevamos a cabo una serie de pasos: En primer lugar, creamos una narrativa cuya aventura iba encaminada a superar una serie de misiones. Seguidamente, dimos de alta al alumnado y ellos crearon su avatar, después creamos los elementos del juego que estaban compuestos por: comportamientos, penalizaciones, poderes (cartas), tienda para poder comprar poderes y niveles. Para poder aumentar de nivel debían de completar las misiones y retos encomendados, todos ellos encaminados a 
trabajar el pensamiento computacional. Los estudiantes, iban consiguiendo diferentes poderes conforme superaban los retos propuestos. Estos poderes podían ser canjeados posteriormente por diferentes beneficios.

La implementación de la intervención de aula invertida gamificada se ha llevado a cabo para introducir el tema del pensamiento computacional en la asignatura de TIC en Educación. En este caso, el elemento con el que se ha trabajado el Pensamiento Computacional y la Robótica Educativa es el robot educativo Bee-Bot. Esta intervención ha contado con las siguientes fases:

\begin{tabular}{|c|c|}
\hline FASES & DESCRIPCIÓN \\
\hline Motivación & $\begin{array}{l}\text { El alumnado visiona un vídeo sobre la importancia de trabajar el } \\
\text { pensamiento computacional en las aulas. Después, surge un debate sobre } \\
\text { cómo trabajarlo en las aulas. }\end{array}$ \\
\hline $\begin{array}{l}\text { Explicación del } \\
\text { proyecto }\end{array}$ & $\begin{array}{l}\text { Explicación de los elementos que componen el proyecto, objetivos y } \\
\text { actividades. Se recalca que la realización de este proyecto culmina con la } \\
\text { elaboración y presentación de un producto final. }\end{array}$ \\
\hline $\begin{array}{l}\text { Investigación y } \\
\text { puesta en práctica }\end{array}$ & $\begin{array}{l}\text { Los estudiantes investigan diferentes aspectos relacionados con el } \\
\text { pensamiento computacional y preparan una presentación. Después, } \\
\text { ponen en práctica los conocimientos aprendidos. en las fases anteriores } \\
\text { mediante plataformas con juegos para trabajar el pensamiento } \\
\text { computacional. Los que acaban más rápido y con mejores resultados, } \\
\text { obtienen poderes (cartas insignia) para canjear por recompensas reales. }\end{array}$ \\
\hline Reflexión & $\begin{array}{l}\text { Tras la exposición de la parte teórica, los estudiantes reflexionan acerca } \\
\text { de todo lo aprendido y realizan una entrada en su blog personal. }\end{array}$ \\
\hline $\begin{array}{l}\text { Elaboración del } \\
\text { producto }\end{array}$ & $\begin{array}{l}\text { Se divide al alumnado en grupos de } 6-7 \text { personas y se les explica la tarea } \\
\text { del tapiz para el robot Bee Bot. Aquellos grupos con más implicación, son } \\
\text { recompensados con ciertos poderes. }\end{array}$ \\
\hline $\begin{array}{l}\text { Presentación del } \\
\text { producto final }\end{array}$ & $\begin{array}{l}\text { Terminado el producto, lo presentan y hacen una demostración con el } \\
\text { robot. Los grupos con mayor número de poderes conseguidos en el } \\
\text { desarrollo del proyecto, eligen su hora de presentación. }\end{array}$ \\
\hline $\begin{array}{l}\text { Evaluación del } \\
\text { proyecto }\end{array}$ & $\begin{array}{l}\text { El alumnado evalúa su implicación en el proyecto (autoevaluación) y el } \\
\text { trabajo realizado por sus compañeros de grupo (coevaluación), mediante } \\
\text { una rúbrica realizada por el profesor. }\end{array}$ \\
\hline
\end{tabular}

Tabla 1. Fases de la intervención basada en FL y gamificación, para el desarrollo del $P C$ 


\section{Resultados}

Según los resultados cuantitativos, estos los vamos a agrupar en cuatro dimensiones:

\section{Utilidad de la metodología aula invertida gamificada}

A la gran mayoría de los estudiantes encuestados les ha resultado útil esta intervención para comprender mejor los contenidos relacionados con el pensamiento computacional (ítem 1 del cuestionario), siendo un 69,4\% los que están completamente de acuerdo, un 27,8\% los que están de acuerdo, un 2,8\% en desacuerdo y nadie completamente desacuerdo (Gráfico 1). El 83,3\% de los encuestados piensan que estas prácticas educativas favorecen el estudio y el trabajo del estudiante, (ítem 2 del cuestionario) siendo el $16,7 \%$ el que está de acuerdo y nadie desacuerdo ni completamente desacuerdo (Gráfico 2).

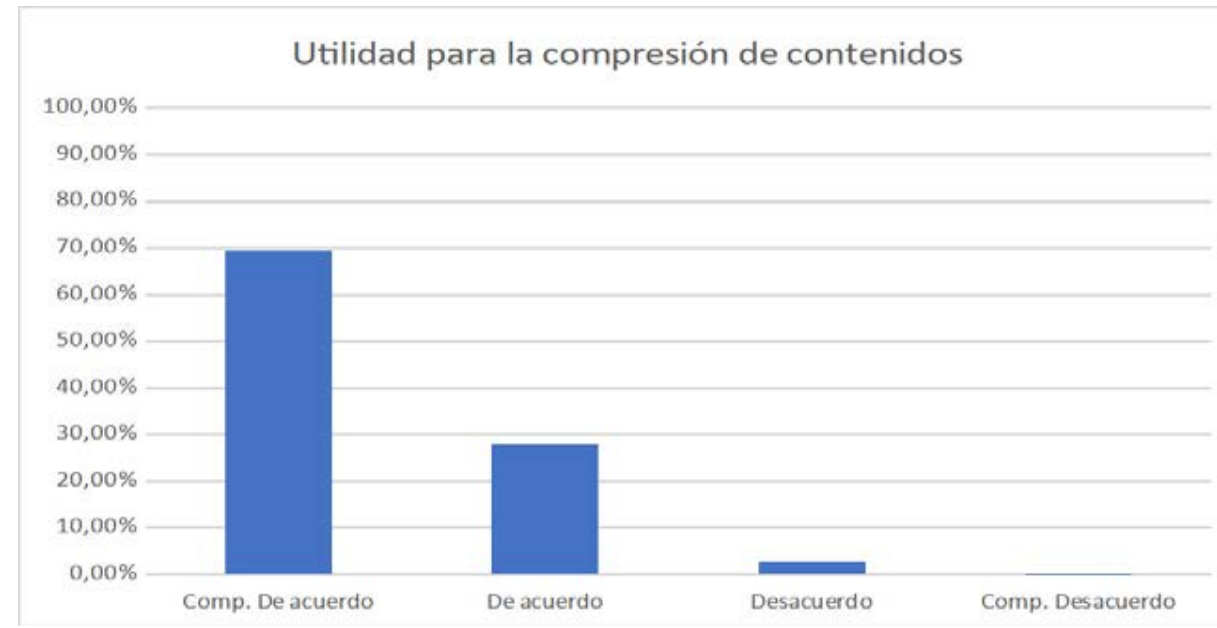

Gráfico 1. Utilidad para la comprensión de contenidos. (Elaboración propia)

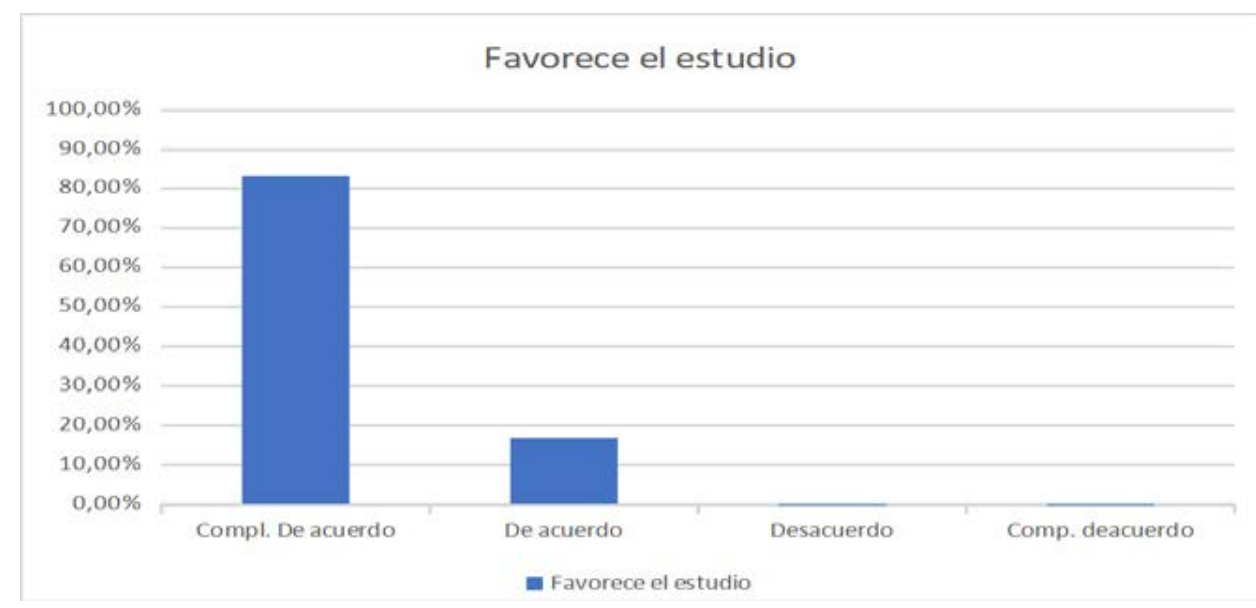

Gráfico 2. Favorece el estudio. (Elaboración propia) 


\section{Percepción sobre el rendimiento académico}

En cuanto a si el alumnado piensa que ha mejorado tu rendimiento académico gracias al nuevo modelo educativo, (ítem 3 del cuestionario), un 47,2\% está completamente de acuerdo, otro 47,2\% de acuerdo, frente al 5,6\% que está desacuerdo y nadie completamente desacuerdo (Gráfico 3).

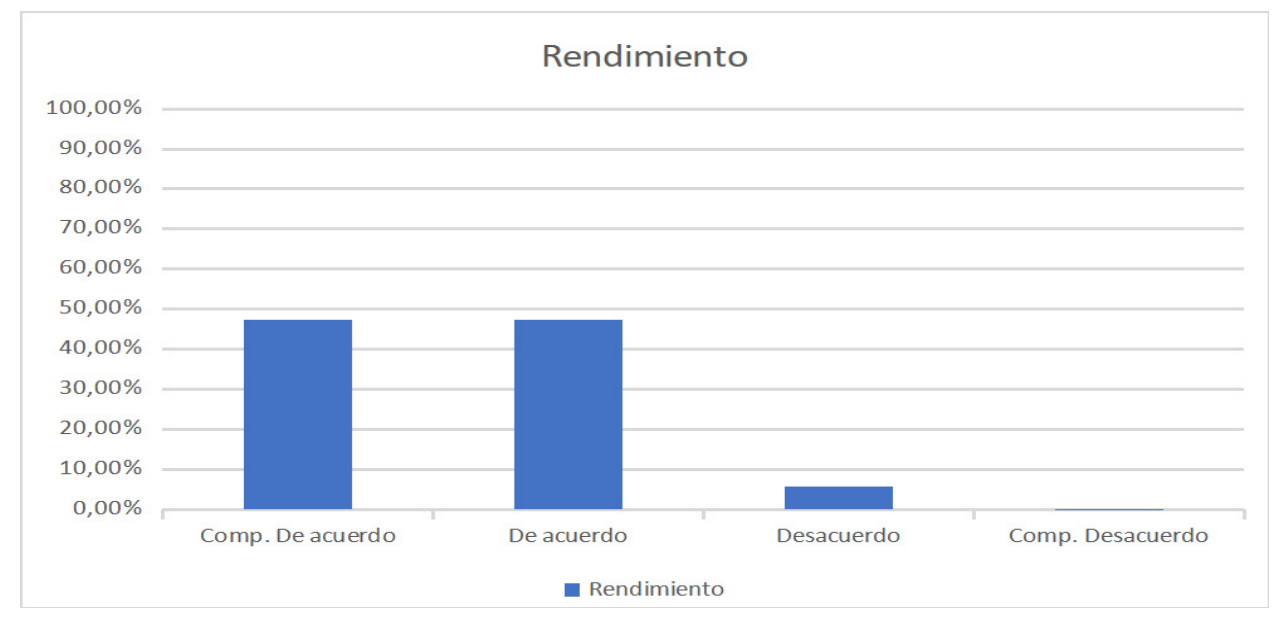

\section{Gráfico 3. Percepción sobre el rendimiento académico. (Elaboración propia)}

\section{Percepción de los estudiantes sobre el aula invertida gamificada}

Respecto a la motivación incrementada gracias a este tipo de metodologías activas, (ítem 4 del cuestionario), un 77,8\% está completamente de acuerdo con ello, un $22,2 \%$ de acuerdo y nadie desacuerdo ni completamente desacuerdo (Gráfico 4). En relación al grado de satisfacción por parte del alumnado, (ítem 5 del cuestionario), el 30,6\% dicen estar completamente de acuerdo, un 63,9\% de acuerdo, y, por otro lado, un 5,6\% desacuerdo y nadie completamente desacuerdo (Gráfico 5).

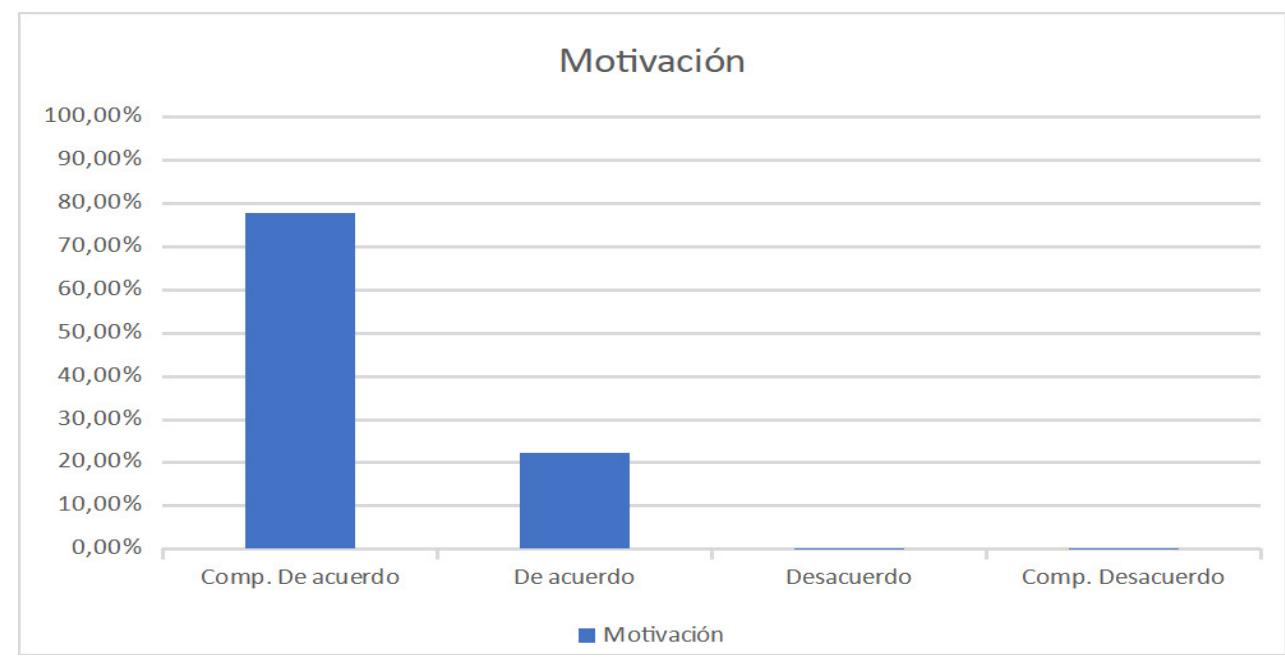

Gráfico 4. Incrementa la motivación. (Elaboración propia) 


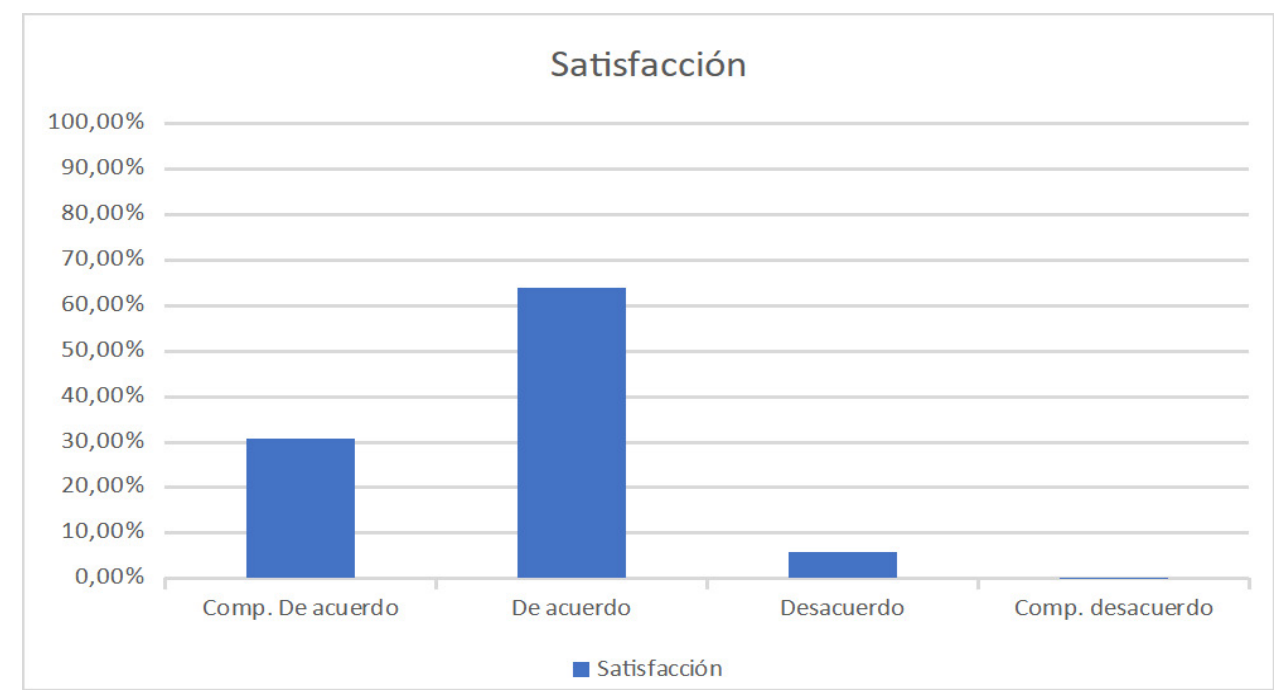

Gráfico 5. Grado de satisfacción del alumnado. (Elaboración propia)

\section{Continuidad del aula invertida gamificada en los sucesivos cursos académicos}

Ante la propuesta de seguir empleando este tipo de metodología para el próximo curso académico, (ítem 6 del cuestionario), un 66,7\% dice estar completamente de acuerdo, mientras que un 30,6\% está de acuerdo, el 2,8\% desacuerdo y nadie completamente desacuerdo (Gráfico 6).

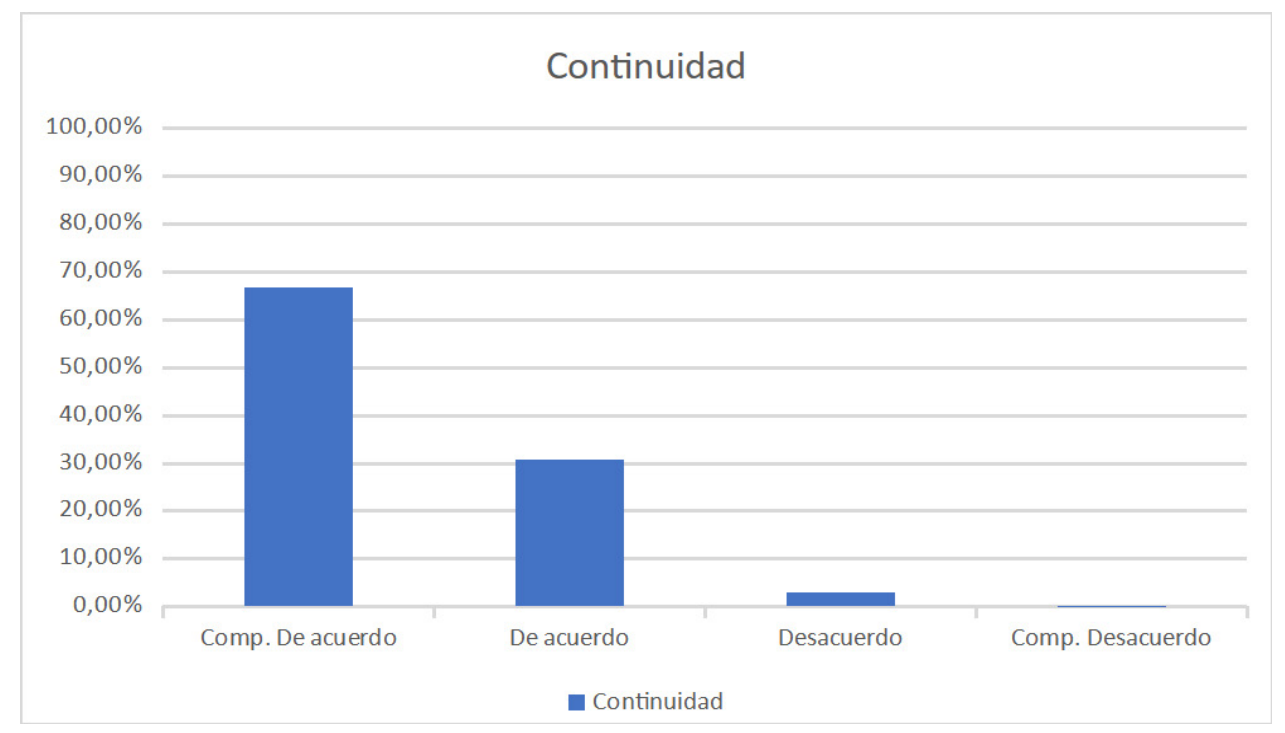

Gráfico 6. A favor de su continuidad en los próximos cursos. (Elaboración propia)

\section{Recomendación del aula invertida gamificada en otras asignaturas}

Finalmente, sobre si ellos mismos recomendarían este tipo de metodología para ser implantada en otras asignaturas, (ítem 7 del cuestionario), el 69,4\% afirma estar completamente de acuerdo, un $27,8 \%$ de acuerdo, un $2,8 \%$ desacuerdo y nadie completamente desacuerdo (Gráfico 7). 


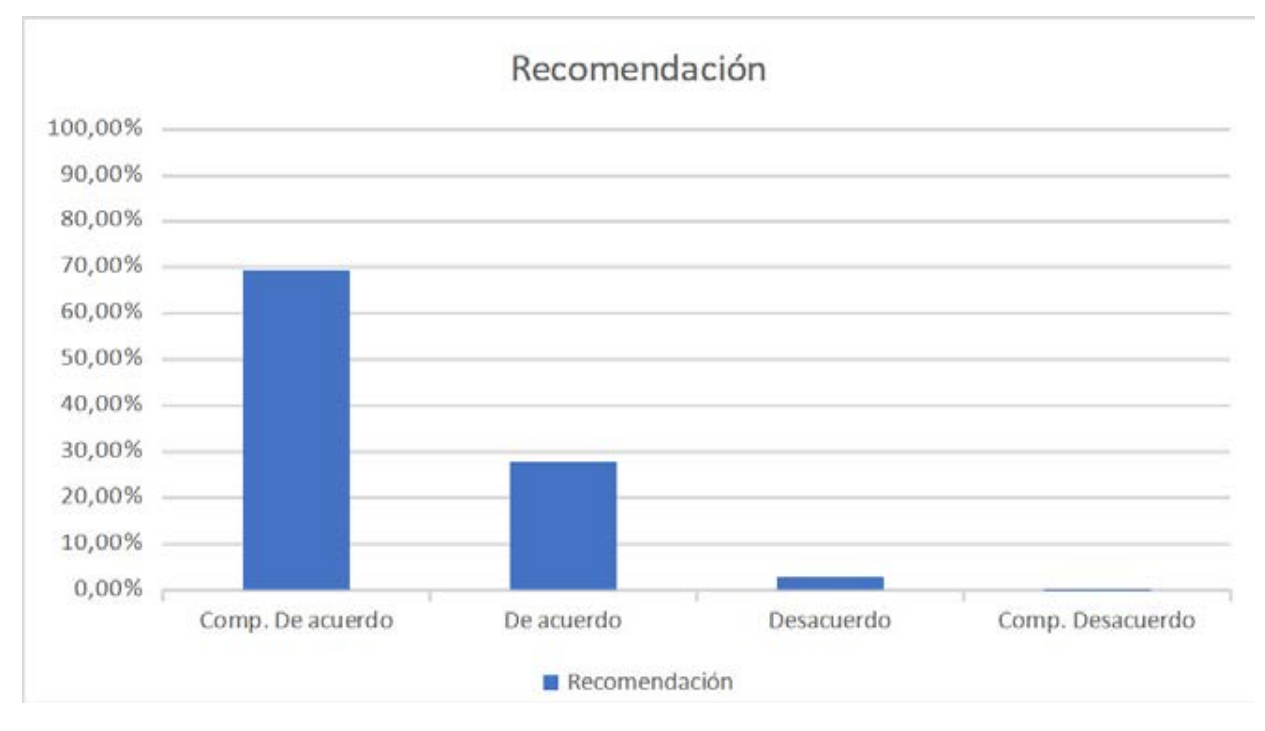

Gráfico 7. Recomendación para aplicarlo a otras asignaturas. (Elaboración propia)

En cuanto a los resultados cualitativos, a continuación, se destacan algunas expresiones relacionadas con la motivación:

- "Es muy motivante para el alumnado".

- "Mayor motivación por parte de los alumnos".

- "Motiva mucho al alumnado y ayuda a su desarrollo puesto que el interés que este genera hace que las personas aprendan más ya que el interés es la base de todo aprendizaje".

Asimismo, también se destacan aspectos relativos a la autonomía:

- "Es un método mucho más dinámico en el que el alumnado se implica más en el aprendizaje".

- "Trabajo autónomo, descubrimiento personal potenciación del interés y la curiosidad, de aprender jugando".

Finalmente, mencionar otros aspectos resaltados:

- "Si te pierdes algún detalle, dificulta mucho seguir trabajando".

- "Se necesita más tiempo que en el método tradicional".

- "Conlleva mucho trabajo y planificación". 


\section{Discusión y conclusiones}

En este estudio se ha analizado la motivación y satisfacción del alumnado del grado de maestro de educación primaria tras implementar la estrategia metodológica aula invertida gamificada. El proyecto se ha compuesto de 7 fases (motivación, explicación del proyecto, investigación y puesta en práctica, reflexión, elaboración del producto, presentación del producto final y evaluación del proyecto), y al finalizar se administró un cuestionario para su evaluación.

Como hemos podido observar en la revisión de la literatura, las prácticas educativas que combinan aula invertida con gamificación son positivamente valoradas por los estudiantes (Martínez Ruiz, 2019). El aula invertida gamificada tiene un efecto positivo sobre el alumnado este hallazgo es coherente con el estudio realizado por Zainuddin (2018) quién examinó el rendimiento de aprendizaje de los estudiantes y la motivación entre aula invertida gamificada y un modelo de instrucción de aula invertida no gamificada.

En vista a los resultados obtenidos, se puede valorar y deducir que la propuesta didáctica de aula invertida gamificada llevada a cabo ha sido valorada como satisfactoria en aspectos como la motivación y la satisfacción (Parra-González et al., 2020), y en el fomento del interés por el aprendizaje (Bognar et al., 2019). En este sentido, y según estos autores, la implementación de este tipo de metodologías emergentes en estudiantes universitarios tiene una incidencia directa en la motivación. Otro aspecto que cabe destacar es que el uso de estas estrategias metodológicas conlleva a que el alumnado necesite de una elevada planificación para poder seguir el proceso de enseñanza aprendizaje (Parra-González et al., 2020).

En cuanto a las limitaciones de este estudio podemos encontrar que la intervención solo se ha llevado a cabo durante un periodo corto de tiempo, un mes y con un solo grupo de estudiantes. Si bien el instrumento utilizado ha servido para una primera aproximación a explorar la motivación en la satisfacción de los estudiantes no podemos saber cuál hubiera sido la opinión de estos con otro tipo de intervención al no contar con el grupo control ni tampoco tenemos evidencias reales del efecto de esta en el aprendizaje real del pensamiento computacional ya que este trabajo se encuentra en una fase exploratoria inicial de un proceso de DBR. En las siguientes fases del proyecto será necesario revisar con una mayor precisión este tipo de variables, así como los efectos derivados en el aprendizaje de los estudiantes. De este modo, queda mucho por trabajar para que las metodologías activas como puede ser el aula invertida gamificada sea una realidad en todos los centros educativos universitarios.

\section{Referencias}

Adell, J., Esteve, F., Llopis, M. A., y Valdeolivas, M. G. (2017). El pensamiento computacional en la formación inicial del profesorado de infantil y primaria. En $V$. Abella García, V. Ausín Villaverde y V. Delgado Benito (Eds.), Actas de las XXV Jornadas Universitarias de Tecnología Educativa JUTE 2017. Aulas y Tecnología Educativa en evolución (pp.151-158). Burgos, Universidad de Burgos. 
Adell, J., Llopis, M. A., Esteve, F., y Valdeolivas, M. G. (2019). El debate sobre el pensamiento computacional en educación. RIED. Revista Iberoamericana de Educación a Distancia, 22(1), 171-186. https://doi.org/10.5944/ried.22.1.22303

Bergmann, J., y Sams, A. (2009). Remixing chemistry class: Two Colorado teachers make vodcasts of their lectures to free up class time for hands-on activities. Learning \& Leading with Technology, 36(4), 22-27.

Bognar, B.; Sabli , M.; Škugor, A. (2019). Flipped Learning and Online Discussion in Higher Education Teaching. In Didactics of Smart Pedagogy; Daniela, L. (ed.), Springer, pp. 371-392.

Comisión Europea. (2018). Recomendación del Consejo de 22 de mayo de 2018 relativa a las competencias clave para el aprendizaje permanente (Texto pertinente a efectos del EEE) (2018/C 189/01). Diario Oficial de la Unión Europea.

Fernandez, A., Olmos, J. y Alegre, J. (2016). Pedagogical value of a common knowledge repository for business management courses. @tic: Revista d'Innovació Educativa, 16, 39-47.

Ferrari, A. (2012). Digital competence in practice: An analysis of frameworks. European Commission, Joint Research Centre (JRC). Sevilla.

Jordan Lluch, C., Pérez Peñalver, M. J., y Sanabria Codesal, E. (2014). Investigación del impacto en un aula de matemáticas al utilizar flip education. Pensamiento matemático, 4(2), 9-22.

Martínez- Jiménez R. y Ruiz- Jiménez (2019). Interviniendo el aula en asignaturas de gestión de empresas utilizando diferentes herramientas metodológicas. DOI: https://dx.doi.org/10.17561/ree.v2019n2.3.

Mendez, R. y Trillo, F. (2010). El papel de la información universitaria en el proceso de formación de actitudes de los estudiantes hacia la Universidad. Revista de Educación, 353, 329-360.

Parra-Gonzalez, M., Lopez Belmonte, J., Segura-Robles, A. y Fuentes Cabrera, A. (2020). Active and Emerging Methodologies for Ubiquitous Education: Potentials of Flipped Learning and Gamification. Sustainability, 12(2), 1-12.

Plomp, T., y Nieveen, N. (2009). An introduction to educational design research. Netherlands Institute for curriculum development (SLO).

Redecker, C. y Punie, Y., (2017). Digital competence framework for educators (DigCompEdu). Brussels: European Union. https://ec.europa.eu/jrc/en/digcompedu

Sáinz, M., Pálmen, R., y García-Cuesta, S. (2012). Parental and secondary school teachers' perceptions of ICT professionals, gender differences and their role in the choice of studies. Sex roles, 66(3), 235-249.

Roig-Vila, R. (2019). Investigación e innovación en la Enseñanza Superior. Nuevos contextos, nuevas ideas. Alicante, España: Octaedro. 
Sánchez-Vera, M. del M., y González-Martínez, J. (2019). Pensamiento computacional, Robótica y Programación en educación. Revista Interuniversitaria de Investigación en Tecnología Educativa, (7). https://doi.org/10.6018/riite.407731

Santiago, R. y Bergmann, J. (2018). Aprender al revés. Flipped Learning 3.0 y metodologías activas en el aula. Barcelona: Paidós Educación, pp. 240

Werbach, K. (2012). For the win: how game thinking can revolutionize your business. Wharton: Wharton Digital Press.

Zainuddin, Z. (2018). Students' learning performance and perceived motivation in gamified flipped-class instruction. Computers \& education, 126, 75-88. 


\section{Formación del Profesorado en Investigación Educativa Mediante una Aplicación Móvil}

\section{Ayuso del Puerto, Desirée}

ORCID (https://orcid.org/0000-0002-6290-7391)

Universidad de Extremadura

deayusodelp@unex.es

\section{Galván Malagón, Carmen}

ORCID (https://orcid.org/0000-0002-6754-9167)

Universidad de Extremadura

mcgalvan@unex.es

\section{Gutiérrez Esteban, Prudencia}

ORCID (https://orcid.org/0000-0001-5328-5319)

Universidad de Extremadura

pruden@unex.es

\section{Alonso Díaz, Laura}

ORCID (https://orcid.org/0000-0001-7880-4592)

Universidad de Extremadura

laulonso@unex.es 


\title{
FORMACIÓN DEL PROFESORADO EN INVESTIGACIÓN EDUCATIVA MEDIANTE UNA APLICACIÓN MÓVIL
}

\author{
Ayuso del Puerto, Desirée \\ Galván Malagón, Carmen \\ Gutiérrez Esteban, Prudencia \\ Alonso Díaz, Laura
}

\section{Resumen}

La formación investigadora del profesorado se ha revelado como uno de los retos pendientes en la actualidad, máxime porque como colectivo, ha sido más consumidor de investigación que productor de la misma (Robinson, 2003). Tanto es así, que se puede distinguir entre el profesorado que elabora el conocimiento y quien lo consume al trasladarlo a su aula o escuela.

El presente trabajo realiza una revisión sistemática de la literatura para analizar experiencias formativas virtuales en investigación educativa, dirigidas al profesorado en activo. Los datos recabados muestran que el éxito de las propuestas pasa por combinar distintas metodologías docentes, así como diseños tecno-pedagógicos que incluyan diversidad de recursos y que permitan diseñar, implementar, evaluar y reflexionar sobre la formación desarrollada.

Al mismo tiempo, se apuesta por la implementación de una aplicación móvil, diseñada ad hoc y dirigida al desarrollo de las competencias investigadoras del profesorado en todas sus dimensiones, siguiendo el enfoque del aprendizaje móvil, especialmente, aquellas relacionadas con la elaboración del conocimiento y su transferencia a la realidad educativa.

\section{Palabras clave}

Formación del profesorado, Investigación educativa, Formación, m-learning. 


\section{Introducción}

La finalidad de este trabajo es revisar y analizar la literatura científica existente sobre programas formativos para apoyar al profesorado a aprender, incorporar e implementar conocimiento en su actividad docente diaria, generado a partir de los resultados de sus investigaciones en el aula. Ésta es la finalidad del proyecto BRIST (Building a Research Infraestructure for School Teachers) financiado por el programa Erasmus+, acción K2 (https://www.4teacheresearch.org/) y en el que se enmarca esta revisión de la literatura.

En la base del proyecto está la investigación traslacional, un tipo de metodología aplicada cuyo objetivo es trazar un puente entre la teoría y la práctica educativa (Aymerich et al., 2014), es decir, entre personal docente e investigador a fin de poner a su disposición conocimiento científico relevante y útil que fortalezca los procesos de enseñanza-aprendizaje (Hernández y Sánchez, 2018). En la investigación traslacional, se utilizan los recursos disponibles basados en la mejor evidencia científica publicada; colaborando con profesionales de múltiples disciplinas para promover políticas para la sostenibilidad de sus resultados, y buscar recursos, fondos y entrenamiento en investigación traslacional (Hernández y Sánchez, 2018).

Siguiendo las indicaciones sobre Investigación Traslacional (McGaghie, 2010; Hernández y Sánchez, 2018) esta revisión de la literatura tendría lugar en la primera fase de la investigación traslacional, en la que se seleccionan los descubrimientos de la investigación teórica que serán trasladados posteriormente a los destinatarios de la formación, en este caso el profesorado.

Para lograr trazar ese puente entre la teoría y la práctica educativa es necesario generar previamente procesos minuciosos de revisión de la literatura que permitan definir el panorama actual de la investigación en el aula. En esta línea, el proyecto se apoya en teorías como la de Robinson (2003) cuando hace referencia a la importancia de fortalecer la función investigadora de las y los profesionales, que justifica por tres razones: en primer lugar, la obligación ética y profesional y la responsabilidad de profesorado e instituciones educativas de revisar las consecuencias que tiene la toma de decisiones sobre qué enseñar. El propósito de esas reflexiones sería el de mejorar la conexión entre la calidad de la enseñanza y la calidad de los logros del alumnado; la segunda razón, está relacionada con las prácticas docentes y la falta de un procedimiento único que garantice el éxito del rendimiento de las y los estudiantes. Será el profesorado el que tenga que crear las condiciones necesarias para obtener los resultados deseados en base a la investigación. El tercer motivo que esgrime Robinson (2003) para que el profesorado adopte el rol investigador es que es una forma muy positiva de desarrollo profesional.

Además, esta formación investigadora debe tener en cuenta el contexto tecnológico y docente actual, donde la competencia investigadora debe ir unida a la competencia digital, desarrollando el rol docente como investigador (Medathil et al., 2013), pero también como prosumidor de contenidos. Del mismo modo, se debe apostar por una investigación pedagógica (Perines, 2018), que facilite la innovación educativa y la transformación de la escuela. Se debe procurar la movilización del conocimiento (Cooper, 2015), donde el profesorado reconozca los logros alcanzados y reflexione acerca de los cambios que han tenido lugar en el proceso de enseñanza-aprendizaje (Guisasola et al, 2001), gracias al desarrollo de investigaciones en Educación. 
Dado que en algunas instituciones de Educación Superior donde se forma a docentes no siempre se incorpora la formación tecnológica en sus planes de estudios, es importante continuar abordando la cultura tecnológica desde una óptica pedagógica. Se pretende así vencer mitos y resistencias respecto al uso de las tecnologías en determinadas situaciones y contextos educativos (Madlela, 2015). Una aplicación móvil permitiría poder continuar, en cualquier momento y lugar (aprendizaje ubicuo), dicha formación y a través de la cual, además el profesorado puede intercambiar experiencias y recursos, recibir ayuda e identificar las necesidades educativas de sus estudiantes (Goodnough et al, 2014).

\section{Método/Descripción de la experiencia}

Con el fin de sistematizar de manera organizada la evidencia encontrada acerca de programas formativos para docentes en materia de investigación educativa, la presente investigación recoge un minucioso análisis de la literatura específica de reconocimiento internacional. La metodología sigue los pasos establecidos por Okoli \& Schabram (2010) que comprenden desde el establecimiento de la revisión, la realización de la búsqueda y cribado de la literatura, hasta la extracción y síntesis de los datos. Así, se busca identificar modelos de programas formativos eficaces desarrollados previamente y conocer los vacíos existentes en la investigación relativa a estos.

Para la búsqueda se seleccionaron términos claves relacionados con nuestra investigación que fueron combinados gracias al uso de los operadores boléanos. A continuación, se recogen los términos empleados: Programas de formación docente, Investigación Educativa, Formación en investigación, Investigación traslacional, Formación del Profesorado, Uso de tecnología, Profesorado. Las ecuaciones de búsqueda resultantes, tanto en castellano como en inglés, fueron introducidas en una amplia cobertura de bases de datos que cuentan con el aval de la comunidad científica: Web of Science (WOS), Scopus, ERIC y Google Scholar.

Si bien, para la selección de la muestra, se definieron unos criterios de selección y exclusión que fueron tomados en consideración por todas las investigadoras:

\begin{tabular}{|l|l|}
\hline Criterios de exclusión & Criterios de inclusión \\
\hline Trabajo duplicado. & $\begin{array}{l}\text { Programa de formación de intervención con profesores activos en el } \\
\text { entorno escolar. }\end{array}$ \\
\hline $\begin{array}{l}\text { No relacionado con } \\
\text { tecnologías/investiga- } \\
\text { ciones educativas. }\end{array}$ & $\begin{array}{l}\text { Programa de capacitación de intervención con maestros activos basa- } \\
\text { do en el uso de un programa de tutoría/ asesoramiento (evaluación por } \\
\text { pares). }\end{array}$ \\
\hline & $\begin{array}{l}\text { Intervención activa del programa de formación docente basada en el } \\
\text { uso de herramientas digitales/ recursos tecnológicos. }\end{array}$ \\
\hline & $\begin{array}{l}\text { Evidencia de mejora en el desempeño y el aprendizaje docente (crea- } \\
\text { ción de recursos y materiales curriculares, desarrollo de proyectos y ac- } \\
\text { tividades de carácter innovador, diseño y desarrollo de investigaciones } \\
\text { por parte de los docentes) }\end{array}$ \\
\hline $\begin{array}{l}\text { Evidencia de mejora en las actitudes hacia el desarrollo de la investiga- } \\
\text { ción aplicada en el aula (investigación acción). }\end{array}$ \\
\hline
\end{tabular}

Tabla 1. Criterios de inclusión y exclusión considerados para el filtrado de la documentación. 
Para la recogida de los datos, se confeccionó una plantilla con toda la información de las publicaciones primarias (año de publicación, autores, revista/libro, base de datos, metodología y principales resultados).

\section{Resultados}

Tras establecer la muestra participante de este estudio en 16 documentos, se ha procedido al análisis de los datos en base al objetivo planteado al inicio de nuestra investigación. Así, observamos que los temas que más se abordan en los documentos bajo estudio es la Formación docente, seguida de la Investigación en Educación, la Investigación-Acción y la práctica docente.

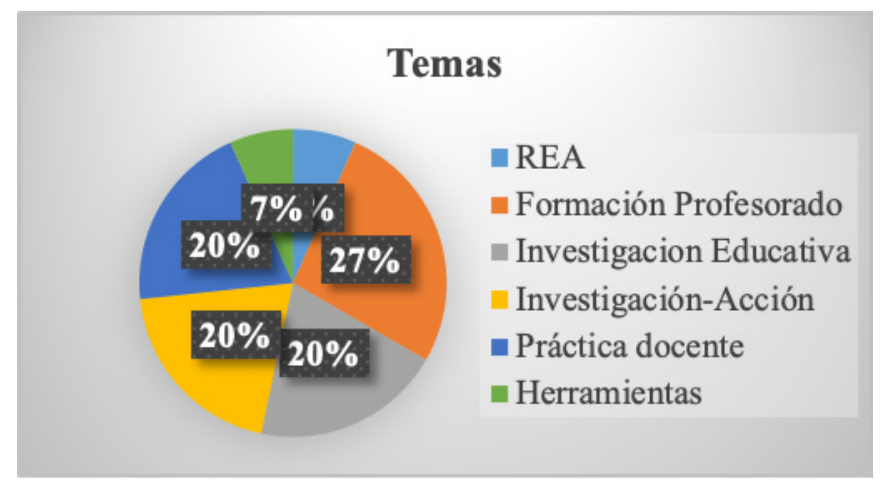

\section{Figura 1. Distribución de publicaciones por temas abordados.}

En cuanto a los países donde se ubican las producciones, observamos que la temática suscita el interés de investigadores e investigadoras de distintas zonas geográficas. No obstante, destaca Canadá como el país donde más investigaciones se están realizando al respecto (25\%). Se observa también un notable interés en la Unión Europea (18.75\%) y uno de los países que la conforman, España (12.5\%).

\begin{tabular}{|l|c|}
\hline País o unidad política & № \\
\hline Unión Europea & 3 \\
\hline España & 2 \\
\hline Suiza & 1 \\
\hline Diversos países & 1 \\
\hline Nueva Zelanda & 1 \\
\hline India & 1 \\
\hline Canadá & 4 \\
\hline USA & 1 \\
\hline Chile & 1 \\
\hline Sudáfrica & 1 \\
\hline
\end{tabular}


En esta línea, a nivel continental, se concentra un mayor número de investigaciones en Europa (43,8\%). Si bien, América con un $37.5 \%$ no se haya muy lejano, lo cual denota que existe también un gran interés por la temática. No obstante, todos los continentes cuentan con publicaciones sobre la temática, aunque no sean numerosas.

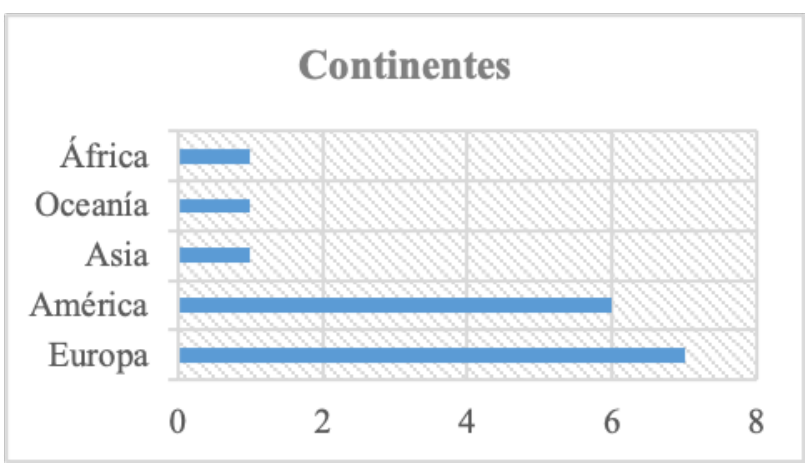

\section{Figura 2. Distribución de publicaciones por continentes.}

Atendiendo a la tipología del programa formativo, observamos que el $12.5 \%$ de los estudios se propone el uso de Workshops como modelo de desarrollo del programa. En la misma proporción, otros estudios plantean un proceso de reflexión basado en la propia práctica docente. Seguidamente, con un $6.25 \%$ en ambos casos, se recoge la estructuración del programa bajo un formato curso o de proyecto, aunque esta última modalidad contemplaría también el desarrollo de un curso y la participación en debates por parte de los participantes.

Finalmente, atendiendo a los niveles educativos, los datos arrojan un interés notable en la etapa de Bachillerato (18,8\%). No obstante, aparecen contempladas en el resto de las etapas educativas (Educación Primaria, Educación Secundaria Obligatoria, Universidad) con la salvedad de Educación Infantil.

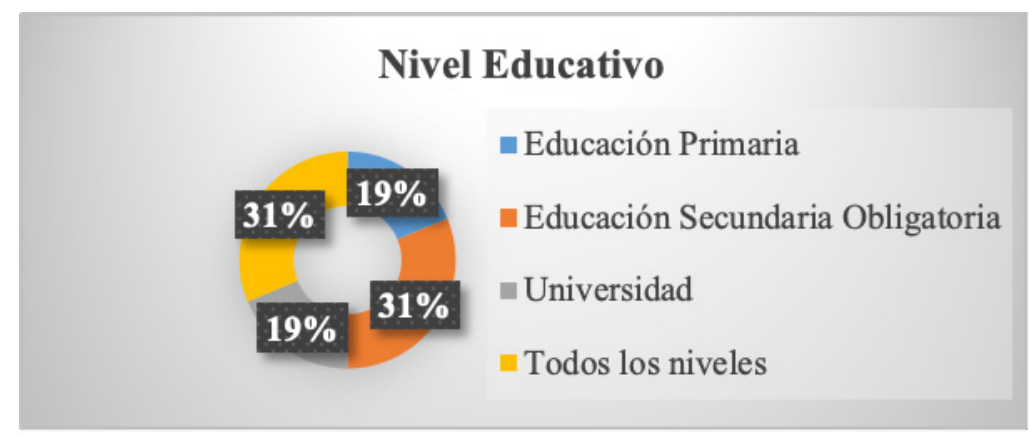

Figura 3. Concentración de publicaciones atendiendo a la etapa educativa.

\section{Discusión y conclusiones}

De acuerdo con los artículos revisados, algunas de las experiencias utilizaron bien solo LMS o bien LMS acompañados de otras tendencias educativas que también utilizan las TIC, como escenarios de aprendizaje informal y/o escenarios de aprendizaje 
distribuido. Además, un hecho común en los programas de formación online es el uso de aplicaciones desde dispositivos móviles (iPad, por ejemplo, Marin et al., 2013). A este respecto, Lerma et al. (2020) desarrollaron una experiencia interesante mediante el uso de una aplicación móvil para estudiantes universitarios del MIT, con el objetivo de fomentar estrategias de aprendizaje como el pensamiento crítico, la búsqueda de datos, la autorregulación cognitiva y la regulación del esfuerzo.

En cuanto al enfoque pedagógico seguido en los programas de formación docente, observamos que está relacionado principalmente con el aprendizaje activo y constructivista (Zavala et al., 2007; Lorist \& Swennen, 2017; Roxa, 2018). Así, en el estudio de Zavala et al. (2007), el profesorado primero experimenta toda la secuencia de actividades y posteriormente, reflexiona sobre las dificultades de aprendizaje de sus propios alumnos y las reconocen. Después, analizan sus experiencias docentes con sus compañeros en pequeños grupos de colaboración y finalmente, leen y discuten literatura específica de investigación en Educación Física, donde los investigadores han abordado extensamente esas dificultades de aprendizaje.

Atendiendo al desarrollo del programa formativo, encontramos que las experiencias son diversas. Madathil et al. (2013) organizaron un taller que constaba de cuatro etapas diferenciadas: i) asignación previa al taller, ii) taller principal con dos días de sesiones sincrónicas sobre conceptos de metodología de investigación y una semana de actividades prácticas asincrónicas, iii) final de dos semanas después del taller asignado y iv) tutoría para realizar un estudio de investigación (Madathil et al., 2013). En cambio, Zavala et al. (2007) diseñaron un curso que se estructuraba en torno a la investigación educativa con la finalizar de proporcionar a los docentes en servicio un primer contacto con la estrategia de aprendizaje activo.

En cualquier caso, las experiencias analizadas contribuyen a la investigación traslacional en tanto que colaboran en el enriquecimiento de la práctica docente desde una perspectiva formativa de carácter teórico. Se trata, como hemos podido observar, de experiencias de formación que vienen a favorecer el aprendizaje aplicado que defendía Dewey, el filósofo de la democracia y del cambio social, otorgando un carácter práctico y renovado al binomio teoría y práctica. Finalmente, con esta revisión se contribuye a la futura capacitación docente en investigación educativa, pues se ofrecen modelos a los centros y al profesorado que permitirán la adquisición de competencias investigadoras para el desempeño de la labor docente.

\section{Agradecimientos}

La presente investigación se enmarca dentro del proyecto de investigación "Building a Research Infrastructure for School Teachers -BRIST-" que ha sido co-financiado por el Programa Erasmus+ de la Unión Europea. Esta publicación sólo refleja el punto de vista de las autoras y la Comisión Europea no se hace responsable del uso que pueda hacerse de la información contenida en este documento.

Asimismo, la participación de la primera autora ha sido financiada por el Ministerio de Ciencia, Innovación y Universidades, a través de un contrato para la Formación del Profesorado Universitario (FPU18/03322). 


\section{Referencias}

Alonso-Díaz, L. (2016). European Union policies on in-service teacher education. In I. Carrillo (Ed.), Democracia y educación en la formación docente (pp. 305-311). Universitat de Vic-Universitat Central de Catalunya.

Aymerich, M., Rodriguez-Jareño, M., Castells, X., Carrion, C., Zamora, A. \& Capellá, D. (2014). Translational Research: A Concept Emerged from Health Sciences and Exportable to Education Sciences. Annals of Translational Medicine \& Epidemiology, 1(1), 1005-1010. http://austinpublishinggroup.com/translational-medicine/fulltext/ atme-v1-id1005.php.

Burden, K., Kearney, M., Shuck, S. \& T. Hall, T. (2019). Investigating the use of innovative mobile pedagogies for school-aged students: A systematic literature review. Computers \& Education, 138, 83-100.

Cooper, A. (2015). A Tool to Assess and Compare Knowledge Mobilization Efforts of Faculties of Education, Research Brokering Organizations, Ministries of Education, and School Districts. Brock Education Journal, 25(1), 1-14. https://doi.org/10.26522/ brocked.v25i1.441.

Earl, L., Manning, S. \& Hargreaves, A. (2001). Learning to change. Teaching beyond subjects and levels. N/A. https://doi.org/10.1017/CBO9781107415324.004.

Goodnough, K., S. Pelech, \& M. Stordy (2014). Effective professional development in STEM education/ The perceptions of Primary /elementary teachers. Teacher Education and Practice, 37(3), 402-423.

Guisasola, J., M.E. Pintos, \& T. Santos (2001). Continuing Teacher Education, Educational Research and Innovation in Science Teaching. Revista Interuniversitaria de Formación Del Profesorado, 41, 207-222. https://www.redalyc.org/pdf/274/27404113. pdf.

Hernández, F. B., \& Sánchez, M. (2018). Investigación traslacional en educación: un puente entre teoría y práctica educativa. Revista Digital Universitaria, 19(4). https:// doi.org/10.22201/codeic.16076079e.2018.v19n4.a4

Lerma-Noriega, C.A., Flores-Palacios, M. L. \& Rebolledo-Méndez, G. (2020). In Context: A mobile application for the improvement of learning strategies at University. Comunicar, Media Education Research Journal, 64(28). https://doi.org/10.3916/C642020-10.

Lorist, P. \& Swennen, A. (2017). Teacher educators' pathways to becoming research active. Utrecht, Netherlands: HU University of Applied Sciences Utrecht. https:// www.narcis.nl/publication/RecordID/oai:hbokennisbank.nl:sharekit_hr\%3Aoai\%3Asurfsharekit.nl\%3A9260cb6b-77d5-471b-9d51-f608f5b639c8

Madathil, J., Murthy, S. \& Iyer, S. (2013). Training In-Service Teachers to do Action Research in Educational Technology. IEEE Fifth International Conference on Technology for Education (t4e 2013), Kharagpur, pp. 192-199. Doi: 10.1109/T4E.2013.53. 
Madlela, B. (2015). ICT opportunities and threats in implementing Teaching Practice Programmes. Universal Journal of Educational Research, 3(6), 351-358.

Marín, C., Hargis, J. \& Cavanaugh, C. (2013). iPad Learning Ecosystem: Developing Challenge-Based Learning using Design Thinking. Turkish Online Journal of Distance Education, 14(2), 22-34.

McGaghie, W.C. (2010). Medical education research as translational science. Science Trans/ational Medicine, 2(19), 19. https://doi.org/10.1126/scitranslmed.3000679.

Montes, R., Gea, M. \& Dondi, C. (2014). OER commitment in universities. edMetic, Revista de Educación Mediática y TIC, 3(2), 7-28.

Okoli, C., \& Schabram, K. (2010). A guide to conducting a systematic literature review of information systems research. SSRN. https://dx.doi.org/10.2139/ssrn.1954824

Patel, A., Rulli, C., Schiff, D. \& Fradera, M. (2015). Teacher Networks Companion Piece. PennGSE Perspectives on Urban Education, 12(1). http://www.urbanedjournal. org/archive/volume-12-issue-1-spring-2015/teacher-networks-companion-piece.

Perines, H. (2018). Educational research: perception of in-service teachers, teachers in training and educational agents. Perspectiva Educacional, 57(2), 123-142. http:// dx.doi.org/10.4151/07189729-vol.57-iss.2-art.649.

Pretrucka, P. et al. (2016). Positive Leadership, Legacy, Lifestyles, Attitudes, and Activities for Aboriginal Youth: A Wise Practices Approach for Positive Aboriginal Youth Futures. International Journal of Indigenous Health, 11(1), 177-197. https://doi. org/10.18357/ijih111201616017.

Ragoonaden, K., Sivia, A. \& Baxan, V. (2015). Teaching for Diversity in Teacher Education: Transformative Frameworks. The Canadian Journal for the Scholarship of Teaching and Learning, 6(3), 1-16. http://dx.doi.org/10.5206/cjsotl-rcacea.2015.3.6.

Robinson, V. (2003). Teachers as researchers: A professional necessity? Set: Research Information for Teachers, 1, 27-30. Doi:10.18296/set.0703.

Roxa, T. (2018). Making use of educational research in higher education. Academic teachers engaged in Translational research. Teaching and Learning Inquiry, 6(2), 6780. https://doi.org/10.20343/teachlearninqu.6.2.6.

Zavala, G., Alarcón, H. \& Benegas, J. (2007). Innovative Training of In-service Teachers for Active Learning: A Short Teacher Development Course Based on Physics Education Research. Journal of Science Teacher Education, 18, 559-572. Doi: 10.1007/ s10972-007-9054-7. 


\section{Virtualización en la Detección de Parámetros Relacionados con el Acoso Escolar Mediante Orden Sistémico Educativo Situacional.}

Escribano Valle, Jon

orcid.org/0000-0001-8261-8864

\section{Castro-León, Elke}

orcid.org/0000-0002-5287-2893

Íñigo Mendoza, Victoria

orcid.org/0000-0001-6037-6307

Nestares Hervías, Eva Ma

orcid.org/0000-0002-5712-3816 


\title{
VIRTUALIZACIÓN EN LA DETECCIÓN DE PARÁMETROS RELACIONADOS CON EL ACOSO ESCOLAR MEDIANTE ORDEN SISTÉMICO EDUCATIVO SITUACIONAL.
}

\author{
Escribano Valle, Jon \\ Castro-León, Elke \\ Íñigo Mendoza, Victoria \\ Nestares Hervías, Eva Ma
}

\section{Resumen}

El proceso de enseñanza-aprendizaje conlleva una evolución en la implicación de nuevas herramientas digitales para la educación del presente y del futuro. Hablar de acoso escolar es hablar de educación entre las aulas. Mediante el modelo de Orden Sistémico Educativo Situacional (OSES) medimos el grado de interacción que cada estudiante tiene con su entorno y lo cuantificamos en métricas para poder crear un mapa individual de cada uno de los estudiantes y un mapa global de todo el aula o muestreo seleccionado a valorar.

El modelo metodológico OSES se divide en cinco fases fácilmente diferenciadas entre sí:

Fase de reclutamiento de la información, fase de transformación binaria, fase de creación de software, fase de interacción personalizada y fase de análisis y conclusiones.

La finalidad de OSES es detectar todas las interacciones que cada estudiante tiene con respecto al resto de sus compañeros de su propia aula, con respecto a otros compañeros de diferentes aulas o incluso con respecto algunos apoyos externos al centro educativo.

Además, OSES relaciona el tanto por ciento que cada estudiante desarrolla en cada interacción con referencia a los valores o competencias que previamente queramos establecer, es decir, relacionados con el acoso escolar, como son el respeto o la empatía.

\section{Palabras clave}

Acoso escolar, OSES, aula, medición, mapa. 


\section{Introducción}

El desarrollo de la tecnología en nuestros días nos lleva a una serie de desafíos en el comportamiento de nuestros estudiantes, pero también nos trae una serie de posibilidades técnicas para medir, evaluar y detectar parámetros relevantes en el entorno educativo.

La rápida y constante evolución de los smarth phones, tablet y artículos similares junto con la ya contrastada herramienta que supone internet, ha llevado a un gran número de estudiantes a realizar acciones muy poco deseables o aprobadas por una civilización educada y comprometida con su sociedad. No debemos denostar todos los avances tecnológicos aplicados en nuestra sociedad, sino que los debemos aprovechar para mejorar, medir y detectar aquellos parámetros que siempre han existido en las aulas de los centros educativas. De esta manera, mediante datos tangibles y objetivos, junto con el resto de las herramientas convencionales, detectaremos la interacción que cada estudiante tiene con su entorno más cercano, relacionando una métrica porcentual con respecto a las competencias o valores que hemos expuesto en dicho estudio.

Según los autores (Heineman, 1977) y (Olweus, 1978) se puede definir el acoso escolar como una forma de violencia que se da entre compañeros y por tanto frecuente en contexto escolar.

Tabla 1. Tipos de agresiones hacía la víctima.

\begin{tabular}{|l|l|l|}
\hline \multicolumn{2}{|c|}{ Tipos de agresiones hacía la víctima } & \multicolumn{1}{|c|}{ Directas } \\
\hline Agresiones físicas & $\begin{array}{l}\text { Empujar, pegar, intimidar, } \\
\text { amenazar... }\end{array}$ & Esconder, romper, robar... \\
\hline Agresiones verbales & $\begin{array}{l}\text { Vocear, burlarse, insultar y poner } \\
\text { motes. }\end{array}$ & $\begin{array}{l}\text { Hablar mal a sus espaldas, hacer que } \\
\text { "Oiga de casualidad", emitir falsos } \\
\text { rumores, pintadas, notas groseras, } \\
\text { carta... }\end{array}$ \\
\hline $\begin{array}{l}\text { Agresiones relacionales } \\
\text { (exclusión social) }\end{array}$ & $\begin{array}{l}\text { Exclusión deliberada } \\
\text { de actividades, impedir } \\
\text { participación en actividades... }\end{array}$ & $\begin{array}{l}\text { Ignorarla, hacer como si no estuviera, } \\
\text { ser transparente para la persona.... }\end{array}$ \\
\hline
\end{tabular}

\section{Elaboración propia en base artículo revista Pediatría Atención Primaria.}

Por lo tanto, el acoso escolar se puede resumir en las siguientes áreas: agresión verbal, agresión física, ciberacoso, intimidación, exclusión social y coacción. (Claudia Bruna, 2021)

Un estudio realizado por la Fundación Mutua Madrileña y la Fundación ANAR destacan que las solicitudes de ayuda que recibió esta ONG, por acoso escolar, aumentaron un 75 por ciento en 2015 con respecto a 2014. Según el informe, siete de cada diez víctimas sufren acoso todos los días. El 40 por ciento de los acosados lo vienen sufriendo desde hace más de un año. El acoso escolar se incrementó un 75 por ciento en España. 
Olweus (1978), señaló tres factores en el ámbito familiar que a su juicio considera decisivos para el desarrollo de modelos de agresión entre los alumnos: 1) actitud emotiva de los padres negativa, socializando a sus hijos sin afecto ni dedicación; 2) la ausencia de límites y permisividad ante la conducta agresiva de su hijo, y 3) uso del castigo físico y el maltrato emocional para afirmar su autoridad.

Podemos destacar el Programa Olweus como referente actual en la prevención del acoso escolar. El Comité Coordinador de Prevención de Bullying de Olweus (OBPP) es un enfoque escolar integral basado en el principio del cambio sistémico cuyo objetivo es crear un ambiente escolar seguro y positivo.

El modelo metodológico Órden Sistémico Educativo Situacional (OSES) es creado para ayudar a los Centros educativos en la detección de la más mínima pista que pueda desembocar en un presente acoso escolar o incluso en su potencial acoso escolar en el tiempo.

Según Hellinger (2010), comenta que las constelaciones familiares, son movimientos sistémicos, muy relacionados con asociaciones sociales de raíces muy fuertes. Vienen a ser terapias en las que el movimiento del alma determina tu situación actual en función de la relación con tu madre, con las personas más allegadas, la familia, desde tu nacimiento hasta ahora.

El modelo metodológico OSES parte de las constelaciones familiares y evolucionada hasta el orden sistémico. Von Bertalanffy (2009), comenta en su teoría general de sistemas (TGS) la importancia social del individuo en un sistema.

El problema de las intervenciones en los centros educativos es la dificultad para conseguir la información necesitaría a la hora de poder detectar el acoso escolar. Mediante las entrevistas personales con el estudiante, observación directa o incluso algún ejercicio, actividad o juego se puede conseguir una información muy valiosa para poder actuar a tiempo. El modelo metodológico OSES viene aportar una solución innovadora para la recogida de los datos, el tratamiento de la información y la interacción con el estudiante.OSES no es un sociograma ni una gamificación, es la creación de un modelo metodológico que nos va a dar una información muy relevante sobre los aspectos que más preocupan y en qué medida de cada uno de los estudiantes.

Los objetivos que se plantean en la hipótesis inicial del modelo metodológico OSES son los siguientes:

- Definir una metodología innovadora para la medición de las interacciones de cada uno de los estudiantes en un grupo control determinado.

- Acotar la medición de dicha evaluación a partir de una personalización una serie de valores relacionados con el acaso escolar, como son el respecto, capacidad para pedir ayuda o la empatía.

- Medir el grado de un valor o competencia que el estudiante emplea con respecto a su entorno más cercano.

- Relacionar las competencias o valores, requeridos en el estudio, de los estudiantes con respecto al recto de actores en su entorno o Extra educativos. 
- Crear un mapa interactivo por cada uno de los estudiantes.

- Crear un mapa interactivo del sistema completo que vamos a trabajar, aula o aulas en las que se aplicará OSES.

Hipótesis: La medición de los valores y competencias en relación con la interacción del estudiante con su entorno más cercano ayuda a detectar casos de exclusión social (potenciales víctimas de acoso escolar) o acoso escolar (posibles casos actuales).

\section{Descripción de la experiencia}

En este trabajo se describe un modelo metodológico aplicable en los centros educativas para detectar el mayor número de parámetros relacionados con acciones verbales, físicas o relacionales (exclusión social) de acoso escolar. El diseño de la programación del modelo ha sido creado por personal docente de la Universidad pertenecientes al Máster de Recursos Humanos junto con profesores del Departamento de Educación.

El objetivo del modelo metodológico es facilitar a los centros educativos el mayor número de parámetros posibles para la detección de comportamientos sociales cercanos a lo descrito anteriormente como acoso escolar.

El desarrollo del modelo parte de uno de los pilares de las constelaciones familiares, Hellinger (2010), seguido de técnicas de orden sistémico para finalizar en una personalización de un software en el que el estudiante interactúa con su propia realidad cotidiana. Echegaray (2008), comenta que el orden sistémico organizacional, es decir, lo que podríamos denominar de forma errónea constelación empresarial, evalúa varias salidas de las que habla Prieto. Con ello, podemos determinar si algunos de las acciones que tomamos en el día a día, influyen en nuestro sistema, es decir, el entorno en el que nos rodeamos.

Durante todo el proceso de interacción dentro del software el o la estudiante estará tutorizado y guiado por una persona especialidad, preferiblemente orientador educativo, preparado para la ocasión.

El modelo con el que trabajamos se denomina Orden Sistémico Educativo Situacional (OSES). OSES consta de cinco fases en la que dividimos los procesos más relevantes que vamos a ejecutar:

a) Fase de reclutamiento de la información. Una primera fase de recogida de toda la información relevante para el posterior tratamiento y personalización en cada estudiante. En esta primera fase se tienen en cuenta los profesionales orientadores de cada centro educativo, la dirección, los profesores y tutores e incluso los propios estudiantes. No sólo es un trabajo de recopilación de la información, sino que, al igual que realiza un director de proyecto, debemos crear canales de comunicación, un lenguaje común, la cultura del centro educativo y contextos, roles, etc.

Estamos creando la arquitectura de software en base al estudio personalizado en un centro educativo, distribuyendo las diferentes capas de información. 
b) Fase de transformación binaria. Una segunda fase en la que personalizamos y categorizamos toda la información. En esta fase determinamos los objetivos que queremos medir y junto con el tratamiento de la información previa categorizamos cada uno de los puntos en parámetros medibles. La información la secuenciamos como un programa de ordenador, es decir, una acción es realizada o no lo es (lenguaje en un código binario). Para la categorización de toda la información nos ayudamos de la herramienta denominada Cuadro de Mando Integral (CMI) o también conocida como Balance Scorecard (BSC), creado por Norton y Kaplan, y personalizado para la ocasión. Es muy importante que los objetivos sean SMART, es decir, Específicos, Medibles, Alcanzables, Relevantes y en Tiempo.

El CMI de Kaplan y Norton (1992) consta de cuatro perspectivas: finanzas, clientes, procesos internos, y aprendizaje y crecimiento.

Olve y Sjostrand, (2002). En cada perspectiva puede desdoblarse de la norma que contenga los objetivos estratégicos de la entidad y los factores claves de éxito.

Figura 1. Componentes del Cuadro de Mando Integral.

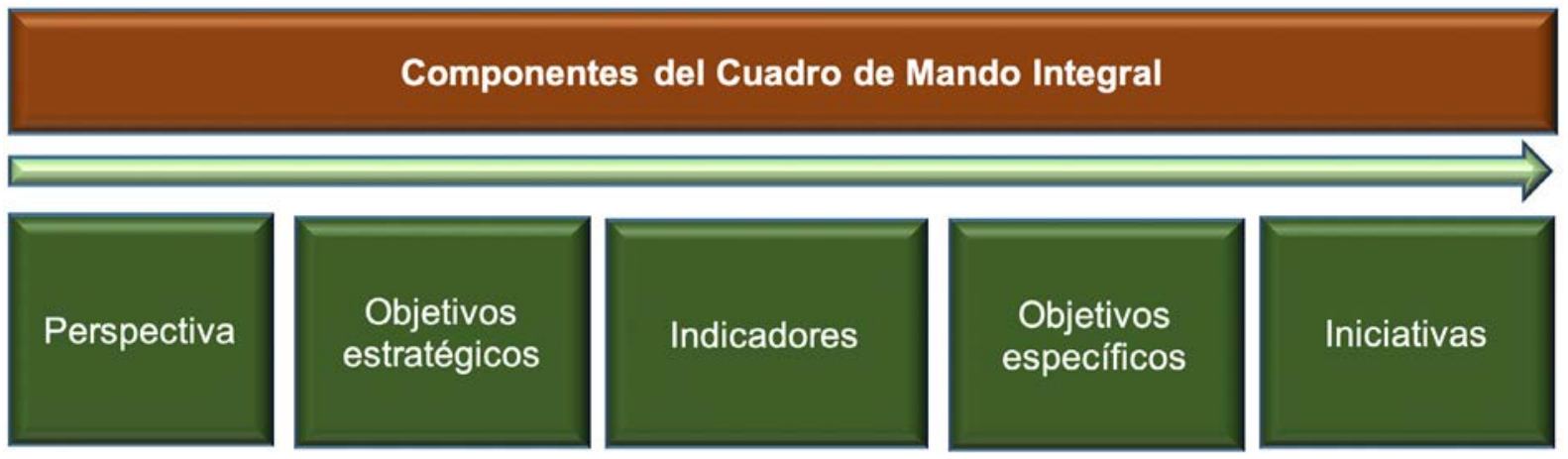

Elaboración propia basada en Kaplan y Norton (1992).

También debemos establecer y determinar los valores que vamos a medir en relación, al acoso escolar. Valores o competencias que vienen representados por el respeto hacía uno mismo y hacía el resto de los compañeros, la capacidad para pedir ayuda, trabajo en equipo, resolución de conflictos, adaptación o capacidad para aprender. En esta ocasión, se han tomado en cuenta está serie de valores, pero en función del centro educativo, ubicación, número de estudiantes, objetivos, etc. se personalizan los valores o competencias.

c) Fase de creación de software. Una tercera fase en la que comenzamos la programación para nuestro relato personalizado, teniendo en cuenta todo los descrito en las dos fases anteriores. Hemos creado La aventura en el castillo una historia personalizada a cada estudiante y que nos va a ayudar a medir una serie de valores y competencias.

En la programación es muy importe la categorización y subcategorización en nuestro Cuadro de Mando Integral de todo aquello que vamos a medir, tanto las respuestas positivas como las negativas, las acciones y las ausencias de ciertas acciones. Todo debe ir descrito en el que denominamos libro de programación de La aventura en el castillo. 
Como ya hemos comentado con anterioridad, al utilizar un código binario de base toda acción y ausencia de acción debe ser medible en un momento determinado de la historia y con relación a un valor o competencia específico.

d) Fase de interacción personalizada. Una cuarta fase en la que actuamos directamente con cada uno de los estudiantes de forma individual y presencial. Una persona formada y con experiencia en OSES (recomendable con formación en orientación educativa) es la encargada de reunirse con el estudiante. La reunión es realizar en un lugar ajeno al aula habitual del estudiante. La sesión es personalizada a individual.

Algunos aspectos relevantes de la reunión La aventuras en el castillo son las siguientes:

- Notificación al estudiante el mismo día de la reunión.

- Realización de la prueba en horario escolar.

- Ubicación en un lugar tranquilo diferente al aula de clase habitual del estudiante.

- Reunión de dos personas, la persona que denominamos guía y el o la estudiante.

- La guía realiza una introducción de entre 2 y 3 minutos, previo al inicio de la aventura.

- La aventura en el castillo tiene una duración máxima de entre 10 y 12 minutos máximos.

El o la estudiante comienza la aventura en un software personalizado para la ocasión en formato de 32 bits. Es una aventura gráfica en la que tendrá que resolver una serie circunstancias. Todas las decisiones que tome o ausencia de estas, en cada momento, quedará registrado para determinar el mapa final del estudiante.

d) Fase de análisis y conclusiones. Una última fase en la que recolectamos todos los datos realizados cada una de las aventuras con cada uno de los estudiantes. La información que nos proporciona el conjunto de las interacciones con el Software nos determinará una serie de parámetros muy relevantes para la medición de las relaciones e interacciones de cada estudiante. Creamos un mapa de interacción individual por cada estudiante y un mapa de interacción general de toda el aula.

Sterh (2007) comenta que los mercados son construcciones sociales e históricas que responden a representaciones respecto de su existencia y funcionamiento, que se han ido desarrollando a la par en un espacio y en un tiempo. En esas representaciones se encuentran los fundamentos de las orientaciones normativas que priman en la acción social de los individuos y en las formas de articulación de las relaciones sociales en su interior.

\section{Resultados}

El modelo metodológico OSES está en modo experimental, previa a la aplicación en un grupo control. 
Los procesos para seguir durante la aplicación del modelo OSES en un centro educativo se aplican en las diferentes fases de creación:

1. Fase de inicio de proyecto. Ponerse en contacto con el centro educativo. Es un trabajo de presentación y mucha comunicación. Entran en juego varios actores y escenarios. El principal trabajo en la unificación de criterios, vocabulario y trámites a seguir entre todos los actores principales.

2. Fase de preparación del proyecto. Es similar a la primera fase de aventura en el castillo. Recopilamos toda la información posible que es útil y necesaria para la personalización de cada una de las aventuras de nuestros estudiantes. También recopilamos información del gabinete de orientación educativo en el centro y preparamos a la persona o personas que van a realizar la función de guía de nuestra aventura. El objetivo principal en esta fase en la personalización de cada estudiante en su entorno educativo más cercano, su aula.

3. Fase de ejecución del proyecto. Realizamos, junto con el centro educativo, una logística de actuación en función del tiempo que vamos a emplear, estudiantes que van a interactuar y recursos que se van a emplear. Creamos un cronograma de actuación, tanto del tiempo empleado por cada estudiante en cada reunión como del tiempo total en cada una de las fases de La aventura en el castillo.

4. Fase de seguimiento y monitorización del Proyecto. Una vez tenemos el proyecto en ejecución, debemos revisar continuamente que cada tarea respeta sus tiempos.

5. Fase de finalización del proyecto. Todos los objetivos han sido cumplidos. Todos los estudiantes han participado en La aventura en el castillo.

6. Fase de cierre del proyecto. Nos reunimos con el centro educativo para dar toda la información recogida durante el proyecto. Entrega del mapa individual de cada estudiante, entrega del mapa global por aulas y parámetros que se han podido medir junto con algunas conclusiones preliminares. Podemos dejar cerrado el proyecto cuando el centro educativo ya tiene toda la información requerida en los objetivos iniciales junto a una exhausta explicación de su lectura.

A continuación, se muestra un cuadro resumen de cada de las Perspectivas en las que se ha trabajado, su ítem correspondiente, el objetivo estratégico que le corresponde, su indicar y el tanto porcentual al que corresponde. 
Tabla 2. Clasificación de los componentes en el CMI y su evaluación.

\begin{tabular}{|c|c|c|c|c|}
\hline Ítem & Perspectiva & Objetivo estratégico & Indicadores & Evaluación \\
\hline$A$ & $\begin{array}{l}\text { Trabajo en } \\
\text { equipo }\end{array}$ & $\begin{array}{l}\text { Identificar la toma de decisión de } \\
\text { "poder ser ayudados" por una o va- } \\
\text { rias personas de su entorno laboral. }\end{array}$ & $\begin{array}{l}\text { Número personas } \\
\text { seleccionas en las } \\
\text { preguntas destinas a } \\
\text { dicha perspectiva. }\end{array}$ & $11,1 \%$ \\
\hline B & Respecto & $\begin{array}{l}\text { Personas seleccionadas afines o no, } \\
\text { que están en relación con el puesto } \\
\text { laboral. }\end{array}$ & $\begin{array}{l}\text { Dentro de grupo per- } \\
\text { sonalizado, selección } \\
\text { de personas afines. }\end{array}$ & $11,1 \%$ \\
\hline $\mathrm{C}$ & Adaptación & $\begin{array}{l}\text { Toma de decisión durante tres pun- } \\
\text { tos clave de la aventura. Capacidad } \\
\text { de adaptación y progresión ante lo } \\
\text { desconocido. }\end{array}$ & $\begin{array}{l}\text { Enfrentarse a lo des- } \\
\text { conocido, afrontar y } \\
\text { seguir adelante o re- } \\
\text { troceder, acomodarse } \\
\text { y terminar. }\end{array}$ & $11,1 \%$ \\
\hline $\mathrm{D}$ & $\begin{array}{l}\text { Capacidad de } \\
\text { aprender }\end{array}$ & $\begin{array}{l}\text { Capacidad de aprender ante con- } \\
\text { sejos de otras personas externas } \\
\text { a tu entorno laboral más cercano. } \\
\text { Seleccionar e incluir en las acciones, } \\
\text { información dada por grupos perso- } \\
\text { nalizados y programados. }\end{array}$ & $\begin{array}{l}\text { Grupo personali- } \\
\text { zado de personas } \\
\text { desconocidas para } \\
\text { el protagonista. } \\
\text { Aceptar y aprender } \\
\text { sobre la información } \\
\text { realizada. }\end{array}$ & $11,1 \%$ \\
\hline$E$ & $\begin{array}{l}\text { Capacidad de } \\
\text { priorizar }\end{array}$ & $\begin{array}{l}\text { Diversidad de información ante una } \\
\text { toma de decisión. Capacidad de } \\
\text { priorizar sobre la mejor decisión po- } \\
\text { sible. Seleccionar la acción correcta } \\
\text { antes situaciones personalizadas y } \\
\text { programadas con varias tareas. }\end{array}$ & $\begin{array}{l}\text { Varios grupos perso- } \\
\text { nalizados ofrecerán, } \\
\text { en diferentes mo- } \\
\text { mentos diferente in- } \\
\text { formación al unísono. }\end{array}$ & $11,1 \%$ \\
\hline $\mathrm{F}$ & $\begin{array}{l}\text { Comunica- } \\
\text { ción asertiva }\end{array}$ & $\begin{array}{l}\text { Capacidad de negación ante infor- } \\
\text { mación perjudicial. Repeticiones en } \\
\text { la negación ante situaciones perso- } \\
\text { nalizadas y programadas al caso. }\end{array}$ & $\begin{array}{l}\text { Ser capaz de afrontar } \\
\text { la información con } \\
\text { argumentación. }\end{array}$ & $11,1 \%$ \\
\hline G & $\begin{array}{l}\text { Capacidad de } \\
\text { asociaciones }\end{array}$ & $\begin{array}{l}\text { Saber las asociaciones más cerca- } \\
\text { nas en su entorno laboral. }\end{array}$ & $\begin{array}{l}\text { Ser capaz de crear } \\
\text { asociaciones. }\end{array}$ & $11,1 \%$ \\
\hline $\mathrm{H}$ & $\begin{array}{l}\text { Capacidad de } \\
\text { pedir ayuda }\end{array}$ & $\begin{array}{l}\text { Ser capaz de solicitar ayuda, fuera } \\
\text { de los controles o medios habitua- } \\
\text { les, ante una dificultad. Intento, por } \\
\text { parte del protagonista, para solicitar } \\
\text { ayuda. }\end{array}$ & $\begin{array}{l}\text { Ser capaz de solicitar } \\
\text { ayuda ante los dife- } \\
\text { rentes grupos perso- } \\
\text { nalizados creados o } \\
\text { fuera de ellos. }\end{array}$ & $11,1 \%$ \\
\hline I & Confianza & $\begin{array}{l}\text { Capacidad de tomar decisión ante } \\
\text { los comentarios o información de } \\
\text { las personas de su entorno laboral } \\
\text { diario. } \\
\text { Seguir los comentarios de diferen- } \\
\text { tes grupos personalizados. }\end{array}$ & $\begin{array}{l}\text { Medir las ocasiones } \\
\text { en las que los grupos } \\
\text { personalizados dan } \\
\text { información sobre } \\
\text { cómo avanzar mejor } \\
\text { en unos momentos } \\
\text { determinados. }\end{array}$ & $11,1 \%$ \\
\hline
\end{tabular}

\section{Elaboración propia.}

Cada una de las Perspectivas debe subdividirse en varios objetivos estratégicos. De esta manera se facilita la traducción a un lenguaje binario, teniendo en cuenta todas las opciones posibles en un momento determinado. Mediante está vía podemos personalizar cada centro educativo, cada aula y cada uno de los estudiantes a los que vamos a presentar La aventura en el castillo. 
En las sucesivas tablas, a modo de ejemplo, se esclarece el trabajo realizado en algunas de las Perspectivas, llegando a niveles de concreción más detallados en las acciones o ausencia de estas, que se toman en los diferentes momentos de la historia.

Tabla 3. Perspectiva trabajo en equipo y respeto.

\begin{tabular}{|c|c|c|}
\hline Perspectiva & Objetivos Específicos & Evaluación \\
\hline$A$ & $\begin{array}{l}\text { A.1. A lo largo de toda la acción, con categoría "A1". Selecciona } \\
\text { cero personas. }\end{array}$ & O\% \\
\hline A & $\begin{array}{l}\text { A2. A lo largo de toda la acción, con categoría "A1". Selecciona, al } \\
\text { menos, una persona. }\end{array}$ & $2,77 \%$ \\
\hline$A$ & $\begin{array}{l}\text { A3. A lo largo de toda la acción, con categoría "A1". Selecciona } \\
\text { dos personas. }\end{array}$ & $2,77 \%$ \\
\hline$A$ & $\begin{array}{l}\text { A4. A lo largo de toda la acción, con categoría "A1". Selecciona } \\
\text { tres personas. }\end{array}$ & $2,77 \%$ \\
\hline$A$ & $\begin{array}{l}\text { A5. A lo largo de toda la acción, con categoría "A1". Selecciona a } \\
\text { más de tres personas. }\end{array}$ & $2,77 \%$ \\
\hline$B$ & $\begin{array}{l}\text { B.1. Ante las preguntas a lo largo de toda la acción, con categoría } \\
\text { "B1", personas afines. Selecciona cero personas. }\end{array}$ & $0 \%$ \\
\hline B & $\begin{array}{l}\text { B.1. Ante las preguntas a lo largo de toda la acción, con categoría } \\
\text { "B2", personas menos afines. Selecciona cero personas. }\end{array}$ & $0 \%$ \\
\hline B & $\begin{array}{l}\text { B.1. Ante las preguntas a lo largo de toda la acción, con categoría } \\
\text { "B1", personas afines. Selecciona una persona. }\end{array}$ & $2,77 \%$ \\
\hline B & $\begin{array}{l}\text { B.1. Ante las preguntas a lo largo de toda la acción, con categoría } \\
\text { "B1", personas afines. Selecciona dos personas. }\end{array}$ & $2,77 \%$ \\
\hline B & $\begin{array}{l}\text { B.1. Ante las preguntas a lo largo de toda la acción, con categoría } \\
\text { "B1", personas afines. Selecciona tres personas. }\end{array}$ & $2,77 \%$ \\
\hline B & $\begin{array}{l}\text { B.1. Ante las preguntas a lo largo de toda la acción, con categoría } \\
\text { "B1", personas afines. Selecciona más de tres personas. }\end{array}$ & $2,77 \%$ \\
\hline
\end{tabular}

Elaboración propia.

Tabla 4. Perspectiva adaptación y capacidad de aprender"

\begin{tabular}{|c|c|c|}
\hline Perspectiva & Objetivos Específicos & Evaluación \\
\hline C & C.1. Ante la pregunta de inicio "C1" decide no continuar. & $0 \%$ \\
\hline C & C.2. Ante la pregunta de inicio "C1" decide continuar. & $3,70 \%$ \\
\hline C & C.3. Ante la pregunta de inicio "C2" decide no continuar. & $0 \%$ \\
\hline C & C.4. Ante la pregunta de inicio "C2" decide continuar. & $3,70 \%$ \\
\hline C & C.5. Ante la pregunta de inicio "C3" decide no continuar. & $0 \%$ \\
\hline C & C.6. Ante la pregunta de inicio "C3" decide continuar. & $3,70 \%$ \\
\hline $\mathrm{D}$ & $\begin{array}{l}\text { D.1. Ante la información recibida por grupos "D1" no se aplica en la } \\
\text { acción ninguna de las medidas. }\end{array}$ & O\% \\
\hline D & $\begin{array}{l}\text { D.2. Ante la información recibida por grupos “D1”. Se aplica en la } \\
\text { acción una de las medidas. }\end{array}$ & $3,70 \%$ \\
\hline $\mathrm{D}$ & $\begin{array}{l}\text { D.3. Ante la información recibida por grupos "D1". Se aplica en la } \\
\text { acción dos de las medidas. }\end{array}$ & $3,70 \%$ \\
\hline $\mathrm{D}$ & $\begin{array}{l}\text { D.4. Ante la información recibida por grupos "D1". Se aplica en la } \\
\text { acción tres o más de las medidas. }\end{array}$ & $3,70 \%$ \\
\hline
\end{tabular}


Cómo parte del resultado final, creamos los denominados mapas en la que se muestra toda la información que caracteriza a nuestro modelo metodológico OSES. Por un lado, cada estudiante refleja la interacción que tiene con los compañeros de la misma aula. El grado de cercanía que tiene con los estudiantes con los que más interactúa o aquellos compañeros con los que menos interactúa. Pero, además podemos relacionar los valores o competencias descritos en un inicio y el tanto por ciento que estos reaccionan con el entorno del estudiante. Se determina el grado de interacción con un estudiante y la carga positiva, neutra o negativa de dicha interacción.

Por lo tanto, creamos un resumen de los resultados obtenemos en la siguiente tabla:

Tabla 5. Resumen (\%) por cada Perspectiva basa en un estudiante tipo.

\begin{tabular}{|c|c|c|c|c|c|}
\hline Valores & Código & $\begin{array}{l}\text { Puntuación } \\
\text { sobre } 11,11\end{array}$ & Máximo & $\%$ conseguido & $\%$ restante \\
\hline Trabajo en equipo & A & 8,3325 & 11,111 & 74,9932499 & 25,0067501 \\
\hline Respecto & B & 5,555 & 11,111 & 49,9955 & 50,0045 \\
\hline Adaptación & C & 3,703 & 11,111 & 33,3273333 & 66,6726667 \\
\hline Capacidad de aprender & $\mathrm{D}$ & 0 & 11,111 & 0 & 100 \\
\hline Capacidad de asociación & $\mathrm{E}$ & 4 & 11,111 & 36,00036 & 63,99964 \\
\hline Capacidad de pedir ayuda & $\mathrm{F}$ & 2,36 & 11,111 & 21,2402124 & 78,7597876 \\
\hline
\end{tabular}

Elaboración propia.

\section{Conclusiones}

Uno de los resultados más sorprendentes son la creación tanto del mapa individual como el mapa por cada una de las aulas. A continuación, se expone un resumen de lo que podríamos llegar a conocer como un mapa de asociaciones del estudiante, es decir, un mapa individual de un estudiante tipo. 
Figura 2. Mapa de asociaciones relacionado con los valores y competencias trabajados.

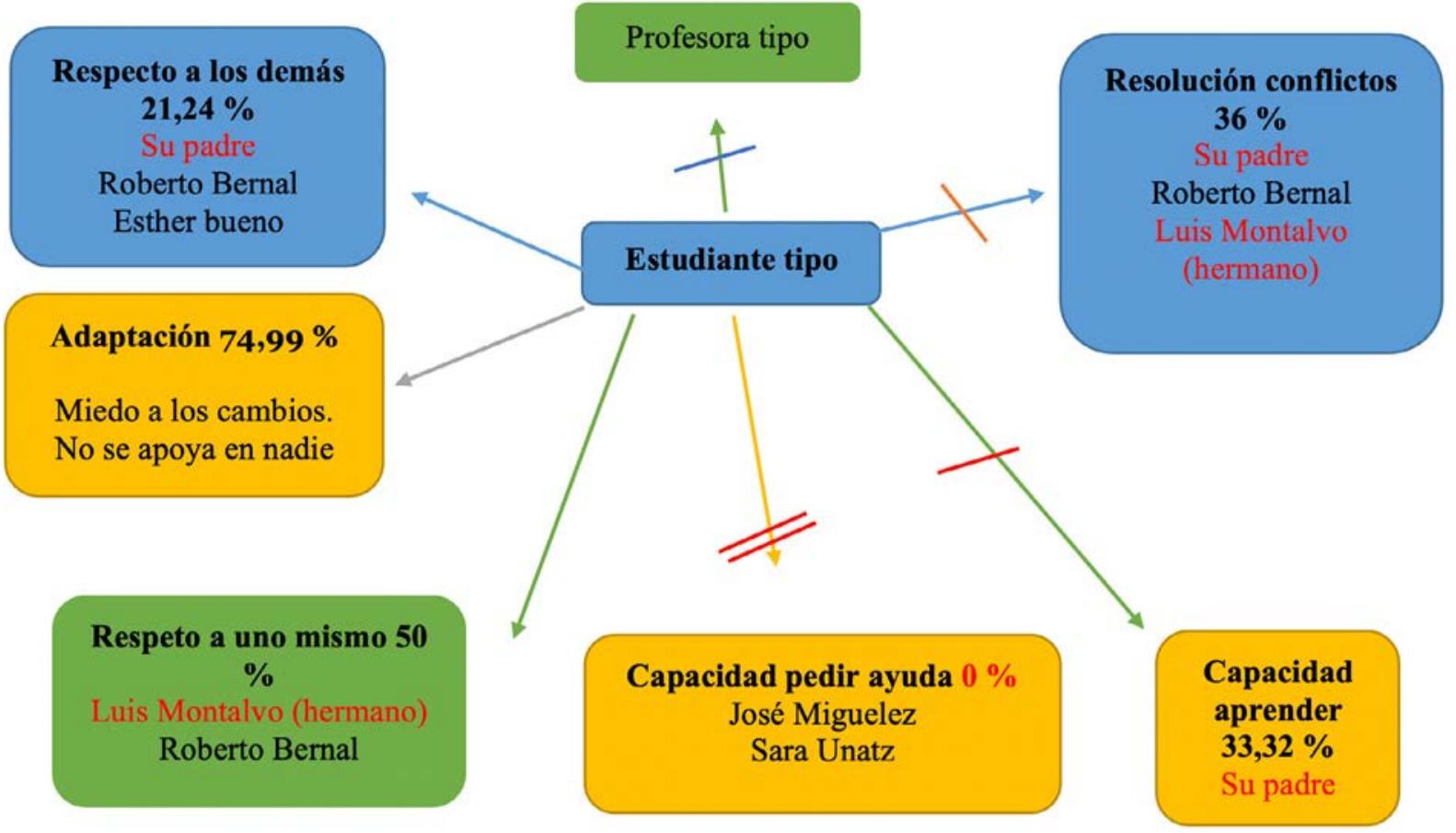

\section{Elaboración propia.}

El mapa individual del estudiante tipo junto con toda la información recogida con respecto a cada de las Perspectivas que se han evaluado a la largo de la historia interactiva, crean un perfil personalizado con una información muy valiosa. Dicha información nos determina el grado, en tanto por ciento, de cada competencia adquirida o no y la interacción de cada competencia con su entorno más cercano. Mostrando los vínculos que un estudiante tiene dentro del aula, fuera del aula, pero en el centro educativo o incluso externos al centro educativo.

Lo más interesante es el grado de interacción y el valor o competencia que desarrolla el estudiante y con quién se apoya dependiendo de las diversas situaciones que puede vivir en cualquier momento de su vida diaria en el aula. Podemos determinar, creado el perfil final del estudiante, la detección que tenemos ante un posible potencial en acciones de ejercer acoso escolar o en acciones para recibir un acoso escolar.

\section{Referencias}

Bruna, C. (2021). Educar para el acoso. Editorial Alba.

Echegaray, Guillermo (2008). Para comprender las constelaciones organizacionales. Editorial Verbo Divino.

Garibay Rivas, Salvador (2018). Enfoque Sistémico: Una Introducción a La Psicoterapia Familiar. [Repositorio Digital] México, D.F. 
Nieto Licht, Cesar (2017). Enfoque sistémico en los procesos de gestión humana. Revista EAN.

Heinemann, P. (1972). Mobbing-group violence by children and adults. Natur och.

Hellinger, B. (2001). Religión, psicoterapia, cura de almas. Editorial Herder S.L.

Hellinger, Bert (2006). El Intercambio: didáctica de constelaciones familiares. Editorial Rigden Institut Gestalt.

Hellinger, Bert (2011). Siguiendo las huellas. Editorial Grupo Cudec.

Kaplan R. y Norton D. P., (1992). The Balanced Scorecard-Mesaures That Drive Performance. HarvardBusiness.

Oñate Cantero A, y Piñuel, Z. (2007). Informe Cisneros X. Violencia y acoso escolar en España. Instituto de Innovación educativa y desarrollo directivo.

Olweus, D. (1978). Aggression in the Schools. Heminsphere Press.

Ortega, R. (1998). La convivencia escolar: qué es y cómo abordarla. Consejería de Educación y Ciencia. Junta de Andalucía.

Olve N.G. y Sjostrand, A. (2002). The Balanced Scorecard. Oxford, U.K.

Stehr, N. (2007). The Social Integration of Science. Institutional and Epistemological Aspects of the Transformation of Knowledge in Modern Society. Edition Sigma.

Von Bertalanffy, L. (2009). Teoría general de los sistemas. Fondo de Cultura.

Van Manen, M. (1998). El tacto en la enseñanza. El significado de la sensibilidad pedagógica. Editorial Paidós. 


\section{Programa de Vinculación de Alumnos de los Posgrados en Inteligencia Artificial, Sistemas Embebidos e Internet de las Cosas de la UBA con Organismos Públicos y Empresas: Métodos y Resultados.}

Menéndez, Martín Nicolás

orcid.org/0000-0001-8101-8699

Universidad de Buenos Aires

mmenendez@fi.uba.ar

\section{Gomez, Pablo Martín}

orcid.org/0000-0002-5146-8573

Universidad de Buenos Aires

pgomez@fi.uba.ar

\section{Lutenberg, Ariel}

orcid.org/0000-0002-3626-79419

Universidad de Buenos Aires

alutenb@fi.uba.ar 


\title{
PROGRAMA DE VINCULACIÓN DE ALUMNOS DE LOS POSGRADOS EN INTELIGENCIA ARTIFICIAL, SISTEMAS EMBEBIDOS E INTERNET DE LAS COSAS DE LA UBA CON ORGANISMOS PÚBLICOS Y EMPRESAS: MÉTODOS Y RESULTADOS.
}

\author{
Menéndez, Martín Nicolás \\ Gomez, Pablo Martín \\ Lutenberg, Ariel
}

\section{Resumen}

El programa de vinculación de los posgrados en inteligencia artificial, sistemas embebidos e internet de las cosas de la Universidad de Buenos Aires posibilita que alumnos que al momento de comenzar su posgrado no tienen definido qué trabajo final realizar elijan una propuesta formulada por un organismo público o empresa. Así el alumno se vincula con un cliente para el cual realiza su trabajo final y además se le asigna un director idóneo en la temática para que lo acompañe en el proyecto. En la actualidad un $20 \%$ de los alumnos elige participar de este programa, lo que representa alrededor de 25 alumnos por año. En este artículo se explica cómo funciona el programa de vinculación y los procesos basados en herramientas digitales mediante los cuales se hace un seguimiento activo del vínculo de cada par alumno-cliente y alumno-director. Se presentan resultados que muestran que la satisfacción es muy alta entre los alumnos, clientes y directores. Se presentan además resultados referidos a los proyectos realizados, al tiempo y dinero invertido en por los alumnos y los clientes, y al tipo de vínculo establecido en cada caso. A partir de estos resultados se analiza cuáles son los factores más determinantes en el éxito de la vinculación y qué elementos del programa de vinculación podrían modificarse a los fines de obtener resultados aún más satisfactorios.

\section{Palabras clave}

Vinculación, universidad, empresa, seguimiento activo. 


\section{Introducción}

En el artículo "An Approach to the Future of Work: Academia and Industry Alliance to Integrate Work and Study" ("Propuesta de alianza estratégica entre la academia y la industria para integrar el trabajo y el estudio") (Lutenberg, 2020) el autor presenta un proceso de vinculación entre la academia y la industria a través de los trabajos finales de posgrado mediante tecnologías digitales. En aquel trabajo se describen los antecedentes (Guido \& Versino, 2016), otros trabajos relacionados (Malone, 2007; The future of work in America, 2021), experiencias similares en otros países (BMW Group Careers 2021; Adidas careers, 2021) y el contexto en el cual se desarrolla la propuesta (Maestría en Sistemas Embebidos, 2021). Es posible mencionar además otros artículos académicos recientes relevantes en la temática de estrategias para la vinculación entre la industria y la academia basadas en el uso de tecnología educativa (Salinas \& Márquez 2013; Bergmann \& Grané, 2013; Cabero, 2007).

En este artículo se presentan nuevos resultados en relación al vínculo entre los alumnos y los organismos públicos o empresas que participan del programa de vinculación. A su vez se presentan mayores detalles respecto al proceso y las tecnologías utilizadas para implementar esta experiencia. El objetivo principal es vincular a alumnos del posgrado con la industria y la academia a través de sus trabajos finales y hacer un seguimiento de este vínculo mediante herramientas tecnológicas. La hipótesis es que mediante una inversión muy reducida de tiempo y dinero es posible que los alumnos completen con éxito su trabajo final y que establezcan un vínculo muy provechoso con empresas y laboratorios.

\section{Descripción de la experiencia}

En la figura 1 se ilustra mediante un diagrama el proceso mediante el cual se implementa la realización de los trabajos finales del posgrado. En particular se muestra cómo se inserta el programa de vinculación que se presenta en este artículo. Se ilustran las distintas acciones que tienen lugar cuando el alumno es admitido al posgrado, cursa las distintas asignaturas en cada bimestre y presenta su trabajo final. 


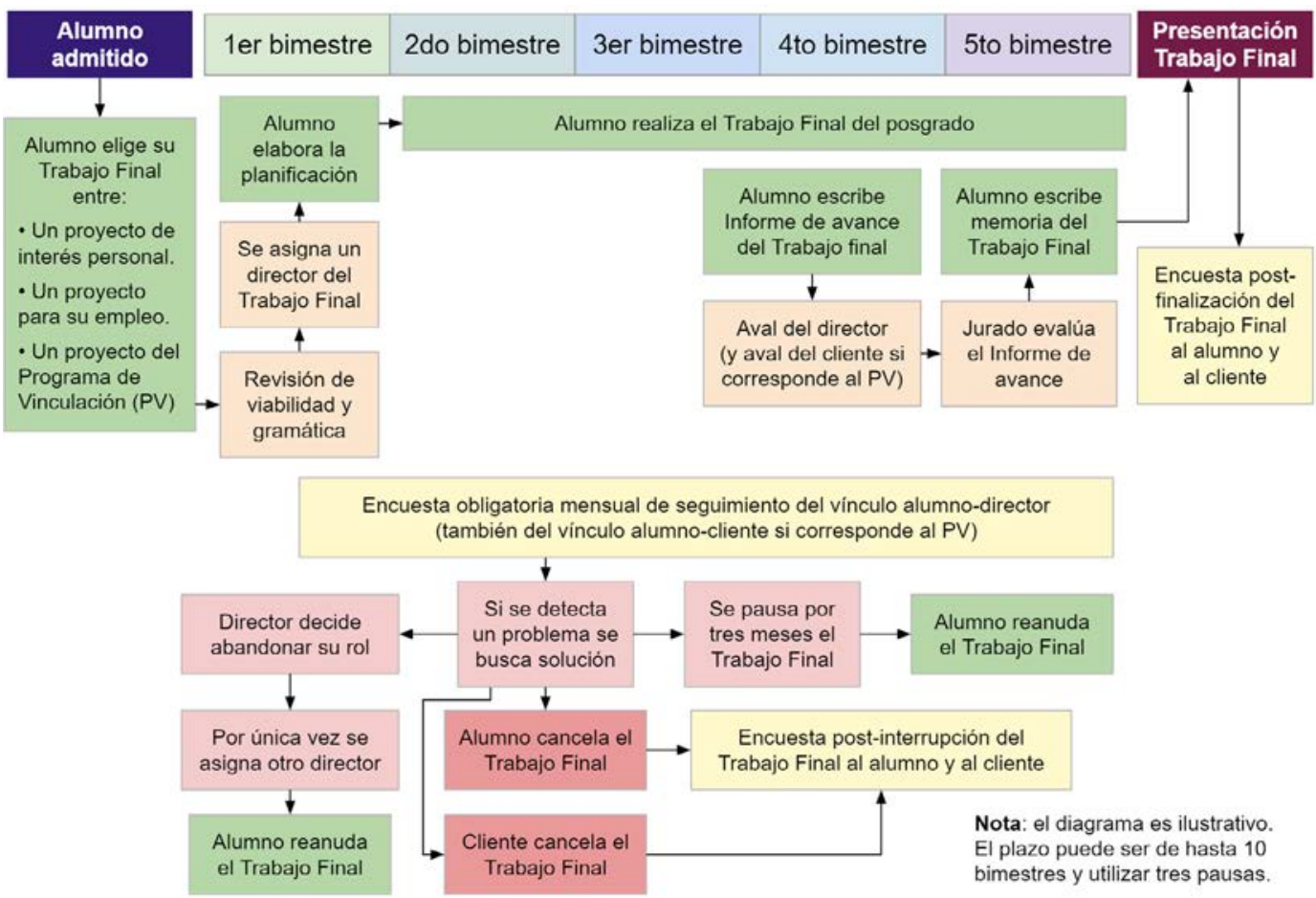

\section{Figura 1. Diagrama ilustrativo del programa de vinculación.}

Los alumnos que son admitidos a los posgrados de inteligencia artificial, sistemas embebido o internet de las cosas deben elegir un tema de trabajo final antes de comenzar el primer bimestre, ya que muchas asignaturas se aprueban realizando una parte del trabajo final. Las pautas son que el trabajo final pueda realizarse en el plazo de un año, demande alrededor de 600 hs y aplique parte de los temas del posgrado.

Los alumnos pueden presentar una propuesta propia o de su actual empleo, o bien elegir una propuesta que en el rol de cliente ofrecen empresas, centros de investigación y organismos públicos de Argentina y otros países en el marco del Programa de Vinculación. En ese caso el alumno debe contactar al cliente y establecer las condiciones para realizar el trabajo final (el posgrado no interviene en este acuerdo). Desde el posgrado se revisa la viabilidad de la propuesta y se ayuda con la redacción.

La planificación detallada del trabajo final se realiza en la asignatura Gestión de Proyectos durante el primer bimestre del posgrado con la asistencia de un director que acompañará al alumno en todo el proceso. El director debe tener un dominio apropiado de la temática del trabajo final y puede ser propuesto por el alumno en común acuerdo con el cliente, o bien ser asignado por el posgrado en caso de ser necesario.

Desde el primer bimestre se hace un seguimiento mensual del vínculo entre el alumno y el cliente. Esto se implementa mediante la herramienta Google Forms (Formularios de Google, 2021) con la que se hacen dos preguntas a cada alumno sobre su cliente: 1) ¿Cómo evalúa la comunicación y la relación interpersonal? y 2) ¿Cómo evalúa la claridad del cliente para expresar sus necesidades? Al cliente se le realizan cada mes dos preguntas mediante Google Forms respecto al alumno: 1) ¿Cómo evalúa la comunicación y la relación interpersonal? y 2) ¿Cómo evalúa la solvencia del alumno para implementar sus necesidades? 
Además cada mes al alumno se le consulta sobre su director: 1) ¿Cómo evalúa la capacidad de su director para expresar sus sugerencias y establecer un buen vínculo? y 2) ¿Cómo evalúa la capacidad técnica de su director para guiar su trabajo final? Al director se le consulta sobre el alumno: 1) ¿Cómo evalúa la capacidad del alumno para expresar sus consultas y establecer un buen vínculo? y 2) ¿Cómo evalúa la capacidad técnica del alumno para resolver su trabajo final?

De esta forma cada mes el cliente y el director responden sólo dos preguntas por cada trabajo final, y cuatro preguntas el alumno. Las preguntas se responden en una escala numérica de 1 a 5 puntos, donde 1 corresponde a muy malo y 5 corresponde a muy bueno. Los resultados se procesan mediante la herramienta Google Sheets (Google Sheet, 2021) y se filtran los que no han respondido en el plazo establecido. A partir de esto se generan correos automáticos mediante las herramientas provistas por la API de Google (Google APIs Explorer and Google Developers, 2021) con los que se insiste para que todos respondan la encuesta, al comienzo de forma general y luego mediante correos personalizados a medida que avanzan los días. Así se logra que la totalidad de los actores respondan la encuesta mensual de seguimiento.

Mediante un script implementado con la API (Application Programming Interface) de Google se escribe un correo personalizado a cada uno de los involucrados que obtuvieron un puntaje menor o igual a 3 puntos en alguna de las preguntas. De esta forma se hace un seguimiento de cada caso con dificultades, a los fines de darle una solución. En muchos casos la solución más efectiva consiste en poner el trabajo final en pausa por un periodo de tiempo. A los fines de sistematizar el proceso se estableció que el periodo de pausa sea de tres meses y que se puedan utilizar un máximo de tres periodos de pausa.

En caso de disconformidad tanto el cliente como el alumno pueden optar por no continuar con el trabajo final. En ese caso se notifica al posgrado y se completa un formulario post-interrupción donde se deja constancia de las condiciones en las cuáles se desarrolló el vínculo. También el director dispone de la posibilidad de renunciar en caso de no estar conforme con el avance del trabajo final. En ese caso se designa un nuevo director. Si el nuevo director también renuncia entonces el alumno pierde la condición de regularidad en el posgrado.

Si todo se desarrolla con normalidad entonces en el cuarto bimestre el alumno presenta un informe de avance del trabajo final que debe contar con la aprobación del director y del cliente. El posgrado asigna un jurado conformado por tres personas para que evalúe el informe de avance, realice recomendaciones sobre el trabajo final (que el alumno debe responder y justificar si las acepta) y determine si el trabajo está en condiciones de ser presentado al finalizar el quinto bimestre.

En caso favorable el alumno cursa la asignatura Taller de Trabajo Final en el quinto bimestre, en la que recibe apoyo por parte de docentes del posgrado para escribir la memoria técnica del trabajo final y realizar la presentación pública del mismo. La memoria y la presentación pueden tener partes censuradas para salvaguardar intereses comerciales o académicos del cliente. Una vez realizada la presentación del trabajo final se completa una encuesta donde se deja constancia de las condiciones en las cuáles se desarrolló el vínculo entre el alumno y el cliente. 


\section{Resultados}

\section{Estadísticas de puntaje mes a mes de cliente-alumno y director-cliente}

Durante el periodo de julio 2019 a agosto 2021 en total 39 alumnos participaron en el programa de vinculación, con un promedio de 15 alumnos participando en forma simultánea. En la actualidad 19 alumnos participan, de los cuales 6 tienen su trabajo final en pausa. En la figura 2 se observa la evolución mensual de los indicadores promedio correspondientes al vínculo entre los alumnos y los clientes, y alumnos y directores.

\section{Evolución mensual de los indicadores (promedio y error estándar)}
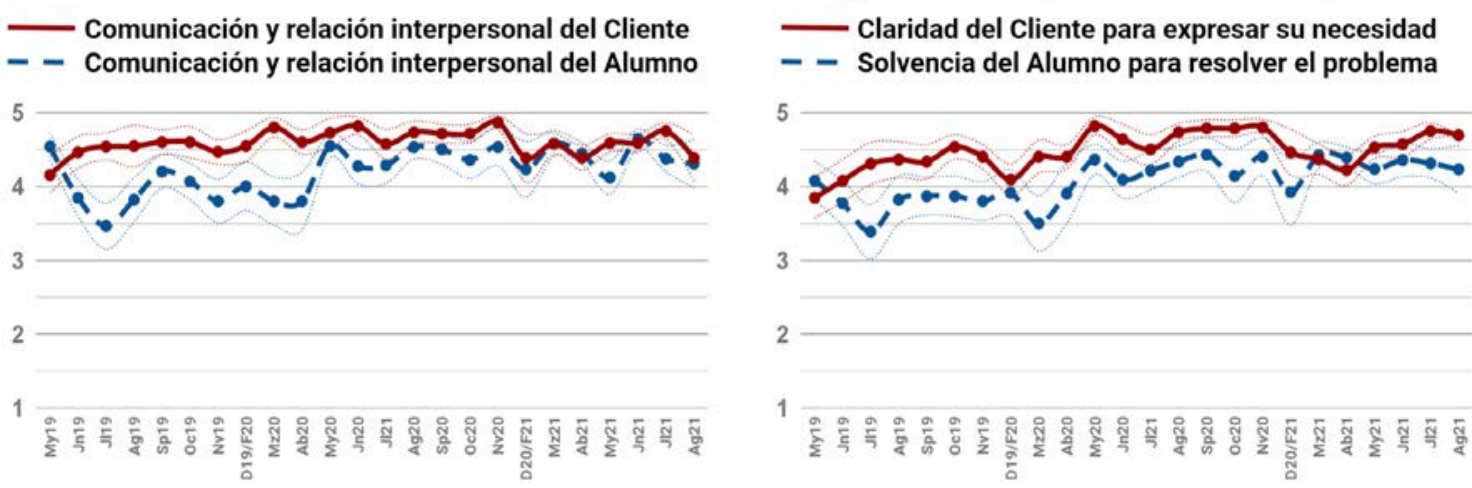

Evolución mensual de los indicadores (promedio y error estándar)
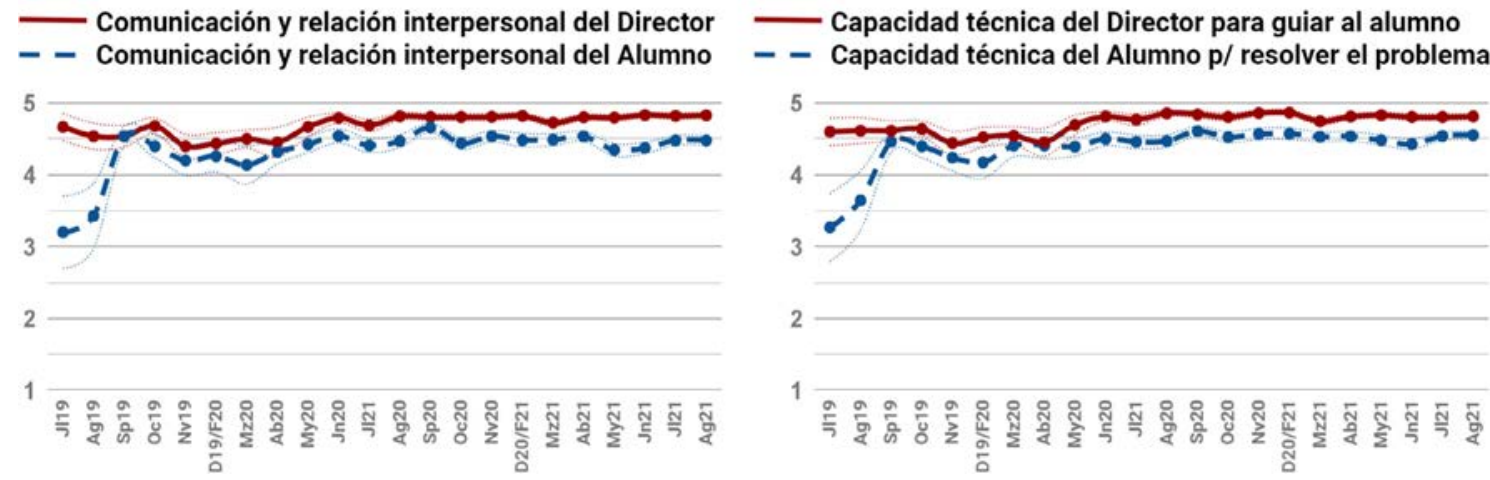

Figura 2. Evolución mensual de los indicadores.

\section{Estadísticas generales de trabajos finales completados y cancelados}

Se analizan a continuación 20 trabajos finales, de los cuales 12 fueron completados y 8 fueron cancelados. En la tabla 1 se presenta al responsable de cancelar el trabajo y el motivo en cada caso. En la figura 3 se puede apreciar el tiempo en meses que demoró completar o cancelar los trabajos finales. En la figura 4 se presenta la valoración del programa de vinculación desde el punto de vista del alumno y del cliente. 
Tabla 1. Responsable y motivos de cancelación del trabajo final.

\begin{tabular}{|l|l|l|l|l|l|}
\cline { 2 - 6 } \multicolumn{1}{c|}{} & \multicolumn{2}{|l|}{ Motivo } \\
\cline { 2 - 6 } \multicolumn{1}{c|}{} & $\begin{array}{l}\text { ¿Quién } \\
\text { canceló? }\end{array}$ & $\begin{array}{l}\text { Escasos } \\
\text { avances }\end{array}$ & $\begin{array}{l}\text { Cambio } \\
\text { de empleo }\end{array}$ & $\begin{array}{l}\text { Motivos } \\
\text { personales }\end{array}$ & $\begin{array}{l}\text { Continúo el proyecto } \\
\text { sin el cliente }\end{array}$ \\
\hline Cliente & $63 \%$ & $100 \%$ & - & - & - \\
\hline Alumno & $37 \%$ & - & $33 \%$ & $33 \%$ & $33 \%$ \\
\hline
\end{tabular}

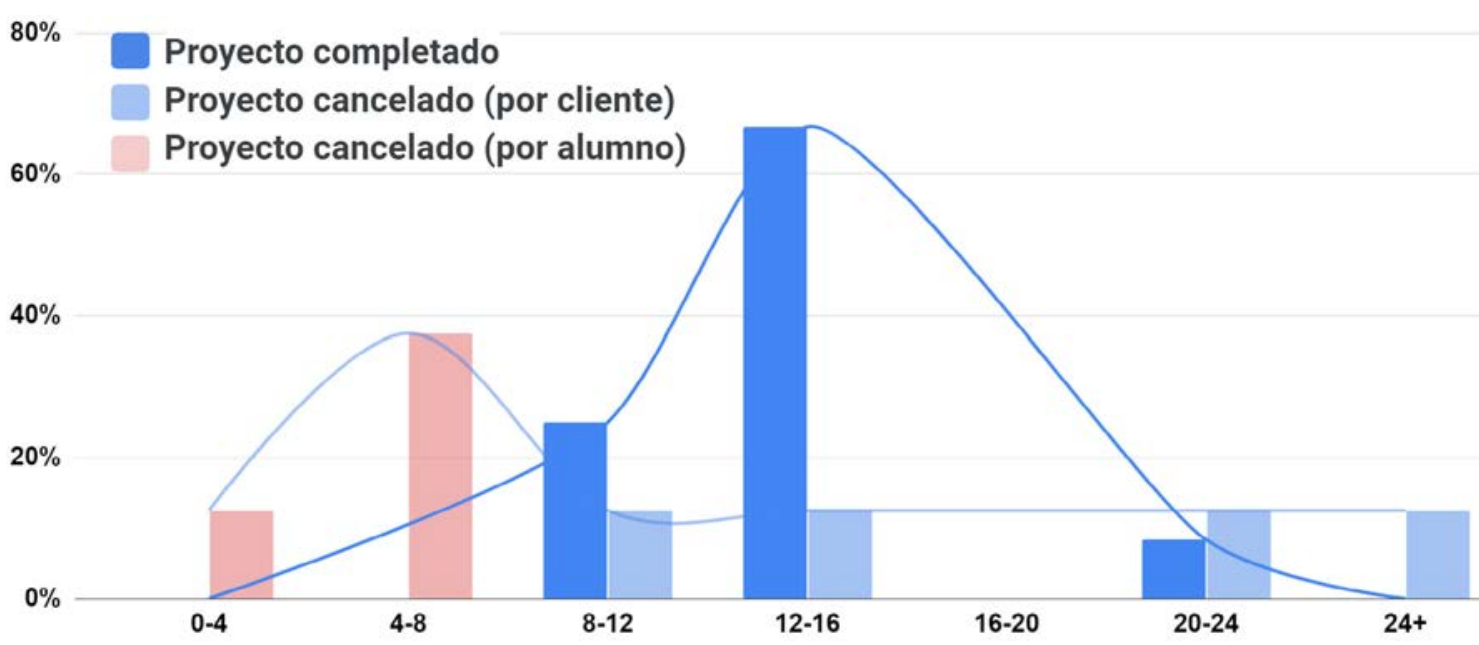

Figura 3. Meses para completar o cancelar el trabajo final.

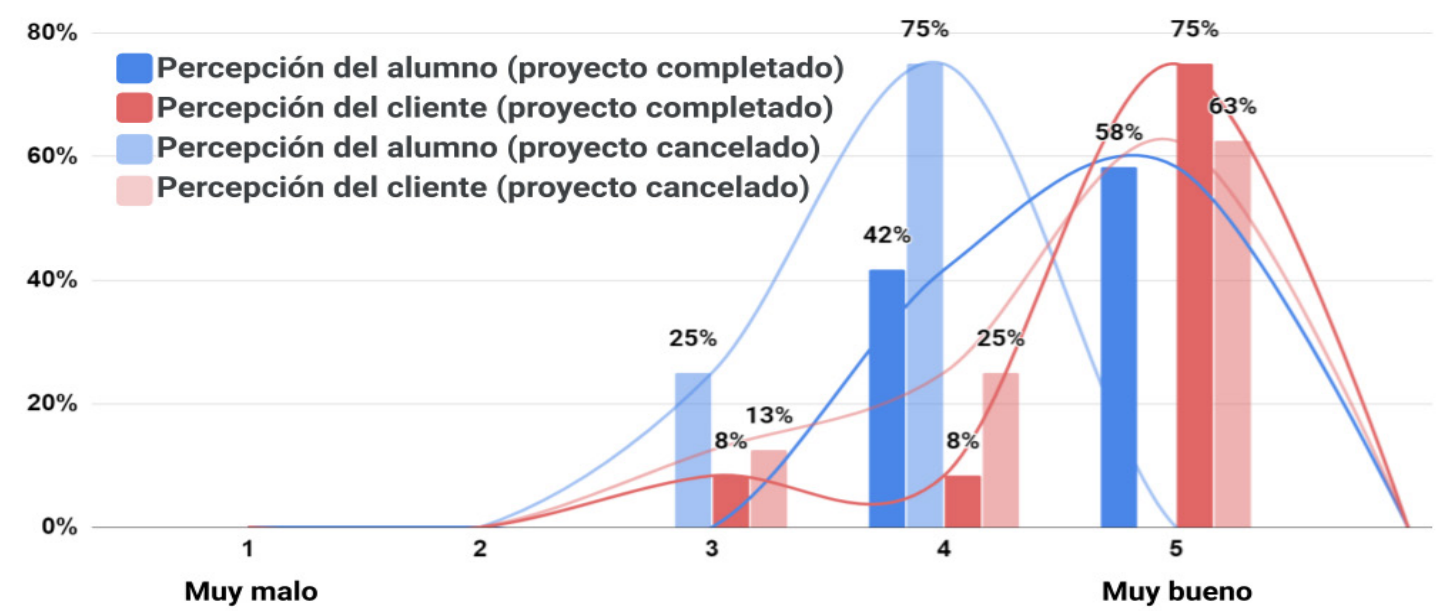

Figura 4. Valoración del programa por parte de alumnos y clientes.

\section{Estadísticas de recursos invertidos}

En la figura 5 y la figura 6 se presenta la distribución de horas semanales destinadas al trabajo final por los alumnos y los clientes, respectivamente, en el marco del programa de vinculación, según lo referido en las encuestas. En la figura 7 y la figura 8 se presenta el resultado obtenido en los relacionado a la inversión económica. 


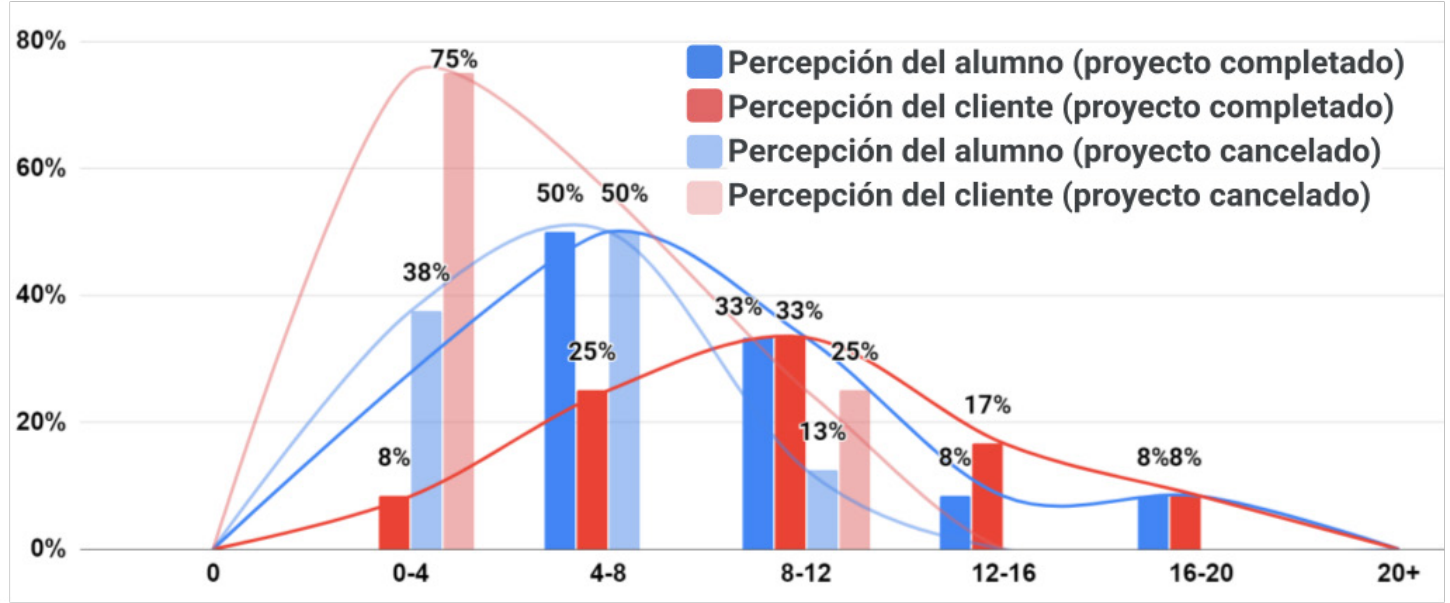

Figura 5. Horas destinadas por el alumno al trabajo final.

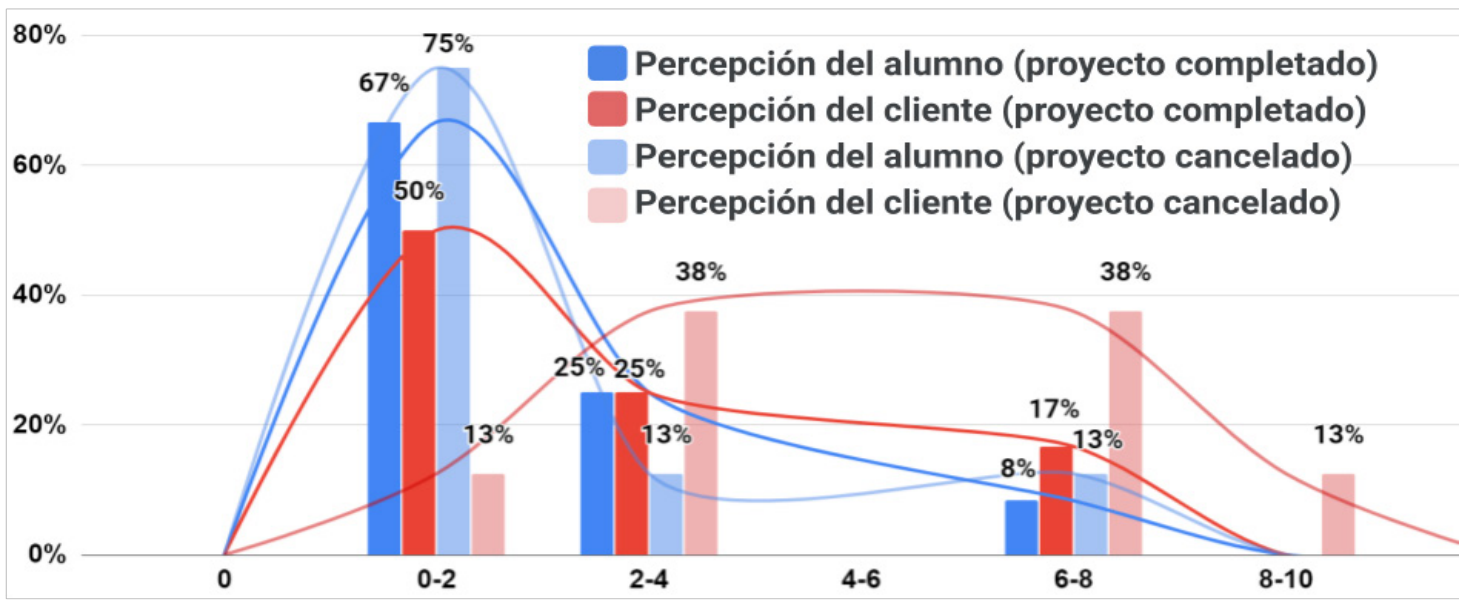

Figura 6. Horas destinadas por el cliente a trabajo final. 


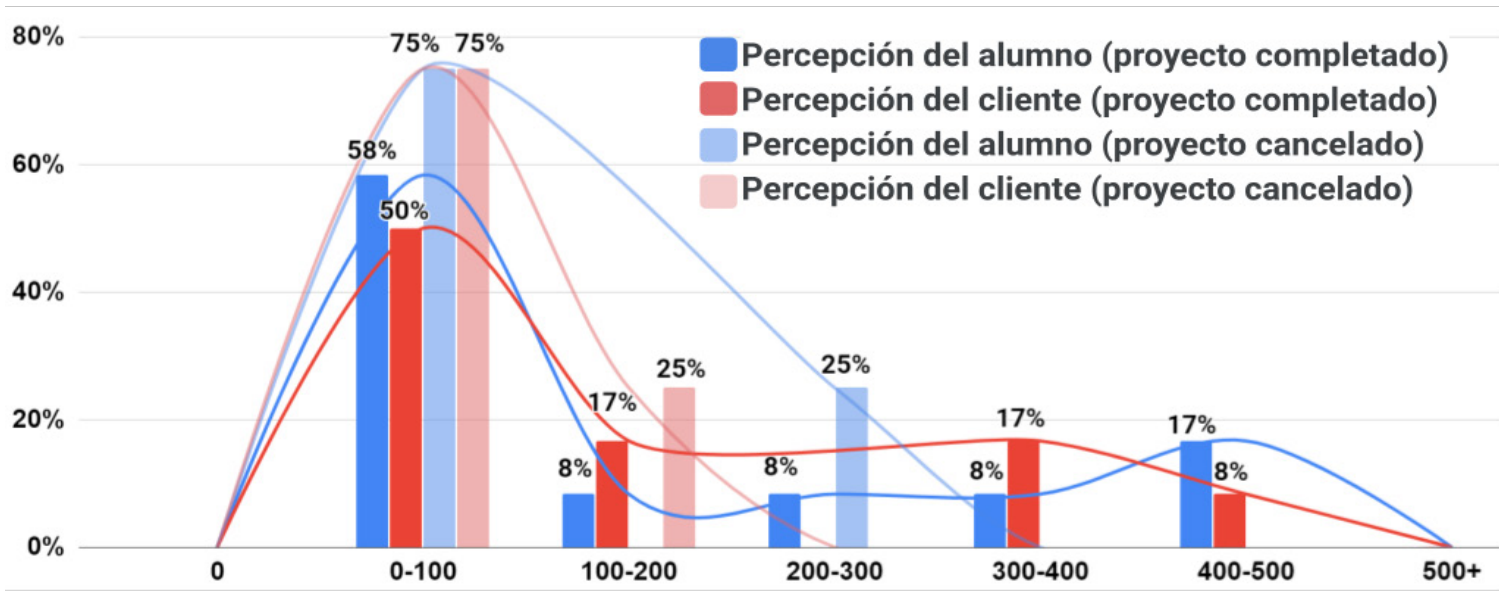

Figura 7. Inversión en materiales realizada por el alumno (en U\$S).

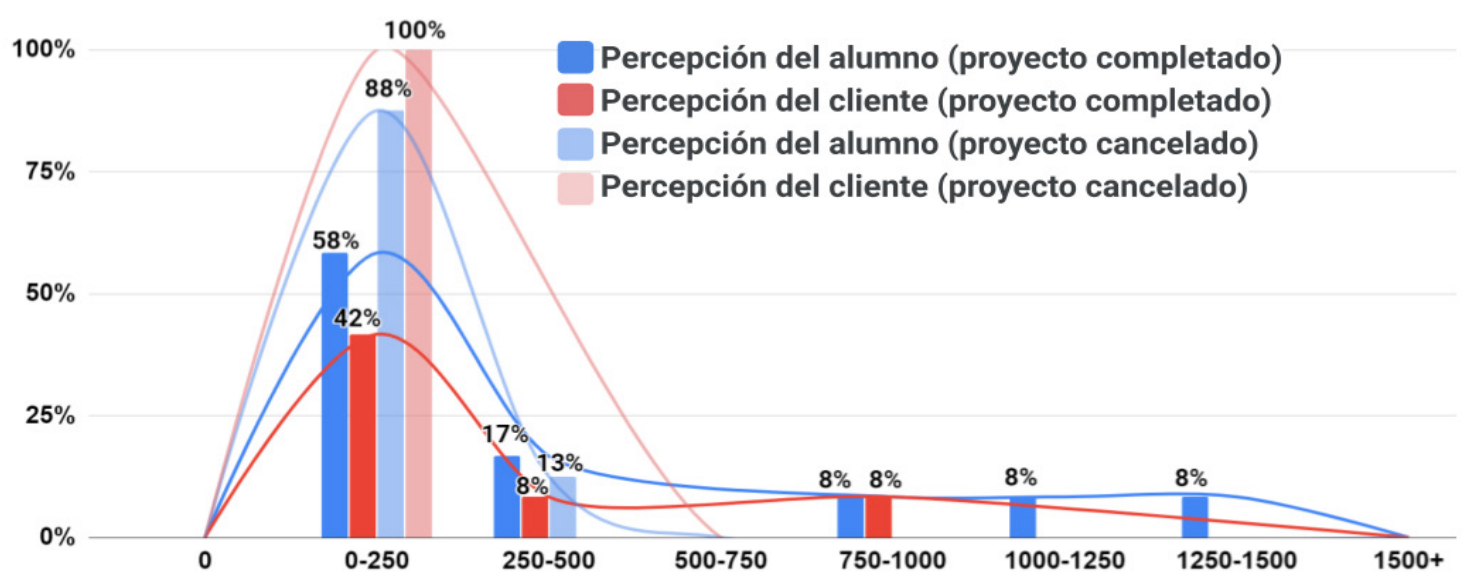

Figura 8. Inversión en materiales realizada por el cliente (en U\$S).

\section{Otras estadísticas de interés}

En la tabla 2 se presentan los resultados obtenidos en las encuestas en relación a la generación de conocimiento y acuerdos de confidencialidad. En la tabla 3 se muestran distintas preguntas relativas al vínculo establecido entre el alumno y el cliente. Finalmente en la tabla 4 se presenta la opinión respecto a la posibilidad de aplicar el programa de vinculación en otros ámbitos. 
Tabla 2. Generación de conocimiento y acuerdos de confidencialidad.

\begin{tabular}{|c|c|c|c|c|c|c|c|c|}
\hline & \multicolumn{4}{|c|}{ Trabajo final completado } & \multicolumn{4}{|c|}{ Trabajo final cancelado } \\
\hline & \multicolumn{2}{|c|}{$\begin{array}{l}\text { Respuesta } \\
\text { del cliente }\end{array}$} & \multicolumn{2}{|c|}{$\begin{array}{l}\text { Respuesta } \\
\text { del alumno }\end{array}$} & \multicolumn{2}{|c|}{$\begin{array}{l}\text { Respuesta } \\
\text { del cliente }\end{array}$} & \multicolumn{2}{|c|}{$\begin{array}{l}\text { Respuesta } \\
\text { del alumno }\end{array}$} \\
\hline & Sí & No & Sí & No & Sí & No & Sí & No \\
\hline $\begin{array}{l}\text { ¿Considera que el trabajo final aportó } \\
\text { desarrollo }(I+D) \text { al producto? }\end{array}$ & $82 \%$ & $18 \%$ & $92 \%$ & $8 \%$ & & & & \\
\hline $\begin{array}{l}\text { ¿Considera que el posgrado intervino } \\
\text { en la generación de conocimiento? }\end{array}$ & $64 \%$ & $36 \%$ & $50 \%$ & $50 \%$ & $0 \%$ & $100 \%$ & $0 \%$ & $100 \%$ \\
\hline $\begin{array}{l}\text { ¿Se firmó algún tipo de acuerdo de } \\
\text { confidencialidad entre las partes? }\end{array}$ & $9 \%$ & $91 \%$ & $17 \%$ & $83 \%$ & $0 \%$ & $100 \%$ & $0 \%$ & $100 \%$ \\
\hline $\begin{array}{l}\text { ¿Hubo algún tipo de problema ligado a la } \\
\text { confidencialidad o a la propiedad intelectual? }\end{array}$ & $0 \%$ & $100 \%$ & $0 \%$ & $100 \%$ & $13 \%$ & $88 \%$ & $14 \%$ & $86 \%$ \\
\hline $\begin{array}{l}\text { ¿El trabajo realizado dio como resultado } \\
\text { alguna patente? }\end{array}$ & $0 \%$ & $100 \%$ & $0 \%$ & $100 \%$ & & & & \\
\hline $\begin{array}{l}\text { ¿El trabajo realizado dio como resultado } \\
\text { algún artículo científico? }\end{array}$ & $0 \%$ & $100 \%$ & $0 \%$ & $100 \%$ & & & & \\
\hline
\end{tabular}

Tabla 3. Características del vínculo establecido entre el cliente y el alumno.

\begin{tabular}{|c|c|c|c|c|c|c|c|c|}
\hline & \multicolumn{4}{|c|}{ Trabajo final completado } & \multicolumn{4}{|c|}{ Trabajo final cancelado } \\
\hline & \multicolumn{2}{|c|}{$\begin{array}{l}\text { Respuesta } \\
\text { del cliente }\end{array}$} & \multicolumn{2}{|c|}{$\begin{array}{l}\text { Respuesta } \\
\text { del alumno }\end{array}$} & \multicolumn{2}{|c|}{$\begin{array}{l}\text { Respuesta } \\
\text { del cliente }\end{array}$} & \multicolumn{2}{|c|}{$\begin{array}{l}\text { Respuesta } \\
\text { del alumno }\end{array}$} \\
\hline & Sí & No & Sí & No & Sí & No & Sí & No \\
\hline $\begin{array}{l}\text { ¿El alumno contó con un seguro de trabajo } \\
\text { tipo ART mientras hacía su trabajo final? }\end{array}$ & $18 \%$ & $82 \%$ & $0 \%$ & $100 \%$ & & & & \\
\hline $\begin{array}{l}\text { ¿El alumno sufrió algún tipo de problema } \\
\text { ligado a accidentes del trabajo mientras hacía } \\
\text { su trabajo? }\end{array}$ & $0 \%$ & $100 \%$ & $0 \%$ & $100 \%$ & $0 \%$ & $100 \%$ & $0 \%$ & $100 \%$ \\
\hline $\begin{array}{l}\text { ¿El alumno fue contratado como empleado por } \\
\text { la empresa mientras hacía su trabajo final? }\end{array}$ & $27 \%$ & $73 \%$ & $25 \%$ & $75 \%$ & O\% & $100 \%$ & $0 \%$ & $100 \%$ \\
\hline $\begin{array}{l}\text { ¿El alumno cobró una remuneración por su } \\
\text { trabajo final mientras lo hacía? }\end{array}$ & $9 \%$ & $91 \%$ & $0 \%$ & $100 \%$ & $0 \%$ & $100 \%$ & $0 \%$ & $100 \%$ \\
\hline $\begin{array}{l}\text { ¿El alumno cobró una remuneración por su } \\
\text { trabajo final una vez terminado? }\end{array}$ & $0 \%$ & $100 \%$ & $0 \%$ & $100 \%$ & & & & \\
\hline $\begin{array}{l}\text { ¿El alumno continuó vinculado a la empresa } \\
\text { una vez terminado el trabajo final? }\end{array}$ & $45 \%$ & $55 \%$ & $33 \%$ & $67 \%$ & & & & \\
\hline $\begin{array}{l}\text { ¿El alumno utilizó instrumental de la empresa u } \\
\text { organización para hacer su trabajo final? }\end{array}$ & $36 \%$ & $64 \%$ & $58 \%$ & $42 \%$ & $50 \%$ & $50 \%$ & $29 \%$ & $71 \%$ \\
\hline $\begin{array}{l}\text { ¿Se utilizó instrumental del posgrado para } \\
\text { hacer su trabajo final? }\end{array}$ & $9 \%$ & $91 \%$ & $0 \%$ & $100 \%$ & $0 \%$ & $100 \%$ & $0 \%$ & $100 \%$ \\
\hline
\end{tabular}


Tabla 4. Posibilidad de aplicar el programa de vinculación en otros ámbitos.

\begin{tabular}{|c|c|c|c|c|c|c|c|c|}
\hline & \multicolumn{4}{|c|}{ Trabajo final completado } & \multicolumn{4}{|c|}{ Trabajo final cancelado } \\
\hline & \multicolumn{2}{|c|}{$\begin{array}{l}\text { Respuesta } \\
\text { del cliente }\end{array}$} & \multicolumn{2}{|c|}{$\begin{array}{l}\text { Respuesta } \\
\text { del alumno }\end{array}$} & \multicolumn{2}{|c|}{$\begin{array}{l}\text { Respuesta } \\
\text { del cliente }\end{array}$} & \multicolumn{2}{|c|}{$\begin{array}{l}\text { Respuesta } \\
\text { del alumno }\end{array}$} \\
\hline & Sí & No & Sí & No & Sí & No & Sí & No \\
\hline $\begin{array}{l}\text { ¿Considera que esta iniciativa podría ser } \\
\text { aplicable a carreras de grado en ingeniería? }\end{array}$ & $91 \%$ & $9 \%$ & $92 \%$ & $8 \%$ & $100 \%$ & O\% & $86 \%$ & $14 \%$ \\
\hline $\begin{array}{l}\text { ¿Considera que esta iniciativa podría ser } \\
\text { aplicable a otras carreras de grado no } \\
\text { ingenieriles? }\end{array}$ & $73 \%$ & $27 \%$ & $92 \%$ & $8 \%$ & $75 \%$ & $25 \%$ & $86 \%$ & $14 \%$ \\
\hline
\end{tabular}

\section{Desenlace de los trabajos finales completados}

En la tabla 5 se presenta un desglose de los trabajos finales completados según su aplicación. Se indica además cuántos de ellos se utilizan o comercializan actualmente. En la tabla 6 se presentan resultados sobre el uso de tecnologías libres en los trabajos.

Tabla 5. Características y uso posterior de los trabajos finales completados

\begin{tabular}{|c|c|c|c|c|c|}
\hline & \multirow[b]{2}{*}{ Casos } & \multicolumn{2}{|c|}{$\begin{array}{l}\text { En uso } \\
\text { actualmente }\end{array}$} & \multicolumn{2}{|c|}{$\begin{array}{l}\text { Se } \\
\text { comercializó }\end{array}$} \\
\hline & & Sí & No & Sí & No \\
\hline Medición de parámetros en línea de producción o laboratorio & $17 \%$ & $100 \%$ & $0 \%$ & - & - \\
\hline Prueba de un concepto o de prototipo de un producto & $83 \%$ & - & - & $\mathrm{O} \%$ & $100 \%$ \\
\hline Producto en el camino crítico comercial de la empresa & O\% & - & - & - & - \\
\hline
\end{tabular}

Tabla 6. Uso de tecnologías libres en los trabajos finales completados

\begin{tabular}{|l|c|c|c|}
\cline { 3 - 4 } \multicolumn{1}{c|}{} & \multicolumn{2}{l|}{ Uso de tecnologías libres } \\
\cline { 2 - 4 } \multicolumn{1}{c|}{} & Nulo & Medio & \multicolumn{2}{c|}{ Alto } \\
\hline Medición de parámetros en línea de producción o laboratorio & $0 \%$ & $0 \%$ & $100 \%$ \\
\hline Prueba de un concepto o de prototipo de un producto & $0 \%$ & $30 \%$ & $70 \%$ \\
\hline Producto en el camino crítico comercial de la empresa & - & - & - \\
\hline
\end{tabular}




\section{Discusión y conclusiones}

Los resultados muestran que el programa de vinculación funciona satisfactoriamente, con una mejora gradual y una media en los indicadores mensuales del vínculo alumno-cliente y alumno-director (figura 2) de alrededor de 4,5 puntos en todos los casos. Para lograr esto fue fundamental establecer un proceso ordenado, implementado con el soporte de herramientas digitales, que gradualmente se adecuó para mejorar el funcionamiento del programa de vinculación. Las herramientas empleadas permiten escalar el proceso a un número muy grande de alumnos sin que esto implique un crecimiento en los recursos necesarios.

En función de lo presentado en "Estadísticas generales de trabajos finales completados y cancelados" es posible determinar que en la mayoría de los casos quién cancela el trabajo final es el cliente y que en todos esos casos la razón principal son los escasos avances. En la figura 3 se observa que prácticamente todos los trabajos finales se completaron antes del año y medio de comenzados. También se puede apreciar que en el caso de que el alumno sea quien cancele el trabajo final esto sucede mucho más rápido que en el caso de ser cancelados por los clientes. Si bien el sistema de seguimiento del vínculo permitió detectar rápidamente problemas en ambos casos, el cliente decidió continuar. Finalmente en la figura 4 se puede apreciar la valoración del programa dónde tanto alumnos como clientes otorgan puntajes altos ya sea que el trabajo final se complete o se cancele. De aquí se desprende que el programa y el acompañamiento que hace el posgrado cumple con las expectativas.

A partir del análisis de los resultados de la sección "Estadísticas de recursos invertidos" se observa que el factor principal que caracteriza a los trabajos finales que se completan adecuadamente es la cantidad de horas que el alumno dedica por semana (figura 5). Incluso se observa que los trabajos finales que se completan le demandan menos horas por semana al cliente (figura 4). En términos de inversión, el monto en general es del orden de unos pocos cientos de dólares para el alumno y el cliente, ya sea que el trabajo final se complete o no (figura 7 y figura 8).

En la tabla 2 se observa que es muy significativo el aporte en I+D (Investigación y Desarrollo) en los trabajos finales completados, y que en alrededor de la mitad de los casos se considera relevante la contribución del posgrado. A su vez se aprecia que casi no hay problemas relativos a la confidencialidad, ni se produjeron como resultado de los trabajos la publicación de artículos científicos o patentes.

En la tabla 3 se observa que no hay problemas relacionados con accidentes de trabajo. Se observa también que uno de cada cuatro alumnos son contratados por el cliente mientras completan su trabajo final en el marco del programa de vinculación. En ningún caso se realizó el pago de una remuneración una vez finalizado el trabajo final. En alrededor de la mitad de los casos el alumno utilizó instrumental de la empresa u organización para hacer su trabajo final.

En la tabla 4 se muestra que casi la totalidad de los alumnos y los clientes consideran que el programa de vinculación podría podría ser aplicable a carreras de grado en ingeniería y a otras carreras de grado no ingenieriles.

En la tabla 5 se observa que la mayoría de los trabajos finales completados en el marco del programa de vinculación corresponde a pruebas de concepto o prototipo 
de un producto, una menor proporción son sistemas para medición de parámetros en línea de producción o en laboratorio y en ninguno de los casos se trata de productos que están en el camino crítico comercial de la empresa.

También se aprecia en la tabla 5 que los sistemas de medición de parámetros se encuentran en uso actualmente, mientras que ninguna de las pruebas de concepto o prototipo llegaron a comercializarse. Esto contrasta con la cantidad de productos que alumnos de los posgrados en el contexto de su empleo desarrollan como trabajo final y que sí llegan a comercializarse (Tesis del Laboratorio de Sistemas Embebidos, 2021).

Se considera que la dificultad para comercializar los sistemas desarrollados en el marco del programa de vinculación se debe esencialmente a dos factores: (1) los productos que tienen posibilidades de ser comercializados en general están sujetos a ventanas de oportunidad muy acotadas, por lo que no se desarrollan en el marco del programa de vinculación, (2) el recorrido para pasar de un prototipo a un producto comercial es muy extenso e involucra una diversidad de saberes, tal que hacen que se requiera de un importante esfuerzo adicional para alcanzar la comercialización.

En la tabla 6 se puede apreciar que el amplio uso de tecnologías libres en los trabajos finales completados. Dado que en el posgrado no existe ninguna pauta al respecto, se concluye que los clientes y alumnos encuentran beneficioso el uso de tecnologías libres y por eso las utilizan en los trabajos finales.

A futuro podría considerarse fomentar estímulos desde las empresas tal que los alumnos puedan abordar como trabajo final proyectos que estén en el camino comercial crítico de las empresas y que por lo tanto requieren ser finalizados en un menor plazo.

\section{Referencias}

Lutenberg, A. (2020). An Approach to the Future of Work: Academia and Industry Alliance to Integrate Work and Study. 2020 IEEE International Conference On Industrial Technology (ICIT). Recuperado de https://doi.org/10.1109/icit45562.2020.9067251

Guido, L., y Versino, M. (2016). Despliegue territorial de un desarrollo de hardware "libre" aplicado a la industria: el caso de la Computadora Industrial Abierta Argentina (CIAA). Revista Horizontes Sociológicos (Asociación Argentina de Sociología), volumen 4, pp. 107-122.

Malone, T. (2007). The Future of Work: How the New Order of Business Will Shape Your Organization, Your Management Style and Your Life. Harvard Business School Press.

The future of work in America. McKinsey Global Institute. Recuperado el 22 de septiembre de 2021 de https://www.mckinsey.com/ /media/McKinsey/Featured\%20 Insights/Future\%20of\%200rganizations/The\%20future\%20of\%20work\%20in\%20 America\%20People\%20and\%20places\%20today\%20and\%20tomorrow/MGl-TheFuture-of-Work-in-America-Exec-summary-July-2019.ashx 
BMW Group Careers. Students and Graduates - Entry-Level and Support Programme. BMW Group Careers. Recuperado el 22 de septiembre de 2021 de https://www. bmwgroup.jobs/de/en/students/entry-programmes.html.

didas Careers - Through sport, we have the power to change lives. Adidas Careers. Recuperado el 22 de septiembre de 2021, de https://careers.adidas-group.com/ teams/students/internships-students

Maestría en Sistemas Embebidos. FIUBA. Recuperado el 22 de septiembre de 2021 de http://laboratorios.fi.uba.ar/Ise/maestria.html.

Salinas, J. y Márquez, M. E. (2013). Proyecto de cooperación al desarrollo para la inclusión digital. REVINDIPA Red de Vinculación Digital de la Patagonia Austral. Palma de Mallorca: Punto Didot.

Bergmann, J. y Grané M. (2013). La universidad en la nube. A universidade na nuvem. Barcelona: LMI. Colección Transmedia XXI. Laboratori de Mitjans Interactius. Universitat de Barcelona. Barcelona.

Cabero, J. (2007). Nuevas Tecnologías Aplicadas a la Educación. McGrawHill, Madrid.

Formularios de Google: crea y analiza encuestas de forma gratuita. Google.com. (2021). Recuperado el 22 de septiembre de 2021 de https://www.google.com/intl/ es-419_ar/forms/about.

Google Sheets: Free Online Spreadsheets for Personal Use. Google.com. (2021). Recuperado el 22 de septiembre de 2021 de https://www.google.com/sheets/about.

Google APIs Explorer and Google Developers. Google Developers. (2021). Recuperado el 22 de septiembre de 2021, de https://developers.google.com/apis-explorer.

Tesis del Laboratorio de Sistemas Embebidos. FIUBA. Recuperado el 22 de septiembre de 2021 de http://laboratorios.fi.uba.ar/Ise/tesis.html. 


\section{Reconceptualizaciones y Giros en la Formación Docente Universitaria en Tiempos de Pandemia: Innovaciones y Nuevos Horizontes}

\section{Capelari, Mirian}

Facultad Regional Buenos Aires-Universidad Tecnológica Nacional mcapelari@frba.utn.edu.ar

\section{Ayuso, María Luz}

Facultad Regional Buenos Aires-Universidad Tecnológica Nacional luzayuso@frba.utn.edu.ar

\section{Ingrassia, Clara}

Facultad Regional Buenos Aires-Universidad Tecnológica Nacional cingrassia@frba.utn.edu.ar

\section{Rodríguez, Dario}

Facultad Regional Buenos Aires-Universidad Tecnológica Nacional drodriguez77@frba.utn.edu.ar

\section{Ragone, María Florencia}

Facultad Regional Buenos Aires-Universidad Tecnológica Nacional fragone@frba.utn.edu.ar 


\title{
RECONCEPTUALIZACIONES Y GIROS EN LA FORMACIÓN DOCENTE UNIVERSITARIA EN TIEMPOS DE PANDEMIA: INNOVACIONES $Y$ NUEVOS HORIZONTES
}

\author{
Capelari, Mirian \\ Ayuso, María Luz \\ Ingrassia, Clara \\ Rodríguez, Dario \\ Ragone, María Florencia
}

\section{Resumen}

En este trabajo se presenta el enfoque de la formación docente en la Facultad Regional Buenos Aires de la Universidad Tecnológica Nacional, y las características innovadoras que lo definen. Se analizan las transformaciones recientes generadas en el devenir institucional y las reconceptualizaciones y giros que se producen en el marco de la enseñanza virtual masiva, inesperada y obligada que impuso el aislamiento social ocasionado por el COVID, con efectos significativos en la formación y en las prácticas docentes. Se narra de modo sintético la estructura del programa de formación, sus ejes, dimensiones y principales resultados alcanzados a partir de la experiencia desarrollada. En el marco del programa, se presenta como un logro fundamental la conformación del "Aula de Comunidad de Práctica en Entornos Virtuales de Aprendizaje", que se configura como espacio colaborativo y autogestionado y como parte central y articuladora de las capacitaciones ofrecidas. Asimismo, se anticipan algunos resultados en relación con las innovaciones generadas, incluyendo la voz de los/as docentes. Se construyen nuevos significados sobre las prácticas educativas a partir de las articulaciones generadas entre la tecnología y la enseñanza, y entre la virtualidad y la presencialidad.

\section{Palabras clave}

Educación superior, pandemia, formación docente, comunidades de práctica, innovación. 


\section{Introducción}

La formación pedagógica y didáctica de la docencia es una dimensión valiosa y prioritaria en las políticas académicas de la Facultad Regional Buenos Aires (FRBA) de la Universidad Tecnológica Nacional. En el año 2018 se creó el Programa Integral de Formación Docente en el ámbito de la Secretaría Académica, a fin de dar continuidad a acciones de capacitación existentes, y de ampliarlas y sistematizarlas desde una perspectiva integral concebida en términos de trayectorias formativas diversas y articuladas entre sí.

A partir de marzo de 2020, y dada la situación sanitaria mundial producto de la pandemia que obligó a las universidades a desarrollar sus clases a través de la virtualidad, el Programa enfrentó enormes desafíos que implicaron nuevas configuraciones y efectos. En este trabajo se aborda el enfoque de la formación docente en la FRBA y las características innovadoras que lo definen. También se analizan las transformaciones recientes generadas en el devenir institucional en sus distintas etapas y los giros que se producen, con efectos valiosos en la formación y en las prácticas docentes. En particular, se presenta el enfoque teórico y la caracterización de una innovación que se considera central: el "Aula de Comunidad de Práctica en Entornos Virtuales de Aprendizaje", que se configura como espacio colaborativo y autogestionado y es parte nodal y articuladora de los espacios formativos ofrecidos. Se anticipan también los resultados recientes, incluyendo las voces de los/as docentes sobre las experiencias transitadas en esta modalidad de formación y los nuevos horizontes que se vislumbran. Las propuestas de modalidades híbridas o mixtas en la formación que surgen a partir de las trayectorias docentes traccionan a replantear el sentido de la educación e imprimen nuevas direcciones a la formación.

\section{Descripción de la Experiencia}

\section{El enfoque del Programa Integral de Formación Docente}

El Programa Integral de Formación Docente adquiere sentido en el marco de un proyecto académico más amplio. Se considera central el anclaje de la formación en una perspectiva ética, social y pedagógica, sustentada en políticas y pedagogías inclusivas como parte fundamental del conjunto de las políticas académicas.

Este Programa establece como punto de partida el valioso conjunto de saberes previos que poseen las y los docentes, para a partir de allí, problematizarlos, desnaturalizarlos y deconstruirlos, con el fin de ampliar, potenciar y diversificar las prácticas de enseñanza. El desafío de trabajar alrededor de la formación didáctica es central en una Facultad de Ingeniería cuyos docentes presentan una formación disciplinar sistemática y muy sólida que no siempre fue acompañada por preguntas del orden didáctico. La perspectiva integral sobre la formación contempla trayectorias formativas diversas, a través de espacios graduales y secuenciales que atiendan las necesidades y recorridos previos de cada uno de los actores involucrados. Se busca contribuir a la construcción de buenas prácticas de enseñanza, al tiempo que potenciar los aprendizajes de los/as estudiantes sustentados en políticas de inclusión que garantice el derecho a la educación superior para todos y todas. 
03 | Políticas y Gestión de las Tecnologías 
Las innovaciones en la enseñanza son un elemento central en la construcción de buenas prácticas docentes y no pueden pensarse descontextualizadas de quienes las construyen en los encuentros en el aula, en la materialidad que sustenta las clases, en el marco de una identidad institucional, en tiempos y espacios determinados que las potencian u obstaculizan. Por este motivo, el Programa incluye el "Observatorio de prácticas de enseñanza en la FRBA para su difusión y socialización en nuevas propuestas de formación", desarrolladas por los/as docentes en la enseñanza y la investigación. Recuperar las prácticas, valorarlas institucionalmente y difundirlas, refuerza este tipo de experiencias en equipos de trabajo que innovan en sus propuestas didácticas, y estimula al conjunto del profesorado a realizar las propias, desarrollarlas y ponerlas en discusión.

La estructura del Programa de Formación incluye cuatro ejes vertebradores, que se entraman y adquieren una impronta innovadora y de impacto institucional. Estos ejes incluyen: a) la vinculación con políticas académicas y su articulación con el desarrollo del curriculum; b) la concepción de formación en el marco de "trayectorias formativas" que realizan los/as docentes, como caminos que se articulan y complementan en el devenir de sus prácticas; c) la innovación; y d) la expansión de los logros y transformaciones posibilitadas en toda la comunidad académica con acompañamiento institucional de los cambios generados (en programas, proyectos de cátedras, departamentos y carreras). Estos ejes, son el marco desde el cual se piensa la estructura del programa, que incluye un conjunto de seis dimensiones que se imbrican entre sí y son interdependientes, tal como puede verse en la figura 1.

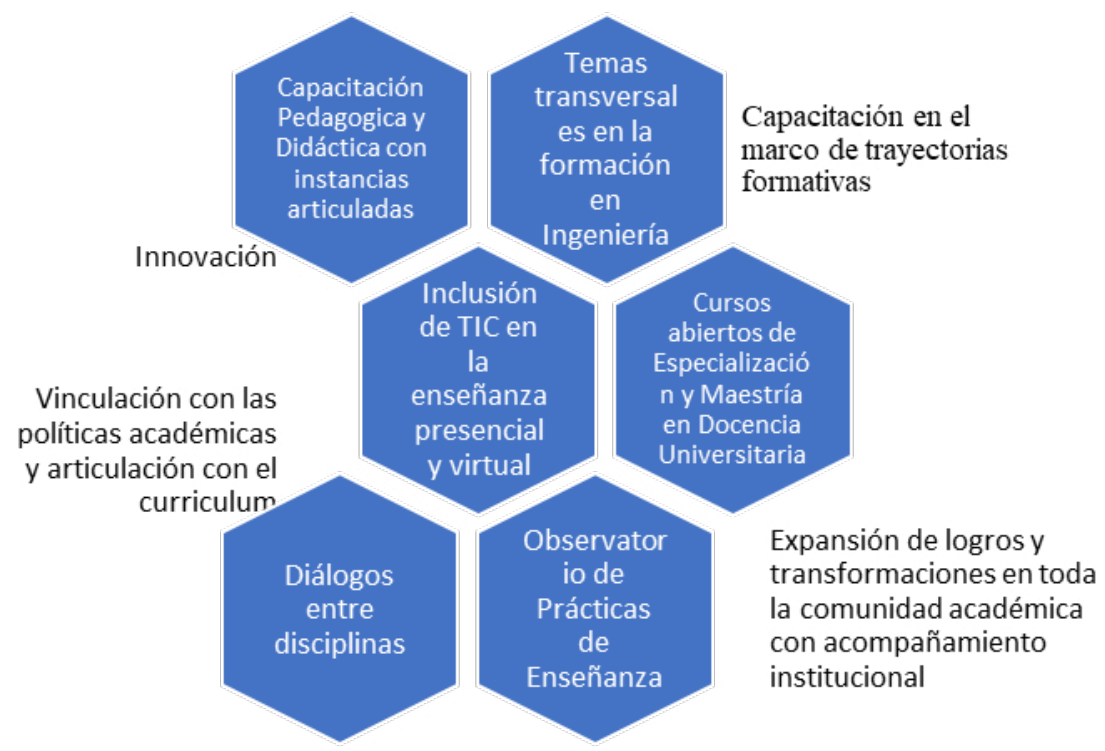

Figura 1: Ejes y dimensiones del Programa Integral de Formación Docente

A partir de marzo de 2020, este Programa se ve interpelado y se reconfigura paulatinamente, atravesando tres etapas fundamentales que se identifican a la actualidad. En sintonía con lo planteado por Maggio (2020) cuando refiere a la transición "de la conmoción a la mutación", podemos identificar una primera etapa de "respuesta a la emergencia". En ella, se abordaron temas urgentes: la rápida creación de aulas virtuales para todos/as, cursos breves de inmersión en la virtualidad, elaboración de 
materiales y estrategias para vincular a estudiantes y docentes al aula. El propósito fundamental fue dar continuidad al vínculo pedagógico. En una segunda etapa, transcurridos los primeros seis meses, se enfatiza en los enfoques didácticos para la enseñanza y evaluación en la virtualidad y sus diferencias con la presencialidad. Estas etapas incluyeron gran cantidad de cursos, micro cursos, tutoriales, webinars, videos, foros e intercambio de experiencias, que permitieron acompañar y sostener la enseñanza y el aprendizaje en la contingencia.

Una cuestión central en este período fue la generación de vínculos de sostén, orientación y ayuda a los/as docentes ante la nueva experiencia transitada. En este marco, se diseñó un espacio colaborativo potente y articulador: "el Aula de Comunidad de Práctica en Entornos Virtuales de Aprendizaje" que abre posibilidades valiosas para el aprendizaje en comunidad. La tercera etapa, situada en la actualidad, se caracteriza por la reconfiguración de los ejes y dimensiones del programa, que recupera nuevas necesidades formación, pero que fundamentalmente acompaña una nueva forma de pensar la formación en ingeniería en la postpandemia y se enlaza a un nuevo proyecto educativo que se está gestando.

En este contexto, la dimensión de "Inclusión de TIC en la enseñanza presencial y a distancia" toma un lugar central y enlaza a las restantes. Virtualidad y presencialidad se acercan y se diluyen sus fronteras en las propuestas formativas. La dimensión del "Observatorio de Prácticas de Enseñanza" también se anuda a esta dimensión, ya que permite visibilizar numerosas experiencias y modalidades de trabajo que se comparten.

\section{Las innovaciones generadas}

\section{El aula "Comunidad de Práctica en Entornos Virtuales de Aprendizaje": un espa- cio para construir conocimientos y aprender colaborativamente}

El Aula de Comunidad de Práctica en Entornos Virtuales de Aprendizaje, es una innovación central en el Programa de Formación Docente, concebida como un espacio compartido entre docentes y el equipo de Educación a Distancia de la Facultad. Comienza a gestarse a partir de marzo de 2020 y se mantiene en crecimiento y expansión permanente, nutriéndose del aporte de la comunidad.

En el marco de la enseñanza virtual masiva y obligatoria, la creación de este espacio se presentó como una oportunidad para: -ofrecer información sobre el uso de los recursos y actividades de Moodle necesarios para dar forma a una propuesta virtual, - llevar adelante un acompañamiento cercano y atento a las preguntas, necesidades y demandas que se les presentaba a los docentes en el contexto de las prácticas virtuales, y fundamentalmente, -compartir experiencias de prácticas docentes en las aulas virtuales. También se pensó en línea a traccionar una apropiación de las nuevas prácticas de enseñanza en la virtualidad impuestas por la situación sanitaria.

Según Maggio (2012) en las prácticas docentes con tecnologías pueden distinguirse dos tipos de usos: inclusión efectiva e inclusión genuina. En el primer caso, el uso de la tecnología está más ligado a la obligación y las tecnologías se integran por razones que no son las de los propios docentes preocupados por mejorar sus prácticas de enseñanza. En el otro tipo, en la inclusión genuina, las tecnologías se integran con sentido didáctico en los proyectos educativos y en las prácticas. Este fue 
uno de los propósitos fundamentales que se promovió desde la creación del Aula. En este sentido, y dado el contexto de no presencialidad en donde los docentes se vieron obligados a usar las tecnologías, se esperaba pasar poco a poco a una inclusión genuina impulsando el trabajo en este espacio de práctica, con la finalidad de vivenciar y experimentar "el hacer con tecnología" y también "el hacer con otros", compartiendo estas experiencias en la comunidad.

Se adhiere en este sentido al enfoque de "comunidad de práctica" de Étienne Wenger (2001) que la define como un grupo social que comparte un interés y que interactúa con el fin de desarrollar conocimientos, compartiendo aprendizajes basados en la reflexión conjunta sobre experiencias prácticas. De este modo, el Aula de Comunidad de Práctica se constituyó como un espacio común, en donde compartir con otros una preocupación y un saber hacer. Es una Comunidad porque al estar convocada por una necesidad, un problema y un interés común, sus integrantes se comprometen a participar en sus actividades, y se involucran para ayudar a sus colegas cada vez que surge una consulta o dificultad. Es también un espacio de Aprendizaje, porque allí se puede desarrollar y compartir un repertorio de recursos, experiencias, prácticas, formas de resolver situaciones nuevas, y aprender de otros y con otros. En el aula están presentes las producciones y aportes de todos/as. Se nuclea el esfuerzo y el trabajo que se comparte, con la finalidad de expandir y enriquecer las prácticas.

Desde una perspectiva sociocultural, el aula recupera, integra y ordena el trabajo comunitario realizado. En términos de Bárbara Rogoff (2003), las personas se desarrollan y aprenden a medida que participan en comunidades. Al involucrarse en actividades socioculturales con otras personas, hacen uso y extienden herramientas y prácticas compartidas y contribuyen a la transformación de prácticas e instituciones. Como señala Maggio (2018), el concepto de inteligencia colectiva y de comunidades de conocimiento, cobra valor en esta propuesta, al movilizar y poner en diálogo competencias y saberes que enriquecen mutuamente a las personas. El aula como espacio colectivo, favorece una colaboración genuina y permite recuperar producciones desarrolladas en los espacios formativos, externalizar y expandir logros y codiseñar propuestas de enseñanza. Las comunidades de práctica pueden ser ámbitos privilegiados para adquirir, compartir y generar nuevos conocimientos (Wenger, 2001).

\section{Caracterización del Aula de Comunidad de Práctica en la actualidad}

En función de los fundamentos previamente desarrollados, el Aula de Comunidad de Práctica, es un espacio que integra el enorme trabajo que se desarrolla en forma conjunta entre los docentes y entre éstos y el equipo de pedagogos/as y especialistas en Educación a Distancia, y se propone a la comunidad educativa como lugar de encuentro, de intercambio y de aprendizaje conjunto. Se encuentra alojada en un aula virtual de la Plataforma Moodle, razón por lo cual se beneficia de las ventajas de este tipo de espacios que permiten la actualización permanente de sus materiales y recursos, la organización de los materiales por tema, el intercambio y la comunicación con colegas, compartir experiencias y conocer el trabajo de los demás.

El Aula contiene una gran variedad de recursos, actividades y tutoriales organizados de tal manera que permiten un recorrido autónomo por parte de cada docente que se complementa con el acompañamiento cercano del equipo de especialistas en 
Educación a Distancia. Se organiza según tres grandes dimensiones: la técnico-pedagógica, la de experiencias e intercambio y la informativa.

En la dimensión técnico- pedagógica se busca ofrecer conocimientos, producción documental y tutoriales relativos al uso de los recursos y actividades del aula. Los/ as docentes pueden acceder a un espacio constantemente actualizado donde esté nucleada toda la orientación, experiencias, materiales y recursos relacionados con el diseño y la gestión de la enseñanza y el aprendizaje virtual a través de las aulas.

En la dimensión de experiencias e intercambio, se propicia el intercambio permanente de los/as docentes con el equipo de Educación a Distancia y de la comunidad docente entre sí, para enriquecer los lazos existentes, crear nuevos, y fomentar el trabajo y el aprendizaje colaborativo. Se incluyen espacios de orientación pedagógica, webinars, relatos de experiencias, actividades y experiencias de ejemplo, reflexiones acerca de las prácticas docentes.

En la dimensión informativa, el Aula funciona a modo de newsletter, con foros de consultas y preguntas frecuentes. Se comunican también las propuestas semanales dedicadas a temas puntuales relativos a la educación en entornos virtuales de aprendizaje.

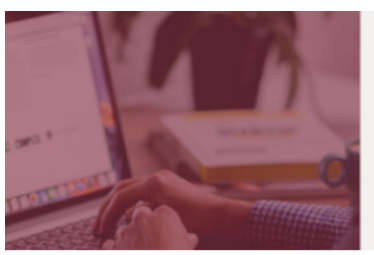

* UTก.BA

COMUNIDAD DE PRÁCTICA EN ENTORNOS VIRTUALES DE APRENDIZAJE Aula virtual autodirigida

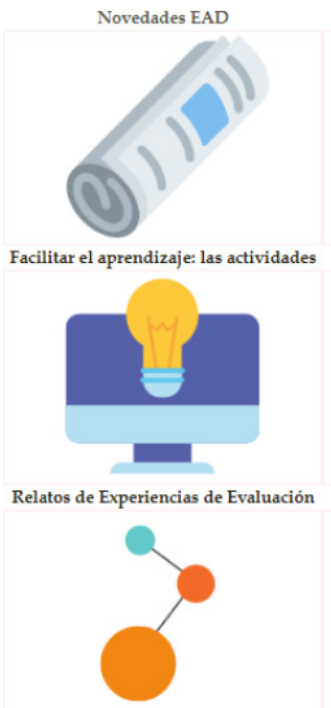

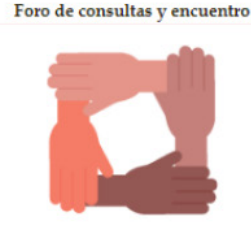

Acompañar y comunicar

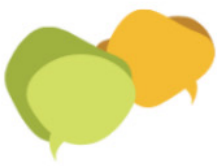

Preguntas frecuentes

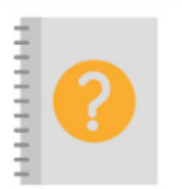

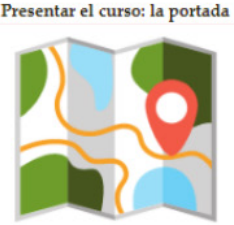

Evaluar el aprendizaje

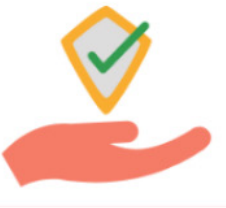

Orientación pedagógica

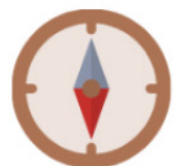

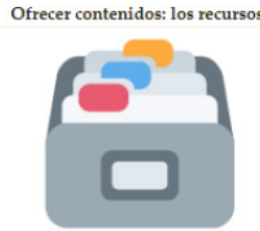

Webinars

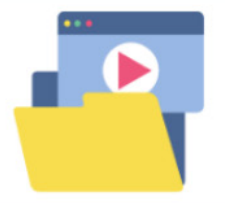

Actividades de ejemplo

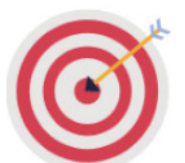

Figura 2: Imagen del Aula de Comunidad de Práctica en Entornos Virtuales de Aprendizaje

La heterogeneidad de la comunidad de prácticas implicó que las secciones del Aula se conciban atendiendo al acompañamiento de docentes en los tres niveles o etapas en los que se puede requerir apoyo, que según plantea Fernández Pampillón (2009) son la tecnológica, didáctica y de innovación y explotación. 
En primer lugar, con respecto a la "etapa tecnológica" inicial en la que los/as docentes aún no cuentan con la destreza necesaria para dominar el entorno a distancia, se ofrecen instructivos y video tutoriales orientadores sobre las funciones y configuraciones de la plataforma virtual, desde lo más básico (edición del perfil, nombres de temas, etiquetas, actividades simples) hasta lo más complejo (actividades complejas como cuestionarios o lección).

Para esta etapa, se generó un recurso dinámico y muy potente: el "Documento de ayuda a docentes", que recopila, organiza y ordena el conjunto de propuestas y respuestas a las consultas realizadas por el profesorado. Se ofrece en el Aula de Comunidad de Práctica para su consulta permanente y permite el acceso de sus contenidos a la toda la comunidad docente de la institución.

En segundo lugar, se busa acompañar a quienes se encuentran en una "etapa didáctica", es decir, acostumbrándose paulatinamente al uso habitual del entorno virtual, pero aun empleando las mismas estrategias que en la presencialidad. Son docentes que pueden ser capaces de generar espacios más ricos, de crear y publicar materiales didácticos, comunicarse con los estudiantes, y realizar un seguimiento personalizado de las actividades de aprendizaje, pero aún necesitan asistencia para diseñar propuestas en educación a distancia, superando el enfoque de la educación presencial de emergencia mediada por tecnologías. Para este grupo de docentes, se incluyen presentaciones interactivas sobre educación a distancia, el rol docente en la virtualidad, usos pedagógicos de los recursos y actividades del campus, y una variedad de estrategias relacionadas con metodologías activas. Como plantea uno de los docentes:

Me gustaría revisar y mejorar la metodología para la segunda instancia de examen parcial. Y espero conseguirlo reformulando la evaluación para el segundo cuatrimestre, en general. Me interesó el recurso de lección. Miré los tutoriales y creo que puedo combinar los materiales en pdf que ofrezco con explicaciones de la teoría, con el desarrollo de ejemplos resueltos o con sugerencias para resolver y añadir un "mini-cuestionario" del tema. Intentaré conocer más sobre estos recursos y ver el alcance que tienen al implementarlos (docente a).

En tercer lugar, en una etapa de innovación y explotación, para quienes ya cuentan con una trayectoria en la gestión de aulas virtuales y propuestas didácticas a distancia, se ofrecen instancias de intercambio para expandir aprendizajes con los demás:

Ante un año tan particular desde un principio pensé en que la clave de este año es no tratar de reproducir clases presenciales y sí pensar en reforzar los puntos fuertes de una cursada "virtual". Lo que me dije fue: "en lugar de tratar de reproducir las cosas buenas que tiene la clase presencial lo mejor va a ser pensar qué cosas buenas tiene la cursada virtual". Analizando que la mayor ventaja es no estar restringido a los horarios fijos de una clase presencial, traté de fortalecer eso en las clases. Por eso opté por clases teóricas en formato asincrónico dándole al alumno la posibilidad de verlas en el momento que fuera más adecuado para ellos.... Además, para incrementar la ventaja de no estar limitado con los tiempos arme grupos de telegram para agilizar las consultas... (docente b). 


\section{Resultados}

En cuanto a resultados cuantitativos alcanzados, pueden señalarse la creación masiva de nuevas aulas virtuales (2300 en 2020) que se acompañó de un alto nivel de involucramiento de los/as docentes en diversos espacios formativos. Se ofrecieron 18 encuentros de formación, con una participación significativa, que implicó la inscripción del $45 \%$ del total de docentes de la Facultad durante el año 2020. En dicho año, se registraron 1345 inscripciones que incluyeron a 547 docentes que participaron de más de una instancia de capacitación. Con relación a aspectos cualitativos, se evidenció la construcción de nuevos significados sobre las propias prácticas a partir de las articulaciones generadas entre la tecnología y la enseñanza, y entre la virtualidad y la presencialidad. Se descubren nuevas experiencias posibles, tales como las clases en espejo, profesores invitados de otras universidades, trabajos interdisciplinares, colaboración inter- cátedras. Se desarrollaron novedosos materiales y herramientas tecnológicas que se incorporaron a la enseñanza.

Un aspecto crucial para señalar en relación con los efectos o impactos, concebidos como "Ios cambios significativos y duraderos operados en la docencia a partir de las capacitaciones", ha sido la fuerte incidencia del contexto de pandemia. El mismo ha traccionado de modo obligado a participar en capacitaciones, para responder al problema de "como generar vínculos pedagógicos y sostener los procesos de enseñanza y aprendizaje ante la suspensión de la presencialidad". Se impusieron nuevas modalidades de intervención mediadas por tecnología, que llevaron incluir a la totalidad de docentes en procesos formativos, impensados en etapas anteriores a la pandemia. Los cambios operados en las distintas etapas que se mencionaron precedentemente, de la conmoción a la mutación, se perciben en las reflexiones y prácticas generadas. Siguiendo a Vaillant (2017), se considera que las comunidades de aprendizaje para la formación docente se sustentan en un trabajo comunitario y colaborativo para la mejora de la enseñanza y para el progreso del aprendizaje de sus alumnos. Este abordaje comunitario al que adhiere el Programa de Formación Docente, se ha visto direccionado por un problema común que se presentó masiva e intempestivamente a la formación universitaria y ha permitido enlazar estas necesidades con formatos que contribuye a un aprendizaje situado y colaborativo, a una interpretación colectiva de preocupaciones que surgen ante la imposición inicial de la formación virtual, a fin de encontrar prácticas valiosas y significativas que encuadren el vínculo pedagógico que comienza a mediatizarse con tecnologías.

En un relevamiento realizado para conocer la opinión y valoración de los/as docentes sobre distintos temas asociados a la experiencia de enseñar en la virtualidad, se obtuvieron respuestas valiosas acerca de las prácticas desarrolladas, su apropiación y su relación con los procesos de capacitación. En particular, rescatamos sintéticamente tres cuestiones señaladas por los docentes como efectos de sus nuevas prácticas durante el 2020:

- Las innovaciones generadas en las aulas. Entre las más importantes señalan: a) elaboración de materiales didácticos; b) descubrimiento de novedosas y valiosas actividades de aprendizaje; c) nuevas modalidades de comunicación con los estudiantes; d) elaboración de los instrumentos de evaluación virtual; e) producción de videos; y f) trabajo colaborativo con otros docentes. 
- La importancia de dar continuidad a la enseñanza virtual en el retorno a la presencialidad. Más del $90 \%$ de los docentes que responden un cuestionario indican que les gustaría seguir implementando estrategias en modalidad virtual al retornar a las actividades de enseñanza presenciales.

- Transformaciones que generó y puede generar la virtualidad en las formas de enseñar y aprender. Recuperando la voz de los/as docentes sobre este tema, señalan que:

- Esta situación de aislamiento ha reflejado un perfil muy interesante con respecto a la digitalización del aprendizaje y dejó de manifiesto que muchas prácticas clásicas son más eficientes desarrollarlas a través de estos medios. Pero también reafirma que hay otras que no pueden ser reemplazadas como son las prácticas en laboratorio. Considero que esto debe ser tomado una bisagra que cambiado totalmente la visión de la Universidad y replantear la metodología de enseñanza, transmisión de conocimientos y reglamentos (docente c).

- Fue muy valioso trabajar de manera colaborativa con otros colegas (docente d).

- Creo que es muy positivo para los alumnos tener a disposición el material teórico y práctico en el aula virtual y la posibilidad de evaluaciones previas a los parciales para mantener el ritmo de estudio (docente e).

- He observado mayor aprovechamiento de la totalidad del tiempo de clases, por parte de los alumnos, comparado con las clases presenciales. Así como también, las consultas, por fuera de las clases, se vieron incrementadas (docente $f$ ).

Algunos/as docentes destacan la posibilidad de favorecer a ciertos grupos de estudiantes, tales como los que viven en zonas alejadas o trabajan y que deben destinar 2 o 3 horas diarias para el traslado a la facultad; quienes no se encuentran en el país o por razones laborales no pueden asistir a tiempo a las clases:

- La modalidad virtual- presencial mixta permitiría abrir los cursos a estudiantes de zonas más alejadas, incluso zonas del conurbano que de noche son complicadas por la seguridad para el regreso de los alumnos (docente g).

- Oportunidad para mejorar las prácticas docentes, y abrir oportunidades a actividades interdisciplinarias:

Creo que la virtualidad está abriendo una oportunidad para actividades o videos interdisciplinarios, talleres que puedan relacionar las materias y desarrollar competencias. O dejar breves videos con resúmenes de las materias a modo de repasos disponibles para futuras consultas (docente $h$ ).

Como plantea Eirín Nemiña (2018), la formación desde la perspectiva de las comunidades de aprendizaje implica tener en cuenta y partir de lo que traen los profesores: su contexto, voces y relatos. Son el bagaje desde el cual se construye y configuran los aprendizajes posteriores. El aprendizaje se concibe además como un proceso activo, donde es clave proporcionar diseñar y compartir experiencias significativas. La construcción de conocimientos se piensa también como una construcción de vínculos interprofesionales, una comprensión colectiva de los problemas a abordar $\mathrm{y}$ de estrategias para hacerlo. 


\section{Miradas compartidas a futuro: la continuidad de la enseñanza virtual en el retorno a la presencialidad}

Una cuestión central para señalar como producto de las experiencias y capacitaciones docentes es que en las sugerencias y propuestas que realizan en la encuesta de referencia, proponen implementar modalidades virtuales de distinta índole, de tipo mixto o híbrido o bien de modo complementario a la presencialidad. En este marco, más del $90 \%$ de los docentes indican que les gustaría seguir implementando estrategias en modalidad virtual al retornar a las actividades de enseñanza presenciales.

En cuanto a la modalidad en que piensan la continuidad de experiencias virtuales en sus asignaturas, de los 438 docentes que responden, el 69,2\% manifiesta que debería ser en un formato mixto, combinando cargas horarias presenciales y virtuales; el 24,2\% considera que debería ser de modo complementario, y debería tenerse la misma carga horaria presencial que antes, y un 6,6\% plantea que podría ser totalmente virtual. También plantean condiciones, criterios y reflexiones sobre estas nuevas formas de enseñar y aprender. A modo de ejemplo, se transcriben algunas opiniones en esta línea:

- Sin duda es un cambio que llegó para quedarse. Debemos aprender a utilizarlo como una herramienta sin abusar y que termine siendo una comodidad. Creo que el uso mixto, debe ser precedido por una correcta definición de los objetivos a alcanzar en la materia (docente i).

- Somos humanos, necesitamos empatizar y eso es muy trabajoso y difícil de lograr en la virtualidad. Un sistema mixto podría reunir lo mejor de ambas modalidades (docente $j$ )

- Considero que sería excelente que para las carreras con gran volumen de inscriptos (como sistemas o industrial), se pueda tener una alternativa de cursar la carrera de forma virtual ... aunque fuera sólo un horario, creo que sería de mucha ayuda para la gente que trabaja e incluso, para los alumnos que sean del interior de la provincia... (docente $k$ ).

- La virtualidad suma mucho valor a la enseñanza, deberíamos migrar a un sistema mixto, donde el dictado presencial se deja para instancias que realmente lo ameriten (docente I).

- Con buena conexión y un ambiente en el que el docente se pueda concentrar me parece interesante la implementación de las clases virtuales y que las asignaturas puedan ser semipresenciales. En este último caso se necesita que el docente tenga todas las herramientas tecnológicas pertinentes a su alcance y un espacio tranquilo... (docente $m$ ).

Creo que hay que aprovechar la educación virtual para fortalecer espacios de enseñanza/aprendizaje (docente $n$ ). 


\section{Discusión y conclusiones}

En este trabajo se han presentado los fundamentos del Programa Integral de Formación Docente, y se abordaron de modo sintético las principales innovaciones y transformaciones generadas, así como los resultados más significativos, incluyendo la perspectiva de los/as docentes. En palabras de Carina Lion (2020) se considera que se han posibilitado "tiempos de creación didáctica" luego de la emergencia y las acciones de mitigación iniciales. A la vez, se identifica la necesidad de mirar el horizonte próximo y advertir los nuevos problemas y retos que se presentan. El desafío mayor, consiste tal vez en consolidar políticas y prácticas institucionales que permitan dar continuidad a la renovación y resignificación de la formación docente para seguir impactando en las prácticas.

En los resultados y efectos generados, confluyen un programa de formación integral con distintos ejes de abordaje que se entraman entre sí, y que se desarrolla como respuesta y en interacción con un contexto que direccionó obligadamente nuevas prácticas atravesadas por la virtualidad. El mismo programa de formación se ve interpelado por este contexto, y evidencia giros y reconfiguraciones rápidas y significativas, como es el caso del desarrollo del Aula de Comunidad de Práctica. Este logro crucial, se define como un valioso espacio colaborativo de construcción conjunta que favorece la conformación de redes, grupos, espacios de trabajo, con interacciones diversas, y que incluyen distintos actores, disciplinas, problemáticas y áreas de intervención. Se advierte la conformación de una verdadera comunidad de aprendizaje en tanto se posibilita la participación y el aprendizaje a través de prácticas conjuntas. Las posibilidades identificadas fueron posibles en el marco de una propuesta integradora en los distintos cursos ofrecidos, que busca acompañar, enlazar y poner en diálogo preocupaciones y problemas para ser abordados colectivamente. El gran desafío hoy es sostener, acompañar y hacer crecer esta comunidad en contextos cambiantes, de transición hacia nuevas formas de enseñar y aprender. La incorporación de propuestas educativas vinculadas a la modalidades híbridas o mixtas en la formación que surgen a partir de las voces de distintos actores institucionales tracciona el replanteo del sentido de la educación e interpela la formación, direccionando a pensar en nuevos trayectos, propuestas y modalidades de acompañamiento.

\section{Referencias}

Eirín Nemiña, R. (2018) Las comunidades de aprendizaje como estrategia de desarrollo profesional de docentes de Educación física. Estudios Pedagógicos, 44 (1), 259-278. https://www.scielo.cl/scielo.php?script=sci_arttext\&pid=S0718-7052018000100259

Fernández-Pampillón Cesteros, A. (2009). "Las plataformas e-learning para la enseñanza y el aprendizaje universitario en Internet” en Las plataformas de aprendizaje. Del mito a la realidad. Biblioteca Nueva. Madrid.

Lion, C. (2020). Enseñar y aprender en tiempos de pandemia: presente y horizontes. Saberes y prácticas. Revista de Filosofía y Educación, Vol. 5 (1). Recuperado de: https://revistas.uncu.edu.ar/ojs3/index.php/saberesypracticas/article/view/3675 
Maggio, M. (2020). Las prácticas de la enseñanza universitarias en la pandemia: de la conmoción a la mutación. Campus Virtuales, 9(2), 113-122. Recuperado de: Campus Virtuales (uajournals.com)

Maggio, M. (2018). Habilidades del siglo XXI cuando el futuro es hoy. Documento básico. XIII Foro Latinoamericano de Educación. Ciudad Autónoma de Buenos Aires: Santillana.

Maggio, M. (2012). Enriquecer la enseñanza. Los ambientes con alta disposición tecnológica como oportunidad. Buenos Aires: Paidós.

Rogoff, B. (2003). The Cultural Nature of Human Development. Oxford: University Press.

Vaillant, D. (2017) Directivos y comunidades de aprendizaje docente: un campo en construcción. Mejoramiento y Liderazgo en la Escuela. Once miradas, 263-294

Wenger, E. (2001) Comunidades de práctica Aprendizaje, significado e identidad. Barcelona: Paidós. 


\section{Análisis Exploratorio de una Escala de uso Académico de Tecnologías Digitales Para la Formación Inicial Docente}

\section{Cerda, Cristian}

orcid.org/0000-0003-0818-218X

cristian.cerda@ufrontera.cl

\section{León, Miriam}

orcid.org/0000-0001-6004-8485

miriam.leon@ufrontera.cl 


\title{
ANÁLISIS EXPLORATORIO DE UNA ESCALA DE USO ACADÉMICO DE TECNOLOGÍAS DIGITALES PARA LA FORMACIÓN INICIAL DOCENTE
}

\author{
Cerda, Cristian \\ León, Miriam
}

\section{Resumen}

El uso académico de tecnologías digitales es esencial para la formación y futuro de los estudiantes de pedagogía. Existen diversas investigaciones que se focalizan en la medición de competencias digitales, sin embargo, no existe un instrumento que mida específicamente el uso académico de tecnologías digitales que realizan los futuros profesores basado en el Marco Europeo de Competencias Digitales para la Ciudadanía (DigComp). Considerando estos antecedentes, este estudio tuvo como objetivo analizar de manera exploratoria las propiedades psicométricas de una Escala de Uso Académico de Tecnologías Digitales (EUATD) en estudiantes de pedagogía chilenos. Se analizó evidencias de validez de la estructura interna, mediante Análisis Factorial Exploratorio $(n=314)$, y consistencia interna de la escala, a través de la determinación del coeficiente alfa de Cronbach. El análisis factorial reveló que el uso académico de tecnologías digitales adquiere una configuración de cinco factores, que explica un $81 \%$ de la varianza. Además, se observó una buena consistencia interna $(\alpha=.93)$. Este estudio permitió analizar de manera exploratoria las propiedades psicométricas de la escala, obteniéndose una estructura acorde a lo planteado teórica y empíricamente. Se espera, a futuro, seguir obteniendo evidencias de la confiabilidad de este instrumento, así como la validez de su estructura, usando la técnica de Análisis Factorial Confirmatorio con métodos robustos. Contar con un instrumento que mida adecuadamente el uso académico de las tecnologías digitales, permitirá conocer el nivel de desarrollo de dicha variable, facilitando la elaboración de intervenciones que potencien las fortalezas y subsanen las debilidades que podrían observarse en este ámbito.

\section{Palabras clave}

Competencia digital, Uso académico, Estudiantes de pedagogía, Uso de Internet, Chile. 


\section{Introducción}

El Marco Europeo de Competencias Digitales para la Ciudadanía (DigComp) presenta habilidades que se consideran necesarias para desenvolverse en entornos digitales (Ferrari, 2013). En dicho documento se entregan orientaciones respecto a los conocimientos, habilidades y actitudes para utilizar tecnologías digitales en cinco áreas de competencias: (i) Información; (ii) Comunicación; (iii) Creación de contenido; (iv) Seguridad; y (v) Resolución de problemas (Ferrari, 2013). Además, se establecen niveles de desempeños básico, intermedio y avanzado (Carretero et al., 2017). Pese a que el DigComp está enfocado en ciudadanos, su uso también podría servir para analizar el desarrollo de competencias digitales en futuros docentes.

El nivel de competencia digital de los profesores puede verse reflejado en el uso académico que realizan de las tecnologías digitales (Gudmundsdottir \& Hatlevik, 2017; Redecker \& Punie, 2017). Este nivel fue clasificado como básico, de acuerdo a un análisis realizado en una revisión sistemática de los años 2015 a 2021 (Zhao et al., 2021). Por lo que se infiere que, si el uso académico de las tecnologías digitales es inferior en docentes, también debería serlo en estudiantes de pedagogía. En el caso de esta población, se considera que el uso de tecnologías digitales con fines académicos involucra principalmente: (i) Buscar información; (ii) Comunicarse; y (iii) Crear material digital (Cerda et al., 2018). Dado el rol modelador de los profesores y la alta penetración de tecnologías digitales en la población nacional es altamente relevante abordar esta temática.

En Chile, ya existe un avance en analizar cuáles son los propósitos de uso de tecnologías digitales en el contexto de formación inicial docente. Cerda et al. (2017) analizaron la relación entre uso académico y recreativo de tecnologías digitales y logro académico. En otra investigación se describe el acceso, tiempo y propósito de uso (académico, recreativo y social) que realizan los docentes en formación con las tecnologías digitales (Cerda et al., 2018). De manera complementaria, desde una óptica cualitativa, se generó un modelo teórico que permite comprender cómo se desarrolla el proceso de aprendizaje autodirigido del saber pedagógico en estudiantes de pedagogía chilenos, cuando utilizan tecnologías digitales con fines académicos (Cerda \& Saiz, 2018). El desarrollo de esta línea de investigación ha permitido seguir indagando en la comprensión del uso de tecnologías digitales con fines académicos en esta población, dada la pertinencia de la temática.

Considerando los antecedentes mencionados, se hace necesario seguir aumentando tanto, las investigaciones en el uso académico de tecnologías digitales en formación inicial docente (Novoa-Echaurren \& Canales-Tapia, 2018), como la medición de dicha competencia. Si bien existen diversos instrumentos orientados a medir competencias digitales en estudiantes universitarios (Wild \& Schulze Heuling, 2021), al igual que instrumentos para medir competencias digitales en docentes en formación (Cabero-Almenara et al., 2020; Flores-Lueg \& Roig, 2016a; Usart et al., 2021), ninguno de ellos considera la medición del uso académico de tecnologías digitales en formación inicial docente basado en DigComp. Dado este vacío, es necesario realizar investigaciones que contribuyan a subsanar esta problemática, aportando a la comprensión de este fenómeno desde la medición de competencias digitales genéricas, pero contextualizadas al ámbito académico. 
Esta investigación tuvo como objetivo analizar de manera exploratoria las propiedades psicométricas de una escala para medir uso académico de tecnologías digitales en estudiantes de pedagogía. En particular, se buscó analizar la estructura factorial de las dimensiones del instrumento y la confiabilidad de cada uno de los factores de la escala. Con el logro de estos objetivos, se espera contribuir a las investigaciones enfocadas en formación inicial docente y el uso de tecnologías digitales, al analizar inicialmente un instrumento que puede seguir perfeccionándose y que aporte a esta temática.

Se considera muy relevante, para esta área de estudio, disponer de una escala que mida uso académico de tecnologías digitales en docentes en formación. Si bien existen otros instrumentos (Flores-Lueg \& Roig, 2016a ; Silva et al., 2019a), contar con una escala con propiedades psicométricas adecuadas permitirá a los investigadores medir de una manera confiable y válida el uso académico de tecnologías digitales de los estudiantes. Con ello se podrá describir este uso, utilizar dicho instrumento en futuras investigaciones donde se establezcan relaciones con otras variables y evaluar en diferentes períodos de tiempo los avances en este tema. Además, se podrá obtener información que puede ser utilizada por los formadores de educadores para así realizar acciones que promuevan la competencia digital. El uso académico de tecnologías digitales no sólo permitirá un uso más efectivo durante la formación inicial docente, sino que también sentará bases para el futuro ejercicio profesional de los educadores.

\section{Método}

\section{Participantes}

En este estudio, participaron 314 estudiantes de pedagogía de dos universidades del sur de Chile. Su edad promedio fue de 21.42 años ( $D E=2.96$ ), donde, 62.7\% (197) eran mujeres y $37.3 \%$ (117) hombres. En cuanto al curso, los participantes se distribuyeron entre: 75 (23.9\%) de primer año; 46 (14.6\%) de segundo; 41(13.1\%) de tercero; 81 (25.8\%) de cuarto; 47 (15\%) de quinto; y 24 rezagados (7.6\%). La selección de los participantes fue realizada mediante muestreo no probabilístico por conveniencia.

\section{Instrumento}

El instrumento utilizado en este estudio, Escala de Uso Académico de Tecnologías Digitales (EUATD), fue elaborado por el equipo de investigación. Para su construcción se consideraron criterios teóricos y empíricos (Streiner, 2008). Teóricamente, el instrumento está basado en algunas categorías del DigComp (Ferrari, 2013; Vuorikari et al., 2016) que pudieran ser medidas considerando un uso académico de las mismas. Empíricamente, se realizó un análisis previo de las variables a medir, a través de registros de acciones diarias desarrolladas por nueve estudiantes de pedagogía en el periodo de quince días. Esto permitió identificar las sub-competencias a medir. Del análisis de este estudio exploratorio y de las consideraciones teóricas, se creó un instrumento con 21 ítems.

Los ítems del instrumento fueron agrupados en categorías coherentes con DigComp. De esta forma, la subcompetencia información y alfabetización informacional, fue medida a través de seis ítems, de los cuales tres estaban relacionados con navegar 
y buscar datos, información y contenido digital y tres enfocados en gestionar datos, información y contenido digital. La medición de la subcompetencia comunicación y colaboración, fue medida a través de diez ítems, siete asociados a interactuar a través de tecnologías digitales y tres en compartir a través de tecnologías digitales. Finalmente, la subcompetencia creación de contenido digital, fue medida a través de cuatro ítems.

Los ítems fueron medidos en términos de frecuencia de uso, usando una escala de 1 a 5. Donde 1 correspondía a Nunca o casi nunca; 2 = A veces; 3 = Término medio; 4 = Muchas veces; y 5 = Siempre o casi siempre. Todos los ítems de este instrumento fueron presentados de manera positiva y agrupados de forma temática. Por tanto, mayores promedios de puntajes en la escala, representan mayores puntajes de percepción de frecuencia de uso académico de tecnologías digitales por parte de los estudiantes de pedagogía.

\section{Procedimiento}

Para el levantamiento de información, y dado el contexto COVID19 existente al momento de la medición, se creó una base de datos con los correos electrónicos de los estudiantes, a los cuales se les envió una invitación explicando los objetivos del estudio, la importancia de su participación y un enlace al cuestionario disponible en la plataforma QuestionPro. Antes de contestar el instrumento, los participantes tuvieron la posibilidad de leer virtualmente un consentimiento informado, el cual fue aprobado por el Comité Ético Científico de la universidad. Esto les permitió a los participantes conocer los objetivos de la investigación, la confidencialidad y privacidad de la información solicitada, junto con la voluntariedad de participar en el estudio. Para el desarrollo de la medición, se enviaron siete recordatorios con un intervalo de tiempo de una semana. A medida que los estudiantes indicaban su voluntad de participar o no en la investigación, QuestionPro los iba excluyendo de los recordatorios. Adicionalmente, los académicos de las asignaturas de educación reforzaron la invitación a participar.

Los datos obtenidos fueron descargados de la plataforma QuestionPro. Previo a su exportación a los programas estadísticos utilizados, se efectuaron acciones de depuración y control de calidad de los datos, conforme a lo recomendado por Muñiz y Fonseca-Pedrero (2008). De esta forma, se pudo tener una base de datos que permitiera realizar los análisis estadísticos correspondientes.

\section{Análisis de datos}

Se analizó la evidencia de validez de la estructura interna, mediante Análisis Factorial Exploratorio. Para ello, se utilizó el programa FACTOR (Lorenzo-Seva \& Ferrando, 2006), considerándose la implementación óptima del análisis paralelo para identificar el número de factores a extraer (Timmerman \& Lorenzo-Seva, 2011). Además, se utilizó la extracción de factores mediante análisis factorial de rango mínimo (MRFA en su sigla en inglés) (Shapiro \& Berge, 2002), y el uso de rotación oblicua Promin (Lorenzo-Seva, 1999). En los casos en que el método de extracción (MRFA) no convergió, se utilizó el método de mínimos cuadrados no ponderados (ULS en su sigla en inglés). 
Atendiendo a la ordinalidad de los datos, se analizó la matriz de correlaciones policórica para valores ordinales, como lo recomiendan Flora y Curran (2004). El ajuste del modelo factorial emergente fue inspeccionado a través del índice de la raíz cuadrada, mediante la observación de los residuales (RMSR en su sigla en inglés). El criterio utilizado para la retención de ítems consideró cargas factoriales iguales o superiores a .30. La consistencia interna fue examinada mediante el coeficiente alfa de Cronbach estandarizado reportado por el programa FACTOR.

\section{Resultados}

Con el objetivo de analizar la estructura factorial de la Escala de Uso Académico de Tecnologías Digitales (EUATD) se utilizó la técnica de Análisis Factorial Exploratorio (AFE). Se comenzó verificando la prueba de esfericidad de Bartlett $\left(x^{2}(136)=4064.2 p<.001\right)$ y la prueba de adecuación muestral de Kaiser-Meyer-Olkin (.90). El análisis de ambas respaldó la idoneidad de los datos y la factibilidad de proceder en la identificación de una estructura de datos subyacentes. Luego, mediante la técnica de análisis paralelo, se identificaron cinco factores que explicaron el $81 \%$ de la varianza. Esta estructura presentó un ajuste adecuado, donde el valor de la raíz cuadrada media de los residuales (RMSR) fue de $=.02$, valor menor al esperado de .06. Se usó rotación oblicua Promin para la extracción de los factores. Al analizar la matriz rotada de los ítems se decidió eliminar tres de ellos, ya que presentaban cargas factoriales dobles, junto a bajas comunalidades. La consistencia interna de la escala total, considerando 17 ítems, calculada mediante el coeficiente alfa de Cronbach fue de .93.

Los cinco factores extraídos en el AFE, respaldaron empíricamente las categorías definidas teóricamente a partir de los antecedentes del DigComp. De esta forma, los factores obtenidos fueron clasificados como: $A=$ Navegar, buscar datos, información y contenido digital; B = Gestionar datos, información y contenido digital; $\mathrm{C}=$ Interactuar a través de tecnologías digitales; $D$ = Compartir a través de tecnologías digitales; y $\mathrm{E}=$ Desarrollar contenido digital. Algunos ejemplos de ítems, en cada factor, son los siguientes: Factor A: "Revisar en Internet sitios web de interés académico"; Factor B: "Organizar en carpetas documentos digitales con información académica"; Factor C: "Comunicarme por Internet con compañeros de curso para informarme sobre tareas asignadas en clases"; Factor D: "Compartir con compañeros de curso / profesores, a través de Internet, sitios web de interés académico"; y Factor E: "Crear / editar presentaciones relacionadas con mis estudios / práctica".

Para explorar con mayor precisión la solución obtenida, se procedió a realizar un Análisis Factorial Exploratorio, con el objetivo de identificar la contribución de cada ítem al factor correspondiente. De este modo, en el factor A los ítems explicaban el $86 \%$ de la varianza y que presentaban valores adecuados de comunalidades y consistencia interna. Para el factor B, se observó que los ítems explicaban el $100 \%$ de la varianza, para el factor C el 99\%, para el D un 100\%, y para el E un $96 \%$. Por tanto, se determinó que los factores, y los ítems que los conformaron, fueron adecuadamente identificados. La Tabla 1 presenta información respecto a la confiabilidad de los factores, números de ítems y comunalidades de los ítems. 


\section{Tabla 1}

Factores obtenidos en AFE $n=314$

\begin{tabular}{|l|l|l|l|}
\hline Factor & Alfa & No Ítems & \multicolumn{1}{l|}{ Comunalidades } \\
\hline A & .92 & 3 & $.70-.98-.73$ \\
\hline$B$ & .84 & 3 & $.69-.74-.51$ \\
\hline C & .96 & 4 & $.87-.96-.92-.77$ \\
\hline$D$ & .92 & 3 & $.69-.95-.78$ \\
\hline E & .90 & 4 & $.75-.61-.86-.73$ \\
\hline
\end{tabular}

\section{Discusión y conclusiones}

En este estudio se analizó de manera exploratoria las propiedades psicométricas de una escala para medir uso académico de tecnologías digitales en estudiantes de pedagogía. Se obtuvo una configuración de cinco factores, coherente teórica y empíricamente, que explica un $81 \%$ de la varianza. Además, se comprobó que el instrumento cuenta con una buena consistencia interna, a través de la determinación de un coeficiente alfa de Cronbach de .93. Aspectos que evidencian que el análisis exploratorio de la Escala de Uso Académico de Tecnologías Digitales (EUATD) permite avanzar hacia el propósito de contar con un instrumento robusto que mida uso académico de tecnologías digitales en educadores en formación.

El análisis específico de los factores reveló, también, evidencias de validez y de confiabilidad adecuadas. Con respecto al primer factor, tres ítems permiten dar cuenta cómo los estudiantes navegan, buscan datos, información y contenido digital con un propósito académico. Algunos estudios reportan que buscar información relacionada con sus estudios, es una de las principales razones del por qué los docentes en formación se conectan a Internet (Fernández et al., 2020), reconociéndose como una de las actividades que más frecuentemente realizan los estudiantes chilenos de pedagogía (Silva, 2017).

El segundo factor incluye tres ítems vinculados a gestionar datos, información y contenido digital. Respecto a esta temática, hay experiencias diversas. En algunos estudios se indica que estas habilidades se encuentran dentro de las que los docentes en formación más desarrollan (Ferrero-de-Lucas et al., 2021), indicándose que corresponden a tareas sencillas (Girón-Escudero et al., 2019). En otros estudios, se reporta que, en este factor, los estudiantes presentan puntajes más bajos, como es el caso de estudiantes uruguayos y chilenos de pedagogía. Los uruguayos presentaron puntajes bajos en la dimensión: Planificación, organización y gestión de espacios y recursos tecnológicos digitales, en tanto, los chilenos obtuvieron puntajes bajos en el indicador: Utilizan diferentes aplicaciones para gestionar contenidos y acceder a la información (Silva et al., 2019a).

El tercer factor, interactuar a través de tecnologías digitales, incluye cuatro ítems vinculados a comunicación por Internet con distintos motivos académicos: Consultar dudas, informarse, coordinar actividades, entre otros. Con respecto a esta temática, hay estudios que muestran que los docentes en formación frecuentemente 
interactúan con propósitos académicos. Ruiz (2016) indica que un 76\% de ellos señalan que están subscritos a un grupo de WhatsApp con sus compañeros de la clase. En tanto, Cabero-Almenara y Marín-Díaz (2014) observaron que a la mayoría de los estudiantes les gusta comunicarse por correo electrónico o mensajes de texto, y que consideran que es una ayuda para su proceso de aprendizaje. Un estudio más reciente señala que altos porcentajes de futuros educadores tienen las competencias necesarias para interactuar a través de tecnologías digitales (Pascual et al., 2019). Pareciera, por tanto, que es un factor frecuentemente desarrollado en esta población.

El cuarto factor, compartir a través de tecnologías digitales, se diferencia del anterior, en que involucra compartir sitios web, documentos u otros archivos con propósitos académicos. En este ámbito, autores como Pascual et al. (2019) y Garrido et al. (2013), señalan que es más difícil, y menos frecuente, que los estudiantes de pedagogía compartan información y contenidos. Los factores previamente señalados se mencionan más frecuentemente entre las acciones realizadas por los estudiantes. En cambio, este aspecto podría ser una acción más compleja de desarrollar. También existe la posibilidad de que la literatura disponible carezca de evidencias en este aspecto, vinculadas a profesores en formación. Ambas situaciones remarcan, por lo tanto, la necesidad de seguir profundizando en el conocimiento de este factor.

El último factor de esta escala, desarrollar contenido digital, involucra la creación de documentos y materiales, usando tecnologías digitales, con fines académicos. Este factor es descrito, en diversos estudios, como el menos desarrollado por los futuros educadores (Cebi \& Reiso lu, 2020; Girón-Escudero et al., 2019; Jiménez-Hernández et al., 2020). Este aspecto es coherente con lo señalado con respecto a la taxonomía de Bloom y las nuevas realidades de la era digital, donde crear se encuentra en la cúspide de las habilidades de orden superior (Cuencia et al., 2021). Ser capaz de crear a través del uso de tecnologías digitales sería la habilidad más compleja de desarrollar, aspecto que demandaría una formación específica para los futuros docentes.

Dada la relevancia de estudiar estos factores, el análisis exploratorio de la Escala de Uso Académico de Tecnologías Digitales (EUATD) permite avanzar hacia el propósito de contar con un instrumento robusto que mida uso académico de tecnologías digitales en educadores en formación. El disponer de un instrumento enfocado en la medición del uso académico será una contribución para la comunidad científica, al facilitar una escala que permita seguir desarrollando conocimiento en esta temática. Por otra parte, permitirá que las instituciones formadoras de educadores sigan ampliando los conocimientos y la evidencia respecto a los distintos factores asociados al uso académico de tecnologías digitales. Además, la medición de estos aspectos podría apoyar la toma de decisiones respecto a qué factores deben ser potenciados con mayor énfasis en un proceso de formación de competencias digitales.

En futuras investigaciones se espera seguir profundizando en la temática de uso académico de tecnologías digitales en los profesores en formación. Un primer avance podría ser la confirmación de la estructura factorial obtenida en este estudio, agregando más evidencias de validez interna. Segundo, apoyado en el uso de este instrumento de medición es factible obtener perfiles de estudiantes que usen académicamente las tecnologías digitales, conociendo -por ejemplo- qué características sociodemográficas presentan. Tercero, el instrumento de medición también puede contribuir -junto a otros- a identificar variables que influyen en el uso académico de 
tecnologías digitales, a través de un modelo de ecuaciones estructurales. En términos generales, este trabajo buscar contribuir a la comprensión del desarrollo de competencias digitales en la citada población.

Estas propuestas son coincidentes con el trabajo desarrollado por otros investigadores nacionales. Autores como Flores-Lueg y Roig (2016b), Ayala-Pérez y Joo-Nagata (2019) Cabello et al., (2020), Garrido-Miranda (2018), Silva y Miranda (2020), y Silva et al. (2019b) dan cuenta de lo fundamental que es potenciar la formación en tecnologías digitales que los futuros docentes reciben en la universidad. Muchos estudiantes señalan que las competencias tecnológicas adquiridas durante su formación inicial docente eran incompletas e insuficientes (Brun \& Hinostroza, 2014). Por lo que se hace fundamental seguir contribuyendo en esta temática.

Como todo estudio, este trabajo presenta algunas limitaciones. La aplicación de este instrumento fue realizada durante el año 2020 y debido a que la docencia universitaria fue realizada de manera virtualizada, esta situación particular podría haber influido en los resultados obtenidos, potenciado de alguna manera la frecuencia de uso académico de las tecnologías digitales. Sin embargo, la presencia de esta variable, también reflejará una nueva realidad que será interesante de comparar con mediciones futuras. En esta misma línea, es interesante recordar que la utilización de las tecnologías digitales está mediada por la disponibilidad, acceso y orientaciones que desde la misma universidad se indiquen a los estudiantes. Dado este punto y la variedad en la formación en tecnologías digitales, disponibles en las mallas de formación inicial docente en Chile (Tapia et al., 2020), es necesario tener en cuenta que lo evaluado en estas dos universidades chilenas podría no darse, de manera similar, en otras universidades del país.

A modo de conclusión, se puede establecer que esta investigación permitió analizar de manera exploratoria las propiedades psicométricas de una Escala de Uso Académico de Tecnologías Digitales (EUATD) en estudiantes de pedagogía. Contar con una estructura factorial acorde a lo planteado teórica y empíricamente, y con una adecuada consistencia interna, es el primer paso para poder desarrollar un instrumento robusto que permita profundizar en el uso académico de las tecnologías digitales en futuros educadores. Esta tarea, por tanto, implica un paso fundamental en el desarrollo de futuras investigaciones en este ámbito. Se espera, a partir del desarrollo de este instrumento, seguir fortaleciendo esta línea investigativa, tan necesaria para la educación de los futuros profesores. Potenciar el uso académico, no sólo permitirá un proceso formativo universitario más efectivo, sino que traspasará al futuro académico y profesional de los docentes en formación, permitiendo un mayor aprovechamiento de las tecnologías digitales para su rol profesional, así como para el de sus futuros estudiantes.

\section{Referencias}

Ayala-Perez, T., \& Joo-Nagata, J. (2019). The digital culture of students of pedagogy specialising in the humanities in Santiago de Chile. Computers \& Education, 133, 1-12. https://doi.org/10.1016/j.compedu.2019.01.002

Brun, M., \& Hinostroza, J. E. (2014). Learning to become a teacher in the 21st century: 
ICT integration in initial teacher education in Chile. Journal of Educational Technology \& Society, 17(3), 222-238. https://www.jstor.org/stable/jeductechsoci.17.3.222

Cabello, P., Ochoa, J. M., \& Felmer, P. (2020). Tecnologías digitales como recurso pedagógico y su integración curricular en la formación inicial docente en Chile. Pensamiento Educativo, 57(1). 1-20. https://doi.org/10.7764/pel.57.1.2020.9

Cabero-Almenara, J., Barroso-Osuna, J., Gutiérrez-Castillo, J. J., \& Palacios-Rodríguez, A. (2020). Validación del cuestionario de competencia digital para futuros maestros mediante ecuaciones estructurales. Bordón. Revista de pedagogía, 72(2), 45-63. https://doi.org/10.13042/Bordon.2020.73436

Cabero-Almenara, J., \& Marín-Díaz, V. (2014). Posibilidades educativas de las redes sociales y el trabajo en grupo. Percepciones de los alumnos universitarios. Comunicar, 21(42), 165-172. https://doi.org/10.3916/c42-2014-16

Carretero, S., Vuorikari, R., \& Punie, Y. (2017). DigComp 2.1: The Digital Competence Framework for Citizens with eight proficiency levels and examples of use (EUR 28558). https://ec.europa.eu/jrc

Çebi, A., \& Reiso lu, . (2020). Digital competence: A study from the perspective of pre-service teachers in Turkey. Journal of New Approaches in Educational Research, 9(2), 294-308. https://doi.org/10.7821/naer.2020.7.583

Cerda, C., \& Saiz, J. L. (2018). Aprendizaje autodirigido del saber pedagógico con tecnologías digitales. Generación de un modelo teórico en estudiantes de pedagogía chilenos. Perfiles Educativos, 40(162), 138-157. https://doi.org/10.22201/iisue.24486167e.2018.162.58756

Cerda, C., Huete, J., Molina, D., Ruminot, E., \& Saiz, J. L. (2017). Uso de tecnologías digitales y logro académico en estudiantes de pedagogía chilenos. Estudios Pedagógicos, 54(3), 119-133. https://doi.org/10.4067/s0718-07052017000300007

Cerda, C., Saiz, J. L., Villegas, L., \& León, M. (2018). Acceso, tiempo y propósito de uso de tecnologías digitales en estudiantes de pedagogía chilenos. Estudios Pedagógicos, 44(3), 7-22. https://doi.org/10.4067/S0718-07052018000300007

Cuencia, A., Álvarez, M., Ontaneda, L., Ontaneda, E., \& Ontaneda, S. (2021). La taxonomía de Bloom para la era digital: Actividades digitales docentes en octavo, noveno y décimo grado de Educación General Básica (EGB) en la habilidad de «Comprender». Revista Espacios, 42(22), 11-25. https://doi.org/10.48082/espacios-a21v42n11p02

Fernández, J., Otero, L., Fernández-Morante, C., \& Cebreiro, B. (2020). Actitudes y uso de Internet y redes sociales en estudiantes universitarios/as de Galicia: Implicaciones personales y sociales. Revista Prisma Social (28), 145-160. https://revistaprismasocial.es/article/view/3372/4085

Ferrari, A. (2013). DIGCOMP: A framework for developing and understanding digital competence in Europe. Publications Office of the European Union. https://doi. org/10.2788/52966 
Ferrero-de-Lucas, E., Cantón-Mayo, I., Menéndez-Fernández, M., Escapa-González, A., \& Bernardo-Sánchez, A. (2021). TIC y gestión del conocimiento en estudiantes de magisterio e ingeniería. Comunicar, 29(66), 57-67. https://doi.org/10.3916/C662021-05

Flora, D. B., \& Curran, P. J. (2004). An empirical evaluation of alternative methods of estimation for confirmatory factor analysis with ordinal data. Psychological Methods, 9(4), 466-491. https://doi.org/10.1037/1082-989x.9.4.466

Flores-Lueg, C., \& Roig, R. (2016a). Diseño y validación de una escala de autoevaluación de competencias digitales para estudiantes de pedagogía. Pixel-Bit. Revista de Medios y Educación, (48), 209-224. https://doi.org/10.12795/pixelbit.2016.i48.14

Flores-Lueg, C., \& Roig, R. (2016b). Percepción de estudiantes de pedagogía sobre el desarrollo de su competencia digital a lo largo de su proceso formativo. Estudios Pedagógicos, 42(3), 129-148. https://doi.org/10.4067/s0718-07052016000400007

Garrido-Miranda, J. M. (2018). Intención y práctica con TIC en formadores de profesores: Congruencias, colisiones y autoeficacia. Estudios Pedagógicos, 44(3), 253269. https://doi.org/10.4067/S0718-07052018000300253

Garrido, J., Contreras, D., \& Miranda, C. (2013). Análisis de la disposición pedagógica de los futuros profesores para usar las TIC. Estudios Pedagógicos, 39(Especial), 5974. https://doi.org/10.4067/s0718-07052013000300005

Girón-Escudero, V., Cózar-Gutiérrez, R., \& González-Calero, J. A. (2019). Análisis de la autopercepción sobre el nivel de competencia digital docente en la formación inicial de maestros/as. Revista Electrónica Interuniversitaria de Formación del Profesorado, 22(3), 193-218. https://doi.org/10.6018/reifop.373421

Gudmundsdottir, G. B., \& Hatlevik, O. E. (2017). Newly qualified teachers' professional digital competence: Implications for teacher education. European Journal of Teacher Education, 41(2), 214-231. https://doi.org/10.1080/02619768.2017.1416085

Jiménez-Hernández, D., González-Calatayud, V., Torres-Soto, A., Martínez, A., \& Morales, J. (2020). Digital competence of future secondary school teachers: Differences according to gender, age, and branch of knowledge. Sustainability, 12(22), 9473. https://doi.org/10.3390/su12229473

Lorenzo-Seva, U. (1999). Promin: A method for oblique factor rotation. Multivariate Behavioral Research, 34(3), 347-365. https://doi.org/10.1207/S15327906MBR3403_3

Lorenzo-Seva, U., \& Ferrando, P. (2006). FACTOR: A computer program to fit the exploratory factor analysis model. Behavior Research Methods, 38(1), 88-91. https:// doi.org/10.3758/bf03192753

Muñiz, J., \& Fonseca-Pedrero, E. (2008). Construcción de instrumentos de medida para la evaluación universitaria. Revista de Investigación en Educación, 5, 13-25. http://reined.webs.uvigo.es/index.php/reined/article/view/41 
Novoa-Echaurren, A., \& Canales-Tapia, A. (2018). Pedagogical uses of digital technologies by pre and in-service teachers: Literature review from a global perspective to the Chilean context. Proceedings of the 2 nd Innovative and Creative Education and Teaching International Conference, Spain, 2(21), 1335, https://doi.org/10.3390/ proceedings 2211335

Pascual, M. A., Ortega-Carrillo, J. A., Pérez-Ferra, M., \& Fombona, J. (2019). Competencias digitales en los estudiantes del grado de maestro de educación primaria. El caso de tres universidades españolas. Formación Universitaria, 12(6), 141-150. https://doi.org/10.4067/s0718-50062019000600141

Redecker, C., \& Punie, Y. (2017). European framework for the digital competence of educators: DigCompEdu. Luxembourg Publications Office of the European Union.

Ruiz, C. (2016). Perfil de uso del teléfono móvil e internet en una muestra de universitarios españoles: ¿Usan o abusan? Bordón: Revista de Pedagogía, 68(3), 131-145. https://doi.org/10.13042/bordon.2016.68307

Shapiro, A., \& Berge, J. F. (2002). Statistical inference of minimum rank factor analysis. Psychometrika, 67(1), 79-94. https://doi.org/10.1007/bf02294710

Silva, J. (2017). Inserción de TIC en pedagogías del área de las humanidades en una universidad chilena. Psicología, Conocimiento y Sociedad, 7(2), 80-96. https://doi. org/10.26864/pcs.v7.n2.6

Silva, J., \& Miranda, P. (2020). Presencia de la competencia digital docente en los programas de formación inicial en universidades públicas chilenas. Revista de Estudios y Experiencias en Educación, 19(41), 149-165. https://doi.org/10.21703/rexe. 20201941silva9

Silva, J., Morales, M.-J., Lázaro, J.-L., Gisbert, M., Miranda, P., Rivoir, A., \& Onetto, A. (2019a). La competencia digital docente en formación inicial: Estudio a partir de los casos de Chile y Uruguay. Archivos Analíticos de Políticas Educativas, 27(93), 1-24. https://doi.org/10.14507/epaa.27.3822

Silva, J., Usart, M., \& Lázaro-Cantabrana, J.-L. (2019b). Competencia digital docente en estudiantes de último año de Pedagogía de Chile y Uruguay. Comunicar, 27(61), 33-43. https://doi.org/10.3916/c61-2019-03

Tapia, H., Campaña, K., \& Castillo, R. (2020). Análisis comparativo de las asignaturas TIC en la formación inicial de profesores en Chile entre 2012 y 2018 . Perspectiva Educacional, 59(1), 4-29. https://doi.org/10.4151/07189729-Vol.59-Iss.1-Art.963

Timmerman, M. E., \& Lorenzo-Seva, U. (2011). Dimensionality assessment of ordered polytomous items with parallel analysis. Psychological Methods, 16(2), 209-220. https://doi.org/10.1037/a0023353

Streiner, D. L., \& Norman, G. (2008). Health measurement scales: A practical guide to their development and use. Oxford University Press. 
Usart, M., Lázaro, J. L., \& Gisbert, M. (2021). Validation of a tool for self-evaluating teacher digital competence. Educación XX1, 24(1), 353-373. https://doi.org/10.5944/ educXX1.27080

Vuorikari, R., Punie, Y., Carretero, S., \& Van den Brande, L. (2016). DigComp 2.0: The digital competence framework for citizens. Update phase 1: The conceptual reference model. Publication Office of the European Union. https://doi.org/10.2791/11517

Wild, S., \& Schulze, L. (2021). Re-evaluation of the D21-digital-index assessment instrument for measuring higher-level digital competences. Studies in Educational EvaIuation, 68, Article 100981. https://doi.org/10.1016/j.stueduc.2021.100981

Zhao, Y., Pinto, A. M., \& Sánchez, M. C. (2021). Digital competence in higher education research: A systematic literature review. Computers \& Education, 168, Article 104212. https://doi.org/10.1016/j.compedu.2021.104212 


\section{Propósitos de Uso Académico de Tecnologías Digitales en Formación Inicial Docente}

\section{Cerda, Cristian}

orcid.org/0000-0003-0818-218X

cristian.cerda@ufrontera.cl

\section{León, Miriam}

orcid.org/0000-0001-6004-8485

miriam.leon@ufrontera.cl 


\title{
PROPÓSITOS DE USO ACADÉMICO DE TECNOLOGÍAS DIGITALES EN FORMACIÓN INICIAL DOCENTE
}

\author{
Cerda, Cristian \\ León, Miriam
}

\section{Resumen}

Debido a los permanentes cambios, en el contexto social y tecnológico, la formación en competencias digitales de los futuros docentes es una temática de permanente interés en el mundo académico. Pese a esta relevancia, y a la emergente evidencia existente en Chile sobre este tema, aún es necesario seguir investigando para poder contribuir a una mejor comprensión de este fenómeno. Esta investigación tuvo como objetivo analizar diferencias, según sexo y años de permanencia en el programa, de un conjunto de subcompetencias pertenecientes al DIGCOMP, implementadas con propósitos académicos. En el estudio participaron 615 estudiantes de pedagogía de dos universidades chilenas. Los resultados de la prueba ANOVA bifactorial mixto, mostraron un efecto principal significativo del tipo de subcompetencias digitales, presentándose una tendencia cuadrática, que incrementa progresivamente en las subcompetencias más básicas y que luego desciende en las más avanzadas. Además, se observó un efecto principal significativo del sexo, donde las mujeres reportan una mayor frecuencia que los hombres. También, se identificó un efecto principal que revela que la frecuencia de uso académico de las subcompetencias medidas depende del número de años en los programas de pedagogía de los participantes. Adicionalmente, se encontró un efecto interactivo significativo de las subcompetencias digitales, observándose que los estudiantes de primer año presentaron promedios más bajos, estadísticamente distintos a los otros niveles agrupados en un subconjunto. Esto resultados representan un interesante aporte a la comprensión del tema, que podría apoyar una mejor toma de decisiones a nivel de políticas educativas en formación inicial docente.

\section{Palabras clave}

Competencia digital, uso de internet, estudiantes de pedagogía, Chile. 


\section{Introducción}

Desde la implementación del proyecto Enlaces en Chile el año 1992, la integración de tecnologías digitales, en contextos educativos, ha propiciado el uso de académico de estas herramientas (Centro de Educación y Tecnología, 2008a). La red Enlaces, o Red de Informática Educativa del Ministerio de Educación de Chile, brindó la posibilidad a miles de docentes de integrar tecnologías de la información y comunicación (TIC) en el currículo escolar (Hepp et al., 1996). Las acciones iniciales, asociadas a la comunicación entre establecimientos educacionales a través del programa La Plaza, unidas al uso de software educativo, dieron posteriormente espacio al desarrollo de actividades ligadas a la búsqueda de recursos educativos en Internet. De esta forma, miles de profesores encontraron, a través de estos recursos digitales, soluciones a necesidades propias de su labor docente. Pese este promisorio escenario, los estudiantes de pedagogía debían esperar a titularse, e insertarse en un establecimiento educacional, para integrar el uso de estas tecnologías a sus prácticas pedagógicas.

El año 2005, a requerimiento del Centro de Educación y Tecnología del Ministerio de Educación, un conjunto de universidades empezó a enfocar su atención en la integración de tecnologías digitales en la formación inicial docente. Dos temas esenciales concentraron la atención de los académicos, e investigadores, involucrados en este proceso: (i) Las distintas propuestas existentes en las universidades chilenas para integrar estas tecnologías en sus mallas de formación (Rodríguez \& Silva, 2006) y; (ii) La necesidad de generar, a través de estándares, un piso base que permitiera una integración más efectiva de estas herramientas (Silva et al., 2006). Pese al paso de los años, ambos temas siguen siendo de interés en la comunidad académica, esto, debido a la permanente evolución a la que están sujetas las tecnologías y a la mayor comprensión de lo que implica su integración en la formación de estudiantes de pedagogía. A pesar de este auspicioso escenario, cambios vertiginosos en el contexto social y tecnológico han afectado el proceso de uso académico de estas tecnologías.

El permanente incremento en el acceso a dispositivos móviles, asociado al consumo personal y masivo que hacen los jóvenes a servicios y aplicaciones de Internet, han ampliado los propósitos de usos en que pueden emplearse las tecnologías digitales (Tapscott, 2009). En la actualidad, es posible observar que existen muchas aplicaciones digitales para el desarrollo de tareas diversas, brindando las tecnologías digitales mayores opciones a los usuarios, fenómeno que ha llevado a la elaboración de diversas tipologías que buscan definir perfiles de usuarios de Internet (Blank \& Groselj, 2014). La utilización de variados dispositivos digitales, orientados a satisfacer distintas necesidades personales conlleva, de manera implícita, el desarrollo de competencias digitales que se van adquiriendo a través de la interacción permanente con estas herramientas. Este proceso de aprendizaje es mucho más efectivo cuándo los jóvenes usuarios poseen un mayor nivel de aprendizaje autodirigido (Cerda et al., 2018).

El uso autónomo de tecnologías de la información y comunicación brinda de manera permanente a los jóvenes instancias de autoaprendizaje. Si bien esto luce prometedor, el uso académico de estas herramientas, lidia de forma permanente con el atractivo que posee para algunos el uso recreativo y social de estas herramientas, lo cual también incluye a los estudiantes de pedagogía. Este proceso puede ser afectado si, en las instancias universitarias de formación inicial docente, no se aborda 
la preparación en competencias digitales docentes, o en su defecto, los estudiantes no las adquieren de manera autónoma. Este análisis, aprender a usar tecnologías digitales de manera autónoma, o a través de instancias formales, ya forma parte de la discusión permanente de los últimos años, en torno a la etiqueta de nativos digitales, propuesta por Prensky (2001) hace más de 20 años atrás. Si bien ya existe más claridad conceptual, que muestra que los jóvenes no son nativos digitales (Lluna \& Pedreira, 2017), la reflexión permanente, en el caso de los docentes en formación, es comprender cómo pueden adquirir y aprovechar de mejor forma los beneficios académicos que brindan las tecnologías digitales.

En Chile, la formación en competencias digitales de estudiantes de pedagogía que permita un uso académico de estas herramientas, es un desafío permanente. De acuerdo a Flores-Lueg y Roig (2016), la percepción de estudiantes de último año de pedagogía, en cuanto al desarrollo de competencias digitales, revela que los usos de tecnologías se encuentran más vinculados a un uso instrumental de aplicaciones de ofimática, que al empleo de otras herramientas. De igual manera, Cerda et al. (2018) mostraron que los propósitos de uso se asocian a determinados dispositivos, donde el computador de escritorio y portable se relacionan más con uso académico, mientras que el teléfono móvil lo hace con uso social y la tablet, o tableta, con el uso recreativo. Dicha investigación también concluyó que los usuarios académicos de tecnologías digitales poseen mayores niveles en aprendizaje autodirigido que usuarios no académicos de tecnologías digitales. En ambos casos, la adquisición de competencias digitales para aprender y enseñar sigue estando como tema necesario de ser abordado, especialmente en relación a su medición.

La medición de competencias digitales es un proceso que demanda atención en algunos aspectos. Primero, es necesario definir qué competencias se miden, sean estas competencias digitales docentes, o competencias digitales en general. Segundo, independiente del tipo de competencias, es relevante unir dicha medición a un marco que las organice, como es el caso de los estándares para competencias digitales docentes del Ministerio de Educación de Chile (Centro de Educación y Tecnología, 2008b, 2011), o el DIGCOMP en Europa, para competencias digitales genéricas (Ferrari, 2013; Carretero et al., 2017). Tercero, es esencial analizar la forma en cómo se miden dichas competencias. En la actualidad es factible observar mediciones basadas en percepciones (Flores-Lueg \& Roig, 2016a), frecuencias según propósitos de uso (Cerda et al., 2020), así como nivel de conocimientos ante situaciones que necesitan ser resueltas (Silva et al., 2019). Si bien todas las iniciativas buscan conocer el nivel de dominio de las competencias digitales, solo algunas ellas van de la mano de procesos de formación, aspecto que comúnmente es medido en estudiantes de últimos años. De esta forma se excluye implícitamente a estudiantes de cursos inferiores, que potencialmente no han recibido formación en el área.

Al respecto, es necesario comprender cuál es el alcance real en Chile en relación a asignaturas de tecnologías digitales en formación inicial docente. La revisión de las mallas de formación inicial docente, elaborada por Cabello et al. (2020), muestra que solo un $48.9 \%$ de los programas de formación docente poseen al menos una asignatura de tecnologías digitales. De este porcentaje 1 , un $44.8 \%$ de las asignaturas se orienta a fines pedagógicos, un $32 \%$ a formación general en TIC, un $14.3 \%$ al uso especializado de las tecnologías digitales y solo un $8.1 \%$ a asignaturas avanzadas. 
El análisis de la evolución de esta oferta, realizada por Tapia et al. (2020), muestra un aumento de asignaturas presentes en las mallas de carreras de pedagogía en enseñanza media. Pese a este incremento, pareciera ser que el dominio de logro alcanzado por los estudiantes, se concentra más en usos instrumentales de estas tecnologías, aspecto percibido en el discurso de algunos estudiantes chilenos de último año (Flores-Lueg \& Roig, 2016b). Considerando lo indicado anteriormente, pareciera ser más pertinente variar el foco de medición, pero manteniendo el énfasis académico de las competencias digitales.

Dado el contexto antes enunciado, esta investigación buscó analizar diferencias en el uso académico de algunas subcompetencias digitales, usando como comparación las variables sexo y años de permanencia de los participantes en sus respetivos programas de pedagogía. Se utilizó un instrumento de medición elaborado por el equipo de investigación, basado en el Marco Europeo de Competencias Digitales, DIGCOMP (Ferrari, 2013; Carretero et al., 2017). Este instrumento buscó medir frecuencia de uso de algunas subcompetencias digitales, cuando son desarrolladas con propósitos académicos. De esta manera es factible medir a todos los estudiantes de pedagogía, independiente si han recibido formación en competencias digitales docentes, o han adquirido algunas de ellas de manera autónoma. Se espera que los resultados de este estudio contribuyan a mejorar la comprensión de este proceso, debido a la relevancia que implica la formación de futuros docentes en esta área, al ser las tecnologías digitales herramientas que no solo pueden apoyar proceso de enseñanza, sino que también el de aprendizaje de los estudiantes y de los mismos docentes.

\section{Método/Descripción de la experiencia}

\section{Descripción del contexto y de los participantes}

Esta investigación utilizó un diseño descriptivo no experimental. Formaron parte de este estudio un total de 615 estudiantes de pedagogía (31.39\% de una población total de 1.959 estudiantes), pertenecientes a dos universidades ubicadas en el sur de Chile. La medición consideró estudiantes de carreras para la enseñanza primaria $(n=159,26 \%)$ y secundaria $(n=456,74 \%)$. Para la selección de los participantes se utilizó un muestreo probabilístico por conveniencia. Ambas universidades presentan en sus perfiles de egreso el uso de TIC, y lo desarrollan a través de distintas estrategias, las cuales en algunos casos incluyen formación en asignaturas específicas, mientras que en otras el desarrollo de competencias digitales se promueve de manera transversal.

\section{Instrumentos}

Para medir competencias digitales, se utilizó un instrumento de 20 ítems elaborado por el equipo de investigación. Los ítems midieron frecuencia de uso de un subconjunto de competencias pertenecientes al Marco Europeo de Competencias Digitales (DIGCOMP), factibles de ser medidas con propósitos de uso académico. Estas subcompetencias son: (A) Navegar, buscar y filtrar información y contenidos digitales; (B) Gestionar información y contenidos digitales; (C) Interactuar a través de tecnologías digitales; (D) Compartir a través de tecnologías digitales; y (E) Desarrollar contenido digital. Adicionalmente, los participantes fueron consultados sobre algunos datos demográficos como sexo y años de permanencia en el programa de pedagogía. 


\section{Procedimiento}

El levantamiento de datos se realizó el año 2020. Dado el contexto de pandemia COVID19, y ante la imposibilidad de tomar los datos en forma presencial, se utilizó la plataforma QuestioPro, cuyo enlace fue compartido vía email a los estudiantes. Previo a la participación en la encuesta los estudiantes leyeron un consentimiento informado aprobado por el Comité Ético Científico de la universidad responsable de la investigación, el cual contenía entre otros datos, los objetivos del estudio, así como la voluntariedad en la participación. El cuestionario estuvo disponible durante siete semanas, utilizándose igual número de recordatorios para invitar a los estudiantes a participar. Debido a que no todos los estudiantes utilizan con periodicidad sus correos electrónicos institucionales, se solicitó a los académicos de las asignaturas de educación reforzar la invitación y relevancia de participar en este estudio.

\section{Análisis de datos}

Se realizaron dos análisis de la varianza (ANOVA) bifactoriales mixtos. En el primero, las variables independientes fueron el tipo de subcompetencias digitales (factor intra sujeto) y el sexo de los participantes (factor inter sujeto), en tanto que la variable dependiente fue la frecuencia de uso académico de las cinco subcompetencias. El segundo ANOVA, incluyó las mismas variables anteriores, excepto que el sexo fue reemplazado por los años de permanencia en el programa de pedagogía (desde uno a seis o más años). Se examinaron los efectos principales, e interactivos de las variables independientes. Mientras los efectos principales significativos fueron complementados por un análisis de tendencias, o un examen post hoc, las interacciones significativas fueron seguidas de un análisis de efectos simples. Se utilizó el paquete estadístico SPSS en su versión 20.

\section{Resultados}

Efectos del tipo de subcompetencias y sexo. La prueba ANOVA bifactorial mixto mostró un efecto principal significativo del tipo de subcompetencias digitales, $F(3.4,2084)=214.9, p<.001, \eta_{p}{ }_{p}=.26$, en la frecuencia de uso académico de tales subcompetencias. Este efecto fue mejor explicado por una tendencia cuadrática (ver Tabla 1): En las subcompetencias más básicas ( $A, B$ y C), la frecuencia de uso se va incrementando progresivamente para luego descender en las subcompetencias más avanzadas ( $D$ y E). 


\section{Tabla 1}

Promedios (y desviaciones estándares) de frecuencia de uso académico de cada subcompetencia digital y resultados del análisis de tendencia cuadrática

\begin{tabular}{|c|c|c|c|c|c|c|}
\hline \multicolumn{5}{|c|}{ Subcompetencias digitales } & \multicolumn{2}{c|}{ Tendencia cuadrática } \\
\hline$A$ & $B$ & $C$ & $D$ & $E$ & $\eta 2 \mathrm{p}$ & $p$ \\
\hline 3.50 & 3.63 & 3.91 & 2.91 & 2.85 & .25 & $<.001$ \\
$(0.99)$ & $(1.04)$ & $(1.05)$ & $(1.17)$ & $(1.13)$ & .25 \\
\hline
\end{tabular}

Nota. $A$ =Navegar, buscar y filtrar información y contenidos digitales. $B=$ Gestionar información y contenidos digitales. C = Interactuar a través de tecnologías digitales. $D=$ Compartir a través de tecnologías digitales. $E=$ Desarrollar contenido digital.

Se observó un efecto principal significativo de sexo, $F(1,613)=32.1, p<.001, \eta 2_{\mathrm{p}}=.05$, revelando que las mujeres hacen un uso académico más frecuente de este conjunto de subcompetencias $(M=3.50, D E=0.82)$, que sus pares hombres $(M=3.11, D E=0.81)$.

Finalmente, el efecto interactivo sexo por tipo de subcompetencias no fue significativo, $F(4,2084)=1.84, p<.118$. Así, el efecto del tipo de subcompetencia sobre la frecuencia de uso académico de las mismas no depende del sexo del participante. En la Figura 1, se observa que la frecuencia de uso académico de las subcompetencias en hombres y mujeres conforman perfiles paralelos.

\section{Figura 1}

Promedios de frecuencia de uso académico de las subcompetencias digitales según hombres y mujeres.

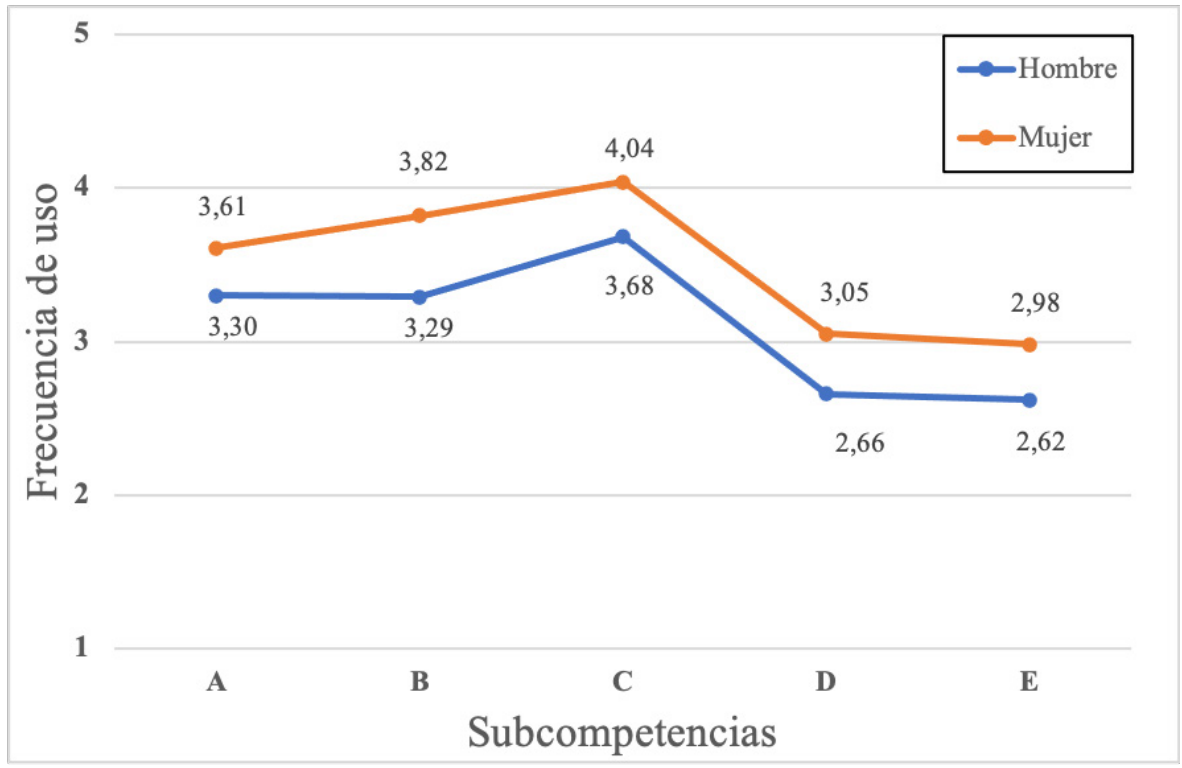

Nota. $A$ = Navegar, buscar y filtrar información y contenidos digitales. $B=$ Gestionar información y contenidos digitales. C = Interactuar a través de tecnologías digitales. $D=$ Compartir a través de tecnologías digitales. $E=$ Desarrollar contenido digital. 
Efectos del tipo de subcompetencias y años de permanencia en los programas. El segundo ANOVA bifactorial mixto, mostró un efecto principal de tipo de subcompetencias, ya identificado en el ANOVA anterior. El efecto principal de años de permanencia fue significativo, $F(1,609)=6.29, p<.001, \eta^{2} p=.05$, dejando en evidencia que la frecuencia de uso académico de las subcompetencias, depende del número de años de los participantes en los programas de pedagogía. Un análisis post hoc (Bonferroni), reveló que aquellos con un año en los programas presentan una frecuencia de uso significativamente menor $(M=3.05, D E=0.82)$, que cada uno de los demás grupos ( $p s \leq .05)$. Por su parte, aquellos con dos, tres, cuatro, cinco y seis o más años, no difieren significativamente entre sí (ps=1.00). En la tabla 2 se presentan los promedios y desviaciones estándares de la frecuencia de uso académico, según años de permanencia.

\section{Tabla 2}

Promedios (y desviaciones estándares) de la frecuencia de uso académico de tecnologías digitales por años de permanencia en los programas.

\begin{tabular}{|c|c|c|c|c|c|}
\hline \multicolumn{7}{|c|}{ Años de permanencia en los programas } \\
\hline 1 & 2 & 3 & 4 & 5 & 6 ó más \\
\hline 3.05 & 3.46 & 3.56 & 3.35 & 3.50 & 3.52 \\
$(0.82)$ & $(0.83)$ & $(0.82)$ & $(0.83)$ & $(0.83)$ & $(0.83)$ \\
\hline
\end{tabular}

El efecto interactivo tipo de subcompetencias, por años de permanencia fue significativo, $F(16.97,2067)=2.9, p<.001, \eta^{2} p=.023$. Así, el efecto del tipo de subcompetencia sobre la frecuencia de uso académico de las mismas, depende de los años de permanencia del estudiante en el programa de formación inicial docente. La Tabla 3 presenta la media y desviación estándar de cada subcompetencia digital, según años de permanencia.

\section{Tabla 3}

Promedios (y desviaciones estándares) de frecuencia de uso académico de cada subcompetencia digital según años de permanencia en los programas.

\begin{tabular}{|c|c|c|c|c|c|}
\hline \multicolumn{7}{|c|}{ Subcompetencias digitales } \\
\hline Años & A & B & C & D & E \\
\hline 1 & $3.29(1.00)$ & $3.43(1.04)$ & $3.62(1.14)$ & $2.58(1.19)$ & $2.34(1.04)$ \\
\hline 2 & $3.58(1.01)$ & $3.75(1.02)$ & $4.12(0.95)$ & $3.13(1.08)$ & $2.74(1.05)$ \\
\hline 3 & $3.68(1.03)$ & $3.85(1.07)$ & $4.02(1.15)$ & $3.07(1.32)$ & $3.17(1.17)$ \\
\hline 4 & $3.44(1.03)$ & $3.53(1.10)$ & $3.96(1.04)$ & $2.93(1.11)$ & $2.91(1.14)$ \\
\hline 5 & $3.59(0.88)$ & $3.73(0.89)$ & $3.96(0.91)$ & $2.98(1.11)$ & $3.23(0.95)$ \\
\hline 6 o más & $3.69(0.78)$ & $3.76(0.89)$ & $3.95(0.94)$ & $2.99(1.15)$ & $3.23(1.17)$ \\
\hline
\end{tabular}

Nota. $A=$ Navegar, buscar y filtrar información y contenidos digitales. $B=$ Gestionar información y contenidos digitales. $C$ = Interactuar a través de tecnologías digitales. $D=$ Compartir a través de tecnologías digitales. $E=$ Desarrollar contenido digital. 
La Figura 2 ilustra la interacción tipos de subcompetencias por años de permanencia en el programa de pedagogía. Análisis de efectos simples mostraron que los grupos no difieren significativamente (ps > .05), en la frecuencia de uso académico de las dos subcompetencias más básicas ( $A$ y $B$ ). En la subcompetencia $C$, los estudiantes con un año en el programa presentan una menor frecuencia de uso ( $p=004)$, que aquellos con dos años. En la subcompetencia D, nuevamente, el grupo con un año de permanencia reporta una frecuencia de uso menor ( $p s<.05)$, que los grupos con dos y tres años. Finalmente, en la subcompetencia E, los estudiantes con un año exhiben frecuencia de uso menor que cada uno de los otros cinco grupos ( $p s<.001)$.

\section{Figura 2}

Promedios de frecuencia de uso académico de las subcompetencias digitales según años de permanencia en el programa.

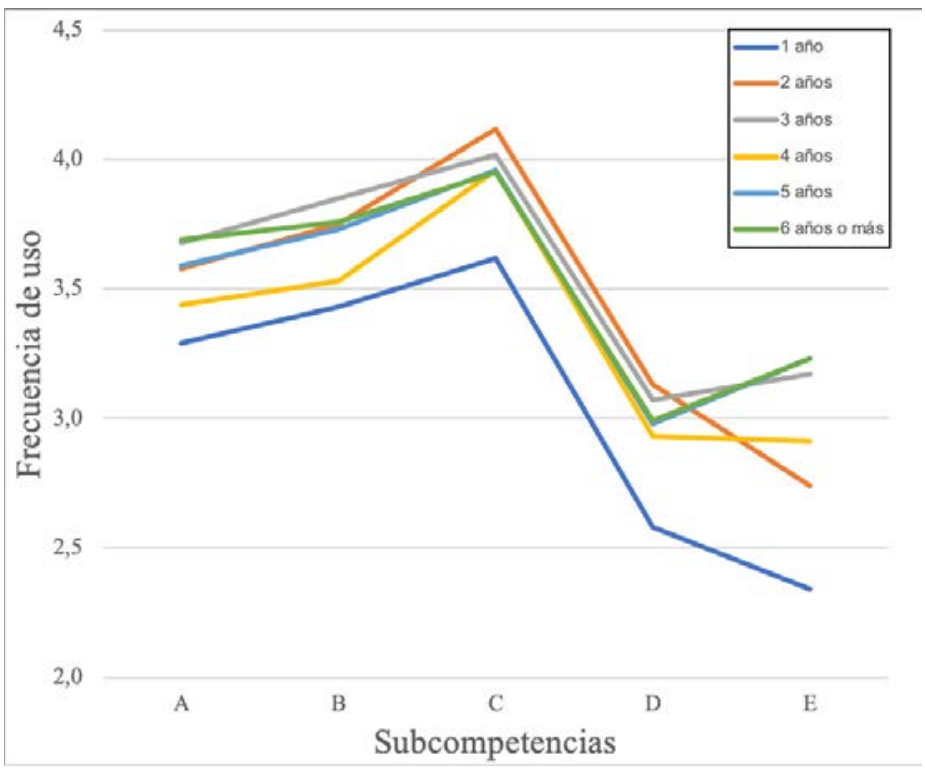

Nota. $A$ = Navegar, buscar y filtrar información y contenidos digitales. $B=$ Gestionar información y contenidos digitales. C = Interactuar a través de tecnologías digitales. $D=$ Compartir a través de tecnologías digitales. $E=$ Desarrollar contenido digital.

\section{Discusión y conclusiones}

Esta investigación tuvo como propósito indagar el rol de las variables sexo y años de permanencia en el programa, como elementos asociados a la frecuencia de usos de tecnologías digitales con fines académicos. Los resultados indican que las mujeres poseen mayores frecuencias de usos de tecnologías digitales que sus pares hombres. De igual modo, los años de permanencia en el programa muestran diferencias significativas entre los estudiantes de primer año y el resto de la población estudiada, lo que revela un nivel de dominio básico de competencias digitales, que se adquiere en segundo año y se mantiene hasta el final del programa de formación.

La revisión de la literatura en el área, que permita comparar los resultados de esta investigación, con otros estudios, presenta algunos desafíos. Muchas de las investigaciones 
están centradas en medir competencias digitales docentes y no competencias digitales genéricas. Además, en general los reportes disponibles involucran principalmente a estudiantes de últimos años de pedagogía, dificultando la comparación con otras cohortes, así como el análisis de la evolución de las competencias, según los años de permanencia que posean los estudiantes en los programas de formación.

Considerando esto, es posible identificar en la literatura nacional resultados diversos con relación al rol de la variable sexo. Algunos reportes no muestran diferencias significativas según sexo en competencias digitales docentes (Silva et al., 2019), mientras que en otras investigaciones se observaron diferencias a favor de los hombres, lo cual difiere de los resultados presentados en este estudio. La medición de competencias digitales docentes desarrollada por Flores y Roig (2017), en las cinco dimensiones de los estándares TIC elaborados por Enlaces en Chile, mostró diferencias a favor de los hombres en las dimensiones social, legal y en la escala total. Las mismas investigadoras (Flores-Lueg \& Roig-Vila, 2019), también encontraron diferencias a favor de los hombres en competencias digitales docentes en los factores Prácticas evaluativas con TIC y generación de entornos educativos virtuales, Conocimiento sobre posibilidades del uso de TIC en su ámbito curricular y en el puntaje total de la escala. En cuanto a la comparación según los años de permanencia en los programas de pedagogía, Badilla-Quintana et al. (2013), reportan diferencias entre tres cohortes (2007, 2009 y 2011), con resultados mixtos, entre estudiantes de diferentes programas de pedagogía, en dimensiones como nociones básicas, estándares pedagógicos, gestión del conocimiento, profundización del conocimiento y aspectos sociales, éticos y legales. Estos datos presentan similitudes y también diferencias, con los resultados aquí reportados.

La interpretación de los resultados obtenidos en esta investigación debe ser analizados considerando algunos aspectos. Primero, es necesario tener en cuenta que, si bien los estudiantes de pedagogía, así como sus pares universitarios, desarrollan competencias digitales de manera autónoma, la formación explícita de dichas competencias puede afectar positivamente el dominio de las mismas. Segundo, pese a que Chile cuenta con estándares de formación inicial docente en tecnologías digitales, dichos estándares solo funcionan como ejes orientadores de lo que un futuro docente debe saber hacer y no necesariamente aseguran el dominio de las competencias digitales docentes definidas. Además, el estancamiento expresado en la frecuencia de uso de tecnologías digitales, a contar del segundo año, podría revelar dos aspectos importantes. Por una parte, el bajo aprendizaje autónomo que logran los estudiantes de pedagogía de estas herramientas, o la escasa formación en el área. El escenario podría ser interpretado de peor forma si se analiza que los estudiantes, pese a ese bajo nivel de desarrollo de competencias digitales, logran avanzar en la malla curricular dominando competencias básicas como "Navegar, buscary filtrar información y contenidos digitales", en desmedro de aquellas más complejas, pero de mayor pertinencia pedagógica como "Compartir a través de tecnologías digitales" o "Desarrollar contenido digital".

Por otra parte, es muy relevante indicar que la realización de esta investigación se enmarcó en la ejecución de un proyecto de investigación que busca indagar propósitos de uso académico de estudiantes de pedagogía. Dicha iniciativa consideró un periodo de cuatro años (2019-2022), tiempo en que la formación de los estudiantes de pedagogía convivió con diversos fenómenos, que directa o indirectamente, afectaron el desarrollo del mismo. Ejemplos de lo citado fueron la explosión social que vivió Chile 
de octubre del 2019, que redundó en la paralización de actividades académicas por varios meses, junto con la aparición de la pandemia mundial producto del COVID 19, hecho que impulsó la virtualización, no sólo de la docencia universitaria, sino también de otros aspectos de la vida de la población en estudio. Todos estos elementos marcaron un escenario distintivo que pudo afectar los resultados obtenidos.

Coincidente con lo enunciado, este estudio no está excepto de limitaciones. Primero, dado el contexto de pandemia y la voluntariedad de participar en esta investigación, pudo haber ocurrido que quienes participaron contestando el cuestionario, hayan sido estudiantes con un perfil más alto de uso académico de tecnologías digitales. Segundo, la medición de propósitos de uso académico podría haber sido influida por un mayor desarrollo de tareas de este tipo, producto de la virtualización de la docencia. Tercero, como en toda medición de percepciones, se asume que las conductas expresadas en términos de frecuencia poseen un correlato de realidad, estableciendo una suerte de coherencia entre lo que los estudiantes reportan y lo que en verdad ocurre. Finalmente, es necesario indicar que, al estar los estudiantes sometidos a docencia virtual, los otros propósitos de uso de tecnologías digitales que ellos desarrollaban naturalmente, como son el uso social, recreativo y económico, también estuvieron afectos a modificaciones.

Para el desarrollo de futuras investigaciones se sugiere tener en cuenta los siguientes elementos. Primero, es esencial considerar en el análisis de resultados la participación en asignaturas que involucren formación explícita en el uso de tecnologías digitales, sean estos cursos centrados en paquetes de productividad, o en estrategias de integración curricular de tecnologías digitales. Segundo, es necesario comprender si las asignaturas TIC impartidas se adscriben a un determinado marco de competencias digitales, o a estándares de uso de las mismas. Tercero, es conveniente constatar el nivel de promoción en el uso de tecnologías digitales, con fines académicos, que promueven los docentes a cargo de la formación de los estudiantes de pedagogía. Tener en cuenta estos tres elementos permitiría saber, si el desarrollo de competencias digitales con fines académicos se produce a través de experiencias personales, por la formación adquirida en asignaturas TIC, o por medio de actividades de aprendizaje en otras asignaturas de la formación inicial docente.

Considerando los resultados del estudio se puede concluir que los atributos personales como sexo, unido a años de permanencia en los programas de pedagogía, se relacionan con la frecuencia de uso académico de competencias digitales. Más investigación en el tema permitirá apoyar de mejor manera la toma de decisiones, indagando especialmente si el dominio de competencias digitales, como elemento facilitador del uso académico de estas herramientas, se desarrolla de manera autónoma, o es factible de ser apoyado a través de intervenciones específicas propias de la formación inicial docente.

\section{Referencias}

Badilla-Quintana, M. G., Jiménez-Pérez, L., \& Careaga-Butter, M. (2013). Competencias TIC en formación inicial docente: Estudio de caso de seis especialidades en la Universidad Católica de la Santísima Concepción. Aloma-Revista de Psicologia, Ciències de l'Educació i de l'Esport, 31(1), 89-97. http://www.revistaaloma.net/index.php/aloma/article/view/191 
Blank, G., \& Groselj, D. (2014). Dimensions of Internet use: Amount, variety, and types. Information, Communication \& Society, 17(4), 417-435. https://doi.org/10.1080/1369118X.2014.889189

Cabello, P., Ochoa, J. M., \& Felmer, P. (2020). Tecnologías digitales como recurso pedagógico y su integración curricular en la formación inicial docente en Chile. Pensamiento Educativo, 57(1), 1-20. https://doi.org/10.7764/PEL.57.1.2020.9

Carretero, S., Vuorikari, R., \& Punie, Y. (2017). DigComp 2.1: The Digital Competence Framework for Citizens with eight proficiency levels and examples of use (EUR 28558). https://publications.jrc.ec.europa.eu/repository/handle/JRC106281

Centro de Educación y Tecnología. (2008a). Enlaces: 15 años integrando tecnologías a la educación chilena. Ministerio de Educación.

Centro de Educación y Tecnología. (2008b). Estándares TIC para la formación inicial docente: Una propuesta en el contexto chileno. Ministerio de Educación.

Centro de Educación y Tecnología. (2011). Competencias y estándares TIC para la profesión docente. Ministerio de Educación.

Cerda, C., León, M., Saiz, J. L., \& Villegas, L. (2020). Medición de propósitos de usos de tecnologías digitales en estudiantes de pedagogía: Validación de una escala. En E. Colomo, E. Sánchez, J. Ruiz, \& J. Sánchez (Eds.), La tecnología como eje del cambio metodológico (pp. 1239-1242). UMA editorial.

Cerda, C., Saiz, J. L., Villegas, L., \& León, M. (2018). Acceso, tiempo y propósito de uso de tecnologías digitales en estudiantes de pedagogía chilenos. Estudios Pedagógicos, 44(3), 7-22. https://doi.org/10.4067/S0718-07052018000300007

Ferrari, A. (2013). DIGCOMP: A framework for developing and understanding digital competence in Europe. Publications Office of the European Union. https://doi. org/10.2788/52966

Flores, C., \& Roig, R. (2017). Gender and its impact on pedagogy students' self-perceived digital competence. IJERI: International Journal of Educational Research and Innovation, (8), 79-96. https://www.upo.es/revistas/index.php/IJERI/article/ view/2429

Flores-Lueg, C., \& Roig, R. (2016). Percepción de estudiantes de pedagogía sobre el desarrollo de su competencia digital a lo largo de su proceso formativo. Estudios Pedagógicos, 42(3), 129-148. https://doi.org/10.4067/S0718-07052016000400007

Flores-Lueg, C., \& Roig, R. (2016a). Diseño y validación de una escala de autoevaluación de competencias digitales para estudiantes de pedagogía. Píxel-Bit. Revista de Medios y Educación, (48), 209-224. https://doi.org/10.12795/pixelbit.2016.i48.14

Flores-Lueg, C., \& Roig, R. (2016b). Percepción de estudiantes de pedagogía sobre el desarrollo de su competencia digital a lo largo de su proceso formativo. Estudios Pedagógicos, 42(3), 129-148. https://doi.org/10.4067/s0718-07052016000400007 
Flores-Lueg, C., \& Roig-Vila, R. (2019). Factores personales que inciden en la autovaloración de futuros maestros sobre la dimensión pedagógica del uso de TIC. Revista Iberoamericana de Educación Superior, 10(27), 151-171. https://doi.org/10.22201/ iisue.20072872e.2019.27.345

Hepp, P., Laval, E., Moënne, G., \& Ripoll, M. (1996). Monitoring the 'Enlaces' educational computer networks. Education and Information Technologies, 1, 5-20. https://doi. org/10.1007/BF00144333

Lluna, S., \& Pedreira, J. (2017). Los nativos digitales no existen: Cómo educar a tus hijos para un mundo digital. Deusto.

Prensky, M. (2001). Digital natives, digital immigrants part 1. On the Horizon, 9(5), 1-6. https://doi.org/10.1108/10748120110424816

Rodríguez, J., \& Silva, J. (2006). Incorporación de las tecnologías de la información y la comunicación en la formación inicial docente el caso chileno. Innovación Educativa, 6(32), 19-35. https://www.redalyc.org/pdf/1794/179421198003.pdf

Silva, J., Gros, B., Garrido, J. M., \& Rodríguez, J. (2006). Estándares en tecnologías de la información y la comunicación para la formación inicial docente: Situación actual y el caso chileno. Revista Iberoamericana de Educación, 38(3), 1-16. https://rieoei. org/historico/deloslectores/1391Silva.pdf

Silva, J., Usart, M., \& Lázaro-Cantabrana, J.-L. (2019). Competencia digital docente en estudiantes de último año de pedagogía de Chile y Uruguay. Comunicar, 27(61), 33-43. https://doi.org/10.3916/c61-2019-03

Tapia, H., Campaña, K., \& Castillo, R. (2020). Análisis comparativo de las asignaturas TIC en la formación inicial de profesores en Chile entre 2012 y 2018 . Perspectiva Educacional, 59(1), 4-29. https://doi.org/10.4151/07189729-Vol.59-Iss.1-Art.963

Tapscott, D. (2009). Grown up digital: How the net generation is changing your world. McGraw-Hill. 


\section{La Gestión de la Tecnología en la FCV UBA, los Avatares del Tsunami Virtual}

\section{Fabiana Grinsztajn}

\section{Roxana Szteinberg}

\section{Gabriel Sánchez}

\section{Mariana Vaccaro}

Universidad de Buenos Aires

Facultad de Ciencias Veterinarias

posgradodocencia@fvet.uba.ar 


\title{
LA GESTIÓN DE LA TECNOLOGÍA EN LA FCV UBA, LOS AVATARES DEL TSUNAMI VIRTUAL
}

\author{
Fabiana Grinsztajn \\ Roxana Szteinberg \\ Gabriel Sánchez \\ Mariana Vaccaro
}

\section{Resumen}

Durante el año 2020 y 2021 la emergencia sanitaria obligó a una virtualidad casi al $100 \%$ en la carrera de Veterinaria de la UBA. Gracias al proceso de transformación de cultura digital, desarrollado en la facultad desde el año 2015 y con antecedentes previos que facilitaron la incorporación paulatina de TIC en las actividades académicas, el tsunami de la pandemia no nos arrasó, sino que aceleró los procesos de digitalización y constituyó una oportunidad para la mejora y consolidación de procesos ya instalados, acelerados por el tsunami pandémico que también fue tecnológico. No obstante, fueron numerosos los desafíos en virtud del contexto y variados los problemas que fue necesario enfrentar. Se presentan los avances realizados que se capitalizan de cara al futuro, teniendo en cuenta las políticas de gestión de la tecnología en la facultad y los resultados alcanzados.

\section{Palabras clave}

Enseñanza con tecnología, innovación, gestión tecnopedagógica. 


\section{Introducción}

Desde hace varios años la facultad incorpora la cultura digital a los proyectos académicos, entendiendo la naturaleza ubicua de la misma y la necesidad de formar estudiantes que se encuentren en condiciones de moverse en mundos a la vez analógicos y digitales. Sin embargo, esta incorporación se realizaba en forma gradual y con un proceso de planeamiento estratégico especialmente orientado a dotar de competencias digitales a los docentes, facilitando la transformación. Pero llegó el tsunami de la pandemia y de pronto todo lo aprendido y transitado debió activarse y ponerse en juego en pocos días. Así, fueron diversos los problemas a enfrentar en el proceso vertiginoso de transformación de un sistema de enseñanza presencial en otro completamente virtual durante el 2020.

El Equipo tecnopedagógico dependiente de la Secretaría Académica, que implementaba hasta el 2019 el Programa Integral de Cultura Digital en la Facultad de Veterinaria, procuró dar una respuesta ágil a los requerimientos urgentes que surgieron desde el inicio del aislamiento. Constituido por expertos en pedagogía, tecnología y ciencias veterinarias, el equipo trabaja en forma interdisciplinaria, y desde el modelo TPACK, que procura la intersección prodigiosa del saber tecnológico, el saber disciplinar y el saber pedagógico, tres esferas que favorablemente combinadas en un equilibrio dinámico, se interrelacionan para construir soluciones efectivas en la enseñanza con tecnologías.

Entre los problemas que reclamaban una acción inmediata podemos citar:

- Un dominio dispar entre los docentes tanto de estrategias de enseñanza en la virtualidad, como en el manejo instrumental de herramientas y software apropiados para la enseñanza en entornos virtuales.

- Formatos en clases por videoconferencia que pretendían emular, en algunos casos, la clase presencial, con la consecuente desconexión emocional de los estudiantes ante clases magistrales y verbalistas que, al reiterarse, generaban tedio y desmotivación, así como ausencia de feedback para el docente.

- Necesidad apremiante de contar con un repertorio de tutoriales que explicaran desde funciones básicas del aula virtual de Moodle, para los menos expertos, hasta otras más específicas como la organización de grupos de trabajo, procurando no dejar de satisfacer a quienes, habiendo superado los niveles iniciales de acceso y adopción tecnológica, habían avanzado hacia estadíos de apropiación y creación (Sandholz y Reilli, 2014), por lo que solicitaban orientaciones para el uso de software educativo más complejo que les permitiera, por ejemplo, diseñar microclases en video a partir de plantillas o producir materiales didácticos interactivos.

- El reclamo por parte de los equipos docentes de contar con variadas oportunidades de capacitación en diferentes temáticas.

- La inquietud, comprensible ante una situación sin precedentes, de verse ante la necesidad de tomar exámenes parciales y finales en una modalidad diferente, lo que planteaba serias dudas acerca de la confiabilidad de dichos exámenes, los instrumentos propicios para evaluar, los protocolos a seguir y las decisiones a tomar ante imponderables surgidos durante los exámenes. 
Desde 2015 el Equipo Asesor Tecnopedagógico había iniciado un proceso de trabajo sistemático, orientado a la integración de la cultura digital en la institución, programa basado en la convergencia de un conjunto de líneas de acción diseñadas a partir de algunas certezas tomadas como punto de partida. Una de ellas es que ninguna acción aislada sino la interconexión de un conjunto estratégico de líneas de trabajo combinadas y articuladas, constituye la principal razón de que la cultura digital se transfiera progresivamente a cada cátedra, a sus respectivos docentes y a los estudiantes. Este diseño articulado ha configurado una urdimbre, en la que cada línea de acción es un nodo interconectado con otros con los que conforma una red. En la imagen se muestran esos "nodos" que habilitan el acceso a producciones como videos, presentaciones, materiales didácticos y ejemplos varios al escanear los códigos QR.

Imagen 1: Proyecto Integral de cultura digital FCV UBA

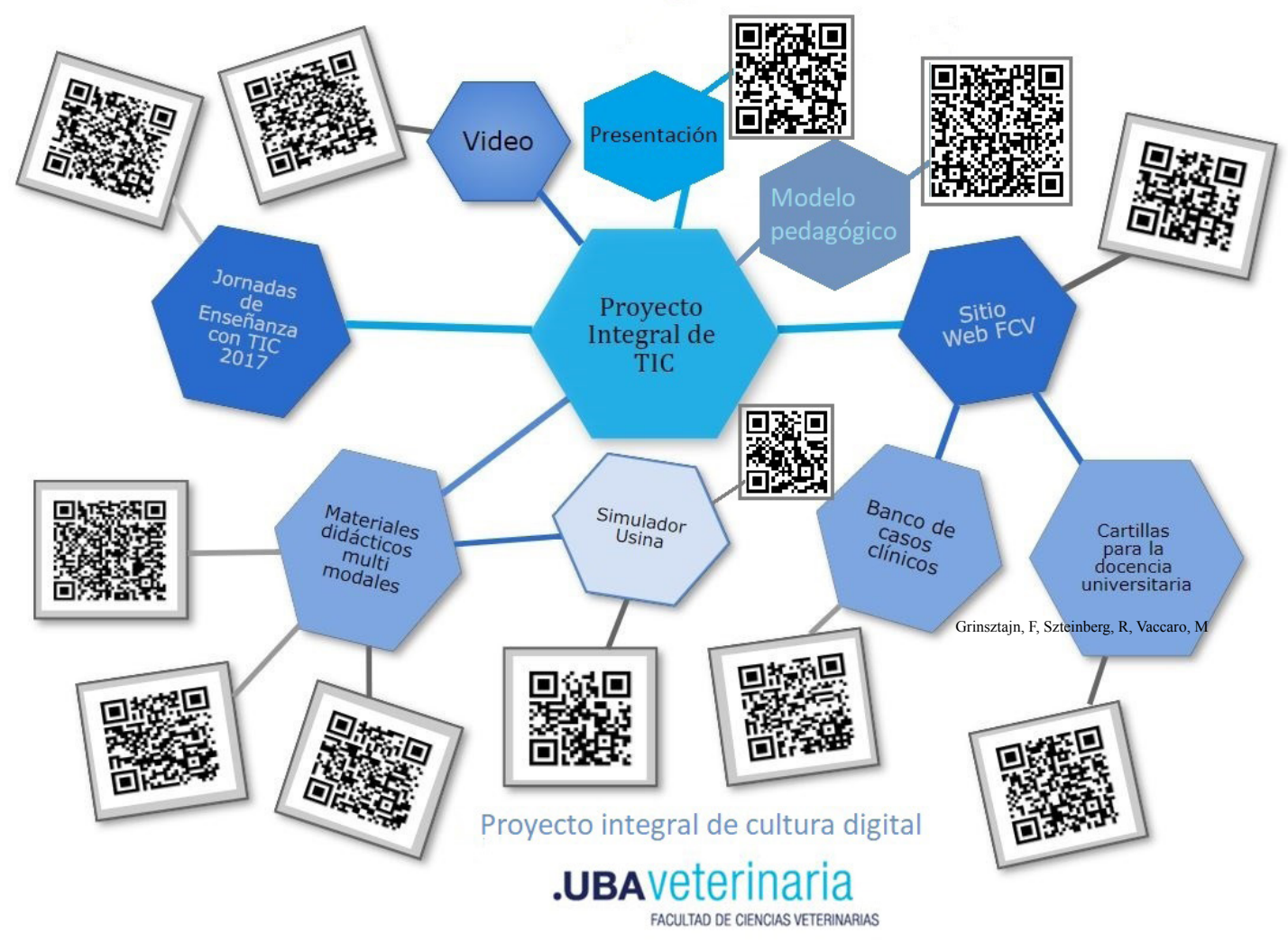

Grinsztajn, F, Szteinberg, R, Vaccaro, $M$

Estas líneas de acción trazaron el itinerario previo y fueron el antecedente que permitió al Equipo Tecnopedagógico emprender nuevos desafíos durante 2020 - 2021.

Se describen las acciones llevadas a cabo desde la Secretaría Académica, y el Equipo tecnopedagógico, con el propósito de dar respuesta a los problemas planteados al inicio del ciclo 2020, en que la carrera de Veterinaria debió virtualizarse. 


\section{Método/Descripción de la experiencia}

\section{La experiencia de virtualización de la carrera de Veterinaria de la UBA}

\section{Reuniones preparatorias}

A inicios del 2020 se realizaron reuniones de planificación y toma de decisiones con cada jefe/a de cátedra junto con el Decano, la Secretaría Académica y la Coordinación de innovación Curricular y Planeamiento Estratégico. En estas reuniones se establecieron los ejes claves para el desarrollo de acciones en cada asignatura, teniendo en cuenta la naturaleza del contenido a enseñar, el lugar que ocupa cada asignatura en el plan de estudios, las características y formación digital previa del cuerpo docente. A partir de estas decisiones se resolvió dotar a la totalidad de la carrera de un espacio en el campus virtual, para concentrar en ese entorno el desarrollo de las propuestas de trabajo. Es un universo total de 56 asignaturas obligatorias, 5 optativas y 4 prácticas supervisadas.

Las asignaturas son dictadas por 37 cátedras, de las cuales algunas dictan una asignatura y otras dos o más. Al comienzo del Aislamiento Social Preventivo Obligatorio (ASPO) el 70,27\% de las cátedras ya se encontraba dictando al menos una de sus asignaturas incluyendo un entorno virtual de apoyo (aula) en el campus o estaba en transición hacia ello. Se las considera en transición si al menos uno de sus cursos ya contaba con aula virtual y parte del plantel docente estaba capacitado, aunque todavía no hubieran ofrecido esta actividad a los alumnos. A un año de comenzado el ASPO el $100 \%$ de las cátedras dispone de un aula virtual para todas las asignaturas que dictan.

Se diseñó un plan de orientación a la docencia que consistió en:

a) Favorecer un marco de trabajo reglamentado por la facultad.

b) Organizar espacios de capacitación ágil.

c) Facilitar recursos tecnológicos tanto en software como hardware y conectividad a los referentes clave del desarrollo de la actividad remota.

d) Garantizar el acceso a los estudiantes y brindarles apoyo adicional.

e) Sostener de manera continua el asesoramiento tecnopedagógico a las cátedras.

f) Reunir en un espacio virtual único el conjunto de recursos y materiales de apoyo a la docencia, a modo de sala de profesores.

g) Organizar reuniones de trabajo y formación digital entre cátedras y Equipo tecnopedagógico, o bien intercátedras para la formación docente.

h) Elaborar protocolos para la toma de exámenes finales. 
Las acciones se organizaron en tres grupos:

1. Diseño de recursos para ser alojados en un minisitio web

2. Talleres de capacitación

3. Asesoramiento tecnopedagógico específico

\section{Desarrollo de minisitio}

En el sitio web de la Facultad de Ciencias Veterinarias se diseñó un minisitio que es el paso obligado para el ingreso al campus virtual. El Propósito principal del mismo fue procurar que de manera accesible y ágil los docentes tuvieran acceso a un repositorio de materiales de apoyo a la docencia.

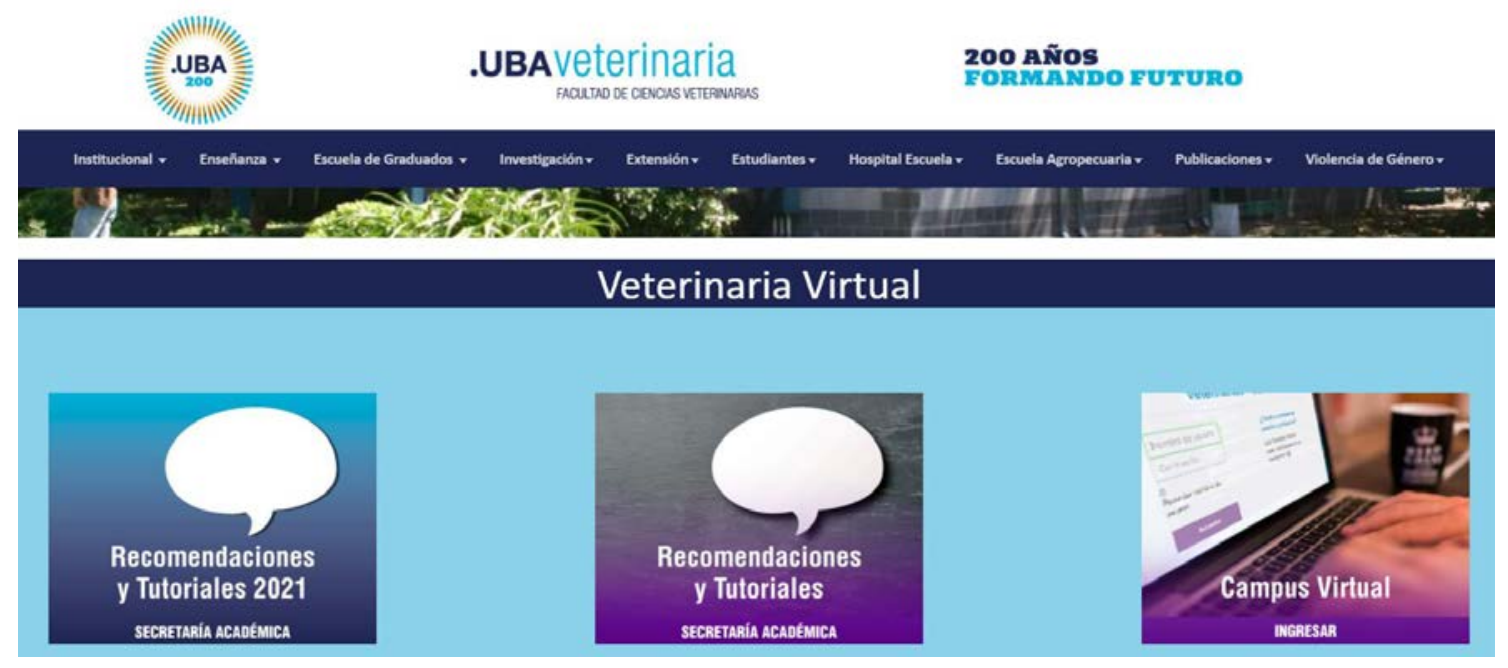

\section{Imagen 2: Minisitioweb}

El minisitio aloja contenidos elaborados por el Equipo Tecnopedagógico y contiene tres ventanas para accesos diferentes: Campus virtual, Recomendaciones y tutoriales (2020), Recomendaciones y tutoriales (2021). Los materiales disponibles son recursos educativos abiertos, por lo que no se requiere contar con usuario ni contraseña de acceso. Se incluye una pestaña destinada a brindar orientaciones a los estudiantes que desarrolla el área de Orientación a los estudiantes dependiente de la Secretaría Académica. Asimismo, se dispuso un acceso directo a repositorios bibliográficos digitales. 


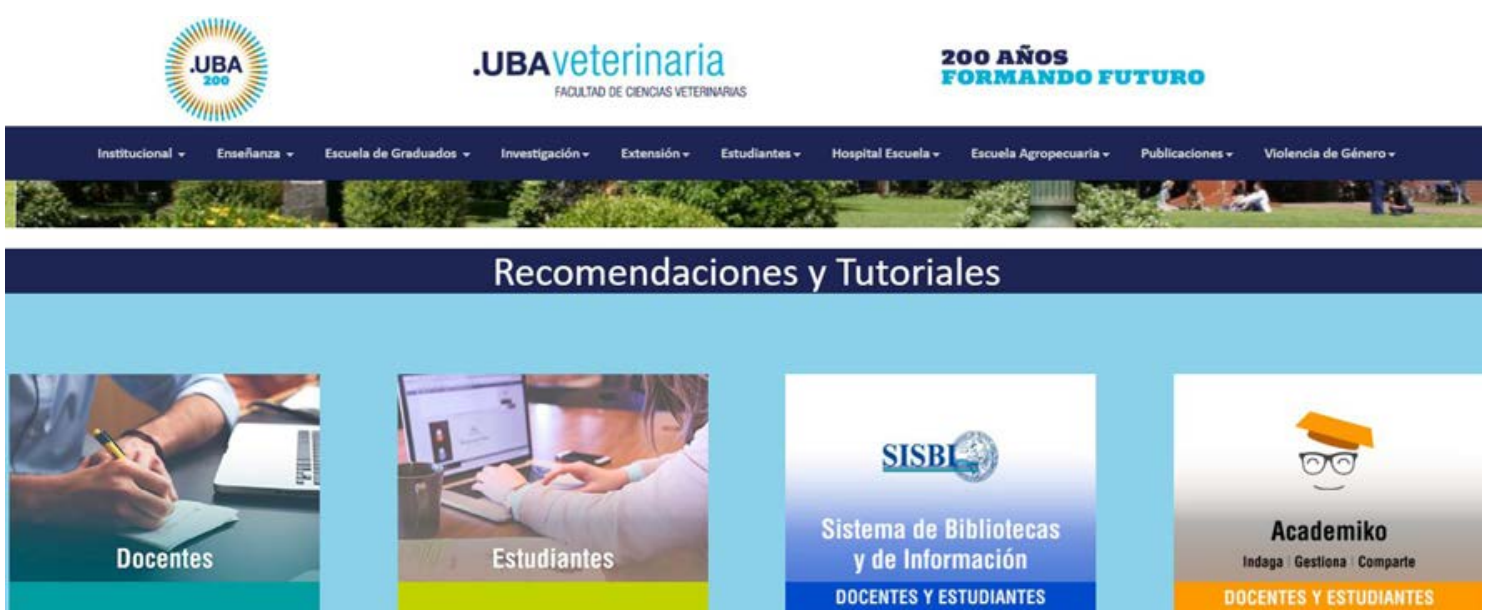

\section{Imagen 3: ventana del minisitio web /Acceso al minisitio web}

Ingresando a la ventana "Recomendaciones y tutoriales", es posible acceder a los materiales producidos durante 2020. A modo de cápsulas de conocimiento (Rueda Bruner, 2009), se proponen una serie de orientaciones para que los docentes puedan, en forma autónoma, organizar el contenido de sus asignaturas en el campus virtual y diseñar las clases virtuales. En el minisitio las cápsulas para docentes en formatos breves, atractivos, claros, y multimediales, incluyen una variedad de propuestas de orientación para la tarea: configuración de aula virtual, guías para la navegación en el campus, tutoriales sobre uso de campus virtual en Moodle, que se presentan en formato de texto, en video y en programas interactivos. Se proponen diferentes alternativas para la realización de propuestas de enseñanza activas, interactivas, mediante estrategias que utilizan una variedad de recursos y actividades; así como propuestas de modalidades alternativas de evaluación. La diversidad de formatos y lenguajes empleados en el diseño de tutoriales, tiene por finalidad favorecer su comprensión, visualización o lectura, haciéndolos amigables y autocontenidos.

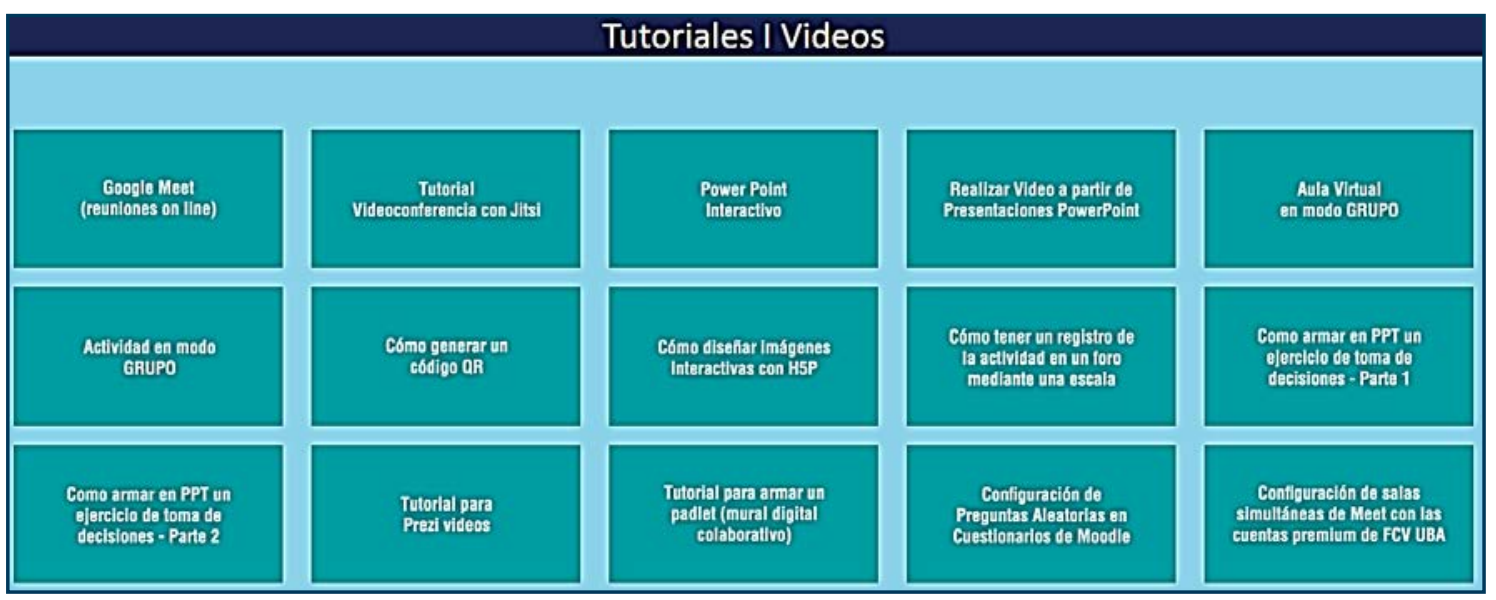



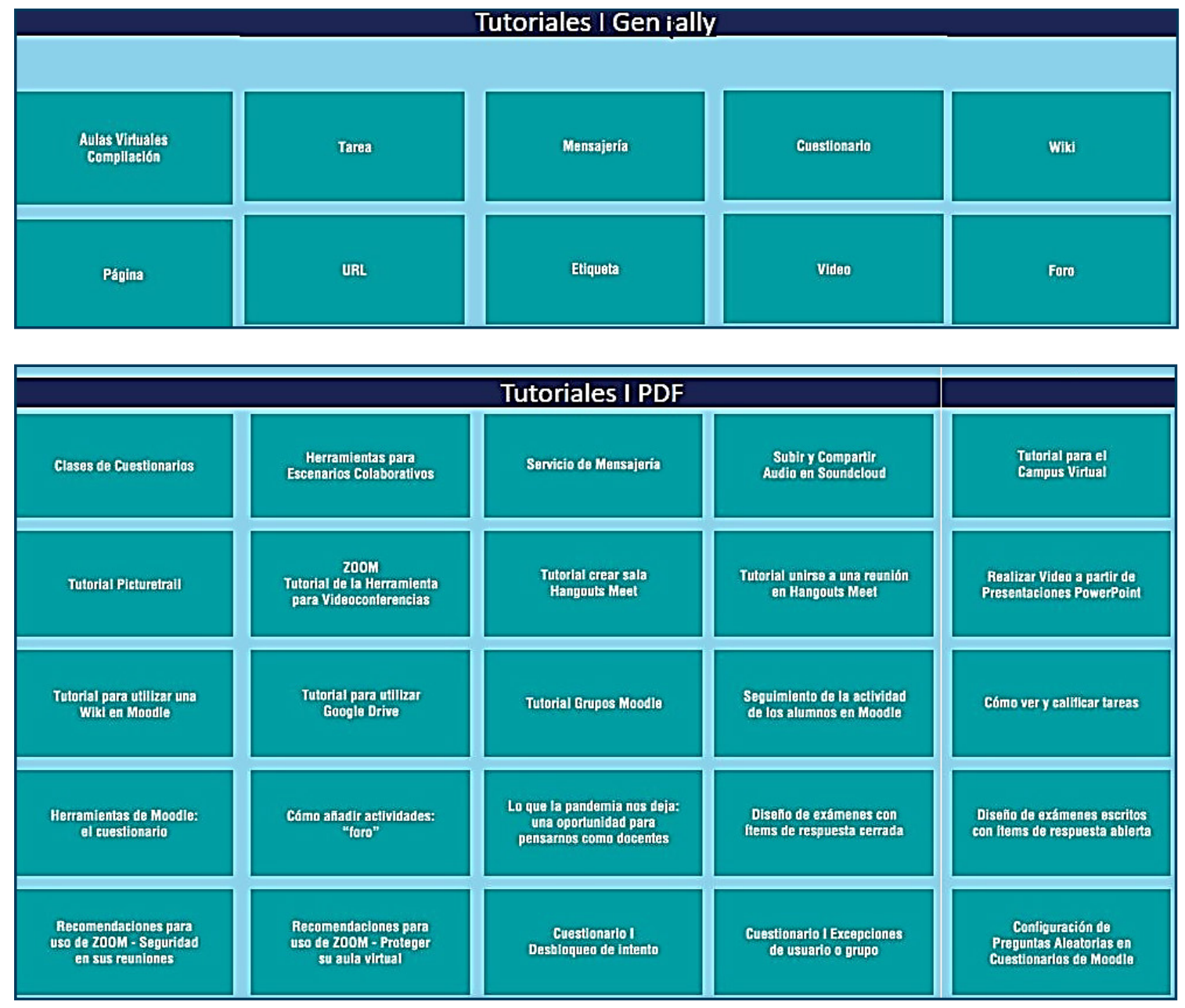

\section{Imagen 5: Tutoriales}

\section{Talleres}

Procurando dar respuesta a la notoria demanda de dispositivos de capacitación específica, que contribuyeran a dotar a los docentes de herramientas adecuadas para la enseñanza virtual, se realizaron 13 talleres de capacitación en las siguientes 6 temáticas: "Primeros pasos para configurar el aula virtual", "Diseño de imágenes interactivas", "Evaluar en la virtualidad", "Protocolo para exámenes finales virtuales", "Cuestionarios en Moodle", "Diseño de videos interactivos", "Enseñanza mediada por TIC empleando casos, problemas y simuladores".

Se estableció un cupo máximo de 35 participantes, para dar lugar a una mayor participación y posibilidades de intervención de los docentes cursantes, así como para generar espacios de consulta. Las grabaciones de dichos talleres se incluyen en el minisitio web.

\footnotetext{
${ }^{1}$ Enlaces a las grabaciones de los talleres, disponibles en el minisitio.
} 


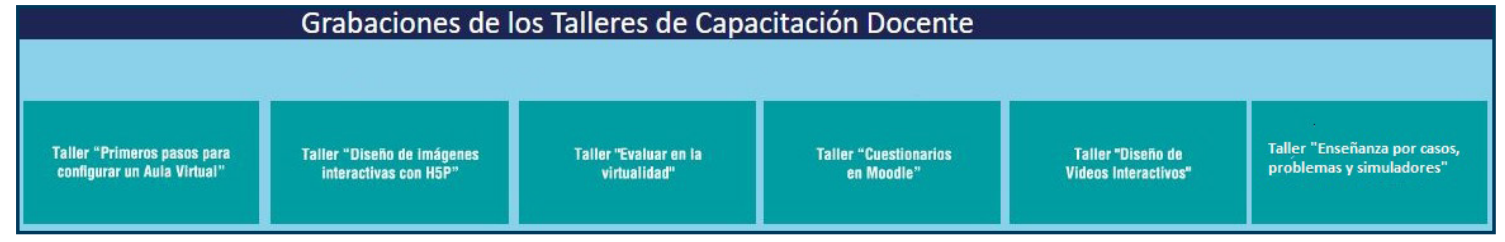

\section{Imagen 6: Grabaciones}

Los talleres de capacitación docente incluyeron actividades sincrónicas participativas, que se alojaron en el aula virtual "Talleres online" del campus, entorno combinado con la plataforma de videoconferencias Meet, que permitió a los docentes disponer de estos espacios de encuentro, y resolución de actividades, lo que facilitó que rápidamente se pudieran incorporar las propuestas de utilización de las plataformas educativas, actividades interactivas y modalidades de enseñanza virtual, con foco la centralidad de la actividad del estudiante en los procesos de enseñanza y aprendizaje. Participaron 430 de las capacitaciones durante 2020 y 2021.

\section{Talleres on line}

Área personal / Cursos / Talleres on line / Galería

\begin{tabular}{|c|c|c|c|c|c|}
\hline Introducción & Voicethread & Ejemplo H5P & Galeria & Tutoriales & Galería de simuladores \\
\hline \multicolumn{6}{|l|}{ Pinza } \\
\hline \multicolumn{6}{|c|}{ Parto de la Yegua. Quiz } \\
\hline \multicolumn{6}{|c|}{ Digestivo de Rumiantes Quiz } \\
\hline
\end{tabular}

Imagen 7: campus de talleres online

\section{Asesoramiento tecnopedagógico}

Los pedidos de asesoramiento de las cátedras frente a situaciones especiales, ya que el dominio de estrategias de enseñanza en la virtualidad, así como del manejo instrumental de herramientas y software apropiados para la enseñanza remota, es diverso entre los docentes, fueron respondidos por mail o en encuentros sincrónicos. Consistieron en la recomendación de software para diseñar un material o actividad específica; el diseño de cuestionarios de examen que resultaran confiables; organización de estudiantes en grupos para tareas en el aula virtual; herramientas disponibles para que estudiantes con hipoacusia accedieran a las locuciones en los videos de la cátedra; orientaciones pedagógicas y técnicas sobre la organización del aula virtual; sugerencias sobre estrategias didácticas en las clases por videoconferencia; sobre cómo producir archivos de audio y alojarlos en plataformas de podcast; modos convenientes para tomar asistencia de manera automática en las clases por Meet o reiniciar el aula virtual sin perder los recursos y actividades del cursado previo, entre otras. 


\section{Resultados y Conclusiones}

Sorteando la educación universitaria del futuro, con actividades inimaginadas meses atrás, que precipitan prácticas pedagógicas emergentes Adell, J. Castañeda, L. (2012) y suscitan reflexiones y discusiones nuevas acerca de la enseñanza, el aprendizaje, la evaluación, la práctica, los contenidos. De pronto el tsunami se convirtió en una oportunidad de mejora y de ese modo se concibió la tarea de apoyo a la docencia en la FCV-UBA. Resultó innovadora la modalidad de enseñanza que adoptaron numerosas materias, cuyos responsables interpretaron que no era posible emular la presencialidad en la enseñanza remota, por lo que implementaron el modelo de flipped classroom o clase invertida. Esta transformación implicó desarrollar contenidos virtuales a los que pudieran acceder los estudiantes de manera asincrónica. Asimismo, los docentes dotaron de interactividad a dichos recursos, a fin de que los estudiantes pusieran a prueba lo aprendido, resolviendo, por ejemplo, diferentes desafíos durante la visualización de un video interactivo o participando de actividades gamificadas que permitieran demostrar comprensiones profundas.

Se desarrollaron instrumentos de autoevaluación mediante software diverso, a fin de que el automonitoreo les permitiera a los cursantes obtener información y resultados sobre sus avances.

Materiales didácticos interactivos diseñados con software como H5P, Genial.ly, ejercicios de drag and drop, imágenes enriquecidas con capas de información en diferentes lenguajes, videos que proponen la resolución de desafíos durante su visualización, ejercicios que se valen de la metodología de aprendizaje basado en juegos; juegos serios como los simuladores que plantean problemas a resolver y rutas de navegación que dependen de las decisiones adoptadas; son ejemplos de medios educativos que alojaron las aulas virtuales.

La modalidad de coevaluación comenzó a ser experimentada por algunas asignaturas. Desafiando esa estructura de poder asimétrico, tan frecuente en la enseñanza tradicional, ha representado un verdadero reto para los docentes que se atrevieron a pensar la evaluación no como un acto de control sino como un acto de reconocimiento del otro en su valor.

En 2021, al cabo de la implementación de dos talleres sobre "Enseñanza mediada por TIC utilizando casos, problemas y simuladores", se les propuso a los docentes que diseñaran sus propios simuladores de toma de decisión, luego de experimentar con ejemplos producidos por el Equipo tecnopedagógico, a fin de presentarlos y compartirlos durante el evento "Desafío Veterinario 2021", a realizarse durante el mes de agosto. Será un encuentro virtual de intercambio de producciones que, seguramente, serán inspiradoras para los asistentes.

\section{Referencias}

Adell, J. Castañeda, L. (2012) ¿Tecnologías emergentes pedagogías emergentes? En J. Hernández, M. Pennesi, D. Sobrino y A. Vázquez (coord.). Tendencias emergentes en educación con TIC. Asociación Espiral, Educación y Tecnología. págs. 13-32. Barcelona 
Grinsztajn, F., Szteinberg, R., Vaccaro, M. (2018) "Tecnologías emergentes e innovación educativa: nuevos desafíos para la enseñanza universitaria de las ciencias veterinarias" Conferencia desarrollada en las Primeras Jornadas de inclusión de tecnologías digitales en la educación veterinaria" Facultad de Ciencias Veterinarias de la Universidad Nacional de La Plata.

Grinsztajn F., Szteinberg R. Vaccaro, M. (2018) Inclusión de TIC en la enseñanza universitaria: la experiencia de la Facultad de Ciencias Veterinarias UBA Congreso Internacional de Educación Superior Universidad 2018: "La universidad y la agenda 2030 para el desarrollo sostenible”. La Habana, Cuba.

Rueda Bruner S. (2009) Uso de Cápsulas Educativas para enriquecer el aprendizaje. Memorias. III Congreso de Innovación Educativa. Tecnológico Monterrey. México. 2009 [acceso 18/1/2019]; IV (6).

Disponible http://sitios.itesm.mx/va/dide2/enc_innov/3er08/memorias/pdfs/susana_rueda_01.pdf [ Links ] 


\section{Universidades Ante la Comunidad Digital: Adecuación de la Academia a las Redes Sociales, una Comparativa Entre España y Francia}

Mira-Aladrén, Marta

https://orcid.org/0000-0002-6088-0324

\section{Lozano-Blasco, Raquel}

https://orcid.org/0000-0002-0100-1449

\section{Latorre-Martínez, Ma Pilar}

https://orcid.org/0000-0002-8486-6885 


\title{
UNIVERSIDADES ANTE LA COMUNIDAD DIGITAL: ADECUACIÓN DE LA ACADEMIA A LAS REDES SOCIALES, UNA COMPARATIVA ENTRE ESPAÑA Y FRANCIA
}

\author{
Mira-Aladrén, Marta \\ Lozano-Blasco, Raquel \\ Latorre-Martínez, Ma Pilar
}

\section{Resumen}

El nuevo paradigma generado por las redes sociales implica la adaptación de las organizaciones a la nueva realidad virtual. En este caso las universidades tienen el desafío de comunicar a través de las redes sociales información atractiva y relevante a su comunidad digital. El objetivo de este estudio es analizar los perfiles institucionales de 36 cuentas corporativas correspondientes a 36 universidades (24 españolas y 12 francesas) en Twitter durante un periodo de tres meses. Se compara su presencia, impacto y rendimiento por medio de indicadores clave de rendimiento o KPIs (Key Performance Indicators). Los resultados muestran que, aunque existen diferencias entre las universidades francesas y españolas, es común una estrategia por la cual tratan de aumentar sus seguidores y mantener o aumentar el compromiso por la comunidad. Se concluye cómo la comunicación que realizan las universidades presenta rasgos similares a las publicaciones realizadas por influencers. En definitiva, las universidades, mediante sus cuentas corporativas, han sido capaces de adaptar su comunicación a la nueva realidad social, asumiendo e incorporando los elementos propios de la cultura digital.

\section{Palabras clave}

Universidad, Twitter, comunicación, educación superior, redes sociales. 


\section{Introducción}

Entendiendo los mensajes en redes sociales desde las funciones del lenguaje, se entiende que trascienden aquella meramente comunicativa, trasladándose a un plano más emocional dada la interacción y la expresión de opiniones y sentimientos, más allá de la mera publicidad de información. Por tanto, el qué y cómo se dice cobra un papel fundamental en la interacción y respuesta que generarán esos mensajes, aunque partan de una cuenta corporativa. Más aún si cabe en una época de pandemia como la actual y viniendo de instituciones académicas, cuyos mensajes cuentan con una autoridad científica mayor (Ruz, 2020). En este sentido, resulta crucial analizar el sentimiento que se genera para comprender la totalidad del mensaje y la percepción de los destinatarios (Yu, 2013; Ceron, 2014). Todo ello, apoyado en la captación de datos mediante Fanpage Karma y el análisis por reconocimiento de algoritmo. Además, se profundizará en el análisis en función de la polaridad y sentimiento de las publicaciones recabadas.

Con este planteamiento en mente, el presente trabajo se propone los siguientes objetivos: 1) conocer el comportamiento en Twitter de las universidades a ambos lados de la frontera y las respuestas al mismo; 2) analizar la comunicación institucional de las universidades durante el primer período de clases considerando las medidas instauradas contra la Covid-19; y, 3) comparar la comunicación en Twitter de las universidades del norte de España y el sur de Francia y los resultados que han obtenido.

Para alcanzar estos resultados, se parte de la hipótesis de que la comunicación de las universidades en Twitter se ha visto influenciada por la pandemia de la covid-19, existiendo diferencias entre países con respecto a las emociones y polaridad expresadas. Ésta tratará de ser corroborada mediante el uso de diferentes metodologías vinculadas a la información, la comunicación y las redes sociales.

Las redes sociales han modificado nuestra forma de relacionarnos. Entre algunos de los cambios generados por la digitalización se encuentra el mayor acceso a la información, por lo que parece interesante estudiar cómo se accede a la misma. En este sentido, las redes sociales adquieren una relevancia especial incrementando aspectos como la participación, la transparencia o la transferencia de conocimiento (Rendueles, 2019; Ispizua, 2018; Buhr, 2017; Ballestero, 2017; MlyT, 2014; Castel, 2010). Un ejemplo de ello es la creación de diferentes legislaciones por parte de países como España, con la Ley 19/2013, de 9 de diciembre, de transparencia, acceso a la información pública y buen gobierno o la Carta de Derechos Digitales Española que se encuentra en proceso de debate y elaboración para su aprobación. En este sentido autores como Rendueles Ilegan a hablar de una nueva concepción de ciudadanía, la ciudadanía digital, que tendría condiciones de posibilidad añadidas a la tradicional. Algunas de éstas serían el acceso a conexión o la formación necesaria para el uso y acceso a la información (Rendueles, 2016).

Dentro de este cambio de paradigma destaca la brecha generacional generada entre nativos digitales y personas que se han tenido que adaptar a esta nueva realidad. En este sentido, nativos digitales pueden considerarse a aquellas personas que han crecido en interacción con las nuevas tecnologías y, por tanto, procesan la información de forma diferenciada (Prensky, 2001; Linne, 2014; Rendueles, 2016). Algunos de los estudios acerca de la relación de los nativos digitales con la información proveniente de Internet destacando, por ejemplo, el de García-Avilés et al. (2014). 
Este artículo estudia la credibilidad de esta generación con respecto a la información por medios digitales, constatando que es mayor profesores y periodistas, que, en los políticos, los famosos o las empresas. Por el contrario, el artículo de Calva Nagua et al. (2019), define como la mediación de las tecnologías en las relaciones interpersonales ha incrementado la vulnerabilidad de los nativos digitales, no teniendo éstos una percepción del riesgo de su uso inadecuado y una falsa sensación de inmunidad. Resultados similares a los de Kamin'ski, et al. (2021), donde se observa que los tuits más populares durante la pandemia de la Covid-19 provenían de celebridades y políticos frente a los de instituciones científicas y sanitarias. Pese a esta disparidad de resultados, el estudio de Tavares y Melo (2019), indica la utilidad de esta relación formal e informal de los nativos digitales con las tecnologías para como herramienta de formación en el proceso de enseñanza-aprendizaje y de creación de vínculos formativos entre profesorado y alumnado y de lazos sociales entre el propio alumnado.

Del mismo modo se ha estudiado la importancia del mensaje para entender la sociedad y el acceso a la información. Por ejemplo, en el estudio presentado anteriormente de García-Avilés et al. (2014), la fiabilidad de las fuentes, la corrección y la hipertextualidad condiciona, también, la confianza en el mensaje de los nativos digitales. En el caso de los resultados de Kamin'ski, et al. (2021), las publicaciones más populares tenían un carácter mayoritariamente positivo, mientras que las que obtuvieron peores resultados lanzaban mensajes en su mayoría negativos. En este sentido, indican la necesidad de profundizar en la polaridad y atracción de los diferentes modos de comunicación para acercar estas instituciones a la sociedad.

En este sentido, tal y como plantean Thelwall y Levitt (2020), estudiar la polaridad de las publicaciones resulta de utilidad para gestionar la respuesta a los mismos y entender la credibilidad y aceptación de la información publicada. El análisis basado en la rueda de emociones de Plutchick (2001) es una herramienta que favorece este análisis ayudando a la clasificación de las palabras que aparecen en dichos mensajes en función de su positividad o negatividad (Hu y Liu, 2004). Este procedimiento parece haber dado resultados óptimos en otros estudios centrados en el análisis de la comunicación institucional (Ferrer-Serrano et al., 2020).

\section{Método/Descripción de la experiencia}

\section{Descripción del contexto y de los participantes}

En consonancia con el objetivo planteado, y dado el carácter transfronterizo del estudio, la muestra seleccionada se ha centrado en las cuentas corporativas de Twitter de los perfiles generales de las universidades públicas y privadas del norte de España y el sur de Francia. Esta selección se realizó con el fin de contrastar el comportamiento institucional, y las respuestas al mismo entre los dos países, pese a su proximidad geográfica. La muestra final fue de 36 cuentas de universidades (24 españolas y 12 francesas). Estas universidades se escogieron atendiendo a los rasgos sociales similares del territorio que ocupan, atendiendo a un criterio de significatividad. Además, se recogió una selección de un total de 5.000 tweets, siendo éstos los tweets con más likes de las cuentas seleccionadas. Todo ello se recogió mediante la aplicación Fanpage Karma, que permite la monitorización y captación tanto de $\mathrm{KPIs}$ (indicadores clave de rendimiento o medidores de desempeño) como de posts y tweets para su posterior análisis. 


\section{Instrumentos}

Para realizar el análisis de los datos recabados se emplearon las cuatro herramientas presentadas a continuación:

Fanpage Karma, una aplicación que permite recabar y monitorizar datos, así como lograr diferentes KPIs de gran utilidad para la comprensión de la actividad e interacción en redes sociales (Latorre-Martínez, 2018). En este caso se han seleccionado los siguientes: Número de seguidores; Número de Me gusta; Total de Reacciones, Comentarios, Compartidos; Crecimiento de seguidores (absoluto); Compromiso (la cantidad diaria de retweets y favoritos entre número de seguidores); Interacción de las publicaciones (número de interacciones dividido por el número de impresiones).

Flourish, una herramienta que favorece la visualización de estos datos, a través de diferentes figuras que se presentarán a lo largo del texto.

Meaning Cloud, en concreto su paquete analítico Emotion Recognition, un software de análisis de sentimiento por algoritmo empleado con el fin de profundizar en las expresiones emocionales presentadas. Se analizaron las variables: polaridad, emotividad, subjetividad, ironía y emociones según rueda de Plutchik (2001). Éstas se aplicaron sobre los tweets más significativos de las cuentas seleccionadas, de acuerdo a sus KPIs.

\section{Procedimiento}

El período de tiempo seleccionado fue de tres meses, del 1 de noviembre de 2020 al 31 de enero de 2021. Con esta franja de tiempo se pretendía analizar las valoraciones del primer período de clases con las medidas de seguridad frente a la Covid-19 instauradas, comparando las respuestas a las mismas y su comunicación a ambos lados de la frontera.

En primer lugar, mediante el uso de la aplicación Fanpage Karma y una metodología de monitorización de redes sociales, se obtuvieron por un lado los KPIs seleccionados referentes a las cuentas de las universidades; y, por otro, las 5.000 mejores publicaciones de dichas cuentas.

A continuación, por medio de un proceso de minería de datos mediante reconocimiento lingüístico por algoritmo, facilitado por la aplicación Meaning Cloud. Gracias a este análisis se pudo conocer la polaridad y las emociones, según la rueda de Plutchick (2001) de los mensajes lanzados, en otras palabras, el software clasifica las palabras que aparecen en las publicaciones en función de su positividad o negatividad (Hu, 2004). 


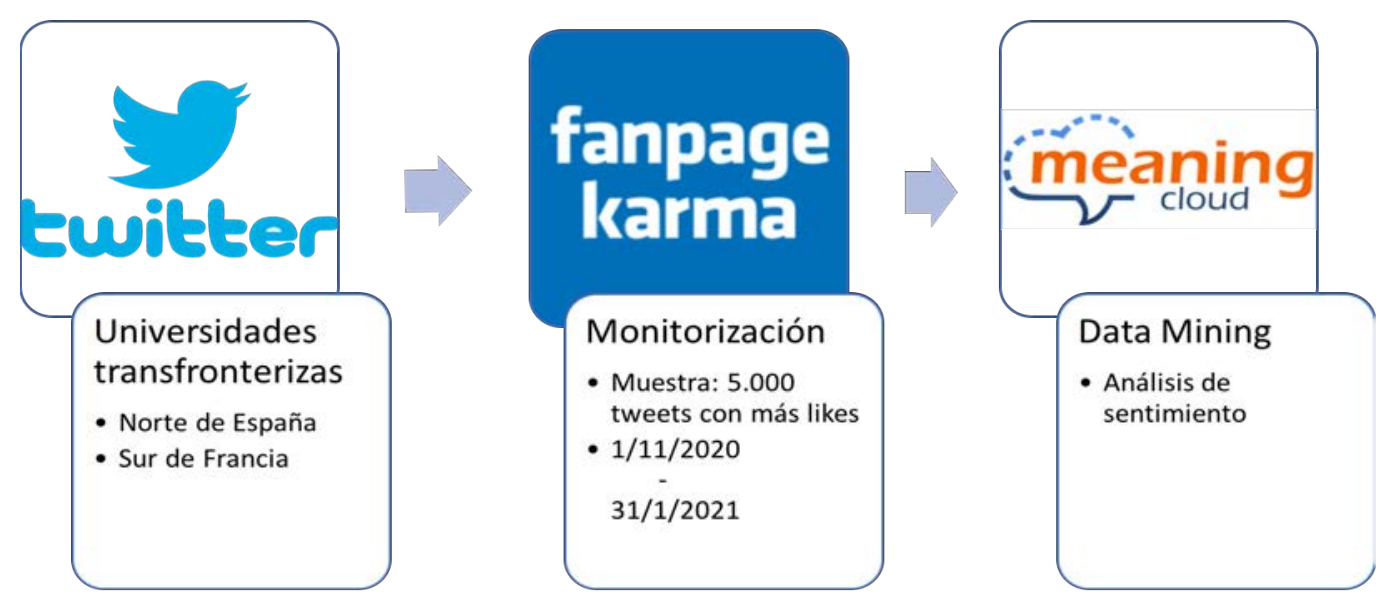

Figura 1. Esquema del procedimiento aplicado

\section{Resultados}

En términos generales, los resultados obtenidos muestran una mayor relevancia de las universidades españolas en relación con el número de seguidores. Este hecho contrasta con el análisis de otros KPI como el crecimiento de seguidores o el compromiso, donde destacan unos mejores resultados de las instituciones francesas. De este modo, puede afirmarse que, pese a que los centros españoles cuentan con un mayor número de seguidores, existe una menor interacción de los seguidores con las cuentas universitarias, sin todavía haber considerado el tipo de comunicación ni su utilidad. En relación con este indicador, destaca la Aix-Marseille Université, con un porcentaje de 0,44, siendo la única que supera el 0,4. A este centro le siguen: la UT3 Paul Sabatier, la Universidad de Zaragoza, la Universidad de Montpellier y la de Lleida. Todas ellas con un compromiso entre 0,29\% y 0,36\%. Destaca que tanto el número de fans como el compromiso de éstos, parece no tener una correlación lineal con el total de reacciones, donde la Universidad de Zaragoza se encontraría a la cabeza, con un total de 8.336, seguida de Aix-Marseille Université, la UPF de Barcelona, la Universitat de Barcelona y la Universidad de Navarra. Puede observarse en los siguientes gráficos de forma más visual: 
Tabla 1. Visualización con Flourish de diferentes KPI

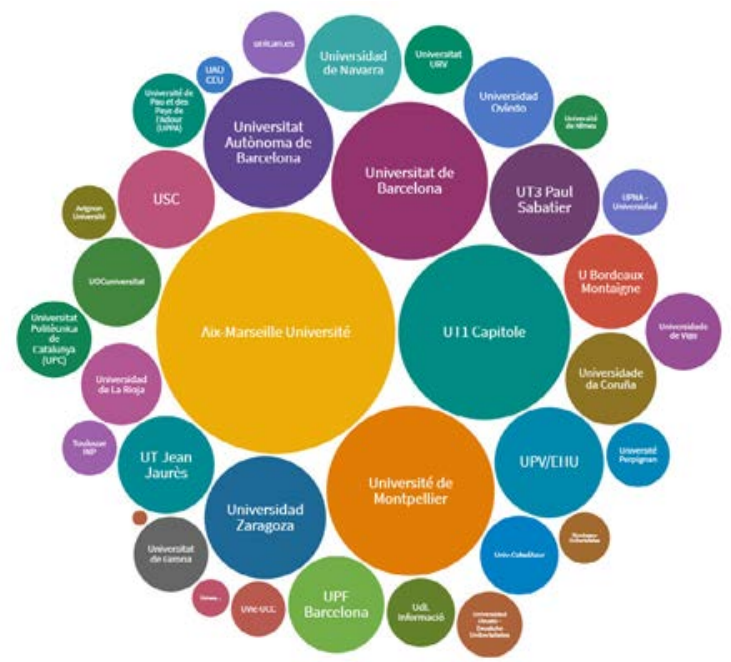

Cuentas en función del crecimiento absoluto de fans

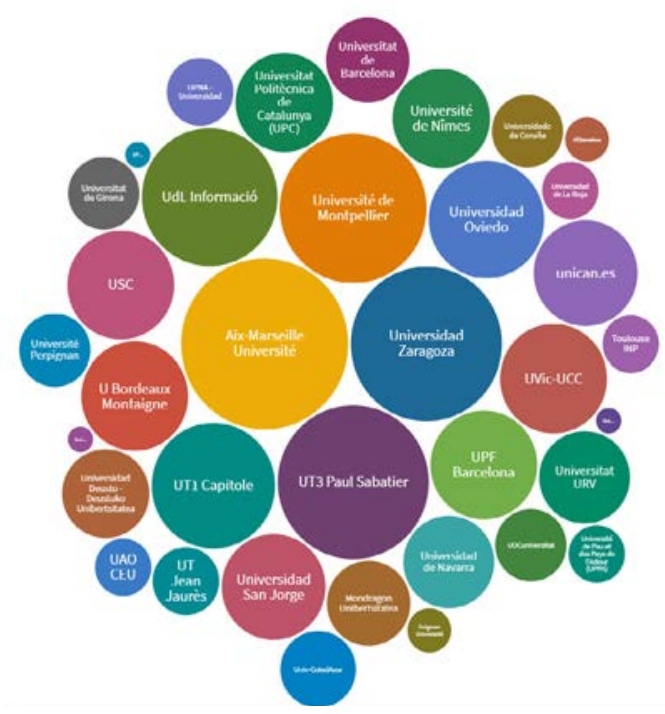

Cuentas en función del compromiso

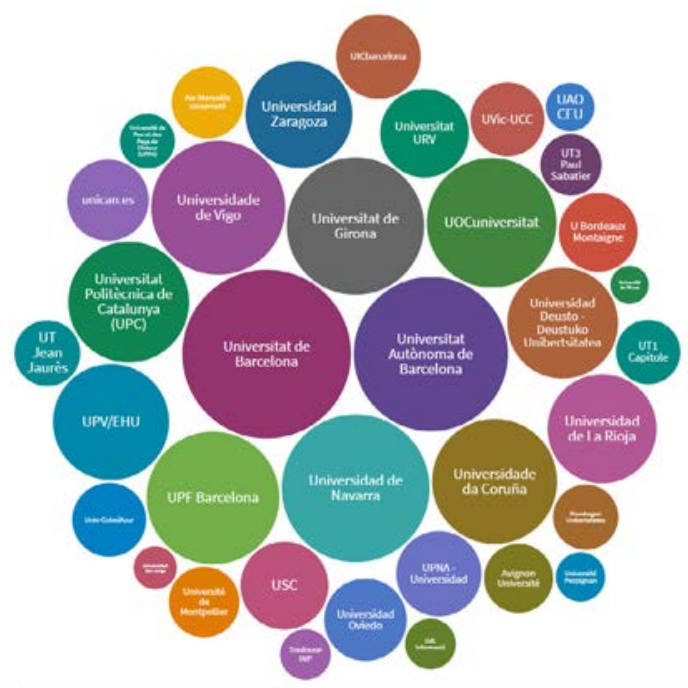

Cuentas en función del número de seguidores

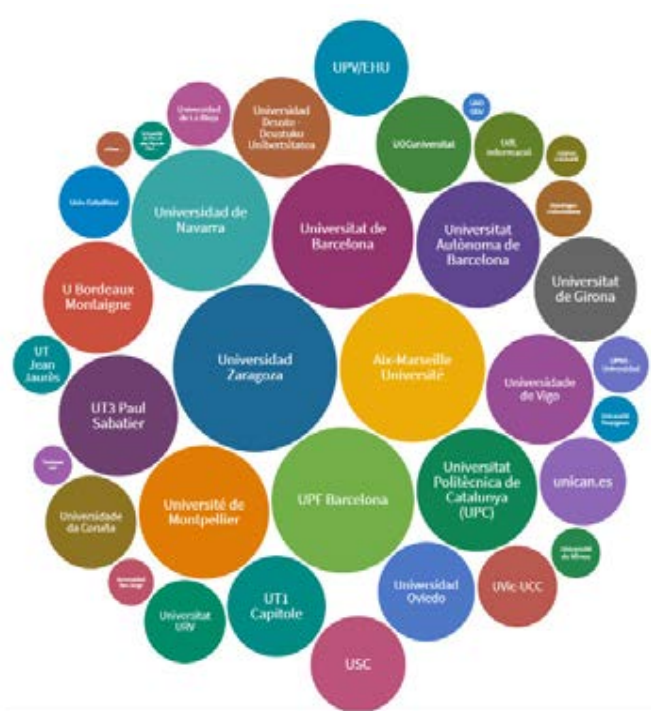

Cuentas en función del total de reacciones

Por último, conviene considerar los datos de la actividad de las diferentes universidades. En primer lugar, en cuanto al número de publicaciones destaca la Universidad de La Rioja, con 1019, seguida de la Université de Bordeaux Montaigne, la Universidad Oberta de Catalunya, la UT3 Paul Sabatier y la Universidad de Zaragoza. Esta distribución de tweets destaca que no se realiza de forma periódica y uniforme por parte de todas las universidades, ya que se puede observar como la principal cuenta continúa siendo la Universidad de la Rioja, seguida de la Oberta y la de Zaragoza. En cambio, les siguen la Universitat de Girona y la Politècnica de Catalunya, que no aparecían anteriormente. Atendiendo a la frecuencia semanal, la Université de Bordeaux Montaigne pasaría al puesto 10 y la UT3 Paul Sabatier al 12. Por ello, se puede afirmar que, sus tweets están más concentrados en determinados momentos, mientras que 
la Oberta y la Politècnica son más constantes, cuestión que podría vincularse con su número de seguidores. A continuación, analizaremos en profundidad el porqué de estos datos, atendiendo al tipo de comunicación y utilidad de los mismos.

Por otro lado, se analizó la polaridad de los mensajes recabados, es decir el grado de positividad o negatividad de los mismos (Hu y Liu, 2004). Se analizó tanto a nivel general como desglosado por países, con el fin de poder realizar una comparación a nivel transfronterizo.

Tabla 2. Polaridad presentada a nivel general y diferenciada por países

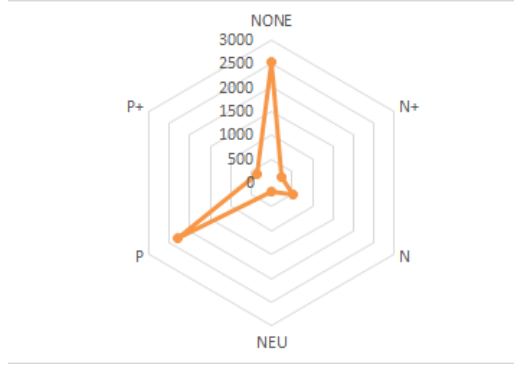

General

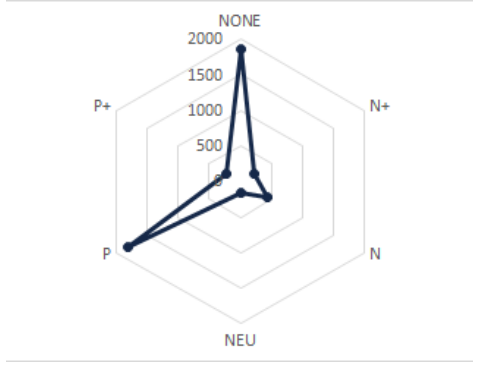

España

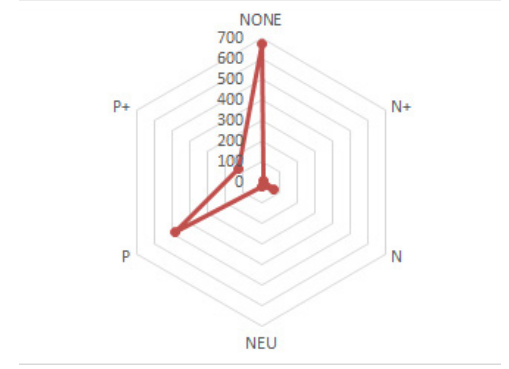

Francia

Como se puede observar, la positividad es predominante en los mensajes de las instituciones de ambos países, destacando a su vez que en ninguno de los casos destaca el número de mensajes con positividad o negatividad muy fuertes. En cambio, sí destaca, también en ambos casos, la cantidad de mensajes que no se pueden asociar con ninguna polaridad en concreto. Pese a estas similitudes, se ha detectado un mayor número de mensajes, proporcionalmente al del resto del país, del uso de mensajes negativos no extremos en España con respecto a Francia. Priorizándose en este segundo el uso de la positividad y dejándose en último lugar los mensajes fuertemente negativos, mientras que en España se dejan el último lugar los mensajes fuertemente positivos o negativos y los neutrales. De este modo, puede afirmarse que existen diferencias en el modo de comunicación de las instituciones universitarias a nivel transfronterizo, siendo más neutral en España y más positivo en Francia.

Tras este análisis, se procedió a la profundización en las emociones presentes en los mensajes recabados, dando lugar a la siguiente gráfica: 


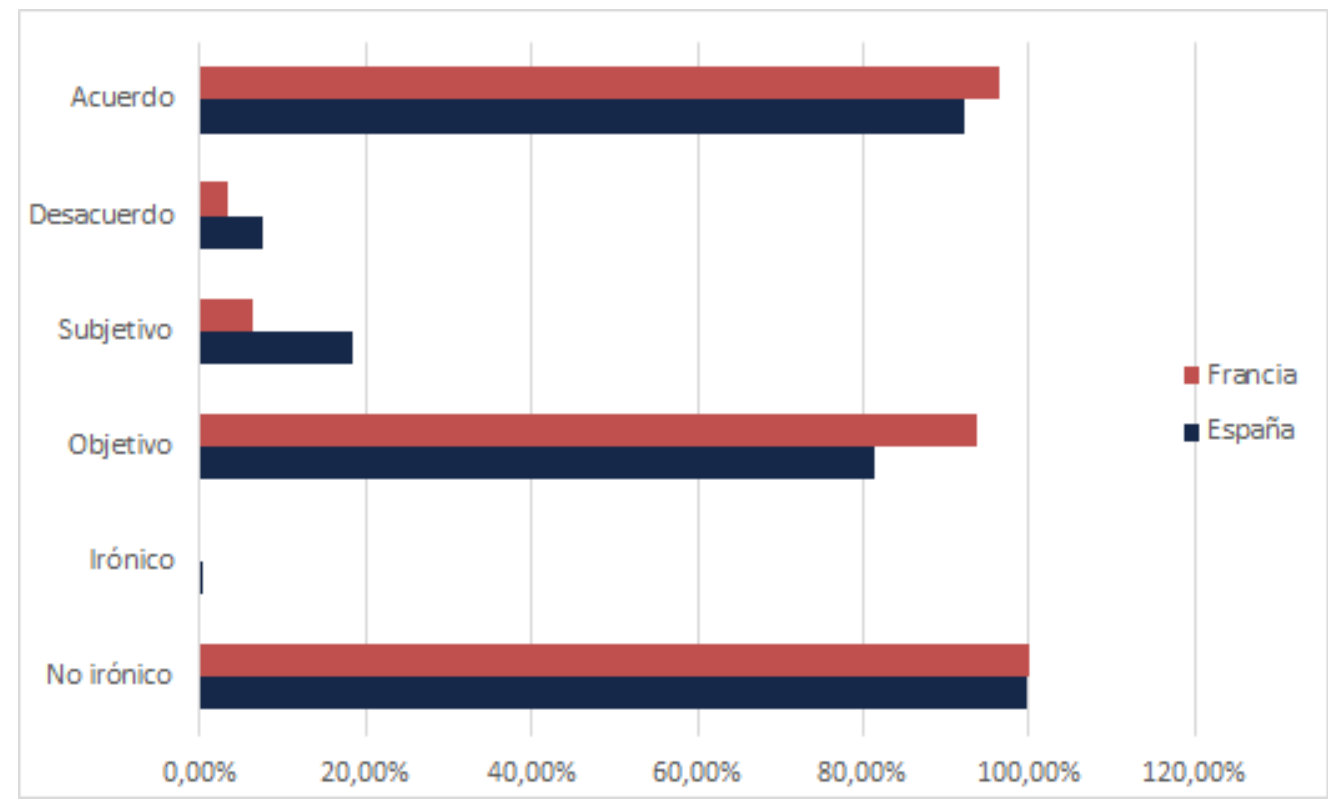

\section{Figura 2. Emociones de los mensajes por países (en porcentaje)}

Atendiendo a estos resultados, puede afirmarse que más del $80 \%$ de los mensajes lanzados por las universidades de ambos países se caracterizaban por ser objetivos, mostrar acuerdo y, sobre todo, no ser irónicos. Es decir, de acuerdo a los resultados obtenidos en polaridad y las emociones, puede afirmarse que estas instituciones tienen predilección por comunicar con menor carga emocional. Pese a ello, del mismo modo que ocurría en la polaridad, se perciben ciertas diferencias entre los mensajes publicados a ambos lados de la frontera. Se ha detectado una mayor subjetividad y desacuerdo en los pertenecientes a instituciones españolas, cuestión vinculada a la menor neutralidad de sus mensajes en el ámbito de la polaridad. A continuación, se realizó la prueba chi-cuadrado para cada una de las variables por país, dando como resultado, la evidencia de diferencias significativas en variables como me gusta, polaridad o subjetividad, pero no en la ironía.

Tabla 3. Diferencias entre países mediante la prueba de Chi-cuadrado de Pearson

\begin{tabular}{|c|c|c|}
\hline Variables & Chi-cuadrado & p \\
\hline Me gusta & 235,24 & $\mathbf{0 , 0 0}$ \\
\hline Confianza & 91,44 & $\mathbf{0 , 0 0}$ \\
\hline Polaridad & 140,54 & $\mathbf{0 , 0 0}$ \\
\hline Acuerdo & 30,03 & $\mathbf{0 , 0 0}$ \\
\hline Subjetividad & 121,15 & $\mathbf{0 , 0 0}$ \\
\hline Ironía & 2,63 & 0,10 \\
\hline
\end{tabular}

Con el fin de entender la relación entre estas variables y profundizar en la realidad de los mismos se estudió la correlación entre ellos. Tras la realización de la prueba de $Z$ de Kolmogorov-Smirnov, obteniendo una significación estadística menor de 0.05 , se comprobó que los resultados no se ajustaban a la normalidad. En base a 
esta información, se estudió la existencia o no de correlación mediante Spearman, obteniéndose los siguientes resultados:

Tabla 4. Correlación entre las variables analizadas

\begin{tabular}{|c|c|c|c|c|c|c|c|}
\hline & 1 & 2 & 3 & 4 & 5 & 6 & 7 \\
\hline \multicolumn{8}{|c|}{ 1.Número de Me gusta } \\
\hline $\begin{array}{l}\text { 2.Interacción de las } \\
\text { publicaciones }\end{array}$ & ,838** & & & & & & \\
\hline 3.Confidencia &,$- 053^{* *}$ &,$- 044^{* *}$ & & & & & \\
\hline 4.Polaridad & ,090** &, $118^{* *}$ &,$- 242^{* *}$ & & & & \\
\hline 5.Acuerdo &,$- 042^{* *}$ &,$- 036^{* *}$ & ,718** &,$- 102^{* *}$ & & & \\
\hline 6.Subjetividad & ,026* &, 000 &,$- 189^{* *}$ & ,319** &,$- 172^{* *}$ & & \\
\hline 7.Ironía & ,024 & , 019 &,$- 113^{* *}$ &, $033^{*}$ &,$- 058^{* *}$ &, $030^{*}$ & \\
\hline
\end{tabular}

${ }^{1 *} \mathrm{p}<0.05,{ }^{* *} \mathrm{p}<0.01,{ }^{* * *} \mathrm{p}<0.001$

Atendiendo a la tabla anterior encontramos como la variable "Número de me gusta" correlaciona positivamente con "Interacción de las publicaciones" $(r=0.838, p<0.01)$, "Polaridad" ( $r=0.09, p<0.01)$, "Subjetividad" ( $r=0.026, p<0.05)$ e "Ironía" $(r=0.024$, $\mathrm{p}>0.05)$. Del total de datos, destaca la correlación existente entre "Interacción de las publicaciones" y "Número de me gusta". Es decir, puede afirmarse que a mayor número de me gustas se genera una mayor interacción, logrando, por tanto, un mayor impacto de los mensajes lanzados desde las instituciones. Otras relaciones a destacar serían las de acuerdo y confidencia y, por otro lado, subjetividad y polaridad, ésta última con un coeficiente de correlación mucho menor.

Con el fin de analizar estas diferencias en el impacto de sus publicaciones, se realizó un análisis en profundidad de los KPI "Número de Me gustas" e "Interacción de las publicaciones". El primero hace referencia a la cantidad de likes o "me gustas" que ha recibido una publicación; y, el segundo, haría referencia, también, a los retuits, mensajes compartidos, guardados, etc. De este modo, se tratará de conocer qué características de la comunicación generan una mayor interacción y gustan más a los y las destinatarias.

Los resultados de la correlación mostraron una interesante relación entre variables. Sin embargo, es necesario realizar una prueba de regresión para determinar la fuerza de las variables. De esta forma, se establece que porcentaje de la varianza del "número de me gustas" es explicado. Concretamente, el 52,3\% de los me gusta son explicados por la interacción de las publicaciones, y la subjetividad, teniendo en ambos una relación positiva. En primer lugar, atendiendo a la variable "Número de Me gustas" como variable dependiente se obtuvo un $\mathrm{R}^{2 * * *}$ de 0,523 con un Error Estándar de la estimación de 11,658, F de 1117,332 y los siguientes coeficientes: 
Tabla 5. Coeficientes para la variable dependiente "Número de Me gustas"

\begin{tabular}{|c|c|c|c|c|c|}
\hline \multirow[b]{2}{*}{ Modelo } & \multicolumn{2}{|c|}{$\begin{array}{l}\text { Coeficientes no } \\
\text { estandarizados }\end{array}$} & \multicolumn{2}{|l|}{$\begin{array}{l}\text { Coeficientes } \\
\text { estandarizados }\end{array}$} & \multirow[b]{2}{*}{ Sig. } \\
\hline & B & Desv. Error & Beta & $\mathbf{t}$ & \\
\hline (Constante) & 5,476 & 9,123 & & ,600 & , 548 \\
\hline $\begin{array}{l}\text { Interacción } \\
\text { publicaciones }\end{array}$ & 9969,623 & 122,298 & ,723 & 81,519 & ,000 \\
\hline Confidencia &,- 019 & ,098 &,- 003 &,- 189 & ,850 \\
\hline Polaridad &,- 147 & ,083 &,- 017 & $-1,773$ & ,076 \\
\hline Acuerdo & $-1,159$ & ,934 &,- 017 & $-1,241$ & ,215 \\
\hline Subjetividad & 2,130 & ,436 & ,046 & 4,884 & ,000 \\
\hline Ironía & $-1,713$ & 4,013 &,- 004 &,- 427 & ,669 \\
\hline
\end{tabular}

A continuación, se realizó el mismo proceso para la variable dependiente "Interacción de las publicaciones". Se obtuvo un $\mathrm{R}^{2 * * *}$ de 0,524 con un Error Estándar de la estimación de 0,000843817915530, F de 1123,481 y los siguientes coeficientes:

Tabla 6. Coeficientes para la variable dependiente "Interacción de las publicaciones"

\begin{tabular}{|l|ll|l|l|l|}
\multicolumn{2}{c}{$\begin{array}{l}\text { Coeficientes no } \\
\text { estandarizados }\end{array}$} & \multicolumn{2}{l}{$\begin{array}{l}\text { Coeficientes } \\
\text { estandarizados }\end{array}$} \\
Modelo & B & Desv. Error & \multicolumn{1}{l}{ Beta } & \multicolumn{1}{l|}{ t } & Sig. \\
\hline (Constante) &, 000 &, 001 & &,- 678 &, 498 \\
\hline Confidencia & $5,439 \mathrm{E}-6$ &, 000 &, 011 &, 766 &, 444 \\
\hline Polaridad & $3,291 \mathrm{E}-5$ &, 000 &, 052 & 5,507 &, 000 \\
\hline Acuerdo & $2,382 \mathrm{E}-5$ &, 000 &, 005 &, 352 &, 725 \\
\hline Subjetividad &, 000 &, 000 &,- 047 & $-4,993$ &, 000 \\
\hline Ironía &, 001 &, 000 &, 020 & 2,243 &, 025 \\
\hline Número Me gusta & $5,223 \mathrm{E}-5$ &, 000 &, 721 & 81,519 &, 000 \\
\hline
\end{tabular}

Atendiendo a los datos expuestos, se puede afirmar que existe una correlación entre el número de "me gustas" y la interacción y la subjetividad de los mensajes. Es decir, gustan más aquellos mensajes que tienen una mayor interacción y mayor subjetividad. En cambio, en relación con los resultados vinculados con la interacción de las publicaciones, se observa que es mayor al ser mayor el número de "me gustas", pero, por el contrario, mayor objetividad y positividad. En otras palabras, puede concluirse que, pese a que gustan más las publicaciones que reflejan subjetividad son, finalmente, las objetivas y con mayor carga positiva las que se comparten y generan una mayor interacción en las redes. 


\section{Discusión y conclusiones}

El ecosistema generado por las redes sociales supone un nuevo espacio de interacción humana, en el cual las instituciones no se quedan al margen, sino que participan de este modelo de ciudadanía (Ispizua Dorna, 2018; Buhr et al., 2017). De este modo, se busca desde la academia generar no sólo un espacio que le identifique como comunidad digital mediante las cuentas corporativas de Twitter, sino que se busca la participación, la transparencia y la transferencia de conocimiento (Rendueles, 2019; Ballestero y Pérez, 2017; MlyT, 2014; Castel, 2010). En coherencia con la literatura científica, se encuentra como los resultados de los KPI muestran un interesante crecimiento, de modo que no sólo la cantidad de seguidores media es elevada, sino como existe un fuerte compromiso por los mismos. Los resultados encontrados son coherentes con estudios previos como Ferrer-Serrano et al. (2020), en el que se muestra como las universidades replican las estrategias comunicativas que logran la captación de seguidores y el aumento de compromiso.

Por otra parte, se debe entender a las redes sociales como una metáfora de termómetro social en las cuales podemos ver las inquietudes del ser humano. Esta situación, ha derivado en una comunicación con un carácter muy concreto. El análisis de polaridad de los resultados muestra como las publicaciones están marcadas por una fuerte positividad y un carácter objetivo. Es decir, aunque presentan información de manera objetiva mediante descripciones ausentes de opinión personal, los temas tratados reflejan una importante positividad, es decir, transmiten información bucólica. En este sentido, estos resultados concuerdan con estudios previos en los que se analiza cómo las publicaciones con mayor cantidad de me gusta son aquellas en las que efectivamente se presentan emociones agradables, como la alegría (Hu y Liu, 2004; Plutchick ,2001; Thelwall y Levitt, 2020). Si bien es necesario tener presente que existen diferencias en la positividad entre naciones, aunque la predominancia es a la positividad, en este sentido, los resultados diferenciales entre universidades españolas y francesas tienen coherencia a la luz del estudio de Hu y Liu (2004).

Se concluye que, a pesar de existir diferencias en la comunicación de las universidades españolas y francesas en los perfiles corporativos de Twitter, la academia opta por generar un espacio común para la comunidad digital marcado por una fuerte captación de fans, mantenimiento o crecimiento del compromiso, polaridad positividad y una descripción objetiva de la información.

\section{Referencias}

Ballestero, F. y Pérez, M. (2017). El papel del Estado ante la digitalización de la economía. Estrategia digital y políticas públicas. La economía digital en España, Sept.Oct. (898), pp. 113-129. https://doi.org/10.32796/ice.2017.898

Buhr, D. et al. (2017). ¿Hacia el Bienestar 4.0? La digitalización del Estado de bienestar en el mercado laboral, la asistencia sanitaria y la política de innovación: comparación europea. FES Madrid. http://fes-madrid.org/media/2017_FESpublicaciones/ FES_Bienestar_4.0-p2.pdf 
Calva Nagua, D. X., Galarza Schoenfeld, A. S. y Sare Ochoa, F. I. (2019). Las redes sociales y las relaciones interpersonales de las nuevas generaciones de ecuatorianos. Revista Conrado, 15(66), pp. 31-37. http://conrado.ucf.edu.cu/index.php/conrado

Castel, R. (2010). El ascenso de las incertidumbres: trabajo, protecciones, estatuto del individuo. Fondo de Cultura Económica.

Ceron, A., Curini, L., lacus, S. M. y Porro, G. (2014). Every tweet counts? How sentiment analysis of social media can improve our knowledge of citizens' political preferences with an application to Italy and France. New media and society, 16(2), pp. 340-358. https://doi.org/10.1177/1461444813480466

Ferrer-Serrano, M., Latorre-Martínez, M. P. y Lozano-Blasco, R. (2020). Universidades y comunicación. Papel de Twitter durante el inicio de la crisis sanitaria de la Covid-19. Profesional de la información, 29(6), e290612. https://doi.org/10.3145/ epi.2020.nov.12

García-Avilés, J. A., Navarro-Maillo, F. y Arias-Robles, F. (2014). La credibilidad de los contenidos informativos en Internet para los "nativos digitales": estudio de caso. Palabra Clave, 17(3), pp. 875-894. https://doi.org/10.5294/pacla.2014.17.3.13

Hu, M. y Liu, B. (2004). Mining and summarizing customer reviews. Proceedings of the 10th ACM Sigkdd International conference on knowledge discovery and data mining, pp. 168-177. https://doi.org/10.1145/1014052.1014073

Ispizua Dorna, E. (2018). Industria 4.0: ¿Cómo afecta la digitalización al sistema de protección social? Lan Harremanak, 2018(40), pp. 12-30. https://ojs.ehu.eus/index. php/Lan_Harremanak/article/view/20325

Kamin Ski, M., Szyman Ska, C. y Nowak, J. K. (2021). Whose tweets on COVID-19 gain the most attention: Celebrities, political, or scientific authorities? Cyberpsychology, Behavior, and Social Networking, 24(2), pp. 123-128. https://doi.org/10.1089/ cyber.2020.0336

Latorre-Martínez, M. P., Orive-Serrano, V. y Î́niguez-Dieste, D. (2018). Medición y análisis de la audiencia social de las televisiones autonómicas en Facebook y Twitter. El profesional de la información, 27(5), pp. 1061-1070. https://doi.org/10.3145/epi.2018. sep.10

Linne, J. (2014). Two generations of digital natives. Revista Brasileira de Ciências da Comunicação, 37(2), pp. 203-221. https://doi.org/10.1590/1809-584420149

Ministerio de Industria y Turismo (MlyT) (2014). La transformación digital de la industria española. Informe preliminar. Ministerio de Industria y Turismo de España. http://www6.mityc.es/IndustriaConectada40/informe-industria-conectada40.pdf

Plutchik, R. (2001). The nature of emotions: Human emotions have deep evolutionary roots, a fact that may explain their complexity and provide tools for clinical practice. American scientist, 89(4), pp. 344-350. https://doi.org/10.1511/2001.28.739

Prensky, M. (2001). Digital natives, digital immigrants. On the horizon, 9(5), pp. 1-6. https://doi.org/10.1108/10748120110424816 
Rendueles, C. (2016). "La ciudadanía digital. ¿Ágora aumentada o individualismo post-materialista?”. RELATEC, 15(2), pp. 15-24. https://doi.org/10.17398/1695-288X.15.2.15

Rendueles, C. y Sádaba, I. (2019). Digitalización y cambio social. De las expectativas apocalípticas a la tecnopolítica del presente. Cuadernos de Relaciones Laborales, 37(1), pp. 331-349. https://doi.org/10.5209/crla.66041

Ruz, G. A., Henríquez, P. A. y Mascareño, A. (2020). Sentiment analysis of Twitter data during critical events through Bayesian networks classifiers. Future generation computer systems, 106, pp. 92-104. https://doi.org/10.1016/j.future.2020.01.005

Tavares, V. S. y Melo, R. B. (2019). Possibilities for formal and informal learning in the digital era: what does the digital native youth think? Psicologia Escolar e Educacional, 23, e183039. https://doi.org/10.1590/2175-35392019013039

Thelwall, M. y Levitt, J. M. (2020). Retweeting Covid-19 disability issues: Risks, support and outrage. El profesional de la información, 29(2), e290216. https://doi. org/10.3145/epi.2020.mar.16

Yu, Y., Duan, W. y Cao, Q. (2013). The impact of social and conventional media on firm equity value: A sentiment analysis approach. Decision support systems, 55(4), pp. 919-926. https://doi.org/10.1016/j.dss.2012.12.028 


\section{Aplicación de Juegos Serios como Herramienta de Enseñanza en Tiempos de Pandemía}

\section{Parkinson, Christian}

Universidad Cuenca del Plata

parkinsonchristiananibal_cen@ucp.edu.ar

\section{Martínez, Roxana}

Universidad Nacional de La Plata maria.martinez@info.unlp.edu.ar 


\title{
APLICACIÓN DE JUEGOS SERIOS COMO HERRAMIENTA DE ENSEÑANZA EN TIEMPOS DE PANDEMIA
}

\author{
Parkinson, Christian \\ Martínez, Roxana
}

\section{Resumen}

En la situación actual de pandemia, una numerosa cantidad de actividades se vieron ante la necesidad de adaptarse y la educación no ha quedado exenta de dicha condición. En este punto aparecieron las dificultades de enseñanza virtual en lo que respecta a las actividades asincrónicas, se presenta una metodología de aprendizaje para una modalidad de aula invertida a través de la implementación de juegos serios. Para ello, se propone un proyecto que permite realizar el seguimiento individual y colectivo de estudiantes, con la posibilidad de participar en un repositorio de contenidos universal para la democratización de la información, como a su vez, mediante el uso de juegos serios, aprovechar la atracción propia de los videojuegos multijugador a fin de integrar los contenidos previstos en las entidades educativas. Los resultados obtenidos de pruebas realizadas con estudiantes y docentes fueron positivos, y permitieron llegar a la conclusión de que el uso de juegos serios en ambientes escolares es un factor que beneficia al alumnado tanto en el rendimiento escolar como a su vez, al interés sobre la asignatura. Asimismo, beneficia a las instituciones educativas proporcionando una herramienta para el seguimiento colectivo e individual del rendimiento de los alumnos, como así también de los docentes.

\section{Palabras clave}

Juegos serios, Aprendizaje colaborativo, Aula Invertida. 


\section{Introducción}

En este contexto de pandemia, los institutos educativos se han visto en la obligación de modificar el esquema de clases presenciales a un nuevo escenario de virtualidad del tipo sincrónico y asincrónico en sus actividades de plataformas online, lo que llevó a los docentes de los diversos niveles, a utilizar y a su vez, aprender diferentes herramientas informáticas para reemplazar la presencialidad en las aulas. En base a esta realidad, se realizan investigaciones sobre diferentes estrategias pedagógicas utilizadas mundialmente, en la que la más destacada, es el aula invertida que propone un nuevo rol docente como facilitador del aprendizaje, quien se encarga de organizar la interacción y el debate entre los estudiantes en consonancia con los contenidos ofrecidos previamente mediante las plataformas digitales (Zamar y Segura,2020). Lliteras et al. (2021) indica que "el contenido básico de una materia, en lugar de ser brindado grupalmente en el aula, por lo que se brinda un formato para que cada estudiante lo experimente y trabaje en su casa, y el espacio áulico se transforma en un espacio interactivo a través de una plataforma virtual, donde el docente guía a los estudiantes para que apliquen los conocimientos". Esta situación muestra inconvenientes: tratamiento del proceso de resolución de las actividades realizadas por los estudiantes, ya que, la parte asincrónica abre la posibilidad de que éstos puedan acceder a diversas fuentes bibliográficas no oficiales o bien de carácter erróneo, lo que conduce a incrementar la posibilidad de errores en lo que respecta a la adquisición de conocimientos. Todo esto, conlleva a que es necesario guiar el aprendizaje asincrónico definiendo una trazabilidad y seguimiento en las tareas que se desarrollan como así también, el cotejo de las fuentes bibliográficas. Otro de los puntos, es la desigualdad de recursos con los que cuentan los estudiantes, es decir, las personas de menos recursos son las más desfavorecidas en esta situación. Esto puede analizarse desde problemas económicos, o bien por problemas de discapacidades en cuestiones relativas a la salud, básicamente, no tienen las mismas posibilidades para poder trabajar en las tareas relativas al ambiente asíncrono. Esto podría ser evacuado, con herramientas de IT que permita un acceso más simple, por ejemplo, desde dispositivos móviles (para personas que no cuentan con PC, notebooks, etc.), cómo así también una disponibilidad de servicios para permitir una igualdad de condiciones, en los mayores aspectos que sean posibles. Otro problema a cubrir cómo institución es el seguimiento de actividades docentes, y, por otra parte, el tratamiento de la homogeneización de los contenidos de las asignaturas entre los colegas docentes. En base a lo explicado anteriormente cómo problemática, el objeto de estudio y la estrategia de investigación es la implementación de los juegos serios como instrumento integrador y de acompañamiento para los diferentes actores involucrados, siendo éstos: directivos, gabinete psicopedagógico y estudiantes. En principio, la pregunta que nace es el ¿Por qué utilizar videojuegos? Lárez (2006) afirma que "Los videojuegos constituyen una excelente herramienta de multiestimulación cognitivo afectiva que acelera el aprendizaje, genera placer, y potencia las habilidades digitales, el pensamiento estratégico y la creatividad, dependiendo en mayor o menor medida del tipo o género de videojuego que más se juegue”. Desde la perspectiva docente, García-Sánchez et al. (2019) hace énfasis en que "la inasistencia a clase está asociada al fracaso académico y al abandono o prolongación de los estudios. Varios autores han demostrado la eficacia de los juegos serios en la docencia universitaria: aumento de la motivación, mayor concentración y consecución de los objetivos de aprendizaje marcados", por lo cual, refuerza la idea de que implementar juegos serios para los ciclos escolares puede mejorar sustancialmente el desempeño de los alumnos. La base principal es aprovechar las ventajas de estas aplicaciones para fomentar el aprendizaje con diversión, y a su 
vez, adquiriendo habilidades específicas que permitan el trabajo tanto en forma individual como colaborativo en equipos.

Como antecedentes se puede mencionar al Proyecto SEGAN (2021), los autores Cruz-Lara et al. (2013), lo describen como "un consorcio abierto de intercambio de ideas y conocimientos cuyo objetivo es estudiar, analizar y difundir información sobre los juegos serios". Parkinson y Martínez (2020) agregan que "agrupan a desarrolladores de videojuegos serios, profesores e investigadores, junto con una serie de artículos orientados a la temática, proyectos, y una cantidad numerosa de juegos serios educativos enfocados en diferentes asignaturas para los grados escolares en Europa". Dentro del sitio ofrecen una numerosa cantidad de juegos serios de descarga gratuita de diferentes materias que abarcan tantos los grados de la primaria como los años del colegio secundario. A la hora de nombrar algunos de los juegos presentados se encuentra O A.D. (2021), éste es un juego serio de estrategia orientado al aprendizaje de historia, el mismo permite jugar con distintas civilizaciones (romana, celta, persa, etc.) y se basa en la administración y crecimiento de la metrópolis, construyendo edificios militares, bibliotecas, maravillas, como también creando unidades militares para atacar y conquistar otras civilizaciones. O A.D. brinda la posibilidad de jugar partidas multijugador. Desde el punto de vista de la personalización, O A.D cuenta con la posibilidad de crear mapas propios, además, al ser de código abierto, se puede agregar sobre la base del juego escenarios, misiones, civilizaciones y otros recursos, como contrapartida requiere de conocimientos en programación en $\mathrm{C}++$ para realizar estas modificaciones, e incluso ofrece la posibilidad de participar dentro de la comunidad de desarrolladores.

Dentro del universo de juegos serios se encuentra FreeCiv (2021), cuyos contenidos orientan al aprendizaje de la evolución de las civilizaciones, gracias a la dinámica de juego donde se puede evolucionar ciudades administrando los recursos de comida, oro, población, etc., además, realizar descubrimientos, como la electricidad, comandar y gestionar ejércitos, e incluso, seleccionar la forma de gobierno (anarquía, monarquía, república, comunismo, despotismo, democracia, etc.). Otra dinámica interesante consta de la interacción con otros pueblos, donde el jugador puede tomar la decisión exigir tributos, declarar la guerra, pedir paz, o intercambiar descubrimientos tecnológicos. Al igual que O A.D. el código fuente de este juego se encuentra disponible para poder modificarse e implementar mejoras que se ajusten a los contenidos de los docentes.

Otro trabajo relacionado es la adaptación a juego digital del juego de mesa "Trivia", en el cual, mediante tarjetas de diferentes temas (políticos, matemáticos, literatura, historia, geografía, etc.) se formulan diversas preguntas. La propuesta que Vergara Rodríguez y Mezquita (2016), llevan adelante da como resultado al videojuego serio conocido como Trivia Virtual donde "Los usuarios se mueven a lo largo del tablero siguiendo la dinámica del juego original, intentando responder correctamente a las preguntas que le correspondan" donde el docente asume el rol de administrador, estableciendo cuáles son las temáticas que se involucrarán dentro del juego lo que expande las posibilidades de incluir varias asignaturas, y, además, permitiendo interactuar de forma ubicua al alumnado.

A la hora de mencionar videojuegos aplicados en ambientes áulicos con fines de aprendizaje se encuentra la saga Europa Universalis (2021), que consiste en un juego de estrategia basado en toma de decisiones militares, políticas, y diplomáticas 
(períodos 1419 - 1821). Irigaray y del Rosario Luna (2014) realizan un juicio de valor indicando que "lo interesante de este videogame es su veracidad y profundidad histórica, ningún detalle está librado al azar, además de que su precisión sobre el pasado histórico es de gran utilidad para fines didácticos - por elección de los propios diseñadores de la plataforma, los denominados «sucesos históricos» aparecen automáticamente si las condiciones de ese pasado recreado en la jugada se asemejan a la situación histórica real, lo cual propondrá la toma de decisiones por parte del jugador". A diferencia de los otros juegos serios de historia anteriormente mencionados, Europa Universalis en un juego comercial, su código fuente no se encuentra disponible, por lo cual, no permite realizar personalizaciones que se ajusten a las necesidades particulares de los docentes.

Los objetivos específicos de este trabajo son: Implementar una metodología de seguimiento y colaboración de contenidos, basada en juegos serios; Implementar un proyecto de juegos serios; Trazabilidad de las tareas y seguimiento de los estudiantes; Trabajo colaborativo entre pares; Gestión de un repositorio en común con docentes de las diversas instituciones; Gestión del sistema de premios en base a los objetivos y logros definidos por los docentes.

La hipótesis de la investigación se basa en demostrar que el uso de juegos serios cómo actividad asincrónica permite fortalecer el aprendizaje en un aula invertida.

\title{
Propuesta
}

\begin{abstract}
Alcance
Se propone una metodología educativa para el contexto de actividades asincrónicas junto con el desarrollo de un repositorio de contenidos digitales para los docentes y estudiantes, aprovechando las características del motor del videojuego serio Proyecto 1810 (2021) descriptas por Parkinson y Martínez (2020), como una herramienta orientada al aprendizaje de la asignatura "Historia" para alumnos del tercer año del colegio secundario, cuyo contenido se enfoca en el período de la "Guerra de la Independencia", recreando las batallas, escenarios y envolviendo al alumno dentro del contexto histórico donde se produjo el suceso. Bajo esta premisa se propone la integración de instituciones educativas, permitiendo al docente gestionar sus cursos, evaluar, premiar, y realizar el seguimiento y evolución de sus estudiantes.
\end{abstract}

\section{Integración de las Instituciones Educativas y Modelo Colaborativo}

El modelo de trabajo del juego serio "Proyecto 1810" permite a la integración de instituciones educativas, mediante un proceso de verificación y validación. Para que una institución pueda acceder debe registrarse en el sitio y completar una solicitud donde se ingresan los datos del colegio junto con los de autoridad máxima del mismo, para ser posteriormente contactado y dado de alta con los privilegios necesarios, llegado ese instante el colegio comienza a pertenecer a la comunidad educativa que utiliza la plataforma. A partir de ese momento, esta autoridad (frecuentemente el director) puede registrar a todo su personal docente y psicopedagógico, de los cuales deberán registrarse en la plataforma como también aceptar la invitación realizada por el director para comenzar a trabajar. Además, se presentan perfiles orientados a los docentes que la autoridad escolar puede asignar y remover. Cada docente tiene la 
posibilidad de administrar sus cursos, invitando a los alumnos a participar del mismo. Con el mismo criterio de aprobación, el alumno debe aceptar la invitación al curso para poder formar parte de este. A partir de ese momento, el profesor puede realizar la evaluación y seguimiento de cada alumno, y en base a métricas de basadas en el uso de la plataforma, avance en el juego y respuestas en los exámenes puede detectar tempranamente los temas que generan mayor cantidad de conflictos tanto individual como colectivamente. Cada docente tiene la posibilidad de administrar el contenido de estudio, de dos formas, la primera, propuesta por Parkinson y Martínez (2020), mediante "desarrollo de un Framework basado en parámetros que permita la generación dinámica de escenarios y objetivos", donde además puede agregar ejércitos, personajes históricos y batallas (ver Figura 1), que se integran en el juego sin la necesidad de instalar actualización alguna, y donde el alumno jugando se interioriza dentro del contexto histórico propuesto por el docente, permitiendo simular cualquiera de las 187 batallas de la guerra de la independencia.

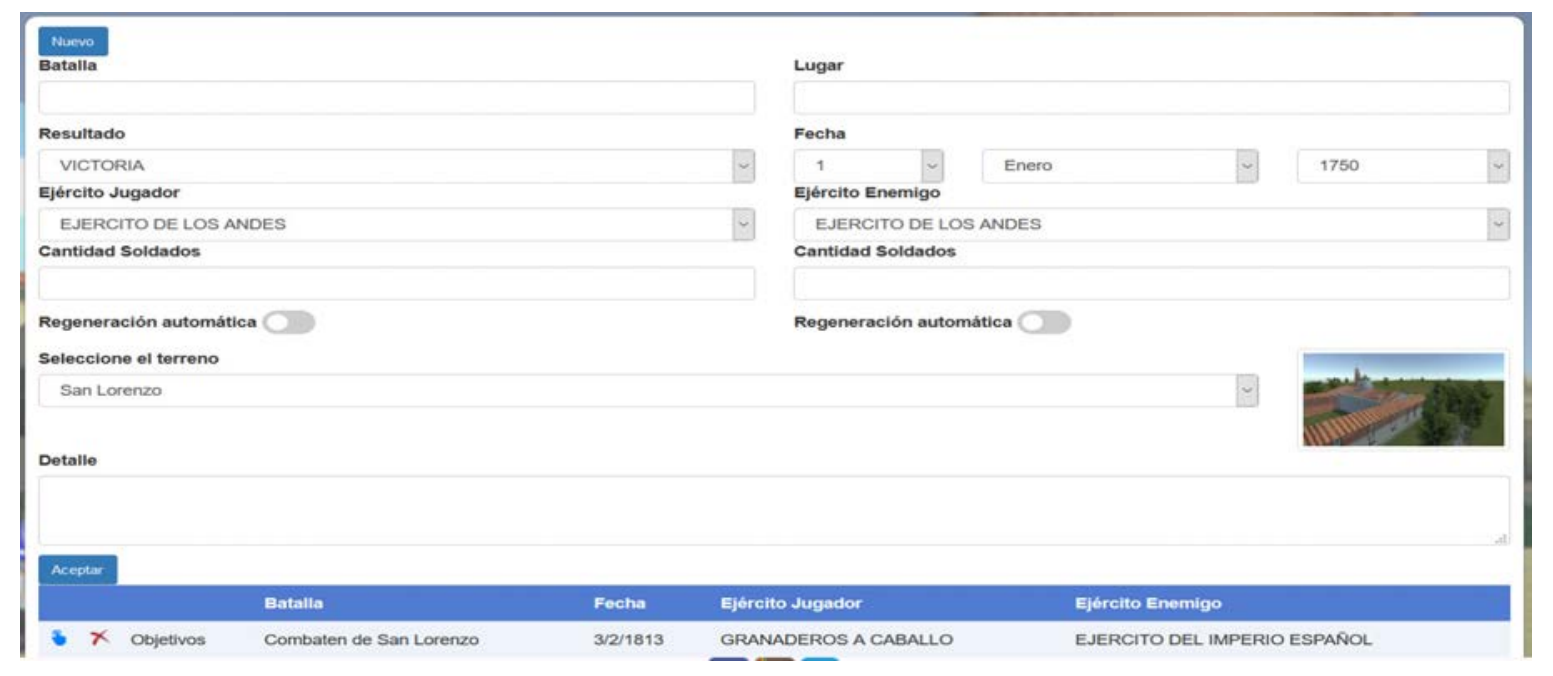

\section{Figura 1. Gestión de Batallas}

La segunda forma de presentar material consiste en la creación de material de estudio, que, a partir de un repositorio centralizado, el docente puede crear, y editar la documentación correspondiente. Todo material creado por los docentes para estar disponible a los alumnos de la propia escuela debe ser evaluado y aprobado por sus pares dentro de la misma institución, y por el gabinete psicopedagógico, quienes determinarán en una última instancia, si el material se descarta, si requiere de modificaciones como también si queda habilitado para ser consultado. Todo el material aprobado dentro de una institución puede ser accedido por estudiantes de otras instituciones, para ello requiere de un proceso adicional de evaluación. Este proceso se basa en la asignación aleatoria del trabajo a otros docentes de la misma asignatura y a integrantes de gabinetes psicopedagógicos, quienes realizarán la evaluación y aprobación del material, como también, pueden exigir o recomendar cambios, o rechazar el mismo. En caso de ser aprobado la publicación quedará disponible para todas las instituciones y usuarios del juego.

A modo de resumen el "Proyecto 1810" cuenta con cuatro perfiles de usuario para poder realizar las diversas acciones dentro del juego serio. La clasificación de los usuarios se conforma de la siguiente forma: 
- Usuario Básico: es el jugador registrado, puede ser parte o no de un grupo de estudiantes, en caso de serlo, puede realizar evaluaciones y acceder a las batallas creadas por los profesores y jugar en modo multijugador, en caso de no pertenecer a ningún curso, puede jugar el juego en la modalidad monousuairo.

- Usuario Profesor / Psicopedagogo: Pueden crear contenidos como también ser parte de la evaluación de contenidos propuestos por pares. Permiten tener sus propios cursos, invitar a alumnos a participar de los mismos, y crear escenarios, batallas, próceres y recrear contextos. Realizar evaluaciones y seguimiento de la evolución y rendimiento estudiantes.

- Usuario Institución: Es aquel que posee la facultad de poder gestionar a todo el staff docente, hacer el seguimiento transversal de los cursos, alumnos y docentes. Aprobar la publicación de contenidos para la visibilidad global.

- Usuario Administrador: posee la facultad de permitir el acceso a instituciones, gestionar contenidos globales del juego y brindar acceso a los directivos de las instituciones.

A continuación, en la tabla 1. se exponen los privilegios de cada uno de los tipos de usuario.

Tabla 1 - Tipos de Usuarios del "Proyecto 1810"

\begin{tabular}{|l|c|c|c|c|}
\hline Privilegio / Tipo Usuario & Básico & Profesor & Institución & Administrador \\
\hline Iniciar Sesión & $\mathrm{SI}$ & $\mathrm{SI}$ & $\mathrm{SI}$ & $\mathrm{SI}$ \\
\hline Gestión de Instituciones & $\mathrm{NO}$ & $\mathrm{NO}$ & $\mathrm{NO}$ & $\mathrm{SI}$ \\
\hline Gestión de Docentes & $\mathrm{NO}$ & $\mathrm{NO}$ & $\mathrm{SI}$ & $\mathrm{SI}$ \\
\hline Gestión de Cursos & $\mathrm{NO}$ & $\mathrm{SI}$ & $\mathrm{SI}$ & $\mathrm{SI}$ \\
\hline Asignación General de Privilegios & $\mathrm{NO}$ & $\mathrm{NO}$ & $\mathrm{NO}$ & $\mathrm{SI}$ \\
\hline Asignación Institucional de Privilegios & $\mathrm{NO}$ & $\mathrm{NO}$ & $\mathrm{SI}$ & $\mathrm{SI}$ \\
\hline Gestión De Exámenes & $\mathrm{NO}$ & $\mathrm{SI}$ & $\mathrm{SI}$ & $\mathrm{SI}$ \\
\hline Creación de Material Didáctico & $\mathrm{NO}$ & $\mathrm{SI}$ & $\mathrm{SI}$ & $\mathrm{SI}$ \\
\hline Evaluación de Material Didáctico & $\mathrm{NO}$ & $\mathrm{SI}$ & $\mathrm{SI}$ & $\mathrm{SI}$ \\
\hline Resolución de Exámenes & $\mathrm{SI}$ & $\mathrm{SI}$ & $\mathrm{SI}$ & $\mathrm{SI}$ \\
\hline Gestión de Ejércitos & $\mathrm{NO}$ & $\mathrm{NO}$ & $\mathrm{NO}$ & $\mathrm{SI}$ \\
\hline Gestión de Batallas & $\mathrm{NO}$ & $\mathrm{NO}$ & $\mathrm{NO}$ & $\mathrm{SI}$ \\
\hline Gestión de Batallas Personalizadas & $\mathrm{NO}$ & $\mathrm{SI}$ & $\mathrm{SI}$ & $\mathrm{SI}$ \\
\hline Gestión de Recursos & $\mathrm{NO}$ & $\mathrm{NO}$ & $\mathrm{NO}$ & $\mathrm{SI}$ \\
\hline Gestión de Objetivos & $\mathrm{NO}$ & $\mathrm{SI}$ & $\mathrm{SI}$ & $\mathrm{SI}$ \\
\hline
\end{tabular}

En función de lo anteriormente expuesto el juego serio "Proyecto 1810" posee las características adecuadas para poder implementar el repositorio de información académica que permita realizar la universalización del conocimiento brindando acceso a todos los participantes del juego independientemente de la institución a la que asistan. 


\section{Descripción del contexto y de los participantes}

Dado que la complejidad del desarrollo se requiere de la participación de diferentes disciplinas, a continuación, se describen los participantes:

- Docentes y Estudiantes de la Licenciatura de Desarrollo de Videojuegos: se encargan de desarrollar todo el juego, desde el game design, el modelado 3D, las mecánicas y dinámicas, musicalización y arte.

- Docentes y Estudiantes de Ingeniería en Sistemas: Al ser una plataforma cliente - servidor se encargan del desarrollo de la plataforma web, backend, y de los recursos de Servidor, e infraestructura.

- Docentes de Historia: Son aquellos que se encargan de validar todos los contenidos que son provistos dentro el juego, validando y verificando fechas, acontecimientos, sucesos y contextos históricos, para lograr una exactitud dentro de la simulación.

\section{Instrumentos}

Se utiliza Unity 3D como motor de videojuegos dado que permite de forma simplificada integrar los recursos gráficos, multimediales, modelos 3D, etc. La facilidad de uso y la cantidad de documentación disponible hacen que este motor sea adecuado para el perfil de estudiantes que llevan adelante el desarrollo, y permite su fácil escalabilidad.

Para el backend se utiliza Visual C\# como lenguaje de programación, en principio para una mejor articulación con el motor gráfico (Unity 3D), por consiguiente como Front end se selecciona ASP. Net, y como motor de base de datos MS Sql Server, dado que es nativo del Framework. Net.

\section{Procedimiento}

Para la documentación del desarrollo se utiliza un GDD (Game Design Document) donde toda la parte del videojuego (Objetivo, guion, recursos, etc.).

Además, se lleva una carpeta de sistema, donde se documentan los casos de uso, especificaciones, diagrama de clases, diagramas de secuencia, y diagramas de entidad relación (lógico y físico).

Se realizan minutas semanales para el avance y asignación de tareas, y todos los avances quedan centralizados dentro de un repositorio "Git" privado.

\section{Resultados}

Las pruebas de usabilidad de la herramienta con la metodología propuesta arrojaron resultados muy alentadores, sobre una base de 153 alumnos, y 2 docentes de colegio secundario, se realizaron pruebas de uso y rendimiento del alumnado, donde se pudo percibir un mayor interés mayor de los estudiantes y mejor rendimiento en los exámenes en aquellas comisiones donde se utilizó la plataforma como recurso extracurricular asincrónico. 


\section{Discusión y conclusiones}

Si bien aún queda un largo camino, se realizaron pruebas con estudiantes de forma tal que fueron favorables para efectuar mejoras y agregados de nuevas funcionalidades, como así también nuevas propuestas adaptadas por parte de los docentes que utilizaron la misma. En lo que respecta a la herramienta, la misma fue adaptada para personas con capacidades diferentes, por ejemplo, subtítulos para hipoacúsicos. El proyecto fomenta a tener una fuente segura y confiable a modo de bibliografía en las tareas pertinentes al aula invertida, cómo también, así también mostraron un mayor entusiasmo en la utilización y modificación de escenarios. Esto demuestra que los juegos serios son una herramienta complementaria como tarea extracurricular para fomentar el aprendizaje.

\section{Referencias}

12. O A.D. (1 de Junio de 2021) http:// https://playOad.com/

Cruz-Lara, S., Manjón, B. F., \& de Carvalho, C. V. (2013). Enfoques innovadores en juegos serios. leee Vaep Rita, 1(1), 19-21.

Europa Universalis. (1 de Junio de 2021). https://www.paradoxplaza.com/europa-universalis-all/

Free Civ, (1 de Junio de 2021) http://www.freeciv.org/

García-Sánchez, F., García-Berna, J. A., Fernández-Alemán, J. L., \& Toval, A. (2019). Aplicación de juegos serios en la enseñanza de Ingeniería de Requisitos y Gestión de Proyectos. Actas de las Jornadas sobre Enseñanza Universitaria de la Informática, 4, 7-14.

Irigaray, M. V., \& del Rosario Luna, M. (2014). Cine y video en el aula: La enseñanza de la Historia a través de videojuegos de estrategia. dos experiencias áulicas en la escuela secundaria. Clio \& asociados, (19), 411-437.

Lárez, B. E. M. (2006). Estimulación emocional de los videojuegos: efectos en el aprendizaje. Teoría de la Educación. Educación y Cultura en la Sociedad de la Información, 7(2), 128-140.

Lliteras, A. B., Gordillo, S. E., Bazzocco, J., Grigera, J., \& Orlando, F. (2021). Érase una vez... un aula presencial. TE \& ET, (28), 117-127.

Parkinson, C., Martínez, R., Vera, P. M., \& Rodríguez, R. A. (2020). Framework para configuración de batallas históricas: generando a través del juego un espacio de aprendizaje. XXVI Congreso Argentino de Ciencias de la Computación (CACIC).

Parkinson, C., \& Martínez, R. Juegos serios como herramienta de interacción y participación en el aprendizaje: Propuesta "Proyecto 1810". Congreso Nacional de Ingeniería Informática-Sistema de Información, CONAIISI, 6., 29-30 nov 2018, Mar del Plata, Argentina. 
Proyecto 1810. (1 de Junio 2021). http://1810.uai.edu.ar

Rodríguez, D. V., \& Mezquita, J. M. M. (2016). Diseño de juegos serios para reforzar conocimientos: una experiencia educativa en Secundaria. Profesorado, Revista de Currículum y Formación del Profesorado, 20(2), 238-254.

Segan, (1 de Junio de 2021) http://seriousgamesnet.eu/

Zamar, M. D. G., \& Segura, E. A. (2020). El aula invertida: un desafío para la enseñanza universitaria. Virtualidad, Educación y Ciencia, 11(20), 75-91. 


\section{Realidad Aumentada en la Intervención de Estudiantes con Trastorno del Espectro Autista.}

\section{Alcívar Pincay, Anabel}

orcid.org/0000-0003-0302-4297

Universidad Laica Eloy Alfaro de Manabí gloria.alcivar@uleam.edu.ec

\section{Pantaleón Cevallos, Yisela}

orcid.org/0000-0002-3732-6616

Universidad Laica Eloy Alfaro de Manabí yisela.pantaleon@uleam.edu.ec

\section{Corral Joza, Karen}

orcid.org/0000-0002-8209-4084

Universidad Laica Eloy Alfaro de Manabí

karen.corral@uleam.edu.ec 


\title{
REALIDAD AUMENTADA EN LA INTERVENCIÓN DE ESTUDIANTES CON TRASTORNO DEL ESPECTRO AUTISTA.
}

\author{
Alcívar Pincay, Anabel \\ Pantaleón Cevallos, Yisela \\ Corral Joza, Karen
}

\section{Resumen}

La tecnología tiene gran importancia en la vida cotidiana actual. El avance tecnológico ha conseguido permear múltiples ámbitos del ser humano, entre ellos, la comunicación, salud, economía y sin duda alguna, la educación; siendo esta última un entorno donde la tecnología ha causado gran impacto y dinamismo en los procesos. Este estudio presenta una experiencia práctica de intervención en las áreas afectadas por el Trastorno del Espectro Autista basada en la realidad aumentada como recurso. La investigación se realiza desde un diseño cuasi-experimental, desde el método de estudio de caso único, en contexto de la educación especial y bajo enfoque de investigación naturalista. Participa un estudiante con Trastorno del Espectro Autista grado 3. La evaluación en pretest y postest, de los ámbitos de interacción social, dificultades de comunicación y conducta restringida, repetitiva y estereotipada se realiza a partir de la observación participante. Los resultados después de la intervención reflejan mejoras en las conductas de demanda instrumental y vocal, respuesta demandas, atención conjunta, intención comunicativa, contacto ocular e imitación. El uso de realidad aumentada mejoró también la motivación, la implicación en la actividad y el disfrute en los procesos de estimulación.

\section{Palabras clave}

Realidad aumentada, TIC y discapacidad, Trastorno del espectro autista, inclusión, discapacidad. 


\section{Introducción}

Las tecnologías de la información y la comunicación -en adelante, TIC- pueden determinar la transformación de las prácticas educativas, y en el contexto de inclusión y justica social, posibilitan la atención a las necesidades que se asocian a diferentes tipos de discapacidades y colectivos en riesgos de exclusión (Cabero-Almenara \& Valencia-Ortiz, 2019). El uso pedagógico de la tecnología ha impulsado un cambio importante en la atención educativa a los niños con necesidades educativas especiales (Cored Bandrés et al., 2021). Las TIC dinamizan los procesos educativos, optimizan los resultados de la intervención, agilitan el desarrolla de tareas, fomentan la interacción social y el trabajo cooperativo, promueven la actividad intelectual, iniciativa, creatividad, la toma de decisión, motivación por aprender, entre otras tantas ventajas (Alcívar Pincay et al., 2016; Cabero et al., 2008; Chacón, 2007).

Son diversas las formas de incorporar TIC en la educación y en la intervención de personas con discapacidad, una de ellas es la realidad aumentada -RA-. Esta tecnología, por sus características innatas relativas a la experiencia interactiva, permite una mejor comprensión de los contenidos y alcance de objetivos, dentro de un marco tecnológico e innovador (Maquilón et al., 2017) y a superar barreras en otros ámbitos de desarrollo social, por ejemplo, las relacionadas con el acceso al empleo (McMahon et al., 2015).

La RA es definida como, un amplio espectro de tecnologías que despliegan materiales generados por computadora, como texto, video o imágenes, integrándolos en el mundo real (Garzón et al., 2017). En relación con el ámbito educativo Dubois et al., (2001) señala que, la RA es una forma de combinar entornos reales y virtuales para facilitar la realización de una tarea en un mundo real.

La RA permite el diseño de materiales educativos atractivos que, pueden ser utilizados en situaciones que resulten beneficiosas para alumnos con necesidades educativas especiales (Chien-Yu et al., 2010). El grado de sofisticación e innovación de la RA propicia aumentos en la motivación de los alumnos (Maquilón et al., 2017). Y en procesos de personas con discapacidad, cobra destacado valor el poder de motivación, el aumento del interés y la implicación del alumnado hacia las tareas, que la implementación de RA aporta (Cacheiro, 2014).

Estudios exploratorios, por ejemplo, el desarrollado por Martín-Sabarís \& Brossy-Scaringi (2017) destacan que, la RM resulta de gran ayuda en el desarrollo y mantenimiento de la atención, el acceso a la información y en la memoria a largo plazo en estudiantes con discapacidad, y sugieren implementar programas específicos de aplicación para la intervención socioeducativa de este colectivo. Se ha demostrado también, a través de estudios de caso, que las dificultades en la adquisición de conocimientos asociadas a la discapacidad pueden mejorar mediante el uso de RM en los procesos formativos, y que ayuda además a mejorar la imaginación y capacidad de abstracción (Gybas et al., 2019).

Previamente, en la misma línea, el trabajo de Yoo (2014) demostró que, incorporar tecnología de RM a las intervenciones de lenguaje para estudiantes con discapacidades permite alcanzar mejores resultados en relación a las intervención tradicionales (sin el uso de tecnologías). En este estudio, en el grupo que se introdujo la RA en la intervención, presentó una diferencia estadísticamente significativa en el reconocimiento de palabras, la comprensión de lectura, la capacidad de atención y el interés por el aprendizaje. 
Las personas con Trastorno del Espectro Autista -TEA-, tienen características neurocognitivas a las que se asocia un peculiar estilo de procesar la información y de percibir e interpretar el mundo, situación que genera la necesidad de adaptar el estilo de enseñanza y las estrategias pedagógicas para responder a su perfil de funcionamiento cognitivo (Baixauli-fortea et al., 2019). EI TEA es una condición que se encuentra dentro de los trastornos del neurodesarrollo, caracterizada por dificultades persistentes en la comunicación y la interacción social, unido a una restricción en los intereses y a la presencia de conductas repetitivas (American Psychiatric Association, 2013).

Los niños con TEA requieren intervenciones educativas basadas en la evidencia que aborden las dificultades nucleares, la atención conjunta, la reciprocidad social, la comunicación, las habilidades mentalistas o el funcionamiento ejecutivo, y que consideren, además, sus fortalezas en el procesamiento visual y su estilo de aprendizaje (Cáceres Acosta, 2017; Morán et al., 2019). Se conoce que, los niños con TEA, muestran una clara atracción hacia los sistemas tecnológicos (Contreras et al., 2016; Cored Bandrés et al., 2021; Pennisi et al., 2016). Y algunos autores, por ejemplo, Láinez et al. (2018) señalan que recursos como la RA ayudan a afianzar el proceso de aprendizaje de alumnos con NEE asociadas al TEA, y en consecuencia, aumentan la posibilidad de establecer relaciones sociales con otras personas, facilitando así su integración en el aula ordinaria.

La RA puede configurarse como una buena herramienta para facilitar el aprendizaje en la población con TEA (Baixauli-fortea et al., 2019; Gilabert-cerdá \& Lorenzo-LLedó, 2021). El proceso de enseñanza-aprendizaje se ve enriquecido por el componente visual que esta tecnología aporta, y que atiende a la característica de aprendices visuales de los alumnos con TEA (Cáceres Acosta, 2017; Escribano et al., 2010; Láinez et al., 2018).

En el caso concreto de los niños con TEA, en consonancia con su estilo de aprendizaje y el interés por los estímulos que se presentan visualmente, la RA puede convertirse en un medio para reconducir los déficits asociados, por ejemplo la comunicación y la interacción social, acceder a conceptos abstractos, ayudar a focalizar y mantener su atención así como favorecer su motivación hacia el aprendizaje y la facilidad de operación de procesos y tareas (Karamanoli et al., 2017; Láinez et al., 2018).

Una herramienta importante que propone el uso de RA para la intervención con estudiantes con TEA es el PictogramRoom, una aplicación gratuita, creada en el 2012 por Fundación Orange, que incorpora un total de 80 videojuegos educativos que abordan dimensiones del desarrollo del niño con TEA. Las actividades son adaptables a características individuales tales como capacidades, intereses, ritmo de aprendizaje, preferencias en colores y ritmos. Su diseño pedagógico permite abordar las dificultades nucleares de las personas con TEA, para potenciar el desarrollo de sus capacidades, utilizando apoyos visuales, música y criterios de jugabilidad que favorecen una buena disposición y motivación para el aprendizaje del usuario (Herrera et al., 2012).

PictogramRoom ofrece una serie de ventajas para el proceso de aprendizaje: permite resaltar visualmente aspectos de la realidad, como los estímulos sociales importantes, y propicia una representación corporal, permitiendo visualmente seguir los movimientos y ser conscientes de las acciones de los elementos animados (Escribano et al., 2010). 
Desde este trabajo de investigación se plantea como objetivo principal, analizar el potencial de la RA en la intervención de las dificultades de nucleares asociadas al TEA, en términos de comunicación e interacción social; y conducta restringida, repetitiva y estereotipada.

\section{Método}

\section{Descripción del contexto y de los participantes:}

El estudio corresponde a una investigación mixta y se realizó en el contexto de la educación especial. Tal como lo plantean Jurado de los Santos \& Sanahuja (1997) la investigación en este escenario educativo y en la atención a las discapacidades, deber ser coherente con la característica más claramente definitoria que esta área posee, la tendencia a la individualización, que significa atender a las variables de desarrollo y las necesidades específicas de cada individuo. Siguiendo la sugerencia de los autores antes mencionados, este trabajo se desarrolla a partir del método de estudio de caso, que se distingue por ser particularista, contextual, descriptivo y holístico (Álvarez \& San Fabián, 2012).

Bajo el método de caso de estudio único, participó un estudiante, de 4 años y 9 meses de edad, con diagnóstico de Trastorno del Espectro Autista, grado 3. Según evaluación de equipo transdiciplinario, las áreas de comunicación e interacción social estaban significativamente afectadas; y mostraba conductas e intereses notablemente restringidos. Y que se encontraba en la fase inicial para implementación del Sistema Pictográfico de Comunicación -SPC-, es decir en la familiarización y aprendizaje de los símbolos, más significativos, motivadores y útiles en su vida cotidiana. La recolección de datos se realizó principalmente mediante observación sistemática de las conductas en las sesiones de intervención, y se complementó con la medición en pretest y postest.

\section{Instrumentos}

Se utilizó una escala para el registro observacional a partir de la adaptación del cuestionario de Arias-Pujol et al., (2015) y el SCQ -The Social Communication Questionnaire- (Rutter et al., 2019), un instrumento de Evaluación de los Trastornos del Espectro Autista en los ámbitos de interacción social, dificultades de comunicación y conducta restringida, repetitiva y estereotipada.

\section{Procedimiento}

La experiencia fue desarrollada por un equipo de profesionales de educación especial. Incluyó 20 sesiones, desarrolladas durante 6 meses, con frecuencia de una sesión semanal, en periodos que oscilaban entre los 30 y 45 minutos, intervalos que se ajustaban a las necesidades del estudiante. Las sesiones, se distribuyeron considerando cuatro sesiones de observación para la valoración inicial, 12 sesiones de intervención, 4 sesiones para evaluación final.

Como técnica de recogida de datos se utilizó la observación participante. Para garantizar precisión en el registro, se grabó la totalidad de las sesiones. Las sesiones fueron desarrolladas de forma directa por uno de los miembros del equipo investigador, educadora especial y con vinculación laboral al centro escolar; quien trabajó 
con el niño desde tres meses anteriores a la intervención con RA, para lograr familiarización y el manejo inicial de pictogramas. En la intervención directa no se vinculó a otros miembros del equipo para preservar la validez ecológica, descrita por Gill \& Younie (2021) como el proceso mediante el cual se puede decir que los resultados son válidos porque se desarrollan en un entorno natural.

Los recursos fueron el software PictogramRoom, un computador personal, dispositivo Kinect, proyector y la cámara de vídeo. Mientras que para el acondicionamiento del espacio físico se consideró las sugerencias de Contreras et al. (2016) que incluyen, espacio suficiente para que el niño pueda realizar los movimientos indicados por la aplicación, con libertad y sin causar daños para sí mismo, objetos u otras personas; distancia entre el dispositivo y el niño de entre 1,5 y 2,5m; habitación con paredes con colores claros y mínimo contacto con el exterior, para optimizar la concentración del niño y para que, tanto el dispositivo Kinect y el usuario, puedan interpretar correctamente los sonidos que se emiten.

Se realizó una selección preliminar de actividades específicas a partir de las características funcionales del niño, sus gustos e interés, información que se recogió con la participación de los padres y otros maestros del niño. Las actividades se fueron ajustando y configurando conforme avanzó el desarrollo de la intervención.

El Comité para el Control Ético de la Investigación de la Universidad Laica Eloy Alfaro de Manabí (acogido a las normas de la declaración de Helsinki) autorizó el diseño y plan de trabajo empírico.

\section{Resultados}

Las mediciones se distribuyeron, en 4 sesiones para evaluación en pretest, 12 sesiones de intervención propiamente dicha, 4 sesiones para evaluación en postest. Se analizaron las grabaciones y el equipo asignó puntuaciones para cada ítem en cada sesión, según la frecuencia de aparición de la conducta, asignando o para nunca aparece la conducta, 1 la conducta aparece raramente, 2 la conducta aparece ocasionalmente, 3 la conducta aparece frecuentemente y 4 la conducta aparece muy frecuentemente. Se calcularon las medias por ítem y por dimensión, y finalmente se comparan medias según momento de la intervención (pretest, intervención propiamente dicha, postest).

\section{Resultados dimensión comunicación e interacción social recíproca}

La tabla 1 y la figura 1 recogen los resultados de la dimensión de comunicación e interacción social recíproca; en general se evidencia avances en todos las variables, pero destacan los resultados alcanzados en las conductas de demanda y de forma particular la instrumental y vocal, y en la misma línea, la variable "responder a una demanda", es decir hacer caso/cumplir la demanda; así también, son destacables los valores alcanzados en "atención conjunta aproximación palabra", descriptor que tributa a mejoras en los resultados en la comunicación (intencionalidad comunicativa); y otras variables que figuran entre los resultados más significativos son contacto ocular e imitación no verbal. Mientras que en las variables que se evidenció menores resultados en esta dimensión corresponden a "atención conjunta aproximación a frase", demanda e imitación verbales. Lo que puede explicarse en que al grado de 
severidad del TEA que el niño presenta, se asocian dificultades significativas en la comunicación y de forma particular en el lenguaje verbal.

\begin{tabular}{|c|c|c|c|c|c|c|c|c|c|c|c|c|}
\hline & \multicolumn{4}{|c|}{ PRETEST } & \multicolumn{4}{|c|}{ INTEVENCIÓN } & \multicolumn{4}{|c|}{ POSTEST } \\
\hline & $\begin{array}{l}\mathscr{y} \\
\stackrel{0}{0} \\
\frac{0}{n} \\
\tilde{d} \\
n\end{array}$ & $\frac{\frac{\pi}{0}}{\frac{\pi}{0}}$ & 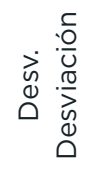 & 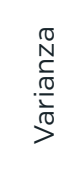 & 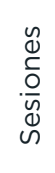 & $\frac{\frac{\pi}{0}}{\frac{0}{0}}$ & 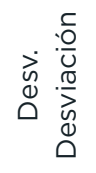 & $\begin{array}{l}> \\
\frac{\pi}{N} \\
\frac{\pi}{2} \\
\frac{\pi}{2} \\
5\end{array}$ & $\begin{array}{l}\mathscr{0} \\
\stackrel{0}{0} \\
\frac{0}{n} \\
\stackrel{\infty}{n}\end{array}$ & $\begin{array}{l}\frac{0}{\overline{0}} \\
\frac{0}{2}\end{array}$ & 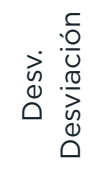 & 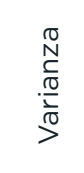 \\
\hline $\begin{array}{l}\text { Mirada atenta al } \\
\text { objeto }\end{array}$ & 4 & 0,75 & 0,50 & 0,25 & 12 & 1,58 & 0,793 & 0,629 & 4 & 2,25 & 0,500 & 0,250 \\
\hline $\begin{array}{l}\text { Demanda } \\
\text { instrumental }\end{array}$ & 4 & 0,25 & 0,50 & 0,25 & 12 & 1,17 & 0,718 & 0,515 & 4 & 2,00 & 0,000 & 0,000 \\
\hline $\begin{array}{l}\text { Demanda no } \\
\text { verbal }\end{array}$ & 4 & 0,25 & 0,50 & 0,25 & 12 & 1,08 & 0,669 & 0,447 & 4 & 1,75 & 0,500 & 0,250 \\
\hline Demanda verbal & 4 & 0,00 & 0,00 & 0,00 & 12 & 0,25 & 0,452 & 0,205 & 4 & 0,75 & 0,500 & 0,250 \\
\hline Demanda vocal & 4 & 0,50 & 0,58 & 0,33 & 12 & 1,33 & 0,651 & 0,424 & 4 & 2,25 & 0,500 & 0,250 \\
\hline $\begin{array}{l}\text { Respuesta a una } \\
\text { demanda (hace } \\
\text { caso) }\end{array}$ & 4 & 0,25 & 0,50 & 0,25 & 12 & 1,25 & 0,866 & 0,750 & 4 & 2,25 & 0,500 & 0,250 \\
\hline $\begin{array}{l}\text { Conducta } \\
\text { proxémica (se } \\
\text { acerca) }\end{array}$ & 4 & 0,50 & 0,58 & 0,33 & 12 & 1,42 & 0,515 & 0,265 & 4 & 2,00 & 0,000 & 0,000 \\
\hline $\begin{array}{l}\text { Atención conjunta } \\
\text { muestra }\end{array}$ & 4 & 0,25 & 0,50 & 0,25 & 12 & 1,58 & 0,515 & 0,265 & 4 & 1,75 & 0,500 & 0,250 \\
\hline $\begin{array}{l}\text { Atención conjunta } \\
\text { aproximación } \\
\text { palabra }\end{array}$ & 4 & 0,50 & 0,58 & 0,33 & 12 & 1,58 & 0,515 & 0,265 & 4 & 2,50 & 0,577 & 0,333 \\
\hline $\begin{array}{l}\text { Atención conjunta } \\
\text { palabra }\end{array}$ & 4 & 0,25 & 0,50 & 0,25 & 12 & 1,08 & 0,515 & 0,265 & 4 & 1,50 & 0,577 & 0,333 \\
\hline $\begin{array}{l}\text { Atención conjunta } \\
\text { aproximación a } \\
\text { frase }\end{array}$ & 4 & 0,00 & 0,00 & 0,00 & 12 & 0,17 & 0,389 & 0,152 & 4 & 0,50 & 0,577 & 0,333 \\
\hline $\begin{array}{l}\text { Atención conjunta } \\
\text { dibujamos }\end{array}$ & 4 & 0,75 & 0,50 & 0,25 & 12 & 1,58 & 0,515 & 0,265 & 4 & 1,75 & 0,500 & 0,250 \\
\hline Contacto ocular & 4 & 0,50 & 0,58 & 0,33 & 12 & 1,50 & 0,798 & 0,636 & 4 & 2,25 & 0,500 & 0,250 \\
\hline Imitación verbal & 4 & 0,00 & 0,00 & 0,00 & 12 & 1,00 & 0,739 & 0,545 & 4 & 1,25 & 0,500 & 0,250 \\
\hline $\begin{array}{l}\text { Imitación no } \\
\text { verbal }\end{array}$ & 4 & 0,50 & 0,58 & 0,33 & 12 & 1,75 & 0,754 & 0,568 & 4 & 2,50 & 0,577 & 0,333 \\
\hline $\begin{array}{l}\text { Expresión facial, } \\
\text { aceptación, } \\
\text { rechazo }\end{array}$ & 4 & 1,75 & 0,50 & 0,25 & 12 & 2,00 & 0,603 & 0,364 & 4 & 2,75 & 0,500 & 0,250 \\
\hline
\end{tabular}


Expresión facial, aceptación, rechazo Imitación no verbal Imitación verbal Contacto ocular Atención conjunta dibujamos Atención conjunta aproximación a frase Atención conjunta palabra Atención conjunta aproximación palabra Atención conjunta muestra Conducta proxémica (se acerca) Respuesta a una demanda (hace caso) Demanda vocal Demanda verbal Demanda no verbal Demanda instrumental Mirada atenta al objeto

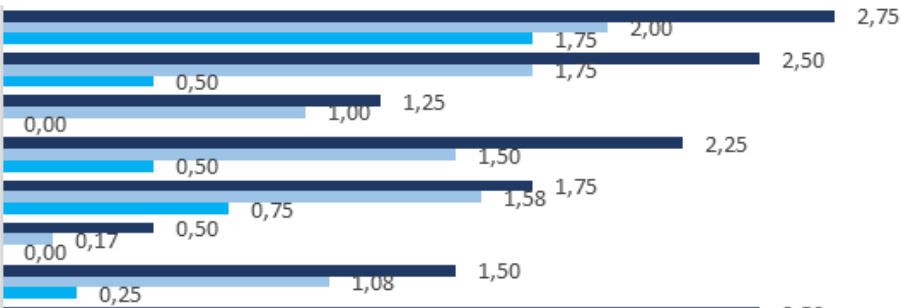
75

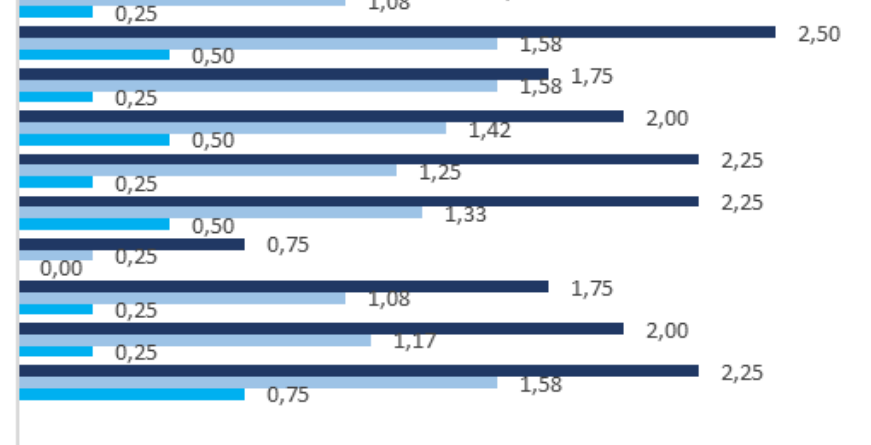

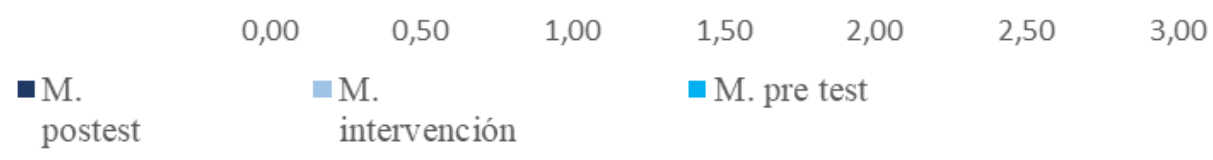

Figura 1: Resultados dimensión comunicación e interacción social recíproca.

\section{Resultados dimensión no interacción social recíproca - conducta restringida, repetitiva y estereotipada.}

Esta dimensión arrojó resultados que merecen especial atención por los logros registrados. A continuación, se muestran los resultados de pretest (tabla 2), de intervención (tabla 3) y de postest (tabla 4); y se consolidan en la tabla 5 y la figura 2 , que muestran a través de comparación de medias, la favorable disminución de la frecuencia de aparición de conductas estereotipadas (visuales, verbales, motoras).

\begin{tabular}{|c|c|c|c|c|c|}
\hline & $\begin{array}{l}\text { Estereotipias } \\
\text { verbales }\end{array}$ & $\begin{array}{l}\text { Estereotipias } \\
\text { visuales }\end{array}$ & $\begin{array}{l}\text { Estereotipias } \\
\text { motoras }\end{array}$ & $\begin{array}{l}\text { Conducta } \\
\text { errática }\end{array}$ & Total \\
\hline Sesiones & 4 & 4 & 4 & 4 & 4 \\
\hline Media & 3,75 & 3,25 & 4,00 & 3,25 & 3,5625 \\
\hline Desv. Desviación &, 500 &, 500 & , 000 &, 500 & 23936 \\
\hline Varianza & ,250 & 250 & , 000 & 250 & ,057 \\
\hline
\end{tabular}

Tabla 2: Resultados pretest - conducta restringida y estereotipada. 


\begin{tabular}{|c|c|c|c|c|c|}
\hline & $\begin{array}{l}\text { Estereotipias } \\
\text { verbales }\end{array}$ & $\begin{array}{l}\text { Estereotipias } \\
\text { visuales }\end{array}$ & $\begin{array}{l}\text { Estereotipias } \\
\text { motoras }\end{array}$ & $\begin{array}{l}\text { Conducta } \\
\text { errática }\end{array}$ & Total \\
\hline Sesiones & 12 & 12 & 12 & 12 & \\
\hline Media & 2,67 & 2,33 & 2,83 & 2,50 & 2,5833 \\
\hline Desv. Desviación &, 651 &, 492 &, 577 & ,798 &, 43082 \\
\hline Varianza &, 424 & ,242 &, 333 & ,636 & , 186 \\
\hline
\end{tabular}

Tabla 3: Resultados intervención - conducta restringida y estereotipada

\begin{tabular}{|l|l|l|l|l|l|}
\hline \multicolumn{2}{|l|}{$\begin{array}{l}\text { Estereotipias } \\
\text { verbales }\end{array}$} & $\begin{array}{l}\text { Estereotipias } \\
\text { visuales }\end{array}$ & $\begin{array}{l}\text { Estereotipias } \\
\text { motoras }\end{array}$ & $\begin{array}{l}\text { Conducta } \\
\text { errática }\end{array}$ & Total \\
\hline Sesiones & 4 & 4 & 4 & 4 & 4 \\
\hline Media & 1,75 & 1,75 & 2,00 & 1,50 & 1,7500 \\
\hline Desv. Desviación &, 500 &, 500 &, 000 &, 577 &, 35355 \\
\hline Varianza &, 250 &, 250 &, 000 &, 333 &, 125 \\
\hline
\end{tabular}

Tabla 4: Resultados postest - conducta restringida y estereotipada

\begin{tabular}{|l|l|l|l|}
\hline Momento & Media & Sesiones & Desv. Est. \\
\hline Pretest & 3,5625 & 4 &, 23936 \\
\hline Intervención & 2,5833 & 12 &, 43082 \\
\hline Posttest & 1,7500 & 4 &, 35355 \\
\hline
\end{tabular}

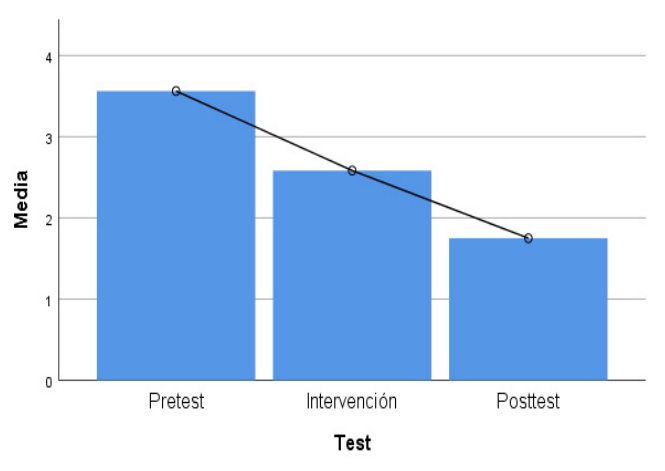

\section{Table 5: Tabla comparativa medias en pretest, intervención y postest, conductas estereotipadas.}

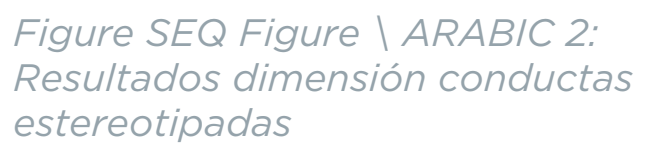

Desde los datos cualitativos, se observó que a medida que el niño se interesaba e implicaba en las actividades, las conductas estereotipadas se reducían e incluso durante la ejecución de la actividad se desvanecían, siendo remplazadas por conductas funcionales que respondían a las consignas de la docente o la interacción con la aplicación.

\section{Resultados sobre la motivación, implicación y atención.}

Se ponderó también la información sobre variables que se esperaba mejorar con la intervención, siendo el caso de la atención, donde se alcanzó una ponderación de $32,7 \%$ en pretest y de $74,2 \%$ en postest, se pudo observar como de forma progresiva, el niño lograba focalizar y mantener la atención, así como alternarla entre 
información de primer plano y de fondo. De forma consecuente se evidenció también mayores niveles de implicación en las actividades y disfrute en la participación, lo que se observó a través de la aceptación de actividades, receptividad, sonrisa y conductas entusiastas como respuesta a las dinámicas y estímulos que se presentaban.

Con relación al manejo de nociones temporo-espaciales, incremento de vocabulario (dimensión comprensiva), reconocimiento de emociones (feliz, triste, asustado, sorprendido), auto reconocimiento y esquema corporal (pretest 28\% - postest 53,2\%); se registraron también resultados positivos. Logrando generalizarlos a otros espacios y actividades.

\section{Discusión y conclusiones}

Los sistemas de RA han alcanzado madurez en entornos educativos y su eficacia ha sido evidenciada en la intervención en estudiantes con discapacidad (Dubois et al., 2001; Garzón et al., 2017; Gill \& Younie, 2021; Maquilón et al., 2017). El objetivo de esta investigación fue analizar el potencial de la RA en la intervención de las dificultades de nucleares asociadas al TEA, en términos de comunicación e interacción social; y conducta restringida, repetitiva y estereotipada.

Al tenor de los resultados de este estudio, se refuerza la línea de investigación propuesta en los últimos años, que señala a la RA como una tecnología con potencial para favorecer los procesos educativos y de intervención terapéutica de estudiantes con TEA (Baixauli-fortea et al., 2019; Chien-Yu et al., 2010; Contreras et al., 2016; Cored Bandrés et al., 2021; Karamanoli et al., 2017; Láinez et al., 2018).

Las mejoras en el ámbito de la comunicación y la interacción social y recíproca, que se encontraron en esta investigación coinciden con lo identificado previamente por (Gilabert-cerdá \& Lorenzo-LLedó, 2021; Láinez et al., 2018). Asimismo, se observa un descenso en comportamientos no sociales como estereotipias o la mirada perdida y un aumento en conductas funcionales y sociales. En concreto, aparecen incrementos significativos en la atención conjunta y en el contacto ocular, en la focalizar y atención sostenida, así como mayores niveles motivación hacia el aprendizaje, dominio de nociones básicas y la facilidad de operación de procesos y tareas (Baixauli-fortea et al., 2019; Karamanoli et al., 2017; Láinez et al., 2018).

La RA implementada a través de aplicaciones que cuenten con un buen diseño pedagógico, como PictogramRoom, favorece la optimización de los resultados, gracias a características que atienden a la inclinación natural de los estudiantes con TEA hacia los sistemas tecnológicos (Contreras et al., 2016; Cored Bandrés et al., 2021; Pennisi et al., 2016), y su característica de aprendices visuales (Cáceres Acosta, 2017; Contreras et al., 2016; Escribano et al., 2010; Láinez et al., 2018). Además de contar con otros elementos estimulantes como la música y criterios de jugabilidad que favorecen una buena disposición y motivación para el aprendizaje del usuario que se encuentra dentro del espectro del autismo (Escribano et al., 2010; Herrera et al., 2012).

En la línea de Jurado de los Santos \& Sanahuja (1997) se destaca que en la intervención con personas con discapacidad, se debe atender a las variables contextuales, de desarrollo, neurocognitivas y necesidades específicas de cada individuo; y recordar que, como lo menciona Cabero et al., (2008) y Martín-Sabarís \& Brossy-Scaringi 
(2017) los resultados que se alcancen estarán, también, condicionados por el tipo y grado de discapacidad que presenta el estudiante y por la capacidad -formación- de los profesionales a cargo, para diseñar y operativizar la intervención. Se sugiere que las propuestas de investigación futura, promuevan el estudio de selección y aplicación de materiales de realidad aumentada con respecto a las características, habilidades y necesidades específicas de los estudiantes con discapacidad (Garzón et al., 2017; Gill \& Younie, 2021; Gybas et al., 2019).

Finalmente se insiste, en que el adecuado uso de las TIC puede ser palanca de cambio en la atención a la discapacidad y las necesidades educativas especiales (Cabero-Almenara \& Valencia-Ortiz, 2019; Cacheiro, 2014; Chacón, 2007; Chien-Yu et al., 2010; Yoo, 2014), aportando múltiples beneficios para promover la inclusión educativa y social de este colectivo, y como fin último propender a mejoras en su calidad de vida (Alcívar Pincay et al., 2016; Cabero et al., 2008; Morán et al., 2019).

\section{Referencias}

Alcívar Pincay, G. A., Bravo Loor, S. D., \& Villafuerte Holguin, honny S. (2016). Estimulación del remanente visual de niños de baja visión, con un programa informático y su efecto en el rendimiento académico. Píxel-Bit, Revista de Medios y Educación, 48, 115-134. https://doi.org/10.12795/pixelbit.2016.i48.08

Álvarez, C., \& San Fabián, J. (2012). Carmen Álvarez Álvarez. Gazeta de Antropologia, 28(1), 1-12.

American Psychiatric Association. (2013). Diagnostic and statistical manual of mental disorders (Quinta edi).

Arias-Pujol, E., Fieschi, E., Castelló, C., Mirallbell, J., Soldevilla, A., Sánchez Caroz, E., Anguera, M. T., \& Mestres, M. (2015). Efectos de la imitación en la interacción social recíproca en un niño con Trastorno del Espectro Autista Grave. Revista de Psicopatología y Salud Mental Del Niño y Del Adolescente, ISSN 1695-8691, No. 25, 2015, Pàg. 9-20, 25, 9-20.

Baixauli-fortea, I., Gómez-García, S., Andrés-Sebastiá, M., \& Berenguer-Forner, C. (2019). Una propuesta de intervención para niños con trastorno del espectro autista a través de la lectura dialógica y la realidad aumentada. Edetania: Estudios y Propuestas Socio-Educativas, 56, 135-150. https://dialnet.unirioja.es/servlet/articulo?codigo $=7518835$

Cabero-Almenara, J., \& Valencia-Ortiz, R. (2019). TIC para la inclusión: una mirada desde Latinoamérica. Aula Abierta, 48(2), 139. https://doi.org/10.17811/rifie.48.2.2019.139-146

Cabero, J., Córdoba, M., \& Fernández, J. M. (2008). Las tic para la igualdad: nuevas tecnologías y atención a la diversidad (E. MAD (ed.)). https://dialnet.unirioja.es/servlet/libro?codigo=345994 
Cáceres Acosta, O. (2017). El uso del pictograma en el proceso de enseñanza-aprendizaje del niño con autismo. Universidad de Las Palmas de Gran Canaria, 1, 1-311.

Cacheiro, M. (2014). Educación y tecnología: estrategias didácticas para la integración de las TIC. (Editorial UNED (ed.)).

Chacón, A. (2007). La atención a la diversidad con medios tecnológico-didácticos. In Nuevas tecnologías para la educación en la era digital (pp. 261-278). https://dialnet.unirioja.es/servlet/articulo?codigo $=2239874$

Chien-Yu, L., Chao, J.-T., \& Wei, H.-S. (2010). Augmented reality-based assistive technology for handicapped children. 2010 International Symposium on Computer, Communication, Control and Automation (3CA), 1, 61-64. https://doi.org/10.1109/ 3CA.2010.5533735

Contreras, V., Fernández, D., Pons, C., Contreras, V., Fernández, A., \& Fabiana Pons, C. (2016). Interfaces gestuales aplicadas como complemento cognitivo y social para niños con TEA. TE \& ET: Revista Iberoamericana de Tecnología En Educación y Educación En Tecnología, no. 17(17), 58-66.

Cored Bandrés, S., Vázquez Toledo, S., Liesa Orús, M., \& Baldassarri, S. (2021). The potential of technology in measuring the development of social skills in children with ASD: An analysis from physiological parameters. Revista de Investigacion Educativa, 39(2), 445-462. https://doi.org/10.6018/RIE.430891

Dubois, E., Nigay, L., Troccaz, J., Bergman, L. D., Willans, J. S., \& Stuerzlinger, W. (2001). Consistency in Augmented Reality systems. Discussion. Lecture Notes in Computer Science, 111-122.

Escribano, L., Herrera, G., Jordan, R., \& Gimeno, J. (2010). PictogramRoom: uso de la Realidad Aumentada para el aprendizaje visual de las personas con Autismo. In M. Belinchón (Ed.), Investigaciones sobre el autismo en español: problemas y perspectivas (pp. 437-448). Madrid: Centro de Psicología Aplicada de la Universidad Autónoma de Madrid (CPAUAM).

Garzón, J., Pavón, J., \& Baldiris, S. (2017). Augmented Reality Applications for Education: Five Directions for Future Research. In Lecture Notes in Computer Science (including subseries Lecture Notes in Artificial Intelligence and Lecture Notes in Bioinformatics): Vol. 10324 LNCS (pp. 402-414). https://doi.org/10.1007/978-3-319-60922-5_31

Gilabert-cerdá, A., \& Lorenzo-LLedó, A. (2021). Análisis de aplicaciones de Realidad Aumentada para la práctica de futuros docentes con alumnado que presenta Trastorno del Espectro Autista Analysis of Augmented Reality applications for the practice of future teachers with students with Autism Spectrum. 13, 18-27.

Gill, R., \& Younie, S. (2021). Evaluating Eye Tracking Technology for Assessment of Students with Profound and Multiple Learning Difficulties. Pixel-Bit, Revista de Medios y Educación, 62, 269-308. https://doi.org/10.12795/pixelbit.88106

Gybas, V., Kostolányová, K., \& Klubal, L. (2019). Using augmented reality for teaching pupils with special educational needs. Proceedings of the European Conference on E-Learning, ECEL, 2019-Novem(July), 185-191. https://doi.org/10.34190/EEL.19.017 
Herrera, G., Casas, X., Sevilla, J., Rosa Escribano, L., Pardo Carpio, C., Plaza, J., Jordan, R., \& Le Groux, S. (2012). Pictogram Room: Aplicación de tecnologías de interacción natural para el desarrollo del niño con autismo. Anuario de Psicología Clínica y de La Salud = Annuary of Clinical and Health Psychology, 8, 41-46. http://institucional. us.es/apcs

Jurado de los Santos, P., \& Sanahuja, J. M. (1997). La investigación en educación especial. Tendencias y orientaciones,. Educar, 21(21), 105. https://doi.org/10.5565/rev/ educar.376

Karamanoli, P., Tsinakos, A., \& Karagiannidis, C. (2017). The Application of Augmented Reality for Intervention to People with Autism Spectrum Disorders. IOSR Journal of Mobile Computing \& Application, 04(02), 42-51. https://doi.org/10.9790/005004024251

Láinez, B., Chocarro de Luis, E., Busto, J., \& López, J. (2018). Aportaciones de la Realidad Aumentada en la inclusión en el aula de estudiantes con Trastorno del Espectro Autista. EDMETIC, 7(2), 120. https://doi.org/10.21071/edmetic.v7i2.10134

Maquilón, J., Mirete, A., \& Avilés, M. (2017). La Realidad Aumentada (RA). Recursos y propuestas para la innovación educativa. Revista Electronica Interuniversitaria de Formación Del Profesorado, 20(2), 183-203. https://doi.org/10.6018/reifop.20.1.290971

Martín-Sabarís, R., \& Brossy-Scaringi, G. (2017). La realidad aumentada aplicada al aprendizaje en personas con Síndrome de Down: un estudio exploratorio. In Latina, Revista de Comunicación (Issue 74). https://doi.org/10.4185/RLCS-2017-1189

McMahon, D., Cihak, D. F., \& Wright, R. (2015). Augmented Reality as a Navigation Tool to Employment Opportunities for Postsecondary Education Students With Intellectual Disabilities and Autism. Journal of Research on Technology in Education, 47(3), 157-172. https://doi.org/10.1080/15391523.2015.1047698

Morán, M. . L., Gómez, L. E., \& Ángeles, A. M. . (2019). Inclusión social y autodeterminación: los retos en la calidad de vida de los jóvenes con autismo y discapacidad intelectual. Siglo Cero Revista Española Sobre Discapacidad Intelectual, 50(3), 29. https://doi.org/10.14201/scero20195032946

Pennisi, P., Tonacci, A., Tartarisco, G., Billeci, L., Ruta, L., Gangemi, S., \& Pioggia, G. (2016). Autism and social robotics: A systematic review. Autism Research, 9(2), 165183. https://doi.org/10.1002/aur.1527

Rutter, M., Bailey, A., \& Lord, C. (2019). Cuestionario de Comunicación Social.

Yoo, J. (2014). The Effects of Augment Reality Based Language Intervention Program on Language Abilities and Learning Aptitudes of Students with Learning Disabilities. The Korea Journal of Learning Disabilities, 11(1), 31-52. 


\section{Papel de la \\ Personalidad Situacional en la Adquisición de Competencias Digitales de Alumnos del Grado de Maestro}

\section{Martín-García, Ma Inés}

Universidad de Castilla-La Mancha (UCLM) mariaines.martin@uclm.es

\section{Cebrián Martínez, Antonio}

Universidad de Castilla-La Mancha (UCLM)

antonio.cebrian@uclm.es

\section{García-Perales, Ramón}

Universidad de Castilla-La Mancha (UCLM)

ramon.garciaperales@uclm.es

\section{López Parra, Emilio}

Emilio.LopezParra@uclm.es 


\title{
PAPEL DE LA PERSONALIDAD
} SITUACIONAL EN LA ADQUISICIÓN DE COMPETENCIAS DIGITALES DE ALUMNOS DEL GRADO DE MAESTRO

\author{
Martín-García, Ma Inés \\ Cebrián Martínez, Antonio \\ García-Perales, Ramón \\ López Parra, Emilio
}

\section{Resumen}

La formación universitaria de los futuros docentes que se lleva a cabo debe estar orientada al pleno desarrollo de las nuevas competencias que exige el siglo XXI. La presente investigación tiene como objetivo la búsqueda de información sobre si los alumnos del Grado de Maestro en España poseen los rasgos de la personalidad concordantes con el desarrollo de las competencias digitales.

En dicha investigación, la muestra seleccionada ha sido el alumnado del Grado de Maestro en la Universidad de Castilla-La Mancha, España, en 2019. El instrumento utilizado es el Cuestionario de Personalidad Situacional CPS (Fernández-Seara, Seisdedos y Mielgo, 2016). Se han analizado las dimensiones en relación a un baremo adecuado, metodología cuantitativa y análisis estadístico.

Respecto a los resultados que se han generado mediante un análisis cuantitativo de las puntuaciones obtenidas, se han hallado puntuaciones medias-altas en las tres variables estudiadas. Esto se significa una relación positiva entre las actitudes de los estudiantes evaluados y la inclusión digital en su proceso de enseñanza-aprendizaje.

Como conclusión, se puede afirmar que la obtención de datos objetivos sobre personalidad situacional es una herramienta de gran utilidad para poder así percibir e identificar las necesidades existentes, formando y reformando el entorno educativo, de forma que se pueda continuar con la labor de mejora de la calidad educativa. También para la elaboración de materiales y proyectos que desarrollen estas capacidades, tomando siempre su evaluación como punto de partida de futuras investigaciones.

\section{Palabras clave}

Inclusión digital, Competencias digitales, Calidad Educativa, Innovación en Educación, Formación Universitaria. 


\section{Introducción}

La presente investigación es un estudio acerca del desarrollo de competencias digitales de los alumnos del Grado de Maestro en Educación Infantil y del Grado de Maestro en Educación Primaria (Castellano y Bilingüe) de la Facultad de Educación de Albacete (Universidad de Castilla-La Mancha, España), a través de las variables de personalidad situacional. Dicha investigación se basa en conocer si este alumnado posee las competencias personales necesarias para adquirir la alfabetización y el compromiso necesario para desarrollar aprendizajes digitales.

Según Gaviria, López y Cuadrado (2019), los procesos psicológicos (la forma en que pensamos y sentimos, las metas que nos fijamos y la conducta social) son el producto conjunto de tres factores: la influencia de los demás, nuestras características personales (rasgos de personalidad, género, edad, entre otras), y nuestra naturaleza biológica heredada a lo largo de nuestra historia evolutiva.

Una herramienta básica en este desarrollo es la orientación educativa, llevada a cabo directamente desde nuestras aulas. Repetto (2008) explica que la orientación para el desarrollo personal estudia los conocimientos, teorías y principios que facilitan los procesos de aprendizaje socio-personal y que fundamentan el diseño, aplicación y evaluación de las intervenciones psicopedagógicas que, desde la perspectiva diagnóstica, preventiva, evolutiva y de la potenciación personal, modifican en los clientes, con un sentido de mejora, sus actitudes, emociones y habilidades sociales, y contribuyen a su desarrollo personal, a lo largo de la vida, y al desenvolvimiento de su contexto y de la sociedad en general. Comprendiendo esta idea, los docentes debemos ser plenamente conscientes de la responsabilidad que tenemos con nuestro alumnado, ya que no son simples vasijas donde volcar los conocimiento a través de clases únicamente magistrales, sino que debemos conocer, entre otras, (además de sus posibles necesidades de apoyo educativo) son los discentes, cómo se relacionan, cómo está su salud emocional, qué nivel tienen de autoconocimiento y autogestión de los acontecimientos, cómo es su proceso de toma de decisiones o cómo son sus procesos psicológicos.

Respecto a la toma de decisiones, debemos aprovechar los conocimientos y resultados de investigaciones previas sobre este tema. Se sabe que, siguiendo a González (2012), la necesidad de justificar la decisión influye sobre la elección y parece estar relacionada con la necesidad de reducir la disonancia cognitiva, también que la toma de decisiones es un proceso dinámico en el que hay que considerar varios factores, tales como, el nivel de conocimiento, los roles, el estado de ánimo, la carga emocional, la presión del tiempo, etc. Por último, las distintas estrategias de decisión se encuentran directamente relacionadas con cuatro objetivos: maximizar la precisión de la decisión, minimizar el esfuerzo cognitivo, minimizar el impacto de las emociones negativas y maximizar la facilidad con la que se pueda justificar la decisión.

Según Gaviria, López y Cuadrado (2019), los procesos psicológicos (la forma en que pensamos y sentimos, las metas que nos fijamos y la conducta social) son el producto conjunto de tres factores: la influencia de los demás, nuestras características personales (rasgos de personalidad, género, edad, entre otras), y nuestra naturaleza biológica heredada a lo largo de nuestra historia evolutiva. 
En relación a la consecución de una educación de calidad, es prioritario que las personas que forman parte del proceso educativo encuentren el mayor bienestar posible tanto físico, como psicológico y emocional. Una forma conseguirlo es llegar a niveles de autoconocimiento y autopercepción que nos permitan tomar decisiones para el futuro de una forma eficaz y determinante (tanto profesores como alumnos). En palabras de Torres Tamayo y Sánchez Rodríguez (2018), el énfasis en el conocimiento de sí mismo como una necesidad del ser humano y, al mismo tiempo, como una condición para la formación y el desarrollo psicológico, es uno de los elementos comunes. Esto justifica el sentido de la inclusión de esta categoría en el campo de estudios e investigaciones de la personalidad.

Tras la realización de un estudio cuantitativo de varios rasgos o tendencias comportamentales en los estudiantes del Grado de Maestro en sus dos especialidades, según Anaya (2002), se puede afirmar que, si la personalidad se entiende como el conjunto de disposiciones, dimensiones o rasgos de una persona, la personalidad es un producto de las relaciones sociales y es un constructo que sirve para categorizar, ante todo, la conducta social.

Gran cantidad de investigaciones previas revelan la carencia existente en la formación digital en el contexto universitario. Según Moreno et al. (2018), la competencia digital que creen poseer los futuros docentes se reduce a la información y obvian las dimensiones de comunicación, creación de contenido, seguridad y resolución de problemas que plantea DIGCOM (Marco Común de Referencia en materia de Competencia digital») (p.10). Un tiempo más tarde, Gabarda et al. (2020), expone que resulta crucial seguir trabajando en la capacitación tecnológica y digital de los futuros docentes, en aras de favorecer el desarrollo de su competencia digital (p.13).

Como objetivo principal del presente estudio es obtener información fiable y precisa sobre los resultados en Eficacia, Control Cognitivo y Tolerancia; siendo todas ellas dimensiones de la personalidad situacional, con el último propósito de conocer el estado de la cuestión en la Facultad de Educación de Albacete para desarrollar con éxito las competencias digitales y valores entre el alumnado.

\section{Método/Descrippción de la experiencia}

La metodología de la que se ha hecho uso ha sido objetiva y cuantitativa, basándose en el núcleo de la investigación científica aplicada a las ciencias sociales. En palabras de Quintanilla, García, Rodríguez, Fontes de Gracia y Sarriá, la investigación científica es un proceso de pasos ordenados, pero global e integrado. Se representa como un proceso circular, porque las conclusiones de la investigación realizada contribuirán al mejor conocimiento del problema de estudio, lo que a su vez permitirá plantear nuevas preguntas que darán lugar a nuevas investigaciones.

A continuación, se explica el procedimiento llevado a cabo en la investigación realizada.

\section{Descripción del contexto y de los participantes}

Actualmente, la presente enseñanza universitaria está basa en dos preceptos fundamentales: el trabajo enfocado a mejorar la calidad educativa actual a través de la innovación y la investigación pedagógica junto con la creciente importancia del bienestar 
de nuestros docentes y discentes. El estudio de ciertas prácticas nos dará una información privilegiada sobre cómo empoderar el proceso de enseñanza-aprendizaje en la enseñanza superior.

El emprendimiento docente tiene su base en la formación actual del profesorado, el cual es una unión de teoría y práctica, donde se puedan comprender las relaciones entre los contextos que rodean a todos los componentes del ámbito educativo. Para ello, resulta interesante localizar las necesidades que pueda presentar el alumnado ya no sólo a nivel de contenidos, sino también psicológico y emocional.

La presente investigación fue realizada en la Facultad de Educación de Albacete (Universidad de Castilla-La Mancha, España), en todas sus especialidades: Educación Infantil y Educación Primaria (modalidades en castellano y en bilingüe: lengua inglesa). De este modo, se ha podido conocer la situación actual del alumnado sobre la coherencia entre el desarrollo de competencias digitales y la personalidad situacional.

La muestra utilizada ha sido de 204 participantes del Grado en Maestro mencionadas con anterioridad.

\section{Instrumentos}

Se han utilizado diferentes instrumentos para la realización del presente estudio. La prueba utilizada para la recogida de datos (puntuaciones) ha sido el Cuestionario de Personalidad Situacional (CPS), Así, Fernández et al. explican que es un cuestionario elaborado en un contexto nacional, con unos determinados contenidos comportamentales y tipificado originalmente en muestras españolas. Se ha intentado analizar el peso de la generalidad intrapsíquica, que a veces no es tanta, y la especifidad comportamental (p.11).

Esta prueba estandarizada consta de 15 variables de personalidad (estabilidad emocional, ansiedad, autoconcepto, eficacia, confianza/seguridad en sí mismo, independencia, dominancia, control cognitivo, sociabilidad, ajuste social, agresividad, tolerancia, inteligencia social, integridad/honestidad y liderazgo) y tres medidas de validez de las respuestas (sinceridad, deseabilidad social y control de respuestas).

Por último, los resultados obtenidos mediante el cuestionario estandarizado se analizaron con un programa informático estadístico de forma cuantitativa y objetiva.

\section{Procedimiento}

En cuanto al procedimiento, asumiendo que todas personas poseen diferencias interindividuales e intraindividuales, se da por cierto que todas tienen también capacidades distintas para atender a sus emociones y factores personales.

Tanto en la literatura como en el mercado existen diversos instrumentos que evalúan las diferencias individuales, en este caso, de la personalidad situacional.

El diagnóstico pedagógico es una disciplina que comenzó a principios de siglo con el objetivo de encontrar nuevas herramientas de detección de dificultades escolares. En sus comienzos, se trataba de utilizar métodos estadísticos que ayudaban 
a diagnosticar problemas únicamente en la escuela por parte de especialistas del ámbito clínico y sanitario (modelo psicométrico).

Tiempo después, con la intervención de educadores como Dewey, Decroly, Claparède, Inhelder, Murray, Ebbinghaus, Thorndike, Parsons, Strong y Kuder se intensificó el diagnóstico propiamente pedagógico que, junto con la intervención, crearon una herramienta de mejora en los procesos de orientación educativa y vocacional indiscutible.

En España, el diagnóstico es introducido en la escuela por la Inspección de Enseñanza Primaria y las Escuelas Normales en las décadas de 1920 y 1930.

Una vez conocido el origen del presente estudio, fueron elegidas las variables más representativas de las personalidad para el desarrollo exitoso de las competencias digitales en los alumnos universitarios.

Se ha tenido en cuenta la importancia, a su vez, de la competencia emocional para realizar una tarea educativa con éxito.

Respecto a las puntuaciones en la variable Eficacia, una persona con puntuaciones bajas explican sujetos poco seguros de sí mismos, que presenta limitaciones y dudas, a la vez que sentimientos de inferioridad e inseguridad ante las situaciones sociales; a su vez, puntuaciones altas en este ámbito muestra ser competente, eficiente y con actitud emprendedora, desarrollando iniciativas propias y lanzada a la actividad, segura, confiada en sí misma y eficaz, aceptando responsabilidades.

En cuanto al Control cognitivo, puntuaciones bajas en este aspecto simbolizan impulsividad verbal y en sus respuestas, bajo control cognitivo, consideración de que el destino está en el azar y en la suerte y locus de control externos; también puntuaciones altas significan una muestra calculadora, precavida y organizada, con control verbal y de las acciones, alto control cognitivo, analítico y reflexivo (fundamental para la competencia digital), atribución real y locus de control interno, poniendo el esfuerzo en sí misma, analiza los distintos puntos de vista, demora las respuestas e intenta solucionar los problemas de forma autónoma.

Por último, puntuaciones bajas en Tolerancia representan una muestra intolerante, intransigente, radical, inflexible, dogmática, en ocasiones tirana; todo ello les hace difícil la convivencia con las ideas y valores de otros que no son ellos mismos. De este modo, valores altos simbolizan personas tolerantes, comprensivas, permisivas, flexibles, buenos en la convivencia, liberales, sociables y con intereses amplios (característica altamente positiva en la adquisición de conocimientos digitales).

\section{Resultados}

La medición de parámetros o variables individuales ha sido un tema de interés desde tiempos inmemoriales. Como afirman Barbero, Vila y Holgado (2015), podríamos remontarnos bastantes años antes de Cristo y ya se apreciaría el interés existente por analizar de alguna manera las diferencias individuales.

Una vez recopiladas todas las puntuaciones necesarias a través del cuestionario CPS, se han obtenido las puntuaciones medias de las puntuaciones típicas de cada dimensión. 
Los resultados se exponen en la siguiente Tabla 1:

Tabla 1. Resultados de las medias en cada dimensión

\begin{tabular}{|l|l|}
\hline Eficacia & 69.02 \\
\hline Control Cognitivo & 67.82 \\
\hline Tolerancia & 64.39 \\
\hline
\end{tabular}

Según el manual de la prueba diagnóstica, todas las puntuaciones obtenidas se pueden englobar dentro la valoración medias-altas, dado que se consideran puntuaciones altas todas aquellas obtenidas por encima de 70.

En relación a los datos obtenidos, según Barbero et al. (2015), sea cual sea el campo de aplicación de la medición psicológica (procesos básicos, personalidad, procesos cognitivos, actitudes, valores, etc.) hay una serie de objetivos comunes fundamentales: estimar los errores aleatorios que conlleva toda medición (fiabilidad de las medidas), y garantizar que la misma no es algo inútil sino que sirve para explicar y predecir los fenómenos de interés (validez de las medidas). Todo ello es asumible en la investigación que nos ocupa.

Dichos resultados tienen una interpretación educativamente positiva, de modo que son el reflejo de que el alumnado del Grado de Maestro de la Facultad de Educación de Albacete son competentes, eficaces, con buen manejo de los procesos y habilidades de autocontrol e independencia de pensamiento y acción para el correcto desarrollo de las competencias digitales, cualidades imprescindibles en los docentes del presente y del futuro.

\section{Discusión y conclusiones}

Como docentes, debemos ser conscientes de la repercusión de las emociones y de la propia personalidad, en este caso, situacional, como herramienta de mejora del desarrollo académico, lo cual se interpretará como una valiosa información relativa a los aspectos que conforman el emprendimiento y la realidad educativa a la que nos enfrentamos actualmente.

Es innegable que la generación actual no es igual a generaciones anteriores y, por ello, se deben actualizar las metodologías pedagógicas como respuesta a las nuevas necesidades que surgen en el aula.

La personalidad situacional es un factor fundamental para que el proceso de enseñanza-aprendizaje sea un trabajo exitoso. Abarcar la competencia emocional y los rasgos de conducta del alumnado debe ser algo fundamental en la labor de todos los maestros y profesores en sus grupos de estudiantes, también en la enseñanza universitaria.

En los alumnos de las facultades de educación, como es el presente caso, los maestros deben poseer una especial sensibilidad, don de la empatía y la innovación pedagógica adopten otro sentido. De acuerdo con Dueñas (2011), los nuevos planteamientos han 
supuesto un cambio muy importante en el proceso diagnóstico al considerar al sujeto como parte integrante activa de este proceso, ya que el funcionamiento cognitivo del sujeto tiene lugar en la interacción del mismo con el ambiente.

Los resultados que han sido obtenidos en esta investigación nos conducen a la idea de que los alumnos del Grado de Maestro de la Facultad de Educación de Albacete (España) son aptos para realizar una inclusión digital eficaz, donde la competencia digital forme parte de su proceso de enseñanza-aprendizaje. De este modo, ellos también podrán integrarlo en la enseñanza de sus futuros alumnos de Educación Infantil y Educación Primaria.

De esta forma, es fundamental que se siga trabajando en mantener estas capacidades, reforzando siempre las conductas que derivan en estos aprendizajes. Con los resultados obtenidos, sería interesante el desarrollo de actividades y tareas de forma intencionada que, aplicadas a los alumnos, amplificaran una o varias de las variables estudiadas con el objetivo de desarrollar también las que tiene relacionadas, como es el caso de la competencia tecnológica. Técnicas de autoconocimiento, desarrollo personal, coaching académico, resolución de problemas, herramientas de desarrollo de las propias capacidades... son ejemplos de cómo los estudiantes pueden trabajar el desarrollo de su potencial a través de la formación universitaria.

La Enseñanza Universitaria debe considerarse como un continuo en el que nunca desaparece el espíritu emprendedor e innovador. Así, podremos hablar del incremento de la calidad en la educación universitaria, en este caso, en el Grado de Maestro en todos sus niveles.

\section{Referencias}

Amor, P. J., Fernández, E., Olmedo, M., Sánchez, Á. y Paniagua, E. (2005). Introducción al estudio de las diferencias individuales. Sanz y Torres.

Anaya, D. (2002). Diagnóstico en Educación. Sanz y Torres.

Barbero, M. I., Vila, E. y Holgado, F. P. (2015). Psicometría. Sanz y Torres.

Brody, N. y Ehrlichman, H. (2000). Psicología de la Personalidad. Prentice Hall.

Collado, P., Guillamón, A., Claro, F., Rodríguez, M., Pinos, H., Carrillo, B. y Ortiz-Caro, F. J. (2017). Psicología fisiológica. Universidad Nacional de Educación a Distancia.

Dueñas, M.a. L. (2011). Diagnóstico pedagógico. Universidad Nacional de Educación a Distancia.

Fernández Seara, J. L., Seisdedos, N. y Mielgo, M. (2016). CPS, Cuestionario de Personalidad Situacional (4. a ed.). TEA Ediciones.

Gabarda, V., Marín, D. y Romero, M.M. (2020). La competencia digital en la formación inicial docente. Percepción de los estudiantes de Magisterio de la Universidad de Valencia. ENSAYOS: Revista de la Facultad de Educación de Albacete, 35(2), [pp.] 1-16. 
Recuperado de [https://revista.uclm.es/index.php/ensayos/article/view/2176/1985]

Gaviria, E., López, M. y Cuadrado, I. (2019). Introducción a la Psicología Social. Sanz y Torres.

González, M. J. (2012). Psicología del Pensamiento. Sanz y Torres.

Moreno, M.D., Gabarda, V. y Rodríguez, A. M. (2018). Alfabetización informacional y competencia digital en estudiantes de magisterio. Profesorado: Revista de currículum y formación del profesorado, 22(3), [pp.] 253-270. Recuperado de [https:// recyt.fecyt.es/index.php/profesorado/issue/view/22\%283\%29]

Quintanilla, L., García, C., Rodríguez, R., Fontes de Gracia, S. y Sarriá, E. (2019). Fundamentos de investigación en Psicología. UNED.

Torres Tamayo, A. y Sánchez Rodríguez, G. (2018). El conocimiento de sí mismo en la formación del especialista en pedagogía-psicología. Opuntia Brava, 8(1), 9-17. https://doi.org/https://doi.org/10.35195/ob.v8i1.238

Tourón, J. (2019). Las altas capacidades en el sistema educativo español: reflexiones sobre el concepto y la identificación. Revista De Investigación Educativa, 38(1), 1532. https://doi.org/10.6018/rie.396781 


\section{Educación Digital en Escuelas Medias: Un Enfoque TRIC Hacia el Aprendizaje Basado en Pensamiento}

\section{Hernández Silvera, Dides Iliana}

Pontificia Universidad Católica Argentina

hernandezsilvera@uca.edu.ar

https://orcid.org/0000-0001-7759-516X 


\title{
EDUCACIÓN DIGITAL EN ESCUELAS MEDIAS: UN ENFOQUE TRIC HACIA EL APRENDIZAJE BASADO EN PENSAMIENTO
}

\author{
Hernández Silvera, Dides Iliana
}

Pontificia Universidad Católica Argentina

hernandezsilvera@uca.edu.ar

https://orcid.org/0000-0001-7759-516X

\section{Resumen}

El estudio pretendió evaluar una propuesta didáctica centrada en el método de aprendizaje basado en pensamiento (TBL) y uso de dispositivo móvil (Mobile Learning) en escuelas secundarias vulnerables de la provincia de Buenos Aires. Se empleó el cuestionario EMPA para valorar motivación intrínseca y extrínseca en el proceso de aprender. Se realizó un estudio Cuasi-experimental, descriptivo-comparativo de corte transversal. Los datos fueron recogidos mediante muestreo por conveniencia. Participaron 157 estudiantes de cinco escuelas (42.2\% académico, 33.1\% alto riesgo y sin criterio 21.7) de entre 17 a 20 años ( $M=18.69$; $D E=.66$, espacios curriculares de Proyecto de Investigación, Filosofía y Psicología. Se administraron pruebas diagnósticas, pre y post uso de la metodología activa determinando el grado de aprendizaje sobre los contenidos curriculares. La modificación de notas luego de la metodología que contempla las TEPs y TRIC como logro de empoderamiento con relevancia del aspecto R-elacional indica mejor desempeño. Las diferencias entre las medias de las notas, observa mayor implicancia con las propuestas. El desempeño significativo destacó el promedio de pruebas pos-proyecto de 6.45 (DE = 1.04). Esta diferencia estadísticamente significativa $(t(132)=-23.00 ; p<.0001)$, eleva el promedio final por encima de la inicial.

\section{Palabras clave}

Metodología TBL- TIC+TRIC, dispositivo móvil, vulnerabilidad. 


\section{Introducción}

Este estudio presenta una propuesta de inclusión educativa virtual a partir de las redes sociales el cual surge del Proyecto Segunda Lectura, cuya finalidad es que los alumnos construyan de forma activa la reflexión de los contenidos presentados en los espacios curriculares. Esta propuesta es sustentada en la metodología de Aprendizaje Basado en Pensamiento (TBL) y el uso de dispositivo móvil o mobile learning (m-learning) como recurso de acceso a las TIC y TRIC.

Durante reuniones pedagógicas cinco escuelas secundarias de zona sur plantean la problemática observada en el alumnado y la necesidad de innovar la propuesta para el ciclo lectivo, en el uso de estrategias que generen mayor autonomía y participación basada en la currícula escolar. Con fines a favorecer un aprendizaje enriquecido por lo tecnológico, la información y la comunicación, surge esta convocatoria que enlaza un modelo más cautivador y faculta el desarrollo sustancial de habilidades para pensar.

En consecuencia, enseñar procedimientos de pensamiento permite situar la práctica por medio de preguntas abiertas o mediante secuencias breves, sin aportar amplias explicaciones para obtener mejores resultados. De esta forma, Swartz (2017) explica que el pensamiento eficaz devendrá del análisis de los contenidos propios de la materia, en este caso, espacios de Educación Secundaria.

En otras palabras, Swartz (2017) se refiere a la importancia de informar acerca de los temas que se tratarán en la clase, introduciéndolos para después indicar qué destrezas de pensamiento y hábitos se ejercitarán en la lección, para finalizar evaluando la totalidad del proceso y generar aprendizaje.

De esta forma el TBL permitiría insertarlos en situaciones cotidianas, mediante el análisis del entorno escuela o barrio, cuyo Eje formativo prescriptivo es el cuidado del ambiente o la convivencia: afectividad, relaciones interpersonales y ciudadanía responsable (DGCyE, 2019). Un ejemplo de ello es, realizar experiencias y prácticas de análisis en trabajos de campo como estrategia didáctica para el aprendizaje de los contenidos en los distintos espacios curriculares.

Esta invitación propone el uso de estrategias TIC desde el recurso m-learning, con fines a motivar al alumnado y mejorar el aprendizaje, sostenido por la metodología de TBL. Este recurso, requiere "digitalizar una actividad" al proceso de ejecutar una tarea o actividad a través del uso del dispositivo móvil (Rodríguez Arce y Coba Juárez Pegueros, 2017).

Sin duda varios son los aspectos por considerar en esta propuesta, al incluir el uso de dispositivo móvil se proponen competencias mediáticas y amplía el conocimiento hacia las redes sociales desde las TRIC. Gabelas, Marta-Lazo y Aranda (2012) expresan que la experiencia en los entornos tecnológicos, descripto como TRIC (tecnologías + relación + información + comunicación) produce interacciones a través de las redes sociales un enfoque educativo en red más versátil.

Adhiriendo a Marta-Lazo y Gabelas Barroso (2016), la forma de enlazar lo tecnológico, la información y la comunicación, genera espacios estables y lazos de confianza que facilitan el intercambio producido como factor R-elacional donde el acrónimo 
TRIC interviene en la oportunidad de aprender. Los autores vinculan este factor con la formación en Habilidades para la Vida en un amplio abanico de cuestiones que incluyen aspectos cognitivos entre otros.

Cabe señalar que el interés por la actividad es despertado, por una necesidad cuyo mecanismo incita a la persona a la acción, y que puede ser de origen fisiológico o psicológico (Carrillo, Padilla, Rosero y Villagómez, 2009). Sin duda, el tema central en este despertar es el concepto de motivación, el cual dentro de la literatura científica y académica ha contado desde hace tiempo con evidente atención (Junco Herrera, 2010; Tirado, Tejero-Díez, 2013).

En este sentido, adhiriendo a Tirado, Santos y Tejero-Díez (2013) la motivación es enfocada a desarrollar en los estudiantes intereses y actitudes favorables al aprendizaje de los contenidos de la asignatura. Cobra relevancia en este punto adentrarse en uno de los tantos escenarios en los que la motivación juega su papel, tal como lo es el ámbito académico. De esta manera, la motivación académica remitiría a la disposición positiva hacia el aprender de manera autónoma.

Quevedo-Blasco, Quevedo-Blasco y Téllez-Trani, (2016), en el desarrollo del cuestionario EMPA reconocen aspectos ineludibles para el progreso de esta propuesta. De esta forma, los autores hacen referencia a la motivación intrínseca (cuando la persona fija su interés por el trabajo, demostrando un papel activo en la consecución de sus fines, aspiraciones y metas), extrínseca (cuando se tienen en cuenta factores de carácter externo, como las ventajas que ofrece la actividad que se realiza, constituyendo un medio para llegar a un fin y no un fin en sí misma) y global del alumnado en el proceso de su aprendizaje.

En relación con estas últimas afirmaciones, los alumnos requieren alcanzar una reflexión personal a partir de lecturas variadas con el fin de alcanzar metas propias y desarrollar el conocimiento necesario para su vida en sociedad.

\section{Antecedentes}

Este estudio se llevó a cabo con adolescentes de escuelas estatales de enseñanza media ubicadas en zonas vulnerables y céntricas de zona sur de la Provincia de Buenos Aires. A efectos de reconocimiento sociambiental de las escuelas donde impacta el proyecto, se observan establecimientos educativos con concepto de vulnerabilidad académica, que hace referencia a aquellos individuos que experimentan una serie de dificultades marcadas a lo largo de su trayectoria escolar que les impiden sacar provecho al currículo y a las enseñanzas dentro del aula de clase.

En efecto, como afirman Díaz López y Pinto Loria (2017), las barreras que pueden presentársele a los jóvenes en su paso por la educación formal pueden ser de diversa índole: emocionales, familiares, interpersonales, relacionadas al proceso de enseñanza y aprendizaje o con el clima de la institución educativa en la que están inmersos; usualmente éstas condiciones vienen acompañadas de factores o fenómenos mucho más complejos o profundos y en la mayoría de los casos, desembocan en fracaso escolar, sobre todo si los proyectos o decisiones académicas no son pensadas para el alumnado. 
A los fines de la implementación del proyecto Segunda Lectura y como continuidad de otras estrategias empleadas en estas instituciones, que reúnen las características poblacionales de: 1. escuelas secundarias céntricas, con población lindantes a asentamientos y zonas accesibles, denominadas con Riesgo pedagógico cuyos alumnos poseen bajo rendimiento académico (Castilla y López, 2006; Regillo Cruz, 2007). 2. la designación de Riesgo Social reseña a otro conjunto de escuelas cuyos alumnos pertenecientes zonas de asentamientos y villas cercanas concurren a las instituciones situadas en zonas riesgo socioambiental, revisado en García (2019). 3. escuelas existentes en zonas de inflamables con características de Alto riesgo, por la proximidad a depósitos de sustancias inflamables, incluyen algunos asentamientos y villas de alrededores (Abelenda, Canevari y Montes, 2016).

La propuesta habilita el trabajo de los alumnos con su caudal de conocimiento, cotidianeidad y lenguaje, para ampliarlo y participar de una metodología activa desde una competencia mediática. Ferrés y Piscitelli (2012), expresan que esta competencia trata de una cultura participativa de los ciudadanos (sociedad del conocimiento), que implica el dominio de conocimientos y destrezas de los temas planteados por docentes y requeridos desde el marco de la propuesta curricular implicando las redes.

A lo largo de un año y disponiendo de acceso a cinco escuelas y siete cursos de nivel medio, se pone en marcha esta metodología de TBL con apoyo de dispositivo móvil que vincula el uso de las redes sociales y la experiencia producida desde las TICs. Específicamente, esta propuesta habitó una invitación a los últimos años de educación Secundaria correspondientes a $4^{\circ}$ y $6^{\circ}$ años de las escuelas mencionadas. Aquí donde se plantea la necesidad del uso de estrategias que favorezcan la motivación por el proceso de aprender, la autonomía en sus desempeños en el contexto relacionado al currículum.

Adquiere relevancia en este punto adentrarse en uno de los tantos escenarios en los que la motivación juega su papel, tal como el ámbito académico. Es necesario situarnos también en la motivación para el aprendizaje adolescente cuya motivación para aprender en contextos vulnerables, no se centra en el rendimiento académico.

En este sentido la característica es mencionada por varios autores al coincidir que la motivación hacia el aprendizaje es esencialmente interpersonal, creada por relaciones internalizadas y por influencias interpersonales (Ramos Ferre, 2014).

Ante la situación planteada, surge la necesidad de valorar la motivación, mediante el cuestionario de Quevedo-Blasco, et al. (2016), a partir del instrumento de medida que un instrumento de medida que operativice la motivación intrínseca, extrínseca y global del alumnado para facilitar al profesorado una herramienta útil en relación con este constructo. Este instrumento proporcionó índices motivacionales en el proceso de enseñanza-aprendizaje como elemento de control de inicio para las estrategias metodológicas a emplear en el aula.

Posteriormente se aplicó la metodología de TBL que posibilitó incentivar en el alumnado la capacidad para efectuar un aprendizaje más consciente y profundo, ser capaz de tomar decisiones acerca de su aprendizaje, generar iniciativas y propiciar descubrimientos convocando la circulación de un aprendizaje más motivador, atractivo y cautivador. De esta manera el papel de las TICs en el fortalecimiento de las TRICs permite como individuos tener oportunidad de ser socialmente capaces de 
integrarse y aprender en una sociedad plural y multicultural. Así mismo convoca a todos los docentes, a desafiar este pensar de una forma distinta, de enseñar-aprender de manera reflexiva y con una mayor llegada al alumno desde lo que trae (Hernández-Silvera, 2021).

En consecuencia, la propuesta en tanto objetivo general representa la finalidad del proyecto, Indagar la relación entre el uso de una metodología activa en torno a la dinámica digital móvil y la motivación al proceso de enseñanza aprendizaje inicial.

Quedan delimitados así los objetivos específicos

- Describir y analizar la influencia de la metodología de TBL en las notas post de acuerdo con el promedio obtenido de alumnos.

- Describir la respuesta del alumnado en tanto motivación al proceso de aprender y la relación con la metodología de dispositivo móvil en las redes sociales.

- Analizar la existencia de diferencias estadísticamente significativas en la valoración de desempeños antes y después del proyecto virtual.

- Analizar la existencia de diferencias estadísticamente significativas en motivación intrínseca y extrínseca de acuerdo con el criterio de vulnerabilidad.

Surgen las hipótesis siguientes:

H1: Cuanto más adaptable y reflexivo sea el recurso metodológico los factores motivadores de naturaleza extrínseca a los que está sometido un alumno, repercutirán en mejor desempeño reportado en notas post.

H2: Cuanto mayor sea la motivación de los alumnos ante la búsqueda de su propio conocimiento, más conocimiento estará dispuesto a recibir y transmitir en el uso de las redes.

H3: Cuanto menor calificación pre-implementación del proyecto, mejor desempeño en el proceso de aprendizaje como respuesta a la intervención de estrategias metodológicas en el aula.

H4: Cuanto menor es la motivación tanto intrínseca como extrínseca, más bajo es el desempeño según el criterio de vulnerabilidad.

\section{Método}

\section{Tipo y diseño de estudio}

Se realizó un estudio Cuasi-experimental, descriptivo-comparativo de corte transversal se hace recopilación de un conjunto estrategias conducentes a la valoración del impacto de la intervención y por ende, al estudio de los eventuales cambios que pueden ocurrir y detectar en los sujetos sometidos a esta intervención en función del tiempo. Los datos fueron recogidos mediante muestreo por conveniencia. La recopilación de la información es a partir del cuestionario de uso de redes y el cuestionario 
EMPA, luego se aplica la metodología TBL con el aporte de las TICs a través del uso del dispositivo móvil. De esta forma, se observan las calificaciones obtenidas a partir de la evaluación diagnóstica (pre) antes del inicio del trabajo con las TICs y M-learning y desde la participación en las propuestas (post) el registro de pruebas y sus los resultados finales.

\section{Participantes}

La muestra se conformó por 157 alumnos de cinco escuelas pertenecientes a escuelas públicas de los últimos años de secundaria de zona sur de Gran Buenos Aires (42.2\% vulnerabilidad académica, $33.1 \%$ alto riesgo y sin criterio 21.7 ). Con una edad comprendida entre 17 a 20 años ( $M=18.69$; DE = .66, espacios curriculares de Proyecto de Investigación, Filosofía y Psicología.

En el momento previo a las intervenciones a los participantes se administró el cuestionario EMPA evidenciando Clara Desmotivación en 91\%, se propone generar una metodología que favorezca el deseo por aprender.

Por otro lado, la muestra contó con tres grupos diferenciados, por un lado, el grupo registrado como vulnerabilidad académica, es decir, individuos que experimentan una serie de dificultades marcadas a lo largo de su trayectoria escolar que les impiden sacar provecho al currículo y a las enseñanzas dentro del aula de clase pertenecían al $63.7 \%$ cuyas calificaciones eran < a 4.

Asimismo, el grupo de alto riesgo proveniente de zona de inflamables está conformado por aquellos que han recursado más de una vez (propio de nueva instancia presencial de cursada) o abandonado y que retoman sus estudios al siguiente año. Representan el $33.1 \%$ de la muestra que se trabajó en este estudio, posee en notas (pre) $74.1 \%$ notas $<4$.

Por último, el grupo de escuelas no consideradas de riesgo pedagógico, ni ambiental 21.7\%; son escuelas céntricas, a las cuales concurren alumnos de zonas cercanas y más alejadas (otras localidades), clasificadas "sin criterio de riesgo" (pedagógico ni ambiental), aunque pertenecen a la categorización de Carrascosa y Leston (2020) de clase obrera, presentaron notas <4 en valoración inicial (pre) el 76,4\%.

El análisis de los datos obtenidos en los registros de los grupos en tanto repitencia-promoción-vulnerabilidad, arrojó los resultados siguientes para repitencia y basado en si recursó alguna vez, según los grupos comprendidos en riesgo pedagógico el $46.5 \%, 11 \%$ alumnos de escuelas con riesgo ambiental y $17.6 \%$ alumnos de escuelas sin riesgo pedagógico o ambiental.

Un dato principal, constituye el cuestionario inicial de uso de redes sirvió para conocer el grado de adhesión a las redes sociales más empleadas fueron WhatsApp $100 \%$, YouTube por el 84,7\%, Instagram 43.4\%, Facebook 4,5\%, Twitter 1,9\%, dejando con $0 \%$ LinkedIn.

\section{Instrumentos}

En primera instancia, se contó con una prueba de evaluación diagnóstica inicial al lectivo, la cual consistió en un cuestionario breve de contenidos mínimos para el ciclo. Luego esos contenidos retomados, ampliados y trabajados, se vuelven a evaluar 
a fin del ciclo lectivo. Además, se observan registros anecdóticos pertenecientes a datos de matrícula donde consta repitencia/promoción y cercanía de la escuela.

A su vez, a la par de la administración de las pruebas (pre) se administra el Cuestionario de evaluación motivacional del proceso de aprendizaje (EMPA) de Quevedo-Blasco et al. (2016). El instrumento se encuentra conformado por 33 ítems, con respuestas de tipo Likert de 5 puntos desde 1 (casi nada) a 5 (siempre), que miden motivación intrínseca, extrínseca y global del proceso de aprendizaje. En el presente estudio se evaluó la motivación extrínseca obteniendo una fiabilidad $\alpha=.91$.

\section{Procedimiento}

En primer lugar, junto a directivos informados del proyecto se participó a los alumnos acerca del estudio, los objetivos y la propuesta general, así como también se informa que su participación sería de carácter anónimo y protegiendo sus datos personales.

En segundo lugar, la invitación a TBL y en el empleo de recursos y estrategias de las redes sociales que visualizan para ampliar el conocimiento de estas. Esta propuesta permitió el uso del recurso M-learning, en una convocatoria para aprender desde el dispositivo móvil y a partir del pensamiento, búsquedas de conocimiento en la Web y reflexiones compartidas acerca de las TICs.

Los proyectos de trabajo contaron con breves presentaciones y con una instancia final de puesta en común, el envío de sus producciones participando en concursos internos de videos y música que permitieron además la discusión de temas curriculares con enfoque cooperativo.

Respecto a las TICs, generar espacios de conversación, juego, recreación, interacción y construcción; no solamente desde las redes sino desde la articulación y la guía docente en la R-elación virtual-dinámica-práctica que hace al conocimiento de estos entornos sociales, un conjunto de oportunidades para aprender habilidades para la vida y socializar.

De esta manera, se observa una respuesta de inserción en red que los incluye en la era digital, donde pensarse en un mundo social y laboral. Asimismo, cómo relacionase en las redes con sus consecuentes cuidados respecto a riesgos, análisis de CV, generar ideas para posibilitar cambios en la sociedad o en el ámbito escolar influyeron en su cotidianeidad digital.

Algunos de los trabajos realizados desde las tres áreas curriculares representan temáticas que les preocupan, en cada espacio curricular: Psicología, conciencia respecto a temáticas más escuchadas en grupos tales como acoso, dependencias, aborto, abuso, alcoholismo. Generaron estrategias participativas de afiches, dossier de pensamientos, listas de interés. Desde el espacio curricular de Filosofía, Ser en sí y para sí: afiches de situaciones más escuchadas o vistas, publicar sus investigaciones en porfolio escolar (subidos por el docente a raiz de contar con datos móviles), pizarra/muro interactivo, debates, listas de interés (Agrupar a aquellos interesad@s para estar informad@s en el Timeline o línea del tiempo para separar eventos y etapas planteadas para el año lectivo). 
A su vez, en el espacio curricular de PROMI (Proyecto y Metodología de la Investigación en Cs Sociales y Economía), suscitar espacios de participación y colaboración en emprendimientos que incluyen búsqueda de información y análisis de situación (comedores, ropero comunitario, situación de calle, espacios verdes, comenzando por hashtag (\#) el cual es transformado en un hipervínculo que dirige la búsqueda. Es decir, es una manera más práctica de agrupar diversos contenidos sobre un tema determinado, facilitando la búsqueda.

\section{Análisis de datos}

Para el análisis de los datos recabados se utilizó el paquete estadístico para Ciencias Sociales SPSS 25. Se testearon en primer lugar el cumplimiento de supuestos de normalidad y homocedasticidad, debido a que ambos no se cumplieron, se procedió al empleo de estadística no paramétrica para responder a los objetivos propuestos. En el caso de los objetivos descriptivos, se procedió a calcular media, desvío estándar y frecuencias porcentuales de las variables evaluadas. En cuanto a los objetivos comparativos, se empleó la Prueba $U$ de Mann-Whitney, con un nivel de significancia estadística de $p<.05$ o menor.

\section{Resultados}

Con referencia al primer objetivo, se buscaba describir y analizar la influencia de la metodología de TBL en las notas post de acuerdo con el promedio obtenido por alumnos. Los resultados encontrados reafirman la $\mathrm{H} 1$ cuanto más adaptable y reflexivo sea el recurso metodológico, más repercutirán en mejor desempeño reportado en notas post. El proyecto Segunda Lectura, a partir del interjuego de TBL y recursos utilizados mediante dispositivo móvil, tanto las aplicaciones como herramientas propias de las redes como este entorno de prácticas culturales y digitales en el uso de las TRIC, como factor R recupera la comunicación horizontal, repercutió en la modificación en las notas post promedio de calificaciones.

En segundo lugar, se buscaba describir la respuesta del alumnado en tanto motivación al proceso de aprender y su relación con la metodología de dispositivo móvil en las redes sociales afirmando que, la motivación de los alumnos ante la búsqueda de su propio conocimiento presentó Clara desmotivación inicial en $91 \%$ y uso las redes más empleadas destaca WhatsApp (100\%) frente al Instagram (43.4\%).

De esta forma, es posible decir que contaban con el uso masivo de una sola red de participación alta, que representan implicancia desde las TRIC como una actividad sostenida en el tiempo. De todas formas, el acceso general en este alto grado de adhesión permitió anticipar la posibilidad de generar redes de conocimiento ampliadas a otros probables desde el dispositivo móvil disponible.

Considerando el cuestionario de Quevedo-Blasco et al. (2016), en el momento previo a las intervenciones los participantes manifestaron un nivel medio de 11,76 (DE $=3,74$ ) en motivación extrínseca. Estos datos podrían representan las ventajas que ofrece la actividad académica que se realiza, constituyendo un medio para llegar a un fin y no un fin en sí misma. 
En tanto, respecto al último objetivo planteado desde la existencia de diferencias estadísticamente significativas en motivación intrínseca y extrínseca de acuerdo con la vulnerabilidad, en motivación intrínseca se encontró un nivel medio de 22,88 (DE $=5,52$ ), reportando bajo interés por el trabajo, un papel pasivo en la consecución de sus fines académicos, referido a aspiraciones en el proceso de aprender. Estas dos variables estudiadas reportan la urgencia en el uso de metodología que permita captar la motivación en el proceso de aprendizaje para el cumplimiento de los fines que provoque motivación académica.

Por último, se propuso analizar si existían diferencias en la motivación extrínseca e intrínseca según los grupos estudiados, se calcularon los estadísticos descriptivos de ambas variables en los tres grupos (riesgo pedagógico, alto riesgo y sin criterio de riesgo), las medias más altas en ambas variables se pueden observar en el grupo riesgo pedagógico y las más bajas en el grupo de alto riesgo (ver tabla 1). Luego se analizó mediante la prueba $U$ de Mann-Whitnet si dichas diferencias eran estadísticamente significativas, en cuanto a la motivación extrínseca no se encontraron diferencias significativas, por otro lado, con relación a la motivación intrínseca se encontró una diferencia estadísticamente significativa entre el grupo de riesgo pedagógico y el grupo de alto riesgo (ver tabla 2).

Tabla 1. Estadísticos descriptivos de la motivación según el grado de vulnerabilidad.

\begin{tabular}{|c|c|c|c|c|c|c|}
\hline $\begin{array}{l}\text { Criterio de } \\
\text { Vulnerabilidad }\end{array}$ & Motivación & $\mathbf{N}$ & Mín & Máx & Media & $\begin{array}{l}\text { Desv. } \\
\text { Desviación }\end{array}$ \\
\hline \multirow{2}{*}{ Riesgo Pedagógico } & Intrínseca & 71 & 14 & 34 & 24,01 & 5,43 \\
\hline & Extrínseca & 71 & 9 & 22 & 12,25 & 4,21 \\
\hline \multirow{2}{*}{ Alto Riesgo } & Intrínseca & 52 & 16 & 36 & 21,42 & 5,94 \\
\hline & Extrínseca & 52 & 9 & 24 & 11,08 & 3,55 \\
\hline \multirow{2}{*}{$\begin{array}{l}\text { Sin Criterio de } \\
\text { Riesgo }\end{array}$} & Intrínseca & 34 & 14 & 28 & 22,74 & 4,56 \\
\hline & Extrínseca & 34 & 9 & 16 & 11,79 & 2,80 \\
\hline
\end{tabular}

Tabla 2. Comparación de la motivación extrínseca según el grado de vulnerabilidad.

\begin{tabular}{|l|l|}
\hline Motivación Intrínseca & \multicolumn{1}{c|}{ Sig. } \\
\hline Riesgo Pedagógico $\quad / \quad$ Alto Riesgo & .026 \\
\hline
\end{tabular}

\section{* La diferencia de medias es significativa en el nivel 0.05}

Seguidamente, con fines a analizar la existencia de diferencias estadísticamente significativas en la valoración de desempeños antes y después del proyecto virtual, los resultados encontrados verifican mejor desempeño en el proceso de aprendizaje como respuesta a la intervención de estrategias metodológicas en el aula. Mientras que las notas previas a la implementación del proyecto tuvieron un promedio de 2.67 (DE = 1.60 ), el promedio de las pruebas pos-proyecto fue de 6.45 (DE $=1.04$ ). Esta diferencia fue estadísticamente significativa $(t(132)=-23.00 ; p<.0001)$. 
Para concluir, los resultados presentados en este trabajo muestran que la condición de cada grupo no es limitante para acceder a otras propuestas pedagógicas, que habiten la motivación en el proceso de aprender. Existe un común denominador que es la metodología apropiada para el curso escolar y las posibilidades de que disponen o de acceso para todos.

\section{Discusión y conclusiones}

El presente estudio buscó evaluar la propuesta didáctica pensada a partir del método de TBL asociado al beneficio de las redes sociales desde dispositivo móvil en escuelas que cumplen criterio de vulnerabilidad pertenecientes a la provincia de Buenos Aires. La enseñanza desde el TBL permite crear un espacio para pensar donde los alumnos pueden escuchar el trabajo de otros grupos y analizar su replicabilidad.

El estudio muestra un alto uso de dispositivos móviles, pero importantes deficiencias en aspectos básicos como la búsqueda de información académica dada por la misma red que habilitan las TICs. Asimismo, la toma de conciencia de las posibilidades que ofrecen las redes sociales para incidir en el desarrollo académico en la red conformó un apoyo al conocimiento académico y hacia un futuro laboral apertura a Linkedln.

Asimismo, el grado de interés en la convocatoria resulta en mejor desempeño, orientación reflexiva a las propuestas de investigación, unidas a destrezas propias de las redes y sus búsquedas a partir de historias en video clip, presentadas en Rap, Trap y Reggaeton, por encima de una simple presentación.

Teniendo en cuenta los niveles bajos de motivación intrínseca y extrínseca detectados el empleo del cuestionario EMPA de Quevedo, et al (2016), el diseño de nuevas actividades basadas en las posibilidades tecnológicas facilitó el proceso de aprendizaje al adaptarse el contenido al uso del dispositivo móvil motivando la participación y aprendizaje de estos grupos en el conocimiento del contenido de las materias con elevada adhesión a la propuesta.

Asimismo, la existencia de una relación directamente proporcional entre Motivación Extrínseca y las TRICs, permitió ver un incremento de las notas post. Una aproximación que puede explicar este hallazgo refiere a la importancia del desarrollo del Factor R-elacional, en competencias necesarias para aprender que muestran una dimensión académica empoderada.

Cobra interés, la propuesta de los espacios curriculares en la educomunicación y su relación con la motivación hacia el proceso de aprender, que para los grupos representa la vinculación al entorno social, cultural de información general, de acceso a otras redes sociales, incluso el despliegue musical habilitando el debate interaula.

Esta propuesta es ampliamente replicable a zonas vulnerables y situaciones como las vividas durante la pandemia de covid19, ya que fueron empleados mínimos materiales y su uso permitió el ingreso y permanencia de los alumnos de esta franja etaria, en el interjuego de aprendizaje-investigación R-elacional con intervención de la tecnología en una propuesta concreta en educomunicación. 
Por último, como limitaciones de la investigación, cabe indicar que los resultados son válidos para los grupos trabajados y en situación presencial, con mínima conectividad dada en forma alternada por datos móviles entre los mismos alumnos, además continuidad y refuerzo guía.

Para finalizar, la necesidad de aunar esfuerzos con la comunidad educativa y formar en R-elaciones donde mayor cantidad de espacios curriculares se sumen potenciando e impulsando a enfrentar nuevos desafíos que nos descubren en las instituciones. Estas metodologías activas y las redes sociales se abren a la educación nuevas oportunidades que responden a las necesidades, posibilidades y capacidades formativas de los grupos y la sociedad actual.

\section{Referencias}

Abelenda, N., Canevari, J., y Montes, N. (2016). Territorios de mayor vulnerabilidad social en la Ciudad Autónoma de Buenos Aires. Recorrido en perspectiva histórica sobre aspectos estructurales no resueltos. Población de Buenos Aires, 13(23), 7-30, Gobierno de la Ciudad de Buenos Aires. Recuperado de https://www.redalyc.org/ jatsRepo/740/74045592001/html/index.html

Castilla, G., y López, G. L. (2006). Riesgo educativo. Algunas aproximaciones teóricas. Recuperado de: https://www.aacademica.org/000-039/269.pdf

Carrascosa, J. y Estévez Leston, B. (2020). Mecanismos de acceso al empleo al comienzo de la trayectoria laboral: Desigualdades de clase, territoriales y educativas. En R. Sautu, P. Boniolo, P. Dalle y R. G. Elbert (Eds.), Tras las huellas del peso de las clases sociales en las trayectorias de vida. Herramientas de investigación cuantitativa. Buenos Aires: CLACSO-IIGG.

Carrillo, M., Padilla, J., Rosero, T., y Villagómez, M. S. (2009). La motivación y el aprendizaje. Alteridad. 4(1), Quito, Ecuador.

Díaz López, C. y Pinto Loría, M. L. (2017). Vulnerabilidad educativa: Un estudio desde el paradigma socio crítico. Praxis educativa. 21(1), 46-54. DOI: http://dx.doi. org/10.19137/praxiseducativa-2017-210105

Dirección General de Cultura y Educación de la Provincia de Buenos Aires. (1a ed). (2019). Marco Curricular Referencial. La Plata: Dirección General de Cultura y Educación de la Provincia de Buenos Aires. Recuperado de http://servicios2.abc.gov.ar/ recursoseducativos/editorial/catalogodepublicaciones/diseno_curricular.html

Ferrés, J., y Piscitelli, A. (2012). La competencia mediática: propuesta articulada de dimensiones e indicadores [Media Competence. Articulated Proposal of Dimensions and Indicators]. Comunicar. (38), 75-82. https://doi.org/10.3916/C38-2012-02-08.

Gabelas-Barroso, J.A., Marta-Lazo, C., y Aranda, D. (2012). Por qué las TRIC y nos las TIC [Internet]. COMe/N Rev Estud Cienc Inf Comun. (9). Recuperado de http://www. uoc.edu/divulgacio/comein/es/numero09/articles/Article-Dani-Aranda.html 
García, S. (2019). Informe Final EISAAR. Barrio Villa Inflamable, Avellaneda.

Recuperado de: http://www.acumar.gob.ar/wp-content/uploads/2016/12/Informe-Final-Villa-Inflamable-Avellaneda.pdf

Hernández-Silvera, D. I. (2021). Desafíos de las TICs, TAC, TEP: Impacto de una propuesta Educativa virtual en Escuelas Secundarias Vulnerables. Revista de Educación Inclusiva. 14(1), 189-199.

Junco Herrera, I. (2010). La Motivación en el Proceso de Enseñanza-Aprendizaje. Temas de Educación. Andalucía, España. Recuperado de https://www.feandalucia. ccoo.es/docu/p5sd7327.pdf

Marta-Lazo, C., y Gabelas Barroso, J. A. (2016). Comunicación digital. Un modelo basado en el factor Relacional, Barcelona, Editorial UOC, p.191.

Ramos Ferre, M. (2014). Estudio sobre la motivación y su relación en el rendimiento académico. Tesis para acceder a la Maestría en Intervención en Convivencia Escolar. De la facultad de Ciencias de la Educación de la Universidad Almería, España. Recuperado de https://www.aacademica.org/000-007/807.pdf?view

Rodríguez Arce, J., y Coba Juárez Pegueros, J. P. (2017). Impacto del m-learning en el proceso de aprendizaje: habilidades y conocimiento. Revista Iberoamericana para el desarrollo y la innovación educativa. (8)15, DOI: 10.23913/ride.v8i15.303.

Swartz, R. J., Costa, A. L., Beyer, B. K, Reagan, R., y Kallick, B. (2017). El aprendizaje basado en el pensamiento. Cómo desarrollar en los alumnos las competencias del siglo XXI. Madrid: Ediciones SM.

Tirado, F., Santos, G., y Tejero-Díez, D. (2013). La motivación como estrategia educativa: Un estudio en la enseñanza de la botánica. Perfiles educativos, 35(139), 79-92. Recuperado de http://www.scielo.org.mx/scielo.php?script=sci_arttext\&pi$\mathrm{d}=$ S0185-26982013000100006\&lng=es\&tlng=es.

Quevedo-Blasco, R., J. Quevedo-Blasco, V., y Téllez-Trani, M. (2016). Cuestionario de evaluación motivacional del proceso de aprendizaje (EMPA). European Journal of Investigation in Health, Psychology and Education, 6(2), 83-105. https://doi. org/10.30552/ejihpe.v6i2.163 


\section{La Representación de la Diversidad en los Materiales Didácticos Digitales de Educación Infantil: ¿Reto o Realidad?}

\section{Pardo Baldoví, M. Isabel}

https://orcid.org/0000-0002-8630-0818

Universitat de València

Misabel.Pardo@uv.es

\section{Vidal Esteve, M. Isabel}

https://orcid.org/0000-0002-3504-8114

Universitat de València

Isabel.Vidal@uv.es

\section{Navarro Sánchez, Sandra}

Universitat de València

sanasan5@alumni.uv.es

\section{Marín Suelves, Diana}

https://orcid.org/0000-0002-5346-8665

Universitat de València

Diana.Marin@uv.es 


\title{
LA REPRESENTACIÓN DE LA DIVERSIDAD EN LOS MATERIALES DIDÁCTICOS DIGITALES DE EDUCACIÓN INFANTIL: ¿RETO O REALIDAD?
}

\author{
Pardo Baldoví, M. Isabel \\ Vidal Esteve, M. Isabel \\ Navarro Sánchez, Sandra \\ Marín Suelves, Diana
}

\section{Resumen}

Los materiales didácticos digitales (MDD) constituyen herramientas de trabajo cada vez más generalizadas en la Educación Infantil. Entre el amplio abanico existente, destaca el creado por el sector editorial. Ante este escenario, es necesario emprender análisis que permitan optimizar los procesos de creación, selección y uso de los MDD. Ya que en función de sus características pueden convertirse en herramientas para favorecer una sociedad más inclusiva y cohesionada o, por el contrario, continuar perpetuando estereotipos sociales. Partiendo de esta cuestión, en el presente trabajo se analiza una muestra de MDD ofrecidos por cuatro editoriales con gran presencia en los centros escolares españoles, en el marco de un proyecto de investigación financiado por el gobierno español. Dada la centralidad del lenguaje icónico en los materiales dirigidos a la Educación Infantil, el trabajo se centra en indagar en qué grado y de qué formas, las imágenes reflejan la diversidad social actual: funcional, sexual y de género, cultural, étnica, etaria. La investigación revela que, pese a las oportunidades existentes, los MDD no constituyen un buen reflejo de la diversidad actual, sino que siguen invisibilizando a los colectivos y diversidades tradicionalmente excluidas y marginadas por el currículum escolar, consolidando el pensamiento hegemónico.

\section{Palabras clave}

Materiales didácticos digitales, Educación Infantil, diversidad, imágenes. 


\section{Introducción}

Las Tecnologías de la Información y la Comunicación están teniendo un impacto innegable en todas las esferas de la sociedad y, con ello, el panorama educativo está experimentando también profundos cambios. Actualmente, existe un amplio catálogo de herramientas disponibles en la red y fuera de ella, que se encuentran al servicio del alumnado y del profesorado transformando la gestión de espacios y los momentos (Gairín, 2012) y las formas de aprendizaje (Sánchez y Ruiz, 2013). Tanto es así, que autores como Azorín y Arnáiz (2013) afirman que "las TIC han irrumpido el proceso de enseñanza-aprendizaje como un vendaval, arrasando con la metodología tradicional y apostando por un nuevo futuro educativo que inexorablemente aboga por el uso de la tecnología como máximo exponente" (p. 15).

De hecho, numerosos autores confirman que las tecnologías digitales suponen un elemento decisivo para normalizar las condiciones de vida del alumnado con diversidad (Toledo, 2013), para favorecer la inclusión de las personas con discapacidad intelectual, sensorial o motriz (Cabero, Córdoba y Fernández, 2007) y para contribuir al aprendizaje autónomo y al empoderamiento del alumnado en general (Sevilla y Solano, 2020). Afirman también que el avance hacia la construcción de materiales accesibles, la formación del profesorado en tecnologías digitales y la innovación con nuevos materiales y propuestas son las claves para lograr un Diseño Universal de Aprendizaje (Rolón, 2020), es decir, un diseño de aprendizaje para todos y todas que celebre la diferencia y genere el máximo desarrollo posible del alumnado que configura la diversidad del aula (Alba, Zubillaga y Sánchez, 2015). Asimismo, la múltiple utilización de materiales didácticos digitales, además de favorecer una atención adaptada a las características individuales de cada alumno, ofrece la posibilidad de dar visiones culturales diferentes que amplían el repertorio de actitudes sobre determinadas culturas y colectivos (Gil-Jaureana, 2012).

En este contexto, tanto las administraciones como el sector editorial están contribuyendo de forma significativa a proporcionar a la comunidad educativa un amplio abanico de recursos para formar parte de esta sociedad digitalizada e interconectada y para llevar a cabo el proceso de integración de las tecnologías en las aulas y la digitalización de los contenidos curriculares (Area, Hernández y Sosa, 2016). Sin embargo, son diversas las investigaciones sobre materiales didácticos a nivel tanto nacional como internacional que han detectado invisibilización u omisión de la figura de la mujer (Ruiz y Moya, 2020), difusión de estereotipos de género (Vaílo, 2016), escasez de diversidad étnica y de clase social (Massone \& Andrade, 2016), de personas mayores (Zapico, 2015), o desproporción ante la presentación de personas con y sin discapacidad (Moya et al., 2017) en sus imágenes o textos.

Por su parte, la Educación Infantil, que es la etapa en la que se ubica este estudio, se caracteriza por aportar enseñanzas básicas en un momento clave del desarrollo tanto físico como emocional del individuo. Asimismo, tal y como refleja el currículum de la Comunitat Valenciana, en el primer bloque, sobre Conocimiento de sí mismo y autonomía personal; en la interacción continua de la niña y el niño con el medio, es fundamental llevarles a reconocer las diferencias y similitudes entre ella o él y los otros. Por ello, la identificación de sus características individuales, así como de las de los demás, son instrumentos básicos para su desarrollo y consecuentemente, para la adquisición de actitudes no discriminatorias, que les llevarán a asumir, aceptar y convivir con los demás (Decreto 38/2008); hecho que dota de valor al objetivo de este estudio. 
Así pues, esta investigación, en el marco del proyecto de investigación "Los materiales didácticos digitales en la Educación Infantil. Análisis y propuestas para su uso en la escuela y el hogar (RTI2018-093397-B-IOO)", tiene como objetivo analizar los recursos que ofrecen para el alumnado de Educación Infantil, cuatro editoriales españolas, con el fin de averiguar en qué medida sus materiales didácticos digitales, como herramientas para favorecer la atención a la diversidad de tipo funcional, sexual y de género, cultural, étnica, etaria; contribuyen a reflejarla en su contenido icónico-textual y de qué formas la representan.

\section{Método}

\section{Descripción del contexto y de los participantes}

Esta investigación se contextualiza en el proyecto de investigación interuniversitario financiado por el Gobierno Español titulado "La escuela de la sociedad digital: análisis y propuestas para la producción y uso de los contenidos digitales educativos" (EDU2015-64593-R)" que pretende explorar y analizar las características técnicas y pedagógicas de los recursos y materiales didácticos digitales dirigidos al alumnado de segundo ciclo de Educación Infantil, así como los usos y prácticas desarrolladas con ellos en el contexto escolar y familiar. En concreto, el Estudio 1 se centra en el "análisis de las plataformas o portales que ofertan MDD para segundo ciclo de Educación Infantil en el contexto español”, y para ello:

Se diseñó y validó un instrumento de análisis de contenidos educativos digitales.

Se aplicó dicho instrumento a una muestra de contenidos seleccionados desde las distintas comunidades autónomas participantes en el estudio (Galicia, Comunitat Valenciana y Canarias), extraídos de distintos repositorios, plataformas y portales web institucionales y comerciales.

Tomando como referencia esta información, el objetivo de esta investigación fue analizar la presencia de la diversidad en el contenido icónico y textual de los distintos materiales y recursos didácticos digitales estudiados por el equipo de la Comunitat Valenciana, en una selección de cuatro editoriales, a saber, Anaya, Edebé, Santillana y Voramar. Dado que es de especial interés el impacto y la influencia que estos materiales digitales pueden ejercer sobre los distintos agentes educativos y sobre las prácticas de enseñanza y aprendizaje desarrolladas en los centros escolares.

\section{Instrumentos}

Con el objetivo de analizar desde la perspectiva de la diversidad dicha muestra de editoriales se ha empleado una metodología cualitativa reflejada en el uso del instrumento Guía para el análisis de materiales didácticos digitales, diseñado ad hoc y validado por jueces expertos a nivel internacional. El instrumento recoge, después de los datos del evaluador y del material o recurso evaluado, una serie de ítems vinculados a las siguientes dimensiones: estructura del material, dimensión tecnológica, de diseño, pedagógica y de contenido, evaluación y seguimiento, y comentarios finales. En concreto, dentro de la dimensión de contenido, esta investigación se centra en los resultados de uno de sus apartados, que recoge información en relación a la pregunta: ¿El contenido icónico y textual refleja la diversidad funcional, sexual, 
cultural, etaria, etc.? Así pues, la variable en la que se centra este estudio es la representación de la diversidad en los materiales didácticos de las editoriales analizadas, en cada una de las categorías que se muestran en la figura 1.

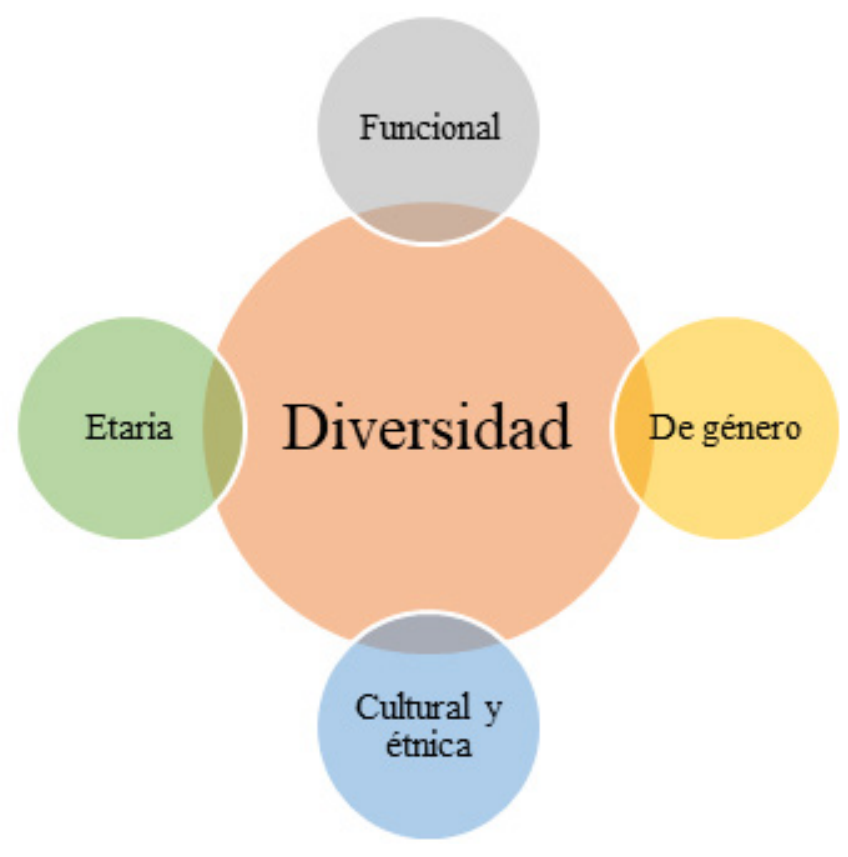

Figura 1. Categorías de análisis de la diversidad. Fuente: Elaboración propia.

\section{Procedimiento}

El procedimiento llevado a cabo para dar respuesta al objetivo de este estudio, tras la elaboración y validación del instrumento de análisis, se estructura en 3 fases:

- Fase 1: Selección, a través del muestreo intencional y razonado (Patton, 2002), de las editoriales participantes en este estudio y capaces de representar la realidad en sus múltiples versiones.

- Fase 2: Análisis del contenido de los materiales disponibles en las páginas web de las editoriales, por parte de los tres equipos que conforman el grupo de investigación y mediante el instrumento específico diseñado ad hoc.

- Fase 3: Elaboración de los informes correspondientes por parte de los 3 grupos de investigación implicados y difusión de los resultados más destacables.

\section{Resultados}

Los materiales didácticos digitales (MDD) analizados, con independencia de la editorial, destacan principalmente por su diseño atractivo y amigable. Se trata de materiales adaptados a las características y necesidades del alumnado destinatario, por lo cual son recursos muy visuales y coloridos, en los que el lenguaje icónico desempeña un papel fundamental. En algunos casos, los materiales didácticos 
digitales incorporan el lenguaje textual, con palabras explicativas de la imagen o instrucciones breves y directas sobre la actividad, pero incluso en estos casos existe un claro predominio del lenguaje icónico. Precisamente, por las características psicoevolutivas del alumnado de Educación Infantil, que en su gran mayoría todavía se encuentra en fase de desarrollo del proceso de lectoescritura.

En consecuencia, las imágenes adoptan en estos MDD un rol protagonista, constituyendo el elemento central de las actividades propuestas, a partir del cual se vertebran los distintos contenidos de aprendizaje. Por ello, resulta tan importante realizar análisis pormenorizados de las imágenes ofertadas, dada la gran influencia que ejercen en el alumnado y en su construcción de las categorías de percepción y comprensión de la realidad social.

A nivel general, en las imágenes predominan los colores intensos y vivos, con el objetivo de captar la atención del alumnado y favorecer su interés. Y en ellas se combinan las fotografías de escenas de la vida cotidiana, principalmente del ámbito familiar y escolar, y de elementos de la naturaleza; con dibujos que muestran escenas similares o que representan personajes fantásticos u objetos animados, con características y rasgos humanos, como monstruos, extraterrestres, material escolar, etc. Con frecuencia, un mismo personaje aparece de manera recurrente en los MDD, tejiéndose un relato en torno al mismo que contribuye a facilitar el aprendizaje del alumnado, al convertir al personaje en un elemento familiar con una narrativa e historia propia. Del mismo modo, a excepción de las actividades y contenidos relacionados con el trabajo de las emociones, los personajes representados suelen mostrar expresiones faciales amables y felices, transmitiendo un mensaje positivo y favoreciendo la conexión emocional con el alumnado de Infantil.

Todas estas características constituyen fortalezas de los MDD analizados, ya que permiten que el alumnado comprenda con facilidad los mensajes y discursos, así como que se vincule afectivamente con ellos, captando su interés y atención, y estimulando su compromiso con el proceso de aprendizaje. A ello contribuye notablemente que se trate de imágenes que pretenden conectar con la dimensión afectiva y familiar del alumnado. Fruto de ello, se opta por un enfoque "universal" o "neutral", por considerarse más amplio. No obstante, es precisamente a raíz de esta característica cuando las fortalezas dan paso a las debilidades y carencias de los MDD, en relación con la representación de la diversidad.

Los MDD están diseñados desde una lógica que pretende ofrecer una visión neutral o genérica de la realidad, tratando de ser contenidos "vacíos", y también "vaciados", de cualquier tipo de carga o connotación política. A raíz de ello, acaban convirtiéndose en imágenes con un carácter marcadamente sesgado, que ofrecen una visión alejada de la realidad social. Es decir, en su intención de mantenerse como materiales neutros consiguen fomentar una visión determinada de la realidad, que se corresponde precisamente con la visión hegemónica, reproduciendo estereotipos y perpetuando así las desigualdades existentes de todo tipo. En este sentido, no se observa que las imágenes presentes en los MDD faciliten el conocimiento de la diversidad socio-cultural y política existente. Sino todo lo contrario, ofrecen una visión parcial y estereotipada de la realidad.

En cuanto a la diversidad funcional, no han podido detectarse imágenes que representen las distintas funcionalidades que componen la sociedad actual, y que 
también tienen su reflejo en la escuela. De forma que las personas con discapacidad continúan permaneciendo ausentes, y su representación es directamente excluida, del currículum transmitido por estos materiales didácticos digitales. Solamente en una ocasión se ha detectado una imagen de un alumno en silla de ruedas. No obstante, también en este caso se trata de una imagen con un importante sesgo y con un currículum oculto muy marcado. En primer lugar, porque solamente se recurre a la representación de la discapacidad motora, obviando otras diversidades funcionales que también están presentes en las aulas actuales y que necesitan visibilización. $Y$ en segundo lugar y más importante, porque el niño con discapacidad motora está acompañado de otro niño que empuja la silla, lo que transmite un discurso de dependencia que contrasta con la aparente autonomía que suelen transmitir otras imágenes de niños o niñas ofrecidas por estos MDD. En las cuales, pese a que se trata de alumnado de Educación Infantil, se les representa solos y con independencia.

Lo mismo acontece con la diversidad etaria. Ya que en cuanto a la representación de la figura humana, las imágenes, ya sean reales o dibujos, suelen plasmar únicamente niños y niñas en edad de Educación Infantil y solo en reducidas ocasiones se representa una persona adulta, siempre ejerciendo roles de madre, padre o docente. Esta focalización en la representación de la infancia, por un lado, facilita la identificación del alumnado con las imágenes representadas, pero, por otro, impide la comprensión o reflexión respecto a otros grupos de edad, así como el establecimiento de relaciones. Igualmente, el colectivo de la tercera edad continúa siendo invisibilizado y marginado, como suele ser habitual en los materiales didácticos.

Pero, además, cabe destacar que tampoco en el caso de las imágenes sobre niños o niñas se refleja la realidad social existente, ya que nuevamente se trata de imágenes profundamente sesgadas que no reflejan ni la diversidad sexual y de género, ni tampoco la cultural y étnica.

En relación a la etnia y la cultura, los niños y niñas representados se ajustan al modelo caucásico tradicional y no se aprecia representación de la gran diversidad de culturas o etnias que componen la escuela actual.

Y en cuanto a la diversidad sexual y de género, los MDD suelen incluir actividades en las que la identidad de género se asocia directamente con los atributos sexuales, con actividades tradicionales de diferenciación entre sexos, negando la gran diversidad existente en la actualidad. E incluso con la asociación de determinados colores o actividades en función del género, si bien en este aspecto se aprecia una optimización respecto a etapas anteriores.

Todas estas ausencias y carencias pueden generar importantes consecuencias no solo para la construcción de las categorías de percepción y comprensión de la realidad social por parte del alumnado, sino también para el propio proceso de formación de la identidad.

Finalmente, cabe destacar que, además de las imágenes, el planteamiento general de los MDD no permite ofrecer un tratamiento diferenciado en función del contexto social, cultural y ambiental de aplicación, lo que nuevamente supone una limitación para favorecer la comprensión y representación de la diversidad. De forma que, si quiere alcanzarse este objetivo, es el docente quien debe destinar esfuerzos directos a contextualizar el material. 


\section{Discusión y conclusiones}

Visibilizar y trabajar adecuadamente la gran diversidad existente en la sociedad actual es un elemento imprescindible para avanzar hacia la construcción de una sociedad más justa, cohesionada, respetuosa e igualitaria. En este sentido, los materiales didácticos digitales pueden constituir una excelente herramienta para favorecer este tipo de trabajo desde la primera infancia, dado que se trata de recursos de trabajo generalizados y ampliamente utilizados en la escuela actual. Sin embargo, dependiendo de sus características y enfoque, también pueden convertirse en herramientas para continuar perpetuando estereotipos sociales y consolidando el pensamiento hegemónico.

Partiendo de esta premisa, el análisis efectuado se ha dirigido a indagar en qué medida los materiales didácticos digitales dirigidos a la Educación Infantil y ofrecidos por cuatro editoriales, con gran presencia en los centros educativos del contexto español, reflejan la gran diversidad presente en la sociedad actual: funcional, de género y sexual, cultural, étnica y etaria. Dada la importancia y centralidad que desempeña el lenguaje icónico en este tipo de MDD, acorde a las necesidades y características del alumnado al que se dirigen, se ha partido del análisis de las imágenes incluidas en los materiales.

Pese a las múltiples fortalezas y oportunidades detectadas en los MDD relacionadas principalmente con el atractivo de su diseño, de colores vivos e intensos, con la inclusión de personajes amigables e historias que captan la atención y el interés del alumnado; se han detectado múltiples carencias en relación al papel que desempeñan en la representación de la diversidad social actual.

Las imágenes ofrecidas en los materiales didácticos analizadas responden a un planteamiento o enfoque que pretende mostrarse "neutral", para poder alcanzar así un potencial universal y facilitar que el alumnado pueda identificarse con su contenido. Sin embargo, el efecto que producen es precisamente el contrario, dado que no constituyen un reflejo de las aulas actuales, ni permiten conocer o acercarse a la diversidad socio-cultural y política existente en la sociedad actual; contribuyendo además a consolidar el pensamiento hegemónico y a perpetuar las desigualdades existentes.

En general, se trata de contenidos muy genéricos y vacíos, que recurren a estereotipos y generalizaciones y que así moldean y fomentan una visión particular de persona, tanto a nivel étnico, como cultural, sexual, de género, funcional o etario. Ya que las imágenes humanas representadas se ciñen exclusivamente a mostrar niños y niñas (claramente diferenciados por sus atributos sexuales) en edad de Educación Infantil y que se corresponden con el modelo caucásico blando. De esta forma se sigue invisibilizando a los colectivos y diversidades tradicionalmente excluidas y marginadas por el currículum escolar, consolidando el pensamiento hegemónico.

Llegados a este punto, consideramos necesario apuntar a dos elementos que, desde nuestra perspectiva, resultan de vital importancia para poder ofrecer una educación inclusiva que permita avanzar hacia la construcción de una sociedad más justa e igualitaria, respetuosa con las múltiples diversidades existentes. En primer lugar, es imprescindible continuar optimizando los materiales didácticos digitales, de forma que, además de su navegabilidad y usabilidad, se optimice su accesibilidad (para 
que puedan ser utilizados por todas las personas) y sobre todo se cuide su lenguaje, tanto textual como icónico, para que sea más inclusivo y refleje la realidad de la sociedad actual, favoreciendo la inclusión de todos y todas. $Y$, en segundo lugar, queremos enfatizar la importancia de la figura y el papel del profesorado como sujeto mediador entre los materiales didácticos y el proceso de aprendizaje del alumnado. En una escuela digital en la que, en ocasiones, surge un cuestionamiento del valor de la figura docente nos gustaría reivindicar su papel clave y protagonista, puesto que, en última instancia, de él dependerá no solo la toma de decisiones respecto a la selección de los MDD, sino también el cómo se apliquen y utilicen estos materiales, qué estrategias organizativas y didácticas los acompañen, y qué tareas se desarrollen de manera complementaria para propiciar aprendizajes verdaderamente significativos y con potencial no solo para comprender la realidad, sino también para transformarla y optimizarla.

\section{Referencias}

Alba, C., Zubillaga, A., \& Sánchez, J. M. (2015). Tecnologías y Diseño Universal para el Aprendizaje (DUA): experiencias en el contexto universitario e implicaciones en la formación del profesorado. RELATEC: Revista Latinoamericana de Tecnología Educativa, 14(1), 89-100.

Area, M., Hernández, V., \& Sosa, J. J. (2016). Modelos de integración didáctica de las TIC en el aula. Comunicar: Revista Científica de Comunicación y Educación, 24(47), 79-87.

Azorín, C. M. \& Arnaiz, P. (2013). Tecnología digital para la atención a la diversidad y mejora educativa. Etic@net: Revista científica electrónica de Educación y Comunicación en la Sociedad del Conocimiento, 13(1), 14-29.

Cabero, J., Córdoba, M. \& Fernández, J.M. (2007). Las TIC para la igualdad. Nuevas tecnologías y atención a la diversidad. Eduforma.

Decreto 38/2008, de 28 de marzo, del Consell, por el que se establece el currículo del segundo ciclo de la Educación Infantil en la Comunitat Valenciana [2008/3838]. Diari Oficial de la Comunitat Valenciana, Valencia, 3 de abril de 2008, núm. 5734, pp. 55018- 55048.

Gairín, J. (coord.) (2012). Gestión del conocimiento y desarrollo organizativo: formación y formación corporativa. Wolters Kluwer.

Gil-Jaureana, I. (2012). Análisis de recursos educativos en primaria desde una perspectiva intercultural. Revista Iberoamericana de Evaluación Educativa, 5(3), 31-46.

Massone, M., \& Andrade, G. (2016). La inmigración a la Argentina en los nuevos materiales digitales. Clio \& asociados, (22), 20-40.

Moya, I., Ruiz, L., Martín, J., Pérez, P. M., \& Ros, C. (2017). La representación de la discapacidad en las imágenes de los libros de texto de Educación Física: cinclusión o exclusión? Retos. Nuevas Tendencias en Educación Física, Deporte y Recreación, 32, 88-95. 
Patton, M. Q. (2002). Qualitative Research \& Evaluation Methods. 3rd edition. Sage Publications, Inc.

Rolón, V. (2020). Diseño universal de aprendizaje y las tecnologías de la información y la comunicación. Revista Paraguaya de Educación, 8(2), 51-60.

Ruiz, S., \& Moya, I. (2020). Las deportistas olímpicas en los libros de texto de educación física: ¿presencia o ausencia de referentes en nuestro alumnado? Retos: Nuevas Tendencias en Educación Física, deporte y recreación, 38, 229-234

Sánchez, J. y Ruiz, J. (2013). Recursos didácticos y tecnológicos en educación. Síntesis.

Toledo, P. (2013). Las tecnologías de la información, la comunicación y la inclusión educativa. En J. Barroso, y J. Cabero (coord.), Nuevos escenarios digitales (pp. 411426). Pirámide.

Vaíllo, M. (2016). La investigación sobre libros de texto desde la perspectiva de género: chacia la renovación de los materiales didácticos? Tendencias pedagógicas, 26, 97-124. http://dx.doi.org/10.15366/tp2016.27.003

Zapico, M. H. (2015). The image of aging in digital curricular materials. En J. Rodríguez, E. Bruillard y M. Horsley (eds.) Digital textbooks, what's new?, pp. 260-274. Universidade de Santiago de Compostela. IARTEM/Servizo De Publicacións USC. 


\section{La Inclusión de las TIC como Apoyo al Alumnado Universitario con Discapacidad a Través de la Revisión Bibliográfica}

Fernández Batanero, José María https://orcid.org/0000-0003-4097-5382 Universidad de Sevilla batanero@us.es

\section{Montenegro Rueda, Marta}

https://orcid.org/0000-0003-4733-289X

Universidad de Sevilla

mmontenegro1@us.es

\section{Fernández Cerero, José}

https://orcid.org/0000-0002-2745-6986

Universidad de Sevilla

jfcerero@us.es

\section{Román Graván, Pedro}

https://orcid.org/0000-0002-1646-9247

Universidad de Sevilla

promán@us.es 


\title{
LA INCLUSIÓN DE LAS TIC COMO APOYO AL ALUMNADO UNIVERSITARIO CON DISCAPACIDAD A TRAVÉS DE LA REVISIÓN BIBLIOGRÁFICA
}

\author{
Fernández Batanero, José María \\ Montenegro Rueda, Marta \\ Fernández Cerero, José \\ Román Graván, Pedro
}

\section{Resumen}

Las Tecnologías de la Información y la Comunicación (TIC) han introducido numerosas transformaciones tanto a nivel social, cultural, económico o educativo. En el contexto educativo, existe un creciente interés por incorporar estas herramientas en la vida académica de los estudiantes con discapacidad. En este sentido, el uso de estas herramientas como medio para favorecer el aprendizaje del alumnado, especialmente con el alumnado con discapacidad, ha sido objeto de numerosos estudios. De este modo, el presente trabajo recoge una revisión bibliográfica con el objeto de conocer como influye el uso de las TIC en el alumnado con discapacidad en la Educación Superior. La muestra la componen un total de 29 publicaciones que aborda la incorporación de las TIC con el alumnado universitario con discapacidad. Los principales hallazgos revelan la necesidad de usar estas herramientas en la etapa universitaria con el alumnado con discapacidad, debido a los múltiples beneficios y oportunidades que ofrece a este alumnado. Sin embargo, pese a los beneficios, este estudio concluye, que en las instituciones universitarias son escasas las prácticas educativas enfocadas a aplicar las tecnologías con el estudiante con discapacidad, debido a la escasa dotación de estos recursos y a la falta de formación y capacitación del profesorado universitario.

\section{Palabras clave}

TIC, discapacidad, educación superior, revisión. 


\section{Introducción}

El presente trabajo presentado forma parte de un proyecto de investigación más amplio financiado por el Ministerio Español de Ciencia e Innovación, en el marco del Programas Estatal de I+D+i orientada a los Retos de la Sociedad (PID2019108230RB-IOO) y la Agencia Estatal de Investigación (AEI) (Referencia del proyecto/AEI/10.13039/501100011033).

La atención al alumnado con discapacidad forma parte de uno de los compromisos principales de las instituciones educativas. En las últimas décadas, hemos observado un creciente interés en la búsqueda de recursos y alternativas que favorezcan la inclusión de estas personas en diferentes ámbitos de la sociedad, siendo la educación uno de los sectores principales para ello (Alba Pastor \& Zubillaga del Río, 2012). En el ámbito educativo la atención y medidas puestas para atender al alumnado con discapacidad ha llevado a la configuración de propuestas como la "Educación Inclusiva" (Acevedo Zapata, 2018). Este modelo educativo pretende ofrecer propuestas pedagógicas que posibiliten el aprendizaje y la supresión de barreras de todos los estudiantes, sin distinción. Sin lugar a duda, es uno de los factores que han permitido a estos estudiantes el acceso a estudios universitarios.

Los estudiantes con discapacidad se enfrentan a una serie de barreras, desde arquitectónicas hasta comunicativas, que impiden su plena inclusión en la sociedad, en general, y en la educación, en particular. En este sentido, el desarrollo tecnológico ha contribuido al desarrollo de las personas y favorecer su relación con el entorno, contribuyendo a una vida más independiente (Ari \& Inan, 2010). Estas herramientas, principalmente aquellas basadas en Internet o plataformas virtuales se han configurado como un recurso prometedor para la supresión de las barreras de las personas con discapacidad. Las Tecnologías de la Información y Comunicación (TIC) están cada vez más extendidas en el mundo educativo, permitiendo ofrecer una educación de calidad acorde a las necesidades de todos los estudiantes. De este modo, en los últimos años, el uso de las TIC como medio para atender a la diversidad del alumnado en la educación ha sido objeto de numerosas investigaciones y experiencias educativas (Ballesta \& Cerero, 2012).

La presencia de estudiantes con discapacidad en el contexto universitario es cada vez mayor. La asistencia de alumnados de diverso origen social y cultural, así como con diferentes características personales, ponen de manifiesto la necesidad de articular propuestas educativas que permitan responder a sus necesidades. En la etapa de la Educación Superior, se deben revisar sus programas y proyectos educativos con el fin de garantizar el aprendizaje y la participación de todo el alumnado (Valee, 2017).

Diversos estudios revelan que estos estudiantes se enfrentan a numerosas barreras en la Educación Superior en comparación con los estudiantes sin discapacidad (Newman \& Madaus, 2015; O’Byrne, Jagoe y Lawler, 2019). En este sentido, surge la necesidad incorporar las tecnologías para promover y facilitar el éxito académico e inclusión de los estudiantes (Ari \& Inan, 2010) en el contexto universitario. Las TIC brindan oportunidades para compensar las necesidades educativas de los estudiantes, por ejemplo, a través de las tecnologías de asistencia (Clouder et al., 2019). A través de estos estudios, el potencial de las TIC en la educación superior está bastante demostrado, sin embargo, para marcar de manera significativa en la vida académica de estos estudiantes es necesario que se aplique de manera apropiada (Adam \& Tatnall, 2008). 
Otro aspecto clave, es la educación inclusiva, la cuál pretende aportar un nuevo modelo de enseñanza, con el fin de promover el éxito de todos los estudiantes, con o sin discapacidades (Grzona, 2014). Actualmente, a raíz de la pandemia COVID-19, el uso de las TIC ha crecido considerablemente en el ámbito educativo, brindando nuevas oportunidades de aprendizaje (Chauchan, 2017). La incorporación de las tecnologías, con el fin de continuar la educación de forma remota, ha cobrado impulso sobre como las TIC son una herramienta esencial para lograr las metas educativas y el éxito de todos los estudiantes (Albashtawi \& Al Bataineh, 2020). De este modo, cuando hablamos de discapacidad en la Educación Superior, las TIC se convierten en herramientas imprescindibles para la inclusión social.

A raíz de estas premisas, el presente estudio pretende describir y analizar el impacto del uso de las TIC para el alumnado con discapacidad en la Educación Superior a través de una revisión bibliográfica. En este sentido, a partir de estas consideraciones y enfocándonos en la necesidad de ofrecer nuevas oportunidades para facilitar la inclusión de los estudiantes con discapacidad en la Educación Superior, se analiza el uso de las TIC en este contexto.

\section{Objetivos}

Los objetivos de este estudio son los siguientes:

- Realizar una revisión bibliográfica del tema "TIC para el alumnado con discapacidad en la Educación Superior”.

- Identificar que temas aparecen con más frecuencia, así como exponer los hallazgos principales y sintetizar las conclusiones obtenidas a partir de la revisión de la literatura.

\section{Método}

Este estudio es un trabajo de revisión bibliográfica de tipo descriptivo con el fin de poder sintetizar, actualizar, conocer las tendencias y líneas de investigación sobre un tema concreto (Guardiola, 1991).

\section{Procedimiento}

Para llevar a cabo esta investigación, se ha optado por la realización de una revisión sistemática de la literatura en las bases de datos electrónicas más destacadas a nivel científico en el ámbito educativo: Web of Science, Scopus, SciELO, Dialnet, ERIC y Google Schoolar. Para la búsqueda se emplearon los siguientes descriptores claves como: TIC, tecnología, universidad, educación superior, discapacidad, inclusión y accesibilidad, tanto en español como en inglés, dependiendo de las particularidades de cada base de datos. A la hora de seleccionar los artículos, se tuvo en cuenta los estándares de calidad de la declaración PRISMA (Preferred Reporting Items for Systematic Reviews and Meta-Analyses) para las revisiones sistemáticas (Moher, Liberati, Tetzlaff, Altman \& Grupo PRISMA, 2009) con el fin de garantizar una mayor transparencia y claridad en la selección. El proceso de búsqueda de la literatura se limitó desde enero de 2009 hasta diciembre de 2020. 


\section{Criterios de selección}

Con el objetivo de asegurar la relevancia de la literatura seleccionada, se han establecido los siguientes criterios de inclusión y exclusión durante el proceso de selección: (1) trabajos que aborden el uso de las TIC en la Educación Superior con el alumnado con discapacidad, (2) trabajos que especificaran los descriptores de búsqueda en el título, resumen y/o palabras clave, (3) trabajos publicados entre 2009 y 2019 y (4) artículos publicados en inglés o español. En relación con los criterios de exclusión se encuentran: (1) trabajos que no tuvieran relación directa con las TIC para el alumnado con discapacidad en la Educación Superior, (2) trabajos duplicados y (3) tipo de documento: resúmenes, actas de congresos, opiniones, o revisiones sistemáticas.

El establecimiento de estos criterios de selección permitió seleccionar los artículos que contenían la información necesaria relacionada con el objetivo del estudio. El proceso de búsqueda y selección se dividió en cuatro fases: identificación, cribado, idoneidad e inclusión. La fase de identificación permitió identificar 295 registros a través de la búsqueda en las bases de datos seleccionadas (Web of Science, Scopus, SciELO, Dialnet, ERIC y Google Scholar), así como 2 registros identificados a través de otras fuentes. En la segunda fase, cribado, se eliminaron 103 artículos duplicados. Tras una revisión de los artículos seleccionados, se excluyeron 56 registros. En la tercera fase, elegibilidad resultaron 138 estudios que fueron revisados a texto completo, excluyendo 109 artículos con razones justificadas. Finalmente, en la fase inclusión, se incluyen 29 estudios para su síntesis y revisión.

Asimismo, se aplicó la técnica de visualización de mapas bibliométricos a partir del software VOSviewer (Van-Eck \& Waltman, 2010), con el fin de obtener una visión profunda del impacto de las TIC con el alumnado con discapacidad en la Educación Superior.

\section{Resultados}

Los resultados de la investigación, tanto cuantitativos como cualitativos, se presentan a continuación a partir del análisis de los estudios obtenidos. Los 29 estudios seleccionados, fueron clasificados y organizados en torno a la identificación de la información más relevante: autor(es), año de publicación, metodología y hallazgos principales.

Como deja ver la figura 1, y atendiendo a la distribución anual de los artículos seleccionados, podemos concretar que el mayor índice de publicaciones de estudios en este campo se concentra en el año 2019 observándose un incremento de publicaciones a lo largo de los últimos años. 


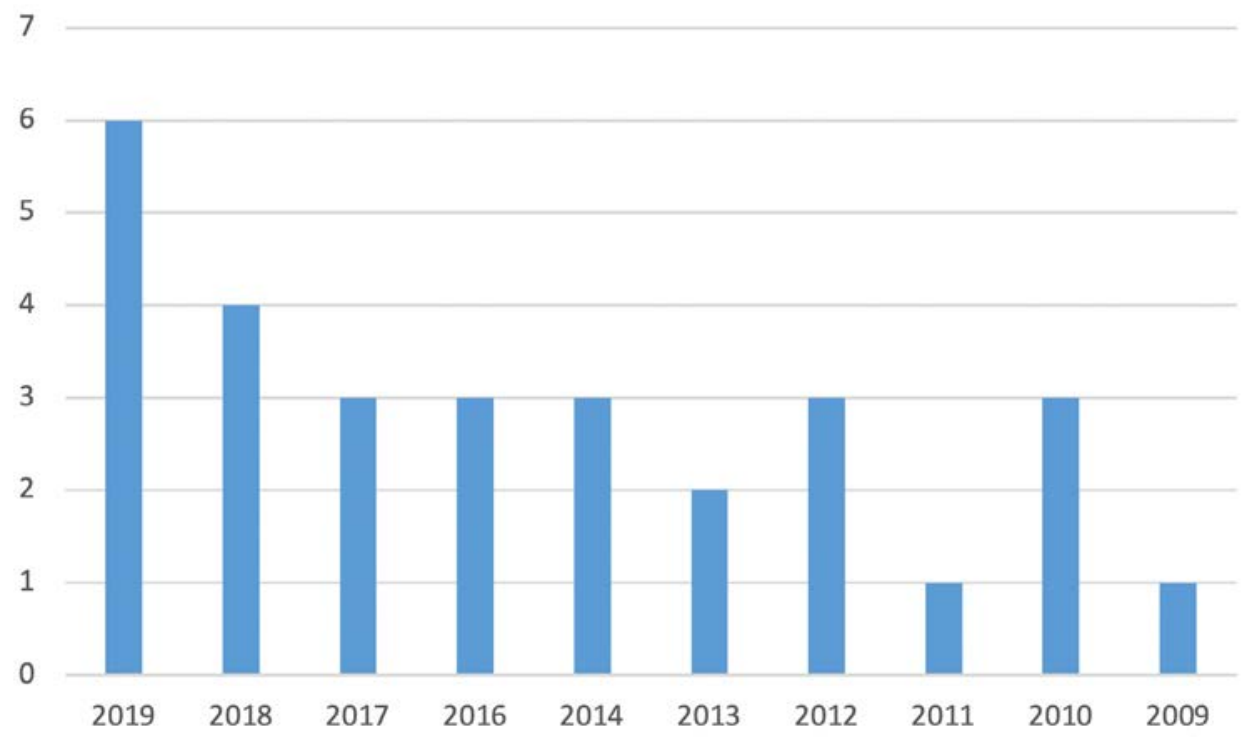

Figura 1. Distribución artículos por año.

En relación con el tipo de metodología utilizada, en la mayor parte predominan los estudios cualitativos (51.72\%), frente los cuantitativos (41.38\%). En menor medida, se encuentran los trabajos que utilizan una metodología mixta o teórica.

El análisis del contenido de los estudios, fue a partir de la revisión de las palabras claves utilizadas por los investigadores y su interrelación, mediante su representación visual a través del software VOSViewer. Finalmente, el programa informático ha extraído un total de 46 palabras clave, con un índice de co-ocurrencia mínimo de 5 veces por palabra. En este sentido, la figura 2 muestra como según el grado de similariedad de las palabras clave, se han conformado 3 clústers o grupos que definen las principales líneas de investigación en este campo.

En este sentido, los tres grupos que podemos encontrar se asocian a tres colores rojo, verde y azul. En primer lugar, el color rojo, esta relacionado con el uso de las TIC en la etapa universitaria con el alumnado con discapacidad. El segundo, de color azul, se relaciona con los desafíos a la hora de integrar las TIC en la Educación Superior con este alumnado. En tercer lugar, color verde, se relaciona con los beneficios que aportan las TIC al alumnado con discapacidad. 


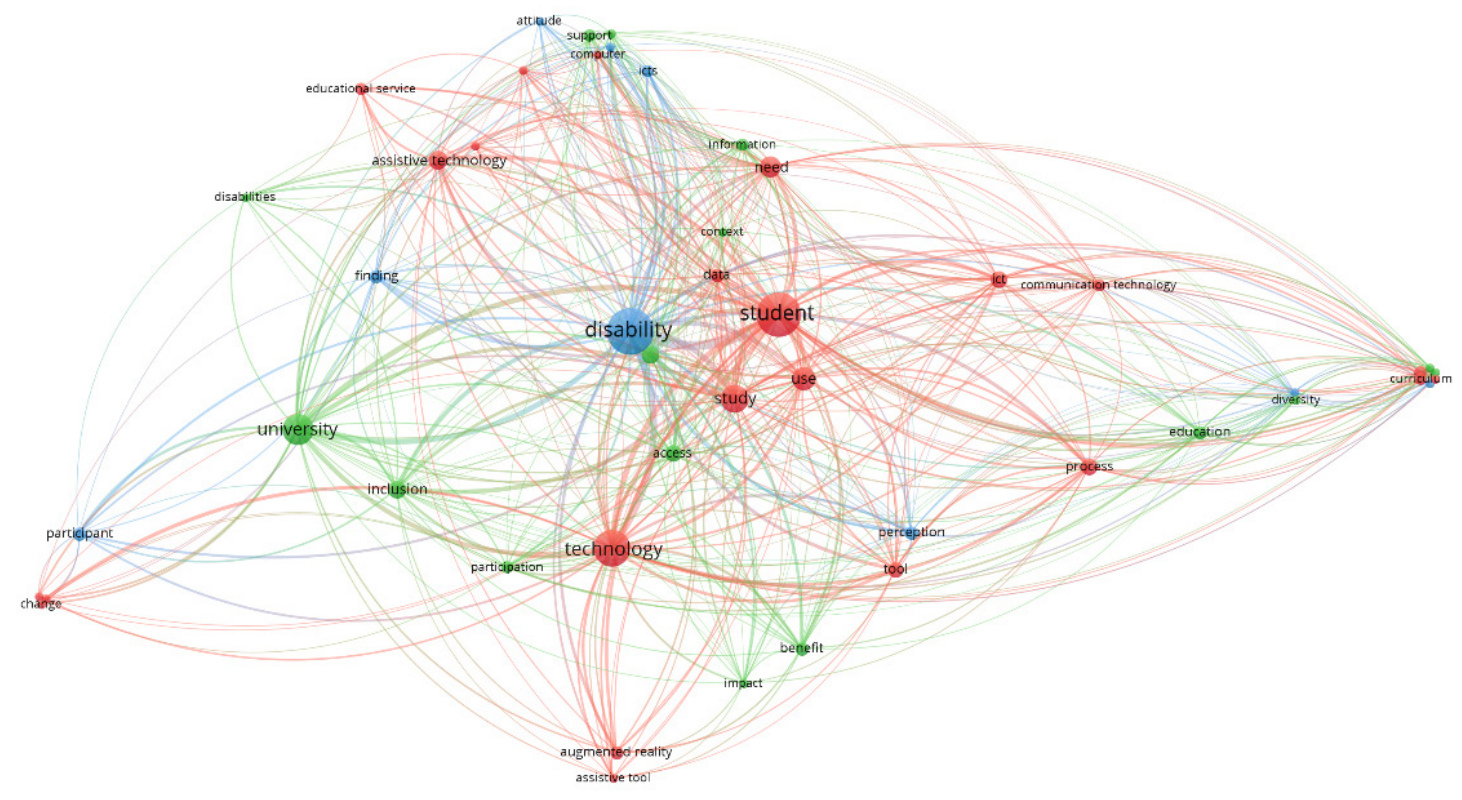

Figura 2. Mapa bibliométrico.

\section{Discusión y conclusiones}

Este estudio ha tenido como objetivo principal conocer el estado general de la investigación científica sobre el uso de las TIC para el alumnado con discapacidad en la etapa universitaria, con el fin de valorar su impacto y tendencias en la investigación. Atendiendo a los resultados del estudio, podemos destacar que la investigación en este campo ha aumentado en la última década, siendo un campo de creciente interés para los investigadores. La tendencia de publicaciones muestra un crecimiento entre el año 2016 hasta 2019, siendo este último su índice con mayor frecuencia.

El análisis y visualización del mapa bibliométrico etiquetado permite extraer una serie de conclusiones a nuestro estudio como que, en el periodo analizado, destacan tres líneas de investigación en este campo, relacionadas principalmente, con la necesidad de usar las tecnologías con el alumnado con discapacidad en la universidad, los factores que facilitan la integración de las tecnologías, y por último, las limitaciones e inconvenientes que encuentran las instituciones universitarias para la integración de las mismas.

A pesar de las valiosas conclusiones extraídas en este estudio, también hemos encontrado limitaciones debido a la escasa difusión de estudios en este campo. Esta revisión nos permite valorar los principales aspectos que permitan integrar las tecnologías en la universidad en la etapa universitaria. 


\section{Referencias}

Acevedo Zapata, S. (2018). Educación Inclusiva y tecnologías de la comunicación. EDMETIC, Revista de Educación Mediática y TIC, 7(1), 4-7.

Adam T. \& Tatnall A. (2008) Using ICT to Improve the Education of Students with Learning Disabilities. In Kendall M. and Samways B. (eds) Learning to Live in the Knowledge Society. IFIP WCC TC3 2008. IFIP - The International Federation for Information Processing, vol 281. Springer, Boston, MA.

Ahmed, A. (2018). Perceptions of Using Assistive Technology for Students with Disabilities in the Classroom. International Journal of Special Education, 33(1), 129-139.

Alba Pastor, C. \& Zubillaga del Río, A. (2012). The use of ICT in the academic activity of college students with disabilities. Revista Complutense de Educación, 23(1), 23-50.

Albashtawi, A. \& Al Bataineh, K. (2020). The Effectiveness of Google Classroom Among EFL Students in Jordan: An Innovative Teaching and Learning Online Platform. International Journal of Emerging Technologies in Learning, 15, 78-88.

Ari, I.A. \& Inan, F.A. (2010). Assistive technologies for students with disabilities: A survey of access and use in Turkish universities. Turkish Online Journal of Educational Technology, 9(2), 40-45.

Ballesta, J. \& Cerezo, M. (2012). Familia y escuela ante la incorporación de las Tecnologías de la Información y la Comunicación. Educación XXI, 14(2), 133-156.

Chauchan, S. (2017). A meta-analysis of the impact of technology on learning effectiveness of elementary students. Computers \& Education, 105, 14-30.

Clouder, L., Cawston, J., Wimpenny, K., Mehanna, A.K.A., Hdouch, Y., Raissouni, I., \& Selmaoui, K. (2019). The role of assistive technology in renegotiating the inclusion of students with disabilities in higher education in North Africa. Studies in Higher Education, 44(8), 1344-1357.

Grzona, M.A. (2014). Educational accessibility in inclusive classrooms: A didactic view. Res. Postgrad., 29, 137-149.

Guardiola, E. (1991). El artículo de revisión: hacia un mayor rigor científico. Revisiones en salud pública, 2, 197-218.

Kurt, A.A., Çolak, C., Dönmez, P., Filiz, O., Türkan, F. \& Odabasi, H.F. (2016). Opportunities for students with disabilities in higher education institutions in Turkey: Where is ICT? International Journal of Special Education, 31(1), 104-113.

Moher, D., Liberati, A., Tetzlaff, J., Altman, D.G. \& Grupo PRISMA. (2009). Preferred reporting items for systematic reviews and meta- analyses: The PRISMA statement. PLoS medicine, 6(7), e1000097. doi:10.1371/journal.pmed.1000097 
Newman, L.A. \& Madaus, J.W. (2015). An analysis of factors related to receipt of accommodations and services by postsecondary students with disabilities. Remedial and Special Education, 36(4), 208-219.

O’Byrne, C., Jagoe, C. \& Lawler, M. (2019). Experiences of dislexia and the transition to university: A case study of five students at different stages of study. Higher Education Research \& Development. doi: 10.1080/07294360.2019.1602595

Pacheco, E., Lips, M. \& Yoong, P. (2018). Transition 2.O: Digital technologies, higher education, and vision impairment. The Internet and Higher Education, 37(1), 1-10.

Preciado Cedillo, D.E., Preciado Cedillo, C.R. \& Laverde Aranza, L.A. (2017). Inclusión de los estudiantes con discapacidad en la educación superior a través del acceso a las TIC. En M.R. Tolozano Benítezand R. Arteaga Serrano (coords.) Memorias del tercer Congreso Internacional de Ciencias Pedagógicas: Por una educación inclusiva: con todos y para el bien de todos (pp. 2052 - 2062). Ecuador: Instituto Superior Tecnología Bolivariano.

Seale, J., Georgeson, J., Mamas, C., \& Swain, J. (2014). Not the right kind of "digital capital"? An examination of the complex relationship between disabled students, their technologies and higher education institutions. Computers \& Education, 82, $118-128$.

Sieben-Schneider, J.A. \& Hamilton-Brodie, V.A. (2016). Doing the Right Thing: One University's Approach to Digital Accessibility. Journal of Postsecondary Education and Disability, 29(3), 221-230.

Valee, D. (2017). Student engagement and inclusive education: reframing student engagement. Internatinal Jorunal of Inclusive Education, 21(9), 920-937. doi: $10.1080 / 13603116.2017 .1296033$

Van-Eck, N. \& Waltman, L. (2010). Software survey: VOSviewer, a computer program for bibliometric mapping. Scientometrics, 84(2), 523-538. 


\section{Funcionalidad de la Inclusión de la Educación en Programación en la Etapa de Educación Primaria}

\section{García-Perales, Ramón}

Universidad de Castilla-La Mancha

Ramon.GarciaPerales@uclm.es

\section{Palomares-Ruiz, Ascensión}

Universidad de Castilla-La Mancha ascension.palomares@uclm.es

\section{Martín-García, María Inés}

Universidad de Castilla-La Mancha mariaines.martin@uclm.es

\section{López-Parra, Emilio}

Universidad de Castilla-La Mancha

emilio.lopezparra@uclm.es 


\title{
FUNCIONALIDAD DE LA INCLUSIÓN DE LA EDUCACIÓN EN PROGRAMACIÓN EN LA ETAPA DE EDUCACIÓN PRIMARIA
}

\author{
García-Perales, Ramón \\ Palomares-Ruiz, Ascensión \\ Martín-García, María Inés \\ López-Parra, Emilio
}

\section{Resumen}

La educación en programación se está integrando de manera progresiva como un contenido del currículum escolar. Ello permite contribuir al desarrollo integral del alumnado, aspecto clave para una educación inclusiva de calidad. En esta investigación, se realiza un acercamiento a los beneficios de la inclusión de la programación educativa en los procesos de enseñanza y aprendizaje desarrollados en las escuelas, en este caso concreto, con alumnos y alumnas españoles de $5^{\circ}$ de Educación Primaria, escolares entre los 10 y los 11 años de edad. De esta manera, se expone una investigación cuyo objetivo ha sido evaluar el grado de interés y motivación hacia las Matemáticas y la consideración de autoeficacia en la cumplimentación de un test matemático, tras un período de escolarización en el que se han desarrollado actividades de programación educativa matemática con Scratch. Para la medición del efecto de este trabajo en las variables mencionadas, se han configurado dos grupos de escolares, experimental o grupo con el que se han desarrollado las actividades de programación educativa, y control o grupo que no ha trabajado programación educativa; antes y después de este trabajo, se han evaluado las dos variables señaladas. Los resultados obtenidos han reflejado el aumento de la autoeficacia en la cumplimentación del test de los escolares pertenecientes al grupo experimental, no observándose incidencia estadísticamente significativa para la variable interés y motivación hacia las Matemáticas para ninguno de los grupos. En definitiva, la tecnología genera innovación y la apertura de los centros educativos a la misma es fundamental.

\section{Palabras clave}

Educación en programación, educación primaria, matemáticas, interés y motivación, autoeficacia. 


\section{Introducción}

La integración de la tecnología en las escuelas ofrece al profesorado una variedad amplia de recursos y oportunidades para desarrollar procesos de enseñanza y aprendizaje con sus estudiantes. Su trascendencia radica en su importancia desde etapas iniciales de escolarización del alumnado (Chaudron et al., 2018; Romero et al., 2017; Sánchez-Vera, 2021). Ello justifica la necesidad de incorporar, tanto de manera teórica como práctica, contenidos en la formación tanto inicial como permanente del docente, aspecto clave en una sociedad en continua transformación como en la que nos encontramos (Pinto y Plaza, 2021).

Las Tecnologías de la Información y la Comunicación (TIC) permiten el incremento del interés y la motivación por lograr aprendizajes nuevos a partir de lo diseñado en el currículum, por lo que su inclusión supone una herramienta de enorme utilidad para el profesorado en el desarrollo de su docencia (Rodríguez-Guevara, 2021). Unos adecuados niveles atencionales y motivaciones suponen un aspecto clave en la adquisición de aprendizajes nuevos. Dentro del abanico de posibilidades que ofrecen estas herramientas, en esta investigación se muestra la utilidad de una experiencia de programación educativa en aulas de 5ำ de Educación Primaria para el área de Matemáticas.

La educación en programación incluye herramientas que facilitan el trabajo de la programación educativa en los contextos escolares (Bers, 2018). Su utilidad y funcionalidad, caso por ejemplo del desarrollo de la creatividad en el alumnado (Passey, 2016), así como la manera de abordar su integración en los procesos educativos, es objetivo de múltiples investigaciones en el campo educativo (Armoni, 2016; Berge, 2017; Wing, 2017). La generalización de su inclusión es un tema para abordar por todos los profesionales de la educación.

Desde la Comisión Europea se remarca esta funcionalidad de la programación educativa en las escuelas en la actualidad (Comisión Europea, 2018). Esto viene reforzado por su carácter instrumental y transversal para el logro de aprendizajes en las áreas que conforman el currículum escolar y en la adquisición de contenidos competenciales (Bocconi et al., 2019; Rodríguez et al., 2020). El trabajo de las competencias clave en educación favorece el desenvolvimiento autónomo y eficaz de los estudiantes en la vida cotidiana, aspecto fundamental en un mundo globalizado e interconectado como en el que nos movemos día a día.

En esta investigación, se ha intentado analizar esta funcionalidad de su inclusión. Para ello, se ha estudiado si trabajar la programación educativa, en este caso con el software de programación matemática denominado Scratch, incrementa el interés y motivación de los estudiantes hacia la Matemáticas y si permite el aumento de su percepción de autoeficacia en la ejecución de tareas matemáticas. Para tal fin, se ha repartido la muestra en dos grupos, experimental o grupo con el que se han desarrollado las actividades de programación educativa, y control o grupo que no ha trabajado programación educativa en su horario lectivo. Las dos variables analizadas han sido recogidas de manera previa o pretest y posterior o postest al trabajo de estas actividades de programación educativa. Por último, los resultados para las dos variables han sido puestos en comparativa con la variable sexo. 


\section{Método}

La tipología de la investigación ha sido cuantitativa a partir del análisis y descripción de las relaciones existentes entre una serie de datos.

\section{Descripción del contexto y de los participantes}

La muestra participante en el pretest ha estado conformada por 3.795 estudiantes repartidos entre 3.629 escolares para el grupo experimental (1.920 hombres o $52,91 \%$ y 1.709 mujeres o 47,09\%) y 166 estudiantes para el grupo de control (82 hombres o 49,40\% y 84 mujeres o 50,60\%). Por otro lado, en el post-test, 2.159 escolares (1.112 hombres o $51,51 \%$ y 1.047 mujeres o $48,49 \%$ ) han formado parte del grupo experimental y 97 del grupo de control (42 hombres o 43,30\% y 55 mujeres o 56,70\%). Estos participantes han sido seleccionados de 16 Comunidades Autónomas y 2 Ciudades Autónomas españolas.

Para mayor conocimiento de esta investigación, el marco teórico y práctico puede consultarse en el informe denominado La escuela de pensamiento computacional y su impacto en el aprendizaje Curso Escolar 2018-2019 (enlace https://cutt.ly/7WjYPVh), experiencia desarrollada por el Instituto Nacional de Tecnologías Educativas y de Formación del Profesorado y el Ministerio de Educación y Formación Profesional de España (Ministerio de Educación y Formación Profesional e Instituto Nacional de Tecnologías Educativas y de Formación del Profesorado, 2019).

\section{Instrumentos}

El software de programación educativo ha sido Scracth en su versión 3. Este recurso didáctico está diseñado para su integración en el proceso de enseñanza y aprendizaje para el área de Matemáticas, fundamentándose su base epistemológica en dos contenidos claves: el concepto de algoritmo y la rotación de 360 (Falcó, 2017). De esta manera, su desarrollo educativo parte de actividades variadas y motivadoras centradas en la producción de historias, animaciones y juegos interactivos. Además, su funcionalidad aumenta al permitir el intercambio de creaciones entre estudiantes. Su trabajo se ha integrado en el currículum escolar ordinario en horario lectivo, principalmente a través del bloque de contenidos de Geometría a lo largo de las sesiones de clase establecidas para el área de Matemáticas.

La información relativa a las variables interés y motivación hacia el aprendizaje en Matemáticas y percepción de autoeficacia en la realización de actividades propias para esta área curricular, han sido recopiladas para ambos grupos de escolares mediante un cuestionario elaborado a partir del software Google Docs. Las escalas utilizadas en el cuestionario han oscilado para ambas variables entre 0 , valor más bajo e indicativo de menor consideración, y 10, puntuación más elevada o consideración superior.

Por otro lado, se ha tenido en cuenta los resultados para la variable sexo (hombre o mujer) con vistas a profundizar en la exposición de los resultados tras la comparativa con las variables indicadas anteriormente. Ambos grupos de alumnos han procedido a cumplimentar dichos cuestionarios de manera previa y posterior al desarrollo de actividades de programación educativa matemática, en este caso, recordamos, únicamente abordadas por parte de los participantes del grupo experimental. El papel de supervisión y ayuda del docente ha sido clave en esta recogida de datos, 
asegurando también el adecuado funcionamiento de los ordenadores para su utilización por parte del alumnado participante.

\section{Procedimiento}

La recogida de la información sobre las variables interés y motivación hacia el aprendizaje en Matemáticas y percepción de autoeficacia en la realización de actividades propias para esta área de aprendizaje se ha desarrollado en los meses de febrero y junio de 2019. Los datos obtenidos han sido anónimos y la confidencialidad de estos ha sido garantizada en todo momento. El tratamiento estadístico de los datos se ha realizado mediante el software SPSS en su versión 26.

Previamente a esta recogida de datos, los docentes de los alumnos y alumnas participantes en el grupo experimental han recibido un curso de formación telemático de 30 horas de duración sobre la conceptualización, desarrollo y generalización al aula del programa Scratch 3. El trabajo con este software se ha producido entre los meses de marzo y mayo de 2019.

\section{Resultados}

La exposición de los resultados se realiza de acuerdo con las dos variables utilizadas en esta investigación, relacionando, en última instancia, ambas con el sexo de los estudiantes para ampliar los resultados alcanzados.

Para la primera de ellas, interés y motivación de los escolares hacia los aprendizajes en el área de Matemáticas, en el pretest se han observado diferencias bajas en los resultados entre grupos, con una media de 7.71 (DT $=2.37$ ) para el grupo experimental y 7.90 (DT = 2.63). Ya en el post-test, los resultados medios han sido para el grupo experimental de 7.75 (DT= 2.37) y para el grupo control de $7.97(D T=2.20$ ). Las diferencias de medias observadas entre grupos y periodos de investigación han sido mínimas, aunque ambos grupos han mostrado evolución entre momentos. Por tanto, esta variable no ha tenido una variabilidad significativa tras el desarrollo de la educación en programación matemática con Scratch.

Para esta variable, tras realizar un análisis multivariante incluyendo la variable sexo de los escolares, ha aparecido un valor $F=489.30$ y $p<.001$. Para profundizar en estos resultados, se ha realizado una comparación de medias para cada sexo según su inclusión en el grupo experimental o en el grupo de control en ambos momentos de la investigación y para la variable interés y motivación hacia las Matemáticas, obteniéndose los siguientes resultados:

\begin{tabular}{|c|c|c|c|c|c|c|c|c|}
\hline \multirow{3}{*}{ Interés } & \multicolumn{4}{|c|}{ Hombre } & \multicolumn{4}{|c|}{ Mujer } \\
\hline & \multicolumn{2}{|c|}{ GE } & \multicolumn{2}{|c|}{ GC } & \multicolumn{2}{|c|}{ GE } & \multicolumn{2}{|c|}{ GC } \\
\hline & $M$ & DT & M & DT & M & DT & M & DT \\
\hline Pretest & 7.93 & 2.36 & 8.16 & 2.75 & 7.46 & 2.36 & 7.65 & 2.50 \\
\hline Post-test & 7.97 & 2.35 & 8.55 & 1.64 & 7.51 & 2.38 & 7.53 & 2.47 \\
\hline
\end{tabular}


Como puede observarse en esta Tabla 1, el sexo masculino ha obtenido resultados más elevados para ambos grupos y momentos de la investigación. A modo de ejemplo, hay que destacar el aumento de las puntuaciones entre momentos de los hombres pertenecientes al grupo de control, las mujeres de este grupo disminuyen sus puntuaciones medias de un momento a otro de la investigación. Por otro lado, hombres y mujeres del grupo experimental aumentan sus resultados medios ligeramente entre momentos. Ello ha derivado en la existencia de las diferencias estadísticamente significativas señalas anteriormente.

En relación con la segunda variable, autoeficacia en la realización de actividades matemáticas, en el pretest han aparecido diferencias entre grupos, siendo la media obtenida por el grupo experimental de 7.15 (DT = 1.99) y para el grupo de control de 7.62 (DT = 1.79). En el post-test, los resultados del grupo experimental han sido de 7.43 (DT = 1.91) y para el grupo control de $7.42(D T=2.13$ ). Como ha podido observarse, el grupo experimental ha aumentado sus medias .28 entre momentos, mientras que el grupo de control ha bajado sus valores medios -.01. Debido a ello, el trabajado desarrollado con Scratch 3 ha tenido un impacto positivo en los valores de autoeficacia del grupo experimental.

Tras poner en comparación esta variable con el sexo de los escolares, el análisis multivariante ha reflejado un valor $F=341.11$ y $p<$. 001. El análisis de las medias de cada sexo de acuerdo con su pertenencia al grupo experimental o al grupo de control en ambos momentos de la investigación y según la variable autoeficacia, ha mostrado los siguientes resultados:

\begin{tabular}{|l|c|c|c|c|c|c|c|c|}
\hline & \multicolumn{4}{c}{ Hombre } & \multicolumn{2}{c|}{ GE } & \multicolumn{2}{c|}{ GC } \\
\cline { 2 - 11 } & \multicolumn{2}{c}{ GE } & \multicolumn{2}{c|}{ GC } & \multicolumn{2}{c|}{ Mujer } \\
\cline { 2 - 11 } & M & DT & M & DT & M & DT & M & DT \\
\hline Pretest & 7.37 & 1.96 & 7.94 & 1.77 & 6.90 & 2.00 & 7.31 & 1.76 \\
\hline Post-test & 7.62 & 1.95 & 7.38 & 2.57 & 7.24 & 1.84 & 7.45 & 1.75 \\
\hline
\end{tabular}

Tabla 2. Medias según el sexo y grupo de pertenencia para el pretest y el post-test para la variable autoeficacia. Fuente: Elaboración propia (2021)

En esta Tabla 2 se ha reflejado los motivos de la significatividad estadística indicada anteriormente. Por una parte, tanto hombres como mujeres del grupo experimental han aumentado sus puntuaciones medias entre momentos de investigación. Además, las mujeres del grupo de control también aumentan sus resultados medios, aspecto no observado en los hombres de este grupo de control. En líneas generales, las cifras de incremento del grupo experimental son superiores a las obtenidas por el grupo de control, por lo que el trabajo de programación matemática desarrollado ha tenido incidencia en esta variable.

\section{Discusión y conclusiones}

La integración de las herramientas tecnológicas a los procesos de enseñanza y aprendizaje está generando procesos de cambio en las escuelas, con la finalidad de 
ajustar las prácticas educativas a las innovaciones existentes y a lo que la sociedad demanda y requiere en el momento histórico en el que nos encontramos. Ello exige a todos los profesionales de la educación, y a los propios estudiantes, capacidad de adaptación permanente ante la variabilidad y celeridad de los cambios existentes en la actualidad, lo que provoca la necesidad de proponer dinámicas y actividades de aprendizaje más visuales e intuitivas (Tapia, 2020), en las que el alumnado tenga una mayor participación en su desarrollo (Arabit y Prendes, 2020).

La incorporación de la educación en programación forma parte de estas herramientas que incitan a la participación, la adaptación, la innovación y la creatividad de los estudiantes. Como se ha manifestado anteriormente, su inclusión en los procesos educativos es interdisciplinar al incidir en los procesos de enseñanza y aprendizaje de todas las áreas del currículum (Basogain y Olmedo, 2020). Por otro lado, la conexión entre estas herramientas y las competencias clave es indudable con el objetivo de favorecer un adecuado desempeño en sociedad.

Tras el desarrollo de esta investigación, se han observado resultados diferentes para las dos variables consideradas, recordamos: interés y motivación hacia el aprendizaje en Matemáticas y autoeficacia percibida en la realización de tareas para esta área del currículum. Por una parte, respecto a la primera, señalar la existencia de una incidencia baja del proyecto de programación matemática desarrollado con Scratch en el alumnado participante tanto del grupo experimental como en el grupo control. En lado opuesto, con relación a la segunda, han aparecido diferencias, ya que los escolares pertenecientes al grupo experimental han mejorado su valor medio del pretest al post-test con respecto a los del grupo control, por lo que se puede concluir que el proyecto de programación matemática desarrollado ha tenido incidencia en los resultados para esta variable analizada.

Por otro lado, al incluir la variable sexo en los análisis, para la primera variable, la existencia de diferencias estadísticamente significativas ha venido derivadas de los resultados más elevados del sexo masculino para ambos grupos y momentos de la investigación. Respecto a la segunda variable, la significatividad ha sido consecuencia del aumento de las puntuaciones de los hombres y las mujeres pertenecientes al grupo experimental para ambos momentos de la investigación, siendo el incremento superior al alcanzado por los escolares del grupo de control.

En definitiva, los centros educativos deberán de ajustar sus actuaciones a las innovaciones y cambios sociales existentes, caracterizados por su celeridad e integrándolos a los procesos de enseñanza y aprendizaje. De esta manera, nos encontramos ante una notable e imparable revolución tecnológica que demanda una amplia formación docente, tanto inicial como continua, y una capacidad elevada de adaptación y ajuste de las prácticas de enseñanza a las demandas y necesidades de cada momento. El aprendizaje permanente tiene una elevada importancia cuando hablamos de tecnologías emergentes, un auténtico desafío para las comunidades y administraciones educativas en el siglo XXI. Los profesionales de la educación no podemos permanecer ajenos a la funcionalidad de estos procesos de cambio y a la necesidad de su inclusión en los procesos de enseñanza y aprendizaje. 


\section{Referencias}

Arabit, J., y Prendes, M. P. (2020). Metodologías y Tecnologías para enseñar STEM en Educación Primaria: Análisis de necesidades. Píxel-BIT Revista de Medios y Educación, 57, 107-128. https://doi.org/10.12795/pixelbit.2020.i57.04

Armoni, M. (2016). Computing in schools - Computer science, computational thinking, programming, coding: The anomalies of transitivity in $\mathrm{K}-12$ computer science education. ACM Inroads, 7, 24-27. https://doi.org/10.1145/3011071

Basogain, X., y Olmedo, M. E. (2020). Integración de Pensamiento Computacional en Educación Básica. Dos Experiencias Pedagógicas de Aprendizaje Colaborativo online. Revista de Educación a Distancia (Red), 20, 1-21. https://doi.org/10.6018/red.409481.

Berge, O. (2017). Rethinking Digital Literacy in Nordic School Curricula. Nordic Journal of Digital Literacy, 12, 5-7. https://doi.org/10.18261/issn.1891-943x-2017-01-02-01

Bers, M.U. (2018). Codings as a Playground: programming and Computational Thinking in the Early Childhood Classroom. Routledge.

Bocconi, S., Chioccariello, A., Dettori, G., Ferrari, A., y Engelhardt, K. (2016). Developing Computational Thinking in Compulsory Education-Implications for Policy and Practice. Comisión Europea. https://doi.org/10.2791/792158.

Chaudron, S., Di Gioia, R., y Gemo, M. (2018). Young children (0-8) and digital technology: a qualitative study across Europe. Unión Europea. https://doi.org/10.2760/245671

Comisión Europea (2018). Comunicación de la Comisión al Parlamento Europeo, al Consejo, al Comité Económico y Social Europeo y al Comité de las Regiones sobre el Plan de Acción de Educación Digital. Comisión Europea.

Falcó, J. M. (2017). Evaluación de la competencia digital docente en la Comunidad Autónoma de Aragón. Revista Electrónica de Investigación Educativa, 19, 73-83. https://doi.org/10.24320/redie.2017.19.4.1359.

Ministerio de Educación y Formación Profesional e Instituto Nacional de Tecnologías Educativas y de Formación del Profesorado (2019). La Escuela del Pensamiento Computacional y su Impacto en el Aprendizaje: Curso Escolar 2018-2019. Ministerio de Educación y Formación Profesional e Instituto Nacional de Tecnologías Educativas y de Formación del Profesorado (INTEF), Área de Experimentación en el Aula.

Passey, D. (2016). Computer science (CS) in the compulsory education curriculum: Implications for future research. Education and Information Technologies, 22, 421443. https://doi.org/10.1007/s10639-016-9475-z

Pinto, G., y Plaza, J. (2021). Determinar la necesidad de capacitación en el uso de las tecnologías de la información y las comunicaciones para la formación docente. Digital Publisher CEIT, 6(1), 169-181. https://doi.org/10.33386/593dp.2021.1.426

Rodríguez-Guevara, J. E. (2021). Integración de las Tecnologías de la Información y la Comunicación en los procesos de enseñanza-aprendizaje. RIESED - Revista 
Internacional De Estudios Sobre Sistemas Educativos, 3(11), 99-111. http://www.riesed.org/index.php/RIESED/article/view/140

Rodríguez, L. J., Serrado, A., Thibaut, E., Velázquez, J. A., López, D., y Bahamonde, A. (2020). Hacia una Nueva Educación en Matemáticas e Informática en la Educación Secundaria. Real Sociedad Matemática Española (RSME) y Sociedad Científica Informática de España (SCIE).

Romero, R., Gutiérrez-Castillo, J. J., y Puig, M. (2017). Innovación y tecnología en Educación Infantil. Editorial Universidad de Sevilla.

Sánchez-Vera, M. del M. (2021). El desarrollo de la Competencia Digital en el alumnado de Educación Infantil. Edutec. Revista Electrónica De Tecnología Educativa, 76, 126-143. https://doi.org/10.21556/edutec.2021.76.2081

Tapia, C. (2020). Tipologías de uso educativo de las Tecnologías de la Información y Comunicación: Una revisión sistemática de la literatura. Edutec. Revista Electrónica de Tecnología Educativa, 71, 16-34. https://doi.org/10.21556/edutec.2020.71.1489.

Wing, J. M. (2017). Computational thinking's influence on research and education for all. Italian Journal of Educational Technology, 25(2), 7-14. https://doi. org/10.17471/2499-4324/922 


\section{La Motivación y el Chat del Aula Virtual como Recurso para Evitar la Deserción en el Ámbito Universitario Durante las Primeras Etapas de la Pandemia}

\section{Soto Pascacio, Flor}

Universidad Tecnológica Nacional BA

sotop.flor@gmail.com 


\section{LA MOTIVACIÓN Y EL CHAT DEL AULA VIRTUAL COMO RECURSO PARA EVITAR LA DESERCIÓN EN EL ÁMBITO UNIVERSITARIO DURANTE LAS PRIMERAS ETAPAS DE LA PANDEMIA}

\section{Soto Pascacio, Flor}

Universidad Tecnológica Nacional BA

sotop.flor@gmail.com

\section{Resumen}

La necesidad de virtualidad debido a la pandemia por COVID-19, trajo nuevos desafíos en materia educativa, se tuvieron que repensar las metodologías y las herramientas utilizadas, además de implementar recursos que resulten inclusivos y ayuden a evitar la deserción y el desgranamiento sobre todo cuando se trata de estudiantes universitarios de primer año. Este trabajo presenta el análisis de la apreciación de los estudiantes con respecto a la aplicación de la metodología utilizada para el dictado de clases virtuales de la materia Ingeniería y Sociedad, que tiene lugar en la currícula de primer año de las ingenierías en UTN BA. En ellas se utilizó la sala de chat del Aula Virtual como herramienta principal, más videoconferencias para resolver dudas. Se realizó una experiencia "ad hoc" en la cual durante el primer cuatrimestre se hizo especial énfasis en una metodología de motivación y seguimiento personalizado más intensiva que en el segundo y una vez concluida cada cursada se implementó una encuesta. La misma fue aplicada a una muestra total de 156 alumnos. Los resultados obtenidos demuestran que los estudiantes consideraron que el chat fue una herramienta inclusiva durante las clases, y por otra parte la motivación y el seguimiento personalizado mantuvieron a los cursos sin índice de desgranamiento ni deserción.

\section{Palabras clave}

Chat, aula virtual, inclusión, pandemia. 


\section{Introducción}

Los cambios socio ambientales y en salud de los últimos tiempos, en el contexto de la pandemia y de la sociedad del conocimiento, demandan con urgencia nuevos enfoques curriculares en la enseñanza de Ingeniería. Estamos trabajando en ello desde uno de nuestros Proyectos de Investigación y Desarrollo en la Secretaría de Investigación e Innovación Tecnológica de la UTN BA (Código del Proyecto: TEUTIBA0006617TC) y lo compartido en este documento es parte de dicha investigación en curso.

Consideramos que uno de nuestros mayores retos como docentes es formar profesionales críticos y capaces de actuar para un desarrollo más sostenible, implicándose con los problemas de la comunidad. La primera de las formas de implicación va de la mano con lograr comprometerse con las competencias requeridas por los nuevos estándares de CONFEDI (2018), vinculadas a algunos de los objetivos del Libro Rojo: “

- Actualizar y consolidar el actual modelo de formación de ingenieros.

- Consolidar un modelo de aprendizaje centrado en el estudiante.

- Definir un modelo comparable internacionalmente.

- Definir un enfoque basado en competencias y descriptores de conocimiento." (p.17)

La pandemia nos ha desafiado a poner en juego nuestra imaginación y creatividad para implementar recursos que resulten inclusivos a la hora de compartir nuestro trabajo mediante plataformas desconocidas tanto para los docentes como para los estudiantes, las cuales debieron ser implementadas de manera urgente a comienzos del 2020. Muchos de los estudiantes y también de los docentes no contaban con todos los recursos necesarios para hacerlo y además responder a la necesidad de evitar la deserción. Para lograrlo nos basamos en La Teoría de la Motivación de Covington (1998/2000), derivada de la Teoría de Jhon W. Atkinson: La motivación al éxito ("achievement motivation"). "Desde su teoría psicopedagógica Covington propone, una estrategia teniendo en cuenta el ámbito afectivo-social y el cognitivo. Sugiere así tres puntos centrales: desarrollar el deseo de aprender siempre, animar a los alumnos a que fijen sus propios objetivos de aprendizaje y desarrollar la capacidad de aprender estratégicamente". También consideramos el proceso de enseñanza-aprendizaje desde un enfoque constructivista (Piaget, Vigotsky y Ausubel) centrándonos en el estudiante como protagonista y tomando al docente en el rol de facilitador e impulsor de la autonomía e iniciativa del estudiante.

Para ello se utilizó la Estrategia de Autogestión del Conocimiento (EAC) como metodología para llevar adelante el trabajo final en equipo realizado por los estudiantes, en el cual le dieron solución a un problema de la vida real detectado por ellos mismos. "La Estrategia de Autogestión del conocimiento, (EAC), es el producto de una investigación desarrollada en la tesina, para la Licenciatura en Tecnología Educativa cursada en la Universidad Tecnológica Nacional, Facultad Regional Buenos Aires." (Costas, 2019). 
Dentro de este marco teórico, el objetivo de esta propuesta es compartir la capacidad inclusiva demostrada por el recurso chat en el Aula Virtual durante la cursada de la materia Ingeniería y Sociedad en el primer año de las carreras de Ingeniería Electrónica e Ingeniería en Sistemas de Información, durante el primer y segundo cuatrimestre del 2020 en pandemia. La gran incertidumbre generada por la imposibilidad de conocer los tiempos y especificidades sobre la modalidad de la cursada con los que nos manejamos al comienzo de la pandemia, determinaron la necesidad de una rápida decisión acerca de la elección de los recursos hipotéticamente más inclusivos del aula virtual. La opción del encuentro sincrónico en el chat durante la totalidad de las horas de clase permitió el trabajo en equipos de los estudiantes junto a la exposición y corrección de los resultados de los mismos con devolución de la docente enriqueciéndose de ese modo el curso completo. Facilitó también que aquellos que no tuvieran buena conectividad pudieran acceder a lo grabado en la sala de chat del aula virtual en cualquier otro momento en el que lo necesitaran. El acceso a la sala de chat resultó más inclusivo que acceder al recurso de la videoconferencia, difícil de sostener por ejemplo sólo con los datos del celular; facilitándose por otra parte también la cursada a los que compartían espacios y conectividad con otros ocupantes en su domicilio. El índice de deserción fue mínimo quedando fuera de la cursada sólo dos estudiantes por comisión que no se conectaron desde un principio.

Según el libro Rojo de CONFEDI (2018), el futuro ingeniero debe:

"Emplear buen juicio a fin de desarrollar modos en que se puedan utilizar, de manera óptima, materiales, conocimiento, y las fuerzas de la naturaleza en beneficio de la humanidad, en el contexto de condiciones éticas, físicas, económicas, ambientales, humanas, políticas, legales, históricas y culturales”. (p. 18)

Consideramos que el trabajo en equipo desde el uso del Chat en el Aula Virtual permitió que se comiencen a trabajar estas competencias blandas desde el principio de la cursada.

Otro de los objetivos de análisis fue conocer las diferencias de apreciación de los estudiantes de la materia Ingeniería y Sociedad dictada en la UTN BA con respecto a la aplicación de la metodología utilizada para el dictado de clases a distancia de la materia durante la pandemia. Este análisis está basado en la experiencia realizada "ad hoc" en la cual durante el primer cuatrimestre se hizo especial énfasis en una metodología de motivación y seguimiento personalizado más intensivo que en el transcurso del segundo cuatrimestre conservando todas las otras variables estables.

\section{Método}

\section{Descripción del contexto y de los participantes}

Durante el primer cuatrimestre los estudiantes encuestados fueron los pertenecientes a la carrera de Ingeniería Electrónica con los cuales se hizo un especial énfasis en una metodología de motivación y seguimiento personalizado mucho más intensivo que durante el segundo cuatrimestre, en el que los estudiantes encuestados pertenecían a la carrera de Ingeniería en Sistemas de Información (todos cursos de primer año de la UTN BA). En ambos casos las encuestas se hicieron en el marco de la materia Ingeniería y Sociedad dictada durante el año 2020, contexto en el cual tuvo comienzo la Pandemia COVID-19. 


\section{Instrumentos}

Se utilizó Google Forms como herramienta para el diseño de la encuesta, el cuestionario se compone de 13 preguntas, las primeras 11 son preguntas cerradas y las últimas dos restantes son preguntas abiertas que permitieron obtener más información sobre la experiencia de los alumnos.

Las preguntas fueron las siguientes:

1. ¿Considera que el chat ha sido una herramienta inclusiva, durante las clases?

2. ¿Qué tipo de conexión a Internet ha utilizado?

3. ¿Por medio de que dispositivo se ha conectado a las clases?

4. ¿Piensa que si las clases hubieran sido por videoconferencia hubiesen podido acceder con la misma facilidad que por chat?

5. ¿Se sintió acompañado y retroalimentado por la docente en las clases y fuera de ellas?

6. ¿Piensa que las videoconferencias ofrecidas fueron las necesarias para aclarar dudas?

7. ¿Considera que los materiales de texto obligatorios hubieran sido suficientes para comprender los conceptos?

8. ¿Piensa que la bibliografía complementaria y los materiales y videos propuestos lo ayudaron a terminar de comprender y motivarse?

9. ¿Considera que tuvo posibilidades de participar colaborativamente en su grupo?

10. ¿Considera eficaz la modalidad de estudio propuesta para el aprendizaje de los contenidos?

11. ¿Considera adecuada la forma de evaluación?

12. Elija tres palabras que reflejen lo que haya generado la cursada de esta materia en usted

13. Observaciones personales

Se puede acceder a la encuesta enviada en la siguiente URL: https://forms.g/e/jBvFT8G45oq9hBfV8

\section{Procedimiento}

La encuesta fue anónima y difundida por mail a los estudiantes una vez concluida la cursada y entregadas las notas. 
Durante el primer cuatrimestre se logró un total de 73 respuestas sobre un universo de 80 estudiantes y durante el segundo cuatrimestre se obtuvieron 68 respuestas sobre un universo de 76 estudiantes. En ambos casos fueron dos los cursos encuestados por cada especialidad para la materia cuatrimestral Ingeniería y Sociedad. Luego de obtenidos los resultados de las encuestas del primer y segundo cuatrimestre se procedió a realizar un análisis comparativo.

\section{Resultados}

A continuación se muestran los resultados del análisis comparativo de las encuestas:

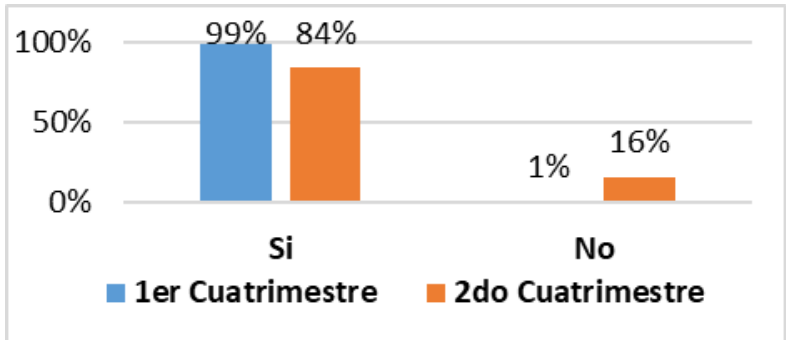

\section{1-Gráfico comparativo de respuestas - 1- ¿Considera que el chat ha sido una herra- mienta inclusiva, durante las clases?}

Se puede observar en el gráfico 1 tanto en el primero como en el segundo cuatrimestre la gran mayoría 99 \% y $84 \%$ de los estudiantes consideró que el chat fue una herramienta inclusiva durante las clases percibiéndose un leve descenso de respuestas afirmativas en el segundo cuatrimestre.

Es dable suponer que, dado que el recurso chat requiere un esfuerzo actitudinal mayor por parte de estudiantes que en general están acostumbrados a la videoconferencia y no habiéndose incurrido "ad hoc" en la especial motivación de la justificación para el uso del mismo, la valoración haya decrecido.

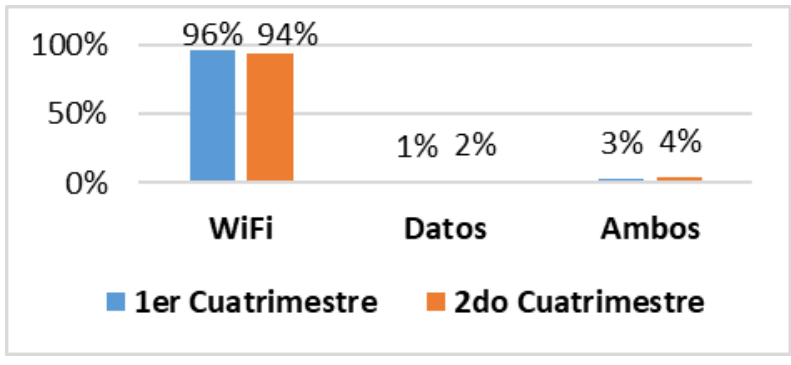




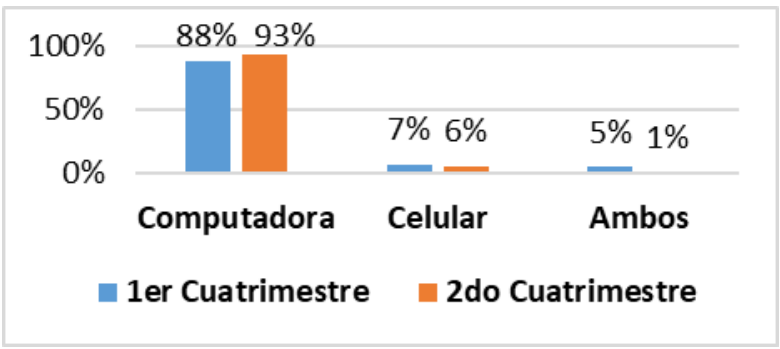

3-Gráfico comparativo de respuestas - 1b- ¿Por medio de qué dispositivo se ha conectado a las clases?

Observando los gráficos 2 y 3 se puede notar que la herramienta chat fue decisiva en relación a la inclusión de los estudiantes que utilizaron datos móviles (1\% y 2\%) y celulares (7\% y 6\%) para poder asistir a clases dado que el uso de videoconferencia requiere de mayor consumo de datos en internet.

Si observamos el gráfico 4, en el segundo cuatrimestre la falta de motivación personalizada y por lo tanto la zona de confort ofrecida por la idealización de la videoconferencia impide que estas respuestas sean coherentes con las de la consigna 1a (gráfico 2). Teniendo en cuenta que para el caso de los estudiantes que representan el $1 \%$ y el $2 \%$ que utilizaron los datos de redes móviles y entre un 3 y $4 \%$ tuvo que utilizar ambos, la herramienta chat fue decisiva en relación a su inclusión dado que el uso de videoconferencia requiere de mayor consumo de datos en internet pudiendo quedar por lo tanto ese porcentaje de estudiantes fuera de la cursada. La motivación y el seguimiento personalizado los mantuvo en un $2 \%$ arriba de la deserción.

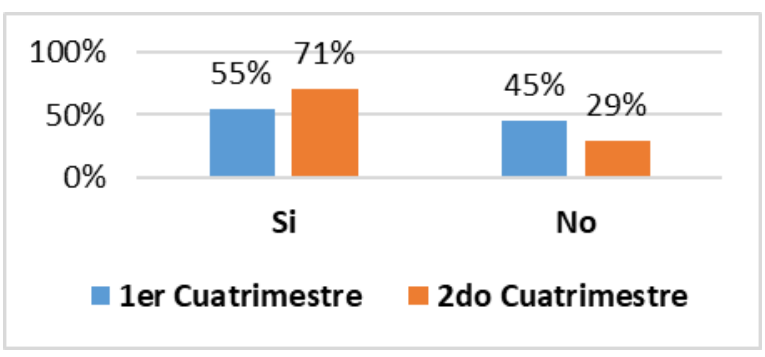

4-Gráfico comparativo de respuestas - 2- ¿Piensa que si las clases hubieran sido por videoconferencia hubiesen podido acceder con la misma facilidad que por chat?

La retroalimentación y el acompañamiento no se vieron modificados en el Aula Virtual, sin embargo repercutió en la forma de valoración de los estudiantes los cuales en un $1 \%$ sintieron que no había sido así dado la ausencia de motivación continua por parte de la docente. (ver gráfico 5) 


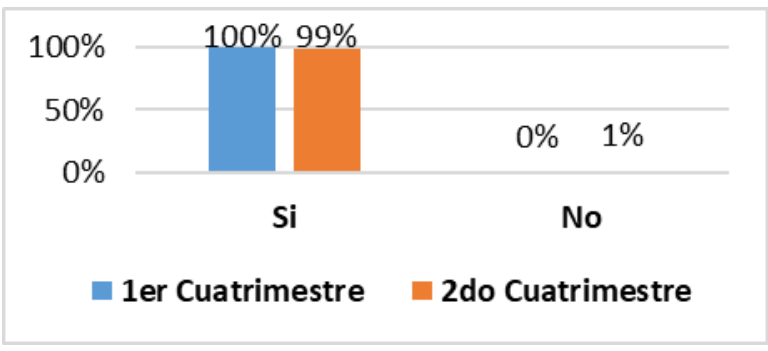

5-Gráfico comparativo de respuestas - 3- ¿Se sintió acompañado y retroalimentado por la docente en las clases y fuera de ellas?

Durante ambos cuatrimestres las videoconferencias no se modificaron en el Aula Virtual, sin embargo repercutió en la forma de valoración de los estudiantes del segundo cuatrimestre, los cuales en un $13 \%$ (ver gráfico 6 ), sintieron que no había sido así dada la ausencia de motivación intensa por parte de la docente.

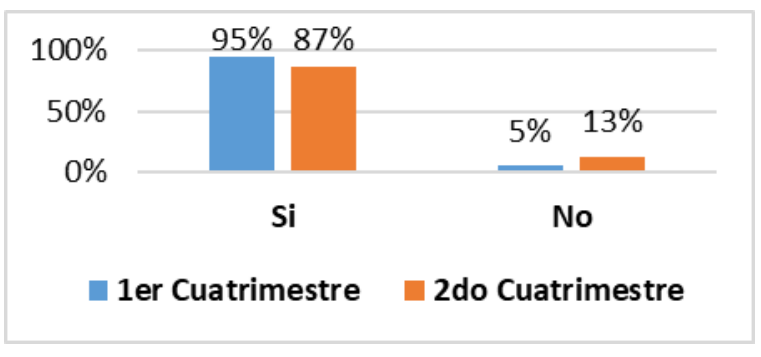

6-Gráfico comparativo de respuestas - 4- ¿Piensa que las videoconferencias ofrecidas fueron las necesarias para aclarar dudas?

Los materiales de texto tampoco no se vieron modificados en el Aula Virtual, sin embargo repercutió en la forma de valoración de los estudiantes durante el segundo cuatrimestre, (ver gráfico 7) los cuales en un 41\% sintieron que no había sido así dado la ausencia de motivación constante por parte de la docente.

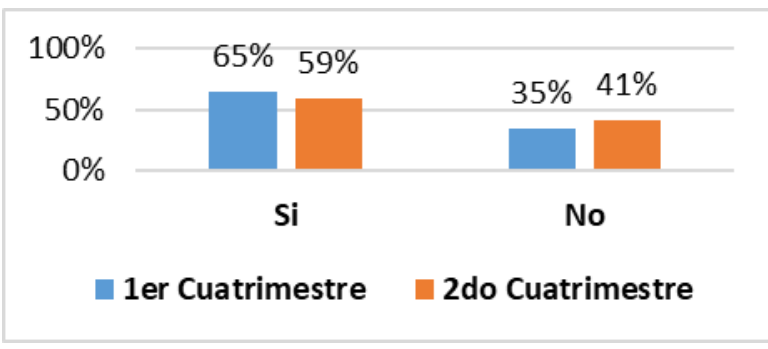

7-Gráfico comparativo de respuestas - 5- ¿Considera que los materiales de texto obligatorios hubieran sido suficientes para comprender los conceptos?

La bibliografía complementaria y los materiales y videos propuestos no se vieron modificados en el Aula Virtual, sin embargo la ausencia de motivación intensa por parte de la docente repercutió en la forma de valoración de los estudiantes los cuales en un $3 \%$ sintieron que los materiales no los ayudaron a terminar de comprender y motivarse. (ver gráfico 8) 


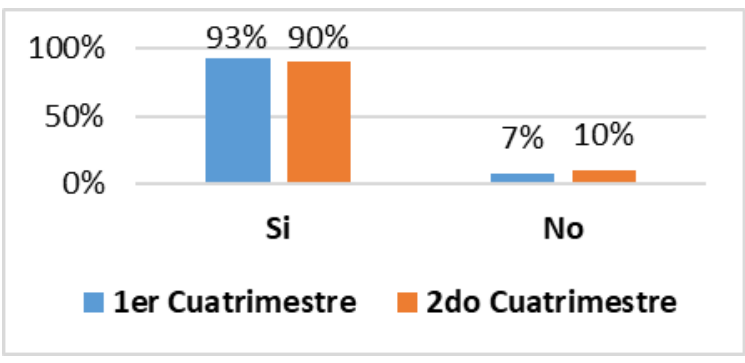

8-Gráfico comparativo de respuestas - 6- ¿Piensa que la bibliografía complementaria y los materiales y videos propuestos lo ayudaron a terminar de comprender y motivarse?

En los resultados del gráfico 9 se puede observar que no hubo una diferencia significativa en cuanto a la participación colaborativa en grupo ya que en los trabajos en grupo la docente no hizo diferencias entre los dos cuatrimestres.

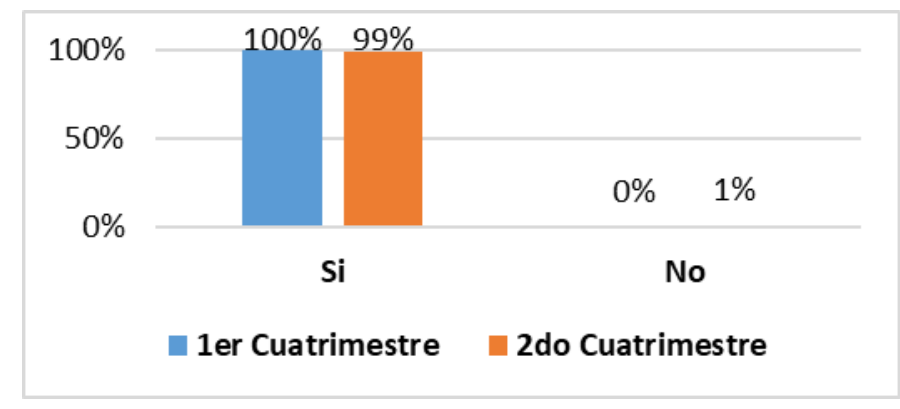

9-Gráfico comparativo de respuestas - 7- ¿Considera que tuvo posibilidades de participar colaborativamente en su grupo?

En los resultados del gráfico 10 se puede observar un leve descenso de respuestas "Si", a pesar de que no se hicieron diferencias en la modalidad de estudio propuesta para el aprendizaje de los contenidos.

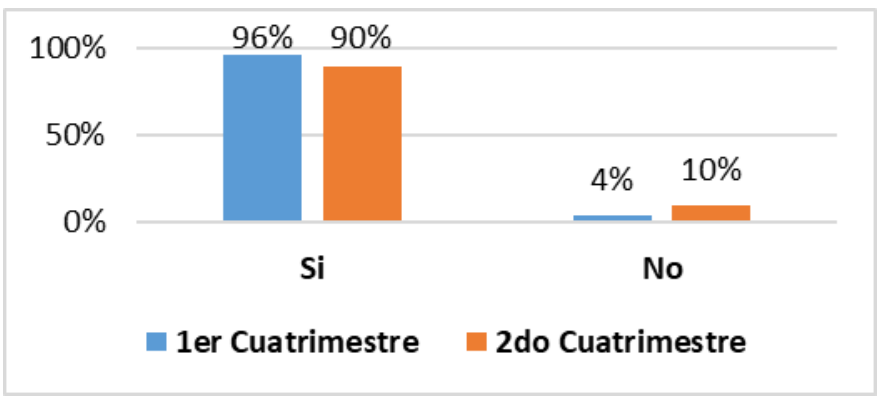

10-Gráfico comparativo de respuestas - 8- ¿Considera eficaz la modalidad de estudio propuesta para el aprendizaje de los contenidos?

Como se puede observar en el gráfico 11 no hubo un cambio significativo en las respuestas del segundo cuatrimestre respecto del primero ya que la cantidad de respuestas "Si" solo disminuyó en un 1\%. Esto ocurrió debido a que no se hizo diferencias entre los dos cuatrimestres en cuanto a la modalidad de evaluación. 


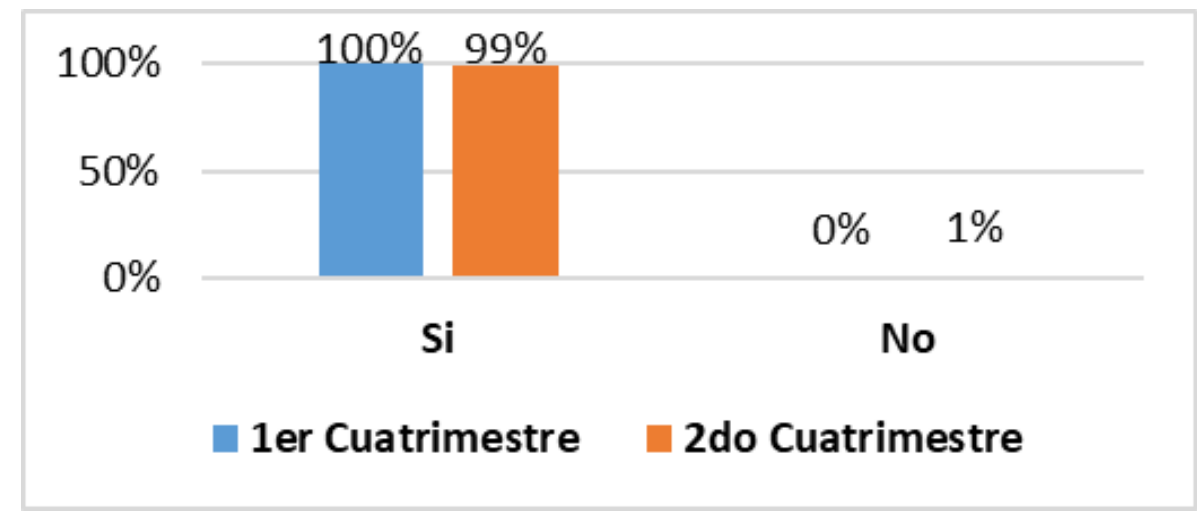

\section{1-Gráfico comparativo de respuestas - 9- ¿Considera adecuada la forma de evaluación?}

Para el análisis de la consigna 10-"Elija tres palabras que reflejen lo que haya generado la cursada de esta materia en usted" se consideraron las 3 palabras mas mencionadas y sus sinónimos, por lo que se consideraron las siguientes categorías, sumando un punto por cada mención sobre las mismas.

- Palabras relacionadas con la Motivación

- Palabras relacionadas con el Aprendizaje

- Palabras relacionadas con el Compañerismo

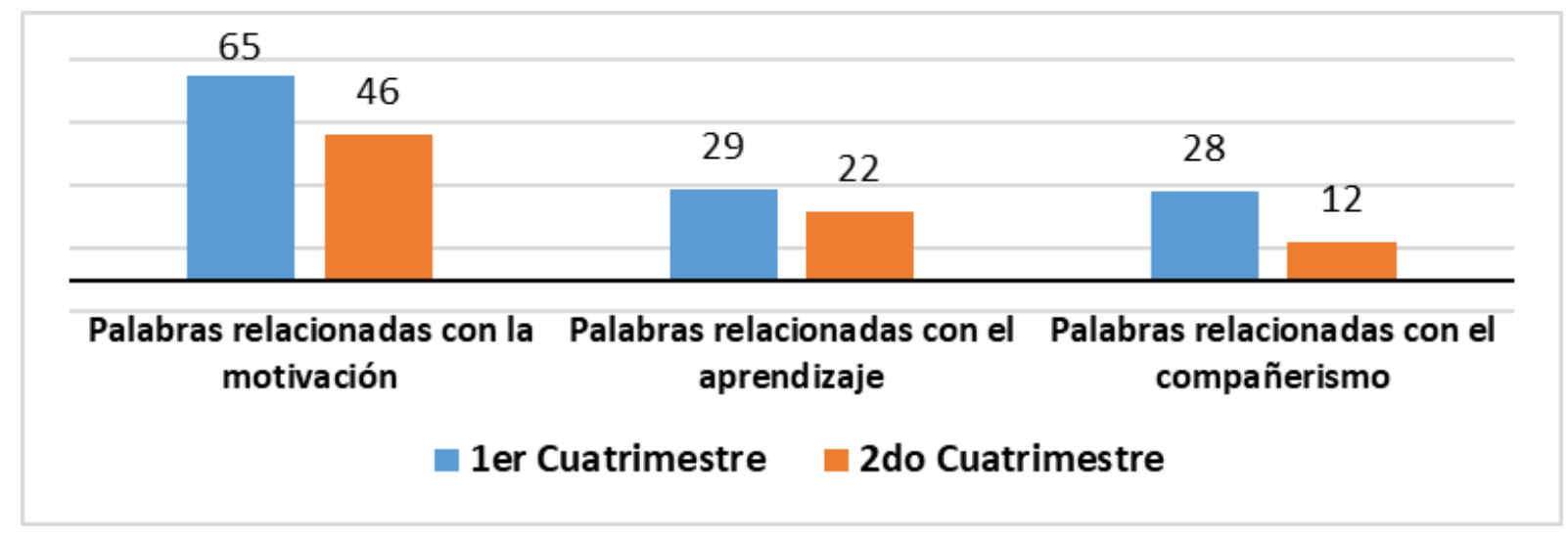

12-Gráfico comparativo de respuestas - 10- Elija tres palabras que reflejen lo que haya generado la cursada de esta materia en usted

Como se puede observar en el gráfico 12, En el segundo cuatrimestre hubo un descanso de casi 20 puntos en cuanto a la cantidad de respuestas que mencionaron palabras relacionadas con la motivación, también se nota un leve descenso de 7 puntos en las respuestas que mencionan palabras relacionadas con el aprendizaje y en cuanto a las respuestas con palabras relacionadas con el compañerismo se observa un descenso de 16 puntos, es dable suponer que esto ocurrió debido a la ausencia del estímulo personalizado, lo cual afectó a la percepción de los estudiantes en cuanto a la sensación respecto de su motivación, aprendizaje y compañerismo de manera notable. 
Para el análisis de las observaciones personales se consideraron las siguientes categorías:

- De acuerdo con la modalidad de evaluación

- De acuerdo con la modalidad del dictado de clases

- Dedicación y acompañamiento de la docente

- Necesidad de tener más videoconferencias para consultas

- Tuvo inconvenientes con la sala de chat/ Aula virtual

- NA: no aplica/ no responde

Como se puede apreciar en el gráfico 13, no se nota una gran diferencia entre las respuestas obtenidas en las categorías "De acuerdo con la modalidad de evaluación", "De acuerdo con la modalidad de dictado de clases", "Necesidad de tener más videoconferencias" y "Tuvo inconvenientes con la sala de Chat/ Aula Virtual”. En la categoría en la que se observa una marcada diferencia entre la cantidad de respuestas del segundo cuatrimestre es en la categoría "Dedicación y acompañamiento de la docente", ya que durante el primer cuatrimestre se obtuvieron 11 respuestas en esta categoría pero durante el segundo cuatrimestre solo 3 encuestados mencionaron la dedicación y acompañamiento de la docente.

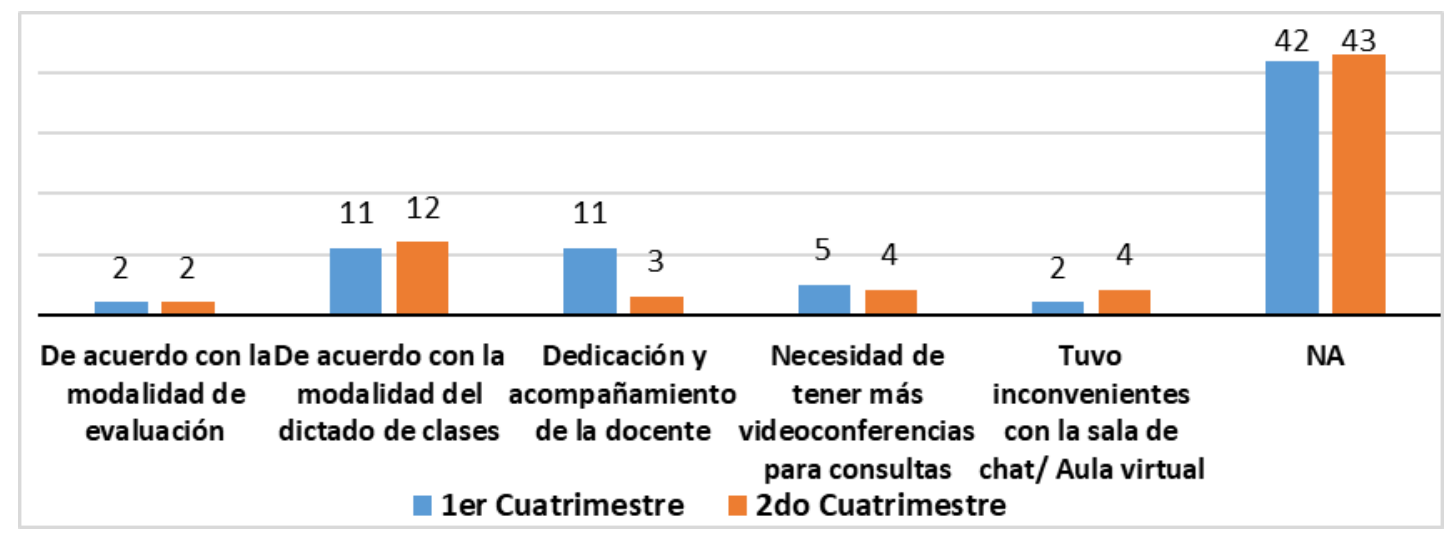

\section{3-Gráfico comparativo de respuestas - 11- Observaciones Personales}

Algunas de las respuestas obtenidas y clasificadas entro de la categoría "Dedicación y acompañamiento de la docente" fueron las siguientes:

"A pesar de las circunstancias que llevaron a esta nueva forma de cursar, siendo un desafió tanto para profesores como para nosotros, los alumnos, fue una muy buena la cursada y se sintió la dedicación y preocupación de la profe."

"Aprendí muchas cosas nuevas, tanto de la materia como de la modalidad virtual en sí. La modalidad para el aprendizaje ayudó mucho en esto, realmente hizo que se facilitaran las cosas, con la sala de chat por ejemplo, que capaz si hubiera sido por videollamada solamente, se hubieran presentado muchos inconvenientes a la hora 
de dar la clase. Otra cosa que fue de gran ayuda para comprender el material de las clases, fueron los videos brindados. Sirvieron mucho para terminar de entender los conceptos. Por ultimo quiero destacar la dedicación, el acompañamiento y comprensión que vi por parte de usted profesora. Siempre nos preguntó cómo íbamos, no solo con su materia, sino que también con las demás, viendo las dificultades que se nos presentaban con internet y que comprendiéramos todos los temas. Como dije anteriormente, me sentí muy acompañada por parte suya. Le agradezco por hacer esto mucho más fácil y que nos volvamos a encontrar en alguna clase o materia!"

"Materia que sin lugar a dudas me puso "los pies sobre la tierra", me entusiasme muchísimo y cambió mi forma personal de ver a la ingeniería con conceptos claros y hasta incluso siendo introspectivo. En cuanto a la docente, siempre presente y muy dedicada sin nada para decir. Muchas gracias por todo."

En la sección Anexos se pueden observar todas las Respuestas a las Observaciones Personales de la categoría: Dedicación y acompañamiento de la docente.

\section{Discusión y conclusiones}

Como pudimos observar durante el desarrollo del análisis de las consignas de la encuesta más del $90 \%$ de los encuestados utilizó Wifi para conectarse a las clases tanto en el primer como en el segundo cuatrimestre, solo entre el $1 \%$ y el $2 \%$ utilizó los datos de redes móviles y entre un 3 y $4 \%$ tuvo que utilizar ambos. Para el caso de los estudiantes que representan entre $1 \%$ y el $2 \%$ que utilizaron los datos de redes móviles y entre un 3 y $4 \%$ tuvo que utilizar ambos, la herramienta chat fue decisiva en relación a su inclusión dado que el uso de videoconferencia requiere de mayor consumo de datos en internet pudiendo haber quedado por lo tanto ese porcentaje de estudiantes fuera de la cursada.

Por otra parte, la motivación y el seguimiento personalizado a partir de la puesta en práctica del trabajo en equipo usando las nuevas metodologías de autogestión para resolver problemas durante las clases, evitó la deserción. Sólo abandonaron dos estudiantes por curso y en realidad no pudieron conectarse desde el primer día de clase.

\section{Agradecimientos}

A Miriam Costas, de la Universidad Tecnológica Nacional Regional Buenos Aires quien fue coautora de este trabajo.

\section{Referencias}

Ausubel, D. P. (1983), Psicología educativa: un punto de vista cognoscitivo. Editorial Trillas.

CONFEDI. (2018). Propuesta de estándares de segunda generación para la acreditación de carreras de ingeniería en la República Argentina "Libro Rojo de CONFEDI". CONFEDI. 
Costas, M. (2019). Formar a los que forman. Una propuesta de innovación pedagógica desde la aplicación de la Estrategia de Autogestión del conocimiento (EAC) en Responsabilidad Social Universitaria. Editorial CEIT.

Covington, M. (2000). La voluntad de aprender. Guía para la motivación en el aula (Trad. C. González). Alianza Editorial. (Trabajo original publicado en 1998)

Piaget, J (1981). Epistemología genética y equilibración. Editorial Fundamentos.

Vigotsky, L.S. (1979), El desarrollo de los procesos psicológicos superiores. Editorial Crítica

\section{Anexos}

Respuestas a las Observaciones Personales de la categoría: Dedicación y acompañamiento de la docente:

Primer cuatrimestre:

"A pesar de las circunstancias que llevaron a esta nueva forma de cursar, siendo un desafió tanto para profesores como para nosotros, los alumnos, fue una muy buena la cursada y se sintió la dedicación y preocupación de la profe."

"Aprendí muchas cosas nuevas, tanto de la materia como de la modalidad virtual en sí. La modalidad para el aprendizaje ayudó mucho en esto, realmente hizo que se facilitaran las cosas, con la sala de chat por ejemplo, que capaz si hubiera sido por videollamada, se hubieran presentado muchos inconvenientes a la hora de dar la clase. Otra cosa que fue de gran ayuda para comprender el material de las clases, fueron los videos brindados. Sirvieron mucho para terminar de entender los conceptos. Por último quiero destacar la dedicación, el acompañamiento y comprensión que vi por parte de usted profesora. Siempre nos preguntó cómo íbamos, no solo con su materia, sino que también con las demás, viendo las dificultades que se nos presentaban con internet y que comprendiéramos todos los temas. Como dije anteriormente, me sentí muy acompañada por parte suya. Le agradezco por hacer esto mucho más fácil y que nos volvamos a encontrar en alguna clase o materia!"

"Materia que sin lugar a dudas me puso "los pies sobre la tierra", me entusiasme muchísimo y cambió mi forma personal de ver a la ingeniería con conceptos claros y hasta incluso siendo introspectivo. En cuanto a la docente, siempre presente y muy dedicada sin nada para decir. Muchas gracias por todo."

"No hay mucho que ya, no hayamos dicho. Más que nada agradecerle por haberse tomado el tiempo de adaptar las clases a los estándares de nuestro curso y las circunstancias. Muchas gracias por todo."

"Me sentí muy bien acompañado, calidad de docentes y compañeros más que excelente."

"Muchas gracias profe por la voluntad de querer enseñarnos y preocuparse por nosotros. Se aprecia mucho." 
"Fue una cursada muy buena, como le había comentado, el año pasado tuve una mala cursada, pero usted dió otro enfoque a la materia mucho más emocionante y a uno le dan ganas de estudiar así. Muchas gracias por todo profe, totalmente agradecido y feliz de poder haberla conocido y cursar con usted!"

"La verdad la materia fue muy llevadera gracias al esfuerzo que ponía profe, al menos a mí me daba la motivación para seguir al ver el esfuerzo que usted hacía por nosotros. Muchas gracias y nos veremos en un futuro."

"Destaco los videos brindados como material de apoyo, me encantó la mirada científica que le daban a los temas, plasmando lo teórico en algo práctico. Agradezco el sobre esfuerzo de usted, el cual me motivo a la hora de estudiar una materia social, viniendo yo de un entorno muy técnico."

"Muy buena onda por parte de la profesora, siempre nos acompañó e hizo amena esta cursada tan particular. Gracias!"

"Personalmente gracias a esta materia hice amigos virtualmente, con los cuales hicimos un grupo de estudio y ayudó mucho a salir adelante en esta situación. Siento que la modalidad de chat al principio se sentía un poco distante, pero simplemente porque era algo nuevo, luego se fueron acortando las distancias y realmente se hizo sentir el acompañamiento del docente. Muchas gracias por esta oportunidad, siento que aprendí mucho de qué es lo que significa ser un ingeniero."

Segundo cuatrimestre:

"Muy buena predisposición de la profesora! Todos los contenidos se comprendieron a la perfección, y muy atenta. Los métodos de evaluación fueron perfectos, todo perfecto."

"El esfuerzo por parte del plantel docente se nota muchísimo, se aprecia todo lo que han hecho. Muchas gracias."

"La materia está muy bien llevada, me sirvieron los conceptos enseñados por esta, y la profesora fue paciente con todos los alumnos y proporcionó muy buen material" 


\section{Herramientas Tecnológicas para la Superación de Barreras Educativas de las Personas con Discapacidad Auditiva Desde un Análisis Bibliométrico.}

\section{Antón Ros, Nuria}

Universidad de Alicante

nuria.anton@ua.es 


\title{
HERRAMIENTAS TECNOLÓGICAS PARA LA SUPERACIÓN DE BARRERAS EDUCATIVAS DE LAS PERSONAS CON DISCAPACIDAD AUDITIVA DESDE UN ANÁLISIS BIBLIOMÉTRICO.
}

\author{
Antón Ros, Nuria \\ Universidad de Alicante \\ nuria.anton@ua.es
}

\section{Resumen}

Ante la emergencia de generar accesibilidad y equidad en las aulas es necesaria la detección y afrontamiento de obstáculos y barreras para que se dé la inclusión en los centros educativos. Una de las herramientas combatientes son las TIC como apoyo al aprendizaje del alumnado y, en concreto, del alumnado con discapacidad auditiva. En este marco, el objetivo ha sido analizar la producción científica sobre los recursos TIC dirigidos a la superación de barreras educativas del alumnado con discapacidad auditiva. Con este fin, se ha llevado a cabo una revisión bibliométrica en la base de datos Web of Science durante el período 2011-2020. Asimismo, se han implementado unos indicadores para precisar aquellos documentos que atribuyen validez y calidad al estudio. Finalmente, se analizaron 56 documentos, de los cuales se obtuvo que el país mayor productor ha sido Estados Unidos, aunque fue el Polytechnic Institute of Oporto el que logró el mayor número de publicaciones. La época más prolija tuvo lugar en 2018, pero no alcanzó su auge en citas hasta 2020. Además, se halló que la calidad de artículos y revistas coincidían en un Q2 de la JCR. De igual modo, se observó que gran parte de los documentos analizados centraron sus propuestas tecnológicas en traducción de textos y voz en lenguaje de signos, y concluyen que no hay una gran producción científica sobre el tópico, lo cual se hace necesario, ya que, como se ha observado, las TIC son fundamentales para superar las barreras educativas.

\section{Palabras clave}

Barreras, discapacidad auditiva, TIC, accesibilidad. 


\section{Introducción}

Las personas con necesidades especiales se enfrentan a una variedad de desafíos y barreras diferentes que los aíslan de su entorno. Vallejos-Villanueva et al. (2019) añaden que deben enfrentarse constantemente a una sociedad que construye barreras que dificultan la comunicación. Por su parte, la OMS (2001) clarifica que las barreras para la inclusión engloban todos aquellos factores físicos, sociales y actitudinales que impiden o dificultan la realización plena del individuo; y según Marchetti et al. (2012) también de los profesores, ya que se encuentran sin medios ni competencia comunicativa para interactuar con el alumnado sordo o con pérdida auditiva. En la misma línea, French (2017) estipula una clasificación que engloba barreras estructurales, ambientales y actitudinales. En cambio, Victoriano Villouta (2017) concreta que las barreras son aquellas que obstaculizan la participación. Una participación a la que deberían tener acceso todas las personas y de manera más específica, las personas con discapacidad auditiva. Para ello, es indispensable que cuenten con recursos y apoyos para superar las barreras educativas para poder alcanzar al máximo su desarrollo personal, intelectual, social y emocional (Lledó, 2008); y así, los proponen Zikky et al. (2017), recursos que deben utilizarse como puente a las brechas que aparecen entre las personas oyentes y con discapacidad auditiva. De entre ellos, destaca la emersión de la tecnología tanto en el proceso de interacción como en el juego educativo. Del mismo modo, El-Gayyar et al. (2016) fundamentan que las tecnologías de asistencia ya desarrolladas reducen muchas de las barreras y simplifican la comunicación entre las personas con necesidades especiales y su entorno próximo. Ante esta gran demanda y bajo la perspectiva de implementar en los centros educativos apoyos y herramientas motivadoras, nuestro estudio estará orientado hacia el instrumento más potente con el que cuentan los docentes, las TIC, que de acuerdo con García (2014), con ellas el aprendizaje del alumnado se ve motivado, participa, se implica y muestra interés. Además, se proporciona un enfoque educativo inclusivo moderno que elimina las desigualdades y las barreras educativas en el proceso de aprendizaje y enseñanza (Kourbetis et al., 2016).

Con objeto de realizar un análisis bibliométrico y temático de la producción científica sobre las TIC dirigidas a superar las barreras educativas de las personas con discapacidad auditiva en el campo de la educación, indexada en la base de datos Web of Science, se implementan una serie de indicadores para revisar el estado de la materia durante los últimos 10 años. Asimismo, para su análisis, se han planteado las siguientes preguntas de investigación:

- ¿Los papers en revistas es el tipo de documento más abundantes en la muestra?

- ¿El periodo de producción más elevado genera los artículos más citados?

- ¿Los autores más productivos se corresponden con las instituciones más prolijas?

- ¿Los documentos analizados tienen un índice de multiautoría superior a 4?

- ¿Las revistas identificadas presentan gran prestigio científico en el campo de la discapacidad auditiva?

- ¿Las revistas, en su mayoría, se escalonan en el Q1 del Social Sciences Citation Index? 
- ¿Las herramientas tecnológicas identificadas se presentan como respuesta a la superación de barreras de acceso, aprendizaje y participación?

\section{Método}

\section{Descripción de los participantes}

La muestra de estudio la conforman 56 documentos publicados durante los años 2011 a 2020, excluyéndose el año 2021 por no haber concluido. Es relevante destacar que, de éstos, en su mayoría eran investigaciones empíricas y tan sólo 8 eran estudios teóricos o revisiones. La búsqueda se llevó a cabo sobre publicaciones en inglés y español del tema de estudio la superación de barreras educativas por las personas con discapacidad auditiva a través de las TIC en la base principal de la Web of Science.

\section{Instrumentos}

La investigación se ha llevado a cabo a través de un diseño bibliométrico retrospectivo y descriptivo que, de acuerdo con Ato et al. (2013), admite el registro y análisis de los documentos. Asimismo, con la bibliometría se pretende cuantificar la actividad científica por medio de indicadores que midan los resultados de ésta (Escorcia \& Poutou, 2008). Para su análisis estadístico y bibliométrico se realizó a través de la base de datos internacional y de carácter multidisciplinar, Web of Science.

\section{Procedimiento}

El estudio se realizó en el primer semestre del año 2021. Se efectuaron diversas fases durante el proceso como la búsqueda, selección y lectura y análisis de los datos. Seguidamente, se inició la búsqueda de la muestra acotando las palabras clave y considerando diferentes combinaciones entre las mismas. Finalmente, se seleccionó como estrategia de búsqueda: ("Hearing disability" or "Hearing impairment" or Deaf or "Hearing loss") and (TIC or tech*) and Barriers. Se insertó en el buscador de la colección principal de la Web of Science, obteniendo 239 resultados. Para que la muestra estuviera lo más ajustada al tópico de estudio se realizó un minucioso proceso de refinación implementando diferentes indicadores. En primer lugar, se utilizaron las categorías de la Web of Science para descartar las investigaciones no pertenecientes al campo de la educación, a la discapacidad auditiva y a las nuevas tecnologías, por lo que se depuró con las categorías: Education Educational Research, Education Special, Audiology Speech Language Pathology, Otorhinolaryngology, Computer Science Interdisciplinary application y Computer Science Artificial intelligence. De igual modo, se procedió con las áreas de investigación propias de la base de datos y, para ello, se seleccionaron: Education Educational Research, Otorhinolaryngology, Computer Science y Audiology Speech Language Pathology. En segundo lugar, se escogieron los documentos escritos en inglés y español. En tercer lugar, se redujo la búsqueda a los últimos diez años, excluyendo el año 2021 por no haber finalizado y por no restar validez a la investigación pudiéndose incorporar nuevos documentos en lo que queda de año. Y, por último, se eliminaron las publicaciones que se duplicaban en más de una disciplina y aquellas que, tras su lectura, no se correspondían con el motivo de la investigación. De este modo, se obtuvo una muestra final de 56 documentos para con, la estadística descriptiva, analizar los resultados en función 
los indicadores establecidos como: los países productores e idioma de publicación, autores e instituciones, categorías y áreas de investigación de la Web of Science, tipos de documentos, calidad de revistas, número de artículos y número de citas por año de publicación y el análisis de contenido de los documentos.

\section{Resultados}

A partir de las preguntas de investigación planteadas y en función de los indicadores de estudio, se han obtenido los siguientes resultados:

\section{Países productores e idioma de publicación.}

Como países más productores encontramos Estados Unidos con el 32,1\% de las publicaciones, seguido de Brasil con el 8,9\% y Australia con el 7,1\%. Es interesante destacar también otros países generadores de investigaciones sobre el tópico como pueden ser Inglaterra, Portugal, Arabia Saudí y España con, únicamente, 3 publicaciones $(5,4 \%)$. Esta repartición se refleja en la predominancia del idioma y es que el $98,2 \%$ de los artículos son en inglés, seguido del español con tan solo el 1,8\%.

\section{Autores e instituciones}

Es primordial para profundizar en la actividad científica sobre las TIC como herramienta para la superación de barreras de las personas con discapacidad auditiva, conocer a sus autores y las instituciones de las que proceden. De este modo, encontramos el Polytechnic Institute of Oporto con el 5,4\% de las publicaciones, del que proceden autores como Emanuel Rocha, Joao Ulisses y Paula Escudeiro con 9, 8 y 53 artículos publicados respectivamente. Además, mencionar a la Columbia University con 2 publicaciones (3,6\%) de la que proceden los Jeffrey W. Kysar, Betsy Szeto y Chris Valentini (114, 14 y 4 publicaciones respectivamente), los cuales se posicionan en la tercera posición con mayor número de citas. Hay que destacar también el Instituto Tecnológico de Costa Rica con 2 publicaciones del que provienen Luis Naranjo-Zeledon y Mario Chacón Rivas (5 y 17 publicaciones). Y en sexta posición se encuentra la Universidad de Alicante, también con 2 artículos, de la que destacan autores como Estela Saquete con 37 publicaciones o Jesús Peral con 40, entre otros. Finalmente, en cuanto al índice de multiautoría, los grupos de investigadores científicos que comparten interés sobre el tópico de estudio predominan aquellos que oscilan entre 2 y 4 autores. Las organizaciones o instituciones destacadas a las que se les atribuye la autoría de 2 publicaciones fuente (artículo, libro, acta u otro tipo de trabajo) son IEEE International Computer Science and Engineering Conference; ACM de la Conference on Human Factors in Computing Systems.

\section{Categorías y Áreas de investigación de la Web of Science}

Para el análisis de este apartado, se tuvo en cuenta la clasificación que establece la Web of Science por categorías y áreas. Para la obtención de resultados se seleccionaron en la búsqueda las categorías: la Education Educational Research, Education Special, Audiology Speech Language Pathology, Otorhinolaryngology, Computer Science Interdisciplinary application y Computer Science Artificial intelligence. La primera de las categorías comprende el 30,4\% de los artículos, en la segunda y en la quinta el $7,1 \%$ en cada una, en la tercera y cuarta el $19,6 \%$ y en la sexta el $16,1 \%$. 
Con respecto a las áreas de investigación, se escogieron Education Educational Research que englobaba 22 publicaciones (39,4\%), Computer Science con $21,4 \%$ y con 11 publicaciones $(19,6 \%$ ) en cada una, las áreas Otorhinolaryngology y Audiology Speech Language Pathology.

\section{Tipos de documentos}

En la muestra de estudio se han distinguido 5 tipos de documentos: los artículos de revistas con el $46,4 \%$, las publicaciones a congresos (proceedings paper) con el $37,5 \%$, las review con el $12,5 \%$ y los early acces y material de editoriales con solo el $1,8 \%$ de entre los documentos seleccionados.

\section{Calidad de las revistas}

Una de las variables mas relevantes es la calidad de las revistas en que se publican estos documentos, por lo que se puede destacar que la revista donde se han publicado la mayor cantidad de artículos es International Jounal of Audiology con 5 artículos (8,9\%); en segundo puesto, se sitúa la Journal of the American Academy of Audiology con 3 artículos (5,4\%); y en tercera posición, International Journal of Pediatric Otorhinolaryngology con 2 artículos (3,6\%). En la figura 1 se recoge la calidad de 11 de las 21 revistas donde se han publicado los artículos.

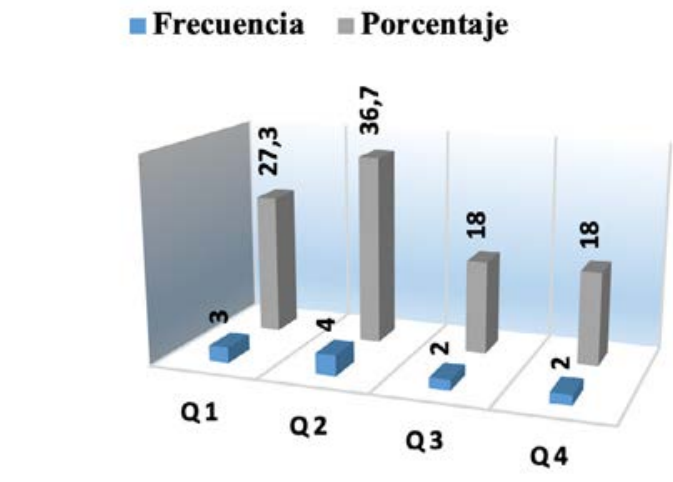

Figura 1. Calidad de las revistas
Frecuencia $\backsim$ Porcentaje

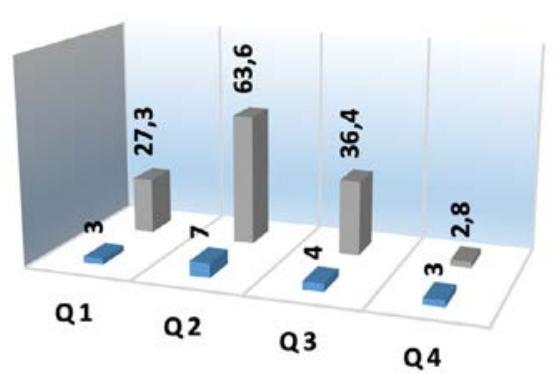

Figura 2. Calidad de los artículos según la revista

Con los resultados de la figura 1, se obtiene que 3 revistas $(27,3 \%)$ pertenecen al cuartil 1 de la Journal Citation Report, 4 revistas $(36,7 \%)$ corresponden al cuartil 2 y con 2 revistas (18\%) tenemos las correspondientes al cuartil 3 y 4 . Por tanto, el mayor número de revistas publicadas, 4 (36,7\%) se sitúan en el Q2.

Desde este análisis y queriendo profundizar más en él, en la figura 2 se presenta la calidad de 11 artículos, de los 27 totales, según el cuartil de la revista donde se ha publicado. Es importante resaltar que los restantes 16 artículos publicados en revistas corresponden al Emerging Sources Citation Index. Además, el 27,3\% de los artículos han sido difundidos en revistas de cuartil 1 y 4 , el $36,4 \%$ se han publicado en revistas del cuartil 3 y los mayores porcentajes de artículos referenciados se hacen en el cuartil 2 con un $63,6 \%$. 


\section{Número de artículos publicados por año de publicación}

Finalizado el análisis de los artículos publicados por año (figura 3), se ha constatado que en el año 2018 tuvo lugar la época más prolija sobre la temática con un $21,4 \%$ de publicaciones llegando a la máxima de 12 artículos. Durante el periodo 2011 a 2020, el segundo puesto de mayor productividad lo ocupan los años 2019 y 2020 con el $16,1 \%$ de los artículos (9), culminando en la tercera posición en el año 2016 con 6 $(10,7 \%)$. Es significativo que en los años 2014 y 2017 las publicaciones desciendan ligeramente la producción general a $2(3,5 \%)$ y 5 artículos $(8,9 \%)$ respectivamente. Finalmente, a la vista de los resultados, en 2020 se observa un decreciente número de publicaciones, pero una mayor cantidad de citas.

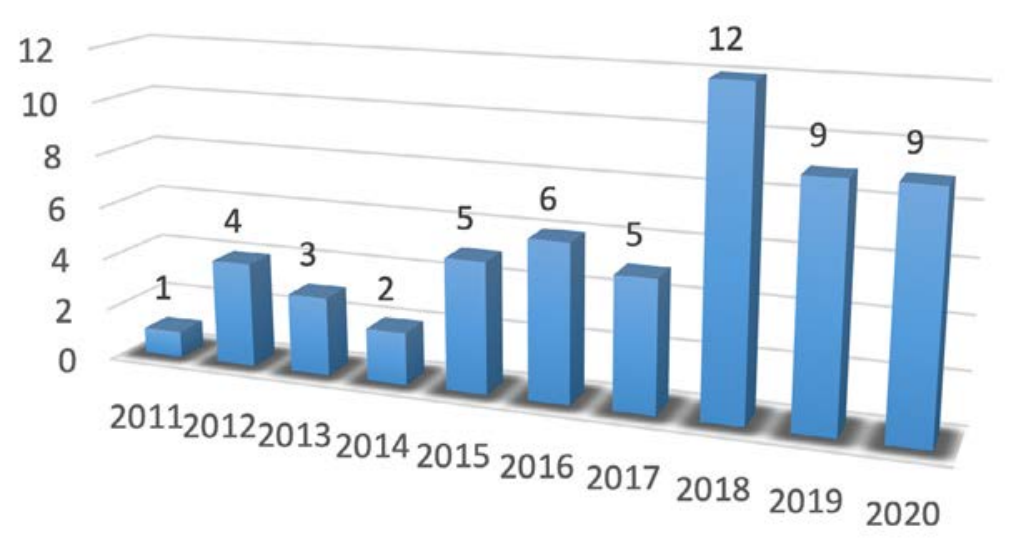

Figura 3. Evolución del número de artículos por año

\section{Número de citas por año de publicación}

Para finalizar, se analizó la evolución temporal del número de citas por año de publicación. Tras analizar la figura 4, se observa que a partir del año 2013 se produce un incremento de citas relacionadas con el tópico de la investigación. A partir de ese año se produce un crecimiento constante (excepto durante el año 2015) hasta el año 2020 donde se alcanza el punto más elevado de citación con 69 citas.

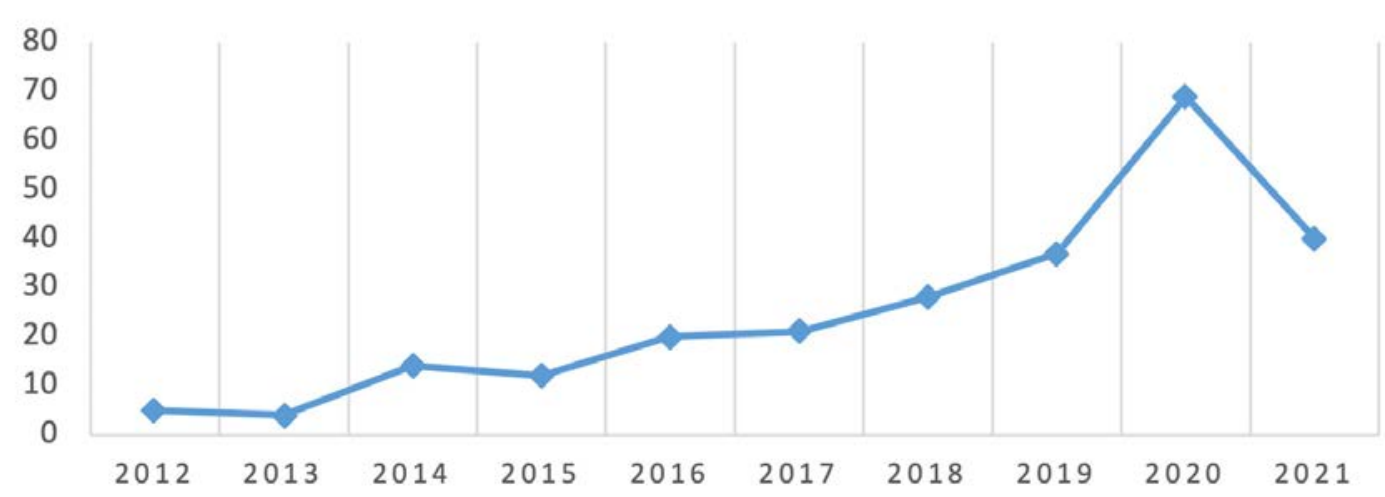


Además, teniendo en cuenta la evolución del número de citas anuales de los artículos, es relevante analizar los 10 artículos más citados y su año de publicación. Estos datos quedan recogidos en la tabla 1.

Meyer, C., \& Hickson, L. (2012). ¿Qué factores influyen en la búsqueda de ayuda para la discapacidad auditiva y la adopción de audífonos en adultos mayores? International journal of audiology, 51(2), 66-74.

$94 \quad 9,40$

Neiva, D. H., \& Zanchettin, C. (2018). Gesture recognition: a review focusing on sign language in a mobile context. Expert Systems with Applications, 103, 159-183.

Szeto, B., Chiang, H., Valentini, C., Yu, M., Kysar, J. W. \& Lalwani, A. K. (2020). Inner ear delivery: Challenges and opportunities. Laryngoscope Investigative Otolaryngology, 5(1), 122-131.

Alyami, H., Soer, M., Swanepoel, A., \& Pottas, L. (2016). Deaf or hard of hearing children in Saudi Arabia: Status early intervention services. International Journal of Pediatric Otorhinolaryngology, 86, 142-149.

Figueiredo, M. Z. D. A., Chiari, B. M., \& Goulart, B. N. G. D. (2013). Communication in deafblind adults with Usher syndrome: retrospective observational study. In CoDAS (Vol. 25, No. 4, pp. 319-324). Sociedade 8 0,89 Brasileira de Fonoaudiologia.

Mckee, M., Moran, C., \& Zazove, P. (2020). Overcoming additional barriers to care for deaf and hard of hearing patients during COVID-19. JAMA Otolaryngology-Head \& Neck Surgery, 146(9), 781-782.

Saunders, G. H. \& Chisolm, T. H. (2015). Connected Audiological Rehabilitation: 21st Century Innovations. Journal of the American Academy of Audiology, 26(9), 768-776.

$7 \quad 1,00$

Cohn, E. R., \& Cason, J. (2012). Telepractice: A Wide-Angle View for Persons with Hearing Loss. Volta Review, 112(3).

El-Gayyar, M. M., Ibrahim, A. S., \& Wahed, M. E. (2016). Translation from Arabic speech to Arabic Sign Language based on cloud 6 1,00 computing. Egyptian Informatics Journal, 17(3), 295-303.

Rolfe, C., \& Gardner, B. (2016). Experiences of hearing loss and views towards interventions to promote uptake of rehabilitation support among UK adults. International journal of audiology, 55(11), 666-673.

7

0,70

0,70

$6 \quad 1,00$

\section{Tabla 1. Los 10 artículos más citados del estudio.}

El promedio de citas por elemento es de 4,45. El artículo más citado corresponde a Meyer \& Hickson (2012) con un valor de 94 citas y un promedio de 9,40 citas anuales. El segundo artículo pertenece a Neiva \& Zanchettin (2018) y tiene 18 citas con un promedio de 4,50 citas. El último de los artículos presenta un número relativamente bajo con 6 y solo 1 cita anual. 


\section{Análisis de contenido}

El análisis del contenido de los documentos permitió identificar 9 categorías temáticas. Los resultados mostraron que los recursos tecnológicos predominantes en la muestra son los traductores de textos y voz en lenguaje de signos, puesto que, en casi todos los documentos, los estudios están relacionados con el área de la comunicación. Se ha de destacar que la mayoría de los documentos tratan las barreras que tienen las personas sordas o con pérdida auditiva y no tanto, aportaciones de recursos tecnológicos para la superación de esos obstáculos. Seguidamente, y con carácter descriptivo, se presenta el contenido temático de la producción científica analizada:

\section{Escucha y lenguaje hablado y manual}

En esta categoría encontramos gran cantidad de estudios que señalan barreras, como el acceso a audífonos y sus reparaciones, pedir ayuda o la escasez de profesionales para atender a niños sordos o con problemas de audición. Por lo que, expresan su deseo de una mayor capacitación en tecnología auditiva avanzada. En otro sentido, también se presentan investigaciones sobre tecnología auditiva, de entre las que destacar:

- La Realidad virtual, sistema de aprendizaje de lenguaje de señas asistido por computadora que incorpora la realidad virtual.

- Tecnología bimodal: por reconocimiento de voz, a través de la construcción de una base de datos que utiliza audio y video para ayudar al aprendizaje.

- Recurso big data, Dispositivos móviles y Plataforma web abierta que desarrolla, compila y ejecuta aplicaciones de traducción de voz a lenguaje de señas. Se utiliza el reconocimiento de voz, se representa mediante avatar y la gramática de traducción está adaptada a la lengua de signos.

- BDC-APP. Proporciona cursos abiertos masivos en línea y juegos utilizados en la educación. Incorpora traductor de lenguaje de señas 3D, traducción gramatical, reconocimiento de voz y conversión de texto a voz.

- LESCO Translator: Traductor que tiene en cuenta la gramática de la Lengua de Signos Española y Costarricense.

- Sistem Isvarat Bahasa Indonesia (SIBI). Aplicaciones de juegos para aprender conocimientos básicos del lenguaje de señas e interactuar con otros.

- ProSign: prototipo de software móvil. Es una herramienta eficaz de comunicación y aprendizaje para utilizar en diferentes situaciones específicas.

- SignMedia SMART ofrece un glosario gratuito de 500 términos en cuatro idiomas de señas nacionales en una plataforma móvil.

\section{Reconocimiento e imitación del sonido}

En esta categoría se han investigado las barreras acerca del implante coclear. Barreras como es que el seguro de salud no da acceso básico al sonido y las tareas de 
imitación en niños con implantes cocleares, lo que provoca un retraso significativo en el logro de la competencia. Así como barreras en la escucha y producción las combinaciones del tono, timbre y ritmo, dado que el tono y el timbre se transmiten mal a través del IC.

\section{Lectura y escritura}

Varias propuestas de estudio apuestan por poder comunicarse a través de internet y del uso de las TIC. En concreto destaca una aplicación interactiva en la que el contenido se presenta en lengua de signos. La forma electrónica multimedia de los libros híbridos combina la presentación del libro impreso, el texto en subtítulos debajo del video, videos con navegación de textos, así como la grabación de audio del texto por un hablante nativo.

\section{Comprensión lectora}

Las investigaciones señalan que para facilitar la comprensión lectora podrían utilizarse: una herramienta capaz de transformar textos educativos en lenguaje natural en español y en textos de muy fácil lectura; otra opción propuesta es realizar videos de signos segmentados en secuencia de imágenes fijas; y, por último, se propone una aplicación software que consiste en crear descripciones emergentes en video y en lenguaje de señas para que aparezcan cuando el usuario pase el cursor sobre un icono.

\section{Locomoción y comunicación}

El informe de casos detectado sobre esta categoría se centra en estudiar si los síntomas de esta discapacidad le han afectado en su actividad diaria, si encuentran dificultades, si afecta en sus relaciones sociales y si utilizaban formas alternativas de comunicación, pero no abarca herramientas tecnológicas para dar una respuesta educativa a las barreras mencionadas.

\section{Rehabilitación audiológica e investigación auditiva}

Esta categoría es la segunda con mayor producción. De entre sus estudios destacan los teléfonos inteligentes para la rehabilitación audiológica o como complemento de las pruebas audiométricas tradicionales utilizando un programa de monitoreo de ototoxicidad. Con ello, se reducen las barreras para el acceso a pruebas eficientes en el tiempo, portátiles y autoadministradas para su uso en la clínica y en el hogar del paciente. Asimismo, se propone la participación activa del paciente en la sintonización del audífono con un prototipo de simulador de sonido. Por último, varios estudios profundizan en la teleintervención o telepráctica. Se trata de un modelo de prestación de servicios para personas con pérdida auditiva, sobre todo servicios preventivos, de habilitación o de rehabilitación a través de la tecnología de telecomunicaciones. La telemedicina y telesalud están estrechamente alineadas con la telepráctica.

\section{Tecnología remota y redes sociales}

Los autores han estudiado las barreras y proponen la tutoría síncrona y remota para la comunidad académica virtual sorda, así como el uso de redes sociales para la instrucción. 


\section{Interacciones sociales}

Las interacciones sociales presentan barreras en la competencia comunicativa con el docente, el intérprete de la lengua de signos y la poca accesibilidad a los materiales y productos educativos. Los investigadores presentan como recursos tecnológicos móviles el Personal Digital Assistant (PDA) y SESSAI (aplicación para interactuar a través de un sistema de reconocimiento automático).

\section{Juegos para la comunicación y la inclusión social}

En esta categoría se estudian barreras en la existencia de variedad de juegos serios y herramientas que sean accesibles para las personas con discapacidad auditiva. Se presenta una plataforma que permite la creación de juegos educativos, del género Quiz con la posibilidad de integrar la tecnología iBeacon. Utiliza síntesis de voz Virtual Sign (traductor de lenguaje de señas bidireccional) y control por comandos de voz.

\section{Discusión y conclusiones}

A lo largo del desarrollo de la presente investigación se ha pretendido analizar, en función de una serie de indicadores, cuál ha sido la producción científica sobre las TIC dirigidas a superar las barreras educativas de las personas con discapacidad auditiva en el periodo 2011-2020. A partir de los resultados obtenidos, se concluye que el tópico está en continua expansión, aunque no se han localizado gran cantidad de publicaciones que investiguen este motivo, lo cual se hace necesario debido a que un entorno con barreras restringirá la labor del individuo (World Health Organization, 2001). Es por ello, por lo que, con el aumento del uso de contenido digital en la educación, las comunidades de personas sordas enfrentaran barreras de comunicación que, como resultado, hacen que la educación sea más inclusiva (Ulisses et al., 2018). Por el contrario, Escudeiro et al. (2018) opinan que la mayoría de las herramientas utilizadas para la difusión de información siguen siendo inaccesibles para ellas. En la misma línea, Rocha \& Escudeiro (2018) creen que, a pesar de la evolución de la ciencia y la disponibilidad de nuevas tecnologías para combatir y promover la igualdad de oportunidades y la inclusión social, aún existe una gran dificultad en la comunicación de estas personas y con los diferentes entornos en los que se insertan.

Respecto a las preguntas de investigación planteadas al comienzo, podemos indicar que la muestra no ha sido muy abundante y es que tal y como determinan El-Gayyar et al. (2016) las investigaciones aún no presentan marcos o recursos de apoyo suficientes a las personas sordas o con pérdida auditiva. Los hallazgos se localizan en los países estadounidenses, con el inglés como el idioma predominante y con los artículos en revistas como tipo de documento más abundante de la muestra de estudio. El periodo de producción más elevado fue en 2018 que, pese a estar en plena efusión, no coincidió con el año que alcanzó el punto más álgido de citas, produciéndose en 2020. En lo que atañe a las instituciones más prolijas, se pueden destacar el Polytechnic Institute of Oporto, Columbia University o el Instituto Tecnológico de Costa Rica entre los que se encuentran los autores más productivos como son Escudeiro, Kysar o Chacón Rivas de entre los más de cien autores que investigan sobre este tópico tan necesario y, es que, según Valencia et al. (2016) las TIC son un medio imprescindible para incluir en las metodologías de aprendizaje y estrategias 
educativas. Asimismo, es relevante señalar que el índice de multiautoría refleja que prevalecen los estudios con grupos de investigadores de entre 2 y 4 autores. Subrayar, además, la presencia en revistas de reconocido prestigio como por ejemplo la International Journal of Audiology. La mayor parte de las revistas se posicionan en un Q2 de la Journal Citation Report y, con tan solo, el diez por ciento menos, es decir el 27,3\% pertenecen al cuartil 1. En resumen, la temática de investigación está en constante crecimiento, lo cual ha llevado a conocer las barreras de las personas con discapacidad auditiva que destacaban los autores y algunos recursos TIC para darles respuesta, aunque tal y como indican Alnfiai \& Sampali (2017), poca investigación ha abordado cómo las nuevas tecnologías pueden ayudar a abordar estos obstáculos. Por su parte, la temática identificada está destinada a potenciar la superación de barreras de acceso, aprendizaje y participación, porque de acuerdo con Kimball et al. (2018), las sociedades modernas se han transformado por la adopción ubicua de la comunicación digital avanzada que ofrece la superación de barreras educativas.

Como investigación futura, se plantea la posibilidad de extender el estudio a otras bases de datos lo que permitiría trabajar con una mayor muestra y comprobar con ello si son suficientes los recursos TIC identificados destinados a potenciar la superación de barreras de acceso, aprendizaje y participación.

\section{Referencias}

Alnfiai, M., \& Sampali, S. (2017, September). Social and Communication Apps for the Deaf and Hearing Impaired. In 2017 International Conference on Computer and Applications (ICCA) (pp. 120-126). IEEE.

Ato, M., López, J.J., \& Benavente, A. (2013). Un sistema de clasificación de los diseños de investigación en psicología. Anales de Psicología, 29(3), [pp.] 1038-1059. Recuperado de https://dx.doi.org/10.6018/analesps.29.3.178511

El-Gayyar, M. M., Ibrahim, A. S., \& Wahed, M. E. (2016). Translation from Arabic speech to Arabic Sign Language based on cloud computing. Egyptian Informatics Journal, 17(3), 295-303.

Escorcia-Otálora, T. A., \& Poutou-Piñales, R. A. (2008). Análisis bibliométrico de los artículos originales publicados en la revista Universitas Scientiarum (1987-2007). Universitas Scientiarum, 13(3), 236-244.

Escudeiro, P., Marques, B., Carvalho, P., Barata, A., Quirón, P., Sousa, A. D., ... \& Ulisses, J. (2018, October). Educational content using Blind/Deaf Communications API. In Proceedings of the Sixth International Conference on Technological Ecosystems for Enhancing Multiculturality (pp. 100-104).

French, S. (2017). Disabled people and employment: A study of the working lives of visually impaired physiotherapists. Routledge.

García, M. (2014). Las TICs aplicadas a las Necesidades Educativas Especiales. (Trabajo Final de Grado en Educación Primaria). Recuperado de https://uvadoc.uva.es/ bitstream/handle/10324/8376/TFG-O\%20376.pdf? sequence=7 
Kimball, S. H., Singh, G., John, A. B., \& Jenstad, L. M. (2018). Implicatios and attitudes of audiologists toward smartphone integration in hearing healthcare. Hearing research, 369, 15-23.

Kourbetis, V., Boukouras, K., \& Gelastopoulou, M. (2016, July). Multimodal accessibility for deaf student using interactive video, digital repository and hybrid books. In International Conference on Universal Access in Human-Computer Interaction (pp. 93-102). Springer, Cham.

Lledó, A. (2008). Claves para una respuesta educativa inclusiva en el alumnado con discapacidad auditiva. En La Discapacidad Auditiva, un modelo de educación inclusiva. Barcelona: Edebé.

Marchetti, C., Foster, S., Long, G., \& Stinson, M. (2012). Crossing the Comunication Barrier: Facilitating Communication in Mixed Groups of Deaf and Hearing Students. Journal of Postsecondary Education and Disability, 25(1), 51-63.

Rocha, E., \& Escudeiro, P. (2018, October). Meta-Model of Serious Game Mechanics for Deaf and Blind. In European Conference on Games Based Learning (pp. 907-XXIII). Academic Conference International Limited.

Ulisses, J., Oliveira, T., Rocha, E., Escudeiro, P. M., Escudeiro, N., \& Barbosa, F. M. (2018, September). Blind/Deaf Comunication API for Assisted Translated Educational Digital Content. In 2018 28th EAEEIE Annual Conference (EAEEIE) (pp. 1-9). IEEE.

Valencia, T., Serna, A., Ochoa, S., Caicedo, A., Montes, J. \& Chávez, J. (2016). Competencias y estándares TIC desde la dimensión pedagógica. Recuperado de Competencias y estándares TIC desde la dimensión pedagógica (icesi.edu.co)

Vallejos-Villanueva, M., Naranjo-Zeledón, L., \& Chacón-Rivas, M. (2019, October). Deaf community integration: sociotechnical systems. In 2019 International Conference on Inclusive Technologies and Education (CONTIE) (pp.196-1964). IEEE.

Victoriano Villouta, E. (2017). Facilitadores y barreras del proceso de inclusión en educación superior: la percepción de los tutores del programa Piane-UC. Estudios pedagógicos (Valdivia), 43(1), 349-369. Recuperado de https://dx.doi.org/10.4067/ S0718-07052017000100020

World Health Organization (2001). Clasificación internacional del funcionamiento de la discapacidad y de la salud: CIF

Zikky, M., Hakkun, R. Y., Rizqi, A. F. A., Hamid, A., \& Basuki, A. (2017, November). Development of educational game for recognizing Indonesian sign language (SIBI) and breaking down the communication barrier with deaf people. In 2017 21st International Computer Science and Engineering Conference (ICSEC) (pp. 1-6). IEEE. 


\section{Resultados Descriptivos del Análisis de Noticias por Parte de Estudiantes Universitarios Posterior a un Seminario sobre Noticias Falsas en Redes Sociales}

Meza Cano, José Manuel orcid.org/0000-0002-9504-7906 Facultad de Estudios Superiores Iztacala, UNAM, México manuel.meza@iztacala.unam.mx

\section{González Santiago, Edith}

orcid.org/0000-0002-7876-6079

Facultad de Estudios Superiores Iztacala, UNAM, México edith.gonzalez@iztacala.unam.mx 


\title{
RESULTADOS DESCRIPTIVOS DEL ANÁLISIS DE NOTICIAS POR PARTE DE ESTUDIANTES UNIVERSITARIOS POSTERIOR A UN SEMINARIO SOBRE NOTICIAS FALSAS EN REDES SOCIALES
}

\author{
Meza Cano, José Manuel \\ González Santiago, Edith
}

\section{Resumen}

Las noticias falsas se han convertido en un problema que pueden tener un impacto en la salud, para ello, fomentar el pensamiento crítico a través de la argumentación se considera importante. Se realizó un seminario de diez sesiones sobre noticias falsas en redes sociales en donde participaron 17 estudiantes de psicología, en la novena sesión contestaron a un instrumento con diez noticias acerca de COVID-19, una escala likert para valorar la veracidad percibida y una pregunta abierta para argumentar su puntuación. Estas noticias fueron elegidas dado que contenían elementos de verdad/falsedad mezclados o fueron noticias tendenciosas y fueron evaluadas previamente por un juez externo quien valoró cada una como Verdadera o Falsa y si presentaron o no evidencia en el texto. Los participantes tuvieron semejanzas y discrepancias con respecto al juez en noticias que mezclan elementos verdaderos y falsos. Las argumentaciones presentaron elementos de pensamiento crítico, especialmente relacionados con procedimientos deductivos como la contrastación de fuentes y con el conocimiento previo, además de búsqueda complementaria de información. Se concluye que es necesario crear este tipo de espacios académicos para favorecer el pensamiento crítico, lo cual puede derivar en intervenciones posteriores que promuevan la toma de decisiones cruciales para el propio cuidado en el contexto de la pandemia por COVID-19.

\section{Palabras clave}

Formación, argumentación, noticias falsas, covid-19, evaluación. 


\section{Introducción}

Difundir información sin verificar la veracidad no es algo nuevo, pero las noticias falsas tuvieron un rápido crecimiento alrededor del siglo XIX (Parra y Oliveira, 2018). En una revisión sistemática que realizaron estos autores se describe cómo a lo largo de la historia, la creación y difusión de noticias falsas, pasó de ser un gancho para aumentar ventas a un instrumento político para manipular masas. A decir de De Ágreda (2018) a partir del surgimiento de las redes sociales digitales, cualquiera puede publicar contenido sin someterlo previamente a los canales de distribución establecidos, en donde la reputación está en función del número de seguidores y la veracidad de los datos no es lo principal, por lo que es la sociedad la que debe aprender a diferenciar los elementos de verdad o falsedad en las noticias.

Según Montero-Liberona y Halpern (2019), las noticias falsas don información sin una base objetiva o que se presenta como real, de manera masiva y a gran escala, por lo que las redes sociales se han vuelto un factor importante para su viralización. El Boletín de la Universidad Nacional Autónoma de México (2020), afirma que, en el contexto mexicano, la red más empleada es Facebook con 82 millones de usuarios y al menos 70 millones asegura haber recibido mensajes que pueden ser erróneos o falsos.

El contexto de la pandemia agrava el problema, pues las noticias falsas pueden conducir a comportamientos que ponen en peligro la vida, por lo tanto es necesario buscar el balance entre la libertad de expresión e información pero la preservación de la salud, para ello pueden emplearse soluciones centradas en las personas a través de acciones educativas (Marco-Franco et al., 2021). Para ello, es necesario revisar algunas variables psicológicas que pueden incidir en la evaluación de noticias en redes sociales e Internet.

\section{Aspectos psicológicos relacionados con la evaluación de noticias}

Como se ha señalado el receptor es un elemento clave, pues al recibir una noticia entran en juego aspectos psicológicos. Entre ellos se encuentran el conocimiento previo del tema. Castillo-Riquelme et al, (2021) afirman que es importante el acercamiento entre el contenido de la noticia y el conocimiento previo del lector, siendo más fácil aceptar una noticia como verdad cuando el contenido cuenta con distorsiones sutiles sobre los hechos que ya se conocen. Asimismo, la credibilidad en la fuente de la que procede la noticia activa la toma de decisiones con base en la veracidad percibida (Montero-Liberona y Halpern, 2019).

Según Castillo-Riquelme et al, (2021) algunas personas se guían por sus primeras impresiones, minimizando los esfuerzos cognitivos adecuados para discernir elementos de verdad de los que no lo son, lo cual está asociado a la falta de análisis crítico, estos atajos son referidos como sesgos cognitivos. Pennycook y Rand (2018) afirman que las personas que se sobreestiman en sus habilidades y conocimientos (sesgo de sobreconfianza) tienden a asumir familiaridad en temas de los que no tienen conocimiento, basándose en sus intuiciones. Al parecer existe una asociación negativa entre la disposición para pensar analíticamente una noticia y dos factores: la sobreestimación de uno mismo y la veracidad percibida de las noticias falsas. Esto es preocupante cuando las encuestas sugieren que los ciudadanos no confían en la información de los medios de comunicación, pero se sienten razonablemente seguros de su capacidad para distinguir las noticias falsas de las reales (Marco-Franco et al., 2021). 
Otro aspecto importante son los hábitos de consumo de información en Internet, Galarza (2021) indagó sobre la percepción de las noticias falsas como verdaderas y la relación con la frecuencia de consumo de noticias en diferentes medios, encontrando que las personas que consumen información a través través de periódicos (impresos y en línea) tienen una menor tendencia a creer en las noticias falsas sobre COVID-19. En línea con estos hallazgos, se considera que una variable pertinente es el desarrollo del pensamiento crítico, a partir del fomento de la argumentación, pues con ello se pueden favorecer otras habilidades como el pensamiento analítico o el cuestionamiento de las propias creencias.

\section{La argumentación como medio para el desarrollo de pensamiento crítico}

La formación y evaluación del pensamiento crítico en estudiantes se encuentra dentro de los estándares educativos a nivel global, así lo han declarado los organismos internacionales (OCDE, 2019; UNESCO, 2020). En un estudio realizado por la LLECE en 2019 (UNESCO, 2020) se menciona la importancia de prestar atención al área de decodificación, reflexión y evaluación de textos como parte de una comprensión lectora que haga frente a la actual época donde se consumen grandes cantidades de información a través de los medios electrónicos, específicamente se centra en la reflexión y evaluación de textos dado que se trata de una destreza relevante en este contexto, en donde las personas están expuestas a textos de dudosa calidad o a información sesgada en Internet. En este estudio se concluye que los aprendizajes vinculados a estas áreas relacionadas a la comprensión lectora podrán incentivar el desarrollo del pensamiento crítico.

Cardozo y Pinto (2017) mencionan la importancia del pensamiento crítico como una habilidad transversal que todo docente debería fortalecer en el estudiantado, como una forma de vivir la ciudadanía desde el juicio crítico ante su acontecer. Estos autores afirman que sólo a través de la argumentación, oral o escrita, es posible generar reflexión ya que "emitir un juicio sobre la realidad no puede quedarse en la acción pasiva del mismo, es necesario constatar que tal realidad es así y dar razón del porqué es así" (pág. 30). En contexto con el tema de este trabajo, la importancia de la argumentación no sólo radica en el desarrollo de un pensamiento crítico que permita hacer frente a la cantidad de información; la argumentación proporciona las bases, desde la escritura y la lectura, para la discriminación de noticias falsas de las que son reales o con sustento científico. De Zubiría (2006) describe tres funciones de la argumentación: sustentar, convencer o evaluar, esta última función cobra relevancia al ser una función que permite la indagación y evaluación de distintas fuentes u opciones para la libre elección.

Un argumento es una proposición, es una oración aislada que significa algo que debe justificarse. Mientras una opinión es subjetiva y personal que persigue el beneficio particular siguiendo una lógica de conveniencia, un argumento presenta características claras (Cardozo y Pinto, 2017): es probabilístico, ramificado, multidimensional, complejo y multideterminado que implica reconocer la discrepancia o conflicto, a su vez, es un medio para encontrar la verdad. Existen argumentos de distintos tipos: los causales llevan a que se produzca lo afirmado, los empíricos que ejemplifican lo afirmado, los analógicos discurren de un caso/ejemplo específico de otro, los de autoridad recurren a una fuente imparcial, bien informada que sustenta lo afirmado y los deductivos que recurren a leyes generales para sustentar lo afirmado. 
Alcolea (2020) apela a la racionalidad como la defensa de la razón, declara que la argumentación es una interacción racional y social que fortalece el pensamiento crítico y el desarrollo de habilidades lógicas como cuestionar la credibilidad de fuentes de información. Además, se debe estar dispuesto a apoyar una posición en medida de lo racional y estar bien informado, proporcionar fuentes confiables, tener en cuenta el contexto global, ser empático con los distintos niveles de conocimiento y sofisticación de los demás, así como de sus sentimientos, tener siempre la mente abierta a los distintos puntos de vista o argumentos proporcionados que sean distintos a los que se defienden.

Lo mencionado por los autores citados, dan cuenta de la importancia de contar con espacios donde los estudiantes ejerciten el diálogo y la argumentación de forma guiada en un entorno estructurado que permita el desarrollo de habilidades relacionadas, en primer lugar, a la comprensión lectora seguida de la escritura, el pensamiento crítico y la argumentación. ¿Qué ven en una noticia? ¿Cómo discriminan sus fuentes de información? y más importante ¿Cómo argumentan su postura ante una noticia? En este escenario se desarrolló un seminario para discutir los aspectos psicológicos que pueden influir en la discriminación de noticias falsas en redes sociales. Como consecuencia, los participantes obtuvieron un amplio conocimiento sobre estrategias a emplear para analizar las noticias y ejercer el pensamiento crítico, para ejercitar estas habilidades se diseñó un instrumento que incluyó diez noticias. Por lo anterior, el objetivo de este trabajo es describir la evaluación por parte del grupo del seminario de diez noticias sobre COVID-19.

\section{Método}

Estudio descriptivo, con un enfoque mixto, de corte transversal, pues la evaluación de las noticias se dio en un único momento.

\section{Descripción del contexto y de los participantes}

El grupo estuvo conformado por 17 estudiantes pertenecientes a las licenciaturas en psicología de la FES Iztacala, UNAM, México, del sistema escolarizado y a distancia. Edad media de 29.7 años, 13 mujeres y 4 hombres.

\section{Instrumentos}

Según Galarza (2021) la evaluación de noticias falsas puede tener un efecto "suelo", puesto que puede ser demasiado obvia su falsedad. Aunado a esto, a pesar de algunos sitios de Internet mexicanos con buena intención, no existe como tal una verificadora de noticias falsas que publique cotidianamente en el contexto nacional. Por lo tanto se seleccionaron 10 noticias sobre Covid-19 que tuvieran diferentes niveles de falsedad o que incluyeran información tendenciosa o desinformación (Bernal-Triviño y Clares-Gavilán, 2019). Estas noticias fueron previamente revisadas por un juez sin formación específica sobre análisis de noticias, contó con nivel licenciatura, quien etiquetó cada noticia como verdadera (V) o falsa (F) y describió si mostraban evidencia en el texto. Posteriormente, para el uso con el grupo en formación, se empleó Formularios de Google con un consentimiento informado, una pregunta sobre el nivel de pericia para diferenciar las noticias falsas y las diez noticias sobre COVID-19. En cada reactivo se mostró el título de la noticia, el enlace a la noticia y la 
pregunta ¿Qué tan verdadera consideras que es la noticia? y una escala en donde 1 indicaba Nada verdadera y 10 Totalmente verdadera. Posteriormente se solicitó que argumentaran su puntuación en un campo de respuesta abierto.

\section{Procedimiento}

El escenario fue un seminario en línea titulado "Aspectos psicológicos sobre noticias falsas en redes sociales" llevado a cabo del 25 de febrero al 6 de mayo de 2021, para un total de 10 sesiones y 20 horas de trabajo. Las sesiones semanales tuvieron una duración promedio de 90 minutos empleando Google meet. El coordinador dirigió cada sesión sincrónica en la cual se revisaron y discutieron los siguientes temas y productos académicos: Posverdad y noticias falsas (Gómez, 2019), Creencias epistemológicas (Perry, 1970), El concepto de noticias falsas: fake news, desinformación (Rodríguez, 2019), Análisis de noticias falsas en redes sociales (Sued y Rodríguez, 2019), ¿Cómo trabaja una verificadora de noticias falsas? (Bernal-Triviño y Clares-Gavilán 2019), Factores implicados en la difusión de noticias falsas (De la Fuente, 2018), Noticias falsas y aspectos cognitivos (Castillo-Riquelme et al., 2021), Noticias falsas y salud (Montero-Liberona y Halpern, 2019), Alfabetización visual (Domínguez, 2020) y el cierre del seminario. Al término de cada sesión los participantes realizaron actividades de reflexión, análisis y resúmenes de los artículos revisados, las entregas se realizaron a través de Google Classroom. Posterior a la sesión 9 se solicitó a los participantes contestar al instrumento, durante la sesión 10 se discutieron los resultados con el grupo.

\section{Resultados}

Respecto al nivel de habilidad para diferenciar noticias falsas, en donde $1=$ Nulo y 10 = experto, el grupo contestó con una media de $M=7.35$, DE=1.45. Por lo que se puede ver que en su mayoría se valoraron con buenas habilidades. Para mostrar la evaluación grupal de cada noticia y el contraste con respecto al juez se realizó la tabla 1.

\begin{tabular}{|c|c|c|c|c|}
\hline \multirow[b]{2}{*}{ Noticia } & \multicolumn{2}{|c|}{ Juez } & \multicolumn{2}{|c|}{ Grupo } \\
\hline & $V \circ F$ & Evidencia & $M$ & DE \\
\hline $\begin{array}{l}\text { Ncovid1.Miguel Bosé: “El coronavirus es la gran } \\
\text { mentira de los gobiernos". https://www.elperiodico. } \\
\text { com/es/gente/20200605/miguel-bose-covid-19- } \\
\text { coronavirus-7988374 }\end{array}$ & $F$ & No & 6.70 & 3.21 \\
\hline $\begin{array}{l}\text { Ncovid2. Proyecto ID 2020: ¿micro-chip en la vacuna } \\
\text { para el Covid-19? https://www.portafolio.co/tendencias/ } \\
\text { proyecto-id-2020-micro-chip-en-la-vacuna-del- } \\
\text { covid-19-545130 }\end{array}$ & V & No & 4.70 & 3.21 \\
\hline $\begin{array}{l}\text { Ncovid3. Muere voluntario de la vacuna contra la COVID-19 } \\
\text { de AstraZeneca en Brasil https://www.aa.com.tr/es/mundo/ } \\
\text { muere-voluntario-de-la-vacuna-contra-la-covid-19-de- } \\
\text { astrazeneca-en-brasil-/2014526\# }\end{array}$ & V & No & 5.94 & 3.17 \\
\hline $\begin{array}{l}\text { Ncovid4. Nosode, tratamiento contra el COVID-19 que ha } \\
\text { salvado miles de vidas https://www.elvalle.com.mx/estado- } \\
\text { de-mexico/story/19618/nosode-tratamiento-contra-el- } \\
\text { covid-19-que-ha-salvado-miles-de-vidas }\end{array}$ & $\mathrm{F}$ & No & 3.76 & 2.51 \\
\hline
\end{tabular}


Ncovid5. Cuba aplicará a su población medicamento homeopático para prevenir la COVID-19 https://www. cadenagramonte.icrt.cu/articulos/ver/95094:cubaV No aplicara-a-su-poblacion-medicamento-homeopatico-paraprevenir-la-covid-19

Ncovid6. Vacuna COVID-19 de AstraZeneca sí tiene vínculo claro con trombosis: Responsable de EMA https:// noticieros.televisa.com/ultimas-noticias/vacuna-covid19-de-astrazeneca-si-tiene-vinculo-claro-con-trombosisresponsable-de-ema/

Ncovid7. Preocupación de infertilidad por vacunas contra el COVID-19 https://www.telemundo51.com/noticias/ local/preocupacion-de-infertilidad-por-vacunas-contra-elcovid-19/2171638/

Ncovid8. Estudio avala el uso del dióxido de cloro para prevenir y curar covid-19 https://www. humanosporlaverdad.com/noticias/estudio-avala-el-uso-

del-dioxido-de-cloro-para-prevenir-y-curar-codiv-19

Ncovid9. No hay necesidad de vacunas porque no hay pandemia https://www.instagram.com/p/CL12_DOH5c/?igshid=e49j8zvrdtmj

Ncovid10. El miedo a los trombos con la vacuna de AstraZeneca obstaculiza el camino de regreso a la vida normal https://elpais.com/ciencia/2021-04-07/el-miedo-alos-trombos-con-la-vacuna-de-astrazeneca-obstaculiza-elcamino-de-regreso-a-la-vida-normal.html?ssm=TW_CM

\begin{tabular}{ll|ll}
$V$ & No & 4.88 & 2.9 \\
\end{tabular}

\section{Tabla 1. Muestra ID de cada noticia, el titular y enlace, la valoración del juez, así como la media y la desviación estándar del grupo.}

La noticia con un valor más alto, más creíble, fue Ncovid10 8M=7.05 DE=3.13), mientras que la noticia con una media menor fue Ncovid9 ( $M=1.35 \mathrm{DE}=1.05)$. Noticias como Ncovid2 se acerca al valor de 5, por lo que no era ni totalmente falsas, ni totalmente verdadera. Respecto a la comparación con el juez existieron concordancias, como en Ncovid9 en donde tanto el juez como el grupo la valoraron como falsa, sin embargo, en casos como Ncovid1 el juez la marcó como falsa, pero el grupo con una tendencia hacia verdadera. En relación con la evidencia mostrada en las noticias, el juez marcó como noticias con evidencias en el caso de Ncovid6 y Ncovid10, lo que parece coincidir con su juicio de ser verdaderas, mientras que el grupo coincidió en el caso de Ncovid 10 con tendencia a verdadera. A pesar de mostrar evidencia, tanto el juez como el grupo marcaron el caso de Ncovid8, con tendencia hacia falsa.

Con la finalidad de dar cuenta de las argumentaciones de los participantes respecto a las noticias, se presentan a continuación algunos fragmentos realizados por ellos, así como el ID clave de la noticia y la valoración que hicieron de ella en la escala de 1 a 10.

En la noticia Ncovid1 el participante P9 colocó el valor de 8, argumentando lo siguiente:

"La noticia es verdadera... Sin embargo, el que él la crea no la hace verdad. Además el sitio está inundado de anuncios y el título es sensacionalista para tener clicks y vistas a la página." 
Como puede notarse, su argumento va en contra de la autoridad que podría representar el sujeto que emitió la opinión de la noticia, además de que hace alusión no sólo al contenido, sino también al aspecto gráfico de la página y a la posible finalidad de la fuente, más allá de informar, obtener visitas.

En la noticia Ncovid2 el participante P17 colocó el valor de 1, argumentando lo siguiente:

“...casi al final el mismo artículo niega los rumores acerca del chip en la vacuna, el título es muy engañoso y es necesario leer todo el artículo para darnos cuenta que es falso."

En esta argumentación es de importancia señalar que aplica estrategias como es el revisar la totalidad del artículo, no únicamente el título o los primeros párrafos, para así emitir un juicio sobre la noticia.

En la noticia Ncovid3 el participante P7 asignó el valor de 3, y argumentó:

"...Ofrece datos muy sesgados con respecto a las cifras de fallecidos en los países que enumera ya que solo ofrece la cifra... es decir los países que se nombran son países que cuentan con una considerable extensión territorial y por ende cuentan con mayor número de habitantes bajo esa lógica los países con amplio territorio físico tenderán a arrojar datos de fallecidos mucho más altos que un país más pequeño."

En este argumento se observa que aplica estrategias de recuperación de información, confronta lo que está leyendo con lo que ya conoce sobre la relación habitantes-territorio para intuir la veracidad de la noticia, lo que habla de un análisis crítico y vínculo contextualizado de la información.

En la noticia Ncovid4 el participante P13 colocó un puntaje de 3, argumentando lo siguiente:

"Este tipo de noticias me parece incluso peligroso difundirlas debido a que se está haciendo referencia a un medicamento homeopático que no se tiene la certeza de que ha salvado miles de vidas, como lo promocionan en su título... Se muestra una sola opinión, la del creador del producto, ni siquiera se verifica con otro tipo de opiniones..."

Como puede señalarse, recupera conocimiento previo y toma un posicionamiento acerca de la homeopatía y su efectividad en el tratamiento de las enfermedades. Además de que señala la importancia de verificar la información a través de la contrastación de fuentes.

En la noticia Ncovid5 al participante P13 asignó el valor de 5, es decir ni falsa ni verdadera, argumentando:

“...sucede lo mismo que en la nota anterior, de lo que no se tiene certeza es de que estos medicamentos realmente funcionen como prevención ante la población, de acuerdo a instituciones como la OMS. Por lo que me quedo en un punto intermedio con esta nota." 
Este comentario cuestiona y duda, no adopta una postura clara debido a que, aunque tiene datos proporcionados por una organización mundial reconocida, acepta que tiene poca certeza con respecto a toda la información leída en la noticia que refiere.

En la noticia Ncovid6 el participante P11 asignó un valor de 8 y argumentó:

"El título apela al miedo que provoca la vacuna contra la COVID, convenientemente excluye que los casos son 'muy raros'. El subtítulo aclara que no se sabe qué causa la relación entre la vacuna y la trombosis, hecho que puede ser difícil de entender para algunas personas que por error pueden asignar causalidad."

En este argumento se observan estrategias de confrontación de datos dentro de la misma nota, identifica contradicciones y concluye mencionando que para ciertos lectores la nota puede llegar a ser un argumento inductivo sin ser necesariamente válido o verdadero.

Para la noticia Ncovid7 el participante P11 asignó un valor de 6, argumentando:

"Esta noticia se ofrece en un portal de medio convencional, no pude encontrar el nombre del autor o de la agencia noticiosa de donde se saca la nota.. la fuente parecen ser los posts de redes sociales que se mencionan en el último párrafo, pero de los cuales no se muestra alguna evidencia...”

En este argumento para rechazar la veracidad de la noticia, se cuestiona y evalúa elementos identificados previamente en sitios que son confiables como nombre de autor o agencia noticiosa, e identifica similitud con las publicaciones que se difunden en redes sociales convencionales, concluye determinando que no se presenta ningún tipo de evidencia.

En la noticia Ncovid8 el participante P13 colocó un valor de 2 y argumentó:

“...Escribir en un titular que incluso cura el covid-19 es bastante peligroso para las personas que pueden llegar a creer este tipo de notas. Se está dando una información en favor de un solo estudio cuando hay otros datos que también deberían darse a conocer sobre el tema..."

En este argumento se apela a la estrategia de confrontación de datos de distinta fuentes, al mencionar que la noticia leída proporciona información de un sólo estudio por lo que resalta el peligro que significa la sola interpretación del título de la noticia.

En la noticia Ncovid 9 el participante P12 asignó el valor de 1, argumentando:

"Una publicación de una red social personal, que retoma una captura de pantalla sin citar fuente provoca una malinterpretación de la información, omitiendo la responsabilidad de verificar que el contenido compartido tenga algún medio de verificación previo."

El argumento contiene varias estrategias de evaluación ante lo que está leyendo: identifica la veracidad o seriedad de la fuente, la forma en que se presenta la información, la falta de citas de fuentes de información adicionales que sustenten lo declarado en la noticia y menciona la carencia de elementos presentes para su verificación. 
En la noticia Ncovid10, el participante P7 colocó el valor de 1, argumentando:

"Con tanta noticia sensacionalista que lo único que publica son notas con encabezados muy alarmantes y que apelan a las emociones del miedo y la incertidumbre."

Esta argumentación señala especialmente el sensacionalismo como mecanismo para impactar en las emociones, el hecho de que lo vea claramente y así lo enfatice ya es de por sí un resultado favorable, que evita que sea una noticia aceptada sin crítica.

\section{Discusión y conclusiones}

El objetivo de este trabajo fue describir la evaluación por parte del grupo de participantes del seminario de diez noticias sobre COVID-19. El objetivo se logró a través del análisis de las respuestas del instrumento, tanto en la escala sobre la veracidad de la noticia como en las argumentaciones presentadas.

En línea con las recomendaciones de Galarza (2021), las noticias incluidas en el instrumento fueron consideradas como tendenciosas o con ciertos niveles de falsedad/ verdad. Este hallazgo lleva a plantear que hay una buena cantidad de noticias que no pueden considerarse dicotómicamente verdaderas/falsas por completo, lo que se acercaría a la realidad compleja que se encuentra en Internet como fuente de información. Es por esta razón que algunas noticias fueron asignadas con valores promedios de 5 o 6 (ni verdaderas, ni falsas). Por otro lado, las argumentaciones dan cuenta en su mayoría de que los participantes recurrieron a estrategias de razonamiento y análisis lo que va más allá de la aceptación acrítica y de la primera impresión generada por la noticia (Castillo-Riquelme et al, 2021), especialmente mostraron contrastación de fuentes y con conocimiento previo y búsqueda de información complementaria, lo que se consideraría pensamiento crítico, con énfasis en argumentos deductivos (Cardozo y Pinto, 2017), que pudo ser favorecido durante el seminario. Este tipo de espacios académicos pueden derivar en intervenciones que promuevan el uso estrategias de análisis para valorar la credibilidad de las noticias (Montero-Liberona y Halpern, 2019), inclusive para aquellas noticias que mezclan distorsiones sutiles (Castillo-Riquelme et al, 2021) o, como en este caso, sean noticias tendenciosas.

A decir de Cuenca (1995) aunque el emisor sea una autoridad, el pensamiento crítico y la argumentación permitiría analizar la información, esto es importante en el contexto actual de la pandemia en donde las decisiones pueden impactar en la salud (Montero-Liberona y Halpern, 2019). Por ejemplo, Montagni et al., (2021) afirman que que para promover la vacunación contra el SARS-CoV-2, se recomienda aumentar la capacidad de los individuos para detectar noticias falsas y los conocimientos en salud mediante programas de educación; mientras que Marco-Franco et al., (2021) señalan que el mayor miedo con respecto a la vacunación contra la COVID-19, es el miedo a los efectos secundarios y la eficacia de la vacuna, ambas ideas difundidas a través de noticias falsas.

Entre las limitaciones del estudio se mencionan que no se contó con una línea base para medir el impacto del seminario, sin embargo, contar con un juez inicial sin formación en el seminario permitió indagar en semejanzas y diferencias en aspectos 
como la dicotomía de verdad/falsedad, visibilizando que existen elementos de veracidad/falsedad en las noticias, no únicamente extremos. También es importante señalar que revisar las noticias y desarrollar argumentos no es algo que se haga en condiciones cotidianas (Pennycook y Rand, 2018), pero es necesario si se desea tener ciudadanos críticos sobre la información que impacta en su salud.

\section{Agradecimientos}

Trabajo realizado gracias al proyecto PAPIIT-UNAM <IA302121> "Creencias Epistemológicas Específicas a Internet y su relación con la discriminación de noticias falsas en redes sociales".

\section{Referencias}

Alcolea, J. (2020). Del pensamiento crítico a la argumentación (crítica): Bordeando la irracionalidad. Lógoi. Revista De Filosofía, (38). https://revistasenlinea.saber.ucab. edu.ve/index.php/logoi/article/view/4628

Bernal-Triviño, A., y Clares-Gavilán, J. (2019). Uso del móvil y las redes sociales como canales de verificación de fake news. El caso de Maldita. es. Profesional de la Información, 28(3). https://doi.org/10.3145/epi.2019.may.12

Castillo-Riquelme, V., Hermosilla-Urrea, P., Poblete-Tiznado, J. P., \& Durán-Anabalón, C. (2021). Noticias falsas y creencias infundadas en la era de la posverdad. Universitas, Revista de Ciencias Sociales y Humanas, (34), 87-108. https://doi.org/10.17163/ uni.n34.2021.04

Cardozo, C. J. y Pinto, P. D. (2017). Argumentación, pensamiento crítico y la comunidad de indagación como escenario para su desarrollo. En Amador, L. B., Vélez, D. J., Cardozo, C. J., Pinto, D. M. y Mora, P. A. Argumentación y desarrollo del pensamiento crítico en entornos virtuales de aprendizaje. (pág. 28-39). UNAD https://hemeroteca.unad.edu.co/index.php/book/issue/view/179

Cuenca, M. J. (1995). Mecanismos lingüísticos y discursivos de la argumentación. Comunicación, lenguaje y educación, 7(2), 23-40

De Ágreda, Á. G. (2018). Posverdad y 'fake news'. Falsas noticias, no noticias falsas. Telos: Cuadernos de comunicación e innovación, (109), 18-21. https://dialnet.unirioja. es/servlet/articulo?codigo $=6855661$

De la Fuente, M. H. (2018). Factores implicados en la difusión de fake news mediante las redes sociales. En: Comunicación persuasiva en las aulas: nuevas tendencias (pp. 207-224). Gedisa.

De Zubiría, J. (2006). ¿Qué es argumentar? En: De Zubiría, J. Las competencias argumentativas: La visión desde la educación. (pág. 105-137). Editorial Magisterio. 
Domínguez, M. (2020). La alfabetización visual como defensa ante las noticias falsas: Visual literacy as a defense against fake news. Revista de Estilos de Aprendizaje, 13(26), 85-93. http://revistaestilosdeaprendizaje.com/article/view/2012

Galarza, R. (2021). ¿ Quién cree las fake news? Análisis de la relación entre consumo de medios y la percepción de veracidad de noticias falsas sobre la enfermedad COVID-19 en Nuevo León, México. AdComunica, 235-264. https://doi.org/10.6035/21740992.2021 .21 .13

Gómez, R. (2019) Psicología y posverdad. Noticias falsas, pensamiento autoritario y rigidez cognitiva. http://dx.doi.org/10.13140/RG.2.2.23499.75043

Marco-Franco, J. E., Pita-Barros, P., Vivas-Orts, D., González-de-Julián, S., \& Vivas-Consuelo, D. (2021). COVID-19, Fake News, and Vaccines: Should Regulation Be Implemented?. International Journal of Environmental Research and Public Health, 18(2), 744. https://doi.org/10.3390/ijerph18020744

Montagni, I., Ouazzani-Touhami, K., Mebarki, A., Texier, N., Schück, S., \& Tzourio, C. (2021). Acceptance of a Covid-19 vaccine is associated with ability to detect fake news and health literacy. Journal of public health (Oxford, England). https://dx.doi. org/10.1093\%2Fpubmed\%2Ffdab028

Montero-Liberona, C., \& Halpern, D. (2019). Factores que influyen en compartir noticias falsas de salud online. El profesional de la información, 28(3). https://doi. org/10.3145/epi.2019.may.17

OCDE (2019). El trabajo de la OCDE sobre Educación y Competencias. https://www. oecd.org/education/El-trabajo-de-la-ocde-sobre-educacion-y-competencias.pdf

Parra, V. P. y Oliveira, L. (2018). Fake news: una revisión sistemática de la literatura. Observatorio (OBS*) Special Issue, 054-078. https://doi.org/10.15847/obsOBS12520181374

Pennycook, G., Rand, D. (2018). Who falls for fake news? The roles of bullshit receptivity, overclaiming, familiarity, and analytic thinking. Journal of Personality, 88, 185200. DOI: $10.1111 /$ jopy.12476

Perry, W. G. (1970). Forms of intellectual and ethical development in the college years: a scheme. New York: Holt, Rinehart \& Winston.

Rodríguez, C. (2019). No diga fake news, di desinformación: una revisión sobre el fenómeno de las noticias falsas y sus implicaciones. Comunicación, (40), 65-74. http:// dx.doi.org/10.18566/comunica.n40.aO5

Sued, G. E., y Rodríguez, M. (2019). Noticias falsas en Facebook: narrativas, circulación y verificación. Los casos de Argentina y México. Estudios sobre el Mensaje Periodistico, 26(3), 1229-1242. https://doi.org/10.5209/esmp.65136

Universidad Nacional Autónoma de México (2020). Además de pandemia por COVID-19, México enfrenta propagación de noticias falsas. Boletín UNAM. Consultado el 15 de septiembre de https://www.dgcs.unam.mx/boletin/bdboletin/2020_318.html 
UNESCO (2020). ¿Qué se espera que aprendan los estudiantes de América Latina y el Caribe? Análisis curricular del Estudio Regional Comparativo y Explicativo. https:// es.unesco.org/sites/default/files/comunicado-regional-lanzamiento-analisis-curricular-23.07.2020.pdf 


\section{Uso y Apropiación de Tecnología con Perspectiva Interseccional y Feminista de Género: Una Experiencia en la Universidad Pedagógica Nacional Unidad 095 para Reducir la Desigualdad}

\section{Ramírez Camacho, Adriana Guadalupe}

Universidad Pedagógica Nacional Unidad 095 México aramirez@g.upn.mx 


\title{
USO Y APROPIACIÓN DE TECNOLOGÍA CON PERSPECTIVA INTERSECCIONAL Y FEMINISTA DE GÉNERO: UNA EXPERIENCIA EN LA UNIVERSIDAD PEDAGÓGICA NACIONAL UNIDAD 095 PARA REDUCIR LA DESIGUALDAD
}

\author{
Ramírez Camacho, Adriana Guadalupe \\ Universidad Pedagógica Nacional Unidad 095 México \\ aramirez@g.upn.mx
}

\section{Resumen}

En las universidades se hace visible la desigualdad que presentan especialmente las mujeres en el uso y apropiación de los recursos de tecnología, pues en un mismo grupo de personas son evidentes las diferencias en el conocimiento, las habilidades, las destrezas y la disposición que poseen para utilizarla. Algunos de estos factores son resultado del contexto del cual provienen o se desenvolvieron, mismos que a su vez favorecen o limitan el acceso a internet, a un dispositivo o computadora, al conocimiento y a los espacios de formación. Por lo que, en la Universidad Pedagógica Nacional Unidad 095 (México), además de indagar sobre el contexto social en el que se desarrollaban las estudiantes, se diseñó una estrategia que quebrantara esos entramados institucionales y estructurales que desfavorecen este uso y apropiación, pensando un espacio que brindara las posibilidades de acción y la potenciación de las capacidades individuales y colectivas. La creación del Centro de Recursos para la Investigación, la Enseñanza y el Aprendizaje (CRIEA) permitió atender estas desigualdades que presentan las estudiantes y a las que se suman las discriminaciones por género, raza, etnia, edad, que generan nuevas desigualdades de exclusión en su formación académica, el desempeño laboral y la posibilidad de creación e incidencia por no saber utilizar la tecnología. Mediante los talleres de formación que a partir de 2019 se han implementado en el centro se ha atendido la exclusión digital y su relación con la violencia de género, fenómeno que estaba latente con mayor presencia en este espacio universitario.

\section{Palabras clave}

Apropiación de tecnología, inclusión digital, desigualdad y género. 


\section{Introducción}

El uso y apropiación de la tecnología es un eje temático que ha sido objeto de diversas investigaciones que indagan su efecto en la vida de las personas en su desarrollo personal, académico y profesional, la mediación y acceso a la cultura, al conocimiento y a la información, la comprensión de las interrelaciones en la comunicación, y en la generación y producción para el crecimiento económico basado en la convergencia de las telecomunicaciones y la electrónica, y que con el internet "son capaces de producir, almacenar y transmitir información digital y de funcionar en red como plataforma organizativa de las diversas actividades humanas y sociales que soportan." (Aguilar, Bustamente y Cano, 2013:60)

Este eje temático también investiga desde diversas perspectivas cuáles son los factores y dimensiones que condicionan este uso y apropiación, dado que es evidente que existen dinámicas de acceso desigual al conocimiento y a la información, y estas desigualdades se manifiestan con mayor o menor fuerza en los diversos contextos donde generan dinámicas alternas de inclusión y/o exclusión y cierto acceso a privilegios. El uso y apropiación de la tecnología también se ha estudiado desde su concepción como objeto de poder, pues es mediante la tecnología que podemos ejercerlo, y en este sentido, el género y la tecnología como menciona Graciela Natansohn (2019) "están mutua y tensamente conformadas; la tecnología es, al mismo tiempo, fuente y consecuencia de los arreglos de género y por eso, recurso fundamental del patriarcado." (p. 6)

Los antecedentes de esta experiencia tienen su origen en proyectos previos en los que surgió la necesidad de indagar sobre cómo las mujeres se apropian y usan las tecnologías de la información y la comunicación (TIC), esto es, especialmente en las estudiantes de la Licenciatura en Educación Preescolar Plan 2008 (LEPO8) en la Universidad Pedagógica Nacional (UPN) Unidad 095 Azcapotzalco, ubicada en la Ciudad de México. En esta investigación previa se hizo evidente que algunas de las razones que limitan o favorecen esta apropiación y uso de TIC por parte de las estudiantes, son barreras generadas por cuestiones de desigualdad estructural, pobreza, marginación, no tener acceso a un equipo de cómputo o al internet, y también a las construcciones identitarias diversas que, por el simple hecho de ser mujeres, la mayoría adultas, algunas madres de familia, y con historias de vida en donde la discriminación, la violencia de género y los estereotipos estuvieron presentes, aumentaron sus temores, enfatizaron sus carencias e impactaron en su autoestima y en su esfuerzo por salir adelante.

Como antecedente, también está una investigación que indaga sobre la necesidad de brindar acompañamiento al equipo docente que impartía esta licenciatura. Sin embargo, el proyecto Cultura Digital y Género es el antecedente directo y origen de lo que se comparte en esta experiencia, pues de manera paralela a la exclusión digital existente se manifestaban con mayor frecuencia situaciones de violencia de género en las integrantes de la comunidad educativa por lo que era necesario hacer visible la desigualdad no sólo estructural sino también institucional que se revelaba.

Los objetivos de la experiencia se pueden sintetizar en los siguientes: 
- Determinar si las prácticas de uso y apropiación de la tecnología de las mujeres estudiantes de la comunidad 095 de la UPN está relacionado directamente con los marcadores de diferencia como edad, género, nivel educativo, y el contexto social en el cual se desarrollaron y si la colaboración y la socialización en un espacio creado con esa intención lo favorece de manera distinta.

- Determinar cómo inciden las desigualdades estructurales e institucionales manifestadas en la exclusión digital, así como las capacidades individuales en la apropiación y uso de tecnología en mujeres estudiantes de la comunidad educativa.

- Identificar las formas en que la comunidad educativa percibe la apropiación y uso de la tecnología.

- Explorar las condiciones que determinan este uso y apropiación mediante la implementación de una propuesta de pedagogía feminista con mirada interseccional que busque reducir la exclusión en el uso y apropiación de la tecnología y de forma paralela atender el fenómeno de la violencia de género que se presenta en la comunidad.

\section{Descripción de la experiencia}

\section{Diagnóstico de uso y apropiación de tecnología}

La población en la que se llevó a cabo la experiencia es la comunidad educativa de la Unidad 095 Azcapotzalco de la UPN. La población de la Unidad 095 está principalmente conformada por mujeres y el grupo presenta dificultades y barreras en la inclusión digital. También hay manifestaciones de violencia, principalmente de género.

Para comprender mejor los procesos de apropiación de las tecnologías en los diversos ámbitos de interacción de las personas integrantes de la comunidad se diseñó un instrumento que se aplicó en abril de 2019, el cual indaga sobre estas variables referidas a la edad, el nivel educativo y la profesión de las mujeres que conforman este grupo. Asimismo, para conocer con mayor precisión el estado inicial de las habilidades digitales de la comunidad educativa de la Unidad 095 así como su percepción de cómo perciben que las TIC aportan valor a su aprendizaje y a la reducción de la exclusión digital y de género.

En el cuestionario se agregó una pregunta referida a cómo fue la primera vez que la persona utilizó la computadora, y otra sobre el uso de las tic en su aprendizaje. En este sentido, se busca analizar diversas dimensiones como la experiencia previa de apropiación, cómo usa y qué dispositivos posee, con qué frecuencia los usa, en qué horarios, entre otras.

En el análisis de los datos desagregados del total de participantes de la comunidad educativa de la Unidad 095 que respondieron el cuestionario, se puede concluir que el $91 \%$ de los/las encuestados/as son mujeres y sus edades oscilan entre los 18 y más de 60 años de edad, sin embargo, la mayoría está en un rango de edad entre 18 y 29 y 30 y 39 años. Es importante mencionar que la matrícula que se está considerando en este diagnóstico es la que estaba vigente en el semestre 2019.1 en la Unidad UPN 095. 
El cuestionario está basado en la Matriz de Habilidades Digitales de la UNAM que fue desarrollada por la Coordinación de Tecnologías para la Educación- h@bitat puma de la Dirección General de Cómputo y de Tecnologías de Información y Comunicación (DGTIC) de la UNAM, como "una matriz de habilidades en el uso de tecnologías de información y comunicación basada en algunos de los estándares nacionales e internacionales de certificación en TIC con el propósito de estructurar y organizar en distintos niveles las habilidades tecnológicas a desarrollar en los estudiantes de bachillerato y licenciatura." (DGTIC, UNAM, 2014,1)

El cuestionario también incluye algunos ítems adaptados del estudio de la Asociación Mexicana de Internet (AMIPCI) de 2014 en donde se indaga sobre el uso y frecuencia del internet en los internautas en México y se montó en la herramienta de cuestionario de Drive de Google.

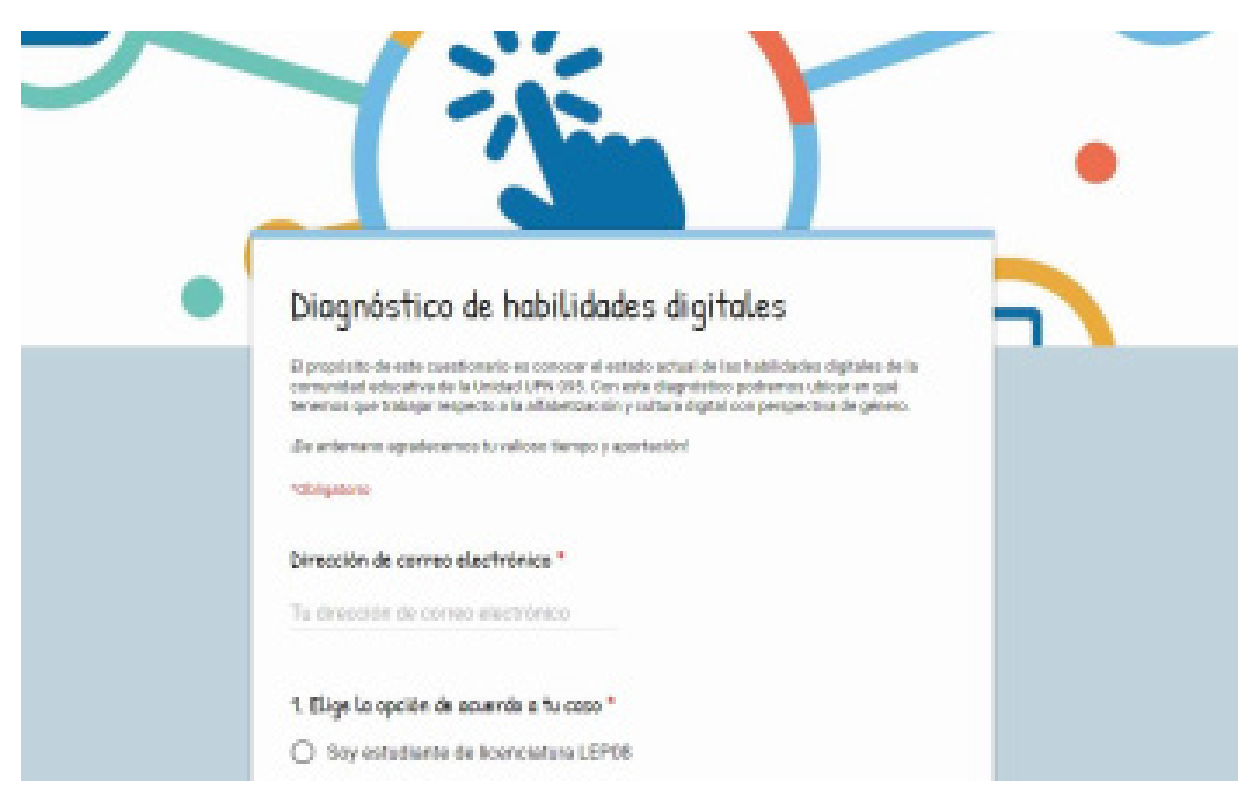

Figura 1. Pantalla principal de cuestionario "Diagnóstico de habilidades Digitales" en Drive.

Algunos resultados representativos del cuestionario son los siguientes:

- El 91\% de los encuestados son mujeres.

- La mayoría de los encuestados está en un rango de edad entre 18 y 29 y 30 y 39 años.

- El $42 \%$ de los/as encuestados/as lleva utilizando internet más de 13 años.

- En promedio se conectan de 3 a 6 horas diarias al Internet.

- Se conectan más desde casa.

- Se conectan más por el dispositivo del celular, y en segundo lugar por medio de laptop, ipad y/o computadora de escritorio. 
- La primera experiencia de uso de la computadora es principalmente por una experiencia escolar.

- La autovaloración que hacen de sus habilidades de acceso a la información es diversa, pero resalta la necesidad de mejorar en aspectos de búsqueda de información en internet, uso de metabuscadores, personalización y organización de sitios de búsqueda.

- Destaca la necesidad de mejorar habilidades de uso de chats y videollamadas, crear y abrir archivos compartidos, gestionar carpetas de correos electrónicos, sincronizar cuentas, instalar antivirus.

- La respuesta es más alta en la población de encuestadas que estudian en la Licenciatura en Línea y demuestra alto grado de habilidades en el uso de plataformas LMS.

- La mayoría requiere habilidades en procesadores de texto, Excel, presentaciones electrónicas, uso de macros, tablas dinámicas y bases de datos.

- Un gran porcentaje requiere capacitación en seguridad digital.

- En cuanto al manejo de medios se detecta una necesidad de conocimiento y uso de imágenes, audio, edición de video.

- Hay una alta necesidad de capacitación en el manejo de Hardware.

- La gran mayoría de los/las encuestados/as reconoce que las habilidades digitales le han apoyado a mejorar sus procesos de enseñanza y aprendizaje.

- La mayoría reconoce la aportación de las TIC como base del desarrollo de competencias de investigación y difusión del conocimiento.

- La mayoría expresa que mediante la inclusión digital podemos promover la igualdad en el acceso a la información y al conocimiento.

- Hay un alto interés por participar y colaborar en un espacio de construcción de conocimiento colaborativo dentro de la Unidad.

El análisis de datos es importante para conocer si este nivel educativo, la edad y el género, así como los conocimientos, la experiencia previa, el interés por el aprendizaje y uso de las tecnologías expone como grupo a estas mujeres en un riesgo de exclusión digital y a la vez, plantear la hipótesis de que al incluirlas, al apropiarse de ellas, las potencialice.

A partir de la detección de las causas que se consideran generan la exclusión digital y con una perspectiva de género manifestadas en los resultados de este diagnóstico se pensó en una estrategia integral de inclusión digital. Por lo que la experiencia aborda una nueva representación de la violencia mediante las tecnologías de la información y la comunicación que se refleja en la exclusión digital. 
Hacer estos cuestionamientos y reflexiones fue importante porque permitió a nivel administrativo tomar decisiones y diseñar estrategias para la inclusión digital, basándonos en que una de las desigualdades presentes que generan esta exclusión detectada en el diagnóstico es la referida al uso y apropiación del código.

Otras desigualdades existentes, identificadas como necesidades del grupo de mujeres de la comunidad 095 son las referidas a la búsqueda de información, a la seguridad digital, al uso de hardware y software, procesadores y bases de datos, uso de medios digitales, entre otros que les permitan mejorar sus procesos de enseñanza y aprendizaje, hacer investigación y comunicar sus resultados, y en sí promover la igualdad en el acceso a la información y al conocimiento.

Por todo lo anteriormente mencionado, la experiencia se enfocó en explorar cuáles son las principales barreras en la inclusión digital del grupo de mujeres de la comunidad educativa de la Unidad 095 Azcapotzalco y plantear el diseño de una propuesta estratégica integral que permitiera desarrollar una cultura digital incluyente, en donde se desarrollen las mismas posibilidades de acceso, uso y apropiación de las TIC para cualquier integrante de la comunidad educativa.

Lo que interesó en un primer momento fue realizar un diagnóstico preciso que permitiera contar con la información del estatus de inclusión digital de la población objetivo y diseñar las estrategias de alfabetización con perspectiva de género con base en las aptitudes y conocimiento, así como en la percepción de usar o entender la tecnología.

Este diagnóstico fue muy importante para identificar las formas en que la comunidad educativa percibe su relación con la cultura digital, explorar las condiciones que las determinan y las barreras que la limitan.

La información de una de las respuestas abiertas del cuestionario diagnóstico brinda elementos para hacer un análisis tratando de desagregar diversas categorías como el acceso, la igualdad de género y la equidad en las oportunidades de acceso.

Otros datos importantes que se generaron a partir del análisis del cuestionario diagnóstico son los siguientes:

- Las formas de apropiarse y usar la tecnología varían en los distintos integrantes de la población objetivo por lo que la mirada de la interseccionalidad permite analizar la interrelación entre estas desigualdades.

- Esta situación varía en los diferentes programas que se imparten en la Unidad y en los distintos espacios (académicos, administrativos y de servicios de apoyo).

- Existe evidencia de la discrepancia en las que las y los integrantes de la comunidad educativa valoran su desempeño en una cultura digital.

- Los integrantes de la comunidad educativa provienen de distintos contextos y acercamientos a la cultura digital.

- Hay desigualdad en el reparto, acceso o posibilidad de uso de los recursos de la tecnología. 
- La violencia estructural o cultural se interrelaciona con la inclusión al uso de la tecnología.

- Esta experiencia nos permitirá entender que existe una raíz sociocultural en la violencia de género. y una desigualdad manifestada en la inclusión digital.

- Existe la necesidad de contar con un espacio para favorecer las redes de aprendizaje.

Con estos datos y con el interés de la comunidad plasmada en las respuestas del cuestionario se pensó en un espacio en donde se pudiera consolidar este propósito de transitar a la inclusión digital con perspectiva de género.

Así, en mayo de 2019 se da origen al Centro de Recursos para la Investigación, la Enseñanza y el Aprendizaje (CRIEA) y a partir de esa fecha se han impartido 40 talleres con este propósito.

\section{La creación del Centro de Recursos para la Investigación, la Enseñanza y el Apren- dizaje (CRIEA)}

La universidad es un centro de saberes que responde a las demandas de formación de sus estudiantes fomentando una conciencia de solidaridad y de compromiso social, y que da respuesta también a su función de extensión universitaria estableciendo un vínculo con la investigación e interrelacionandose con la docencia. En el CRIEA se organizan y llevan a cabo talleres de extensión universitaria con perspectiva de género impartidos por académicos y académicas de la Unidad 095, así como formadores externos especialistas en diversos rubros (como la fotografía con enfoque de género, la salud y la educación física y la robótica educativa y STEAM), y en donde también participan activamente como talleristas y/o evaluadores estudiantes de licenciatura de pedagogía y psicología educativa en formación.

Se ha evidenciado el avance en la alfabetización y promoción de cultura digital en beneficio de la igualdad de oportunidades, del empoderamiento, agenciamiento y ensamblaje de las mujeres de la comunidad educativa, tanto en los y las talleristas como en los participantes. Sin embargo, es importante abordar y dar seguimiento a esta experiencia porque la exclusión digital es fuente de desigualdades. Existe un problema de desigualdad en la forma en la cual se distribuye la tecnología y el acceso a la información y al conocimiento. Si no hay conocimiento y no hay información, las diversas manifestaciones de la violencia pueden normalizarse pues las personas no tienen acceso a conocer sus diversas interpretaciones y/o manifestaciones.

Cada taller brinda un espacio para favorecer el uso y la apropiación de herramientas de tic a la vez que una reflexión para la igualdad de oportunidades con perspectiva de género, el conocimiento de los derechos de las mujeres y su bienestar.

No sólo son los académicos quienes imparten los talleres y el conocimiento no es exclusivo de quien asiste a una institución educativa. EI CRIEA posibilita que la población estudiantil en formación cuente con un espacio de creación de sus propios recursos digitales, guiones de enseñanza, instrumentos de evaluación de talleres, rompiendo el paradigma del discurso de la pedagogía tradicional al de una pedagogía digital. Esto es, apropiándose del espacio y de las herramientas tecnológicas 
para hacer conciencia a su vez, a otras personas de la importancia de reconocer sus derechos de acceso al conocimiento y al uso de las herramientas de tic.

Por ejemplo, si se imparte un taller de Canva, éste no solamente se enfoca en el uso del recurso, sino en mirar la posibilidad de la apropiación del código para hacer carteles, que anteriormente sólo estaba en manos de los profesionales del diseño gráfico, y que los mensajes de estos carteles integren un mensaje de empoderamiento para las mujeres.

Si se imparte un taller de escritura, se sensibiliza y reflexiona en la posibilidad de expresión mediante la narración de su historia de vida, recuperando las fortalezas de la participante y buscando el agenciamiento y ensamblaje.

\section{Resultados}

La presente experiencia representa una innovación dado que existen pocos antecedentes o son insuficientes como para poder establecer una primera base, y resulta de gran impacto e importancia en las acciones que desde las universidades se pueden hacer para la apropiación y uso de la tecnología con perspectiva de género, dando respuesta a la necesidad de contar con prácticas pedagógicas creativas ante la desigualdad estructural e institucional latentes en estos espacios de formación.

Esta experiencia se enmarca en un contexto y espacio que también tuvo que integrarse a la estructura institucional que en un principio no entendía su razón de ser pero después encontró que había sido una acertada anticipación a los tiempos que se venían pues hubo algunas limitantes de colegas o las autoridades inmediatas, así como de infraestructura.

EI CRIEA es una respuesta a la falta de propuestas concretas por parte de la universidad para atender estas necesidades de alfabetización, inclusión digital y de violencia de género.

La apropiación se favorece con la mediación de los talleres y la ejecución de proyectos de intervención, con otros usos que se le dan a las herramientas de la tecnología, y con el tránsito a la pedagogía digital, en donde las y los estudiantes despliegan las capacidades en el uso de las tic que ya poseen y renuevan pedagógicamente este acercamiento en sus propios docentes, quienes también aprenden nuevas prácticas al cursar los talleres.

Las desigualdades se pueden ir reduciendo, y somos las universidades en nuestras funciones sustantivas, quienes debemos generar estas transformaciones y cambios en beneficio de la formación de nuestros estudiantes y en la construcción de una mejor sociedad.

\section{Discusión y conclusiones}

Para entender mejor las problemáticas que condicionan el uso y apropiación de la tecnología es necesario que primero:

- se indague más sobre el concepto de apropiación, 
- se mire con la lupa del feminismo el estatus de dominio que el patriarcado y la tecnopolítica con el control y la vigilancia han dado a la tecnología;

- se comprenda la multidimensionalidad de las desigualdades que generan la exclusión digital, principalmente en las mujeres,

- se reflexione sobre cómo se construyen las categorías identitarias en una sociedad cargada de desigualdades, y

- se haga evidencia, con la mirada de la interseccionalidad, de estas relaciones de poder, de la simultaneidad de las desigualdades y la invisibilidad de algunas realidades que la rigidez de las categorías sociales determinan.

Cabello profundiza en que "la apropiación de la tecnología que realizan las personas implica una dimensión cognitiva, pero también emocional, sensible, que convoca a la experiencia y el ámbito de la vivencia pero que siempre se realiza en interacción con otros y que tiene otro componente central que es el hecho de estar siempre situado, es un proceso que se realiza de manera contextuada y por tanto, involucra un componente constitutivo de desigualdad, diferencia, atención no sólo al acceso, a la información social de los bienes tecnológicos, sino también a los modos como se participa en la producción, en la circulación y consumo de recursos y representaciones sobre tecnología, el acceso a los recursos para poder integrar estas tecnologías en los planes de acción y en la generación de obras." (Cabello, 2020)

Es por ello que los espacios que se abren en las universidades deben favorecer la colaboración, la empatía, la sororidad y la educación para la paz, la erradicación del racismo, la discriminación y la no violencia.

\section{Referencias}

Aguilar, S, Bustamante, L. y Cano, J. (2013) Uso y apropiación de la tecnología de información y comunicación:dos conceptos para la negociación internacional en organizaciones productivas.

Recuperado de http://www.scielo.org.co/pdf/ean/n75/n75a05.pdf

Cabello, R. [I Encuentro GT CLACSO] (21 de octubre de 2020) Tecnósfera infantil: apropiación de tecnologías como aprendizaje [Video] YouTube

https://www.youtube.com/watch?v=FYm2ilh-AmQ

Natansohn, G. y Paz, M. (2019) Ciberfeminismos contemporáneos, entre usos y apropiaciones. Recuperado de http://www.scielo.br/pdf/cpa/n56/1809-4449-cpa-56-e195622.pdf

DGTIC, UNAM. (2014) Matriz de Habilidades Digitales de la UNAM. Coordinación de Tecnologías para la Educación- h@bitat puma de la Dirección General de Cómputo y de Tecnologías de Información y Comunicación (DGTIC). Recuperado de https:// educatic.unam.mx/publicaciones/matriz-habilidades-digitales.html 


\section{La Competencia Digital de Estudiantes Universitarios: El caso de una Universidad Privada en la Ciudad de Querétaro, México.}

\section{Sánchez González, Maribel}

Universidad Autónoma de Querétaro

maribel.sang@gmail.com 


\section{LA COMPETENCIA DIGITAL DE ESTUDIANTES UNIVERSITARIOS: EL CASO DE UNA UNIVERSIDAD PRIVADA EN LA CIUDAD DE QUERÉTARO, MÉXICO.}

\section{Sánchez González, Maribel}

Universidad Autónoma de Querétaro

maribel.sang@gmail.com

\section{Resumen}

El uso de las tecnologías digitales está cada vez más extendido entre la población para diferentes fines incluyendo el educativo, y la pandemia por COVID-19 incrementó su demanda porque obligó a las instituciones educativas a migrar a entornos de aprendizaje virtual. La familiaridad que los jóvenes tienen con la tecnología provoca que se asuma que poseen las competencias digitales suficientes para desarrollarse de manera natural en el uso de las TIC. Basado en lo anterior, se realizó un estudio para evaluar los niveles de competencias digitales de los estudiantes que se enfrentan a nuevos retos en la educación multimodal. Su propósito es dar a conocer los primeros resultados de una tesis doctoral que permitirá el desarrollo de un plan de formación en competencias digitales. En este estudio, participaron 61 estudiantes con una media de 21.11 años. El marco teórico se fundamenta en el Modelo DigComp, y se lleva a cabo mediante una metodología cuantitativa. La recolección de datos para el diagnóstico se realizó mediante el instrumento INCOTIC 2.0 y fueron analizados con el programa SPSS21, dando como resultado un nivel medio de las competencias digitales, de las cuales, las áreas más prioritarias a atender son: alfabetización comunicativa y multimedia, así como también el área que evaluó las actitudes y expectativas hacia las TIC.

\section{Palabras clave}

Competencias digitales, alfabetización digital, entornos de aprendizaje virtual, educación superior, tecnología educativa, estudiantes universitarios. 


\section{Introducción}

En los últimos años, la sociedad ha experimentado grandes avances a nivel de la tecnología educativa, y si bien a raíz de la pandemia su uso se ha incrementado por la necesidad de llevar una educación a distancia, lo cierto es que incluso desde antes del confinamiento, las y los jóvenes estudiantes son quienes parecieran estar más en contacto con el uso de las tecnologías digitales, y debido a esa familiaridad con la tecnología se piensa que poseen competencias digitales suficientes para desarrollarse y enfrentar los retos del aprendizaje en línea. No obstante, la falta de apropiación de la tecnología para el proceso de aprendizaje de las y los estudiantes o en su defecto que no hayan desarrollado competencias digitales, puede ser un impedimento para que puedan transitar a diferentes modalidades educativas y en el contexto actual en el que se han visto obligados a desarrollarse en los entornos de aprendizaje virtual, se hace necesario evaluar los niveles de competencias digitales para que los y las estudiantes puedan enfrentar los nuevos retos en la educación multimodal.

Aun cuando en las generaciones de estudiantes que hoy cursan la educación superior, la tecnología ha sido un elemento presente en su vida cotidiana, no necesariamente implica que posean altos niveles de competencias digitales, ya que, si bien esta generación ha aprendido a utilizar las TIC, casi siempre, en contextos familiares, de ocio y tiempo libre, y fundamentalmente con la necesidad de comunicarse y relacionarse personalmente. De acuerdo con Cabezas y Casillas (2017) "no han aprendido su uso desde un punto de vista que se podría denominar, académico y profesional" (p.68). Bajo este escenario, las instituciones educativas tienen la gran responsabilidad de brindar los medios para que los estudiantes desarrollen competencias digitales suficientes para hacer frente a este modelo de aprendizaje virtual, toda vez que ante la situación actual post pandemia se ha acelerado esta inmersión a la tecnología en los entornos educativos, lo que hace aún más necesario que los estudiantes saquen mayor provecho de los entornos virtuales como un medio de aprendizaje que posibilite una mayor incorporación de herramientas telemáticas y con ello se fortalezcan sus competencias digitales (Prendes, M., Solano, I., Serrano, J., González, V., y Román, M., 2018). Para Gutiérrez-Porlán, I., Román-García, M., \& Sánchez- Vera, M., (2018) "La clave está en dar un paso más y aprovechar los espacios en que los alumnos se están relacionando y socializando para llegar a convertirlos en verdaderas oportunidades de aprendizaje".

En la bibliografía se puede encontrar estudios que se han realizado para dar cuenta de la importancia que tiene el desarrollo de competencias digitales en los estudiantes, tal es el caso del estudio: Formación en competencias digitales para estudiantes universitarios basada en el Modelo DigComp, (González, V., Román, M. y Prendes, M., 2018). El objetivo de este estudio fue mejorar la competencia digital del alumnado de 2 do. de pedagogía, mediante la realización de tareas enfocadas a trabajar cada una de las áreas competenciales del Marco Europeo (Creación de contenidos, Información, Seguridad, Comunicación, Solución de problemas). Para esta investigación se utilizó un diseño cuasi-experimental que incluyó un diseño de pre-test y post-test y una serie de actividades diseñadas explícitamente para trabajar cada una de las áreas. La muestra de participantes fue de 115 estudiantes. De acuerdo con este estudio los investigadores concluyeron que la competencia digital es un elemento clave dentro de la formación de los futuros profesionales de todos los ámbitos (González, V. et al., 2018) también destacan la importancia de trabajar en la formación de competencias 
digitales ya que esto permite ayudar a los estudiantes a mejorarlas. En los resultados de su investigación, se pudo observar evidentes cambios en las pruebas aplicadas (pre-test y post-test) en todas las áreas de competencia digital de los alumnos.

Otro estudio que se puede mencionar es el Proyecto CAPPLE: Competencias para el aprendizaje permanente basado en el uso de PLE (Entornos Personales de Aprendizaje): Análisis de los futuros profesionales y propuestas de mejora, desarrollado por Prendes, González, Román y Serrano (2018), este estudio permite comprender de una forma global, cómo los estudiantes utilizan sus competencias digitales en los procesos académicos de aprendizaje. Es un proyecto de investigación coordinado por Ma. Paz Prendes en el que han participado un total de 34 investigadores procedentes de 6 universidades diferentes. La investigación se llevó a cabo mediante un diseño no experimental, de tipo exploratorio y basado en el uso de un cuestionario como instrumento de recogida de información. El principal objetivo del proyecto CAPPLE fue describir y analizar las estrategias y herramientas concretas utilizadas habitualmente por estudiantes universitarios de último curso (de 75 universidades diferentes) de todas las ramas de conocimiento para enriquecer su proceso de aprendizaje, dentro y fuera de las aulas, especialmente aquellas que tienen lugar en contextos electrónicos. El artículo que describe este estudio concluye mencionando que, en el análisis llevado a cabo, se comprobó que la mayoría de los estudiantes de último grado tiene presencia en la red, siendo para ellos un espacio habitual para comunicarse. Sin embargo, deja claro que queda mucho por hacer para lograr que los estudiantes universitarios aprovechen adecuadamente este medio, como espacio de aprendizaje, ya que el alumnado no ha logrado incorporar herramientas telemáticas para tareas vinculadas a los procesos de gestión del conocimiento y aunque los estudiantes sí buscan información en Internet, lo hacen con limitadas estrategias de búsqueda. (Prendes, M. et al., 2018)

Un estudio de metasíntesis realizado por Acosta (2016) en el que se busca establecer si los resultados soportan, las posturas que afirman que los jóvenes, poseen unas competencias digitales generalizadas y de alto nivel. En este estudio se analizaron 20 artículos publicados en los últimos 15 años, de los cuales se ha buscado evaluar las competencias digitales de los jóvenes, los principales hallazgos que se reportan es que la afirmación de que los jóvenes sean nativos digitales no se soporta fácticamente $y$, por ende son deducciones realizadas en apenas un subgrupo de personas, por otro lado, señala un aspecto sobresaliente, y es el hecho de que se debe ser cuidadoso en generalizar, ya que, algunos estudios hacen mención a que todavía existe una brecha digital que no permite el acceso por igual a toda las personas, por lo tanto, existen jóvenes que nunca han tenido acceso a las TIC, o bien, su acceso es muy limitado.

Henríquez-Coronel, P., Gisbert, M., y Fernández, I. (2018) realizaron un estudio donde evalúan la competencia digital que se realiza en América Latina y sus principales hallazgos mediante la revisión del estado del arte. De 2789 artículos fueron seleccionados 11 atendiendo a los criterios establecidos por las autoras. Los resultados encontrados indican que el grado de competencia digital de los estudiantes muestra hallazgos diversos. La competencia que mejor puntaje obtuvo fue la relacionada con la búsqueda y acceso a la información mientras que la de más bajo puntaje ha sido la que se relaciona con el aprendizaje social. Concluyen este estudio mencionando que "la competencia digital es base para promover la cultura digital de los estudiantes y la escuela no debe presuponer que los nativos digitales tengan la competencia, sino que debe ocuparse de los procesos alfabetizadores en esta materia"' (Henríquez-Coronel, et, al., 2018). 
Por su parte, Gisbert, M., González, J. y Esteve, F. (2016), realizan un estudio en donde dan cuenta del panorama de las competencias digitales a partir de la revisión del estado del arte por medio de una metodología cualitativa orientada a la revisión y el análisis de la documentación relevante. En este estudio concluyen que, sin duda, aun cuando las universidades han ido respondiendo de forma efectiva a través de estrategias que coadyuvan al fortalecimiento de competencias digitales, es necesario agilizar y operativizar el proceso de evaluación de las mismas, y en los diversos niveles educativos. Así como contar con instrumentos que ayuden a estandarizar este proceso ya que aun cuando hoy se cuentan con instrumentos de diagnóstico cumplen la función de orientar, pero es necesario que sean ampliados para que además contribuyan en los procesos de certificación y acreditación de forma oficial, en ese sentido, cabe mencionar que en la búsqueda realizada para este proyecto de investigación, a la fecha, no se ha identificado algún instrumento creado y validado en México.

Por último, Orostíca (2021) en Navarro, S., Juárez, G. (2021), realiza un estudio en donde, reporta los resultados de la aplicación del instrumento INCOTIC 2.0 en una Universidad de Chile. En una muestra de 476 estudiantes encuestados, los resultados de esta investigación muestran que los niveles de competencia digital se encuentran en un nivel moderado para las dimensiones de alfabetización tecnológica y comunicacional y mayormente capacitados en las dimensiones de alfabetización informacional y multimedia.

Por lo anterior, se puede corroborar la importancia que tienen las competencias digitales en el proceso formativo de los estudiantes, máxime en las condiciones actuales en donde la pandemia ocasiono que la educación migrara a entornos virtuales de forma vertiginosa, de esta forma se hace necesario desarrollar un trabajo que promueva el desarrollo y el fortalecimiento de estas competencias.

Es por ello que el presente estudio que se deriva de una tesis doctoral en la cual se propone la implementación de un plan de fortalecimiento de las competencias digitales para los estudiantes universitarios, como primera fase se consideró realizar un diagnóstico de las competencias digitales utilizando el instrumento INCOTIC 2.0, que mide el nivel de competencias digitales a través de un cuestionario de autopercepción por parte de los estudiantes.

En esta fase, el estudio tiene como objetivo conocer el nivel de competencias digitales que poseen los estudiantes de la Escuela de Psicología en una Universidad privada de la ciudad de Querétaro, México. Esta información permitirá confirmar la viabilidad de un plan de formación para el fortalecimiento de las competencias digitales de estos estudiantes.

\section{Método}

El término de competencias digitales es un concepto del que no se tiene una decisión unánime acerca de su definición, por lo que no es extraño encontrarnos diferentes formas de conceptualizarlo. A continuación, se muestran algunas de las nociones que diversos autores han propuesto para definirlo: 
De acuerdo con la UNESCO (2019) la competencia digital se entiende como "el conjunto de aptitudes, conocimientos y comprensión necesarios para realizar algo con éxito al nivel de una norma profesional". De forma más específica y ligado a la formación educativa encontramos que la competencia digital se puede definir como el "conjunto de destrezas y conocimientos que el propio individuo debe adquirir y consolidar como medio imprescindible para avanzar en sus estudios, en cualquier etapa formal y a lo largo de la vida" (Gisbert, M., González, J., y Esteve, F., 2016).

La UNESCO (2011) propone su propio marco de referencia sobre la competencia digital, y refiere tres niveles de adquisición: 1. alfabetización digital, el cual permite a los estudiantes ser más eficientes en el manejo de la tecnología; 2. Profundización en el conocimiento, el cual permite ahondar en el conocimiento de los diferentes ámbitos disciplinares; 3. Creación de conocimiento, en el que el manejo eficiente de la tecnología permite la creación de nuevo conocimiento.

Mientras que Ferrari (2013) desarrolla el marco de referencia de la Comisión Europea, el cual se basa en la revisión de 5 áreas de la competencia digital: información, comunicación, creación de contenido, seguridad y resolución de problemas que se resume en 21 competencias necesarias para ser un usuario competente en entornos digitales y es a través de ellas que se mide.

El modelo más conocido de competencia digital es el DigComp (Ferrari, Neza y Punie, 2014) el cual es un referente para comprender lo que implica ser "digitalmente competente".

El modelo DigComp ofrece una descripción exhaustiva de los conocimientos, habilidades y actitudes que las personas necesitan desarrollar para la formación de competencias en 5 áreas de la competencia: información, comunicación, creación de contenido, seguridad y solución de problemas.

El diagnóstico previo a la intervención busca conocer el nivel de competencias digitales de estudiantes universitarios que se incorporan a ambientes de aprendizaje virtual, para ello el marco teórico se fundamenta en el Modelo del Marco Común Europeo de la competencia digital. Con esta premisa, el planteamiento metodológico que se ha seleccionado para esta investigación es el de la metodología cuantitativa. Lo anterior llevó a considerar para el diagnóstico de las competencias digitales de los y las estudiantes, el uso del cuestionario de autoevaluación de competencias INCOTIC 2.0.

\section{Descripción del contexto y de los participantes}

El estudio se realizó en la Escuela de Psicología de una Universidad privada de la ciudad de Querétaro, México, durante el semestre 2021-1. Se seleccionó una muestra no probabilística por conveniencia de 61 estudiantes, 50 mujeres (82\%) y 11 hombres (18\%), con un rango de edad entre 18 y 40 años y una media de 21.11 años, siendo estudiantes de los semestres segundo (27.9\%), cuarto (11.5\%), sexto (42.6\%) y octavo (18\%).

\section{Instrumentos}

Previo consentimiento informado, se utilizó el instrumento "INCOTIC: A diagnostic self assessment tool for digital competences at the University studies" un instrumento de autopercepción de la competencia digital del alumnado universitario. En su 
versión más reciente, INCOTIC 2.0, analiza cuatro áreas de alfabetización de la competencia digital: informacional, comunicativa, multimedia y tecnológica, así como actitudes y expectativas hacía las TIC. Los niveles de confiabilidad por consistencia interna (Alpha de Cronbach) reportada para el total del instrumento es de .856.

\section{Componentes del cuestionario diagnóstico:}

Las preguntas que contiene el instrumento INCOTIC 2.0 se basan en cuatro aspectos de la Competencia Digital:

- Informacional: mide los procesos de acceso, gestión, evaluación y aprovechamiento de la información para el aprendizaje en los estudios universitarios.

- Tecnológica: mide la gestión del software o hardware así como el tratamiento de los datos en diferentes formatos o con la comunidad digital.

- Multimedia: mide la creación y compresión de contenidos mediáticos.

- Comunicativa: mide la comunicación con herramientas digitales, lo que implica no sólo comunicar sino también compartir la información.

Además de la información relacionada a la competencia digital se incluye una serie de ítems que miden las actitudes y expectativas hacia las TIC, y finalmente una sección de biodatos, que recoge información sobre género, edad, carrera y semestre.

\section{Procedimiento}

La información se obtuvo a lo largo de un mes, en el cual se aplicó el instrumento a los estudiantes de manera grupal, utilizando los grupos por semestres, para tal fin se solicitó apoyo de sus profesores de asignatura para participar en el horario de clase y pedirles a los estudiantes que respondieran a un cuestionario. Se aclaró que su participación era voluntaria, que la información recabada era anónima, y sobre la importancia de que respondieran de forma sincera, explicándoles que sus respuestas se utilizarían para fines de investigación, y sirviéndose para tal fin del consentimiento informado.

\section{Resultados}

El instrumento ha sido distribuido a una muestra de 61 estudiantes, todos ellos matriculados en la carrera de Psicología, en todos los grados que se imparten en el periodo lectivo $2021-1$ y conforman un $79.2 \%$ del total de los estudiantes inscritos en la modalidad semestral. En función al semestre que cursan los estudiantes, la muestra se distribuye de la siguiente forma: un $27.9 \%$ de segundo semestre, un $11.5 \%$ de cuarto semestre, un $42.6 \%$ de sexto semestre y $18 \%$ de octavo semestre. 


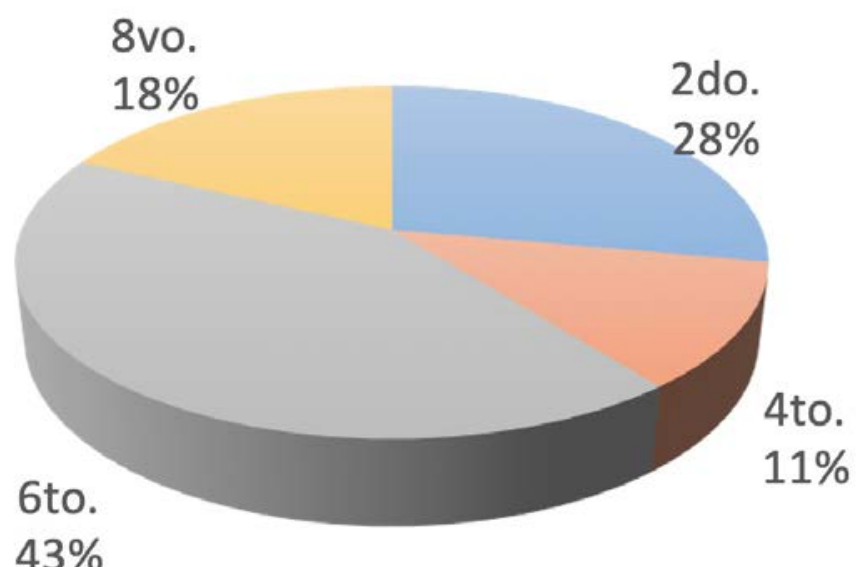

2do. 4 to. $\quad 6$ to. $\quad 8$ vo.

\section{Gráfico 1. Distribución de la muestra por semestre}

A partir de esta primera exposición se pueden observar los indicadores generales que este instrumento permite obtener, todos ellos en una escala de 1 a 5 :

\begin{tabular}{|l|l|l|}
\hline \multicolumn{1}{|c|}{ Media } & .6467 \\
\hline Índice de alfabetización informacional & 3.90 & .6817 \\
\hline Índice de alfabetización tecnológica & 4.06 & .7127 \\
\hline Índice de alfabetización multimedia & 3.95 & .7020 \\
\hline Índice de alfabetización comunicativa & 3.30 & .6879 \\
\hline Índice de actitudes y expectativas hacía las TIC & 3.90 & .60 \\
\hline
\end{tabular}

\section{Tabla 1. Indicadores generales INCOTIC 2.0}

Para interpretar mejor los datos obtenidos, es preciso mencionar que INCOTIC 2.0 cuenta con una tabla de retroacciones para cada nivel de la competencia digital, el cual sirve como referencia para contrastar los resultados. A continuación, se muestran los valores generales en donde se especifica el nivel de competencias digitales, de acuerdo a los resultados obtenidos en una escala del 1 al 5. (Tabla 1). Mientras que en la tabla 3 , se muestran los rangos de referencia para la escala de actitudes y expectativas ante las TIC. 


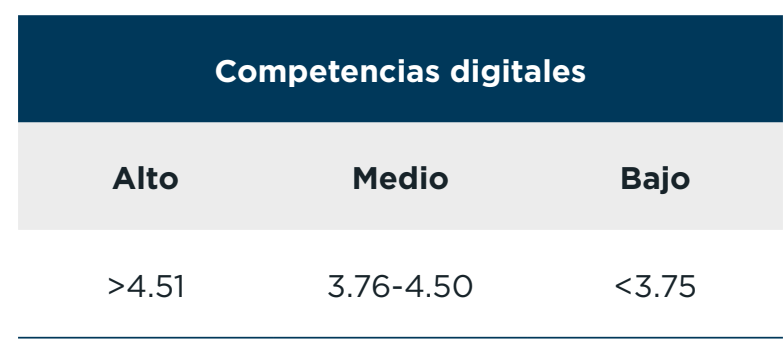

Tabla 2. Nivel de competencias digitales INCOTIC 2.0
Actitudes y expectativas hacia las TIC

\begin{tabular}{ccc} 
Alto & Medio & Bajo \\
\hline 4.34 & $3.89-4.33$ & $<3.88$ \\
\hline
\end{tabular}

Tabla 3. Nivel de actitudes y expectativas hacia las TIC, INCOTIC 2.0

En la Tabla 1 se pueden observar los niveles autopercibidos de cada una de las alfabetizaciones (informacional, tecnológica, multimedia y comunicativa). Y también podemos conocer el nivel de actitudes y expectativas que los participantes tienen acerca del impacto de las TIC en su formación académica.

En el caso de esta muestra, se puede observar que el índice de alfabetización tecnológica es el que puntúa más alto es una escala de 1 a 5 con una media de 4.06, colocándose en un nivel medio de la competencia (3.76-4.50), mientras que el índice de alfabetización comunicativa es el que puntúa más bajo con una media de $\mathbf{3 . 3 0}$, el cual le corresponde un nivel bajo de la competencia $(<3.75)$.

En el caso de los biodatos, su análisis revela una diferencia poco significativa con relación al género, se observa en la Tabla 4 que la media de mujeres es de $\mathbf{3 . 8 0}$ mientras que en los hombres de $\mathbf{4 . 0 0}$ de la puntuación total, situándose ambos en un nivel medio de la competencia (3.76-4.50).

\begin{tabular}{lccc} 
Género & Media & Desv. típ. & Nivel \\
Mujer & 3.80 & .5412 & Medio \\
\hline Hombre & 4.00 & .3809 & Medio \\
\hline Total & 3.84 & .5187 & Medio \\
\hline
\end{tabular}

\section{Tabla 4. Puntuación total de la competencia digital por género:}

Por otro lado, en la Tabla 5 se puede observar una distribución de cada ítem por área examinada, esta tabla permite identificar los valores de las medias en cada uno de los reactivos y con esto analizar en qué aspectos de la competencia se puede incidir con mayor precisión, esto resulta de gran relevancia para el diseño de la intervención que se llevará a cabo como parte del proyecto doctoral del que se desprende este estudio. 
Indicador de Perfil tecnológico

Soy una persona que usa mucho las herramientas digitales en mi vida personal.

$3.95-1.384$

Soy una persona que usa mucho las herramientas digitales para estudiar.

$3.72 \quad 1.240$

No podría vivir sin conexión a Internet.

3.49

1.312

No podría vivir sin celular.

3.39

1.282

Indicador de alfabetización informacional

Media

Desv. típ.

Confirmar un dato obtenido en la Wikipedia a partir de fuentes más fiables.

$4.03 \quad 1.154$

Saber por dónde empezar cuando me plantean una actividad de clase.

$3.95 \quad 1.007$

Usar un gestor bibliográfico para un trabajo de clase.

3.70

1.174

Averiguar si un libro está disponible en el catálogo digital de la universidad.

\section{Indicador de alfabetización tecnológica}

Media

Desv. típ.

Conectarme con el celular al wifi de la universidad.

4.77

.716

Digitalizar un documento con buena resolución.

4.33

.926

Diseñar una plantilla personalizada para una presentación.

4.23

1.071

Convertir a PDF una hoja de cálculo.

3.90

1.546

Enviar un correo electrónico con un destinatario en copia oculta.

3.08

1.574

\section{Indicador de alfabetización multimedia}

Media

Desv. típ.

Elegir la mejor opción (cámara de fotos, cámara del celular, etc.) para grabar un vídeo.

$4.25 \quad 1.075$

Valorar cuándo las presentaciones de mis compañeros son demasiado coloquiales.

$4.03 \quad 1.110$

Darme cuenta de cuándo me engañan con algún mensaje multimedia.

3.82

1.057

Resumir las ideas principales de un documental de divulgación científica en un mensaje de 280 caracteres.

3.70

1.160

\begin{tabular}{lcc|}
\hline Indicador de alfabetización comunicativa & Media & Desv. típ. \\
\hline Hacer una videoconferencia con más de tres amigos. & 4.85 & .441 \\
\hline $\begin{array}{l}\text { Trabajar colaborativamente en un documento compartido en la } \\
\text { nube. }\end{array}$ & 4.62 & .897 \\
\hline $\begin{array}{l}\text { Enviar a mis amigos un vídeo de 2Gb por Internet. } \\
\text { Preparar mi videocurrículum para una oferta de trabajo en una } \\
\text { multinacional. }\end{array}$ & 3.21 & 1.439 \\
\hline $\begin{array}{l}\text { Publicar mis contenidos digitales con una licencia Creative } \\
\text { Commons. }\end{array}$ & 2.10 & 1.221 \\
\hline
\end{tabular}




\begin{tabular}{|c|c|c|}
\hline Indicador de actitudes hacia las TIC & Media & Desv. típ. \\
\hline $\begin{array}{l}\text { Me facilitan la comunicación con mis compañeros y con mis } \\
\text { profesores. }\end{array}$ & 4.20 & 1.077 \\
\hline Disfruto usándolas. & 4.02 & 1.025 \\
\hline Me resulta fácil usarlas. & 3.97 & 1.032 \\
\hline Me ayudan a aprender de forma autónoma. & 3.92 & 1.005 \\
\hline Usarlas potencia mi creatividad. & 3.74 & 1.182 \\
\hline Usarlas favorece una mejor escritura. & 3.66 & 1.209 \\
\hline Aprendo mejor utilizándolas. & 3.64 & 1.252 \\
\hline $\begin{array}{l}\text { Deberían estar más presentes en el currículum (en mi plan de } \\
\text { estudios). }\end{array}$ & 3.64 & 1.141 \\
\hline Usarlas al aprender aumenta mi motivación. & 3.30 & 1.242 \\
\hline Indicador de tecnoética & Media & Desv. típ. \\
\hline $\begin{array}{l}\text { Me comporto con educación cuando interactúo con otras personas } \\
\text { en internet. }\end{array}$ & 4.61 & .802 \\
\hline Me preocupan mi seguridad y mi privacidad en Internet. & 4.18 & 1.088 \\
\hline $\begin{array}{l}\text { Respeto la propiedad intelectual de los recursos que encuentro en } \\
\text { Internet (documentos, imágenes, vídeos). }\end{array}$ & 4.08 & 1.085 \\
\hline $\begin{array}{l}\text { Cuando soy testigo de un comportamiento poco ético en Internet } \\
\text { lo denuncio. }\end{array}$ & 3.82 & 1.232 \\
\hline
\end{tabular}

\section{Tabla 5. Distribución de indices por ítem especifico}

En este diagnóstico, se han podido realizar otros análisis, considerando otras variables, no obstante, serán presentados en próximos resultados.

\section{Discusión y conclusiones}

Como se mencionó al inicio, la educación es una de las áreas que a partir de la pandemia por COVID-19 ha tenido que enfrentar el reto de incorporarse a entornos virtuales de aprendizaje de forma acelerada. En ese sentido, es necesario fortalecer las competencias digitales de los estudiantes como una manera de ofrecer mejores habilidades para hacerle frente a la nueva era de la educación multimodal entendida como un sistema en que se definen los principios y lineamientos que conllevan la implementación de modelos educativos a distancia, abiertos o mixtos, en donde una de sus principales características es que se flexibilizan los procesos educativos promoviendo una serie de estrategias didácticas altamente mediadas por la tecnología., (Guzmán, T., 2016). Una educación que sea además inclusiva y que permita a los estudiantes mejorar las actitudes y expectativas que actualmente tienen frente a esta modalidad educativa.

Para lograr lo anterior, fue necesario realizar un estudio exploratorio que permitiera corroborar si la necesidad de fortalecer las competencias digitales de los estudiantes universitarios, y con ello obtener un diagnóstico de necesidades que orientara en el diseño de un plan de fortalecimiento. 
A partir de los resultados que el instrumento aportó, se puede afirmar que la muestra reporta que los niveles autopercibidos de cada una de las alfabetizaciones (competencias: informacional, tecnológica y multimedia) se encuentran en un nivel medio ya que cada una oscila en una media entre 3.90 y 4.06 toda vez que el nivel medio comprende un rango que oscila entre 3.76 y 4.50, a excepción de la alfabetización comunicativa que arrojó una media por debajo de los rangos anteriores, situándose en un nivel bajo de la competencia al alcanzar una media de 3.30. Por lo anterior, se detecta como área de oportunidad la alfabetización comunicativa, informacional y multimedia ya que son las que reportan medias más bajas, en contraste con la alfabetización tecnológica.

Por otro lado, se considera importante no desestimar los resultados que nos aporta el rubro de actitudes y expectativas hacia las TIC que apenas alcanza una media 3.90, que da por resultado un nivel medio, ya que este nivel se sitúa en un rango que oscila entre 3.89 y 4.33

Algunas de las cuestiones que se puede afirmar derivado de este diagnóstico, es que los estudiantes de Psicología de esta Universidad no poseen un nivel de autopercepción en competencias digitales alto, pese a su condición de jóvenes pertenecientes a la generación centennial (comprendida como aquella generación que nació a partir del año 2000), generación, que como hemos podido señalar anteriormente, se le ha atribuido una mayor facilidad en uso de la tecnología.

En el análisis más específico de cada item podemos encontrar que algunas de las áreas que se requieren fortalecer son las relativas a la alfabetización comunicativa, en donde ubicamos algunas de las medias más bajas, uno de los ejemplos es en el uso de las licencias para compartir contenidos digitales, en donde la autopercepción que presentan está muy por debajo del promedio, arrojando una media de 1.75, o como en el caso del item: preparar mi videocurrículum para una oferta de trabajo en una multinacional que arroja una media de 2.10 , ejemplos como estos, en contraste con los resultados en los ítems: conectarme con el celular al wifi de la universidad que obtuvo una media de 4.77, o bien, elegir la mejor opción para grabar un video que obtuvo una media de 4.25, permite concluir que aunque los jóvenes que estudian en esta Universidad, si bien, tienen acceso a dispositivos digitales, no necesariamente su uso está orientado a su formación académica.

Estos resultados son consistentes con los resultados que se identifican en los estudios a los que se ha hecho mención anteriormente, lo cuales también reportan la importancia de fortalecer las competencias digitales de los estudiantes, ya que aunque poseen ciertas habilidades en el uso de las TIC, estos son limitados en ciertas áreas competenciales, ya que el uso que se da, está más relacionado al ocio, a la comunicación social, pero no necesariamente al uso de la educación formal, en ese sentido, se justifica la importancia de implementar un plan de intervención que contribuya en el fortalecimiento de las competencias digitales de los estudiantes de nivel superior y con ello contribuir en una mejora en la experiencia en su tránsito por la educación virtual, que en este tiempo post pandémico ha abierto una oportunidad a la educación virtual e hibrida.

No se puede negar la importancia de que las instituciones educativas realicen acciones pertinentes para que de forma inicial, cuenten con la información respecto al nivel de apropiación a la tecnología y competencias digitales que poseen los 
estudiantes, y a partir de ello, ofrecer estrategias que coadyuven en su formación académica, toda vez, que a raíz del confinamiento, las instituciones educativas se han visto en la necesidad de migrar a la educación virtual, y se vuelve una responsabilidad el poder dotar tanto a los estudiantes, como a la comunidad académica, de las herramientas necesarias para hacerle frente a esta nueva era de la educación.

\section{Referencias}

Cabezas, M. y Casillas, S. (2017). ¿Son los futuros educadores sociales residentes digitales?

Revista Electrónica de Investigación Educativa, 19(4), 68. https://doi.org/10.24320/ redie.2017.19.4.1369

Ferrari, A., Neza, B. y Punie, Y. (2014). DIGCOMP: A Framework for Developing and Understanding Digital Competence in Europe. eLearning Papers, 38, 3-17.

https://www.researchgate.net/publication/282860020_DIGCOMP_a_Framework_ for_Developi ng_and_Understanding_Digital_Competence_in_Europe

Henríquez, P., Gisbert, M. y Fernández, I. (2018) La evaluación de la competencia digital de los estudiantes: una revisión al caso latinoamericano. Chasqui. Revista Latinoamericana de Comunicación, Quito, 137 . 93-112 https://doi.org/10.16921/chasqui. v0i137.3511

Gisbert, M., González, J. y Esteve, F. (2016). Competencia digital y competencia digital docente: una panorámica sobre el estado de la cuestión. RIITE. Revista Interuniversitaria de Investigación en Tecnología Educativa, 0, 74-83. http://dx.doi. org/10.6018/riite/2016/257631

González Calatayud, V., Román García, M., \& Prendes Espinosa, M. P. (2018). Formación en competencias digitales para estudiantes universitarios basada en el modelo DigComp. Edutec. Revista Electrónica de Tecnología Educativa. 65, 1-15

https://doi.org/10.21556/edutec.2018.65.1119

Gutiérrez-Porlán, I., Román-García, M., \& Sánchez-Vera, M. (2018). Estrategias para la comunicación y el trabajo colaborativo en red de los estudiantes universitarios. Comunicar, 54 (26), 98. https://doi.org/10.3916/C54-2018-09

Guzmán, T. (2016). Sistema Multimodal de Educación: Principios y lineamientos de la educación a distancia, abierta y mixta de la Universidad Autónoma de Querétaro. Dirección de Educación a Distancia e Innovación Educativa. 7. https://www.uaq.mx/ docsgrales/informatica/Sistema- Multimodal-de-educacion-UAQ.pdf

Navarro, S., Juárez, G. (2021). Evaluación de la competencia digital de la Universidad Viña del Mar. Ciências humanas: Estudos para uma visão holística da sociedade: vol // Artemis. 10.37572/EdArt_280621385. 
Prendes, M.P., Solano, I., Serrano, J.L., González, V. y Román, M. (2018). Entornos Personales de Aprendizaje para la comprensión y desarrollo de la competencia digital: análisis de los estudiantes universitarios en España. Educatio sig/o XXI, 36(2), 130.

https://doi.org/10.6018/j/333081

UNESCO. (2011). UNESCO ICT Competency Framework for Teachers. Paris. https:// iite.unesco.org/pics/publications/en/files/3214694.pdf

UNESCO. (2019). Marco de competencias de los docentes en materia de TIC UNESCO. Francia. https://unesdoc.unesco.org/ark:/48223/pf0000371024 
Eje temático

Aprendizaje

en Red

000

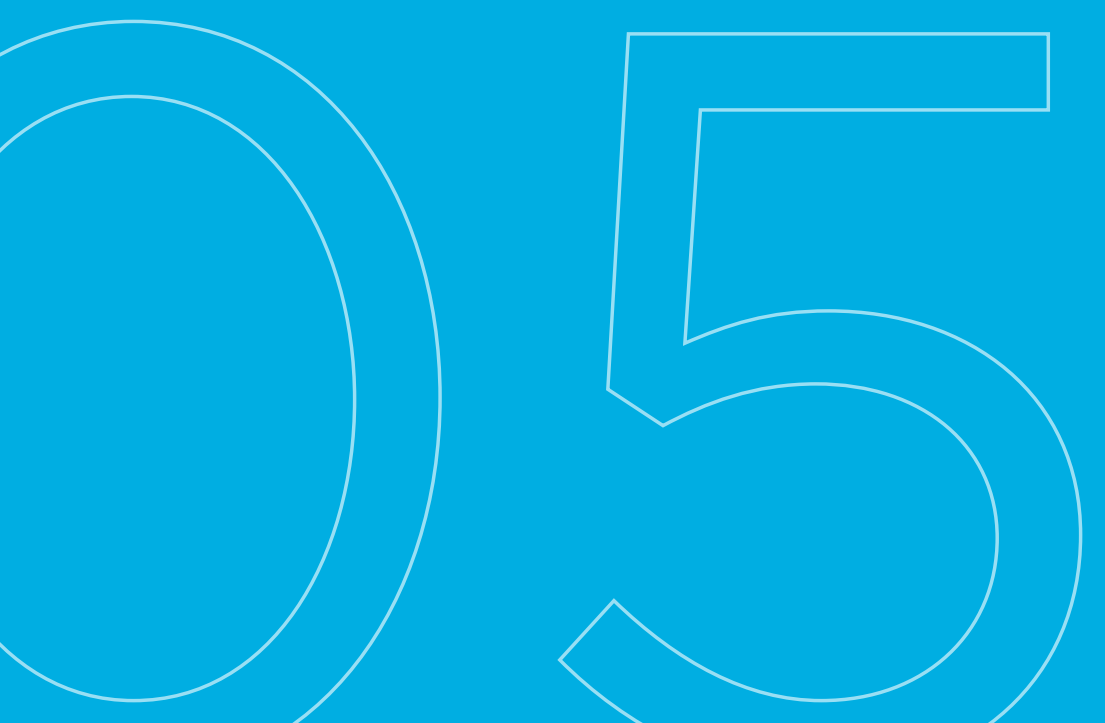




\section{Evaluación de Preguntas de Opción Múltiple Utilizando Herramientas de Clasificación Estadística dentro del Ámbito de las Ingenierías}

\section{Dadamia, Danilo}

Universidad de Buenos Aires, Facultad de Ingeniería ddadamia@fi.uba.ar

\section{Ferrini, Adrián}

Universidad de Buenos Aires, Facultad de Ingeniería aferrin@fi.uba.ar

\section{Gomez Toba, Gonzalo Hernan}

Universidad de Buenos Aires, Facultad de Ingeniería ggomezt@fi.uba.ar 


\title{
EVALUACIÓN DE PREGUNTAS DE OPCIÓN MÚLTIPLE UTILIZANDO HERRAMIENTAS DE CLASIFICACIÓN ESTADÍSTICA DENTRO DEL ÁMBITO DE LAS INGENIERÍAS
}

\author{
Dadamia, Danilo \\ Ferrini, Adrián \\ Gomez Toba, Gonzalo Hernan
}

\section{Resumen}

En el marco de la emergencia sanitaria que estamos atravesando como sociedad, a raíz de la pandemia COVID 19, por la cual se encuentran suspendidas las clases presenciales dentro del ámbito de la Educación Superior, y en relación con el cumplimiento de las condiciones de regularidad, resulta necesario sustituir la modalidad presencial de exámenes parciales por un sistema de evaluación virtual. Una de las metodologías más utilizadas en la evaluación virtual es la de exámenes de preguntas de opciones múltiple (POM) o multiple choice question (MCQ), en inglés. Las respuestas dadas por los estudiantes, al contestar pruebas de tipo POM, es una fuente de información de interés, que nos permite identificar qué dificultades o errores tienen los estudiantes que las contestan y también como contraparte adquirir experiencia para identificar preguntas que pudieran mejorarse. El objetivo de este trabajo es realizar una evaluación de las dificultades que afrontaron los estudiantes de la cátedra de Física I de la Facultad de Ingeniería de la UBA (Universidad Nacional de Buenos Aires), ante las evaluaciones de tipo POM que se han aplicado tanto en evaluación final de curso, como en evaluaciones parciales, con el fin de mejorar este tipo de metodología para futuros exámenes. Para lograr esto, se planteó un análisis estadístico en el cual, la utilización de algoritmos de aprendizaje supervisado y no supervisado pueden ser herramientas para agrupar una colección de tópicos, de acuerdo con su grado de similitud, como k-means, gradient boosted trees, y support vector machine. Estos análisis de clasificación estadísticos fueron implementados en RapidMiner Studio Versión 9.9

\section{Palabras clave}

MCQ, Evaluación, Moodle, RapidMiner, k-means, GBDT (Gradient Boosted Decision Trees), SVM (Support Vector Machine). 


\section{Introducción}

La evaluación, en todos los estadios del desarrollo humano, es un proceso por el cual se obtiene información necesaria para la toma de decisiones. Implica recolectar información/conocimiento, para su análisis, que mediante comparación reflexiva con determinadas instancias de referencia o patrones de deseabilidad, permita orientar la acción o la toma de decisiones. En el ámbito de la Educación Superior, este concepto adquiere características de singular importancia, dado que la evaluación tiene también un carácter formativo, por lo que instrumentar las acciones adecuadas para garantizar su calidad promueve la excelencia del conocimiento que se construye en las universidades y otros centros educativos de estudios superiores. En el caso de la institución tiene la arista de acreditación lo cual nos compromete, como docentes, a estar atentos a la calidad del proceso de enseñanza y, a los estudiantes, a aprehender herramientas que mejoren su proceso de aprendizaje con la consecuente acreditación que lograrán.

Los exámenes de preguntas de opción múltiple POM, están ampliamente difundidos como herramienta en la evaluación a distancia. La evaluación de selección múltiple es una prueba objetiva en la cual se presenta una situación o problema, en forma de pregunta directa, y varias opciones de respuesta posible. Es por esto, que las pruebas de POM suelen denominarse "pruebas objetivas" por su demostrada alta fiabilidad, aunque para ello deben estar bien diseñados. De hecho, confeccionarlos adecuadamente requiere un cierto nivel de experiencia. Respecto a su validez, son adecuados para medir un espectro amplio del conocimiento y se pueden usar con seguridad para medir los componentes relacionados con los conocimientos y, hasta cierto punto, la capacidad de aplicarlos, siempre y cuando se formulen adecuadamente (Haladyna et al., 2011). En general este tipo de evaluación es útil para medir conocimientos memorísticos, hechos concretos, identificar relaciones causa-efecto, diagnosticar conocimientos específicos, interpretar consignas.

La evaluación con POM, permite abarcar grupos numerosos donde la corrección tradicional podría estar sesgada, ofrece ciertas garantías de igual tratamiento para todos los estudiantes. Estas pueden dividirse en preguntas en donde se selecciona como respuesta "verdadero" o "falso" y aquellos que requieren seleccionar una única respuesta de un universo de respuestas propuestas o distractores, que en el caso de las evaluaciones de Física I fue del orden de cinco. Este último es el modelo adoptado en los exámenes propuesto de la materia en donde se contempló que para las respuestas de tipo numérica, el error numérico fuese del orden del 10\%, para evitar que el sistema califique inadecuadamente los errores de redondeo que pudiera arrastrar el estudiante.

Este tipo de preguntas constaron de un enunciado y una pregunta introductoria. Las dificultades que suelen presentarse en este tipo de exámenes son: que las opciones o el enunciado sean vagos, el lenguaje o la estructura de las opciones no sean homogéneas, las opciones no tengan un orden lógico; los enunciados sean innecesariamente complicados; las opciones brinden pistas por estar emparejadas o ser exhaustivas donde algunas de las opciones pueden eliminarse debido a que otras opciones cubren todos los resultados posibles; la respuesta correcta sea más extensa, más específica o más completa que las demás opciones; se incluya una palabra o frase tanto en el enunciado como en la respuesta correcta; los datos numéricos no se presenten de manera uniforme, etc. (Paniagua y Swygert, 2016). 
En este trabajo inicial, dado la complejidad de este tipo de evaluaciones, incursionaremos en el análisis de grandes bloques de preguntas del tipo POM, utilizando herramientas estadísticas que usan las ciencias de datos para evaluar grandes volúmenes de información, bajo ciertas consideraciones temáticas, como asumir que cada bloque pregunta dentro de una clase tiene el mismo nivel de dificultad. El objetivo es reconocer correlaciones que nos permitan agrupar las respuestas de estas evaluaciones, con características comunes que puedan ser reconocidas y nos permitan mejorar estas actividades de acreditación.

\section{Método/Descripción de la experiencia}

Para este trabajo en particular, se tomaron la evaluación del tema Sistema de Partículas o Puntos Materiales y Cuerpo Rígido, de la unidad de Mecánica Elemental de la asignatura Física I, del tercer semestre de la carrera de Ingeniería de la UBA, considerado como primer semestre del segundo ciclo de formación inmediato posterior al CBC (Ciclo Básico Común de la UBA). La población de la evaluación es de 340 estudiantes, que corresponde también a ese número de intentos dado que cada estudiante puede hacer un sólo intento, de manera sincrónica, en un tiempo máximo de desarrollo de dos horas y media.

El primer análisis exploratorio de la evaluación se basó en el uso de herramientas expuestas en los reportes estadísticos de los cuestionarios provistos por Moodle: indicadores de discriminación, facilidad, dificultad y consistencia (Documentación: Moodle docs en español, 2019). Este primer análisis no permitió evaluar la consistencia interna de todo el cuestionario. El segundo análisis que se hizo, con la asistencia de las herramientas informáticas para minimizar la subjetividad, permite reflexionar sobre las respuestas generadas por los estudiantes, y así clasificar y agrupar las mismas, de tal manera de establecer la ponderación de cada una en la obtención de la nota final del cuestionario. Para lograr esto, se recurrió a algoritmos del tipo: agrupamiento k-medias (k-means), potenciación de gradientes: GBDT (Gradient Boosted Decision Trees), máquina de vector soporte: SVM (Support vector machine) (Boehmke y Greenwell, 2020). Para armar y correr las herramientas de clasificación estadística se utilizó el software libre de licencia AGPL RapidMiner Studio (RapidMiner)

\section{Resultados}

En los documentos de Moodle se sugieren indicadores que se han utilizado para generar una tabla: 1) Promedio/Facilidad; 2) Dificultad; 3) Discriminación. (Nota: el EVEA utilizado a principios del aislamiento no contaba con el complemento estadístico. Se decidió, realizar por planilla de cálculo el desarrollo parcial de lo que aconseja Moodle). Los resultados globales se muestran en el siguiente gráfico telaraña, radar chart. 


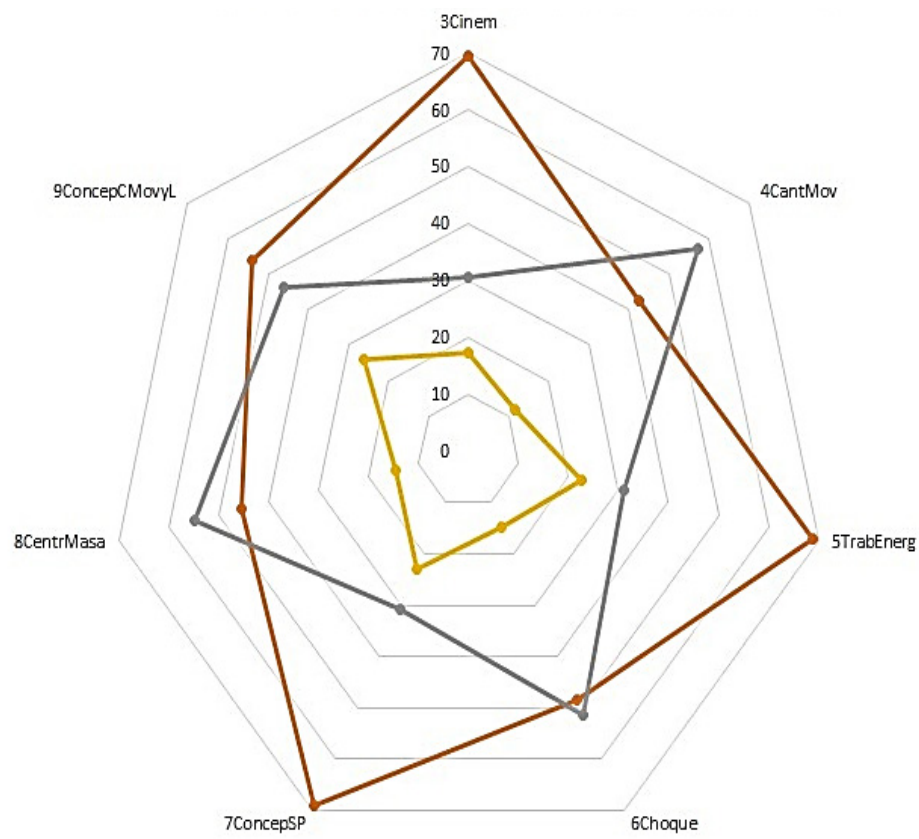

Figura N: grafico de radar, donde en cada vértice se detalla el tipo de pregunta evaluada. Cada color representa el promedio (naranja), la dificultad (gris) y la discriminación de las mismas (amarillo).

El resultado de consistencia interna de todo el cuestionario fue del orden de $41,1 \%$ lo que nos da una idea, de lo poco satisfactorio del mismo. Esto se traduce en la recomendación de hacer mejoras en las preguntas que tengan mayor impacto en la nota final.

Para el estudio estadístico con k-means, GBDT, y SVM, uniformizamos la respuesta de tipo POM, de tal manera de dividir en 4 clases la obtención de la nota final: insuficiente, aprobado, bueno y muy bueno. Esto nos permitió, para cada método, establecer cuáles eran las preguntas de mayor peso que impactaban en la obtención de cada clase. De los gráficos podemos ver como se agrupan las preguntas POM, independientemente del método de clasificación estadístico utilizado para cada una de las clases establecidas insuficiente, aprobado, bueno, muy bueno.

Cluster $0_{(112)}$ Cluster $1_{(129)}$ Cluster $2_{(99)}$

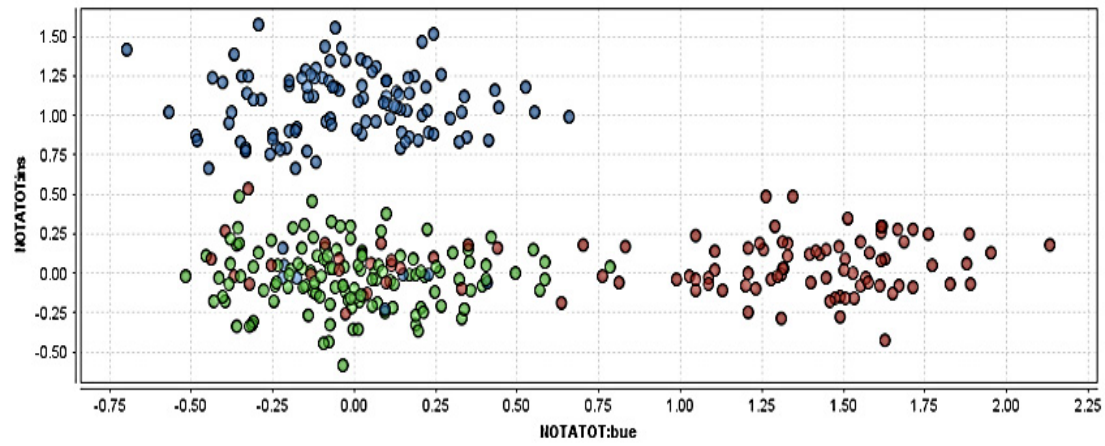

Figura N²: gráfico de salida corrido con k-means, en donde podemos visualizar la preponderancia de las respuestas 4, 5 y 9 para la clase aprobado y bueno. 


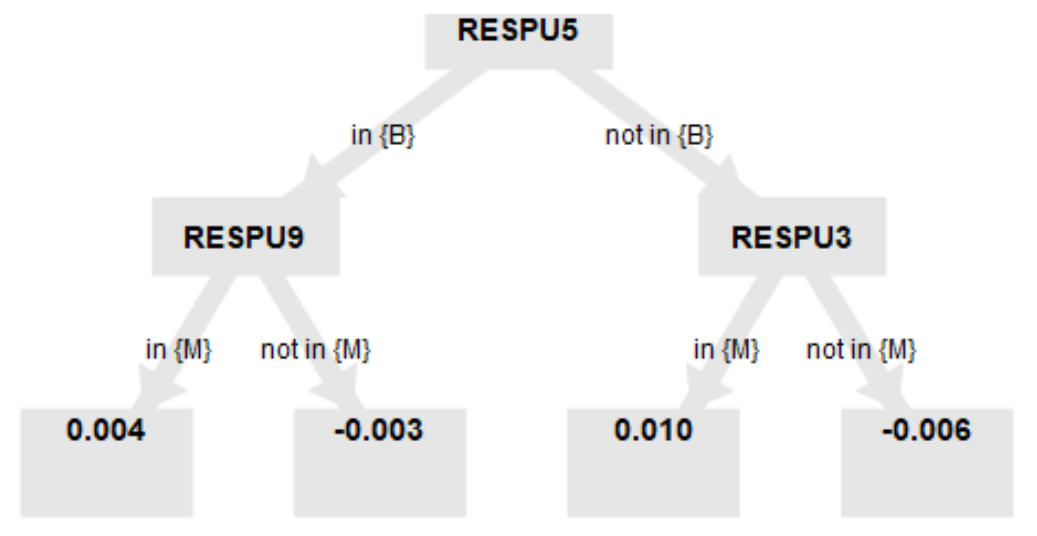

Figura N³: gráfico de salida corrido con GBDT, en donde podemos visualizar la preponderancia de las respuestas 5 y 9 para la clase aprobado.

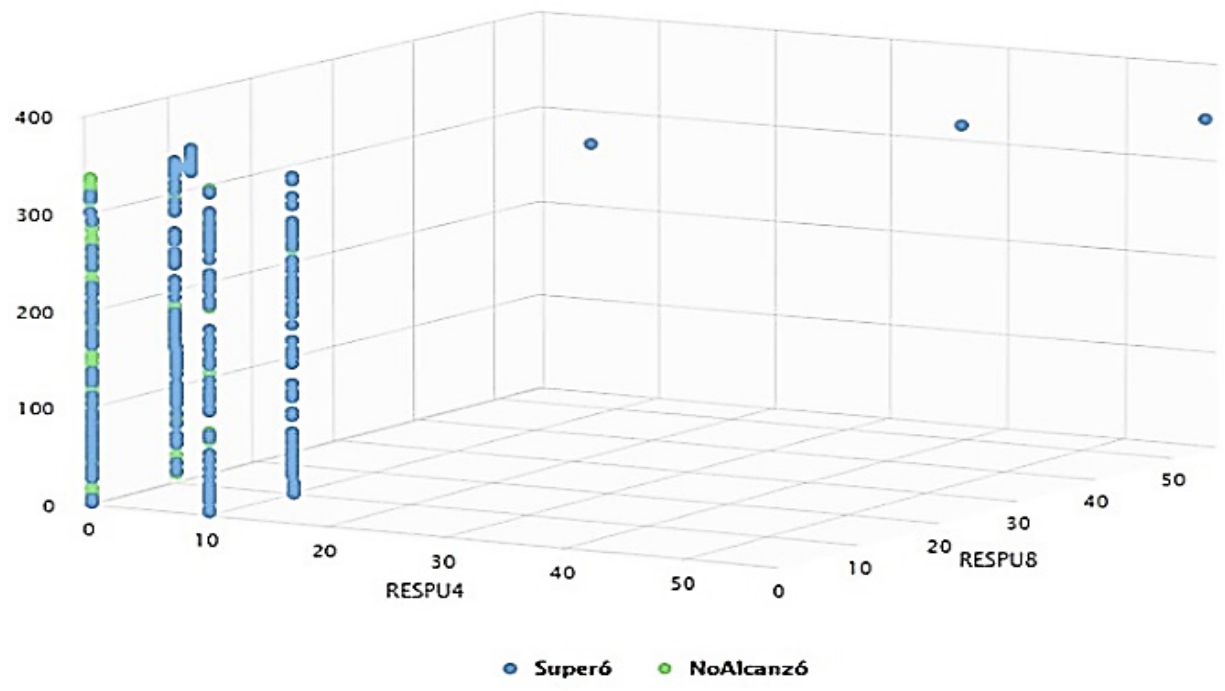

Figura N4: gráfico de scatter plot 3D, corrido con SVM, en donde podemos visualizar la preponderancia de las respuestas 4 y 8 para la aprobación o no aprobación del cuestionario.

Del análisis de cada una de las clases obtuvimos, independientemente del método, los siguientes resultados: para la clase insuficiente, las preguntas que condicionan la mismas son 4, 6 y 8, la clase aprobado fueron 5 y 9, la clase bueno fueron 9 y 4 y para muy bueno las preguntas 4, 6 y 8 . De las nueve preguntas analizadas de POM, aquellas relacionadas con las propiedades del centro de masa, tanto de manera numérica como conceptual (4, 6 y 8), eran las que tenían mayor impacto en la nota final, pero también tuvieron menor discriminación confirmada por todos los métodos; lo cual indica la necesidad de revisión. 


\section{Discusión y conclusiones}

Planteado el objetivo de analizar el tipo POM de evaluaciones a distancia, dentro del marco educativo, con indicadores y herramientas que tengan un fundamento estadístico-científico. Se puede evaluar las POM minimizando el aporte subjetivo de la mirada docente. Por lo tanto contar con una herramienta analítica de baja subjetividad nos permitirá generar una base para la reflexión y mejoramiento de estas evaluaciones.

Para realizar este tipo de análisis fue necesario generar una base de datos de variables consistentes, para que la herramienta estadística permita realizar un correcto procesamiento de la evaluación. La generación de los indicadores de discriminación, facilidad, dificultad y consistencia, basados en la herramienta estadística de Moodle nos permitió una primera aproximación al problema, que se usó como pivot de programación de los clasificadores estadísticos del tipo k-means, GBDT, y SVM. Los valores bajos de discriminación aportados por los indicadores de tipo Moodle, resultaron tener pesos importantes en las herramientas de los clasificadores estadísticos.

La utilización de este tipo de metodologías permitió determinar, cuáles eran las preguntas de mayor impacto sobre el resultado final, discriminando cada una de las cuatro clases establecidas. Esto permitió concluir que las mismas estaban centradas alrededor de la temática de propiedades del centro de masa, tanto de manera numérica como conceptual.

\section{Referencias}

Boehmke, B., Greenwell, B. M. A. (2020). Hands-On Machine Learning with R. CRC. Press Taylor \& Francis Group. ISBN: 978113849568. Recuperado en junio 2021, de https://bradleyboehmke.github.io/HOML/.

Cao,F., Liang J., Jiang G. (2009). An initialization method for the K-Means algorithm using neighborhood model. Computers \& Mathematics with Applications. 58. pp 474-483. 10.1016/j.camwa.2009.04.017. Recuperado en septiembre 2021, de https://www.researchgate.net/publication/220512399_An_initialization_method_for_ the_K_-Means_algorithm_using_neighborhood_model

Coadou, Y. (2013). Boosted Decision Trees and Applications. EPJ Web of Conferences DOI: 10.1051/. Recuperado en septiembre 2021, de https://inspirehep.net/ files/7e6542b5c90f3616cb63675046c9380a

Cover, T., Hart, P. (1967). Nearest neighbor pattern classification, en IEEE Transactions on Information Theory, vol. 13, no. 1, pp. 21-27, Enero 1967, doi: 10.1109/TIT.1967.1053964. Recuperado en septiembre de 2021, de https://ieeexplore.ieee.org/document/1053964

Documentación: Moodle docs en español. (2019). Recuperado en junio 2021, de https://docs.moodle.org/all/es/Reporte_de_estad\%C3\%ADsticas_de_examen.

Haladyna, T. M., Haladyna, R., Merino Soto, C. (2011). Preparación de preguntas de opciones multiple para medir el aprendizaje de los estudiantes. OEl-Revista Iberoamericana de Educación (ISSN: 1681-5653). 
Kim, J., Kim, B., Savarese, S. (2012). Comparing Image Classification Methods: K-Nearest-Neighbor and Support-Vector-Machines. Applied Mathematics in Electrical and Computer Engineering. Recuperado en septiembre de 2021, de http://www.wseas. us/e-library/conferences/2012/CambridgeUSA/MATHCC/MATHCC-18.pdf

MacQueen, J. B. (1967). Some Methods for classification and Analysis of Multivariate Observations. Proceedings of 5th Berkeley Symposium on Mathematical Statistics and Probability 1. University of California Press. pp. 281-297. MR 0214227. Zbl 0214.46201.

Paniagua, M., Swygert, K. A. (2016). ¿Cómo elaborar preguntas para evaluaciones escritas en las áreas de ciencias básicas y clínicas?. National Board of Medical Examiners (pp.7-13). Recuperado en junio 2021, de https://www.nbme.org/sites/default/ files/2020-1/DownloadingtheGoldBook_ES.pdf

Universidad de Oviedo. Apuntes de Grado de Ingeniería Informática del Software https://www.unioviedo.es/compnum/laboratorios_py/kmeans/kmeans.html

IBM: documentacion del SPSS Modeler https://www.ibm.com/docs/es/spss-modeler/SaaS?topic=models-how-svm-works

Boser, B.E., Guyon, I.M. and Vapnik, V.N. (1992) A Training Algorithm for Optimal Margin Classifiers. Proceedings of the 5th Annual Workshop on Computational Learning Theory, Pittsburgh, 27-29 July 1992, 144-152. http://dx.doi.org/10.1145/130385.130401

Breiman, L. (June 1997). "Arcing The Edge” (PDF). Technical Report 486. Statistics Department, University of California, Berkeley.

Friedman, J.H., 1999. Greedy function approximation: a gradient boosting machine. Technical Report, Department of Statistics, Stanford University.

RapidMiner Studio. Recuperado en junio 2021, de https://rapidminer.com/products/ studio/

\section{Anexo: clasificadores Estadísticos}

\section{k-means}

Los algoritmos de clustering son considerados de aprendizaje no supervisado. Dado que busca patrones en los datos sin tener una predicción específica como objetivo (no hay variable dependiente). En lugar de tener una salida, los datos solo tienen una entrada que serían las múltiples variables que describen los datos. Fue utilizado por primera vez por J.B.MacQueen (1967). El algoritmo consta de tres pasos:

1. Inicialización: una vez escogido el número de grupos, $k$, se establecen $k$ centroides en el espacio de datos, escogiéndolos aleatoriamente.

2. Asignación objetos a los centroides: cada objeto de los datos es asignado a su centroide más cercano. 
3. Actualización centroides: se actualiza la posición del centroide de cada grupo tomando como nuevo centroide la posición del promedio de los objetos pertenecientes a dicho grupo. (Universidad de Oviedo)

Para nuestro trabajo cada estudiante es un elemento $X$ en un espacio de $m$ dimensiones $\left(\mathrm{x}_{1}, \mathrm{x}_{2}, \ldots, \mathrm{x}_{\mathrm{n}}\right)$ que son las respuestas. El algoritmo $k$-means construye $\mathrm{k}$ grupos donde se minimiza la suma de distancias de los objetos, dentro de cada grupo $Z=$ $\left\{z_{1}, z_{2}, \ldots, z_{k}\right\}$, a su centroide. Las agrupaciones de $k$-means se logran mediante evaluación de mínimas distancias euclideas entre los datos y el centroide de cada cluster. El problema se puede formular de la siguiente forma:

$$
\min _{z}\left(E_{(u i)}\right)=\min _{z} \sum_{i=1}^{k} \sum_{x_{j} \epsilon z_{i}}\left\|x_{J}-u_{i}\right\|^{2}{ }^{(1)}
$$

donde $Z$ es el conjunto de datos cuyos elementos son los objetos xj representados por vectores, donde cada uno de sus elementos representa una característica o atributo. Tendremos $k$ grupos o clusters con su correspondiente centroide $Q_{i}$.

En cada actualización de los centroides, desde el punto de vista matemático, imponemos la condición necesaria de extremo a la función cuadrática $E\left(Q_{i}\right)$ derivando la misma e igualando a cero. Luego para la siguiente iteración, se toma el promedio de los elementos de cada grupo como nuevo centroide.

Como dijimos al principio el ordenamiento no es supervisado, pero en este trabajo el resultado de los reportes provistos por Moodle, ayudó a establecer K, para hacer una división inicial de los clusters, dado que una de las debilidades es encontrar un valor de $\mathrm{K}$ tal que agrupe sin apartar valores que sean cercanos pero que tampoco particione en conjuntos que repitan características de otros conjuntos.

\section{Support Vector Machine (SVM)}

SVM es un algoritmo de aprendizaje supervisado que se utiliza en muchos problemas de clasificación y regresión, fueron propuestos por Boser, Guyon and Vapnik en 1992. (Boser et al., 1992). Funciona correlacionando datos a un espacio de características de grandes dimensiones de forma que los puntos de datos se puedan categorizar, incluso si los datos no se puedan separar linealmente de otro modo. Se detecta un separador entre las categorías y los datos se transforman de forma que el separador se puede extraer como un hiperplano. Tras ello, las características de los nuevos datos se pueden utilizar para predecir el grupo al que pertenece el nuevo registro. (IBM)

El algoritmo SVM estándar está formulado para problemas de clasificación binaria; los problemas multiclase normalmente se reducen a una serie de problemas binarios. El entrenamiento de SVM se asemeja a resolver un problema de optimización cuadrática para ajustar un hiperplano que minimice el margen flexible entre las clases.

Si el conjunto no se presenta como separable se puede establecer un margen blando que permite adaptar el tamaño del margen. SVM sin embargo, se adapta a cierta clasificación multimodal mediante el uso de funciones de "deformación" del espacio denominados kernel, entre los más difundidos de estos se encuentran: lineal y radial. 
Sean $\mathrm{x}_{1} \mathrm{y} \mathrm{x}_{2}$ las clases a separar:

El kernel lineal se define como: $K\left(x_{1}, x_{2}\right)=x_{1}^{T} x_{2}$

El kernel radial (RBF) o guassiana se define como:

$\exp \left(-\frac{\left\|\mathrm{x}_{1}-\mathrm{x}_{2}\right\|^{2}}{2 \gamma^{2}}\right)$

El valor de $\gamma$ controla el comportamiento del kernel y está asociado con su ancho.

Para nuestro trabajo el kernel gaussiano fue el que obtuvo mejores resultados de separabilidad de las componentes. Para hacer esto y considerar todas las clases construimos una función clasificadora global directamente considerando todas las diferentes clases a la vez. Las máquinas biclasificadoras SVM generalizadas dan solución al problema de la multiclasificación.

\section{Gradient Boosted Decision Trees (GBDT) Potenciación de gradientes}

Los árboles de decisión son modelos predictivos formados por reglas binarias (si/ no) con las que se consigue repartir las observaciones en función de sus atributos y predecir así el valor de la variable respuesta. La idea de la GBDT fue originada en la observación realizada por Leo Breiman (Breiman, 1997) y Posteriormente Jerome H. Friedman (Friedman, 1999) desarrolló algoritmos de aumento de gradiente.

Este método esta formados por un conjunto de árboles de decisión individuales, entrenados de forma secuencial, de forma que cada nuevo árbol trata de mejorar los errores de los árboles anteriores. La predicción de una nueva observación se obtiene agregando las predicciones de todos los árboles individuales que forman el modelo. 


\section{La Telepresencia en un Programa Doctoral en Red. Perspectivas de Estudiantes, Docentes y Administrativos}

Orellana Hernández, Martha Lucía Universidad Autónoma de Bucaramanga morellana@unab.edu.co

Angulo Mendoza, Gustavo Adolfo Université TÉLUQ gangulo@teluq.ca 


\title{
LA TELEPRESENCIA EN UN PROGRAMA DOCTORAL EN RED. PERSPECTIVAS DE ESTUDIANTES, DOCENTES Y ADMINISTRATIVOS
}

\author{
Orellana Hernández, Martha Lucía \\ Angulo Mendoza, Gustavo Adolfo
}

\section{Resumen}

Con la finalidad de formar investigadores de alto nivel que contribuyan al desarrollo científico del país, un consorcio de tres universidades colombianas se constituyó para desarrollar un programa doctoral en ingeniería que incluye tres áreas de investigación: automática, energía e informática. El Programa recibió la aprobación del Ministerio de Educación de Colombia para ser ofrecido en modalidad presencial. Para satisfacer la exigencia de presencia física, los estudiantes asisten al campus de la universidad en la cual se encuentran inscritos y los cursos son impartidos por un profesor desde un aula de telepresencia de cualquiera de las tres universidades asociadas. La emergencia sanitaria declarada en marzo de 2020 obligó a suprimir el requisito de la presencia física y a impartir los cursos totalmente a distancia. Esta nueva realidad fue el catalizador para que las autoridades universitarias consideraran la transformación de la forma de desarrollar el Programa. Este trabajo presenta un análisis de esta transformación contemplada, comparando los puntos de vista de las diferentes partes interesadas. En general, los participantes valoran las posibilidades que brinda la presencia física, pero también las ventajas de poder participar en forma remota en los cursos. Resulta entonces interesante la puesta en marcha de un dispositivo de formación híbrido que integre la modalidad presencial y la formación a distancia en modo síncrono. En ese sentido, los participantes subrayan la importancia de que los profesores fortalezcan sus competencias tecnopedagógicas y de diseño instruccional para desarrollar los cursos en esta modalidad, y sugieren aprovechar la modalidad presencial para actividades complementarias a los cursos.

\section{Palabras clave}

Telepresencia, educación en línea, modo síncrono, modo híbrido, formación posgradual. 


\section{Introducción}

El Doctorado en Ingeniería, es un doctorado en red desarrollado por tres universidades colombianas que cuentan con acreditación de alta calidad: Universidad Autónoma de Bucaramanga (UNAB), Universidad Autónoma de Manizales (UAM) y Universidad Autónoma de Occidente (UAO), miembros de la Red Mutis.

Ser un doctorado en red permite articular las fortalezas de tres universidades: grupos de investigación; la mejor infraestructura de cada institución, como lo son los laboratorios y bases de datos compartidas; equipo docente y sus relaciones con colegas del orden nacional e internacional; alianzas nacionales e internacionales con el sector público y empresarial; recursos para la movilidad de los estudiantes y para fomentar el impacto regional del Programa; cursos ofrecidos por uno o más docentes de las tres instituciones, además de los docentes externos nacionales e internacionales; y sostenibilidad financiera.

A febrero de 2021 se ofertan en Colombia 378 programas de doctorado, la totalidad de ellos en modalidad presencial (SNIES, 2021). En contraste, se ofertan 2226 programas de maestría de los cuales 131 programas se imparten en la modalidad "en línea" y 33 programas en la modalidad a distancia "tradicional". Aunque el Ministerio de educación de Colombia no haya condicionado la acreditación de programas de doctorado a la adopción de una modalidad en particular, el Ministerio de Ciencia, Tecnología e Innovación establece dentro de las condiciones para el otorgamiento de becas para estudios doctorales, que el programa de doctorado al cual aspira el candidato se imparta en modalidad presencial y muchas veces también que el candidato realice sus estudios a tiempo completo (Minciencias, 2017; 2019a; 2019b; 2020).

Para tratar de responder a la necesidad de presencialidad que la situación contextual impone, al tiempo que se ofrece un programa sostenible, el consorcio desarrolló un doctorado en red que permite, de un lado, articular las capacidades de cada institución en términos de recursos para la investigación, cuerpo profesoral e infraestructura y, de otro lado, incrementar el número de potenciales candidatos al expandir la zona de influencia del Programa. Así, los estudiantes toman los cursos asistiendo a un aula de telepresencia en la universidad en la cual se encuentran inscritos. Se configura así un modo híbrido de formación que integra el modo presencial y la formación en línea en modo síncrono (Woo et al., 2019) como se muestra en la figura 1.

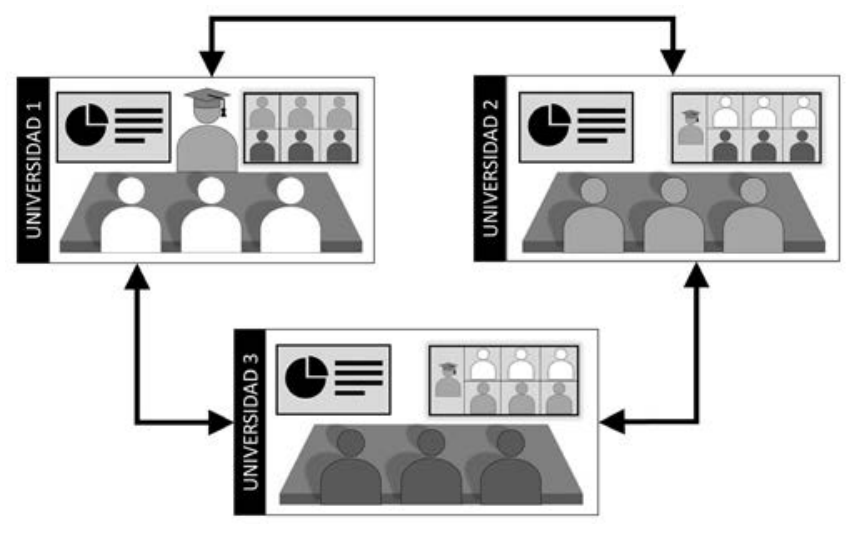

Figura 1. Difusión de las clases en modo híbrido. 
Una vez terminadas, las clases grabadas son guardadas para que en cualquier momento un estudiante o docente pueda acceder a ellas y consultar lo visto en clase. Las aulas virtuales en la plataforma Moodle permiten centralizar y asegurar el acceso a los materiales actualizados de las clases, así como la interacción de estudiantes y profesores en espacios fuera de clase. Así, añadiendo el modo asíncrono, se completa un dispositivo de formación que combina asistencia presencial, asistencia en línea síncrona, e interacción y acceso asíncrono a los materiales, dispositivo al que Beatty (2019) se refiere como "comodal".

Si bien la modalidad de formación híbrida mencionada permitía responder a la exigencia de presencia física y a la vez ampliar la zona de influencia del programa de doctorado, varios factores llevaban a considerar una modalidad que favoreciera la promoción del Doctorado en otras zonas del país donde la oferta de programas doctorales en ingeniería no se ha desarrollado aún. La autoevaluación realizada en 2019 mostró que una difusión a distancia permitiría a los potenciales candidatos de otras regiones del país, o incluso de países vecinos, realizar los cursos obligatorios sin desplazarse a una de las tres universidades.

A partir de ese momento, la dirección del Programa contempla una transformación progresiva de este, dada la dificultad manifestada por varios profesionales interesados en inscribirse al Doctorado, que residen en otras ciudades y desearían poder continuar laborando a tiempo parcial mientras adelantan sus estudios doctorales también a tiempo parcial. Aunque la naturaleza del Programa exige en ciertos momentos el trabajo en laboratorios especializados que se encuentran en los campus de las universidades, la posibilidad de seguir los cursos en línea aportaría un nivel de flexibilidad buscado por estos profesionales.

Debido a la crisis sanitaria provocada por la pandemia de la COVID-19, lo que se había pensado como una transformación progresiva durante los años siguientes resultó siendo un paso que debía hacerse de manera acelerada en el lapso de pocas semanas. Desde el comienzo de la crisis, Colombia registró un aumento vertiginoso en el número de casos y en septiembre de 2020 llegó a ser el quinto país a nivel mundial en casos confirmados y hacia mediados de agosto de 2021, más de 123000 personas habían muerto en el país debido a la enfermedad (JHU, 2021).

Ante tal situación extremadamente crítica en el país se imponían medidas excepcionales. Entre ellas, la formación en línea se convirtió en la norma en todos los niveles de enseñanza desde el prescolar hasta la universidad. Así, el programa de doctorado implementó esta modalidad, eliminando, de forma temporal, la obligación de presencia física en los campus universitarios. Tanto docentes como estudiantes empezaron a seguir los cursos desde sus domicilios.

Específicamente, este trabajo busca alcanzar los siguientes objetivos:

- Identificar los puntos de vista de estudiantes, profesores y administrativos con respecto a esta transformación.

- Examinar las posibilidades y características de un dispositivo de formación híbrido, para implementarlo una vez superada la crisis sanitaria.

- Identificar los retos y las posibilidades que ofrece la coexistencia de múltiples modos de difusión. 


\section{Descripción de la experiencia}

\section{Descripción del contexto y de los participantes}

Desde un enfoque de práctica reflexiva, analizamos los puntos de vista de estudiantes, profesores y administrativos en relación con el dispositivo de formación híbrido implementado en el Programa y su transformación a una modalidad enteramente a distancia como consecuencia de la crisis sanitaria. Para ello se han realizado entrevistas a representantes de las partes interesadas en las tres universidades. La participación se realizó sobre una base voluntaria como respuesta a una invitación hecha desde una de las coordinaciones institucionales del Programa. La siguiente tabla sintetiza las características de los participantes:

Tabla 1. Características de los participantes.

$\begin{array}{llll}\text { Categoría } & \text { Código } & \text { Universidad } & \text { Experiencia en educación a distancia } \\ \text { Estudiantes } & \text { E2 } & \text { UNAB * } & \text { Ninguna } \\ & \text { E3 } & \text { UAO }{ }^{* *} & \text { Ninguna } \\ \text { P1 } & \text { Invitado } & \text { Varios programas de primer y segundo ciclo } \\ \text { Profesores } & \text { P2 } & \text { UAO } & \text { Varios cursos de ciclo superior } \\ & \text { P3 } & \text { UAO } & \text { Como diseñador pedagógico y como estudiante } \\ \text { G1 } & \text { UAM *** } & \text { Muy poca experiencia } \\ \text { Administrativos } & \text { G2 } & \text { UAM } & \begin{array}{l}\text { Algunos cursos como estudiante de doctorado y } \\ \text { algunas capacitaciones }\end{array} \\ & \text { G3 } & \text { UAO } & \text { Algunos cursos a distancia y en modo híbrido }\end{array}$

* Universidad Autónoma de Bucaramanga. ** Universidad Autónoma de Occidente. *** Universidad Autónoma de Manizales

\section{Instrumentos}

Las entrevistas se realizaron utilizando un cuestionario semiestructurado que se puede consultar siguiendo este enlace: https://monurl.ca/guiaentrevista

\section{Procedimiento}

Los temas tratados durante las entrevistas incluían los retos, las posibilidades y los obstáculos de una formación no presencial específicamente en el programa de doctorado. Las entrevistas tuvieron una duración de entre 10 y 20 minutos con un promedio de 18 minutos. Una vez realizadas, estas fueron transcritas para luego proceder a su codificación con el objeto de identificar los temas emergentes. A continuación, se presentan los principales resultados. 


\section{Resultados}

\section{Perspectivas de los estudiantes}

En cuanto a los principales criterios tenidos en cuenta para la elección del programa de estudios, los estudiantes señalan que su estructura "en red" y la posibilidad de explotar la infraestructura de investigación de las tres instituciones son características muy interesantes del Programa: "Pude visualizar el potencial que puede tener la red desde el punto de vista de acceso a los laboratorios en las tres universidades" (E3).

En concordancia con los resultados del meta-análisis de Gray \& Crosta (2019), la flexibilidad ha sido mencionada en forma repetida por los estudiantes entrevistados como un elemento primordial. Ellos valoran especialmente la posibilidad de elegir la modalidad que les acomoda mejor: "si a uno le dicen, si quiere venga, pues yo voy, porque me gusta ir. Pero si me dijeran: siempre tiene que venir, so pena por ejemplo de algún castigo, entonces la percepción de la experiencia no se siente igual” (E2). Así, la combinación de modalidades favorecería la inclusión de estudiantes con diversos perfiles gracias a la posibilidad de tomar los cursos según la modalidad que se acomode mejor a la situación de cada estudiante:

Considerar unos aspectos multidimensionales que puede tener un estudiante de doctorado que no es necesariamente un estudiante a tiempo completo [...], que dentro de la misma complejidad que puede tener la vida, contemplar que algunos pueden tener proyectos, o trabajan en una empresa y pues, permite esas facilidades en cuanto al horario (E2).

A pesar del importante valor que representaría para los estudiantes la posibilidad de escoger la modalidad de participación en los cursos, los entrevistados concuerdan en señalar que la presencialidad debería ser la modalidad a privilegiar para algunos aspectos de la formación doctoral: "las reuniones con el director de tesis y con el codirector, me parece que son importantes que se puedan hacer de manera presencial. Yo siento que fluye mejor la conversación. Está uno más atento” (E1).

De otro lado, las interacciones presenciales son percibidas como necesarias para favorecer la dimensión socioafectiva de la formación, especialmente durante la primera etapa de la formación doctoral: "uno se toma un café con ellos y esa interacción ayuda para que al comienzo seamos un grupo. Si hubiéramos arrancado de manera remota no se hubiese formado un nivel de unión y de comunicación como el que se tiene" (E1). Una vez que se ha construido un sentimiento de pertenencia a un grupo, la co-presencia física no parece tener la misma relevancia: "en este momento, cuando ya he logrado conocer a las personas, conocer a los compañeros, que he logrado empezar dinámicas de trabajo soportado en las tecnologías, para mí es mucho más fácil no encontrarme [con ellos]" (E2). Un estudiante señala que las interacciones con sus pares pueden ser igualmente ricas y pertinentes independientemente del medio empleado: "hay a quienes nos interesa la interacción y conocer otras miradas y creo que eso no está ligado [al hecho que] tiene que ser presencial [...]. La interacción la hace cada uno con los medios que se tienen" (E3). Esta observación ratifica las conclusiones de Herndon-Stallings (2018) sobre la importancia de las conexiones a través de redes sociales en un contexto de estudios de posgrado a distancia. 
Una infraestructura tecnológica apropiada y el acceso a las fuentes de información científica, como son las bases de datos, son factores que favorecen la percepción de presencia cognitiva, incluso en un contexto de formación a distancia: "Yo no siento mayor diferencia gracias a esa infraestructura tecnológica" (E2); "Yo no me sentí incomodo porque la clase fuera a distancia. Lo veía como una clase normal. Ya me había mentalizado que existía esa opción" (E3).

La combinación de modalidades exige que se tenga en cuenta a todos los estudiantes sin importar la modalidad en la que cada uno participa. Esto representa un gran desafío en el diseño pedagógico de los cursos y un aspecto de especial importancia para evitar un sentimiento de exclusión debido a la modalidad que se haya escogido. A partir de lo dicho por los estudiantes, queda claro que existe aún un importante trabajo por hacer a nivel del diseño pedagógico con el propósito de equilibrar la representatividad de cada modalidad:

Había unos profesores que uno decía; "vea, yo no necesito estar en la clase porque este señor está muy bien preparado; tanto en el software que manejábamos como... él tenía conectada su tableta y todo lo dejaba... incluso los apuntes de clase los enviaba. Uno veía la preparación. Pero entonces había otros profesores que no tenían esa pericia [...]. Porque a la hora de tú preparar el curso tienes que saber si el curso se va a dictar tanto presencial como virtual. El profesor tiene que plantear su clase de esa manera. De que las actividades tanto presenciales como virtuales se manejen... la cátedra tiene que estar bien montada para eso. No creo que se pueda hacer rápido. Me imagino que tiene que haber una transición donde se vea que efectivamente el curso está adaptado para eso. (E1).

Lo expresado por los estudiantes entrevistados se encuentra en consonancia con los resultados del estudio de Colpitts et al. (2020) en el cual se muestran cuatro elementos que resultan fundamentales en la decisión de los estudiantes de emprender un doctorado en modalidad híbrida: primero, la flexibilidad que permite equilibrar el trabajo doctoral con las responsabilidades profesionales y familiares. Segundo, el apoyo que proporciona la cohorte tanto en el plano formal como en el plano informal de la formación doctoral. Tercero, la posibilidad de individualizar la formación de acuerdo con los intereses, la motivación y la situación de cada estudiante. Y cuarto, la posibilidad de implementar una estrategia de supervisión de grupo que brinde la oportunidad de compartir periódicamente el progreso, lo que sirve como fuente de apoyo y de motivación.

\section{Perspectivas de los docentes}

Antes de la crisis sanitaria, los tres profesores entrevistados ofrecían sus clases en modo híbrido, desde el aula de teleclase de una de las universidades asociadas. Siguiendo esta modalidad, los profesores dictaban la clase en forma presencial al grupo de estudiantes inscritos en esa universidad mientras los otros dos grupos de estudiantes se encontraban reunidos en las aulas de teleclase de las otras dos universidades. Durante el confinamiento decretado como consecuencia de la crisis sanitaria, los profesores entrevistados ofrecían sus cursos remotamente desde sus casas, al igual que se daba la participación de los estudiantes. 
Los tres profesores coinciden en que la diferencia que hace el que los estudiantes se desplacen a las aulas de teleclase de sus universidades, aun cuando el profesor no pueda estar presencialmente sino en una de esas aulas, radica principalmente en las posibilidades que brinda la presencialidad para conocerse personalmente profesores con los estudiantes, estudiantes con sus compañeros, y profesores con otros profesores:

Es verdad que si uno mira solamente el conocimiento, pues es probable que se pueda conseguir simplemente por medios virtuales; pero desde mi punto de vista la presencialidad aporta el conocerse personalmente [...] y lo cambia todo cuando te conoces a nivel personal, hace que sea más fácil después hacer cualquier cosa [...] la virtualidad ofrece muchas ventajas, pero un poco de presencialidad, como fue también en mi caso, le da un plus que yo lo considero muy importante (P1).

Consideran que las relaciones que se establecen durante los encuentros presenciales promueven y facilitan la realización posterior de otras actividades académicas y no académicas, la creación y fortalecimiento de redes, y la creación de sentido de pertenencia con el Programa. Sin embargo, subrayan que para conseguir este propósito estos encuentros podrían ser propiciados también en momentos y con fines diferentes a las clases, e idealmente en actividades que reúnan a profesores y estudiantes:

Aprovechar la presencialidad en laboratorios, en equipos de trabajo, en reuniones de investigación, y propiciar al máximo las interacciones entre personas (P3).

Los entrevistados sugieren que cuando el profesor no se limita a transmitir conocimiento, sino que promueve clases participativas que involucran tanto a los estudiantes como al mismo profesor, se evidencia una diferencia en favor de las teleclases; se facilita acercarse al otro, consultarle al otro y trabajar con el otro. Adicionalmente, como lo menciona P2, "el tener un grupo de estudiantes reunidos presencialmente en un aula de teleclase, ayuda a generar una sensación de inmersión para los estudiantes que se ven obligados a conectarse remotamente". P2 señala igualmente que estar en un aula de teleclase con un grupo local de estudiantes, de alguna manera le permite al profesor, a partir de una muestra del grupo total, medir fácilmente cómo ellos se están sintiendo y si se están logrando los resultados esperados, sobre todo teniendo en cuenta que sus clases se caracterizan por ser muy participativas.

Por otro lado, al discutir sobre el efecto de la modalidad remota en la calidad de los cursos, los profesores coinciden en que, más que la modalidad, lo que puede afectar la calidad es la preparación del profesor y contar con los recursos tecnológicos requeridos, para brindar la clase en una u otra modalidad: "una nueva modalidad implicaría una transformación de los procesos de docencia; tener en cuenta que el medio transforma tanto al receptor como al emisor" (P3).

Las percepciones de los profesores entrevistados sugieren que en un escenario de combinación de modalidades en el Doctorado, es importante tener en cuenta el componente presencial para el desarrollo personal y social de los estudiantes, así como también fundamentos para el aprendizaje en línea que ayuden a los profesores a hacer un mejor trabajo en las diferentes modalidades y a enriquecer la experiencia del estudiante con interacciones con un instructor en vivo, con los compañeros y con la vida real, como lo menciona Serdyukov (2017). 


\section{Perspectivas de los administrativos}

Los administrativos que fueron entrevistados participan en los comités en donde se toman decisiones tanto pedagógicas como administrativas del Programa. Ellos están en contacto con los estudiantes y con los profesores titulares e invitados de las tres universidades asociadas.

Los administrativos están de acuerdo en que los estudiantes podrían tomar las clases conectados remotamente, sin necesidad de desplazarse a las aulas de teleclase de sus universidades: "pues al menos lo que percibo, lo que escucho, es que igual podrían hacerlo [tomar la clase] desde su propia oficina y no necesariamente en el aula [...] en otro espacio de la institución, desde sus casas o desde sus empresas" (A1).

Las teleclases permitieron al Programa dar respuesta a la preocupación inicial del Ministerio de Educación, de cómo en un doctorado en red las universidades podrían asegurar las condiciones técnicas y académicas requeridas tanto para los profesores como para los estudiantes de las tres universidades. De otro lado, la interacción que tiene lugar entre los participantes de las aulas de telepresencia favorece la experiencia del estudiante, aunque el profesor no se encuentre presencialmente en todas las aulas.

Ese espíritu, esa atmósfera que se crea cuando tú estás en un grupo es mucho mejor, digamos, que cuando tú estás de forma individual [...] si los estudiantes están allá concentrados pues de pronto entre ellos van como a generar esa atmósfera de compañerismo para captar la información que está dando un profesor que no está en la sede [...] y están ahí como dispuestos a recibir esa clase [...] y aquí hay también factores de cansancio, porque uno se cansa más cuando recibe una clase detrás de una pantalla, tanto para ver como para escuchar (A2).

En cuanto a la modalidad de conexión remota, esta puede presentar una desventaja, no insalvable, para estudiantes y profesores, de no contar con las condiciones requeridas en el sitio desde el que se conecten:

Unos tienen limitaciones de espacio; otros tienen limitaciones económicas, no tienen una buena conexión, no tienen tal vez un buen computador; otros tienen limitaciones de tiempo, porque tienen que atender a sus hijos, a su familia, a unas personas que tal vez estén cuidando. $Y$ todo eso entonces los hace desconcentrar (A2).

Creo que a veces también se presta para que estemos más dispersos, porque estamos en la casa y pues hay más fuentes de distracción (A3).

Pero las personas pueden ir mejorando estas condiciones y para los estudiantes que no se les facilita trasladarse hasta el aula de teleclase de su universidad, ahí la conexión remota se presenta como una opción: "evitar ese desplazamiento que a veces se vuelve un poco traumático [...] ventajas como el ahorro de tiempo" (A1). En estos casos la interacción en tiempo real con los compañeros que se encuentran en las aulas de teleclase, ayuda a generar una mejor experiencia para los estudiantes:

Nuestro objetivo es que los estudiantes sientan que están en una sola aula, que si alguno habla el otro le escucha [...] la idea es que todos tengamos el micrófono abierto y todos sientan que están en un mismo espacio [...] que sintamos 
como que tenemos al otro aquí al lado y que podemos con él hacer cualquier otra actividad que nos permita construir, no sólo con el profesor sino también con los compañeros (A2).

Sobre la relación que podría tener la modalidad con la calidad de los cursos, las personas entrevistadas coinciden en que, más que la modalidad, lo importante es asegurar las condiciones requeridas para el éxito de la enseñanza y aprendizaje en una u otra modalidad:

Yo creo que puede haber cursos de excelente calidad en forma virtual o remota [...] y también puede haber cursos de muy mala calidad en forma presencial. (A1). "Sería tema de las actividades que se desarrollan y la manera de hacerlo (A3).

Si el Programa puede asegurar estas condiciones, una modalidad combinada permitiría ampliar la cobertura sin arriesgar la calidad: "podríamos permitir que personas de otras ciudades, de otros países, puedan estar en nuestro programa. Y eso nos exigiría a nosotros seguir manteniendo o aumentando los niveles de calidad" (A2).

\section{Discusión y conclusiones}

En este texto hemos presentado la experiencia de tres universidades colombianas que se asociaron para ofrecer un programa de doctorado en red en el dominio de la ingeniería. Los cursos del Programa se imparten en modalidad híbrida y desde cualquiera de las tres universidades asociadas, gracias a un sistema de videoconferencia. La crisis sanitaria vivida en 2020 obligó a impartir el Programa enteramente a distancia eliminando así la obligación de presencia física en las aulas de teleclase. Esta crisis suscitó una reflexión en torno a las aprehensiones de las autoridades de la administración pública responsables de las orientaciones en materia de educación superior relativas a la posibilidad de ofrecer programas de doctorado a distancia. En lo que respecta al programa de doctorado en red aquí abordado, la crisis ha sido solo un elemento catalizador de una transformación que ya se anunciaba.

En un país emergente como Colombia, un programa doctoral en red permite, primero, articular las fortalezas de cada institución y, segundo, aumentar el área de influencia del programa. En el programa doctoral que hemos analizado, la asociación de tres universidades permitió ampliar su radio de acción permitiendo de este modo un aumento en el potencial de candidaturas. No obstante, la cobertura del Programa puede aún aumentarse si se logra llegar a otras regiones del país. En la actualidad no hay estudiantes inscritos provenientes del Caribe colombiano, ni de la región insular, ni de la Orinoquía, ni de la Amazonía, ni tampoco del Pacífico colombiano (ver Figura 2). 


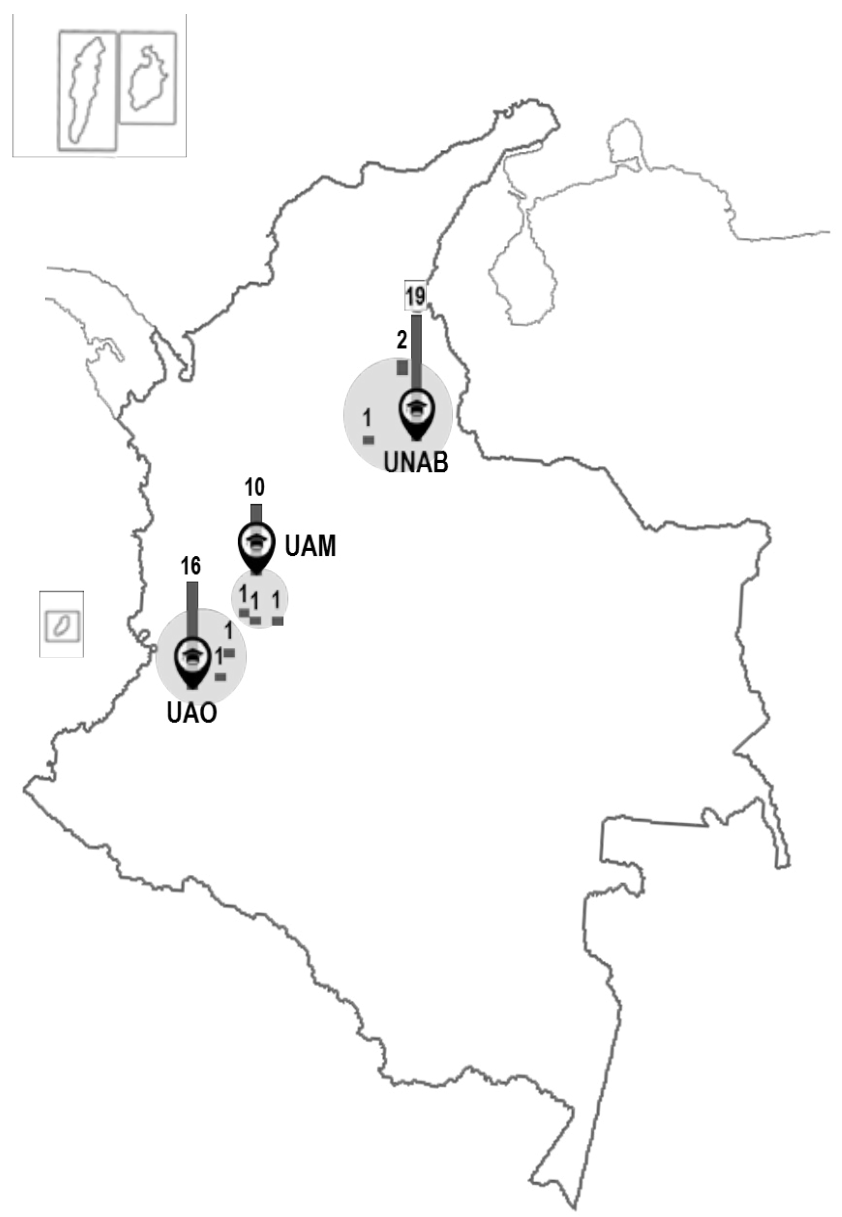

Figura 2. Lugar de origen de los estudiantes, a febrero de 2021. (N=53)

La formación a distancia surge entonces como una posibilidad que permitiría llevar el Programa hasta las regiones del país donde la oferta de formación doctoral no está desarrollada.

De otro lado, el Programa se inscribe dentro de un área de estudios que exige la realización de actividades de experimentación que requieren materiales y herramientas especializados. De este modo, resulta indispensable mantener un cierto componente de presencialidad. Sin embargo, en otras áreas tales como las ciencias humanas o sociales, la posibilidad de ofrecer programas de posgrado totalmente a distancia resulta más plausible. Para los candidatos trabajadores, para aquellos con responsabilidades familiares o para quienes habitan en regiones del país donde la oferta de programas de posgrado es limitada o incluso nula, esta fórmula permitiría compaginar sus estudios con otros ámbitos de la vida. Sobre este particular, los trabajos de Kumar (Kumar \& Coe, 2017; Kumar \& Dawson, 2018; Kumar et al., 2013) que documentan el proceso de diseño, implementación y evaluación de programas de doctorado en línea orientados a profesionales investigadores, nos parecen especialmente inspiradores.

En cualquier caso, tanto para estudiantes y profesores como para los administrativos resulta claro que debiera garantizarse un cierto componente de presencialidad para apoyar a los estudiantes que lo necesitan y para realizar algunas actividades donde la presencia física resulta ineludible. Hay que reconocer que la realización de 
un doctorado comporta una gran carga emocional y, en tal sentido, las interacciones presenciales son de un inestimable valor en aras de mitigar las dificultades relacionadas con la dimensión socioafectiva. De este modo, es posible proponer actividades que favorezcan el intercambio y la socialización entre los actores educativos.

Según lo señalado por los estudiantes, profesores y administrativos entrevistados en relación con las teleclases, podemos establecer que, idealmente, debería privilegiarse la asistencia presencial de quienes puedan desplazarse hasta su universidad. De este modo, confluirían estudiantes que habitan dentro del área de influencia de la respectiva institución, reunidos en aulas de teleclase, con estudiantes que siguen los cursos a distancia en modo síncrono. Otros espacios de presencialidad podrían dedicarse a actividades complementarias a las clases.

La combinación de modalidades es un enfoque que comienza a ganar terreno en el diseño pedagógico de cursos de posgrado. Este enfoque permite la coexistencia de la formación presencial y de la formación a distancia tanto en modo síncrono como en modo asíncrono. Consideramos que esta es una alternativa sostenible para la difusión de programas de formación posgradual a escala nacional en un contexto de rareza de experticias en algunas áreas. Sin embargo, para que la estrategia sea verdaderamente inclusiva, es importante repensar el diseño pedagógico de los cursos considerando todos los modos de difusión. Esto exige formar al cuerpo docente en la combinación de modalidades y una toma de conciencia con relación al nuevo espacio de la clase, la cual se convierte en una experiencia multi-espacial.

Finalmente, un elemento esencial en la formación en investigación en estudios de posgrado, sobre todo en un contexto de formación a distancia, es el reforzamiento del sentimiento de presencia que se manifiesta en la disponibilidad de los otros actores y en el sentimiento de conexión entre ellos. La construcción de una comunidad de aprendizaje es una estrategia interesante que podría explorarse para reforzar este sentimiento de presencia al tiempo que se ofrecen a los estudiantes otras oportunidades de formación y de acompañamiento.

\section{Referencias}

Beatty, B. J. (2019). Hybrid-flexible course design. Implementing student-directed hybrid classes. Provo, Utah: EdTech Books. https://edtechbooks.org/hyflex

Colpitts, B. D., Usick, B. L., \& Eaton, S. E. (2020). Doctoral student reflections of blended learning before and during covid-19. Journal of Contemporary Education Theory \& Research, 4(2), 3-11. DOI: 10.5281/zenodo.4247601

Gray, M. A., \& Crosta, L. (2019). New perspectives in online doctoral supervision: a systematic literature review. Studies in Continuing Education, 41(2), 173-190. DOI: 10.1080/0158037X.2018.1532405

Herndon-Stallings, M. (2018). Online Doctoral Students and the Importance of Social Network Connections [thèse de doctorat, Walden University]. Walden Dissertations and Doctoral Studies. https://scholarworks.waldenu.edu/dissertations/5346 
JHU (2021). Coronavirus resource center. Johns Hopkins University. https://coronavirus.jhu.edu/map.html

Kumar, S., \& Coe, C. (2017). Mentoring and student support in online doctoral programs. American Journal of Distance Education, 31(2), 128-142. https://doi.org/10.10 80/08923647.2017.1300464

Kumar, S., \& Dawson, K. (2018). An online doctorate for researching professionals: Program design, implementation, and evaluation. Athabasca University Press. https://doi.org/10.15215/aupress/9781771992077.01

Kumar, S., Johnson, M., \& Hardemon, T. (2013). Dissertations at a Distance: Students' Perceptions of Online Mentoring in a Doctoral Program. The Journal of Distance Education, 27(1). Repéré à http://www.ijede.ca/index.php/jde/article/view/835/1481

Minciencias (2017). Convocatoria de doctorados en el exterior. https://minciencias.gov.co/convocatorias/oportunidades-formacion/convocatoria-doctorados-en-el-exterior-2017

Minciencias (2019a). Convocatoria de doctorados en el exterior. https://minciencias.gov.co/convocatorias/oportunidades-formacion/convocatoria-doctorados-en-el-exterior

Minciencias (2019b). Convocatoria del Fondo de Ciencia, Tecnología e Innovación del Sistema General de Regalías para la conformación de una lista de proyectos elegibles para ser viabilizados, priorizados y aprobados por el OCAD en el marco del Programa de Becas de Excelencia Doctoral del Bicentenario. https://minciencias.gov.co/convocatorias/plan-bienal-convocatorias-fctei/convocatoria-del-fondo-ciencia-tecnologia-e-innovacion

Minciencias (2020). Convocatoria de doctorados en el exterior. https://minciencias. gov.co/convocatorias/formacion-y-vinculacion-capital-humano-alto-nivel/convocatoria-doctorados-en-el?fbclid=IwAR1YSeFtJMJBBABOh-o_KnznMrGwVLsf6wpZf5UD2X6s1WCaUIAYkowXRW4

Serdyukov, P. (2017). Innovation in education: what works, what doesn't, and what to do about it? Journal of Research in Innovative Teaching \& Learning, 10 (1), 4-33. https://doi.org/10.1108/JRIT-10-2016-0007

SNIES (2021). Consulta de Programas (version 4.5) [ensemble de données]. Ministerio de educación de Colombia. https://hecaa.mineducacion.gov.co/consultaspublicas/programas

Woo, B., Evans, K., Wang, K., \& Pitt-Catsouphes, M. (2019). Online and Hybrid Education in a Social Work PhD Program. Journal of Social Work Education, 57(1), 138-152. https://doi.org/10.1080/10437797.2019.1661921 


\section{Revisión Sistemática de la Literatura Sobre Experiencias Formativas con Redes Sociales en Educación Superior}

\section{Gabarda Méndez, Vicente}

orcid.org/0000-0001-6159-5173

Universitat de València

vicente.gabarda@uv.es

\section{Cuevas Monzonís, Nuria}

orcid.org/0000-0001-9366-3038

Universidad Internacional de Valencia

nuria.cuevas@campusviu.es

\section{Cívico Ariza, Andrea}

orcid.org/0000-0003-3094-5841

Universidad Internacional de Valencia

andrea.civico@campusviu.es

\section{Colomo Magaña, Ernesto}

orcid.org/0000-0002-3527-7937

Universidad de Málaga

ecolomo@uma.es

\section{Sánchez Rivas, Enrique}

orcid.org/0000-0003-2518-2026

Universidad de Málaga

enriquesr@uma.es 


\title{
REVISIÓN SISTEMÁTICA DE LA LITERATURA SOBRE EXPERIENCIAS FORMATIVAS CON REDES SOCIALES EN EDUCACIÓN SUPERIOR
}

\author{
Gabarda Méndez, Vicente \\ Cuevas Monzonís, Nuria \\ Cívico Ariza, Andrea \\ Colomo Magaña, Ernesto \\ Sánchez Rivas, Enrique
}

\section{Resumen}

Desde hace algunos años, la tecnología se ha ido integrando en las diferentes esferas de nuestras vidas. En el caso de las redes sociales, por ejemplo, se han constituido como uno de los principales escenarios de socialización, comunicación y ocio, especialmente entre los más jóvenes. Su potencial, sin embargo, va mucho más allá del ámbito personal y social, pudiendo aportar beneficios en el diseño, implementación y evaluación de los procesos formativos de cualquier etapa. Partiendo de este hecho, el presente estudio se orienta a conocer la relación entre las redes sociales y la educación superior, poniendo especial hincapié en su uso como recurso metodológico para la enseñanza y el aprendizaje en la universidad. Utilizando como método de trabajo la revisión sistemática de la literatura, se analiza la producción científica que vincula las redes sociales y la universidad publicada en la base de datos Dialnet durante el periodo 2015-2021. Los resultados arrojan que esta producción científica sobre este fenómeno no es demasiado prolífica a pesar de su presencia generalizada en otras esferas, que la mayor parte de los estudios toman como muestra a los estudiantes y que, de manera generalizada, hay una percepción positiva acerca de la integración de las redes sociales como recurso metodológico, independientemente del contexto geográfico, las titulaciones o las materias en que se centran los estudios analizados.

\section{Palabras clave}

Redes sociales, educación superior, aprendizaje, enseñanza, estudio bibliográfico. 


\section{Introducción}

En los últimos años, estamos viviendo un proceso reflexivo generalizado acerca del modo en que se diseñan e implementan los procesos formativos, tratando de aportar visiones alternativas que favorezcan su desarrollo. El primer paso fue trasladar la atención desde el docente hacia el estudiante, convirtiendo a éste en el protagonista del aprendizaje y dotándole de autonomía para regularlo de manera ajustada a sus intereses y necesidades. Por otro lado, la llegada de la tecnología a las diferentes esferas de la vida (personal, social y profesional), permitió reflexionar sobre su integración en la dimensión académica. Por un lado, otorga unas posibilidades casi infinitas en forma de soportes físicos o software que permiten construir nuevos escenarios formativos y, por otro, múltiples posibilidades para que el aprendizaje sea algo más dinámico, atractivo y visual.

Más allá de la tecnología que se diseña con una finalidad didáctica, como materiales didácticos digitales, videojuegos educativos o aplicaciones, hay una tendencia por tratar de incorporar otros recursos que, aun con una finalidad inicialmente diferente, pueden contribuir a la mejora de la enseñanza y el aprendizaje. Este es el caso de las redes sociales, una realidad comúnmente aceptada y utilizada, a día de hoy, como espacio de comunicación y socialización.

Y es que, las redes sociales se han convertido en una de las alternativas de ocio más comunes en la población, especialmente la más joven. Según datos de The Social Media Family (2021), en España hay más de 29 millones de usuarios de las diferentes redes sociales, siendo por orden de uso Youtube, Whatsapp, Facebook e Instagram las más utilizadas. La situación es similar en Latinoamérica donde, a pesar de haber diferencias reseñables entre los países, la tasa de penetración de las redes sociales supera el $80 \%$ en países como Chile, Uruguay o Perú (Statista, 2021). Es reseñable, igualmente, que en este contexto son las mismas redes sociales las que se utilizan con mayor frecuencia, aunque en orden diferentes (Facebook, Whatsapp, Instagram y Youtube).

Esta realidad ofrece, por tanto, una oportunidad de valor innegable para tratar de integrar las redes sociales en las dinámicas formativas regladas, dando un salto de los espacios informales a los formales.

En los últimos años, y en base a las experiencias que se han ido desarrollando en diferentes contextos geográficos y las diferentes etapas educativas, la literatura científica ha ido incorporando propuestas que han analizado el potencial pedagógico de las redes sociales. De este modo, González-Hernando et al., (2020) concluyen en su utilidad para la mejora de las competencias digitales y la formación continua, mientras que Prada-Núñez et al., (2020) ponen de manifiesto su potencial para la interacción entre docentes y discentes, el aprendizaje colaborativo o el desarrollo de competencias comunicativas, especialmente en tiempos de confinamiento. Debe tenerse en cuenta, no obstante, que cada red puede otorgar múltiples posibilidades en función de su naturaleza (Alcívar, 2020), siendo precisa una reflexión consciente de cómo debe integrarse cada una de ellas en los procesos formativos.

A partir de esta realidad, y para aproximarnos de manera más específica a las experiencias desarrolladas con redes sociales en la educación universitaria, este trabajo propone una revisión sistemática de la literatura científica de los últimos cinco años alojada en la base de datos Dialnet. 


\section{Método}

Este estudio se fundamenta en un análisis bibliográfico acerca de la literatura científica sobre la implementación de las redes sociales en la educación superior.

Para realizar la búsqueda bibliográfica, se ha utilizado como base de datos Dialnet, a fin de dar cobertura a la producción científica especialmente de origen iberoamericano. En relación a los términos de búsqueda, se han empleado "redes sociales", "estudiantes", "proyecto" y "universitario" para poder identificar estudios que centraran su atención en la utilización de las redes sociales como recurso formativo.

La búsqueda devolvió un total de 134 resultados que han sido filtrados en base a los criterios de inclusión que se ofrecen a continuación:

Tabla 1. Criterios de selección de documentos

\begin{tabular}{ll} 
Tipología & Artículos científicos \\
Disponibilidad & Acceso abierto y texto completo \\
\hline Tipo de estudio & Investigación empírica \\
\hline Participantes & Profesorado o alumnado de educación superior \\
\hline Fecha de publicación & $2015-2021$ \\
\hline Idioma & Castellano o inglés \\
\hline
\end{tabular}

\section{Fuente: Elaboración propia}

Tras la selección de artículos en todas las bases de datos, se realizó una búsqueda inversa. Todo el proceso, fundamentado en el método PRISMA (Urrútia y Bonfill, 2010), se muestran en la Figura 1:

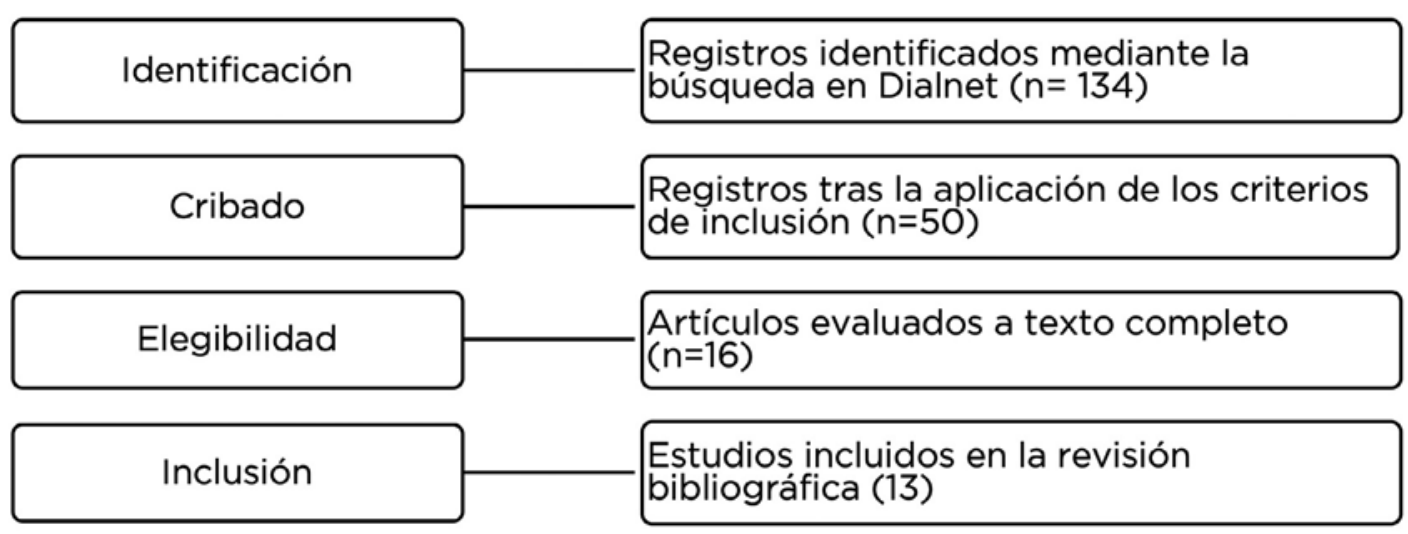

Figura 1. Proceso de selección de documentos. Elaboración propia.

Con los 13 documentos seleccionados se realiza un análisis de contenido que, se centrará en las siguientes variables de estudio: 
Tabla 2. Variables de análisis

\begin{tabular}{|c|c|c|}
\hline & Año & Año de publicación \\
\hline \multirow{3}{*}{ 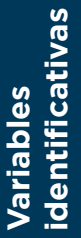 } & País & Contexto geográfico de la investigación \\
\hline & Autoría & Relación de autores y coautores \\
\hline & Idioma & Lengua en que se publica el artículo \\
\hline \multirow{3}{*}{ 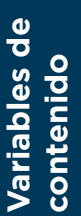 } & Muestra & Participantes del estudio \\
\hline & Objetivos & Fines que persigue el estudio \\
\hline & Resultados & Principales hallazgos del estudio \\
\hline
\end{tabular}

Fuente: Elaboración propia

\section{Resultados}

En la tabla 3, se recogen los datos de las 13 investigaciones objeto de estudio respecto a variables identificativas y de contenido que se detallan en la tabla 3:

Tabla 3. Análisis bibliográfico

\begin{tabular}{|c|c|c|c|c|c|c|}
\hline Año & País & Autoría & Idioma & Muestra & Objetivos & Resultados \\
\hline 2015 & España & $\begin{array}{l}\text { Estévez y } \\
\text { García }\end{array}$ & Español & $\begin{array}{l}32 \text { estu- } \\
\text { diantes de } \\
\text { Ingeniería } \\
\text { Civil }\end{array}$ & $\begin{array}{l}\text { Mejorar el uso de } \\
\text { las redes sociales } \\
\text { en el ámbito } \\
\text { profesional por } \\
\text { cuenta propia. }\end{array}$ & $\begin{array}{l}\text { Los estudiantes tienen una buena } \\
\text { percepción de sus capacidades } \\
\text { iniciales relacionadas con el } \\
\text { emprendimiento, el autoempleo } \\
\text { o la difusión. Asimismo, valoran } \\
\text { positivamente el uso de redes } \\
\text { sociales para favorecer la capacidad } \\
\text { creativa, la comunicación y el } \\
\text { aprendizaje del uso de normas } \\
\text { comunitarias en redes sociales o } \\
\text { cuestiones de privacidad. }\end{array}$ \\
\hline 2016 & México & $\begin{array}{l}\text { Martínez y } \\
\text { Ramírez }\end{array}$ & Español & $\begin{array}{l}33 \text { estu- } \\
\text { diantes de } \\
\text { Derecho }\end{array}$ & $\begin{array}{l}\text { Analizar el uso de } \\
\text { las redes } \\
\text { sociales digitales } \\
\text { en la comunidad } \\
\text { estudiantil } \\
\text { universitaria } \\
\text { como } \\
\text { herramienta para } \\
\text { la socialización y } \\
\text { colaboración }\end{array}$ & $\begin{array}{l}\text { El estudiantado utiliza } \\
\text { principalmente las redes sociales } \\
\text { digitales con fines no académicos. } \\
\text { Cuando se utilizan con fines } \\
\text { académicos, las más usadas son } \\
\text { Facebook y Twitter, se emplean } \\
\text { para comunicarse con sus } \\
\text { compañeros y sus docentes, así } \\
\text { como para realizar actividades de } \\
\text { grupo. Tienen, por otro lado, una } \\
\text { actitud favorable con respecto } \\
\text { a la integración de las TIC en las } \\
\text { prácticas pedagógicas de sus } \\
\text { docentes, considerando que aporta } \\
\text { beneficios a los diferentes agentes, } \\
\text { así como a las propias instituciones } \\
\text { y la sociedad en general. }\end{array}$ \\
\hline
\end{tabular}




\begin{tabular}{|c|c|c|c|c|c|c|}
\hline 2016 & México & $\begin{array}{l}\text { Marini, } \\
\text { Jácome y } \\
\text { López }\end{array}$ & Español & $\begin{array}{l}329 \text { estu- } \\
\text { diantes }\end{array}$ & $\begin{array}{l}\text { Analizar el uso } \\
\text { de redes sociales } \\
\text { digitales en } \\
\text { actividades de } \\
\text { comunicación, } \\
\text { socialización y } \\
\text { colaboración }\end{array}$ & $\begin{array}{l}\text { Los estudiantes utilizan } \\
\text { aplicaciones como WhatsApp, } \\
\text { así como otras redes sociales y } \\
\text { correo electrónico para compartir } \\
\text { y publicar información en el ámbito } \\
\text { privado. Sin embargo, se realizan } \\
\text { pocas actividades de creación } \\
\text { y colaboración en términos } \\
\text { académicos, siendo Facebook } \\
\text { la red social más utilizada para } \\
\text { comunicarse con docentes y pares. }\end{array}$ \\
\hline 2016 & México & $\begin{array}{l}\text { Borromeo } \\
\text { y Ramírez }\end{array}$ & Español & $\begin{array}{l}79 \text { docente } \\
\text { universita- } \\
\text { rios }\end{array}$ & $\begin{array}{l}\text { Conocer el uso de } \\
\text { las TIC por parte } \\
\text { del profesorado } \\
\text { universitario en } \\
\text { su proceso de } \\
\text { enseñanza. }\end{array}$ & $\begin{array}{l}\text { Los docentes utilizan en mayor } \\
\text { medida el correo electrónico y } \\
\text { las redes sociales (Facebook y } \\
\text { Twitter) como herramientas para } \\
\text { la socialización, la comunicación e } \\
\text { intercambio de información. }\end{array}$ \\
\hline 2018 & España & $\begin{array}{l}\text { Peña, } \\
\text { Rueda, } \\
\text { Pegalajar }\end{array}$ & Español & $\begin{array}{l}1192 \text { estu- } \\
\text { diantes de } \\
\text { diferentes } \\
\text { titulaciones }\end{array}$ & $\begin{array}{l}\text { Estudiar las } \\
\text { percepciones de } \\
\text { los estudiantes } \\
\text { sobre las } \\
\text { posibilidades } \\
\text { didácticas de las } \\
\text { redes sociales } \\
\text { para el desarrollo } \\
\text { de competencias } \\
\text { genéricas. }\end{array}$ & $\begin{array}{l}\text { El alumnado hace uso de este } \\
\text { tipo de recursos con fines } \\
\text { personales y académicos, siendo } \\
\text { Twitter, Facebook o Instagram } \\
\text { las de mayor uso. Confían en su } \\
\text { potencial para ofrecer nuevos } \\
\text { canales de comunicación, facilitar } \\
\text { la organización y planificación } \\
\text { del trabajo, la socialización, } \\
\text { la resolución de dudas, el } \\
\text { conocimiento de otras culturas } \\
\text { y la generación de nuevas } \\
\text { ideas. El alumnado universitario } \\
\text { considera positiva la inclusión de } \\
\text { las redes sociales en el proceso } \\
\text { de enseñanza-aprendizaje para } \\
\text { la adquisición de competencias } \\
\text { genéricas }\end{array}$ \\
\hline 2019 & Chile & $\begin{array}{l}\text { Ruay y } \\
\text { Campos }\end{array}$ & Español & $\begin{array}{l}18 \text { estu- } \\
\text { diantes de } \\
\text { Pedagogía }\end{array}$ & $\begin{array}{l}\text { Verificar si la } \\
\text { exposición } \\
\text { metódica y } \\
\text { autorregulada } \\
\text { a un canal de } \\
\text { YouTube incide } \\
\text { favorablemente } \\
\text { en el desarrollo } \\
\text { de habilidades del } \\
\text { idioma inglés. }\end{array}$ & $\begin{array}{l}\text { Se concluye que la utilización de } \\
\text { Youtube incide favorablemente } \\
\text { en la motivación, el interés, la } \\
\text { valoración del aprendizaje del } \\
\text { idioma y el aprovechamiento } \\
\text { del tiempo libre para desarrollar } \\
\text { aprendizaje autónomo y de } \\
\text { autoaprendizaje. }\end{array}$ \\
\hline 2019 & Ecuador & $\begin{array}{l}\text { Morán- } \\
\text { Chilán, } \\
\text { Pibaque- } \\
\text { Pionce y } \\
\text { Parrales- } \\
\text { Reyes }\end{array}$ & Español & $\begin{array}{l}\text { Estudiantes } \\
\text { (muestra } \\
\text { no detalla- } \\
\text { da) }\end{array}$ & $\begin{array}{l}\text { Conocer el uso de } \\
\text { redes sociales y } \\
\text { de las estrategias } \\
\text { para la lectura } \\
\text { crítica. }\end{array}$ & $\begin{array}{l}\text { Los estudiantes consumen } \\
\text { habitualmente las redes sociales, } \\
\text { especialmente Facebook, donde } \\
\text { hacen uso de estrategias de lectura } \\
\text { crítica de manera mayoritaria. } \\
\text { Estas estrategias inciden en el } \\
\text { fortalecimiento del conocimiento y } \\
\text { (tanto en la producción, como en } \\
\text { la difusión o en la adquisición). }\end{array}$ \\
\hline 2020 & España & $\begin{array}{l}\text { Gallardo- } \\
\text { López y } \\
\text { López- } \\
\text { Noguero }\end{array}$ & Español & $\begin{array}{l}137 \text { estu- } \\
\text { diantes de } \\
\text { Trabajo } \\
\text { Social }\end{array}$ & $\begin{array}{l}\text { Explorar } \\
\text { el impacto } \\
\text { educativo del uso } \\
\text { de Twitter como } \\
\text { recurso didáctico } \\
\text { y la percepción } \\
\text { de los estudiantes } \\
\text { sobre su utilidad. }\end{array}$ & $\begin{array}{l}\text { Hay una alta participación de los } \\
\text { estudiantes en Twitter dentro de la } \\
\text { experiencia diseñada (contenidos } \\
\text { compartidos, comentarios, ...), } \\
\text { aportando beneficios en la } \\
\text { creación colectiva del aprendizaje, } \\
\text { desde la colaboración, la } \\
\text { participación y la cohesión de } \\
\text { grupo. }\end{array}$ \\
\hline
\end{tabular}




\begin{tabular}{|c|c|c|c|c|c|c|}
\hline 2020 & España & $\begin{array}{l}\text { Alonso y } \\
\text { Terol }\end{array}$ & Español & $\begin{array}{l}86 \text { estu- } \\
\text { diantes de } \\
\text { Comunica- } \\
\text { ción Audio- } \\
\text { visual }\end{array}$ & $\begin{array}{l}\text { Mejorar la } \\
\text { comunicación } \\
\text { alumno-profesor, } \\
\text { aumentar y } \\
\text { mejorar la } \\
\text { atención en } \\
\text { la asignatura } \\
\text { fuera del aula y } \\
\text { mostrar un uso } \\
\text { responsable del } \\
\text { móvil y las redes } \\
\text { sociales. }\end{array}$ & $\begin{array}{l}\text { Se concluye que Instagram es } \\
\text { una herramienta con potencial } \\
\text { para un mayor aprovechamiento } \\
\text { de la asignatura y aumentar } \\
\text { la atención de la asignatura } \\
\text { fuera del tiempo docente en el } \\
\text { aula. Esta red social favorece, } \\
\text { asimismo, la comunicación } \\
\text { del docente con el alumnado, } \\
\text { estableciendo relaciones más } \\
\text { cercanas y fomentando el interés } \\
\text { hacia la asignatura y despertando } \\
\text { inquietudes entre sus alumnos. }\end{array}$ \\
\hline 2020 & $\begin{array}{l}\text { España } \\
\text { y } \\
\text { Polonia }\end{array}$ & Oria & Español & $\begin{array}{l}85 \text { estu- } \\
\text { diantes de } \\
\text { Lenguas }\end{array}$ & $\begin{array}{l}\text { Aumentar la } \\
\text { motivación de los } \\
\text { participantes para } \\
\text { utilizar el lenguaje } \\
\text { y mejorar sus } \\
\text { estrategias de } \\
\text { escritura en } \\
\text { lengua inglesa. }\end{array}$ & $\begin{array}{l}\text { Edmodo ofrece un entorno de } \\
\text { interacción social real y motivador, } \\
\text { cercano a la experiencia habitual } \\
\text { de las redes sociales que tienen } \\
\text { los jóvenes, pero dentro de un } \\
\text { contexto académico y supervisado. } \\
\text { El proyecto ha contribuido al } \\
\text { desarrollo de las destrezas de } \\
\text { redacción, a la reflexión sobre sus } \\
\text { propios procesos de escritura y al } \\
\text { pensamiento crítico. }\end{array}$ \\
\hline 2020 & España & $\begin{array}{l}\text { Crespo y } \\
\text { Sánchez- } \\
\text { Saus }\end{array}$ & Español & $\begin{array}{l}25 \text { estu- } \\
\text { diantes de } \\
\text { Lingüística } \\
\text { y Lenguas } \\
\text { Aplicadas }\end{array}$ & $\begin{array}{l}\text { Examinar } \\
\text { los hábitos y } \\
\text { expectativas } \\
\text { de uso de las } \\
\text { redes sociales } \\
\text { y recursos } \\
\text { audiovisuales de } \\
\text { los estudiantes en } \\
\text { la búsqueda de } \\
\text { información. }\end{array}$ & $\begin{array}{l}\text { Los recursos audiovisuales } \\
\text { (píldoras), así como el uso de redes } \\
\text { sociales, blogs y otras aplicaciones } \\
\text { permiten extender los contenidos } \\
\text { académicos a otros espacios } \\
\text { asociados con el entretenimiento. } \\
\text { Los estudiantes valoran la } \\
\text { generación de contenidos en } \\
\text { otros espacios en su formación } \\
\text { para poder acceder a una mayor } \\
\text { cantidad de información, por } \\
\text { constituir un elemento motivador y } \\
\text { para poder ampliar conocimientos. }\end{array}$ \\
\hline 2021 & España & $\begin{array}{l}\text { Figueras- } \\
\text { Maz, } \\
\text { Grandío- } \\
\text { Pérez y } \\
\text { Mateus }\end{array}$ & Inglés & $\begin{array}{l}897 \text { estu- } \\
\text { diantes }\end{array}$ & $\begin{array}{l}\text { Conocer } \\
\text { la percepción } \\
\text { que tienen los } \\
\text { universitarios } \\
\text { españoles sobre } \\
\text { el uso de las } \\
\text { redes sociales } \\
\text { con fines } \\
\text { didácticos en el } \\
\text { aula }\end{array}$ & $\begin{array}{l}\text { Hay un uso escaso de las redes } \\
\text { sociales con fines didácticos y } \\
\text { creativos en los espacios formales } \\
\text { (organizados por el profesor). Esto } \\
\text { se contrapone con una habitual } \\
\text { utilización informal y espontánea } \\
\text { de los estudiantes, destacando } \\
\text { Whatsapp, Facebook e Instagram. } \\
\text { Se valora positivamente el } \\
\text { potencial para la comunicación } \\
\text { directa e instantánea y se exponen } \\
\text { como limitaciones su capacidad } \\
\text { de distracción y la posible invasión } \\
\text { de su privacidad por parte de los } \\
\text { docentes. }\end{array}$ \\
\hline 2021 & $\begin{array}{l}\text { Colom- } \\
\text { bia }\end{array}$ & Nieto & Español & $\begin{array}{l}17 \text { estu- } \\
\text { diantes de } \\
\text { Periodismo }\end{array}$ & $\begin{array}{l}\text { Analizar la } \\
\text { implementación } \\
\text { de una } \\
\text { experiencia } \\
\text { transmedia con } \\
\text { base Aprendizaje } \\
\text { Basado en } \\
\text { Problemas (ABP) }\end{array}$ & $\begin{array}{l}\text { Se concibe el ABP como un } \\
\text { recuso útil para un aprendizaje } \\
\text { significativo e integral, así como } \\
\text { la utilidad de las redes para } \\
\text { mejorar la estrategia, producción } \\
\text { técnica y periodística para la } \\
\text { multiplataforma para relacionarse } \\
\text { con sus audiencias. }\end{array}$ \\
\hline
\end{tabular}


Atendiendo en primer lugar a las variables identificativas, es reseñable que hay un número de estudios publicados muy similar los últimos años, destacando las cuatro publicaciones de 2020, que parecen vislumbrar un aumento de la producción científica de manera reciente.

Por otro lado, en relación con el contexto geográfico donde se contextualizan las investigaciones, aproximadamente la mitad de ellas son en España (7 de las 13), aunque una de ellas ofrece una visión compartida junto a Polonia. Destacan también los estudios desarrollados en México (un total de 3), dejando poca representación para otros países (solamente encontramos un artículo de Colombia, otro de Chile y otro de Ecuador. En relación al idioma, a excepción de una propuesta en inglés, el resto están escritas en español, representado la práctica totalidad de los objetos de estudio.

Por último, en relación con la autoría, solamente hay dos artículos firmados por un único autor, por lo que la mayor parte de las propuestas se realizan en co-autoría (entre dos y siete autores).

Atendiendo por otro lado a las variables que conforman el análisis del contenido, todos los artículos, a excepción del de Borromeo y Ramírez (2016) que centran su propuesta en los docentes, toman como muestra a los estudiantes universitarios.

En cuanto a las áreas y titulaciones en que se centran los estudios, hay diversidad, aunque predominan los contextualizados en titulaciones del área de ciencias sociales como en Lenguas (Crespo y Sánchez-Saus, 2020; Oria, 2020), Periodismo y Comunicación Audiovisual (Alonso y Terol, 2020; Nieto, 2021), Trabajo Social (Gallardo-López y López-Noguero, 2020), Derecho (Martínez y Ramírez, 2016) o Pedagogía (Ruay y Campos, 2019). Hay, por otro lado, tres estudios de enfoque más global que toman en consideración a estudiantes de diversas áreas y titulaciones (Figueras-Maz et al., 2019; Morán-Chilán et al., 2019; Peña et al., 2018), cuyas muestras destacan por su amplitud.

Las finalidades de los diferentes estudios pueden resumirse en dos áreas fundamentales: mientras que una parte muy reducida de los estudios ponen el énfasis en la utilización que hacen los estudiantes o docentes de las redes sociales, la mayor parte se orientan a conocer la percepción que estos agentes tienen de ellas como recurso metodológico para los procesos formativos. En el primer bloque, podrían incluirse los estudios de Borromeo y Rodríguez (2016), quienes indagan sobre el uso que hacen los docentes en su proceso de enseñanza o los de Martínez y Ramírez (2016), Marini et al., (2016), Peña et al., (2018) o Figueras-Maz et al., (2021), quienes analizan el uso de las redes sociales por parte de los estudiantes, tanto en el ámbito privado como en el académico. Mientras tanto, el resto de estudios tratan de aproximarse, de manera específica, al modo en que se integran las redes sociales en el hecho educativo. Algunas propuestas analizan herramientas concretas como Youtube (Ruay y Campos, 2019), Facebook (Morán-Chilán et al., 2019), Twitter (Gallardo-López y López-Noguero, 2020), Instagram (Alonso y Terol, 2020) o Edmodo (Oria, 2020), mientras que otras recogen las percepciones de los estudiantes de un modo más genérico (Crespo y Sánchez-Saus, 2020; Estévez y García, 2015; Nieto, 2021).

Los resultados, por último, aportan información específica sobre las dos cuestiones aludidas en los objetivos: por un lado, parece haber consenso en que las redes se utilizan con mayor frecuencia en el ámbito privado y el tiempo de ocio que con fines 
académicos. Sin embargo, se identifican algunas diferencias en función de qué red social se utiliza con mayor frecuencia cuando se usa con fines académicos. Concretamente, hay predominancia de Facebook y Twitter en el contexto latinoamericano (Borromeo y Rodríguez, 2016; Martínez y Ramírez, 2016) y más presencia de Twitter e Instagram en el contexto español (Figueras-Maz et al., 2021; Marini et al., 2016). Atendiendo, por otro lado, a la percepción que tienen los agentes sobre el potencial de las redes sociales en el aprendizaje, es generalmente positiva. Concretamente, consideran que contribuye a la mejora de la creatividad (Estévez y García, 2015), la motivación (Alonso y Terol, 2020; Crespo y Sánchez-Saus, 2020) la comunicación, la socialización y la colaboración (Gallardo-López y López-Noguero, 2020; Peña et al., 2018), así como el fomento del pensamiento crítico y el aprendizaje autónomo (Oria, 2020; Ruay y Campos, 2019).

\section{Discusión y conclusiones}

El análisis de la literatura ha permitido identificar que, a pesar del uso generalizado de las redes sociales en la esfera personal y social, la producción científica sobre su utilización en el ámbito formativo es aún escasa. Esta realidad nos conduce a reflexionar sobre posibles respuestas: por un lado, la más obvia, se vincularía a la falta de experiencias reales de diseño de procesos formativos con redes sociales. Esta razón, a su vez, puede tener una respuesta multidimensional, siendo necesario atender a cuestiones como la política educativa, el nivel de competencia digital de los docentes o las percepciones sobre los beneficios de la tecnología en general y de las redes sociales en particular para el desarrollo de los procesos formativos para poder dar una respuesta global y fundamentada. Sumamos, además, una última reflexión acerca de la falta de conciencia clara sobre la definición en sí de las redes sociales, que puede dificultar tener una visión realmente rigurosa de la producción científica vinculada a este constructo.

Sin embargo, a pesar de la escasez de literatura científica, la revisión realizada ha permitido identificar que hay una percepción positiva acerca del potencial de las redes sociales como herramienta metodológica, aunque parece que su utilización se vincula a características clásicas inherentes al propio recurso como la comunicación unidireccional de contenidos o las herramientas integradas de chat y sin darle un sentido didáctico completo, en consonancia con la tesis de Ramos (2017). Además, los resultados permiten ver que se utilizan redes sociales de diferente naturaleza con usos diversos (Alcívar, 2020), así como refrendar los beneficios de las redes sociales para la mejora de la dimensión comunicativa, la interacción entre docente y discente y el aprendizaje colaborativo (Prada-Núñez et al., 2020).

Cabría, no obstante, poder extender el análisis a otras bases de datos, así como a otras etapas educativas, de manera que se pudiera tener una visión más holística del fenómeno de estudio. De esta manera, se podría seguir indagando sobre el potencial pedagógico de estos recursos que, siendo de uso cotidiano por parte de los agentes en la esfera informal, podrían servir de puente para la conexión con la esfera formal, mejorando la calidad de los procesos de enseñanza y de aprendizaje. 


\section{Referencias}

Alcívar, A.M. (2020). Usos educativos de las principales redes sociales: el estudiante que aprende mientras navega. Revista Científica Ecociencia, 7, 1-14. https://doi. org/10.21855/ecociencia.70.294

Alonso, N. y Terol, R. (2020). Alfabetización transmedia y redes sociales: Estudio de caso de Instagram como herramienta docente en el aula universitaria, Icono 14, 18(2), 138-161. http://doi.org/10.7195/ri14.v18i2.1518

Borromeo, C.A. y Ramírez, M. (2016). Uso de redes sociales en docentes de lengua inglesa y pedagogía: ¿Diferencias por disciplina? Ensayos Pedagógicos, 1, 189-205.

Crespo, M. y Sánchez-Saus, M. (2020). Píldoras formativas para la mejora educativa universitaria: el caso del Trabajo de Fin de Grado en el Grado de Lingüística y Lenguas Aplicadas de la Universidad de Cádiz. Education in the knowledge societyEKS, 21, 1-10. https://doi.org/10.14201/eks.19228

Estévez, J. y García. A. (2015). Las Redes Sociales para la mejora de la capacidad de emprender y de autoempleo. IJERI: International Journal of Educational Research and Innovation, 4, 101-110.

Figueras-Maz, M., Grandío-Pérez, M.M. \& Mateus J.-C. (2021). Students' perceptions on social media teaching tools in higher education settings. Communication \& Society, 34(1), 15-28. https://doi.org/10.15581/003.34.1.15-28

Gallardo-López, J.A. y López-Noguero, F. (2020). Twitter como recurso metodológico en Educación Superior: Una experiencia educativa con estudiantes de Trabajo Social. Alteridad, 15(2), 174-189. https://doi.org/10.17163/alt.v15n2.2020.03

Gonzalez-Hernando, C., Valdivieso-León, L., y Velasco-García, V. (2020). Estudiantes universitarios descubren redes sociales y edublog como medio de aprendizaje. RIED. Revista Iberoamericana de Educación a Distancia, 23(1), 223-239. http://dx.doi. org/10.5944/ried.23.1.24213

Marini, V., Jácome, N. y López, R. (2016). Uso de redes sociales digitales entre estudiantado universitario. Comunicación, socialización y colaboración. Ensayos Pedagógicos, 1, 131-149.

Martínez, K.P. y Ramírez, A. (2016). Redes sociales en educación superior. Transformaciones tecnológicas, de socialización y de colaboración entre estudiantado universitario. Ensayos Pedagógicos, 1, 93-111.

Morán-Chilán, J.H., Pibaque-Ponce, M.S. y Parrales-Reyes, J.E. (2019). Redes sociales como estrategia educativa de lectura crítica. Dominio de las Ciencias, 5(2), 238-252. http://dx.doi.org/10.23857/dc.v5i2.1091

Nieto, N. (2021). Enseñanza del periodismo transmedia en Colombia, una experiencia pedagógica con estudiantes universitarios. Cuadernos.Info, (48), 215-236. https://doi.org/10.7764/cdi.48.27827 
Oria, B. (2020). Edmodo como herramienta de aprendizaje telecolaborativo online en el aula de inglés. Encuentro revista de investigación e innovación en la clase de idiomas, 28, 49-70.

Peña, M.A., Rueda, E., Pegalajar, M.C. (2018). Posibilidades didácticas de las redes sociales en el desarrollo de competencias de educación superior. Píxel-Bit. Revista de Medios y Educación, 53, 239-252. http://dx.doi.org/10.12795/pixelbit.2018.i53.16

Ramos, S. (2017). Redes sociales en Educación Primaria; revisión bibliográfica y propuestas. Publicaciones didácticas, 79, 168-185.

Prada-Núñez, R., Hernández-Suárez, C.A. y Maldonado-Esteve, E.A. (2020). Diagnóstico del potencial de las redes sociales como recurso didáctico en el proceso de enseñanza en época de aislamiento social. Revista ESPACIOS, 41(42), 260-268. http://doi.org/10.48082/espacios-a20v41n42p22

Ruay, R. y Campos, E. (2019). La plataforma YouTube como estrategia para el autoaprendizaje de la lengua inglesa. Boletín Redipe, 8(12), 129-142.

Statista (2021). Tasa de penetración de redes sociales en América Latina y Caribe por país en enero de 2021. https://es.statista.com/estadisticas/1073796/alcance-redes-sociales-america-latina/

The Social Media Family (2021). Estudio sobre el uso de redes sociales en España. https://www.epdata.es/datos/usuarios-redes-sociales-espana-estudio-iab/382

Urrútia, G., y Bonfill, X. (2010). Declaración PRISMA: una propuesta para mejorar la publicación de revisiones sistemáticas y metaanálisis. Medicina clínica, 135(11), 507511. http://doi.org/10.1016/j.medcli.2010.01.015 


\section{Una Investigación Cualitativa Acerca del Oficio Docente en la Actualidad}

\section{Pereira de Lucena, María Julia}

ORCID https://orcid.org/0000-0002-1593-0417

mjulialucena@gmail.com 


\section{UNA INVESTIGACIÓN CUALITATIVA ACERCA DEL OFICIO DOCENTE EN LA ACTUALIDAD}

\section{Pereira de Lucena, María Julia}

ORCID https://orcid.org/0000-0002-1593-0417

mjulialucena@gmail.com

\section{Resumen}

En el presente trabajo, compartiremos algunos avances de una investigación cualitativa acerca de la recreación del oficio docente en los escenarios actuales de enseñanza. La misma se inscribe en el marco de la Maestría en Tecnología Educativa de la Universidad de Buenos Aires. Interesa comprender las maneras en las que los docentes reconstruyen su propio oficio a partir del reconocimiento que realizan acerca de la especificidad de las modalidades. Recuperamos para el análisis situaciones de hibridación, de convergencia de escenarios y fusión de modalidades. La población investigada fueron docentes involucrados en la capacitación a distancia dirigidas a profesores universitarios desde 2019 hasta 2021 inclusive. Por lo tanto, realizaremos algunas reflexiones y análisis vinculados a la educación prepandémica, pandémica y pospandémica.

\section{Palabras clave}

Educación a distancia, capacitación docente, educación pandémica, educación pospandémica. 


\section{Introducción}

En el presente trabajo, compartiremos algunos avances de una investigación cualitativa acerca de la recreación del oficio docente en los escenarios actuales de enseñanza. La misma se inscribe en el marco de la Maestría en Tecnología Educativa de la Universidad de Buenos Aires.

El objetivo central consiste en comprender cuáles son las maneras en las que los docentes reconstruyen su propio oficio a partir del reconocimiento que realizan acerca de la especificidad de las modalidades (presencial, mixtos o a distancia). Nos interesa focalizarnos en las características del diálogo didáctico en los escenarios actuales de enseñanza. Siguiendo a Burbules (1993), nos proponemos indagar en qué momentos nos encontramos ante situaciones de diálogo genuino en la enseñanza; es decir, relaciones comunicativas pedagógicas que se estén sustentadas por la inteligencia cognitiva y también por sentimientos recíprocos de interés, confianza, respeto, aprecio, afecto y esperanza de los involucrados, teniendo en cuenta que nos encontramos ante una sociedad y un sistema educativo antidialógicos (Burbules, 1993). De hecho, Bauman (2014) sostiene que nos encontramos olvidando lentamente el arte del diálogo, o bien nunca lo hemos aprendido.

La población investigada fueron docentes involucrados en distintos programas de capacitación a distancia dirigidos a profesores universitarios desde 2019 hasta 2021 inclusive, por lo que se transitó el cambio entre educación prepandémica, pandémica y pospandémica.

En relación a los problemas a investigar, podemos detallar los siguientes:

- ¿De qué manera se expresa / recrea el oficio de enseñar en los escenarios actuales tanto virtuales como presenciales? ¿Existen especificidades según la modalidad?

- ¿Qué rupturas y continuidades se pueden vislumbrar en el rol docente en los escenarios actuales?

- ¿Qué estrategias se despliegan/ construyen para generar el diálogo didáctico?

Sobre los objetivos de la investigación, nos propusimos:

- Identificar, analizar y comprender la construcción del oficio de enseñar en los escenarios actuales.

- Interpretar las maneras en las que el oficio docente se expresa en los escenarios actuales tanto presenciales como virtuales.

- Construir categorías de análisis en torno al oficio de enseñar en clave actual y en el marco de los escenarios virtuales y presenciales, y sus especificidades según la modalidad.

En relación a los antecedentes, hemos hallado diversos estudios relacionados con el objeto de investigación desde diferentes perspectivas. 
En primer lugar, encontramos investigaciones sobre hibridaciones y fusiones en los escenarios actuales de enseñanza. Lion, Mansur y Lombardo (2015) enfatizan el concepto de hibridación en el que convergen perspectivas didácticas, gnoseológicas, psicológicas, políticas, sociales y culturales. Las autoras se refieren al contexto actual de convergencia tecnológica en donde existe un borramiento de los límites entre, por ejemplo, los planos lúdico, comunicacional e informativo, lo que configura la hibridación. El borramiento de límites (que consiste en una ampliación o extensión de las posibilidades, y no una mera confusión) también ocurre entre los roles de lector y autor, por ejemplo, o los espacios públicos y privados.

García Canclini (2003) afirma que la hibridación es un proceso sociocultural complejo en el que las estructuras o prácticas se combinan para generar nuevas. En el caso de la educación a distancia, históricamente siempre se combinó con momentos presenciales y actualmente, siguiendo a Lion, Mansur y Lombardo (2015) buscamos una mirada disruptiva con las diferentes formas vigentes de conceptualizar y concebir dicha opción educativa (semipresencial, virtual, bimodal, etc.). Las autoras también remiten a este concepto ya que implica la creación de múltiples combinaciones de las estrategias de enseñanza, que podrían potenciar propuestas y "generar entradas diversas a la enseñanza" (Lion, Mansur y Lombardo, 2015: 107). En el caso de la educación a distancia, las autoras plantean que su reconceptualización se ve fortalecida por la reconcepción del tiempo y el espacio. En el contexto actual, "los aprendizajes no se circunscriben a unos espacios concretos como las aulas, ni a unos contenidos estandarizados en los diseños curriculares, ni siquiera es solo una cuestión entre profesores y alumnos" (Lion, Mansur y Lombardo, 2015: 110), lo cual según las autoras es una invitación a reconcebir la educación a distancia, abriendo nuevas posibilidades frente a los cambios, como una opción pedagógica que puede implementar proyectos educativos diversos, y ofreciendo ayudas a los docentes que piensan y median para facilitar los aprendizajes de los estudiantes, en el lugar en donde estén, en la construcción de pensamientos críticos y flexibles, de conocimientos complejos y significativos que les ayuden en la comprensión del mundo.

Al respecto, Maggio (2013) afirma que la supuesta hibridación en realidad consiste en la sobre generalización de las plataformas virtuales de aprendizaje (soluciones estandarizadas que habilitan usos que contrastan con los que realizan los sujetos culturales atravesados por las tecnologías cuando se desconectan del campus. Este es un ejemplo del achatamiento de propuestas que producen la pérdida de identidad de la modalidad a distancia. La posición de la autora consiste en recuperar dicha identidad para reconcebir las propuestas de educación superior.

En segundo lugar, podemos encontrar investigaciones sobre la docencia en distintas modalidades educativas. Ruiz Méndez (2016) presentan los resultados de una investigación sobre los cambios pedagógicos que experimentaron cinco docentes y cinco coordinadores académicos de programas de educación a distancia en cinco instituciones de educación superior en México. Dicha investigación se desarrolló bajo un enfoque cualitativo, mediante el método etnográfico, con la aplicación de entrevistas semiestructuradas, la observación de algunos sistemas de gestión de aprendizaje y la aplicación de cuestionarios a estudiantes. Se observaron cambios en los profesores que cuentan con experiencia en modalidad presencial y comienzan a desarrollar su oficio complementándolo con "asesoría en línea" y prácticas insertas en el campo de la educación a distancia. El marco teórico seleccionado para esta investigación fueron autores como Barbero (teoría de las mediaciones) y 
García Aretio (teoría del diálogo didáctico), haciendo hincapié en la autonomía y la independencia (aspectos puestos en tela de juicio por Litwin y Maggio). En esta investigación, se detectó el desarrollo de habilidades por parte de los profesores tales como autonomía, autogestión y para la administración del tiempo, y promoción del uso de tecnologías con los estudiantes.

Por otra parte, hemos encontrado investigaciones sobre la docencia en la educación a distancia que alimentan el análisis de nuestro objeto de investigación. Litwin (2003) sostiene, que para que sea considerado como bueno, un programa de educación a distancia debe tener un cuerpo docente preocupado por la comprensión de los estudiantes. Dicho cuerpo debe investigar en su campo y manifestar verdadera preocupación por favorecer los procesos de aprender (Litwin, 2003: 12). En este sentido, Maggio (en Litwin, 2003) afirma que

“... en las perspectivas tradicionales de la modalidad a distancia era común sostener que el tutor guiaba orientaba, apoyaba el aprendizaje de los alumnos, pero no enseñaba. (...) En las perspectivas pedagógicas más actuales, alimentadas con el producto de trabajos de investigación en el campo de la didáctica, el docente genera propuestas de actividades para la reflexión, apoya su resolución, sugiere fuentes de información alternativas, ofrece explicaciones, favorece los procesos comprensivos; es decir, guía, orienta, apoya, y en ello consiste su enseñanza”. (Maggio en Litwin, 2003: 138 - 139).

La autora afirma que, en los programas de educación a distancia, el espacio de intervención del profesor no suele estar garantizado, lo que produce que él debe potenciar al máximo sus condiciones docentes y potenciar las oportunidades de enseñanza. Maggio (en Litwin, 2003) sostiene que la esencia del ser docente consiste en enseñar autónoma y reflexivamente, y enseñar a pensar en el marco de una sociedad democrática (Maggio en Litwin, 2003: 159). En 2013, la autora ratificó su posición, afirmando que las propuestas de educación a distancia deben ser motores de calidad e innovación. La autora sostiene que uno de los resabios de la modalidad que deben ponerse en tela de juicio consiste en que el diseño y el desarrollo de la propuesta esté a cargo de expertos disciplinares, y que la implementación de la cursada se encuentre designada a tutores que posean un dominio superficial de contenido y que cuenten con habilidades de "acompañante terapéutico" (Maggio, 2013: 3).

Por otra parte, Badia, Meneses y García (2017) han realizado una investigación sobre la identidad del profesor como docente virtual. La misma tiene un enfoque distinto al que utilizaremos en nuestra investigación ya que se realizó un estudio cuantitativo a través de la aplicación de cuestionarios que se analizaron con técnicas estadísticas. En contraposición a este antecedente, nuestra intención en la presente investigación no será establecer tipologías sino profundizar en el conocimiento del oficio docente en los escenarios actuales de enseñanza.

\section{Descripción del contexto y de los participantes}

Coll y Monereo (2011) afirmaron que formamos parte de la sociedad de la información, que se caracteriza por la capacidad de sus miembros para obtener y compartir cualquier cantidad de información, de manera prácticamente instantánea, desde cualquier lugar y en la forma preferida, y con un costo muy bajo. En estos momentos, 
estaríamos iniciando una nueva subetapa caracterizada por el desarrollo de las redes inalámbricas e internet móvil. Los autores afirman que es un escenario que tiene las siguientes características: la complejidad, la interdependencia y la imprevisibilidad; información, sobreinformación y ruido, la rapidez de los procesos y sus consecuencias, la escasez de espacios y tiempos para la abstracción y la reflexión, la preeminencia de la cultural de la imagen y del espectáculo, la transformación de las coordenadas espaciales y temporales de la comunicación, la homogeneización cultural, la aparición de nuevas clases sociales (los info- ricos y los info - pobres). En este sentido, Cobo (2016) afirma que uno de los aspectos críticos por resolver no están en los dispositivos como tales (es decir, los contenedores) sino en los contextos, enfoques, modelos pedagógicos y procesos de transformación socio- tecno- pedagógicos. Además, el autor nos invita a una reflexión muy interesante.

En relación a la selección de los casos a investigar, se orientó al reconocimiento de buenas prácticas docentes llevadas a cabo por docentes reputados. Litwin (2016) retoma a Jackson, quien señaló que los principios pedagógicos de dichas prácticas consisten en una "masa compacta de cinco cosas: ser justo en el trato; dominar la disciplina; estimular, premiar o corregir; reconocer errores; corregir a tiempo (Jackson, 2002: 66)" (Litwin, 2016: 219).

Sobre los criterios de diseño intencional de la muestra, se trató de pequeñas muestras no aleatorias ya que la intención no ha sido la generalización. Se generará un muestreo de avalancha (Strauss y Corbin, 1998), por lo cual le solicitaremos a los informantes que recomienden a posibles participantes (docentes bien reputados) a través de un efecto de bola de nieve o muestreo en cadena y teniendo en cuenta especialmente lo expuesto por Litwin (2016) en relación a la idea de revisitar las clases de maestros (en este caso, profesores) excepcionales ya sea por su dominio del contenido, su fuerza en la explicación o su potencia para favorecer la comprensión de los estudiantes y utilizar sus síntesis, analogías o recursos.

\section{Instrumentos}

Para obtener la información empírica, se realizaron entrevistas en profundidad semiestructuradas individuales, observaciones de las prácticas de los docentes reputados y análisis documental.

Se realizó una guía de la entrevista para asegurarnos la exploración de los temas claves de la investigación pero las mismas serán abiertas, en profundidad, no directivas ni estandarizadas. Se mantendrán una serie de encuentros cara a cara y/o virtuales con los profesores. Inicialmente, se realizarán preguntas generales y descriptivas; luego se introducirán preguntas más sustantivas y comprometedoras, a medida que se va ganando confianza (Sirvent y Monteverde, 2016b). Se comunicaron los motivos a los entrevistados y se les informó sobre el tratamiento anónimo de los datos que se obtendrán (Taylor y Bogdan, 1987).

También se realizaron observaciones de situaciones de enseñanza en contextos virtuales. Siguiendo a Sirvent y Monteverde (2016b), resulta importante realizar un registro de observación lo más completo y rico posible, sin resumir, y abordar todas las cuestiones posibles, tales como: quiénes están en la situación, dónde está situado el grupo, cómo se organiza el mismo, qué está sucediendo, qué contextos se pueden identificar, qué hacen los miembros de los grupo o de la escena (activi- 
dades, conductas), cómo participan y se relacionan entre sí, qué comportamientos se repiten, qué se dicen entre sí y cuáles el contenido de sus conversaciones. Se realizaron acuerdos previos a la entrada a terreno, teniendo en cuenta: permisos, definición del para qué se va a observar, el grado de implicancia, el número de observadores por situación y lugar, etc. (Sirvent y Monteverde, 2016b: 4). Además, se llevó a cabo el método comparativo constante (Glaser y Strauss, retomado en Taylor y Bogdan, 1987), en el cual el investigador "simultáneamente codifica y analiza los datos para desarrollar conceptos. Mediante la comparación continua de incidentes específicos de los datos, el investigador refina esos conceptos, identifica sus propiedades, explora sus interrelaciones y los integra en una teoría coherente" (Taylor y Bogdan: 155).

Se construyó una "teoría fundamentada" (Strauss y Corbin, 1998), derivada de datos recopilados sistemáticamente y analizados. Dichos autores afirman que la recolección de los datos, el análisis y la teoría que surgirá de los mismos guardan una relación sumamente estrecha entre sí; la teoría fue emergiendo a partir de los datos obtenidos, su sistematización y la creatividad (Strauss y Corbin, 1998).

\section{Procedimiento}

Planteamos una investigación con diseño cualitativo e interpretativo de acuerdo a las razones que se exponen a continuación. Se reconocieron casos de docentes que tenían una buena reputación al interior de instituciones educativas en ciertos escenarios actuales de enseñanza.

Según Sirvent y Rigal (2016) los pares lógicos o modos suposicionales son aquellas dualidades que caracterizan a los grandes debates en la historia de la metodología de las Ciencias Sociales y la epistemología. Dichas dualidades implican enfatizar uno de los términos sin excluir necesariamente al otro. Se trata de los supuestos sobre el hecho social y su conocimiento que son predominantes en diferentes enfoques sobre la realidad social y el "hacer ciencia" sobre dicha realidad; y se encuentran fundamentados en los encuadres de cada una de las tradiciones paradigmáticas: positivismo, hermenéutica y teoría crítica. Consideramos que la presente investigación enfatizará los siguientes pares lógicos o modos suposicionales (Strauss y Corbin, en Sirvent y Rigal, 2016). Abordamos el raciocinio inductivo (proceso de abstracción creciente), a través de la construir una teoría que haga comprensivos los datos mediante un proceso en espiral (combinación de obtención de información y análisis) y partiendo de los incidentes de la realidad (base empírica). En este sentido, no se enfatizó la deducción o la pretensión de encontrar datos que verifiquen la teoría, sino que se construyó teoría que hiciera comprensivos los datos (Sirvent y Rigal, 2016) ya que uno de los objetivos centrales de la investigación consistió en interpretar las maneras en las que el oficio docente se expresa en distintos escenarios de enseñanza.

En línea con lo expuesto en este apartado, resulta importante retomar a Maggio, Lion y Perosi (2014), quienes investigaron las prácticas de enseñanza en ambientes de alta disposición tecnológica construyendo un diseño cualitativo e interpretativo. El objetivo de las investigadoras no fue generalizar sino reconocer las propuestas de excepción o de autor en el campo de la enseñanza, identificándolas y comprendiéndolas en sus contextos naturales y en las condiciones de práctica habituales "con un abordaje que en su matriz investigativa abreva en las fuentes de la didáctica crítica". 
Para ello, se valieron del reconocimiento de las buenas prácticas de la enseñanza como punto de partida para la construcción de una agenda de nuevo tipo, tal como se desea incluir en el presente proyecto de investigación ya que nos proponemos identificar, analizar y comprender la construcción del oficio de enseñar en los escenarios actuales. Así, planteamos un modo de generación conceptual, centrándonos en la construcción de categorías y esquemas conceptuales (tramas teóricas) a partir de una base de información empírica. Dichas categorías darán cuenta de "la descripción y comprensión holística del hecho social investigado" (Sirvent, 2016: 20). Así, abordaremos un modo comprensivo de acercamiento al objeto de investigación: el oficio docente en los escenarios actuales de enseñanza, pretendiendo vincular la teoría y la empiria en la elaboración de conceptos y relaciones entre conceptos que permiten una aproximación dialéctica a una realidad determinada. No se espera producir resultados cuantificables; en cambio, esperamos construir categorías de análisis en torno a cómo se expresa el oficio de enseñar en los escenarios actuales.

Se enfatizó el contexto de descubrimiento (en este caso, inserto en instituciones del nivel superior), centrándonos en la identificación de teorías y proposiciones a partir de una base de información empírica (Glaser y Strauss, 1967, retomados por Sirvent y Rigal, 2016). Asimismo, partimos del reconocimiento de la subjetividad e implicación por parte del investigador, ya que asumimos que no podríamos investigar desde una supuesta externalidad sino que nuestra intención es adentrarnos en el objeto a investigar (relación de internalidad e implicancia) y luego tomar cierta distancia para lograr un pensamiento reflexivo y científico. De esta manera, como mencionamos anteriormente, nos acercamos a un modo de generación conceptual porque intentaremos lograr fertilidad teórica para describir e interpretar al oficio docente en los escenarios actuales de enseñanza a través de la comprensión; es decir, de captar el significado, el sentido profundo que los docentes le atribuyen a sus acciones vinculadas al oficio de enseñar.

\section{Resultados}

\section{Discusión y conclusiones}

En el presente trabajo, compartimos algunos de los avances de una investigación cualitativa acerca de la recreación del oficio docente en los escenarios actuales de enseñanza. Dicha investigación intenta comprender cuáles son las maneras en las que los docentes reconstruyen su propio oficio a partir del reconocimiento que realizan acerca de la especificidad de las modalidades.

La mayoría de los docentes coincidieron en establecer que existe una esencia en el oficio docente, que resulta independiente de la modalidad en que se desempeñen. Dicha esencia consiste en conocer al estudiante y su contexto, valorarlo, reconocer su capital cultural, construir su propuesta docente en base a este conocimiento, generando vínculos de confianza y apertura con los estudiantes, y construyendo un espacio de disponibilidad por parte del docente. Podemos enlazar las afirmaciones de los docentes, con algunas construcciones propias del campo disciplinar de la Didáctica, que (según Camilloni, 1997 y 2015), es la teoría de la enseñanza, una ciencia social que se ocupa de estudiar las prácticas de enseñanza y que tiene como misión describirlas, explicarlas, fundamentar y enunciar normas para la mejor resolución de los problemas que estas prácticas nos plantean a los docentes, y es heredera y deudora 
de muchas otras disciplinas (principalmente, de la Psicología y de la Filosofía). Litwin (1997) agrega que esta teoría acerca de las prácticas de enseñanza deben ser significadas en los contextos socio-históricos en que se inscriben. Esto se relaciona con lo expuesto por los docentes, ya que ellos hicieron hincapié en conocer el contexto de los estudiantes en su individualidad y también en tanto grupo, para poder enseñar mejor. Parafraseando a Litwin (2016), las universidades que soñamos y necesitamos, que recordamos con añoranza, constituyen una plataforma en la que es posible reconocer las ideas y concepciones de una Pedagogía del oficio docente, optimista y esperanzadora. Entender el sentido del oficio en relación con la sociedad, los tiempos actuales y la vida de quienes integran las prácticas educativas, implica realizar una contextualización en las demandas del presente, es entenderlo para intentar educar para una sociedad más justa. En este sentido, Bruner (2012) manifiesta que debemos considerar a la educación y el aprendizaje en su contexto cultural situado, teniendo en cuenta que la cultura da forma a la mente y nos aporta la caja de herramientas gracias a la cual construimos nuestros mundos y nuestras propias concepciones de nosotros mismos y de nuestros poderes. Lion, Mansur y Lombardo (2015) adhieren a esta postura, afirmando que debemos comprender en profundidad los contextos particulares y específicos en los que se desarrollan las prácticas de la enseñanza, dado que estos condicionan y enmarcan las prácticas y se constituye en el ámbito en el que cobran verdadero sentido (Litwin, 1997, retomado en Lion, Mansur y Lombardo, 2015) para que sean pertinentes y con sentido formativo. Podemos encontrar que en el trabajo de campo, hubo una preocupación constante por el contexto de enseñanza.

La investigación continuará desarrollando y profundizando en estos aspectos, y es nuestra expectativa seguir compartiéndolos y debatiéndolos.

\section{Referencias}

Area Moreira, M. (2004). Cap. Los medios de enseñanza o materiales didácticos. Caracterización y tipos. En: Los medios y las tecnologías en educación. Madrid: Pirámide.

Badía, A., Meneses, J. y García, C. (2017). La identidad del profesor como docente virtual: Roles, enfoques y sentimientos. El caso de la Universitat Oberta de Catalunya (UOC). Disponible en: http://femrecerca.cat/meneses/files/badia_meneses_garcia_es_2017.pdf

Buckingham, D. (2008). Más allá de la tecnología. Aprendizaje infantil en la era de la cultura digital. Buenos Aires: Manantial.

Burbules, N. C. (1993). El diálogo en la enseñanza. Teoría y práctica. Buenos Aires: Amorrortu.

Bustos Sánchez, A. y Coll Salvador, C. (2010). Los entornos virtuales como espacios de enseñanza y aprendizaje. Una perspectiva psicoeducativa para su caracterización y análisis. Revista Mexicana de Investigación Educativa, 14,44.

Castells, M. (1996). La era de la información: economía, sociedad y cultura. Madrid: Alianza. 
Castells, M. (2003). "Panorama de la Era de la Información en América Latina ¿es sostenible la globalización?” En: ¿Es sostenible la globalización en América latina? Santiago de Chile: FCE.

Cobo, C. (2016). La innovación pendiente. Reflexiones (y provocaciones) sobre educación, tecnología y conocimiento. Montevideo: Debate.

Coll Salvador, C. y Monereo, C. (Eds.) (2011). Psicología de la educación virtual. Madrid: Morata.

García Canclini, N. (2003). "Noticias recientes sobre hibridación”. Trans: Revista Transcultural de Música, 7.

Lion, C. y Perosi, V. (2012). "Conocimiento, hipertexto y enseñanza: perspectivas interpeladoras para el análisis crítico". En Seminario Manuales, libros por áreas e itinerarios hipertextuales en la historia reciente de la educación. 1958 - 2008. Universidad Nacional de Luján: CIFASIS.

Lion, C., Mansur, A. y Lombardo, C. (2015). "Perspectivas y constructos para una educación a distancia re-concebida". En Revista del Instituto de Investigaciones en Ciencias de la Educación, 37.

Litwin, E. (Comp.) (2000). Tecnología educativa. Política, historias, propuestas. Buenos Aires: Paidós.

Litwin, E. (Comp.) (2003). La educación a distancia. Temas para el debate en una nueva agenda educativa. Buenos Aires: Amorrortu.

Litwin, E. (2009). Tecnologías educativas en tiempos de internet. Buenos Aires: Amorrortu.

Litwin, E. (2016). El oficio de enseñar. Condiciones y contextos. Buenos Aires: Paidós.

Maggio, M. (2012). Enriquecer la enseñanza. Los ambientes con alta disposición tecnológica como oportunidad. Buenos Aires: Paidós.

Maggio, M. (2013). Sobre cómo la educación a distancia puede ayudarnos a re-concebir la educación superior. Disponible en: https://www.educ.ar/recursos/121411/ sobre-como-la-educacion-a-distancia-puede-ayudarnos-a-re-concebir-la-educacion-superior

Maggio, M. Lion, C. y Perosi, V. (2014). Las prácticas de la enseñanza recreadas en los escenarios de alta disposición tecnológica. Polifonías Revista de educación, 5, 3, p. $101-127$.

Ruíz Méndez, M. R. (2016). Análisis pedagógico de la docencia en educación a distancia. Perfiles educativos, 38 (154). Disponible en: http://www.scielo.org.mx/scielo. php?script=sci_arttext\&pid=S0185-26982016000400005\&lang=es 
Sirvent, M. T. (2002). Universidad, ciencia e investigación en educación: contradicciones y desafíos del presente momento histórico en Argentina. En: Revista de la Biblioteca del Congreso de la Nación: Pensar la ciencia I, 121, 9-27.

Sirvent, M. T. y Monteverde, M. C. (2016a). Recapitulación: características de la investigación científica. Material de cátedra. Carrera Maestría en Tecnología Educativa, Universidad de Buenos Aires.

Sirvent, M. T. y Monteverde, M. C. (2016b). ¿Qué implica observar? Material de cátedra. Carrera Maestría en Tecnología Educativa, Universidad de Buenos Aires.

Sirvent, M. T. (2016). Los diferentes modos de hacer ciencia de lo social. Documento borrador del libro de Sirvent, M. T. y Rigal, L. (Manuscrito en revisión). Metodología de la investigación social y educativa: diferentes caminos de producción de conocimiento.

Strauss, A. y Corbin, J. (1998). Bases de la investigación cualitativa. Técnicas y procedimientos para desarrollar la teoría fundamentada. Medellín: Editorial Universidad de Antioquia.

Taylor, S. J. y Bogdan, R. (1987). Introducción a los métodos cualitativos de investigación. Barcelona: Paidós. 


\section{La Virtualidad, Dispositivo para Favorecer la Agencia en las Prácticas Letradas del Profesorado en Formación Inicial}

Hernández Yépez Ma. Antonia ORCID orcid.org/0000-0001-7728-3043 antonia.hernandez@benft.edu.mx

Salinas Quintanilla Alma Ma. del Amparo ORCID orcid.org/0000-0003-4269-025X

salinasamparo@gmail.com 


\title{
LA VIRTUALIDAD, DISPOSITIVO PARA FAVORECER LA AGENCIA EN LAS PRÁCTICAS LETRADAS DEL PROFESORADO EN FORMACIÓN INICIAL
}

\author{
Hernández Yépez Ma. Antonia \\ Salinas Quintanilla Alma Ma. del Amparo
}

\section{Resumen}

La construcción de prácticas letradas, durante la formación inicial del profesorado, implica un proceso complejo que ha sido abordado escasamente; y que, en tiempos de pandemia, su complejidad se incrementa, ante la ausencia de la presencialidad en las aulas y la migración a la virtualidad, como el espacio para los aprendizajes en red. Las prácticas letradas son entendidas como los saberes lingüísticos, culturales y educativos, que construyen los sujetos, de manera cotidiana y contextualizada en las aulas, durante las tareas escolares. Ante esta situación, se realizó investigación cualitativa con perspectivas fenomenológica y hermenéutica, cuyo propósito permitió la reflexión, interpretación y comprehensión de los significados y vivencias relacionadas con las prácticas letradas, durante la formación inicial de 11 profesores, en el contexto áulico: in situ; y mediados por la virtualidad, en una escuela normal. Los resultados permitieron identificar aspectos conceptuales relacionados con la agencia en la construcción de prácticas letradas; aspectos subjetivos que caracterizan a un modelo de formación inicial presencial; y aquellos, mediados por la virtualidad. Ante todo, se identificó la necesidad de migrar hacia diseños curriculares flexibles que permitan un manejo adaptativo de la colaboración y autonomía.

\section{Palabras clave}

Formación inicial, virtualidad, agencia, prácticas letradas. 


\section{Introducción}

A partir del ciclo escolar 2016-2017, en la escuela normal donde se realizó esta investigación, se inició el uso de la plataforma virtual Google Classroom, con el fin de impulsar a los docentes formadores en el manejo de las nuevas tecnologías de la información y comunicación. Su uso se coordinó a partir de la asignación de correos electrónicos por Gmail, tanto para docentes como para profesores en formación, según investigaciones realizadas por Guevara Maldonado, Magaña Domínguez y Picasso Hinojosa (2019) sobre el uso de la plataforma Google Classroom, en la escuela normal en cuestión, se percibió que los docentes formadores la desconocían y no le dieron uso a esta plataforma en el período comprendido entre 2016 a 2019.

La mayoría de los encuestados contestaron el instrumento sin conocer ni utilizar la plataforma por lo que no conocen los alcances que se pueden llegar a tener con ella y la facilidad de comunicación con los alumnos, ya que piensan que se utiliza en su clase dentro de la institución, y no como apoyo fuera de clases, de manera no presencial, que es precisamente como se debe utilizar. (p. 13).

Sin embargo, fue justamente el contar institucionalmente con esta plataforma, lo que permitió al docente formador hacer frente a la necesidad de comunicación a distancia y desarrollar las clases en línea, a partir del mes de abril del 2020. De esta forma los docentes se vieron comprometidos a aprender a utilizarla a la par de los profesores en formación. Ya que "los entornos virtuales exigen formas, estrategias, posturas y conocimientos diferentes a los que usualmente se necesitan para leer y escribir con soporte de papel, impreso o manual" (Casillas Alvarado y Ramírez Martinell, 2018, p. 12). El uso de las Nuevas Tecnologías de la Información y Comunicación (NTIC) en la formación docente inicial, en el momento actual, permite adentrarse en "un nuevo paradigma educativo que se caracteriza por la inclusión de tecnologías que permiten la virtualidad, la educación en red; y que, en consecuencia, están cambiando el rol del maestro, de los estudiantes e incluso de las instituciones" (Zorro Rodríguez, 2012, p. 219).

En este contexto virtual, las prácticas sociales del lenguaje, de los futuros profesores de educación primaria, comprenden actividades que implican leer, escribir y hablar en el aula de clase. Durante estas prácticas letradas, a veces complejas, dadas las diferentes formas en que los docentes formadores desarrollan cada clase, el trabajo del estudiante es interpretar lo que señalan los textos, leerlos y escribir sus opiniones sobre los mismos, lo que implica poner en juego sus conocimientos previos sobre los temas que tratan y relacionarlas con lo que proponen los autores revisados, con el fin de aplicar lo aprendido en sus prácticas docentes con alumnos en escuelas primarias; que debido a la pandemia, también se realizan de forma virtual, apropiándose, poco a poco, del lenguaje específico de un docente en formación, de una literacidad académica que les es propia.

Las prácticas letradas realizadas desde la virtualidad cuentan con el apoyo de textos en línea, los escritos se realizan en el ordenador y se suben a las plataformas establecidas para su evaluación; así como, los intercambios orales se realizan durante la clase en línea. "La formación inicial tiene que integrar los conocimientos académicos, las concepciones personales y el conocimiento práctico, y contribuir a generar en los profesores en formación su propio conocimiento didáctico del contenido" (Mellado Jiménez, 2003, p. 353). El proceso se torna complejo, porque, 
los profesores en formación, en sus redacciones, muestran grandes dificultades, al tratar de cumplir con las tareas; sobre todo, en el acceso a los espacios digitales, al carecer de dispositivos o de una red estable. Así, a medida que el profesor en formación se introduce en su función docente, en un entramado complicado ante carencias cognitivas y de infraestructura, construye un lenguaje especializado que lo identifica con su profesión.

La literacidad académica (formas específicas de lectura y escritura) está conectada con otros elementos: 1) con formas orales de utilizar el lenguaje y con otras modalidades sensoriales; 2) con formas particulares de interactuar, creer, valorar y sentir, y 3) con modos específicos de usar objetos, instrumentos, tecnologías, símbolos, espacios y tiempo. (Gee, 2004, p. 6)

Ante ello, los profesores en formación inicial deben poner de manifiesto sus competencias a través de evidencias, que tienen que ver con la puesta en juego de lenguaje docente específico. Esta serie de evidencias, suelen representar retos para su elaboración; pero, integran un bagaje discursivo y textual del proceso formativo por competencias del futuro docente.

Diversos autores han desarrollado investigaciones sobre los procesos que siguen los estudiantes de educación superior en su encuentro con las prácticas letradas propias de este nivel. Señalando que éstos no están preparados para enfrentarlas y que por ello presentan dificultades para apropiárselas, en un proceso de lucha y negociación con los docentes que actúan como mediadores pedagógicos (Sito y Kleiman, 2007; Mesía Marino, 2008; Zavala, 2009 y 2011; Vargas Franco, 2013; Martínez García y Posada Carmona, 2017; Freeman, 2019).

En estas tareas mediadoras, Zavala (2009), señaló que, la literacidad académica "constituye la apropiación de prácticas discursivas orales y escritas que se desarrolla como parte del sentido que las personas dan a su experiencia en el proceso de socialización" (p. 7), esto es, durante las interacciones que realizan los profesores en formación, dentro y fuera del aula.

Los enfoques de la escritura, la lectura y oralidad de los estudiantes en contextos académicos se han abordado desde tres modelos. El primer modelo es el de habilidades de estudio, que "considera que la escritura y la alfabetización son principalmente una habilidad individual y cognitiva" (Lea y Street, 2006, p. 227), donde el sujeto desarrolla sus habilidades de lectura, escritura y oralidad, predomina el trabajo individual en el aprendizaje. El segundo modelo, parte de una postura que se ha denominado socialización académica, por lo que, "el modelo de socialización académica presupone que los discursos y géneros disciplinares son relativamente estables y que una vez que los estudiantes han aprendido y comprendido las reglas básicas de un discurso académico particular, pueden reproducirlo sin problemas (Lea y Street, 2006, pp. 227-228). El tercer modelo, literacidad académica que desde un enfoque integrador, comprende los anteriores y se enfoca en

la creación de significado, la identidad, el poder y la autoridad y pone en primer plano la naturaleza institucional de lo que "cuenta" como conocimiento en cualquier contexto académico particular. Es similar en muchos aspectos al modelo de socialización académica, excepto que considera los procesos involucrados en la adquisición de usos apropiados y efectivos de la alfabetización 
como más complejos, dinámicos, matizados, situados y que involucran tanto cuestiones epistemológicas como procesos sociales, incluidas las relaciones de poder entre personas e instituciones e identidades sociales. (Lea y Street, 2006, p. 228)

En esta perspectiva sociocultural se ubican los Nuevos Estudios de la Literacidad (NEL), "que buscan entender cómo las estructuras de poder orientan las prácticas sociales" (Sito y Kleiman, 2017, p. 166) en oposición a una concepción que observa a la lectura y escritura vista de manera neutral. De acuerdo con Barton y Hamilton (2004), "la literacidad, es esencialmente social y se localiza en la interacción interpersonal. Es ante todo algo que la gente hace; es una actividad localizada en el espacio entre el pensamiento y el texto" (p. 109). Se destaca entonces, que "la literacidad hace referencia a la práctica social de lo letrado en cualquier contexto sociocultural" (Zavala, 2004, p. 438). Así, la unidad básica de esta teoría sociocultural de la literacidad está constituida por las prácticas letradas (lectura y escritura). "Las prácticas son, al mismo tiempo, los procesos sociales que conectan a las personas entre sí y que incluyen conocimientos compartidos representados en ideologías e identidades sociales" (Barton y Hamilton, 2004, p. 112). En este sentido, la literacidad aplica en todos los ámbitos, uno de ellos, es el académico, que se desarrolla cotidianamente en los contextos escolares (presenciales o virtuales) en los que se construyen diversas prácticas letradas, dado que al "conjunto de prácticas letradas articuladas entre sí, que pueden asociarse a un contexto social específico [a la escuela, a la familia, al trabajo, a la iglesia, a la comunidad, etc.] se le conoce como literacidad" (Zavala, 2009 , p. 27). Estas prácticas se realizan de manera cotidiana en interacción, a través de las diversas manifestaciones del lenguaje, "el ser humano al entrar en contacto con la cultura a la que pertenece se apropia de los signos que son de origen social para internalizarlos" (Chaves Salas, 2001, p. 60), en el aula, espacio eminentemente social, tanto alumnos como docentes socializan el conocimiento, utilizando para ello, diversas agencias mediadoras.

Actualmente, ante la contingencia vivida durante la pandemia, el contexto escolar de pronto se cierra y ante la ausencia de estudiantes y profesores, el aula arquitectónica permanece vacía; no así, la creación y recreación de las prácticas letradas, que ante esta vivencia; y utilizando la virtualidad, favoreció la agencia mediadora de profesores en formación para dar continuidad a la tarea educadora. De esta manera, el profesorado en formación inicial en la escuela normal recuperó las prácticas de lectura y escritura como actividades insustituibles para el logro de los aprendizajes, acorde con lo expresado por Zavala (2009) al considerar que "la literacidad siempre implica una manera de usar la lectura y la escritura en el marco de un propósito social específico" (p. 23). Desde este enfoque, se observa que leer y escribir no son sólo habilidades psicolingüísticas y cognitivas, sino que van más hacia la interacción social que el sujeto realiza en el contexto cultural en el que se encuentre, en este caso, desde la virtualidad.

En las escuelas normales, estas prácticas letradas poseen finalidades específicas, en este caso el logro de las competencias marcadas por el perfil de egreso, porque, "para entender cómo funciona la lectura y la escritura no basta con observarlas en sí mismas. De lo que se trata, más bien, es de observar las prácticas sociales particulares donde se desarrollan las diversas formas de lectura y escritura" (Zavala, 2009, p. 30). Prácticas letradas en las que están presentes el lenguaje en acción, el contexto de la situación, la interacción, las relaciones sociales, las identidades, 
las representaciones, entre otras situaciones más. que evidencian el uso discursivo disciplinar que les es propio de acuerdo con su formación académica.

La práctica educativa, desde un enfoque por competencias, privilegia un modelo educativo fundamentado en el interaccionismo sociocultural, cuyos postulados teóricos señalan, que

La cultura del aula está constituida por la interacción entre profesores y estudiantes.

Las reglas y convenios emergen interactivamente, tanto los referentes a la disciplina como los de índole social.

La comunicación emerge de la negociación y los significados compartidos. (Leguizamón Romero, 2017, pp. 61-62)

Desde estos supuestos, la comunicación, los procesos pedagógicos y el seguimiento de normas son básicos para la interacción de los participantes en el contexto en el que se desenvuelven; que, en un ambiente constructivista se convierte en mediación pedagógica. Entendida como

el acto de enseñar, en un ambiente de inclusividad, se entiende a ésta [la mediación] como la práctica docente que promueve la construcción de aprendizajes significativos a través de espacios de análisis, crítica y reflexión. En el que las personas interactúan de manera autónoma, participando y colaborando creativamente en la construcción de aprendizajes. (Salinas Quintanilla, 2012 p. 159).

Principios rectores en la construcción de prácticas letradas del profesorado en formación inicial, en las que el proceso de mediación se favorece desde la virtualidad; dispositivo que detonó la agencia de profesores en formación inicial como sujetos reflexivos que poseen experiencias, pensamientos, conocimientos y diversas competencias propias de la profesión docente (Zavala, 2011). La agencia como el actuar en un contexto sociocultural determinado, la virtualidad; en el que los profesores en formación inicial se comprometieron e interactuaron con sus compañeros y docentes formadores en la construcción, sistematización y reflexión de prácticas letradas, en un contexto altamente vulnerable y complejo, el MERS-CoV.

Ante la emergencia, los profesores en formación inicial y los docentes formadores utilizaron recursos tecnológicos de apoyo a la mediación, como el correo electrónico, el teléfono móvil, el computador, para establecer la comunicación; y con ello acordar los procedimientos que permitieron la realización de diversos eventos evento. Además de otros, como el chat, whatsapp y diversas salas virtuales. De manera que, la construcción de prácticas letradas se abordó desde una perspectiva constructivista sociocultural, a partir de la agencia de los docentes formadores, profesores en formación inicial y el contexto en el que se encontraba cada uno de ellos; así como, el dispositivo personal, móvil y/o computador, que permitió el ejercicio de la virtualidad.

En este sentido, las relaciones e interacciones pedagógicas que se establecen entre los docentes formadores y los profesores en formación inicial, a través de la mediación durante el desarrollo de las clases en las aulas (presenciales o virtuales), parten de lo señalado en el Plan de Estudios de la LEP 2018, que se basa en un enfoque 
centrado en el aprendizaje, que "ocurre en contextos socioculturales e históricos específicos, de los cuales no puede abstraerse, es decir, tiene un carácter situado" (SEP, 2018, p. 87). Esta acción se realiza a partir de las competencias genéricas y profesionales de los programas establecidos en el plan de estudios; pero también, a partir de la combinación de capital cultural, tanto del docente formador, como del profesor en formación, elementos esenciales en el logro de la mediación. Sin duda, el capital cultural del profesor en formación aporta elementos clave en este proceso de agencia, que les permite expresar sus percepciones, ideas y conocimientos; así como las habilidades y destrezas específicas del trabajo virtual para favorecer el desarrollo de competencias específicas del quehacer docente.

De esta forma, la mediación pedagógica determina el rumbo a seguir en las interacciones académicas que se generan en cualquier modalidad de enseñanza presencial y/o virtual; donde, la comunicación inmersa en el contexto sociocultural otorga significado a las prácticas letradas que se construyen cotidianamente. Pero ¿cómo construyen las prácticas letradas los profesores en formación inicial al utilizar la virtualidad como dispositivo para favorecer la agencia mediadora? Interrogante que permitió adentrarse en el propósito de este estudio cualitativo para describir, interpretar y comprehender los significados y vivencias relacionadas con la agencia, en la construcción de prácticas letradas de los profesores en formación inicial, en un contexto mediado por la virtualidad.

\section{Método}

La estrategia de investigación utilizada es de corte cualitativo con una perspectiva fenomenológica y hermenéutica, donde se asumió la tarea de describir los significados que un grupo de estudiantes normalistas construyen al desarrollar sus prácticas letradas virtuales durante el proceso inicial de formación docente. Se apoya en la dimensión metodológica de la hermenéutica analógica barroca. Desde la analogía, se busca interpretar lo expresado por el autor desde la tradición del intérprete, es decir se indaga sobre la intencionalidad "qué movió al autor a decir lo que dijo y el por qué lo dijo así y no de otro modo" (Saavedra Ramírez, 2000, p. 36). Esta postura metodológica estuvo mediada por los aportes teóricos de Zavala (2009 y 2011), desde una perspectiva etnográfica, al "observar las prácticas sociales específicas donde se desarrollan estas diversas formas de lectura y de escritura” (Zavala, 2009, p. 19). Constructos que se recuperaron y permitieron, en un primer momento, realizar una revisión documental exhaustiva para identificar los fundamentos epistemológicos de la literacidad académica bajo el enfoque del constructivismo sociocultural, apoyados en los Nuevos Estudios de la Literacidad. Posteriormente, ante la contingencia vivida, MERS-CoV, se realizaron lecturas exhaustivas para la selección y utilización de los espacios virtuales pertinentes que permitieron la continuidad del ejercicio investigativo.

\section{Descripción del contexto y los participantes}

En esta experiencia participaron 11 profesores en formación, entre 19 a 24 años de edad y una docente formadora, que, ante la pandemia, se recluyeron en sus domicilios particulares, donde empezaron a tomar clases a distancia, con serias dificultades en la comunicación virtual, al enfrentar problemas de conexión a internet. Situaciones que estuvieron presentes en las vivencias relatas por los participantes de la investigación. 


\section{Instrumentos}

Como un instrumento, que permitió la sistematización de experiencias vividas, se utilizó la carta. Documento narrativo en el que los estudiantes expusieron sus experiencias letradas, formativas, interacciones y procesos de mediación pedagógica que se realizaron en las interacciones virtuales con los docentes formadores. Se recuperaron estos documentos personales que contenían relatos de los alumnos, escritos en primera persona sobre parte de su vida escolar, a manera de "reflexiones sobre un acontecimiento o tema específicos" (Taylor y Bogdan, 1987, p. 140).

\section{Procedimiento}

Una vez recolectadas las cartas se realizó el análisis, reflexión, interpretación y comprehensión de los significados y vivencias de las prácticas letradas. Enseguida, se codificó su contenido, para luego establecer categorías emergentes derivadas del análisis hermenéutico realizado. De esta manera, un primer acercamiento al texto permitió familiarizarse con los significados textuales, que posteriormente, permitieron adentrarse en los aspectos intertextuales que adquieren significado en la contextuación. Sin embargo, se puede decir, que éste no es un proceso lineal, responde a un formato dialéctico en el que la contextuación es una determinante transversal para lograr un análisis que conlleve a la comprehensión del fenómeno estudiado, la virtualidad como dispositivo para favorecer la agencia mediadora en la creación y recreación de prácticas letradas.

\section{Resultados}

\section{Construcción de prácticas letradas, de la presencialidad a la virtualidad}

Bajo la óptica de los Nuevos Estudios de la Literacidad, se estudió el ámbito social, cultural y el momento histórico donde se desarrollan las actividades comunicativas que dan origen a las prácticas letradas in situ. En esta investigación se interpreta y comprehende la agencia, en la construcción de prácticas letradas, de los profesores en formación inicial, desde la bivalencia, presencial y la virtualidad.

\section{La agencia en la construcción de prácticas letradas desde la presencialidad}

Los profesores en formación inicial expresaron que las clases presenciales regularmente, iniciaban con la entrada del docente al aula de clase. "En el momento que entró la maestra se sentó en el escritorio y pasó lista, yo estaba en mi mesabanco esperando que empezara la clase" (C1, A.1, h.1). En este contexto presencial la dinámica de cada clase dependía de la forma en cómo el docente formador proponía a los profesores en formación, las actividades a desarrollar. La agencia desarrollada en la interacción grupal giraba en torno al cumplimiento de las evidencias habladas y/o escritas, tomando como fundamento la lectura de un texto. "Los trabajos que con mayor frecuencia realizábamos eran lecturas" (C3, A3, h.1) con base en los programas de estudio (SEP, 2020). En este sentido señalaron que "en muchas ocasiones las lecturas dan pie para que se forme el debate" (C2, A2, h.2) donde el pensamiento crítico afloraba ya que, "el material de trabajo daba mucho para realmente sacar nuestro pensamiento crítico y claro poner a debate nuestras ideologías" (C2, A2, h.2). En estas oportunidades de diálogo expresaban su agencia, porque ésta "en 
general, hace referencia a la capacidad socioculturalmente mediada que tienen los individuos para actuar y elegir en el marco de los efectos de las fuerzas ideológicas que han construido su subjetividad" (Ahearn 2001, Ashcroft et al. 2000 como se citó en Zavala, 2011, p. 52). Así, los profesores en formación expresaron sus ideas, de acuerdo con lo que ellos mismos son como persona; pero también, con base en la formación docente recibida. Las situaciones iniciaron, muchas veces de preguntas, sobre todo, al iniciar la clase "la maestra siempre planteaba la interrogante al azar ¿qué vimos la clase anterior? y de ahí partían un sinfín de preguntas." (C2, A2, h.1). En este punto, la mediación que desarrollaba el docente permitía estas interacciones. "Esta práctica mediadora de la enseñanza logra establecer un puente entre el alumno y el conocimiento, entre lo que sabe y lo que no sabe, entre sus saberes previos y los conceptos, entre su presente y su porvenir" (Salinas Quintanilla, 2012, p. 160). Así, los docentes formadores, a través de la mediación, guiaron a los estudiantes a leer, analizar, comparar, llegar a acuerdos e intercambiar ideas que a través de estos eventos letrados les permitía construir la literacidad académica propia de un docente en formación en una escuela normal.

\section{De la presencialidad a la virtualidad, retos y fortalezas en la agencia para la cons- trucción de prácticas letradas}

Ante la pandemia del MERS-CoV, de imprevisto la escuela se cerró, migró a la intimidad de los hogares y adoptó modelos virtuales para dar continuidad al aprendizaje en línea. Situación que implicó un cambio drástico, sobre todo en los profesores en formación, que tuvieron la necesidad de realizar diversas actividades, entre ellas la construcción de prácticas letradas, apoyados en nuevas aplicaciones y estrategias tecnológicas, que les abrieron nuevas expectativas en la comunicación dentro de una literacidad académica virtual.

Ante esta nueva normalidad de educación a distancia ha cambiado mucho la forma en que se enseña y la forma en que se aprende, pasamos de estar sentados en nuestros bancos escuchando la clase del maestro, compartiendo ideas, escuchando opiniones y desarrollando actividades a verlos a través de una pantalla (C7, A7, h.1).

Desde la virtualidad, se inició una nueva modalidad educativa en la que profesores en formación y formadores de docentes con el uso de la tecnología continuaron con las actividades pedagógicas, señaladas en planes y programas de estudio, como la construcción de prácticas letradas. Un recurso muy utilizado son las plataformas virtuales, Google Classroom, Google Meet y Zoom, donde "los alumnos pueden estar en contacto con el maestro" (C7, A5, h.1) en interacción con sus compañeros y docente para participar en la agencia de prácticas letradas.

Ha sido una comunicación muy buena con la maestra en cuanto expresarnos, dar nuestras propias conclusiones hasta las explicaciones, si se trata de trabajar, nos manda trabajos por classroom, que es una plataforma digital en la que la utilizamos para hacer tareas o trabajos, y nosotros tenemos que hacerlo conforme a las fechas establecidas (C7, A7, h.1).

La comunicación, oral y escrita, como elemento importante en la agencia entre docentes y alumnos se desarrolló de manera ágil, en la red social de Whatsapp. "Las clases comienzan a través de un enlace de Meet que es enviado por Whatsapp 
por los grupos de los maestros" (C7, A7, h.1). El ritmo de trabajo académico siguió, aunque con otra modalidad, donde agregaron palabras nuevas a su lenguaje académico, como classroom, meet, whatsapp, videollamadas, entre otras. Además, establecieron interacciones digitales, aprendizajes en línea, en otras palabras, prácticas letradas en línea.

Desde la modalidad virtual se identificaron diversos contextos que contienen elementos análogos a la modalidad presencial. Inicialmente, aparece la clase donde se da la asignación de textos para ser leídos por los estudiantes, quienes "elaboran un organizador gráfico, un collage, diapositivas, un resumen, conclusión o cualquier cosa que se le ocurra a la docente con el fin de que para la próxima clase una cierta cantidad de alumnos exponga ese tema y medio charlar" (C7, A7, h.1).

Un segundo contexto comprende aquellas clases virtuales en donde los docentes tienen una metodología más incluyente en el aula, cuando se "inicia dando una introducción del tema, si es un tema nuevo nos da ese tiempo y espacio para ir despejando las dudas que tengamos" (C9, A9, h.1).

Un tercer escenario, tiene que ver con el docente que monopoliza la charla sin interacción con los alumnos, al proyectar hasta 30 diapositivas o videos, donde les dice "les voy a proyectar unas diapositivas para que me escuchen y pongan atención y nos va explicando el tema" (C15, A15, h.1), así se pueden ir las 2 horas de clase, escuchando al docente "todo es escuchar a la maestra, y en algún momento puede llegar a cansar" (C15, A15, h.1).

Por lo que se puede deducir, que la agencia en la construcción de prácticas letradas desde la virtualidad presenta debilidades, al menos, con el acceso y conexión a los recursos tecnológicos. Aunque, una vez establecida la comunicación, ésta se realiza de manera ágil y permite la expresión de experiencias, conocimientos, percepciones que los profesores en formación han construido desde el aula y desde la experiencia en otros centros educativos. Sin embargo, en muchos casos la usabilidad de los dispositivos virtuales permanece anclada en modelos tradicionalistas de la educación. El maestro enseña, el alumno aprende.

\section{Discusión y conclusiones}

En tiempos de la pandemia del MERS-CoV, la construcción de prácticas letradas por los profesores en formación favoreció la agencia mediadora desde diversos contextos, mayormente desde la virtualidad, con la utilización de plataformas como, Meet, Classroom y Zoom. Contextos desde los que se favoreció la construcción de prácticas letradas, específicas de la formación docente; que, en este caso, se vieron enriquecidas por el lenguaje tecnológico, como expresiones significativas de la modalidad virtual en educación. Las experiencias vividas por profesores en formación y formadores de docentes visibilizaron diversos contextos que caracterizan al proceso constructivo de prácticas letradas desde un modelo tradicional hasta aquellos que presentaron espacios para la autonomía y la colaboración como elementos constitutivos de una agencia mediadora. 


\section{Referencias}

Barton, D. \& Hamilton, M. (2004). La literacidad como práctica social. Zavala, V., Niño-Murcia, M. \& Ames, P. (Eds.) Escritura y sociedad: nuevas perspectivas teóricas y etnográficas. Red para el Desarrollo de las Ciencias Sociales en el Perú.

Casillas Alvarado, M. A. \& Ramírez Martinell, A. (2018). Leer y escribir en la era digital. Hernández \& Hernandez D., Cassany, D. \& López González. R. (Coord.) Háblame de Tic. Prácticas de lectura y escritura en la era digital. 5. Brujas.

Chaves Salas A. L. (2001). Implicaciones educativas de la teoría sociocultural de Vigotsky. Revista Educación, septiembre, 25, (2), 59-65.

Freeman, K. (2018). Investigating First Year Undergraduate EAL Students' Academic Literacy. https://doi.org/10.25904/1912/994

Gee, J. P. (2004). Oralidad y literacidad. Zavala, V., Niño-Murcia, M. \& Ames, P. (Eds) Escritura y sociedad: nuevas perspectivas teóricas y etnográficas. Red para el Desarrollo de las Ciencias sociales en el Perú.

Guevara Maldonado, L. A., Magaña Domínguez, E. A. \& Picasso Hinojosa, A. L. (2019). El uso de Google Classroom como apoyo para el docente. Memoria del 3er Congreso Nacional de Investigación sobre Educación Normal, 2, 2. http://www.conisen.mx/ memorias2019/memorias/5/P717.pdf

Lea, M.R., \& Street, B.V. (2006). The "Academic Literacies" Model: Theory and Applications. Theory Into Practice, 45 (4), 368-377.

Leguizamón Romero, J. F. (2017). Patrones de interacción comunicativa del profesor universitario de Matemáticas. Un estudio de caso. Revista Praxis \& Saber, 8. (16), 57-82.

Martínez García, D. A. \& Posada Carmona, J. A. (2017). Literacidad Académica: Experiencias de apropiación de prácticas de lectura y escritura en la formación de estudiantes indígenas. Universidad de Antioquia. Facultad de Educación.

Mesía Marino, Y. L. (2008). Falta de articulación de las diferentes voces de la literacidad académica: un estudio en un centro preuniversitario. Facultad de Letras y Ciencias Humanas. Pontificia Universidad Católica del Perú.

Mellado Jiménez, V. (2003). Cambio didáctico del profesorado de Ciencias Experimentales y Filosofía de la Ciencia. Enseñanza de las Ciencias, 21 (3)., 343-358. https://ddd.uab.cat/pub/edlc/02124521v21n3/02124521v21n3p343.pdf

Saavedra Ramírez, G. (2000) La hermenéutica analógica de Mauricio Beuchot. Revista de Filosofía. 32, (2), 23-40.

Salinas Quintanilla A. M. A (2012). La Mediación y el acompañamiento en los aprendizajes escolares en un ambiente de inclusividad. Méndez Domínguez J \& Gómez Medina, M. (Eds.) Experiencias Investigativas de Interculturalidad Educativa, Colección ConCiencias Humanas y Sociales 8. Universidad Autónoma de Tamaulipas. 
Secretaría de Educación Pública. (2018). Planes de estudio 2018. Licenciatura en Educación Primaria. DGESPE. https://www.cevie-dgespe.com/index.php/planes-de-estudios-2018/63

Sito, L. \& Kleiman, A. (2017). "Eso no es lo mío": un análisis de conflictos en la apropiación de prácticas de literacidad académica. Revista Universitas Humanística, 83, 159-185.

Taylor, S. J. \& Bogdan, R. (1987). Introducción a los métodos cualitativos de investigación. Paidós.

Vargas Franco, A. (2013). Revisión entre iguales, escritura académica e identidad en la formación docente en una universidad colombiana. Tesis doctoral. Universitat Pompeu Fabra.

Zavala, V. (2004). Literacidad y desarrollo: los discursos del Programa Nacional de Alfabetización en el Perú. Zavala, V., Niño-Murcia, M. \& Ames, P. (Eds). Escritura y sociedad: nuevas perspectivas teóricas y etnográficas. Red para el Desarrollo de las Ciencias sociales en el Perú.

Zavala, V. (2009). ¿Quién está diciendo eso?: Literacidad académica, identidad y poder en la educación superior. Kalman, J. \& Street, B. (Eds.). Lectura, escritura y matemáticas como prácticas sociales. Diálogos con América Latina. Siglo XXI.

Zavala, V. (2011). La escritura académica y la agencia de los sujetos. Cuadernos Comillas, 1, 52-66.

Zorro Rodríguez, A. (2012). Estrategias de enseñanza mediadas por las nuevas tecnologías de la información y la comunicación para fortalecer la enseñanza de lenguas extranjeras. Goyés Morán, A. C. \& Oviedo, P. E. (Eds.). Innovar la enseñanza. Estrategias derivadas de la investigación. Kimpres. 


\section{A Interatividade no Processo de Ensino e Aprendizagem no Contexto do Ensino Online Emergencial}

\section{Vieira de Almeida, Douglas}

ORCID (orcid.org/0000-0003-4660-4080)

douglas.almeida@cedu.ufal.br

\section{Pereira da Silva, Flávio}

ORCID (orcid.org/0000-0001-7714-5791)

flavio@npd.ufal.br

\section{Leopoldo Mercado, Luis Paulo}

ORCID (orcid.org/0000-0001-8491-4080)

luispaulomercado@gmail.com 


\title{
A INTERATIVIDADE NO PROCESSO DE ENSINO E APRENDIZAGEM NO CONTEXTO DO ENSINO ONLINE EMERGENCIAL
}

\author{
Vieira de Almeida, Douglas \\ Pereira da Silva, Flávio \\ Leopoldo Mercado, Luis Paulo
}

\section{Resumo}

Abordamos neste trabalho a interatividade como requisito fundamental para a construção do conhecimento nos espaços de aprendizagem online (EAO) durante o ensino online emergencial (EOE). A interatividade entre profesores e estudantes torna o processo de ensino e aprendizagem mais eficaz, contribuindo com a qualidade e os resultados esperados na disciplina. Analisamos, também, a mudança no papel do profesor na sala de aula, este assumindo o papel de facilitador e mediador entre o estudante e o conhecimento construido no processo de ensino e aprendizagem, além de o estudante assumir uma postura mais ativa nessa costrução do conhecimento, desenvolendo ainda mais a criticidade e a reflexão acerca do que está sendo estudado. Destacamos alguns recursos que podem ser utilizados de forma síncrona e assíncrona, como: Whatsapp, Padlet, Socrative, além da importância no planejamento do material didático que podem contribuir com a interatividade no contexto do EOE, permitindo uma partipação mais ativa do estudantes, bem como o desenvolvimento da colaboração e da cooperação. O objetivo deste estudo foi investigar os benefícios da interatividade na construção de conhecimento entre os diversos sujeitos do processo educativo no contexto do AEO. A metodologia envolveu pesquisa webgráfica em relatos de experiências realizadas durante o EOE, levantando subsidios para uma maior eficácia no processo de ensino e aprendizagem.

\section{Palabras-chaves}

Interatividade, Aplicativos, Ensino e Aprendizagem, Ensino Online Emergencial. 


\section{Introdução}

Devido à pandemia da Covid-19, as instituições de ensino superior (IES) recorreram à aplicação do ensino online emergencial (EOE) como alternativa à manutenção das aulas. Professores e estudantes iniciaram um período de adaptação ao novo contexto educacional, agora, mediados pelas tecnologias digitais da informação e comunicação (TDIC).

A partir disso, novas experiências foram e estão sendo desenvolvidas. Para atender as necessidades de estudantes e profesores, as IES precisaram desenvolver estratégias que favorecessem o processo de ensino e aprendizagem, dentre elas, as que envolvam a interatividade.

A interatividade se apresenta como item fundamental a esse processo. É uma forma de diálogo entre as pessoas e os diversos elementos físicos de um computador, permitindo essa comunicação por intermédio de uma interface que permite a troca de informações (Lemos, 1997).

A interatividade propõe o diálogo entre os sujeitos na sala de aula online, permitindo que o professor se abra às necessidades de seus estudantes e que estes tragam sua realidade para a sala de aula, a partir da troca de saberes, da conexão construtiva em sala de aula, da busca por respostas aos problemas da realidade. Ela se apresenta como um desafio explícito para os todos os atores que participam do processo de comunicação e tem como principal objetivo atender as demandas da sociedade moderna, desde que possa ser garantida a partir de um processo de planejamento centralizado no aprendizado (Silva, 2001).

A interatividade se torna requisito essencial para a construção do conhecimento, inclusive quando se trata no uso das TDIC na educação, pois tornar as aulas mais significativas e dinâmicas é requisito fundamental para a elaboração de um curso mais dinâmico, desafiador, criativo e renovado a partir da integração destas tecnologias ao currículo (Mercado et al., 2019).

O EOE caracteriza-se na aprendizagem e planejamento das atividades e ambientes usando as TDIC. Dessa forma, a habilidade do professor na escolha das TDIC e nesses aplicativos web é essencial para que ele apresente um bom design do curso.

Hodges et al. (2020, p. 3) afirmam que "o processo de design e a consideração criteriosa de diferentes decisões deste design têm impacto na qualidade do ensino. $\mathrm{E}$ é esse cuidado no design que está ausente na maioria dos casos nessas mudanças de emergência".

O professor, nesse contexto, deve se apresentar como um usuário ativo, pois encontra-se sempre presente, faz o uso dos momentos sincronos e assincronos para a construção do conhecimento dos estudantes, promove um feedback motivador por intermédio das ferramentas ou dos atores que participam do processo e determina se o estudante está apto a absorver novos conteúdos (Hodges et al., 2020). Assume o papel de mediador, conteudista e designer de forma a saber os conhecimentos na abordagem de suas aulas. 
Para Kenski (2003) a ampliação das diversas formas de se comunicar por intermédio das TDIC justifica que toda aprendizagem é fruto das mediações tecnológicas do tempo presente, com isso, novos valores e comportamentos são desenvolvidos pela sociedade a partir do uso intenso de determinada TDIC.

Na pandemia da Covid-19, os espaços de aprendizagem online (EAO) são constituídos por um conjunto de ferramentas síncronas e assíncronas como Google Meet, Microsoft Teams, Zoom, Big Blue Button etc, tornaram-se essenciais para que ocorresse a interatividade, a partir da troca de conhecimentos entre professores e estudantes, sendo elemento central no seu desenvolvimento.

\section{Metodologia}

O objetivo do estudo foi pesquisar os benefícios da interatividade na produção de conhecimento entre os diversos agentes do processo educativo no contexto do EOE.

Visando colaborar na prática docente e pesquisas na área em questão será discutida a interatividade nos EAO no cenário do EOE. Para isso, serão apresentados recursos que possam contribuir no planejamento do professor de forma a favorecer uma maior interação no processo de ensino-aprendizagem possibilitando situações que desenvolvam o estímulo e à participação de todos os sujeitos envolvidos na construção do conhecimento.

A partir de uma pesquisa wegbráfica e com base em relatos de experiencias, identificamos contribuições para uma maior eficácia no processo de ensino e aprendizagem no período de EOE.

Para isso, apresentaremos recursos síncronos e assíncronos que contribuem com a interatividade entre os agentes do processo de ensino e aprendizagem e que são importantes para o diálogo, a criatividade, a autoria, a reflexão e a construção do conhecimento: mensageiros instantâneos (Whatsapp e Telegram); ambiente de compartilhamento de informações (Padlet); mapas mentais na web (Mindmeister, Venngage e Miro); mapas conceituais (Cmap Cloud), construção de diagramas na web (Draw.lo e Lucidchart) e aplicativo web para aprendizagem (Socrative).

\section{Interatividade nos EAO}

Na pandemia da Covid-19, as IES viram no EOE a oportunidade de utilizar plataformas para a manutenção de suas aulas. Para isso, foram necessárias a implementação de mudanças significativas de forma a atender as necessidades dos estudantes que estudavam presencialmente.

Além de formar os professores para este contexto, as plataformas de ensino e os EAO, foram essenciais para que as aulas pudessem ser ministradas para os estudantes. Fatores sociais e econômicos precisaram ser analisados para que os estudantes em situação de vulnerabilidade pudessem assistir às aulas, reduzindo os prejuízos já causados pela pandemia. 
Destacamos a interatividade entre os estudantes e os professores, pois essa interatividade traz uma nova forma de comunicação em sala de aula, a qual vem como um dos fatores a modificar "a comunicação no sentido da participação-intervenção, da bidirecionalidade-hibridação e da permutabilidade-potencialidade" (Silva, 2014, p. 223), tornando o ambiente da sala de aula num espaço de diálogo, potencializando a criatividade dos estudantes, com mais autonomia para se conectar com os conteúdos de aprendizagem.

A interatividade é um dos fatores determinantes para ajudar a desenvolver o papel ativo do estudante nos EAO, sendo necessária, pois o diálogo e a troca de informação entre as partes, faz com todos tenham a possibilidade de agir e intervir no processo de construção de conhecimento.

Com o advento das TDIC, a interatividade se estabelece como fator essencial na promoção de um aprendizado ativo para o estudante. O mundo contemporâneo exige que o professor assuma um novo papel no contexto de sala de aula e incentive o estudante a assumir uma postura ativa na busca pelo conhecimento e no processo de formação profissional (Coll; Monereo, 2010).

Os conflitos e os desafios de uma sociedade contraditória e em crise requerem que o estudante assuma um papel de protagonista no processo de ensino, vivencie experiências pedagógicas, proponha-se ao exercício da cidadania e da participação em sociedade. Estas ações do estudante, constituídas pela interatividade, promovem a construção de respostas, o apontamento de caminhos e a construção de uma aprendizagem mais ativa.

É preciso que o professor reveja os conceitos de sala de aula de forma a construir um espaço transformador, que despertem no estudante suas habilidades e competências. Ensinar na cultura digital não se constitui como um momento de transferência ou reprodução de um conteúdo e de aprender.

No contexto do EOE novos recursos vêm sendo implementados nos EAO, criando possibilidades de aprendizagens e assim, instigando estudos acerca de um universo em expansão com o surgimento de metodologias que favoreçam a aprendizagem ativa.

A expansão dos recursos midiáticos disponíveis no campo educacional vem propiciando, cada vez mais, a necessidade de aperfeiçoamento por parte dos professores em todas as modalidades de ensino, dessa forma, o planejamento se apresenta como elemento fundamental a prática educacional do professor.

No EOE, o planejamento e o desenvolvimento das aulas e dos recursos utilizados em sala de aula são desenvolvidos pelo professor, que além de construir o material didático, necessita implementar uma metodologia que promova a interação nas diferentes ferramentas online e assim garanta a interatividade.

O objetivo de constituir um processo de ensino e aprendizagem que gera um aprendizado ativo e contribua na autonomia do estudante, diminui a possibilidade de um atendimento, muitas vezes, feito no improviso como no ensino presencial. É importante que os atores pertencentes a este modelo de ensino realizem com antecedência o planejamento, de forma a garantir a qualidade do processo. Neste sentido, é importante que o professor conduza os estudantes ao mesmo propósito, incluindo 
na execução das diversas ferramentas síncronas e assíncronas encontradas nos ambientes virtuais de aprendizagem (AVA) (Cortelazzo et al., 2018).

\section{Recursos de Interatividade no contexto da EOE}

O planejamento docente no EOE precisou ser adaptado para atender as demandas dos estudantes, passando para uma aprendizagem digital e se preocupando com inclusão digital desses no atual contexto.

Foi preciso os professores compreenderem melhor a utilização de recursos mediados pelas TDIC, seja de maneira síncrona ou assíncrona. Para isso, a adaptação nos EAO foi fundamental para conhecer as possibilidades que esses espaços disponibilizaram e a partir de recursos que podiam ser trabalhados através da internet.

Como foco deste estudo, destacamos alguns recursos que favorecem a interatividade entre os protagonistas do processo de ensino e aprendizagem e que são necessários para o diálogo, a criatividade, a autoria, a reflexão e a construção do conhecimento.

Iniciaremos com aplicativos de mensagens instantâneas, muito utilizados no EOE como ferramenta de comunicação de forma síncrona e assíncrona.

\section{Whatsapp e Telegram como mensageiros instantâneos}

O Whatsapp e o Telegram são aplicativos disponíveis nos dispositivos móveis e através do planejamento do professor e sua aplicação podem contribuir com a interatividade no processo de ensino e aprendizagem.

São plataformas amplamente utilizadas pelos estudantes a todo momento. Os professores podem usar o recurso como suporte para suas aulas, experimentando ou conhecendo outras funcionalidades ou aplicações das redes sociais, uma forma de evitar a dispersão, muito presente no contexto online. Dessa forma os estudantes podem utilizar ferramentas do seu cotidiano como um ambiente de aprendizagem reflexiva e colaborativa.

Ao utilizar esses aplicativos, o professor pode lançar atividades com base nos conteúdos discutidos nas aulas dialogadas, fortalecendo a interatividade entres os estudantes e o professor, gerando discussões pertinentes ao objeto proposto a partir dos diálogos propostos pelo professor.

\section{Padlets como ambiente de compartillhamento de înformações}

A utilização dos Pallets possibilita desenvolver a criatividade dos estudantes, pois "permite a criação de um mural ou quadro virtual dinâmico e interativo para registrar, guardar e partilhar conteúdos multimídia. Funciona como uma folha de papel, onde se pode inserir qualquer tipo de conteúdo (texto, imagens, vídeo, hiperlinks)" (UFSCAR, 2018) de forma individual ou compartilhada com outras pessoas, visando a criação de um espaço colaborativo. 
Os Padlets se assemelham ao blog, porém com recursos interativos e visibilidade mais atraente, permitindo ao usuário a leitura de textos melhores,a través de uma interface mais amigável.

\section{Mindmeister, Venngage e Miro para elaboração de mapas mentais na web}

O professor poderá integrar aos momentos síncronos e assíncronos o uso de mapas mentais, diagramas que podem ser construídos a partir de uma ideia central, confeccionado a partir de palavras-chave que permitem sua ampliação, à medida que o estudante passa a desenvolver novos conhecimentos.

O aplicativo Venngage permite criar mapas mentais e também permite elaborar apresentações, infográficos, relatórios, poster, currículo, entre outros. É uma ferramenta shareware, possui recursos disponibilizados gratuitamente e disponibiliza modelos a partir das necessidades do usuário.

O aplicativo Miro, além de ser um aplicativo de navegabilidade simples, apresenta uma área de trabalho bem funcional e visualmente com as mesmas funcionalidades apresentadas no Mindmeister. O aplicativo é gratuito, com muitas funções que permitem a interatividade. Há uma funcionalidade para compartilhar o mapa de forma a permitir que outros usuários possam interagir e assim cooperar na construção do mesmo. O compartilhamento pode ser por uma conta do gmail ou e-mail. O ambiente permite que outras pessoas possam visualizar, comentar, editar ou não ter acesso. Além disso, para os usuários que possuem acesso ao mesmo arquivo, há a possibilidade de interagir por intermédio de uma interface de chat disponibilizado pela ferramenta.

Os usuários podem exportar seus mapas mentais em formato pdf, código html para ser incorporado em um blog, como imagem ou salvar o mapa como um modelo para ser utilizado posteriormente, permitindo a colaboração e cooperação, além de oportunizar ao professor poder acompanhar o desenvolvimento da atividade proposta.

No quesito de interatividade, estes aplicativos permitem que os recursos existentes promovam que os estudantes, de forma interativa, remodelem seus mapas a partir da mediação do professor.

\section{Cmap Cloud para construção de mapas conceituais na web}

Outro recurso que se assemelha muito aos mapas mentais são os mapas conceituais, diagramas classificados como representação visual do conhecimento. São representados por figuras geométricas, as mais conhecidas são em formato de elipses, também conhecidos como nós. Cada nó representa um conceito que se liga por intermédio de uma frase de ligação, representado por uma seta, a outro conceito sendo muito utilizado para trabalhar a aprendizagem colaborativa. É uma atividade de estímulo ao pensamento reflexivo e um instrumento para refletir significados. Nos mapas conceituais, o professor poderá apresentar conteúdos referentes a sua unidade curricular, bem como elaborar atividades colaborativas, como individuais. 
O Cmap Cloud salva os dados de construção da atividade na nuvem, permitindo serem recuperados na versão desktop conhecida como Cmap Tools, sendo uma alternativa para os momentos síncronos ou assíncronos, quando o professor e ou os estudantes associam ou refletem sobre os significados.

\section{Draw.Io, Lucidchart como recursos de construção de diagra- mas na web}

Draw.lo, Lucidchart são ferramentas web para construção de diagramas, utilizados para construção de organogramas, modelo entidade-relacionamento, diagrama de fluxo de dados, de circuitos elétricos ou diagramas para desenvolvimento de programas na engenharia de software. São recursos utilizados na Administração e na Ciência da Computação, principalmente para o desenvolvimento de software. Permitem o download, a importação em formato de imagem, pdf e o compartilhamento das atividades promovidas, podendo estas, serem salvas na web por intermédio do google drive, dropbox, onedrive entre outros.

Os professores podem fazer uso destas ferramentas no contexto do EOE, solicitando e acompanhando os estudantes ao construírem de forma colaborativa diagramas a partir dos conteúdos lecionados.

\section{Socrative como aplicativo web para aprendizagem}

O Socrative é um aplicativo web que permite que os estudantes participem dos momentos online por intermédio de atividades tipo quiz, corrida espacial. As questões podem ser do tipo múltipla escolha, verdadeiro ou falso e resposta curta.

Para fazer acesso a atividade, o professor deverá elaborar uma atividade baseada no conteúdo da sua unidade curricular e liberar um código que deverá ser utilizado para acesso pelo celular por um código. As atividades podem ser importadas para outras aulas, caso seja necessária, diminuindo o retrabalho de montar uma nova atividade.

A corrida espacial é um recurso do Socrative interessante quando se pretende realizar uma competição, como por exemplo uma gincana. Esta função permite que cada estudante escolha uma cor de avatar para participar da atividade. Ao acessar a atividade o estudante deverá responder a um conjunto de questões randômicas. Para cada questão correta o avatar avança uma casa. O professor poderá determinar o número de casas existentes a partir do número de questões que desejar. No momento da corrida o professor poderá compartilhar sua tela com os estudantes, de forma que cada um veja seu avatar e dos demais. Ganha quem acerta mais questões e melhor se classifica.

O aplicativo gera logs dos acessos, bem como cria um ranking de respostas. O professor poderá utilizar esta função para elaborar uma prova e estes dados podem ser exportados para o formato pdf ou planilha eletrônica.

Uma vantagem desses aplicativos web é que todos permitem serem compartilhados. São recursos relevantes para o professor por permitir: verificar a aprendizagem dos estudantes, acompanhar o desenvolvimento dos exercícios, remodelar os gráficos construídos em caso de erros entre outros. 


\section{Planejamento de atividades interativas no EOE}

Com a diversidade de recursos digitais e o EOE, o perfil do professor exige novas habilidades, como a formação para a cultura digital, o conhecimento de metodologias mediadas pelas TDIC, que contribuam para a aprendizagem digital, formando estudantes mais críticos e que busquem se reinventar para assim contribuir com a sociedade. O professor assume diversos papéis, "ora é gestor, ora é mediador, ora é facilitador ou orientador, com a possibilidade de otimizar atividades e tarefas por meio de recursos e tecnologias" (Camargo; Daros, 2021, p. 20) busca se adaptar às novas realidades no contexto do EOE.

Nesse contexto, o planejamento do professor é fundamental para contribuir com as novas práticas mediadas pelas TDIC, principalmente com propostas pedagógicas inovadoras para todas as formas de ensino, seja presencial, online ou híbrida. A interatividade tem papel fundamental nesse planejamento, pois potencializa a criatividade e "esta pode ser estimulada como o uso de recursos digitais" (Camargo; Daros, 2021, p. 21).

Cada vez mais pensamos em metodologias que possam trazer o estudante para participar mais ativamente do processo de ensino e aprendizagem, mas também sabemos que a interação entre pessoas e grupos é fundamental para esse processo e a criação de conteúdos por parte do professor em EAO necessita de competências que vai muito além do uso das ferramentas.

O investimento na formação continuada de professores na cultura digital, a partir de competências digitais são essenciais para o planejamento de aulas nesse contexto do EOE, pois o papel do professor precisa ser repensado pelas IES e fazer isso é "atribuir novo sentido, de modo a tornar a aprendizagem visível na sala de aula digital. Para um ecossistema de mudança, é preciso instrumentalizar os profissionais, criar redes de colaboração entre os pares e reposicioná-los de modo que sejam valorizados" (Camargo; Daros, 2021, p. 22).

Um planejamento adequado pode contribuir com a criatividade dos estudantes, meIhorando a capacidade de resolver problemas, somados à interatividade e a partir de atividades colaborativas, fortalecendo os ecossistemas digitais, pois "a riqueza do ecossistema que junta dados, informações e conhecimento com o digital e com recursos humanos que sejam habilitados a lidar com interação humana e direta e por via de informação cria o ambiente ideal para uma transformação digital" (Rocha et al., 2021, p. 17).

\section{Interatividade como consequência do design do material didático em ambientes de EOE}

De acordo com Papert (1994), a elaboração do ambiente de aprendizagem exige o desenvolvimento de materiais pedagógicos que colaborem no desenvolvimento da aprendizagem.

No contexto da EOE, o papel do professor vai além, pois ele precisará propor atividades nas diversas ferramentas disponíveis de forma a planejar a comunicação e aprendizagem dos estudantes, além disso, precisará verificar quais tipos de interações 
serão desenvolvidas no ambiente (Pimentel, 2010), características que constituem design instrucional (DI), que analisa de forma sistemática as condições de aprendizagem e consiste em resolver problemas de ensino, o objetivo principal é caracterizar um projeto de experiência de aprendizagem satisfatória (Smith; Ragan, 1999).

O DI compreendem a ana ise de requisitos, o desenho e o desenvolvimento de artefatos utilizados no EOE de forma transdisciplinar. Emprega contribuições de teorias da aprendizagem como comportamentalismo, construtivismo e o sócio-construtivismo de forma a atender a diversidade proposta pelas ferramentas online (Gotardo et al., 2012).

No EOE, o DI se estabelece como um projeto instrucional que acontece quando o professor realiza uma combinação de ferramentas online em sua aula. É uma proposta de escolha de recursos educacionais online podendo ser utilizados concomitantemente ou sequencialmente.

A escolha dos aplicativos online deve ter como principal objetivo propiciar a construção de conhecimento. Dessa forma, o DI auxilia os estudantes a construírem seus blocos de conhecimento de forma colaborativa, cooperativa e/ou reflexiva.

Porém o professor não deve se apoiar apenas em um bom design, precisa ir além. Para promover interatividade, as aulas elaboradas nos EAO devem ser bem planejadas, mediadas em tempo hábil e promover feedback motivador, pois o saber será constituído pelos estudantes.

Durante o processo de interatividade o professor se apresenta como um mediador cujo papel fundamental está na construção do conhecimento dos estudantes. É um direcionador para que os assuntos discutidos não percam o foco. Ele deve ter clareza sobre os artefatos que irá utilizar, bem como os objetivos do curso de forma a proporcionar confiabilidade e qualidade no curso oferecido. "A interatividade deve ser assegurada de forma que auxilie a autoaprendizagem e supra a ausência física de estudantes e professores" (Freire, 2009), principalmente nos momentos assíncronos.

\section{Interatividade como critérío de avaliação no EOE}

No EOE temos diversos recursos que podem ser utilizadas para desenvolver uma maior interatividade entre estudantes e professores e entre esses e os conteúdos curriculares trabalhados. Eles possuem características que podem favorecer a aprendizagem ativa, gerar autonomia dos estudantes, dar suporte a qualquer tipo de atividade realizada pelo estudante em diferentes situações de ensino aprendizagem.

Cada recurso disponibilizado nos EAO deve ser pensado, repensado e planejado para se adaptar a cada objetivo da aula online proposta, para que não ocorra um fracasso no processo, assim como no presencial, todos os recursos precisam ser de conhecimento e domínio do professor para que ele possa mediar qualquer conhecimento existente.

Nesses recursos, o Padlet como ferramenta de pesquisa e interação entres grupos no decorrer das aulas, propicia aos estudantes um ambiente de construção de conhecimento a partir de atividades desenvolvidas por eles. Nesses espaços, 
professores podem utilizar critérios de avaliação, a partir de relatos dos estudantes ao pesquisarem os temas propostos em aula e desenvolvidos por cada estudante individualmente ou por grupos criados a partir de metodologias adotadas pelo professor.

A interatividade também pode ser avaliada por discussões em grupos de Whatsapp e Telegran, a partir de atividades planejadas pelo professor e que gerem discussões nesse aplicativo de troca de mensagens, até mesmo em forma de debates, os quais o professor avaliará a articulação, a criticidade e as reflexões que os estudantes venham a desenvolver a partir do objeto estudado. Um ponto que favorece a interação nestes aplicativos é que pode ser utilizada de forma síncrona e assíncrona, pois o estudante que não estiver conectado no momento da atividade proposta, poderá em outro momento se conectar e participar da discussão.

Além desses recursos, nos EAO como Zoom, Google Meet e Big Blue Button, o professor também pode avaliar a interatividade a partir da troca de mensagens durante a aula síncrona, de forma a verificar inclusive a participação ativa dos estudantes.

A autoria dos estudantes nesses EAO precisam ser valorizadas pelos professores, principalmente nesse contexto do EOE, pelas inúmeras possibilidades de pesquisas na internet, inclusive para que participem de resoluções de problemas em casos práticos e a partir de discussões que se geram em torno da aprendizagem digital.

Por fim, destacamos o aprender fazendo individual, colaborativo ou por meio de revisão por pares, e como os estudantes aprendem nesse processo, mas também "observando suas reações e ouvindo-os durante as discussões" (Badillo et al., 2021, p. 75). O professor pode desenvolver atividades personalizadas com base no monitoramento dos desempenhos dos estudantes, fazendo com que possam escolher atividades que se identificam mais, seja por meio da gamificação, atividades baseadas em problemas (ABP) ou até mesmo por troca de mensagens via Whatsapp ou Telegran.

O ideal é sempre buscar os feedbacks dos estudantes para entender se o programa do componente curricular está conseguindo atingir os objetivos propostos para a construção do conhecimento dos mesmos no EOE.

\section{Resultados}

No atual contexto de EOE o professor necessita ter habilidade técnica, pelo fato de desenvolver habilidade em intercambiar as diversas possibilidades de aplicativos online, além de elaborar uma metodologia que se baseie num planejamento que propicie a construção de conhecimento nos EAO.

Necessita ter habilidade pedagógica, pois, apesar do período emergencial, verifica-se que alguns estudantes apresentam vulnerabilidade social como dificuldades tecnológicas, financeiras, além da falta de habilidade com TDIC, entre outras.

É necessário um planejamento que promova o conhecimento da unidade curricular dos estudantes sobre o quantitativo de aulas nos momentos s cronos e assíncronos, as avaliações, as atividades, bem como suas datas de disponibilização e entrega nos EAO. 
As propostas assíncronas podem ser utilizadas como a exploração de vídeos, leituras de textos para serem assistidos, lidos ou promoverem reflexões, desta forma, o professor não sobrecarrega os estudantes com devolutiva de atividades.

Para uma mediação que promova uma fluidez no entendimento dos conteúdos, os estudantes devem ser informados do planejamento da unidade curricular. Todo esse material deverá ser de fácil acesso para apresentar todas as etapas da aprendizagem do componente curricular. Inclusive contendo datas de atividade a serem postadas e com prazos de encerramento.

Como a EOE é um contexto novo, o professor necessita refletir sobre o uso de aplicativos web em suas aulas. As escolhas devem estar relacionadas a facilidade de uso dos softwares, ao conhecimento de suas funcionalidades e as mediações, dessa forma o processo de aprendizagem poderá acontecer.

Além disso, as mediações são muito mais importantes, são através delas que o professor poderá averiguar quais são as necessidades dos estudantes e assim poderá conduzir a um processo de construção do conhecimento baseado nas necessidades de cada aprendiz quando promove a interatividade por intermédio dessas ferramentas.

\section{Discussão e conclusões}

A partir do estudo realizado, foi possível compreender o papel da interatividade nos EAO no contexto do EOE. Percebeu-se que o processo de aprendizagem sem troca e diálogo constante entre professores e estudantes, não fortalecerá o processo de aprendizagem, desestimulando o desenvolvimento da criticidade e da criatividade desses estudantes.

Destacamos que o planejamento da ação pedagógica se torna essencial ao desenvolvimento do processo de ensino e aprendizagem, principalmente no EOE. Professor e estudantes precisam estar conectados seja de forma síncrona e/ou assíncrona, desenvolvendo habilidades e competências para a cultura digital.

A interatividade pode ser tornar um grande aliada nesse processo, fortalecendo o desenvolvimento da autoria dos estudantes e fazendo com eles tenham possibilidades de utilizar recursos que estimulem a reflexão e a criticidade, com o objetivo de atender as demandas da sociedade contemporânea, a partir da velocidade das informações com o avanço da globalização.

Os EAO disponibilizam recursos que podem estimular a interatividade. É necessário que os professores reconheçam a necessidade do diálogo dentro e fora dos EAO, estimulem a troca de conhecimentos entre todos e conheçam os recursos propiciados nos aplicativos para que possa utilizar a metodologia indicada ao contexto do EOE.

Por fim, destacamos a importância dos feedbacks dos estudantes em meio a utilização desses recursos pelos professores, pois faz-se necessário essa partilha para que todos entendam que professor e estudantes precisam ser protagonistas no processo de ensino e aprendizagem para que a construção do conhecimento seja eficaz, partindo do pressuposto que o diálogo sempre seja presente. A aprendizagem quando colaborativa, todos saem ganhando, principalmente quando há um olhar 
individualizado para cada estudante, buscando identificar as fragilidades e desafios que cada um está enfrentando em meio ao contexto do EOE.

\section{Referências}

Badillo, E. (et al.) (2021). Ciclos de avaliação e verificação da compreensão. In Lemov, D (Org.). Ensinando na sala de aula on-line: sobrevivendo e sendo eficaz no novo normal. Porto Alegre: Penso, 2021.

Camargo, F.; Daros, T. (2021). A sala de aula digital: estratégias pedagógicas para fomentar o aprendizado ativo, on-line e híbrido. Porto Alegre: Penso.

Coll, C.; Monereo, C. (2010). Psicologia da educação virtual: aprender e ensinar com as tecnologias da informação e da comunicação. Porto Alegre, Brasil: Artmed.

Cortelazzo, A. L. (et al.) (2018). Metodologias ativas e personalizadas de aprendizagem: para refinar seu cardápio metodológico. Rio de Janeiro: Alta Books.

Freire, K. (2009). Design instrucional: aplicabilidade nos desenhos pedagógicos na EaD on-line. Disponível em http://www.abed.org.br/congresso2009/CD/trabalhos/1352009130007.pdf. Acesso 25 jun. 2021.

Gotardo, R. A. (et al). (2012). Teorias de aprendizagens na EAD: fundamentação no uso dos recursos de design instrucional e design interacional. SIED: EnPED-Simpósio Internacional de Educação a Distância e Encontro de Pesquisadores em Educação a Distância.

Hodges, Charles; Moore, Stephanie; Lockee, Barbara; TRUST, Torrey; BOND, Mark. (2020). The difference between emergency remote teaching and online learning. Disponivel em https://er.educause.edu/articles/2020/3/the-difference-between-emergency-remote-teaching-and-online-learning. Acesso em 23 jun. 2020.

Kenski, V. M. (2003). Aprendizagem mediada pela tecnologia. Diálogo Educacional, volume (4), número (10). [pp.] 47-56. Disponível em: http://www2.pucpr.br/reol/pb/ index.php/dialogo?dd1=786\&dd99=view\&dd98=pb. Acesso em 20 ago. 2020.

Lemos, A. (1997). Anjos interativos e retribalização do mundo. Sobre interatividade e interfaces digitais. Disponível em: http://www.facom.ufba.br/ciberpesquisa/lemos/ interativo.pdf. Acesso em: 09 jun. 2021.

Mercado, L. P.; Gomes, M. G.; Silva, C. G. (2019). Metodologia do ensino superior com tecnologias da informação e comunicação: estratégias de ensino experienciadas. Educação em Perspectiva, Viçosa, MG, volume (9), número (2), [pp]. 453-478. Disponível em: https://periodicos.ufv.br/educacaoemperspectiva/article/view/7049. Acesso em: 9 jun. 2021.

Papert, S. (1994). A máquina das crianças: repensando a escola na era da informática. Porto Alegre: Artes Médicas. 
Pimentel, F. C. (2010). Interação on-line: um desafio da tutoria. 111 f. Dissertação (Mestrado em Educação Brasileira) - Centro de Educação, Programa de Pós Graduação em Educação, Universidade Federal de Alagoas, Maceió.

Rocha, D.; Gouveia, L.; Peres, P. (2021). Práticas pedagógicas inovadoras: novos desafios. In Rocha, D.; Ota, M.; Hoffmann, G. (org). Aprendizagem digital: curadoria, metodologias e ferramentas para o novo contexto educacional (pp. 13-28). Porto Alegre: Penso.

Smith, P. L.; Ragan, T. J. (1999). Instrucional Design. 2. ed. Toronto: John Wiley \& Sons.

Silva, M. (2001). Sala de aula interativa a educação presencial e à distância em sintonia com a era digital e com a cidadania. In Congresso Brasileiro da Comunicação, 24., Campo Grande, 2001. Anais... Campo Grande: Intercom.

Silva, M. (2014). Sala de aula interativa: educação, comunicação, mídia clássica, internet, tecnologias digitais, arte, mercado, sociedade e cidadania. (7). São Paulo: Loyola.

Ufscar. (2018). Tutorial Padlet: criando murais. Secretaria Geral de Educação a Distância da Universidade Federal de São Carlos. Acesso em: 10 set 2021. Disponível em: https://inovaeh.sead.ufscar.br/wp-content/uploads/2019/04/Tutorial-Padlet.pdf. 


\section{Percepción de los Equipos Directivos Valencianos Sobre la Gestión Educativa del Confinamiento por la Covid-19 y sus Soluciones Digitales a la Pandemia}

\section{Álvarez Herrero, Juan Francisco}

orcid.org/0000-0002-9988-8286

Universidad de Alicante

juanfran.alvarez@ua.es 


\title{
PERCEPCIÓN DE LOS EQUIPOS DIRECTIVOS VALENCIANOS SOBRE LA GESTIÓN EDUCATIVA DEL CONFINAMIENTO POR LA COVID-19 Y SUS SOLUCIONES DIGITALES A LA PANDEMIA
}

\author{
Álvarez Herrero, Juan Francisco \\ orcid.org/0000-0002-9988-8286 \\ Universidad de Alicante \\ juanfran.alvarez@ua.es
}

\section{Resumen}

Entre marzo y junio de 2020, España al igual que en muchas otras partes del mundo, estuvo sometida a una situación de confinamiento domiciliario a raíz de la pandemia de la COVID-19. Ello provocó que las instituciones educativas tuviesen que adaptarse en un tiempo récord a una modalidad de enseñanza-aprendizaje online. $Y$ esto puso en jaque al sistema educativo, sacando a relucir multitud de problemas e inconvenientes. Pasado este acontecimiento, corresponde analizar lo ocurrido y de esta forma aprender para evitar volver a repetir los mismos errores. Con la idea de tener una visión más directa y amplia del problema, quisimos saber las percepciones de los equipos directivos de enseñanzas no universitarias de la Comunidad Valenciana sobre las dificultades y errores cometidos durante el confinamiento. Para ello se pasó un cuestionario a 102 directivos valencianos y se contrastaron los resultados obtenidos con las opiniones y percepciones de un focus group de 10 directivos/as que no habían participado en el cuestionario. Los resultados de ambas intervenciones vienen a confirmar que los directivos encuentran que una baja competencia digital tanto de discentes como de docentes ha sido el principal problema con el que se han encontrado, además de la insuficiente capacidad de los docentes para enseñar eficazmente de manera online. Llegamos a la conclusión de que es necesaria una formación que permita desarrollar la competencia digital docente y así de manera indirecta también se estará procurando por la del discente. Urgen planes formativos en el desarrollo de la competencia digital docente.

\section{Palabras clave}

Gestión educativa, COVID-19, Tecnología educativa, Equipos directivos, percepción. 


\section{Introducción}

La aparición de la pandemia de la COVID-19 en nuestras vidas, supuso un antes y un después a todos los niveles y en todos los ámbitos conocidos. Sin lugar a dudas, el momento más duro de los vividos en este último siglo ha sido el confinamiento domiciliario al que nos vimos abocados en la mayor parte del mundo, entre marzo y junio de 2020. Ello obligó a cambiar muchos de los cánones hasta entonces perfectamente establecidos. $Y$ en el mundo educativo supuso el tener que pasar en un tiempo récord, de unas clases presenciales, a una modalidad online que dependía enormemente de la tecnología digital para su desarrollo.

Las instituciones educativas, los docentes y los discentes, así como el resto de la comunidad educativa, tuvo que adaptarse a esta nueva situación. Y gracias a las tecnologías digitales, se pudo mantener vivo el proceso de enseñanza-aprendizaje de los estudiantes. Por supuesto, una situación así, puso en jaque todo lo establecido, y ello originó que se pusiese en entredicho la función docente, así como todo el sistema educativo (Trujillo et al., 2020). Aunque hubo centros e instituciones que funcionaron muy bien durante este periodo de tiempo, la gran mayoría presentó serios problemas y se cometieron errores, a los que hoy, ya en frío y habiendo pasado un tiempo prudencial, debería invitar a su análisis y reflexión (García, 2021), para en un futuro no caer en los mismos errores.

Como adelantábamos, hubo centros que afrontaron exitosamente la situación y que consideraron la situación como una oportunidad para el cambio y la innovación (Delcker y Ifenthaler, 2021). Se desarrollaron buenas prácticas, se pusieron en juego metodologías activas coherentes con la situación, y se hizo una correcta implementación de las tecnologías digitales en las clases que se impartían (Khlaif et al., 2021). También en muchas ocasiones se contó con la inestimable e imprescindible colaboración de las familias (Muñoz y Lluch, 2020).

Sin embargo, los principales problemas que ahora se destacan de esta etapa vivida pasan por mencionar:

- Falta de dispositivos y de buenas conexiones a Internet que permitan el intercambio de información y la comunicación entre los agentes del proceso de enseñanza-aprendizaje (Lorente et al., 2020).

- Una nula o mala adaptación de las clases presenciales a una modalidad online de enseñanza que se rige por otros métodos y premisas diferentes a los de una clase presencial (Aznar, 2020). Así, hubo centros educativos que sencillamente no pudieron mantener una normalidad en el desarrollo del curso académico, y otros donde las acciones que se realizaban se traducían en algo carente de toda efectividad y por tanto en las que no se producía ningún aprendizaje. Hubo docentes que se limitaron a proporcionar videos, recursos, materiales y archivos a su alumnado con la pretensión de que este siguiese por su cuenta con el proceso de enseñanza-aprendizaje.

- Las contradicciones entre administraciones educativas, direcciones de centros y equipos docentes sobre el que y como hacer, originó confusión y desencanto entre familias y alumnado, provocando en muchas ocasiones algo que se ha venido a llamar absentismo COVID, y que pasaba por el hecho de que el alumnado aparcaba los estudios para dedicarse a otras actividades que le fueran más atractivas y placenteras (Álvarez-Herrero, 2020a). 
- La situación sanitaria originó problemas de salud mental, miedos, estrés y ansiedad entre el profesorado, el alumnado y también en sus familias. Estas situaciones repercutían directamente en dificultar el seguimiento y el normal desempeño de los procesos de enseñanza-aprendizaje (Bailey y Schurz, 2020).

Podríamos seguir mencionando otros problemas y errores de estos tiempos vividos de crisis pandémica, pero ya entramos en particularidades de menor incidencia. $Y$ como decíamos, queremos centrarnos en analizar estos para mirar hacia adelante, en la búsqueda de soluciones y acciones que prevengan y otras que, al haberse conocido y desarrollado en esta dramática situación, sean válidas y beneficiosas para seguir manteniéndose e implementándose aun cuando todo esto haya pasado.

Es importante remarcar el papel que han jugado y siguen jugando las tecnologías digitales en todo este tiempo. Gracias a ellas, el sistema educativo y su función en la sociedad, se vio a salvo y consiguió en muchos casos mantener la tarea docente de seguir formando personas aun cuando la sociedad vivía momentos de parálisis y conmoción (Álvarez-Herrero et al., 2021). Y esas mismas tecnologías que tuvieron en su día su momento de fama y gloria, y que parecía que en estos últimos años habían perdido protagonismo en la enseñanza frente a otras cuestiones que interesaban más como las metodologías activas; han visto como han vuelto a recuperar esa prioridad (Álvarez-Herrero, 2020b). Y es que su uso, que, aunque por necesidad principalmente, les puede permitir que al haber comprobado su potencial y el gran papel que pueden desempeñar cuando se implementan concienzudamente (con sentido y como valor añadido); permanezcan en el sistema aportando los beneficios que ofrecen y pueden seguir ofreciendo. Sin embargo, no faltan las voces que siguen alertando de lo peligrosas que pueden resultar si se hace un mal uso de ellas (Gavilán-Martín et al., 2020; Sánchez, 2020) y de ahí que se las quiera apartar y que, en una vuelta a la presencialidad, cuando ya no sean imprescindibles, se las aparte o se las abandone en el olvido. Las críticas vienen siempre desde los mismos sectores y argumentando los mismos factores: crean adicción, crean alienación y falta de socialización, solo consiguen despertar interés por su carácter lúdico, facilitan la distracción y la desmotivación por otros saberes y conocimientos, generan el que no se desarrollen competencias y habilidades en habilidades y destrezas que no se ponen en juego cuando se usan estas, etc. (Botero y Rodríguez, 2020)

Pero, por otro lado, su uso e implementación también origina un sinfín de beneficios y el desarrollo de diversas competencias básicas entre los estudiantes, lo que las hace unas excelentes aliadas de la consecución de un aprendizaje significativo por parte del alumnado (Tkachuk et al., 2021).

Volviendo a su uso en los momentos de crisis pandémica que hemos vivido, como ya adelantábamos, las tecnologías digitales han sido imprescindibles para salir adelante, y de ahí que haya mucho que agradecerles (Arshad, 2020). Y precisamente por ello, al no tener un dominio de las mismas, como se creía e incluso se aseguraba en muchos momentos (Martínez-Garcés y Garcés-Fuenmayor, 2020), ha hecho que esta falta haya sido considerada como uno de los principales problemas que nos hemos encontrado en la gestión educativa del confinamiento por la COVID-19 (König et al., 2020).

Como acabamos de ver, ya se han dado estudios en los que se analiza tanto las percepciones de los docentes como de los estudiantes sobre la gestión educativa y el 
desarrollo de la pandemia (Hernández-Ortega y Álvarez-Herrero, 2021; Muthiprasad et al., 2021; Özer, 2020). Pero esta investigación pretende ir más allá, y aporta la novedad de traer las percepciones de los equipos directivos de los centros educativos de enseñanzas no universitarias, pues estos son los llamados a liderar la educación en el presente y un futuro próximo (Pollock, 2020), y nadie mejor que ellos para analizar lo ocurrido y de esta manera poder proponer soluciones y enmendar errores para que no vuelva a pasar o estar prevenidos si se volviese a dar el caso (Stone-Johnson y Miles, 2020).

Nos marcamos dos objetivos en esta investigación:

- Conocer las percepciones que tienen los equipos directivos de centros educativos de enseñanzas preuniversitarias de la Comunidad Valenciana (España) sobre cómo ha sido la gestión con las tecnologías digitales durante el confinamiento domiciliario por la COVID-19, y más concretamente, identificar los principales problemas que han surgido durante este periodo y los meses posteriores.

- Conocidos los problemas surgidos, proponer acciones que permitan corregir y enmendar los errores y problemas surgidos, para que de esta forma no vuelvan a darse ante otras posibles eventualidades en un futuro.

\section{Método/Descripción de la experiencia}

\section{Descripción del contexto y de los participantes}

A raíz de la participación como ponente de un congreso de equipos directivos de la Comunidad Valenciana, celebrado en febrero de 2021, del investigador principal de este estudio, se aprovechó para recoger, mediante un simple cuestionario confeccionado ad hoc, las percepciones de una gran mayoría de los equipos directivos de centros educativos de niveles preuniversitarios valencianos. En dicho cuestionario, se les preguntaba sobre sus percepciones acerca de los principales problemas que habían detectado en la gestión del confinamiento y su relación con las tecnologías digitales. Hubo un total de 136 personas asistentes a la ponencia, de las cuales solo 102 participaron en el cuestionario (un 75\%). Por ello, y con la intención de contrastar y dar mayor fiabilidad a estos resultados, se realizó con posterioridad (en marzo de 2021) un focus group con 10 personas de equipos directivos de diferentes centros educativos preuniversitarios valencianos que no habían asistido a la ponencia ni realizado el cuestionario. En este focus group se debatió y discutió abiertamente sobre el mismo tema, introduciendo además un nuevo punto de debate que consistió en la proposición por parte de estos directivos de posibles soluciones y respuestas a los problemas y errores encontrados durante el confinamiento y los meses posteriores al mismo.

\section{Instrumentos}

El cuestionario se elaboró para la ocasión utilizando la aplicación conocida como Mentimeter y obedecía a una única pregunta cerrada con 9 posibles respuestas que decía así:

¿Cuál ha sido el principal problema detectado en tu centro educativo durante el confinamiento domiciliario de marzo a junio de 2020 ? 
A. Falta de dispositivos tecnológicos y/o conexión a Internet

B. Mala gestión de la administración educativa

C. Mala gestión de la dirección del centro

D. Deficiente competencia digital del profesorado

E. Deficiente competencia digital del alumnado

F. No haber sabido enseñar de forma efectiva en la modalidad online

G. No haber sabido aprender de forma efectiva en la modalidad online

H. Sufrir de estrés, ansiedad, enfermedades o problemas de salud mental, bien en primera persona o en algún familiar o conocido

I. Absentismo del alumnado que se ha distraído con otras cosas

Esta herramienta posibilita lanzar la pregunta en directo, de forma síncrona, pues se puede proyectar desde su página web a la audiencia de la ponencia. Las respuestas se recogen de forma inmediata y tanto el ponente como los asistentes (participantes y no de la ponencia) pueden visualizar en todo momento los resultados que se van dando. Esto si bien puede condicionar la respuesta de aquellos participantes que se demoran más en sus respuestas, dada la inmediatez del proceso consideramos que es prácticamente despreciable la influencia que se puede ejercer en la muestra de estudio. No obstante, como ya hemos adelantado, también se quiso dar fiabilidad y confianza a los resultados obtenidos en este cuestionario, a través de la realización de un focus group con miembros de equipos directivos que no habían asistido a la ponencia ni habían realizado el cuestionario, y quienes, por tanto, desconocían los resultados obtenidos en este.

En el focus group, donde se contó con 10 personas de equipos directivos que no estuvieron presentes en el congreso donde se pasó el anterior cuestionario, se abrió el diálogo de forma abierta con la misma pregunta, pero sin ofrecer ninguna posible respuesta. Dicho focus group se realizó a través de una videoconferencia de Google Meet, donde se inició con una breve exposición o respuesta a la pregunta formulada por parte de cada uno de los participantes, a lo que posteriormente se abrió un turno libre de participación por si se deseaba añadir o debatir las respuestas dadas por el resto de participantes. Como novedad y extra a lo que se hizo con los participantes de la ponencia del congreso, en esta ocasión se hizo una segunda pregunta a los participantes del focus group, esta vez sin opciones, y en la que se les pedía que propusiesen posibles soluciones o respuestas a dar a los problemas y errores cometidos durante estos meses de pandemia vividos, en pro de conseguir una mejora en el desarrollo de los procesos de enseñanza-aprendizaje del alumnado. Nuevamente se procedió de igual manera que en la primera pregunta y así primero se siguió un orden de dar respuesta por parte de cada uno de los asistentes al focus group, para posteriormente abrir un turno libre de palabra por si se deseaba ampliar o debatir esta segunda pregunta. 


\section{Procedimiento}

El cuestionario se pasó durante la celebración del congreso: El liderazgo de los equipos directivos, en febrero de 2021. Y el focus group se realizó en la primera semana del mes de marzo. Dado que en el caso del cuestionario, se trata de una única pregunta, y en el caso del focus group son dos preguntas pero tan solo son 10 participantes, los datos del cuestionario se recogieron en forma de porcentajes a partir de la misma aplicación Mentimeter, y los resultados del focus group fueron agrupados y recogidos en una hoja de Microsoft Office Excel, diferenciando las dos preguntas (Pregunta 1 y Pregunta 2), así como las intervenciones de cada uno de los participantes (directivo1, directivo2, etc...).

\section{Resultados}

Los resultados obtenidos vamos a diferenciarlos entre los obtenidos en el cuestionario de los participantes en la ponencia del congreso de miembros de equipos directivos de la Comunidad Valenciana, de aquellos otros obtenidos en el focus group.

\section{Cuestionario}

Recordemos que fueron 102 los miembros de los equipos directivos asistentes a dicho congreso que respondieron en el cuestionario a la pregunta realizada, y así se puede ver sus respuestas en la Figura 1. En ella, se puede apreciar que las cuatro problemáticas más mencionadas por los equipos directivos tenían que ver con una deficiente competencia digital tanto del discente (26\%), como del docente (22\%), así como el no haber sabido enseñar de forma efectiva en la modalidad online (15\%), y la falta de recursos o dispositivos tecnológicos y una deficiente o nula conectividad a Internet (13\%). Solo estas variables ya suman el $76 \%$ de los problemas.

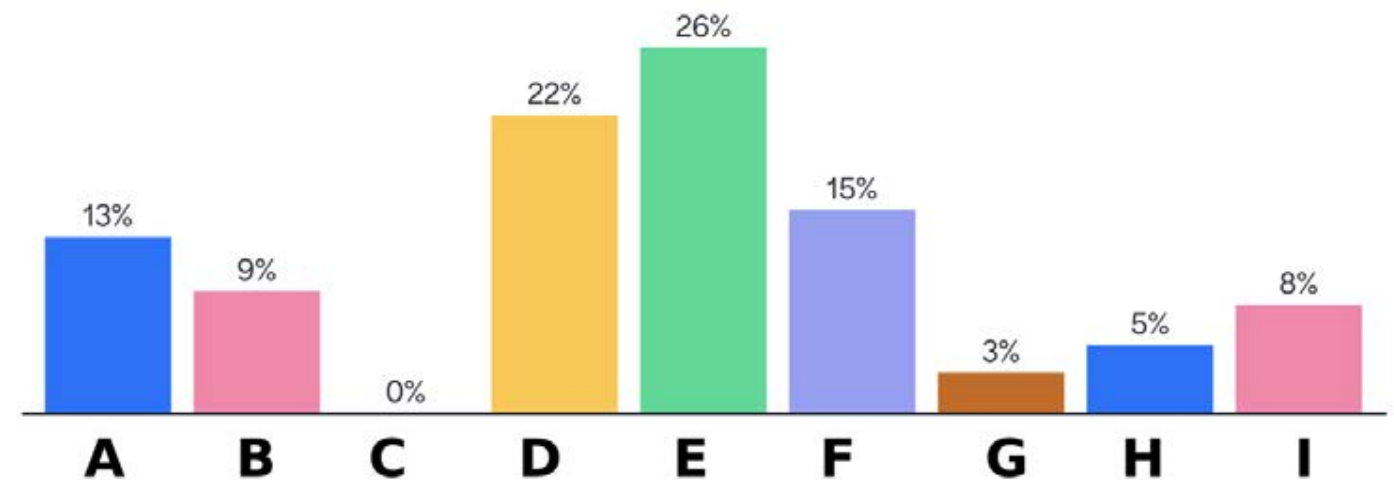

Figura 1. Porcentajes de las respuestas dadas a los problemas percibidos por los equipos directivos en la gestión del confinamiento domiciliario por la COVID-19

Se constata poca capacidad de autocrítica entre los directivos, pues no hubo ni una sola respuesta que achacase los problemas o errores cometidos durante el confinamiento a una mala gestión por parte de la dirección del centro. En cambio, aunque con porcentajes muy bajos, sí se encuentra algo de culpabilidad en la mala gestión 
realizada por la administración educativa ( $9 \%$ ) y al alumnado que se ha declarado absentista durante toda esta etapa ( $8 \%$ ) y que ha preferido distraerse o dedicarse a otras actividades y descuidar de esta manera su formación académica.

Con todo ello podemos afirmar que la variable tecnológica o de las tecnologías digitales en la problemática surgida durante el confinamiento domiciliario a causa de la COVID-19 es bastante elevado, pues estamos hablando de que es algo más que de la problemática total.

\section{Focus group}

El focus group aunque dio resultados muy similares, destacó en primer lugar la deficiente competencia digital del docente (destacada por 8 de los 10 participantes), y ya en segundo lugar la del discente.

Al posibilitar intervenciones abiertas, y aunque se pidió a los participantes que en su primera respuesta debían elegir una de las opciones (para de esta forma poder equiparar y comparar los resultados con los obtenidos en el cuestionario por los asistentes a la ponencia del congreso), ello originó que se estableciese un orden de relevancia entre las opciones presentadas. Y eso hiso que también se diese mucha importancia a variables que en el cuestionario quedaron relegadas a posiciones más bajas. De ahí que una de las variables que también salió como destacada fue la falta de preparación docente para haber sabido trasladar los procesos de enseñanza-aprendizaje a una modalidad no presencial, así como también la falta de preparación del alumnado para atender este tipo de enseñanza online. Curiosamente, una de las problemáticas que en el cuestionario salió destacada y que fue la falta de dispositivos y de conectividad a Internet, en el focus group se situó por debajo del resto de variables a excepción de la mala gestión por parte de la dirección del centro, que volvió a no presentar ninguna persona que la destacase. En este último caso, si se incidió por parte de tres directivos, en la mala gestión y los momentos en los que se creó confusión por las directrices mandadas desde la administración educativa autonómica y las directrices estatales del gobierno y ministerio de educación.

Atendiendo a la segunda pregunta que se les hizo a los participantes de este focus group sobre que diesen posibles soluciones o respuestas a estos errores y problemas cometidos y comentados en la primera pregunta, hubo también bastante unanimidad al afirmar la mayoría de los directivos participantes en la necesidad de formar al alumnado, pero sobretodo al profesorado en competencias digitales y que el desarrollo de las mismas los llevase a cubrir con garantías situaciones como las vividas. Se pidió en este sentido una mayor implicación de las administraciones educativas para ofrecer planes formativos y ayudas en este sentido para la formación en centros. $Y$ volviendo a los centros educativos, los directivos reconocían que la situación vivida ha propiciado cosas buenas, pues ha permitido una mayor cohesión de los equipos docentes que se han unido ante la adversidad para salir juntos de ella, así como que ha propiciado una mejora de la competencia digital del profesorado, que ante la necesidad planteada por el confinamiento, recurrió a la autoformación y trató de solventar por si mismo aquellos problemas tecnológicos y digitales que le fueron surgiendo. Todo ello se ha transformado en estos tiempos actuales, en que, en el regreso a las aulas, el profesorado ha seguido haciendo uso de algunos de los recursos y estrategias digitales utilizados durante el confinamiento, aquellos en los que ha encontrado que producen una mejora en su trabajo docente y en el proceso 
de enseñanza-aprendizaje, traduciéndose en definitiva en una mejora del aprendizaje de su alumnado.

\section{Discusión y conclusiones}

A tenor de los resultados obtenidos y de los objetivos que nos habíamos planteado, podemos identificar como principales problemas percibidos por los equipos directivos de los centros educativos no universitarios de la Comunidad Valenciana, como la deficiente competencia digital tanto de discentes como de docentes es el de mayor incidencia, siguiéndole la falta de saber adaptarse de una modalidad de enseñanza presencial a una online por parte de docentes y también de discentes. Así, si las tecnologías digitales han sido cruciales para poder afrontar la situación del confinamiento y la crisis pandémica en general, como vemos, para los directivos educativos valencianos, también las tecnologías han sido las causantes, por su falta de desarrollo y de saber aplicarlas, de los principales problemas ocurridos. Estos resultados coinciden con los obtenidos de investigaciones en las que se han recogido las percepciones de docentes y estudiantes (Hernández-Ortega y Álvarez-Herrero, 2021; Muthuprasad et al., 2021; Putri et al., 2020; Ramos-Huenteo et al., 2020), así como en otras de directivos de centros educativos tanto de España (Palau et al., 2021) como de otros países (O'Connell y Clarke, 2020; Reid, 2021; Song et al., 2020; Thornton, 2021).

Aunque con un porcentaje muy bajo, también hemos encontrado que sí se ha detectado como problema el llamado absentismo COVID-19, más frecuente entre el alumnado de educación secundaria y propiciado por la situación originada ante el caos de no saber como dar respuesta a la evaluación y seguimiento del aprendizaje del alumnado durante este periodo. En cuanto a la falta de dispositivos tecnológicos y de conectividad a Internet, dado que son muy diferentes los resultados obtenidos en el cuestionario y en el focus group y que ello posiblemente se deba a lo variado y particular de dicho problema (depende de cada situación particular y va por centros o instituciones, casos en los que se da mucho y casos en los que apenas se da), no podemos afirmar que sea un problema que se perciba como importante por parte de los directivos.

Tras los resultados obtenidos en el cuestionario a la primera pregunta, así como las propuestas lanzadas por los directivos en el focus group a la segunda pregunta, damos respuesta al segundo objetivo de esta investigación, concluyendo que es necesaria una actuación urgente en planes de formación docente que lleven al desarrollo de su competencia digital. Son incluso los propios docentes quienes se han dado cuenta de esta acuciante necesidad y así la demandan (Álvarez-Herrero y Hernández-Ortega, 2021). Pero esta formación debe ser de calidad y no caer en errores clásicos de centrarse en la herramienta o el recurso, sino ir más allá y ofrecer al profesorado estrategias y habilidades que le permitan saber qué, cómo, cuándo, dónde y porqué implementarlas. Solo de esta manera las tecnologías, cuando sea aconsejable implementarlas, gozarán de sentido y permitirán dotar al aprendizaje de ese valor añadido que hará de este algo más significativo y duradero. Nadie mejor que los directivos de centros educativos; que han tenido que lidiar con estos problemas sanitarios y a la vez procurar que se siguiese manteniendo la calidad de los procesos de enseñanza-aprendizaje; para proponer y dirigir hacia las posibles soluciones que permitan afrontar este problema y los que puedan venir de su misma índole (Pollock, 2020). 
Nos proponemos en un futuro seguir indagando en esta línea de investigación con una muestra más amplia e incluso comprobando si en otras regiones de España se obtienen los mismos resultados, para con ello, seguir proponiendo acciones que ayuden a combatir y a prevenir situaciones como la vivida. Además, también será interesante investigar en un futuro si se dan diferencias entre los problemas y deficiencias más graves detectadas en centros educativos de infantil y primaria, y los de secundaria por otro lado. Así como también se debe analizar y estudiar si la percepción de las mujeres presenta alguna diferencia con respecto a la percepción de los hombres.

\section{Referencias}

Álvarez-Herrero, J. F. (2020a). Repercusión de la COVID-19 en el aprendizaje entre el alumnado de secundaria. En Conference Proceedings CIVINEDU 2020 (pp. 710-711). Adaya Press.

Álvarez-Herrero, J. F. (2020b). Evolución de la percepción del docente de secundaria español sobre la formación en TIC. Edutec, Revista Electrónica De Tecnología Educativa, 71, [pp.] 1-15.

Álvarez-Herrero, J. F., y Hernández-Ortega, J. (2021). Percepción del docente de Educación Secundaria español sobre la necesidad de una formación en TIC a consecuencia de la COVID-19. En L. Vega-Caro, A. Vico y D. Recio (Eds.). Nuevas formas de aprendizaje en la era digital: en busca de una educación inclusiva (pp. 215-236). Dykinson.

Álvarez-Herrero, J. F., Martínez-Roig, R., y Urrea-Solano, M. (2021). Uso de las tecnologías digitales en educación infantil en tiempos de pandemia. Campus Virtuales, 10(2), [pp.] 165-174.

Arshad, M. (2020). COVID-19: It's time to be thankful to our ICT professionals. Information Technology \& Electrical Engineering, 9(2), [pp.] 23-31.

Aznar, F. J. (2020). La Educación Secundaria en España en Medio de la Crisis del COVID-19. International Journal of Sociology of Education, Special Issue: COVID-19 Crisis and Socioeducative Inequalities and Strategies to Overcome them, [pp.] 53-78.

Bailey, J. P., y Schurz, J. (2020). COVID-19 Is Creating a School Personnel Crisis. American Enterprise Institute.

Botero, F., y Rodríguez, G. (2020). Los peligros de la virtualidad en la pandemia de COVID-19. Pediatría, 53(3), [pp.] 81-82.

Delcker, J., y Ifenthaler, D. (2021). Teachers' perspective on school development at German vocational schools during the Covid-19 pandemic. Technology, Pedagogy and Education, 30(1), [pp.] 125-139.

García, L. (2021). COVID-19 y educación a distancia digital: preconfinamiento, confinamiento y posconfinamiento. RIED. Revista Iberoamericana de Educación a Distancia, 24(1), [pp.] 9-32. 
Gavilan-Martin, D., Merma-Molina, G., Urrea Solano, M. E., Alvarez-Herrero, J. F., y Fernández-Herrero, J. (2020). Los peligros ocultos de la red en el ámbito escolar: ciberbullying, grooming y sexting. En E. Colomo, E. Sánchez, J. Ruiz y J. Sánchez (Coords.). La tecnología como eje del cambio metodológico (pp. 1314-1316). UMA Editorial.

Hernández-Ortega, J., y Álvarez-Herrero, J. F. (2021). Gestión educativa del confinamiento por COVID-19: percepción del docente en España. Revista Española De Educación Comparada, 38, [pp.] 129-150.

Khlaif, Z. N., Salha, S., Affouneh, S., Rashed, H., y ElKimishy, L. A. (2020). The Covid-19 epidemic: teachers' responses to school closure in developing countries. Technology, Pedagogy and Education, 30(1), [pp.] 95-109.

König, J., Jäger-Biela, D. J., y Glutsch, N. (2020). Adapting to online teaching during COVID-19 school closure: teacher education and teacher competence effects among early career teachers in Germany. European Journal of Teacher Education, 43(4), [pp.] 608-622.

Lorente, L. M. L., Arrabal, A. A., y Pulido-Montes, C. (2020). The Right to Education and ICT during COVID-19: An International Perspective. Sustainability, 12(21), 9091.

Martínez-Garcés, J., y Garcés-Fuenmayor, J. (2020). Competencias digitales docentes y el reto de la educación virtual derivado de la covid-19. Educación Y Humanismo, 22(39), [pp.] 1-16.

Muñoz, J. L., y Lluch, L. (2020). Educación y Covid-19: Colaboración de las familias y tareas escolares. Revista Internacional de Educación para la Justicia Social, 9(3), [pp.] 1-15.

Muthuprasad, T., Aiswarya, S., Aditya, K. S., y Jha, G. K. (2021). Students' perception and preference for online education in India during COVID-19 pandemic. Social Sciences \& Humanities Open, 3(1), 100101.

O'Connell, A., y Clarke, S. (2020). A school in the grip of Covid-19: Musings from the principal's office. International Studies in Educational Administration, 48(2), [pp.] 4-11.

Özer, M. (2020). Educational Policy Actions by the Ministry of National Education in the times of COVID-19 Pandemic in Turkey. Kastamonu E itim Dergisi, 28(3), [pp.] 1124-1129.

Palau, R., Fuentes, M., Mogas, J., y Cebrián, G. (2021). Analysis of the implementation of teaching and learning processes at Catalan schools during the Covid-19 lockdown. Technology, Pedagogy and Education, 30(1), [pp.] 183-199.

Pollock, K. (2020). School Leaders' Work During the COVID-19 Pandemic: A Two-Pronged Approach. International Studies in Educational Administration, 48(3), 38.

Putri, R. S., Purwanto, A., Pramono, R., Asbari, M., Wijayanti, L. M., y Hyun, C. C. (2020). Impact of the COVID-19 pandemic on online home learning: An explorative study of primary schools in Indonesia. International Journal of Advanced Science and Technology, 29(5), [pp.] 4809-4818. 
Ramos-Huenteo, V., García-Vásquez, H., Olea-González, C., Lobos-Peña, K., y Sáez-Delgado, F. (2020). Percepción docente respecto al trabajo pedagógico durante la COVID-19. CienciAmérica, 9(2), [pp.] 334-353.

Reid, D. B. (2021). Suppressing and sharing: how school principals manage stress and anxiety during COVID-19. School Leadership \& Management.

Sánchez, D. A. (2020). Los peligros y los beneficios del uso de las TIC en el proceso de enseñanza-aprendizaje. En G. O. Rodríguez-Garay, M. P. Álvarez-Chávez y S. Husted (Coords.). Comunicación, educación y juventud: nuevas formas de aprender y enseñar en la era digital (pp. 153-172). Egregius.

Song, H., Wu, J., y Zhi, T. (2020). Online Teaching for Elementary and Secondary Schools During COVID-19. ECNU Review of Education, 3(4), [pp.] 745-754.

Stone-Johnson, C. y Miles, J. (2020). Principal professionalism in the time of COVID-19. Journal of Professional Capital and Community, 5(3/4), [pp.] 367-374.

Thornton, K. (2021). Leading through COVID-19: New Zealand secondary principals describe their reality. Educational Management Administration \& Leadership, 49(3), [pp.] 393-409.

Tkachuk, V., Yechkalo, Y., Semerikov, S., Kislova, M., y Hladyr, Y. (2021). Using Mobile ICT for Online Learning During COVID-19 Lockdown. En A. Bollin et al. (Eds.). Information and Communication Technologies in Education, Research, and Industrial Applications. ICTERI 2020. Communications in Computer and Information Science, vol 1308. Springer.

Trujillo-Sáez, F., Fernández-Navas, M., Montes-Rodríguez, M., Segura-Robles, A., Alaminos-Romero, F. J. y Postigo-Fuentes, A. Y. (2020). Panorama de la educación en España tras la pandemia de COVID-19: la opinión de la comunidad educativa. Fad. 


\section{Colaborando en Línea con Madres, Padres y Docentes para Promover la Alfabetización Emergente en Preescolares}

\section{Vega Pérez, Lizbeth}

ORCID (orcid.org/0000-0002-0269-0987)

Universidad Nacional Autónoma de México Ivega@unam.mx

\section{Poncelis Raygoza, María Fernanda}

Universidad Nacional Autónoma de México psininos@hotmail.com

\section{Núñez Márquez, Guadalupe}

Universidad Nacional Autónoma de México gnunezm@comunidad.unam.mx

\section{Guarneros Reyes, Esperanza}

ORCID (orcid.org/0000-0002-2955-5814)

Universidad Nacional Autónoma de México

esperanzagr@gmail.com 


\title{
COLABORANDO EN LÍNEA CON MADRES, PADRES Y DOCENTES PARA PROMOVER LA ALFABETIZACIÓN EMERGENTE EN PREESCOLARES
}

\author{
Vega Pérez, Lizbeth \\ Poncelis Raygoza, María Fernanda \\ Núñez Márquez, Guadalupe \\ Guarneros Reyes, Esperanza
}

\section{Resumen}

Mucho antes del ingreso a la instrucción formal, los niños y las niñas preescolares aprenden acerca del lenguaje escrito a través de la observación y la participación en actividades cotidianas. Madres, padres y docentes promueven este aprendizaje modelando y reforzando los esfuerzos diarios de los niños y las niñas. Si se capacita a madres, padres y docentes en estrategias efectivas, probadas empíricamente, este desarrollo de la alfabetización emergente se potencia. Este estudio tuvo como objetivo probar la efectividad de un paquete de capacitación en línea a padres y maestras para la promoción de la alfabetización emergente en preescolares. Se trabajó con 47 madres, padres y docentes de 4 Estancias de Bienestar y Desarrollo Infantil (EBDIs) de la Ciudad de México, con una escolaridad promedio de Licenciatura, en un diseño de criterio cambiante. Los participantes recibieron un paquete de capacitación (programa en línea y manual multimedia) de 16 sesiones, a través de la plataforma Moodle. Los resultados muestran diferencias significativas ( $Z=-3.299, p=.001$ ) entre el número de estrategias utilizadas por los participantes antes y después del programa, así como en el incremento en las estrategias consideradas "logradas" por ellos mismos ( $Z=-3.207, p=.001)$. Los resultados se discuten en función de las características del paquete que pueden relacionarse con ellos y de las implicaciones de este tipo de programas.

\section{Palabras clave}

Capacitación a madres, padres y docentes, alfabetización emergente, capacitación en línea, niños preescolares, manual multimedia. 


\section{Introducción}

Los primeros años de vida son fundamentales para el desarrollo psicológico en general y del lenguaje en particular. En estos primeros años, los niños y las niñas aprenden acerca del lenguaje oral y escrito participando en actividades cotidianas en interacción y colaboración con sus pares, así como con sus madres, padres y docentes. Estos intentos de los(las) niños(as) por comprender las características del lenguaje escrito se denominan "Alfabetización emergente", que se define como "el conocimiento y la conducta de los niños relacionados con la lectura y la escritura cuando aún no son alfabetizados convencionalmente”. (Justice y Kaderaveck, 2002, P.12).

Madres, padres y maestros juegan un papel fundamental en el desarrollo de la alfabetización emergente, ya que el hogar y el escenario preescolar son los principales ambientes con los que interactúa un(a) niño(a) de esta edad. Por ello, si se quiere promover el desarrollo de la alfabetización, además de trabajar con los niños y las niñas, es muy provechoso incidir en los agentes socializadores más representativos en estos ambientes, como son las madres, los padres y los (las) docentes. Estudios realizados con madres, padres y docentes evidencian la utilidad de que unos y otros reciban capacitación en el uso de estrategias efectivas, surgidas de la literatura, para la promoción de la alfabetización emergente en sus niños(as) (Guevara y Rugerio, 2014; Luna, Vega y Poncelis, 2016).

La efectividad de los programas de capacitación depende de que compartan ciertas características que, según la literatura, potencian la probabilidad del logro de los objetivos a) Basar la formación profesional y de los adultos en general, en los hallazgos de investigación, b) Integrar los resultados de la investigación con las experiencias de los participantes c) La colaboración entre los participantes, la cual se basa en objetivos comunes que han sido acordados por las partes involucradas d) Finalmente, se requiere apoyar a madres, padres y docentes mediante estrategias que les permitan trasladar las habilidades recién adquiridas a las actividades de su vida cotidiana (Parrilla,1996; Panitz,1996; Hoffman y Pearson, 2000; Peña y Quinn, 2003; Bean y Morewood, 2007; Darling-Hammond y Richardson, 2009; Knight, 2009; Grossen, 2012; Vega, 2013).

Otra característica de los programas efectivos de capacitación es el acompañamiento instruccional, a través del cual se forma un vínculo respetuoso entre dos personas, que propicia un proceso gradual de enseñanza y aprendizaje para ambos (Skiffington, Washburn y Elliott, 2011; Gómez, 2012; Luna, Vega y Poncelis, 2016; Vega-Pérez y Pérez- Estrada, 2016).

La forma de entrega de los programas también influye su efectividad: los recursos multimedia incrementan esta efectividad, tanto directamente en los participantes, como en los (las) niños(as) de manera indirecta (López, y cols., 1998; Warschauer y Healey, 1998; Kamil, Intrator y Kim, 2000; Vega y Poncelis, 2010; Behjat, Yamini y Sadegh, 2012). Por otra parte, gestionar los programas de capacitación a través de la red, mediante plataformas que permitan tanto la revisión de contenidos, como su aplicación en situaciones simuladas y la interacción entre los participantes: aprendices e instructores y entre los propios aprendices (Bell y Kozlowski, 2002), facilita la colaboración, el intercambio de experiencias y que el usuario tenga mayor control sobre su aprendizaje (Brown, 2001; DeRouin, Fritzsche, y Salas, 2004; Bell y Kozlowski, 2007). 
Con base en los fundamentos presentados, el presente proyecto tuvo como objetivo: Probar la efectividad de un paquete de capacitación en línea a madres, padres y docentes para la promoción de la alfabetización emergente en niños y niñas preescolares.

\section{Método/Descripción de la experiencia}

\section{Descripción del contexto y de los participantes}

Participaron 47 madres/padres y personal educativo de 4 EBDIs de la Ciudad de México (34 madres/13 P.E.), seleccionadas mediante un muestreo no probabilístico intencional (Padua, 1979) con una escolaridad promedio de Licenciatura, en un diseño de criterio cambiante (Arnau, 1984).

Se tuvo una primera reunión con madres, padres y maestras en cada una de las estancias infantiles para presentarles los objetivos, procedimientos y aspectos éticos del programa. Esta reunión se realizó en los escenarios que cada EBDI designó (sala de usos múltiples, comedor, auditorio). El programa de capacitación se aplicó a través de una plataforma Moodle, desarrollada específicamente para esta investigación.

\section{Instrumentos}

La variable independiente fue un paquete de capacitación que constó de 16 sesiones que se entregaban vía la plataforma Moodle. Este paquete incluye libros, videos, ejercicios, ejemplos, wikis, foro y un manual multimedia de apoyo.

Para medir la variable dependiente: Estrategias para la promoción del desarrollo de la alfabetización (véase Tabla 1), se utilizaron una rúbrica (disponible en https://drive.google.com/file/d/linZYr3ZtUSZoBzRZotKQT3jD4LUPYkpK/view?usp=sharing), con varios niveles de desempeño y criterios para su calificación, que se usó como pre-test y post-test, y una lista cotejable (disponible en https://drive.google.com/ file/d/1zNggiM7fbfNZk3RdZUTE57zDGumGjcs6/view?usp=sharing) que contenía las estrategias compartidas y tres niveles de desempeño (logrado, en proceso, no logrado), elaboradas para este programa. También se aplicó un cuestionario de satisfacción con el programa.

Tabla 1. Estrategias de lectura antes, durante y después de la lectura.

\begin{tabular}{l|l|l|}
\hline Antes de la lectura & Durante la lectura & Después de la lectura \\
\hline & Pistas visuales & Discusión \\
Arreglo del área para la & Pistas verbales & Confirmación \\
actividad & Anticipación & Retroalimentación \\
Activación de conocimientos & Predicción & Contar y recontar \\
Muestreo & Elaboración de inferencias & Enlazar información \\
& Instrucción directa & Organizar información \\
\hline
\end{tabular}




\section{Procedimiento}

La figura 1 muestra el procedimiento que se siguió para la aplicación del programa

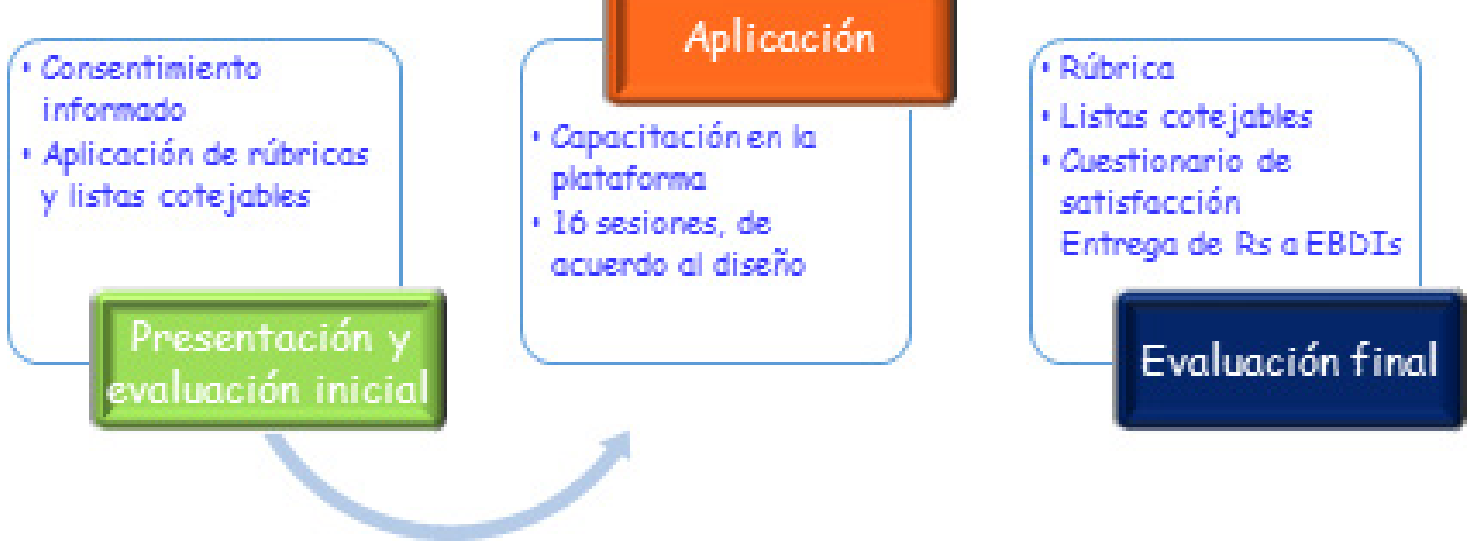

Figura 1. Procedimiento de aplicación del programa

A las madres y los padres que se interesaron en participar en el estudio, se les envió un código de acceso a la plataforma Moodle en que se alojaba el programa. La primera actividad en la plataforma fue la lectura de una carta de consentimiento informado en la que se explicaron los aspectos éticos que se tomaron en cuenta para la realización de este estudio, así como los posibles riesgos y los beneficios de participar en él. Esta carta está disponible en https://drive.google.com/file/d/1tjAP-UXZz5SUE5gJPGHilOPoorHEmoMw/view?usp=sharing. Una vez que los y las participantes firmaron la carta de consentimiento informado, se les ofreció una capacitación para navegar en la plataforma.

Como se puede observar, se tuvieron tres fases en el procedimiento: Presentación y evaluación inicial, aplicación del programa y evaluación final.

Cada una de las 16 sesiones constaba de actividades de revisión teórica, ejercicios, ejemplos y tareas para el hogar. Los y las participantes recibian retroalimentación de su desempeño y acompañamiento durante la realización de las tareas por parte de las investigadoras, que fungían como tutoras ( 5 psicólogas). Se contaba también con un manual multimedia de apoyo, con los mismos contenidos que el programa y que los y las participantes podían consultar cuando así lo consideraran. En cada sesión del programa se hacía referencia a las páginas del manual que correspondían a dicha sesión. Se tuvieron 2 evaluaciones (al inicio y al final) por parte de las evaluadoras con las rúbricas y las listas cotejables y 4 autoevaluaciones que realizaron los y las participantes con las listas cotejables a lo largo del programa. 


\section{Resultados}

Los análisis y resultados que se presentan corresponden a los puntajes obtenidos en las diferentes evaluaciones que se hicieron durante el programa y fueron analizados con el paquete IBM Statistics 26. Los análisis de significancia de dichos resultados se efectuaron mediante pruebas de Friedman (para pre-test/post-test que realizaron las tutoras) y Wilcoxon (para las autoevaluaciones que realizaron las participantes).

Uso de estrategias desde la autoevaluación de los/las participantes: se reporta un incremento significativo en el puntaje del uso de las estrategias a lo largo de las cuatro autoevaluaciones que realizaron los participantes ( $x 2=16.009, \mathrm{gl}=3, \mathrm{p}=.001)$. Comenzando con un puntaje promedio de $X=47.46$ y concluyendo con un puntaje promedio de $X=53.36$ de un total máximo de 57 (ver Figura 2).

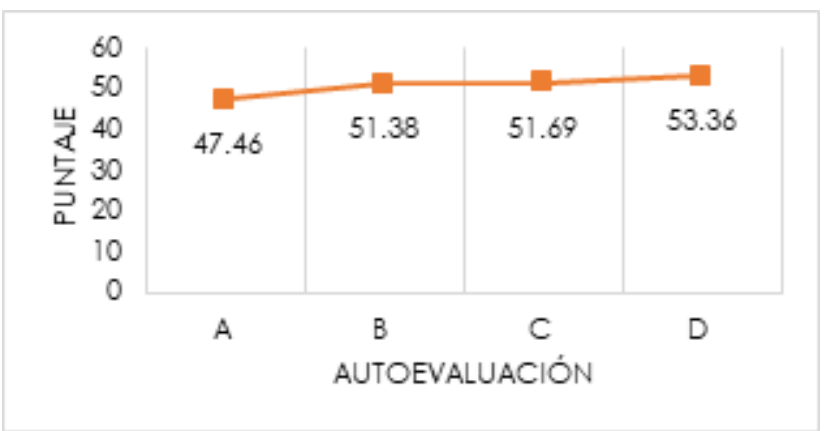

\section{Figura 2. Puntaje promedio en las autoevaluaciones a través de la lista de cotejo}

Las estrategias que más se diversificaron en los y las participantes, con base en su autoevaluación, después de participar en el programa fueron: Antes de la lectura: acondicionar el espacio antes de la actividad, pistas verbales. Durante la lectura: hacer preguntas sobre la historia e instrucción directa, promover la discusión. Después de la lectura: corroborar predicciones, proporcionar retroalimentación, explicar comentarios en la retroalimentación y realizar preguntas para la comprensión de la lectura.

Uso de estrategias de las y los participantes evaluadas por las tutoras: Se identificó un incremento significativo en los puntajes postest con relación al pretest en el uso de estrategias por los y las participantes ( $Z=-3.299, p=.001)$. Este incremento se puede observar en la figura 3. El puntaje máximo posible es 57 . Se presenta el puntaje promedio para el pre y el postest. 


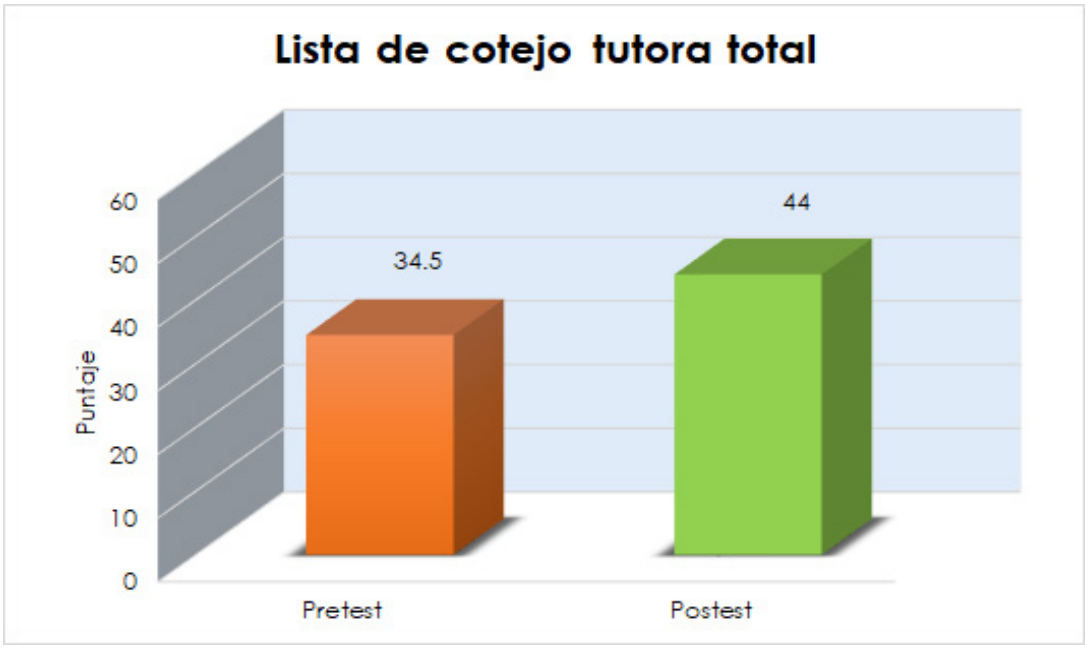

Figura 3. Puntaje promedio en la lista de cotejo evaluada por las tutoras en el total de la muestra

Las estrategias que las tutoras identificaron que más incrementaron las y los participantes fueron: Antes de la lectura: mostrar portada del texto. Durante la lectura: hacer preguntas sobre la historia, hacer preguntas sobre personajes u objetos, instrucción directa y modelamiento. Después de la lectura: proporcionar retroalimentación y realizar preguntas para la comprensión de la lectura.

Cambios en las estrategias logradas, en proceso y no logradas. La tendencia que se observa fue decrementar las estrategias no logradas $(Z=-3.065, p=.002)$ y en proceso e incrementar el porcentaje de estrategias logradas ( $Z=-3.207, .001$ ), comenzando con un puntaje promedio de $X=64.78 \%$ de estrategias logradas al principio del programa de capacitación y terminando con un puntaje promedio de $\mathrm{X}=$ $82.73 \%$ después de su participación en el programa. Esto se observa en la figura 4.

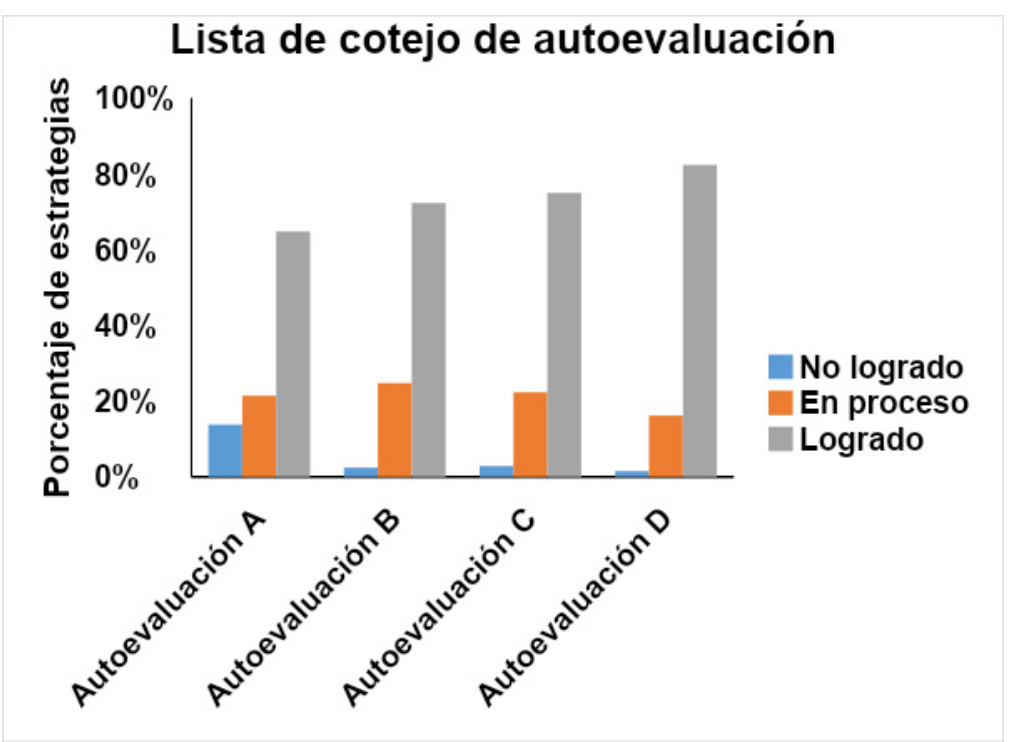

Figura 4. Estrategias logradas, en proceso y no logradas, de acuerdo con la autoevaluación de los participantes. 
La tendencia que se observa en la autoevaluación, y que se muestra en la figura 4, se corroboró en las evaluaciones realizadas por las tutoras.

Rúbrica de desempeño. Otra fuente de información para identificar los avances en el uso de las estrategias fue la rúbrica de desempeño, en la que también se observó un incremento significativo. ( $Z=-2.963$, p.=.007). Esta rúbrica se calificaba con base en criterios de desempeño, de acuerdo con las características que debía tener la aplicación de las estrategias. El puntaje máximo posible era 24 . Se presenta el puntaje promedio para el pre y el postest (véase Figura 5).

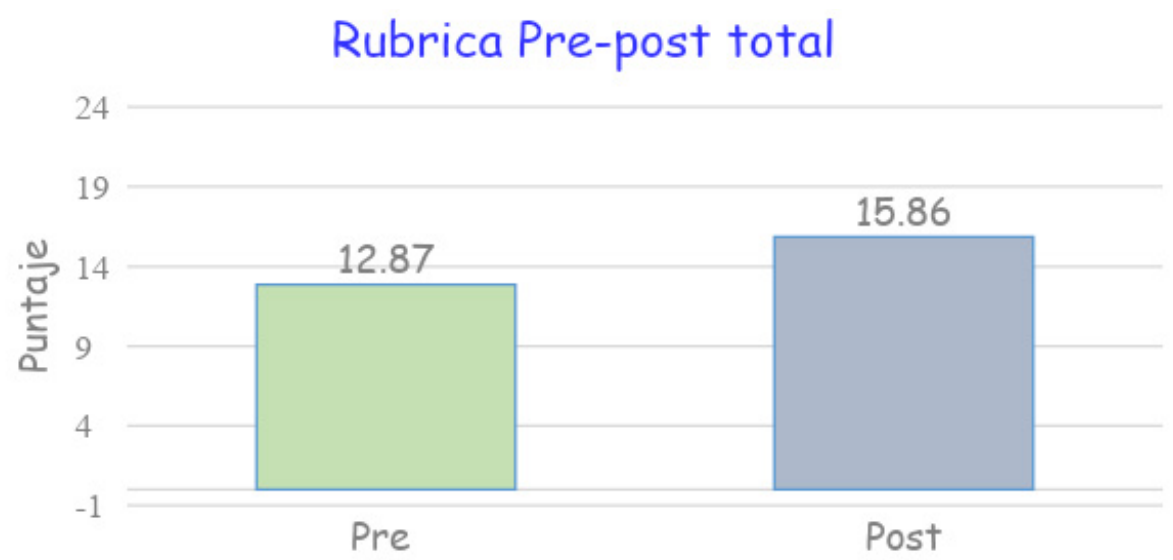

Figura 5. Resultados (puntaje medio) de la evaluación de los participantes con la rúbrica de desempeño.

Grado de satisfacción de los y las participantes: se identifican los siguientes porcentajes en los rubros evaluados: Acompañamiento (93.33\%), contenido (92.43\%), uso de la plataforma (89.07\%) y recursos (88.39\%). Estos resultados se ilustran con algunos comentarios de los participantes:

- "...me he sentido muy afortunada de poder aprender cada vez más sobre las estrategias para la alfabetización, desde el uso de las pistas visuales y verbales que van posibilitando a los alumnos para adentrarse en un tema o en una lectura $y$ que a su vez despierte su interés por la actividad, hasta llegar a la movilización de saberes y acomodación de los nuevos a partir de las predicciones y las inferencias"

- "Valoro mucho la oportunidad que me dieron al compartir estrategias..."

- Creo que la posibilidad de un foro siempre es enriquecedora, por la visión de otras madres y padres respecto de sus propias experiencias.

\section{Discusión y conclusiones}

El objetivo de la investigación se cumplió, ya que se probó la efectividad del paquete de capacitación en línea para padres y maestras para la promoción de la alfabetización emergente en preescolares. El paquete fue validado mediante su aplicación a un grupo de madres, padres y personal educativo de estancias infantiles quienes 
incrementaron significativamente su desempeño al final del programa. Los y las participantes no sólo incrementaron el uso de estrategias, como se aprecia en la autoevaluación realizada por ellos mismos, que coincide con la evaluación de las tutoras, sino que además lo diversificaron. Otra medida de la efectividad del programa la constituye el hecho de que a medida que las y los participantes incrementaban su porcentaje de uso de las estrategias, esto se reflejaba en el incremento de las estrategias logradas y el decremento de las estrategias en proceso y las no logradas.

Al analizar las respuestas de los y las participantes también resulta interesante ver cómo fue cambiando su concepción del desarrollo del lenguaje en estos años y la manera de promoverlo, siendo más precisa y profunda al final del programa. Los recursos del paquete apuntaban a lograr que madres, padres y docentes analizaran su propio desempeño y reflexionaran sobre él y que también basaran el conocimiento que se estaba construyendo en sus experiencias previas y en la aplicación de las estrategias a sus actividades cotidianas. Se considera que todo ello formó una base sólida de conocimiento sobre el que se construyó esta mejor comprensión del desarrollo de las niñas y los niños así como la forma de promoverlo (Darling- Hammond y Richardson, 2009; Vega, 2013).

Abundando en las características del paquete, es importante mencionar que los contenidos y su secuenciación se basan en la evidencia empírica. De acuerdo con Grossen (2012) es necesario basar las estrategias a utilizar en la capacitación en resultados de estudios controlados pues ello permite seleccionar sólo aquellas que han demostrado ser mejores que otras opciones y esto hace que el cuerpo de conocimientos se fortalezca y se afine al incorporar resultados de investigaciones previas a nuevas investigaciones.

Otra ventaja de este paquete es que retoma la experiencia de los (las) usuarios(as) y ello hace que, como ya se mencionó, exista una base sólida sobre la cual construir el nuevo conocimiento (Vega, 2006) y más probable el aprendizaje significativo, ya que docentes, madres y padres pueden encontrar mayor sentido y utilidad a las estrategias compartidas. Esta práctica también propicia la reflexión sobre el propio desempeño.

Por otra parte, la colaboración que se dio entre las y los receptores del programa y las tutoras es otra de las estrategias de enseñanza que resultó útil pues como lo enfatizan Parrilla (1996) Panitz (1996) y Zañartu (2002) el compartir experiencias, valorando lo que cada uno aporta, establecer objetivos comunes, y la responsabilidad compartida de las acciones para lograrlos, propicia el control del aprendizaje y la construcción conjunta del mismo por todos los participantes (madres, padres, maestras y tutoras).

Otra bondad del programa, que se considera parte indispensable y fundamental del mismo, es el acompañamiento instruccional, el cual consiste en proporcionar apoyo y retroalimentación al momento en que las y los aprendices despliegan las habilidades recién adquiridas en actividades auténticas o de la vida cotidiana. El acompañamiento propicia la reflexión sobre el propio desempeño, la autorregulación del aprendizaje y la generalización a actividades y escenarios reales en los que se desempeñan las personas (Skiffington, Washburn y Elliott, 2011; Gómez, 2012; Luna, Vega y Poncelis, 2016; Vega-Pérez y Pérez- Estrada, 2016). 
El uso de materiales multimedia también constituye una ventaja, ya que permite la interacción del participante con los materiales, debido a su versatilidad, y a que la información llega por diferentes canales y propicia también que el (la) participante pueda regresar una y otra vez a realizar su revisión, en caso de que considere que su comprensión no ha sido adecuada, por lo que además este tipo de materiales permite que el usuario reflexione sobre su propio desempeño y autorregule su aprendizaje (López, 1998; Warschauer y Healey, 1998; Kamil, Intrator y Kim, 2000; Vega y Poncelis, 2010; Behjat, Yamini y Sadegh, 2012).

El presentar los materiales en línea conlleva ventajas adicionales: Ello facilitó una gestión más dinámica del paquete de capacitación, y un mayor acceso al mismo, así como una reducción de los costos de su implementación (Brown, 2001; Bell \& Kozlowski, 2002) y mayor oportunidad de interacción entre usuarios(as) y capacitadores(as), facilitando el aprendizaje colaborativo (Bell y Kozlowski, 2007). Autores como DeRouin, Fritzsche, y Salas (2004) mencionan que otra ventaja del e-learning consiste en que el usuario tiene mayor control sobre su aprendizaje, lo cual se pudo evidenciar claramente ya que los y las participantes fueron capaces de reflexionar sobre su nivel de desempeño a lo largo del programa y trasladar el resultado de esta reflexión a la autoevaluación que realizaron mediante la lista cotejable, la cual fue confiable, en virtud de que coincidió con la evaluación realizada por las tutoras del programa.

Dentro de los recursos del programa en línea, los foros resultaron de gran utilidad ya que permitieron que los y las aprendices compartieran sus experiencias y se retroalimentaran mutuamente. Autores como Riley, San Juan, Klinkner y Ramminger (2008) mencionan que el aprendizaje que se desarrolla entre pares tiene características diferentes al que se desarrolla, en este caso entre capacitadores y capacitados, ya que los pares, al encontrarse en el mismo nivel de desarrollo, se generan entre sí conflictos cognoscitivos que conducen al aprendizaje de habilidades diferentes y de diferente manera que el que se da entre expertos y novatos.

La aplicación del paquete en línea también proporcionó elementos para identificar aquellos aspectos del programa y la plataforma que no eran lo suficientemente claros o manejables y que será necesario modificar para contar con la versión final, ya validada, del mismo.

Por todo lo anterior, se considera que este paquete puede constituir una herramienta útil para la capacitación de profesionales y padres/madres, así como para la promoción de la alfabetización emergente en niños y niñas preescolares.

\section{Referencias}

Arnau, J. (1984). Diseños experimentales en psicología y educación. Vol II. México, Trillas.

Bean, R.M. y Morewood, A. (2007). Best Practices in Professional Development for Improving Literacy Instruction. En: L. B. Gambrell, L.M. Morrow, y M. Pressley (Eds.). Best Practices in Literacy Instruction, 3ra ed., (pp. 373-394). New York: Guilford Press. 
Behjat, F., Yamini, M. y Sadegh, M. (2012). Blended Learning: A Ubiquitous Learning Environment for Reading Comprehension. International Journal of English Linguistics. 2 (1), 97-106.

Bell, B. S. y Kozlowski, S. W. J. (2002). Adaptive Guidance Enhancing Self-Regulation, Knowledge, and Performance in Technology- Based Training. Personnel Psychology, 55, 267-306.

Bell, B. S., Kozlowski, S. W. J. (2007). Advances in technology-based training [Versión electrónica]. En S. Werner (Ed.), Managing human resources in North America (pp. 27-43). Abingdon, UK: Routledge. Disponible en: https://digitalcommons.ilr.cornell.edu/cgi/viewcontent.cgi?referer=https://www.google.com/\&httpsredir=1\&article $=1422 \&$ context=articles. Recuperado el 6 de agosto de 2014

Brown, K. G. (2001). Using Computers to Deliver Training: Which Employees Learn and Why? Personnel Psychology, 54(2), 271-296.)

Darling-Hammond, L., y Richardson, N. (2009). Teacher Learning: What Matters? Educational Leadership, 66(5),46-53.

DeRouin, R., Fritzche, B., Salas, E. (205). E Learning in organizations. Journal of Management. 31, (6). 920-940.

Gómez, L. (2012). Acompañamiento. Una herramienta de enseñanza-aprendizaje para personas adultas. (Tesis de maestría inédita). Universidad Nacional Autónoma de México, Facultad de Psicología, México, UNAM

Grossen, B. (2012) what does it mean to be a research-based profession? Disponible en http://personalweb.donet.com/ eprice/resprf.htm. Recuperado el 30 de julio de 2014.

Guevara, Y. y Rugerio, J. P. (2014) Programa para promover prácticas alfabetizadoras de preescolar en escuelas de nivel sociocultural bajo. Journal of Behavior, Health, \& Social Issues, 6(1), 23-36.

Hoffman, J. y Pearson, P. D. (2000). Reading teacher education in the next millennium: What your grandmother's teacher didn't know that your granddaughter's teacher should. Reading Research Quarterly, 35(1), 28-44.

Kamil, M. L., Intrator, S. M. y Kim, H. (2000) The effects of other Technologies on literacy and literacy learning. En M. L. Kamil, P. B. Mosenthal, P. D. Pearson, \& R. Barr (Eds.). Handbook of Reading Research (Vol III, pp. 771 - 788). Mahwah, NJ: Lawrence Erlbaum Associates.

Knight, J. (2009). Coaching: The key to translating research into practice lies in continuous, job-embedded learning with ongoing support. Journal of Staff Development, 30(1), 18-22.

Justice, L. M. Kaderavek, J. (2002). Using shared storybooks to promote emergent literacy. Council for Exceptional Children, 34 (4), 8-14. 
López, A. (Coord.) (1998). Enciclopedia de informática y computación. Tomo III multimedia. Madrid: Cultural.

Luna, M.L., Vega, L. y Poncelis, M.F. (2016). La promoción del desarrollo del lenguaje en niños preescolares por medio de un proceso de acompañamiento a la docente. En: J. L. Costa (Ed.) Psicología y educación: Presente y futuro(pp. 407- 414). Madrid: Asociación Científica de Psicología y Educación.

Panitz, T. (1996). A definition of collaborative vs cooperative training. Recuperado de: http://colccti.colfinder.org/sites/default/files/a_definition_of_collaborative_vs_ cooperative_learning.pdf

Parrilla, A. (1996). Apoyo a la escuela: un proceso de colaboración. España: Mensajero.

Peña, E. D. y Quinn, R. (2003). Developing an effective collaboration team in speech language pathology. A case study. Communication Disorders Quarterly, 24 (2), 53-63.

Riley, D., San Juan, R., Klinkner,J., Ramminger, A. (2008). Social and emotional development. St. Paul Minn: Redleaf Press.

Skiffington,S., Washburn, S. y Elliott, K. (2011). Instructional coaching. Helping Preschool teachers reach their full potential. Young Children (66)3, 12-19

Teale, W. H. \& Sulzby, E. (Eds.) (1986) Emergent Literacy: Writing and reading (pp. 50- 89). Norwood, NJ: Ablex.

Vega, L. (2006) Los años preescolares. Su importancia para desarrollar la competencia lectora y el gusto por la lectura. En: L. Vega, S. Macotela, I. Seda \& H. Paredes (Eds.) Alfabetización: Retos y perspectivas. México: Fac. de Psicología, UNAM.

Vega, L. (2013). La colaboración entre profesionales para la promoción del desarrollo y bienestar infantil. En: I. Seda \& R. Pastor (Eds.) Perspectivas múltiples en el cuidado y bienestar infantil: Investigación, teoría y práctica fundamentada. México: Facultad de Psicología, UNAM.

Vega-Perez L., Perez-Estrada G (2016). Collaboration between teachers and psychologists to promote oral language development in toddlers. Ponencia presentada en la Reunión Anual 2016 de la American Educational Research Association (AERA). 8 al 12 de abril Washington, D.C. http://www.aera.net/repository.

Vega, L., Montes de Oca, M.A, Poncelis, F., Guarneros, E y Pérez, G., (2014). Capacitación a docentes para la promoción de la alfabetización emergente en niños preescolares. Proyecto PAPIIT IT 300514. México: DGAPA UNAM.

Vega, L. y Poncelis, M. (2010) Estrategias para la promoción de la comprensión del lenguaje oral y el conocimiento de las características del lenguaje escrito para niños preescolares. [Manual multimedia]. Proyecto PAPIIT IN 304608. México: DGAPA y Fac. de Psicología, UNAM.

Warschauer, M., y Healey, D. (1998). Computers and language learning: An overview. Language Teaching, (31), 57-71. 


\section{Dificultades del Alumnado Universitario y Medios para el Desarrollo de la Evaluación Durante el Covid-19}

\section{Lorenzo-Lledó, Alejandro}

Universidad de Alicante alejandro.lorenzo@ua.es

\section{Lledó Carreres, Asunción}

Universidad de Alicante

asuncion.lledo@ua.es

\section{Pérez-Vázquez, Elena}

Universidad de Alicante elena.pv@ua.es

\section{Antón Ros, Núria}

Universidad de Alicante

nuria.anton@ua.es 


\title{
DIFICULTADES DEL ALUMNADO UNIVERSITARIO Y MEDIOS PARA EL DESARROLLO DE LA EVALUACIÓN DURANTE EL COVID-19
}

\author{
Lorenzo-Lledó, Alejandro \\ Lledó Carreres, Asunción \\ Pérez-Vázquez, Elena \\ Antón Ros, Núria
}

\section{Resumen}

En la actualidad se afronta una crisis provocada por el virus SARS-CoV-2 (COVID-19), declarada por la OMS como pandemia mundial. Esta situación sobrevenida ha afectado a todos los ámbitos de la sociedad, entre ellos, el universitario. En este sentido, la enseñanza universitaria ha pasado de ser presencial a ser, en su mayoría, online con diferentes modalidades para su implementación. A partir de esta situación, se ha planteado como objetivo general conocer el desarrollo del proceso de enseñanza-aprendizaje en la docencia universitaria en el contexto de la COVID-19. Para ello se ha adoptado un enfoque cuantitativo con diseño no experimental y transversal. Para la recogida de datos se diseñó ad hoc un cuestionario, que fue cumplimentado por una muestra participante de 367 estudiantes de los Grados de Maestro de la Universidad de Alicante durante el curso 2020/2021. Los resultados han constatado que el 70,8\% del alumnado ha encontrado dificultades para seguir la enseñanza no presencial. En este sentido, se han detectado dificultades de falta de motivación para seguir las clases o problemas de conexión al aula virtual. Asimismo, se constatado el paso a la evaluación a través de pruebas escritas online y prácticas grupales online. A modo de conclusión, cabe afirmar que el cambio de modalidad de enseñanza ha incidido sustancialmente en los aprendizajes, debiendo ser objeto de mejoras permanentes.

\section{Palabras clave}

COVID-19, educación universitaria, enseñanza online, dificultades, evaluación. 


\section{Introducción}

En la actualidad se afronta una crisis provocada por el virus SARS-CoV-2 (COVID-19), declarada por la OMS como pandemia mundial. Esta situación ha afectado a la totalidad de sectores de la sociedad (Monzón, 2020), y en el ámbito educativo, según un informe de la ONU (2020), el 94\% de los centros educativos sufrieron sus efectos. En este sentido, el mayor cambio ha venido dado por la imposibilidad de seguir con la modalidad presencial de las clases, pues, las medidas restrictivas para evitar la propagación del virus alteraron la impartición normal de las clases de manera sincrónica con todo el alumnado presente de manera física en el aula.

La pandemia cambió el escenario educativo y, como indica Porlán (2020), obligó a una rápida adaptación de la comunidad educativa a unas nuevas condiciones de enseñanza y aprendizaje. Esta situación sobrevenida de tanta gravedad ha afectado a todos los niveles educativos, entre ellos, el universitario. La materialización oficial de esta nueva situación se reflejó en España con la publicación del Real Decreto 463/2020, de 14 de marzo, que estableció la paralización de la enseñanza presencial en todos los niveles educativos, tanto universitarios como no universitarios. En este sentido, se originó un cambio drástico y, tal como indican Ferro et al. (2021), supuso la obligada adaptación de todos los académicos, personal de administración y funcionarios a una modalidad de enseñanza virtual que tuviera similitud con la presencialidad del estudiante.

En el contexto universitario de manera específica se sustituyeron con celeridad los entornos de aprendizaje presenciales por entornos no presenciales a través de aulas virtuales $\mathrm{y}$, de este modo, se estableció una modalidad de aprendizajes con actividades síncronas y asíncronas (Flores et al., 2020). Por lo tanto, se impone un aprendizaje caracterizado como híbrido, semipresencial o combinado (Alvarado, 2020). Este escenario implantado se ha caracterizado como una enseñanza remota de emergencia (Hodges et al., 2020), diferenciándose entre la educación a distancia, que se planifican y diseñan experiencias de enseñanza y aprendizaje online y esta educación emergente con mediación tecnológica, donde no hubo tiempo a realizar la planificación (Zubillaga y Gortazar, 2020). Cabe recordar que la Red Española de Agencias de Calidad Universitaria (REACU, 2020 estableció la siguiente diferenciación terminológica para la Educación superior:

- Presencial: Face to face teaching.

- A distancia: Print-based; Video/audio conferencing; Online (Synchronous/ Asyncrhonous).

- Semipresencial: Blended/hybrid progammes.

En la situación de pandemia cobran protagonismo las plataformas digitales que las universidades tienen que crear para llevar a cabo este aprendizaje no presencial u online. Asimismo, se hace uso de una serie de plataformas como Google Meet, Microsoft Teams, Zoom o Skype Empresarial, que pasan a ser recursos necesarios y habituales en todas las universidades para hacer posible la docencia (García-Peñalvo y Corell, 2020).

A pesar de que las instituciones universitarias ya disponían de plataformas virtuales, pero no con la finalidad de impartición de docencia, se han tenido que definir 
una serie de pautas para la utilización de las plataformas de aprendizaje en línea o campus virtuales, de manera que se garantice el efectivo aprendizaje de los estudiantes a distancia. Esta enseñanza a distancia se ha manifestado a través de diferentes modalidades, totalmente online o bien mixta o híbrida. En este sentido, la enseñanza híbrida se caracteriza por ser una instrucción online y presencial con tecnologías (Graham, 2006) o, en otras palabras, una opción presencial y no presencial que se puede realizar de modo sincrónico y asincrónico (Osorio y Duart, 2011). Por tanto, este aprendizaje híbrido, semipresencial o combinado, comparte elementos de las clases presenciales con apoyo de plataformas digitales para el aprendizaje (Alvarado, 2020).

Esta realidad de los escenarios de aprendizaje online implantados ha afectado a los diversos aspectos del proceso de enseñanza-aprendizaje, acelerándose el proceso de transformación digital. A los posibles problemas originados por la brecha digital, se suman las exigencias de formación tanto para el profesorado como para el alumnado ante los escenarios educativos no presenciales. De este modo, la celeridad en el paso de una enseñanza presencial a una virtual y la requerida adecuación de la docencia ha provocado una nueva planificación de las asignaturas y de los exámenes acordes a los espacios generados de la universidad (García-Planas y Taberna, 2020).

Uno de los elementos del proceso de enseñanza y aprendizaje que más interés y reflexión ha generado dentro de la comunidad educativa y científica ha sido la evaluación. El Espacio Europeo de Educación Superior (EEES, 2010) potencia una evaluación continua, con distribución igualitaria entre los conocimientos teóricos y los conocimientos prácticos, que hace pertinente conocer los medios utilizados y las estrategias aplicadas durante la pandemia por COVID-19 para la evaluación de los aprendizajes.

En la Universidad de Alicante (2020, España) se ha implementado la enseñanza híbrida, identificada como una docencia dual en la que el profesorado imparte la docencia de manera presencial en el aula y el alumnado dispone de una planificación que le permite optar por la semipresencialidad o por el aprendizaje enteramente online. Para ello, desde la plataforma virtual de UACloud se ha habilitado un aula virtual a la que accede tanto el profesorado como el alumnado y que supone el punto de encuentro virtual en el cual se desarrollan las clases. Este tipo de enseñanza sobrevenida ha supuesto una serie de nuevos escenarios educativos, tanto para los docentes como para el alumnado, referidos a los procesos de enseñanza y aprendizaje, con especial relevancia en la adaptación de los contenidos a los espacios virtuales, recursos y materiales, la metodología adaptada a un escenario no presencial y la evaluación de los aprendizajes en la modalidad online.

Como señaló la UNESCO IESALC (2020), este nuevo escenario educativo con el cambio de modalidad de enseñanza no ha sido recibido muy positivamente, ya que los contenidos que se ofrecen no fueron diseñados como una educación superior a distancia, sino que más bien se trató de paliar, sin una mayor preparación previa, la ausencia de clases presenciales con clases virtuales. En este sentido, al mismo ritmo que sucedían los cambios ocasionados por la pandemia, han ido surgiendo numerosos estudios (Cueva y Terrones, 2020; Fardoun et. al, 2020; Gil-Villa et al., 2020; García Aretio, 2021; Grande-de-Prado et al., 2021) que han abordado los nuevos escenarios educativos creados y las dificultades experimentadas con la finalidad de extraer indicadores de cambio de las estrategias y prácticas docentes que propicien una enseñanza más personalizada y se satisfagan las necesidades del estudiantado en cada materia. 
Por consiguiente, la implementación de este modelo de enseñanza no presencial no ha estado exenta de dificultades, que hace recomendable investigar sobre el proceso de enseñanza-aprendizaje desarrollado. En este sentido, el presente estudio se plantea como objetivo general conocer el desarrollo del proceso de enseñanza-aprendizaje en la docencia universitaria en el contexto de la COVID-19. De este objetivo general se derivan los siguientes objetivos específicos:

1. Identificar las dificultades experimentadas por el alumnado para el seguimiento de la enseñanza online.

2. Conocer las dificultades experimentadas por el alumnado en la enseñanza online.

3. Conocer los medios utilizados por el profesorado para la evaluación de los aprendizajes en la enseñanza online.

\section{Método}

Para el presente estudio se ha adoptado un enfoque metodológico cuantitativo con un diseño no experimental y transversal.

\section{Descripción de los participantes}

La muestra de participantes se ha seleccionado mediante una técnica de muestreo no probabilística por conveniencia y se ha conformado por 367 estudiantes de la Universidad de Alicante, de los cuales el 59,4\% pertenecían al Grado de Maestro en Educación Infantil y el 40,6\% al Grado de Maestro en Educación Primaria. Por su parte, el 36,2\% de los participantes eran de primer curso, el 36,2\% de segundo curso, el $24 \%$ de tercer curso y el $3,5 \%$ de cuarto curso.

\section{Instrumento}

Tomando como punto de partida la producción científica sobre la temática abordada, se procedió a diseñar un cuestionario ad hoc. Este cuestionario está estructurado en varias partes y secciones, siendo los 5 primeros ítems para la identificación de la muestra y los 3 ítems siguientes para las dificultades en la docencia no presencial. Posteriormente, se incluyen 15 ítems en una escala Likert, distribuidos en tres dimensiones referidas a las metodologías para aprender en la enseñanza universitaria en tiempos de COVID-19, los recursos utilizados y la evaluación desarrollada. Por último, se incluyen 8 preguntas a modo de conclusión sobre las percepciones sobre la enseñanza recibida.

\section{Procedimiento}

La recogida de información se llevó a cabo de forma online a través de Google Forms durante el curso 2020/2021, pudiéndose acceder tanto al alumnado que estaba presente en las aulas, como el que se encontraba fuera de ellas. Se obtuvo el consentimiento del alumnado tras informarle de los objetivos de la investigación y de que su participación era voluntaria. También se comunicó que los datos obtenidos serían confidenciales y que sólo se utilizarían para los objetivos del estudio. 
Asimismo, una vez planificado e implementado el procedimiento de recogida de datos se procedió al análisis de los datos obtenidos mediante el paquete estadístico SPSS 22. En este sentido, se analizaron los estadísticos descriptivos con frecuencias, porcentajes, medias y desviaciones típicas.

\section{Resultados}

A continuación, se presentan los resultados obtenidos en función de las variables cuantificadas y de los objetivos propuestos.

\section{Presencia de dificultades del alumnado en la enseñanza online}

Seguidamente, en la figura 1, se presentan los resultados relativos a la existencia de dificultades experimentadas por el alumnado para seguir la enseñanza online.

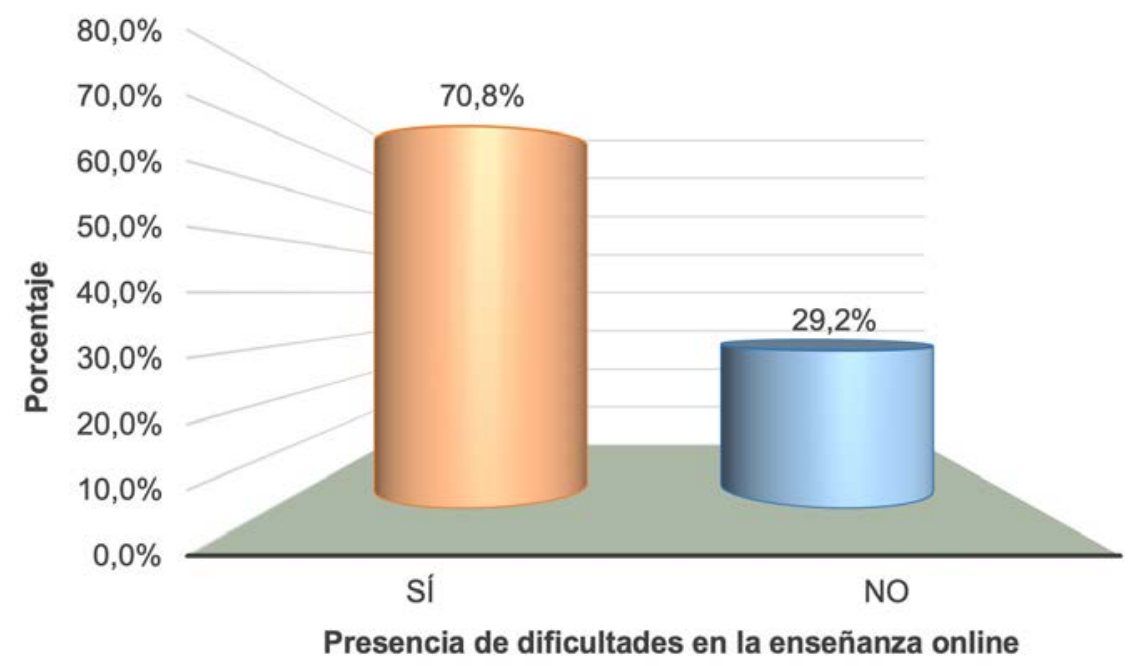

Figura 1. Porcentajes de la presencia de dificultades experimentadas en la enseñanza online

Como se puede observar, los resultados muestran un porcentaje elevado de alumnado $(70,8 \%)$ que ha experimentado dificultades durante la enseñanza online.

En relación con el grado de dificultad experimentado, se presenta la figura 2. 


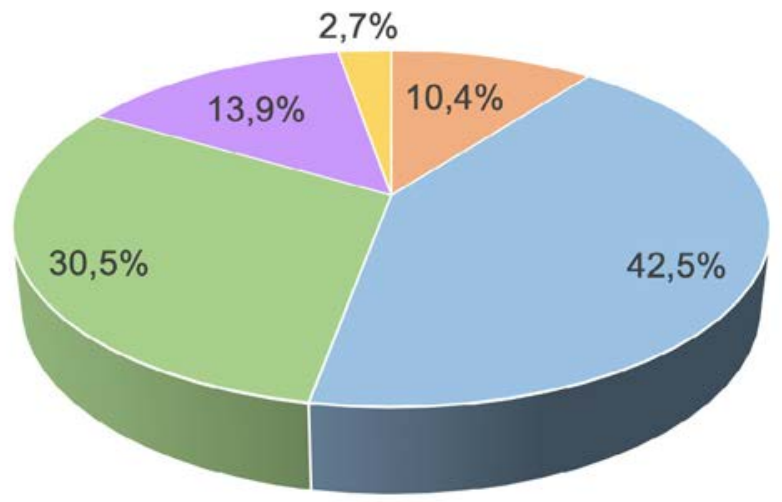

" Nada difícil " Poco difícil " Moderadamente difícil " Bastante difícil = Muy difícil

Los resultados obtenidos muestran que al $42,5 \%$ del alumnado le ha supuesto poca dificultad la adaptación a la nueva modalidad de docencia y al 30,5\% una moderada dificultad.

\section{Dificultades experimentadas por el alumnado en la enseñanza online}

En la tabla 1 se muestran las diferentes dificultades encontradas por el alumnado durante la enseñanza universitaria en tiempos de COVID-19 en función de las respuestas obtenidas con elección múltiple.

\begin{tabular}{|l|l|l|}
\hline Dificultades en la enseñanza online & $\mathbf{f}$ \\
\hline Medios tecnológicos personales inapropiados. & 34 & 1,7 \\
Problemas de conexión con el aula. & 220 & 10,8 \\
Falta de coordinación con las clases presenciales y las online. & 142 & 7,0 \\
Falta de interacción con los compañeros/as. & 177 & 8,7 \\
Falta de interacción con el profesorado. & 197 & 9,7 \\
Los problemas de conexión con otras plataformas: Meet, Zoom, etc. & 89 & 4,4 \\
La gestión del tiempo para el estudio. & 99 & 4,9 \\
La falta de guía y orientación por parte del profesorado. & 126 & 6,2 \\
Sensación de soledad en el aprendizaje. & 193 & 9,5 \\
Falta de motivación para seguir las clases. & 228 & 11,2 \\
La falta de preparación de profesorado. & 2 & 0,1 \\
No poder concentrarme al estar en casa. & 157 & 7,7 \\
Profesores no capaces de gestionar aulas virtuales. & 10 & 0,5 \\
Una carga desmedida de trabajo. & 216 & 10,6 \\
Dificultades de comprensión al no poder interactuar con el profesor. & 143 & $\mathbf{7 , 0}$ \\
\hline Total & $\mathbf{2 0 3 3}$ & $\mathbf{1 0 0 , 0}$ \\
\hline
\end{tabular}


Los resultados obtenidos muestran que el porcentaje más elevado de alumnado (11,2\%) experimentó la falta de motivación para seguir las clases, seguido del 10,8\% que tuvo problemas de conexión en el aula virtual. Asimismo, se experimentaron dificultades por problemas de conexión con el aula $(10,8 \%)$ y la carga excesiva de trabajo en esta nueva modalidad de enseñanza (10,6\%). En menor porcentaje, también se experimentó falta de interacción con el profesorado $(9,7 \%)$, sensación de soledad en el aprendizaje (9,5\%) o falta de interacción con los compañeros (8,7\%). Los porcentajes más bajos de alumnado experimentaron dificultades relacionadas con la falta de capacidad del profesorado para gestionar aulas virtuales $(0,5 \%)$ o con la falta de preparación del profesorado $(0,1 \%)$.

\section{Medios utilizados por el profesorado para la evaluación de los aprendizajes}

En relación con los resultados obtenidos sobre los medios utilizados por el profesorado para evaluar los contenidos teóricos, se presenta la tabla 2:

\begin{tabular}{|c|c|c|c|c|c|c|c|c|c|c|c|c|}
\hline $\begin{array}{l}\text { Medios utilizados en } \\
\text { la evaluación de los }\end{array}$ & & & & & & JF & & & & & & \\
\hline & f & $\%$ & f & $\%$ & f & $\%$ & f & $\%$ & f & $\%$ & M & DT \\
\hline Pruebas escritas online. & 38 & 10,4 & 64 & 17,4 & 88 & 24,0 & 74 & 20,0 & 103 & 28,1 & 3,38 & 1,33 \\
\hline $\begin{array}{l}\text { Pruebas escritas } \\
\text { presenciales. }\end{array}$ & 265 & 72,2 & 63 & 17,2 & 26 & 7,1 & 5 & 1,4 & 8 & 2,2 & 1,44 & 0,85 \\
\hline $\begin{array}{l}\text { Resolución de problemas } \\
\text { online. }\end{array}$ & 33 & 9,0 & 65 & 17,7 & 112 & 30,5 & 102 & 27,8 & 55 & 15,0 & 3,22 & 1,17 \\
\hline $\begin{array}{l}\text { Preguntas de evaluación } \\
\text { en clase. }\end{array}$ & 84 & 22,9 & 99 & 27,0 & 111 & 30,2 & 54 & 14,7 & 19 & 5,2 & 2,52 & 1,14 \\
\hline $\begin{array}{l}\text { Simulacros de examen en } \\
\text { clase. }\end{array}$ & 106 & 28,9 & 126 & 34,3 & 74 & 20,2 & 40 & 10,9 & 21 & 5,7 & 2,30 & 1,16 \\
\hline
\end{tabular}

Nota: $\mathrm{NF}=$ nada frecuente; $\mathrm{PF}=$ poco frecuente; $\mathrm{MOF}=$ moderadamente frecuente; $\mathrm{BF}=$ bas-

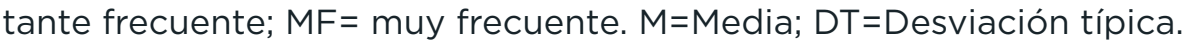

Tabla 2. Grados de frecuencia de uso de los medios para la evaluación de los contenidos teóricos

Los resultados obtenidos reflejan que el 48,1\% del alumnado ha sido evaluado en los contenidos teóricos de manera bastante frecuente y muy frecuente con pruebas escritas online, siendo la media más alta $(3,38)$. Por otro lado, se ha evaluado al $42,2 \%$ del alumnado con bastante frecuencia y mucha frecuencia a través la resolución de problemas online $(M=3,22)$. Asimismo, se han usado las preguntas en clase para evaluar con bastante frecuencia y mucha frecuencia al 19,9\% del estudiantado. En contraposición, los simulacros de examen en clase y las preguntas escritas presenciales han sido los medios menos usados con medias de 2,30 y 1,44 , respectivamente.

Por lo que respecta a los medios utilizados por el profesorado para evaluar contenidos prácticos, a continuación, se presentan los resultados en la tabla 3. 


\begin{tabular}{|c|c|c|c|c|c|c|c|c|c|c|c|c|}
\hline \multirow{2}{*}{$\begin{array}{l}\text { Medios utilizados en } \\
\text { la evaluación de los } \\
\text { contenidos prácticos. }\end{array}$} & \multicolumn{2}{|c|}{ NF } & \multicolumn{2}{|c|}{ PF } & \multicolumn{2}{|c|}{ MOF } & \multicolumn{2}{|c|}{ BF } & \multicolumn{2}{|c|}{ MF } & & \\
\hline & $f$ & $\%$ & $f$ & $\%$ & $f$ & $\%$ & $f$ & $\%$ & f & $\%$ & $M$ & DT \\
\hline $\begin{array}{l}\text { Prácticas grupales } \\
\text { online. }\end{array}$ & 3 & 0,8 & 7 & 1,9 & 25 & 6,8 & 69 & 18,8 & 263 & 71,7 & 4,58 & 0,77 \\
\hline $\begin{array}{l}\text { Prácticas individuales } \\
\text { online. }\end{array}$ & 21 & 5,7 & 96 & 26,2 & 104 & 28,3 & 77 & 21,0 & 69 & 18,8 & 3,20 & 1,18 \\
\hline $\begin{array}{l}\text { Resolución común } \\
\text { entre toda la clase de } \\
\text { supuestos prácticos. }\end{array}$ & 53 & 14,4 & 120 & 32,7 & 117 & 31,9 & 46 & 12,5 & 31 & 8,4 & 2,67 & 1,12 \\
\hline $\begin{array}{l}\text { Prácticas no evaluables, } \\
\text { pero sí formativas. }\end{array}$ & 69 & 18,8 & 142 & 38,7 & 103 & 28,1 & 32 & 8,7 & 21 & 5,7 & 2,43 & 1,06 \\
\hline
\end{tabular}

Nota: $N F=$ nada frecuente; $\mathrm{PF}=$ poco frecuente; $\mathrm{MOF}=$ moderadamente frecuente; $\mathrm{BF}=$ bastante frecuente; MF= muy frecuente. M=Media; DT=Desviación típica.

Tabla 3. Grados de frecuencia de los medios utilizados en la evaluación de los contenidos prácticos

Como se puede observar, el alumnado fue evaluado de los contenidos prácticas en un $71,7 \%$ a través de prácticas grupales online, llegando la media a 4,58. Asimismo, el $39,8 \%$ del alumnado fue evaluado con bastante frecuencia y mucha frecuencia a través de prácticas online $(M=3,20)$. Con medias inferiores a 2 se encuentran la resolución común de supuestos prácticos y las prácticas no evaluables, pero sí formativas. En este sentido, con poca frecuencia, el 32,7\% del estudiantado fue evaluado con la resolución entre toda la clase de supuestos prácticos y el $38,7 \%$ a través de prácticas no evaluables, pero sí formativas.

Por lo que respecta a los medios utilizados para el control de asistencia a las clases, se presenta la tabla 4 con los resultados obtenidos.

\begin{tabular}{|c|c|c|c|c|c|c|c|c|c|c|c|c|}
\hline \multirow[t]{2}{*}{$\begin{array}{l}\text { Medios utilizados para el } \\
\text { control de la asistencia a clase }\end{array}$} & \multicolumn{2}{|c|}{ NF } & \multicolumn{2}{|c|}{ PF } & \multicolumn{2}{|c|}{ MOF } & \multicolumn{2}{|c|}{ BF } & \multicolumn{2}{|c|}{ MF } & & \\
\hline & $f$ & $\%$ & $f$ & $\%$ & f & $\%$ & $f$ & $\%$ & f & $\%$ & M & DT \\
\hline $\begin{array}{l}\text { Pasando lista y } \\
\text { preguntando al alumnado } \\
\text { en el aula virtual. }\end{array}$ & 53 & 14,4 & 82 & 22,3 & 88 & 24,0 & 77 & 21,0 & 67 & 18,3 & 3,06 & 1,31 \\
\hline $\begin{array}{l}\text { Comprobando si el } \\
\text { alumnado está conectado } \\
\text { al aula virtual de la } \\
\text { Universidad de Alicante. }\end{array}$ & 21 & 5,7 & 57 & 15,5 & 83 & 22,6 & 116 & 31,6 & 90 & 24,5 & 3,53 & 1,18 \\
\hline $\begin{array}{l}\text { Comprobando el trabajo del } \\
\text { alumnado en plataformas } \\
\text { externas al aula virtual de la } \\
\text { Universidad de Alicante. }\end{array}$ & 63 & 17,2 & 93 & 25,3 & 101 & 27,5 & 70 & 19,1 & 40 & 10,9 & 2,81 & 1,23 \\
\hline $\begin{array}{l}\text { El profesorado no ha hecho } \\
\text { control de asistencia. }\end{array}$ & 97 & 26,4 & 131 & 35,7 & 83 & 22,6 & 30 & 8,2 & 26 & 7,1 & 2,33 & 1,15 \\
\hline
\end{tabular}

Nota: $N F=$ nada frecuente; $\mathrm{PF}=$ poco frecuente; $\mathrm{MOF}=$ moderadamente frecuente; $\mathrm{BF}=$

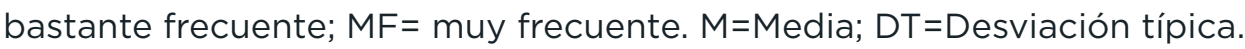


Como se puede observar, el medio de control de asistencia a las clases con la media más alta $(3,53)$ es la comprobación de la conexión al aula virtual de la Universidad de Alicante, usándose con bastante y mucha frecuencia para el 56,1\% del estudiantado. También un medio notablemente usado para el mencionado propósito es pasar lista y preguntar al alumnado en el aula virtual con porcentajes de $21 \%$ y $18,3 \%$ en las categorías de bastante frecuente y muy frecuente, respectivamente. Por su parte, los resultados obtenidos reflejan que el profesorado ha utilizado la comprobación del trabajo realizado por el alumnado en plataformas externas al aula virtual de la Universidad de Alicante con bastante frecuencia y mucha frecuencia en un $30 \%$.

\section{Discusión y conclusiones}

El objetivo general del presente estudio ha sido identificar las dificultades encontradas y los medios de evaluación utilizados en la puesta en marcha del modelo de enseñanza online en la Universidad de Alicante en el curso 2020/2021 durante el COVID-19 desde la perspectiva de los estudiantes a través de un cuestionario. Ante una situación totalmente nueva y surgida de manera imprevista, los hallazgos han puesto de manifiesto que el estudiantado ha vivido una serie de dificultades en los procesos de enseñanza-aprendizaje desarrollados.

El alumnado universitario participante en el estudio ha experimentado en un porcentaje alto $(70,8 \%)$ dificultades para el seguimiento de la enseñanza online. En esta situación de pandemia mundial el alumnado universitario se está enfrentando a múltiples desafíos y de índole diversa, que pueden crear un clima de aprendizaje en desacuerdo a sus necesidades, tal como reflejan los resultados obtenidos. En esta línea, García (2021) apunta que las percepciones negativas por parte del estudiantado sobre la enseñanza durante el COVID-19 se debe a que la docencia a distancia se implementó sin planificar previamente diseños pedagógicos rigurosos y tampoco con docentes lo suficientemente capacitados. Este cambio brusco que ha originado formatos híbridos, a menudo confusos, dejando en muchos casos la presencialidad de las clases a elección a los estudiantes, ha terminado por afectar notablemente a la calidad del proceso de enseñanza-aprendizaje.

Por lo que respecta a las dificultades concretas que ha vivido el alumnado en el seguimiento de la enseñanza online, acorde con la mayoritaria percepción de dificultades en la adaptación, el 11,2\% del estudiantado tuvo falta de motivación para seguir las clases. En este sentido, este hallazgo puede deberse, como señalan Shafaq, et al (2021), a que el contexto de aprendizaje en línea ofrece un enfoque pedagógico distinto al aprendizaje cara a cara, implicando un ajuste y una mayor disposición a participar en una experiencia de aprendizaje eficaz. El mencionado autor añade que si se satisfacen las necesidades de los estudiantes se originaría de manera positiva un nexo entre el clima de aprendizaje y la motivación de los estudiantes.

Acorde con lo expuesto, las dificultades halladas en el estudio relativas a la falta de interacción con el profesorado y con los compañeros/as, contribuyen a los sentimientos de insatisfacción del alumnado en su experiencia de aprendizaje. En los hallazgos mencionados, cabe tener también presente, tal como indica García-Peñalvo (2020), que el grado mayor de flexibilidad y autonomía que la enseñanza no presencial ofrece al alumnado puede suponer un riesgo para el abandono, debido a la soledad que el alumnado puede llegar a sentir. En este sentido, y de manera coherente, 
se ha identificado que el 9,5\% del alumnado ha sentido sensación de soledad ante el aprendizaje y el 4,9\% le ha resultado difícil gestionar el tiempo en el estudio. Por su parte, Pérez-López et al. (2021) sostienen que la disminución de la comunicación y la sensación de soledad puede generar en la enseñanza no presencial el efecto de aislamiento y con ello conductas de desmotivación, tal como se ha reflejado en los resultados del presente estudio. Los autores mencionados anteriormente, en la misma línea de los resultados obtenidos relativos a una carga desmedida de trabajo en esta modalidad de docencia, constatan que un porcentaje elevado de alumnado del $75 \%$ considera que el formato online les ha exigido una dedicación mayor en comparación a las clases presenciales.

Si se atiende a las dificultades tecnológicas, el 10,8\% del alumnado ha sufrido problemas en relación con la conexión al aula virtual. Este hecho constatado, tal como apunta García-Peñalvo (2020), está vinculado con la infraestructura física, que debe cubrir necesidades de conectividad, servidores, espacio de almacenamiento y producción de contenidos audiovisuales, entre otros. A ello, está unido también la labor de los servicios de apoyo y mantenimiento que deben tener los estudiantes ante los posibles problemas en esta situación de cambio acelerado, que no ha permitido una transformación digital a todos los niveles. En la Universidad de Alicante se integró el aula virtual en la plataforma ya existente de Campus Virtual. Esta adaptación supuso un esfuerzo y una rápida formación, tanto para los docentes como para los estudiantes, que los resultados obtenidos han constatado que no ha estado exenta de dificultades en el ámbito tecnológico.

Por lo que respecta a los medios utilizados por el profesorado para la evaluación de los aprendizajes, se constata claramente el cambio a las pruebas escritas online, como manifiesta el porcentaje acumulado en las categorías de moderadamente frecuente, bastante frecuente y muy frecuente (72,1\%). Esto refleja que la evaluación durante el COVID-19 ha sido mayoritariamente en formato online de prueba escrita, siendo considerablemente menos frecuentes las pruebas escritas presenciales, los simulacros de las pruebas en clase y las preguntas de evaluación en las clases online. En este hecho cabe tener en cuenta que la evaluación es un elemento complejo en los procesos de enseñanza-aprendizaje y diverso en su aplicación, que debe ser objeto de una planificación rigurosa. De este modo, para la evaluación durante la situación de pandemia, se han difundido diversas recomendaciones. Prueba de ello, son las orientaciones dadas por la ANECA (2020), que ponen el énfasis en comunicar al alumnado todos los cambios referidos a la evaluación durante el COVID-19. Con esto se trata de garantizar la transparencia de los cambios en la transformación de la evaluación presencial en un sistema de evaluación no presencial, su difusión y la equidad de oportunidades para el estudiantado (Castells Oliván y Pingarrón Carrazón, 2020).

En el ámbito más concreto de cada universidad, las recomendaciones que estas emitieron de manera autónoma para llevar a cabo la evaluación online se plasmaron en las guías docentes de las diferentes asignaturas, de modo que se informaba al alumnado. Los resultados obtenidos han constatado que los medios más utilizados para el caso de los contenidos teóricos han sido las pruebas escritas online y la resolución online de problemas, con porcentajes acumulados superiores al $72 \%$ de moderada, bastante y mucha frecuencia. Por su parte, en la evaluación de los contenidos prácticos se ha reproducido la misma evaluación que en la modalidad de clases presenciales, priorizando las prácticas grupales online (71,7\%), y menor porcentaje 
$(39,8 \%)$ las prácticas individuales. Esta evaluación ha sido continua y se ha realizado más frecuentemente a través de las herramientas propias de la plataforma de la Universidad de Alicante. Cabe añadir que la evaluación ha sido uno de los aspectos que más reticencia ha generado entre el profesorado por la cuestionable fiabilidad de las herramientas de evaluación para reflejar realmente el grado de consecución de los aprendizajes (Pérez-López et al., 2021).

A partir de los hallazgos obtenidos cabe afirmar que el estudio ha puesto de manifiesto que en el contexto universitario se ha abordado una situación sobrevenida que ha supuesto un cambio significativo en el aprendizaje de los estudiantes. En este sentido, en base a los resultados obtenidos y teniendo presente los objetivos propuestos se indican las siguientes conclusiones:

1. El alumnado ha experimentado mayoritariamente dificultades en la enseñanza no presencia, pero la dificultad en la adaptación ha sido poca o moderada.

2. Las dificultades experimentadas por el alumnado están referidas principalmente a la falta de motivación, los problemas de conexión con el aula y el exceso de trabajo.

3. En la evaluación, los medios más frecuentemente utilizados han sido los exámenes online, las prácticas grupales y el control de asistencia por la conexión al aula virtual.

El estudio presentado debe servir para un primer diagnóstico de la situación que se está viviendo en la universidad en tiempos de COVID-19 y debe llevar a reflexionar sobre las estrategias de enseñanza aplicadas. Una vez identificadas las dificultades y los medios de evaluación utilizados, se presenta la oportunidad de mejorar los nuevos escenarios educativos creados para satisfacer las necesidades del alumnado y la generación efectiva de los aprendizajes.

\section{Referencias}

Alvarado Nando, M. (2020). Una nueva forma de educar en educación superior. Desafíos para la continuidad. En Alvarado, Rosario y Robles, La pandemia de la COVID-19 como oportunidad para repensar la educación superior en México. Universidad de Guadalajara: México.

ANECA (2020). Estrategia de la ANECA para el aseguramiento de la calidad en la enseñanza virtual. Madrid: España https://bit.ly/2wVIVbX

Castells Oliván, M. y Pingarrón Carrazón, J. M. (2020). Recomendaciones sobre criterios generales para la adaptación del sistema universitario español ante la pandemia del Covid-19, durante el curso 2019-2020. Madrid, España: M. d. Universidades.

Cueva, M. A. L., y Terrones, S. A. C. (2020). Repercusiones de las clases virtuales en los estudiantes universitarios en el contexto de la cuarentena por covid-19: El caso de la PUCP. Propósitos y Representaciones, 8(SPE3), 588. 
Fardoun, H., González-González, C. S., Collazos, C. A., y Yousef, M. (2020). Estudio exploratorio en Iberoamérica sobre procesos de enseñanza-aprendizaje y propuesta de evaluación en tiempos de pandemia. Education in the Knowledge Society, 21, 17. doi:10.14201/eks.23437

Ferro, E. F., Gutiérrez, N., Añasco, N., González, M., Villafaña, L., Flores, P. G., y Cid, F. M. (2021). Satisfacción de las clases online de estudiantes de educación física de una universidad de chile en tiempos de pandemia. EmásF, Revista Digital de Educación Física, 12(69), 10-19.

Flores, K. N., González-Díaz, R. R., y Lobo, E. E. (2020). Estrategia alternativa para la resolución de conflictos en las redes sociales digitales. CIID Journal, 1(1), 103-113.

García Aretio, L. (2021). COVID-19 y educación a distancia digital: preconfinamiento, confinamiento y posconfinamiento. RIED. Revista Iberoamericana de Educación a Distancia, 24(1), 09-32. http://dx.doi.org/10.5944/ried.24.1.28080

García-Peñalvo, F. J., y Corell, A. (2020). La COVID-19: ¿enzima de la transformación digital de la docencia o reflejo de una crisis metodológica y competencial en la educación superior? Campus Virtuales, 9(2), 83-98.

García-Peñalvo, F J. (2020). Modelo de referencia para la enseñanza no presencial en universidades presenciales. Campus Virtuales, 9(1), 41-56.

García-Planas, M. I., \& Taberna Torres, J. (2020). The transition from the classroom to non-classroom teaching at the UPC during the COVID-19 pandemic. IJERI: International Journal of Educational Research and Innovation, 15(1), 177-187. https://doi. org/10.46661/ijeri.5015

Gil-Villa, F., Urchaga, J.D. y Sánchez-Fernández, A. (2020). Proceso de digitalización y adaptación a la enseñanza no presencial motivada por la pandemia de COVID-19: análisis de la percepción y repercusiones en la comunidad universitaria. Revista Latina de Comunicación Social, 78, 99-119.

Grande-de-Prado, M.; García-Peñalvo, f. J.; Corell Almuzara, A.; Abella-García, V. (2021). Evaluación en Educación Superior durante la pandemia de la CoVId-19. Campus Virtuales, 10(1), 49-58.

Hodges, Ch., Moore, S., Lockee, B., Trust, T., y Bond, A. (2020). The Difference Between Emergency Remote Teaching and Online Learning. Educause Review. https:// bit.ly/3dZIh6U

Monzón, N. S. (2020). Formación docente universitaria y crisis sanitaria COVID-19. CienciAmérica: Revista de divulgación científica de la Universidad Tecnológica Indoamérica, 9(2), 109-114.

ONU (2020). Policy Brief: The World of Work and COVID-19. United Nations: New York.

Osorio, L. A., \& Duart, J. M. (2011). Análisis de la interacción en ambientes híbridos de aprendizaje. Comunicar, 19(37), 65-72. https://doi.org/10.3916/C37-2011-02-06 
Pérez-López, E., Vázquez, A., y Cambero, S. (2021). Educación a distancia en tiempos de COVID-19: Análisis desde la perspectiva de los estudiantes universitarios RIED. Revista Iberoamericana de Educación a Distancia, 24 (1), 331-342.

Porlán, R. (2020). El cambio de la enseñanza y el aprendizaje en tiempos de pandemia. Revista de Educación Ambiental y Sostenibilidad, 2(1), 1502.

Shafaq, S., Ali, A., Memona, F., Ahman, A y Soomro, A. (2021). Aprendizaje en línea durante la pandemia de COVID-19: aplicación de la teoría de la autodeterminación en la 'nueva normalidad', Revista de Psicodidáctica 26, 169-178.

UNESCO IESALC (2020). Covid-19 y educación superior: de los efectos inmediatos al día después. Análisis de impactos, respuesta y recomendaciones. París, Francia: UNESCO. Recuperado de http://www.iesalc.unesco.org/wp-content/uploads/2020/04/ COVID-19-060420-ES-2.pdf

Zubillaga, A., y Gortazar, L. (2020). COVID-19 y educación: Problemas, respuestas y escenarios. Fundación COTEC para la innovación. https://bit.ly/2AtszSH 


\section{El Uso de los Blogs en la Educación Infantil en Tiempos de Pandemia. Análisis de su Uso y Función}

\section{Álvarez Herrero, Juan Francisco}

orcid.org/0000-0002-9988-8286

Universidad de Alicante

juanfran.alvarez@ua.es 


\title{
EL USO DE LOS BLOGS EN LA EDUCACIÓN INFANTIL EN TIEMPOS DE PANDEMIA. ANÁLISIS DE SU USO Y FUNCIÓN
}

\author{
Álvarez Herrero, Juan Francisco \\ orcid.org/0000-0002-9988-8286 \\ Universidad de Alicante \\ juanfran.alvarez@ua.es
}

\section{Resumen}

A consecuencia de la pandemia de la COVID-19, a nivel mundial, se vivió un confinamiento domiciliario que en España se dio entre marzo y junio de 2020. Ello supuso en el contexto educativo pasar de una modalidad de enseñanza presencial a una modalidad online. Esta adaptación tuvo que realizarse en todos los niveles educativos, de infantil a universidad, con los agravantes y problemas que todo ello supuso. Para la Educación Infantil supuso un mayor reto dado que en estas edades, el alumnado crea una dependencia muy grande con el docente, y este se convierte en guía y acompañante en el proceso de enseñanza-aprendizaje y donde además la presencialidad, el contacto y la socialización se vuelven muy importantes. Uno de los recursos más utilizado por los docentes de infantil en este tiempo ha sido el blog educativo, y así, con la inestimable ayuda de las familias se hizo posible la continuidad de la acción docente. Ante esta situación, quisimos conocer que uso y función se dio a los blogs educativos de esta etapa, y al contar con un estudio de las mismas características y anterior a la pandemia, quisimos comparar si se daba una diferencia. Para ello, se analizaron 60 blogs educativos de Educación Infantil, y se comprobó que durante la pandemia se les dio un uso mayor que antes de la misma, y que básicamente la función que desempeñaron fue la de ser utilizados como recurso de aprendizaje para sus alumnos. Con todo ello, podemos afirmar que los blogs educativos han sido, en este tiempo de crisis, unos excelentes recursos que han facilitado el aprendizaje y acompañado a docentes, discentes y familias de Educación Infantil en estos tiempos de crisis pandémica.

\section{Palabras clave}

Educación Infantil, Blogs, COVID-19, Aprendizaje online, TIC. 


\section{Introducción}

La pandemia del coronavirus o de la COVID-19 como se la llama mundialmente, originó una profunda conmoción y paralización del mundo. En muchos lugares las primeras medidas que se tomaron para tratar de combatirla fueron la realización de unos confinamientos domiciliarios. En España este confinamiento se produjo, casi sin tiempo a su asimilación y preparación, entre marzo y junio de 2020 . Ello supuso que de forma repentina las escuelas e instituciones educativas de todas las etapas y niveles tuvieran que adaptar su tradicional modalidad de enseñanza presencial a una modalidad online (Trujillo-Sáez et al., 2020).

En la etapa de Educación Infantil esta situación de tener que dar continuidad a la educación del alumnado desde los domicilios y sin presencialidad, supuso un gran reto para los docentes de la etapa (Jacovkis y Tarabini, 2021). Precisamente en estas edades tan tempranas, los niños y niñas requieren y crean una dependencia continua de su maestro o maestra y esta relación con el docente, así como con la del resto de estudiantes de su clase, requiere del contacto, genera emociones y sensaciones que son imposibles que se den en la distancia y a través de una conexión que se produzca por videoconferencia o por teléfono, por no hablar del proceso de socialización que se empieza en esta etapa (Fernández-Ruiz, 2021). Además de todo esto, los docentes tuvieron que enfrentarse a toda la problemática que la propia pandemia originaba (situaciones difíciles en los domicilios, donde a la dramática situación sanitaria se le unía la laboral, social, cultural y económica, dando lugar a numerosos problemas de salud mental) (Hernández-Ortega y Álvarez-Herrero, 2021; Park et al., 2020), así como el ser capaces de transformar sus clases presenciales, a clases online donde su nivel de competencia digital iba a ponerse en juego. Una competencia digital docente que se suponía desarrollada ya que las tecnologías digitales habían dejado de ser, en los años anteriores a la pandemia, una prioridad entre las necesidades de formación manifestadas por los docentes (Álvarez-Herrero, 2020). Y a raíz de la pandemia y la comprobación de que esta competencia no la tenían bien desarrollada, surge de nuevo la necesidad de formarse en tecnologías digitales (Álvarez-Herrero y Hernández-Ortega, 2021; Saldaña, 2020).

Así, durante el confinamiento, los docentes de infantil tuvieron que echar mano de todo tipo de recursos y estrategias para llevar los aprendizajes a las casas de su alumnado, contando con la complicidad y la ayuda de las familias para hacerlo posible. Las tecnologías digitales con sus amplias posibilidades, sirvieron de excelente ayuda a los docentes. Aun así, ello no impidió que en algunos casos no hubiese una continuidad del proceso de enseñanza-aprendizaje y las clases se interrumpieron, incluso en algún caso durante todo el confinamiento (Fernández-Ruiz, 2021). En otros casos, hubo docentes que siguieron haciendo uso de recursos analógicos, y después de hacer fotocopias o acopio de fichas y otros materiales, bien hacían que las familias pasasen por los centros y las recogiesen, bien las hacían llegar a los domicilios del alumnado por otros medios. También se dio el caso de que hubo docentes que realizaron llamadas telefónicas con indicaciones a las familias de lo que podían o debían hacer con sus hijos (Malta y Fraga, 2021). Sin embargo, las opciones más utilizadas por los docentes de Educación Infantil, pasó por el uso de las tecnologías digitales (Casero y Sánchez, 2020; Dayal y Tiko, 2020; Muhdi et al., 2020)). Desde la opción más sencilla de mandar por correo electrónico material para que pudiesen trabajar en casa, a opciones más complejas en las que se hacía uso de todo tipo de recursos digitales como videoconferencias, juegos online, videos, aplicaciones, realidad aumentada o incluso robótica. Todo ello propició un mayor desarrollo de la 
competencia digital docente, viendo así los docentes que esta dramática situación también les reportó alguna ventaja (Fusté, 2021; García-Zabaleta et al., 2021).

Con todo ello, uno de los recursos que de siempre ha dado mucho juego en esta etapa educativa, es el uso de los blogs educativos (Caldeiro-Pedreira y Castro-Zubizarreta, 2019). Muchos docentes de infantil los han utilizado y utilizan, para publicar y comunicar aquello que hacen con su alumnado, así como también para reflexionar y compartir con otros docentes sobre la práctica educativa del día a día de la Educación Infantil (Becerra et al., 2021). De ahí que podamos considerar que estos blogs pueden tener diferentes funciones. Así, podemos entender los blogs como:

- Blogs de aula: donde el docente comparte con su alumnado y sus familias en las entradas del blog, aquellas actividades que han trabajado o propuestas de actividades que pueden trabajar, para consolidar y construir conocimiento.

- Blogs de recursos: que son aquellos donde el docente comparte recursos que se pueden utilizar para seguir aprendiendo, pero sin mostrar ejemplos de uso de los mismos y/o sin indicar que posibilidades presentan para dichos procesos.

- Blogs docentes: en los que el docente reflexiona sobre su práctica docente, compartiendo sus impresiones y propiciando la interacción a través de los comentarios de otros docentes.

Se da muchas la circunstancia de que un mismo blog puede aunar más de una de estas funciones y ser a la vez blog de aula y blog de recursos o blog de aula y blog docente, o incluso las tres funciones a la vez. Ante una situación como la vivida, estos blogs han podido utilizarse como medio de comunicación e información para con las familias y el alumnado de esta etapa, en una función que se encasilla dentro de los blogs de aula. Así se han convertido en excelentes recursos para el aprendizaje guiado y compartido desde el uso de la información y la comunicación en una modalidad no presencial de la enseñanza. En estas entradas, los docentes han podido compartir aquellas actividades que se pretende realizar con su alumnado, con las indicaciones a las familias y los recursos necesarios para llevarlas a cabo.

Con alumnado del grado de magisterio en Educación Infantil, ya se comprobó (Álvarez-Herrero, 2018), que la utilización de los blogs en su formación, servía como elemento precursor de lo que en un futuro podía ser un blog de aula. Y algunas investigaciones también nos hablan del uso de los blogs entre los docentes de esta etapa.

Con todo ello, y con la pandemia entre nosotros, quisimos investigar si a raíz de esta situación, los blogs han tenido un mayor uso y si este uso ha sido principalmente este que acabamos de comentar, el de ser unos excelentes recursos que favorecen el aprendizaje a través de la información y comunicación compartida entre el docente, sus estudiantes y las familias de estos.

Así, nos marcamos dos objetivos en esta investigación:

- Conocer cual ha sido el uso que se ha dado desde Educación Infantil en España a los blogs educativos en tiempos de pandemia, y si su función ha sido principalmente la de servir como recurso para el aprendizaje fomentando la información y la comunicación entre docente y alumnado. 
- Comparar si se ha producido un mayor uso de estos blogs entre antes de la pandemia de la COVID-19 y tras un año después de haber sido declarada y haber pasado un periodo de confinamiento domiciliario que obligó a unas clases online.

\section{Método/Descripción de la experiencia}

\section{Descripción del contexto y de los participantes}

Previamente a la investigación que aquí detallamos, en el último cuatrimestre de 2019, se realizó una investigación en la que se analizaron 60 blogs de maestras y maestro de Educación Infantil, utilizando una ficha que se elaboró para tal fin. Se trata de 60 blogs que podemos considerar son los más activos y conocidos de maestras y maestros españoles. Estos blogs, que se pueden ver en esta entrada del blog del investigador de este estudio: https://bit.ly/60blogsEl, son solo una pequeña muestra de los muchos blogs que hay de docentes de la etapa, pero que como ya hemos comentado, por su relevancia y repercusión, son los que hemos considerado en este estudio.

Dichos blogs han vuelto a ser analizados y cumplimentadas sus fichas, en el último cuatrimestre de 2020, pasado el confinamiento domiciliario y en un nuevo curso académico, el 2020-2021, que se desarrolló con presencialidad del alumnado de educación infantil en las aulas, formando los denominados grupos burbuja.

Entre estos blogs, mayoritariamente blogs que se publican en castellano, encontramos también algunos ejemplos que se publican en catalán. Se han descartado blogs que publican en otros idiomas oficiales de las diferentes regiones españolas, pero consideramos por la poca repercusión de estos, que no alteran los propósitos ni los resultados de la investigación que llevamos a cabo.

\section{Instrumentos}

Para el análisis de dichos blogs se diseñó, construyó y validó una ficha de análisis a la que se le llamó ANABLOG (Figura 1) y que recoge diferentes variables a contemplar en tal análisis:

- url

- autoría

- blog de aula, de recursos o docente

- última actualización

- frecuencia de entradas

- factor TIC (utiliza las TIC en el aula, en sus propuestas de intervención y actividades con su alumnado)

- licencias y derechos

- links a blogs amigos

- admite comentarios

- subscripción (permite subscribirse para recibir avisos de cuando se producen nuevas entradas)

- contacto y redes sociales (ofrece información sobre las redes sociales en las que está presente el docente)

- capturas de pantalla (de la cabecera del blog y de alguna entrada relevante a modo de ejemplo) 
- puntos a favor y en contra (que consideraciones a favor y en contra encontramos en el blog propuesto)

- fecha y autoría del análisis (quien y cuando se ha realizado el análisis del blog)

\section{BLOGS DE EDUCACIÓN INFANTIL}

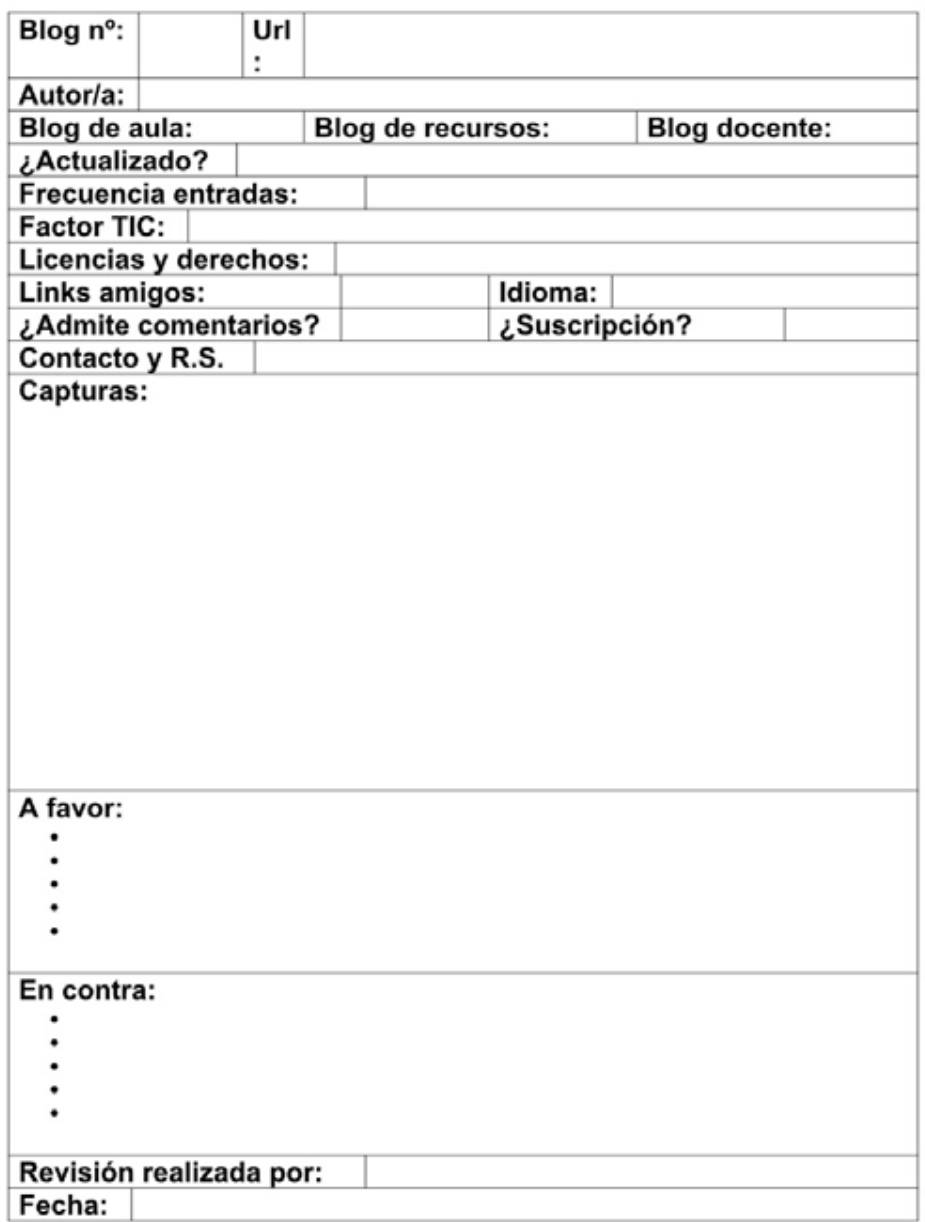

Figura 1. Ficha ANABLOG para el análisis de Blogs de Educación Infantil

\section{Procedimiento}

En el curso académico 2019-2020, concretamente durante el primer cuatrimestre (de septiembre a diciembre de 2019), se realizó un primer análisis de los 60 blogs comentados. Y tras el confinamiento por la pandemia del coronavirus, en el curso académico 2020-2021, concretamente durante el primer cuatrimestre (de septiembre a diciembre de 2020), se realizó un segundo análisis de dichos blogs.

Los datos recogidos de un análisis y otro se trasladaron codificados a unas hojas de Microsoft Office Excel, donde se tuvo especial interés en analizar las variables que nos pueden ayudar a dar respuesta a los objetivos de esta investigación como son: tipo de blog (aula, recursos o docente), actualizado o no, y frecuencia de publicación. El resto de variables no se han tenido en cuenta para esta investigación, a no ser que por sus características aportasen información sobre la función o uso del blog y/o sobre la frecuencia y cantidad de publicaciones que se han dado en el blog antes y después de haberse declarado la pandemia de la COVID-19. 


\section{Resultados}

Los resultados obtenidos vamos a presentarlos comparando las dos investigaciones, la realizada en los meses finales de 2019 y la realizada en los meses finales de 2020. Así como también vamos a discernir entre las funciones y usos dados por los blogs antes y después de la declaración de la pandemia; y la frecuencia y número de publicaciones realizadas antes y después.

En la Tabla 1 comparamos los resultados extraídos de las funciones comprobadas en los análisis de los 60 blogs antes y después de la pandemia. Hay que tener en consideración que, dado que pueden cumplir con más de una función, hemos contabilizado todas las opciones posibles de funciones de los blogs, por lo que se muestran frecuencias acumuladas.

\begin{tabular}{|l|c|c|}
\hline Función del blog & $\mathbf{2 0 1 9}$ & $\mathbf{2 0 2 0}$ \\
\hline Aula & 41 & 52 \\
\hline Recursos & 23 & 49 \\
\hline Docente & 36 & 12 \\
\hline
\end{tabular}

\section{Tabla 1. Funciones de los blogs de Educación Infantil antes y después de la pandemia. Fuente: elaboración propia}

De los resultados que podemos comprobar en la Tabla 1, vemos que, si bien en los blogs pre-pandemia era más frecuente encontrar un uso de dichos blogs como blogs docentes, durante y tras el confinamiento, estos blogs pasaron a ser más blogs de recursos y blogs de aula, que se disparan, mientras que el uso de los blogs como blogs docentes baja en frecuencia. Es muy significativo el crecimiento que experimenta el uso de los blogs como blogs de recursos, pues este uso crece más de un $200 \%$, así como el decrecimiento del uso como blogs docentes que fue del $300 \%$.

Por otro lado, cuando observamos los resultados obtenidos a la hora de ver la frecuencia o periodicidad de publicaciones (valor medio de la periodicidad mensual contabilizada entre noviembre de 2018 y noviembre de 2019, y de noviembre de 2019 a noviembre de 2020, respectivamente) y el número de publicaciones realizadas en un mismo tiempo (3 meses dentro del curso escolar, septiembre, octubre y noviembre de 2019 y 2020, respectivamente), podemos ver en la Tabla 2 como también la comparación entre unos datos y otros deja bastante claro lo ocurrido.

\begin{tabular}{|c|c|c|c|c|c|c|}
\hline & & 2019 & & & 2020 & \\
\hline frecuencia & 10 menos & de 2 a 5 & más de 5 & 10 menos & de 2 a 5 & más de 5 \\
\hline publicaciones & 16 & 23 & 21 & 7 & 11 & 42 \\
\hline № total & 10 o menos & de 10 a 30 & más de 30 & 10 o menos & de 10 a 30 & más de 30 \\
\hline 3 meses & 13 & 27 & 20 & 6 & 14 & 40 \\
\hline
\end{tabular}


Tal y como podemos apreciar en la Tabla 2, tanto la frecuencia como el número total de publicaciones en tres meses (de septiembre a noviembre de 2019 y 2020 respectivamente), se han visto significativamente incrementados en 2020 . Esto deja constancia de que a raíz de la pandemia los docentes de Educación Infantil han hecho un mayor uso de los blogs educativos, utilizando esta herramienta como medio para el intercambio de información y comunicación con su alumnado y sus familias, y dándole un uso como recurso de aprendizaje. Así, si antes de la pandemia vemos que la frecuencia y uso de los blogs es más bien discreta, habiendo algunos blogs que prácticamente no se usan; tras la declaración de la pandemia, su frecuencia y uso se ha revitalizado, haciendo que las publicaciones sean constantes y numerosas, con incrementos del $200 \%$.

Otro dato revelador del uso que se ha hecho de estos blogs durante y posteriormente al confinamiento, que no se aprecia en estas tablas de resultados, pero sí en las fichas de análisis realizadas, ha sido el número de comentarios que se encontraban en las entradas. Si bien, en 2019 eran muy escasos o casi inexistentes, posteriormente, en 2020, se ha incrementado su número de una forma considerable, encontrando una interacción entre docentes y familias y entre docentes de diferentes centros educativos que compartían sus recursos y actividades en estos momentos tan delicados.

Tal y como hemos apreciado en la Tabla 2, también encontramos un pequeño número de blogs que han permanecido sin actividad, tanto en el 2019 como en 2020, lo que es indicativo de alguna de estas posibles razones: sus autoras/es han cesado en su actividad docente, han abandonado el uso de los blogs como recurso docente o bien han abierto unos nuevos. Aunque al tratarse de un número residual, no afecta en las conclusiones que se pueden extraer de estos resultados.

\section{Discusión y conclusiones}

A raíz de los resultados obtenidos y fijándonos en los objetivos que nos habíamos marcado en esta investigación, podemos afirmar que los blogs en la etapa de Educación Infantil han sido unos recursos ampliamente utilizados durante el confinamiento domiciliario y en los meses posteriores, para con ellos, seguir desarrollando los procesos de enseñanza-aprendizaje del alumnado de esta etapa. Así lo reflejan tanto los datos de los usos o funciones que han desempeñado, siendo mayoritario el uso como blogs de aula y blogs de recursos; como el número total de publicaciones y la frecuencia de estas, números que se han incrementado significativamente tras la declaración de la pandemia de la COVID-19. Este aumento de actividad, dada esa mayor frecuencia y número de publicaciones en forma de entradas, ese mayor número de interacciones en forma de comentarios, así como por el contenido de los posts y el número de comentarios e interacciones producidas en los mismos; nos permite asegurar que el uso que se ha hecho de los mismos, ha buscado el facilitar a su alumnado y sus familias, recursos, estrategias y actividades con las que seguir adelante en los procesos de enseñanza-aprendizaje, dejando muchos de ellos de ser blogs docentes para convertirse en blogs de aula y/o blogs de recursos. Ello confirma al igual que otros estudios (García y García, 2021; García-Gómez y López-Gil, 2020) que los blogs son excelentes recursos para complementar la enseñanza en Educación Infantil, aunque siempre con la mirada puesta en la necesaria implicación de las familias para un correcto uso y acompañamiento (Rabal et al., 2021). También el estudio de Álvarez et al. (2021), nos confirma que, durante el confinamiento y los 
meses posteriores a este, los blogs han sido uno de los recursos más utilizados por los docentes de Educación Infantil para llevar adelante su tarea docente en la etapa.

Queda por ver si cuando se vuelva a la plena normalidad, se sigue haciendo un uso regular de los blogs, manteniendo aquellas experiencias y actividades que hayan dado buenos resultados, o si el hecho de volver a la presencialidad hará que los blogs queden relegados a ser únicamente instrumentos de comunicación de las actividades hechas en el aula y/o blogs de reflexiones de los docentes de la etapa. Confiemos en que su uso durante este periodo de plena necesidad haya permitido a los docentes explorar y conocer las amplias posibilidades que los blogs ofrecen como recursos aptos para el aprendizaje, y con sus excelentes valores añadidos y así como su uso como complemento de los conocimientos que se trabajan en el aula presencial. No estaría de más que su uso se revitalizase entre este colectivo de docentes, dadas sus excelentes ventajas que presenta, y así ofrecer planes de formación en la confección y mantenimiento de los mismos. Pues si bien la tecnología nos permite cada día más, que su uso sea más fácil e intuitivo, estaría bien que se pudiese incidir en aquellas posibilidades didácticas y pedagógicas que pueden ofrecer estos excelentes recursos.

\section{Referencias}

Álvarez-Herrero, J. F. (2018). Alumnado universitario analizando blogs de Infantil como práctica precursora de futuros blogs de aula. En Libro de Actas // Congreso Internacional en Tecnologías e Innovación Educativa (pp. 38-40). Universidad Internacional de Valencia.

Álvarez-Herrero, J. F. (2020). Evolución de la percepción del docente de secundaria español sobre la formación en TIC. Edutec, Revista Electrónica De Tecnología Educativa, 71, [pp.] 1-15. Recuperado de [https://doi.org/10.21556/edutec.2020.71.1567]

Álvarez-Herrero, J. F., y Hernández-Ortega, J. (2021). Percepción del docente de Educación Secundaria español sobre la necesidad de una formación en TIC a consecuencia de la COVID-19. En L. Vega-Caro, A. Vico y D. Recio (Eds.). Nuevas formas de aprendizaje en la era digital: en busca de una educación inclusiva (pp. 215-236). Dykinson. Recuperado de [http://bit.ly/TICprofESO]

Álvarez-Herrero, J. F., Martínez-Roig, R., y Urrea-Solano, M. (2021). Uso de las tecnologías digitales en educación infantil en tiempos de pandemia. Campus Virtuales, 10(2), [pp.] 165-174. Recuperado de [https://bit.ly/INFticCOVID]

Becerra, C. V., Martín, S., y Bethencourt, A. (2021). Análisis categórico de materiales didácticos digitales en Educación Infantil. Edutec. Revista Electrónica De Tecnología Educativa, 76, [pp.] 74-89. Recuperado de [https://doi.org/10.21556/edutec.2021.76.2039]

Caldeiro-Pedreira, M., y Castro-Zubizarreta, A. (2019). ¿Cómo enfrentar la educación en la era de la interactividad?: Recursos y herramientas para docentes de educación infantil y primaria. Praxis Pedagógica, 20(26), [pp.] 33-53. Recuperado de [http:// doi.org/10.26620/uniminuto.praxis.20.26.2020.33-53] 
Casero, M. D. L. O., y Sánchez, M. D. M. (2020). Situación educativa del alumnado del grado de educación infantil ante un cambio de enseñanza presencial a virtual, debido al COVID-19. En E. Colomo, E. Sánchez, J. Ruiz, y J. Sánchez (Eds.). La tecnología como eje del cambio metodológico (pp. 950-953). UMA Editorial.

Dayal, H. C., y Tiko, L. (2020). When are we going to have the real school? A case study of early childhood education and care teachers' experiences surrounding education during the COVID-19 pandemic. Australasian Journal of Early Childhood, 45(4), [pp.] 336-347. Recuperado de [https://doi.org/10.1177/1836939120966085]

Fernández-Ruiz, M. R. (2021). Nativos pandémicos: la educación virtual en Educación Infantil durante el confinamiento por COVID-19. Estudios sobre Educación, 41, [pp.] 1-22. Recuperado de [http://doi.org/10.15581/004.41.010]

Fusté, M. (2021). Encuentros online en educación infantil: Una experiencia vincular y educativa en tiempos de COVID-19. Páginas de Educación, 14(1), [pp.] 52-72. Recuperado de [https://dx.doi.org/10.22235/pe.v14i1.2204]

García, J., y García, S. (2021). Uso de herramientas digitales para la docencia en España durante la pandemia COVID-19. Revista Española De Educación Comparada, 38, [pp.] 151-173. Recuperado de [https://doi.org/10.5944/reec.38.2021.27816]

García-Gómez, S., y López-Gil, M. (2020). El blog de aula y el WhatsApp ċherramientas útiles para la comunicación entre maestras y familias? Edutec. Revista Electrónica De Tecnología Educativa, 72, [pp.] 17-33. Recuperado de [https://doi.org/10.21556/ edutec.2020.72.1613]

García-Zabaleta, E., Sánchez-Cruzado, C., Campión, R. S., y Sánchez-Compaña, M. T. (2021). Competencia digital y necesidades formativas del profesorado de Educación Infantil. Un estudio antes y después de la Covid-19. Edutec. Revista Electrónica De Tecnología Educativa, 76, [pp.] 90-108. Recuperado de [https://doi.org/10.21556/ edutec.2021.76.2027]

Hernández-Ortega, J., y Álvarez-Herrero, J. F. (2021). Gestión educativa del confinamiento por COVID-19: percepción del docente en España. Revista Española De Educación Comparada, 38, [pp.] 129-150. Recuperado de [https://doi.org/10.5944/ reec.38.2021.29017]

Jacovkis, J., y Tarabini, A. (2021). COVID-19 y escuela a distancia: viejas y nuevas desigualdades. Revista de Sociología de la Educación-RASE, 14(1), [pp.] 85-102. Recuperado de [https://doi.org/10.7203/RASE.14.1.18525]

Malta, M., y Fraga, L. (2021). COVID-19 and early childhood in Brazil: Impacts on children's well-being, education and care. European Early Childhood Education Research Journal, 29(1), [pp.] 125-140. Recuperado de [https://doi.org/10.1080/135029 $3 \times .2021 .1872671]$

Muhdi, Nurkolis, y Yuliejantiningsih, Y. (2020). The Implementation of Online Learning in Early Childhood Education During the Covid-19 Pandemic. Jurnal Pendidikan Usia Dini, 14(2), [pp.] 247-261. Recuperado de [https://doi.org/10.21009/JPUD.142.04] 
Park, E., Logan, H., Zhang, L., Kamigaichi, N., y Kulapichitr, U. (2020). Responses to Coronavirus Pandemic in Early Childhood Services Across Five Countries in the Asia-Pacific Region: OMEP Policy Forum. International Journal of Early Childhood, 52(3), [pp.] 249-266. Recuperado de [https://doi.org/10.1007/s13158-020-00278-0]

Rabal, J. M., Galian, L., Arias, L., y Martínez, L. (2021). Didáctica de las TIC e importancia de participación de las familias en Educación Infantil. Validación CPPNTRFE. Brazilian Journal of Development, 7(1), [pp.] 8919-8933. Recuperado de [https://doi. org/10.34117/bjdv7n1-605]

Saldaña, J. (2020). Educación Infantil y enseñanza online durante el confinamiento: experiencias y buenas prácticas.Etic@net.Revista científica electrónica de Educación y Comunicación en la Sociedad del Conocimiento, 20(2), [pp.] 336-348. Recuperado de [https://doi.org/10.30827/eticanet.v20i2.16214]

Trujillo-Sáez, F., Fernández-Navas, M., Montes-Rodríguez, M., Segura-Robles, A., Alaminos-Romero, F. J. y Postigo-Fuentes, A. Y. (2020). Panorama de la educación en España tras la pandemia de COVID-19: la opinión de la comunidad educativa. Fad. Recuperado de [http://doi.org/10.5281/zenodo-3878844] 


\section{Formación de Estudiantes Predoctorales para el Buen Uso de Imágenes Científicas}

\section{Mir, Ricardo}

Universitat Politècnica de València rimimo@upv.es

orcid.org/0000-0003-1506-4683

\section{Muñoz, Adolfo}

Universitat Politècnica de València amunyoz@upv.es

\section{Seguí-Simarro, Jose María}

Universitat Politècnica de València seguisim@btc.upv.es

orcid.org/0000-0001-7675-4169 


\title{
FORMACIÓN DE ESTUDIANTES PREDOCTORALES PARA EL BUEN USO DE IMÁGENES CIENTIIFICAS
}

\author{
Mir, Ricardo \\ Muñoz, Adolfo \\ Seguí-Simarro, Jose María
}

\section{Resumen}

El aprendizaje online supone en la actualidad una herramienta adecuada para una formación transversal a demanda y modulada por el propio estudiante. De esta manera, cada estudiante puede construir en parte su propio currículo según sus intereses y/o necesidades. En el caso particular de las ciencias de la vida, la formación recibida por el alumnado está basada fundamentalmente en conocimientos teórico-prácticos relacionados con conceptos, procesos biológicos y tecnologías, mientras que otros aspectos, como el manejo de imágenes científicas, quedan por lo general, fuera del ámbito pedagógico de esta disciplina. Por esta razón, hemos planteado un curso online de posgrado dirigido a alumnos en fase de formación predoctoral. El curso que presentamos en esta comunicación está orientado a dar pautas generales sobre cómo tomar, editar, analizar y presentar imágenes y recursos gráficos en general, con validez para la documentación de resultados experimentales del campo de las biociencias. Disponemos, además, de una serie de herramientas que nos permiten estudiar la acogida del curso, detectar las principales limitaciones durante el aprendizaje por parte del alumnado, y mejorar el curso en ediciones posteriores.

\section{Palabras clave}

Biociencias, fotografía digital, investigación, formación transversal, formación on line. 


\section{Introducción}

Durante su formación académica, los futuros investigadores adquieren conocimientos y competencias específicas de su campo, así como otras más generales, transversales a las distintas áreas de conocimiento científico y tecnológico. La Declaración de Bolonia del 1999 apunta, entre otros, al desarrollo y promoción de las competencias clave del alumnado como un aspecto fundamental para su formación integral e inserción laboral (Alonso et al, 2009). Por ello, la incorporación de competencias a los estudios universitarios mediante una formación transversal dirigida resulta un elemento formativo básico (Gallifa y Garriga, 2010). Estas competencias transversales se pueden definir como competencias genéricas, comunes a la mayoría de las profesiones, y que se relacionan con la puesta en práctica conjunta de aptitudes, rasgos de personalidad, conocimientos y valores adquiridos (Clemente-Ricolfe y Escribá-Pérez, 2013).

La adquisición de dichas competencias transversales puede realizarse mediante la realización de prácticas en empresa (Álvarez-Santullano, et al. 2018), o bien por cursos dirigidos en formato online durante la etapa de formación del alumnado (Lechuga et al, 2014). Este último formato ha sido adoptado por numerosas universidades del territorio español. En particular, la Universitat Politècnica de València (UPV) cuenta con una serie de programas de doctorado agrupados en diferentes ámbitos, como el de la Agroalimentación y Biotecnología, la Arquitectura, el Arte, las Ciencias, la Economía y Ciencias Sociales, las Tecnologías de la Información y Comunicación, así como la Ingeniería Civil y la Ingeniería Industrial. Los programas de doctorado de la UPV incluyen, además de las actividades de formación específicas, una serie de cursos, generalmente de 20 horas de duración (2 ETCS), cuyo objetivo es la adquisición de competencias de tipo transversal que complementen la formación del alumnado obtenida previamente en los respectivos grados. Estos cursos, por lo general, están enfocados a la adquisición de conocimientos que sean aplicables a las tareas desarrolladas por el alumnado durante su tesis doctoral, y se imparten de forma virtual a través de la plataforma online PoliformaT de la UPV, la cual permite no sólo el almacenamiento y la difusión de material didáctico, sino la comunicación directa con el profesorado y la evaluación del éxito pedagógico del curso.

Las imágenes constituyen un elemento fundamental para la documentación y transmisión de los resultados obtenidos en los laboratorios de investigación en el ámbito de las biociencias. A pesar de ello, la formación de los investigadores en cuanto a la adquisición y tratamiento de imágenes es escasa y, en muchas ocasiones, el aprendizaje para el manejo de imágenes se realiza de forma autodidacta según las necesidades de los investigadores. Este hecho puede conllevar, por un lado, al aprovechamiento parcial de las posibilidades que pueden ofrecer tanto los equipos de adquisición de imágenes como los programas informáticos para su manejo o edición. Por otro lado, es frecuente que en publicaciones científicas de diferente índole primen los aspectos estéticos frente a los meramente científicos.La manipulación inadecuada, intencionada o no, se ve agravada además con la digitalización de las publicaciones y el envío electrónico de los trabajos (Gilbert, 2009). De hecho, el $68 \%$ de los casos abiertos por indicios de manipulación en publicaciones científicas por la Office of Research Integrity fueron resueltos como fraude en 2007-08. En 1989-90 este porcentaje fue del 5\% (Gilbert, 2009). Ambas razones apuntan a la necesidad de adquisición de conocimiento adecuado para la manipulación y el manejo de imágenes científicas. 
En la actualidad se ha consolidado un curso para el manejo y análisis de imágenes dependiente del Gabinete de Fotografía Científica de la Universidad de Alcalá (Madrid, España), si bien este abarca una gran cantidad de conocimientos teórico-prácticos, distribuidos en 145 horas docentes, y está dirigido no sólo a científicos y personal de apoyo a la investigación, sino también a especialistas forenses, profesores de diferentes áreas y fotógrafos profesionales (López, 2014). Una formación más específica, concisa y práctica acerca de lo que supone el uso y manejo habitual de imágenes científicas, sin embargo, no parece existir en la actualidad en países de habla hispana.

El objetivo del curso que presentamos en esta comunicación, el cual denominamos Imagen científica y está enfocado a estudiantes de doctorado del ámbito de las biociencias, es una presentación concisa de conceptos básicos relacionados con la fotografía digital, el manejo de instrumental y programas de fuente abierta para el montaje de figuras multipanel o comunicaciones en formato presentación y poster, así como para el análisis cuantitativo de imágenes y la creación de videos time-lapse. Además, se desarrollan los aspectos más importantes de la macro y microfotografía aplicadas al campo científico. Todos estos conocimientos se ofrecen a través de la plataforma PoliformaT, dependiente de la UPV, y tienen un enfoque esencialmente práctico con el fin de que puedan ser utilizados para las respectivas investigaciones predoctorales del alumnado. El curso tiene una duración total de 20 horas lectivas y un formato exclusivamente online.

Los objetivos específicos del curso que presentamos en esta publicación son:

- Ofrecer una formación transversal a alumnos de doctorado en el campo de las biociencias para la adquisición, manejo, y publicación de imágenes científicas.

- Adquirir una competencia por parte del alumnado para la generación de figuras multipanel para su publicación en comunicaciones científicas.

- Aumentar la concienciación acerca de la importancia de un buen manejo de las imágenes digitales.

- Evaluar la acogida de la asignatura, y la tasa de éxito académico del alumnado.

\section{Método/Descripción de la experiencia}

\section{Descripción del contexto y de los participantes}

El curso de Imagen científica que proponemos en esta comunicación pretende mostrar conceptos y directrices generales que mejoren la adquisición, tratamiento y utilización de imágenes científico-técnicas con el fin de obtener su máximo aprovechamiento. Este curso se oferta dentro del conjunto de cursos de competencia transversal de la UPV de la escuela de doctorado, y está, por lo tanto, dirigido a estudiantes en período predoctoral. Si bien el enfoque general del curso está dirigido al ámbito de las biociencias, no se exige una formación previa específica, sino únicamente estar matriculado en un programa de doctorado de alguna universidad, incluida la UPV. Por esta razón, y para evitar confusiones a la hora de elegir los cursos obligatorios por parte del alumnado, en la guía docente disponible en la propia 
plataforma PoliformaT se especifica "El curso está orientado a la rama de ciencias de la vida (biología, biomedicina, biotecnología, bioquímica, veterinaria, ciencia animal, agronomía, tecnologia de alimentos, etc.)". En cualquier caso, los aspectos de tipo científico-técnico desarrollados a lo largo de la parte teórica del curso se han tratado usando un lenguaje generalista, y se ha recurrido a explicaciones detalladas de estos con el fin de evitar posibles problemas de comprensión por alumnos de áreas no afines.

\section{Instrumentos}

El curso tiene una duración de seis semanas, y está diseñado para una docencia en formato telemático utilizando la plataforma PoliformaT dependiente de la UPV. Esta plataforma nos permite programar temporalmente las actividades de cada tema, así como el examen final de la asignatura. Además, PoliformaT nos ofrece una serie de parámetros que nos permite evaluar el éxito docente mediante diferentes estrategias. En primer lugar, se contabiliza el número de alumnos con voluntad de participar en el curso (pre-matriculados), y el número de alumnos que finalmente se matriculan. También se puede inferir a partir de las calificaciones obtenidas por el alumnado el porcentaje de alumnos que abandona el curso, bien al principio de este, o bien después de haber superado una o varias unidades temáticas. Además, PoliformaT nos ofrece una relación gráfica de las calificaciones finales obtenidas por el conjunto del alumnado. Finalmente, PoliformaT permite la distribución de una encuesta a todo el alumnado para la evaluación del curso, que admite sugerencias para su mejora. Este conjunto de instrumentos nos permite determinar dificultades encontradas por el alumnado en temas específicos del curso, y mejorarlo en ediciones posteriores.

\section{Procedimiento}

La materia docente del curso está dividida en dos bloques temáticos. El primero (temas 1,2 y 3 ), es de tipo general y se tratan aspectos relacionados con los fundamentos sobre la naturaleza de la luz, su percepción y su captación en forma de imágenes fotográficas digitales, continuando con la composición, edición y análisis de éstas para su introducción óptima en posters, presentaciones orales y artículos científicos. Para ello nos basamos en dos programas informáticos de fuente abierta: GIMP e ImageJ/Fiji. El segundo bloque (temas 4 y 5 ) es de naturaleza más práctica. Por un lado, se guía al alumnado hacia la adquisición de fotografías con su propio equipo -que puede ir desde una cámara de fotos digital profesional de tipo Reflex hasta un móvil de última generación- aprovechando tanto las fuentes de iluminación natural como artificiales a su alcance para crear composiciones bien expuestas de máxima calidad. Por otro lado, se introducirán algunas características específicas de la adquisición y tratamiento de imágenes microscópicas, y se propondrán casos prácticos a resolver con los programas descritos en la parte general, ImageJ/Fiji y GIMP, o bien con programas alternativos de los que el alumnado pueda disponer.

El curso está estructurado en 5 bloques temáticos, que se van a impartir secuencialmente en el espacio de una semana por cada tema. Los temas son, por orden cronológico: Introducción a la fotografía digital (Tema 1), Edición digital de imágenes: GIMP (Tema 2), Análisis digital de imágenes: ImageJ/Fiji (Tema 3), Macrofotografía (Tema 4), y Microfotografía: imágenes en microscopía (Tema 5). El material didáctico englobado en cada tema consta de un texto escrito, estructurado en diversos 
puntos, los cuales incluyen además de la materia en cuestión, una introducción, conclusiones, y un apartado de los aspectos a destacar dentro de cada tema. Dentro de cada tema se incluyen, además, una serie de preguntas de naturaleza teórica, y dos actividades de tipo práctico evaluables por parte del profesorado, relacionadas con la unidad temática en cuestión.

El primer día del curso se convoca una reunión entre el alumnado y los profesores vía Microsoft Teams para explicar el procedimiento de aprendizaje y de evaluación, así como aclarar dudas que puedan surgir. Además, se pulsa la opinión y motivaciones del alumnado. A partir de este primer día, todo el material didáctico del curso queda disponible para el alumnado. Transcurrida la primera semana, el alumnado deberá haber resuelto las actividades (tareas) del tema 1, ya que estas quedan cerradas y, por tanto, no disponibles. Las tareas realizadas deben presentarse al profesor subiéndolas en plazo a la plataforma PoliformaT. Sucesivamente, durante las siguientes semanas se irán cerrando las tareas de los siguientes temas. Al final del curso, aunque el material didáctico siga disponible para el alumnado, éste ya no podrá presentar ninguna de las tareas. Durante la sexta y última semana del curso, el alumnado podrá repasar los aspectos teórico-prácticos de los diferentes temas, y se concretará una hora para realizar la prueba final.

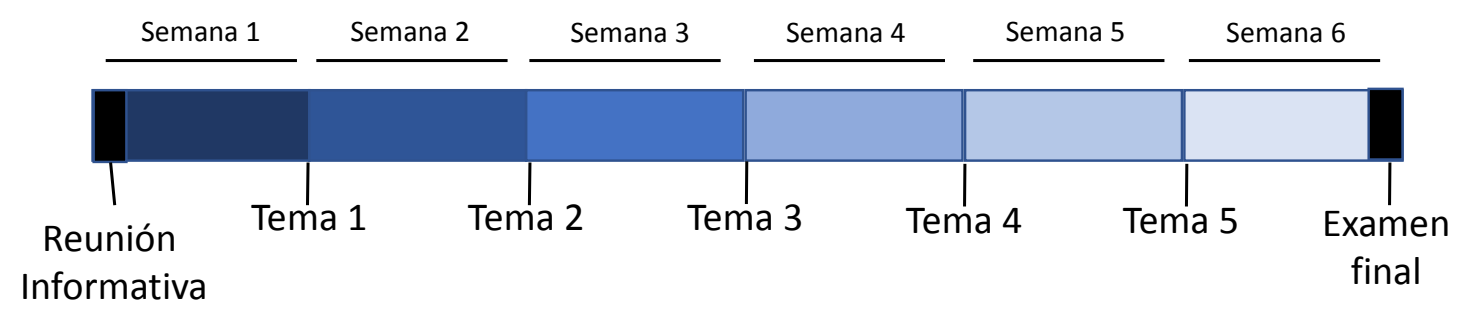

\section{Figura 1. Distribución cronológica del proceso de aprendizaje y evaluación del curso de Imagen científica.}

Finalmente, la evaluación del curso se realiza considerando la evaluación continua de las actividades propuestas en cada una de las 5 tareas, las cuales cuentan un $40 \%$ de la nota final, y la realización de un test de tipo teórico-práctico con preguntas tipo de las diferentes unidades temáticas, el cual constituye el $60 \%$ de la nota final. El período de presentación de cada una de las tareas es de una semana tras haber finalizado la parte teórica. Para la realización del examen teórico-práctico, se establecen dos franjas horarias (horario de la España peninsular, GMT+1) en el mismo día separadas 12 horas entre sí, para favorecer la realización del examen tanto en España como en países latinoamericanos con husos horarions muy diferentes. Cada alumno tiene un único acceso al test y un plazo de una hora para finalizarlo desde el momento en que lo inicie.

\section{Resultados}

\section{Contexto general y comunicación con el alumnado}

El curso se ha ofrecido durante los cursos lectivos 2019/2020 y 2020/2021, en los cuales han participado un total de 50 y 49 alumnos, respectivamente. En ambas ediciones el alumnado pertenecía tanto a la UPV, como a otras universidades españolas 
y latinoamericanas. La acogida del curso por parte del alumnado ha sido positiva, hasta el punto de que en la segunda edición hubo más del doble de solicitudes que de plazas. Se prevé la tercera edición para el curso lectivo 2021/2022.

En ambas ediciones del curso, la comunicación con el profesorado se ha establecido de manera fluida a través de varios canales digitales de comunicación, como e-mail convencional, servicio de mensajería interna, chat y foro de la plataforma PoliformaT, o herramienta de chat de la aplicación Teams de Microsoft. Además, el uso de la herramienta "Foros" de la plataforma PoliformaT se ha establecido para ser utilizada para la aclaración de aspectos de interés general de la asignatura, y la discusión global de aspectos de interés relacionados con la asignatura.

Finalmente, de las encuestas por parte del alumnado obtenidas en la primera edición del curso (2019/2020) se infirió la necesidad de incorporar material didáctico en formato audiovisual, el cual fue generado e incluido en la segunda edición del curso (2020/2021).

\section{Éxito académico}

En ambas ediciones se ha observado un grado relativamente elevado de abandono del curso, siendo este del 26\% (13 alumnos) y del 22.4\% (11 alumnos) en el primer y segundo año, respectivamente (Figura 2). La mayoría del alumnado que decidió abandonar el curso procede de programas de doctorado de disciplinas artísticas, así como del campo de la lingüística o de la arquitectura. A pesar de especificar en la guía docente que el curso estaba enfocado al campo de las biociencias, algunos alumnos nos comunicaron su desconocimiento a este respecto, y su decisión de abandono del curso por la poca utilidad que le encontraba en su área de conocimiento. En ambas ediciones del curso, el número de alumnos suspendidos es muy bajo, siendo un $2 \%$ (1 alumno) y un 4\% (2 alumnos) del total de alumnos matriculados en la primera y la segunda edición del curso, respectivamente (Figura 2). Mayoritariamente, en ambas ediciones del curso las calificaciones obtenidas han sido de notable, siendo el número de aprobados y sobresalientes similar en ambas ediciones (Figura 2).

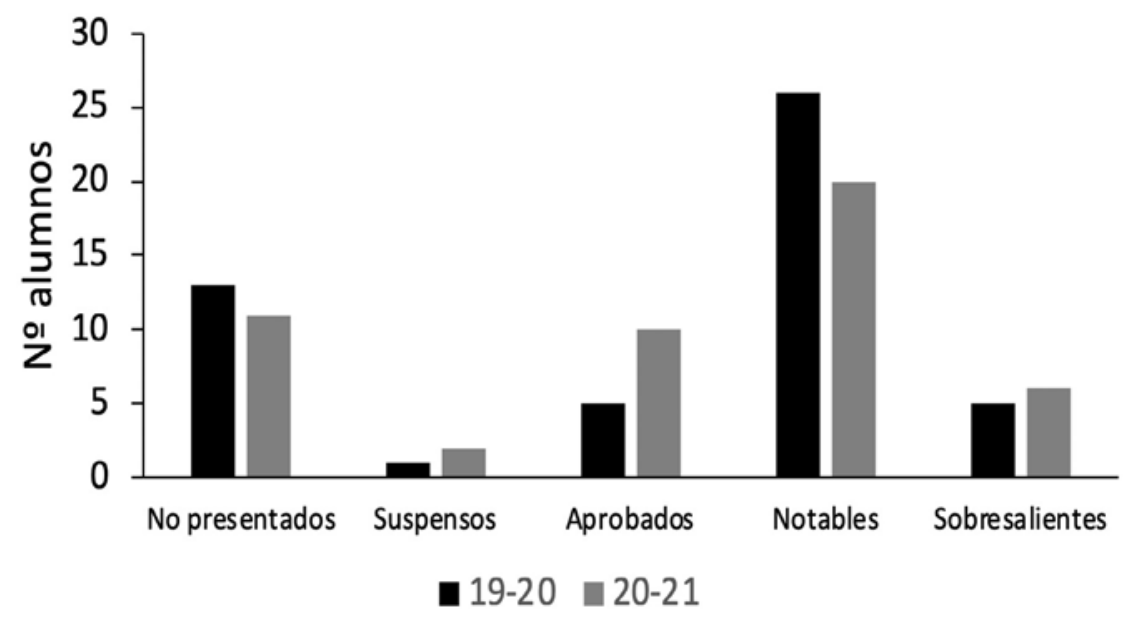

Figura 2. Número de alumnos "No presentados", y con calificaciones finales del curso de Imagen científica de suspenso (menos de 5), aprobados (entre 5-6,9), notables (entre 7-8,9) y sobresalientes (entre 9 y 10), en la primera edición (2019-2020, barras negras), y la segunda edición del curso (2020-2021, barras grises). 
Estos datos, sin embargo, nos ofrecen una visión global del proceso de aprendizaje del alumnado, y en general, de la idoneidad del material docente aportado. Sin embargo, no podemos inferir si el alumnado ha tenido algún problema específico con alguna de las partes del curso. Para ello hemos analizado la calificación de tareas individuales correspondientes a los 5 temas, además de en la prueba teórico-práctica final. Las gráficas de la figura 3 nos indican el número total de alumnos no presentados (N.P.) y suspendidos (Susp.) en la primera (Figura 3A) y en la segunda edición del curso (Figura 3B). La cantidad de alumnos no presentados desde la tarea 1 es ligeramente inferior al número de alumnos que no han acabado el curso, tanto de la edición del 19-20 (9 alumnos frente a 13) como de la edición del 20-21 (11 alumnos frente a 14). Si bien el número de alumnos no presentados desde la primera tarea fluctúa ligeramente a lo largo de la progresión del curso, no parece que haya un punto de inflexión durante el curso donde se haya detectado un abandono notable del alumnado. Este dato nos indica que tanto los materiales aportados, como el proceso de enseñanza-aprendizaje general, son adecuados. En cuanto al número de alumnos suspendidos, únicamente para la tarea 2 de la primera edición, la tarea 5 de ambas ediciones, y la prueba teórico-práctica, han habido alumnos que no han superado satisfactoriamente la evaluación. Este número, sin embargo, es muy bajo (entre 1 y 3; Figura 3). Como conclusión de este apartado se puede afirmar que el alumnado ha seguido correctamente el curso.

A

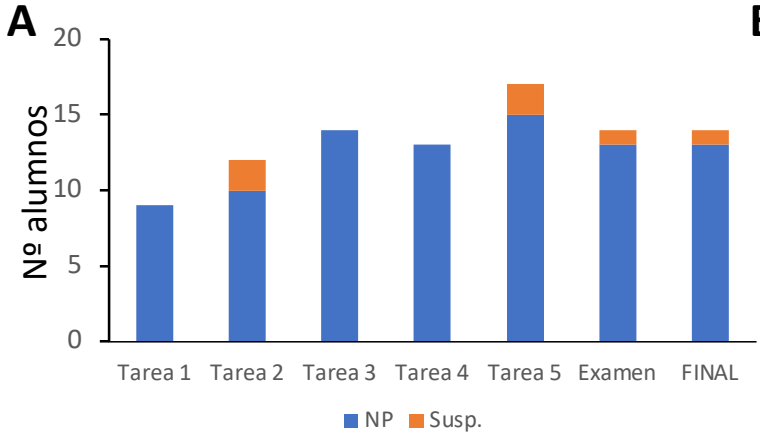

B

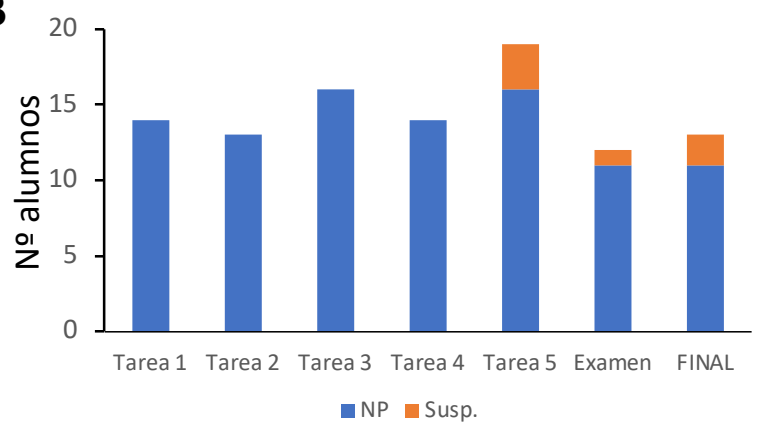

Figura 3. Número de alumnos no presentados (N.P.) y suspendidos (Susp.) en las diferentes tareas evaluables (tarea 1 a 5), el examen teórico-práctico final (Examen), y el global del curso (Final), durante (A) en la primera edición del curso en el año lectivo 2019-2020, y (B) la segunda edición en el año lectivo 2020-2021.

\section{Evaluación del curso por parte del alumnado.}

Tras la finalización del curso, el alumnado tiene la oportunidad de evaluar de forma voluntaria y anónima la calidad de la enseñanza recibida mediante la elaboración de encuestas de preguntas cerradas (Tabla 1), así como como preguntas abiertas donde tienen la posibilidad de comunicar los aspectos tanto positivos como negativos del curso.

En general, el curso ha obtenido una buena valoración para la mayoría de las preguntas cerradas (Tabla 1). Algunos aspectos importantes, sin embargo, son mejorables. Por un lado, la relación del curso con las actividades pre-doctorales de los 
alumnos ha adquirido una valoración de 6,2 y 5,6 en la primera y la segunda edición del curso, respectivamente. Además, en la primera edición del curso se obtuvo tan solo un 5,7 de valoración en cuanto a la satisfacción general del curso, mientras que en la segunda edición se obtuvo un 6,7.

Por otro lado, los comentarios recibidos en las preguntas abiertas sirven al profesorado para reordenar, reestructurar, completar o modificar el material docente, así como el proceso general de enseñanza-aprendizaje. En este respecto, varios comentarios tras la primera edición del curso apuntaban a la necesidad de material audiovisual que ayudara a una mejor comprensión de los temas 2 y 3 . Este material fue incorporado en la segunda edición del curso. Además, para ambas ediciones del curso se han recibido comentarios relativos a la especificidad del curso en el ámbito de las biociencias, y se ha sugerido ampliar el curso a otros ámbitos de conocimiento, como el de la arquitectura. Este cambio supondría, sin embargo, una ampliación sustancial del material docente, incluso del profesorado, y debe ser debidamente considerado.

\begin{tabular}{|c|c|c|}
\hline & $19-20$ & 20-21 \\
\hline La organización del curso ha sido buena & 7,6 & 7,9 \\
\hline Los contenidos se han desarrollado adecuadamente durante el curso. & 7,2 & 7,7 \\
\hline Los profesores del curso dominan la materia & 9,1 & 9,4 \\
\hline El método de autoevaluación de las actividades propuestas es adecuado. & 7 & 7,9 \\
\hline El curso se ha adaptado perfectamente a mi ritmo de aprendizaje. & 6,5 & 7,5 \\
\hline Los profesores han atendido con rapidez y eficacia las consultas realizadas. & 8,9 & 8,9 \\
\hline $\begin{array}{l}\text { Los medios de comunicación empleados han logrado eliminar cualquier } \\
\text { obstáculo espacio-temporal. }\end{array}$ & 7,4 & 7,5 \\
\hline $\begin{array}{l}\text { Mis problemas técnicos relativos al funcionamiento del curso en la web han } \\
\text { sido atendidos con rapidez. }\end{array}$ & 8,3 & 8,9 \\
\hline $\begin{array}{l}\text { La formación recibida está completamente relacionada con mi formación } \\
\text { transversal en investigación. }\end{array}$ & 6,2 & 5,6 \\
\hline $\begin{array}{l}\text { Mis expectativas ante el curso han quedado cubiertas y, en general, estoy } \\
\text { satisfecho con el resultado. }\end{array}$ & 5,7 & 6,7 \\
\hline $\begin{array}{l}\text { Los materiales docentes habilitados en PoliformatT para el curso son } \\
\text { coherentes con los contenidos del programa, representan una importante } \\
\text { ayuda para su aprendizaje y para alcanzar los objetivos del curso }\end{array}$ & 7,2 & 7,5 \\
\hline
\end{tabular}

Tabla 1. Calificaciones obtenidas en los dos años lectivos en la evaluación del éxito docente mediante preguntas directas ofrecidas al alumnado. Han participado 21 alumnos (año lectivo 2019-2020) y 12 alumnos (año lectivo 2020-2021). Las puntuaciones van de 0 (completamente den desacuerdo) a 10 (completamente de acuerdo). 


\section{Discusión y conclusiones}

El curso de doctorado "Imagen Científica" ha tenido una buena acogida por parte del alumnado. Una de las claves de su éxito ha sido su naturaleza online, que ha permitido que los futuros investigadores que compaginan este curso con las investigaciones conducentes a la elaboración de su Tesis Doctoral, puedan tener una libertad total a la hora de planificarse el trabajo de laboratorio y su propia formación, no estando limitados por un curso presencial de horarios fijos. Además, su naturaleza online ha permitido la participación de estudiantes de distintos países de habla hispana de diferente huso horario, y supone como tal una construcción de conocimiento colaborativo, inclusivo y con una fluida interacción entre el alumnado y el profesorado (Vázquez-Cano et al, 2015).

La comunicación es la base para construir un ambiente educativo adecuado (Aparici y Kaplún, 2003). A pesar de su naturaleza no presencial, se ha establecido una comunicación fluida, directa y cercana entre el profesorado y el alumnado, que ha servido no sólo para la resolución de dudas de las actividades a realizar, sino también para la discusión de cuestiones particulares del alumnado relacionadas con su actividad científica, así como para la mejora del curso para ediciones futuras. Además, mediante la herramienta Foros de PoliformaT, se han podido exponer al conjunto de participantes del curso problemas técnicos particulares, dudas o cuestiones de interés general relacionadas con la materia del curso.

La naturaleza fundamentalmente práctica del manejo de imágenes científicas hace necesario un enfoque práctico de la asignatura, al igual que sucede con la enseñanza de disciplinas científico-técnicas en general (Barberà y Valdés, 1996). Por esta razón, una buena parte del tiempo que el alumnado debe invertir en la consecución del curso está centrado en actividades de tipo práctico. Además, el uso de imágenes generadas en experimentaciones científicas reales no sólo motiva al alumnado, sino que también facilita que las herramientas y conocimientos adquiridos por el alumnado sean directamente extrapolables a sus propias investigaciones.

La distribución cronológica de las tareas a realizar durante el curso ha ayudado a que el alumnado trabaje de una forma continua, lo cual facilita asimilación y el desarrollo progresivo de contenidos (Delgado-García y Oliver Cuella, 2017), y evita, además, la saturación del profesorado a la hora de corregir y resolver dudas en los momentos finales del curso. Por lo general, y atendiendo a las sugerencias y opiniones del alumnado, los plazos para el aprendizaje y la entrega de las actividades de cada tema han sido apropiados. Además, la evaluación continua y por temas independientes nos ha permitido observar posibles puntos de complejidad en el temario en el conjunto del curso. A este respecto, no se han observado puntos específicos del temario donde el alumnado haya encontrado dificultades especiales para el aprendizaje.

A pesar de haber obtenido una calificación global buena, y unos comentarios por lo general favorables en las preguntas de respuesta abierta, hemos detectado un elevado porcentaje de alumnos no presentados, la mayoría de los cuales abandonaron el curso desde el inicio del curso, y que refieren que el enfoque del curso les genera desinterés y el consecuente abandono. Este alumnado proviene del campo de las bellas artes mayoritariamente, y el de la arquitectura y de la ingeniería en menor grado, todos ellos alejados de la disciplina de las biociencias. Una posible razón de 
este hecho podría ser la imposibilidad de seguir la terminología, las explicaciones y los ejemplos del campo de las ciencias de la vida, pese a que se ha tratado de simplificar el lenguaje todo lo posible, de describir y explicar los ejemplos usados de una forma generalista, y la comunicación profesor-alumno ha sido fluida, incluso para resolver dudas del planteamiento científico. Sin embargo, no se puede obviar que el curso está enfocado a las ciencias de la vida y los ejemplos que en él se exponen deben provenir de dicho ámbito, lo cual implica el uso ocasional de algún término científico de dicho ámbito. Y para eso, se requiere cierto conocimiento mínimo previo por parte del alumnado. Si no se tiene, lo más aconsejable es no cursar este curso. Quizá una posible vía de solución de este problema sea recalcar más aún para próximas ediciones el enfoque del curso. En cualquier caso, en la guía docente del curso, la cual está disponible previamente a la matrícula, se especifican los objetivos y las materias docentes del curso, así como las aptitudes previas recomendadas. Además, el hecho de que haya habido participantes en el curso provenientes de disciplinas alejadas que han superado con éxito el curso, es indicativo de que el procedimiento de enseñanza-aprendizaje está adaptado correctamente a diferentes disciplinas, y puede ser considerada como una enseñanza transversal.

\section{Referencias}

Alonso, L.E., Fernández. C.J. y Nyssen, J.M. (2009). El debate sobre las competencias. Una investigación cualitativa en torno a la educación superior y el mercado de trabajo en España. Madrid: Agencia Nacional de Evaluación de la Calidad y Acreditación-ANECA.

Álvarez-Santullano M.M., de Prada-Creo E., Pino-Juste, M. (2018). Study on technical capacity and transversal competencies developed in university internships. Estudios pedagógicos (Valdivia). 44 (3) 155.

Aparici, R. Kaplún M. (2003). Comunicación educativa en la sociedad de la información. Universidad Nacional de Educación a Distancia. Madrid.

Barberà, O. y Valdés, P. (1996). El trabajo práctico en la enseñanza de las ciencias: una revisión. Enseñanza de las ciencias: revista de investigación y experiencias didácticas. 14 (3) 365-79.

Clemente-Ricolfe, J.S. y Escribá-Pérez, C. (2013). Análisis de la percepción de las competencias genéricas adquiridas en la universidad. Revista de Educación, 362, 535-561.

Delgado García, A.M; Oliver Cuella, R. (Abril de 2006). «La evaluación continua en un nuevo escenario docente». Vol. 3, N¹. Archivado desde el original el 12 de julio de 2017. Consultado el 29 de noviembre de 2015.

Gallifa, J. y Garriga, J. (2010). Generic competences in higher education: Studying their development in undergraduate social science studies by means of a specific methodology. Perspectives in Education, 28(3), 70-86.

Gilbert, N. Science journals crack down on image manipulation. Nature (2009). 
Lechuga, M., Fernández-Arteaga, A., Ríos F., Fernández-Serrano M. (2014). Utilización de Entornos Virtuales Educativos y Recursos Educativos Abiertos (OpenCourseWare) en cursos de Ingeniería Química de la Universidad de Granada, España. Formación universitaria. Volume7. Issue4. Page3-14.

López, J.C. (2014). Entrevista a Luis Monje. Xatacafoto.

Vázquez-Cano, E., López-Meneses, E. y Barroso, J. (2015). El futuro de los MOOC: retos de la formación on-line, masiva y abierta. Revista española de pedagogía. 


\section{Curso Virtual de Capacitación y Sensibilización Dirigido a los Docentes de la Institución Educativa Técnica Jacinto Vega de Santa Maria Boyacá Acerca de Educación Inclusiva}

\section{Borbón Cipriam, Aura Ruth}

orcid.org/0000-0002-6132-9673

Corporación Universitaria Minuto de Dios

aura.borbon@uniminuto.edu.co 


\title{
CURSO VIRTUAL DE CAPACITACIÓN Y SENSIBILIZACIÓN DIRIGIDO A LOS DOCENTES DE LA INSTITUCIÓN EDUCATIVA TÉCNICA JACINTO VEGA DE SANTA MARIA BOYACÁ ACERCA DE EDUCACIÓN INCLUSIVA
}

\author{
Borbón Cipriam, Aura Ruth \\ orcid.org/0000-0002-6132-9673 \\ Corporación Universitaria Minuto de Dios \\ aura.borbon@uniminuto.edu.co
}

\section{Resumen}

El municipio de Santa María se ubica en el departamento de Boyacá y enfrenta problemáticas de tipo social como el suicidio, el abuso sexual, la desaparición forzada y el desplazamiento, el maltrato y la desintegración familiar. Esas situaciones fueron identificadas gracias a la aplicación de matriz de análisis documental al plan de desarrollo municipal para el periodo de 2016 a 2019, y caracterizadas gracias a la aplicación de encuesta a la comisaria de familia municipal. Tales hechos impactan a los niños, niñas y jóvenes de la institución educativa Jacinto Vega, e influyen en su desempeño tanto a nivel académico como comportamental. El contexto de los estudiantes es desconocido por parte de los docentes quienes, a raíz de esto, reflejan actitudes de indiferencia e insensibilidad. Realizándose documentación, diseño e implementación de curso virtual conformado de documentos tipo PDF con contenido sobre inclusión, necesidades educativas especiales, discapacidad y tipos de discapacidad, estrategias generales para el trabajo con estudiantes en condición de discapacidad, cortometrajes, musicales, videos y textos de autoría propia orientados a la promoción de valores como empatía, respeto y solidaridad, y aplicándose como parte final un cuestionario con la finalidad de dar valoración cuantitativa a los conceptos y elementos de sensibilidad contemplados por el profesorado posterior al desarrollo del curso, logra establecerse que la propuesta surge efecto de capacitación y sensibilización sobre el grupo de 26 docentes que participaron del proyecto.

\section{Palabras clave}

Inclusión, capacitación, sensibilización, contexto. 


\section{Introducción}

La situación identificada como punto de partida para el proyecto es la observación en el contexto Santamariense de conflictos sociales que hacen de un gran número de niños, niñas y jóvenes una población vulnerable. Además, al interior de la institución se evidencian alumnos en condiciones de discapacidad que no cuentan con las certificaciones de tipo médico, siendo esta una situación que aporta a la vulneración de sus derechos, pues al no figurar en el Sistema de matrícula SIMAT como estudiantes con discapacidad, no puede accederse a la flexibilización del currículo y el estudiante tiende a reprobar los diferentes espacios académicos, esto debido a que los docentes desconocen el contexto y la realidad de los estudiantes y a pesar de que en algunos casos la condición de discapacidad es evidente, los docentes adoptan posturas indiferentes y poco amables con este tipo de aprendices. Atendiendo a esto, es el equipo de docentes la población objeto de estudio sobre la cual se plantea la ejecución del proyecto consistente en documentación, diseño y aplicación de un curso virtual orientado hacia la capacitación y sensibilización del profesorado frente al tema de inclusión educativa. Como material para el contenido del curso se abordan documentos tipo PDF con información acerca de discapacidad, tipos de discapacidad, Necesidades Educativas Especiales, estrategias para el trabajo al interior del aula de clase con estudiantes en condiciones de discapacidad; cortometrajes con contenido reflexivo sobre empatía, respeto y solidaridad ante las diferencias, textos de autoría propia con la finalidad de persuadir sobre las realidades de los estudiantes, videos sobre los tipos de conflicto que impactan el entorno santamariense con el ánimo de darlos a conocer a los docentes, y canciones que mencionan la importancia del respeto y reconocimiento de la diversidad. La plataforma sobre la que se diseñó el curso da la posibilidad de que los docentes plasmen sus concepciones de forma escrita, además que permite la opción de poner a prueba los conocimientos adquiridos a partir de quiz y cuestionarios.

Como antecedentes se tuvieron en cuenta veintidós hallazgos que se relacionan directamente con el tema de investigación de este proyecto. Estos estudios fueron desarrollados a nivel nacional e internacional los cuales se mencionan a continuación: Carballo (2018) quien realizó la investigación titulada "Una escalera hacia la inclusión educativa en la universidad: desarrollo y evaluación de un programa de formación para el profesorado", Rivera (2017) en su tesis doctoral titulada "Educación inclusiva y formación inicial docente, una experiencia en la región de Coquimbo Chile", Omaña y Alzolar (2017) en su artículo "estrategia pedagógica para la inclusión del estudiante con discapacidad", Niño (2016) en su trabajo "Estrategias inclusivas en el aula. propuesta frente a las dificultades cognitivas en el ciclo dos de educación básica en el colegio brazuelos I.E.D”, Cante et al. (2015) en su tesis de maestría a nivel nacional "¿inclusión o educación inclusiva? Estrategias didácticas en la educación para todos", Landazuri (2019) en su investigación "Preparación de los docentes sobre la inclusión y atención a la diversidad en la educación inicial básica", Gómez et al. (2016) desarrollaron el proyecto "La inclusión en el contexto educativo. Principios pedagógicos para la transformación de un paradigma”, García (2018) en su trabajo titulado "Formación y capacitación del profesorado para la atención del alumnado de diversidad cultural y discapacidad intelectual o del desarrollo en contextos educativos. Análisis de la influencia de las metodologías docentes y de los espacios en la enseñanza y el aprendizaje en Educación Primaria y Educación Secundaria", Luque (2017) en su artículo "La formación del docente en la educación inclusiva universitaria", Herreros (2017) en su tesis de maestría "la formación del docente ante la 
diversidad en el aula", Tornel (2015) en su tesis doctoral sobre "Formación docente del profesorado de Educación primaria en diversidad cultural. Un elemento clave para la transformación y actualización de los centros educativos", Sosa (2015) realizó su tesis doctoral "Necesidad formativa del profesorado universitario de la a Universidad Nacional Pedro Henríquez Ureña UNPHU, en relación con la atención a la diversidad", Sierra (2019) en su trabajo sobre "Estrategia de formación docente orientada al fortalecimiento de la educación inclusiva en la catedra de Gestión Básica de la Información - GBI UNIMINUTO, Sede Principal”, López y Noguera (2019) desarrollaron su tesis de maestría "formación docente en inclusión de niños con necesidades educativas especiales", Molina (2017) desarrolló una "Propuesta de formación docente para la educación inclusiva de estudiantes en situación de discapacidad intelectual", Guapucal y Jaguandoy (2015) realizó un artículo denominado "La formación docente como estrategia pedagógica para fortalecer la educación diversa", Castellanos (2015) en su tesis doctoral "Formación del profesorado del municipio de armenia, Quindío - Colombia, en torno a la inclusión escolar”, Orozco et al. (2014) trabajaron en un proyecto denominado "Capacitación eficiente desde lo gerencial para los docentes en inclusión educativa", Quishpi (2020) en su tesis de maestría "La sensibilización del docente en la inclusión educativa de estudiantes con discapacidad", García (2017) en su tesis de pregrado "Proyecto de capacitación y sensibilización sobre inclusión educativa de niños con necesidades educativas especiales dirigido a docentes del centro de desarrollo infantil Chiquititos", Osorio et al. (2017) en su trabajo sobre "Sensibilización y orientación pedagógica a docentes en procesos de inclusión educativa en el aula", y Benítez (2015) en su tesis de maestría "Talleres de Sensibilización: De la mano y el corazón Un camino hacia la inclusión educativa”. Además de estos antecedentes, se articuló información ofrecida por autores como: Plancarte (2017) quien hace mención a la noción de limitaciones únicamente de tipo físico o cognitivo cuando se habla de inclusión (p. 214), hallándose argumento para proponerse un trabajo orientado hacia la capacitación docente sobre inclusión. Otro autor dice que "La diversidad en el ser humano presenta tres características claves: es un hecho natural, complejo y múltiple", "está siempre presente entre los alumnos y que debemos convivir con ella" (Muntaner, 2010, p 4), y asume la educación como "un proceso orientado a responder a la diversidad de las necesidades de todos los alumnos incrementando su participación en el aprendizaje, las culturas y las comunidades, reduciendo la exclusión en y desde la educación" (UNESCO, 2005, como es citada por Muntaner, 2010, p 8). Montero y Gewerc, (2018), dicen que en las instituciones se deposita la esperanza de hacer de los estudiantes seres íntegros y con un mejor futuro a través del uso de medios, herramientas y estrategias, orientadas hacia la construcción de sociedades más justas (p 8). Castillo (2016) por su parte, dice que es crucial la participación activa de los docentes en procesos de capacitación en aras de ofrecer calidad en la atención a las necesidades diversas de los estudiantes. ( $p$ 272). Se asume que al no contar con conocimiento acerca de un tema, puede incurrirse en violencia, ante esto, se cita a Gallego, Acosta, Villalobos, López, y Giraldo (2016) quienes comentan, acerca de cómo estos actos violentos producen baja autoestima y desmotivación por parte de los estudiantes ante los procesos de aprendizaje, además de impactos negativos sobre la emocionalidad de los niños (p118), trayendo a memoria que, como lo mencionan Marchesi y Díaz, la docencia es una labor que sugiere una responsabilidad moral, esto hace que sea importante contemplar aspectos como el emocional y el afectivo de los estudiantes (p. 7).

Los objetivos planteados fueron los siguientes: objetivo general: "Diseñar e implementar un curso virtual educativo dirigido a los docentes de la Institución Educativa 
Técnica Jacinto Vega del municipio de Santa María Boyacá sobre inclusión educativa orientada a su capacitación y sensibilización", objetivos específicos: "caracterizar los tipos de conflicto que impactan el entorno Santamariense para tratar los temas de la propuesta educativa de acuerdo con el decreto 1421 de 2017 que define la educación inclusiva", "construir la propuesta educativa virtual a través del modelo de aprendizaje basado en problemas con el fin de ofrecer información a los docentes que les permita reconocer el contexto estudiantil" e "implementar la propuesta educativa en los docentes para capacitar y sensibilizar, así, apoyar al profesorado con información y herramientas para el desarrollo de sus prácticas pedagógicas"

Respecto a la hipótesis se dijo que al diseñarse una propuesta educativa (curso virtual sobre inclusión educativa) se logrará informar y sensibilizar a los docentes de la Institución educativa Técnica Jacinto Vega y su actitud frente a los estudiantes será mejor.

\section{Método/Descripción de la experiencia}

Para el caso de esta investigación se optó por el enfoque cuantitativo con alcance descriptivo teniendo en cuenta que el proyecto se centra en trabajar con un equipo de docentes acerca de problemáticas de tipo social que impactan la vida de sus estudiantes y que requieren ser reconocidas para desarrollar verdaderos procesos de inclusión, tema sobre el cual también los profesores recibirán capacitación y sensibilización.

\section{Descripción del contexto y de los participantes}

El municipio de Santa María está ubicado en el departamento de Boyacá al oriente del país, es una población pequeña de aproximadamente 5.000 habitantes y se caracteriza por poseer una zona rural extensa, durante décadas el municipio se ha visto afectado por actividades como el narcotráfico y la minería no siendo ajenos a la situación general de orden público colombiano. En cuanto a educación, el municipio cuenta con instituciones de tipo privado y público dentro de las que se encuentra la Institución Educativa Técnica Jacinto Vega, este colegio cuenta con un total de 16 sedes 4 de tipo urbano y 12 en las áreas rurales muy apartadas, reúne un total de 47 docentes provenientes de ciudades como Bogotá, Tunja, Sogamoso, Duitama, Bucaramanga, entre otras. Son pocos los docentes que reconocen el contexto Santamariense y los conflictos que se desarrollan en este, además en cuanto a capacitación acerca del tema de inclusión es poco el apoyo que se recibe desde la secretaría de educación. Hasta hace dos años se viene contando con un profesional que apoya a los profesores en la elaboración de los planes individuales de ajustes razonables PIAR. Para el desarrollo del curso virtual se seleccionó una población de 26 docentes de las diferentes sedes, con un mínimo de antigüedad de 3 años.

\section{Instrumentos}

Los instrumentos por los que se optó para la recolección de la información fueron tres: matriz de análisis documental, encuesta y cuestionario.

\section{Procedimiento}

Inicialmente se desarrolla matriz de análisis documental la cual fue aplicada a documentación importante como: el decreto 1421 de 2017, el plan de desarrollo del 
periodo 2016 a 2019 del municipio de Santa María, el Aprendizaje Basado en Problemas ABP, la influencia de la música en las emociones y el aprendizaje, discapacidad, tipos de discapacidad, necesidades educativas especiales, estrategias de trabajo en el aula de clase con estudiantes con discapacidad de tipo física, sensorial, intelectual y mental, y plataformas LMS, siendo toda esta información útil tanto para la identificación de los tipos de conflicto del contexto Santamariense, como para el diseño del curso virtual sobre inclusión educativa dirigido a los docentes. Seguido a este instrumento se aplicó la encuesta a la comisaria del municipio y a partir de sus resultados se logró caracterizar los conflictos identificados con anterioridad. Para terminar, se hizo uso del cuestionario como herramienta para medir el nivel de comprensión de los docentes frente al tema de inclusión, el reconocimiento del contexto y la apropiación de elementos que sugieren sensibilidad.

\section{Resultados}

Gracias a la aplicación de los instrumentos de recolección de información se logran obtener los siguientes resultados: dentro del entorno Santamariense se identifican ciertos conflictos dentro de los que se destacan: el desplazamiento forzado, la desaparición forzada, el abuso o violencia de tipo sexual y familiar al igual que la desintegración de la misma y el suicidio. Al caracterizarse estos hechos victimizantes se logra definir que: la localidad presenta un reporte de 32 personas (todas mayores a los 40 años) desaparecidas que se adjudican a la delincuencia común. En cuanto a la cifra de desplazamiento forzado, se habla de 114 personas quienes provienen de zonas como la región de la Amazonía y la región Andina siendo el $30 \%$ de ellos población infantil y al arribar al municipio, se establecen en el sector rural, cuentan actualmente con acceso a educación y salud aunque enfrentan condiciones de desigualdad social y no cuentan con apoyo para la restitución de sus derechos. En cuanto a la violencia sexual se promedia una cifra de 25 casos en el año manifiestos en las zonas rurales en su mayoría, las víctimas oscilan entre los cero y los veinte años de edad y son familiares o personas cercanas a la familia quienes ejecutan estos actos violentos. En cuanto al suicidio se tiene una cifra de 4 casos en los últimos 5 años, acto consumado por personas de más de 30 años de edad y las causas de dicho acto no se especifican. Referente a la desintegración y la violencia familiar se señala el estrato uno como sector en donde se presenta el mayor número de casos, generalmente son los hombres quienes llevan a cabo estas acciones de tipo físico, económico, sexual, emocional, de género y psicológico, es usual que la configuración de familia conste de madre cabeza de hogar con hijos debido a que el divorcio y el abandono por parte del varón de la casa es común. Todos estos hechos se asumen como factores que afectan las emociones, el comportamiento y el rendimiento académico de los niños, niñas y jóvenes santamarienses.

Habiendo desarrollado el curso virtual con los docentes, se aplicó el cuestionario el cual contenía 15 preguntas en donde 10 median la parte de capacitación y se logró establecer la siguiente gráfica: 


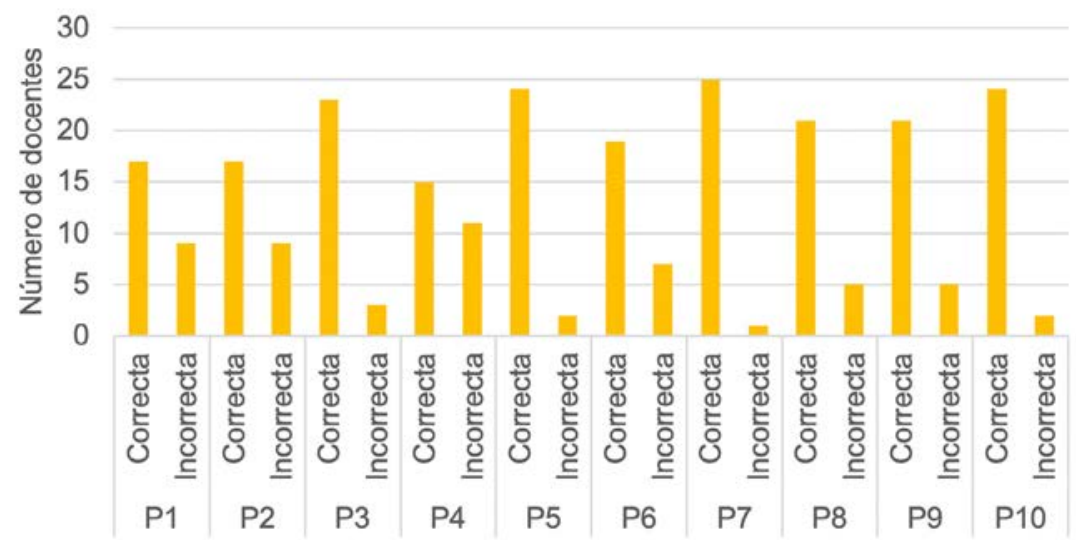

Preguntas y tipo de respuesta

Imagen 1. Respuesta de los docentes a cuestionario, preguntas que miden capacitación

Se evidencia que los docentes en su mayoría respondieron las preguntas de forma acertada, es decir que lograron apropiarse de conceptos y conocimientos relacionados con la temática de inclusión educativa y con el contexto de sus estudiantes.

Las ultimas 5 preguntas midieron elementos de sensibilidad adoptados por los docentes. Según las respuestas dadas por los profesores a esta sección de preguntas, se establece la siguiente gráfica:

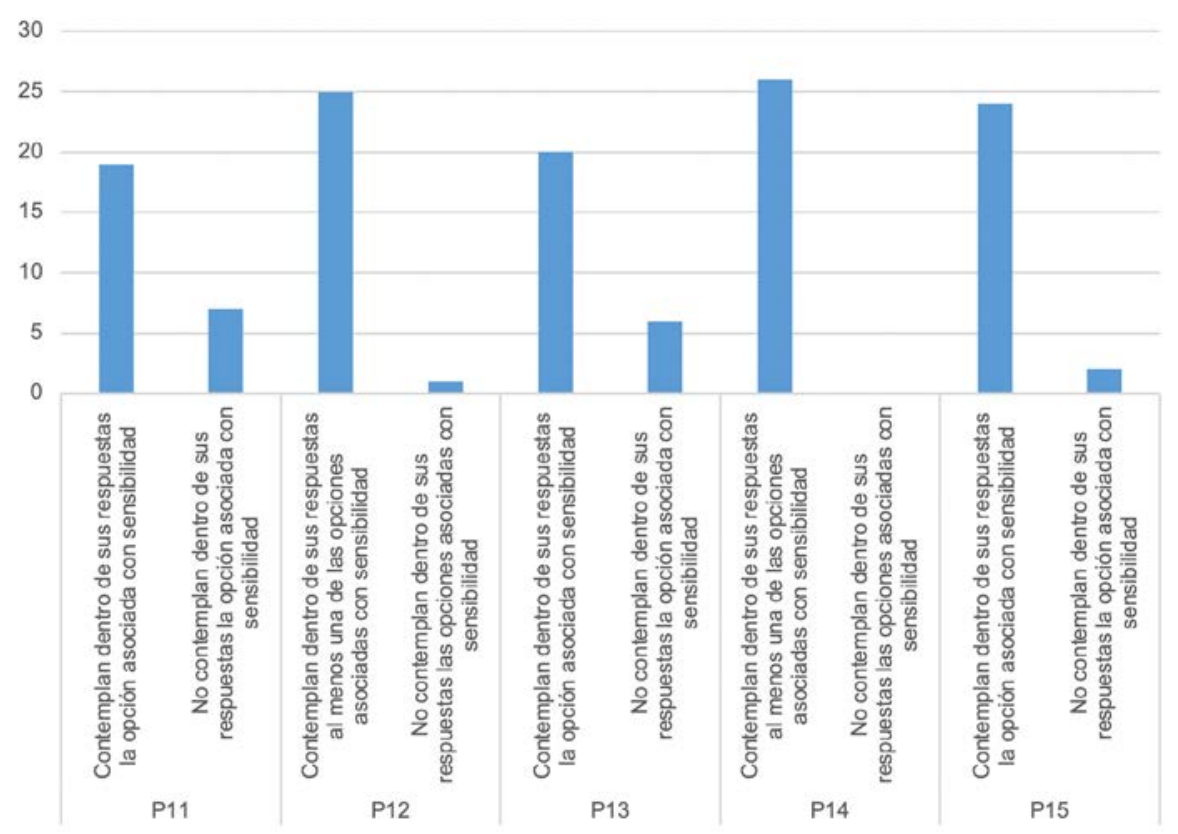

Imagen 2. Respuesta a sección de preguntas que miden elementos de sensibilidad.

De acuerdo con las respuestas dadas por los docentes, puede apreciarse la consideración de elementos que sugieren sensibilidad ante situaciones que así lo requieren, esto teniendo en cuenta que las preguntas formuladas giran en torno a una situación particular expuesta en estudio de caso. 


\section{Discusión y conclusiones}

De acuerdo con los objetivos establecidos, las prácticas desarrolladas y los resultados obtenidos, puede concluirse que:

En el contexto Santamariense se identifican diversos tipos de conflictos social, los cuales pueden y deben ser contemplados y reconocidos dentro de los escenarios educativos para la flexibilización de los currículos, pues estos acontecimientos pueden impactar de forma significativa el aspecto mental de los estudiantes generándose limitaciones o barreras para su optimo desempeño en el ambiente escolar, teniendo en cuenta que estas pueden clasificarse dentro de las discapacidades de tipo mental que bien menciona el decreto 1421 de 2017 emitido por el Ministerio de Educación Nacional.

Se realizó una amplia revisión bibliográfica a partir de la cual se logró el diseño de la propuesta educativa de tipo curso virtual comprendida por material que ofreció a los docentes no solo conceptualización acerca de inclusión educativa, sino se brindó información acerca de estrategias que pueden ser implementadas para el trabajo con estudiantes en las diferentes condiciones de discapacidad al interior del aula de clase, además se dio a conocer la importancia de reconocer y tener en cuenta el contexto y las realidades de los estudiantes al momento de desarrollar las diferentes actividades y temáticas académicas.

Posterior a la aplicación del curso con el equipo de docentes logra identificarse el reconocimiento de la necesidad de cambios de actitud por parte del equipo docente en aras de ser promotores de procesos inclusivos al contrario de lo que se ha venido desarrollando: segregación, exclusión e insensibilidad.

Se concluye que, a partir de la propuesta educativa en modalidad virtual, dirigida a los docentes, puede generarse o promoverse procesos autoreflexivos frente al tema de inclusión, y por ende al desarrollo de dinámicas al interior de la institución que realmente den respuesta a las diversas demandas de atención de los estudiantes provenientes de ambientes en condición de vulnerabilidad.

Si bien la aplicación de cursos o demás formas de capacitación no son en su totalidad efectivas para que los procesos de inclusión de desarrollen al interior de las instituciones, sí es cierto que se aporta al mejoramiento de las condiciones de vulnerabilidad por la que atraviesan muchos estudiantes ya que se logró acercar a los docentes al contexto de los niños y persuadir al profesor acerca de la importancia de la actitud y la puesta en práctica y promoción de valores como el respeto, la tolerancia y muy especialmente, la empatía.

\section{Referencias}

Barrón. C. (2015) Concepciones epistemológicas y práctica docente. Una revisión. REDU - Revista de Docencia Universitaria. P 35-56. Recuperado de http://red- u.net/ redu/files/journals/1/articles/899/public/899-3923-1-PB.pdf

Benítez. C. (2015) Talleres de Sensibilización: De la mano y el corazón Un camino hacia la inclusión educativa. [Tesis de maestría. Tecnológico de Monterey] Obtenido 
de https://repositorio.tec.mx/bitstream/handle/11285/622466/O2Claudia+Milena+Ben\%C3\%ADtez+Sep\%C3\%BAlveda.pdf?sequence=1

Cante. A. Conejo. M. Quevedo. E. Ramírez. H. y Rodríguez. E. (2015) ¿̇Inclusión o educación inclusiva? Estrategias didácticas en la educación para todos. [Tesis de maestría. Universidad de San Buenaventura] Obtenido de http://biblioteca.usbbog. edu.co:8080/Biblioteca/BDigital/137831.pdf

Carballo. R. (2018) Una escalera hacia la inclusión educativa en la universidad: desarrollo y evaluación de un programa de formación para el profesorado. [Tesis de doctorado. Universidad de Sevilla] Obtenido de https://idus.us.es/bitstream/handle/11441/77585/Tesis\%20Doctoral.\%20R.\%20Carballo.pdf?sequence=1\&isAllowed=y

Castellanos. A. (2015) Formación del profesorado del municipio de armenia, Quindío - Colombia, en torno a la inclusión escolar. [Tesis de doctorado. Universidad de Salamanca] Obtenido de https://gredos.usal.es/bitstream/handle/10366/129396/ DPETP_CastellanosLopezA_Formacionprofesorado\%2OFormacion\%20del\%20profesorado\%20del\%20munici_20151208132154981.pdf?sequence=1\&isAllowed=y

Castillo. J. (2016) Docente inclusivo, aula inclusiva. Revista nacional e internacional de educación inclusiva. p 264-275. Recuperado de https://revistaeducacioninclusiva. es/index.php/REl/article/download/64/59

Decreto 1421 de 2017 Por el cual se reglamenta en el marco de la educación inclusiva la atención educativa a la población con discapacidad. Ministerio de Educación Nacional. Obtenido de http://es.presidencia.gov.co/normativa/normativa/DECRETO\%201421\%2ODEL\%2029\%2ODE\%2OAGOSTO\%2ODE\%202017.pdf

Gallego. L. Orozco. J. Villalobos. Y. López. A. Giraldo. G. (2016) Violencia del docente en el aula de clase. Revista de Investigaciones Universidad Católica de Manizales (UCM). p. 116-125. Recuperado de http://www.ucm.edu.co/wp-content/ uploads/2018/05/81-166-2-PB.pdf

García. G. (2017) Proyecto de capacitación y sensibilización sobre inclusión educativa de niños con necesidades educativas especiales dirigido a docentes del centro de desarrollo infantil Chiquititos. [Tesis de pregrado. Universidad del Azuay] Obtenido de http://dspace.uazuay.edu.ec/bitstream/datos/7569/1/13451.pdf

García. Y. (2018) Formación y capacitación del profesorado para la atención del alumnado de diversidad cultural y discapacidad intelectual o del desarrollo en contextos educativos. Análisis de la influencia de las metodologías docentes y de los espacios en la enseñanza y el aprendizaje en Educación Primaria y Educación Secundaria. [Tesis de doctorado. Universidad Camilo José Cela] Obtenido de https://repositorio.ucjc.edu/bitstream/handle/20.500.12020/793/Tesis_\%2Ofinal_ Yolanda.pdf?sequence=1\&isAllowed $=y$

Gómez. R. Guío. A. y Hurtado. Y. (2016) La inclusión en el contexto educativo. Principios pedagógicos para la transformación de un paradigma. [Tesis de maestría. Universidad Pedagógic Nacional] Obtenido de http://repository.pedagogica.edu. $\mathrm{co} /$ bitstream/handle/20.500.12209/704/TO-18955.pdf?sequence=1\&isAllowed=y 
Guapucal. M. y Jaguandoy. Y. (2015) La formación docente como estrategia pedagógica para fortalecer la educación diversa. [Universidad de Manizales] Obtenido de http://webcache.googleusercontent.com/search?q=cache:dhl2E7atCK8J:revistasum.umanizales.edu.co/ojs/index.php/plumillaeducativa/article/download $/ 1607 / 1654+\& c d=54 \& h l=e s-419 \& c t=c l n k \& g l=c o$

Herreros. L. (2017) La formación del docente ante la diversidad en el aula. [Tesis de maestría. Universidad Rey Juan Carlos] Obtenido de http://riberdis.cedd.net/bitstream/handle/11181/5675/La_formaci\%C3\%B3n_del_docente_ante_la_diversidad_ en_su_aula.pdf?sequence $=1$

Landazuri. M. (2019) Preparación de los docentes sobre la inclusión y atención a la diversidad en la educación inicial básica. [Tesis de maestría. Universidad Laica Vicente Rocafuerte de Guayaquil] Obtenido de http://repositorio.ulvr.edu.ec/bitstream/44000/3183/1/TM-ULVR-0163.pdf

López. C y Noguera. T, (2019) Formación docente en inclusión de niños con necesidades educativas especiales. [Tesis de maestría. Universidad de la costa] Obtenido de https://repositorio.cuc.edu.co/bitstream/handle/11323/5783/Formaci\%C3\%B3n\%20 docente\%20en\%20inclusi\%C3\%B3n\%20de\%20ni\%C3\%B1os\%20con\%20necesidades\%20educativas $\% 20$ especiales.pdf?sequence $=1$

Luque M. (2017) La formación del docente en la educación inclusiva universitaria. Obtenido de https://www.researchgate.net/publication/330812200_LA_FORMACION_DEL_DOCENTE_EN_LA_EDUCACION_INCLUSIVA_UNIVERSITARIA_TEACHER_TRAINING_IN_INCLÜSIVE_HIGHER_EDUCATION

Marchesi. A. Díaz. T. La docencia, una profesión emocional y moral. Las emociones y valores del profesorado. p 9-13. Recuperado de https://www.oei.es/historico/valores2/Lasemocionesprofesorado.pdf

Molina. M. (2017) Propuesta de formación docente para la educación inclusiva de estudiantes en situación de discapacidad intelectual. [Tesis de maestría. Universidad Sergio Arboleda] Obtenido de https://repository.usergioarboleda.edu.co/bitstream/handle/11232/1308/Propuesta\%20de\%2Oformaci\%C3\%B3n\%2Odocente\%20 para\%2Ola\%20educaci\%C3\%B3n\%2Oinclusiva. pdf?sequence=1\&isAllowed=y

Montero. L y Gewerc. A. (2018). La profesión docente en la sociedad del conocimiento. Una mirada a través de la revisión de investigaciones de los últimos 10 años. Recuperado de https://www.um.es/ead/red/56/montero_gewerc.pdf

Muntaner, Joan Jordi (2010) De la integración a la inclusión: un nuevo modelo educativo. En Arnaiz, P.; Hurtado, Mạ.D. y Soto, F.J. (Coords.) 25 Años de Integración Escolar en España: Tecnología e inclusión en el ámbito educativo, laboral y comunitario. Murcia: Consejería de Educación, Formación y Empleo.

Niño. B. (2016) Estrategias inclusivas en el aula. propuesta frente a las dificultades cognitivas en el ciclo dos de educación básica en el colegio brazuelos I.E.D. [Tesis de maestría. Universidad Distrital de Colombia] Obtenido de http://repository.udistrital.edu.co/ bitstream/11349/4231/1/ESTRATEGIAS\%2OINCLUSIVAS\%20EN\%20EL\%2OAULA1.pdf 
Omaña. E. y Alzolar. N. (2017) Estrategia pedagógica para la inclusión del estudiante con discapacidad. Instituto pedagógico de Caracas Venezuela. Obtenido de https:// dialnet.unirioja.es/servlet/articulo?codigo $=6296695$

Orozco, M. Mosquera. J y Herrera. A. (2014) Capacitación eficiente desde lo gerencial para los docentes en inclusión educativa. [Especialización. Universidad Católica de Manizales] Obtenido de https://ucm.edu.co/biblioteca/?s=Capacitaci\%C3\%B$3 n+$ eficiente+desde+lo+gerencial+para+los+docentes+en+inclusi\%C3\%B3n+educativa\%E2\%80\%9D+con+el+objetivo+de+desarrollar+gerencialmente+un+programa+de+capacitaci\%C3\%B3n+eficiente+en+Inclusi\%C3\%B3n+para+los+docentes+de+la+Instituci\%C3\%B3n+Educativa+Chipre

Osorio. C. Cortina. A. Jiménez. M. Rodríguez. M. (2017) Sensibilización y orientación pedagógica a docentes en procesos de inclusión educativa en el aula. [Especialización. Universidad Autónoma de Bucaramanga] Obtenido de https://repository.unab. edu.co/bitstream/handle/20.500.12749/833/2017_Tesis_Rodriguez_Camacho_Maria_Fernanda.pdf?sequence $=1 \&$ isAllowed $=y$

Plancarte. P. (2017). Revista Nacional e Internacional de Educación Inclusiva Inclusión educativa y cultura inclusiva. p 213-226. Recuperado de https://dialnet.unirioja. es/descarga/articulo/6545223.pdf.

Quishpi. A. (2020) La sensibilización del docente en la inclusión educativa de estudiantes con discapacidad. [Tesis de maestría. Universidad Laica Vicente Rocafuerte de Guayaquil] Obtenido de http://repositorio.ulvr.edu.ec/bitstream/44000/3833/7/ TM-ULVR-0186.pdf

Rivera. P. (2017) Educación inclusiva y formación inicial docente, una experiencia en la región de Coquimbo Chile. [Tesis de doctorado. Universidad de Alcalá] Obtenido de https://ebuah.uah.es/dspace/bitstream/handle/10017/38236/Tesis\%20Pabla\%20 Rivera\%2Olribarren.pdf?sequence=1\&isAllowed=y

Sierra. A. (2019) Estrategia de formación docente orientada al fortalecimiento de la educación inclusiva en la catedra de Gestión Básica de la Información - GBI UNIMINUTO, Sede Principal. [Tesis de maestría. Corporación Universitaria Minuto de Dios] Obtenido de https://repository.uniminuto.edu/bitstream/handle/10656/10620/ TM.GS_SierraAlexandra_\%202019.pdf?sequence=1\&isAllowed=y

Sosa. L. (2015) Necesidad formativa del profesorado universitario de la a Universidad Nacional Pedro Henríquez Ureña UNPHU, en relación con la atención a la diversidad. [Tesis de doctorado. Universidad de Sevilla] Obtenido de https://idus.us.es/ bitstream/handle/11441/36595/TESIS\%2OLESBIA.pdf;jsessionid=95147C6A90A8FCE6BF2FCOC7471E5770?sequence=1\&isAllowed $=y$

Tornel. N. (2015) Formación docente del profesorado de Educación primaria en diversidad cultural. Un elemento clave para la transformación y actualización de los centros educativos. [Tesis de doctorado. Universidad de Murcia] Obtenido de https:// digitum.um.es/digitum/bitstream/10201/47001/1/Tesis\%20doctoral\%2ONURIA\%20 TORNEL\%202015.pdf 


\section{El Aula Virtual de Traducción para la Formación Profesional: Recursos Digitales para el Aprendizaje Interactivo}

\section{Gava, lleana Yamina}

Universidad Nacional de Córdoba yamina.gava@unc.edu.ar

\section{Blanco, Candela}

Universidad Nacional de Córdoba candela.blanco@mi.unc.edu.ar

\section{Cobresle, Kemel Karim}

Universidad Nacional de Córdoba

kemel.cobresle@mi.unc.edu.ar 


\title{
EL AULA VIRTUAL DE TRADUCCIÓN PARA LA FORMACIÓN PROFESIONAL: RECURSOS DIGITALES PARA EL APRENDIZAJE INTERACTIVO
}

\author{
Gava, lleana Yamina \\ Blanco, Candela \\ Cobresle, Kemel Karim
}

\section{Resumen}

Somos testigos del papel preponderante de las aulas virtuales en la actualidad. En el ámbito de la formación de traductores, existe una creciente necesidad de investigaciones sobre cómo utilizar estos entornos para una formación más eficaz y relevante para los futuros profesionales (Díaz Alarcón, 2018; Gava y Aguirre Sotelo, 2016). Desde el año 2019, se llevan a cabo proyectos en el marco del Programa de Formación de Investigadores de la Facultad de Lenguas de la UNC (Gava y Spataro, $2019,2020,2021$ ) que han permitido explorar las perspectivas de docentes y discentes sobre el uso de recursos digitales y aulas virtuales en la plataforma Moodle en nuestro contexto en particular, y elaborar un marco teórico-metodológico para un mejor aprovechamiento de estos espacios y herramientas. Se utilizó un diseño descriptivo, exploratorio e interpretativo en el marco de la investigación cualitativa (Denzin y Lincoln, 2012; Hatch, 2002). Los resultados presentados en este trabajo evidencian puntos de encuentro entre las percepciones de estudiantes y docentes sobre el aula virtual para el aprendizaje de la traducción en relación con el uso didáctico de entornos y recursos digitales, la motivación, la interacción y el rol de los estudiantes y docentes. El análisis bibliográfico documental permitió esbozar sugerencias didácticas para repensar el aula virtual y el aprendizaje de la traducción en la virtualidad. Se espera que estos hallazgos contribuyan al diseño de propuestas y proyectos didácticos que faciliten el aprendizaje interactivo en línea y la adquisición de la competencia traductora de futuros profesionales de la traducción.

\section{Palabras clave}

Aula virtual, formación profesional, didáctica de la traducción, recursos digitales, aprendizaje interactivo. 


\section{Introducción}

La era digital no solo ha traído consigo herramientas y entornos educativos novedosos, sino también grandes desafíos. Recientemente, la emergencia sanitaria impulsada por la pandemia mundial del COVID-19 forzó a las instituciones educativas en todo el mundo a implementar la Enseñanza Remota de Emergencia (Hodges et al., 2020), lo que ha puesto en evidencia la importancia de adquirir y aplicar habilidades digitales y conocimientos específicos para enseñar y aprender a través de diversos entornos, entre los que se destacan las aulas virtuales (AV). En el ámbito de la formación de traductores existe una creciente necesidad de investigaciones sobre cómo utilizar las TIC para una formación profesional más eficaz (Díaz Alarcón, 2018; Gava y Aguirre Sotelo, 2016). Las potencialidades didácticas de las AV evidencian su constitución en tanto espacios y objetos de investigación para la mejora de la calidad educativa. En la Facultad de Lenguas, UNC, las AV se utilizan de distintas maneras y con resultados favorables; no obstante, no se cuenta con información suficiente sobre las percepciones de docentes y estudiantes en cuanto al aprendizaje en la virtualidad, lo que contribuiría a una mejor implementación de estos contextos de enseñanza-aprendizaje (Gava y Aguirre Sotelo, 2016; Sestopal y Gava, 2011). Como sugiere Torres Burgos (2015), "los estudiantes no sólo se ven en la necesidad de adquirir el conocimiento declarativo, sino además desarrollar habilidades frente al uso de los recursos y las herramientas que se usan en el ámbito de la traducción (conocimiento operativo), dada su condición práctica” (p. 137). Es por ello que, desde el año 2019, se llevan a cabo proyectos impulsados por el Programa de Formación de Investigadores de la Facultad de Lenguas de la UNC (Gava y Spataro, 2019, 2020, 2021) que permitieron explorar las perspectivas de docentes y discentes sobre el uso de las AV en Moodle y elaborar un marco teórico-metodológico para su mejor aprovechamiento.

Desde el punto de vista metodológico, las AV favorecen la autonomía y la construcción colaborativa del conocimiento; por lo tanto, el socioconstructivismo es un fundamento adecuado para el aprendizaje virtual (Chan Núñez, 2016). Según sostienen Martínez de la Cruz, Galindo González y Galindo González (2013), "en su carácter pedagógico, el fundamento teórico del entorno virtual de aprendizaje es el socioconstructivismo, el cual considera a los entornos virtuales de aprendizaje como lugares privilegiados para la adquisición y creación de conocimientos" (p. 5). En cuanto a su utilidad y relevancia para la didáctica de la traducción, diversos estudios han demostrado que el uso de las tecnologías digitales se ha incrementado notablemente en el ámbito de la formación de traductores debido a su relevancia y potencial para facilitar el aprendizaje del proceso traductor y la adquisición de la competencia traductora profesional. Algunas investigaciones exploran las AV y otras herramientas en línea para la adquisición de la competencia traductora, en particular el empleo de entornos interactivos como los foros y wikis para desarrollar tareas similares al trabajo profesional (Álvarez Álvarez, 2012; Galán Mañas, 2009; Gava y Aguirre Sotelo, 2016; Torres del Rey, 2005). Álvarez Álvarez (2012) rescata que tanto el método de trabajo como el entorno laboral de los traductores ha sido modificado de manera drástica por las TIC, "por lo que estos cambios han de reflejarse en el ámbito de la formación de futuros profesionales" (p. 304). De este modo, el uso de las tecnologías digitales se considera indispensable en la formación de traductores, no solo para el desarrollo de las competencias lingüísticas y traductológicas específicas, sino también para fomentar las competencias genéricas como el trabajo grupal y el aprendizaje autónomo. Asimismo, se han llevado a cabo estudios 
más recientes sobre el potencial de la ludificación para la formación profesional de los traductores en áreas de especialidad (Martín Matas, 2020; Romana, 2018). Estos estudios evidencian los beneficios y desafíos de estas experiencias de aprendizaje para la motivación, la autonomía, el pensamiento crítico y la adquisición de habilidades de interacción y gestión de proyectos interdisciplinarios en entornos que simulan la realidad profesional del futuro traductor. Estos estudios brindan un marco orientador para el presente trabajo, que se centra en el empleo de las AV para la enseñanza y el aprendizaje de la traducción en un contexto particular.

En cuanto a los objetivos y la metodología de esta investigación, cabe aclarar que mientras las hipótesis constituyen un tipo de predicción de resultados, las preguntas de investigación como las que se plantean en este estudio tienden a ser abiertas, por lo que son un punto de partida y eje de estudio de trabajos exploratorios e interpretativos (Hatch, 2002; Patton, 2002). Este trabajo parte de estas preguntas de investigación: 1) ¿Cuáles son los beneficios, problemáticas y desafíos que los docentes y alumnos perciben sobre el uso de las AV para la enseñanza y el aprendizaje de la traducción especializada en la universidad? y 2) Sobre la base de las respuestas a la pregunta 1, ¿qué lineamientos contextualmente relevantes de la literatura en este ámbito podrían ser aplicables para subsanar las posibles dificultades didácticas y facilitar el aprendizaje interactivo de la traducción en los entornos virtuales explorados en este estudio? Se postulan dos objetivos centrales: 1) Analizar los beneficios y dificultades percibidos por docentes y estudiantes en cuanto al AV en cursos de traducción especializada. 2) Realizar un análisis documental que permita explorar propuestas pedagógicas y resultados de investigaciones previas sobre el uso educativo de las TIC para abordar los desafíos detectados sobre la utilización del AV para el aprendizaje interactivo de la traducción. Para la consecución de estos objetivos, se utilizó un diseño exploratorio, descriptivo e interpretativo en el marco de la investigación cualitativa (Denzin y Lincoln, 2012; Hatch, 2002).

\section{Método}

\section{Descripción del contexto y de los participantes}

Como se mencionó anteriormente, este trabajo se inscribe en el seno de proyectos de mayor envergadura en los que se estudiaron las perspectivas de estudiantes y docentes sobre las AV de diversas cátedras (10 en total) de las carreras de grado de la Facultad de Lenguas (UNC), sección inglés. Dadas las características del presente trabajo y los objetivos que se plantean, se han seleccionado los datos vinculados con dos asignaturas de traducción especializada de la carrera de Traductor Público Nacional de Inglés. Una de estas asignaturas se ubica en el tercer año de la carrera, que constituye el primer trayecto de traducción especializada del Traductorado, mientras que la segunda asignatura seleccionada se ubica en el quinto y último año de esta carrera. Se considera que esta elección permitió obtener cierta variedad de percepciones en cuanto a las miradas de los docentes y las experiencias de aprendizaje de los estudiantes. Participaron dos docentes y 144 estudiantes de manera voluntaria, lo cual representa un $85 \%$ del total de asistentes regulares a las clases de estas asignaturas. 


\section{Instrumentos}

Se utilizaron tres instrumentos de investigación. Para la recolección de los datos sobre las percepciones de los participantes se emplearon entrevistas semiestructuradas (Dörnyei, 2007) y encuestas cualitativas (Jansen, 2003). Hacia el final del ciclo lectivo 2019 se entrevistaron dos docentes (una de cada asignatura), cuatro estudiantes (dos de cada asignatura) y se encuestaron 140 estudiantes: 104 de tercer año y 36 de quinto año. Las entrevistas se realizaron de manera personal y se grabaron para su posterior transcripción. Las encuestas se administraron a través de documentos de Google Forms, lo cual facilitó su administración y procesamiento. Para evitar el sesgo en los datos, no se aplicaron criterios de selección, sino que se contó con la participación voluntaria de los estudiantes y docentes. En el año 2020, se procedió a la conformación del corpus documental de la bibliografía recopilada sobre el uso de las TIC en el ámbito de la didáctica de la traducción, conforme a los parámetros y procedimientos que se describen en la siguiente sección.

\section{Procedimiento}

Se utilizó una metodología cualitativa que permitió la descripción detallada de los resultados (Hatch, 2002; Patton, 2002). Muchos son los expertos que argumentan a favor de los diseños cualitativos de investigación en contextos educativos, debido principalmente a que los estudios cuantitativos no siempre logran dar cuenta de la complejidad de los factores lingüísticos, individuales y de interacción social vinculados con el aprendizaje. Por lo tanto, en este trabajo se aplicó un diseño exploratorio e interpretativo cuyos procedimientos son inductivos y deductivos. Según el modelo sugerido por Hatch (2002), en la primera etapa de investigación se examinaron y agruparon los datos de las encuestas y entrevistas en conjuntos con características comunes susceptibles de análisis conforme al propósito de esta investigación. Una vez agrupados los datos, se procedió a la identificación de características distintivas en las respuestas de los estudiantes y docentes. Sobre la base de estas caracterizaciones, se elaboraron descripciones de los patrones observados, que permitieron establecer recurrencias y particularidades de interés para este estudio. Seguidamente se compararon, contrastaron y agruparon los patrones identificados. Estos procedimientos evidenciaron las áreas de relevancia en los datos explorados en consecución del primer objetivo de investigación.

En la segunda etapa, se procedió al análisis bibliográfico documental conforme a lo planteado en el segundo objetivo de investigación. Adherimos a tres características principales de la investigación bibliográfica documental: holística, interpretativa e inductiva (Arnald, 1992, en Gómez, 2011). En consecuencia, para el análisis bibliográfico se adoptaron los parámetros para la valoración crítica de artículos de investigación que sugieren Garcés Cano y Duque Oliva (2007): identificación de las características del artículo, literatura contemplada, metodología de investigación, resultados, discusión, implicaciones y conclusiones. Esto permitió delimitar el corpus de estudio conforme a las áreas de relevancia detectadas en la primera etapa de investigación. Consideramos que el principal valor de esta investigación documental radica en su característica "reconstructiva: con nuevas preguntas reelabora un conocimiento que ha producido unos resultados y un saber previos y en esta medida modifica los fenómenos objeto de reflexión y lectura hermenéutica que favorezca la discusión orientada a realizar nuevos aportes" (Gómez, 2011, p. 230). Estos procesos interpretativos permitieron identificar propuestas para la utilización de recursos didácticos que po- 
drían aportar soluciones a las principales dificultades observadas en cuanto al uso de las $\mathrm{AV}$ en la formación de traductores en el contexto de este estudio.

\section{Resultados}

Los resultados alcanzados en la primera etapa de esta investigación revelan opiniones de los participantes en cuanto a los beneficios y dificultades del AV. Según las preguntas de investigación que guían este trabajo, analizaremos los puntos de encuentro detectados entre las precepciones de estudiantes y docentes en relación con cuatro ejes: el uso de entornos y recursos digitales, la motivación para el uso del aula virtual, la interacción y el rol de los estudiantes en el AV. Cabe señalar que, dada la naturaleza exploratoria y descriptiva de este estudio, se priorizaron las opiniones de los participantes conforme a su relevancia según el objetivo de investigación, independientemente de su índice de frecuencia en el corpus bajo análisis (Patton, 2002). El análisis bibliográfico documental realizado en la segunda etapa permitió esbozar sugerencias específicas relacionadas con el uso didáctico de recursos y entornos digitales para la enseñanza y el aprendizaje de la traducción en la virtualidad. Estos hallazgos contribuirían por un lado a ofrecer soluciones a las falencias y dificultades detectadas, y por otro lado podrían reforzar las ventajas percibidas del uso del AV y las actividades en línea para el aprendizaje interactivo de la traducción. En la siguiente tabla, se presenta un resumen descriptivo de los principales resultados de este estudio.

\begin{tabular}{|c|c|c|}
\hline $\begin{array}{l}\text { Aspectos del } \\
\text { AV }\end{array}$ & $\begin{array}{l}\text { Beneficios y dificultades del } \\
\text { uso del AV }\end{array}$ & $\begin{array}{l}\text { Recursos digitales y propuestas didácticas para } \\
\text { potenciar el aprendizaje de la traducción en la } \\
\text { virtualidad }\end{array}$ \\
\hline \multirow{6}{*}{$\begin{array}{l}\text { A. Entornos } \\
\text { y recursos } \\
\text { digitales }\end{array}$} & $\begin{array}{l}\text { BENEFICIOS: } \\
\text { A.1.1 Medio para adquirir y } \\
\text { optimizar competencias } \\
\text { de traducción y práctica } \\
\text { profesional. }\end{array}$ & $\begin{array}{l}\text { Práctica del modelo de competencia profesional } \\
\text { interdisciplinaria y transversal para visibilización de } \\
\text { proyectos (Arrés López, 2012). Proyectos sociales } \\
\text { colaborativos (crowdsourcing) (García Santiago, } \\
\text { 2016). Aprendizaje por proyectos de traducción } \\
\text { (Kiraly, 2015). Actividades de simulación de equipos } \\
\text { de traducción reales (Gutiérrez Artacho et al., } \\
\text { 2016). }\end{array}$ \\
\hline & $\begin{array}{l}\text { A.1.2 Espacio aglutinador de } \\
\text { recursos didácticos y fuentes } \\
\text { de documentación }\end{array}$ & $\begin{array}{l}\text { La personalización del curso: espacio aglutinador } \\
\text { de recursos multimedia y materiales variados } \\
\text { (Mansilla y González-Davies, 2017). }\end{array}$ \\
\hline & $\begin{array}{l}\text { A.1.3 Las wikis para la } \\
\text { práctica de traducción } \\
\text { colaborativa. }\end{array}$ & $\begin{array}{l}\text { Las wikis permiten simular el trabajo profesional a } \\
\text { nivel individual y grupal (García Santiago, 2016). }\end{array}$ \\
\hline & $\begin{array}{l}\text { A.1.4 Complemento esencial } \\
\text { para la presencialidad. }\end{array}$ & $\begin{array}{l}\text { El AV como espacio necesario para la educación } \\
\text { semipresencial y online (Díaz Alarcón, 2018). }\end{array}$ \\
\hline & $\begin{array}{l}\text { A.1.5 Actividades de } \\
\text { repaso, retroalimentación y } \\
\text { evaluación. }\end{array}$ & $\begin{array}{l}\text { La evaluación como proceso: las autoevaluaciones } \\
\text { convierten a los estudiantes en agentes activos, } \\
\text { reflexivos y responsables de su aprendizaje (Galán } \\
\text { Mañas, 2009). }\end{array}$ \\
\hline & $\begin{array}{l}\text { DIFICULTAD: } \\
\text { A.2.1 EI exceso de contenido } \\
\text { y su disposición dificulta a } \\
\text { veces el seguimiento de las } \\
\text { tareas. }\end{array}$ & $\begin{array}{l}\text { Interfaz amigable y fácil de navegar: disposición } \\
\text { clara y pautada de los contenidos y actividades en } \\
\text { el AV de traducción (Mansilla y González-Davies, } \\
\text { 2017). }\end{array}$ \\
\hline
\end{tabular}




\begin{tabular}{|c|c|c|}
\hline B. Motivación & $\begin{array}{l}\text { DIFICULTAD: } \\
\text { B.1.1 El AV resulta menos útil } \\
\text { y motivadora que las clases } \\
\text { presenciales. }\end{array}$ & $\begin{array}{l}\text { Actividades en línea de simulación del trabajo } \\
\text { profesional y elementos de ludificación e incentivan } \\
\text { a enfrentar desafíos y aumentarían la motivación } \\
\text { (Gutiérrez Artacho, Olvera Lobo y Hunt Gómez, } \\
\text { 2016, Mansilla y González-Davies, 2017; Martín } \\
\text { Matas, 2020; Romana, 2018). }\end{array}$ \\
\hline \multirow{2}{*}{$\begin{array}{l}\text { C. Interacción } \\
\text { y comunica- } \\
\text { ción }\end{array}$} & $\begin{array}{l}\text { BENEFICIO: } \\
\text { C.1.1 Los foros para } \\
\text { comunicarse y aprender } \\
\text { colaborativamente. }\end{array}$ & $\begin{array}{l}\text { Creación de foros de discusión relacionados con } \\
\text { los contenidos curriculares (Gómez Rey, Hernández } \\
\text { García y Rico García, 2009). El foro de debate } \\
\text { como centro de la comunidad de práctica (Mansilla } \\
\text { y González-Davies, 2017) }\end{array}$ \\
\hline & $\begin{array}{l}\text { DIFICULTAD: } \\
\text { C.2.1 Escasa participación en } \\
\text { los foros de debate. }\end{array}$ & $\begin{array}{l}\text { Las actividades (preguntas) y debates construidos } \\
\text { en torno a las contribuciones de los estudiantes y } \\
\text { su procesos de aprendizaje favorecen la interacción } \\
\text { y la interdependencia positiva (Mansilla, y } \\
\text { González-Davies, 2017). }\end{array}$ \\
\hline \multirow[b]{2}{*}{$\begin{array}{l}\text { D. Rol de } \\
\text { estudiantes y } \\
\text { docentes }\end{array}$} & $\begin{array}{l}\text { BENEFICIO: } \\
\text { D.1.1 Autonomía del estudiante } \\
\text { y acompañamiento docente } \\
\text { para la realización de } \\
\text { actividades. }\end{array}$ & $\begin{array}{l}\text { Integración de las TIC como herramientas para que } \\
\text { el estudiante abandone el papel de sujeto receptor } \\
\text { y sea constructor de su aprendizaje (Díaz Alarcón, } \\
2018 \text { y otros) }\end{array}$ \\
\hline & $\begin{array}{l}\text { DIFICULTAD: } \\
\text { Los estudiantes se limitan } \\
\text { a realizar actividades, sin } \\
\text { proponer actividades o } \\
\text { compartir contenidos. }\end{array}$ & $\begin{array}{l}\text { Desarrollo de una asignatura virtual que simule la } \\
\text { actividad profesional y estimule la participación de } \\
\text { los estudiantes en la producción de conocimiento y } \\
\text { el aprendizaje de la competencia traductora (Arrés } \\
\text { López, 2012; Arrés López et al, 2012). } \\
\text { Utilización de textos sugeridos por los estudiantes } \\
\text { para ejercicios de traducción (Mansilla, y González- } \\
\text { Davies, 2017). }\end{array}$ \\
\hline
\end{tabular}

\section{Tabla 1: Síntesis de los resultados}

Los resultados del análisis de las entrevistas y encuestas revelan que los docentes y estudiantes perciben beneficios puntuales del uso del AV en la modalidad mixta (blended learning). En primer lugar, observamos que los alumnos consideran que existen diversas utilidades del AV como complemento de las clases presenciales, como por ejemplo: contactar a los docentes para obtener información sobre cuestiones relacionadas con cada asignatura mediante el foro de consultas, realizar aportes e intercambiar sugerencias terminológicas y temáticas por medio de los foros de debate, adquirir conocimientos previos a la clase presencial a través de las actividades y recursos incluidos en el AV, acceder a las presentaciones de clase (documentos Power Point y recursos multimedia), y lograr así una mayor profundización de los conocimientos. Según lo expresa un alumno: "las horas cátedra no alcanzan... el aula virtual sirve muchísimo para ampliar los conocimientos y resolver dudas". A su vez, los estudiantes afirman que las AV les permiten repasar contenido antes de las instancias evaluativas y que, además de brindarles conocimientos sobre el uso de las nuevas tecnologías, las AV les resultan de gran utilidad para realizar práctica de la traducción desde la colaboración. Es por esto que muchos estudiantes eligieron a las wikis como uno de los recursos más útiles del $\mathrm{AV}$. En este sentido, un grupo de estudiantes también reconoció que el trabajo en línea a través del AV les permite desarrollar nuevas competencias vinculadas a su futura labor profesional. Por otro lado, en cuanto a la comunicación y el aprendizaje colaborativo, los estudiantes manifestaron que la implementación de foros de debate es se suma utilidad para mantener un diálogo constante no solo con los docentes, sino también 
con otros estudiantes. Además, tanto los docentes como los estudiantes afirmaron que las $\mathrm{AV}$ son espacios útiles para la recopilación y organización de recursos de documentación, entre los cuales destacan los blogs, diccionarios, glosarios y libros especializados de cada asignatura.

Los docentes también perciben ventajas tales como la comunicación con los estudiantes, la flexibilidad que ofrece la plataforma para trabajar con contenido multimedia y la posibilidad de diseñar actividades con retroalimentación automática mediante la herramienta cuestionarios de Moodle. Además, se valora el AV como un entorno que favorece el aprendizaje desde la colaboración, por medio de la traducción y revisión conjunta de textos en las wikis y los trabajos prácticos grupales a través de la herramienta tareas de Moodle. Se destacan así las opiniones relacionadas con la dimensión individual y social del aprendizaje. A modo de ilustración, un docente señala que el principal beneficio del AV es que "permite realizar investigaciones lingüísticas pertinentes dentro de un plazo, pero con tiempos que trascienden la presencialidad", y opina que, teniendo en cuenta las características de una universidad pública con muchos alumnos y pocos profesores, "para poder hacer un seguimiento más particularizado, el uso y la incorporación de AV supone una ventaja justamente para responder a esta necesidad". En cuanto a la dimensión social, los estudiantes también se muestran interesados en los aportes de sus pares y en socializar esas contribuciones.

Respecto a las dificultades y desafíos del AV para el aprendizaje mixto en las cátedras objeto de este estudio, es interesante observar que, aunque todos los participantes opinan que Moodle es una herramienta muy valiosa, algunos experimentan dificultades en el uso y la mayoría percibe que las prestaciones de la plataforma no se aprovechan por completo. Por ejemplo, un estudiante considera que la organización del aula es unidireccional (profesor-alumno) y sugiere que debería ser más equilibrada e interactiva. Otro estudiante menciona como desventaja la falta de predisposición por parte de algunos alumnos para que el AV funcione como extensión de la clase presencial y el incentivo que se necesita por parte del docente para que los alumnos participen en algunas actividades, como los foros, por ejemplo. Otros opinan que debería mejorarse la organización de los materiales y algunos experimentaron dificultades para navegar por la plataforma y encontrar recursos. Se sugirió también que el $\mathrm{AV}$ a veces no resulta tan motivadora como las clases presenciales. Un docente también sugiere mejorar la organización de los materiales y recursos por medio de hipervínculos, teniendo en cuenta que "los alumnos quizás se abruman un poco con tanta información. En vez de verlo todo publicado, quizás un enlace sería más simple y menos abrumador". Según se observa en la tabla 1, existen propuestas basadas en estudios realizados en el campo de la didáctica de la traducción que podrían ser útiles para mejorar el uso del AV en relación con las principales dificultades observadas.

\section{Discusión y conclusiones}

Este estudio permitió abordar el uso de las AV en dos asignaturas de la carrera de Traductor Público Nacional de Inglés de la Facultad de Lenguas (UNC) desde las perspectivas de los docentes y alumnos, verdaderos protagonistas del proceso de aprendizaje. Se evidenciaron no solo las potencialidades y beneficios de estos entornos digitales, sino también aquellos aspectos que presentan dificultades y que, 
por lo tanto, deberían abordarse para realizar mejores en la formación de traductores en la actualidad. En este sentido, se exploraron propuestas existentes en la literatura en este ámbito que permiten sugerir mejoras y posibles innovaciones para el uso pedagógico de recursos digitales. Estos hallazgos revelan que para lograr cambios significativos se deberían realizar las siguientes acciones: disponer de diseños más amigables para los entornos virtuales de aprendizaje, proponer actividades de simulación profesional que incentiven la motivación de los estudiantes de traducción, y otorgar mayor centralidad a la coconstrucción del conocimiento mediante la interacción entre docentes y alumnos -y entre alumnos entre sí- para que el aprendizaje ocurra más allá del entorno del aula tradicional.

Dado que los participantes de esta investigación perciben que las principales ventajas del AV consisten en la optimización de los procesos relacionados con la comunicación y la práctica de la competencia traductora mediante wikis de traducción, revisiones colaborativas, cuestionarios de autoevaluación y foros, se debería optimizar el uso de estos recursos y actividades. Asimismo, debería existir una disposición clara y pautada de los contenidos del AV para facilitar la navegación y el seguimiento de las tareas. Se deberían, además, utilizar otros recursos y herramientas, por ejemplo, foros de ayuda para intercambios entre estudiantes y actividades de simulación de equipos de traducción reales, con el propósito de ampliar la variedad de actividades y potenciar el aprendizaje interdisciplinario (Arrés López; 2012 y Martín Matas; 2020). En consecuencia, el AV se convertiría en un factor promotor de la formación profesional en tanto que facilitaría la construcción del conocimiento de manera autónoma y a la vez colaborativa, relevante y significativa (Mansilla y González-Davies, 2017).

Asimismo, en cuanto a la incorporación de las TIC para la formación de traductores, docentes y alumnos perciben que favorece el aprendizaje en grupos numerosos porque permite fomentar la autonomía y mejorar la práctica de la traducción. Esto se debe a que el uso efectivo de las TIC puede ofrecer mayores oportunidades para la documentación y la investigación, además de un acercamiento a la práctica profesional de la traducción, según se ha demostrado también en otros estudios referidos en este trabajo. Tal como sugieren Gava y Aguirre Sotelo (2016), el uso del AV es esencial como complemento de clases presenciales, ya que "el futuro traductor deberá ser capaz de interactuar de manera efectiva en los entornos virtuales de nuestro mundo globalizado para lograr una correcta inserción en el mundo laboral y las comunidades académicas actuales" (p.109). Según se desprende de esta investigación, la realización de trabajos prácticos, a modo de encargos de traducción, significaría un avance en este sentido ya que permite introducir a los estudiantes universitarios al mundo de la traducción profesional.

Finalmente, un aspecto fundamental del enfoque socioconstructivista en la educación virtual es el rol de los docentes y alumnos (Chan Nuñez, 2016). En las encuestas y entrevistas realizadas en este estudio, se pone de manifiesto que algunos docentes y alumnos tienen un rol activo y creador en el uso de las AV, mientras que otros manifiestan la necesidad de adquirir habilidades específicas que les permitan producir conocimiento a partir del uso de la tecnología. Esto puede deberse a diversos factores como la escasa formación y capacitación en el uso de las AV o a cuestiones relacionadas con la motivación para el aprendizaje. En consecuencia, uno de los principales desafíos que se desprenden de esta investigación es la formación de docentes y alumnos para la construcción del conocimiento de manera autónoma, 
colaborativa y significativa por medio de una plataforma virtual. Esto, a su vez, contribuiría a que los individuos adquieran un rol de participación más activo en las AV.

En conclusión, dadas las características del contexto de estudio, en el que el uso de las $\mathrm{AV}$ es relativamente reciente y las investigaciones en este ámbito son incipientes, se puede considerar que este trabajo representa un avance en este sentido. No obstante, existen limitaciones debido a la cantidad reducida de asignaturas que se exploraron y al contexto de enseñanza y aprendizaje mixto. Por lo tanto, se sugiere complementar los resultados con investigaciones sobre percepciones de docentes y estudiantes de otras asignaturas de traducción y en contextos de enseñanza remota a distancia como los que han surgido en estos dos últimos años a raíz de la pandemia global por el COVID-19. Sería necesario, también, ampliar el análisis documental y realizar estudios longitudinales en la modalidad mixta y a distancia. Un abordaje más amplio de las opiniones y percepciones de los sujetos podría proporcionar un punto de partida para realizar propuestas didácticas e institucionales tendientes a mejorar la democratización y virtualización de la educación en esta área de especialidad, atendiendo a la diversidad de contextos de enseñanza y aprendizaje.

\section{Referencias}

Álvarez Álvarez, S. (2012). La tecnología al servicio de la enseñanza de la traducción: Diseño de un curso de traducción económica en modalidad mixta (presencial-virtual) y su experimentación en el aula. [Tesis doctoral, Universidad de Valladolid].

Arrés López, E. (2012). Desarrollo de la competencia profesional con el trabajo colaborativo en proyectos innovadores de software libre. IX Jornadas Internacionales de Innovación Universitaria.

Arrés López, E., Díaz García, A. L., Díaz García Alcalde Peñalver, E. (2012). Formando auténticos profesionales: aula virtual de simulación de la actividad profesional real. IX Jornadas Internacionales de Innovación Universitaria.

Chan Núñez, M. E. (2016). La virtualización de la educación superior en América Latina: entre tendencias y paradigmas. RED-Revista de Educación a Distancia. 48(1). DOI: https://www.um.es/ead/red/48/chan.pdf

Denzin, N. y Lincoln, Y. (2012). Manual de investigación cualitativa. Barcelona: Gedisa.

Díaz Alarcón, S. (2018). Metodología práctica para la traducción especializada en formato virtual. EDMETIC, 7(2), 135-145.

Dörnyei, Z. (2007). Research methods in applied linguistics: Quantitative, qualitative and mixed methodologies. Oxford: OUP.

Galán Mañas, A. (2009). La enseñanza de la traducción en modalidad semipresencial. [Tesis doctoral, Universidad Autónoma de Barcelona]. 
Garcés Cano, J. E. y Duque Oliva, E. J. (2007). Metodología para el análisis y revisión crítica de artículos de investigación. Innovar, 17(29), 184-194. https://revistas.unal. edu.co/index.php/innovar/article/view/19596

García Santiago, M. D. (2016). El uso de blogs y wikis en la formación del traductor. Tradumática, 14, 147-155.

Gava I. Y. y Spataro, C. A. (2019). La implementación de las aulas virtuales en las cátedras de las carreras de grado de la sección inglés de la Facultad de Lenguas (UNC): Percepciones de docentes y alumnos. Programa de Formación de Investigadores. SeCyT FL, UNC (Resolución HCD 568/2019).

Gava I. Y. y Spataro, C. A. (2020). Enfoques y propuestas teórico-metodológicas para abordar las problemáticas y desafíos detectados por docentes y alumnos sobre las aulas virtuales en las carreras de grado de inglés de la Facultad de Lenguas, UNC. Programa de Formación de Investigadores. SeCyT FL, UNC (RD 645/2020).

Gava I. Y. y Spataro, C. A. (2021). Una aproximación al estudio de las aulas virtuales en las carreras de grado en ILE. En H. E. Gargiulo, V. H. Sajoza Juric y A. C. Cad (Editores). Actas $V$ Jornadas Internacionales de Tecnologías Aplicadas a la Enseñanza de Lenguas, p. 122-129.

Gava, I. Y. y Aguirre Sotelo, E. N. (2016). La autonomía y la construcción del conocimiento: el uso de entornos virtuales para la formación en traducción. En V. H. Sajoza Juric, A. Cacciabue, M. V. Tuya, V. Rodríguez y S. Bacco (Comp.). Interpares 3. El traductor y sus incumbencias: lo tradicional, lo nuevo y lo inesperado, 107-116. Ciudad Autónoma de Buenos Aires: Federación Argentina de Traductores.

Gómez Rey, I., Hernández García, E., y Rico García, M. (2009). Moodle en la enseñanza presencial y mixta del inglés en contextos universitarios. RIED, 12(1), 69-193.

Gómez, L. (2011). Un espacio para la investigación documental. Vanguardia Psicológica, 226-233.

Gutiérrez Artacho, J., Olvera Lobo, M. D. y Hunt Gómez, C. I. (2016). Incorporación de las nuevas tecnologías de la innovación y un modelo didáctico adaptado a la formación en Traducción e Interpretación. Innovagia 2016: III Congreso Internacional Virtual sobre Innovación Pedagógica y Praxis Educativa.

Hodges, C. Moore, S. Lockee, B. Trust, T. y Bond, A. (2020). The difference between remote teaching and online learning. EDUCAUSE Review.

Jansen, H. (2013). La lógica de la investigación por encuesta cualitativa y su posición en el campo de los métodos de investigación social. Paradigmas, 5(1), 39-72.

Kiraly, D. (2005). Project-based learning: A case for situated translation. Meta: Translators' Journal, 50(4), 1098-1111.

Mansilla, D., y González-Davies, M. (2017). El uso de estrategias socioafectivas en el aula virtual de traducción: una propuesta didáctica. Revista Digital de Investigación en Docencia Universitaria, 11(2), 251-273. 
Martín Matas, P. (2020). Participar en Traducistán 2.0. La asesoría de comunicación en redes sociales como elemento interdisciplinar. En A. M. de Vicente y J. Sierra (Coords.). Aproximación periodística y educomunicativa al fenómeno de las redes sociales. McGraw-Hill Interamericana de España.

Martínez de la Cruz, N., Galindo González, R. y Galindo González, L. (2013). Entornos virtuales de aprendizaje abiertos, y sus aportes a la educación. En XXI Encuentro Internacional de Educación a Distancia. Educación Virtual en los Cinco Continentes.

Patton, M. Q. (2002). Qualitative research and evaluation methods. Tercera edición. California: Sage Publications.

Romana, M. L. (2018). Traducistán, el país de los traductores. Innovación Didáctica: Ludificación en traducción económica. En C. Fortea, M. J. Gea, C. Gómez Pérez, M. Guirao, E. Maqueda, M. Marotta y A. Roales (Eds.). Nuevas perspectivas en Traducción e Interpretación. (pp. 237-250). Madrid: Escolar y Mayo Editores S.L.

Torres Burgos, J. J. (2015). Desarrollo de la sub-competencia instrumental en estudiantes de traducción, a partir de la enseñanza de recursos terminográficos online. [Tesis de maestría, Universidad Autónoma de Manizales].

Torres del Rey, J. (2005). La interfaz de la traducción: formación de traductores y nuevas tecnologías. Granada: Comares. 


\section{Plataforma REA como Espacio para la Formación Virtual en el Puesto de Trabajo, a Través de Metodologías Activas}

\section{Martínez Guzmán, María Dolores}

https://orcid.org/0000-0003-4523-4655

Instituto Politécnico Nacional México

mdmartinezg@ipn.mx 


\section{PLATAFORMA REA COMO ESPACIO PARA LA FORMACIÓN VIRTUAL EN EL PUESTO DE TRABAJO, A TRAVÉS DE METODOLOGÍAS ACTIVAS}

\section{Martínez Guzmán María Dolores}

https://orcid.org/0000-0003-4523-4655

Instituto Politécnico Nacional México

mdmartinezg@ipn.mx

\section{Resumen}

La presente comunicación, muestra los resultados de investigación del proyecto SIP20201321, realizado en el Instituto Politécnico Nacional en México, denominado Plataforma Tecnológica REA como espacio para la Formación Virtual en el Puesto de Trabajo, a través de Metodologías Activas. Dicho estudio tiene como propósito diseñar contenidos mediados en la plataforma REA (Recursos Educativos Abiertos, de desarrollo propio) que apoyan empresarios de Pymes (pequeñas y medianas empresas) en la Ciudad de México (CDMX) para favorecer sus actividades laborales y mejorar la toma de decisiones financieras y de negocio que favorezca la permanencia en el mercado

Los contenidos digitales albergados en la plataforma REA se construyen a través del uso de diversas metodologías activas y tienen como finalidad, servir como herramienta tecnológica para facilitar el aprendizaje en la toma de decisiones financieras y de negocio en los empresarios, a través de contenidos prácticos, los cuales no tienen una finalidad académica, sino práctica, sencilla y resumida para que cualquier persona aunque no tenga un perfil financiero la pueda aplicar en el puesto de trabajo.

Los resultados muestran que la plataforma REA en el diseño con los contenidos digitales, a través del uso de metodologías activas, facilita la formación de capital humano al presentar en su modalidad, un diseño y arquitectura de ambiente de aprendizaje virtual, en el que permite que los sujetos puedan capacitarse, adaptándose a sus necesidades de tiempo, espacio, así como a los recursos tecnológicos de los que dispone, es accesible y no requiere de un gasto para la organización o empresa.

\section{Palabras clave}

Plataforma REA, contenidos digitales, Formación puesto de trabajo, Pymes, Metodología activa. 


\section{Introducción}

En México y en el mundo se está desarrollando la cuarta revolución industrial, que se manifiesta en una gran complejidad e interconexión entre múltiples sectores, los cuales deben trabajar conjuntamente para entender mejor las tendencias emergentes (Schwab, 2016, pág. 14). En este contexto, radica la importancia de la creatividad y la necesidad de la gestión de talento del capital humano para adaptarse y modificar los modelos de negocios y crear nuevos servicios en sus organizaciones y con esto, apoyar en la cadena de valor para el rendimiento y permanencia en esta nueva economía.

Vivimos en una economía basada en el conocimiento que surgió a partir de la tercera revolución industrial, donde el capital humano es la fuente de la riqueza que tienen las organizaciones. Siendo este capital humano, al que debemos dedicar los esfuerzos de formación que garanticen la capacidad de gestionar el talento con creatividad e innovación continua para emprender nuevos servicios y modelos de negocios. (Martínez, 2017, pág. 222).

En la Ciudad de México, la problemática de formación de capital humano es un tema muy complejo y de profundo análisis, debido a que estamos viviendo en una economía que a partir de la pandemia COVID-19, se ha acentuado la incertidumbre en todos los ámbitos y el laboral no está exento a nivel mundial. Ahora más que nunca, se hace necesario dotar al capital humano de formación en el puesto de trabajo, utilizando las herramientas tecnológicas, y, sobre todo atendiendo a necesidades muy puntuales en el desempeño del trabajo. Es en este contexto que a partir de la Plataforma REA (de desarrollo propio) se han desarrollado y albergado contenidos digitales, tomando como base las metodologías activas, con la intención de diseñar ambientes de aprendizaje virtual, encaminados a facilitar la formación no formal del capital humano, desde una perspectiva asíncrona. Padilla, et al. (2015) plantean que la formación del capital humano para la gestión del talento es un reto ineludible para la innovación empresarial, debido que los constantes cambios y la rapidez en que se modifican los negocios dejan fuera del plano la formación en el puesto de trabajo, existe una necesidad de formación del capital humano y una oportunidad de crear nuevos esquemas que fortalezcan la gestión de talento en sus trabajadores para ampliar las capacidades de las empresas en diversos ámbitos relacionados a los negocios.

En este orden de ideas, Cueto (2013) considera fundamental fortalecer la formación en el puesto de trabajo del capital humano a través del uso de las TIC para contribuir en la gestión del talento y de esta manera apoyar en aumentar los niveles de productividad del país. La situación por la que atraviesan las Pymes en México enfrenta entre otros aspectos: limitada cultura tecnológica, carencia de personal calificado, por mencionar algunos elementos de la gestión empresarial.

El propósito de la presente investigación es el desarrollo de contenidos digitales a través de metodologías activas para ser utilizados en la formación en el puesto de trabajo de los empresarios de las PYMES de servicios manufactura y comercialización en la Ciudad de México; tomando en consideración la falta de tiempo de que disponen éstos para su capacitación. Para esta finalidad, se propuso diseñar dichas metodologías activas aplicando las herramientas tecnológicas integradas en la Plataforma REA, a través de recursos educativos abiertos que apoyen el aprendizaje del trabajador o empresario en temas selectos de finanzas adaptado al tiempo y espacio del destinatario. 
La estructura, interfaz, diseño y usabilidad de la plataforma desarrollada, representa una forma flexible, accesible y de fácil adaptación a las necesidades de formación del grupo destinatario.

\section{Objetivo}

Desarrollo de la Plataforma Tecnológica Recursos Educativos Abiertos (REA) para la formación virtual de capital humano en el puesto de trabajo, a empresas Pymes de servicios, manufactura y comercialización de la Ciudad de México, en temas selectos de finanzas, a través de metodologías activas para favorecer la toma de decisiones financieras en la gestión empresarial.

\section{Método/Descripción de la experiencia}

En la presente investigación, los sujetos de estudio estuvieron integrados por un grupo de 4 empresas con sede en la CDMX y que por fines de confidencialidad no se mencionan los nombres, su composición es: dos de las empresas proveen servicios de outsourcing y de acuerdo con el número de empleados corresponden a una empresa pequeña y otra mediana, de las dos empresas restantes una se dedica a la manufactura y comercialización de alimentos, cuyo segmento de mercado es más gourmet a diferencia de la última empresa, que únicamente comercializa algunos productos menos selectos, las últimas dos empresas no tienen trabajadores registrados y de ninguna de las ellas se conocen los ingresos anuales que generan, por ello, la estimación del tamaño se realiza con los datos conocidos.

\section{Instrumentos}

La presente investigación toma como fundamento el diagnóstico de necesidades de formación de capital humano en temas financieros, dicha investigación se basa en una metodología mixta de recopilación de información en la que se utilizaron instrumentos que aportaron información cualitativa que consta de una entrevista a profundidad, así como de un cuestionario con enfoque cuantitativo los cuales están enfocados a conocer las necesidades de formación, así como el diagnóstico para conocer si el grupo de empresas cuentan con la infraestructura y conocimientos tecnológicos básicos requeridos para la Formación de capital humano en de contabilidad financiera a través de contenidos digitales.

La validación de los instrumentos se realizó, a través de técnica de jueceo en el que se adecuó el instrumento a las necesidades del grupo destinatario.

\section{Diseño de la investigación}

Esta investigación es del corte exploratorio y descriptivo, de acuerdo con los objetivos establecidos anteriormente, se denomina exploratoria, ya que es un tema poco estudiado y se pretende incursionar mediante el desarrollo de la Plataforma REA para ser utilizada en la formación de capital humano en Pymes dirigida a empresas de servicios de la Ciudad de México para aumentar su permanencia en el mercado global y generar productos y servicios. 
Para el desarrollo de los contenidos digitales, a través de metodologías activas, de acuerdo con Cobo (2011) se trata de un trabajo multidisciplinario, ya que de los resultados obtenidos en esta investigación se plantea el diseño y desarrollo de la Plataforma REA como herramienta tecnológica empleada en la formación de capital humano.

Las Etapas que guiaron el desarrollo de los contenidos digitales, a través de metodologías activas con el uso y aplicación de herramientas digitales y que se albergan en la Plataforma Tecnológica (REA), se describen a continuación:

\section{Etapa de Desarrollo-Aplicación}

1. Desarrollo de la Arquitectura de la plataforma tecnológica diseño de interfaz para estructura, programa de base de datos que permite diseñar, almacenar, registrar autoralmente, manipular y editar contenidos digitales

2. Desarrollo de Administradores de contenido para presentar información estructurada en base a categorías y contenidos personalizada del usuario; utilizar recursos informativos divididos y organizados, controlar y dar seguimiento a la trayectoria de las actividades

3. Desarrollo Administradores de contenido para presentar información estructurada en base a categorías y contenidos, personalizada del usuario; utilizando recursos de software libre divididos y organizados para controlar y dar seguimiento a la subida de contenidos digitales, atendiendo a estándares SCORM

4. Desarrollo de la interfaz y base de datos para validar contenidos digitales

5. Desarrollo de contenidos a través de metodologías activas, con el uso y aplicación de herramientas digitales en temas selectos de contabilidad financiera para la formación de capital humano empresarios de empresas Pymes de la Ciudad de México.

\section{Resultados}

A partir de los resultados obtenidos en la aplicación de la metodología mixta en los instrumentos de recopilación de información, cualitativo y cuantitativo, se plantea lo siguientes resultados:

Las empresas sujeto de estudio, que utilizaron los contenidos en temas de contabilidad financiera, a través del uso de metodologías activas, manifestaron en los resultados de la entrevista a profundidad, la utilidad de aplicar los contenidos digitales para comprender mejor la información financiera como herramienta que les permite tener un panorama más amplio sobre la situación financiera del negocio.

Se pudo constatar que los sujetos del grupo de empresas, tienen interés de recibir formación de capital humano en línea con el uso de metodologías activas, éstas le permitieron tener más interacción con el contenidos y aplicar a situaciones reales en el ámbito laboral, específicamente en la interpretación del estado de resultado integral, y, gracias a la entrevista a profundidad, se identificaron diversas áreas de oportunidad como: temas de control interno, análisis de puestos de trabajo, estados 
financieros proforma elaborados pero no utilizados para fines de planeación y verificación de resultados, entre otros aspectos financieros.

Si bien es cierto que se encontraron diversas áreas de oportunidad, dichos temas no son parte del alcance de la presente investigación, en virtud de que el alcance de esta se centra en la formación de capital humano en el ámbito financiero, por ello, únicamente se mencionan los hallazgos al formar parte de los resultados presentados.

Por último, se confirmó que los sujetos de estudio cuentan con las herramientas y conocimientos tecnológicos básicos para formarse en línea. (ver Gráfica 1), así como la necesidad de formarse en temas financieros para la ejecución de sus funciones (ver Gráfica 2)

En la empresa, o de manera personal ¿cuenta con acceso de internet?

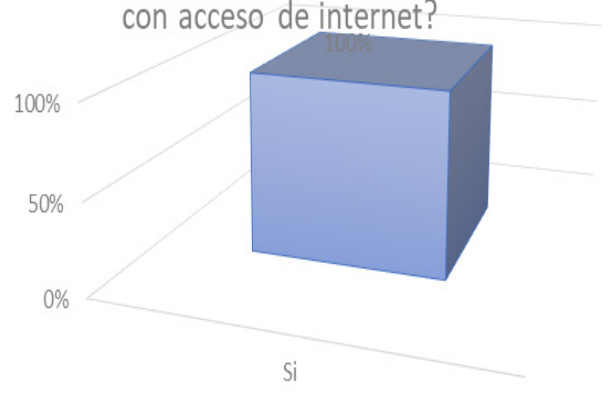

Gráfica 1. Acceso a internet para los sujetos de estudio.

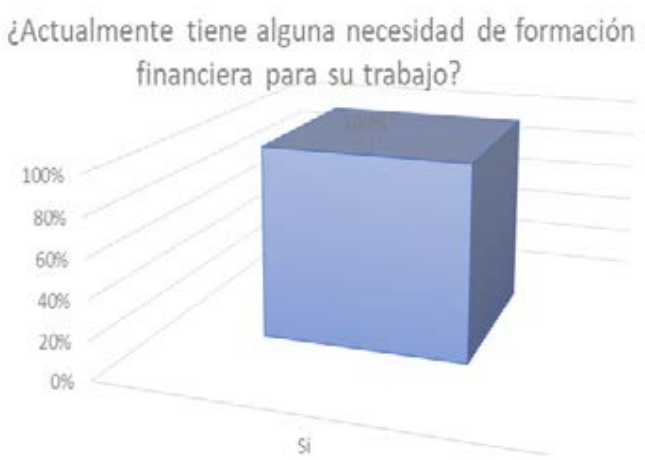

Gráfica 2. Necesidades de formación financiera para ejecución del trabajo.

Con base en los resultados del diagnóstico de necesidades y de infraestructura tecnológica, las herramientas utilizadas en la plataforma REA para el diseño de contenidos digitales a través de metodologías activas en tema de contabilidad financiera, son; open zurce y de código abierto como editor y para la grabación y transmisión de video por internet, también se utilizaron las herramientas y aplicaciones que ofrecen Office 365 como Teams, Paint, entre otras.

La estructura que se siguió en los metadatos para lograr adaptación en SCORM de todos los contenidos digitales elaborados es la siguiente:

1. Objetivo

2. Contenido

3. Actividad

4. Evaluación 
A continuación, se muestran algunas imágenes de uno de los contenidos digitales utilizando metodología activa, denominado Balance General, el cuál sigue la estructura mencionada. (ver figura 1 y figura 2 )

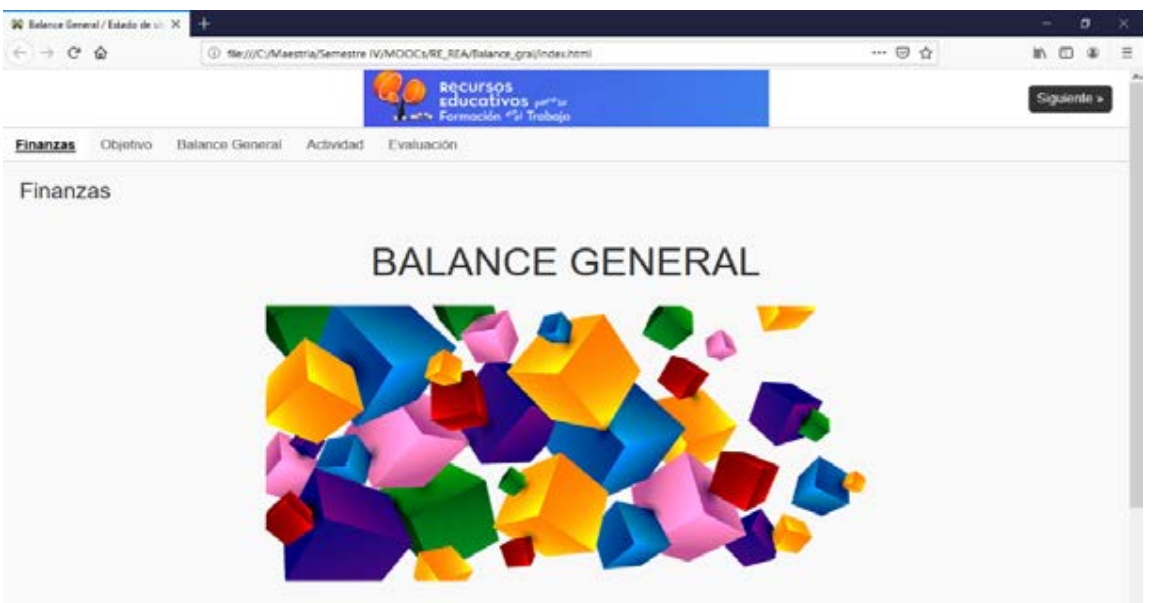

\section{Figura 1. Contenido digital sobre "BALANCE GENERAL"}

El objetivo, está constituido por un enunciado global sobre el resultado final que se pretende alcanzar, es decir, responde a: ¿Qué?, ¿Dónde? y ¿Para qué?

En seguida encuentra la figura 2, corresponde al ejemplo del objetivo de uno de los contenidos digitales denominado Balance General.

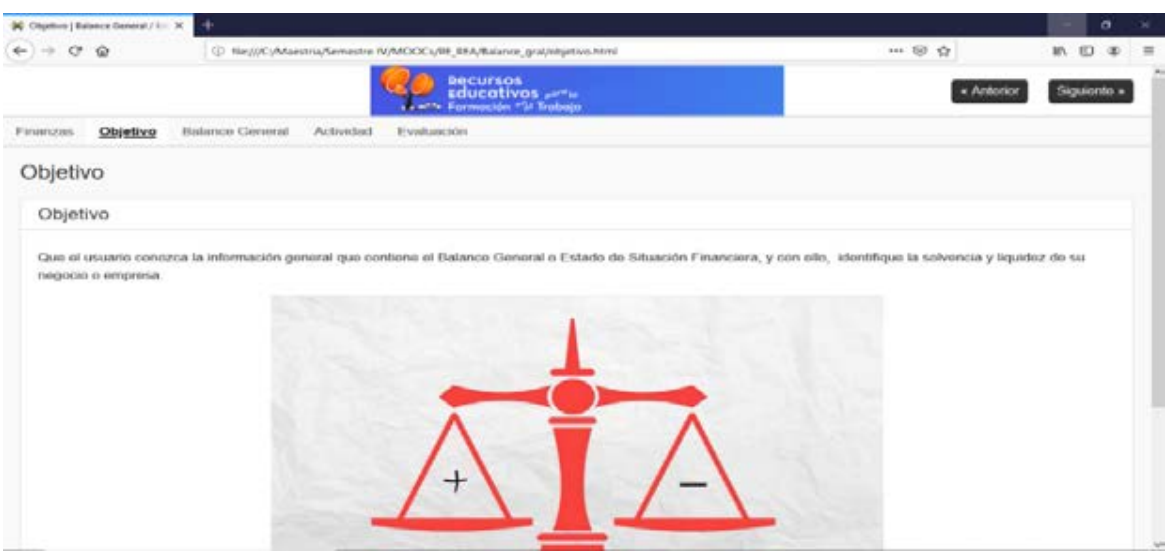

\section{Figura 2. Objetivo del contenido digital denominado Balance General}

El contenido, incluye una descripción clara y concisa del material diseñado y desarrollado para cada uno de los temas, que es ofrecido a los participantes, inscritos o visitantes, en la plataforma Rea, sea éste, audiovisual, auditivo, animación u otro tipo. Elaborado con alguna de las herramientas mencionadas anteriormente. Ejemplo Figura 3 


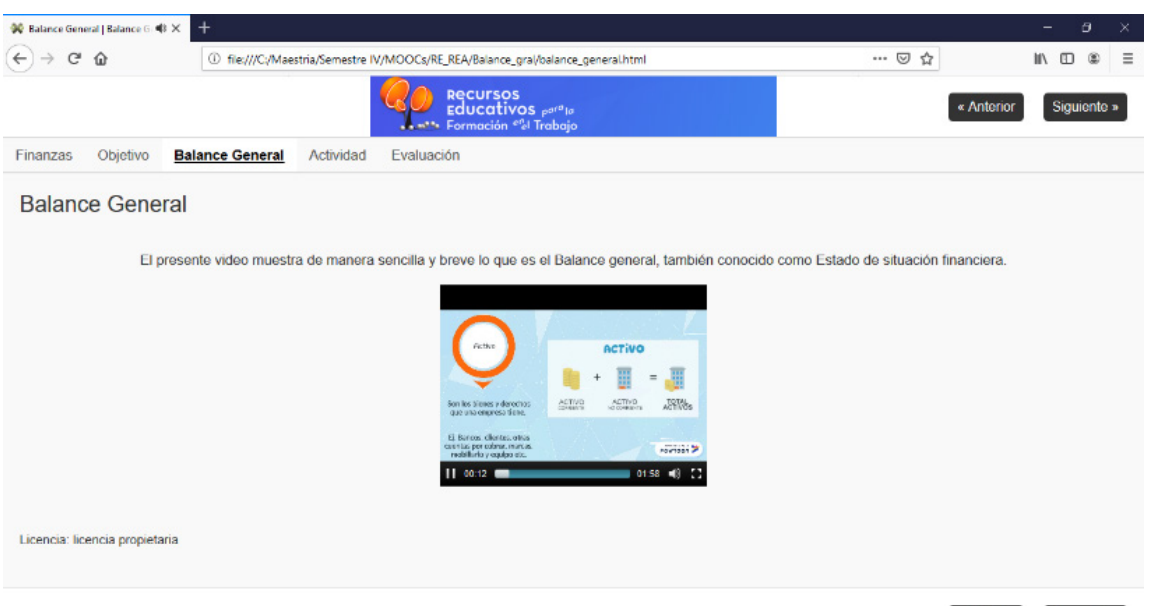

Figura 3. Contenido del denominado Balance General.

La actividad, describe la acción o acciones, a llevar a cabo para cumplir lo descrito en el objetivo del tema elaborado. El ejemplo se muestra a continuación en la figura 4.

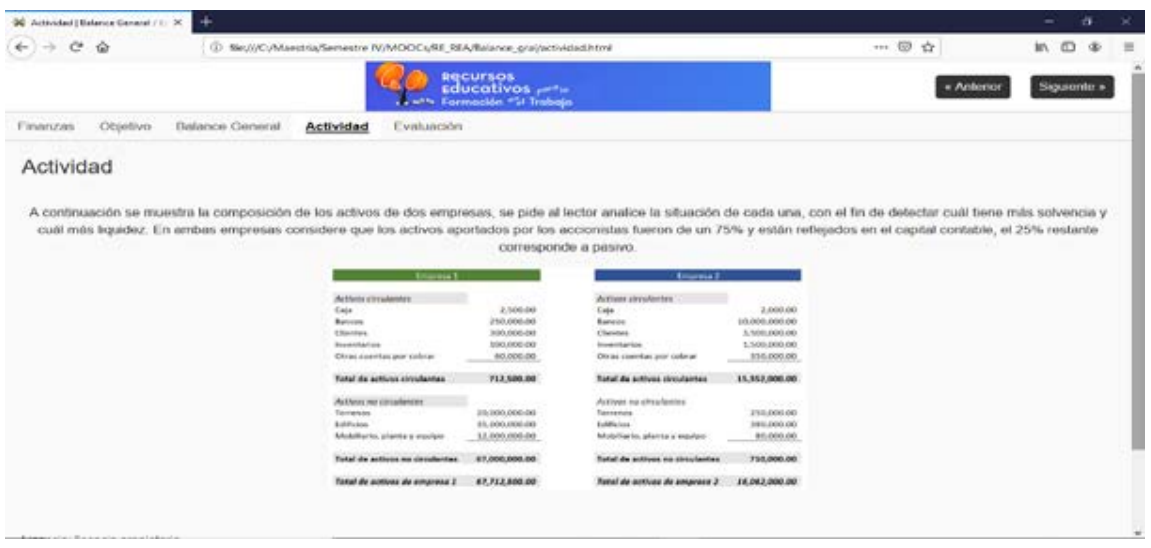

Figura 4. Actividad del contenido digital denominado Balance General.

En relación con la evaluación, cada contenido digital tiene una valoración del producto de presentado aplicable al desempeño laboral de los participantes. Para esto, la autora de la presente investigación define criterios que se evalúan en cada parte del proceso, en correspondencia al contenido ofrecido, al finalizar la evaluación se agrega una reflexión donde se pregunta al participante si la información es aplicable a su trabajo cotidiano. El ejemplo se puede observar en la figura 5. 


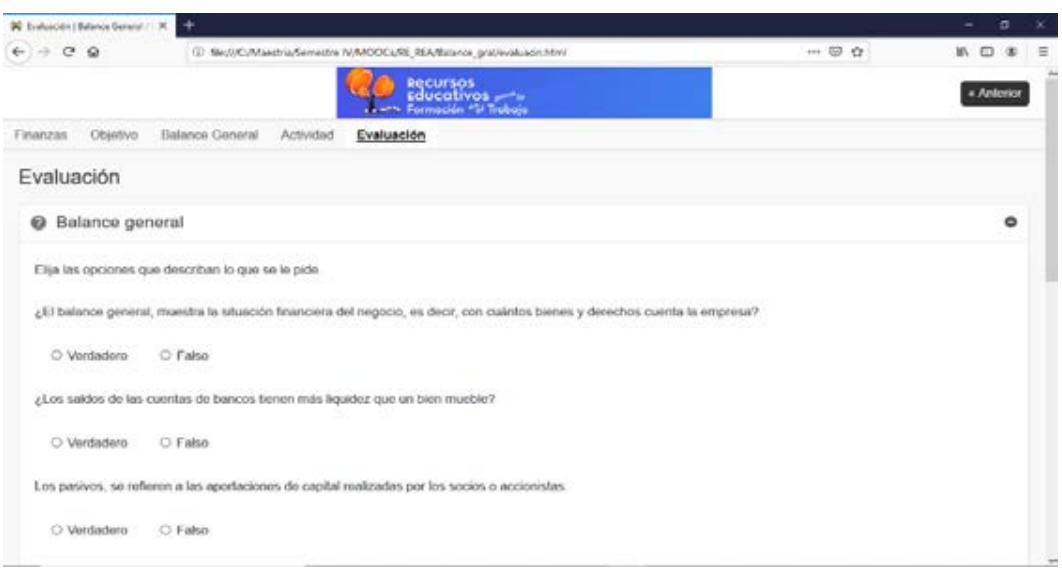

Figura 5. Evaluación del contenido digital denominado Balance General.

Una vez concluido el deseño de los contenidos digitales, éstos se suben a la Plataforma educativa REA con la finalidad de que el participante acceda a ello de manera directa, es bueno recordar, que no solamente los participantes inscritos pueden visualizar los contenidos, también se encuentran disponibles para los visitantes.

A continuación, se muestra la portada de la plataforma REA, ver figura 6

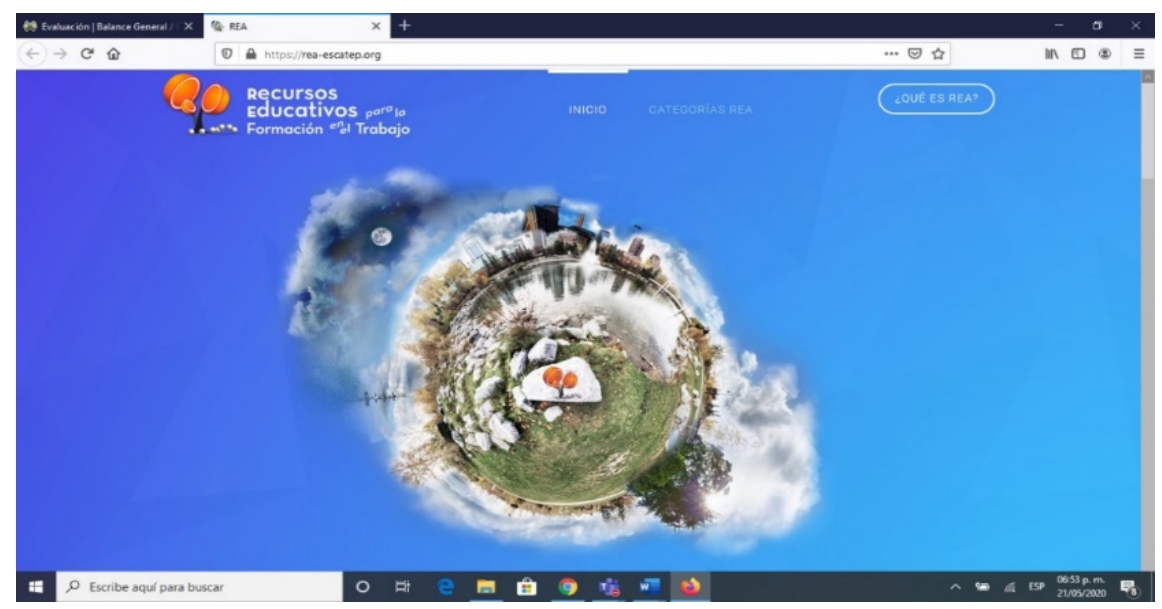

Figura 6. Sitio de la plataforma REA. "Anónimo", (2020). Recuperado de https:/l rea-escatep.org/

A partir de lo anteriormente descrito, los resultados de la presente investigación dan cuenta de la importancia que reviste en la actualidad, por un lado, utilizar metodologías activas, en el desarrollo de contenidos digitales y por otro, desarrollar plataformas tecnológicas para llevar la formación en el puesto de trabajo, y de esta manera, apoyar la gestión de talento del capital humano en la organización en cualquier entidad que requiera de la formación continua de sus trabajadores.

Dicha aportación hasta este momento, permite contribuir de manera puntual en la formación de los empresarios de cualquier giro y tamaño de la empresa con el propósito de facilitar el uso de la tecnología, ya que muchos aún no tienen acceso 
o ésta o es muy incipiente, y también, ofrecer un recurso tecnológico importante que apoye la gestión de talento del capital humano, en la actualización de diversos temas que apoyen el posicionamiento de la empresa en el mercado, y de esta manera, se aplique en el ambiente de la organización como negocio en marcha para favorecer en la conservación de fuentes de empleo y unidades económicas generadoras de ingresos, razón por la cual se puede considerar que la Plataforma REA mencionada, puede ser transferible a contextos similares e impactar en el ámbito social y económico sostenible.

\section{Discusión y conclusiones}

Las características de los contenidos digitales como recursos educativos abiertos, a través de metodologías activas, permite que los usuarios le encuentren mayor sentido a su formación, desde el momento que la forma de aprender, tiene como propósito interactuar con el contenido, en la selección de metodología para facilitar el cómo aplicar lo aprendido en el ámbito laboral y específicamente atendiendo una problemática para el desempeño de sus funciones, esto es posible, gracias a la selección puntual y específica de las herramientas digitales para facilitar el aprendizaje, de ahí su connotación de metodología activa, que hace que el sujeto viva, lo aplique en la realidad y el uso de la herramienta, apoya en el aplicación del contenido de una manera más lúdica e intencionada, por otra parte ofrece a los usuarios, elementos muy valiosos en su formación, si se considera su disponibilidad, rapidez de acceso y actualización, así como su bajo costo y adaptabilidad.

El desarrollo de plataformas tecnológicas objetos de esta investigación, utilizando la aplicación de metodologías activas a través de diversas herramientas digitales tales como el video, gráficos, sonido, presentaciones interactivas, infografías, nubes de gags dinámicas y herramientas para actividades interactivas, contribuyen a favorecer en el adulto un aprendizaje más situado a su realidad laboral para aplicar a la solución de problemas a los que se enfrenta en el desempeño de sus funciones.

En el desarrollo de la plataforma objeto de estudio, se trabajan actualmente con herramientas open zurce en ambientes virtuales de aprendizaje, esto permite a las empresas, la constante formación en el puesto de trabajo del capital humano de manera accesible, a bajo costo, acorde al contexto y a las necesidades del grupo destinatario.

Los hallazgos encontrados en la presente investigación fundamentan la importancia de replantear la formación en el puesto de trabajo del capital humano como una herramienta para favorecer la gestión de talento que permita la formación continua en el ámbito laboral en las Pymes de cualquier giro y tamaño. Atendiendo para este estudio, básicamente los siguientes aspectos:

- Definir el desarrollo de la organización en términos de todos los elementos que la integran y favorecen con el fin de mejorar el ambiente organizacional en pro de una mejor productividad y satisfacción del trabajador

- Orientar hacia el éxito las conductas de todos sus miembros.

- Ofrecer elementos para que los empresarios desarrollen estrategias encaminadas a ser una empresa sustentable. 
- Favorecer la cultura tecnológica en las Pymes en México para fortalecer la formación de capital humano calificado y contribuir a su permanencia en el mercado.

Se confirma en este estudio, que la formación continua y actualizada de todos los integrantes en una organización de cualquier giro y tamaño, se convierten en una parte imprescindible de toda estrategia de desarrollo, crecimiento y permanencia de las organizaciones y que la adopción de metodologías activas en el proceso de formación, del adulto le permite acercarse a los avances tecnológicos y educativos de manera continua para favorecer su desarrollo personal.

Dicha investigación puede impactar de manera importante, no sólo en el ámbito del trabajo, sino también, en desarrollo de ambientes de aprendizaje virtual en programas de educación a distancia para lograr que éstos sean pertinentes y que se ajusten a las necesidades del usuario, del contexto, del programa y de la organización, desde una perspectiva social e inclusiva.

\section{Referencias}

Cobo, R., \& Moravec, J. W. (2011). Aprendizaje Invisible. Hacia una nueva ecología de la educación. Barcelona: Colección Transmedia XXI

Cueto, A. (2013). Capability Maturity Model (CMM) y la Gerencia. Col. Laboratori de Mitjans Interactius / Publicacions i Edicions de la Universitat de Barcelona. ombia: I Jornadde Gerencia de Proyectos en TI - ACIS 2003.

Martínez, F. (2017). Administración Estratégica Inteligente. El pensamiento Estratégico en la 4ta. Revolución Industrial y su economia de Creatividad e Innovación. Ciudad de México: Instituto Mexicano de Innovación y Estrategia, A.C.

Padilla, S., Quintero, L., \& Sales, J. (2015). Dinámicas grupales en la capacitación empresarial por competencias. Las micro, pequeñas y medianas empresas en el desarrollo económico, cultural y tecnologico de México, 63-74.

Schwab, K. (2016). La cuarta revolución industrial. México: Penguin Random House. 


\section{La Evaluación Formativa, el Recorrido de una Experiencia de la Pontificia Universidad Católica Argentina en Tiempos de Pandemia.}

\section{Mujica, Ma. Genoveva}

Pontificia Universidad Catolica Argentina.

Campus Nuestra Señora del Rosario.

Facultad de Derecho y Ciencias Sociales.

genoveva_mujica@uca.edu.ar

\section{Sisto, Marcela Inés}

Pontificia Universidad Católica Argentina.

Campus Puerto Madero - Buenos Aires. SIED,

Sistema Institucional de Educación a Distancia

msisto@uca.edu.ar 


\title{
LA EVALUACIÓN FORMATIVA, EL RECORRIDO DE UNA EXPERIENCIA DE LA PONTIFICIA UNIVERSIDAD CATÓLICA ARGENTINA EN TIEMPOS DE PANDEMIA.
}

\author{
Mujica, Ma. Genoveva \\ Sisto, Marcela Inés
}

\section{Resumen}

El presente trabajo tiene como propósito describir una experiencia realizada desde el Sistema Institucional de Educación a Distancia (SIED) de la Universidad Católica Argentina, durante el periodo 2020-2021 en el contexto del Covid19. La plataforma EVA-UCA en los últimos años era un entorno virtual de apoyo a la presencialidad, pero en marzo de 2020 junto al software de teleconferencias Zoom se transformaron en el aula sin paredes para el desarrollo de propuestas de enseñanza y de aprendizaje. Allí surgieron los siguientes interrogantes: ¿Cómo enseñamos a distancia sin perder la calidad y calidez de la educación superior? ¿Qué propuestas favorecen la evaluación desde una postura integral? Desde un paradigma centrado en los estudiantes, situándonos en un modelo basado en el desarrollo de competencias desde la perspectiva humanista y cristiana. Se incrementaron y acompañaron las propuestas de formación docente continua de la universidad con espacios de reflexión y diálogo desde la perspectiva de los entornos virtuales de aprendizaje. Como resultado, se confeccionó un instrumento que presenta: a) tres propuestas de evaluación: objetivas, cualitativas y procedimientos de evaluación auténtica: b) treinta y dos actividades afines a las propuestas mencionadas para realizar desde la plataforma EVA y; c) cuatro modalidades de evaluación; asincrónica, sincrónica, individual o grupal.

\section{Palabras clave}

Evaluación formativa. Educación Superior. Educación integral. Docencia Universitaria. 


\section{Introducción (contenido y objetivos)}

El comienzo del COVID 19, nos ha interpelado como profesores frente a los siguientes interrogantes: ¿̇estamos preparados como docentes para realizar formación continua en los entornos virtuales?; ¿qué actividades de los EVA conocen o reconocen como instrumentos de evaluación?; ¿qué propuestas favorecen la evaluación desde una postura integral? Evaluar es medir los logros adquiridos por los alumnos, valorar las competencias y habilidades desarrolladas al concluir su proceso formativo, o de forma genérica, analizar las mejoras cualitativas operadas en los estudiantes. La evaluación en Entornos Virtuales entraña ciertas peculiaridades, el aprendizaje mediado por herramientas tecnológicas implica un alto grado de incertidumbre: enfrentar la soledad, formato de los materiales, otros medios de comunicación, diferentes a la presencialidad, otras.

La evaluación en prácticas formativas a distancia implica un proceso de autorregulación del aprendizaje, es decir, que los estudiantes adopten técnicas y estrategias apropiadas y sistemáticas para seguir el ritmo y cumplir con el calendario de entrega de actividades y participación en las dinámicas contempladas. Como sostienen Anijovich y Cappelletti (2017), la evaluación es una oportunidad para que los estudiantes puedan identificar lo que saben y cuánto saben visibilizando sus construcciones cognitivas y las habilidades para recrear sus conocimientos aplicarlos en diversas situaciones, reconocer cuestiones que necesitan revisar para modificar, completar, profundizar y llevar a la práctica lo aprendido en diferentes contextos, más allá de la aprobación, la promoción y la certificación, requisitos indispensables para avanzar formalmente en sus carreras.

Se considera que la evaluación formativa continua en las plataformas virtuales de aprendizaje constituye una innovación en procesos de enseñanza y de aprendizaje. En relación a la primera, desde el rol del profesor, favorece el incremento de la comunicación sincrónica y asincrónica, permite incorporar la retroalimentación inmediata en las actividades realizadas por el alumno, las motivaciones del estudiante aumentan al comprobar que puede disponer de orientaciones inmediatas de sus desempeños. Este factor desencadenante de motivación sostenida y creciente autonomía sólo puede ocurrir cuando se garantiza y hace operativa la devolución por parte del profesor de dichas tareas. El conocimiento de las posibilidades que la retroalimentación ofrece como parte de las buenas prácticas docentes y cómo ello influye en el aprendizaje académico, es enriquecedor desde la mirada de la enseñanza. Esta práctica contribuye a la formación continua de los docentes para que puedan utilizar, de forma eficiente, la retroalimentación. Consecuentemente, esto permite que los alumnos potencien sus capacidades y se formen de la mejor manera posible para responder a las necesidades que surgen en su ámbito profesional. "...Algunos estudios pioneros en este campo (Sinclair y Coulthard, 1975; Mehan, 1979; Gumperz y Cook-Gumperz, 1986), observaron una estructura básica de los intercambios cotidianos en clase: iniciación-respuesta-evaluación o retroalimentación (conocida como secuencia IRE), con muchísimas variantes según los estilos docentes y según el tipo de conversación (si se orienta más al debate o al intercambio en pequeños grupos, por ejemplo) ..." (Ministerio de Educación, Cultura, Ciencia y Tecnología de la Nación, INFoD, 2017). Cabe señalar, que la eficacia de la evaluación formativa va a depender en gran medida del tipo de retroalimentación que el docente ponga en juego a la hora de evaluar. Según Anijovich y González (2011) la retroalimentación es propia de un sistema que tiene como finalidad mejorar el aprendizaje y 
autorregularlo. Además, de comprender los modos de aprender y valorar los procesos y resultados, la retroalimentación se caracteriza en el marco de la evaluación formativa como un proceso de diálogos, de intercambios, demostraciones y formulación de preguntas. La retroalimentación tiene el propósito de ser utilizada para modificar la enseñanza y el aprendizaje, lo cual va más allá del solo hecho de proyectar el rendimiento, o desempeño, que ha obtenido el estudiante.

La segunda posibilidad se basa en las oportunidades que los entornos virtuales de aprendizaje, ofrecen para desarrollar estrategias metodológicas específicas como nueva forma de abordar las asignaturas, con propuestas que favorezcan un incremento progresivo en la responsabilidad del alumno sobre su propio proceso de aprendizaje. Las denominadas e-actividades fomentan propuestas interesantes en consonancia con la mirada de un estudiante protagonista su propio aprendizaje, que reúnen condiciones: pertinentes según los contenidos y la información suministrada, el tiempo para su resolución, tipologías diversificadas, con los criterios de evaluación claros, y adecuadas al nivel formativo de los estudiantes. (López Pastor, V. M. 2016: 128-130).

En consecuencia, los objetivos específicos de esta experiencia son:

- Proponer una metodología para dar respuesta a los desafíos de la evaluación desde la modalidad formativa en Educación Superior en el Contexto Covid 19.

- Favorecer instancias de evaluación formativa que permitan a los profesores una mirada integral y personalizada de los aprendizajes de los estudiantes universitarios.

- Valorar las distintas modalidades de evaluación formativa: asincrónica, sincrónica, individual o grupal para dar respuesta a la especificidad de cada asignatura.

- Ponderar la diversidad de técnicas e instrumentos apropiados para el contexto de emergencia educativa, considerando propuestas de evaluación formativa y continua: objetivas, cualitativas y procedimientos de evaluación auténtica.

- Incentivar la retroalimentación positiva del aprendizaje desde una perspectiva humanista cristiana.

\section{Descripción de la experiencia}

\section{Descripción del contexto y de los participantes}

La Pontificia Universidad Católica Argentina creada en 1958, cuenta con una matrícula de 20.000 alumnos en 4 sedes ubicadas en: Buenos Aires, Mendoza, Paraná y Rosario. En contextos de incertidumbre, son los equipos pedagógicos, de profesores, asistentes administrativos y directivos, de cada unidad académica llevaron a la práctica la posibilidad de implementar dispositivos para la organización de las clases a distancia sin pérdida de días de clases. Cada uno con su recorrido, pero con la convicción de pensar cómo generar, a la distancia, una relación con el conocimiento que de ninguna manera se limita a la resolución de actividades. En tanto, quienes no habían entrado nunca en el universo de la educación a distancia, como quienes 
veníamos trabajando en experiencias relacionadas a la misma, detectamos muy rápidamente que la virtualidad no funciona si se piensa como una presencialidad. Es otra lógica y requiere pensarse desde otro lugar. La evaluación forma parte de este reto educativo.

En función de acompañar este proceso se diseñó un aula de ayuda a los docentes desde el SIED (Sistema Institucional de Educación a Distancia) en el que se incorporaron entre otros materiales: marcos institucionales para el desarrollo de las clases en el contexto de covid 19, el proyecto institucional, la normativa de EAD de la Universidad, propuestas pedagógicas, rúbricas para la autoevaluación, bibliografía sugerida, manuales para la configuración general de EVA. Al mismo tiempo se ofrecieron variadas instancias de capacitación mediante talleres y seminarios a cargo del equipo pedagógico del SIED acompañados por los equipos de cada sede, referentes académicos y administrativos.

La incorporación de las nuevas tecnologías en las prácticas cotidianas de enseñanza y aprendizaje de la Universidad traen aparejadas nuevas preocupaciones en relación con aquellas cuestiones que Internet redefine, con la alta exposición a la web sino modos de leer, modos de escribir, criterios de autenticidad de la información, modos de comunicación y de producción del saber. Para los profesores, el trabajo probablemente estuvo centrado en la definición de criterios que permitan buscar y seleccionar la información válida para darle continuidad al desarrollo del pensamiento crítico, creativo, en pos de seguir generando propuestas de aprendizaje profundo. Para los alumnos, también requirió un proceso de apropiación de la tecnología en pos de los aprendizajes a distancia. A medida que se prolongaba el confinamiento se fueron enriqueciendo las propuestas y complejizando los desafíos. La experiencia se realizó desde el SIED como sistema transversal a toda a la Universidad y especializado en Educación a Distancia destinado a todos docentes, de la cual se encuentran participando 950 profesores de las cuatro sedes y de todas las carreras.

Entre los materiales ofrecidos (Anexo 4) se pueden destacar los manuales y tutoriales para el uso de la plataforma, los foros destinados a consultas pedagógicas y técnicas, propuestas de planificación de secuencias didácticas, ejemplos de actividades, posibles recursos y herramientas compatibles con a plataforma de la Universidad, una sección especialmente dedicada a la evaluación en EVA y un espacio para compartir buenas prácticas.

A continuación, se puede observar a modo de resumen un cuadro que se confeccionó para orientar la evaluación formativa en Educación a Distancia, el mismo (Anexo 1) presenta: a) tres propuestas de evaluación: objetivas, cualitativas y procedimientos de evaluación auténtica: b) treinta y dos actividades afines a las propuestas mencionadas para realizar desde la plataforma EVA y; c) cuatro modalidades de evaluación; asincrónica, sincrónica, individual o grupal. 


\begin{tabular}{|c|c|c|c|}
\hline $\begin{array}{l}\text { Propuesta de } \\
\text { evaluación }\end{array}$ & $\begin{array}{l}\text { Propuesta de } \\
\text { Actividad en Eva }\end{array}$ & Plataforma UCA EVA & Modalidad \\
\hline 1. Objetiva & $\begin{array}{l}\text { 1.1 Verdadero/Falso } \\
1.2 \text { Elección Múltiple }\end{array}$ & $\begin{array}{l}\text { 1.1 Tarea Foro } \\
\text { 1.2 Tarea Foro }\end{array}$ & $\begin{array}{l}\text { 1.1 Escrita individual } \\
\text { Asincrónica o sincrónica } \\
\text { individual } \\
1.2 \text { Escrita individual } \\
\text { sincrónica o asincrónica }\end{array}$ \\
\hline 2.Cualitativa & $\begin{array}{l}\text { 2.1 Entrevista } \\
2.2 \text { Nota de campo }\end{array}$ & $\begin{array}{l}\text { 2.1Tarea } \\
2.2 \text { Tarea. Foro. } \\
\text { Lección }\end{array}$ & $\begin{array}{l}\text { 2.1 Asincrónica } \\
\text { Asincrónica individual o } \\
\text { Pares } \\
\text { 2.2 Asincrónica } \\
\text { Asincrónica individual o } \\
\text { Pares }\end{array}$ \\
\hline $\begin{array}{l}\text { 3. Procedimientos } \\
\text { de Evaluación } \\
\text { auténtica }\end{array}$ & $\begin{array}{l}\text { 3.1 Ensayo } \\
3.2 \text { Mapas mentales } \\
3.3 \text { Gamificación }\end{array}$ & $\begin{array}{l}\text { 3.1 Tarea Lección } \\
\text { 3.2 Tarea Lección } \\
\text { 3.3 Ahorcado } \\
\text { crucigrama }\end{array}$ & $\begin{array}{l}\text { 3.1 Asincrónico o sincrónico } \\
\text { individual } \\
\text { 3.2 Asincrónico o } \\
\text { sincrónico grupal } \\
\text { 3.3 Sincrónica o asincrónica } \\
\text { Pares/grupal }\end{array}$ \\
\hline
\end{tabular}

Cuadro 1, . Propuestas y variables para la evaluación en EaD - Sintesis Sisto M, 2020, Material SIED. Aula virtual de Ayuda Docente SIED UCA

Como parte de la experiencia se consultó a los profesores acerca de ¿Qué propuestas de enseñanza incorporé durante este tiempo? Entre las estrategias mencionadas se destacan: estudio de casos, aprendizaje invertido, trabajo colaborativo, gamificación, trabajos de laboratorio usando simuladores, análisis de material audiovisual, podcast para la introducción de nuevos temas, debates, storytelling, situaciones de mircoenseñanza entre otras. En la combinación entre espacios sincrónicos y asincrónicos se destacan los foros, wikis, taller, cuestionarios, H5P, lección y glosarios, cápsulas de aprendizaje, y herramientas externas como mentimeter, kahoot, quizziz, muros colaborativos, entre otros.

Al mismo tiempo mencionaron propuestas de autoevaluación, coevaluación y la retroalimentación como parte de las buenas prácticas en este contexto.

En segundo término se indagó acerca de cuáles serían las estrategias para seguir poniendo en práctica. La mayoría de los docentes señala que seguirá profundizando en el uso de las incorporadas y mencionan el interés por seguir capacitándose, además de manifestar su agradecimiento a la institución por los espacios de formación continua ofrecidos.

Entre las inquietudes surgió el análisis de las posibilidades para evaluar de manera procesual y continua tanto a través de la Plataforma EVA UCA como en los encuentros sincrónicos a través de Zoom, potenciando al mismo tiempo la combinación entre ambos. La evaluación es, sin duda alguna, un proceso complejo. La evaluación 
de los aprendizajes de los alumnos, en un momento particular y sin precedentes, se vuelve un reto aún mayor, en consonancia con los dilemas y los desafíos que habitualmente genera. Desde esta perspectiva las nuevas tecnologías ofrecen ricas posibilidades para una evaluación de nuevo tipo, sostiene Lipsman (2014) caracterizada por la transparencia, debate, intercambio y discusión de los actores involucrados. Surgió así la necesidad de acompañar a los profesores, ofrecerles instancias de reflexión, promover la lectura acerca de la e-evaluación y de pensar, re pensar, diseñar y ajustar sus propuestas de aprendizaje, considerándola desde una mirada integral como parte del proceso y no solo como resultado. Como sostienen Tenutto, M., Brutti, C. y Algarañá, S. (2010) se trata de crear dispositivos de enseñanza que permitan integrar la evaluación al proceso formativo por medio de la autoevaluación, la co-evaluación, heteroevaluación y meta-evaluación. Dentro de los entornos virtuales de aprendizaje, diversos autores destacan que la evaluación formativa es un elemento muy útil y eficaz a la hora de valorar el aprendizaje de los alumnos. Por un lado, Alonso Díaz y Blázquez Entonado (2016) conceptualizan la evaluación formativa como un proceso compartido, colaborativo y democrático de recogida de información. La misma, ayuda a fomentar la reflexión crítica de los procesos y conduce a la toma de decisiones relativas a cada situación. A grandes rasgos, la finalidad es mejorar el proceso de enseñanza-aprendizaje.

Por otro lado, Maenza (en Cebrián, 2016), menciona que dentro del ambiente virtual se emplean tanto las ideas de evaluación de programas educativos, como las de evaluación de medios. Por lo tanto, los elementos propios de una evaluación deben ser aquellos relacionados con los aspectos didácticos y pedagógicos del programa educativo del entorno virtual. A diferencia de una evaluación llevada a cabo dentro de la presencialidad, hay que tener en cuenta, aquellos elementos que conciernen a la técnica y el funcionamiento de la organización del entorno virtual, es decir, sus costos, la distribución, el tiempo, entre otras cuestiones. Varias investigaciones; Black y William, 1998; Black et al. 2003; Osorio Sánchez y López Mendoza, 2014, han demostrado que, efectivamente, la evaluación formativa ayuda a mejorar el desempeño y la autonomía de los estudiantes, en su proceso de aprendizaje.Desde el área Pedagógica del SIED UCA fue elaborado un documento a modo de repaso de algunos aspectos fundamentales de la evaluación a distancia en el que se incluye un cuadro que esquematiza y describe de forma sintética las diferentes propuestas de evaluación; sus características; las actividades de la plataforma EVA UCA que pueden ser instrumentos de evaluación y la modalidad de las distintas propuestas evaluativas tanto en sincrónica como asincrónica.

\section{Discusión y conclusiones}

La intención de este trabajo ha sido identificar y sistematizar evidencias de las prácticas de evaluación, durante las instancias de formación docentes, ofrecidas por el SIED durante el año 2020, a fin de ponderar las experiencias de los profesores durante la asistencia a estos espacios con el propósito de favorecer instancias de evaluación formativa que integren la retroalimentación positiva del aprendizaje desde una perspectiva humanista y cristiana.

En este sentido podemos advertir opiniones, experiencias e indicios que invitan a la reflexión sobre la evaluación formativa en el ámbito universitario en Entornos Virtuales, registradas como las voces de los profesores en el Foro de Buenas Prácticas de 
evaluación, donde se invitó a los colegas, a compartir sus experiencias, ejemplos y comentarios respecto del tema evaluación. Así lo señala la Prof. Sede Buenos Aires Facultad de Ciencias Económicas: "Lo que me ha resultado útil ha sido dar consignas de trabajo sin cerrar el tema del todo. Y seguir planteando desafíos para la clase que ha seguido. Cuando el tema ya se termina y lo cierro en una clase, les planteo alguna pregunta, algún desafío, alguna incógnita que los lleve a consultar el material en EVA y también que los redireccione para la clase siguiente." Es emocionante ver que, al final del trimestre, y sin estar en comunicación personal, se ha podido sostener la atención y continuidad para llegar al final del trimestre. Gracias por estas ayudas. Sirven mucho". Registro 10 de junio de 2020.

Otra docente, prof. de Sede Paraná Facultad de Psicología: "Muchísimas gracias por el material brindado, es verdaderamente muy claro y enriquecedor. En nuestro caso, nos gustaría realizar la evaluación parcial a través de un cuestionario en EVA, ya que haremos preguntas específicas con respuestas de múltiple opción, verdadero falso, o de respuestas cortas. La consulta es si tienen a disposición alguna guía o tutorial para poder realizar el cuestionario ya que dentro del mismo hay muchas opciones (temporalización, calificación, esquema, comportamiento de las preguntas, opciones de revisión, apariencia, restricciones extra sobre los intentos, retroalimentación global, ajustes del módulo, restricciones de acceso, marcas y competencias). A su vez si tienen consejos para su utilización”. Registro 10 Abril 2020.

Otro prof. Facultad de Ciencias Agrarias consulta: "Estimados, a ver si alguien puede ayudarme con esto. Voy a hacer la evaluación por EVA. Se abre y se cierra el mismo día en un horario definido, por ejemplo 07-06 de 18 a 19. En la medida que responden el cuestionario y lo envían, les devuelve el resultado automáticamente. Yo quiero hacer que el resultado les llegue después de las 19 hs, es decir, después que entregaron todos. No encuentro cómo hacerlo!!! Muchas gracias por su ayuda!!!! Saludos", prof. de Ciencias Agrarias, registrado 6 de abril 2020

Otro aporte en este sentido es en otro Foro, de la prof. de la Facultad de Ciencias Médicas Sede Buenos Aires "Estimados colegas, quería compartir mi experiencia con el recurso sincrónico Zoom. Ni bien lo probé me pareció excelente. A medida que fui utilizándolo también lo vi versátil y sobre todo intuitivo. Las aplicaciones son variadas: desarrollo de clases, comunicación y consulta entre colegas, el poder compartir las pantallas e ir viendo y aprendiendo de quienes tienen mayores habilidades en su manejo...las posibilidades son múltiples y variable.". Y el del Prof. Facultad de Psicopedagogía, Sede Mendoza agrega: "En mi caso, estoy haciendo foro y wiki con los grupos, experiencia sin igual si queremos construir textos a la par y debates pedagógicos llenos de sueños, ideales y desafíos, todo pasa por la escritura y compartir lo que piensas con el otro". Registro 30 de marzo, 2020.

Finalmente, concluimos que tanto la creación de las instancias de formación continua ofrecidas por la Universidad como parte del Programa de Formación para Docentes Universitarios a propuesta del Sr. Rector Dr. Miguel Ángel Schiavone, en el marco del Proyecto Institucional 2018-2022 (Anexo 2) y con el fin de incentivar "que los profesores posean las competencias académicas, científicas y humanistas necesarias para la docencia...", a las que se integraron: el Aula de Ayuda docente que cuenta la normativa de Educación a Distancia de la universidad, un espacio destinado a la planificación, desarrollo de propuestas en EVA, una pestaña dedicada al tema evaluación, los Manuales y Tutoriales para el uso de la plataforma, un área de 
consultas y preguntas frecuentes, recursos, una solapa dedicada a la comunidad de aprendizaje en la que se comparten experiencias valiosas. Se destaca, además, una pestaña en la que se incluyen los Talleres realizados para acompañar en especial a los profesores que necesitaban profundizar en algunos temas y por último un espacio que integra el aprendizaje combinado a través de Aulas Híbridas con las grabaciones de las capacitaciones dictadas por el SIED y materiales para el regreso a la presencialidad. (Anexo 3)

Cabe destacar que gracias a los recursos humanos y materiales que ha asignado la Universidad, el apoyo al sostenido de estos espacios que promueven el diálogo entre los encuentros sincrónicos y asincrónicos entre los profesores de diferentes Facultades, Cátedras y Sedes de la UCA ha sido posible trascender las distancias impuestas por el contexto de Pandemia. En este sentido, coincidimos en la necesidad de potenciar el encuentro; y "Generar experiencias que se conviertan en compromiso emocional de por vida a largo plazo para generar sentido de pertenencia a la universidad (Pardo, Corbo: 2020)", y agregamos con una mirada humanista cristiana e integral de la evaluación de los aprendizajes, promoviendo espacios de mejora para favorecer instancias de evaluación formativa que integren la retroalimentación positiva de los aprendizajes como uno de los desafíos prioritarios para los próximos años.

\section{Referencias}

Anijovich, R. y Capelletti, G. (2017). La evaluación como oportunidad. Buenos Aires: Paidós.

Anijovich, R. y González, C. (2011). Evaluar para aprender. Conceptos e instrumentos. Buenos Aires, Aique.

Alonso Díaz, L. y Blázquez Entonado, F. (2016). El docente de educación virtual: guía básica: incluye orientaciones y ejemplos del uso educativo de Moodle. Madrid: Narcea Ediciones.

Cebrián, M. Góngora Rojas, A. y Pérez Vicente, M. D. (2016). Enseñanza virtual para la innovación universitaria. Madrid: Narcea Ediciones.

Instituto Nacional de Formación Docente, 2017. Estudio nacional 2016-2017 Prácticas de enseñanza en el contexto del aula en los niveles primario y secundario Documento recuperado de http://dges-cba.edu.ar/bd_dges/recursos/noticias_destacadas/2019/2019_12_13_10_31_24_INFoD-Primer_Estudio_Nacional_2016-2017.pdf

Lipsman, M. (2014). El enriquecimiento de los procesos de evaluación mediados por las TIC en el contexto universitario. Revista Iberoamericana de Evaluación Educativa, 7(2), (pp. 215-222).

López Pastor, V. M. (2016). Evaluación formativa y compartida en educación superior propuestas, técnicas, instrumentos y experiencias. Narcea Ediciones.

Pardo Kuklinski, Hugo; Cobo, Cristóbal (2020). Expandir la universidad más allá de la enseñanza remota de emergencia Ideas hacia un modelo hibrido post-pandemia. Outliers School. Barcelona. 
Sinclair, J. y Coulthard R.M. (1975), Towards the analysis of discourse. The English used by teachers and pupils. Oxford, Oxford University Press.

Sanchez Troussel, Lorena Beatriz; Manrique, Maria Soledad; Los usos de la retroalimentación en la enseñanza y en la formación; Universidad de Buenos Aires. Facultad de Filosofía y Letras; 1; 2017; 313-330

Tenutto, M., Brutti, C. y Algarañá, S. (2010). Planificar, enseñar, aprender y evaluar por competencias: conceptos y propuestas. Buenos Aires: Digital \& Papel.

\section{Anexos}

1. Link del Instrumento completo. Propuestas para Evaluar

2. Proyecto Institucional UCA 2018-2022. http://uca.edu.ar/es/la-universidad-institucional/proyecto-institucional

3. Vicerrectorado de Investigación e Innovación Académica. SIED Aula de Ayuda docentes.

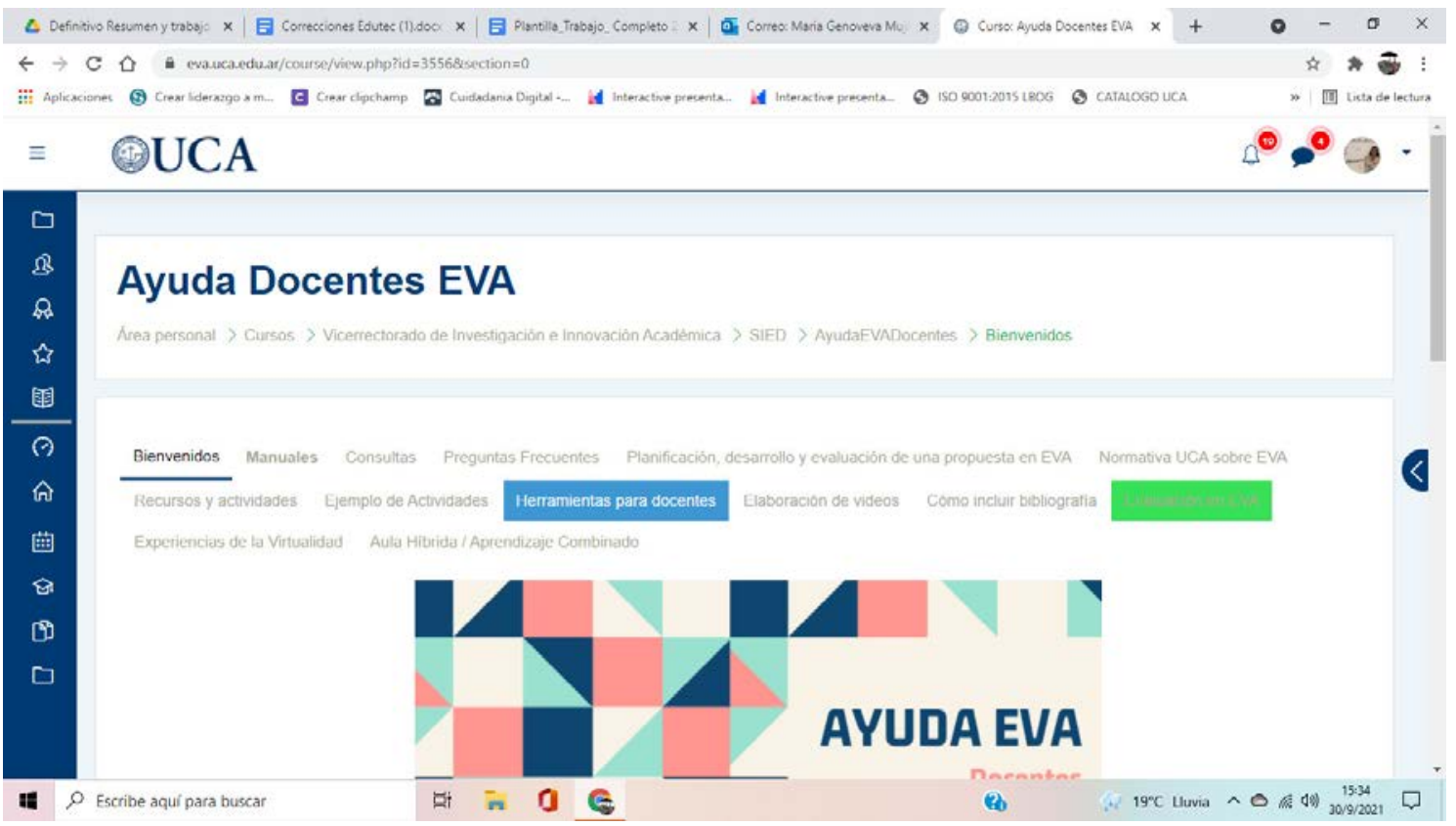




\section{El Trabajo Colaborativo Mediado por TIC: Aportes para la Formación Integral en Experiencias Universitarias de Internacionalización Curricular en Casa}

\section{Bayonés, Marcela}

https://orcid.org/0000-0002-1808-4826

mbayones@fce.unl.edu.ar

\section{Vargas, Matías Rodrigo}

https://orcid.org/0000-0002-7550-6853

mrvargas@fbcb.unl.edu.ar

\section{Gramaglia, Carina}

https://orcid.org/0000-0002-9314-4040

cgramaglia@fcv.unl.edu.ar

\section{Guedes, Mauricio}

https://orcid.org/0000-0001-7670-8070

mausguedes@ufmt.br

\section{Clérico, Gracia María}

http://orcid.org/0000-0001-5823-326X

graciamariaclerico@gmail.com 


\title{
EL TRABAJO COLABORATIVO MEDIADO POR TIC: APORTES PARA LA FORMACIÓN INTEGRAL EN EXPERIENCIAS UNIVERSITARIAS DE INTERNACIONALIZACIÓN CURRICULAR EN CASA
}

\author{
Bayonés, Marcela \\ Vargas, Matías Rodrigo \\ Gramaglia, Carina \\ Guedes, Mauricio \\ Clérico, Gracia María
}

\section{Resumen}

La Internacionalización Curricular (IntC) en Casa posibilita la inserción en el currículum de estrategias de enseñanza y de aprendizaje que faciliten la comprensión de culturas internacionales y locales. A partir de la habilitación de espacios de trabajo colaborativo entre estudiantes y docentes de distintos países, se busca propiciar el desarrollo de competencias interculturales y contribuir a la formación integral en la Educación Superior. El aporte transversal de las Tecnologías de la Información y la Comunicación (TIC) se considera fundamental para dicho objetivo permitiendo expandir fronteras en la educación en red, así como viabilizar nuevas prácticas pedagógicas. En este artículo se procura indagar sobre las estrategias de trabajo colaborativo en red mediado por las TIC utilizadas en la IntC. Para este objetivo se propone identificar tres elementos: el tipo de intervención del docente, la participación de los alumnos y los recursos utilizados en dichas experiencias colaborativas. Para ello se toman como casos a tres experiencias de IntC en Casa desarrollados por la Universidad Nacional del Litoral (UNL) con otras universidades extranjeras. Los resultados de estas propuestas permiten verificar que el trabajo colaborativo mediado por las TIC, puede ser un elemento motivador y favorecedor para el desarrollo de propuestas de IntC que contribuyen a la formación integral de los estudiantes.

\section{Palabras clave}

Internacionalización Curricular en Casa, Tecnologías de la Información y la Comunicación, Trabajo Colaborativo, Formación Integral, Educación Superior. 


\section{Introducción}

En este artículo presentamos un avance del Proyecto Curso de Acción para la Investigación y Desarrollo (CAI+D) 2020 de la Universidad Nacional del Litoral (UNL) relativo a las experiencias interculturales en la Internacionalización Curricular en Casa. Su objetivo general es indagar, desde un enfoque interdisciplinario, las prácticas interculturales puestas en juego en nueve proyectos de Internacionalización Curricular (IntC) en Casa de la UNL desarrolladas en el marco del Programa de Internacionalización de Espacios Curriculares de Carreras de Grado de la Secretaría de Desarrollo Institucional e Internacionalización. Uno de sus objetivos es indagar sobre el papel de las Tecnologías de la Información y la Comunicación (TIC) en estas experiencias.

La internacionalización de la Educación Superior consiste en el proceso de integración de una dimensión internacional, intercultural o global en el propósito, las funciones y la provisión de educación superior (Knight, 2004 citado por Luchilo, 2017). Una de sus estrategias es la IntC en Casa que, como señala Morosini (2018), incluye cualquier actividad académica relacionada internacionalmente, con excepción de la movilidad estudiantil y docente. En este contexto se considera fundamental el aporte transversal de las TIC, al posibilitar la expansión de las fronteras en la educación, viabilizar nuevas prácticas pedagógicas y desarrollar estrategias de trabajo colaborativo entre pares en pos de fortalecer competencias cognitivas y sociales, el mutuo intercambio, la comunicación y reflexión, y la resolución de problemas para desenvolverse en medios globalizados y multiculturales. Las TIC han convertido al aula en un espacio virtual (sincrónico o asincrónico), y al trabajo grupal en trabajo cooperativo o colaborativo (Sanz et al., 2008). El desarrollo de trabajos colaborativos permite a los estudiantes aprender conjuntamente y compartir tanto responsabilidades como logros.

Como lo expresa Revelo-Sánchez et al. (2018), la formación de los grupos es heterogénea en habilidades y características de los miembros, y les exige habilidades comunicativas, relaciones simétricas y recíprocas, así como un deseo de compartir la resolución de las tareas.

Al situar a los estudiantes en estos espacios se propicia que no solo adquieran contenidos estrictamente disciplinares, sino también otras competencias que contribuyen a la formación integral. Es posible destacar al respecto:

Cuando en la universidad se habla de formación integral de ciudadanos, es importante tener clara la concepción que ella tiene del "ser humano" presente en el estudiante que inició su proceso de formación en el momento en que fue concebido, lo continuó en la familia, la escuela y otros entornos sociales en los cuales ha transcurrido su vida. Cuando llega a la universidad, ésta igualmente aporta al proceso de formación a nivel personal, a través del recorrido curricular y de las experiencias que vive en el contexto universitario, el cual tiene componentes sociales propios de los encuentros interculturales y generacionales de las personas que en ella convergen, en función del logro de sus fines personales, familiares y sociales. En este contexto, el estudiante debe continuar su proceso de formación, razón por la cual, la universidad debe aportar lo mejor de sus posibilidades para recrear y fortalecer sus talentos, aptitudes y capacidades (Escobar Potes et al., 2010: 70-71). 
Tomando como referencia las conceptualizaciones realizadas por diversas investigaciones sobre el trabajo colaborativo, Revelo-Sánchez et al. (2018) define al mismo como:

[...] el proceso en el que un individuo aprende más de lo que aprendería por sí solo, fruto de la interacción de los integrantes de un equipo, quienes saben diferenciar y contrastar sus puntos de vista, de tal manera que llegan a generar un proceso de construcción de conocimiento. (Revelo-Sánchez et al., 2018, p. 117)

La incorporación del trabajo colaborativo en el aula como una estrategia didáctica, que redunde en un aprendizaje en conjunto, requiere de la utilización de técnicas que lleven a la práctica esta estrategia. Por esta razón es importante precisar cuáles son los componentes que interactúan en el acto didáctico que según lo definido por Delgado Fernández et al. (2009) son: el docente, el alumnado, el contenido o materia, el contexto del aprendizaje y las estrategias metodológicas o didácticas.

Con respecto a estas últimas, según Barkley et al. (2007, citado en Revelo-Sánchez et al., 2018) las estrategias metodológicas o didácticas más comunes son el diálogo, la enseñanza recíproca entre compañeros, la resolución de problemas, los organizadores de información gráfica y las de redacción.

Teniendo en cuenta que este artículo se propone indagar sobre las estrategias del trabajo colaborativo mediadas por las TIC en el contexto de tres casos de IntC en Casa, se considerarán los siguientes componentes: la intervención docente, la participación de los estudiantes y las estrategias metodológicas utilizadas. Para valorar el impacto de estos componentes en el trabajo colaborativo, se utilizarán como instrumentos de análisis la información recogida a través de diversas encuestas aplicadas a los estudiantes de cada Proyecto estudiado.

\section{Descripción de las experiencias de IntC en Casa}

La experiencia de IntC en Casa de la Cátedras de Psicología y Psicoanálisis se desarrolla desde 2016, a través de una red de docentes de asignaturas del campo de la psicología de seis cátedras pertenecientes a dos universidades argentinas UNL y Universidad Autónoma de Entre Ríos (UADER) y tres brasileñas: Universidad Federal de Mina Gerais (UFMG), Universidad Federal dos Vale do Jequitinhonha e Mucuri (UFVJM) y Universidad Federal de Mato Groso (UFMG). El eje de la propuesta consiste en llevar a cabo un mismo trabajo práctico en ambos países que consiste en la implementación de un estudio de caso de adolescentes desde una perspectiva intercultural, para establecer comparaciones entre jóvenes de distintas regiones a la luz de los aportes teóricos de las disciplinas involucradas. La tarea implica momentos de trabajo grupal con el auxilio del material ofrecido en un aula virtual compartida.

La modalidad de trabajo es la realización de un estudio de caso compartido, incluyendo clases conjuntas y la participación en una instancia de socialización, que permite intercambiar los principales hallazgos entre los grupos de estudiantes de ambos países.

Se acude a las tecnologías para la organización de las aulas virtuales, de las clases conjuntas y videoconferencias, para la filmación de los espacios de socialización entre los cursos y el desarrollo de las reuniones de equipo de docentes y estudiantes. 
El trabajo colaborativo se vio enriquecido en 2020 cuando se propuso compartir el trabajo de estudio de casos en grupos con estudiantes de otro país, denominados grupos mixtos. Atendiendo a las sugerencias estudiantiles, en ese año se incorporaron instancias previas al desarrollo específico del trabajo práctico para que cada grupo realice una presentación de su región, su cultura y su universidad a sus pares extranjeros. Esta instancia resultó muy significativa y contribuyó a fortalecer el trabajo conjunto, aportando al logro de los objetivos interculturales de la IntC.

La experiencia de las cátedras de Química Biológica y Bioquímica Nutricional involucra a UNL y la Universidad de Chile (UC) durante los años 2019-2020, tiene por objetivo analizar el estilo de vida de la población universitaria de ambos países para evaluar la importancia fisiológica-nutricional de los alimentos y sus componentes. La realidad sociopolítica y epidemiológica atravesó las actividades planificadas, por lo que se aplicaron presentaciones digitales con un enfoque innovador, permitiendo un intercambio de metodologías de enseñanza que enriqueció a ambas partes. Se intercambiaron las modalidades de trabajo utilizadas por cada cátedra, incorporando distintas metodologías didácticas para favorecer la labor docente, entre ellas se destaca la utilización del debate crítico y autogestionado por los estudiantes.

La experiencia de Cátedras de Informática constó de tres ediciones desarrolladas entre la UNL y la Universidad de la República (UDeLaR - Uruguay); UNL y la Universidad De León (UDeLeón - España) y UNL-UDeLaR-UDeLeón, durante 2017, 2019 y 2021, con la misma metodología de trabajo. El objetivo general de la experiencia es promover y coordinar, a través de una propuesta académica, la creación y desarrollo de un espacio ampliado de enseñanza superior en entornos virtuales, de referencia internacional y la construcción de nuevos escenarios educativos en el marco de la identidad cultural. El cronograma y planificación de actividades se realizó a través de videoconferencias, consensuando la creación de un espacio virtual en la plataforma Moodle provista por el Centro de Telemática de la UNL. Se estableció un trayecto formativo utilizando diversos formatos digitales (imagen interactiva, foros, mensajería instantánea, wikis), para compartir el material teórico y propiciar la participación en equipos de trabajo mixtos integrados con estudiantes de las distintas universidades intervinientes.

\section{Resultados}

Se presentan a continuación los resultados obtenidos por cada experiencia acerca de la indagación de tres de los componentes que forman parte del trabajo colaborativo.

Respecto al tipo de intervención docente, los resultados verificados dan cuenta que el mismo es diferente en los tres casos y, a su vez, va variando con el tiempo.

Las cátedras de Psicología evidenciaron un cambio progresivo, pasando de una modalidad de trabajo que proponía la organización autónoma de los estudiantes, a otra más directiva que propicia la concreción de tareas conjuntas con sus pares del otro país. Se avanzó hacia una propuesta de docencia compartida, de modo tal que los estudiantes pueden interactuar con los profesores de ambos países, quienes asumen el rol de facilitadores de la propuesta. También se introdujo la figura de los monitores, estudiantes más avanzados que ya atravesaron la experiencia y orientan a sus pares en las posteriores ediciones. 
En Química Biológica, la intervención se evidenció en la planificación de las actividades áulicas, los materiales y recursos didácticos compartidos. Los docentes desarrollaron las guías de actividades, preseleccionaron los temas a abordar y socializaron los criterios de evaluación mediante la aplicación de un sistema de rúbricas. Durante la escritura de los informes asumen el rol de asesores técnicos, mientras que en los debates entre los grupos asumieron el rol de moderadores.

En Informática la mediación docente fue permanente. La distribución de las actividades se realizó en un espacio virtual delineado donde los docentes presentaron las consignas, conformaron los equipos con integrantes de las distintas universidades y compartieron los instrumentos de evaluación con los cuales fueron valorados los trabajos presentados.

La percepción estudiantil respecto a estas diferentes modalidades de intervención docente también varía: los estudiantes que cursaron Psicología revelaron la importancia de la cercanía:

"Siento que no nos dejaron solos nunca, siempre aclararon nuestras dudas en cualquier momento del día, siempre estuvieron bien predispuestos, siempre con una sonrisa y buscando que nosotros podamos comprender y razonar todo a conciencia".

En otra de las apreciaciones estudiantiles del mismo proyecto ellos destacan el valor del docente para favorecer el clima de trabajo:

"Considero que, si bien el diálogo con los profesores y profesoras de Brasil podría haber sido mayor, se generó un ambiente cálido que fomentó la confianza para preguntar y pensar conjuntamente. Cada docente brindó, desde su lugar, información clave para el desarrollo de los informes y la comprensión de la teoría".

También en la experiencia de las cátedras de Psicología la disponibilidad es considerada como otra cuestión clave:

"Me gustó mucho, ya que los profesores de las dos universidades estaban muy atentos y a disposición de los grupos para poder ayudarlos a comprender y traducir el trabajo que realizamos"

En relación a la intervención de los docentes en la experiencia de Informática, considerando los resultados de las encuestas respondidas por los estudiantes que protagonizaron el trayecto, los mismos destacan el acompañamiento y asesoramiento continuo de los docentes. Así lo expresan:

"En mi opinión los docentes me parecen excelentes, se preocupan por el alumno y lo ayudan mucho por más que sea vía virtual ya que es complicado enseñar una materia cómo ésta”

Además, destacan la predisposición del equipo docente y su ayuda en la motivación:

"Me ha encantado la gran predisposición por parte de la mayoría de los docentes como también la motivación para participar, me sentí 100\% acompañado por ellos y he aprendido muchas cosas que me servirán a futuro". 
En la indagación sobre la participación de los estudiantes, se evidencia una heterogeneidad de situaciones: en Psicología, llevan adelante el estudio de casos en forma grupal, cuentan con momentos de socialización entre ambos países y algunos grupos se integran con estudiantes del otro país. Además, son invitados a participar en los foros del aula virtual diseñados para la presentación, la conformación de los grupos y la discusión de los casos. Asisten a conferencias y encuentros organizados en ocasión de movilidad docente, en donde se desarrollan clases conjuntas entre ambos países. Esta experiencia tuvo un desafío adicional a las otras, por el hecho de la diferencia de los idiomas en los grupos mixtos. En la evaluación obtenida por parte de los estudiantes, se lo señaló en varias oportunidades, algunos lo manifiestan como una dificultad, mientras otros lo descubren como una posibilidad de aprendizaje. Así lo pone de relieve un alumno:

"(En esta experiencia aprendí) Compañerismo, respeto por las ideas y pensamientos de los demás y sobre todo aprendí un poco del idioma”.

También en esta experiencia se pone de manifiesto la posibilidad que les ofrece el trabajo con pares extranjeros para desplegar actitudes que contribuyen a la relación con otros:

"En cuanto a la virtud a cultivar, la paciencia y tolerancia del otro como alguien diferente y particular. También la importancia de una fluida comunicación y respetar y usar lo más eficientemente posible el tiempo disponible para alcanzar las metas establecidas.

Para los que cursaron Química Biológica, un recurso que resultó valioso fue el debate autogestionado, que se utilizó para propiciar la reflexión crítica sobre los contenidos abordados en cada cátedra. Los docentes se limitaron a la planificación de las actividades, siendo los estudiantes quienes tuvieron un rol principal y activo en el proceso de análisis, reflexión y exposición de los trabajos. Las valoraciones realizadas por los estudiantes revelan que dicha metodología despierta y motiva en la investigación e indagación de los tópicos analizados, ofrece una alternativa para el estudio de los conceptos teóricos disciplinares, así también les implica un reto a la hora de abordar estos contenidos, ya que la autonomía en tiempos tempranos de la carrera admite el espacio de aprendizaje en el error.

En la propuesta de Informática se implementó el uso de las wikis, espacios que habilitaron una tarea colaborativa de indagación de una temática propia de la disciplina Informática en relación a Ciencias Veterinarias. Cuando se consultó a los estudiantes de los proyectos acerca de la participación de los pares, hubo percepciones muy variadas, algunas muy positivas y otras en cambio ponían en evidencia la necesidad de fortalecer las estrategias para fomentar el intercambio.

Respecto al tercer componente del trabajo colaborativo tenido en cuenta en el presente trabajo, las estrategias didácticas utilizadas en las diferentes experiencias, se destacan la utilización de casos compartidos, de debates críticos y el uso de wikis, que se vieron favorecidas por la utilización de diferentes recursos tecnológicos. Así, las cátedras de Psicología acudieron a distintos medios y herramientas digitales: WhatsApp, Google Translator, Google Drive, Google Meet y Zoom. Dichas herramientas también son utilizadas para llevar a cabo las instancias de trabajo de los equipos docentes. Para conformar los grupos entre estudiantes que no se conocían 
previamente, se organizó un foro en el aula virtual compartida, y se fueron implementando los distintos pasos de las actividades previstas. Para apoyar el desarrollo del estudio de casos compartidos, se implementaron clases semanales virtuales y se reorganizó el aula virtual de UNL, añadiendo a docentes y estudiantes de otras universidades.

En las percepciones de los estudiantes los instrumentos tecnológicos se consideraron "muy accesibles, fáciles de utilizar, con gran disposición de herramientas para mejorar nuestro desempeño estando a distancia", tal como lo afirma un alumno. Se destacó la utilidad de la grabación para realizar los trabajos prácticos. Inclusive afirmaron: "Sin esos recursos no podríamos haber realizado la experiencia".

Al responder acerca de cuáles fueron los desafíos que se les presentó para llevar adelante la tarea propuesta, ellos incluyen el manejo de la virtualidad, en sus diferentes usos. Tal como lo afirmó un estudiante, "tanto en la entrevista como para comunicarnos entre nosotros". Esta afirmación da cuenta que tuvieron que llevar adelante una serie de aprendizajes y adaptaciones en la tarea para poder aprovechar los recursos tecnológicos.

En las cátedras de Química Biológica se presentaron clases teóricas asincrónicas, mediante la creación de diapositivas con una narración de los docentes con temáticas específicas de cada cátedra. Además, se desarrollaron recursos audiovisuales sobre las distintas técnicas utilizadas por ambos países.

En las distintas ediciones de las experiencias de Informática se creó un Entorno Virtual que habilitó la interacción entre docentes y estudiantes de las distintas Universidades, para favorecer el aprendizaje significativo de contenidos comunes de las disciplinas involucradas. La mediación tecnológica predominante fueron los espacios colaborativos de trabajo (wikis) que los estudiantes utilizaron para el cumplimiento de las consignas y para la entrega de una tarea común. Los instrumentos de evaluación utilizados fueron diversos, incluyendo cuestionarios, rúbricas y encuentros de socialización.

Así valoran los estudiantes este acceso a la virtualidad:

"He aprendido lo que es y cómo utilizar una wiki como también Google slides que me servirá para presentaciones futuras".

Es significativo el valor que adquirieron las TIC para fomentar el trabajo colaborativo, tal como se reconoce en la siguiente respuesta de un estudiante:

"Me pareció muy interesante aprender a utilizar la tecnología para realizar trabajos en equipo".

Los resultados obtenidos de las experiencias desarrolladas evidencian las ventajas que ofrecen las tecnologías como mediadoras, habilitando al docente a propiciar, situar y acompañar a los estudiantes en trabajos colaborativos mixtos internacionales. 


\section{Discusión y conclusiones}

Estas tres experiencias de IntC en casa desarrolladas desde UNL, en la que participan ocho universidades y cinco países, muestran al trabajo colaborativo mediado por TIC como una estrategia factible y conveniente de utilizar para alcanzar sus objetivos interculturales y contribuir así a la formación integral de los estudiantes.

El análisis de los resultados permite recoger evidencias al respecto en los tres componentes del trabajo colaborativo analizados: la intervención docente, la participación estudiantil y las estrategias metodológicas utilizadas.

Existen opiniones heterogéneas por parte de los autores respecto a la intervención de los docentes en los trabajos colaborativos, así Echazarreta et al. (2009) manifiesta que es necesario un control del proceso de aprendizaje por parte de los docentes, y reglas definidas previamente, mientras que otro autor considera que la intervención del docente/tutor se debería reducir a su expresión mínima, ya que la autogestión de los grupos es fundamental (Sanz et al., 2008). En el contexto del aprendizaje significativo, entendido como tal a la interacción entre los aprendizajes nuevos y los previos, el rol docente cumple una importancia fundamental, dado que debe construir elementos didácticos que favorezcan dicha interacción, ocupando un lugar de mediador y acompañante del estudiante (Gómez Vahos et al., 2019).

En estos proyectos, la valoración del alumnado da cuenta de la importancia de contar con una guía docente, destacan el valor que adquiere el apoyo que les ofrecen para desempeñar la tarea colaborativa y así no sólo adquirir información o realizar la tarea asignada, sino también aprender estrategias de vinculación con los docentes y compañeros extranjeros. La incorporación de pares que ya atravesaron previamente estas instancias de IntC y se comprometen a ayudar a los estudiantes muestra ser de gran utilidad para atender algunas necesidades del grupo a la vez que contribuyen a obtener información para orientar y/o readaptar las estrategias didácticas en caso de ser necesario.

Los encuentros que se generan en estos grupos de trabajo permiten entrar en contacto con un ambiente cultural diverso y esto contribuye a generar aprendizajes para saber desenvolverse con el extranjero, lo que se ve potenciado cuando se forman grupos mixtos con un objetivo común: el desarrollo de una actividad planificada. En este sentido, Revelo-Sánchez et al. (2018) afirman que los grupos de trabajo colaborativos se configuran articulando las habilidades individuales para el desarrollo de un objetivo en común. En ciertos casos los alumnos manifiestan la importancia de una motivación para lograr esa meta en común; con esta finalidad se considera importante el apoyo del docente para que el trabajo en grupos colaborativos sea asumido por sus miembros, como grupos de encuentros:

[...] esto, en el sentido de Carl Roger, significa que el encuentro con el otro edifica, hace crecer, transforma, por cuanto modifica actitudes, puntos de vista y colabora en la construcción de una visión mejorada de la vida con otros y junto a otro. (Maldonado 2007, p. 270)

La participación de los estudiantes se ve favorecida cuando se propician este tipo de instancias colaborativas y se diseñan estrategias didácticas destinadas específicamente a lograr tal fin. En ese sentido, se evidencia la pertinencia y utilidad que 
tuvieron las distintas técnicas didácticas aplicadas. ya que la socialización de las mismas permite ampliar las posibilidades de ser utilizadas en los diferentes proyectos de IntC para alcanzar sus fines. Asimismo, la aplicación de instancias evaluativas llevadas adelante por cada proyecto de IntC resultan de gran utilidad para identificar las fortalezas y debilidades de las estrategias implementadas. En base a sus resultados, las propuestas implementadas en cada experiencia son readaptadas en cada nueva edición. A su vez, estos intercambios posibilitan identificar la importancia de diseñar y aplicar instrumentos que evalúen los aportes de la IntC a la formación integral de estudiantes universitarios.

Las estrategias metodológicas utilizadas en algunas de las propuestas se desarrollaron en un marco de "multimodalidad" (Rama Vitale, 2019), en el que se combinan instancias presenciales y virtuales, con un progresivo incremento en el uso de las herramientas que promueven las nuevas tecnologías. De más está aclarar que, al momento de comenzar la situación de pandemia, estas propuestas de IntC pasaron a ser implementadas de manera exclusivamente virtual, tanto de manera sincrónica como asincrónica. En este sentido, se destaca que el trabajo colaborativo haciendo uso de las TIC facilita y potencia los aprendizajes en condiciones como las impuestas por la pandemia de Covid-19. Es de subrayar que estas tecnologías se constituyen en herramientas mediadoras claves para el trabajo colaborativo. Esto concuerda con Sanz et al. (2008), sobre la utilización de estas tecnologías como transformadoras de los espacios áulicos y del trabajo colaborativo.

La socialización de los resultados obtenidos en los casos indagados en este artículo, en relación a la aplicación del trabajo colaborativo mediado por TIC, puede ser un elemento motivador para el desarrollo de otras experiencias que busquen contribuir a la formación integral de sus estudiantes y al reconocimiento de la diversidad desde un enfoque intercultural.

\section{Referencias}

Barkley, E. F., Cross, K. P. y Major C. H. (2007). Técnicas de aprendizaje colaborativo: manual para el profesorado universitario. Morata.

Clérico, G.M., Ramírez Barbieri, A. y Gaspar, E.Y. (2019). La virtualidad en la internacionalización curricular, ¿un apoyo para el encuentro intercultural? Cuadernos Universitarios, 12, 51-62.

Delgado Fernández, M., y Solano González, A. (2009). Estrategias didácticas creativas en entornos virtuales para el aprendizaje. Revista Electrónica "Actualidades Investigativas en Educación", 9(2), 1-21.

Echazarreta, C., Prados, F. y Poch, J. (2009). La competencia "El trabajo colaborativo" Una oportunidad para incorporar las TIC en la didáctica universitaria. Descripción de la experiencia con la plataforma ACME (UdG). UOC Papers: revista sobre la sociedad de conocimiento, 8, 1-11. 
Escobar Potes, M. P., Franco Peláez, Z. R. y Duque Escobar, J. A. (2010). La formación integral en la educación superior. Significado para los docentes como actores de la vida universitaria. Revista Eleuthera, 4, 69-89.

García Pérez, S. L. (2010). El papel de la tutoría en la formación integral del universitario. Tiempo de educar, 11(21), 31-56.

Gómez Vahos, L. E., Muñoz, L. E. M., y Londoño-Vásquez, D. A. (2019). El papel del docente para el logro de un aprendizaje significativo apoyado en las TIC. Encuentros, 17(2), 118-13.

Knight, J. (2004). Internationalization Remodeled: Definition, Approaches, and Rationales. Journal of Studies in International. Education, 8(1), 5-31.

Luchilo, L. (2017). Enfoques alternativos sobre la internacionalización del curriculum. Debate Universitario CAEE-UAl, 6(11), 37-51.

Maldonado Pérez, M. (2007). El trabajo colaborativo en el aula universitaria. Laurus, 13(23), 263-278.

Morosini, M.C. (2018). Internacionalização do currículo: produção em organismos multilaterais. Roteiro, Joaçaba, 43(1), pp. 115-132. https://doi.org/10.18593/r.v43i1.13090

Rama Vitale, C. (2019). Políticas, tensiones y tendencias de la educación a distancia y virtual en América Latina. EUCASA.

Revelo-Sánchez, O., Collazos-Ordoñez, C. y Jiménez-Toledo, J. (2018). El trabajo colaborativo como estrategia didáctica para la enseñanza/aprendizaje de la programación: una revisión sistemática de literatura. TecnoLógicas, 21(41), 115-134.

Sanz, C., Madoz, C., Zangara, A. y Albanesi, B. (octubre de 2008). El trabajo colaborativo y cooperativo mediado por TICs. Herramientas informáticas utilizadas en la mediación y experiencias realizadas [Objeto de conferencia]. XIV Congreso Argentino de Ciencias de la Computación, La Rioja, Argentina. http://sedici.unlp.edu.ar/ handle/10915/21995 
Eje temático

Escenarios

con

Tecnología

$\circ \circ 0$

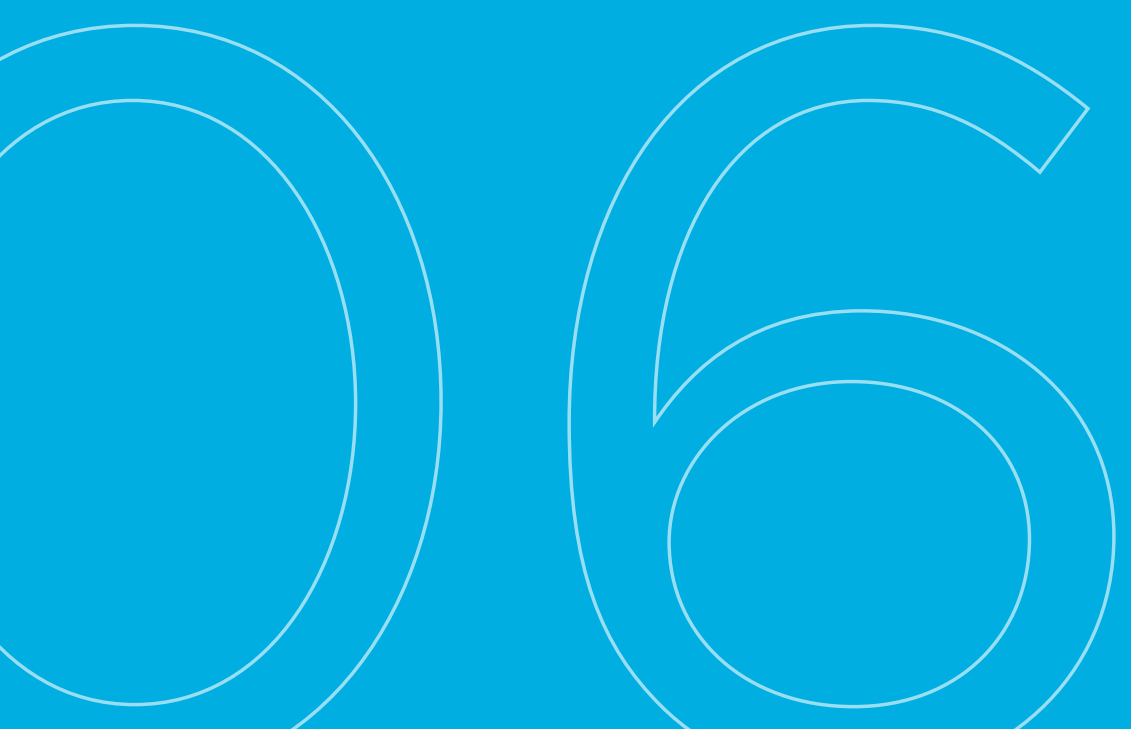




\section{Interacciones y Consideraciones Sistémicas en el Aula Virtual}

\section{Lara, Luis Rodolfo}

orcid.org/0000-0002-9682-3743

Irlara@exactas.unca.edu.ar 


\title{
INTERACCIONES Y CONSIDERACIONES SISTÉMICAS EN EL AULA VIRTUAL
}

\author{
Lara, Luis Rodolfo \\ orcid.org/0000-0002-9682-3743 \\ Irlara@exactas.unca.edu.ar
}

\section{Resumen}

En la actualidad surgen en forma permanente nuevos entornos mediados por tecnologías que permiten al docente interactuar con los estudiantes. Este trabajo hace referencia al estudio sistémico realizado sobre las interacciones que suceden en un ambiente específico: el aula virtual. Se considera el concepto de Escenario Interactivo de Aprendizaje (EIA) como el punto de encuentro, más allá de un espacio y horario determinado, donde intervienen el docente y los estudiantes; un estudio del EIA como un sistema implica considerar estos recursos interactivos capaces de promover procesos de comunicación en múltiples direcciones como también el acceso a contenidos y actividades multimedia. Se analiza la apertura sistémica que presentan estos entornos, incorporando el concepto de entropía que considera el intercambio de acciones con el entorno, donde se incluya interacciones tanto unidireccionales (acceso a contenidos e información) como bidireccionales y multidireccionales (actividades y diálogos espontáneos con canales de comunicación en diversas direcciones y sentidos). Recabando datos de una experiencia concreta, la asignatura "Electrotecnia Aplicada" de la carrera Tecnicatura en Informática de la Universidad Nacional de Catamarca (Argentina) dictada a distancia, se pudo fundamentar la inclusión de ciertos recursos interactivos, aceptando, desde una perspectiva sistémica, que un entorno de aprendizaje abierto y con una entropía estable, constituye una condición necesaria para promover un adecuado intercambio de flujo de información en un entorno interactivo de aprendizaje.

\section{Palabras clave}

EIA, escenario interactivo de aprendizaje, sistema, entropía, interacciones. 


\section{Introducción}

Las acciones a distancia entre el docente y los estudiantes precisan de un entorno interactivo de enseñanza y aprendizaje, de esta manera, resulta relevante realizar un estudio sistémico de los recursos y elementos que constituyen estos ambientes, ya que es posible obtener indicios y pautas de diseño para la incorporación de elementos interactivos en estos entornos que puedan favorecer el proceso de acceso a la información y la comunicación de todos los participantes de una clase.

Este estudio indaga sobre las acciones comunicativas que se producen en un entorno interactivo de aprendizaje; desde esta perspectiva es relevante el concepto de interactividad, Estebanell (2002) la define como una característica intrínseca que presentan los materiales que incrementa cualitativa y cuantitativamente la capacidad de los usuarios de intervenir en el desarrollo de las posibilidades que ofrecen estos entornos, de manera que se pudiese mejorar sus posibilidades de trabajo y aprendizaje. Así, los niveles de interactividad que puede presentar un espacio están definidos por las posibilidades y grados de libertad que tiene el usuario cuando actúa con el sistema, así como la capacidad de este sistema en relación al usuario. Esto dependerá de las características que presenten los recursos del entorno, para permitir distintos tipos de interacciones. Sims (1997) citando a Jonassen expresa la interactividad como una actividad entre dos organismos, y con una aplicación basada en computadora, que involucra al estudiante en un verdadero diálogo.

Se propone el concepto de Escenario Interactivo de Aprendizaje (EIA) como aquel espacio donde se realizan las interacciones para promover estrategias adecuadas de enseñanza y aprendizaje. El EIA es la estructura, los cimientos donde el docente implementará actividades, presentará contenidos, atenderá las consultas y llevará a la práctica todas las estrategias planteadas en su planificación didáctica.

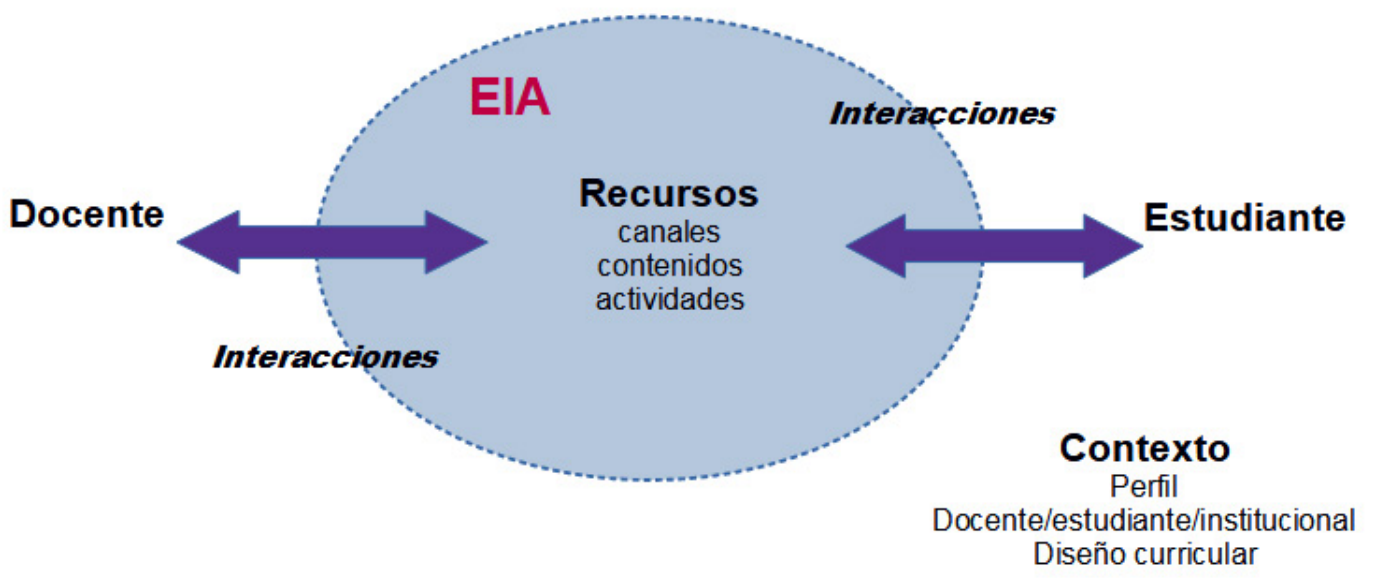

\section{1 - El escenario interactivo de aprendizaje (EIA)}

Al estudiar el EIA (Figura 1) se considera los siguientes elementos de análisis:

a) Interacciones: contemplan aquellas que se producen en un proceso de aprendizaje en un entorno virtual que proponen Anderson y Elloumi (2008): interacción 
docente-estudiante, estudiante-estudiante, estudiante-contenido, docente-contenido, docente-docente y contenido-contenido.

b) Recursos: se consideran aquellos elementos que están incluidos en el entorno que permiten establecer las interacciones mencionadas. Presentan diferentes funciones:

- $\quad$ canales de comunicación: como el foro de debate, mensajería privada o grupal, mensaje por redes en diferentes formatos.

- $\quad$ contenidos e información: como hipervínculos a documentos digitales, sitios webs, videos, audios y material multimedia.

- $\quad$ actividades: como cuestionarios, foros (para implementar la participación y colaboración de los estudiantes), wiki, glosario, juegos.

c) Contexto: es con quien interactúa el mencionado sistema, comprende los rasgos particulares que constituye el perfil del docente y estudiante, las características que presenta el ambiente institucional y los aspectos que hacen referencia a la estructura curricular de la asignatura (modalidad de cursado, disciplina, planificación) y considera:

- $\quad$ perfil del estudiante: estrategias de aprendizaje que emplea, motivaciones, competencias y los conocimientos previos que posee, por ejemplo.

- $\quad$ perfil del docente: estrategias de enseñanza, competencias y planificación.

- $\quad$ características de la institución educativa y del diseño curricular: disciplina, modalidad de cursado, creencias.

- $\quad$ infraestructura técnica que dispone el estudiante, el docente y la institución educativa (espacio físico, hardware, conectividad y software disponible).

Con una adecuada organización de recursos, adaptada al contexto institucional y con una apertura apropiada del sistema, se puede crear un EIA que ofrezca oportunidades de enseñanza y aprendizaje por diferentes vías y canales, dependerá de las estrategias, planificación y metodología empleada por el docente y el estudiante para lograr el cometido. Los dispositivos tecnológicos permiten que esas interacciones se puedan realizar independientemente del espacio y tiempo; implementando la clase bajo distintas configuraciones (presencial, b-learning o híbrida y a distancia).

La incorporación de las nuevas tecnologías ha cambiado el concepto de comunicación y las formas en que interactúan las personas, como mencionan Cabero y Llorente (2007), tales cambios se están estableciendo en diferentes direcciones y sentidos como la ubicación espacial donde pueden estar los participantes de la acción educativa, los tiempos en que pueden estar ubicados, la tipología de lenguajes que pueden movilizar, o las herramientas que pueden utilizar para comunicarse.

Estas interacciones que se producen en un entorno de aprendizaje pueden ser consideradas en términos de los actores que participan en el proceso, Anderson y Elloumi (2008) mencionan las interacciones que se pueden implementar en un escenario interactivo de aprendizaje: 
a) Interacción estudiante-estudiante: se valora la interacción entre pares, las tareas involucradas en el trabajo colaborativo muestran los potenciales beneficios en el aprendizaje. La interacción entre pares es fundamental para el desarrollo de comunidades de aprendizaje, que permiten a los estudiantes desarrollar habilidades interpersonales e investigar cuerpos tácitos de conocimiento compartidos por miembros de la comunidad, así como el estudio en el currículo formal.

b) Interacción docente-estudiante: se apoya en una variedad de procesos de comunicación (asíncrona y síncrona) y formatos (comunicaciones de texto, audio y vídeo). El surgimiento de las mejores prácticas reconoce ahora que el flujo de la comunicación sea mucho menos centrado en el docente, produciendo la aparición de un mayor compromiso de aprendizaje y participación por parte de los propios estudiantes.

c) Interacción estudiante-contenido: la web es compatible con estas formas más pasivas de interacción estudiante-contenido, pero también ofrece nuevas opciones, como la inmersión en microambientes, ejercicios en laboratorios virtuales y tutoriales en línea asistido por computadora.

d) Interacción contenido-contenido: es una nueva forma de interacción en donde el contenido puede interactuar con otras fuentes de información automatizadas para actualizarse constantemente y adquirir nuevas capacidades, a través de actualizaciones y la interacción con otras fuentes de contenido.

e) Interacción docente-docente: crea la oportunidad para sostener a los docentes mediante el desarrollo profesional y soporte de comunidades de apoyo. Estas interacciones animan a los docentes para aprovechar el crecimiento y descubrimiento del conocimiento, en su propia área temática y dentro de una comunidad académica específica.

f) Interacción docente-contenido: se enfoca en la creación de contenidos, como objetos de aprendizaje, unidades de estudio, cursos completos y actividades asociadas al aprendizaje. Los materiales de estudio tienen un rol importante en el proceso de enseñanza y aprendizaje, sobre todo en educación a distancia, ya que flexibilizan las actividades y procesos realimentados que se dan en la clase.

Considerando el sentido de la transmisión del flujo del proceso de comunicación, se propone las siguientes interacciones que se pueden presentar en un entorno interactivo de aprendizaje:

- Interacción unidireccional: la interacción solo afecta a uno de los agentes intervinientes en el proceso de comunicación, no se produce un diálogo, el mensaje se transmite en un solo sentido. Por ejemplo, la lectura que hace una persona de una página de un libro, en este caso la interacción es asimétrica ya que solo quien lee es susceptible de recibir el mensaje.

- Interacción bidireccional: en este caso la interacción se establece entre dos agentes y se influyen mutuamente en el proceso de comunicación, hay un diálogo, los dos tienen las mismas posibilidades de intervenir (es una relación simétrica). Un caso común que se presenta es una conversación a distancia utilizando el teléfono entre dos personas, los dos tienen la posibilidad de recibir el mensaje y continuar el diálogo sincrónico que se está produciendo. 
- Interacción multidireccional: es similar a la bidireccional, pero pueden intervenir en el proceso más de dos agentes, estableciéndose un diálogo entre todos los participantes con el mismo nivel jerárquico. Un ejemplo es una videoconferencia donde todos pueden intervenir si el moderador lo permite.

El objetivo de este trabajo es analizar, desde un enfoque sistémico, los elementos interactivos disponibles en el aula virtual de un curso dictado a distancia. Introduciendo en el análisis los conceptos como entropía y sistema abierto con el fin de identificar las condiciones necesarias para que existan interacciones adecuadas que promuevan acciones formativas. Un estudio sistémico en el EIA permite elucidar los elementos interactivos que intervienen, el rol que cumple cada uno de ellos, sus características y su interacción con el ambiente. Desde este enfoque, Sánchez Cerezo (1991) define al sistema como "un conjunto organizado de elementos diferenciados cuya interrelación e interacción supone una función global” (p. 480). El concepto de entropía es alcanzado por varios autores desde la física, la química (Castellan, 1987, Atkins, 1991) y el proceso de comunicación; y tiene varias interpretaciones, pues, es una medida de la pérdida de energía (Clausius), es una medida de aleatoriedad o desorden (Boltzman) y a la vez, está relacionada con la cantidad de información que se puede transmitir por un canal (Shannon y Weaver, 1949).

Según la físico-química, todos los sistemas, están sujetos al segundo principio de la termodinámica, la entropía; la naturaleza parece "preferir" el desorden y el caos. La inclusión del concepto de entropía tiene antecedente en su influencia con entornos interactivos de aprendizaje (Lara, 2020) donde se plantea desde una perspectiva teórica la incorporación de este concepto en el EIA.

Considerando la Teoría General de Sistemas, existen diversos tipos de sistemas, un sistema aislado es aquél que no intercambia información con el entorno o ambiente, el segundo principio de la termodinámica afirma que la entropía de un sistema aislado crece permanentemente, cuando un sistema de este tipo alcanza una entropía máxima, ya no puede experimentar cambios: ha alcanzado el equilibrio, el sistema se fusiona con su ambiente y este cambio es irreversible. En este tipo de sistemas, la transmisión del mensaje sucede en un solo sentido (interacción unidireccional), y el rol del estudiante es de ser un mero receptor, sin posibilidades de intervenir en forma activa en el proceso. Un ejemplo de sistema aislado es una clase (como conferencia magistral) grabada en video, donde el estudiante no tiene ninguna posibilidad de intervenir, modificar o consultar sobre el contenido emitido (a menos que sea por otra vía).

En cambio, un sistema abierto, al ser permeable con el ambiente, compensa esa producción de entropía interna creciente, incorporando información de ese entorno, es decir, produciendo una entropía negativa o neguentropía. La neguentropía es una medida de orden, de este modo, se mantiene el sistema estacionario y a un nivel alto de ordenamiento (una entropía estable), así el sistema se diferencia del ambiente con quien interactúa. Un sistema abierto puede presentarse como aquel que importa información (corriente de entrada), la transforma (proceso de transformación) y luego exporta al ambiente esa nueva información ya procesada (realimentación). Con el producto de esa exportación, el sistema está en condiciones de obtener nuevamente sus corrientes de entrada necesarias para llevar a cabo el proceso de transformación que lo caracteriza y diferencia del resto de los sistemas. De este modo, como afirma Sarabia (1995) "en un sistema abierto, se deben tener en todo 
momento despejado sus canales de información con el entorno y asumir el conflicto que supone la aceptación de la diversidad" (p. 56). Entonces, permeabilizar la frontera sistema-ambiente llevará al sistema a una situación de inestabilidad, pero si el sistema tiene un diseño adecuado, lo conducirá a un nivel más evolucionado y complejo. Un sistema abierto con fines educativos necesita de una configuración donde los elementos que lo constituyen estén relacionados en forma adecuada y su funcionamiento permeable a los estímulos externos. Las interacciones que se producen deben ser en diferentes direcciones y sentidos (unidireccionales, bidireccionales y multidireccionales), aquí el estudiante tiene la posibilidad de participar activamente en el proceso, intercambiando información con el docente o con sus compañeros por diversos canales alternativos, diseñando contenidos, proponiendo debates, entre otras actividades.

\section{Descripción de la experiencia}

\section{Descripción del contexto y de los participantes}

En esta investigación se trabajó con 46 estudiantes, con un promedio de edad de 22 años de la asignatura "Electrotecnia Aplicada" del segundo año de la carrera de pregrado Tecnicatura en Informática de la Universidad Nacional de Catamarca (Argentina), asignatura dictada a distancia en el primer cuatrimestre de 2020 por la condición de emergencia sanitaria. El curso duró 12 semanas, se realizó un encuentro por videoconferencia por semana, con una duración de 90 minutos y se dispuso de un aula virtual Moodle con los siguientes recursos:

a) Recursos de comunicación: se habilitó un enlace a videoconferencia por Meet (donde el docente presentaba el tema y se admitía consultas y debates) en forma sincrónica, este encuentro era grabado para que puedan acceder a este evento los estudiantes que no podían asistir. También se incluyeron foros de debate (de consultas y propuestas de resolución de problemas) y mensajería personal, admitiendo principalmente interacciones docente-estudiante y estudiante-estudiante. Desde la perspectiva de la direccionalidad de estas interacciones, podían presentarse asincrónicas unidireccionales, bidireccionales y multidireccionales.

b) Recursos para acceder a contenidos e información: se incluyó el foro Avisos (donde el docente anunciaba novedades sobre el cursado de la materia), material multimedia (guías de estudio, material instruccional, videos grabados de los encuentros sincrónicos y otros videos que hacían referencia a la temática del curso), calendario, agenda e informe de seguimiento. Estos recursos admitían interacciones docente-contenido, estudiante-contenido y contenido-contenido, presentaban características unidireccionales y se repitieron en los 7 temas (unidades temáticas) que abarcó la asignatura. Son elementos eminentemente asincrónicos ya que permiten acceder a ellos en cualquier momento, flexibilizando el cursado de la asignatura.

c) Recursos para realizar actividades: como el cuestionario, foro de participación para la resolución de problemas planteados y el glosario. A diferencia de los foros, los cuestionarios permitieron interacciones bidireccionales con realimentaciones programadas (según la intervención realizada por el estudiante). Presentaban específicamente interacciones estudiante-contenido y tenían el rasgo de ser bidireccional. Estos recursos tenían un lapso de tiempo determinado para trabajar (de dos a tres días). 
El aula virtual tuvo la siguiente configuración gráfica:

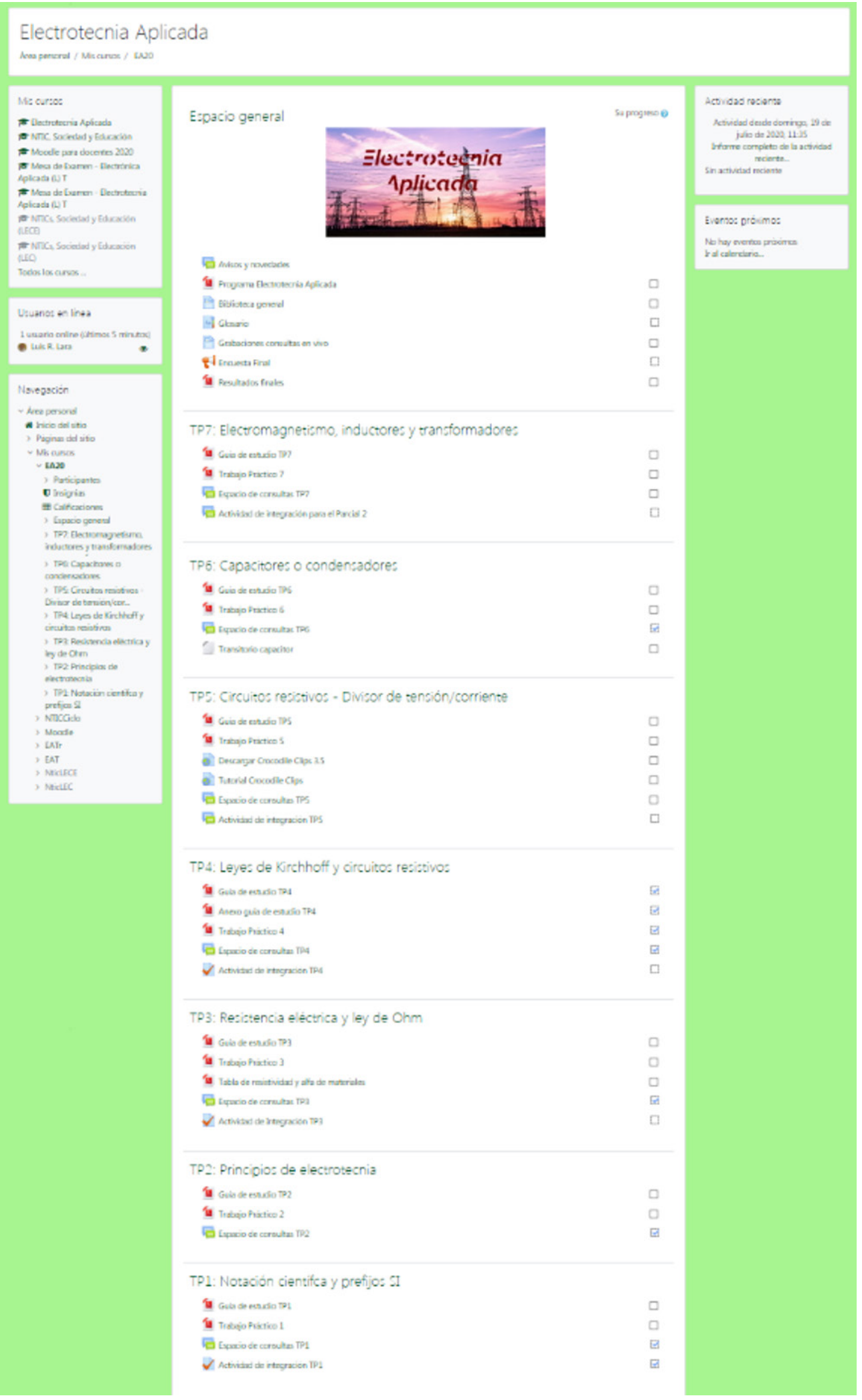

2- Interfaz del aula virtual 
La función que tienen los recursos incluidos en el aula virtual no depende solamente de sus características tecnológicas, puede suceder que alguno de ellos sea lo suficientemente versátil (permiten diversos tipos de configuraciones) para admitir diferentes funciones y tipos de interacciones. Un caso puntual es el foro de debate, puede ser una fuente simple de información sin posibilidades de participar o comentar (canal unidireccional), que es el caso del espacio de aviso del docente; o puede permitir la intervención de todos los participantes de la clase en un tema determinado (canal multidireccional).

\section{Instrumentos y procedimiento}

Para la recolección de datos se acudió a los resultados obtenidos de dos encuestas anónimas, la primera se realizó al inicio del curso y tuvo como objetivo identificar el contexto de los estudiantes (infraestructura disponible, motivaciones) y la segunda, realizada al final del cursado hizo referencia a la estructura del aula virtual, metodología del cursado y la preferencia de los recursos interactivos disponibles. También se analizó el informe estadístico que proporciona Moodle acerca de las vistas que tuvieron cada una de las actividades que se realizaron en el aula virtual.

\section{Resultados}

De las herramientas utilizadas para obtener los datos pertinentes, se pudo reconocer el contexto en cuanto a la disponibilidad de infraestructura tecnológica que tuvo el estudiante al realizar el cursado de la asignatura. Considerando la disponibilidad de dispositivos informáticos:

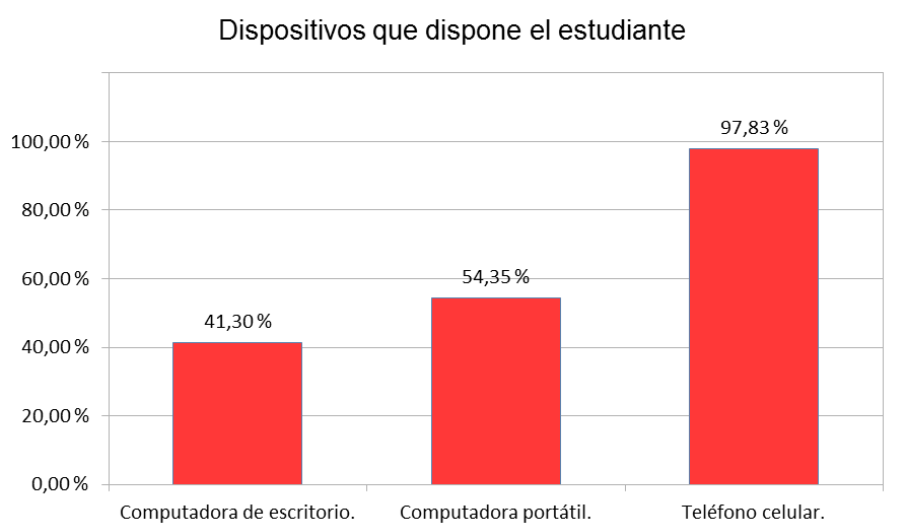

\section{3- Dispositivos que dispone el estudiante}

Se observa que prácticamente todos los estudiantes tenían teléfono celular y más de la mitad dispone de una computadora portátil. Por otro lado, el $74 \%$ de los estudiantes tenían acceso de alguna forma a Internet, de ellos el $26 \%$ ingresaban por red de datos móviles del celular, del cual tenía un acceso limitado según el abono del servicio que disponían.

Otra cuestión relevante fue que el $76 \%$ de los estudiantes compartían el dispositivo con otra persona, lo que condicionó fuertemente su empleo y a la flexibilidad que pretende ofrecer esta modalidad, ya que no tenían libre disponibilidad del equipo para conectarse al aula virtual. 
Con respecto a los recursos del aula virtual que los estudiantes consideraron más útiles para su estudio:

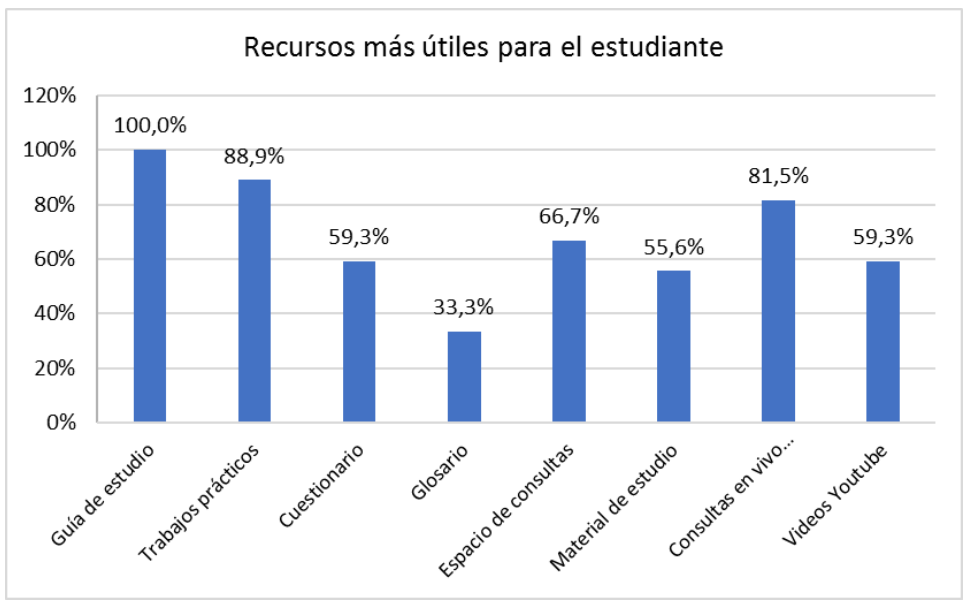

\section{4- Recursos del aula virtual preferidos por los estudiantes}

Se puede apreciar que los recursos más elegidos por los estudiantes estuvieron repartidos entre materiales de estudio y acceso a la información (guías de estudio $100 \%$, consignas de trabajos prácticos $89 \%$ y videos de YouTube 59\%), son interacciones estudiante-contenido y presentan características unidireccionales y asincrónicos. También se consideraron aquellos recursos que permiten el establecimiento de la comunicación entre todos los participantes (consultas en vivo 81\%, foro de consultas 67\%), son interacciones docente-estudiante, estudiante-estudiante y tienen el rasgo de ser multidireccional. También se incluye una actividad de autoevaluación (cuestionarios 59\%) donde los estudiantes realizaban esta tarea al final de cada unidad temática, esta actividad también se puede considerar una interacción docente-estudiante y es bidireccional con una realimentación generalmente programada por el docente, que orientaba al estudiante según la respuesta dada.

Al consultar a los estudiantes si le agregarían algún recurso adicional al aula virtual, se obtuvo el siguiente resultado:

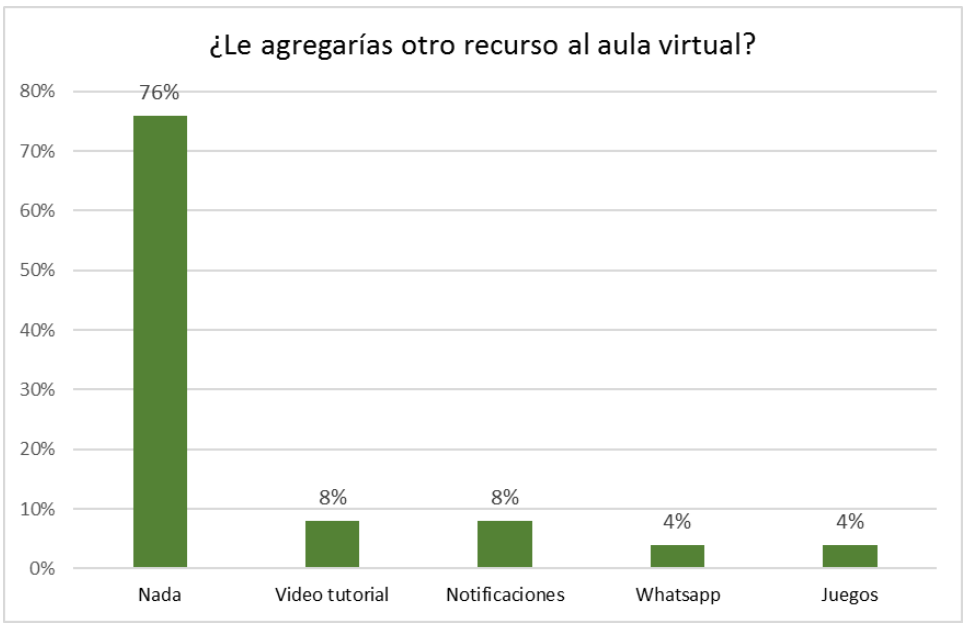


El 76\% afirmó que no era necesario agregar ningún recurso adicional al aula virtual, el $8 \%$ consideró que era necesario agregar un módulo de notificaciones que anuncie en sus dispositivos sobre las últimas novedades que se produjeron en el aula virtual, otro $8 \%$ reflexionó que es necesario la presencia de más videos tutoriales, un $4 \%$ manifestó que algunas actividades podían trasladarse a la modalidad de juegos (gamificación) y otro $4 \%$ propone incorporar la aplicación Whatsapp como vínculo de comunicación adicional al aula virtual.

\section{Discusión y conclusiones}

Incluir el concepto de entropía en el diseño de entornos interactivos es un aporte adicional a otros factores que se contemplan en la propuesta de construcción de un aula virtual (como la elección de elementos interactivos, análisis gráfico de los elementos, complejidad de las herramientas, compatibilidad de recursos, entre otros).

Es fundamental, en la etapa de diseño de estos entornos, considerarlos como un sistema abierto, un sistema real que interactúa con el contexto, le afecta sus influencias, pero a la vez, se diferencia de él; siendo permeable a los estímulos externos y dispuesto a estar sometido a alteraciones del sistema por parte de los usuarios intervinientes. La entropía proporciona indicios si el sistema es estable, comenzará a crecer con aquellos recursos que se incorporen al aula virtual que produzcan un diálogo unidireccional, es decir la interacción estudiante-contenido como la lectura de las guías de estudio, consignas de trabajo (trabajos prácticos) y observación de videos que hacen referencia a un tema específico. Para contrarrestar ese crecimiento de entropía se recurre a la presencia de recursos que permiten interacciones bidireccionales y multidireccionales. Esto se logra con una apertura del sistema, lo que implica mantener una entropía estable; una corriente neguentrópica (entropía negativa) significa incorporar canales de comunicación que permitan intervenir en un mismo nivel de jerarquía dialógica a todos los participantes de la clase (interacción docente-estudiante/s, interacción estudiante-estudiante). En este punto, los foros fueron los recursos más utilizados en el aula virtual, más allá de las que se puedan producir en los encuentros sincrónicos y los cuestionarios (como actividad dentro del aula virtual).

De esta manera, analizando los elementos más elegidos del aula virtual por los estudiantes, se identificaron recursos que permiten diversas vías para interactuar tanto con los contenidos como con el resto de los participantes de la clase, estos canales alternativos sumados a la flexibilidad que propone la modalidad, facilitaron condiciones que favorecieron los procesos de comunicación y acceso a la información. Aunque también hay que tener en cuenta que influye factores que hace referencia al contexto particular de cada participante, como la disponibilidad de la infraestructura tecnológica (disponibilidad de dispositivo y conectividad a Internet) y las condiciones de trabajo que tiene el docente y los estudiantes. 


\section{Referencias}

Atkins, P. (1991). Fisicoquímica. Addison-Wesley Iberoamericana.

Cabero, J. y Llorente, M. (2007). La interacción en el aprendizaje en red: uso de herramientas, elementos de análisis y posibilidades educativas. Revista RIED, 10 (2), 97-123. http://www.biblioteca.org.ar/libros/142140.pdf

Castellan, G. (1987). Fisicoquímica. Addison-Wesley Iberoamericana.

Estebanell, M. (2002). Interactividad e interacción. Revista Latinoamericana de Tecnología Educativa, 1(1), 23-32. https://bit.ly/35XcFNK

Lara, L. R. (2020). Un enfoque sistémico de los escenarios interactivos de aprendizaje. ReseachGate. https://doi.org/10.13140/RG.2.2.28432.23048/1

Sarabia, A. (1995). La teoría general de sistemas. Isdefe.

Sánchez Cerezo, S. (1991). Léxicos tecnología de la educación. Santillana.

Sims, R. (1997). Interactivity: A Forgotten Art?. Computers in Human Behavior, 13(2), 157-180. https://doi.org/10.1016/S0747-5632(97)00004-6

Shannon, C. y Weaver, W. (1949). The mathematical theory of communication. University of Illinois Press. 


\section{Virtualidad en Asignaturas del Área de Ingeniería Estructural}

Folino, Paula

orcid.org/0000-0001-5508-0755

Universidad de Buenos Aires

pfolino@fi.uba.ar

\section{Traiber, Claudia}

Universidad de Buenos Aires

ctraiber@fi.uba.ar 


\title{
VIRTUALIDAD EN ASIGNATURAS DEL ÁREA DE INGENIERÍA ESTRUCTURAL
}

\author{
Folino, Paula \\ Traiber, Claudia
}

\section{Resumen}

Este trabajo tiene como objetivo general analizar la experiencia del dictado de clases a distancia en asignaturas de grado y posgrado de Ingeniería Civil, específicamente del área de Ingeniería Estructural, en las que esta metodología de enseñanza fue implementada por razones de fuerza mayor en el marco de la situación de pandemia generada por el Covid. El análisis que se presenta se basa en información recolectada a través de encuestas que tienen la particularidad de involucrar tanto a alumnos como a docentes. Considerando las ventajas y desventajas observadas de esta metodología de enseñanza en comparación con la tradicional metodología presencial, y con la convicción de que se ha logrado un importante avance en lo que respecta a la incorporación de TICs en la enseñanza que debería capitalizarse, el objetivo particular de este trabajo es decidir, en base a los resultados obtenidos, si es conveniente incluir la enseñanza virtual de manera permanente y combinada con actividades presenciales. En primer lugar, se describen las características de las asignaturas y de los alumnos y docentes involucrados. Luego, se resumen y analizan los resultados recopilados a través de encuestas y finalmente, se presenta y se justifica una propuesta de metodología de enseñanza a futuro en el marco de las asignaturas consideradas.

\section{Palabras clave}

Clases virtuales, Enseñanza de la ingeniería, Diseño Estructural. 


\section{Introducción}

En los planes de estudio de las distintas universidades del mundo, la formación de un ingeniero civil incluye al menos tres tipos de asignaturas: las relacionadas con ciencias básicas, las tecnologías básicas y las tecnologías aplicadas. En esta formación, tanto la carga horaria y como la calidad de las actividades prácticas, resultan sumamente relevantes (Shaaban, 2013).

Este trabajo se enfoca en asignaturas pertenecientes al grupo de tecnologías aplicadas y vinculadas en particular al área de Ingeniería Estructural. En esta área, los contenidos y la metodología de enseñanza fueron evolucionando en el tiempo (Aparicio \& Ruiz Teran, 2007; Forcael et al., 2019) debido, básicamente, al surgimiento gradual pero continuo de nuevas teorías y de nuevas herramientas tecnológicas para realizar diseños estructurales, nuevos métodos constructivos, distintos requerimientos respecto a lo que un ingeniero civil debe poder hacer y, por último, a la recopilación de datos teniendo en cuenta la opinión de alumnos (Sageev \& Romanowski, 2001; Newson \& Delatte, 2011; Pan et al. 2021). Motiva este trabajo la experiencia recopilada en un año y medio (2020-2021), período en el que, debido a la situación de aislamiento obligatorio generado por la pandemia global, debió implementarse la metodología de enseñanza a distancia para las actividades de las asignaturas involucradas en este trabajo, incluyendo las clases teóricas, las explicaciones prácticas, las consultas y los exámenes. Es altamente probable que, sin esta situación de fuerza mayor, la comunidad académica del área en consideración nunca hubiera aceptado realizar una experiencia semejante. Por lo tanto, analizar de manera objetiva cómo resultó esta experiencia y cómo fue percibida por los actores involucrados, resulta una oportunidad única.

Siguiendo a García-Alberti et al., 2021, se coincide en que hay grandes desafíos por delante en la metodología de la enseñanza de las tecnologías aplicadas, de manera de capitalizar la experiencia ganada y mejorar así la calidad general de la enseñanza en la ingeniería. Por lo tanto, el objetivo de este trabajo es identificar las ventajas y desventajas de la metodología de enseñanza a distancia utilizada en las asignaturas en cuestión, y proponer con qué tipo de metodología convendría continuar.

\section{Descripción de la experiencia}

\section{Descripción del contexto y de los participantes}

Este trabajo incluye información recopilada de alumnos y docentes de asignaturas de grado y posgrado del Departamento de Construcciones y Estructuras de la Facultad de Ingeniería de la Universidad de Buenos Aires (FIUBA), en el ámbito de la Ingeniería Civil y en particular, de la Ingeniería Estructural.

Las asignaturas de grado son "Hormigón I" y "Geotecnia Aplicada", ambas cuatrimestrales, cursando un promedio de sesenta alumnos por curso. Corresponden, respectivamente, al séptimo y octavo cuatrimestres del plan de estudios actual de la carrera de Ingeniería Civil, que tiene un total de doce cuatrimestres. "Hormigón I" tiene una carga horaria semanal de ocho horas áulicas. Incluye la enseñanza de las etapas de un proyecto estructural y el diseño estructural de elementos estructurales 
básicos de hormigón armado. "Geotecnia Aplicada" tiene una carga horaria semanal de cuatro horas áulicas e incluye la enseñanza del diseño estructural de distintos tipos de fundaciones y tabiques de contención.

El presente análisis incluye también alumnos y docentes de cursos de posgrado pertenecientes al plan de estudios de la Maestría en Construcción y Diseño Estructural, donde los alumnos son ingenieros civiles, de distintas nacionalidades y distinto nivel de experiencia profesional. También son cursos cuatrimestrales, de 40 alumnos aproximadamente.

En cuanto a los docentes de grado y posgrado encuestados, en su mayoría son Ingenieros Civiles, y tienen una amplia trayectoria tanto profesional como académica.

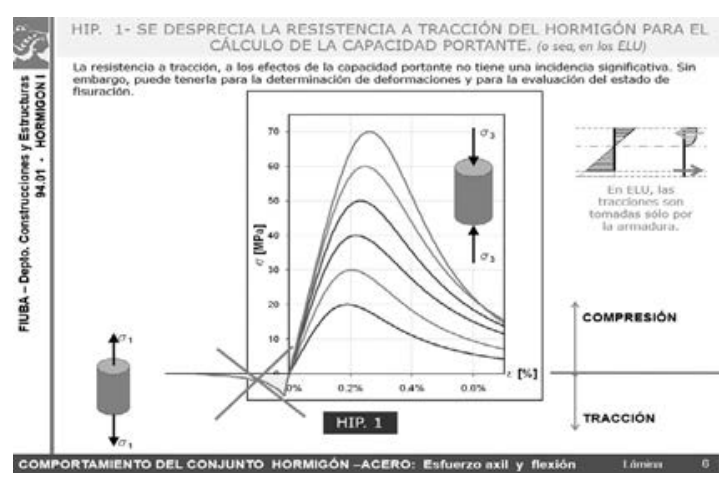

(a)

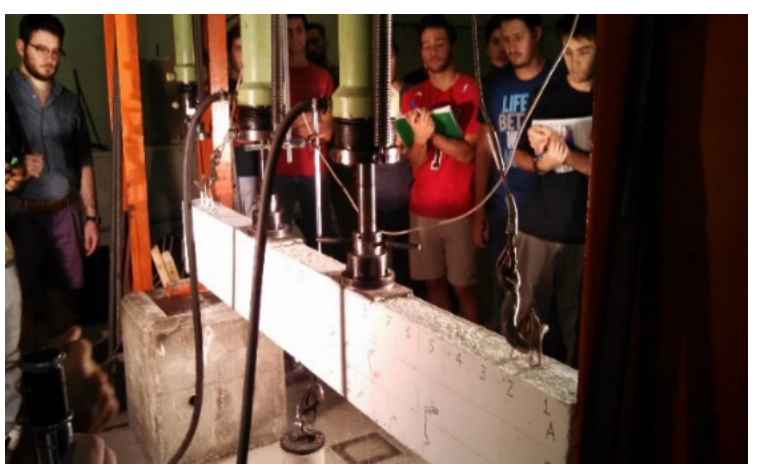

(b)

Figura 1: (a) Típica filmina de clase teórica y (b) Imagen de ensayo en laboratorio.

\section{Características de las actividades que se desarrollan en los cursos}

En todas las asignaturas se incluye el dictado de clases teóricas y de explicaciones de ejercicios prácticos (Ver Fig. 1a). Los alumnos desarrollan una serie de trabajos prácticos que consisten en problemas a resolver. En particular, en "Hormigón I" los alumnos asisten y participan interactivamente, en un ensayo a rotura de una viga de hormigón armado en escala real en el Laboratorio de Materiales y Estructuras (Ver Fig. 1b). La metodología de corrección de trabajos prácticos, consiste en clases de consulta con docentes, al menos una vez por semana. Para aprobar las asignaturas, los alumnos deben cumplir con un $75 \%$ de asistencia, aprobar trabajos prácticos, exámenes parciales y por último, un examen final integrador.

\section{Modificaciones en la metodología de enseñanza a partir del año 2020}

Todas las actividades se desarrollaban en modo presencial hasta marzo de 2020 , fecha en la que drásticamente pasaron a ser en su totalidad a distancia debido a la situación de pandemia global. Para las clases teóricas, en la modalidad presencial se utilizaba proyección de filminas y en la modalidad virtual, clases sincrónicas, en 
tanto que las explicaciones prácticas, para las que antes se utilizaba en general pizarrón, fueron transformadas y adaptadas a filminas para ser proyectadas sincrónicamente en la modalidad a distancia. Igualmente, se recopilaron videos de ensayos experimentales previos para ser compartidos virtualmente con los alumnos. En cuanto a las consultas con los docentes, a partir del 2020 se utilizaron distintos medios, desde mensajes y foros a través del campus universitario, mensajes telefónicos y conexiones especiales sincrónicas. En cuanto a los exámenes en modalidad virtual, se utilizó la plataforma Moodle y/o formularios Google para exámenes parciales, mientras que para los exámenes finales se mantuvo la modalidad oral individual, pero a distancia.

\section{Procedimiento}

Con el objeto de analizar la experiencia realizada mediante el dictado de cursos a distancia y proponer a futuro una metodología de enseñanza que se adecúe a los objetivos de los cursos y al mejor uso de los recursos tecnológicos disponibles, se recopilaron datos a través de distintos medios. En este trabajo, se presentan en particular los resultados de una encuesta de las siguientes características: Se elaboraron dos series de 12 preguntas (Ver Fig. 2), una para alumnos y otra para docentes, con algunas preguntas coincidentes. Se utilizó un formulario Google. Se envió el link de la encuesta a un grupo de 340 personas del plantel de docentes y alumnos del Departamento de Construcciones y Estructuras. Se decidió que la encuesta no fuera anónima, por un lado, para involucrar directamente a los integrantes de la comunidad académica invitados a completar la encuesta y por otro, para tener la certeza de la composición del grupo que respondió. El nivel de respuesta fue de un $67.4 \%$, estando la muestra final conformada por: Grupo de alumnos: 159 en total, incluyendo 109 alumnos de grado y 50 de posgrado. Grupo de docentes: 70 en total, incluyendo 21 docentes responsables de cursos y 49 docentes auxiliares. 


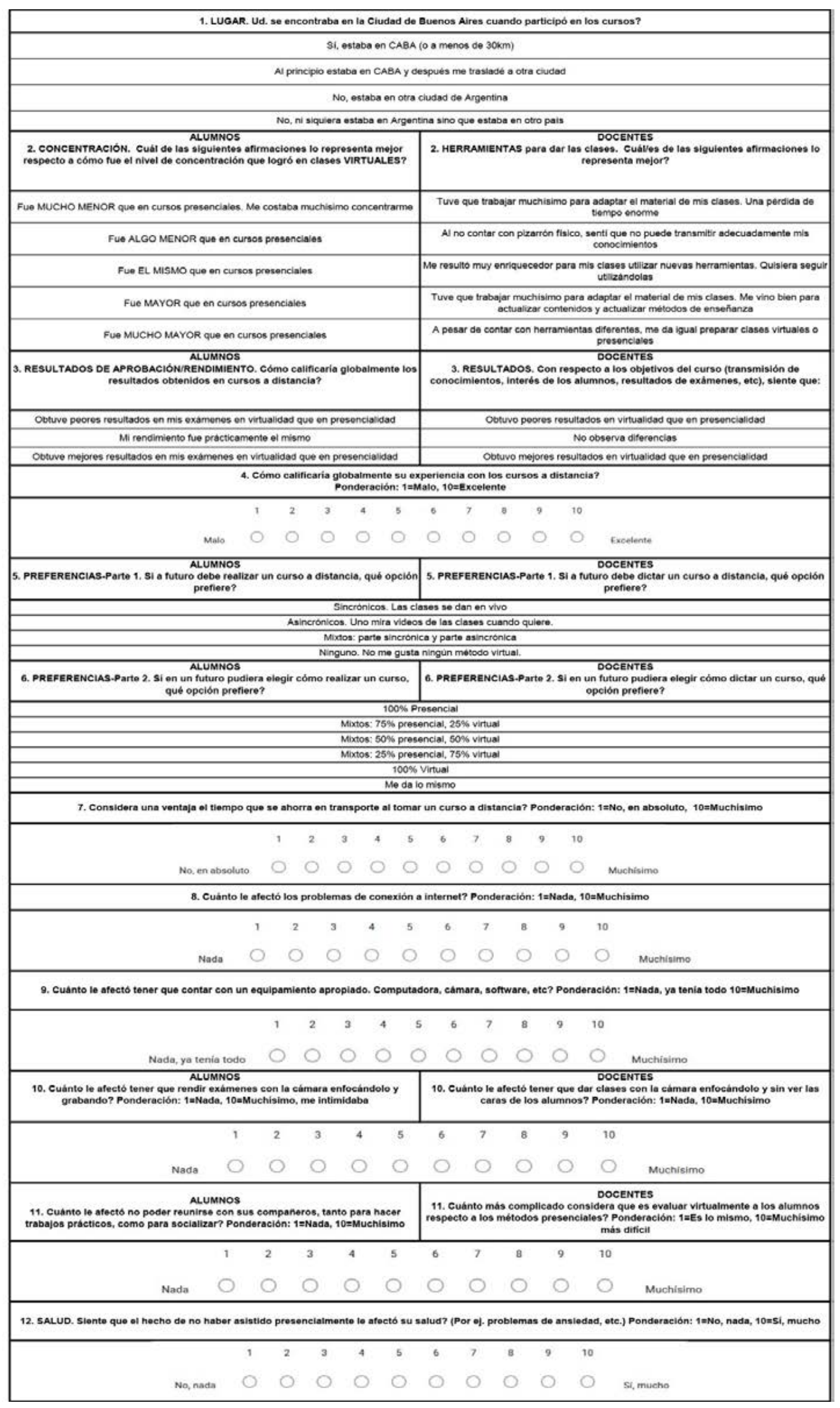




\section{Resultados}

En la Fig. 2 se presentan las preguntas de la encuesta. A continuación, para cada pregunta, primero se describen los objetivos buscados con la misma y luego se resumen los resultados obtenidos y finalmente, se realiza un análisis de los mismos. Cabe mencionar que al final de la encuesta, existía la opción de dejar comentarios adicionales. Casi la mitad (45\%) de los que respondieron la encuesta dejaron comentarios, lo que indica un alto grado de compromiso de los involucrados. El análisis de esos comentarios no se presenta en este trabajo sólo por un tema de extensión, ya que fueron detalladamente analizados y tenidos en cuenta.

Pregunta 1: Esta pregunta está destinada a analizar desde dónde se tomaron o se dictaron los cursos. Es claro que, en clases presenciales, el 100\% de los participantes debe estar en el mismo lugar. El objetivo buscado era conocer cuál fue el movimiento de los participantes frente a esta nueva modalidad.

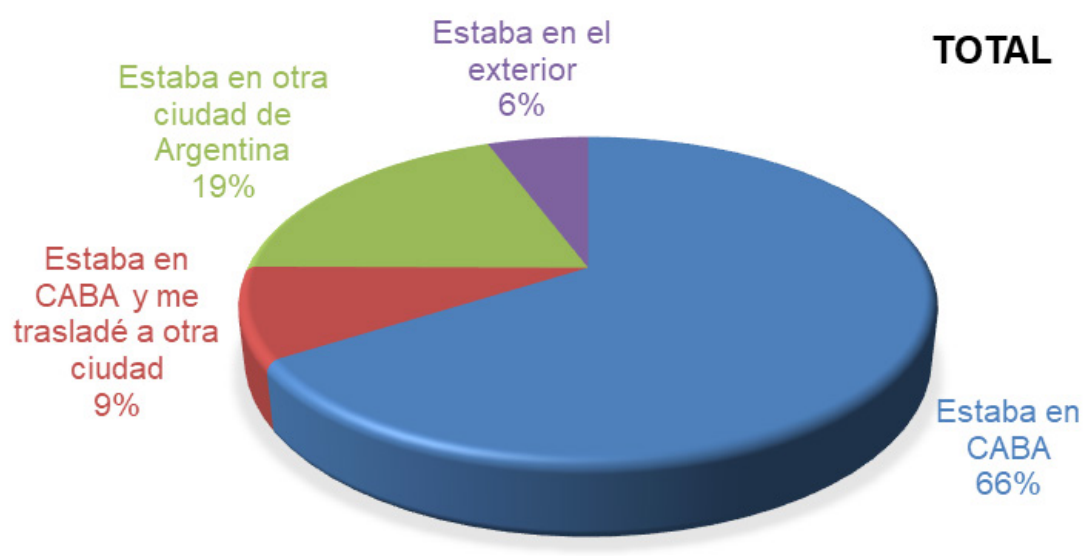

1. LUGAR. Ud. se encontraba en la Ciudad de Buenos Aires cuando participó en los cursos?

Figura 3: Respuestas a la pregunta 1: Ud. se encontraba en la Ciudad de Buenos Aires?

Los resultados se presentan en la Fig. 3 donde se observa que un $34 \%$ de los participantes no estaba en la Ciudad de Buenos Aires. Un pequeño porcentaje del total (6\%) se encontraba incluso fuera del país, aunque se destaca que se trata casi en su totalidad de estudiantes de posgrado (sólo dos alumnos de grado informaron estar en el exterior).

Pregunta 2: Esta pregunta se formuló de manera diferente para alumnos y para docentes. Para los primeros, se preguntaba sobre el nivel de concentración logrado durante clases virtuales. En cambio, para los docentes, se preguntaba acerca de su valoración acerca de las herramientas utilizadas. Aunque puedan parecer aspectos muy diferentes, no lo son. Esto se debe a que, de alguna forma, las respuestas dan información de cómo se sintieron ambos grupos como usuarios directos de esta modalidad. 


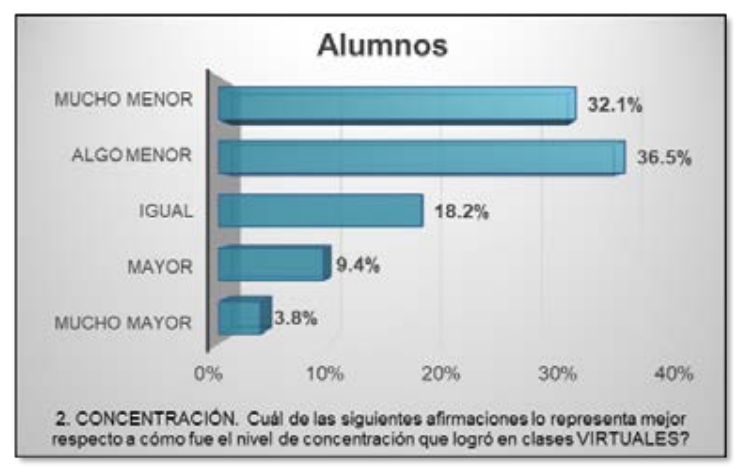

(a)

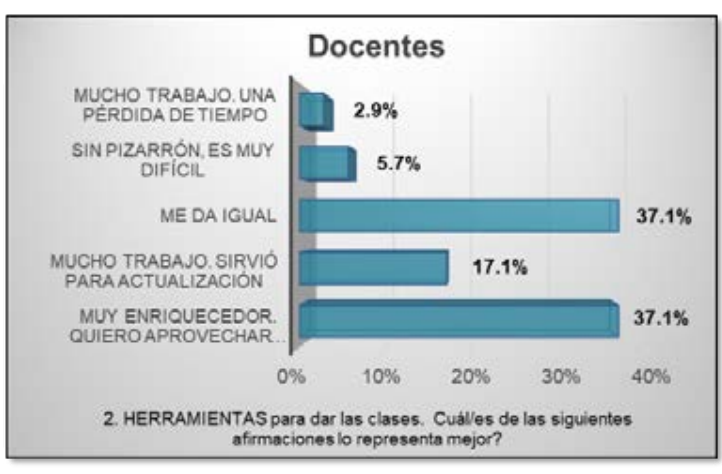

(b)

\section{Figura 4: Respuestas a pregunta 2: (a) Alumnos: Nivel de concentración alcanzado y (b) Docentes: Percepción del trabajo realizado utilizando nuevas herramientas.}

Los resultados (Ver Fig. 4) delatan una tendencia inversa. Por un lado, en el grupo de alumnos el mayor porcentaje de respuestas corresponde a una valoración negativa, en el sentido en que la mayoría indica que el nivel de concentración logrado fue algo o mucho menor que en cursos presenciales. Por el contrario, la mayoría de las respuestas de los docentes son valoraciones positivas en cuanto a los cambios que debieron realizar para adaptar las clases a la virtualidad y a la utilización de nuevas herramientas. Ciertamente, las respuestas a esta segunda pregunta se completan con las correspondientes a las siguientes preguntas.

Pregunta 3: Esta pregunta era levemente diferente para alumnos y docentes, pero básicamente apunta a la valoración de los objetivos alcanzados. A los alumnos, se les preguntaba sobre los resultados de aprobación. A los docentes, se les preguntaba su percepción de en qué medida se alcanzaron los objetivos del curso.

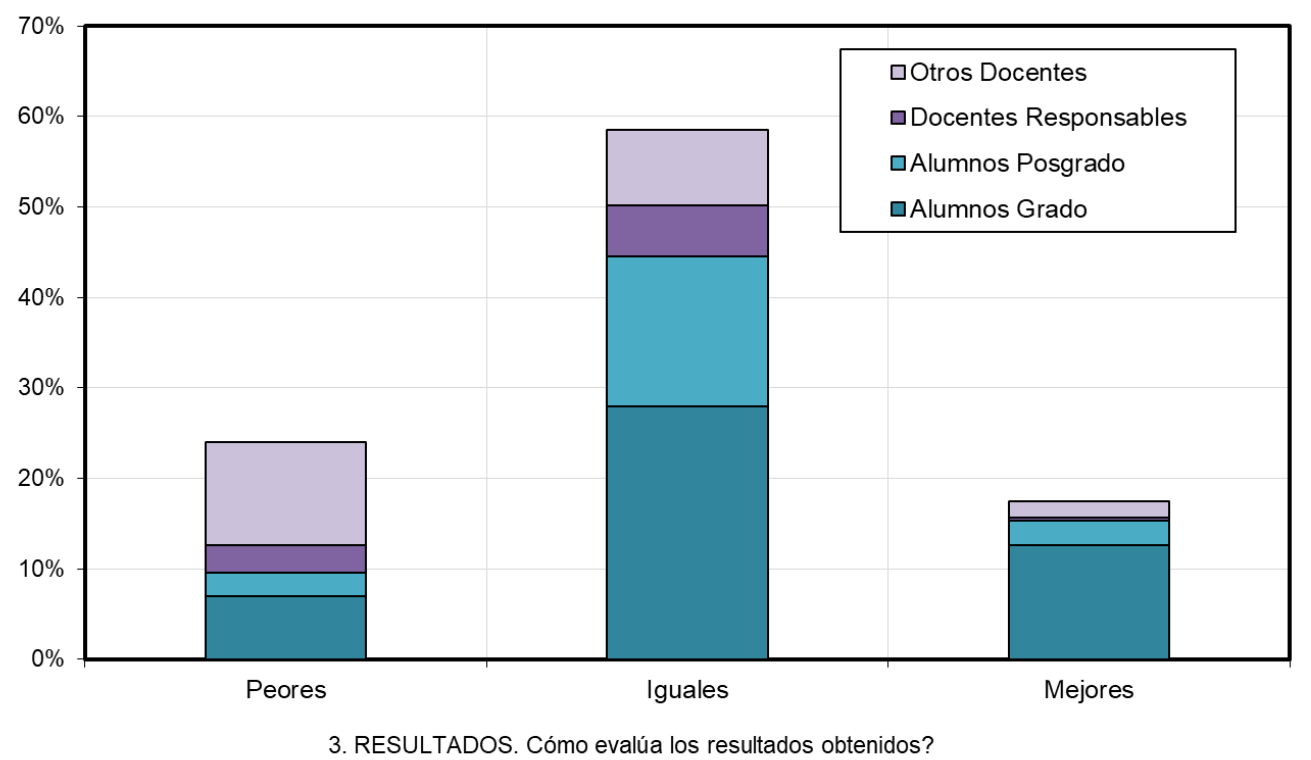

Figura 5: Respuestas del conjunto a la pregunta 3: Alcance de objetivos 
Los resultados (Ver Fig. 5) indican que la gran mayoría no percibe importantes diferencias entre el alcance de objetivos para las distintas modalidades de enseñanza. Sin embargo, si se observa en la Fig. 6 , donde se diferencian las respuestas de alumnos y docentes, se aprecia que la ponderación de resultados es mucho más negativa en el caso de los docentes.

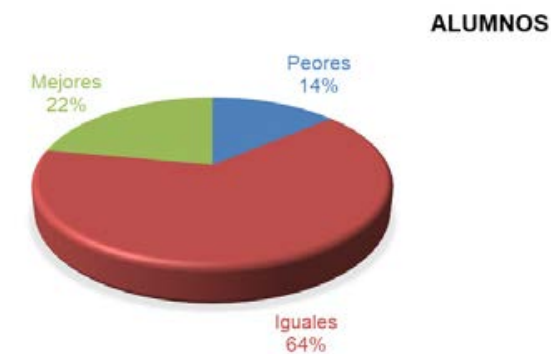

3. RESULTADOS. Cómo evalủa los resultados obtenidos?

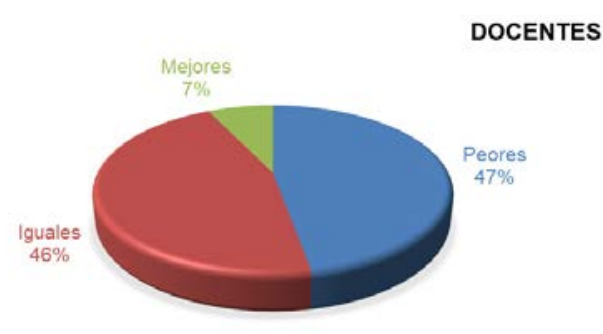

3. RESULTADOS. Cómo evalúa los resultados obtenidos?

(a)

Figura 6: Respuestas a la pregunta 3: Alcance de objetivos (a) Alumnos y (b) Docentes.

Pregunta 4: Esta pregunta se enfoca en la valoración que los encuestados hacen como balance global de la experiencia consistente en su participación en cursos a distancia.

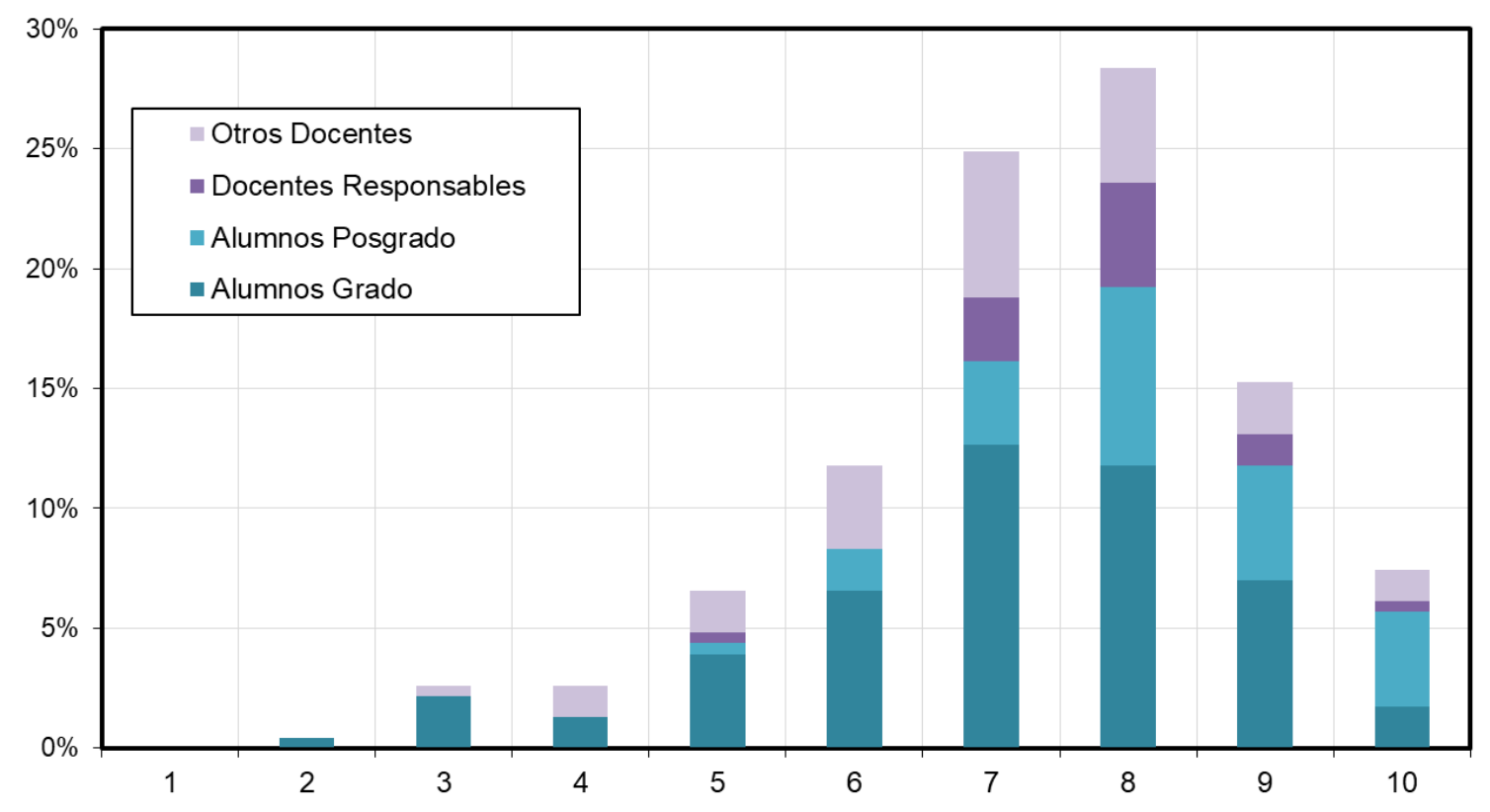

4. Cómo calificaría globalmente su experiencia con los cursos a distancia? Ponderación: 1=Malo, 10=Excelente

Figura 7: Respuestas del conjunto a la pregunta 4: Ponderación de la experiencia de haber participado en cursos virtuales 
A pesar de las distintas falencias que tanto alumnos como docentes informan que observan sobre los cursos virtuales, los resultados (Fig. 7) respecto a cómo ponderan la experiencia en su conjunto son altamente positivos y notoriamente iguales para alumnos y docentes. En el caso del grupo de alumnos, el resultado promedio es una ponderación de 7.40 puntos, mientras que para docentes es de 7.30.

Pregunta 5: En este punto se preguntaba qué metodología prefiere (sincrónica, asincrónica, mixta o ninguna) en el caso de tener que participar en un curso a distancia.

En la Fig. 8 se presentan los resultados de las respuestas a la pregunta 5, diferenciando alumnos y docentes. Casi la mitad de todos los encuestados se inclina por una metodología mixta, aunque vale la pena aclarar que, en vista a los comentarios que los encuestados podían dejar en el último punto, se concluye que por metodología mixta se refieren a que se pueda disponer de la grabación de las clases sincrónicas. Curiosamente, sólo entre el grupo de alumnos hay un porcentaje del 5\% que preferiría no tomar ese curso si es virtual, mientras que ningún docente elige no dar el curso si sólo lo podría dar a distancia. También se destaca que un $11 \%$ de los alumnos se inclina por la modalidad asincrónica, mientras que esa opción no fue elegida por ninguno de los docentes.

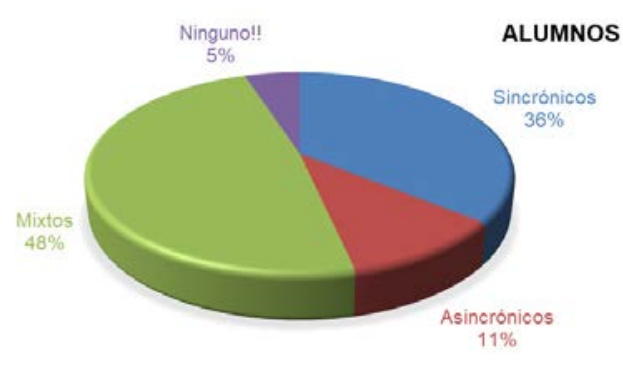

5. En un curso virtual, qué modalidad prefiere?

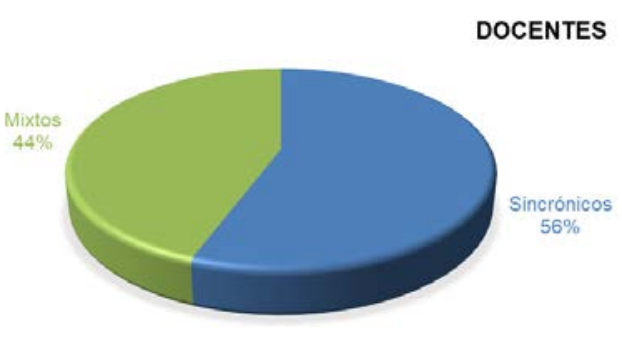

5. En un curso virtual, qué modalidad prefiere? (a)

\section{Figura 8: Respuestas a la pregunta 5: De tener que participar en un curso virtual, qué metodología prefiere? (a) Alumnos y (b) Docentes}

Pregunta 6: Aquí se preguntaba en el caso de poder elegir la modalidad de enseñanza en los cursos a darse en un futuro, qué metodología elegiría, dando como opciones extremas cursos totalmente virtuales y totalmente presenciales y opciones intermedias mixtas. Ciertamente, las respuestas a esta pregunta son las de mucho interés para los objetivos de este trabajo. 


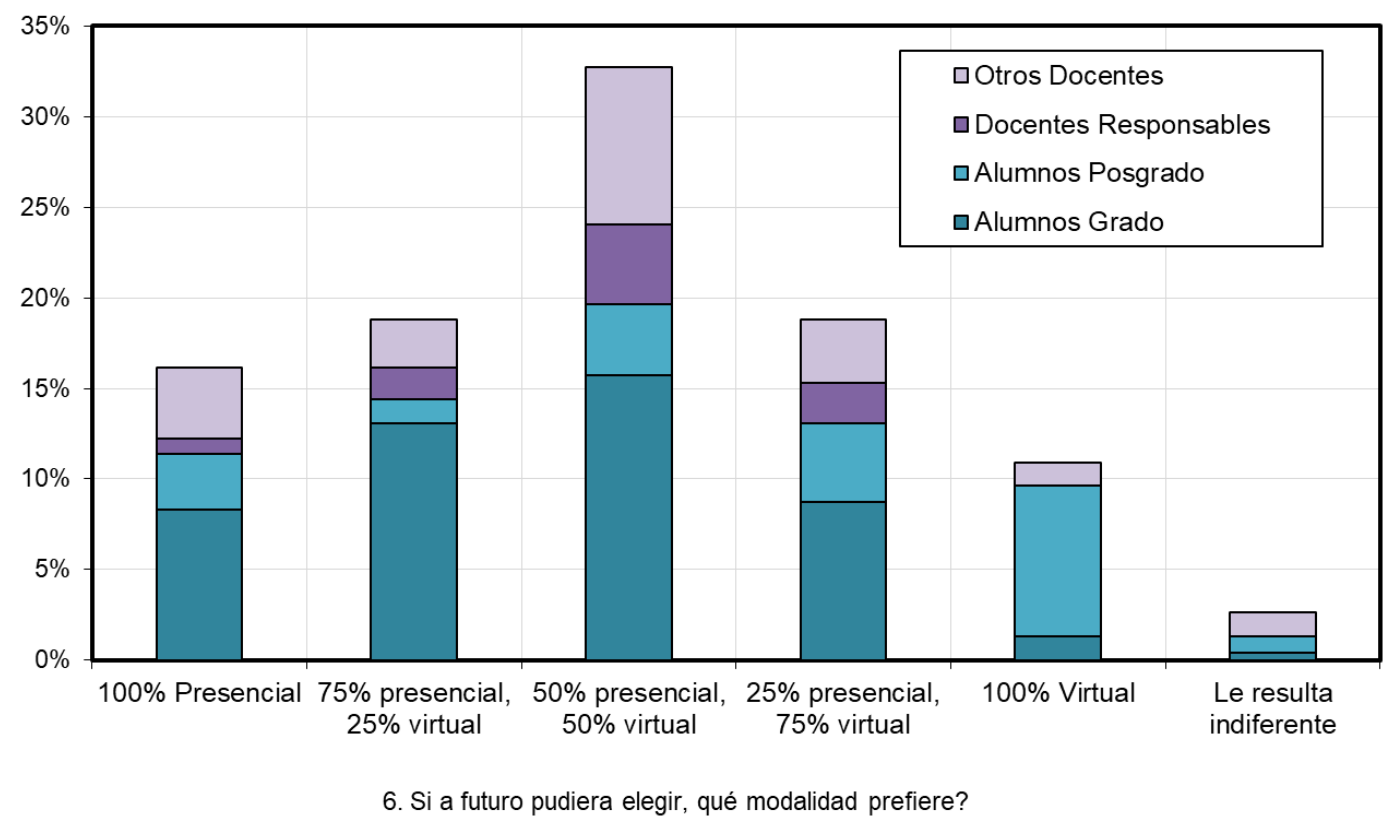

Figura 9: Respuestas del conjunto a la pregunta 6: Qué modalidad prefiere a futuro si pudiera elegir?

Las respuestas a la pregunta 6 se presentan en su conjunto en la Fig. 9 y diferenciadas según el rol en la Fig. 10. Sólo una pequeña minoría se muestra indiferente frente a esta pregunta. La mayoría de las respuestas, corresponden a opciones mixtas en las que hay al menos un nivel de $25 \%$ de presencialidad. Sin embargo, se observa que claramente domina la opción de igual porcentaje de presencialidad y virtualidad.

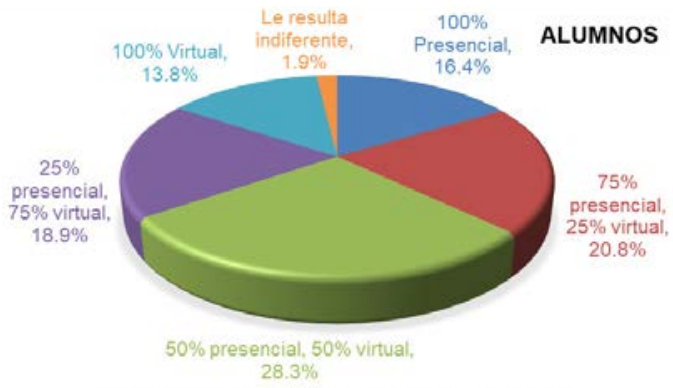

6. Si a futuro pudiera elegir, qué modalidad prefiere?

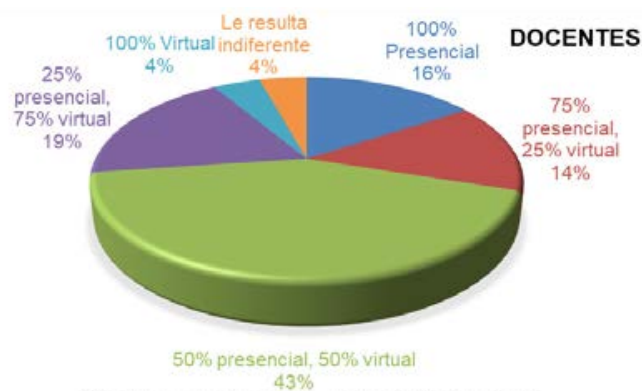

6. Si a futuro pudiera elegir, qué modalidad prefiere?

Figura10:Respuestasalapregunta 6: Quémodalidadprefiereafuturosipudieraelegir? (a) Alumnos y (b) Docentes

La opción de volver de manera total a la presencialidad, sólo fue elegida por un 16\% de los encuestados, coincidiendo este porcentaje para alumnos y para docentes, como puede verse en la Fig. 10. Esto resulta de crucial importancia: desde el lado de los alumnos, significa que, si bien expresan en otros puntos su deseo de volver 
a la actividad presencial, valoran que de alguna medida se continúe con el dictado de cursos en algún porcentaje de modo virtual. En el caso de los docentes, podría entenderse que no desean volver atrás sino capitalizar lo que han incorporado por razones de fuerza mayor.

El extremo opuesto, es decir, la opción de continuar en un 100\% con modalidad a distancia, obtiene un 11\% de adhesión entre los encuestados. En la Fig. 9 puede observarse que esta opción es mayoritariamente elegida por alumnos de posgrado. Esto es muy lógico ya que la posibilidad de acceder a cursos de formación continua de la Universidad de Buenos Aires, sin tener que abandonar el lugar de residencia ni las ocupaciones habituales, sin dudas es de mucho interés para profesionales que no residen en la ciudad de Buenos Aires o que, debido a su intensiva actividad profesional, les resulta difícil trasladarse a las instalaciones de la Universidad.

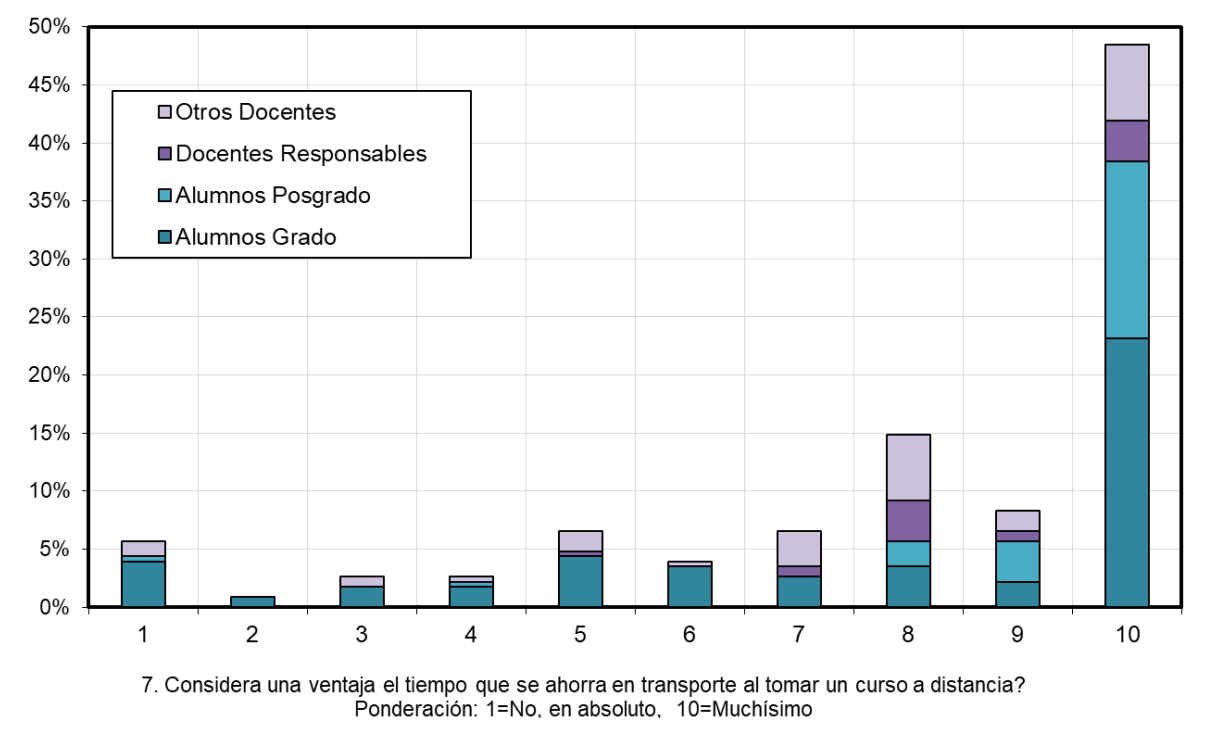

Figura 11: Respuestas del conjunto a la pregunta 7: En qué medida considera una ventaja el ahorro de tiempo en transporte al tomar/dictar un curso a distancia?

Pregunta 7: En este punto se preguntaba cuánto valoran los encuestados el ahorro de tiempo que implica la virtualidad al no tener que asistir al lugar donde se da el curso.

Como se observa en la Fig. 11, la mayoría de alumnos y docentes valoran muy positivamente el ahorro de tiempo que implica no tener que transportarse a la sede del curso. El resultado promedio del conjunto es una ponderación de 8.00 puntos.

Pregunta 8: Considerando las quejas frecuentemente escuchadas respecto a la alta incidencia de los problemas de conexión, en este punto se preguntaba cuánto se vio afectado por este tipo de problemas. 


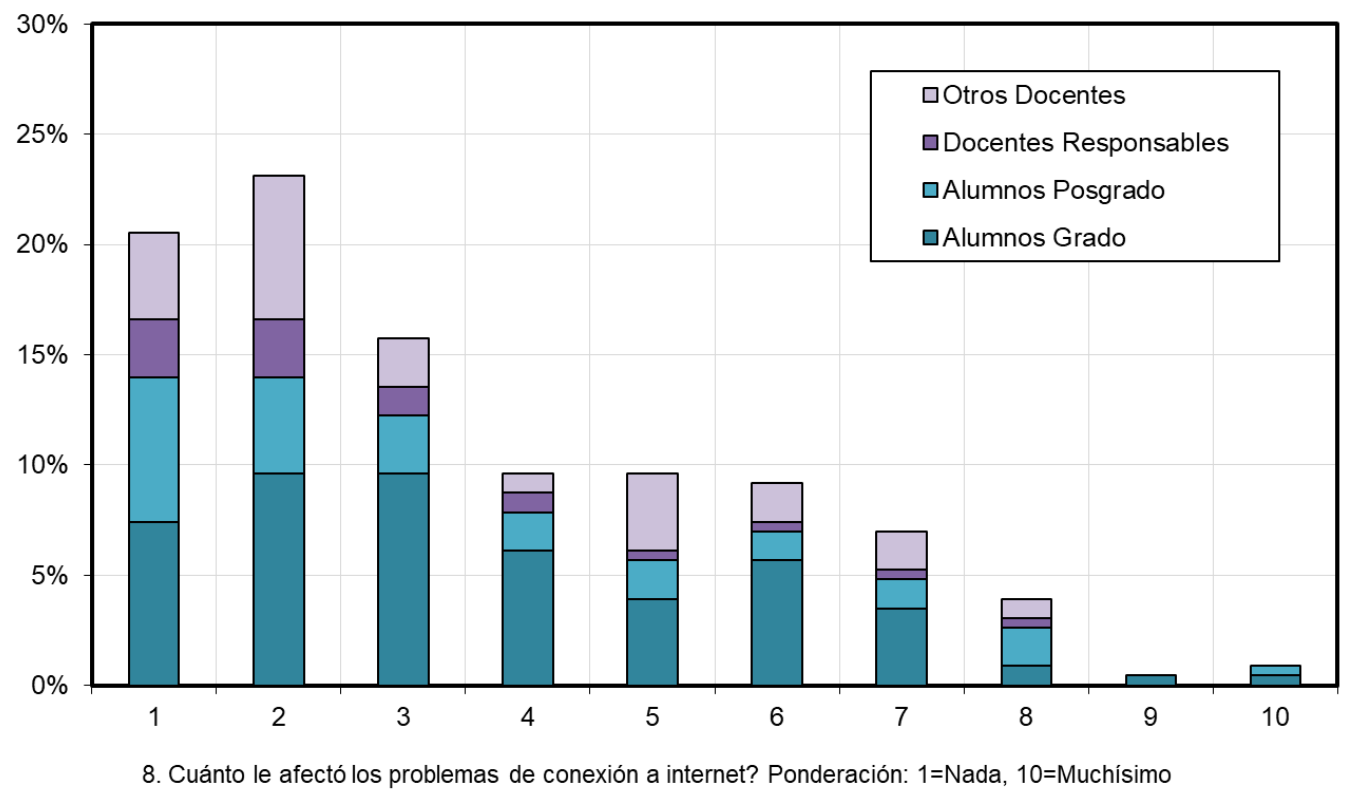

Figura 12: Respuestas del conjunto a la pregunta 8: En qué medida sufrió problemas de conexión?

Si bien en la Fig. 12 se observa una alta dispersión en las respuestas, la valoración promedio de cuánto se vio afectado por problemas de conexión resulta de 3.50 puntos, sin mayores diferencias detectadas entre los grupos de alumnos y de docentes. Los resultados permiten concluir que estos problemas tienen una importancia de baja a media.

Pregunta 9: Con la idea de indagar cuál era la situación de los encuestados respecto a si disponían o no de equipamiento apropiado al inicio de la pandemia, en este punto se preguntaba al respecto. Cabe aclarar que este tema fue muy discutido en Argentina, en ámbitos relacionados con educación primaria y secundaria, concluyéndose que un alto porcentaje de alumnos de esos niveles no contaba con el equipamiento necesario para tomar clases virtuales.

Los resultados a la pregunta referida al equipamiento se presentan en la Fig. 13, en la que se puede apreciar que no resulta un punto relevante para la mayoría de los encuestados. La valoración promedio resultó de sólo 2.50 puntos. Se observó una leve diferencia entre los grupos de alumnos y docentes, habiéndose registrado para los primeros un valor medio de 2.30 puntos, mientras que los docentes reportaron una incidencia algo mayor, con un valor medio de 2.90 puntos. 


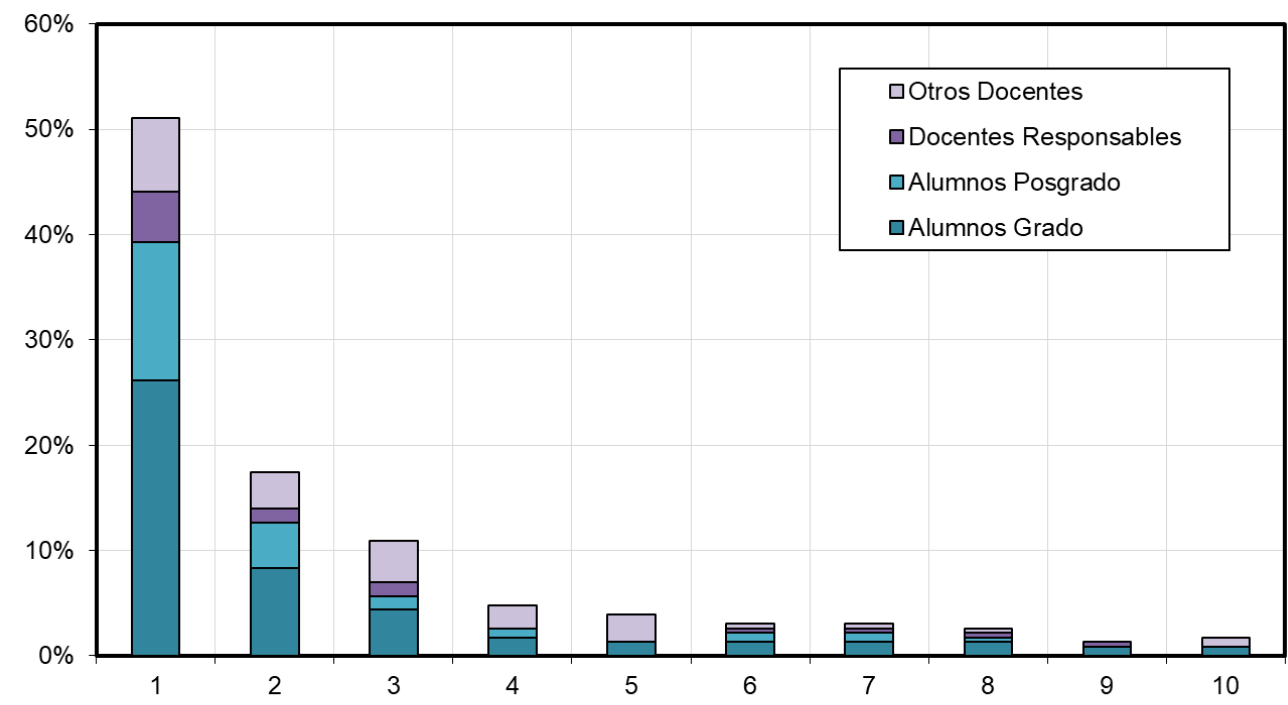

9. Cuánto le afectó tener que contar con un equipamiento apropiado. Computadora, cámara, software, etc? Ponderación: $1=$ Nada, ya tenía todo 10=Muchísimo

Figura 13: Respuestas del conjunto a la pregunta 9: En qué medida se vio afectado por necesitar cierto equipamiento apropiado para tomar/dictar un curso a distancia?

Pregunta 10: En este punto, a los alumnos se les preguntaba en qué medida les afectó el hecho de tener que rendir exámenes parciales y finales con una cámara enfocándolos y grabando. Por otra parte, a los docentes se les preguntaba sobre cómo sienten que les afectó no poder ver a los alumnos en las clases y, por lo tanto, no poder ver en vivo sus reacciones a la exposición. De alguna manera, son dos caras de un mismo problema relacionado con la virtualidad.

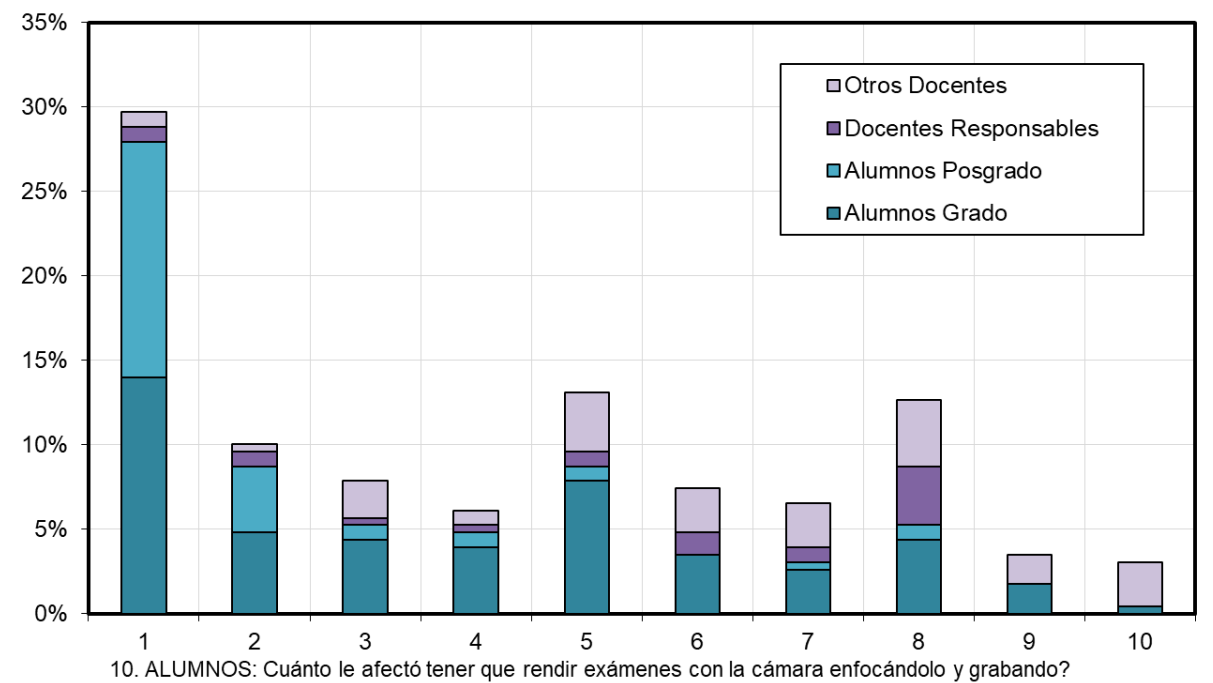

10. DOCENTES: Cuánto le afectó tener que dar clases con la cámara enfocándolo y sin ver las caras de los alumnos? Ponderación: $1=$ Nada, 10=Muchísimo

Figura 14: Respuestas del conjunto a la pregunta 10: En qué medida se vio afectado por el uso de cámara, grabación de clases y exámenes y no ver en vivo las reacciones de los alumnos? 


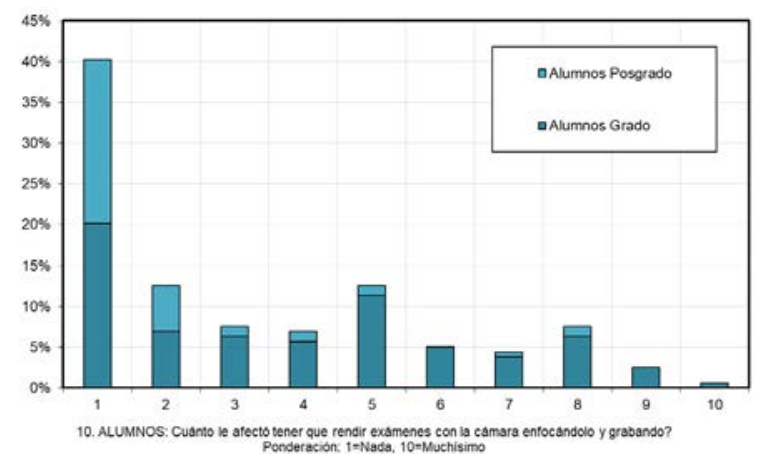

(a)

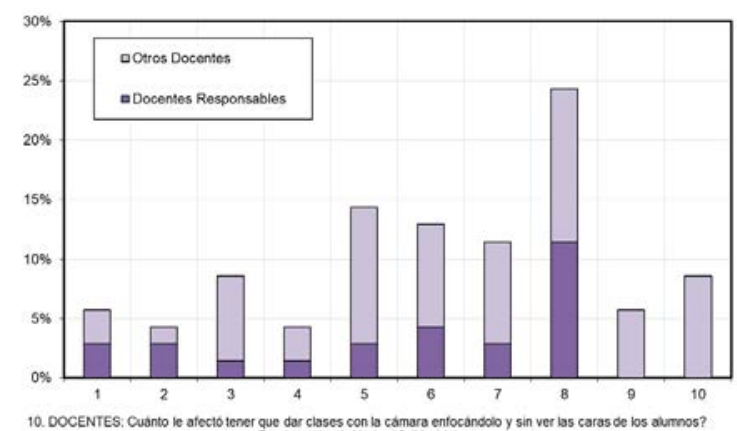

(b)

Figura 15: Respuestas a la pregunta 10 relativa al uso de cámara y grabaciones: (a) Alumnos y (b) Docentes.

Los resultados a la pregunta 10 se muestran en las Figs. 14 y 15 . Si se observa la respuesta del conjunto, puede concluirse que claramente este es un tema muy subjetivo y que no hay una clara tendencia en las respuestas. Si se separan las respuestas según el rol de alumno o docente, se observa que mientras que hay alumnos (Fig. 15a) que se han sentido muy intimidados por el hecho de tener que rendir exámenes con una cámara enfocándolos, para otros no ha resultado un tema relevante. Para el grupo de alumnos la ponderación media de este aspecto fue de 3.30 puntos.

Con respecto al grupo de docentes (Fig. 15b), si bien se observa también una alta dispersión indicando subjetividad en las respuestas, hay un mayor porcentaje que declara que el hecho de no poder ver en vivo la reacción de los alumnos en el transcurso de clase, es un aspecto negativo relacionado con la virtualidad. Para el grupo de docentes la ponderación media de este aspecto fue de 6.20 puntos. Es decir, lo consideran claramente un aspecto negativo, pero de importancia media.

Pregunta 11: En este único caso, la pregunta para alumnos era totalmente diferente de la correspondiente a docentes. A los primeros se les preguntaba acerca de cuánto les afectó no poder interactuar con sus compañeros y profesores. A los docentes, se les preguntaba qué tanto más difícil consideran que es evaluar a distancia en comparación con las evaluaciones presenciales. 


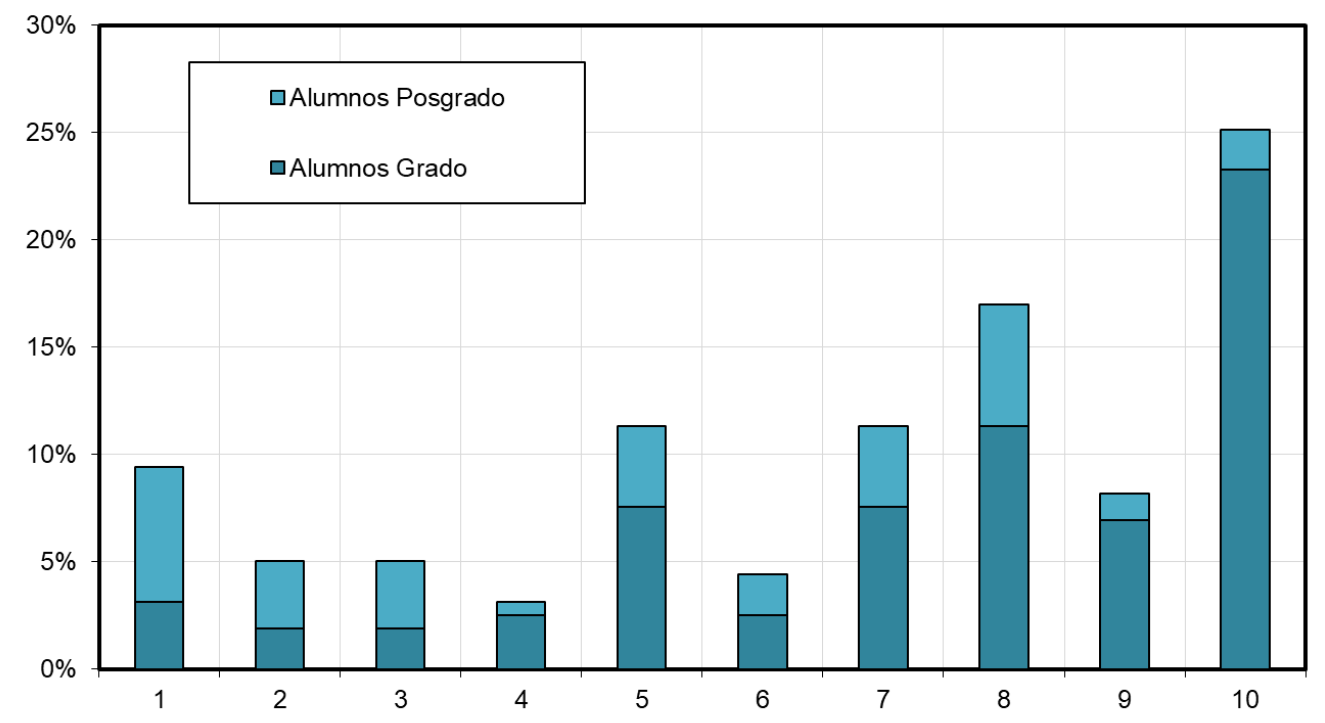

11. ALUMNOS: Cuánto le afectó no poder reunirse con sus compañeros, tanto para hacer trabajos prácticos como para socializar? Ponderación: 1=Nada, 10=Muchísimo

Figura 16: Respuestas a la pregunta 11 a Alumnos: Cuánto le afectó no poder interactuar presencialmente?

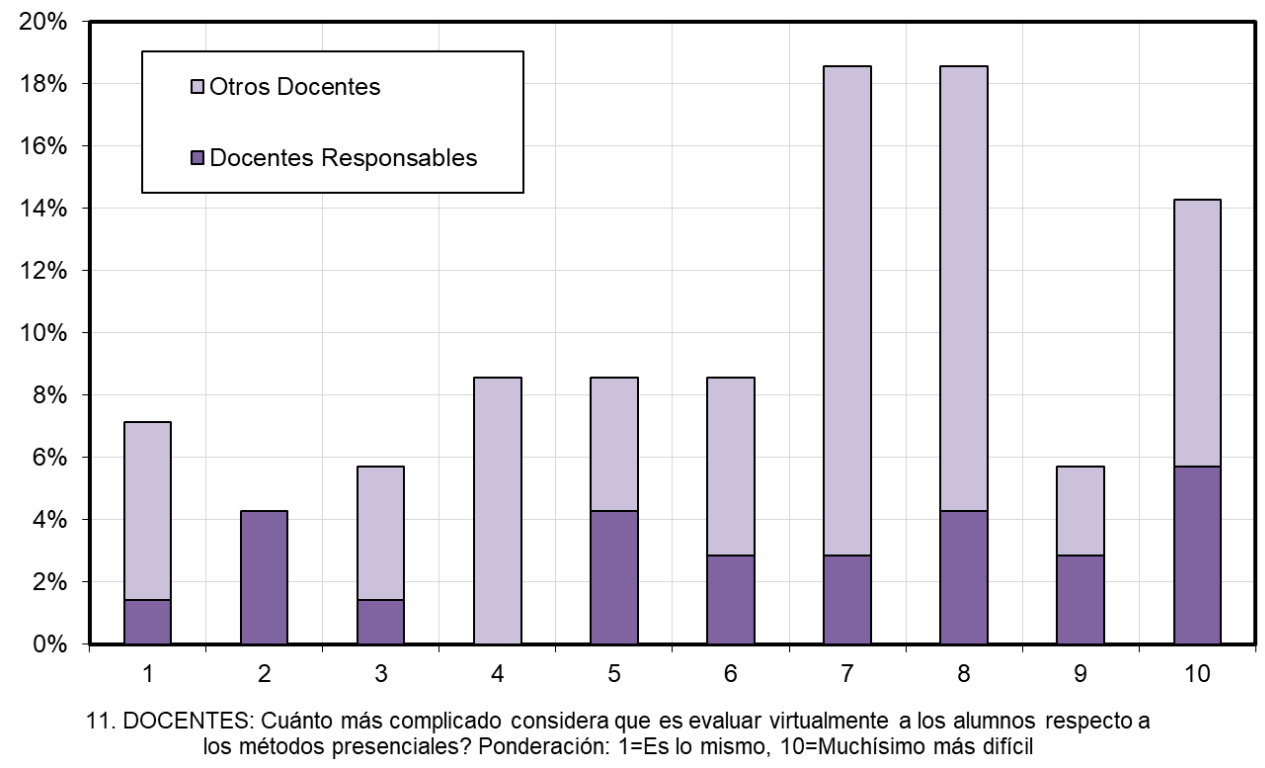

Figura 17: Respuestas a la pregunta 11 a Docentes: Cuánto más difícil le resultó tomar exámenes en virtualidad?

Las respuestas de los alumnos (Ver Fig. 16) muestran que la gran mayoría se sintió afectado por la pérdida de interacción propia del ambiente universitario. La valoración media de este aspecto fue de 6.70 puntos, indicando que es valorado negativamente, aunque con una importante dispersión.

Con respecto al grupo de docentes, las respuestas se presentan en la Fig. 17. También en este caso se puede apreciar una importante dispersión, arrojando un valor medio de 6.30 puntos, que representa una valoración negativa, pero de importancia media. 
Pregunta 12: La última pregunta se destinó a evaluar aspectos de la salud. Se decidió incluir este aspecto dado que, durante la pandemia, se identificaron distintos casos de alumnos con ataques de ansiedad, síntomas de agotamiento o incluso, depresión. Se decidió preguntar también a los docentes si se habían sentido afectados en este sentido.

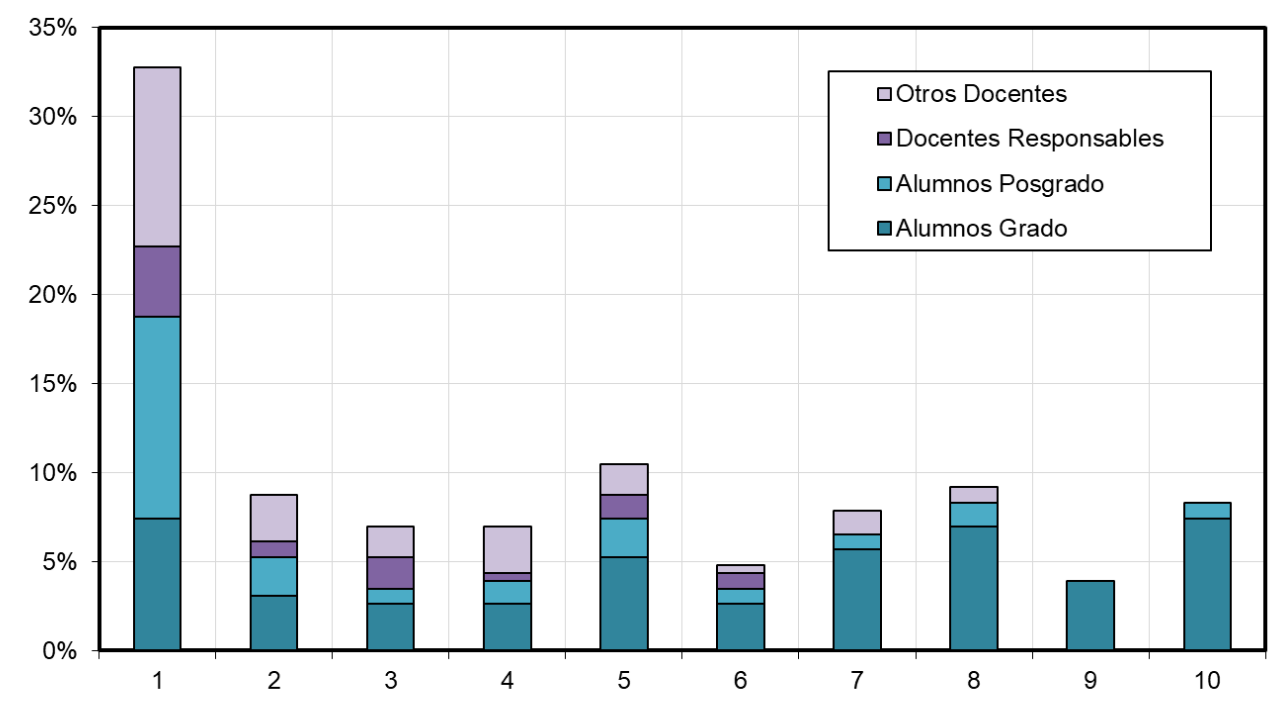

12. SALUD. Siente que el hecho de no haber asistido presencialmente le afectó su salud? (Por ej. problemas de ansiedad, etc.) Ponderación: $1=$ No, nada, $10=$ Sí, mucho

Figura 18: Respuestas a la pregunta 12 del conjunto: En qué grado siente que la virtualidad le produjo problemas de salud?

Los resultados a la pregunta 12 se muestran en la Fig. 18. Nuevamente se observa una importante dispersión de resultados lo que implica que las diferentes personas atravesaron la situación de manera diferente, independientemente de su rol. El valor medio obtenido fue de 5.00 puntos para los alumnos y de 2.70 para los docentes, indicando que los alumnos se sintieron mucho más afectados en su salud.

\section{Discusión y conclusiones}

En base al análisis de los resultados presentados en la sección anterior, correspondientes a respuestas de alumnos y docentes de grado y posgrado de asignaturas del área de tecnologías aplicadas del Departamento de Construcciones y Estructuras de FIUBA, se obtienen las siguientes conclusiones:

- Respecto a los alumnos: La mayoría preferiría la vuelta a la presencialidad, aunque no total sino mediante la incorporación de una metodología de enseñanza mixta. En mayor o menor medida, los alumnos expresan haber experimentado una afectación de su salud durante el largo período de confinamiento. No informan importantes variaciones de su rendimiento respecto a la presencialidad (Confirmado con el análisis de los registros de notas de las asignaturas analizadas), aunque sí una mayor dificultad para lograr concentración durante las clases virtuales. Por ese motivo, sumado a posibles problemas de conexión, en general informan que les resulta de suma utilidad contar con la grabación de las clases. No se detectan importantes falencias por falta de equipamiento. 
- Respecto a los docentes: Se destaca la capacidad de adaptación que demostraron los docentes cuando se vieron obligados a recurrir a nuevas tecnologías. A pesar de informar algunas falencias, la mayoría tampoco preferiría volver a una presencialidad absoluta, sino a métodos de enseñanza mixtos. Expresan claramente que la presencialidad es particularmente superadora de la virtualidad en lo relativo a exámenes y a prácticas.

Por todo lo expuesto, se diseñará una metodología de enseñanza mixta, presencial y a distancia, que se complementen. Para las dos materias de grado analizadas, se propone un 50\% presencial y un 50\% virtual. En cambio, para las de posgrado, se propone un $75 \%$ virtual, y un $25 \%$ presencial, pero con una opción a $100 \%$ para alumnos que así lo prefieran.

\section{Referencias}

Aparicio, A. C., \& Ruiz-Teran, A. M. (2007). Tradition and innovation in teaching structural design in civil engineering. Journal of Professional Issues in Engineering Education and Practice, 133(4), 340-349.

Forcael, E., Garcés, G., Bastías, E., \& Friz, M. (2019). Theory of teaching techniques used in civil engineering programs. Journal of Professional Issues in Engineering Education and Practice, 145(2), 02518008.

García-Alberti, M., Suárez, F., Chiyón, I., \& Mosquera Feijoo, J. C. (2021). Challenges and Experiences of Online Evaluation in Courses of Civil Engineering during the Lockdown Learning Due to the COVID-19 Pandemic. Education Sciences, 11(2), 59.

Newson, T. A., \& Delatte, N. J. (2011). Case methods in civil engineering teaching. Canadian Journal of Civil Engineering, 38(9), 1016-1030.

Pan, C., Chen, N., Liu, S., \& He, J. (2021). Study on Teaching Measures of Civil Engineering Construction Course with New Engineering Education.

Sageev, P., \& Romanowski, C. J. (2001). A message from recent engineering graduates in the workplace: Results of a survey on technical communication skills. Journal of Engineering Education, 90(4), 685-693.

Shaaban, K. (2013, April). Practical teaching and its importance in teaching civil engineering. In Global Innovators Conference 2013 (Vol. 2013, No. 2, p. 4). Hamad bin Khalifa University Press (HBKU Press). 


\section{Interactuar en la Virtualidad: Experiencia en Cursos Iniciales de Física Universitaria}

\section{Chiabrando, Laura}

Universidad de Buenos Aires

Ichiabra@fi.uba.ar

\section{Duplaá, María Celeste}

Universidad de Buenos Aires

coluplaa@fi.uba.ar

\section{Garea, María Teresa}

Universidad de Buenos Aires

mgarea@fi.uba.ar

\section{Repetto, Viviana Cristina}

Universidad de Buenos Aires

vrepetto@fi.uba.ar 


\title{
INTERACTUAR EN LA VIRTUALIDAD: EXPERIENCIA EN CURSOS INICIALES DE FÍSICA UNIVERSITARIA
}

\author{
Chiabrando, Laura \\ Duplaá, María Celeste \\ Garea, María Teresa \\ Repetto, Viviana Cristina
}

\section{Resumen}

En este trabajo se indaga sobre algunas de las modalidades de comunicación entre estudiantes y docentes, incorporadas en la modalidad de educación a distancia impuesta por el aislamiento preventivo social y obligatorio debido al COVID-19. En este contexto, las clases tradicionalmente presenciales empezaron a dictarse con encuentros en línea, desarrollo de materiales asincrónicos y la incorporación paulatina o profundización del uso de distintas formas de comunicación entre docentes y estudiantes, así como de los estudiantes entre sí. La indagación sobre estas formas de comunicación, desarrollada en este trabajo, se realiza a partir de encuestas a docentes y estudiantes de cursos de la asignatura Física I de la Facultad de Ingeniería de la Universidad de Buenos Aires. Se presentan y analizan los resultados de dichas encuestas, teniendo en cuenta que fueron realizadas en el marco de un trabajo de investigación-acción, dado que las inquietudes surgen de las docentes que forman parte de las prácticas que se estudian. Se encuentra que los docentes valoran las herramientas asincrónicas e intentan utilizar alguna herramienta sincrónica, ya que los estudiantes prefieren este tipo de comunicación. También se observa que los estudiantes se comunican masivamente no sólo con sus compañeros de curso, sino también con los de otros cursos de la misma asignatura. Se puede observar que en todos los casos hay variedad en las herramientas utilizadas. Sin embargo, aún no hay acuerdo en cuáles son las mejores formas para interactuar en la virtualidad.

\section{Palabras clave}

Interacciones, comunicación, formación a distancia, nivel universitario. 


\section{Introducción}

En este trabajo se propone describir cómo se modificaron las interacciones entre docentes y estudiantes universitarios debido al cambio de prácticas de enseñanza presenciales por virtuales, en el contexto del aislamiento preventivo social y obligatorio debido al COVID-19 que se dispuso en la República Argentina a partir del 20 de marzo del 2020 por el decreto $N^{\circ} 297 / 2020$.

En particular, se consultó a docentes y estudiantes de Física 1 de la Facultad de Ingeniería de la Universidad de Buenos Aires (FIUBA). Ésta es una asignatura obligatoria para todas las carreras de Ingeniería que se cursan en esta Facultad. Si bien es una cátedra única, por la cantidad de estudiantes, la oferta horaria consta de 17 cursos presenciales y 2 cursos semi-presenciales para estudiantes recursantes. En condiciones normales los cursos presenciales tienen una carga horaria de 8 horas semanales de clases en la Facultad y disponen de un aula virtual en el Campus FIUBA (https://campus.fi.uba.ar/). La actividad que se propone en el aula virtual de los cursos presenciales, en general, es complementaria. En cambio, los cursos semi-presenciales tienen una carga horaria de 4 horas presenciales y actividades obligatorias asincrónicas en el aula virtual que completan la carga horaria.

A partir del primer cuatrimestre del 2020 no se dictaron clases presenciales en esta asignatura. Es por esto que en los cursos tradicionalmente presenciales se modificaron drásticamente las prácticas docentes. Inicialmente el único contacto de los docentes con los estudiantes fue el aula virtual y la mayoría de los cursos empezaron a dictar clases utilizando encuentros en línea, apoyados por materiales teóricos comunes grabados en videos por los profesores de los distintos cursos. Por su parte los estudiantes, tuvieron que adaptarse a las nuevas formas de cursada y de comunicación.

A lo largo del tiempo los docentes han preparado distintos materiales y estrategias de trabajo para complementar las clases sincrónicas virtuales que se dictan en los horarios de las anteriores clases presenciales. Cursando el tercer cuatrimestre con esta modalidad, los docentes, acostumbrados a la comunicación propia de los cursos presenciales, han intentado incorporar nuevas herramientas para compensar la forma tradicional de dar clases en un aula utilizando, fundamentalmente, el pizarrón. Se disponen de foros en el aula virtual, clases en plataformas por streaming y distintas aplicaciones para comunicarse con los estudiantes en forma sincrónica o asincrónica. Las nuevas condiciones imponen una modificación de las prácticas, los docentes ya no cuentan con "las expresiones de las caras" del estudiantado cuando dictan sus clases. Por otro lado, los estudiantes perdieron el contacto personal con docentes o compañeros en la cursada y adoptaron nuevas formas de comunicación.

Esta situación inédita obligó a docentes y estudiantes a adaptarse en la virtualidad. Este desafío fue aún mayor para aquellos docentes que lo tuvieron que hacer sin la experiencia previa de haber incorporado tecnologías en sus clases presenciales.

Mercader Juan (2019) analiza las razones por las que algunos docentes se resisten en a incluir tecnologías en la clase y también encuentra que los docentes que sí utilizan herramientas tecnológicas no suelen actualizarlas. Entre las principales resistencias encontradas se destacan: el hábito, la gestión de la innovación, la falta de formación, el trabajo a contrarreloj y la inversión en actualización. Se concluye que la utilización de las tecnologías digitales es escasa, que su empleo no depende 
tanto de la edad o estabilidad laboral, sino de la predisposición y autopercepción de las propias competencias digitales; y que una de las mayores barreras es la falta de planificación y evaluación sobre cómo las tecnologías digitales se deben institucionalizar en la universidad.

En relación al uso de las aulas virtuales, las plataformas educativas se utilizaban mayoritariamente para publicar contenidos sin considerar las posibilidades de generar nuevos escenarios de enseñanza (Del Prete y Cabero Almenara, 2019). En el contexto actual es necesario pensar cuál es la función docente y cómo establecer nuevas formas de comunicación con los estudiantes.

Este trabajo parte, fundamentalmente, de las experiencias de las autoras como docentes en algunos de los cursos de Física I, una de las asignaturas iniciales de las carreras de FIUBA. En este contexto surge la inquietud de saber cómo se modificaron las interacciones. En particular: ¿cuáles son las herramientas que utilizan los docentes para comunicarse con los estudiantes?, ¿cómo valoran esas herramientas?, ¿cómo prefieren los estudiantes comunicarse con los docentes del curso?, ¿de qué forma y para qué se comunican con otros estudiantes?

En función de estas preguntas, se diseñó una encuesta a docentes y otra a estudiantes con los siguientes objetivos:

- describir las herramientas que utilizan los docentes para comunicarse con sus estudiantes,

- analizar la valoración de los estudiantes de las herramientas de comunicación que utilizan los docentes en sus cursos,

- indagar las herramientas de comunicación que utilizan los estudiantes para comunicarse entre sí.

A continuación, se presenta el marco de la investigación y un análisis de los resultados de las encuestas. Por último, en las discusiones finales, se comparan los resultados obtenidos en ambos grupos.

\section{Método}

La metodología de este trabajo es la investigación-acción porque las inquietudes surgen de los docentes que forman parte de las prácticas que se estudian. Como indican Kemmis y Mc Taggart (1988) este tipo de indagación es muy pertinente en el ámbito educativo porque permite comprender el contexto y considerar alternativas para mejorar las prácticas de enseñanza. Considerando los objetivos de este estudio, el enfoque es descriptivo de tipo cualitativo (Yuni y Urbano, 2014).

\section{Descripción del contexto y de los participantes}

Como señalan Aveleyra y Rossi (2021) esta situación inédita obligó a docentes y estudiantes, sin experiencia previa, a adaptarse a la modalidad a distancia. En Física I se desplegó un importante trabajo en equipo en el que los docentes de los 19 cursos de la asignatura, guiados por la Coordinación, compartieron y acorda- 
ron pautas y criterios relacionados con la planificación de las tareas de clase, los materiales didácticos y la evaluación. Estas acciones conjuntas de los docentes compensaron las diferencias en las competencias digitales de los distintos actores y dejaron satisfechos a los alumnos. Sin embargo, según agregan los autores es necesario complementar este indicador con la evaluación de los objetivos a alcanzar y las características del curso. En relación a los foros indican lo que ya se viene percibiendo desde hace tiempo y es que los estudiantes valoran otras herramientas de comunicación alternativas. Prefieren la inmediatez y preguntar por grupo de Whatsapp entre compañeros.

Las autoras de este trabajo forman parte de dicho equipo docente y para realizar este estudio, se consultó a docentes de todos los cursos de la asignatura y a estudiantes de los cursos propios.

\section{Instrumentos}

El instrumento para obtener datos es la encuesta. Se diseñaron dos encuestas: una para consultar a docentes y otra para estudiantes de Física 1. El formato de las encuestas es digital (en un formulario Google Forms) y se envió el link invitando a los participantes para responder en forma anónima.

Ambas encuestas tienen una estructura similar. Constan de preguntas cerradas (opción múltiple) donde los encuestados responden si usan ciertas herramientas o modalidades de comunicación. Es importante destacar que las herramientas fueron seleccionadas a partir de la experiencia docente de las autoras, excluyendo de las mismas las plataformas de streaming utilizadas por la mayoría de los cursos para sus clases sincrónicas. En ambas encuestas también hay preguntas abiertas para indagar las opiniones sobre las aplicaciones y conocer si se utilizan herramientas o modalidades de comunicación que no fueron consideradas en las otras preguntas.

El esquema de la encuesta a docentes es la siguiente:

1. Foros de consulta en el Campus FIUBA: ¿Utilizás esta herramienta? Si-No. Valoración.

2. Preguntas en línea: ¿Utilizás esta herramienta? Si-No. Valoración.

3. Presentaciones grupales: ¿Utilizás esta modalidad de trabajo? Si-No. Valoración.

4. Otras herramientas: ¿Utilizás otras herramientas para comunicarte con los estudiantes? ¿Cuáles? ¿Por qué?

Esta encuesta fue respondida por 29 docentes de la asignatura Física 1, que cuenta con aproximadamente 70 docentes entre profesores y auxiliares graduados o alumnos. Las preguntas se basaron en la utilización de las herramientas utilizadas en los cursos de las autoras.

La estructura de la encuesta a estudiantes es similar:

1. Foros de consulta en el Campus FIUBA: ¿Participás en este espacio? Si-No. Valoración. 
2. Preguntas en línea: ¿Utilizan esta herramienta en tu curso? Si-No. Valoración.

3. Presentaciones grupales: ¿Utilizan esta modalidad de trabajo en tu curso? Si-No. Valoración.

4. Otras herramientas: ¿Participás de espacios para comunicarte con otros estudiantes? ¿Cuáles? Valoración

Esta encuesta fue respondida por 260 estudiantes de Física 1 en cursos donde las autoras forman parte del equipo docente. El total de alumnos que estaban inscriptos en dichos cursos, al momento de realizarla, es aproximadamente 400. En esta encuesta se pretende ver la impresión de los estudiantes ante el uso de algunas de las herramientas utilizadas y también indagar sobre sus propuestas de utilización de otras formas de comunicación.

\section{Procedimiento}

En la primera etapa se hizo un análisis de las respuestas de los docentes, armando categorías a partir de la valoración de las herramientas o espacios de comunicación y un listado de las otras herramientas que utilizan. El mismo proceso de análisis se realizó con las respuestas de los estudiantes. Por último, en las discusiones finales, se compararon los resultados obtenidos de las respuestas en ambos grupos.

\section{Resultados}

En esta sección se muestran los resultados de ambas encuestas, teniendo en cuenta que en ellas los participantes podían elegir múltiples opciones.

La mayoría de los docentes participa en los foros de consulta de su curso del campus virtual y lo considera útil (Figura 1). Valoran esta herramienta por la posibilidad de tener un registro escrito. Los que no lo usan, reconocen que les cuesta explicar por escrito, les lleva mucho tiempo o indican que a los alumnos no les interesa.

¿Participás en los foros de discusión/consultas de tu curso en el campus?

29 respuestas

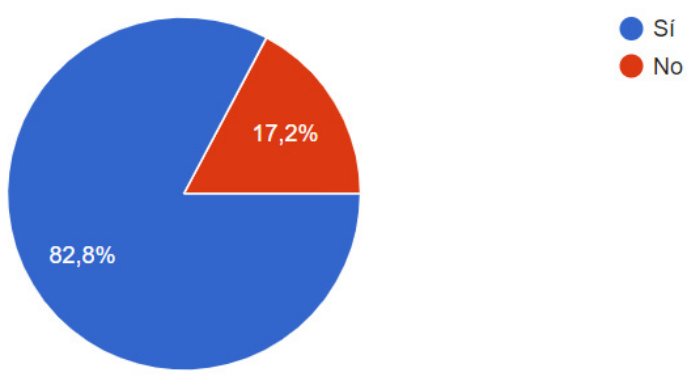

Figura 1: Respuestas docentes respecto a la participación en los foros. (Fuente: Google Forms). 
La gran mayoría de los docentes no usan herramientas de consulta rápida en línea durante la clase sincrónica (Quiz, Mentimeter, etc). Indican que no tienen tiempo, no les interesa o que no han podido aprender a usarlas. Sin embargo, quienes las emplean reconocen el aumento de participación de los alumnos y que les permiten detectar las ideas de los estudiantes en forma ágil.

Respecto a las actividades sincrónicas en pequeños grupos de alumnos, la gran mayoría de los docentes las valoran como muy útiles pues las perciben más cercanas a la clase presencial. Quienes no usan esta modalidad señalan que les cuesta hacer participar a los alumnos o consideran que no es posible interactuar de esta manera en forma virtual.

Algunos docentes indican que usan otras herramientas de comunicación con los estudiantes (Whatsapp, correo electrónico, etc). Muchos consideran que no hace falta ninguna otra herramienta y solo pocos mencionan que convendría incorporar Discord.

En cuanto a los estudiantes, la mayoría no participa de los foros de consulta en el campus (Figura 2). Prefieren consultar a sus compañeros porque les cuesta expresar su duda en forma escrita o prefieren la interacción oral. Los pocos que participan lo valoran porque pueden conocer las dudas de sus compañeros y aprender de ellas en un registro escrito.

¿Participás en los foros de discusión/consultas de tu curso en el campus?

244 respuestas

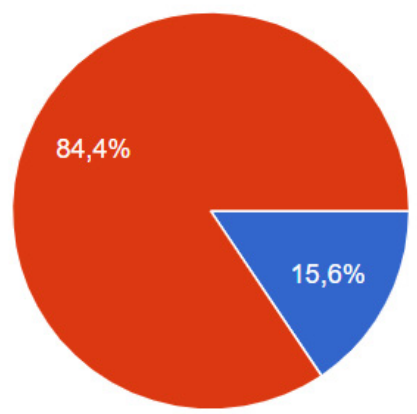

Figura 2: Respuestas de estudiantes respecto a la participación en los foros (Fuente: Google Form)

En los cursos donde se utilizan programas en línea de consulta rápida en la clase sincrónica, los estudiantes indican que esta herramienta les resulta muy útil. Lo mismo pasa en relación a las presentaciones grupales de ejercicios o trabajos de laboratorio: les resulta útil porque interactúan en forma directa con los docentes y entre ellos. A muy pocos no le gustan estas herramientas pues consideran que pierden tiempo. 
¿Te resultan útiles?

137 respuestas

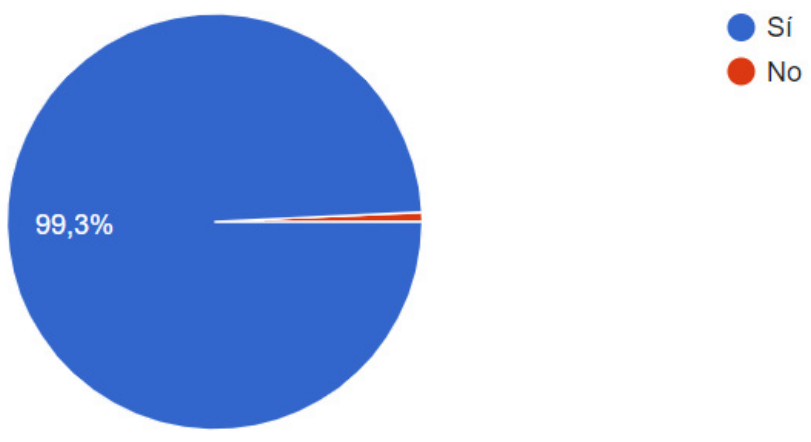

En relación a la comunicación entre estudiantes (Figura 3), la mayoría reconoce que participa de foros de comunicación entre pares, utilizando mayoritariamente Whatsapp y Discord pero también en menor proporción Telegram, Slack y Facebook. Les resultan útiles porque pueden consultar con sus compañeros las dudas y pueden acceder a materiales de otros cursos. Entre las sugerencias, los estudiantes proponen el uso de estas herramientas armando otros grupos con los docentes, pues consideran que de esta forma sus dudas y consultas serían evacuadas más rápidamente.

¿Participás en otros foros de comunicación entre estudiantes?

244 respuestas

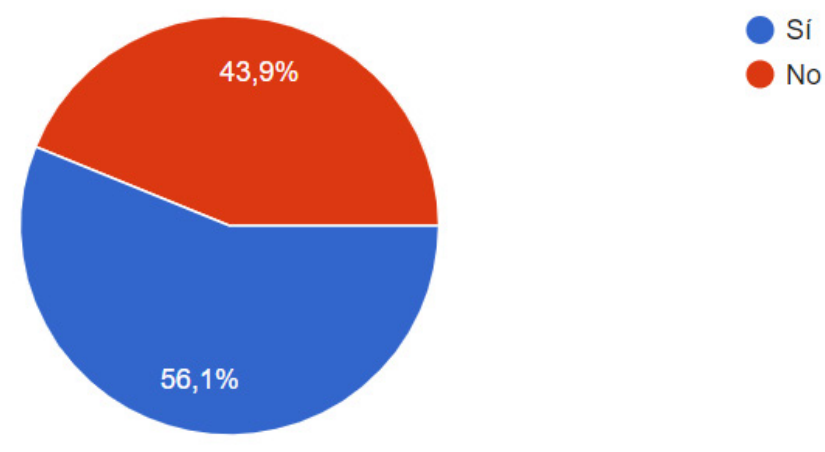

Figura 3: Respuestas de estudiantes respecto a la comunicación entre pares (Fuente: Google Forms)

\section{Discusión y conclusiones}

En este trabajo se propuso analizar la incorporación de distintas herramientas de comunicación entre docentes y estudiantes en dos poblaciones distintas. Se hicieron encuestas a docentes de otros cursos de la misma asignatura (Física I - FIUBA). En estas encuestas se consulta sobre la utilización de las herramientas que las autoras utilizan en sus respectivos cursos y se indaga sobre otras herramientas utilizadas por los docentes. 
Hay una amplia coincidencia, por parte de los docentes, sobre la utilidad del uso de los foros del campus virtual, herramienta que ya se usaba en los cursos presenciales desde hace años. Las autoras acuerdan con esta percepción; sin embargo, surge claramente de la encuesta para alumnos que no es la herramienta que ellos eligen, pues prefieren otros modos de comunicación (Figuras 1 y 2). Este contraste en las valoraciones que hacen docentes y estudiantes en torno al uso de los foros del campus virtual, deberían llevar a que nos preguntemos si tiene sentido seguir invirtiendo tiempo en mantener viva esta herramienta de comunicación.

En cuanto a otras herramientas de comunicación en clase entre docentes y alumnos, como las consultas rápidas en línea, son menos utilizadas por parte de los docentes debido a desconocimiento o falta de tiempo para implementarlas, pero a su vez valoran su incorporación como estrategia de acercamiento. Los estudiantes acuerdan con esto y suelen participar activamente porque les permite expresarse sin tanta exposición.

También, en los cursos en los que se utiliza, docentes y estudiantes valoran el trabajo sincrónico en pequeños grupos, tanto para la resolución de problemas como para los trabajos prácticos de laboratorio. Los estudiantes proponen también la incorporación de otras herramientas que permitan la comunicación más fluida con los docentes fuera del horario de clases, pero los docentes en su mayoría son renuentes a este tipo de conexión continua.

Como análisis final se concluye que los docentes intentan incorporar más herramientas de comunicación sincrónica con los estudiantes y valoran su uso, lo mismo que los estudiantes. Sin embargo, aún no hay acuerdo en cuáles son las mejores formas de interacción en la virtualidad.

\section{Referencias}

Aveleyra, E. E. y Rossi, D. S. (2021). Aprender en la virtualidad. Revista Iberoamericana de Tecnología en Educación y Educación en Tecnología, Volumen (28), [pp.] 403-408.

Del Prete, A. y Cabero Almenara, J. (2019). Las plataformas de formación virtual: algunas variables que determinan su utilización. Apertura, 11(2), [pp.] 138-153.

Kemmis, S. y Mc Taggart, R. (1988). Cómo planificar la Investigación-Acción. Laertes.

Mercader Juan, C. (2019). Las resistencias del profesorado universitario a la utilización de las tecnologías digitales. Aula Abierta, 48(2), [pp.] 167-174.

Yuni, J. A. y Urbano, C. A. (2014). Técnicas para investigar. Brujas. 


\section{Desarrollo de Habilidades Comunicativas en la Segunda Lengua Inglés en Niños con Discapacidad Intelectual Leve por Medio de un Tablero Didáctico Digital}

Gutierrez Montenegro, Lina

Corporación Universitaria Minuto de Dios lina.gutierrez-m@uniminuto.edu.co 


\title{
DESARROLLO DE HABILIDADES COMUNICATIVAS EN LA SEGUNDA LENGUA INGLÉS EN NIÑOS CON DISCAPACIDAD INTELECTUAL LEVE POR MEDIO DE UN TABLERO DIDÁCTICO DIGITAL
}

\author{
Gutierrez Montenegro, Lina \\ Corporación Universitaria Minuto de Dios \\ lina.gutierrez-m@uniminuto.edu.co
}

\section{Resumen}

La Institución Educativa La Armonía se encuentra ubicada en el Municipio de Mosquera- Cundinamarca, Colombia; su crecimiento ha sido tan relevante que es una de las instituciones a nivel municipal que más estudiantes ha acogido con Necesidades Educativas Especiales (NEE), por lo tanto, el presente artículo se centra en la Discapacidad Intelectual Leve, siendo esta una de las discapacidades más frecuentes en los estudiantes focalizados en grado séptimo y octavo de la Institución. En este sentido y como docentes de inglés, se evidencia poco acompañamiento en los procesos formativos y de socialización con este tipo de población, desarrollando pocas habilidades comunicativas entre sus pares, dejándolos a un lado y sin incorporarlos a las actividades propuestas en el currículo, de esta manera, surge la necesidad de implementar una herramienta " tablero didáctico digital" que responda a estas necesidades y permita el fortalecimiento de las habilidades comunicativas speaking, listening, writing y reading, desde la asignatura de inglés, a través de actividades interactivas del tablero didáctico digital One Note for Windows 10, tales como: escribir, dibujar, grabar voz, subrayar, observar videos, insertar fotos etc. Basado en los resultados del grupo experimental y grupo control, se concluye que al interactuar el grupo experimental con la herramienta digital se les facilita el aprendizaje de una segunda lengua, porque están aprendiendo al ritmo de ellos de una manera lúdica y novedosa, desarrollando habilidades comunicativas con los mismos contenidos que sus compañeros regulares, alcanzando un avance significativo en su proceso de aprendizaje sobre el grupo control.

\section{Palabras clave}

Habilidades comunicativas, tablero didáctico, inclusión, discapacidad intelectual leve, inglés. 


\section{Introducción}

Las instituciones educativas han empezado a incluir niños con diferentes discapacidades o necesidades educativas a las aulas, sin embargo, la Institución Educativa La Armonía no cuenta con un programa, capacitaciones y herramientas que faciliten el trabajo a los docentes en el desarrollo de actividades con los estudiantes de NEE en el aula, por consiguiente y en un caso particular, los docentes de inglés en sus actividades formativas y académicas, no incluyen a los estudiantes con necesidades educativas especiales y los apartan de los estudiantes regulares realizando actividades diferentes a las planteadas en el currículo, por ejemplo: dibujar, rayar, transcribir, colorear o simplemente los dejan sin realizar ninguna actividad.

Por otro lado, los estudiantes con discapacidad intelectual leve, focalizados en grado séptimo y octavo en un rango de edad entre 12 a 17 años, no comprenden ni analizan información dada por los docentes y en ocasiones se les dificulta el seguimiento de instrucciones, la gran mayoría de veces se debe repetir y hacer mímica hasta cinco veces la misma instrucción, por ello, se les dificulta aún más adquirir y comunicar diferentes situaciones en la segunda lengua. De esta manera, surge la necesidad de desarrollar una herramienta "tablero didáctico digital" que ayude al desarrollo de las habilidades comunicativas de la segunda lengua inglés, para incluir a este tipo de población en las actividades propuestas de la clase y que puedan los estudiantes ser partícipes de las mismas sin quedar atrasados de las temáticas o sin adquirir ningún conocimiento.

La estrategia de investigación en el proyecto, se hace a través del uso del tablero didáctico digital en las clases de inglés con el grupo experimental, teniendo en cuenta un enfoque metodológico cuantitativo, debido a que se recolectan y analizan datos, la población se pude medir, se comprueba una hipótesis y se hace un acercamiento con el objeto de estudio.

Teniendo en cuenta el objeto de estudio y el problema de investigación se encuentran diferentes posturas de autores que hablan al respecto.

Inicialmente, Castro, Espino y García (2018), en la tesis titulada "Reflexiones sobre la enseñanza inclusiva del inglés apoyada por tecnologías emergentes", enfocaron su estudio a las tecnologías emergentes y optimizar su uso para la enseñanza inclusiva del inglés enfocado a aquellos estudiantes que son dejados de lado en las clases.

Otro aporte significativo se encuentra en Rabazo y Gómez (2018), dentro del cual realizaron la investigación "Bilingüismo en personas con discapacidad intelectual", reconociendo la capacidad de los niños con discapacidad intelectual de adquirir más de un idioma y afirmando que "las políticas educativas vayan encaminadas a favorecer el plurilingüismo a través de enfoques metodológicos comunicativos y que incorporan una lengua extranjera como lengua vehicular" (p. 10).

Un antecedente que aproxima el uso de herramientas digitales y su relación con la comunicación, se encuentra en la investigación de Sabogal y Velásquez (2014) titulada "Implementación de un tablero digital de bajo costo", allí mencionan el uso del tablero digital interactivo, como herramienta de comunicación en los procesos de enseñanza- aprendizaje, para el acompañamiento y apropiación del uso de las tecnologías, donde, "permite que los estudiantes se involucren en la forma como 
se les entrega la información, manejando su entorno de una forma natural como si estuvieran escribiendo o dibujando." (p. 64).

Siguiendo a Rodríguez (2014) y su investigación "Consideraciones y lineamientos para fomentar el uso de los tableros digitales interactivos en los ambientes de aprendizajes educativos en los municipios de Medellín e Itagüí", se hizo una descripción de los factores en el uso de los tableros didácticos digitales interactivas para las practicas pedagógicas.

Teniendo presente los anteriores antecedentes y su relación con la investigación sobre el desarrollo de habilidades comunicativas en inglés, para niños que tienen la discapacidad intelectual leve, en la Institución Educativa la Armonía, se presenta el siguiente objetivo:

Diseñar e implementar un tablero didáctico digital para mejorar las habilidades comunicativas en inglés de speaking, reading, writing and listening en estudiantes de grado séptimo y octavo con discapacidad intelectual leve.

Así mismo, surge la siguiente hipótesis: los estudiantes con discapacidad intelectual leve interactúan con el tablero didáctico digital fortaleciendo las habilidades comunicativas en inglés.

Por lo tanto, el tablero didáctico digital es aplicado en la clase de inglés debido a que es la asignatura con menos participación en actividades propuestas, ya que no logran desarrollar fácilmente sus habilidades comunicativas en inglés y en su gran mayoría son excluidos del aula por requerir el uso frecuente del inglés.

\section{Método}

\section{Descripción del contexto y de los participantes}

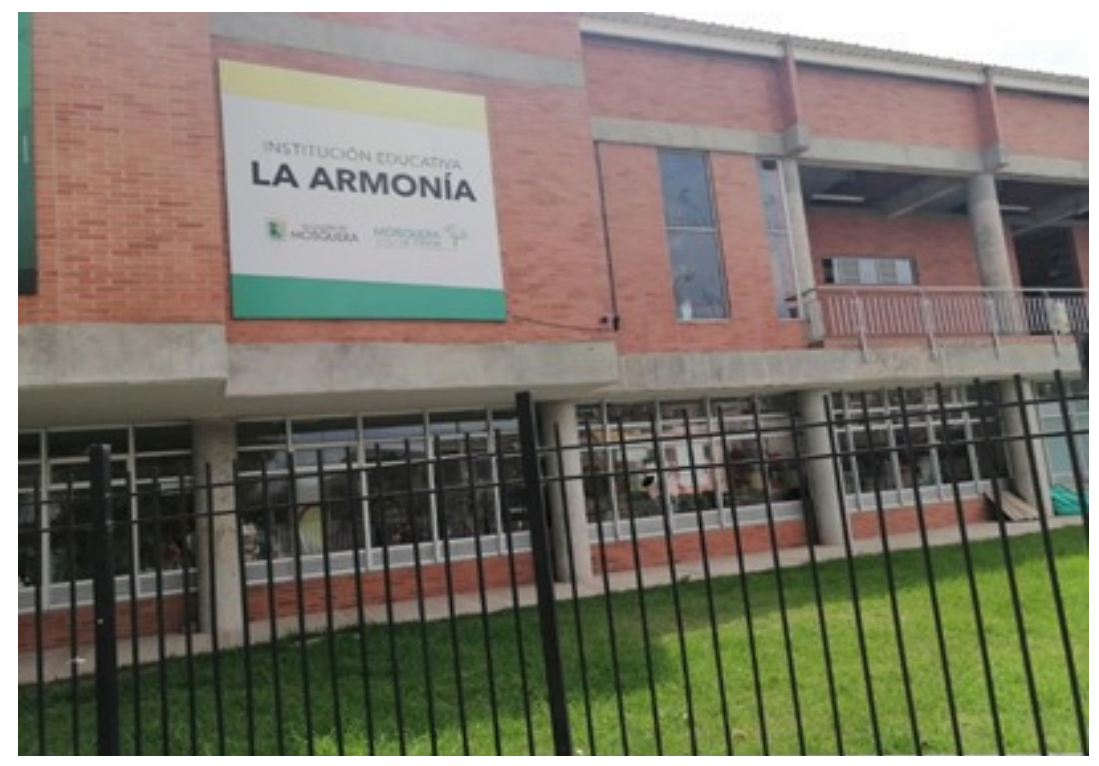


La Institución Educativa La Armonía, fue la primera Institución a nivel Nacional en implementar la jornada única en el 2015; cuenta con 2500 estudiantes en todas sus sedes y jornadas, incluyendo 60 estudiantes de inclusión en todos sus niveles educativos, de los cuales 11 estudiantes tienen discapacidad intelectual leve y están focalizados en los grados séptimos y octavos. Los estudiantes están en un rango de edad de 12 a 17 años y algunos de ellos no cuentan con un proceso lector ni escritor, esto, dificulta el aprendizaje de una segunda lengua debido a que, en su mayoría al no comprender ni seguir instrucciones son excluidos dentro del aula sin permitir una evolución de su aprendizaje, al mismo tiempo motiva a realizar procesos didácticos con una herramienta digital que responda a dichas necesidades.

El enfoque de la investigación es cuantitativo, por lo que es secuencial y probatorio, valida datos e información por medio de técnicas e instrumentos que ayudan a obtener unos resultados verídicos al momento de diseñar y aplicar el tablero digital. Por otra parte, tiene un alcance correlacional debido a que, sus dos variables se relacionan, en este caso, la variable dependiente (habilidades comunicativas) y la variable independiente (tablero didáctico) permitiendo comprobar que hay un impacto del tablero didáctico sobre el fortalecimiento de las habilidades comunicativas, y finalmente el diseño metodológico cuasiexperimental, ya que los grupos estaban conformados desde la institución y se busca el efecto que tiene la variable independiente sobre la variable dependiente.

\section{Instrumentos}

Los instrumentos que se utilizaron para la recolección de datos fueron los siguientes: cuestionarios para la caracterización de la población, cuestionarios evaluativos o rúbricas evaluativas para cada habilidad comunicativa y una matriz de captura de información para seleccionar el mejor recurso educativo digital en el diseño del tablero didáctico digital. Antes de aplicar los instrumentos, se procedió a reunir la documentación firmada del consentimiento informado del padre, madre o acudiente del estudiante y también el asentimiento informado del propio estudiantado, para aplicarlas en la investigación.

El primer instrumento "caracterización de los estudiantes" permitió recolectar información de los rasgos cognitivos de los estudiantes con discapacidad intelectual leve, género, edad y curso o grado de escolaridad.

El segundo instrumento "Rubrica de speaking: habilidades comunicativas en inglés" residió sobre el proceso comunicativo de la habilidad speaking a través del uso del tablero didáctico grabando videos o notas de vos respondiendo una pregunta en inglés "what do you like to do in your free time?". Se establecieron 4 criterios y desempeño en relación a la fluidez verbal, pronunciación y uso del vocabulario trabajado en el tablero didáctico, estos a su vez, fueron cuantificados mediante una escala de bajo (1.0 a 3.4), básico (3.5 a 3.9), alto (4.0 a 4.4) y superior (4.5 a 5.0). 


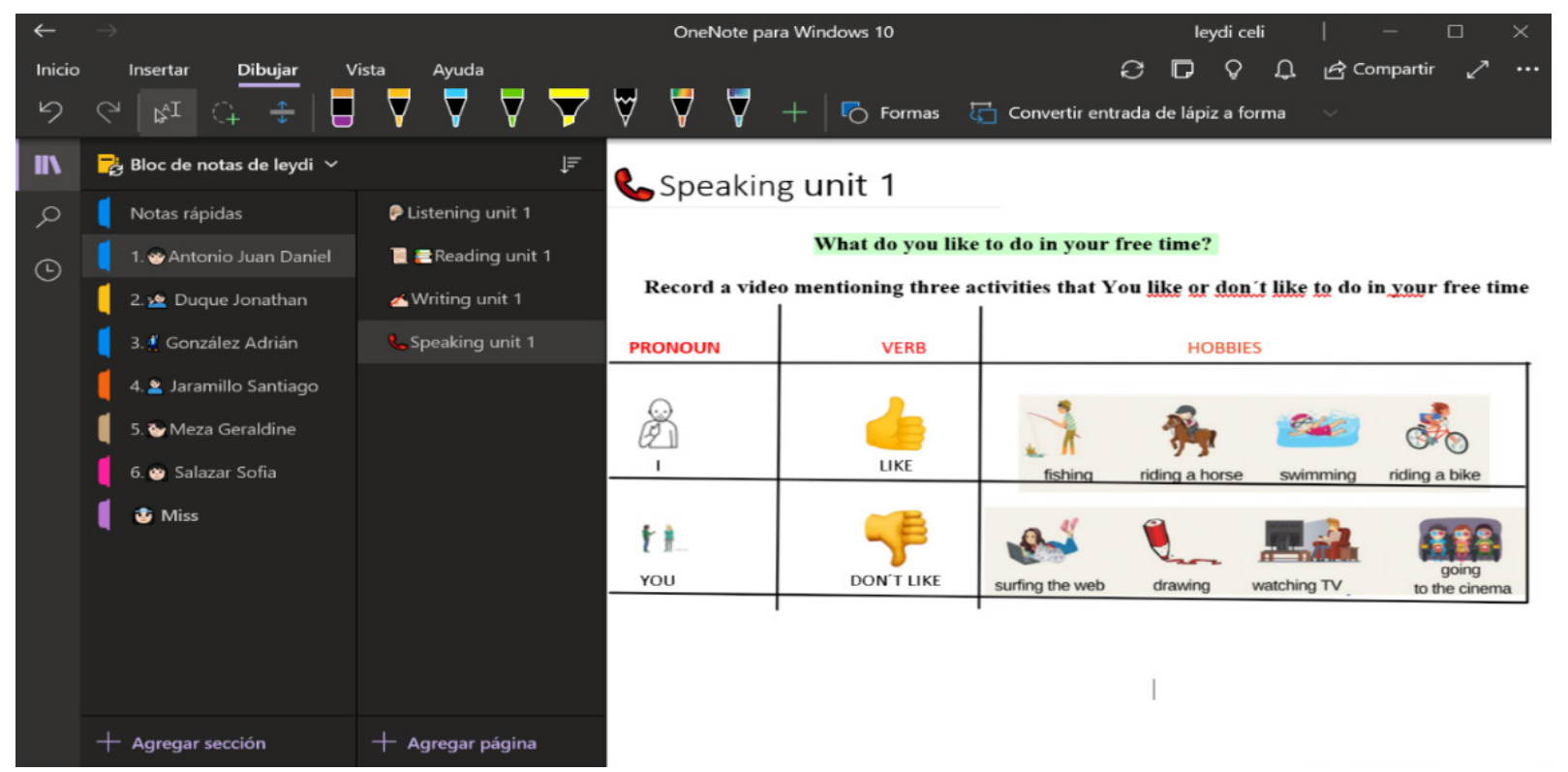

Imagen 2: captura de imagen del uso del tablero digital en la actividad de speaking. Autoría propia.

El tercer instrumento "cuestionario evaluativo de listening y writing" se estableció con dos preguntas de opción múltiple, 2 preguntas de completar información y 1 pregunta con opción de respuesta de verdadero o falso. Con este cuestionario, se pudo conocer el proceso comunicativo de estas dos habilidades a través del uso del tablero didáctico, escuchando y viendo un video para luego responder a las 5 preguntas.

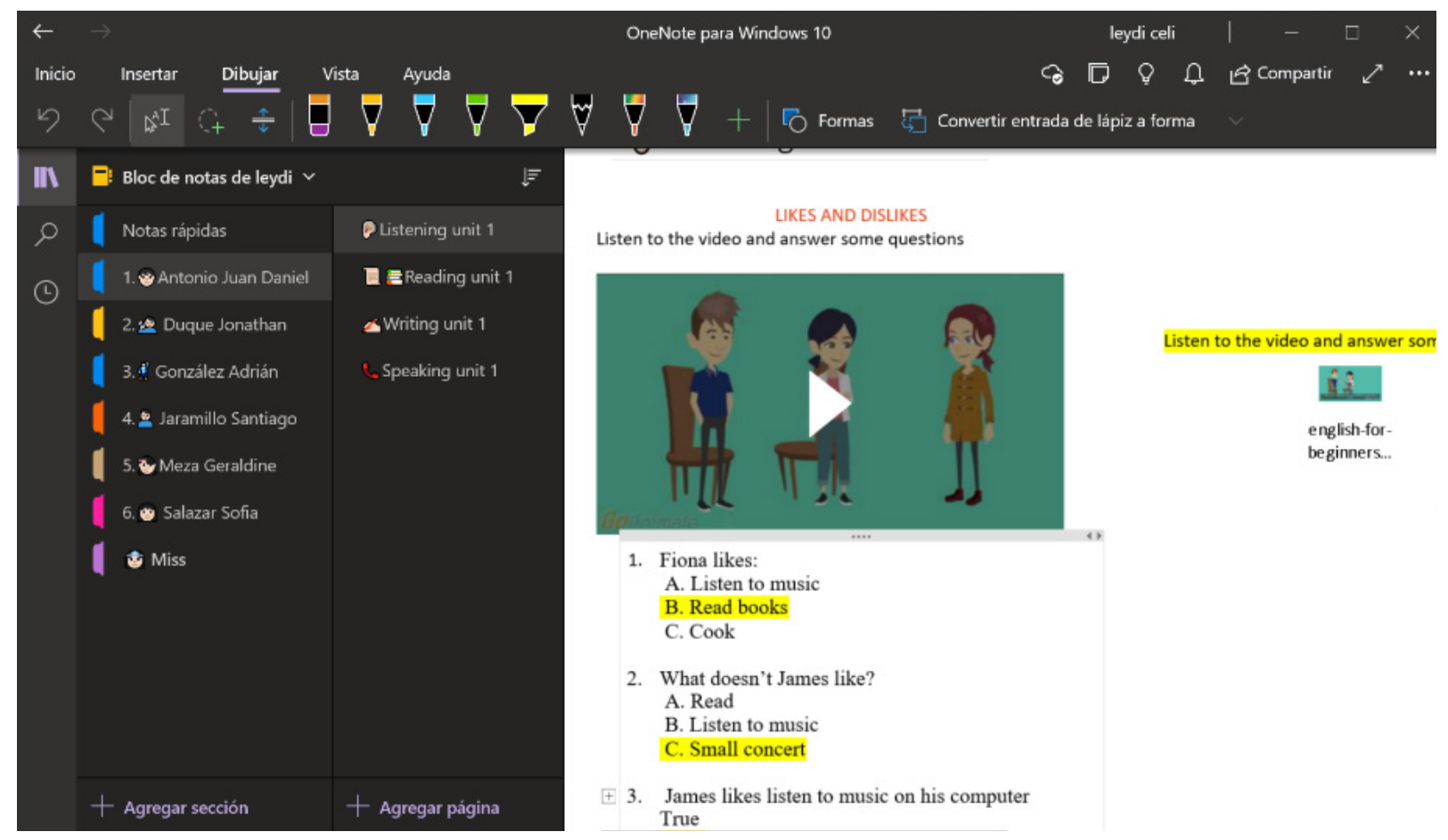

Imagen 3: captura de imagen del uso del tablero digital en la actividad de listening and writing. Autoría propia. 
El cuarto instrumento "rúbrica reading" permitió capturar la información de esta habilidad a través del mismo vídeo de la habilidad del listening y writing, ya que contiene subtítulos en inglés; allí el estudiante puede leer 3 oraciones y las docentes, por medio de una grabación, evalúa la actividad con base a 4 criterios y desempeños centrados en pronunciación y fluidez verbal; la cuantificación se dio en la escala bajo (1.0 a 3.4), básico (3.5 a 3.9), alto (4.0 a 4.4) y superior (4.5 a 5.0).

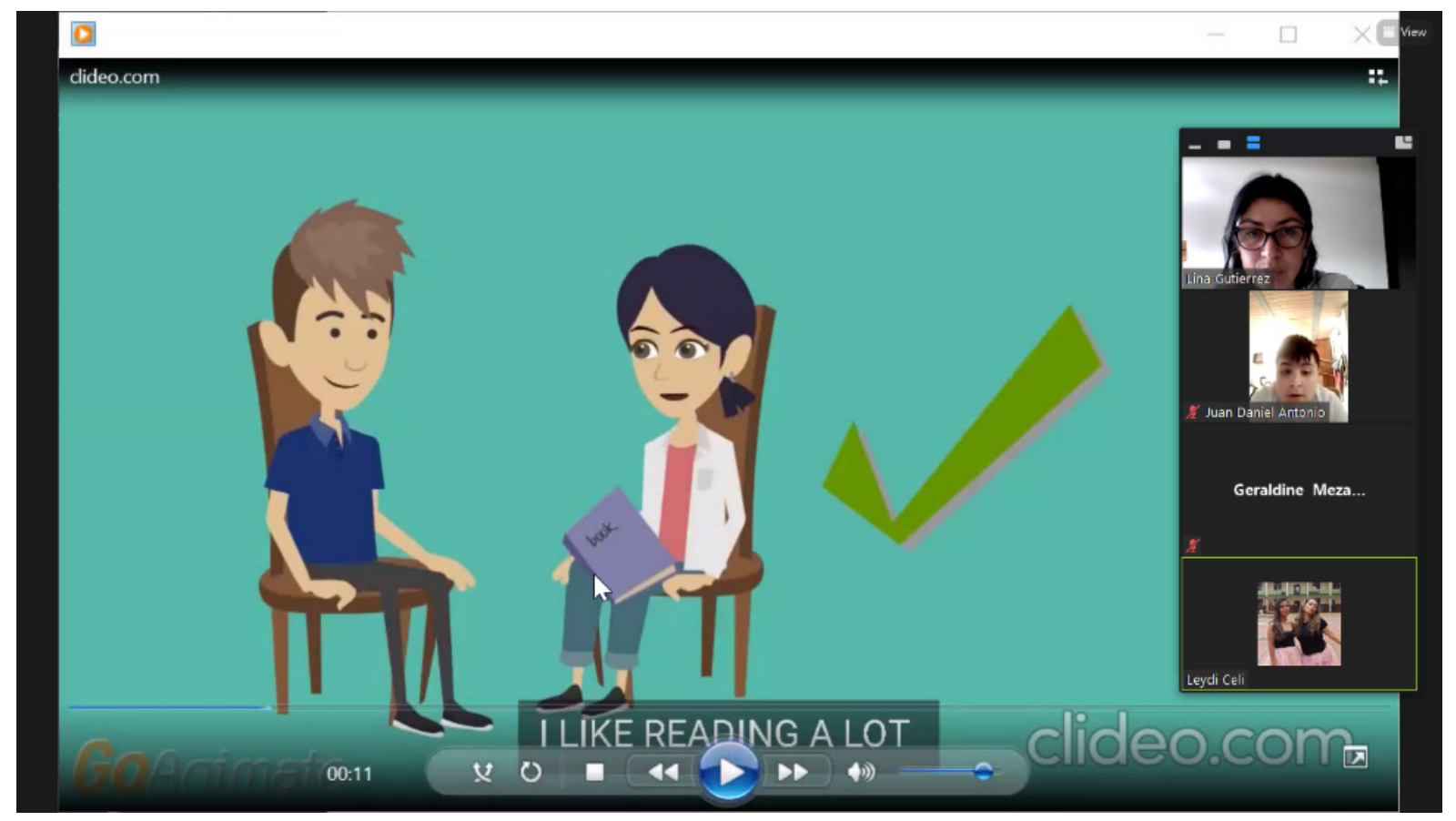

Imagen 4: captura de imagen, seguimiento profesoral en la actividad de reading. Autoría propia.

El quinto instrumento "matriz de captura de información: diseño tablero didáctico" consintió en recoger información acerca del diseño y mejor plataforma a utilizar en el tablero didáctico con los estudiantes. Los ítems claves fueron las características, pertinencia para el sector educativo, publicación, tipo de licencia, interactividad de arrastrar imágenes o colocar texto y la naturaleza propia de la herramienta.

\section{Procedimiento}

El modo de ejecución en la investigación, se dieron a partir de las siguientes fases:

- Identificación del tema de interés: se selecciona el tema teniendo en cuenta que la Institución Educativa tiene estudiantes de inclusión en todas sus jornadas y sedes, pero la gran mayoría de estudiantes con discapacidad intelectual leve están en grado séptimo y octavo, tienen un proceso académico y de comunicación bajo frente a los demás estudiantes regulares, por otro lado, son los grados donde las investigadoras imparten su cátedra.

- Planteamiento del problema y antecedentes: se realiza la descripción del problema y la formulación de la pregunta de investigación partiendo de la población de estudio y la asignatura de inglés, aunado diferentes investigaciones nacionales e 
internacionales que ayudaron a soportar y comprender diferentes contribuciones y puntos de vista frente a la problemática presentada.

- Marco referencial: durante esta etapa, se indaga sobre teorías y estudios recientes que afirman o refutan la adquisición de una segunda lengua en niños con NEE, específicamente con discapacidad intelectual leve, de esta manera, se agruparon los diferentes decretos, investigaciones, artículos entre otras en tres grandes categorías: educación inclusiva, pedagogía y habilidades comunicativas.

- Selección del enfoque y diseño de la investigación: de acuerdo al rumbo de la investigación, el enfoque seleccionado es el cuantitativo y el diseño de investigación cuasiexperimental, que permitieron analizar y observar datos medibles dentro de un grupo que ya estaba conformado por la Institución y el SIMAT (Sistema de gestión de matrícula).

- Elaboración de hipótesis: se planteó la delimitante sí "los estudiantes con discapacidad intelectual leve fortalecen los procesos de comunicación, en la adquisición de la segunda lengua, a través del uso del tablero didáctico digital”.

- Selección de la muestra y población: se focaliza los estudiantes de grado séptimo y octavo de la Institución, debido a que, en estos grados es donde están los estudiantes con discapacidad intelectual leve y las docentes investigadoras orientan la asignatura de inglés. Se estableció un grupo control y un grupo experimental, posterior a la selección de la muestra no probabilístico por conveniencia.

\begin{tabular}{|l|c|cc|c|}
\hline GRADos & \multicolumn{1}{c}{$\begin{array}{c}\text { CANTIDAD ESTUDIANTES CON } \\
\text { DISCAPACIDAD INTELECTUAL LEVE }\end{array}$} & \multicolumn{2}{c|}{ FENERO } & \multicolumn{2}{c|}{ M } & RANGO DE EDAD \\
\hline Séptimo & 7 & 1 & 6 & $12-17$ \\
\hline Octavo & 4 & 1 & 3 & $13-15$ \\
\hline Total & 11 & & 11 & 11 \\
\hline
\end{tabular}

Tabla 1: población de discapacidad intelectual leve séptimo y Octavo I.E. La Armonía. Autoría propia.

- Diseño de los instrumentos y tablero didáctico: teniendo en cuenta el objetivo planteado se diseñaron cinco instrumentos para ser analizados y validados por dos expertos, atendiendo a las sugerencias dadas por ellos, se realizaron las respectivas adecuaciones para aplicarlos. Asimismo, se diseñó el tablero didáctico con la mejor plataforma analizada en la matriz de captura de información, la cual suplía las necesidades de la población a trabajar debido a la variedad de herramientas que tiene.

- Aplicación de los instrumentos: el instrumento uno se aplicó a toda la muestra de estudio y los demás instrumentos se aplican específicamente al grupo experimental, implementando el tablero didáctico digital y realizando un acompañamiento con las docentes de inglés. 
- Recolección y análisis de datos: se recolectan los datos por medio de gráficas y estadísticas las cuales muestran los resultados de la implementación del tablero didáctico y el desarrollo de las habilidades comunicativas de la segunda lengua en la población con discapacidad intelectual leve.

Reporte de resultados: se presentan los resultados de la investigación teniendo en cuenta el objetivo de la investigación.

\section{Resultados}

Para analizar los resultados arrojados por los diferentes instrumentos se tuvo en cuenta las tres categorías: educación inclusiva, pedagogía y habilidades comunicativas en inglés. Para cada categoría se diseñó uno o más instrumentos que permitieron confirmar y refutar el planteamiento problema y la hipótesis. Los datos se analizaron por medio de gráficas, mostrando resultados favorables en el uso del tablero didáctico digital.

En el primer instrumento se logra identificar las características individuales de cada estudiante, por ejemplo, seguimiento de instrucciones, concentración, tipo de discapacidad, emociones, memoria y comunicación, permitiendo a los docentes identificar fortalezas y debilidades de los estudiantes para trabajar las actividades en clase.

El segundo, tercer y cuarto instrumento corresponde a las rúbricas o cuestionarios evaluativos, los resultados muestran que a través del uso del tablero didáctico se obtiene un avance en el desarrollo de habilidades comunicativas: speaking, reading, writing and listening de la segunda lengua inglés, al ser una herramienta didáctica, innovadora e interactiva que los estudiantes manipulan con la supervisión y orientación del docente.

El último instrumento logró establecer la mejor herramienta para el diseño del tablero didáctico digital, escogiendo la mejor opción (One Note for Windows 10) de cinco plataformas indagadas: Scribbar, Notebookcast, Jamboard y One Note for Windows 10. Esta plataforma seleccionada, permitió estimular el aprendizaje por medio de actividades individuales y grupales, cada niño tuvo su propia pizarra digital consintiendo un seguimiento personalizado de las actividades.

En la comprobación de la hipótesis, se tuvo presente la correlación de Pearson y se encontró un rango de 1 a 0.5 y -1 a -0.5 . Con este resultado, la hipótesis planteada es aceptada y refuerza la idea de la incorporación de un tablero didáctico digital para la enseñanza de habilidades comunicativas del idioma inglés, para estudiantes con discapacidad leve.

\section{Discusión y conclusiones}

El tablero didáctico digital es una herramienta útil que proporciona procesos de aprendizaje de la segunda lengua de una manera diferente y dinámica. La interactividad, actividades, dinámicas, participación del estudiantado con NEE y orientación por parte de las docentes, generan que el proceso de enseñanza y aprendizaje sea enriquecedor y se adquieran competencias en las habilidades comunicativas del inglés. 
Se debe difundir el uso del tablero didáctico digital para llevarlo a todas las áreas del conocimiento con los demás estudiantes de inclusión. Esta estrategia para la enseñanza, resulta ser una buena elección para llevar un buen proceso de aprendizaje por medio de la virtualidad.

Con el uso del tablero didáctico digital los estudiantes con discapacidad intelectual leve pueden desarrollar actividades propuestas desde el currículo, sin ser excluidos desde la clase en inglés, fortaleciendo sus habilidades comunicativas. La atención y dedicación que lleva esta población con el uso de dicha herramienta digital, permite una mayor concentración y agrado para aprender.

En la búsqueda de información sobre habilidades comunicativas en inglés y herramientas digitales con estudiantes de discapacidad intelectual leve, se encontraron muy pocos antecedentes nacionales que ayudaran a la construcción del proyecto de investigación.

\section{Referencias}

Castro Villalobos, S., Espino Casar, L., y García Martínez, A. (2018). Reflexiones sobre la enseñanza inclusiva del inglés apoyada por tecnologías emergentes. Revista cubana de Educación Superior, 38(1), [pp.] 1-19. Recuperado de [http://scielo.sld.cu/ $\mathrm{pdf} / \mathrm{rces} / \mathrm{v38n1/0257-4314-rces-38-01-e12.pdf]}$

Rabazo Méndez, M. J., y Gómez Acuña, M. (2018). Bilingüismo en personas con discapacidad intelectual. Revista de psicología INFAD, 3(1), [pp.] 63-71. Recuperado de [https://www.redalyc.org/jatsRepo/3498/349856428006/index.html]

Rodríguez Vides, A. (2014). Consideraciones y lineamientos para fomentar el uso de los tableros digitales interactivos en los ambientes de aprendizajes educativos en los municipios de Medellín e Itagüí. [Tesis de maestría, Universidad EAFITR]. Repositorio institucional EAFIT. [https://repository.eafit.edu.co/bitstream/handle/10784/2854/ AntonioRodr\%C3\%ADguezVides_2014.pdf?sequence=3]

Sabogal, R., y Velásquez, V. (2014). Implementación de un tablero digital de bajo costo. Revista INVENTUM, 9(16), [pp.] 63-67. [https://doi.org/10.26620/uniminuto. inventum.9.16.2014.63-67] 
Aprendizajes en Física Universitaria: Descripción de una Experiencia con Uso de Recursos Computacionales Desarrollados Mediante Lenguaje de Programación Python

\section{Saccone, Fabio Daniel}

https://orcid.org/0000-0001-9921-6626 


\title{
APRENDIZAJES EN FÍSICA UNIVERSITARIA: DESCRIPCIÓN DE UNA EXPERIENCIA CON USO DE RECURSOS COMPUTACIONALES DESARROLLADOS MEDIANTE LENGUAJE DE PROGRAMACIÓN PYTHON
}

\author{
Saccone, Fabio Daniel \\ https://orcid.org/0000-0001-9921-6626
}

\section{Resumen}

En el actual contexto de Enseñanza Superior con modalidad a distancia extendida, se han visto afectadas las currículas de las materias correspondientes a las carreras CTIM (Ciencia, Tecnología, Ingeniería \& Matemáticas), las cuales tienen un desafío adicional en lo que corresponde a las experiencias de laboratorio, ya que los aforos y la existencia de material de uso común, limitan estas prácticas que son imprescindibles en la formación de los y las estudiantes. Atendiendo que los ingresos más bajos en nuestros países de Latinoamérica tienen déficit de conectividad de internet desde el hogar, parte de las actividades curriculares deben derivarse al modo asincrónico.

Para aquellos y aquellas estudiantes y docentes que tengan motivaciones en sumar un aprendizaje adicional y herramientas de validación de modelos, puede resultarles útil emplear entornos de programación libres, tales como Python, que puede instalarse en diferentes OS y posee recursos de ayuda muy difundidos en la web. De esta manera, con una orientación docente, las y los alumnos pueden editar códigos propuestos y desarrollarlos. En este trabajo, se describen algunos códigos que fueron programados en Python y se compartieron como experiencia de aprendizaje con alumnos de Física del primer año de la carrera de Ingeniería de la UBA (Mecánica Elemental y Óptica Física).

Finalmente, se hace una valoración de la experiencia realizada en un curso de Física, correspondiente al primer año de las Carreras de Ingeniería de la UBA.

\section{Palabras clave}

Software educativo, Pensamiento computacional, Desarrollo de competencias digitales, Python. 


\section{Introducción}

Sin lugar a duda, la educación universitaria ha visto acelerada su transición a una modalidad semipresencial, a partir de la emergencia sanitaria que originó la pandemia de COVID 19. Aquellas instituciones iberoamericanas que no tenían herramientas de enseñanza en modalidad virtual, rápidamente debieron implementarlas, y sus docentes y estudiantes iniciaron el año lectivo 2020 con cursadas a distancia. Si bien con el avance de la inmunización de la población, se han logrado normalizar algunas experiencias de enseñanza-aprendizaje en las aulas y los laboratorios, estas sólo corresponden a las materias finales de carrera, con baja matriculación estudiantil. En varias universidades de Latinoamérica, no se ha dado un retorno a la presencialidad aún y esto repercute fuertemente en aquellas carreras con modalidad práctica.

En particular y con cursos de alta matriculación, las carreras CTIM (Ciencia, Tecnología, Ingeniería \& Matemáticas) tienen un desafío adicional en lo que corresponde a las experiencias de laboratorio, ya que los aforos y el empleo de material de uso común, limitan estas prácticas que son imprescindibles en la formación de los y las estudiantes. Diferentes alternativas, como la realización de experimentos con elementos de uso común en sus hogares, aunque obligadas debido al contexto, priva a los y las estudiantes de fijar conocimientos con herramientas profesionales, las que reducen las incertezas y aseguran repetibilidad [OBri], [Bob].

Ante esta situación, una alternativa complementaria a la experimentación es el uso de recursos didácticos de simulación. En el caso de la enseñanza de la Física, hay diferentes opciones en la red [Phet] y también apps, que son recursos de uso libre. Sin embargo, se trata de herramientas sofisticadas que, si bien son útiles para el análisis de las variables, son desarrolladas por expertos en software. Es importante resaltar que la percepción de metas logradas en el aprendizaje de la Física Universitaria depende de una buena habilidad comunicacional del docente y de una capacidad de auto-organización del estudiante [Klei].

Para aquellos y aquellas estudiantes y docentes que tengan motivaciones en sumar un aprendizaje adicional [De/g] puede ser útil emplear entornos de programación libres, tales como Python, que puede instalarse en diferentes OS y posee recursos de ayuda muy difundidos en la web [Pyth]. Se trata de un lenguaje de programación muy potente para aplicaciones profesionales en las disciplinas CTIM, en particular en Ciencia de Datos, Automatización e Inteligencia Artificial [Kius]. Existe bibliografía consultada en este trabajo, de aplicaciones para la simulación en Física [Malt]. Su integración a entornos de administración de paquetes que corren en diferentes sistemas operativos ha permitido una difusión entre docentes, investigadores y estudiantes que sigue en aumento. De esta manera, con una orientación docente, las y los alumnos pueden editar códigos propuestos y desarrollarlos

\section{Método/Descripción de la experiencia}

En esta sección del resumen se muestran ejemplos físicos resueltos mediante programación con lenguaje Python, que fueran compartidos en la experiencia con los alumnos y las alumnas del curso. 


\section{Descripción de los códigos implementados}

\section{Experiencias de Mecánica Elemental (Cinemática y Dinámica de cuerpos puntuales)}

Se desarrollaron códigos Python (ver Sección Instrumentos), para modelizar y dar los resultados en ejemplos simplificados de 1) Caída libre, 2) Determinación de la altura de órbitas de satélites, 3) Problema de encuentro de dos móviles en movimientos rectilíneos uniformes (MRU) y uniformemente variado (MRUV), 4) Sistema Masa-Resorte

Se procede a explicar cada ejemplo enunciado:

\section{Caída libre}

Se denomina así a la caída de un objeto, considerado puntual, desde una determinada altura, sin velocidad inicial, y despreciando la presencia de la resistencia viscosa del aire. El cuerpo es acelerado por la gravedad en dirección al suelo. El algoritmo propuesto (Caída Libre.ipynb) permite calcular la altura relativa al suelo y velocidad que posee un cuerpo puntual, transcurrido un determinado tiempo $t$. En la figura 1: puede verse el algoritmo y una salida del código propuesto

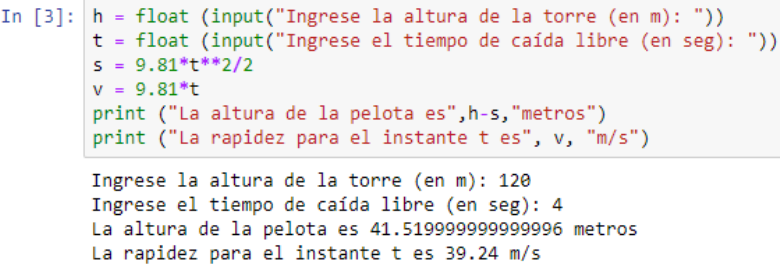

Figura 1: Detalle del código "Caída Libre.ipynb" y una salida de cálculo de la altura y rapidez, adquirida en caída libre a los 4 segundos por un objeto soltado desde 120 metros de altura.

\section{Cálculo de la órbita de un satélite}

Tal como establece la Ley de Gravitación Universal, la interacción entre dos cuerpos mediante la atracción gravitatoria genera los movimientos de orbitación, si el sistema aislado tiene conservación del momento angular. Por ejemplo, la rotación de satélites, ya sean naturales o artificiales, en torno de la Tierra es un problema de fuerzas centrales y su movimiento queda circunscripto a una órbita circular de rapidez uniforme y período T. Para un determinado período del satélite, puede determinarse la altura $h$ respecto de la superficie terrestre mediante la relación:

$$
h=\sqrt[3]{\left(\frac{G \times M \times T^{2}}{4 \times \pi^{2}}\right)}-R
$$

donde $\mathrm{G}$ es la constante de gravitación universal, $\mathrm{M}$ y $\mathrm{R}$ son la masa y radio terrestre, respectivamente. 
El código Gravitación.ipynb permite determinar las alturas de las órbitas de los satélites, mediante la ley de Gravitación Universal. Según sea el período de la órbita, se puede determinar la altura desde la tierra en $\mathrm{km}$. (Sugerencias: analizar geoestacionarios, $\mathrm{T}=24 \mathrm{hs}$, y de órbitas bajas, $\mathrm{T}=90 \mathrm{~min}$ )

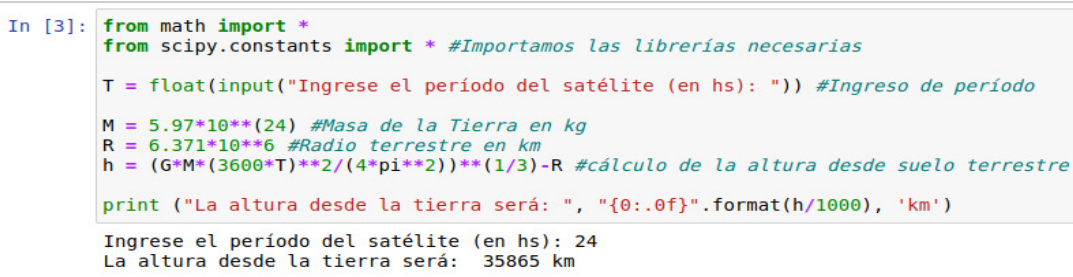

Figura 2: salida del código Gravitación.ipynb, que determina la altura de un satélite en función de su período. Se muestra el ejemplo de una órbita geoestacionaria (período de 24 hs)

\section{Problema de encuentro de dos móviles}

Los problemas de encuentro de dos móviles que recorren trayectorias rectilíneas, se describen mediante ecuaciones, o bien lineales (MRU) o bien cuadráticas (MRUV), que vinculan las funciones de posición como función del tiempo. En la Figura 3 se muestra una salida gráfica de un problema de encuentro de dos móviles con MRU, resuelta con el código MRU.ipynb y en la Figura 4 el encuentro de dos móviles con MRUV resuelto con el código MRUV.ipynb

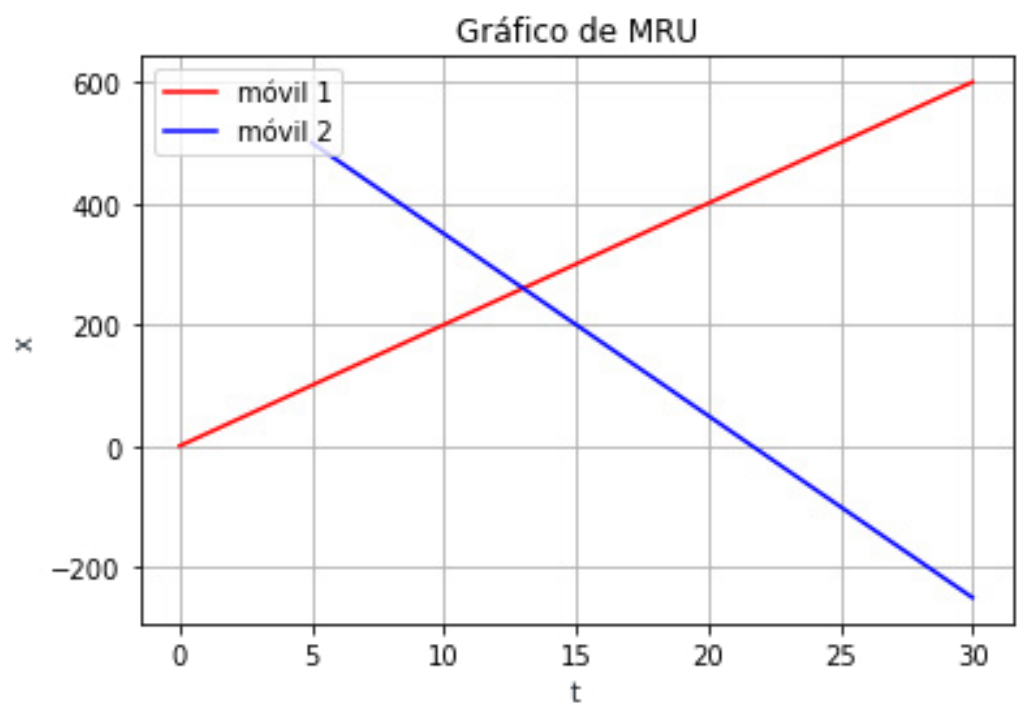

Figura 3: salida donde se grafican las posiciones de ambos móviles que viajan en direcciones opuestas, en una misma recta. La intersección representa la posición de encuentro al tiempo de encuentro 
Encuentro de dos móviles que realizan MRUVs (móvil 1 parte antes o al mismo tiempo que el 2) Ingrese la posición inicial del móvil 1 (en $\mathrm{m}$ ): 0

Ingrese la velocidad inicial del móvil 1 (en $\mathrm{m} / \mathrm{s}): 10$

Ingrese la aceleración constante del móvil 1 (en $\left.\mathrm{m} / \mathrm{s}^{\wedge} 2\right): 5$

Ingrese el tiempo inicial del móvil 1 (en seg): 0

Ingrese la posición inicial del móvil 2 (en m): $\theta$

Ingrese la velocidad inicial del móvil 2 (en $\mathrm{m} / \mathrm{s}$ ): 0

Ingrese la aceleración constante del móvil 1 (en $\left.\mathrm{m} / \mathrm{s}^{\wedge} 2\right): 20$

Ingrese el tiempo inicial del móvil 2 (en seg): 5
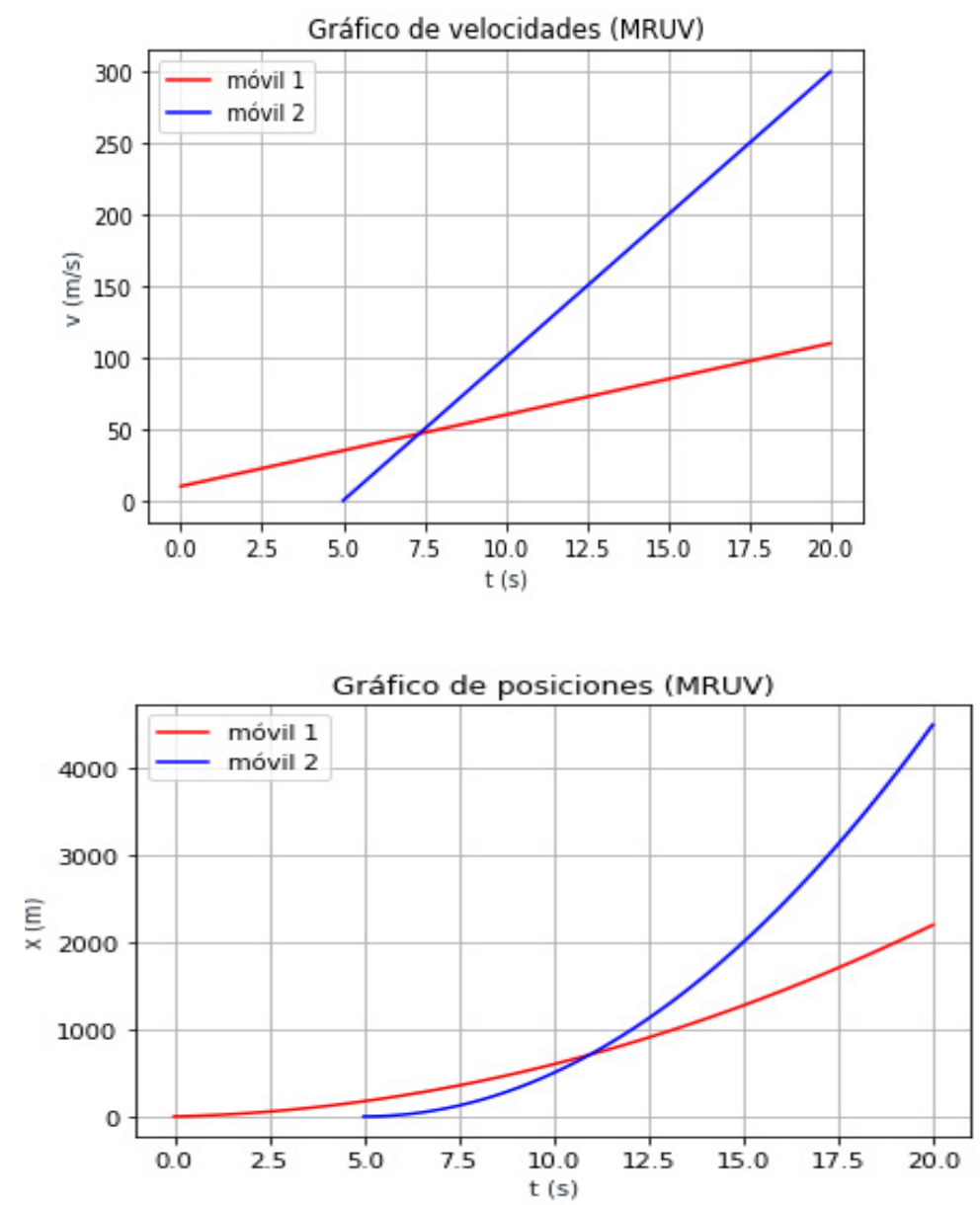

Figura 4: salida donde se grafican las velocidades y posiciones de ambos móviles que viajan en iguales direcciones, en una misma recta empleando el código MRUV. ipynb. La intersección representa la posición de encuentro al tiempo de encuentro. En la gráfica de velocidades puede observarse la mayor pendiente en velocidad del móvil 2 (recta azul), dado que posee una mayor aceleración. 


\section{Sistema masa-resorte}

En este caso se trata de una masa suspendida que cuelga de un resorte de constante elástica $k$ y que es estirado/comprimido una distancia yo de la posición de equilibrio del sistema.

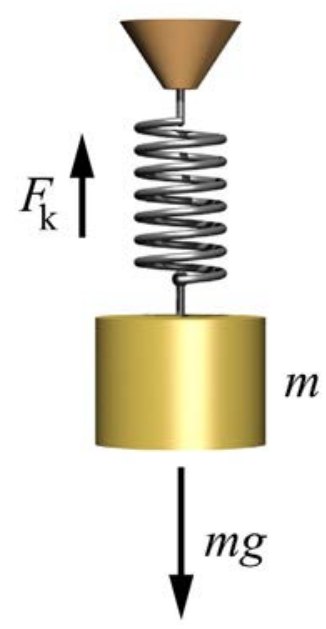

Luego, al iniciarse el movimiento, la masa se desplaza con velocidad en la dirección contraria al estiramiento/compresión. La amplitud de dicha oscilación va disminuyendo, bajo la acción de la fuerza viscosa y que se estima a partir del coeficiente de arrastre

Ingrese la constante del resorte $(\mathrm{N} / \mathrm{m}): 1$

Ingrese la masa (en $\mathrm{kg}$ ): 1

Coeficiente de arrastre D (en $1 / \mathrm{m}): 0.05$

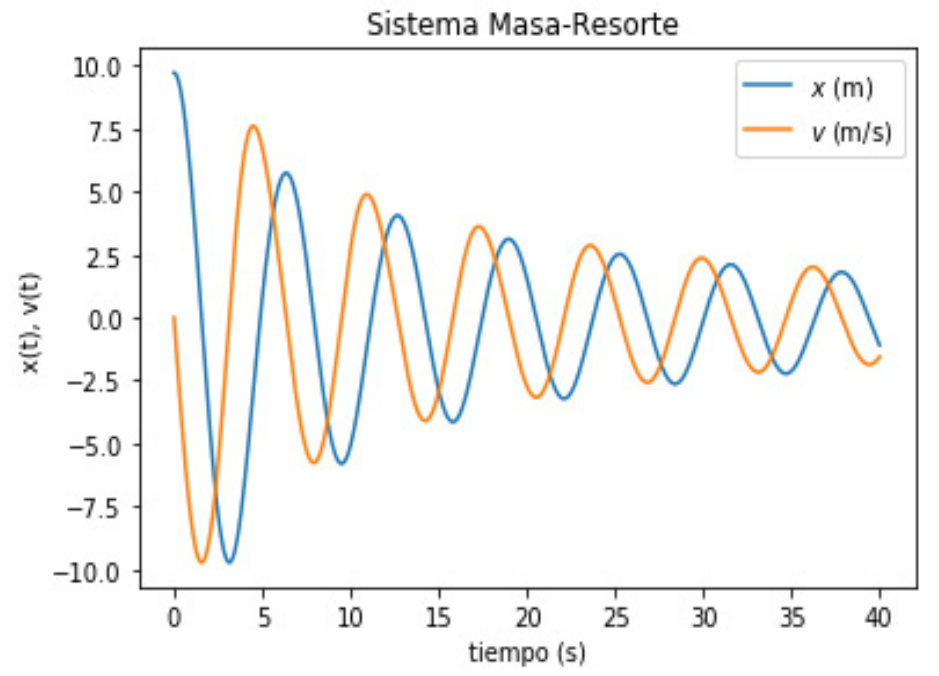

Figura 5: Amplitud de oscilación y velocidad en la dirección vertical, para una masa vinculada a un resorte y que es estirada/comprimida una distancia inicial de $10 \mathrm{~m}$ 


\section{Experiencias de Óptica Física}

También se desarrollaron códigos en Python para mostrar gráficamente las intensidades luminosas de las franjas que se observan en experimentos de Difracción de una y de dos rendijas. Se describen a continuación los dos códigos "Difracción. ipynb" y "Difracción dos rendijas.ipynb"

\section{Difracción de una rendija}

El primero de ambos corresponde a la situación donde un frente de onda plano de radiación luminosa se difracta luego de incidir normalmente sobre un plano que contiene una ranura [Serw]. La aproximación de la difracción bajo la condición de Fraunhofer se presenta cuando la distancia de la pantalla es mucho mayor que el tamaño de la rendija. Luego de difractar, el frente de onda se deforma y en su plano medio adopta una simetría circular. En el caso de rendijas rectangulares, se observa un patrón de franjas paralelas. La figura 6, representa esta última situación.

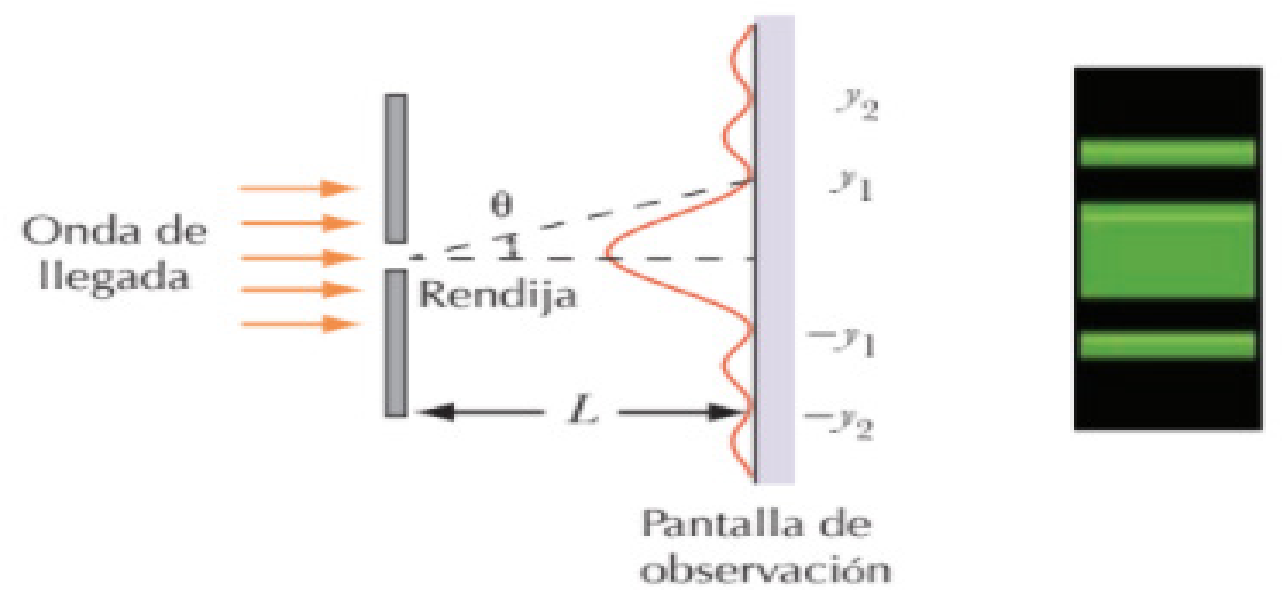

Figura 6: Patrón de Difracción de Fraunhofer de un frente de onda plano incidiendo normal al plano de la rendija de ancho a. Los mínimos de intensidad (franjas oscuras) corresponden a las posiciones y1, y2, -y1, -y2, etc.

La intensidad relativa respecto al máximo, que se da en el punto/franja central de la pantalla, se describe mediante la ecuación:

$$
I_{r e l}(\theta)=\frac{I(\theta)}{I_{\text {máx }}}=\left(\frac{\sin (\pi a \sin (\theta / \lambda))}{\pi a \sin (\theta / \lambda)}\right)^{2}
$$

El código permite ingresar los parámetros del experimento: ancho de la rendija a, longitud de onda (Fig. 7) 
Ingrese la longitud de onda $\lambda$ (en $\mathrm{nm}$ ): 450

Ingrese el ancho de ranura a (en nm): 1500

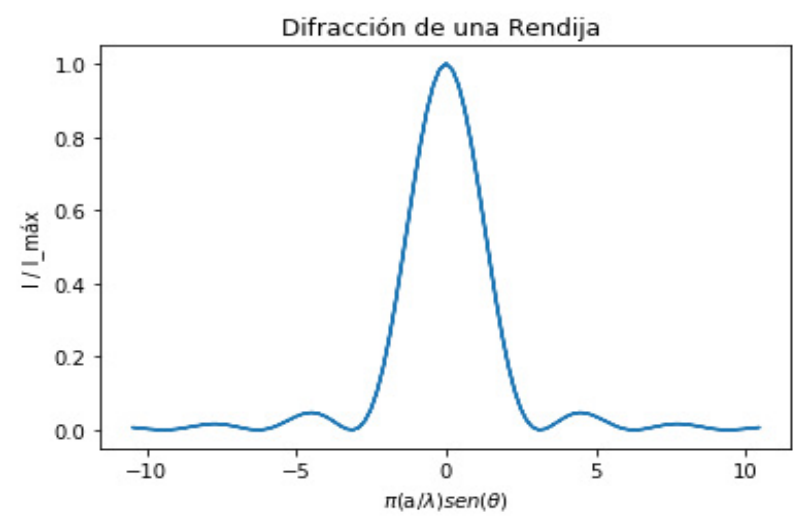

Figura 7: gráfico de la intensidad relativa de un experimento de difracción bajo las condición de Fraunhofer, en función de los parámetros ancho de la rendija, a, y longitud de onda del frente plano,

\section{Difracción de dos rendijas}

En el experimento simulado mediante el código "Difracción Dos Rendijas.ipynb" nos encontramos en una situación de aproximación de Fraunhofer pero para la cual el frente de onda plano incide normalmente sobre un plano que contiene dos rendijas de ancho a, separadas una distancia $d$. El patrón observado, se corresponde con la superposición entre la difracción y la interferencia de dos rendijas (experimento de Young). La figura 8 representa esquemáticamente la experiencia y la figura 9 una salida del código descripto.

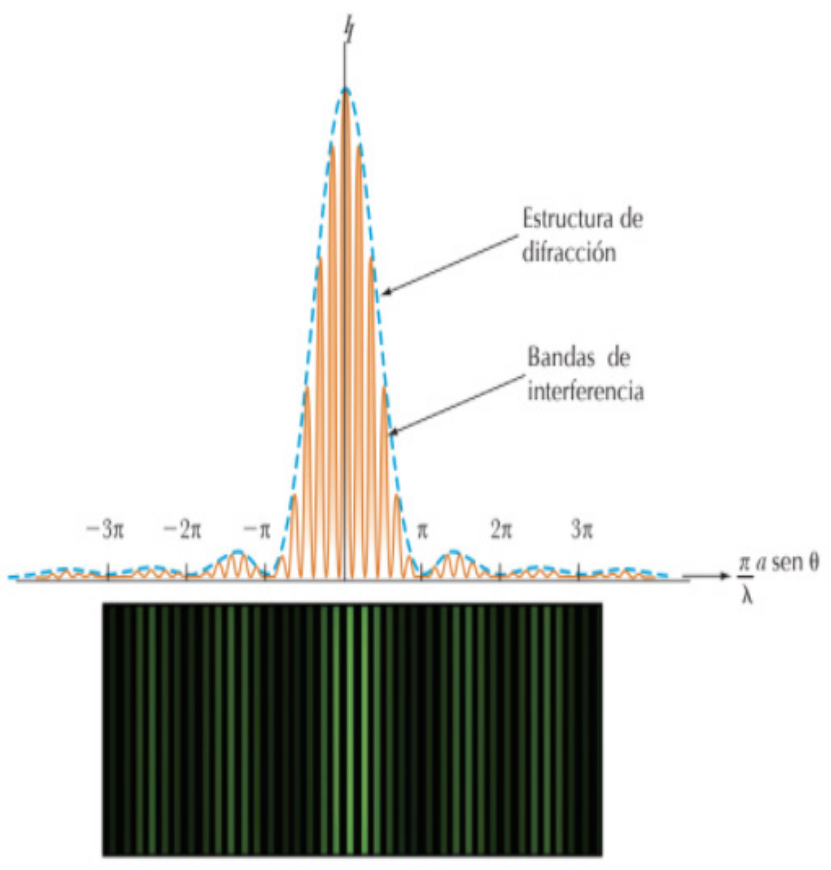

Figura 8: Patrón observado en un experimento de Young de dos rendijas, en condiciones de Difracción de Fraunhofer. 


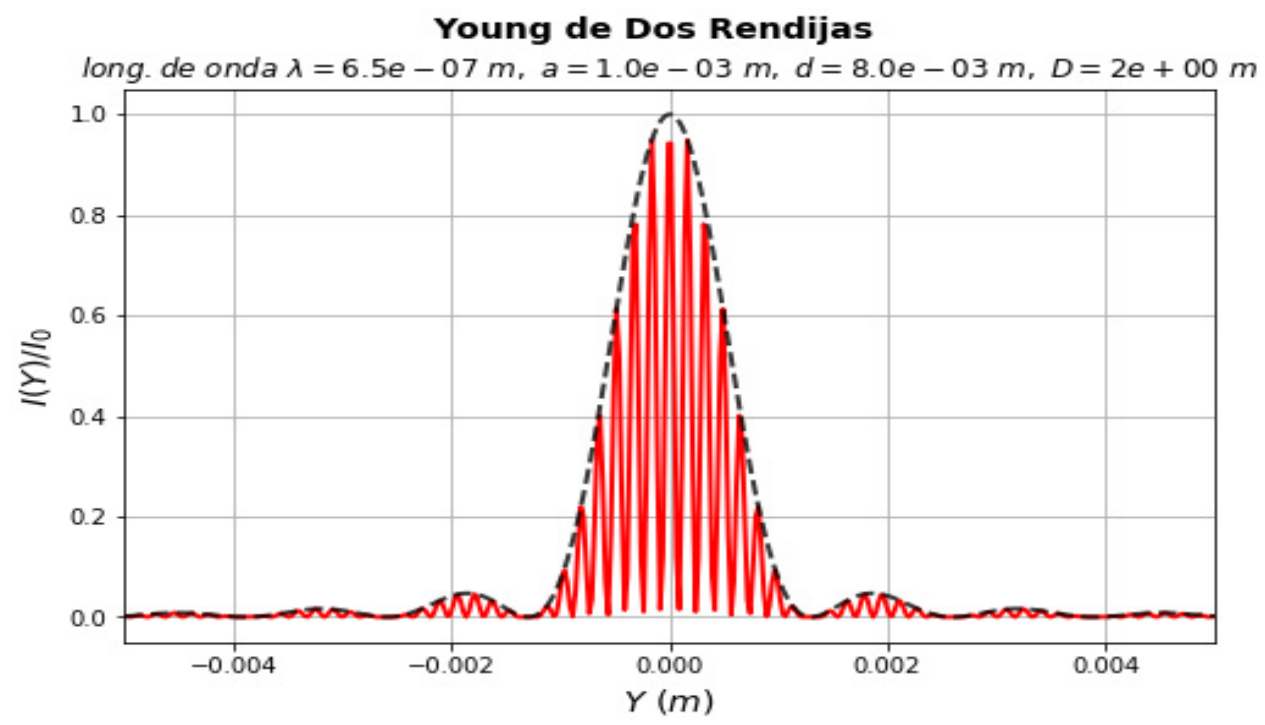

Figura 9: salida del código "Difracción de dos rendijas. ipynb" que permite experimentar las características del patrón de intensidades observado en un experimento de Young de dos rendijas, variando los parámetros físicos correspondientes.

\section{Descripción del contexto y de los participantes}

En contexto de modalidad de dictado de clases a distancia debido a la situación de aislamiento/distanciamiento social preventivo y obligatorio, dictado por las autoridades gubernamentales argentinas. Los alumnos y alumnas, pertenecientes a cursos semestrales de Física 1 del Departamento de Física de la Facultad de Ingeniería de la Universidad de Buenos Aires (FIUBA), fueron entrenados en los algoritmos y se les brindó herramientas básicas sobre los entornos de programación utilizados.

\section{Instrumentos}

Códigos escritos en Python 3 que se corrieron en Jupyter Notebook [Jupy] integrado al entorno Conda [Cond]. Los alumnos pudieron descargarlos de la Plataforma Moodle del Campus Virtual de la FIUBA y experimentar con los mismos en forma asincrónica. En el enlace https://github.com/fsacconeUBA/Physics puede accederse a los códigos Python compartidos en la experiencia: Caída Libre.ipynb, MRU. ipynb, MRUV.ipynb, Gravitación.ipynb, Masa-resorte.ipynb, Difracción.ipynb y Difracción dos rendijas.ipynb

\section{Procedimiento}

Se presentaron y describieron en la plataforma Meet de Google durante el dictado de clases y se compartieron en el Campus Virtual FIUBA de plataforma Moodle. Se consultó sobre la experiencia a los estudiantes con encuestas en Google Form. 


\section{Resultados}

De la encuesta voluntaria y permanente surge que la experiencia tiene buena acogida. Una amplia mayoría de quienes respondieron, pudieron correr los códigos, menos de la mitad no tenía antecedentes en programación y la mayoría mostró una comprensión de los algoritmos. Al consultarles sobre su experiencia global con el curso, la mayoría de las respuestas se ubicaron en " muy bueno-excelente", sin opiniones "malo" y minoría de "regular-bueno". A continuación, un par de comentarios dejados por los estudiantes: "...opino que se puede llevar la enseñanza de los temas de física 1 a otro nivel con programación...", "Es muy buena la idea de enlazar las materias para que al ingreso se tenga una idea de la verdadera utilidad de los temas...", "...parece ser una herramienta muy útil"

En las siguientes imágenes puede verse el resultado de la encuesta.

¿Pudiste correrlos?

21 respuestas

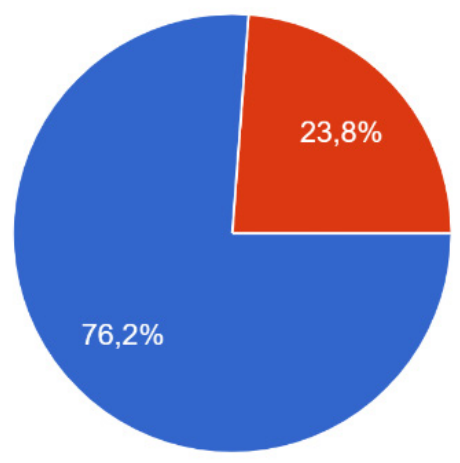

Sí

No

¿Tenías conocimientos de programación?

21 respuestas

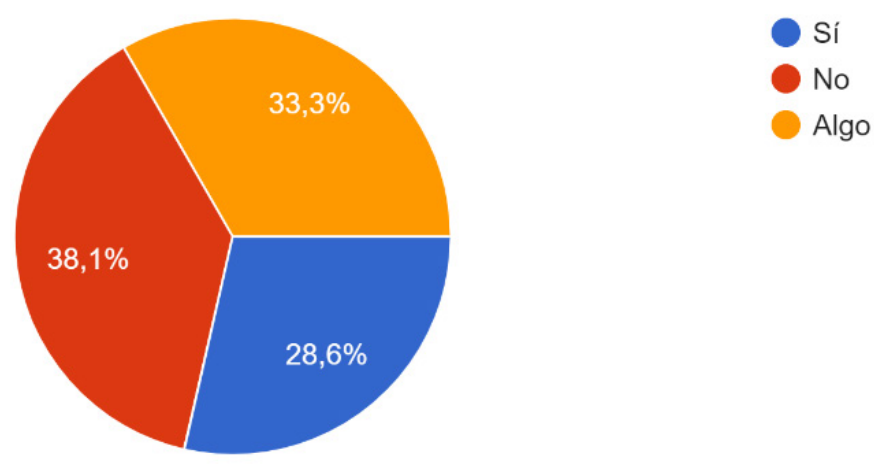


¿Te resultaron complejos?

21 respuestas

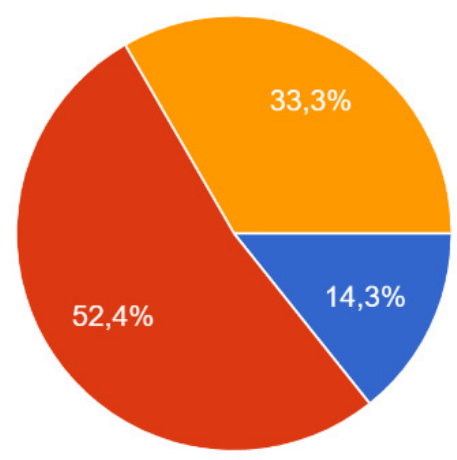

Del 1 al 5, ¿cómo calificarias la experiencia de modelado y simulación de problemas físicos usando Python?

21 respuestas

15

10

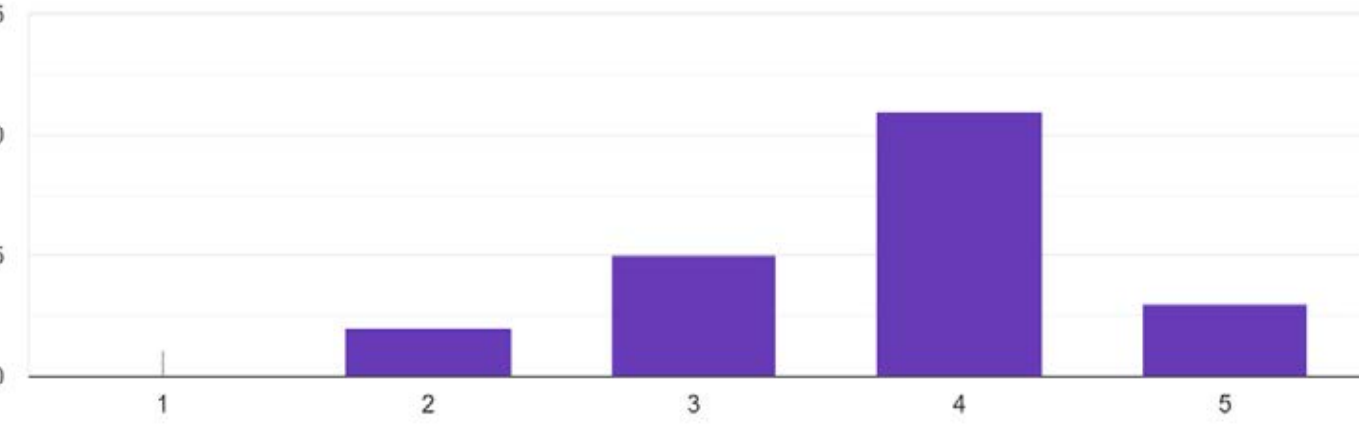

\section{Discusión y conclusiones}

De la experiencia, surgida a partir del curso de la materia de Física 1 de la FIUBA en modalidad a distancia, se verifica que la complementación de los aprendizajes de las bases teóricas de Mecánica Elemental y de Óptica Física con el desarrollo de códigos propios entre docentes y estudiantes, es de gran utilidad para la profundización de los conceptos. Los alumnos y las alumnas han podido trabajar asincrónicamente con los códigos, según su propio ritmo y conocimiento del lenguaje, luego de una presentación de los mismos durante las clases en modalidad virtual.

Estos códigos permiten, a las y los estudiantes, familiarizarse con un lenguaje de programación como Python, el cual tiene un enorme potencial en las carreras CTIM dada su aplicación en procesos de Automatización, Ciencia de Datos e Inteligencia Artificial. De este modo, los estudiantes pueden llevarse un aprendizaje útil, ya en la fase temprana de su carrera, que podrán ir profundizando y aplicarla en la etapa profesional. 
Finalmente, cabe mencionar que las opiniones vertidas por los y las estudiantes, acerca de la experiencia, la califican como estimulante para su aprendizaje de los contenidos de la materia y mejora su valoración global del curso.

\section{Referencias}

[Bob] Bobrof, J.; Bouquet, F.; Delabre, U. (2020, May 27). Teaching experimental science in a time of social distancing. The Conversation, https://theconversation. com/teaching-experimental-science-in-a-time-of-social-distancing-139483

[Cepa] CEPAL-UNESCO (2021), La educación en tiempos de la pandemia de Covid 19 (Informe), https://repositorio.cepal.org/bitstream/handle/11362/45904/S2000510_ es.pdf?sequence=1\&isA/lowed=y

[Cond] Conda (2021), https://conda.io/projects/conda/en/latest/index.html

[Delg] Delgado, F. Teaching Physics for Computer Science Students in Higher Education During the COVID-19 Pandemic: A Fully Internet-Supported Course. Future Internet 2021, 13, 35

[Jupy] Proyecto Jupyter (2021), https://jupyter.org/

[Klei] . P. Klein, L. Ivanjek, M. N. Dahlkemper, K. Jeli i , M.-A. Geyer, S. Küchemann, and A. Susac, Studying physics during the COVID-19 pandemic: Student assessments of learning achievement, perceived effectiveness of online recitations, and online laboratories. Physical Review - Physics Education Research 17, 010117 (2021)

[Kius] Kiusalaas, J. (2013), Numerical Method in Engineering with Python, Ed.: Cambridge University Press.

[Malt] Malthe-Sorensen, A. (2015), Elementary Mechanics Using Python - A Modern Course Combining Analytical and Numerical Techniques, Ed.: Springer.

[OBri] Daniel J. O'Brien. A guide for incorporating e-teaching of physics in a post-COVID world, American Journal of Physics 89 , 403-412 (2021)

[Phet] PHET Colorado (2021), Simulaciones Interqctivas de Física, https://phet.colorado.edu/es/simulations/filter?subjects=physics\&type=html\&sort=alpha\&view=grid

[Pyth] Python (2021) The Python Tutorial, https://docs.python.org/3/tutorial/index. html

[Serw] R. Serway y J. Hewitt (2009, 7ma. Edición), Física para Ciencias e Ingeniería, Vol. 2, - Cengage Learning, México DF 


\section{Ponele Onda a tu Voz y Contalo en Forma de Podcast}

\section{Federico Emanuel Ravera Marbán}

Universidad Católica Argentina

Federico_ravera@uca.edu.ar 


\section{PONELE ONDA A TU VOZ Y CONTALO EN FORMA DE PODCAST}

Federico Emanuel Ravera Marbán

Universidad Católica Argentina

Federico_ravera@uca.edu.ar

\section{Resumen}

Las nuevas formas de consumo y el contexto de enseñanza virtual han ocasionado que las estrategias y métodos de transmisión de contenidos tengan modificaciones en su forma tradicional de aprendizaje y difusión. El confinamiento y las clases virtuales han obligado a los docentes a adaptar sus encuentros curriculares de una forma más atractiva y dinámica, aprovechando incluso los recursos tecnológicos brindados por diferentes plataformas. Justamente, es en este contexto tan particular donde el podcast se ha convertido en una forma de consumo muy usada por los jóvenes, con lo cual puede ser un recurso de aprendizaje y difusión de contenido académico y educativo.

\section{Palabras clave}

Podcast - Enseñanza - TICs - Tac. 


\section{Introducción}

\section{Problema}

Los entornos de enseñanza virtual ocasionaron que los docentes adapten sus contenidos académicos s y se replanteen su forma de transmisión, para poder tener una mejor recepción y participación con sus estudiantes.

\section{Antecedentes}

Los medios de comunicación y las formas de interacción que los usuarios tienen con ellos se muestran en constante cambio con el correr del tiempo. Cambios y formas que a la vez deben ser comprendidos y analizados en un contexto determinado, es decir, en tiempo y espacio; donde las mediaciones y posibilidades tecnológicas han favorecido diversas formas de interacción y producción acompañadas de nuevas maneras de consumo.

La revolución de internet ha posibilitado tanto a los usuarios como a los medios de comunicación poder acceder a producciones, contenidos, programas, discursos, segmentos, entrevistas y formatos multimediales que abarcan desde diferentes ámbitos hasta plataformas.

Si tenemos que mencionar algunas de consecuencias (o resultados) ocasionados por estos nuevos soportes comunicaciones se puede hacer referencia a la hibridación discursiva, la ruptura de la transmisión en "vivo" propiamente dicho, la aparición de nuevos medios de comunicación (independientes, alternativos, comunitarios), nuevas producciones y el uso de diferentes soportes tecnológicos para poder apreciar e interactuar con los diferentes contenidos ofrecidos en "la era de la hiperconectividad" cómo lo ha mencionado en su momento el comunicador Roberto Igarza.

Con respecto a la ruptura del "vivo" (también denominado consumo a la carta) en referencia a las producciones multimediales, se propone en este caso tomar como punta de iceberg la aparición de los podcast para lo cual es conveniente utilizar la definición comunicador Tony Sellas Guell, quien en el apunte de la materia "Radio y de nuevos formatos digitales de la universidad" de la Universidad de Catalunya, define que el podcasting es un sistema de distribución de archivos de audio, de forma automatizada, mediante la suscripción que realiza el usuario en base a los intereses que desee escuchar (2007,p2).

Mediante la revolución de internet, cualquier usuario que posea una computadora y tenga acceso a la web, puede tanto producir como escuchar un contenido audiovisual cuando lo desee, sin importar la relación de tiempo y el espacio mencionada anteriormente. Esto ha ocasionado que se puedan escuchar (o incluso ver y compartir) entrevistas, acústicos, secciones radiales, series, programas televisivos, fragmentos, recortes, conferencias y videos en el momento que los usuarios o cibernautas lo deseen. Sólo se necesita contar con un dispositivo (celular, Tablet, pc, Smart TV) que se pueda conectar a internet para disfrutar de los contenidos en cualquier momento o lugar. Este concepto, años atrás, era impensado de llevar a cabo. Si un oyente no escuchaba la entrevista radial en vivo, dependía del comentario de sus allegados para saber qué fue lo dijo el entrevistado. Como sostiene el mencionado comunicador Tony Sellas "el podcasting es un canal mediante el cual se pueden distribuir contenidos audiovisuales a un público muy amplio” (2007, p11). 
En la actualidad, las producciones audiovisuales pueden verse y escucharse en cualquier momento y lugar. El consumo a "la carta" es habitual en los usuarios que miran su serie favorita viajando en tren o sentados en el sillón de su casa después de comer. Los audios de las secciones radiales se comparten por las redes sociales de las emisoras, donde los usuarios a la vez continúan difundiendo el contenido a sus contactos, los cuales, a la vez, se escuchan en un momento posterior a su emisión, confirmando la ruptura del "vivo". Estamos en presencia de una generación que al nacer ya contaba con esta forma de consumo y es habitual en su vida cotidiana. Les cuesta comprender que antes se vivía sin Youtube y sin conexión permanente.

Un factor fundamental es la tecnología con la cual el usuario consume y puede acceder a estos contenidos. Anteriormente, las producciones que estaban sustentadas en la imagen sólo se podían apreciar mediante un televisor; las ediciones gráficas se podían leer por medio de la compra de diarios o revistas y los programas de radio se escuchaban únicamente a través de un dispositivo radial, ya sea portátil o fijo. El consumo estaba supeditado a la producción de contenidos que confeccionaban los medios de comunicación. Esto cambió. Primero fueron las computadoras personales las que permitieron al usuario poder tener acceso contenidos digitales producidos por fuera de los medios masivos de comunicación, mediante blogs o plataformas webs independientes por citar algunos. Los usuarios comenzaron a crear y publicar productos que podían ser apreciados por cualquier navegante virtual. Posteriormente los celulares de tercera generación se convirtieron en el dispositivo más utilizado para el consumo multimedial. Actualmente, con un celular se pueden producir, crear y consumir todos los contenidos digitales que venimos mencionando. Se puede ver el acústico que una banda musical está haciendo (o hizo) en una radio, se puede leer una nota de formato gráfico, escuchar el programa radial favorito, ver el capítulo de una serie de televisión mientras se viaja en colectivo o escuchar un podcast mientras se sale a correr, por citar algunos ejemplos.

En el congreso Red COM (2008) que se llevó a cabo en la ciudad de Salta, una de las conclusiones que se compartieron sobre la principal característica de estos nuevos medios fue la siguiente:
"Se encuentran atravesados por lo multimedial y se retroalimentan constan- temente entre sí provocando una hibridación entre los tradicionales soportes radiales, audiovisuales y gráficos, es la constante interacción y conectividad que tiene el usuario como resultado de los avances tecnológicos, mediante los cuales se encuentra integrado en una red que posee múltiples dispositivos digitales que le permiten una constante conexión a los productos y contenidos que se suben a la red". (Red COM, 2008, p.5)

Los tiempos cambian y las nuevas formas de producción y consumo también. Esto genera nuevos hábitos en los usuarios y también en la manera de vincularse con los contenidos. Y hay una generación que nació con estas nuevas formas de consumo y producción: los jóvenes. Denominados "generación z" por algunos, pero lo cierto es que estos usuarios que tienen entre 13 y 24 años poseen formas de consumo distintas a las tradicionales y asimilan de manera casi natural los cambios comunicacionales actuales. Estos jóvenes, que nacieron con la revolución tecnológica y la expansión de internet, tienen incorporados los conceptos que se mencionaron anteriormente y para ellos es lo más normal del mundo poder ver o escuchar un contenido cuando lo deseen, donde el tiempo y el espacio pasan a otro plano. Ellos desconocen lo que 
implicaba esperar una semana para ver tu serie favorita en el horario pautado por el canal de aire, o sintonizar la radio en un determinado día porque el cantante de rock del momento iba a brindar una entrevista.

Estas nuevas generaciones, consumen los contenidos cuando ellos quieren y en el lugar que lo deseen. Ya sea mediante alguna plataforma gratuita, paga, por medio de la interacción en las redes sociales o visitando la home principal del sitio que desean. Basta solo con tener conexión y listo: consumo a "la carta".

\section{Nuevos entornos de educación digital}

Por lo expuesto anteriormente y por haberme perfeccionado en el ámbito radiofónico docente, considero importante y oportuno reconocer que las nuevas formas de consumo e interacción que tienen los jóvenes pueden ser aplicadas en los entornos de educación. Es por ello, que en esta ponencia se propone analizar y compartir una de las nuevas producciones multimediales que es poco utilizada en los ámbitos educativos: el podcast. Si bien en mi tesis de maestría me he centrado en las nuevas formas de consumo y los cambios de hábitos de escucha radial; en esta oportunidad, y considerando los contextos virtuales de enseñanza obligados por la pandemia de Covid-19, propongo reflexionar sobre el podcast como una herramienta de producción académica de contenidos, que beneficie tanto a estudiantes como a docentes.

En estos tiempos de confinamiento y clases virtuales mediante, los docentes nos vemos obligados a adaptar nuestros contenidos académicos. La pantalla permite y ofrece muchos aspectos positivos, como por ejemplo conectarnos desde casa, o no perder tiempo en viaje, o interactuar con contenidos de audio y video entre otros; pero también cansa. Agota tener una clase mirando la pantalla del celular o leer un apunte digitalizado desde en una Tablet. Las materias que tienen mucho contenido "práctico" se ven afectadas. Hay muchos distractores que atentan contra las clases y se ha comprobado que el tiempo de atención no es el mismo que en entornos presenciales. Por citar algunos casos: no es lo mismo para un estudiante de periodismo hacer un programa de radio desde su casa que asistir a un estudio preparado y acondicionado; o para un estudiante de medicina tener un encuentro virtual con el médico de guardia que les cuenta un caso pantalla de por medio en vez de estar en contacto directo con el paciente y en el hospital. Quizás el podcast pueda utilizarse como una herramienta de complemento académico para que los estudiantes complementen el contenido una vez terminada la clase o para aprovechar una de formas de consumo de nuestros jóvenes estudiantes.

\section{Educar en tiempos de virtualidad}

La real academia española define la palaba educar como "Desarrollar o perfeccionar las facultades intelectuales y morales del niño o del joven por medio de preceptos, ejercicios, ejemplos" (en del.rae.es/educar). Si bien la frase tiene mucho criterio y es concreta en lo referido a la definición propiamente dicha, desde la experiencia docente universitaria, y ante el contexto mencionado, se pueden agregar varias relaciones y conceptos que pueden hacerla más enriquecedora.

Para comenzar la propuesta de ampliar la definición, se puede decir que educar también implica una responsabilidad por adaptarse a los tiempos actuales y a los cambios que se ven presentes en nuestro mundo, tanto en el ámbito propio de las carreras cómo en el contexto propiamente dicho. 
Las carreras universitarias y los perfiles se van modificando constantemente, ya sea por el propio dinamismo de las profesiones o por la aparición de nuevos puestos de trabajo surgidos es esta era de globalización. Carreras nuevas, nuevos espacios de trabajo, replanteos tradiciones y cambios históricos, obligan a los docentes y a los establecimientos educativos a tener una actualización constante en sus contenidos y en las formas de transmisión.

Sin ir más lejos, este contexto de pandemia obligó tanto a docentes como a estudiantes a formarse mediante clases virtuales, lo cual implicó un cambio rotundo en la forma de transmisión de contenidos, usos de plataformas, dispositivos, digitalización de material, programas y contenidos de las materias, adecuación del tiempo de clases junto con los ya conocidos problemas de conectividad y de espacios de trabajo y estudio por mencionar algunos.

Docentes y estudiantes han tenido que adaptarse a los tiempos actuales con una pandemia que modificó los espacios y las relaciones en todo sentido. Se pueden discutir los beneficios y contras de la educación en pandemia en otra ponencia, pero lo concreto es que hoy los estudiantes de todos los niveles cursan las materias en condiciones de aprendizaje que no son las ideales debido a múltiples factores que pueden ir desde problemas de conectividad, falta de dispositivos hasta distractores propios de ámbito hogareño.

Sumado a lo anteriormente mencionado con respecto a la pandemia y la virtualidad, también se puede agregar que una de las obligaciones que tiene todo docente, implica estar en permanente contacto con esas modificaciones en post de la formación de los estudiantes para poder brindarles las herramientas adecuadas para los tiempos que corren. Por poner un ejemplo, se puede mencionar la formación universitaria de las carreras de comunicación, las cuales han ido cambiando con el correr de los años debido a los nuevos perfiles profesionales solicitados por los medios junto con la aparición de nuevos puestos de trabajo. Hoy un periodista debe contar con los conceptos tradicionales de la profesión, pero a ellos debe sumarles conocimientos de edición de audio, manejo de video, discursos de redes sociales, herramientas sobre audiencias y manejo de la tecnología. La formación periodística actual requiere nuevos conceptos de estudio junto con nuevas de transmisión de contenidos, en otras palabras, implica para el docente un aprendizaje constante para poder lograr la transmisión adecuada del conocimiento.

Esta situación reflejada en el área de la comunicación puede tranquilamente aplicarse en cualquier disciplina o ámbito. Las carreras y contextos profesionales cambian. La labor docente también.

Otro concepto que se puede agregar a la definición citada inicialmente de la Real Academia Española es el de la forma de transmisión del conocimiento. La oralidad atraviesa todas las disciplinas y los seres humanos nos comunicamos mediante la palabra. La palabra convence, persuade, contagia, intriga, aclara y muchas veces nos deja con más dudas que certezas (lo cual es muy bueno porque nos obliga tanto a docentes como a estudiantes a pensar una solución para esos interrogantes). Entonces se debe tener en cuenta que, al momento de compartir el conocimiento, hay que prestarle atención la forma en la que se cuenta ya que ese recurso será clave para logar que los estudiantes escuchen, palabra no menor en los tiempos actuales. 
El escuchar implica prestar atención, refiere internalizar y analizar lo que el otro está contando. Los docentes al realizar esta tarea están incorporando en los estudiantes conceptos, ideas, definiciones para que ellos las comprendan y puedan formarse como profesionales. Pero para que los estudiantes escuchen, es necesario contarlo de la forma adecuada: con pasión, con ganas de compartir el conocimiento, con contenidos actuales y comprendiendo los canales de emisión y la recepción de nuestros estudiantes.

Estimado lector, cómo puede apreciar, a la definición utilizada como punto de partida le estamos agregando muchos aspectos y conceptos, los cuales la van convirtiendo en una definición cada vez más completa y enriquecedora.

Ahora bien, así como las profesiones y los mercados van modificando la formación y los perfiles de las carreras, existen también nuevas herramientas de enseñanza que vale la pena explorar. Mediante la revolución tecnológica y el acceso a las nuevas tecnologías, los docentes pueden aprovechar diferentes recursos para lograr una mejor recepción de los conceptos compartidos con los estudiantes.

El podcast es una de las nuevas formas de consumo en nuestro país qué dentro del mencionado contexto de pandemia y virtualidad, es muy utilizado por los estudiantes. El sitio Podcaster@s, portal reconocido en ámbito de los podcasts y que incluso es tomado como referente por la firma Spotify, arrojó el siguiente resultado en la encuesta 2021 colaborativa que se hizo sobre el consumo de podcasts:

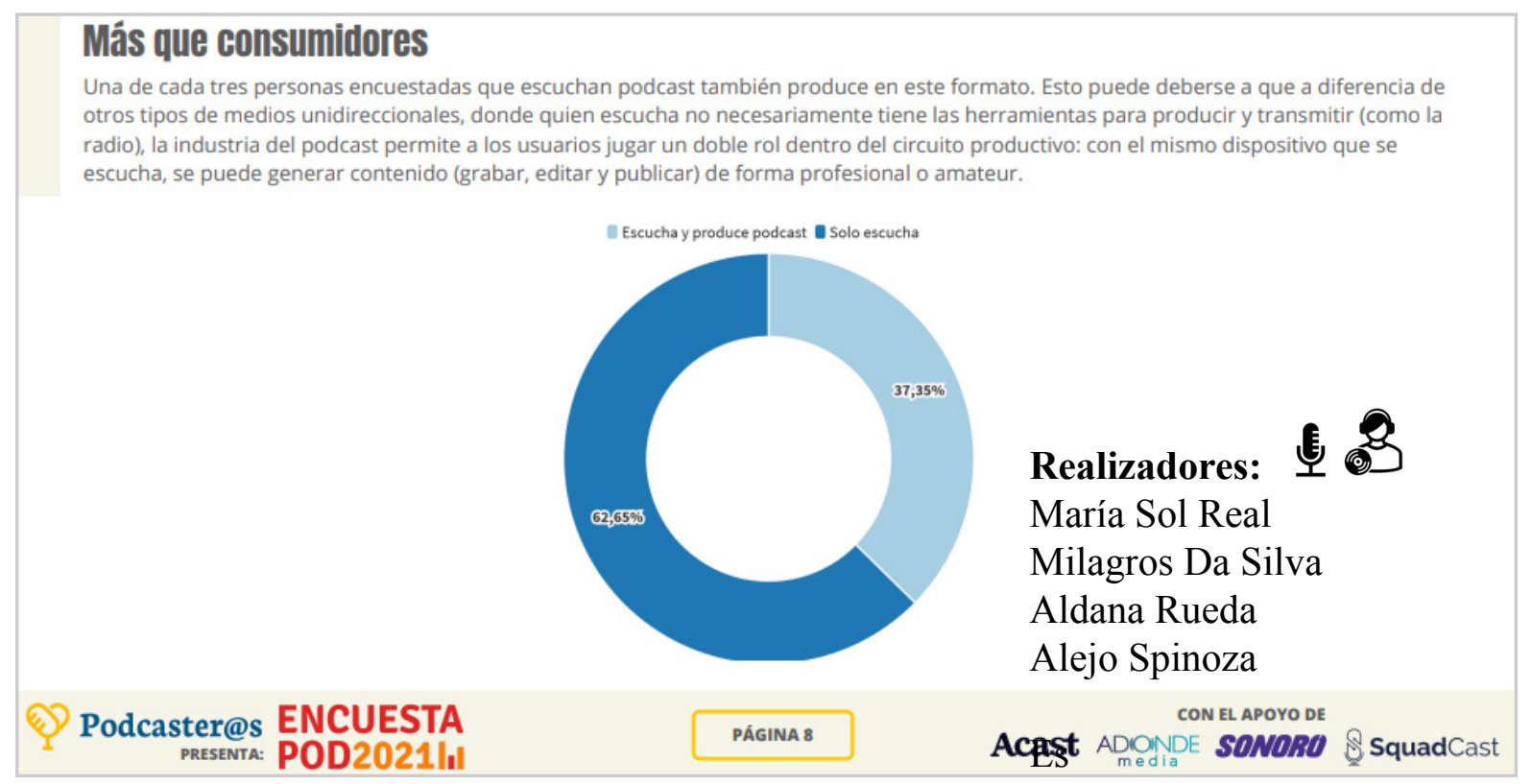

*Referencia: Reporte Encuesta Pod2021, 2021, p.8 


\section{El podcast: una nueva forma de aprender}

\section{Breve contexto histórico de una nueva producción sonora}

El podcasting es una nueva forma consumo que tiene sus orígenes por los años 90 , donde mediante la revolución tecnológica y el acceso a internet, diferentes creadores se dieron cuenta que podía subir sus ediciones sonoras en la nube para que los usuarios los puedan escuchar dónde quieran y cuando quieran (Sellas T. 2007, p8).

La posibilidad de ofrecer contenidos sonidos alojados en blogs, páginas webs o plataformas multimediales organizó nuevas formas de escucha y de producción sonora. Si bien todo usuario necesita poder contar con acceso a la web para poder acceder o escuchar los podcasts alojados, la expansión de internet comenzó a propagarse también hacia la telefonía móvil lo cual ocasionó que los usuarios puedan acceder a los contenidos mediante nuevos dispositivos y plataformas accesibles. Es decir que, si bien en los inicios de la revolución de internet un usuario necesitaba de un ordenador con cable de red para poder escuchar los podcasts, en la actualidad basta con tener un smartphone para poder escuchar o descargar los archivos sonoros cuando quieran, dónde quieran y por la plataforma que sea más amigable.

De esta manera, el podcast originó una nueva forma de consumo y modificó la relación de espacio/tiempo en lo referido a producciones de índole radial, comentarios, terturlias, comentarios o entrevistas que anteriormente sólo podían ser escuchas en vivo. Se modificaron los espacios virtuales de consumo "a la carta" rompiendo el modelo de continuidad y secuencialidad que anteriormente se conocía (Herreros, C, 1998, p. 16)

Se hace referencia a estos formatos porque desde la aparición del magazine (aparato de cinta), pasando por los cassettes, cds, ipood y pendrives; las personas tuvieron la posibilidad de escuchar música cuando querían mediante diferentes dispositivos. Pero en lo referido a contenidos de producción propia, se puede decir que el podcast fue un cambio en la manera de producción y consumo. Cualquier usuario comenzó a producir contenidos propios. Es en esta etapa dónde comienzan a tener protagonismo las producciones de contenidos de forma autónoma, con nuevas formas de interacción y consumo por medio de nuevos canales virtuales de publicación. Como afirma Cebrían Herreros en su obra "Comunicación interactiva en los Cibermedios" surge la figura del prosumidor de contenidos, el cual es resultado de una combinación de las palabras emisor-receptor, y a partir de este momento cualquier persona puede crear sus propias producciones y subirlas a la web (Herreros C, 2009, p.18).

Desde ya que en ese entonces no había plataformas tan accesibles y populares cómo las que actualmente se encuentran disponibles para los usuarios, pero por medio de blogs, páginas webs, servidores gratuitos, hardwares de edición libre o links, los usuarios podían acceder al contenido sonoro. Pero la posibilidad estaba y se fueron mejorando las condiciones de accesibilidad y producción con el correr de los (pocos) años.

Esto implicó dos cambios importantes que se pueden mencionar: 1) a partir de ahora cualquier persona con acceso a la tecnología y a internet podía crear y publicar contenido y 2) el usuario que recibía esa información podía escucharla donde y 
cuando quiera. Pero no es un dato menor volver a mencionar que en este espacio de "cibermedios" la mediación de la tecnología cumple un papel preponderante ya que para poder acceder a estas nuevas formas narrativas discursivas es necesario poder tener acceso a internet y contar con algún dispositivo de escucha.

El consumo a la carta se volvió una realidad y las búsquedas de las audiencias específicas fueron cada vez más puntuales y sofisticadas. El creador (llámese podcaster) que encontró un público acorde para su contenido, comenzó a ofrecer una serie de episodios que mediante la combinación sonora de los cuatro elementos que forman parte del discurso radiofónico (palabra, música, silencio y efectos sonoros) y comenzó a generarse un cambio de mentalidad tanto en manera de producir como de consumir: escucho cuando quiero y dónde quiero.

Inicialmente se puede decir que los primeros podcasts eran producciones sonoras de corta duración y que no estaban atados a la premisa de la actualidad. Nunca vencían. El contenido que se subía podía ser escuchado en cualquier momento porque el objetivo era subirlo en la web y que no perdiera vigencia.

Con el correr de los años esa premisa se fue modificando. Actualmente el usuario puede encontrar podcasts largos, otros más cortos, algunos con temas de coyuntura y actualidad, otros que analizan temáticas puntuales y particulares, algunos son entrevistas que se comprenden y tienen sentido en un contexto histórico determinado, hay muchos que experimentan el radioarte, hay de índole educativa, social, de bienestar, medio ambiente, etcétera. Pero la esencia es la misma, el usuario los escucha cuando quiere, dónde quiere y para ello necesita acceso a un archivo de audio que está alojado en la nube.

En una nota publicada por La Nación a mediados del año pasado, se compartieron los datos arrojados por la agencia Reuters Institute en un relevamiento realizado sobre el consumo de podcast en nuestro país y el artículo reflejó que desde el año 2014 existe un crecimiento sostenido en la producción y escucha de podcasts. El estudio mostró que un $31 \%$ de los argentinos relevados en centros urbanos han escuchado alguna vez un podcast. Las emisoras radiales han incorporado la producción de podcasts dentro de sus contenidos y los datos arrojados por una encuesta realizada por la agencia Drop the Mic sostuvieron que el teléfono móvil es el principal dispositivo elegido para la escucha de podcast. (Fuente: Lanacion.com.ar)

A continuación, se adjunta un gráfico con una publicación realizada por el sitio EIDigital quien publicó unos gráficos obtenidos por el portal Fastcompany en referencia al consumo de podcast desde el año 2014 hasta el 2020. (Fuente: ElDigital.com) 


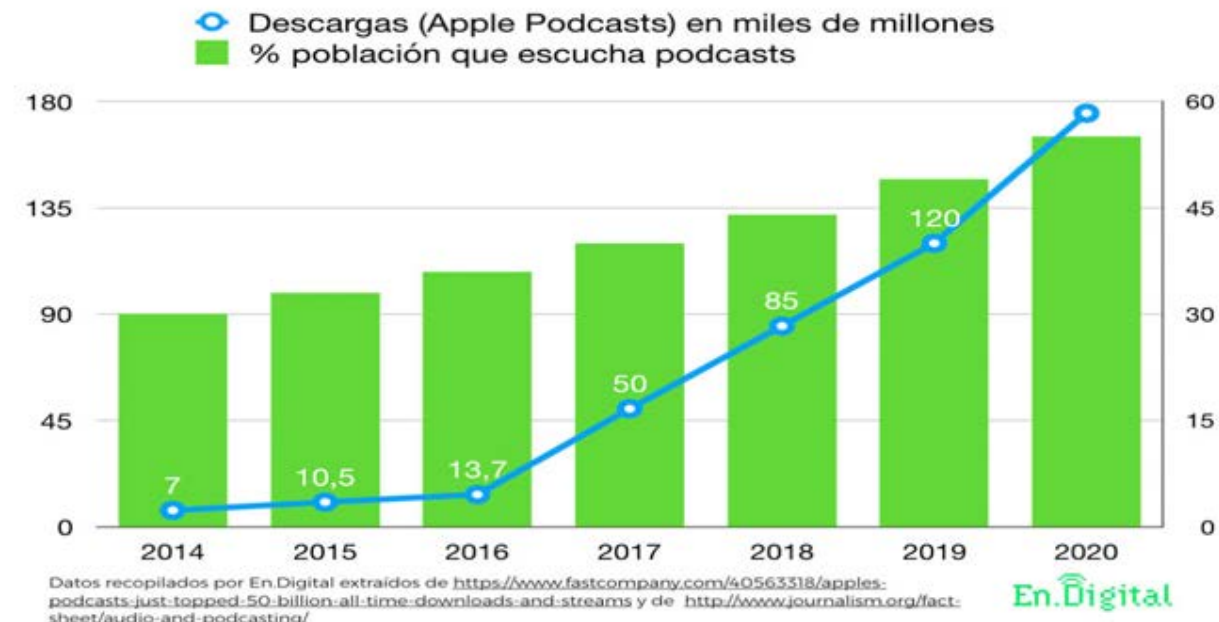

Sumado a ello, hay que mencionar que las plataformas de acceso han ido evolucionando con el correr de los años y el concepto de accesibilidad forma un rol preponderante en la actualidad. Plataformas como Sopotify, Ivoox, Mixcloud, Soundcloud y demás (por mencionar algunas) ofrecen a los creadores de contenidos y a su público una forma de acceso mucho más rápida y eficiente. Con herramientas que mejoran la segmentación de las audiencias y que incluso permiten la difusión mediante la vinculación con las redes sociales, donde cualquier similitud con Netflix no es pura coincidencia.

Se comparte a continuación un gráfico publicado por el sitio web "un billete chattanooga", donde especialistas en estudios de branding y consumos multimediales muestran las plataformas utilizadas para la escucha de podcast: Fuente Chattanooga.com

\section{¿QUÉ APLICACIONES USAN PARA ESCUCHAR PODCASTS?}

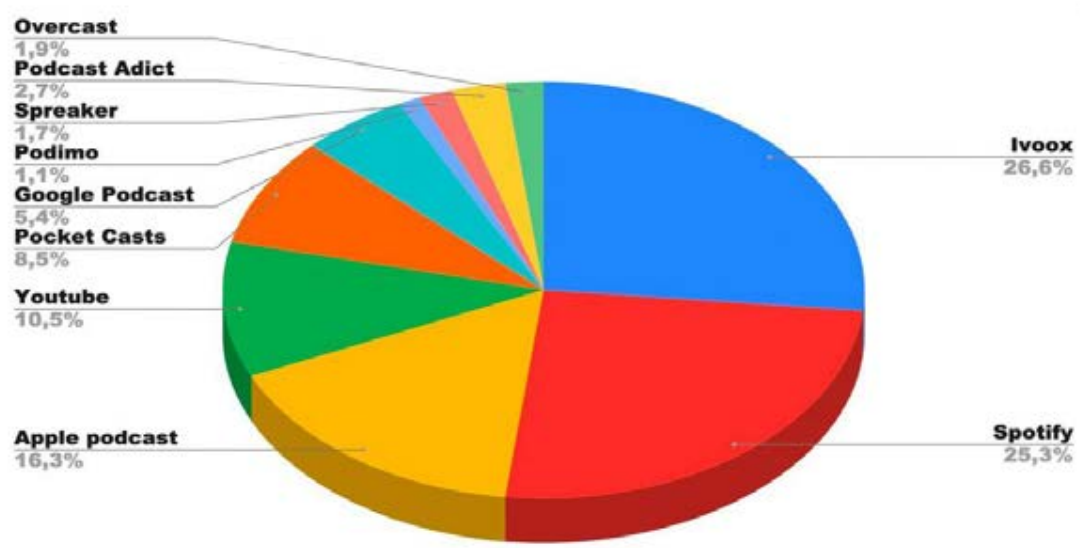




\section{El podcast: una nueva forma de aprender}

Como se mencionó inicialmente, el contexto de la pandemia por covid-19 obligó a los establecimientos educativos a modificar y actualizar sus contenidos en referencia a los entornos virtuales de educación. Si bien algunas casas de estudios ya contaban con experiencias de semi presencialidad o cursos virtuales, la mayoría de las instituciones tuvieron que invertir en tecnología, servidores, adaptación de contenidos, digitalización, formación y especialización de docentes y conocer nuevas formas de vinculación con los estudiantes de todos los niveles: inicial, primario, secundario, grado y posgrado.

Muchos docentes tuvieron que interiorizarse sobre estas nuevas formas de vinculación, tanto académica como interpersonal, para lograr transpolar los contenidos académicos que se brindaban en aulas o espacios académicamente adecuados (laboratorios de informática o ingeniería, estudios de radio, aulas de diseño, salas de plástica, clases de conservatorio, etc.) a plataformas de videollamadas virtuales como pueden ser Zoom, Google Meet o Microsoft Teams por mencionar algunas.

Esto implicó modificar y adaptar los contenidos y currículas a entornos completamente distintos dónde muchos de ellos contenidos tuvieron que explicarse de una manera diferente y, a la vez, esta situación implicó relacionarse con los estudiantes de una forma diferente.

Dentro de la mencionada adecuación, y hablando particularmente del área radial de enseñanza que es el área donde me desempeño, se puede decir que el consumo de los podcasts ha tenido crecimiento de escucha en nuestro país y se encuentra en una especie de auge. No sólo vinculado con el aumento del nivel de escucha, sino también con la producción de contenidos:

\section{Gustos y preferencias}

El Top 5 mantiene desde 2019 a Historia como la temática más elegida. Los podcast sobre espectáculos y política también siguen estando entre los favoritos. Sin embargo, tanto Arte como Tecnología disminuyeron su escucha respecto a la edición anterior de EncuestaPod, mientras que los shows de Investigación periodística y los de Comedia/Humor sumaron oyentes.

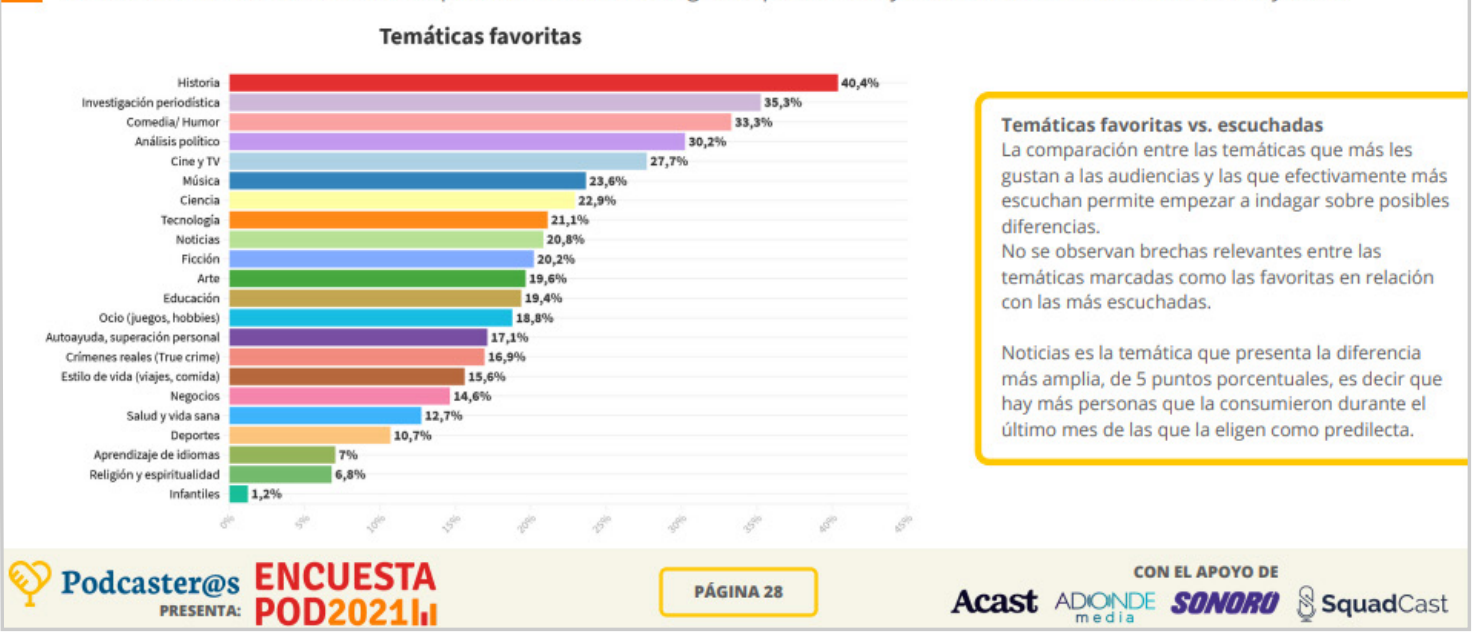

Fuente: Reporte Encuesta Pod2021, 2021, p.28 
El podcast se ha estabilizado como una forma de consumo en los jóvenes, quienes ahora en vez de escuchar la radio de forma tradicional, escuchan los contenidos que les interesan y por diversas plataformas.

Estas nuevas maneras de consumir contenido sonoro pueden ( $y$ deben) ser tenidas en cuenta por los docentes de todas las áreas y niveles. Si los estudiantes escuchan podcasts de series o música que son de su interés, quizás también puedan escuchar un podcast que el docente le ofrezca para complementar el contenido brindado en la clase.

Hay diversas maneras de relacionar y vincular los contenidos propios de cada carrea o unidad académica con el sonido y se puede aplicar en diversos niveles. Desde un cuento infantil para que posteriormente sea analizado en la sala de nivel inicial, hasta el planteamiento de un problema de ingeniería civil.

En una clase de historia el docente puede invitar a los estudiantes a escuchar un podcast el cual bajo un género de ficción puedan recrear una imagen visual (fomentando la imaginación) del suceso mediante una combinación sonora y contenido de estudio. Ese podcast puede tener recursos sonoros de archivo que, combinados por medio de una edición de sonido adecuada, recree en los estudiantes una imagen visual de manera tal que comprendan mejor lo que significó ese proceso para nuestro país.

Se puede citar el caso de un grupo de estudiantes universitarios de tercer año de la licenciatura en comunicación social de la Universidad Nacional de la Matanza quienes tomaron como objeto de trabajo sonoro la asignatura de "Historia" y su producción de podcasts fue llevada a cabo mediante un género ficcional, donde un grupo de chicos viajaban a través del tiempo para vivir en "vivo y en directo" (magia radial sonora mediante) sucesos históricos que se dictan en la secundaria.

Mediante un trabajo de investigación periodística, entrevistas con profesores de historia del ámbito de secundario, recopilación de archivos sonoros y teniendo en cuenta los contenidos de la materia aprobados por el Ministerio de Educación; este grupo de estudiantes también ahondó en la creatividad sonora ofreciendo a los docentes de secundario un podcast que buscó recrear los sucesos históricos en una forma original y adecuada con las nuevas formas de consumo juvenil mencionadas anteriormente.

Invitamos en esta oportunidad al lector a escuchar el episodio titulado "La Asunción", que hace referencia al retorno de la democracia donde los protagonistas serán testigos del discurso del presidente Raúl Alfonsín: (Ctrl + click mouse)

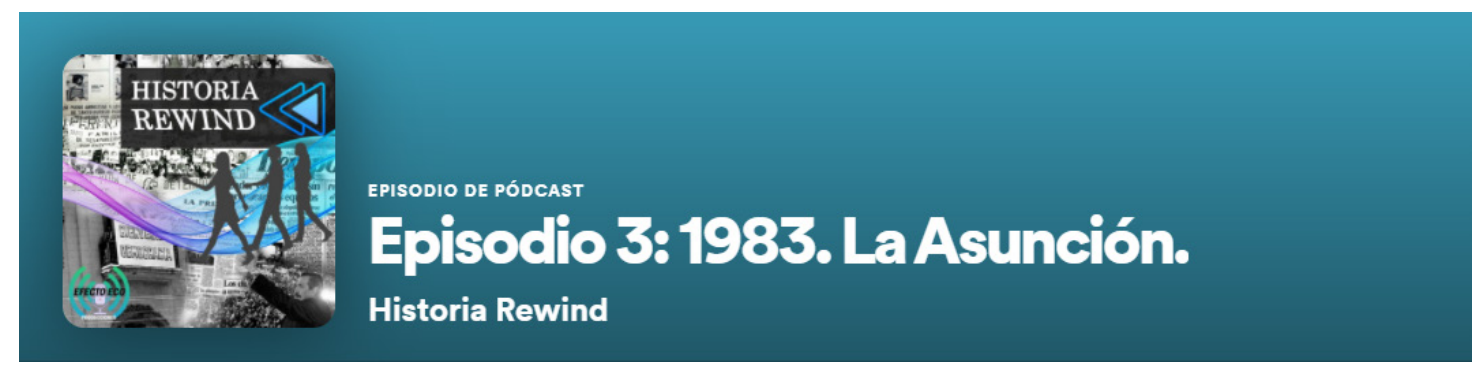


Si los jóvenes consumen podcast, quizás se pueda usar esta nueva forma de producción cómo una nueva manera de vinculación de los estudiantes con los contenidos académicos. Nadie habla de reemplazar la clase de historia con un podcast. Por el contrario, la propuesta es sumarle a la clase de historia una nueva herramienta de aprendizaje mediante un soporte que es muy utilizado por los estudiantes.

Armad Balsebre sostenía que el discurso radiofónico busca recrear una imagen visual en los oyentes mediante la combinación de los cuatro elementos anteriormente mencionados. El podcast tiene en su esencia, mucho de lo que menciona Balsebre. Hace trabajar la mente, obliga al usuario a imaginar... a pensar... a internalizar. Y esa quizás pueda ser una nueva forma para la transmisión de los contenidos académicos, puede ser un nuevo recurso de vinculación con los estudiantes, los cuales a su vez pueden escucharlo en la clase o cuando lleguen a sus hogares.

Otro ejemplo que se puede traer como referencia es el ciclo de podcasts denominado "Tres Minutos en la Edad Media" donde varios docentes universitarios cuentan en tres minutos diferentes hechos y temáticas vividas en la edad media. Por iniciativa de la Dra. En historia Mariana Zapatero, docente de la Universidad Católica Argentina, diferentes profesionales de varias universidades colaboraron en la creación del podcast. El ciclo llegó a tener de forma orgánica más de 12.000 seguidores que iban pidiendo por las redes sociales nuevos capítulos. En colaboración con Radiofónicos en vivo!, la radio digital de la Facultad de Ciencias Sociales de la UCA, se editaron mas de 20 episodios que abarcan desde la cocina medieval y los animales de la época hasta la vida y obra de varios. Los episodios están alojados en la plataforma de spotify y las escuchas siguen creciendo.

Compartimos con el lector el acceso al podcast y lo invitamos a sumergirse en una época distinta:

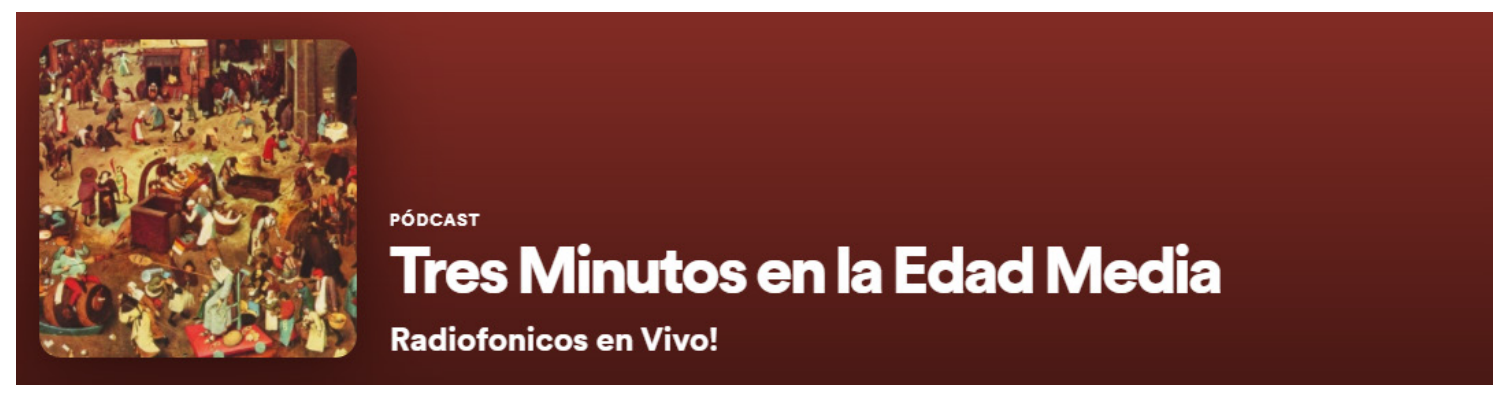

\section{SI LOS HACEMOS CREAR y JUGAR, TAMBIÉN LOS HACEMOS PENSAR}

En el apartado anterior, se hizo referencia a lo productivo que puede ser para un docente contar con el podcast como herramienta de enseñanza. ¿Pero qué ocurre si los propios estudiantes tienen que crear un podcast con contenido educativo y que a la vez sea entretenido?

En una de las materias de las cuales formo parte, se les propuso a estudiantes del tercer año de la carrera de comunicación social, crear podcasts educativos para estudiantes del secundario con contenidos que se dicten dentro de los planes de estudio aprobados por el ministerio de educación nacional. 
El desafío implicó que los futuros comunicadores tuvieran que interiorizarse sobre los temarios de las materias, elegir una de ellas, hablar con los docentes para comprobar si los contenidos eran los adecuados y ofrecer una propuesta atractiva y entretenida, ya que el público apuntado eran estudiantes de tercer año que lidia con muchos distractores.

Una de las propuestas elegidas por uno de los grupos fue sobre para la materia "Literatura", dónde la intención fue que los estudiantes que escuchen el podcast, además de prestar atención a los contenidos brindados en la pieza sonora, tuvieran que "jugar" con el contenido escuchado y si elegían la respuesta correcta podían llegar al final del podcast. La intención fue hacer un podcast educativo interactivo que implicara una participación activa por parte del usuario que lo escuche (que no sólo escuche, sino que además promoviera a la acción).

La respuesta correcta se elegía por medio del uso del "scroll" del reproductor de Spotify lo cual implicó un gran trabajo de edición por parte de los estudiantes creadores del podcast ya que las diferentes respuestas se encontraban distribuidas en distintos minutos del podcast. Es decir, que el ejercicio de escucha hacía al usuario avanzar o retroceder por la pieza sonora, fomentado la escucha y la participación interactiva con el podcast para poder llegar al final. Incluso, si el usuario completaba el recorrido, obtenía un cofre con alguna definición o frase literaria de algún autor a modo de recompensa.

Si el lector tiene ganas de interiorizarse sobre contenidos literarios y desea participar del desafío literario y juagar en el podcast, lo invitamos a que haga click en el siguiente enlace para intentar llegar al final del episodio que realizaron los estudiantes de la licenciatura en comunicación social de la Universidad Nacional de la Matanza: (Ctrl + click mouse)

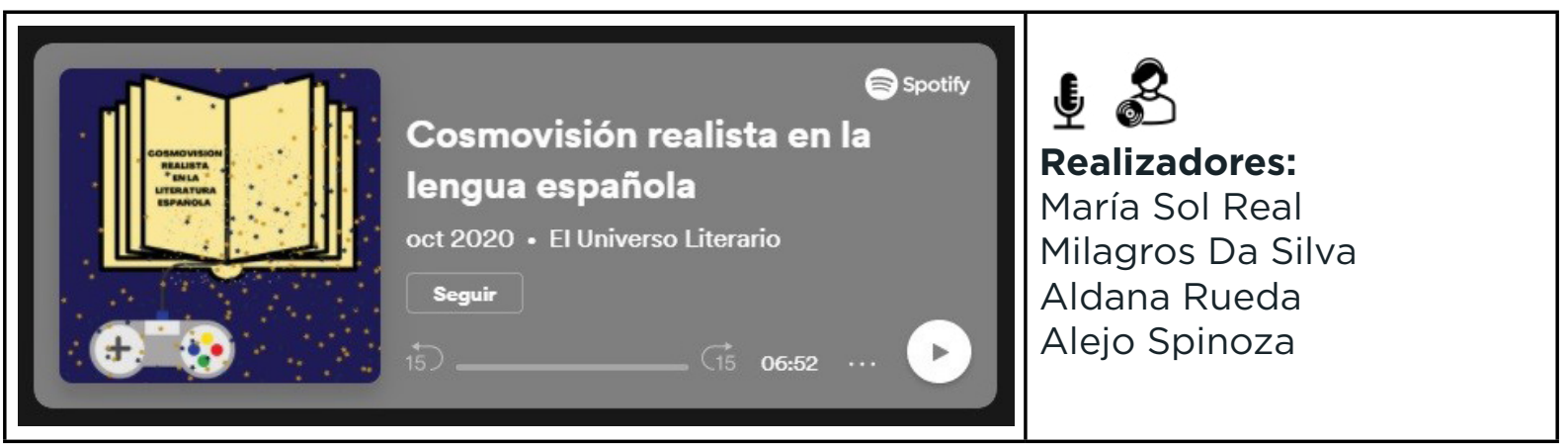

La propuesta implicó un doble desafío para los estudiantes creadores del podcast, ya sea desde el complejo sistema de montaje sonoro que tuvieron que realizar cómo la creación de un producto educativo que también sea atractivo para los estudiantes de secundario.

El "jugar para aprender" representó una manera diferente para intentar que los contenidos educativos sean escuchados por el público juvenil al cual está dirigido. Este proceso también fomentó la creatividad de los estudiantes universitarios. Los desafió a pensar cómo contar la literatura de una manera diferente, de una forma entretenida para un público específico. La confección de este ejercicio fomentó la creatividad y los estudiantes de ambos espacios (universitarios realizadores y estudiantes 
de secundario que escucharon) comprendieron que existen diferentes herramientas tecnológicas que favorecen la educación.

Actualmente, en la mencionada carrera los estudiantes se encuentran realizando un podcast con contenido musical para chicos del nivel inicial, dónde el objetivo es acercar géneros musicales y los sonidos de los instrumentos a niños de entre 4 y 5 años. Mediante un lenguaje adecuado para el público en cuestión, se le ofrecen al usuario diferentes situaciones cotidianas que tienen como excusa conocer los ritmos y géneros musicales y luego se le propone que arme un instrumento en su hogar como actividad recreativa familiar. El piloto tuvo muy buena aceptación por parte de las directoras de dos establecimientos educativos de nivel inicial, junto con la aprobación de las maestras especiales del área musical.

La licenciada en psicopedagoga Mariela Caputo que forma parte de la plataforma educativa Ticmas (Solución Integral de Educación), sostuvo en una nota publicada en el portal de Infobae que "por medio del juego nos encontramos con el devenir, con lo incierto" y esto promueve el tiempo para pensar y actuar ante los desafíos del mundo real. Caputo es máster en Neuropsicología Clínica y Neuroeducación y doctorando de la faculta de Medicina.

En esta sintonía también podemos mencionar las definiciones que Diego Vergara Rodríguez, de la Universidad Católica de Ávila, realiza sobre el concepto de gramificación cuyo fin es promover el aprendizaje y la resolución de problemas a través de un pensamiento lúdico, fomentando aspectos como la creatividad y la constancia. En el seminario brindado este año por medio de la plataforma digital de la Universidad, el docente contó las experiencias que implementó en sus clases y confirmó que las actividades lúdicas pueden complementarse con plataformas digitales, las cuales hacen que ellos estudiantes tengan que jugar y pensar para llegar a una solución.

La propuesta en esta ponencia es reflexionar sobre el podcast como herramienta complementaria de aprendizaje, donde por medio de diferentes estrategias y pensando distintos formatos, intentamos que fomenten la creatividad, el pensamiento y promovemos la acción de ambos espacios estudiantiles: los estudiantes que crean los contenidos y los estudiantes que deben escucharlo para completar el recorrido sonoro, de manera tal que el podcast sea de utilidad para que los docentes tengan un recurso más al momento de compartir el conocimiento.

\section{Resultados:}

Más allá de los resultados satisfactorios que brindó la propuesta sonora del uso del podcast como herramienta educativa para la docencia, se pueden deducir algunas conclusiones:

- Se utilizó el podcast como un complemento educativo de las clases de literatura e historia en las instituciones secundarias que colaboraron en el proceso de creación.

- Los estudiantes que escucharon el podcast reflejaron interés y les pareció novedosa y atractiva la propuesta. 
- El haber creado un "podcast interactivo" llevó a los usuarios (estudiantes) a tener que escucharlo con detenimiento para poder responder las preguntas adecuadamente y de esta forma llegar al final del episodio.

- Todos los estudiantes vieron positivo que el podcast haya estado alojado en una plataforma accesible y familiar en cuanto a su uso: Spotify.

- La participación no sólo se reflejó en la escucha, sino que además promovió a la acción mediante el juego con el scroll.

- Los estudiantes universitarios que crearon la pieza sonora comprendieron que los podcasts pueden ser una herramienta de aprendizaje y no sólo un recurso para entretener.

- La dinámica propuesta llevó a los creadores a tener que pensar y encontrar la forma adecuada de contar la literatura de una manera entretenida en post del público pensado (estudiantes de secundaria).

- Los universitarios desarrollaron diferentes espacios de creatividad que abarcaron desde la idea del podcast, su realización mediante la exploración de recursos expresivos sonoros hasta la complejidad en la edición, fomentando también la imaginación.

- Las devoluciones de los docentes consultados fueron muy satisfactorias y todos coincidieron que el podcast les sirvió como complemento y herramienta educativa.

- Los docentes adquirieron nuevos conocimientos tecnológicos vinculados a la edición de sonido y confección de las piezas sonoras para poder realizar ellos mismos sus propios podcast educativos

- Se promovieron cursos de edición y sonido para docentes con la intención de ofrecer recursos y herramientas en entornos virtuales de educación.

\section{Bibliografía}

Herreros, M. (2008). La Radio en Internet. Buenos Aires: Editorial La Crujía

Herreros, C. -(1998) La expansión de la Ciberradio de Mariano Cebrián Herreros Revista Venezolana de información, tecnología y conocimiento - ISNN 1690-7515

Herreros , C (2009) Comunicación Interactiva en los Cibermedios

Ortiz, M. A y Marchamalo, J. (1994) Técnicas de comunicación en radio: la realización radiofónica. Barcelona: Paidós Ibérica.

10 Congreso de Red COM (2008). "Contactos Hipersegmentados y Desinformados en la era de la Globalización" Universidad Católica de Salta - 4, 5 y 6 de Septiembre - Recuperado en: http://campostrilnick.org/wp-content/uploads/2012/03/articulo-sobre-la-convergencia2.pdf 
Toni Sellas Güell (2007) - "Revolución del podcasting la comunicación"

Podcater@s - (2021) - Reporte Encuesta Pod2021

\section{Webgrafía}

La Nación: Podcast, porqué hoy se convirtió en un verdadero negocio mundial, en:

https://www.lanacion.com.ar/lifestyle/podcast-por-que-hoy-se-convirtio-verdadero-nid2419239/)

El digital: Podcasting, un mercado que está despegando, en:

https://en.digital/blog/podcasting-un-mercado-que-esta-despegando-a-lo-grande/854

Un billete en Chattanoga - Encuesta a oyentes sobre podcast, en:

https://unbilleteachattanooga.com/encuesta-oyentes/

Entrevista: Qué es el aprendizaje basado en el juego y cómo se le puede poner en práctica, en:

https://www.infobae.com/educacion/2021/06/24/que-es-el-aprendizaje-basadoen-el-juego-y-como-se-lo-puede-poner-rapidamente-en-practica/

Artículo de Diego Vergara "Gramificación Educativa: un movimiento emergente" publicado en espacio Eniac en:

http://espacioeniac.com/gamificacion-educativa-un-movimiento-emergente-por-diego-vergara-y-jose-maria-mezquita/

Real Academia española: definición de "educar", en: https://dle.rae.es/educar 


\section{Integración Curricular de Aplicaciones Educativas en el Ámbito de la Enseñanza de Lenguas Extranjeras. El Caso de Beelinguapp para Aprender Español en la Universidad Portuguesa}

Sapiña, Joan

orcid.org/0000-0001-5947-0478

joan.sapinya@gmail.com

\section{Cao Míguez, Ana Belén}

orcid.org/0000-0002-0642-4459

abcm@ubi.pt 


\title{
INTEGRACIÓN CURRICULAR DE APLICACIONES EDUCATIVAS EN EL ÁMBITO DE LA ENSEÑANZA DE LENGUAS EXTRANJERAS. EL CASO DE BEELINGUAPP PARA APRENDER ESPAÑOL EN LA UNIVERSIDAD PORTUGUESA
}

\author{
Sapiña, Joan \\ Cao Míguez, Ana Belén
}

\section{Resumen}

La necesidad de implementar una metodología de enseñanza online o híbrida en el sistema universitario se ha convertido en una realidad global con la pandemia de COVID-19. Consideramos que, en tal contexto, y en el caso del aprendizaje de segundas lenguas ( $A S L$ ), los recursos tecnológicos provenientes del aprendizaje no formal o informal ya disponibles, como las apps, pueden contribuir a una mejora de la enseñanza reglada. Ahora bien, antes de proceder a la integración de una aplicación preexistente dentro del diseño curricular de una disciplina educativa, deben sopesarse cuestiones como en qué aspectos del ASL resultará útil o si puede introducirse en todos los niveles del Marco Común Europeo de Referencia para las Lenguas (MCER). El presente trabajo procura examinar si el input recogido en la aplicación Beelinguapp en los niveles iniciales/intermedios es relevante, adecuado y beneficioso para el aprendizaje de Español como Lengua Extranjera (ELE) en el sistema universitario portugués, es decir, por estudiantes de lengua materna portuguesa. Los resultados muestran que la mayoría del input ofrecido por la aplicación, al menos en lo que concierne específicamente al diseño de aprendizaje de ELE para lusohablantes, no reúne las condiciones de relevancia y adecuación. Así, las conclusiones del estudio son poco favorables a la incorporación de esta app en el diseño curricular de las asignaturas de ELE impartidas en la enseñanza superior portuguesa, dado que la proximidad lingüística entre el portugués y el español crea una serie de particularidades en el aprendizaje no contempladas en dicho recurso.

\section{Palabras clave}

Apps educativas, ELE, m-learning, integración curricular, input. 


\section{Introducción}

La progresiva necesidad de implantar metodologías de enseñanza a distancia o, más recientemente, la hibridación del tradicional sistema de enseñanza universitario como consecuencia de la pandemia de COVID-19 han puesto de manifiesto la importancia de incluir diferentes TIC en las instituciones de aprendizaje formal. Ante ese desafío, han sido muchos los centros y docentes vinculados a la enseñanza superior que se han planteado la posibilidad de incluir en el diseño curricular de sus disciplinas las herramientas, recursos y aplicaciones disponibles en el mercado, usadas ya en ámbitos de aprendizaje no formal con resultados a todas luces beneficiosos, como es el caso, por ejemplo, del aprendizaje de segundas lenguas (ASL) en el mundo empresarial (Stefanello y Faccioni Filho, 2017).

No obstante, cabe considerar que los recursos empleados frecuentemente en el aprendizaje no formal, como las apps, si bien se asemejan al aprendizaje formal en la medida en que se mantiene una intencionalidad y conciencia del aprendizaje clara por parte de todos los actores de la situación de aprendizaje (Schugurensky, 2000), no siguen necesariamente un currículum acorde al Marco Común Europeo de Referencia para las Lenguas (MCER) del Consejo de Europa (2001/2002), ni una metodología didáctica coherente con los objetivos del programa y del aprendizaje formal. En otras palabras, el aprendizaje no ocurre bajo el mismo molde y, por tanto, el uso de aplicaciones en el aprendizaje no formal responde a necesidades formativas muy específicas, a menudo relacionadas con el crecimiento personal o profesional (Cabero Almenara y Vázquez-Martínez, 2013).

Consecuentemente, la integración de estos recursos y aplicaciones en el diseño curricular y en la enseñanza reglada de ASL requiere una previa comprobación y estudio sobre en qué campos, destrezas o planos lingüísticos puede suponer una mejora. En nuestro caso específico, nos interesa ponderar si dicha integración puede resultar provechosa para el aprendizaje de Español como Lengua Extranjera (ELE) en el ámbito universitario portugués, es decir, con un alumnado abrumadoramente lusófono. Naturalmente, somos conscientes de que la integración en el diseño curricular de cualquiera de estas TIC requiere también del apoyo de las diferentes instituciones educativas implicadas, que deben realizar un esfuerzo por capacitar y desarrollar la competencia digital del cuerpo docente, así como de una opinión favorable de dicho cuerpo, ya que, generalmente, conforme la edad del docente aumenta también se incrementan las reticencias a adoptar TIC o apps en la enseñanza reglada (Cavus, Shukshina, Chernova, Telezhko, Ishmuradova y Zakharova, 2020). Asimismo, es necesario también tener en consideración la opinión del alumnado, habitualmente más favorable a la inclusión de las tecnologías propias del $m$-learning no solo porque las valoran como herramientas que ayudan en la gestión de sus actividades académicas, sino también porque las conciben como elementos pedagógicos válidos (Nobre y Moura, 2017).

Si bien estas condiciones previas corresponden al contexto educativo en el que la app va a ser integrada, es necesario subrayar que la incorporación de recursos tecnológicos en el ASL de los sistemas universitarios es una realidad creciente que puede acarrear beneficios específicos no solo en el ámbito estrictamente lingüístico (Loewen et al., 2020), en el que nos centraremos aquí, sino también en los factores individuales que mejoran el rendimiento académico, como la motivación u otros (González Cuéllar y Sapiña, 2016; Maquiné et al., 2020) o, incluso, en aspectos 
relacionados con la interculturalidad (Sapiña, 2017). Así pues, la implantación de estos recursos en la enseñanza reglada puede suponer evidentes mejoras en el ASL, dado que, tal como han señalado Kuimova, Burleigh, Uzunboylu y Bazhenov (2018), se acelera la velocidad de dicho aprendizaje y se fomentan experiencias independientes y colaborativas de aprendizaje, en consonancia con las características de la aplicación específica y su integración en el diseño curricular. Los mismos autores indican que, además, las apps proporcionan oportunidades para practicar y promover el aprendizaje de forma permanente y fuera de clase.

En ese sentido, la oportunidad que ofrecen las aplicaciones de aumentar la interacción y exposición a un input en la lengua meta de aprendizaje (L2) puede suponer una importante mejora de ese mismo aprendizaje, ya que la clase no ofrece una gama de situaciones diversas y ricas para usar la L2 (Lightbown, 2000). De hecho, y a título de ejemplo, el aprendizaje intencionado o formal de vocabulario es muy costoso en esfuerzo y no hay dudas de que requiere más tiempo y dedicación que los que se pueden destinar durante la clase, tal como resulta evidente que hay palabras que se han aprendido sin haber sido instruidas, es decir, de forma incidental (Agustin Llach, 2013, p. [2]). Son, en efecto, numerosos los estudios que señalan los beneficios en el ASL de una mayor exposición al input de la L2 en diferentes planos lingüísticos y con diferentes tecnologías y pruebas (Rodrigo, Krashen y Gribbons, 2004; Peters, Noreillie, Heylen, Bulté y Desmet, 2019; Godwin-Jones, 2019, p. 461); es más, algunos de ellos subrayan que el aprendizaje autoguiado, el placer por la lectura y los storytelling son aún más eficientes en el ASL que el "estudio" (entiéndase el aprendizaje formal) de dicha lengua, al menos en lo relacionado con la adquisición de la competencia léxica (Mason, 2010).

Por consiguiente, estimamos que la app Beelinguapp podría ser, a priori, una buena herramienta para el aprendizaje de ELE, ya que, precisamente, se basa en la narración de historias de diversa índole, algunas de ellas en formato de conversación (dialogadas) y de variada temática. Además, dispone de un contenido de acceso libre bastante amplio, aunque no es íntegramente gratuito y, por ese motivo, el acceso a todo el contenido es mediante un servicio premium. Esta aplicación funciona mediante la narración oral en la L2 de una historia, previamente seleccionada, donde el aprendiente puede, al mismo tiempo, seguir dicha narración mediante la lectura tanto en su lengua materna (L1) como en la L2 que haya seleccionado. La posibilidad de que el aprendiente pueda comparar ambas lenguas permite cierto ejercicio de reflexión contrastiva, un aspecto que puede redundar en una mejora del ASL, especialmente cuando, como en nuestro caso, se trata de lenguas próximas (Izquierdo Merinero y Pérez de Óbanos Romero, 2006; Pérez de Óbanos Romero, 2019).

En definitiva, la presente investigación trata de arrojar luz sobre si la inclusión de la app Beelinguapp en el diseño curricular de las asignaturas de ELE impartidas en la enseñanza superior portuguesa podría reportar beneficios en el aprendizaje de algunas de las competencias del MCER, especialmente en relación con la exposición a un input relevante y adecuado (Krashen, 1982/2009), como enseguida veremos. Hemos tenido en cuenta en nuestro análisis que nos hallamos ante un alumnado lusohablante aprendiente de ELE; es decir, que el ASL tiene lugar entre idiomas de una gran proximidad lingüística y cultural (Ilari, 2013). Las lenguas afines o próximas plantean una serie de cuestiones particulares que no pueden soslayarse, como los fenómenos de intercomprensión (Séré, Hidalgo Downing y Vela Delfa, 2010), de facilitación provocada por la transferencia de la L1 (Alexopoulou, 2011) o las interferencias con la 
L1, las cuales pueden generar importantes fosilizaciones o errores persistentes en la interlengua o lengua propia de los aprendientes (Sánchez-Iglesias, 2003, 2011). Estas peculiaridades del proceso de aprendizaje entre lenguas próximas deben tomarse en consideración en el análisis de materiales educativos del tipo que sean, analógicos o digitales, incluyendo aplicaciones como en nuestro caso.

\section{Método}

Como acabamos de señalar, en este trabajo partimos de la hipótesis del input comprensible formulada por Krashen (1982/2009) en el marco de su teoría de la adquisición de L2, según la cual, para ser relevante, la exposición al input lingüístico debe tener, por un lado, suficiente contenido comprensible y, por otro lado, debe exigir o suponer un esfuerzo progresivo para aumentar o desarrollar competencias superiores en la L2, si bien este planteamiento inicial ha sido ampliado y matizado desde otros postulados, como la hipótesis del output o la hipótesis de la carga de la implicación de la tarea (Agustin Llach, 2013).

Con el objetivo de determinar si el input de la app Beelinguapp es relevante y adecuado para nuestros aprendientes, caracterizados por ser lusófonos y pertenecer a diferentes niveles según el MCER (Consejo de Europa, 2001/2002), hemos estudiado la calidad del input, siguiendo la estela de otros trabajos que relacionan el input, la comprensión y los beneficios en diferentes aspectos del ASL (Loschky, 1994). No obstante, reiteramos que hemos prestado especial atención a que nos encontramos ante dos lenguas próximas; esto es, dos lenguas que comparten un mismo origen (el latín), que presentan grandes semejanzas con relación a lo fono-fonológico, morfosintáctico, pragmático o sociocultural y cuyas comunidades de hablantes mantienen lazos históricos muy relevantes. Así, la proximidad lingüístico-cultural entre el español y el portugués genera una intercomprensión inicial (Revilla Castaño, 2002) y una facilitación del aprendizaje (Carmorlinga, 1997), al menos en los primeros estadios. Esta proximidad lingüística ha sido ampliamente estudiada (Vigón Artos, 2005) y existe cierto consenso entre la comunidad docente de ELE para lusófonos en señalar las particularidades que presentan estos aprendientes, especialmente en los niveles iniciales (donde son falsos principiantes), y la consecuente necesidad de adecuar el ASL incidiendo, por ejemplo, en el ya mencionado abordaje contrastivo (Pérez Pérez, 2007).

\section{Procedimiento}

El instrumento utilizado en este estudio ha sido el análisis cuantitativo del input lingüístico que proporciona Beelinguapp en el modo usuario mediante el empleo de la estadística descriptiva. Para ello, hemos procedido a segmentar y, posteriormente, clasificar el input disponible en tres textos incluidos en la sección "Frases y conversaciones" de la app en cuestión. La segmentación del input que presentan dichos textos se ha realizado por unidades léxicas, contemplando las diversas categorías de palabras desde el punto de vista morfológico: sustantivos, adjetivos, adverbios y locuciones adverbiales, verbos y perífrasis verbales, determinantes, pronombres, preposiciones y locuciones preposicionales, nexos oracionales, conectores textuales, etc. De ese modo, hemos obtenido un corpus constituido por 678 ítems.

Más concretamente, los textos de la aplicación de donde hemos extraído el corpus para su ulterior análisis han sido los titulados "La primera cita", "En el restaurante" 
y "En una fiesta", todos ellos en formato de diálogo, seleccionados porque, además de ser de acceso gratuito, se ajustan al enfoque comunicativo y funcional que preconiza MCER (Consejo de Europa, 2001/2002) y giran en torno a temáticas propias de los descriptores previstos para los niveles iniciales e intermedios en el mismo MCER. Conviene recordar que, gracias a sus características, ya descritas más arriba, la aplicación que examinamos permite trabajar dos destrezas receptivas (o actividades comunicativas de comprensión, como las llama el MCER) simultáneamente: la comprensión oral y la comprensión escrita. A este respecto, cabe aún reseñar que Beelinguapp alterna dos grandes variedades diatópicas de la L2, el español de América y el de España (las llamaremos así por mera comodidad, aunque estas designaciones requerirían de considerables precisiones filológicas en las que, por motivos obvios, no entraremos aquí). En lo que concierne a la L1 (recordemos que la app permite leer los textos en las dos lenguas a la vez, mientras se escucha la narración en la L2), Beelinguapp prioriza las traducciones al portugués de Brasil.

\section{Taxonomía del input}

Teniendo en consideración el grado de proximidad e intercomprensión lingüística entre la lengua materna de los aprendientes (L1) y la lengua objeto de aprendizaje (L2), se ha creado una taxonomía del input consistente en una escala de cuatro categorías, relacionadas fundamentalmente con la dificultad en la comprensión de dicho input.

Por una parte, las dos primeras categorías recogen input que no presenta prácticamente ninguna dificultad para su comprensión por parte de un lusohablante. Se trata de palabras cuya similitud formal entre la L1 (portugués) y la L2 (español) es total - casi total, y que no varían tampoco en significado o valor gramatical, por lo que su comprensión no supone ningún esfuerzo para el aprendiente lusófono de ELE. Así, se distinguen: (i) el input idéntico, constituido por palabras con una completa semejanza formal entre la L1 y la L2, como por ejemplo mesa o casa (cuya sibilante es sorda en español y sonora en portugués, pero que se escriben igual en ambas lenguas); (ii) el input con meras diferencias ortoépicas u ortográficas entre ambas lenguas, como es el caso de esp. estaba / port. estava o de esp. hola / port. olá (que no solo presenta una diferencia ortográfica sino también una ortoépica, puesto que en español es una palabra grave y en portugués es aguda), siendo dichas diferencias, en cualquier caso, irrelevantes en lo que atañe a la comprensión.

Por otra parte, las dos últimas categorías establecidas para agrupar el input abarcan elementos que pueden presentar algún grado de dificultad en la comprensión, aunque este sea mínimo, a saber: (iii) input con un alto grado de comprensión o fácilmente comprensible (como esp. mucho / port. muito); (iv) input de bajo grado de comprensión o, incluso, no comprensible (por ejemplo, esp. ventana / port. janela).

\section{Resultados}

Según se ha indicado anteriormente, el corpus recogido en este estudio está compuesto por un total de 678 ítems (palabras), procedentes del vaciado de los textos "La primera cita", "En el restaurante" y "En una fiesta" de la sección "Frases y conversaciones" de Beelinguapp, 
Como puede verse en el gráfico 1, destaca el elevado porcentaje de input perteneciente a la categoría (i), el cual alcanza un 33\%. Recuérdese que en esta categoría se recoge el input compartido entre el portugués y el español; esto es, el input constituido por palabras que son exactamente iguales en ambas lenguas desde el punto de vista formal u ortográfico (las mínimas diferencias fonéticas resultan, como ya hemos dicho, totalmente superfluas para el propósito que nos ocupa: medir el grado de comprensión), además de mantener su valor semántico y gramatical. A modo de ejemplo de los vocablos incluidos en (i), todos ellos idénticos en portugués, pueden señalarse sustantivos como restaurante, mesa, amigo, esposo, meses, semana, dentista, músico o barba; adjetivos como educado, reservada, emocionada, real o alto; formas verbales como estás o verificar; adverbios como tarde o definitivamente; y preposiciones como de, por o para.

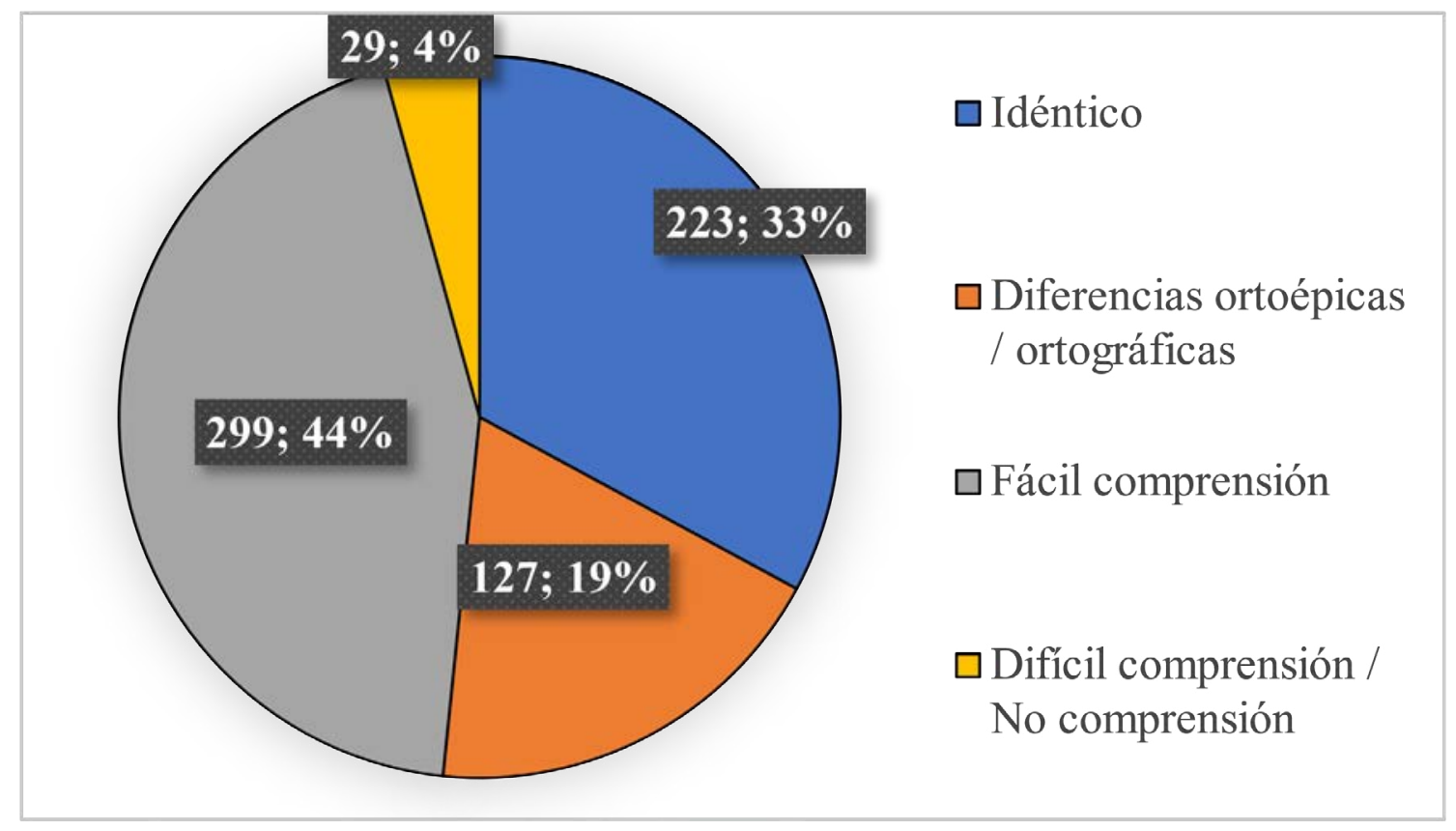

\section{Gráfico 1. Número y porcentaje del total de input según su semejanza y comprensión lingüística}

En el mismo gráfico 1, se observa un considerable porcentaje de palabras de la categoría (ii). Estas representan el 19\% del total del corpus y sus diferencias se limitan a cuestiones ortográficas u ortoépicas que, al fin y al cabo, tampoco representan un grave obstáculo para la comprensión. Así, forman parte de esta categoría los sustantivos cabello, familia y tío (en portugués, cabelo, família y tio, respectivamente); el adjetivo tailandés (port. tailandês), verbos como estaba o sentí (estava y senti en port.); el interrogativo cuántas (port. quantas), la ya citada interjección hola (port. olá) o la preposición con (port. com). Repárese que, sumadas estas dos primeras categorías (i y ii), nos hallamos con que más del $50 \%$ de palabras de nuestro corpus no supone un aprendizaje significativo para estudiantes de ELE cuya L1 es el portugués, por las razones ya expuestas anteriormente: se trata de un proceso de ASL en el que la L2 y la L1 son lenguas próximas, y por ello, dicho proceso posee características específicas.

Aparte de registrarse ese más de $50 \%$ de ítems que no presentan ninguna o casi ninguna dificultad en la comprensión (52\%, para ser más exactos), un $44 \%$ del input es 
de fácil comprensión para los aprendientes (categoría iii), puesto que en este caso las diferencias formales entre las unidades léxicas de la $L 1$ y la $L 2$, a menudo solamente morfológicas, no constituyen un obstáculo importante para poder acceder a su significado. De este modo, nos hallamos ante palabras que presentan cambios tales como la diptongación (fiesta/festa, bueno/bom), las desinencias verbales (fueron/foram), la sufijación (verdadero/verdadeiro) u otras mínimas variaciones que no impiden la rápida comprensión, como las presentes en sustantivos como noche/ noite, gusto/gosto; en formas verbales como presentar/apresentar, desear/desejar, conocíamos/conhecíamos, estuviese/estivesse; en posesivos como el mi en mi casa ([a] minha casa en portugués); en adverbios como mucho/muito; etc. Así, pues, en iii, se han recogido vocablos formalmente muy cercanos entre las dos lenguas, pese a lo cual pueden ofrecer algún obstáculo para la comprensión, a diferencia de (ii). Además, se ha considerado dentro de esta misma categoría la fórmula de agradecimiento gracias (en portugués, obrigado/-a), por tratarse de un elemento que forma parte del léxico del español previamente conocido por un lusohablante, dada la proximidad cultural entre las comunidades de habla en cuestión.

Por último, resulta especialmente notorio que tan solo un $4 \%$ del corpus pertenezca a la categoría iv, donde se contempla el input de bajo o nulo grado de comprensión. En dicho input se registran casos como los sustantivos botella (garrafa en portugués), ventana (janela), cena (jantar), pavo (peru), abuela (avó), mariposas (borboletas), cita (en el contexto de las relaciones románticas; esto es, encontro en port.) o chispa (en "haber chispa" entre dos personas: haver química en port.); adjetivos como delgado (magro), envidiosos (invejosos) o guapo (bonito o bem-parecido, aunque podría haberse considerado un caso similar al de gracias); conjunciones como pero (mas); preposiciones como según (segundo); formas verbales como trajo, del verbo traer (port. trouxe), chatearon (que es un falso amigo: en port. existe el verbo chatear, pero se traduciría por "molestar" o "fastidiar" en español) o charlando (tanto para esp. chatear como para esp. charlar, la L1 recurre a una sola expresión verbal: en el portugués brasileño sería bater um papo, en el portugués europeo habría equivalentes como conversar). Debe subrayarse que, conforme ya hemos visto, y siguiendo los presupuestos teóricos de Krashen (1982/2009), este input es el más relevante para el alumnado lusófono al suponer algún tipo de dificultad en el ASL.

\section{Discusión y conclusiones}

Después de haber recogido y analizado los datos, concluimos que la aplicación Beelinguapp no se revela como una TIC muy adecuada, eficaz o favorable para el aprendizaje de ELE por aprendientes cuya L1 es el portugués, ya que no presenta un input relevante. Por un lado, dicho input obtiene un muy elevado porcentaje de palabras idénticas o casi idénticas en ambas lenguas, que suponen más de la mitad de nuestro corpus, y, por otro lado, también se registra un alto porcentaje de input, superior al $40 \%$, que ofrece poca dificultad de comprensión. Estos resultados son coherentes con estudios previos que remarcan la fuerte intercomprensión entre lenguas románicas, como ya hemos señalado anteriormente. Es más, la intercomprensión entre lenguas afines puede alcanzar tal importancia como para que aprendientes de lenguas próximas, pero que nunca han tenido instrucción (formal o informal) con anterioridad en la L2, sean capaces de aprobar test de comprensión lectora de un nivel superior (Ainciburu, 2012, p. 48). 
Esta investigación incide en señalar que aquellas apps que no tienen en cuenta en su diseño la proximidad/distancia lingüística entre la L1 y la L2 obvian fenómenos importantes para el ASL, como, en nuestro caso, la intercomprensión o la facilitación, producidos por la gran afinidad lingüística entre el portugués y el español. Según ya hemos indicado, conviene que el alumnado esté expuesto a un input que presente un equilibrio entre ítems comprensibles e ítems que supongan algún esfuerzo por su parte. Solo así la exposición al input supondrá mejoras en el ASL. En el presente trabajo, se verifica que Beelinguapp ofrece al aprendiente lusohablante de ELE un exceso de exposición a un input comprensible y que requiere poco o nulo esfuerzo (un 96\%). Este hecho podría generar que, al menos para el perfil específico del alumnado de nuestro estudio, la realización de actividades de comprensión oral y/o escrita con los textos seleccionados, de cierta complejidad, no produzca mejoras en su ASL, conduciéndolo, a la postre, a la desmotivación, al obtener una alta satisfacción comunicativa (Durão, 2007), independientemente de su nivel del MCER (intermedio o inicial).

Ahora bien, aun cuando esta investigación concluye que el input ofrecido por la aplicación Beelinguapp no es adecuado para el perfil concreto de nuestros aprendientes de ELE (universitarios lusófonos), consideramos que los resultados aquí ofrecidos no desestiman, ni son contradictorios o incompatibles con los beneficios apuntados en estudios previos sobre el uso de apps en contextos educativos con aprendientes de otras lenguas, ni tampoco con las mejoras en diferentes factores individuales y extralingüísticos del aprendizaje (como las creencias y actitudes sobre la lengua y la cultura objeto de instrucción, la autoeficacia, el autoconcepto académico, etc.) que respaldan esos mismos estudios.

Asimismo, es necesario subrayar que Ainciburu (2014, p. 5) ya advirtió acerca de la imposibilidad de que las editoriales de ELE adaptasen el material didáctico (los manuales de clase) para cada grupo de aprendientes meta y que, por tanto, dicha adaptación debía ser asumida y ejecutada por el docente en su planificación didáctica. De la misma manera, estimamos que no es viable que una app, más aún si es de acceso total o parcialmente gratuito como Beelinguapp, tenga en consideración esta cuestión en su diseño.

En definitiva, tras este estudio se ha decidido que la inclusión de Beelinguapp en el diseño curricular de asignaturas de ELE en instituciones de enseñanza superior portuguesas no es una opción recomendable. Sin embargo, sí puede resultar positiva como actividad complementaria u optativa, sobre todo en los niveles iniciales, con el objetivo de reforzar el personal learning environment del alumnado, fomentando así la autonomía en el aprendizaje y la consolidación del input comprensible, bien como la posible mejora de algunas destrezas receptivas, especialmente la comprensión oral, tal y como indican otros trabajos (Gangaiamaran y Pasupathi, 2017). Por último, la adopción de esta app como un recurso optativo o complementario podría igualmente repercutir en una mejora de factores individuales del ASL. Por consiguiente, sería necesario llevar a cabo un estudio exploratorio y/o empírico que comprobase si se producen dichas mejoras. 


\section{Referencias}

Agustin Llach, M. d. P. (2013). Dinámica del aprendizaje incidental de léxico en lengua extranjera. Revista Nebrija de Lingüística Aplicada, 14, [1-6]. https://doi. org/10.26378/rnlael714204

Ainciburu, M. C. (2012). Definición y alcance del término intercomprensión en la adquisición de lenguas afines. En A. Cassol, A. Guarino, Mapelli, F. Matte Bon, P. Taravicci (Eds.), Metalinguaggi e metatesti. Lingua, letteratura e traduzione. Atti del XXIV Congresso AISPI (pp. 41-50). AISPI Edizione. https://cvc.cervantes.es/literatura/aispi/pdf/23/23_041.pdf

Ainciburu, M. C. (2014). El léxico en L2: la adquisición del vocabulario y sus mitos. ¿Existe el vocabulario rentable? Signos ELE, 8, 1-18. https://p3.usal.edu.ar/index.php/ ele/article/view/2087/2633

Alexopoulou, A. (2011). La función de la interlengua en el aprendizaje de lenguas extranjeras. Revista Nebrija de Lingüística Aplicada a la Enseñanza de las Lenguas, 5(9), 86-101.

Cabero Almenara, J. y Vázquez-Martínez, A. I. (2013). Los Entornos Personales de Aprendizaje: uniendo lo formal, informal y no formal para la construcción del conocimiento. En M. C. Fonseca Sardi (Coord.), Los entonos personales de aprendizaje. Visiones y retos para la formación (pp. 9-26). Universidad Metropolitana de Caracas. https://libros.uat.edu.mx/index.php/librosuat/catalog/view/32/23/80-1

Camorlinga, R. (1997). A distância da proximidade - A dificuldade de aprender uma língua fácil. Intercâmbio, 6, 1-19.

Cavus, N., Shukshina, L., Chernova, O., Telezhko, I., Ishmuradova, A. y Zakharova, V. (2020). Perceptions of Foreign Language Teachers for M-Learning. International Journal of Emerging Technologies in Learning (iJET), 15(23), 95-107. https://www. learntechlib.org/p/218467/

Consejo de Europa (2002). Marco Común Europeo de Referencia para las Lenguas: aprendizaje, enseñanza, evaluación (Instituto Cervantes, Trad.). Ministerio de Educación, Cultura y Deporte, Subdirección General de Cooperación Internacional. https://cvc.cervantes.es/ensenanza/biblioteca_ele/marco/cvc_mer.pdf (Original publicado en 2001).

Durão, A. B. A. B. (2007). La interlengua. Arco Libros.

Gangaiamaran, R. y Pasupathi, M. (2017). Review on Use of Mobile Apps for Language Learning. International Journal of Applied Engineering Research, 12(21), 1124211251. http://www.ripublication.com/ijaer17/ijaerv12n21_102.pdf

Godwin Jones, R. (2019). Future Directions in Informal Language Learning. En M. Dressman y R. W. Sadler (Eds.), The Handbook of Informal Language Learning (pp. 457-470). Wiley-Blackwell. https://doi.org/10.1002/9781119472384.ch30

González Cuéllar, I. y Sapiña, J. R. (2016). Las competencias generales y comunicativas en Duolingo. Análisis desde la perspectiva de la didáctica del español como 
lengua extranjera. En R. Roig Vila (Coord.), Tecnología, innovación e investigación en los procesos de enseñanza-aprendizaje (pp. 2531-2537). Octaedro.

Ilari, R. (2013). O português no contexto das línguas românicas. En E. B. P. Raposo et al. (Eds.), Gramática do português (Vol. 1, pp. 49-66). Fundação Calouste Gulbenkian.

Izquierdo Merinero, S. y Pérez de Óbanos Romero, G. (2006). Estrategias de reflexión contrastiva para la clase de ELE. En P. Benítez Pérez (Coord.), Actas del III simposio internacional José Carlos Lisboa de didáctica del español como lengua extranjera (pp. 431-439). Instituto Cervantes de Río de Janeiro.

Krashen, S. D. (2009). Principles and Practice in Second Language Acquisition. (19 ed. Internet). Pergamon Press. http://www.sdkrashen.com/content/books/principles_and_practice.pdf. (Original publicado en 1982).

Kuimova, M., Burleigh, D., Uzunboylu, H. y Bazhenov, R. (2018). Positive Effects of Mobile Learning on Foreign Language Learning. TEM Journal, 7(4), 837-841. https:// doi.org/10.18421/TEM74-22

Lightbown, P. M. (2000). Anniversary article. Classroom SLA research and second language teaching. Applied linguistics, 21(4), 431-462. https://doi.org/10.1093/ APPLIN/21.4.431

Loewen, S., Isbell, D. R., y Zachary, S. (2020). The effectiveness of app-based language instruction for developing receptive linguistic knowledge and oral communicative ability. Foreign language annals, 53(2), 209-233. https://doi.org/10.1111/flan.12454

Loschky, L. (1994). Comprehensible Input and Second Language Acquisition: What Is the Relationship? Studies in Second Language Acquisition, 16(3), 303-323.

Maquiné, G. O., Coelho, I. M. W. da S., y Figueiredo, S. (2020). Ferramentas digitais para o ensino remoto de línguas adicionais em tempos de pandemia: considerações sobre o Duolingo. Educitec. Revista de Estudos e Pesquisas sobre Ensino Tecnológico, 6, 1-20.

Mason, B. (2010). Comprehension is the Key to Efficient Foreign Language Education. (Self-Selected Reading and Story-Listening are the Solutions). The Bulletin of Shitennoji University, 49, 371-379. http://benikomason.net/content/articles/comprehension_is the key to efficient_foreign_language_education_-_self-selected_ reading and_story-listening_are the_solutions.pdf

Nobre, A. y Moura, A. (2017). Mobile Learning Scenarios in Language Teaching: Perceptions of Vocational and Professional Education Students. En D. René y C. Aubin (Eds.), Mobile Learning: Students' Perspectives, Applications and Challenges. Education in a Competitive and Globalizing World. Nova Science Publishers. http://hdl. handle.net/10400.2/6897

Pérez de Óbanos Romero, G. (2019). Procesamiento del input en la didáctica de lenguas afines: Un estudio basado en la Instrucción de Procesamiento para la enseñanza de las oraciones concesivas a aprendices brasileños. Delta, 35(2), 1-34. https:// doi.org/10.1590/1678-460X2019350207 
Pérez Pérez, N. (2007). La enseñanza de español a lusohablantes portugueses: ventajas e inconvenientes. En S. M. Saz (Ed.), Actas del XL// Congreso Internacional de la Asociación Europea de Profesores de Español (pp. 28-35). Asociación Europea de Profesores de Español (AEPE).

Peters, E., Noreillie, A.-S., Heylen, K., Bulté, B. y Desmet, P. (2019). The impact of instruction and out of school exposure to foreign language input on learners' vocabulary knowledge in two languages. Language Learning, 69(3), 747-782. https://doi. org/10.1111/lang.12351

Revilla Castaño, I. (2002). Español LE para hablantes de portugués. La proximidad de las lenguas como factor facilitador de la comprensión en la enseñanza/aprendizaje de una lengua extranjera. [Tesis doctoral inédita]. Universitat de Barcelona.

Rodrigo, V., Krashen, S. y Gribbons, B. (2004). The Effectiveness of Two Comprehensible-Input Approaches to Foreign Language Instruction at the Intermediate Level. System: An International Journal of Educational Technology and Applied Linguistics, 32(1), 53-60. https://doi.org/10.1016/j.system.2003.08.003

Sánchez-Iglesias, J. J. (2003). Errores, corrección y fosilización en la didáctica de lenguas afines: análisis de errores en la expresión escrita de estudiantes italianos de E/LE. [Tesis doctoral, Universidad de Salamanca]. Gredos. https://gredos.usal.es/ handle/10366/116103

Sánchez-Iglesias, J. J. (2011). Entre la fosilización y la evaluación: viejos y nuevos aprovechamientos de los errores. Revista Nebrija de Lingüística Aplicada 10(5), 8197. http://hdl.handle.net/10366/115910

Sapiña, J. R. (2017). La digiculturalidad y la enseñanza de español para extranjeros: una experiencia didáctica para la interacción oral y la interculturalidad. En R. Roig-Vila (Ed.), Investigación en docencia universitaria. Diseñando el futuro a partir de la innovación educativa (pp. 723-732). Octaedro. http://rua.ua.es/dspace/handle/10045/71193?locale $=$ en

Schugurensky, D. (2000). The forms of informal learning: Towards a conceptualization of the field. WALL Working Paper, 19, 1-8.

Séré, A., Hidalgo Downing, R y Vela Delfa, C. (2010). Dos plataformas de enseñanza de intercomprensión plurilingüe: Galanet y Galapro. En M. R. Caballero Rodríguez y M. J. Pinar Sanz (Coords.), Modos y formas de la comunicación humana (Vol. 2, pp. 399-406). Ediciones de la Universidad de Castilla-La Mancha.

Stefanello, C. A. y Faccioni Filho, M. (2017). M-Learning Applications as Language Teaching Tools: Study Cases and Comparisons. ReTIC. Revista Tecnologia da Informação e Comunicação: Teoria e Prática, 1(2), 29-40. http://portaldeperiodicos.unisul.br/index.php/ReTIC/article/view/5305

Vigón Artos, S. (2005). La enseñanza de la gramática del español como lengua extranjera a lusófonos. En M. A. Castillo Carballo et al. (Coords.), Las gramáticas y los diccionarios en la enseñanza del español como segunda lengua: deseo y realidad. Actas del XV Congreso Internacional de ASELE (pp. 903-914). Universidad de Sevilla. 


\section{Repositorios de Universidades Argentinas: Oportunidad para Potenciar el Acceso Abierto y la Alfabetización Informacional}

Coraglia, María Inés

ORCID https://orcid.org/0000-0002-5816-525X

Vázquez, Manuela

ORCID https://orcid.org/0000-0001-9716-990X 


\title{
REPOSITORIOS DE UNIVERSIDADES ARGENTINAS: OPORTUNIDAD PARA POTENCIAR EL ACCESO ABIERTO Y LA ALFABETIZACIÓN INFORMACIONAL
}

\author{
Coraglia, María Inés \\ Vázquez, Manuela
}

\section{Resumen}

El presente trabajo se propone analizar la evolución de los repositorios institucionales universitarios de Argentina, en relación con los lineamientos del acceso abierto. Bajo esta problemática se plantea un análisis conceptual y documental sobre el estado de los mismos y las posibilidades de constituirse como materia prima de construcción de conocimiento. En esta línea de trabajo se conceptualizan los repositorios institucionales universitarios en relación al acceso abierto, y se realiza una búsqueda documental en el material disponible en línea determinando que el Sistema Nacional de Repositorios Digitales (https://repositoriosdigitales.mincyt.gob. ar/vufind/) contiene a la fecha 43 repositorios asociados, de los cuales 29 corresponden a Instituciones de Educación Superior (7 repositorios de Universidades de Gestión Privada y 22 repositorios de Universidades de Gestión Pública). A su vez, se relaciona con la necesidad de potenciar la Alfabetización Informacional dado que además de producir material, se requiere desarrollar las habilidades y competencias que permitan buscar, analizar y utilizar dicha información. Si bien la ley 26.899 dispone la creación de repositorios, en la actualidad se visualiza que sólo una de cada tres Universidades de gestión pública ha dado respuesta al requerimiento de la misma y que sólo la mitad del material disponible proviene de dichas entidades. Se plantea de este modo la necesidad de reforzar estas iniciativas para que se genere una sinergia positiva que promueva el crecimiento de todo el sistema de conocimiento de las Universidades argentinas.

\section{Palabras clave}

Repositorios Institucionales, Acceso Abierto, Alfabetización Informacional, Construcción del Conocimiento. 


\section{Introducción}

El acceso abierto constituye actualmente una política mundial que supone la democratización del conocimiento. Por ello, en el año 2013 se sancionó la Ley 26.899 en Argentina, la cual exige a las instituciones científicas del país brindar acceso abierto a las investigaciones a través de sus "Repositorios Digitales Institucionales". Tres años más tarde, se refuerza su importancia mediante la reglamentación de la misma.

El objetivo de la presente investigación es determinar el grado de cumplimiento de dicha ley, la influencia de la producción de Universidades de gestión pública dentro del sistema general y analizar el grado de importancia otorgado por cada institución en función de la cantidad de documentos publicados a lo largo de los últimos 10 años.

\section{Método}

El método seleccionado para dar respuesta a la problemática y objetivos planteados es el análisis documental, ya que acceder a la información pública y disponible en línea resulta la estrategia más conveniente para determinar el grado de accesibilidad a la misma.

\section{Descripción del contexto y de los participantes}

Se analizan en forma remota a través de las páginas web y la información de acceso público el perfil de cada Universidad respecto de sus repositorios institucionales.

\section{Instrumentos}

El instrumento de la investigación es una grilla elaborada por los autores, para el análisis pormenorizado y sistematizado de los repositorios institucionales.

\section{Resultados}

\section{Definiendo conceptos}

\section{Acceso Abierto}

El punto de partida de abordaje del acceso abierto está constituido por las declaraciones que le dieron origen. Así, las declaraciones de Budapest, Bethesda y Berlín sentaron las bases y sus aportes son reconocidos como la "definición BBB de Acceso Abierto" (Swan, 2013, p. 17)

El acceso abierto a la literatura significa su disponibilidad gratuita en Internet, permitiendo a cualquier usuario leer, descargar, copiar, distribuir, imprimir, buscar o enlazar los textos completos de estos artículos. La única restricción es sobre la reproducción y distribución, y el tipo de licenciamiento que den los autores que les permita asegurar la integridad de su trabajo y el derecho a ser debidamente reconocido y citado (Iniciativa de Acceso Budapest Open, 2002). 
De este modo, el Acceso Abierto supone que se otorgan a los usuarios un derecho libre, irrevocable, universal y perpetuo de acceso y licencia para copiar, utilizar, distribuir, transmitir y presentar el trabajo públicamente y hacer y distribuir obras derivadas, en cualquier soporte digital para cualquier finalidad responsable, sujeto a la apropiada atribución de la autoría.

"El acceso a la información y al conocimiento es un prerrequisito básico para construir Sociedades del Conocimiento inclusivas con fuertes bases para la paz duradera y el desarrollo sostenible" (UNESCO, 2017, p. 30)

\section{Repositorios institucionales}

Tal como define Franganillo (2008), repositorio institucional refiere a los archivos abiertos, de ámbito institucional y de acceso público, que almacenan trabajos en soporte digital.

\section{Repositorios de Universidades argentinas}

Concretamente, Argentina cuenta desde el año 2013 con la Ley 26.899 que establece la Creación de Repositorios Digitales Institucionales de Acceso Abierto, reglamentada posteriormente en 2016. La misma exige a las instituciones que componen el Sistema Nacional de Ciencia, Tecnología e Innovación (SNCTI), (y por ende reciben financiamiento del Estado Nacional), desarrollar repositorios digitales institucionales de acceso abierto, para la publicación de los resultados de la producción científico-tecnológica de sus investigadores, tecnólogos, docentes, becarios de posdoctorado y estudiantes de maestría y doctorado.

Es en este sentido que se crea el Sistema Nacional de Repositorios Digitales que contiene a la fecha 43 repositorios asociados, de los cuales 29 corresponden a Instituciones de Educación Superior (22 Universidades de Gestión Pública 7 Universidades de Gestión Privada), los cuales se detallan a continuación:

\begin{tabular}{|l|l|}
\hline Gestión Pública & Gestión Privada \\
\hline Universidad de Buenos Aires & Pontificia Universidad Católica Argentina \\
\hline Universidad Nacional de Avellaneda & Universidad Católica de Córdoba \\
\hline Universidad Nacional de Córdoba & Universidad Católica de Salta \\
\hline Universidad Nacional de Cuyo & Universidad de San Andrés \\
\hline Universidad Nacional de La Matanza & Universidad del Aconcagua \\
\hline Universidad Nacional de La Plata & Universidad FASTA \\
\hline Universidad Nacional de Lanús & Universidad Maza \\
\hline Universidad Nacional de las Artes & \\
\hline Universidad Nacional de Luján & \\
\hline Universidad Nacional de Mar del Plata & \\
\hline Universidad Nacional de Misiones & \\
\hline Universidad Nacional de Quilmes & \\
\hline Universidad Nacional de Río Negro & \\
\hline Universidad Nacional de Rosario & \\
\hline Universidad Nacional de San Martín & \\
\hline Universidad Nacional de Tucumán & \\
\hline
\end{tabular}




\begin{tabular}{|l|l|}
\hline Universidad Nacional de Villa María & \\
\hline $\begin{array}{l}\text { Universidad Nacional del Centro de la } \\
\text { Provincia de Buenos Aires }\end{array}$ & \\
\hline Universidad Nacional del Comahue & \\
\hline Universidad Nacional del Litoral & \\
\hline Universidad Nacional del Nordeste & \\
\hline Universidad Nacional del Sur & \\
\hline
\end{tabular}

Tabla 1: Universidades argentinas de gestión pública y privada que poseen repositorios institucionales asociados al Sistema Nacional de Repositorios Digitales.

Por lo tanto, si consideramos los datos publicados sobre el sistema universitario argentino (https://www.cin.edu.ar/instituciones-universitarias/) actualmente sólo el $31 \%$ de las instituciones de educación superior de gestión pública han dado respuesta al requerimiento de la ley.

\section{UNIVERSIDADES DE GESTIÓN PÚBLICA}

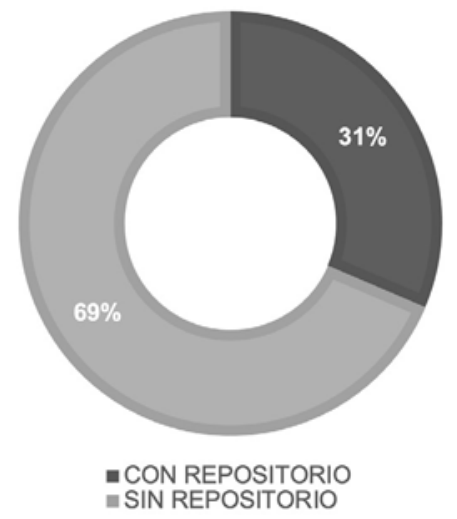

\section{Gráfico 1: Porcentaje de Universidades de gestión pública con y sin repositorio}

Concretamente, Argentina cuenta desde el año 2013 con la Ley 26.899 que establece la Creación de Repositorios Digitales Institucionales de Acceso Abierto, reglamentada posteriormente en 2016. En este sentido, el modelo de Acceso Abierto contemplado en la Ley implica que los usuarios de este tipo de material pueden, en forma gratuita leer, descargar, copiar, distribuir, imprimir, buscar o enlazar los textos completos de los artículos científicos y usarlos con propósitos legítimos ligados a la investigación científica, al desarrollo tecnológico, a la innovación, a la educación o a la gestión de políticas públicas.

Este marco jurídico impulsa a los investigadores e instituciones financiadas por el Estado a poner a disposición de la sociedad todo tipo de producción científica, tecnológica y académica a través de repositorios digitales, de modo que tenga mayor visibilidad, sea gratuita y de fácil acceso, a la vez que, a través de estos medios contribuya a la ciencia, la tecnología y la innovación tanto en el orden nacional como internacional. La única condición que se establece, para la reproducción y distribución del material que contengan los "Repositorios Digitales Institucionales" es la obligatoriedad de dar cuenta de la autoría intelectual, 
citar a los autores y salvaguardar la integridad de la investigación. (Universidad Nacional de Córdoba, 2016)

En consecuencia, se considera imprescindible replantear la importancia de este tipo de iniciativas, ya que constituye la base indispensable a la hora de fomentar el trabajo colaborativo mediante el acceso libre al conocimiento. Como lo expresa Bustamante (2020) "en todo el mundo, el acceso a las oportunidades comienza con el acceso a la información y el conocimiento. El acceso público a la información permite a las personas tomar decisiones informadas que puedan mejorar sus vidas" (p. 111).

\section{Alfabetización Informacional}

Además de tener acceso, las personas, y en particular los integrantes de la comunidad educativa universitaria, tienen que tener herramientas que le permitan indagar dentro de todo el universo de información y conocimiento disponible. Aquí es donde resulta crucial la Alfabetización Informacional.

El acceso al conocimiento implica el aprendizaje en ambientes formales e informales. También incluye la promoción de competencias de alfabetización mediática e informacional (AMI), las cuales permiten que usuarios se empoderen y hagan uso pleno del acceso a Internet (UNESCO 2013a; Kuzmin y Parshakova, 2013) (UNESCO, 2017, p. 31).

La Alfabetización Informacional (ALFIN) es un elemento primordial del acceso abierto dado que una vez que la información está disponible en los repositorios institucionales, los alumnos, docentes y toda la comunidad educativa universitaria requieren desarrollar un conjunto de habilidades y destrezas en la búsqueda y consumo de la misma. Esto implica un ciclo completo que articule las necesidades de información a fin de poder encontrar, localizar, evaluar y utilizar aquella información pertinente de forma eficaz y responsable que provoque el aprendizaje del que surge el conocimiento (Salmoiraghi, 2012).

"La alfabetización informacional comprende el conocimiento y necesidades de los individuos y la habilidad para identificar, localizar, evaluar, organizar y crear, utilizar y comunicar información eficazmente para enfrentar aspectos o problemas; es un prerrequisito para participar eficazmente en la Sociedad de la Información y es parte de los derechos básicos de la humanidad para un aprendizaje de por vida". (UNESCO, 2003)

En la Declaración de Alexandria 2005 de la UNESCO se establecen las características de la ALFIN:

1. Reconocer la necesidad de información.

2. Localizar y evaluar la calidad de la información.

3. Almacenar y recoger la información.

4. Emplear en forma efectiva y ética la información localizada.

5. Emplear la información localizada en la producción y comunicación de conocimientos. 
A su vez, entre las diez primeras competencias que se destacan en el Proyecto Tuning varias refieren a desarrollar habilidades informacionales, reforzando y reconociendo la relevancia de la Alfabetización Informacional como paradigma educativo. (Pinto, Sales y Martínez-Osorio, 2009).

Se destaca la diferencia entre la tradicional formación de usuarios y la Alfabetización Informacional, considerando que la primera sólo consiste en charlas de capacitación sobre la búsqueda y recuperación de la información, sin seguimiento de los resultados obtenidos. En cambio, ALFIN complementa la formación de usuarios con el seguimiento y evaluación de todo el proceso haciendo hincapié en la valoración de la información obtenida, es decir, el espíritu crítico. (Torres, 2019).

\section{Discusión y conclusiones}

Tomando como fuente de consulta el Sistema Nacional de Repositorios Digitales se visualiza una preponderancia de las Universidades de gestión pública representando el $70 \%$ del total y el $81 \%$ si sólo se consideran Universidades.
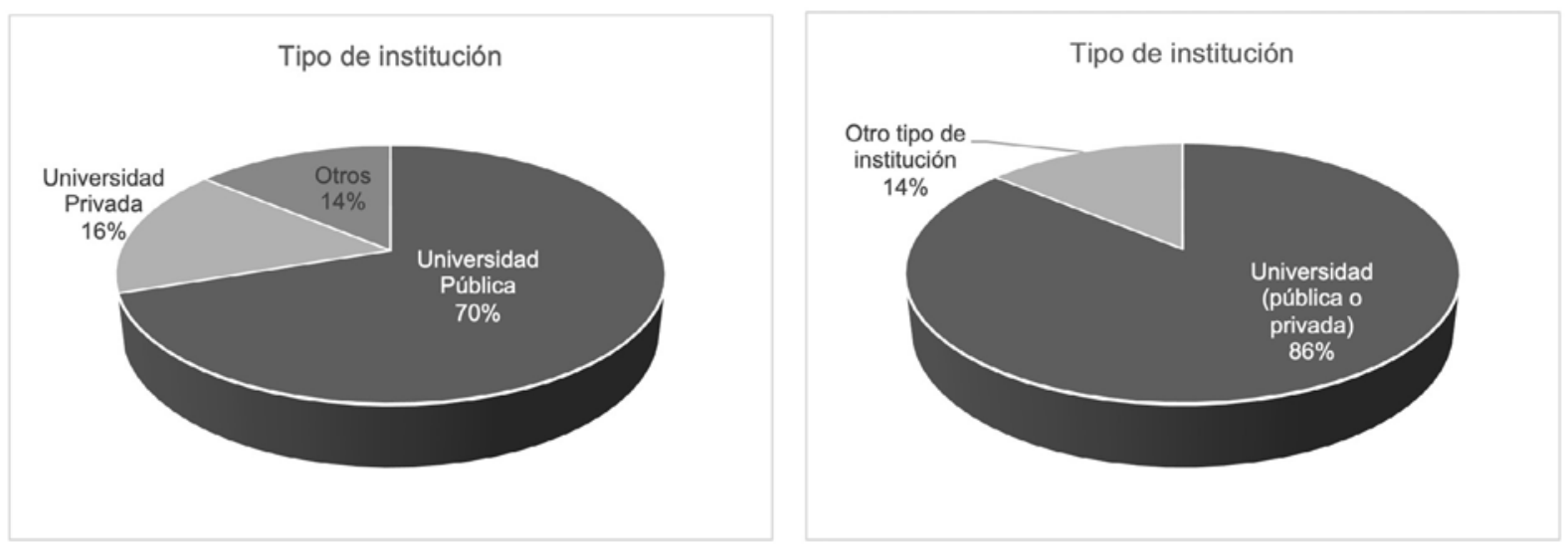

\section{Gráfico 2: Preponderancia de las Universidades de gestión pública como fuente de consulta del Sistema Nacional de Repositorios Digitales}

Sin embargo, si se analiza la procedencia de los documentos, sólo poco más de la mitad (55\%) es producido por dichas Universidades lo cual implica el alto potencial que poseen dichas instituciones para aprovechar la ventaja competitiva que implica compartir el conocimiento mediante un repositorio. Asimismo, se debe complementar con la Alfabetización Informacional a fin de fomentar dicha ventaja. 


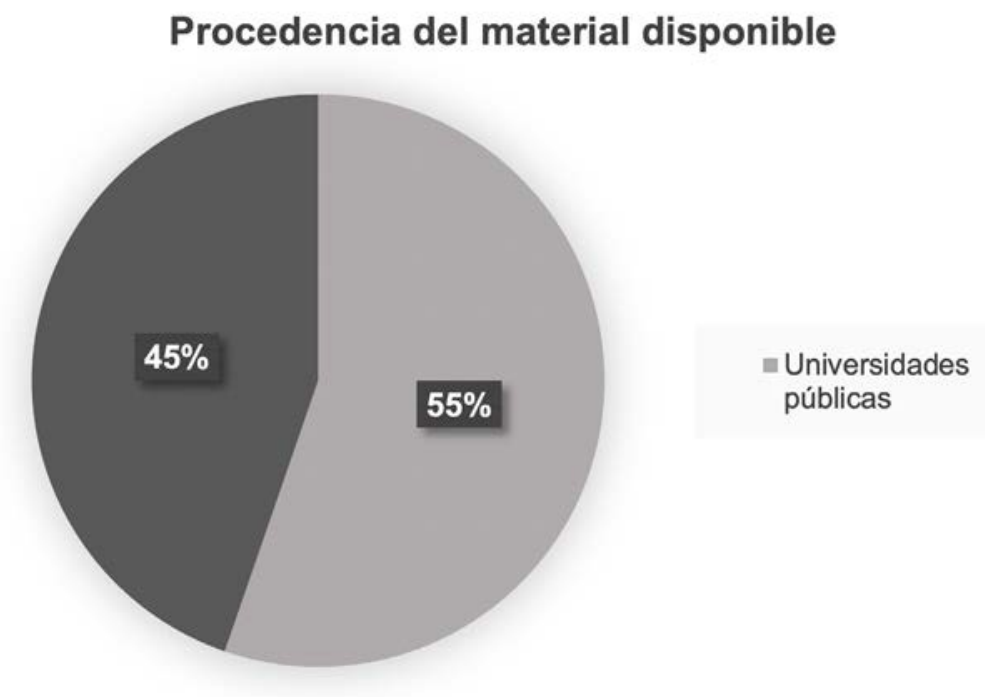

\section{Gráfico 3: Procedencia del material disponible}

A su vez, se observa que casi la totalidad de los documentos posee acceso completo al mismo, siendo ínfima la proporción que está restringida, embargada o sólo permite ver resumen.

\section{Tipo de Acceso}

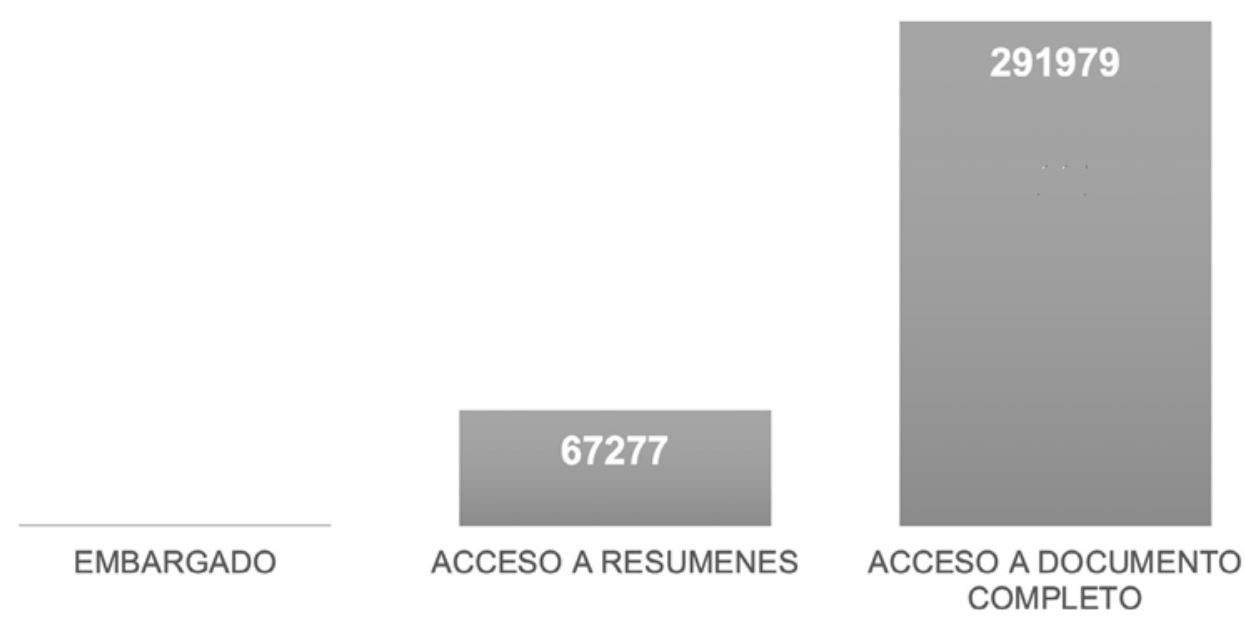

\section{Gráfico 4: Tipo de acceso de los documentos}

Ello demuestra que se cumple lo establecido por el artículo $\mathrm{N}^{\circ} 5$ de la Ley $\mathrm{N}^{\circ}$ 26.899: "deberán depositar o autorizar expresamente el depósito de una copia de la versión final de su producción científico-tecnológica publicada o aceptada para publicación" (2013). También refleja la buena intención de trabajar de modo colaborativo con el resto del sistema y de la sociedad. 


\section{Del cumplimiento de la ley a las consecuencias de la pandemia}

Se está viviendo un momento sin precedentes en la historia de la educación superior del que solo se podrá dar una solución exitosa cuando impere el sentido común sobre la sinrazón y la generosidad en la que cada uno, profesor, estudiante o personal de servicios, de lo máximo de sí mismo y sea flexible con lo que recibe del resto de la comunidad. (García-Peñalvo et al, 2020).

Considerando los aportes de Coraglia y Vázquez (2020) será necesario replantear las estructuras mismas de la institución universitaria, revalorizando su misión y objetivos, y propiciando los espacios de generación y transmisión de conocimiento. La situación nos recuerda que la Universidad no es un espacio físico sino una comunidad de profesores y alumnos que aprenden juntos: "convertir todo el espacio en campus.” (Sánchez Ostiz; Fernández-Gubieda, 2020, p. 14).

Es en este contexto que analizando al $31 \%$ de las Universidades de gestión pública que posee repositorios, se evidencia una creciente evolución de los documentos publicados en los últimos 10 años, a excepción del año pasado y el vigente.

\section{DOCUMENTOS PUBLICADOS EN LA ÚLTIMA DÉCADA POR UNIVERSIDADES DE GESTIÓN PÚBLICA}

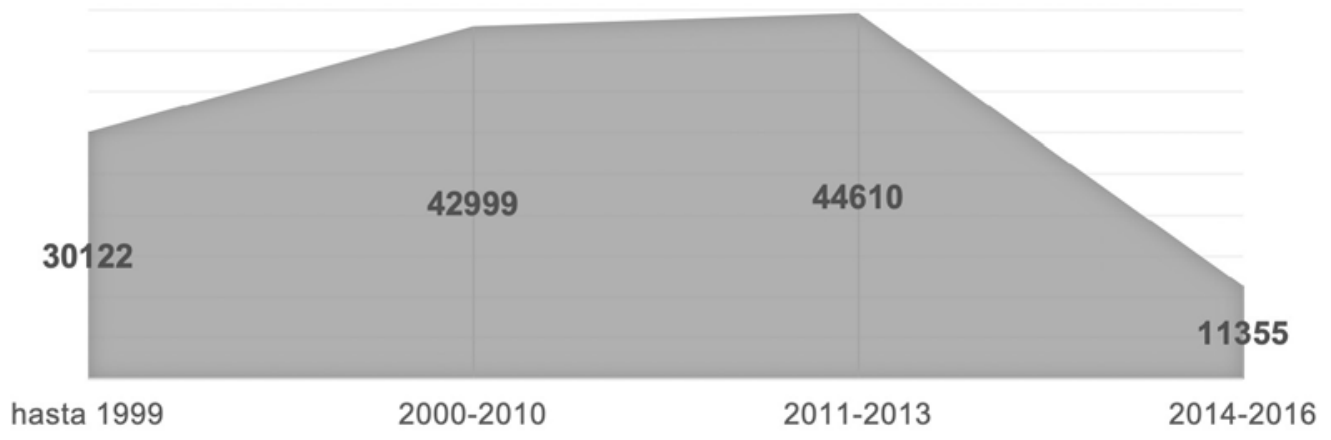

Gráfico 5: Documentos publicados en la última década por universidades de gestión pública

Entre 2011 y 2013 las Universidades comenzaron a otorgarle mayor importancia a los repositorios institucionales impulsadas por la sanción de la Ley 26.899 y entre 2014 y 2016 la cantidad de documentos aumentó un 43\%. Con la posterior reglamentación, entre 2017 y 2019 fue el pico máximo de publicación evidenciando una tendencia creciente hasta 2020 donde la pandemia parece haber impactado negativamente en la cantidad de documentos disponibles en los repositorios de las Universidades de gestión pública dado que disminuyó considerablemente desde entonces. 


\section{Cantidad de documentos en repositorios digitales por rango de fechas}

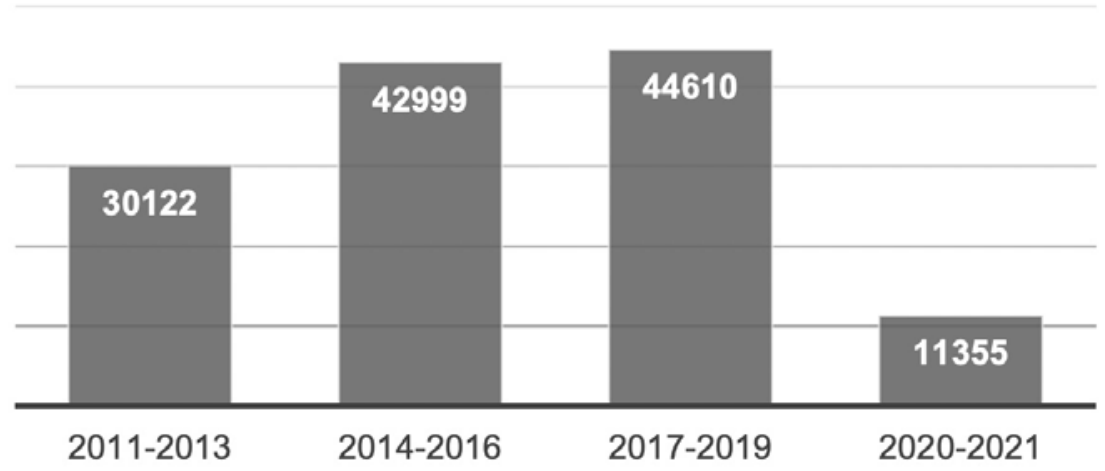

\section{Gráfico 6: Cantidad de documentos en repositorios digitales por rango de fechas}

Los efectos de la pandemia en las instituciones de educación superior fueron analizados por Coraglia y Vázquez (2020) quienes consideraron que "frente a esta emergencia sanitaria, las Universidades han reaccionado para seguir en funcionamiento valiéndose de los recursos que tenían a su alcance con gran compromiso de todos los actores involucrados" (p. 160). A partir de ahora, se requiere "optimizar el aprendizaje de nuestros alumnos, desbloquear el talento de nuestros profesores y reinventar la universidad online." (Fernández-Gubieda Lacalle, 2020, p. 14)

\section{Clasificación de las Universidades según la cantidad de documentos}

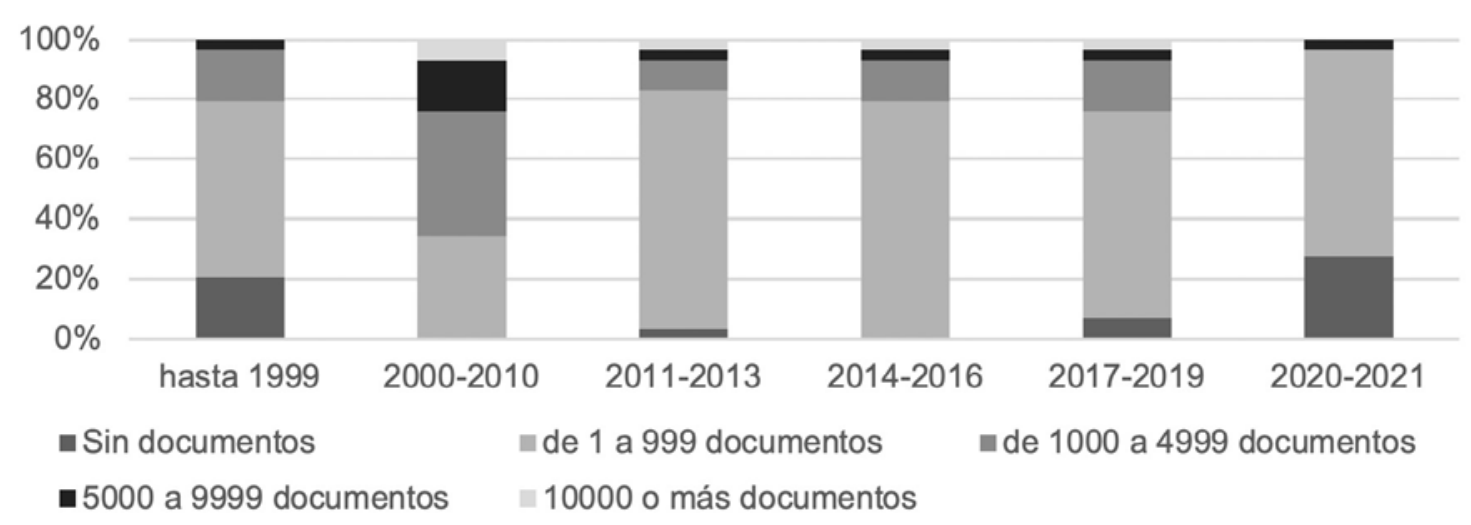

\section{Gráfico 7: Clasificación de las Universidades según la cantidad de documentos}

Teniendo en cuenta la cantidad de documentos provistos por las Universidades, se observa que la gran mayoría (74\% en promedio) provee entre 1 y 999 documentos cada tres años, mientras que sólo una pequeña proporción (14\%) publica entre 1.000 y 5.000 y sólo dos Universidades exceden esos valores.

En función del diagnóstico presentado, y con todo el aprendizaje ganado durante la pandemia, se espera que las Universidades dediquen esfuerzos en retomar la 
práctica de publicar documentos en sus repositorios y aquellas que aún no lo poseen, lo concreten a fin de colaborar con el crecimiento de todo el sistema de conocimiento de las Universidades argentinas.

Paralelamente, se recomienda incorporar la Alfabetización Informacional, ya que el poner a disposición es sólo una parte de proceso, resulta relevante además dotar a alumnos, docentes, investigadores y demás usuarios de las herramientas que permitan el acceso, uso y distribución eficiente y ética de esta información. Es en este sentido que cobra importancia la función formadora de las bibliotecas universitarias: "las bibliotecas cada vez se integran más en el aprendizaje, intentando ser un puente entre el aula y los espacios de prácticas para favorecer el éxito y la mejor integración del alumno" (Alonso Arévalo, 2018, p. 74), siendo esta más que una opción, una cuestión de supervivencia, como lo manifiestan Hendrix (2010) "para poder subsistir, las bibliotecas universitarias deberán basarse en la creación de relaciones e interacciones interpersonales. El acto de aprender (una misión importante de las bibliotecas universitarias) será tanto social como cognitivo" (Varela-Prado y Baiget, 2012, p. 123).

\section{Referencias}

Alejandría, D. (2005) Declaración sobre la alfabetización informacional y el aprendizaje a lo largo de la vida: Faros para la Sociedad de la Información. http://archive. ifla.org/III/wsis/BeaconlnfSoc.html

\section{Alonso Arévalo, J. (2018). Makerspaces y bibliotecas. Editorial UOC}

Budapest, D. (2002). Iniciativa de Budapest para el Acceso Abierto. https://www. budapestopenaccessinitiative.org/translations/spanish-translation

Bustamante, T. (2020). Bibliotecas sostenibles: Objetivos 2030. Desiderata, II/ (14), 110-112. https://dialnet.unirioja.es/descarga/articulo/7335636.pdf

Coraglia, M. I. y Vázquez M. (2020) La Universidad y sus respuestas frente a la pandemia Revista Nuevas Propuestas(55) 146-153 http://www.ucse.edu.ar/wp-content/ uploads/2020/11/Revista_NuevasPropuestas_Eesp_Nro55-EdUCSE.pdf

Sánchez Ostiz, P.; Fernández Gubieda, S. (2020) Jugando con las piezas del cubo. En Fernández-Gubieda Lacalle, S. (Ed.). Docencia rubic. Aprendizajes de la enseñanza universitaria en tiempos de la COVID-19. (pp. 13-18). EUNSA.

Franganillo, J. (2008). Depósitos: un factor psicológico de desconfianza. BiD: textos universitaris de biblioteconomia $i$ documentació, 20 http://hdl.handle. net/2445/16864

García-Peñalvo, F.; Corell, A.; Abella-García, V.; Grande, M. (2020): La evaluación online en la educación superior en tiempos de la COVID-19 Education in the Knowledge Society 21 (0), 12/1-12/26 https://hdl.handle.net/11162/201047 
Hendrix, D. (2010). Relationships between Association of Research Libraries (ARL) Statistics and bibliometric indicators: A principal components analysis. College and Research Libraries (71) 32-41 https://hdl.handle.net/20.500.12588/18

Ley $N^{\circ}$ 26.899/2013 Repositorios digitales institucionales de acceso abierto. Boletín Oficial de la República Argentina, 32.781, Primera Sección, 3-4. http://servicios.infoleg.gob.ar/infoleglnternet/anexos/220000-224999/223459/norma.htm

Pinto, M., Sales, D. y Martínez-Osorio, P. (2009). University library personnel and information literacy training: from self-perception to realities and training challenges. Revista española de Documentación Científica, 32(1). 60-80 https://doi.org/10.3989/ redc.2009.1.634

Salmoiraghi, M. P. (2012). Propuesta para la implementación de un centro de recursos para el aprendizaje y la investigación en la biblioteca del instituto de formación técnica superior [Tesis de grado. Universidad Nacional de Mar del Plata] http://humadoc.mdp.edu.ar:8080/bitstream/handle/123456789/78/Salmoiraghi_tesina.pdf?sequence $=1$

Sistema Nacional de Repositorios Digitales (s/f) Ministerio de Ciencia Tecnología e Innovación. https://repositoriosdigitales.mincyt.gob.ar/vufind/

Swan, A. (2013). Directrices para políticas de desarrollo y promoción del acceso abierto: UNESCO. https://unesdoc.unesco.org/ark:/48223/pfO000222536_spa

Torres, S. (2019). Material de Cátedra Extensión Bibliotecaria de la Especialización en Gestión de Bibliotecas. Buenos Aires: Universidad de Ciencias Empresariales y Sociales.

Universidad Nacional de Córdoba (2016). Reglamentaron la Ley de Repositorios Digitales Institucionales de Acceso Abierto.

https://www.unc.edu.ar/ciencia-y-tecnolog\%C3\%ADa/reglamentaron-la-ley-de-repositorios-digitales-institucionales-de-acceso

Praga, D. (2003) Hacia una sociedad alfabetizada en información http://portal.unesco.org/ci/en/files/19636/ 11228863531PragueDeclaration.pdf/PragueDeclaration.pd

UNESCO (2017) Las piedras angulares para la promoción de sociedades del conocimiento inclusivas. Acceso a la información y al conocimiento, libertad de expresión, privacidad y ética en la Internet global. Estudio final. https://cetic.br/media/ docs/publicacoes/8/las-piedras-angulares-para-la-promoci\%C3\%B3n-de-sociedades-del-conocimiento-inclusivas.pdf

Varela-Prado, C. y Baiget, T. (2012). El futuro de las bibliotecas académicas: incertidumbres, oportunidades y retos. Investigación Bibliotecológica, 26(56), 115-135 http://www. scielo.org.mx/scielo.php?script=sci_arttext\&pid=S0187-358X2012000100006\&ln$\mathrm{g}=\mathrm{es} \& n r m=i s o \& \operatorname{lng}=e s$ 


\section{La Inclusión como Derecho Habilitador en la Modalidad Virtual: Universidad Autónoma de Tamaulipas}

\section{Espinosa Barajas, Jeny Haideé}

Universidad Autónoma de Tamaulipas

jhespinoza@docentes.uat.edu.mx

\section{Lladó Lárraga Dora.Ma.}

ORCID (0000-0003-2368-3695)

\section{Ruíz Méndez, Manuel}

ORCID (0000-0002-8440-945) 


\title{
LA INCLUSIÓN COMO DERECHO HABILITADOR EN LA MODALIDAD VIRTUAL: UNIVERSIDAD AUTÓNOMA DE TAMAULIPAS
}

\author{
Espinosa Barajas, Jeny Haideé \\ Lladó Lárraga Dora.Ma. \\ Ruíz Méndez, Manuel \\ García Leal, María \\ Hernández Ramírez, Mauricio
}

\section{Resumen}

La pandemia del COVID-19, forzó a las escuelas a migrar a una educación remota y con ello se evidenció la necesidad de implementar estrategias de diseños universales mediados por las tecnologías de información y comunicación como una medida de inclusión para llegar a todos los y las estudiantes en la virtualidad. Por lo anterior, y considerando que la prioridad es el estudiantado, se procedió a capacitar, sensibilizar y concientizar al personal docente para que consideraran procesos de enseñanza-aprendizaje-evaluación flexibles, pertinentes, accesibles e incluyentes con diseños universales mediados por la tecnología. El objetivo del presente trabajo fue visibilizar los principios del Diseño Universal de Aprendizaje (DUA) y las formas de inclusión en Microsoft Teams para crear entornos de enseñanza-aprendizaje-evaluación que atendieran la diversidad de necesidades de las y los estudiantes de la modalidad virtual en la Universidad Autónoma de Tamaulipas. Las formas de inclusión incluyeron alternativas tecnológicas de percepción y comprensión de la información, entrega de tareas y formas de motivación. Los resultados mostraron que los principios del DUA y los recursos tecnológicos de Microsoft Teams permitieron que el personal docente de la universidad, desarrollara procesos de enseñanza-aprendizaje-evaluación inclusivos en la modalidad virtual para atender la diversidad de necesidades del estudiantado.

\section{Palabras clave}

Inclusión educativa, inclusión tecnológica, diversidad. 


\section{Introducción}

En tiempos de pandemia Covid-19, los sistemas educativos tuvieron que hacer frente al desafío de una enseñanza remota de emergencia para una gran diversidad de estudiantes. El propósito educativo de conformar aulas incluyentes diferenciadas por la sensibilidad, el reconocimiento, el respeto y la valoración de la diversidad migró a la virtualidad.

Uno de los organismos internacionales como la UNESCO (2016 y 2017) menciona que la inclusión en la educación es una de las principales estrategias que existen para reducir las desigualdades y reducir los problemas de marginación y exclusión $y$, con ello, atender la diversidad de necesidades de aprendizaje de todo el estudiantado, modificando y cambiando los contenidos, las estructuras y las estrategias para atender a todos por igual.

El término de inclusión educativa simboliza el compromiso de hacer que las instituciones y entornos de aprendizaje sean lugares donde todas y todos sean valorados y en donde la diversidad se visualice como una oportunidad de innovación y no como un problema (UNESCO, 2019).

Los factores sociales, económicos y culturales favorecen o disminuyen la inclusión en la educación, es por ello que se requieren diseños que reconozcan la diversidad de necesidades relacionadas por el género, la edad, la pobreza, la discapacidad, el origen étnico, la lengua, la situación de desplazamiento, las creencias, las actitudes, los estilos de aprendizaje, entre otros elementos (UNESCO, 2020).

Al respecto y como lo mencionan Cabero y Córdoba (2009), las Tecnologías no pueden convertirse en un componente más de exclusión, sino que deben contribuir a crear sociedades más justas; sean de Información y Comunicación (TIC), para el Aprendizaje y el Conocimiento (TAC) o para el Empoderamiento y la Participación (TEP), las tecnologías fungirán como recursos facilitadores y transmisores de información y recursos educativos para atender la diversidad de necesidades y características individuales del estudiantado.

Del mismo modo, la Secretaría de Estuación Pública en México (SEP, 2018) refiere que el apoyo de la tecnología aumenta la capacidad de una institución educativa para dar respuesta la diversidad de necesidades formativas y a reducir las barreras en el aprendizaje y la participación de todos los y las estudiantes.

En marzo 2020, la Universidad Autónoma de Tamaulipas implementó un Plan Académico-Tecnológico para responder a la contingencia de la pandemia COVID-19 y continuar con los procesos de enseñanza aprendizaje en la modalidad mixta opción virtual.

La estrategia tecnológica consistió en capacitar a la planta docente en el uso de la Plataforma Tecnológica Universitaria de Microsoft 365; lo cual incluyó herramientas de comunicación y colaboración en la nube como el correo electrónico, Teams, Stream, Sway, Office Online, MindMeister, entre otras.

Durante el 2020, se llevaron a cabo dos procesos de capacitación masiva; el primero se desarrolló en el mes de marzo para continuar con el periodo escolar primavera 2020 (enero a mayo) con temas básicos que permitieran crear un primer 
acercamiento del personal docente con el estudiantado, en el cual se atendieron a 734 profesores universitarios. El segundo proceso de capacitación se realizó durante los meses de junio, julio y agosto, debido a la extensión de la contingencia y para iniciar con el periodo escolar de otoño 2020 (agosto a diciembre); en este caso, la capacitación abarcó a un número mayor de docentes siendo 2250 en total. Los temas que se presentaron integraron herramientas tecnológicas más específicas que permitieran no solo una comunicación efectiva sino crear recursos didácticos y lecciones digitales para lograr alcanzar la calidad de los procesos de enseñanza-aprendizaje con la comunidad estudiantil universitaria. Aunado a lo anterior y como resultado de las limitaciones y dificultades presentadas por estudiantes durante la pandemia, en este segundo proceso se integró el tema de la inclusión en la modalidad virtual. Algunas de las situaciones de vulnerabilidad fueron la conectividad, el acceso a la red de Internet, el acceso a dispositivos tecnológicos, estrés, falta de motivación, problemas emocionales, responsabilidades familiares, cansancio, dificultades en el aprendizaje, condición de discapacidad, entre otras. Por tal motivo, uno de los aspectos principales a considerar en la inclusión fue adoptar los principios del Diseño Universal para el Aprendizaje (DUA) en Microsoft Teams, lo cual sirvió como un marco de referencia para garantizar que todos los y las estudiantes accedieran en igualdad de condiciones a los aprendizajes.

EI DUA ofrece diversas formas de acceder a los aprendizajes y utiliza principios que son un conjunto de estrategias que permiten la flexibilidad, transformación e innovación en la práctica docente.

De acuerdo con el Centro de Tecnología Especial y Aplicada (2011) los principios del DUA son: 1) proporcionar múltiples formas de representación de la información, 2) proporcionar múltiples formas para la acción y expresión del aprendizaje y 3) proporcionar múltiples formas de implicación.

El primer principio corresponde a proporcionar la información a través de diferentes modalidades, es decir por medio de recursos visuales, auditivos, táctiles y audiovisuales. Para ello se implementó una alternativa de percepción para Microsoft Teams con texto digital mediante Word y Power Point Online, incluyendo las características de accesibilidad; una alternativa de comprensión con lectura fácil y con contenidos significativos; una alternativa de percepción con el servicio de video de Stream, presentaciones dinámicas en Sway, y; reuniones de videoconferencia para la alternativa de comprensión con audio y video. Además, se implementó una alternativa de percepción de la información con MindMeister para diseñar y crear mapas mentales.

El segundo principio consiste en permitir las diversas formas en que los y las estudiantes pueden expresar sus aprendizajes; en este sentido, variar los métodos de respuesta y optimizar el acceso a las herramientas permitirá la fluidez de las comunicaciones con el estudiantado. También es importante que con las herramientas tecnológicas se promueva la autoevaluación para que ellos mismos puedan monitorear y dar seguimiento a sus actividades académicas y tengan la oportunidad de ir descubriendo sus áreas de oportunidad o sus fortalezas. Así mismo, resulta útil manejar diferentes instrumentos de evaluación como rúbricas, pruebas orales y/o escritas, guías de observación, listas de cotejo, portafolios, entre otros; y ofrecer una retroalimentación pertinente. Para esta pauta se trabajó para la comprensión, con los medios tecnológicos alternativos de Tareas y Formularios en Microsoft Teams. El recurso de Tareas permite crear, revisar y calificar actividades por medio de 
puntuaciones, rúbricas y retroalimentaciones; aquí el estudiantado puede subir actividades en diferentes formatos como documentos de texto, de documento portátil (.pdf), presentaciones electrónicas, hojas de cálculo, imágenes, videos, audios, entre otros; además el estudiantado puede volver a subir el archivo cuando él o la docente devuelva la tarea con observaciones. El recurso de Formularios permite crear y compartir cuestionarios y encuestas en línea; los cuestionarios son una estrategia para medir los conocimientos del estudiantado de una manera formativa. Conjuntamente, incluyen elementos de accesibilidad como el lector inmersivo para facilitar la lectura y la comprensión de los textos o la lectura en voz alta.

El tercer principio implica proporcionar diversas opciones para captar el interés del estudiantado y opciones para resaltar el esfuerzo y las relevancias de los objetivos de aprendizaje propuestos; de tal manera que se sientan motivados, acompañados y se disminuyan sus distracciones. Para ello se propuso utilizar diferentes medios de integración de la información y comunicación para la comprensión con las herramientas disponibles en los Teams de Clase como Publicaciones, Calendario y Chat. El recurso de Publicaciones permite iniciar conversaciones o crear anuncios para todos los miembros de un Teams por medio de texto, audio, emojis, gif, adhesivos o adjuntando archivos; las y los estudiantes pueden responder los mensajes o crear nuevas conversaciones. El recurso de Calendario permite crear reuniones de videoconferencia, programar eventos y calendarizar las tareas; el estudiantado puede revisar cada una de las videoconferencias y las actividades para las clases. El recurso de Chat, permite establecer conversaciones privadas, esto ayuda a mantener una comunicación directa, incluso son útiles para desarrollar tutorías o asesorías.

El objetivo del presente trabajo fue visibilizar los principios del Diseño Universal de Aprendizaje (DUA) y cómo favorecer las formas de inclusión en herramientas tecnológicas como el Microsoft Teams, para crear entornos de enseñanza-aprendizaje-evaluación que atendieran la diversidad de necesidades del estudiantado de la modalidad virtual en la Universidad Autónoma de Tamaulipas (UAT).

\section{Método}

\section{Descripción del contexto y de los participantes}

La Universidad Autónoma de Tamaulipas implementó un Plan Académico-Tecnológico para responder a la contingencia de la pandemia COVID-19 y continuar con los procesos de enseñanza aprendizaje en la modalidad mixta opción virtual. La estrategia tecnológica consistió en capacitar a la planta docente en la herramienta de comunicación y colaboración en la nube denominada Microsoft Teams.

\section{Procedimiento}

Se llevaron 4 procesos de capacitación, el primero se desarrolló en el mes de marzo para continuar con el periodo escolar primavera 2020 (enero a mayo) con temas generales que permitieran crear un primer acercamiento de docentes con los y las estudiantes. El segundo proceso de capacitación se llevó a cabo durante los meses junio, julio y agosto, debido a la extensión de la contingencia y para iniciar con el periodo escolar de otoño 2020, los temas que se presentaron fueron con recursos tecnológicos más específicos para lograr la calidad del aprendizaje con los y las estudiantes universitarios. 
En el segundo proceso se integró el tema de la inclusión en la modalidad virtual como resultado de las limitaciones y dificultades presentadas por estudiantes durante la pandemia. Algunas de las dificultades o limitaciones manifestadas fueron la conectividad, el acceso a la red de Internet, el acceso a dispositivos tecnológicos, estrés, falta de motivación, problemas emocionales, condición de discapacidad, responsabilidades familiares, cansancio, dificultades en el aprendizaje, entre otras situaciones.

Para lo anterior se adoptaron los principios del Diseño Universal para el Aprendizaje (DUA) con Microsoft Teams como un marco de referencia para garantizar que todos los y las estudiantes accedieran en igualdad de condiciones a los aprendizajes.

\section{Instrumento}

Al finalizar la capacitación del grupo de 2250 docentes, se aplicó una encuesta virtual por medio de la herramienta de formularios de Microsoft 365, con el objetivo de identificar si se consideraban docentes inclusivos en los procesos de enseñanza-aprendizaje.

La encuesta se diseñó en 3 secciones. La primera sección para conocer su género, la segunda sección para conocer los datos de identificación institucional como lo es su número de empleado y el nombre de la escuela a la que pertenecen y la tercera sección con el objeto de valorar su nivel de inclusividad en la práctica docente. Los ítems planteados fueron:

1. Soy un(a) docente que considero las diversas necesidades educativas de los y las estudiantes al planear mis estratégicas didácticas.

2. Soy un(a) docente que proporciona el material de clase a través de diferentes modos.

3. Soy un(a) docente que facilita la entrega de tareas o trabajos.

4. Soy un docente(a) que permito que las tareas, actividades y evaluaciones las presenten de manera oral, escrita o gráfica.

5. Soy un(a) docente que conoce de tecnología inclusiva.

\section{Resultados}

La implementación de los principios del DUA con Microsoft Teams permitió sensibilizar y concientizar a la planta docente sobre la diversidad de necesidades que pueden presentar las y los estudiantes en la modalidad virtual.

Las herramientas tecnológicas que se utilizaron para implementar las alternativas de percepción y comprensión en Microsoft Teams fueron: Publicaciones, Reuniones de Videoconferencia, Chat, Calendario, Tareas, Cuestionarios (Forms), Stream, Sway, MindMeister, Word Online y Power Point Online.

Los principios del DUA y los recursos tecnológicos de Microsoft Teams permitieron que los y las docentes de la Universidad Autónoma de Tamaulipas desarrollaran procesos de enseñanza-aprendizaje-evaluación inclusivos en la modalidad virtual y de esta forma atender la diversidad de necesidades del estudiantado.

De la encuesta aplicada, se obtuvieron 1158 respuestas, de los cuales 622 fueron del género femenino y 536 del género masculino. La distribución del personal por escuela se muestra en la tabla no. 1. 
Nombre de la escuela

Facultad de Comercio, Administración y Ciencias Sociales Nuevo Laredo

Facultad de Enfermería Nuevo Laredo

Unidad Académica Multidisciplinaria Reynosa Aztlán

Unidad Académica Multidisciplinaria Reynosa Rodhe

Unidad Académica Multidisciplinaria Río Bravo

Facultad de Medicina e Ingeniería en Sistemas

Computacionales de Matamoros

Unidad Académica Multidisciplinaria Matamoros - UAT

Unidad Académica Multidisciplinaria Valle Hermoso

Facultad de Ingeniería y Ciencias

Facultad de Enfermería y Obstetricia

Facultad de Medicina Veterinaria y Zootecnia “Dr. Norberto Treviño Zapata”

UAM Ciencias, Educación y Humanidades

UAM Trabajo Social y Ciencias para el Desarrollo Humano

Facultad de Comercio y Administración Victoria

Facultad de Derecho y Ciencias Sociales Victoria

Unidad Académica Multidisciplinaria Mante Centro

Facultad de Arquitectura Diseño y Urbanismo

Facultad de Comercio y Administración Tampico

Facultad de Enfermería Tampico

Facultad de Música y Artes "Mtro. Manuel Barroso Ramírez"

Facultad de Ingeniería "Arturo Narro Siller"

Facultad de Derecho y Ciencias Sociales Tampico

Facultad de Medicina "Dr. Alberto Romo Caballero"

Facultad de Odontología Tampico

CELLAP Victoria

CELLAP Tampico

CELLAP Reynosa

CEINA

Escuela Preparatoria No. 3

Escuela Preparatoria Mante

Instituto Ecología Aplicada

Secretarías del área central de la Rectoría

Total
Total encuestados

44

26

43

53

5

19

55

45

58

31

34

46

56

59

61

30

38

73

43

23

58

96

35

4

17

15

18

21

12

20

5

15

1158

Respecto al primer ítem: Soy un(a) docente que considero las diversas necesidades educativas de los y las estudiantes al planear mis estratégicas didácticas, el 93\% respondió que sí, el 5\% respondió que no y el $27 \%$ respondió que no siempre.

En el segundo ítem: Soy un(a) docente que proporciona el material de clase a través de diferentes modos, el $96 \%$ contestó que sí, el 3\% respondió que no y el 14\% respondió que no siempre. 
Para el tercer ítem: Soy un(a) docente que facilita la entrega de tareas o trabajos, el 94\% respondió que sí, el 3\% respondió que no y el 3\% respondió que no siempre.

En el cuarto ítem: Soy un docente(a) que permito que las tareas, actividades y evaluaciones las presenten de manera oral, escrita o gráfica, 88\% contestó que sí, el 7\% respondió que no y el $5 \%$ respondió que no siempre.

Y para el quinto ítem, Soy un(a) docente que conoce de tecnología inclusiva, el 53\% del personal respondió que sí, el $38 \%$ que no y el $9 \%$ no lo sabe.

\section{Discusión y conclusiones}

La necesidad de abordar este escrito deriva de la detección de situaciones educativas que vivieron los docentes universitarios ante la apremiante transición de una práctica educativa presencial a la modalidad virtual y la inminente necesidad de incorporar herramientas tecnológicas a su práctica educativa.

Algunos principios del Diseño Universal de Aprendizaje (DUA), promulgan la importancia de atender a los estudiantes a través de múltiples formas de representación de la información, de proporcionarles múltiples formas para la acción y expresión del aprendizaje y múltiples formas de implicación, pero, ¿cómo hacerlo de manera tan imprevista y sin la formación y experiencia en el manejo de herramientas tecnológicas? La capacitación docente sobre las distintas herramientas tecnológicas que podrían incorporarse en el proceso formativo en la modalidad virtual, tal y como lo establece el DUA, impulsó el desarrollo de una estrategia que incluyó una variedad de herramientas que se pusieron a disposición de los docentes, buscando con ello, subsanar y atender algunas de las situaciones de vulnerabilidad que fueron manifestadas por las y los estudiantes ante la pandemia COVID-19, y que hacían referencia a las dificultades en el aprendizaje, a condiciones de discapacidad y falta de inclusión, a la problemática de conectividad y de acceso a dispositivos tecnológicos, derivado de ello una falta de motivación, de cansancio provocado en ocasiones por tener que asumir algunas de las responsabilidades familiares.

La estrategia implementada por la UAT fue la incorporación masiva de la herramienta Microsoft Teams, creando aulas virtuales de aprendizaje en las que se propuso el uso de una diversidad de herramientas compatibles con Teams como lo es: texto digital de Word y Power Point Online, uso de video de Stream, presentaciones dinámicas en Sway, sesiones de videoconferencia, MindMeister para diseñar y crear mapas mentales, procesos de seguimiento y evaluación formativa y sumativa a través de la herramienta de Tareas y Formularios en Microsoft Teams. Se integraron diferentes medios de integración de la información y comunicación a nivel grupal, propiciando trabajo colaborativo o a nivel individual para los procesos de retroalimentación, como publicaciones, calendario y chat. Finalmente, se integraron elementos de accesibilidad como el lector inmersivo para facilitar la lectura y la comprensión de los textos o la lectura en voz alta.

Los resultados de la encuesta aplicada, evidencian que el personal docente se percibe a sí mismo como sujetos que propician la inclusión educativa al momento en que respondieron que consideran las diversas necesidades educativas del estudiantado al planear las estratégicas didácticas; que proporcionan el material de clase a través 
de diferentes modos, que facilitan la entrega de tareas o trabajos, que permiten que las tareas, actividades y evaluaciones las presenten de manera oral, escrita o gráfica y que conocen de tecnología inclusiva.

Como puede evidenciarse, con la implementación de la estrategia institucional, se atendieron los requerimientos derivados de la implementación de la educación virtual, al mismo tiempo que se consideraron estrategias inclusivas para atender necesidades del estudiantado ahora ubicados tan lejos geográficamente hablando.

Como lo menciona la UNESCO (2016; 2017 y 2020), la inclusión se basa en la valoración de la diversidad. Esto significa que no existe un estudiante modelo, sino que el diseño de estrategias deber hacerse pensando en que toda la comunidad estudiantil es diferente. Así también como lo menciona Cabero y Córdoba (2009) y la SEP (2018), la tecnología es un medio que ayuda a dar respuesta a la diversidad.

Por lo tanto, las instituciones educativas son las responsables de garantizar el derecho a la educación de todas las personas, el DUA y la tecnología desempeñan un papel fundamental en la inclusión.

\section{Referencias}

Cabero, J., y Córdoba M. (2009). Inclusión educativa: inclusión digital. Educación Inclusiva, 2, 61-77. Recuperado de http://rabida.uhu.es/dspace/bitstream/handle/10272/11296/Inclusion_educativa.pdf?sequence=2

Organización de las Naciones Unidas para la Educación la Ciencia y la Cultura. (2016). Educación 2030: Declaración de Incheon y Marco de Acción para la realización del Objetivo de Desarrollo Sostenible 4: Garantizar une educación inclusiva y equitativa de calidad y promover oportunidades de aprendizaje permanente para todos. UNESCO.

Organización de las Naciones Unidas para la Educación la Ciencia y la Cultura. (2017). Guía para asegurar la inclusión y la equidad en la educación. UNESCO

Organización de las Naciones Unidas para la Educación la Ciencia y la Cultura. (2019). Compromiso de Cali sobre Equidad e Inclusión en la Educación. UNESCO

Organización de las Naciones Unidas para la Educación la Ciencia y la Cultura. (2020). Informe de Seguimiento de la Educación en el Mundo de 2020, inclusión y educación: todos sin excepción. UNESCO.

Secretaría de Educación Pública. (2018). Estrategia de equidad e inclusión en la educación básica: para alumnos con discapacidad, aptitudes sobresalientes y dificultades severas de aprendizaje, conducta o comunicación. SEP 


\section{Análisis del Uso de Vídeos Didácticos en Una Situación de Emergencia Sanitaria. Comparación de Dos Escenarios: Docencia Remota de Emergencia y Docencia Híbrida}

\section{Museros, Pedro}

orcid.org/0000-0002-1389-0204

pmuseros@mes.upv.es

\section{Lapuebla-Ferri, Andrés}

orcid.org/0000-0001-9667-236X

anlafer0@mes.upv.es

\section{Espinós, Ana}

orcid.org/0000-0001-7335-4676

aespinos@mes.upv.es

\section{Benlloch-Dualde, José V.} orcid.org/0000-0002-4885-2806 jbenlloc@disca.upv.es 


\title{
ANÁLISIS DEL USO DE VÍDEOS DIDÁCTICOS EN UNA SITUACIÓN DE EMERGENCIA SANITARIA. COMPARACIÓN DE DOS ESCENARIOS: DOCENCIA REMOTA DE EMERGENCIA Y DOCENCIA HIIBRIDA
}

\author{
Museros, Pedro \\ Lapuebla-Ferri, Andrés \\ Espinós, Ana \\ Benlloch-Dualde, José V.
}

\section{Resumen}

En el presente trabajo se estudia el papel de los vídeos didácticos en el estudio de la materia Elasticidad y Resistencia de Materiales, por parte de estudiantes universitarios de grado, durante la pandemia de la COVID-19. Para ello, se comparan dos escenarios docentes singulares. El primero corresponde al segundo cuatrimestre del curso 2019-20, en una situación de confinamiento durante la cual la docencia se desarrolló forzosamente mediante metodologías en línea, lo que se ha venido denominando docencia remota de emergencia. El segundo escenario corresponde al segundo cuatrimestre del curso 2020-21, en el que la relajación de las medidas sanitarias propició un escenario de docencia hibrida, en virtud de la cual las metodologías y herramientas características de la docencia en línea se alternaron con otras más típicas de la docencia presencial, y por lo tanto más familiares para el estudiantado. Los vídeos didácticos, inicialmente desarrollados en el marco de un proyecto institucional para la mejora del proceso de enseñanza-aprendizaje de la materia, resultaron ser de gran ayuda en ambos contextos. Esto se puso de manifiesto en las encuestas realizadas, cuyos resultados revelaron un elevado nivel de satisfacción por parte del estudiantado, que demandaba asimismo el futuro desarrollo de más material en este formato.

\section{Palabras clave}

Vídeos screencast, Conceptos umbrales, Docencia remota de emergencia, Docencia híbrida, Elasticidad y Resistencia de Materiales. 


\section{Introducción}

Durante los cursos 2018-19 a 2020-21 se ha desarrollado en la Universitat Politècnica de València, España (UPV) un Proyecto de Innovación y Mejora Educativa (PIME) que ha implicado a tres centros: la Escuela Técnica Superior de Ingeniería Industrial (ETSII), la Escuela Técnica Superior de Ingeniería de Caminos, Canales y Puertos (ETSICCP) y la Escuela Técnica Superior de Ingeniería Informática (ETSINF) en tareas de asesoría estratégica].

En el PIME se han desarrollado recursos multimedia en forma de vídeos didácticos tipo screencast, orientados a la docencia y el aprendizaje de asignaturas relacionadas con la materia Elasticidad y Resistencia de Materiales (ERM). Esta materia se imparte bajo diferentes denominaciones según escuelas técnicas y titulaciones, aunque se corresponden con la asignatura que tradicionalmente se conoce como Resistencia de Materiales o, más recientemente, como Teoría de Estructuras, si bien en ciertas escuelas a nivel nacional es también frecuente el nombre de Elasticidad y Resistencia de Materiales, caso de la propia UPV. Esta materia sienta, a partir de los conocimientos de Mecánica Racional o Newtoniana, las bases para comprender el funcionamiento resistente de las estructuras civiles, industriales, arquitectónicas y de todo tipo, así como los procedimientos para predimensionar sus elementos principales (vigas, columnas, cables...). Se trata, por lo tanto, de una materia tan clásica como fundamental, obligatoria en los planes de estudios de todas aquellas titulaciones que habilitan para el ejercicio de la profesión en arquitectura, ingeniería e ingeniería técnica. Hablamos pues de la ingeniería estructural, la responsable de producir el hardware: edificios, puentes, naves industriales, presas, bastidores, torres, depósitos, antenas, estadios, rascacielos, etc.

Esta materia, tradicionalmente, requiere de un esfuerzo considerable para el estudiantado de los centros donde se imparte. El motivo es que, a la propia dificultad conceptual de un corpus de conocimientos nuevo y extenso, se une la necesidad de manejar con soltura el álgebra y los sistemas de ecuaciones, la geometría y trigonometría, así como un buen número de conceptos fundamentales de Mecánica, la geometría de masas, etc. Si a estos requerimientos se les une, además, el frecuente e ineludible recurso a la (algo etérea) visión espacial, el "cóctel" resulta muy completo y formativo, pero también dotado de una considerable exigencia.

En este marco de retos en el aprendizaje, transversal a escuelas de ingeniería y arquitectura, se planteó el PIME al que, por razones obvias, se le denominó proyecto STRUCT+MÈDIA (Lapuebla-Ferri et al., 2020). El proyecto fue desarrollado por profesorado perteneciente al Departamento de Mecánica de los Medios Continuos y Teoría de Estructuras de la UPV, apoyados por un experto en tinta digital (Benlloch Dualde, 2014).

EI PIME se desarrolló con normalidad hasta mediados de marzo de 2020, cuando fue publicado el Real Decreto 463/2020, por el que España entraba en el estado de alarma por emergencia sanitaria. Desde ese momento, la pandemia de la COVID-19 ha condicionado la docencia a todos los niveles, obligando, tanto al profesorado como al alumnado, a adaptarse a la situación mediante la asunción de compromisos hace poco impensables. Así, entre el 15 de marzo y el 21 de junio de 2020, periodo de duración del primer estado de alarma, se confinó a la práctica totalidad de la población algo que no se había visto desde hacía siglos. De este modo, la tradicional 
docencia de carácter presencial hubo de transformarse durante el segundo semestre del curso 2019-20 en docencia remota por situación de emergencia sobrevenida. Los profesores de asignaturas de ERM de la UPV intentaron entonces poner en valor esos vídeos docentes, inicialmente planteados para una mejora educativa progresiva de la materia.

Asimismo, durante el curso 2020-2021, si bien ya no existía una situación de confinamiento total, las medidas restrictivas necesarias para el control de la pandemia durante la segunda ola y sucesivas, hicieron necesario que se trabajara en la UPV en un escenario de docencia hibrida, parte de la cual se realizó presencialmente, y otra en remoto. En esta nueva situación, los vídeos docentes de ERM significaron también un gran apoyo al alumnado en su labor de aprendizaje. El uso de los vídeos por parte del estudiantado, y su demostrada utilidad, especialmente durante los primeros meses de la pandemia, es parte del análisis que aquí se presenta mediante el conteo de registros de acceso y fechas de consulta.

En síntesis, los objetivos del presente trabajo son:

- Presentar la colección de materiales didácticos multimedia, todos ellos de acceso abierto, creados en el marco del proyecto STRUCT+MĖDIA de la UPV para asignaturas de ERM.

- Analizar la utilización de estos recursos multimedia durante el periodo de docencia remota de emergencia, en el segundo semestre del curso 2019-2020.

- De forma análoga, analizar el uso de dichos recursos en el escenario de docencia híbrida durante el curso 2020-21, comparándolo con la docencia remota del curso anterior.

\section{Descripción de la experiencia: uso de screencast en docen- cia remota de emergencia y en docencia híbrida.}

\section{Antecedentes: encuestas de percepción}

La experiencia descrita se centra en las asignaturas de ERM en las titulaciones de Grado en Ingeniería en Tecnologías Industriales (GITI, 300 alumnos) y Grado en Ingeniería de la Energía (GIE, 60 alumnos) impartidas en la ETSII. La percepción previa de los estudiantes en ambas titulaciones se investigó mediante el siguiente cuestionario, que les fue enviado a partir de la segunda semana de docencia de la asignatura. Se empleó una escala Likert desde 1 (totalmente en desacuerdo) a 5 (totalmente de acuerdo).

Q1. La probabilidad de aprobar la asignatura este curso es...(1=muy baja, 5=muy alta)

Q2. La probabilidad de abandonar la asignatura este curso es...(1=muy baja, $5=$ muy alta)

Q3. Esta asignatura es una de las más difíciles del curso. 
Q4. Esta asignatura es importante para su labor profesional futura.

Q5. Esta asignatura es importante para el desarrollo de su labor profesional.

Q6. ¿A qué factor/es asociaría principalmente la dificultad de esta asignatura?

La propia complejidad de la materia. / La falta de materiales de apoyo adecuados. / El rigor empleado en las calificaciones. / La necesidad de conocimientos previos. / Los sistemas de evaluación utilizados. / La opinión transmitida por compañeros de otros cursos. / No la considera difícil

Se recibieron un total de 89 encuestas. La Tabla 1 muestra los resultados promedio de ambas titulaciones de grado en cada una de las cuestiones.

Tabla 1. Respuestas a las cuestiones de la Encuesta de Percepción de ERM en la ETSII.

\begin{tabular}{|l|c|}
\hline \multicolumn{1}{|c|}{} & Puntuación \\
\hline Q1 & 3,71 \\
\hline Q2 & 1,53 \\
\hline Q3 & 3,02 \\
\hline Q4 & 3,94 \\
\hline Q5 & 3,57 \\
\hline
\end{tabular}

Es destacable que el estudiantado resaltó la importancia de la asignatura para su labor profesional (Q4) con 3,94 puntos, reconociendo además la dificultad de la misma (Q3) con 3,02 puntos. En cuanto a las respuestas a la cuestión Q6, se destacó "la complejidad de la materia" ( $28 \%$ de respuestas), "el rigor en las calificaciones" (17\%) y "la necesidad de conocimientos previos" (17\%), lo que viene a confirmar la percepción de dificultad del estudiantado.

\section{Estructuración del PIME STRUCT+MĖDIA}

La concepción inicial del PIME respondía a la preocupación inicial por parte del profesorado de que buena parte de los estudiantes había demostrado un dominio escaso de los denominados conceptos umbrales (Meyer \& Land, 2005) de las asignaturas involucradas, es decir, los aspectos que presentaban mayores dificultades para el estudiantado. Esta preocupación inicial era compartida por todo el profesorado que se encuadraba en el PIME, cuya experiencia docente en la materia superaba individualmente los diez años. Para facilitar el desarrollo del PIME, se decidió agrupar los conceptos umbrales de la materia en un número más reducido de Temas Fundamentales (TF).

Para determinar los TF se elaboró una encuesta de prospección dirigida al estudiantado de la asignatura en el curso anterior. Los resultados obtenidos dejaron claro cuáles eran los TF que causaban mayores quebraderos de cabeza al alumnado, si bien algunos de los TF fueron elegidos a priori por los profesores, dado que así lo aconsejaba la experiencia. 
Como respuesta, se decidió crear materiales didácticos que generasen un efecto incentivador constatable en estudiantes de la materia ERM. Para que los materiales fuesen lo suficientemente atractivos por sí mismos, se optó por la grabación de vídeos didácticos en formato screencast, en los que se graba una presentación de diapositivas animadas en la pantalla del ordenador, junto con el audio de una narración.

Los objetivos iniciales fijados para el PIME fueron:

1. Determinar, sobre bases objetivas, los temas fundamentales de la materia ERM.

2. Incentivar el trabajo autónomo del estudiantado en los temas fundamentales.

3. Mejorar la percepción del estudiantado y el rendimiento académico en las asignaturas implicadas.

4. Aumentar el nivel de concienciación de los estudiantes respecto a la responsabilidad ética y profesional de los cálculos de estructuras.

5. Generar materiales audiovisuales docentes de calidad que contribuyan a la imagen positiva de la UPV.

6. Publicar los resultados principales del PIME en congresos y revistas para contribuir a la transmisión de conocimiento, así como a la visibilidad y a la proyección internacional de la UPV.

7. Apoyar la implantación a medio plazo del paradigma de clase inversa (flipped teaching) en la docencia de las asignaturas involucradas.

La colección de vídeos generados se organiza como matriz de recursos en torno a tres niveles de dificultad (básico, medio y avanzado) y a tres temas fundamentales del análisis de estructuras isostáticas planas: cálculo de reacciones, obtención de leyes y diagramas de esfuerzos en vigas y obtención de leyes y diagramas de esfuerzos en estructuras básicas (pórticos).

La matriz $3 \times 3$ de recursos de la Fig. 1 muestra, junto a los recursos y los niveles, los TF escogidos, dejando para futuros estadios del PIME la elaboración de vídeos didácticos de los restantes. En tanto que el desarrollo del PIME sigue activo, la matriz refleja el estado actual de los trabajos. 


\begin{tabular}{|c|c|c|c|}
\hline & CÁLCULO DE REACCIONES & ESFUERZOS EN VIGAS & ESFUERZOS EN PÓRTICOS \\
\hline \multirow{2}{*}{$\begin{array}{c}\text { NIVEL } \\
\text { INTRODUCTORIO }\end{array}$} & \multirow[b]{2}{*}{ NO REQUERIDO } & $\begin{array}{l}\text { Criterios de signos para esfuerzos en vigas } \\
\text { FINALIZADO }\end{array}$ & \multirow{2}{*}{$\begin{array}{c}\text { Criterios de signos para esfuerzos en vigas } \\
\text { y pórticos } \\
\text { FINALIZADO }\end{array}$} \\
\hline & & $\begin{array}{c}\text { Tramos y secciones para cálculo de leyes de } \\
\text { esfuerzos en vigas y pórticos } \\
\text { FINALIZADO } \\
\end{array}$ & \\
\hline \multirow{2}{*}{$\begin{array}{l}\text { NIVEL } \\
\text { BÁSICO }\end{array}$} & $\begin{array}{l}\text { Cálculo de reacciones en un pórtico } \\
\text { isostático: nivel básico (soporte en ménsula) } \\
\text { WORK IN PROGRESS }\end{array}$ & $\begin{array}{l}\text { Diagramas de esfuerzos en una viga } \\
\text { isostática: nivel básico (viga en ménsula) } \\
\text { FINALIZADO }\end{array}$ & $\begin{array}{c}\text { Diagramas de esfuerzos en un pórtico } \\
\text { isostático: nivel básico (pórtico con carga } \\
\text { horizontal) } \\
\text { FINALIZADO }\end{array}$ \\
\hline & $\begin{array}{c}\text { Cálculo de reacciones en una viga isostática: } \\
\text { nivel básico (viga biapoyada con voladizo) } \\
\text { WORK IN PROGRESS }\end{array}$ & $\begin{array}{c}\text { Diagramas de esfuerzos en una viga } \\
\text { isostática: nivel básico (viga biapoyada con } \\
\text { voladizo) } \\
\text { FINALIZADO }\end{array}$ & NO PREVISTO \\
\hline \multirow{2}{*}{$\begin{array}{c}\text { NIVEL } \\
\text { INTERMEDIO }\end{array}$} & $\begin{array}{c}\text { Cálculo de reacciones en una viga isostática: } \\
\text { nivel intermedio (viga con rótula) } \\
\text { WORK IN PROGRESS }\end{array}$ & $\begin{array}{c}\text { Diagramas de esfuerzos en una viga } \\
\text { isostática: nivel intermedio (viga con rótula) } \\
\text { FINALIZADO }\end{array}$ & $\begin{array}{c}\text { Diagramas de esfuerzos en un pórtico } \\
\text { isostático: nivel intermedio (pórtico con } \\
\text { una barra inclinada) } \\
\text { FINALIZADO }\end{array}$ \\
\hline & $\begin{array}{c}\text { Cálculo de reacciones en un pórtico } \\
\text { isostático: nivel intermedio (pórtico con } \\
\text { barra inclinada) } \\
\text { WORK IN PROGRESS }\end{array}$ & $\begin{array}{c}\text { Diagramas de esfuerzos en una viga } \\
\text { isostática: nivel intermedio (cargas } \\
\text { antisimétricas) } \\
\text { FINALIZADO }\end{array}$ & NO PREVISTO \\
\hline \multirow{2}{*}{$\begin{array}{c}\text { NIVEL } \\
\text { AVANZADO }\end{array}$} & $\begin{array}{c}\text { Cálculo de reacciones en un pórtico } \\
\text { isostático: nivel avanzado (carga triangular) } \\
\text { FINALIZADO }\end{array}$ & $\begin{array}{c}\text { Diagramas de esfuerzos en una viga } \\
\text { isostática: nivel avanzado (viga continua con } \\
\text { rótula) } \\
\text { FINALIZADO }\end{array}$ & \multirow{2}{*}{ NO PREVISTO } \\
\hline & $\begin{array}{l}\text { Cálculo de reacciones en una viga isostática: } \\
\text { nivel avanzado (viga continua con rótula) } \\
\text { FINALIZADO }\end{array}$ & $\begin{array}{c}\text { Diagramas de esfuerzos en una viga } \\
\text { isostática: nivel avanzado (carga triangular) } \\
\text { FINALIZADO }\end{array}$ & \\
\hline
\end{tabular}

Fig. 1. Matriz de recursos didácticos de vídeos docentes tipo "screencast".

En la actualidad, la matriz de recursos didácticos de la Fig. 1 está prácticamente completada, y es de esperar que lo esté al 100\% a lo largo del curso actual. Los vídeos generados son de acceso abierto a través del repositorio institucional de la UPV (RiuNet) o de la plataforma Media UPV. Los enlaces a los vídeos alojados en esta última se encuentran en la bibliografía.

Esta matriz de recursos servirá como guía para generar en un futuro vídeos didácticos relacionados con otros TF.

\section{Población objetivo del PIME STRUCT+MÈDIA}

Como se ha mencionado en la introducción, la población objetivo inicial del PIME era el alumnado de ERM en dos centros de la UPV. Por brevedad se expondrán y comentarán los resultados obtenidos en la experiencia seguida en la ETSII, al ser los más significativos.

En la ETSII se contaba con un total de 400 estudiantes, repartidos entre las dos titulaciones previamente mencionadas: GITI (300 estudiantes) y GIE (60 estudiantes). Pese a tratarse de dos titulaciones distintas, en ambas se imparte la asignatura Elasticidad y Resistencia de Materiales, de idéntica denominación y contenido. De este modo, el material didáctico multimedia generado podía emplearse indistintamente 
en ambas. Cabe indicar que en la situación pre-pandemia la metodología de enseñanza-aprendizaje era puramente presencial, incluyendo sesiones de teoría y resolución de problemas en el aula (clase magistral) y prácticas experimentales de laboratorio.

\section{Empleo de los recursos didácticos en docencia remota de emergencia}

Durante el segundo semestre del curso 2019-2020 se cambia repentinamente a docencia en línea por la situación de pandemia anteriormente descrita. Las universidades tradicionales, de la noche a la mañana, pasan a ser universidades on-line. En estas condiciones, la docencia universitaria adquiere una modalidad que se ha dado en denominar docencia remota de emergencia, tal como se decía al principio.

A partir de este viraje, el empleo de los vídeos por parte del alumnado se convierte en regular. La Fig. 2 muestra el conteo de accesos a los vídeos de la asignatura ERM en GITI y GIE. Se trata de accesos registrados durante los primeros meses de la pandemia. En las gráficas se observa un marcado (y esperado) incremento en fechas próximas a exámenes (finales de marzo, mediados de abril y mediados de junio), con fuertes picos en los accesos. Aun así, el nivel medio de visitas a los vídeos no es residual, sino que muestra un empleo más frecuente por parte de estudiantes que siguen la asignatura con cierta continuidad. Las conclusiones extraídas para la titulación GIE son similares. Estas cifras constituyen una evidencia de la utilidad del material didáctico creado en el PIME.

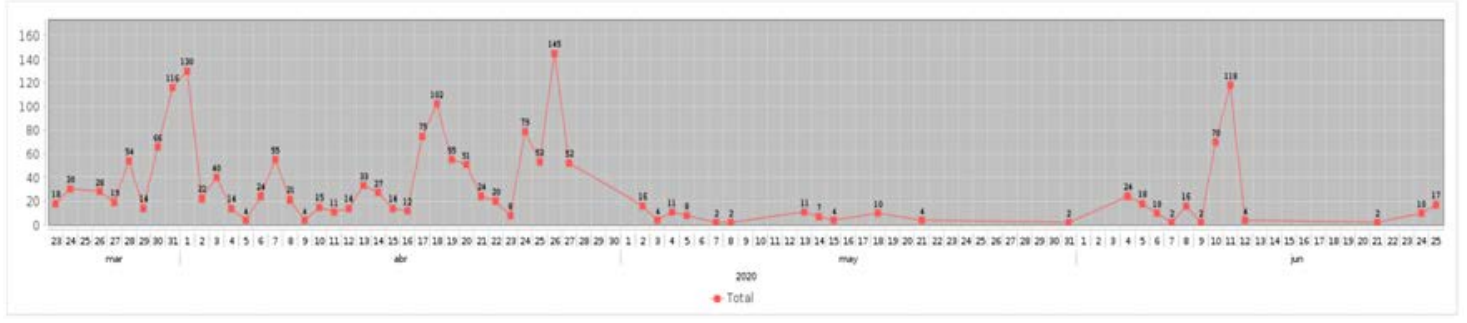

(a)

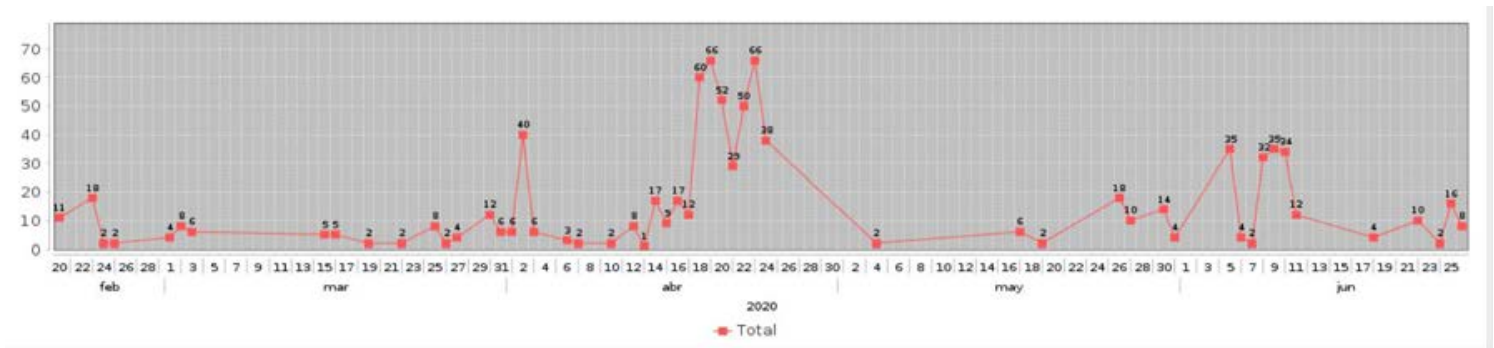

(b)

Fig 2. Conteo de accesos a vídeos screencast durante el 2o semestre de 2019-20. Escenario de docencia en línea de emergencia. (a) GITI. (b) GIE.

La tendencia de visualización de los vídeos se observa también en el conteo de accesos a cada vídeo de forma individual. Por ejemplo, en la Fig. 3 se muestran las estadísticas de visualización en GITI del screencast denominado "Diagramas de esfuerzos en un pórtico isostático: nivel básico (pórtico con carga horizontal)", tal y 
como aparece en la matriz de la Fig. 1. Los picos de la gráfica corresponden, nuevamente, a los días previos a la realización de los exámenes parciales de la asignatura.

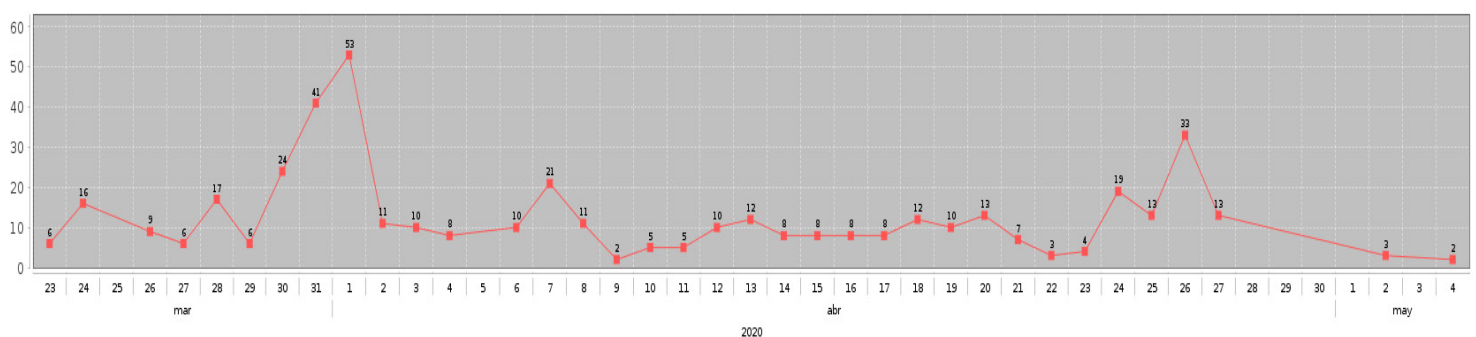

Fig 3. Conteo de accesos en GITI al vídeo "Diagrama de esfuerzos en un pórtico isostático: nivel básico (pórtico con carga horizontal)".

\section{Empleo de los recursos didácticos en docencia híbrida}

En contraste con lo anterior, en el curso 2020-21 la docencia se ha desarrollado con carácter híbrido, con ciertas actividades presenciales y otras en remoto.

La Fig. 4 muestra los accesos registrados en la asignatura ERM de GITI y de GIE. De manera similar a lo observado durante el curso 2019-20, se observan nuevamente claros picos de visitas en fechas previas a exámenes; en cambio, el nivel medio de accesos es visiblemente inferior. Si se observan los accesos a un vídeo en particular, como los que se muestran en la Fig. 5, esta tendencia sigue observándose.

Conclusiones similares se extraen al analizar los datos de GIE, si bien los picos de acceso en los días previos al examen del segundo parcial (mediados de junio) son más evidentes en esta titulación. Conociendo la idiosincrasia de la escuela, cabe deducir, por lo tanto, que el alumnado opta por seguir la asignatura empleando otros materiales disponibles más "tradicionales" cuando no están obligados a recurrir al modo on-line (como debieron hacer forzosamente en el segundo semestre del curso 2019-2020). En todo caso, la lectura de estos resultados debe ser positiva, pues la demanda de los recursos multimedia ha sido elevada cuando el estudiantado ha tenido necesidad de emplearlos.

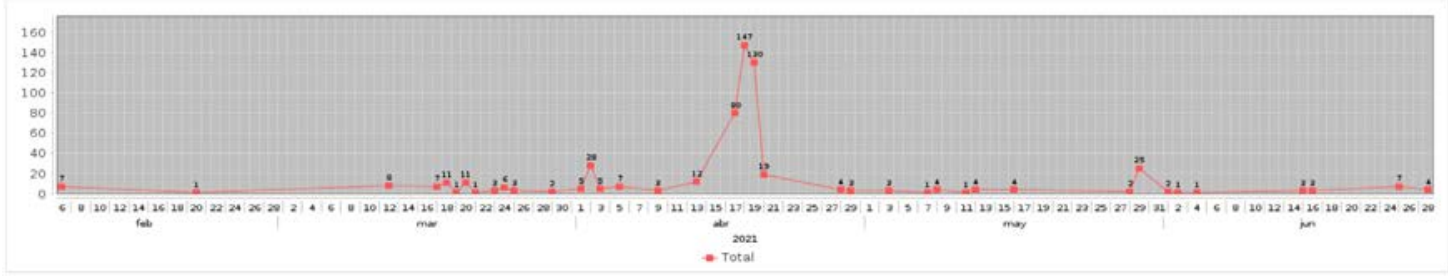




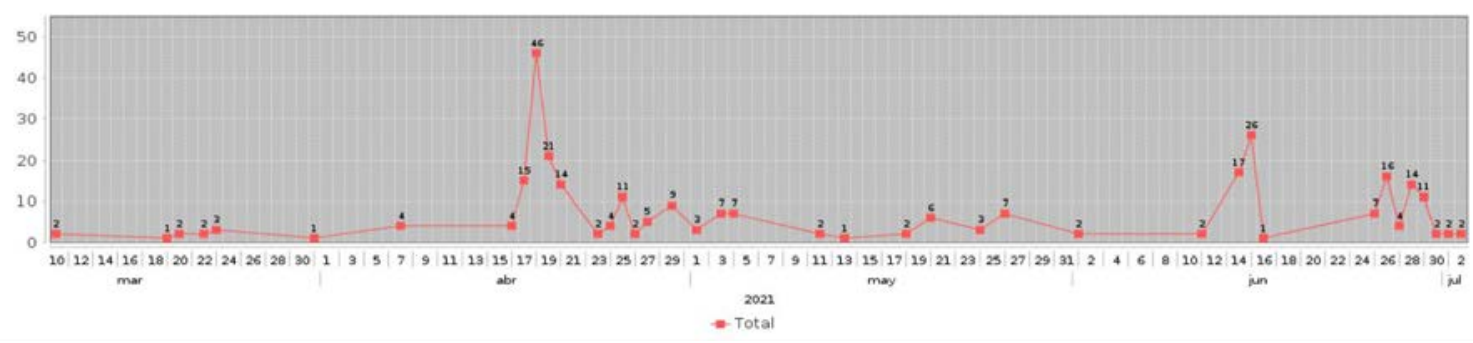

(b)

Fig 4. Conteo de accesos a vídeos screencast durante el 2º semestre de 2020-21. Escenario de docencia híbrida. (a) GITI. (b) GIE.

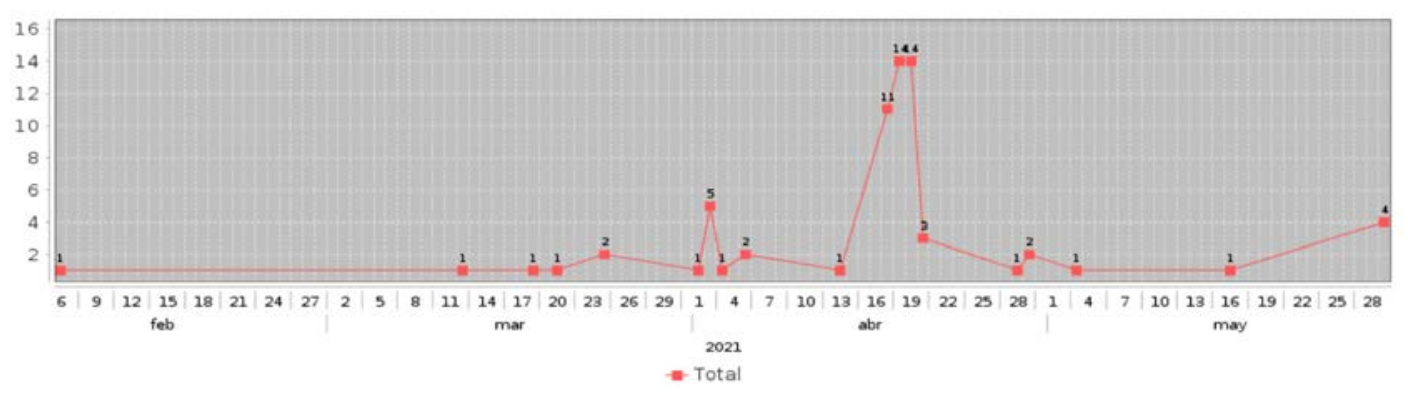

Fig 5. Conteo de accesos en GITI al vídeo "Diagramas de esfuerzos en un pórtico isostático: nivel intermedio (pórtico con soporte inclinado)".

\section{Resultados}

Según los datos de analítica del aprendizaje, las Figuras 2 a 5 muestran un amplio uso de los recursos multimedia en fechas previas a evaluaciones. Por lo tanto, se puede afirmar que el estudiantado, aun disponiendo de los tradicionales libros y apuntes, ha incorporado muy significativamente el uso de los vídeos, mostrando así una tendencia esperable a estudiar empleando el método que se considera más eficiente para aprender y ser capaces de superar la asignatura. Cuestión aparte es que esa forma de estudiar resulte a la postre o no la más efectiva, asunto que, sin duda, excede el ámbito de esta contribución.

\section{Encuestas de satisfacción}

En cuanto a la satisfacción del alumnado con el nuevo material docente, se cuenta con dos encuestas realizadas, respectivamente, en el curso 2019-20 (GITI) y en 2020-21 (GIE). En GITI, la mayoría de las respuestas fueron "más bien de acuerdo (MBA)" o "totalmente de acuerdo (TDA)" con la utilidad de los nuevos vídeos, en porcentajes sumados próximos al 90\% (MBA+TDA). En iguales porcentajes indicaron además que este material les ha ayudado a comprender la asignatura, y demandaron "más vídeos similares a estos". En GIE los resultados fueron análogos (Fig. 6), llegando al 80-90\% tras sumar MBA+TDA. Las respuestas, como puede constatarse, resultan muy alentadoras. 
Indica tu grado de acuerdo con la siguiente afirmación: "En su conjunto, los videos desarrollados hasta el momento, me han ayudado a comprender la asignatura".

16 respuestas

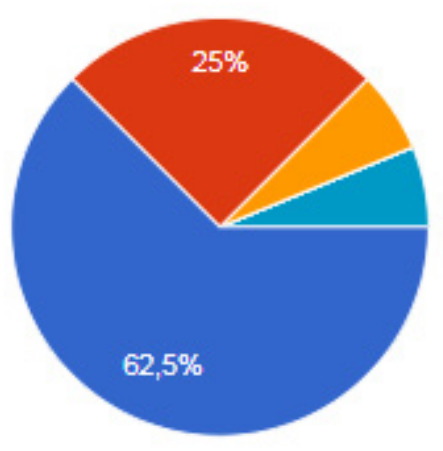

Totalmente de acuerdo

- Más bien de acuerdo

Indiferente

Más bien en desacuerdo

Totalmente en desacuerdo

No he visto los vídeos

Indica tu grado de acuerdo con la siguiente afirmación: "Me gustaría que, en las asignaturas relacionadas con la Resistencia de Materiales y el

Análisis Estructural, se desarrollasen más vídeos al estilo de los anteriores".

16 respuestas

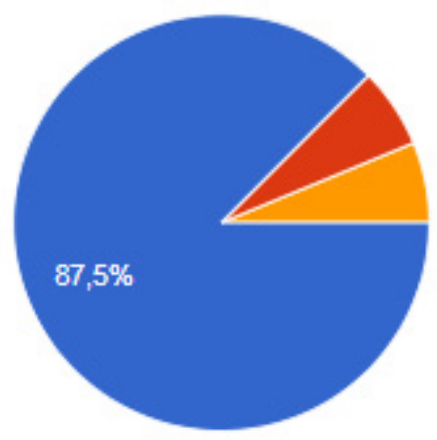

Totalmente de acuerdo

Más bien de acuerdo

Indiferente

Más bien en desacuerdo

Totalmente en desacuerdo

Fig 6. Resultados de dos de las cuestiones de la encuesta de satisfacción de GIE en el curso 2020-21.

\section{Conclusiones}

Según los indicadores objetivos, la primera conclusión de los autores es que las encuestas de satisfacción realizadas en el PIME muestran que los alumnos valoran positivamente el material en formato vídeo, y también que los recursos de este tipo que se han creado durante el PIME les han resultado útiles, pues demandan mayoritariamente que "se creen más screencast similares". Es un mensaje claro que se debe tener en cuenta para próximos cursos. 
Aun de forma subjetiva, se ha detectado además que un número creciente de estudiantes realiza comprobaciones de los cálculos. Si bien se trata de una buena praxis para llegar a resultados correctos en exámenes, no hay que dejar de lado las implicaciones éticas de la misma, en tanto que un eventual colapso estructural puede causar la pérdida de vidas. Se debe profundizar en este aspecto, pues se está formando a profesionales que deberán dar soluciones técnicas y tomar decisiones de responsabilidad. No es suficiente con plantear bien la solución de los ejercicios, es necesario que el estudiantado se esfuerce en llegar a resultados correctos y, más importante todavía, juzgar adecuadamente su validez.

En cuanto a la proyección a futuro, el PIME STRUCT+MÈDIA realmente puede considerarse todavía vivo, pues los indicadores de la evolución de la percepción en los próximos cursos darán respuesta a cómo los nuevos materiales, su potencial uso en flipped classroom, su compleción mediante módulos de aprendizaje y ulteriores screencast, así como su difusión en los medios más oportunos, puede (y debe) mejorar la percepción de estas asignaturas, su rendimiento, el compromiso ético relativo a los cálculos, y, en fin, el aprendizaje en su conjunto.

Creemos que esta innovación puede transferirse a cualquier asignatura obligatoria de los primeros cursos de las titulaciones de grado. Las recomendaciones principales son las siguientes: (a) consultar a los alumnos en cuanto a los temas que más les interesaría disponer de material docente multimedia; (b) publicitar con cierta frecuencia estos vídeos en las clases de teoría y práctica, y con recordatorios vía e-mail; (c) sopesar cuidadosamente la duración que deben tener los vídeos, pues es fácil caer en el error de alargarlos en exceso; (d) utilizar tecnologías de tinta digital.

Cabe concluir, en definitiva, que la pandemia ha actuado como catalizador del uso cada vez más habitual de los vídeos docentes de ERM, a tenor de los resultados observados en la etapa de docencia en línea de emergencia y docencia híbrida. Estos materiales audiovisuales han demostrado ser muy útiles en estos contextos, pudiendo afirmarse que los vídeos "han llegado para quedarse". En vista de las conclusiones extraídas en este trabajo, los autores esperan ampliar la colección de vídeos en el futuro.

\section{Agradecimientos}

Este trabajo se ha realizado en el marco del Proyecto de Innovación y Mejora Educativa PIME/2018/B19, financiado por los Vicerrectorados de Recursos Digitales y Documentación, y el de Estudios, Calidad y Acreditación, de la Universitat Politècnica de València.

\section{Referencias}

Benlloch Dualde, J. V. (2014). Propuesta metodológica para el uso de las tecnologías de tinta digital en los procesos formativos del ámbito de la educación superior [Universitat Politècnica de València]. In RiuNet. https://doi.org/10.4995/Thesis/10251/38250 
Lapuebla-Ferri, A., Benlloch-Dualde, J.-V., Bessini-Muñoz, J.G., Espinós Capilla, A., Jimenez Mocholi, A.J., Llopis-Pulido, V., Mazarredo Aznar, L., Moreno-Puchalt, J., Almerich-Chulia, A., Perelló Roso, R. y Museros, P. (2020). Actualización de métodos y recursos didácticos en docencia de Teoría de Estructuras para Escuelas Técnicas Superiores: un enfoque multimedia. En Redes-INNOVAESTIC 2020: Libro de actas. Roig-Vila, R., Antolí Martínez, J.M., Díez Ros, R. (Eds.)., pp. 368-369.

Meyer, J. H. F., \& Land, R. (2005). Threshold concepts and troublesome knowledge (2): Epistemological considerations and a conceptual framework for teaching and learning. Higher Education, 49(3), 373-388. https://doi.org/10.1007/s10734-004$6779-5$

RiuNet. Repositorio institucional de la Universitat Politècnica de València. Acceso: https://riunet.upv.es.

Vídeos docentes tipo screencast (Figura 1), disponibles en abierto en los siguientes enlaces/canales: Enlace 1®https://media.upv.es/\#/catalog/channel/3bfe1600-ee1a-11eb-b199-95fa9d6ff27e. Enlace 2® https://media.upv.es/\#/portal/ channel/b96a4c70-ee39-11eb-94a2-fb77a6968705. Enlace $3{ }^{\circledR}$ https://media.upv. es/\#/portal/channel/973bfc60-ecd9-11e9-be94-190c292b8eb4. 


\section{Repositorio Institucional de Acceso Abierto de FICH UNL: Diseño, Desarrollo e Implementación de un Software de Gestión de Producciones Científico Académicas}

\section{Bas, Natalia}

Universidad Nacional del Litoral nbas@fich.unl.edu.ar

\section{Giorgetti, Carlos}

Universidad Nacional del Litoral cgiorgetti@fich.unl.edu.ar

\section{Romero, Lucila}

Universidad Nacional del Litoral

Iromero@fich.unl.edu.ar 


\title{
REPOSITORIO INSTITUCIONAL DE ACCESO ABIERTO DE FICH UNL: DISEÑO, DESARROLLO E IMPLEMENTACIÓN DE UN SOFTWARE DE GESTIÓN DE PRODUCCIONES CIENTIIFICO ACADÉMICAS
}

\author{
Bas, Natalia \\ Giorgetti, Carlos \\ Romero, Lucila
}

\section{Resumen}

En la era de las redes y tecnologías de la información, favorecer la comunicación abierta de los resultados de la investigación científica y de la producción académica de las universidades se ha convertido en un compromiso de científicos, instituciones, docentes, bibliotecarios y otros administradores de la información. En este contexto, el movimiento para el Acceso Abierto ha desarrollado un alto nivel de madurez en la renovación de los modelos de comunicación científica. En este trabajo se presenta el diseño, desarrollo e implementación de un software de gestión para las producciones científico académicas de FICH UNL almacenadas en un Repositorio de Acceso Abierto. El proyecto de software de gestión se encuentra enmarcado en un modelo que contiene el proyecto institucional de base, la identificación del equipo de trabajo, sus roles y actividades, así como los procedimientos llevados adelante para la implementación del repositorio. El software de gestión fue diseñado para favorecer la interoperabilidad en base al cumplimiento de estándares, creando las condiciones para que los productos de las investigaciones y los materiales de enseñanza estén disponibles, preservando su propiedad intelectual y contribuyendo con la sociedad del conocimiento libre y plural, fomentando la reutilización, garantizando la calidad, visibilidad e impacto de la producción universitaria académica y científica.

\section{Palabras clave}

Repositorio institucional, acceso abierto, objetos educativos digitales, interoperabilidad, software de gestión de producciones. 


\section{Introducción}

El Acceso Abierto (AA) refiere a la disponibilidad gratuita en Internet de la literatura científica, permitiendo a cualquier usuario leer, descargar, copiar, distribuir, imprimir las obras sin barreras financieras, legales o técnicas; con la sola restricción, en cuanto a la reproducción y distribución, de dar a los autores el control sobre la integridad de sus trabajos y el derecho a ser adecuadamente reconocidos y citados. (Budapest Open Access Initiative, 2002). Este movimiento permite el acceso sin restricciones a la producción científica, modificando no sólo los mecanismos de consulta y recuperación de información científica sino también su lógica de producción, difusión y uso. En este contexto, el papel de los modelos alternativos de la comunicación académica, tales como los Repositorios Institucionales (RI), adquieren una importancia creciente.

Tiempo atrás comenzaron las primeras iniciativas para crear repositorios abiertos de documentos especializados. Algunas de estas iniciativas, tales como Budapest (2001), Bethesda (2003) y Berlín (2003), han conducido a un crecimiento del movimiento a nivel mundial, siendo cada vez más las instituciones científico-académicas que dan su apoyo, conscientes de sus beneficios asociados. Por un lado, los autores de las publicaciones, logran expandir su audiencia, incrementando así su visibilidad y el impacto de su producción dentro del campo disciplinar de pertenencia. Por otro lado, los usuarios tienen acceso abierto a toda la producción, eliminando las barreras económicas que existen entre los países, poniéndolos en igualdad de condiciones en cuanto al acceso a la información.

Estos aspectos se incluyen en un escenario de diversidad y complejidad crecientes, dado que en el actual contexto presencial-virtual de las universidades, en condiciones de cambio también constantes, se suma la presencia de diferentes prácticas pedagógicas, con una variedad disciplinar, interdisciplinar y transdisciplinar. En este sentido, las cuestiones implicadas en los procesos de producción, circulación y recepción de contenidos digitales y especialmente los educativos, denominados Objetos de Aprendizaje (OA), requieren una nueva comprensión cultural y un cambio en las prácticas y perspectivas de todos los actores implicados, contribuyendo a una gestión más eficiente de los recursos, mejorando la calidad de la enseñanza y el aprendizaje y permitiendo configurar la memoria intelectual de la universidad.

Un OA es una unidad didáctica digital independiente, cuya estructura está formada por un objetivo de aprendizaje específico, un contenido, actividades y actividades de corrección automática, y que puede ser reutilizada en diferentes contextos tecnológicos y educativos. Además, cuenta con metadatos que propician su localización dentro de los repositorios y permiten abordar su contextualización.

En Argentina, la Ley de Acceso Abierto establece que las instituciones del Sistema Nacional de Ciencia y Tecnología que reciban financiamiento del Estado Nacional deberán crear sus Repositorios Digitales Institucionales de Acceso Abierto y gratuito en los que se depositará la producción científico tecnológica resultante del trabajo de investigadores, tecnólogos, docentes, becarios postdoctorales y estudiantes de maestría y doctorado.

Entre los principales factores que afectan a la implementación y al éxito del RIAA para OA se pueden mencionar los políticos y organizativos, en cuanto a la postura de la institución y de los servicios implicados en la puesta en marcha, definición de 
procesos y gestión del repositorio y sus contenidos; legales, en relación a la propiedad intelectual y derechos de copyright sobre los materiales educativos y cómo gestionarlos; y tecnológicos, relativos a la implementación, funcionamiento y uso del sistema de repositorios y de los propios OA.

Todas estas exigencias se tendrán que tener en cuenta al definir el concepto de Repositorio Institucional de Acceso Abierto, RIAA, entendido como "un repositorio digital que reúne la colección de materiales de enseñanza y aprendizaje de producción propia de los miembros de una institución académica en el desarrollo de sus actividades, creado con el objetivo de facilitar el almacenamiento, la gestión, el acceso, la distribución y la preservación de los recursos que forman la colección, y cuyo fin último es fomentar el intercambio y la reutilización de estos recursos como soporte a las actividades de enseñanza aprendizaje".

Por lo expresado anteriormente, en FICH UNL se planteó el siguiente objetivo: "Diseñar, implementar y transferir a partir de los actuales marcos organizacionales de la Facultad de Ingeniería y Ciencias Hídricas $(\mathrm{FICH})$ de la Universidad Nacional del Litoral (UNL) un modelo metodológico y tecnológico para Repositorios de Acceso Abierto (RAA) de objetos de aprendizaje en función de su adopción exitosa por parte de la comunidad académica que constituya el portal de acceso a su producción académica, científica e investigativa de la FICH UNL". Como parte de este modelo, se diseñó, desarrolló e implementó un software de gestión de las producciones científico académicas.

\section{Método/Descripción de la experiencia}

\section{Descripción del contexto y de los participantes}

La propuesta del modelo involucró un trabajo interdisciplinario donde los aspectos sociales y de desarrollo tecnológico adquirieron similar relevancia en pos del diseño de un modelo de repositorio que atienda a las necesidades de docentes, investigadores y alumnos, que promueva el intercambio y reutilización de los materiales de docencia e investigación, mediante la carga, administración y preservación del contenido digital educativo producido en la $\mathrm{FICH}$.

Para ello, se usó una estrategia efectiva de sensibilización y concienciación de la comunidad educativa para convocar usuarios potenciales; con un programa de formación que minimice las reticencias frente a la complejidad y la exigencia de las tareas asociadas al repositorio; y servicios de apoyo que simplifiquen estas tareas, restando cargas añadidas a los usuarios y asegurando la calidad de los recursos. Ofreciendo incentivos que reconozcan el valor de la producción docente y el esfuerzo y tiempo invertido en su creación.

Para la ejecución del proyecto se conformó un equipo de trabajo con roles y tareas que se llevaron adelante de manera conjunta con Secretaría Académica, entre los que se puede mencionar: Responsable de la implementación de RIAA en FICH: encargado de evaluar las necesidades institucionales y priorizarlas. Planificar. Definir políticas de acción. Organizar charlas y jornadas de socialización. Evaluar los recursos disponibles. Definir mecanismos para la conservación digital de las producciones. Establecer alternativas de licencias de uso. Administrador: encargado de definir me- 
canismos de descripción de archivos. Colaborar con el autoarchivo/gestionar archivos de usuarios sin experiencia. Organizar contenido. Identificar colecciones. Gestionar el repositorio.

Específicamente, para el proyecto informático se designaron los siguientes roles:

Responsable del proyecto informático: encargado de establecer el plan de trabajo, recursos, esfuerzo, cronograma, riesgos. Definir un modelo de procesos de software. Identificar stakeholders y usuarios. Definir mecanismos de descripción de archivos. Describir en forma completa las producciones (según estrategia propuesta). Posibilitar la personalización de la descripción de OA mediante la integración de estándares. El equipo informático se completó con diseñadores gráficos, analistas y desarrolladores.

\section{Proyecto de software}

Como parte del desarrollo del proyecto institucional, se diseñó, desarrolló e implementó el software de gestión del repositorio. Para el desarrollo se siguió un modelo en cascada, el cual toma las actividades fundamentales del proceso de especificación, desarrollo, validación y evolución, y las representa como fases separadas y consecutivas (Sommerville, 2016): (i) Definición de requerimientos. (ii) Diseño del sistema y software. (iii) Implementación y prueba unitaria. (iv) Integración y prueba del sistema. Finalmente el software se instaló en el servidor perteneciente al área de Educación a Distancia de FICH.

A continuación se presentan en forma breve los productos obtenidos luego del cumplimiento de las diferentes etapas de la metodología.

\section{Análisis de requerimientos}

En esta etapa, se llevaron a cabo actividades destinadas a identificar los requerimientos funcionales y no funcionales del sistema. Para ello, se aplicaron diferentes técnicas de educción con los stakeholders. El análisis realizado permitió tomar decisiones sobre educción de las tecnologías a utilizar para el desarrollo del software. Para ello se recopiló y comparó información de diferentes herramientas y lenguajes, seleccionando las más adecuadas de acuerdo a los requerimientos relevados y a las restricciones identificadas. Como resultado de esta etapa se elaboró la Especificación de Requerimientos de Software (ERS).

\section{Diseño}

En esta etapa se realizó el diseño arquitectónico del sistema, para lo cual se evaluaron diferentes patrones arquitectónicos para determinar si eran aplicables al problema a resolver y, particularmente, si favorecían al alcance de los requerimientos no funcionales del mismo. En base al análisis previo, se diseñó una arquitectura estableciendo los componentes del sistema y sus relaciones.

Luego se continuó con el diseño de las interfaces de usuario y el modelado 

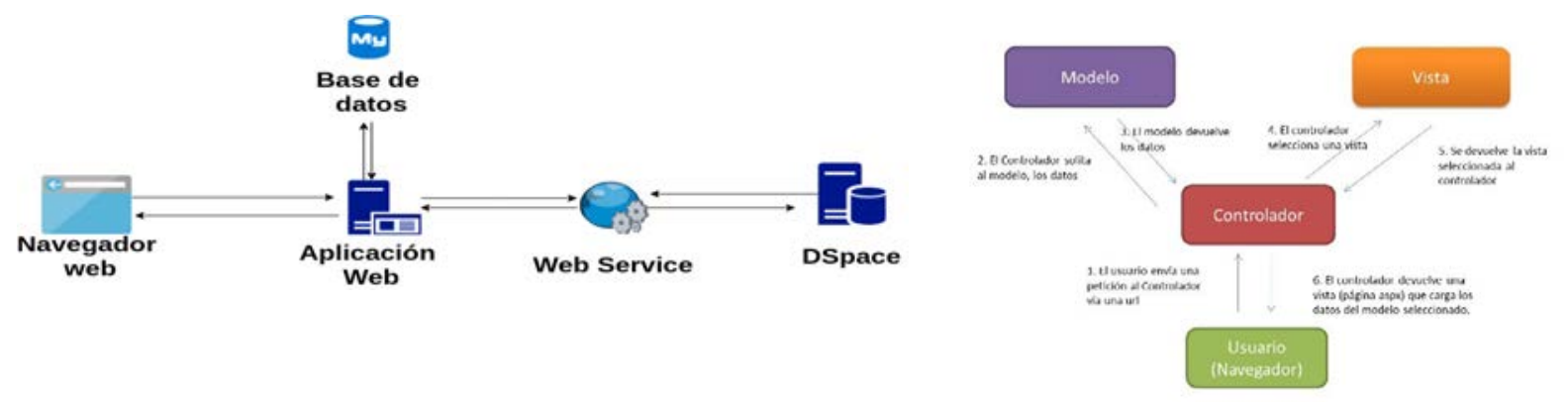

Figura 1.a Arquitectura del software de gestión de producciones RIAA FICH

Módulos del sistema:

Aplicación Web: La aplicación web se desarrolló en PHP bajo el framework Symfony, y será el encargado de gestionar los datos almacenados en la plataforma DSpace. Se compone de un portal público de consulta, el cual proporcionará las herramientas necesarias para la búsqueda y visualización de documentos publicados, y un portal administrativo, en el cual un usuario autenticado tendrá la posibilidad de crear, modificar y eliminar recursos según como lo permitan sus privilegios.

Base de datos: El motor de base de datos que se utilizó fue Mysql, base de datos de tipo relacional para almacenar toda la información que necesite y genere la aplicación web para administrar los recursos de DSpace.

DSpace: Plataforma que se utilizó como repositorio de recursos digitales.

WebService: Se utilizó una API con tecnología REST ofrecida por DSpace para la consulta de datos o la ejecución de operaciones sobre sus recursos.

La figura 3 muestra el diseño de IU de la portada del software de gestión realizado por el equipo de diseño del área de Educación a Distancia de FICH. La propuesta del equipo de diseño fue incorporar miniaturas y previsualizaciones de los ítems, producciones y objetos del repositorio de manera de facilitar la detección de novedades, recursos más visitados, componiendo una propuesta innovadora siguiendo la lógica de red social. 


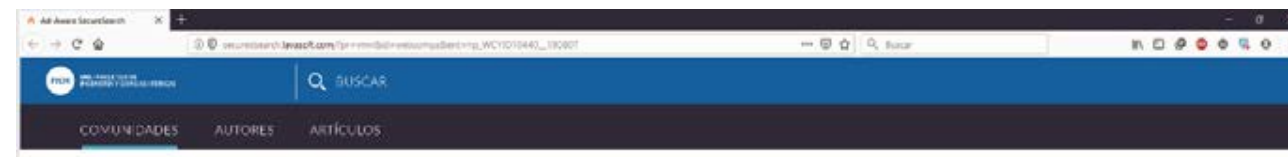

Aice Theo de articulo.
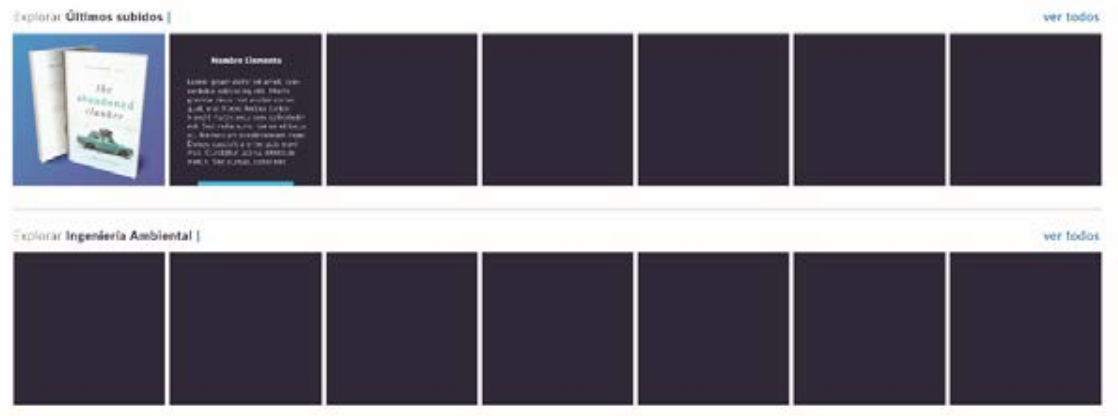

Figura 2. Diseño de IU de la portada

\section{Descriptores}

Para facilitar la localización de las producciones, en el software de gestión incluye el estándar Dublin Core ${ }^{1}$ (DC) que permite la descripción de cualquier recurso digital sin distinción de tipos de colecciones, con una extensión prevista a IEEE LOM. En la tabla 1 se muestra la lista de posibles metadatos tomando como base (Giorgetti C., Romero, L., Gutiérrez, M. 2012) favorecer la comunicación abierta de los resultados de la investigación científica y de la producción académica de las universidades se ha convertido en un compromiso de científicos, instituciones, docentes, bibliotecarios y otros administradores de la información. La nueva situación requiere plantear políticas y mecanismos de comunicación diferentes, en los que los flujos de difusión sean más rápidos y eficaces. A raíz de esto, el movimiento para el Acceso Abierto ha desarrollado, en muy poco tiempo, un alto nivel de madurez en la renovación de los modelos de comunicación científica y el planteamiento de alternativas sostenibles a los modelos existentes. En este contexto, un nuevo desafío emerge: la necesidad de describir correctamente a los recursos almacenados en los repositorios de manera que puedan ser descubiertos por motores de búsquedas y, de esta manera, facilitar su localización. Para afrontarlo es necesario tener en cuenta los diferentes tipos de Objetos Digitales Educativos (ODE. Para cada metadato se incluye etiqueta, esquema (estándar al que corresponde el descriptor), término específico, carácter y el texto de ayuda para el usuario del software. El valor del carácter se corresponde con las directrices del Sistema Nacional de Repositorios Digitales ${ }^{2}$ (SNRD) y puede tomar alguno de los siguientes valores: (i) Obligatorio: el elemento siempre debe estar presente en el registro de metadatos, (ii) Obligatorio si es aplicable: si se puede obtener el elemento, debe agregarse al registro de metadatos, (iii) Recomendado: se recomienda el uso del elemento, (iv) Opcional: el hecho de utilizar o no el elemento queda a criterio del repositorio.

'https://www.dublincore.org/specifications/dublin-core/dces/

${ }^{2}$ https://repositoriosdigitales.mincyt.gob.ar/vufind/ 
Tabla 1. Listado de metadatos

\begin{tabular}{|c|c|c|c|c|}
\hline Etiqueta & Esquema & Término & Carácter & Ayuda \\
\hline Título & dc/lom & title/title & $\begin{array}{l}\text { obligato- } \\
\text { rio }\end{array}$ & $\begin{array}{l}\text { Ingrese el título del OA en el idioma de su con- } \\
\text { tenido. }\end{array}$ \\
\hline Autor/(es) & dc/lom & $\begin{array}{l}\text { creator/life cycle. } \\
\text { contribute.role.author }\end{array}$ & $\begin{array}{l}\text { obligato- } \\
\text { rio }\end{array}$ & Ingrese el nombre del (de los) autor(es) del OA \\
\hline $\begin{array}{l}\text { Colabora- } \\
\text { dor }\end{array}$ & dc/lom & $\begin{array}{l}\text { contributor/life cycle. } \\
\text { contribute }\end{array}$ & opcional & $\begin{array}{l}\text { Ingrese el nombre de la entidad responsable } \\
\text { de realizar contribuciones al contenido del OA. } \\
\text { Ejemplos de contribuciones pueden ser una per- } \\
\text { sona, una entidad o una organización. }\end{array}$ \\
\hline Resumen & dc/lom & $\begin{array}{l}\text { description/general. } \\
\text { description }\end{array}$ & $\begin{array}{l}\text { obligato- } \\
\text { rio }\end{array}$ & $\begin{array}{l}\text { Utilice este campo para la descripción del conte- } \\
\text { nido del OA. El resumen puede tener hasta } 100 \\
\text { palabras }\end{array}$ \\
\hline filiación & dc & description & opcional & Ingrese la filiación institucional de el/los autores \\
\hline $\begin{array}{l}\text { Palabras } \\
\text { Clave }\end{array}$ & dc/lom & $\begin{array}{l}\text { subject/general. } \\
\text { keyword }\end{array}$ & $\begin{array}{l}\text { obligato- } \\
\text { rio }\end{array}$ & $\begin{array}{l}\text { Ingrese hasta } 10 \text { palabras clave que colaboren } \\
\text { en la descripción del contenido instruccional del } \\
\text { OA. Pueden ser palabras o expresiones bre- } \\
\text { ves tomadas del título, de la descripción o del } \\
\text { contenido. Se recomienda el uso de vocabulario } \\
\text { controlado. }\end{array}$ \\
\hline Editor & dc/lom & $\begin{array}{l}\text { publisher/life cycle. } \\
\text { contribute.role. } \\
\text { Publisher }\end{array}$ & $\begin{array}{l}\text { obligato- } \\
\text { rio }\end{array}$ & $\begin{array}{l}\text { Ingrese el nombre de la entidad responsable de } \\
\text { hacer disponible el OA. Puede ser una persona o } \\
\text { una organización. }\end{array}$ \\
\hline $\begin{array}{l}\text { Fecha de } \\
\text { publicación }\end{array}$ & dc/lom & $\begin{array}{l}\text { date/life cycle. } \\
\text { contribute.date }\end{array}$ & $\begin{array}{l}\text { obligato- } \\
\text { rio }\end{array}$ & $\begin{array}{l}\text { Ingrese la fecha de publicación del OA. Puede } \\
\text { ingresar la fecha completa, formato DD/MM/ } \\
\text { AAAA o solo ingresar el añó, formato AAAA }\end{array}$ \\
\hline Tipo & dc/lom & $\begin{array}{l}\text { type/educational. } \\
\text { learningResource- } \\
\text { Type }\end{array}$ & opcional & Indique la versión del OA \\
\hline Formato & dc/lom & $\begin{array}{l}\text { format/technical. } \\
\text { format }\end{array}$ & $\begin{array}{l}\text { obligato- } \\
\text { rio }\end{array}$ & $\begin{array}{l}\text { Ingrese el soporte digital del OA. Especifique } \\
\text { nombre, tipo y tamaño del archivo }\end{array}$ \\
\hline Idioma & dc/lom & $\begin{array}{l}\text { language/general. } \\
\text { language }\end{array}$ & $\begin{array}{l}\text { obligato- } \\
\text { rio }\end{array}$ & $\begin{array}{l}\text { Indique el idioma del contenido del OA. Si el } \\
\text { idioma no aparece en el listado, por favor mar- } \\
\text { que 'Otro'. Si no corresponde, marque 'N/A' }\end{array}$ \\
\hline $\begin{array}{l}\text { Rango de } \\
\text { edad }\end{array}$ & lom & $\begin{array}{l}\text { educational.typical } \\
\text { age range }\end{array}$ & opcional & Indique el rango etareo \\
\hline ISBN & dc/lom & $\begin{array}{l}\text { Identifier/general. } \\
\text { identifier.entity }\end{array}$ & $\begin{array}{l}\text { Obligato- } \\
\text { rio si es } \\
\text { aplicable }\end{array}$ & Ingrese número de ISBN si el OA es un libro \\
\hline $\begin{array}{l}\text { Titular } \\
\text { de los } \\
\text { Derechos }\end{array}$ & dc/lom & $\begin{array}{l}\text { rights/right. } \\
\text { description }\end{array}$ & $\begin{array}{l}\text { obligato- } \\
\text { rio }\end{array}$ & $\begin{array}{l}\text { seleccione el tipo de acceso del OA permitido } \\
\text { basado en los derechos de autor }\end{array}$ \\
\hline $\begin{array}{l}\text { Colabora- } \\
\text { dores }\end{array}$ & dc & contributor & opcional & Ingrese el nombre del o de los colaboradores \\
\hline $\begin{array}{l}\text { Patrocina- } \\
\text { dores }\end{array}$ & dc & description & $\begin{array}{l}\text { Obligato- } \\
\text { rio si es } \\
\text { aplicable }\end{array}$ & Ingrese el nombre del o los patrocinadores \\
\hline Relación & dc/lom & relation/relation & opcional & $\begin{array}{l}\text { Ingrese una referencia a un OA o publicación re- } \\
\text { lacionada. Por ejemplo, en el caso que el OA sea } \\
\text { parte de una colección, puede consignarse el } \\
\text { nombre de la colección y el número de serie y/o } \\
\text { volumen. O puede ingresar la referencia a otras } \\
\text { versiones del OA, a otras ediciones o al OA en } \\
\text { otro idioma. }\end{array}$ \\
\hline Audiencia & lom & audience & opcional & $\begin{array}{l}\text { Indique los principales usuarios para los cuales } \\
\text { el OA fue desarrollado. Debe seleccionar valores } \\
\text { de la lista propuesta }\end{array}$ \\
\hline
\end{tabular}




\begin{tabular}{|l|l|l|l|l|}
\hline Contexto & Iom & educational.context & opcional & $\begin{array}{l}\text { Indique el entorno en el cual el OA podra ser uti- } \\
\text { lizado.. Por ejemplo “Universitario de grado". } \\
\text { "Universitario de posgrado". Podra seleccionarse } \\
\text { mas de una opcion }\end{array}$ \\
\hline Dificultad & lom & educational.difficulty & opcional & $\begin{array}{l}\text { Indique el grado de dificultad que usualmente } \\
\text { presenta la interaccion con el libro en el contex- } \\
\text { to seleccionado. Seleccione una de las opciones } \\
\text { propuestas. }\end{array}$ \\
\hline $\begin{array}{l}\text { Tipo de } \\
\text { interactivi- } \\
\text { dad }\end{array}$ & Lom & $\begin{array}{l}\text { educational. } \\
\text { interactivity }\end{array}$ & opcional & $\begin{array}{l}\text { Indique el tipo de participación del usuario que } \\
\text { propone el OA }\end{array}$ \\
\hline Fuente & dc/lom & $\begin{array}{l}\text { source/ relation. } \\
\text { resource }\end{array}$ & opcional & $\begin{array}{l}\text { si es una versión digitalizada de un original indi- } \\
\text { que el mismo }\end{array}$ \\
\hline Estado & lom & lifecycle.status & $\begin{array}{l}\text { obligato- } \\
\text { rio }\end{array}$ & $\begin{array}{l}\text { Ingrese el estado del OA. Si no se modifica, el } \\
\text { estado es "borrador" }\end{array}$ \\
\hline $\begin{array}{l}\text { Nivel de } \\
\text { Agregación }\end{array}$ & lom & $\begin{array}{l}\text { general. } \\
\text { AggregationLevel }\end{array}$ & $\begin{array}{l}\text { obligato- } \\
\text { rio }\end{array}$ & Ingrese el nivel de granularidad del OA \\
\hline
\end{tabular}

\section{Desarrollo e integración}

Las dos últimas etapas del proceso de desarrollo del sistema, desarrollo e integración, consistieron en tomar toda la documentación proveniente de las instancias de requerimientos y diseño, y obtener un software ejecutable haciendo uso de las herramientas y tecnologías seleccionadas para tal fin. Dado el enfoque del proceso que se escogió, ambas fueron acompañadas a su vez por distintos métodos de prueba, con el objetivo de demostrar que el software cumplía con los requerimientos y hacía lo que se esperaba, y descubrir secuencias de entradas o datos que hacían que su comportamiento fuere incorrecto, indeseable o no cumpliere la especificación

Como parte de las pruebas del software, integrantes del equipo de EaD de FICH asumieron diferentes roles frente al software de gestión y resolvieron tareas pautadas. Para cada tarea asignada debían registrar la salida esperada y la salida obtenida en diferentes fichas. Para este fin, se pusieron a disposición del grupo diferentes Objetos de Aprendizaje y producciones científicas con sus correspondientes metadatos.

La figura 3 muestra la ficha correspondiente al usuario administrador.

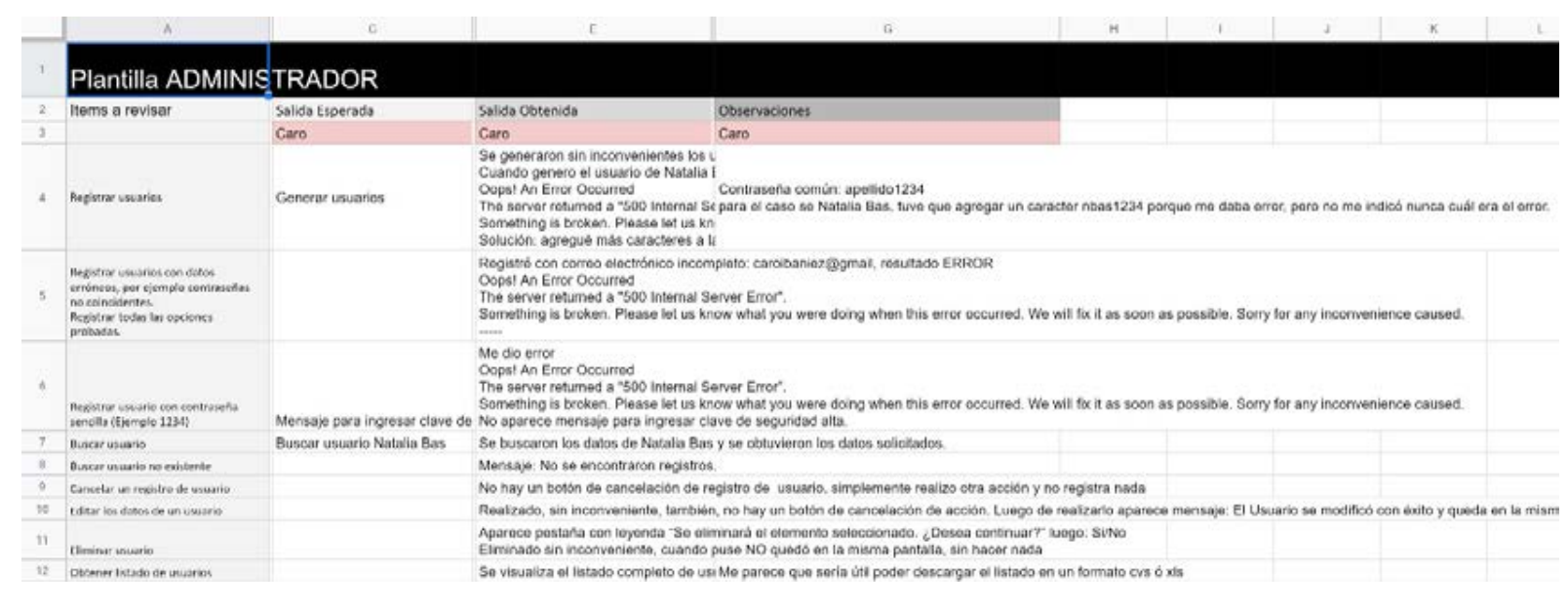




\section{Licencia}

El Repositorio Institucional Abierto RIA FICH es el Repositorio Institucional de Acceso Abierto de la Facultad de Ingeniería y Ciencias Hídricas de la Universidad Nacional del Litoral creado para gestionar y mantener una plataforma digital de acceso libre y abierto para la difusión de la creación intelectual de la institución y resguardando a su vez los derechos de los autores. Para ello se dispuso de la implementación de licencia Creative Commons:

\begin{tabular}{|c|c|}
\hline $\begin{array}{l}\text { (cc) () } ९ \text { EY NC ND } \\
\text { Reconocimiento- } \\
\text { NoComercial- } \\
\text { SinObraDerivada } \\
\text { CC BY-NC-ND }\end{array}$ & $\begin{array}{l}\text { Atribución (Attribution): En cualquier explotación de la obra autorizada } \\
\text { por la licencia será necesario reconocer la autoría (obligatoria en todos los } \\
\text { casos) } \\
\text { No comercial (Non Commercial): La explotación de la obra queda limitada } \\
\text { a usos no comerciales. } \\
\text { Sin obras derivadas(no Derivate Works): La autorización para explotar la } \\
\text { obra no incluye la posibilidad de crear una obra derivada (traducciones, } \\
\text { adaptaciones, etc). }\end{array}$ \\
\hline $\begin{array}{l}\text { (cc) () } \\
\text { Reconocimiento- } \\
\text { NoComercial- } \\
\text { No } \\
\text { Compartirlgual } \\
\text { CC BY-NC-SA }\end{array}$ & $\begin{array}{l}\text { Atribución (Attribution): En cualquier explotación de la obra autorizada } \\
\text { por la licencia será necesario reconocer la autoría (obligatoria en todos los } \\
\text { casos). } \\
\text { Sin obras derivadas (No Derivate Works): La autorización para explotar la } \\
\text { obra no incluye la posibilidad de crear una obra derivada. } \\
\text { No comercial (Non Commercial): La explotación de la obra queda limitada } \\
\text { a usos no comerciales. } \\
\text { Compartir igual (Share alike): La explotación autorizada incluye la } \\
\text { creación de obras derivadas siempre que se mantenga la misma licencia al } \\
\text { ser divulgadas. }\end{array}$ \\
\hline
\end{tabular}

\section{Resultados}

El equipo de trabajo definió comunidades y colecciones para el repositorio según estructura institucional, académica y de ciencia y técnica: departamentos, asignaturas, grupos y centros de investigación, docentes e investigadores. Entre los usuarios directos de la tecnología implementada se encuentran integrantes del equipo de gestión, profesores, grupos de I+D y estudiantes de nivel universitario. Los profesores pueden reutilizar y compartir materiales didácticos.

Las colecciones identificadas fueron: Artículo Publicado, Artículo Aceptado para Publicación, Documento de Conferencia, Libro, Parte de libro, Tesis de Doctorado, Tesis de Maestría, Proyecto final de carrera, Defensa de proyecto final de carrera, Software, Documento de trabajo, Informe técnico, Informe de Investigación, Informe, Reseña o Revisión, Revista, Trabajo de divulgación, Material didáctico, Documento institucional, Otro (fotografía, mapa, radiografía, película, conjunto de datos, entre otros).

En la figura 3 se muestra la portada del software, opciones para la gestión de comunidades, colecciones, usuarios; opciones de búsqueda de artículos. También incluye miniaturas para previsualizar contenido.

En la figura 4 el ingreso de datos de docentes de la materia Mecánica Computacional. El sistema permite la búsqueda de autores. 


\begin{tabular}{|c|c|c|c|}
\hline 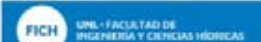 & Q BUSCAR & & I admineadmincoom - \\
\hline
\end{tabular}

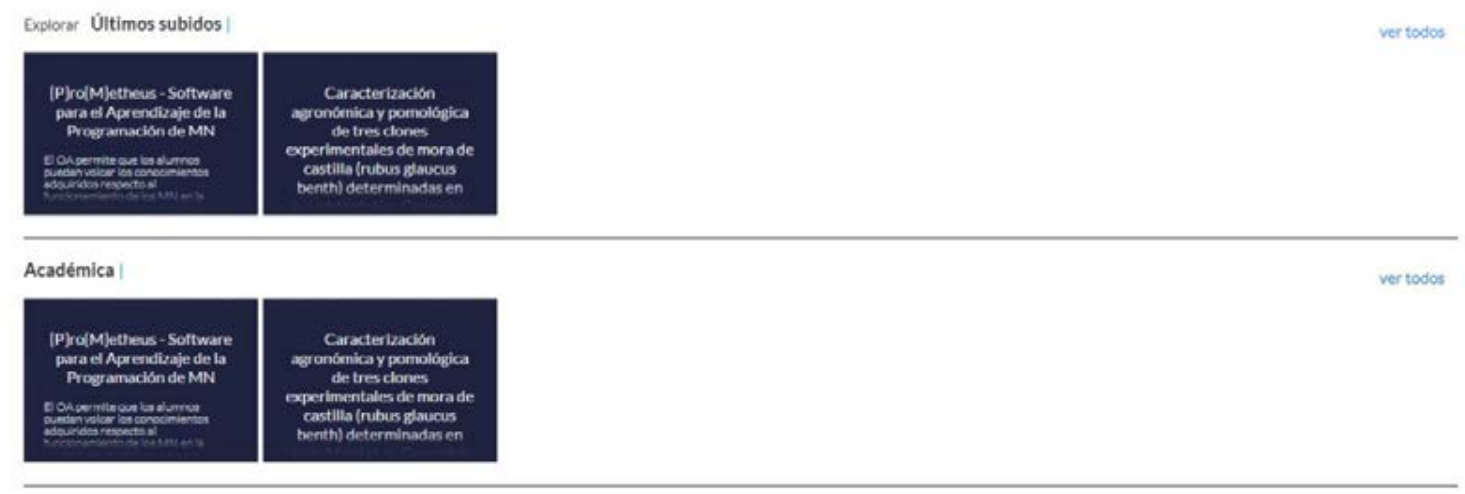

Figura 3 - Portada RIAA FICH

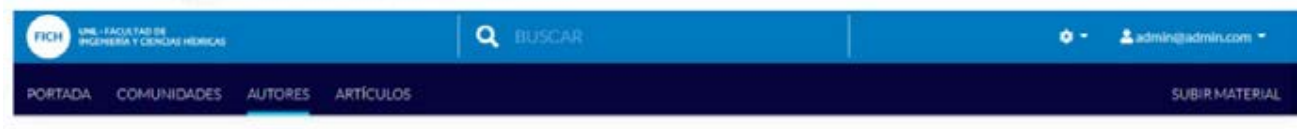
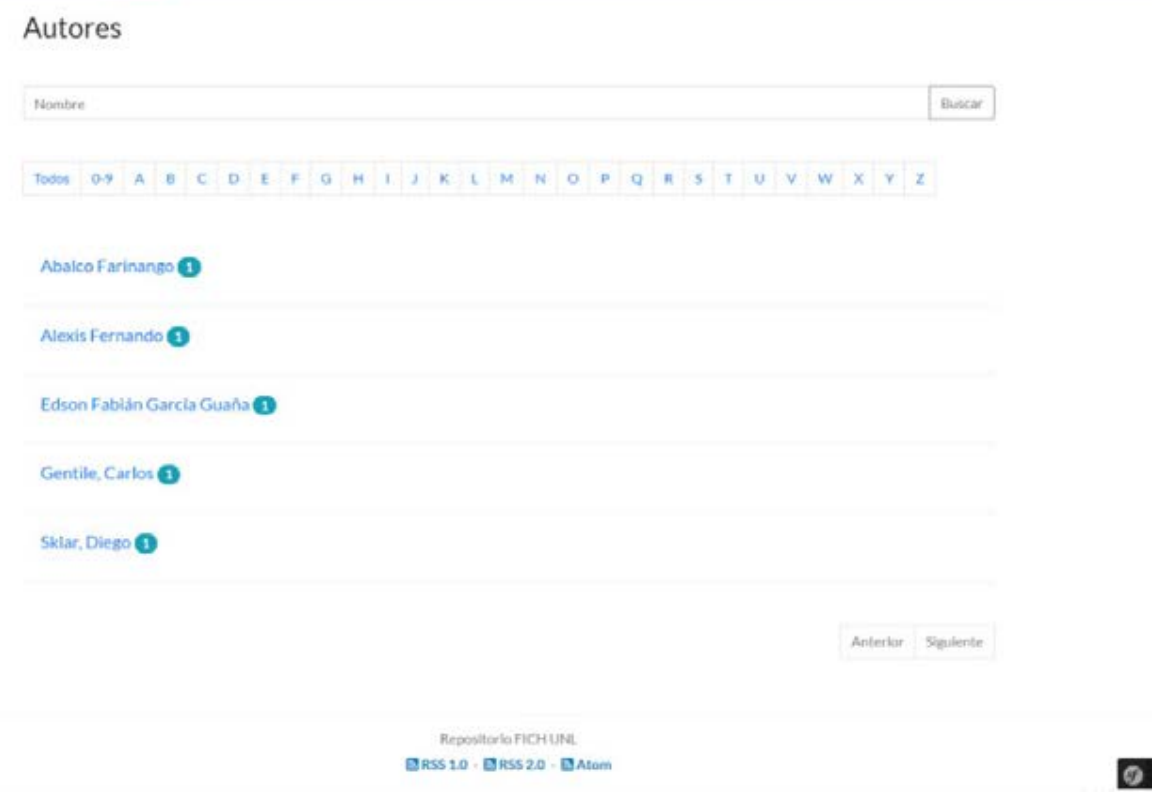

Figura 4. OA en RIAA FICH UNL

En la figura 5 se muestra un OA para la enseñanza de Métodos Numéricos utilizado en la asignatura Mecánica computacional de la carrera Ingeniería Informática disponible para docentes y estudiantes. 


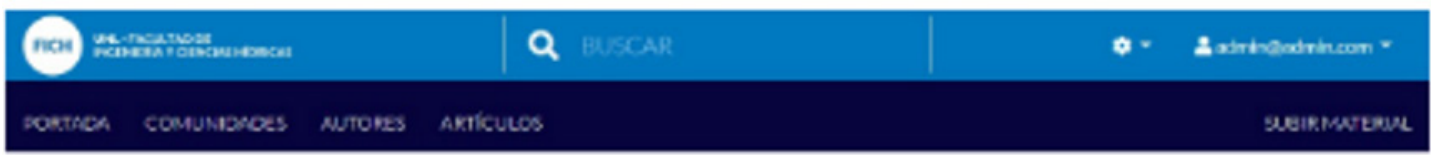

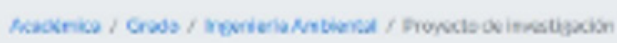

[P]ro[M]etheus - Software para el Aprendizaje de la Programación de MN

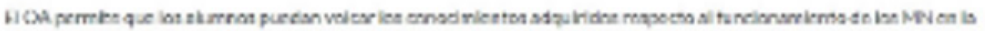

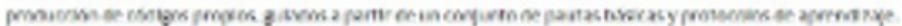

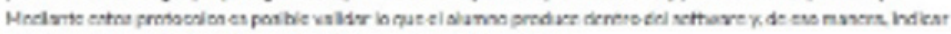

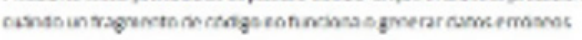

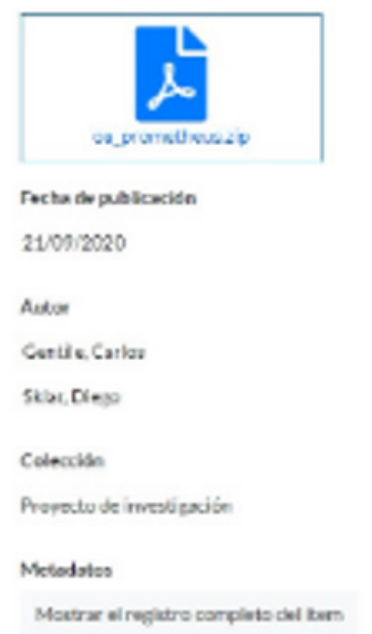

Seponkoria fioi una

Qnss 10 - Enss20- Q Q Mion

\section{Figura 5. OA en RIAA FICH UNL}

En la figura 6 se puede observar que el sistema permite consultar las publicaciones de un autor determinado.

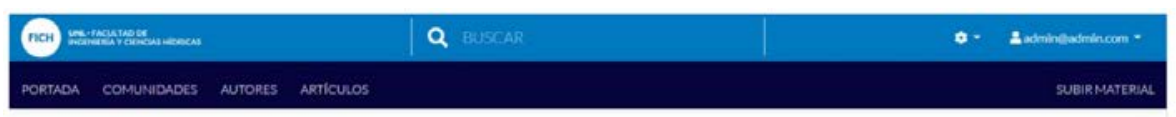

Gentile, Carlos

[P]ro!M] jetheus - Sottware para el Aprendizaje de la Programación de MN ElOA permine que los an
cholios gropion aci.

\section{Discusión y conclusiones}

En el presente trabajo se presenta el diseño, desarrollo e implementación de un software de gestión enmarcado en un modelo metodológico y tecnológico que atiende al conjunto de problemáticas que implican la promoción, desarrollo, implementación 
y uso de un RAA en la FICH UNL. El modelo tiene la finalidad de archivar, preservar, y distribuir en varios formatos la producción de material de enseñanza y científico-tecnológico.

El software permite la gestión de los OA del RIAA favoreciendo la interoperabilidad en base al cumplimiento de estándares, creando las condiciones para que los productos de la investigación y los materiales de enseñanza estén disponibles, preservando su propiedad intelectual y contribuyendo con la sociedad del conocimiento libre y plural, fomentando la reutilización, garantizando la calidad, visibilidad e impacto de la producción universitaria académica y científica.

El equipo informático, a su vez, desarrolló sus tareas inmerso en un equipo multidisciplinario que tiene a su cargo la aplicación de estrategias que permitan abordar los aspectos tecnológicos, organizacionales, pedagógicos y sociales en pos de la implementación del RIAA y su adopción exitosa por parte de la comunidad universitaria.

Como trabajo futuro se plantea la necesidad de implementar otros estándares de metadatos de objetos de aprendizaje para completar la descripción de los mismos y posibilitar su localización inteligente.

\section{Referencias}

Budapest Open Access Initiative. (2002). Budapest open access initiative. Online: http://www. soros.org/openaccess/read.shtml.

Bueno-De-la-Fuente, G., \& Hernández Pérez, A. (2011). Estrategias para el éxito de los repositorios institucionales de contenido educativo en las bibliotecas digitales universitarias.

Joy, S., O'Neill, O., \& Howie, J. (2005). Implementing learning resource management systems. The COLIS project: collaborative online learning and information services. Adelaide: MELCOE, 187-210.

Collis, D. J., \& Montgomery, C. A. (1995). Competing on Resources: Strategy in the 1990s.

D. Wiley et al., «Overcoming the limitations of learning objects», Journal of Educational Multimedia and Hypermedia, vol. 13, n.o 4, pp. 507-521, 2004.

A. Chiappe Laverde, Y. Segovia Cifuentes, y H. Y. Rincón Rodríguez, «Toward an instructional design model based on learning objects», Education Tech Research Dev, vol. 55, n.o 6, pp. 671-681, oct. 2007, doi: 10.1007/s11423-007-9059-0.

M. Naharro, B. Espinosa, C. González, F. Cerdá, y G. Felix, «Los objetos de aprendizaje como recurso de calidad para la docencia: criterios de validación de objetos en la Universidad Politécnica de Valencia.», p. 12.

Sommerville, I. 2009. «Software Engineering 9th Edition.

Standard for Learning Object Metadata. IEEE 1484.12.1-2002, 15 July 2002. Disponible en: http://Itsc.ieee.org/doc/wg12/LOMv4.1.htm. 


\section{La Gamificación Como Herramienta de Aprendizaje de Una Segunda Lengua y su Percepción como Fuente de Motivación en Estudiantes de Grado}

\section{Fruttero, María José}

Universidad Nacional de Córdoba, Facultad de Lenguas majofruttero@mi.unc.edu.ar

\section{Gimenez, Lucía}

Universidad Nacional de Córdoba, Facultad de Lenguas lucia.gimenez@mi.unc.edu.ar

\section{Rossiano, Paula}

Universidad Nacional de Córdoba, Facultad de Lenguas paula.rossiano@mi.unc.edu.ar

\section{Periales, Sol Ximena}

Universidad Nacional de Córdoba, Facultad de Lenguas solperiales@mi.unc.edu.ar

\section{Rejep Vargas, Milagros Martina}

Universidad Nacional de Córdoba, Facultad de Lenguas milagros.rejep@mi.unc.edu.ar 


\title{
LA GAMIFICACIÓN COMO HERRAMIENTA DE APRENDIZAJE DE UNA SEGUNDA LENGUA Y SU PERCEPCIÓN COMO FUENTE DE MOTIVACIÓN EN ESTUDIANTES DE GRADO
}

\author{
Fruttero, María José \\ Gimenez, Lucía \\ Rossiano, Paula \\ Periales, Sol Ximena \\ Rejep Vargas, Milagros Martina
}

\section{Resumen}

Con el objetivo de dar cuenta de cómo la gamificación puede funcionar tanto como una herramienta de aprendizaje como de motivación para la adquisición de una segunda lengua, hemos realizado una experiencia áulica en el contexto de la Universidad Nacional de Córdoba, con estudiantes de primer año de la Facultad de Lenguas, sección inglés, en una asignatura común a todas las carreras de dicha sección. Para poder fomentar la motivación del aprendizaje de la lengua, se han empleado herramientas lúdicas como Kahoot y Quizizz, a través de las cuales los estudiantes pueden practicar diferentes aspectos del idioma. Debido a la pandemia, las clases se dictan a través de la plataforma Meet y las actividades lúdicas se comparten a través de códigos y se realizan de manera sincrónica. Para recolectar datos sobre su percepción de aprendizaje con las herramientas empleadas se utilizó una hoja de observación y se analizaron los resultados de cada actividad realizada para así corroborar el potencial impacto del empleo de gamificación en el aprendizaje de este grupo de participantes. Considerando los resultados obtenidos, se puede concluir que existe una correlación entre el uso de la ludificación y la percepción de aprendizaje de la lengua y la motivación del alumnado, si bien esta relación varía según la naturaleza de la ludificación.

\section{Palabras clave}

Gamificación, lengua extranjera, motivación, percepción, aprendizaje. 


\section{Introducción}

Gracias al avance de la tecnología en las últimas décadas, el área educativa ha logrado evolucionar y progresar con innovaciones que han favorecido no solo a los profesores sino también a los alumnos. Dicho proceso se vio acelerado producto de la pandemia y la necesidad de que la educación se impartiera de manera virtual. Para fomentar una adecuación efectiva a este nuevo escenario de enseñanza aprendizaje en línea, algunos docentes han fomentado el uso de herramientas ludificadas para fomentar la motivación, el involucramiento y el aprendizaje.

Shroff y otros (2020) definen a la gamificación como la integración de elementos digitales lúdicos en contextos no-lúdicos. Este proceso de integración se ha dado ya que diferentes investigadores han evidenciado el impacto de estas actividades en la motivación del alumnado (Deterding, 2012; Kapp, 2012; Shroff y otros, 2020). La gamificación con recursos tecnológicos ha sido y sigue siendo una experiencia que genera motivación a los alumnos, permitiéndoles salir de un aprendizaje rutinario del idioma, para encontrarse con una experiencia lúdica donde se incluyen las diferentes áreas del idioma extranjero, como la gramática, el vocabulario, las habilidades del habla y de la escritura, entre otras (Kim et al., 2018).

Le (2021) investigó sobre el impacto de las actividades ludificadas en el nivel de involucramiento de alumnos que estudian inglés como segunda lengua a nivel universitario. Con tal fin, la investigadora empleó reportes electrónicos escritos por sus alumnos y entrevistas para poder explorar la percepción de sus alumnos en relación al uso de la gamificación y su impacto en el aprendizaje de una segunda lengua. Los datos obtenidos se categorizaron en tres temas: involucramiento de comportamiento, involucramiento emocional e involucramiento cognitivo. Los resultados indicaron que los alumnos lograron un nivel de involucramiento profundo en estas tres categorías en las clases mediadas por actividades ludificadas. Se observó que los alumnos participaban y contribuían más en clase. Se notó también mayor esfuerzo en la resolución de tareas. Al mismo tiempo que se incrementó su nivel de interés, disminuyó la ansiedad vinculada con el aprendizaje de la lengua extranjera.

Wulayo y Bucol (2021) indagaron sobre el uso de la gamificación para aumentar el involucramiento de los alumnos e incentivarlos a aprender un mayor volumen de palabras en lengua extranjera. Los participantes de esta investigación eran alumnos de nivel bajo de proficiencia en la segunda lengua. Para llevar a cabo la investigación, los investigadores generaron dos ciclos de aprendizaje. El primero se llevó a cabo sin mediación de tecnología y en el segundo se implementó la aplicación de Quizlet como herramienta de aprendizaje de vocabulario en el hogar. Luego de que cada ciclo de aprendizaje finalizara, se realizaron exámenes para evaluar la adquisición de vocabulario. Los resultados de ambos exámenes se compararon y contrastaron. Se puso en evidencia que las actividades ludificadas pueden tener un impacto positivo en el aprendizaje de vocabulario.

Castillo-Cuesta (2020) analiza el uso de actividades ludificadas para incentivar el aprendizaje de una segunda lengua, en particular, vocabulario y gramática a nivel universitario. Los participantes de este estudio fueron 68 alumnos de nivel B1. Se usaron cuestionarios y rúbricas para recolectar datos. Los juegos se implementaron por un periodo de cinco meses, focalizados en verbos modales, gerundios o infinitivos. Los resultados obtenidos muestran una mejora en el aprendizaje de vocabulario, especialmente en los temas relacionados con trabajo y educación. 
Ahumada y otros (2020) investigaron acerca de la gamificación en los procesos de enseñanza y aprendizaje - el m-learning como oportunidad para incorporar la ludificación en el aula, en cursos masivos de Estadística. Las actividades ludificadas fueron utilizadas con el fin de ayudar a los alumnos a prepararse para el examen parcial, planteando actividades sobre temas que eran de gran importancia para dicho examen y que presentaban una gran dificultad. La investigación demostró que el uso de la gamificación trajo aparejada una mejora en los resultados del parcial. También se plantea que los estudiantes percibieron dicha instancia de ludificación como positiva.

El empleo de juegos o actividades gamificadas para fomentar el aprendizaje en una segunda lengua y así, poder estimular la motivación estudiantil no es un tema que sea de frecuente investigación dentro de la Universidad Nacional de Córdoba. Sin embargo, se han realizado investigaciones sobre el uso de la ludificación en el proceso de enseñanza, aunque no particularmente en una segunda lengua. Es por ello que en el presente trabajo buscaremos explorar la percepción sobre la efectividad del uso de la gamificación en relación con el aprendizaje de una segunda lengua y el efecto en la motivación de los alumnos de primer año en la Facultad de Lenguas, UNC.

\section{Descripción de la experiencia}

\section{Descripción del contexto y de los participantes}

La experiencia en cuestión se llevó a cabo en una materia de primer año que se especializa en la enseñanza de inglés como lengua extranjera, en una comisión en particular, dentro de las ocho comisiones que existen. Esta materia, al ser común a todas las carreras de la sección de inglés (Profesorado, Traductorado o Licenciatura), busca incrementar el nivel de vocabulario, gramática, el uso de la lengua extranjera y el desarrollo de las habilidades como lo son el habla, la escritura, y la comprensión lectora y auditiva.

Los estudiantes son un total estimado de 100, de los cuales no todos participan regularmente en cada encuentro virtual, ya que por distintos motivos se pueden ausentar en algún encuentro sincrónico y participar en el siguiente. Al momento de realizar las observaciones sincrónicas se encontraban alrededor de 71 alumnos en el aula. Si bien el rango etario es amplio, porque no hay límite ni restricción con respecto a la edad para comenzar estudios universitarios, la edad promedio de los alumnos ronda entre 17 y 20 años.

Como ya se mencionó anteriormente, el dictado de clases sincrónicas se realiza de manera virtual desde el 2020 a través de Google Meet. Asimismo los alumnos tienen un porcentaje de tareas y actividades que se publican en la plataforma Moodle que provee la facultad. Cada alumno cuenta, a su vez, con un correo electrónico institucional. Es con esa cuenta institucional que los alumnos tienen acceso al aula virtual y a las sesiones sincrónicas, lo que facilita la acreditación de la identidad de los alumnos.

Al formar parte de una comunidad tan amplia como lo es la Universidad Nacional de Córdoba, los estudiantes provienen de variados contextos sociales y diferentes provincias. Como resultado, existe una brecha importante entre las posibilidades 
económicas para contar con aparatos tecnológicos y fluida conectividad y así, poder participar cómodamente y de manera adecuada de las actividades gamificadas propuestas por las profesoras, como lo son Kahoot y Quizizz. Ésta es una variable que se ha tenido en cuenta a lo largo de la investigación, ya que podría tener una gran influencia en los resultados arrojados.

\section{Instrumentos}

Los instrumentos que hemos utilizado han sido las ya mencionadas herramientas lúdicas Kahoot y Quizizz. Por un lado, Kahoot es una herramienta con bastantes años desde su creación y es uno de los instrumentos más conocidos y utilizados dentro del aula en nuestro contexto universitario y cuyo uso se incrementó a lo largo de la experiencia virtual que una gran mayoría ha atravesado debido a la pandemia. La modalidad del juego consiste en una serie de preguntas u oraciones previamente diseñadas por los docentes, que se proyectan en la pantalla que se está compartiendo. Cada pregunta u oración tiene un mínimo de dos (2) y un máximo de cuatro (4) opciones entre las cuales cada estudiante debe elegir. Mientras que las preguntas y opciones se ven en la pantalla compartida, el alumno responde en su propia pantalla (ya sea a través de la computadora o el celular), por lo que se requiere de una buena conectividad. Lo atractivo de este juego es que las opciones llevan diferentes formas y colores, las cuales cada alumno puede encontrar en su propia pantalla para presionar. Una vez que todos los alumnos hayan respondido, o cuando se termina el tiempo establecido, lo que ocurra primero, en la pantalla proyectada se puede observar la pregunta inicial con las respuestas y cuál era la correcta. A su vez, se proyecta un gráfico con el número de participantes que eligieron cada opción. Posteriormente, se puede observar un podio con puntajes y los nombres de los alumnos en el orden correspondiente. Al finalizar completamente el cuestionario, queda registrada la información en el sitio web, en la cuenta de la persona que haya diseñado la actividad. Por otro lado, Quizizz consiste en un cuestionario que puede ser asignado como juego en el momento de la clase, como tarea (en cuyo caso los resultados le llegan al docente) o como actividad individual, según lo señalado por Ruiz (2019). Por ende, se trata de una actividad realizada de manera individual por cada alumno mirando únicamente su propia pantalla; sin embargo, así el juego/actividad se realice sincrónica o asincrónicamente, al igual que en Kahoot, se puede observar el podio con el puntaje de cada alumno y el porcentaje de quiénes eligen la opción correcta.

Se seleccionaron estos instrumentos ya que ambos cuentan con rasgos de la ludificación que contribuyen a la motivación de los alumnos para realizar la práctica del idioma en una forma diferente a la tradicional. La presencia de elementos ludificados, como el podio, los puntos, la retroalimentación inmediata, la posibilidad de cometer un error y encontrar de manera colaborativa la respuesta correcta, la interfaz interactiva y la competencia, contribuyen a aumentar el interés y la atención de los estudiantes.

En el caso de la experiencia con Kahoot, la actividad constó de nueve preguntas sobre la comprensión genérica de un texto situado en el manual de cátedra "Technology and Communication". En la actividad propuesta en Quizizz las preguntas consistían en los nombres de ciertas redes sociales, por lo que el tema era más bien relacionado a lo cotidiano y no tanto a sus conocimientos de la materia, lo que podría haber influido en la cantidad de respuestas. 
Como herramienta de recolección de datos se empleó una hoja de observación de clase digitalizada a través de un formulario de Google (Apéndice A). El formulario cuenta con secciones divididas para cada juego por separado, en las cuales se evalúa con el mismo criterio la motivación, la actitud y la atención del estudiante durante la actividad. Estos criterios son evaluados según la frecuencia de participación: nunca, a veces, frecuentemente, siempre o no corresponde. El formulario también cuenta con un espacio libre para comentarios en donde se registró los comentarios expresados por los alumnos y otras reacciones que no estaban contempladas en las opciones múltiples pero que eran de gran relevancia para la presente investigación; así como también percepciones personales de los observadores con respecto a la clase.

\section{Procedimiento}

La docente del curso elaboró diferentes propuestas didácticas para cada clase en la que se diseñaron actividades, que se focalizaban en la enseñanza del vocabulario y la gramática mediada por actividades ludificadas. Las actividades se desarrollaron de forma sincrónica en las sesiones de Meet ya que la docente compartía con los alumnos un código de acceso. En cada sesión dos ayudantes alumnas de la cátedra que habían recibido entrenamiento sobre cómo completar los datos empleando la hora de observación, se encontraban conectadas tomando notas y completando la hoja de observación. Dado que los alumnos se encontraban familiarizados con estas alumnas, el proceso de recolección de datos mediante observación no irrumpió en el desarrollo normal de la clase.

Se realizó la observación de clases en las que estas actividades ludificadas fueron utilizadas para practicar la gramática y vocabulario en la lengua meta, y para revisar la comprensión lectora de los estudiantes. Se utilizó un formulario de Google (Apéndice A) con distintos enunciados de opción múltiple para poder facilitar la compilación y posterior análisis de la información observada. Dicho formulario se completó de manera conjunta entre los integrantes del grupo de investigación, el cual luego fue completado de a pares para disponer de una mayor información. Los datos obtenidos mediante la escala de likert fueron fácilmente procesados mediante el formulario de Google. Los comentarios de las ayudantes en el cuadro de observaciones fueron empleados para dotar al análisis de mayor profundidad.

\section{Resultados}

Teniendo en cuenta el objetivo de la presente investigación, nos enfocamos en los resultados arrojados en cuanto a la motivación de los alumnos y a su percepción sobre el aprendizaje de la segunda lengua.

Por un lado, al evaluar la motivación de los alumnos, distintos resultados se han observado con el uso de las distintas herramientas de ludificación utilizadas. En cuanto a Kahoot, se han observado distintas variables. Por un lado, la gran mayoría de los estudiantes han participado durante las actividades de manera activa utilizando el chat de la plataforma Meet. Los alumnos hicieron uso del chat para manifestar, mediante interjecciones u otras palabras, su actitud expectante y entusiasta frente a la actividad. A su vez, en su mayoría, los alumnos se mantuvieron conectados durante el lapso de las actividades propuestas, realizaron comentarios en el chat con respecto a la actividad e intercambiaron ideas con sus compañeros. Hubo ocasiones 
en las que los alumnos explícitamente expresaron su actitud positiva hacia el uso de Kahoot, tales como que disfrutaban de la música y que les resultaba divertido. Todo esto pareciera indicar que, en el caso de Kahoot, la ludificación logró aumentar la motivación de los estudiantes de grado. Por otro lado, fue menor la recurrencia de ocasiones en las que los alumnos participaron activando el micrófono. Hipotetizamos que esto podría relacionarse con la influencia de otras variables, como lo son problemas de conectividad, o timidez, entre otras. Cuando hubo participación, ésta fue de manera voluntaria, y aquellos alumnos que tenían cámara encendida estaban mirando a la pantalla y prestando atención, lo que apoyaría el indicio mencionado. Sin embargo, los resultados arrojados con respecto a Quizizz fueron distintos. Se observó una menor participación tanto en el chat como mediante interjecciones $u$ otras palabras, así como tampoco hubo muchas instancias de alumnos activando el micrófono para realizar comentarios ni intercambiar ideas. Una posible causa de esta diferencia podría ser la naturaleza de cada ludificación: durante la actividad de Quizizz,los estudiantes deben trabajar de manera más autónoma e individual en comparación con Kahoot, en el cual es más fácil interactuar y socializar las respuestas después de cada pregunta. A su vez, en esta ocasión los alumnos expresaron algunos comentarios negativos en cuanto a aspectos que habían halagado en Kahoot. Expresaron que, si bien les gustaba la música, era demasiado fuerte y que eso, a su vez, les impedía escuchar a la docente. Se observa entonces cómo un mismo factor influye de manera diferente en cada ludificación. Por otro lado, en general, el número de alumnos que comenzó la actividad la terminó, lo cual es un buen indicio. En ambas instancias de ludificación se observó poco uso del micrófono durante el desarrollo de las actividades pero, como se mencionó anteriormente, esto podría estar relacionado con otras variables. A su vez, un inconveniente que se observó fue que, en general, los alumnos que ingresaban más tarde en su mayoría no lograban integrarse con facilidad a la actividad. Esto podría tener un impacto negativo en su motivación. Pareciera ser el caso, entonces, que distintos aspectos de la ludificación afectan en el grado de motivación que la actividad genera.

Otro enfoque en las observaciones estuvo puesto en la percepción de los alumnos en cuanto al aprendizaje de la segunda lengua. Estos resultados se pueden ver plasmados en los comentarios y actitudes de los estudiantes en relación con la actividad realizada. Si bien algunos alumnos valoraron la actividad, ciertos datos indican que no todos los alumnos perciben la gamificación como efectiva para el aprendizaje de la segunda lengua. Por ejemplo, los alumnos no se notaron muy entusiasmados al principio con ninguna de las plataformas y solo cuatro respondieron las preguntas generales sobre el juego antes de comenzar a jugar. A su vez, de los 71 alumnos presentes, solo 35 pudieron o quisieron participar de manera voluntaria en el caso de Kahoot, y 37 en Quizizz. Algunos participaron solo luego de que la docente lo solicitó. De aquellos que no participaron, únicamente un alumno informó a través del chat de la videollamada que tuvo problemas de conexión. A su vez, del total de los participantes, no todos respondieron la totalidad de preguntas, con un promedio de 32 y 33 respuestas por pregunta, si bien variaba según el tema y la complejidad. Se observó, a su vez, que la cantidad de preguntas sin responder varió a lo largo de los cuestionarios, por lo que otras variables como la complejidad podrían haber influido. Teniendo estos datos en cuenta, pareciera que no todos los alumnos ven a la gamificación como una herramienta que conduzca al aprendizaje. 


\section{Discusión y conclusiones}

Al igual que Ahumada y otros (2020), nosotros también encontramos un aumento en la motivación de los estudiantes frente al uso de la ludificación. Sin embargo, a pesar de los resultados observados por Wulayo y Bucol (2021) y Castillo-Cuesta (2020), en nuestro caso se observa que la percepción de los alumnos sobre el impacto de la ludificación en el aprendizaje de una segunda lengua no son tan positivos como los resultados de dichas investigaciones arrojan. La percepción no es constante en todas las actividades ludificadas que se presentaron, sino que varía según la herramienta que se utilice y el tipo de actividades que se proponga al alumnado. Como lo notaron las observadoras, las actividades que más involucraban a los alumnos eran las de opción múltiple, mientras que en las de producción la participación declinaba. De acuerdo con Perdomo Vargas y Rojas Silva (2018), la ludificación podría incrementar hasta un $40 \%$ la posibilidad de aprender. Para que esto sea posible, se debe tener en cuenta las características de los estudiantes y los objetivos de aprendizaje, crear contenido atractivo y educativo, crear un ambiente de aprendizaje en el juego, entre otras acciones. Por ejemplo, el diseño de las actividades debe contar con elementos multimediales atrayentes que incentiven a los estudiantes. Entre los componentes que son atrayentes para los estudiantes se encuentran los podios, acumulación de puntos, recompensas, y la posibilidad de enmendar errores para poder alcanzar una mayor puntuación. Esto explica la diferencia en los resultados arrojados por Quizizz y Kahoot, ya que en el caso del último, en el cual se utilizan estos componentes atrayentes, se observa un mayor grado de motivación que en el caso de Quizizz.

Perdomo Vargas y Rojas Silva (2018) también identifican la retroalimentación dirigida y frecuente entre los factores que conllevan al aprendizaje y estimulan la motivación. En este sentido, podemos hipotetizar que Kahoot se presenta como una herramienta un poco más efectiva que Quizizz, ya que el feedback suele estar un poco más diferido al tener que contestar todas las preguntas antes de ver el feedback. El acceso a elementos ludificados como el podio también se hace al final de la actividad, mientras que con Kahoot, los estudiantes tienen acceso a esta información de manera inmediata. Esto puede mantener la atención del alumno cautiva por mucho más tiempo. Hay ciertos aspectos positivos que se pueden observar en las dos herramientas, como la libertad para equivocarse, la rápida retroalimentación y la muestra del progreso a lo largo de la actividad.

Al igual que la investigación llevada a cabo por Le (2021), los resultados obtenidos en la presente experiencia áulica parecen indicar que la ludificación trae aparejada un aumento de motivación. Sin embargo, se descubrió que las actividades realizadas con Kahoot que implican acciones y reacciones simples tienen mayor impacto que las de Quizizz, en las que el alumnado debe involucrarse de manera más activa desde la producción de la lengua.

Por lo antedicho, podemos decir que en nuestro contexto universitario, las actividades ludificadas promovieron la motivación de los alumnos y el aprendizaje de una segunda lengua con diferentes grados de éxito. El diseño de este tipo de actividades se encuentra estrechamente relacionado con la recepción que los alumnos tienen de estas actividades y, por lo tanto, del éxito de las mismas. Combinar diseños, estrategias, estímulos y herramientas es esencial para incrementar la motivación e incentivar el aprendizaje de una lengua extranjera, en especial el vocabulario y la gramática. 


\section{Referencias}

Ahumada, M. I., Arias, V., Caro, N. P., López, C. M., Fioretti Camusso, M. V., y Gallo Libra, A. M. (2020). La gamificación en los procesos de enseñanza y aprendizaje. Sistematización de experiencias y buenas prácticas docentes universitarios. El m-learning como oportunidad para incorporar la ludificación en el aula, en cursos masivos de Estadística. Red Innova Cesal. Recuperado de: http://www.innovacesal. org/redic_gamificacion/redic_reportes_finales_gamificacion_foro2018/14/14.pdf

Castillo-Cuesta, L. (2020). Using digital games for enhancing EFL grammar and vocabulary in Higher Education. International Journal of Emerging Technologies in Learning, 15(20), 116-129.

Deterding, S. (2012). Gamification: designing for motivation. Interactions, 19(4), 14-17.

Kapp, K. M. (2012). The gamification of learning and instruction: game-based methods and strategies for training and education. John Wiley \& Sons.

Kim, S., Song, K., Lockee, B., y Burton, J. (2018). Gamification in learning and education. Enjoy learning like gaming. Springer.

Le, L. T. (2021). A real game-changer in the ESL classroom? Boosting Vietnamese learner engagement with gamification. Computer-Assisted Language Learning Journal, 21(3), 198-212.

Perdomo Vargas, R., y Rojas Silva, J. (2018). La ludificación como herramienta pedagógica: algunas reflexiones desde la psicología. Revista de Estudios y Experiencias en Educación, 18(36), 161-175. Recuperado de: https://www.redalyc.org/jatsRepo/2431/243158860009/html/index.html

Ruiz, D. (2019). Quizizz en el aula: evaluar jugando. Observatorio de Tecnología Educativa, 4. Instituto Nacional de Tecnologías Educativas y de Formación del Profesorado. Ministerio de Educación y Formación Profesional. Recuperado de: https://intef. es/observatorio_tecno/quizizz/

Shroff, R. H., Keyes, C. J. y Wee, L-H. (2020). Gamified pedagogy: Examining how a phonetics app coupled with effective pedagogy can support learning. Electronic Journal of Foreign Language Teaching, 17, 104-116.

\section{Apéndice A}

Hoja de observación de clase.

Observación de clase - Cada vez que el docente lleve a cabo actividades lúdicas con el fin de promover el aprendizaje de una segunda lengua, los observadores tienen que tener a mano esta grilla. Primero localizar la actividad correspondiente y luego seleccionar los descriptores que mejor describan lo que ustedes han podido observar. 


\section{Sección 1 - Kahoot}

\section{La motivación del alumnado durante la actividad.}

1. El alumnado participa activamente usando el chat.
a) nunca
b) a veces
c) frecuentemente
d) siempre

2. El alumnado manifiesta a través de interjecciones $u$ otras palabras su actitud expectante frente a la actividad
a) nunca
b) a veces
c) frecuentemente
d) siempre

3. El alumnado se mantiene conectado durante toda la actividad.
a) nunca
b) a veces
c) frecuentemente
d) siempre

4. Durante la actividad los alumnos realizan comentarios sobre la actividad e intercambian ideas con sus compañero
a) nunca
b) a veces
c) frecuentemente
d) siempre

5. Los alumnos participan activando el micrófono.
a) nunca
b) a veces
c) frecuentemente
d) siempre

\section{La actitud del alumnado durante la actividad}

1. El alumnado participa de forma voluntaria en la actividad.
a) nunca
b) a veces
c) frecuentemente
d) siempre

2. Los alumnos solo participan cuando el docente lo pide.
a) nunca
b) a veces
c) frecuentemente
d) siempre 


\section{La atención del alumno durante la actividad.}

1. Los alumnos con cámaras prendidas miran la pantalla en la que se resuelve la actividad.
a) nunca
b) a veces
c) frecuentemente
d) siempre
e) no corresponde

2. Los alumnos preguntan varias veces qué hacer
a) nunca
b) a veces
c) frequentemente
d) siempre
e) no corresponde

3. El docente debe repetir las instrucciones varias veces.
a) nunca
b) a veces
c) frecuentemente
d) siempre
e) no corresponde

4. Los alumnos que se conectan más tarde logran integrarse a la actividad con facilidad.
a) nunca
b) a veces
c) frecuentemente
d) siempre

5. Los alumnos que se conectan más tarde no logran integrarse.
a) nunca
b) a veces
c) frecuentemente
d) siempre

Comentarios sobre la actividad: registrar problemas técnicos, algo que les haya llamado la atención.

Rta:

\section{Sección 2 - Quizizz}

\section{La motivación del alumnado durante la actividad.}

1. El alumnado participa activamente usando el chat.
a) nunca
b) a veces
c) frecuentemente
d) siempre 
2. El alumnado manifiesta a través de interjecciones $u$ otras palabras su actitud expectante frente a la actividad
a) nunca
b) a veces
c) frecuentemente
d) siempre

3. El alumnado se mantiene conectado durante toda la actividad.
a) nunca
b) a veces
c) frecuentemente
d) siempre

4. Durante la actividad los alumnos realizan comentarios sobre la actividad e intercambian ideas con sus compañero
a) nunca
b) a veces
c) frecuentemente
d) siempre

5. Los alumnos participan activando el micrófono.
a) nunca
b) a veces
c) frecuentemente
d) siempre

\section{La actitud del alumnado durante la actividad}

1. El alumnado participa de forma voluntaria en la actividad.
a) nunca
b) a veces
c) frecuentemente
d) siempre

2. Los alumnos solo participan cuando el docente lo pide.
a) nunca
b) a veces
c) frecuentemente
d) siempre

\section{La atención del alumno durante la actividad.}

1. Los alumnos con cámaras prendidas miran la pantalla en la que se resuelve la actividad.
a) nunca
b) a veces
c) frecuentemente
d) siempre
e) no corresponde 
2. Los alumnos preguntan varias veces qué hacer.
a) nunca
b) a veces
c) frecuentemente
d) siempre
e) no corresponde

3. El docente debe repetir las instrucciones varias veces.
a) nunca
b) a veces
c) frecuentemente
d) siempre
e) no corresponde

4. Los alumnos que se conectan más tarde logran integrarse a la actividad con facilidad.
a) nunca
b) a veces
c) frecuentemente
d) siempre
e) no corresponde

5. Los alumnos que se conectan más tarde no logran integrarse.
a) nunca
b) a veces
c) frecuentemente
d) siempre
e) no corresponde

Comentarios sobre la actividad: registrar problemas técnicos, algo que les haya llamado la atención.

Rta:

Espacio para subir archivos / fotos de notas tomadas a mano: 


\section{El Modelo de Formación de Aulas Amigas Como Dinamizador de un Ecosistema de Innovación Educativa}

\section{Agudelo, Olga Lucía}

ORCID (orcid.org/0000-0002-8532-4260)

Colombia

olga.agudelo@cvudes.edu.co

Aulas amigas

oagudelo@aulasamigas.com.co

\section{Chica, Sandra Milena}

Aulas amigas

smchica@aulasamigas.com 


\title{
EL MODELO DE FORMACIÓN DE AULAS AMIGAS COMO DINAMIZADOR DE UN ECOSISTEMA DE INNOVACIÓN EDUCATIVA
}

\author{
Agudelo, Olga Lucía \\ Chica, Sandra Milena
}

\section{Resumen}

Uno de los principales retos al que se enfrentan los docentes en la sociedad del conocimiento, implica el desarrollo de nuevas habilidades y éste comienza desde los procesos de desarrollo profesional con la inclusión de las TIC en las gestiones que tiene a su cargo. Por ello, no es suficiente con tener instituciones bien dotadas, con mejores recursos, hay que centrar los esfuerzos en tener maestros que sepan qué hacer con los recursos disponibles, cómo usarlos en torno a proyectos de innovación, que tengan las competencias necesarias para formar los ciudadanos del siglo XXI o al menos, los deseos de formarse continuamente y mantenerse a la vanguardia en nuevas metodologías y en las herramientas tecnológicas que van surgiendo. Aulas AMiGAS ha propuesto un ecosistema de innovación con un Modelo de formación que responde a esas necesidades, apoyado en apropiación, recursos, herramientas e infraestructura tecnológica, redes y comunidades de práctica y un observatorio que aporta en la medición de impacto. Un modelo completo de formación docente para el desarrollo de competencias digitales que se ha sido diseñado a partir de la práctica, con una metodología de investigación basada en diseño, que se flexibiliza de acuerdo a las características de cada contexto, que se adapta a los ambientes urbanos y rurales y se enriquece con un portafolio de proyectos

\section{Palabras clave}

Formación, competencias digitales, ambientes de aprendizaje, informática educativa, innovación. 


\section{Introducción}

En un panorama donde las nuevas tecnologías exigen una formación diferente y unos ambientes de aprendizaje que respondan a las necesidades actuales, se busca generar ambientes de aprendizaje innovadores, enriquecidos con nuevas tecnologías y que respondan a las necesidades y características de los contextos.

Pero ¿se cuenta en las escuelas con la capacidad necesaria para enfrentar estos retos?, ¿los maestros están capacitados para que sus procesos de enseñanza respondan a los desafíos?, ¿̇se están brindando las herramientas y recursos necesarios para que la educación esté alineada con los desafíos de la era de la innovación? No se puede desconocer que la ausencia de recursos y materiales para la docencia en las instituciones públicas es un problema que complica el quehacer docente y amplía la brecha de desigualdad. (Zapata y Lopera, 2018), es así como, de acuerdo con Cabero y Martínez (2019), los desafíos para la educación se plantean en dos direcciones, por un lado, un reto tecnológico y, por otro lado, el reto pedagógico.

Desde la década de los 90 se ha intentado investigar la dimensión sistémica de la innovación, al punto de debatir si la innovación puede ser explicada desde el enfoque de ecosistema, con el fin de justificar la naturaleza evolutiva de las interrelaciones de los distintos actores, sus actividades innovadoras y su entorno (Oh, Phillips, Park \& Lee, 2014)

La "ecología de la innovación" depende parcialmente de la presencia de elementos como el talento, las empresas, las instituciones y el capital; pero más aún de sus identidades, es decir, las capacidades de red, la cultura de la confianza y la cooperación pragmática (Jucevi ius and Grumadait, 2014).

Los agentes que componen un ecosistema de innovación, interactúan e intercambian conocimiento entre sí en un entorno o unidad espacial determinada, que está estructurada por las interacciones de los diferentes elementos contenidos en este. (Escobar, Cárdenas \& Bedoya, 2017).

En este sentido, Aulas AMigAS como empresa, se ha dedicado a diseñar e implementar proyectos en un ecosistema de innovación educativa y en el camino, ha desarrollado un modelo de formación y apropiación docente, plataformas de contenidos educativos y tecnología de punta, que han permitido la inclusión efectiva de las TIC en las aulas de clase, con el objetivo de fortalecer las habilidades en el manejo de las tecnologías de la información y la comunicación para mejorar las prácticas educativas.

El modelo de formación de Aulas AMiGAS, como dinamizador de todo su ecosistema deinnovación, genera procesos donde se forma y acompaña a los docentes en este camino, donde se les entregue no solo herramientas, sino metodologías y didácticas que les permitan generar procesos de enseñanza -aprendizaje significativo, desde entornos apoyados en TIC. Procesos de formación que no finalizan con la certificación, sino, que más allá de la apropiación, los acompañen a experimentar en el aula, a sistematizar su experiencia, divulgarla y a continuar aprendiendo entre pares, en comunidades de práctica y que los proyecten hacia la investigación, Salinas (2016). 


\section{Método/Descripción de la experiencia}

Basándose en la metodología de investigación basada en diseño que, según De Benito e Ibañez (2016) es un tipo de investigación orientado hacia la innovación educativa, cuya característica fundamental consiste en la introducción de un elemento nuevo para transformar una situación, lo que permite diseñar programas, paquetes didácticos, materiales, estrategias, entre otros, que se someten a pruebas y validación, y, una vez mejorados, se transfieren a la realidad escolar, Aulas AMiGAS trata de responder a los problemas detectados en la realidad educativa apoyándose en modelos disponibles y teorías pedagógicas como metodologías activas, entornos de aprendizaje apoyados en TIC y tecnologías emergentes, proponiendo posibles soluciones.

El Ecosistema de Innovación Educativa Aulas Amigas (Figura 1), surge para dar respuesta a los grandes desafíos que Es enfrentan en la era de la Cuarta Revolución Industrial, donde no solo se deben atender retos tecnológicos y pedagógicos sino también los que se desprenden del reconocimiento desde nuestra dimensión social y humana (El Ser).

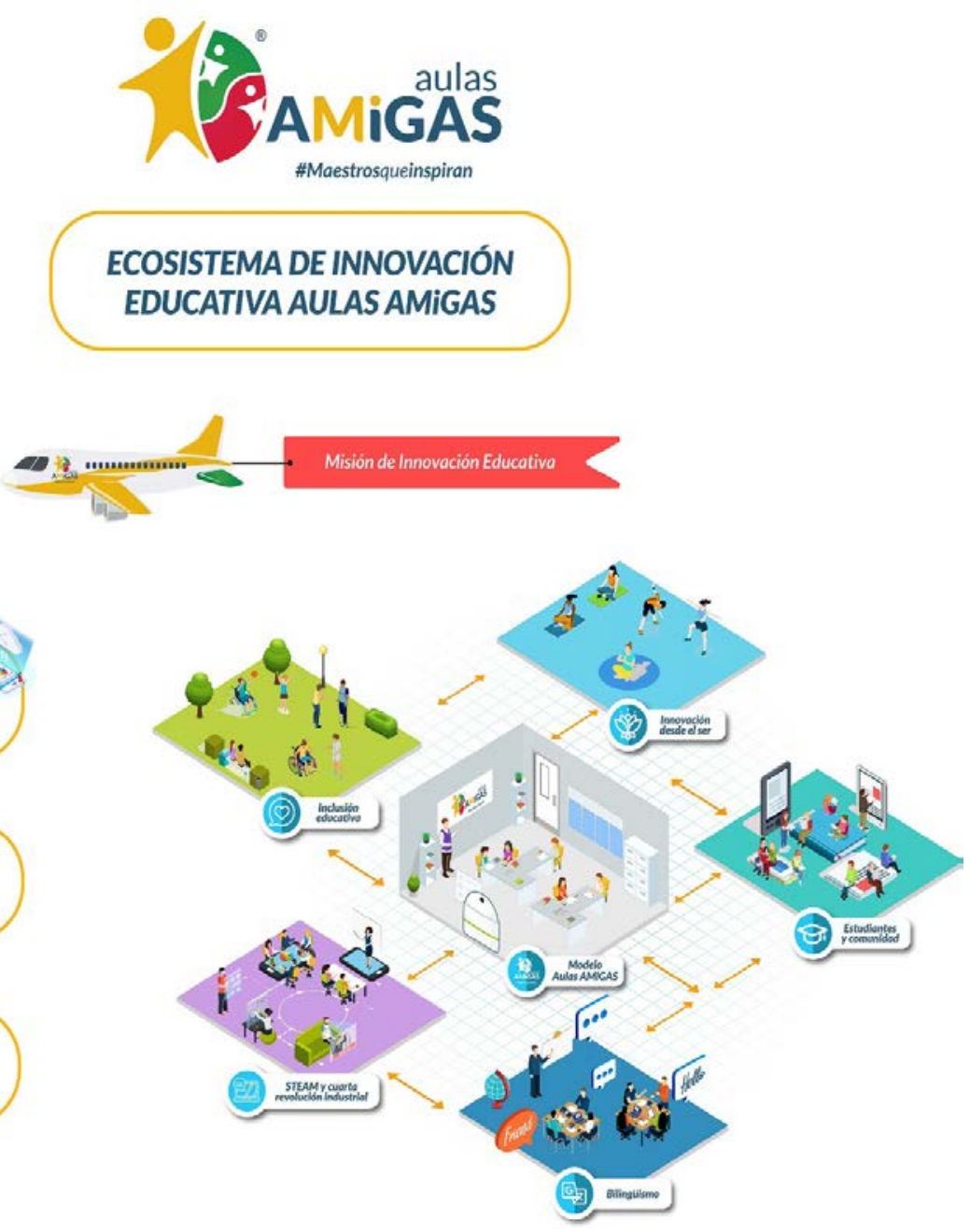

Figura 1- Ecosistema de Innovación Educativa- Aulas Amigas- Fuente propia 
Cada uno de los componentes del Ecosistema tiene la capacidad de trabajar de forma independiente, para atender problemáticas específicas o hacer parte de soluciones integrales, generando un alto impacto a nivel educativo y social.
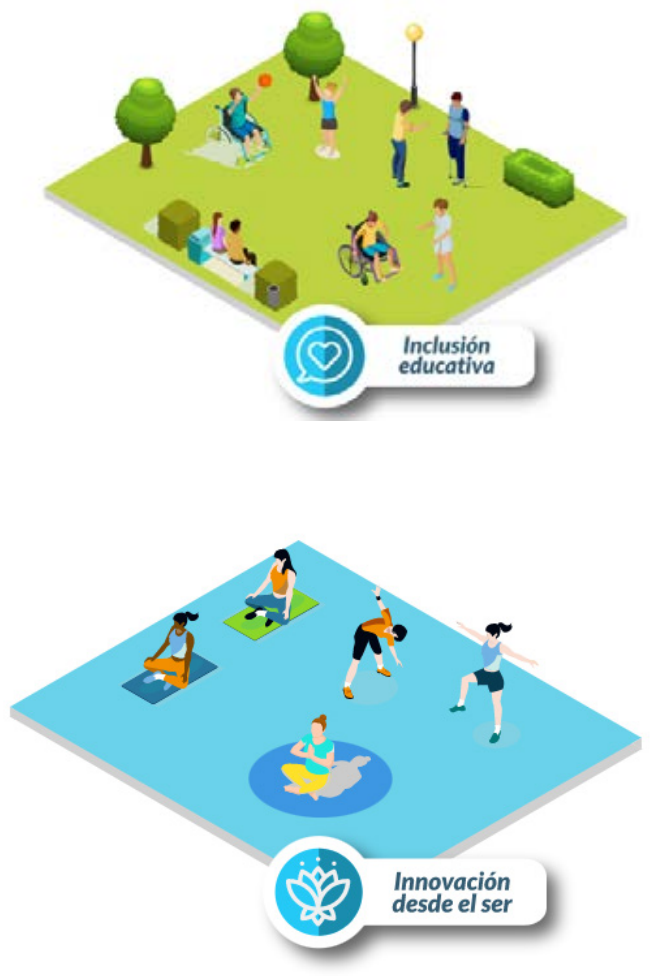

Inclusión educativa: Este componente tiene como objetivo brindar a la comunidad una serie de herramientas y metodologías que fortalezcan en ellos, desde el reconocimiento y respeto por la diversidad, hasta la puesta en marcha de acciones para el cumplimiento de la normatividad vigente en temas de inclusión educativa.

Cuando se habla de innovación educativa se piensa en proyectos que respondan a los avances tecnológicos actuales. Sin embargo, el talento que requiere la Era de la Cuarta Revolución Industrial nos exige pensar en otro tipo de competencias y habilidades transversales que deben ser potencializadas desde la dimensión más importante que poseemos: La dimensión humana y social.

Pensar en innovar, también es pensar en el desarrollo del SER, un ser humano capaz de adaptarse y responder de la mejor manera a los continuos cambios de la era actual. Es por esto, que nuestro componente Innovación Educativa desde el SER tiene como objetivo brindar herramientas a los maestros y estudiantes para potencializar en ellos habilidades como la Inteligencia emocional, la flexibilidad cognitiva, el razonamiento crítico, la comunicación, el trabajo en equipo entro otros.

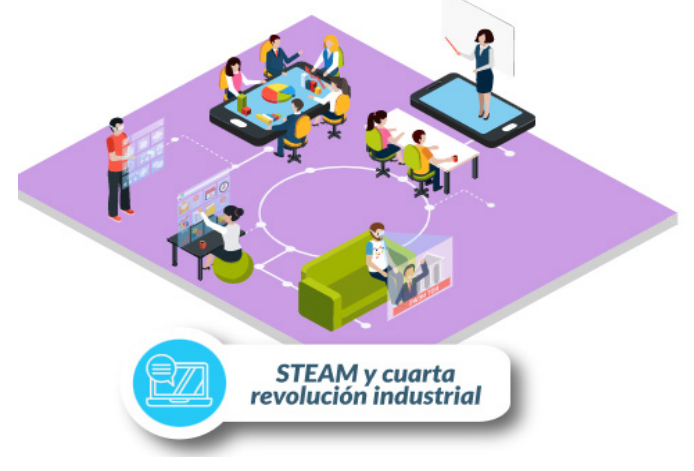

En una era dominada por tecnologías exponenciales como inteligencia artificial, robótica, blockchain, internet de las cosas (IOT), entre otras, se hace cada vez más indispensable el actualizar y formar a las nuevas generaciones para que puedan responder a los retos profesionales y laborales que esto conllevan.

Este componente tiene como propósito acercar herramientas y metodologías que permitan empoderar a los docentes para que puedan desarrollar estas nuevas habilidades y competencias en sus estudiantes. 


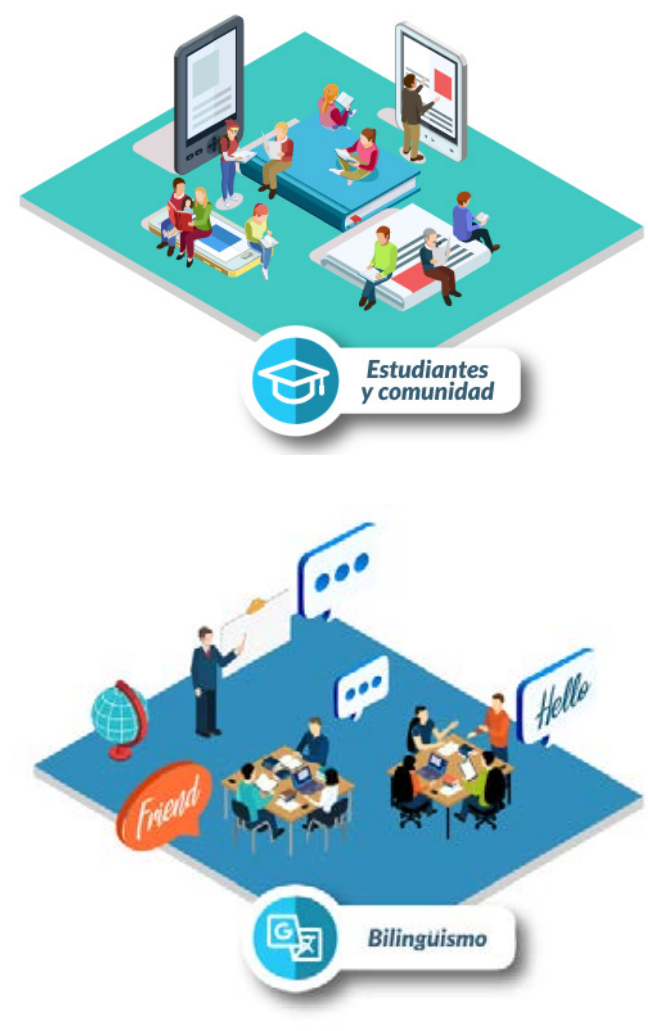

La Educación es un asunto de todos, es por esto que desde Aulas Amigas se incluye en el Ecosistema un componente que acerque herramientas innovadoras a la comunidad educativa en general: estudiantes, padres de familia, docentes, directivos y entes territoriales. Cada uno de estos actores, tiene un rol específico e indispensable en el proceso y hemos pensado en cada uno de ellos.

La ciudadanía global es una realidad que se viene gestando desde hace muchas décadas, gracias a los avances tecnológicos se ha hecho cada vez más común el intercambio cultural, económico y de conocimiento, entre nuestros países. Este intercambio entre grupos de personas solo es posible, si existen los medios para comunicarse de forma efectiva y es allí donde el conocimiento de un segundo idioma se hace completamente indispensable.

Por lo anterior, este componente busca brindar las herramientas necesarias para fortalecer en los estudiantes y docentes los procesos de enseñanza y aprendizaje de un segundo idioma, para este caso el inglés el cual es catalogado como el idioma de la comunicación internacional, el comercio y las finanzas.

\section{Descripción del contexto y de los participantes}

El modelo de formación propuesto por Aulas AMiGAS está dirigido a los docentes de todas las áreas y niveles educativos, que deseen formarse e implementar tecnologías en sus entornos de enseñanza y aprendizaje. Se ha ido desarrollado con la participación de maestros colombianos, en entornos urbanos y rurales, especialmente en aquellos con problemas de conectividad y acceso a recursos tecnológicos, en tres ciclos iterativos, con el apoyo de entidades gubernamentales y empresas con responsabilidad social, que vienen asumiendo la formación de los docentes. 


\section{Procedimiento}

\section{Modelo Aulas AMiGAS}

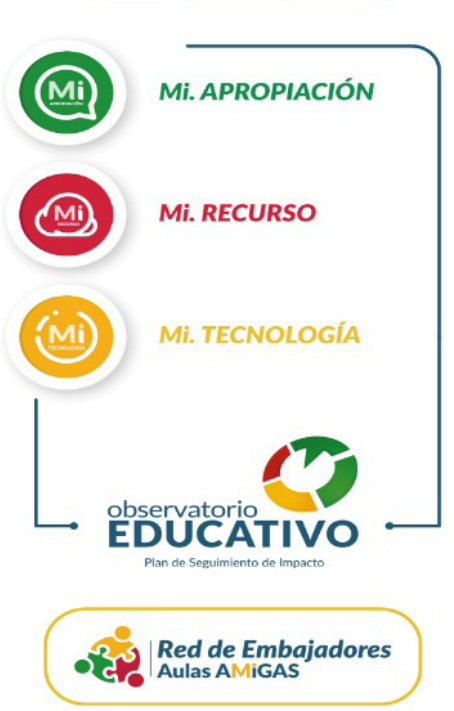

Como eje articulador del ecosistema de innovación educativa AULAS AMiGAS, se ubica el modelo de formación, que reúne estrategias que buscan romper con las barreras para aplicar las TIC en las escuelas, llevándolas al aula de clase de manera INTEGRAL con el fin de que los procesos se ejecuten de manera efectiva. El modelo se compone de tres ejes principales y un eje transversal que permite realizar el seguimiento del proyecto; además, de un valor agregado definido como una comunidad de práctica para compartir conocimientos, proyectos y experiencias. (Figura 2).

Mi.APROPIACIÓN: Un programa de apropiación pedagógica pensando en las necesidades de los actores claves del proceso de enseñanza-aprendizaje de los estudiantes, el cual, se basa en las competencias del maestro del siglo XXI propuestas por UNESCO y adoptadas por el MEN. La apropiación incluye:

- Comunicación y sensibilización.

- Diagnóstico de competencias.

- Apropiación presencial inicial.

- Apropiación virtual.

- Acompañamiento.

Mi.RECURSO: El proceso se complementa con el acceso de los maestros a una plataforma digital que cuenta con una serie de recursos y herramientas TIC que facilitarán su trabajo dentro y fuera del aula de clase, apoyando su labor desde la planificación, consecución, creación de contenidos y actividades interactivas, entre otros; además herramientas que permiten la continuidad de clases de manera sincrónica, asincrónica, y una APP para la realización de clases de manera offline por parte de los estudiantes. Consta de:

- Plataforma para creación y gestión de clases online y offline.

- Más de 30.000 clases y actividades interactivas.

- Bancos de preguntas.

- App de comunicación.

- App de trabajo Off line 
Mi. TECNOLOGÍA: Permite el acceso a recursos tecnológicos como TOMi 7 (dispositivo que cuenta con patente), proyector y otros dispositivos de apoyo al docente, que incluyen PDI y las redes intranet que se definen como conectividad sin internet. Incluye:

- TOMi 7.

- Conectividad "Internet sin internet"

- Planeación y gestión académica con medios tecnológicos.

- Herramientas complementarias.

\section{COMPONENTES TRANSVERSALES:}

Las redes de aprendizajes son espacios en los cuales sus participantes interactúan, compartiendo información y colaborando para crear un conocimiento

Las redes de aprendizajes de Aulas Amigas son espacios virtuales que apoyan el proceso de formación presencial, facilitan la asesoría de los formadores, generan canales de comunicación entre pares y enriquecen las prácticas de aula desde las experiencias de las otras aulas.

La Red de Embajadores Aulas AMigAS es un espacio de co-construcción entre los docentes que forman parte del proceso Aulas AMiGAS. Dentro de los objetivos de la Red, está el crear proyectos colaborativos entre docentes de diferentes ciudades y/o países beneficiados con el proyecto y nacen como complemento y valor agregado a la formación presencial de las Aulas amigas instaladas en las instituciones educativas, como apoyo en la implementación del proyecto, como espacio de encuentro a manera de comunidad de práctica, para intercambios de información y conocimiento en red y como estímulo para impulsar procesos de innovación.

La Red de Embajadores de Aulas Amigas es, además, un punto de inicio para la divulgación de las mejores prácticas, pues es allí en donde inicia la sistematización de los procesos, con el reconocimiento de lo que se hace en la práctica y el intercambio que permite convertirla en una experiencia significativa.

\section{Resultados}

Desde el año 2018, en el cual se empieza a consolidar el modelo Aulas AMiGAS, se han intervenido 2783 aulas y se han formado 5009 docentes del territorio colombiano. Ahora el modelo trasciende las fronteras del país.

La medición de impacto es muy importante en el diseño de estrategias para conseguir los resultados buscados. El Observatorio Educativo permite trazar metas de impacto y hacer seguimiento del proyecto. El proceso inicia con una prueba de caracterización con datos demográficos, de conectividad y recursos y una prueba diagnóstica que se contrasta con un post test al finalizar la apropiación. El avance de los maestros y el impacto que se logra desde ellos en la educación son observados y medidos día a día, incluso si en sus aulas no tienen acceso a internet. 
En las pruebas de percepción y satisfacción de los docentes participantes, se concluye que las estrategias utilizadas con la incorporación del modelo Aulas AMiGAS, dan una nueva perspectiva de formación en el aula apoyada por tecnología, lo que se puede evidenciar con sistematización de experiencias en la Red de Embajadores, artículos y publicaciones como las de Bárcena y Zarache (2019), Ramírez (s.f), Briceño (2019) o Rivera (2021).

\section{Discusión y conclusiones}

A manera de conclusión y de punto de partida para la discusión se plantea que:

El modelo Aulas AMiGAS logra aplicar la tecnología y la pedagogía de una manera integrada que pone la primera al servicio de la segunda, sin priorizar las herramientas y dispositivos y teniendo como meta el desarrollo de competencias para el siglo $\mathrm{XXI}$ a través de metodologías activas.

El modelo propuesto no finaliza con la certificación de las horas de formación, sino que esta se convierte en punto de partida para las asesorías técnicas, tecnológicas y pedagógicas in situ y virtuales, que se realizan para la implementación en el aula, teniendo en cuenta que, aunque con el proceso de apropiación se avanza en el desarrollo de competencias digitales, el docente requiere de apoyo constante para llegar a la aplicación.

El acompañamiento posterior a la formación, las comunidades de práctica y la asesoría para la sistematización de experiencias, genera motivación hacia la investigación pedagógica y la innovación educativa, lo cual se convierte en punto clave para maestros que inspiran.

\section{Referencias}

Bárcenas Alvis, J. C., \& Zarache Donado, I. M. (2019). Herramientas de autor para la enseñanza y aprendizaje de la física mecánica según estilos de aprendizajes en estudiantes de la media (Doctoral dissertation, Universidad de la Costa).

Briceño, L. (2019). Usos de las TIC en preescolar: Hacia la integración curricular. Panorama, 13(24), 20-32.

Cabero Almenara, J., \& Martínez Gimeno, A. (2019). Las tecnologías de la información y comunicación y la formación inicial de los docentes: modelos y competencias digitales.

de Benito Crosetti, B., \& Ibáñez, J. M. S. (2016). La investigación basada en diseño en Tecnología Educativa. Revista Interuniversitaria de Investigación en Tecnología Educativa.

Escobar, J. F., CARDENAS, M. F., \& Bedoya, I. B. (2017). De los sistemas a los ecosistemas de innovación. Revista Espacios, 38(34). 
Jucevi ius, G., Grumadait , K., 2014. Smart Development development of innovation ecosystem. Procedia-Soc. Behav. Sci., 156, 125-129. doi:10.1016/j.sbspro.2014.11.133

Oh, D.S., Phillips, F., Park, S., Lee, E., 2014. Innovation ecosystems: a critical examination. Technovation 54, 1-6. doi:10.1016/j.technovation.2016.02.004.

Ramírez Vélez, J. M. Propuesta didáctica desde un enfoque epistemológico para mejorar los procesos de enseñanza y aprendizaje de los números primos.

Rivera Gaitán, E. (2021). Fortalecimiento del pensamiento lógico matemático para la resolución de problemas con secuencias didácticas creadas en TOMI digital e incorporadas en el dispositivo digital TOMI 7 en los estudiantes del grado quinto de la institución educativa rural Jesús Antonio Amezquita de Rio Blanco, Tolima (Master's thesis, Universidad de Cartagena).

Salinas, J. (2016). La investigación ante los desafíos de los escenarios de aprendizaje futuros. Revista de Educación a Distancia (RED), (50). Ejemplos

Zapata Ramírez, C., \& Lopera, J. M. (2018). Fórmulas de cambio: Maestros innovadores. En Repositorio.minciencias.gov.co 


\section{Evaluación Remota en Química Universitaria con Herramientas de Google}

Gottardo, Marcelo

orcid.org/0000-0002-7547-0299

Dominighini, Claudio

orcid.org/0000-0001-6663-6878

\section{Cataldi, Zulma}

orcid.org/0000-0002-8526-6531 


\title{
EVALUACIÓN REMOTA EN QUÍMICA UNIVERSITARIA CON HERRAMIENTAS DE GOOGLE
}

\author{
Gottardo, Marcelo \\ Dominighini, Claudio \\ Cataldi, Zulma
}

\section{Resumen}

En esta publicación se presentan los resultados parciales de avance de una investigación de evaluación remota sincrónica mediante el uso de los teléfonos celulares, desarrollada en la Universidad Tecnológica Nacional, Facultad Regional Buenos Aires. Esta investigación iniciada en 2017 facilitó la realización de las evaluaciones durante la pandemia del año 2020, ya que coincidió con la fase de la implementación remota. La evaluación se aplicó en cursos que funcionaron como prueba piloto de química y química general durante 2017, 2018 y 2019. En 2020 se realizaron exitosamente 2904 evaluaciones remotas sincrónicas. La población estudiada fue de 1721 alumnos de primer año de distintas ingenierías: sistemas, mecánica, textil, electrónica, civil, naval, eléctrica e industrial. Todas las evaluaciones fueron grabadas en las plataformas disponibles Meet o Zoom y archivadas en un drive institucional de la facultad. No se encontraron diferencias estadísticamente significativas entre los baremos de 2020 comparados con los que se realizaron de manera presencial durante 2018 y 2019. La experiencia fue implementada en google forms, y se llevó a cabo con los dispositivos móviles individuales de cada alumno, lo que permitió dar continuidad al proceso educativo durante la pandemia. Esto llevó a constituir un grupo de trabajo multidisciplinario con docentes y estudiantes becados para poder terminar en tiempo y forma cada una de las etapas de avance.

\section{Palabras clave}

Evaluación remota, evaluación sincrónica, química. 


\section{Introducción}

Esta investigación se originó a partir de la necesidad de evaluar a una gran cantidad de alumnos en las clases de prácticas de laboratorio de química y química general. En las clases de prácticas de laboratorio de la facultad se evaluó durante 2017 una muestra 450 alumnos correspondientes a 11 cursos. Al finalizar la clase los alumnos fueron evaluados individualmente sobre los contenidos de la práctica, que realizaron en pequeños grupos. Aunque en cada clase de laboratorio había un jefe de laboratorio y dos ayudantes, la corrección de las evaluaciones tradicionales llevaba demasiado tiempo. A partir de 2017 en los 11 cursos (tomados como muestra) de un total de 64 se aplicó una evaluación con 40 preguntas con cinco opciones (una correcta y 4 descriptores de errores) sobre contenidos específicos de laboratorio. La respuesta se recogía con una grilla en papel y se corregía inmediatamente con una plantilla perforada y se indicaba a cada alumno las respuestas equivocadas que podían consultar en unos cuadernillos en los que se aclaraba el error cometido. Estos cuadernillos explicaban cada descriptor de error (respuestas incorrectas) y el posible motivo de esa elección. Avanzado 2017 se introdujo la posibilidad de pasar estas evaluaciones de opciones múltiples a Google Forms (Homocianu \& Airinei, 2015; Sotalín \& Jovita, 2019) a fin de sistematizar las respuestas y las retroalimentaciones en forma automática, dejando de usar las grillas papel y el cuadernillo de explicación de los distractores y en su lugar usar los teléfonos celulares (Cataldi et al 2012a). Durante 2018 se iniciaron las pruebas en los mismos cursos (distinta cohorte) con el uso de códigos Quick Response (QR) con excelentes resultados (Gottardo 2020). Simultáneamente, durante 2018 se comenzó a aplicar esta forma de evaluación en 10 cursos piloto (Cataldi et al 2010) como alternativa mixta (escrito presencial y envío de respuestas por Google Forms), se les pidió que volcaran las respuestas en un formulario que al finalizar les indicaba la nota provisoria que tendrían si concordaban sus respuestas con las resoluciones en papel. Las respuestas se sistematizaron con el uso del teléfono celular de cada alumno por medio de Google Forms. Durante 2018 se llevaron a cabo las pruebas piloto, se ajustaron y se realizaron nuevas con la cohorte 2019. Cabe aclarar que dentro de los grupos piloto se dejaron cursos sólo en formato papel y no se registraron diferencias estadísticamente significativas en el rendimiento de los alumnos. Lo desarrollado durante 2017 a 2019 permitió aplicar la evaluación remota sincrónica en química durante 2020 y 2021 con los siguientes objetivos: analizar el rendimiento de un conjunto de herramientas tecnológicas para implementar la evaluación remota sincrónica en química básica universitaria y comparar los resultados obtenidos con los de las evaluaciones tradicionales presenciales de 2018 y 2019.

A fin de alcanzar los objetivos se plantea un entorno de evaluación mixto (híbrido) usando herramientas tecnológicas en forma sincrónica y remota, en el marco de la enseñanza y del aprendizaje de la química universitaria en las carreras de ingeniería.

El marco teórico de esta contribución se basa en la importancia de la evaluación que ha sido puesta de manifiesto por numerosos autores e investigadores como Álvarez Méndez (2011); Anijovich (2010); Camilloni (2017); Perrenoud (2008); Santos Guerra (2005), entre otros, quienes manifiestan que evaluar es comprender no sólo el proceso de aprendizaje del alumno sino todos lo implicado en el proceso de enseñanza. Así, la evaluación debe cumplir al menos dos funciones: ajustar pedagógicamente la propuesta de enseñanza y evaluar los resultados de los aprendizajes. 
Evaluar consiste en emitir juicios de valor acerca de algo, con alguna finalidad: se evalúa para tomar decisiones con respecto a la marcha de un proceso, por ese motivo la evaluación no tiene un fin en sí mismo, no se evalúa por evaluar (Camilloni, 2017). En cursos numerosos la evaluación presencial resultaba trabajosa y consumía mucho tiempo de corrección. Esta investigación se generó inicialmente como una alternativa para disminuir el tiempo que los docentes usan en las tareas administrativas y dedicar ese tiempo a tareas de guía, aclaración de dudas y elaboración de soluciones a problemas de aprendizaje.

En el marco de la enseñanza de la ingeniería se promueve el aprendizaje significativo y relevante desde la propia experiencia de los alumnos, con evaluaciones basadas en retroalimentación y reflexión, lo que permite un crecimiento continuo que potencia el aprendizaje colaborativo y la autodirección.

\section{Método}

Se describen la investigación que sobre una serie de implementaciones educativas que se desarrollaron a partir de 2017 con alumnos de primer año de todas las carreras de ingeniería de la Universidad Tecnológica Nacional - Facultad Regional Buenos Aires (ingenierías: química, eléctrica, textil, industrial, naval, civil mecánica, sistemas de información y electrónica) en las materias Química y Química General. Los participantes son estudiantes que cursaron estas asignaturas desde 2017 a 2021.

El instrumento de evaluación que se utilizó fue diseñado y acordado por los directores de cátedra. Implementado con Google Forms, solicitando a los alumnos que fotografíen las resoluciones de los problemas en papel y las adjunten como imágenes en el formulario para permitir a los docentes su corrección remota (Imagen 1). Esta última estrategia fue la utilizada a partir de 2020.

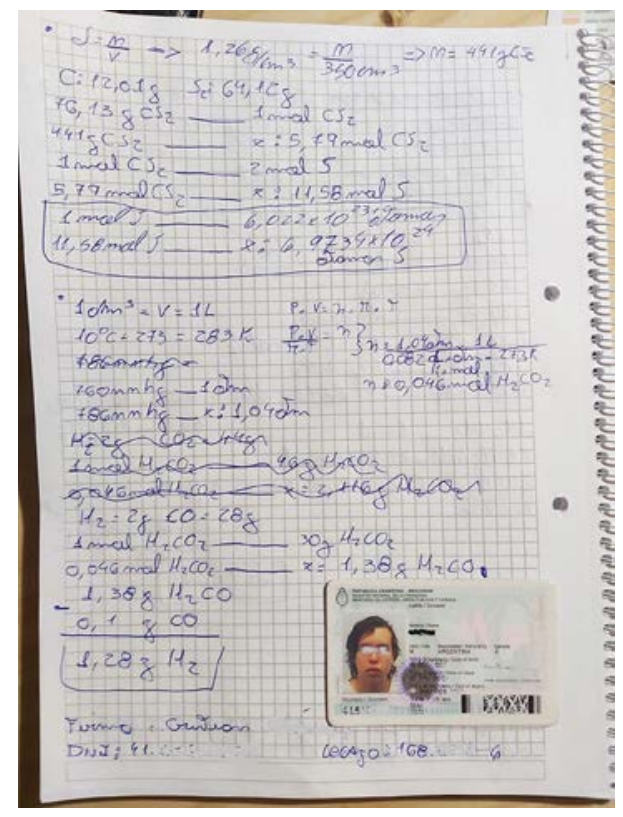

Imagen 1: Copia de una de las fotos enviadas para su corrección. 
En el diseño del instrumento de evaluación se mantuvo el nivel de complejidad de las evaluaciones parciales presenciales establecidas en la planificación de las cátedras. La cámara del teléfono celular permitió a los alumnos acceder al formulario mediante la lectura del código QR presentado durante el examen y además fotografiar las resoluciones de los problemas junto con su documento para adjuntarlas en el formulario (Imagen 1). Los problemas presentados en el instrumento tenían respuestas predeterminadas, una de ellas correcta y el resto de las opciones contenía distractores (o descriptores de errores) que estaban explicados en la retroalimentación y que correspondían a errores comunes recurrentes, no se ponían opciones si no estaban asociadas a un error de concepto, de cálculo, de unidad, entre otras.

Los estudiantes debieron acreditar su identidad con la documentación correspondiente que adjuntaron al formulario. Durante las evaluaciones debieron comunicarse por Zoom o Meet con sus docentes, y las preguntas las pudieron formular mediante el chat de las plataformas.

Se diseñaron 175 temas de evaluaciones equivalentes con diez problemas que presentaban cinco posibles respuestas cada uno, siendo sólo una correcta. Los estudiantes debieron justificar su elección mediante la resolución correspondiente cuya foto adjuntaron al formulario (Imagen 1). Previo a la evaluación los estudiantes pudieron realizar una práctica en el uso de la herramienta de evaluación a fin de familiarizarse con un modelo diseñado para ese fin que podían repetir la cantidad de veces que creyeran necesario (Rosales, 1997). Las correcciones eran automáticas con sugerencias para realizar la interpretación de los resultados, ya que la retroalimentación (feedback) era instantánea.

Todas las evaluaciones remotas sincrónicas que fueron grabadas contaron con el consentimiento previo de cada alumno.

La versión electrónica permitió que los estudiantes recibieran la calificación obtenida al momento de finalizarla, con una explicación detallada de los posibles errores cometidos en la resolución de cada problema para su análisis a modo de autoevaluación.

Las evaluaciones se realizaron en Google Forms (Bubaš \& Čižmešija, 2017; Sotalín \& Jovita, 2019), y se llevó a cabo con los dispositivos móviles individuales de cada alumno, lo que permitió dar continuidad al proceso educativo. La herramienta Google Forms, además de ser la plataforma otorgada por la universidad con almacenamiento ilimitado asociado al e-mail institucional, presentó ventajas con respecto a otras aplicaciones: gratuidad, disponibilidad, accesibilidad, posibilidad de trabajo colaborativo, almacenamiento ilimitado para alumnos y profesores y además es utilizable y compatible con otros formatos comunes.

Para este tipo de herramientas hay que usar un diseño educativo específico centrado en la reconceptualización de los errores.

A continuación, se muestran ejemplos de la distribución de puntuaciones de un examen en un curso y los datos estadísticos asociados (Figuras 1 y 2), también la resolución de un problema realizada por un estudiante citado anteriormente en (Imagen 1) 


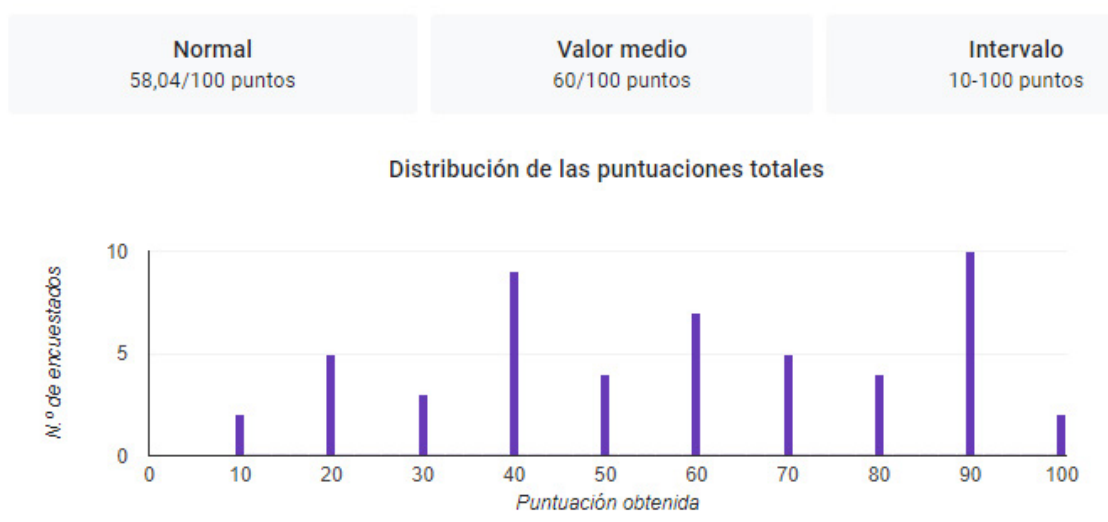

Figura 1: Distribución de puntuaciones, promedio y mediana (Tema 162 sobre 51 alumnos)

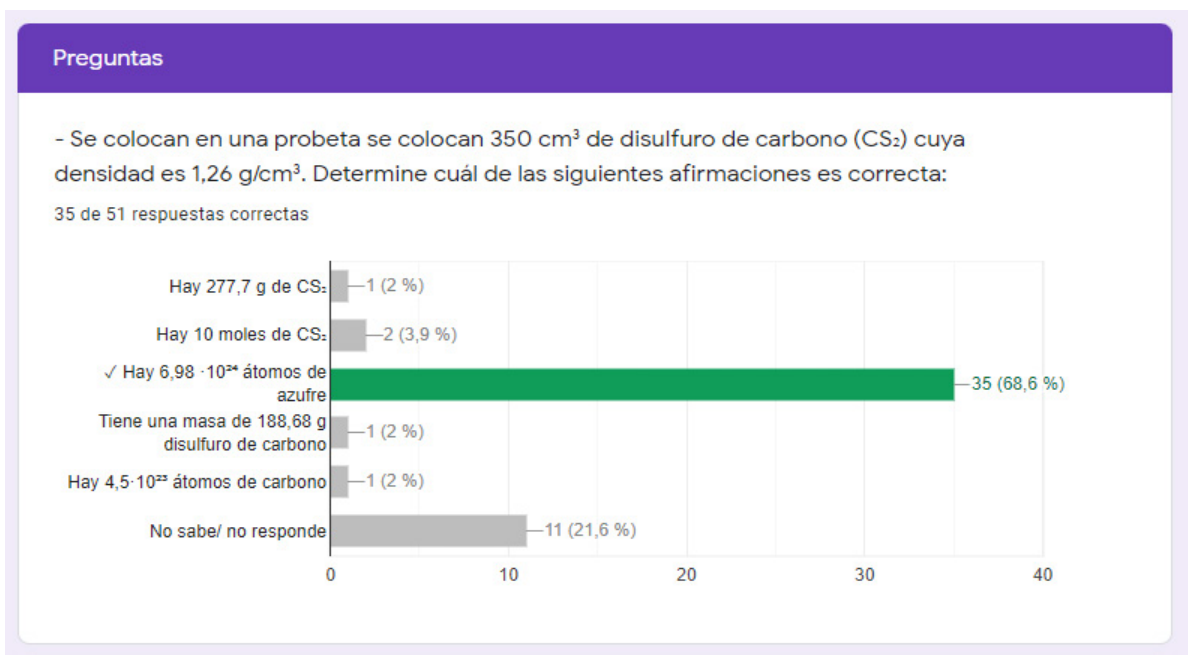

Figura 2: Ejemplo de estadísticas de una pregunta (tema 162 sobre 51 alumnos)

Tanto el orden de las preguntas como el de las alternativas de respuesta fueron aleatorias para cada alumno.

Se registraron solo 11 alumnos sobre 2904 que prefirieron esperar a la presencialidad para rendir sus evaluaciones a pesar de tener conexión a internet y dispositivo móvil. Los principales sistemas operativos usados en celulares fueron Android en un 71,7\% e iOS con el 24,7\% de los casos (Gottardo, 2020).

El uso de la herramienta tecnológica sincrónica remota, cuya plataforma para esta investigación fue Google Forms permitió que los datos automáticamente fueran volcados en una hoja de cálculo, con un diseño pensado y ajustado didácticamente, posibilitó al alumno no solo detectar sus errores sino también relacionar los conceptos estructurados significativamente y tener el potencial de aplicarlos en nuevas situaciones problemáticas de mayor complejidad. Para que una evaluación sea significativa para un estudiante ésta debe tender a ser una autoevaluación, es decir, formar al estudiante para la autonomía y para la autorregulación de sus aprendizajes o sea aprendizaje autónomo. 
El tiempo de resolución estaba acotado a 90 minutos para las evaluaciones parciales y 120 minutos para los exámenes finales, siendo tiempo probado para que pudieran resolver la evaluación en su totalidad.

\section{Resultados}

En el año lectivo 2020 se realizaron: 3027 evaluaciones individuales (considerando parciales, recuperatorios y finales), de química y química general. El tiempo de resolución promedio de los exámenes fue de 1 hora 41 minutos y el puntaje promedio incluyendo los reprobados fue 6,4 en una escala de 10 que coincide con el porcentaje históricos de un 75\% (+/- 2\%) de alumnos aprobados de los cuales el 50,1\% obtuvieron en el ciclo lectivo 2020 la promoción directa.

Durante 2020, el contexto de pandemia aceleró la implementación a la totalidad de los cursos y alumnos en forma sincrónica remota. La misma se llevó a cabo en 64 cursos en tres turnos de lunes a sábados de todos los turnos que contempla a la totalidad de los 28 docentes de ambas asignaturas. Se realizaron exitosamente 3027 evaluaciones remotas sincrónicas en la población estudiada de 1440 alumnos de primer año de distintas ingenierías: sistemas, mecánica, textil, electrónica, civil, naval, eléctrica e industrial, considerando las evaluaciones parciales con sus recuperatorios.

El promedio de tiempo de realización de las 3027 evaluaciones fue de 100 minutos incluida la toma y subida de las fotos de las resoluciones. Al finalizar la evaluación se obtuvo una planilla con los datos tanto de cada estudiante como del grupo evaluado y discriminado por problema o ejercicio, esto permitió tener una visión del proceso global de evaluación. La planilla de cálculo se usó a modo de base de datos ya que permite incorporar todos los datos de las evaluaciones de todos los alumnos del año lectivo (Figura 3).

Cada profesor tenía acceso a una hoja de cálculo propia con los datos por curso, por fecha, por alumno, por tipo de evaluación (parcial, recuperatorio o final), entre otros, en tiempo real pudiendo controlar la entrega, la nota y las fotos de las resoluciones en forma inmediata desde cualquier lugar con conexión a internet, incluso desde su propio celular (Figura 3).

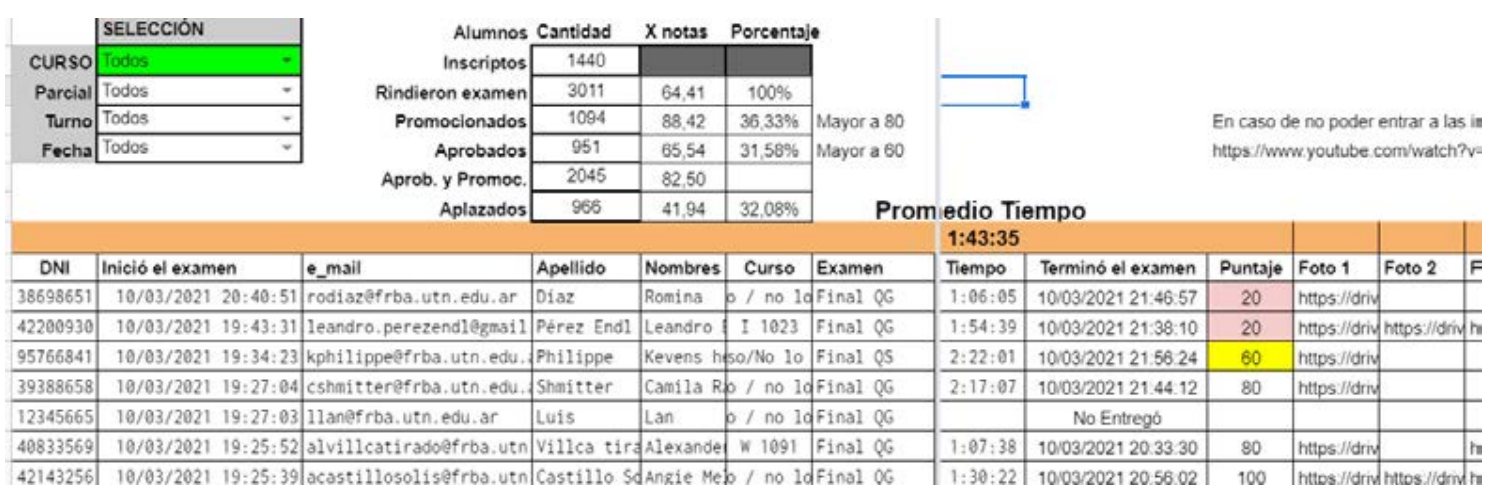




\section{Discusión y conclusiones}

Se analizaron todas las herramientas tecnológicas disponibles y como se señaló anteriormente, la más adecuada fue Google Forms dentro del paquete G-Suite provisto por la facultad.

Los datos de las evaluaciones de los estudiantes se obtuvieron discriminados por problemas y se sistematizaron en una planilla general junto con las fotos de las resoluciones enviadas, esto permitió tener una visión integral del proceso y usando filtros generó la posibilidad de obtener relaciones con los datos históricos presenciales de 2018 y 2019. Así los directores de cátedra pudieron corroborar la visión integral y centralizada de los resultados de las evaluaciones de todos los cursos. Los estudiantes fueron evaluados con problemas de complejidad equivalentes, lo que favoreció la democratización del proceso evaluativo.

Ante la necesidad de tener que evaluar durante el período de aislamiento preventivo de 2020, se realizaron los ajustes al diseño de la investigación que se venía trabajando y ajustando durante 2018 y 2019.

Las etapas de implementación se vieron aceleradas durante los meses de mayo y junio de 2020 ya que se debía llegar al mes de julio para tomar las evaluaciones parciales con desarrollo libre de errores. Esto nos llevó a armar un grupo de trabajo multidisciplinario (docentes y becarios estudiantes) para poder terminar en tiempo y forma.

Durante 2020 se realizaron exitosamente 2904 evaluaciones remotas sincrónicas (3027 en el año lectivo). No se encontraron diferencias estadísticamente significativas entre los baremos de 2020 comparados con los que se realizaron de manera presencial durante 2018 y 2019. Durante 2021 se continuó trabajando en mejoras de visualización de los resultados y de recuperación de datos de la planilla de cálculo utilizada.

El diseño de cada evaluación requirió muchas horas de elaboración, dado que se debía hacer una selección y adecuación muy precisa de los problemas para que los posibles resultados pudieran ser un indicador confiable para la confirmación de aciertos y detección de errores.

La versión electrónica permitió que cada alumno recibiera la calificación obtenida al momento de finalizar la evaluación, con una explicación detallada de los posibles errores cometidos en la resolución de cada problema para que los pudieran analizar a modo de autoevaluación (Gimeno Sacristán, 1998). Esta selección específica de respuestas erróneas favorece la adecuación de conceptos en tiempo real y le permite al alumno interpretar, internalizar y reestructurar los conocimientos en un tiempo más breve.

Se destaca que en cada evaluación los estudiantes disponían de un espacio para hacer comentarios y sugerencias referida al instrumento y a la estrategia de evaluación, en la actualidad se están procesando esas observaciones que permitirán formular nuevas investigaciones y plantear acciones de mejora.

Se prevé continuar usando esta forma de trabajo para evaluaciones híbridas (presenciales y remotas simultáneamente) cuando se recobre la presencialidad, dado 
que su fortaleza reside en que permite visualizar y comparar datos de todos los cursos y de todos los alumnos para poder efectuar el seguimiento de cada uno de ellos en el trayecto educativo.

Se agradece la colaboración de los docentes, auxiliares y becarios que participaron desinteresadamente en el desarrollo y toma de las evaluaciones y a quienes forman parte de distintos Proyectos de investigación de esta facultad regional. Este proyecto sobre evaluación educativa contó también con el asesoramiento de docentes investigadores de la Facultad de Informática de la Universidad Nacional de la Plata.

\section{Referencias}

Álvarez Méndez, J. M. (2011). Evaluar para conocer, examinar para excluir. Ediciones Morata, SL.

Anijovich, R. (2010). La evaluación significativa. Paidós. https://books.google.com. ar/books?id=_uGxcQAACAAJ

Bubaš, G., \& ižmešija, A. (2017). Google Forms and Smartphones: evaluation of an alternative to clicker systems for collecting feedback from students. 9th International Conference on Education and New Learning Technologies,

Calderón Loeza, G. Y., \& Sáncez Escobedo, P. (2021). Impacto del uso de dispositivos móviles en el aprendizaje de estudiantes adolescentes.

Camilloni, A. R. W. d. (2017). Jornadas "Clínica de Cátedras": Clases de Problemas. In. Buenos Aires: UTN-FRBA.

Cataldi, Z., Chiarenza, D., Dominighini, C., Donnamaría, M. C., \& Lage, F. J. (2010). TICs en la enseñanza de la química. XII Workshop de Investigadores en Ciencias de la Computación,

Cataldi, Z., Méndez, P. y Lage, F. J.; 2012b Evaluación y autoevaluación usando dispositivos móviles. TEyET 2012. VII Congreso de Tecnologías en Educación y Educación en Tecnologías. UNNOBA 11 y 12 de junio. ISBN 978-987-28186-0-9

Cataldi, Z., Méndez, P., Dominighini, C y Lage, F. J. 2012a Dispositivos móviles en educación superior y entornos personalizados de aprendizaje. TICs en Educación: Nuevas herramientas y nuevos paradigmas. Entornos de Aprendizaje Personalizados en dispositivos móviles. 26 y 27 de abril. UN Misiones. Pags.1014-1019.

Calderón Loeza, G. Y., \& Sáncez Escobedo, P. (2021). Impacto del uso de dispositivos móviles en el aprendizaje de estudiantes adolescentes.

Dominighini, C., Gottardo, M., \& Cataldi, Z. (2017). Uso de TIC en la enseñanza de química básica universitaria con aplicación de metodologías activas y evaluación continua y dinámica. Revista de Informática Educativa y Medios Audiovisuales, 14(22), 14-19. (LIE-FI-UBA) 
Gimeno Martín, D. (2018). Adicción a las TIC en adolescentes: Estudio sobre el uso y abuso de smartphones en el aula Universitat Politècnica de Catalunya].

Gottardo, M. O. (2020). Innovaciones en el Laboratorio de Química: Experiencias de evaluaciones con celular inteligente I Jornada de Intercambio de Experiencias Docentes Innovadoras, Buenos Aires. https://ria.utn.edu.ar/bitstream/handle/20.500.12272/4632/I\%20Jornada\%20de\%2Ointercambio\%20de\%20experiencias\%20docentes\%20innovadoras.pdf?sequence=1\&isAllowed=y

Gottardo, M. O., De Seta, E. G., \& Sánchez, P. C. V. (2020, 4-6/10/2020). Experiencia sobre Evaluación Utilizando los Teléfonos Móviles de los Alumnos. VII Jornadas Nacionales y II Latinoamericanas de Ingreso y Permanencia en carreras Científico-Tecnológicas IPECyT 2020, San Miguel de Tucumán, Tucumán- Argentina (Virtual x COVID19).

Homocianu, D., \& Airinei, D. (2015). General Purpose System for Generating Evaluation Forms (GPS4GEF). Proceedings of The 14th International Conference on Informatics in Economy (IE 2015) Bucharest-conferenceie.ase. ro

Perrenoud, P. (2008). La evaluación de los alumnos. Ediciones Colihue SRL.

Romero-Rodríguez, J. M., Rodríguez-García, A. M., \& Aznar-Díaz, I. (2017). Una aproximación al establecimiento de indicadores de calidad para la evaluación de buenas prácticas docentes en mobile learning. Innovación docente y uso de las TIC en educación, 1-9.

Rosales, C. (1997). Criterios para una evaluación formativa (4 ed.) [Educación]. Narcea.

Santos Guerra, M. A. (2005). La evaluación como aprendizaje. Editorial Bonum.

Sotalín, P., y Jovita, A. (2019). Guía digital del uso de formularios de Google Forms para la evaluación en Básica Superior. Quito.

Zanek, F. (2018). Aplicaciones de celulares y herramientas virtuales aplicadas al dictado de una asignatura universitaria (H. D. Kuna, E. Zamudio, \& A. Rambo, Eds. 1ra Digital ed., Vol. 1) [Digital]. Universidad Nacional de Misiones - Facultad de Ciencias Exactas Químicas y Naturales. http://sedici.unlp.edu.ar/bitstream/handle/10915/68745/Documento_completo.pdf-PDFA.pdf?sequence=1\#page=53 


\section{COVID19 y Nuevos Retos en la Docencia de Botánica: la Respuesta en la Red Vives de Universidades}

\section{Simon Pallisé}

orcid.org/0000-0001-7513-9363 


\section{COVID19 Y NUEVOS RETOS EN LA DOCENCIA DE BOTÁNICA: LA RESPUESTA EN LA RED VIVES DE UNIVERSIDADES}

\section{Simon Pallisé, Joan}

orcid.org/0000-0001-7513-9363

\section{Resumen}

Se ha evaluado el diseño de recursos, las actividades y las metodologías docentes empleadas frente a la crisis COVID-19 en la enseñanza teórica y práctica de asignaturas directamente vinculadas al ámbito docente de la Botánica, en 13 universidades europeas integradas en la Red Vives de Universidades. Se han realizado entrevistas a profesorado para los cursos 2019-20 y 2020-21 en enseñanzas a nivel de grado, identificando y analizando un total de 60 experiencias en el ámbito docente de la Botánica. Las clases teóricas se impartieron a distancia, mayoritariamente a través de plataformas institucionales y de forma en general satisfactoria, si bien con una carga suplementaria de trabajo notable. Las prácticas de laboratorio y de campo han requerido la creación y/o adaptación de recursos en línea en parte útiles como herramientas docentes complementarias, pero que no pueden substituir de forma satisfactoria las actividades presenciales correspondientes. La situación ha acelerado el tránsito a modalidades en línea, con limitaciones en la sociabilidad, en el trabajo en equipo y en la mejora del trabajo autónomo de los estudiantes. El rendimiento académico en el conjunto de asignaturas para el periodo considerado ha sido prácticamente similar o mejor al de los cursos anteriores. Finalmente, el desarrollo del proyecto ha redundado en establecer una colaboración entre docentes de Botánica de distintas universidades.

\section{Palabras clave}

COVID, Botánica, metodología docente, Xarxa Vives, docencia en línea. 


\section{Introducción}

La pandemia del COVID19 ha tenido un impacto significativo y extenso en la educación universitaria a nivel mundial. Las respuestas iniciales rápidas, se centraron en la transformación del aprendizaje presencial hacia una formación en línea en la mayoría de los países del mundo (Crawford et al., 2020). A la vez, sin embargo, esta súbita alteración del mundo de la educación superior ha sido un revulsivo importante para todo lo que rodea a la innovación docente relacionada con la transformación digital de la universidad del siglo XXI. En este momento, la pandemia está forzando la experimentación global en la educación superior y, sin duda, la crisis actual del COVID19 también ha creado oportunidades en el ámbito de la docencia (Torrecillas, 2020). Varias universidades en todo el mundo (Aristovnik, 2020) han considerado esta disrupción como un reto que puede favorecer nuevas oportunidades para acelerar los cambios a nivel universitario.

Dentro del mundo universitario, las metodologías docentes aplicadas a menudo se ven muy limitadas por la aceptación o rechazo de sus principales protagonistas: profesores y estudiantes. No son pocos los estudios (Fernández-Gubieda, 2020) que remarcan un cambio de paradigma como consecuencia del paro presencial debido a la pandemia en las instituciones educativas por un periodo no claramente definido. Los análisis preliminares de las experiencias iniciales -ciertamente forzadas y en muchos casos improvisadas-aportan ideas y reflexiones que seguro serán útiles en próximos cursos. Diversos estudios (González et al., 2020) demuestran que el incremento del rendimiento académico en la fase de pandemia ha sido consecuencia, en gran parte, por el sobreesfuerzo que han hecho estudiantado y profesorado.

Los departamentos de Botánica, los cursos de Botánica y los currículos de Botánica están desapareciendo gradualmente de la mayoría de las universidades del mundo anglosajón y en muchas otras partes del mundo (Essig, 2015, entre muchos otros). Una búsqueda bibliográfica sobre metodología docente universitaria en esta disciplina permite ver que la mayoría de los artículos relacionados son anteriores a 2010. Sólo últimamente las universidades chinas tienen cierto interés por esta materia (Guo et al., 2017; Huang et al., 2020) pero ligada al resurgimiento de la medicina tradicional china, muy ligada a las plantas medicinales. En este marco, la Botánica como ciencia tiene, además, la particularidad de un fuerte componente teórico a veces muy descriptivo (lo que dificulta su estudio por parte del alumnado), al que se suma un fuerte componente práctico tanto en las clases de laboratorio como en las de campo. Ello implica que sea una asignatura "compleja", y a veces pesada, en el sentido de que las experiencias de virtualización conllevan problemas adicionales.

El Grupo de Innovación Docente en Botánica Aplicada a Farmacia (GIBAF) del cual forman parte los firmantes, tiene como una de sus líneas de trabajo la innovación en evaluación y el e-Training (Simon et al., 2015, 2016b) y durante 6 años investigó en el entorno del Blended Learning y la semipresencialidad en tres proyectos consecutivos del REDICE (Simon et al., 2013, 2016a, 2017, 2018) en el ámbito universitario.

La finalidad de este estudio ha sido analizar la adaptación a la modalidad no-presencial o de "presencialidad adaptada" en la disciplina de la Botánica en las universidades de la Red Vives (Red Vives de Universidades, 2020). Para todas estas universidades se han identificado y analizado los recursos creados entorno a la situación de pandemia y la docencia. Se ha analizado los cambios metodológicos generales 
llevados a cabo y se determinado qué metodologías y actividades diseñadas en la crisis COVID19 pueden significar un motor de cambio real en la docencia de la Botánica y como ha afectado al rendimiento académico final.

\section{Método/Descripción de la experiencia}

\section{Descripción del contexto y de los participantes}

Los autores son miembros del Grupo de Innovación Docente GIBAF, acreditado por la Universidad de Barcelona (UB). El ámbito docente considerado es el de grado universitario o su equivalente, referido a asignaturas con carácter troncal del área de Botánica. Han participado en el estudio 32 profesores de las 13 universidades con docencia en Botánica integradas en la Red Vives de Universidades (Red Vives, 2020), institución sin ánimo de lucro que representa y coordina la acción conjunta de 22 universidades europeas de España, Francia, Andorra e Italia (Figura 1). El período considerado abarca los cursos 2019-20 y 2020-21. El estudio ha sido financiado a cargo del Proyecto de investigación en docencia REDICE2O-2560 (UB).

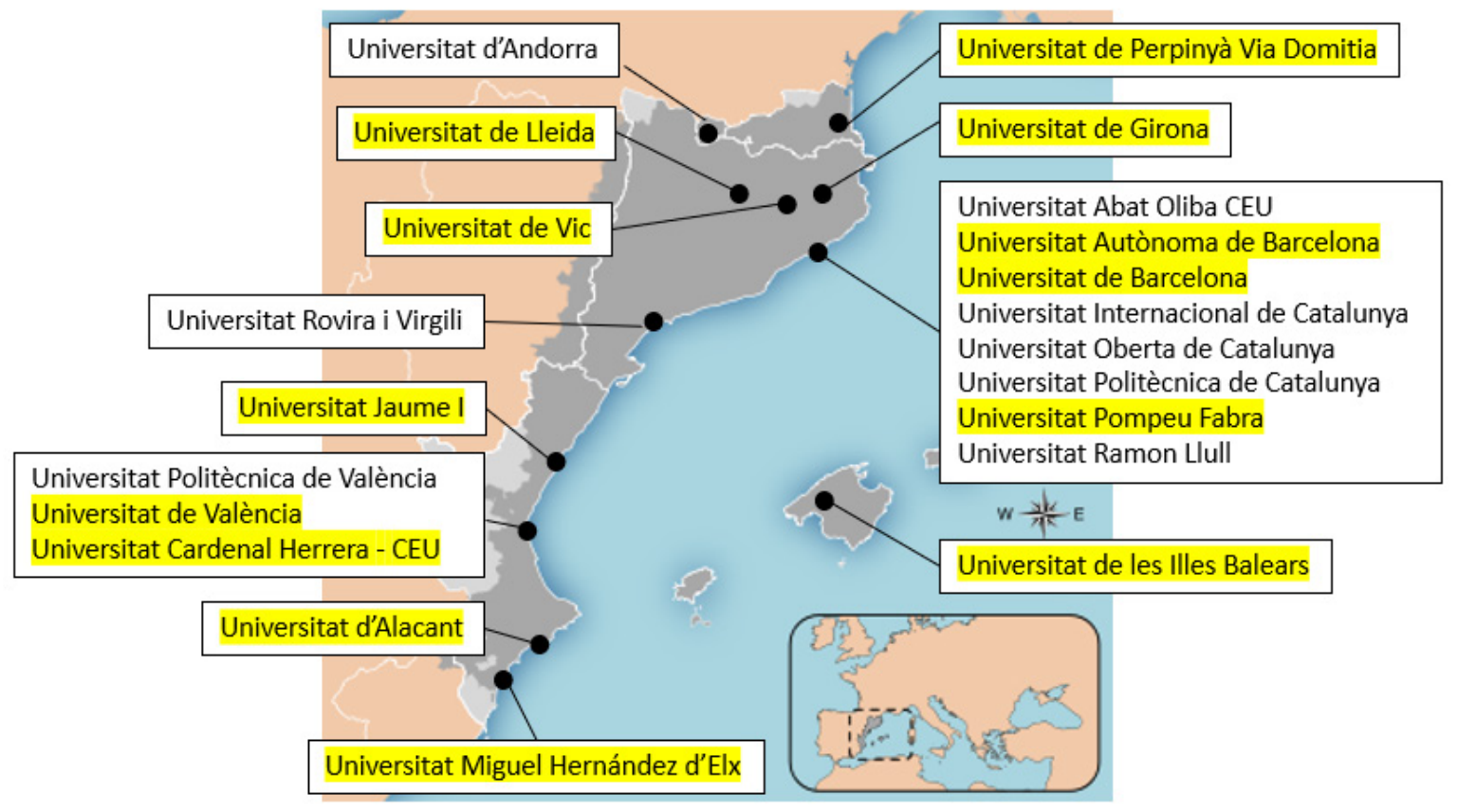

Figura 1. Universidades de la Red Vives (en amarillo, universidades participantes)

\section{Instrumentos}

Como instrumento de recogida de información, se ha utilizado un formulario de Google Forms (GIBAF, 2021) para cada ABCD (Actividad·Botánica.COVID.Docencia) identificada en los cursos 2019-20 y 2020-21. En cada caso se han documentado los aspectos generales académicos y los particulares de la actividad, combinando preguntas de selección múltiple, con casilla de verificación, desplegable, escala lineal, con preguntas de respuesta abierta. 


\section{Procedimiento}

Para cada universidad se contactó con un profesor de la materia a quien se le explicó el proyecto. Este profesor, a su vez, identificó para su universidad todos los grados y las asignaturas troncales que era necesario incluir en el estudio. Posteriormente, fue el responsable de distribuir el enlace de los formularios y coordinar su difusión. La relación de los 32 profesores que han participado de cada universidad se puede consultar en los agradecimientos.

\section{Resultados}

En total se han documentado 60 actividades docentes para 10 grados diferentes (Biología, Biología Ambiental, Biotecnología, Ciencias Ambientales, Ciencias de Mar, Ingeniería Agroalimentaria y Agroambiental, Ingeniería Agroalimentaria y del Medio rural, Ingeniería Forestal y del Medio natural, Farmacia y Licence Sciences de la Vie). La distribución de actividades evaluadas por universidad, grado, curso y asignatura se muestra en la Tabla 1.

El conjunto de resultados indica que la mayor parte de actividades fueron programadas en los dos primeros cursos, con un ligero predominio sobre el primer curso (la docencia de la Botánica en las universidades analizadas tiene lugar en los primeros cursos, semestres o ciclos, por su carácter de asignatura básica) (Figura 2A). El conjunto de estas actividades fue en un 75\% para la evaluación acreditativa, siendo en el $68 \%$ de los casos, una actividad de tipo obligatorio. Con respecto a cursos anteriores, los resultados académicos de estas asignaturas en el contexto COVID19 fueron similares al curso anterior en un $41 \%$ y con mayor éxito académico en un $45 \%$ (Figura 2B).

La participación por parte de los estudiantes a estas actividades COVID19 fue muy alta y cercana al 85\%. El total de las 60 actividades evaluadas han obtenido 4.955 participaciones individualizadas de estudiantes, distribuidas en 16 actividades de más de 100 estudiantes, 24 actividades entre 51-100, 17 actividades entre 20-50 y 3 actividades entre 1-25 (Figura 2C).

\begin{tabular}{|c|c|c|c|c|}
\hline UNIVERSIDAD & GRADO & ASIGNATURA & CASOS & CURSO \\
\hline \multirow{3}{*}{$\begin{array}{l}\text { Universitat Autònoma de } \\
\text { Barcelona (UAB) }\end{array}$} & Biología & Botánica & 1 & 10 \\
\hline & Biología Ambiental & $\begin{array}{l}\text { Análisis de la vegeta- } \\
\text { ción }\end{array}$ & 1 & $3 ㅇ$ \\
\hline & Ciencias Ambientales & $\begin{array}{l}\text { Fisiología Vegetal y } \\
\text { Botánica }\end{array}$ & 1 & $1 ㅇ$ \\
\hline $\begin{array}{l}\text { Universitat CEU Cardenal } \\
\text { Herrera (UCH-CEU) }\end{array}$ & Farmacia & Botánica Farmacéutica & 1 & $3^{\circ}$ \\
\hline \multirow{4}{*}{$\begin{array}{l}\text { Universitat de Barcelona } \\
\text { (UB) }\end{array}$} & Ciencias del Mar & Botánica marina & 1 & $2^{\circ}$ \\
\hline & Biología & Botánica & 5 & $2^{\circ}$ \\
\hline & Ciencias Ambientales & $\begin{array}{l}\text { Biología vegetal apli- } \\
\text { cada }\end{array}$ & 3 & $3^{\circ}$ \\
\hline & Farmacia & Botánica Farmacéutica & 5 & 1 \\
\hline
\end{tabular}




\begin{tabular}{|c|c|c|c|c|}
\hline $\begin{array}{l}\text { Universitat de Girona } \\
\text { (UdG) }\end{array}$ & Biología & Botánica & 6 & $2^{\circ}$ \\
\hline \multirow{2}{*}{$\begin{array}{l}\text { Universitat de les Illes } \\
\text { Balears (UIB) }\end{array}$} & \multirow[t]{2}{*}{ Biología } & Botánica I & 1 & $2^{\circ}$ \\
\hline & & $\begin{array}{l}\text { Recursos para la Valo- } \\
\text { ración de la Biodiver- } \\
\text { sidad }\end{array}$ & 2 & 3 \\
\hline $\begin{array}{l}\text { Universitat de Lleida } \\
\text { (UdL) }\end{array}$ & $\begin{array}{l}\text { Ingeniería Forestal y del } \\
\text { Medio Natural }\end{array}$ & Botánica Forestal & 2 & 10 \\
\hline \multirow[t]{2}{*}{$\begin{array}{l}\text { Universitat de Perpinyà } \\
\text { Via Domícia (UPDV) }\end{array}$} & \multirow[t]{2}{*}{$\begin{array}{l}\text { Licence Sciences de la } \\
\text { Vie }\end{array}$} & $\begin{array}{l}\text { Diversité et Evolution } \\
\text { du Monde Végétal } 1\end{array}$ & 2 & $2^{\circ}$ \\
\hline & & $\begin{array}{l}\text { Diversité et Evolution } \\
\text { du Monde Végétal } 2\end{array}$ & 5 & $2 \circ$ \\
\hline \multirow{3}{*}{$\begin{array}{l}\text { Universitat de València } \\
\text { (UV) }\end{array}$} & Ciencias Ambientales & Botánica & 3 & 10 \\
\hline & Farmacia & Botánica & 3 & 10 \\
\hline & Biología & Botánica & 1 & $1^{\circ}$ - \\
\hline $\begin{array}{l}\text { Universitat de Vic / Cen- } \\
\text { tral de Catalunya (UVic- } \\
\text { CC) }\end{array}$ & Biología & Botánica & 2 & $2^{\circ}$ \\
\hline Universitat Jaume I (UJI) & $\begin{array}{l}\text { Ingeniería Agroalimen- } \\
\text { taria y del Medio Rural }\end{array}$ & Botánica & 1 & $2^{\circ}$ \\
\hline \multirow{4}{*}{$\begin{array}{l}\text { Universitat Miguel Hernán- } \\
\text { dez d’Elx (UMH) }\end{array}$} & Biología & Botánica & 1 & $2^{\circ}$ \\
\hline & Biotecnología & Botánica & 3 & $1^{\circ}$ \\
\hline & Ciencias Ambientales & Botánica & 1 & $1^{\circ}$ \\
\hline & $\begin{array}{l}\text { Ingeniería Agroalimen- } \\
\text { taria y Agroambiental }\end{array}$ & Botánica & 3 & $2 \circ$ \\
\hline $\begin{array}{l}\text { Universitat Pompeu Fabra } \\
\text { (UPF) }\end{array}$ & Biología & Botánica & 4 & 10 \\
\hline Universitat d'Alacant (UA) & Biología & Biodiversidad vegetal & 2 & $2^{\circ}$ \\
\hline
\end{tabular}

\section{Tabla 1. Relación de asignaturas y número de experiencias (casos) agrupadas por grado y universidad, con detalle del curso donde se han llevado a cabo.}

Las tipologías de las actividades diseñadas se enmarcaron en docencia práctica en un $60 \%$ (20\% actividades de campo y un $40 \%$ actividades de laboratorio) y, en menor medida, un 40\%, para teoría/seminarios (Figura 2D). 
A. Curso donde se ha realizado la actividad

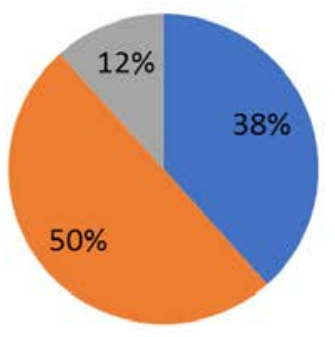

E Primero

= Segundo

w Tercero

w Cuarto

a Quinto
B. En la asignatura donde se ha programado la actividad, el resultado académico ha sido:

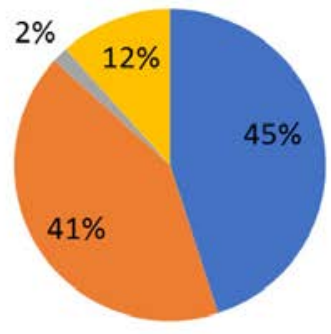

= Mejor que el curso anterior

= Igual que el curso anterior

= Peor que el curso anterior

$n \mathrm{NS} / \mathrm{NC}$

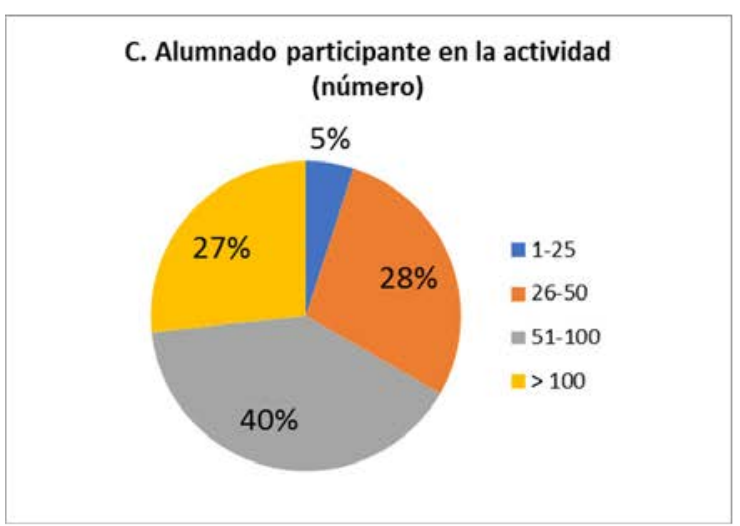

\section{E. La actividad se ha llevado a cabo:}

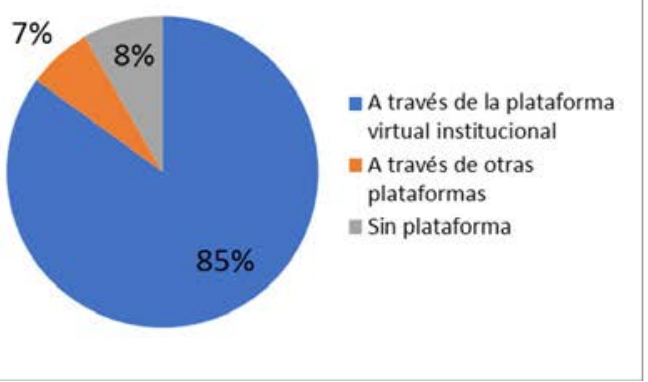

D. La actividad se ha programado para:

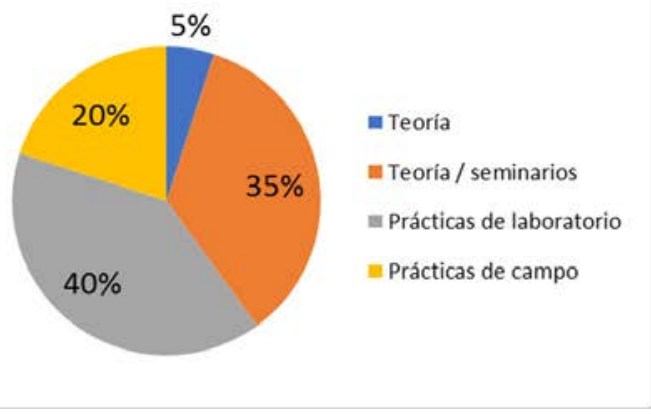

\section{F. Consolidación de la actividad en el futuro}

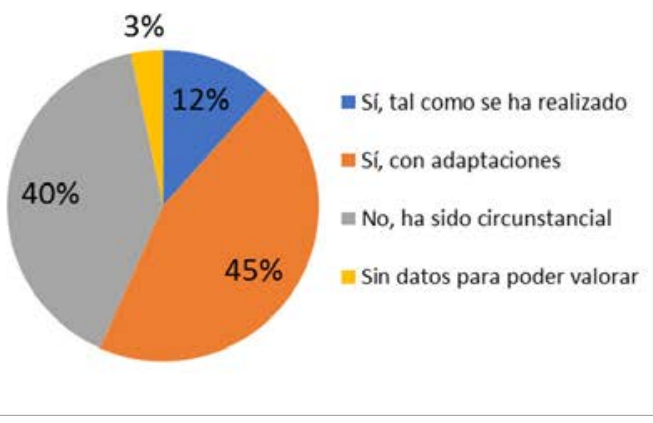

Figura 2. Distribución de resultados: $A$. Curso donde se ha realizado la actividad; $B$. Resultado académico; C. Alumnado participante en la actividad; D. Modalidad docente de la actividad (teoría, seminarios, prácticas de laboratorio y de campo); E. Plataforma tecnológica utilizada; F. Prospectiva de consolidación de las actividades.

El soporte tecnológico utilizado para las experiencias y actividades fue mayoritariamente el de las propias plataformas institucionales (85\%) con claro predominio del LMS Moodle. Un 8\% de las actividades se realizó con otros recursos/servicios ajenos a las plataformas institucionales y el resto (7\%) no utilizó herramientas específicas de soporte (Figura 2E). 
En la prospectiva de consolidación de estas actividades para el siguiente curso 2020-2021, se prevén utilizar en un $12 \%$ sin modificación alguna, en un $45 \%$ con continuidad, pero adaptables al nuevo contexto y en un $40 \%$ estas actividades no se han aprovechado para el curso posterior (Figura 2F). La mayor parte del profesorado implicado en el diseño de estas actividades (73\%), considera que las propuestas ofertadas sirven de base para la innovación docente.

El grado de satisfacción de los estudiantes, establecido mediante encuestas internas y percepción del propio profesorado, fue en un $84 \%$ buena o muy buena (Figura 3A). El grado de satisfacción del profesorado fue en este mismo intervalo del $65 \%$ (Figura 3B), destacando como principal inconveniente el enorme esfuerzo de preparación de las actividades.
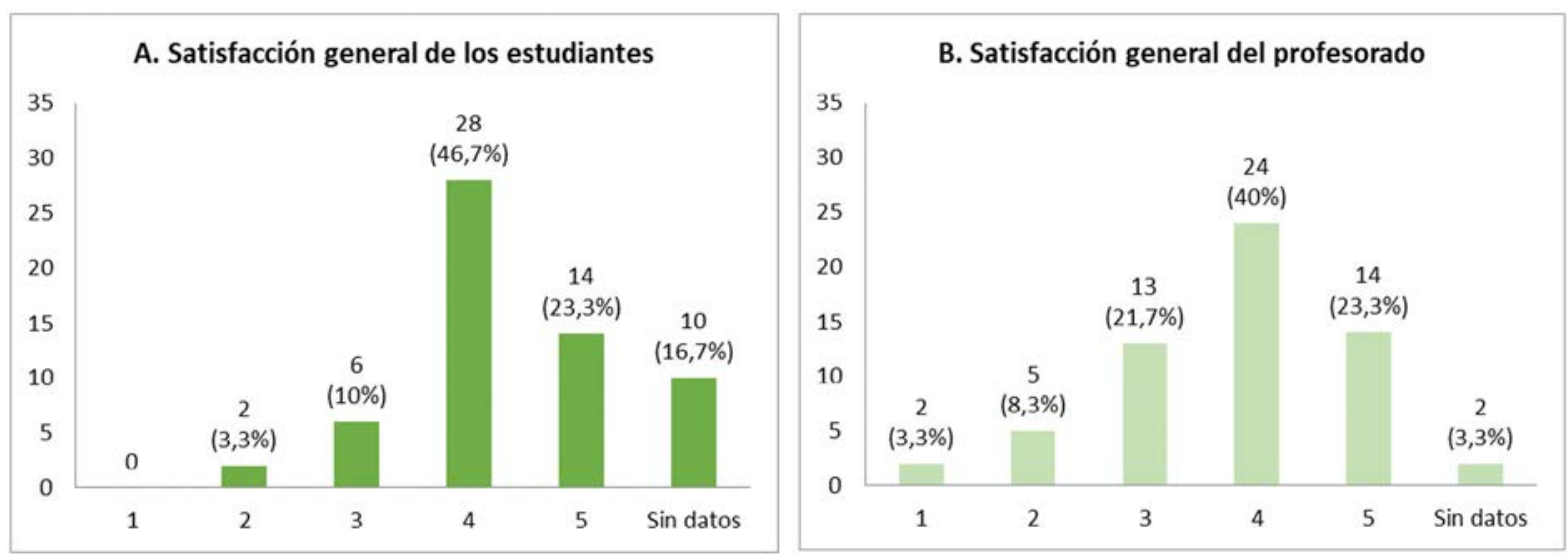

Figura 3. Grado de satisfacción de las actividades evaluadas: A. Satisfacción de los estudiantes, B. Satisfacción de los profesores.

\section{Discusión y conclusiones}

El profesorado participante destaca la rapidez de la actuación docente en la respuesta frente al cambio académico súbito causado por la aparición del COVID19, para amoldarse a las clases no presenciales sin afectar el currículum de las asignaturas. Como en muchas otras universidades españolas (García-Peñalvo \& al., 2020) y aún a costa de una carga de trabajo notablemente mayor para estudiantes y profesores, se alcanzó el objetivo básico de salvar el curso académico. En general, los estudiantes han reconocido el esfuerzo del profesorado; sin embargo, las condiciones de trabajo y la tensión propia de la situación han tenido consecuencias en la vida personal de la comunidad universitaria, como recientemente ha demostrado una encuesta de la UB (Universitat de Barcelona, 2021).

Deben tenerse en cuenta dos factores con respecto a los estudiantes participantes. En primer lugar, los grupos a los que se dirigieron principalmente las actividades fueron numerosos, correspondientes a grupos enteros de estudiantes (Figura 2C), lo que implicó un esfuerzo considerable de tiempo y dedicación a tareas de interacción y seguimiento; por el contrario, los grupos con número reducido de alumnos $(<25)$ con los que desarrollar actividades complejas, muy creativas o que requieren mucho apoyo por parte de los docentes fueron una parte pequeña (5\%). En segundo 
lugar, la participación de los estudiantes no fue voluntaria ni elegida frente a otras opciones disponibles en muchos casos: la oferta analizada era la única opción de cursar las asignaturas sin perder el curso. El profesorado ofreció otras actividades de participación voluntaria, más o menos minoritaria (Simon et al., 2020a, 2020b) o bien la actividad conllevaba la aportación de puntuación suplementaria para la superación de la asignatura.

Los resultados académicos razonablemente buenos obtenidos lo fueron durante el curso 2019-20, disponibles cuando se cerró la encuesta y, en parte, son explicables por la realización de exámenes a distancia, sin control de identidad o de aislamiento de los estudiantes, fenómeno ya detectado en otros estudios (Garcia-Peñalvo, 2020). En el curso siguiente (2020-21), acabado de cerrar al escribir estas líneas, la formación deficiente en cursos preuniversitarios en régimen de pandemia o el abandono y ausentismo pueden explicar el descenso notable en el año siguiente y subrayar la condición de emergencia no programada de las soluciones presentadas en las actividades evaluadas.

La necesidad actuó como motor de cambio para decidirse por innovaciones docentes (como clases en streaming o actividades diseñadas específicamente), sin reticencias notables entre el profesorado y aceptación desigual por el alumnado, que tuvo dificultades de conectividad en cierta proporción menor. Al respecto, la proporción ciertamente es menor pero significativa por tratarse de signos de la brecha digital debida a la falta de medios y recursos -espacios para el estudio, ordenadores portátiles, conexión de internet de calidad, etc. Las universidades hicieron frente a estos casos mediante la dotación de ayudas específicas previa solicitud (Universitat de Barcelona, 2020). Los cambios en la organización del curso han disminuido el tiempo real de docencia, pero han permitido la dedicación a competencias no nucleares y han favorecido el trabajo autónomo del alumnado. El trabajo individual del estudiante ha requerido una tutorización más intensa y la creación de recursos de motivación por parte de los profesores, aunque algunos alumnos han abandonado el seguimiento del curso.

El aprovechamiento, con las adaptaciones necesarias, de recursos diseñados previamente fue, a la vez, solución de emergencia y oportunidad de ensayo y evaluación. La creación de recursos nuevos es considerada por los profesores como posiblemente útiles para futuros cursos, pero no necesaria y automáticamente en su formato actual, puesto que fueron creados para responder a una situación de emergencia y pueden requerir ajustes más meditados.

Las clases teóricas en formato en línea o mixto requirieron una formación de urgencia del profesorado con resultados satisfactorios. Algunas plataformas institucionales han demostrado limitaciones y ya están siendo revisadas por las universidades (Torrecillas, 2020). Las actividades con programación temporal ofrecieron la posibilidad de adaptación al ritmo personal de estudio de los alumnos. En este sentido, la situación ha favorecido (estimulado/obligado) el trabajo individual del alumno y, en consecuencia, ha potenciado el aprendizaje autónomo de búsqueda de información el conocimiento de disposición ubicua de documentación (Apps, recursos en línea, etc.) en paralelo con el necesario acompañamiento y tutorización que han jugado un papel muy importante.

La interacción entre docentes y discentes (dentro del grupo o entre estamentos) ha sido heterogénea: en ciertos casos, frecuente y satisfactoria, en otros insuficiente y 
pasiva, situación multicausal (estrategias docentes, idiosincrasias personales, experiencia previa, funcionamiento de plataformas, etc.). A lo largo del curso ha habido un cierto abandono de las sesiones virtuales, en un contexto de incertidumbre, circunstancias personales, desorientación y déficit de atención sobre todo en estudiantes de primeros cursos. El seguimiento y tutoría del profesorado ha conseguido a menudo limitar con eficacia dichas situaciones. Se han desarrollado modelos específicos para garantizar la calidad de la evaluación virtual (identidad del examinando, evitación del plagio) que, en parte, han conseguido su objetivo y en parte no, lo que se refleja en un éxito académico elevado teniendo en cuenta las limitaciones del curso.

Una de las impresiones positivas de las experiencias de este período que han referido los encuestados ha sido la posibilidad de realizar actividades nuevas o tener la oportunidad de abordar otras competencias no nucleares que esperaban su ocasión en los planes docentes. Ello incluía, por ejemplo, la posibilidad de los estudiantes de participar en el proceso de evaluación, tanto de su propio trabajo como el de sus compañeros, así como la oportunidad de empezar a redactar informes y hacer presentaciones.

Aunque la tipología de las asignaturas analizadas (primeros cursos, enseñanza experimental) no responde al perfil de estudiantes para los que es ideal una estrategia semipresencial, tal como se detectó en las mismas universidades participantes hace unos años (Simon \& al., 2013), para las clases teóricas se considera que se ha conseguido alcanzar objetivos de aprendizaje que en la situación de pandemia sobrevenida no se tenía claro que hubieran podido alcanzar (por decirlo así, se ha salvado el curso, se ha cubierto el programa y resuelto la emergencia).

Las clases prácticas (de laboratorio y de campo), en el ámbito de la Botánica comportaron, en líneas generales, un esfuerzo mucho mayor de creación de materiales y recursos específicos, con un grado de éxito y satisfacción, sin embargo, menor que el de las clases teóricas. La propia idiosincrasia del objetivo de conocimiento (diversidad taxonómica de organismos, sistemas naturales y sus estructuras biológicas) y de la metodología de estudio lo dificulta por principio.

Entre los recursos específicos creados para la situación COVID-19 en el laboratorio destacan los bancos de imágenes (de plantas, de preparaciones microscópicas, etc.) y vídeos, nuevos o refuerzo de los existentes y que estarán disponibles desde ahora para su utilización docente futura, así como ejercicios de identificación, módulos de autoaprendizaje y el uso de aplicaciones (App). A pesar de ello, la adquisición de habilidades de laboratorio (manipulación de organismos y de instrumental, seguridad en el laboratorio, etc.) hace insustituible la presencialidad, opinión manifestada mayoritariamente por los encuestados.

En relación con el trabajo de campo, la dificultad de proceder en virtualidad es mayor. Se han creado ex novo actividades de demostración o incluso clases de campo virtuales, con gran esfuerzo técnico y éxito notable en el contexto de pandemia que, en general, serán conservadas como recursos de reserva (inclemencias meteorológicas, incidencias académicas, etc.), pero no se contemplan como recursos de uso ordinario futuro, salvo excepciones. El trabajo de campo es la modalidad que un número mayor de profesores ha identificado como de presencialidad insustituible. Algunas aplicaciones preexistentes, sin embargo, han sido perfeccionadas y han encontrado su lugar en los próximos cursos ordinarios, con el valor añadido del 
desarrollo de competencias adquiridas de manera autónoma por los estudiantes. En particular, destaca la recuperación de uso de los jardines (en recintos de campus universitarios o no) como nuevo espacio docente, asociado al uso de TIC (códigos $Q R$, etc.). Un ejemplo en la UB puede consultarse en Blanché \& al. (2021).

El análisis del conjunto de iniciativas promovidas por la situación COVID-19 en los grados estudiados describe que la crisis sanitaria ha actuado ciertamente como motor de cambio en la práctica de la docencia universitaria en el ámbito de la Botánica, con producción de nuevos recursos, ensayos de nuevas metodologías y experimentación docente en modalidades no presenciales. En el contexto concreto de las asignaturas, se muestra que ciertas actividades son poco virtualizables y que existe un componente específico que hay que considerar.

Finalmente, el propio desarrollo del proyecto y los intercambios de información y de experiencias entre profesores de universidades de la Red Vives, que habitualmente no comparten ámbitos de reflexión docente, ha estimulado la generación de un espacio de colaboración que va a tener lugar en los meses venideros. Se prevé la organización de un foro de debate y de intercambio de experiencias, que contemple también el aprovechamiento de esfuerzos y uso compartido de recursos para contribuir a la mejora y a la innovación docente en el ámbito de la Botánica.

\section{Agradecimientos}

A los 32 profesores y profesoras de las 13 universidades que han colaborado documentando las 60 actividades objeto del presente estudio: Concepción de Linares, Javier López, Mercè Galbany, Ramon Pérez (Universitat Autònoma de Barcelona); Isabel Martínez-Solís (Universitat CEU Cardenal Herrera); Carles Benedí, Carme Barceló, Empar Carrillo, Ignasi Soriano, Joan Simon, Joan Vallès, Jordi Rull, José M. Blanco, Lourdes Chamorro (Universitat de Barcelona); Lluís Vilar (Universitat de Girona); Joana Cursach, Maurici Mus (Universitat de les Illes Balears); Josep Antoni Conesa (Universitat de Lleida); Cristophe Bélin, Valerie Hinoux (Universitat de Perpinyà Via Domícia); Gerardo Stübing, Josep Antoni Rosselló, Ricardo Garilleti (Universitat de València); Aaron Pérez Haase (Universitat de Vic - Universitat Central de Catalunya); Paloma Sánchez (Universitat Jaume I); Concepción Obón; Esther Berrendero, Gisela Díaz (Universitat Miguel Hernández d’Elx); Elisabeth Moyano, Nora Pérez (Universitat Pompeu Fabra); Maria Ángeles Alonso, Manuel Benito Crespo (Universitat d'Alacant). A Maria Teresa Albero y a Ignasi Casadesús de la Red Vives de Universidades por el soporte incondicional durante la realización del trabajo. Al Institut de Desenvolupament Profesional IDP-ICE de la UB por la financiación del proyecto.

\section{Referencias}

Aristovnik, A., Kerži , D., Ravšelj, D., Tomaževi , N., \& Umek, L. (2020). Impacts of the COVID-19 pandemic on life of higher education students: A global perspective. Sustainability, 12(20), 8438. doi: https://doi.org/10.3390/su12208438 
Blanché, C., Benedí, C. Bosch, M. \& Simon, J. (2021). Biodiversitat a l'abast: El jardí del campus. Dipòsit Digital de la Universitat de Barcelona. Colección INNOVADOC. http://hdl.handle.net/2445/178910

Crawford, J., Butler-Henderson, K., Rudolph, J., Malkawi, B., Glowatz, M., Burton, R., Magni, P. \& Lam, S. (2020). 'COVID-19: 20 countries' higher education intra-period digital pedagogy responses', Journal of Applied Learning \& Teaching, 3(1), 1-20. doi: https://doi.org/10.37074/jalt.2020.3.1.7

Essig, F.B. (2015) - Studying botany in college - OUP Blog - Oxford University Press's. https://blog.oup.com/2015/08/studying-botany-plants-college/

Fernández-Gubieda, S. (2020). Docencia Rubic: aprendizajes de la enseñanza universitaria en tiempos de la Covid-19. https://dadun.unav.edu/bitstream/10171/59097/1/ RubicSueltas.pdf

García-Peñalvo, F. J., Corell, A., Abella-García, V., \& Grande, M. (2020). La evaluación online en la educación superior en tiempos de la COVID-19. Education in the Knowledge Society, 21, 12. doi: http://doi.org/10.14201/eks.23013

GIBAF (2021). Projecte REDICE-2020 - Formulari de l'enquesta del projecte REDICE-2020-. Universidad de Barcelona. http://gibaf.org/documentacio

González, T., de la Rubia, M. A., Hincz, K. P., Comas-Lopez, M., Subirats, L., Fort, S., \& Sacha, G. M. (2020). Influence of COVID-19 confinement in students performance in higher education. https://arxiv.org/abs/2004.09545v1

Guo, Q. M., Song, Y. M., Wan, P., Sun, Z. Y., Bao, H. Y., \& Gao, D. M. (2017). Research and Exploration on Reform of Blended Teaching Model of Pharmaceutical Botany. Chinese Journal of Experimental Traditional Medical Formulae, 23(16), 4-7.

Huang, Y., Han, T., \& Jia, G. (2020). Exploration on the Teaching Reform of Medicinal Botany Based on PBL Mode and Diversification Teaching. Curriculum and Teaching, 3, 29-33. doi: https://doi.org/10.23977/curtm.2020.030106

Red Vives de Universidades (2020). https://www.vives.org/quienes-somos/

Simon, J., Benedí, C. \& Blanché, C. (2013). La semipresencialidad como respuesta a los Nuevos retos de la universidad. La visión de las universidades de la Xarxa Vives, 124 pp. Octaedro-ICE.

Simon, J., Benedí, C., Blanché, C. \& Bosch, M. (2016a). La semipresencialidad en educación superior: casos de estudio en los grados de la Universidad de Barcelona. Revista Electrónica de Tecnología Educativa (Edutec-e), 58, 6-32. EDUTEC. ISSN 1135-9250. doi: https://doi.org/10.21556/edutec.2016.58

Simon, J., Benedí, C., Blanché, C. \& Bosch, M. (2016b). Propuestas metodológicas para la implementación de una estrategia de e-training. En Roig-Vila, R. (ed.). Educación y Tecnología. Propuestas desde la investigación y la innovación educativa: 257-258. Ed. Octaedro. Barcelona https://rua.ua.es/dspace/bitstream/10045/61788/1/2016 Educacion-y-tecnologia.pdf 
Simon, J., Benedí, C., Blanché, C. \& Bosch, M. (2017). Blended Learning en el sistema universitario de Cataluña: De la semipresencialidad hacia el aprendizaje combinado. In Silva, J. (Ed.). Educacion y Tecnologia: una mirada desde la investigación y la innovación: 469-473. ISBN: 978-956-393-378-9. Centro de Innovación e Investigación en Educación y Tecnología de la Universidad de Santiago de Chile.

Simon Pallisé, J., Benedí, C., Blanché i Vergés, C., Bosch i Daniel, M., \& Torrado Fonseca, M. (2018). Análisis cuantitativo y cualitativo de la semipresencialidad del sistema universitario de Cataluña. RIED. Revista Iberoamericana de Educación a Distancia, 2018, 21(1): 113-133.

Simon, J., Benedí C., Blanché, C. \& Bosch, M. (2020a). De la enseñanza presencial a la virtual: una experiencia forzada en una asignatura de grado universitario. In Colomo, E., Sánchez, E., Ruiz, J. \& Sánchez, J. (Coords.). La tecnologia como eje del cambio metodológico: 1333-1336. Universidad de Málaga. UMA editorial. Málaga.

Simon, J., Benedí C., Blanché, C. \& Bosch, M. (2020b). Una activitat formativa en l'àmbit del confinament per la COVID-19. Dipòsit digital de la Universitat de Barcelona. Colleccions OMADO i INNOVADOC. http://hdl.handle.net/2445/166644

Torrecillas, C. (2020). El reto de la docencia online para las universidades públicas españolas ante la pandemia del Covid-19. ICEI Papers, 16. Universidad Complutense de Madrid.

Universitat de Barcelona (2020). Programa d'ajuts ConnectaUB. https://www. ub.edu/web/ub/ca/universitat/coronavirus/connectaUB/index.html

Universitat de Barcelona (2021). Vicerectorat d'Igualtat i Gènere. L'impacte de la crisi sanitària en la vida personal, familiar i professional de la UB. Edicions de la Universitat de Barcelona, Barcelona. http://hdl.handle.net/2445/178013 


\section{Eficacia de una Intervención Online Grupal Basada en el Protocolo Unificado Transdiagnóstico para la Gestión Emocional}

\section{Arrigoni, Flavia}

ORCID: orcid.org/0000-0001-5664-6167

Prof. Pontificia Universidad Católica Argentina.

Doctoranda Facultad de Educación,

Departamento de Psicología, Universidad de Cádiz

flavia.arrigoni@uca.es 


\title{
EFICACIA DE UNA INTERVENCIÓN ONLINE GRUPAL BASADA EN EL PROTOCOLO UNIFICADO TRANSDIAGNÓSTICO PARA LA GESTIÓN EMOCIONAL
}

\author{
Arrigoni, Flavia \\ ORCID: orcid.org/0000-0001-5664-6167 \\ Prof. Pontificia Universidad Católica Argentina. \\ Doctoranda Facultad de Educación, \\ Departamento de Psicología, Universidad de Cádiz \\ flavia.arrigoni@uca.es
}

\section{Resumen}

La presente investigación trata sobre la aplicación y evaluación del Protocolo Unificado Transdiagnóstico para el tratamiento de los Trastornos Emocionales grupal, online, en contextos no clínicos. Se implementó el PUT estandarizado de ocho módulos desarrollado en 12 sesiones semanales con el objetivo de examinar su eficacia. Participaron 134 personas. El objetivo general fue evaluar su eficacia en un formato grupal, online; y, los objetivos específicos fueron: incrementar la calidad de vida, el optimismo y el afecto positivo y disminuir la sintomatología depresiva y ansiosa, el afecto negativo, las conductas rumiativas, el malestar psicológico y la evitación experiencial. Se trata de una investigación con un enfoque cuantitativo, exploratorio, descriptivo e interactivo, con un diseño cuasi-experimental, pre-post test para muestras pareadas. Los instrumentos de evaluación fueron: OASIS, ODSIS, QLI-Sp, COP, PANAS, RRS, CORE-OM, BEAQ, ficha sociodemográfica ad hoc y Escala de opinión. Se hallaron diferencias estadísticamente significativas entre las mediciones pre y post test en Optimismo $(\mathrm{t}=-2,216 ; p<.028)$, conducta rumiativa $(Z=-2,179 ; p<$ .029), CORE OM Funcionamiento ( $t=2,250 ; p<.026)$, CORE OM Riesgo $(Z=-2,338$; $p<, 019)$ y conducta evitativa $(t=3,012 ; p<.003)$. Resultó eficaz en los contextos no clínicos aplicado.

\section{Palabras clave}

Protocolo Unificado Transdiagnóstico, tratamiento grupal online, contextos no clínicos. 


\section{Introducción}

La pandemia y las medidas de confinamiento implicaron una restricción a las habituales fuentes de reforzamiento individual y social, la disrupción del normal devenir de la propia cotidianeidad, pudiendo instalarse en algunas personas el estrés, el miedo, la tristeza o la ansiedad, incrementando el malestar psicológico y afectando en última instancia el bienestar general de las personas (Consejo General de la Psicología de España, 2020a).

La psicología de la salud tiene mucho para aportar en la aplicación y evaluación de programas de prevención de la salud, tanto en contextos clínicos como en otros no clínicos, de manera tal que es posible gestar intervenciones psicológicas desde servicios sociales, servicios de atención universitaria, asociaciones de personas con alguna patología en particular, entre otros.

Barlow et al. (2019) han diseñado un programa eficaz para el tratamiento de los trastornos emocionales, sencillo de implementar y con una óptima relación coste/ beneficio: el Protocolo Unificado para el tratamiento Transdiagnóstico de los Trastornos Emocionales (PUT). Incluye técnicas cognitivo conductuales, tales como la reestructuración cognitiva o la exposición, y otras basadas en "estrategias de regulación emocional y técnicas de conciencia emocional” (Rosique et al., 2019, p. 81). Compuesto por ocho módulos, cuenta con material bibliográfico de guía: un manual para el terapeuta y otro para el paciente (Barlow et al., 2019a, 2019b).

Sus principios terapéuticos son: fomentar la conciencia emocional plena, lograr una mayor flexibilidad mental, la identificación y modificación de las conductas emocionales y la eliminación de las respuestas de evitación, la exposición interoceptiva para incrementar la conciencia y tolerancia de las sensaciones físicas asociadas a las emociones y, por último, la exposición a experiencias emocionales en contextos de la vida real para eliminar las conductas evitativas o de supresión emocional (Barlow et al., 2019b). Prevé asimismo la asignación de tareas para la casa entre sesiones.

La American Psychological Association (2013) define la telepsicología como "la prestación de servicios psicológicos mediante las tecnologías de la información y comunicación" y el Consejo General de Psicología de España (2017) como "la prestación de servicios psicológicos empleando tecnologías de la información y de la telecomunicación, mediante el procesamiento de la información por medios eléctricos, electromagnéticos, electromecánicos, electro-ópticos o electrónicos" (p.8).

Debido al creciente auge de internet y las nuevas tecnologías de la información y comunicación (TIC) la Guía para la Intervención en Tele-Psicología (De la Torre Martí y Pardo Cebrián, 2018), busca regular los servicios psicológicos ofertados a través de las TIC. Una de las posibles intervenciones en formato online son las videoconferencias, basadas en la interacción de paciente y terapeuta en una plataforma virtual. Ante la situación generada por la pandemia, la European Federation of Phychologists' Associations (EFPA) dispuso que la consulta online, especialmente a través de video chat, podría ser una alternativa viable para ofrecer atención y terapia psicológica (Consejo General de la Psicología de España, 2020b).

La APA (2020) elaboró una guía sobre buenas prácticas para el desarrollo de la telepsicología, en la cual incluye ciertas consideraciones relativas a la tecnología, a la configuración del espacio u oficina virtual, al consentimiento y a la identidad de los usuarios. 
Incluso antes de la pandemia, universidades de todo el mundo habían ya comenzado a utilizar este formato para promover el bienestar del alumnado, estas se incrementaron luego de la virtualidad impuesta en las instituciones educativas. Así, por ejemplo, el Uni-Wellbeing (Mullin et al., 2015) aspira dar respuesta a las necesidades de asistencia psicológica de los estudiantes universitarios en un contexto no clínico mediante la aplicación del PUT en un formato online. Este programa ha sido implementado en universidades como la Universidad de Aberdeen (Escocia), la Universidad de Roehampton y la de Newcastle (Inglaterra), entre otras. En España se han desarrollado programas online, por ejemplo, el "Programa Sonreír es divertido" basado en el PUT (Mira et al., 2016). Sandín et al. (2019) han diseñado una aplicación online para adolescentes denominada "Aprende a Manejar Tus Emociones-AMTE" (Botella et al., 2019). Asimismo, Osma (2019) ha reportado los resultados de diversas investigaciones sobre la aplicación del PUT online y grupal en contextos no clínicos.

El Servicio de Atención Psicológica y Psicopedagógica (SAP) de la Universidad de Cádiz (UCA) aspira satisfacer las necesidades personales y académicas del alumnado, y promover un óptimo funcionamiento durante su estancia en la universidad (Universidad de Cádiz, 2021). De los datos aportados en la Memoria 2018-2019 del SAP, se desprende que en tal periodo se recibieron un total de 523 nuevas solicitudes del alumnado de la UCA, de las cuales el $23,5 \%$ se debían a problemas de ansiedad y el $8,2 \%$ a problemas del estado del ánimo (SAP, 2019). Si bien de la Memoria del curso 2019-2020 se desprende que el alumnado de la UCA realizó menos solicitudes, un total de 404, los dos principales motivos por los que solicitan atención psicológica individualizada fueron ansiedad (24,4\%) y problemas del estado del ánimo $(17.7 \%)$ (SAP, 2020), por lo que se evidencia un incremento de las solicitudes de atención psicológica debido a estas problemáticas. Asimismo, en la Memoria del curso 20202021, se observa que, si bien el SAP recibió un total de 373 solicitudes, los dos principales motivos por los que se solicitó atención fueron, por un lado, problemas relacionados con la ansiedad (34,9\%), y, por otro lado, problemas del estado emocional y de ánimo (26,5\%) (SAP, 2021). Así, es posible concluir que, mientras que en el curso 2018-2019 tres de cada diez solicitudes de estudiantes universitarios eran motivadas por problemas de ansiedad o del estado del ánimo, en el curso 2019-2020 cuatro de cada diez versaban sobre tales problemáticas, alcanzando en el curso 2020-2021 una mayor prevalencia: seis de cada diez solicitudes se debieron a problemas de ansiedad y del estado del ánimo. Esto permite concluir que, al menos en la comunidad UCA, en dos años se duplicaron las solicitudes de atención psicológica por problemas relacionados con la ansiedad y el estado del ánimo del alumnado.

El objetivo general de la presente investigación fue examinar la eficacia de la aplicación en formato grupal online del PUT con miembros de la comunidad educativa de la UCA y de una Asociación vinculada a la misma. Los objetivos específicos fueron: (1) incrementar la calidad de vida, el optimismo y el afecto positivo de los participantes; y (2) disminuir la sintomatología depresiva y ansiosa, el afecto negativo, las conductas rumiativas, el malestar psicológico y la evitación experiencial de los participantes. 


\section{Método}

Se diseñó una investigación cuantitativa con enfoque exploratorio-descriptivo, e interactivo, con un diseño cuasi-experimental, pre-post test para muestras pareadas (Hernández Sampieri y Mendoza, 2018). Arnau y Gómez (1995) definen la perspectiva cuasi-experimental como aquella en la que "el criterio de asignación de los sujetos o unidades a las condiciones de tratamiento o condiciones de estudio no se rige por las leyes del azar" (p. 15).

\section{Descripción del contexto y de los participantes}

Los participantes fueron 134 personas, con una edad promedio de 26,2 años de edad ( $D T=14,91972$; rango de 17 a 71 ), de los cuales el $86.6 \%$ eran mujeres, el $12.7 \%$ varones y un $0.7 \%$ prefirió no decirlo. Los 134 participantes fueron asignados a uno de los 5 grupos considerados: 9 mujeres de una Asociación que aglutina a mujeres con un diagnóstico de cáncer de mama, 13 alumnos del Aula Universitaria de Mayores de la UCA, 9 estudiantes universitarios que solicitaron atención psicológica en el Servicio de Atención Psicológica de la Universidad de Cádiz (curso 2020-2021) y 103 estudiantes universitarios de los dos primeros cursos de una carrera de corte humanístico (38 pertenecían al 1ำ curso y 65 al $2^{\circ}$ curso).

Se implementó el PUT estandarizado de ocho módulos desarrollado en 12 sesiones semanales de hora y media de duración, en un formato grupal online. Se establecieron dos tipos de intervenciones: 1) sincrónica, que implicaba un video chat entre terapeuta y participantes, y 2) sincrónica/asincrónica, resultante de la combinación de video chat en algunas sesiones y videos grabados compartidos en la plataforma virtual para otras sesiones. Todos los grupos participaron de una intervención sincrónica con excepción de los 103 estudiantes universitarios de los dos primeros cursos de una carrera de corte humanístico, cuya intervención en línea fue sincrónica/asincrónica.

\section{Instrumentos}

Con el fin de evaluar la eficacia del programa implementado, se contó con dos medidas de las variables en estudio de cada unidad de análisis tomadas en dos tiempos distintos. La totalidad de las sesiones de los distintos grupos involucrados fueron desarrolladas desde el mes de septiembre 2020 hasta febrero 2021. Se aplicaron los siguientes instrumentos autoadministrables, validados en España y con adecuados índices de validez y confiabilidad: Overall Anxiety Severity and Impairment Scale- OASIS (Campbell-Sills et al., 2009); Overall Depression Severity and Impairment Scale- ODSIS (Bentley et al., 2014; Mira et al., 2019); Quality of Life Index- QLI (Mezzich, Cohen y Ruipérez, 1996), versión Española- QLI-Sp (Mezzich et al., 2000); Cuestionario de Optimismo- COP (Pedrosa et al., 2015); Escala de Afecto Positivo y Negativo-PANAS (Watson, Clark y Tellegen, 1988), cuya adaptación española ha sido llevada a cabo por Sandín et al. (1999) y López Gómez, Hervas y Vázquez (2015); Escala de Respuestas Rumiativas - RRS (Nolen-Hoeksema y Morrow, 1991); la Clinical Outcomes in Routine Evaluation-OutcomeMeasure (CORE-OM, 2020) versión española de Feixas et al. (2012); el Brief Experiential Avoidance QuestionnaireBEAK (Gámez et al., 2014), adaptado al español y validado por Vázquez-Morejón et al. (2019); además de una ficha sociodemográfica ad hoc y la Escala de satisfacción/ opinión sobre el tratamiento, adaptación española de Borkovec \& Nau (1972). 


\section{Procedimiento}

La investigación constó de dos fases: 1르 Evaluación (pre y post test); y $2^{\text {a }}$ Intervención (12 sesiones del PUT). En la fase de evaluación se realizaron mediciones de las variables dependientes en estudio: ansiedad, depresión, calidad de vida, optimismo, afecto positivo y negativo, respuestas rumiativas, malestar psicológico y evitación experiencial, y en la de fase de intervención se desarrolló el PUT (variable independiente). Todas las sesiones de los distintos grupos fueron coordinadas por la misma terapeuta con más de 15 años de experiencia clínica. Atendiendo a que la propuesta fue completamente online, para la evaluación pre y post prueba se construyó un formulario de Google, en el cual se incluyeron tanto el consentimiento informado como las técnicas seleccionadas. En lo que respecta a la temporización, cabe destacar que la totalidad de los encuentros fueron desarrollados en el periodo comprendido entre los meses de septiembre del año 2020 y febrero del 2021: las participantes que pertenecen a la Asociación así como los estudiantes universitarios de los dos primeros cursos de una carrera de corte humanístico fueron incluido en el PUT desde los meses de septiembre a diciembre de 2020; los participantes del SAP desde noviembre 2020 a enero 2021; y, por último, el alumnado del AUM desde el mes de diciembre 2020 hasta febrero 2021.

Para el cálculo de los resultados se utilizó el paquete estadístico SPSS-21 (IBM Corp.). Obtenidos los datos descriptivos de las pruebas psicométricas empleadas, la prueba estadística de Kolmogorov Smirnov se utilizó para explorar la normalidad de la distribución y se consideró un nivel de significancia estadística $\alpha<0,05$. Para los datos que arrojaron una distribución normal se utilizó la prueba paramétrica $t$ de Student y para los que arrojaron una distribución no normal se utilizó la prueba no paramétrica Wilcoxon test.

El estudio se llevó a cabo de acuerdo con las directrices de la declaración de Helsinki, la normativa actual de la Unión Europea y la legislación española vigente sobre protección de datos. Las participantes dieron el consentimiento informado previo al inicio del estudio.

\section{Resultados}

Los datos descriptivos obtenidos por los participantes en los diferentes instrumentos utilizados en el estudio pueden verse en la tabla 1. 


\begin{tabular}{|c|c|c|c|c|c|}
\hline Puntuaciones Pretest y Postest & Mínimo & Máximo & Media & $\begin{array}{l}\text { Desviación } \\
\text { Típica }\end{array}$ & $\begin{array}{c}\text { Incremen- } \\
\text { to }\end{array}$ \\
\hline Pretest OASIS & ,00 & 18,00 & 6,57 & 4,28 & \multirow{2}{*}{$-0,07$} \\
\hline Postest OASIS & ,00 & 19,00 & 6,50 & 4,24 & \\
\hline Pretest ODSIS & ,00 & 17,00 & 4,71 & 4,29 & \multirow{2}{*}{$+0,41$} \\
\hline Postest ODSIS &, 00 & 15,00 & 5,13 & 3,84 & \\
\hline Pretest QLI-Sp & 17,00 & 100,00 & 71,92 & 15,43 & \multirow{2}{*}{$+0,63$} \\
\hline Postest QLI-Sp & 36,00 & 100,00 & 72,55 & 14,66 & \\
\hline Pretest COP & 16,00 & 45,00 & 31,32 & 5,38 & \multirow{2}{*}{$+0,94$} \\
\hline Postest COP & 20,00 & 41,00 & 32,26 & 4,59 & \\
\hline Pretest PANAS A.P. & 13,00 & 49,00 & 31,87 & 6,33 & \multirow[b]{2}{*}{$+0,32$} \\
\hline Postest PANAS A.P. & 19,00 & 50,00 & 32,19 & 6,04 & \\
\hline Pretest PANAS A.N. & 10,00 & 44,00 & 24,25 & 7,87 & \multirow[b]{2}{*}{$-0,74$} \\
\hline Postest PANAS A.N. & 10,00 & 39,00 & 23,50 & 7,03 & \\
\hline Pretest RRS & 22,00 & 78,00 & 46,69 & 13,09 & \multirow[b]{2}{*}{$-2,28$} \\
\hline Postest RRS & 22,00 & 76,00 & 44,41 & 11,36 & \\
\hline Pretest CORE OM Bienestar & 1,00 & 15,00 & 7,47 & 2,67 & \multirow[b]{2}{*}{$-0,06$} \\
\hline Postest CORE OM Bienestar & 1,00 & 14,00 & 7,41 & 2,65 & \\
\hline Pretest CORE OM Problema & 2,00 & 44,00 & 19,61 & 8,08 & \multirow[b]{2}{*}{$-0,88$} \\
\hline Postest CORE OM Problema & 3,00 & 43,00 & 18,72 & 7,98 & \\
\hline $\begin{array}{l}\text { Pretest CORE OM Funciona- } \\
\text { miento }\end{array}$ & 1,00 & 37,00 & 15,20 & 6,27 & \multirow{2}{*}{$-1,17$} \\
\hline $\begin{array}{l}\text { Postest CORE OM Funciona- } \\
\text { miento }\end{array}$ & , O० & 30,00 & 14,03 & 5,90 & \\
\hline Pretest CORE OM Riesgo &, 00 & 12,00 & 2,32 & 2,64 & \multirow{2}{*}{$-0,43$} \\
\hline Postest CORE OM Riesgo &, 00 & 9,00 & 1,88 & 2,33 & \\
\hline Pretest CORE OM VISI & 4,00 & 96,00 & 44,61 & 17,15 & \multirow[b]{2}{*}{$-2,55$} \\
\hline Postest CORE OM VISI & 8,00 & 95,00 & 42,05 & 16,55 & \\
\hline Pretest CORE OM VISI-R & 4,00 & 86,00 & 42,29 & 15,51 & \multirow[b]{2}{*}{$-2,11$} \\
\hline Postest CORE OM VISI-R & 8,00 & 87,00 & 40,17 & 15,14 & \\
\hline Pretest BEAK & 16,00 & 77,00 & 49,29 & 10,51 & \multirow[b]{2}{*}{-3} \\
\hline Postest BEAK & 15,00 & 77,00 & 46,29 & 11,33 & \\
\hline
\end{tabular}

Tabla 1. Datos estadísticos descriptivos de los resultados pre- y postest obtenidos por las participantes en todas las pruebas realizadas

A partir de los datos resultantes del cuestionario OASIS, tras la participación en el programa, se observó una leve disminución en la interferencia y gravedad asociada a la ansiedad de los participantes. Si bien no se hallaron diferencias estadísticamente significativas entre las mediciones pre y post test $(t=, 170 ; p>, 865)$, la participación en el programa disminuyó la ansiedad. La reducción cuantitativa media observada en el post test fue de 0,07 puntos (ver tabla 2). 


\begin{tabular}{|c|c|c|c|c|c|}
\hline \multirow[b]{2}{*}{ Pruebas Administradas } & \multicolumn{2}{|c|}{ Pre test } & \multicolumn{2}{|c|}{ Post test } & \multirow[b]{2}{*}{$t / Z$} \\
\hline & Media & SD & Media & SD & \\
\hline $\begin{array}{l}\text { Overall Anxiety Severity and Impairment Scale- } \\
\text { OASIS }\end{array}$ & 6,57 & 4,28 & 6,50 & 4,24 & ,170 \\
\hline $\begin{array}{l}\text { Overall Depression Severity and Impairment Scale- } \\
\text { ODSIS }\end{array}$ & 4,71 & 4,29 & 5,13 & 3,84 & $-1,144$ \\
\hline Quality of Life Index- QLI, versión Española- QLI-Sp. & 71,92 & 15,43 & 72,55 & 14,66 &,- 534 \\
\hline Cuestionario de Optimismo-COP & 31,32 & 5,38 & 32,26 & 4,59 & $-2,216^{*}$ \\
\hline $\begin{array}{l}\text { Escala de Afecto Positivo y Negativo- PANAS, factor } \\
1 \text { (afecto positivo) }\end{array}$ & 31,87 & 6,33 & 32,19 & 6,04 &,- 590 \\
\hline $\begin{array}{l}\text { Escala de Afecto Positivo y Negativo- PANAS, factor } \\
2 \text { (afecto negativo) }\end{array}$ & 24,25 & 7,87 & 23,50 & 7,03 & 1,171 \\
\hline Escala de Respuestas rumiativas-RRS & 46,69 & 13,09 & 44,41 & 11,36 & $-2,179 *$ \\
\hline $\begin{array}{l}\text { Clinical Outcomes in Routine Evaluation - Outcome } \\
\text { Measure (CORE-OM), EscalaBienestar }\end{array}$ & 7,47 & 2,67 & 7,41 & 2,65 &,- 308 \\
\hline $\begin{array}{l}\text { Clinical Outcomes in Routine Evaluation - Outcome } \\
\text { Measure (CORE-OM), EscalaProblema }\end{array}$ & 19,61 & 8,08 & 18,72 & 7,98 & $-1,649$ \\
\hline $\begin{array}{l}\text { Clinical Outcomes in Routine Evaluation - Outcome } \\
\text { Measure (CORE-OM), EscalaFuncionamiento }\end{array}$ & 15,20 & 6,27 & 14,03 & 5,90 & $2,250^{*}$ \\
\hline $\begin{array}{l}\text { Clinical Outcomes in Routine Evaluation -Outcome } \\
\text { Measure (CORE-OM), EscalaRiesgo }\end{array}$ & 2,32 & 2,64 & 1,88 & 2,33 & $-2,338^{*}$ \\
\hline $\begin{array}{l}\text { Clinical Outcomes in Routine Evaluation - Outcome } \\
\text { Measure (CORE-OM), VISI }\end{array}$ & 44,61 & 17,15 & 42,05 & 16,55 & 1,843 \\
\hline $\begin{array}{l}\text { Clinical Outcomes in Routine Evaluation - Outcome } \\
\text { Measure (CORE-OM), VISI-R }\end{array}$ & 42,29 & 15,51 & 40,17 & 15,14 & 1,701 \\
\hline Brief Experiential Avoidance Questionnaire - BEAK & 49,29 & 10,51 & 46,29 & 11,33 & $3,012 * *$ \\
\hline
\end{tabular}

$\left(^{*}\right) p<0,05 ;(* *) p<0,01$

Tabla 2. Valores medios, desviación estándar (SD) y comparaciones entre los resultados pre y postest en las diferentes pruebas obtenidos por las participantes.

En el cuestionario ODSIS, se observó un leve incremento en la interferencia y gravedad asociada a la depresión. No obstante, no se hallaron diferencias estadísticamente significativas entre las mediciones pre y post test $(Z=-1,144 ; p>, 253)$. La participación en el programa no generó mejoras en la interferencia y gravedad asociada a la depresión, el incremento cuantitativo medio observado en el post test de 0,41 punto.

A partir de los datos resultantes del QLI-Sp, tras su participación en el programa, se observó un incremento en la calidad de vida de los participantes. Si bien no se hallaron diferencias estadísticamente significativas entre las mediciones pre y post test $(t=-, 534 ; p>, 594)$, es posible aseverar que la participación en el programa promovió mejoras en la calidad de vida de los participantes. El incremento cuantitativo medio observado en el post test fue de 0,63 puntos. De los datos resultantes del COP, se observó un incremento en el Optimismo de los participantes tras su participación en el programa. El incremento cuantitativo medio observado en el post test fue de 0,94 puntos. Se hallaron diferencias estadísticamente significativas entre las mediciones pre y post test $(t=-2,216 ; p<, 028)$, por lo que es posible afirmar que participar en el programa de intervención aumentó el optimismo de los participantes. 
En relación a los datos obtenidos a partir del PANAS, el análisis factorial agrupa los 20 ítems en dos factores: factor 1 (afecto positivo); y factor 2 (afecto negativo). En relación al afecto positivo, en las mediciones post test de los participantes, se observó un leve incremento tras la participación en el programa, aunque no existen diferencias estadísticamente significativas entre las mediciones pre y post test $(t=-, 590 ; p>, 556)$. Por otro lado, en relación a la variable afecto negativo, en las mediciones post test se observó una disminución de las mismas, aunque los resultados obtenidos de la prueba $t$ Student no arrojaron diferencias estadísticamente significativas ( $t=1,171 ; p>, 244)$. En cualquier caso, el afecto positivo se incrementó en 0,32 puntos; y el afecto negativo se redujo en 0,74 puntos.

En cuanto al sexto instrumento utilizado, la Escala de Respuestas Rumiativas, adaptación española, del análisis de los resultados obtenidos en las mediciones post test fue posible observar una reducción de las conductas rumiativas tras la participación en el programa. Los resultados obtenidos de la prueba Wilcoxon test arrojaron diferencias estadísticamente significativas $(Z=-2,179 ; p<, 029)$. En este caso, la rumiación se redujo en 2,28 puntos.

De los datos resultantes del CORE-OM se observó lo siguiente: el análisis factorial agrupa los 34 ítems en 6 factores: Bienestar, Problema, Funcionamiento, Riesgo, VISI y VISI-R. Una menor puntuación refleja mayor bienestar y progreso en el tratamiento. En relación al factor Bienestar, se observó una muy leve disminución en las mediciones pre-post test. No obstante, no se hallaron diferencias estadísticamente significativas entre las mediciones pre y post test $(Z=-, 308 ; p>, 758)$. La disminución cuantitativa media observada en el post test fue de 0,6 puntos. En relación al factor Problema, se observó una disminución en las mediciones post test, lo que refleja una reducción de los problemas y/o síntomas tras la participación en el programa, aunque sin alcanzar la significación estadística $(Z=-1,649 ; p>, 099)$. La disminución cuantitativa media observada en el post test fue de 0,88 puntos. En relación a la escala Funcionamiento, se observó una disminución en las mediciones post test, lo que refleja un incremento del funcionamiento tras la participación en el programa (las diferencias fueron significativas estadísticamente: $t=2,250 ; p<, 026$ ). La disminución cuantitativa media observada en el post test fue de 1,17 puntos. En lo que respecta a la escala Riesgo, se observó una disminución en las mediciones post test, lo que refleja una disminución del malestar y percepción del riesgo. La disminución cuantitativa media observada en el post test fue de 0,43 puntos. Se observaron diferencias estadísticamente significativas en la escala del riesgo tras la participación en el programa $(Z=-2,338 ; p<, 019)$. En la escala general de Visibilidad (VISI), se observó una disminución en las mediciones post test, lo que refleja un incremento del bienestar tras la participación en el programa, así como también progreso favorable en el tratamiento. No obstante, no se hallaron diferencias estadísticamente significativas entre las mediciones pre y post test $(t=1,843 ; p>, 068)$. La disminución cuantitativa media observada en el post test fue de 2,55 puntos. Los resultados obtenidos en el VISI dan cuenta, no solo de una disminución del malestar psicológico, sino también, de un progreso en el tratamiento. En relación a la escala VISI-R (Visibilidad menos riesgo), se observó una disminución en las mediciones post test, aunque no llegaron a ser diferencia estadísticamente significativas $(t=1,701 ; p>, 091)$. La disminución cuantitativa media observada en el post test fue de 2,11 puntos.

De los datos obtenidos a partir del BEAK tras la participación en el programa, fue posible observar una reducción en las conductas evitativas. Los resultados de la prueba 
$t$ Student arrojaron diferencias estadísticamente significativas $(t=3,012 ; p<, 003$ ). Numéricamente, las conductas evitativas se redujeron en 3 puntos.

En la fase de evaluación post test se aplicó la escala de satisfacción/opinión. Los resultados evidencian niveles aceptables de satisfacción con los distintos aspectos vinculados al programa de intervención recibido (ver tabla 3).

\begin{tabular}{|l|c|c|c|c|}
\hline Puntuaciones & \multicolumn{1}{c}{ Mínimo } & Máximo & Media & $\begin{array}{c}\text { Desviación } \\
\text { Típica }\end{array}$ \\
\hline Lógica del tratamiento & 3,00 & 10,00 & 8,84 & 1,29 \\
\hline Satisfacción con el tratamiento & 3,00 & 10,00 & 8,61 & 1,40 \\
\hline Recomendaría el tratamiento & 3,00 & 10,00 & 8,80 & 1,34 \\
\hline Utilidad del tratamiento para otras personas & 3,00 & 10,00 & 8,64 & 1,39 \\
\hline Utilidad del tratamiento para su problema & 1,00 & 10,00 & 7,82 & 1,81 \\
\hline Aversividad del tratamiento & 1,00 & 10,00 & 2,22 & 1,86 \\
\hline
\end{tabular}

Tabla 3. Resultados (M y SD) obtenidos en la escala de satisfacción/opinión sobre el tratamiento (adaptación española de Borkovec \& Nau).

\section{Discusión y conclusiones}

El tamaño y tipo muestral no permite generalizar los resultados. Sin embargo, en contextos terapéuticos, este tipo de estudios con control parcial (Van Dalen y Meyer, 1971) o no aleatorizado (Anderson et al., 1980), permiten una suficiente verificación de la variable independiente.

Las variaciones en las mediciones pre post test permiten confirmar que la aplicación del PUT en formato grupal online resultó eficaz en los contextos no clínicos aplicados: se hallaron diferencias estadísticamente significativas entre las mediciones pre $\mathrm{y}$ post test en Optimismo ( $\mathrm{t}=-2,216 ; p<.028)$, conducta rumiativa $(\mathrm{Z}=-2,179 ; p<$ .029), CORE OM Funcionamiento ( $t=2,250 ; p<.026)$, CORE OM Riesgo ( $Z=-2,338$; $p<$,019) y conducta evitativa ( $t=3,012 ; p<.003$ ). Asimismo, los participantes evidenciaron progreso en el tratamiento ya que se obtuvo una reducción cuantitativa de 2.55 puntos en las puntuaciones post de la escala VISI del CORE OM.

Considerando que los tratamientos psicológicos dispensados online son una aproximación emergente para desarrollar el acceso a las terapias cognitivo conductuales basada en la evidencia (Sandín et al., 2020), se estima que el presente trabajo puede ser un valioso aporte. Los resultados son alentadores ya que los tratamientos psicológicos en "formatos grupales y online son los más coste-efectivos" (Osma \& Sauer-Zabala, 2019, p. 333)

Este estudio sobre telepsicología reviste cierta importancia ya que "amándola u odiándola, la práctica de la telepsicología se instaló para quedarse en la práctica de la salud mental y la investigación en salud mental" (Campbell \& Norcross, 2018, p. 5). 


\section{Referencias}

American Psychological Association (2013). Guidelines for the practice of telepsychology. APA. https://www.apa.org/pubs/journals/features/amp-a0035001.pdf

American Psychological Association Services (2020). Office and Technology Checklist for Telepsychological Services. https://www.apa.org/practice/programs/dmhi/ research-information/telepsychology-services-checklist.pdf.

Auquier, A., Hauchk, W.W., Oakes, D., Vandeale, W. \& Weisberg, H. (1980). Statistical methods for comparative studies. New York: John Wiley.

Barlow, D., Farchione, T., Sauer-Zavala, S., Murray Latin, ... \&Cassiello-Robbins, C. (2019b). Protocolo unificado para el tratamiento transdiagnóstico de los trastornos emocionales. Manual del terapeuta. (2 ${ }^{a}$ Ed.). Madrid: Alianza.

Barlow, D., Farchione, T., Sauer-Zavala, S., Murray Latin, H., ... \&Cassiello-Robbins, C. (2019a). Protocolo unificado para el tratamiento transdiagnóstico de los trastornos emocionales. Manual del paciente. (2 ${ }^{a}$ ed.). Madrid: Alianza.

Beecham, J., Bonin, E., Görlich, D., Baños, R., Beintner, I., Buntrock, C., et al., (2019). Assessing the cost and cost-effectiveness of ICare internet-based interventions (Protocol). Internet Interventions, 16, 12-19. https://doi.org/10.1016/j.invent.2018.02.009

Bentley, K., Gallagher, M., Carl, J. \& Barlow, D. (2014). Development and validation of the Overall Depression Severity and Impairment Scale. Psychological Assessment, 26(3), 815-830. Doi: https://doi.org/10.1037/a0036216

Borkovec, T. D. \&Nau, S. D. (1972). Credibility of analogue therapy rationales. Journal of BehaviorTherapy and Experimental Psychiatry, 3, 257-260.

Botella Arbona, C., García Palacios, A., Días García, A., González Robles, A. \& Castilla López, D. (2019) protocolo de tratamiento transdiagnóstico online para los trastornos emocionales. En J. Osma Lopez (coord.) Osma, J. (2019). Aplicaciones del Protocolo Unificado para el tratamiento transdiagnóstico de la disregulación emocional (pp. 297- 318). Madrid: Alianza.

Campbell, L. \& Norcross, J. (2018). Do you see what we see? Psychology's response to technology in mental health.Clinical Psychology: Science and Practice, 25(2), 1-5. Doi: https://doi.org/10.1111/cpsp.12237

Campbell-Sills, L., Norman, S., Craske, M., Sullivan, G., Lang, A., Chavira, D., et al. (2009). Validation of a brief measure of anxiety-related severity and impairment: the Overall Anxiety Severity and Impairment Scale (OASIS). Journal of Affective Disorders, 112(1-3), 92-101. Doi: https://doi.org/10.1016/j.jad.2008.03.014

Consejo General de la Psicología de España (2020a). Recomendaciones dirigidas a la población para un afrontamiento eficaz ante el malestar psicológico generado por el brote de coronavirus-Covid-19. [Consultado 2021 Marzo 19]. Disponible en: http:// www.infocop.es/view_article.asp?id=8627 
Consejo General de la Psicología de España (2020b). El rol de los psicólogos en Europa frente al coronavirus-comunicado de la EFPA. [Consultado 2021 Marzo 19]. Disponible en: http://www.infocop.es/view_article.asp?id=8636

Consejo General de Psicología de España. (2017). Guía para la práctica de la telepsicología. http://www.cop.es/pdf/telepsicologia2017.pdf

CORE-OM [sitio web oficial en español]. 2021. [Consultado 2021 Marzo 6]. Disponible en: http://www.ub.edu/terdep/core.

De la Torre Martí, M. \& Pardo Cebrián, R. (2018). Guía para la intervención en telepsicología. Madrid: Colegio Oficial de Psicólogos de Madrid. 02/07/2020. Recuperado a partir de: https://www.copmadrid.org/web/publicaciones/guia-para-la-intervencion-telepsicologica

Feixas, G., Evans, C., Trujillo, A., Saúl, L., Botella, L., Corbella, S., et al., (2012). Versión española del CORE-OM: Clinical outcomes in routine evaluation-outcome measure. Revista de Psicoterapia, 23(89), 109-135. Recuperado de: https://pdfs.semanticscholar.org/0393/2ff3b7c974f94d2d72f4ac63c184f01a4566.pdf

Gámez, W., Chmielewski, M., Kotov, R., Ruggero, C., Suzuki, N. \& Watson, D. (2014). The brief experiential avoidance questionnaire: development and initial validation. Psychological Assessment, 26(1), 35-45. Doi: https://doi.org/10.1037/a0034473

Hervás, G. (2008). Adaptación al castellano de un instrumento para evaluar el estilo rumiativo. Revista de Psicopatología y Psicología Clínica 13(2). Doi: https://doi. org/10.5944/rppc.vol.13.num.2.2008.4054

IBM Coorp. SPSS Statistics 21.

López Gómez, I., Hervas, G. \&Vázquez, C. (2015). Adaptación de la "Escala de afecto positivo y negativo" (PANAS) en una muestra general española. Behavioral Psychology/Psicología Conductual, 23(3), 529-548. Recuperado de: https://www.researchgate.net/publication/287391848_Adaptacion_de_la_Escala_de_afecto_positivo_y negativo_PANAS_en_una_muestra_general_espanola

Mezzich, J., Cohen, N. \& Ruipérez, M. (1996). A Quality of Life Index: Brief description and validation. Paper presented at the International Congress of the International Federation for Psychiatric Epidemiology. Santiago de Compostela, Spain.

Mezzich, J., Ruipérez, M., Pérez, C., Yoon, G., Liu, J. y Mahmud, S. (2000). The Spanish version of the quality of life index: presentation and validation. The Journal of Nervous and Mental Disease, 188(5), 301-5. Doi: https://doi.org/10.1097/00005053200005000-00008

Mira, A., González Robles, A., Molinari, G., Miguel, C., Díaz García, A., Bretón López, J. \& Botella, C. (2019). Capturing the severity and impairment associated with depression: the Overall Depression Severity and Impairment Scale (ODSIS) validation in a Spanish clinical simple. Frontiers in Psychology, 10, 180. Doi: https://doi.org/10.3389/ fpsyt.2019.00180 
Mullin, A., Dear, B., Karin, E., Wootton, B., Staples, L. Johnston, L., et al., (2015). The UniWellbeing course: A randomized controlled trial of a transdiagnostic internet-delivered cognitive behavioural therapy (CBT) programme for university students with symptoms of anxiety and depression. Internet Interventions 2, 128-136. Doi: http:// doi.org/10.1016/j.invent.2015.02.002

Nolen-Hoeksema, S. \& Morrow, J. (1991). A prospective study of depression and posttraumatic stress symptoms after a natural disaster: The 1989 Loma Prieta earthquake. Journal of Personality and Social Psychology, 61, 115-121. Doi: https://doi. org/10.1037//0022-3514.61.1.115

Norman, S., Campbell-Sills, L., Hitchcock, C., Sullivan, S., Rochlin, A., Wilkins, K. et al. (2011). Psychometrics of a brief measure of anxiety to detect severity and impairment: the Overall Anxiety Severity and Impairment Scale (OASIS). Journal of Psychiatric Research. 45(2), 262-8. Doi: https://doi.org/10.1016/j.jpsychires. 2010.06.011

Osma, J. \& Sauer-Zabala, S. (2019). Protocolo unificado: líneas futiras y nuevos retos. En J. Osma Lopez (coord.). Aplicaciones del Protocolo Unificado para el tratamiento transdiagnóstico de la disregulación emocional (pp. 319- 334). Madrid: Alianza.

Osma, J. (2019). Aplicaciones del Protocolo Unificado para el tratamiento transdiagnóstico de la desregulación emocional. Madrid: Alianza.

Pedrosa, I., Celis-Atenas, K., Suárez-Álvarez, J., García-Cueto, E. \&Muñiz, J (2015). Cuestionario para la evaluación del optimismo: Fiabilidad y evidencias de validez. Terapia Psicológica, 33(2), 127-138. Recuperado de: https://scielo.conicyt.cl/pdf/ terpsicol/v33n2/art07.pdf

Rosique, M., Sandín, B., Valiente, R., García-Escalera, J. \&Chorot, P. (2019). Tratamiento transdiagnóstico de un caso clínico con elevada comorbilidad de trastornos emocionales: aplicación del protocolo unificado. Revista Argentina de Clínica Psicológica, 28(1), 79-91. Doi: http://doi.org/10.24205/03276716.2019.1092

Sandín, B., Chorot, P., Lostao, L., Joiner, T., Santed, M. \&Valiente, R. (1999). Escalas PANAS de afecto positivo y negativo: validación factorial y convergencia transcultural. Psicothema, 11(1), 37-51. Recuperado de: http://www.psicothema.com/psicothema.asp?id=229

Sandín, B., Valiente, R.M., García-Escalera, J., Pineda, D., Espinosa, V., Magaz, M. \&Chorot, P. (2020). Protocolo unificado para el tratamiento transdiagnóstico de los trastornos emocionales en adolescentes a través de internet (iUP-A): Aplicación web y protocolo de un ensayo controlado aleatorizado. Revista de Psicopatología y Psicología Clínica, 24,197-215. https://doi.org/10.5944/rppc.26460

Servicio de Atención Psicológica y Psicopedagógica (2019). Memoria Anual 20182019. https://sap.uca.es/wp-content/uploads/2019/O7/MEMORIA-2018_19.pdf?u

Servicio de Atención Psicologica y Psicopedagógica (2020). Memoria Anual 20192020. https://sap.uca.es/wp-content/uploads/2021/01/Memoria-2019_2020.pdf?u 
Servicio de Atención Psicologica y Psicopedagógica (2021). Memoria Anual 20202021. https://sap.uca.es/wp-content/uploads/2021/09/Memoria-Anual-2020-2021-1. pdf?u

Universidad de Cádiz (2020). Memoria 2019-2020 del Servicio de Atención Psicológica y Psicopedagógica. Disponible en:https://sap.uca.es/wp-content/ uploads/2021/01/Memoria-2019_2020.pdf?u

Universidad de Cádiz (2021). Servicio de Atención Psicológica y Psicopedagógica. Disponible en: https://sap.uca.es

Van-Dalen, D.B. \& Meyer, W.J. (1971). Manual de técnica de la investigación educacional. Barcelona: Paidós.

Vázquez-Morejón, R., León Rubio, J., Martín Rodríguez, A. \& Vázquez Morejón, A. (2019). Validation of a Spanish version of the Brief Experiential Avoidance Questionnaire (BEAQ) in clinical population. Psicothema, 31, 3, 335-340. Doi: https://doi. org/10.7334/psicothema2019.60

Watson, D., Clark, L. \&Tellegen, A. (1988). Development and validation of brief measures of positive and negative affect: The PANAS scales. Journal of Personality and Social Psychology, 54(6), 1063-1070. Doi: https://doi.org/10.1037/0022-3514.54.6.1063 


\section{Simulación de los Problemas de Mezcla y Drenado de un Tanque: Implementación de un Objeto de Aprendizaje en un Curso de Ecuaciones Diferenciales}

\section{Haye, Elisabet}

Facultad de Ingeniería y Ciencias Hídricas, Universidad Nacional del Litoral ehaye@fich.unl.edu.ar

\section{Genzelis, Lucas}

Facultad de Ingeniería y Ciencias Hídricas, Universidad Nacional del Litoral lucas.genzelis@gmail.com

\section{Zucarelli, Agostina}

Facultad de Ingeniería y Ciencias Hídricas, Universidad Nacional del Litoral agostinazucarelli@gmail.com 


\title{
SIMULACIÓN DE LOS PROBLEMAS DE MEZCLA Y DRENADO DE UN TANQUE: IMPLEMENTACIÓN DE UN OBJETO DE APRENDIZAJE EN UN CURSO DE ECUACIONES DIFERENCIALES
}

\author{
Haye, Elisabet \\ Genzelis, Lucas \\ Zucarelli, Agostina
}

\section{Resumen}

Los ingenieros a menudo estudian sistemas que experimentan variaciones o cambios, por lo que la modelación matemática y las ecuaciones diferenciales como herramienta para su construcción, tienen un gran valor en la resolución de problemas reales, permitiendo estudiar dichos cambios en las variables claves de un sistema y obtener una comprensión más profunda de los fenómenos físicos subyacentes e incluso predecir el comportamiento de ese sistema.

La necesidad de nuevos entornos virtuales de aprendizaje orientados hacia un modelo centrado en el alumno, hacen propicio el desarrollo de Objetos de Aprendizaje $(\mathrm{OA})$ que, acompañados con un buen diseño instruccional, ofrecen una nueva metodología para el diseño de materiales educativos. El presente trabajo, tiene como objetivo describir el desarrollo de un OA interactivo para la asignatura Ecuaciones Diferenciales (ED) de la Facultad de Ingeniería y Ciencias Hídricas, basado en la visualización dinámica y simulación de los problemas de mezclas y drenado de un tanque, a través de la variación de parámetros que intervienen en las ED que lo modelan. Su propósito es contribuir a la adquisición de habilidades matemáticas, vinculadas a modelar, interpretar, argumentar y comunicarse en un lenguaje preciso, y al mejor desempeño de los estudiantes. Se describen además las características de los componentes centrales de su diseño: contenidos, elementos de contextualización, los softwares de simulación y actividades de aprendizaje. Los resultados obtenidos en evaluaciones y la opinión de los estudiantes permitió evidenciar que la propuesta resultó motivadora y su implementación contribuyó a la comprensión y visualización de los modelos.

\section{Palabras clave}

Ecuaciones diferenciales, modelado, simulación interactiva, objetos de aprendizaje. 


\section{Introducción}

Ante la vertiginosa expansión del conocimiento, los bajos rendimientos en los primeros años de las carreras, particularmente en matemática, y las nuevas demandas profesionales y sociales, se hace imprescindible desde la universidad, la reflexión y puesta en práctica de enfoques originales para transmitir el conocimiento.

La Facultad de Ingeniería y Ciencias Hídricas (FICH) en la ciudad de Santa Fe, Argentina, se enmarca desde hace varios años en un Plan de Rediseño Curricular estableciendo líneas de acción hacia una Formación por Competencias, para abordar la problemática del desgranamiento, la deserción y la gran duración del cursado, apuntando a mejorar el desempeño y permanencia de los estudiantes y la calidad y evolución de las carreras.

Un enfoque a tener en cuenta como base del proceso educativo en la Formación por Competencias en Matemática para carreras de Ingeniería es la Teoría de la Matemática en Contexto de las Ciencias, desarrollada por Camarena Gallardo, P. (2009). Según la misma la matemática no debe presentarse desarticulada de otras asignaturas, sino como una herramienta para el desarrollo de competencias profesionales y para la vida. Por otro lado, Camarena Gallardo, P. (2015) menciona que, en la actualidad, los enfoques que deben persistir en matemáticas, apuntan al desarrollo del pensamiento matemático, la resolución de problemas, la argumentación, la comunicación oral y escrita, los aprendizajes contextualizados y, fundamentalmente, la modelación y el uso de las tecnologías como mediadora del aprendizaje. Para el tema del presente trabajo, la modelación y simulación merecen especial atención.

Entre las actividades que pueden ser propuestas dentro de la enseñanza de las ecuaciones diferenciales (ED) se resaltan las de visualización, ya que enfrentan al estudiante a dar consistencia a los resultados que obtenga. Para ello, resulta sumamente propicio el empleo de medios computacionales y softwares interactivos, dado que generan con rapidez representaciones gráficas muy provechosas para entender las propiedades de sus soluciones y de los sistemas dinámicos, y favorecen la participación de los estudiantes a través de la experimentación, logrando una mejor apropiación de los significados. Como ejemplo, Rodríguez, R. (2012), Rodríguez, R. y Quiroz, S. (2014) y Molina García, (2015) proponen diversas actividades y técnicas didácticas en un curso de ED, donde se pretende lograr el desarrollo de competencias de modelación, y de uso de herramientas tecnológicas varias, entre las que se destacan las herramientas de simulación. De sus investigaciones, los autores concluyen que a medida que se generen actividades que surjan de problemáticas reales y el alumno sea capaz de apreciar el potencial de las ED para modelar, comprender, explicar o simular; se espera lograr una mayor motivación e interés en el alumno, pero sobre todo un aprendizaje significativo.

Los docentes de la asignatura ED que se dicta en la $\mathrm{FICH}$, han empleado por años una variedad de softwares libres (como GeoGebra, Winplot, Wolfram Alpha o Maxima), que fueron utilizados para tareas extra áulicas seleccionadas de la bibliografía básica del curso (Zill, D. y Wright, W., 2015) como parte de los requisitos para alcanzar la regularidad. Además, se han empleado, en ocasiones, otros recursos multimedia, como aquellos disponibles en Khan Academy y también ambientes interactivos seleccionados del Instituto Tecnológico de Massachussets (MIT). A pesar de que los estudiantes manifestaron entusiasmo en estas actividades, los resultados de las primeras evaluaciones no permitieron observar mejoras significativas en los aprendizajes ni en su 
capacidad interpretativa, principalmente en lo referente a los fenómenos modelados. Una de las posibles causas de estos resultados poco satisfactorios puede ser que las funcionalidades de los diferentes programas no se adaptaron en ocasiones a los criterios de la cátedra, particularmente en el tema de modelado con ED de primer orden, donde no se ha podido hallar un recurso que contemple a todos los modelos que se estudian y donde el alumno pueda explorar, visualizar y simular las diferentes situaciones, contrastando y verificando resultados, y estimulando así su desarrollo cognitivo.

La necesidad de nuevos entornos virtuales de aprendizaje orientados hacia un modelo centrado en el alumno, hacen propicio el desarrollo de Objetos de Aprendizaje (OA), los cuales ofrecen una nueva metodología para el diseño de materiales educativos. "Un OA es un conjunto de recursos, autocontenible, diseñado y creado en pequeñas unidades digitales, con un propósito educativo para maximizar el número de situaciones en las que se puede utilizar." (Rosanigo, Z., Bramati, P., López, C., Bramati, S. y Cotti, C., 2014, p. 1090).

Para un abordaje diferente del tema "Modelado con ED de primer orden", que tenga en cuenta las dificultades asociadas en los aprendizajes del tema, el equipo docente de ED encaró la tarea de diseñar un OA interactivo, basado en la visualización y exploración abierta, que reúna en un solo lugar todas las utilidades que se necesitan. Su desarrollo se enmarcó dentro de la presentación de Propuestas de Innovación para el Mejoramiento de la Enseñanza de Grado de la $\mathrm{FICH}$, que posibilitó un trabajo conjunto con especialistas informáticos.

El diseño de este OA estuvo enfocado -en primera instancia- al estudio cualitativo de las ED de primer orden a través de campos de pendientes y a la simulación interactiva de dos problemas de aplicación clásicos, mezclas y drenado de un tanque, por medio de un software de simulación para cada modelo. Se diseñó asimismo un conjunto de actividades donde el alumno pudiese explorar, visualizar, interpretar, argumentar y simular diferentes situaciones, contrastando y verificando resultados provenientes de procedimientos analíticos aprendidos durante el cursado. Las finalidades de este OA son que el mismo: sirva al estudiante de apoyo y acompañamiento didáctico en cualquier modalidad de cursado, oriente los procesos de aprendizaje autónomo permitiendo que el alumno sea protagonista en el desarrollo de las habilidades de pensamiento necesarias para el logro de competencias matemáticas, y de esta manera se cautive su interés y se contribuya a un mayor desempeño y compresión de los temas tratados.

\section{Descripción de la experiencia}

La asignatura Ecuaciones Diferenciales es introductoria a las ecuaciones diferenciales ordinarias y a los sistemas de ecuaciones diferenciales y se ubica en el cuarto cuatrimestre del Ciclo Básico de las carreras Ingeniería Ambiental, Ingeniería en Informática e Ingeniería en Recursos Hídricos.

Durante las primeras cuatro semanas de cursado se desarrolla el tema de ED de primer orden, donde en los objetivos, además de la comprensión de los conceptos básicos y de la adquisición de habilidades para aplicar los métodos de resolución, se pone énfasis en reconocer problemas que puedan modelarse matemáticamente mediante estas ED y en el análisis interpretativo de las soluciones de estos modelos a través de gráficas y campos direccionales. Como apoyo didáctico y acompañamiento 
a las clases semanales, el OA fue incorporado en el aula virtual de la asignatura dentro de la plataforma educativa e-FICH. El empleo del entorno virtual permitió formas de interacción entre los estudiantes y entre estudiantes y docentes al momento de despejar dudas y allanar dificultades, y su uso fue previsto hasta el primer parcial, instancia planificada para la evaluación de dichos temas. Esta propuesta fue implementada en los cursados 2019 y 2020 y se orientó a resolver dificultades de comprensión detectadas en años anteriores y propiciar una mejora e innovación clara de las metodologías de enseñanza aplicadas hasta el momento. Se centró en el tema ED de primer orden y específicamente en los modelos de mezcla y drenado de un tanque, con actividades de formación experimental.

\section{El Objeto de Aprendizaje}

El Objeto de Aprendizaje (OA) ofrece un conjunto de recursos digitales, está autocontenido con un propósito educativo y está constituido por tres componentes internas: contenidos (objetivos, consideraciones del material, planteo y desarrollo del problema, modelado con la ecuación diferencial pertinente, video tutorial con ejemplo de aplicación en el simulador), actividades de aprendizaje experimentales con retroalimentación como autoevaluación y elementos de contextualización (introducción y modelado matemático de los problemas de mezclas y drenado en un tanque y elementos asociados de la teoría de ecuaciones diferenciales de primer orden).

El vehículo elegido para desarrollar este OA interactivo ha sido la herramienta de autor eXeLearning (https://exelearning.net/), editor gratuito y de código abierto, de fácil descarga, que permite al docente, sin grandes conocimientos técnicos, generar materiales educativos digitales permitiéndole incluir todo tipo de contenidos (por ejemplo textos, imágenes, vídeos, recursos dinámicos creados con otras aplicaciones, enlaces, etc.) en un formato estándar (el empaquetado SCORM) que puede usarse en la plataforma Moodle (en nuestro caso), con la posibilidad de crear diseños propios y, a futuro, ser reutilizado en repositorios públicos.

Para el diseño de los componentes centrales del OA se utilizaron los recursos que facilita eXeLearning que, al tratarse de una aplicación multiplataforma, ha permitido:

- la creación de un árbol de navegación básico que facilite la navegación, la selección y el ordenamiento de las secuencias de aprendizaje.

- la escritura de los contenidos como presentación, objetivos propuestos, características generales del material y descripción del contexto del problema asociado a cada modelado, como también inclusión de imágenes y videos.

- la inclusión de elementos multimedia como videos y el software educativo de simulación.

- la incorporación de actividades interactivas sencillas destinadas a la autoevaluación de los aprendizajes: preguntas de tipo test, de verdadero/falso, de espacios en blanco, etc. Las actividades, a través de una retroalimentación, van guiando al estudiante por los diferentes contenidos generando una especie de diálogo entre el estudiante y el material.

- la exportación del contenido generado al formato HTML, que puede utilizarse en cualquier explorador de internet. 


\section{Softwares educativos de simulación}

El contexto elegido para el desarrollo de cada software educativo es el estudio del modelado matemático, simulación y visualización de la conducta dinámica de los sistemas asociados a los problemas de mezclado y drenado de tanques. Dicha elección se sustenta en que estas temáticas son unas de las que mayor aplicabilidad tienen en la formación de las carreras de ingeniería a las que pertenecen los alumnos. Asimismo, la forma particular de la estructura de la ED que modela a cada problema resulta muy interesante para el diseño de un recurso tecnológico adecuado para la simulación del suceso y para el análisis y visualización de los cambios en la representación de sus soluciones ante la variación de los parámetros intervinientes en los respectivos modelos.

\section{Problema de mezclas}

Si se mezclan dos soluciones salinas de distintas concentraciones en un recipiente, la cantidad de sal contenida en la mezcla dentro del recipiente puede ser descripta, en cada instante de tiempo, mediante una ecuación diferencial lineal de primer orden. Con la implementación del software propuesta, el alumno puede explorar lo que ocurre con la solución del problema planteado al variar los parámetros que describen al mismo, como ser cantidades iniciales de líquido y de sal o razón de entrada y salida de líquido, así como sus concentraciones. Las modificaciones que realiza el estudiante son acompañadas de animaciones en colores que varían de acuerdo a los parámetros seleccionados, de tal forma que es posible percibir físicamente el aumento o disminución de concentraciones y/o razones de entrada o salida en un proceso de mezcla.

El módulo del OA correspondiente a este problema cuenta con dos secciones. En la primera (Figura 1) el estudiante debe ingresar la cantidad inicial de líquido y de sal, concentración y caudal de entrada, caudal de salida, capacidad del recipiente (es posible simular un tanque de capacidad infinita) y el tiempo máximo de simulación. En la segunda parte (Figura 2), se exponen los resultados de la simulación, empleando una animación interactiva que el estudiante puede pausar, retroceder $\mathrm{y} / \mathrm{o}$ adelantar, así como las gráficas de las curvas que representan la evolución temporal de la cantidad de sal, el volumen total de líquido, y la concentración de la solución.

\begin{tabular}{|c|c|c|c|c|c|}
\hline \multicolumn{3}{|l|}{ Cantidad Inicial de Liquido } & \multicolumn{3}{|c|}{ Color } \\
\hline 100 & Metros Cúbicos & $v$ & \\
\hline \multicolumn{3}{|l|}{ Cantidad Inicial de Soluto } & \multicolumn{3}{|c|}{ Color } \\
\hline 50 & Kilogramo & $v$ & & & \\
\hline \multicolumn{6}{|l|}{ Concentración de Entrada } \\
\hline \multicolumn{3}{|l|}{3} & & & $\mathrm{~kg} / \mathrm{m}^{3}$ \\
\hline \multicolumn{6}{|l|}{ Caudal de Entrada } \\
\hline \multicolumn{3}{|l|}{2} & & \multicolumn{2}{|l|}{$\mathrm{m}^{3} / \mathrm{s}$} \\
\hline \multicolumn{6}{|l|}{ Caudal de Salida } \\
\hline \multicolumn{3}{|l|}{5} & & \multicolumn{2}{|r|}{$\mathrm{m}^{3} / \mathrm{s}$} \\
\hline \multicolumn{6}{|l|}{ Capacidad del Recipiente } \\
\hline \multicolumn{6}{|c|}{ Marque para indicar si la capacidad es llimitada } \\
\hline \multicolumn{3}{|l|}{150} & \multicolumn{3}{|r|}{$m^{3}$} \\
\hline \multicolumn{6}{|l|}{ Tiempo Máximo Simulado } \\
\hline 100 & & & & & $\mathrm{~s}$ \\
\hline
\end{tabular}




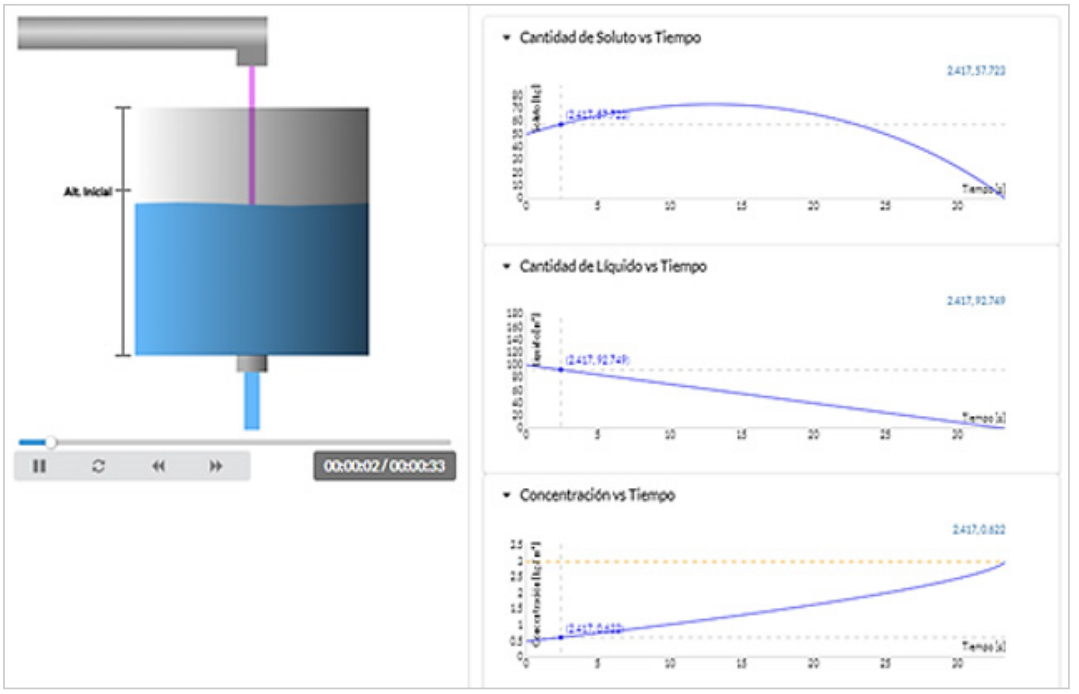

Figura 2. Problema de mezcla: resultado de simulación.

\section{Problema de drenado en un tanque}

La altura del líquido contenido en un tanque que se vacía a través de un agujero presente en su parte inferior o lateral puede describirse en cada instante de tiempo mediante una ED no lineal de primer orden, empleando la Ley de Torricelli de Hidrodinámica. Mediante la implementación de este modelo en el software, el alumno es capaz de analizar y distinguir lo que ocurre en las soluciones de la ecuación diferencial que describe al problema cuando se modifica la forma del tanque o los parámetros del fluido considerado.

El correspondiente módulo del OA consiste en tres pestañas: "Tipo de Tanque", "Parámetros" y "Simulación". En la pestaña "Tipo de Tanque" en la Figura 3, se presentan diferentes posibilidades referentes a la geometría del tanque. Con el propósito de dar un máximo grado de libertad al alumno no sólo se incluyen geometrías fijas, sino que se ofrece también la posibilidad de ingresar un tanque de geometría arbitraria, como una función de la forma $r(h)$, que relaciona el radio del tanque con su altura en cada punto. Esta opción es la más novedosa de este módulo, ya que no se ha observado otros programas similares que dispongan de una opción semejante. 


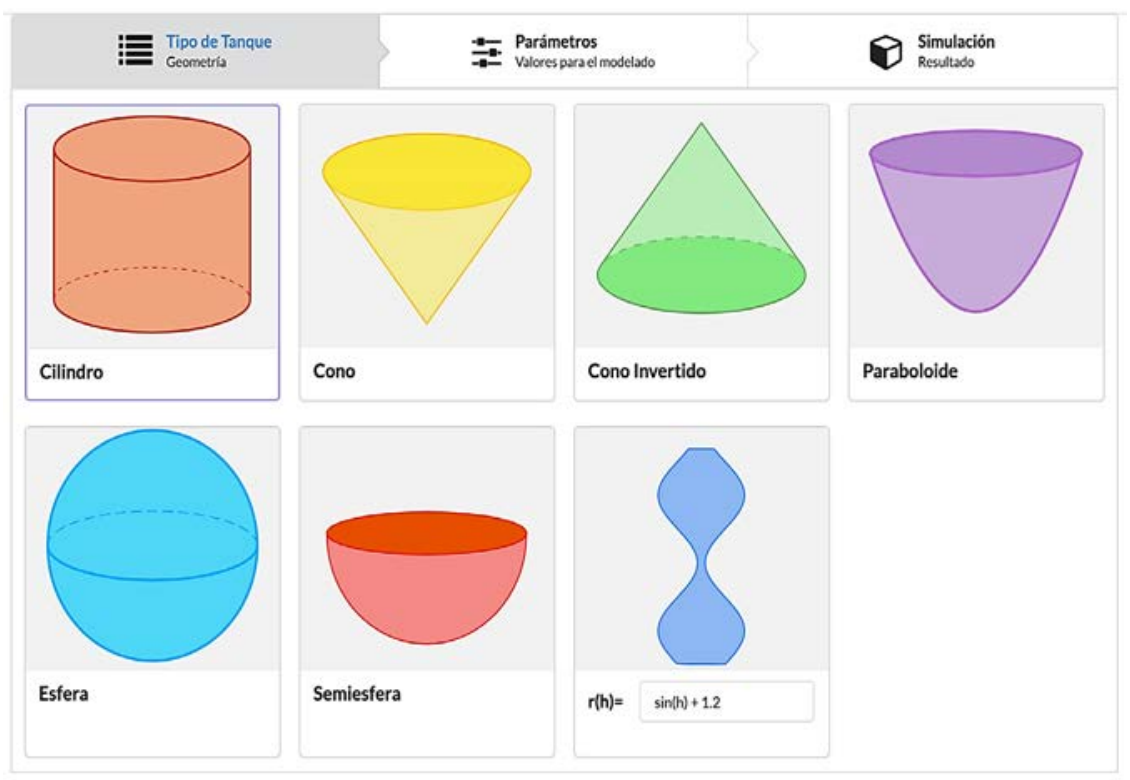

Figura 3. Problema de drenado: pestaña "Tipo de Tanque".

La pestaña "Parámetros" permite definir el valor de diferentes constantes involucradas en el problema. Cabe aclarar que las opciones que se presentan aquí no son fijas, sino que dependen de la geometría seleccionada. Por ejemplo, para un tanque de geometría semiesférica, los valores que pueden configurarse son los que se observan en la Figura 4. Hay dos elementos que pueden destacarse. En primer lugar, la posibilidad de combinar diferentes unidades de medida, como el usar pulgadas para definir el orificio de salida y metros para definir el radio del tanque. En segundo lugar, la posibilidad de definir la altura a la cual se encuentra el orificio de salida del líquido. Esto constituye una novedad respecto de otras propuestas didácticas similares, en las cuales el líquido siempre se drena desde la base del tanque.

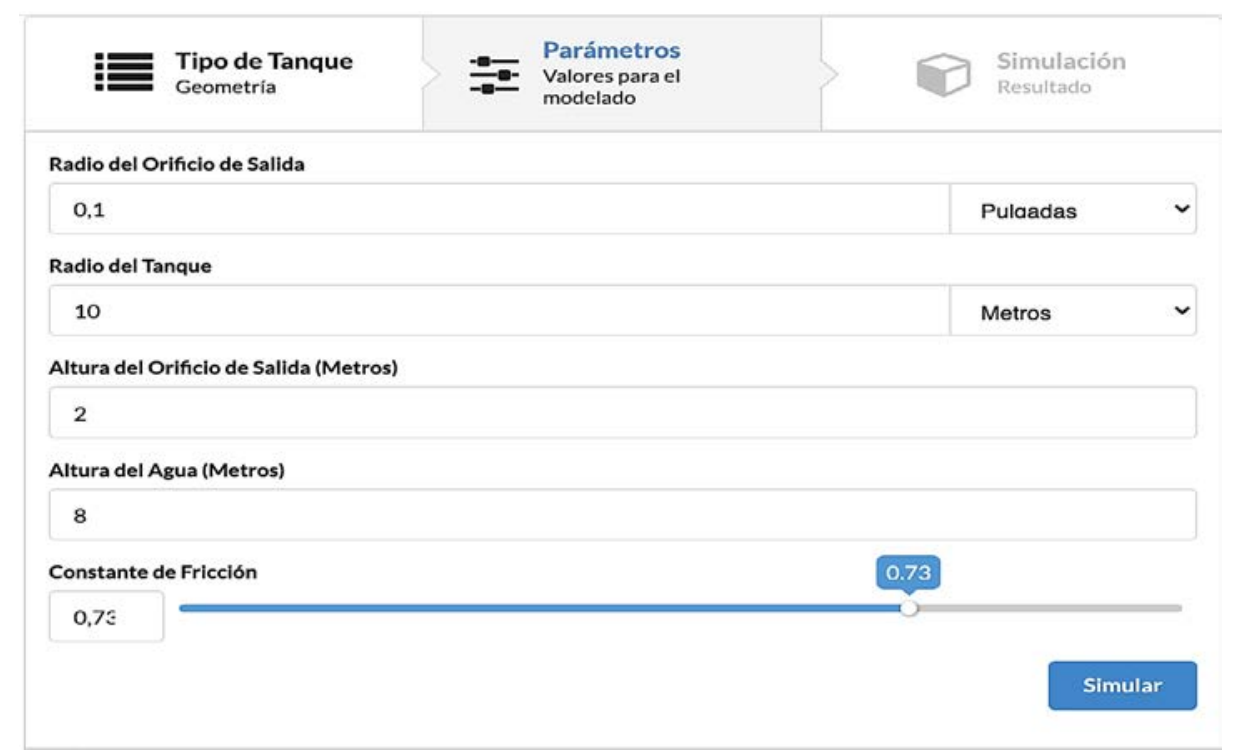

Figura 4. Problema de drenado: pestaña "Parámetros" (geometría: semiesférica). 
Finalmente, en la pestaña "Simulación" (Figura 5), puede observarse el resultado del experimento programado. En la parte derecha de la pantalla se presentan las curvas correspondientes a la evolución temporal del nivel de altura de líquido (arriba) y de su volumen (abajo). Asimismo, a la izquierda de la pantalla se presenta un video en tiempo real que permite observar una animación de la simulación realizada.

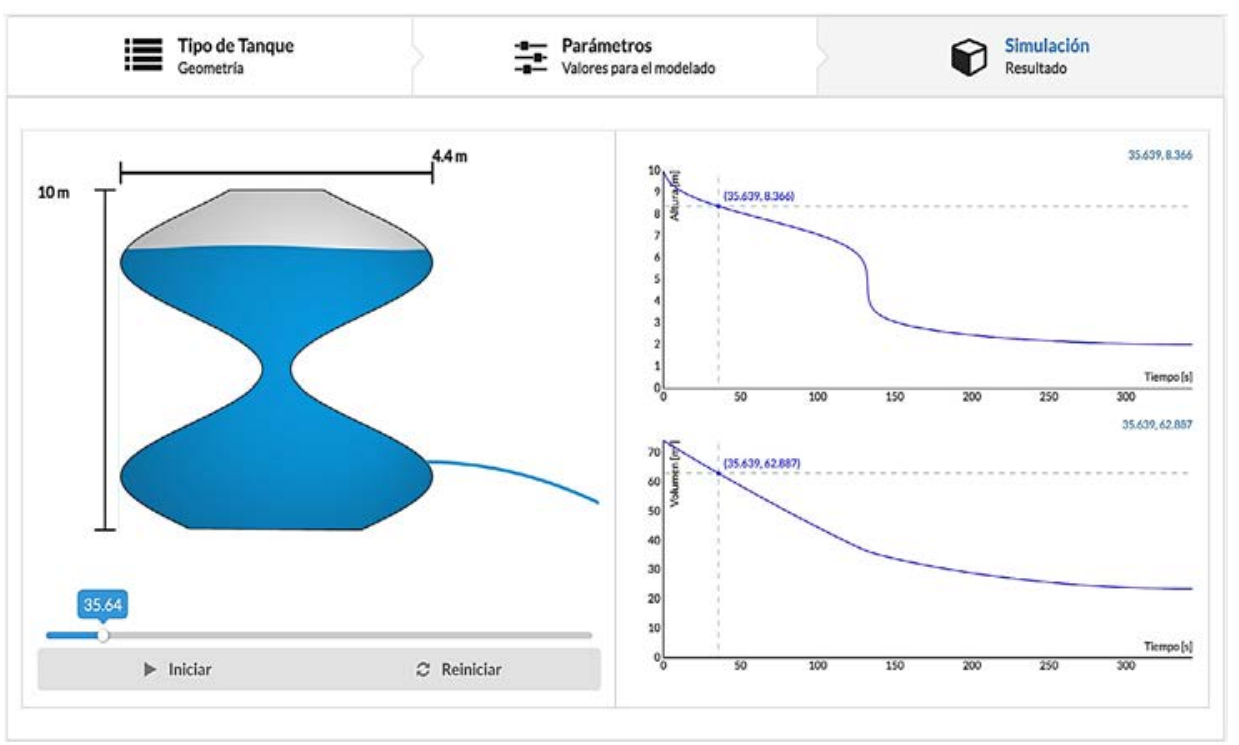

\section{Figura 5. Problema de drenado: pestaña "Simulación".}

Debe destacarse que en ocasiones este tipo de ejercicios da lugar a que los alumnos inquieran, en el espacio de debate áulico, sobre cómo plantear y resolver de forma analítica las ED correspondientes a las diferentes geometrías. Esto incluso sirve como disparador para hacer una breve reseña sobre los métodos de solución numérica que serán estudiados en profundidad en materias del ciclo superior de las carreras de ingeniería. Así, no sólo se logra aumentar el interés de los estudiantes en la asignatura Ecuaciones Diferenciales, sino también en otras que se articulan verticalmente sobre la misma.

\section{Resultados}

Para poder evaluar objetivamente el impacto de la incorporación del OA en el rendimiento de los estudiantes y en su nivel de deserción de la asignatura, se analizó información obtenida durante los cursados de ED durante los años 2016 a 2019 (cursado presencial) y el año 2020 (cursado virtual). Los datos recabados corresponden al porcentaje de alumnos que abandonaron la materia sin presentarse a rendir ninguna evaluación, así como a las calificaciones de los estudiantes en el primer parcial de la asignatura, cuyo contenido se relaciona con la temática abordada en el OA. Esta información se presenta organizada en la Tabla 1. Las columnas resaltadas en color gris (2019 y 2020) corresponden a las cohortes donde fue utilizado el OA. 


\begin{tabular}{|l|c|c|c|c|c|}
\hline & $\mathbf{2 0 1 6}$ & $\mathbf{2 0 1 7}$ & $\mathbf{2 0 1 8}$ & $\mathbf{2 0 1 9}$ & $\begin{array}{c}\mathbf{2 0 2 0} \\
\text { Cursado virtual }\end{array}$ \\
\hline Total de inscriptos & 148 & 134 & 139 & 146 & 142 \\
\hline Abandonos & $36.49 \%$ & $34.33 \%$ & $33.09 \%$ & $19.18 \%$ & $19.01 \%$ \\
\hline Puntaje [0, 40) & $48.94 \%$ & $54.55 \%$ & $55.91 \%$ & $33.9 \%$ & $40 \%$ \\
\hline Puntaje [40, 60) & $32.98 \%$ & $30.68 \%$ & $34.41 \%$ & $29.66 \%$ & $19.8 \%$ \\
\hline Puntaje [60, 100] & $18.08 \%$ & $14.77 \%$ & $9.68 \%$ & $36.44 \%$ & $40.87 \%$ \\
\hline
\end{tabular}

Tabla 1. Datos de los cursados de ED 2016-2020: abandonos y calificación en el primer parcial.

El análisis de los datos expuestos permite apreciar el impacto de la incorporación del OA en las distintas variables de interés, a saber, el desempeño académico y el nivel de deserción temprana de los estudiantes.

\section{Encuestas a estudiantes}

Con el propósito de medir y valorar la percepción de la función educativa del OA por parte de los estudiantes, se realizaron encuestas a las cohortes donde el mismo fue implementado, en los años 2019 y 2020 . Esto permitió valorar con mayor precisión el grado de satisfacción de los estudiantes con la herramienta, así como su aporte a los procesos de enseñanza-aprendizaje, con el objeto de poder, en un futuro, realizar modificaciones que permitan el incremento de los mismos.

La encuesta realizada se apoyó en preguntas como: ¿qué tan sencillo le resultó utilizar el OA?; ¿pudo utilizarlo de manera fluida?; ¿̇en qué contribuyó a su proceso de aprendizaje?; ¿cambiaría o mejoraría algún aspecto?; si se le presentó un problema, ¿recibió una retroalimentación adecuada?

Más del 90\% de los estudiantes coincidieron en que el OA propuesto resultó útil para visualizar, simular y comprobar posibles soluciones y contribuyó a su aprendizaje y a la mejor comprensión de los contenidos vinculados a las ED de primer orden. Más del $70 \%$ destacó que su empleo fue sencillo y que constituyó una propuesta de enseñanza diferente a las realizadas en cursados anteriores.

Respecto a la claridad de los contenidos multimedia incorporados en el OA, como los videos explicativos, así como a las retroalimentaciones por parte de los docentes, la apreciación general fue "muy buena". Se destacó un elevado porcentaje de estudiantes que afirmaron que los módulos de "Mezclas" y "Drenado de un tanque" fueron de mucha utilidad.

Las encuestas permitieron, además, plantear se realicen mejoras en los diversos módulos, a saber, incorporar más ejemplos y problemas para que los estudiantes resuelvan, detallar las retroalimentaciones en los cuestionarios de autoevaluación y mejorar las herramientas de graficación. 


\section{Discusión y conclusiones}

El desarrollo e implementación de este OA diseñado como un entorno de aprendizaje dinámico, ha sido una iniciativa y desafío de la cátedra Ecuaciones Diferenciales de la $\mathrm{FICH}$, como apoyo y acompañamiento a los estudiantes, que buscó promover la retención en el cursado, el desarrollo de competencias y el dominio del tema ED de primer orden, particularmente de los conceptos asociados a los problemas de mezclas y drenado de un tanque.

Incluir el OA en el proceso de enseñanza-aprendizaje, tanto en la modalidad presencial como virtual, permitió desarrollar en los estudiantes habilidades de autoaprendizaje debido al atributo de reunir en un sólo lugar aspectos como: conocimientos previos, contenidos, actividades interactivas de simulación y de autoevaluación, además de que pudieron ser accedidos en cualquier momento. Sin embargo, los autores de este trabajo no lo consideran como un sustituto de la labor docente sino como un recurso o estrategia adicional para, no sólo motivar al estudiante, sino para lograr una mayor comprensión desde un enfoque más integral del tema, sobre la base de la experimentación y visualización de los comportamientos de los modelados, a través de simulaciones y herramientas interactivas.

De los resultados de las encuestas realizadas a los estudiantes se aprecia que, en general, valoraron positivamente el OA, en cuanto a la utilidad, facilidad y practicidad. Así mismo, de los resultados de las evaluaciones parciales se evidencia que su uso resultó un apoyo didáctico valioso, permitiendo mejoras significativas en los aprendizajes de los estudiantes, reflejados en un mejor desempeño para el modelado, la interpretación y comunicación de la conducta dinámica de los problemas de mezcla y drenado del tanque planteados en diferentes contextos, como también para otros problemas clásicos de aplicación.

Finalmente, a modo de reflexión final sobre la experiencia realizada con el OA, damos cuenta de la importancia del uso de herramientas tecnológicas para la enseñanza de ED, fundamentalmente las de simulación, y que, aunque haya implicado un gran esfuerzo su diseño y elaboración, los resultados sumamente gratificantes compromete a la mejora del OA y al desarrollo de nuevas propuestas de innovación en función de las necesidades de los estudiantes.

\section{Referencias}

Camarena Gallardo, P. (2009). La Matemática en el Contexto de las Ciencias. Innovación Educativa, 9(46), 15-25.

Camarena Gallardo, P. (2015). La educación matemática en el siglo XXI: Conclusiones del presente y futuro. La educación matemática en el siglo XXI. Colección PAIDEIA SIGLO XXI, 319-341. Disponible en https://www.ipn.mx/assets/files/innovacion/docs/libros/la-educacion-matematica/conclusiones.pdf

Longmire, W. (2000). A Primer on Learning Objects. Recuperado de https://kennison.name/files/learning/learning-object-design.pdf 
Molina García, J.C. (2015, mayo). Aplicaciones de Ecuaciones Diferenciales mediadas por simulaciones interactivas. Ponencia presentada en la XIV CIAEM Conferencia Interamericana de Educación Matemática en Tuxtla Gutiérrez, Chiapas, México.

Orozco Rodríguez, C. M. (2017). Objetos de Aprendizaje con eXeLearning y GeoGebra para la definición y representación geométrica de operaciones con vectores y sus aplicaciones. Tesis doctoral. Universidad de Salamanca. Recuperado de http:// repositorio.grial.eu/handle/grial/772

Rodríguez Gallegos, R. (2012, octubre). Diseño de un curso de ecuaciones diferenciales alrededor de la modelación matemática y la simulación computacional. Conferencia del XII Congreso Nacional del Comité Mexicano de Investigación Educativa. Recuperado de https://www.researchgate.net/publication/275155714

Rodriguez, R. y Quiroz, S. (2014). Modelación y uso de tecnología en un curso de ecuaciones diferenciales. In book: Tecnología computacional en la enseñanza de las matemáticas. Recuperado de https://www.researchgate.net/publication/275155722_ modelacion_y_uso_de_tecnologia_en_un_curso_de_ecuaciones_diferenciales

Rosanigo, Z., Bramati, P., López,C., Bramati, S. y Cotti. C. (2014). TIC y Objetos de Aprendizaje en ambientes centrados en el alumno. Libro del XVI Workshop de Investigadores en Ciencias de la Computación (WICC 2014), 1089-1992. Recuperado de http://sedici.unlp.edu.ar/handle/10915/43877

Zill, D. y Wright, W. (2015). Ecuaciones Diferenciales con problemas con valores en la frontera. CENGAGE Learning. 


\section{Crecimiento Competencial en la Escuela y su Relación con Transferencia Digital en Proyectos de Huertos Escolares}

\section{Blanc, Sara}

ORCID http://orcid.org/0000-0001-6439-2902

\section{Benlloch-Dualde José V.}

ORCID http://orcid.org/0000-0002-4885-2806

\section{Grindei, Laura}

ORCID https://orcid.org/0000-0002-2742-7798

\section{Nájera, Inmaculada}

Fundación CajaMar Comunidad Valenciana,

Camino del Cementerio Nuevo, s/n, 46200 Paiporta (Valencia),

Apartado de Correos 194, Paiporta (Valencia) 


\title{
CRECIMIENTO COMPETENCIAL EN LA ESCUELA Y SU RELACIÓN CON TRANSFERENCIA DIGITAL EN PROYECTOS DE HUERTOS ESCOLARES
}

\author{
Blanc, Sara \\ Benlloch-Dualde José V. \\ Grindei, Laura \\ Nájera, Inmaculada
}

\section{Resumen}

¿Cómo pueden las universidades, empresas y centros de investigación participar hoy en día en la transferencia tecnológica y en la educación en valores relacionados con los Objetivos de Desarrollo Sostenible (ODS)? Actualmente, en las políticas para la incorporación de las competencias digitales en educación primaria y preuniversitaria se habla poco sobre la cooperación entre escuelas e instituciones de educación superior o investigadores del sector privado. Sin embargo, esta cooperación puede resultar muy beneficiosa cuando se trata de implementar una vía de transferencia de conocimiento y apoyo que permita introducir actividades en el aula que integren la competencia digital en la enseñanza en todas las materias y no solo en las Tecnologías de la Información y Comunicación (TIC). Este estudio describe un escenario de cooperación centrado en fomentar el desarrollo de competencias digitales en los estudiantes de primaria y secundaria en varios países europeos alineando la práctica con los Objetivos de Desarrollo y Sostenibilidad. La transferencia de conocimiento se basa en apoyar a los profesores en su formación personal y contribuir con herramientas TIC para que los docentes puedan diseñar actividades participativas, colaborativas e inclusivas que reducan la brecha entre las asignaturas del plan de estudios, la ciencia y la tecnología. Por lo tanto, el proyecto lidera una nueva experiencia aplicada a los huertos escolares. La cooperación para la transferencia propuesta podría representar un ejemplo para que otras instituciones de educación superior se involucren en la implementación de actividades que hará que sus estudiantes sean más sensibles al medio natural, más responsables de su consumo y más conscientes de la reducción y el reciclaje de residuos, y, al mismo tiempo, más "competentes digitalmente".

\section{Palabras clave}

CTI, TIC, STEAM, huertos escolares, asociaciones estratégicas. 


\section{Introducción}

El marco ERASMUS + lidera la transformación de la educación en Europa. Las alianzas estratégicas están enfocadas a la transferencia de conocimiento tanto en horizontal, al mismo nivel educativo, es decir, escuelas primarias y secundarias, formación profesional, educación de adultos o educación superior, como en vertical a través de la colaboración entre estos niveles.

Especialmente en tecnología, la implicación de los diferentes actores en la educación preuniversitaria podría representar ventajas significativas en los resultados de aprendizaje. La tecnología evoluciona rápidamente y cambia nuestra percepción del mundo. No es solo la forma de buscar información o charlar entre nuestros contactos, es la forma de conectar con la realidad y de cómo un conocimiento profundo en tecnología empodera a los más jóvenes para transformar su futuro. Que ellos sean parte activa de este cambio, y no meros espectadores, debe ser el componente transformacional en la educación en Ciencia, Tecnología e Innovación (CTI), tanto en la educación primaria como secundaria. Pero para conseguir esta transformación, las TIC deben introducirse en educación incentivando la creatividad colaborativa y su uso para la resolución de problemas de cierta dificultad.

Actualmente, la CTI es transversal a cualquier cambio en todos los sectores económicos y sociales. Algunas mega tendencias, como el uso eficiente de los recursos naturales y la energía o el cuidado del medio ambiente son claros ejemplos de la apuesta por la digitalización. La Organización para la Cooperación y el Desarrollo Económicos (OCDE) es consciente de la necesidad de acercar la tecnología a la sociedad para cerrar las brechas existentes que ralentizan el logro de los Objetivos de Desarrollo Sostenible, UNESCO (2017).

Cerrar esta brecha implica la adquisición de nuevas habilidades en los más jóvenes para garantizar una adaptación sectorial continua y liderada por la tecnología. Por ejemplo, los sistemas expertos, la inteligencia artificial o el aprendizaje automático son solo algunos de los temas que la OCDE aborda en el Science, Technology and Innovation Outlook (2018). Sin embargo, las habilidades digitales y tecnológicas son complejas y no siempre es fácil trabajarlas conjuntamente con los currículos escolares para propiciar el crecimiento individual del aprendizaje cognitivo, del aprendizaje socioemocional y del conductual. Sería más sencillo adquirir correctamente las habilidades digitales si el aprendizaje comienza en la escuela primaria y secundaria y a través de diversas asignaturas o materias obligatorias. Además, debido a la rápida evolución tecnológica, actores especializados como universidades o centros de investigación podrían tener un papel relevante en el cambio transformacional. La transferencia de conocimientos de las instituciones de educación superior a las escuelas puede centrarse en problemas específicos que sensibilicen a los estudiantes y les permitan encontrar soluciones innovadoras y creativas a los problemas por sí mismos.

En este artículo, presentamos los resultados de un ejemplo de cooperación entre instituciones de educación superior, escuelas de primaria y secundaria e investigadores del sector privado. En concreto, el trabajo se ha realizado bajo el marco de "eSGarden: Huertos Escolares para Futuros Ciudadanos" (2018). A través de su papel social de proveedores de conocimientos avanzados y promotores del progreso, las universidades y los centros de investigación sirven a su compromiso con la sociedad promoviendo la transferencia de conocimiento entre universidad, empresa y sociedad. 
Los objetivos del proyecto de estudio son dos:

- Establecer un marco de cooperación para apoyar a las escuelas en el desarrollo de actividades relacionadas con el huerto escolar basado en necesidades y beneficios para el alumnado. Este marco se basa en el desarrollo de competencias tecnológicas y la concienciación en el cuidado del entorno.

- Obtener estadísticas sobre la facilidad de incorporar mecanismos que faciliten la adquisición de competencias digitales en el marco Europeo de Competencia Digital (DigComp) en actividades de aprendizaje de asignaturas de cualquier tipo, no exclusivas de tecnología o informática.

\section{Descripción de la experiencia}

El proyecto ERASMUS+ eSGarden: Huertos Escolares para Futuros Ciudadanos de 2018 facilitó un estudio sobre el uso de huertos ecológicos como caso de estudio para poner en marcha prácticas innovadoras en el área digital, y siempre dentro del programa curricular. El proyecto conecta el mundo virtual y el real con el objetivo de motivar a los estudiantes a aprender. Comenzó con la creación de huertos escolares, que son espacios inclusivos del mundo real que facilitan un entorno inclusivo y adecuado para aplicar metodologías de aprendizaje práctico y trabajo en equipo.

Como resultado del proyecto, cada escuela participante en el estudio ha podido implementar un programa educativo que tiene como centro el huerto escolar. En este programa diversas asignaturas, profesores y cohortes del alumnado participan en actividades de aprendizaje diseñadas atendiendo a las necesidades específicas de los estudiantes de cada escuela.

La tecnología se incorpora en las actividades de forma progresiva y en diferentes espacios, no solo en el propio huerto. Las actividades se integran en las asignaturas curriculares para trabajar en paralelo contenidos específicos y competencias transversales de diferente índole, a la vez que los estudiantes adquieren conciencia y sensibilización por el entorno natural.

\section{Descripción del marco competencial}

Además de los Objetivos de Desarrollo Sostenible de UNESCO (2017), en cuanto a competencias digitales debemos referenciar el marco Europeo DigComp. Iniciado como proyecto en 2010, el Joint Research Centre (JRC), del servicio de ciencia y conocimiento de la Comisión Europea, desarrolló el marco europeo de competencias digitales, dirigido tanto a ciudadanos como a estudiantes. Desde la primera versión, denominada DigComp 1.0 (Ferrari, 2019), se ha convertido en un marco de referencia para comprender lo que significa ser digitalmente competente a nivel europeo. DigComp 2.0 (Vourikari, Punie, Carretero, van den Brande, 2016) actualizó la terminología y el modelo conceptual, y también introdujo ejemplos de implementación en diferentes niveles.

La versión actual, conocida como DigComp 2.1 (Carretero, Vourikari, Punie, 2017) (Redecker, 2017) está estructurada en cinco dimensiones. La Dimensión 1 divide la competencia digital en cinco áreas clave: i) Alfabetización en información y datos; 
ii) Comunicación y colaboración; iii) Creación de contenido digital; iv) Seguridad; y v) Resolución de problemas. La dimensión 2 define cada una de las 21 competencias a través de los resultados del aprendizaje. En la dimensión 3, estos resultados de aprendizaje se asignan en ocho niveles de adquisición, que van desde fundamentales hasta altamente especializados. Para completar el marco, la dimensión 4 y 5 debe ofrecer ejemplos de uso sobre la aplicabilidad de la competencia a diferentes propósitos. Son estos ejemplos de uso el objetivo de nuestro estudio.

\section{Bases de la cooperación entre agentes}

La transferencia de conocimiento se basa en la contribución al desarrollo de nuevas capacidades en el profesorado y personal de las escuelas. La escuela es conocedora de la potencial mejora de sus estudiantes en muchos aspectos. Sin embargo, para que los estudiantes crezcan en competencias, sus profesores también deben crecer bajo un ecosistema adecuado. El objetivo es acompañar a las escuelas en el camino, suministrándoles ideas y también recursos, pero dejando que sean las propias escuelas las dueñas de sus decisiones.

La cooperación entre actores en varias etapas de la siguiente manera:

Etapa O. Determinación del enfoque. Antes del inicio del proyecto cooperativo, la definición del enfoque debe considerar preocupaciones comunes y definir una estrategia que incluya un estudio de caso, un marco metodológico y competencial, así como la identificación de las herramientas más adecuadas.

Etapa 1. Definición de capacidades y establecimiento de la mejora. La definición de la estrategia reconoce las diferencias de los socios y sus capacidades, teniendo en cuenta sus necesidades y experiencia. Cuando nos centramos en un proyecto educativo, algunas decisiones son ad-hoc para la escuela y otras son replicables en otras escuelas. Por tanto, necesitamos valorar cuáles son las carencias específicas para abordar el proyecto, los desafíos que finalmente permearán en el programa educativo de la escuela y los resultados públicos del propio programa de cooperación.

Etapa 2. Proponer formas y recursos de interacción. Tanto la cooperación como la colaboración entre el propio profesorado necesitan recursos eficientes de comunicación en línea para intercambiar recursos multimedia, hojas guía, tutoriales, encuestas de valoración y otros materiales, además de gestionar la cooperación, intercambiar ideas, revisar propuestas o fijar objetivos.

Etapa 3. Análisis y diseño de planes de ruta. Algunos elementos a considerar son los siguientes:

- Análisis de cuestiones como el contexto socioeconómico, el nivel de escolaridad y las características de la comunidad escolar.

- Las fortalezas de la escuela para enfrentar el cambio garantizando su sostenibilidad una vez finalizado el proyecto y las debilidades de la escuela para anticipar posibles amenazas a los desarrollos de los proyectos.

- La selección de cohortes de trabajo. Una cohorte es un grupo objetivo bien definido de estudiantes o profesores que necesitan mejorar en algunas competencias. 
Etapa 4. Diseño y realización de las actividades de aprendizaje. Las actividades describen un proyecto educativo donde interactúan varios profesores y asignaturas a lo largo de un semestre o trimestre. Las actividades están formadas por tareas que tratan de alcanzar diferentes resultados de aprendizaje, reforzando conceptos umbrales y evitando la repetición de contenidos entre asignaturas.

Estado 5. Evaluación sobre el progreso y éxito de las actividades. Por ejemplo, para medir los impactos, resultados y beneficios individuales y generales para establecer nuevos desafíos futuros y conexiones de red entre los socios, la comunidad y los actores externos.

La Figura 1 muestra las interacciones del proyecto donde se desarrollan las 5 etapas descritas.

Las interacciones del proyecto deben favorecer la metodología central de PDAOC en la Figura 1: Planificar, Hacer, Actuar, Observar y Verificar. La mayoría de las actividades del proyecto combinan colaboración entre actores. Por ejemplo, destacamos la retroalimentación y la preparación de recursos para actividades de aprendizaje. Sin embargo, hay actividades propias de las escuelas y no deben estar influenciadas por actores externos. Tal es el caso de los planes de ruta y el diseño de actividades de aprendizaje donde la toma de decisiones en estas cuestiones sólo depende de las propias escuelas.

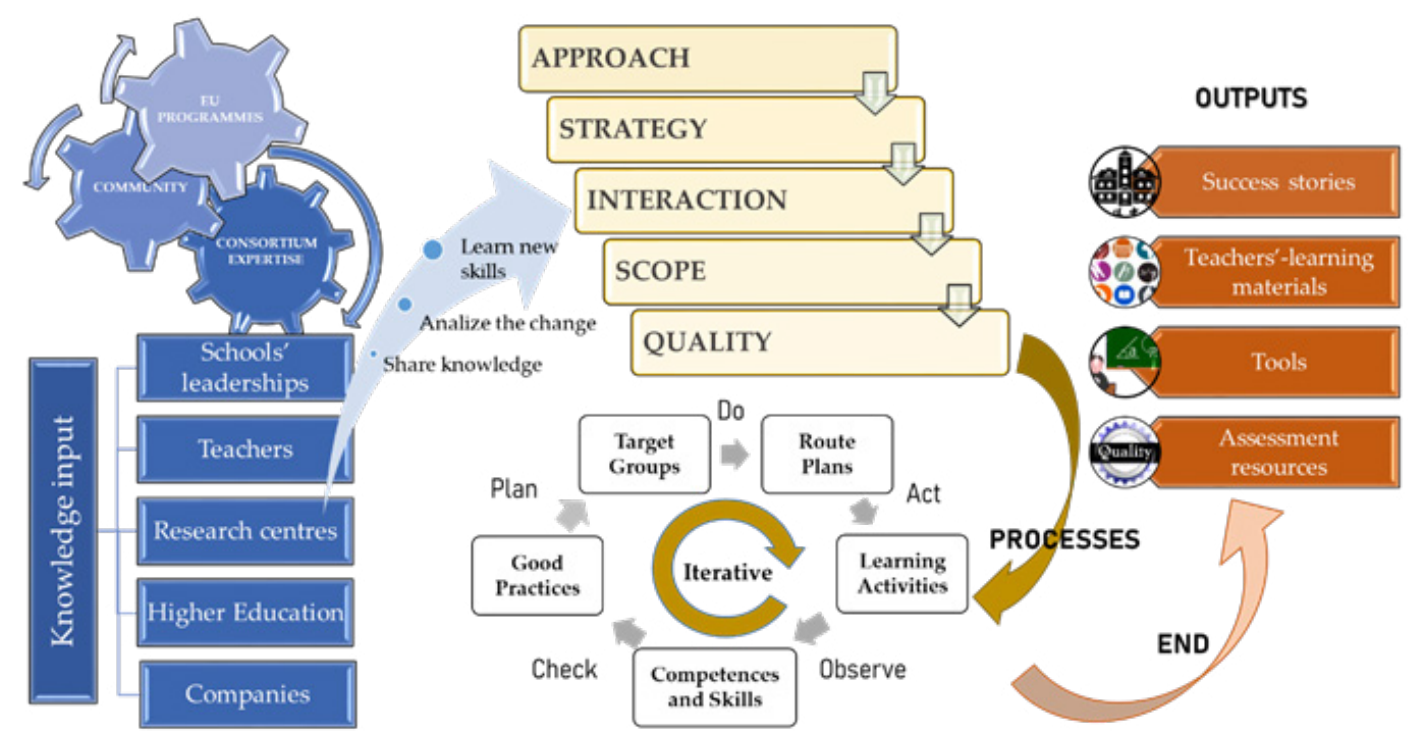


En la Figura 2 se muestra un ejemplo de acciones y quién interviene en ellas:

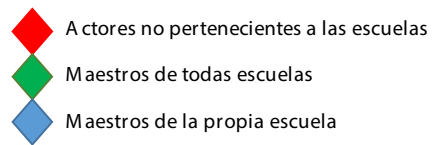

Diseñar el marco del programa educativo

Transmitir conocimiento para desarrollar nuevas habilidades digitales

Compartir ideas, buenas prácticas y experiencias

Diseñar e implementar actividades de aprendizaje

Crear materiales y recursos de transferencia

Preparar el huerto \& aprender a cultivar y mantener el huerto

Realizar tareas con el alumnado entre escuelas

Evaluar el impacto de la transferencia

Evaluar el aprendizaje del alumnado

Figura 2. Ejemplo de colaboración en acciones de la alianza.

\section{Resultados}

En el proyecto han participado cuatro escuelas de primaria y secundaria en España, Portugal, Eslovenia y Grecia. Cada escuela ha desarrollado un programa consistente en entre tres o cuatro actividades de aprendizaje. Cada actividad se ha implementado como un proyecto educativo. Todos los alumnos y alumnas de la misma edad en cada escuela participan en la actividad, con una muestra final de más de 300 estudiantes. Cada actividad implica, al menos, tres asignaturas del programa educativo curricular y tiene una duración de no menos de un trimestre.

Las edades de los estudiantes varían entre 7 y 16 años según la Figura 3.

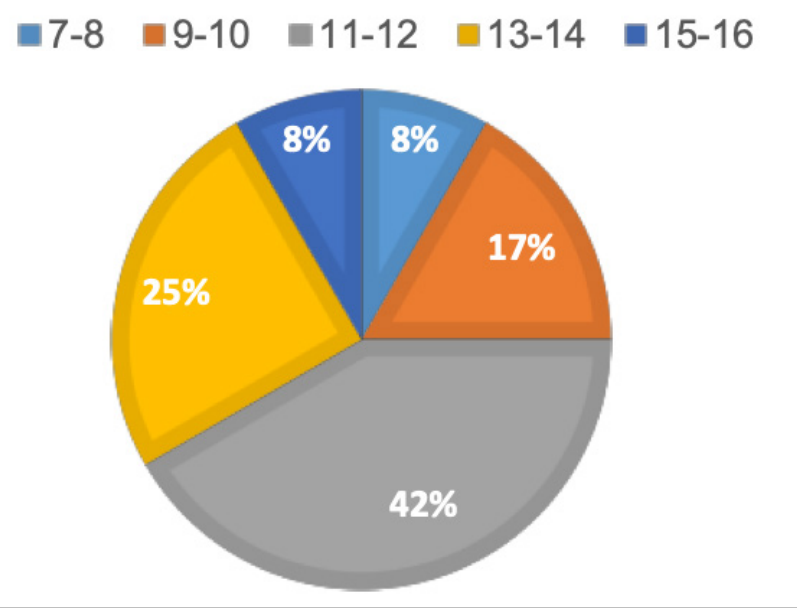

Figura 3. Edades de las cohortes participantes. 
En cuanto al número de resultados de aprendizaje curriculares trabajados por asignatura, vemos en la Figura 4 que, en general, son capaces de identificar más de 10 resultados que se pueden trabajar con cada actividad de las propuestas.

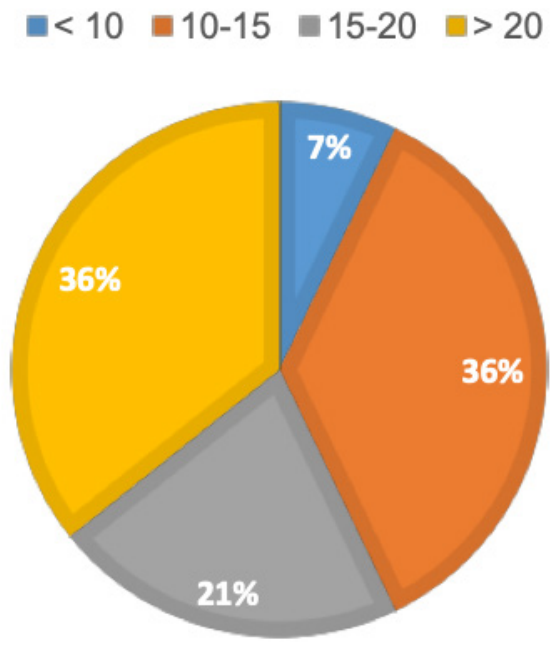

\section{Figura 4. Distribución según el número de resultados de aprendizaje curriculares esperados.}

La dificultad tecnológica de cada actividad propuesta varía, desde niveles sencillos donde se incorpora la tecnología en el uso de plataformas educativas, creación de videos o libros digitales, o el uso de aplicaciones educativas que favorecen las dinámicas de clase como son las conocidas Kahoot o Socrative.

Los niveles intermedios en cuanto el uso de tecnología incorporan el uso de apps educativas, impresión 3D y aplicaciones de modelado CAD en matemáticas, motores de búsqueda en Internet y reconocimiento básico de funcionalidades asociadas a los sistemas de almacenamiento de ficheros.

Finalmente, para realizar actividades más complejas, se incluye el diseño e implementación de blogs o la programación con kits educativos. Por ejemplo, la creación de un blog se puede definir como una cadena de tareas que comienza i) adquiriendo información o nuevo conocimiento utilizando buscadores o recursos educativos diseñados por organismos de confianza, ii) clasificando esta información, analizando o reflexionando sobre ella para una comprensión profunda y iii) finalmente, gestionando la información en sí misma para hacerla útil a otros, incluyendo el uso de herramientas de alojamiento y presentación.

Todas las actividades utilizan la tecnología como vehículo de trabajo y comunicación, mientras que la temática se relaciona con el huerto escolar, por ejemplo, buscar información, diseñar planos y hacer cálculos para planificar los espacios, construir cajas de compost, semilleros, recoger datos en una app o construir prototipos en 3D. Otras actividades están relacionadas con la nutrición, con la concienciación sobre el consumo del agua, la producción local, la huella de carbono o la geografía e historia relacionada con los espacios cultivables de la zona. 
Tras la implementación de las actividades, se realizó una encuesta al profesorado implicado para valorar la relación entre la actividad implementada y 52 objetivos en competencia digital. Los objetivos consultados están basados en la herramienta diseñada por el Instituto de Educación Esloveno descrito como recurso T15 en el recurso de la JRC "DigComp into Action: Get Inspired, Make it Happen" (Krajnc, 2018). Se han seleccionado 52 objetivos que abarcan los 5 bloques competenciales de DigComp y hemos considerado alcanzables con actividades desarrolladas en la escuela.

Las Tablas 1 a 5 muestran la valoración porcentual de las 14 actividades donde se indica con un 1 si el objetivo no se trabaja en absoluto y con un 5 si se trabaja completamente. Recordemos que cada actividad involucra diferentes asignaturas y tareas a lo largo de, al menos, un trimestre.

Tabla 1. Objetivos sobre el nivel de trabajo en la competencia digital "Information and Data Literacy"

\begin{tabular}{|c|c|c|c|c|c|c|}
\hline & OBJECTIVES & 1 & 2 & 3 & 4 & 5 \\
\hline \multirow{11}{*}{ 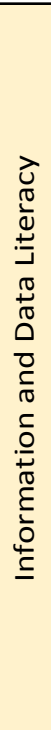 } & $\begin{array}{l}\text { They look for simple data online (picture, data). They can help themselves with different sources: } \\
\text { teacher, peer, e-material ...) }\end{array}$ & $0,0 \%$ & $0,0 \%$ & $7,1 \%$ & $14,3 \%$ & $78,6 \%$ \\
\hline & They know several search engines and they can find the desired information with different keywords. & $0,0 \%$ & $0,0 \%$ & $0,0 \%$ & $57,1 \%$ & $42,9 \%$ \\
\hline & $\begin{array}{l}\text { They choose meaningful keywords to search for information in search engines. They can assess how } \\
\text { well they chose the keywords they typed into a search engine. They correct keywords according to the } \\
\text { success / failure of the hits. They know that paid advertising pages are also included in the hits. }\end{array}$ & $0,0 \%$ & $0,0 \%$ & $21,4 \%$ & $35,7 \%$ & $42,9 \%$ \\
\hline & $\begin{array}{l}\text { They can obtain and compare data from at least two sources. They explain why the data found is not } \\
\text { always from reliable sources. }\end{array}$ & $0,0 \%$ & $0,0 \%$ & $28,6 \%$ & $42,9 \%$ & $28,6 \%$ \\
\hline & $\begin{array}{l}\text { They critically evaluate the data found online. They can identify resources that are more reliable. They } \\
\text { know they can't find all the data online. Based on the found data, they make relevant conclusions or } \\
\text { summaries. }\end{array}$ & $0,0 \%$ & $0,0 \%$ & $14,3 \%$ & $50,0 \%$ & $35,7 \%$ \\
\hline & $\begin{array}{l}\text { They have different strategies for distinguishing between reliable and unreliable data and sources. They } \\
\text { research, understand, (dis) take into account the different views of the authors of the found data. They } \\
\text { recognize prejudices, frauds and manipulations in the data found. They understand how search engine } \\
\text { algorithms affect the display of data. }\end{array}$ & $0,0 \%$ & $0,0 \%$ & $57,1 \%$ & $14,3 \%$ & $28,6 \%$ \\
\hline & They save a file, they find saved files on their device. & $0,0 \%$ & $0,0 \%$ & $7,1 \%$ & $7,1 \%$ & $85,7 \%$ \\
\hline & They can save the file to the selected folder on the device & $0,0 \%$ & $0,0 \%$ & $14,3 \%$ & $14,3 \%$ & $71,4 \%$ \\
\hline & They can save files to various digital locations (hard drive, USB, cloud ...) and also find them. & $0,0 \%$ & $0,0 \%$ & $14,3 \%$ & $7,1 \%$ & $78,6 \%$ \\
\hline & $\begin{array}{l}\text { They can organize / store files in a meaningful way so that others can easily find them. They can } \\
\text { suggest to others how to organize their data storage. They can save files in different formats. }\end{array}$ & $0,0 \%$ & $0,0 \%$ & $28,6 \%$ & $28,6 \%$ & $42,9 \%$ \\
\hline & They can search for files and folders using advanced search methods on a computer or in the clour & $0,0 \%$ & $7,1 \%$ & $42,9 \%$ & $21,4 \%$ & \\
\hline
\end{tabular}


Tabla 2. Objetivos sobre el nivel de trabajo en la competencia digital "Communication and Collaboration"

\begin{tabular}{|c|c|c|c|c|c|c|}
\hline \multirow{19}{*}{ 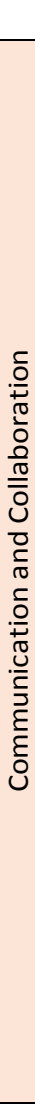 } & OBJECTIVES & 1 & 2 & 3 & 4 & 5 \\
\hline & In the online classroom, they can send messages to selected classmates and use the chat room. & $0,0 \%$ & $0,0 \%$ & $7,1 \%$ & $0,0 \%$ & $92,9 \%$ \\
\hline & They communicate independently with the help of various tools (e-mail, Skype, social networks ...) & $0,0 \%$ & $0,0 \%$ & $7,1 \%$ & $0,0 \%$ & $92,9 \%$ \\
\hline & $\begin{array}{l}\text { They publish and share content on various digital media (email, SMS, mms, online classrooms, cloud } \\
\text { services). }\end{array}$ & $0,0 \%$ & $0,0 \%$ & $7,1 \%$ & $0,0 \%$ & $92,9 \%$ \\
\hline & They share their opinions, data and content with peers in various formats, citing sources. & $0,0 \%$ & $0,0 \%$ & $14,3 \%$ & $35,7 \%$ & $50,0 \%$ \\
\hline & $\begin{array}{l}\text { They actively share their data, content, and knowledge in a way that benefits the community. They use } \\
\text { different data sharing tools that they choose according to their target audience. }\end{array}$ & $0,0 \%$ & $7,1 \%$ & $21,4 \%$ & $57,1 \%$ & $14,3 \%$ \\
\hline & They work with classmates on preparing documents in the cloud. & $0,0 \%$ & $7,1 \%$ & $21,4 \%$ & $14,3 \%$ & $57,1 \%$ \\
\hline & $\begin{array}{l}\text { They can use tools to track changes in a document and work with peers to create content together. They } \\
\text { can send an updated (or commented) documents. }\end{array}$ & $0,0 \%$ & $0,0 \%$ & $28,6 \%$ & $14,3 \%$ & $57,1 \%$ \\
\hline & They follow the rules of joint content creation and collaboration set by the teacher. & $0,0 \%$ & $0,0 \%$ & $0,0 \%$ & $42,9 \%$ & $57,1 \%$ \\
\hline & $\begin{array}{l}\text { They participate in creating content as a team member. They use collaboration tools, blogs, social } \\
\text { networks. }\end{array}$ & $0,0 \%$ & $0,0 \%$ & $14,3 \%$ & $21,4 \%$ & $64,3 \%$ \\
\hline & $\begin{array}{l}\text { They know which online tools allow them to interact with users. Through their work, they can take on an } \\
\text { active civic role (for example, discussions on civil topics in forums ...). They know how to discuss their } \\
\text { active citizenship with peers. }\end{array}$ & $0,0 \%$ & $7,1 \%$ & $14,3 \%$ & $35,7 \%$ & $42,9 \%$ \\
\hline & $\begin{array}{l}\text { They can actively participate in democratic initiatives in civil society (petitions, lobbying, parliament). } \\
\text { They can find and participate in a variety of communities, networks and social networks that meet their } \\
\text { civic interests and needs. They also know how to encourage others to act actively and responsibly. }\end{array}$ & $0,0 \%$ & $14,3 \%$ & $42,9 \%$ & $35,7 \%$ & $7,1 \%$ \\
\hline & $\begin{array}{l}\text { In various online environments, they behave responsibly and know how to react to inappropriate } \\
\text { behavior. }\end{array}$ & $0,0 \%$ & $7,1 \%$ & $0,0 \%$ & $50,0 \%$ & $42,9 \%$ \\
\hline & $\begin{array}{l}\text { They understand and follow a code of conduct in an online community. They know what is appropriate } \\
\text { and inappropriate behavior in different digital environments and communities. }\end{array}$ & $0,0 \%$ & $0,0 \%$ & $7,1 \%$ & $28,6 \%$ & $64,3 \%$ \\
\hline & They report inappropriate behavior from others. & $0,0 \%$ & $0,0 \%$ & $7,1 \%$ & $57,1 \%$ & $35,7 \%$ \\
\hline & They protect their password and do not share it with others. They know who to turn to if problems arise. & $0,0 \%$ & $0,0 \%$ & $7,1 \%$ & $42,9 \%$ & $50,0 \%$ \\
\hline & $\begin{array}{l}\text { They know that my actions are seen online by others, so they do not post or share content that may } \\
\text { harm them or others. }\end{array}$ & $0,0 \%$ & $0,0 \%$ & $0,0 \%$ & $28,6 \%$ & $71,4 \%$ \\
\hline & $\begin{array}{l}\text { They take responsibility for their actions online and control the information about themselves that others } \\
\text { can see. They understand that their actions affect others as well. }\end{array}$ & $0,0 \%$ & $0,0 \%$ & $0,0 \%$ & $42,9 \%$ & $57,1 \%$ \\
\hline & $\begin{array}{l}\text { They can check their digital footprint. They can check the information about themselves that can be } \\
\text { found online. }\end{array}$ & $0,0 \%$ & $7,1 \%$ & $28,6 \%$ & $21,4 \%$ & $42,9 \%$ \\
\hline
\end{tabular}

Tabla 3. Objetivos sobre el nivel de trabajo en la competencia digital "Safety"

\begin{tabular}{|c|c|c|c|c|c|c|}
\hline \multicolumn{2}{|r|}{ OBJECTIVES } & 1 & 2 & 3 & 4 & 5 \\
\hline \multirow{8}{*}{ 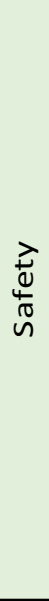 } & They know there is a danger in using technologies that can affect the performance of their digital device. & $0,0 \%$ & $0,0 \%$ & $7,1 \%$ & $35,7 \%$ & $57,1 \%$ \\
\hline & $\begin{array}{l}\text { They know that their device may be used by unauthorized persons. They know how to protect their } \\
\text { device (install an antivirus program and create a strong password). }\end{array}$ & $0,0 \%$ & $0,0 \%$ & $14,3 \%$ & $42,9 \%$ & $42,9 \%$ \\
\hline & $\begin{array}{l}\text { They recognize different types of dangers (intrusions, infections, theft of personal data, violence ...) } \\
\text { when using digital technologies. They understand appropriate steps to protect their devices from } \\
\text { malicious code and fraud. They know how to update my operating system and applications. }\end{array}$ & $0,0 \%$ & $0,0 \%$ & $28,6 \%$ & $50,0 \%$ & $21,4 \%$ \\
\hline & $\begin{array}{l}\text { They can create a secure password according to the given rules and they also change it regularly. The } \\
\text { username they create does not reveal their identity. }\end{array}$ & $0,0 \%$ & $0,0 \%$ & $14,3 \%$ & $42,9 \%$ & $42,9 \%$ \\
\hline & $\begin{array}{l}\text { They make prudent decisions when accepting the terms of use of online services regarding the use of } \\
\text { the personal data third parties collect. They advise others on how to protect their privacy. }\end{array}$ & $0,0 \%$ & $7,1 \%$ & $28,6 \%$ & $42,9 \%$ & $21,4 \%$ \\
\hline & $\begin{array}{l}\text { They know that using digital devices for too long is bad for their health. They understand they must } \\
\text { control the time of use. }\end{array}$ & $0,0 \%$ & $0,0 \%$ & $21,4 \%$ & $14,3 \%$ & $64,3 \%$ \\
\hline & $\begin{array}{l}\text { They don't print unless absolutely necessary. They know that the use of technologies can have a } \\
\text { negative impact on the environment. }\end{array}$ & $0,0 \%$ & $0,0 \%$ & $0,0 \%$ & $57,1 \%$ & $42,9 \%$ \\
\hline & $\begin{array}{l}\text { They distinguish between different levels of environmental impact of digital technologies. They know how } \\
\text { to choose digital equipment that least burdens the environment. }\end{array}$ & $0,0 \%$ & $7,1 \%$ & $14,3 \%$ & $35,7 \%$ & $42,9 \%$ \\
\hline
\end{tabular}


Tabla 4. Objetivos sobre el nivel de trabajo en la competencia digital "Digital Content Creation"

\begin{tabular}{|c|c|c|c|c|c|c|}
\hline \multicolumn{2}{|r|}{ OBJECTIVES } & 1 & 2 & 3 & 4 & 5 \\
\hline \multirow{7}{*}{ 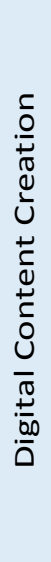 } & They can create simple content (image and text). & $0,0 \%$ & $0,0 \%$ & $0,0 \%$ & $0,0 \%$ & $100,0 \%$ \\
\hline & $\begin{array}{l}\text { They independently choose software or tools that meet their needs for creating digital content. They } \\
\text { understand the possibilities and limitations of different digital formats. }\end{array}$ & $0,0 \%$ & $0,0 \%$ & $0,0 \%$ & $50,0 \%$ & $50,0 \%$ \\
\hline & $\begin{array}{l}\text { They change digital content (text, image, web pages) and take into account the contribution of the } \\
\text { authors. }\end{array}$ & $0,0 \%$ & $0,0 \%$ & $7,1 \%$ & $57,1 \%$ & $35,7 \%$ \\
\hline & $\begin{array}{l}\text { They use own materials or the materials of others in creating new content. They use medium-advanced } \\
\text { content editing and reshaping features. They know how to guide others in transforming content. }\end{array}$ & $0,0 \%$ & $0,0 \%$ & $28,6 \%$ & $50,0 \%$ & $21,4 \%$ \\
\hline & They know different databases and resources that they can combine and reuse. & $0,0 \%$ & $21,4 \%$ & $21,4 \%$ & $28,6 \%$ & $28,6 \%$ \\
\hline & $\begin{array}{l}\text { They recognize content that is protected (by the Copyright and Related Rights Act or CC). They know } \\
\text { that copying or disseminating the content of others without the permission of the author or citing the } \\
\text { source is criminal. }\end{array}$ & $0,0 \%$ & $0,0 \%$ & $35,7 \%$ & $35,7 \%$ & $28,6 \%$ \\
\hline & $\begin{array}{l}\text { They understand copyright protection and licensing rules when using digital content. They know under } \\
\text { what conditions it is possible to use copyrighted content (even without permission). They can explain } \\
\text { what rights they have as an author and what obligations they have as a user of copyrighted content. }\end{array}$ & $0,0 \%$ & $0,0 \%$ & $35,7 \%$ & $35,7 \%$ & $28,6 \%$ \\
\hline
\end{tabular}

Tabla 5. Objetivos sobre el nivel de trabajo en la competencia digital "Problem Solving"

\begin{tabular}{|c|c|c|c|c|c|c|}
\hline & OBJECTIVES & 1 & 2 & 3 & 4 & 5 \\
\hline \multirow{8}{*}{$\begin{array}{l}00 \\
\stackrel{0}{2} \\
\frac{1}{2} \\
0 \\
\frac{\varepsilon}{0} \\
\frac{0}{0} \\
\frac{0}{0} \\
0\end{array}$} & $\begin{array}{l}\text { They know the difference between hardware and software. They can assess whether there is a hardware } \\
\text { or software error in their device and notify an adult. }\end{array}$ & $0,0 \%$ & $7,1 \%$ & $21,4 \%$ & $21,4 \%$ & $50,0 \%$ \\
\hline & $\begin{array}{l}\text { They know that with the help of digital tools they can do some tasks faster or better. They can use at least } \\
\text { one program in solving a task. }\end{array}$ & $0,0 \%$ & $7,1 \%$ & $0,0 \%$ & $28,6 \%$ & $64,3 \%$ \\
\hline & They can solve tasks using digital tools (at least one program) in groups guided by the teacher. & $0,0 \%$ & $0,0 \%$ & $14,3 \%$ & $14,3 \%$ & $71,4 \%$ \\
\hline & They can solve tasks using digital tools (at least one program) individually at home and in the school. & $0,0 \%$ & $0,0 \%$ & $7,1 \%$ & $28,6 \%$ & $64,3 \%$ \\
\hline & $\begin{array}{l}\text { They understand the possibilities and limitations of digital tools. They can advise others in choosing the } \\
\text { most appropriate digital tools (in their level). }\end{array}$ & $0,0 \%$ & $0,0 \%$ & $21,4 \%$ & $50,0 \%$ & $28,6 \%$ \\
\hline & $\begin{array}{l}\text { They know technology gives them access to different services. They can find the basic data of some } \\
\text { services (for example, working hours of libraries, dispensaries, location of hospitals ...) }\end{array}$ & $0,0 \%$ & $0,0 \%$ & $21,4 \%$ & $50,0 \%$ & $28,6 \%$ \\
\hline & $\begin{array}{l}\text { They know that data for some services (banks, hospitals, local businesses) is available online. They can } \\
\text { find this information independently. They help others find this information. }\end{array}$ & $0,0 \%$ & $7,1 \%$ & $14,3 \%$ & $35,7 \%$ & $42,9 \%$ \\
\hline & $\begin{array}{l}\text { They understand that technologies make it easier to access online services. They know which services } \\
\text { are important to them. They can perform basic operations on certain services (for example: check the } \\
\text { balance on the bank account, extend the books in the library ...) }\end{array}$ & $7,1 \%$ & $7,1 \%$ & $0,0 \%$ & $50,0 \%$ & $35,7 \%$ \\
\hline
\end{tabular}

Destacando aquellos objetivos que tienen una desviación hacia el 3 o menor, en la Tabla 1 destacamos la respuesta sobre la capacidad de diferenciar fuentes fiables o no. También destacamos el objetivo relativo a la búsqueda y gestión de archivos. En la Tabla 2 destacamos la referencia a la participación ciudadana y democrática, y finalmente, en la Tabla 4 destacamos el objetivo relacionado con el conocimiento de bases o fuentes de datos.

En general, los indicadores menos valorados no responden a aprendizajes que representen una dificultad excepcional. Se podrían integrar en las actividades planteadas con alguna tarea específica y guiada por el profesorado. Por tanto, vemos que es posible diseñar actividades en asignaturas curriculares que fomenten el aprendizaje en al menos 52 aspectos de la competencia digital. 


\section{Discusión y conclusiones}

El proyecto descrito representa una iniciativa para la colaboración entre diferentes agentes en un marco de apoyo a las escuelas con el fin de diseñar programas educativos que favorezcan el aprendizaje en la competencia digital.

La tecnología se introduce en las actividades del alumnado, a modo de proyectos educativos, donde colaboran diferentes asignaturas alrededor de una temática. En el caso del proyecto descrito, esa temática son los huertos escolares y, por ende, el medioambiente, la conservación, el consumo sostenible, la nutrición y el reciclaje.

En esta experiencia hemos visto como sí es posible diseñar actividades formativas alineadas con los objetivos curriculares de diferentes materias y donde se trabajen al menos 52 objetivos relativos a la competencial digital. Este resultado debe animar a las escuelas a facilitar un cambio transformacional en las metodologías educativas que favorezca la adquisición de la competencia digital y otros valores ciudadanos a través de las propias asignaturas curriculares. Así como a agentes como las universidades o los centros de investigación, a apoyar la transferencia del conocimiento a fin de que los avances en la tecnología y la ciencia lleguen a los niños y jóvenes en las escuelas.

Este trabajo está cofinanciado por el programa Erasmust de la Unión Europea. El contenido de este artículo es responsabilidad exclusiva de los autores y ni la Comisión Europea, ni el Servicio Español para la Internacionalización de la Educación (SEPIE) son responsables del uso que pueda hacerse de la información aquí difundida.

\section{Referencias}

UNESCO (2017). Education for Sustainable Development Goals. Learning Objectives. Recuperado de https://www.iau-hesd.net/sites/default/files/documents/247444e. pdf (accedido el 24 de junio 2021).

OECD Science, Technology and Innovation Outlook (2018). Adapting to technological and societal disruption. Recuperado de https://www.oecd.org/sti/Brochure_ STIO_2018_web.pdf (accedido el 24 de junio 2021).

"eSGarden: Huertos Escolares para Futuros Ciudadanos" (2018). EU project website: https://ec.europa.eu/programmes/erasmus-plus/projects ERASMUS+ KA201. Number: 2018-1-ESO1-KA201-050599 (accedido el 24 de junio 2021).

Ferrari, A. (2013). DigComp: A framework for developing and understanding digital competence in Europe. Punie, Y., Bre ko, B.N., Eds.; Publications Office of the European Union: Luxembourg.

Vourikari, R.; Punie, Y.; Carretero, S. van den Brande, L. (2016). DigComp 2.0: The Digital Competence Framework for Citizens. Update Phase 1: The Conceptual Reference Model. Publications Office of the European Union: Luxembourg. 
Carretero, S.; Vuorikari, R. and Punie, Y. (2017). DigComp 2.1: The Digital Competence Framework for Citizens with eight proficiency levels and examples of use, Publications Office of the European Union: Luxembourg.

Redecker, C., (2017). European framework for the Digital Competence of Educators: DigCompEdu. Punie, Y. Ed.; Publications Office of the European Union: Luxembourg.

Krajnc, R. (2018) T15 Indicator describing individual digital competence. The Students Competence Framework by the Slovenian Education Institute. Incluido en el libro de Kluzer, S. y Pujol Priego, L. del Joint Research Centre "DigComp into Action: Get Inspired, Make it Happen". Recuperado de https://docs.google.com/spreadsheets/ d/116fOc-D3KK945ZC5nMJDHaBDm2kNhpJ25Ucl1PPM2BE/edit\#gid=1097700938 (accedido el 24 de junio de 2021). 


\section{Las Estrategias Metacognitivas y Socioafectivas para el Aprendizaje Autodirigido y Colaborativo de la Traducción Especializada a Distancia}

\section{Gava, lleana Yamina}

Universidad Nacional de Córdoba, yamina.gava@unc.edu.ar 


\title{
LAS ESTRATEGIAS METACOGNITIVAS Y SOCIOAFECTIVAS PARA EL APRENDIZAJE AUTODIRIGIDO Y COLABORATIVO DE LA TRADUCCIÓN ESPECIALIZADA A DISTANCIA
}

\author{
Gava, lleana Yamina \\ Universidad Nacional de Córdoba, \\ yamina.gava@unc.edu.ar
}

\section{Resumen}

Los cambios tecnológicos y socioeconómicos suceden a una velocidad vertiginosa y tienen un gran impacto en la educación. El nuevo paradigma educativo, impulsado en gran medida por estas transformaciones, otorga mayor centralidad al aprendizaje estratégico, autodirigido y colaborativo. Esto representa desafíos para la formación de traductores y se evidencian áreas de vacancia en el estudio de los modos de aprender en la virtualidad (Alonso y Calvo, 2015; Gava y Sestopal, 2015; Mansilla y González-Davies, 2017; Zou, 2015; entre otros). En este trabajo se presentan algunos resultados parciales obtenidos en el marco de una tesis doctoral cuyo objetivo principal es el estudio del aprendizaje estratégico de la traducción en línea. El corpus de estudio se conformó por producciones de estudiantes de cuatro cursos de posgrado de traducción especializada a distancia en una universidad argentina. Se aplicó una metodología cualitativa con un enfoque inductivo-deductivo en combinación con procedimientos de la Teoría Fundamentada (Strauss y Corbin, 2002), lo cual permitió caracterizar estrategias metacognitivas y socioafectivas utilizadas para el aprendizaje de la traducción. Los resultados muestran que la aplicación de estrategias específicas coadyuva al desarrollo de la competencia traductora y facilita el empoderamiento individual y grupal. Se evidencia también la relevancia de su enseñanza explícita. Sobre la base de estos hallazgos, se esbozó una taxonomía de estrategias para el aprendizaje de la traducción. Como corolario, se propone un enfoque pedagógico centrado en el aprendizaje estratégico, lo cual representaría un aporte de utilidad para la didáctica de la traducción en la actualidad.

\section{Palabras clave}

Estrategias de aprendizaje metacognitivas, estrategias de aprendizaje socioafectivas, traducción especializada, educación a distancia. 


\section{Introducción}

La educación en el nivel superior se vincula con la práctica profesional. En el campo de la traducción es posible observar que los cambios tecnológicos y socioeconómicos actuales no solo benefician la labor del traductor profesional, sino que también tienen un impacto positivo en la formación de traductores ya que brindan un abanico de nuevos escenarios y posibilidades didácticas y formativas. No obstante, estas transformaciones y posibilidades plantean desafíos y generan tensiones entre los actores involucrados en el proceso educativo, sus necesidades y contextos, todo lo cual ha contribuido a ampliar la agenda investigativa en estas últimas décadas.

En los contextos de educación a distancia (EaD) en nuestro país, tal como sugieren González y Martín (2017), es necesario "recorrer nuevos caminos, entender y estar atentos a estas tensiones y ver las oportunidades y desafíos en sus contextos de forma de construir una oferta heterogénea, con prácticas contextualizadas, desafiantes, atentas a su territorio" (p. 10). En el ámbito específico de la formación de traductores, la literatura evidencia áreas de vacancia, tanto a nivel nacional como internacional, en cuanto a la investigación sobre el uso didáctico de las TIC para el aprendizaje estratégico, autodirigido y colaborativo (Alonso y Calvo, 2015; Gava y Sestopal, 2015; Mansilla y González-Davies, 2017; Zou, 2015, entre otros). Estos y otros estudios ponen de manifiesto el amplio potencial y las características multifacéticas de las propuestas que incluyen el uso de las tecnologías digitales para el aprendizaje estratégico de la traducción. Lo cierto es que mientras más valor se le asigne al aprendizaje a lo largo de la vida y más relevantes resulten las habilidades y estrategias que el mundo técnico-profesional de la era digital necesita, más imperioso será preguntarnos cómo se adquieren esas habilidades y estrategias. Es por ello que resultan relevantes las metodologías de enseñanza que permitan que los estudiantes actúen sobre su propio aprendizaje e impulsen el desarrollo de estrategias específicas de utilidad para futuras situaciones profesionales.

El estudio y la aplicación de estrategias de aprendizaje han cobrado relevancia en la pedagogía general desde hace algunas décadas; sin embargo, en el campo de la didáctica de la traducción se consideran incipientes. No se cuenta aún con clasificaciones de estrategias lo suficientemente detalladas que contemplen de manera específica el aprendizaje de la traducción (Hurtado, 2011). Las clasificaciones de estrategias de aprendizaje de la traducción surgen de diversas áreas. Según Bergen (2009), se ha comprobado que las estrategias de aprendizaje de lenguas extranjeras son aplicables a la formación en traducción porque este proceso implica también el dominio de una (o más) lengua extranjera. En esta investigación abordamos las estrategias de aprendizaje de la traducción mediante descripciones basadas en datos empíricos, lo cual podría contribuir a la configuración de clasificaciones para esta área en particular. Para clasificar estas estrategias se tomarán como punto de partida la taxonomía para la EaD propuesta por Valenzuela (2000), las clasificaciones de estrategias indirectas (metacognitivas y socioafectivas) diseñadas por Oxford (1990, 2011, 2017), la taxonomía de estrategias de aprendizaje metacognitivas y socioafectivas de O'Malley y Chamot (1994), además de otros aportes en el área de la pedagogía general (Herrera-Torres y Lorenzo-Quiles, 2009; Lachat Leal; 2008, Llano; 2007) y la traductología que exploran la efectividad del desarrollo de habilidades metacognitivas y socioafectivas en la formación de traductores (Amirian y Baghiat, 2013; Angelone,2010; Bergen, 2009; Fernández y Zabalbeascoa, 2011; Mansilla y González-Davies, 2017; Zou, 2015). 
Nuestro estudio de las estrategias de aprendizaje de la traducción en línea parte de un marco teórico socioconstructivista (Kiraly, 2014; Vygotsky, 1978), que se nutre de enfoques para la construcción colaborativa del conocimiento (Bruffee, 1999) y el uso educativo de las tecnologías digitales (Área y Adell, 2009; Chan Nuñez, 2016; Lion, 2006; Pym, 2013, entre muchos otros). Estos enfoques aportan conceptualizaciones clave, entre ellas el concepto fundamental de "estrategias de aprendizaje" en tanto conjuntos de habilidades y mecanismos cognitivos, metacognitivos y socioafectivos para la resolución de tareas específicas que pueden ser mejorados por medio de la enseñanza explícita y conducen al aprendizaje eficaz.

Se aplicó un diseño investigativo cualitativo, exploratorio y descriptivo, que parte de las siguientes preguntas: 1.a) ¿Se aplican estrategias metacognitivas y socioafectivas para el aprendizaje de la traducción especializada en los cursos de posgrado a distancia objeto de este estudio?; 1.b) Si esto ocurre, ¿qué estrategias específicas se observan?; 2) ¿Cuál es la perspectiva de los docentes y discentes sobre el aprendizaje estratégico? 3.a) ¿Qué recursos didácticos que promueven el aprendizaje estratégico de la traducción?; 3.b) Sobre esta base, ¿qué dinámicas y recursos sería recomendable aplicar a fin de facilitar el uso de estrategias metacognitivas y socioafectivas en la formación de traductores en la virtualidad? Para responder a estas preguntas, se propusieron los siguientes objetivos: 1) caracterizar los tipos de estrategias metacognitivas y socioafectivas para el aprendizaje de la traducción observadas en las aulas virtuales de los cursos objeto de este estudio; 2) examinar la perspectiva de los docentes y discentes sobre el aprendizaje estratégico ; y 3) realizar un análisis crítico de las dinámicas y recursos pedagógicos que facilitan el uso de estrategias metacognitivas y socioafectivas a fin de proponer lineamientos para potenciar el aprendizaje estratégico de la traducción especializada a distancia.

El presente trabajo da cuenta de algunos resultados parciales en el marco de una tesis doctoral sobre el aprendizaje estratégico de la traducción en línea.

\section{Método}

\section{Descripción del contexto y de los participantes}

Los cursos objeto de este estudio son cuatro y forman parte de las carreras de posgrado a distancia de las Especializaciones en Traducción de la Facultad de Lenguas (UNC). Estos cursos se dictan a través de la plataforma Moodle. Dos de ellos corresponden a la Especialización en Traducción Científica y Técnica y los otros dos, a la Especialización en Traducción Jurídica y Económica. Dada la variedad de áreas temáticas y comunicativas de estas asignaturas, se consideró que esta selección sería representativa del objeto de estudio y aportaría datos suficientes para la conformación del corpus. Los participantes de las entrevistas y encuestas fueron los estudiantes (50 en total) que cursaron las asignaturas y los docentes (4 profesores a cargo y 4 tutores) de cada curso. Todos participaron de manera voluntaria.

\section{Instrumentos}

Los datos que conforman el corpus provienen de dos fuentes principales. Por un lado, se examinaron los textos escritos que integran las clases virtuales de los cuatro cursos antemencionados. Para esto, se archivaron en documentos editables las 
tareas de traducción y las interacciones entre docentes y alumnos en los foros y wikis las aulas virtuales examinadas en este estudio. Estos datos proporcionaron las unidades de análisis para el estudio del uso de estrategias de aprendizaje de la traducción especializada.

Para la triangulación de los resultados, al finalizar el cursado de cada asignatura se entrevistó a los docentes y se administró una encuesta a los estudiantes. Como es sabido, las entrevistas y encuestas proporcionan un medio para explorar las perspectivas de los participantes, ya sea que se utilicen como único instrumento de investigación o en combinación con otros instrumentos y tipos de datos. En este estudio, se utilizó una entrevista semiestructurada (Dörnyei, 2007) -cuyo uso está ampliamente difundido en el campo de la lingüística aplicada- con preguntas orientadas a conocer sus precepciones acerca del rendimiento de los alumnos en relación con el aprendizaje estratégico, autodirigido y colaborativo. En cuanto a las encuestas, creemos importante señalar que, a diferencia de su aplicación en el campo de la investigación cuantitativa, "el tipo de encuesta cualitativa no tiene como objetivo establecer las frecuencias, promedios u otros parámetros, sino determinar la diversidad de algún tema de interés dentro de una población dada" (Jansen, 2013, p. 43). Es por ello que el propósito de las encuestas utilizadas en este estudio fue indagar sobre la perspectiva de los estudiantes en cuanto a las estrategias de aprendizaje aplicadas.

\section{Procedimiento}

Se utilizó el método de análisis inductivo-deductivo de nueve pasos propuesto por Hatch (2002) en combinación con los procedimientos de muestreo teórico, codificación, categorización de los datos y comparación constante sugeridos por la Teoría Fundamentada (Strauss y Corbin, 2002). Este diseño metodológico propició la conformación del corpus, el examen profundo de los datos y la descripción detallada de las categorías que emergieron de este estudio. En la tabla siguiente se sintetizan las etapas de investigación.

METODOLOGÍA DE ANÁLISIS DE LOS DATOS

ETAPA 1: Muestreo teórico: Conformación de las unidades de análisis a partir de conceptos sensibilizadores del marco teórico de la investigación

ETAPA 2: Codificación abierta: Creación de dominios temáticos (categorías y subcategorías de estrategias de enseñanza y aprendizaje)

ETAPA 3: Codificación axial: Identificación de patrones recurrentes y esporádicos

ETAPA 4: Revisión de las categorías y subcategorías identificadas en la etapa 2

ETAPA 5: Codificación selectiva: Integración, revisión y selección de categorías y subcategorías de estrategias según su representatividad

ETAPA 6: Reagrupamiento y redefinición de (algunas) categorías Selección de unidades de análisis para la conformación del corpus final

ETAPA 7: $\quad$ Síntesis descriptiva de los resultados

ETAPA 8: Diseño de la taxonomía de estrategias de enseñanza y aprendizaje

ETAPA 9: Selección de ejemplos del corpus para la descripción de los resultados 
Según se ilustra en la tabla que antecede, en la primera etapa se procedió a construcción del muestreo teórico y la codificación inicial. El muestreo teórico consistió en la recolección de datos que permitiesen desarrollar las conceptualizaciones y caracterizaciones que se propusieron alcanzar en esta investigación. Para esto, se establecieron marcos de análisis o unidades de sentido en las producciones de los estudiantes en el aula virtual. Se constituyeron unidades con características susceptibles de análisis, conformadas por oraciones o conjunto de dos o tres oraciones. Estos marcos se identifican a partir de los conceptos sensibilizadores interrelacionados (Patton, 2002), es decir, los conceptos teóricos en los que se fundamenta este estudio: el socioconstructivismo, el uso didáctico de las TIC y la construcción del conocimiento mediante el aprendizaje estratégico, autodirigido y colaborativo.

Seguidamente, se procedió a la codificación abierta de los datos. Es así que, en la segunda etapa, se crearon los dominios temáticos según las relaciones semánticas identificadas en las unidades de sentido. Se agruparon los datos en categorías y subcategorías preliminares de estrategias de aprendizaje de la traducción especializada. Luego se realizó la codificación axial, en la cual "las categorías se relacionan con sus subcategorías para formar unas explicaciones más precisas y completas sobre los fenómenos" (Strauss y Corbin, p. 135). Así pues, mediante el método de comparación constante propuesto por la Teoría Fundamentada, la tercera etapa de análisis consistió en comparar y contrastar las unidades de sentido para identificar patrones recurrentes y esporádicos. En la cuarta etapa, se realizó una revisión de las categorías y subcategorías creadas en la segunda etapa, lo que implicó modificar algunas de estas clasificaciones. La quinta etapa de análisis se centró en la codificación selectiva de los datos. Esta fase interpretativa de la investigación consistió en "integrar y refinar las categorías" (Strauss y Corbin, p. 158). Como resultado de este proceso, se descartaron algunas unidades de análisis y se incluyeron otras más representativas. En la sexta etapa, se redefinieron algunas de las categorías creadas, lo que contribuyó a una mayor precisión de las descripciones de cada subcategoría.

En la séptima etapa, el análisis se centró en los temas recurrentes o hilos conductores que proporcionasen un sentido de unidad y coherencia general a las clasificaciones de estrategias de enseñanza y aprendizaje creadas en este estudio. Una vez identificados los temas recurrentes, la octava etapa consistió en el diseño de la representación final para lo cual se creó una taxonomía descriptiva de estrategias metacognitivas y socioafectivas para el aprendizaje de la traducción especializada en entornos virtuales. En la última etapa, se seleccionaron ejemplos representativos de las estrategias incluidas en la taxonomía creada, que sirven de sustento para la interpretación de los resultados.

\section{Resultados}

\section{Clasificación de las estrategias de aprendizaje de la traducción}

En cuanto al primer objetivo de investigación, los resultados revelan la aplicación de estrategias específicas. Las estrategias metacognitivas identificadas se agrupan en seis categorías principales: atención selectiva, automonitoreo, procesos evaluativos, planificación, pensamiento divergente y reflexión, según se detalla en la tabla a continuación. 
Estrategias metacognitivas de aprendizaje de la traducción especializada en EaD

Categorías

Estrategias

de atención selectiva

Estrategias de automonitoreo

Estrategias de planificación

Estrategias de pensamiento divergente

Estrategias de reflexión

\section{Subcategorias}

- Identificación del objetivo de la tarea de aprendizaje de la traducción (o la manifestación de la necesidad de conocer dicho objetivo), basada en Oxford (1990, 2017)

- Identificación y valoración de la relevancia de la información en relación con el proceso traductor o la tarea de aprendizaje de la traducción, basada en Lachat Leal (2008).

- Automonitoreo del proceso traductor en la consecución de la tarea, basada en Bergen (2009) y "autorregulación del aprendizaje" de Oxford (1990, 2017); Llano (2007).

- Identificación de necesidades de aprendizaje

- Reconocimiento de las propias capacidades (fortalezas) en relación con la tarea o el proceso traductor.

- Reconocimiento de las propias limitaciones (debilidades) en relación con la tarea o el proceso traductor.

- Autocorrección, basada en O Malley y Chamot (1994), Oxford (1990, 2017), Valenzuela (2000).

- Identificación de aciertos (éxitos) en las tareas de aprendizaje, basada en Oxford (2017), Valenzuela (2000).

- Reconocimiento de la guía del docente (mediante la aceptación de la retroalimentación)

- Gestión de la tarea de traducción según las pautas, basada en "planificación de la tarea" de O Malley y Chamot (1994), Oxford $(1990,2017)$ y Valenzuela (2000).

- Gestión del tiempo y los recursos para la consecución de las tareas, basada en Valenzuela (2000).

- Identificación de problemas relacionados con el texto fuente, dificultades subjetivas y errores de traducción, basada en Amirian y Baghiat (2013), Angelone (2010), Lachat Leal (2008), Fernández y Zabalbeascoa (2011), Zou (2015).

- Sugerencias de posibles soluciones para problemas y errores de traducción, basada en Amirian y Baghiat (2013), Angelone (2010), Lachat Leal (2008), Zou (2015).

- Aplicación de soluciones o propuestas para los problemas y errores de traducción identificados, basada en Amirian y Baghiat (2013), Angelone (2010), Lachat Leal (2008), Fernández y Zabalbeascoa (2011), Zou (2015).

- Reflexiones sobre el proceso traductor, basada en Bergen (2009) y Zou (2015).

- Referencias acerca del proceso de aprendizaje, basada en O Malley y Chamot (1994) y Oxford, (2017).

- Reflexiones críticas sobre el papel de traductor en áreas de especialidad

- Reflexiones críticas sobre la producción del otro (pares y expertos) 
Las estrategias socioafectivas se agrupan en dos categorías asociadas a procesos interaccionales, por un lado, y factores actitudinales y motivacionales por el otro, como se ilustra en la siguiente tabla.

\begin{tabular}{|c|c|}
\hline Categorías & Subcategorías \\
\hline \multirow{9}{*}{$\begin{array}{l}\text { Estrategias aso- } \\
\text { ciadas a procesos } \\
\text { interaccionales }\end{array}$} & - Apreciación de la contribución, guía o corrección del docente \\
\hline & - Apreciación del trabajo de los pares \\
\hline & - $\quad$ Empatía, basada en Oxford (1990, 2017). \\
\hline & $\begin{array}{l}\text { - Socialización de conocimientos y experiencias relacionadas con el } \\
\text { aprendizaje }\end{array}$ \\
\hline & $\begin{array}{l}\text { - Contribuciones tendientes a facilitar la construcción del conocimiento } \\
\text { de manera cooperativas, basada en "construcción del conocimiento de } \\
\text { manera cooperativa mediante la resolución de un problema o tarea de } \\
\text { aprendizaje, recopilación de información y retroalimentación" de Bergen } \\
\text { (2009), Fernández y Zabalbeascoa (2011), Llano (2007), O Malley y Cha- } \\
\text { mot (1994). }\end{array}$ \\
\hline & $\begin{array}{l}\text { Preguntas que solicitan explicaciones o retroalimentación del docente } \\
\text { o los pares, basada en O Malley y Chamot (1994), Oxford, (1990, 2017), } \\
\text { Valenzuela (2000). }\end{array}$ \\
\hline & $\begin{array}{l}\text { Respuesta a las preguntas o comentarios de los pares con el propósito } \\
\text { de asistir en el proceso de aprendizaje, basada en Bergen (2009), Lachat } \\
\text { Leal (2008), Valenzuela (2000). }\end{array}$ \\
\hline & - $\quad$ Respuesta a la retroalimentación docente \\
\hline & - Búsqueda de consenso \\
\hline \multirow{4}{*}{$\begin{array}{l}\text { Estrategias } \\
\text { asociadas a } \\
\text { manifestaciones } \\
\text { actitudinales y } \\
\text { motivacionales }\end{array}$} & $\begin{array}{l}\text { - Manifestación de preferencias sobre aspectos relativos a la tarea de } \\
\text { aprendizaje }\end{array}$ \\
\hline & - $\quad$ Saludos / agradecimientos / expresiones de aliento (uso de emoticones) \\
\hline & $\begin{array}{l}\text { Expresión de actitudes o sentimientos relacionados con el aprendizaje } \\
\text { en áreas de especialización, basada en O Malley y Chamot (1994), Oxford } \\
(1990,2017) \text {. }\end{array}$ \\
\hline & $\begin{array}{l}\text { - Manifestación de motivación o falta de motivación para realizar las ta- } \\
\text { reas de aprendizaje, basada en Valenzuela (2000) }\end{array}$ \\
\hline
\end{tabular}

Tabla 3. Clasificación de las estrategias socioafectivas de aprendizaje de la traducción especializada en EaD

Las subcategorías para las que no se consignan las fuentes bibliográficas, corresponden a aplicaciones que surgen de este estudio. Como se mencionó anteriormente, se observaron múltiples usos de las estrategias incluidas en esta taxonomía. Debido a las limitaciones de este trabajo, transcribimos solo algunas instancias. Por ejemplo, las estrategias metacognitivas de planificación se aplican en relación con el control del proceso de traducción. Las producciones de los estudiantes ponen de manifiesto el uso de la estrategia de gestión de la tarea según las pautas, para organizar las tareas de traducción, según se vislumbra en este aporte en una wiki: "Hola chicas, si les parece dividimos el texto en tres partes y traducimos una cada una para después entre todas criticar, corregir o modificar lo que sea necesario a cada parte". Con frecuencia, su uso se instancia mediante las estrategias socioafectivas vinculadas con procesos interaccionales, como la búsqueda de consenso expresada al comienzo del aporte analizado. 
En cuanto a las estrategias asociadas a los procesos interaccionales, la comunicación con los pares y docentes condujo a la construcción de saberes mediante el intercambio de opiniones, resolución de problemas, corrección de errores y decisiones traslativas en distintas etapas del proceso de aprendizaje de la traducción. A modo de ilustración, transcribimos esta contribución que corresponde a la subcategoría respuesta a las preguntas o comentarios de los pares con el propósito de asistir en el proceso de aprendizaje:

- Estudiante: [nombre de la alumna], primero hago algunos comentarios sobre tus observaciones a la parte que traduje:

- Sobre omitir o no "mujeres" y "varones", si bien se rescata el género en "los" o "las" jóvenes, es cierto que poniendo "mujeres" y "varones" el énfasis es mayor, así que me parece mejor incluirlos.

- Tu observación sobre la frase rebuscada, estoy de acuerdo con tu versión. Me gusta mucho más.

- Sobre la pérdida de "I think", podría ser "Creo que a todas". (Comentarios de una wiki)

Otra estrategia de aprendizaje que se utilizó con frecuencia en los foros de debate es la apreciación del trabajo de los pares, como expresó una alumna: "Hola, profesora y compañeras. Muchas gracias por los comentarios y aclaraciones tan detallados, son sumamente útiles. Gracias compañeras por compartir los enlaces, ison muy generosas! ... el prezi es muy divertido; ile pone un poco de humor al domingo!". La estudiante reconoce aspectos positivos en los aportes de otros estudiantes y su uso se soslaya con otras dos subcategorías de estrategias socioafectivas: apreciación de la contribución y guía del docente y con expresiones de actitudes o sentimientos relacionados con el aprendizaje. El uso de estas estrategias podría ser de utilidad para aprendizaje autónomo y colaborativo mediante la comprensión del trabajo de los pares. Estas y otras instancias detectadas en el corpus de este estudio revelan el papel central de del uso de las estrategias de aprendizaje identificadas y pone de manifiesto el rol de los estudiantes como protagonistas del proceso de aprendizaje de la traducción especializada. Seguidamente analizamos las opiniones de los estudiantes y docentes.

\section{Percepciones de los participantes sobre el aprendizaje estratégico}

Los resultados de las encuestas y entrevistas permitieron corroborar la relevancia de las estrategias socioafectivas y metacognitivas para el aprendizaje de la traducción, en consecución del segundo objetivo de investigación. Los estudiantes encuestados indican haber percibido numerosos beneficios de estas tareas conjuntas, entre los que se destacan: el intercambio de ideas con los pares y el docente, las sugerencias sobre recursos de documentación terminológica y lingüística, la posibilidad de aclarar dudas y aprender de los errores propios y ajenos, la distribución de las tareas, el apoyo del grupo y el enriquecimiento de los conocimientos mediante la interacción grupal; todo lo cual, según afirman varios de los encuestados, permite lograr un aprendizaje más profundo e integral. Por ejemplo, un estudiante expresa lo siguiente: 
[El trabajo colaborativo] es muy beneficioso ya que podemos aprender de los compañeros y sacarnos dudas sin necesidad de acudir al profesor. Estas actividades me parecen interesante, además, para poder desarrollar una actitud colaborativa entre colegas ya que la tarea del traductor es, en sí, solitaria, pero considero que es importante mantener una comunicación fluida con otros profesionales.

En cuanto a las opiniones de los docentes, la mayoría se refirió a la utilidad pedagógica de las herramientas digitales y su importancia para el aprendizaje colaborativo y autorregulado, Según estos docentes, el uso de un muro para compartir producciones (padlet), los intercambios en los foros y las traducciones colaborativas en wikis y documentos compartidos en google drive facilitaron el aprendizaje conjunto. En cuanto al uso del foro, casi todos los profesores concordaron que fue el medio principal para el acompañamiento continuo y la guía en el proceso de aprendizaje. Uno de ellos expresa la siguiente opinión:

Para mí el foro es la clave; el foro más la aplicación de lo que aprendieron en el foro en sus tareas individuales. La oportunidad de intervenir en los foros hacía que ellos tuvieran que leer; de alguna forma eso mostraba si estaban leyendo o no. ... Entonces era donde uno venía lo que iban razonando y aplicando para después ya hacer la tarea individual. ... El foro fue la forma de aprender entre todos.

Algunos participantes de esta investigación también percibieron ciertas desventajas del trabajo colaborativo debido a la falta de distribución equitativa de las actividades entre los miembros del grupo. Varios alumnos comentaron que tuvieron dificultades para coordinar las actividades debido a cuestiones de tiempo, horarios y compromisos laborales o personales de cada integrante. Estos estudiantes manifestaron que les faltó tiempo para analizar algunas elecciones terminológicas y realizar una adecuada revisión de la traducción. Uno de ellos explica: "La distancia, las actividades que cada uno realiza y el trabajo que tiene cada uno dificultan la coordinación de un horario para compartir materiales, opiniones y correcciones". Estas dificultades también fueron percibidas por los docentes, como señaló uno de ellos: "No quiero hacer muchas actividades colaborativas como la wiki porque cada uno tiene horarios muy distintos y es difícil ponerse de acuerdo". Estas opiniones de los docentes y estudiantes, tanto sobre las ventajas como las desventajas del aprendizaje colaborativo, ponen de relieve la relevancia y necesidad del uso de estrategias que propicien el aprendizaje autorregulado y el trabajo conjunto en la virtualidad.

En relación con el tercer objetivo de este estudio, se sugiere aplicar enfoques pedagógicos socioconstructivistas que se articulen en torno a las competencias de los docentes para la enseñanza estratégica en la virtualidad (Bautista, 2011), al rol del alumno para el aprendizaje estratégico en EaD (Valenzuela, 2000) y al uso didáctico de recursos digitales. Según Bautista, el docente debe ser capaz de 1) captar y expresar emociones (dimensión afectiva); 2) implementar estrategias para transmitir empatía; 3) crear y mantener un clima de motivación; 4) disponer de un entorno rico en recursos y actividades que faciliten el aprendizaje; 5) atender a las necesidades e intereses individuales durante el proceso de aprendizaje; 6) investigar y reflexionar sistemáticamente sobre la propia práctica docente en entornos en línea. Consideramos que estas competencias son básicas porque la ausencia de alguna de ellas podría obstaculizar en alguna medida la aplicación de un enfoque pedagógico que propicie el aprendizaje estratégico. En cuanto al rol del alumno, se sugiere que las 
tareas de aprendizaje se centren en el desarrollo de habilidades y estrategias de comunicación interpersonal, colaboración, reflexión crítica, automonitoreo, planificación, gestión del tiempo y los recursos, ya que estas destrezas no solo coadyuvan al aprendizaje eficaz, sino que también son esenciales para el ejercicio de la profesión en los entornos virtuales de la actualidad. Estas actividades podrían realizarse a través de foros, wikis y otros recursos digitales que facilitan el aprendizaje estratégico, autónomo y colaborativo. Además, en relación el desarrollo de estrategias socioafectivas para el aprendizaje de la traducción, Mansilla y González-Davies (2017) señalan que "si no están bien diseñadas, las actividades colaborativas pueden ser una fuente de frustración en una clase virtual. El uso de la tecnología apropiada en actividades bien diseñadas es fundamental” (p. 268). Asimismo, según los hallazgos de este estudio y las recomendaciones de la literatura, se deberían priorizar los recursos y entornos que permitan a los sujetos ser creadores de su propio aprendizaje, interactuar con la tecnología y el contenido de manera creativa, aplicar el pensamiento crítico y construir el conocimiento de manera colaborativa.

\section{Discusión y conclusiones}

Este estudio ha contribuido con evidencia empírica sobre el empleo de estrategias específicas para el aprendizaje de la traducción en la virtualidad. Las instancias analizadas demuestran que estas estrategias favorecen el desarrollo de la competencia traductora, lo cual a su vez revela que su enseñanza explícita sería beneficiosa para promover el aprendizaje autodirigido y colaborativo en la formación de traductores especializados. El diseño investigativo basado en procedimientos de la Teoría Fundamentada permitió obtener descripciones detalladas del corpus y sistematizar estos resultados en una taxonomía de estrategias metacognitivas y socioafectivas específicas. Algunas de estas caracterizaciones se basan en estudios precedentes que evidencian la relevancia y necesidad de fomentar de manera sistemática el uso de estrategias de aprendizaje específicas en el ámbito de la traducción (Angelone, 2010; Bergen, 2009; Fernández y Zabalbeascoa, 2011; Zou, 2015, entre otros) y otras constituyen contribuciones de esta investigación. La dimensión metacognitiva se materializa cuando los estudiantes emplean estrategias como el automonitoreo, la planificación, el pensamiento divergente y la reflexión. Por otra parte, las estrategias socioafectivas de interacción y manifestaciones de la motivación facilitarían la construcción colaborativa del conocimiento. El uso concertado de estas estrategias coadyuvó al aprendizaje autónomo y colaborativo de la traducción en los contextos explorados.

Las percepciones de los participantes sobre los beneficios de las actividades y herramientas digitales permiten corroborar que las tareas y soportes utilizados (foros, wikis, padlet y documentos compartidos) favorecen el aprendizaje estratégico. Según los datos recabados en esta investigación, tanto las estrategias vinculadas con los procesos metacognitivos como aquellas que se imbrican en la dimensión socioafectiva podrían contribuir al aprendizaje autónomo y colaborativo en la virtualidad. Asimismo, las problemáticas y desafíos que los estudiantes y docentes manifestaron haber enfrentado en la educación virtual contribuyeron a ratificar la necesidad de la enseñanza y el aprendizaje estratégicos de la traducción especializada en entornos de EaD. No obstante, este estudio presentaría limitaciones en cuanto al alcance de los resultados, si se intentaran aplicar estas estrategias en otros contextos de enseñanza de la traducción, como por ejemplo en cursos semipresenciales, y con otros participantes. Es por ello que se sugiere diseñar nuevos estudios que se enfoquen 
en otras modalidades y en niveles, con la formulación de preguntas de investigación similares a las que guiaron este trabajo a fin de poder ampliar, profundizar, confirmar y tal vez cuestionar o problematizar los hallazgos aquí presentados.

Como corolario, se propone un enfoque pedagógico centrado en el aprendizaje estratégico de la traducción especializada para el empoderamiento individual y grupal. Este enfoque facilitaría la formación de futuros profesionales que deberán enfrentar las demandas del mercado laboral actual, entre las que se destacan las habilidades de autogestión, autorregulación y pensamiento crítico para la resolución de problemas de traducción mediante la interacción en equipos de trabajo en la Red.

\section{Referencias}

Angelone, E. (2010). Uncertainty, uncertainty management and metacognitive problem solving in the translation task. En G. Shreve y E. Angelone (Eds.), Translation and cognition (pp. 17-40). Amsterdam: John Benjamins.

Alonso, E. y Calvo, E. (2015). Developing a blueprint for a technology-mediated approach to translation studies. Meta, 60(1), 135-157. Recuperado de https://doi.org/10.7202/1032403ar

Bautista, G. (2011). El acompañamiento del estudiante: profesorado para una nueva forma de aprender. En B. Gros (Ed.), Evolución y retos de la educación virtual: Construyendo el e-learning de/ siglo XXI (pp 51-71). Barcelona: Editorial UOC. Recuperado de https://redined.mecd.gob.es/xmlui/handle/11162/66735

Bergen, D. (2009). The role of metacognition and cognitive conflict in the development of translation competence. Across Languages and Cultures, 10(2), 231-250.

Chan Núñez, M. E. (2016). La virtualización de la educación superior en América Latina: entre tendencias y paradigmas. RED-Revista de Educación a Distancia. 48(1). https://www.um.es/ead/red/48/chan.pdf

Gava, I. Y. y Sestopal, M. D. (2015). Las estrategias socioafectivas y cognitivas para el aprendizaje de la traducción mediante la interacción en foros electrónicos. En S. Trovarelli, I. Y. Gava y M. C. Orgnero Schiaffino (Eds.), Aprendizajes significativos con TIC en la Educación superior. (Vol. 4). Actas de las XV Jornadas y II Congreso Latinoamericano de Enseñanza de Lenguas Extranjeras en el Nivel Superior. Lenguas y culturas: desafíos actuales de la diversidad y la integración, 48-61. Córdoba: Facultad de Lenguas, UNC. Recuperado de https://rdu.unc.edu.ar/bitstream/handle/11086/5572/JELENS\%202015\%20Volumen\%204.pdf?sequence=1

Díaz Barriga Arceo, F. y Fernández Rojas, G. (2002). Estrategias docentes para un aprendizaje significativo: una interpretación constructivista. (2a Edición). México: McGraw-Hill Interamericana.

Dörnyei, Z. (2007). Research methods in applied linguistics: Quantitative, qualitative and mixed methodologies. Oxford: OUP. 
Fernández, F. y Zabalbeascoa, P. (2012). Developing trainee translators' strategic subcompetence through metacognitive questionnaires. Meta, 57(3), 740-762. Recuperado de https://doi.org/10.7202/1017089ar

González, A. H. y Martín, M. M. (2017). Educación superior a distancia en Argentina: tensiones y oportunidades. Trayectorias Universitarias. Enseñanza mediada por tecnologías: Desafíos y oportunidades en la universidad, 3(4), 3-11. Recuperado de https://revistas.unlp.edu.ar/TrayectoriasUniversitarias/issue/view/353

Hatch, J. A. (2002). Doing qualitative research in education settings. Albany: State University of New York.

Herrera-Torres, L. y Lorenzo-Quiles, O. (2009). Estrategias de aprendizaje en estudiantes universitarios. Un aporte a la construcción del Espacio Europeo de Educación Superior Educación y Educadores, 12(3), 75-98. http://www.redalyc.org/ pdf/834/83412235005.pdf

Jansen, H. (2013). La lógica de la investigación por encuesta cualitativa y su posición en el campo de los métodos de investigación social. Paradigmas, 5(1), 39-72. Recuperado de https://dialnet.unirioja.es/servlet/articulo?codigo $=4531575$

Kiraly, D. C. (2014). A social constructivist approach to translator education: Empowerment from theory to practice. (2a Edición). Nueva York: Routledge.

Lion, C. (2006). Imaginar con tecnologías: Relaciones entre tecnologías y conocimiento. Buenos Aires: Ediciones La Crujía. Editorial Stella.

Mansilla, D., y González-Davies, M. (2017). El uso de estrategias socioafectivas en el aula virtual de traducción: una propuesta didáctica. Revista Digital de Investigación en Docencia Universitaria, 11(2), 251-273. Recuperado de https://doi.org/10.19083/ ridu. 11.568

Oxford, R. L. (1990). Language learning strategies: What every teacher should know. Boston: Heinle \& Heinle.

Oxford, R. L. (2017). Teaching and researching language learning strategies: Self-regulation in context. (2a Edición). Nueva York: Routledge.

O Malley, J. y Chamot, A. (1990). Learning strategies in second language acquisition. Cambridge: Cambridge University Press.

Patton, M. Q. (2002). Qualitative research and evaluation methods. 3a Edición. Los Angeles: Sage Publications.

Strauss, A. y Corbin, J. (2002). Bases de la investigación cualitativa: Técnicas y procedimientos para desarrollar la teoría fundamentada. Antioquia (Colombia): Editorial Universidad de Antioquia.

Valenzuela, R. (2000). Los tres "autos" del aprendizaje: aprendizaje estratégico en educación a distancia. Ege, 1(2), 1-11. Universidad Virtual de Monterrey. Recuperado de http://ftp.ruv.itesm.mx/pub/portal/pdffiles/revista_ege_2.pdf 
Vygotsky, L. S. (1978). Mind and society: The development of higher mental processes. Cambridge, Massachusetts: Harvard University Press.

Zou, Y. (2015). The concept and instruction of metacognition in translation competence development. International Forum of Teaching and Studies, 11(1-2). Recuperado de http://americanscholarspress.us/journals/IFST/pdf/IFOTS-2-2015/v11n2-art7.pdf 


\section{Conectando Aprendizajes: Experiencia de Atención a Estudiantes Durante la Pandemia en la Escuela Normal Superior de Bucaramanga}

\section{Ayala Moreno, Johanna Beatriz}

ORCID https://orcid.org/0000-0001-7348-5131

johanna.ayala@cvudes.edu.co

\section{Chapeta, Germán}

german@nsb.edu.co 


\title{
CONECTANDO APRENDIZAJES: EXPERIENCIA DE ATENCIÓN A ESTUDIANTES DURANTE LA PANDEMIA EN LA ESCUELA NORMAL SUPERIOR DE BUCARAMANGA
}

\author{
Ayala Moreno, Johanna Beatriz \\ Chapeta, Germán
}

\section{Resumen}

Las medidas adoptadas para hacer frente al Covid19 han impuesto transformaciones aceleradas en las instituciones educativas para trasladar la educación a las casas, la pregunta que se aborda en el contexto de educación básica y media de Colombia es: ¿Cómo perciben los estudiantes de octavo y décimo la estrategia de trabajo académico en casa implementada en el área de tecnología en la Escuela Normal Superior de Bucaramanga? Se realiza un estudio de caso en el paradigma cualitativo en el que se aplica una encuesta de percepción en dos grupos focales y dos momentos distintos. Las categorías de análisis de los resultados corresponden con los elementos de la estrategia educativa y evidencian diferencias en la percepción sobre elementos del libreto de aprendizaje, manteniendo similitud en la tendencia de aumento en los niveles de satisfacción y valoración. El estudio ubica a la persona en el centro de la acción educativa al permitir la comprensión de la experiencia desde la perspectiva del estudiante e identificar aspectos potenciales de mejora.

\section{Palabras clave}

Educación en casa, Covid19, libreto de aprendizaje, tecnología educativa. 


\section{Introducción}

En un momento en que la investigación en tecnologías educativas venía surgiendo con el desafío de buscar soluciones a las actuales necesidades formativas mediante estrategias que integren los elementos tecnológicos, pedagógicos y culturales que convergen en los nuevos escenarios educativos (Salinas, 2012), nos enfrentamos a la situación insólita de la pandemia del Covid19, que obligó al sistema educativo a modificar todos los procesos de formación que tradicionalmente se desarrollaban en los establecimientos educativos, para garantizar el derecho a la educación de niños y adolescentes desde la seguridad de sus hogares (CEPAL, 2020)

Las condiciones impuestas hacen más complejo el proceso educativo soportado en las tecnologías, el fenómeno de la adaptación acelerada ha sido motivo de estudio desde múltiples perspectivas, enfoques e intereses. Este "experimento masivo excepcional" desvela la realidad de la brecha digital, no sólo en condiciones de conectividad y acceso a la tecnología, sino también en las competencias digitales de maestros, estudiantes y familias a lo largo y ancho del planeta (Bozkurt et al., 2020; Moreira y Zapata, 2020).

A pesar de la premura, se han logrado experiencias particulares y colectivas que van más allá de una "enseñanza de emergencia" basada en la simplificación de las prácticas tradicionales presenciales; iniciativas que buscan el sentido pedagógico del aprendizaje remoto, la interacción sincrónica y asincrónica, el aprendizaje activo, la agencia del aprendizaje, la evaluación formativa y el rol de la familia (Bates, 2020; García, 2020; Garduño, et al, 2020; Naidu, 2020; Salinas, 2020; Sianes y Sánchez, 2020)

En el caso particular de la Escuela Normal Superior de Bucaramanga, ENSB, el reto fue encontrar una estrategia didáctica que articule aspectos como:

- Condiciones diversas de acceso a internet y ausencia de dispositivos electrónicos en un $30 \%$ de la comunidad estudiantil.

- Colectivo de maestros con marcada heterogeneidad de conocimientos, actitudes y experiencias favorables a la incorporación de las TIC en el proceso de enseñanza, aprendizaje, evaluación y comunicación.

- Desconocimiento de estrategias de planeación, desarrollo, seguimiento y evaluación de educación virtual o a distancia y en la mayoría de los integrantes de la comunidad educativa.

En este contexto se propuso utilizar como estrategia de secuencia didáctica para el trabajo en casa con los estudiantes un libreto de aprendizaje, adaptado del guion de aprendizaje para la virtualización de la Universidad Industrial de Santander (Barbosa, 2010)

Este recurso de planeación logra darle un horizonte significativo al proceso de enseñanza aprendizaje porque muestra una coherencia cognitiva al articular las competencias disciplinares, ciudadanas y laborales con sus respectivos desempeños para derivar en productos, evidencia de aprendizaje, que inspiran la planeación y desarrollo de actividades de enseñanza, aprendizaje, comunicación y evaluación dosificadas en el tiempo, también determina los recursos necesarios tecnológicos y los conocimientos requeridos para desarrollar el proceso de enseñanza. La explicación detallada de las 
actividades, sustituye la presencialidad y propicia el incremento de la autonomía del estudiante al ir desarrollando el proceso por su cuenta o con el apoyo de sus padres. El Libreto contempla también la programación de encuentros sincrónicos con una regularidad para realizar seguimiento y evaluación, en estos espacios se resuelven las dudas y se comparten los avances logrados o las dificultades presentadas.

El Libreto de Aprendizaje, logra potenciar varios niveles de integración curricular porque posibilita planear y desarrollar proyectos de grado, aula o integración de dos o tres áreas, de esta forma, se alcanza una coherencia significativa que incide en la motivación y afectividad del estudiante, al encontrar relevante el proceso.

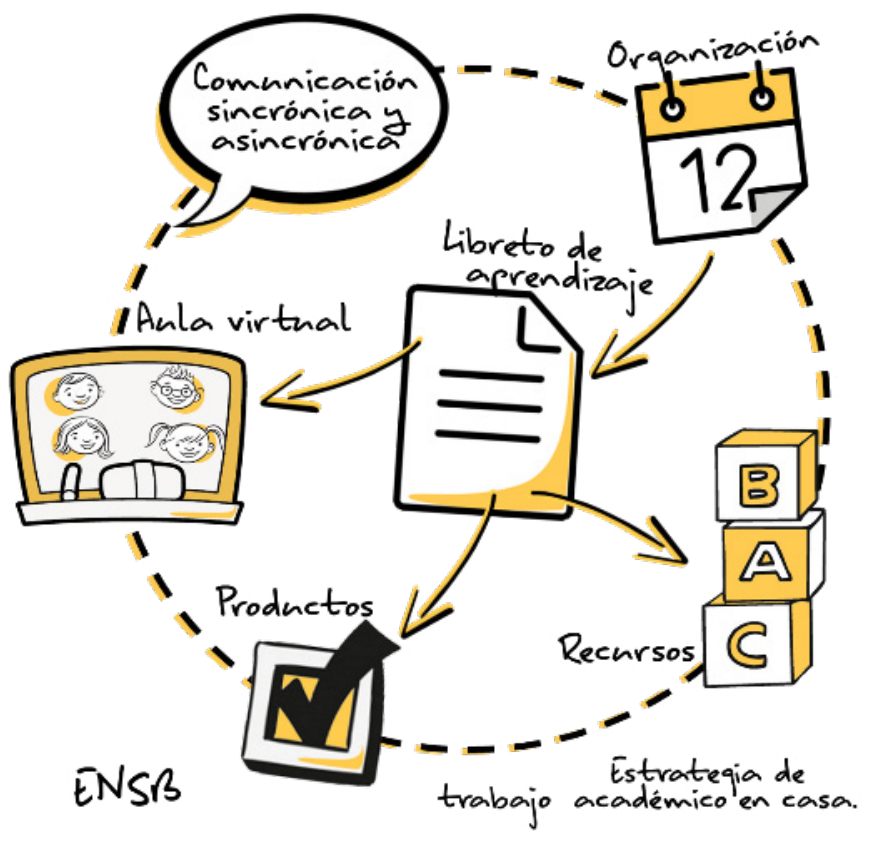

\section{Figura 1. Estrategia de trabajo académico en casa}

Los espacios y herramientas virtuales disponibles se articulan para soportar la estrategia de trabajo en casa. Se parte del agendamiento del trabajo sincrónico y asincrónico en el pizarrón de tareas de la plataforma de gestión académica que favorece la autonomía y el auto control; se media por canales redundantes de comunicación sincrónica y asincrónica, tales como grupos de WhatsApp y correo institucional, lo cual se adapta a las condiciones y preferencias de cada estudiante y se hace operativo con las herramientas de Google Work Space: Classroom, Meet y Documentos, que permite múltiples formas de interacción, producción y trabajo colaborativo.

\section{Método/Descripción de la experiencia}

Se presenta un estudio de caso enmarcado en el paradigma de la investigación cualitativa, que busca resolver la pregunta: ¿Cómo perciben los estudiantes de octavo y décimo la estrategia de trabajo académico en casa implementada en el área de tecnología en la ENSB? 


\section{Descripción del contexto y de los participantes}

La ENSB, fundada hace 146 años, tiene una población de 4050 estudiantes, organizados en 111 grupos desde preescolar hasta el Programa de Formación Complementaria y con un colectivo de 145 maestros.

Según el decreto 1236 de 2020 del Ministerio de Educación de Colombia, la Escuela Normal, en su naturaleza como institución de formación de docentes se caracteriza por la reflexión permanente sobre los procesos de formación y tiene entre sus fines contribuir al desarrollo y fundamentación de la práctica docente, y desarrollar capacidades para el mejoramiento y la innovación, así como capacidades para repensar permanentemente el proyecto educativo y su práctica pedagógica respondiendo a las necesidades de la sociedad.

Para el estudio se seleccionó una muestra no probabilística por participación voluntaria de 568 estudiantes de los grados octavo y décimo.

Tabla 1. Distribución de la muestra

\begin{tabular}{|c|c|c|}
\hline Grado /año & Septiembre 2020 & Junio 2021 \\
\hline Octavo & 244 & 165 \\
\hline Décimo & 129 & 30 \\
\hline
\end{tabular}

\section{Instrumentos}

Se aplicó una encuesta de percepción con 32 preguntas en escala tipo Likert y 4 preguntas abiertas, en dos momentos; en septiembre de 2020, seis meses después del cierre de las instituciones educativas en Colombia y en junio de 2021.

\section{Procedimiento}

El estudio de caso es completamente contextual, se llevó a cabo en el ambiente natural en medio del fenómeno masivo sin precedentes de la adaptación del escenario educativo de la escuela a la casa, apoyado en las tecnologías educativas. Se aplicaron las fases de un estudio de caso adaptadas del Hardvard Business School (Hernández et al., 2014)

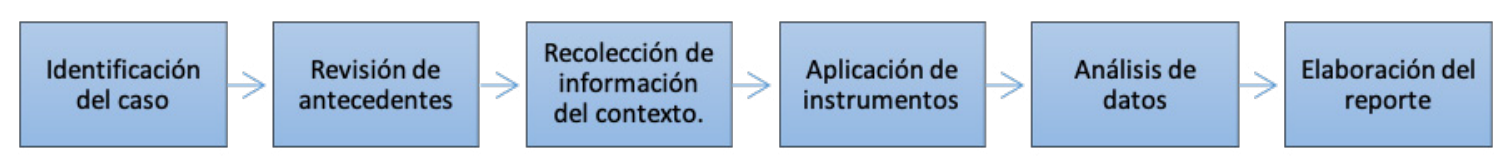




\section{Resultados}

Los datos recolectados se analizaron teniendo en cuenta las siguientes categorías:

- Valoración de los libretos de aprendizaje.

- Utilidad de los recursos ofrecidos.

- Nivel de aprendizaje adquirido.

- Metodología y participación en encuentros virtuales

- Eficiencia de Google Classroom para soportar la escuela en casa.

- Expectativas del trabajo en grupo.

A continuación, se presentan los resultados más significativos.

Los aspectos relacionados con el libreto de aprendizaje se valoraron con una escala tipo Likert de tres opciones: es adecuado, es regula y se debe mejorar. En la tabla dos se muestra el porcentaje de estudiantes que respondió es adecuado.

Tabla 2. Valoración de los libretos

\begin{tabular}{|c|c|c|c|c|}
\hline \multirow{2}{*}{$\begin{array}{l}\text { Características de los libretos de aprendizaje valo- } \\
\text { radas en nivel de adecuado por los estudiantes }\end{array}$} & \multicolumn{2}{|c|}{ Décimo } & \multicolumn{2}{|c|}{ Octavo } \\
\hline & 2020 & 2021 & 2020 & 2021 \\
\hline Extensión & $75 \%$ & $87 \%$ & $81 \%$ & $82 \%$ \\
\hline Facilidad de comprensión & $64 \%$ & $87 \%$ & $69 \%$ & $78 \%$ \\
\hline Estética y Presentación & $92 \%$ & $96 \%$ & $91 \%$ & $87 \%$ \\
\hline Tiempo asignado para el desarrollo de cada producto & $78 \%$ & $96 \%$ & $77 \%$ & $83 \%$ \\
\hline Claridad en condiciones de entrega de cada producto & $79 \%$ & $96 \%$ & $80 \%$ & $83 \%$ \\
\hline
\end{tabular}

El aspecto que más bajo porcentaje obtuvo fue la facilidad de comprensión del libreto, sin embargo, este también fue el aspecto que obtuvo una mayor variación comparando los dos años, en grado décimo aumentó $23 \%$ y en octavo el $9 \%$.

En grado décimo el segundo aspecto en tener un aumento significativo fue la claridad en las condiciones de entrega de los productos, con un $17 \%$.

Los aspectos que más reflejan diferencia entre los dos grados fueron el tiempo asignado para la el desarrollo de cada producto y la claridad en las condiciones de entrega de los mismos, en los cuales, en el año 2021 el porcentaje de adecuado del grado décimo fue $13 \%$ mayor que el de octavo.

La utilidad de los recursos educativos se valoró con una escala tipo de tres opciones, a saber: poco útiles, regularmente útiles y muy útiles. En la tabla 3 se muestra el porcentaje de estudiantes que en cada grado respondió "muy útil" a cada uno de los tipos de recursos incorporados en la formación. 
Tabla 3. Utilidad de los recursos educativos

\begin{tabular}{|l|c|c|c|c|}
\hline $\begin{array}{l}\text { Recursos educativos utilizados considerados muy úti- } \\
\text { les por los estudiantes }\end{array}$ & $\mathbf{2 0 2 0}$ & $\mathbf{2 0 2 1}$ & $\mathbf{2 0 2 0}$ & $\mathbf{2 0 2 1}$ \\
\hline Video tutoriales paso a paso & $89 \%$ & $87 \%$ & $74 \%$ & $88 \%$ \\
\hline Enlaces a páginas Web para profundizar & $77 \%$ & $78 \%$ & $73 \%$ & $80 \%$ \\
\hline Simuladores & $76 \%$ & $96 \%$ & $82 \%$ & $87 \%$ \\
\hline
\end{tabular}

Los recursos que tuvieron una variación más significativa en los dos años fueron los simuladores, que en el grado décimo aumentó en un $20 \%$; seguido de los video tutoriales paso a paso que tuvo un aumento del 15\% en el grado octavo.

La percepción sobre la utilidad de los enlaces a páginas Web para profundizar se mantuvo con menor variación en los dos años y los dos cursos.

Respecto a los encuentros virtuales se recogieron datos sobre el nivel de satisfacción sobre cinco criterios, en su orden lograron un mayor nivel la cordialidad por parte de la docente, la claridad en las explicaciones y los materiales que se presentan; los niveles más bajos de satisfacción fueron obtenidos por la duración y el horario.

El 15\% de los estudiantes manifestó que siempre participa en los encuentros, el 54\% a veces y un $30 \%$ reporta que asiste, pero no participa. Algunos de los motivos que expresaron para la no participación son el temor a equivocarse, la falta de comprensión y las limitaciones por conectividad, falta de dispositivos o fallas técnicas.

El 18\% de los estudiantes manifestó no querer realizar actividades colaborativas en los siguientes periodos, mientras que el $27 \%$ consideró que tal vez le gustaría. En la justificación a esta respuesta expresaron la preferencia por el trabajo individual, la dificultad para comunicarse y organizarse con los compañeros de equipo, las limitaciones técnicas y la falta de compromiso de algunos compañeros.

En cuanto a los aprendizajes adquiridos, se indagó sobre aprendizajes transversales y aprendizajes sobre temáticas específicas para cada grado. En la figura 3 se muestran los porcentajes acumulados de los dos grados en las siguientes competencias transversales:

- HTC: manejo de herramientas para el trabajo colaborativo.

- ATSP: aplicaciones tecnológicas para la solución de problemas. 


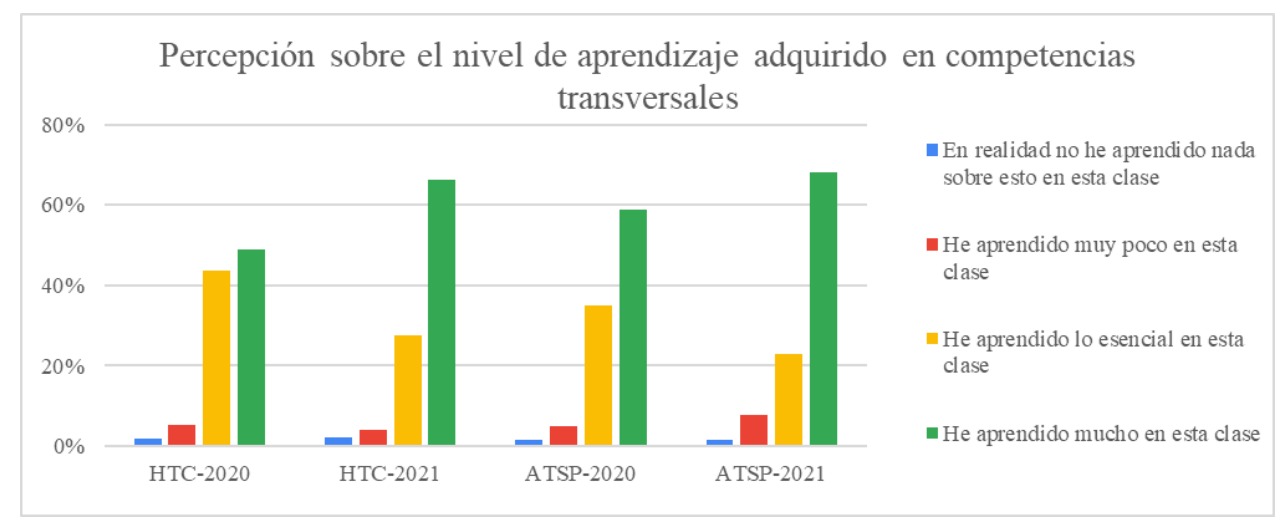

Figura 3. Percepción sobre el nivel de aprendizaje adquirido

En la competencia de herramientas de trabajo colaborativo se observa una mayor diferencia entre un año y otro, sin embargo, en las dos competencias aumenta en el segundo año.

La percepción sobre la eficiencia del Google Classroom como aula virtual se midió con una escala tipo Likert de cinco niveles. Se valoraron ocho aspectos:

- La programación de los encuentros.

- La comunicación con el docente.

- La publicación de libretos y recursos.

- La facilidad para encontrar las tareas.

- La entrega de tareas.

- Hacer comentarios o preguntas sobre tareas.

- El uso desde celular o computador

- Las notificaciones.

De acuerdo con la percepción de los estudiantes, Classroom resulta ser una herramienta muy eficiente para apoyar la escuela en casa, ya que facilita la publicación de los libretos y recursos, permite encontrar con facilidad las tareas o asignaciones para entregar los productos, se puede usar con la misma facilidad desde dispositivos móviles o PC y permite recibir notificaciones.

En la figura 4 se muestran los resultados generales de los tres aspectos que recibieron menor valoración de eficiencia. 


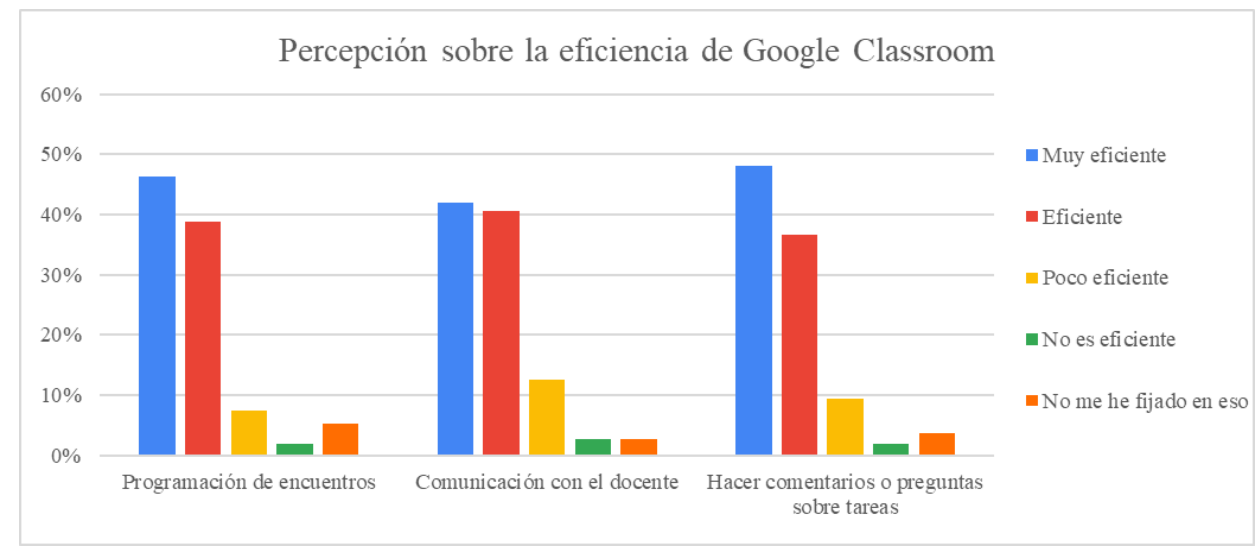

Figura 4. Percepción sobre la eficiencia de Google Classroom

\section{Discusión y conclusiones}

La estrategia de trabajo académico en casa de la ENSB articula elementos esenciales de la pedagogía del aprendizaje en línea y se ve favorecida por una baja brecha digital en comparación con otros estudios publicados, en los cuales la adaptación a las nuevas necesidades ha consistido en dar continuidad a las mismas prácticas presenciales, soportadas por TIC en condiciones de menores índices de acceso. (Rincón et al., 2020)

El estudio aporta a la comprensión de la experiencia de aprendizaje en línea de los estudiantes de educación básica y media, que es un campo de investigación que reclama atención. Otros estudios han encontrado diferencias significativas en distintos niveles (Yan et al., 2021), en nuestro caso, los dos grupos de enfoque evidenciaron diferencias en su percepción sobre la facilidad de comprensión de los libretos, el tiempo asignado a cada producto y la utilidad de los recursos de aprendizaje; los cuales obtuvieron porcentajes más altos en los estudiantes de décimo grado, posiblemente se deba a su capacidad de adaptación y autogestión del aprendizaje, sin embargo, se mantiene la tendencia en el aumento de los niveles de satisfacción y valoración de los elementos de la estrategia de trabajo académico en casa.

La valoración de la facilidad de comprensión de los libretos, con la valoración más baja en el año 2020, evidencia su complejidad. Los estudiantes estaban acostumbrados a recibir guías pedagógicas de actividades y temáticas puntuales e inmediatas, mientras que el libreto expone una visión total de la propuesta pedagógica del periodo.

Por otra parte, la evaluación mediante productos conlleva para ellos un cambio de paradigma frente a lo que "me van a evaluar", ya que muchas de las actividades realizadas dejan de ser calificables por sí mismas de manera aislada y pasan a ser insumos para construir un producto, que finalmente permitirá demostrar el nivel de competencia.

El trabajo académico desde casa implica la autonomía y el autocontrol del propio proceso de aprendizaje por parte del estudiante; el cambio abrupto motivado por el confinamiento a causa de la pandemia supuso una adaptación forzada. Los resultados comparativos del 2020 y 2021, en cuanto al tiempo asignado para cada producto y la claridad en las condiciones de entrega, dan cuenta de una paulatina adaptación al trabajo independiente, con mayor incidencia en el grado décimo. 
Por otra parte, las herramientas tecnológicas empleadas ayudan a soportar el nuevo escenario de la educación remota. En el caso se analizó la eficiencia de Google Classroom, sin embargo, la estrategia de trabajo académico en casa de la ENSB involucró otras herramientas y canales de comunicación que no se incluyeron en el estudio, pero que merecen ser atendidos en futuros estudios, ya que le dan flexibilidad y ubicuidad al escenario formativo y permiten al estudiante configurar sus propios entornos personales de aprendizaje.

Ahora bien, los elementos que intervienen en una experiencia educativa son incontables, por lo tanto, la percepción del estudiante no es suficiente para validad en forma global una estrategia formativa; sin embargo, resulta pertinente para el momento de incertidumbre y zozobra a causa de la pandemia por Covid19, que afecta a todas las dimensiones del ser humano. Esta mirada ubica al ser humano en el centro de acción educativa y permite hacer los ajustes para configurar el entorno protector y efectivo que se requiere.

En la Escuela Normal, resulta de particular importancia involucrar a los estudiantes en la validación de las estrategias de aprendizaje y la comprensión holística de los escenarios formativos, debido a la misión vocacional de formación de formadores.

A puertas de la nueva normalidad que nos marca el retorno gradual a la presencialidad surgen nuevos cuestionamientos sobre los aprendizajes que nos dejó el sobrevivir al confinamiento y en particular, ¿qué elementos de esta estrategia de trabajo académico en casa se quedarán en la presencialidad?

\section{Referencias}

Barbosa, J. (2010) El guion de aprendizaje como eje para la virtualización. InnovaCESAL, Reportes de J. C. Barbosa, IPRED-UIS. http://ead.uis.edu.co/acreditacion/ documentos_tec/ReportesINNOVACESAL_IPREDUIS_2.pdf

Bates, T. (2020). Why, 'logically', online learning is superior to face-to-face teaching. https://www.tonybates.ca/2020/10/30/why-logically-online-learning-is-superior-to-face-to-face-teaching.

CEPAL (2020) La educación en tiempos de la pandemia de Covid-19. Informe. Oficina Regional de Educación para América Latina y el Caribe. https://repositorio.cepal. org/bitstream/handle/11362/45904/1/S2000510_es.pdf

Bozkurt, A. et al. (2020) A global outlook to the interruption of education due to Covid-19 Pandemic: Navigating in a time of uncertainty and crisis. Asian Journal of DistanceEducation,(15)1[1-126]. http://www.asianjde.com/ojs/index.php/AsianJDE/ article/view/462/307

Garduño, E., Montes, L, Medina, L y Medina L. (2020) Categorización pedagógica Freiriana de buenas prácticas docentes en educación básica durante la contingencia por Covid-19. Paulo Freire. Revista de Pedagogía Crítica, 24, [1-18]. http://revistas. academia.cl/index.php/pfr/article/view/1827/2044 
García, S y Santana, P. (2020) La transición a entornos de educación virtual en un contexto de emergencia sanitaria: estudio de caso de un equipo docente en Formación Profesional Básica. Revista de Educación a Distancia, 65. DOI: http://dx.doi. org/10.6018/red.450791

Hernández, Fernández y Baptista, (2014) Metodología de la investigación, sexta edición. Bogotá, editorial Mc Graw Hill.

Rincón, C. et al. (2020) El normalismo rural ante la pandemia covid-19. Tránsito de lo presencial a lo virtual. En La tecnología como eje del cambio metodológico. https:// riuma.uma.es/xmlui/handle/10630/19862

Ministerio de Educación Nacional de Colombia. (2020). Decreto 1236 "Por el cual se adiciona el Capítulo 7 al Título 3 Parte 3 Libro 2 del Decreto 1075 de 2015 - Único Reglamentario del Sector Educación- y se reglamenta la organización y el funcionamiento de las Escuelas Normales Superiores como instituciones educativas formadoras de docentes. https://www.mineducacion.gov.co/1759/w3-article-400865. html? noredirect=1

Salinas, J. (2020) Educación en tiempos de pandemia: tecnologías digitales en la mejora de los procesos educativos. Revista Innovaciones Educativas, 22, [17-21]. DOI: https://doi.org/10.22458/ie.v22iespecial.3173

Sianes, A. y Sánchez, L. (2020) E-learning en 15 días. Retos y renovaciones en la Educación Primaria y Secundaria de la República de Croacia durante la crisis del Covid-19. How have we Introduced distance Learning? Revista Española de Educación Comparada|36,[181-195]. http://revistas.uned.es/index.php/REEC/article/ view/27637/21668

Moreira, A. y Zapata, M. (2021). Presentación del número especial de RED Transición de la educación convencional a la educación y al aprendizaje en línea, como consecuencia del Covid19. RED, (21)65 https://revistas.um.es/red/article/view/462271

Yan, L et al. (2021). Students' experience of online learning during the COVID-19 pandemic: A province-wide survey study. British Journal of Educational Technology. https://bera-journals.onlinelibrary.wiley.com/doi/full/10.1111/bjet.13102 


\section{Diseño de Estrategias Mediadas por Scratch para Apoyar el Proceso Lector en Niños y Niñas Disléxicos}

\section{Garcia Medina, Maria Angelica} orcid.org/0000-0001-8454-9137

Corporación Universitaria del Caribe CECAR maria.garciame@cecar.edu.co

\section{Acosta Meza, David de Jesus}

orcid.org/0000-0003-4796-3579

Corporación Universitaria del Caribe CECAR david.acosta@cecar.edu.co

\section{Primera Diaz, Haison Luis}

Corporación Universitaria del Caribe CECAR haison.primera@cecar.edu.co

\section{Álvarez Aguirre, Oscar Alberto} Corporación Universitaria del Caribe CECAR oscar.alvareza@cecar.edu.co 


\title{
DISEÑO DE ESTRATEGIAS MEDIADAS POR SCRATCH PARA APOYAR EL PROCESO LECTOR EN NIÑOS Y NIÑAS DISLÉXICOS
}

\author{
Garcia Medina, Maria Angelica \\ Acosta Meza, David de Jesus \\ Primera Diaz, Haison Luis \\ Álvarez Aguirre, Oscar Alberto
}

\section{Resumen}

Diseño de estrategias mediadas por scratch para apoyar el proceso lector en niños y niñas disléxicos, partiendo de la problemática, como a través de estrategias mediadas por scracth se mejora la lectura en niños y niñas con dislexia de la Institución Educativa Mateo Pérez, en el grado tercero, institución educativa del contexto rural, con 323 estudiantes, comunidad agrícola y pecuaria. Se planteó como estrategia fomentar la lectura en estudiantes que presentaban dislexia, con el propósito de mejorar el proceso lector en los estudiantes hacia competencias comunicativas, obteniendo los resultados en el desarrollo del descifrar y decodificar mensaje en los estudiantes a partir de las lecturas dirigidas mediadas por las secuencias didácticas propuestas. Además, en el diseño de las secuencias didácticas se tuvo en cuenta las necesidades básicas de los estudiantes pare comprender y aproximarse a lo observado, describiendo e interpretando la imagen con textos escritos, donde se evidenciaba el progreso en los educandos de superar las dificultades disléxicas. De igual forma se potencio el interés y la motivación de los estudiantes en la participación de las lecturas de imágenes, divirtiéndose con las secuencias didácticas. Se concluye que los procesos lectores mediados por secuencias didácticas y herramientas innovadoras motivan la participación de los estudiantes en los procesos de comprensión textual superando dificultades de aprendizajes y necesidades básicas de los estudiantes, hacia competencias comunicativas superiores.

\section{Palabras clave}

Dislexia, estrategias, scratch, trastorno especifico de aprendizaje. 


\section{Introducción}

La dislexia es uno de los trastornos de aprendizajes más frecuentes entre los niños escolarizados; este, compromete el proceso de la lecto-escritura. De allí la preocupación por diseñar herramientas que contribuyan con el diagnóstico y ayuden a mejorar el problema. Así mismo - la dislexia- está categorizada por (Association American Psychiatric, 2013) como una dificultad de aprendizaje que compromete las capacidades de los individuos. Por lo cual, el proyecto propone ayudar a aquellos niños y niñas que sufren del trastorno en el aprendizaje de la lectoescritura - dislexia - mediante el desarrollo de secuencias didácticas a través del scracth. En las aulas de clases se observan niños con dificultades de aprendizaje, siendo la lectoescritura un proceso complejo por la variedad de procesos psicocognitivos implicados (Salgado y Espinosa, 2008, p. 155), el proceso de lectoescritura se realiza en tres fases las cuales son: logogrífica, alfabética y ortográfica (Frith, 1986, citado en Goethals, s.f.). Por tal motivo es importante que los niños y niñas desarrollen las habilidades necesarias para adquirir una buena escritura, ya que esta representa la forma de trasmitir sus ideas, sus afectos y sus emociones. Es un propósito en la institución educativa mejorar la lectura en estudiantes con dislexia, para promover los desempeños comunicativos en los educandos.

Dentro de las codificaciones establecidas en el DSM-V se especifica el código F81.0 que denota la dificultad en la lectura abarcando: la precisión en la lectura de palabras, velocidad o fluidez de la lectura y comprensión de la lectura. La dislexia es el termino alternativo para referirse a esta dificultad de aprendizaje, caracterizándose por los problemas en el reconocimiento de palabras en formas precisa o fluida, deletrear mal y poca capacidad ortográfica (Association American Psychiatric, 2013).

La dislexia es una de las causas para que niños y niñas tengan una mala lectura y escritura así como dificultad para procesar símbolos del lenguaje, por lo que es de vital importancia detectar esta patología a tiempo para intervenir a los niños y niñas que la padecen, por este motivo se plantea una solución que involucre situaciones donde los niños y niñas interactúen a través de simulaciones que permitan recrear las fases del proceso de lectoescritura, es así como se involucran las tecnologías de la información y comunicación (TIC), ya que estas se pueden considerar como los principales instrumentos con los que puede contar el docente para intentar paliar las dificultades en el aprendizaje de la lectura derivadas de la dislexia (Núñez y Santamarina, 2016).

Diversas investigaciones intercalan el uso de situaciones medidas por las tecnologías de la información y la comunicación para el tratamiento de la dislexia o como medio para la corrección de estas, es el caso del proyecto desarrollo de habilidades de lectura a través de los videojuegos: estado del arte, llevado a cabo por Torres-Toukoumidis, Romero-Rodríguez, Pérez-Rodríguez, y Björk en 2016, donde analizan la vinculación sistemática de los videojuegos hacia el progreso de la lectura dentro del ambiente mediático y digital, como resultado establecieron que los videojuegos en el programa curricular formativo, fortalece el interés por la lectura acomodada al contexto digital y mediático, lo que permite abrir una ventana de conexión entre los lectores y motivando la interacción colaborativa entre individuos.

Por otro lado, Pozo en 2019 en su tesis investigativa denominada desarrollo de un juego de aprendizaje para los niños con dislexia diseidética de seis a nueve años de edad de la unidad educativa "Agustín Cueva Dávila", a través de la herramienta 
Game Maker Studio, indican que este tipo de iniciativas facilitan el proceso de enseñanza y entrenamiento de habilidades visuales y espaciales, brindando a los maestros de la institución un instrumento de apoyo para fortalecer estas habilidades en los niños con dislexia y en los niños con dificultades.

De igual forma, Ortiz en 2019, establece una propuesta denominada manual didáctico ilustrado para niños con dislexia de 7 a 11 años para ser usado como instrumento de apoyo de lectura y desarrollo de actividades diarias, donde los niños aprenden a través de contenido visual.

Es así, como estos estudios convergen en que las estrategias y tratamiento mediados por tecnologías propician en niños y niñas con trastornos de aprendizaje dislexia una mejoría dada la oportunidad de interactuar y repetir las actividades innumerables veces así mismo es más atractiva y da motivación en los niños para la utilización de la misma.

Por tal motivo, se establece como punto de partida el diseño de estrategias mediadas por scratch para apoyar el proceso lector en niños y niñas disléxicos.

\section{Tipos de dislexia}

La dislexia se establece como la incapacidad de procesar los símbolos del lenguaje, es decir, un niño o niña no puede cumplir las tareas escolares cuando se hacen uso de sonidos discontinuos del lenguaje hablado o símbolos del lenguaje escrito. La dislexia no se presenta de igual forma en los niños los síntomas son variados y es percibida con un continuo que puede abarcar formas moderadas de confusión de símbolos a síndromes complejos de inhabilidad (Jordán, 1991, p. 12). En ese sentido se establece tres tipos de dislexia la visual, auditiva y disgrafía.

Tabla 1. Tipos de dislexia según Jordán

\begin{tabular}{|c|c|c|}
\hline Dislexia visual & Dislexia Auditiva & Disgrafía \\
\hline $\begin{array}{l}\text { Inhabilidad para captar el signifi- } \\
\text { cado de los símbolos del lenguaje } \\
\text { impreso. Este tipo de dislexia no } \\
\text { se establece a partir de los proble- } \\
\text { mas de visión deficiente que pueda } \\
\text { presentar un niño, sino la imposibili- } \\
\text { dad de comprensión de lo que. Las } \\
\text { personas con este tipo de dislexia } \\
\text { perciben entras invertidas, desenca- } \\
\text { denando en los niños una dificultad } \\
\text { de lectura de las palabras. }\end{array}$ & $\begin{array}{l}\text { Se percibe como la inhabi- } \\
\text { lidad de reconocer sonidos } \\
\text { separados en el lenguaje } \\
\text { oral. El niño con este tipo de } \\
\text { dislexia no puede identificar } \\
\text { diferencias leves entre los so- } \\
\text { nidos vocales o consonantes, } \\
\text { por lo que no es capaz de } \\
\text { asociar sonidos específicos } \\
\text { con los respectivos símbolos } \\
\text { impresos. }\end{array}$ & $\begin{array}{l}\text { Se presenta cuando no se } \\
\text { puede coordinar los mús- } \\
\text { culos de la mano y el brazo } \\
\text { a los efectos de escribir de } \\
\text { manera legible. La escritura } \\
\text { de niños con este tipo de } \\
\text { dislexia se presenta con una } \\
\text { especie de garabatos. }\end{array}$ \\
\hline
\end{tabular}

Nota. (Jordán, 1991)

\section{Adquisición de la lectoescritura}

El proceso de leer y escribir permite a los niños y niñas descubrir nuevos escenarios y entornos, mientras la escritura le permite trasmitir sus ideas, sentimientos y emociones de ese mundo circundante. Para el proceso de lectura y escritura Uta Frith en 1985 estableció tres fases denominadas como: logográfica, alfabética y ortográfica. 
Tabla 2. Fases del proceso de lectoescritura

Logográfica

\begin{tabular}{|l|l|l|}
\hline $\begin{array}{l}\text { Reconocimiento global de las } \\
\text { palabras partiendo de su forma. }\end{array}$ & $\begin{array}{l}\text { Relación de los grafemas con } \\
\text { sus respectivos fonemas. }\end{array}$ & $\begin{array}{l}\text { Reconocimiento de la palabra } \\
\text { sin un análisis fonológico de } \\
\text { esta. }\end{array}$ \\
\hline
\end{tabular}

Nota: Adaptado del manual orientativo para padres y educadores. Dificultades infantiles de aprendizaje. (Salgado y Espinosa, 2008, pp. 155-156)

En ese sentido, Benedet (2013 citado en Tamayo, 2017) indica que los niños y niñas aprenden a hablar de forma natural pero el proceso lectoescritor se de a través de la instrucción, por el cual el cerebro crea las estructuras normales necesarias para sustentar esta habilidad.

Por otro lado, Miles (2004) expresa que los idiomas fonemáticamente regulares como el español el aprendizaje de los grafemas y fonemas no será una mayor dificultad dado que se presenta una correspondencia regular con la práctica del proceso de lectoescritura lo cual conlleva a que una persona con dislexia se le facilite el aprendizaje de estos, la dificultad radica en la velocidad de lectura y la aplicación de las reglas ortográficas en la conformación de la escritura (Tamayo, 2017, p. 425).

\section{Dislexia en el aula}

Los signos de dislexia se presentan generalmente cuando los niños y niñas están en edad escolar temprana, e inician el proceso de lectura y escritura. En la grafica se puede evidenciar algunas señales que pueden identificar un maestro en los niños que puedan presentar el trastorno.

Figura 1. Señales para identificar dislexia en el aula.

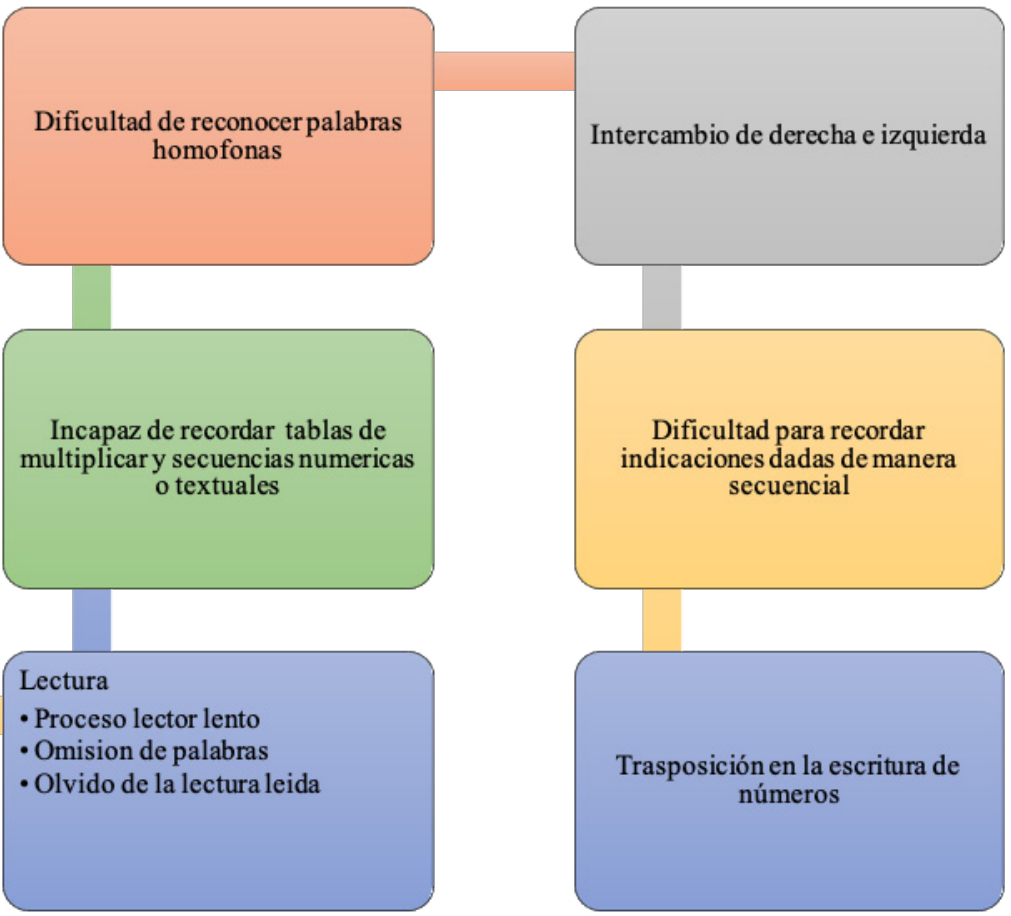




\section{Método/Descripción de la experiencia}

El proceso investigativo se enmarco dentro del enfoque cuantitativo, la cual generalmente parte de un problema definido por el investigador, en el cual utiliza la recolección de datos para probar hipótesis con base en la medición numérica y el análisis estadístico, con el fin establecer pautas de comportamiento y probar teorías (Hernández, Fernández, y Baptista, 2014, p. 4). El tipo de estudio fue de profundidad descriptiva, porque busca describir el estado, las características, factores y procedimientos presentes en fenómenos y hechos que ocurren en forma natural, sin explicar las relaciones que se identifican (Lerma, 2010, p. 63).

\section{Descripción del contexto y de los participantes}

Estudiantes de la Institución Educativa Mateo Pérez y la muestra será probabilística, solo participan niños y niñas que tiene el trastorno de aprendizaje - dislexia.

\section{Instrumentos}

Para el desarrollo de las estrategias se tuvo encuenta las dimensiones y variables establecidas en el instrumento de evaluación conductual para detectar errores de tipo disléxico en la lecto-escritura de niños de segundo a quinto de primaria, IDETID - LEA, desarrollado por Laura Aragón en 2007, el cual consta de tres partes: prueba de dictado, de lectura y de copia. Cada una de ellas consta de una subprueba que evalúan las diferentes generalizaciones como silabas, vocales, palabras, enunciados, textos en prosa, versos, como se observa en la tabla 3.

Tabla 3. Ejemplificación del instrumento IDETID - LEA

\begin{tabular}{|c|c|c|}
\hline Prueba & Descripción & Ejemplo \\
\hline Dictado & $\begin{array}{l}\text { Consta de cuatro } \\
\text { subpruebas: dictado } \\
\text { de vocales, dictado de } \\
\text { palabras, dictado de } \\
\text { enunciados y dictado } \\
\text { de párrafos. } \\
\text { El evaluador debe leer } \\
\text { en voz alta y clara cada } \\
\text { una de las vocales, } \\
\text { enunciados, palabras y } \\
\text { párrafos. }\end{array}$ & $\begin{array}{l}\text { - Vocales } \\
\text { a, e, i, o, u } \\
\text { - Lista de palabras } \\
\text { - Melón } \\
\text { - Deber } \\
\text { - } \quad \text { Noda } \\
\text { - Gallo } \\
\text { - Enunciados } \\
\text { - El gemelo de Luis es más chico que él. } \\
\text { - El pañuelo de Rosa. } \\
\text { - Textos en prosa y versos } \\
\text { El otoño } \\
\text { El tiempo en otoño es delicioso. No hace frío ni calor y hay } \\
\text { flores y pájaros. }\end{array}$ \\
\hline
\end{tabular}




\begin{tabular}{|c|c|c|}
\hline Lectura & $\begin{array}{l}\text { Consta de cuatro } \\
\text { subpruebas: lectura } \\
\text { de sílabas, lectura de } \\
\text { palabras, lectura de } \\
\text { enunciados y lectura } \\
\text { de textos en prosa y de } \\
\text { versos. } \\
\text { Se recomienda grabar } \\
\text { la lectura del niño para } \\
\text { posterior revisión. }\end{array}$ & $\begin{array}{l}\text { - Sílabas } \\
\text { - } \quad \text { Bre } \\
\text { - Jo } \\
\text { - } \quad \text { Nu } \\
\text { - Am } \\
\text { - Palabras } \\
\text { - María } \\
\text { - } \quad \text { Parque } \\
\text { - Haba } \\
\text { - } \quad \text { Regadera } \\
\text { Enunciados } \\
\text { Yo tengo un perro que ladra fuerte y se llama Quique } \\
\text { El zapato de Hugo tiene un hoyo en la suela } \\
\text { Textos en prosa y de versos } \\
\text { Los caballitos } \\
\text { iQué lindo paseo me dio mi papá! Fuimos a la feria del } \\
\text { pueblo y me subió al carrusel. Había jirafas, toritos y } \\
\text { coches; también caballitos de madera pintados de negro, } \\
\text { rojo, blanco y café. Me gustó mucho subir a los caballitos } \\
\text { y oír la alegre música. Con unos cuantos pesos me divertí } \\
\text { como nunca. }\end{array}$ \\
\hline Copia & $\begin{array}{l}\text { Consta de cuatro sub- } \\
\text { pruebas: sílabas, lectu- } \\
\text { ra de palabras, lectura } \\
\text { de enunciados y lectura } \\
\text { de textos en prosa y } \\
\text { de versos. El evaluador } \\
\text { dispondrá hojas de pa- } \\
\text { pel las cuales utilizará } \\
\text { el niño para copiar el } \\
\text { texto indicado. }\end{array}$ & $\begin{array}{l}\text { - Sílabas } \\
\text { - } \quad \text { Ba } \\
\text { - Jai } \\
\text { Palabras } \\
\text { - } \quad \text { Pablo } \\
\text { - Olga } \\
\text { - Llorar } \\
\text { - Ira } \\
\text { Enunciados } \\
\text { - } \quad \text { Dos globos cayeron en el pozo. } \\
\text { - } \quad \text { La está lloviendo en Santa Rosa. } \\
\text { Textos en prosa y de versos } \\
\text { El circo } \quad \\
\text { Este es un circo muy grande. Se llama Circo Modelo. Aquí } \\
\text { trabaja Bobito el chistoso, un payaso tan bueno como } \\
\text { gracioso. Bobito dijo que les pondrá unas orejas de burro a } \\
\text { los niños que no sepan leer. }\end{array}$ \\
\hline
\end{tabular}

Nota. Adaptado de Aragón 2007.

\section{Procedimiento}

La investigación se llevó a cabo en tres fases, la primera se realizó caracterización del trastorno específico de aprendizaje - dislexia, como se evalúa y posibles estrategias para la corrección de estas en niños y niñas. La segunda fase, se establece con el diseño de las secuencias didácticas partiendo de las estrategias para corregir la dislexia y la fase tres consistió en el diseño de los escenarios en scratch. 


\section{Resultados}

\section{Diseño de secuencias didácticas para fortalecer la lectura en niños y niñas disléxicos}

Para el desarrollo de las secuencias didácticas se establece los modelos diseñados por Diaz (1996) que establece que toda secuencia debe tener una organización de las diferentes actividades de aprendizaje que realizará el estudiante, así mismo, conllevan a crear situaciones que le permita al estudiante potenciar sus capacidades y habilidades. En ese sentido, se diseñan las secuencias didácticas: Identificando el alfabeto, Detective de palabras, Descubriendo Palabras, Reconociendo el alfabeto en una oración, las cuales permitan a niños y niñas disléxicos a corregir error de tipos de adiciones u omisiones en lectura y copia de textos.

\section{Evaluación de la secuencia didáctica}

Las secuencias didácticas fueron valoradas por expertos a través de una rubrica estructurada con criterios que establecen la pertinencia de esta. La escala de rango de valoración se estableció desde deficiente, aceptable, bueno y excelente abarcado un rango de cero a diez. Las puntuaciones obtenidas por cada una de las secuencias diseñadas abarcaron el rango de ocho a nueve que establece la aplicabilidad y eficacia de la secuencia didáctica.

Tabla 4. Escala de valoración secuencia didáctica

\begin{tabular}{|c|c|}
\hline Calificación & Rango \\
\hline Excelente & 10 a 9 \\
\hline Bueno & 8 a 7 \\
\hline Aceptable & 6 a 4 \\
\hline Deficiente & 3 a 0 \\
\hline
\end{tabular}

Tabla 5. Puntaje de valoración por par experto

\begin{tabular}{|c|c|c|c|}
\hline \multicolumn{4}{|c|}{ Valoración secuencia didáctica } \\
\hline $\begin{array}{c}\text { Identificando El } \\
\text { Alfabeto }\end{array}$ & $\begin{array}{c}\text { Detectives de las } \\
\text { palabras }\end{array}$ & Descubriendo Palabras & $\begin{array}{c}\text { Reconociendo el } \\
\text { alfabeto en una oración }\end{array}$ \\
\hline 9,45 & 9,34 & 9,09 & 9,31 \\
\hline
\end{tabular}

\section{Scratch como mediador tecnológico para el diseño de las secuencias didácticas}

Scratch, es un entorno gráfico de programación desarrollado por un grupo de investigadores del Lifelong Kindergarten Group del Laboratorio de Medios del MIT, bajo la dirección del Dr. Mitchel Resnick. Scratch permite el desarrollo del pensamiento computacional, de allí su importancia. Para ello es necesario que el docente innove y utilice herramientas tecnológicas, y con ello evitar que los estudiantes se encuentren de una forma pasiva donde respondan sólo a lo planificado (Franco-González, García-Herrera, Guevara-Vizcaíno, y Erazo-Álvarez, 2020, p. 405). 
Cada escenario contempla la secuencia didáctica diseñada, por ejemplo, la secuencia didáctica, identificando el alfabeto, se inicia con una narración guiada que permite establecer que actividad debe desarrollar el niño o niña, las indicaciones son puntuales y se obtiene incentivos que permite que el sino o niña identifique si la opción elegida es correcta o no, en caso negativo el juego se reinicia, lo que permite apropiación del tema desarrollado.

Figura 2. Identificando el alfabeto
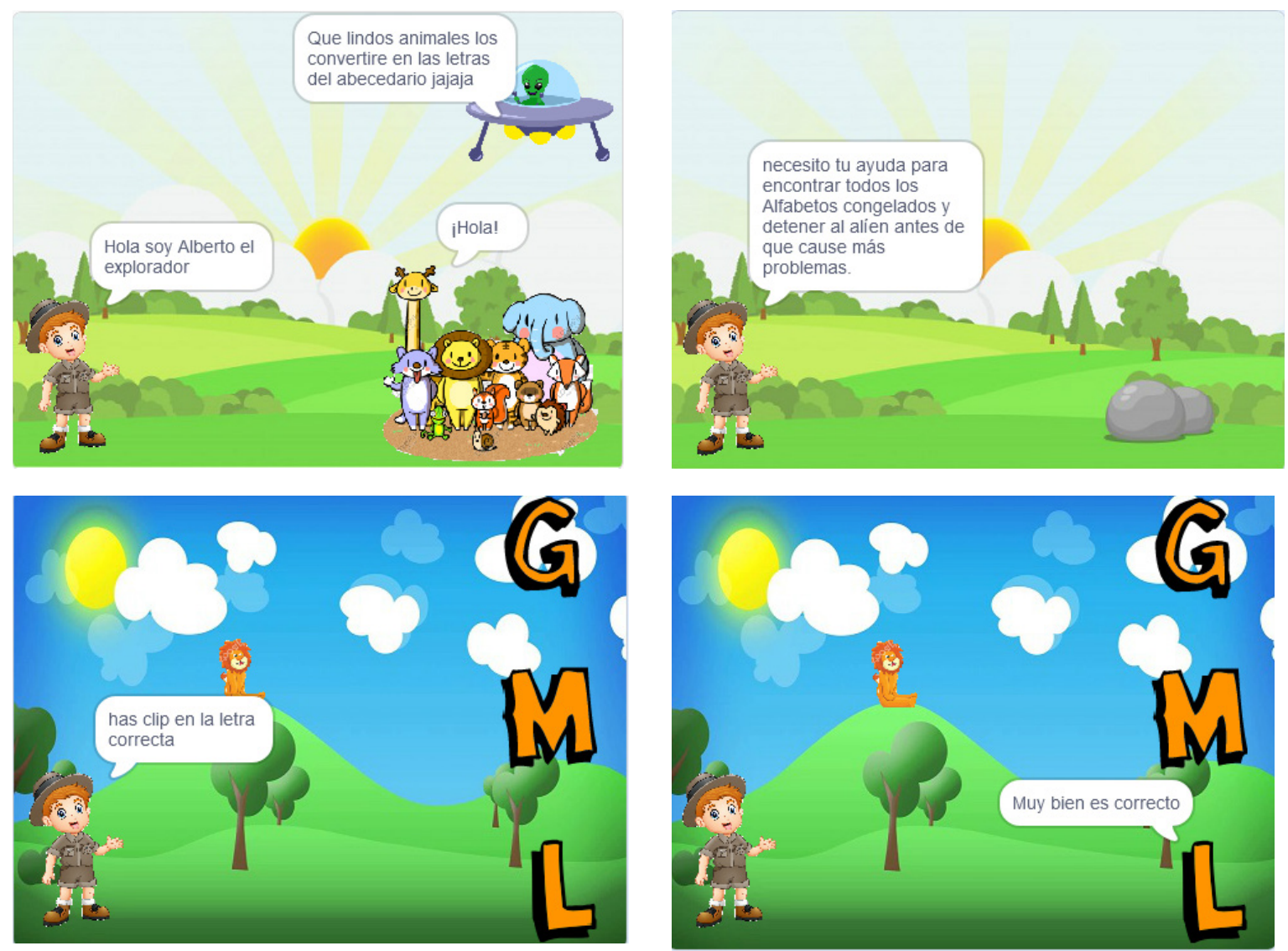

La secuencia didáctica descubriendo palabras, tiene la finalidad que el niño o niña forme diferentes palabras utilizando diferentes letras que se listan. 
Figura 3. Descubriendo palabras
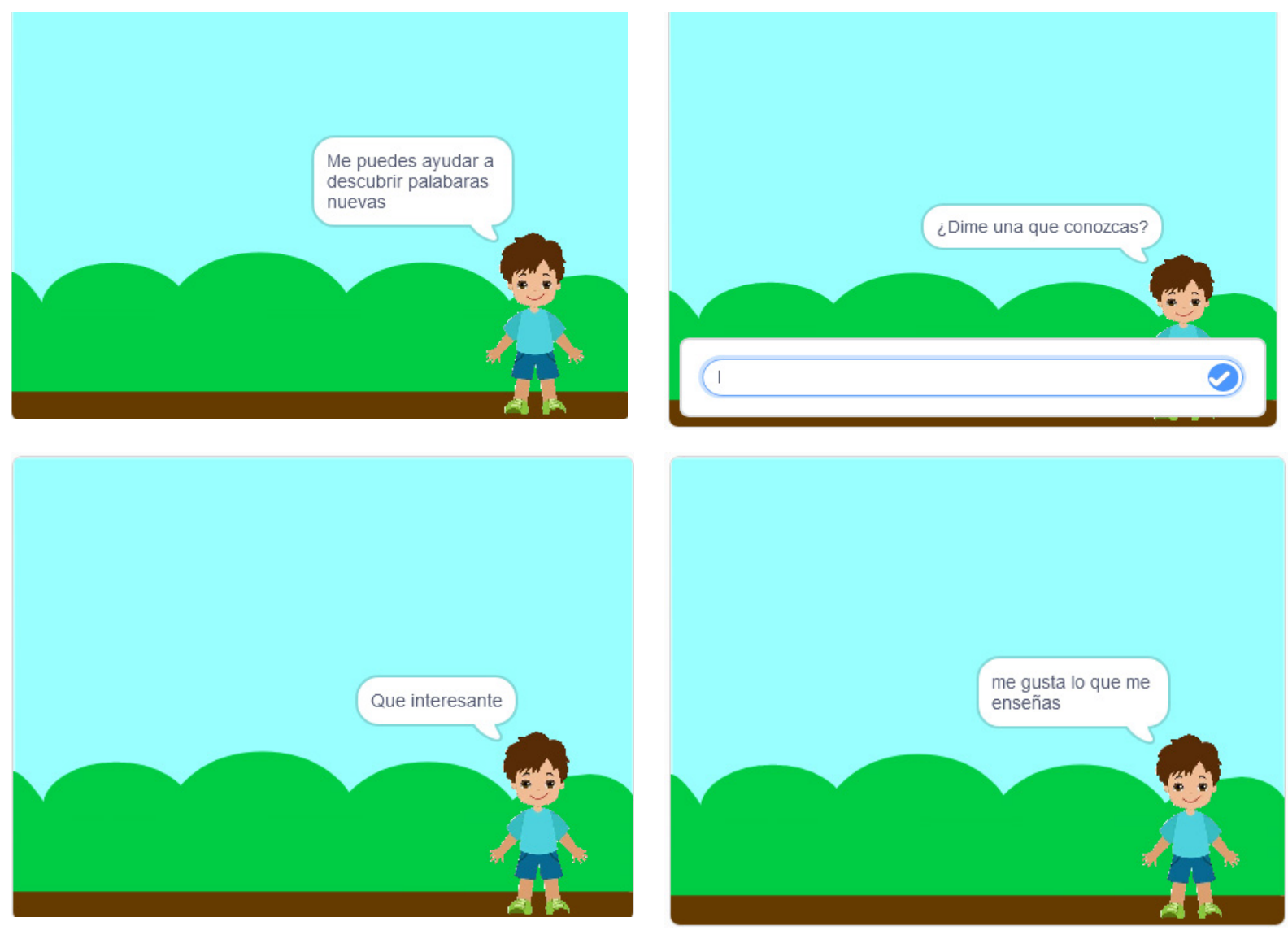

La secuencia didáctica detective de palabras potencia la comprensión del alfabeto mediante actividades de repitencia y de memoria, el niño o niña deberá disertar en tre las palabras cortas y largas que se presenta en el escenario.

Figura 4. Detective de palabras
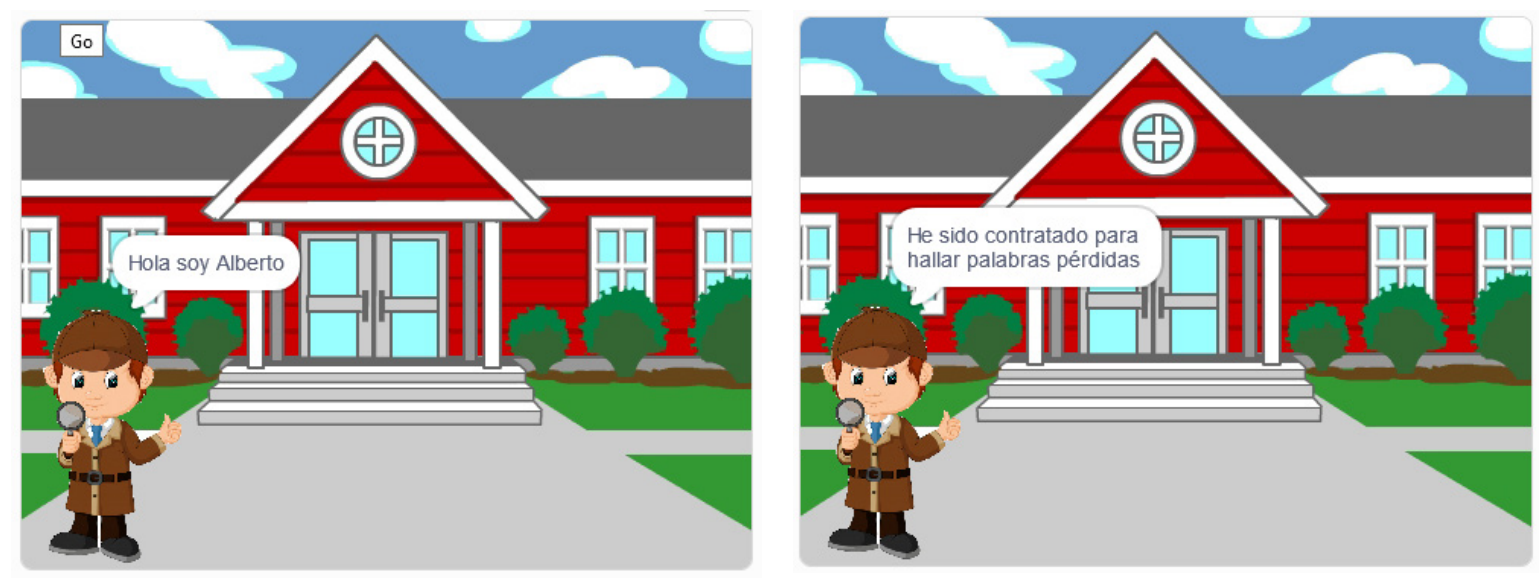

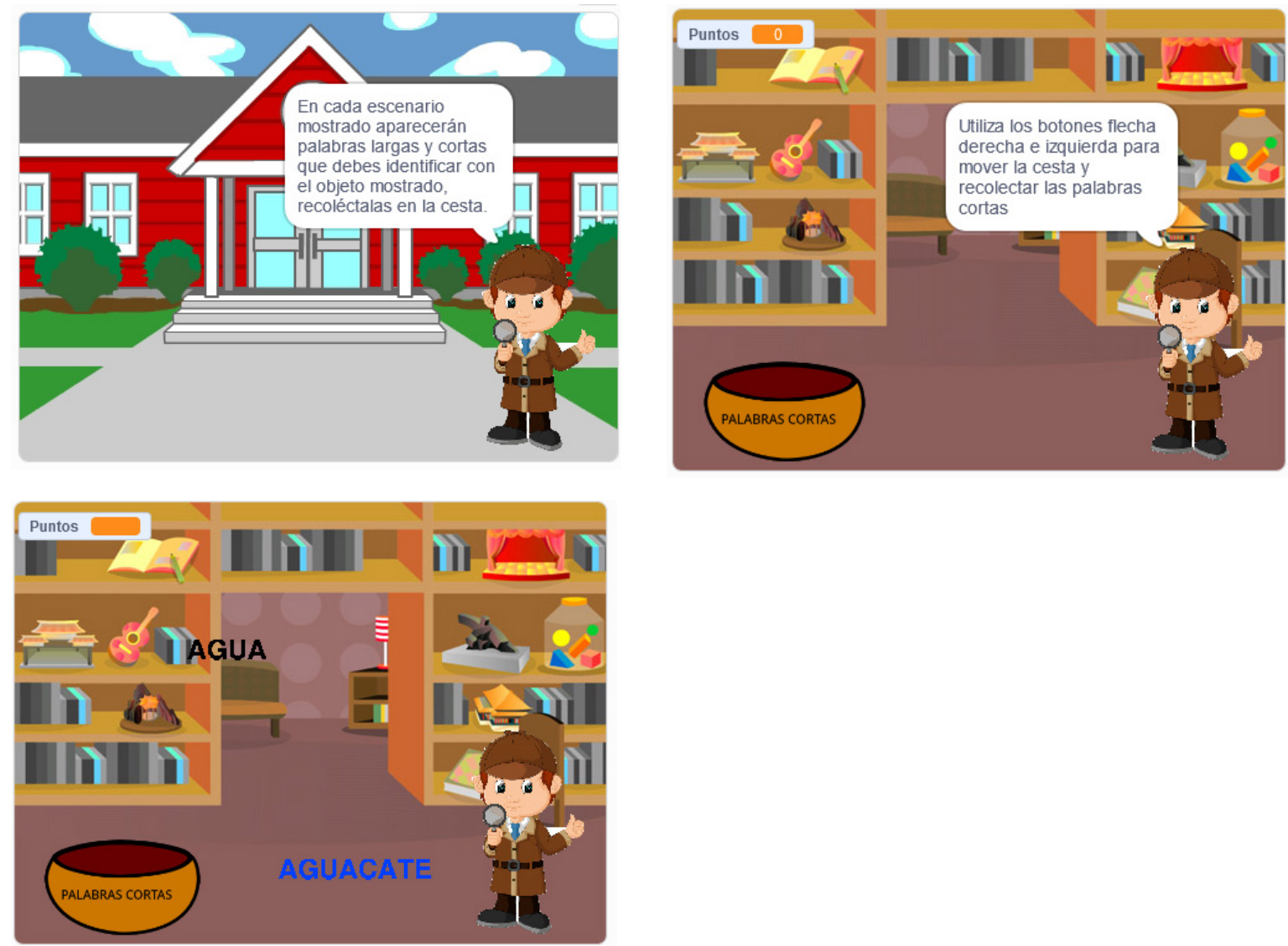

\section{Discusión y conclusiones}

A partir de la dificultad detectada en los estudiantes y valorando el contexto de la institución educativa y los recursos tecnológicos se organizan las secuencias didácticas al alcance de los educandos para fomentar los procesos lectores hacia el mejor desempeño de las competencias comunicativas, desde el decodificar y descifrar mensajes, para avanzar en la interacción social. Además, se pretende que los docentes en el proceso de enseñanza adopten nuevas estrategias que ayuden a los educandos a superar estas dificultades, innovando desde escenarios innovadores de aprendizajes. De igual forma contextualizar los procesos de enseñanza de acuerdo a las necesidades de aprendizajes de los niño y niñas buscar las estrategias que se adapten a los estilos de aprendizajes de cada educando, reconociendo que tenemos aulas con niños diferentes y heterogéneos.

El uso de tecnologías y las secuencias didácticas integran diversos procesos cognitivos para que el niño desarrolle habilidades que le permitan realizar las tareas acordes a su contexto y necesidades.

Por ende, aportar una visión integradora al momento de desarrollar actividades en el cual es de suma importancia cuando en esta se tiene niños o niñas con dislexia, por ende, el maestro debe diseñar estrategias didácticas que conlleven instrucciones cortas y claras para que estos comprendan las acciones que debe realizar. De igual forma, estas actividades deben ser mediadas con las TIC para generar mayor interés en los niños y niñas. 
El diseño de secuencia didácticas para niños y niñas disléxicos deben estar fundamentadas en los modelos de adquisición de lectura que permitan la decodificación correspondiente de los tamaños de los fonemas, en cuanto al reconcomiendo de las unidades ortográficas se establece que el silabeo es el mecanismo más apropiado (Carrillo y Marín, 1996), en ese sentido, el uso de escenarios interactivos compensa este proceso al momento en que el niño o niña interactúa y es capaz de realizar la actividad varias veces y descubrir cuando avanza en cada intento.

Es así como, hoy día el uso de herramientas didácticas mediadas por las TIC facilita primeramente actividades multimodales en el aula de clase donde los estudiantes son cocreadores de sus conocimientos, fortaleciendo diversas habilidades incluyendo habilidades lectoras y acercamientos de los niños y niñas.

\section{Referencias}

Aragón, L. (2007). Fundamentos teoricometodológicos de una evaluación conductual dirigida a la dislexia. Aragón, Evalaucion y tratamiento de niños disléxicos (2 ed., p. 335). Trillas.

Association American Psychiatric. (2013). Guía de consulta de los criterios diagnósticos del DSM-5 (5 ed.). Arlington.

Brousseau, G. (2007). Iniciación al estudio de la teoria de las situaciones didácticas. Libros del Zorzal.

Carrillo, M. y Marín, J. (1996). Desarrollo metafonológico y adquisición de la lectura: Un programa de entrenamiento. Ministerio de Educación y Ciencia CIDE.

Díaz-Barriga, Á. (2013). Guía para la elaboración de una secuencia didáctica. UNAM. shorturl.at/evFLO

Franco-González, D., García-Herrera, D., Guevara-Vizcaíno, C. y Erazo-Álvarez. (2020). Scratch para la enseñanza de Lenguaje de Programación en Primero de Bachillerato. Revista Arbitrada Interdisciplinaria KOINONIA. 5(5). http://dx.doi. org/10.35381/r.k.v5i5.1050

Goethals, R. (s.f.). Teoría de la adquisición de la lectura-escritura según Uta Frith. https:// www.edunoi.com/teoria-de-la-adquisicion-de-la-lectura-escritura-segun-uta-frith/

Hernández, R., Fernández, C., \& Baptista, M. (2014). Metodología de la Investigación (6 ed.). Mcgraw-hill.

Jordán, Dale. (1991). La dislexia en el aula (2 ed.). Paidós Educador.

Lerma, H. (2010). Metodología de la investigación. Propuesta, anteproyecto y proyecto. ECOE ediciones.

Miles, T. (2004). Algunos problemas en determinar la prevalencia de la dislexia. Revista electrónica de Investigación Psicoeducativa y psicopedagógica. 2(2). https:// doi.org/10.25115/ejrep.v2i4.1147 
Nessy. (2017). Dyslexia: 10 Classroom Indicators. https://www.nessy.com/uk/ teachers/dyslexia-classroom-10-indicators/\#more

Núñez, M. y Santamarina, M. (2016). Una propuesta de mejora de la dislexia a través del procesador de textos: "Adapro". Hekademos: revista educativa digital. (19), 2025. https://dialnet.unirioja.es/servlet/articulo?codigo $=6280713$

Ortiz, S. A. (2019). Propuesta de un manual didáctico ilustrado para niños con dislexia de 7 a 11 años que sirva como instrumento de apoyo de lectura y desarrollo de actividades diarias. [Trabajo de grado no publicada]. Universidad de las Américas. https://bit.ly/3IYPw5N

Pozo, S. (2019). Desarrollo de un juego de aprendizaje para los niños con dislexia diseidética de seis a nueve años de edad de la unidad educativa "Agustín Cueva Dávila", mediante la herramienta Game Maker Studio. [Trabajo de grado no publicada]. Universidad Técnica del Norte. http://repositorio.utn.edu.ec/ handle/123456789/8986

Salgado, A., y Espinosa, N. (2008). Dificultades infantiles de aprendizaje. Detección $y$ estrategias de ayuda. S.A. Cultural.

Tamayo, S. (2017). La dislexia y las dificultades en la adquisición de la lectoescritura. Profesorado. Revista de currículum y formación de profesorado. 21(1). https://www. redalyc.org/articulo.oa?id=56750681021

Torres-Toukoumidis, A., Romero-Rodríguez, L., Pérez-Rodríguez, M.-A., y Björk, S. (2016). Desarrollo de habilidades de lectura a través de los videojuegos: Estado del arte. Ocnos. Revista De Estudios Sobre Lectura, 15(2), 37-49. https://doi.org/10.18239/ ocnos_2016.15.2.1124 


\section{Utilización y Adaptación de Diferentes Innovaciones Tecnológicas Durante la Covid19 y la Postpandemia.}

\section{Sánchez García, José Manuel}

Orcid.org/0000-0002-4240-5095

Universidad de Sevilla josesanchez@us. 


\title{
UTILIZACIÓN Y ADAPTACIÓN DE DIFERENTES INNOVACIONES TECNOLÓGICAS DURANTE LA COVID19 Y LA POSTPANDEMIA.
}

\author{
Sánchez García, José Manuel \\ Orcid.org/0000-0002-4240-5095 \\ Universidad de Sevilla \\ josesanchez@us.
}

\section{Resumen}

Para Sánchez y Toledo (2017) la convergencia de Tecnologías de la Información y la Comunicación (en adelante TIC) en diferentes ámbitos se viene produciendo de forma paulatina desde hace tiempo. El impacto de la Covid19 en 2020 y 2021 ha acelerado el uso educativo de diferentes tecnologías que comenzaban a integrarse en las aulas. Metodologías como, Flipped Classroom; tendencias como Bring Your Own Device o Realidad Aumentada a los que se han añadido otras tecnologías ya existentes. El uso intensivo de las redes, la formación docente y la actitud de los estudiantes han mostrado deficiencias en este periodo. Se han superado las predicciones del Informe Horizon 2020 (Alexander et al., 2019; Brown et al., 2020; Johnson et al., 2015) el aumento de la demanda y uso en los ámbitos empresariales y educativos, el uso de dispositivos inadecuados, la brecha digital, económica y generacional han mostrado las debilidades del uso de las redes. Se analizan diferentes trabajos recabados incidentalmente en repositorios científicos que abordan su uso durante la Covid19. Se usa en esta investigación software de análisis de datos cualitativo asistido por computador (CAQDAS de sus siglas en inglés) Atlas.Ti 9. Este nos muestra cuales han sido las innovaciones tecnológicas incorporadas. Este periodo de cambio y crisis puede ser visto como una oportunidad para analizar las debilidades y amenazas, las fortalezas y oportunidades. Es por ello necesario implementar soluciones y crear marcos de colaboración y gestión para la implantación de todas estas tecnologías en la enseñanza en entornos digitales (Muñoz, 2020).

\section{Palabras clave}

Innovación, interdisciplinar, modelos pedagógicos, conectividad, cambio tecnológico. 


\section{Introducción}

Se plantea como objeto de estudio la convergencia de distintas metodologías y TIC así como los cambios que se han producido en el ámbito educativo durante la pandemia de Covid19. Para ello se han adaptado diferentes programaciones diseñadas para el ámbito presencial a entornos formativos en línea de forma muy rápida (Socolovsky, 2020) con distintos grados de éxito. En diferentes países se ha implementado un distanciamiento social y periodos de cuarentena que han hecho necesario el uso de entornos digitales de aprendizaje en los hogares, que ha llevado al uso de entornos mixtos en los que conviven TIC con presencialidad.

En la adaptación a esta nueva circunstancia se han utilizado las herramientas disponibles, muchas de ellas presentes en las redes y utilizados desde hace tiempo. Usándose la red de los hogares y los dispositivos de nuestro entorno cercano, portátiles, ordenadores de sobremesa, teléfonos, programas educativos en televisión y radio, Smart TV... así como programas de video conferencia y comunicación que no se diseñaron con fines educativos (lyengar, 2020; Mustapha et al., 2021). El uso de las tecnologías mediadas por dispositivos precisa de un conocimiento previo que permita al usuario trabajar de forma fluida (Socolovsky, 2020) conocimientos en muchos casos adquiridos mediante la práctica no a través de un aprendizaje reglado. Estas aplicaciones y dispositivos utilizan cámaras y micrófonos que muchos docentes no han usado previamente. Se pudo apreciar al inicio de su uso que se producían cortes, mala calidad de imagen, entornos inadecuados de trabajo en los hogares, etc. El ancho de banda se mostró insuficiente y los equipos presentaban mala calidad en cámaras y micrófonos lo que nos lleva a preguntarnos si esta es una tecnología madura para este propósito. Más allá de las plataformas educativas que en muchas ocasiones son una videoconferencia en grupo, una presentación compartida o una clase magistral emitida en streaming. Si se tiene en cuenta que todo este ecosistema digital se percibe como parte del Ambiente Personal de Aprendizaje (Personal Learning Environment", PLE) percibido como un nuevo entorno tecnológico o una nueva estrategia de aprendizaje (Cabero \& Llorente, 2011)J. \&amp; Castañeda Quintero, L. (2010 se han modificado de forma radical. Se adaptaron los hogares como escuelas con las limitaciones que puede suponer y se presentan nuevas estrategias de enseñanza-aprendizaje. Del mismo modo que se analiza la actuación en los centros educativos y docentes durante los periodos de cuarentena. Este trabajo analiza un número limitado de artículos en los que encontramos aspectos comunes (bastante extendidos) sobre la convergencia de distintas tecnologías. Surgen preocupaciones sobre la desvirtuación del papel del profesor respondiendo a la pregunta de si el docente es necesario en el proceso de enseñanza aprendizaje o puede ser sustituido por ordenadores y programas. La adopción de nuevos medios y su uso educativo en el entorno de los hogares nos da una respuesta clara, el colegio, el instituto o la universidad son algo más que las materias que imparten. La creación de materiales adecuados para una enseñanza online o Blended Learning requiere de mayor preparación y esfuerzo. Se necesitan conocimientos ligados a la materia y habilidades relacionadas con las TIC, desde la forma correcta de exponer las materias hasta la creación de los contenidos. Esto propicia y hace patente que es necesario en el proceso de formación de los discentes que se dirija a la obtención de las competencias necesarias durante su formación. Objetivos que han de quedar claros y definidos en las programaciones docentes realizadas específicamente para la enseñanza a distancia (Vargas, 2021) 
El profesorado y las instituciones han realizado un gran esfuerzo integrando en todos los niveles de enseñanza diferentes tipos de adaptaciones que se estaban comenzando a integrar de forma paulatina en los centros docentes como plataformas, a las que se han migrado o adaptado contenidos. Se han usado herramientas simples como el Email, para permanecer en contacto con los alumnos. Videoconferencias para impartir clase o atender a los alumnos en tutorías. Este uso intensivo ha llevado a detectar fallos en la conectividad aunque esta necesidad aparece igual en todos los países por lo que docentes y alumnos perciben que es necesaria una red con mayor capacidad, mas económica y estable que elimine la brecha digital entre países y regiones proporcionando el mismo acceso para de esta forma poder percibir la educación como un derecho (Socolovsky, 2020; OCDE, 2021)

\section{Método}

Se analizan 10 artículos que tratan el uso de tecnología y su impacto en la docencia durante la pandemia partiendo de la Teoría Fundamentada (Grounded Theory) mediante de uso de programas CAQDAS. Análisis para el que se usara Atlas.Ti 9. Se busca conocer distintos tipos de herramientas, tendencias, estrategias, tecnología y soluciones para impartir docencia durante la Covid19. La rápida adaptación de los materiales a la docencia online, o Blended Learning (Mustapha et al., 2021; Nasution et al., 2021). El uso de las XR como Realidad Aumentada, Realidad Virtual, Realidad Mixta como tecnologías emergentes (Brown et al., 2020) uso de plataformas (Moreira, 2017; Fernández Torres et al., 2021), tareas enriquecidas (Harris, 2021). Estrategias como Flipped Classroom o el uso de determinados dispositivos propios superando las expectativas de las tendencias BYOD (Brown et al., 2020; Sánchez-García \& Toledo-Morales, 2017). El acceso a repositorios con Objetos de Aprendizaje y Recursos Educativos Abiertos, así como el uso de todas estas tecnologías y tendencias generan sinergias que mejoran el proceso de enseñanza-aprendizaje. La formación inicial del profesorado necesita adaptarse para enfrentarse con éxito a los retos que plantean estos cambios. Es necesario el fomento por parte de los estados y las instituciones del uso y desarrollo de tecnologías en línea. La implementación internacional de planes de alfabetización digital y programas para la eliminación de la brecha digital que la pandemia ha permitido percibir con claridad. Lugo y otros (Lugo et al., 2020) plantean de forma sistemática un decálogo que analiza las necesidades más perentorias a cubrir en un futuro cercano para de esta forma implementar políticas digitales que ayuden a mejorar la formación.

Se busca desde la teoría emergente la presencia en los artículos analizados de distintas adaptaciones o uso TIC en el periodo de pandemia desde inicio de 2020 has las fechas más recientes. Pare ello se ha realizado una búsqueda en diferentes bases de datos y repositorios de artículos en los que aparecieren los términos, educación, innovación, TIC y covid19. De los que se seleccionan aquellos que nos parecieron relevantes por indagar sobre los ítems que interesan a esta investigación. Para el análisis de los artículos se usó Atlas.Ti 9 encontrando unidades dotadas de sentido que nos permiten observar que tecnologías e innovaciones se han implementado.

Observamos que la codificación con esta herramienta es válida al ser realizada por expertos o personar formadas para su uso (Castaño, 2003). Al tratarse de un trabajo limitado y al ser el codificador el mismo autor con un buen nivel de experticia en el uso de esta herramienta podemos dar por valida la codificación. El uso de muchas 
de estas herramientas en diferentes ámbitos educativos durante la Covid19 y en los periodos de aislamiento hace que prácticamente todo el personal vinculado a la educación haya tenido contacto con diferentes medios informáticos orientados a docencia en línea. Por ello algunos de los códigos utilizador se pueden considerar "ex ante". Pese a ello estos ítems aparecen de forma clara en los trabajos analizados. Los que han aparecido de forma clara como unidades dotadas de sentido han sido:

Tabla 1. Tablas de códigos utilizados.

\begin{tabular}{|l|l|}
\hline Código & Significado \\
\hline ACC & Acceso a internet con los medios adecuados para impartir clase. \\
\hline CLIM & $\begin{array}{l}\text { Clima y ambiente de aula, cambios en las relaciones y comportamientos en la ense- } \\
\text { ñanza durante la pandemia. }\end{array}$ \\
\hline ROV & Relativo a la COVID-19 \\
\hline$C r M$ & Creación de materiales por parte profesores y alumnos. \\
\hline DDM & Dotación de materiales para impartir clase. \\
\hline$E E L$ & Enseñanza en línea o enseñanza virtual. \\
\hline$E V A L$ & Preocupaciones en los relativo a la forma de evaluación de los alumnos. \\
\hline$F C L$ & Clase Invertida, Flipped Classroom. \\
\hline FORM & $\begin{array}{l}\text { Formación necesaria para implementar todas las nuevas metodologías e innovacio- } \\
\text { nes tecnológicas. }\end{array}$ \\
\hline$M A I L$ & Uso de correo electrónico \\
\hline$P L A T$ & Plataformas que se han usado, como Moodle u otra similar. \\
\hline$R S$ & Redes sociales. \\
\hline TIC & Tecnologías de la información y la comunicación. \\
\hline VID & Video. \\
\hline VIRT & Virtual. \\
\hline$W A P P$ & Uso de WhatsApp y de mensajería instantánea. \\
\hline
\end{tabular}

Se ha tenido especial cuidado con la codificación pues en ocasiones las búsquedas realizadas pueden ser confusas al existir para la palabras homónimas y antónimas que pueden llevar a confusión. El análisis con Atlas.Ti 9 nos da como resultado una red de conceptos que interrelaciona surgiendo tres categorías generales que agrupan diferentes conceptos. Estas pueden variar en un análisis más amplio y evolucionaran a lo largo del tiempo si analizamos los artículos que aparezcan dentro de un año, dos o cinco. Dependiendo de como se adapten los sistemas educativos. Se analizan en este trabajo diez artículos de diferentes autores, Castillo \& Castillo (2021), Cano et al. (2020), Ramírez-Montoya (2020), Sangrá (2020), Moreno-Correa (2020), Carrascal et al. (2020), González \& Fernández (2021), Chan et al. (2021), Bonilla (2020), Sandoval (2020) todos ellos en español para facilitar las búsquedas y mejorar la codificación con Atlas.Ti 9.

Utilizando los datos obtenidos de se genera una tabla comparativa de las diferentes estrategias educativas utilizadas para la cual y en aras de una mayor claridad utilizaremos la forma abreviada para cada ítem que hemos usado en el análisis con Atlas. Ti 9 que aparecen en la Tabla no 1. 


\section{Resultados}

El análisis realizado con Atlas.Ti 9 presenta la típica forma de árbol en la que se ordenan y aparecen las distintas categorías y los códigos definidos tras el análisis de los artículos. Si bien la relación entre los mismos no esta en este caso claramente definida pues los diferentes códigos coocurren de forma permanente. Esto determina que el concepto de convergencia es claro no pudiendo separarse algunos de los ítems. El análisis presenta tres categorías: Una referente al hardware (HARD) en la que se integran el acceso a las redes (ACC), con relación a la parte física de las mismas y siendo un elemento esencial sin el cual no es posible la comunicación. Integrado por servidores, líneas de fibra óptica o cable, conmutadores y un amplio numero de máquinas y servicios que en muchas ocasiones no tenemos en cuenta desde nuestros puestos de trabajo o nuestros hogares. La dotación de material (DDM), estudiada de forma profusa en la escuela, aulas de informática, pizarras digitales y un largo etcétera que han tenido que ser sustituidas por los dispositivos presentes en los hogares. De forma general aparecen en los textos el uso y referencia a las TIC que de forma transversal esa presente en todos los códigos, siendo habitualmente relacionado con los diferentes dispositivos mas que con su uso.

Fig. 1. Árbol de códigos obtenido con Atlas.Ti 9. (Elaboración propia)

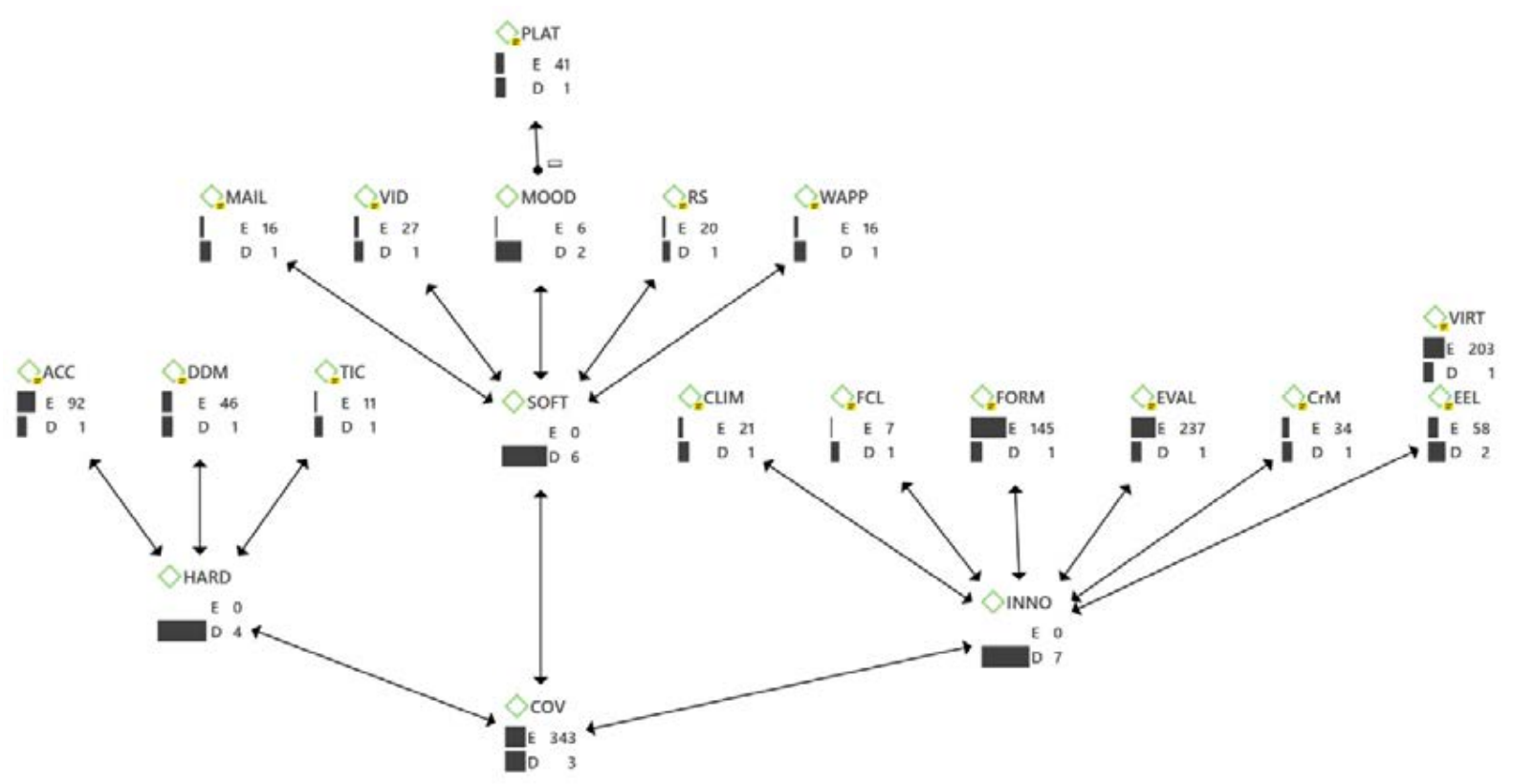

Otra de las categorías es la relacionada con el software (SOFT) utilizado, que en muchas ocasiones ya se venía integrando en el ámbito educativo, y que se ha adaptado de forma acelerada y por otro lado el uso de programas que en principio no tenían esta función. El caso mas notorio es el de las plataformas educativas, siendo la que mas aparece en la codificación Moodle (MOOD). Por otro lado, se ha usado mucho el correo electrónico (MAIL), el video (VID) en todas sus formas, streaming, subido a plataformas o a YouTube, en forma de videoconferencia grupal, o para las tutorías. Las redes sociales (RS) o programas de mensajería instantánea, siendo el mas presente WhatsApp (WHPP). La dimensión INNO relacionada con la innovación 
es quizás la mas compleja y en la que aparecen de forma más clara la convergencia necesaria entre diferentes tendencias. Aunque en menos medida aparece el cambio en el clima de aulas (CLIM) que se ha modificado de forma radical, primero por el periodo de cuarentena, posteriormente por el distanciamiento social. Otro de los conceptos que aparece es el de clase invertida. Útil si tenemos en cuenta el mayor tiempo en el que los alumnos permanecen fuera del aula y que esta metodología permite un mayor aprovechamiento del tiempo que el alumno permanecen en el centro. La formación es otro de los aspectos clave que se han codificado (FORM), aparece por parte del profesorado que ha tenido que dotarse de unas competencias en informática, redes, creación de materiales online ( $\mathrm{CrM})$, enseñanza online ( $E E L)$, y nuevas capacidades de evaluación (EVAL) en un lapso muy breve.

Como se ha recogido en el párrafo anterior muchos de los códigos coocurren, estando presentes en ocasiones en la misma unidad dotada de sentido. El esquema de coocurrencias que presenta el análisis indica que son necesarias las sinergias e interacciones de distintos elementos para conseguir una educación eficaz.

Fig. 2. Coocurrencias entre códigos. (Elaboración propia)

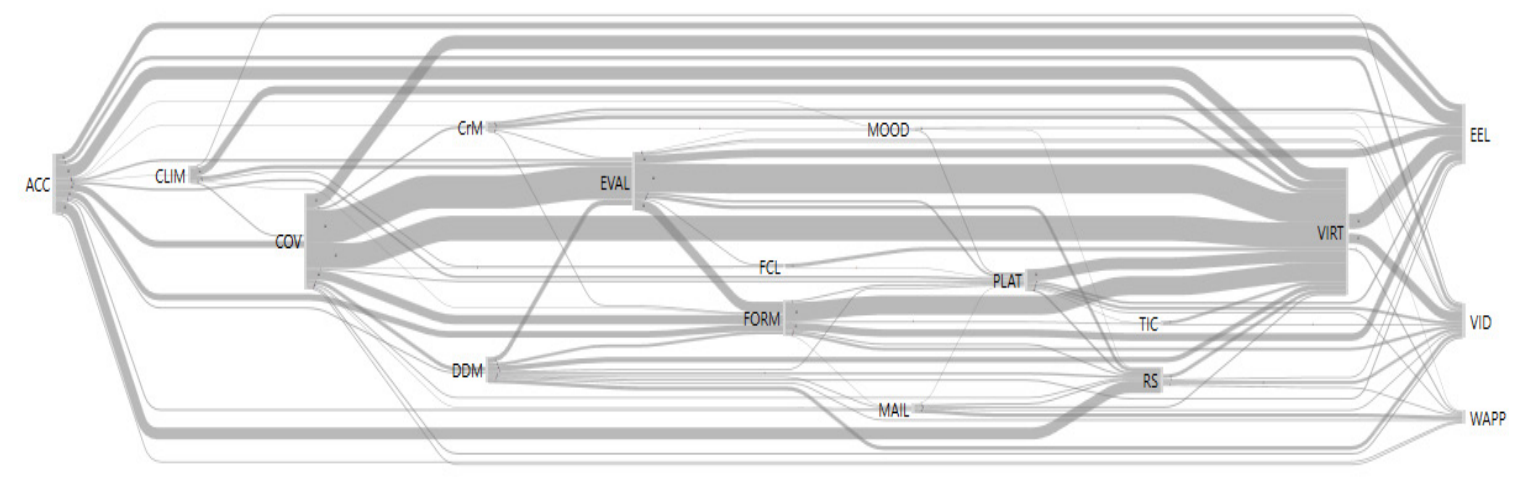

\section{Discusión y conclusiones}

La crisis sanitaria global ha impactado en todos los ámbitos de la vida, en la enseñanza especialmente debido a los distintos cierres de centros educativos durante la cuarentena en prácticamente todos los países. Esto ha actuado como un test de estrés mostrado las necesidades y deficiencias que presentan los entornos educativos partiendo de la cual es posible analizar las debilidades, amenazas, fortalezas y oportunidades que se están generando con la implantación de entornos digitales de forma masiva. Debido a lo cual es necesario implementar soluciones así como crear marcos de colaboración y gestión para la implantación de todas estas tecnologías y los nuevos entornos digitales en la enseñanza (Muñoz, 2020). Diferentes artículos muestran debilidades relacionadas con la implantación digital, uso de las TIC, conectividad a la red, formación inicial del profesorado en aspectos relacionados con la digitalización, la falta de evaluación del impacto de las políticas digitales y contenidos no adaptados a los entornos digitales. Estos nuevos entornos generan amenazas como la brecha digital o la falta de desarrollo de políticas educativas. Surgen fortalezas: facilidad de adaptación de los contenidos o el interés de los docentes y la existencia de comunidades muy amplias que realizan los trabajos de adaptación 
de los contenidos a las nuevas circunstancias y medios. Estas fortalezas llevan a considerar las oportunidades de alfabetización digital y mejora de las competencias digitales, creación de estándares internacionales educativos, identificación de problemas estratégicos y establecimiento de objetivos educativos, Conexión universal mínima para uso educativo, adaptar y diseñar nuevos contenidos educativos orientados a entornos digitales en línea. Creación de estándares específicos liderados por equipos multidisciplinares de docentes e informáticos que gestionen la información de forma sencilla. La convergencia de tecnologías y metodologías diferentes en el ámbito educativo ha llevado a identificar las necesidades urgentes. Uno de los elementos necesarios es definir de qué forma hemos de construir el currículo cuando este se prepara para la enseñanza no presencial o en aquella que hemos de tener en cuenta la influencia de los entornos mediados por la tecnología para que permitan la dotación de competencias por parte del alumnado. Se han de implementar y recomendar unos requisitos mínimos en cuanto a las características técnicas de los equipos y a que edades a las que van dirigidos los contenidos educativos. Así como especificaciones para su creación mediante el uso de gestores de contenidos agiles y amigables implementados de forma específica para educación. Dotando a los centros y alumnado de las herramientas de hardware, software y acceso a la red.

\section{Referencias}

Alexander, B., Ashford-Rowe, K., Barajas-Murphy, N., Dobbin, G., Knott, J., McCormack, M., Pomerantz, J., Seilhamer, R., \& Weber, N. (2019). EDUCAUSE Horizon Report: 2019 Higher Education Edition. https://library.educause.edu/-/media/files/ library/2019/4/2019horizonreport.pdf?la=en\&hash=C8E8D444AF372E705FA1BF9D4FFODD4CC6FOFDD1

Bonilla-Guachamín, J. A. (2020). Las dos caras de la educación en el COVID-19. CienciAmérica, 9. https://doi.org/10.33210/ca.v9i2.294

Brown, M., McCormack, M., Reeves, J., Brooks, C., \& Grajek, S. (2020). The Horizon Report Trends. In EDUCAUSE Review, 55.

Cabero, J., \& Llorente, M. C. (2011). Entornos personales de aprendizaje ( PLE ). July 2015, pp. 83-95.

Cano, S., Collazos, C., Flórez-Aristizabal, L., Moreira, F., \& Ramírez, M. (2020). Experiencia del aprendizaje de la Educación Superior ante los cambios a nivel mundial a causa del COVID-19. Campus Virtuales: Revista Científica Iberoamericana de Tecnología Educativa, 9.

Carrascal, S., de Vicente, A., \& Sierra, J. (2020). Transformación e innovación educativa durante la crisis del COVID-19. Estilos y modelos de enseñanza y aprendizaje. Revista Estilos de Aprendizaje / Journal of Learning Styles, 13. Núm. Especial.

Castaño, C. (2003). Introducción a la metodología de investigación cualitativa. Revista de Psicodidáctica, 14. 
Castillo Olivares, A. del. (2021). El impacto de la COVID-19 en el profesorado de Educación Superior y sus concepciones sobre la evaluación. Campus Virtuales : Revista Científica Iberoamericana de Tecnología Educativa, 10.

Chan, D. (2021). Impacto del distanciamiento social por el virus de la COVID-19 en la Educación Superior Argentina : la arista docente. Revista Innovaciones Educativas, 23.

Fernández Torres, M. J., Chamizo Sánchez, R., \& Sánchez Villarrubia, R. (2021). Universidad y pandemia: la comunicación en la educación a distancia. Ámbitos. Revista Internacional de Comunicación, 52. https://doi.org/10.12795/ambitos.2021.i52.10

González-Nieto, A., \& Fernández-Cárdenas, J. M. (2021). Innovación educativa ante el Covid-19 : una perspectiva comparada en el contexto mexicano. Revista de Educación Superior del Sur Global - RESUR, 11. https://doi.org/10.25087/resur11a11

Harris, C. (2021). The role of 'Rich Tasks' an interdisciplinary and digital approach to learning post COVID-19 //. PIXEL-BIT, 61.

Iyengar, R. (2020). Education as the path to a sustainable recovery from COVID-19. Prospects, 49.https://doi.org/10.1007/s11125-020-09488-9

Johnson, L., Adams Becker, S., Estrada, V., \& Freeman, a. (2015). NMC Horizon Report: Edición Educación Superior 2015.

La innovación educativa en los tiempos del Coronavirus. (2020). Salutem Scientia Spiritus, 6.

Lugo, M. T., Ithurburu, V. S., Sonsino, A., \& Loiacono, F. (2020). Políticas digitales en educación en tiempos de Pandemia: desigualdades y oportunidades para América Latina. Edutec. Revista Electrónica de Tecnología Educativa, 73. https://doi. org/10.21556/edutec.2020.73.1719

Muñoz García, L. (2020). ¿Podría la pandemia ayudarnos para que la educación no llegue tarde al futuro?. Avances En Supervisión Educativa, 34. https://doi. org/10.23824/ase.v0i34.701

Mustapha, I., Van, N. T., Shahverdi, M., Qureshi, M. I., \& Khan, N. (2021). Effectiveness of Digital Technology in Education During. IJIM: International Journal of Interactive Mobile Technologies, 15.

Nasution, A. K. P., Surbakti, A. H., Zakaria, R., Wahyuningsih, S. K., \& Daulay, L. A. (2021). Face to Face Learning vs Blended Learning vs Online Learning (Student Perception of Learning). Journal of Physics: Conference Series, 1783. https://doi. org/10.1088/1742-6596/1783/1/012112

Ramírez-Montoya, M.-S. (2020). Transformación digital e innovación educativa en Latinoamérica en el marco del COVID-19. Campus Virtuales : Revista Científica Iberoamericana de Tecnología Educativa. 9. 
Sánchez-García, J.-M., \& Toledo-Morales, P. (2017). Tecnologías convergentes para la enseñanza: Realidad Aumentada, BYOD, Flipped Classroom Converging technologies for teaching: Augmented Reality, BYOD, Flipped Classroom. RED. Revista de Educación a Distancia. 55 https://doi.org/DOl: http://dx.doi.org/10.6018/red/55/8

Sandoval, C. H. (2020). La Educación en Tiempo del Covid-19 Herramientas TIC: El Nuevo Rol Docente en el Fortalecimiento del Proceso Enseñanza Aprendizaje de las Prácticas Educativa Innovadoras. Revista Tecnológica-Educativa Docentes 2.0, 9. https://doi.org/10.37843/rted.v9i2.138

Sangrà, A. (2020). Tiempo de trasformación educativa Educational transformation time Tempo de transformação educacional Educación en tiempos de pandemia: estrategias para la mejora de los procesos educativos. Revista Innovaciones Educativas, 22.

Socolovsky, Y. (2020). Preguntas a la coyuntura. Reflexiones, problemas y preocupaciones acerca del trabajo docente, el uso de las tecnologías y las desigualdades ante la pandemia. Trayectorias Universitarias, 6. https://doi.org/10.24215/24690090e028

Llorens, A., Alarcón, J. \& Brañes, J. (2021). Alfabetización digital y TIC en la educación secundaria en Chile: diagnóstico en tiempo de pandemia. Interciencia, 46. 


\section{Resultados en el Uso de Realidad Aumentada en Introducción a la Ingeniería Electrónica al Inicio de la Pandemia Covid-19}

García Marra, Sebastián

Universidad de Buenos Aires

segarcia@fi.uba.ar

\section{Carducci, Leonardo Martín}

Universidad de Buenos Aires

Icarducci@fi.uba.ar

\section{Bonelli, Fernando}

Universidad de Buenos Aires

fbonelli@fi.uba.ar

\section{Veiga, Ricardo Alfredo}

Universidad de Buenos Aires

rveiga@fi.uba.ar 


\title{
RESULTADOS EN EL USO DE REALIDAD AUMENTADA EN INTRODUCCIÓN A LA INGENIERÍA ELECTRÓNICA AL INICIO DE LA PANDEMIA COVID-19
}

\author{
García Marra, Sebastián \\ Carducci, Leonardo Martín \\ Bonelli, Fernando \\ Veiga, Ricardo Alfredo
}

\section{Resumen}

El uso de instrumental es una parte esencial de la carrera de Ingeniería Electrónica. Por este motivo, en la Facultad de Ingeniería de la Universidad de Buenos Aires (FIUBA), la asignatura Introducción a la Ingeniería Electrónica busca, en forma temprana, el aprendizaje de la operación básica de un instrumento de medición llamado osciloscopio. Con el objetivo de facilitar el acceso a este instrumento se desarrolló una aplicación de Realidad Aumentada que permite emular las funciones básicas de un osciloscopio. En este trabajo se comparan los resultados obtenidos en el uso de la aplicación durante una primera etapa de validación, con estudiantes que ya habían tenido acceso previamente al instrumento físico, y una etapa con otro grupo que solamente tuvo acceso al software de Realidad Aumentada, sin entrar en contacto con el instrumento real. También se destacan los resultados obtenidos al utilizar esta aplicación durante la pandemia COVID-19, como herramienta fundamental para la adquisición de habilidades tanto prácticas como teóricas.

\section{Palabras clave}

Ingeniería electrónica, realidad aumentada, software educativo, osciloscopio. 


\section{Introducción}

La asignatura "Introducción a la Ingeniería Electrónica" forma parte del plan de estudios actual de la carrera de Ingeniería Electrónica de la Facultad de Ingeniería de la Universidad de Buenos Aires y está prevista también para el futuro plan de estudios. La asignatura tiene como objetivos principales ofrecer a cada estudiante las primeras herramientas conceptuales y prácticas relativas a la disciplina y, al mismo tiempo, servir como herramienta motivacional para que continúen sus estudios. Asimismo, se busca desarrollar sus habilidades prácticas relacionadas con las mediciones de laboratorio y el manejo de instrumental (Ferreira Aicardi, et al., 2013; Etchepareborda et al., 2018; Carducci, 2016).

La estrategia de enseñanza principal utilizada es el Aprendizaje Basado en Proyectos (ABP o PBL en inglés) y sus variantes (Savage et al., 2009; Knight et al., 2007). De esta forma se recorre el contenido de la asignatura a través de un proyecto que fomenta además el desarrollo de ciertas habilidades (Veiga et al., 2014), contemplando sus Zonas de Desarrollo Próximo (Vygotski, 2009) al tener en consideración la formación previa de los estudiantes. En la medida en que se avanza con el proyecto, se plantean diferentes situaciones problemáticas que generan la necesidad de utilizar el instrumental adecuado para realizar mediciones sobre diferentes circuitos básicos.

En particular, un instrumento especialmente desarrollado para visualizar y medir señales eléctricas que varían a lo largo del tiempo, llamado osciloscopio, suele ser complicado de entender y de operar, fundamentalmente por su naturaleza y por el tipo de magnitudes que mide. En la Figura 1 se puede apreciar uno de los modelos utilizados habitualmente en el laboratorio donde se desarrolla la asignatura.

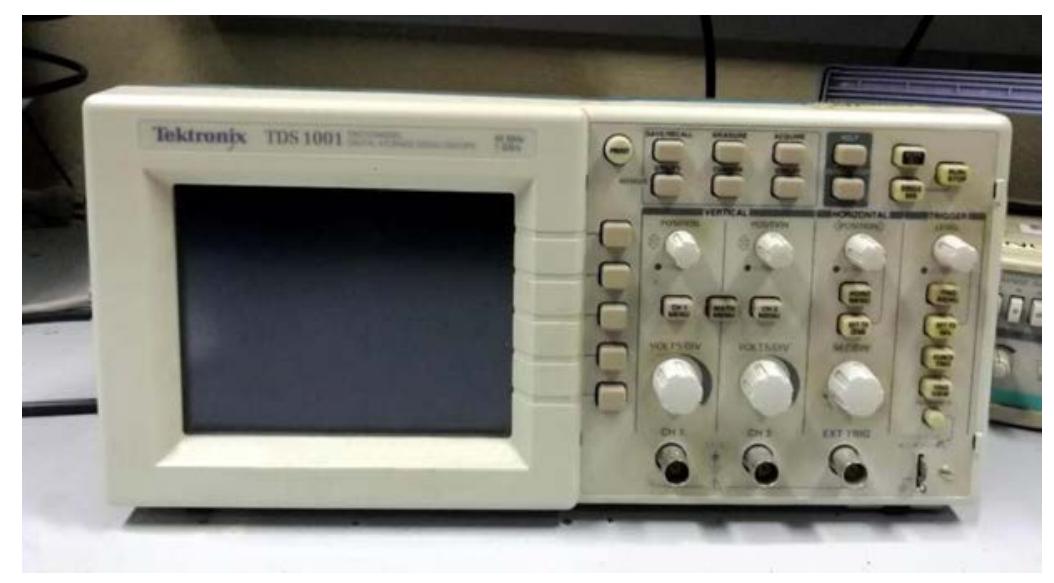

\section{Figura 1: Osciloscopio empleado en el laboratorio}

Por otra parte, tampoco resulta sencillo dominar todas las funciones del instrumento estudiadas en la asignatura. A su vez, la especificidad de uso y su alto costo hacen que rara vez pueda encontrarse uno en los hogares, haciendo que los laboratorios de la facultad sean el único ámbito en el que es posible interactuar con este instrumento. Todas estas circunstancias hacen especialmente interesante la oportunidad para desarrollar una herramienta que pueda "llevarse" al hogar para seguir 
practicando de manera interactiva. Para esto se diseñó una aplicación de Realidad Aumentada (RA) para teléfonos celulares (García Marra et al., 2020) (Fig. 2), que fuera desarrollada en el marco del proyecto UBATIC liderado por el Centro de Tecnologías Educativas de la FIUBA, aprovechando las experiencias previas en el uso de esta tecnología en el ámbito educativo de la ingeniería (Aveleyra, et al., 2018), pero tratando de evitar algunas de las consecuencias observadas por Alptekin y Temmen (2019).

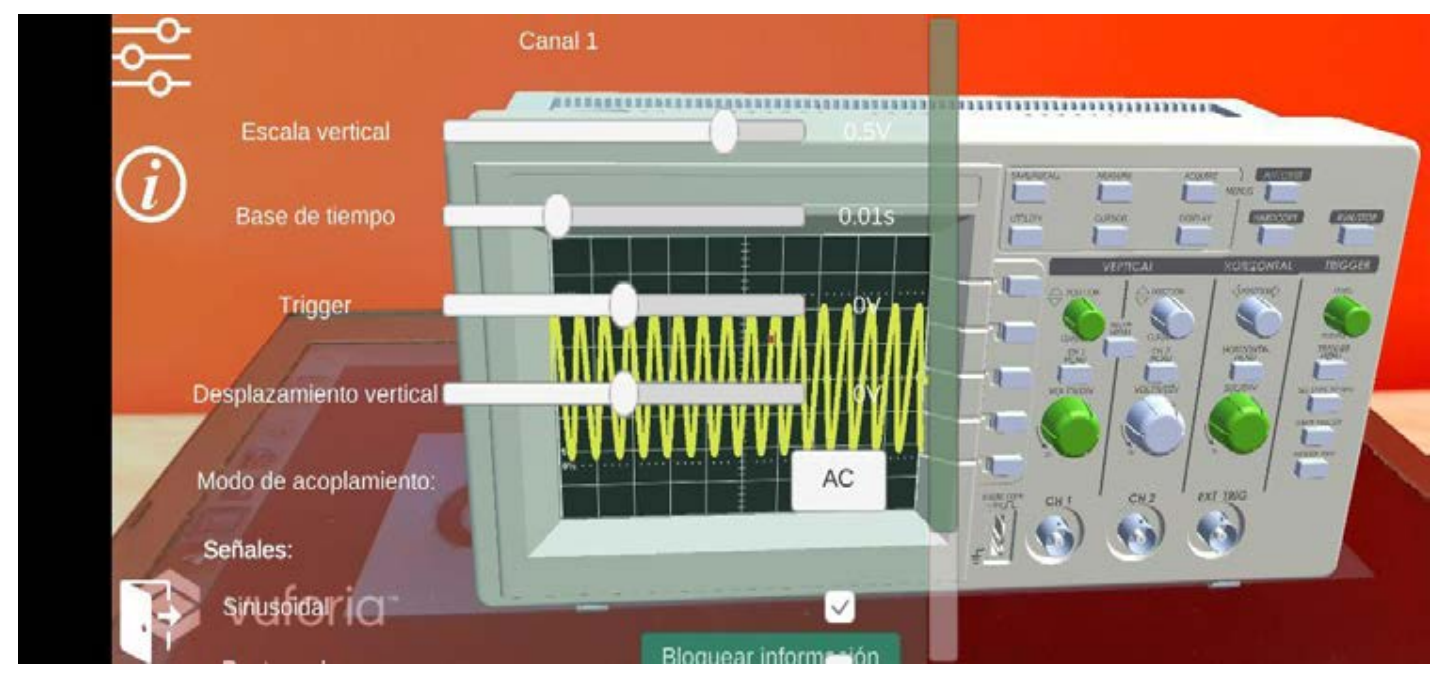

\section{Figura 2: Aplicación de RA diseñada para el Osciloscopio}

Así, mediante el uso de un software de simulación del instrumento que complemente su uso en un ambiente real, se buscaba facilitar la comprensión y enriquecer la experiencia de aprendizaje. También se esperaba que cada estudiante, independientemente de su asistencia al laboratorio, contara con la oportunidad de practicar durante más tiempo. Por otra parte, se pretendía disponer de una práctica simulada que pudiera realizarse cuantas veces fuera necesario, y al mismo tiempo utilizar la aplicación mientras se realizaba una medición real, consultando la información que provee para comprender el uso de cada control del instrumento.

En un trabajo anterior (García Marra et al., 2020) se había presentado el diseño y desarrollo de esta aplicación, mientras que en éste se presentan algunos resultados de una prueba de validación del funcionamiento operativo previo a su puesta en producción, así como la primera experiencia de uso por parte de estudiantes que no habían tenido la oportunidad de utilizar el osciloscopio real en forma previa.

\section{Descripción de la experiencia}

La experiencia se desarrolló en dos fases:

a) Etapa de validación de la herramienta a fines de 2019.

b) Primer caso de uso real a comienzos de 2020. 
La primera etapa fue diseñada para efectuar pruebas que permitieran evaluar la usabilidad, al tiempo de poder detectar posibles fallas en el software que no hubiesen sido detectadas previamente. Originalmente, para la fase de uso real se había previsto integrar la aplicación de RA sobre el instrumento físico en un proceso interactivo. Sin embargo, la situación surgida por la pandemia de COVID-19, forzó un cambio de estrategia que se transformó en una oportunidad para utilizar la herramienta en un contexto educativo totalmente diferente.

\section{Etapa de validación}

\section{Descripción del contexto y de los participantes}

Para realizar esta etapa de la experiencia, se contó con la colaboración de estudiantes del segundo cuatrimestre del 2019 que habían aprendido previamente a utilizar el instrumento real.

\section{Instrumentos}

Los instrumentos utilizados para esta etapa fueron: a) la aplicación de software de realidad aumentada y b) una encuesta para obtener la información relevante, posteriormente a la experiencia práctica de usar un osciloscopio real.

\section{Procedimiento}

En esta primera fase de prueba de la aplicación se armaron grupos de seis estudiantes, que trabajaron de manera individual y en simultáneo, con su dispositivo móvil y un marcador (marker) para la realización de la actividad práctica. Este marcador permite que la aplicación pueda ser utilizada incluso fuera del ámbito del laboratorio.

La actividad se inició con una explicación breve indicando en qué consistía, pero sin ofrecer detalles del uso de la aplicación; así se buscaba establecer el desempeño alcanzado frente a esta aplicación desconocida, y la velocidad de identificación y adaptación para su correcto uso.

La actividad constó de dos partes:

1. Recorrer el osciloscopio en modo "exploración", identificar el uso de cada control y registrar si había elementos o funcionalidades que eventualmente eran desconocidas.

2. Pasar al modo "medición" y medir los valores solicitados para tres señales diferentes.

Se les asignó un tiempo de 15 minutos para resolver la actividad, para que luego pudieran indicar sus percepciones mediante una encuesta. 


\section{Primer caso de uso real}

\section{Descripción del contexto y de los participantes}

En este caso, se realizó la experiencia con estudiantes del primer cuatrimestre del 2020. Originalmente se había planificado realizar esta actividad en forma presencial como parte de la primera actividad relacionada con el uso del osciloscopio, en el aula e inmediatamente después de explicar teóricamente su utilidad y funcionamiento básico como instrumento de medición. También se había previsto, como tarea fuera del aula, la realización de la medición de alguna señal mediante el uso de la aplicación.

Debido a la situación de pandemia, esta etapa de implementación de la aplicación se llevó a cabo completamente durante la cursada en modalidad virtual. Ante este cambio de contexto, el procedimiento realizado con la aplicación difirió del utilizado en la primera etapa de validación y con el originalmente planificado; ya que durante la cursada presencial el software fue utilizado para complementar el aprendizaje obtenido en el laboratorio, mientras que en la virtualidad la aplicación se convirtió en una de las herramientas principales, debido a la falta de acceso a un laboratorio con instrumentos reales.

\section{Instrumentos}

Los recursos utilizados durante esta fase fueron: a) la aplicación de software de realidad aumentada (segunda versión), b) el enunciado del trabajo práctico a desarrollar y posterior informe presentado por el grupo de estudiantes y c) una encuesta para obtener la información relevante, posterior a la experiencia y entrega del trabajo práctico.

\section{Procedimiento}

En este caso, se armaron grupos de tres estudiantes, que trabajaron de manera individual en sus casas y eventualmente en simultáneo a través de medios electrónicos. Cada estudiante utilizó su dispositivo móvil con la aplicación de software y el marcador ya mencionado.

La actividad realizada durante la virtualidad consistió en la ejecución de un trabajo práctico con la elaboración de un informe. Se la explicó en una clase virtual y constó de dos partes:

1. Recorrer el osciloscopio en modo "exploración", identificar el uso de cada control y cuando correspondiera, registrar si había elementos o funcionalidades que desconocían.

2. Pasar al modo "medición" y medir los parámetros solicitados para cada una de las tres señales especificadas en la actividad práctica. Los parámetros pedidos eran los que usualmente se medían en la práctica con el osciloscopio real y como parte del trabajo integrador que llevaban a cabo anteriormente a la situación de pandemia. 
Esta tarea involucró no sólo el manejo de los modos básicos del instrumento, sino también la realización de mediciones relacionadas con otros conceptos de electrónica según la planificación de la asignatura.

Es importante notar que la aplicación utilizada en esta etapa sufrió cambios orientados a mejorar la experiencia del usuario desde su primera versión, algunos de los cuales fueron:

- Operación individual de cada control en el "modo exploración", resaltando en el frente del osciloscopio el control "físico" que se estaba operando.

- Agregado del control de desplazamiento vertical de la señal.

- Mejoras generales para la usabilidad, tales como el tamaño del puntero del modo exploración, textos, menús, etc.

\section{Resultados}

\section{Etapa de validación}

La encuesta realizada a 31 estudiantes, una vez finalizada la actividad sobre el uso de la plataforma, sirvió para recopilar información acerca de la experiencia personal, la cual se muestra a continuación.

En la Fig. 3 se puede observar la simpleza en el uso de la aplicación, resultándole "simple" o "muy simple" al $71 \%$ de quienes respondieron la encuesta. Mientras que el $81 \%$ aseguraba que le resultó muy útil y clara la información desplegada para cada control del instrumento (Fig. 4).

\section{¿Qué tan simple de usar te resultó}

la aplicación?

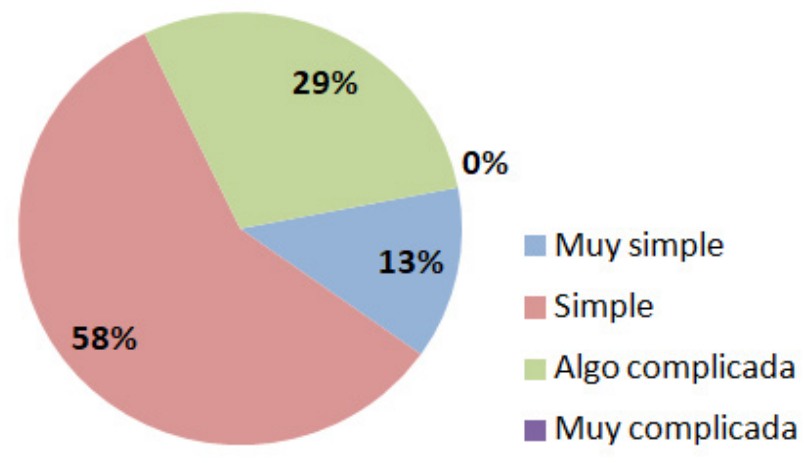




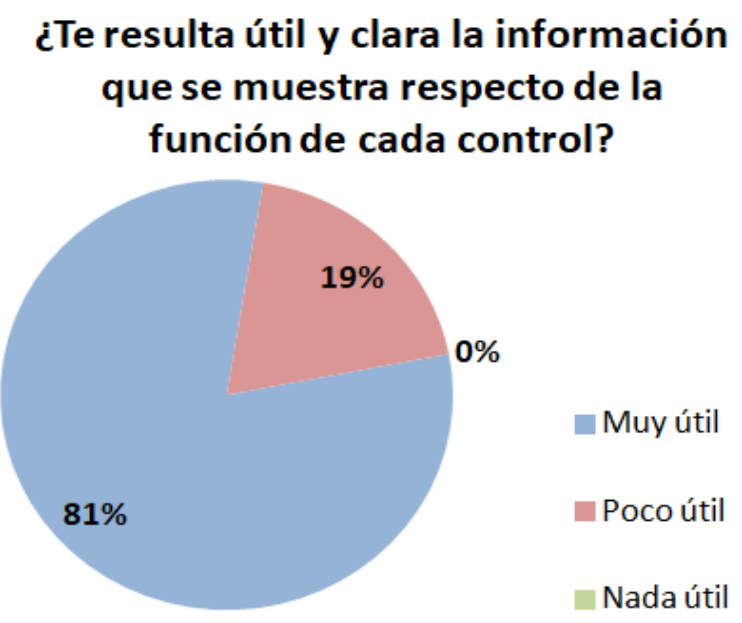

Figura 4

Adicionalmente, la consigna de la actividad solicitada fue clara para el total del público objetivo (Fig. 5). Y finalmente, el $32 \%$ de quienes respondieron la encuesta asegura que gracias al uso de la aplicación mejoró su comprensión de algún concepto del osciloscopio (Fig. 6). Las respuestas de estos últimos se pueden agrupar en: a) comprender las mediciones con el instrumento, b) entender los controles del instrumento y c) verificar otros conceptos.

\section{¿Te resultaron claras las consignas de medición en cada caso?}

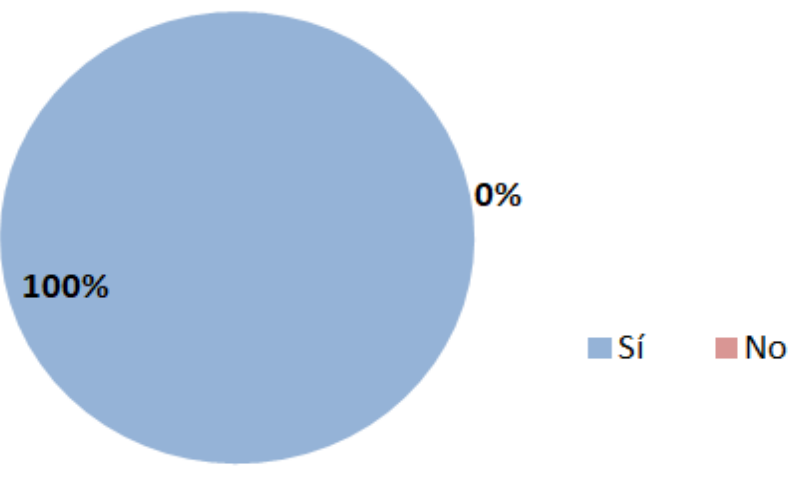




\section{¿Te ayudó la aplicación a comprender mejor algún concepto del uso de osciloscopio?}

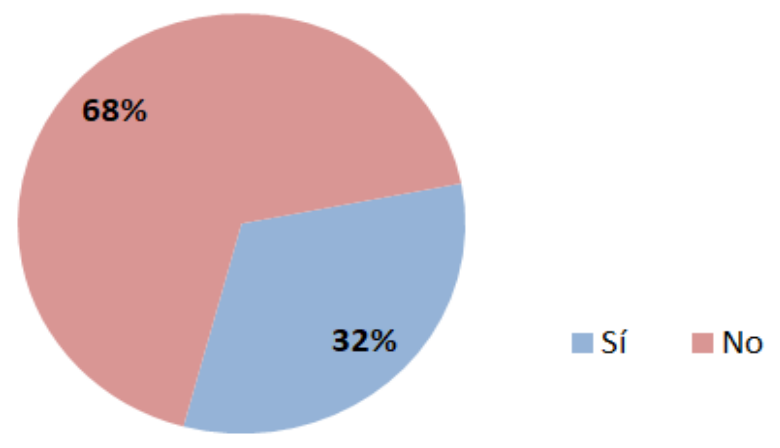

Figura 6

\section{Primer caso de uso real}

La encuesta realizada a 32 estudiantes, luego de realizar la actividad con la aplicación de software, brindó la información cuyos resultados resumidos se presentan a continuación.

\section{Usabilidad}

La primera pregunta se refería a la complejidad o simplicidad de uso de la aplicación (Fig. 7). El 69\% de las respuestas indicaban que la aplicación fue "simple de utilizar", mientras que $12 \%$ la encontró "muy simple" y solamente un $19 \%$ "algo complicada", no habiendo nadie que indicara que la misma fuese muy complicada de usar. Por otra parte, el resultado obtenido con esta nueva versión muestra un incremento de 10 puntos porcentuales respecto del año anterior, si se consideran aquellas respuestas que indicaron como "simple o muy simple de utilizar", pasando del $71 \%$ al $81 \%$. Y teniendo en cuenta que en esta ocasión cada estudiante estaba realizando su primer acercamiento al instrumento, mientras que en la etapa de validación ya contaban con la experiencia de haberlo utilizado físicamente en forma previa. Adicionalmente, dadas las condiciones de virtualidad, cada estudiante tuvo que familiarizarse con la aplicación sin una guía directa por parte del docente. 


\section{¿Qué tan simple o complicada de utilizar te resultó la aplicación?}

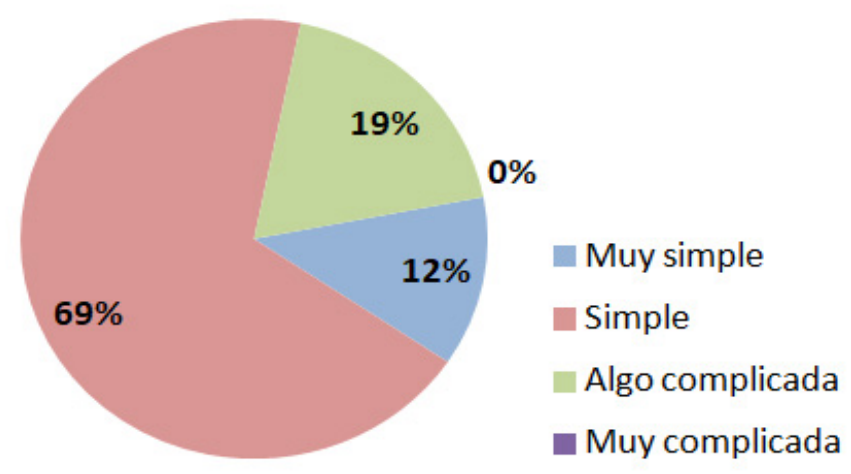

Figura 7

\section{Conceptos aprendidos}

La segunda pregunta estaba relacionada con la utilidad de la aplicación para posibilitar un mejor entendimiento de algunos de los conceptos relativos al uso del osciloscopio. El $72 \%$ de las respuestas destacaron que el uso de la aplicación ayudó a comprender mejor algún concepto, mientras que el porcentaje restante indicó que comprendió mejor un concepto pero que todavía le quedaron algunas dudas (Fig. 8).

\section{¿Te ayudó la aplicación a comprender mejor algún concepto del uso de osciloscopio?}
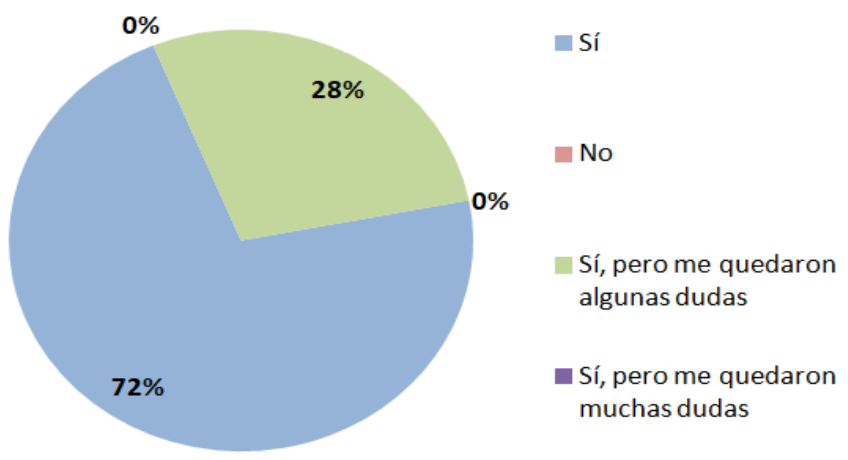

Figura 8

Adicionalmente, y vinculada a la pregunta sobre la comprensión de conceptos, se hizo otra indagando sobre aquellos que la aplicación había contribuido a comprender mejor. La pregunta era de opciones múltiples, por lo que los porcentajes no suman $100 \%$. Así se pudo apreciar que hay dos conceptos muy particulares que fueron indicados con mayor frecuencia (Fig. 9): 
- Trigger (control de disparo): El control de trigger es uno de los conceptos más abstractos y difíciles de entender cuando se trata de los controles más usuales del osciloscopio. Por ende resulta notable que ésta haya sido una de las funciones principalmente indicadas como mejor comprendidas por quienes habían respondido "sí" a la pregunta anterior.

- Tiempo de crecimiento: El tiempo de crecimiento no corresponde a un control del instrumento, sino a un parámetro asociado a un tipo de señal, y que suele ser de difícil incorporación.

\section{¿Qué concepto te ayudó a entender mejor?}

(Seleccionar todas las que correspondan)

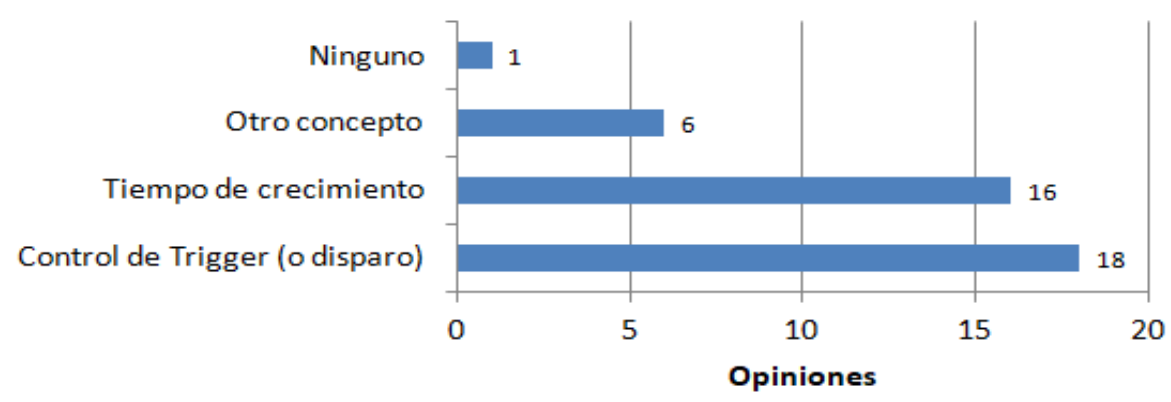

Figura 9

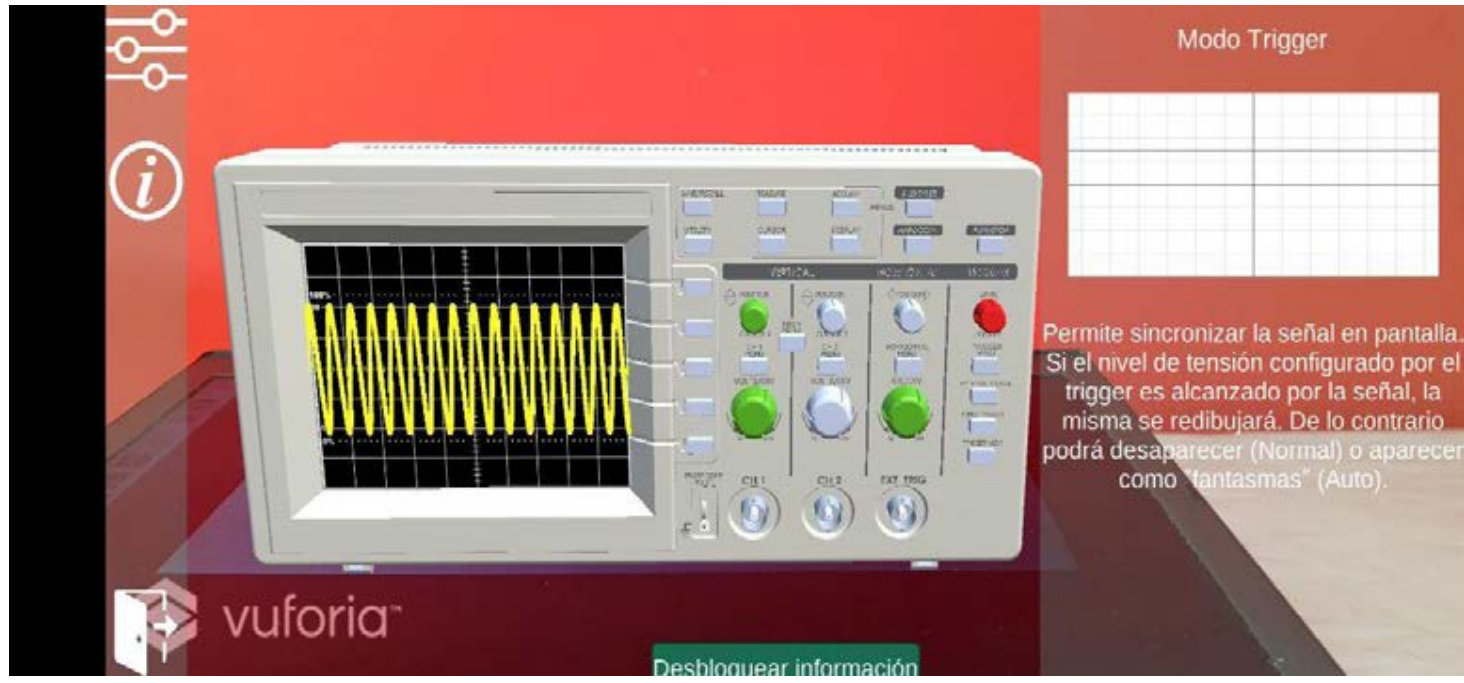

Figura 10: Modo exploración control de ajuste de trigger

No obstante estos resultados, vale destacar también que algunas expresiones libres manifestadas por estudiantes ante la consulta acerca de qué conceptos no terminaban de comprender, nuevamente el trigger aparece como elemento central. Aunque esta experiencia se enmarca en la situación de pandemia y que éste es un control abstracto que está siendo analizado completamente desde la virtualidad, también refleja una posible oportunidad de mejora en la propuesta de valor y uso de la aplicación. 


\section{Otros resultados de la encuesta}

Adicionalmente se relevaron otros aspectos interesantes vinculados con potenciales oportunidades de mejora en términos de la usabilidad de la aplicación, así como también sugerencias sobre mayor variedad de señales a medir, para multiplicar las posibilidades de exploración del instrumento mediante el uso de la aplicación.

\section{Conclusiones}

Una vez finalizada la etapa de validación, se pudo comprobar que la aplicación resultó útil como complemento para reforzar y afianzar conocimientos ya obtenidos durante las prácticas en el laboratorio. También se obtuvieron datos relevantes sobre su usabilidad, que permitieron mejorar la aplicación para la segunda versión utilizada en la primera actividad de uso real; algo valorado muy positivamente por quienes respondieron la segunda encuesta.

Si bien la aplicación nunca se pensó para reemplazar la actividad presencial, su uso durante la situación de pandemia permitió que cada estudiante tuviese un acercamiento al instrumento, algo que hubiese sido muy complicado en un proceso completamente virtual.

Se podría concluir también que la utilización de la aplicación en forma posterior al uso práctico del instrumento real, introduciría un grado de afianzamiento adicional respecto de la experiencia adquirida. Esto se sustenta en lo observado en la etapa de validación, ya que un 32\% había comprendido mejor algún concepto en el uso del osciloscopio a partir de la utilización de la aplicación, aun cuando ya tenían experiencia previa en el uso práctico del osciloscopio. Por otra parte, el empleo previo de la aplicación podría suplantar una parte de la práctica presencial, dado que el $72 \%$ de quienes hicieron la actividad en condiciones de virtualidad completa, sin haber realizado las actividades prácticas usuales de manejo del instrumento, manifestaron haber mejorado su comprensión de algunos conceptos involucrados. Quedaría aún pendiente comprobar el resultado de su uso en forma simultánea con el manejo físico del osciloscopio en el laboratorio.

\section{Referencias}

Alptekin, M., \& Temmen, K. (2019). Teaching an Oscilloscope through Progressive Onboarding in an Augmented Reality Based Virtual Laboratory. In 2019 IEEE Global Engineering Education Conference (EDUCON) (pp. 1047-1054). Dubai, United Arab Emirates: IEEE.

Aveleyra, E. E., Racero, D. A., \& Gómez Toba, G. (2018). The Didactic Potential of AR in Teaching Physics. In 2018 IEEE World Engineering Education Conference (EDUNINE) (pp. 1-3). Buenos Aires: IEEE.

Carducci, L., Corbellini, E., Burman, A., García Marra, S., Bierzychudek, M., Veiras, F., Etchepareborda, P., Iglesias, M., Cabibbo, D., Zacchigna, F., Mello Teggia, M., Alvarez-Hamelin, J. I., \& Veiga, R. A. (2016). Desarrollo de un Sistema de Comunicaciones 
en una Asignatura de Introducción a la Ingeniería Electrónica. I/I Congreso Argentino de Ingeniería - CADI 2016 y IX Congreso Argentino de Enseñanza de la Ingeniería - CAEDI 2016.

Etchepareborda, P., Bierzychudek, M. E., Carducci, L., Veiras, F. E., Zacchigna, F. G., Corbellini, E., García Marra, S., Iglesias, M., Mello Teggia, M., Alvarez-Hamelin, J. I., \& Veiga, R. A. (2018). A Project-Based Learning Method Applied to an Introductory Course in Electronics Engineering. In 2018 IEEE World Engineering Education Conference (EDUNINE) (pp. 1-4). Buenos Aires, Argentina: IEEE.

Ferreira Aicardi, F., Graña, J., \& Veiga, R. A. (2013). Primeras experiencias en Aprendizaje Basado en Proyectos en asignaturas introductorias a la Ingeniería Electrónica. XV Reunión de Trabajo en Procesamiento de la Información y Control.

García Marra, S., Maitia Petros, D. I., Lambre, J. M., Veiga, R. A., \& Aveleyra, E. (2020). Desarrollo de un Osciloscopio con Realidad Aumentada para un Curso Introductorio de Ingeniería Electrónica. 2020 IEEE Biennial Congress of Argentina.

Knight, D., Carlson, L., \& Sullivan, J. (2007). Improving Engineering Student Retention through Hands-On, Team Based, First-Year Design Projects. Proceedings of the International Conference on Research in Engineering Education.

Savage, R. N., Chen, K. C., \& Vanasupa, L. (2009). Integrating project-based learning throughout the undergraduate engineering curriculum. IEEE Engineering Management Review, 37(1), 25. https://doi.org/10.1109/EMR.2009.4804346

Veiga, R. A., Ferreira Aicardi, F. L., \& Graña, J. (2014). Estrategias didácticas adaptadas al perfil de los estudiantes en Introducción a la Ingeniería Electrónica. In CONFEDI, // Congreso Argentino de Ingeniería - CADI 2014 y VIII Congreso Argentino de Enseñanza de la Ingeniería - CAEDI 2014.

Vygotski, L. S. (2009). El Desarrollo de los Procesos Psicológicos Superiores (Tercera Edición). Crítica. 
Colección Universidad

Título: Escenarios y recursos para la enseñanza con tecnología: desafíos y retos

Primera edición: febrero de 2022

(c) Ema Elena Aveleyra, Melisa Alejandra Proyetti Martino (coords.)

(c) De esta edición:

Ediciones OCTAEDRO, S.L.

C/ Bailén, 5 - 08010 Barcelona

Tel.: 932464002

octaedro@octaedro.com

www.octaedro.com

ISBN: 978-84-19023-85-8

DOI: https://doi.org/10.36006/16361

Diseño de interiores y maquetación: Victoria Pasin

Diseño de cubierta: Octaedro Editorial

NOTA EDITORIAL: Las opiniones y contenidos de los textos publicados

en esta obra son de responsabilidad exclusiva de los autores.

Publicación en Open Access - Acceso abierto $\partial$ 


\section{Escenarios y recursos para la enseñanza con tecnología: desafíos y retos}

La educación está inmersa en un contexto de crisis y cambios que ha impactado en todos los niveles a nivel mundial. Es una oportunidad desafiante para que supuestos e interrogantes, modelos, métodos y prácticas de integración entre educación y tecnología tengan una impronta positiva en la enseñanza. No se debiera continuar con la dicotomía entre las modalidades presencial y virtual de la enseñanza o con la mera introducción de las tecnologías en el aula, sino avanzar en cómo a través de escenarios dinámicos y recursos tecnopedagógicos es posible mejorar la inclusión y la calidad de los aprendizajes.

Este libro ofrece diferentes experiencias, propuestas y estudios que se estructuran en cinco bloques temáticos: Innovación docente, Investigación en Tecnología Educativa, Políticas y Gestión de las Tecnologías, Inclusión Digital, Aprendizaje en Red y Escenarios con Tecnología. Se espera que signifiquen un aporte para repensar y rediseñar la educación en este nuevo contexto que nos interpela.

Ema Elena Aveleyra (coord.) Profesora de Matemática y Física. Especialista en Informática Educativa y Magíster en Gestión de Proyectos Educativos. Profesora Adjunta Regular en áreas de Física y Matemática en las Facultades de Ingeniería (FIUBA) y Ciencias Económicas de la Universidad de Buenos Aires. Directora del Centro de Tecnologías Educativas y del Laboratorio de Entornos Virtuales de Aprendizaje de la FIUBA. Investigadora categorizada y directora de varios proyectos de docencia, investigación y extensión de la UBA. Presidenta del Comité Organizador de EDUTEC 2021.

Melisa Alejandra Proyetti Martino (coord.) Magíster de la Universidad de Buenos Aires en Ingeniería Matemática, Licenciada en Enseñanza de la Matemática y Profesora en Matemática. Profesora en cursos y especialización para la capacitación docente, en la Facultad de Ingeniería de la Universidad de Buenos Aires (FIUBA), y de Matemática en nivel terciario y universitario en universidades nacionales. Investigadora en el Laboratorio de Entornos Virtuales de Aprendizaje e integrante del Centro de Tecnologías Educativas de la FIUBA. Participante de Proyectos UBACyT en temas varios de investigación educativa. Integrante del Comité Organizador de EDUTEC 2021. 